\title{
P. Soraller
}

\section{Handbuch der Pllanzenkrankhe len}

Dertte antige

Lrster borl 


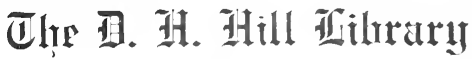

Nortl Caralua

3601
165
30.1

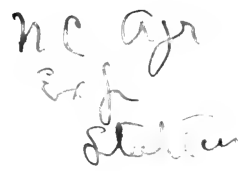


liace Pue

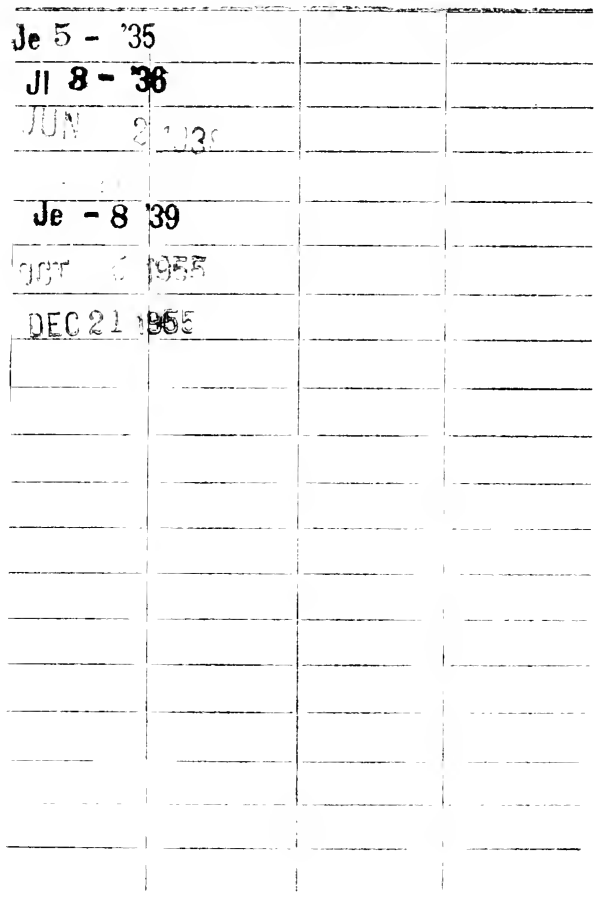






\title{
Handbuch
}

der

\section{Pflanzenkrankheiten}

\author{
vom \\ Prof. Dr. Paul Sorauer.
}

Dritte, vollständig neubearbeitete Auflage

in Gemeinschaft mit

Prof. Dr. G. Lindau, und Dr. L. Reh,

Privatdozent an der Universität Berlin Assistent am Naturhistor. Musenm in Hamburg herausgegeben

von

Prof. Dr. P. Sorauer, Berlin.

BERLIN

Verlagsbuchhandlung paúl Parey.

Vertigg fur Landwirtscliaft. Gartenbau und Forstwesen.

$\rightarrow I I, H c d e m a m s t r a s s e ~ 10$.

1909. 


\title{
Handbuch
}

der

\section{Pflanzenkrankheiten}

vom

\author{
Prof. Dr. Paul Sorauer.
}

\section{Erster Band. \\ Die nichtparasitären Krankheiten.}

Bearbeitet

von

Prof. Dr. Paul Sorauer, Berlin.

Mit 208 Textabbildungen.

BERLIN.

Verlagsbuchhandlíg Padl Parey.

Verlag für Landwirtschaft, Gartenbau und Torstnesen

SW., Hedemannstrasse 10. 
Alle Rechte auch das der Übersetzung, vorbehalten.

Altenburg, s.:A.,

lierersche Hothuchdruckerci

stephan reibel \& $1 \%$. 


\section{Vorwort.}

Fiir die dritte Auflage meines Handbuches halie ich die Unterstützung von Herrn Prof. Dr. Lindau und Hern Dr. Reh erbeten. Ersterer hat in dem zweiten Bande unseres Werkes die pflanzlichen Parasiten behandelt, letzterer die tierischen Feinde in einem dritten Bande zu bearbeiten übernommen.

Eine solche Hilfe sehien mir notwendig, weil die seit dem Erscheinen der zweiten Auflage veröffentlichten Untersuchungen so zahlreich sind, dats zur Bewältigung des Materials lange Zeit erforderlich wäre. Es würde daher mrermeidlich sein, dafs der Anfang des Werkes bereits zu veralten beginnt, wenn die letzten Bogen erscheinen. Auch selbst bei der hier vorgenommenen Arbeitsteilung lälist sich dieser T̈belstand nieht ganz umgehen, und wir haben uns dadurch zu helfen gesucht, daß wir einige der wiehtigeren nenen Arbeiten in einem ... Nachtrage" erwähnen. Wenn, von der älteren Literatur namentlich, Arbeiten rermitst werden, so erklärt sich dies ans dem Umstande, dats wir hauptsächlich diejenigen Studien herbeigezogen haben, die zur Stïtze unserer [)arstelhung notwendig gewesen sind. Ein anstührlicher Literaturnachweis ist nur bei monographischer Behandlung der einzehnen Krankheiten möglich.

Die Bearbeitung des ersten Bandes, der die nichtparasitären Krankheiten umfatst, hatte ich mir vorbehalten. Nach meinem bereits im Vorwort der zweiten Auflage genügend gekemneichneten Standpunkt ist es erklärlich, daf dieser Band der umfangreichste ist, weil ich auf die Kemntnis der durch Witterungs-, Boden- und Kulturverhältnisse hervorgerufenen Krankheiten das Hauptgewicht lege. Die durch diese Faktoren herrorgerufenen störungen sind nicht nur die hänfigsten und nachhaltigsten, sondern sie bilden anch vielfach die Einleitung für parasitäre Erkirankungen.

Deshalb war ich besonders bestrebt, gestiitzt auf eigene Studien und die Beobachtungen anderer Forscher, zu zeigen, wie dieselbe Pflanzenspezies je nach Lage und Bodenbeschaffenheit in ihrem Autban und ihren Lebensgewohnheiten sieh ändern kamn; je nach der versehiedenen Konstitution, die ein Individum erlangt, ist dasselbe bald mehr zn einer gewissen Erkrankungsform geneigt, bald widerstandstähiger.

Dies gilt auch für das Verhalten den parasitären Grganismen gegnüber, und daraus ergibt sich, daf, letztere nicht nur durch direkte Virnichtungsmittel bekämptt werden müssen. sondern dal's das Haun,tgewicht auf eine Änderung des Mutterbodens eines jeden Parasiten, 
d. h. anf eine Konstitutionsänderung der Nährpflanzen zu legen ist. Wir müssen also in der Anzucht widerstandstähiger Rassen unsere wesentliehste Anfgabe sehen. Diese Theorie von der Prädisposition der rinzelnen Organismen prarasitären Angriffen gegenüber, mit welcher der Untroradulnete bei Ilerausualue der ersten Auflage dieses Werkes allein stand, zählt nunmehr viele der bedeutendsten Forscher zu ihren Anhängerı.

Und $k$ hotte ich, wird die Idee, die ich seit Beginn meiner wissenschaftliehon Tätigkeit verfochten, nämlich die Ausgestaltung einer rationellen Pflanzenliggiene endlich zum Durchbruch kommen. Wir müssen lernen, den Organismus vor Erkrankung von vornherein zu bewahren. und dürfen erst in zweiter Linie, notgedrungen, dazu sthreiten, den bereits erkrankten Organismus zu heilen.

In dem ersten Bande hehandelt der erste Abschnitt die Mechanik des Krankheitsprozesses, und der zweite trägt die Überschrift „Geschichtliches". Diese Bezeichnmmg soll andenten, daß ich nicht eine Geschichte der Plyytopathologie schreiben wollte, weil dazu riel eingehendere Vorstudien gehören. Aber es schien mir erwïnscht, schon jetzt den Versuch zu wagen, den Werdegang der Disziplin zu skizzieren, um zu zeigen, wie die jetzigen Ansehaumgen im Laufe der Zeiten sich heransgebilket haben.

Bei Lurchsicht des speziollen Teils dürfte der Leser finden, daf's auch in der vorliegenden Auflage wieder eine gröfsere Zahl eigener Untersuchmgen niedergelegt worden ist. Die in der Phytopathologie unbedingt notwendige Unterstützung der Krankheitsbeschreibungen durch Abbilkmngen ist in bedentend erweitertem Matise durchgefiilnt worden. Dem Charakter les Buches entsprechend sind namentlich anatomische Zeichmugen neu hinzugekommen.

In dem Bande üher parasitäre Krankheiten finden wir diesmal melnfach synoptische Tafeln zusammengestellt, $u$ m dem Leser die einzelnen Gattungen einer Fanilie in ihren Unterscheidungsmerkmalen zur Vergleichung übersichtlich zi machen.

Die neuen Zeichnungen sind von Fxäulein H. Detmann und Fränlein E. L üt ke anngeführt worden, donen ich für ihre Tätigkeit bestens danke.

Vor allem aber danke ich meinen Herren Mitarbeitern. Sie hatten mit mir die sehwierige Aufugabe zu lösen, das Material in einem vor der Bearheitung kontraktlich festgesetzten Raume zur Darstellung zu bringen. Während der Bearbeitung sahen wir uns vor die Entscheidung gestellt, entweder den ganzen Stoff in knapperer Form, als wir ursprünglich in Aussicht genommen, vorzuführen oder einzelne Kapitel ansfülırlich zu bearbeiten und andere wesentlich kürzer zu fassen. Wir wällten den letzteren Weg. indem wir die ms am wichtigsten scheinenden Abschnitte eingehend behandelten, diejenigen Gruppen aber, the schon in anderen Werken eine genügende Bearbeitung gefunden haben, entsprechend einengten.

schänebrer, im Olitober 190s. 


\section{I n h a 1 t.}

\section{Einleitung.}

Erster Abschnitt. Das Wesen der Kramkheit Seite

1. Umgrenzung des Krankheitsbegriffes . . . . . . . . . . . . . 1

2. Die Entstehung der Krankheit . . . . . . . . . . . . 4

3. Die Beziehungen der Pflanze zu ihrer Umgebung. . . . . . . . . . 6

4. Die parasitären Krankheiten . . . . . . . . . . . . . . 10

5. Epidemien . . . . . . . . . . . . . . . . 15

6. Künstliche Immunisierung und innere Therapie . . . . . . . . 20

7. Prädisposition . . . . . . . . . . . . . . . . 22

8. Prädisposition und Immunität . . . . . . . . . . . . . 23

9. Erblichkeit der Krankheiten und Prädisposition. . . . . . . . . 28

10. Degeneration . . . . . . . . . . . . . . . . 31

Zweiter Abschnitt. Geschichtliches............ . 37

\section{Spezieller 'Teil.}

\section{Erster Abschnitt. Krankheiten durch ungïnstige Boden- verhältuisse.}

Erstes Kapitel. Die Lage des Bollens. . . . . . . . . . . . . . . . . 69

1. Die Erhebung über dem Meeresspiegel. . . . . . . . . . . . . . . . . 69

a) Allgemeine habituelle Änderungen . . . . . . . . . . . . . . . . . . 69

Bei krantartigen Gew ächsen. . . . . . . . . . . . . . . . . . . 69

Ausbildung der oberirdischen Achse der Holzuflanzen . . . . . . 73

b) Anpassungen des Wurzelkörpers der Holzpflanzen. . . . . . . . 75

pezielle Erkrankungen . . . . . . . . . . . . . . . . . . . . . . 78

Rickgang in der Kultur der Lärche. . . . . . . . . . . . . . 78

2. Neigung der Bodenoberflïche

a) Zu steile Lage. . . . . . . . . . . . . . . . . . . . . . . . . . . . . 8

Stelzenwuchs . . . . . . . . . . . . . . . . . . . 89

b) Zu tiefe Lage. . . . . . . . . . . . . . . . . . . . . . . . . . .

Zu tiefes Pflanzen der Bäume. . . . . . . . . . . . . .

Zu tiefe Lage der Saat . . . . . . . . . . . . . . . . . . . . . 104

Wurzeln aus der Spitze der Getreidekörner . . . . . . . . . . . . 113

3. Grofse horizontale Differenzen . . . . . . . . . . . . . . . . . . . . . 11

Glasige Getreidekörner . . . . . . . . . . . . . . . . . 126

4. Kontinental- und Seeklima. . . . . . . . . . . . . . . . . . . 128

5. Einflufs des Waldes. . . . . . . . . . . . . . . . . . . . . 132

Zweites Kapitel. Ungiustige physikalische Bodenbeschaffenheit . . . 18.

1. Beschränkter Bodenraum . . . . . . . . . . . . . . . . 13:

Die Wurzelkrümmungen. . . . . . . . . . . . . . . . . . . . . 135

Der Zwergwuchs (Nanismus). . . . . . . . . . . . . . . . . . . 139

Die Dichtsaat . . . . . . . . . . . . . . . . . 144 
2. Unpassende Bodenistruktur. . . . . . . . . . . . . . . . . 145

a) Leichte Bülen . . . . . . . . . . . . . . . . . . . . . . . . . . . 145

Nachteile les sandhodens . . . . . . . . . . . . . . . 140

Senkung des Grundwasserspiegels . . . . . . . . . . . . . . 148

bas Absterben der Grlen . . . . . . . . . . . . . . . . 1,o

Die strafsenpflanzungen. . . . . . . . . . . . . . . . . 1.51

Wirkungen der Tourre hei den Feldfüchten . . . . . . : . . . . . . 153

Inrch Trockenheit unterhrochene Keimung. . . . . . . . . . 1 .

Behandlung der Cehölzsamen . . . . . . . . . . . . . . . . 1.66

Verscheinen liei Getreide und Hülsenfrüchten . . . . . . . . . . 158

Fadenbildung der Kartoffeln (Filositas) . . . . . . . . . . . . . 159

Durehwachsen der Kartoffeh . . . . . . . . . . . . . . . . . . 161

Kinollenbildung olne Laub . . . . . . . . . . . . . . . . . . . 16:?

Oberirdische Kartoffelknollen . . . . . . . . . . . . . 163

Notreife des Obstes . . . . . . . . . . . . . . . . . . . . $16: 8$

Fuchsige Pflamen . . . . . . . . . . . . . . . . . 164

Weitere Froheinungen der Notreife. . . . . . . . . . . 165

Mehligwerden der Früchte . . . . . . . . . . . . . . . . lii.

Die stipuflecke. . . . . . . . . . . . . . . 166

Steinigwerden der Birnen und die Lithiasis . . . . . . . . . . . 169

Für trockne Büden geeignete Obstsorten . . . . . . . . . . . 173

Stanchlinge. . . . . . . . . . . . . . . . . . 17t

Terhatum (Pilosis . . . . . . . . . . . . . . . 17

Das Terholzen der Wurzehn. . . . . . . . . . . . . . . . . 17y

Ballentrocknis der Ericaceen . . . . . . . . . . . . . . . . . . 180

Nittel gegen den Wassermangel im Boden . . . . . . . . . . . 181

Berieshmo. . . . . . . . . . . . . . . . . . 181

Bodenbearbeitung . . . . . . . . . . . . . . . . . 18

Bodenbeleckung. . . . . . . . . . . . . . . . . . . . . . . 183

Mit Pflinzen bestandener Boden . . . . . . . . . . . . . . . 18t

Waldstreu . . . . . . . . . . . . . . . . . . 186

Itie Wälder . . . . . . . . . . . . . . . . . . . . . 18

Die Brache. . . . . . . . . . . . . . . . . . $1 \leq 7$

b) Lelmboden . . . . . . . . . . . . . . . . . . . . . . . . . . 1 $1=$

Allgemene Charakteristik. . . . . . . . . . . . . . . . . 18

Das Terschlämmen des Bodens . . . . . . . . . . . . . . . . . 140

Die Verbesserung der sich verdichtenden Böden. . . . . . . . . 193

Die C̈bertlutungen . . . . . . . . . . . . . . . . . . 195

Die Versumpfung. . . . . . . . . . . . . . . . . . . . . 196

Das Verbrennen der Pflanzen im nassen Boden........ . 19s

Terspätete saat. . . . . . . . . . . . . . . . . 200

Ausanern der Saaten . . . . . . . . . . . . . . . . . . . . 201

Versamem der Topforewächse . . . . . . . . . . . . . . . . . . 203

Das unvorsichtige Begiefsen. . . . . . . . . . . . . . . . . . . . 016

Gebranch der Topfuntersätze . . . . . . . . . . . . . . . . 200

Der Abbau der Kartoffeh. . . . . . . . . . . . . . . . . . . . 20

Enpfindlichlieit der süskirschen . . . . . . . . . . . . . . 2oy

Die Lohkrankheit . . . . . . . . . . . . . . . . . . . . . . . . . . . . . 211

Ringelkranklieit der Rotbuche. . . . . . . . . . . . . . . . . . 219

Wurzelerkrankung der echten Kastanien (mit nero). . . . . . . 219

Wurzellmand der Futter- und Zackerräben . . . . . . . . . . . o.21

Tropenkulturen . . . . . . . . . . . . . . . . . . . . . . . . .

Wurzelfiule des Zukerrohrs. . . . . . . . . . . . . . . 20

lirankheiten der Bammolle . . . . . . . . . . . . . . . . . . . . . . . . .

Ricintiskultureli . . . . . . . . . . . . . . . . . . . . . . . 200

Tabak . . . . . . . . . . . . . . . . 230

liaffee . . . . . . . . . . . . . . . . . . . . . . . . . . .

Kaka und Tee. . . . . . . . . . . . . . . . . . . . . 231

Anderweitige Tropenkulturen . . . . . . . . . . . . . . . . . . 232

Nittel zur Beseitiqung der Nathteile shwerer Böden . . . . . . 233

Auffegen. . . . . . . . . . . . . . . . . . . 2:3

Kalken, Jergeln. Gipsen . . . . . . . . . . . . . . . . . . 238

3. Die Nachteile der Heideböden . . . . . . . . . . . . . . . . . . . . . ㅡt1

Die siuren im Boden. . . . . . . . . . . . . . . . . . . . . . $\stackrel{2}{41}$

Rohhumu . . . . . . . . . . . . . . . . . . . . . . 
Ortstein .

Bodenvergiftumg durch Schrefelmetalle.

250

. . . . 252

Der Nutzen der Fichte . . . . . . . . . . . . . . . . . . . . . 254

Die Veränderung im Moorboden durch die Kultur. . . . . . . . . . . 57

Der Rindenmuln . . . . . . . . . . . . . . . . . . . . . . . . . . 5

Die gärtnerischen Heide erdekulturen

Das Fleckigwerden der Orchideen . . . . . . . . . . . . . . . . . . . . . . . . . . . 262

Drittes Kapitel. Ungiinstige chemische Bodenheschaffenheit . . . . . . 264

1. Verhalten der Nährstoffe zum Bodengerïst . . . . . . . . . . . . . . 26i4

A. Bodenabsorption infolge chemisch-plytsikalischer Vorgängre. . . . . 2064

B. Arbeit der Bodenorganismen. . . . . . . . . . . . . . . . . . . . . 26s

2. Verhalten der Nährstoffe zu den Pflanzen . . . . . . . . . . . . . . . 271

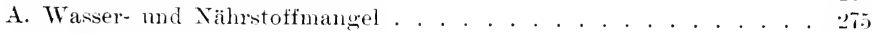

a) Wassermangel . . . . . . . . . . . . . . . . . . . . . . . . . . . . . . . . . . . . . . . . . . .

Einflats der verschiedenen Vegetationstecken . . . . . . . . . . . . . . . . . . . . .

Das Welken. . . . . . . . . . . . . . . . . . . . . . . . . . . . . . . .

Die Produktionsänderung durch Wassermangol . . . . . . . . . . . . . . . $\quad .77$

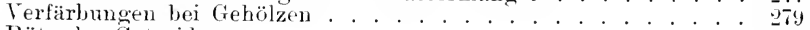

Röte des Getreiles . . . . . . . . . . . . . . . .

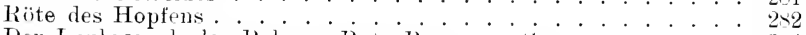

Der Laubramch ler Reben. Rote Brenner Seng . . . . . . . . . 2s.:

Vergilbung durch Veredlungsunterlage . . . . . . . . . . . . . . . . . . . . . . . . .

Verfriihtes Vertrocknen des Laubes. . . . . . . . . . . . . . . . . . . . . . . . . . . 24

Das Ausbremen des Rasens. . . . . . . . . . . . . . . . . . . . . . . . . . . . 205

Milchglanz . . .

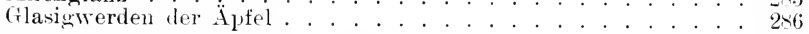

b) Produktionsïnderung durch Stickstoffmangel . . . . . . . . . . . . . . . . . . . . . . . . . . . .

Hungerzustände bei Kryptoganen. . . . . . . . . . . . . . . . . . . . . . . . . . $\quad .27$

Taublütigkeit, Infruchtbarkeit . . . . . . . . . . . . . . . . . . . . . . . . 289

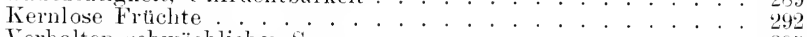

Terbalten schwächlicher Samen . . . . . . . . . . . . . . . . . . . . . . . . .

Abwerfen der Frïchte. . . . . . . . . . . . . . . . . . . . . . . . . . . . . . 295

Vertrocknen der Blïtenstionde bei Kierpflanzen

Domenbildung. . . . . . . . . . . . . . . . . . . . . . . . . . . . . . . .

c) Produktionsänclerung durch Kalimangel. . . . . . . . . . . . . . .297

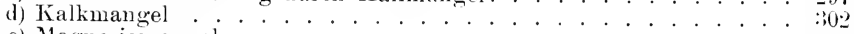

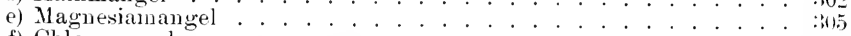

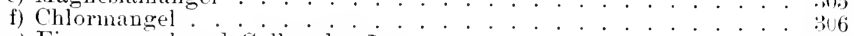

g) Eisenmangel und Gelbsicht (Icterus)

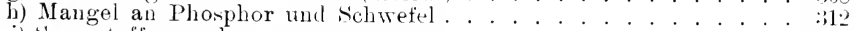

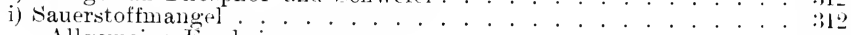

Allgemeine Erscheinimgen.

Brusone-Krankheit des Reises . . . . . . . . . . . . . . . . . . . . . . . .

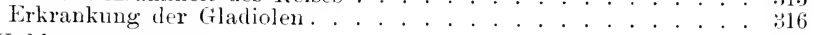

k) Kohlensiiuremangel . . . . . . . . . . . . . . . . . . . . . . . . . . . . . 316

B. Wasser- und Nährstoffüberschufs. . . . . . . . . . . . . . . . . . 319

a) Wasserïberschufs. . . . . . . . . . . . . . . . . . . . . . . . . . . . . . . . . . . . . . . . . . . . . . . . . . . . . .

Nisse : . . . . . . . . . . . . . . . . . . . . . . . . . . . . . . .

Drainzöpfe . . . . . . . . . . . . . . . . . . . . . . . . . . . . . 319

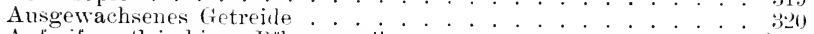

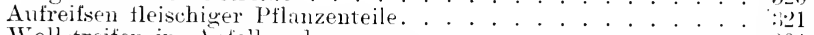

Wollstreifen in Apfelkernhaus . . . . . . . . . . . . . . . . . . . . . . 34

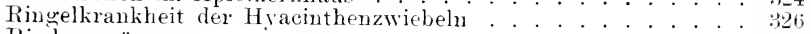

Rinilensprünge . . . . . . . . . . . . . . . . . . . . . . . . . . . .

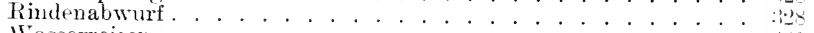

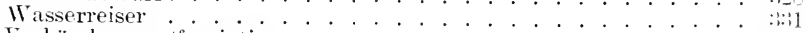

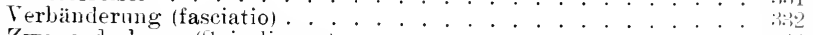

Zwangsdrehung (Spiralisnus)

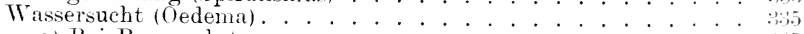

a) Bei Beerenobst . . . . . . . . . . . . . . . . . . . . . . . . . . . . . .

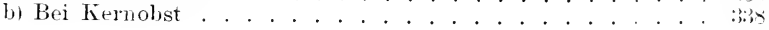


seite

Geschwulst an Johamnisbrot . . . . . . . . . . . . . 339

Die ruckschreitende Metamorphose (Verlaubung). . . . . . . . . . 340

Die Gelte des Hoptens . . . . . . . . . . . . . . . . . . 343

Gabelwus der Reben . . . . . . . . . . . . . . . . 345

Der Blattfall . . . . . . . . . . . . . . . . . . . . 346

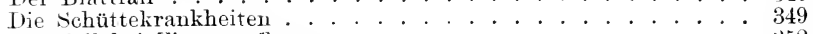

Blattfall bei Zimmerpflanzen . . . . . . . . . . . . . . . . . 352

Ablösungsprozefs der Blütenorgane . . . . . . . . . . . . . . . $35: 3$

Abröhren der Weinblïten . . . . . . . . . . . . . . . . . . . . 354

Abstofsen junger Blütentrauben bei den Hyacinthen. . . . . . . 356

Zweigabsprünge. . . . . . . . . . . . . . . . . . . . . 87

b) Erhöhung der Nährstoffkonzentration. . . . . . . . . . . . . : 360

Veränderangen der Wiesen . . . . . . . . . . . . . . : 362

Rieselfelder... . . . . . . . . . . . . . . . . . . 864

schorfkrankheiten. . . . . . . . . . . . . . . . . . . . 367

Iie vorschreitende Netamorphose . . . . . . . . . . . . . . : : . . . . . . . . . . .

Knospendrang (Blastomania). . . . . . . . . . . . . . . . . . . : :77

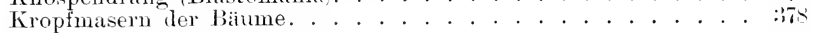

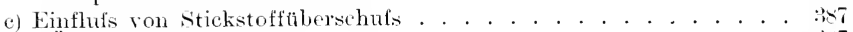

Uberdiugtes Saatgut . . . . . . . . . . . . . . . . . . . . . . . . . . . . . . . . . . . . . . . . . . . . . .

Tlerdüngte Rüben . . . . . . . . . . . . . . . . . . . . . *99

Uberdimgte Kartoffeln . . . . . . . . . . . . . . . . . . . . . . . . . . 390

Chilisalpeter hei Holzgewächsen . . . . . . . . . . . . . . . . . 391

Überdüngung bei Gemüsen und anderen Feldgewächsen. . . . . . 392

Stickstoffuberschufs bei Zierpflanzen. . . . . . . . . . . . . . . 39:3

Kräuselkranklieit der Kartoffeln. . . . . . . . . . . . . . . . . . 395

d) Kalk- und Magnesiäiberschufs . . . . . . . . . . . . . . . . . . 399

Kalküberschufs bei dem Weinstock . . . . . . . . . . . . . . . . . 402

e) Kaliuberschufs . . . . . . . . . . . . . . . . . . . . . . . . . . . . . 40:3

f) Phosphorsäureüberscliufs . . . . . . . . . . . . . . . . . . . . . . . 405

g) Kohlensäureäberschufs . . . . . . . . . . . . . . 406

Zweiter Abschnitt. Schädliche atmosphärische Einflüsse.

Viertes Kapitel. Zu trockue Luft. . . . . . . . . . . . . . . . . . 408

Die Knospenbeschidigung. . . . . . . . . . . . . . . . . . . . . . . 408

Der Hitzelaubfall. . . . . . . . . . . . . . . . . . . . . . 411

Der Honigtau . . . . . . . . . . . . . . . . . . . . . . . . . . . . . 412

Herz- und Trockenfänle der Futter- und Zuckerriben. . . . . . . . . . . + +14

Mangelhafte Blïtenentfaltung.................. 416

Zimmerkulturen . . . . . . . . . . . . . . . . . . . . 419

Hartschaligkeit der Leguminosensamen. . . . . . . . . . . . . . . . . . 420

Fünftes Ka pitel. Ëbermäsige Luftenchtigkeit . . . . . . . . . . . 422

Wachstumsmohis bei anhattemler Luftfeuchtiglieit . . . . . . . . . . . . 42.

Einflufs fenchter Luft auf durch Trockenheit heschädigte Pflanzen. . . 425

Korkw uchermengen . . . . . . . . . . . . . . . . . . . . 425

Korksucht der Kakteen . . . . . . . . . . . . . . . . . . . . 427

Zerfressene oder gefensterte Bläter . . . . . . . . . . . . . . . . . . . . 40

Korkbildung an Frächten . . . . . . . . . . . . . . . . . . . . . . 4:32

Gelbsureukelumg (aurigo) . . . . . . . . . . . . . . . . . . . . 434

Intunescenzon . . . . . . . . . . . . . . . . . . . . . . . . 435

Hantkrankheit der Hiacinthen . . . . . . . . . . . . . . . . . . . . . 4. 4

Glakigwerden der Kakteen . . . . . . . . . . . . . . . . . 45t

Scehstes Kapitel. Nebel . . . . . . . . . . . . . . . 458

siebentes kapitel. Regengiise................ . 460

Achtes Kapitel. Hacel. . . . . . . . . . . . . . . . . 462

Nenntes Kapitel. Wind. . . . . . . . . . . . . . . . . tio

Zehntes Kapitel. Elektrische Entladungen.............. . 479

Blitzschlige . . . . . . . . . . . . . . . . . . . . . . . 479

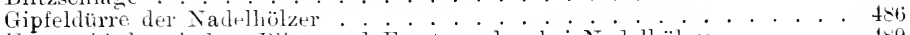

Intershied zwischen Blitz-und Frostwunden bei Nadelhälern . . . . . 4 4 
Beschädigungen der städtischen Baumpflanzungen

Wirkung von Streublitzen an Weinstöcken. . . . . . . . . . . . . . . 49:3

Streublitze auf Feldern und Wiesen . . . . . . . . . . . . . . . . . . . 495

Nachteile bei der Elektrokultur . . . . . . . . . . . . . . . . . 496

Elftes Kapitel. Wärmemangel. . . . . . . . . . . . . . 497

A. Allgemeiner Teil . . . . . . . . . . . . . . . . . . 497

Lebensäufserungen bei niedrigen Temperaturen. . . . . . . . . . . 497

Die Herbstfärbung . . . . . . . . . . . . . . . . . . . 500

Gefrieren und Erfrieren . . . . . . . . . . . . . 504

Theorien über das Wesen der Frostwirkung . . . . . . . . . . . . 507

Störungen durch Erkältung . . . . . . . . . . . . . . . 512

B. Spezielle Fälle der Frostwirkungen. . . . . . . . . . . . . . . . . . 513

Sufswerden der Kartoffeln . . . . . . . . . . . . . . . . . . . . . 513

Schofsrüben . . . . . . . . . . . . . . . 515

Frostgeschmack der Weinbeeren . . . . . . . . . . . . . 517

Veränderungen an Blütenorganen . . . . . . . . . . . . . . . . . 517

Rostringe an Frïchten . . . . . . . . . . . . . . . . . . 52.

Verhalten älterer Laubblätter bei akuter Frostwirkung. . . . . . . 523

Mangelhafte Ergrïnung jüngerer Blätter . . . . . . . . . . . . . . 025

Frostlaubfall . . . . . . 526

Verhalten der Rüben und Kohlgewächse bei Frost. . . . . . . . . 530

Frostblasen . . . . . . . . . . . . . . . . . . . 581

Kammartige Zerschlitzung der Blätter . . . . . . . . . . . . . . 583

Aufziehen der Saaten. . . . . . . . . . . . . . . . . 5...

Innere Verletzungen bei jungem Getreide. . . . . . . . . . . . . . . 56

Innere Verletzungen im Getreidehalme. . . . . . . . . . . . . . . 5:3

Halmknicken. . . . . . . . . . . . . . . . . . 541

Kahlährigkeit . . . . . . . . . . . . . . . . 541

Bewegungserscheinungen durch Frost . . . . . . . . . . . . . 546

Abfrieren iilterer $Z$ weigspitzen . . . . . . . . . . . . . . . . . . . . . . 552

Kirschbaumsterben am Rhein . . . . . . . . . . . . . . . . . . 553

Zweigbrand bei Waldbäumen . . . . . . . . . . . . . . . 557

Abfrieren von Frühahrstrieben. . . . . . . . . . . . . 558

Erfrieren der Wurzeln. . . . . . . . . . . . . . . . . . . . .661

Frostspalten . . . . . . . . . . . . . . . . . . . . orft

Frostbeulen . . . . . . . . . . . . . . . . . . . .

Frostrunzeln . . . . . . . . . . . . . . . . . . . . 57:

Frostlappen, Korklocken . . . . . . . . . . . . . . . . . . . . 574

Verfärbungserscheinungen im Achsenkörper . . . . . . . . . . . . 575

Frostlinie . . . . . . . . . 577

Innere Zerklüftungen des Achsenkörpers . . . . . . . . . . . . . . .79

Offene Frostrisse . . . . . . . . . . . . . . . . . . . .

Krels (carcinoma)

a) Apfelkrels . . . . . . . . . . . . . . . . . . 584

b) Astwurelkrebs bei Obst- und Taldbäumen . . . . . . . . . 591

c) Kirschenkrebs . . . . . . . . . . . . . . . . . . 592

d) Der Krebs (Grind) des Weinstockes. . . . . . . . . . . . . . . . . 594

e) Krebs an Spiraea . . . . . . . . . . . . . . . . . . . 596

f) Der Rosenkrebs . . . . . . . . . . . . . . . . . . 599

g) Brombeerkrebs . . . . . . . . . . . . . . . . . . . . . . . . $60 \%$

Die übereinstimmenden Momente bei den Krebrgeschwälsten . . . . 60.5

Der Brand (Sphacelus) . . . . . . . . . . . . . . . . . . 10016

Parenchymholznester . . . . . . . . . . . . . . . . 110

Falsche Jahresringe (Doppelringe) . . . . . . . . . . . . . . . . . 6il:3

Experimentelle Erzengung von Parenchrmholz durch Frostwirkung lit

Die Theorie der mechanischen Frostwirkmo . . . . . . . . . . . 617

Die Cuticularsprengungen . . . . . . . . . . . . . . . . . . . . ti21

Frostschntzmittel . . . . . . . . . . . . . . . . . . . .

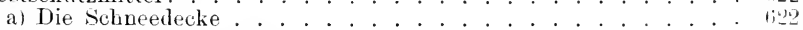

b) Die Verwendung des Wassers

c) Die Windwirkungen . . . . . . . . . . . . . . . .

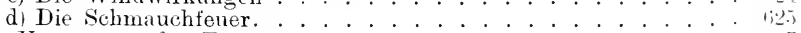

Die Yoraussage der Fröste. . . . . . . . . . . . . . . . . . . . . . . 10

Frosthärtere Obstsorten . . . . . . . . . . . . . . . . . . . .

Schneedruck und Eicanhang. . . . . . . . . . . . . . . . . . 
Zwölftes Kapitel. Wärmeiiberschuls

Seite

$6: 34$

Der Hitztod . . . . . . . . . . . . . . . . . . . . . 634

Mangelhafte Ausbildung unserer Gemüse in den Tropen . . . . . . . . . 635

Die Terschiebmng der gebränchlichen Saatzeiten in unseren Breiten . . . 6:36

Das Verbrennen der Blätter im Freien . . . . . . . . . . . . . . . 637

Die Brennflecke in len Gewächshäusern . . . . . . . . . . . . . . . . 640

Entlaulung . . . . . . . . . . . . . . . . . . . . 640

Somnenbrand an Bläten und Früchten . . . . . . . . . . . . . 642

Die Beschäligung der Trauben durch Somenbrand. . . . . . . . . . . . 642

Sonnenrisse . . . . . . . . . . . . . . . . . . . . . 644

Einflufs zu boher Bodenwärme. . . . . . . . . . . . . . . . . . . 644

Fehlschlagen der Ananas. . . . . . . . . . . . . . . . . . . . . . . . . 647

Tas Glasigwerden ron Orchideen. . . . . . . . . . . . . . . . . . 647

Fehlschläge bei der Blumenzwiebeltreiberei. . . . . . . . . . . . . . . . 648

Saatgut, das durch Selbsterlitzung gelitten hat . . . . . . . . . . . . 649

Dreizehntes Kapitel. Lichtmangel. . . . . . . . . . . . . 649

Thas Verspillern . . . . . . . . . . . . . . . . . . . . . . . 649

Die Beschattung . . . . . . . . . . . . . . . . . . . . . 652

Das Lagern des Getreides . . . . . . . . . . . . . . . . . . . . 658

Lichtmangel als Krankheitsdisposition . . . . . . . . . . . . . . . 661

Vierzehntes Kapitel. Lichtiiberschufs................ 666

\section{Dritter Abschnitt. Enzymatische Krankheiten.}

Fïnfehntes Kapitel. Verschiebungen der enzymatischen Funktionen . 669

Allgemeines . . . . . . . . . . . . . . . . . . . . 669

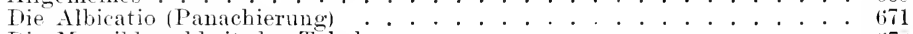

Die Mosaikkrankheit des Tabaks . . . . . . . . . . . . . . . . . . . . (i78

Tie Pockenkranklıeit des Tabaks . . . . . . . . . . . . . . . . . . . . . 683

Weifser Rost des Tabaks. . . . . . . . . . . . . . . . . . . . . . . . 683

Erkrankung der Erdnüsse in Deutsch-Ostafrika. . . . . . . . . . . . . . 684

Die Schrumpfkrankheit des Naulbeerbaumes . . . . . . . . . . . . . 684

Die Serehkrankheit des Zuckerrohres. . . . . . . . . . . . . . . . . . . 686

Die Col,hsche Zuckerrohrkrankheit. . . . . . . . . . . . . . . . . . . . 690

Peach Yellow . . . . . . . . . . . . . . . . . . . . . . 691

Der Gummiflufs der Kirschen . . . . . . . . . . . . . . . . . . . . . . . . 693

Der Gummiflufs bei anderen fewächsen . . . . . . . . . . . . . . . . . 701

Gummiflufs der Akazien. . . . . . . . . . . . . . . . . . . . . . 701

Gummiflufs der Pomeranzen. . . . . . . . . . . . . . . . . 701

Die Dintenkrankheit der echten Kastanie. . . . . . . . . . . . . . . . 702

The Gummose der Feigenbäume . . . . . . . . . . . . . . . . . . . . 703

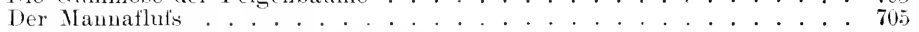

Iler Harzflufs . . . . . . . . . . . . . . . . . . . . . . . . 705

Harzbildung bei dicotylen Gewichsen . . . . . . . . . . . . 709

\section{Vierter Abschnitt. Einfluls schällicher Gase und Flüssigkeiteu.}

Sechzehntes Kapitel. Die Ranchgase . . . . . . . . . . . . 711

Sichweflige säure. . . . . . . . . . . . . . . . . . 711

Salziinre, Chlor . . . . . . . . . . . . . . . . . . . . . 717

Flufssiure (Fluorwasserstoffinue) . . . . . . . . . . . . . . . . 722

Stickstoffäuren . . . . . . . . . . . . . . . . . . . . $72: 3$

Ammoniak . . . . . . . . . . . . . . . . . . . . . . . 723

Teer- un A

Brom . . . . . . . . . . . . . . . . . 72

siebzehutes Kapitel. Feste Auswurfstoffe der schornsteine mol mitgefïhte Destillate..................... 724

Schwefelwasserstoff. . . . . . . . . . . . . . . . . . 734

Sodastaub . . . . . . . . . . . . . . . . . . . . . . . . $7: 3$

Fangptlanzemmethode . . . . . . . . . . . . . . . . . . . . 7366

Leuchtgas und Acetrlen . . . . . . . . . . . . . . . . . . . . . . . $7: 36$ 
Achtzehntes Kapitel. Abwässer . . . . . . . . . . . 739

Kochsalzreiche Abwässer . . . . . . . . . . . . . . . . . . . . 739

Chlorcalcium- und chlormagnesiumhaltige Abwässer . . . . . . . . . . . 742

Chlorbaryum . . . . . . . . . . . . . . . . . . . . . . 743

Zinksulfathaltige Abwiisser. . . . . . . . . . . . . . . . . . . 743

Eisensulfathaltiges Wasser. . . . . . . . . . . . . . . . . . . . 744

Kupfersulfat- und kupfernitrathaltige Abwässer . . . . . . . . . . . . . . 745

Neunzehntes Kapitel. Schädliche Wirkungen von Kulturhilfsmitteln . 746

Anstreichmittel. . . . . . . . . . . . . . . . . . 746

Anaesthetica . . . . . . . . . . . . . . . . . . . 756

Schädigungen durch Düngemittel. . . . . . . . . . . . . . . . . . 757

Fünfter Abschnitt. Wumden.

$\mathrm{Zw}$ anzigstes Kapitel. Wunden des Achsenorganes. . . . . . . . . 762

Allgemeines . . . . . . . . . . . . . . . . . . . . 762

Die Schröpfwunde . . . . . . . . . . . . . . . . . . . . 766

Wildschaden . . . . . . . . . . . . . . . . . . . . . 771

Überwallung der Querwunde mehrjähriger Achsen . . . . . . . . . . . . 773

Überwallungsvorgänge bei einjährigen Zweigen . . . . . . . . . . . . . 775

Der Ringelwulst. . . . . . . . . . . . . . . . . . . . . . 777

Die Schälwunde . . . . . . . . . . . . . . . . . . . . . 787

Biegen der Zweige. . . . . . . . . . . . . . . . . . . . . . . . . . . . 800

Das Drehen der Zweige . . . . . . . . . . . . . . . . . . . . . . . . . . .

Wirkung des Einschnürens der Achse . . . . . . . . . . . . . . . . . . sut

Zweigstecklinge . . . . . . . . . . . . . . . . . . 811

Verwendung verschiedener Achsenorgane zu Stecklingen . . . . . . . . . 814

Die Veredlung . . . . . . . . . . . . . . . . . 819

Die Okulation. . . . . . . . . . . . . . . . . . . s.3

Kopulieren und Pfropfen . . . . . . . . . . . . . . . . . . . . 828

Die Lebensdaner veredelter Individuen . . . . . . . . . . . . . . . . . . . . . 829

Die natürlichen Verwachsungsprozesse . . . . . . . . . . . . . . . 837

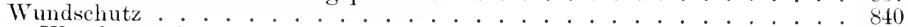

Wundgummi . . . . . . . . . . . . . . . . . . . . . . . . 841

Die Schleimflüsse der Bäume . . . . . . . . . . . . . . . 84t

Wurzelverletzungen . . . . . . . . . . . . . . . . 845

Maserige Überwallungsränder

Rindenknollen . . . . . . . . . . . . . . . . . . . . . .

Blattverletzungen . . . . . . . . . . . . . . . . . . si1

Blattstecklinge . . . . . . . . . . . . . . . . . 864

Beschädigungen des Laubapparates . . . . . . . . . . . . . . . . . . . . . ct69

Nachträge. . . . . . . . . . . . . . . . . . . . . . 81 


\section{Verzeichnis der Abbildungen.}

Fig. 1. 2. Wurzeln zwischen Felsspalten . . . . . . . . . . . . . . . 76

3. Fichtenwurzel mit fleischiger Ersatzwurzel. . . . . . . . . . . . . 77

" 4. Stelzenfichte bei Schönmïnzach . . . . . . . . . . . . . . . . . . 90

" 5, 6. stelzenkiefern aus dem Grunewald. . . . . . . . . . . . . . . 92

, $\quad$, \&. Harzgallen auf Stelzenwurzehn . . . . . . . . . . . . . . . 93

.9. Roggensännling bei tiefer Lage . . . . . . . . . . . . . . . . . . . . . . . . . 110

" 10. Querschnitt durch den untersten Knoten einer jungen Roggenpflanze 112

" 11. Weizenkörner mit Wurzeln aus der dem Embryo gegenüberliegenden

Spitze . . . . . . . . . . . . . . . 113

12, 13, 14. Mikroskopische Bilder von Fig. 11 . . . . . 114, 115, 116, 117

15. Künstlicher Zwergwuchs bei Thuja cotusa . . . . . . . . . . . 140

16. Fadenhranke Kartoffel. . . . . . . . . . . . . . . . . . . . . . . 160

" 17. Kartoffelknolle mit Kindelbildung . . . . . . . . . . . . . . . . . 161

18. Zelle mit eigenartigen Inhaltsstoffen aus dem Fleische eines Apfels 167

19. Birne an Lithiasis erkrankt . . . . . . . . . . . . . . . . . . . 171

20. Mikroskopisches Bild ron Fig. 19 . . . . . . . . . . . . . . . . . 172

21, 22. Vergleichende Längsschnitte durch eine wilde und kultivierte

Nohrrübe . . . . . . . . . . . . . . . . . 180

23. Apfelwurzel nit aufgebrochenen Lohstellen . . . . . . . . . . . . 210

24. Querschnitt durch eine lohkranke Stelle der Apfelwurzel. . . . . . 211

25, 26. Lohkranke Rinde am Apfelstamm. . . . . . . . . . . . . 212, $21 \%$

27. Kirschenzweig mit Lohpolstern . . . . . . . . . . . . . . . . . . 214

28. Neubildungen auf der Sichälwunde eines Kirschenstammes . . . . . 217

29, :30. Wurzeln von Kiefer und Eiche auf Ortstein. . . . . . . 246, 247

31. Moorkiefer aus der Linneburger Heide . . . . . . . . . . . . . . . 24s

32. Krebsartige Wundstelle einer Moorkiefer . . . . . . . . . . . . 249

3.. Fichtenfanilie durch natürliche Ableger entstanden . . . . . . . . 255

:34. Wiche mit Senkerbildung. . . . . . . . . . . . . . . . . 256;

3.). Nulnige Kieferuborke. . . . . . . . . . . . . . . . . . . . . . . 260

:36. Kernlose Birne . . . . . . . . . . . . . . . . . . . . . . . 293

:37, 3. Querschnitt durch Zweig und Dorn von Rhumnus cathartica 298, 299

39. Typische Blattbeschädigungen bei Kalimangel . . . . . . . . . . . 301

40, 41. Normale und lei Chlormangel erwachsene Buchweizenpflanzen 306,307

42. Bohne dureh Wasserüberschufs aufgeplatzt . . . . . . . . . . . . 322

43, 4. Wollstreifen im Apfelkernhaus. . . . . . . . . . .324, 325

45. Clmenlorke mit polsterartigen Geweheinseln . . . . . . . . . 2329

46. Ilmenrinde in Wucherung. . . . . . . . . . . . . . . . 330

47, 4九. Verbinderung hei Fichte . . . . . . . . . . . . . . 333

49. Verbindermer bei Erle . . . . . . . . . . . . . . . . . 334

50. Wassersucht bei Ribes amemu . . . . . . . . . . . . . . . . . 336

51. Verlaul,te Hopfenkätzchen . . . . . . . . . . . . . . . . . . 343

52. Tiefschorfkranke Zuckerrübe. . . . . . . . . . . . . . . . . 367

5:3. Lenticellenwucherung an der Kartoffelknolle . . . . . . . . . . . 369

it. Zapfensucht hei liefer . . . . . . . . . . . . . . . . 373

5.5. Sprossende Birnenfrüchte . . . . . . . . . . . . . . . . . . 374

56. Durchwachsener Lärchenzapfen . . . . . . . . . . . 375 
Fig. 57. Rosettentrieb der Kiefer. . . . 377

58. Entrindete Kropfmaser von Ahorn . . . . . . . . . . . . . . . . :37!

59, 60, 61. Maserspiefs bei Malus sinensis . . . . . . . . . . . . . 380, 3×1

62, 63, 64, 65. Perlartige Maserbildung bei der schwarzen Johannis-

beere. . . . . . . . . . . . . . . . . . 382, $38: 3,344$

66. Schema des Verhaltens der Düngemittel zueinander. . . . . . . 400

67, 68. Querschnitte durch Knospendecken von (purcus und Pinus. . 409

69. Querschnitt durch äie spitzenregion einer noch nicht entfalteten

Blume von Hineastrum rolustum . . . . . . . . . . . . . . . . . 41

70, 71. Korkwucherung bei I'lyllocactus . . . . . . . . . . . . . 42\&, 42!

72. Gefenstertes Kartoffelblatt . . . . . . . . . . . . . . . . 4:31

73, 74. Korkwarzen am Stiel einer Weinbeere . . . . . . . . . . . $4: 32,433$

75. Intumescenz bei Cassir tomentona . . . . . . . . . . . . . . . . . . . . 436

76. Intumescenz bei Myrmecodia mhinata. . . . . . . . . . . . . . . . . 437

77. Intumescenz an Weinbeeren. . . . . . . . . . . . . . . . . . . . . . 499

78. Intumescenz an Knoten einer Haferpflanze. . . . . . . . . . . . . . 441

79, 80, \$1, 82. Intumescenz am Zweig von Acaria pendulı . . . . 442, 44:;

83, 84. Intumescenz an Perigonzipfel von ('ymbidinm Lomi . . . 444, 445

85 , 86. Intumescenz an Erbsenhiülse. . . . . . . . . . . . . . 446, 447

87. Querschnitt durch ein Blattknötchen des frummilıaumes . . . . . . 450

88, 89. Hautkranke Hyacinthenzwiebel . . . . . . . . . . . . . 452, 45:3

90. Glasige Stelle an Cerms mycticalus. . . . . . . . . . . . . . . . . . . . 456

91. Hagelschlagstelle am Roggenlahm . . . . . . . . . . . . . . . . . . . . 463

92. 93. Weizenähre durch Hagelschlag beschïdigt. . . . . . . . 464, 465

94. Hagelschlagstelle an Tomatenfrucht . . . . . . . . . . . . . . . . . 466

95. Windgescherte Fichten . . . . . . . . . . . . . . . . . . . . . 473

96. Craspedodrome und camptodrome Nervatur. . . . . . . . . . . . 477

97. Yom Blit\% getroffene Eiche. . . . . . . . . . . . . . . . . . . 481

9.. Überwallte Blitzwunden an Fichte . . . . . . . . . . . . . . . . . . . . . . 483

99. Holzbilung der Fichte in einem Blitzjahre. . . . . . . . . . . . . . 485

100. Querschnitt einer gipfeldürren Fichte . . . . . . . . . . . . . . . . . . 487

101. Kiefer, künstlicher Frost . . . . . . . . . . . . . . . . . . . . . . . . . 489

102. Fichte, künstliche Blitzspur . . . . . . . . . . . . . . . . . . . . . 450

103. Durch künstlichen Frost beschädigtes Blumenblatt eines Apfels . . 519

104. Junger Apfelfruchtknoten durch Frost beschädigt . . . . . . . . . 5:0

105. Junge Blïtenknospe vom Apfel durch Frost verletzt . . . . . . . . 5:1

106. Herlostliche Trennungsschicht eines Kastanienblattes. . . . . . . . . .

107. Frostblase am Apfelblatt . . . . . . . . . . . . . . . . . . . 5:31

108. Kammartig zerschlitztes Kastanienblatt . . . . . . . . . . . . . . 534

109. Junges Roggenblatt, frostlueschädigt. . . . . . . . . . . . . . . . . . 5:37

110. Natïrliche Lückenbildung in Roggenblattscheide . . . . . . . . . 5:

111. Roggenhalm, frostbeschädigt . . . . . . . . . . . . . . . 539

112, 113. Nembranverquellungen an Blattscheide vom Roggen . . . . . . . . .

114, 115, 116. Kahlährigkeit bei Roggen. . . . . . . . . 542, 54:, 54t

117. Rotholzbildung am Fichtenast. . . . . . . . . . . . . . . . . . 501

11s, 119. Rotholz und Zugholz bei Fichte. . . . . . . . . . . . . . . . . 5i1

120. Kirschenstamm mit Valsa lencostoma. . . . . . . . . . . . . . . . . . . 554

121. Künstlich frostbeschäligte Knospe der Kirsche . . . . . . . . . . . . 59

122. Frostleiste an Acer compestre. . . . . . . . . . . . . . . . . . . 56.

12:3. Eichenstamm durch Polyporus sulfureus zerklüftet . . . . . . . . . . 567

124. Stärkeranken im Weidenzweige . . . . . . . . . . . . . . 570

125, 126. Frostbenle an Zweige einer Sübkirsche. . . . . . . . . 5il, तi:

127. Birnenzweig mit Korklocken . . . . . . . . . . . . . . . . . . 5it

128. Birnenzweig durch künstlichen Frost zerklüftet . . . . . . . . . . 5iti

129. Membranquellung durch künstliche Frostwirkung . . . . . . . . . . 5iv

130. Kirschenzweig durch künstlichen Frost zerklïftet . . . . . . . . . . . . il

131. Augenkissen eines Lärchenzweiges durch künstlichen Frost greprengt in'

132. Künstlicher Frostrib am Apfelzweig in Überwallung . . . . . . . is

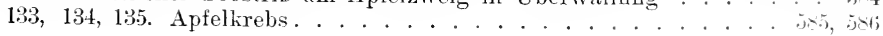


Fig. 136. Jugendzustande des Apfelkrebses . . . . . . . . . . . . . . 588

$"$ 137. Beschïdigung der Zweigbasen durch Frost . . . . . . . . . . . . . . . 589

" 13.. Astwurzelkrebs . . . . . . . . . . . . . . . . . . . . . . . 591

" 1:39. Kirschenkrebs. . . . . . . . . . . . . . . . . . 593

140. Weinkrebs . . . . . . . . . . . . . . . . . . . 594

141. Krebs an spriren . . . . . . . . . . . . . . . . . . . . . . . . . . . . 597

. 142, 143. Rosenkrels. . . . . . . . . . . . . . . . . . . 600, 601

" 14t. Brombeerkrebs . . . . . . . . . . . . . . . . . . 604

" 145. Frostplatten der Birnenrinde . . . . . . . . . . . . . . . 606

. 146, 147. Brandstellen am Birnenstimm . . . . . . . . . . . 607, 608

" 148, 149. Innere Frostwunde eines Eichenzweiges . . . . . . . . . 615, 619

" 150. Nachtfrostliurve nach Dr. Lang. . . . . . . . . . . . . . . 628

". 151. Durch somenbrand getötete Blattstelle von Cliria nolritis . . . . . 639

" 152, 153, 1.5t. Licht- und śchattenblätter der Buche . . . . . . . . . . 655

" 15. Sübkirschenzweig mit Gummilücken . . . . . . . . . . . . . . . 695

. 156. Zellkerne im gummibildenden Gewehe. . . . . . . . . . . . . . 698

. 157. Tracheïdalparenchym mit resinogener śchicht . . . . . . . . . 706

.. 15s, 159, 160, 161. Resinoseherde im Bernstein . . . . . . . 707, 708, 709

" 162. Haferblatt durch Salzsïuredämpfe getötet. . . . . . . . . . . . 719

" 16:2, 164. Durch schweflige Sïure beschädigte Buchen- und Birken-

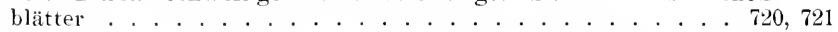

165. 16t, 167. Durch Salzsäure beschädigte Rosen-, Buchen- u. Birken-

blätter. . . . . . . . . . . . . . . . 721, 722

168. Durch Teerdämpfe beschädigte Blätter. . . . . . . . . . . . . . 726

$169,170,171$. Apfelfrüchte durch Bordeiuxmischung geschädigt . . 75:3, 754

172. Apfelblatt durch Bordeauxbespritzung durchlöchert . . . . . . 755

" 173, 174, 175. Schröpfwunde... . . . . . . . . . . . 767, 768

" 176. Ausgehöhlter Kiefernstamm . . . . . . . . . . . . . . . . . . 769

" 177. Stammscheibe von Fichte mit überwallten Harznutzungswunden. . 770

" 178. Überwallte Śchnittfliiche eines Astes . . . . . . . . . . . . . . 773

" 179, 180, 181. Schnittflïche eines einjährigen Kirschenzweiges . . . . . 776

$" 18:, 1 \times 3,184,185$. Geringelte Weinrebe . . . . . . . . . . 779-785

. 186. Kallusbildung aus jungen Rindenzellen an einem geschälten Stamme. 792

" $187,1 \times 8,1 \times 9$. Neubildungen auf geschältem Kirschenstamm . . . . 795-797

190, 191, 19:, 19:, 194. Neubildungen an der Biegungsstelle eines Apfel-

zweiges . . . . . . . . . . . . . . . . . 801, 802, 803

195. Verwundung beim Drehen eines Zweiges . . . . . . . . . . . . . 805

" 1965. Schnürstelle eines durch Draht geschnürten Zweiges . . . . . . . s s9

" 197. Fuchsiensteckling . . . . . . . . . . . . . . . . . \$12

. 198. Rosensteckling . . . . . . . . . . . . . . . . . . . . . \$13

" 199. Rosenokulant . . . . . . . . . . . . . . . . . . . 82;

"200. Rindenpfröpfling mit Adventivknospen (Assculns) . . . . . . . . . 827

"201. Kiefer mit ablaktiertem zweiten Stamm. . . . . . . . . . . . 8:38

202. Wundfäule mit Gefäliverstopfung (Weinstock) . . . . . . . . . . . 843

203. Erlenwurzel durch Eußtritte ahgeschliffen. . . . . . . . . . . . . 846

204. Maserige Überwallungskappe eines Aststumpfes der Eiche. . . . . 850

205. Rindenkuollen aus einem Apfelstamm. . . . . . . . . . . . . 856

206. Isolierte Holzkörper in der Rinde eines Birnenzweiges . . . . . . 858

207. Kallusbildung im Blatte von Leucojum cermum . . . . . . . . . . 862

, 208. Blattsteckling einer Begonie. . . . . . . . . . . . . . . . . . \$ \$ 


\section{Einleitung.}

\section{Erster Abschnitt. Das Wesen der Krankheit.}

\section{Umgrenung des Krankheitsbegriffes.}

Als reste Anfigales argiht sieh die Notwendigkeit, das vou uns zn

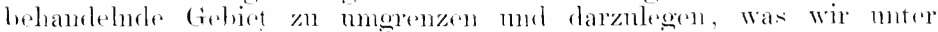
.. Kranklepit" verstrien.

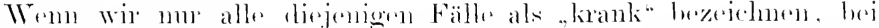

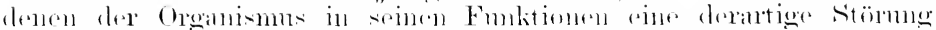

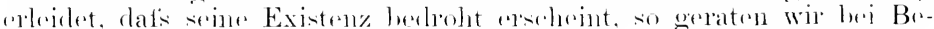

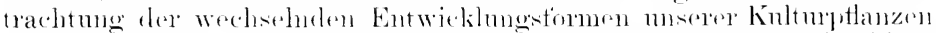

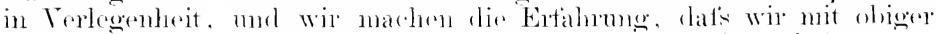
Erklärung nicht anskommen. Wir wison heispolsweise, lats momer Kohlarten, Kohlrahi mol Blomenkolsl von einor dem Hederich ähnlichen

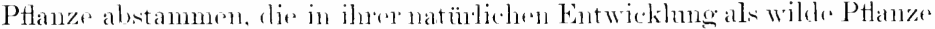

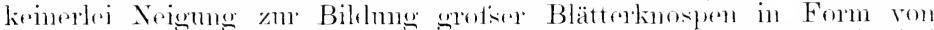

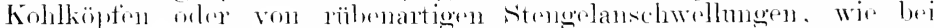

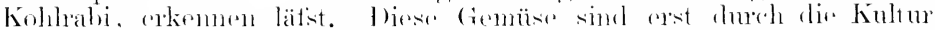

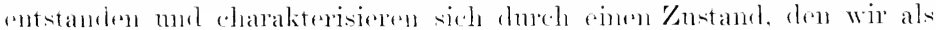

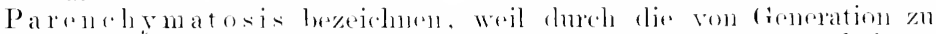

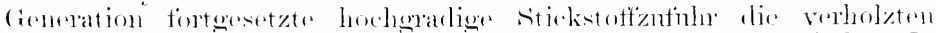

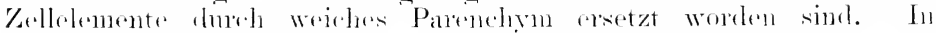

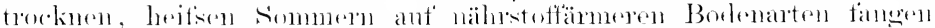

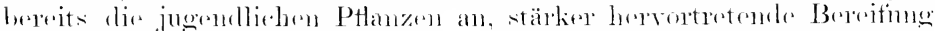

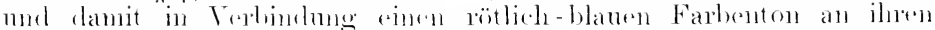

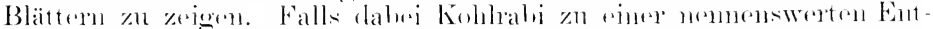

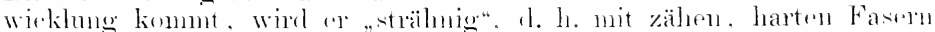

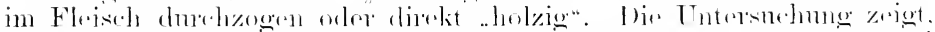

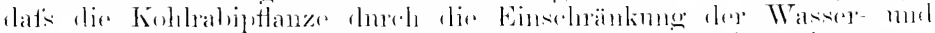

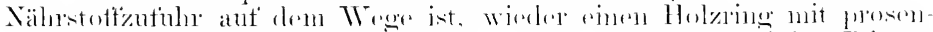
chrmatischen Elementen anszuliblen. wie ex hed der wilden Pflanze

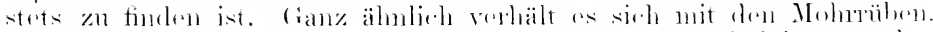

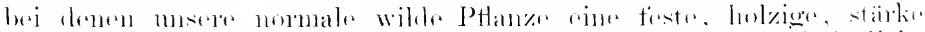

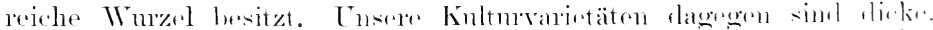

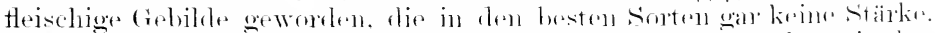

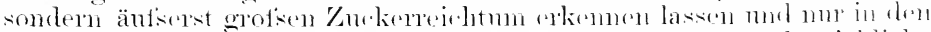

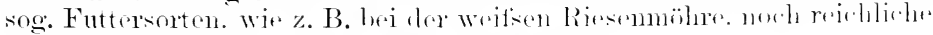


stäliespeichermeg zeigen. Experimentell ist seinerzeit ron Hoffunx-

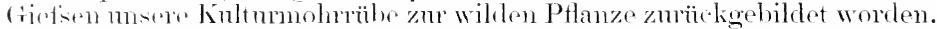

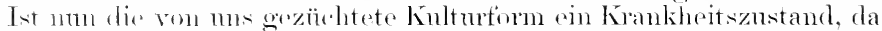

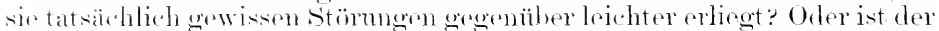
Rücligane der Kulturtom zur nomalen wilden PHanze eine Krankheit?

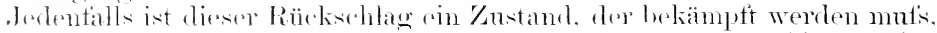
woil ex für mosere Kultubestrolmugen sich als mzweekmätsig erweist.

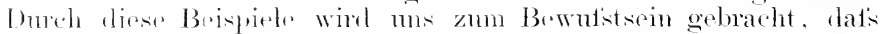

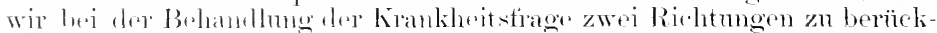
siehtigen habell. Wir halen natürlieh zunäehst den Selbstzweck les Groanismms in Ange zn hehalten. Und dieser Selbstzweck, den der Cloanismus durch seine Entstehung elhält, ist: zu leben, und zwar möglichst lange zu letwen. Alles, was eimmal entstanden ist. bleibt als

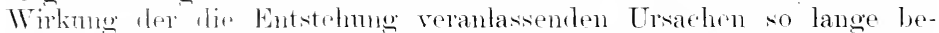
stehen. bis ain stälores Faktor kommt, der das Gefüge stört mul

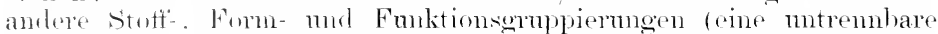

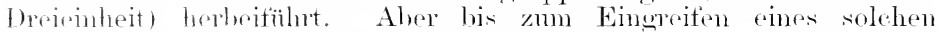
stärowen Falitors rerteidigt das gewordene Indivirlum mit der Summe her seiner sulstanz innewohnenten Krätte sein hisheriges Getïge, d. h. seine Individnalität. zu der anch rine in alloemeinen bestimmbare Altersgrenze gehört. Diese mechanisch notwendige Verteidigung seiner Intividualität gegenüber den stets rüttelnflen äufiseren Faktoren dürfen wir als "sidlisterhaltungstrieb" bezeichnen.

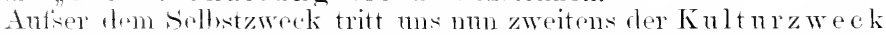
entgegen, der sich aus dem Verhältnis der Pflanzen zu unsern menschlichen Bedürtinissen entwickelt. Zustände des pflanzlichen Organismus. die musm Knlturbestrebungen zuwiderlaufen, werden wir als unzweckmätsig zu lokämptin snchen. Aber solehe Zustände branthen in keiner

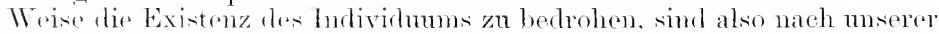
oligen Esklärnng keine Krankheiten, mul dennoch fallen sie in das (rebiot des Pathologen als störungen, die bekämpft werden müssen.

tanz ähnlichen solnwierigkeiten bei rler Ungrenzung des Krankheitsbegriffus bogegnen wir hei den gefüllten Blumen, soweit diese Füllung larant bernlit, lats dic stanlgefätise sich in Blmenblätter nmwandeh nut labei anch dio Giftel verkïmmern. Dies fühnt zur vollstänfligen Tnfrurhtharkit des Lulivilumms. Die Lebenstauer der einzelnen Pflanze

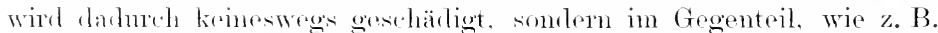

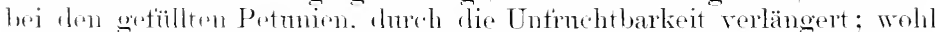
aber wirl lor sellstzwed der spezies beeinträchtigt. Demn derartis gefïllte Blïten vermögen nieht mehr samen zu produzieren. mal wïrde

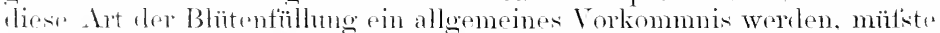
rine solehe Art luim Mangel vegetativer Vermehrmgsorgane sehliefslich ansiterben. I)iese dir Existenz der Art bedrohende Abweichung dor

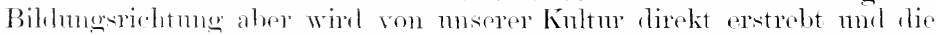
Rïrkkrhe zur normalen. samentragenten Form bekämptt. Es wider-

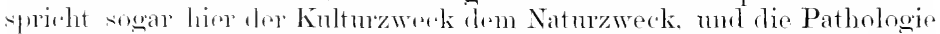

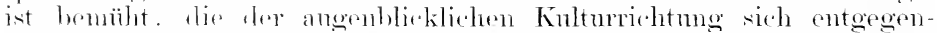

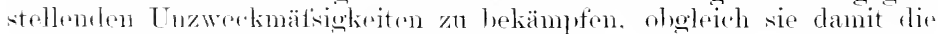

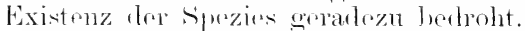

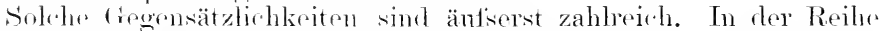
der Fälle. lwe denen nur sinzelne Oroane erkanken, kann eine derartige lokale stïrung den (resamtorganismus schädlich beeinflussen:

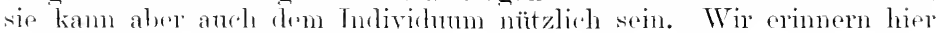


an das Abwerten der jungen Früchte lureh Dürrs. Ine hulturzwerk ist natürlich geschäıligt: aber die (j)omomie tles Bammes hat insofirn einen Vorteil, als ter Bam die Reservestoffir spart, die zur Aushilılung der Fruchtmenge erforderlich rewesen wär. Infolge dieser Esparnis

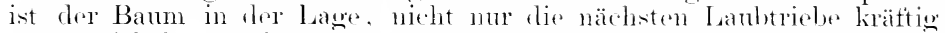
zu entwickeln. somblern anch zahlreiche Fonchthnospen anzulegen, was unterblieben wär. wenn eine volle Erntr den Stamm erselüptt häte.

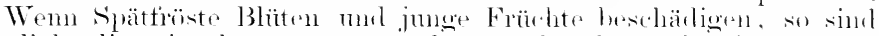

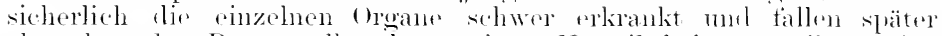
ab: aber der Bam selhst liam einen Vorteil haben, weil er rine.

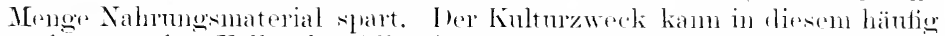

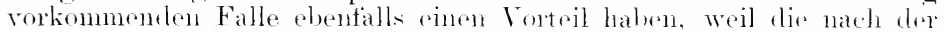

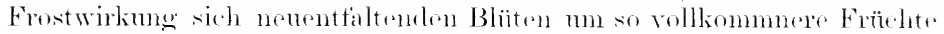
lieferm, die eine erhöhte Rente gerben.

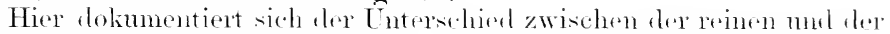

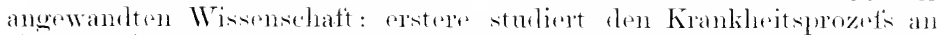

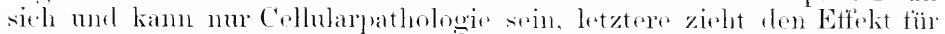
das erkrankte Indivilumm und fessen wirtschattliche Bedentmog in Betracht. Wir haben beite Richtmenen zu repeinigens, indem wir in unserer Darstellung dis rein wissenschattlichen stumben als Basis tiir

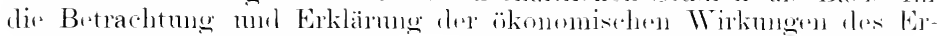
krankmostalles henutz+n.

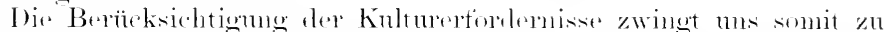

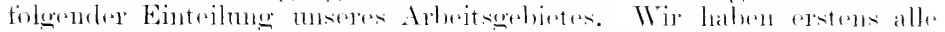

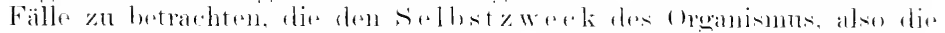

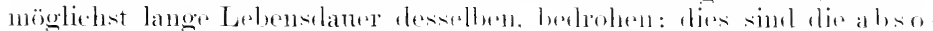

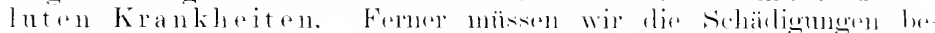

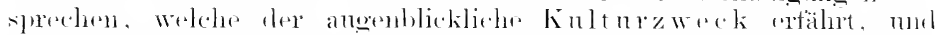

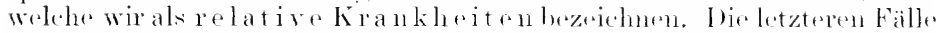

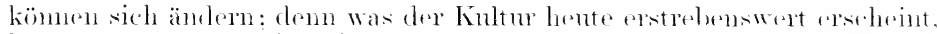

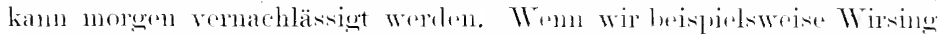

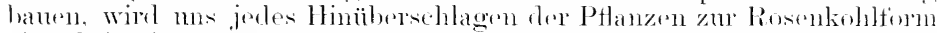

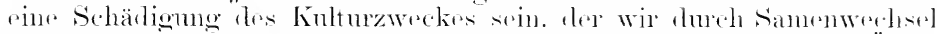

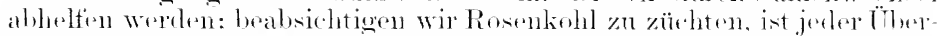

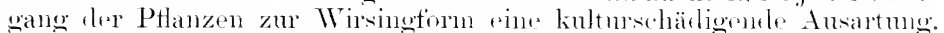

Schiefslich rerdienen anch diejenigen Fälle pine Beachtung, lue

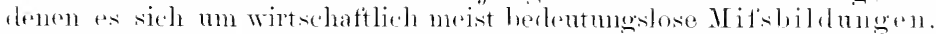

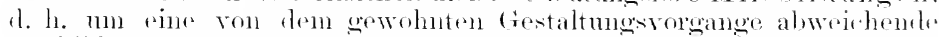

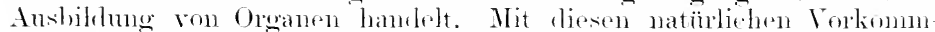

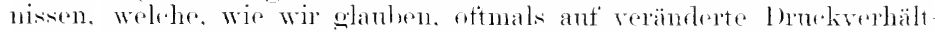
nisse und andere merhanische Einflïse hei der Anlage der Oronue

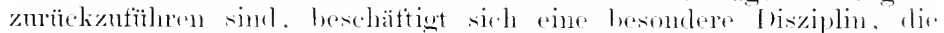
'Teratologie. Dieselle int aber als ein Kwoig der Pathologie and

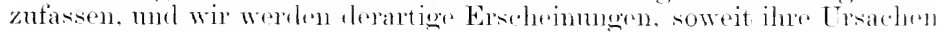
erkamt oder mit einiger sirherheit vermutet werelen kïnnen. obentalls zur Bospreshumg zu ziehen haben.

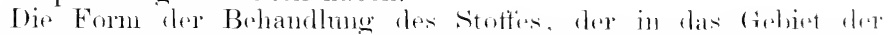
Pflanzenkrankheitslehre orler Phytofothologir taill . Wird nade

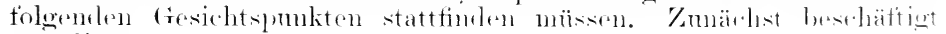
lins dir.

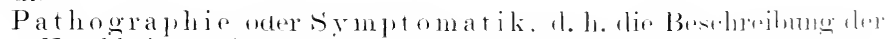

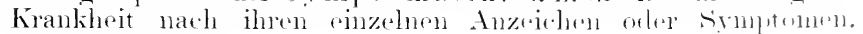
Iamm folgt ile 
Pathogenid oder Ätiologie, nämlieh are Untersmehmo über dir Entstehme lor Krankheit. Erst nach Erkmotnis der Trachen ist $\therefore$ möglich, tie

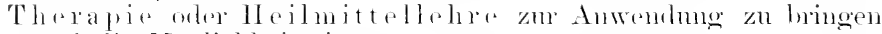
mol dir Möglichlieit riner

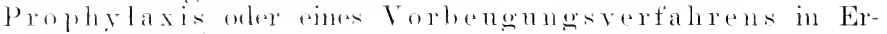
wïgmi!n zu zichen.

\section{Die Entstehung der Krankheit.}

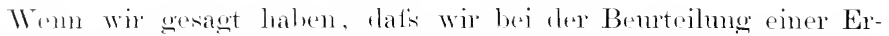

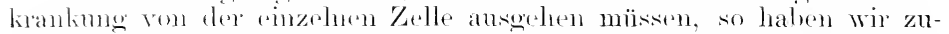
näclist uns bewutist zu werelm, weleh ein liomplizierter Organismus die Telle selbst ist und wir Authau mol Funlition derselben von der Beschatfenheit, Lagerumg mol Wirkme der sie zusammensetzenden Micellen ablı̈̈ngen.

Fassen win beispielsweise einige quellungsvorgänge ins Ange.

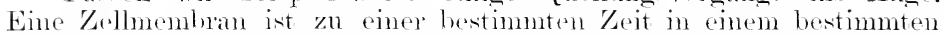
Gade mit Imbihitionswasser durchtö̈nkt, ll. h. die dureh die Kohäsion zusammengehaltenen Colnhosemicollen sinel mit Wasierhïllen von ge-

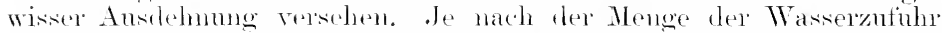
werelen die Micellen hald weiter ausemandernüthen oder sich einander nähern, d. h. die Mrmhran wird balı lockerer, balit dichter werden. Elonsolehe Schwankmogen erzielen wir im Plasmakörper der Zelle bei Einwirkmo wasserentziehenter Mittel. Gleiche Vorwänge beobachtet man am Chloroplyyllkon, wem man (z. B. hei einem Getreideblatt) in einem Fall schwache salzsäneelämpte, im andern Fall sclowefelwasirestoft einwilken lätst. Bei jener sielit man len Chloroplasten sehrumpten, hei diesem wird das chlorophyllkom zu einem bleich-

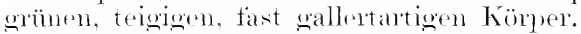

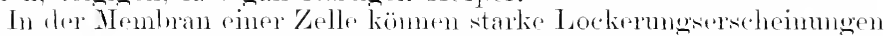
manchmal anf cinzelne stellen heschünkt soins. Als Beispiel kömmen

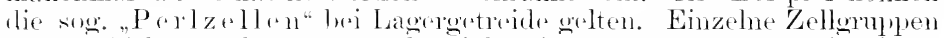

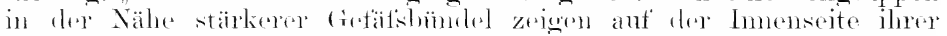

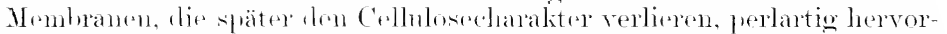

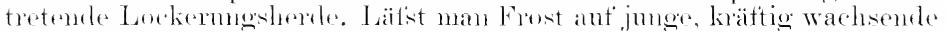

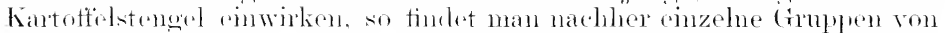

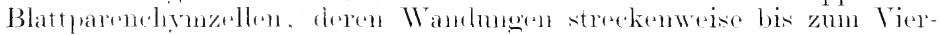

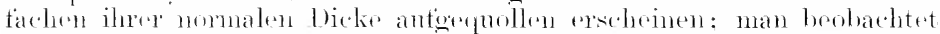

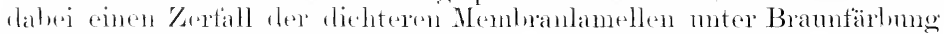
is strichastige Bruchstückr, welehe in riner gleichartigen, helleren (immelsulstanz eingelostet liegers.

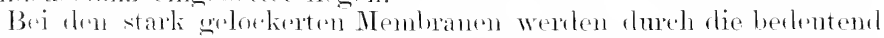

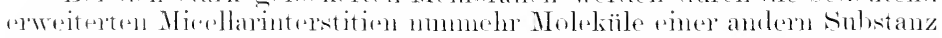

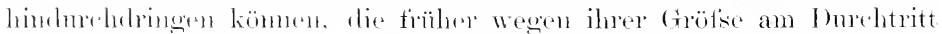
bethindert gevesen sind. Trom der Frost Verändermegen im Plasma-

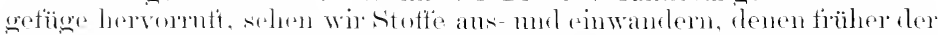

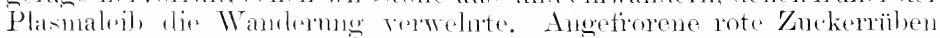

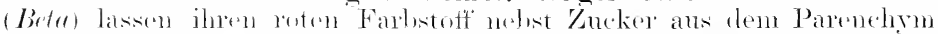

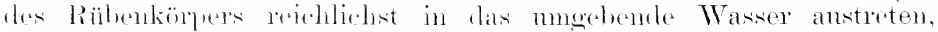

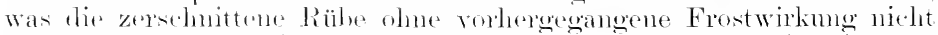

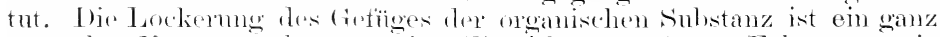
normaler Vorgang, der von ler Eimwirlung äntierer Faktoren, wie 
Wasserzufuhr, Lieht, Wärme nsw. in seiner Intensität abhängig ist. Überschreiten diese normalen Vorgänge eine gewisce Gronze, so fühnen sie zu Störmoen, die Gefïgr und Funktion der Zelle derart alterieren. tatis sie zur Erhaltung des Lebens mutanglich werden. Jerler andere Vorgang des Zelllebens verhält sich ohenso. Unter dem Einfluts der

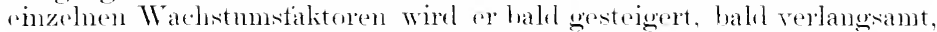
und wir wissen, dats jede Funktion des Lebens je narh der Wirkmo jedes emzohen Vegetationstaktors zwischen woiten trenzen penclelt. Die Grenzwerte bezelehon wir als Minimm und Maximum: dir Funktionshöhe, in weleher ein Lebensvorgang alie Entwielihng ars Organismus am meisten törlert, bezeichnen wir als optimnm.

Dat Penteln der Fumbionen mo das (Y)timm innerhalh der die Entwicklung fördernden Granzen kömen wir als .Breit ter (tesundheit" ansprechen. Dieselbe ist nicht zn verwechselu mit der .Breite des Labens". Drm der Gronismus bam noeh leben jenseits der Breite der Gesmulheit: mur suld seine Funktionen

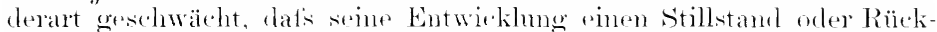

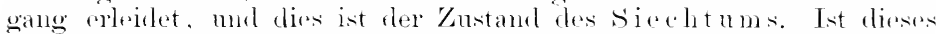

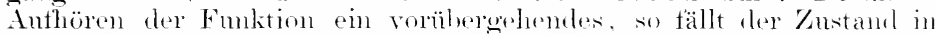

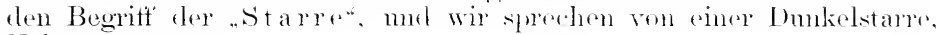
Kältestarre nNw.

Aber wir mäsisen uns hüten, zu glanben, datis der Eintritt des

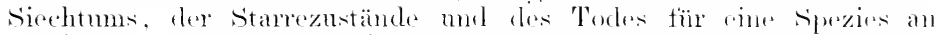

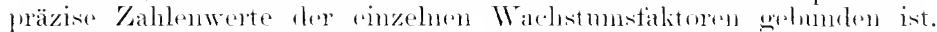

Wem wir beispielsweise zwei Stecklinge dostellum Pflanze ant-

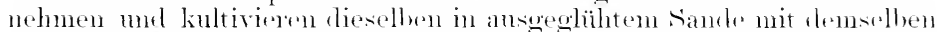
Nährstoffquantum längere Zrit, wolwi der pine Steckling stets im Warm-

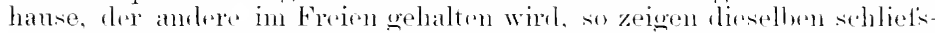

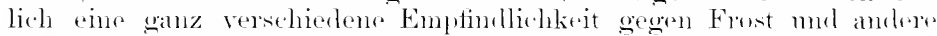

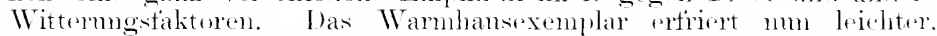
d. h. seine Minimalgrenze für dir Erhaltmog des Lebens ist nach oben gerürlit. 'Trmpreaturem, welche das Freilandexemplar noeh immerhalh

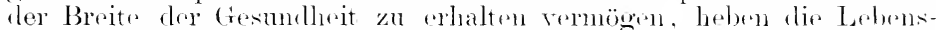
vorgänge bei dem Warmhansexemplar bereits ant. Ganz ähnlichr Verschifehmgen zeigen die Versuche betrefte der Maximal- mul Minimalgrenzen bei andern Wachstumstaktoren, so dats wir zu lon seluhtis kommen, dats jede Pftanzo four jeden stanelort ihre rigene

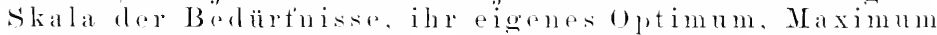
und Minimum, also ihre spezifisch eigene Breite der Gesumtheit besitzt.

Beachtenswert ist fermer der Lmstand, dat's die einzelnem Funktionen zu versehiedenem Zeritun erlöschen.

Wem wir beispielsweise Kartoffellinollen bei etwa - ${ }^{\circ}$ C. einige zeit liegen lassen, zeigt sich, lats der Atmmesprozedis trïher nach-

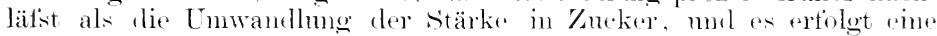

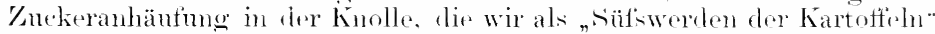
bezeichnen. Bei langamer Erhöhmo dor Temperatur ant otwa +100C'.

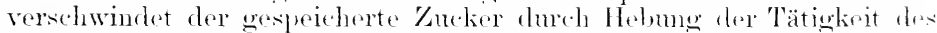
Protoplasmas mul des Veratmumgsprozesses.

Wenn Cruken, Tahak mol andere wämelselürftige Pflanzen längrers.

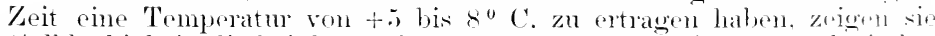
Gelblaubigkeit, die bei dauernder Wärmesteigerume weder verseliwinder. Die Pflanzen sterben nicht, aber Aximilation mul Wachstmu werten 
derartig herabgerlütckt, dati sich nummehr Vorgänge (Gummibilemog) rinleiten kömen, die zmm vorzeitigen Tod tles Individums führen. Wie im vorliegenten Falle der Wärmemangel. wirlien in andern Fällen Nährstoffmanger. lishtmangel. kmz jefle Herabmindermg eines Vege-

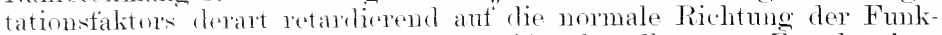
tionem, dats das richtige Ineinandergreifen derselben zum Zwecke enes förderlichen stotfworlsels alogelenkt wird. Es entstehen num andere Verbindungen nut Funktionsichtungen (z. B. (iärungen), die einen

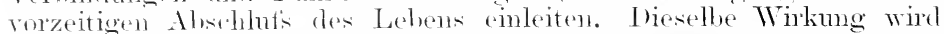
dureh jexlen Ïhersehnt's, jefle Anmäherme an die Maximalgrenze eines Tequationstalitors rinterten mïsicen.

In sehe viden Fällen dentet sich das singetretene siechtum durch sine C'hlorose an, flie mmerlich ich einstellt und langsam tortschreitet. selbst wenn os der Beobachtung gelänge, den ersten Anfang einer chlorose zu crlinmen, so wionde tamit loineswegs der Antang des siechtums getumflen worden sein: denn die erston molekularen Um-

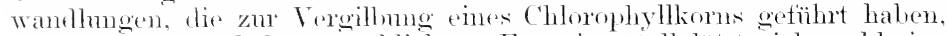
sind mo doch mbelannt geblieben. Experimentell läfst sich wohl eine

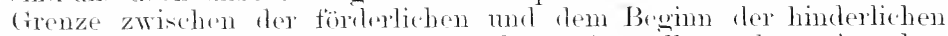
Gö̈ts eines rimzeluen Tiahstmotaktors teststellen, aber wir sehen dabei immer nu das Enflesultat med nicht den Werdegang, d. h. die dieses Endergehnis anleitenden Prozesse. Für moser TVahmehmmgsremögen stellen sieh tiesmuldeit nud Krankheit als Zu sände dar, diennmerklich ineinander übergehen.

\section{Die Beziehungen der Pflanze zu ihrer Ungebung.}

Bei dem im vorigen Abschnitt muternommenen Versuche, darzulegen, wie Gesmelheit und Krankheit Znständ. darstellen, die wie die bliefler eincr Kette incinamerereifen, hatten wir zmuächst die sog. Konstitutionskrankheiten im Auge. Wir verstehen darmer

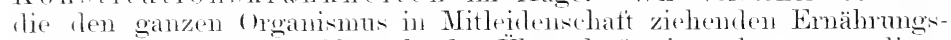
störnngen intolge von Mangel ofler Übershutis eines der notwendigen Vergetationstatoren. Fiesen Allgemeineratinkngen gegen-

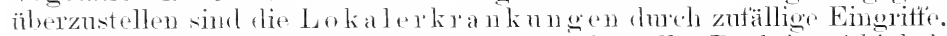
Hier steht zunäehst ler fresantorganismms in voller Roaktionsfähiglieit einer nu an einem einzelnen Uran wirksam welelenten štömug gegen-

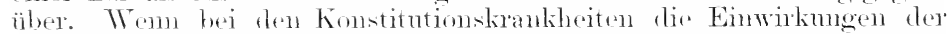
notwomeligen anorganisehen Wachstmmstaktoren in Betracht liommen,

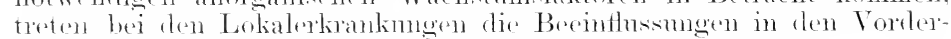

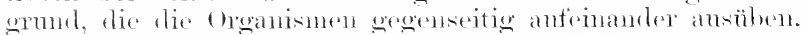

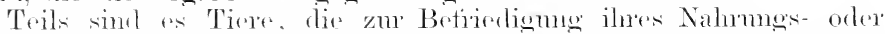

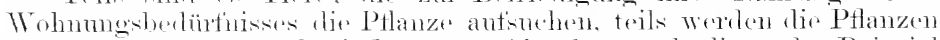

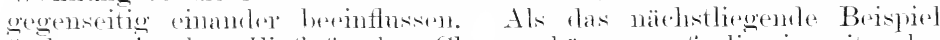

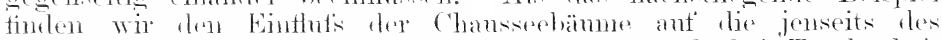

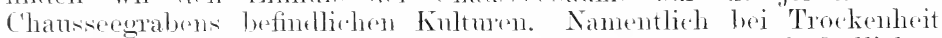
lemerken wir. dats tie in Bereich der Bammlinone hefindlichen

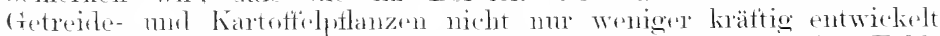

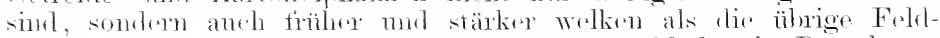

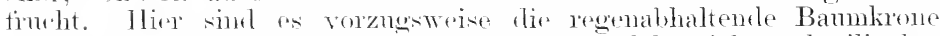
und hie wasserentzielunden Bammorzeln, welehe sich nathteilig hemerkbar marhen. A uf dem Felfle selbst finden wir nicht selten eimzehe stellen, auf denen die saat äufserst kïmmerlich steht, weil der TVind- 
halm die Getreideptlanzen erstickt hat. Dir Aussaat ist nicht manecelhaft gewesen, wohl aber sind die Keimmog mol .Jugendentwicklumg durch Kälte und Sanerstoftinangel zurücligehaltun worden, weil der Acker undurchlässige Stellen besats. Dort wird in Frïhjahr die Nässe. lange im Boden verbleiben; derselbe orwännt sich datureh sehwerer und leidet Sanerstoffinot. Der. Windhahm (Apera spica renti), dor iiberall auf den Getreideteldern vorhanden, ist wenign empfindlich und entwickelt sich mor solchen Verhältnissen schnoller als die Getredesat. Durch das erlangte Ïbergewicht erdrückt er dir cretreideptlänzchen. Ganz ähnlich verhält es sich mit den and('n Unkränt'rn, die durch ihre schnellere Entwicklung nicht nur den Kulturptlanzen Bodemührstofte wegnehmen, sondern sie auch durch Beschattung schärligen. Eigentlich

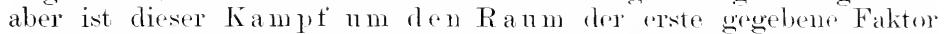
jeder Ptlanzengemeinsehatt und kommet bei allen Feld- und Wallliulturen zum Auschuck. Anf dem Getreidefolde mol in jerlem Waldbestande erdrïckt das ursprïnghich an kräftigsten warhsende Individumm die schwächlichere Ungebmo. Es ist die alloemein gïltige Gowalt des Stärkeren, die bei jedem Zusammenleben dor (hoanismen zmm Ausdruck kommen muls.

Dieses Zusammenleben in der soeben geschilderten Art und Teise in rämmlicher Entfernumg kömnen wir als Nachbarschat bezeidnnen zur Unterscheidumg rom der geganseitigen Berinflusmmg der tromisnen bei räumlicher Vereinigmg. Ein derartiges Verhältuis (s y mb iose) muls intimer sein, da ein Organismus ant dem andern lebt. Je nachdem der Einthis ein gegenseitig tördernder oder hrmmonder ist, unterschied DE BAKr (18tit) eine mutualistische von eince ant agonisti-

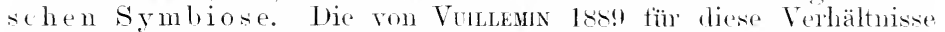
gewählte Bezeichmmg "S'ymbiose" mo "Antibiose" will ms weniger glücklich rscheincm.

Beispiele einer mutualistischen Gemeinschatt, die von van Benerlen 1878 anch als $\mathrm{Kom} m$ ens a lism $\mathrm{ms}$, als Tisehgemeinsehat bezeichnet worden ist, finden wir in don in starer, hexenbesenartiger Verzweigmen über die Bodenoberfläche hervortretenden Wuralbüschehn bei den Sagopalmen (cycadea'), die in ihren grotien Rindenlücken zahheiche Ketten von Nostoc beherbergen. Ähnliches zeigt dic Gattumg Gumert. Ferner findet sich mannigach in der Literatur wähnt der Fall, wo aine unserer Salvinia natans ähnliche Wasserpflanze. Azolla curolinima, riner andern Nostocace mit länglichen (iliedern (Amburma) Unterkunft in den Achselhöhlen ihrer Blätter gewährt.

I)as zugänglichste Beispiel tïr Mutualismus bietet der Autban des Flechtenkörpers, in welchem Pilz und Alge in gegenseitiger Hilfeleistmü danernd verbunden bleiben: Lichen ism ns.

Ähnlich gedentet wird die Srmbiose gevissu Pilmureelien mit den Wurzeln von Fagus, Corylus, Custuma mul mohrepen Comiforen,

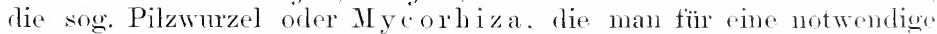
allgemeine Einrichtmo anzusehen gewohnt ist. Anschliefsent an dis Mycorhiza ist die von Hother ${ }^{1}$ ) und STönuer als Bactoriorhiza bezeichnete schutzvorrichtung zu erwähnen (bei Bitu und P'ismm). E. dringen rom Boden aus Bakterien in die äulseren tallschichton dor

1) Hintafer und Petros, Cntersuchumgen ïber die Keimlingskrankheiten del Zucker- und Runkelrüben. Arbeiten d. Biolog. Abt. am Kais. Grisumlleitramte. Bd. IV. Heft :3. 1904 . 


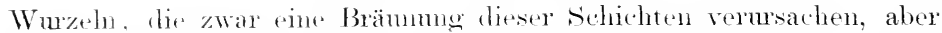
sonst tie Gesmollurit dre Pflanze nicht besomlers stören. Diese Bakterien rerhindern (nach Hotsek) aber das Eimbingen anderer, sehädbieher Oromismone (IMoma nsw.).

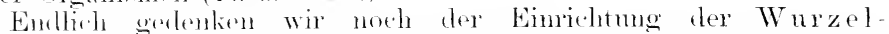
knällehen, fle in versehiedenter Gestalt und Gruppiermo bei den

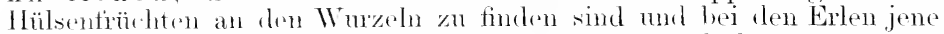
hekannten traulrenförmigen Körper darstellen, lie als kugelige Nester kurzverzweigter Wurch nicht selten in Fanstgratse beobachtet werlen. Jie den Stickstotf der lutt der Pflanze nutzbar machenden Organismen in arn Knöllelon, die als Rhizohium Lamomimosarmm Frank oder Bacillus rudicirola Beijerinek bes den Hülsentiüthtlern beschrieben worden sind. gehören abenso wir die Erzenger der silberweitsen Knöllehen bei Isopyrum

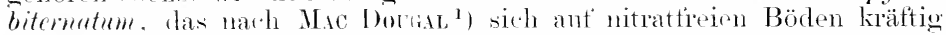
ontwickelt, den Baliterion an. Dagegen seheinen die nenen Untersuchungen von B.örkenhes $\left.{ }^{*}\right)$ zu beweisen, dats bei den Erlen es sich un einen Hyphempilz lanelelt.

Bei der antagonistischen Srmbiose hat le BAR den Ausdruck saplophytismus verwenclet, mol. JoHow hat $18 s, 9$ den Begrift' spezialisiert, inclem ex Holosaprophyten (chlorophyllose) von Hemisaprophyten (chlorophyllïhrende) nuterschieden hat.

Dem oegeniibergestellt hat Bischoff den Begritt Parasitismus. Der Anstruck .Parasit" ist nach Strdew ${ }^{3}$ ) im Jahre 172! ron MIchel bei Balanophoreen zum ersten Male gebrancht worden ${ }^{4}$ ). nut entsprechend der Eintrilung ter Saprophyten hat Sarauw die Holofarasiten (ohme Chlorophyll) von ILemiparasiten (mit Chlorophyll versehen) unterschierlen.

Unter Saprophytismus versteht man die Fähigkeit eines Organismus, von der in 7 ersetzung begriffenen organischen Substanz sich ornähren zn können, während der Parasit anf das in lebendigen Organismus dargebotene Material angewiesen ist.

Priaten wir diess (iliederung in den Ernährumgstomen, so erkemnen wir. dats eine solche scharfe systematisthe Scheidung, wie ïberall in der TVissenschaft, mur ron dex jugendlichen Disziplin vor-

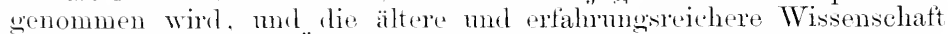
ïberzengt sich, dats Ïbergänge zwischen den einzehen Gruppen rorhanden sind.

Verwleicht man tas Verhältuis der Narhbarschaft zur Erührungsgenossenschatt (Symbiose), so zeigt uns eben jeder Wald mel jectes tortreidetell, wie bestäntig oin Organismus den antern herinthuts, je nachdem der eine dem antern Nährstoffe, Wasser mul Licht ïbrig lätist. Ebenso wie die rämmliche Entformung keine fester fichanke für die Ernährungsform bildet, kommt anch die Gliedermon lex Organismen in solehe mit reiner Mineralernährume und in solehe ler anf organische Substanz angewiesenen in Wegfall.

Ter tatsärhlich vorhantene Vorgang besteht tarin, dafs die zur

1) Minnesota Botanical Ntulies 1894 .

2) Bлmкалm: Beitrige zur Kenntnis des Pilzes in den Wurzelanschwellungen von Almus incanu. Zeitschr f. Pflkr. 1904. S. 129

3) S.r.mw, G F. L., Rodsrmbiose og Mykorrhizer saerlig hos Skovträerne. Botanisk Tidsskift 1898 . Heft $: 3$ u. 4 .

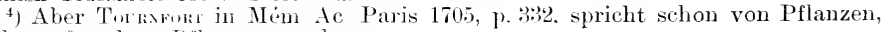
welche auf andern Pflanzen vachsen. 
selbständigen Ernährung geeigneten Pflanzen ihr Nährstoffinaterial, obwohl sie es ans rein mineralischer Unterlage hezichen können, doch auch nebenbei den Humussubstanzen entnelmen, die durch die Tätiokeit einer reichen Bakterienflora im Boden die Nährstoffe in antinelmmharer Form liefern. Man denke an die Vorteile der Bewirtschattume unserer Älier mit tierischem Dung.

Ganz besomeles stark aber hat die Nenzeit an der Grenzwand zwischen Saprophytismus und Parasitismus gerüttelt, indem sie immer reichlicher Beispiele dafür bringt, dats die als obligate Parasiten angesprochenen Gronismen in bextimmten Entwickingsphasen einer saprophyten Ernährung zugänglich simd, und anderseits, daf's die in zahllosen Fällen uns begegnenden saprophyten eine parasitäre Lebensweise annehmen können.

Einen Einblick in die Art nud Weise, wie soleher Wrahsel in der Emährungsweise zustande lommt, gewähren uns die Untersuchungen von Mrroshr ${ }^{1}$ ). Die in Institut von PFefFer in Lriprig vorgenommenen Experimente zeigen, dats Pilzhyphen chemisch reizbar sind und von ihrer Wachstumstichtung entweder nach der reizenelen substanz hin (positiver (lhemotropismus) oder von derselben tort (negativer ('h.) alogelenkt werden kömmon. Ja, auch ilu Wachstmmsmodus kann sich ändern, indem z. B. bei hoher Konzentration der Lösumg Neigumg zur Sprotsbildumg sich einstellt. (irrade unsere gewöhnlichsten Schimmelformen, die gelegentlich zu Parasiten werlen (Mucor, Penicillim, Asproillus), zeigen oine solehe Rerizbarkeit stoffen gegenüber, die als Inhaltsistofto der Kellen der phanerogamen fiewäthse fast stets rorauswestzt werlen können. Aulser Dextrin und den neutralen phosphorsauren salzen ist es besonders der Kucker, der in hervoragender Weise die Pilzhyphen anlockt, talls nicht zu hohe Konzentration vorhandem ist. So wirkt z. B. 'Traubenzucker bei solo oiger' Lösung für den bei der Fäulnis des Obstes tätigen Mucor stolonifer repulsiv. Sämen dagegen und Alkalien wirken ron romherein abstofisend. Die Keimschläuche der Sommersporen von Credo lincaris, einem Getreideroste, werden durch Pflaumen- mul Weizenhlattrlekokt angelockt. Besonders interessant sind die Kulturergebnisse bei Penicillimm glancum, dessen Hrohen die Zellwände sines Blattes durchbohrten, das mit einer zweiprozentigen Rohrzuckeräsmo imprägniert war. Ebenso drangen sic in kïnstliche Cellulosemembranen und in die Epidermis von Zwichelschalen ein, die aut' rint'r Nährgelatine lagen.

Dies sind äulserst wichtige Fingerzeige, welche die zahlreichen Fälle von Erkrankungen durch Penicillium zu erklären vermögen. Es ist bekamnt, dal's dieser Schimmel, der hänfigste Fäuhniser'reger bei dem Kemobst, sich erst auszubreiten beginnt, wem der Reifeprozel's die Stärke in Zucker ungewandelt hat. Und hetreff's des Eindringens von Penicillimm in Zwiebelschalen finden wir reichlich Beispich in den bisweilen zu Prozessen führenten Fällen der Fäuhnis von Tulyen-, Hyazinthen- und Lilienzwiebeln, die besonders dann stark auftritt. wemn nasse Jahre ein Auseifen der Zwiebeln verhindern, und wem dieselben mit autsergewöhnlichem Zuckerreichtum aut Lager gebracht und damn frïhzeitig zur 'Treiberei verwendet werden.

1) Mrrosh Maxam, Über Chemotropismus der Pize. Bot. Zeit. LII 1 194. S. $1-27$. 
So sthen wir. wie tie Besthaftenheit des Zellinhalts und ter Zellmemhran der Nährpflanze ausschlaggebend tür rin Einbohren von Pilzhyphen und für den Übergang lescalunhyton zum Parasiten werden kann.

\section{Die parasitären Kamkheiten.}

fiestützt ant lie vereinzelten, sorofältig studierten Fälle von Palasitismus. verallowmeinerten viele Beobachter den Begrift der yarasituren Erkrankmug lahin, dat's sie eine solehe überall da amnahmen, wo (homismen in Krankheitsherden sich angesammelt zeigten. In virle Fälen stützte man sich aut das Experiment, indem man einem Nänorganismms die parasitären Lebewesen einimptte und eine lokale Gewehcerkankmo zu erzengen vermochte.

Bei dieser ITethole häutten sich die scheinbaren Nachweise parasitärer Krankheiten derart, dats man zu der Ammahme gedrängt worke. s gäbe kam eine Erkrankmng. hei der Parasiten nicht beteiligt wären. Diese Imptinethoden im Laboratorim führten allmählich zm der Erksmonis. dats bei zahlreichen Krankheitsersheinmen keine spezifisehen Parasten. sondem allemein verbreitete Mycelpilze und Bakterienformen die Ursache wärn. Je weiter die Studien fortschritten, desto mohr Fälle gelangten zur Kemtnis, bei denen durch Imptimn von Sporen muserer hänfigsten sichimmelyilztormen, wie Botrytis, Prnicillinm, Cludosporium u. lgl., sowie der verhreitetsten Bodenbaliterien, Bucillus subtilis mol culgutus, gesunde firwebe zur Erkrankumg gebracht worden sind.

Damit wurle endlich die Frage nahegelegt, woher es wohl kommen mag, dats derartig allenthaihen vorhandene Organismen nur in manchen Fällen farasitär ein Gewebe anzugreifen vermögen und ein anderes Mal sich saprophytisch mit hereits ahgestorbener organischer substanz hegnügen?' la dieser Frage gesellte sich eine zweite, die ans den änfierst schnoll sich mehrenten Ertahrmgen entsprang, dats hei gleichen Impfmethoden gewisse Varietäten oder anth Individuen witcrstandstäho sich erwiesen, während andere mit Leichtigkeit dem parasitären Angritt erlagen. Was war die Trsache derartiger Vershiodenheiten?"

Ein Teil der Forseher zog zur Erklärung solcher Fälle die Virnlenztheorio horbei. Es wmole hervorgehoben, dats der Parasitisms als Kampt zweier tromismen gegeneinander in jedem cinzehen Falle davon abhängen müliste, wer von den Kämpfenden der stäkrese sei. Wem die Angriffswatte des Parasiten z. B. ein ron densellem auseschierlones Enzym sei, las die Fähigkeit habe, den Zellstotf' dor Sährptlanze zu lösen. so sei rrklärlich, dats dieser Prozeds mu so sthneller stattinden würle, je mehr in einer Zeiteinheit von rinem derartig lïsenden Ferment gebildet würde. Da man num "xperimmtell nachweism komte, dats hei Knltmen ant verschiedenen Nährö̈len dio Angriffikratt des Parasiten wechselte, so durte man sich sagen, datis lort. wo er zum Krankheitserreger wirklich wurde, seine Probuktion an Enzymen eine besonders reichliche gewesen, er lesonflers giftig (vimlent) wewesen soin muls. Lie meisten Beispiele für tir wechsolnch. Tirulenz lieferten die Bakterienknltmen: doch wurlen anch hed den Mreelpilzen solche Fälle testgestellt. Sehr bekannt ist die Angabe von IE B.AR über die äberall anzutretfende, als 
Botrytis cincrea bezeichnete Sichimmeltorm, deren Mycel sich durch di. gewöhnliche saprophyte Ernähnug erst zu einer gewissen Kräftigkeit entwickelt haben muls, wenn es parasitär werden und lebendige Pflanzenteile mit Ertolg angreiten soll. Ich konnte tïr die Konidien dieses Pilzes gleichsimige Resultate erlangen. Es wmden ant weiche Begonienblätter massenhaft sporen ansoestrent und dic Anssat reichlich fercht erhalten. Nach eimigen Tagen lieds sich beobachten, dats an denjenigen Blattstellen, wo die sporen in divken Hanten anteinandergelegen hatten, eine Erkrankmg des Blattes morer Brämmug des (iewebes eingetreten war: dort, wo die sporen vereinzelt antgelegen, ist ein Angriff nicht testzustellen gewesen. Die Wirkmug der von der einzehen Spore ansgeschiedenen Fermentmenge hatte sich demnath als mgenügend rrwesen, während die Hänfimg des Angriftismaterials die Intektion zurege gebracht hatte.

Es wird num leicht verständlich, dats die Parasiten, wie jeder andere Organismus, sich dam am kiätigsten entwickeh. Wenn die Ernährmgsbedingmegen am gimstigsten sind, mol datis, je krätiger und zahlreicher ihre regetativen Oroane ansogbildet werden, ihre Enzymansscheidmogen mud remgenäls ihre Angrittsstärke sich steigeru, also ihre Virulenz rhöht wird.

Aber diese Vorgänge genügen nicht zu' Erklärmg der' 'Tatsarhe, dats ant einem Felds bei einer Anzahl neleneinander angehanter Varietäten einzelne derselben völlig zerstërt worden kömmen, wälnend danebenstehende wonio besthärligt werden oder vidled ht ganz mversohrt hleiben. Da in solehen Fällen die Wittermesserhältnisse mol sonstigen Vegetationstaktoren wleich gimstig für den Parasiten sind mol trotzdem anf einer Varietät er sich sehmell und krätig anshreited und ant der andern nicht, so muts in diesen beiden Fällen dar Muttruboden selbst, d.h. also die spezifische Besthaftenheit der Nahrytlanze, ansichlaggebend für die Erkrankmg gewesen sein. Damit gelangen wir zm Erkemntnis, dats tür das Znstandekommen einer parasiären Krankheit nicht die Anwesenheit des Parasiten allein matsenelend ist. sondern anch die Beschatfenheit des Nährorganismus mitsmechen kamn.

Die vielfachen Impfversmehe haben anch dazu getührt, die sich auf andern Grganismen ansiedthden Lebewesen. die imstande sind, das Gewebe anzugreiten, derart zu klassifizieren. dats man eine Gruppe als absolnte Parasiten anspricht, wemn sis imstande ist, die Nährpflanze in allen stadien ihrer nomalen Entwicklmng anzugreifen. Ton dieser (impue hat matl solehe Grganismen als Wundparasiten abgetrennt, welche den mit seinen nomalen schutzvorrichtungen versehenen Urganismms nicht angreiten können. sondern erst derjenigen Gewebeverändermg bedürten, welche eine Wimdtläche darbietet. Bei einer grotsen Anzahl parasitärer Vorkommisse haluen wir erkannt, dats der Parasit erst dam den fïr soine Entwicklmes nötigen Mutterboden hei riner Ptlanze findet, wem diesellue in ihrer Produktion verändert und in ihren Funktionen bereits abgeschwächt ist. Hier werden Znstände eintreten. wie sic in den von Mixosн ausgefülnten Experimenten (s. vor. Abschnitt) ansschlaggehend wurden. Diese Gruppe fïhrt die Bezeichnung, schwächeparasiten".

Namentlich in diese letztere Gruple gehören dic zahheichen Arten. die in vielen (ienerationen anf abgestorbener orouniseluer substanz leben, also als saprophyten angesprochen werden müssen mel gegelegentlich parasitär werden (fakultative Parasiten). Hier ver- 
wischt sich also die tirenze zwischen Parasitismus und Saprophytismus, und sellist hei denjenigen trattmogen, die zu den strengsten fobligaten) Parasiten wehören, wie z. B. bei den Brandarten, finden wir Entwicklumgshasen mit salrophyter Ernährmng.

IVem wir num aber die Familien mserer strengsten Parasiten unter den Mreelpilzen, nämlich die Brand- mul Rostarten genaner in Angensehein nehmen. so finden wir duch die nemesten Untersuthmgen in vielfacher Bestatigung hesonders eine Tatsache in den Vordergrmol gerïckt, nämlich die Abhängigkeit der Wachstumsenergie des Parasiten von soiner Nährptlanze. Wir haben Beispiele, welche zeigen. dats drerselh, Pilz ant' einzehnen Arten derselben Nährutlanzengattmng an demselben standort bald ïppig in zahlee bald spälich in kleinen Formen anfritt, je nachdem die eine Art fleischigere Blätter und die andere derbere besitzt. Ja, die Roste sind derart von ihren Nährpflanzen abhängig, dats sich biologische Rassen (formar speciales) bililen, die bei aller gestaltichen T̈bereinstimmung floch insofern Untershiede zeigen, als sie sich einer hestimmten Nährptlanze anpassen und selbst bei sorgfäliger Imptung ant der ver. wandten Nährptlanze nieht meln oder nur in geringem Grade zur Entwicklung gelangen. so haben wir von unem gewöhnlichen Getreirleschwarzost eine sipezialform für Roggen, eine solche tür Weizen und eine solche tür Hater nsw. Und die Mrkologen hegen die Überzengung, dats diese Ansbildung zu einzehen Rasien lurch frewölmung an spezielle Nährptlanzengeschlechter eine weitrerlmeitete, fortranernd mehr zutage tretende Erseheinmog ist. Was bedentet num eine derartige Rassenbildmo anders, als dats die Parasiten $m$ it ihren Ansprüchen äuf́serst eng an die Boschatienheit der Unterlagen gebunden sind mil sich terner binden? Wenn aber der strengste Parasit erwiesencrmatsen so abhängig von semer Nährptlanze ist, damn sieht man, wie vollständig er mit den nicht-parasitären Pflanzen darin ïbereinstimmt, dats er ganz bost imm te Ernährungsverhältnisse heansprucht, und dats mit dem Wechsel dieser entwedex. der Parasit seinen ('harakter ändert mol sich anpat'st oder verschwindet.

Wie wir mo diese Anpassmgserscheinmogen etwa zu denken haben, denten die Beobachtmgen ron StanL ${ }^{1}$ ) hei Mramrceten-Plasmodien an. Wemn in lem Kulturgefatse das Wasser dureh eine 1 bis go oige Traubenzuckerlösmg ersetzt wurde, starlen bei plitzlicher Einwirkmng die Plasmorlion al, ontre flohen die Znckerlösmng. Almählich aber vertrugen sie diese, hatten sich also an eine konzentriertere Lösung gewöhnt (vielleidht durch einen gewissen Wasserverlust), mnd zwar derart, dats sie, in roinos Wasser zuriekgebracht, nummehr beträchtliche Schädigmuen zoigten.

Ëber die Rassonlihlung äutsert sich Pfeffer $\left.{ }^{2}\right)$ : "Die vorliegenden Erfahrmesen ... lassen rkemen, dats die tropristische Sensibilität derselben Art von Baktrien, Flagellaten usw. je nach den voransgegangenen Kulturbedingungen graduell versehieden austält. So ist es zul verstehen, datis man bei derselben Art, in der Natur und in künstlichen Kulturen, zuwrilen wine sohr ansehnliche, zuweilen eine geringe oder verschwindonde: Reaktionsfaligkeit gegenüber einem bestimmten Tropistiemm findet. Ja, es mulis nach anderweitigen Erfahrungen möglich

1) SruHL in Bot. Z. 1.84, S. 16:i-6it.

¿) Prefrer, Pflanzenphysiologie, 2. Aufl. Bd. II. S. 76:3. Leipig 1904. 
erscheinen, dats Rassen gezüchtet werlen kömen, bei welchen eine zuvor vorhandene, bestimmte tropistische Sensihilitit theilweise oder gänzlich verloren regangen ist."

Der Parasitismus ist nichts Antsergewöhnliches, nicht etwa ein imerhalb der Kulturzeit non aufgetretener Falitor. Er ist als eine mit der Entwicklung des organischen Lebens allmählich in die Erscheinung getretene und num gegebene notwendige Ernährmgstom zu betrachten, die als das Endwlied einer Kette von Bezichungen anzusehen ist, welche

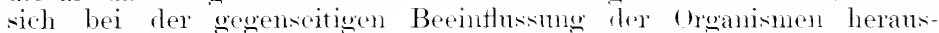
gebilclet hat.

Er ist das Enlglied riner Kette, die mit denjengen Oromismen begimnt, welche die Fähighest haben, ans anowanischem Material durch die Arbeit des Lichtes organische sulstanz zu hilden. Es schliefien sich daran die trewächse mit geringerem Lichthediurfins, wie wir sie bei den sog. Humuxbewohern vorfinden. Wo eine Bejgabe von des. schneller zersetzbaren organischen substanz eine wesentliche Erleichterung des Enährmgsorganges dastellt. Jo mehr bei der wachsenden Kahl der Organismen der Kampt mu das Licht an Bedentung gewinnt, desto näherliegend wind dic Anshildmog von Oronnismenreihen mit äutserst schwachen Lichthertüfnis und immer notwendiger werdendem Bedüutinis nach einem Ernährugsmodus, bei dem das Rohmaterial schom in der Form moniseler, leichter zu bearbeitender Substanz gehoten wirl, wie wir os hei dem Sapmophytismus vorfinden.

Wemn bei dem Kampet um das Licht bei der ständie im Laute der zeiten wachsenden Individnenzahl sich notwendigerweise anch des.

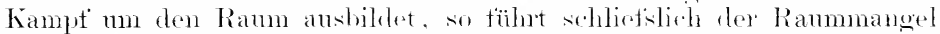
zu jenen Anpassungstomen des Pflanzenwelt, dir nu antangs oder überhaupt nicht moler don Erolboden als Wolnstäte heansfruchen. sondern einen andern Oromismms als Ansierllungshol sich ansersehen.

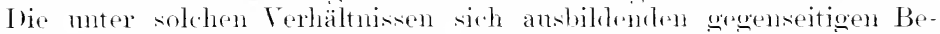
ziehmoen sind teils firmulliche teils feintliche. wie sie in der mutualistischen mel antagoniseben sirmbiose zutage troten.

Cnter den einen andern Oroanismus als Wolnstäte henmtzenden Pthanzenarten sehen wir dam die versehiedenstru Hiltsvorrichtumen zur Ermöglichmug der Ermährmg sich anshilden. Vom Lichenismm ans gewimt die Boihilto dos Rhizinen-Apparates immer glötsere Be-

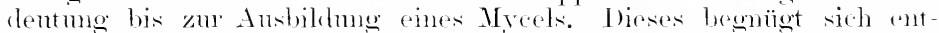

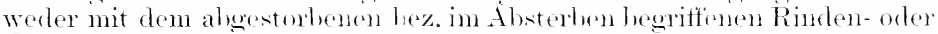
Blattmaterial seines Wints oflo liam seine Existenz num firsten, wemn es

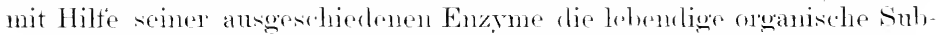
stanz angreitt mol dann den Parasitismus in dir Ersheinmo routt.

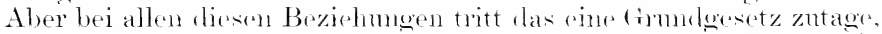
rats jeder (1) reanismus an eine bestimmte Boschaftenheit

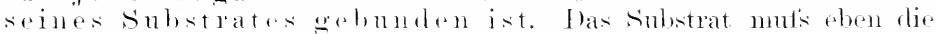

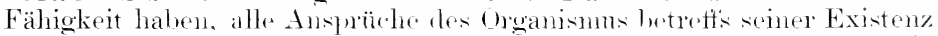
zu befriedigen: sonst kam or nicht werleihen. Also anch alle die Oruanismen, welche wir als Parasiten zu bezeidnen phlegens. stellen ihre ganz bestimnten Ansurüche an einen Nähorwanismus. Wie eng

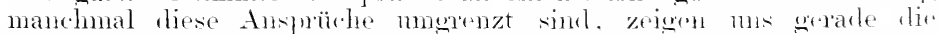

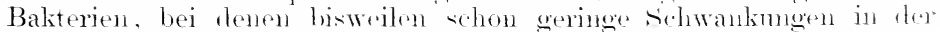
Wärmezufuhr, in der Acilität dos Nährstofteremisehes n. del. zmm Ersetzen bestimmter Arten durch andere. angeratistere tïhron. 
Um nur einigr nene Brispiele anzuführen, erwähnen wir die Untersuchungen von Thous Mrsburs ${ }^{1}$ ), (ler sowohl Mycelpilze als auch Bakterien in Kultur nahm. Ton ersteren fand er bei Hypocrea rufa, datis eine steigerung des osmotischen Drudies elst die Pigmentbildung

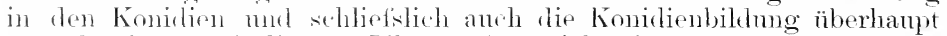
untercliucke. Bei diesem Pilze ändert sich die Farbe der Konidien mit der Reaktion des Merliums. Bri samer Reaktion werden gröne, bei allaliseler Reaktion gellhe sporen gelildet. Gut ernährtes Mycel gibt im lomkeln kine Fruktifikation, wohl aber zeigt sich bei schlechter Ernäbrume rine Komilienhilume. Die gello Farbe im Nycel von Asperatlus niger ist aegen Licht sehr empefindlich und wird binnen wenigen stunclen turch las Livht schwarz. Der auf Kartoffeln kultivierte Bucillus mber bultims, der sog. "Kieler Bazillus" (s. Breunur, Tntersuchmeen des Trinkwassers der stadt Kiel, 18,8), der nach LALkexp ant gewisen Nährhöden säne, ant andern Alkali hildet, wird in seiner Farbstotfinoduktion durch den Nährboden dahin beeinflutst. dats er bei samer Beschaffenheit violette, bei alkalischer Reaktion orangerote Farbe mowickelt.

Bei einer zweigbildenden streng aëroben Bakterie aus dem Sputum lei Pnemmonia, Burillus Bresturui, beobachtete Lepeschkin 2), dats lieselbe sich anf stark alkalischem und stark samem Boden entwickeln kann, aber tas alkalische Siubstrat allmählich sauer macht. Bei Anwosenheit von Zucker (Duxtrose) tritt unter Zerfall der stäbchen in ()irlien ein rosa Farbenton aut: bei Anwesenheit grötserer Mengen stickstoffhaltiger Verbindungen (Asparagin, Lecithin, Peptone) färbt sich lie Bakteriemmasse orangegelb. I)as Wachstumsoptimum liegt etwa

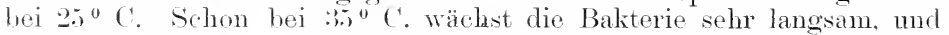
hei $38^{\circ} \mathrm{C}$. ist sie nicht melu wachstumstähig: hei 5.50 C. wird sie retötet.

Wenn also für die Parasiten sich eine deutich zutage trotende Abhängigkeit von der Beschaffenheit les Nährbodens erweisen lälst, so ist natürlich das nächst. liegende Ertordernis, dat's wir bei Bekämpfung derselhen versuchen müssen, len günstigen Nährboden zu cotzielen und in einen dem speziellen Parasiten nnQünstigen zu verwandeln.

Da num die Kultumptlanze durch die Tatsache, daf's sie in empfängliehen mul widerstand sühigeren Varietäten existiert, den Beweis lief'ert. dats en rine Möglichlieit cibt, den durch die lebentige Pflanze dargestellten Nährboden zu ändern, so ist die Herstellung soleher widerstandsfäliger Individurn dureh die Kultur die erste Pflicht moserer Bestrobungen betreffis Bekämpfing parasitärer Krankhriten. Sic ist wirksamer als die jetzt herrsehencle, ans einer engen Anshammgsweise hervorgegangene Nethode der lokalen Bekämpfung orler Abhaltmg dor Parasitrn, tie höchstens für kleine Herde wirksam ansfïhrlar, aber boi dem Botriebe im grotien schon ans mechanischen (roüuden molurehtiïnbas ist.

Von den hier entwickelten Gesichtspunkten ans ist der Parasitismms lieine solehe (refahr, als welche or jutzt hingestellt wird.

1) Tmons Munux, Über Änderungen der Farben bei Pitzen und Bakterien. Centralbl. f. Bakteriologie usw. II. Alet. 1904. Bd. XIII. Nr. 911.

2) Lepromis, Zur Kenntnis der Erblichkeit bei den einzelnen Organismen nsw. ('ontralbl. f. Bakteriologie usw. II. Aht. 1904. Bd. XII. Nr. 22/24. 
Wenn der Parasitismus eine bestimmte, in der natürlichen Entwicklung der Lebewesen im Laufe cler Zeiten notwendig gewordene Ernährungsform für gewisse Gruppen ron Granismen ist, so muls er im Haushalt der Natur sein Gleichgewichtsstatlim haben. Es müssen Einrichtungen existieren, welche dem Parasitismus das Gegengewicht halten. Er mufs an seiner Wirksamkeit bohinclert werten kömnen durch gleichzeitig wirksame Faktoren: dem somst könnten die Nährorganismen überhaupt nicht mehr existieren. Dieses fregengewieht liegt eben darin, llatis die Parasiten ganz bestimmte, hänfig nogezogene Existenzorenzen haben. Eine solche rrenze, dit der Parasit muter normalen Verhältnissen nicht zu überschreiten remag, ist derjenige Tustand eines Lebewesens, den wir als "gesmo" zu bozeichnen pHegen. ohne ihn bis jetzt mäzisieren zu kömmen. Denn da die Verteidiger fler extremen Parasitentheorie anch solche Mikroorganismen als gefährliche Parasiten hingestellt haben, die allenthalben saprophytisch stets vorhanden sind, mul die Wirtsptlanzen in ihrer Gesamtheit bisher doch nicht erlegen sint, so mïssen sie eben bei ihrer normalen, d. h. herkömmlichen, von Generation zn Generation sich oleidsimniw wiederholenden Entwicklung Sehutzvorichtungen besitzen. Als solche sehen wir kontinuierliche Wachs- und Korkïherzüge, bestimmte Acitlität des Zellinhalts n. dol. anftreten.

Dats wir jetzt mit unsern Anschaumgen immor mehr Anhänger finden, beweisen die Angahen eines mserer hedentendsten Parasitologen, des am Pastemselien Institut tätigen Merschnikoff ${ }^{1}$ ). Er sagt. nachtem er eine Anzahl von Beispielen dafïr angefühlnt hat, dafs das Zustandekommen der parasitären Krankheit dur.h zwei Ursachen. nämlich erstens den Parasiten und zweitens pinen im Innern des Organismus gelegenen Empfänglichkeitszustand hedingt wird, folgente(S. T): „Sind diese innern Ursachen olmmächtig. die Entwicklume der Krankheitserreger zu hemmen, so entsteht eine Krankheit: wem sie aber dem Eindringen der Bakterien festen Widerstand leisten. so ist der betreffende Organismus geschützt und erweist sich so als immun." (s. (i): „Man kam nicht mehr der Ansicht sein, dat's jedesmal, wem ein Krankheitserreger in einen für die betreffencle Krankheit empfänglichen Organismus eindringt, die Gegenwart desselben mausbleiblich die spezifische Erkrankmng hervorruft. LöfFuEs's Entdeckmng der Diphtheriebacillen im Rachen gesunder Kinder ist seitrlem häufig bestätigt worden, und remoch ist es mmöglich, an der ätiologischen Bedentung dieses Bacillus für die Diphtherie zu zweifeln. Anderseits hat es sich gezeigt, daf's der Kochsche Vibrio, obwohl er der wahre Erreger der asiatischen Cholera ist. demnoch im Vertanmostractus gosunder Personen vorkommen kamn."

Der gesunde Organismus besitzt eben eine natürliche Immunität. und eine Störung derselben bildet die Berlingmo für den parasitären Angritf.

\section{Epidemien.}

Temn wir Endemie als eine Lokalsenche bezeichnen können. deren Zustandekommen an bestimmte, örtich engbegrenzte Verhältnisis. gebunden ist. so wirk Epidemie eine Landesieuche genamt werlen

1) Immunität bei Infektionskrankheiten von Elıs Mtricnsinfr, Professor an Institut Pasteur zu Paris. Autorisierte Übersetzung von Dr. Julius Mever. Jena, Gustar Fischer, 1902. 
kïmnen. Der Anshok „s'uthe" dentet die Vielheit der erkrankten Indiviluen in Grepensatz zum vereinzelt anftretenden Krankheitsfall an. Epirtemit kenmzeichnet somit dio Erscheinmo, dafs gemeinsames Erliranken zahlreicher Individuen unter äbereinstimmenden Formen ïber weite Länderstreken Platz gegriften hat.

Wem eine Epidemie anshicht, sind also Kustände vorhanden, welche den Organismms zahlreicher Individuen in seinen Funktionen so stark erschüttern, dat's er mit einem vorzeitigen Abschluts seines Lebens bedrolit ist oder schliefslich diesem Absehluts zugeführt wird. Tie Erschüttermg heruht anf äntseren Ursachen. Wenn dieselben in Form parasitäer (homismen anftreten, so sind sie in ihrer Existenz, wie wir in vorhergehenden Kapitel gezeigt, abhängig von den ihre ïhermätsige Vermehrung begünstigenden Wachstumstaktoren, zu denen eine Lockerung der Immmitä des Nährorganismus gehört.

selbst hei der Ammahme, dats ein in den versenchten Ländern nicht einheimischer Parasit dureh Einwanderung die Epidemie hervorgerufen hätte, ändert dieser Unstand nichts an der Tatsache, dats die vorhandenen Wachstumstaktoren anssehlagegend für das Kustandekommen der Epidemie sind. Demes mag einwandern, was will, sei es Tier orler Mycelpilz oder Bakterie, so hat diese Einwanterung für das Zustandekommon einer Epidemie keine Bedentung, wem die Einwanderer lieme Gelegenheit zu grotser Vermelnung mil Ansbreitumg finden. Wer erimnert sich beispielsweise nicht an die effektreichen Darstellungen ïlser das Einschleppen des Koloradokäfers, als den Vernichter unseres Kartoffelbaues, äher die massenhafte Einfuh der san José-Sichildlans, der Vernichterin unserer Obstknlturen, u. dgl.? Eingeweihtere wisisen anch, wie vielfach Einfuhrerlote und Desinfektionszwang bereits gefordert und teilweise erlangt worden sind zum Schutze gegen die Einschleppung parasitärer Pilze (Thite-rot des Weinstoeks $11 \mathrm{sw}$.).

Die Erfahrme hat geleht, dats nicht otwa cine theoretisch exträumte, aher praktisch mmögliche vollstänthge Abtötung oder Fernlaltung deratiger Parasiten ms vor Epidemien bewahrt hat, sondern dex Comstand, dats dir genannten schädinge nicht den entsprechenden klimatischen Boden für ihre Vermehrmeg fanden. Ungekehrt wolle man sich an die Rehlansplage erimern, die trotz aller mensehenmöglichen Anstrengmgen mid Antwendme vieler Millionen immer weiter sich ansbreitret. Ine Roblans findet eben in Emopa genïgend sünstige Existenzbedingmeng und trotzt deshalb soldhen

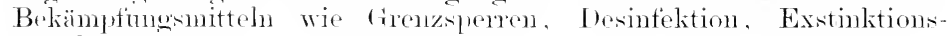
verfahren usw.

Man wirl sich hei ruhiger Üherlegmen wohl allmählich klar daräher worlen, datis kleine und kileinste Lebewesen, dic dureh Gegenstände des Handels eingefïhnt werden orler gar durch stanb und TTind mit

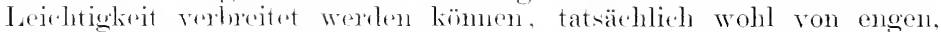
abgeschlosienen Rämmen, abor nicht von ficiliegenden, ausgedehnten () blichkeiten ternzuhalten sind, mel dat's man richtiger verfährt, eine allseitige Verbreitumg-möglichkeit deratiger Organismen vorauszusetzen,

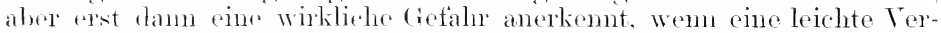
mohrungsähigkeit terselben nacherwiesen worden ist.

Temn num bei allen parasitäen Einwantlermgen nicht die Gegenwart des Parasiten, sondern die seine Aushreitung begünstigenden Umstänle auschlaggehend für das Znstandekommen einer Epidemie sich 
erweisen, damn ist auch die Ändermo dieser Umstände das geboteno Bekämpfungsmittel.

Betreff's der Abhaltungs- und Vorbengungsmatisregeh aber gibt uns die Epidemie insotem besondere Fingerzeige, als sie dureh ihr Autreten über grotse Länderkomplexe alle die Faktoren als Ursachen anssehliefist, die in den emzelnen versenchten Landstrichen voncinander' abweichen. Demn da trotz der Abweichungen soleher Faktoren, wie z. B. Lage, Bodenbeschaftenheit, Bewirtschattungsmethode u. dgl., die Erkrankung grotse Individuengruppen ergreift, kömnen diese Faktoren nicht die Ursache sem; viehmehr ist diesclbe in denjenigen Einflïsisen zu suchen, die eben in den sämtlichen Ländern oleich sind, mul das ist tatsächlich num die Wittermmg.

Bei den endemischen Krankheiten dagegen pflegen meist Borlenverhältnisse ansschlagoebend zu wirken. Entweder sio sind als direkte Krankheitsursache zu betrathten, indem sir durch ungiunstige chenische oder physikalische Eigenschatten die Funktionen der Pflanzen danernel stören, oder sie wirken indirekt, die Vermehrung der Parasiten und ihre Angriffsstärke begïnstigend, wobei sic in der Regel lie Wachstmmsenergie der Wirtsptlanzon gleichzeitig herahdrücken. Das häufigste Torkommen in dieser Richtung int Bodemnässe. Bei starker wasserhaltender Kraft dichter, schwerer Böden in ebener oder muldenartiger Lage pflent Anhäufung ron Wasser sich einzustellen, das keinen Abflutis tindet umi Sanerstotfmangel mit Kohlensäureüberschut's elzengt. Die Pflanzen zeigen lie Funktionstörung durch Verändermog des Chlorophyllapparates an : die allmählich goll, werdenden Blätter bilden ein hequemes Ansiedlungslett tïir gewisse Pilzorupleri.

Bei den Endemien mul Epidemien dentet das gleichzoitige Erkranken grotser Mengen von Individuen aut ein längeres stadinm ler Torbereitnug his zum tatsächlichen Ausbruch der senelle hin.

Dem nach muserer Autfasimng aller Erscheimmgen des Lebens als dynamische Vorgänge tharakterisiert sich jede Erkrankung als die mittelbare orler mmittelhare Folge mechanischer Strifse, welche die einzehen Wachstumsfalitoren auf die Zusammensetzung und Funktionen der Sulstanz ausüben. Das Leben riner Zelle ist ein beständiger Kampt der in ten labilen organischen substanzverbindungen angenbheklich vorhandenen Schwingmastormen mit den Stötsen, die die Wachstumsfaktoren mansgesetzt auf sir ausïben. Eine Änderung der substanz und damit auch ihrer Funktion tritt sofort ein, wenn der Stot's eines Wachstumfaktors so stark ist, dats er die bisherige Schwingungstorm zu änflern imstande ist.

Solange die stöfse in inrer Geramtheit den Etfekt haben, dats sie die Entwicklung des Gesamtoromismus, des pflanzlichen Indivirhums, fördern. bleibt die Pflanze immerhall, der Breite der Gesmonheit. Wird die Zelle orler der Zellenkomplex derart verändert, dafs schliefslich der Gesantaufhan leidet, erfolgt die Erkrankung.

Nun haben wir aber in der jederzeit durch Beispiele zu erhärtenden Tatsache der hevorzugten Erkrankung einzeher Kulturvarietäten mnter gleichen Wachstumserhälnissen mit andern den Beveis vor uns, dafs die organische sulstanz den gleichen stötsen in den verschieflenen Individuen versthieden grotisen Widerstand entgegenzusetzen vermag. Dies würde heifsen, dats bei dem einen Individum mehr Stölse notwendig sind, damit es aus der Breite der Gesundheit heransgefracht 
werle. Wemn nun bei der Epillemie stets grotse Individnenmengen plötzlich erkranken, so mïssen sich miter diesen neben den besonders hintälligen anch solehe befinden, bei denen schon eine grötsere Menge von Stötsen, also ene längere Daner der Einwirkmg nötio ist, damit sie krank werden. Es muts also bis zum Aushruch der Epidemie eine längere Zeitdaner der krankheiterzengenden Einflüsse. die wir in ten Wittermestaktoren erbliken, rorangegangen sein.

somit ist nach mserer Auftassmug jede Epilemie gleichsam die Explosion einer längere Keit vorher langsam statgefundenen Ladung. Ihre Ersache ist daher nicht oder toeh nicht ansschliefslich in den angenhlicklich vorhandenen Wachstmmstaktoren, sontern in der Hänfung der sthon längere Zeit vorher gleichsimin wirksam gewesenen Stöfse zu suchen. Bei parasitäen Epidemien ist das massenhatte Anftreten der Mikroorganismen durchans nicht flas erste Starlimm der Erscheinmo. sondern sthon ein sthlntisettekt langer Vorbereitmoen. Und diese Torbereitungen bestanclen einerseits in der allmählichen Herstellung der für die enorme Vermehrmg gïnstigen Lebenshedingungen der Mikroorganismen, anderseits in der, wie wir glanben. damit stets verbundene'n allmählichen schwäehmy einger und korrelativer steigerung anderer Funktionen des Nähroromismus.

Wenn wir heispielsweise die bekannteste Pilzepielemie, die hrantfänle der Kartoffeh, ins Ange tassen, so lehrt die Beobachtung, dafs eine Periode warmer, trüber, schwüler Tage dem Ausbruch vorherzugehen ptlegt. Der Pilz. Phytophthora infestans, ist stets vorhanden. Seine stamenswert schnelle Vermehrung aber kommt in Freien nu zustande, wemn reichliche Niedersthläge und eine warme, unbewegte Luft die Entstehmng und das Anssehlüpten der Schwärmsporen tortgesetzt beginstigen. Eine derartige Wittermo regt lie Kartotfelptlanze sowie alle andern Gewäkhse zur Steigerung der Znekerbildung, zu schmellerem Wachstum der Stengol und der erhöhten Produktion junger Blätter, d. h. zm Erzengung eines besonders empfänglichen Mutterbodens tïr den Pilz an, der die altgewordenen Organe verschmäht. Daher sehen wir die Erkrankmng ganzer Felder bimnen wenigen Tagen.

Wir beolachten dagegen rime Phrtophthora-Epidemie nicht, wenn

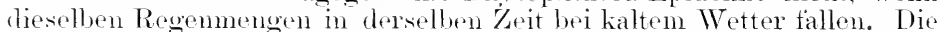
Epidemie kommt auch nicht zustande, wemn bei hoher Wärme und bedecktem Himmel danernd starke Winde wehen. Ein gleichartiges Verhalten zeigen die Rostopilemien des Getreides. Wie tie Mehrzahl der Pilze lieben die Getreidorost die anhaltende Funchtigkeit: aber wir haben kemeswegs stets in fenchten Jahren Rostepidemien, obgleich

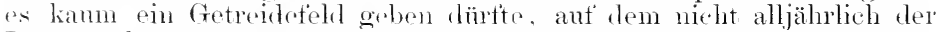
Rost vorhanden wäre. Die Epidemir bildet sich elst ans, wemn zur Keit des Vorhandensins jugendlicher Blätter Perioden wamer Tage mit hänfigen, wemn anch an sich merhoblichen Regenfällen ein längeres Festhalten der Fenchtigkeit zwisehen den Ptlanzen ermöglichen. Kalte. nasse sommer lassen keine Rostepielemien sich entwickeh. Ähnliches beobachten wir bei bakteriosen Epidemien.

Also Ephlomien sind Krankheitstomen, die nur dureh weitgreifende Faktoren gezeitigt worlen. Nur hestimmte Witterumskombinationen von längerer Daner sind als die einleitende Ursache zu betrachten. Natürlich wirl die Intensität der Epidemie lokal variieren. weil ärtiehe Faktoren spezielle Beginstigmgen schaffen werclen. Daraus erklärt sich das Anftreten von Nestem, in denen die senthe zuerst erseheint 
und am spätesten verschwindet, falls nicht alle Individuen gemeinsam in kurzer Zeit abgetötet werden. Daraus erkärt sich ferner der Rückgang der Epidemie zur Endemie, d. h. zu engbegrenzten hrankheitsherden. Unter den durch tierische Parasiten hervorgerutenen Epidemien sind die dureh Getreidetliegen veranlatsten hei uns die luänfigsten. Sie pflegen zustande zu kommen, wenn nach gïnstigen Überwinterungsbedingungen für die vereinzelt in manchen (iegenden stets vorhandenen (tetreidethegen Perioden anhaltend warmer, trockner Witterung eintreten. Soweit statistische Angaben bis jotzt reichen, lassen sich bereits mehrfach bevorzugte llerde mel Ausgangsumkte der senchenartigen Ausbreitung feststellen. So roweist sich beispielsweise die Provinz Posen für Getreidefliegen als hesonders gïnstiger Boden. von dem aus eine Epidemie nach Brandenburg, Pommern und Westprentien auszustrahlen ptlegt. Der ganze Osten Heutschlands leidet mehr an Fliegenschäden als der ITesten. Nordwestemropa ptlegt häufiger und intensiver von der hartotfelfänle heimgesucht zu werden als chrer südwesten und Sü̈losten usw.

Nach den hier entwickelten Anschammgen muts einc Behandlung der Epidemien durch die Bekämptimg der zutage tretenden sirmptome die geringste Anssicht ant Erfolg bieten. weil diese symptome eben nur Folgeerseheimmgen von lange vorher liegenden Anfangsitarlien sind. Tremn die Parasiten erst in mgehemer Vermehrmg vorhanden, rrwoist es sich rergeblich, mun die Mikroorganismen abtöten zn wollen, weil kein Insekticid oder Fungieid sie anch nur amähernd der llamptmasse nateh erreicht und noch weniger sie zum Alsterlen loringt. So wis die senchen sich durch alloemeine, im grofien wirkencle Faktoren ainleiten. mïssen sie durch grotse Nittel bekämptt werden, welche hei Parasiten die Existenzbedingungen nuterbinden und die Konstitution. 1. h. die Funktionsriehtumg des Nähroroanismus ändern. Wenn beispielsweise lange Nässeperioden die bakteriosen Kartotfelrotze. die wir als . N a t's fäule" zusammenfassen, in epidemischer Auslreitung auttreten lassen. kam ein anderes Mittel als gesteigerte Bodenelurchlïttung kamm zur Anwendmo gelangen. Soweit es sich um spezifische Anaërobien handelt, wird durch die erhöhte sauerstoffzufinh denselben dor begïnstigende Wachstumstaktor (Sanerstoffinangel bei Kohlensäureäberschuts) entzogen und autserdem ihnen sowie len andern Bakterien rlie (irundberlingmg reichlicher Vermehrmg, der Wasserreichtum, rermindert. In dieser Weise arbeitet anch die Natur im orotisen. Wem nach den Regenperioden trocknes, windiges We tor längere Keit anhält, so dats der Boden abtrocknet und eine reichliche Lutzirkulation sich einstellt, kommen die Rotzerkrankungen von selbst zum Stillstand. Die Empfehlung aller Matsnahmen zur speziellen Beseitigung ron Infelitionsmaterial durch Entfernen rotziger Kartoffeh rom Acker orler tiefes Unterackern oder Verlnemmen von filzkrankem stroh bei retreideepidemien halten wir für Arlseiten, deren Erfolg hedentungslos gexen-

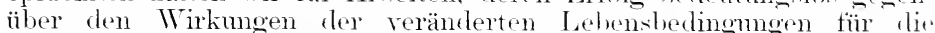
Parasiten sind. Die Nenge des Ansteckungsmaterials kommt bei Erkrankmoen weiter Gebiete gar nicht in Betratht. zmmal hei Rot\% krankheiten Bodenbakterien mitwirken. die einen eisernen Bumbu bestand biklen. Wem atmosphärische Eintlüsse sich in hestimmtrn Böden derart geltend machen, dats gewisso Bakteriengrmpen di. Kartoffeln oder andere Feldfrüchte anzugreifen vermögen. ist ilio \%ahl der ursüunglich rorhandenen Krankheitserreger fast Fedentungsos. 
Die letztgenannten Beispiele betreft's parasitärer Evidemien durch solehe Mikroorwanismen, die im Borlen oder der Luft als stets rorhanden anzmelnmen sind. machen ms aher klar, wie geringe Anssicht anf Erfolg jeglicher Bokimptimg ander eimmal ansebrohenen Epidemie sich hictot. Ein grotierer sihutz mserer hulturn liegt in der vor-

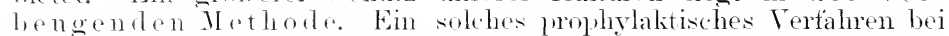
Epidemien kam sich, abgesehen von der Arshildumg der allgemeinen Pfamzenhrgiene. aber daturels einleiten lassen, tats wir eine Topo-

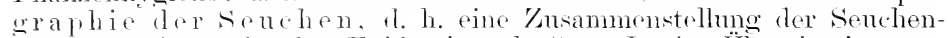
herle tür jede pinzelue Epirlemie shatten. In der Ëbereinstimmung

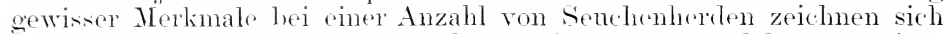
famn einzelne Faktoren als grundlegend für das Kustandekommen einer Epidemie besonders aus. wie z. B. flie Trockenheit bei leichten Bodenarten als begiunstigend für tie Fliegenopidemie bei retreide oder für die Herztäule bei /uckerriben sich arweist nsw. Nach Feststellung derartig wefährlicher. Witterungs- mul Bodenkombinationen für jede einzelne Epidenie wirt man vorlengend dureh Kultumatinahmen eingreifen kömnon, sobald die bethohlichen Kombinationen einige Zeit anhalten. Tirelit parasitentötende Mittel, wis Kup fervitriolhesuritzmoen oder schwetelbestäubmgen. werten nu dam equdemienhindernd wirken, wenn sie vorbengend gebrancht werden.

\section{Künstliche Immmisierung und immere Therapie.}

Es ist naturgemäts, dats in der Phytopathologie sieh derselbe Irleengang entwickelt wie in der Medizin, und lemgemäts nicht auffällig. dats allmählich die Ansicht zutage tritt, die Pflanzen kïnstlich zu immunisieren, d. h. ilne Körperbeschaffenheit oder sättemasse derart zu ändern, dats die Parasiten nicht mehr den erforderlichen Nährboden zur Ansiedlung bezw. zu einer grötseren Ansbreitung finden.

Es liegen bereits melmere Arbeiten in diesor Richtumg vor, bei denen teils, der ser m therapio folgend, Immunisierungstoffe von den Parasiten selbst abgeleitet zur Verwenflung welangten, teils Mineralsalze benutzt wurden. Kur ersteren Richtung wehören die Versuche von Beatrerie ${ }^{1}$ ), der mit Botryt is cimora experimentierte, und von RAY ${ }^{2}$, der die versehiedenartigsten Parasiten in Angrift nahm und zu dem Resultate gelangte, lats die parasitären Organismen sich in künstlichen Kulturen dureh das Nährmedium heeinflussen lassen. Dabei erweist wich ihre Virulenz stets geringer als unter natürlichen Verhältnissen. Durch Anslangen der Kulturon lassen sich Flüssigkeiten gewimnen, die zur Immmisiermog der Wirtspflanze des betreffenden Crganismus rerwendhar sind. Sim schliefst der Autor weiter: die infizierten Pflanzen bilden doch eigentlich anch Kulturen des betreffenden Parasiten: mithin müssen sich durch Verreiben und Extrahieren der erkrankten Pflanzenteile Flïssigkeiten gewinnen lassen, die eine W irkung ähnlich der des Parasiten selbst auszuïben imstande sein werden. WV enn man sie durch erhöhte 'Temperatur' modifiziert, kann man sie zum Immunisieren verwenden.

1) Bracverie, .J., Essai d'immmisation des végetaux contre les maladies cryptogamiques. Compt. rend. Paris 1901. II, S. 107.

2) Rax, J., Cultures et formes attenuées des maladies cryptogamiques. Compt. rend. Paris 1901. II, S. 307 . 
Als Vertreter der andern Richtung der Immunisiermessersuche ist besonders E. Marchal. ${ }^{1}$ ) zu nemnen, der mit Mineralsubstanzen arbeitete, die teils zu den Nährstoffen wehören, teils als Gifte anznsprechen sind. Er säte salat in SAchs seher Nährlösmng mer Zugahe pilztötender Stotfe aus. Die jungen Pflänzchen wurlen nach Entwicklung der ersten zwei lis drei Blätchen mit Zookonidien von Bromia Lartuca infiziert und dam in feuchter Luft erhalten. Dip nicht durch pilztötende Stotte in der Nähstottlösmo immmisierten Ptlanzen wurden alsbald rom Pilze angegriften. Ton den rerwendeten salzen erwies sich eine Beigahe von drei bis vier Zehntansendsteh hupfer. vitriol zur Nährlösmug als dentlich resistenzerhöhent. Eine Beigale von 1/1000 Kuptervitriol zeigte keinerlei immmisiremle Wirkmo mehr. Mangansulfat wirkte weniger vollkommen. Eisenvitriol gar nicht. Anch Kalisalze (bis ${ }^{/ / 100}$ ) vermochten die Resistenz zu erhöhwn, während Nitrate und merkwïrdigerweise auch Phosphate sie verminterten.

Die Idee, dureh Ändermo des Zellsattes mittels Zutuhr fremrler substanzen die Emptänglichleit des Indivilumms gegen pflanzlich.

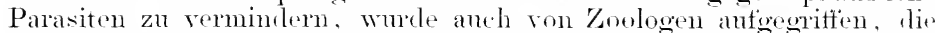

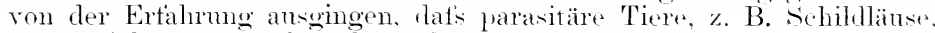
namentlich gern geschwächte Pfanzen antisuchen.

Nummehr war anch der Gedanke nahrgelegt, allgemeine schwächrzustände hei Konstitutionskankheiten sowie Emprainglichkeitszustand. parasitären Angritten gegenüber dadureh zu heilen, dats man salze be stimmter Art dem Ptlanzenliörler extra-rarlical zutïhrte. Diese nicht durch die Wurzeln hesorgte stotfantinahme wurle ,innere Therapie" genamnt und methodisch ansogebildet.

In Jahre 1s:4 verötfentlichte J. sichewrros") einen Artikel: „Ëber die Jomehtränlinng des Holzes lelenter Bämme nit Farbstotflösmgen" mol beschriel, daled die von ihm dazu lionstruierten Apparate. die wir hier als Nähröhre und Nährwanne bezeichnen. Die Röhre ist ron Stahl, an einen Ende zugespitzt mol wird mit diesem Ende in die Rinde eingetrieben, während das andere Ende derselben mittels eines Korkes verschlossen wirt, durch dessen Mitte ein Bohrer hindurehgeht. Die Röhre wird durh besontere öfthungen mittels eines Schlauches aus einem öröseren Behälter mit der Versuchsflüssigkeit getüllt. Hieranf wird ler Bohrer langsam his zu der gewünschten Tiefe in das Holz eingetïhrt, wobei in den so webildeten Kanal unmittelbar nach dem Bohrer Flüssigkeit (nicht aber' Luft) eintreten liam. Der Verfasser, der anch noeh andere Apparate knnstruiert hat, erwähnt hierbei die Versuche Hanurs, die den Nachteil hatten, dafs Lutt in die Wunde eintreten konnte. Er führt sodann Versuche an, die 1s!5, 1s!n; und 19or in der Krim von Gartenbesitzern zur Heilung der Chlorose ausgeführt worden sind.

Später veröffentlichte Moknzecki ${ }^{3}$ ) eine Anzahl nach derselben Nethode ansgetührter, gelumgener Versuche der Heilung der Chlorose an Obstbämmen. wobei er auch hervorhebt, dafs die Sehildiäuse von den geheilten Zweigen verschwuden wären. Er sowohl wie sichewrisor

1) Marchat, E., De limmunisation de la laitue contre le meunier. Compt. rend. 1902. CXXXV, s. 106\%.

2) Iwax Scuewrisw, Berichtigung usw. Zeitschrift für Pflanzenkrankheiten. 1904. S. 70 .

3) Moкrzeкi, s. A., Über die innere Therapie der Pflanzen. Zeitschr. f. Pflanzenkrankheiten. 1903. S. 25\%. 
setzen orotse Hotfinungen aut dieses Terfahren nicht nu betreffs der Hebung konstitutioneller Ernährungsstörmgen, sondern anch bezüglich der Tertreitumg parasitärer oruanismen.

Ich persönlich stehe der Frage kïhler gegenüber und meine, rlafs die Wirksamkeit ler Wethode eine sehr beschränkte sein wird. Nach meinen mit Giften ausweführten Versuchen der Einführumg von Lösmoen in den stamm bleiht die Wirkung immer lokal und strahlt von der Einfïhrungsitelle im besten Falle auf eine Anzahl Äste und eine grölsere stammstrecke hin allmählich ans. Die durch die Wurzelernährumg bedingte Konstitution der Pflanze wird dadurch nicht verändert. Ich salh hei meinen Tersuchen mit Oxalsäure das Entstehen von Gummifluts an Kirschloämen bei einer Anzahl von Ästen, die zum Teil später abstarben: aber in folgenden Jahre ging die Gummose nicht weiter, und die Bäme produzierten fernerhin wieder gesunde Triehe. Ebenso wie diese giftige Lösmng wird anch jede Nährstoffmischung oder ein Heilserum anf enge Grenzen heschränkt bleiben und im besten Falle einen vorïhergehenden guten Einflutis anniben: aber die phrsiologische Arbeitsrichtmog der ganzen Pflanze wird nicht danernd verändert werten kömmen.

\section{i. Prädlisposition.}

Als "Prädisposition" bezcichnen wir diejenigen Zustände, welche gewisse Individuen leichter und schneller einer Krankheitsursache zugänglich machen als andere Individuen dersellen Art.

Dats derartige Fälle existieren, ja sogar die Regel bilden, beweisen die täglichen Erfahrmoen hei dem Massenanhan einer Kulturpflanze. Diese Erfahrungen haben im sprachgebranch bereits ihren Ansdruck gefunden, da wir von zarten und harten Varietäten und von verzärtelten Intividuen sprechen. Die Beobachtmmen zeigen, dats nicht nur die verschiedenen Knlturvarietäten derselben Pflanzenart, sondern anch die einzelnen Individuen derselben Varietät sowohl den Wittermasextremen, wie z. B. Kälte und Hitze, als anch parasitären Angriffen gegenüber eine rerschieden grotse Widerstandskraft hesitzen. In letzterer Beziehung genögt der Hinweis, dats die Praktiker und ebenso anch die wissenschaftlichen Forscher jetzt die Fordermo antistellen, widerstandsfähigere Varietäten zn züchten.

In welcher Weise eine grösere individnelle Genoigtheit, einem prasasiären Angritf zu erliegen, zustande kommt, darüher sind wir vorlänfig mu in der Lage, die Richtnng anzuclenten. Wir haben in den vorigen Abschnitten bereits der Untersuchmoen gedacht. welche zeigen, wie für hestimmte Mycelprilze einzelne stottgrupen, die in der Pflanzenzelle produziert werden, wie z. B. /ucker, in gewisser Konzentration anlockent. in anderer repulsir wirken. Thie Menge dieser Stottomppen wirl von den verschiedensten Faktoren bestimmt. wie wir im nächsten Kapitel norh eingehender zeigen wollen. Je nachdem num die Quantität derartiger stottwechselprorhkte grots oder klein int, wird sie für lic Ernährung eines Parasiten sich begïnstigend, im andern Falle aber moeeignet erweisen.

Um in dieser Beziehung wenigstens ein Beispiel hier anzuführen,

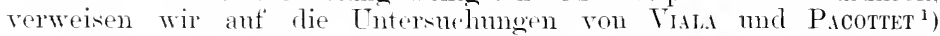

1) Vian, P., et Picottex, Sur la culture du black-rot. Compt. rend. Paris 1904. T. CXXXVII, S. 306. 
über die Blackrot-Krankheit des Weinstotks. Die nit dem die Krankheit erzengenden Pilze Guignardia Bidurllii unternommenen Kulturen stellten fest, dafis die Entwicklnng des Pilzes in erster Linie vom Gehalte les Nährsubstrats an Zucker mnd organisehen sämren abhängig ist. Nur junge Blätter wurden infiziert: sie enthielten 1.7.5 " Weinsäure unt 4,30. Glukose, während die alten Blätter mur Śpmen der genamnten Stotfe erkemen lietsen. Die Beeren waren von der Keit an emptänglich, wo sie zu schwellen hegannen, mnel diese Emptänglichkeit hielt his zmm Begim des Reitestadiuns an. Während dieser Zeit hesatsen sie 32 bis $24^{0} 0$ säme mol 11 his $5 t^{0}$ o Zurker. Während der Reife

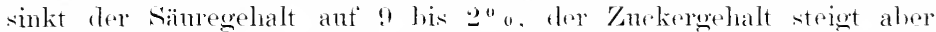
dabei so bedentend, dats nmmehr der Pilz die Beeren nicht anzugreifen vermag. Mit dem Writstänlepilz verhält es sirh dagegen gerade mmgekehrt. Ans diesem Terhalten erklät sieh die antiailig verschiedene Widerstandstähigkeit dor aimzehen Rolsorten. Ehenso erklärt sich der Tmstanel, that's Blacknot-Epidemien im sommer nach Kälteprerioden mit nachtolgenden leichten Regenfällen antizntreten pHegen. In dieser Zeit ist nämlich der Sämregehalt hesomelers grots mol die /uncerlildmog gering.

Ahnliche sehwankungen in der Konzentration rles Wellsattes hilken im Terein mit den Lotkermeserseheinungen der Membranen, den wechselnden sirammngsvorgängen in den feweben mol andern mothamischen Verändermgen anch hie Zuständs qü̈tserer Emptindlichkeit der Pflanzen gegen Wittermasextreme: mil die nenere Forschmng ist bemüht, immer mehr makro- mo mikroskopische Merkmale antzu-

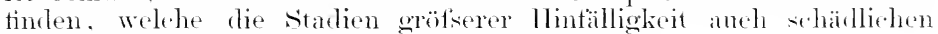
farasitäron Angriffen gegenüber charakterisieren.

Die in dem vorliegenden Beispiele geschilderten Zustände dor gosteigerten Neigmng des Weinstoeks, lem Blackrot-Pilze zugänglith zn sein, sind ganz normale Entwicklungsphasen, die von der Wittermng beeinflutist werden, und wir dïrfen laher solehe Vustände als nor'male Prädisposition ansprechen. Dieser gegenüber wäre als ab. norme Prädisposition der Fall zu moterseheiden, hei welehem die Pflanze oder ein Organ derselben dureh andere Einflüsise bereits in einen Zustand der sichwäthe oder des siechtums geraten ist. mol in

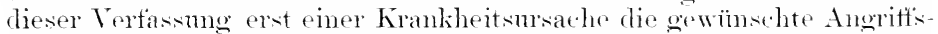
Häche bietet AIs Beispiel erimern wir an die Bosiedlumg honigtankranker Blätter durch tie Sichwälzepilze, an die Angritfe drer sog. schwächeparasiten und die Einwandermng holzzerstïrender s.thwämmo von IVnudtlächen ans.

\section{s. Prädisposition und Immmoitä.}

Wir haben in einem finheren Kapitel bereits herrorgehoben, datis unsere Anschammgen ïber das Zustantekommen parasitärer Erkrankungen eine Entrostütumg von berufenster seite erfahren haben. Metschnikoff ${ }^{1}$ ), der ah Professor am Pasteuk'sehen Institut für Infelitionskrankheiten wohl mbestritten als genaner Kenner der pathogenen Mikroorganismen anzusehen ist, äutsert sich folgendermatisen: ...... Exalito bakteriologische Untersuchungen hahen zu dem Resultat getührt. dats immerhalb der reichen Bakterientlora, wolche der gesmule Mens h lo-

1) Metscinikoff, Immunität bei Infektionskrankheiten. Jena 1902. S. th. 
herhergt, sich auch of die Vertreter der pathogenen Bakterienarten finclen. Abgesehen ron dem Diphtheriehaeillus mol dem Choleravibrio, welche ja so häufig vollvirulent bei ganz gesunden Menschen nachgewiesen worlen sind, hat es sich gezeigt, dals gewisse pathogene Mikroorganismen, ler Pnemmokolkus, die Staphrlokokken, Streptokokkon und ('olibacillon, sich regelmälsio oder fast stets in der MikrobenHora des gesunden Menschen rorfinten.

These Entrleckung hat mit Notwendigkeit zu der Folgerung führen müsten, latis a utser lem Krankheitserreger noch eine zweite Ursache für die Infektionskrankheiten hesteht, nämlich die Jisposition oder der Mangel an Immunität. Ein Individum, welches eine der gonamten pathogenen Bakterienarten beherbergt, bethätigt gegenüber flenselhen eine danernde ofler vorübergehende Widerstandsähigkeit. Aluer sohald die Ursache dieser Immmität schwindet, eroreift der Krankheitserreger die Oberhand um ruft die spezifische Erkrankung hervor."

Betretis der Immunität der Pflanzen erimnert Metschnikof an die von ms bereits erwähnten (Tntersuchungen ron DE BARY ${ }^{1}$ ) über Botrytis, deren Mreel die tallwände zn durchbohren imstande ist, weil es eine Flüsigkeit absondert, ,welche ein rerdauentes Ferment und tie für dies Ferment notwendige ()xalsäme enthält. Das Vorhandensein dieser Art ron Toxin konnte DE B.rs in der Mazeration des Mycels der Srlentimin nathweisen .... Erhitzt man den Saft auf 52 ${ }^{\circ}$, so vermag er the Cellulosemembranen nicht mehr zu verdanen, ist jedoch noch imstande, Plasmolvse helvorzurnfen .... Die Resultate ron DE BARY's Untersuchumgen siml durch LAURent') bestätigt und zum Theil vervollständigt worden."

Wir laben diese Tatsachen mit den Worten Metschnikoffs wiedergegeben, $m$ dessen Anschanmgsweise zu charakterisieren. Der hier in Betracht kommende Hauptfaktor, nämlich die Wirksamkeit des Fermentes gegen jugendliche, seine Unwirlisamkeit gegen alte Membranen, wibt dem Vertasier Veranlassume zu dem Veroleiel der BotrytisErkrankungon mit den Kinderkrankheiten bei Mensehen (Masern, Scharlach). Älublich den Memhranverändermeng bei dem Altern der Zellen wirken in andrun Fällen die versehiedenen Verkorkmos- und Korkbilhungspozse, wie sie beispielsweise hei Wunden gefunden werden. Betroffs dieser helet Metsenvikoff, gostützt auf Untersuchungen von MAssatit ${ }^{3}$ ), hervor, tats die Orome je nach ihrem Alter verschieden auf len trammatisclien Reiz antworten. Junge Blätter von Cliria z. B. reagiren durch Callusbildmng. ältere mit einfachem Wundrehlufs durch eino Korklage. Writere schntzmittel bilden (̈le. Harze, Balsame, Milıhsäfte und (xummiharze, die hei Velwmrlungen austreten.

Eingehent hehamblt dre Terfasser die Studien von Lavkese ${ }^{4}$ ). wellhe im zwriten Teile dieses Werkes hei den Bakterien sich wieder 'rwähnt finden. An diestr Stelle wollen wir aber die Immunitätsvorrichtmorn genen hakteriolle Angriffe besonders betonen. Die Art res Colibarilhs, mit der Laukent arbeitete, scheidet ein die Cellulose der Kartoffelknollen lïsendes Ferment aus mol produziert anderseits

1) DE Bisir, Bot. Teit. 18tit.

2) Lampexr, Annal. de I'Institut Pismin. Bd. XIII, S. 44.

3) Massur, La eicatrisation chez les plantes. Brüssel 1897.

4) Lirnwr, Recherehes expérimentales sur les maladies des plantes. Annal. de l'Inst. Pistrir. Cit. Zeitschr. f. Pflanzenkr., 1900. S. 29. 
einen alkalisch reagierenden Saft, dessen Anwesenheit zum Zustandekommen der Verlaumg seitens der Baliterien nötig ist. Nun ist zwar Bacillus coli communis von Natur aus kein Pflanzemparasit : er läist sich aber in einen solchen verwandeh. Dies geschieht, indem man ilm zuerst auf Kartoffeln kultiviert, deren Widerstandskaft dureh Eintanchen in alkalische Lösmgen geschwächt ist, mo ihn dam aut diesclhe Kartottelsorte ïberträgt. Der Kampf zwischen Colibacollus und Kartoffel beruht also eigentlich anf ther clemischen Wirkung der alkalischen Sekrete des ersteren regen den samen Zellsatt der Kartoffel. Nach einer Düngme mit Kalisalzen nol Phosphaten widerstanden Möhren und Kartofteh den Bacillus. Dagenen zeigte eine Phosphatelüngmo bei Topinambur, dats diese num empfindlicher groen einen Mrcelpilz. die Botrytisform der Srlontinin Libertimin. wurde.

Ebenso deutlich zeigt sich der Einfluts starker stickstottilungung in einer Vermindermg der Widerstandsähigkeit der Kartotfeh nach unsern Beobachtmoren gegenüber der Nalstäule. Reichliche Dünomg mit Nitraten, Ammoniaksalzen ofler stallmist lätst selbst lie widerstandsfähigsten Sorten der Kartoffeltänle erliegen. Lablient erklärt sith das verschiedenartige Terhalten der Parasiten gegeniiber derselhern Döngmo daduch, dats hei den Bakterien das answeschiedene Ferment die Zelhmembran nur in alkalischen oder schwachsamen siatten anzugreifen vermag. Eine gesteigerte Acilität des Zellsattes. wir solche durch die Bilding saurer salze intolge der Phosphatelüngmen angeregt wird, macht die Pflanze diesen spaltpilzen gesenüher num immmn. Dieselhen Ergehnisse hetrett's der schützenden TVirkmg der Phosphorsiunte erhielt ich hei loüngmusversuchen mit Zuckerrähn, lwi denen Burillws

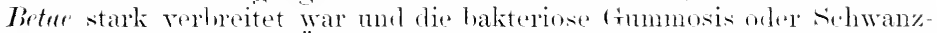
fäule hervorrief. Das Überhandnehmen der Bakteriosen bei reichlicher. Anwendung von stickstoffhaltigen Dïngemitteln liefse sich in der Weise erklären, rlats die Acidität des Zellsattes dadureh verringert wird. Für die sclerotinia liegen die Verhälnisse (nach oE Bdry) gerade mongekeht. Das Ferment lerselben verdaut die Kellmemliran nur in samer Flüssiokeit. Ähnlich diurten sich die meisten Mrcelpilze verhalten.

Wem im rorliegenden Beispiel in der wechselnden Beschaftenheit des Zellsaftes hald ein Immmitätstaktor, halı ein zu prasitärer Erkrankmo disponierender Umstand ms entgegentritt, so worden wir durch Merschisoff (a. a. O. S. 30) aut einen weiteren Torgang lingewiesen. Er eitiert die Untersuehungen von va Rrselberihe i), der namentlich bei Epidermiszellen von Tirdescantia fand. lat's dieselben. in eine konzentriertere als die bisher gewohnte Lösmngelracht, eine steigerung des intracellularen Druckes zeigen: bei tem umgekehrt angestellten Versuch nimmt der Druck ab. Diese Veränderumgen des osmotischen Iruckes werden durch tie Verschicdenheit ter Konzentration des Zellsaftes verusacht. mol diese ist wiederm als di. Folge chemischer Teränderungen anzuselen. Kommt dir Zelle mit einer zu hoch konzentrierten Lösung in Berährung. so libldet sir Oxalsäme, welche stark osmotisch wirkt. Im nomalen Satte wirs

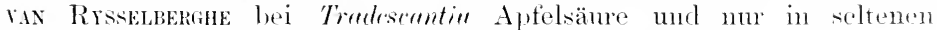
Fällen spuren von Oxalsäure nach. Nach mehrtägigem Liegen des Pflanzenteils in stark konzentrierter Rohrzuckerlösmg fand sich (1)al-

1) Osmotische Reaktion der Pflanzenzellen. Mémoires couronnés de l'Academir r. d. Beigique. Brïssel 1899. 
säure in deutlich wägbaren Mengen. Demnach patst sich die Pflanze lor höhern Konzentration ihres Jedimms an und produziert Oxalsämre, um den Druck des Zellsattes zu steigern. Termutlich hat sich die sänre anf'Kosten des Trauhenzucker's gebildet. Der gesteigerte säuregehalt wird als schutzmittel gegen hakterielle Angriffe wirken; er wird seitens mehrerer Forscher anch als Alwehmittel gegenüber den Angritfen rom schnecken und Blattläusen gedentet.

sichr bedentsam erscheinen uns die Fersuche mit Tradescantia in mmgekehter Richtung. Wenn man fewebe dieser Pflanze ans einer hochkonzentrierten Lösmng in eine stark verdïnnte brachte, so wurden in Zellsatt Niellerschläge von Kalkoxalatkristallen beobachtet, wohurch eine Vermindermo des osmotischen Druckes eingeleitet worde. Bei dem Zurückbringen des Pflanzenteils in eine stärkere Lösmng sah man infolge ernenter Sïnrebildmo die Oxalatkristalle sich wiederum l̈sen. Ith sah bei dem Austreiben der Kartoffelknollen einen Teil des Kalkoxalatsandes verschwinden, was wohl anch der gesteigerten säurehildung zugeschrieben werden darf.

Dhese Selbstreguliertung des Sämegehaltes bohandelt anch Pfrffer ${ }^{1}$ ), indem er daraut autinerksam macht, dats durch die an Basen gebundenen organischen sämen doch vielfach der 'Turgor erzengt wird. Da sich derselbe während und nach dem Wachstum konstant erhält, muls mit der Volmmzmahme der Zelle und der dadurch erzielten Verdümmng des Zellsaftes die säurebildung in entsprechendem Matse beschlemigt werden. Jede antsergewïhnliche Turgorsteigerung, wie z. B. bei dem Arbeiten gegen Wirlerstände, wird dementsprechend eine Vermehrma der säureproduktion in sich schlietsen. Umgekehrt ist z. B. bei Crassulaceen eine Terminlermng des sämregehaltes hei Temperaturerhöhumg und durch die Belenchtung nachgewiesen worden. Gleichsimnig mit (liesen Resultaten sind die von Снававот und Невект ${ }^{2}$ ) erlangten. Im Schatten whehs die Menge der zusammengesetzten organischen säuren sehr wesentlich. Anch die freien flüchtigen sämren erfahren eine steigermo. Der Gehalt an diesen ist in etiolierten Ptlanzen grötser als in andern. Die Unterdrückmng der Inflorescenzen vermeht ihn in den Blättern ant Kosten der andern Organe.

Für msere Betrachtungen ïher die Prädisposition und Immunität haben wir als Beispiel autier dem säuregehalt noch den Zuckergehalt herbeigezogen. Welchen Schwankmgen derselbe schon durch den Temperaturwechsel ausgesetzt ist, geht am besten aus den von Pfefrek (Phriologie I, S. 514) citierten Untersuchungen von Fischer ${ }^{3}$ ) hervor. Bei den sogenamnton Stärkebämmen, wie Linde und Birke, sieht man bei dem Überführen von Zweigen im Winter aus dem Freien in das warme Zimmer, dats sich bimen wenigen stunden in der Rinde stärke hildet, aus drer in der Kälte wieder Zucker entsteht. Durch den Wechsel der 'Temperatur lälst sich diese Tmwandlung wiederholt herbeiführen. Und eine derartige Znckerliblung scheint bei vielen Pflanzen durch Temperaturerniedrigmo einzutreten. Wenn num durch irgendwelche Ursachen der aus der Stäke rebildete Zucker aus einem Organ abgeführt wird, kann das gesante Gewebe verarmen. Einen Beweis da-

1) Pflanzen ${ }^{2}$ ysiologie, II. Aufl., I. Bd. s. 487.

2) Cmanar, Eic, et Hemar, Recherches sur l'acidité végétale. Compt. rend. hebd. 1904. CXXXVIII, 1714.

3) A. Fiscuer, Jahrlb. f. wiss. Bot. $1 \varangle 91$, Bd. 22. 
für liefert PFEFFer durch die in semen Institut answeführten Versuche von $\mathrm{Hansteen}^{1}$ ) und Puriewitsch ${ }^{2}$ ). Es gelang nämlich, durch danernde Entführung des diosmierenden Zuckers die isolierten Endosperme von Gräsern sowie die alggetremten Kotyledonen von Plussolus usw. zur Entleerung der stärlie, die cinzelne Zwiehelschuppe von Allim Cepa zur Abgabe der Glykose zu bringen. Wemn nur wenig Wasser vorhanden war, in das der Zucker ans den Gronen ühorgehen komnte, trat alsbald stillstand in ler Entleerung ein, weil schon cine zwei- his dreiprozentige Znckerlïsmng die stärkemmwandlung sistiert. Es mufs also viel Wasser vorhanden sein oder sonstige Ableitmng sich bieten. wenn die Entleerung vollständig sein soll. TWurle die Zuckerlösmng noch konzentrierter den Organen dargeboten. komnte umgekehrt eine Wiederanfüllmng derselhen mit stärke festerestellt werden.

Liese Beispiele mögen gen̈̈gen, um zu zeigen, wie im Pflanzenleibe sämtliche stotfwechselvorä̈nge und infolge dorselben sïmtliehe Aufbauprozesse heständigen quantitativen Ändermugen muterliegen, die von dem ersten Angriffirmukte eines die Ändermg veranlasisenden Faktors nach allen Seiten hin ansstrahlen. Jede lokal auftretend. Ändermo ist eine störung des hisherigen Gleichowichtszustandes in der moleknlaren Lagerumg. Wenn die Störmg sich in einer Zelle vollzieht. muls sie, sowrit diffusible stoffe in Betracht lommen, in die Nachbarschaft sich fortpflanzen. wie alle dynamischen Vorgünge.

Jeder Ort, an dem ein Neuban sich vollzicht. ist rin Terluranchszentrum: die Stoff'zufuhr nach dem Neuhan tühlnt zur Entlecrumg anderer (̈) rtichkeiten. Jerle lokale steigermug in dor Photosinthese iibt ihre Wirkmo ant die zmächst mbeteiligtr. Thomelmong ans. - Und mm wirken ummiterbrochen die einzehen TFarhstmofiktoren aut den Pflanzenleib ein und stören die angenhlickliche (ileirligewichtslage bald in dieser. bald in jener Richtung. Tir halen also ein tortwährendes Hin- und Herfluten aller Lehensworgänge vor ms, das noch verstärt wird durch die eigne Reaktionsfihigkeit des Individnmms. Denm wir dürten nicht vergessen, dat's zur Herstellung dos gestörten (ileichgewithts der Oroanismus bemïht sem wirl, seine Produktion an einzehen stoffen zu steigern. Wem z. B. eine dmeh die Emährmy bodingte Vermehrmo hasischer Verlindungen sich einstellt, wird ein erhöhter säuregehalt herleigefïhrt werden müssen und mongeliehrt. Tnd imerhalb rieser notwendig sich ergebenden fortrlauernden s.'.hwankmngen liegen die Znstände, dic wir als normale Prädisposition bezcichnen. Dabei kam derselhe Zustand, der ein Hinfälligheitstatium einer bestimmten Krankheitsursache gegenïber dastollt, oiner andern Erkrankmosursache gegenüber sich als Inmmitässtadium betätigen. Beweise dafïr lieten die angrtühnten Beispiele einer Mrveracidität des Zellsaftes, die immmisierend gegenüler gewissen Baliterienangriffon und prädisponierend tür Mrcelpilze sich erwiesen hat. In den vermehrten Zuckergehalt. verliunden mit dem turgorsteigernden Einfluts ler säure, erkemnen wir einen prärlisponierenden Znstand für Frostbeschädigmoen und andicrsits ein Torbaumittel gegen die störenden Einwirkungen der Trockenheit nsw.

Wir haben also in der ganz natürlichen Entwicklung des Organis mus fortwälnend Prädispositions- mol Immmitätsmstände vor uns. Dir.

1) Haxseex, Flora, 1\$94. Ergänzungsband.

2) Prinewriscu, Ber. d. Deutsch. bot. Ges., 1896. S. 207. 
selben sind in jedem Individum in resshiedenem Grade rorhanden, da jeder Organismus spezielle Emährungsverhältnisse hat und dieselben Tachstumstaktoren verschieden rerwertet. Daraus erklät sich die Erscheinung, dats einzehe Individuen mitten in einer Gesamtheit derselhen Art erkranken oder mmgekehrt mitten in einem Erkrankmoszentrum gesumd bleiben ${ }^{3}$ ).

\section{Erblichkeit der hrankheiten und der Prädisposition.}

In den letzten vier Jahrzehnten sind von einer gröfseren Anzahl bedentender Forscher woitere Torsuche gemacht worden, das Wesen der Frblichkeit theoretisch zu erklären. Nam hat dabei als Träger der Verrbmestähigkeit die jugendlichsten Zustände, das embryonale Plasma". Tresonders ins Ange gefat'st, und zum Teil in den Zelliernen eine substanz wesucht, wolche als bevorzugter Träger der Vererbungstähigkeit anzusmechen wäre.

Die erwähnten Hypothesen der Biologen wurden besonders zur Erklärung der Wierlerholung der Gestaltungs'orgänge in den anfeinanderfolgenden Gemerationen der Organismen aufgestellt. Wir erinnern nu an die Donwn'schen "*emmulae", an die "Plasticlulen" von HaEckel, an tas .Keimplasma" von Wessixs, an ein Ahnenplasma, an das Idioplasma ron Nïgen, an die Pangene von Le Tries nsw.

Nach unserer Auffassung bedarf es zur Erklärung des Erblichkeitsvoranges weder ciner besondern Lokalität, wie etwa der embryonalen Zellen, noch einer besondern Keim-oder Erbmasse oder eines Ahnenflasmas: dem die Erblichkeit ist ein "mechanisches Mufs", eine notwendige, ïberall vorhandene mechanische Folge der Struktur der organischen Substanz.

sobald man dic organische Substanz ebenso wie die anorganisele als eine Atomveremigno betrachtet, die ihren Charakter, also ihre spezifischen Eigentïmlichkeiten dadurch erhält, dafs die Atome in den Nolekülen in rersehiedenartiger Lagerung mol Sehwingmussorm sich

1) Die jetzt herrschende Parasitentheorie bleibt entweder eine Erklärung dieser Tatsachen schuldig oder beschränkt sich auf die Giftfestigkeit. Die verschiedene Viderstandsfihigheit den Witterungsextremen und andern nichtparasitären Einflüssen gegenüber bleiht mberücksichtigt. So erwähnt Atraku Fiscuen *): „Freilich kommen individuelle schwankungen genug vor, auch beim Menschen; eine persönliche Immunität mnerklärlicher Art, die zum Teil unter den Begriff der Disposition fällt, seheint zu bestehen. Auch mit dem Alter ändert sich die natürliche Immunit:it, wie die Kinderkrankheiten zeigen. (O) diese selbst nicht als Immunsierungskrankheiten, die den jungen Erdenbürger für das bakterienumgebene Dasein vorbereiten und festigen sollen, aufzufassen wären, mag unerörtert bleiben."

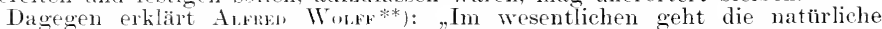
Widerstandsfähigkeit gegenüber Toxinen froportional der Fähigkeit der Organe, die Ciftmoleküle an sich zu ketten und an der Einwirkung auf das Gehirn zu verhindern. Zwischen den scheinbar so diametral entgegengesetzten Phänomenen der angebornen Tnempfindlichkeit und der hochoradigsten Empfänglichkeit einzelner Tierkörper hestehen somit nur quantitative, keine qualitativen Differenzen; diese beruhen allein in der verschiedenen Fähigkeit der Organe der einzelnen Tierspezies, Toxine zu binden und eventuell zu neutralisieren."

*) A. Fromer, Vorlesungen über Bakterien. II. Aufl. S. 347. Jena, Gustav Fischer. 1903.

**) A Artien Worrf, Uber Grundgesetze der Immunität. Centralbl. f. Bakteriologie, Parasitenkunde usw. I. Alt. Originale. Bd. XXXVII. Heft 3. S. 701. 1904. 
vorfinden, dann stellt alle Substanz den cileichgewichtszustand bestimmter Bewegungstormen dar. Wenn man auch nicht die wnzähligen Kombinationen der molekularen Sthwingungen präzisieren und nicht die aus den versthiedenen Lagermosverhältnissen sich ergebenden Spannmgen und anderweitigen methanischen Folgen konstmieren kann, so dart man doch jeclen organischen Authan als die Folge einer Summe ganz bestimmter, einauder bedingentrer Kombinationen molekularer Bewegungen bezoichnen.

Demgemäts ist das Plasma einer Birne zwar ein Plasma, dessen einzehe Micellen die molelunlaren Sichwingmestormen der plasmatischen Substanz im allgemeinen anfweisen, aber doeh spezifisehe S.thwingmesund Lagermosverhältnisse hesitzen, welche sie von don gloichsitnierten Micellen des Aptelplasmas nuterscheiden. Also in jerlem kleinsten Teilchen, in jedem Biogen ilgend eines organischen Individums ist ein individueller (charakter zu finden. der als der Ausdruck einer summe bestimmter Beweoungsformen intolge des Beharrungsvernögens konstant bleiben muts.

Diese Beständigkeit ist ane mechanische Notwendigkeit: dem eine jede Bewromng verhart in der vorhandenen Form so lange. bis eine andere Krattäulserung sie modifizieren wird, und jede substanz, die doch der Ansdruck mind Träger der Bewegung ist, verhart in ihrer Form und ihren Nerkmalen, his antere Einwirkmngen moleknlare Umändermongen veranlasien' ${ }^{\prime}$ ).

Aber wem wir z. B. rom Protoplasma sprechen, mïssen wir uns bewntst werden, dats wir rlamit nicht eine emlieitliche, chemisch test charakterisierte Substanz, sondern eine grotse, zahlreiche Formen ent-

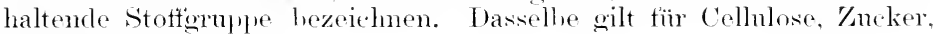
Gerbsänre usw. usw.

Die Annahme so zahheicher Substanzvariationen als es Indivirlnen gibt, verliert das Befremaliche, sobald wir 1 s erimnern, datis wir täglich die gleiche Anzahl frestaltsvariationen 10 ms sehen: demn tatsächlich gleicht roch kein Individum vollständig einem andern.

Wem aber jedes Bingen cine spezificthe Einheit ist, so behält es (immer mer der Voranssetzung, dats lin von antisen kommenter Stot's seine Molekularormprierme ändert) seinen Charakter bei, gleichviel wo es im Pflanzenköryer seimen Platz hat, und ol es als Celluloseform oder als somatisehes oder embryonales Plasma auftritt; denn alle diese substanzen sind ja nur anseinander hervorgehende Gruppiermusformen. Die Biogene, wolehe hei dem Aufban des Embryo, also dem Anfang der nenen freneration. Terwendung finden. bringen somit die sehwingungsformen. die sie repräsentioren, in dem nenen Individmum so gut zum Ausdruck wie in lem alten. l)ieses Beibehalten ter molekularen Bewegunostom in der neurn Genration ist Erblichkeit. Und wir sind anch keineswegs erstamt, ans dem Mohrübensamen wieder Mohrübensulstanz hervorgehen zon sohen. Wir sind anch nicht erstamit, ans der zurkerredehen Karotte wieder sine Karotte und nicht eine stärkereiche Futtermöhre entstehen zu sehen. Es ïbertragen sich somit ancli diejenigen substanzkombinationen, welehe die

1) Diese Anschaumg von der sipezifität eines jeden Biogens von jeglichen Organismus hat bereits Nou, ausgesprochen, inden er angifit, dafs die Eizelle einer Linde in ihrer Totalität eben schon eine Linde ist und nichts anderes sein und werden kann. - Nou. Beobachtungen und Betrachtungen über embryonale Substanz Sond. ${ }_{n}$ Biolog. Centralblatt", Bd. XXIII, Leipzig 1902. s. 925. 
charakteristischen Eigenschaften unserer Kulturvarietäten darstellen. Wem wir in rraktischen Betriebe die beitlen genannten Möhrenvarietäten neleneinander anbauen wïrden. hätten wir Gelegenheit zu beobathten. Jat's hei Eintritt gewisser Frostgrade die Karotten anfrieren, währent die Futtermöhren noch mbeschädigt bleiben.

Lie Kältempinflichleit der Sulstanz einzelner Varietäten derselben Art ist das leichtest zu heobachtente Beispiel der Erblichkeit solches Eigensehaften, welche eine Prätlisposition für Erkrankungen darstellen. Joder (O)stzüchter ist imstande, (1)stsorten zu nemmen, die bei ihm durch den Frost beschädigt werden, wälrend andere, danebenstehente Sorten gesmul bleihen. Unter den Florlshmen zeigen sich diesellien Verhälnisise. und bei den Getreidearten ist es eine allgemeine Erfahrung, dafis z. B. unter den Weizensorten die squarehead-Formen am loithtesten answintern.

Dirselbe versehiedene Widerstandsfähigkeit der einzehnen Kulturvarietäten finden wir anch andern Krankheitsursachen gegenüber, wie z. B. gegen Wärmeüberschuts und Trockenheit, gegen Wasierüberschuts usw. An den Kulturvarietäten ist ungemein viel $\mathrm{zn}$ lernen, und ihr Studium verdient grölsere Beachtung, als ihm bisher zu teil geworden ist.

So liefert die Kultur uns eine Zierpflanze, den Hahnenkamm (Colosia cristutu), der einen stengel besitzt, desisen Vegetationsseheitel eine breite. mamigfach gewmolene Fläche darstellt. Diese bandartig breite Umformmo des usprünglich cylindrischen stengels (firsciatio) ist samenbeständig geworden. Die gefüllten Blüten erhalten sich von einer Generation zu andern. Sehwächliche orler einseitige Ansbildung von Sexnalorganen kann zur erblichen Eigenschatt werden, wie z. B. hei der schwarzen Johamisbeere, bei den Erdbeerkulturen im Alten Lande bei Hamburg usw.

Ans solchen Beispielen erkemnt man, welche tieforeifenden Aländerungen vom gewohnten Entwicklungsmodus durch den samen äbertraghar werden. Jerle Abändermo berlentet einen Stots anf eine hisherige Eigenschaft, der so stark gewesen ist, lats er dieselbe danernd zu epshüttem remochte. Die Eigenschaften res Organismms besitzen eine verschieden grotise stabilität, d. h. die Bewegungsform, die sie repräsentieren, ist manchmal lureh einen schwathen stots zu irritieren. währent sie in andern Fällen dureh die stärksten Eingriffe der nmgelenden Wachstmmstaktoren nicht verändert werden kann. Zn den äntierst locker fixierten Eigenschaften gehören die Blütenfarbe, der Wasser- unı Zurckrgehalt. die Grötsenverhältnisse der Organe, die sehon mit tem standort wechseh kömnen. Am schwersten zu erschüttern sind die Stellungsrorhälnisse der Organe und die Zusammensetzung tler Biogene, 1. h. ller substanztypus, welcher eben die Substanz eines Kohlkopfes ofler eines Birnbaumes als solehe unterscheidbar von der anderer Pflanzen machen. Als unerschüterlich ist keine Eigenschaft eines Groanismus anzusehen: aber eine Anzahl Eigenschaften werden sich von fienoration zu Generation in der bisherigen Form erhalten. weil kein Stotis ron genügender Stärke zurzeit vorhanden ist, der an ihnen rüttelt. Tlejonigen Eigensehatten aher, welche den in der Jetztzeit vorhandenen Faktoren zugänglich sind, werden je nach der Kräftigkeit lles Eingritt's den stötsen erliegen und sich ändern kömmen. und diese Ändermgen sind, eben weil sie molekulare Umlagermoen hedenten, als schwingmusformen so lange infolge des Beharrmgsvermögens konstant, his nene Stötse eine nene Bewegungsrichtung ein- 
leiten. Sie erhalten sich auch in der Organform, die wir Samen nemen. und müssen demgemäls in dem nenen Individum sich fortsetzen, also erblich sein. Es werden mithin anch zweckwirlrige Znstände, also solche, welthe die Abkïrzung der Lebenstaner des Individumms einleiten, wie z. B. geringere Festigkeit der substanz, erblich sein, und in diesem Sinne wird man mit einer Erblichkeit der Krankheiten und der zu einer Erkrankung besonders geneigt machenden Zustände (Prädisposition) rechnen müssen.

Neben der [̈bertragung derartiger phrsiologischer, eine Erkrankung fördernder Eigensehaften des IVirtsorganismus von einer freneration auf die andere ist in nenerer Zeit noch die Möglichkeit einer Verplnmw von Parasiten durch die Samen der WVirtsphanze diskutiert worden. Enskson ${ }^{1}$ ). einer der hervorragendsten Forseher auf' dem (rebiete der Rostliankheiten, beschreibt in seinen Arbeiten eine Anzalıl Zustände bei rostigen Getreideblättern, welche ihn zu ler Ansicht geführt haben, dafs bei den Rostpilzen embryonale Entwicklumgstarlien existieren, in denen die Pilze als nacktes Plasma (Mrkoplasma) mit dem Plasma der Wirtszelle vereinigt autreten. Derartige symbiontische Zustände kömen bei der Ausbilinng des samens vorhanden sein und als rulender Keim der Rostkrankheit in der nächsten Generation sich vorfinden. Bei Wittermesverhälnissen, welche der Pilzentwicklung gionstig sind, kommt dam die Rosterkinkmo durch die erblich äbrenommenen mykoplasmatischen Anlawen in fler bisher hekamnten Form zum duslincheli.

Die anferordentliche schwierigkeit der Frage hetretfis der Existenz von Parasiten in einem Mrkoptasmastadium hat hisher verhindert, ein frstes Urteil äber die Ekikssosschen Ansichten zu gewimnen. Wenn anch die Möglichkeit mykoplasmatiseher Zustände zugegroben werten muts, glauben wir persönlich doch, dats die sicherlich richtigen Beobachtungen von Erikssos anch noch eine andere Dentung zulassen, da die geschilderten Formen bisher immer nur in der Nähe answebildeter normaler sporenlager gefumlen worten sinul.

\section{Degeneration.}

Von Zeit zu Zeit tritt, namentlich in praktischen Kreisen, die Behauptmo allgemeiner herror, dats msere Kulturpflanzen degenerieren, 1. h. in der Q quantität mul qualität ihres Ertrages nachlassen mod in einzelnen Varietäten schlietslich aussterben. I)er Tod derartiger, lange gepflegter Kulturformen, der gleichzeitig an den rershiedensten örtichkeiten eintreten soll, wird vicltach anf Altorschwächo zurückgeführt, indem man hehauptet, dats anch diejenigen Formenkreise, dir Wir als sorten oder Varietäten zu bezeichnen pflegen, ein hestimmtes Alter wie die einzelnen Individuen nicht zn ïherschreiton remü̈gen. I) Ansehanme stïtzt sich namentlich ant msere Ohsthäme, deren

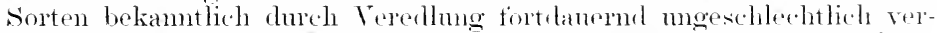
mehrt werden. Solehe sorten stammen in der Regel von einem einzigen, in einer hestimmten fregend gezüchteten Individum, dessen Zweig. alsbald als Edehreiser in allen Ländern Verbereitmo finden. Man neint mm. datis alle dureh mogeschlechtliche Vermehrmes entstantenen Individuen doch eigentlich nur die Fortsetzmog des zuerst ans simm

1) S. Literatur in ..Zeitschr. f. Pflanzenkrankh.", Jahrg. 190:: u. 1904. 
hervorgegangenen Bammes darstellen: da mu jedes Individum seine Lebenslaner hahe, so müsse anch dieses vielköptig gewordene Individumm, das wir .. sorte" nemen, nach einem bestimmten Zeitram dem Tode verfallen. Larans erklärs sich die üherall gleichzeitige Erbranlinng und das Ansiterhen manther sorte. Als Beispiele dieser Art werden angetïhnt: Gold-Peping mul Borsdorfer, zwei Apfelsorten, üher deren Degeneration in den siebziger Jahren des vorigen .Jahrhundelts cine eingehende Literatur entstand $\mathbf{I}$ ).

Auch andere alte Olstsorten (namentlich Äptel) sollen überall gleichzeitig an Unfruchtbarkeit leichen, kebsig werden und absterhen. Kartoffelvarietäten. welche früher als vorzüglich allgemein anerkannt wurlen. hewähren sich jetzt nicht mehr mol verschwinden rom Markte. Die Grangenbäume. welche früher in den Gärten Europas in äulserst liräftigen, alten Exemplaren zu finden gewesen, kranken allerorts trotz der besten Pflege. Tnd die berühmten Orangerien von Sanssonci, Dresden, Kassel, Tersailles usw. sind versehwunden oder nur noch durch wenige, oft kränkelnde Stämme vertreten. Ja, selhst in Italien sind weite Anpflanzmngen von Citronen- und Orangenbämmen von vorläufig mheilbar erscheinenden Krankheiten ergriften. Ursache soll oine allmählich in zmmehmendem Matse sich geltend machende Schwäche des Wuchses mit Erkrankmo des Wurelkörpers sein. Tom Weinstock und G̈lbamm. der Granate, den Eriken des Kaplandes, den anstralischen Schmetterlingsblütlern and Nrrtaceen, die frïher als .Nenholländer" in besondern Glashänsern den Schmuck und Stolz der Gärten bildeten, lätst sich dasselhe hehampten. Und selbst bei msern Getreidearten bemerkt man das Terschwinden der guten alten śorten. so surechen die Vertreter der Degenerationstheorie.

I) Anschanmg von der Kontimnität eines Indivichums rturch alle Edelreiser, denen dam die Unterlage oder der Mutterstamm gleichsam nur als Amme rlient, hat als Basis die Voranssetzmng, dafs diesos Individum während der ganzen Daner seiner Sortenexistenz in allen fiegenden mol anf den versehiedenen Teredlungsmterlagen alle seine Charaktere mrerändert beihehält. Dem in dem Angenblick, wo zugegeben werden mülste, dafs der einzehe Standort oder die Art des Tildlings einige Eigenschaften ändere, mülste auch die Möglichkeit eingeränmt werden, dats die Höhe des Lebensalters durch Ernährumg geändert werden kömnte.

Darmm behampten anch die Verteidiger der Degeneration und der Theorie ron den teststehenden Lebensaltern der Varietäten (unter den Botanikern namentlich J Jssex) die stabilität der Charaktere mr stützen sich eben daranf, daf's der siortencharakter durch Samen und durch Stroklinge, sowie durch Veredlumg stets derselbe bleibe. Zn den beliebten Beweisen gehören die Fälle, wo bestimmte Zweigahweichmoen, die hei einem Exemplar entstanden sind (Buntblättrigkeit. Kershlitztblättrigkeit, hängende /weigformen, Verbändermugen nsw.) stets in derselben Form durch Veredlung anf nene Wildlinge übertragen werden kömmen.

Derartigen Angahen stehen in erster Linie die stets zahlreicher

1).. Wearing out of varieties." Gardeners Chronicle 1875. ,Varieties do the wear out?"* ibid. "Degeneration durch Altersschwäche“ in The Fruit Manual 1875. .Golden Pippin degenerated" in Gard. Chronicle 1875. Vergl. Bericht über die Verhandl. d. Sektion für. Weinban in Trier 1875 usw. usw. 
werdenden Ptioptergebnisse gegenüber. welche die gegenseitige Beeinflussung und Abändermg der durch Pfiroptung miteinander verbundenen Individuen zeigen. Man weits, dats eine Form der albicatio, also Weilslaubigkeit, die wir etwa als .marmoriert" hezeichnen kömnen, vom Edelreis anf den Wildling ïlertragbar ist. Man kemnt die Unterschied. in der Entwicklmng cines Edelreises, je nachdem os ant Zwergmnterlage oder Wildling veredelt wird. Ehenso reichlieh sind die Beispiele der Verändermgen der Früchte in Grötse. Ban. Färhme und Geschmack je nach standort mod Klima.

Endlich vergesse man nicht dic Ertahrmes dats moter grotsen Anssaaten unserer holturvarietäten wir stets solche finclen, die .sich nicht halten". d. h. die von Golmt ans ein derartig selwächliches WVachstmm zeigen, dat's sic hald wieder aus der Kultur verschwinden. Das hedeutet ein Aussterlen ganz junger Varictäten: hier fällt also die Senilität als Trsache gänzlich fort.

Was num die Behanptung anbetrifft, dafs hochgeschätzte Obstsorten tiöherer Zeiten jetzt nicht mehr gedeihen wollen und gleichzeitio allerorts ansterlhen. so ist es interessant, einge Mitteilmoen ans der Zeit. in welcher die Ilegenerationsfiage anf der Tagesorthmo stand. gerarte äbre cinige als ansiteluend hezeichnete Obstsorten zu erhalten. Honi veröffentlichte im .. The Frut Mamual" 187.), dats über den ..Engliswen fold-

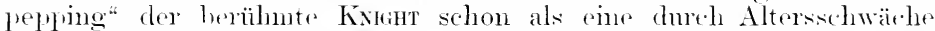
ansartende sorte soklagt habe. Von dem . Kentish Pippin" hale

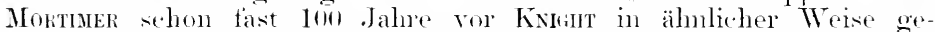
sprochen. Beide sorten sind alser noch jotzt in gesunden Exemplaren in England vorhanden. Tie langlohig (sagt Howi) mol kräftig Kultursorten sein kïmen. beworise die "Winter-Peamain", wolche als die alteste englisehe Aptelsortr anzusehen sei, da sie sohon mm das . Iahr 1200 in sehriften genamnt werde. Seln alt ist anch der Borstorfer Apfel und die ïherall liekannte Pflamme "Reine Clancte", welche nach Bolle (cit. Oberderk, Pomolog. Monatshefte 1ris, s. 240, Borché und Bolle, Monatssehrift d. Ver. z. Beförd. d. Gartenb. 187., s. 484) aus dem 15. Jahrhmolert stammen muts. da sie zu Ehren der Clandia. der (temahlin Ludwigs XII. (1490) henamt worte.

Durch diese wenigen Beispiele hereits werden wir darauf hingewiesen, dats dio Theorie ciner Degeneration durch Altersschwäche der einzehen hulturvarietäen oder furch andere Uriachen darlurch zustande gekommen ist, dats zeitweise in vielen Lokalitäten sich ein anhaltender Rütkgang in der Produktion mol tresmdheit gezeigt hat. mol dats man derartige Beolachtmoen verallgemeinert hat. Dasis in manchen fegenden hisher lewähte Fulturomen eine gedeihliche Entwicklumg nicht mehr zeigen mul dureh andere arsetzt werken müssen. ist eine Erscheinmeg, die sich nicht ablengnen lätst. Aber diese Tatsache beweist nur, da eine jolle Kulturform lestimnte Ansprüche an Boden und Klima stellt, dat's diese Ansuriethe an einer Anzahl von Örtichkeiten nicht mohr hefrierligt werlen kömen. Ton einer Degeneration wïrde sith mu dam spechen lassen, wenn in allen Orten, auch solchen, welehe die hisher zusagenden Berlingungen heibehatten haben. eine Kulturvarietät znglumde cinge. Datïr fehlon aher die Beweise.

Das Versagen der Varietäten nach langem Anhan liam zwoicrled Ursachen haben: entweder haben sich die Anbanverhältnisse geändert. oder der Charakter der Varietät ist eim anclerer goworlen. 
Dats die Kulturverhälntisse an irgend einer (O)tlichkeit in jeelem Jahre andere sind, ist eine 'Tatsache, der wir ms meist zu wenig hewutst werlen. Alugeshen davon, datis die Wittermo des emen Jahres von der des Vorjahres strots alweicht, ist aber auch der Boden beständig ein anderer. nut zwar einerseits dadurch, datis Zeit und Modus

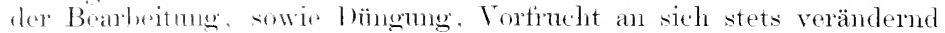
einwirken, anderseits, datis dirse veründerte Ackerkrume anch ver-

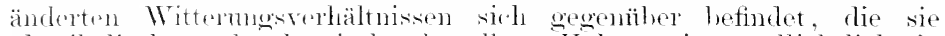

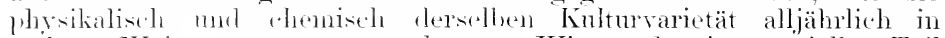

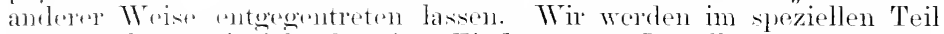

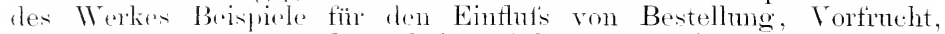

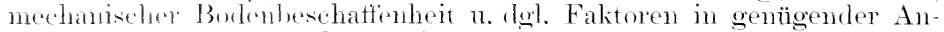
zahl antïlnren nul rselen, wie diese den Charakter nud die Widerstandstähiglisit z. B. gesen Föste zu beeinflusien imstande sind.

Zweitens meintern wir. dats das Versagen siner Kulturvarietät anch davon herrïhren kamn, lats die Varietät ihen Charakter ändert. Nacli nuserer Antfassumg gibt es bei allen Oruanismen keine Stabilität, gilst es keine strikte stotfliche oder westaltliche Wieclerholmo irgend eines Vorganges, weil der Oromismus in dor kleinsten Zeiteinheit sich ändert, in jertem Angenblick denselben Wachstmmsaktoren als ein anderer gegenibberstelit, mol anf den Wege ler Anpassung fortschreitet. Tnd jede Tarietät ist fïr uns, wie jede andere Sippen-oder Gruppenbezcichnum nur ein Rahmen ans gemeinsamen Merkmalen, in welchem die Intividuen fortwinend theh kleinere Abweichungen schwanken. Stickstotfïledschuts hildet eine andere Pflanzensubstanz als eine mätsige stickstoffnahrung, Kalmanged bant ein anderes Organ wie Kalinelehtum. Lichttïlle bant die Kellwand in anderer Weise als Lichtnang(el, viel Wärme produziert mehr Zncker als geringe Wärmemengen nsw. Präzise Beisfiele bieten die entsprechenden Kapitel über die Wirkung dor einzehen Wachstmotaktoren. Also de Organismus ist wir. Wachs. das durch die stötse dereinzelnen Vegetationstaktoren heständig in andere substanzformen gopretist wird.

I) Sulstanzhesehaffenheit des Pflanzenleibes aber ändert sich nicht nur dureli die molekularen Umlagerungen, die wir als chemische Änderungen bezeidmon, sondern auch durch die grobmedianisehen, bei denen die chenische Kusammensetzmng mberïht bleibt. Die mechanische Wasseremlagermo in die Gewebe, die mit dem Wrasser eingesehobenen inkrustierendon substanzen, die Spammosverhältmisse in den Membranen mol in Zellinhalt sind Faktoren, die ständig wechseln nut einander heständig wechselnd hoeinthusien. Die geringste Steigermen der Lichtzufuhr ist ain Stotis, der nicht num den Assimilationsprozets beeinthutst, sonclem der indirekt anch anf alle andern Funktionen

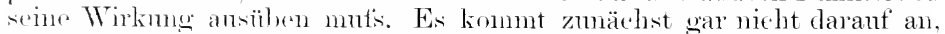
lats wir deratige Wirkmgen präzisieren kömmen: es genügt der Nachwejs, dats sie stattfinden müssen.

Num lestrachten wir eimmal die normale Form, in welcher die Stötse fer einzelnen Wachstumstalitoren anf den Ptlanzenkörper einwirken. Ta bemerlin wir rine eigenartige Abwechshmg. Bei Anbruch des

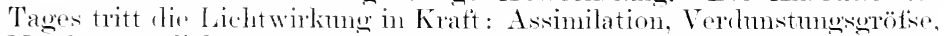
Mrombranverdickmo usw. Werten gesteigert, und der Gesamtantbau spiegelt alle die Erscheinmon dor I ichtarbeit ab. Bei Begimn der Nacht treten, nachrlem die Nachwirkmgen des Lichtes ausgependelt 
haben, die Oxydationsvorgänge, die gesteigerten Turgorersheinungen, die Stärkeumwandhug u. dgl. in den Vortergrund. Terselbe Weehsel lätst sich in den die Pllanze umgebenden Modien, in Luft und Boden, beobachten. Die Wärmeahmahme und steigerme des Wassergehaltes müssen mächtig ant den Pflanzenkönper eimwirken. Zn dem Weasel zwischen Tag mol Natht gesellt sich der Eintht's res Jahreszoiten, der den Ptlanzen nath dex Produktionszeit die Periode der Rule aufzwingt. Wir finclen also in dre Natur eine ..korrigitrende Periodizitii ".

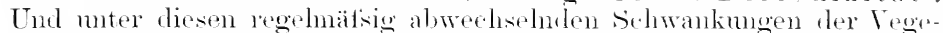

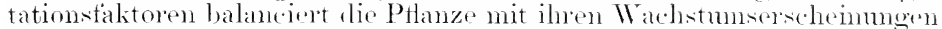
und vollzieht ilnen normalen Entwicklungsganes.

Da Daner und Wirkme dieser Periofen in jedem .Jahrgange amblere sind, ist anch die Produktion jecler Ptlanze eine andere. mul darlureh chaliterisieren sich lie pinzelnen Jahnönge. Wir sprechen von trocknen und nassen Jahreängen, und wisen aus Erfahrung, dats in ersteren beim Getreide der Körnergehalt reich, der strohoralt wowen der geringeren l falmlänge geringer ansaillt. In massen . Jahren ist es

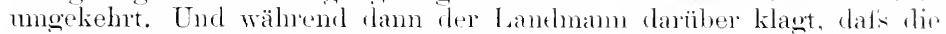
Backfähigkeit des Melles leitet, betont er, datis er in der eroieligen Strohernte einen Ersatz finclet.

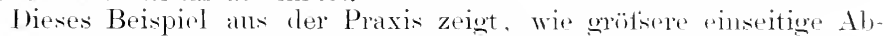
weichungen von der louchsehmittsperiodizitat sich sofort bemerkhar dadureh machen, dats num einzehne Eienensehaften des Ptlanzenliöpers hevorzugt werden. Solange derartige Einseitigheiten der Aushilimug das ptlanzliche Individum in siner Existenz nicht ledrohes, nehmen wir die Exnteergebnisse hin und suchen etwaige Schäilen des hinlurzweckes (wie z. B. das wenig backtähige tretreide, huch Vermischen mit kleberreichen Könern aus trocknen, warmen (iegenden) anszugleichen.

Aler das emseitige Vorherschen eines hestimmten Wittermesfaktors kam anch zur direkten Erkrankmog füluen, inclem sich die. Wirkungen hänten (Akkumulation). Man kamn eine derartige Anhäufung der Etfekte mit der Zmahme ler (reschwindigkeiten bui einem fallenden Körper veroleithen, wo sich die Falluänme wie die Qnarlrate der Fallzeiten verhalten. Wem wir statt der sichwerkaft einen andern Faktor. z. B. eine nasse, trïbe Wittermo ammehmen, dam wird die Wirkung derselben am ersten Tage sich derart geltend machen, dat's das tewebe wasserreicher wird, wobei die Wantwerdickmo gegen rlas nommale Mat's zurïckbleibt. Am närhsten Tage gesellt sich zu der Wirkmo des ensten Tages die gleichopot'se des zweiten, und das bereits gelockerte Gewebe wird mum noch weiter welockert, und ant diese ITeise smmmieren sich die an sich nicht krankheiterzengendent Stölse ant den Ptlanzenleib zu einer trötse, dic schlietslich dir Existenz desselben berboht. Im palitisehen Leben sehen wis dies schon imerhalb einer Vecotationsperiode, z. B. hei dem Lacern des tretreides in regenreichen zeiten. Die Fenclitiolit hat die $/ \mathrm{cll}$. streckum an der Halmbasis hedentend geförlert, ier I ichtmangel aber die Wandverdickung wesentich gehemmt, mul der Erfolg ist num. dats die gesehwächte llahnbasis dem Heledangritt des Windes krinen genügenden Widerstand zn leisten remag mol rinknirlit. Je narl der Daner und den sich einstellenden Folgeersoheinmoen dieser Hahn-

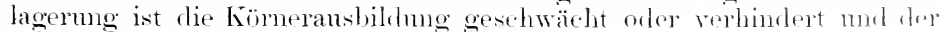
Halm einem vorzeitigen Tode geweiht.

Entsprechend obigen mechanischen Änderungen ter \%ellwand ist 
hei andern einseitio sich häutenden stätsen seitens eines Vegetationstaktors der Zellinbalt Änkermgen muterworfen, die zur Erkrankmog fïhren. Wir finden in stark geelüngten Bammschulen ganze Quartiere

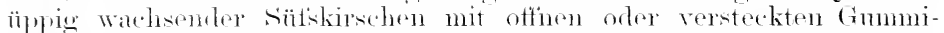
helelen, mel in Forstiampen gnt ansiehente Kiefernbeote, die im Holzkïrper die Antänge der Resinose tragen. Namentlich bei Gartenkulturen, in lenen dnehschnittith mit den höchsten stickstoftgaben gearbeitet wirl, rkranken plïtzlich ganze Kulturen mol werden heiscite gelegt, weil . dit Pflanzen nivht nehr wathsen wollen". Mir simel genügend derartige Fälle zugegmgen, hei denen rinzelue Küchter meldeten, dats Begonien, Primmla sinensis fl. pl., Nelken, Maiblumen, Cyclamen n. dgl., die sie sonst stets in gröster Vollsommenheit bei denselben Kulturmethoden erzogen haben, von Jahr zn Jahr melı im Wachstum zurücklikiben und, "legenerieren".

Bei musen Feldkulturen lälst sich Ähnliches wahmehmen. Kartoffelsorten, wolche früher taldlose Erträge waben, werden jotzt felderweise

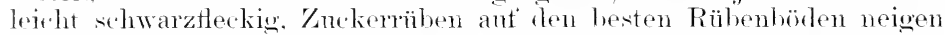
zur sichwanzfänle. Bei den Wurzellsand der Rühen ist beobachtet worden, dats besonders stark die Stecklingspflanzen erkianken, währenel die aus dem Samen von lesten und schwersten Zuckerrülen rrzogenen Pflänzchen fast gar keinen Wurzellrand zeigten. Treibgurken in den Glashäusem, Feldgurken in nassen kalten .Jahren gehen an Gummosis zugrumde u. dol.

Meine Ertahrungen bei der Heilung derartiger Vorkommnisse tühren zu dem Schlusse, dats wir es in solchen Fällen mit cinseitiger steigernng einer bestimmten Entwicklungsrichtung, meistens hervorgernten durch stickstott- und Wasserïberschuts, zu tum hahen. Unsere heständig intensiver werdende Düngerwirtschaft tührt nicht selten zu einer bestechenden Üppigkeit der Pflanzen mul rlam zu einem plötzlichen Collapsus, wenn der das Gegengewicht haltende Faktor nicht in der entsprechenden Nenge zur Triksankeit gelangt. In Fällen nachgewiesener hochgratiger stickstoftzutuh fam ich dement-prechent die Anwendung rom phosphorsamen Kalk vortrilhaft.

solche rinseitigen Entwicklungsichtungen werden anch in der Aushilkmg des Samens zum Anshlruck lommen müsen. Wem derartiges Saatgut unter denselhen Frnährungsverhältnissen, unter denen es entstandlen ist, von Generation zn Generation weiter kultiviert wird, müssen hestimmte Eigenschaften sines Standorts dmoh Gewohnheit erblich werlen. In moserer Anftassungsweise, dats alle Eigenschaften eines Organismus dynamische /ustände, molekulare Schwingungsgruppiermgen darstellen, würde die ( gedentet werden müssen. Das Trägheitsvermögen aller Materie veranlatist dieselbe, genan in derselhen Bewegmosichtung und-geschwindiglieit zu hleiben, die sie zunächst emptangen hat. So, wie der Organismus rimmal angestofisen ist, pendelt er weiter, his irgend ein Vegetationsfaktor seine Wachstumseschwindigkeit orles anch seine Wachstmusrichtung andert.

Die Praxis verwertet diesen Umstand hei dem „s samenwechsel", d. h. bei der Verwendung von Saatgut aus Gogenden, die eine bestimmte wïnschenswerte Eigenschaft ausgebildet haben. So ist der Bezug schwerlischen Getreides seitens mitteleuropäischer Landwirte damm tin ansogelchnter, weil man die kürzere Vegetationszeit der nordischen sorten ansnutzen will. Während der Typus des englischen Weizens 
besonders entwickelte Mehligkeit ist, produzierm die miter entgegengesetzten klimatischen Verhältnissen befindlichen Gegenden vorzmgsweise glasige Weizcn nsw.

So wie diese nützlichen Trpen des Getreides ak Produkte lokaler Vitterungs- und Bodenverhältnisse entstanden simb, so könen anch Schwächezustände der Kulturptlanzen lokal erzenot uml durch samen übertragen werden. Trem diess Schwächezustände dmoh tileichbleiben der Ursachen sich von Generation zu feneration wiederholen und sich hänfen, so kömnen sie cndlich zn vollständiger Hintälligkeit mul dureh die Akkumulation zur Einleitung firihzeitigen 'Todes tühren.

Aber dies ist trotzdem keine Degeneration ler Art oder Varietät: dem alle diese Eigenschatton kömnen in andern Kulturverhältnissen wieder zurïcklionstruiert werden. Das ersehen wir ans dem Umstande, dat's die nützlichen Sondereigenschaften, die wir hei dem samenwethsel eingeführt haben, nur wenige Jahre rorhalten. I)am ändern sich dis eingeführten Kulturtormen und nehmen solehe Eigensehatten an, welch. der klimatische mol der Bodencharakter der Anbangegend zïchtet.

Anch dies sind Ertahrmoen der Praxis, wolche heständig versucht. die nach iroend ener Richtung hin hodrupodulitiven Arten fremder. Klimate an irgend eine Kultmgegend zu gowönen (Akklimatisation).

Will man obige Fäle einer Akkmmbation vom Eigenseluaten, die zur Schwächung der Produlition mo vorzeitigem Torde tühren, als "Legeneration" hezeiehnen, so darf man höehstens von lokaler, vorubergehender loegeneration aner Anzahl rom Individurn spochen. Es ist aleer eigentlich nur aine Depression der Entwicklmosrichtung, die durch äutsere Faktoren, wie Kultursingritfo, wieder behohen worden kam. Eine danemde Depersion im Wachstum intolge des sonilitat einer mspringlich langlebigen Varietat ist imerliall, einer bestimnten Erdepoche nieht anzmelmen. Las Versehwinden von Kultmrarietäten erklärt sich durch ihre geringere Rentahilität infolge mangelnder Anpassmgsfähigkeit an misere heständig intensiver werdende Bewirtschattuingsweise.

\section{Zweiter Abschnitt. Geschichtliches.}

Bei einer so jungen Disziplin wie der Phytopathologie wird man kamm eine Geschichte der Wissensehatt voramsetzen. Und in der Tat ist der Zeitpunkt, seit welehem die Lehre von den Pflanzenkrankheiten als besonderer Wissenszreig von den Mutterdisziplinen sich losgelöst hat, ms so naheliegend, dats wir seinen Entwirklungsang noeh vollständig zu übersehen vormögen.

Wem aber auch die Forsehungstorm noeh net ist, so ist doch das Material, nämlich die Neldmmgen über die Krankheiton der Pflanzen. ein sehr altes, in her Geschichte weit zurückreichendes, nud wir kïmen nicht fehloehen. wenn wir annehmen, dats die Krankheiten seit der Existenz der Pflanzen vorhanden und die Beohachtmenen äher dieselbes zu der Zeit angefangen hahen, in welkher eine Pflanzenkultur hegomnen 
hat. Denn wir heobathen tortwährend, wie schwerwiegende Beschädiyungen die Witterungsextreme hervorufen, und zwar nicht num solche, lie angenthiclich die Ptlanze töten, sondern mehr noch derartige störmengen, dir das Individum in Ban und Funktion schwächen und es langsam rinem rorzeitigen Torle entgegentïhren, also krank machen. Die Eingritte schädigender Witterungrverhälthisse werden stets vorhanden gewesen soin und sich in verschiedenen Formen geäutsert haben.

Eine der älesten Bezeichnmgen gewisser Krankheitsformen, die ms "uteregenterten. ist ler Name "Brand". und deshalb wollen wir versuchen. an der Hand ler unter diesem Xamen zusammengefalsten Krankheitser heinungen den Werelegang unserer Disziplin zu verfolgen.

Wie die suateren Mitteilungen erselen lassen, sind von den Autoren zumächst wohl alle. Erseheinmgen als . Brand" hezeichnet worden. welche dem Ange in der Farhe des Verhannten oder Verkohlten, also seliwarz sntgegentraten. Demgemäts umfafts der .Brand" einerseits die Krankheit-gruppen an Binmen. hei denen die tote Rinde ein gesthwäztes Anssehen ammahm, anderseits anch die Beschähligungen des fetreides, deren Ursathen wir jetzt auf Brand-oder Rostrilze zurïcktïhren kïmmen.

Wenn wir zunächst in dor Biisel nach Angahen üher Krankheiten und speziell äber Brand stehen. so fimlen wir z. B. folgende stelle ${ }^{1}$ ): .. Wenn eine 'Tenerung. oler Pestilenz, oder Tlüre, oder Brand, oder Henchrecken, ofer Rampen im Lande sein wird, oder sein Feind im Lande seine Tore belagert ......-. Eine andere sitelle lautet: "Her Her' wird I)ich schlagen mit schwolst, Fieher, Hitze, Brumst. Diure giftiger Luft und Gelhsucht und wird Dich verfolgen, bis er Dich nimbringe." ${ }^{2}$ )

Ans diesen stellen zieht Ermssos ${ }^{3}$, den Schluts, dafs es sich hei diesen meln als zweitausend Jahre alten Nitteilungen um Brand und Rost an Getreide gehandelt hahe. Er zitiert das Tort sichidelafôn (Hitze) tïr Brand und Jerakôn (frelbheit) tür Rost.

Aut Brand im retreide weisen anch folgende. hereits von Pander ${ }^{*}$ ) herheigezogene Ansingüche hin: . Ich plagte Ench mit dürrel Zeit und mit Brantkorn: so fiatsen anch die Raupen alles. was in Emen Gïrten, Wrinhergen. Feigenhäumen und (̈)hänmen wuchs." The sehn hezeichnend für die Grötse der Mitsernte ist die stelle in HAfal"): . Wenn einer zum Kornhaufen kam, der zwanzig Mafis haben sollte. so waren kaum zelun da: kam er zur Kelter und meinte fünfzig Eimer zu schëpfen. so waren kamn zwanzig da. Denn i.h plagte Euch mit Ibïre. Brandliorn und Hagel in aller Eurer Arheit."

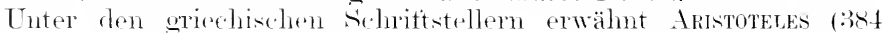
his 3.2. v. ('hr.) horeits die Rostjahre, und Theophast von Eresos (:37 bis 2sti v. Chr.) kennt sthon die verschiedene Emptönglichlieit der einzelnen (ietreiderarienäten gegenüber den Rosterkiankungen ‘). Er

1) 1. Buch Könige, Kap. 8. 37. - 2. Buch Chronika, Kap. 6, 28.

2) 5. Buch Mos., Kap. 2s, 22.

3) Eniksux, Die Getreideroste. Stockhohm 1894. \$. \$. (Hier eingehende geschichtliche Mitteilungen über Rost.l

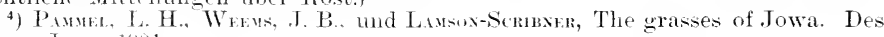
Moines. Jowa 1901.

5) Anos, Kap. 4, 9.

6) Hagai 2,17 . 18.

7) Naturgeschichte der Gewächse. Übersetzt und erläutert von Sprexisu. Altona 182:. 'I. 
berichtet anch üher die zweite Art dor als Brand bereichneten Erscheinmogen, nämlich über den Rindenbrand der Bämme. indem rr (Buch IV. Kap. 14) sagt, dats die zahmen Bämme an mohreren Krankheiten leiden. Unter diesen sind einige allen Bämmen gemonsam: andere suchen nur bestimmte Bammarten hein. Fine Gemeinsame Krankheit ist es, tafs sie ron Würmern oley vom Brante ererittin werden.

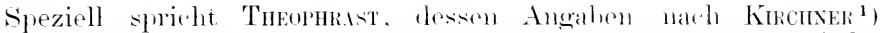
sicherlich aut eignen Beobachtumgen heruhen. vom Brand mol Krels der Feigenbämme, mul erwähnt dabei, dats sich die Krankheiten der Bämme nach dem Klina wie hei den Tieren) zu richten scheinen, la in einigen fregenten die Bämne gesmol seien. Ibre Frigendamm, sagt er dam weiter, wird am meisten vom Brand mol Kols ergatfen. Brand (Sphatirlismos) aber nennt man, wem die Wnown schwarz werten, Krels (Kralos), wem es die Kwoige wroldu. Der wilde Feigenban dagegen bekommt weder den Krebs norh den Brand.

Ther eine Trsathe des Brandes belehrt mo die Angaler. dats rinige verderbliche Zutälle durch den Einfluts der Witterme mul des standortes entstehen. Man köme eigentlich lerartige Kutälle nicht rocht als Krankheit bezeithnen, wie z. B. das fefrieren, nut was einige den

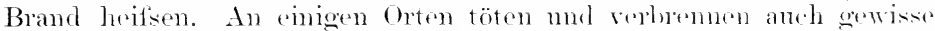

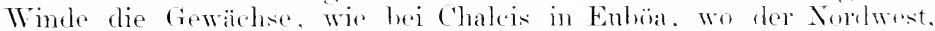
wemn er kmy vor der Sommenwende weht, kalt ist: er malelt die Bänme

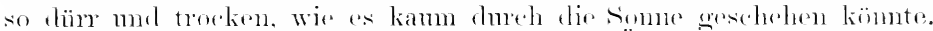

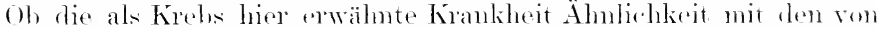
mos jetzt als Krehs bezoichneten Wnehermeen hat, bleibt zwoifolhaft. sicher aber ist. lats Holzwnehermoten ehentalls beohathet

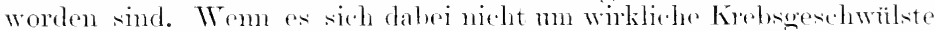

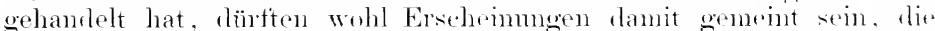
wir jetzt als Knollemmaser ansprechen wï̈den. Weratige Gesehwïlste sah 'Theophrast bei dem Ölham mel benement sie Naged ofer fiehort' (loxas - lopas). weil sie gleichsam naptfömige Nägel an den Bïnmen darstellen. Ton diesen Nägeh sagt Strexriel dats sie in menerer Zeit sehr häufig hei den ()liven in Italion vorkïmen. Sie zeigen sich als runde, warzige. in der Nitte naptformig vertiefte Answiblese du Rinde, meter denen sich anch ähnliche Ansehwellungen des Holzhörpers vorfinden.

Es ist kamm zu glanben, dats die von dom sehant beohachtemelen Schüler des Aristoteles geäntserten Ansichten ïher dir hier erwähnten

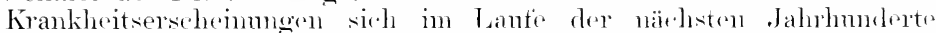
wesentlich geändert haben: dem sonst wïrde der berïhmte Enerklopädist, der von 2;

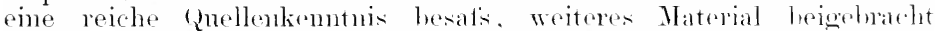
haben. zumal er gewiscenhatt die von C.sTo (de le rustica) mul anderm schriftstellern gemachten Angahen ühor den Einfluts der Gestime mut das Sterben der Bämme infolge von Kälte. Hitze, moinustiger Lage.

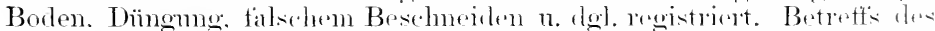

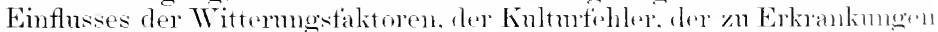

1) Kurcuser. Die botanischen Schriften des Theophrast von Erexos. Sond. Jahrb. f. klassische Philologie. Leipzig 1sit.

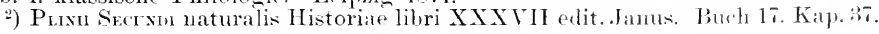


disponierenten Tmstände nsw. enthalten die in seiner "Naturgeschichte* niedergelegten Erfahrungen änliserst viel Beachtenswertes.

In der Ansgalse der .. Römisehen Prosaiker" ron Osiander und scнws hat der T̈thersetzer des Plinius (KüLB) eine Zusammenstellung der von diesm lenutzten (Smellen mul spezielle Bemerkmngen ïber die in der .Natmoeschichte" angetührten Schritsteller gegeben. Für fine vollständige (ieschichte der Phytopathologie liegt hier ein reiches Naterial vor. Wir dürfen ms mit dem Hinweis ant diese sorgfältig gesammelten griechisehen und römischen Quellen begü̈gen und vielleicht nur noch an cinigen Citaten zeigen, wie weitgehende Erfahrungen hereits an Begim unserer Zeitreehnung vorhanden waren.

Nach obiger Bearheitung finden sich im siebzehnten Buch von Plinins Naturatechithte, Abshmitt XXXVII, de Anschaumgen des Verfassers äher die Frostwirkungen. Er sagt: „Auch kommen nicht die schwäthsten Bämme durch den Frost in Gefahr, sondern die grölsten, und es werden also, wenn sie Not leiden, die höchsten Giptel dürr, weil der von der Kälte gehemmte saft nicht bis dahin gelangen kann." T̈ther rie Erscheinmogen, welche wir jetzt als .Frostbrand" bezeichmen wïrden, finden wir folgencle Notiz: .. Der böse Einfluts der Gestirne beruht ganz auf dem Himmel: deshalb muts man zu diesen Einwirkmgen auch den Hagel sowie den Brand um ten durch Reif verursachten Sthaden rechmen. I)er Brant ergreift nämlich die zarten Pflanzen, wenn sie, dmuch die Frühlingswärme gelockt, hervorzubrechen wagen, und versengt die milchigen Angen der Keime, was man an der Blïte ,Kohle' nemnt."

Betreffis der sorgfältig kultivierten Weinstöcke heilst es: „Ein anterer schlimmer Einflutis der Gestime (Wittermasfaktoren) ist das Berieseln (roratio, das Antfallen kalten Taues, Übers.) während sie verblühen, oller wenn die Beeren, ehe sie wachsen, zu harten Körnern vertorren. Sie werden auch krank. wenn sie gefieren, und der Brand nach dem Beschneilen lie Augen rerletzt. Dieselbe Folge hat auch eine mzeitige Hitze: demn alles hat sein bestimmtes Ma l's und Ziel." Wir fassen jetzt diese Erfahrungen präziser in der Lehre vom Optimum, der Minimal- und Maximalgrenze der Wachstumsfaktoren zusammen.

Bezïglich der fehlerhatten Kultumethoden wird angeführt, dafs Krankheiten entstehen, wenn der Winzer die Reben zu fest bindet oder beim Umeramen die Wurzeln verletzt mo den Stamm entrindet oder quetscht. Unter allen diesen Unständen ertragen sie (die Stöcke) weit schwerer Kälte und Hitze, weil jeder Nachteil von aufsen in die Wunde eindringt.

Unter den Heilmitteh wirt das schröpfen empfohlen. weil die ditkwerdende Rinde die Stanme zmsammensehnürt und sie wïrgt. Als Schutz gegen die Winterfröste wirl erwälnnt, lats man im Winter, wenn Schnce liegt, nm die Weinstörke Wassergräben ziehe, damit sie die Kailte niclit lrandig mache.

Die reichlichsten Aufichlïsse ïber aie Kultumethoden und die dahei auftretenten Ïbel dürften in der in zehnten Jahrhundert erschienenen sammlung von Excerpten aus alten Ackerbauschriftellern, der "Groponilia", zu finden sein. Wir stützen uns aut die Bücher der bekamten vier römischen (teoponiker Marcus Cato, Terentius Varko, Pallades und Junits Moneritus Columelat, in denen besonders der Dïngerwirtschaft und dem Pfropfen Aufmerksamkeit geschenkt wird. 
Eine Znsammenstellung der Bücher über Landwirtschaft der genannten

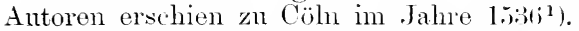

Diesem Werke entlehne ich anch diejenigen stellen, welche zeigen. dats die Bezeichmung "Rost" als Krankheitsmache sehr tirïhen [r. sprumgs ist. So erwähnt Vakko im ersten Kapitel unter den Gottheiten "qui maxime agrialarmm duees sunt". . . . (suarto Robigum, et Floram, quibus propitiis, neque rubigo finmente, atquer arbores, corrumpit, neque non tompestive florent. Itaque publicae Robigo firiate, robigalia, Florae ludi, florulia instituti." Wahrscheinlich walt der Auschnck "Rost" tür alle rostfirbigen krankhaften Vertäbumgen der trewächse:

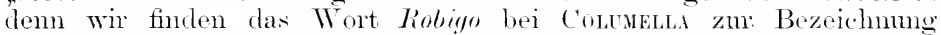
einer Weinkrankheit gebrancht, die durch das Räuchem der Weinberge bei Frostgefahr vermieden werden kam. In seinem Buche „de arboribus" behandelt Kapitel XIII: Ne mbigo rincum rexet. Es wirel empfohlen: "Palearum aceruos inter ordines uerwo tempore positos habeto in uimea: eum frigus contra temporis eomsuctudinem ne intellextis, omme is areruos incmelito. ita fumus nebulum it rubiginem remoubit." - Betrett's des wechselnden Gebranches von "Robigo" und "Rubigo" findet sich in der "Enarratio prisearmm rocum" folgende Stelle: . Robigo. deus, quem putabant rubiginem auertere, est autí Rubigo morlous segrtum"2).

Von den Beobachtungen und Anschanmugen der Röner, die in Plinins sich zusammengetatst finclen. zehrten dis näehsten anderthall,

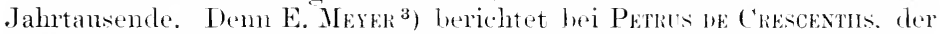
1305 sein grotses Werk schrieb, welches in len ersten acht Büchern von der Landwirtsehaft handelt, dats seit Pstusur's niemand über Landwirtschatt in lateinischer sprache geschrioben hätte. Aus der griechischen sammlung der Geoponika besat's man nur Bruchstücke.

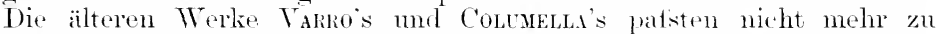
den Verhälnissen der Zeit, so dats ein zeitgemälses Buch über Landwintschatt ein Beclïrnis war. Aher obgleich Petres ue Crescentis eine wissenschaftliche Begrïndung der Landwirtschaft anstrebte mol, der Liebhaberei des Altertums und des Mittelalters entsprechend. zahlreiche Anweismngen zmm Pfiropten der Bämme verschiedener Art gal). enthält sein Werk doch eigentlich weniger, als die Bücher der alten Antoren. Ebenso wiederholt im Jahre lion anch noch CoLEkr's ${ }^{4}$ nm die früheren Angaben über Rindenauttreibungen, .. Schwulst der Bewne". mnter denen eine janchige Flïssigkeit sich entwickle. Dabei erhält sich der Glanbe an den Einfluts der Gestime in merschütterlicher Festigkeit.

Beispielsweise erzählt ms noch der ehrenwerte Rostocker Professor Peter Lauremberi in seiner 1631 erschienenen "Horticultura" s), dats gewisse Gestirne, wie der Orion. Pleiaden n. a., besonder's schädlichen Einfluts ausïben. und dafs intolge schädlicher Witterumgseinflüsse die sogenannten "heimlichen Übel" entstehen, zu ilenen Rost. Karbunkel und Brand gehören.

1) De re rustica M. Catonis liber I. M. Terentii Varronis lil, III, Palladii lib. XIV et I. M. Columellae lib. XIII Priscarum vocum in libris de re rustica enarrationes, per Georgium Alexaudrinum. Coloniae. Jotmes Grmmicus. Anno MDXXXY.

2) Hier wie bei den übrigen Citaten folgen wir in der Schreibweise grnau unsern Quellen.

3) Geschichte der Botanik. Bd. IV, S. 145.

4) M. Johaxis Consm, Oecononia und Hautsbuch usw. Ander Theil. Wittenberg 1600. Buch V. Kap. 12.

5) Petri Latremingil, Rostochiensis Horticultura. Erancofurti 16:31. Cap. AXXY. 
Einen Fortshritt in der Erkenntnis der Bedentung der Krankhoiten kïmnen wir natürlich nm hei den Praktikern erwarten, deren Bemïhnmgen hei der Kultm am emptindlichsten durch die sich geltend machenden Bushärlignugen gestört werlen. In dieser Beziehmo interessant ist das semerzeit berïhnte Werk des ,Kurtürstlichen Gartenvorstehers Hexkich Hesze" ${ }^{1}$ ). Er spricht über das Dürrwerden der Äste. das er den ..kalten Brand“ nennt. ., Sonsten hat man drey HauptErachen, mo welcher willen die Bäme handig werden. Erstlich wearn üherflïsiger Fenchtigkeit, welche in Entzündung des saftes zwischen Foltz mol Rinde ersticket mo alstam die Rinde erhebet, hrandig und diure machet. Wie andere Ursache ist diese, dafs otfitmals mherlachtsamer Weise und mit Tnverstand ein Bam anders gesetzet wirfl, als er vorher gestanden. Dieses ist ihnen hochschädlich, dem die Rincle so hramntarlig ist und gegen Morgen oder Mittag gestanden hat. ist tasslbst viel härter, als an den seiten, so gegen Norl oder Alenel gestamilen hat, als welche gemeiniglich grïn, zart mol mzeitig ist - alsdem muts ohntelilhar ein sihale daraus entstehen, sintemalen die Norkbeite dor Mittags-somne gar nicht gewohnet und wirr sie nicht allein von dre grotisen Hitze gedöret, somflern anch im Frühling durch harte Nachtfïste ershrecket mol die Rinde in dio Höhe gezogen, hernachmals durch die somme den Tag ïher ansgetrueknet mol rertnemet, worans alshald der Brand entsteht. wie er dem gemeiniglich an der seite, so green Mittag stehet, remerket wirl." - Hier haben wir positive eigno Beobachtmoen vor mm. - Verfasser erzählt nm veiter, wie er derartigr verkehrt gesetzte Bänme dennoch dadurch erhalten, lat's er in den ersten Jahren nach dem Versetzen ant der nach Mittag gewendeten fakrhen Seite des Bammes emen Tmschlag von Kuhkot, Haferspren. Ixim und Asche angetracht hahe.

"Tie dritte Trsache aher kommt daher, wenn ein Banm mit einem Brodmesser goptiontet winl usw." Vielleicht hat llesze cine parasitäe Infektion rabei in Auge gehabt mol zn erklären versucht.

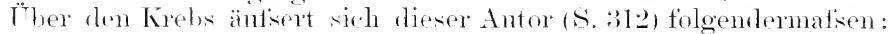
.. Dats der Krebs eigentlich daher rïhret, wem ein Bamm zu der \%eit, wemn der Mond im Zeichen des Krebses oder skorpion länft, gepfropfet wird . . . ." "Diese Krankheit kam man daran erkemnen, daf's die Rinde hin mul wieder Biicklein anfwürfet mol mos derselben es gloidssam tor mel sehwatz ist, wolehes dam immer weiter mon sich greiffot, his es endlich den wanzen stamm eimmimmt. Es werden zwar von ein nud anderen weitläntfitige Trsathen des Krebses angeführet, alloin die olwen angeführte ist doch die allerwahrhaftigste."

Zur diesem Ansspruch des berïhmoen Gärtners macht der Heransgeber folgenden Knsatz: ...... Was don Krobs anlanget, so wird niemand längnen kömmen. dalis soleher offt oben ant den Bäumen, mul zwar $\mathrm{xm}$ dom Enflath, weleher zwischen dem stamm und den Arsten auf denen Zwiesth sich sammlet, entstehet. Derowewen es höchst nöthig ist, dats man die Zwiesel allezeit rein halte und sie von allom Unflath sänhere. So entspringet auch der Krels offt von eben flemselhen autfwallenden saffte, ans welchem der Brand entstehet und hahen diese zwey Krankheiten offt einerley Trsache."

[ler Tertasser heschreilst hier dentlich rie Erscheinung, die wir

1) Hexpicu Hrazas, Neuo Gartenlust usw., vernehret und mit dreven nütz-

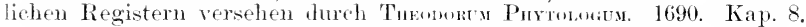


jetzt als Astwurzelkrebs bezeichmen, und wenn wir statt des ,autiwallenden Safftes" die Frostbeschädigungen mit nachträglicher Ansiedlung der Nectria ditissima setzen, so entspricht die I)arstellumg moserer jetzigen Anffassmo üher Brand und Krels.

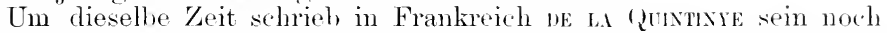
hente gesuchtes Buch: "Le partait jardinier" ${ }^{1}$ ). Wir tinden darin den Krebs kurz als eine Art Galle erwähnt (signifie me manire de galle on de pomriture seiche), welche sich in cler Rinde mul im Holze bildet, wie man dies häntix an den Birnen (Poire le Robine, Petit Muscat, Bergamotte), sowohl am stamm als an len \%weigen, findet. Der Begriff der IIolzgeschwïlste bei dex Bezeichmmg "Krebs" findet sich dam weiter bei suäteren (rartenschriftstellern, wie z. B. hei Fischer ${ }^{2}$ ).

Ant' eigenen Fülsen, d. h. ant' eigener vielfacher, praktischer Erfahrung

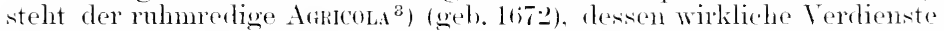
in den zahlreichen, 171: bis 1715 ansoctïhrten Versnchen ïber die wgeschlechtliche Vermehrung der Gewächse (namentlich anch Wurzel-

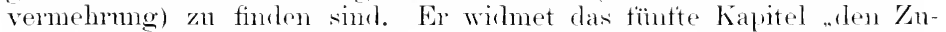
fällen und Krankheiten" nsw. mol änfsert sich z. B. folgendermatsen: „Es regieret aber der Mohlthan, Rubigo, zuweilen wie sine Senche muter den Bänmen, der im Fröhling, wamn sich die Erde erötthet mud die verschlosisenen lömpti anfangen über sich zu steigen. lie meisten beschädiget, und ist nichts anders, als oin selne seharfor mol beissender Than. welder von den Erdelünsten, die sie ïhersich hat zusammengezogen, herrihret ... Inittens findet sirh eine krankheit hei den Bämmen ein. welehe der Somenhrand, oder Brand, wrele, genemnet wird. bieser ist aber zwoirelei. Exstlich wirl er so genommen, wam ein sulitiler Regen orler Than antällt, mml dis Somnenstrahlen darzwischen scheinen, mul lest sich ant' die Blätter. I balurels werden die Löeher mol Fasern schlapl mo reweitert: die Sommolitze aher ziehet selhige alsobalden zusammen. Damit werden die Blätter verhermet. hegimnen bram und schwarz zn werden mud fallen ab. Tor das andere, so findet sich ein solcher wrolo oder Brand, in den innerlichen Theilen des Bammes, in dem Nark .... Die wahre Urich aher. warmm der Bramel in Versetzung eines Bammes das Mark brantig macht, mag wol diese sein, weil der gemeinen frätner (fewohnheit ist, dafs, wam sie einen Bamm versetzen, sie anch gemeiniglich die INnzel heschneiden, mol wissen nicht, was sie dem Bamme vor einen Schaden verursachen. Dem die kleinsten Wïrzlein ziehen den meisten Saft ans der Erden an sich, die schmeiden sie weg.... Weil num die Nirzel samt den Mark offen und free ist, so tritt die Fonchtiglieit hinein, mul verletzet das Mark ..."

Betreftis des Krebses finclen wir den ,aufwallenden saft" als Ursache. betont in dem 1751 erschienenen Gartenlexikon von Rienes ${ }^{4}$ ). "Krels, Bamkrebs, Kanker, Fresser. Also wird der schädliche Zutal an den

1) Le parfait jardinier etc. Par fen Mr. de la Quintinye. Paris 1695. T. 1, p. 31.

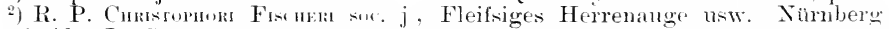
1719. 5 Abt. I. S. 168 .

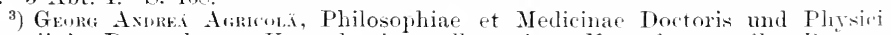
Ordinarii in Regensburg. Versuch einer allgeneinen Vermehrume aller Bäume. Standen und Blumengewächse anjetzo auf ein neues äbersehen usw. von C. G. Bransern. Regensburg 1772. Der Originaltitel lantete: .. Teu und nie fuhörter, doch in der Natur und Vernunft wohlbegründeter Versuch einer I niversalvermehrung aller Bäume, Standen und Blumengewächse." 1716.

$\left.{ }^{4}\right)$ Rimin, Kurz abgefalstes Gartenlexikon usw. Nordhansen 1751. S. 420. 
Bämmen genamnt. welcher sich an der Rinde dersellen äusert, da solche hin und wieder Buckeln hekommt mul antspringet. worant, wam dem fiessenclen Tehel nicht zeitig abgeholfin wirk, ein Ast nach dem andern und endlich der wanze Barm rerdirbet. . . . I) we wale Ursach aber dieses schädlichen \%ufals an den Bänmen ist entweder die höse Eigenschaft des Ertroiches. und die daher entstehende oder aufwallende höse sitte, so sich zwischen der Rinde entzïnden. welche wemn man sie abnimmt. schwarz aussieht. ofler der antwallende ïberflüssige geile satt. welcher wem er in Antwallen keinen Ansgang findet, erstikken und verderben mus, welches denm andh der Anlas zu der anfgeworfenen und antgeborstenen Rinde ist."

l) jetzigen Antoren setzen statt des aufwallenden Saftes den Ansdruck "sattstockmo".

Als Mittel gegen den Krebs empfichlt der Autor das Ansstheiden der kranken stelle und Verstreichen mit Bamwachs. Wonn der Boden die Ursache ist. sollte man diesen his ant die Wurzeln wegnehmen und furch besseren ersetzen. Bei sattüberfülle soll man in Felmuar den stamm an der Basis anbohren und das Loch nach 1 his 2 Tagen mit einem festen Holzpflock rerkeilen oder eine starke Wurcel spalten, .. da danin der iiberfliissige saft men abziehe".

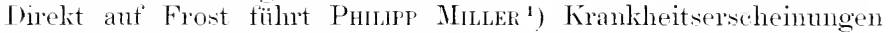
zurïck. die er mit dem Namen .. Brand " bezeichnet. Im wesentliehen sind die Muberischen Urteile eine Wiedergale der Hows'sehen Ansichten, der miter Brand (blast) nicht nu Frost, sondern anch somenlrand u. dgl. versteht. Wiehtig wird Hates ${ }^{2}$ ) durch die Erwähnung der Übertragbarkeit des Krebses dmoh Veredlung und der bisweiligen Heilung desselhen durch Ausselmeiden. Bemerkenswert ist die Beobachtung des englischen Experimentators äher den Einflufs der trocknen Friilujalnswinde, die das Lanb versengen: "The considerable quantity of moistme which is perspired from the branches of trees, during the cold winter season, plainly shews the reason, why in a long series of cold northeasterly winds, the blossoms and tender romum set firuit and leares are in the early spring so frequently blasted, viz. Iy having tho moisture exhaled taster than it can be suplied firom the trees."

(irolise Aufmerksamkeit wendet I) und erwähnt, dats die Bänme manchmal von Geschwälsten heimgesucht werden. Dicse sind um so leichter zu heilen, je jünger sie sind. Es löst sich an irgend einer Stelle des stammes die Rinde rom Holze, und zwischen beide tritt eine fressende Eiterflïssigkeit. Diese Art

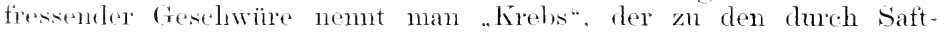
ïherschul's erzengten Krankheiten gezählt wird.

Das Niederächsische Gartenbucht) sieht die Veranlassmng zu Brand nud Krels in zu dichtem stand der Bänme, nicht zusagendem Botlon 11 s.

Während das Altertum und das Mittelalter sich bei ihren Beobach-

1) Das Englische Gartenluch oder Phum Mru,ers Gärtnerlexikon usw. Nach der fünften Ausgabe ins Deutsche übersetzt von Hrin. Nürnlierg 1750. S. 136.

2) Statical Essais containing Vegetable Staticks etc. by Steph. Hales. 2nd edit. London 17:31. I, 海 ffe, 147, : 699 II, 265.

3) La physique des arbres par Diнasu. du Monceau. Paris 1758. S. 339.

4) Caspar Bachome Vollständiges niedersächsisches Land- und Gartenbuch.

Flensburg und Leipzig 17i.2. I, S. 151. 
tungen ïber Pfianzenkrankheiten meist ant tie Wahmehmung der dem blotisen Auge entgegentretenden ansgebildeten Frscheinmoen beschränkten mal tast nur bei den Veredlmgen durch den Versuch zu Lösung der Fragen des Pflanzenlebens sehritten, sohen wir mit Hals.s mol Drhanes das Experiment seine Wiehtigkeit erlangen.

Gleichzeitio mit der Experimentalphysiologie hegimnt num anch der weitere Auban der phytopathologischen Systeme.

Die (ieschichte der Systematik der Pflanzenkrankheiten behandelt SEeTzex ${ }^{1}$ ), dem wir hire tolgen.

Iemmath finclen wir bereis ein tertiges system bei Touknefort ${ }^{2}$, dessen erste Klasse dir Krankheiten aus imnern Vrsachen zusammenfatst gegenüber der zweiten Klasse, der dureh autsere Ursachen hervorgerutenen Krankheiten. Kur ersten Klasse rechuet er 1) La trop crande abondance du suc nomrieier: 2) le clétant on manque de ce sne: :3) quelques manvaises qualités qu'il peut accuérir: t) la distribution inégale dans les différentes parties des plantes. In der zweiten Klasse befinden sich: 1) La grêle: 2) la gelée: :3) la moisissme: 4) les plantes, qui naissent sur d'antres plantes; i) la piquemre des insectes: i) différentes tailles on incisions, que l'on fait aux plantes.

Die Ansehammgen 'Tonknefok's's finden wir in msern hentigen sistemen wieder. Denn wir ormpieren rlie Kranklueitställe nach

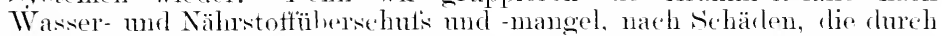
Wittermasextreme (Frost. Hagel) hervorgeruten werden, usw. Ebenso behandeln wir als osesonderten Absehnit die Wmolen und die hier bei TounneforT zmm restrn Male anftretenden parasitären Krankheiten.

Teniger glïcklich ist tas kmz nach dem 'Tonnserontschen erschienene System von Zwsier ${ }^{3}$ ), das ebenfalls zwei Hauptgrupjen annimmt: 1) Alloemeine, 2) spezielle Krankheiten. Die erste umfatist: La gangrène - le desséehement - la surabondance de suc - le branchage excessit - me esprice de galle, qui manche l'ecorce. In der zweiten Hauptgrmpe finden wir: Le desséehement des racines la separation de lem écore - la grossem excessive fles racines, qui retienent tout le suc do la plante - les excroissances -- les coups et les blessures. Ans der sionderung der nahe verwandten Erscheinmongen ersehen wir, dats der Vertasser sein Material nieht beherrschte.

Eine den Laien leicht tatsliche Anordnumg betolgt das Ersfarth'se he Sistem *), das als Einteilmosmodus die verschiedenen Hebensalter fler PHanze benutzt. In ter ersten Klasse werden die Krankheiten der Keimmgsperiode, in fler zweiten die der eigentlich vegetativen Zeit mul in der dritten die Strirmoen der Sexualperiode ahgehandelt. Immerhalb jeder Klasse werden die Einflüsse der Wittermasextreme, die Tierbeschädigmgen mul sonstigen Verwmelmogn hesprochen, und es figuriert auch bereits ein Kajitel „a rubigine ant pruma". Die ein-

1) Srstematum generaliorum de morbis plantarum brevis diiudicatio. Publico examini submittit UTicus Jorke Stratzes. Gottingae MDCCLXXXIX.

2) Observations sur les maladies des plantes par ir. Tor rowarn. Mém. de l'Ac. Roy. des Sciences à Paris 1705, p. 332.

3) Jo. Ju. Zwwam, Diss. ned. inauguralis de valetudine plantarum fecunda et adversa. Basileae 1708 .

4) Chms. Sigisursu Ersantr, Diss. phys. de morbis plantarum. Lipsiae 1723. 4". 
gehende Klasitiziermen zeigt, dats der Verfasser die Materie gnt durehgearlueitet hat.

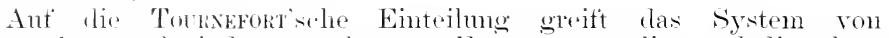
Aldsion ${ }^{1}$, zurück, indem es als prste Haupteruppe die maladies dôes i des canses "xtrmes". als zweite die "maladies dues à des causes internes" antstallt. Man merkt in der Einteilmug bereits die Fortschritte der mikroshopishen Untersuchmgen mol die steigende Anfmerksankeit, die den parasitären Pilzen zugewendet wird. Dem in

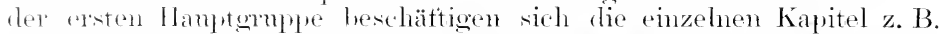

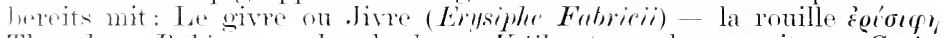
Thenghr. Reubigo) - le charbon (Istilugo) - la pourriture (Curies Fabrol $n \times w$.

I'r Antor stïtzt sich vieltich aut' die 'Terminologie von FAbricius, der wahrsheinlich sehon vor Erscheinen des foxamtsystens in einzelnen Ahlandlungen soine Stulien niedergelest hatte. Denn das vollkommene sirstem womele erst im .Jahre $1774^{2}$ ) publiziert.

Fabricus stiutzt sich sicherlich aut eigene Beobachtungen. Man merkt dies weniger ans der Autstellung der Ham,torupen als aus den Enterabteilmaen der emzelnen Kapitel, bei welchen unter der äntserlich oleithen Erscheinmo eine Gliederms der Fälle nach den verschedenen Trsathen hreits hegonnen wird. So sehen wir beispielsweise in der ersen Hampormpe: "Ttrugthargiórente sygdomme", d. h.

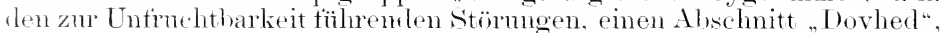
was wir mit Bleichsucht oder (relbsucht ïbersetzen möchten. Dieselbe wirl gegliedert in I), af Regu, af Kulde, af Rôg usw. Bemerkenswert ist die Beobachtung, dat's autser Regen, Kälte und andern Falitoren anch eine trellsucht durch $\mathrm{R}$ anch hervorgelnacht werden kamn. In der zweiten Hamptgruppe: "Udtrerente Srugd.", also den Atrophien. findet sich im Abschnitt "Quxelelse" die Terspillerung (Etiolement) dureh ,stedets Indshtning" (clichter stancl) und dumeh Mangel "paa Lrs" (Lichtmangel), durch selhlingpttanzen mol Insektenheschädignngen. Von diesen Erschemungen wird eine andere truple: "Tærong" (Tabes, Jamisce bei Amasson) abgetrennt, wo die Vergilbumg durch Nälnstoffmangel, durch ungeeignete Bodenverhältnisse, durch zu starke Verdunstmog nath dem Terpflanzen usw. besprochen wird. Die dritte Hanpteruppe heschäftigt sich mit "Flyrlende sygdomme", also den saftHïssen, wozn der llonigtan gerechmet wird. In der vierten Grupe lefinden sich die "Raathemele Srodomme", was mserer Auftassmo nach die Weichtäulen, die rerjauchenclen Bakteriosen oler Rotze bezeichnen dïrfte. Unter den Ursachen figmieren auch die "SnyltePlanterne", also die varasitären Pflanzen. In der füntten und rechsten (xmple werden die Wumlen, Frostspalten, Gallen und Monstrositäten alighamelelt.

In . Jahe 1779 ersehien in dentscher Übersetzung das ZaLLingersche ${ }^{3}$, systen mit dem dentlichen Bestreben, dic 'Terminologie der Medizin anf die Pflanzenpathologie zu ïbertragen. ZaLLinger nimmt

1) Answox, Su les maladies des plantes; in „Familles des plantes“. Tom. I, 1. 42. 1763. 8".

2) Forsôg til en Athandling on Planternes Sygdomme ved Jon. Cursts. Funn'ms; ind der kongelige Norske Videnskabers Selskab skrifter fente Deel. Kiôbenh. 1774. Sid. $4: 31$ 49.

$\left.{ }^{3}\right)$ Abhandlung äber die Krankheiten der Pflanzen, ilner Kenntnis und Heilung:

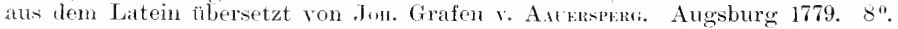


fïnf Klassen an: 1) Phlegmasiue oder Entzündmuskrankheiten: 2) Pur lyses seu debilitut's, das sind die lähmenden Gichten oder Entkrättungen: 3) Abtlüsse nud Ansleerungen; 4) Cucheriar, ïhle Leibesheschattenheit: 5) Hauptmängel der Teile.

Un die Antfassung ales Antors zn kennzeichnen, snchen wir nath der Krankheit, die wir nebst Brand als leitenules Beispiel in moser ganzen Darstellung hemutzen, nämlich nach dem hrehs. Zabliviel stellt denselben in tie Klasse der Cachexien zur Unterabteilumg der Benlengeschwüre, zn denen er die Rhathitis ofler Interwaths dis Leontiasis oter Rauhwarzen an der Hant n. a. rechnet. Ien Brand. Gangrena s. Splucelus, erwähnt er als anormale Cachexie nelien Phthiriasis oder der Lansistht mol der Vermiculatio, der Erzengmen von Würmern. Man kann aus dieser Grumprermes schliefsen, dates der Autor sich dabei von drm hänfig geneinsancen Auttreten der Ersehei nungen hat leiten lassen: dem die toten Rindenstellen lieten einen bevorzugten Ansiedlumsherel für Insekten. Itas, was wir jetzt als Getreidehrand bezeichnen, fimlen wir als Ustilago orler Mitiogeburt de. samens in der Klasse der Ausleerumgen. Fabricils hatte den . Kraels". Cuneer, in die Klasse der Fänhiskrankheiten veluraht.

In seiner Anleitung zur Kenntnis der Pflanzen verötfentlichtr. Batsch ${ }^{1}$ ) anch eine Ühersicht der Krankheiten, welehe ar in solche ein teilt, die in . Verderlmis der festen nud flüssigen 'Theile". also in der Konstitution der Pflanze legrindet sind, und in solehe, welehe .dureh Thiere und Gewächse" verirsacht werlen.

Man würele sich aber täuschen, wenn man nusere kryptogamen Parasiten in letzterem Alschmitte suchen wollte. Ibieselhen finden sich vielmehr in der ersten Klasise, getren der sehon bei Zablistike dent lieh zutage tretenden ت̈berzengmug (s. Ustilago), lats die parasitären Organismen nichts selbständiges, sondern nur Entwicklungstormen der höheren Pflanzen sincl. So hat Barsen nuter den Konstitutions krankheiten eine Gruppe: .Brandige Veränderung des Wresen". deren erste Familie die Erscheinmugen nunfatst. wo der Zerfall des trewebes in ein Pulver "Brand. Ustilago", stattfindet. Die zweite Familie enthält die Unformung der Gewebe in eine „schwammige Masse (Mutterkorn, Clurus)".

Diese Anschanungsweise gelangt nun für die nächste Keit zur Herrschaft, wie wir im folgenden Abschnitt sehen werden.

Durch die Arbeiten der erwähnten Autoren und die Erfahrungen auf dem Gebiete des praktischen Gartenhanes sowio durch das grotise

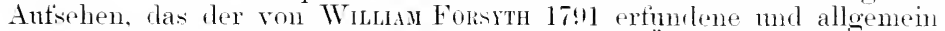
äherschätzte Banmkitt hervorgerufen. war die Überzeng'nng von der wirt: hattlichen Bedentmog ter Pflanzenklankheiten in so weite Kreise. gedrungen, dat's nummehr spezielle Bücher äber diese Disziplin erseheinen komnten.

Sehon das Jahr 1795 macht ms mit drei derartigen Werken he. kamnt. Das erste, ron PLENK ${ }^{2}$ ) geschriebene, behandelt die hrankheiten der sämtlichen damals wichtigen Knlturptlanzen mul basis't

1) A. J. G. C. Butron, Versuch einer Anleitung zur Kenntniss und Geschichte. der Pflanzen usw. I. Theil. Halle 1787. S. 284.

2) Plexk, Physiologie und Pathologie der Pflanzen. Wien 1795. 
anf eingehender Beobachtung. Betretts unseres leitenden Beispiels, des Krebses. berichtet der Antor folgendes: "Ein schwammigter grotiser Answnehs an einer stelle des stammes, ans der anch bei der dörrsten Wittermo pine ätende Fenchtigheit ansflietst, die den ganzen Umfang der Geschwolst anffitist. So wurde eine Pyrus Cydonia, an die oin sumpt grenzte, von dem Bammebs befallen, indelis die andern, an cinem höhern ort gepflanzten quittenbämme gesund blieben. Der Nahrmessatt wird, wie es scheint. von der Schärfe des stehenden ITassers so ätzend, dats er die Gefätse des Bammes anffitst. Die Arten des Bambrebses sind nach Verschiedenheit des Sitzes zweierlei: 1) Der ottene Bammkrebs. Wemn die Krobsnoten an der äntsern (herfläche der Rinde erscheinen. -) Der verborgene Krebs, wenn sich zwischen der Rinde und dem Holze eine scharte krebsartige Janche ansammelt, aber nirgends ans der Rinde flietist. In beiden Fällen fällt der Bam in eine mnheilbare schwindsucht, wofern man nicht sogleich die mit dem Krebs hehaftete Stelle ansschneidet und die Wunde mit dem Wundkitt verklel,t." Bei dem Brande mnterscheidet Plexk einen trocknen und fenchten Brand: miter ersterem versteht er .eine schwarze mod dürre Terwelkung der Blätter oder emes andern Theiles einer Pflanze" und als "fenchten Brand" bezeichnet er die .feuchte mo weiche Ansartmo der Ptlanzen in eine fanligte Janche".

Fast denselben Wortlant bei der Erklärmng des Krebses finden wir in dem sonst viele eigne Beobachtungen anfweisenden Buche von S'chreger ${ }^{1}$ ). Bezüglich der Branderscheinmoen, wobei die Rinde oder andere Teile des Bammes schwarz und mürbe anssehen und sich rerzehren, sagt er: „Dergleichen schwarze Flecken der Rinde tressen immer mehr $n$ sich und greifen anch das Holz an, so dafs die erstere endlich als algestorhen abspringt und das letztere dürr, schwarz mol wie verbramnt erscheint." - Diese Erklärmg deckt sich genan mit den Erscheinmngen, die wir jetzt wahrnehmen, wenn der Frost stärkere Rindenbeschädigmen veranlatst. und in der Tat kommt dieser Beobachter anch zu demselben Schlusse hetrefts der Ursache: „Zn seiner Entstehmo kömmen die Qnetschmgen durch Schlossen Veranlassmo geben; ferner kalte Nachtreife. Mehr scharlet noch der Reif in tiefen and fenchten. als in hohen und trocknen Gegenden. Windige Nächte schaden daher weniger, als wann es reift. Wemn die Bänme durch starke Winterkälte erfrieren und eingehen, so ist die Ursache ihres Torles meistentheils ein daher entstandener Brand. Dies geschieht theils, wem die strenge Kälte im Herbste zu zeitig kommt, wo der Saft in den Bämmen noch in lehhafter Bewegmug ist, theils im Frühjahr, wenn die Säte schon, wie man sagt, eintreten. Der letztere Fall ist der gefählichste. Nitten im Winter erfrieren sic anch bei sehr grotser Kälto sclten, es sey dem, dats es den Tag zuror geregnet habe." - Seite 4:0

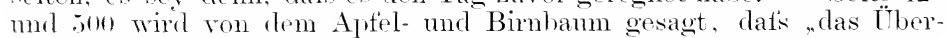
mats ron fettem, oeligem Dünger leicht den Brand und Krebs erzengt", also eine Prädisposition schattit.

Das dritte der im .Jahre 1795, erschienenen Bücher, von Ritter r. Ehrenfels ${ }^{2}$, spezialisiert sich noch mehr, indem es mu die Ohst-

1) Erfahrungsmäfsige Anweisung zur richtigen Kenntniss der Krankheiten der Wald- und Gartenbäume. Leipzig 1795.

2) Ritter v. Enrmpres, Über die Krankheiten und Verletzungen der Fruchtund Gartenbäume. Bresslau. Hirschberg und Lissa 1795. 
bäume behandelt. Der Autor erklärt, dats dem Brande alle Bannarten unterworten wären, und dats ., diese Fäulung. welche sich zuerst in der Rinde und dam im Ifolze selbst offenbaret". die gewälnlichste Bamkrankheit sei, the in einigen Büchem anch als Krebs bezeichnet werte. Die Beschreihmo, die r. Ehrexfers gibt, ist so dentlich, dats sie mit der jetzt als Nectria-Krebs bekannten Erscheimmo sofort identifiziert werden kann. Er sagt: . Die Zeichen dieses bïsen /untals sind daher vor allem eine shwarzo oder schwärzliche Rinde, welche oft schon $;$ his \& Tage nach dieser Erscheinung anfismingt, kleine. Rizen bildet und nach und nach ihren Kusammenhang mit dem Stamm des Banmes verliert, so dats die Rinde an dem sthatt nur locker anklebt. Nach ciniger Zeit tremnt sich die lockere Rinde ganz und gar rom Stamme los und enthlötst das Holz des Baumes. In Clieser Epoche hiltt sich freilich die Lebenskratt der kranken Pflanze. wie sie sich nur helten kamn, und stëtst manfhërlich die teindlichen oder kranken Theile von sich: aber diese Kraft ermattet anch znletzt, und der Bamm stirbt. - Der Bam rersucht eine nene Rincle zu banen - diese Rinde windet sich in mehr oder weniger ïbereinanderlicgen. den Falten herans and sucht sich üler die enthlëtsten stellen anszudehnen ..... Als Ursache giht Verfasser Verletzungen an, wie z. B. ein mrelständiges Ansästen, Insektenbeschädigmeen n. dol.: .ja zuweilen liegt die Anlage znm Brand in der Tisposition des Banmes sellist: eine Disposition, die die Bämme von dem Boden, in dem sie anfleben, von ihrer Abstammong und ron einer molngen Kultur r'halten."

In dem zu Antang des vorigen Jahrhunderts ersehienenen Pomologischen IJandwörterluch argänzt ('Hnss' ${ }^{1}$ ) die obigen Mitteilnngen dureh die Angabe: der Brand ., kommt auch vielmahls her rom Ferfrieren in Winter".

Auf eigne Beohachtmigen stïtzt sich fermer Bunder $\left.{ }^{2}\right)$, der vom Brancle sagt: . Inese Krankheit ist eine Folge indirekter sehwäche unel entsteht gomeiniglich an solchen Bämmen, welche vorher durch starkes 'Treiben und Inïngen in ihrem Wachsthum beschlennigt worden sind, oder welche man ant rinem magern Gartenboden in cin nur oberwärts stark verbessertes Erdreieh rersetzt hat. Bei Kirschbäumen äulisert sich aus den nämlichen Ursachen anch noch ein anderes Tehel, der Harz oder Grmmithuls."

I) Theorie von dem Einfluts des Bodens und der Itingung als oiner der hauptsächliehsten Trsachen der Pflanzenkrankheiten tritt nummehr für einige \%eit in den Hintergrmd gegenüher der vielseitigen mor ansgedehnten Forsehung anf dem rebiete des Pilzlehens.

Wenn anch rlas Altertum bereits eine Anzahl etsharer mul wiftiger. schwämme kamnte, so hegann eine aufmerksame Betrachtming nul systematische Bearbeitung doch erst im Mittelalter mit der Anfistellmm ron Srstemen des Pflanzemreichs. Nach den Angaben von Corm (Anleitum zum studium der Mrkologie) war es zuerst Axureas Catsursis 1.583 weleher in seinem heriihmten Buche "De plantis" dis Pil\% zusammenstellt. Er heschreilet 10 Gattungen: Tuluer. Peziza, Fundus.

1. Pomologisches theoretisch-praktisches Handwörterbuch. Lei lrig 1sog.

2) Srstematisches Handbuch der Obstbaumkrankheiten. Berlin $1 \times 1$.

Sorauer, Hanubueh. 3. Autl. Frster Banı. 
Bobletus. Suillus, P'rmulus. Prateolus, Fumiliola, Scoroglia. Fungus

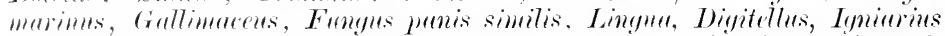
met Ayarinm. Wie es scheint, sind hire anch seetiere mit aufgenommen worlent.

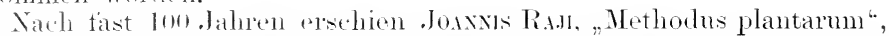
lomlini lox-2: 1710 folgte Bö̈rнave mit seinem "Tnelex plantarmm horti Tumbino-Batasi", mul 171! trat Tounkfokt mit seinen "Institutiones liei herhariar" hervor.

Jas llauptwerk, ant das die jetzige Mrkologie noch zurükgreifen mulis. orshine 17.2! in Nuntu's "Nova plantarum genera", in welchem ant melu als 100 seiten mol zwölf Tateh die Pilze sorotältigst be-

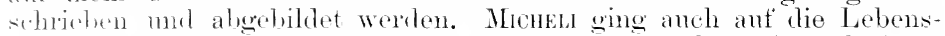
"richolnumgen wenance ein und war der erste, welcher die Anheftung

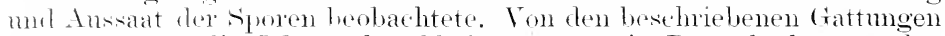
seren die fïr die Pflanzenkankheiten später in Betracht kommenden

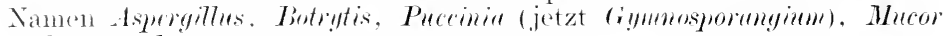
unel Leyeonfela genamint.

In selneller Reihenfolge erseheinen dann: "Nethodus tungormm" von (iLEnTsch (1753), die "Fungorm agri ariminensis historia " ron Batratid (1755), in welcher bereits ein besonderes Kapitel die Nützlichkeit mol schädlichleit der Pilze behandelt. Die seharfe systematische

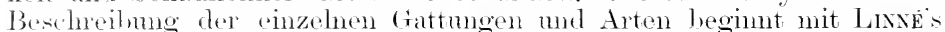
"Systema Naturae" (17:5), dem "Nethodus sexualis", den "Geñera

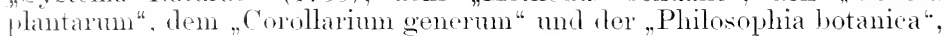
leren dritte Ausalie, 1790 ron WhLderow besorgt, eine genaue Autzählung aller Botaniker bis 1788 enthält. In diesem Werke wird auch sine Anzahl Krankheiten (Fames, Polysorkin, Cancer usw.) genamnt. In der ms vorliegenden Whluesowschen Ausgabe finclen sich s. :45 folgencle Bemerkmoen ïler parasitäre Krankheiten: „Erysiphe' Th. est Muror allows, capitulis fuse is sessilibus, quo folia asperguntur, frequens in Humulo, Lamio, Avere" usw. - "Rubigo est pulvis ferrugineus. foliis sulstus arlspersus, trequens in Alehemilla, Rubo saxatili .... -

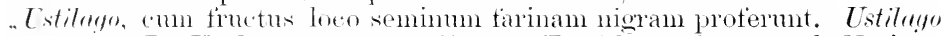
Hordri ( . B. Lstilug" Armar (. B." — Es folgen damn noch Notizen ïlor. Nutterkorn, ( икш. - Wichtiy tïr die Pathologie ist, datis der scharfe systematiker sich nicht verchweigen kam, datis eigentlich kein Individum dem and pon weicht mol Flina wie Boden beständig modifizierend anf den Orondismus eimwirken. Es heifst nämlich in cler Philosophia botaniea: "Variefates tot sunt quot differentes plantae ex ejusdem speciei semina stut proluctae. Tarietas est planta mutata a causa aceidentali: climate. solo, valon's. ventis etes: reslucitur itaque in solo mutata." -

Sherell mit den sulderanen Pflanzen heschäftigt sich Scopous Wel "l)iscertationes al scientiam natmalem pertinentes" (1772). Im Jahre 17so begam dio Meransgabe von Bulunso's "Herbier de la France." Paris, in whelhem anf

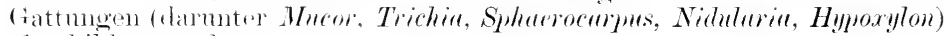
aligebiletet werdem.

Natehdem 178:3 in Jona Batseh' "Elenchus fungormm" und 1788 his 1791 Bustos's . Historia tumgorum, eirca Halifax sponte naseentium " elsehienen waren, in welchrn nur tie Lixxésehen Gattungen sich wiederfinclen, kam 17!n die wrotvolle, an eigenen Beolachtumgen reiche Abeit Tons: .. Fumpi medilenburenses solecti", in Lïneburg herans. Die 
äufserst sorgsamen Abbildungen unfassen unter anderen die Gattungen Acrospermum. Stilhem, Ascophora, Tubercularia, Holotinem, Folutella, Hysterium, Vermicularia, Pilobolus, die wir jetzt bei den Krankheitserregern wiederfinden. Auch A. r. Hovborder hat in seinem .Florae fribergensis specimen" (17!:3) eine gröfsere Anzahl ( iattugen beschrieben.

Aber alle diese Trteiten sind gheichsam nur als "Beiträge" zu bezeichnen. Eine zusammentassende, methodische systematili lieferte erst Persoos's tür lange Zeit matigebende n'ronopis mothodiea" (tiöttingen 1801). In England erschien von 1797 lis 1809 oin 4:39 Tateln weschätztel Abbildmoen bietendes Work rom Janes sowerby unter dem Titel "Coloured figures of english Fmogi or Mushrooms".

Immer mehr neigen sich num die Mrkologen den mikroskopischen Pilztormen zu, wemm auch die damalige (optik genauere studien noch versagte. Dies bezicht sich zmüchst ant tie in ten ,schitten naturforsthender Fremule zu Berlin" (:3. Jalngang 1sog 10) veröffentlichte Arbeit von Linck: "Observationes in Ordines plantarmm natmales" ume anf las an Kopien aus fröheren Büchern reiche Abhildmeswerk von

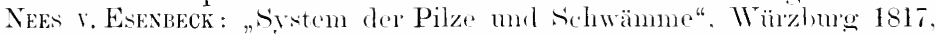
das dine Znsammenstellung "der Ansichten der tiefern Venetationsstufen, in geschichtlichen Fragmenten" enthält. Wir finclen darin anch die Aussprïche der Forscher, welche tür die Urzengmus dintreten, mul der Antor selhst, wemn wir die sehwölstige natmphilosophische Dar stellumg recht verstehen, tatst die parasitären Pilze in ihren nieshigsten

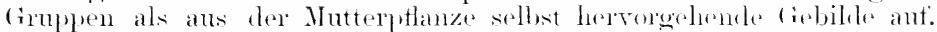

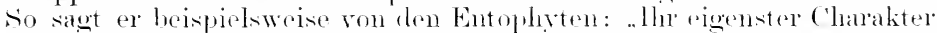

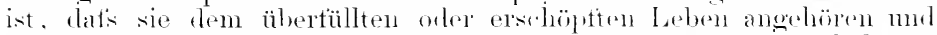
sich, ohne auts (ranze sith aushreitende Entnischmeg. mspringlich nul an einzelnen, aus dem fiesammtleben heraus in dio Besonderlueit gobildeten Stellen, gew ̈̈hnlich, doch nicht immer, zuerst muter der gemeinschattlichen Bedeckung. entwickeh. Die Abhängigleit der infusoriellen Zelle von dem höhern Organismus offenbart sich hior stets dureh ihr Aufsitzen mittelst eines mehr oder minder verlängerten sticls. l)i. Zelle wächst crst, che sie sich treimacht, mel die Verlängerumg an ihrem Grunde ist der Ausdruck des nirht plätzlich, sondern organisch aufgehobenen Polaritäts-Verhälnisses, das clureh die Hauptjtianze in siv" ïbertritt." Bei der (iattung Cyuthus (s. 14l) heilst as: .Der ganze Stamm, den wir besthriehen, ist nur ein der Erde entsprosiener stanlfaden. Der Stauh des Nitaubjilzes rzengt sich selbst . . . ."

Nummehr erscheint las klassische Werk von Euss Friss ${ }^{1}$ ), mit semen fïr die clamalige /e it scharton Gattumg- nud Artdiagnosen die ganze belannte Formenwelt des Pilzreichs umfassent.

Die Literatur legimnt num dur.h Einzelarbeiten und wissenschattliche sowie praktische, ten. Acker- mul Gartenlan mofassoncle Handbücher mel schriften, welehe die Krankheiten berühren ('Tessier. Järer,

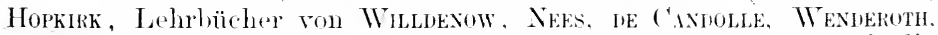
Reichenbich, Re, KIeser), derart zu wachsen, das wir nul noch die für die Geschichte der Pathologie markanteston Erscheinmogen herrorzuheben vermögen.

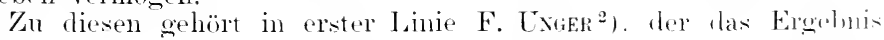

1) Srstema mycologicum T. I bis III. Lundae 1:21. Grylliswaldiar 1-2y his 1832. .-. Elenchus Fungorum. Grvph. 1s.

:) Die Exantheme der Pflanzen und einige mit diesen verwandte Krankheiten der Gewächse. Wien 1833. 
äntierst Heifiger und gewissenhafter sturlien in seinen „Exantheme der Pflanzen" 1s:3: veroffintlichte. Der in einem kleinen abgelegenen Alpentale lobende Arzt wilit in einer Anzahl sehr sanber mol naturgetreu sellstgezeichmeter Abbildmoen seine Beobathtmgen wieder nut haut ant dieselben seine I ehre von den Krankheiten ant. "Die meisten Kramkheiten der Pflanzen spielen in den saiften .... Die fehlerhafte Anshildumg mol die zahlreichen Almormitäen im chemischen Vorgange les Nahrungsites, sowie ähnliche Fehler des höher belebten Lebenssaftes, sind die Trsatho von mmähligen Krankheiten, die sich durch mangelhatte Anshilelung der Ptlanzensuldstanz, dureh Anhäufung von Excretionstotfen, dureh Authokerung des Parnchyms, dureh veränderte Beschatfenheit der Sekreta nisw orler durch Zustände von entgegengesetztem Charakter äntsern. Ïbrrhaupt dïrfen die meisten quantitatir mol qualitativ veränderten Vosöingo der pflanzlichen Chylopoese als die Qnelle ron Krankheiten angesehen werden, die sich meln furch veränderte sulstanz als durch Alienation der Form zu erkemnen geben. Der ('ulturstand, in den ein grotser Theil der Pflanzen versetzt wirl, wirkt so nachtheilig ant den (homismus, dats wenigstens der grötste Theil solcher Pflanzen krank genamit zu werden rerdient...."

TV̈̈hrend wir nach diesen Darlegmgen vermmten mïssen, dats der Antor die Krankheiten als Funktions- und Billungsabweithungen im Haushalt des Organismus auffassen würde, liommt Uxier zn der Ansicht. datis die Krankheit etwas Fremulartiges sei. "Dem wie sich das Kosmische. Elementarische als Älterliches orler Torbildliches zu dem Organischen, Kindlichen, Gegenbildlichen verhält, ehenso der Organismus zur Krankheit, die nichts anders als ein zwerter, niederer Organismus ist, dessen Elemente shon in einem andern höhern verborgen liegen." In dieser Ansehaumg liegt die Forthildmmg. des ron BATsch geäntierten Gedankens über das Wtsen der parasitären () loanismen.

„Zu den Krankheiten der Gewächse, sagt Trowk, „lie am wenigsten selhstständigkeit verrathen, die in ihrer Wrumelgestalt noch so immig mit demjenigen Organismms, den sie hefallen, verwebt sind, gehören ohnstreitig die Fomen. die wir mit Bleichsmeht (étiolement). Wassersucht (anasarca), (rellsucht (icterus), Windsmeht (timpanitis), Tabescenz, Mitswarhs, den Prothurien n. a. m. bezeichmen, mol welche bei weitem die Mehrzahl ansmachen. Grölisere Selbstständigkeit zeigt flas ungehemre Heer ron Mitshilılungen, denen immer Fehler der säftemasse mal dadurch ein Verweilen ant tiefern Bildungsituten zu Grumble hegt. Ueber diese erliebt sich der Honigthan (Saccharoymesis diubetica), dessen pathischen Prozess zuerst L. Trevinases mol seine miversellere Bedentung H. H. Sinmm erkamten. Terwandt mit diesem ist mstreitig Ger Mehlthan: das höhere Organisationshestreben der ausgeschwitzten säte offenhart sich hier dureh organische Bildungen, hie dem Honigthan noeh fehlen. Noch scllstständiger werden diese organischen Bilılumgen im Rutisthane (Fuligo vagums). Endlich tritt der Krankheitsorganismus in den Exanthemen und den ihmen verwandten Formen als eigenartiges geschlossenes Ganzes hervor . . . . Hierher gehören die Parasiton; die hörhsten nuter ilmen, wie einige Arten von Loranthus, scheinen sich vom Nutterkörper gänzlich losgerissen zu haben." - 
Unger's Anschanumgen teilen anch NeEs r. Esenbeck und A. Inenk ${ }^{1}$ ). die betrefts der Stauhnilze erklären: „.... die Pilze stehen hier dentlich aut der tiefsten Stufie..... . . Fit Recht betrachtet man sie als Krankheitsstotfe, als Exantheme der höheren Pflanzen." "Es bildet sich im allgemeinen der Blattpilz dmel eine Coagulation der in die Intercellulargänge ergossenen sütte."

Unter dem Einthuts dieser Ansicht sehrieb anch Theonor Hartei seine Arbeit über die Rot- mul Weitstänle der Kieter. bei der er zuerst (lie Mitwirkung von Pilzen (Nachtfasern. Nyctomyres) teststellte?). Die Entstehmo dieser Pilze tüihte er anf einen Zertall der Kollwandmugen zuriuck.

Ton den Terken, die mehr die allowenenen Konstitntionskrankheiten ins Auge fassen und die Pilze kamm brrïhren, nemnen wir die von (iEmer ${ }^{3}$ ) nud LINuLEY ${ }^{4}$ ), die in wesentlichen sich ant praktischen Erfahrungen anthanen. Dagegen zeigt wielermu Wibguns ${ }^{5}$ ), dats seine Angaben sich anf mikroskopische studien stïtzen und hierhei auch die Chemie ihre Berïcksichtignng findet. Beispielsweise gilst er an, dats die Janche des Brandes sowohl als des Krelses Gallert- mul Humussäure, aber die des Brambs melur frallertsäne enthalte. Beide Krankheiten erscheinen ilm nicht parasitarer Xatur, und der Krebs (C'aries, Necrosis) entstehe immer . ans storkmog mel Verderloniss der

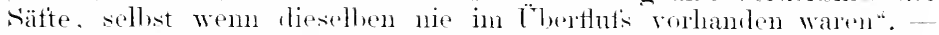

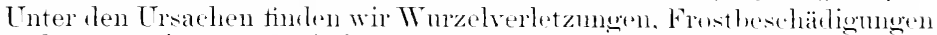

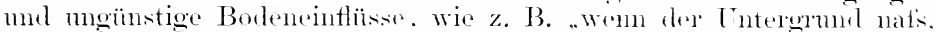

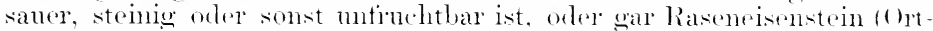
stein) entlı̈̈l".

Nacholem mittlemweile das geotise Pilzwerk von CoRm ${ }^{6}$, zu er-

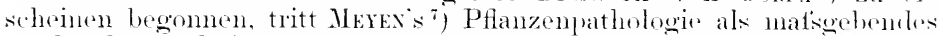
Buch. das auch jetzt noch zu Rate gezogen zu werelen verelient, hervor. Er teilt die Materie in näntsere Krankheiten" mul „Innere Krankheitell".

Zn den ersteren rechnet er antser don Verwumburen dureh Mensehen und Tiere. Maser- nud Gallenbildnngen aneh die phanerogamen und kryptoganen Parasiten, von denen Estilagineen und Tredineen sowie antere Pilze nach dem damaligen standpunkt ansfïlntieh abgehandelt werden. Nriex toilt nicht mehr den Uxiks sehen Stamprmkt, dats die Parasiten als Atterorganismen clas Produlit einer in jecler Pflanze ruhenden Bildumgsichtung. der Krankheit, seien mul je nach der Beschatfenheit mol Fratt des Nähroranismus in einer mehr oller weniger entwickelten Gestalt nud sielbständigkeit zutage treten. Im Gegenteil hebt seine Pflanzenpathologite lei Besprechmo der Brand-

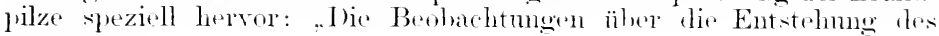

1) Das Srstem der Pilze, I. Abt. Bonn 1\$37.

2) Abhandlung über dic Verwandlung der polveotylen Pflanzonzelle in Pilzund Schwammgebilde und dif daraus herrorgehende sogentunte Fïulniss des Holzes. Berlin 1 $15: 3:$.

3) Die Krankheiten und Feinde der Olstbämme. Nünchen 1s.:-

4) The Theory of Horticulture. London 1:40.

5) Die Krankheiten und krankhaften Mifsbildungen der ciewälhse ron lus. A. F. Wramax sen. Bratumschweig losis.

6) Icones Fungorum hueusque cognitorum. Prac $18: 37$ l,is 15:4t.

7) Pflanzen] athologie. Lehre ron dem kranken Lelon mild Bilden der Pflanzon.

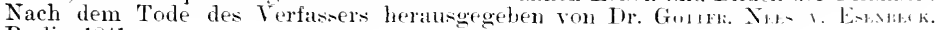
Berlin 1841. 
Brandes zeigen ant das dentlichste, dafs wir es hier nit wahren Entophyten zu tum haben: wir werden sehen, wie sich einige Brandarten als eigne parasitische (iewächse im Imern der Zellen der von ihnen befallenen Pflanzen zeigen und dats man die Brandmasse nicht mit dem thierischen Eiter zn veroleichen hat."

Der Haupttitel für MErex's ..Pflanzempathologie“ lautet eigentlich: .. Hantbuch ifr Pflanzenpathologie und Pflanzenteratologie. Heransaegeben ron Dr. ('hr. Gottrk. Nees r. Esenbeck. I. Bd. Pflanzenprathologie." Nach diesem Titel wäre ein zweiter Teil, nämlich eine Teratologie, noch zn erwarten gewesen. Meres selbst hatte die Absicht, eine solehe zu hearbeiten, aber nach den Mitteilungen des Heransgehers kem literarisches Material dafür hinterlassen. Als Nees r. EsexPECK num relbst eine Bearbeitmo vornehmen wollte, erschienen die „Eléments de Tératologie régétale. on Histoire abrégée des anomalies de lorganisation dans les régétaux: par A. Mourin Tandon, Doct. sciene. et méd. ete. directeur du jartin des plantes de Toulouse. Paris 1s41". Als Vorgänger dieses Werkes sind zu nemen C. F. J Jfger: "Über die Nitsbildmingen der Gewächse". 1814, und Thon. Hopkikк: .Flora anomala". 1si\%. Wir ersehen ans der deutshen Übersetzung

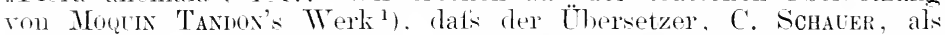
spezialist in der Lage war. manche Hitsrerständnisse und Fehler des Antors, namentlich in den dentrchen Citaten, zn beriehtigen und Ergänzmngen ans eigenen Beobachtungen zu geben. Mouris Taxion sagt: .. Unter dem Ausdruck Mitsbildungen, Monstrositäten (Monstra) rersteht man meist angeborene, mehr onler woniger bedeutende und complicirte Abweichmgen ron dem Tyms einer Art, welche fehlerhafte Entstellmgen herrorrufen und dem regelmäfsigen Gange der Funktionen hinderlich oder hemmend entgegentreten." Besser wïrde uns clie Definition von re Cindolde (Théor. élément. 1. éd. p. fori) gefallen, wonach Momstrosität jede Störmo der Ökonomie eines Gewäthses ist, welche eine Formseränderung der Grqane nach sich zieht mul ans einer immeren Anlage. fast niemals ans cincr sichtlaren Ursache entspringt.

Das Werk ron Monn Tanow int wegen semer ansqezeiehneten Literatmmachweise anch jetzt noch jerlem Spezialisten mentbehrlich. -

Um diese Zeit erhält dis Lehre ron den Infektionskrankheiten einen nenen Anstots durch das Üherhandhehmen der Kartotfelkrankheit, die anch jetzt noch als einer der gefürchtetsten Feinde unserer Landwirtschaft eine bronder" Anfinerksamkeit in Anspruth nimme und als Krant oder Plytoflithoratiunle in den Lehrbüchern hesehrieben wird.

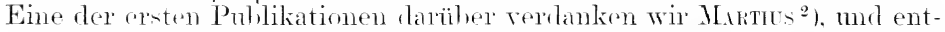
sprechend don äntserst schweren schärligmuen dos Nationalvermögens dureh diese Krankheit folgt von da ab eine Fhut von Veröftentlichungen.

1) Pflanzenteratologie. Lehre von dem regelwidrigen Wachsen und Bilden der Pflanzen. Von A. Mriners Taxwos. Übersetzt und mit Zusätzen von Dr. I. ( . Sintrear. Berlin $18+2$.

2) Die Kartoffelepidenie der letzten Jahre. München 1842. 
von denen wir num die von Focke ${ }^{1}$ ), P.rex ${ }^{2}$ ), Schomp ${ }^{3}$ ), SPerrschnendi ${ }^{4}$.

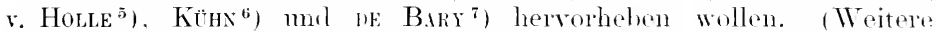
Literatumachweise finden sich bei der spezicllen Bepreehmog der einzelnen Krankheiten.)

Dats eine derartige Erscheinmo wie die Kartotfolepidemie dis

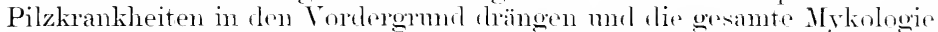
befinchten mutste. war sellsstverständlich, zmmal anch dic alionomisthe Wichtigkeit der Brandpilze immer grötere Bearlitung zn finden begann.

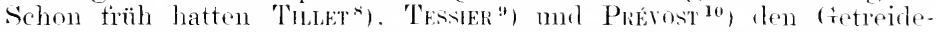

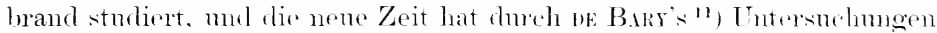

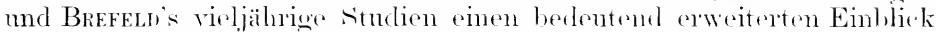
in das Wesen dieser Frankheiten und auch ïles dir Mittel zu ilner Bekämptumg elangt. Von den Brandkrankheiten ans hat sieh vornelm-

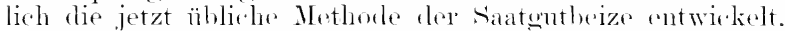

Indem wir betrefts der ïberwätigend roielen myloblogisehen Arbeiten ant den speziellen Teil des Buches, ter die parasitären Krankheiten behandelt, verweisen, wollen wir hier nm zu riniuen der latuptsächlichsten, die wesimton Pilzfamilien helandehulen drheiten zmö̈ckkehren. Des grotisen Werkes von Euss Friss, das $18: 32$ vollendet wome, ist bereits gedacht worden. Im Jahre lisil ersehien der erste.

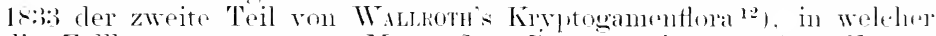

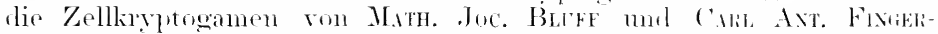

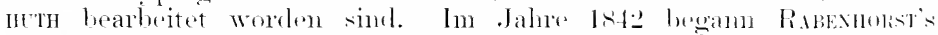

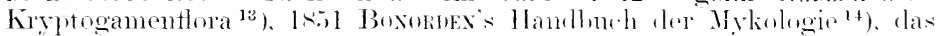

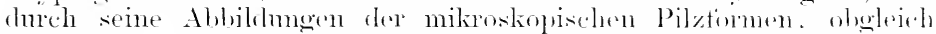

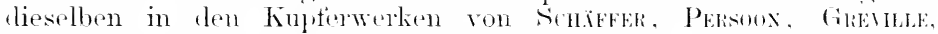

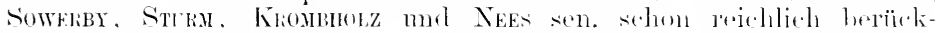

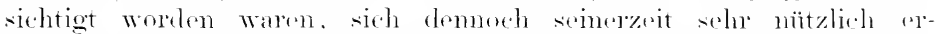
wies. Zwar existierten auch hereits die nleones tumgormon" rom ('on-s und seine mit sehr kleinen Kedehmmgen versehene, trïher ewähnte

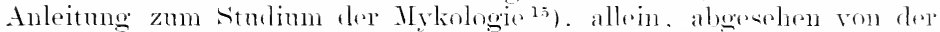

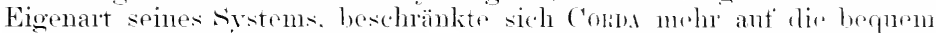
sichtharen Entwicklungstadien, während Boxonws eingehember den Ban der frewebe testzustellen suchte. Dieser Autor Petont Tritis gegenüber, dats die prasitären Pilze mbedingt selleständige olomis-

1) Die Krankheit der Kartoffeln im Jahre 1845. Bromen 184ti.

2 Les maladies des pommes de terre, des hetterives. des blés ot des vignes. Paris 1

3) Soncir, Bericht über die Kartoflelpflanze und deren Krankheitrin. Berlin 1 $\div 54$.

4) Das Faulen der Kiurtoffelknollen. Flora 18.7. Bot. \%. 16.;.

5) Über ten Kartoffelpilz. Bot. Zeit. 1s..

6) Die Krankheiten der Kulturgewähse, ihre Ursachen mod Verhätumer. Berlin 185.

7) Die Kartoffelkrankheit. Leipzim 1×ril.

8) Dissert. sur la cause qui corrompt les uratines de lide, 175.5.

9) Traité des maladies des graines, 17.8.

19) Mémoire sar la cause de la carle des blés. 1sot.

11) Entersuchungen über die Brandpilze. Berlin 1-5:3.

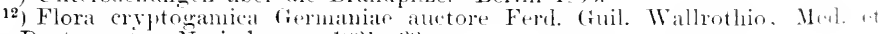
Chir. Doctore ete. Forimlerenar 1 $-31-3: 3$.

13) Kryptogamenflora von Dentschliud. Bd. I. Leigrig 1s4t. 2. Aufl. 1-1'll $188+1903$.

14) Handbuch der Allgemenen Mrkologie usw. mit 12 Taf. Abl. Stuttgart 1-i1.

15) Anleitung zmm Studium der II vkologie nebst kritiseher Butherimug aller bekannten Gattimgen. Prag 1>4t. 
men wären. bohampted aher, ., lat's die Spaltöfthmgen es sind, welehe die sporen anfinelumen mol in den danit in Virlindung stehenden Lntthöhlen zur Entwickhng bingen". Er sagt, latis Algen, Flechten mol Moose, whlohe kine spaltöttimngen laben, und ebenso junge /weige mul Äse firei som Parasiten sind. Betretts der Wirksamkeit dex Parasitem änl'sert or sich dahin, dats sio ,zmüchst eine Hrpertrophie mol I heneration der helasteten Theile verursachen; wo sie aber nu veremzelt vorkommen, wird die Vegetation der Bläter dachreh gar nicht gestört". Narli ilm ist trocknes Wetter der Verbreitung der Panasiten wesentlich förderlich, weil dieses die Verstänbming der Sporen hegünstigt, weshall, cueoma und Ploummidinm nie hänfiger als in trocknen fonmern gefmulen werden, auch das den Saten so verderbliche Conmm anolimm, der gelbe Kormbrand, der im Jahre 1845 so vielen sichaden anrichtete."

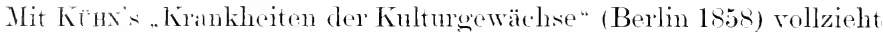
sich der von Merex hereits angestrehte Zweck der Verschmelzung wissenschaftlicher sturlien mit den praktischen Erfahrmeen behufs Behandlung der Pflanzenkrankheiten in der glücklichsten Weise. So notwenlig mut so hervorragend die rein wissenschafthichen Untersuchnngen in den einzohen telieten der Phytoprathologie anch immer sein mögen. so erhalten vie doch ext ilme volle Berlentung durch eine Prüfung im praktischen landwirtschaftlichen Betricbe. Nur in der praktischen Kultur kam man die Hamptfrage lösen. ob die Verhältnisse in der fieien Natur diescllo Entwicklung von Parasiten oder andern Krankheitserregern ebenso zulassen, wie sie sich im Laboratorim gezeigt hat. Und darm ist es notwendig. dat's die Plytopathologie sich anf paktischen Kemotnissen des Acker- mol Gartenlanes sowie der Forstwirtschaft anthane. Jic Untershiede, die in der Medizin sich herans. geliblet halon zwischen dem wissenschaftlichen Forscher und dem praktischen Arzte, nuïsen notgednungen anch in der Disziplin der Pflanzenkrankluiten sich anshililen. Tie praktische seite bezeichmen wir als die Lehe rom "Pt'lanzenschutz".

Lie nxtiologischen studien gehören zn den mentbehrlichen Grundwissenschaften ifes Pflanzenschutzes, mol daher hahen wir dieselhen in ler Geschichte der Phytopathologie mit nöglichster Anfmerksamkeit berückichitigt. Fortfalirend in diesom Bostreben nennen wir zunächst

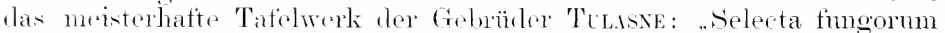
"arpologia". Paris. mol las als Sammelwerk willkommene aber mit meist recht enoben Abliblmugen versehene englische Werk von Berketey: "Ontlines of British Fungologr", Londom isto. Vom besonderem Werte

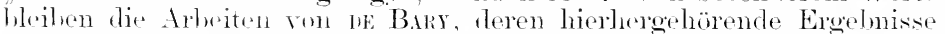
sich in der .Morploologie mul Phrsiologie der Pilze. Flechten mul

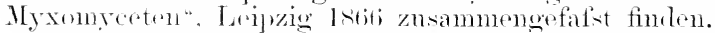

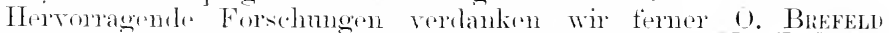
dureh seine .. Thtersulnmgen äher die sehimmelpilze", Leipzig 1871,

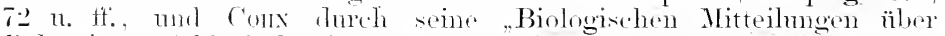
Bakterien", schlesiscle Ges.t. vaterl. Kultur, 187, sowie durch seme

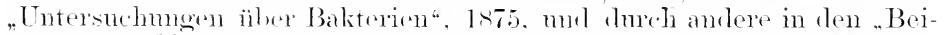
trägen zur Biologie , lex Pflanzen" entlaltenen stmelien. Cons hat darin

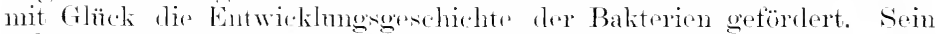

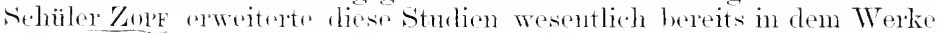

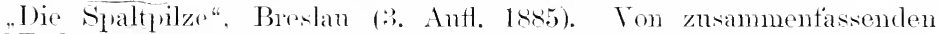
Werken ans dieser Zeit sind noch zu nemuen: Eusu, "Der gegen- 
wärtige Standpunkt der Mykologie mit Rücksicht auf die Lehre von den Infektionskrankheiten.", Berlin (2. Aufl. 1872), und ferner Wrvter, "Die Pilze Dentschlands, Österreichs und der Schweiz", I.eipzig 1884.

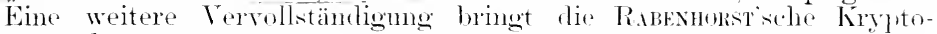
gamenflora.

Die umfassendste systematische Zusammenstellumg der gesamten Pilze bietet P. A. Siccinoo's sylloge timgormm", desien XI. Band mit einem .suplenentm miversale". Patavii 1s.5, erschienen ist. Daran schliefst sich in Jahre lsen srowes .Index miversalis et locupletissimus nominm flantarum hospitium specierumque omminm fungormo", Berolini. Fratres Borntraeger. Das Buch enthält alle bis 18:\% bekannt gewordenen Pilze. Neitere supplementhände (XIV bis XVI) erschienen ls!!! his lon:2 und werelen noth forteresetzt.

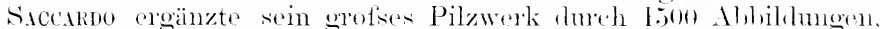

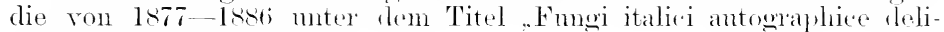
neati", Patavii. erschienen.

An Stelle der skizzenhatten Zeichnungen dieses Werkes beanm A. N. Berlese rine serie äul'serst sauberer, farliger Alhilılungen unter tem Titel .. Ieones fungorum at nsm Sylloges Sacearelianae adeommo-

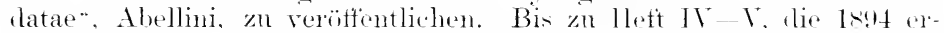

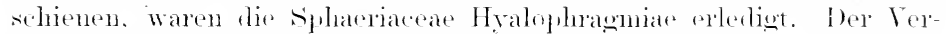

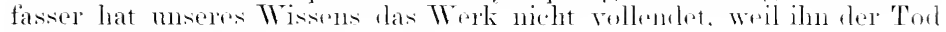
zu friih dahingerattit lat.

Ehentalls tarbige Abliblumen finden wir in cooks , Mreographia

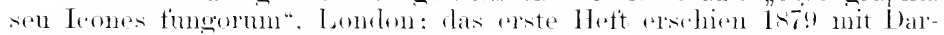
stellung der Discomperenter

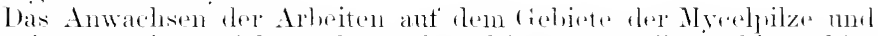
Baliterien zu einer nicht mehr zn bewältigenden Fïlle verbietet hier rin weiteres Eingehen ant die Materie mil zwingt ms. aut den seit

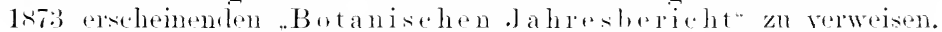

Dats auch die 'Treatologie seit Nouces Taxos ihre writere Entwicklumg getumelen hat, ist sellestrerständlich. Ton Werlen, die das Gesantmaterial behandeln. sind hervorzuheben: M. Masters. . Venetable Teratology". London 1site. nut O. PExzle, ..Pflanzenteratologite". systematiseh geopluet. (remma 1s!n--94, das als das vollständigste Nachschlagebuch aut diesem Gebiete bezeichnet werlen dart'.

Ein weiteres Eingehen ant die mykologische Literatur müssen wir des beschränkten Rammes wegen unterlasson. Der Leser findet aber die gewïnschte Ergänzmng in zweiten Bande dieses Werkes. Notwentip.

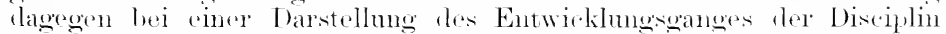
erscheint noeh ein kuzer Hinweis anf die zahlreichen Ansuaben natiorlichen getrockineten Materials in Herlyarientorm. Von don Exikikatenwerken, die speziell sich mit Ptanzenkrankheiten befassen, seien lier

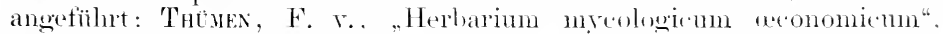

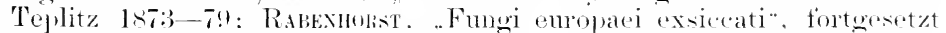

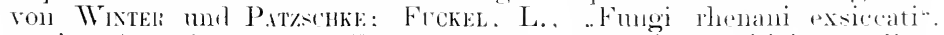

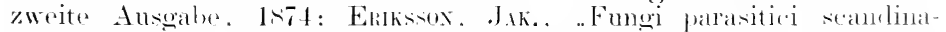

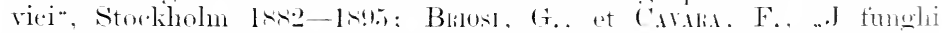
parassiti delle piantr coltivate on ntili essicati, lolinnati " herenti".

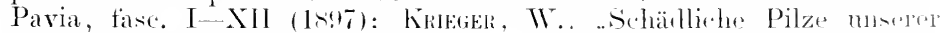

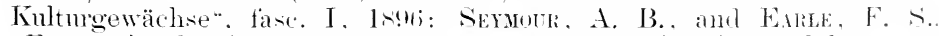

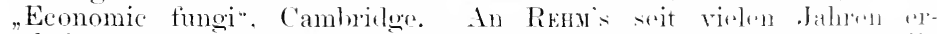

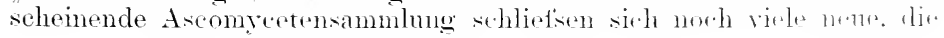


allgemeine Pilzflora einzelner Länder darstellende Exsikkatenwerke an,

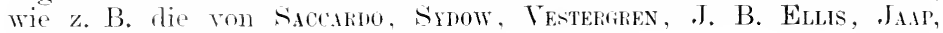
Вевік und Kabıт. Pösci nкw.

Während die Pthanzenlirankheitslehre die teratologischen Erscheinmoen nur so weit heranzmzichen versucht, als sie für die einzelnen Torkommmise eine bestimmte Störung in den Enöhrmas- oder Banrerhältnissen als Trwache nachweisen oder wenigstens vermuten kam, war sie cezwmon. immer eingehender die Tierwelt zu berücksichtigen. Als beconters verlnritete, das ganze Material oder grötsere Gebiete zusammentassonde Werke. die als Unterlage tienen, sind zu nennen: Ritzebriti, .l Die Forstinsekten". Berlin 1839-1844, umd: "Die Waldverderbnis". Berlin 186ti-68: A. Gerstäcker, "Handbuch der Zoologie", II. Br.: Arthoporlen, Leipzig 1813: E. L. Taschenberi, „Entomologie tïr (rärtuer und Gartenfremole", Leipzig 1st1, und: .Die der Landwirtschaft schädlichen Insekten und Würmer". Leipzig 1865. Ferner:

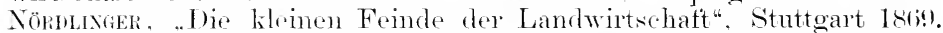
Kuntenbach, "Die Pflanzenfeinde aus der Klasse der Insekten". Stuttgart 187t, und Ritzens Bos. . Tierische schädlinge und Nützlinge", Berlin 1891.

Teniger reichhaltig an Material, aher dem praktischen Bedürfnis des Iaien meln angepalist dureh seine farbigen Tafeln int tas vom C. Frexch im Auftrage des Ackerbandepartements von Viktoria heransregebene .Handliook of the destructive insects". Melboume 1891.

In demselben Jahre erschien eine kleinere Spezialarbeit über Gallenhildmgen von H. R. v. S̈chlechtendal: .Die Gallbildungen (Zoocecidien) der dentrchen Gefätipflanzen". Zwickan 1891, and zehm Jahre später sin umfassendes systematisches Werk von G. Darboux und C. Horaki, "Catalogne systématique des Zoocécidies de l'Emrope et du Basin méditerranéen", Paris 1901.

Durch viele sorgfältig ausgefïlnte Originalzeichnmoen empfiehlt sich die "Forstliche Zoologie" von K. Eckitess, Berlin 1897. Speziell dem Gartenhan dienen die populären Sthriften von H. v. Schlunv, von denen wir hervorheben: .Die Schädlinge des Obst- und Weinbanes," . Die Schädlinge des Gemiisebanes," Frankfiurt a. O. 1898, und den ..Praktischer Ungezieferkalender," Frankfurt a. 0. 1902. Ebenfalls dem pralitisclyen Bediürnis angepatst ist der .schutz der Olstbäume gegen feindliche Tiere" von E. L. Taschenberti (?. Antl. von O. Taschenberi Stuttgart 1901 .

Bei der weiteren Entwicklung der Disziplin des Ptlanzenschutzes zeigt sich das Bentreben, für einzehe der hauptsächliehsten Kulturptlanzen Hilfstü̈cher herzustellen. Als Beispiele tühren wir an: Eisbeis, . Wie kleim Fomde des Rübenbanes", 1ss:. mit sauber ansgeführten

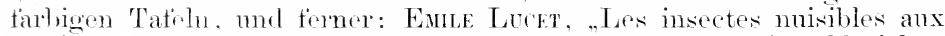
Rosiers sanvages et cultivés en Franco". Paris 1s98, mit zahlreichen Tateh in sihwarzlun.k. Am ansgebildetsten ist die im Dienste des Pflanzenschutzes arlsitende Zoologie in den Vereinigten Staaten von Nortamerilia. wo die Zoologen an den zahlreichen Versuchsstationen rer Einzelstaten, als anch speziell die ..Division of Entomology" des Department of Agrienlture zu Washington teils durch nene Forschungen, teils durch Verbreitung popmlärer Abhandlungen die Lehre von den Feinden der Kulturptlanzen mngemein fördem. Eingehendere Hinweise 
auf die zoologische Literatur finden sich im dritten Bante dieses Handbuches.

Entsprechend dem immer nehr sich vertiefenden Verständnis für die nationalökonomische Bolentmo der Phytopathologie hat sich seit

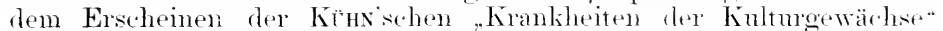
die Zahl der Lehr- mul Handhörcher der Phytopathologe allmälich

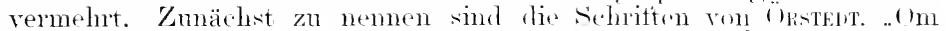
Srodomme hos Planterne. som foraarsages af sonvlteswampe. navnlig

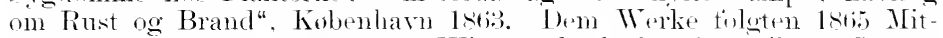
teilmogen des Vertassers äber Wirtswehsol ter Rostpilze (Gymmosporangizm Sabinac). Sotam erschien das Buch von HaLbibs ${ }^{1}$ ), der wegen seines besontern stambmutes in oiner fosehichte der Pflanzenkrankheiten eingehenter berïckichtigt werden muls. Diese Hatuerschen Anschammoen, die zn scharfien literarischen Ansoinandersetzmegen,

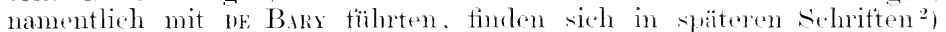
wiederholt mol erwitert. In seinen .Pestirashlseiten der Knltur. gewächse" liefert llatuel eine Reihe von Untersuchmogen äher die Peromosporeen. me gland, damit die Riehtigleit seiner .Plastiden-

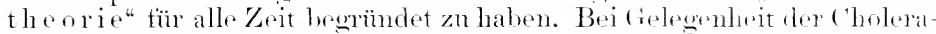

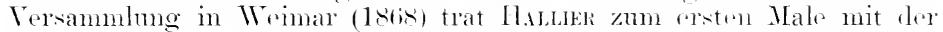

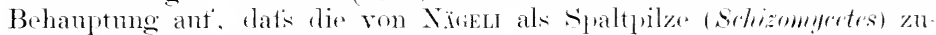

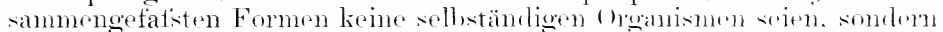

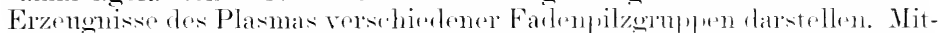

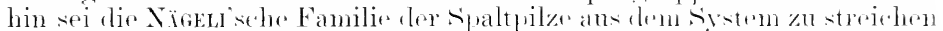
mel die gesamten lutektionskrankheiten anf dio Wirkung derartiger

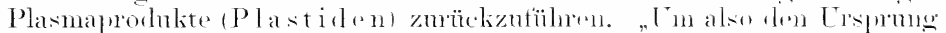

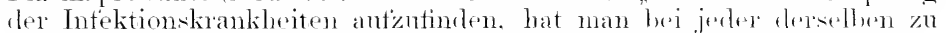
meternchen, weleher hestinme Pilz ans seinem Plasma die Kontagions-

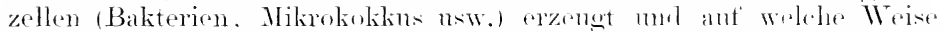
das veschieht." Betretts der dumeh die Phytophthow er\%eneten Kartottel-

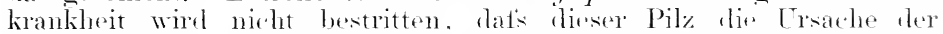
Krankheit sei, aber reses weniger direkt, als viohmehr durch dir Bakterien. . Tor allen Dingen habe ioh bewiesen. dati die Bakterien, welehe dis ahsolute Errache der Kartotfielyest sinel. von den Plastiden der Phytophthora crzongt werlen. mel dats diese sind sie erst eimmal ansgebildet, zur Erzengung der Pest dluchans genïgen. und es des Mreals ind der Knospen der Phytophthora gar nitht mehr brelart." Seine

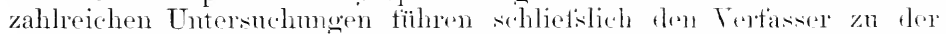
Erkemutnis, dats bei allen hotektionskranklesiten, menschlichen. tierischen und pflanzlichen. zweitellos drei Momente in Betracht

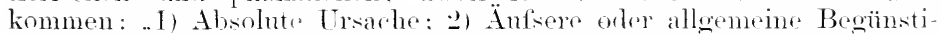
gung (Gelegenheitsursache oder 1)isposition): i) Persönliche Brgïnstignng. d. h. Emptänglichleit des Erlirauliendrn."

bie Ansehammg. das hei allen Krankheiten nicht mm dio direkte Ursache. sondern anch lie fiöheren. vorboreitenden stadien nut bei den parasitären Aneritten dio den Parasiten in soiner Entwirklmo begïnstigenden Nelenmmsänd, ainsthlieflich dex I)isposition des Xährorganismus zn berieksichtigen sind. hatte znerst sostcen in seimen .Handbuch der Pflanzenkramkheiten“. I. Anfl. Borlin, Panl Parer. 1ATt.

1) Phytopathologie. Tie Krankheiten der Kulturgewiahse. Leiprig 1-ri-.

2) Die Plastiden der niederen Pflanzen. Leipzig Bas. Die Protkinkheiten (Infektionskrankheiten) der Kulturgewächse. Stuttgart 18\%. 
in die Phrtopathologie eingetührt. Eine woitere Begründmng lieferte tie zweite Anflage des genamnten Werkes (18si) und ein speziell tür den Praktiker genthrehener Anszug: . Tie schäten der einheimischen Kulturpflanzen" lsst. Nor langxam haben diese Ideen sich Bahn bredhen kïnnen. wis dies die näthstfolgendon Handbücher erkemen lassen. Von diesen nemen wir das durch zahloeiche eigne Forsehungen gerchätzte: .Lehrlmeh der Bammkrankheiten" von RoBERT Haltis, Brylin 18s. (II. Autl. 1ss!). Die dritte Anflage, in welcher ler Verfasser nummeler röeklatskos eine Prärlisposition anerkemnt mol eine ätliche. zeitliehe. indivisuelle, erworbene nul krankhatte Prädisposition

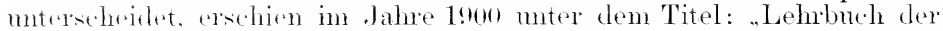
Pflanzenkrankheiton". Berlin, Julins springer. - Als Vorarbeit für diese Lehrlötcher anzuspechen ist eine studie über die Zersetzmmgerscheimmorn des Ilolzes, die nnter dem Titel: "Wichtige Krankheiten

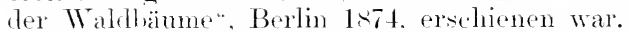

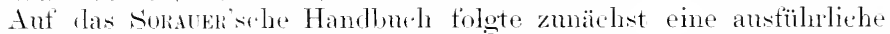
Bearbeitung von Fraxk: "Die Krankheiten der Pflanzen", Breslau

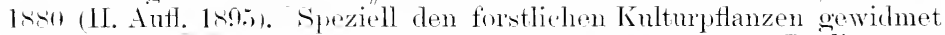
ist das ,Lehronch des Forstrehntzes" von 1I. Nördungel, Berlin 1884. Tmfassemler und mit einem Atlas versehen ist das Werk ron solda, .Note di Fitopratologia". Firenze 18s's, dem eine Alveit ron Broxehoks, „Le rigtigste Plantestgdomme", 18st, in Norwegen voranwing. In dieses Jahrzelnt fallen anch eine Anzahl beachtenswerter Artikel von Jexsen, von denen (nach Rosthup) hier erwähnt sein mas: . Kartoffelsyen kan overvindes red en let udtorlig Drrkningsmaare". Kjölenhavin $18 \times 2$.

Während lie lisherigen Autoren die Krankheiten nach ihren erwiesenen ofler angenommenen Ursathen geor het hatten, trat Kinchnek mit einem srezicll für len praktischen tebranch eingerichteten Terke: "Dic Krankhriten und Besehädigungen unserer landwirtschaftlichen Kulturptlanzen", Stuttgart 1s!n), hervor. Hier sind die Krankheiten nach den einzelnen Fulturpflanzen angeführt und nach ihrem dem blotisn Ange entergentretenden Habitus aeschildert. Systematische wistenchattliche Eräänzungen werden am Ende des Buches zusammengestellt.

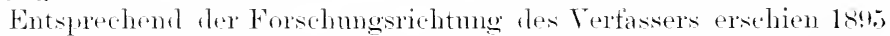
sin reich illustriertes Werk, das nur dic parasiären Krankheiten belandelt: "Pflanzenkrankheiten, dureh kryotogame Parasiten rerursacht", vom Kinl Fremerli r. Tubevf, Berlin, Julins springer. Der Parasitismus wird hier als eine Form der Symbiose dem Terstänthis des

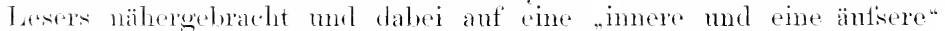
I isposition zm Erkrankung hingewiesen. Die innere hängt non dem Custante dor Energie des lelenclen Protoplasmas der Wirthszelle" al, währenel die äntsers Lisposition . besonders ant anatomisehen Verhältnisisen hasielt".

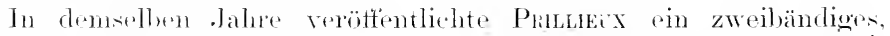
an rignen Lntristehmogn reiches Wrik: . Maladies des plantes agri-

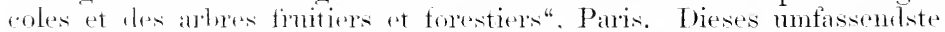
Werk der tranzïsishlen Literatur besthäftiet sich anch mm mit den parasitäen Klankheitrn. I)iesolben werken streng wissensehaftlieh behandolt: jedoeh wirel antiverdem dom pralitischen Bedürtinis insotern Rechnung getragen, als die Bekämptimgsmittel berïrkichtigt werden. Der mgealnte Anfsehwmg, den die sturlien über die Baliterien 
infolge ihrer vielseitigen äkonomischen Bedentung nahmen. machte es notwendig, dats of B.ry's "Vorlesmongen äber Baliterien" einer Nenbearbeitung und Eröinzmeng moterzogen wmolen. Eine dritte, von Mon durch eigne Albeiten erweiterte mol mit genamen Literaturangaben versehene Anthor ersehien im . Jahe 1901 in lapipaig.

Mittlerweile hatte dir stets tïhlbarer wordentr. Notwendigkeit, dio praktischen Kreise mit dem Wesen der Pflanzenkinkheiten vertrant zn machen, dahin enotïhrt, dats die grofise Dentselue landwirtschattstesellschatt die Heransgahe ontspechender Publikationen in die lland nahm. Im Jahre 1892 ersehien lie erste. 1s!n die zweite Antlage des ..Ptlanzenschutz", hearleitet von A. B. Frask und P. Sokdver. Die Verfasser strebten die denklar knaplste I arstellmo an, gliederten die Krankheiten nach don Nährphanzen mol belandelten jerle Krankheit in drei Abschnitten: Erkenmmng, Entstehmo mol Bekämptimg. Der Text worde durels zahlreiche Abbildungen anf' farligen 'Tateln eroänzt.

Nach derselben Methorle verötfentlichten Fkask rine ansführlichere Bearbeitung mter dem Titel: „Kampfluch gegen dic Sehädlinge unserer Felitiüchte". Berlin 1s!t, und Sorater ein mit zahlreichen Textfiguren versehenes Tierk: „Schutz der Obstbämme gegen Krankheiten“, Stuttgart 1 (?)1).

Von fremdsprachigen Büchern fällt mm diese /eit die Heranswabe eines durch reichen Tatelschmmek sich emptehlenten Werkes: "Do ziekten ron het suikerriet ol' Java" rom H. Wakkek mol (i. West,

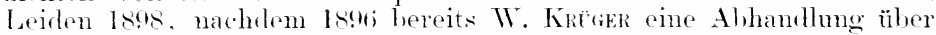
die Znckerrohrlinaliheiten in den .Berichten dre Versuchsstation für Zuckerrohr in West-Java, Kagok-Tegal" geliefort hatte. Hieselbe beschäftigt sich eingehend mter gewissenhafter Litcratmbemutzmo mit ler siereh-Krankheit.

Die Kaffeekrankheiten speziell behandelt DELAckor in seinem 19(n) in zweiter Autlage erschien rnen Buche: .Les maladies et les emmemis des Cafëiers". Paris. Zwei Jahre später erschien: „Fungus diseases of stone-fruit trees in Australia" hy I). Mo Alpise, Melloomrne.

Während die letztgenamuen Werke nur spezielle Kulturptlanzen im Ange haben. zeitigt das Berlütnis nach einer monfassenden Bearbeitung des gesamten Krankheitsgelietes nach langer Zwisehenperiode endlich wierler oin IIandbuch: ..Plantepatologi" IIaandhog i Leeren om plantesrodomme at $\mathrm{E}$. Rostrup, Kobenharn 19(1). Jieses romehm ansgestattete, durch vicle sanher. originalzeichmongen gewinnende Werk legt den Hamptschwerpmlit ant die Pilzlirankheiten, die der Verfasser hurch viele eigne, seit 1871 publizierte Beohachtungen vermeht hat. Yur Erleichterung des Antfindens der einzelnen Krankheiten ist eine Anfzählung derselhen, nach den Wirtsptlanzen geortnet, am schlutis des Werlies beigegeben.

Das neneste Werk, das als ein herlentsamer Kulturfortschritt im allgemeinen zn bezeichmen ist. erschien 190:3 in japanischer sprache mol liegt ms mit dentschem Titel vor: .. Lehrbuch der Ptlanzenkranklieiten in .Japan". Ein Handbuch fïr Land- mol Forstwirte. (rärtner mo Botaniker. Vom Abita InetA. III. Anfl. Tokio 19n:2. Das mit einem Tokabnlarim ter technischen Austrücke in dentscher. onglischer und japranischer sirnathe versehene Werk ist mit 1:3 Tateh und $14 t$ in feiner Linienzeichnmo ansgeführten Textfigmen (mejst narh deutschen Autoren) versehen.

Bei einer Wiscenshatt, die wie die Phytopathologir bestimmt ist. 


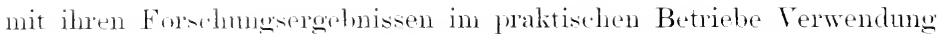
zu finden, malnte sich alsbald das Bediutinis geltend, durch farbige Abbikmmen drm Laien das Erkenen der Krankheitstormen und -erreger zu erleiditern. De-hall, finden wir, abgesehen von ten speziellen Pilzwerken. violfinh las Bestreben, durch farhige Hahitusbilder den Text

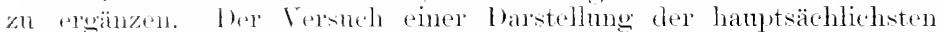
Krankhriten in Form eines Atlas mit kmzen Beschreibungen der Tafelfinmen komute "rst wagt werlen, nachdem eine weiter ansgebreitete

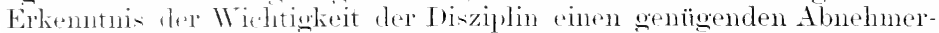

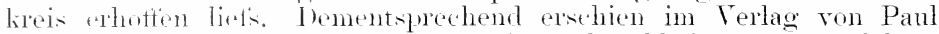
Parry in Bulin Soldek's .. Atlas der Ptlanzenkrankheiten", von welchem seit i-si his jotzt seths llefte in Folioformat ansgegehen worden sind.

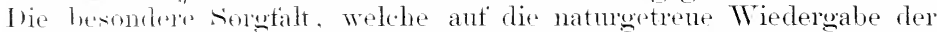

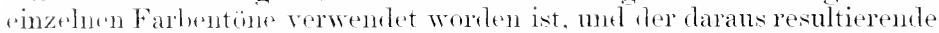
Preis liveren den Atlas weniger in den hreisen der Praktiker, als in den

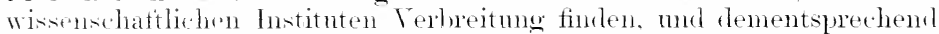
machte sich allnählich das Bediufnis nach der Herausabe eines weniger

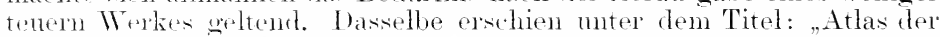
Grankheiten ma Bushäligmeren unserer landwirtschaftlichen Kultur.

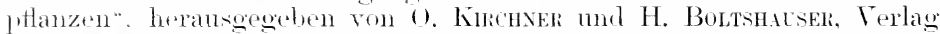
von Lumes, stuttwart, nud liegt jetzt in sechs Heften vollständig vor. Ile ermutigenden Erfahrungen, welche mitterweile die Dentrelue Jandwirt-chatti-fieselschatt mit der llerausgabe des bereits erwähnten kleinen Buches .PHanzensehutz" gematht, zeigten, dats eine Aushreitung der Kenntnisse ïher die Krankheiten zurzeit in den Kreisen der praltischen Landwirte an erfolgreichsten durch diesen kuzen Leitfaden chrohgetïhrt werden kann, und sie gab denselben in nener Bearbeitung

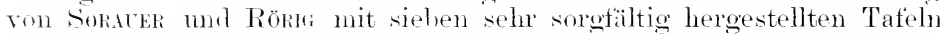
in Jahre 1!nt in dritter Anflage herans. Speziell dem srstematischen studium der Krankheiten tienent ist der "Atlas des Conférences de

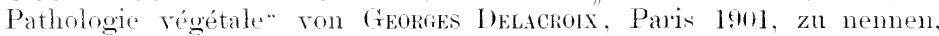

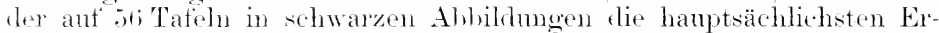
krankungen der Kulturytlanzen darstellt. Frö̈nzend reröffentlichte

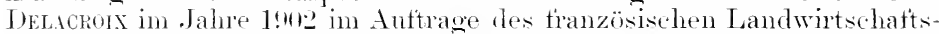
ministerimm ein kleines ITrk: "Malarlies des plantes cultivées". Paris. das hamptsächlich tür die Praxis geschrieben ist.

Ler berlentendste wissenschaftliche Fortschritt liegt selbstrerständlich in der monographischen Bearbeitung der einzelnen Krankheitsweliete, mol auch diesen Weg hat die jumge Disziplin der Pathologie Fereits heschitten. Entsprechend der Wichtigkeit der Krankheiten sind «s lesonders dir Rostpilze, nanentlich tie Getreideroste, denen ringehende stulien wewilmet woiden sind. In Jahre 189495 wurde

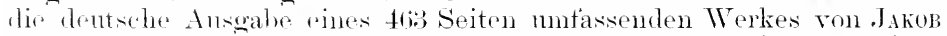

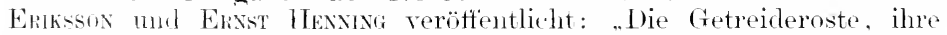

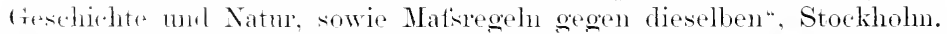

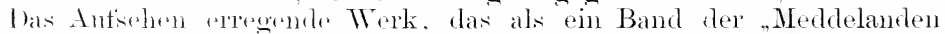
fran Kongl. Lantthruls-Akatemiens Experimentalfält" zunächst erschien,

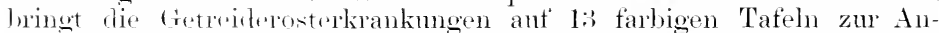
shaume und stellt hesonders tie spezialisierung des Parasitismus bei den Getreiderostpilzen test. Autsertem weht das Werk auf die Beprechmo dor disponierenden Faktoren cin und prït die Lage physikalische med chemisele Borlembeschaffenheit, Vorfoucht, Saatzeit usw.

Mit erweitertem Programm erschien 1!n4 eine ebenso sorgfältigr. 
auf' eignen Studien fulsende Arbeit ron H. KLeban urter dem 'Titel: "Die wirtswechsehden Rostpilze". Versuch einer (iesamtrarstellmw ihrer biologischen Verhältnisse. Berlin 1944. (iebr. Bornträger. Eine Tabelle gibt in chonologischer Reihentolge rine Anfzählme der heteröeischen Rostpilze seit den ersten, 1rit auswefïhrten Versuchen von de Bary mit Puccinim gramimis. Der Text helamelelt in möplichster Austülnlichkeit moter Hinweis ant die oisschlägige literatm die Alstufing der Unterselifele mol die Umorenzmog der Arten. die sireziali-

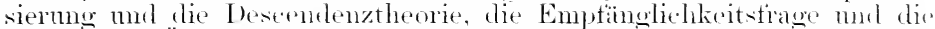
Frage der Ëbertragbarkeit ler Rostlrankheiten mittels der Sanen.

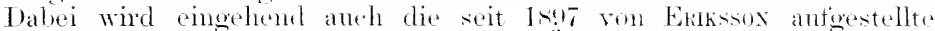
Myco plasma-'Theorie besprochen. T̈her diesen Punlit ist bereits früher berichtet worden (s. s. 31). Die nenesten studien verötfintlichte

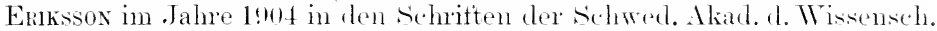

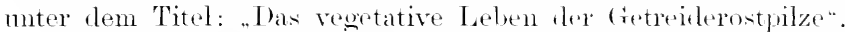

Als ein weiterer herlentsamer Fortsehritt in ler Buschaffune wissenschattlicher Grumbllagen ist terner die "Pathologische PHanzenanatomie" von Exsst Küste. Jena lon:3, hei Gustar Fiseher zu nemen. Ton der Erfahrumg geleitet, tafs eine seharfe Tremmmg der Natmrormen in normale mod anormale nieht durchtïhrlar ist, püift der Verfasser die Erscheinungen nach dem physologivehen Gesichtspmkte, also nach der Funktionstüthtigheit der Gewebe. Entweder werden die rewaln dureh Einflïsse irgenel welcher Art gehindert, zu funktionstüchtigen. d. h. normalen, sich auszubilen, oder fimktionstïchtige (xewehe erfahnen nachträgliche Veränderungen, hei welehen sie ihn Funktionstähigkeit nanz oder teilweise einbüfs'n, oder es entstehen nene firwebe am Pflanzenkörper, derart, dats die erkrankten mol verunstalteten Orom. des letzteren entweder gar nichts für den (iesamtorganismus leisten. oder doch weniger als diejenigen, die wir als momale bezeichnen." Wir haben in dem vorliegenden Werke einen erfoloreichen Versuch zu sehen, die Entwieklungsmechanik des ptlanzliehen ()ronismus darzustellen.

Die Ausbildung der periodischen Literatur hängt mit den Bestrebungen nach einer Organisation des Pflanzensehutzes zusammen. Das leitende Prinzip war die praktische Frage, wie sith die Ausbreitung der Krankheiten und Feinde der Kulturptlanzen am hesten verhindern und ihre direkte Bekämptung sich am vorteilhaftesten bewerkstelligen lasse.

Dieser Frage waren zuerst die Vereinigten Staaten ron Nordamerikia dadurch nähergetreten, dats ron seiten res Ackerhamministeriums (Department of Agriculture) im Jalme 18s Institute zum Stulium der Phytopathologie mol der landwirtschaftichen Inselitenkumb gesthatten wurden. I)iese äufserst tätigen Institute mol Versuchstationen galen zunächst Jahresberichte mul später aufertem speziahmblikationen über wissenschaftliche Untersuchmgen herans. Einen genaneren Einblick in die Oroanisation des Dienstes gewährt ler Bericht ans dem

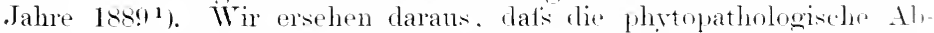
teilung inre Untersuchumen in einer bestimnten /eits.hritt . Thu. Jommal of Mreologr" verötfentlichte und auterdem poulär Bu-

1) Report of the chief of the section of regetable pathology for the year $1=-4$. Published by autority of secretary of agriculture. Washington 1890 . 
sehreihmen einzelner ter haups:ithliehsten Krankheiten in Form von Flugblattern (Bulletin) verlueitete. Einen selı grotsen Teil der Taitigkeit beans nombe die Korrespondenz, die vorzugsweise in Beantwortung ron Anfragen ans den Kreisen der Praktiker bestand nut

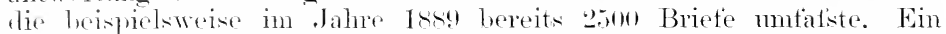
Ianptaugenmerk wrode auf das Verfahren gerichtet, die situdien-

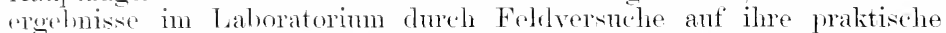
Branchbarkit zn prïlen. Behnt's Anstïhlumg derartiger praktischer Anlanversuche installierte die pathologische Alteilmo liestimmte Persönlichkeiten (Agents) zur T̈herwachmo der Ansfühmug. Temn die Resultate sol.her Freilandversuche aus verschiedenen Gegenden ïbereinstimmend gente waren, nm allgemeine Schlïsse ziehen mol Mat'snahmen zur Bekän],tung daraus ableiten zu können. wurde zur Veröftentlichung der Ergehmise gescluritten.

In Dentschland zeigten sich die ersten Bestrehngen nach einer Organisation aut dem Aekerbankongrets zu Wien im . Jahre 1sen, wo Eriksison und Sorauer den Antrag einbrachten, den Regierungen ähnliche Natsregeh zu empifehlen, wie sie in Norlamerika bereits durchgeführt wurlen. Behufs Ausarbeitmo eines speziellen Arbeitsplanes und Entfaltung einer werbenden Tätigkeit worle eine „Internationale phrtopathologische Kommission " ans Vertretern aller" emopäischen Kulturländer gegrïnlet und Soracer als sichrifttühluer derselben heantragt, die entsprechenden Publikationen zu veranlassen. Iles gab die Anregung zur (riüdmo der .Zeitsehrift fï̈r Pflanzenkrankheiten", deren erster. Jahrgang Is!l erschien. Ehenso wurlen nummehr die Bestrebungen behuts Eimrichtung von Versuchsstationen nul ähnlichen Instituten zur speziellen Pflege des Pflanzenschutzes in verschiedenen Ländern intensiver und erfolgreicher.

speziell in Prentsen war schon im . Tahre $188\left(1^{1}\right)$ ein sehr eingehendes Referat von Kons-Breslan: "Über die Begründung einer wissenschaftlichen Centralstelle behufs Beobachtung und Tilgung der Feinde ler Landwirtschaft ans dem Reiche der Pilze mol Insekten", publiziert worden. Eine Anregung in diesem Sinne sollte bei der Reichsregierung seitens des Dentschen Iandwirtschaftsrates erfolgen. Im Jumi 18s? brachte Jubus Kithn, durch dessen Bemühmugen die Versuchsstation in Halle a. S. mnter Hoblicng's Leitung gegründet wurle, denselben Gegenstand bei der Dentschen Landwirtschafts-Gesellschaft zur Sprache, mol 1890 gründete die Dentsche Landwirtschafts-Gesellschaft einen sonderausschuts für Pflanzenschutz", dessen Vorstand von Jubus Küns, A. 3. Frank und P. Śorauer gehildet wurde. Der Sonderansischuts errichtete ein Notz von Auskunftstellen für die praktischen Landwirte, welches das anze Dentsche Reich umspannte, und veröffentlichte, nachdem Sonacks für die Aufitellung einer Statistik eingetreten und mit einer statistischen Bearbeitmo ïher den Getreiderost im Jahre 18!) l hegomen hatte, fortlanfende .. J ahresberichte des sondera $u s s c h u s s e s$ fï̈r Pf'lanzenschutz".

Im .Jahre 1s:0 wurde auch das Phytopathologische Laboratorim zu Paris unter Priblenx mol Delackorx eröftinet und an 11. April 1891 zu Amsterdam die nierlerländische Sektion der Internationalen phytopathologischen Kommision gegrindet, welche die Anregung gab, dats Rrtzema Bos 18!5, als Leiter ,Fes.. Phytopathologischen Laboratoriums

1) Archiv des Deutschen Landwirtschaftsrates, Heft \&, s. 307. 
Willie Commelin Stholten" nach Amsterdam berufen wrule. Im "Jahre 189.5 erschien ant Anregung des Niederländischen phytopathologischen Vereins und der Phytolrathologischen Ahteilung der Botanischen Gesellschaft Dodonaea die .'Ti.jekchrift over lulantenziokten", herausgegeben von .J. Ritzena Bos mol G. Staks. Nittlerweile war in dem

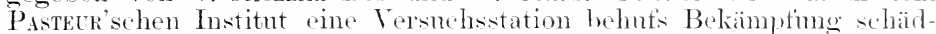

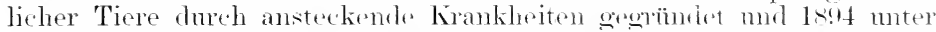
die Leitumg von Metschnihoff gestellt worlen. Rastlos tätig war Eniksison als Leiter des Experinentalfältet zu Alhano hej Stokholm. Er gah Ls!5 die Beweisexemplare tïr die spezialisierten cotreiderostformen herans, nachdem ihm helunts dieser studien in Fobruar lonl eine Enter. stützmng von lonom hronen staatlicherseits hewilligt worden war. I) Rostfrage, die auch fï̈ den Weizenban Australiens die höchste Bedentung besitzt, hatte seit $1888 \mathrm{zum}$ jählichen /msammentritt einer Konferenz von Mitglieder'n der anstralischen Kolonien geführt, die einen offiziellen Bericht: "Rnst in wheat "onterence", für eine längere Reihe von bahren veröftentlichte.

In Dentschland folgte anf' die .. Zeitschrift für Pflanzenkrankheiten" ron Sorauer in Jahre Is!r die .. Forstlich-naturwissenschat't liche Zeitschritt" ron C. v. Tubeuf, wolche den Krankheiten des Pflanzen ebenfalls besondere Antmerksankeit withete. In .Jalue 1s!s wurde die .. Kol. havrische Station für Pflanzensehntz" sogründest und r. Tubecf's Leitung unterstellt. Antiserdem womlen die Reterate in dem

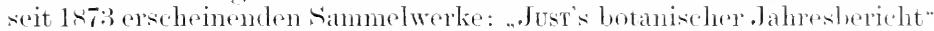
wesentlich reichlaltiger, ta num eine gö̈lsere Anzahl von heitsehritten das Gehiet der Pflanzonkrankheiten speziell in ihr Programm anfinahm. /u diesen gehört in erster Linie das von UHLwory mil HAxsex heransgegebene "Centrallulatt tür Bakteriologiæ. Parasitenkunte nud Infektionskrankleiten" sowie die ron Herosimes mul P. Hennisgs redigierte .Hedwigia". das von Lotsy bearbeitete .Bota nische Centralblatt", fermer Biemerusx's .Centrallilatt fül

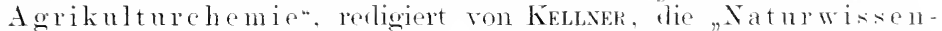
schattliche Zeits.hrift t’ür Land- und Forstwirtschat"

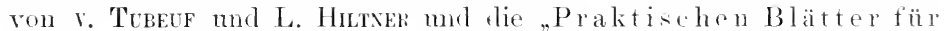
Pflanzenban nnd Pflanzenschutz" von L. Holtser. Speziell über tropische Kulturpflanzen finden wir eingelende pathologische Mitteilungen im .Tropenpt'lanzer". Zeitschrift f. tropische Land wirtschaft ron O. Warbugi mul F. Wohltusn, sowie in den dazngehörigen "Beiheften", welche die Organe des . Kolonialwirtsehatt fichen Komitees zn Berlin" sinch. In den dentschen ostafitianischen

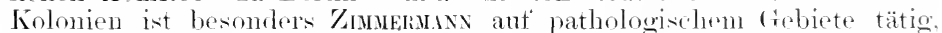
wie seine Mittoilnngen ans dem hiologisch-landwirt schattlichen Institut Amani" beweisen. In Östereich wmo

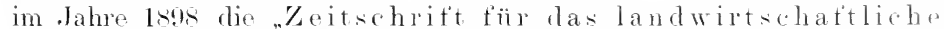
Versuchswesen in Östrreieh" gugrindet. In tolgenden Jahn hegann P. Nypes cine Reihe von Veröffontlichmeren mnter dem Titsl:

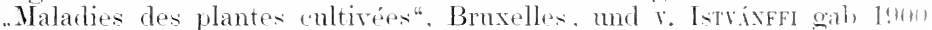
den ersten Band der .. Annales de l'Tnstitut Central ampélologique Irova!

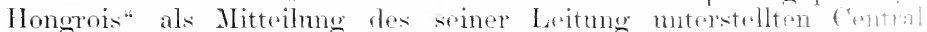
Weinbaninstituts heraus. Anch hier wirl den Krankheiten besonutw

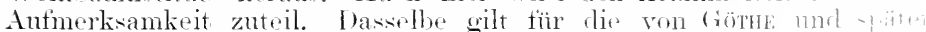

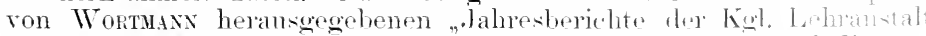
für Obst-. Wein- und Gartenhan" zu Geismhein a. Rh. nunl Tis won 
MëLler-Thuriat bearbeiteten , Jahresherichte der .Dentsch-schweizerischen Tersuchsstation für (1)st-. Wrin- und Gartenban zu Wädensweil", zürich.

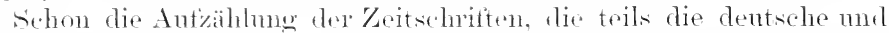
fremelspachliche Literatm reforieren, toils originalarbeiten bringen,

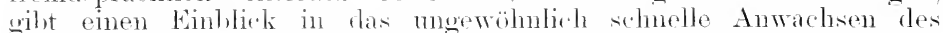
Stotfes, das mit Notwemligheit aine einhertlehe /onsmmenfassung in einem sammelwerke profelple.

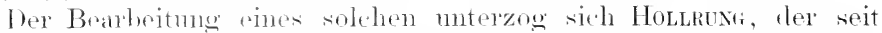

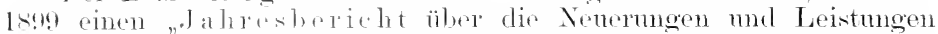

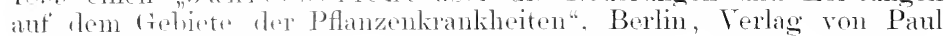
Parey, herancuibt.

Somit hat dir junge Disziplin der Plytopathologie denselben literarischen Aplatat crlangt, den die alteren ibsiplinen besitzen, mol ler zmm wisconsehattichen Fortschritt unbedingt nötig ist. Alrer anch die praktische seite der Phytopathologir, nämlich der Pflanzensehutz. hat lie erwïnsehte Fortentwicklmog gefmelen.

Lie lxis von Kow angeregte, 18s!l von KüHn wirksam befürwortete. von Sokstek anf Ion intronationalen landwirtschatitlichen Kongresien und in der 'beitschrift tür Pflanzenkrankheiten weiter ausgebante Irle der Eimichtung spezidler Institute wurle 1891 im Prenfischen Abgenthetenhanse von ScHotz-Luprz in Form eines Antrages zur allomeinen Kenntnis gebracht. An 27. April desselben . Jahres veröfontlichte dor Reirhsanzeiger, dafs der Antrag Schultz-Lupitz der Kol. Staatsregierung zur Erwägmng überwiesen worlen sei, und alsbald trat das Landwirtschattliche Winisterium in lie Prüfumg der Frage ein. inwieweit Anreh Erweiterumg der ihm nnterstehenden wissenschaftlichen Institute ler Pflanzensehutz geförlert werden könne. Je ringelbender mol vielseitiger aber die Beratungen wurden, desto mehr kam der Gedanke zum Durchbuch, latis wirkisame Mafsnahmen in Interesse des Pflanzenschutzes nur dum ein Reichsinstitut erlangt werden kömen. Ein solches wurde num dureh Bewilligmng sehr reicher Tittel in Form einer..Biologischen Abteilung für Land- und Forstwirtseloft" dem Reichsgesmdheitsante angegliedert und ist rom 1905 ah ein solbstänliges Institut les Reiches. Die zurzeit unter Auerhouds Leitung stohende Abteilmeg besitzt in Dahlem bei Berlin nelen den entspechenden Laboratorien ein seln ausaedehntes Tersuchsfoll und publiziert tie Resultate ilner Arbeiten in zwanglos erscheinenden Heften, von denen das riste im .Jahre 1900 ancogegeben wourde. Antiser diesen wissenschattlichen Arbeiten veröffentlicht die Biolegisehe Alsteilumg anch popmläre Flugseluriten und farbige Plakate

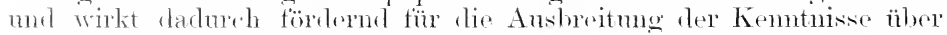
dis hänfigsten tierischen und ptlanzlichen sohädlinge in den Kreisen der Pralitiker. demen anch kostenlos direkt Auskmft in Angelegenheiten des Pflanzenschutzes erevilt wircl.

Noben dre rwähnten Reirlsanstalt, die numehr den Titel: „Kais. Biologiselue Anstalt tiir Land- nud Forstwirtschat' " fühlor, finden wir in len dentsehen Einzelstaaten noch vielfach Einrichtmoen zur PHege des PHanzensehntzes, die teils sich an bestehende Institute der Hochschulen und Versuchsiationen angliedern, teils selbständige schöptungen darstellon. Ton letzteren ist anfier den bereits erwähnten Tnstituten zn llalle mol feisonheim noch die im Jahre

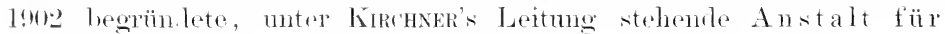


Pflanzenschutz in Hohenheim zu nemen. Anch in den ïhrigen europäischen Ländern finden wir eine eifrige Förderung des studiums der Pflanzenkrankheiten, wie die Teröftentliehmoen der Institute beweisen. Zu diesen erehörn: ..Bulletin de la station Agromomique de l'Etat à Gembloux", Bruxelles (Ev. Marchis), mul "Travaux do la station de pathologie régétale", par Delickorx, Paris, dis bereits genamute "Tijolschrift orer Plantenziekten" (Ritzent-Bos) und die .. Lam

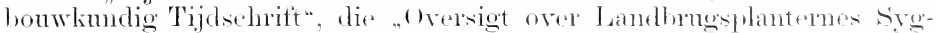
domme", Kjöbenharn, in "Tidsskift tor Landbrugets Planteari", Kjöbenhave (Rostrop), die "Lplsatser i pralitisk Entomologi", stock-

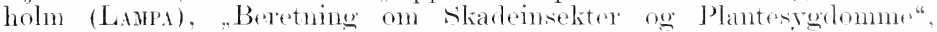

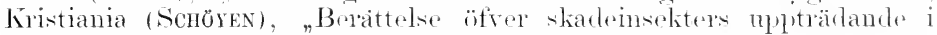
Finland" (E. Retter), in "Landbruksstyrelsens meddelanden". Helsingfors, "Ammal report of the consultine botanist" (C'ARкитнкs), in .Jomm. Royal Agric. sioe.", Lonton.

Dats anch die antselemopaischen staten in den Butrehmgen zur

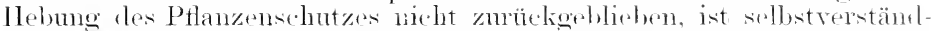
lich. Die ansgedehnteste Fïnleme hat die Disciplin nath wis vor in

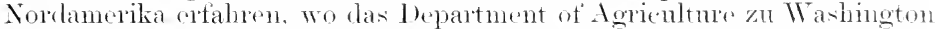
seime hesondere Antmerlisamlest nmmehr auch don tierisehen Feinden zngewendet hat. Antser der Errichtung der "livision of Entomology. die durch gehaltrolle Untersuchungen wesentlieh zur Kemntris ilop

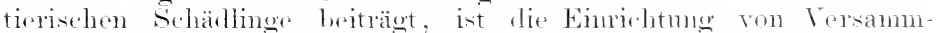

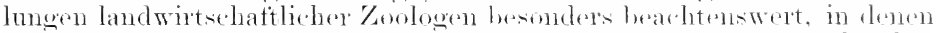

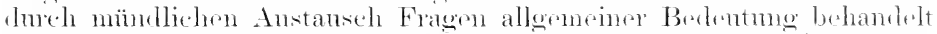
werlen. Antserdem bearbeiten zahlerehe Forseher an den Eniversitaten mul Versuehsstationen das Geliet mit erfrenlichem Ertolge. Ton hetzteren erwähnen wir die Landwiltsehattliche Versuchsetation les states New Sork zu freneva und die New . Jerey Agricultural college Experiment station. Weitere Angaben bietet der spezielle Tril muses Buches, in welchem die verschiedenen Bulletins der den Pflanzenchutz phegemben Institute citiert werden.

Antser den zahlreichen Publikationen in dun Vereiniegten Staaten von Nordamerika liefern anch die Keitschiften anderer Länder beachtenswerte Beiträge zur Kemntnis der Krankhoiten tropiseher Kultumphanzen. Dahin gehören die .Mededeelingen van het Proetstation voor suikerriet in West-Java", die Mitteilungen der "Prostistation voor Cacao te Salatiga". Malang, das ..Boletim da Agrionltura", S. Panko, "Boletim del Instituto Fisieo-freographieo de Costa Rica", "vueens-

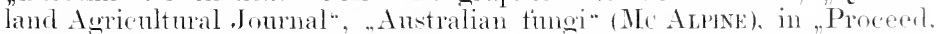
Tinnean soe of Ner sontl Wales", .Administration Roports Roral Botanical Gardens". ("relon, . Renort of the l)epartment of lanel recorels and agrienlture", Madras, nud "The Jommal of the College of seiture. Imperial University of "Tolio", Japran. Betreffis der zahleeichen andern

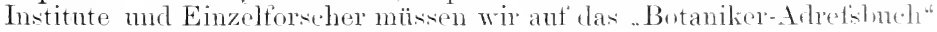
von .J. Dörfler, Wien 1!n', verweisen.

\section{Nachschrift.}

In den rorgeführten Nitteilungen haben wir ressucht, nir het mun anf das literarische Material hinzuweisen, sondern anch die leitumine Ideen der einzelnen Zeitepochen zum Ansiluek zu hringun. nus zu zeigen, wie nusere Wiscenschatt sich allmählich aut ihren jetzigen 
Standpunkt heranfoearleitet hat. Gewifs nicht ohne Interesse sind die Wandtungen der Ansichten über das Wesen und die Rolle der parasitaren Gramismen. Aler nicht minder interessant sind die als roter Faden dureh alle Beriehte zu verfolgenden Hinweise der Autoren anf

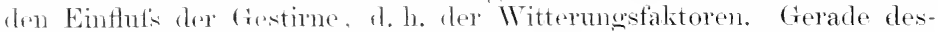
halb haben wir in oft lïngeren (Citaten die Anschanung früherer Keiten

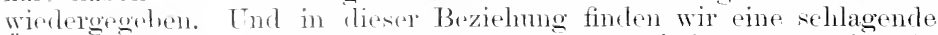
Thereinstimmme von den ältesten Zoritem an, indem stets die Abhängigleit soleher Ershrinungen, die wir jotzt als parasitäe kemnen selernt haben. von den limatischen und Bodenverhältnissen, zum Teil anch selon vous den Kultminafsegeh betont wird.

Diese likn. welche anch die leitende in dem hier vorliegenden Buche ist. hat leu Vurfasser seinerzeit reranlatist, die ersten Versuche zu einer sitatistik der Pflanzenkrankheiten zu unternelmen. Dise Tersule, dir, wie erwähnt, mit Hilfe der Dentschen Land-

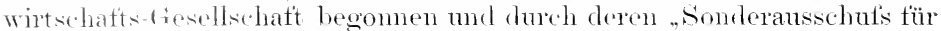
Pflanzenschutz" fortgesetzt worden sind, haben nun dadurch ihre An-

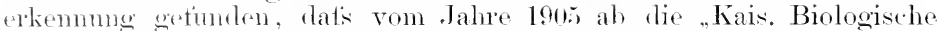
Anstalt für Land- und Forstwirtschaft" die Statistik der Pflanzenkrankheiten ühernehmen wirel.

Die Wichtigkeit einer Statistik aut mserem Gebicte wird rielfach angezweifelt mit dem Hinweis, dats gerade msere gefälnlichsten Krankheiten stcts rorhanden sind und die Angaben der sammelnden Persönlichkeiten über Intonsität der Erkrankung nud Grölse des wirtschaftlichen Terlustes so individuell heeinflufst erscheinen, dafs sichere positive Zahlen niemals erhalten werden kömnen.

Diesen Einwendungen gegenüber ist zu betonen, dat's ich nicht deswegen die Statistik in die Hand genommen habe, mm präcise Zahlen ïher Ausloreitung and wirtschafthehe Wirkung der einzelnen Krankheiten zu erlangen. (Übrigens wird anch in dieser Beziehung die Borichterstattmo mit der zunehmenden schulung des Beobachterpersonals almöhlich so genau wie auf allen febieten des organisehen Lelsens werlen.) Die Hauptanfqabe der Statistik liegt in fem Nachwrs der Broichmoen, welche die einzehen Krankheiten zu den lokal ofer allomein sich geltendmachemlen klimatischen und Bodenverhälnisisen sowir zu den Kulturfaktoren haben. Das Studium ler leicht zu konstatiorenden extremen Erkrankungstormen und die Feststellung, hrm weldo Faktoren dieses Extrem zustande gekommen ist, bildet has tromelethingende Feld der statistik.

In diesen situdion liegt die Zukmutt der Pathologie.

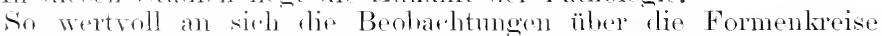
mul Lebensansfü̈rhe dor parasitären Mikroorganismen sind, so bilden sie doch immorhin nur ein Glied in der Kette der Forschmongen mud erlangen ilnen Wret mu in der Feststellumg ilues Verhaltens in nerhalb dor freien Natur nud dos iiblichen Wirtsehates-

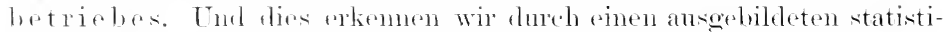
selon Llenst, der nus lohrt, unter welehen Verhältnissen die Krankheiten sieh strigern oder vermindern.

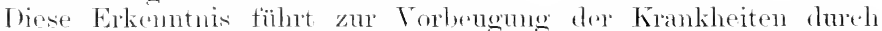

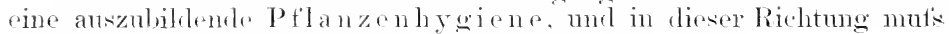
tie Pathologie sich in Zukuntt weiterentwickeln. 


\title{
Spezieller Teil.
}

Erster Abschnitt.

\section{Krankheiten durch ungiinstige Boden- verhältnisse.}

\author{
Erstes Kapitel. \\ Die Lage des Bodens.
}

Wenn anch die Krankheiten, die bei mö̈untiger Lage des hulturlandes sich einstellen. besser bei den Einzeltalitoren, durch wolche dip Lage dem Pflanzenwachstum verderblich wird, besprochen werden, sn haben wir doch für notwendig gehalten. im folgenden die allgemeinen Verhältnisse verschiedener Lagen zu skizzieren. Denn gerade für dip leitende Idee in diesem Handbuch, für den Hinweis auf die sich heransbildende Disposition zu gewissen Erkrankungen, ist es von besonderer Wiehtigkeit, zu zeigen. wie der stofthehe und gestaltliche Aufban einer Pflanzenart sich mit den Standortsverhältnisien ändert, wie einzelne Funktionen bald heralogedrütekt bald gefördert erscheinen, und wie demnach die einzehen Lokalitäten ihren bestimmten Charakter den Pflanzen aufdrücken, welche dadurch den einzehnen Schädigungsursachen gegenüber sich ganz verschieden verhalten müssen.

\section{Die Erhebung über den Meeresspiegel.}

a) Allgemeine habituelle Ïnderungen.

Bei krautartigen Gewächsen.

Dafs mit der zunehmenden Höhe einer Kulturfläche über den Meeresspiegel die Wärme eine immer geringere wird. und daf diswe Wärmeabnahme der matigehende Falitor für die Begrenzung A.P. Vegetation ist und somit die Ernte im (rebirge eine rerspätete sein nntbedarf keiner weiteren Austïhrung. Dafs diese rerspätete Ernte grofín Sehwierigkeiten für das Trocknen des Getreides bietet und bescind re Vorrichtungen im Hochgebirge nicht selten erforderlich mathi unl dafs trotzdem manchmal ein sehwarzwerden der Käner in- 
folge eintretender Pilzregetation stattfindet, ist allgemein bekannt. Ein Beispicl in fräzisen Zahlen liefert Axiot ${ }^{1}$ ), nach dessen Beobachtmngen sich die Ernte des Winterrogerens in Frankreich dmehsehnittich $m$ vier Tage verzögert, went die Höhe nm $100 \mathrm{~m}$ zunimmt. Aufmerksam zu machen ist aher dalee ant den L'mstant, dafs mit der zunehmenden Höhe die Verdünnmong dor Luft dic Wärme derselben remindert, dats also anch diese Terdüinnmung ganz wesentlich ant die Ausbildung der Toretation whken mnts. I azn kommen die Fenchtigkeitsverhältnisse, welche abgesehen von dor physikalischen Bodenhesehatfenheit, für alpine Regionen niederer Breiten andere sind als für Ptanzen ans der Ebene der artischen \%one. Imnerhalh, derselloen Breite wird das Gebirge als liälerer körver mehr Wasserdampt verdichten und daher reichlichere Niederschäge erhalten als die Ehene. Es wird daher anch mehr schnee fallen, mol das zmm schmolzen dieser grötseren Schneemasse erforderliche Trämequantum wird also der Tegetation entzogen. selhst wenn der schnee im Frïhjahr geschmolzen, wird trotzdem noch die Pflanze im Gebinge zunächst weniger ron der Sounenwärme Torteil ziehen kïnnen als die in der Ebene, indem die \%errissenheit der Bodenolortläche wirksam wird. Ein quadratmeter GrmoHäche, der eine stark zerklüftete Bodendecke besitzt, hat eine viel grösere, in mentlich viele schiefe Ebenen zerspaltene oberfläthe; anf diese muls sich dieselhe Wämmenenge verteilen wie anf ganz dhenem Lande, descen einzehe Punkte somit stärker erwärmt werden. In diesem Falle hefinden sich die Gebirgsietten gegenüber den Ebenen. Es erklärt sich ans den bisherigen Angahen, das mit der Erhebmo ïher den Meeresspiesel sich die durch Wämo wesentlich beförderten Prozesse der Verwittermg and Verwesmo verlangsamen müssen. Es erklärt sich ferner, dat's derartige eigentïmliche Kombinationen der Wachstmmsfaktoren charakteristische Formen erzengen werden, bei denen der kurze, gedrungene Wuchs das hekamnteste Merkmal ist. solehe Wuchsfomen erhalten sich zmächst durch die samen komstant. Derartig erblich gewordene klimatische Formen sind als "ökologische Tarietäten"z) bezeichnet worden.

Wenn wir anfang gosast haben, dats die Lnttemperatur in den Höhen geringer ist, so muts anderseits betont werden, dats mit der Töhe die Intensität der Bestrahlung zmmimmt mol allmählich höhere Bodenwärme erzenet. Es würde deshall, das Gebirgsklima niederer und mittlerer Breiten sith duch grösere Lichtintensität und grösere Bodenwäme sehr giinstig rom dem der Ebenen in einer Polarzone, dic dieselhe Luttempratur hat, mutersheilen. Der geringere LnftAruck anf den Bercen muls eine steigerme der Transpiration zur Folge hahen, wie Friems ${ }^{5}$ ) angil,t, nud die erhähte Lichtzufuhr eine Steigermog der Assimilationstätigkeit des Blattes: folgheh arbeitet die typische

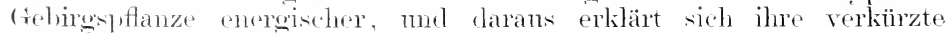
Vegetationszeit.

Nach den Beohachtmmen von Boxwer ${ }^{4}$ ), der am Monthlane mul

1) Der Naturforscher, 18-3, Nr. 24

2) Lebensgeschichte ier Blïtenpflanzen Mitteleuropas. Von Kurcuxen, Loww und C. Scneörer. Stuttgart, Ther 1904. S. 116.

$\left.{ }^{3}\right)$ Friedil, Action de la pression totale sur l'assimilation chlorophyllienne. C. rend. 1901. Cit. Bot. Jahrest. 1901. Abt. II. S. 221.

4) Buxwar, Etude expérimentale de l'influence du climat alpin sur la végétation etc. Bull. Soc. Bot. France. Tom. 35. 1888. 
in den Prrenäen Versmelsärten angelegt hatte, trat in Alpenklima bei einer" grofisen Anzahl lirantiger Gewälse cine Vorkiuzmug der Triebe ein, die zmm Nanismus fïhrte. Bei den Hochgebirgsexemplaren wird das Palisademparenchym stärker entwickelt mol chlorophylheicher. Dementsprechend ist die assimilatorische Arbeit eine gesteigerte. Tem man Blätter derselhen Śpezies von Exemplaren der Ebene mud ans dem Gebirgsarten, die gleichzeitig abgeschniten worlen, prüte, zeigton

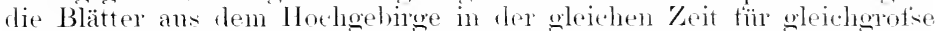
Flächen eine stälkere Sancrstoffentwicklung. Solehen alpinen ('harakter soll man bei Pflanzen dadureh liünstlich züchten kïmen, dats man sie wähend der Nacht in Eis packt, wähent man sie tassibler in nomalen Wachstumsverhältnissen helätst ${ }^{1}$ ).

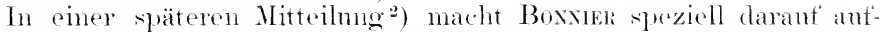
merkam, dat's sich durch die in den alpinen Rowionen stattfindente steigermo der Transpriation und Asimilation leinht exlälen lasses. weshalb Pflanzen der Ehene, ins Alpenklina geluacht, eine relativ orötsere Nenge an Zucker, sitäke. ätherischen Glen, Farbstoffen, Alkaloirlen mul andern Produkten der C'hlorophyllarbeit rutwickeln.

Wie selu der spezifische klimatisehe Charakter sotort den Entwicklmosmotus einer Pflanzentpezies herinflutst. zeigen die bekannten

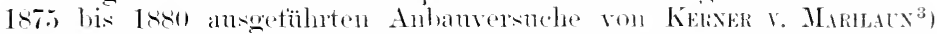
mit samen, die ron dersellen mul zwar vor Fremolhestäulmug apsehützt erzogenen Mntterpflanze stammten. Ein Teil dor Samen wride

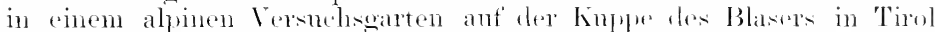

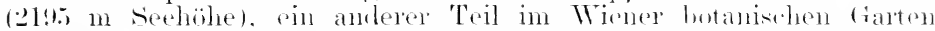
ansogat. Anf' der Kunpe des Blasers erfolgte das Keimen der Samen

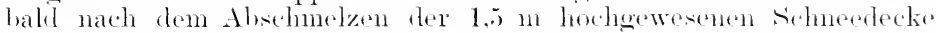

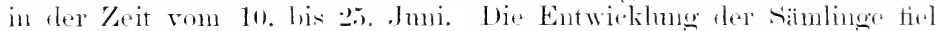

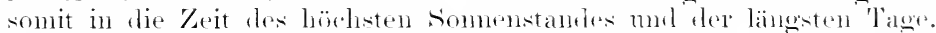

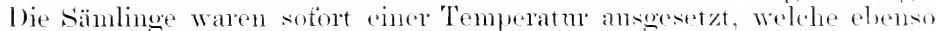
hoch orler noch etwas höher war als die den Versmehsptlanzen in Wiener hotanischen (rarten im März bei einer 'Tageslänge von zwölt stunden zuteil gewordene. An den Pflanzen. Welche nicht dmele die cinzelnen Fröste im Juni, Juli mol sellst im Angust getötet worden waren. worden Ende Angust mul Anfang september Blïten heobathet.

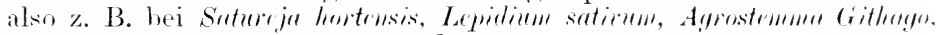

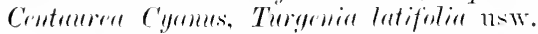

Die im alpinen Fersuchorten erwalsesuen Pflanzen zelehneten sich den in Wiener botanischen tiarten rutwickelten Exemplaren wegen-

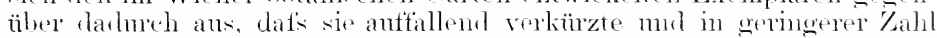
rntwickelte stengelolieder besaken. Ferner sah man, dats an don

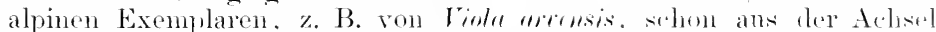
des dritten mul vienten Lanbblattes sich Blïten entwickeltons, wälnemel in Wien dies erst bei dem siobenten und achten Lanbblatt stattanul. Die Zahl der Blïten war geringer mod die Blïtenblätror, ähnlich des

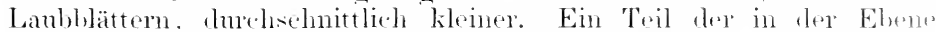
einjährigen Arten, die genügent \%eit mul Wämme zur śamenan-

1) Paramix. Influence des changements des températures sur la respiration des plantes. Revue gén. de Botaniıue, 1×99. ร.. 242.

2) Boxiran, Gusur, Influence des hautes altitudes sur les fonctions des vécritaux. Compt. rend. de l'Acad. scienc. Paris. Tom. CXI. 1890. ('it. Bot. Cent $1891 . \quad$ Nr. 12.

3) Pflanzenleben. Bd. II, ‥ 45:3ff. Wien. 1898. 
bildung gefmulem hattru. wude aut der Kuppe des Blasers langlebiger dachuh, dats in folgenden Jahre ans dem nutersten Teil des Stengels neue sipuss sich entwickelten. Anch ein fiöheres Aufblühen komnte man beobachten.

Entsprechend dem Tmstande. dats mit der zunehmenden Höhe die Intensitït der Besommung wächst. war audh die ant dem Anthocyan beruhende Blütrufärhmg intensiver. Blmmen, die in der Ebene weits waren, zeigten aut den Alyen eine violette Unterseite ihrer Blumen-

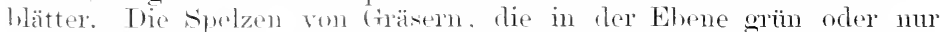
matt violett waren. whrlen in der Alpemregion threh reichlichere Anshildumg vou Anthocran dunkel hramviolett ${ }^{1}$ ). Die Blätter von Scdum

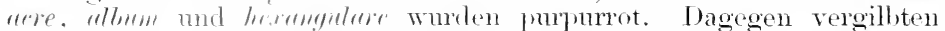

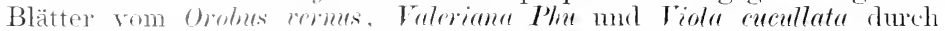
den Lichtïlorshots im alpinen Tersuchsgarten, die im Tal an schattigen Orten onimlaubig heibm.

Bei dem Einthets des Gebirgsklimas handelt es sich nicht num $\mathrm{mm}$ die Tärmedifferenzen der Jahresmittel und der einzelnen .Jahreszeiten, sondern namentlich anth um die Luftfeuchtigkeitsverhältnisse. Wärme und Luftenchtigkeit in ihrer Gesamtmonge und in ihrer zeitlichen Terteilung sind neben der Lichtzufuhr ausschlagoebend für die Vexetation, Die Lnftenchtigkeit beeinflutst, wie erwähnt, die für die Ptanzen verfüglare Lichtmenge: dem der Wasserdampf hat etwa die tünttache Alsorptionsgrölise füu die Lichtstrahlen gegenüber einer trocknen Luft.

Da nun der absolute Gehalt der Luft an Wasserdampf mit der Höhe abnimmt, so wird auch weniger Licht im Gebirge absorbiert. namentlich cla cler Lichtstrahl einen kürzeren Weg zurückzulegen hat, zm zum Eroboden zu kommen, gegenülser den Gegenden in Mesresniveau. Tat's der absolute Fenchtigkeitsgehalt der Lutt mit der Höhe ahnimmt, ist selbstrerständlich, dem die Temperatur wird eine immer geringere, mol die Luft muts ihren Wasserdampt kondensieren nnd in flüsiger Form absehen. Aber die relative Eenchtigkeit nimmt zunächst im Gebirge zu, mul dies ist der Grund, weswegen wir das Gebirgsklima als ein feuchtes und regnerisches zu bezeichnen pflegen. In Beziehung zur Luftfonchtigkeit steht auch die Bewölkung.

Diese Zunahme der relativen Fenchtigkeit mol die abnehmende Luftemperatur lildou die Ursachen für eine schmelle Begrenzmng mserer Kultubestrehmoen, soweit diesolben sich aut die Gewinnmo fon samen in Golirosergonen erstrecken. Wir wissen, dafs die Blïten- und samenbildumg pine Wärmesteigerung im Verhältnis zur Erhaltung dor vegetativen Periode beansprucht. Deshalb sehen wir, lats das fetreide in Geloinge, wie anfangs erwilhnt, vielfach nicht ansreift nut ebonso Kloe und andere Leguminosen kein genügendes saatgnt liefirn. Es kommt zu den erwähnten Vorhältnissen noch ein

1) Ton nambaften 'Forschern wird die Ansicht vertreten, dafs das Anthocran zum Schutz der Pflanze gegen zu starke Besonmung entwickelt werde. Kroxis (1. c. Bd. I, s. 50s) vermutet, dafs in den bei Wirmenangel anftretenden Blumenrötungen das, was an direkt zugeleiteter Wäme den Blïten abgeht, "durch jene Wïme ersetzt wird, welche lurch Vermittlung des Anthocrans aus"den Lichtstrahlen gewomen wird". "Wir glauben beobachtet zu haben, dafs zwar der rote Farbstoff sich häufig bei Wïrmenangel entwickelt, aber auch bei Wärmereichtum sich dann einstellt, weun im Verhältnis zur Wärme ein Lichtüherschuf's bei znckerführenten Geweben sich geltend macht. 
anderer Umstand hinzu, anf welchen $\mathrm{PAX}^{1}{ }^{1}$ ) autinerksam gemacht hat. Es ist nämlich der Insektemeichtum schon bei 2:30n 10 num halb so grots wie in der Ebene; daher spielen Windhoutler in Hochgebirge eine grötsere Rolle; anch wirl die rermehrte sichwierigkeit der Insektenbestäubung dadweh teilweise ansgeglichen, dats eine mogeschlechtliche

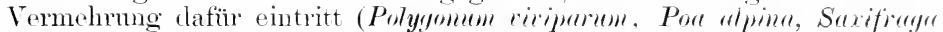
cenua): ferner sind zehn Elftel aller Arten stamlen, mol sellst die bei uns einjährige Viold tricolor wird in ten Alpen anselamend.

Autserdem ist noch darauf hinzuwisen, dats bei fortgesetzten Kultur. versuchen im Höhenklima kurzlebige Gebirgsarietaten sich ansbilklen, die zwar quantitativ geringeres, aber qualitativ noele zufierlenstellendes Saatgnt liefern. Solches bietet die grölsere Möglichlieit, die Ernte im Gebirge noeh glücklich einzubringen, und hat (nach ScHIEbLek) ${ }^{2}$ ) den Vorteil, in tieferen Lagen zmächst seine verkürzte Vegetationszeit heizubchalten, also in den norlisehen Klimatren vorteilhate Verwendume zu finden.

\section{Ausbildung der oberirdischen Achse der Holzpflanzen.}

Gegenüber einer vielverbreiteten Ansicht ist zu rwähnen, dafi7wergwuchs im Hochgehirge nicht dem sehmeedruck zuzusehreilien ist, da wir noch Banmgestalten in den Regionen haben, wo der meiste Schnep fällt. Die śchneedecke wird bekanntlich nitht rtwa immer stärlier, je grötser die Erhehmg des Hothgebirges sich gestaltut, somrlern steigt

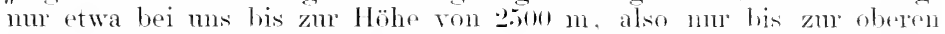
Grenze der Zwerghiefire des Zwergwacholines mul dir Alpenrosen. Höher hinaut nehmen die Niederschlagsmengen ah. Fichten, Lärchen-

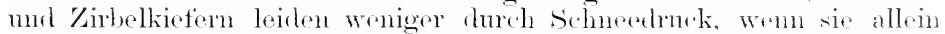

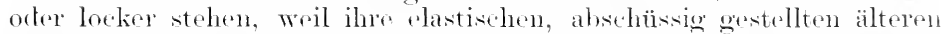
Kweige the angesammolten S.hneemassen bei Wind feichter alogleiten lassen. Andere Gehölze, wie Salix serpyllifolia und Rilummus fumiln, entgehen übermätsigem sehneedruck häufig dureh ihre Ansiedlmo an steilen Felswänden, von denen der selmes schnell ahstïzt. Alrer anch

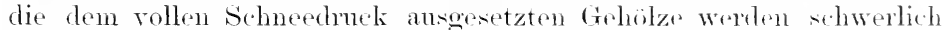
durch die Last des stehnees oder furch den Wind zum Ansch miegen an den Boden veranlatst. Viehmehr dart man mit KekNer annohmen, dat's es die Bodenwärme ist, die ihnen in direkter Nähe der Erile die besten Existenzbedingmegen bietet. In den Hodralpemegionen ist der Boden viel wämmer als die Luft, die vormöge ihrer zunehmendon Verdïmmung und ihres sehnell abmehmenten ITasseroghaltes weniger Somenlicht absombert. (tenannter Autor eitiert, dafís z. B. auf dem Gipfel des Montblane $(4 \$ 10 \mathrm{~m})$ die Intensität des sommenliehtes nu $24 \%$ grötser ist als im Nivean von Paris. Auf dem Pic du Mirli (2877 $\mathrm{m}$ ) beobachtete man eine Trmperatur des bosonnten Bodens von

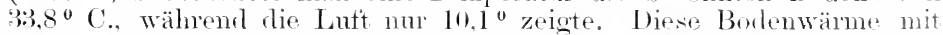
der Lichtintensität erkärt die beschlemingte Entwicklung mod das frïhe Blïhen der alpinen Ptlanzen.

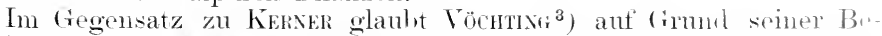
obachtmogen an Mimulus Tilingii, dessen junge Triebe ron bestimmentu

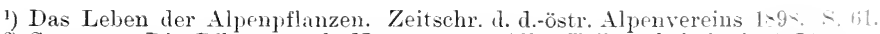

2) Scmerler, Die Pflanzenwelt Norwegens. Allg. Teil. ('hristiania 1-i:

3) Vöchтsя, H., Über den Einflufs niedriger Temperatur anf die sprofsrinthtung. Ber. Deutsch. Bot. Ges. XVI. 1898. S. 37. 
Alter bei niedrigr Temperatm im Frülling sich niederlegten, bei Wärmesteigormen sich anfrichteten, dats das Hinkriechen der Alpenptlanzen an Boflon teilweise orler ganz dem Einfluts der niedrigen Temperaturen zuzuselneiben sein mö̀hte. Wir vermögen diese Anffassung nicht zu trilen.

Betreftis des Warhstmmsmodus der Bämme in den alpineu Regionen

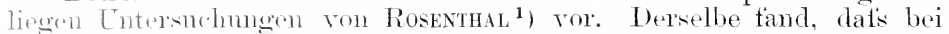

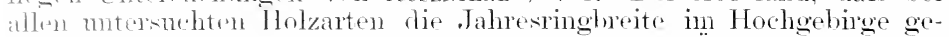
linger als im Tieflame ist. Die Excentricität der Äste ist meist sehr stark, aher die Richtnng des stärkisten /mwaches veränderlich. Das

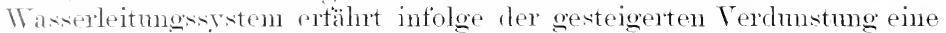
arotiere Ansibildung. Bei den Dikotyledonen wird der höhere Anteil an Leitmosonelo durth die Vershmälermo des Jahresinges erreicht; hei den Narlelhölzern wurde eine beträchtliche Vermindermo des spätholzringes getiunden.

Die im (iebirgo fortwährend durch die Verwittermosersheinmongen sich vollziehenden Borlenmtschmoen bewirken Schietstellungen der Bämme nud rlamit Ändermien in der Holzanshildung dersellen. Hartg $^{2}$ ) wies nach, lat's bei stämmen und Asten der Fichte, colald sie zur Horizontalen sich neigen, anf der Unterseite hreitere .Jahresringe mol son. "Rotholz" (Holz mit kuzen Tracheiden und starker Terholzung), anf der Oberseite schmale Jahresinge ans "Zngholz" (lange Trachoiden mit sehwacher Terholzmos) gebildet werden. Nach (rovanozz ${ }^{3}$ ) wirl diese verschiedenartige Ansbildung des Holzringes dex Coniferenzweige zu hygrometrischen Messmugen von den Bewohnern der Piemonteser Alpen benutzt, da das klemzellige, dickwandige Rotholz ganz andere hygroskopische Eigenschaften als das Zugholz besitzt. I) Rotholzseite eines geschälten Zweiges wird in trockner Luft konkav, in tenchter konvex.

Nath den Untersuchmgen ron CiesLdk ${ }^{4}$ ) scheint der Ligningehalt des Fichtenholzes an der oberen Grenze des banmartigen Vorkommens geringer als in tioferen Lagen zn sein.

Dats der gentungene Wuch bei alpinen Formen erblich für die nächsten (Gencrationen ist, weht ans den Beobachtmoen von Ciestar ${ }^{5}$ ) hervor, wonach Fichten ans Samen von Bimmen gebirgiger Standorte hei Knltur in der Ebene geringeren Zuwachs zeigten als die muter gleithen Bedingmoen arzogenen Pflanzen von Bämmen der Ehene. Eviler hat dieselbe Beobachtming bei Ansiaatversuchen in der torstlichen Tersuchsstation hei Zürich gemacht. Ans Keimversuchen mit Samen von Fichte, Kiefer uml andern Waldbämmen schliedst M. KınsTz ${ }^{6}$ ), lats für die in niederen Regionen heimischen Fithtensamen die Minima, ()ptima mud Maxima der Keimmostemperatnren höher liegen als für die ans höheren Lagen stammenden Samen.

Bei den Kintumen in Höhenlitima ist aber anch ferner zn berick-

1) Rustrmiı, M., Ü],er die Ausbildung der Jahresringe an der Grenze des Bammuchses in den Alpen. Irssert. Berlin, cit. Bot. Centralbl. 1904. Nr. 4:3.

2) H.nтu, R., Holzuntersuchungen. Berlin. Springer 1901.

3) Grumurza. Sul movimento igroscopico dei rami delle Conifere. Malpighia XV, cit. Bot. Jahresb. 1901. Abt. II. S. 191.

4) Crast.ur, A., Uther den Ligningehalt einiger Nadelhölzer. Mitt. a. d. Forstl. Tersuchswesen (1sterreichs, 18!n7. Heft XXIII.

5) Centralbl. f d. gesamte Forstwesen, 1894, Bd. 20, S. 145.

6) Kinxrz, Vergleichende Keimversuche mit Waldbaumsamen aus klimatisch verschieden gelegenen Orten Mitteleuropras. Ref. Bot. Zeit. 1879. S. 597. 
sichtigen, dats sich die Gebirgserhebungen versehingen verhalten, je nachdem sie isolierte Kegel oder Hochplateans dastellen. Da Bastrahlung und Ausstrahlume des Bodens auf dis Temperatm der iln bedeckenden Luftschichten von bedentendem Einflut's sind, so wirel

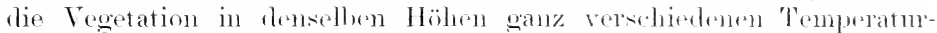
differenzen gegenïlwestehen. Anf tem Hochplatran is während der

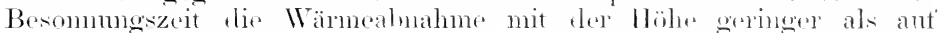

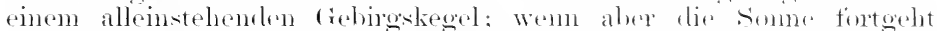

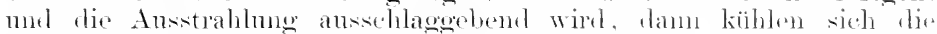
moteren Luftedichten über dem Hochplatean anch mehr al, Es sinel also the täglichen T'emperatursehwankmogen dort viel grötser mel

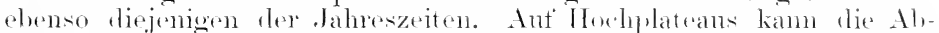
kïhlung lis zum Frost heralsinken. währent die isolierte Kuppe noch daver bewaher heibt.

Dasselle Verhalten zeigt sich zwischen Tal nud Hähe, mul wir laben erst liäzlieh eine Anzahl Beispiede ans Italien kennen onelemt.

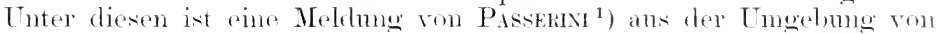
Florenz besomelers dentlich. In der Nacht rom 1!!. 20. April 1901: rank

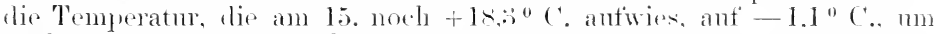
nach nem stmulen wieder ant + 12.2" C. zu steigen. Währemel din

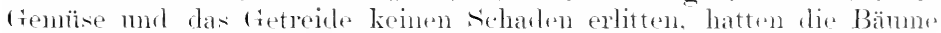

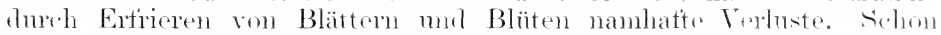
50 $\mathrm{m}$ höher waren Schädigmeon nicht meth wahromehumen.

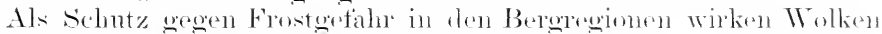

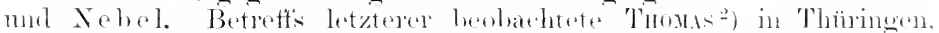
lat's aut den in Nebel gehïllten Ilähes das jumere Burhemlanb nicht

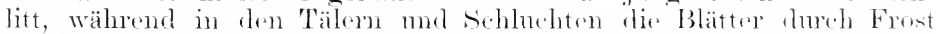

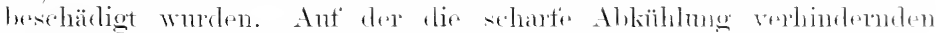
Eigenschat ter Neled hat sich die künstliche Frostrephümo dureli Exzengung ron Rauch aufoebant.

\section{Anpassungen des Wurzelkörpers der Holzpflanzen.}

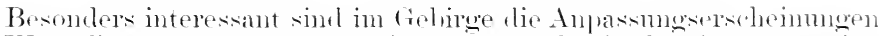

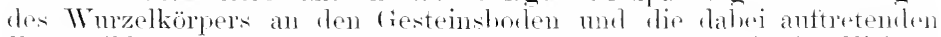
Ersatzhildmgen. In der nathstehenden Finm l sehen wir wine Fiehenwuzel, welehe sich durch rine fresteinswalte ihren Wregebahnt und

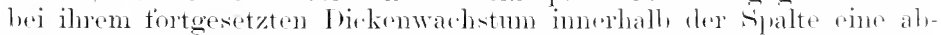
geflachte brettartige (iestalt angenommen hat. Nach dem Anstritt ans hem Gestein ist lor Wurzelkïrper zur erlindriselen Form zuritek-

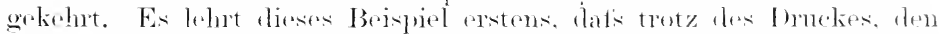

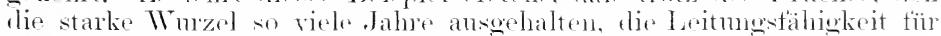
Wasser mol plastisches Material in flem brottartion Trib nicht muterhrochen worden ist. Zwoitens bemerken wir oberhall, ler loettartigen Abflachung ein Hervortreten arlventiver Wurchn. Beidr Vorgänge

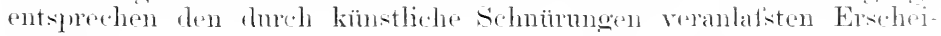
numigen.

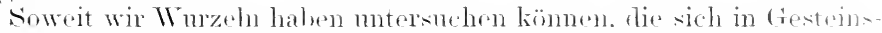
spalten abgetlacht hatten. Lomnten wir bemerken, datis die luntention.

1) Pismerix, Sui danni prodotti alle piante del ghiacciato ete. Bull. Soe. B it. ital. $190 \%$, \$. 308 .

2) Tuwn, Fr, Scharfe Horizontalgrenze der Frostwirkung an Buchem. Thin'. Nonatsblätter. April 19ij. 
Abflachung des Wrurzelkörpers dadurch zustande gekommen, dafs die alljährlich sich bildenden Holzringe an den seiten, wo sie sich frei (nitwickeh liomuten, also in der Richtung der Spaltfläche, selur stark ansighildet, dagegrn an den Seiten, wo die Wurzel dem trestein angepretist gemesen, aut ein Ninimum reduziert und schliefslich unkenntlich wurden. An den freien šeiten war das Holz gefätsreich, in einzelnen

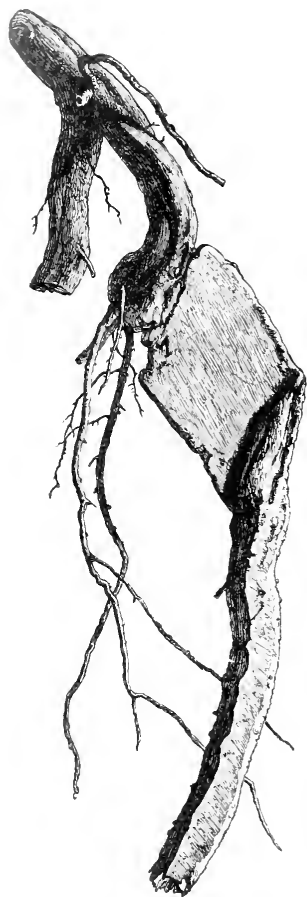

Fig. 1.

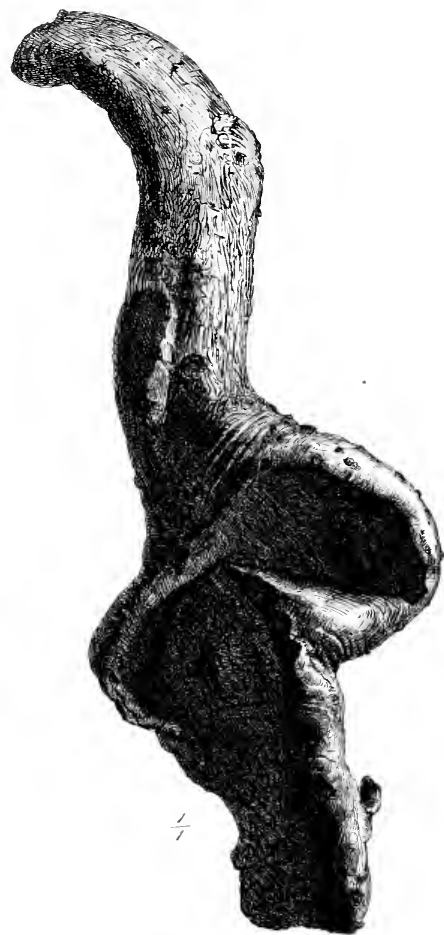

Fig. 2.

Wurzehn von (mereus pedunculata zwischen Felsspalten. (Nach IöвnER-NoвBE.)

Jahresringen sogar sehr breit und mit dicker Rinde versehen; an den unter Druck des (iesteins stehenden Wurzelseiten wurde das Holz gefätslos, kurzzollig mol ans schief anfsteigenden, statt vertikal verlaufenden Iolzfaser'n gebildet. Schliefslich erkennt man keine Jahresringdifferenzierung mehr, und man sieht nur noch ein ganz schmales Korkband anf dem bisweilen parenchymatisch kurzelligen Holze ohme erkemmbare Markstrahldifterenziermg antliegen.

Trotzdem ist die cambiale Tätigkeit an der brettartigen Wurzelstelle nicht erloschen, wie man dies bei dem Übergange des abgeflachten, 
in den cylindrisch weiter wachsenden Wurchteil sieht. The anatomischen Verändermgen in den zwischen frestein sinprelsten Wuzeh nähern sich so antfillig dru durch künstliche selmürmo an oherirdischen Achsen crlangten Resultaten, daf's wir in dieser Beziehmo auf unsere späteren studien in dem Kapitel "Wumflen" rorweistn kömnen.

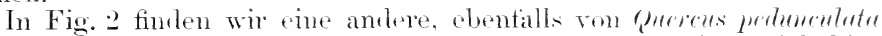
stammende Wurzel, die wahrsheinlich mu zwisch"n steinen sich hindurchgeprefist hat. Sio hat bei der Begegnume mit dem Hindernis ilnes

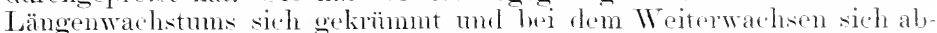
geflacht. Mit zmehmendem Alter ist lie gepretste Mnzelfläche ins Freie gelangt und hat an den freigeworlenen Sieiten dine orhöhte Ansbildung der Holzringe erfahren, die sich nun ähnlich wie T̈herwallungs-

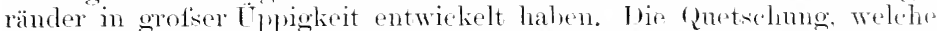
die Wurzel erlitten hatte, dürte ähnlich wie eine Ringelung wewirkt mul wie bei dieser eine Art Ringelwulst oberhalb der Iruckstelle erzengt haben (s. Ringelung in Kapitel . Wunden").

Uher den anatomisclen Befimed in den Antangstadien derartiges. Abtlachungen des Wirzelkiorpers kömen wir wns dueh die Tutersuchumgen von Lopkoke ${ }^{1}$ ) einen Begritt' machen. Torselle beobachtete

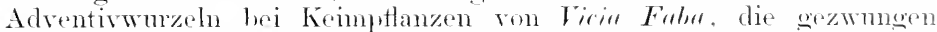
waren, unter dem seitendruck ron nicht ansemanderwejehenden

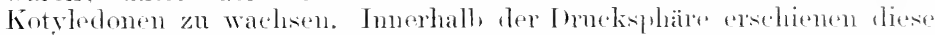
zarten Wurch bandartig verbeitert, und nach Anstritt aus der Inuckregion wuden sie wieder normal crlindrisch, wir dies mese alten abgebildeten Eichonwuzeln obentalls erkemen lasson. Bui den gamz jungen Wurzeln der saubohne sah Lorkone an din nicht durche dir. Kotyledonen gedrüekten Seiten die Epidermiszellen sich zu Wmzelhaaren verlängen. An dru gepetsten seiten dagegen waren nicht nur die Epidermiszellen tangential abgeplattet, somiern and die zwei bis vier äutseren Rimlenschibhten bedentend geprotist, so daf's sis eins Art peripherischen (iürtels $u m$ die Nurzel an cliesen seiten bilileten.

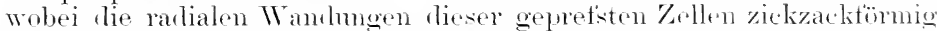
gefaltet wie bei emem Blasohalge orschienen. I lie unter dem Inuck der Kotrledonen stehenden Zellen erwiesen sich auch stottlich rerandert, indem ihre Membran'n entweder rerkorkt orter ssant ihrem Ixmen mit einer Art sichutzenmmi imprägniert waren".

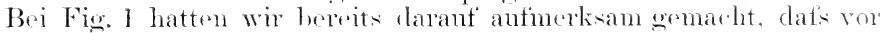

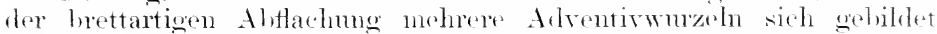
haben. Wie man sieht. hat hier die Wrued vor dem Eintritt in die

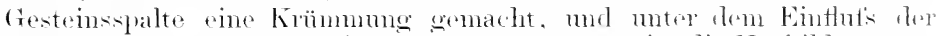

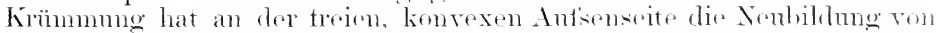

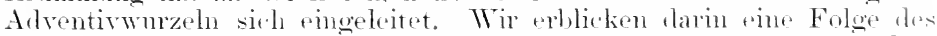
Krömmmoseizes, len NoLs ${ }^{2}$ in seiner Arbeit ansfïhrlich hespochen hat. Tie Eigenheit, dat's hei Wurzeln. die infolese eines ihrem Länen wachstmm entgegentretenten Hindernises sich lizumnen müssen. an

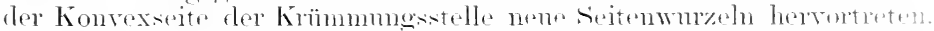

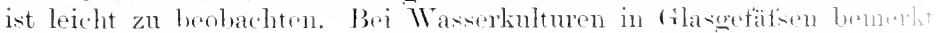

1) G. Lopronk, Terbänderme infolge des Kö̈ptens. Ber. Tentsch. But it Bd. XXII. Heft 5. S. 309

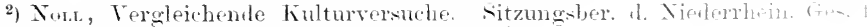
Naturkunde. Cit. Bot. Jahresber. 1901. II. s. 304. 
man diest Erstheinmng, Wenn kräftige Wrmzeln den Boden des Glascrefäses epeichen nud sich num nmegen.

In Geling trittt man lerartige Torkommnisse bisweilen als Hilfsroprichtmugen an Hachstreichenden, jüngeren Bammwryeh an, wenn

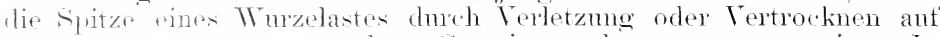
lem frestein verloren gegangen ist. In

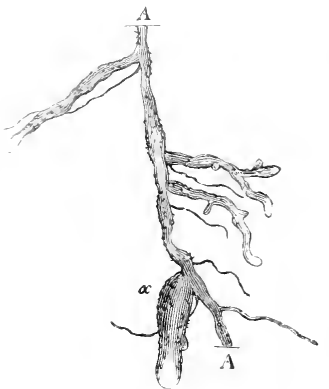

Fig. 3. Ast einer Fichtenwurzel, an der sich oberhalh lar abgestorbenen spitze eine fleischige Ersatzwurzel gebildet hat. (Nach NoBre.) Fig. :3 sehen wir eine solche Ersatzwurzel, die oherhall, der algestorbenen sivitze des Hauptastes $(A A)$ sich entwickelt hat. Das Ersatzorgan ist vicl liäftiger und fleischiger als the frïher gehildeten seitenwurzeln.

Die Arrentrwarzelbildung infolge des Krümmungsreizes oder einer Verletzung der Wurzel wird älrigens technisch in der Bammzucht fortwilhend rerwertet. Bei dem Verfiflanzen der Sämlinge mserer Wald- und Obsthäume wird entwerler die Pfahlwurzel sehneckenförmig gekriimmt in das Pflanzloch gelmacht, oder sie wird 110 etwa rin Drittel verkürzt. Stärkeres Zurütkschneirlen ist nicht empfehlenswert, weil die Adrentivwtuzell,ildung immer schwächer wirrl, je älere Regionen der Achse gekrümmt oder angeschnitten werlen.

\section{b) Speziclle Erkranknngen. \\ Rückgang in der Kultur der Lärche.}

Als ein rhlagendes Beispiel für die Nachteile, die sich bei der Kultur von Pflanzen ans dem Gebirgsklima in der Ebene heransbilden, möehten wir den rielfach hemerkten Rückgang der Lärehempflanzungen

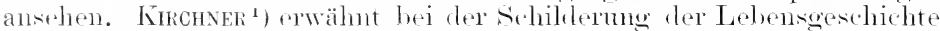
dieses Waldhatmes, dats derselhe ein echter Hothgehirgsbam des "ruropäischen Alpen- und Karpathenststems soi. Der natürliche Verbreitmgshezirk restreckt sich von iler l auphiné durch die Schweiz

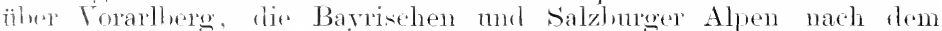
Mähriseh-sehlesisehen Gesenke, den Karpathen bis zu dem Hügelland sü̈lpolens. Die obrere Höhengrenze liegt für die Lärche etwa leej $24100 \mathrm{~m}$, die nutere in den Alpen lea $423 \mathrm{~m}$, im sthlesischen Grentike ungefäh hei $357 \mathrm{~m}$. Während sie in Schottland, Schweden, Norwegen sehr gut gerfoiht, kommt sie im mittlern und nördlichen Inetschland sowir in Frankeich nicht gut fort. Bei gemeinsamem Vorkummen pthegt mit Ansnahme der ofrersten Höhenregionen meist dir Lärche von dere Fichte zurückgedlängt zn werden, falls nicht letztere anf trocknem Bublen stelit und dam im Längenwathstum hinter der ersteren zuritrkbleilst. Von allen pinheimischen Narlelhölzern ist die Lärehe der am messten lichtheflüftige Barm, der mit einer so starken Transpiration ansugestattet ist, dafis dieselloe nicht nur alle Nadelhölzer, sondern anch die meisten Laubläume ïbertrifft. Wegen der Un-

1) Lebensgeschichte der Blütenpflanzen Mitteleuropas. Bd. 1. Lief. 2. S. 157. Stuttgart, Tlmer 1904. 
empfindlichkeit, welche sis in ihrem natiolichen Verloreitmespeniote gegen dis Winterkälte zeigt, ist die Lärche viel mehr in ihrom (iodeihen von der im sommer herrschentern Wärme ahlängig: sie liebt

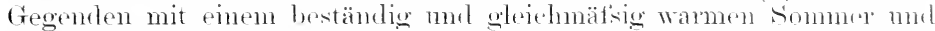

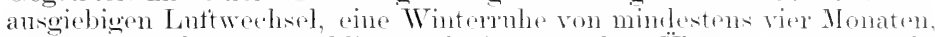

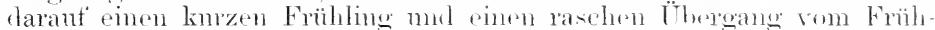
ling zum sommer. Bei ihreg äulserst trühen Belaubune remag sie eine sehy kmye Vegetationszeit anszmmutzen.

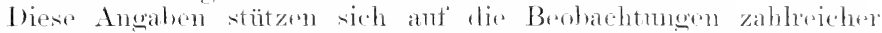

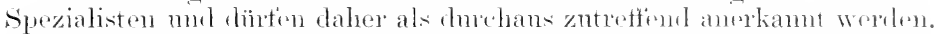
Betreffs der stofflichen /usammensetzmere ohalten wir oinen Einhlieli

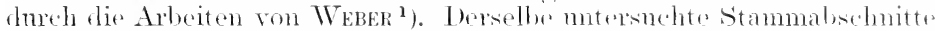

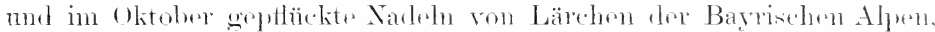
aus tem Spesiart, aus der Maintalebene nsw. Trotz dro Versehiedenartigkeit des Bodens ergaben sich doch ïberoinstimmente Resnltate

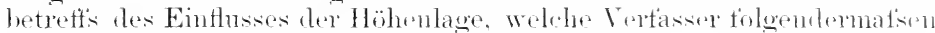
zusammenfatist :

Die organisehe Sulstanz der Narleln nimmt in einer lemerkens werten Regehnäsigkeit mit der alsoluten llähe dor standorts zn: mopkeht stellt sich der trehalt an Reinasehe. Der Asthemerolt ist

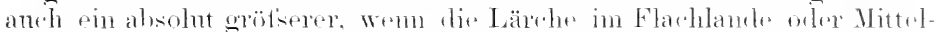
gehirge wächst, so dat's also zur Heqstellung dry gloichru

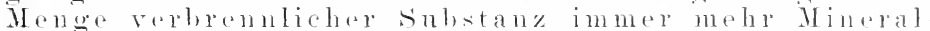

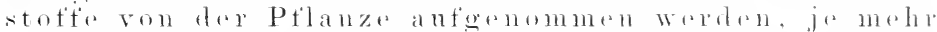

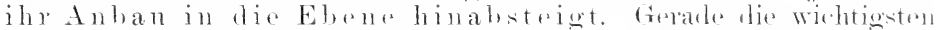

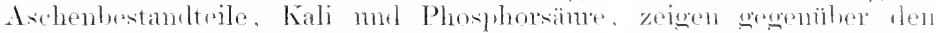

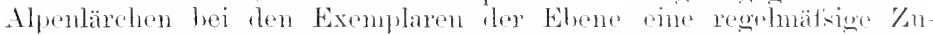
nahme. Betrettis des Kalligehaltes steht zwas anch dir Lärole der Ethene obenan, doch scheint hier dir Bodenbeschatfenheit sehe matsgebent zu sein. Magnesia mul sehwefelsämo zeigen mubelentemus. Eisenoxyd mol Kieselsäure wiederum örtsere /mnahme.

Aur den WeBER'schen Untersuchmeren erkennt man, wis sehr sieh

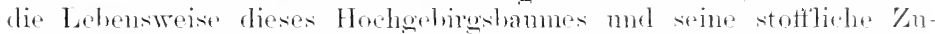
sammensetzmo mit tem Niedersteigen in die Ebene ändern, mul es ist the Frage nummehr nahegelegt, ol, sich nicht and der anatomische Ban bei den gänzlich ahwoichenden Lebenserhälnissen in der Ehene ändern wirel. For allen Dingen hietet die Ehene die starken liontraste drex äntserst intensiven sommerhitze mit starker. Winterkïle: dazu kommun die langamen Frihjahre mit ihren lisweilen im Fobruar, stets abru

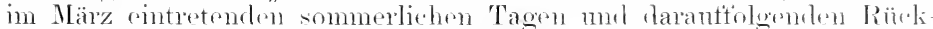

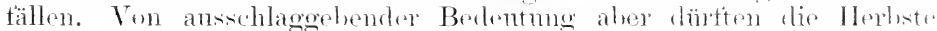

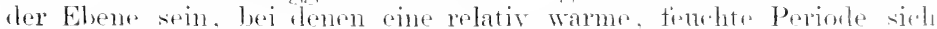

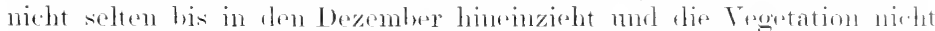
zum Absehlutis kommen läist. Man dronke nu an mosere Eichen- mut Aptelbämme, die das Lanb an den Sirtzen der Zwoige häufig genme

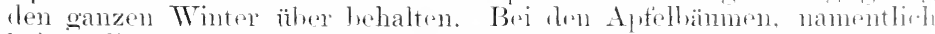
bei spraliex- und schmurtomen, bilden manche sorten im Hophet wan keine 'Terminalknospe ans. sombern das jüngste Blatt l, leilst pinfach in.

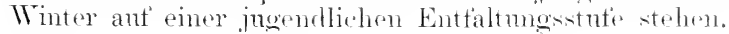

3) R. Weber, Einflufs des standortes auf die Zusammensetzung der L wh on

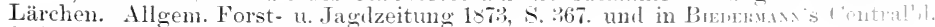
f. Agriculturchemie, 1×7.5, s. $23.3 \%$. 
Bei ler Lärche äutsern sich derartig lange fenchte, relativ warme Herlste in der Form. dats nach dem nomalen sommerlichen Absehluts des . Jahresinges noch eimmal einge Lagen Frïhlingsholz gelihtet werlen. wie ith direlit zu heobachten mehrach Gelegenheit gohaht hale. Also in der Ebene finclet in solchen Fälen der Eintritt einer vollkommenen Rulureriode, den Kinchses als erforderlich zur normalen Entwicklnng der Lärche betont, nicht statt, und die nächstliegende Folge wird hänfig der Verlust der gerïhnten Frostwiderstandskraft sein. Nit dem Eintritt der Frostrumben öfthen wich die Einfallspiforten für alle Wundparasiten, die bei dem vielfach dichten Bestande der Lärche in dre Elvene und der dadurch bedingten fenchten, mbewegten Luft die gïnstigste (ielegenheit zur Ansiedlung mol Ansbreitmng finden. Daher schen wir so reichlich den Pilz des sog. Lärchenkrebses,

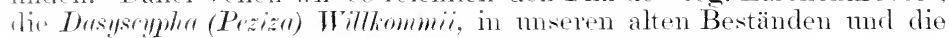
mit Flechten ïberzogenen stämme des stangenholzes.

Ans diesen dor Natur des Bammes gänzlich zuwiklerlanfenden Anbanverhälnissen in der Elsene erklärt sich die Klage, dals die Bämme in Nordwest- mel Mitteldentsehland und in Frankreich durchsehnittlich kein tremliges Groleihen zeigen. Und dies ist der Grund für den Rücksehlag, der ant die allgememe Begeistermg der Forstlente fiur den Lärehenanban eingetreten ist.

In neuster Zeit bricht sich die Erkenntnis von der Fehlerhaftigkeit monerer Kultmmethoden mor der Halthsigkeit der weitverbreiteten Annahme, dafs die Lärche allenthalben angepflanzt werden kömme, in forstlichen Kroisen mehr und mehr Bahn. Am bezeichnendsten ist das Erscheinen eines klemen Sehriftchens ron dem Forstmeister Bones in Hameln ${ }^{1}$, welther beobachtete, dafs der Lärchenkrebs nur dort anftritt, wo der Bamm in Unterdrickung gebaut wird oder allmählich hurch den Einfluts anderer Bestäncle in Unterdïickung gerät. Der rote Faden in seinen beachtenswerten Darstellungen ist, "ratis die somme die Amme der Lärehe ist". - In T̈bereinstimmmo mit dieser Erfahrung steht das Eroebnis simer Umfiage der englischen Dendro-

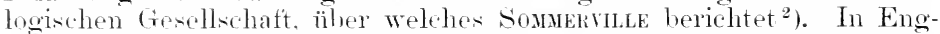
land scheint der Lärehonkels danach in Zmahme begriften zu sein und vorzugweiso Bämme ron 7 bis 15 . Jahren heimzusmchen. Fenchtigkejt bei geshlossenen Lagen hegünstigt die Krankheit, die anf den llähen weniger als in den Niedermgen anftritt. Tiele praktische Forstlente luhanpten, dats eine Tererbung der Krankheit durch den siamsn stattfinde: mul wem anch Sommerille diese Anschammg nicht teilt, so mas "r doch die Ammahme einer erhliehen Disposition nicht von der llanel weisen. Aneh sei die Behamptung, dats die Bammschulen dir Krankhoit verhreiten, nicht gänzlich zu verwerfen.

Wir vostehen nummehr vollkommen derartige Angaben, die auth in Dentseluland nitht solten zu hören sind. Solkhe Disisositionen zur Erhankung hestelen ehen in dem veränderten Wachstmmsmodus, der

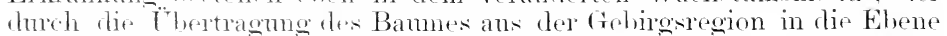

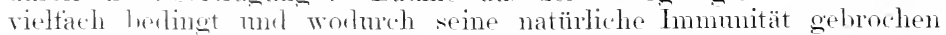
wirl. l)ats die Bammshulen mit ihrer ans wirtsehaftlichen Grönden

1) Tie Lärche ilu leichter und sicherer Anban in Mittel- und Norddeutschland dureh die erfolgreiche Bekimpfung des Lärchenkrebses. Leipzig 1899.

2) Report by Dr. Somenime on the inquiry conducted by the Society into. the disease of the larch. Transact of the English arboricultural Society. Vol. III. Part IV. 189:--94. 
entschuldbaren sthnellen Anzucht der sämlinge in wodïngtem Borlon diese Verweichlichmng der Lärche begünstigen, ist rerständlich: Ähnliches finden wir auch hei anderen Natelhoilzern. Wir haben beispielsweise Gelegenheit gehaht, ans Bammschnlen mul forstlichen saatkämpun Kiefernsämlinge zu untersuchen. die an der schüttr zu leidru lregannen, nud haben stets damn nachweisen kömmen, dats bereits im ersten Jahresringe die Antänge von Resinosis vorhanden waren.

Ämliche Resultate hetretts der Differenz des Aschengehaltes wie bei der Lärche fand WeBer ${ }^{1}$ ) anch bei dem Buchenlatub. Bei Untersuchmogen ans 11 versehieflenen standorten erab sich, dafs das Arehemprozent in den Hochlagen über form m Moreshöhe ein bedentend niedrigeres war als bei Buchenlaub ans don 'Tieflagen. Letzteres zeigte in seiner Asche aher einen geringen 'T'uil an Kali, Phosphorsäure und schwefelsäne, während die Blättre ans den Hochlagen so reich wie junges Lanh an diesen Stotten sich erwiesen: bei Kalk mul

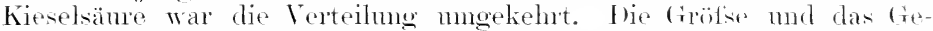
wicht eines Durehsedmittshattes nehmen mit der liöhe ab. Betretts

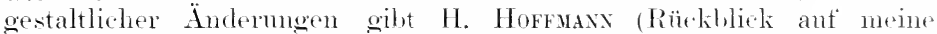
Tariationsversuthe. Bot. K., 1881, \$. 4:31) das Beispiel an, dat's Suli, herbacen und reticulate. rom Hochgebirese in tie Niederume verptlanzt, sich mit ihren nenen sprossen antichten, statt am Boflon zu liegen.

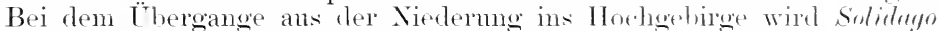

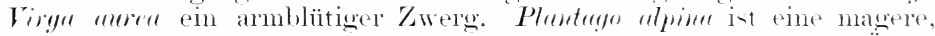

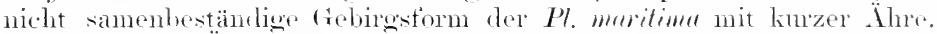
Die Länge der Älne stieg in ter Niedermog in zweiter (reneration son 15 anf ls mm: die Blätter wurden heiter und selbst gerähnt. Die Blüten

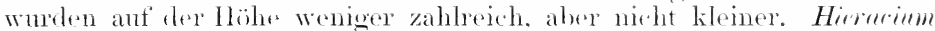
alpium brachte in der Niefermes einzehe Exemplare mit hohen, stark verzweigten stengeln: Astre alpims wurde in einzehnen Exemplaren hreitblätriger. Gmaphalium Lonutoqudium, das Edelweits. Iorkert in der Ebene seine Blïtenköptehen mul Brhaarmng.

Die Erfahrmgen, welche bei dem C̈bertragen der I ärohen ans dem Gelirge in die Ehene gematht worden sind, erseheinen uns als seln ernste Mahnungen, die natürlichen Ansprüche der Bämme mehr zu berüchsichtigen und nicht, gestïtzt vielleicht anf eine Bodenanalyse. zn slanben, dats jeder Bann dort gedeihen mïsse, wo Nährstotte für ihn

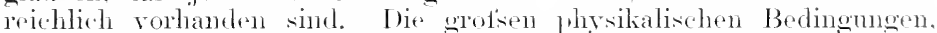
wie Durchlüftungs-, Belenchtmos- mul Fenchtigkeitsverhältnisse, sint auschlaggebende Faktoren, welche, entsprechend herückichtigt, die

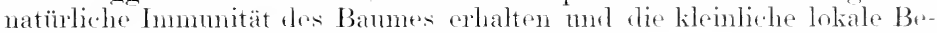
kämpfing der Parasiten überflüsisig marhen.

\section{Milserfolge bei unsern Tropenkulturen.}

Wie jede Sation mit Berginn ihrer Kolonialtätolisit. mässen anth

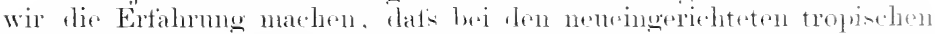
Kulturen grotise Fipluste eintreten. Ein wesentlicher Faktor tür th

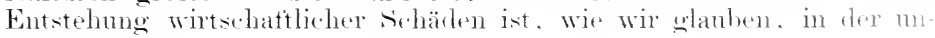

1) Wraner, Einflufs des Standortes auf den Aschengehalt des Buchwnlauth.

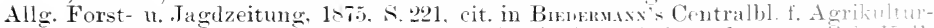
chemie, 1875, II, S. 325. - (Der jrozentische Aschengehalt und namentinti hialk und Kieselsäure steigen $u m$ so mehr, je langramer die Pflanzen wahsen. 
genïgenden Berücksichtigung der heimatlichen Vegetationsverhältnisse zu suchen, ans denen dis tropischen Nutzpflanzen in ihren verschiedenen Kulturformen stammen. Butreff's der Übertragung von Pflanzen ans der Ebene in ein Hähnolinna ist nächst der abnehmenden Luftemperatur die Zunahme der relativen Fenchtigkeit ron besonderer Wichtigkeit. Diese Verhälnisise setzen z. B. dem Getreidehan eine schnelle Grenze. Nach Fesca's Mitteilungen (l. c. p. 42) gedeihen msere Getreidearten in den nietleren Regionen der Tropen überhaupt nicht, und in den Höhen wird tas Reiten der Samen moicher. Ant'.Java und Ceylon wird der Anban miserer Getreidearten and Hülsenfiüchtler behufs Samen-

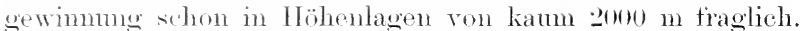

Tom hesonterem Wert ist dagegen, namentlich für tropische Kultmen, die Verringerung der Gegensätze zwischen Sommer- mel Wintertemperatur. Manche Pflanzen, denen os in der Ebene zu heits ist, gedeihen in dem gleichmätsigeren Höhenklima besser. So erwähnt Fesca ${ }^{1}$ ), dats der Kakao am besten in tropischen Höhenlagen von etwa $500 \mathrm{~m}$ gedeiht, der arabische Kaffee in tom bis 1200 mo Höhe und mehr. der Tee in 1000 bis $2(x)$ m. Für das Zuckerrohr dagegen sind Lagen notwendig, in denon Periosten mit hohen Wärmegrarlen anftreten. Dement-prechend dehnt wich der Anbau des Zuckerrohrs in den subtropisehen Ebenen viclfach bis zum 35. Breitengrate, im Mittelmeergebiet sogar bis zum 36. Breitengrade ans, wo das Temperatumittel während zwei bis drei Sommermonaten über 250 (C. steigt. Der Anban von Fabrikrohr erfolgt aber selbst im engeren Tropengürtel selten höher als bis :301 m. Wohl wird es noch höher hinant angeptlanzt, atrer nur noch zu Stecklingswecken benutzt, weil der Zuckergehalt zu schnell ahnimmt. In solchen Höhen entgeht aber das Rohr der jetzt so gefürchteten "serehkrankheit", und man hat deshalb anch vorgreschlagen, die Fabrikfelder derart zu regenerieren, dats man von ergiebigen Kultursorten stecklingsfelder in Höhenlagen eimrichtet mur deren Taterial wieder zur Kultur in der Ebene benutzt.

Anch bei anderen tropischen Kulturen ist nicht die Gleichmäfsigkeit tes Klimas ansischlaggebend, sontern das Vorhantensein hoher Sommertemperaturen, da dieselben zur Frnchtreite notwendig sind. So findet man wohl im engeren Tropengürtel noch Koknspahmen bis $1000 \mathrm{~m}$ Höhe. aber fruchttragende Exemplare sieht man schon in 900 m Höhe relten. Ehemso fühnt FEsca die Pompelnums an, the kühlere Wintertemperatur verträgt, aber zur Fruchtreife hohe sommerwärme beansmucht. Deshall, gelangt dieselbe z. B. in Japan zwischen 31 und :3.. ${ }^{\circ}$ Br. mit einem Jahresmittel von $16,5^{\circ}$ C. noch zur Reife, währent sie in Bandoeng anf Java bei $714 \mathrm{~m}$ Höhe unt einem Jahresmittel von 22.7" C. krine Früthte ansreift. Die Temperatur für die Fruchtreite liefert Japan in den Monaten Juli und Angust, wo das Monatsmittel ïber $26^{\circ} \mathrm{C}$. hinansgeht und noch in september ïber $24^{\circ} \mathrm{C}$. beträgt. Solke 'T'omperaturmittel werden aber in Bandoeng niemals erreicht.

Vorteillaft macht sich der Gebirgscharakter bei der Teekultur geltend. Der reichliche Nieflerschläge liebentle Teestrauch ist seiner Ileimat nach eine sul,tropische Pflanze. Durch Ausnutzung des Höhenklimas kamn er in den Tropen mit Vorteil gehant werden. So findet

1) Der Pflanzenbau in den Tropen und Subtropen von Prof. Dr. Fesca. T. I. Berlin, Sülserott, 1904 . S. 41 . 
er sich anf Java, Ceylon und in Indien bis $2000 \mathrm{~m}$ Meereshöhe; die höchsten Pflanzungen im Himalaja finden sich etwa bei $2.200 \mathrm{~m}$. Der Tee aus höheren Lagen ist sogar der gesthätztero; in den tropisthen Ebenen werden zwar grölsere Blattmengen geerntet, aber die Qualität der Blätter ist eine geringere.

Bei der Kaffeelultur sïndigen wir vieltach durch Einführung dor Pflanzen in schattenlose Ebenen. Der Katfer ist eine tropische Höhenpflanze, welthe (ileichmälsigkeit des Klimas lieht. Das Mitsraten in der Ebene wird oft genug ant die grotsen 'Temperatur- und Fenchtigkeitsthwankungen zurïckzutïhren sein. die sich in ter Ehene um so stärker seltend machen müssen, je weniger für Beschattmng sorge getragen wird. In der subtropischen zone wird die sommertemperatur zu hoth und dir Wintertemperatur zu gering, so dats das Wachstum des Bammes. das normalerweise munterbrochen vor sich gehen soll, zeitweise cinem stillstand erleidet.

In noch höheren firade beansprucht der Kakad, dem es kamm jemals zu warn werden kamn, eine gleichmälige hohe Fenchtigleit der Luft und des Bodens nebst Windschntz mol schatten. Innerhall, seines Anbangebietes, des engeren Tropengürtels his etwa jou m Meereshöhe, bilket er zahlreiche Formen, aber bei allen obologischen Varietäten machen sich dieselben Ansprüche an den Klimacharakter weltend.

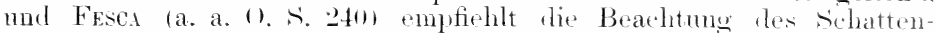
bedürtnisses namentlich tür junge Kulturen. Eine hiorhergehörige

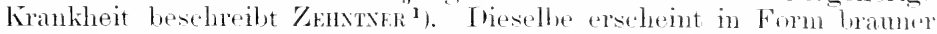
Flecke in der Rinde rin- lis zweijähriger Bämmehen. Nich dem Verptlanzen sind die stämmehen mehr dem Winde nud der some answesetzt. und mu platzen einzehe Rimlenstellon ant.

\section{Neigung der Bodenoberflaiche.}

Bei Prütung der hkalen Abändernngen in den Eintlïssen dor seographischen Lage tällt ferner die Neigung der Bodenobertläche ins Auge. Es handelt sich dabei hampträchlich nm sine Neigung ron 1 bis $11^{\circ}$ und allentalk bis 1:0 gegen den Horizont: dem die stärlier gorneigten Böden werton sich schon schwerer zu Acker eignen. Über einen vorteilhaften Einthuts der Neigmo der Borlenohrerfläche hat NoLL ${ }^{2}$ ) berichtet. Seine Versuche zeigten, lats ant hïnstlich hergerichtetem

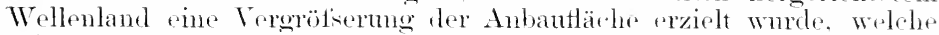
bei salatkultur die Emtemenge mo $31 \%$ steigerte. Aber selbst lwi geringen Neigmugen macht sich mit der Keit doeh anch ein bereits erwähnter strireniler Einflufer geltend. Die Regengüsse nämlich führen die Feinerde allmählich ahwärts mol lassen das Quarzskelett des Bodens zurück.

Die Himmelsgegend. nach weleher hin das Kultmond groned ist.

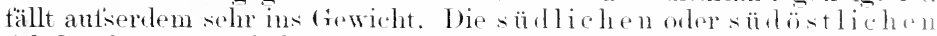
Abdachungen sind wegen der onotien Wittermosichwankmoen di. gefählichsten. Die hier hersehende höhre Temperatm rerumacht im Frähjahr eine schmellere Entwicklung, in sommer eine groitiop. Gefahr des Vertrocknens der Vegetation: dem sie ist nitht nur tör , li.

1) Proefstation roor Cacao te Salatiga.

Bull. 4.

$\left.{ }^{2}\right)$ Nor.., Vergleichende Kulturversuche.

Cit. Bot. Jahresb. 1900. II. C :34. 
sï̈lwinde, sondern anch tï̈ die trocknen (1st- und sïdostwinde und

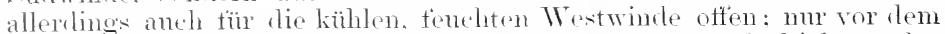
Nordwincle ist sie geschützt. Ina aber wibrend des Fribjahrs. also der Hampregetationszert die trocknen Winde rorherschen, so trocknen die südlichen Ahhänge ganz hesonders aus, und an Bergen ist infolgedessen die südseite am schwersten wieder zu bepflanzen und findet sich daher meist liahl.

Ein Vorteil der siüllage kam sieh in kurzen, kühlen sommern zeigen: hier liam dureh solehe Lawe allein bisweilen die Fruchtreife kmolebiger Pflanzen exnöglicht werken. Darm nutzt man am besten die Neigme nach sizrlen lurch die Kultur solcher Gewächse aus, wolche

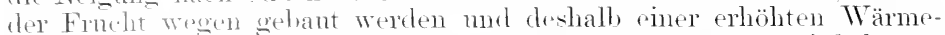
und Lichtriplinng Trediurten. Eine kältere Lage dagegen wird besser tïir l, Anban solcher Gewächse Verwendung finden, deren Blatt- und Holzkinger zur Verwertmo bestimmt ist.

Bei der Kultur monocarper Gewächse, wie unsere Gemüse sind, knomt die Schädlichkeit der sonst so bevorzugten Iage, nämlich die l.j.hte Beschärligmng dureh Frïhjahrsfröste, nur dann zur Geltmng, wenn dis Bestellumg mit Pflanzen zeitig im Frühjahr vorgenommen wird. (ivcitiser ist der sehaden hei empfindlichen polvearpen Ptianzen, wovon mnsere Nutshänme ein gutes Beispiel liefern. Hier finden wir in giunstigen, wamen Lagen häufig eine Mifsernte, während in demsthen Jahre die rauhen Lacen reichlich Nüsse liotern. Im ersteren Falle laben die durch stärkere Erwärmmos frühor heransgelockten jungen Triebe und Blïtenknospen durch einen Nachtfiost gelitten, der an den in hohen, ranhen Lagen befurtlichen Exwmplaren, die in dor Entwicklmo noch zuritek waren, schadlos rorïbergegangen ist.

In der Gartenkultur sncht man bei Benntzung der Vorteile solcher Lagen die Nachteile der Frühjahrsfiöste zu vermeiden, indem man die Pflanzen kïnstlich zurïrkhält. Dies geschicht dureh längere Becleckung, inclem entweder noch schmee ant die zarten Pflanzen geschanfelt oder Iatten mul stren noeh vermehrt werden. Bei Obstbäumen hänft man Anehnee, Eis und Deckmaterial nm die Basis, nm die Erwärmung des Bodens mol die Erregung grötserer Nurzeltätigheit möglichst hinanszuscliiebent.

Die kalte nördliche Lage wird sich zur Benutzmg durth Wiese nul ITald emptohlen. Ostabdachungen werden tür sandige Bodenarten wegen ilures schuelleren Anstrocknens getährieh und taher hej schwerem Borlen volteilliatter: momelichrt verhält sich die fenchte Niestarite.

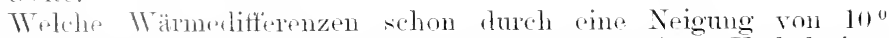
lierorgerutin wedfen kömen, wem man alle übrigen Verhältnisse

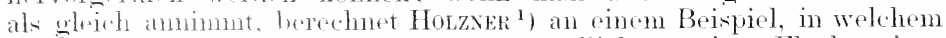

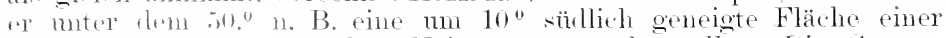

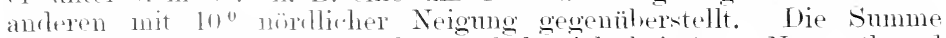

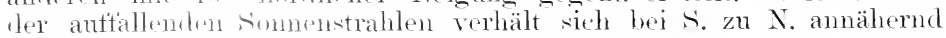
wie :?: ").

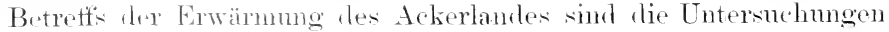

1) Honzan, I ie Beobachtumgen über die sichütte der Kiefer oder Föhre und die Winterfärbung immergrüner Gewächse. Freising 1877. 
von Wolny ${ }^{1}$ ) besonders erwähnenswert. In dieser Arbeit finden sich Beobachtungen von KEnsks ${ }^{2}$ ) über die verschiedene Erwärmm dlex einzelnen Seiten eines IIïgels eitient, die an die rorhergehenten Bemerkungen sich zunächst anschliefsen. Das Mittel ans dreijährigen Beobachtungen eloah, dats die Expositionen in abmehmenter Wänne

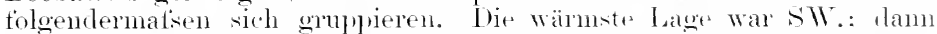

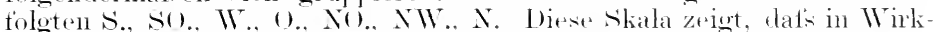
lichkeit die einzehen lagen sich nicht so verhalten. wie man theoretisch anfänglich wohl vermuten sollte. Man mörhte zunäehst ghauben, dal's fïr gleiche Abstände der somne rom Meridian aneh ilie hosolation gleichstark wäre, also die sïrlostseite flieselbe Wämmenenge wie die

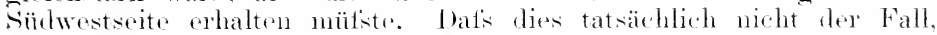

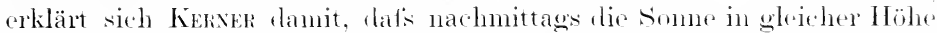
krätiger wirke. Weil dir Saturation lor Luft mit Wasserelampef nachmittags niechiger mol daher auch die Absorption der somenstrahlen weringer sei als in den Vumittagstumlen. Ein weiterer Gimd wirel von Lokenz ${ }^{3}$ ) eitiert. Die Nïrlwestseite hat nämlich länger Zeit als diw

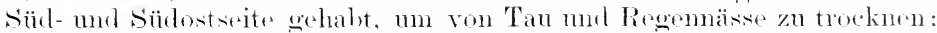

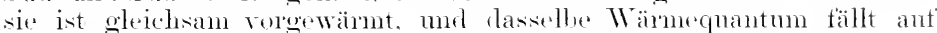
rinen trockneren Boflen, den es demgemäls moln prwärnt.

Wiehtiger für die Kulturen als der lahreselnohsehnitt ist aber das Monatsmittel, eventuell das Wämemaximum in den einzehen .Jahreszeiten. In dieser Beziehmo ergehen die Kanks sehen 'Thermoneterleobachtungen, lats nur im IV inter (vom November his April) das Maximum der Bodentemperatur auf ler siddwestseite liegt, daf's dagegen voll Mai bis Angust dies südostseite

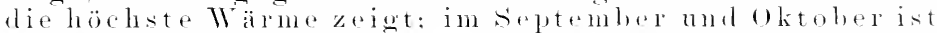
lie siulseite am höchsten erwärmt. Diese Wanterung des Maximums diüfte sich durch lie in Hochsommer eintretenden trocknen

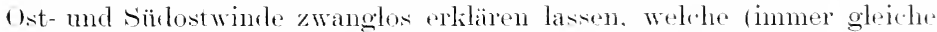
physikalisehe Bodenbeschaffenheit voransgesetzt) den Boden schneller ahtrocknen und damit besser erwärmmestähig machen.

Während die Untersuchungen von KERNER in einem natïrlichen. aus diluvialem sande lestehenden, mit ziemlich steilen, grasheratehenen Bösthungen versehenen Hügel bei Innshruck angestellt wurden, experimentierte Woblxy mit rinem kïnstlich ans gesiehtem, hmosem Kalksandboden errichteten Hïgrel, dessen Mantel zur Horizontalebene einen Winkel von $15^{\circ}$ liblete. Hier waren also die Verhältnisse den zum Ackerbau tatsächlich noch verwendbaren steigmown des Landes angepatit.

Die Woulvisehen Beobachtungen bestaitigen zunächst die von Kerser erhaltenen Rusultate betretiti der Wandermug des Wärmemaximmms ron südost im Sommer nach südwest im Winter. Frrner

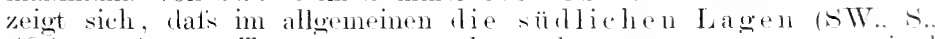
so.) grötseren Temperatursehwankungen a wsesetzt sind gegenüber den anderen, von dentrn die nördliche Aldachung die ge

1) Wouxx, Lntersuchungen über den Einflufs der Exposition anf die Firwärmung des Bodens. Forschungen auf dem Gebiete der Agrikultmphssik. Bit. I. S. 263 .

2) Kerser, Über Wandexungen des Maximums der Bodentemperatur. Zejtshr. d. österr. Ges. f. Meteorologie. Bd. VI, Nr. 5, 1871, s. $65 \mathrm{ff}$.

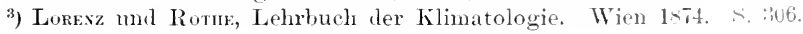


ringsten Schwankungen aufzureisen hat. Bei einer anderen Versuchsreihe zur Feststellung der 'Temperatur der Seitenflächen von Beeten hei verschiedencr Lage gegen die Himmelsrichtung, im Vergleich zur 'Temperatm' einer obenen Ackerflache in $15 \mathrm{t} \cdot \mathrm{m}$ Tiefe während der wämeren Jahreszeit argal, sich folgendes. Die Südseite ist an wämsten: dann tolot im Mittel die ebene Ackerfläche, an dritter stelle die Ost- mud Westseite. währent die nördliche Abdachung des Beotes als die kälteste erscheint. Wemn mun die Beete von Ost nach Irest gorichtet sind. Fommt eine Längsfläche nach süden, die andere nach Norden zu liegen, nnd so haben diese beiden Flächen dir grösten Temperaturdifferenzen, die sich in der Vegetation wohl abspiegeln kömmen. Es ist rlaher günstiger, wenn man ïberhaupt den Acker in Beete legen will oder muts, dieselben von Nord nach Süt verlaufen zn lassen. Am vorteilhaftesten wegen der gleichmätsigen mel durchschnittlich höheren Enwärnmong ist der Anban in ebener Ackerfläche, deren Temperatur zwar niedriger als die eines nach süden geneigten Abhanges ist, aber die sämtheher anderen Expositinnen ïbersteigt.

Die Torteile der sïdlich geneigten Lage treten, wie spätere Versuche ${ }^{1}$ ) ergaben, aber anch nu dam in die Erscheinmo, wem stets genügrnde Fenchtigkeit vorhanden ist. Bei trockner Witterumg oder mregelmälsig verteilten Niederschlägen vermindern sich die Ernteerträge. Ja, bei extrem trockner Witternng wurden anf der Nordseite, die sonst die geringsten Ernten liefert (mol zwar um so geringere, je stärker der Neigmngswinkel ist), die höchsten Erträge erzielt. Darauf folgten West- mnd Ostseite: die geringste Produktion zeigte sich auf der süidseite.

Natürlich smechen anch noch andere Verhältnisse stets mit, so z. B. wird bei himreichender Fenchtigkeit und zusagender Feinkörnigkeit des Bodens auch die Bodenfarbe wirksam. Te dunkler die Erde. desto mehr wird das Pflanzenwachstum gefördert. Bodengemische ergeben bessere Ernten wie reine Torf-, Sand- orler Lehmböden.

\section{a) Zusteile Lage.}

Bodenflächen von mehr als 15 bis $20^{\circ}$ Steigme anf kleinem Rame werken, soreit als möglich, als Wiese und Weideland benutzt werden müsen, wenn micht der Garten- und Weinban eine temre Terrassiermng lohmen. Wenn die Steigung einer Fläche einem halben rechten Winkel nahelommt, ist dringend zu raten, jed. vorhandene Vegetation zu helasien und in geeigneter Anpflanzmng die Bewald $n \mathrm{~g}$ zu versuchen orler zu vervollständigen.

Es liegt in dieser Verwendung so stark geneigter Flächen nicht nm die lieste Nutzung, sondern anch der beste Schutz der an diese Flächæn sich anschliefsenten monteren Kulturländereien. Derartig steile Lagen, die num das (rebirge bictet, haben selten, selbst bei Bewaldung, cine tiefe Krume. Diestlbe kann sich aber nur gegenüber starken Regengüsen oder (hei anhaltender Trockrnheit und reichem sandgehalte) anch bei Stümen erhalten. wem sie von den Wurzelnetzen

1) Wollnx, E., Untersuchungen über die phrsikal. Eigenschaften des Bodens auf das Produktionsvermögen der Nutzgewächse. Forsch. Geb. d. Agrikulturphysik XX, Heft 3, 1898, s. 991. 
der stark im Felsgestein verankerten Bänme duchsponnen ist. एhu Moospolster der Waldungen erhalten die für weitere /ersetzungen der Gesteine so notwendige Fenchtigkeit und veruehren die Geneigthrit zur Quellenbildung, deren segen in der Ehene erst zm Geltumg kommt. Betretts des Wachstmmsmodns der Bämme in steilen Lagen ist leicht zu beobachten, dats das Mark exzentrisch orworlen ist. MER ${ }^{1}$ ) beobachtete hei den Tamen und Fichten der Togesen, datis an steilen Abhängen die Jahresinge an der nach dem Anfstieg hin grerichteten Baumseite sich stärker entwickeh als nach dom Alhange zu, was namentlich an der stammbasis hervortritt. An narh Norden und Osten gelegenen Abhängen werden die Tamen und fichten nicht nm höher und stärker, sondern anch bei dem dinzelnen Banmo entwickeln sich nach den genamnten Himmelsqegenden die Jahresinge krätiger. Wem lie Bäume sich krümmen müssen, zeigen an der Krümmmugstelle die Jahresringe der konvexen seite sich stäker entwickelt.

Wir haben leider in msern Kulturländern Beispiele genng, welehe die traurigen Folgen der Abholzmng steiler Ahhänge zeigen. Die Brwaldung war hier das Produkt mehrhumblertjähriger, ineinandergreitender Vorgänge, welche mit der Ansiedlung von K'ustenflechten ant dem nackten Felsgestein wahrscheinlich begannen. Dmeh das /mriekhalten der Verwittermosprodukte haben diese und allmälilich grötsere Pflänzchen zur Bildung einer Bodenkrume den Anfang gemacht mal mit ihren verwesenden Lejbern die ersten Humusubstanzen geliefert, the zum Gedeihen höherer Pflanzen den Boden immer passender machten. Finmal der Vegetationstecke heraubt, schwemmen dio Regengrisso die Krume abwärts und legen in der Höhe den steinigen Boden narkt, während sie in der Ehene die Kulturen versohlämmen. Je grötser die Entwaldung im Gebirge, desto umregelmälsiger wird der Vasserreichtum der Gebirgsflüsse, desto häufiger Üherschwemmmmon unel Versandungen im Frühjahr und Wasserarmut der Flulisänfe in dürren sommern.

Abgesehen von den direkten Verwundungen, die herabueschlämmt. Erdmassen durch die mitgeführten steine hervorbringen. liegt die Hauptbeschädigung wesentlich in dem Bedecken der bisher der treien Luft mogehindert ansgesetzt gewesenen Pflanzenteile. Die meisten Pflanzen aber sterben ah, wem sie danernd tiefor gestellt werden, um nur diejenigen, welche die Fähigkeit besitzen, leicht Arlventivwrom zu machen, vertragen Bodenaufsehüttungen. Unter den krantartigen Pflanzen sind die Dïnengräser (Arundo armaria L., Elymus armarius I. u. a.) hervorzuheben: auch unsere Quecke (Agromyrum repens I'. I;) arbeitet sich mit Leichtigkeit ans starker Verschüttung empor. Unter den Bäumen vertragen Weiden und Pappeln und namentlich der ant Kies und sand vorkommende, an den Kïsten Deutschlands, Frankreichs und Englands zu findends, mit seinen flachstrejohenden Wurzeln zm

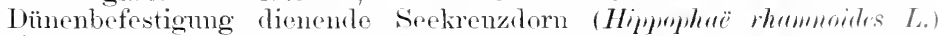
in Verschütten ohne grofisen Nachteil. Dagegen ist die stammhasis mancher Bäume, wie z. B. der Obsthäume, gegen starke Bodrnaufschüttungen sehr empfindlich. Bisweilen wird anch unvorsichtignweise bei dem Vorpflanzen der Bämme oder dem Planieren grotin Flächen die fröher frei gewesene Stammbasis durch zu tiofes Pflanzms

1) Mer, Des causes qui produisent l'excentricité de la moelle dams lex sajpins. Compt. rend. t. CVI, 1888, ,. 313. 
mit Ercle umgeben. I)ir dadurch hervorgerufenen Krankheitserseheinungen sind im folgenden anstührlicher behandelt. Tnter den Toptpflanzen vertragen die Ericaceen das zu ticfe Einpflanzen am wenigsten. Wan muts ammlnnon, dats ther sanerstotimangel für die threh Antlagrung grofiser Erdmassen zu tief gelegten Wurzeh die Ursache des Alisterliens ist.

Antior dem Verschlämmen der tiefliesenden Gelände verdient auch dir Wmyelentblötsmg durch Nachlutschen des Bodens eine erhöhte Antmerksamkeit. So lange der Waldbestand intakt bleibt, bilden die notzartig ineinanlergewachsenen Wmyeh, wie gesagt, ein so engmaschiges Geflecht, dati der Boden imerhalb desselben festgehalten wird. TI'nn aber eimmal durch Menschenhand oder stïme Lücken gerissen worten sind, so dats Entwuzelung eingetreten, damn stellen sich $1 m$ so schneller Nachschübe von Boden höhcr gelegener Standorte cin, je lockerer der Boden ist und je mehr der TVind Zugang in die Bestantestücke erhält. Abgesehen von den im Hoehgebirge muanthaltsan sich abspielenden Vorgängen dieser Art, lenen wir meist machthos gegenüberstehen, vollziehen sich aber anch im Flachland beständig Verämlermgen tes Waldbestandes, die das Blotislegen der Wr meln durch Bodemnachschühe zur Folge hahen. Ganz besonders ist dies der Fall in Waldungen auf' hïgeligem 'Terrain bei Durchlegung von Stratien. Der Waldboden ist meist locker oder wird durch das Abtrocknen gelockert, und sobald die stratse einen mit grötseren Bämmen bewaehsenen Hïgel durchschneidet, trifft man am Rande des Durehstichs die stelzenartig freistehenden Wurzeln, zwisehen denen ter Boden heransgerutscht oder fortgespült worden ist. Da die blolsgelegte Seite ler Wurzelkrone die Terankerung res Bammes im Boden schwächt und die verminderte Wasserzufuhr die Kronenausbildung beeinträchtigt. so ist der schaden ein toppelter.

TVenn man gegeniiber solchem rücksichtslosen Durchkrenzen der Waldbeständle zugumsten möghichster Abkürzung der Wege geltend macht, tafs der durh die Freistellung der an den Weg orenzenden Waldfächen gesteigerte Holzzuwachs der Bämme den schaden aufhebe. so ist dies als ein Irrtum zu bezelchnen. Allerdings bewirkt die Freistellmng nnter Umstänten wesentlichen Znwachs, wie beispielsweise HaRTu's ${ }^{1}$ ) Untersuchungen dartun. Er fand an drei seit 17 Jahren freistehenden 147 jährigen Kiefern, dats der Zuwachs in den ersten zehn Jahren sich verdoppelt hatte, namentlich am unteren stammteile, wo auch tie Holzgiite, l. h. das Trockengewicht, zugenommen hatte. Aber es zeigte sich auch, dats der Zuwachs auf das frïhere Mat's zurieksank, als die Bodemnahrung durch angepflanzte Fichten in Anspruch genommen wurle. Bei Bäumen mit einseitig freigelegten Wurzaln aber wird der geringere Wassergehalt des Bodens das an und für sich spärliche Nährstottkajital des Sandes zu geringerer Verwendung kommen lassen und somit lie Liehtstellung den Zuwachs kamm steigern. Aber selbst, wemn hurch die plötzliche Lichtstellung eine bedentende Zuwachssteigerung erzielt wird, ist lamit doch noeh nicht immer ein wirtschafthicher Forteil verbunden. Denn erstens vermehrt sich die Ästigkrit der Stämme, und zweitens wird das durch sehnellen Zuwachs entstehend. Holz grobfascrig. Dies geht ans den Beobachtmogen von

1) Harmi, Über den Lichtstandszuwachs der Kiefer. Allg. Forst- u. Jagdzeitung LXIT, 1888, Januar. 
Ciestar und JANkd ${ }^{1}$ ) hervor, welche das nach weitständiger hulturnethode erzogene Fichtenholz untersmehten. Bei sehr starker Massenproduktion zeigte das Holz ein auffällig geringes spezitisches liewicht intolge schwacher Ausbildung des Herbstholzes nul einer muewöhnlichen Weite der Tracheiden im Hampteil des . Tahresinges.

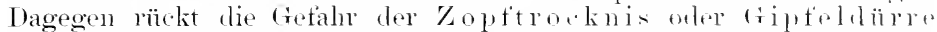
vieltach nahe. Dies gilt anch tïr die im geschlossenen Bestand erwachsenen Laubhölzer. Die plötzlich treigestellt. Krone. deren Blätter nach Bau und Funktion einer mälsigen Belichtung angepatst sind. vermag nicht die 'Transpirationssteigermong mol den Lichtïberschuts zu ertragen, und die Zweigspitzen troknen teilweise zurïck. Es ist daher im Interesse ter Erhaltung alter Bammbestinde namentlich auf sand. hoden dringend zu raten, die Inuchehneilung ron Hïgehn hei Wegeanlagen zn rermeiden und lieber den Weg um die Hïgel herum zn legen. Plötzliche Freistellung kam aber nach Hokтig ${ }^{2}$ ) anch zu seluäligungen fähren, wemn durch lie erhöhte Lichtzutuhr das frextenteil von Zopttrocknis, nämlich hochgradige steigerung der Kromenentwicklmo.

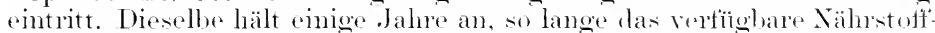
quantum in Borlen auspicht. Dureh die infolge der hohen Licht zutiuln sich vollziehend. Vermehrme des Blattmaterials werelen natiirlich viel grötsere Mengen von Mineralstoften nötie als hed Wachstmm

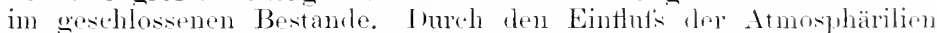

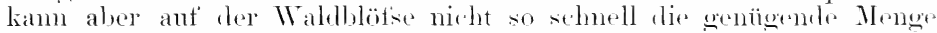

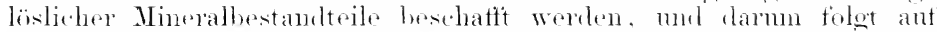
eine Reihe tetter Jahre ein Riickschlag in Zuwachs der freigestellten Bänume, der dureh "Bodenvermagernno" herbeigetïhrt wird. Bui

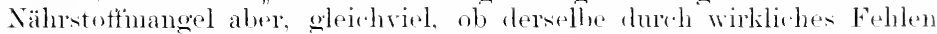
des Materials oler duch mognügende Autinahme seitems des Bamm

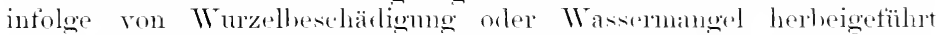
wirl, verschlechtert sich nicht nu die Zuwachsegüfe, sondern anch die Ilolzheschattenheit. Es wird, ähnlich wie bei zu beschlemigtem Wathstum, nur das dïmnwandigere Frïhjahrsholz. das Leitumgsgewebe gebildet, aber wenig orler gar liein Festigmeswerebe. Wie wir es im suätholz ror uns hahen.

\section{Stelzenwuchs.}

Im Anschluts an die rorstehenden Betrachtumeren emptiehlt es sich. der Erscheinung noch näher zu treten, dafis grotse. Waldhämus mit dem älteren 'Teil ihrer Wruzeläste autserhall, des Bodens sich liefinden, so dats tie stammbasis von einer Anzahl ron Stelzen getragen wird. [Der Sachteil dieser Stellung ist die geringere Verankernug der Bämne, die datureh lem Windwurt leichter unterliegen. Teilweise kommt eine ge ringere Wasserversorgung nur eine eigenartige Wurelempfindlichlieit hinzll.

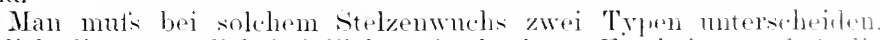
nämlich die namentlieh bei Fichten beobachtete Eischeinnug. dati , lie

1) Cuestar, A., und Jaxka, G., Studien über die Qualität rasih rrwachather Fichtenholzes. Centralbl. f. A. gesante Forstwesen. 1912. Heft $s$.

2) Hartig, R., C̈ber den Einflul's der Kronengröfse und der Naihrstoffunfuhr :uludem Boden auf tie Gröfse und Form des Zuwichses usw. Forst]. naturw. Ztitschrift VII, 1898, S. 78. 
Stammbasis hocls ïber dem Borlennivean erhaben ist und die starken Aste der Wurzellrone überhampt niemals im Erdboden gewesen sind.

Der andere Fall. der bei Kiefern ant stark welligem Santboden micht selten. zeigt, dats die stammbasis frïhler rom Boden berleckt gewesen mud hainfig anch jetzt noch anf dem Bodemiveau ruht; es

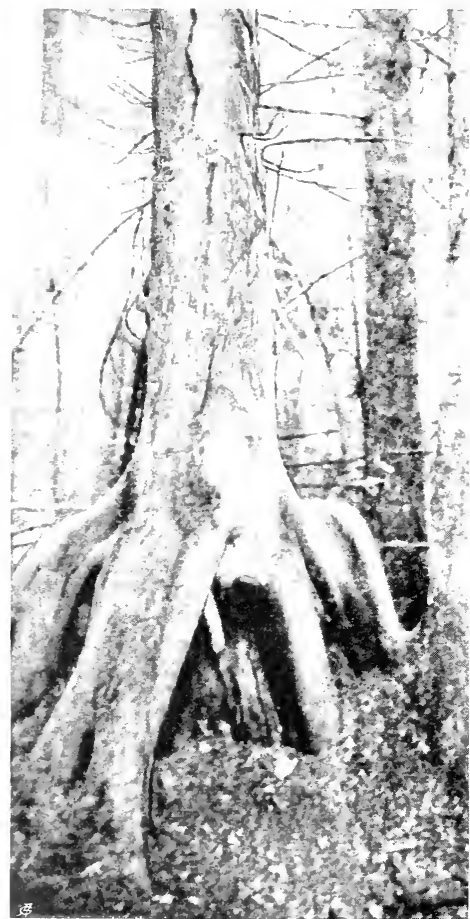

Fig. 4. Stelzenfichte hei schönmïnzach bein Stïhewasen. Nach L. KLein.) bleibt dabei ein Teil der Wurzelkrone von Erde bedeckt, während der andere Teil durch Absturz entblifst worden ist. In extremen Fällen rutscht der gesamte Borlen merer der Stammbasis fort, so dats ler Baum gänzlich aut'Stelzen steht.

Beispiele für den ersten Typus finden wir von L. KLesN ${ }^{1}$ ) beschrieben und ahgebildet (Fig. 4). Er erklärt das Zustandekommen der Erscheinung folgendermatisen: Wem im (rebirge Fichten oder Tamnen geschlagen werden, bleibt ein Stammstïck (Stock) stehen. Ein solcher stock verwittert nun allmählich an seiner Oberfläche, die sich mit Moosvegetation bedeckt. Im Moospolster siecleln sich später Taccinien und derol. an, und so entsteht unter denselben eine dïmne Humusschicht. Wennnun durchnatürlichen Samenanflug auf die bemooste Stockfläche Fichten oder Tammen gelangen, so kriechen die jungen Würzelehen bei fortschreitendem Wachstmm muter der Moostecke nach allen seiten ïlıer die Oherfläthe des Stockes und damn an dessen seiten bis in den natiorlich gewachsenen Boden hinab. $u m$ sich dort, wie jede anclere Trurzel, weiter zu entwickeh. Im Laufe der Jahrzehnte erstarken tie Wurzehn, wähnend der alte Stock langsam vermodert. Die Frage, weswegen man meist Fichten, viel seltener Tamen und gar lieine Laubhölzer mit Stelzenwuths finclet, heantwortet sich KLEIN damit, tatis der Trasspledarf der Laubhölzer etwa zehmmal so grof's sei, wie derjenige lor Narlelhölzer, und dafs daher oin Laubholzsämling anf der stammfläche tïr die Daner nicht genügend Wasser zu seiner Weiterentwicklumg fimelet. Temn anch nicht Stelzenwuchs, so doch ähnliche Vorkommnise kamn man bei Laublüumen immerhin finden. WVir meinen den .Hïlsenwnehs", der besonders bei Weiden antitrit. Dort, wo noch alte Wriden an den Landwegen sich erhalten, begegnet

1) KLeiv, L., Die botanischen Naturdenkmäler des Grofsherzogtums Baden u. ihre Erhaltmo. Festrede. Karlsruhe 1904. S. 13. Fig. 7. 
man bisweilen der Erscheinung, dats ans dem vermoderten Imnern des hohlgewordenen alten stammes ein neuer Stamm selbständig heranswächst, so dat's der Holzzylinder des alten stammes wie eine weite Hïlse den jungen Bam umgibt. Bei der Kopthichwirtschaft des Weidenbetriebes, bei welchem alljährlich oder in jedem zweiten Jahre die Krone gänzlich abgeschlagen wird, 1 m möglichst zahlreich junge Ruten zu gewinnen, sind derartige Fälle erklärlich. Bei der sthmellen Vermorschung des Weidenholzes an grotsen Hiel,fächen bilden sich durch anfgewirbelten stratisenstaub in den Vertiotimgen der WTmofläche sehr schmell Erdnester, die von den verschiedensten Dnkräutern alshald besät werden. Gelangt num eimmal lieimfähiger Weidensame in ein derartiges Erdnest, to findet das junge Pflänzehen genügenden Raum zu seiner Entwicklumg, und die Wurzeh gelangen dureh den Mulm des alten stammes encllich zum natürlich fewarlsenen Boden. Auch sieht man den Fall, dats eine Adventivwrizel ron hesonderer Stärke von der Hiebfläche in der Bammlirone immerhall des hohlen Stammes abwärts wäthst und las Bild eines jungen siämmehens wietlergibt.

Ein Fall, der in seiner Entstehung wahscheinlich ant dieselben Verhältnisse wie bei dem Stelzenwnchs der Fichte zurückzuführen ist, wude noch in rlen achtziger Jahren des vorigen .Jahrhmderts in Kohlhasenbrïk bei Nenhabraberg(Regierungsbez. Potslam) gezeigt. Ant der Dorfstratise stand ein etwa 75 em hoher stumpt eincr alten Eiche, der durch Vermorschung des gesanten Kernholzes eimen weiten Hohlzylinder bildete: dieser war bis zur halben Höhe mit llolzmuhn nul Frde angefüllt, und flarin stand eine etwa dreifsigjänige gestunde Eich" wie in ciner Hälse.

In Fichtenwaldungen begegnet man bisweilen ten son. "Harfenbäumen", bei denen aus oinem windgestürzten, aber mit einem Teil seiner Wurzeh im Boden befindlichen und daher lebend bleibenden Stamme eine Anzahl Seitenäste senkrecht als besonclere stämme sich erheben. Thre Eruährung wird dadurch ermöglicht dats sir Adventivwurzeln entwickeln. Die Fichte ist ïherhampt dasjenige Nadelholz, fas am leichtesten durch Adventivorgane allerlei Beschädigungen zu überwinden imstande ist.

Sie verträgt am besten das sehneideh und wird daher am hequemsten zur Heekenbillung benutzt. Nur müsen die Heeken stets unter Schnitt gehalten werden, da sie sonst mten kahl werden. Die Leichtigkeit geköptter stämmchen, nene Gipfeltriebe zu bilden, dir ebenso bei Araucaria zu finden ist, wirt in ler (rärtnerei bei der Stecklingsvermehrmo mit Vorteil benutzt.

Äufserst spröde in ihren Regenerationserschrinungen dagegen ist die ältere Kiefer, bei welcher der vorerwähnte zweite 'Typus ron Sitelzenwuchs daturch häufig zustante kommt, dats bei hïgeligem standont durch Abstechen eines Hügels der lockere Sandloden abwärts rutseht. Im Kampfe um die Existenz aber kann die Kiefer. wenn sie aus samen erwachsen, eine Blotslegung der Wurzeh wieder viel hesser rertragen als Fichte und Tanne. mul dies kommt von der sprzifischen Neinmen der Wurzehn, senkrecht in die Tiefe zu gehen. In den heiden Alibildungen, welche zwei Exemplare von Pims silvestis ans don (trumewald (hinter Paulsborn) bei Berlin darstellen. ist dieses senk rechte Abwärtsstreben in schönster. Weise auch bei den seitenwemzeh sichtbar. 


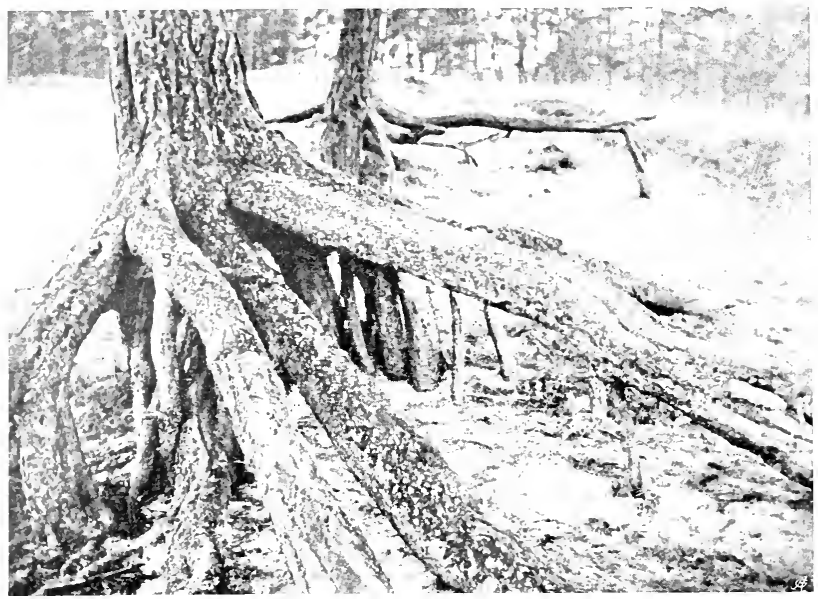

Fig. $\therefore$. stelzenkiefer aus dem Grunewald bei Berlin. (Orig.)

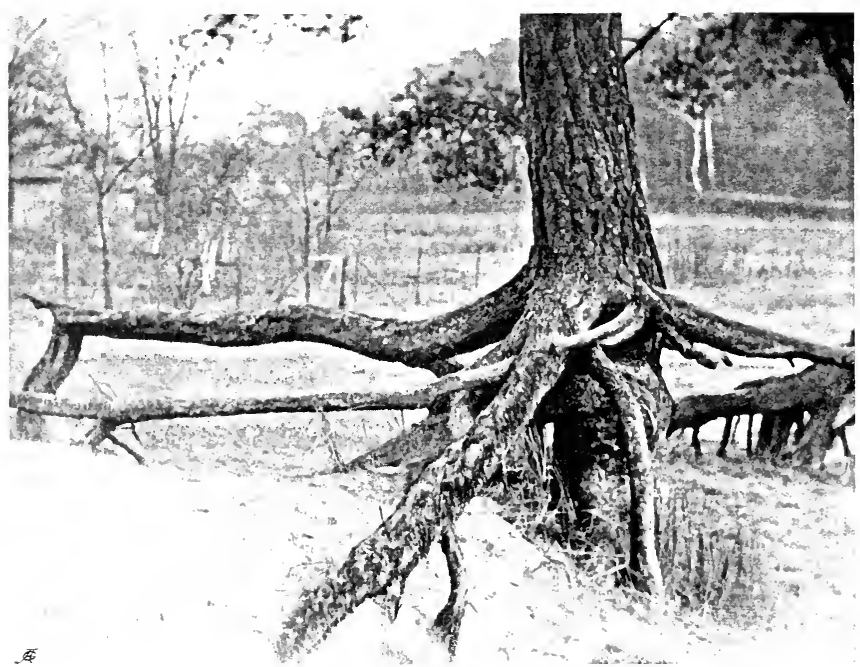

Fin. 6. Stelzenkiefer ans dem (rmuewald bei Berlin. (Orig.) 
Fig. : zeigt uns zwei hintereinanter stehende Kiefern. wolche ihre Stammbasis etwa $1 \mathrm{~m}$ hoch vom Boden entternt tragen. T)ie starken Hauptäste der Wrurzelkrone senden ihre Seitenäste, die sämtlich divekt ant der Unterseite entspringen. derart in die Erde, dats dieselben parallel.mul zwar tast senkrecht rindringen, was darant hinweist, dats die Kiefer ein Tiefwurzler ist. I)as hinter disem etwa bojährigen Bamme stehende Exemplar ist jünger. Es ist in Fig. ti von einer anderen sieite antgenommen und zeigt das im revhten Tinkel ertolgte Anstroten der sieitenwruzeln vou den msintinglich horizontal anscelneitotem Hampästen der Wurzelkrone. Hier erkennt man aber in der Nitte des sitelzenalparates anch noch dentlich die ms rimgliche Pfahlwurzel, die als die Hamptstïtze senkreeht in die Erele gegangen ist mul anch jetzt noch den wesmitlichsten Anteil an der Verankerung des gut benadelten Stammes in sandboden liat.

ITir haben dieser Form des Stelzenwuchses eine grökere Antmerksamkeit zugewendet. weil now ein anderes Vorkommuis erähnenswelt ist. Es zeigen sich nänlich ant'der Oberseite rler starken, mit Borke dick bekleideten Wurzoläste reihonweise zahlreiche. Holzhnollen. Diesellen sind in Fig. 7 in natürlicher

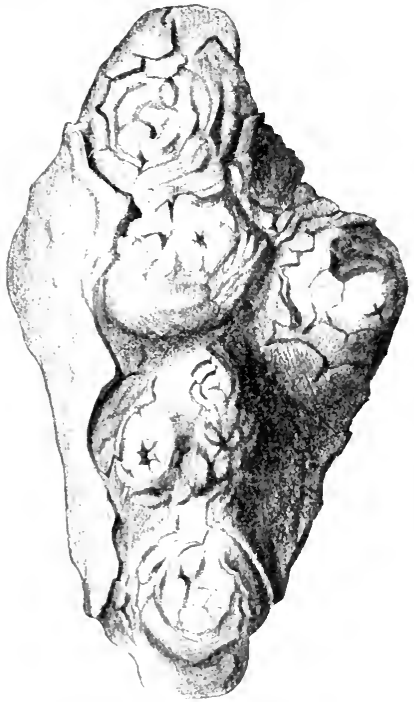

Fig. 7. Harzgallen mit Maserwuchs auf der Oberseite der Stelzenwurzol der Kiefer (nat. (rr.). (Orig.) (trötse dargestellt mirl bilden lalblingelige, his $1,5 \mathrm{~cm}$ hohe warzenähnlichr Erhebungen mit trichterfömig vertiofter Mitte: in Färlmog und Borkenbedeckmostimmen sie mit drom ïhrigen Wurzelkïrler üborein.

Man vermutet zunärhst, datis man es mit adrentiver sprotshilinug zn tum habe, wobei rie jungen sposise alsbald alogestorben mul überwallt sind. Diese Vermuntmug liegt mu so näher. Ja die Gebilde nur ant der INmzeloberseitr zu beobarliten sind. Und es ist bekamnt, lat's bei Stämmen, die zu Arrentiv-

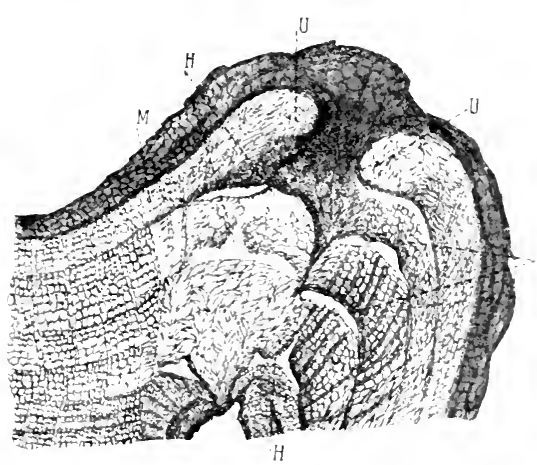

Fig. Querschnitt dureh eine Hargalle anf stelzonwurgel der Kiefer. (i)rig.) hilchmgen geneigt sincl. tatsäehlich stets auf der stäkst beliehteten seite die roiche, his zur hin

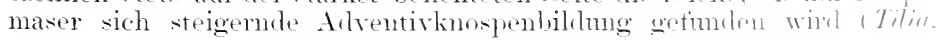


A(e). Indes hat sich diese Vermutumg meist nicht bestätigt, wie ein querschmitt (Fig.s) erkemnen lätst. Derselbe zeigt die siebenjährige Überwallung eines Frankheitsherdes, der durh eine gleichartige Harzmasse vebildet ist. Diese durch Resinose des Holzkörpers entstandene Harzgalle ist nach aulsen anfgerisien und im folgenden Jahre überivallt worden. Die Ïlurwallmngränder, die in den ersten Jahren noch mitcinander verwachsen waren, sind in der späteren Zeit aber immer weiter voneinander zmïlkgetreten. und auf diese Weise ist die trichterförmige ()tfhung am (iiptol der Holzknolle entstanden. Die nenen Jahresinge verharzen alljälulich, und zwar stets im ersten Frïhlingsholz, das zum Teil ans parenchmatisch gestalteten Zellen besteht. Durch das Zusammentrocknen der resinosen Gewebe, teilweise auch duch Harzaustritt, entstehen die Harzlücken (H), die immer schwieriger zu überwallen sind. $\rightarrow$ dat's die letzten T̈herwallungsuänder $(U)$ schon weit roneinander entfernt bleiben. Dabei zeigen dieselben einen äufserst mregehmäsigen Ban, der zwischen je zwei starken Markstrahlen immerhalb desselben .Jahresinges oft wechselt. In der Zeichmmg zeigt $G$ das normale Holz im (querschnitt und $\boldsymbol{M}$ den vollständig wimmerigen Verlant der Tracheiden im Längsschnitt immerhalb desselben Jahresringes, wie bei den echten Masern.

Trir mïssen daher diese Gebilde den Harzgallen amreihen und können betreff's ihrer Entstehmg nichts anderes amehmen, als dats die blotisgelegte Wruzel an ihrer den Witterungsextremen am meisten ausgesetzten Oberseite durch dieselben kleine schädigungsherde erhalten hat, die das fiewebe zur Terharzung bezw. zur vollständigen resinosen schmelzung veranlatisten. Als schädigungsursache möchten wir den Frost, md zwar den Spätfrost, ansprechen. Dem die Schädigung zeigt sich, wie gesagt, stets an den stellen des zuerst gebildeten Frühlingslolzes. I)ie Entstehmng dieser Harzgallen zeigt somit an, daf's die im Stelzenwuchs blotivgelegten Wurzehn cine grösere Empfindlichkeit besitzen. TTem dies der Fall ist, werden aber auch weniger extreme Fälle zu berüclisichtigen sein und eine weitere Mahnung bilden, den Wruzelkürper nach Mögliehkeit vor gänzlicher Entblötsung zu bewahren. Das teilweise Blofislegen der an ter Bodenoberfläche verlanfenden starken Wurzeläste und selbst das Abschleifen des Holzkörpers durch den Futstritt des Menschen an viel begangenen Wegen halten wir für wirtschaftlich bedentungslos. Die oberseits an ihrem Holzkorper geschädigte Wurzel produziert dann $u m$ so stärkere Jahresringe auf der entgegengesetzton in der Erde befindlichen seite.

Am liesten erkennt man die Terschiedenartigkeit der Bewurelung bei nuseren häufigsten Nadelhölzern, wenn man die sämlingspflanzen unter wanz gleichen Terhältnissen nebeneinander erzieht. Dieser V'ersuch ist von NoBBE ${ }^{1}$ ) ausqefüht worden und hat folgende Resultate ergeben. Sechs Wonate nach der Aussaat besafs die Kiefer 3135 Wurzelfasem in einer Gesamtlänge von $12 \mathrm{~m}$, lie Fichte 2.3 Fasern von zusammen $2 \mathrm{~m}$ länge mud die Tanne 134 Fasern von $1 \mathrm{~m}$ Gesamtlänge. In gediungtem sandboden vermochte der Kiefernsämling mit seiner Pfahlwurzel nahezu rinen Meter tiof bimmen einem Jahre einzudringen, während Fichte und 'Tamme unter absolut gleichen Tersuchshedingungen nu' ein Drittel so tief hinabgingen. ragleich erzengt lie junge Kiefer fünf Wruzel-

1) Dönxen's Botanik für Forstmänner. IV. Aufl., neu bearbeitet von Fr. Nonı.. Berlin. Paul Parey. 1N86, S. 130. 
ordnungen, die Fichte vier, die Tamne drei. Unter den Laubbäumen vermögen Eiche und Buche nach den Tharandter Versuehen ebenfall im ersten Jahre ein weitrerzweigtes Wrupelsytem mit einer tast meterlangen Pfahlwurzel zu bilden.

Aus diesen Zahlen erklärt sich die verschiedene Wasserhedürtiokeit der Nadelholzsaat. Fichte mud Tamne mit ihrem sthwächeren und alsbald flach sich ansbreitenden Wurzelappant branchen fenchte Bortenkrume, während die Kiefer derselben entbehren kamn. ja. sogar leicht darunter leidet; sie bildet in den saatkämp'sn, in clonen Tamme und Fichte gut gedeihen, sehr häufig in dem jugendlichen stämmehen pathologische Harzgänge in IIolz und schüttet. Ier Thefinang der Kiefer erklärt auch ihre sog. "tenïgsamkeit" mut ihr gesumles Wathstmm auf fast sterilem Sande. Wie die Lupine rersteht sie aus den tiefent Bodenschichten ihren Wasser- und Nährstotfledarf zu derken: aber sie verlangt eine gute Durchlüttung.

Allerdings wirt tleser nationliche Vorteil einer sofort in grotse Tiefe gehenden Pfahlwmzel nur verwertet, wenn dis saatmethorle und nicht die Anfzutht Iurch Verpflanzen zur Anwendung wangt. Bei den in forstlichen hreisen bestehenden Meimmosvershorlunheitem ïber die beste Anzuchtmethode wïrlen wir betrefts der Kiefer mos stets ant Seite derer stellen, welehe die Ansaat an ort und sitelle lrefürworten. Bei Fichte und Tamne halten wir das Verpflanzen ans dem saatkamp

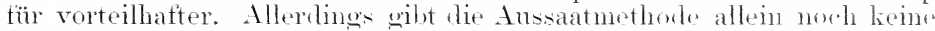
(iarantie für gesmole Entwicklung, sondern, wiv wir glanben. werden Boden und Lage oft ansehlaggebend sein. las jetzige Bestreben, überall Kiefern zu ptlanzen, weil diese die sehnellste mul darmm hestr Bodenrente geben, rermögen wir nitht gutzuheitsen. Wir dïrten nur in msern Forsten die Bestänte tiffgelegener ofler mooriger stellen mit denen treiliegender troekner (regenden vergleichen, $m$ m $z$ sehen, wis an erstgenamnten Lokalitäten ein dürftiger Wuehs nit hänfig vorzeitigen Nadel. abwurf sich einstellt und wie anthägeligem Sandholen mit tiefotehendem Ermolwasser die Bäume in ihner vollen Kräftigkeit sich entfalten, ja. selbst bei Wurzelenthlïsmo his zur Stelzigkeit sich gnt erhalten.

Ein Vorkommen von Stelzenwurzeh im simmpiralid, in welchem

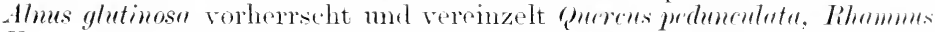
Framgula und Salix cineren anftreten, erwähnt Rechnger ${ }^{\mathbf{1}}$ ).

Es ist übrigens noeh eine dritte Trarhe drs Stelzenwehses zu erwähnen, die sich ladmreh motersheidet, dats die Bämme positir emporgehoben werden, während bei den heiden hisher hesprochenen Fällen die Stammbasis an ihrer Ausaatstelle verbleiht. Derartige Vorkommmisse werden von $\mathrm{TH}^{\top} \mathrm{HIE}^{2}$ ) besprochen. Auf' felsigrm Boden. glaubt er. wo die Wureln gezwngen sind, flach zu streichen, hïmnen die besonders schart zm Greltmeg gelangenden Frost- mul Trockenperioden allmählich ein Emporhehen der Bämme rinleiten.

\section{b) 7n tiefe Lage.}

\section{Zu tiefes Pflanzen der Bäume.}

Fast alle msere Bämme stehen in ihrem späteren Lebensalter nicht an der Stelle. an weleher sie ihre ersten jugentliehen Entwirklung-

1) Recirscier, Bot. Beobacht. in Schur. cit. Bot. Jahresber. 1942, I, A. : $: 37$.

2) Wmite, Thimome, Mechanical elevation of the roots of trees. The Arit Gray. Bull. Cit. Bot. Tahresb. 1×97, I, S. 85. 
stadien durhoemacht haben. Bei der Obstkultur ist ein nochmaliges Verptlanzen der jugendlichen stämme sogar Torschift, um eine reiche Terzweigmng des II nuzelkïrpers zu erhalten, mon diese Torschrift sagt anch, dafs nan sich hüton solle, dio Bämme wesentlich tiefer zu p,flanzen, als sie bisher gestanden haben. I) Erfahrme leht num auch, dats in der Tat Bämue durch Nichtheachtung dieser Wamung zugrunde wohen kömen. Viele Praktiker emptehlen sogar, einen jeden Bam an seinem nenen Pflanzorte genan anch wiofer nach den Himmelsserenden so zu mientieren, wie er vorher gestanden, intem sie meinen, lafir mamigtache Rindenbeschädigmngen durch Hitze und Frost dadurch vermieden werdern kïnnen.

I) Frage, ob dis Bänme ihre Zweige, die nach verschiedenen Himmelsgegenden gerichtet sind, anch verschieden ansbilden, hat OTто ${ }^{1}$ ) an Aptel-, Birn- mul Kirshbäumen zu lösen versucht. Er fand bei der chemischen Analyse wasentliche Lifferenzen in der Zusammensetzung der reschiolon orientierten emjährigen Zweige. Der Wasser- und stickstoffigelualt ist an niedrigsten, der Trockensubstanzgehalt am höchsten auf' ler Ostreite: am höchsten ist der Wasser- und Stickstoffgehalt auf der Norkseite, was andenten würle, dats dort die Kweige nicht so ansoereift wären wie anf den anderen Bamseiten.

Köress $\left.{ }^{2}\right)$ sieht in dem grötreren Wasserreichtum und der geringeren Holzreife der Zweige die Ursache für einen verminderten Blütenansatz. T̈horhaupt erweist sich die Anzahl der Blüten und Früchte von der Thasserzufuhr zum Baume im vorhergegangenen Jahre ablängig. Der Bamn trägt reichlicher, wemn dio Wasserzufuhr gering war. Anatomisch lassen sich die Untershiede in der Ansbildung der \%weige je nach den Himmelsorenden kamm feststellen, da der Ban dessellen Jahresringes immerhali, der varshiedenen Internodien eines Zweiges zu sehr selewankt $\left.{ }^{3}\right)$.

Anch iilier die hoi einem Tieferpflanzen der Bänme sich einstellenden anatomischen Veränderungen, die sich im stamm rorfinden, wissen wir wenig Positives: minflestens nichts allgemein fiültiges. In einigen Fällen ist Ausfïllnng der Gefätise durch brame, gummiartig crstarte ITassen, in

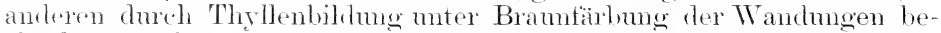
obachtet worden: anch gummose quellungen der Tembranen sind nicht selten. Aleer as sind ties sämtlich nur gelegentliche Beobachtungen, mul ein experimentelles studim der Frage tehlt noeh.

Wir beschänken uns deshalh anf dir. Tiedergahe der Erfahrungen, die ïher dron Einfluts der beiden hanptsächlich hei zu tief geptlanzten Bämnen anftretenden Faktoren. flem Sanerstoffinangel und dem kohlen-

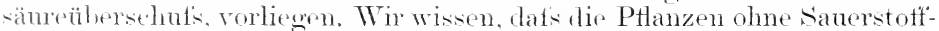

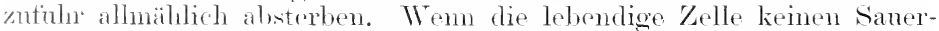
stoft antinehmen kann, ändert sie die Richtmo ihrer bisherigen Lehensfinktionen: suater oht sie in einen starrezustand ïber, indem die Bewromeserstrommgen des Plasmas anthören, die Empfindlichkeit tüir lieize veloten geht und das Wachstum sistiort wird. Ile Pflanze stirht ahor nicht ghich: sie atmet noch lang Zeit Kohlensäme weiter

1) Orr., Arbeiten der ('hemischen Versuchsstation zu Proskau. Cit. Bot. Centralblatt 1900. Bul. 82, Nr. 1011.

2) Krinssi, F., Übex die Beziehumg des Wassers zur Reife der Holzpflanzen. Biedermann's ientralbl. 1902. ร. 161.

3) Suraner, Beitrag zur Kenntnis der Zweige unserer Obstbäume. Forsch. a. d. Gebiete d. Agrikulturphysik, Bd. III, Heft 2 . 
aus und kam sellst nath längerem scheintode durch ermente sanerstotfzutuhr wieder ihre gewohnten Funktionen anfinehmen. Dieses Fortleben ohme Sauerstoffzufuhr (anaërobe), wobei also ter für tie Lebensprozesse notwendige Sanerstotf ron der Substanz der Pflanze sellost geliefert werten muts, ist als intramolekulare At num ng bezeichnet worden.

Betreftis ter veränderten Stofflbildung im Pflanzenluibe ist von

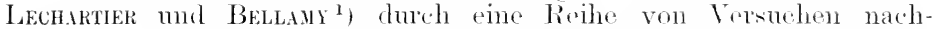
gewiesen worden, dats nicht nur in unserm Kernobst und anderen Früchten. sondern auch in Blättern und Wurzehn Alkohol in der ohne Sanerstoffzutuhr vegetierenden Parenchymzelle sich hildet. STockist hat in neuester Zeit auch Milehsäure nachgewiesen. Sindst hei Pilzen (Agaricus compestris) fand MünTz ${ }^{2}$ ) eine beträchtliche Henge von Alkohol und Wasserstotf hei längerem Autenthalt in samerstofffieder Luft. I as Material zu diesem Alkohol kann nur dic Knekerart, die alloin hier vorhanden, nämlich der Mannit, gegeben haben, während hei anderen Pilzen, die in einer Atmosphäre von Kohtensänre nur Alkohol colmo Wasserstott) produzieren, the Trehalose in Gämmg ïbergesangen sein muts. War der Aufenthalt in der sanerstotfiteien Atmosphäre kein zu langdanemder, so kam der Pilz wierler seine nomalen Lebrusfimktionen ausïben, was neuertings KkAssosiselsk ${ }^{3}$ ) tö̈ Mucor spimoses

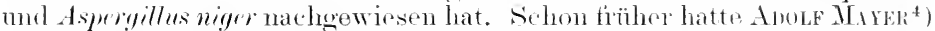

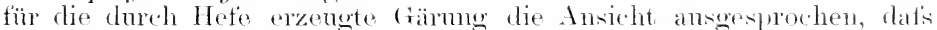

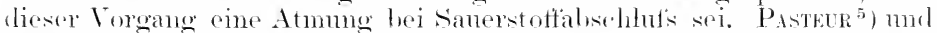
Böm "i) hatten rigentlich schom nachgewiesen, dats sich in ganz gloiehrer Woise anch allo höher organisierten Land- mel Wasserpflanzen verhaltrn, indem sie in sanerstotfiteirn Medien einen Teil ihres sulstanz durch eine Gärmog zu Kohlensäne und Alkohol, wie die Hete bei

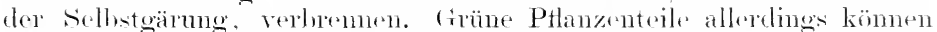
sich hei himeichend intensiver Belenchtung dureh \%erlegung der numittelhar vorher ahgespaltenen Kohlensäure wieder eime tiir die normale Atmung geeignete Atmosphäre herstellen. Aërobe und anaërobe Atmmg hänged zusammen: mol der anä̈robe Stoffweehsel reluas, wenn er anch das fedeihen nicht emöglicht, doch einige \%eit himdurch das \%ugrundegehen autzuhalten, und diese Verzögermug wird um so gröfser sein, je niedriger die 'Temperatur ist. So citient haispielsweise Prefren ${ }^{7}$ ) die Benbachtungen von CHunakow, dafs das Erlösehen ter Kohlensänueproduktion, also der Lrbensfahigkeit, bei Keimlingen von Mais hei

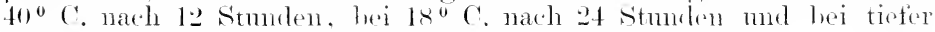
Temperatur erst nach ringen Tagen sich einstollte. Wem ein Oreanismus oder ein (ilied sich äberhant in geringer Lebenstätigkeit be-

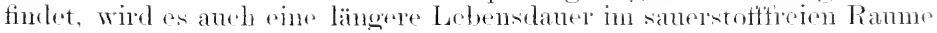

1) De la fermentation des pommes et des poires. Compt. rend. t. LXXIX, 1. 949. - De la fermentation des fruits ib. 1. 1006.

2) Comptes rend. LXXX I, p. 17s.

3) Krasuserskr, Atmme und Gïrung der schimmelpilze usw. C'entrath. Bakteriologie usw., 1904, Bd. XIII, Ni. $22 \% ?$

4) A. Trarer, I'ntersuchmoen über die alkoholische (iarmg. Landwirtah. Versuchsstationen, 1871.

5) Faits nonveaux pour servir a la conaissance de la théorie des fermentations proprement dites. Compt. rend. 1872, S. T<4.

6) Binm, Über die Respiration von Landpflanzen. Sitzmgsber. d. k. Akal. 1. Wissensch. 67, I. Abt.

¡) Pfeffer, Pflanzenphysiologie, 1897, Bd. I. S. 544.

sorauer. Handbuch. 3. Aufl. Erster lianu. 
bewahren. so haben sich in solchem Äpel und Birnen bei mä1siger Tempratur monatelang erhalteu lassen, während schnellebige Schimmelpilze mul aërobe Bakterion bald zugrunde gingen. Bei Keimlingen hlonerogamer Pthanzen (Ticin Fubu, Ricimes usw.) zeigt sich eine steigerung des intramolekularen stoftumsatzes.

Nach Strich's Untersuchungen ${ }^{1}$ ) lassen bisweilen einzelne Pflanzen mer Pflanzenteile zmä̈lnst gar liemen Einfluts dos sanerstoffoehaltes ler I unt ant dic Atmmog erliemnen, da sie in emer Wasserstoffatmosplüre gerate so viel Kohlensäme bilden wie in atmosphärischer Lutt. Bei "so Sanerstoft' in der Luft war der Atmungsquotient noch nornal: hei geringerem Gehalt (2) bis $4 \%$ ) wrole er zugumsten ter Kohlensänre geänflet, indem intranolekulare Atmung eintrat. Bei längerem Antenthalt der Pflanzen in sauerstoffarmer Atmosphäre stellt sich allnählich der normale Atmmosquotient wieder her unter Verminderumg der absolnten 0 - und C $C^{2}$-Nengen. Bei allmählicher Entzichnng des sanerstofts wird die intramoleknlare Atmmng erst bei hetrï.htlich niedrigerem Sanerstoffiprozentsatz angeregt als bei plötzliv her Terkleinerung desselben.

Brffel1's ${ }^{2}$ ) Experimente führen zu dem Sohlusse, daf's die Allioholväinng bei allen Pflanzen, von den niedrigsten bis zn den höchsten, stattfinden kann, soluald Sanerstoffabschlutis eintritt. Es zeigt sich alere wine sehr wesentliche Differenz bei den einzelnen Alkohol prochrierenden Organismen. Während hei der Hefe (Saccharomyces) die (ïirmonersheinmo als Höhepunkt der normalen Leistmo des Organismus (der bei dem Vorgange der /uckerzersetzung wirklich wächst) anzusehen ist, erscheint rr bei den Zellen phanerogamer Pflanzen al ahmormer, frühzeitig mit dem Tode ter Zelle endigender Prozefs. Derselbe unterscheidet sich von der reinen, nu Alkohol und Kohlensäure rorluzierenden Gärma der Hefe wesentlich dmreh Auftreten weiterel Zersetzungsporlukte, nuter denen Fuselöle und sïmren besonder: autfillig sind. Unter don eine wirkliche Alkoholwirmng noch einleitenden Pilzen ist abur anch schon ein grotiser Unterschied betreftis ihrer Fïhigkeit, Alkohol zu vertragen. Für Sacharomuces ist erst hei 12 Gewichtsprozenten die Wachstums- bei 14 die Gärmosgrenze. Bei Muror rucrmosus, der auch ohne freien sanerstott vom Zucker lebt. finctet sich schon bei $4^{1 / 2}$ und $5^{\frac{1}{2}} \%$ Alkohol Wachstmms- und Gärmosorenze: Muem stolomifor dagegen wächst gar nicht mehr mot wirkt schon Tex 1, ;o Alkohol nicht mehr gärmmorregend. Ex ist aus diesen Resultaten zu schlietsen, dats anch tie phanerogamen Grewächse in selur rorshiedenem Grate mnter densellen äntseren Verhältnissen zur Alkoholbilktung gelangen mol dieselben in verschiedenem Matse ertracente.

Siäter spricht Müntz ${ }^{3}$ ) ganz allgemein den Alkohol als eines der Larstzungspodulite der organischen Substanzen an, der sich sowohl ant' dre offerfläche der Erde als im Boden wie in der Meeresticte bildet mul sich nach den ficsetzen der I tampfispannmo in der Atmosphäre verhreitet.

1) Sncu, (', Die Atmung der Pflanzen bei verminderter Sanerstoffspannung und bei Verletzungen. Flora 1891. S. 1.

2) Über Gärumg IJI, Torkommen und Verbreitung der Alkoholgärung im Pflanzenreiche. Bot. Zeit. 1876, s : $: 81$. $\therefore 709$

9) Aus Compt. rend. t. LXXXXII, p. 499. cit in Biedermam's Centralbl. 1881, 
Dats bei Alkoholgärung auch organische säuren und darmter Essigsäure auftreten, kann nicht autfallend erscheinen. Es ist num seln wahrseheinlich. dat's eine Anhäutung derartiger säuren endich als citt auf den Organismus wirken muts, und dats hei Wurzeln. welehe rom atmosphärischen Sauerstotf' ganz oder nahezn gänzlich ahgeschlossen sind, ein allmälliches Absterben sich einstellen wirel.

Bei den zu tief gepflanzten Bämmen wird der sanerstoffimangel für die Wurzehn, bei denen ein sehr starkes, vielleicht das der olserirdischen Pflanzenteile noch übersteigentes Atmmosbedïrtinis narh-

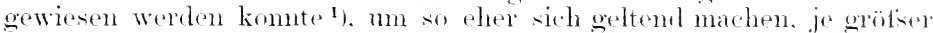

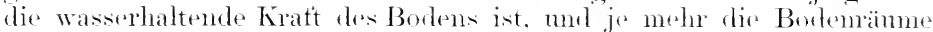
dureh Wasser abgeschlossen sind. Dieses Wasser in der Tnumbum

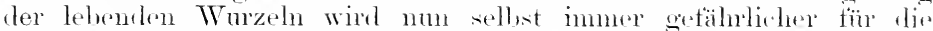
stärkeren noch gesmolen Wurzeh mol fïr die eingesculte Stammlasis, indem os sich immer meln mit Kohlensäme beladet. Wem man wesunde Pflanzen in kohlensäurereiches Wasser setzt, fangen sir an zn welken mud ein Abstelben der Blätter zu zeigen ${ }^{2}$ ). Von besomelorem Interesse sind die studien rom KostrofF ${ }^{3}$ ) ülor die Nasseraufinahmo. in nicht genügend durehlüttrten, also sanerstoffarmen und kohlensänro. reichen Böden. Durch die Kohlensäme erwiesen sich die Wasserautinahme und die Transpiration herabgedrötekt. Pflanzen. Iteren Trumeh in riner kohlensänereichen Atmosphäre verweilten, verloren alsbald ihren Turgor und worden schlatt: hei längerem Antinthalt gingen sie zugrmude. Bei Versuehen in piner Vasserstoflatmosphäre. wo also nur der Samerstoffimangel deprimieremel wirel, zeigte sich, dats

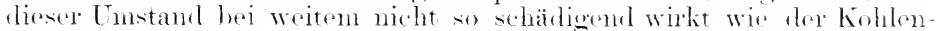
säureüherschuts.

Es wirel also hei den zu tief liegenden Bammumeln oin Ves. giftumgstod sich einstellen, der erst hie zarten trome. suater dir äleren Wumelverzweigungen refatst, mol shichzeitig werden die janchign Zersetzmosuroduktr anch den ganzen Erolbolen zum Pflumenwachstum untanglich mathen. Böнм ${ }^{4}$ führt rin Beispiel in den ahsterbenden, zu tief geptlanzten Ailanthes der Rinsstratise in Wien an. Diese Bämme hatten sehom seit .Jahren in Wachstmm nachoelasson: demn dir. Jahresinge. wolehe in den exten .Jahren nach der Pflanzmer noch oft mohr als 3 cm Broite antwiesen. waren in den letzten . Jahren

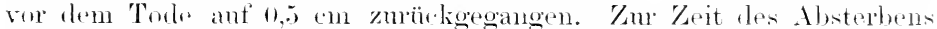
erwies sich die Erde der Wrmzelballen so schädlich, dats samen verschiedener Pflanzen. welehe teils otten, teils monter tulmberten filasolocken in solche rersenchte Erde eingelegt wurlen. alsbald in Finlnis übergingen. Tle samen entwickelten sich aber ïprig. nachdem dirse Erde, wiederholt uit Wasser lefenchtet, in dïnnen sidhichten währent acht warmer Julitage dem Eintluts der Atmosphär ansogetzt worden

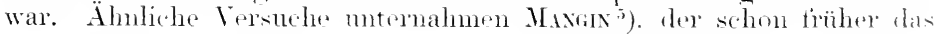

1) Marek, Agrikulturchemie, 5. Anfl, 1901, Bd. 1, s. 116 . s. 209 .

2) Wor, W.. Tageblatt der Naturforscher-Versammlung zu Leipzig. 1si.2.

3) Kostupf, Einfluss verschiedener äusserer Faktoren auf die Wasseranfuahnu. der Pflanzen. Dissert. Leipzig 1897, cit. Naturw. Rundschau, 1897, Nr. 4T.

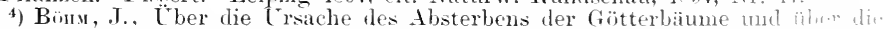
Methode der Neubepflanzung der Ringstrasse in Wien. Faesy \& Frick.

5) Maxis, L., Sur la végétation dams une Atmosphere viciée prar la resplifation. C. rend. 1896, s. 747 . 
liränkliche Anssehen der Alleebäume in Paris der schlechten Beschaffenheit des Bodens zugeschrieben hatte. In solchem ans der Umgebung der kranken Wruzehn entnommenen Boden ausgesäte Samen und Knollen zeigten eine gestörte Entwicklmo.

Die Luttproben aus der Nähe der kränkelnden Wurzehn (Ailantlus) (T'qal)en samerstoftimangel und Überwiegen der Kohlensäure, und MavgrN ${ }^{3}$ ) remutet, dats der sauer'stoffimangel aut' Redulition dureh Sulfüre zurückzutïhren sei. Sicherlich werden bei dem Verjauchungsvorgang der Wruzeh zahlreiche Mikroorganismen mitwirken. Indes wiurde ein solches Eingreifen der ent-prechenden Bakterien eben nicht stattinden, wenn nicht Sanerstoffmangel im Boden sich eingestellt hätte.

Betrachten wir jetzt die imnerhall, des Erdbodens hefindliche stammluasis. an weleher hei zu tief gepflanzten Bäumen mit schwammiger Rinde. wie bei dem obenerwähnten Ailanthus in Wien, diese Eänzlich rermorscht. Je nach dem Alter und dem Rindenbau des Bammer sowie nach der phrsikalischen Bodenbeschattenheit wird früher oder später in dem verschütteten stammstïck pine störung der absolut nötigen Luftzirkulation eintreten. Diese Strirung wird sich anth in den beiden Durchliiftungssrstemen des stammes, nämlich in dem (refätsssstem des Holzkörpers und dem durch lieine grötseren IIohlyärme mit demselben kommunizierenden Rindensvstem, geltend machen. Das von mehr oder weniger stark entwickeltem Korkkörper geschützte grüne Rindenparenchym wird von der atmosphärischen Luft momsuilt: dieselhe dringt dureh die Lenticellen in die Intercellularräume und zirkuliert in denselben. Die Luft in den Gefätisen des Holzkörper's, die wohl zum Teil durch das Wasser aus den Wurzehn, zum grotien Teil durch I liffusion von den seiten her in die crefätse gelangt, zinkuliert anch, wie früher bereits erwähnt, ja, es findet wahrseheinlich, wie aus den Untersuchungen von 0 . HönneL ${ }^{2}$ ) herrorgeht, eine tägliehe Periodicität bei dieser I furthlüttung statt. Die ursprünglich wassererfiilltrn Gefäfse leeren sich in Laufe des Tages teilweise oder gänzlich, da die äberstehenden und umgebenden Gewebe das Wasser entziehen. Der verdmstende Blattkürper des Bammes bedarf sehr grotiser Wassermengen und sangt dieselhen ans dem Holzkörper der Äste. die ihren Terlust an dem Stamme lecken, in welchem also eine saugwelle bis nach der Basis hin und von da bis in die Wurzeh fortschreitet. Da melur Trasser den refätien entzogen wird, als angenblicklich nachflietion kann, so entsteht ein luftverdümnter Raum in denselben, der einen 110 so grötseren negativen Druck (Sangkraft) besitzt, je weniger Inft anfangs vorhanden oder langwam dureh die Nembranen diffiundiert; derm $u$ so mehr muts sich das ursprünglich kleine Luftrolumen zur Ansfüllung des immer grötser werdenden Hohlrames ausdehnen. In der Nacht. in weleher die T'romstung gehemmt oder doch sehr herabgedrïtekt ist, sangen die Grö̈tse des Stammes wieder grotse Wassermengen ant, ja. es wird häufig dieses saugbestreben noch durch einen

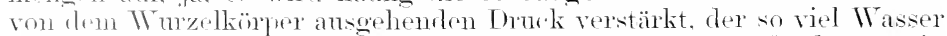
in clie cretätse pressen kam, dats ein Teil durch die Wandungen in die moebenden Zellen mel Zwirehenzellrämme gelangen kënnte. Ist

1) Maxix, L. Sur laëration du sol dans les promenades et plantations de Paris. C. rend. 1895 , II. s. 1065 .

a) v. Huincr, Beitrige zur Luft- und Saftbewegung in der Pflanze. Pringsh. Jahrb. f. wissensch. Bot." Bit. XII, Heft 1. S. 120. 
die aus dem Wrurzelkörper heranfgesogene und -geprefiste Flïsigkeit gestund, dam wird sellst eine grötsere Infiltration der Intercellnlarräume ohne Nachteil tür den PHanzenkörper vorïhergehen, wie MouL ${ }^{1}$ ) gezeigt hat. Wemn aber die Wassermasse bereits mit rärmosproduliten ans den verjanchenden Wm\%elspitzen beladen ist, dam sehen wir durch diesen Vorgang Giftstotte in den besonders empfindlichen splint und Rindenkörper getrieben, mol num breitet sich auch hier leicht das Absterben aus.

Die zu tief' gepflanzten Bäume sterbm aher meist num in schwerem. mit Tasser damernd überladenem Boden: in leichten Borlenarten kïmmern sie wohl. hloilen aber am leeben. Wom der schwere Borten mit seiner Wasserfïllung die Stammbasis mogibt mol die durch die Lenticellen stattfindendr. Intercellulardurhlüttumg verhindert. mïssen aber anch relbständig Alkoholgärung mol Essigsämebildnng in den Rindenzellen auftreten und zu einem Absteplen fïhleen, das sich radial aut die Kambiumzone mol den jungen, bei der Wasserleitmo besonders tätigen splintliöruer tortsetzt.

Es lifeilit dam von Jahr zu Jahr ein immer kleiner werdemter Cylinder aus Keruholz in der Mitte des stammes ïlnig. der das Wasserbedütnis des obrirrlischen Teiles derken soll. I las wasserärmere Kernholz aher wird anch weniger zu Wasserleitme tanglich sein, mol die toten fewebe des Holzkïruers, die allerdings auch noch Wassol mechanisch leiten. werlen durch ihre Hiltis nicht hinmeichen, das Wasserbedürfnis der Krone zu decken. Infolgedessen wollit eudlich der Bam oder treibt im Frühjahr seine hinospen nicht mole ans.

Der Umstand, dafs die nieht parasitären Fänhisprozesse im verschütteten Stammende in der Nähe der Bodrnolertläche anflören, führt zu der Termutung. dats die hersetzungsporlnkte nicht die gesunde Phanzenzelle, somlem erst rine abnorm funktionierende, geschwähte anzugreifen vemö̈gen. Eine solche sichwächmng ist anch tatsächlich da. Es ist anfangs erwähnt worden, dats die rom sanerstoft der Lutt abgeschlossene, Pehenskrättige, stoftieiche Zelle alshald antängt. durch die Wirksamkeit von Fermenten (Alkoholase) Alkohol zu entwickeln. der vorher nicht da war mol auch wirder vorshwindet. Wenn man atmosphärische Luft der Ptanze neu hinzutüht. Es ist feruer nathgewiesen worden. dats die Pflanze bei sauerstotfabschluts lange \%eit weiter Kohlensäure in heträchtlichen Nengen ausceheidet (intramolekular atmet), aber dats liese Kohlensäuremengen bei längerer Tersuchsdaner sich doch als kifeiner herausitellen wie diejenigen der in saurestofthaltiger Luft atmenden Pflanzen ${ }^{2}$ ). Da die Kohlehydrate (Stäke Zneker) das Material zur Atmmo ahgelen, so ist ans lon obigen Tatsatehen zu entnehmen, dats diese Inhaltsitotfe der cellen in abmorner Weise hei

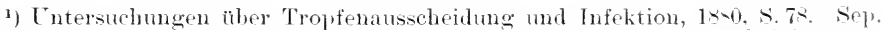
aus Verslag en Medededing d. Koninkligke Akad. Amsterdama, cit bei Prerrin, Pflanzenphysiologie, 1s-1, I, s. 159.

2) Wormax (Über die Beziehmgen der intramolekularen zu normalen Atmumg der Pflanzen. Inangmaldissertation. Wüzburo 1 79) gibt zwar an, dafs die Kohlensäuremengen bei der intramolekularen und nomalen ttmung greich grofs sind: os will mir aber scheinen, dafs die kure Daner seiner Versuche ihn noch hat Nartlwirkungen der bisherigen normalen Funktionen mit beobachten lassen. El ..il

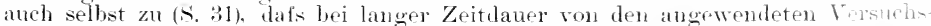
objekten ohne Zutritt von Sanerstoff eine geringere Quantität an Kolnensinu

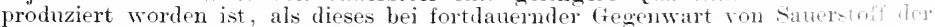
Fall gewesen wäre. 
Sanerstoffabschlufs verarbeitet werden. Man kam mit Pfeffer ${ }^{1}$ ) die Atmung als einen ans zwei ineinandergreifenden Vorgängen sich herstellenden Prozets auffassen. Ter erste Torgang ist die in Gärungserscheinungen sich kundgebende, intramolekulare Atmung, die Boromin ${ }^{2}$ ) auch immere Verbremung nemnt: der zweite, nu muter Sauerstoffzufuhr von antien mösliche Toroang ist die sofortige weitere Verbremmmg der (tärungsporlukte im Angenblick ihrer Entstehme. Wem dieser letztere, fïr das Zelleben mbedingt notwendige Alit unterhleibt, dam verliert nitht nu die sanerstoftlose stammzone des zu tief gepflanzten Bammes ihr Atmungsmaterial. wird also an Reservestoffen immer ärmer, sondern sie bildet mun auch diejenigen Produlite, die zur Fäulnis und zum Tode ler Zelle tühren. Die mugenügende Atmung also ist die notwendige Torbedingung für das Absterben. und in dem Madse, als ler verschüttete Teil, sich der Botenoberfläche nähernd, allmählich immer mehr und mehr sianerstoff bekommt. wird aneh der Gärungsprozefs sich abschwächen und in den normalen Terbrennungsprozets ïbergehen, somit anch die Fänlnis allmählich ihre Grenze finclen. $\mathrm{E}$ handelt sich dam nur noch darum, dats der Baum die Möglichkeit hat, oberhalb dieser (irenze im Erdboden nene Wurzeln zu bilden, um den durch die Transpiration des Laubkörpers entstehenden Wasserverlust zu decken. Die kïmmerliche Produktion. welche man in dem ersten Jahre häufig wahrnimmt, verschwindet, je mehr plastisches Material abwärts wandern und zu Neubildungen am Holzringe des Stammes und Wurzelkörpers verwendet werden kamn. Je schneller das Wachstum, desto gröfser die Energie der Atmme, wie schon Saussure gezeigt, und je mehr der flach streichende, nene Wurzelkörper selbst anch rom Lichte herïhrt wird, desto mehr steigern sich seine Kohlehydrate und damit seine Samerstoffabsorption und Kohlensäureabgabe ${ }^{3}$ ).

Das Terhalten der Bämne, die zu tief gepflanzt oder gar teilweise versehüttet wordon sind, hängst selbstverständlich von ihrem srecifischen Charakter ab. Bei Weiden und Pappeln z. B. findet man zwar den in der Erde eingesenkten Teil abgestorben: aber in der Nähe ler Bodenoberfäche erscheint die Fäuhis sistiert. Aus lem stamme haben sich zahlreiche Arventirwmzeln gebildet, und diese ruten einige Keit nach her Terschüttmo wieder eine gesunde Entfaltung der Bamkrone hervor. Der Bamn wird also gerettet, wemn er imstande ist, schmell new Wurzeh in der Nähe der Erdoberfläche zu erzenoen.

Bekamnt als ganz besonders empfindlich gegen das zu tiefe Pflanzen sind die Ericaceen und Eparrideen, bei denen es rorkommt, dats die Stammbasis abstirbt, ohne dals der Wurzelkörper sehr gelitten. Wenn die stämmehen Moos mur Flechtenvegetation an der Basis zeigen, so hat man bereits allen (rrund, vorsichtig zu sein.

Bui der Bammzucht läkt sich nitht eine allgemein gültige Regel betreffs der Pflanzhöhe geben. Abgesehen von der Bodenart, deren Thyskaliswo Beschaffenheit hier auschlaggebend ist, kommt es bei veredelten Bäunen anf die Unterlage an. Die anf Wilding veredelten Ohstsorten pflanze man derart, dats ihr Wurzelhals in der Ebene der Bodenoberfläche bleibt oder selbst etwas darüber hinausagt (bei Moor-

1) Pfeffer, Ther das Wesen und die Bedentung der Atmmng. Landwirtsch. Jahrb. 1878.

2) Borons, sim la respiration des plantes pendant leur germination.

3) Bonmix, Mémoires de l'Acad. impériale des sciences de St. Petersbourg III rérie. $1 \times-1$. 
boden mit grotiser Nässe verwendet man sogar llïgelptlanzung). D)ir auf' Zwergunterlage veredelten Birnen (auf (puite) und Apfel (ant Doucin mor Paradiesapfel) dagegen müssen mindestens so tief in don Boden, dats die Veredlungsstelle im gleichen Nivoau mit der Bodruoberflähe sich befindet, alio die ganze Tnterlage im Boden verbleibt. Es entwickeln sich ans dieser eine grötsere Menge Alventivmmehn, die der Ernährmo sehr tördertich sinrl.

Eine sehöne Kusammenstellung praktiseher Erfahmugen hat Borené ${ }^{1}$ ) regeben. Er weist zmäichst daraut hin, dafs man an alten, gesmelen Bäumen die starken Wurzeln äber den Boden hrrvortreten sehe: dieses Heraustreten des Wmzelhalses sei der normale Fall. Manche Bämme vertragen in der. Jugend ein tiefes Pflanzen, da sie ans der stamm-

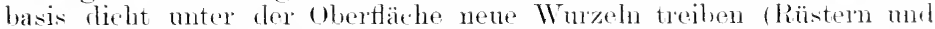
Linden ): andere dagegen sind sehr empfindlich, wis z. B. Birken. Ahorn, Eichen, die meisten Rosaceen. Platanen, Walnässe, Rot- mol Weitsbuchen. Auch tie meiston Nartelhölzer erforlern Anfmerksamkeit hei der Pflanzmos, wie z. B. die trattumgen Pimms, Picen umel Abics mul teilweiso auch Thuja. nämlieh Thuja (Biseta) oriontalis mul die damit verwandten

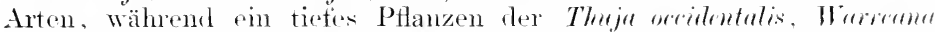
unc plicute zuträglich sich erweist. Selhst 5 his s cm starke siammo sah Bocché eine Nenge nener Wurzehn ans der verselüittetern stamm-

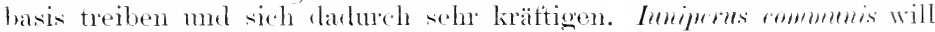
flach stehen: dagegen vertragen I. Solvina mel Verwande eine tiefe Pfanzung mit Vorteil. Von Pappeh mol Wrojelen ist bereits erwähnt,

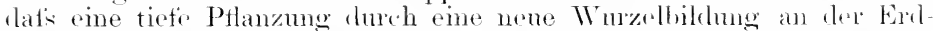
oberfläche sofort ihe fiegengewicht erhält; hei schwarhen siammen finclet man oft, dats die dieht unter der ()berflärles gebileleten Wurzeln die (Herhand äber die äleren, tieferen gewimnen. Fiir vide strämeher ist es tatsäehlieh oft vorteilhafter, sie tiefer zu ptlanzen, als sie trither standen. woil sie durh zahlreiche neue Wurzeh aus den versehütteten stengelhasen sich $11 m$ so melu lirättigen. Dies bemerlit man beispielsweiss bei Calycanthus, Cormus alha umel sibiviea, Ribrs, mamehen Arten fom

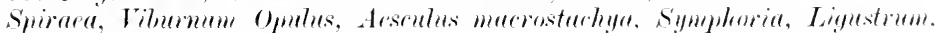

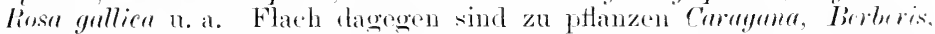

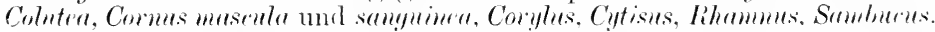

Bei Stratisempllanzungen kam autser den pötzlich notwentien werdenden Auf'schüttmoen anch das Asphalticren und Zementienen

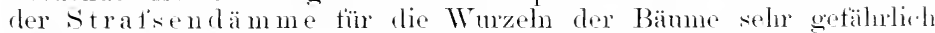
werden. Es ist nicht hlots das Absperren der atmosphärischen Lutt. sondern auch rler Verlust der atmosphärischen Niedorschläge, ant welche die Bäume in grotism städten $\mathrm{mm}$ so meh angewiesen werden. je tiefer durch Kanalisation und derol. monterirdische Bananlagen der frundwasserspiegel gesenkt wird.

Jumge Bämme. Welche nach der senkung tes firundwasser. spiegels gepflanzt werdon. suchen trotz der vermelirten Tiefe der Wasserquelle diese demnorli zu erreichen. Un dies zu erleichtorn. mïssen in solehen Örtichkeitrn die Banmptlanzlöehor wesentlieh tiefor gemacht werken. In Berlin beträgt diess. Vertietime nach Botchl (io) em, so dats jetzt lio Baumlöeher l,5 me tiof eregraben werelon.

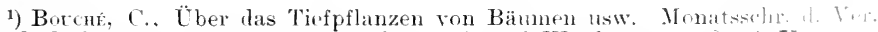
\%. Förd. d. Gartenb., v. Wittmack, 18>0, s. 212, und Wredow a. a. O... . . 


\section{Zu tiefe Lage der Saat.}

I) Erfahrung wird anch jetzt moch vielfach gemacht, dats bei reicher Ansat keintähiger Samen eine verhältuismä1sig geringe Nenge ron Pflanzen erzogen wird. Häufiger, ah man in der Regel glanbt, lient die Trsache in einem zu tieten Unterbringen der samen. Bei

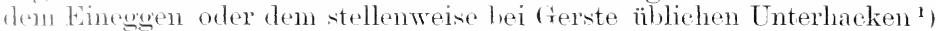
ist s gar nicht zu vermeiden, dat's einzehne samenkörner sehr tief, andere sehn thach zu liegen kommen. (t)eichmätsigkeit kamn nu durch Bestellum mit der Drilmaschine erzielt werden. Aber auch der (rärtuer, lev bei Toptansaaten eine sehr gleichmärige Berleckmng der samen herstellen kam, erlält bei sehr teinen sämereien nicht selten nux einen geringen Prozentsatz an Pflanzen, sellst wem der Same gut mol keimfahise war.

Die Vorgänge, welche die Verluste hervorrufen, sind aber nicht immer dieselben and finden anch nicht immer unter denselben Bedingmgen statt: deshall, ist es auch nicht möglich, allgemeine Regeh zu geben. Es bleibt nichts äbrig, mo sich vor Nachteilen in dieser Bezielumg zu seliüzen, als sieh den Einfluts der einzelnen Faktoren, welche hei der Ansisat zu beachten sinf, klarzmmachen und zu sehen. welche Kombinationen in jedem einzehen Fall rorhanden sind.

low Keimmo lätst eigentlich drei Phasen erkennen. Jede dersellen liamn störmugen erleiden mol Trsache für das Fehlschlagen der Pflanzen werlen. Das erste Stadium umfatist die Q qe llung und kann als ein mechaniseher Voroang antgefatst werden, bei welchem wahrseheinlich dureh Wasselverdichtmog sine Temperatusteigerung boolaclitet worken ist. Fr leitet das zweite Stadimm, die Mobilisiermes der Raservastoffe, eine Kette chomischer Erscheinmenen, ein, mul dies begleiten den dritten Alit, den der gestalthichen Ent wicklung.

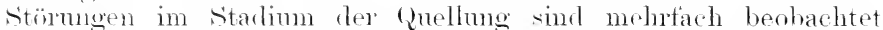
worlen. Nóbe mul Hacrless ${ }^{2}$ ) fanden ganz hesonders hei Papilionaceen und Carsalpiniaceen die Samensehale bisweilen so moluehdringbar füu tropthar Hüssiges Wasser, dats die samen jahrelang den Embryo ohne Regmong, alos immer noch gesund hehielten. Der same keinte nicht, woil "r nicht anfzundlen rermorhte. Bei den Kleesamen erweist sith die obreflächlich gelegen staibehen-ofler Hartschicht, in deren \%ellen ler Farbstoft' sitzt, so im premeabel fïr WV asser. clats Kleesamen bis 14 'Tage lang in rnglischer s'chwefelsäme und jahrelang in Wassel liegen liommen, olme anch nur ihren an und für sieh im Wasser löslichen Farbstotf ans den stälehenzellen zu verlieren. In solehen Fällen hilft nur meehanische Behandlung. (Fater und KLose ${ }^{3}$ ) repmistiten die samen von Luzerne mo Klerarten mit feinem Sande und rivben oin solehe Mischung whthaltendes säckchen 10 Minuten lang muter den Fïlsen. Ohne dats die samen sich wesentlich beschädigt

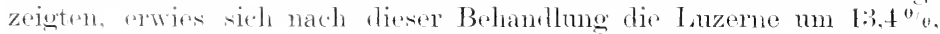

1) Eratis-furew, V'ersuche üher den Nutzen oder Nachteil eimer flachen oder tiefen Bestellung der Gerstenkörner. Necklenb. lantw. Am., 1sit, Nr. 23.

2) Nonse mu Hoxifax, Über die Resistenz ron śamen gegen die äufseren Faktoren der Keimung. Versnchsstationen 1877, s. 71 .

3) Gatra und Kunt, (nellungsunfibigkeit von Kleesanen. Wiener landw. Zeitschr., 1877, Nr. 17, cit. Jahresb. f. Agrikulturchemie, XX. Jahrg., 1877, S. 181. 
Weitisklee um 10,2\% , Hornklee um $37,8^{\circ} \%$ quellungstahiger. NobBe ${ }^{1}$,

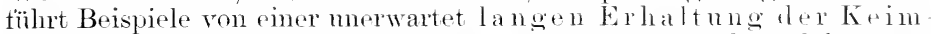

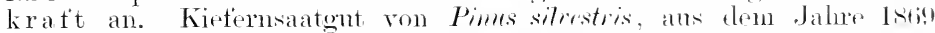
stammend, lieferte nach fïntjälniger Autbewahrme in verschlosienen Gläsern innerhalb eines bewohnten Zimmers noch $33^{\circ}{ }^{\circ} 0$, nach sieben Jahren noch $12 \%$ keimungstähige samen. Rothlee (Trifolinm furetrise) zeigte bei dersellon Authervalume nach 12.Jahren nodh 10,500, Ertse (Pisum suticum) nach 10 . Jahere noch $47.7^{\circ} 0$, Spromule eremsis nach

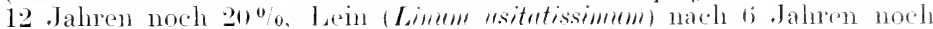

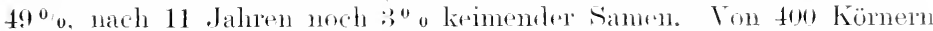

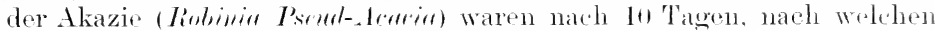
die tür praktische /were enïltige Versuchszeit anthö̈t, 71 Körner, bis

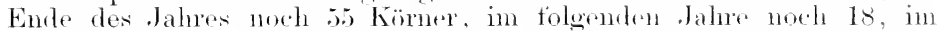
daranftolgenden noch 7 mol nach 7 .Jahren noch 1 Same gekeint. und zwar bei steter Antbewahrung derselben in zeitwoise ernenertem. destilliertem Wasiser.

Nach diesen Ertahrungen wird es uns olaubhatt erscheinen, dats

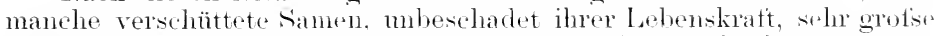
Zeiträume äberlanern. Anch bei den rorerwähnten Akazirnamm war

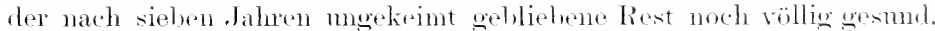
Eine geringe Vepletzung der sianemseluale hatte nath wenigen stmolen Anfignellumg and in der liegel anch baldige Keinume zur Folge.

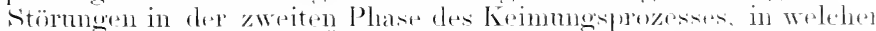

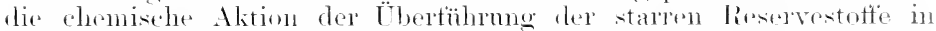

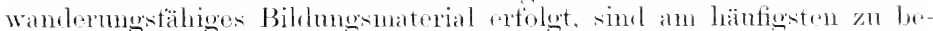

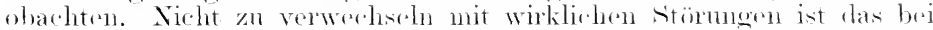

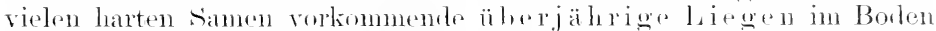

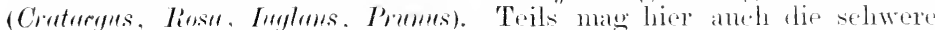

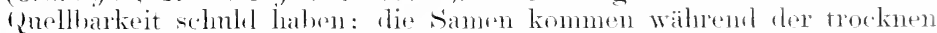
sommerzeit wieder in pinen Znstand fler Rule. Anderseits kam anch bereits Wasser eingerlemgen soin mul zur Bildung von Fermenten. welche die Mobilisiermo des anderen Reservomaterials anleiten, Veranlassung gegeben haben: aber diese Fermentwirkmo solbst int eine his zum Eintritt der trockuen sommerperiode zu langsame, 1 m ein. genügende Emährung dos Embrọ zu ermöglichen. Bei einzelnen Individurn und Varietäten alter schwerkemenden Arten zeigt sin ein Keimmor und Entwicklung schon bei llerbstsaat in folgenden Frül. jahr. Lies geschieht namentlich damn, weme man die samen hale naels

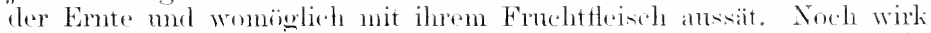
samer preist sich has .stratiẗizieren". (l. h, das schuchtemweise Einlegen der Samen in mit same geföllte fretätse während des Winters.

bie wirklichen störungen zeigen sich bed Mangel der zur Keimung notwendigen äntseren Brdingmoen. Sahin gehören antser Fanditigkoit

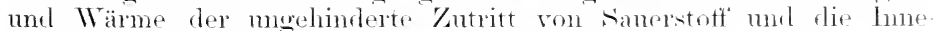
haltumg der Zeit der Reaktionstähigkeit dos șanens.

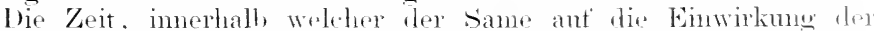

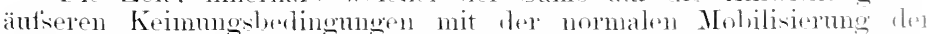

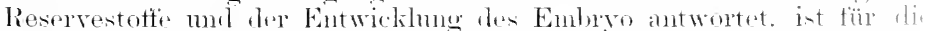

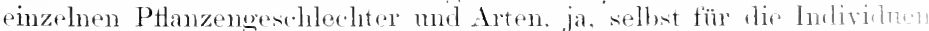

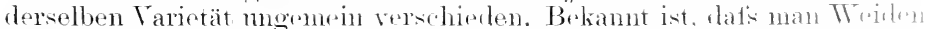
Pappeln und Ulmen sofort nach der Ernte ansiäen muts. da sir nat

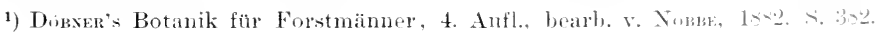


wenigen Tagen oder. Wochen ihre Keimkraft schon einbülsen, während man bei timren und Melonen kätigere, tinchtbarere Pflanzen oft erhält, renn tie samen ein Jahr gernht haben. Die Samen mancher mnserer Obst- mol Wahlbänme keimen zwar meist noch nach einem oder mehreren Jahren, aber die Zahl der langsam waehsenden, sehwächlichen Exemplare nimmt mit dem Alter des Saatwites zu.

Als der wiclitigste Faktor neben dem Wasserzutritt, der für die (pnelhmg notwentig. ist, wie erwälnt, der Sanerst off anzusehen. Die samen bramelen nicht eimmal so viel Trasser zm Keimmng, als ihre Snlstanz ïberhampt bis zur sättignng imbibieren kamn: die vegetative Tätigkeit dos Keimlings beginnt schon vor (dieser Zeit ${ }^{1}$ ). Bei anfänglichem Manow an tropfloar flüsigem Wasser, das endosmotisch anfgenommen werkn kam, nimmt lex same anch ans der Atmosphäre hroroskopiseh Wasser auf ${ }^{2}$ ). verdichtet anch Wassergas anf der Oberfläche, ja, nath Art der porösen Körper kondensiert er anch Wasserstoft, stickstott, Sanerstoft und andere (tase. DEHÉRAIs und LANJRIN ${ }^{3}$ ) fanden, dat's aus der atmosphärischen Luft' der gequollene same verhältnismätsig mehr Sanerstoff als Stickstoff anfinimmt, so dafs in einem geschlossenen Ramme mehr stickstoff zmückhleibt; vom dritten Tage ab begimnt er, Kohlensäme dafür abzugeben, und diese Prodnktion steigert sieh, so datis bald mehr Kohlensänre vorhanden, als der in dem eingeschlossenen Luttrolnmen befindlich gewesene und allmählich ganz versehwmdene sanerstoff hätte liefern können. I)ie übrrmätsige Kohlensänreproduktion ist also als ein Produkt der Oxydationsrorgänge der im Samen sich einleitenden imneren Verbrennmo zn betrachten.

Die Verfasser stellen sich den Beginn der chemischen Alitionen im samen in der Weise vor, daf's die schmelle, bei den verschiedensten samen anfangs konstatierte Gasverdichtmmg latente Wärme des Gases notwendig trei werden lälst, und diese Wärme steigert die Temperatur des eingeschlossemen Samerstoffs genügend, nm eine Oxydation begimnen zu lassen.

Thamit ist dor Anstols zm nomalen Lösung des Reservematerials des samens gegehen; die dmeh die Oxydation frei werdende Wärme hegïnstigt immer mehr diese Torgänge, welche sich nach aufsen hin dmeh die Produktion von Kohlensänre kundgeben.

Die Erwecknng des schlnmmernden samens wird nach dieser Anftassmng durch die Lockermo vorbereitet, welche die samen- hale infolge ihrer Qnellmng durch W asser erleidet: die gelockerten, füir frase durehlässig gewordenen Zellschichten gestatten $\mathrm{mm}$ ein schnelles Eindringen der Gase, die mit ihrer Kondensation also den ersten Anstofis zu denjenigen Verhremmngsprozessen geben, welche den T̈hertritt der Reservestoffe in eine diffisible, wandermngsähige Form veramlassen. D)a man bei Pflanzen mit sameneiweifs beobachten kann, dat's die Lïsung der Stärke rom jungen Pflänzchen, bei den Monokotylen von dem samenlappen ans beginnt, so wird man ammehmen

1) Jahresb. f. Agrikulturchemie, 1880, S. 213.

2) R. HuFmaxi in Jahresbericht der agrikulturchemischen Untersuchungsstation in Bïhmen, 1864 , s. 6, und F. HaperLaner in Zeitschrift für deutsche Landwirte, $186: 3$, S. 355 . Beide Arbeiten im Auszuge in Jahresb. f. Agrikulturchemie, Jahrg. VII, 1864, S. 108 u. 111.

a) Compt. rend. $1 \times 74$, t. LXXVII, S. 1488, cit. in Biedermann's Centralbl. $\mathrm{f}$. Agrikulturchemie, 1874 , II, S. 185. 
kömnen, dat's der stickstoftreichste Teil, nämlich das plasmastrotzende Gewebe des Embryo, zuerst zu Unsetzumgsersheinungen durch den sanerstott angeregt wird und mun selbst durch Entwicklmng reicher: Enzyme amregend weiter aut die Umgehme wirkt.

Die störung in der zweiten Keimmosphase kann nu erfolgen durch sanerstoffinangel oder anch dure Uberschnts an Kohlensäme. Die grotise Schädlichlicit der letzteren geht ans den von l)EHÉris mo

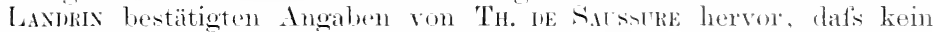
(ias der heimnng so nachteilig sei. wie werade dis Kohlensäure. Samen, welehe in einer Misthme von sanerstoff und IVasserstoff gehalten werden, keimen wie in atmosphärischer Lnft; « genügt jedoch, einer Atmosphäre von sancrstotf rinige Hundertstel Kohlensämre zuzutühren, um die Keimung still strhen zu selhon, solbald

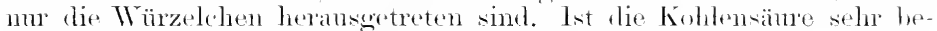

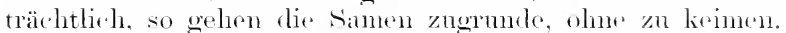

Anch anderen ruhenden Pflanzenteilen ist die Kohlensäure in Über-

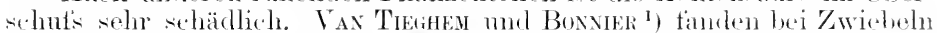

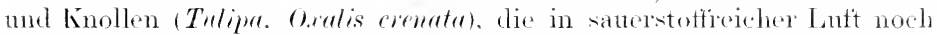
weiter atmeten. also Kohlensïne produzierten, dats sie in einer Atmosphäre von reiner Kohlensäure Alkohol billeten. Jeratige Tulpen\%wiebeln, welehe einen Monat hindureh in sauestotitieier Lutt welegen. waren erstickt und blieben anch ferner ohne jede weitere Entwicklung.

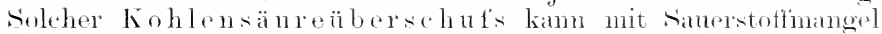
gemeinsam num bei eines zu tiefen Lage der saat anftreten. Dirse shadenbringende Höhe der Bodendectie, wellhe die Keimmo des samens rerhindert, läst sich aber nicht dureh bestimmte Valiten ans-

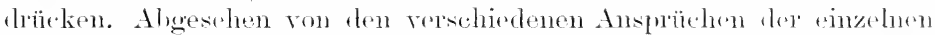
Pthmzenarten difteriert aher tïr dieselhe Art dio zuläsige llähe der Bedeckmos nath Bodenbesehattenheit. Nenese und Vertrilung der Niederschläge nsw. Daher weichen die Resultate der vieltate vorgenommenen Versuche äber die beste Anssaattiefe anch vomemander ab. sobale sie ant hestimmte Zahlenangaben eingehen. Sie stimmen aber alle darin überein, dat's man in zweifolluaten Fällen lieber zu Hach als zu tief säen soll.

Der Z week der Bodeckung ist die Betentigung der jungen Pflanze nud die Erhaltmo eines ausgiebigen Fenchtigleitsorades. Der Lichtabsehluts kommt weniger in Betracht. Vor allem ist die Erhaltung einer zum Keimen genïgenden Fenchtigleit ins Ange zn fassen. Ist eine solehe vorhanden. Clam werden die Wurzeln selbst hes oberHächlicher Lage des samens alsbald in ten Borlen einrlingen. somit wärle eine ganz flache saat aller samen zu emptehlen sein, wenn nicht die trocknen Frülijahrsperioden kämen. welche die Bodenoberfläche so weit austrocknen kömnen, dats rine vorïbergehemelo oder sollst danemele Sistierung der Lebenstätigleit im Keimling stattfindor.

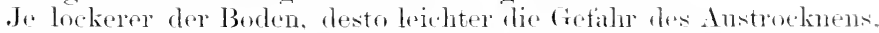
desto tiefer also muts dio sat zu liegen kommen. In fregenden mit trocknem Erïhjahr wirel schwerer Boden eine gle zulassen, selbst bei geringer saattiefe. Derselbe Borlen und diesollw.

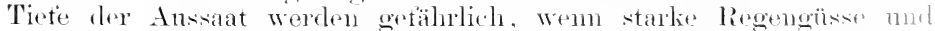

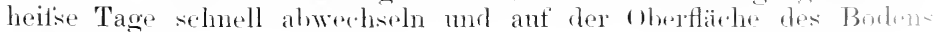

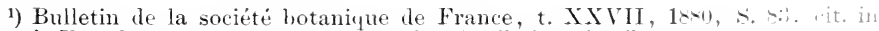
Woulxy's Forschungen auf dem Gebiete der Agrikulturphysik. 
eine feste Kruste arzengen, welche die Luftzufinh zu den im regsten sitotfwechsel befindlichen Samen nahezu abschmeidet. Die im samen eingeschlossone Bimnenluft hält nicht lange vol. Die Durchlüftumg des Pflanzenkörprers ist aber mumgänglich nötig; selbst ler ruhende Same leidet antistordentlich, wem ihm die Bimmentut entzogen wird. Die scharte Krustenhildnng des Bodens kam eine an und für sich nicht schïlliche siattiefe somit zur Ursache bedentender schädigmeng werden lasven.

Wie seh" der Inftmangel die Keimtähigkeit der saat beeintlutst. erhellt ans den (itaten von de Vries ${ }^{1}$ ). Hiemach injizierte HaberLaxdo Runkelknänel muter der Luftpumpe und beobachtete, dats sie $71,13 \%$ Wasser antinahmon; es keimten num ron diesen teilweise luftleer gemachten samen nm $30 \%$, währent von den zur Kontrolle aufoestellten normalen Samen (1) $^{\circ} / 0$ keimten. Bei einem zweiten Versuche worde die vesante luft durch Wasser unter der Luftpmmpe ersetzt. und es keimten jetzt nur noch $8 \%$ gegen̈̈ber $72 \%$ bei der Kontrollprobe.

Anch war die \%eit, welche die samen zur keimmo luanchten, bei den nommalen eine kürzere. Es ist wohl anzmnehmen, dat's die Entfermmo speziell des Sauerstotfs aus dem samen und die Erschwermo einer Iniffision nener Quantitäten dieses rases in die Intercellularrämme dir Tristhe der Erlösthmo der Keimkraft sind. Dutrocher ${ }^{2}$ ) sah auch bei erwachsenen Pflanzenteilen den Tod hänfig eintreten, wemn dieselhen mit Wasser injiziert waren. Bei schnellem Anttanen gefrorener f'leiscliger Pflanzenteile, die infolge einer Infiltration der Intercellularrämme mit Wasser ein glasiges durehscheinendes Aussehen haben, dürfte der durch das Wasser bedingte Abschlufs der bellen von der Lutt wesentlich mit zu deren Tode beitragen.

Von den mehrtach durchoefühten praktischen Versuchen präzise Zahlenwerte fïr die beste Sattief'e des retreides zu gewimen, sind die von Roesteli. Titschert, Eknert mol Wollny die eingehendsten. Roestel ${ }^{3}$ ) gibt fïr lockeren, kräftigen Ackerborlen 2 bis $4,5 \mathrm{~cm}$ als gïnstigste Tiefo an.

Die 'Tretschent'schen Versuche ${ }^{4}$ ) bestreben sich, die in verschieden physikalisch konstruierten Bodenarten maximalen frenzen der günstigen saattief'e festzustellen. Für Sandhoden ergab sich als rationelle Maximaltiefe 10 cm, für hmmosen Boden s cm. für kalkhaltigen Ton-mol Lehmhoden is :m.

Letztere beide Bodenarten litten von der trocknen Wittermon, so dats die seichtere Answat schlechtere Erfolge gab. Ein später im - Jahre wiederholter Vorsuch (August bis Soptember) ergab für alle Bodenarten eine saattiefo ron nur $2.5 \mathrm{~cm}$ als sehr moünstig der Trockenheit wron: Tomboden erwies sich in diesem Falle bei $10 \mathrm{~cm}$ Saattiefe am günstiusten. Man sieht darans, mit welcher Reserve die bestimmten Zahilen anformommen werden müsien. EkкERT ${ }^{5}$ ) experimentierte mit

1) Dr: Vin , Keinungsgeschichte der Zuckerrübe, Landwirtsch. Jahrb. r. Thiel, 1879, S. 20 .

2) Dutracher, Mémoires ete. édition Bruxelles s. 211, cit. von 1r: Vhes 1. c.

3) Annalen der Landwirtschaft, Bd. 51, S. 1.

4) Tietseneri, Keimmosversmehe mit Roggen und Raps. Halle 1872.

5) Еккект, Über Keimumg. Bestockung und Bewurehmg der Getreidearten usw.

Inauguralidissertation. Leiprig $1>74$ 
Roggen. Hafer und tierste in Lehmboden, Teichsehlamm, sandhoden und Gartenerde. Bei Anssaten ron Rogoen in freistehende Holzkïsten zeigte sich ein Untershiod zwischen 2 bis $8 \mathrm{~cm}$ Baleckung im Aufgehen der Pflanzen (infolge der gloichmäsigen allseitigen Jurehlüttung) nicht. Bei Versuchen im Freien erselien lie Bestokmo m so gunstiger, je geringer die Tieflawe der saat: doch hezieht sich dies meln ant die Zeit des Erscheinens der sprosse als aut die Qualitä dreselhen. Hater mul Gerste vertragen eher pine tiefere Unterlungung als Rogren. Bei

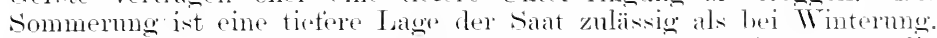

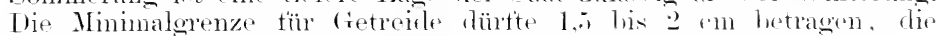
Maximalgrenze tïr gïnstige lesultate wohl hei ti am liegent.

spätere Versuche descellen Verfassers ${ }^{1}$ ) zichen oinen anderon, sehr

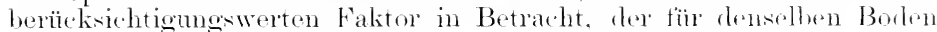
wiederm molifizierend ant die zuläsige saattiofe einwirlit. Ibe Qualität des satatentes ist hisweilen anssohlagrebend. Ant the Keimfahigkeit sehien die (pualität des Saaweizens, mit den zuerst experimentiert wurle, allerlings ohne Einfluts. aber die Entwicklung der jungen Ptlanze war bei gleicher saattiete mo so gunstiger, je besine las Saatkorn war. Bei einer mittleren saattefie fes hamblelt sich mu Versuche im Sandhoden) von 5 em ergaben alle (pualitäten das längste Stroh: bei derselben Tiefe waren anch die Alnen an lingsten. I) a

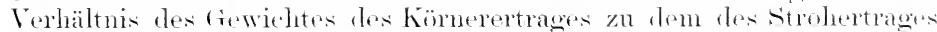

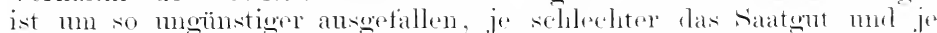
tiefer die Ausiat gemacht worden war. The Versure mit freste he stätigten die Eroebnisse, welche bei Weizen gewomnen worlen waren:

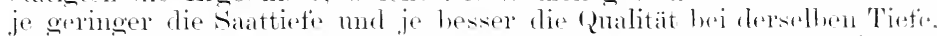

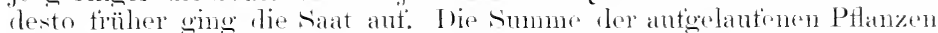
war bei dem geringeren satente keine geringere aber dor Einfluts der saattiete machte sich bei dieser (pmalität darin geltend, dats das stroh um so länger war, je seichter die Unterbringung. In allgomeinen wirt

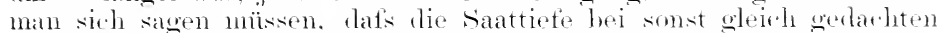

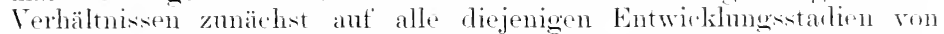
Einfluts soin wirl, die mit dem Jugendstadim zusammenhängen. Eist aber auch die quantität der Körneremte dureh die Anzahl dre

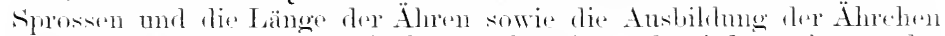
von der jugendlichen Fntwicklmng ahhängige und wird somit vom der

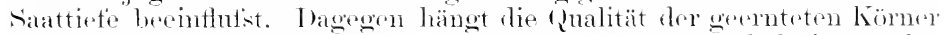
ron drom Emährungszustand, und den Wittermescerhälthissen dis

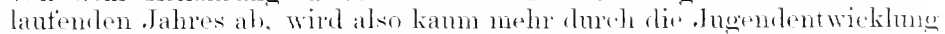

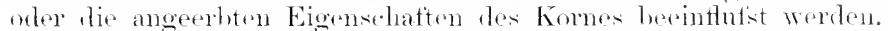

Vorquellen der siamen, das mehrtach hei anhaltend trockner saatzeit fü̈ leichten Borlen amptohlen worken ist, hat seine grotsen

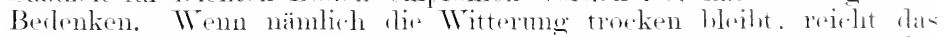

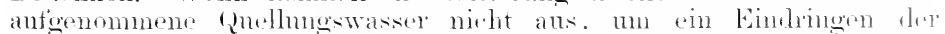

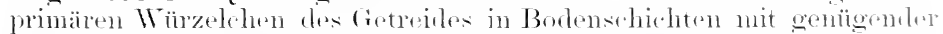

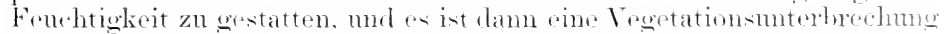

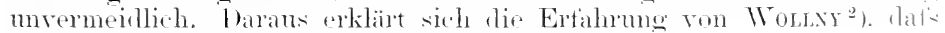
Vorquellen später ansieit'nel. Ptanzen lietert.

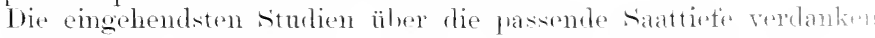

1) Ekкert, Kulturversuch mit Weizen mul Gerste verschienener Qualitit His. Finhling's Landw. Zeit.. 1875, Heft 1: 187t, Heft 1 11. 2.

2) Bot. Centralbl., Bd. XXX, Nr. 15 (1887), s. 48. 
wir Tolmx ${ }^{1}$ ), der für Getreide feststellte. dats 2 bis etwa 3 cm tiefe Aussaat die besten krnteresultate liefert. Darüber hinaus fand sich, wie Jöhtiesser ${ }^{2}$ ) hereits besonders hervorgehoben, ein merklicher Rütkgang. Letztgenamer Antor wah auch, datis der Roggen dabei am cmpfindlichsten, der Weizen am wenigsten litt. Bei den Ḧ̈ilsentiüehten ist die saatticte bedentungsloser: dagegen erwiesen sich hleearten, Rüben mor Raps sehr abhängig von der Höhe der samenbedeckmng, die

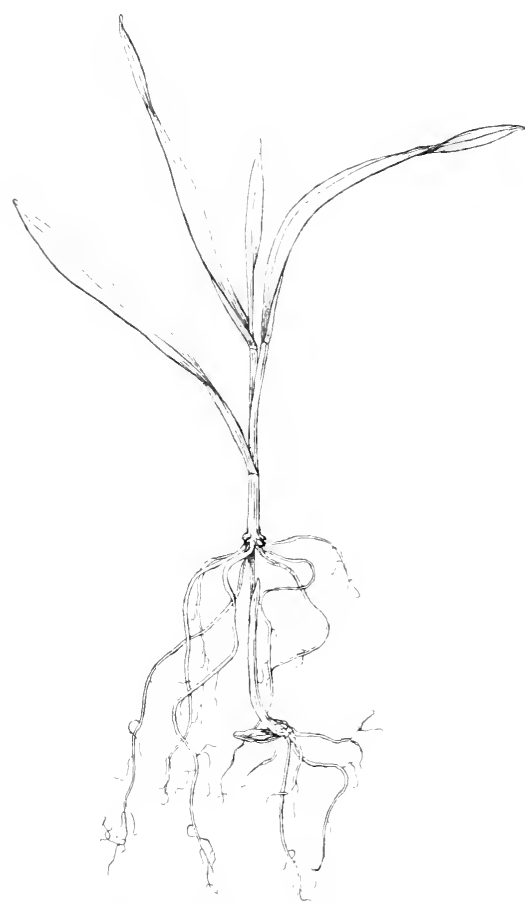

Fig. 9. Rogrensimling bei tiefer Lage des cimenkorns. Emporhebung des Bestockungsknotens in die Niahe der Bodenoberfläche. (Orig.) unel schnell besinflutist werden. Für Kartoffeln haben schon die Versuche von NoBbe ${ }^{4}$ ) und Küns ${ }^{5}$ ) ergehen, dats in traglichen Fällen das

1) Wot.xy, Saat und Pflege der landwirtschaftl. Culturpflanzen. Berlin 1885.

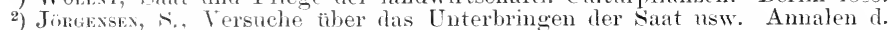
Landw, in d. Kgl. Prenss. Staaten. Wochenblatt 187:, Nr. 11.

3) Srussisf. Tntersu humgen über den Einflufs verschiedener Anssaattiefen usw. Landwirtsch. Jahroucher 1 1807 .

4) Nonв;, Handbuch der Samenkunde, 1876, S. 184.

5) Kiux, Berichte aus dem phrsiolog. Laborat. Halle, Heft I, S. 43. 
seichtere Auslegen das vorteilhafteste sein wirl. Bei der Treiberei der Blumenzwiebeh entstehen bisweilen namhatte Verhuste rarlurch, dats die Zwiebehn (Hyacinthen) zu tief' in die Töpte gentlanzt uler mit den Töpten zu hoch bis zun starlium der Durchwurzelung mit Erole br. deckt werden. Namentlich wenn der Deckborlen schwer mol tencht und die Zwiebeln im Vorjahr hei fenehter Wittermes niclit geniigend ausgereift sind, pflegt leicht der ..Rotz" (s. d. Bal. II) sich einzustellen.

Interessant ist der Vorgang ler selhstregulierumg lor Sat tiefe seitens einzehner Pflanzengesehlechter. Bri don firastru. mul zwar an besten erkemmar hei moseren fietreitererten. ist das erste

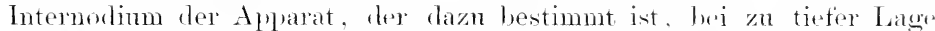
des samenkorns den dio stengelanlage und die Seitenknospen lererenden zweiten Knoten, den Bestockmosknoten, in die lockere, starli

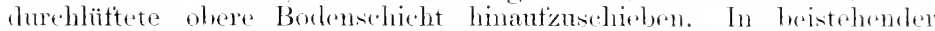
Fig. "rolielien wir das hereits nahezn entherte Samenkorn mit soiners schwach gebliebenen, leseits im Kom angelegt gewesenen (primären) Wurzeln. Aus dim samenkorn hat das erste (überverlängerte) Inter'nodium den zwiten Knoten lis in die Nähe der Erdobertläblue hinantgescholien, und erst in dieser günstigen Lage haben sich die nummehr auf Lubenszeit verbleibenten sekundären Wumeh entwickelt mul kommen die Anlagen der stritentriebe zu writerer Anshilemen. Bei flacher Ansisat bleiben beide knoten dicht besinamder und arben im Quersehnitt nmstehentes Bihl(Fig. 10). Das (rowehe los hnotens ersoheint

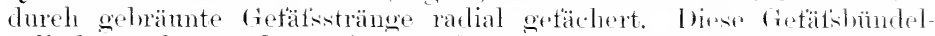
cylinder gehören den primären Wurzeln an mul arranken bereits

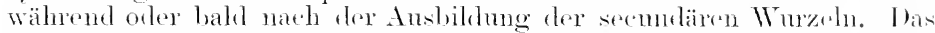
finulgewele des Knotens zeigt dieht an der wenig zelligen Markscheibe

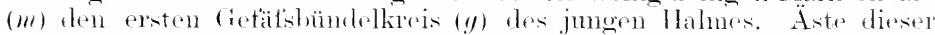

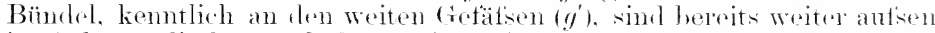

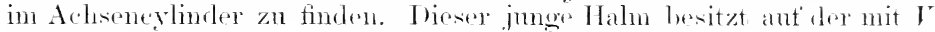
bezelcheten seite noeh gleichnäsig zusammenhängentes Rinulengewebe: nach der entgegengesetzten seite $I)$ zu alor haben sich hereits das erste, tarblos bleibentes seheidentörmige Blatt (s./) mel die Anlage

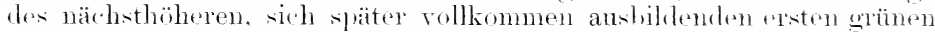
Blattes (bl) rom Rindongewebe abgetrennt. In do Arhas dieses ersten Blattes aliennt man schon die meristematisty. Anlage der ersten seitenknospe (lin). wolche das vor ihr liegemele grüne Blatt mit

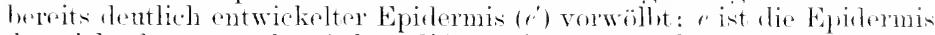

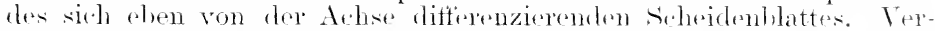
folgt man das (punktierte) (iewebe der Anlage des ersten grïnen

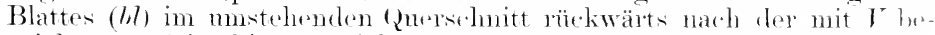
zeichneten seite hin, so sieht man, fats dasselbe in rinen fartsosen. aber huch seine verhältnismätsig grotsen. Lut't tührenelen Intereellular-

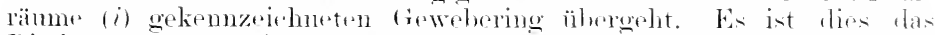
Rindengewebe des jumgen llahnes, nud man erkennt somit. dat's jerles

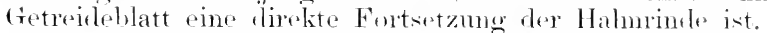

Dieser Rindenring hängt anch anf der sieite $J^{\prime}$ noch nit llem fir. webe des soheirlenblattes zusammen. mol os ist bemerlenswert. dats diese seheide schon in sinem so jungen starlinm der Halmolittioner-

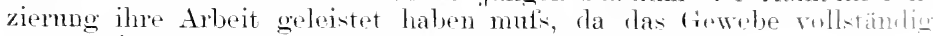
verarmt ist und lïekig (l) zu werden leginnt.

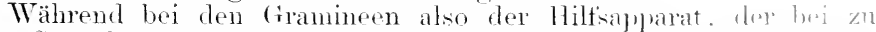
tiefer Saat den Vegetationskegel in die reichdurchlüftortr I3mhonkinume 
fïhren soll, in der (bis ! cm beohachteten) Streckung des untersten mo im Notfall anch noch des nächsthöheren Internodimms besteht, finden wir hei den Legmminosen und anderen I)iliotyledonen eine andere Einrichtmo. Bei Bohnen z. B. bemerken wir zmächst anch eine den Bedürfnissen entsprechende vermehre Terlängermug des hypokotylen Gliedes, so

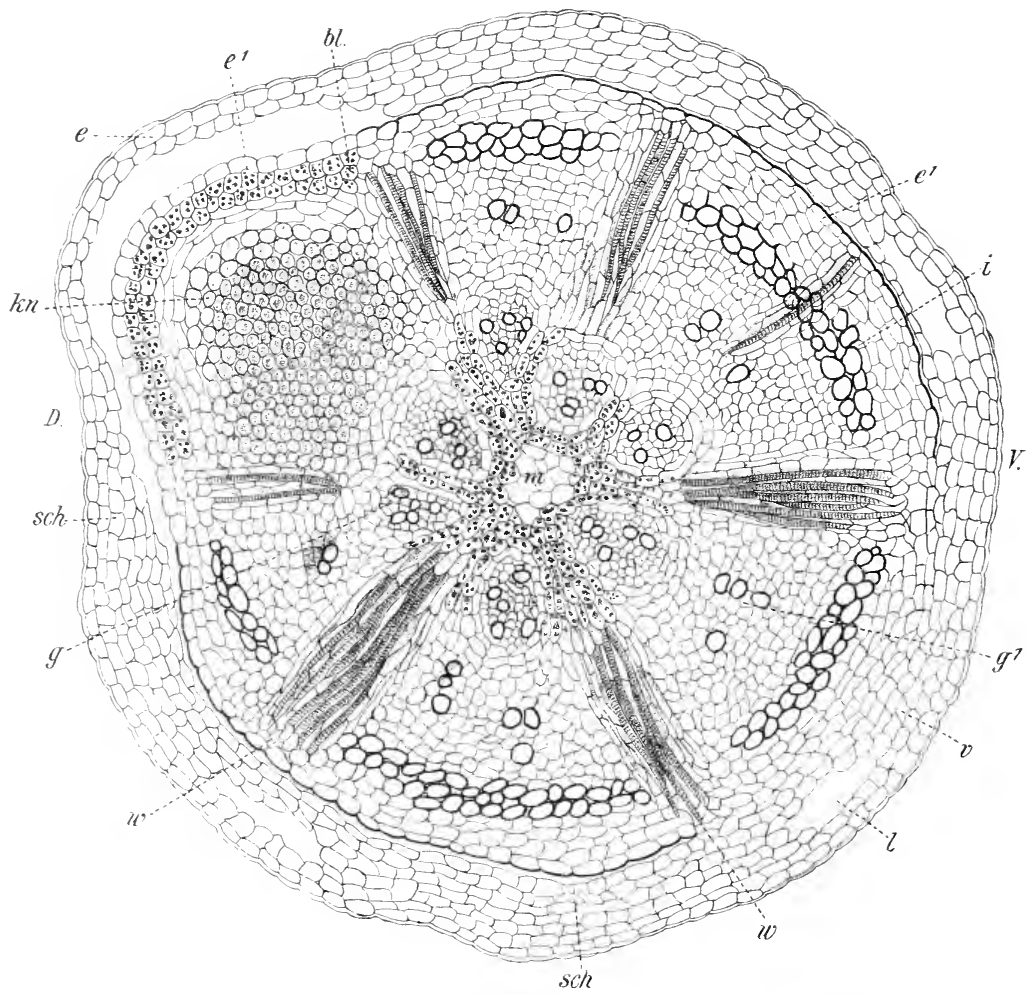

Fig. 10. Querschitt dureh den nutersten Kuoten einer jungen Rogrenplanze. Bu(listabenerkliarung in Text (Orig.).

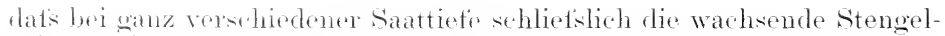
spitze lisi allem Pfanzen in ammähernd derselben Höhe sich hefindet. Natïrlich wird die Kröttigkeit der Ptlanzen bei gleichen saatgut durch che grötisere saattiote remminlert. Jo mehr sich das hypokotyle Glied volängern muls, damit sein, dem cekrïmmten Rïeken des Lastträgers vergleichlarer. olwere Teil die Erollast durchbrechen mol die Kotyledomen ans Livht hingen kamn, lesto mehr Reservestotfe werdén verbrancht. Es ist daher yanz chlörlich. dat's ans grof'ser Tiefe kommende Pflanzen schwächlicher sincl, selbst weun sie nicht erst im 
Samen Reservestoffe durch starke intramolekulare Atmmog verlieren. solches wird aber autserdem der Fall sein, wenn nach ter zu tiefen Einsaat sich andauernd nasses Wetter einstellt, so lats simerstoffmangel entsteht.

Welche Mengen ron Reservestoffen durch intramolekulare Atmmmg und Alkoholbildung verloren gehen kömmen, zeigen die Versuche von (tomlewsi und Palzenidsz ${ }^{1}$ ). Sterilisierte Erbsen im evacuierten Ramme produzierten in der ersten Zeit fast so viel Kohlensänue wie bei der normalen Atmmng in Luft. Die Gesamtmenge botrug ïber $20 \%$ der ursprünglichen Troekensubstanz der Samen. Die Menge des gebildeten Alkohols entsprach der Menge der Kohlensäure. Erst in der sechsten Woche hörte die Kohlensäureproduktion der in sterilisiertem Wasser liegenden Erbsen ganz aut, und bis dahin waren etwa fo $\%$ der vorhaudenen Trockensubstanz in Alkohol und Kohlensäure gespalten worden. Das ist anch bei dem Getreide der Fall. Diese Schwächmug wird bei letzterem durch die Arbeit der selsundären Wurzeh am Bestockungsknoten wieder leseitigt. Bei den Hülsenfiüchten kam num rin ähmlicher Vorgang der Selbsthilfe eintreten, indem, wie WoLLN nachgewiesen, an dem äberverlängerten hypokotylen triedle Adventivwurzeln gebildet werden. Er beobachtete solche an dom erdhederkten stengelteile autser bei den Ackerbohnen auch bei Erbsen. Wicken. Linsen, Lmpinen, und von Pflanzen anderer Familien noch bei Rajs und Sommenblumen. Aber tic Leguminosen kommen häufig gar nicht in die Lage. von einen derartigen Hilfsapparat Gebranch zu machen, da sie, sellst bei normaler saatticfe und Keimtähigkeit, leicht anderen Fährlichkeiten erliegen, wie in dem Abschnitt über. Hartschali $\underline{\text { r }}-$ keit" besprochen werten soll.

\section{Wurzeln aus der Spitze von Getreidekörnern.}

Wir glauben hier am besten eimen Fall anselulietien zu kïmen, der dur.h seine Eigentümlichkeit und Seltenheit verfient. der Wissenshatt rhalten zu bleiben.

Herr Landwirtschaftslehrer WuLfes in Jarom Merklenbmo-

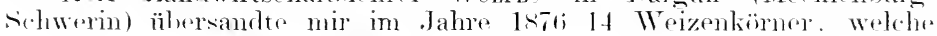
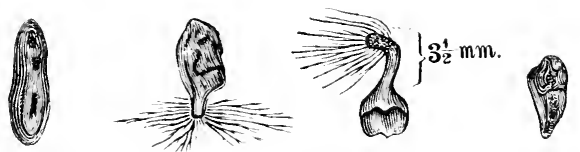

Fig. 11. Wizenkimer nit Wurzehn. welche nicht vom Embryo stanmen, sondern ans der hypertrophierten Fruchthat an der Spitze des Samenkorns entspringen.

furch Hypertrophie den Embryo nicht seitlich an sameneiweits, sondern mitten im Endosperm cingeschlossen zeigten. Die Körns. waren im Herhst gesät und, zmm Teil mit Wurzeln aber ohne Triel, in Frïhjahr im Boden wieder autgefinden worden. Ihre Grestalt (Fig. 11 u. 12) war entweder schlank birnenfömmig oder anch an einern

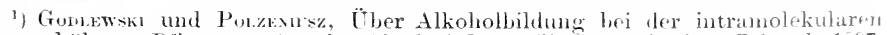
Atmung höherer Pflanzen. Anzeig. Akad. d. Wiss. Krakau, cit. Bot. Jahrent, 1×97, S. 142 . 


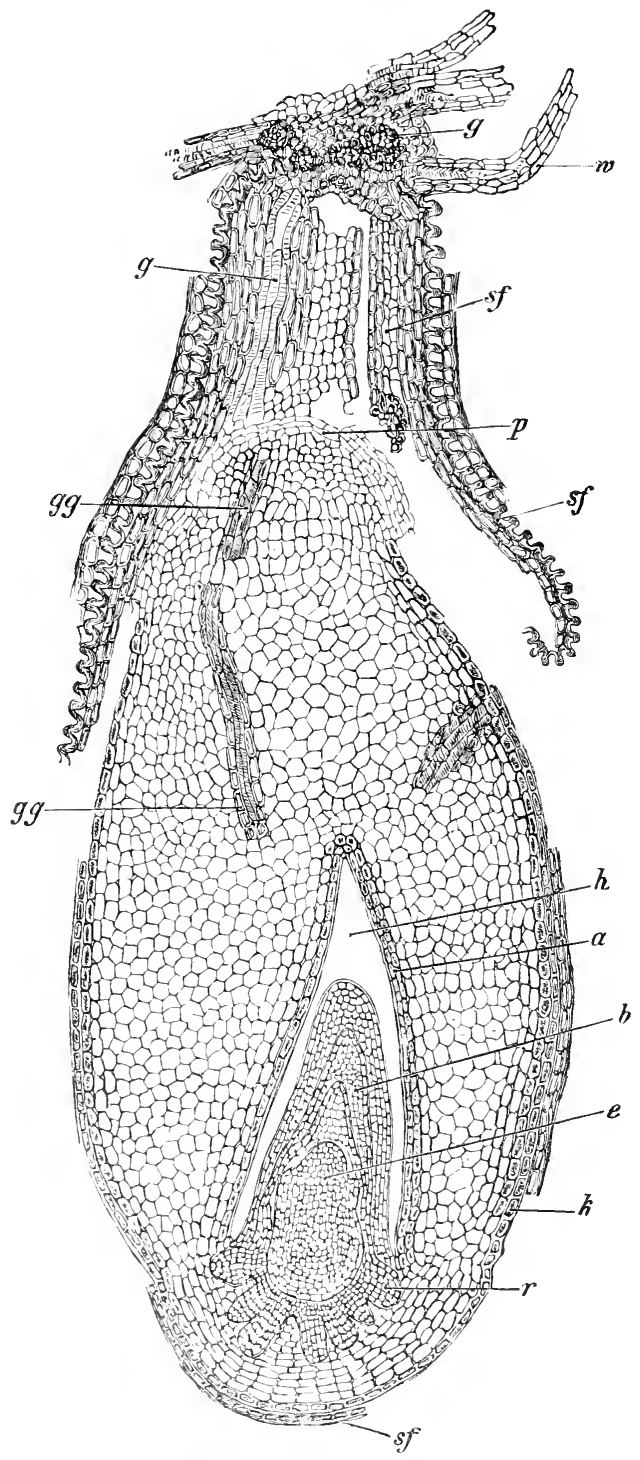

Fig. 12. Weizenkorn mit hypertrophierter Fruchthat und Wurzelbildung an seiner Spitze. Embro zentral statt lateral. Buchstabenerklïrung im 'Text (Orig.). 
Ende cylindrisch und am anderen, sich schmell verjüngenden, die Form eines Geigenhalses amnehmend. Bei manchen Körne'n (Fig. 11 u. 12) war die Verlängerumg des schmalen, dem Embrvo entgegengesetzten Endes so bedeutend, dat's dadurch ein 2 his :3, $\mathrm{mm}$ langer, nach oben gekrümmter Hals gebildet wurde.

Bei 12 Körnern, deren Länge von ${ }^{3 / 4}$ his $1^{1 / 4} \cdot(\cdot m$ schwankte, trug der Hals eine grotse Anzahl ron l bis 2 cm langen, sehr dünnen, fädigen. dicht büschelig gestellten Wurzeln. welche tast ihrer ganzen Länge nach behaart waren.

Wenn man die hier und da gesprengte, stellenweise runzelige Fruchtschale von dem Korn vorsichtig mit der Nalel abzuheben snchte. fand man, dats dieselhe an einzelnen Stellen norh dicht auf dem Kom aufgekittet war und in der Umgehmng dieser meist etwas dumkler gefärbten stellen abhrach: dagegen blieb ihr oberer Teil fast stets in festem Zusammenhange mit lem sehnabelförmigen Fortsatze, ler sicl dann im ganzen wie eine strohige Kappe ron dem eigentlichen samenkorn abheben liefs (Fig. 12). Der Hals stand also zur Zeit der Untersuchung mit dem eigentlichen Samenkorn in keiner anderen Verbindung als durch die Fruchtschale, aus deren Substanz er auch gebildet zu sein schien. Im trischen Zustancle des Kornes hat derselbe sicher test auf dem samen anfosessen, da einzehe konkare stellen. Welche man mit der Lupe an der inneren Kappenwand wahrnahm. zu den kleinen, konvexen Erhabenheiten patsten. welche ant' dem samenliorne sichtbar waren.

Aulser dem merkwürdigen, shohabeltërmigen Fortsatze mit seinen Wurzeh war aber noels der Umstand anffallend, dats die sonst ïberall vorhandene Furche diesen Weizenkïrnern fehlte: ebensowenig war der Keimling. welther an der Basis des normalen Kornes sitzt und durch die Fruchtschale hindureh sofort kemntlich ist. hei den aufgefumbenen Körnern bemerkbar. Der Mehlkörper selbst endlich zeigte bei dem Yerschneiden nur zum kleinen Teil jene weitse Farte des aesunden Kornes: er war namentlich rom Rande her auf weits Strecken glasig durchscheinend und gelblich. leer treruch war ranzig. Die tïr den Stärkenachweis matsgehende Blautärbung bei Zutritt ron .Jod trat nur in denjenigen Gewebepartien des Kornes intensiv ant. welche auf dem firchen Schnitte weifs und mohlartig sirh zeigten, während dir glasigen Stellen meist nur leicht hellhlauen \%ellinhalt anfwiesen.

Die Klebershicht war bei den ans Mecklenburg eingesandten Kömern was nicht nnd die dümne Samenschalo nur monollkommen entwickelt. An Stelle dor Kleberschicht (Fig. 12/i) betand sich tatelförmiges Parenchrm. dessen Inhalt nicht wesentlich von dem des darunterliegenden Geweber abwich.

l)as Autfallendste an den so abweichend gebauten Weizenkömern war abex jedenfalls die Lago des Embrow an enterengesetzten Fnde ron demjenigen. Welehes die Wurzeh (Fig. I르) trug. qenan in der Mitte des Kornes (ähnlich wie hei den Trphacenn gloichmätsig von

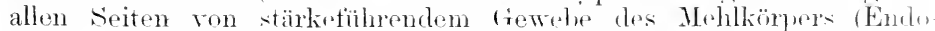
sperm) eingeschlosin. Während bei den normal cobanten Weizen. körnern der Keimling autien an der Basis des Kurnes sitzt und mit dem Nehlkörper durch ein besonderes Organ das Scutellum (der Samenlappen) verbmden ist, liegt hier der Keimling (Fig. 1:丷, ohm. samenlappen in einer zentralen Höhlung (Fig. 1:2h) rles Kornes.

Diese Höhlung ist hei rinigen Körnem ellipsoirlisch. hei anderen 
dreiseitio: bei einigen geht sie etwa bis in die Mitte des Kornes, bei anderen erstreckt sie sich. nach oben immer enger werdend, bis an die Spitze, ja bis in das Gewebe der Kappe hineim. Auf der Imnenseite ist sie mit einer, aus zwei tafelförmigen /ellreihen mit kleberähnlichem Inhalt gebildeten Schicht (Fig. 12a) ausgekleidet, welche deutlich an die sonst bei gesunden Körnern aufsen auf dem Mehlkörper aufoelagerte Kleberschicht erimnert.

Die tütenförmig überemandergeschachtelten jungen Blätter des Keimlings zeigen keine wesentliche Abweichung: dagegen ist die Zahl der kranzförmig fast in gleicher Höhe entspringenden Keimwurzeln

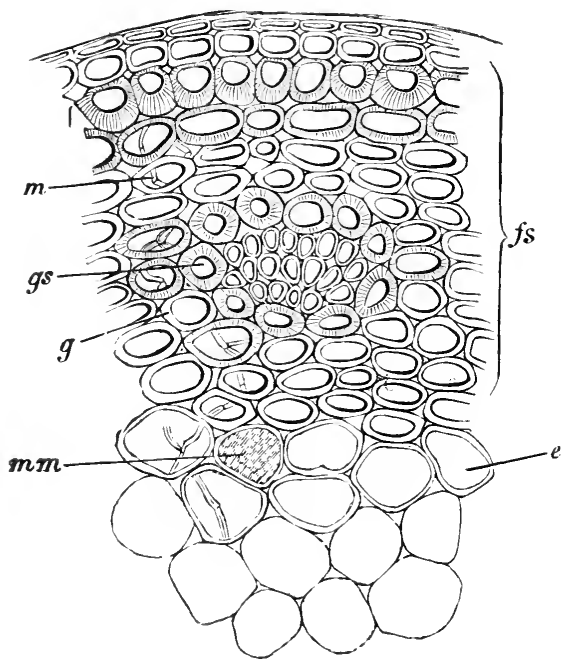

Fin. 13. Mrceldurchzogene, hypertrophierte Fruchthant.

(Fig. 1. $r$ ) stets aut 6 bis 8 vermeht, und diese Wurzeln erscheinen von einer nach Art der Korkzellen geordneten, 6 bis 8 Zellenreihen starken, stärkefreien Parenchymschicht bedeckt.

Aut diesem Gewebe ruht die vereinigte und veränderte Samen- und Fruchtschale (Fig. 12st), welche am trocknen Korn nach der spitze hin immer dicker, derbwandiger, zellenreicher wird und ummerklich sich zu der Kappe ausbildet, die an ihrer spitze die Wurzeln (Fig. 12 2 ) trägt.

Ton den Wrmzeln aus setzt sich rückwärts der Gefä1sbündelstrangin die Kappe hinein fort. Hier findet man oft mehrere Stränge an der Spitze der Kappe zu einem. horizontal laufenden, ringförmigen, dickeren Gefä1snetze, an einen Halmknoten erimmernd, vereinigt.

Noch weiter von der Spitze abwärts sieht man die Gefälsbündelstränge (Fig. 12g) isoliert in der Nähe des äufsern Umfanges immerhalb der Kappe abwärts lanfen, ja sie lassen sich in den Mehlkörper des Kornes hinein verfolgen (Fig. 12gg). Das normale Korn hat keine ausgebildeten Gefätsbündel im Endosperm und nur eine Anlage dazn im Samenlappen. Hier aber ziehen sich die Gefälsbündel in mehrfach mregelmälsigem Verlauf durch den Mehlkörper und nmgeben selbst bei einzelnen Körnern halbkreisförmig den Keimling, welcher, trotzdem die Körner vom Herbst his zum Frühjahr in der Erde gelegen, sich nicht entwickelt hatte.

Bei \%erlegung der kranken Körner in einzelne, zur mikroskopischen Untersuchung geeignete Querschnitte konnte man num die wahrscheinliche Ursache dieser antfallenden Verbildung alsbald auffinden. An denjenigen Stellen des Komes, an welchen die Fruchtschale sich durchans nicht rom Korn lïsen wollte, sondern eine zusammenhängende, feste. 
gleichmätsige, etwas dunkle Masse bildete (Fig. 13), lietsen sich dicke, reichverzweigte. oft mit kurzen. linäuelartigen Astanhäufingen versehene Mycelfäden nachweisen. Die Fäden des farblosen, stark lichtbrechenden Irvels wohsen quer durch die sehr dicken Wandungen (Fig. $13 \mathrm{~m}$ ) der Zellen der miteinander versehmolzenen Frucht- umil Samenschale. Da, wo die Zellen inhaltsreicher und dümmandiger wurden, in Gewebe des Mehlkörper's. häutten sich die Mvieltärlen und fïllten einzelne Zellen ganz aus (Fig. 1:3 mm).

In der Umgebung soleher Stellen war the Stärke gelöst, der plasmatische Inhalt erhalten, aber fest, wie nath dem Eintrocknen. In anderen Zellen zeigte sich das feine Netz plasmatischer Substanz, das bei Anwesenheit der Stärkekörner kaum merklich war, allein vorhanden: es besats genan die Anordnumg, als wemn es sich noch $m$ m die Stärkekörner herumlagerte: aber statt der Körner waren meist nu' unch die entsprechenden Hohlräume vorhanden. Daher die gelbliches. clurchscheinende Beschaffenheit der betreffenden stellen, zwischen welcheu, mehr nach der Mitte des Kornes zu. inselartige Zellgrupen mit starkem Stärkegehalt eiugestrent lagen. Diese gemischten Regionen erwiesen sich bei Jodzusaty unter schwacher Vergröfserung hellblan.

Wie abweichend an diesen stellen das kranke Korn gebaut war, zeigt am besten der Vergleieh rom Fig. 13 mit Fig. 14. Letztere stellt einen schnitt ans der entsprechemulen stelle eines gesumden Kornes dar. Dio ans der Fruche und Samenliaut gemeinsehatitlich gebildete Schale des Kornes (Fig. $13 \mathrm{~m}$. $1+f s$ ) hat bei dem kranken Korn mehr als die dreitache [riekr der gesmolen

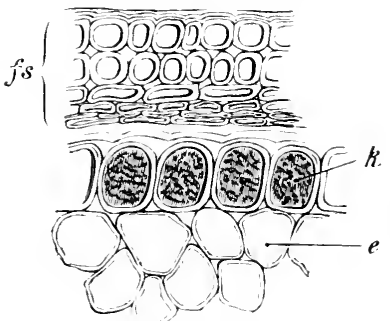

Fig. 1t. Normale Fricht-undsianenhaut nebst Kleberschicht. schale. Beig sehen wir in der krankhaft entwickelten Fruchthant cin ansgebildetes Gofälsbündel nit zienlich dentlich kemtlicher trefätsbündelscheide y.s. Bei dem krank’’n Korne geht die wuehernde. Fruchthaut direkt in den Mehlkörper ö̈her, während bei dem gesmden die eiweitsreiche Kleberschicht (Fig. 14li) zwischen heiden (iewebeformen liegt.

Dies ist im wesentlichen der Befund gewesen, der sich bei Untersuchung dor eingesandten Körner ergeben hat. Die Körner erscheinen somit total verbildet. und da die Verbildung sowohl in der Lage des Keimlings: als anch in der Ausbildung des Mehlkörpers und namentlis:h in einer Wuchermo der Fruchtschale sich geltend macht. so liegt darin der Beweis. lats diese Deformation zur Zeit der Anlage des Kornes ant dem Halme sich vollzogen haben muts. Dic Befinehtmin. hat noch normal stattgefunden. da der Emhryo sowohl Blätter und Vegetationskegel als auch Wurceln (letztere in erhöhter Anzahl) autweist. Aber alshald muts ein lokaler Reiz aut das Gewebe der Fruchthaut dieselbe zur Zellvermehrung angeregt und dabei dir Verschiebung des Embrro von der seite nach der Witte des Endosperms veranlalist haben. Dieser Reiz ist währent der ganzen Ausbildung des Konnes tätig gewesen und hat die Neigung zur vegetativen Tätigkeit derart gesteigert, daf' hereit. der ('harakter des Endosperm eine Änlerung

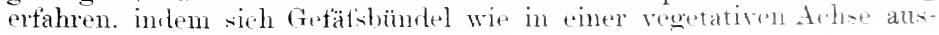


bildeten. The hamptsächlichste Steigermg der Zellvermehrmg erblicken wir in der spitze des Samenkorns, wolche den Charakter einer vegerativen Arhse ammimmt und durch die Verschlingung der Gefätsbïndel flas Bild eines Halmknotens darstellt. Ans diesem Halmknoten sind reichlich Wurzeh hervorgegangen, mol es wäre nicht mwahrscheinlich, dats bei oiner gröseren Turchlüttung der Botlenshichten die Anlage von Blattknospen stattgefunden hätte. Wir wiurden dam einen ähnlichen Fall wie hei dikotyledonen Gewächsen vor uns gehabt haben, wem sich bei diesen, wie mehrtach heobathtet worden, regetative Achsen aus dem Fruchtknoten entwickeh.

Für derartige Vorgänge aber lag die Saat zu tiet. Es fehlte der Hiltsapparat zur Hebung des Kornes an die Bodemoberfläche, nämlich die streckmo des ersten Internodiums am Keimling. Infolgedessen ertolote bakteriose Verjanchung bei Sanerstotfinangel, die sich durch den ranzigen freruch nach Buttersäure anzeigte.

Dieser Terlanf ist der trumd, weswegen der vorliegende Fall an dieser stelle erwähnt wird. Wäre es möglich gewesen, den Pilz, der sicher als die Ursache des Reizes zur vegetativen Terbildung angesehen werden darf, näher zu bestimmen, dürte der Fall besser bei den frarasitären Krankheiten untergebracht worden sein. Die Unmöglichkeit aber, das usprüngliche Pilzmyeel an den von Bakterien und schimmelrilzen durchsetzten Fruchtknoten weiter zur Entwicklung zu bringen, läfst nur Termutungen über die Natur des Parasiten zu. Nur das eine ist sicher, dats das den Reiz ausïbende Nrcel nicht zu den Schwärzepilzen (Cludosporium nsw.) gehörte. Nach BrEFELD's nenen Untersuchmngen ïber das Eindringen der Brandkeime in die Blüten des Getreides liegt jetzt die Vermutung am nächsten, dats die noch während der Blüte eingewanderten Brandsporen bald nach der Befinchtung des Kornes sekeimt und dureh das langsame Vordringes ihres Mrcels den Reiz anf' die Fruchthant ansgeült hahen.

\section{3. (irolse horizontale Differenzen.}

Die intivichelle Entwicklnng immerhalb derselhen Ptlanzenspezies whol elenso wie durch die rertikalen Erhelmugen des Standorts anch chrch tie horizontalen Versehiebungen ihrer Kulturstätten von Nord

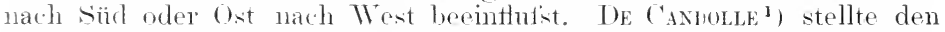
Siatz aut. dat's menter annähernd gleichen Breitengraden mel Höhen die 'T'mperatursmmen ührs o" im schatten für dieselbe Entwicklmossphase (Blïtereit, Lanbfall 11sw.) in den westlichen Gegenden Emopas höher sind als in den östlichen. The Beobarhtungen zeigen, dat's innerhall, des emropäischen Klimacharakters die Dauer der Tegetationspeliode nach Nordosten hin ab-, nach sürlwosten zmimmt. TVestemropa läkt wegen der vielen (tolirgszüge und plateanartigen Unterbrechmgen die Erscheinmg wenigor dentlich zm Ansdruck kommen wie die smotien phenen Landifalen Rutslands, über wollhe eine sehr bemerkenswerte Arlesit rom KowaLEwsi ${ }^{2}$ ) berichtet. Dieselbe stützt sich anf Angaben von 2.20) in allen fiegenten des enopäischen Rufslands

$\left.{ }^{1}\right)$ Siur la méthode de sommes de température appliquée anx phénoménes de régétation. Separatalyzug der Bibliothèque universelle de Genève, 1875

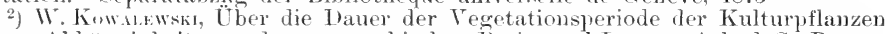
in ihrer Abhängigkeit von der geographischen Breite und Länge. Arb. d. St. Petershurger Naturforscherges., XT, 1844(russisch), cit. Bot. C'entralbl., 18\$4, Nr 51, S. 367. 
zerstrent wohnenden Landwirten, welehe den reitpmlit der saat und Ernte ihres Getreides gemeldet haben. Da die Kultm sich den klimatischen Verhältnissen ampassen muts, so geben die üblichen Saat- und Emtezeiten ein Bild der vorhandenen Vegetationsbedingmgen.

Es findet nun die Anssaat des Winterroggens im sïdlichen Teile des Cherson schen Gonvernements am 1.i. September statt ${ }^{1}$ ), um Archangelsk dagegen schon am 1. Angust. Inie Streifen der gleichzeitigen mittleren Ausisaat von Winteroggen verlanfen nicht parallel den Breitengraden, somlern von NW nach so gesenkt, lanten also fast in derselben Richtung wie die Isochimenen. Tie Itffermz der Erntezeiten von Winterroggen im hohen Norden (Archangelsk) mnd in süden (Cherson) erstreckt sich. wie die Saatzeit, ant anderthall, Monat. I)ie Dauer der saatperiode ron sommergetreide ist im hohen Norden mm drei- bis viermal kürzer als an den südgrenzen: an der westlichen Grenze ist dieselbe zwei- bis zweieinhalbmal länger als im Osten. Die Ernteperiode ist in Norden elentalls dreimal kürzer als im sücten, im Westen anderthalb- bis zweimal so lang als im 0sten. Die streifin gleichzeitiger Reite des sommergetreides sind rom siW nach NO werichtet, stimmen also in ihrer Richtung mit don Fotheren ïberein.

Die Daner der Vegetationsperiode beträgt in süden mid Südwesten Rutslands mu sis bis llo Tage hei Roggen, Buchweizen, Lein und (ierste, dagegen bereits 110 bis 125 Tage bei commerweizen. Hirse, Hafer und Erlse: die längste Vegetationsperiode (lio) bis lis, Tage) hesitzen /anckerrübe, Mais und Kartoffeln. Somit überstrigt im siiden dic längste Vegetationsperiode die kürzeste fast $m$ das Loppelte. Dagegen sind in Norden die betreffenden Prioden nieht nur überhampt kürzer. somdern anch stärlier zusammengedrängt. Im hohen Nordin und Nordosten übersteigt die bitferenz zwischen der längsten and der kürzesten Vegetationsperiode nicht 10 bis 20 Tage.

Bei derselben Kulturpflanze imerhall, des emopäischen Rnislands nimmt die Schmelligkeit der Entwicklung durchschnittlich mit der Breite zu. So besitzt beispielsweise der Hafer im Gonvernement (therson (Sïden) eine Vegetationsperiode von 1:3 Tagen. Weizen mnd Gerste eine solche von 110 Tagen; in Norden dagegen vermindert sich die Vegetationsdaner des Thaters anf gs (Al'hangelsk), des Weizens anf sc, der Gerste aut is Tage. Innerhalb derselben geographisthen Brejte findet man in Westen eine längere Vegetationslaner als im Osten.

Die Ursachen der Verkürzung der Fegetationsperiolen kömmen also nicht in der Wärmesumme liegen, welche die Pflanzen unter dem entsprechenden Breitrngrade emptangen: dem sonst müfisten die Pflanz'n ehen im sïden bedentend schmeller ihre Entwicklumg durchlanten als im Norden, zumal sich die südliche sichwarzerde viel stärker rrwärnt als der sehwerere. oft tonige mid tem hte Boden des Nordens. Autiserdem drängt auch der in siüden vorhandene Nangel an Fenchtigkeit noch schneller zum Abschluts der Vegetation. Es mufis also ein anderer Faktor masgebend sein, und diesen erblickt Kowalewsi in der Insolationsdaner. Er nimmt num als mittlere Aussaatzeit des Haters den r. Mai, als mittlere Emitezeit desselben den 20. August an und findet somit für die !s tägige Vegetationsperiode in Archangelsk eine Insolationsdaner von 2010) Stunden: rechnet man noch die Periode der hellen Nächte dazu, so steigt diese Grötse bis auf 2240 stmurten. In ('herson wind

1) Alle Daten nach dem in Rufsland thblichen alten Stil. 
der Hater an 20. März gesät und am 20. Juli geerntet. In dieser 12:3tägigen Tegetationsepoche finden sich aber nur 1850 Insolationsstunden. Autserdem, sagt Kowalewskl. muls bemerkt werden, dafs die Kultursorten des Nordens an kleinere Wärmemengen angepafst sind und daher. in den sïrlen ïbertragen, verhältnismälsig früher reifen. Dieses Resultat stimmt mit demjenigen, später zu erwähnenden überein, das Schübeler (Die Pflanzenwelt Norwegens) gefunden. Auch von Canada sollen ähnliche Beobachtungen vorliegen.

/ur ferneren Erklärung der Veränderung der Vegetationsdauer zieht Kowalewsi die grötsere Intensität der Beleuchtung, die geringere Wolkenmenge und gröfsere Fenchtigkeit der Atmosphäre herbei und glaubt, gestützt auf Finntzix's Untersuchungen, dafs im Süden z. B. das Lichtoptimum der Assimilation äbersehritten wird und daher hemmend wirkt. Dies entrpräche dem bei den vertikalen Erhebungen erwähnten Vergilben schattenliebender Pflanzen der Ebene bei dem Anban im Hochgebirge. Indes brancht man nicht auf eine hemmende Wirkung des südlichen Lichtüberschmsses zurückzugreifen, wem man die WiEsser'schen Anschauungen acceptiert. Zur Erklärung der lichtverwertung seitens der Pflanzen im hohen Norden betont W IEsNek $^{1}$ ) nach seinen Untersuchungen. dats im hochnordischen (rehiete (Tromsö) bei gleicher somnenhöhe und gleicher Himmelsbedeckung die chemische Intensität des gesamten Tageslichtes gröfser als in Wien und Kairo, dagegen kleiner als in Buitenzorg anf Java sich erweist. Das Lichthlima des hochnordischen Gebietes ist durch eine relativ grotse Gleichmälsigkeit der Lichtstärke ansgezeichnet, welche in keinem andern Vegetationsgebiete erreicht wird. Die Pflanzen der arktischen Vegetationsorenze erhalten die grötste Nenge des Gesamtlichtes. Hier fällt bei der niedrigen Wuchsform jede Selbstbeschattung durch das eigne Laul, fort, and selbst die Holzgewächse in benachbarten südlicheren fiebieten zeigen nur eine minimale schattengebende Verzweigung.

Über das Verhalten der Pflanzen bei kïnstlicher horizontaler Verschiebung durch tie Kultur liegen schon fröhere Anbauversuche mit Getreide nordischer Abstammung vor ${ }^{2}$ ), ïber welche Wiтuack referiert hat. Derselbe kam zu folgenden Schlüssen: PHanzen aus dem Norden entwickeln sich in Mittelewropa zwar etwas langsamer. holen aber später die einheimischen ein oder eilen ihnen sogar voraus. Man sieht also, dats die im Norden angewöhnte kurze Vegetationsdauer manchmal durch die erhöhte Wärme des südlicheren standortes noch mehr ahgekürzt wird. vorausgesetzt, dafs man es auch mit trocknem Klima zu tum hat. Das fouchte Klima Englands mit den niedrigen Maximaltemperaturen verzögert die Reife. Der Feuchtigkeitsgehalt der I $n$ f't ist sehr malisgebend und kann überall Verzögerung der Reife veranlassen: ebenso wie nngekehrt Gegenden mit grotsen Trockenperioden. Steppenklima und ähnlichen, von den Breitengraden nicht abhängigen Verhältnissen absegrenzte Herde mit frühzeitig reifenden Pflanzenformen bilden können. Allzn grofse Trockenheit verzögert allerdings die Entwicklmm. wie dies experimentell festgestellt worden ist. Wir verweisen betrefts cler Bodentrockenheit auf die Versuche ron STAHI-

1) Wrsser, J., Beitrïge zur Kenntnis des photo-chemischen Klimas im arktischen Gebiete. Sitz. Akad. d. Wiss., Wien CVII, cit. Bot. Jahresb. 1898, I, A. 586.

") Über vergleichende Kulturen mit nordischem Getreide. Von Drems'n, Kinкuкn,

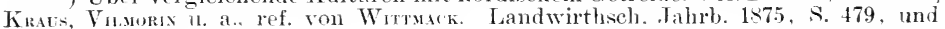
$1 \vee 76$, s. $61 ? \mathrm{ff}$. 
Schröper, die in dem Kapitel "Wasserïberschuts. angetiilut werdrn. Dafs der Zeitpunkt der Einwirkung der WV̈̈rme sehr wichtig. ist wohl erklärlich. Wärme im . Juli und August ist vorteillatter als im Mai uml Juni; bei den Regen ist es mmoekehrt.

Auf die Bedentung der phỵikalisehen Borlenbeschattionheit. nänlich anf die Beschlemnigung der Reife lurch locker Böden. wir. man auch durch die IVITTusk'sche Zusammenstellumg hingewiesen, ebenso wie auf den Umstand, dats im allgemeinen für dieselbe fretreilt. sorte die Vegetationszeit in östlichen Gegenden kür\%er als in den west. lichen ist.

Gestützt anf die Erfahrmngen, dat's die Kultursorten nördlicher Klimate ihre kürzere Vegetationsdaner in der nächsten Entwicklmmssperiode beibehalten, hat sich ein schwungvoller Handel mit nordischem Saatgnt ansgebildet. Indes ist nicht zn vergessen, dats man dabei dis Quantität der Ernte im Auge behalten muls. I)ieselhe hängt, reichliche Nährstotfzufuhr gleichnälisig roransgesetzt, doch stets ron dir Daner der vegetativen Periode, also der Bestockmośceit al,. Je länger das Getreide /seit hat, regetative Organe anznlegen (und dies reschicht innerhalb einer fenchten, kühlen .Jahreszeit). Gesto reichlicher ertolgt die Bestorkung und damit die Ausbildung einer grölseren Anzahl ron Ähren aus dem einzelnen s'amenkorn.

Wenn man sich verleiten lätst, im Westen entstandene, langlebige. durch Produlitionsreichtum auscezeichnete siorten nach llem Gsten zu ühertragen, läntt man Gefahr. Gaks dieselhen im Ustrn clen Frösten orliegen. Das schlagendste Beispiel finden wir hei den enelischen WVeizen-

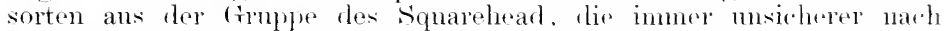
Osten hin werden. weil sie auswintern. Betretfs der Frostwilerstandsfähigkeit liegen Erfahrmoen vor, dats die siamen norelis her Gegenden in südlichen Breiten Pflanzen ergeben, welehe nicht nur bisweilen. troty antänglicher Verlangsamnng der Futwickhng. frïher roifin. sourlern au h den Frösten hesser widerstehen.

Aus den Ergebnissen langjähriger Beobathtungen s'chïBtLkis ${ }^{1}$ ) ist hervorzuheben. dats die durch eine kurze Vegetationszeit in nordischen oder alpinen Klimaten \%ur (Kewohnheit gewordene schnellwïehsigkeit nach vier-bis tüntjährigem Anban in niederen Breiten wieder verforen geht. Ungekehrt gewöhnen sich langlebige sorten in einigen .Jahren eine linrze Tegetationszeit an. Gelber ITiilmermais von Tohenheim z. B., der im . Jahre 18.02 zu ('hristiania in 120 Tagen reitte. verkürzte bei wiederholter Aussaat seine Vegetationszeit bis $18.7 \mathrm{~mm}$ 30 'Taw口. In Christiania heträgt die Entwieklungszeit der Gerste !n 'Tage: las ans Alten $\left(7^{\circ}\right)^{\circ}$ ) stammende Saatgut brauthte $n$ m $\ldots$ Tage (s. Kow.tewikl).

Von den dmreh die nördliche Lage rerursachten stoffliehen Eigentümlichkeiten. welche violtach mit den Ändermogen der PHanzen hui dem Aufsteigen aut das Hochgehiro übereinstimmen, ist besondirs wichtig. dats der Znckergehalt der Früchte nach Norden hin ab-. das

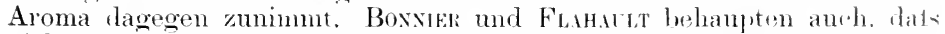
nicht nur die Grötse. sondern anch die grïne Farler der Blätter an Dunkelheit im Norden zunimmt ${ }^{2}$ ). Eine Zusanmenstellnne ${ }^{3}$ ). Wol.h.

1) Scmurtar. Die Pflanzenwelt Norwegens. 1873, .̦. 77 u. ff.

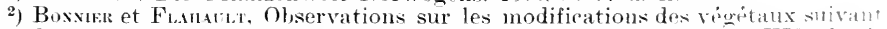
les conditions phrsiques du milieu. Annal. d. se. nat. Botaniqu., t TI. Jaris 1879 , p. 93 .

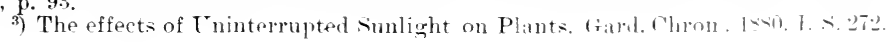




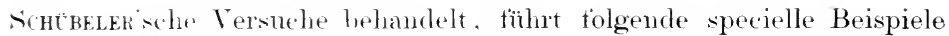
an. Bei Weizen. dessen samen aus Ohio und Bessarabien bezogen war. stellte sich eine jährlich zunehmende dunkle Färbung der Körner .in, bis diese dis gelbbrame Farbe des einheimischen norwegischen Winterweizens erhalten hatten. Ähnliche Resultate waren mit Mais, Bohmen, Erhsen, Sellerie n. a. erlangt worlen. Sellerie, der vom Kankasus bis Vorderindien, in Atrika (Ägrpten. Habesch, Algier) wächst und in Eurona vom Mittehmeer bis zur Ostsee zu finden ist, geht jetzt

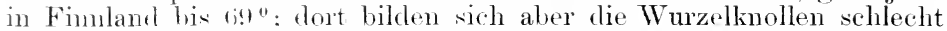
aus: die Wïrzhaftigkeit wind jedoch im Norden schärfer ${ }^{1}$ ). Die bereits erwälnnte grötsere Jntensität der Blütenfarben, die parallel der Steigerung dieser Eigenschaft mit zunehmender Erhebung über den Meeresspiegel sich zeigt, erschien hei den meisten Gartenblumen auch bei dem Fort-chreiten nach Norden. Betretf's der Bildung aromaticcher Stoffe ist als Beispiel autser sellerie noch der Wacholder anzufïhren, der in Norwegen viel reicher an (i) als in Centralemopa ist: anch Zwiebel mol Knolilanch sind in Norwegen mgemein schart. Die Erdbeeren sind saner, aher aromatisch, während diese Früchte nath ö̈̈zE in ('oimbra ansgezeichnet siits, aber tast ohne jedes Aroma sind. Die Pflammen hloiben oft so saner, dats sie den aus südlicheren Gegenden stammenden Frïchten gegenüler als mreif anzusehen sind. Bei dem Wein lätst sich eine ähnliche Beobachtung machen: Man vergleiche den süsen portugiosischen Wein mit tem weniger suitien, aber blumereichen Rheinwein.

Bei Betrachtme der horizontalen Differenzen, die sich in der Abnahme der Regenmenge. in der Zunahme der Klarheit der Luft, von Westen nach Gsten. in den Belenchtungsverhältnissen zwischen südlichen und nördlichen fiegenden nsw. äntsern. dürfen wir einen Umstand nicht vergessen. ant welehen ne ('AnoLLE ${ }^{2}$ ) bereits aufmerksam gemacht hat. llerselhe ist zwar experimentell noch nicht genügend gefestigt, findet alwe in der praktischen Erfahrung seine vielfache Bestätigung. Es ist nämlich die gröfore, vollkom $\mathrm{kmere}$ Winteruhe der Ptlanzen. Nach Inn: ${ }^{3}$ ) tritt die Belaubmo der in Mitteleuropa und Coimbra normal greteihenden Bäume in Coimbra etwa einen Monat frïher und deren Laubvertärbmg moetähr anderthalb Wochen später cin als bei uns. Somit ist die Winterruhe dort etwa sechs Wochen kïrzer. Die Daner und Vollkommenheit der. Winteruhe mut's aber für die sichnelligkeit der nachherigen Entwicklung einflukreich werden. Man kamn wohl amnehmen, dat's hei Andaner einer Temperatm. wolche die Funlitionen nicht sämtlich zum stillstand luringt, sich eine Anzahl vegetativer Prozesse mit lans samem, aher stetigem Ntoffrerbauch (Oxydationsprozesse) vollzieht, ohme dats die Pflanze Ersatz durch nen assimiliertes Material ehält. Antierdem scheint es, dats manche Enzyme, welche die Energie des Stoffiverhsels hedingen, erst während ejner vollkommmen Winterruhe in der nötigen Menge zur Entwicklumg gelangen oder vorhereitet walen. Tritt keine vollkommme Ruhe ain. so dürte dies namentlich bei zwei- nud mohrjährigen Stauden und den Knospen der Zweige an Holzgewärhsen tïhlhar worlen: diesellen wrolen frïher treiben,

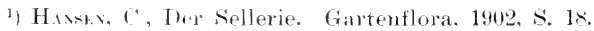

$\because$ A. 1. ('ixborr. sur la methode des sommes de température appliquée aux phénomenes de la régétation. Archiv. des sc. jibrsiques etc. Nonv. sér. LIII. LIT. Fenf 1875. (.it. Bot. Jahresber., 1875. S. 5-5.

3) Ims, Phämologisehe Mittrilungen. ('it. Bot. Jahresb., 1898, II, \$. 409. 
aber sehwäthere Organe produzieren (kloinere Blätter. mö̈loere Anzalıl minfuchtharer Blumen).

Des zumehmenden Gewichtes der samm in den nördlichen Breiten ist im vorhergehenden schon gedacht worden: es liegen aber auch Untersuchungen von PETERMas ${ }^{2}$ ) vor. welche eine hohe $\mathrm{Ke}$ im krat schwedischer samen vou Kleearten. Lieschoras (Ihlom protens L.). von Fichte und Kiefer gegenüber dentschen, französischen und belorishen samen beweisen. Iie in der Tat chehsehnittlich oin grötseres Gewicht besitzenden schwedischen samen betätigen ihre grötsere Keimkratt nicht nu durch die Zahl der lieimtähigen Körner, sontern auch dureh die Energie, mit welcher die Keimmur von statten geht. Diese Ergebnisse lasien sich recht gut durch eine grötiere Entwiclimusenergie der PHanze infolge vollkommuerer Winteruhe erlilären.

Dic Beolachtungen haben ihre sehr beachtenswerte praktische seite insofern, als sie klärend ant' die Kultumethode des samenwechsels wirken. Es wird nicht genügend sein. ïherhampt nu Saatent aus anderen tregenden einzutiihen, sondern w wird notwendigerschemen, vor allen Dingen sich zu fragen, welehe Eigensehatten man an der Kulturpflanze zu verbessem wïnselit, und in weldhen Klimaten diese gesuchten Eigenschatten zu höherer Ausbildmeg gelangen. Vou dorther bezogen, wird das saatgut dam den gew ünschten Ertolg zejown.

Die Kulturertolge, welche surh Benutzming von Pflanzen anderer Klimate erlangt werden, halten aber. wie "rwälnt, in der Regel nu fïr seler wenige Vegetationsperioden vor. Nanehnal tritt der Finfluts des jetzigen Stanflortes schom in der zwoiten Vegetationsepoche ant und stempelt die Pflanzen der tiemden Klimate schell wieder zu einheimischen Produkten. Alstbämme, aus Angers hezogren, trieben nud blühten ant Malorka schon zu Enele der Nonats Felruar, während die einheimischen erst einen Monat später blïhtrn ${ }^{2}$ ). Eine zwei Jahre später wederum ans Angers eingetrottene sendmg zeigte dieselle Erseheinumg. Jie Obsthäume der ersten Sendung bïhten jetzt aher bereits später, nämlich wleichzeitig mit den einheimisthen. Sielten vollzieht sich ter Übergang ron dem hisher erblichnu zu einem neuen, likmatisch hedingten Entwicklungsmorlus so schnell, als er sich bei der Rückkehr verliert: doch haben wir bei mseren Gemiisen anch Beispiele schneller Änderung der bisherigen Eigensehatten. In Tropenklima behalten diesellen nur in "rsten .Jahre annähernd ihren Charakter: aher schon in zweiten Jahre greben die samen rlieser cingetïhrten Pflanzen gestreskte, verholzende Exemplare ${ }^{3}$ ). Das sind eben unsore ins Variben gekommenen Kulturtormen. Von sehnellen Ändemmeen wildwarhsender sipecies ist nichts bemerklieh. wie die Hofruswichen Versuche mit Parallelsaaten gewisser Formen ron Plusenlus mal Tritirum in Gietisul. (ienua. Montpellier, Portici und Palormo ${ }^{4}$ grzeigt hahen. Dagegen erwähnt Hofrx.ux langsame. in Laute vieler finerationen erst zustande gelsommene Andermgen: so wird lifims communis in den Tropen hammartig mul

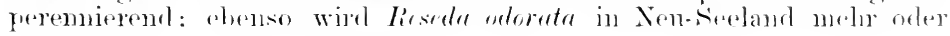

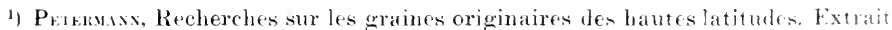
du t. XXVIII. des Mémoires couronnés et autres Mémoires publies lar l'A 'ad. rovalr de Belgique, Bruxelles 1<7\%.

") Gartenzeitung von Wursuck, 1s82, s. 374.

3) Deutsche Gärtnerzeitung, 1853, Nr. 17.

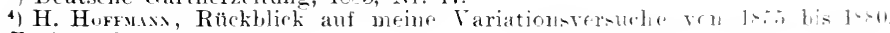
Bot. Z.. 1t:1. S. $4: 30$. 
weniger ansdauernd und anderseits Bullis promis in Petershurg ein: jährig.

Zu den langsam sich vollziehenden Änderungen im Wachtumsmodus rehört die Ausbildung der Jahresringe bei unseren Bäumen. Allerdings schwankt die Verteihung zwischen gefäfreichem Frühlingshol\% mid getatsarmem sommerholz innerhalb desselben Breiteugrades in jedem. Jahre je nach Zahl und Verteilung der Niederschläge: aber hei ter dureh tie horizontalen Differenzen der Lage gegebenen Veränderung der Durchschnitswitterung werden derartige Verschiedenheiten konstant. und es bilden sich dadurch ökologische Varietäten. Anf solche anatomischen Unterschiede in der Entwicklung derselben spezies in südlicher nnd nördlicherer Lage geht Bonnies ${ }^{1}$ ) ein. Er verglich Exemplare der Linde, Rotbuche, Akazie u. a. aus der Gegend von Toulon (mit 2botägiger Vegetationszeit) mit solchen bei Fontainebleau (Vegetationszeit 17 Tage) und fand. dafs das Frähjahrsholz im südeu besser entwickelt und reicher an vielfach weiteren Gefätsen ist. Hier kommt allerdings der Reichtum an Frühjahrsniederschlägen im Mittelmeergehiet in Betracht. Das Sommerholz des südens dagegen ist reicher an Libriformfasern und besteht oft nur aus solehen. während bei Fontainebleau sich auch im sommer noch zahlreiche Gefäfse bilden. Tie Blätter der Toulon-Pflanzen erwiesen sich um ${ }^{1 / 3}$ oder $\mathbf{2}$ mal dicker und mit mehr Schichten von (längerem) Palisadenparenchym versehen gegenüber den nördlicher erwachsenen Pflanzen. Die Spaltöffnungen sind zahlreicher, das Sclerenchym kräftiger und die Cuticula verstärkt. Die Toulon-Pflanzen repräsentieren den Charakter der Mediterranflora im allomeinen.

Der gröseren Intensität der Blütenfarben bei dem Antsteigen der Pflanzen von der Ebene nach dem Gebirge und dem Übergang ans niederen Breiten in die nordischen Regionen ist bereits gedacht worden. Nenerdings ist anch die Anfmerksamkeit auf die sich ändernde Färbung der Laubblätter in erhöhtem Mafie hingelenkt worden und hat eine eigenartige Deutung als schutzvorrichtnng erfahren. sehr austïhrlich behandelt MaC MrLax ${ }^{2}$ ) diese Verhältnisse. Er spricht von „wärmenden Farben" (warming-up colours) und meint dabei besonders die rote Farbstoffreihe, die in kälteren Regionen reichlicher vertreten sei. Alpine und Polarpflanzen sind häufiger mit blauen oder violetten Blumen als mit gelben zu finden, die Zweigenden oftmals gerötet. Durch den roten Farbstoff werde die Temperatur etwas erhöht und der Eimflufs der Kälte dadurch etwas abgeschwächt. Wemn man von zwei ühereinstimmenden Thermometern die Kngel des sinen mit einem grïnen, rlie des anderen mit einem purpurfarbigen Blatt nmbindet. so macht sich nach kurzer Zeit bei Somnenbeleuchtung am purpurfarbigen Blatt eine Temperaturerhöhung rom $1 ;$ bis $10^{\circ}$ geltend. Ebenso fand er. dats ein Thermometer, in ein Bund Veilchen gesteckt, höhere Temperatur anzeigt als in einem Bunde Schlüsselblumen. nachdem beide einige Zeit in der Sonne gelerren.

Die harhstiche Färbung kömne als eine entschiedene Realition der Pflanze anf die erniedrigte Temperatur aufgefalst werden. Durch den roten Farbstoff bilde die Pflanze sich eine Wärmequelle.

1) Boxier, Cultures expérimentales dans la région méditerranéenne ete. Cit. Bot. Jahresb. 1902, [I, S. 299.

2; Cيжи Mr Mur., Mimnesota Plant Life. Saint Paul, Minnesota. 1399, S. 417 
Darum sind so viele Frühlingshlumen rot mad riolett mol Herbst. blumen blan oder rot.

In den warmen Klimaten nehmen dio Gewächse oft kigensehatten an. welche das direkte Gegenteil von denen der Polar oder Gebirgsptlanzen sind. In den Tropenpflanzen sind die Reservestotfbehälter weniger stark entwickelt als in verwandten Arten kälterer Gegenden. Die Knospen sind weniger geschützt, filzige Öberziige ant Blätern und Zweigen (mit Ansmalme der Wiistempflanzen) soltener. Viele winter. liche Gewohmheiten fallen fort: es gibt weniger zweijährige Pflanzen. lie wärmenden Farben treten mehr zuriek, indem weifse, gelbe und gefleckte Blumen (Orchideen) vorherrschen.

Die Natur bilde den roten Farbstotf ans, mu das ïberschüssige licht nicht verloren gehen zu lassen und es in Wärne nmzusetzen und es als wachstumförelerude Kraft anszumutzen.

Wir kömmen ms mit tieser Theorie voranshedachter Nïtzlichkeit des roten Farbstoffs als eines wämeerzengenden und lichtabschwächenden Apparates nicht hefiemulen, wem wir auch gern gelten lassen wollen, dats. we nn der rote Farbstoff einmal erzengt worden ist, er in der anwegebenen Weise wirksam sein wird. Datis die Pflanze ihn zum Schutze gegen Kälte erzengt. wem die Temperaturen niedrig werden, ist schon darum nicht glanhhatt, weil man es in der Hand hat, eine Rötmng der Blätter bei den heilsesten sommertemperaturen hervorzuruten. Bei den gerbstoffreichen Rosifloren (z. B. bej Craturgus) habe ich die rote

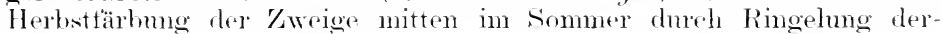
selben binnen wenigen IVochen zn erzengen vernocht. Und der Thustand, dats im sommer immerhalh weniger 'Tage dis Interseite vieler Blätter sich rot färl,t, sohald man sie nach oben kelırt, ist allgemein hokannt. Fernere Beispiele liefern die Parasiten. An demselben Kirschhamm z. B. werden die Blätter der von Exousrus ('rowsi befallenen Äste lenchtend rot, während die wesunden grün bleiben. Bei vielen Fleckenkrankheiten erscheinen die kreismuden Pilzherde rot nusämont. Amaryllideen, deren Blätter in sommer absterben (Hibnastrum u. a.). lickommen raminnote Flecke und Streiten.

somit glauben wir. dals der rote Farlsetoff als cine notwendige, an eine relativ ïbereiche Lichtzutinh geloundene Realition der /elle anf den Einfluts rerschiedener Faktoren anzusehen ist. Einer dieser Faktoren kam auch dir 'Temperatmerniedrigung sein, die sich bei hori zontalen oder vertikalen Verschielumgen des Standorts einstellen wird.

Blieken wir ant die vieltachen Verändermugen zuriuck. welche die Pflanzen im gestaltlichen und stofflichen Anflian durch dis horizontalen Verschiebungen ilures Standorts erfahren, so werden wir ms der ت̈berzengung nicht rersehliefsen kömen, dafs in diesen Versehio. bungen nicht selten der Grund fö̈r eine loisposition zur leichteren Erkrankung oder andersoits zo gräserer Imm nnität $z n s u r h o n s e$ su wird.

Wir haben bereits anf die grökere Frostempfindlichlieit westlichror squarehead- Weizen in istlichen Gegenden lingewiesen und rimern jetzt daran. dats auch parasitäre Erkrankungen von dem im siaatgut erblich mitgebrachten verschiedenen Entwicklungsmorlus der Tirts. pflanzen abhängig sein kömm. Man denke brispielsweise an die 'T'at sache. dafis manche parasitare Pilze zu bestimmten .Jahreszeiten ant treten oder sich doeh besonders reichlich verbreiten. Falls solche Pilze nur den jungen Blättern gefährlich werden. wird tür rin. phidenisiste 
Ansbreitung es ausschlaggebend sein. ol zur Zeit der reichsten sporenausstreung viel junge Blätter vorhanden simc. Lieser Imstand hängt aber davon ab. Wie schnell eine Pflanze in einem bestimmten Klima ihren Entwicklungseyklus durchläutt.

Hat sie eine langsame Entwicklung, so ist die Periode, in der sie junge Blätter darbietet, eine langdanernde und damit die Gefahr der Pilzinfektion eine sehr nahegerïckte. Reift pine (z. B. aus nördlicheren oder östlichen (regenden eingefühte) Varietät schuell, dam kamn zur \%eit der haupträchlichsten Sporenverbreitung der ganze Blattapparat schon ausgereift und rlamit widerstandsfähig gegen viele Parasiten sein.

solche Tmstände verdienen grötsere Beachtmmg. als ihnen bisher zn teil geworden. Sie worden anch bei der Erklärung der ..Biologischen Rassen" einzelner Parasiten in Erwägung gezogen werden müssen: dem es ist durchaus nicht mwahssheinlich, dats manchmal Intektionen nächstrerwandter Wirtspezies nur darum nicht gelingen. Weil pine Nährpflanze sich zur Intektionszeit schon in einem tortgeschrittenen Entwicklungsstadinm befindet. bei welchem der Blattapparat abgereifter. d. h. derbwandiger und inhaltsärmer ist. Lat's die Pilzinfektion an ein bestimmtes Entwicklungstadium der Nährpflanze gebunden, zeigt sich beispielsweise hei (len Rostpilzen des (xetreides. ERIsssos ${ }^{1}$ ) erwähnt. dat's bei frühreifen sorten auch der Rost fïüher autrete. und die nemen Beobachtungen liefern Beispiele, wie die Puccinia-Arten des Getreides ihre bestimmte Zeit des Auftretens haben. So zeigte sich ${ }^{2}$ ) im . Jahre 1904, dafs hamptsächlich und zuerst Puccimin ghumamm bei Weizen anfoetreten ist: daranf folgte $P$. dispros, the sich aher nur noch derjenigen oroane und siorten bemächtigte, welche noch nicht abgereift waren. Daher sah man späte, langsam reifende Weizensorten reichlichst mit $P$. dispersa und spärlich mit $P$. glumamm. die frühreifenden Varietäten aber in entgegengesetzter Weise hesiedelt. Bei Iagergetreide fand sich Plec. gramimis.

Als ein Produkt klimatischer Einflïsse anzusehen sind

\section{Glasige Getreidekörner.}

Glasig nennt man diejenigen Getreidekörner. deren Endosperm hart. tast durchscheinend und in querschnitt gran oder röthch gefärbt ist. während bei den gewöhlichen mehligen Kömern das Endosperm weich, weifs. porä und leichter zerreiblich erscheint.

Das Glasigwerden der Körner pflegt häufiger im Norden und osten Europas als in den westlicheren Teilen anfzutreten. was aut einen Einfluts der Intthockenheit bei hoher Lichtintensität hinweist. In den feuchteren westirhen Regionen erlangen die regetativen Organe

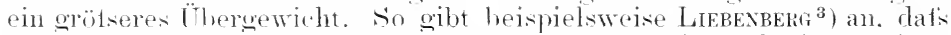
die somst answezeichnete nordische trerste zwei Nachteile besitze. nämlich emen zu grolsen Prozentsatz glasiger Körner und eine zu dumkle Färbmng, die rom Beregmen des erntereifen Getreides herrühre. Diese Regengüse zur Erntezeit beeinflussen naturlich nicht mehr die

1) Enusus, .T., sur lorigine et la mopa gation de la rouille des céréales par la semence. Ann. seienc. nat. Bot. TIII sér.. tom. XIV und XV. Paris 1902.

2) Jahresb. d. Sonderinuschusses f. Pflanzenschutz. Dentsche Landw. Ges. 190.) Getreiderost.

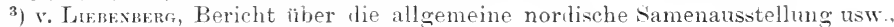
$18 \times 0$, cit. Bot. Centralbl., 18\%., Nr. 43. S. 115. 
Kornausbildung, welthe in eine meist trockne Periode langer Tays fällt. Bei der langen Lichtwirkung werden auch dic Roggensorten intensiv gefärbt. Derselhe Autor berichtet. lats hei der retreicle ausstellung in Schweden die Itaferproben durchsehnittlich nur 2.2.tit bis $32,04^{\circ}$ o spelzengewicht besatsen. während dasselbe bei österreichischen und französischen zwischen $25.230^{\circ} 0$ und $38.30^{\circ}{ }_{0}$ schwankte. In allgemeinen kam die Ansicht von HABERLANot ${ }^{1}$ als gültig anerkannt werden: derselhe spricht aus, dats ein kontinentales Klima glasiges Körner erzenge, dat's dagegen kühle, feuchte sommer orler künstlichrer Nährstoff- und Wasserreichtum mehlige. spezifisth leichtere und stickstottärmere Getreidekörner produzieren.

Der glasige Kustand des Getreidrkornes besteht nath den von Grönund ${ }^{2}$ ) an mehliger und glasiger (terste angestellten Untersuchungen darin, daf's die stärkehaltigen \%ellen des sameneiweifses bei dem mehligen Korne die Zwischenrämme zwischen den einzelnen Stärkekörnchen mit Kellsaft erfïllt zeigon. wälrend di+ glasigen Körner diese /Wwischemräume mit Protoplasma ausgefüllt brsitzen. Die Arbeit von .Jondxista (Allg. Braner- und Hoptenzeitung. Isst, $\mathrm{Nr}$. Ts und 79) nimmt einen wrötieren Luftgehalt in der wanzen Masse des Kornes und nicht blot's zwisehen den Ẅändrn bei flen mehligen Körnern an. Bei der Keimung wird das glasige Korn zn einem mehligen. Nach Gröstcon, der äbrigens keine Beziehme zwischen Witterma und Entstehmo des glasigen Zustandes anerkemnt. keimen whasge Körner leichter und hesser mol wehen krätigere Pflanzen. Ohgleich der Verfasser auch ron stark stickstoffhaltigem Boden wlasige Köner als unhestreitbar annimnt, so glauht er doch, dats magerer. sandiger. schlecht kultivierter Boden diese eigentümliche Bildung viel sicherer erzengt. Bei reiner Kalidüngung sah er ein mehliges Korn entstehen. Ïbrigens kommen beide Formen in verschiedenen Ïbergängen in dersellin Ähe hisweilen ror. Bei der Entstehung glasiger fï̈rner möchte ivh ammehmen. dat's im sandigen. schnell trocknenden Boden der Prozel's der stärkbildung abgekü̈zt wird, und da Kali das Korn mehlig macht, so möehte ich viel eher glauben, dats die Leistung des Kali zu triih boschränkt wird, und zwar dadureh. dats andere Prozesse. nämlich die Reifivorgänge, zu trïh und intensiv eintreten. Dies wird les starker Licht. und Wärmewirkmo $n$ so triaher weschehen. je weniger Wasser vorhanden ist. Für die Ansicht eines Überwiegens des Reiteprozesses zur Zeit, wo noch Mehllereitung stattfinden sollte, spricht auch die Mitteilung von SixIo ${ }^{3}$ ), dats man in (Astprenfen das (Hasigwerden des Weizens dem Umstande zuschreibt, dat's or ïberreif ant dom Halmo wird. Analytisch gestützt findet sich diese Ansicht durch die Untersuchungsergebnisse rom R. Potт ${ }^{4}$ ), der lei vier glasigen Wrizensorten einen flurchschnittlich höheren Prozentsatz an Asche tand als bei mehligen Körnern. I ie Körner haben durch die schmelle Reite obru ihre Mineralstotfe nicht vollkommen zur Bildung der organischen sul, stanz ausgenutzt. Man vergleiche auch die hohen Prozentsätze dor

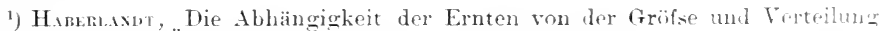
der Niederschläge. Öster. landw. Wochenbl.. 1к7.5, s. 3.5.

2) Nach einer Preisschrift des Verf. cit. im Tahresbericht f. Agrikulturhemin. XXIII (18>0), S. 214.

$\left.{ }^{3}\right)$ Botanisches Centralbl., 18>0. \$. 310 .

4) Tahresbericht f. Agrikulturchemie, $1870-72$, II, s. .). 
Körner an Stitistoff hei Haferptlanzen, die durch Wassermangel oder Wasserüberschut's verkümmerten (s. Kap. "Wasserüberschut's").

Man dïrtte ïber die Natur der glasigen Körner sich am leichtrsten klar werden, wemm man die Untersuchungen von PETRI und von JoHANsix ${ }^{1}$ ) berïcksichtigt. Ersterer wab bereits im Jahre 1870 an, lats qlasige Kömer furch Anfweichen in Wasser mehlig werden könnem: letzterer bestätigt diese Beobathtumg. Es wurden 200 Kilo (ierste zm Hälfte mit Wasser befeuchtet, bis sie $15 \%$ anfoenommen hatten, daranf getroclinet, ausuebreitet und gewendet, bis wieder das msprïngliche fiewicht preicht war. Der Prozentsatz an mehligen Kïrnern war jetzt in, während er im ursprünglichen Material nur 1! hetrug. Bei Kulturersuchen wurle gefunden, dats bei frïher Aussaat eine stickstoffämere, mehligere Gerste sich ausbildete, während bei -pätrrer saat das Ernteprodukt stickstoffreicher ansfiel. Diese Ertahrmm weist laraut hin, dat's man im (tasigwerden der Kömer nur eine merhanische V'ershiedenheit zu erblicken hat, die sich ausbildet, wemm die Zeit ter Kormreife duch Wassermangel bei Licht- und Wärme überschnts sehr abgekürzt wirl. Ein allmählicher Reifeprozels lätst dem Korn längere Zeit zur Anshildung eines vermehrten Stärkerorrats mer Beiluehaltmo eines grötseren Wassergehaltes der Substanz, der später durch Luft teilweise ersetzt wird. Dies bezieht sich namentlich ant das Protoplasma in den Endospermzellen. In diesem liegen die stärkekörner eingebettet. Bei schnellem Reifen kittet das Plasma sich dicht mom die Kömer, und das Korn erscheint qlasig. Bei langsamerer Reife und grötserem Wassergehalt bant sich die Zelle lockerer, indem zwischen den stärkekörnem mehr Zellsaft und später Luft vorhanden ist: mol dann ist bei grötseren, lnfterfüllten Intercellularrämmen las Korn monrehsiheinend und mehlig. Je mehr das Protoplasma ïherwiegt, desto melı Neigmo zm tasigkeit, und deshalb sind auch normalerweise, wie z. B. hei dem Maiskorn, die äntieren Lagen des Samenkorns whasig und lie imeren mehlig. Diese Verhältnisse erklären die Beobachtmgen von schnouer ${ }^{2}$ ), dats im Weizenkorn mehlige mud olasige Partien abwechseln kömmen.

Die oben mitgeteilte Erklärung für das Kustandekommen der rlasigkirit rhält eine Bestätigung durch die Vorsuchsesultate, die von der lentschen Jandwirtschatts-(tesellschaft erhalten worden sind ${ }^{3}$ ). Der Bericht toilt mit: l)ir ( Ilasigkeit der Kömer hängt mehr von den Wachstmmshedingmen als der sorte ah. Glasiger sind tie sorten mit kïrzerer Tegetationsdaner, wie Lupitzer, Strube's begrannter

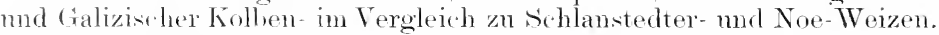
Dit Ertragsähiglieit ler sorten steht im allgemeinen im ungekehrten Vorlältnis zm Tilasigkeit ihrer Körner.

\section{Kontinental- mod Seeklima.}

llas charatiristishe Merkmal der von dem Meere beeinflutisten fiegenden lwsteht in den oringeren sichwankmogn zwischen Sommerund Wintertempraturen. da lie Sommer länger und kiiluler, die Winter

1) Jom nnwa Bemerkungen über mehlige und glasige Gerste (Cgeskrift for Landsmand), 1887. cit. Pifberis. Centralbl., 1888, s. 5.51.

2) Scomsurk, Lehre vom I'flanzenbau auf physiologischer (irundlage. Wien $1 \times 96$.

3) Mitteilungen der Saatzuchtstelle über wichtige siortenversuche. Saatlinte vom fi. Dez. 1904. Deutsche Iandwirtsi-h.-Ges. 
wärmer sind. Unter dem Einfluts des Atlantisehen Gzeans sehen wir ras Frühjahr zeitiger eintreten, den Herbst länger währen als in den frogenden mit Kontinentalklima. Doch ist der Etfokt ant die Vegetation trotz des fï̈heren Anfangs nirht der erwartete: demn dio Blütezeit der frehölze ist hei der geringeren Fröhjahrswärme höchstens wenige Wochen trïher und die Fruchtreife ist kaum fï̈her, ja, verzögert sirh sogar manchmal und findet bisweilen gar nicht statt. Man denke an den in Enoland im Froien nicht mehr reifenden Wein. Wir Luft ist das ganze

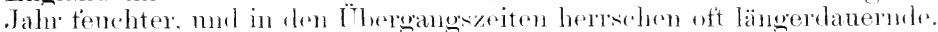
starke Neliel.

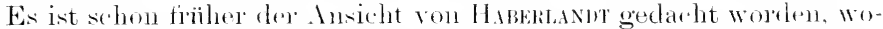
nach Frïhreite der Pflanzen sowohl in nördtichen als in sïtlichen Breiten mit derselben larehtigkeit fintreten mol Veranlassung zur Bildmog entsprechender Varietätrn werten kamn. Es spielen eben hierbei dis Fenehtigkeitsverhältnisse malsgebent mit, und solehe kommen num in grotsen soluwankmoen lei dem Kontinentalklima werenüber einem

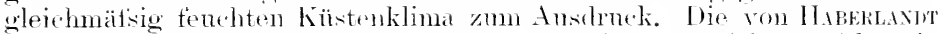
ansgeführten Anbanversmeh.') ergaben in lieser Boziehmug folgende Erfahrungen. Tas ans fenchten Klimaten bezogene saatgut liefert ver.

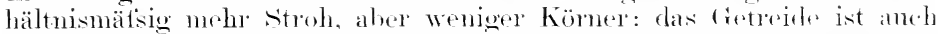
leichter dem Lagern unteworten. Dageoen kann man bei saatgut ans trocknen Gegenten mit kumem Fröhliahr nut heitsem, trocknem sommer die Prodnktion geringerer stroh- aber reicheres Känesertäge le-

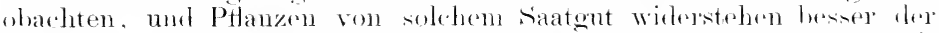

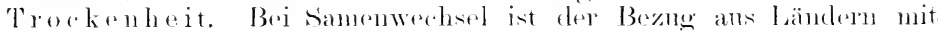

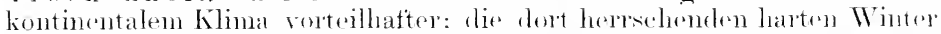
leseinflussen das körmerperelnkt in der Weise, dats die ans demselben entstandenen Pflanzen weniges der fortahe des Answinterns ausgesetzt

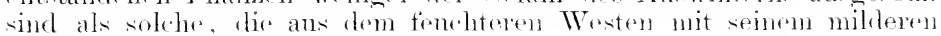
Winter nach (Sistru verptlanzt werteu.

Jas Kontinentallima hringt kleine, abor speritisele schwere Körnore hervor. während rin kïhler und fenchter sommer oder künstliche. reiche Wasser mel Nährstotfonfuhr zwar das Korn veromoticern, aber

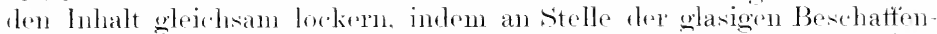

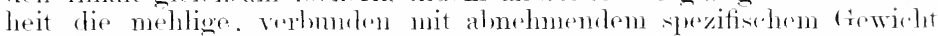
mol abmehmentem sticlistoffigehalt, anftritt.

Wirhtig für den samonwerhsel ist entlich die Beobatehtumg, dats

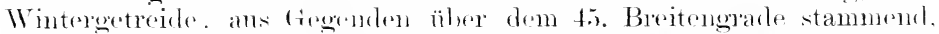
hei mos in Eröhjahr angehant, in demselben .Jahe nicht meh zmm

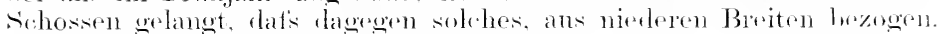
loi mos sich wie sommeleretrejele verhält.

Bei dem grofien hutresese, das sich allseitig den Kolonien znwemlet, ist a nötig. dis tropischen Verhältnisse näher in Betracht zn

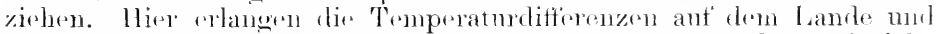

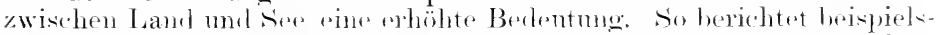

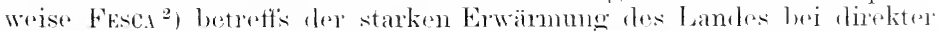

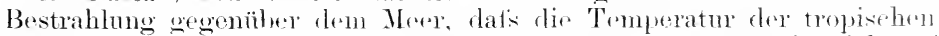
Mrore selten nehr als :30" (. lecträgt, während las frestrin sich ant

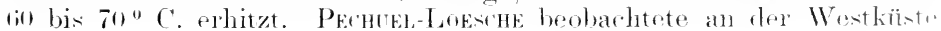

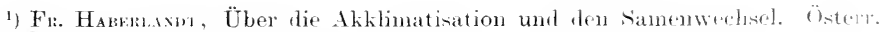
landw. Wochenbl., 1875, Nr. 1.

?) Pflanzenbau in den Tropen und subtropen. S. 2:?. 
von Atrika in $;^{0} s$. Breite zwischen 1. Januar und 4. März nicht weniger als 36 mal eine Bodentemperatur über $75^{\circ} \mathrm{C}$. Demgegenüber aber stehen nächtliche Abkühlungen auf' 150 (C. und weniger. Tagesschwankungen der Bodentemperatur ron 30 bis $40^{\circ} \mathrm{C}$. werden in den Tropen häufig sein, wogegen die Tagesschwankungen des Meeres höchstens $1^{\circ} \mathrm{C}$. betragen dürtten.

Infolge der verschiedenen Erwärmung ron Land and Neer muts an Tage bei der intensiven Bestrahlung ïber Land ein Minimum entstehen, welchem die Inft rom Meere her zuströmt: ungekehrt in der Nacht. Diese See- und Landwinde sind bei den stärkeren Gegensätzen der Erwärmung von Land und Meer in den Tropen und Subtropen bedeutend intensiver nud rin Faktor, mit dem zu rechnen ist. Die Lutt über dem Neere ist nach Stivo ${ }^{1}$ ) beinahe frei von Schimmelpilz-. Bakterien- mnd Hefekeimen, während die Luft über dem Lande (untersucht wurde Strafsen- mol Gartenluft in Tokyo) namentlich in feuchten und warmen Perioden besonders keimreich ist. Der Seewind wirkt somit luftreinigend. Nach den Polen hin nehmen die Seewinde ab, da tas Meer allmählich eine höhere mittlere Wärme annimmt wie das Land und auch die Tagesschwankungen des Bodens weringer werden.

Den periodischen Tageswinden entsprechen durch die starke Erwärnung der grotsen Kontinente aus demselben Grunde die wechselnden Jahreswinde, die Monsme, denen die Vegetation sich anpassen mufs.

Von der Lage zum Meer und der Höhe der Temperatur sind auch die als Regen auftretenden Niederschlagsmengen abhängig und dementsprechend sind diese im warmen Seeklima am stärksten, im Kontinentalklima am geringsten. Den dentschen Nordseekiisten entspricht mugefähr ein Jahresmittel von $90^{\circ} \mathrm{C}$. Bei $80^{\circ} / 0$ Sättigung würde die Luft $7.26 \mathrm{~g}$ Wasserlampt im Kubikmeter enthalten. Wenn sich die Luft anf + " C. abkïhlt, so vermag sie nur noch $6.9 \mathrm{~g}$ Wasserdampf pro Kubikmeter zu halten. und es muf sich also die Infferenz als Niederschlag ausscheiden. Wenn eine Tropenlutt von 250 ('. bei derselben Sätigung $(80 \%$ ) sich betindet, entlält sie 18.48 g Wasserdampf und scheidet bei einer $\mathrm{Al}$ -

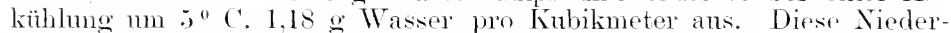
schlagsmenge beträgt also mehr als das Dreifache ron der bei derselben Temperaturerniedrigung betrottenen Luft von $9^{\circ} \mathrm{C}$. an den Nordsecküsten. Daraus rrkären sich die starken tropischen Regenfälle und namentlich dir starke Taubildnog. die stellenweis als rinzige Wasserquelle för eine gewisise Zeit in heifsen Klimaten ansreichen muts.

So wenig bei Anbanrersuchen dir Bodenanalysen und die Temperaturmittel cinen irgend genügenden Einblick in eine etwaige Nährstoffverwertung seitens der Kulturpflanzen bieten, ebensowenig kam der jährlichr. Regenfall einen Anhalt über die Fenchtigkeitsverhältuisse riner Groend geben. Denn es kommt wesentlich auf die Bodenvorhältuisise mil die Verteilung der Niederschläge auf die einzelnen Monate an. Die Wüste Sahara empfängt (s. Fesca) in einem grofisen Teile inres tielietes die gleiche und eine grösere Regenmenge. die für Deutschlands Ackerban als ausreichend gilt (if) ( $\mathrm{m})$, ohne dafs dort ein wrentliches Eroelnis erzielt würde. Demn anf einem stark erhitzten Boden verdumstot die gröfste Menge der Fenchtigkeit sofort. Die

1) S.rm, Cutersuchungen äber die atmosphärischen Pilzkeime. Jonrn. College of Science. Tokvo. Tol. Prill. 
erwünschtest. Verteilung der Regen in den Tropen ist nicht die gleich. mäfsig über das ganze. Jahr sich erstreckende, sondern diøjenige, die bri uns besteht, nämlich dats zu Beginn der Vegetationszeit eine Periode reichlicher Niedersehläge sich einstellt und rlamn eine Zeit der Trocken heit folgt. Die in rler Regenzeit reichliche Bewölkung trägt zur Her stellung der kïhleren Temperatur, die zur Entfaltung der regetativin Organe besonders günstig ist, wesentlich bei.

Im Seeklima ist die Bewölkung stärker als im Kontinentalklima. In den Gebieten grofser Lufterockenheit, wie z. B. am Mittelmeerbecken, sincl mehrfach im .Jahresmittel nur $20 \%$, in den trockensten Monaten oft nur $10^{\circ}$ o des Himmels bewölkt, in den teuchten Tropen nieht selten mehr als sil ${ }^{\circ}$ o. Da aber die Bewölkung dio Bestralılung und Ausstrahlung vermindert. so mut's in den niederen Breitru eine Ernierlrigung, in den höhern Breiten eine Erhöhung der Temperatur stattfinden. Diese 'Temperaturerniedrigung und Bewölkung sind für manche Kulturen ein Bedürfnis und dïrfen nicht aul'ser acht gelassisu werden, uncl wir glauben beispielsweise mit Znмkrmsx ${ }^{1}$ ), datis manuhe Erkrankungen in den Kaffeeplantagen. namentlich das übermätsign Fruchttragen. auf die mangelnde Berïcksichtigung des Schattenbediurtnisses zurückzutühren sind. Ehenso möchten wir glauben, dats dis richlichen Pilzkr,ankheiten, die sit Beginn der Teekultur im Kakkasms

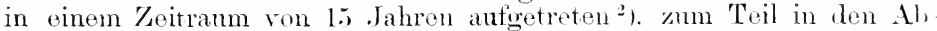
weichungen des kaukasischen Klimas ron dem der Heimat dee Tees ihren tipund haben.

Dats sich die Futwicklung des PHanzenleibes den oinzelnen Komhinationen der klimatischen Wachstumsfaktoren anpatst. ist sellstrer ständlich. und rlie nenere Biolngie berïcksichtigt nummehr auch diest: Umstände, wie z. B. die Arbeit von Haxsink: $\left.{ }^{3}\right)$ zeigt. der rom stenu phyllen Windhlätern (wie hei dem Weidentypus), von Lerler- und Windblättern (Palmentypus), von xerophilen Laderblättern (.Myrtus. Laurus), ron Taublättertypen (Bromeliaeeen. Pandaneen). Dickblätern (Crassula- und Mesembrvanthemumtypus) nsw. spricht. Das am meisten in die Augen springendr. $\mathrm{B}$ ispiel bildet die strandregetation mit ihrem Halophytencharakter. Die fleischige und glasige Berchattenheit der Vegetationsorgane fïhrt Brick $^{+}$) aut die reichlichen Natronsalze zurïck. die einen änferst starken 'Turgor im Parenchrm voranlassen.

Je mehr wir Bewoise datür sammeln. dats der Organismus sich den klimatisehen Faktoren anpalst. desto meh werden wir von der Fehlorhattigkeit lor Anselnaung ïberzengt werken, dats man straflodie klimatisthen Sippen. die sich bei jeder Kultursorte bilisn. beliebig versehioben kïnn. Wenn anch die Gesamtsummen der klimatischen Faktoren in zwei räumlich weit entfernten Örtlichkeiten ühereinstimmen mögen. so ist damit noch keme Garantie tür das eqleich

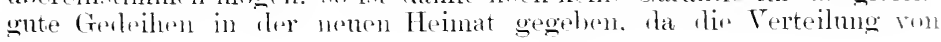

1) Zimsenmas, Sonderberichte über Land- und forstwirtschaft in DeutschOstafrika. Bil. I. Heft 5. 1903.

2) Sieschew, Travaux du jardin bot, de Tiflis VII, 1. Verhamdl. 1. Lutrmat landwirtsch. Congresses in Rom $190 \%$.

3) Hixima, A., Phrllobiologie nebst Übersicht der biologischen Blatttrpen usw. Leipzig, Borntrïger. 1903.

4) Виск. Beiträge zur Biologie und vergleichenden Anatomie lej haltischen Strandpflanzen. Cit. Bot. Jahresh. 1-85, I, S. T65. 
Litht. Wärmo und Fenehtigkeit anf die rinzehen Wachstmosperioden

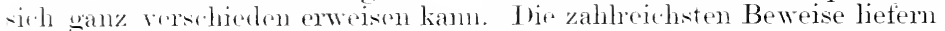
div Erkankungen derjenigen Neuholländrr-md Kapptlanzen, die, einem troelinen Klima angepatst. ilw Ixelen in mseren somenamen, feuchten

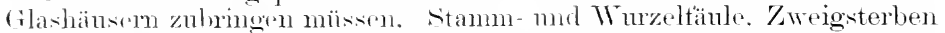
dureh Butrytis ms. schädigen die Kulturen in jedem Winter hedenk-

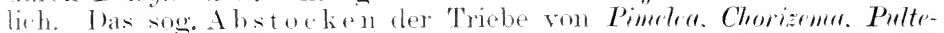

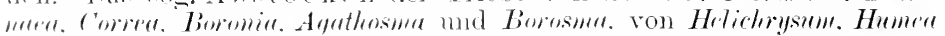

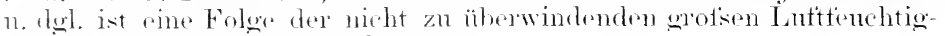
kejt in moseren Vienetationshänserus.

\section{$\therefore$ Einfluls des Waldes.}

Der Einfluts diex Lane nut Bodenbeschatfenheit aut die Vegetation wirk lokal moditiziont durch die Bewaldumg. und diesem Punkte hat dir Patholonie rims crhöhte Autmerksamkeit zuzuwenden. Der Wahl ähnelt in seinem Einflufs grötseren Wasserflächen: dem da die organische substanz wine höhere specifische Wärme als die Nineralsubstanz besitzt. wind der hewachsene Boden bei gleicher Besonnung sich weniger stark erwänmen als das nackte Gestein oder der Sand. Die Sommerlitze wird also lureh Wald gemilhert. Bei der reichliehen Verdunstung des Laubliarpers dex Bäume wird die Lutt eine nm so feuchtere sein, j. dichter der Bustand und je geringer die Luttbewegung ist. Entsuechent der stärlieren Virdunstume diurte ïber den Wäldern leichter Wolkenhildung erfolgen. mul diessbe wird auch nicht so leicht zerstrut werelen. La der relative Fouchtigleitsgehalt der Lutt in und ïher dem Talde onotser ist, wird leichtere mul reichlichere Taubildung rintreten. Die Wueht der Regengüsse wird vermindert. Da die sharfen Regen. namentlich bei geneigter Lage. rom Erdeeich nicht so schuell anternommen werden kömme rimmen die Wassermassen rom

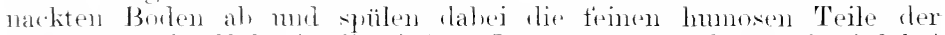
Folder vou der Höh in dir tieferen Lagen. Der Foldbestand wird bei jährlicher. Wiederhohumg dioses Vorganges drartig geändert, lats die hohen Lagen veramen mel ein num wonis truchtbares Bodenstelett

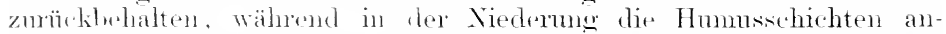

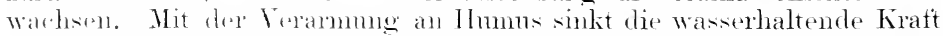

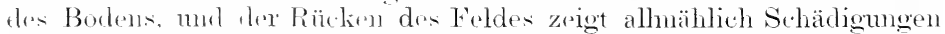
durch Wassmangel. Buj shweren Börlen führt das beständige Auf-

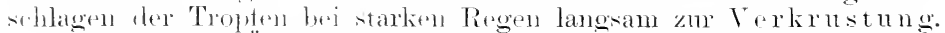

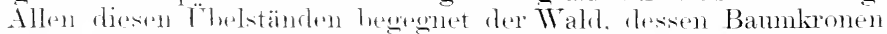

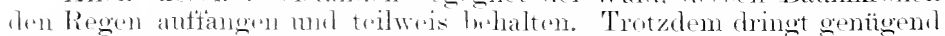

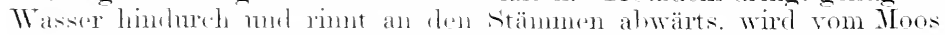

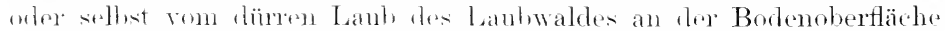

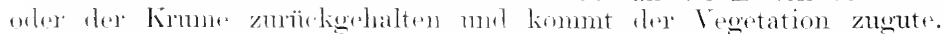
Finge positive Kahlen ïber die hies theoretisch eröterten Verhältnisse

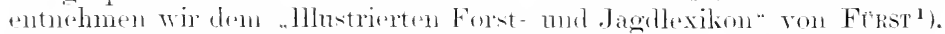
(instïtzt ant die Beobarhtumen dre forstiehen meteorologisches statiomen wirl angegelyen. rafs die Luftemperatur im . Jahresdureh-

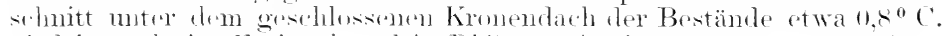
niredriger als in Freirn ist. Dio Differen\% ist im sommer am grötsten

1) Illustriertes Forst- und Jigdlexikon, II. Aufl. Herausg. Dr. Henum Fins. Burlin 1904, Paul Parer. S. :384. 
(bis :30 C.). während sie im Frähling nnd Herlst dem .Jahresturchselnitt gleichkommt und im Winter tast versehwindend ist. „Div Tomperatm. schwankungen sind unter den Kronenschirm geringer als im Eresien."

Die Temperatur des bewaldeten Bodens ist zu allen Jahreszeritrn nm 1 bis $: 0^{0}$ C. niedriger als diejenige im Freilande. Die absolute. Fenchtigkeit ist im Walde und im Freion nicht verschierlen, dagegen wegen der niedrigeren Tompratur dic rolative Frubtigkeit im IValus

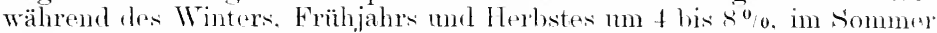
um 12 bis 200" höher als im Freien. l)ie Verdumstung einer fiein

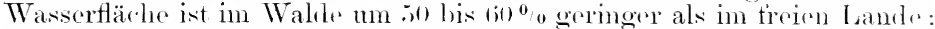

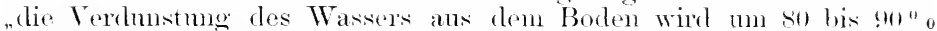
herabgesetzt." Fou then Nieflersehlägen wrelen je nach Holzart, Altel'

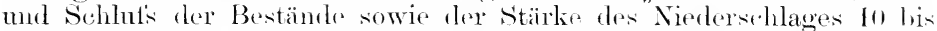
70 ${ }^{0} 0$ von den Baumkronen zurïckgehalten, hei sohwachem Regen viel-

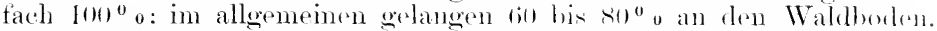

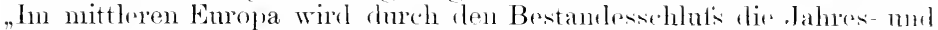

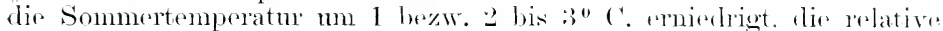

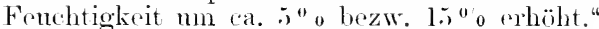

Da man die crötse der Fernwirkung von ansegedelenten Waldungen noch nicht festgestellt hat. so bleibt die Erage des Eintlusses der Bu. waldumg auf das Klima eine offene: abere eine Wirkume des Walıles

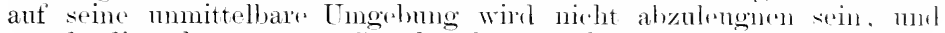
gerarte diese kommt rom Standpmukt der Phytopathologie in Brotracht.

Der Unterschied in eler Insolation. dis im Walde sehe woring. im fireien Felde soh schmell wurl stark durch Erwärmmo dos Bodens umb seiner darüberliegendon louftschichten sich weltemel machen muts, wirl eine ausgleiehende Luftströmung evengen mössen, die namentlich in

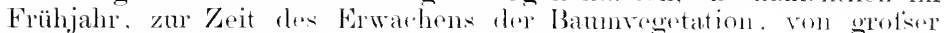
Berlentung werden kann.

Einen Einblick in das Leben der Waldrecretation geben die. Tntre-

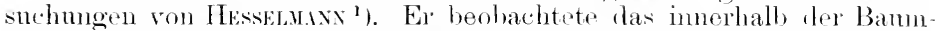
kronen sich vollziehende regelmätsige Absterben der \%weige und tand. dafs deren Blätter be Esche. Birke mel Eberesehe noch stark, bei Hasehuts merklich weniger in assimilatorischer 'Tätigkeit begriften waren. Wenn gut belenchtete Zweige absterben sind Korrelationserscheinungen dabei in spiele. Die schattenertragenden Bäume biltrn ansgeprägte Licht- und Schattrub]ätter ans: die lichthedürftigen Bämme zeigen rliese Differenz nicht. Dir Assimilationstätigkeit der Bodenflora ist in den unbelaubten Bamm- mel Stranchbeständen im Frühling soln lebhaft mul sinkt mit der Belaubung - bei den Schattenptlanzen intolge der Blattstruktur langsamer als bei somenpflanzen — bis zmm sainzlichen Authöron. Mit dem verminderten "Nahrungskonsmm" sinkt aurh die Atmungsintensität. Alereschnittene Schattenblätter von Comallarin majalis n. a. bilden sowohl in der somne wie in schatten mehr stärke als ebense behantelte Somnenblätter mol zersetzen bei demselben

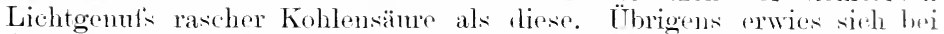
Convallaria die Stärkespercherume un so weringer, je trockner der Boden war. Gleicherrotse Blattfächen von Blättern mit Palisitenzellen transpirieren weit stärkel als diejenigen, deren Blätre di. Schattenblattstruktm besitzen.

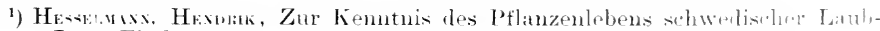

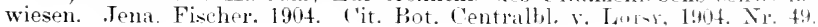




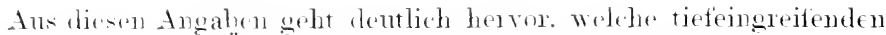

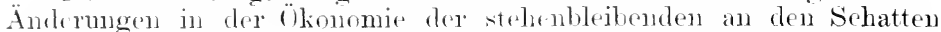

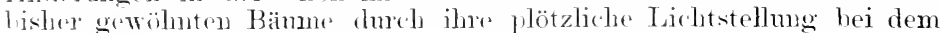
Niedrechlagen von Walduartion sich vollziehen müssen. In Parkanlagen rärht sich sine zu starke plötzliche Anslichtung durch Entfrum zahlrejoher Bämm uicht selten durch teilweises oder gänzliches Alsterben dex Bammlinen bej das stelongeblielenen Exemplaren.

Wir mïssen mosere Anfinerkiamlirit ancls noch ant einen anderen Punkt lenkin:

Man hotrarhtre oinmal die nit (H)sbäumen beptlanzten Chausseen in der Elone. namentlich die Kirsclualleen. und man wird Beispiele sonug finden, hej dencis die stämme anf der Süd-oder Südwestseite anfigesprumeras. mit Fotz'n ahgeplatzter Ringellorlie bedeckt sind und liantig anch noch Gummilimmen an clen Wundstellen erkennen lassen. lie Tutremehmg ergibt alle Merkmale der Frostbeschädigungen, und diese rklären wir damit, dats die von Wald entblötste Ebene getährlich werklenden Temperaturextremen im Frühjahr ausgesetzt ist. Die Feln'nar- mul Märzomn molilisiert fïhzeitig dic Reservestoffe. indem sie sich in ilnex ganzen Intensität an die Stämme anlegt und durch lio Bodruletlexion in ihrer. Wirkung verstärkt wird, mod das wasser-

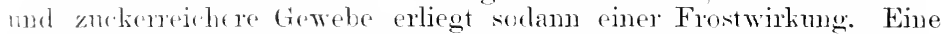
truchtere Atmosphäre in dor Ungebung vou Wasise- oder Waldflähen ist temperatmanselechend und frostschüzend.

selhstrerständlich wirken in Gegenden mit grötieren Boden"rhebungren. Wo sich die Differenzen zwischen Tal und Bero bereits hemerklich machen, diese bestimmend und oft ansichlaggebend mit: aber in dre Ehene wird die Bewaldmo zum sehr beachtenswerten Faktor. I)as Niederschlagen grötserer Waldbeständs in weiten Ebenen lächt sich nicht wu vielfach am Besitzer allein, sondern anch in der weiteren Umgelomng. indem es die Gefährdung dureh die śpätfröste steigert. In dieser Beriehmug glauben wir, dats namentlich viele kleine Waldbestände. rurch eine wotse Ebene verteilt, von Nutzen sein werden: dem aut "ins bedentende Fermwirkum eines emzigen grotien Waldes diirfte kaum zu rechmen sein.

Anorliannt ist ferner der Nutzen des Waldes als Windschutz, talls nicht (robirgrälden densolhen übernehmen. Wie jede Lichtseite aber anch ihr. Sichattruseite mit sich hringt, so finden wir auch schärligende Einfliises des Thalkes ant die angrenzende Feldflur. Je wach seiner Lage zum Felde kam der Wald die meist von Westen kommenden sommerlichen Rexengüss ablıalten, so dats wir trockne, windstille Feldstreifen in der umittrlharen Nähe omes Waldes exhalten: ofler der Wald läfst im (iegenteil dess Feldstreifon tï̈ die Regen zugänglich und verhindert rine "rwiuschte schull, Abtrocknung der siaten. Im ersteren Falle kann der. Waldsam rin schützender Kufluchtsherd fǜ schädliche Insekten wredrus. So ist molnfach beobachtet worden, dats die Zwergrikade von trocknen Waldrändern ans ihre T̈berthntung der Ärker begonnen hat. Als Bejsiel drr Begünstigung von Krankheitserregern dureh rine lange sich haltende. Fenchtigkeit in der Nähe des Waldsaumes dienen die Medelusen üher äösere Intensität der Erkranlsumg

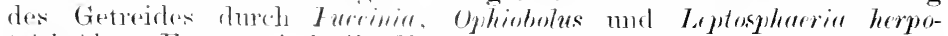

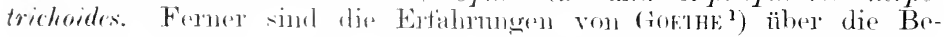

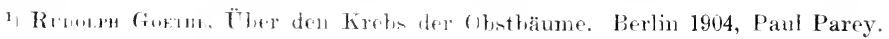


giunstigung anzutühren, welche der durch Nictria ditissima hervorgerufene Pilzkrebs der Obstbäume durch den standort erfährt. Die Neigung zur Krebserkrankmng wird durch einen erhöhten Feuchtigkeitsgehalt der Lutt begünstigt, wie ihn die oberen Lagen gebirgiger Gegenden oder auch kalte Talböden darbieten. "Die Bäume zeigen an solchen Stcllen dürftiges Wachstum und sind mit Moosen und Flechten bedeckt. Ähnliehes beobachtet man in der Nähe von ausgedehnten Wäldern. aus denen bis in den sommer hinein kühle. fenchte luft ströint."

\section{Zweites Kapitel.}

\section{Engiinstige physikalische Bodenbeschaffenheit.}

\section{Beschränkter Bodenraum.}

Die Wurzelkrümmungen.

Für den praktischen land- und forstwirtsehaftlichen Betrieb spielt die Frage der Beschränkmos des Bodemaumes, wenn damit nicht Nähstoffmangel verbunden ist, eine untergeorlnete Rolle: dem die Ernährungsstörmngen, die dureh Überwachsen mel Reiben dieht aneinandergeprefister Wurzeln oder deren Einwachsen zwischen Gesteinsspalten entstehen, erlangen keine wirtschattliche Bedentung. Anders dagegen liegt die sache bei dem gärtnerisehen Betriebr mul der Kimmerkultur der Pflanzenlicbhaber.

In diesen Kreisen sind aber die Meinungen äber einen Einfluts des allzureringen Bodenrammes fü̈r die Wurclausbreitung sehr geteilt. Vorherrschend und anch seitens mancher Agrikulturchemiker ausgesprochen ist die Ansicht, dats flie mechanischen Wirkungen bei dicht aneinandergeprefisten und in mamnigfachen Krïmmungen durchcinandergewirten Wuzeln ohne Einfluts auf das Cefleihen der Pflanzen sind. Es könne sich hei beschränktem Bodenraum immer nur darum handeln, dat's ein Nährstoffmangel sich sehnell geltend mache, mol diesem sei mit Torteil durch Hüngumg abzuhelfen. Wer heste Beweis liege in der Anzurht der sog. .. II arktpf'lanzen" der Gärtuer in crotsen Städten, die, dem Geschmack des Publikums entsprechend, äulserst kräftige Büsche von Blïtrupflanzen (Fuchsien, Pelargonien, Begonien nsw.) in rolativ sehr kleinen Blumentöpfen heranzuziehen wissen.

Die 'Tatsache ist richtig. die Dentung aber unzutreftend.

Die Beschränkung einel grotien Wurzelmasse auf einen kleinen Raum hat zunächst die. Vermehrung der Wurzelkrümmungen zur Folge, nud diese Krünmmo bildet flie Teranlassung zur gesteigerten Produktion von Seitenwurzeln. Diese Erscheinung lätst sich leicht bei Wasserkulturen beobachten. Wenn eine stärkere Wurzol den Boden des cilasgefälses erreicht, und die Spitze sich mun umzulegen gezwmgen ist, entstehen alsbald neue Seitenwureln. NoLL ${ }^{1}$ ) hat diesem Umstante? ein besonderes studium gewidmet. Er fand, dats an gekrimmten Wurelstrecken die Seitenwurzeln einseitig aut der Konvexflanke an

1) Nom, F., Ëber den bestimmenden Einflufs der. Wurzelkrümmmmen auf Ent

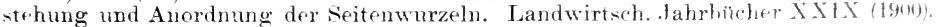
s. :itil. 


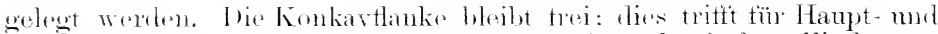

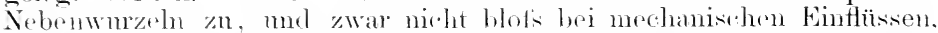

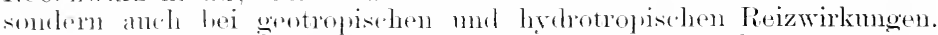

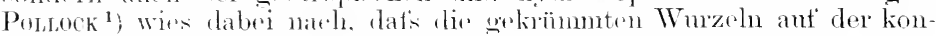

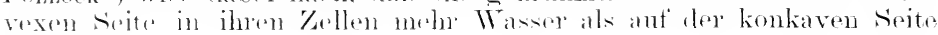
(sithialten.

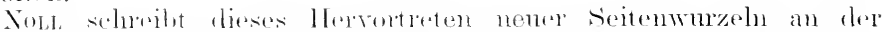

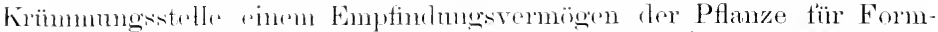
verhälnisise des eigonen Kärpers (Morpliästhosie) zu. Man kann

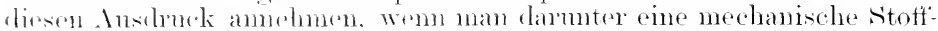

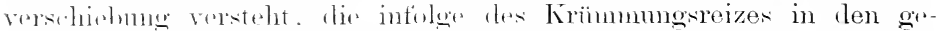

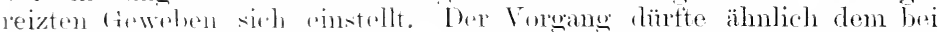

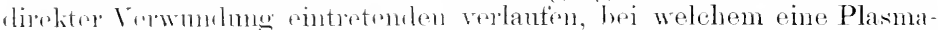
anhäntine in den der Wunlflache henachbarten Zellen sich nachwoisen lätst. Sulletrerstandlieh begegnet man anch Seitensprossungen an konkaven strllen gekrïmmter. Wurzeht aber in solehen Fällon war dir Anlage des seitrnorgans shom vorhanden, hevor die Krïmmong der Muttriwmzel statturefumen hatte.

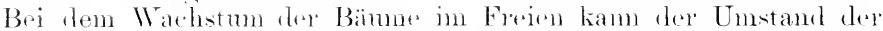
Entwieklung ron Sisitrmmosh an der Konvexseite praktischen Vorteil haben. indem die Pflanze fester verankert wird mol sich Borlenrämme

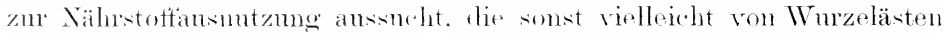
nieht durehzogen worten wären. Aher in dem Falle. wo der cresantworzelballen nu einen bestimmt zugwiesenen engen Bolenram zur Verfügung hat. wir bei den Toptknlturen. entstehen Nachteile, dio in Are Prorluktion der oranischen śuhstanz zun Ausdruck kommen mïssen.

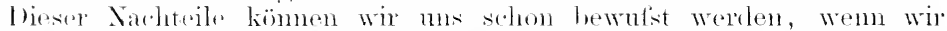
rinen sog. durhorewrzelten Topthallen näher betrachten. Die grölste Menge dor jungen Wurzehn ist nach der Peripherie gedrängt mol derart

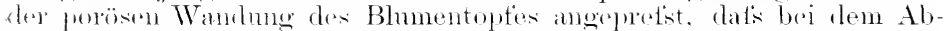
heben do Topfes zahlreiche Fasern abreiten. Ein Teil der WVurzel-

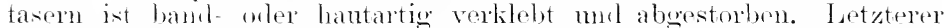
Tmstamel fällt namentlich bei Palmen mol lracaenen ins Auge, bei renen die toten Wurzeh mo noch ans der Stele, dem Achsemzylinder. und hem wie eine papierartige Hülse zusammongetrockneten äutseren Rinclenkïrper hestehen.

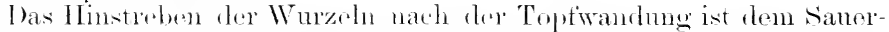
stoffledürtinis des Wnrzelkürlers zuzuschreiben. Dasselbe kann natürlich un so weniger befrierligt werden. je dichter das Wurzelnetz den Erdhallon durehspmmen hat. I azu kommen num die eigenen A us-

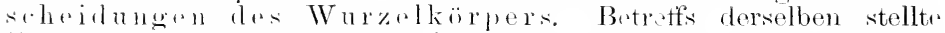
("zaPE") fest. dats sie sowohl in touchter luft als anch bei Wasserkulturen nachwejshar sincl. Im dampfigesätigten liame bemerkt man dieselben nicht selten in trestalt von Tröptehen an den WVurzelhaaren infolge starken Inmenclunckes dre \%ellen.

Ansqeschieden werden minimale Mengen von Kali, Kalk, Magnesia, Salzsäme. Schwefelsïme und Phosphopäme. von denen das Ralinmphosphat, das dir bekannte Rötung des Larkmuspapiers veranlatst, etwas

1) Poblosk, Jum, The mecanismm of root curvature. Botan. Gaz. Chicago, XXIX, 1900. S. $1 \mathrm{ff}$.

2) Czirk, Fis, Zur Lehre von don Wurzelatsscheidungen. Jahrb. für wiss. Bot. 1896. Bd. 29. Heft III. 


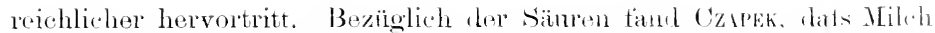
säure und Essigsäure sich nicht nachweisen lietsent dagegen wan Ameisensäure in Form des Kaliumsalzes als Ditfusionsproinkt ilto. lebenden jüngsten Wurehpartien nicht selten autzufinulen. Bai der. Hyazinthe wurde Kaliumoxalat ausueschiorlen. Tor allem abor kommt die Kohlensäure in Betracht, welche anch das Anätzon der trestrims

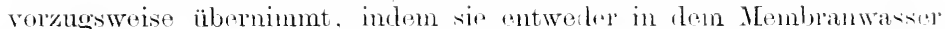
der Wurzelhaarzellen oder in Wasser ler Bolleninterstitien pübst aufititi.

Mit diesen Wurelanssuheirnngen, namentlieh dem MEonolialium phosplat, und der Kohlensäme ist mun zn rechnon. Bi den 'Toptkulturen handelt es sich besonders nm die letztere, die in grotsen

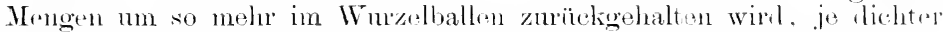

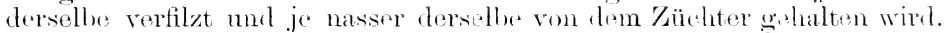
Dir Kohlensäureprodulition wird andserdem bedentend dureh den Atmung prozets der Mikroorganismen im Boden vernolut, wolehe zum Authan ihres leples dio Kohlenhydrate und andere organische sulstanzen zer.

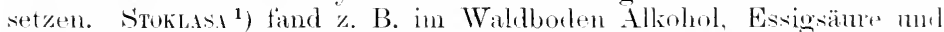
Ameisensämre, bis schliefishich Kohlentioxyd nebst Wasserstotf gobildet wirl; letzterer oxydiert wohl grölstenteils zu Wascer. Das Abstaluen eines Teils der Vurzeln dur.h Sanerstoffinangel und Kohlensäneüberschuts ist also ein allmählich zur troltung kommenter Prozels bi der Kultur der Pflanzen in kleinen Töpten, anch wron man denselhen durch Döngung überroichlich Nährstottinaterial zutührt. Wirrl

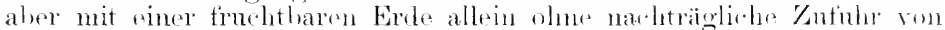

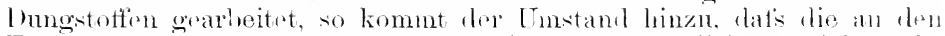

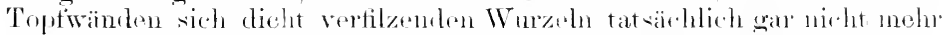

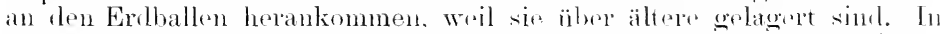

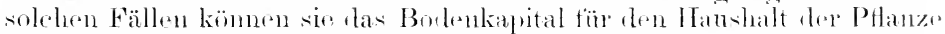
nicht mehr mutzhar machen.

Das der äbermäfsig beschünkte Bodenram an sich dir. Produlition

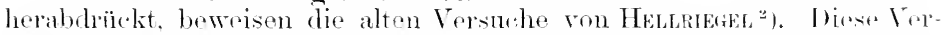
suche wurden in der Art auscefülut, late mannigfache sowohl sin-

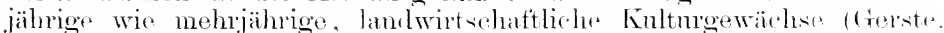
Erbsen. Buchweizen, Klee nsw.) in verschieden hohe Glasegetation in möglichst gleichmäkige tartenerde cresät wurden und mutre Bobachtunw aller für tie Sant- mul Wasserknlturen geltenclen Kautelon aut dirm

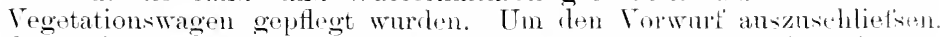
datis bei den erlangten Rsultaten nicht das verschiedine Bolmoolnmen.

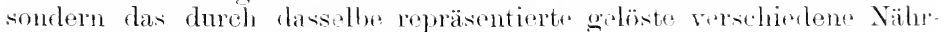

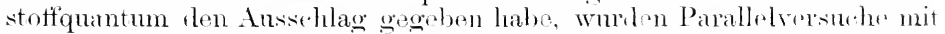
reicher Düngergahe unter sonst ganz gloichen Verhältnissen angestellt. Das Ergebnis dieser Versuche war. lak sich gar kein Untrsehied in der Produktion zugunsten der gedüngten PAanzen zeigte, dat's somit die nicht gedüngten alles, Was sio an Nährstotfen tï̈ ilure Prodnktions branchten, in der ungediungten Gartenerde vorgefunden laban mutsten. Ein indirekter Beweis lag anch noch in den Versuchsesultaten. whlur die ungediungten Pfanzon boi Vergleich miteinandel liefirton.

1) Sroktasi und Emasr, Über den Ursprung. die Menge und die Bedmutung d... Kohlendioxvds im Boden. Centralbl. f. Bakteriologie usw. II. Ah. B l. CIS 1905. S. 723.

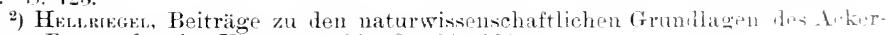
baues Braunschweig. Vieweg, 1s:?. S. 1:4-2.24. 
Div Erute zeigte nämlich, dats ter Klee in seinem ersten Lobens-

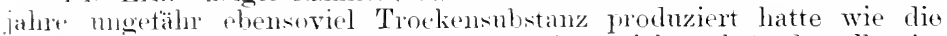
iilorigen Ptlanzenarten. Dies hinderte abex nicht, dafis derselbe im \%witrn Jahne ant demselben Boten eine zweite. nut zwar eine zwei-, lest. dreimal so grotive Ernte erzengte mo selbst in eimem dritten Jalire noch so viel PHanzensmbstanz produzierte wie im ersten Jahre. Man sieht daraus, dat's leei kemem der Versuchstöpte die Nährstoffnenge eine Rolle spielen liomnte. da überall Nährstoffe im T̈berschnts vorlianderen waren.

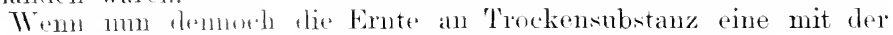

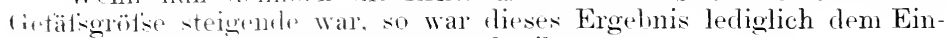
Huts des Budenvolumens zuzuschreiben.

low Versuch-ptlanzen standen in Glaszylindern von unten bezeichneten Limensionem und Inhalt. erhielten stets an Wasser zwischen :30 lis tio", ler wasserhaltenden Kraft des Bodens und ergaben: Klec:

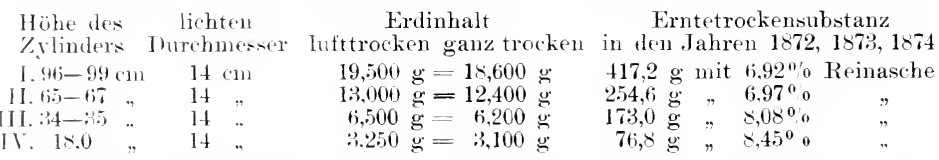

La bei den Gefatisen mit sehr grotsem Bodenvolumen durch das zn Anfang stattfindende plötzliche Zutühren der grotsen Wassermengen, lie den Boden aut $60^{\circ}$ o seiner. Wasserkapazität sättigen sollten, ein zu plotes Festsetzen mol daher ein etwas abnormes Verhalten einiger PHanzen eingetreten war, so hat Helliegel in seinen Erntetabellen hesonders die Ergebnisse von Grötse III und IT herangezogen. Dahei stulte sich hraus, dat's bei den Erbsen eine Bodemmenge von

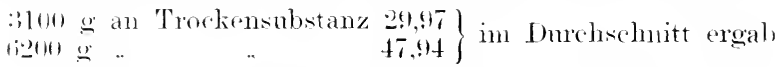

$$
\begin{aligned}
& \text { Exhsen, also Vorhälnis des Bodens } 1: 2,
\end{aligned}
$$

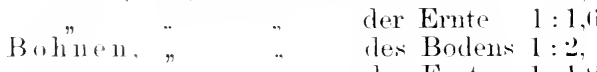

Bei fierste alls dem Jahre Isid fanden sich genau dieselben Verhälnisse in dem Emterergehnisse wie bei den Bohnen. Wir unterlassen dite Tiedergabe der anderen Kahlen, da die hier angetührten deutlich genug zeigen, dats, wenn bei zwei gleich weiten, aher rerschieden hohen (iofiilsten, die heide Nihrmaterial im Überfluts hatten und stets die zusagende Menge Wasser erhielten, die Bodenmenge sich wie $1: 2$ verhielt, lin Ernte sich wie $1: 1,1 ;$ bis 1,8 heransstellte. Es ist also rin in the Angen springender Einfluts des Bodenvolumens konstatierbar. und es ist nmm die Frage. wie sich dieser Einfluts erklären lä1st.

Hrobikita tand. datis die Höhe des Ertrages im nmgekehrten Verhaltnis zu dersumme der meehanischen Widerstände, welche der Entwicklung des Wurzelnetzes der Versuchspflanzen entgergentraten, stand.

Wrmn die Gärtne'l bei ihren Marktkulturen stheinbar das Gegenteil erziclen, nämlich trotz der kleinen Blumentöpte schr schnell gewachsene, hoeh ausoghildete. oberirdische Achsen, so erklärt sieh dies auf folgende einfache Weise. Dit Gäntner wrben äutierst nahrhatte Erden, so dat's hochkonzentriert، Läsungen in Boulen sich vorfinden. Vergleichende 
Messungen aber zeigten mir, dats der Wurzelapparat in reichen Nährstofilösungen aus wesentlich kürzeren Ästen sich anflaut als in schwach konzentrierten: mithin ist tatsächlich also wenjuger gegenseitige Belästigung der Wurzelfasern untereinander vorhanden. Anfierdem aber arbeitet der Wruclkörper in derselben /eiteinheit hei seinem Aufenthalte in Glashause oder Mistbeetkasten weit stärker als dort. wo die Pflanzen sich selbst überlassen sind, im Freien: dem diese Glaskästen haben sämtlich Bodenwärme. Num lommt schlief'slich noch hinzu, daf's auch die oberirdische Achse in Verhältnissen sich hefindet, die sine ganz hesonders schnelle und reiche Ausbildung ermöglichen. Nie an Tasserdampf und Kohlensäure reiche Atmosphäre veranlatst rine möglichst stark Vergä́lserung der einzehen Zellen unter verhältnismätsig geringer Transpiration: daher die Turgescenz und hedentende streckung ins Laublïnpers, die sich namentlich bei Blattptlanzen geltend machen. Es. wird also bei den gärtnerischen Kulturen in kleinen 'Täpfen der Wurzelapparat tiöher und besser aufgebaut und ansgenützt. so dat's dir. Schädigungen der Wurcelkrümmungen und Quetschungen erst zu einer \%eit sich geltend machen, in welcher die oberirclische Achse schou eine erhebliche Produktion hinter sich hat. Dat's aber die Gärtner die Nach. teile der kleinen Täpfe sehr gut kemen und. wemn nötig, auch zu vermeiden wissen, geht aus den sog. , M astkulturen" hervor. Hierbei werden die Exemplare immer wieder in orötsere Töpte rerfflanzt, sobald die Wurzeläste nur einigermation zahheich die Vand des Gefätses erreicht haben.

\section{Der Zwergwuchs (Nanismus).}

Als eine interessante Verwertung fles Einfluss leschänlton Bodenraumes mödhten wir die im Handel unter der Bezeichnung .japanische oder chinesische Lobensbä ume" lefindlichen Kwergkoniteren antühren. Die umstehend. Figur bringt die Ansicht von einem lebenden Exemplar, das von der althekamnten Firma .J. C. S'нun' (Berlin) als Thuja obtusa bezeichnet und ms fireundlichst zur Verfïgumg gestellt worden ist. Der Bam hat mit dem 'Topt eine Höhu. von sti cm und von der Erdobertläche an von 60 cn. Die gröliste Breite der hrone beträgt st em. Die in mehrfache vorspringend. Leisten sich teilende Stammbasis hat $19 \mathrm{~cm}$. der Stamm in der Kronenhöhe, wo die erste Verästelung sich zeigt, 1르 'm Thurchmesser. Das mit dichter Krone rersehene gesunde Exemplar. dessen Altor auf 160 .Jahr geschätzt wurde, solltw :i, Mk. kosten.

In der Literatur finden sich mehrfach Notizon. welche anf die von Japanern und Chinesen geähtr Kmst hinweisen, hundertjährige Zwergexemplare von Bämnen als 'Tatelschmuck zn zichen ${ }^{1}$.

1) In einem Artikel aher "Zwerglildung in Pflankenreich" (Gartenwelt 1504

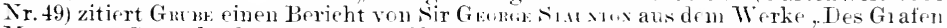
Macartney Gesandtschaftsreise nach China", Berlin 179k. si.n.w. sah auf den Tischen im Audienzsaale zu Ting-hai Fichten, Eichen und Prmmeranzenbaime, deren heiner höher als zwei Fufs war und die oft reich mit Früchten besetzt erschienen. Anf der Erde des Topfes um die Stammbasis waren steine aufgeschichtet. die verwittert und mit Moos üborzogen waren, um dem Topfe das dissehen hohen Alters zu geben. .An diesen künstlichen $Z$ wergen aus dem Pflanzenreiche schien man in China durchgehends sehr viel Gesehmack zu finden: denn wir fanden sif in eler Folge in jedem einigermatsen angesehenen Hawise." Es wird dann weiter erzad $f_{1}$ t. dafs die "liliputischen" Bäume dadurch vemehrt würden. dats nan 1 m pinzeln. Zweige Lehn oder Gartenerde befestigt mud dienelhe foucht hält, his die Zwfic" 
Tnsere Tntersuchung pines Stammstiuckes ron einem abgestorbenen Bamm zerstort den Nimbus des Wunderbaren. mit dem diese Züchtungen japanisher und chinesischer Gartenkmnst bisher ungeben gewesen.

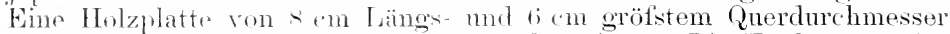
wat, das Bild änlserst "xzentriseher Jahresringe. Die Entfernung des Tarkkörpers rom Rindentoil betrug anf der einen Stammseite $1, \therefore \mathrm{cm}$,

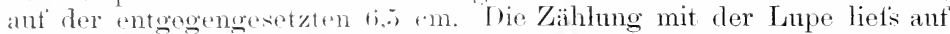
liesor Stammseite : J Jahreringe. ant der schmalen nur 15 erkennen.

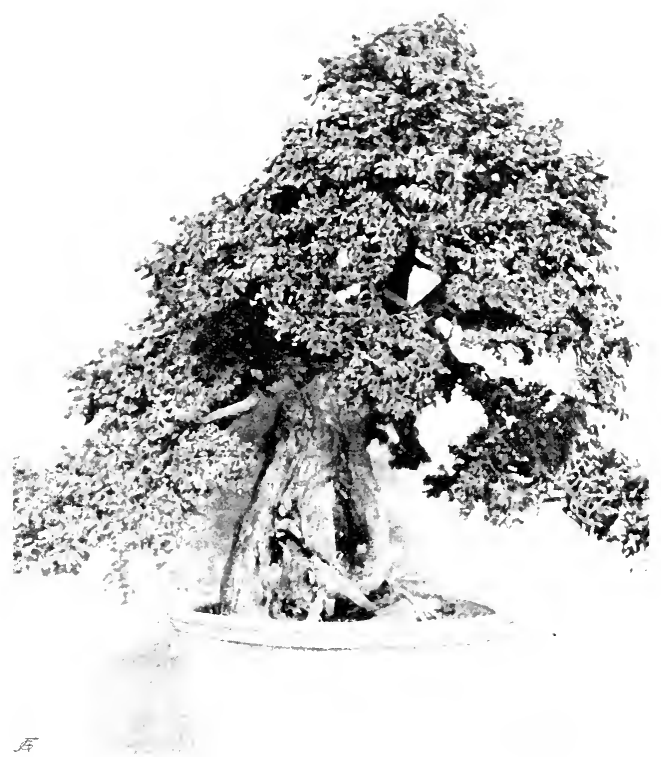

Fig. 15. Zwergexemplar von Thuja obtus, von $60 \mathrm{~cm}$ Höhe und $80 \mathrm{~cm}$ Breite. (Orig.)

Ian sitht an ler stammbasis die Spaltung der oberirdischen A.lise in eine Inzahl aus dem Topf hervoriagender Wurzeliste

Anf der im Wachstum beginstigten seite fiel es ant. dats dis Breite ter cinzelnen . Jahresinge sehr werhselte. Man konnte rier Zonen

in den Frdballen hin in nem. Wurzeln entwickeln und num abgeschnitten werden. Das Verfahren wird nach Unterbinden eines Zweiges oder Gipfeltriebes und Einlüillung der sichnürstello mit Moos auch in einzelnen Fällen jetzt noch bei uns geübt. E; geschah in ('hina, weil man beobachtet hatte, dafs der künstlich herbeigeführte Zwergcharakter erblich werde. Unterstïtzt wird diese erblich gewordene Neigung allerdings bei dem nenen Individum noch dadurch, dafs man die Endknospe des Hanpttricbes abdreht und denselben durch Draht in verschiedene Richtungen biegt. "Will man den Zwergbämmchen das Ansehen eines alten, bereits halb abgestorbenen Baumes verschaffen, so bestreicht man den Stamm oft init Sirup. ladurch werden Ameisen herbeigelockt, die, inden sie die sülsigkeit aufzehren, zu 
unterscheiclen. Jede derselhen endete mit sehr schumlen Ringen. deren Trache ïlen äntserst enghmig und durch Verkiemme liannwandig waren. Sonst war das Holz gesund. In Rindenliörper entsprach in seinen Dimensionen der Holzscheibe, d. h. "r war an der engringigen Seite $1, \therefore \mathrm{mm}$, an ler weitringigen $+\mathrm{mm}$ dick. An einer S.hmalseite fand sich eine eingelnehtete Stelle, bei der rine geringer Fntwicklung des Holzkörpers durch pine stärliere, bis $5 \mathbf{5} / \mathbf{2} 1 \mathrm{~m}$ dicke Borlienbildmug ausgeglichen war. Hier verät sich in clen einzelnen Borkenschmppen zwischen den Tatelkorklagen oime Noigmes zu Füllkork ähnlicher Loclierung.

Aus dem vorstehenden Betmole ist zmö̈rhst orsiehtlich. datis dic. Angaben über das hohe Alter der Bämne irrtümlieh sinel. Mrehr wie einige dreitsig Jahre diunften derartige Bäme nicht alt sein, mol ihr Zwergwuchs wird nach muserem Dafürhalten darlurch erzielt, datis die Pflanzen

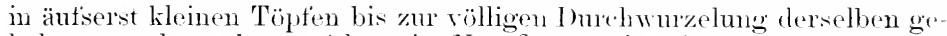
halten werdon. Damn folgt ein Verpflanzen in ein slötseres Gefäts, wobei die Wnrelkrome ïber don Topf emporgeholsen wird, mm dem Wurzelballen möglichst viel Frile zu Ausuntzung zu gewähren. Nach dem Jahre des Verpflanzens rntstehen zmächst weite. Jahresinge. und diese verengern sich tam wieder in dem Matke als der Topt durchwurzelt wird, his der /uwachs ein äntserst seringer geworden ist. und dor letztgebillete Jahresing nur aus wenigen. geliäunten llerlst holz-Tracheïden sirh aufluant. Anf' liese Wrise entstelit die stelzenartige, von den frei herausragenden Wurelästen gotragene stammbasis.

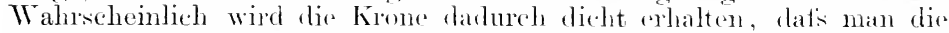
\%weigspitzen leicht hesehneislet und hiemit eine stäkese lewzwrigune

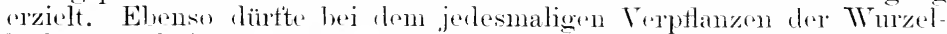
ballen beschmiten werden. Dats die Bämns fonchtgehalten wuden. schliefisen wir ans den vereinzelt auftretenden Fïllkorklorkerumgen in der Borke. Jedentalls dïrtte es auch los ms keine sebwierigkeiten haben, Bäume aus den Gattmogen Thuju. Thujopsis, Biotu, Cupressus und ähnlichen durch Beschränkmo des Borlenrammes zn derartigen zierlichen 7 weroformen heranzuzichen.

Ein sutsprechendes Verfahren wird hier mod da schon fïr Laulgehölze emptohlen. Bei der Treiberei der holzigen Blütensträincher ist es wünschenswert. lileine. möglichst reichblütige Exemplare zum Verkaut

gleich die Rinde beschädigen und ihr dadurch ein brämlichen, halhwerwittertw Ansehen geben."

Ein etwas anderes Verfahren schildert Rex ${ }^{1}$ bei don lapanern, welche die Verzwergung oder "Nanisation" ats "Tsukurmono" bezeichnen. Wir finden diesen Anstruck in den nenen Lehrbuch der Pflanzenkrankheiten von Imis") nicht. Nach Ren wird schon durch die Auswahl besonders kleiner sanden aus wenig entwickelten Individuen auf den Zwergwuchs hingearbeitet. Es komm hinzu ein häufiges Beschneiden und Verpflanzen der Baumchen in kleine Töpte, wie wir dies aus den oben in Text beschriebenen Querschnitt erschlosisen haben. Ferner werden Stamm und Äste gedreht und zur Horizontalen herabgebogen. Auch Abkühlung des Wurzelballens soll zur Anwendung gebracht werten Als in Jajan zur Zwerganzucht hesonders verwendete Pflanzen worden genannt: die spielarten von Airv. lulmatum. die durch Einspitzen oder Anplatten "greffe par approche" veredelt

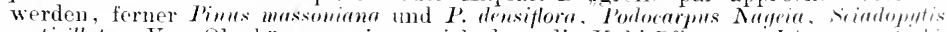

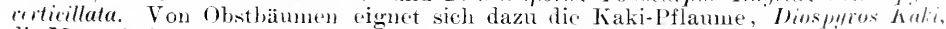

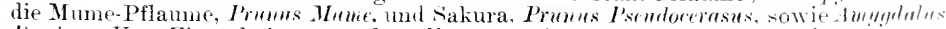

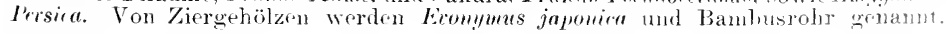

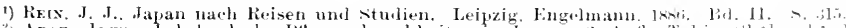

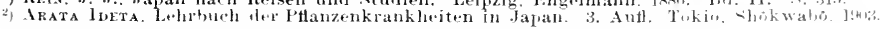


zu haben. \%ur Erroichung dieses /werks werden die sträncher in kleine Tüpte geptlanzt, zurïcligeschnitten uncl his zum Frühjahr möglichst lange in kïhlen, dunklen Kellern gehalten. um das Erwachen der Vegetation äber dio natürliche trenze hinaususchieben. Eiskeller. leisten in lieser Beziehmng grotise Dienste. Wem die Tegetation sirh hereits in Froion hedentend entwickelt hat. werden die Blïtensträucher lesausoebracht. Sio laben damn zur Ausbildung der Triebc rine ganz andere Komblination ler Vegetationstaktoren. An Stelle dre t'uchtrn Frühjahrslutt, ller verhältnismätsig geringeren Somenwärms nun , ler längeren. kïhlen Nächte, erhält die Pflanze trockene, lichtreichere, lange Tage mit wenig Niederschlägen. Infolgedessen bleiben die /weige kur\%. und lie Augen bilıten sich leicht zu Blütenknospen aus.

Nicht ïbertlïssie wirl es sein, daranf aufmertsam zu machen, dats man bei Antbewahrung der Sträucher in warmen Kellen das Gegenteil erreicht, nämlich rollständige Unbrauchbarkeit zum Treiben. Der warme. dunkle Aufhewahrungsort erzengt verspillerte, sehr zeitigr Trielse, dis bei drom endlichen Transport der Pflanzen ins Freie entwoder durch V'ertrocknen zugrunde gehen oder allmählich langsam zu peitshentömign, blitenlosen Ruten erstarken. Das gespeichert gewesene Material ist im Kollor zur Bildnng dor verspillerten Triebe versilnwindet worden.

Das häufigste Torkommuis ist the Verzwergung a s W Wasserma noel. Wie jerler Organismus hat anch die Pflanze die Fähigkeit. len verschierlenen Verhältnissen innerhall, woiter Grenzen sich anzupassen. Ein Intividum kamn, wenn as ron . Jugend anf an sehr geringe Wassermengen gewöhnt wird, mit der Hälfte der Wassersmmm. anckommen, die eine unter. Wasserüberschuts sich entwickelnde Pflanze lerselben Art und Varietät brancht. Natürlich ist der Aufbau des ganzen Individums diesen Terhältnissen angemessen. Eingehender. Untersuchungen liegen bei der (rerstenptlanze vor ${ }^{1}$ ), wel he bei verschielenem Wassergehalt des Bodens (10, 21), f1) und 60\% der wasserhaltenden Kraft) liultiviert worden war. Der giunstigste Wassergehalt fïr die Kultur diurfto etwa bei st)-60\% der Wasserkapazität eines Botens zu suchen sein.

Im Versurh zeigte sich. dat's die Pflanze selbst bei nur $10 \%$ o IVassel sir.l mit ihrer Organisation eingerichtet hatte: es war ahsolut wenig. Blatt- und IVurzelsubstanz gebildet worden, aber das Verhältnis zwischen Kärnern mul stroh war das normale: also etwa ahensoviel Trockensubstanz in der Form von Körnern als in Form von Stroh. Bei derselben Nenge an Nährstoffen im Boden wuchs dio Trockensubstanz, je mehr die Pflanzenwuras Wasser zugeführt erhielt. Bei zuviel Wasser (ako über to " o ler wasserhaltenden Kraft hinaus) wurde absolut woniger Trockensubstanz produziert. und tiese geringere Nenge wurde moch. wertloser, da das Virhältnis zwischen stroh und Körnern sich zu ur-

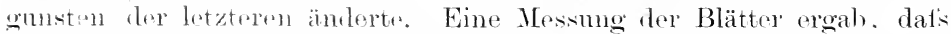
lieselben um so länger mol breiter wurden, jo meln Wasser gleichmälsig zugeführt wordrn war. Dirse gröferen Blätter bei stärkerer Wasser-

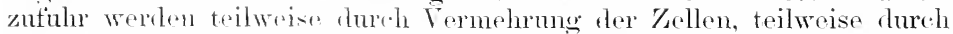
gröfsere Anstehmun driselhen herlingt. Wenn die einzelnen Oberhautzellen grötser sind, dam ist von vornheroin anzunehmen, datis auch

1) Surduer, Einflufs der Wasserzufuhr auf die Aushildung der Gerstenpflanze. Bot. Zeitung 1 1 73 . S. 145. 
die der Oberhaut angehörenden Atmungsapparate, die spaltöffinungs zellen, an der grölseren Streckung teilnehmen. also gröker sein werden. dats sie aber anch durch die grötsere Streckmo der Oherhantzellen weiter voneinander aerückt erscheinen werlen. Die direlite Mesimn bestätigte diese Anmahme, so dats also pro quarlatzentimeter emes im Wasserreichtum gewachsenen Blattes weniger. aber grobsere spaltöffinungen zu finden sein werden, als bei den mter Wasserarmut de Bodens erwathsenen Pflanzen. Die Untersudhmoen von H. MöLer ${ }^{1}$, haben festgestellt, dats solche Pflanzen. welche intolge von Wassermangel verzwergen ( $\mathrm{N}$ an ismus). sich in ihrem Autbau anders verhalten als solche. bei denen eine Verzwergmo durch Mangel sämtlicher Mineralstoffe in ungenügend konzentrierter Lösmg hrrorgehracht wird. Bei letzteren wird dic geringere Breite der Blätter nicht durch ge. lingere Breite der Zellen, wir bei Wassermangel. sondern durch geringere Menge der Zellen wahrscheinlich veranlatist, da die Messmogen dieselbe Zellenbreite und lieselbe frötse der sipaltöttimmgen bx. Pflanzen aus genügenrler Nälustottlösung und aus mgenügend konzentrierter Lösmg nachwiesen. Diese Differenzen sind erklärlich: os wird bei mangelhatter Zutuhr ler Gesamtmineralstotte die Zellrermohrum leiden, bei Wassermangel allein dagegen dis verminderte Zellstreckmu. in den Tordergrund treten. Wie einige Versurhe ron Mäbles mit Bromms mollis zeigen, ist dieser Namismus nicht erhlich. da aus Samen von Zwergptlanzen Riesmexemplare gezogen werlen kïmen. Indes rrzengen bei gleichen Voxetationsbelingungen dir von normalen Pflanz'n abstammenden samen floch kräftigere Exemplare als las von rerzwergten Phanzen herrülurende śaatout.

Der von Möblek stulierte Fall des Nanismus an Nährstottinangel ist aut sandigem Boden nirht selten: dabei spielt der Mangel an Stickstott' die Hauptrolle. Hier pflegt der Nanismus sirh larlureh zu charakterisieren, dats sich autser der alloemeinen Ruluktion dic Vor. hälnisse der einzelnœn produzierten Oroane zueinanıler rerschieben. Im Verhälnis zur Gesamtproduktion erlangt der Wurclkörper grölser.

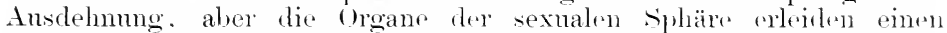
grötseren Rückgang. Tie Anzahl der Blütenanlagen ist äutiserst gering. An stelle einer Traube oder Rispe finden wir manchmal nur eine einzige Blume. und da. wo rine gröfere Nenge von Blumen angelegt ist, produzieren nur einzelne wirklich keimfähige samen. Daî di. Blattformen dabei anch vereinfacht werlen. ist fricht zu verstehen.

Bei Besprechmog dos Kwerwohses mus hier auch derjenigen Fälle gedacht werden, die nicht nachweishar mit den Bodenverhältnisien oder sonstigen äulseren Vegotationstaktoren in Verbindung stehen. sondern durch Knospenvariation zustande kommen. Der bisherige Wachstumsmodus wird durch einen stot: oder Reiz, der vorïbergehent oder damernd wirkt, derart verändert. daf's die organisehe Substanz anstatt in schlanken, diumnen, orotsblätterigen Zweigen von greringeren. Zahl in Form ron zahlmeicheren küzeren. meist dickeren. kurzlaubigen Zweigen Verwendung finder und auf diese Weise Hexenbesen tar stellt. In manchen Fällen ist die Anregung zu lerarti@ verändert+r. Wachstumsrichtung in parasitären Eingriffen gefunden worilen. Nament lich die Pilzgattung Taphrina (Eroascus) übt aut die Zweige vers hiodenor.

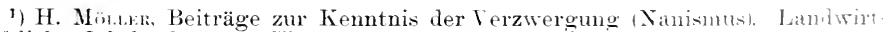
schaftliche .Jahrbicher ron Thiel. 185:3. S. 167. 


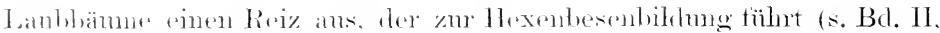
$\therefore$ 17!): in anderen Fällen finders wir Rostpilze oder Milben aus der

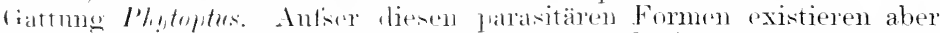

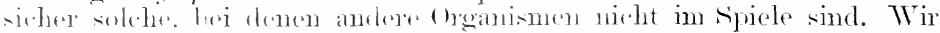
sahen manchmal. namentlich hei kiantartigen, selmollwïchsigen Pflanzen

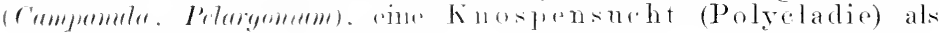
Komplationserselyomusg antionten.

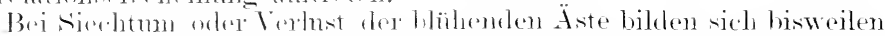

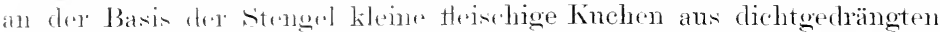
Kinspenanlagen, von denen einzelne sich zu schwäthlichen Kweigen ver-

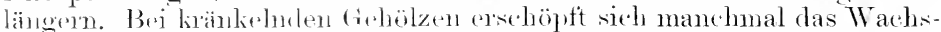

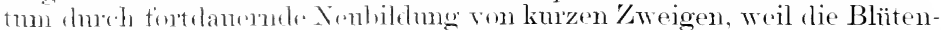

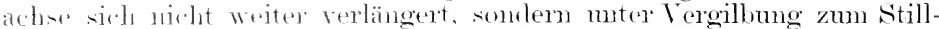

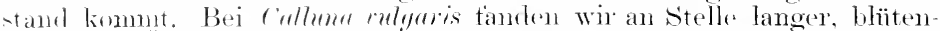

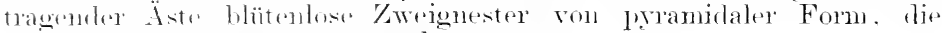

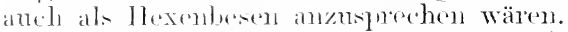

In anderen Fïllon rutstelit Polycladie mol Buschtorm rourh Entwiklome nomal angester. aber bisher schlatend geblicbener seiten-

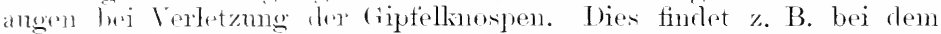

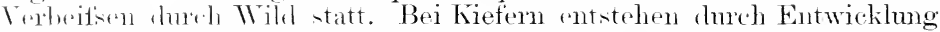

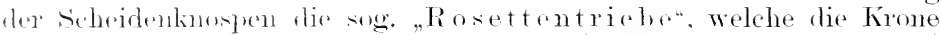
lnschförmig mathen: ähnlich erscheinen die sog. .Kuhbiische" hei

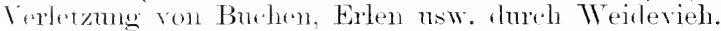

\%ahloreh sind lin reinen Knospenvariationen, bei denen

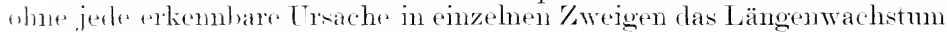
luschränlit wind mul datür eine reichere und schnellere Entwicklmug von seitrumeigen sich einstellt. Ton den eigentlichen Hexenbesenformon ist man zm\%eit grneigt, die zahlreichen lingeligen Büsche der Firhtenhexmbesen hiolier zu rechnen ${ }^{1}$ ). Die meisten Beispich liefern lie viclen Lindturvietaiten mserer Gärten in den sog. Kugelformen ler Narlelhälzer und in den Kwergtomen der Blütensträncher. Bei

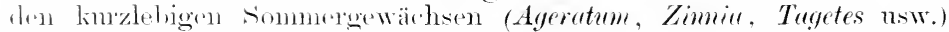

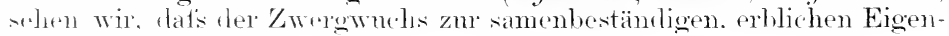
whatt werelen liamm.

\section{Die Dichtsaat.}

Eine Beschänkmes des Bodemaumes mol ein Kampt mm Wasser mul Nïhstoffimatrial kommt bei einer zu dichten saat stets zustande. l ler Kampt' dor Pflanzen miteinander um ihro Nahrumg tritt am frühesten mol schärtsten in den sandigen Böden ein. Autser der Verzweromen

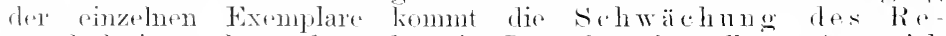
loodnktionsaktes hesonders in Betracht. Derselbe äntsert sich

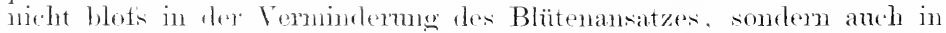

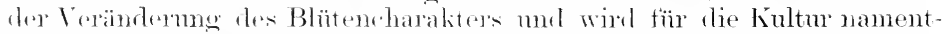

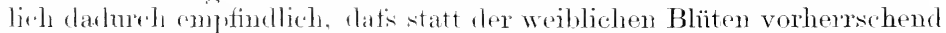
mämliche entstehen. Hiex spicht hesomeles der movermediche Stick-

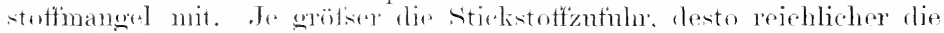
Jasmareichen Mreristeme.

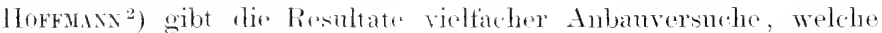

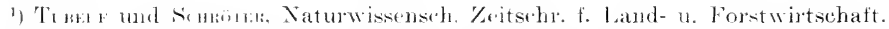
1905.5 .5254$.

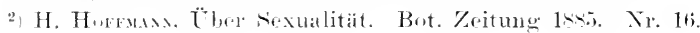


sowohl in Töpten, als auch im freien Lande behuf's Feststellung des Einflusses der Dichtsaat hei verschiedenen Pflanzen ansqefüht worden sind. Es kamen dabei anf 10n Weibchen zur Entwicklung an Mämmchen:

$$
\text { von }
$$

\section{Lyphois thiman}

Lychis respertina

Hercurialis amma

Riumer Acetosella

Spinacia olevacen mehreren Aussaaten bei dichter saat

$2: 3: 1$
$2(1)$
$15(1)$
$1(11)$
1.20
$20:$ hei lockerem Stande der Pflanzen

Bei ('amalis erhielt or widersurechende Resultate, was seine Erklärung finden würde, wem man die Angaben von Fisch ${ }^{\prime}$ ) berücksichtigt. dats die Geschlechtsverhältuisse bei Hanf sehon im Saatgut vorher fixiert seien, also äutsere Einflïsse keine Änderungen mehr hervorzuruten vermögen. Belhome behamptet, dats die Form der Hanfsamen schon eimen Schluts auf das fieschlecht der späteren Pflanzen zulasse, indem die länglichere orler kugeligere Gestalt, wie bei den Vogeleiern, auf ein männliches oler weibliches Individnum hinweise.

Da die bei Dichtsaat sich einstellenden Erscheinungen in wesentlichen sich anf Nährstotfimangel zurückführen lassen. werden wir weitere Beispiele bei Besprechmng des stickstotfmangels herbeiziehen.

\title{
2. Unpassende Bodenstruktur.
}

\author{
a) Lueiclite Bödיn.
}

\section{Nachteile des Sandbodens.}

Die Art der Aneinanderfügung ter einzelnen Borlengemengteil. bezeichnen wir als Strukturverhälnisse. Wenn einfach die Bodenbestandteile in einzelnen Körnern übereinandergelagert sind, werden wir ron einer Einzelkornstruktur sprechen: bei msern Kulturhöden jodoch finden sich die eimzelnen Borlenteilchen zu verschiedenartigen Aggregaten rereinigt. und dam bezeichnen wir den Zustand als Krömelstruktur. Während im ersteren Falle jedes Borlenkorn eine einheitliche Beschaffenheit hat, sind die Borlenköner im zweiten Fall. porös und nicht eimheithich zurammengesetzt, daher leichter umznändern. l)at's sich bei rerschiedenartiger Beschaffenheit des Bodens Krïmelbildmg einstellt. beruht auf dem Gehalt an löslichen Salzen, aut der Tätigkeit der Tierwelt im Boden md der Wirkung der Pflanzenwurzeln und ihrer Ansteheidmoen. sowie anf den phrsikalischen Prozessen der Bodenbearbeitung. .Je nach cler (iröfe der einzelnen Bodenkïrner und der Form ihrer Lagerung werden die Zwischenrämme verschierten grolis sein. Ranass berechnet die irötse des Porenvolumens gleichorofser Boden partikelchen. je nachdom sie gleichmäfsig reihenweise übereinander oder zwisehenemander gelagert sind. sehwankend zwischen $47.14^{\circ}$ o (lockerste Lagerung) und 2.5.9.5 "0 des (hesamtvolumens (dichtestes (refüge)2).

Während bei der Krümelstruktur wegen der verschiedenen Einzelbestandteile, welche die Krïmel zusammensetzen. durch merhanische

\footnotetext{
1) Fiscin, Ber. der Deutsch. Bot. Gesellsch. 1×87. Bd. V, Heft 3.

2) Rinws, Bodenkunde, II. Aufl., S. 222. Berlin. J. Springer, 1905. 
und chemische Einflüsse eine fortwälrende Veränderung in Grölse und Lagermo stattfindet, ist hei der Einzelkornstruktur, die im Stein- und sambloden am sthärtsten auscepügt ist, das physikalische Verhalten

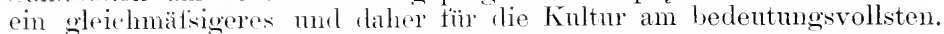

Über den Einflutis wirklither stembörlen und die Veränderungen. welche die Wrumeln lurch Hineinwarhen in Gesteinsspalten erleiden kömen. ist hereits frührr gesprothen worden. Die schädigmngen der

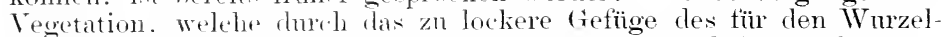
kïrper zur Vorfügung stchenden stembodens veranlatist werden, erscheinen gemilılort. Wenn dic steinblöcke durch Verwitterung zu Geröllbülen werden. Ex entstehen. namentlich bei leicht zersetzbaren (iesteinen (nan he Granite, (ineise, Syenit nsw.) feinerdige Bestandteile, welche den Wrumeh reichere Nahrung und grölsere Befestigung bieten. ber shädlichst wirkende Faktor ist neben der starken Erwärmbarkeit die arotice Trerlienheit. Welche die Zersetzmng der organischen Substanzen verhimlert und zur Bildung von Rohhumus und unter Umstänclen s jäter zur Moorbildung führen kamn. Mit diesen Verhältnissen hat namentlich die Waldkultur im Gebirge zu rechnen. Für die Feldkulturen in der Ebene kommen die Sandböden in Betracht. Sobald riescllien grötsere Beintengmuen von tonigen Stoffen haben (lehmige sante) wler von Humms besitzen (humose Sande), werden sie zu unsern bestprodnzierenden Kulturböden und finden daher hier keine weitere Beriucksichtigung. Die sandigen Bodenarten werden nur dam der Kultur teindlich. wenn der Sand wirklicher (quarzsand ist und entweder rein oder in einem extrem hohen Prozentsatz (70-?(1)\%) vorhanden ist.

In solchen Fällen ist in erster Linie das geringe Absorptionsvermögen als Kulturhindernis zu nemmen. I)ie Grankheiten, welche durch TVasser- und Nährstoffimangel hervorgeruten werden, sind dem sandholen vorzmgsweise eigen. Je mehr tonige und humushaltige Beimengungen sich vorfinden, desto mehr schwindet die Gefahr, soweit sie nicht durch Answaschen erheblicher Mengen leicht löslicher Nineralstoffo in anderer Weise wieder herrorgerufen wird.

Fin solches d uswaschen wird um so schmeller erfolgen, je mehr die an sich hei der starken Erwärmbarkeit und Durchlüftung leichte Zersetzmng der organischen Substanzen noch dureh andere Unstände pestrigert wirl. Daher muts man besonder's vorsichtig mit der Freistellume und sitrenentnalime in Waldmoen sein. Bei clichten Sandböl'n stratt sich die Fortführung der die Fenchtigkeit zurückhaltenden Stren oftmals darlurch, datis die noch vorhandene organische Substanz nur $n 0$ h sehr wenig durch atmosphärische Einflüsse und Bakterien zersetzt wirl und als Roh hum $n$ s sich ansammelt, der sehliefslich zur Ortsteinhibhung Tranlassung geben kann. Naeh Ramasx kömnen in tieferen Lagen die Rohlmmusahlagerungen allmählich zur völligen Versumptumg führen, wie dir grotsen Jogre Norddentschlands zeigen, die fast ausnahmslos aus ler Versmping ursprünglich von WTald bestandener Flächon hervorgegangen siml. Der Humus wird erst wohltätig durch seine Mischmon mit irm sande, indem dann rlie Krömelmo des Bodens und soin Wassorghalt westeigert, seine Erwämmostäligkeit lierahgedrüclit wird.

Eine wesentliche gefinhrohencle Eigensehaft der sandreichen Bodenarten ist eben die stark" Erwämmbarkeit mo Ausstrahlungsfähigkeit. Reiner siand lusitzt das stärkstr Wärmeausstrahlungsvermögen und infolgerlessen anch lie grötsto Betaunnosfähigkeit. Wärme- 
aufnahme sowie -ansstrahlung werden geringer. je t'einliörniger und weil'ser der Sand ist. Sand der letzteren Art ist solcher, der z. B. reich an Kalkkörnchen ist, während unter den gefärbten Sandarten diejenigen. welche reich an Eisenoxydhydrat sind, sehr warm werden und langsan abkïhlen. also sich ähnlich wie tonhaltige sande verhalten.

Mit den grofsen, dem Sande eigenen Temperaturschwankmuen verbindet sich die schlechte Leitungsfähigkeit für Wärme. Infolge der schwierigen Ausgleichmng hält er zwar seinen Untergrund bei gleichmätsigerer Temperatur, indem er ihn im Winter wärmer, im sommer kühler als unter bindigerer Bodendecke läfst; allein er sellst schadet um so meln durch vergröfserte Frostgetahr. Die schnelle Erwärmbarkeit in den Frühlingstagen lockt die Tegetation zeitig heraus, und die nächtliche starke Abkühlung schadet, während die später erwachende Pflanzenwelt auf wasserhaltenden. tonreichen Bodenstellen unversehrt bleibt.

Die grötste Beschädigung erwächst den Kulturen aber da. wo the mangelhafte Kohärenz des Sandes mit sehr feiner Beschaffenheit desselben zusammenfällt. Wir haben es dam mit Flugsand zu tum. dessen regelmäfsige Schädigungen man an den Dünen wahrnehmen kann. Wenn anch die Dünen die scharfen Seewinde für den Pflanzenbestand in der Nähe der Küsten weniger empfintlich machen, so schaden sir doch dadurch, dafs sie immer mehr landeinwärts, die Kulturen versandend. fortschreiten. Datis der nachts herrschende Landwind den Sant. den der am Tage wehende seewind ühergefegt hat, nicht zurückjagen kann, erklärt sich darlurch, clats bei der starken Betaumgsfähigkeit des' sand gegen Abend bald feucht wird. Wenn bei der Gefahr des Versandens kïnstliche Schutzvorrichtungen zu kostspielig sint, mut's man sehen. die beweglichen sandberge aut natürliche Weise zu festigen. Hicr sind die Sandgräser in erster Linie schätzenswert, da sie durch dir schnelle Wurzelentwicklung an den Knoten der verschütteten Stolonen immer wieder an die Oberfläche kommen und diese Oberfläche zusammenhalten. Arumdo arenarin L. und Elymus wrenurius L. dürften am häufigsten anzutreften sein: antserdem emptehlen sich Arundo balticn Schrad. Carex arenuria L. und, bei genügenter Feuchtigkeit, wohl anch unsere Quecke. Unter den Dikotyledonen ist Hipropliä Mammoiles L. yanz vorzüglich: je nach den Beimengungen im Sandhoden darf man anch mit Salice armarin L., Lycium barbaram L., Ulex enropaens L. und den kalkliebenden Gronistu Arten Versuche wagen.

Gleichviel. ob wir es mit Sandfächen im Binnenlande, wie in der Mark, Olilenburg und Hannover orler mit Dïnensand zu tun haben, s. mufs doch immer die erste Anpflanzung behnt's Festigmng mit niedrigem. sehnellwachsendem Material stattfinden. Dort, wo die Natur im Lautic der Jahre selbst eine dümne Vegetationsdecke übergelegt hat, schone man dieselbe mit allen nur möglichen Xitteln: denn man hat für das endliche Hauptziel aller Kulturbestrebungen. nämlich die Errichtmng eines Schutzwaldes, eine nicht hoch genug zu schätzende Basis. Mag dip Vegetationsdecke noch so mager sein. so hält sie doch den sand und gestattet die Anpflanzung junger Kiefern, die durch ihre ticfoehenden Wurzeln mit den magern Ernährmosverhältnissen am besten fürlich nehmen. Anfangs sehe man nur auf die Erzielung von Strauchregetation und gehe erst hinter dieser landeinwärts zur Anzucht der Baumforn iiber. Stets werden sich auf der Seeseite hei allen Holzqewaichsen ein. Ienge $Z$ weige zeigen, die durch den Wind absterben. Das wichtigste 
Kultumittel ist, diese toten $/$ weigestohen zu lassen. An ihmen hricht sich der seewind und sie liflden eime natürliche Schntzwohr. hinter wolcher das Lauh sich dann lehensfähig erhält.

\section{Senkung des Grundwasserspiegels.}

\%n den Erscheinmeen, die sich in den Sandböden am verhängnisvollsten erweisen, gehört die durch Kanalbanten und Fhtsregulierungen stots hänfiger eintretende senkmng des (irmondwasserspiegels. Im Gegensatz zu der in den oberen Erdmassen festgehaltenen .Bodenfenchtiokeit" bildet las in die 'Tief'e absickemde und ant undurchlässigen Bodenschichten sich ansammelnde Grundwasser den Reservevorrat für die Wruch in \%eiten anhaltender Trockenheit.

In solchen Gegenden, die, wie das Alpengebiet und die bayrische Hocharme, eine hohe absohte Menge der Niederschläge und geringere Verdunstung haben, erlangen die von dem Verlanf' der jährlichen Niederschläge beherschten sichwankungen des Grundwasserspiegels für die Tegetation mu geringe Bedentung. In regenden aber mit geringen absolnten Nioderschlagsmengen mnd hoher Verdunstmo, wo die jährlichen frumblwaserschwankungen ron der Verdunstungsoröfse abhängig sind, wie z. B. in nordeleutschen Flachlande, und wo ler gleichmätsige Alifall der tirmudwasserkmre ant ein allmähliches Abfliefsen dmoh (nellen und Flïsse hindentet (s. Ramans a. a. O. S. 275), wird eine Tieferlagerung des Wasserspiegels von Kanälen und Flüssen von äntierst schwerwiegendem Eintlut's. Der Boden trocknet gegen den Herbst hin stark aus, mod die Vegetation ist anf das kapillar festgehaltene Wasser angewiesen, das mo so geringer wird, je sandiger und grobkïmiger das Erdreich ist. Ohne den Zuschuts des (trmudwassers kann sich damemet der Bammons nicht halten.

Wrm anch der (iruntwasserspiegel im I anfe der Jahre in seiner durchschnittichen Höhe otwa um eimen hallen Meter sehwankt, so gleicht sich doch ein Tiefstand alsbald wieder ans, und die Vegetation hat sich dissen Verhältnissen angepatst. Der Wassergehalt und das Trasserbedürtis der Pflanzen stehen im Zusammenhang mit den Fenchtigkeitsverhältnissen des Bodens, wie Hengcock ${ }^{\mathbf{1}}$ ) dmeh Vergleichskultmen in prarzsand, Lehm: salzbolen, Humms usw. gezeigt hat.

Yon dem Wassergehalt des Bodens und der Pflanze hängt anch

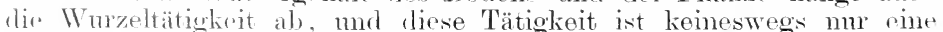
pasive, somdern wie Stchs ${ }^{2}$ ) und spezieller noch MoLisch ${ }^{3}$ ) gezeigt haben, dureh dir. Wnrzelansscheidnngen anch eine wesentlich alitive, das anorganische und das moanishe Bodenmaterial zersetzende. latztgenamer Forscher macht in dieser Hinsicht auf den Unstand antimerksan, datis murerletzte Wurzeln in Berïhrung mit einer verdiimnten fösmo rom ïlremangansamen Kali sich mit einem Niedershlag von Brannstein hedecken, also der Lösmng den Sauerstoff sutreifisu. Nit stengeh und Blättern gelingt der Versuch nicht. Anf

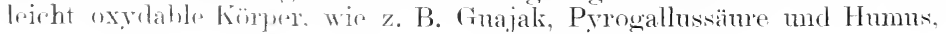

1) Hrmark, G. (i.. The Tielation of the Water Content of the Soil to certain Plants etc. Botaniral Surver of Nebraska. V1. Studies in the Vegetation of the Sitite. 1902.

2) Experimentalphysiologie S. 1 1 9. Bot. \%eit. 1860, S. 188.

3) Musscu, H., Über Wurzelausscheidungen und deren Einwirkungen anf organische Suhstanzen. Sitzb. Kais. Akad. d. Wiss., Wien I. Abt., Okt. 1887. 
wirkt das Wurzelsekret oxydierend. Eine Guajakemulsion wird dadurch geblänt. Das Wurzelsekret betrachtet Mousc'H als einen Autoxydator, der durch passiven molekularen Sauerstoff' oxydiert wird, hierbei sauerstoff' aktiviert und damit die Verbrennumg leicht oxydabler Körper. veranlafist. In Gegenwart von (terbstoffen (Progallussäure, Gallussäure, Tamin), die leichter oxydabel sind al das (tuajakharz, erfolgt die Bläumng nicht; ebenso unterbleibt sie bei Anwesenheit der sanerstoffgierigen Humussubstanzen. Wurden vollständig unversehrte Wurzeh in verdümnte Rohrzuckerlösungen eingetaucht, zeigte sich narh einigen stunden reduzierender /sucker: wahrscheinlich wird diese Un. wandhung durch ein von ter Wurzel ausgeschiedenes Ferment ver. anlafst. Stärkekleister, anf wachsende Wurzeln von Keimlingen gebracht. zeigte nach wenigen Stunden nicht mohr die stärkereaktion, sondern färbte sich durch lod rotviolett: es war also durch die Berührung mit (ter Wurzel die Stärke zunächst in Erythrodextrin iibergetührt worelen und konnte in reduzierenden /ucker übergehen.

Die an der Spitze der Wurzelhaare wahrnehmbaren Wurel ansscheidungen durchtränken nicht nu die Membranen der Zellen, sondern können bei reicher Wasserzufuhr und heraligetrückter Transpiration in Tröptehentorm in lie Umgebung der Wurzel äbertret+1 und mit ihren Säuren (sie röten die blane Lackmusösmg) diø Mineralien anätzen und die organischen stoffe zersetzen. Disse Wurzelarbeit lätst mit der steigenden Trockenheit nach. Wurzeln, dic an einen durchfeuchteten Standort gewöhnt, in einen trockenen webracht werden, arbeiten, wenn die Pflanze eimmal bis zum Welken gekommen ist, auch nach Wasserzufuhr nicht mehr so energisch hetreft's ihrer Wasser. anfinahme als solehe, welche eine Welkperiode nicht durchzmmachen hatten. Hrogcock meint, dats die Wurzelhate sogar absterben.

Wie grots die Energiemenge ist. welche zur "Wasserhebung. zum Einbohren in den Boden und zu den andern Lebensäufsrongen bri einer Wurzel erzengt wird, kamn man ans der Kohlensäureproduktion shliefsen. Kossowisch') lat darüber quantitative Bestimmungen geliefert. Er fand bei Wasserkultmen ron Senfpflanzen, datis dieselluen fïr die in ihren Wurzoln vor wich gehenden Lehensprozesse moefähr dreimal so viel Kohlenstoff assimilieren mutsten. als zur Bildung des Wurzelapparates selhst nötig war.

Die Stärke der Wurzeltätigkeit, namentlich ihre Arbeit des Wassere hobens, dürfte auch von len Temperaturdifferenzen zwischen den Merlien abhängen, in denen die oberirdischen und die in der Erele befindhohen Pflanzenteile sich brfinden. Je gröfser diese Differenz, desto energischer die Arbeitsleistung. Und wie grot's solche Unterschied sein kömmen, beweisen die Messungen von MAcoorat ${ }^{2}$ ) in Botanischen Garten zu New-York. Er tand im Juni die Bodentemperatur in 30 (cm Tiefe zeitweise $\mathrm{mm}$ 200 (. geringer als die der Luft. Natühlich wird der Wassergehalt des Bodens dabei auschlaggelend. und die Differenzen schwächen sich in dem Mafise ah, als der Boden trockner und der Lutt zugänglicher wird. Dit wasserhaltende Kraft. nnd bei Sandboden damit

1) Kussuwrocu, P., Die quantitative Bestimmung der Kohlensäme, die von Pflanzenwurzeln während ilrer Entwicklung ausgeschieden wird. (Russ. Journa) f. experim. Landwirtschaft, 1904, Bit. T, cit. Centralbl. f. Agrikulturchemie. 19m. Heft 6, S. 367.$)$

2) Macuoriu, D., soil temperatures and vegetation. Repr. Monthly Meather. Review for August $190 \%$, cit. Jts. Bot. Jahresb. 1903 . II, ‥ 55\%. 
anch die Produlitionsoroutse. wird bei gleichem Bodenmaterial von der Kiinnerstruktur ahlängen und $m$ so grötser sein, je feinkömiger der sand ist. Wir haben dariber Tersnche rom Livingstos ${ }^{\mathbf{1}}$ ) und Jensen, welche verschiedrue Pflanzenspezies moter sonst qleichartigen Verhälnissen in emen Borlon knltivierten, der verschieden gatse Quarzkïrner in den einzelnen Versuchseihen heigenengt erhielt. Es zeigte sicll. dats das heste Trarlistmm stets dort eintrat, wo der Quarzsand sehr teinkörnip war.

[) nuch die rosstehenten Beohachtungen wewimen wir einen Einl,icls in die Störmgen, die sich in der Tätigkeit der Pflanzenwurzel rimstellen müssen. Wenn das Trasserkapital einer Gegend dadurch sinkt, latis der (immolwasserspienel tiofer gelegt wird. Ein alter Bambestand lobt davon. lat's ein 'Teil soiner tiefgehenden Wureh in dem Grundwassernivean sid befindet, und len Verdunstungsverlust der Kronen in Yeiten zu decken vermag, wo das Botenwasser hmoh längere Trockenperioflen anf' ein Ninimm reduziert ist. Die in den von Grundwasser lurdizogenen Erisshichten entstandenen Wurzeln sind diesen Verhältnisson imgepatist und gehen zugumde oder funktionieren nu mïhsam weiter, wem so der Trockenheit danernd ausgesetzt sind. Es leidet nicht mu die (ikonomie des Bames durch mngenügende Wasser- und Vährstoffzufuhr, sondern anch der Borlen selbst, indem, ganz alogesehen ron der Lahmlegmm der Bakterienarbeit. die die Zersetzung des Bodenkapitals bewirkende Ansscheidungsfähigkeit der Wryelhare und Wuzelspitzen anfhört. Der Boden „verhagert", und die Bämme begimnen an der Peripherie ihrer Kronen tote Äste zu zeigen. Da anf den absterbenden Teilen Parasiten sich ansiedeln, welche die Zerstömo' der frewebe vervollständigen, so wird in der Mehrzahl der Fälle diese Gipfeldürre als wine reim frarasitäre Krankheit erklärt und dementsprechend behandelt.

\section{Das Absterben der Erlen.}

Am empifindlichsten gegen Grundwassersenkmoen erweisen sich die Erlen, mul es ist mschrer, in der Nähe nengezogener Kanäle oder regulierter Flutiänfe kranke Erlenbestände zu finden. Eine sehr beathtenswerte Studie über das Erlensterben hat APPEL ${ }^{2}$ ) in den Arbeiten der K. Biologisehen Anstalt für Land- und Forstwirtschat' zu Dahlem lei Berlin (1!ni) weliefert. Er fand auf den absterbenden Zweigen rine Art aus der als Bewohner siecher oder toter Zweige bekamten Gattumé Talsa, nämnlich Valsa oxystomm, und erkannte, dals dieser Pilz nur damn parasitäs wird, wem die Erlen durch abnome Umstände zu ciner emptänglichen Tnterlage werlen. Nachgewiesenermatsen ist der hamptächliclste disponierende Faktor die Trockenheit. Anch andere Ernährmngsiörungen (Truzelveletzungen, Ringelung usw.) vermögen oino l)isposition für tie Angriffe des Pilzes zn schaffen; aber eine Kräftigme der Erlo in ihren Funktionen führt die Heilung der Krankheit herbei. Wonn man ein Erlensterben anf anscheinend nassen, mutmelıläsigen, eiscnschiössigen Böden finclet, so ist dennoch die 'Trockenheit als Ursache zu hezeichmen. Anf' lerartigen Böden kamn die Erle mit ihron Trumeh nur sehr flach streichen, mod hei anlialtend

1) Livisustos, B., und Jixis, G., An Experiment on the Relation of Soil Physics to Plant Growth. Bot. Gaz. vol. XXXYIIl, cit. Bot. Centralbl. 1904, Nr. 50, s. 617.

$\left.{ }^{2}\right)$ Torläufige Nitteilung in d. Naturwiss. Zeitschr. f. Land-u. Forstwirtschaft. 2. Jahrig. 1904 . 
trockener Witterung stellt sich in den oberen Bodenschichten ein gänzlicher Wassermangel ein, auf den die Erle sofort mit Vertrocknen des Laubes antwortet. Ein weiteres reiches Beweismaterial liefert bedauerlicherweise der Tiergarten bei Berlin, dessen schöner Bambestand, larmer namentlich die Eichen, einen manfhaltsamen Rückgang zeigt.

Natürlich branchen nicht immer Kanal- und Flutiseguliermgen die s'enkung des (rrundwasserspiegels zu veranlassen. Für den Alten Botanischen Garten in Berlin beispielsweise war die Anlage der Cnternmulbahn die Ursache des Versiegens des Wassers in den Teichen und der nummehr schnell fortschreitenden fipfeldüre. In anderen Fällen sahen wir mit dem Anwachsen der Kiegeleien und Tongräbereien in der Nähe von Waldbeständen das Absterlen der Erlen zunchmen. weil die tiefen 'Tongruben das Wasser ans dem Walde gezogen hatten.

Man verschliefst sich vielfach noch dem Hinweise anf die gefälnlichen Folgen der Senkung des frundwasserspiegels fü̈ unsere Bammbestände und betont, dat's dieselben Bammarten, die anf entwässerten Böden an Gipfeldiure leiden, doch in sehr trocknen Lagen gut gedeihrn. Bei diesen Einwänden vergitst man aber, dats nicht die Trasiserarmmt an sich das Eingehen der Bäume bedingt, sondern der scluroffe Öthergang vou bisher reichlicher Bewässermo zu grotiser Trockenluit in den tieferen Bodenlagen. Wir kömnen alle msere Bämme ant sehr trockenen Börlen anpflanzen, und der Organismms entwickelt sich dam den entsprechenden V'egetationsfaktoren gemäls, indem die Blätter klein und derh und die Internodien kurz werden: aber wir kïmmen meist nicht moestratt plützliche grotie Ämlermugen in den Warhstmmstaktoren vornehmen. Lassen sich derartige Störmgen nicht vermeicten, ist mserer Ansicht nach die Regeneration des Bammbestandes das einzig wirksame Mittel. Junge Bänme zwischen die alten geptlanzt passen wich den veränderten Vegetationsherlingmegn an.

\section{Die Strafsenpflanzungen.}

Für die Hyoiene der Städte ist die Erhaltung des Bambestandes an stratsen und Plätzen von höehster Bedeutung. Die grölste Schwierigkeit bietet die immer sorgfältiger werlende Pflasterung der stratsen, bei denen die Zwischemäume zwischen den steinen mit lindendem Material ausgegossen werden, falls nicht gar eine zusammenhängende Asphaltdecke den Boden abschlietist. Der Schaden für die Bämme liegt einerseits im Luftabschluls, andererseits in der nicht hinreichenden Bewässerung, solıald es sich um ältere Bänme handelt. Für junge Pflanzmgen ist die Bamscheibe, namentlich wem sie durch ïbergelegte Eisengitter vor dem Festtreten geschützt ist, ansicichend. Alte Bäume sehen wir um so schneller absterben, je mehr sich zur Vervollkommmung des stratsenpflasters eine Reguliermug der Fut'sgängerbahnen und Senlimng des Grundwasserspiegels gesellt. Dazu kommt in den grofsen Städten die Durchwïlılung des Bodens durch die (Kas- mul elektrischen Leitmogen sowie durch die Kanalisationsö̈hren. Bei allon diesen Arbeiten ist ein Abhacken stärkerer Wurzeläste mvermeidlirh.

Es wird also nicht nur durch die mannigfachen Röhrenleitungen der Raum für die Wurzelausbreitung beschränkt und der Boden noch mehr ausgetrocknet, sondern anch der Aufnahmeapparat rer Bämne tüu Wasser verringert. Deshalb sehen wir die alten Bämme an den sitratisen allmählich moter Absterben der Astsitzen zugrmale gehen. 
Dit cinzelnen Bammaten leiden num in verschiedenem Matse, und gerarle die heliebteste, an meisten angepflanzte Banmart, die Linde, gehört zu len empfindlichsten Bämmen. Bei ilı äulsert sich der EinfHufs der 'Trockenheit des Botens, zu fler sich noch die Iuftrockenheit

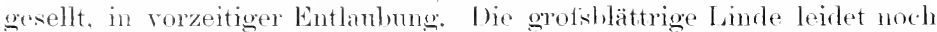
sthmeller als die kleinblätrige linfle, und es ist eine wanz bekannte Erscheinmme, dats in den Sommormonaten. wo der Bewohner der start am moisten den sichatten sucht, Linden und Kastanien of eine Keitlang nur die änfisersten \%weigs itzen noth beblättert haben; die älteren Blätter sind. von dir roten spomne ïherdeckt, vertroeknet und abgefallen. Dir stadtrerwaltumen suthen dureh reichliche Bewässerung der Bamscheiben drm IThelstande alwuhelten mol begünstigen damit den bei vorzeitiger Entlauhme vom Bamm auch ohne künstliche Bewässerumg eingeleiteten Prozets der Neubelaubung im spätsommer. Dabei werden Knospen zur Entfaltmeg gebracht, die rigentlich erst im nächsten Jahre sich entwickeln sollten, und es kommt unter solchen Unständen manchmal (Asculus. Roblimia) eine zweite Blütezeit zustande.

Viele der durch die Bewässermo hrvorgerntenen Triebe reifen

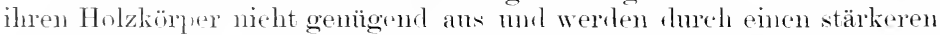
Frost beschädigt. I aher finden wir in einzehen .Jahrgängen mitten in giunstigen Frülinommer manehmal ein \% weigsterben unter Betriligung von Pilzen. Der Winter nämlich hat solche wenig answereitten Zweig. nicht getötet. wohl aber für die Pilzeinwandermg vorbereitet und die erste Teranlassmo zn einem späteren Absterben gegeben. Verwandt mit den hise berithrten Erscheinungen ist mserer Ansicht nach auch das in den letzten .Jahren vieltach die Forscher beschätigende hirse h. baumsterlen am Rhein ${ }^{1}$. Wie bei den Erlen spielt anch hier eine Tulsu (T. Toucostoma) eine Rolle. Wir kommen auf diesen Fall in dem Kapitel über Frostbeschädigmaen wierler zurtick.

Derantigen T̈belständen bei der Stratienbepflanzmo versucht man dmeh dif ITahl weniger empfindlicher Bamarten vorzubengen. In erster Linis sind als solche die Ulmen zu empfehlen. dis anch fen Vorteil habrn, wegen die samen Ranchgase sehr widerstandsfähig zu sein. J nach der Botenart sieht man auch Eichen unr Platanen mit Vorteil verwendet. In hreiten mul luftigen Strafien zeigt ameh Acr platuroides ein gntes tredeihen. leirlet aber öfter an Honigtan. Die Robinie, namentlich die Form der sog. Kugelakazie, bleiht hei grotser 'Trotkenheit noch gnt helanht. bietet aber wrig Sehatten, helaubt sich spät und entlanbt sicle meist schnell im Herbst. Alslann ist eine Erweiterung der Buwässerungsvorrichtungen ins Ange zu fassen, indem man in derjenigen Entfornme von den Stämmen, in welcher die jüngeren Wurzeln zu finden sind, Drainröhen efwa ${ }^{1 / 2}$ m unter dem Pflaster hinzieht und bei Bedürnis ans Hydranten speist. Dabei ist jetoch aufmerksan zu machen, daf's die Bewässcrung dureh Irainstränge nur in den heifsen sommermonaten zur Anwendung gelangen tart", weil sonst Wasserïberfluts im Borlen sich einstellen dürfte. desson Folgen viel verhängnisvoller als die des Wassommogels werden. Endlich glauben wir namentlich da, wo nu Bewässerung dureh Bammseheiben ausführbar ist, das uächtlicho Spritzen der Bamkionen enptelilen zu sollen.

Anf die in Anssicht genommene Bewässerung durelı Drainstränge kommen wir nochmals zurück. indem wir hetonen, daf wir dieselbe

1) S. Deutsche Landwirtschaftl. Presse 1899. Nr. 8:3, 8f, 99. und 1900, Nr. 1\%. 
nur für leichte Böden mit durchlässigem Untergrunde emptehlen. Bui schweren Böden wird das mechanisch funktionierende Arbeiterpersonal ständig weiter bewässern, wem der Boden noch mit Wasser beladen ist, und es treten dam unfehlbar die an anderer Stelle geschilderten Nachteile des Sanerstoffimangels und Kohlensäureüberschusses ein, wodurch die Baumwurzeln zur Fäulnis gebracht werden. Als ein einziges warnendes Beispiel sei an dieser Stelle nur das Ergebnis der Studien von MangiN ${ }^{1}$ ) angeführt, der sich speziell mit dern mangelhaften (tedoihen der Bäume in den städtischen Anlagen beschäftigt hat. Er sah bei solchen verschlämmten Böden den Kohlensäuregehalt der Bodenlnft von 1 \% $\%$ bis anf 5 und 8 , ja sogar bis $24 \%$ gesteigert und den Sanerstoffgehalt auf 1.), 10, 6 und selbst auf $10^{\circ}$ zurückgehen. [lats unter solehen Un ständen alle Bäume absterben. ist selbstverständlich. (Vergl. .7u tiefos Ptlanzen der Bäume", s. (1).)

\section{Wirkungen der Dürre bei den Feldfrüchten.}

Die gerade aut 'sandbödlen an schmellsten sich geltend machenden Folgen eines anhaltenden Wassermangels bei grofser Hitze richten sich natürlich nach dem Zeitpunkt des Eintritts der 'Trockenperiode. Die selbe ist an gefährlichsten, wem sie sich, wie in Jahre 19(1)4, schon in Mai, also zur Zeit der Entwicklung ler vegetativen Organe, einstellt. weil dam der Apparat, der das Material für dio Fruchtausbildumes liefern soll, in seiner Tätigkeit herabgedrïickt wird.

Bei Getreirle leidet nnter mseren Kulturverhälnisisen bei den äblichen Bestellungszeiten an meisten die sommermug. Lies wird verständlich, wenn man bedenkt, dats die im IJerbst hergerichteten Wintersaaten die ganze Herbstzeit und den ersten Fröhling benutzen kömmen, mm ihren TWmzelapparat reichlich auszubilden mul eine genügend. Bestockung zu erlangen: sic geniefsen dabei dis mgestörto Tätigkeit ihrer unteren Blätter. Mithin tritt die Wintersaat kräftig und wohlvorbereitet der Trockenperiode entgegen. während die Sommersaat selbst dort, wo sie normal aufgehen komnte, in viel jugendlicherer Entwicklung in die heifse, wasserlose Periode hineinkommt. Demgenäts reifen die Blätter vorzeitig ab: ihre Arbeitszeit ist also eine beschränkte, uml wenn die Pflanzen ihre Blüten entwickeln und ihre Fruchtknoten wirklich ausbilden, so ist roch verhältnismätsig nur spärlich organisch. Substanz zum Füllen dos Kornes vorhanden. [las Endosperm ist nur mangelhatt mit stärke getüllt: die Korner sind solmal und leicht.

Der zweite wirtsehattliche Sehaden ist die Kürze des strohes. Am meisten zeigt sich dies bei dom sommerhafer, der auf leichten Böden rothalmig und kaum fulshoch wirt med statt der vollen Rispen mm. wenige Ährchen zur Ausbillung bringt. Geringere Schädigungen weist die Gerste anf: dam folgt Weizen und sehliefich der Roggen, der am widerstandstähigsten ist. Wenn die Trockenperiode schon zur Zeit der Einsaat sich geltrond macht. erfolgt ein verspätetes mul ungleirh. mäfsiges Aufgehen der Saat. das zu, ,Zwiewnehs", d. h. einem wan\% unregelmäfsigen Ausreifen des Getreides tührt. Zur Erntezeit findon sich dann zwischen den ausgereiften viele noch grüne Hahne. Letztere stammen von den bei der Saat obenant liegen gebliebenen Kïnern.

1) Maxms, L., Vegetation und Durchlüftung des Bodens. Annal. seienc. agronon. 2. sér., 1896: cit. Centralbl. f. Agrikulturchemie, 1\&98. S. 63-. 
lie zunächst regmoslos sich verhielten, während die tiefer einwhrachten noch Bodenfenchtigkeit genug zmr baldigen Keimung fanden. Tierhei kommen manchmal änficerst legrenzte lokale Verhältnisse zur Wirksamkeit. Sio kam beispielswrise eine Vorfrucht dem Boden schon mehr Wasser ontzogen haben als einc andere, oder aber eine $\mathrm{Kal}$ i 1) ï $n$ gnng vertcilt sich moleichmätsig und erhält an den Stellen, wo sich Salz angrhänt hat. den Boden fenchter. Auch die ganze Entwielinng der Ptlanzw wird dadureh geändert. Mit der Konzentration ler Nähstoffläsmg sah ich mnter sonst gleichen Verhälmissen den Nmzolapparat sich verkïrzen mo den Wasserbedarf der Pflanze wringer werten. Was hei den durch Trockenheit gefährdeten Böden rom grotiser Bedentmeg ist.

Bei dem /nckerribenban mol bei allen den Gemüsen, die als cämlinge in kleinen Rämmen angezogen mol dam anf das Feld gel.flanzt werlen, macht sich in erster Limie die Bodentrockenheit durch Erschwermo oder Terhindernng des Anwachsens der Pflänzlinge geltend, da sich bei dor Trockenheit keme nenen Würzelchen zu bilden vermögen. Sodam lommt das Vertrocknen des Laubkörpers in Betracht, woilurch die Anslibling der Rübe zum Stillstand gelangt. Die Ertahrmong lehrt, (lats, wie bei dem Getreide, gut gedüngte Felder die Trockenhrit hesser äberstehen. Anch die Varietäten scheinen dabei mitzmprechen: es wurde beobachtet, dat's bei den Zuckerriben die sorten mit Hach ansgebreitetem Laulse mehr welken als die mit steil antisteigenden Blattstielen.

Der Einfluts langanhaltender Dürre lei den Kartoffeln kommt nicht so sohr hei dem Ansatz der Knollen als bei deren Ausbildung zur Geltung. bie Knollen bleiben klein und werden notreif. In der Regel kommt die Notreife hei den Frühkartoffeln wirtschaftlich weniger in Betracht, weil diese ihrer Natur nach auf eine kïrzere Vegetationsperiode einwerichtet sind mol weil zweitens sie schmell konsmiert werden. Nur lie Notreife rler Syätkartoffeln ist verhängnisvoll, weil die Füllumg des Knollenkörpers mit stärke mangelhaft mod dadmeh die Haltbarkeit der Kinolle achr beeinträchtigt wird.

Schwere wirtschatiliche Nachteile erzengt die anhaltende Bodendïrre bei den Legminosen, soweit sie als Futterpflanzen angebaut werden. Klee mi Imzerne bremnen teilweise aus oder versagen den zweiten sichnitt. Boi don Obstbämmen sind die Notreife und geringe Haltharkeit der Fruchte sowie vorzeitige Entlanbung die häufigsten Vorkommmise.

Untre den speziellen sichärigmastormen, welche bei langdanernder, intensiver Trockenheit, namentlich in leichtem Boden. wich einstellen kïmmen. verdient sine angehendere Besprechmo die

\section{Durch Trockenheit unterbrochene Keimung.}

Der Fall, dats Wassermangel eintritt, nachdem das samenkorn bereits die sisten Stadien der Keimming durchlanfen, ist seltener bei der Anssaat der trockenen Samen ins treie Iand zu fürchten, als vielmehr dort, wo vor dem Gebranch ein Einquellen des saatgutes stattgefunden hat. Tie Nachteile ciner solchen störung in der Ent-

1) Jahresberichte 1. Sonderausschusses für Pflanzen-chutz. Deutsehe Landw. Ges. 1904 . 
wicklung des jungen Individumms sind je nach der Samenart und je nach dem Entwicklmosstadium, in welchem die Unterbrechmig erfolgt, verschieden. Nach WILI's $\left.{ }^{1}\right)$ mehrfachen Aussaatrersuchen mit Samen von Monokotyledonen und Dikotyledonen scheinen die Samen der ersteren in allgemeinen etwas wirlerstandsfähiger zu sein. Namentlich sind die unbespelzten Cerealien (WVeizen und Roggen) gegen eine während, der Keimung eintretende Trockenheitsperiode wenig empfindlich: Grerste und Hafer sind dagegen schon leichter zn Schaden zn bringen, und sehr wenig Widrstandskraft gegen eine Unterbrechmog der Keimung zeigt der Pterdezahmmais. Schon Stussure ${ }^{2}$ ) fand, dats der Mais eine Austrocknung während der Keimperiode schlecht verträgt, und Tats die Bohmen, der Mohn und die Rapunzel sich elonso verhalten. Nowoczer ${ }^{3}$ ), der seine Versuche in der Art austührte, rlats er die Unterbrechung der Wasserzufuhr mehrmals an remselben Samen eintreten lief's, bis dessen Keimkraft ganz erloschen war, fand, dats dic samen der Getreidearten sich gegen die wechselnden Einflüsse von Fenchtigkeit und Trockenheit resistenter verhalten als Raps, Isein, Klee und Erbsen, die ihre Keimkratt tiüher einbüisten, aber immerhin doch - iner Wiedererweckmng ihrer Tätigkeit nach Austrocknung noch fähig. waren. Bei den tramineen vorzugsweise zeigte sich, dats nach dem jedesmaligen Austrocknen die bereits gebildeten Würzelchen abstarhen und die äutseren Blätter abtrockncten, datis aber bei ernenter Wasserzufuhr sich nene Adrentivwurzeln ans dem ersten Knoten (s. Bd. I, s. 111.2) bildeten und die jüngsten Blätter sich weiter entwickelten. Hauptsächlich gilt dies für llater, mehr oder weniger auch für Gerste. Weizen und Mais.

Als allgemein feststehend ist anzusehen, tats eingequellte und nachher vorsichtig getrocknete samen, die wiederum in Wasser gehracht werden, dasselbe rascher anthehmen als luftrockene, nicht aufgequellte Körner derselhen Grötse. Solche Samen entwickeln sich anfangs wohl auch $\mathrm{mm}$ einige Tage schmeller.

Durch die Versuche von TauTphöes ${ }^{4}$ ) und yon Ehrнarior ${ }^{5}$ ) wird das von vorherein zu erwartende Resultat experimentell testgestellt, dats die Pflanzen $u$ so mehr leiden, je weiter fortgeschritten bei Eintritt ler Trockenperiode der Keimungsprozefs ist, $d$. h. je mehr entwickelt bereits die Plumula erscheint. Die Erbsensamen fand WILL zum Teil wanz besonders empfindlich gegen das Austrocknen. Die Samenschale bekam viele kleine Risse, die sich in rlen meisten Fällen auf die imneren sichichten tortsetzten. Bei dem wiederholten Einquellen löste sich die Stäbchenschicht in grölseren und kleineren Stücken ah, die Samenschale wurde schleimig, und es stellten sich bimnen sehr kurzer Zeit Zersetzungserscheinmen an den Kotvledonen ein, welche die Entwicklmug. der Keimpflänzchen hemmten. Die Entstehung der Risse bei dem Trocknen der gequollenen Samen erklärt sich durch die mehr als $100 \%$

1) WH.t, Über den Einflufs des Einquellens und Wiederaustrocknens auf die Entwicklumgsfähigkeit der Samen, sowie über den Gebranchswert „ausgewachsener Samen als Saatgut. Landwirtsch. Versuchsstationen XXVIII, Heft 1 u. 2 (1842).

2) Annales des sciences nat. Bot. 1827. Janv.

3) Über die Widerstandsfähigkeit junger Keimlinge. Wissenseh, prakt. Unter-

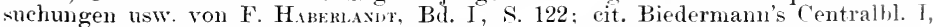
S. 344,1876 .

4) Frembra vox Tartruors, Die Keimung der Samen bei verschiedener Peschaffenheit derselben. München 1876: cit. Bot. Jahresber. 1876, S. . x

5) Deutsche landw. Presse, Jahrg. VIII, Nr. 76: cit, von Will. 
betragende (Nobbe. Handhuch, s. 1.2.) Volumzmahme der samen. dhe ant ihre Sichale einen Druck ansüben und dieselhe passiv dehnen und lockern. Diese Lockerung kamn bei dem Trocknen his zur Brüchigkeit führen. Durch die Risse in der samenschale erhält erstens das wieder befenchtete samenkorn viel mehr atmospluärischen Sanerstoff zu den bereits in Zerset\%mn begniffenen Reservestotten und zweitens anch schneller grotse Wasserquantitaten: es limmen ferner die gelösten, organischen Stoffe viel leichter osmotisth austreten. was alles zmmounsten der Weiterentwicklumg wirksan werten kann. Eine samenschale, die sich langsam gleichmätsig dehnt mul mverletzt l, leilst. wird also wahrscheinlich eine vollständigere Ausuntzung der Reservestotte der Kotyledonen ermöglichen und viel leicht sogar dureh den hei der (knellung hervorgerufenen Spanmungszustand ein Eimpressen rom Flüssiglieiten in das Gewebe der Kotyledonen mul ron gelösten Reservestoffen in den Embryo veranlassen. Anf die bei Her Keimmo antretenden Enzrme und ihre Wirkung kam hier nicht näher cingegangen werten. Wir verweisen in rlieser Beziehung aut die Arbeiten vou Newconbe ${ }^{1}$ ) und (xiüsis ${ }^{2}$ ).

Nach den genannten Versnchsergebnissen kann man mit sicherheit ansiprechen. lats eine Benutzmo angequollenen oder gar schon a uswewachsenen und nachher trocken gewordenen Satgutes nach Frätten zu rermeiden ist. Leh bin aber anch der Meinung, daf's die Verwendumg von gequelltem Saatgut ïberhaupt möglichst zu beschränken und namentlich in trocknen Lagen mit grotser Vorsicht auszuführen ist. Erstens kömnen sich in trockenen Lagen am leichtesten die Zustände, wie sie künstlich durch Anstrocknen gequellter Samen herbeiweführt wurden. in der Natur von selbst bei anhaltender Hitze und Dïre wiederholen und viel schädlicher wirken, als wenn der same bei solchem Wetter ungekeimt im Boden liegt. Wweitens werden die Pflanzen aber anch durh die von Anfang an hohe Wasserzufuhr verwöhnt. I)as (iewelse wird lockerer. wasserveicher und wasserbedürtiger und vertrocknet viel fiöher hei Eintritt grofser Trotkenperioden als bei solchen PHanzen, die von Anfang an bei spärlicher Wassergabe sich entwickelt hahen. Die Verdmstmug ist bei ersteren Pflanzen grölser als bei letzteren. Deshalb wirl in der Praxis vielfach die Regel betolgt, rats man bei schmell sich entwickelnden Gemüseptlanzen (Furken, Bolmen, Kohlarten) das Begietsen nicht aussetzen darf, wemn man in der. Jugend der Pflanzen damit sehr freigebig gewesen ist. Ich habe anch mohrfach stheehtere Pflanzen nach dem Quellen des Saatgutes sich entwickeh gesehen. wogenüber den aus demselben saatmaterial hervorgegangenen, vom 'Anfang an nur anf die naturlichr. Bodentenchtigleit angriesenen Pflanzen.

\section{Die Behandlung der Gehölzsamen.}

Schwerwiegende Nachteile treten besonders hei den Gehölzsamen hervor, wem ler Keimmosvorgang durch 'Trockenheit mterbrochen wirl. An meisten fïhll ar wird dies hei Anssat derjenigen Gehölze. deren

1) Newcomis, F. C., Cellulose-Enzrmes. Annals of Botany 1899, Nr. 49; cit. Bot. Jahresb. 1 199 , II, S. 17!.

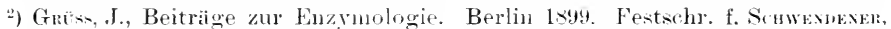
Über Zucker- und stärebilhung in Gerste und Malz. III u. IV. Wochenschr. f. Brauerei 1897 , 1895. 
Samen mur kure Zeit äberhaupt ihre Keimkraft hehalten. NobBe ${ }^{1}$ ) tand, dats die Samen von Weiden schon is his ti Tage nach dem Abflug ihre Keimkratt verlieren. Sohr kurlebig erweisen sich auch die samen ron Pappel und Uhme. Eichehn bleiben in der Regel num bis zum näthsten Frühjahr keimtähig, ebenso wie die Bucheh. Ähmlich durehsehmittlich vorhalten sich Esche. Ahorn und Tamne. Dagegen keimen Fichten- mol Kiefernsamen noch nach :; his 5 .Jahren in ziemlicher Jenge. wenn anch die Ptlänzchen dam hereits schwächlicher sich entwickeln. Natürlich spielen die Ausbildumg des Samens ant'soiner Mutterphanze und the Art der Anthewahrme sine grotse Rolle, und Nobbe fand z. B., dats Samen rom Pims silrestris, die im Wohnzimmer in verschlossenen (tläsern gestanden hatten, nach ; Jahren zu moetälu :30" 0 und nach 7 Jahren noch zu $120 / 0$ keimten: ja selbst nach 10 bis 11. Jahren tanden sich einzelne samen noch entwicklungstähig. Unter denselhen Unständen authewahrt, zeigte Saatgut son Trifolimm matemse nach 12. Jahren noch $10^{\circ}$ ". Pismm sutirmm nach 10. Jahren $47^{\circ}$ " und Sper-

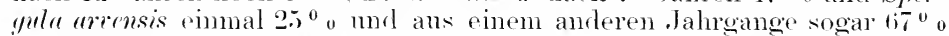
keimfähige Köner. Von Zedern nud Pinien wird angegeben, dat's sie nach 30.Jahren noch gekimt haben \%. Indes empfiehlt es sich, feinsamige Coniferen doch bald nach rler Reife anszusäen. Praktiseh wichtio ist rie Frage. ol man in sommer. Herbst oder Frühjahy die Ausiat vornehmen soll. Der sommer ist wegen der grotsen Fenchtigkeitsschwankungen im Boden die getährlichste \%eit: darm nugeht man bei den Gehölzen, die ein sofortiges Unterbringen der Saat notwendig machen, wio Weiden umel Pappeln, die tretahr, inrlem man stecklingsvermehmug anwendet. Besser ist die Herlstsaat, die bei Eichen. Kastanien, Haselnüssen mul lergl. zur Notwendigkeit wirl. bei den sehr hartschaligen Samen wie rom ('rataegus. Prmms, llex. Sorbus, Rosa, Comms, Berberis, Ribes. ('arpimm. staphylea, Clematis u. a. emptehlenswert ist. Die letztgenamten Arten bleiben namentlich in sandigen Böden, die voriibergehend wieder anstrockenen, oft 2 bis : Jahre moekeimt liegen. Am besten ist die Frïhjahrsaat, weil das saatgut dahei allen Fährlichkeiten des Winters nut der Tierbeschädigungen entzogen ist. Um die \%eit vom Herbst zum Frühjahr nicht zu verlieren. findet las "stratitizieren" der. samen, d. h. das schichtenweise Einlegen der Körner in fencht erhaltenen sand, seine Anwendung.

Bei dem jetzt lebhatt entwickelten Bezuge von sämereien geshätzter Ziergehölze aus dem Vaterlandr ist es wiohtio, die Erfahrungen zu kemen. welche hetreft's des Terhustes der Keimfähigkeit während des Transportes gemacht worden sind. (trat r.senwers ${ }^{3}$ ) hat in der Dentsehen lendrologischen (iesellschatt darant antmerksam gemacht, dats Ahomarten einen längeren Transport nicht vertragen. so dats \%. B. seit Jahren die aus dem Himalaja hezogenen Ahomsamen keine einzige lieimptlanze ergeben hatten. Indes lart' man nicht zu fiöls die saatbeete morechen, da manche samen sehr lange gesmel in der Erde liegen bleiben: so

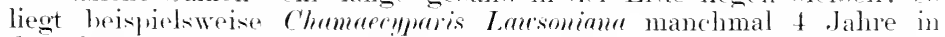
der Erde. namentlich in trockenen lahren. Bej dem Bezuge ron Magnolia hypolouca aus. Japan wurle jahrelang entreder äberhanyt keine Pflanze erzielt of re doch so wenige, dat's die Transportlesten nicht gedeckt wurlen. Die samen rortrockneten unterwegs. Sieitrem

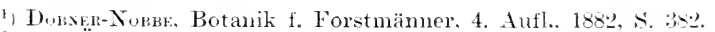

2) u. ${ }^{3}$ ) Lber das Keimen ron fehölzsamen. Dex Handel-gartner 190., Nr. 14. 
nenerdings diese Samen in ihrem natürlichen Fruchtfleisch belassen, und so in Holzkohlenpulver gepackt ankommen, liegen sehr ermutigende Resultate ror.

Wenn rorhin gesagt worden ist. dats die Acer-Arten nur bis zum nächsten Frïhjahr keimfähig bleiben. so ist noch zu ergänzen, dats die Ahornarten aus der Campestre-Gruppe (Acer obtusatum, itulum u. a.) in der Regel erst im zweiten Jahre keimen. Nur vereinzelt findet man schon Keimlinge nach cincm Jahre. In manchen botanischen Gärten sollen aber die Bäume der Campestre-Reihe regelmälsig meist frühkeimende Sumen liefern, und man erklärt dies daraus, dats dort bei der Aussaat die zuerst aufgegangenen Pflänzchen zur Aufzucht benutzt worden sinıl. Darans ergäbe sich der Schlut's, dafs man die Eigenschaft, schnell keimende Samen zu produzieren, durch Selektion beständig machen kann. Dieser Punkt, bei grofsen Aussaaten die am frühesten hervortretenden Keimlinge gesonclert zu samenträger'n heranzuziehen. dürfte her Aufmerkwamkeit der Züchter zu empfehlen sein.

\section{Das Verscheinen bei Getreide und Hülsenfrüchten.}

Bei dieser Wachstumsstörung unterbleibt die Ausbildung der Samenkörner dadurch, dals die Pflanze nicht genügend Wasserzufuhr erhält. Ein solches hochgradiges. Durststadium wird natürlich auf den Böden mit sehr lockerem Gefüge, bei denen die Verdunstung sehr grols und die kapillare Leitung des Wassers aus dem Untergrunde gering ist, am häufigsten zutage treten.

Doch nicht jeder intensive Wassermangel wird ein Verscheinen der Blüten hervorrufen. Es kommt hierbei wesentlich, wie Heldriegel's Versuche bei dem Getreide zeigen, auf das Entwicklungsstadium an, in welchem die Pflanze sich gerade zur Zeit des Eintritts der Wassernot befindet. Wenn. wie in den Versnchen ${ }^{1}$ ) ausgeführt wurde, eine Getreideptlanze ron erster Jugend an nur ein geringes Wasserquantum zır Verfügung hat. so bildet sie alle ihre Organe in derselben. vielleicht sogar in noch etwas längerer Zeit aus, wie die mit reicher Bewässerung rersehene Pflanze; jedoch ist die ganze Produktion schwach. Das Verhältnis der geernteten Körner zur Gesamttrockensubstanz ist aber immer das normale, l. h. die Hälfte Trockensulstanz ungefähr wird in Form von Körnern geerntet. Wie bei allen Vegetationsbedingungen ist anch hise eine unterste Grenze: hält sich clie Wasserzufuhr unter derselben, findet äberhaupt lieine nemenswerte Produltion statt.

Tritt ein bedentender Wassermangel gleich nach den ersten Keimungsstarlien ein, so bleiben die Körner lange (im Tersuch bis sechs Wochen lang) lebendig und entwickeh sich nach dieser Zeit kräftig, solatd reichliche Wasserzufuhr sich wieder einstellt. Noch weniger schärllich erweheint einc Durstperiode, wem die Körner milchreif sind, also ihre normale Grötse erpeicht, aher ihren inneren Ausban noch nicht beendet haben. [lie Arbeit der Ptlanze, welche zu dieser Zeit ïberhaupt keine nene Troekensulstanz mehr bildet. besteht in der Unwandlung und der Fortführung der im Blatt erzengten Substanz nach den Reservestofthbehältern, ilen śamen, lin.

In allen zwischen der Saat- mol Reifeperiode liegenden Entwicklungs-

1) Helıkizer, Beiträge zu den naturwissenschaftl. Grundlagen des Ackerbaues. Braunschweig. Vieweg 1853, S. 598 bis 620 . 
phasen wirkt längerer Wassermangel schädlich, und die Folgen sind 1 m so tiefer eingreifend, je jugendlicher noch die Pflanze bei Eintritt der Durstperiode ist. Wem in der /eit des kräftigsten Schossens eine längere Trockenperiode eintritt, so kann die Pflanze diesen schaden nicht mehr ausgleichen. Die Folgen anhaltender 'Trockenheit sind um so empfindlicher, je mehr Wasser die Pflanze in der Jugend gehabt hat. Wenn sich eine Pflanze bei reichlicher Bodentenchtigkeit bis zmm Blütenansatz ïppig entwickelt hat und es folgt jetzt eine grösers Durstperiode, dann geht die Körneranlage zugrunde: es kann ein melı' ocler weniger umfangreiches Fehlschlagen der Kirnerernte eintreten. was wir dam als "Verscheinen" des tretreicles hezeichnen. Ein recht interessantes Beispiel hat Ritzena Bos ${ }^{1}$ ) bezüglich der "Maartegerst" veröffentlicht. Naartegerst ist Wintergerste, die im März gesät wirıl. Dieselbe war auf Ackerflächen gehracht worken. bei denen die WVintergerste der Herbstsaat ausgefroren war. Nu eine Anzahl der im Herbst gesäten Pflanzen war durch den Winter gekommen umel ging gut bestockt in den Sommer, so daf's dasselle Felil Wintergerste und Märzoerstr. hatte. Letztere litt num im heitsen sommer dureh Verscheinen, wälnend die dazwischen stehenden Pflanzen der Herbstsaat vollkommene Körnerernten brachten. Autser dem Getreide leiden bei uns am häufigsten noch tie Erbsen. Sielbstverständlich kam auch bei anderen Pflanzen ein Fehlschlagen der samenernte durch Vurcheinen der Blütenteile statt finden.

\section{Die Fadenbildung der Kartoffeln (Filositas .}

Die Krankheit (..mules" ter Franzosen) besteht in einer Vorkïmmsrumg der Augen: aus denselben "ntwickeln sich schlanke. ta de n a r t ig." Stengel ron der Dicke enes mittleren Wollfadens. Nicht selten treibon die Angen der ührigens verhältnismätig sehr stärkereichen Knollen überhaupt nicht aus. oder die schwachen Triehe vermögen selbst bei geringer Bodenbedeckmng nicht an die Oberfläche zu lommen, und dis Knollen gehen meist miter' den Erscheinmoen der' Trockentäule zugrunde. Die Krankheit ist bisher nur dort reichlich anfgetreten, wo leicht erhitzbare Böden grofse Trockemperioden zu überstehen hatten.

Fig. 16 stellt den Basalteil pines in Wasserkultur gezüchtesten stecklings von einer fadenkranken Kartotfel dar. Die I imensionen von stengel, Blättern und Knollen entsprechen der natürlichen (irötse. und man ersieht, wie tatsächlich die stengel nur die Dicke eines starken Wollfadens besitzen. Die stolonen (st) sind auch schmächtiger und haben bereits Knölchen $(k)$ angesetzt. von denen einzelne sich an ler spitze verlängert haben und zu grünen Trieben (b) ausgewarhsen sind. oder schuppenförmige, grüne Blättchen entwickehn (d).

Der abgebildete Steckling stammt ans einer Versuchsultur, deren Resultate in der zweiten Auflage dieses Hanthuchs in präzisen /ahlen wiedergegeben sich finden und zu dem schlusse tühren. dats wir in der Fadenkrankheit der Kartotteh erblich gewordene Kustände einer Notreife ror ms haben. Die Mitteilungen ans den ()rtlichkeiten. in denen die Krankheit anfgetreten. namentlich ans dem Marchfeldo bei Wien ${ }^{2}$ ), ïber die daselbst befolgte Kultumethode bestätigen diese Ansicht. Es werden dort nämlich die Kartotteln. welche meist zu din

1) Zeitschr. f. Pflanzenkrankh., 1894, S. 94.

2 Artwartis, Das Marchfeld und seine Bewässerung. Österr. Landw. Wochembl. 1875. Nr, 51. 
trühesten sionten gehören. mëglichst zeitig ausgolegt, nachdem sie vorher norh kïnstlich angetriehen worden sinrl. Bei der steigenden

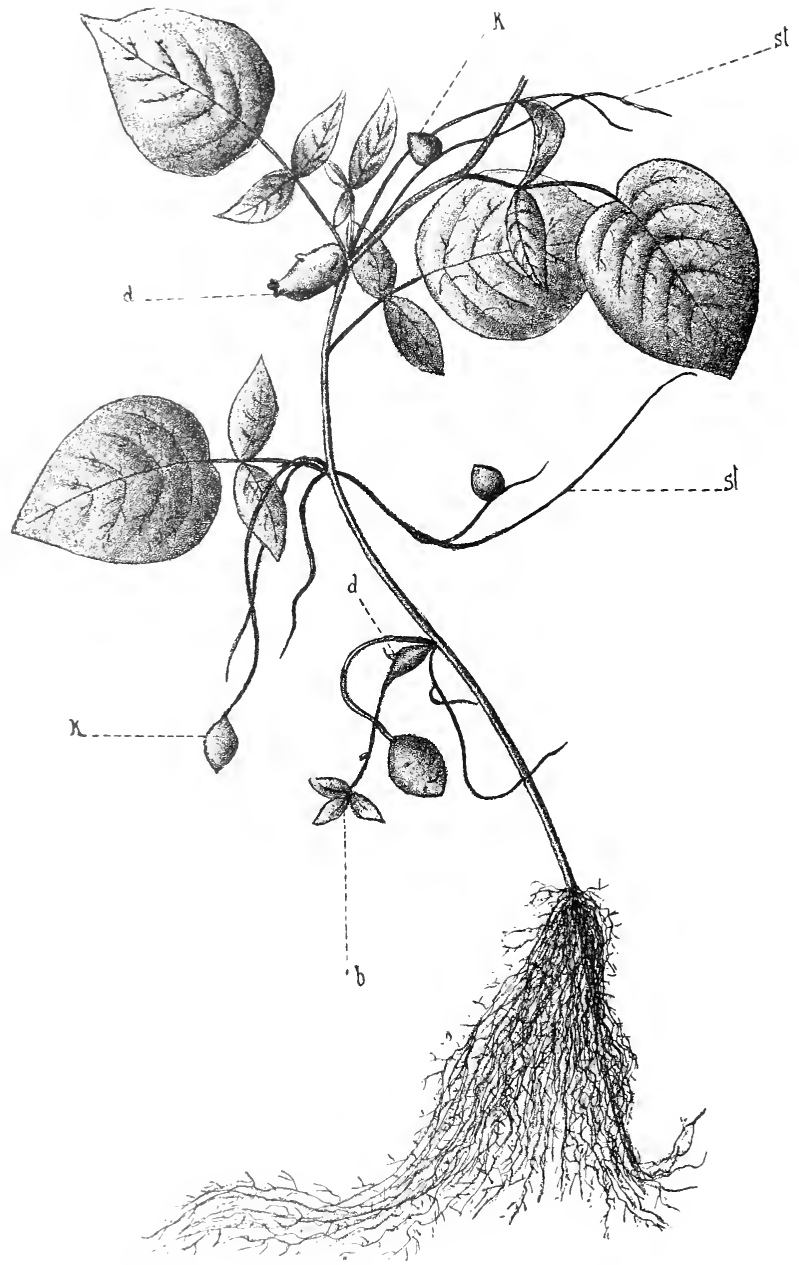

Fig. 16. Batalteil eines in Wasserkultur gezichteten Stroklings von einer fadenkranken Kartoffelknolle, nat. Gr. (Orig.)

Sommertemperatur mel der flachen Tage in den oheren Schehten eines nur mit geringer wasserhaltender Kraft begabten, stark erhitzbaren Bodens Santhoden anf dem Narchfelds hei Wien, Kalkboden bei 
Poitiers) ${ }^{1}$ ) erleidet das Vachstmm del obelindischen Achsin alshatel einen stillstand, und die $n$ m diese Zeit angelegten, noch lange nicht ansgewachsenen Knollen tïllen sich mit stärke, so datis sie sehn zeitig ant h+on Markt gebracht werten könmen und hohe Preise erzielen.

Wem alie Knollen im jugendlichen Kustande anreh Notreife einen Madhstmusstillstand orleiden mnd lam gerentet werlen. so hat anrh

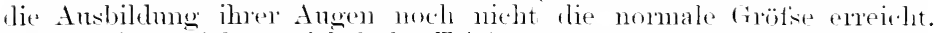
Die ans dieven sich entwickehnlen Triebe mïsen naturemäts schwächlich sein. Wem solehe Knollen im näuhsten Jahr als Satont zu gleirher

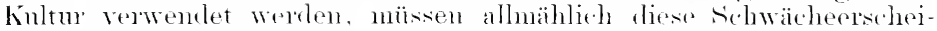

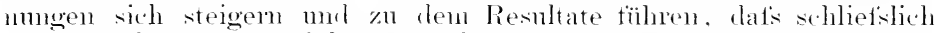

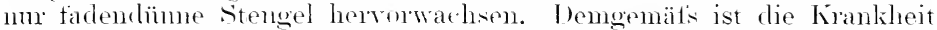
die Folge cines tortgesetzten Kulturfehlers, nämlich einer mznlässigen

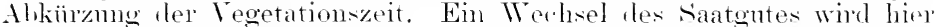

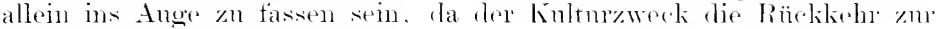
normalen Bestellnug verthiotet.

\section{Durchwachsen der Kal toffeln.}

ln den regenarmen sommern. wie \%. B. inn Jahre 1 mot, war eine rler hänfigsten Klagen. datis die Kartoffeh klein reblieben odu hei an-

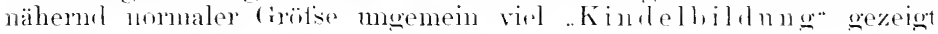

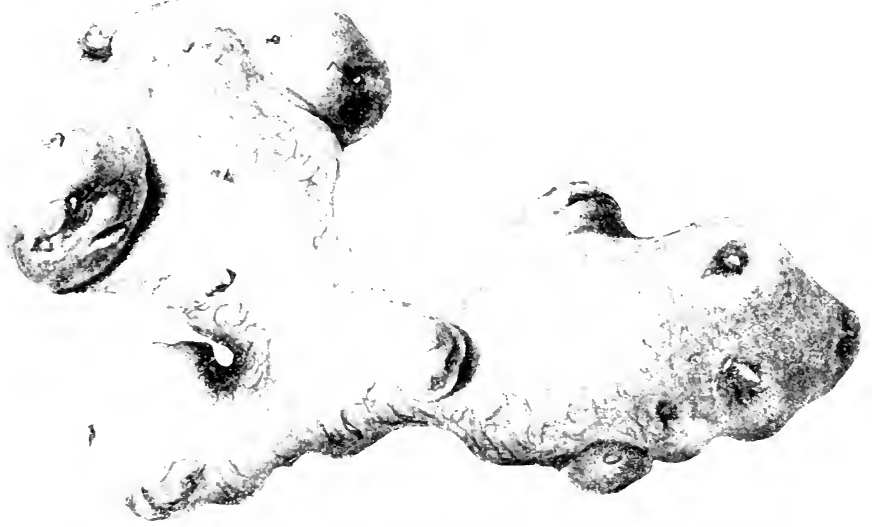

Fig. 17. Durchwahsene Kartoffel: links Anlage vollstindiger Nebenknollen (Kind Ibildumg), rechts nawhtrighliche streckmg des Gipfelendes / Wasserenlen). (1)ig.)

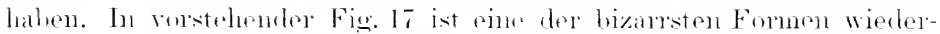
gexpben worten. welche \%wei Arten ler Inuhwathsmg zeigt. nämlich

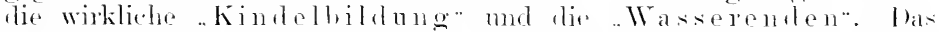

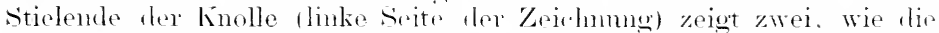

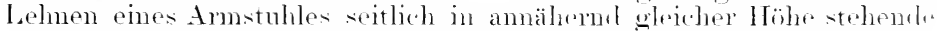
Tochterknollen, und ron la ans nach ter Knollenspitze hin sehen wir di، Tochterknollen immer kleiner werden. his sie in ler Näh' des jüngsten

1) Joumal d'Agriculture pratique: cit. Biedermann's Centralbl. f. Agrikulturchemie, 1873. Nr. 10, und Amalen d. Lamdwirtsch. 1973, Worhenhl. Ni. 16. 


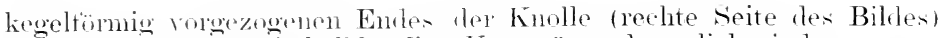

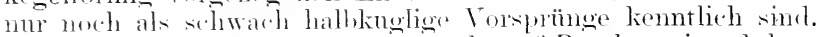

Die Vrebildung der hnollo herulit ant Prolepsis, d. h. vorzeitiger Entwicklumg dor Angen. l)ie Erklärmo für diese Erscheinung liegt schr nalıe. I) Kantoffelstande entwickelt. nachdem sie einige \%eit krätiges lanh, wehildet. alhnilulieh flie Spitzen oder Seitenangen der

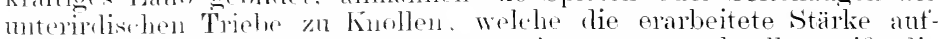
speichern. Ir trockener dir sommerzeit, $n$ so schneller reift die

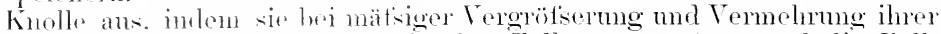

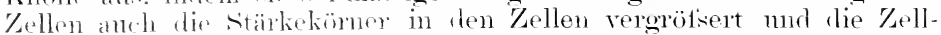
wände verliclit. Allmählich verlieres die Zellwände mit Ausnahme der jugendlichstrn an Ange die Fïhigkeit, wich herlentend zu strecken.

Wom nm nach lïngerer Troekenheit und vorgeschrittener Reifis cin bedentender. Vasserantitrieb in die Knolle gelangt, wird der Druek des lurch reichlieh Wasseranfinahme vermehrten \%ellinhalts sich namentlich in den jungen /ellen des Anges geltend machen mol ihre noeh leicht dehmbarm Wandmoen strecken, d. h. das Ange lreginnt zu warhsen. Aus den Angen werden junge /wreige, welche sich verlängern. bis sio die Borlenobertläche erveichen. Dies ist der seltenere. nur bei anhaltend tenchter Wittermo eintretende Fall. In der Regel siml so roriberachende Rroenperioden. welche einen kurz dauernden Traserauttriel, in der Knolle hervorrufen: dam hleibt der Trieb kum und verdiekt sich zur sekmolären Knolle (Kindel).

I at: dir \%ellen mit der Reife der Knolle ilme Dehnbarkeit resrerlieren, sieht man recht dentlich an der Korkschale. die hei jungen Fnollen immer glatt ist. Wem die Knollen recht reif sind, ist lie s.hale bei ter Melurahl der Kartoftelsonten, namentlich den roten. rauh. Dir zuerst dicht miteinander verbundenen Zellen der Korkischale kiomon schlietich dem Thuck des sich ausdehnenden Parenchyms der Wnolle nicht mehr durch Tehnung der Wandmugen folgen, sondern werden an zahbeichen strllen anseinandergesprengt, woduch die Rinde risig wirt. Unter don Ritistellen haben sieh nene Korkzellen gebildet. Thas Eintreten der Risigiverelens der schale hängt natuirlich ron der Sorte ah. Jo risiger bei somst glattschaligen Sorten eine Knolle ist. un so reifer mol stälireicher ist dieselhe.

Das londhwarhen der Knollen hat nun in vielen Fällen insoforn cinen shädlichen Eintluts, als sich dadurch die Quantität stärke, die wir als Bodentrntr entmehmen, in minder leicht gewinnbarer Form darstellt. Man erhält neben den grofien Knollen eine Menge kleiner. dis wemiger reif mul daher stäkeärmer sind. Die bereits vorhandenen

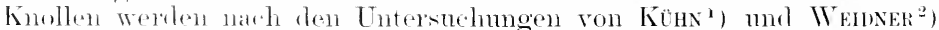
dureh das Kintellitren nicht ärmer an Stärke. Diejenige, welehe in den sekundäron Kunllen sich vorfindet, stammt nicht ans den Mutterknollen. somblern ist in len Blattorganen nengebildete mol ron tort herahgeranderte. Nu lwi den Stöcken. deren Krant schom abgestorben ist, hingt plitzlich romente Wasterzufuln die Kindelbildung auf Kosten des Stäkegulaltes der alten Knolle herror. Beirle. Mutter und Kimn. haben erst den stärligalıalt einer nicht durchwachsenen Knolle.

Die sog. " Wasserenden" sind nichts amleres als die durch eine nachträgliche Wasser\%utuhy zu crnentem Wachstum angeregten (ip)tol-

1) Zeitschr. 1. Landw. ('entralver. der Prov. Sachsen 186-, S. :22.

2) Anmalen des Mecklenb. patriot. Ver. 1868, Nr. 39. 


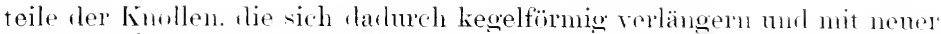
Stärke tïllen (s. dic rechte scite der Figm 17). l) Fe Fïllumg ist ehemn mangelhatt wie hei den eigentlirhen "Kindeln".

\section{Knollenbildung ohne Laub.}

Vemn man Knollen zur Zeit ilnes natürlichen Anstreihens nicht in Erde bringt. sondern in einem trockenen. wenig belichteten Ramme bis zur nächsten Ernteperiorle aut' hewahrt, erntet man hisweilen einc Anzahl kleiner Knollen. Dieselhen stehen entweder dirht an der Mutterknoll, ofler hängen an kurzen stolonen, die sich ans den Angen entwirkolt haben. Während bei rechtzeitiger Wasser- und Lichtzufuhr diesellum Angen zu heblätterten grünen Trichen geworlen wären. luat hei dr trockencu dunkeln Authewahrung das austreibeme Ange sich zu drom fadenartigen nur mit Schohumen statt der Blätter besetzten Ansläuter (stolo) ausqehildet, und dessen sipitze hat alshald wieder zur hinollo sir.h verdiclit.

\section{Oberirdische Kartoffelknollen.'}

Es kommt vor. rlats bei Hach gelegten nicht wehäutelten Knollen las Kraut noch grün bleibt. Währent der Wnzelapparat chrch dir Trockenheit oder Tiere stark beschädigt wirl. Wem ein nachtolgenfler Regen den reschwächten Wurzelkörper so weit in Funktion erhält, rats rlie oberirlischen Achsen am Leben bleiben, entwickehn sich an ihnen aus den Seitenangen kloinc getärbte Knollen. Anch miter anderon Verhältnissen ist diesel Vorgang möglich: loch stimmen die Verhältnisse stet darin überein. dats der Wurzelapparat elkankt ist mul mu sehr geringe Wassermongen ans dem Boden den helaubten strumeln zutühlen kimn. Man kamn sellst stecklinge ans äleren stengelteilen dazu hringen. in ihren Blattarhsoln Knollen anzusetzen.

\section{Notreife des Obstes.}

In .Jahren mit anhaltender' 'Trockenheit, wie z. B. lont, trotru äutserst häutio die Klagen ant, clats das Kermobst nicht haltbar sei. Das sommerobst ist zwar schmoller reit' mol kam \& lis 14 'Tage triuhr. aut den Markt gebracht werclen. aber der (reschmack lä1st zu wiinschen ïbrig. Das Winterobst bleibt in der Regel kleiner, ist weniger saftio und aromatisch und geht entworler schneller in Fäuhnis über, orler aber es brancht viel längere Zeit anf dem Lager. un verkantifähig zu werelen. Der erstre Fall lätst sich auf den leichten Börlen beobachten: drel letztere ist damn gefumblen worklon ${ }^{1}$ ). Wenn ant schwerem Boden nath ler Trockenperiofle noch Regen sintritt, der ein Weiterwachsen r.r. bisher fluch den Wassemangel zmïckgehaltenen Fröchte vermalst.

Das weschihlerte Verhalten tindet seine Erklärmng bei Erwägung des Lmstamrles. datis Güte mul llaltharkeit der Frïchte von zwei Faktoren abhängig sint. Zumächst muts jede Frucht eine genügende Zeit zur Einwanderung des zu ihrex Aushildung nötigen Wassers und Nährstoffmaterials haben. Was in die Zeit der Schwellumgsperiode tällt. All mählich stellen sich dam dir Oxvdationsvorgänge des Reifeprozes-m

1) Monatsschrift für Pomologie und praktischen Obstbau von Ombrnfa k und Lik.s, 186:, s.. 272. 
rin. hei welthen das hisher in Form von siäre gespercherte Reservematerial veratmet wirl. Je länere die Frucht Keit hat, das ans den Blätrun einwandernd. Matrial zu speichern, desto reichlicher ist sie

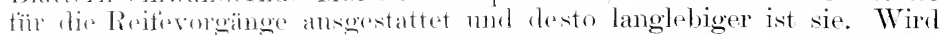

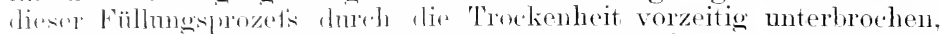

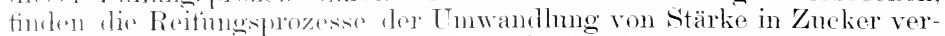
hätrismälisy worly Matrial vor. Bei normaler, d. h. abwechselnd sommer hein mel Regen bietender sommerwitterme nimmt anch die Wrucht während les Rorifororganges antiser Wasser noch Mineral-

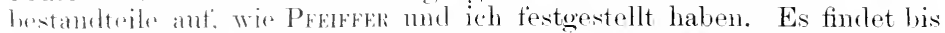
limz vor der Vollecite sine alsolute Zunahme an Mineralstotfen statt;

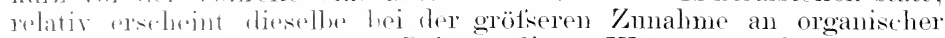
sulstan\% natiollich kleiner. Bei ständigem Wassermangel morbleibt dirso \%utuhr, mul die Frïthte veratmen mun schnell das spärliche llaterial. Jer sämerorat ist gering und die Zuckerbildung spärlicher:

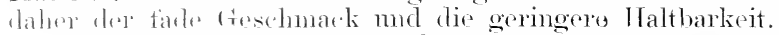

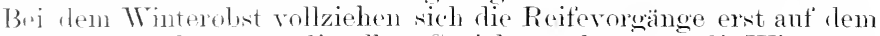

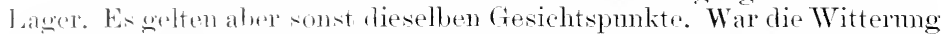

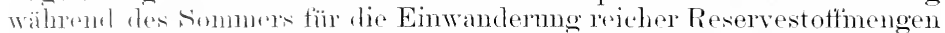
wimstiy. weht dir Frutht wohl vorbereitet anf das Winterlager mul irlält sich lange atsund. Bei geringer Menge von Reservestoffen lebt si. sirli wen schuell ans. In Jahren, in denen nach einer langen Thetsenperiods eine anhaltend kïhle, triilse Keit eintritt, tängt das Wintrobst. nachdem a in seinem Wachstmm durch die Trockenheit rinen langen stillstand whitten, von nenem zu wachsen und Material

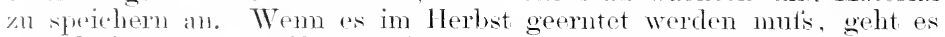
wohälnismäsig mreifor ant das Lager und brancht mu länger Zeit, nu reif' zn werden. Las sind nachher die (in ganzen selteneren) Fälle, in loum die Früchte unverhälnismälsig lange ant dem Lager liegen

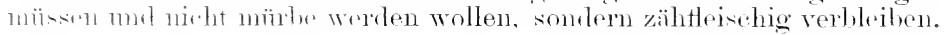

\section{Fuchsige Pflaumen.}

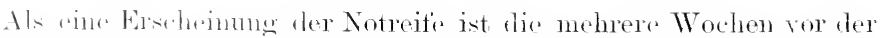
nommalon Reitergeit eintrotende fuchsig-rote Verfärbmong der Pflammen zn

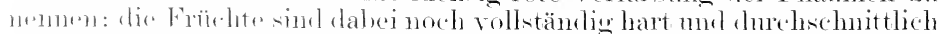
lialh so wrotis als dir normal amsereiften. In der Regel fallen die

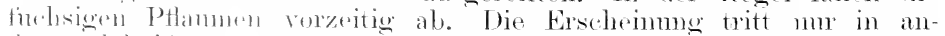

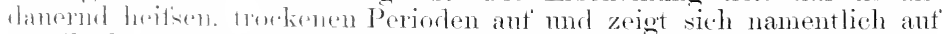

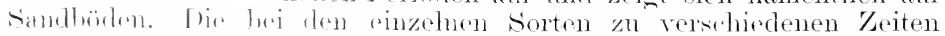

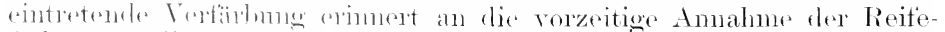

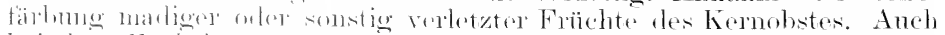

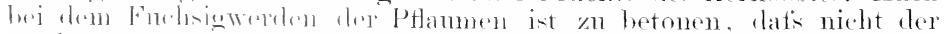

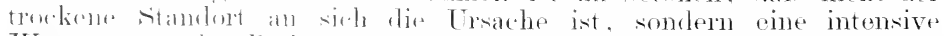

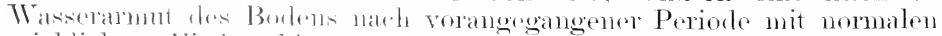

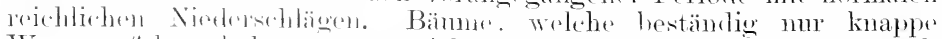

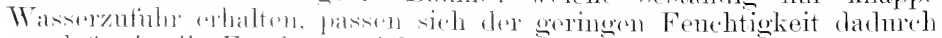

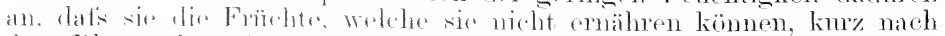

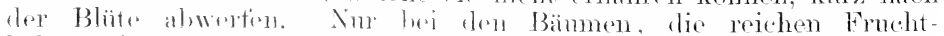

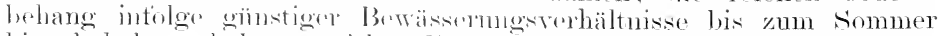

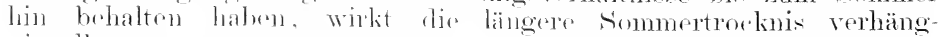
nisvoll.

Als Torbonemugmittel kann die renlitzeitige Fortsetzmng der 
Wasserzufuh durch Begietisen angesehen werden. Man warte nithl zu lange mit der Nathhilte durch reiches Begiefsen. Fängt man zu spät mit der Bewässerung an, fallen häufig nicht nur dic fuchsigen. sondern alle Frïlolite al.

\section{Weitere Erscheinungen der Notreife.}

Selbstrorstänllich lïnmen bei allen Ermchtoattmugen dis Folgen einer andauernden Trockruheit der Bodens nach normaler Frïhlingfenchtigkeit sich geltend machen. l)as Abwerten von Blätern mul Frïchten ist ein häufiges Vorkommmis: die mangelhafte Ausbildung dor an der Pflanze verbleibenden (hoane die minder in tie Angen springende Erseheinung. Bei (l)st und Kartoffeh resultiert darans oine geringe Haltbarkeit in den Autbewahrungsäumen, hei dem tretreide rime Schmächtigkeit der Körner. Wir kommen auf andere Fäle noch spätr. zu sprechen. wenn wir der Fotgen moew öhnlicher luttrockenheit ar. denlien.

\section{Mehligwerden der Früchte.}

Bei Kernobst. namentlich den frühen siolten, zeigt sich in hesonder heitsen Sommern ant sandigen Börlen die Erseheimnng. dats das Frucht Heisch nicht sattig und linaclend, sondern mïrbe, sattarm, mehr tarle. wie aromatiseh schmokend und hei louck zu mohligem Brei leicht zerfallend sich rarstellt. Diesellen sorten sind in kïhleren .Jahren oder an anderen Standorten, ja selbst von lemsellow Baume hei fiöhzeitigerer Ernte nicht melig. sondern gehen von dem festen dureh den sehmelzenden direkt in den woinig-teigigen odre in ten tanligen \%ustand iiber.

sperielle Untersuchungen sind mir äber den verlienenden Fall n:cht bekannt geworden. E. kimm daher nu rermutungweise ansgesporthen werden, dats das Mehligwerden dor Frïchte aut cinem durch Trasiermangel in andere Bahnen gelenkten Alit des Reifungsinozesis beruht. Diese Ablenkmug dïrfte nicht mehr an den Zusammenhane der Frneht mit drom Bame gelsunden sein. sondern spät in Leben drer Frucht, etwa zur Zeit der alfoemeinen Lösmg der hutrecollularsubtanz des Fruchtfleisches sich einstellen. Bei dos normalen Fruchtreife tritt

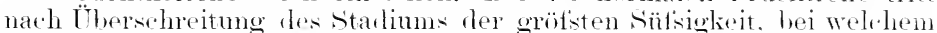
die Früchte bereits ,selumelanul". 1. h. die Zellen ihres Fruchtfleisches leicht voneinander trembar sind. ant Kosten des Zuckers die Alkohol-

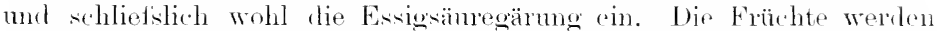
weinig-teigig unter stetig fortsehreitender Brämung. Ein Teil des as bildeten Alkohols verlindet sich nach Freyr ${ }^{1}$ ) mit den Frucht-änren zn den Äthern, welche das Aroma rer Früchte bedingen. Kühle 'Trmperatm' verhindert das schmell. Verbremen des Zukers. I) mit der Reife gering werdende Wasserzutuhr zur Frucht aus dem Zwoige erliärt. dats hes grotser Sommerhitze dir Frucht autiserordentlich schnell auslebt und dabei stark Kohlensäure nnd TVasser algeibt. In dem wasserärmeren. hor $l_{1}$ durchwämten Fruchtfleisehe diutte aber die Lïsmg der Interecllular substanz, die wir zu den Politinen lechnen, nicht in der gewöhnlichren

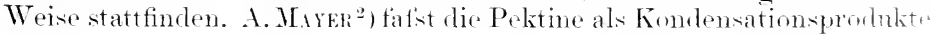

1) Compt rend. LVIII, S. (i.)6.

2) Agrikulturchemie 5. Anfl.. Bd. I, s. 141. Heidelberg $19 m 1$. 


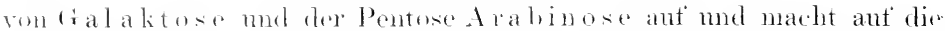
Fignoümlichkist aufmerksam, dats sie durch ein hesonderes Enzym

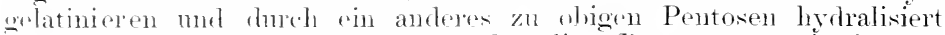
werten. Man dant wohl anmehmen. dats diese Prozesse quantitativ oder unalitativ hai dem Mehligwerten dro Frucht rerändert werden. Ex

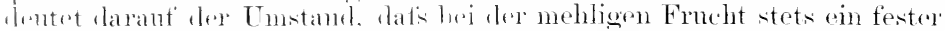

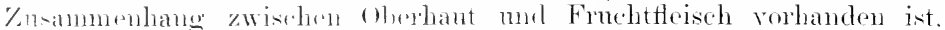
"alnend hei dem nomalen weing-teigigen Zustande die Oberhant rom

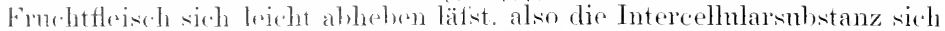

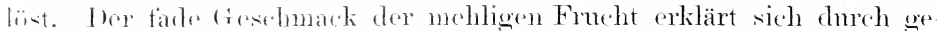

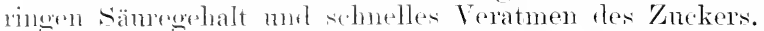

\%m Borvintume der Ansicht, dats Wämeäberschufs einen rela tivon Mangel an organischen sänen in einer Frucht veranlassen kamn, mulis an the 'Tatsache erinnert werten, dat's in den Blättern die nächtlich wehilketen sïnen an folgenden Tage grotsenteils wieder veratmet

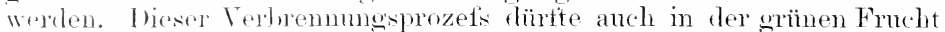
stattinden. nud as ist wohl denkbar, dats derselbe in ten langen. lroitsen sommertagen so intensiv ist dats ein grotser Teil der ent-tandenen vämren rerschwindet. Unter solchen Tmständen kommt die woinige (rärung gar nicht zustancle.

Fiir dis Anschanung, dats das Mehligwerten der Früchte bei Wascerarmut der Zellen mer breiartigem Zerfall der Intercellularsnlstanz sintritt, wenn die Bedingungen für eime weinige fä̈rmo nicht

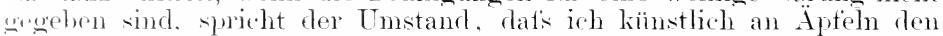
Forgang hervorzurufen vermochte. Es worten Früchte ress hiedener sorten nach normaler Bammeife in trocknen Sand eingeschichtet unt rom Herlst lis zum nächsten Sommer in einom kïhlen, hellen Keller anthwahrt, $n$ das Ansleben der Frucht möglichst langsam eintreten 211 lassen. Dahei zeigte sich, dats einzelne Frïchte mit vollkommen muretetzer Wachsolasm im August noch gesmet, aber vollständig

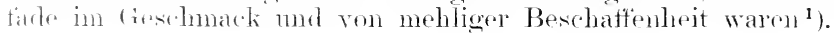

\section{Die Stippflecke.}

In Flaish the Komolistes, vorzugweise des Äptel, entstehen luame. zähe, mitmes hitter schmekende, zerstrente Flecke. Befinden sich liostlow in mmittelbarer Nähe der sehale, machen sie sich als

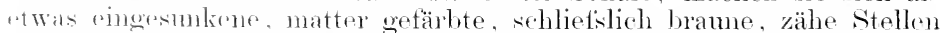
lenerphat. Int lockren B̈̈rlen in trockenen Jahren. wie das .Jahr

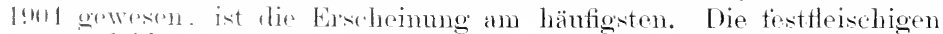

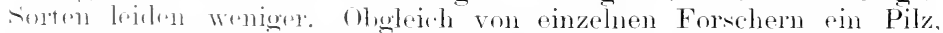

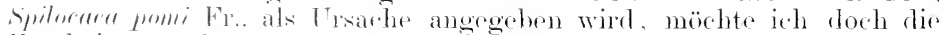
Erstheimmog als eine Folge zu schnellen Anslebens einzelner \%ell-

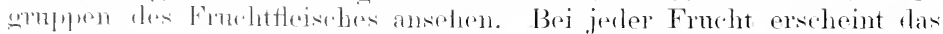

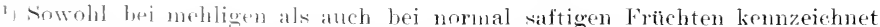
sich das stadium der Reifo lurch das Erscheinen eigenartiger Stofforuppen, die

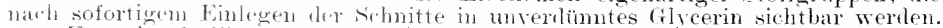

[moteliende Figur stellt rine Zolle ans dem F]eisehe eines Apfels (filoria mundi) nach sofortigem Einlegen des solmittes in Glycerin dar. Der zarte plasmatische IVandbelag, der faltig zusammengezomen, ist in der Zeichmmo teilweise fortgratasen: er drängt die lier dargesteliten Inhaltsmassen mehr onter weniger zusumman. Auch die in den meisten Zellon sofort in die Augen springende, meist in einer Eeke liegende, selu grofse Vakuole, welche ich als Sïurevakuole ansprechen mörhte, fehlt, mu die stofte deutlicher zu zoigen, welche bei der Glycerinreaktion 
(iewrobe des Fruchtfleisches mugleichmätig mit Reservestotten getüllt. Wem vorzeitige Bodentrockenheit die Leitung der zur vollen Ausbildung der Frucht notwendigen Menge organischen Materials verhindert, werden einzelne (iewebegrupen besonrlirs arm an Inhaltsstoffen bleiben und rlann schmeller sich ansleben. Die Antänge der

hervortreten. Es sei hier bald betont, dafs nicht alle Zellen ..die dargestellte Komhination zeigen; schön fant ich sie im Aufsenfleisch bei reifen Äpfeln. Birnen und Pfirsichen. Die Cntersuchungen weisen darauf hin, dafs eine dem \%urker nahestehende substanz in verschiedenen Übrogangsformen in den Zellon vorhanden ist. Zwischen "inzehnen gröfseren oder zahlreichen, sehr kleinen Vakuolen findet sich diese Substanz, dem Plasnaleibe eingebottet oder frei im Zellsafte, (ntwoder als vereinzolte trübe Tropfen oder als mehr geradlinige Massen, die dom Ausselien nach etwa von toigiger Beschaffenheit sein dürften. Janchmal findet man sie in noch stärker lichtbrechender und noch festerer Form als knollige, warzige, unregehmäfsige Anhäufungen. Diese festeste Frm scheint auch in Gestalt kleinster sandartiger, den Wandbelage eingebetteter Körnchen vorzukommen, anf welche man erst aufmerksam wird, wem dieselben zu Tropfen oder (durch Vakuolenbildume) zu kleinen Blaischen in Glycerin aufquellen. Allen drei Formen krmmt eine Quellmosfihhgkeit in Glycerin zu. Bei Berobichtung miter Wasser werden die Tropfen leicht mIrutlich und verschwinden, aber im auxgeprefisten Apfelsafte bleihen sie kemntlich und von den verschiedrmen Vakuolen unterscheidbar. Das Quellumgsprodukt in reiner ausgebildetsten Form auf der Höhe der Entwirklung ist num durch die strahlige Mittelfigur in unserer Abbildung dargestellt, während der teigartige \%ustand der Substanz durch die darunterliegende schraffierte Fläche mit geschweiften Konturen augedentet ist. Thie wolkige [mliällung ist der in dersillen Ebene liegende Teil des Plasmisackes, welcher larbstoffkörnchen und zwei Vakuolen umschliefst.

Der Quellungsvorgang ist bei den ohen geschilderten drei llassen der gleiche. tritt aber in verschiedener. Intensität ein. Am schnellsten mol ausgebildetsten erscheint er bei der Tropfenform: er nimmt ab, je fester dic Substanzen werden. Bei Wasserzutritt verschwinden zherst die Tropfen: an ilner Stelle bleibt bisweilen ein

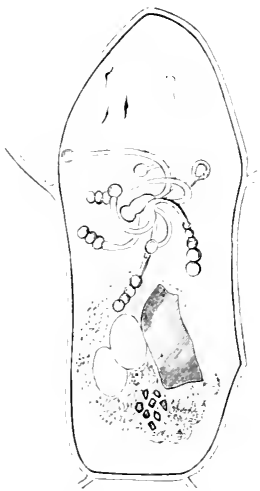

Fig. 1s. Parenchymzelleaus dem Fleische eines reifen Apfels nach Behandlung. mit unverdünnt. Glycerin. (O) rig.) feinkörniger Rückstand an Rande der Plasmahülle; etwas spïter werden die teigigen Massen unsichtbar, und die durch das Plasma gebildeto Grenzlinie wird kroisrund: die polypenartigen Formen werden langsam durchscheinenter, dif Warzigen Massen graugekörnelt und trübe, ohne sich an einem Tage ganz zu lösen. Wenn man die gern der Wandung anliegenden, zwischen Vakuolen eingebetteten, triben Kugeln bei Begimn des Wassereintritts betrachtet, benerkt nan häufig eine von innen heraus beginnende Quellung einzelner Inhaltsgruplen, dif bis zur Vakuolenbildung sich steigert. Ähnliches findet man hei flycerin, bei welchem der Vorgang langsamer sich einstellt und die verïnderten Zuständf sich länger erhalten. Durch diesen Quellungsvorgang der in den träben Tropfen eingebetteten Substanzen erscheint deren Inneres bisweilen derart von einer ouler mehreren Vakuolen angefült, dafs die eigentliche truble IIasse mur noch als schmaler Imfassungsing der Takuole auftritt, der in Wasser immer durchscheinender wird, bis er älerhaupt nicht mehr kemutlich ist. Eine eigentliche Lösung der Substanz wurde nicht beobachtet. Wem die frischen Schnitte erst in Wasser liegen, treten die trüben Tropfen nicht mehr auf, woraus zu schliefsen, dafs die Substanz rom Wasser aufgenommen wird. Wohl ater wurde in mehreren Fiallen beobachtet (bei Reinetten), dafs, wenn nach einer schnell voribergehenden Wassereinwirkmo die Tropfen verschwunden waren, ein feinkörniger Rückstand hlieb. Bei Glycerinzusat; quollen diese soliden kïruchen entweder zu Tropfen oder zu einzelnen fadenförnigen sichlänchen aut. Vielleicht sind es nur diese Körnchen, webche in den Tropfen und den ïbrigen, ohenerwihnten, als verschiedene Aggregatzustände einer Grundsubstanz angesponthencm Formen eingehettet. zu polypenartigen Ausstrahlungen aufquellen. Non sifht nänulich an solchen Tropten, welche durch eine Vakuole zu einem dickundigen Blizichen el- 


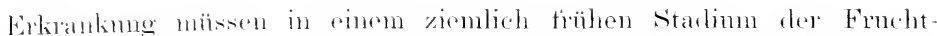

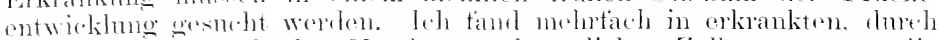

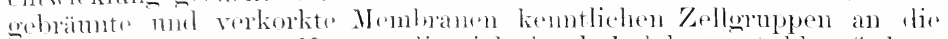

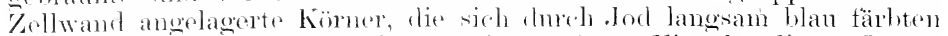

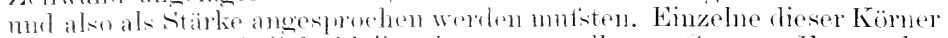

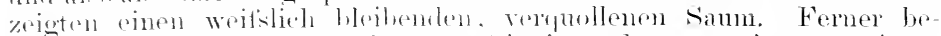

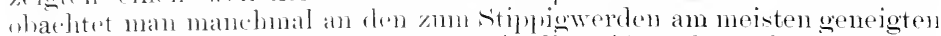

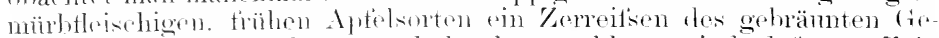

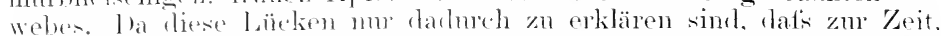

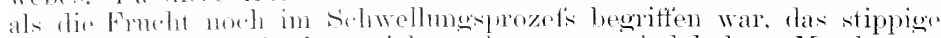

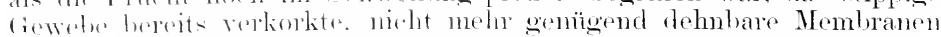

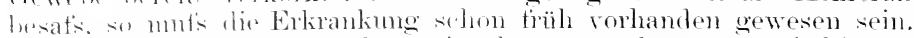

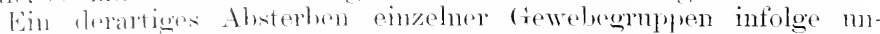

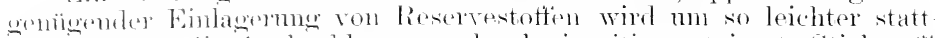

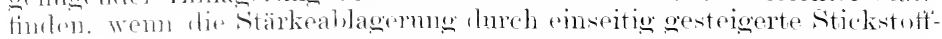

weitert sind, Jal's nur einzehe Punkte aus der stark lichthrochenden, gallertartion answhenden II andung sich schlanchartig verlingern. Indes sind solche fester Kömben vor der Quellung nicht in der IT and beobachtet worden. Die quellenden stellen stiilyen sich entweder zu gleichnätsigen, exlindrischen schliachen oder perbonnartigen Ketten ans, welehe in einzelnen Fillen den Wandbelag erreichn limmen und dam als knotige Biander die Zelle quer durchopanen. Dureh die

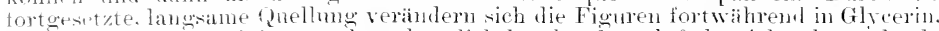

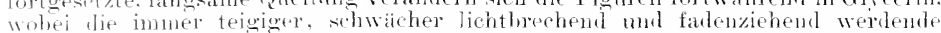
substanz das Bostrelien bekmolet, zur Tropfenform zurückzukehren. Entwedes nehmon einige der Hanptarne der ohen dargestellten Polypenfigur immer nehr substanz anf und werden zu breiten Bändem, die sehliefslich zu kugligen Tropfen sich

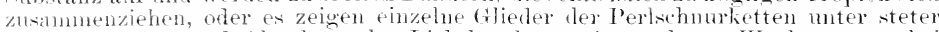
Volumzunahme und Abmahme der Lichtbrechmg ein stäreres Wachstmm, wohei die kleinoren kugligen Kottenglieder und die sie etwa verbindende Fadensubstany immer shmaler werden, endich zerreifsen mu in dio wröfseren Trojen hineingezogen werden. Dime Tropfen waren in den ansepraigtesten Fälen noch nach

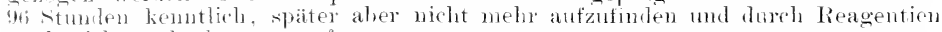
anch nicht mehr herorzurufen.

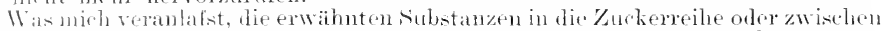
lie Zuckor- mul Gerbstoffroilie zu stellen, ist ihr Torkommen in densellon Zellen, whe dur h difrerin zustumenziehbare, stark lichthrehende, lurch Alkohol auszirhbar. die libpterreduktion zeigende, grolse Tropfen enthalten, in welche die

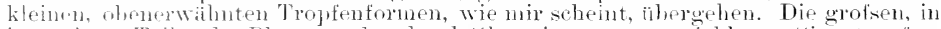
hesomblem Teilon des Plasmasackes durch Glycerin zusimmenziehbaren sirujtropfen. dip allmählich wieder verschwinden, lassen sich durch Anwendung von dopjeltHromsaturem hali zum Teil fixieren, da sich in ihnen rin bleibender, brambörniger

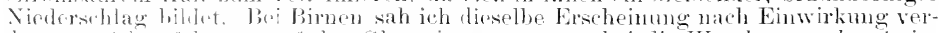

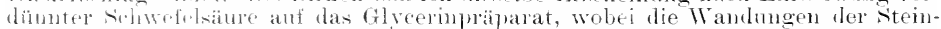

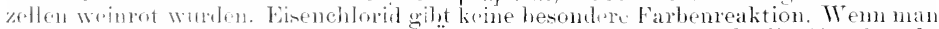

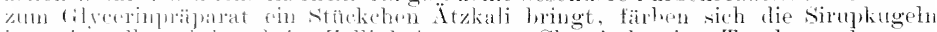

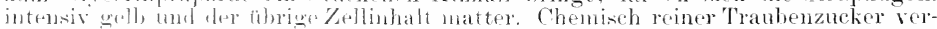

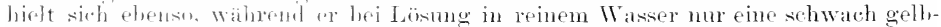

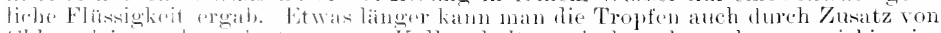
chlorafcium oder alpetersaturem Kalk whalten; sie bewahren dam zwei bis vier Thage ilupe starke Linhthrechung. Bei Anwemlums von salpetersaurem silber entsteht in vielen Sirujkugeln rin hrambïniger Niedersehlag, der entweder aus

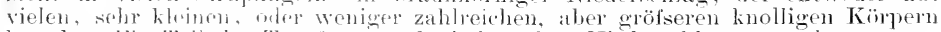

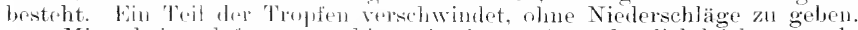

Mir sheint, dals man os hien wit winer antserordentlich leicht veränderlichen. in Wasser und Clkohol leicht, in Glycerin sehwerer löslichen substanz 20 tun hat,

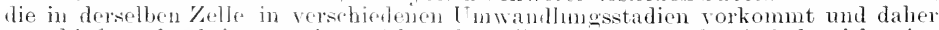
verschiedene Ratitionen zeigt. Si.hon das offene Liegen an der Luft bewirkt eine Veränderung, da fin Apfol, der an der frischen Schnittfläche die Sirupkugehn in Nasse anfwies, nach wrigen stunden an derselben schnitufläche durch Glycerin keine Tropfen mehr zeigto. sondern soldhe "xt tiefer im Gowobe wieder auffinden liefs. 


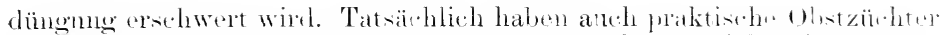

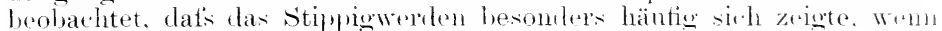

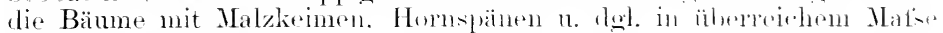
gerlüngt worden waren.

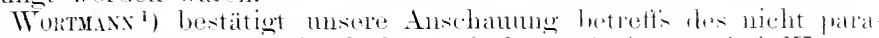

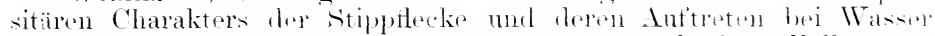

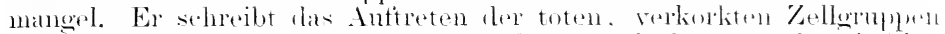

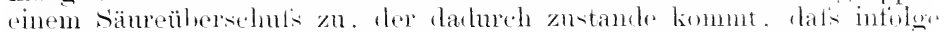

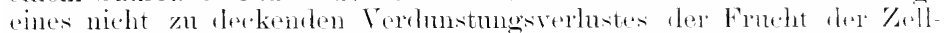
satt allmählich komzentrierter wiml. Der absolnte sämegehalt nimmt

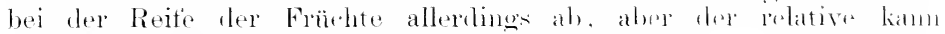

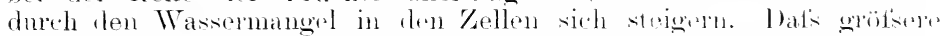

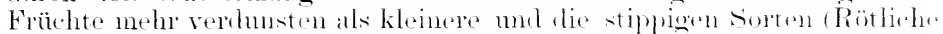

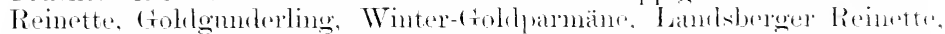

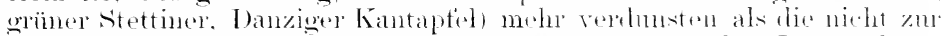

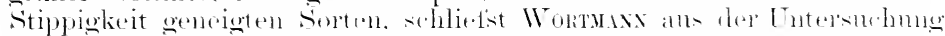

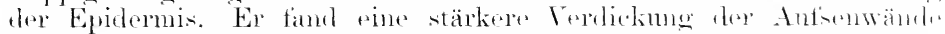

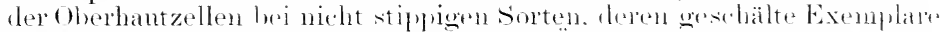

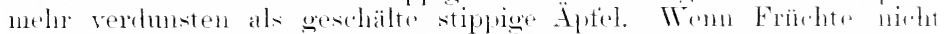

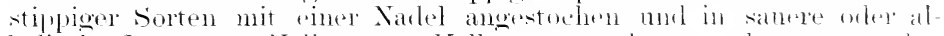

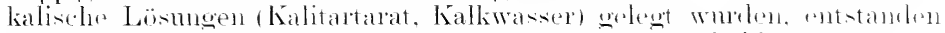

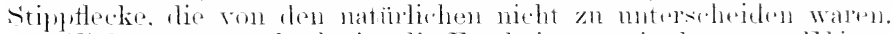

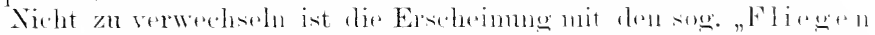

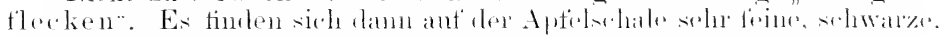

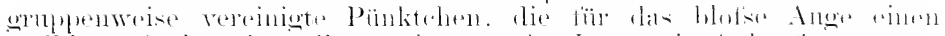

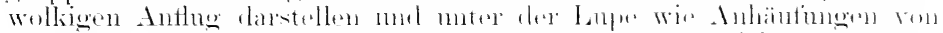

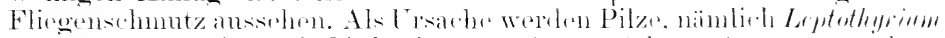

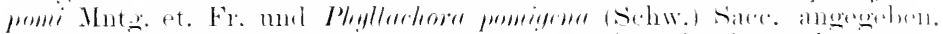

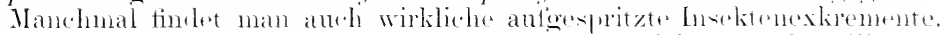
in denen diese Pilze regutiepen. Da dio Sohale sieh muter den Flionen-

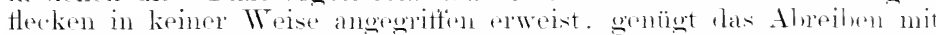

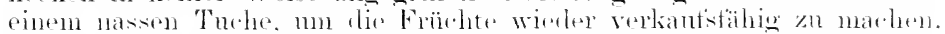
Eine andere, manchmal als stipptlecke hezelehnete Erscheinume ist das

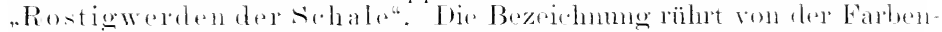

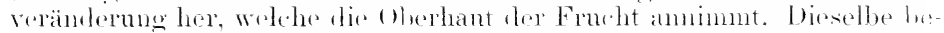

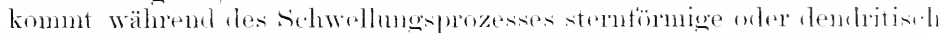

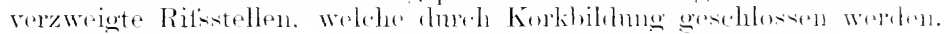

\section{Das Steinigwerden der Birnen und die Lithiasis.}

E- ist eine häntig zu heobachtencle Tatsache. latis Birmen ant

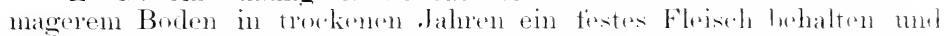

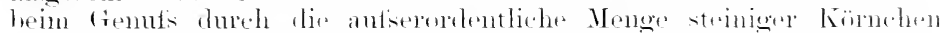

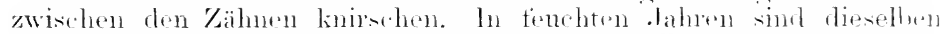
Birnensorten weichtleishig. mol wom den steinen int wenig zu bomerken.

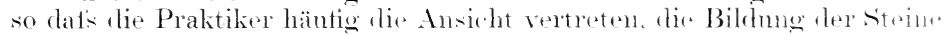
in den Birnen sei die direkte Folge wrotser Trovkenhrit.

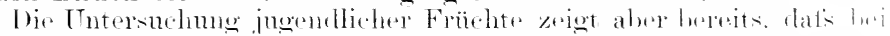

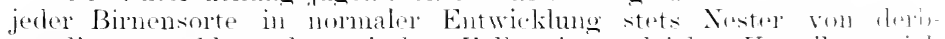
wandigeren, sklerenchymatischen Kellen in moledeher Vorteilnue-ich

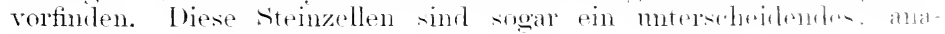

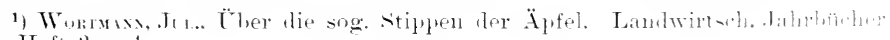
1×92. Heft :? u. 4 . 
tomisehes Merknal zwisehen Birne nud Aptel $\left.{ }^{1}\right)$. Es ist also nicht das

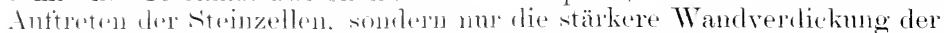
sets romanlenen. aber in maneluen sorten relativ sehwachwandig

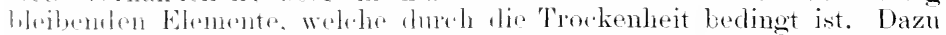
limmmt, dats iler /usammenhang mit dem momgebenden in trockenen

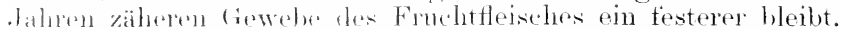

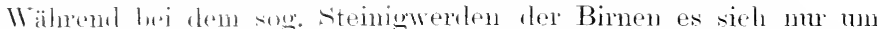

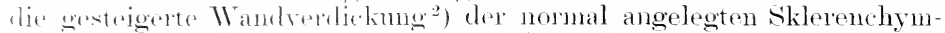

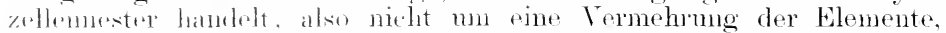

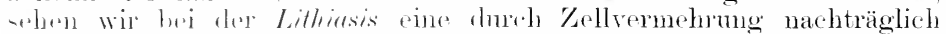

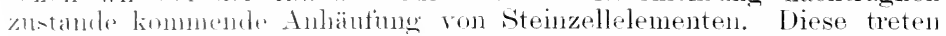
aluh shliedslich über dis Ghertläche der Frucht hervor und bilden

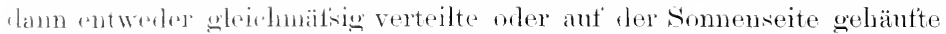
lollhrame, kreisrunte. Flocke oder durch Verselumelzung laudkarten-

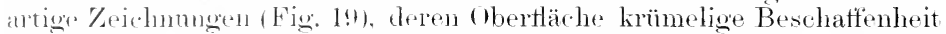
\%erint. Nicht solten leiden dieselben Birnsorten anch ron Fusicladim (․ II. Bu.): jerloch lasisen sich die Lithiasisflecke lejcht durch ihre kriumelige Beschaffenheit und die anfoeworfenen Wundränder von den ulftrn, meist goschwärten Pilzflecken unterscheiden.

sio weit his jetzt die Beobachtungen reichen, leiden nur einzelne sorten an Lithiasis, mol zwar bililen manche vorhersehend rundliche Flerkr. während hei anderen hamptsächlich zickzackartige klatfende Risere entstehen. Nicht immer sind die steinnester vertieft: manchmal treton sic als selwach korkfarbige Polster über die ohertläche hervor.

1) Ti nux. Menoire sur la difference qu'offrent les tissus cellulaires de la jomme ot de lat poire ete. Paris. Compt. rend. 18:0, I, s. $711 \mathrm{ff}$.

$\leadsto$ Der Stoff, aus welchem die schichtig verdickten Wände der Steinzellen be-telien. hat von Emm.. den Namen Glykodrupose erhalten. Der Name wurde deshall, gegeben, weil der Forscher glaubte, dafs die chemische Zusammensetzmo dieser Zellen lie glfiche wie in dem Gewebe ist, das den Stein der Pflaumen und Firschen (1)"furm,1) bildet. Die dureh mäfsig konzentrierte Salzsäure zerlegte Sulsstanz rrab zur Hälfte des Gewichtes Traubenzucker in Lösung; die ungelöst zuräckheilsende Hälfte führt nun den Namen Drupose; diese hinterläl'st bei dem Kochen nit Salpetersäne and Auswaschen mit Wasser, Ammoniak und Alkoliol eine wellolichweife ('ellulose. Enmox schliefst ans seinen Untersuchungen, dafs die Sulstanz der Steinzellen aus einem Kohlenhrdrat entstanden sei, md zwar durch Austritt von Wasser und hauerstoff aus stärke odor Gummi, während bei dem norlnalon Reifungsproze f's zur Bildmg des Zuckers Wasser aufgenommen werden muifs

Der. Ansiclit, dafs Zucker- und Cellulosebihlumg mitrinander in innigem

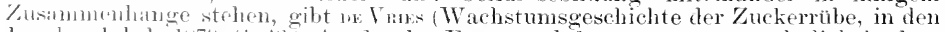

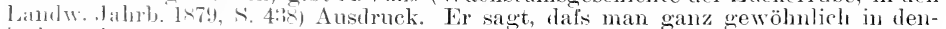
jenigen jungen Kollon eine Anhäufung von Tranbenzucker findet, welche später ilne Want stark verdicken. Peispielsweise sind die Bastfasern des Klees sowohl Wie dic Fasm dre inmeren Strangscheide der Gefälsbïndel, die im aurgewachsenen

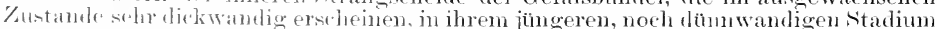

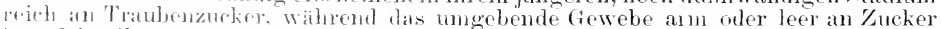

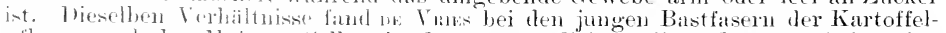
fiflanzer mol des Matsen suldost in den später dickwantigen Haaren findet eine lkkumulation do tuckers rol der. Wandverdickmg statt, so z B. in den Haaren

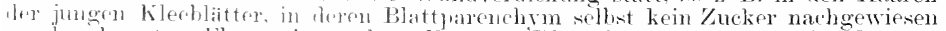

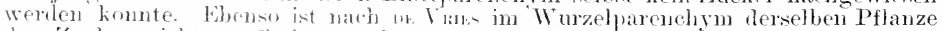

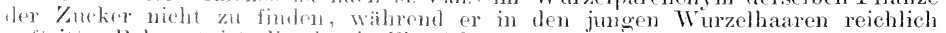
anftrit. Bekamnt ist dic durh Einwirkung verdümer Schwefelsäure nach Erhitzumg mögliche loeführung dere cellulose in Dextrin und Zucker. Man veroleiche auch die nemeren I'ntersuchumgen üher dis Hemicellulosen: Mamm. Galactan und Aratian.

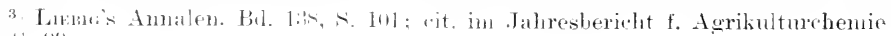
IN6ti. S. 99 . 
An den gesunden Stellen der stemlinanken Birne ist ein ganz normaler Bau zu finden, d. h. unterhalb der schmalzelligen, nicht sehr lickwandigen, farblosen Epidermis (Fig. 20") liegen drei bis vier schichten meist tangential gestreckter ofler kubisher Parenchrmzellen (1), hie plasmareicher als die tieferliegenden (rowehe sind und Chlorophyll, alser keine Stärke fïhren. l)ie stärke findet sich erst in rem lmentleisehe allmählich ein. und ihre Kömex pflegen an (iröfse nach lem Samengehäuse hin zuzmohmen. Unterhall, der äut'seren chlorophyll. reichen 7ellagen loginnt die Einlagerumg dor steinzollemmester ist). lie im normalen Fleisch wenigzellige (impipen hilden und bei den dorlHeischigen Früchten nur dureh kloine \%wischenfelder ton zartem Parenchym (zp) geschieden sind. Ton der Peripherie nacli dem Immern der Frucht fortscheitrut, werden die steinzellingruplen suälicher. und das momgebende Paren- hyom nimmt eine sternfömige Anordnimg an.

In den ersten Stadion der Erlirankung finclet man bei den stets noch giunen mi harten Frïchten, dats untelhall, dar mverlotzten und farblosen Epidomis ein\%hr Yellen keine Chlorophyllkïrper besitzen. sondern einen hraumen, stark lichthechenden, klumpiog zusammenwohallen Inhalt haben. Almählich vermehrt sirh die \%ahl dieser orolnäunten \%ellen. und nun hricht die Oberlsant ant. Tnter der aufgebrochenen stelle, rie sich furch Kusammentrocknen mul lirimeligen \%ertall der (rewelse zu einer (irube (gi) zunächst vertieft, findet man anch mitten im Fruchtfleiseh hramwandiges absterbendes Gewebe (b). das später hisweilen zerreitist und Lïcken bildet. Bisweilen in diesen Lïcken, stets aber in den offenen gripherischen truben $(y)^{\circ}$ ist tarbloses sehlankes Mroel zu finclen, das eine nachträgliche Einwandermo darstellt mol den Gewebrertall beschlemigen diutte.

Die antälligste Erscheinume lustelit mm darin, lats mach Ent

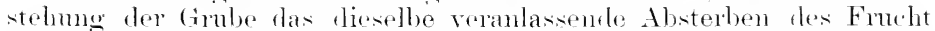
Heisclues authört und sich num gesthlosine Nassen nengelibleter. skemenymatischer Elemente in taichertörmiger Anorehmug polsterartie vorzuwiben beginnen (f). Diese Kiscen aus steinzellen treiben das

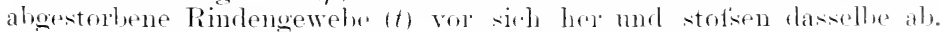

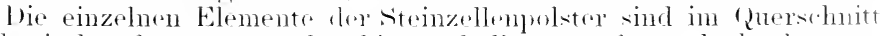

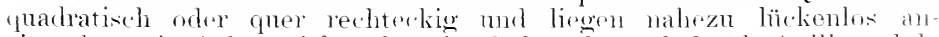

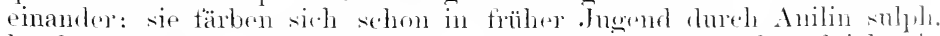
leuchtend goll, mol lösen sich anch in spätesten Alter leicht in

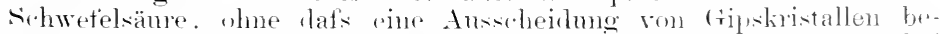

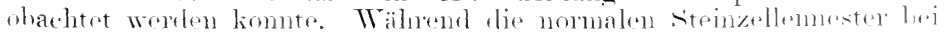




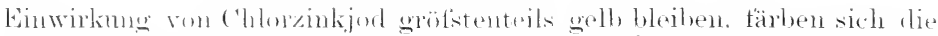

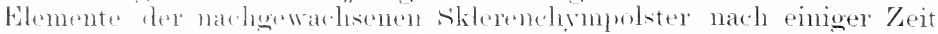

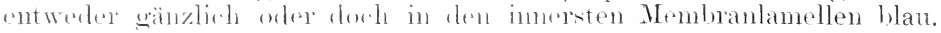

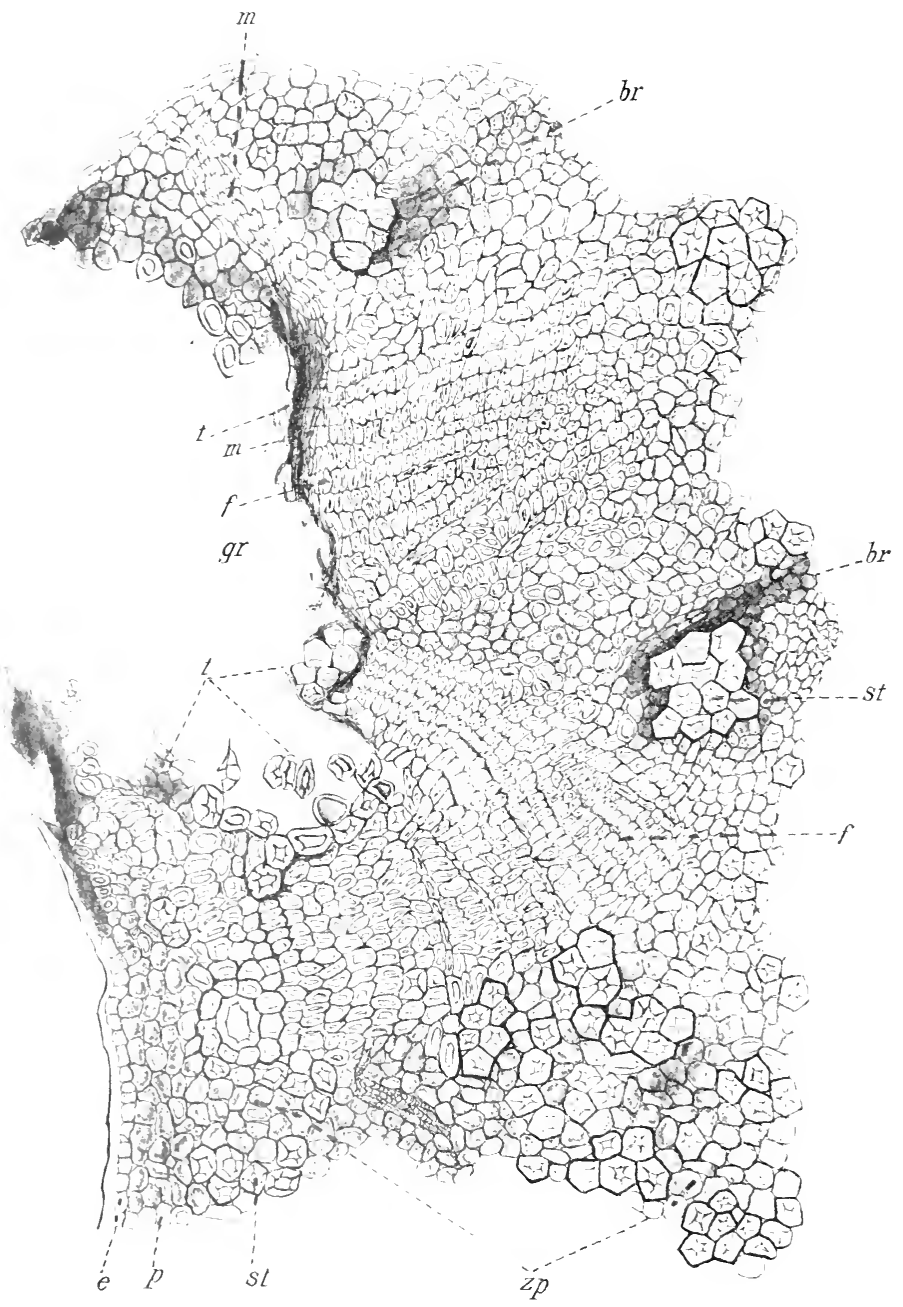

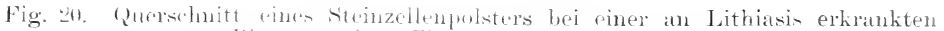
Bime (1) rig. Figurenerhlirumg im Text. 
Das Wathstum dieser silerenchrmpolster ertolgt durch rine Meristemselicht (m), die sich unterhalh der abgestorlonen Rindenlagen bildet und zunäehst ansieht, als ob sio zu ciner don Krankhoitsleerd abschlietsenden Tafelkorklage werken wollts, wie dies liei den Fusicladimmolstern zo leobachten ist. Jies ist jedoch nicht der Fall, sonden die Meristemlage bleilst. solange dir Fruch noch grün und krantartig ist. in Tätigkeit. Sarh autsenhin hilder sir (meist

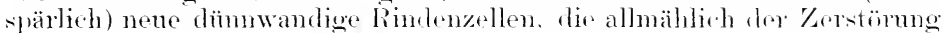
durch Bakterien mol Mredpilzr wiederum anlwimfallen. Während sie ant ihrer inneren. dem (meist samemlosen) Kernhanse zugewendeten Sieite die dickwandigen Elemente der steinzellyolster vermeht.

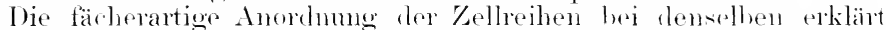

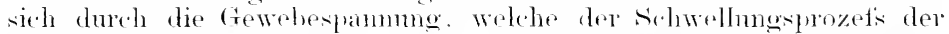

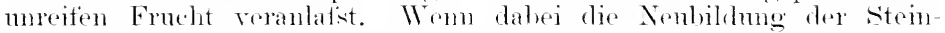
zellen stärker ist, als die Ausdehnung fos parenchromatischen EruehtHeisches, dam wölben sich dir stenizellgruppen polstrertig vor. In der Regel halten aber heide Vorgänge gleichen s.hritt. mnd darhurh. dats schlietslich das pathogene Meristem abstirlot und die antiseren steinzellen sich in ihrem Vorlancle lorkeru, entsteht rle krömelige Beschattenheit der siteinflecke.

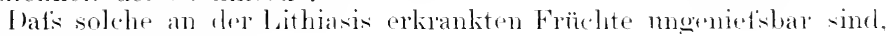
ist selbstrerständlich.

Da die Erscheimme nirht hei allen Sorten zu finden ist mold sellost

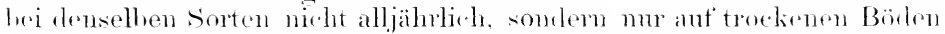
in trockenen .Jahren zu störenter Entwieklung gelangt, so liregt die

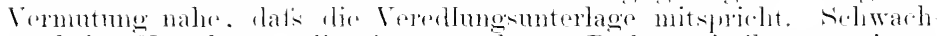
wïrhsige Enterlacen, die einem trockenen Boden nit ihrem gernegen

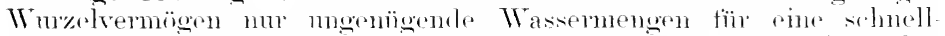
wïrhsige Krone entnehmen liönnen. werden besonders das steinigwerden begïnstigen. Sollte laher lir. Krankheit sich äter wielerholen. so versuche man bei /worghänmen aut leichtem Boden ein Vorodehn der Birnen anf möglichst sehnellwöchsige Qnittenvarietäten. Bej stand.

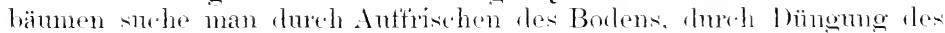
Thtergrumles mod rejehliche Bowässermog mel in - hartnächigen Fällen -

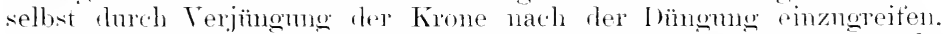

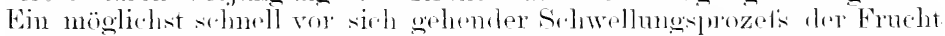

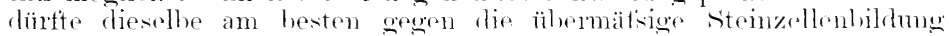
s. hï̈zen.

\section{Für trockene Böden geeignete Obstsorten.}

Gemäts der leitenden Iter museres Handhuches. dats man vielen Krankheiten vorbeugen känne. Wenn man tür minese Kulturptlanzen stets die ihrem Charalster sutsprechenden Lebenswerhältuisise eingehender berücksichtiges würde. weben wir hier hei den dureh Troekenheit hegünstigten Krankheiten des Obstes rine Anf'zählung hekimuterer Kultursorten. Welche speziell für trorkene Bälen gerignet sind $\left.{ }^{1}\right)$ :

Virginischer Rosenaptel. Emele Juli. L. Ntr. Scharlachrote Parmänr. Herbst. L. Sitr. Landsherger Reinette. Herbst. I. Nitr. Danziger Kant-

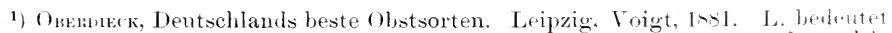
empfehlenswert für den Landwirt; Str. geeignet zur Anpflanzung an straf win. lie Ionatsbezeirhnung hinter dem sortemamen weist auf die \%eit der Vollr ife hiu. 
aptel. Herlst. I. Winter-troldparmäne. Winter. L. Str. Reinette vom () leans. Winter. sitr. (Fiir len landwirt da, wo besserer Bonlen ist.) Golher Belleflenr. Winter. L. Sitr. Alantapfel. L. Dentscher troldpopping. Winter. L. Muts bis Mitte oder Ende olitober am Banme sitzen. (ibotise Kasseler Reinette. Winter bis sommer halthar. l. Sitr. Purpurenter ('ominot, Winter his ciommer.

Birnon tïr trockene Bälen: Hamoversche Jakobsbine. Encle

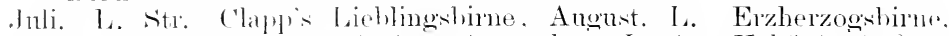
Angust. 1. Finte frane. Anfaug Šeptember. L. Str. Kuhfuts. Anfang surptember. L. Str. Natame Trevre. September. Experen's Horrenbirne. Ende september. L. Str. Bosc's Flaschenbine. Ende oktober. L. Marie Enive. Antang Norrmber. L. Str. Josephine von Nrecheln, lozember. Matame Konte. Jannar. Kampervenus. Kochbirne fïr den Eanzen Winter. 1. Sitr.

Bei Kirschen ist hekannt, lats dieselben rinen gut durchliuftoten, trokenen Boden durchüngig lieben. Dagegen ist es bei Pflammen. the durchishnittlich anf einem feuchten, schweren Boden besser gredrihen mol meist anch sïlsere Früchte liefern, wünschenswert, eine Anzalil der weniger Wasser beanspruchenden sorten kennen zn lernen.

Biomlecks Frïhzwetsche. Antang August. Frïhe Aprikosempflame. Mitre Angust. Anna Lawson. Ende August. Bunter Perdrigon, Encle Angust. Grotise Reinedaule. Anfang September. Althann s Reinerlande, Antang September. Tiolette Jerusalemsptlaume. Anfang sintember. Anna spath, Nitte september. Hanswetsche. Ende serutember. Als stratisenbaum empfiehlt sich die Pflame schon ibrer Wuchsform wegen nicht sehr.

Als Sorten, diw anf trocknen, leichten Börlen in Küstenklima sirh hewähren, sind zn nemen ${ }^{1}$ ): 1. Äpfel: Landsherger Reinette. Pmpurroter Comsinot, Charlanowskr, Getlammter Karlinal, Bammanss Reinetto: fï̈ dio Provinzen an der ()xtsee mol Nordsee eignet sich ganz losonelers der Prinzenaptel. 2. Birnen: Gute Grane. Bose Flanchen-

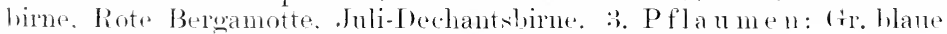

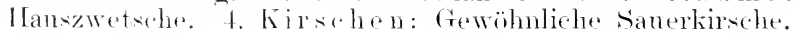

\section{Stauchlinge.}

Wie fast älerall in ther Natur werlen dieselben Ettelite durch verschiedronartige Mittel erzielt. Auch bei dem Zwergwolss ist der be-

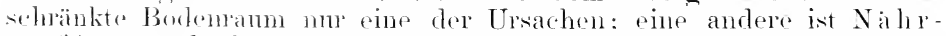

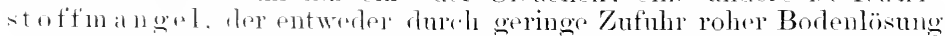
zum Wurcikörper oter anch durch Verminderung von organischer Reservenahrung hervorgerufen werden kann. Letzteren Fall werden wir

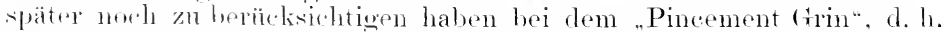
tem Abstutzen ron Blättern zm Verhinderung "des Austreibens der in ihren Achseln hefindlithen Angen. und bei der Entstehmo zwerghafter

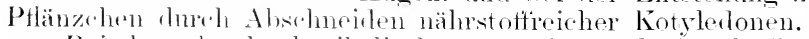

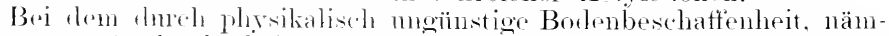
lich zu grofice dorkerleit. veranlatsten Nanismus kanu aber auch der Wassermangel allein in Betracht kommen. Man darf sich nur vergegenwärtign. dats sellst hei peichlichem Gehalt des Borlens an

1) Nach brieflicher Mitteilung ron Herm Baumshulbesitzer Kurmos in Ludwig slust. 
mineralisthen und organisthen Nährstotfen die trö̈lie rer PHanze von ler Streckumy der ainzelnen Zellen abhängt mul liese durch den von der Wasserzufuhr ans der Wurzel beeinflusten 'Turom regnlinert wird. und man liommt alsbald zu tem sehlusse, dats einf geringe Wasser. zufuhr wälrend der Vegetationszeit kloine, zwerghatte Exemplare er. zengen muts. Jede Exkursion ïher sandige strecken, denon win tenchter Untergrund tehlt oder loch seln entfernt lirgt, gibt Beispiele genun. Öber die Verkürzmng der Zetlen bei Wassermanerel habe ich ansfülurliche Messmegen veröftentlicht $\left.{ }^{1}\right)$. Für die Verzwergme bei Mangel

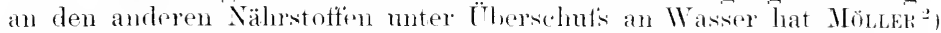
den experimentellen Nachwois geliefert murl anch den Satz hestätigt. dats hei gering konzentrierten Sänlösmngen der Wumelapparat relativ

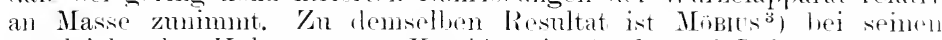
verwleichenden Kulturen von Xanthimm in sand- und Lehmboten gi.. langt. Er fand bej dיu Sandpflanzen stärkere Verzweigung des Wurzel. und Stammkïrpers, kleinereschmalere Blätter nud eine geringere Anzahl von Drüsenhaaren gegenüber den in tehmboden er"zogenen Exemplaren. Bei letzteren schien dagegen der trehalt an Kalkoxalatkistallen weringer zu sein. Die bormen woden ant Sandhoden kleiner, aber ilis Membranen aller verholzten Elemente. wie es schien, wesentlich flickis.

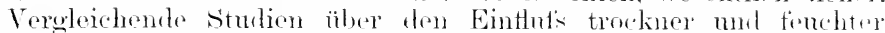

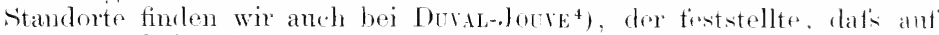
trocknen. heitien Standorten lesomders die Ansbildung der Hartha-t-

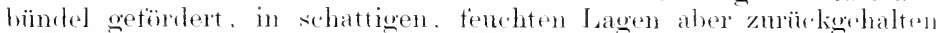

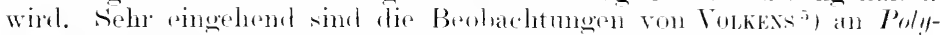

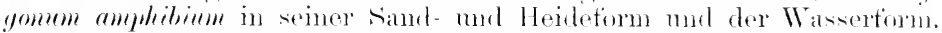
Bei der sandform ist ler stengelomtang ant Kosten des zontralen Luftkanals geringer: die Rindenzellen sind stärkes verolickt. mul zwischent Rinde und Phlö̈m schieht sich ain ziemlich hreiter ling ungenoin verdickter, nechanischer hellen ein. Es hildet sich ein geschlosiener Holzzylinfler. desien trefälisystem fast zwri- bis troimal so stark entwickelt ist als bei dem der Wasserstengel: hei letzteren arleichtert das Fehlen dickwamliger Elemente und das Anttreten starker Lufilücken das schwimmen. l)ie Blattstiele der Wassertorm. Welche ohmo jede mechanische Verstärlinng. simd bis sechsmal so lang. als die dor Landtorn, deren Mittehiphen durels starke Collenchrmstränge verstälit sind. Die Palisarlenzellan der Bläter sind in den Wassersprosinen stärker entwickelt: dagegen fehlen ihnen die stark entwickelten Borstrn ant der Whertlähe mol antierdem die atwas grötseren Epiterniszellen der Oberseite, welche bri der landform sinten schlemigen Inhalt bergen, der von Volkexs als Wasserreservoir in Zeiten groficr 'Trocken-

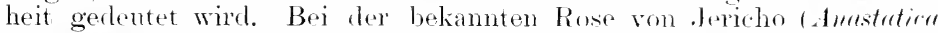
hirrochuntira). disser sich hei Trockenheit koptartig zusammenschlietisenden Wüstenptlanze. herulit das Zusammenueigon der Zweige darant.

1) Sorner, Bot. Zeit. $18 \pi 3$.

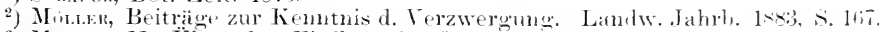

3) Muns, M., Ëber den Einflufs des Bodens auf die struktur von Xanthimm spinosum usw. Ber. 1. Deutsch Bot Ges. 1905, Bd. XXII, Heft 10.

4) Drvar-Jorr, Anordnung der Gewebe im Blatte der Gräser. Bot. Jalims. v. Just 187.5 , S. $4: 32$.

5) Vorkws. Beziehungen zwischen standort und anatomischem Bau der Vegetationsorgane .Jahrb. d. Kgl. Bot. Gartens zu Berlin. Bil. III. 1'-4, cit. Bot. Centralbl. 1-it. Nr. 46. 


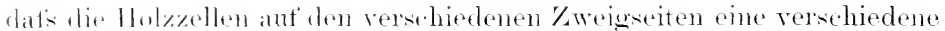

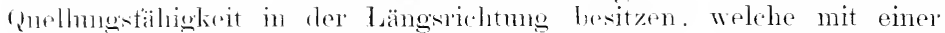
moletelon Verholzme Hand in Hand geht.

Vum vornherein wirt man si.h sagen mïsen. dats jede beschränkte

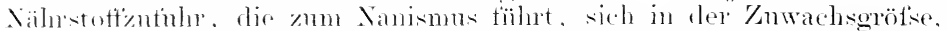
also in der Bildmug der schmoläen fiewehe am meisten ansprägen

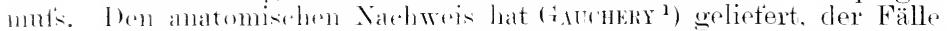

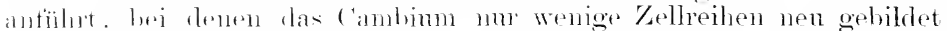

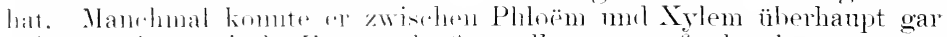

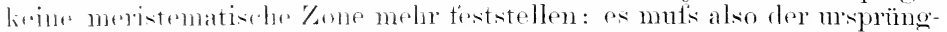

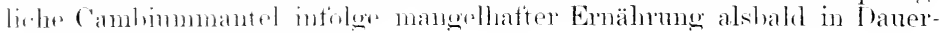
wowhe iiberewangen sein.

Bei den 'PHanzen, div anf' sandigem oder steinigem Boden unter violtarhem Wasermangel zn wathen gezwmgen sind. kommt eine

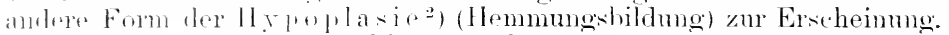
Ex int nicht so sehr dis \%ahl der \%ellelemente. welche remindert er-heint als dopen firifise: « bilden sich nämlich Exemplare ans, dis

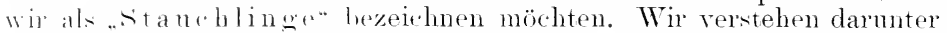
Ilolzptlanzen, die nicht his zur Verzwergmng in ihrem Waehstmm zurütkwhalten werten. wohl aher threh die autfällige Verkürzung ihrer Achsenorwane eimen gedrükten, knorrigen Habitus zeigen.

Bri diesem Habitus gilt als "harakteristisches Merkmal die schart hrrortretende gesteigerte spiralige Drehmog der Holzelemente des stammes. Jie schönsten Beispiele sehen wir bei syringu nund Craturgus. IIir kimmen uns das /ustandekmmen der verstäkten spiralwindung whlären. wenn wir die Rithtme der Holzzellen ak die l)iagonale eines Parallelogramms zweier Kätte antiassen.

An seheitel jeder sieh streekenden tehse wirkt einerseits das

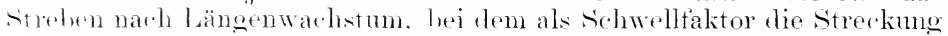

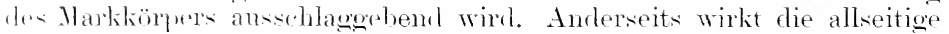
loreritserung der jugendlichen Zellen anch als Ersache tür die radiale Answeitmng destammkïrpers. Wenn wir ms eine in der Längsstreckung lrogittine. gan\% jugentliche Holzzelle im Cambiummantel piner Stamm- pritze donkm. so wird dieselhs m so weniger ans ihrer mspünglichen

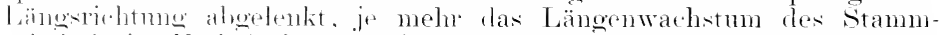
- hreitels im Vophaltnis zum Dickenwachstmm äberwiegt. Je mehr aber liv reirhlich angelentru jungen Holzzellen. während sie sich verlängern.

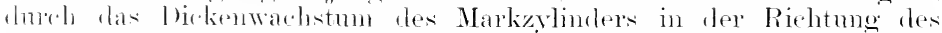
stammmatins nar.h autson godrürkt werden, desto schärter wird ihre

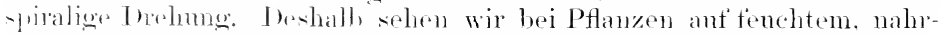

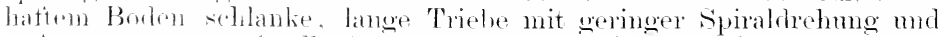

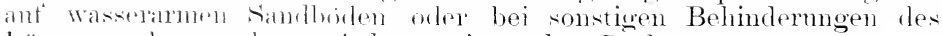
längenwals-tums limze Achsen mit starker Dhelumg.

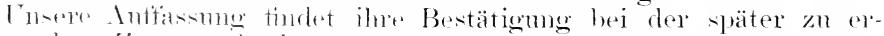

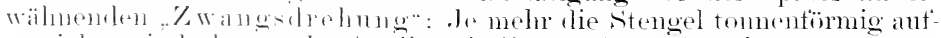

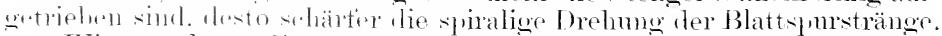

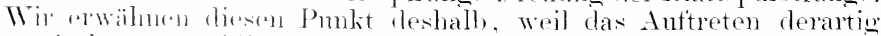

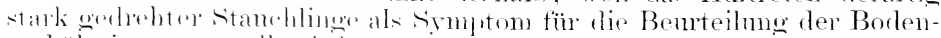
vorhälniss watroll wirl.

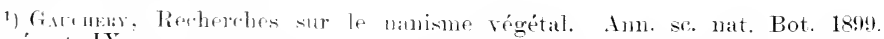
VIII sér., t. IX.

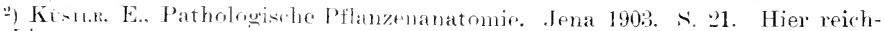
liche Literatus. 


\section{Verhaarung (Pilosis).}

Pflanzen ant trockenem Boden erhalten schon ein hehaarteros Anssohen, selbst wenn sich nicht mehr Haare als anf tencht stehenden Exemplaren derselben Art ausbilden. Wem eine hestimmte Menge Haare auf einem Blatte gebildet wiod, so rücken diese Haare auf einen kleineren Ramm dadurch mehr zusammen, dats the sie tremenden Epidermiszellen kürzer bleiben. Hieraus erklärt sich teilweis schon die Beobachtung, lafis Hochgebirgsptlanzen bei der Kultur in der Ebene weniger behart erscheinen: diese Pflanzen worden üppiger, die Dimensionen ilner Organe grötser. die Hare rücken weiter anseinander. Aber es findet in der 'Tat auch anf trockenen Standorten eine rermehrte Neuhildung von Haaren statt. So zitiert Mounn-Tanbor ${ }^{1}$ ) Beobachtmoen rom IsNé, datis ler Pfirsichblätrige Knöterich (Polygomum Persicuria L.) an Wasserrändern ganz kahl, an trockenen sitellen mit Haaren besetzt erscheint: mser Feldquendel (Thymms Serpyllum L.) verliert am Meeresstrande seine Kahlheit und erhält einen kurzhaarigen İberzug. Unser 'Türkenbund ( Lilimm Martngm L.), der' seit langer Zeit in Gärten kultiviert wird, ist kahl: er wird aber wieder behaart wie die wilde Pflanze. wenn er ant sthlechteren Boden kommt usw. Solch. Erscheinungen lassen sich anch hei Gartenpflanzen beobachten. dis durch Selbstanssaat auf sundigen Feldstellen sich mitwickeln.

Eine moew ïhnliche Haarbildung findet forner bei manchen Pflanzenteilen statt, die sich nicht mehr zu ihrer bestimmten Gestalt anshilden. Nach Moqun-'Taxnos hedecken sich die stauhtärlen der theimämnigen Winde mit dicken Wollhaaron: ämlich verhalten sich die stanhfärlen mehrerer Arten ron Wollkant (Torbascum). Wenn dio Stanhbeutel verkïmmern. Die Blätenstiele des Perückenbames (Rhus Cotimes) sind vor der Bhäte mut. wenn sie Frör.hte tragen, kam hehart: wem dagegen die Früchte sich nicht ansbilden, so werden die mifurhtharen Blütenstiele länger. mol es kommen jetzt zahlreiche lange. violette Haare an ihnen zum Vorshein. Letztgenannte Haarbildmoen gehören nicht zu den mit der 'Trockenheit in Verlindung stehenden Erseheinungen, sondern sind als Kormelationsorgane antzufasisen. Das Wasser mel Nähstotfmaterial. das hei der Amsbiletme von stanblenteh oder Fröchten Verwendung tinden sollte. kommt hei Lersömug der Sexnalorgane anderen 1 roantejlen in erhöhtrm Matse zugnte. Toilweisegehören vielleicht anch die nenerdings bei der Parthe nogenosisbeobachteten Esschoinumgen hierher, dats die Niksopyle infolge haarartig verlängerter rellen des (iriffelgewebes ofler der Intrgmmente verstoptt wird ${ }^{2}$ ).

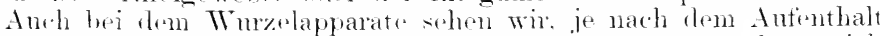
der Wurzel, die Beharmeg wechseh. Bei denselhen Arten kamm sich der Apparat in Form langer, schlanker, pitschentömiger, wenig verzweigter, kahler orler tant kahlor Äste entwickeln. wonn die Irurzel in Wasier orler in emen lockeren, mit Wasier wesätigten sand tancht. lie Wurzeläste werden $n$ m so kibzer, knorriger. verzweigter nud behaarter, je trockener im allgemeinen der Borlen, je mehr also die Wurzel num die fenchte Luft del Bodenzwischenränme zm Verfïgmu

1) Pflanzen-T ratologie, übersetzt von Schur.r. 1842, S. 61.

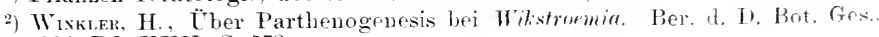
Jahrg. 1904. Bd. XXII. S. 573. 
hat. In gan\% trockiner Luft entwickeln (nach Persecke) ${ }^{1}$ ) die Wurzeln anch keine Haare mehr. Schliefst man Wurzeh in feuchte Lutt ein, sn entwickeln sich dir jungen Wurzelspitzen kurz nuterhalb ihres fortwachsenden Endes ganz härtig. la tast jede Oberhantzelle sich zu einem llaare ansioilpt.

Bei den olerirdischen Ptanzenteilen. welche an trockend Luft gewöhnt sind. muts dre Fonchtigkeitsorad der Luft anffallend gering sein, wem die Hatbildnng intensiv hervorgernfen werden soll, wie ('. Krals's) hei Kartotfillieimen angiht. In selu fenchter lautt sind die Kartotielleime terselben sorte haarlos oder nu mit wenigen nud kiirzeren Haaren hesetzt. Es ist also bei den oberirdischen Organen der Einflutis der tanchten latt gegenüber der trockenen. welche di. Behaarme verhindert: hei den ant tropfbar flïssiges Wasser meist anwewiesenen Wuzeh wird derselbe Etfelit durch danernde Wasiserzufulu erzielt. gexenüber dem haarbefördernden Einfluts der fenchten Luft.

Die extreme Hadbildnng ist daher bei der ober- mol muterirdischen Aclse die Folge gleichsimnig whkenter Ursachen: es wird den Organen lie gewolnheritegemäts notwendige Wassermenge in dem stadium. in welchem sie sich entwickeln. vorenthalten.

Zur Erklärnng der Tatsache, dats grötsere Trockenheit des nmwenden Merlimms die Haarbildung befördert. haben Krass ${ }^{2}$ ) und Mer ${ }^{3}$ ) ile Erscheinmo herbeigezogen, clats mit der heförderten Haarbildnng in trockenen Dedien das Längenwachstum des Organs gemäfigt oder gehemmt ist. Beide Forscher meinen num, dats das Material. das durch die verhindorte Längsitreckmng der Kellen des Achsenzylinders erspart wird, zur Ansliblumg der Haare verwendet wird. Autiser den oben angetüluten Boispiolen von lihus n. a. stïtzen anch Beobachtungen von Herkes dir Ansicht. daf mit der überreichen Haarentwicklung mangelhafte Anstildung andrer. Teile Hand in Hand sohe. Hecked ${ }^{4}$ ) sah

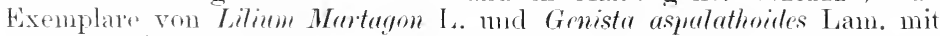
ungewöhnlixher. Behaarmng moter Rerluktion der Blïtenteile. Kravs betont, dats mit der Ahmahme des Längenwachstmms eine Erhöhmog des Turgors in der (2uerrichtung des ganzen Orous stattfinde (wie wir bei der Ansiblung des Markkörpers der ,Stanchlinge" angenommon haben), tey sich and ant die Epidermiszellen erstrectie und dieselben zur Aus-

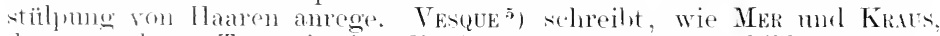
der vermehrten 'Transpiration die Betörderung der Haabildnng zu.

Dic Anrem für die Epidermiszellen zur massenhatten Haarhilumg sfolgt häutig anch ron seiten parasitärer Tiere, wis z. B. von Millwn. dio mit ihren Mandiheln die jugendlichen Blätter verwunden nnd

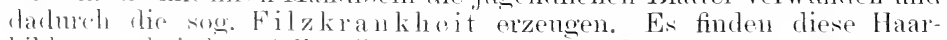

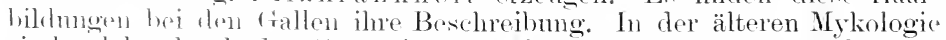
sind solfle thele den sangreiz von Milben entstandenen Haarfilze als

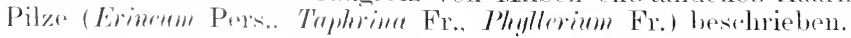

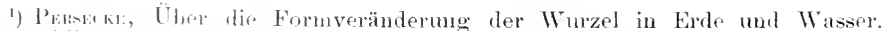
Inauguraldissertation. Leipzig 1>77.

$\Rightarrow$ Kras. Buobahtungen üher Hatarlildmgen, zumichst an Kartoffelkeimen. Flora 1866 , s. $15 \%$

3) Mvi. Rerherches expérinentales sur les conditions de développenent des poils radicaux. Compt. rend. LXXXViII (1\$79), s. 665.

4) Heкke1. Du pilosisme déformant dans quelques végétaux. Compt. rend. t. XCI, 1880, 1. 348 .

5) Sur les causes et sur les limites des variations de structure des régétaux. Cit. Bot. Centralbl. 1 


\section{Das Verholzen der Wurzeln.}

Das Verholzen der Wurzelfiüchte bestoht darind, lats dis \%ell. elemente der Gefälsbündel, welehe durch die Kultmr paronehrmatisch geworden waren, zur prosenchymatischen, holzigen Beschatfenheit dor Stammform zurückliehren. Die Mohrübe z. B.. die uns zur Spreise dient, hat eine Mutterpflanze, deren Wurcel ans einem starken, harten Holzkörper und einer dümen. weichen Rinds hestelit. The Zollen des Holzkörpers sind wie alle übrigen Holzzellen diekwandig, spindeltörmig. zwischen einander gekeilt. In der knltivierten Wurzel sind statt diesor Holzzellen dïnnwandigr. W'nig langgestreckte. fast stumpt anfeinandergesetzte Zellen vorhandron und die Gefätse sellst, die jetzt in zer. streuten fruppen zwischen den parenchymatischen Zellen liegen. sind wenig verholzt. Dir Milchsattgefätse. Welche sirh in der Rinde bilden. wemn die schraubigen, porösen Gefätse in Holzkörper entstehen, sint. abenso wie sämtliche Zellelemente ler Rinde, weiter geworden. An stelle der Stärke, die in der wilden Mohrö̈be das ganze Rindengeweb.

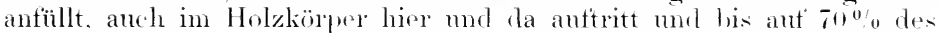
Trockengewichtes steigt, ist in len guten śpeisoriben der Zuncker. getreten, so dats dort num sumen von stärke zn finden sint. Je friner dir. Sorte, um so mehr schwindet der stärliegehalt, wi hed der hollämtischen. blatigellen und der Dnwicker Karotte. Fon diesen finden sich allmählich T̈hergänge nach der wilden Ptlanze hin in anderen Kulturvarietäten. di. als Futter benutzt werlen. wie die Altringhan-Mähw mnd die weits. Pferdemölne. Von allen sorten zeigen sirh ant nagerem Borlon

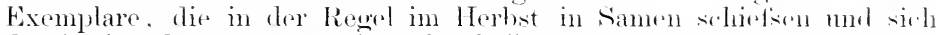

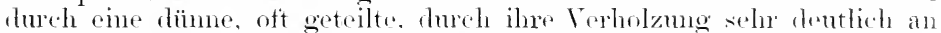
die wilde Mohrrübe erinmernde Wurzel auszedehmen. Eloenso verhält es sich mit Wrucken. steckrïben. Rettichen, Kohlrahi nsw.

Am besten werden dio Entrochiede dureh emen Voroledeh der anatomischen Bilfler klar. In Fig. 21 sehen wir den Längsischitt dur.h eine zweijährige wilde Mohrriibe. " ist das vertikal gestreekte Paren hym les markartigen Zentralteils mit zerstrent stehenden spiralig-porisin Gefätsen: b der Holzkörper aus spindelförmigen Holzzollen nelst (r. fäfsen und pinem Teil der nach der sekmoläen Rinde hin verlanfenden Markstrahlen: r das zum langoestreckten dïmmandioen Pareneliym gewordene Cambium: d sekmuläro Rinde mit ihren dem Verlanf iles Milchsaftgefälse folgenden Resorptionsstellen: e primäre Rinde: $f$ Kork.

Fig. 2.2 ist die entsurechende Partie ans einer zweijährigen kulti. viorten Dohrribe. Die Bu.hstahen bedeuten in beiden Figuren diuselben Teile. und hei Vergleich der gleichbezeichneten Gewelse tritt die Veränderung des Holzkïrpers b und die Zunahme in den I bimension'n der sekundären Rinde bei der knltivierten Möhre klar ror Augæu.

Bei allen Wurcelgemiisen tritt las Verholzen anch normal anf. Wenn sie zu alt werlen. und damn ist flieser Prozefs, wie in den vorzeitin verholzenden Exemplaren. ron einem teilweisen Vorshwinden deZuckers begleitet.

Bekannt ist die Erfahrung. Iats manche unserer tromüseptlanzen in den heifsen Klimaten alshald rerholzen. Gegen letzteren Umstam wird schwerlich Abhilfe zu schatfen sein, da der tropische Wärme-unt Lichtäbersehufs die schmelle Vellolzung ermöglichen. Bיi den Kulturen in den gemäfsigten Klimaten kann das Verholzen durch reichliche $B_{1}$ wässerumg und Döngung bestimmt vermierlen werden: um ist flatei zu 
berachten, dats das Land tieforündig und der Same gut ist. Anf die Answahl des Saatgutes ist hesondere Anfmerksamkeit zu verwenden. weil Same ans trokenen Lokalitäten rime gröfsere Neigung zur Verholzme und zur Vielschwänzigkeit der Wurzeln mithringt.
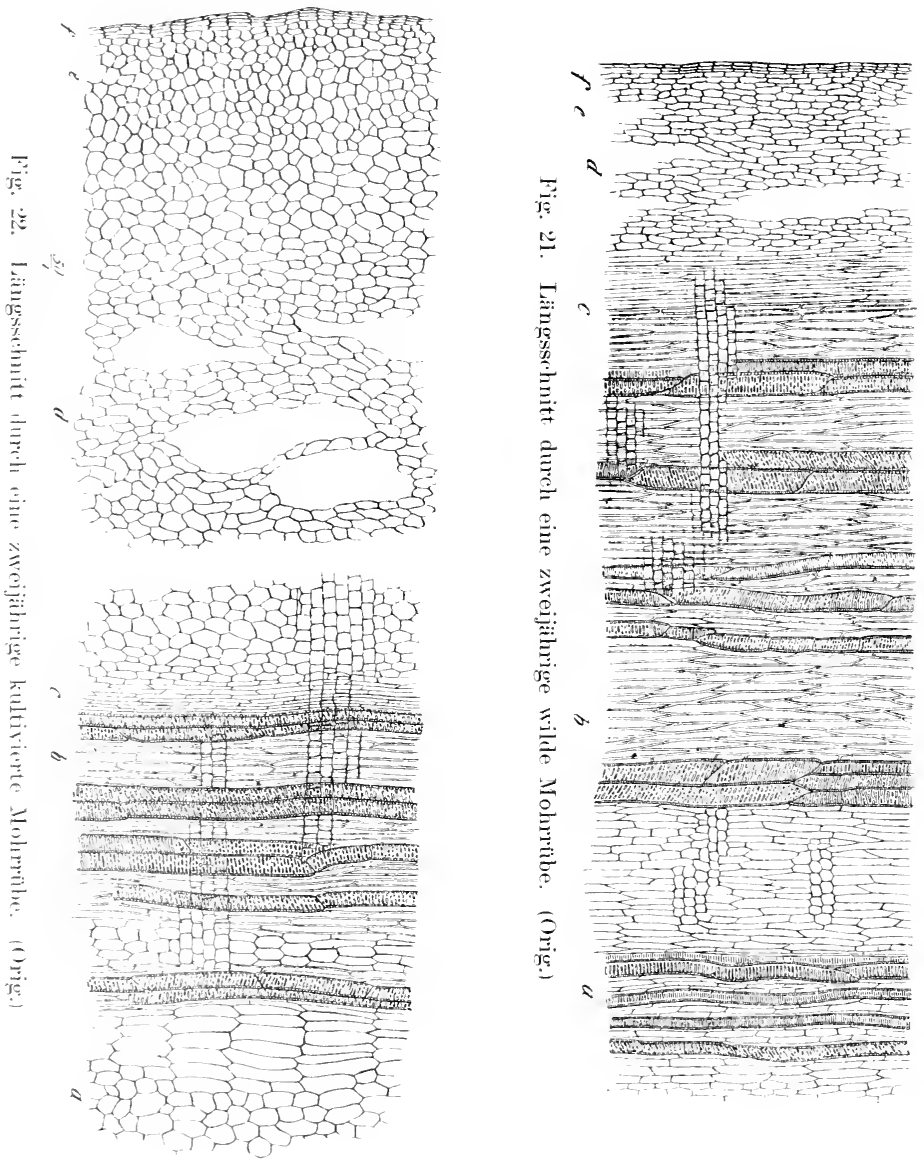

Ballentrocknis der Ericaceen.

Eine eigenartig Empfindlichkeit des Wurzelkörpers gegen Trockenheit ist bei der kinltur der zahlreichen Arten und Varietäten aus den rattungen Erira. Asalen. Rihododendion und andern Ericacem zu herücksichtigen. (ienamute Pflanzen vertragen kein vollständiges Aus- 
trocknen des Wurzelballens. Während andere Pflanzen einen Wassermangel bis zum oftmaligen Welken ohme jerle bemerkbare schädigung an sich vorübergehen lassen und nach Wasserzufuhr weiter wachsen, scheinen die einmal wänzlich trocken gewordenen feinen Wruzeläste der Ericaceen ihre Funktion nicht mehr anfnehmen zu kömmen. Ich untelsuchte in einem Falle die Wurzeln einer ballentrocken gewesenen um nachher 24 Stmolen in Wasser moretanchten Erica gracilis mol fand lie feinen Wurzelenden trotz des Anfenthaltes im Wasser noch geschrumptt. Der Charakter der meisten Ericaceen als Mnor- mul Heitlepflanzen kommt darin zum Vorschein, dats sie (mit Ausnalnme einzelner Arten) in einem reichlich bewässerten, leicht durchliattliaren Boden am besten gedeihen. Dem reichen Luftbedürfnis der Wurzeln muts man dureh Kultur der Pflanzen in kleinen Töpten möglichst Rechnnng tragen. Die Eriken wroeln dam schnell durch. ln glotisen Töpfen versauern die Pflanzen leicht. Auf Ballentrocknis antworten die Eriken und Azaleen mit Blattabwurt. Es ist aber falsch, das hegangene Velsehen dadurch gut machen zu wollen. dafis man num den Toptballon in Wasser steckt und nach Vollsaugen der Erde die Pflanzen in geschlossene Kästen stellt, un die Verdunstung möglichst herabzudrücken und die Pflanzen zur Turgescenz zu bringen. Man lasse sie im tregenteil an ihrem hisherigen standort, aber beschatte sie stärler in lon Mittagsistunden.

\section{Mittel gegen den Wassermangel im Boden.}

Wem sich Wassermangel im Boden durch Rürckgang cler Vegetation krmutlich macht, was auf sandigen Bödlen am hänfigsten einzutreten pflegt, wird man naturgemäts, wo es möglich ist. zur Berieselumg schreiten. Wit solcher Wasserzufuhr erzielt man nicht nur die Er. frischmog der Gewebe, soudern bringt auch eine Autlösung. Zutinh und neve Verteilung der Bodemnährstofte zuwege.

\section{Berieselung.}

Bei der häutigen śenkung des trundwasserspiegels bildet die Bu. riosclung eine Lebenstrage. und es ist interessant, dir Ergebnisse der Untersuchumgen von KöNı ${ }^{1}$ ) über die Wirkmogen des Rieselwassers kemnen zu lernen. Danach sieht man. dat's das W Wasser während des Berieselns einer. Wiose sehr vicl Nährstoffe verliert, und zwar während der wärmeren Jahreszeit erheblich mehr als in der kalten. loie Abnahmo. betriftt jedoch nicht alle Nährstoffe. Wem sich der Kohlensämegehalt des Rieselwassers steigert, nehmen sogar fast immer Kalk nnd Magnesia zu. anstatt ab. Thro Irenge scheint, wie die der Kohlensäure, mit itre Intensität der (oxvdationsvorgänge in Borlen zu steigen und zu fallen. Im Gegensatz zu don vorgenamnten Nährstoffen scheint das Kali zn jeder Zeit rom Boden absorbiert zu werden, da auch im Winter bei der Berieselung sich eine geringe Abnahme dieses wichtigen Minerals im Wasser nachweisen liefs. I) as Natrium, resp. ('hlornatrium zeigte während der Winterrieselung, ebenso wie Salpeter- und schwetelsäurt. fast immer eine gerings /unahme. Wälnend sie in der Vegetationszeit sich vermindern, also wahrscheinlich direkt ron den Pflanzen autgenommen werden.

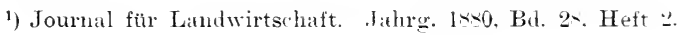




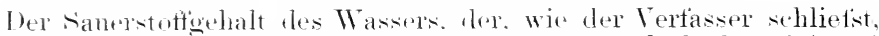
lumeh Oxydation ler organischen Botlensänren anch bodemeinigend wirkt. ist je nath der Art des Berieselnngswassers mnd je nach der Jahreseit verschiedon. Köns fand, dats dieser Gehalt im Erïhjah an hörhstall. im sommer am geringsten und in Herbste wieder zunehmend sich zeigt. Qnellwasser ist sanerstotfereher als ein schon durch hewohnte Grtshaften gegangenes Flutswaser, mo mogekeht vrhalten sifh tie snspentierten. organischen stoffe. die ron dem noch atnenen (2nellwasiel dahel aus dem Boden anfgenommen, von dem reichlich gesätigten Flntisasser dagegen abgesetzt werden.

Temperatmbeobarhtmgen bei fl) cm Tiefe ergaben während der kalteren Jalneszeit eine Differenz in der Wärme bis zn $2.8^{\circ}$ ('. zusmusten des berieselten Landes. mol dieser Temperaturerhöhmo dürfte " zuzuschroiben sein, dats herieseltr. Wiesen eher ergrünen mel später in Herlost veroilben.

IVit schnell wirkenul die Borlenahorption ist, wemn der Boden nicht gesättigt und las Wasser zmm Rieseh hochgradig mit Dnngsttfen brarlen ist, zeigte Köxig durch rinen Versuch, bei welchem er kimstlich Latrinenstotfe dem Rieselwasser beigemengt hatte. Nach rimmaliger Benutzmng des Wassers liets sich nachweisen, dats der Boden st.: " "der organischen stoffe, $74.2{ }^{\circ} 0$ des Ammoniaks, $81,6 \%$ les Kalis nul stis \%o der Phosphorsäme bereits anfoenommen hatte. Narh der dritten Benntzmng desselben Wassers komnten diese Stofte im abtliefisenten Wasser überhampt nicht mehr nachgewiesen werden. Natürlich sind diese Zahlen nur tür den im Versuch gegebenen Fall sïltig mul ändern sich je nach der sättigmo des Bodens mol Wassers. haben also z. B. keine Gïltigkeit für die Ś pül lja nohonberieselung. hei welcher die Böden in verhältnismätsig kurzer \%eit mit Nährstoffen ïberladen soin müsien. Demmoch zeigen die Versuche, welche vielsoitigen Vortrile man bei richtiger Anwendung der Berieselung erreichen kamn. Dir Wiehtigkeit einer künstlichen Boctenbewässermug wird jetzt

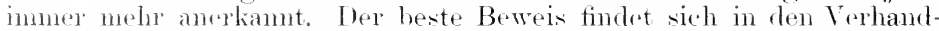
Inngen der Lambleknltur-Ahteilung der Dentschen Landwirtschafts(resellschatt ${ }^{1}$ ). in wolcher die Fragen direkter Wasserzutuhr oder Hebung drs firnudwasserspiegels hereits ventiliert und lie lisher bekannten systeme durch Abbildmoen teilweise erläntert wurden. Lir Torhandlmogn haben zu einem direkten Antrag bei dem Vorstand

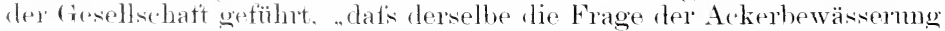
mit möghelester. "Tatliatt in wis Hand mehmo".

$$
\text { Bodenbearbeitung. }
$$

Vorläntig ist man indes bei grotsen landkomplexen doch nur in den swltensten Fällon imstande, olme heflentende Kosten Berieselmosanlagen sinzmidhten. mol ss werlen deshalb billigere, wenn anch weniger durch. wreifende Mittol häntiger zm Anwentung gelangen. Solche Hilfsmittel

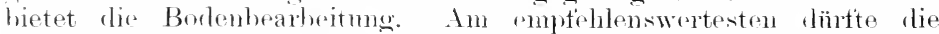
Bodenlorkarnng soin. Es fehlt nicht an Praktikern, welche behaupten, lats das boekern der Arkerkmur doeh mmöglich ein Mittel sein kömo, die Fruchtigkeit dem Boden zn erhalten. und dats

1 Die Möghiłhkeit der Ackerbewässerung in Dentschland. Arbeiten d. Deutsch. Landwirtsch.-Ges. Heft 97. 1904, S. 75. 
diese Manipulation vielmehr als der kürzeste Weg angesehen werden müsse, dem Borlen noch mehr Wasser zu entziehen. Diese Anschaumg ist irrtumlich, wie viele Versuche tartun. Die eingehendsten sind diejenigen von WoLwy ${ }^{1}$ ), der genan vergleithsweise vorgegangen ist mul zon dem Resultate kommt, datis. wenn die obersten Bodenschichten gelockert werden, sie allerdings schmeller abtrocknen, aber darlureh ilen Trasservorrat dex miteren Bodenschichten mehr schonen.

Die Erwärmmg der Ackererde durch [nsolation. die l)uchlüttumg. wem Winde äber die Bodenflärhe streichen, und derol. Einflüsse entziehen den oberen Bodenlagen das Wasser in 10 so höherem cirarle, als dieselben in der Lage sind, den Verlust dureh kapillare /ufuhr aus don tieferen Bodenschichten möglichst reichlich wirder zn decken. Wemn num turch die Lockerung der Krume die Zwischenrämme zwischen ihren Bodenteilchen bedentend veroütsert werden. so wird dir Haarröhrohenanziehung vernindert, und das Wasser strigt in den grofseren \%wischemrämmen des num bröckeligen Borlens nicht nehr in lie Iöhe. Je schmeller der Boden durh Beharken. Eggrn und šchälen zn riner grobbröckeligen Krume gelangt, desto mehr wird rin Anstrocknen der tieferen Schichten, in denen die Wurchn sich hefinden. verlangsant.

l)as entgegengesetzte Resultat wird durch das Festallüeken ( 11 a Izen) des Ackerlandes erzict ${ }^{2}$ ). I)a hierles die meisten nicht kapillaren Hohlräume in kapillare übergetühnt werlen. so wird dis Hebung des Wassers ron unten her besthlemigt mol die Hortlähe länger feucht wehalten. Thter Umständen ist aber am h das Walzen als Mitte] zur Erhaltumg der Bolenteuchtigkeit zu rmptehlen. Dirs wird nämlich aut allen sehr lockeren Bodenaten von qoringer. Wasserkapazität und reichlicher Entergrmulseruhtigkeit am Platze sein, da mit dem Festwerden die Verdunstung der Oberfläche herabgedrütht und die Zuleitung von miten vermehrt wird. Bei hindigen Böden mit grotiser Wasserkapazität wäre natürlich das Walzen geradezu schädlich.

\section{Bodenbedeckung.}

Man kann an stelle der Botenlockernng auch pin Ïberdecken der Kluma mit einem lockeren Material anwenden. In dieser Beziehumg kamm selbst ron dem T̈brrfahren der Krmme mit sand vorteilhatter Gobram gemacht werden. Es werden nicht hots die Fonchtigkeits- sondern wleichzeitig die Wärmeverhältnisse günstig gändert: demm nard Wobley's Versuchen ${ }^{3}$ ) wird dureh die Lockermeng des Bodens

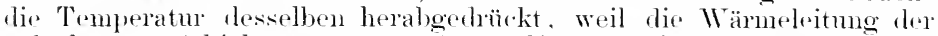
relorkerten sohicht wegen gü̈tserer Mrngen ringesehlossener Luft

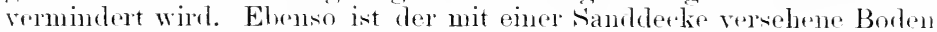
innerhalb der wämeren Jahresorit kälter als der muberleckte, weil die hrlle Farbe der (bertläche di* Assorption der Wärmestrahlen vermindert und lie zmïlekgehaltene grötsere Wassermenge miter dem

1) Wons, Finfluds der Bearbeitung und Düngung auf die Wasserverdunstung aus dew Boden. Osterr. landw. Wochenbl. 1880. S. 151.

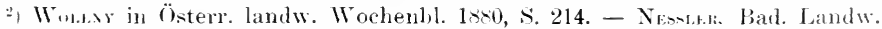
correspondenzl, latt 1860 , s 230 . - P. Warixer, Versuche über das Austrockuen des Bodens bei verschiedenen Dichtigkeitsverhältnissen der Ackerkrume. Bericht der Versuchsstation Tarmstadt 1874. S. $87 \mathrm{ff}$ - - v. K1..\%, Landw. Jahrb. 1876.

?) Einfluls der Abtrocknung des Bodens auf dessen Temperitur- uml Feuchtigkeitsverhältnisse. Forschungen a. d fiel, d. Agrikulturphysik. 1ant. s. 54:t. 
simnle schwerer erwärmbar ist. Würde der Borlen sellst an seiner Gherfläche alitrocknen, so müfsts sich seine Temperatur erhöhen, weil

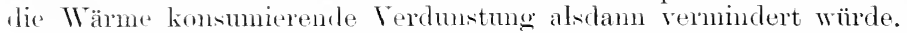

Die Bodenlockerung und Berleckung mildern also die Temperaturextreme: aber sie sind auch noch in anderer Weise nützhch. Es zeigt sich nämlich nach Voulxy (a. a. (). s. 3:37), datis von derselhen Niedersthlagsmenge durch den mit einer sanddecke versehenen Boden während der wämmeren Jahreszeit bedentend mehr Wasser dmelsickert als durch den unberleckten. Es kommt dies daher. datis der mit einer selbst num $1 \mathrm{~cm}$ dicken) Sandschicht bedeckte Boden wasserreicher bleiht, also sehmeller gesätigt ist und daher mehr in tiefere Lagen des Untersmundes abtliefisen läist. Dasselbe Resultat zeigt jede andere Bedeckung mit leblosen Gegenständen, also mit Stalldünger, Stroh. Lohe, selbst mit steinen. Treniger als der nackte Acker läfst der mit einer vegetierenden Phanzendeclis versehene Boden durch.

Ton praktischer Seite liegen auch Angaben vor, welche den Nutzen (ler 'Torferde ant'sandböden hervorheben. So benntzte Watz') die obere, i his $\rightarrow \mathrm{m}$ hohe, als Bremtorf nicht verwerthare Schicht eines Tortlagers. um ein Ackerfeld aus geringem sandboden im Februar 2 cm hodh damit an ïberdecken. Später erlielten diese getorfte und eine daranstoficends nicht getorfte Fläche reichliche stalldüngung. Bei der im sommer eintretenden Hitze und Trockenheit zeigte der im Mai geptlanzte Mais aut' dem getorften Felde einen besseren stand und lieferte cinen höheren Ertrag: ebenso zeigten spätero Ernten sich anf lem getorten stücke ausgiebiger.

Die Wirkmg des Torfes, welch in präziseren Enteergelmissen auch durch NerLivier ${ }^{2}$ ) nachgewirsen, beruht auf seiner Fähigkeit, die [hongtoffie aufzusangen und festzuhalten, die sonst im sandboden fortgespült wïrdon. [) a aber [ö̈ngme, wie ich experimentell festgestellt ${ }^{3}$ ), die Pflanzen befähigt, mit weniger Wasser hessere Ernten zu hringen, so reklärt sich hiermit auch das nümstigere Verhalten bei Trockenheit.

\section{Mit Pflanzen bestandener Boden.}

Es ist oben schon gesagt worden, dafis der mit lebenden Pflanzen hestandene Boden an wenigsten Wasser durchsickeln lätst. Die Sache ist ganz reklärlich, da die Pflanzenwmzeh das Wasser aufiangen. Vergleirhente Untersmehungen ${ }^{4}$ ) ergaben, dat's der Borken mm so mehr an TVasser erschöpft wird. je lichter die Pflanzen stehen. wem auch de Wassererschöptimg nicht proportional der Dichte des PHanzenstandes zomimmt.

Nach diesen Resultaten kamm man rmossen. welehe Differenz im Wassergehalt zwischen cincm nackten, gelockerten und einem mit dichtem Rasen bestandenen Boden sich bei heitser, anhaltend trockner Wittermo heranstilden muts. Es ist also in den Banmsehulen auf lockerem Boden durhaus nicht gleichoultig, ob oft wehackit oder Rasen

1) Zeitschrift d. landw. Ver. in Bayern 1sx: cit. in Biedermamn 's centralbl. $1 \times 3$, S. 136.

2) Finhling's landw. Zeit. 1878, Heft $\succ$.

3) Sonats. Nachtrag zu den studien über Verdunstung. Forsch. auf d. Geb. d. Agrikulturphysik, Bd. I' Heft 1'2.

4) Wouxs, Der Einflufs der Pflanzentecke und Beschattumg auf die physikalischen Eigenschaften und die Fruchtbarkeit les Bodens. Berlin, Parey, 1877, 5. 12ช. 
und Unkraut bis zur Bilelung (xines zusammenhängenden Derelir ledasien werden. Dats lediglich durch die Antiangung des geringen Wasser.

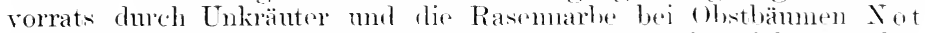
reife und Unfrurhtbarkeit el\%enet werden, ist nicht nu theoretische Schlutifolgerumg. sondern mehriah gomalhte Erfahrume.

Bei forstlichen Kulturen zeigen sich. we boi den Bammaten for. Gärtner. diejenigen Ländereien am getührdetsten. ant welchen die Ptlanzen den Bestand noch nicht geschlossen haben. Kioshöden ohne genögenden Humnsegehalt sind anch tïr älese Beständs his zu lo his 1.j,ährigem Alter getährlich, namentlich wom nach keiner seite hin

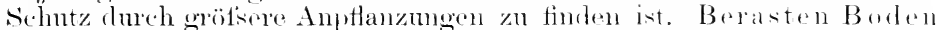

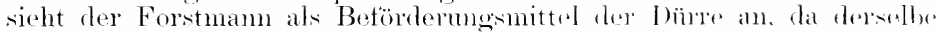
lie Niederschläge fosthält und durch seine starke Vordumstung das aus dem Untergrunde anfistoigende. Wasser schmell drum Boden entführt. Bei Waldbämmen heobachtet man bisweilen tast klosiämmige sitellen um die Stammbasis, aut denen kein Nachwnchs sich erhält. Es wirl dieser Umstand der Reflexion von Sommenstrahlen an den glattrindigen. astreinen stämmen (Buchen. Birken. Tannen) zugesehriohen. Hic von solcher spiegelrinde abprallenden somenstrahlen dïrren den Boden in erhöhtem Matise ans. Unter den Vorbengungsmatisengeln emptiehlt sieh die Anzucht der Pflanzen durch natioliche Besammeg. da die an (1)t mol stelle antstandenen Pflanzen an hesten sich den trockinen Lobialitäten anpassen werklen. Da. wo geptlanzt welelen muls. lenutze man

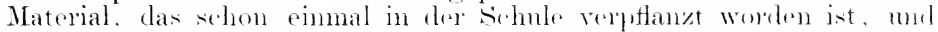

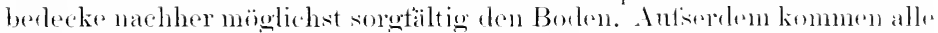

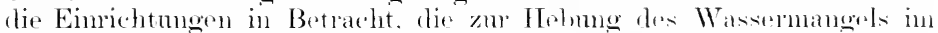

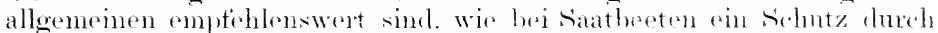
Maner. Zam orley Bammeihen. Bestecken mit Reison. Anhänteln ilen

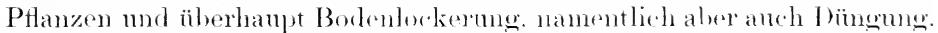
la dic letztere eine Wasserersparnis hedentet. Das Bergetsen ist mur im alleräntsersten Notfalle anzuraten. Bei dem Brsterken der Beete mit Reisig vom Rante ans ist Nadelholz. und unter diesem das frezweig unserer Kiefer oler auch der Weymonthskieter an meisten zu emptehlen:

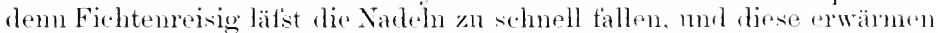
sich sehr bedentend. Tamme wird leicht zu dicht, mul Lanhholzzweig. haben zu selmell wellie und verdorte Blätter. minter denen drer Boden ebenfalls zu wenig seine Fenchtigkejt erhält.

Dats terner auch an sich ein Ausbremen ler saten und do: Rasens bej dichtem Bestande sich einstellen kam. Wähend diesellye

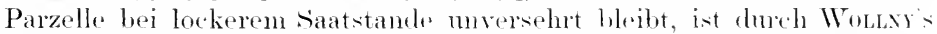
Versuche sehr nahe gelegt. Dem derselbe fand. dat's boi Drillsat dem Boden zwischen den Reihen geringer Mengen von Wasier entzogen

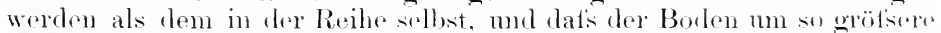
Mengen von Wassel enthält, sowohl zwischen als in ten Reihen, je weiter die Pflanzen vomeinanter entfernt sind ${ }^{1}$ ). E- wird also ancle eine richtige $B e m e s s u n g d r s$ A ussa atquantums anf wasser

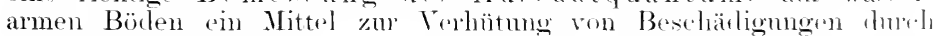
Trockenheit sein.

Nur in ganz bestimmten Fällen kam sich der bestanden Bulen nützlicher erweisen als der nackte. Bei dem lockeren Anban schnell-

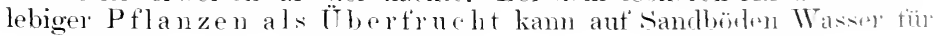

1) Österr. landw. Wochenh. 1-Y0. S. 23:3. 
- pätere samen zmö̈cligehalten werden. Wem nämlich die Anssaat der schnelllobigen Gowächse in Herbst oder ersten Frühjahr erfolot, lam tällt dir. Zuit des mö̈sten Wasserbedartes dieser Pflanzen in die Holst-oder Frühjahrsfenchtigkeit, mol wemn die trockne . Jahreszeit rintritt. neigen dieselben zmm Fruchtansatz und beanspruchen relativ wring Wascrer. Nummohr erhalten sie den oherflächlichsten Borlenlagen lun ihre Beschattmug und 'Taubildung rine ziemlich gleithmäfige Fruhtigkeit, in welcher spät gesäte Samen mol zarte Pflänzchen sich "ntwickeln kimmen. Während disse anf nacktem Boden vertrocknen wïrdens.

Waldstreu.

Froilich dant nicht rorgessen werten, dafs jede Decke die Durchlïftmesfähiglieit des Boclens hemmt, und dats also dort, wo es zur Erhaltmug der Frnchtharkrit daranf ankäme, die Kohlensämre im Boden zur 'Lersetzmo und Löshohmachmg der Gesteinsfragmente benutzen zu miissen, man in der Auswahl der Bodenbedeckmng vorsichtig sein mmts. Wie soln die Bodenderke die Luftzinkulation stört, geht aus Amuox s ${ }^{1}$ ) Versuchen hervor. Bei fo mm Wasserdruck gingen durch "hine Erdichicht von 19,0 qem Quersehnitt und $11,50 \mathrm{~m}$ Höhe immerhalb :imer stmole folgende Lnftmengen hindurch:

$$
\begin{array}{ccc}
\text { Bei Graslecke } & \text { Bei strohdecke } & \text { Cnbedeckt } \\
1,(i) & (i, 30 & 7,32 \text { liter }
\end{array}
$$

Im hesser durchlüfteten Boden wird auch mehr Kohlensäme erzengt, nut diese wird trotz der grölseren Abgabe an die Luft anch in erlï̈ltem Matse im Borlen zur Geltung kommen. Die Wirkung der Brache hestrht cerade in der zmm grotien Teil durch Mikroorganismen einnelriteten grökeren Kohlensämreerzengmo und stärkeren Zersetzung Cer (resteinstrümmer.

Ein anderer Nachteil der Bodenbedeckmo ist die geringere Verwendharkit der meteorischen Niederschläge für den bedeckten Boden. Jo nach der Art dor Decke wird dieser Nachteil verschieden grofs -rin: r wird mu so mehr wachsen, je mehr sich die Substanz der Decke wi. sin sthwamm vollzusangen imstande ist. Als Beispiel für diese Varschiofonartigkeit mögen die Angaben von Rieglek ${ }^{2}$ ) dienen, der Maldstren und 'Torfmoos (Sphagmmm) anf ihre Durchlässigkeit geprütt hat. Vom den in feinem Strahl anf luftrockne Spren täglich anf-

\begin{tabular}{|c|c|c|c|c|c|c|}
\hline & \multicolumn{2}{|c|}{ Bucheustien } & \multicolumn{2}{|c|}{ Tannenstreu } & \multicolumn{2}{|c|}{ sphagnumrasen } \\
\hline & durchgesick & itufges. & lurchges. & aufiges. & durchgesick. & aufges. \\
\hline 1. ' & $4(10,: ;$ & $9 ! 9.7$ & $+41,3$ & $., 5, \pi$ & $21(i, 0$ & 284,0 \\
\hline m r. Taser & $1 \times 7.1 ;$ & 12.4 & $4 ! 191.6$ & 11.4 & $49: 3,5$ & $(i, i)$ \\
\hline
\end{tabular}

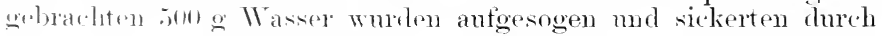

lio Bespitzmes enteprach sinem Regen von $10 \mathrm{~mm}$ Hihe und femnach wordon in ler Buchenstren etwa 20\%0. in der Tamnenstreu "Wa l2" " mml in Noosrasen $57 \%$ o des anfgefallenen Wassers zurück-

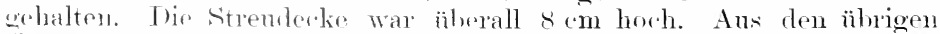
Tabellen eroibth sich. dats in den nächsten drei his vier Tagen noch grökre Mengm täglich von der stren anforesogen wrom, die erst almählich his zmm nemten Tage so weit mit Fenchtigkeit gesättigt

5) Biedromann's ('entrall, 1880), s. 40.5.

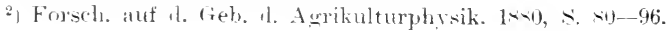


war, thats tast alles nummehr autfallende Wasser abflots. Ein nach heitser, anhaltend trockner. Wittermo sich einstellender Regen von $11 \mathrm{~mm}$ Höhe käme dem Boflen unter Burhenstren nur in Höhe von

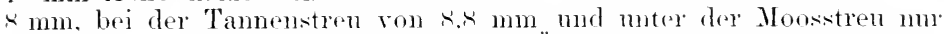
in Hähe von $4,3 \mathrm{~mm}$ zur Verfügung. THrigens äurlern sich die Verhälnisse je nach dor Kraft, mit der das Thasser aut die Stren aut schlägt. Wemn das Wasser tein verstäuht ant das Moospolster gegeben wurle. sog letzteres $70 \%$, der segehenen Fenchtiglieit ant, während diesclbe Wassermenge, in Form eines feinen strahls zugeführt, zmm

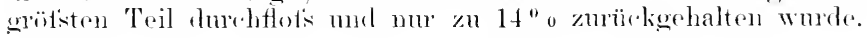

\section{I) ie Wäder.}

Als Mittel zur Schonung der Bodenteurhtiglicit im Acherlandes muts anch die Nähe rom grötseren Baumkomplexen, namentlich Wäldern. angesehen werden. Nach den von Matrhus ') nem bis elf Jahre lang durehgeführten Beobarhtmegen ist die Lutt im Walde in $1.5 \mathrm{~m}$ Höhe curchschnittlich kälter als ïber dem treien Felde, mol zwar ist die l)ifferenz im sommer am stärksten. Einen elanso deprimierenden Einfluts, wie der Wald aut die mittlere Luftempreatur ausibt, besitzt "N anch tïr die Temperatmextreme, die im Walde geringer sincl. Wem anch die Temperaturdifferenzen vielleicht nur $0.5^{\circ} C^{\circ}$. betragen, so werden sie immerhin sich geltend machen, wemn eine hegenwolke über die tiegend hinzieht: es muts über dem Wable der sättigmespmbt der lutt eher areicht werelen und somit der Regen trïher anfangen, also l'eichlicher sein, als anf' lem unbestandenen lande. 'Tatsächlich el-

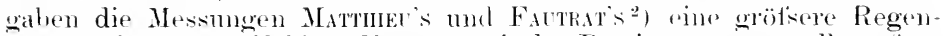
menge über dem Tralde. Hygrometrisebe Bestimmmengen stellten fest. rats die Wasserelamptgewichte in 1 clom Lutt durchschintelich oberhall, rines Fichtenwaldes E,tio botrngen, während sio ïber einem Lanb. wale s.tiog. ïher mbedecktem Boden in dersellon thähe (104 bis 1.2. $\mathrm{m}$ hech) hei $100 \mathrm{~m}$ horizontaler Entfermung rom Narlelwalde 7.39 .2$. in temsellien Horizontalabstande vom Laubwalde s.104 wetrugen. So wie in vertikaler Richtumg die Waldnähe die Lutt teuchter ahält, so

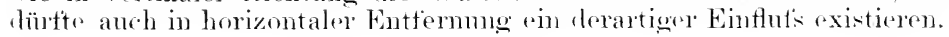

\section{Die Brache.}

Weniger zur Erhaltumg oder Erhöhmeg des Wasservorates in Boten, als vielmeln zur Ansammlumg des ülrigen Nährstoffimaterials ist die .Brache" in Betrarht zu ziehen. Nach Wolnxy ${ }^{3}$ ) Angaben lassen soh die Eigentïmlichkeiten der Brar.he dahin zusammentassen. clats der brachliegende Boden im sommer wärmer. im Winter kälter. lie 'Temperatursehwankmogen z̈berhaupt im Brachlancle grötser als in cem mit Pflanzen bestandenen Boden sinel. Wälnend res Veagetationszeit ist der mit riner Ptlanzenderke überzogene Boden stets von geringerem Wassergehalt als im nackten /nustande. Hieser grötsere Fenchtigkeitsgehalt erhält sich im kahlen Boden anch hei ätrerer $B$ r.

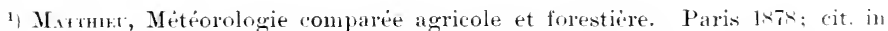
Forschungen auf d. Geb. d. Agrikulturphysik, 1×79. \$. 422-429.

") F.n raAr, Über den Einflufs der Wälder auf den sie berïhrenden Regenfall und die Anziehing der Wasserdämpfe durch die Fichten. Aus ('omplt. rend. 1 BA. 89, Nr. 24: cit. Biedermam's Centralbl. f. Agrikulturchenie, 1-80. \&. 241.

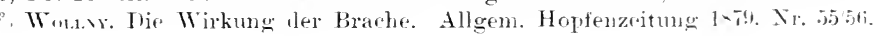


atheitum noth. Let\%terer profitiert auch von den atmosphärischen Niederschlägen melı, indem während der Vegetationszeit durch den machliegenden Boden bedentend grötsere Wassermengen absickern als ans dem mit einer vegetierenten Pflnzenderke versehenen Felde. Der tï̈ das Nährstoffliapital des Bodens am meisten in Betracht kommende Punkt ist aber der Kohlensäuregehalt des Brachlandes. lessen Lutt nach WoLLxy Sutersuchungen ungetähr viermal soviel Kohlensäure, als die des Graslandes enthält. Also das Lösmonomittel für die mineralischen Bodenhestandteile ist $n$ so vieles reichlicher. rorhanden. Woraus sich teilweise schon die gröfsere Ausammlung von Pflanzemmährstoffen in Brarhboden erklärt: teilweise hängt die grö̈ser: Bereicherung anch von ter schmelleren Kersetzmng der organischen substanzen dureh lie stärkeren Temperatursehwankungen, die grötsere Fenchtigkeit und die rogere 'Tätigkeit der' Mikroorganismen ab. Es ist jedoch schliefich laranf hinzuweisen, dats Böden mit geringer wasserfassender Kraft und in wrotser Mächtigkeit (Sandböden) Dei ihrer grotsen I)urchlässigkeit einen bedentenden Teil der Pflanzennälurstoffe in den Unterorund nutzlos abwaschen lassen kömmen. Solche Böden müssen also merade umgekehrt unter PHanzendecke gehalten werden.

Welches ron diesen Mitteln wegen den Wassermangel zur Anwendung gelangen kann, müssen die lokalen Verhältnisse lehren. Jedenfalls ist ersichtich, dat's wir der Trockenheit nicht machtlos gegenüber stehen.

\section{b) Lehmbollen.}

\section{Allgemeine Charakteristik.}

Für die Betrachtnugen der sthätlichen phrsilialischen Eintlüsse auf die Pflanzenwelt haben wir nicht nötig, Lehm- und Tonböden voneinander zu unterscheiden. Wir haben es stets mit Mischungen von Ton und sand zu tun, und nur das Mischmosverhältnis dieser beiden Bestandteile ist versehieden. Tom sandigen orler ".milden" Lehm an schwächt sich der Sandgehalt immer mehr ab bis zum „strengen" Lehm und zu den im tenchten Zustande plastischen Tonböden, bei denen die feinen abshlämmbaren Teile ïberwiegen. Bei mneren Knlturlämlereien werlen die Beimengungen von Kalk und Humus noth modifizierend ins frewicht fallen. Kalk wird die schweren Böden dureh

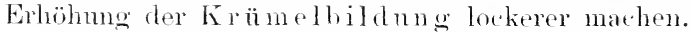

Die Fruchtharkeit ist von der hrümelung direkt abhängig, mul plastixthe Tone sind nufruchtbar. Die nicht gekrïmelten 'Tomböden sind für Wasser undurchläsig und geben daher in ebenen Lagen leicht Gelegenheit zm. Torsmptimg. Je geringer die Komgrötse des Bodens. desto grötser wird die Anfnahmefähigkeit für Wasser so dats bei sehmellfolgemlen starken Differenzen der Wasserzutiuh ganz bedentende Volumenveränd,rungen vorkommen. Darauf beruht das starke Anfreitsen der. Tonbaden bei dem Austroknen. Iäsliche salz' werlen nur shwer answewashen werden kïmen.

los Anstrochnen ist $n$ so wefihrlicher, je mehr eine Botenalt sich dem reinen 'Touboden nähert. der, eimmal troeken geworden, nu sehr langsam wieder IVasser anfnimmt, da sich rasselbe nur schwer zwischen die dicht gelagerten Borlenpartikelchen eindrängen kann. Diese Eigenschaften schwäthen sich in rlem Mat'se ab, als die Sanrlbeimengumgen sich steigern. Bei den strengen Böden wird die Aus- 
trockumng in sommer lisweilen getährlicher als bei den sandbörlen. namentlich wenn eine starke Bannvegetation in fegenden sich entwickelt hat, die ïherhaunt arm an Niederschlägen sind. I) Sommer-

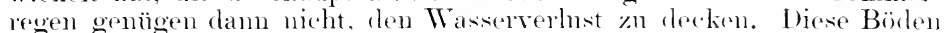
sind somit ant die Wintertenchtigkeit angewiesen mol kïnnen in Jahren, in denen flixelhe gering gewesen und anch die sehmedeck gefehlt hat, hei troekenen Fröhlingen den Pflanzenwols nolur schädigen als die sauthöden. Daraus erklärt sich, dats nach heitsen, trockenen sommern und niedersehlagsarnen Wintern hei alten Bämmen (tiptoldürre. 1. h. Kweigtrodknis, ans Wassemangel sich finstellen kamn.

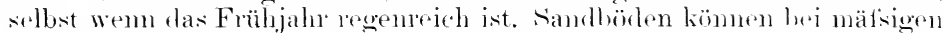

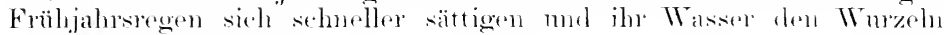
zur Virfügung stellen.

lor schweren Böden werclen .kalt" genannt. Dirs erklärt sich ans dem lohen Wassergehalt, der mit der Feinkörnigkeit der strulim wächst. In manchen Gegenden sterlon ansländische ('oniferen (Abies

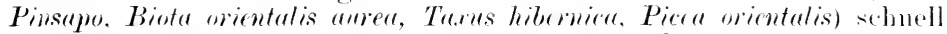
ab. Nan schreibt lies dem Wintertiost zu. finctot aber bei ein. gehenderer Beobarhtumg, datis mu bei grotser Xässe des Bodens die niederen Temperatmen getährlich werele ${ }^{1}$ ).

lie meisten störmoen werden aber, wir wir in tolemelen seluen

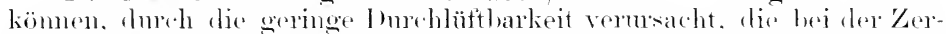
setzung organischer Massen zu Fäulnisersehermungen tïhrt. Haher

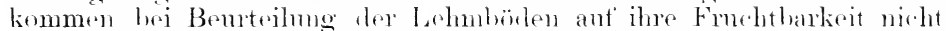
mur der cirad der Krïnelung. somelern anch die Tiete. his zn weleher

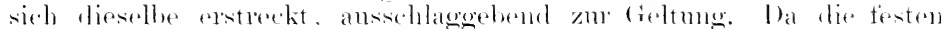

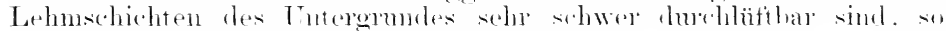

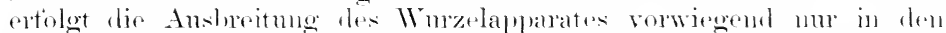

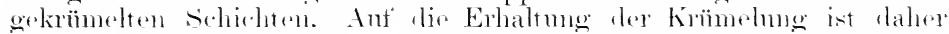

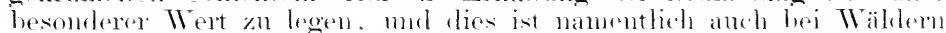

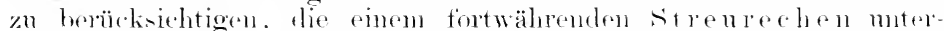

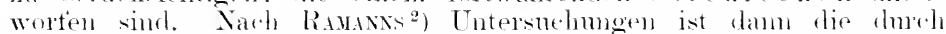
strenentuahme hervorgerutene Borlenverdichtmes so stark, dats ein he-

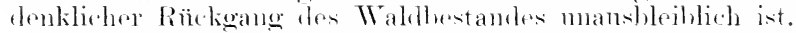

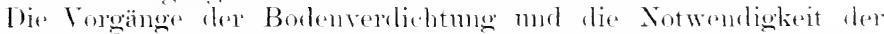
Bodenlockerung sind anch hoi mseren Tropenkulturen sehr in

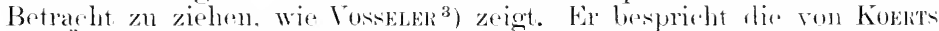

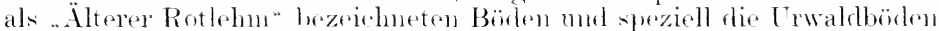

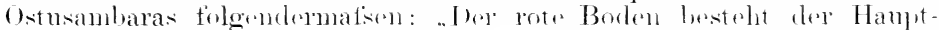

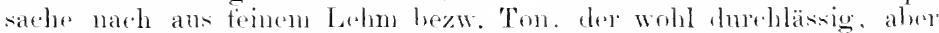
zu fein porös zur Autuahme feiner Ilummspartikeldhen ist, der zudem

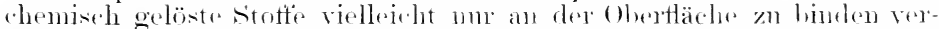

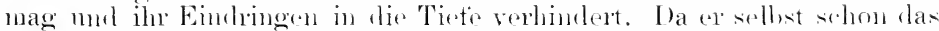

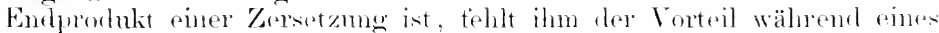

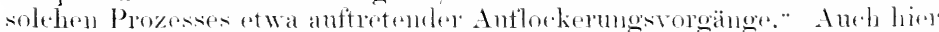

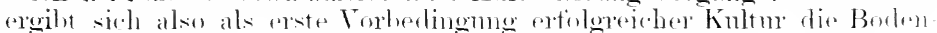
lorkelmug.

1) Conss. W., Beitrag zum Verlalten der Coniferen gegen Witterungseinflüsts. Hamburg 1897 .

2) Rimix, E. Tntersuchung strenberechter Böden. Sond. \%. f. Forst-u. lagd. wesen, XXX. Tahrg, : rit. Bot. Tahresh. 1900. II, S. 415.

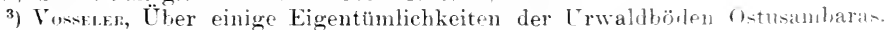
Mitteil. a. d. Biol. Landwirtsch. Institut Amani. 1904, Nr. 39. 
Je toniger ein Borlen ist. Mesto langsamer werden sich infolg's seiner niederen Temperatur die Ptlanzenreste zersetzen. Während in himperchend gekrümelten Bodenarten normale Verwesmor stattfindet, sammeln sich aut dichten Tonbörlen Massen von Rohhumus, also Pflanzenresten. an. lir. wenig zersetzhar, aut dem Borlon aufoelagert hleiben, wril die Berlingungen tüu die Verwesung moiunstig sind. Wenn sehr tenkänige Bodenarten mit wotser IV asserkapazität, also der Fähigkeit, wotso Mengen von Wasser zurtickzuhalten. ohne es tropfenweis wieder ahzugeben. so viel Wasser hokommen. dafs das sirb zwischendrängende Wasser den Zusammenhalt der Substanzpartikelchen untereinander überwindet und dieselben anseinandertreibt, famn erweirht der Boden. Den strengen 'Ton- mul lettenböden ist lieser Zustand besonders eigentümlich: seltener kommt ein lerartiges .\%eroeh "n" bei Lehmborlen ror.

solehes Erweichen des Bodens ist in doprelter Beziehumer wetählich. wenn as im Herhst oder Frïhjahr sich einstellt. Einerseits flietist der Boden olejehsam ab und die Saaten sind bald dem Vertrocknen oler. bei Wintersaten, auch dem Ausfrieren mehr ausqesetzt. Anderseits verlangsamt dieser Zustand die Bearbeitung und $B$ stellung der Felder und wirl Ursache geringer Ernten. Fs ist nïmlich wohl zu herückichtigen. dats bei unseren sämtlichen Kulturgewädhsen die usnelle Bestellzeit durch die Beobachtnng des Terhaltens her Phanzen in unserm Klima sich herausgebildet hat. Man kam jederzeit die Erfahrung machen. datis eine Ver legung der Kulturzeiten Änlerungen im Charakter der Pfanzen herrorruft (T̈berführung ron Winter- in sommergetreide). solche Verlegung der satzeit wirkt oft sthällich. Erimnert sei hier beispielsweise an die Erbsen. [lasselhe saatgut. das bei Ausiaat im zeitigen Frühjahr eine schöne Ernte von gesumlen PHanzen liefert. bringt bei Aussaat im Sommer sehr häufig kurze, rlureh den Meltan aro geschädiote Pflanzen mit kleinen Hülsin hervor. Kohlrabi, zu spät im Frö̈hjahr gepflanzt, werden leicht holzig usw.

Ähnliche Excheinungen sind bei feinsandigen Heirlelörlen (F)ottlehm) zu beobathten. (GraEBsek ${ }^{1}$ ) charakterisiert diese Botenform als eine als fast mehlfeinen Sandkërnern mit nur geringen Tonbeimengungen bestehencle. Die ganze Masse sieht in fenchten Zustande lehmartig aus: im trockenen Zustande aber mitersheidet sie sich rom richtigen Lehm durch ilure Porosität. T)abei kam infolge der äufserst feinen Kornstruktu Flottlehm so hart wie Stein werden. Bei Kulturen, die danernd unter dem PHupe stehen and durch tierischen Dung locker orhalten werden. ist solcher Boden oft vorteilhatt, aber bei den Forstkulturen äutserst schädlich. Denn nach der ühlichen eimmaligen Lockerung setzt sich durch den Regen ter feine sand alsbald wieder fist zusammen und läfst den Luftsatuerstoff zu wenig zu den Bammwrzeln gelangers.

\section{Das Verschlämmen des Bodens.}

Bei heftigen Rugngitssen und Ï̈bershwemmungen werlen Bodenarten mit grofsem trehalt an sehr tein zerkleinerten Teilchen zusammengeschwemmt und bei dem Abdunsten des Vassers in Form einer dichten abschliefsenden Kruste zurückgelassen. Mit der Frinheit seiner Zerkleinerung wächst die wasierfassende Kraft eines Bodenbestandteils

1) Grinas, Handhuch der Heidekultur, 1904, s. 200. 
mogemein. wie hereits erwälnt worden int. Hie obertläche wird dureh

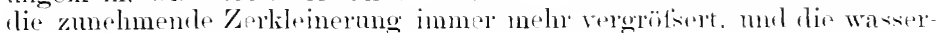
haltende Kratt beruht auf Obertlä(chenanzichung. I)toh Kerkleinerung

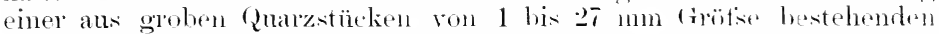
Bodemmasse. die sine absolute Wasserkapazitat ron 7 " o hesals. liets sieh die kapillare Anfsangmeskratt tïn Wasser derart rermehren. dats ein ans dem Quarz hrogestellter fromer Somd mit riner Korngrötse ron

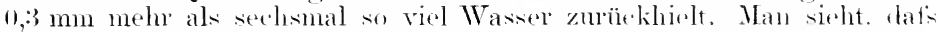

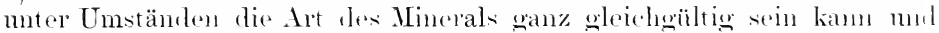

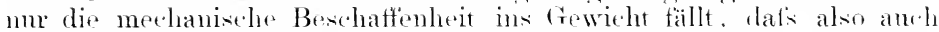
eimmal Qnarzstanb die Rolle les Tones äbernehmen kinnt. Natürlich

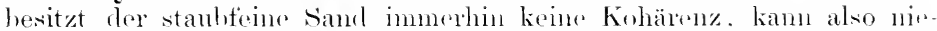
mals für sich allen die Rolle eines Bindemittels äbernehmen. wit. solche der 'Ton hat. Hanptsächlieh sind es aher die Tonbörlen. welche.

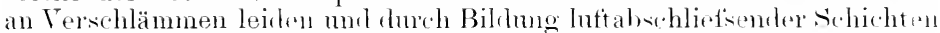
samen und Pflanzenwurzeln zur Fänhis Fringen. Bisweilen bilılen sicls

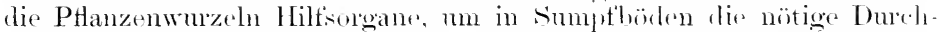
lüttung zu finclen. Erinnert sei in dieser Bezishung an dir der Boden-

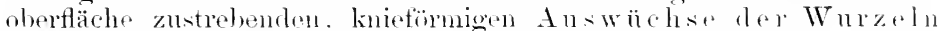

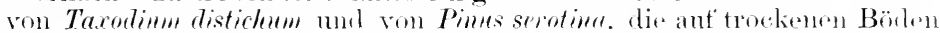

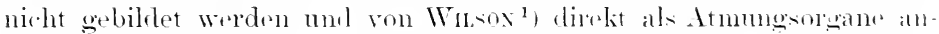
gesprochen werelin.

Ein Beispiel tïu dir Schärligung des Vegotation dureh direkt.

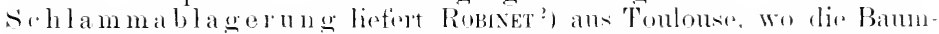

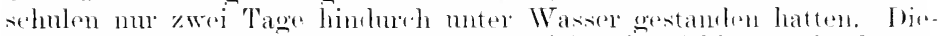
jenigen Pflanzen, an leron Basis sirh nicht viel Schlamm aherelagert.

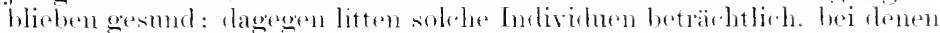

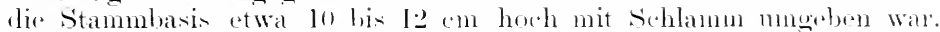

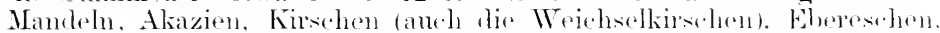

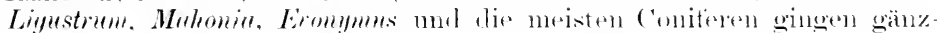

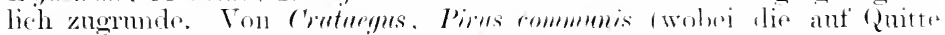
veredelten weniger littens). Pirms Malus. Costumen, Mespilus, Cutrelpu

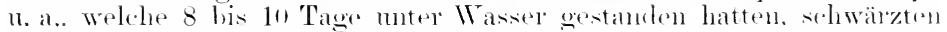
sich nur diejenigen Exemplan's an der Basis mol staphen ab, bei denen

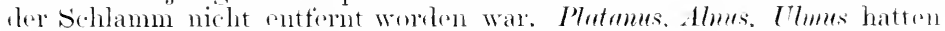
nitht welitten, und Pomulus sowio Solie (Tranerweidens entwickelten sogar ans der stammbasis reichliehe Wurzeln in den selhlamm hinein.

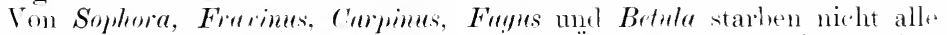

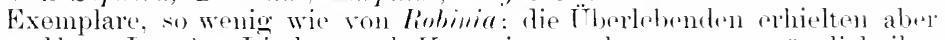
gelbes La nh. Limden mul Kastanien verloren sogar qünzlich ihn Blätter. Immeroriune Pflanzon, anch ein Toil der coniforen. verloren ilno Bläter. soweit sie vom Wasser bedeckt gewesen waren.

Doppelt ins fewicht fallend int diese Anderung der physikalisehen

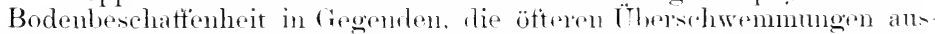
gesetzt sind. und unter diesen leiden solehe. die von sererasser iilue seliwemmt werten. am meistrn. Algesehen von dem sicharlen. dron di.

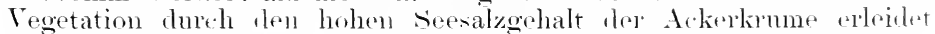

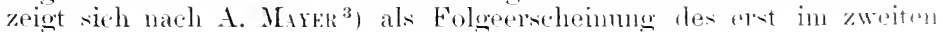

1) Wusens, W. P.. The production of aerating oreans on the roots of swatnp and other plants: cit. Bot. Jahresber. 1889. I, S. 682.

2) Revue horticole; cit. Wiener Obst- u. Gartenzeitung $1876, \therefore$, :3i.

?) A. M.rfi, İber die Einwirkung von Salzlösungen auf die Abotzung-

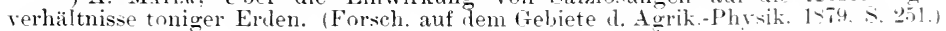


Jahre biswilen bemerkbaren Dhehtschlemmens die Bildumg einer whwar\%n. stark mit schwefeleisen imprägnierten sichicht, die als weiterer sichäliger der Vegetation anzusehen ist.

Auch v. Gonrex ${ }^{1}$ ) heht die Bildung derartiges eisenschüssiger, in Westriestand . Knicli" senamnter Sthichten in humuseichen, lohmigen und tonigen Sthlickablagerumgen der Heeres- und Flutsmarschen heror mel erkiart deren Entstehme damit, dats das Eisenoxyd des Lehmes bei Abechluts der Luft dureh die organische Sub. stan\% zu Eisenoxvilul reduziert wirl, das sich mit der Quellsäure zn quellsaurem Eiscroxvihl verbindet. Das sich nach allen Richtungen lin verbreitemle quellsaure Eisenoxydul oxydiert sich allmählich wieder, volkittet als Eisenoxylhydrat alle Bodenteile test und wirkt mit bei der Bildung des rerrufenen Grtsteins. Wir kommen anf die Ortsteinbildma lwi Besprethmg der Eigenheiten des Moorbodens zurück

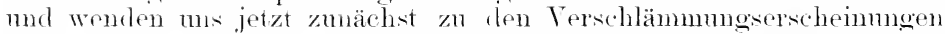
unter dem Eintluts ron Salzlösungen, wie sie hei Anwendung ron I) ïn geralzen sieh einstellen.

Sath den Marekrehen Versuthen zeigt sich, dats in Wasser snspendierte 'Tonteildhen sich in verschiedener' Weise niederschlagen. je nachdem wie in reinem Wassey oder solchem, welehes Kochsalz und andere Beinnougungen whthält, sich schwebend hefinden. In reinem Wasser fallen ilie Teikhen nach ihrer Grötise genaner nach dem Verhältnis ihree (Bhertlächon zn ihren Nassen) nieder. Die feinsten Teilchen heiben muenein lange im $\mathrm{W}^{2}$ asser sehwebend, da sie mit einer heinahe der rhemivchen Auflösmg zu veroleichenden Anziehungskraft von dem Wasser festgehalten werden. Dieser Anziehmoskratt gegeniiber ist die sichwerkraft dieser T'eilchen belanglos. Setzt sich der Ton aus einer Salzlösme nieder, so kamm man, wenn man solchen Ton versuchsweise in rinem Glaszrlinder anfgeschlämmt hat, beobachten, dats sich von oben herab cine aus dichteren. teineren Tonteilchen gebildete Grenzschicht in tem \%ylinter kemtlich macht, oberhalb welcher eine verhältnismätsig sehr klare Flürsigleit steht. Durch die Anwesenheit des Kochsalzes werden die feinen Tonteilehen mehr als dianzes niedergeschlagen (korguliert nach Sichlössii). Es entsteht . Flockung". Die etwas sü̈beren Teile unter ihnen seheinen im sinken verzögert zu werden; Tie teineren werden atwas beschlemigt. Nan hat angenommen, dats durch die Anwerenheit des ralzes wahrscheinlith die Anziehung zwirehen 'Ton und Wasser vermindert wird, da dieses den Ton vollständiger' sinken lätst. Dagegen muts dis Anziehme von Ton zu Ton vernehrt,

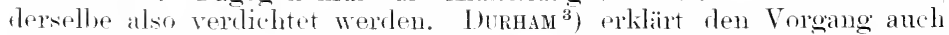
derart. lats die Anziehungskraft tes Wassers. die sonst gänzlich zur suspension des Tones in Anspruch genommen ist. durch thas Salz der lösmmg his aut den letzten Rest gesättigt wird. Nach l)onnam verhalten sich sichwetelsän'e, nach Mrı́n die IIneralsämen überhaupt, wie Krochsalzlïmung: ehenso ist es mit deren Salzen selbst hei einem Ïlsersehutis von fixem Alliali oder Ammoniak.

Nach den jetzt herrschenden Anschanmeen wirken alle Elektrolytr. also alle Körper, welche in wässeriger lösung zum Teil in . Lonen" gespalten werden. Hockend. Nichtelektrolyte sint wirkungs

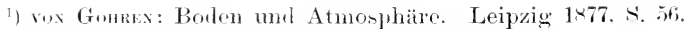

2) Biedermann's Centralbl. 188:, Nov., \$. 78t.

9) ('hem. News.: cit. .Naturfors ber" 1,7s. S. 11:. 
Ios. I ler elektrische Strom tällt die Flocken elontalls ans: es ist daher anzmelmen, dats die in Wasser rerteilten Partikel elektrised geladen sind und man in der Ladung die Urarehe dre Selowingungen zur sucluen hat $\left.{ }^{1}\right)$.

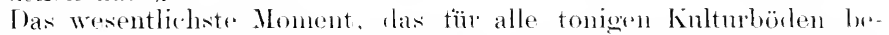
achtenswert ist. liegt in dem Nachweis, dats die salperersamen salze sirh betrefts der Autselulämmbarkeit des Tones den salzsamen nähern und wegen ihrer leichten Answaschbarkeit den Borlen rasch zun Dichterwerelen bringen. Darhureh arklärt sich das mechanische Verderben tomericher Bodenarten durch wierlerholte einse it ige salpeter, lïngung. Nachirm antangs sich schöne Ernten ergeben,

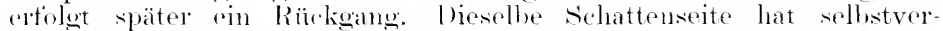

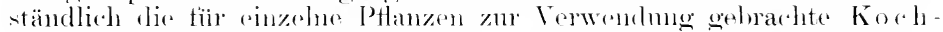
sal l \% l

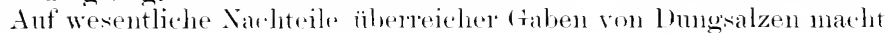
Behress ${ }^{2}$ ) anfmerksan. Es liommt nämlich deren osmotische Wirkmog in Betracht. Dureh diese osmotische Wirkung löslicher salze im Borlen wirt die Deckmo des Wasserbedarts der Pflanze ersehwert, und die Pflanze antwortet darant durch eine zweckentspreshendo Modifikation ihrer Organe. ben physiologischen Wassermangel entsprechent. drückt die Ptlanze ihre Verdunstung herab dureh don Ban fleisehigerer Blätter mit kleineren Intereollularüumen. wie hei den PHanzen der Salzquellen mol des Meresstrander.

Von masern Knlturptamzen leidet an meisten dro 'Tabak, der sich dann werade so verleält wie in heifsen. trockenen sommen. Er lildet theischigere Blättre deren Brembarkeit lurabgesetzt wird. In Bestätigme dieser in kuropa gemachten Boobachtungon erwähnt Hexger ${ }^{3}$ ) vou den Kulturen iles Deli-Tabaks aut' Sumatra, dat's das

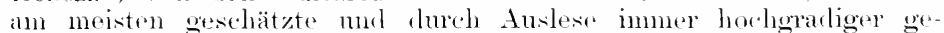

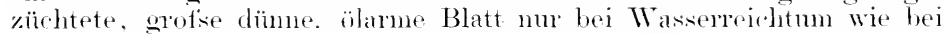
anlattendem Regenwetter sich rntwickelt, wälnend bei trockner Witterung sich kfeine dirke. mit viel Drïsenhaaren versehene. minderwretige Blätter ausbilden.

\section{Die Verbesserung der sich verdichtenden Böden.}

Die Verbesserung der loicht schlietsenden Tonböden wird in der. Erhöhung ihrer Bearbeitungstähigkeit hestehen müsen. Lic s-hweren Böden sind nugrtïge, d. h. sie setzen den Arkerwerkzengen durch iln Anhaften im fouchten /ustancle, lureh ihre Härte in trockenen

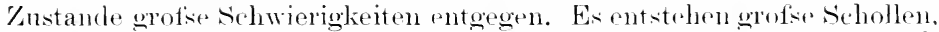

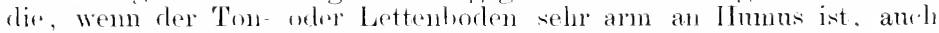
nicht leicht zertallen. Bekanntlich ist die vorteilhafteste Bearbeitumy fïr rlic Fröhjahrshestellmm ras Umbrechen im Herbst und Liegenlassen in ranher Furche: die währent des Winters relolgende Loekermw durch das trefrieren des Wassers in den Bodrnzwischemäumen macht ans ten zähen sichollen rine mürles. Krïmelige Masse.

1) Rumix, E. Bodenkunde II. Aufl., Berlin. J. Sirtinger, 1905, ‥ 225.

2) .J. Benrex, Über Diungungsversuche. Tahresb. d. Vartreter d. angewandten Botanik, II. Jahrg. Berlin, Gebr. Bornträger, 1905, s. 28.

3) Hoxien. F. W. T., Tntersuchungen und Betrachtungen über die Mosaihkrankheit der Tabakpflanze. Zeitschr. f. Pflanzenkrankh.. 1905, Heft $\mathrm{l}$. 
Diese Vorteile aber sind nur tür die Frühjahrsbestellung vorhanden und verschwinden nach starken Regengüssen im Laufe des Sommers. Man muts also gegen die Zähigkeit durch Zufulur von Humus oder Moorerde sorgen. Das Lüngen mit langem, strohigem Mist ist hier aukerordentlich angebracht. (tanz besonders wirksam aber zeigt sich das Kalken und II ergeln des Bodens. Durch die Zufuhr von Kalk. der im Borlen als doppelt kohlensamer z. T. in Lösmug ist, wird das Verschlämmen rerhindert, wie die praktische Erfahrung lehrt.

Es muts ron allen sialzen, anch von den am besten wirksamen Kalk- und Magnesiasalzen eine bestimmte Menge in der Flüssigkeit enthalten sein (der S.hwellenwert der Wirkungen muts überschritten werden). wem ein Alsetzen der Tonteile eintreten soll. Auch in den Flüssen macht sich die flockende Wirkung' gelöster Salze geltend. indem sich z. B. Sinkstotfe in Flüssen aus Kalkgebieten schneller absetzen als aus kalkamen Gegenden ${ }^{1}$ ). Für die Landwirtschaft direkt wird die Krïmelung dadurch wichtig. dat's anf ihr die (tare des Ackers bernht. Die Krümel des Bodens verhalten sich ähnlich wie die Toutlocken. Die Wirkung des Kalkes zeigte Husind dadurch, dats er festen Tonboden mit $1 \%$ Ätzkalk knetete. Während der ursprüngliche Tonboden nach dem Trocknen steinhart wurde, erwies sich der mit Kalk rersetzte bröckelig und mübe. Da neben der andanemden mechanischen Bodenbearbeitung die Salze die Lockerheit des Ackerbodens hedingen, so wird dies auch bei Waldboden in gleichem Matse der Fall sein. Wenn die die Krümelstruktur bedingenden löslichen Salze vermindert werden, wie durch übermälíige Sitreunutzun $\underline{\text { s. }}$ Bedeckung mit Rohhumus. Answaschen aus den oberen schichten ı. dgl., muls eine Bodenverdichtung eintreten.

Bei der Rïbenkultur ist vielfach die Zufuhr von Scheideschlamm aus den Znckertabriken in Gebranch. Der mechanische Einfluts macht sich hier nicht selten dadurch geltend, dafs infolge gesteigerter Erhitzbarkeit und Wasserarmut diese Böden nachher Herz- m d Trorken fäule hervorruten.

Ion grofiem Interesse erscheinen die in einer Arheit von Hubsto ${ }^{2}$ ) niedroelegten Angaben über die .Alkaliböden" Kaliforniens. Die oft mitten zwischen vorzïglichem Kulturlande eingesprengten Alkalistellen mothalten so vicl Salze, datis dieselben sich durch Efflorescenz auf der Obertläche bemerkbar machen. Diejenigen, welche alkalische Karhonate (und teilweise auch Borate) enthalten, zeichmen sich durch die Schwierigkeit oder fast Unmöglichkeit aus, zur Herstellmo einer eigentlichen Ackerkrmme gebracht zu werden. Nach jedem Regen steht anf diesen, durch ihre niedrigere Lage kemntlichen stellen von aufgelöstem Humms gefärbtes, kaffeebrames Tonwasser zuweilen wochenlang. Lieselbe Bearheitung, welche den danebenliegenden guten Boden zu einer aschenartig lockeren Beschaffenheit bringt, macht das Alkaliland zu einem Hanfwerk abgerundeter Schollen von der Gröfe einer Erhse bis zu einer Billarlkugel.

1)ic von dem Alkaliboden ausgelangte, schwarzbrame Lösmo gab nach dem Abdampten. Whühen und Sättigen mit Kohlensäure 0.25.10。

1) RAMLN a. a. O. S. 206.

2) Hur.tns, Über die Flockung kleiner Teilchen und die phrsikalischen und techn ischen Beziehungen dieser Erscheinung. American Journal of sciences and arts XVII March 1879. Forsch. auf I Gebiete d. Agrikulturphysik, 1879, S. 441. 
unverbrennlichen Rückstand; hiervon waren $0.156^{\circ} /$ wieder in Wasier löslich. und dieser lösliche Teil bestand aus Natriumkarbonat $.2 .74^{\prime \prime} 0$, Natriumchlorid :33.48\% ${ }^{\circ}$, Natriumsulphat $1: 3.2^{\circ} \%$. Natriumtriphosphat $1.8: 3^{\circ} \%$.

Die $10.093 \%$ unlöslichen Rückstandes des geglühten IVasserextraktes enthielten Calciumkarbonat $14.12^{\circ}{ }^{\circ} 0$. Calciumtriphosphat $5 .: 57^{\circ}$ " Magnesiumtriphosphat $5,7^{\circ} 0^{\circ}$, Kieselerde in $\mathrm{Na}^{2} \mathrm{CO}{ }^{3}$ löslich $24,37^{\circ}$ ". Eisenoxyd. Tonerde und etwas Ton $50,47 \%$.

In diesem Falle sowie anch bei vielen anderen alkalischen Bodenarten Kaliforniens lringt die Zutat einer hinlänglichen Menge Gills eine auffällige IVirkung hervor. Die kaustische Wirkung les Alkali. karbonates auf Samen und Pflanzen wird sofort aufgehoben, so dat' dort, wo vorher nu, "Alkaligras" (Brizopyrum) und Chenopodiaceen wachsen, bald Mais "und IVeizen ohne s'chwierigkeit forthommen. Zu. mechanischen Änderung der Bodenkrume, zum grötieren Lockerung derselben bedarf der Gijs natürlich längerer Keit.

\section{Die Überflutungen.}

Gegenüber «tr vielfach verbreiteten Ängstlichkeit bei Einbruch von Wassermassen in Kulturländereien rürfte hervorzuheben sein. dats, abgesehen natürlich von Answaschung von Nährstotfen wnd den mechanischen Schärligungen durch den Wellendruck, die Vegetation nicht übermälsig emptindlich gegen eine längere Bedeckmog des Borlens mit Wasser ist. Namentlich die Holzptlanzen besitzen. wie Überschwemmungen zeigen, pine glokse Widerstandstähigkeit, die $m$ in länger anhält, je länger di॰ Wassermassen in Bewegrmg bleiben.

Die Nachteile stellen sich erst hochoradig pin, wemn es sich 1 m stagnierenrles Wasser handelt, das lange Zeit äber der Bodenobertläch. verbleibt, Für kïrzere \%eit gehört die İTherflutung in der Form der Überstaun $\mathrm{g}$ zu den nützlichen Kulturmatsegeh. Allerdings wirr sie immer gefährlicher als jene Bewässerungsmetholen scin. bei welchen der Boden der Luft stets zug̈̈nglich bleibt (Berieselung). Der in dem Rieselwasser enthaltene sanerstoff ruft Oxydationen in rlen Wiesenböden hervor, da das unterirdisch abtliefsende Drainwasser eine gæringere Nenge Samerstoff' und gleichzeitig eine gesteigerte Menur. Kohlensäure und sichwefelsäure im Vergleich zu dem aufieselnden TVasser aufwoist 1). Solange sich genügend Sauerstotf vorfindet. vollziehen sich die langsamen Verbremmoserscheimmgen der organischen Substanz, die wir als Vorwesung bezeichnen, hauptsächlich dur.h die Arbeit der Mikroorganismen zu Kohlensäure, Wassor. Ammoniak und Salpetersäno. Tritt dagegen durch andanernde Überstaumg Sanerstoffmangel ein. so begimnt jener Zersetzungsvorgang trils rein chemisher Natur, teils mer Mitwirkung von Bakterien, hen wir als Fä nI nis bezeichnen. mut dessen Endfurdnkte in Terhindungen bestehen. die noch oxydierbar sind.

Finden die Wasseransammlungen in Lagen statt, in denen gänzlich undurchlässige Bodenschichten den vertikalen Wasserabfluts ver. hindern und anch der horizontale Abflufs erschwert ist. tritt Tor. sumptung ein.

1) Wonx, E., Die Zersetzung der organischen Stoffe und dis Humusbildungen. Heidelberg 1 1897. Carl Winter, S. 351. 
Mit dex Bodenvernässung heginnen diejenigen symptome sich zu

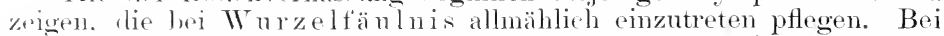
Laubbämen. namentlich den ()lstläumen unf dem Weinstoek, macht sich vorzeitige (relblanhigkeit lemerkar, die an den Zweigen von muten nach oben fortschreitet. Lieser fortschreitende Gang des Auslebens mo Abfalls der Blätter von der Kweigbasis nach der Spitze hin spricht dafür, dats die tortwachsenden \%weige zur Ausbildung ihrer jungen Blätter lis älteren entleeren, wie dies anch beim allmählichen Vertroknen der Fall ist. Dadurch muterscheidet sich diese Blattverwilbung von der Bleichlaubigkeit infolge von Frostwirkungen, bei denen dor jugendliche Blattapparat gestört nud in seiner normalen chlorophyllarbeit behindert wird.

\section{Die Versumpfung.}

An verhängnisvollsten wird das stagnieren der Nässe in Forstbetriehe. wo die Frostempfindlichkeit der Bämme nach R. Harrig's ') Beobachtungen westeigert wird und das Ausfirieren und Ant'ziehen in den Saatbreten stattfindet. In den jungen Kiefermbeständen Norddeutsehlands beobachtete HART: ${ }^{2}$ ) die W Wrzelfänle in verheerendem Grade. Sie beginnt zwischen dem zwanzigsten und dreifsigsten Jahre, intem nach kurzer Zeit kïmmerlichen Wachstums die noch völlig gliün benadrolten Bämme mmfallen, sobald schneedruck oder Wind ant sie rinwirken. Ex erweist sich ramn die Pfahlwurzel (s. Stelzenwuchs S. (12) bis an die stammbasis hinauf natistaul, während die meisten flachstreichenden Wurzeln gesund rrscheinen. In Fichtenbeständen ist solche Wurzelfäulnis wohl auch zu finden, macht wich aber weniger hemerkbar, weil das oberflächlich verlaufende Wurzelsystem den Baum mabhängiger von ton wrigen in die Tiefe limabsteigenden Wurzeln matht.

Besonters in der Mark Brandenhme läkt sich heobachten, wie die Gesundheit der Kicfern dann authört. Wenn dis ihr am meisten zusagenden Sandfächen von Bodenmulden monterbodien werlen, in denen Wasseransammlungen sich zu Moortümpeln ausbilden. Bis an den Rand der moorigen stellen sind die Bäume geradsehäftig und verhältnismäfsig languatelig: in dem Augenblick, wo das schwarze Moor begimnt, wird der IT uchs krïppellatt, werden die Nadeln kurz, und der Baum zeigt ganz sthmale, nicht selten anskeilende Jahresringe.

Gerade in der von den Behörden wohl gewïnschten, weil rentabelsten, Ausilehumg der Kiefernamptlanzung anf nasise Bodenlagen ist es nicht zn verwundern, dat's dis Erseheimmgen der Vurzeltäule hej diesem Natellotz in so grotier Austelmung zu finden sind. E'mpfichlt sich turehaus, die Kiefernkultur anf' dis sandigen, freien Lagen zu heschränken mul bei scluweren. nassen Böden solche Holzarten zu wählen. welche rrfahrungsgemäts die Nässe am besten vertragen. An Orten, wo ein lestimmtes Wirtschaftssystem die Bestände nicht regelt, finden sich im lante der . Tahre lnuch die oröfsere Widerstandsfähigkeit im Kampfe ums Dasein von sellst die entsprechenden Holzarten ein. Ex ist megefähr dasselle wic das allmähliche Platzgreifen

1) Hasta, R., Lehrbuch der Pflanzenkrankheiten. Ill. Anfl., Berlin, Springer 19100, s. $26: 3$.

2) Die Wurzelfäul \%ersetzungserscheinungen des Holzes. Berlin, Jul. Springer. 15is S. 75 
frostlarter Holzarten (Hainbuche. Birke, Zitterpappel) in Frost lächern. Am besten verträgt die Roterle diestagnierende Nässe: autserden sieht man Schwarz- und Silberpappel sowie die meisten Weiden und die Ruchbirke auf nassem Boden godeihen. Manchmal finclet man auch Eschen: diesclben haben aber dam ganz mosshesetzte stämme und krebsartige (reschwiurstellen.

Un den Sibälen der Versmofung zu begennen. wird man deren Urisache genau firststellen müssen. Bisweilen ist rs nur Mangel an Luftzug, mol dam liam eine teilweise Befirimng des Landes vom

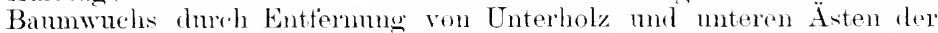
Bäume, Inuchtorstung usw. schon helfen. Nanchmal bei geringer Ver-

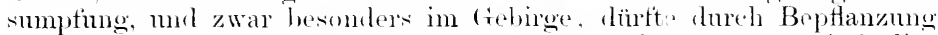
mit Nadelhölzern (Fichte) abgeholfen werken kömnen: es sind tirs solche Fälle, in denen eine vermehrte verturstende oberfläche genïgt, mon Wasseransammlungen in Boden zu vermeiden. Durch Heran-

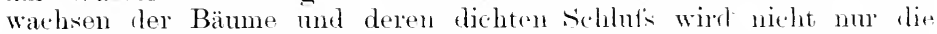
verdunstende Oberfläche immer grötser. sondern es kamm durch das dichte Laubdach auch immer weniger Wasser auf don Boten hinab.

Das radikalste Mittel, die Entwässermeg dureh llyainage oder (ipäben, ist gerade hei Forsten erst nach reiflicher Erwïgung aller öt lichen Verhältnisse in Anwendung zu hringend da das Verfahren biweilen grötsere Nathteil, als Vorteile bringt. Dies ist vorzugsweise in Gebirosforsten der Fall. wo leicht die Ermiedrigme des Wasserstantes

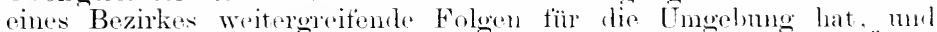
Strecken, namentlich Hänge nit starken Banmwurs. die keinen f̈̈lerschuts an $\mathrm{W}$ asser hatten, trockner gelegt worden. Die an das bisherige Mat's von Fenchtiglieit wowolnten Bäume gelen zurïck und dïrften zum Teil absterben. In der Ebene sind derartigr seluotfir s'chwankungen dureh die Drainage wringer zu tüurhten.

Wir wïrden anf die S'mmpthildums hier nicht woiter einzugehen laben, wemn nicht, algesehon von den Gasexhalationen, ladur.lı sichädigungen der Kulturflächen herrorgeruten würden. dats solcho sumpt- und Bruchwässer zeitweise zum Abfluts qulangen. Vorzugsweise ist hier dio Wiesrnschätligmg im Ange zu hehalten, da manch. mal schädliches Sumpt- mol Brichwasser zur Berieselung Verwendung

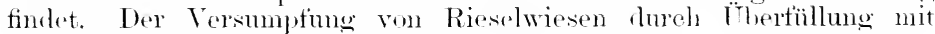
sionkistotfen mag mu nehenbei gedacht werdon.

Betreffis der (rasexhalationen sind die Angaben ron Bischof und Popoff anzufïhres ${ }^{1}$ ). Die ontstehenden (tase sind of reich an KohlenWasserstoffen. namentliel Methylwasserstoft (Sumptigas $\mathrm{CH}^{4}$ ). Popofr mtersuchte das fas. das sich in einem Kolbon entwickelte, in welchem eine Schlammmasso mit kïclenabtälen n. dorgl. sich befand. Di. Schlammmasse bliel : ${ }^{1}$. Woche hei anfangs 17. später 7 bis 10"('. im Kolben und rgah bei den aufemanderfolgenden, meist naeh \%wischen räumen von zwei his vire Tagen stattfindenden Tntrisuhungen (ragemische vou folgender porentiseher /usammensetzung:

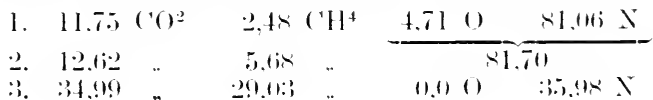

1) Brisune's Lehrbuch der chenischen und physikalischen fieologie, II. Aufl. Pupoff in Pflïger"s Archiv. f. Physiologie. Bd. X. S. 11:: 


\begin{tabular}{|c|c|c|c|c|c|}
\hline$\therefore 1$ & $\left(0^{4}\right)^{2}$ & 42.54 & $\mathrm{C}^{\circ} \mathrm{H}^{4}$ & 01110 & $1.65)$ \\
\hline (i, $(i, 1)(1)$ & $\mu$ & 40.70 & .. & $0,11 \ldots$ & 1.30 \\
\hline $4 \therefore !$ & .. & $\therefore 4.1$ & . & 0.0. & 0.11 \\
\hline $4: 3,: ;$ & .. & ;i) & .. & $11.0 \quad$. & (1).1 \\
\hline
\end{tabular}

Man ersicht ans diesen Zahlen, dat's zu Anfang des Versuchs die im Kollen befindliche atmosphärischr. Luft zum Teil ausgetrieben, zum Teil rerbrancht wird. indem der Sanerstoff' zur Oxydation der organischen Restr im schlamme diente. Solange freier Sanerstoff rorhanden war. äber'wog die Bildung von Kohlensäure diejenige des sumpfgases: dagenen drehte sich dieses Verhältnis um. sobald der Sanerstoff' rerzehrt war.

Von der Ansicht ansgehend. dats es wesentlich die im schlamme bot'indliche C'ellulose' ist, welche unter Mitwirkung niederer Organismen zersetzt wird, hrachte Poporf remes Filtrierpapier mit einer geringen schlammmasse in einen Kolben und fand bei Untersuchung des nach einiger '/eit gebildeten Gases die Kusammensetzung desselben

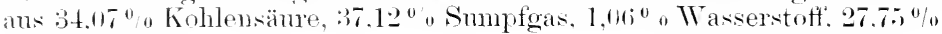
stickstoff:

In der Nähe der sümpte riechen wir aber nicht selten anch dentlich sch lo felwasserst of ff. Derselbe rüht zum Teil von den fanlenden Eiweifskörpern her. die Lencin, Trrosin und andre Stoffe bei ihrer Zersetzung bilden und schliefslich in Kohlensäure, Sumptgas, Ammoniak uкw. zerfallen. I le von DetMer citierten Beobachtungen von ErisMAx ${ }^{3}$ ) gestatten einen Einblick in die quantitative Znsammensetzmng ler in 24 Stunden abgegebenen (iasmenge von 18 cbm Exkrementen. die in einer wenig ventilierten Alutrittgrube sich befanden.

Die Masse ergal, $11,1+4 \mathrm{~kg}$ Kohlensäure, ?.140) $\mathrm{kg}$ Ammoniak,

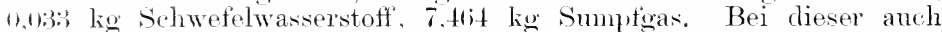
Wasserstoff und Stickstoff' entwickelnden Fäulnis sollen von den Is cbm in 24 Stumlen 13,45 lig. Sanerstoff aufgenommen worden sein.

Ex zeigt sich hierbei eine rerhältnismä1sig sehr geringe Entwicklung ron Hes. Und man muls daher amehmen. dats. wem sich in siimpten mil anderen Grten so grotse Mengen von Schwetelwasserstoff ansbilden, diese ihren Trsprung einer durch die organische Substanz herlingten Rerluktion schwefelsaurer Salze im Boden verdanken.

Tiber solehe Reduktionsvorgänge in der Moorsubstanz fassen Patiel ${ }^{2}$ ) und Oswald die Resultate ihrer Untersuchungen dahin zusammen, dats l,ej Inftabschlut's autier Schwefelwasserstoff noch Schwefelmetalle anftreten. und datis neben dieser Reduktion der schwefelsauren Salze anch Ammoniak sich ans den stickstoffhaltigen substanzen des Moores bildet. In der Entstehung dieser Stoffe, von denen die Verfasser es mbestimmt las;en. ob dieselbe nur bei Luftabsehlut's erfolgt, dürfte die Schädlichlieit des stawnieronden $\mathbb{W}^{*}$ assers ebentalls zn snchen sein.

\section{Das Verbrennen der Pflanzen im nassen Boden.}

In sommern, welche sich ituch starle Temperatmextreme auszeichnen, findet man in Kulturen von schnell wachsenden. grotiblättrigen Pflanzen, wie \%. B. hei dem Hopten, dats an recht heitien, hellen. windigen Tagen besonders die Pflanzen fenchter standorte welken. 
In nassen Löchern sicht man bisweilen die unteren und mittleren Blätter gelb- mol bramrandig werden und zum Teil derartig zusammentrocknen. dats sie in der Hand zn Pulver zerrieben werten kïmnen. Die Exemplare sind teilweise ron der Some verbramt. Das Anttallende der Erscheinmo lient mu darin. lats crerade an denjenigen A.kerstellen, an welchen das ganze Jahr über himeichende Fenchtiokeit vorhanden. das Verbremmen sich einstellt, währomel in höheren. trockenen Lagen, die dem Winde noch mehr ansgesetzt sincl. die Pflanzen weniger zu loiden plegen. Ile vom Verfasser answetühten vergleichenden Kulturversuche ${ }^{1}$ ) geben

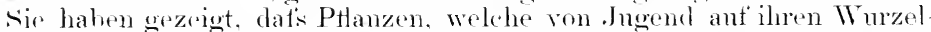
alparat in einem sehr wasserreichen Borlen onter in Wasser nutwickeh, lorart organisiert sind, dafs sie pro (2uadratcentimeter Blattfläche viol mehr Wasser verdmsten als Exemplare derselben Alstammung mit lemselben Nährstoffquantum und genan denselben ïbrigen Vegetationsbrelingungen, aber geringerer. Wasserzufuhr zum Borlen. Es ist ene interessante. vorlänfig noch nicht gewïrdigte Erscheinmmg. dats sehr viele nuserer Kulturpflanzen ans den verschiedmsten Familien zm Produktion von l a ansereifter Trockensubstanz mter den ihmen optimalen Lebensbeelingmen ammähent gleiche smmmen ron Wraser rorlunsten. mid zwar hewegt sich die Menge des ansoghanchten Wassers

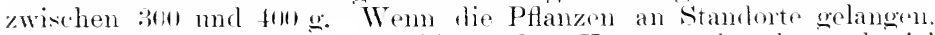

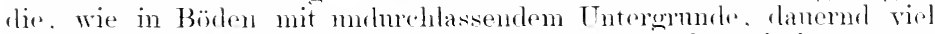
Wasser zm Vertïgnmg haben, so wird sich in den Bodenzwischemämmen rine ständige Nähstofflösmg vorfinclen, welehe je nach dem lioslichen Bodenkapital eine mehr ofler weniger hoch komzentrierte ist. Strigt dir Konzentration über das der Pflanzenart zmsagende Mats.s, dam wächst lie Ptlanze kïmmerlicher, bleiht kurzglierlig. kleinlaubig aber meist dmkelonïn. Ist die Konzentration gerade passend. dam ist das Wachstum ein sehr reiches und üppiges, und der Wasserverloranch ist rabei absolut sehr grotis, aber berechnet fro (tramm produzierter Trocken. sulstanz klein. Die Pllanze verwendet muter solehen ITmständen das Borlenwasser am nützlichsten. An ühermätig nassen stellen aber ist der Fall nicht selten. dat's die Borlenliosung am an einzelnen Xähr. stottien ist.

In solchen Verhälnissen sieht man den mö̈sten IVasserverbranch, gleichsam als ob die PHanze die grötsten Anstrengmuen mache, um von len am sparsamsten vorhandenen Nährstoffen möglichst viel herbrizuschatfen. Die Blätter, welche unter solchen Terhältnissen gelildet werden. sind zwar grots med schön ansqebreitet, ahor sehr wenig wielerstandstähig sowohl wegen Kälte als anch gegen Ilitze: sie er-

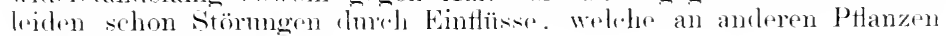
smrlos vorïherwohren.

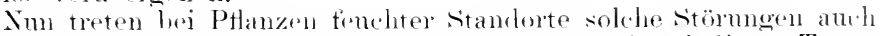
trïher ein. An heitien und namentlich auch noch windigen Tagen ist die Verdmstmo eine enorm gesteigerte: die answohanchite Wascermenge ist lam wesentlich götser als die durch die Achsenorgane znreführte. Infolgedessen sehen wir em Welken der Blätter hei seln vielen Pflanzen. Je wenger eine Pflanze po quadratcentimeter Flächs newohmheitsgemäts anshaucht, desto länger genügt sellst hei vxtrem

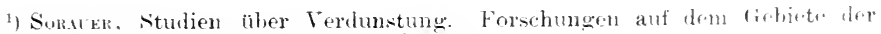
Anrikulturphrsik, Bd. III. Heft + u. S. S. $43 \mathrm{ff}$. 
heifsen Tagen die vom stengel zugefïhrte Wassermenge zum Ersatz des Transprirationsverlustes. Die Pflanzen nasser standorte die. wir experimentell festgestellt, in derselben /eiteinheit viel meln rerdmsten als die Exemplare von trockenen Bodenlagen. sind somit znerst an der Frenze angelangt, bei welcher ein WVasscrmangel in fler /elle schärlich wirkt. Bei ihnen vertroknen rle Blätter znerst. und zwar sind es wetler die allerjünsten, noch the dem normalen Lebensente am nächsten stchenden ältesten Blätter. sondern in der Regel die kräftigst arbeitenden und zmm Teil noch in der streckung begriffenen. Mittel.

I de Entwässerung der betrettenden Borlenstïclie bleibt das sicherste

\section{Verspätete Saat.}

\%u den Nachteilen der nasien Böden gehört als häutiges Vorkommnis rine Versuätung in der Bestellzeit. I)ie Folgen sind durch Ver-

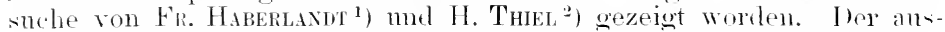
führlichste ist der von HaberLanut im Jahre 1 siti mit den vier sommerretreidearten angestellte, bei welehem an jedem 1. mul 15. der Monate

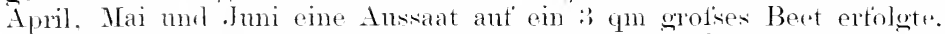
Die Resultate lassen sich folgendermatien zusammenfasien: Has Erntequantum nahm hei allen Sommergetreidearten mo so mohr ah. je später die Answat vorgenommen worlen war. Ljes war zunächst begründet in der wesentlich schwächeren Bestockmo der suät gesäten Körner und prägte sich an meisten in der geringeren Kahl der wirklich finchtharen llalme ans. Nicht nur in qnantitativer Bozichmog, sontern anch der Qualität nach war eine Abnahme sehr in die Angen springend. Das Strohgewitht stieg mit der Versuätme der Saat: es crhöhte sich überhampt gegenüber clem Körnergewicht der Anteil der Emte an Stoppeln und Vurzeh morerhälnismätsig. Anch die Qualität der Kämer selbst nahm sehr ah: (rexste- nnd Haferkörner besatsen bei Ernten ron später Ansisat einen grötseren Gewichtsanteil an spelzen: je kleiner die einzehen Früchte waren, desto mehr zeigte sich dieses Mitiserhältnis.

Die späteren saaten wnrden in höherem Grade ron Muttrekrou, Neltan. Rost, namentlich anch ron Blattlä usen befallen. Sie nahmen ührgens sowohl his zmm Sehossen als anch bis zm Blüte- und Reifezeit eine höhere Wärmesumme in Anspruth als die fïhlieren Aussaaten. Selhst das Keimmosvermögen der geernteten Kömer war din versehiedenes. mul zwar ein moünstigeres hei flenjenigen, die von Pflanzen später Saat abstammten. Erstens war der Prozentsatz an kemenden Körnern rin geringerer: zweitens branchten die Körnex von den spät gesäton mol spät geernteten Pflanzen anch längere Keit lis zur Krimung.

Ans den fröher ron Hibencasor angestellten Versuehen in dieser Richtung, bei denen sich ebonfalls oine peringere Entwieklung der Körner sowohl drun Volmmen als auch dem absolnten und spezifischen Gewicht nach beohachten liefs. geht anch hervor, tafs die Ursach. der Differenz zwischen syäten nud frühen Saatrn nicht die Bodenfeuchtigkeit allein ist. In diesen Vursuchen hatten die Pflanzen ron

1) Fr. Hıвкими, Die Beziehungen zwischen dem Zeitpunkt dex Aussat und der Ernte bein Sommergetreide. Oster. landw. Wochenbl. 1476, Nr. 2; 1877, Nr. 2.

2) H. Tnm, Über den Einflufs der Zeit der Aussat auf die Entwicklung des Getreides. Ref. in Biederm. Centralhl. f. Agrikulturchemie. 1×7: ค. 47. 
Antang an wenigende Wasserzutidne mol zeigten doch das abwerehente. Verhalten.

Die Versuche von Thes besehätigen sich mit der verschiecten späten Aussaat in Herbste. Dir Erntezeit war für alle Pflanzen selbst von weit anseinanderliegender Saatzeit nahezu dieselb': aber der Er trag war lwi spät gesiten seler gering, soweit sic überhaupt am l, greblichen waren. Wohl mit Recht macht Thes hier aufmerksan, datis die spät gesäten Pflanzen bei der entsprechenten Frïhjahrswittermug weichzeitio mit den früh gesäten scholsten. olme dats sie Zeit wohahit hatten, wie die ans frïher Saat stammenden PHanzen, genünentes Material für roichliche Entwiekhmg zu sammeln. Natïrlich sprelt hierboi dir. Beschattenheit des saatontes anch eine wesentliche holle. Ir älter das Saatgut ist. desto langsamer lassen sich die Reservestofte mobilisieren. Bei der Reito mul Nachreife achen die Kneker- und Anyd-

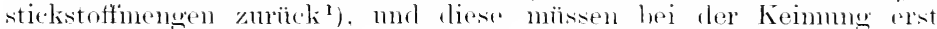

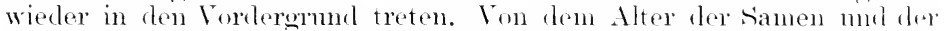
Beschaffenheit des Bodens hängt das mehr oler weniger wïnstige Anfgehen ah. Bei dieser Gelegenheit wollen wir die Warmme cinflechten,

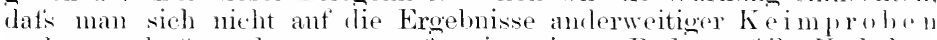
verlassen dart, sondern man muls seine eignen Börlen ant iln Verhalten zu den versehiedenen samen solbst direkt pritin. Salatent, das nach den ïblichen Keimpolven sich bewährt, kamn. namentlich in schorem Bärlen.

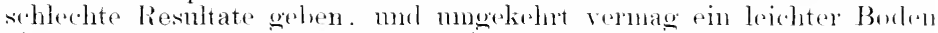

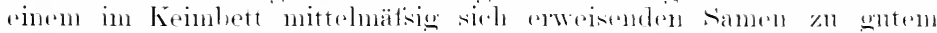

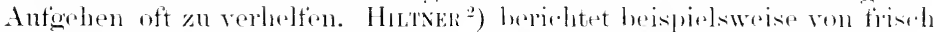

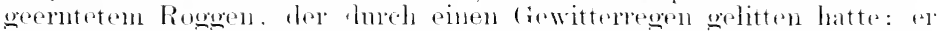

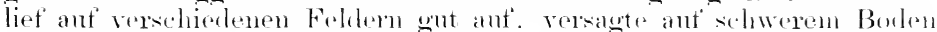
aber änzlich. ln einem anderen Falle vorshimmelte hoggen, der hei

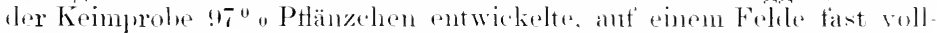

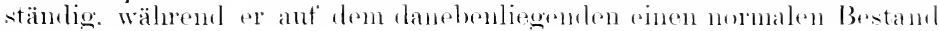
eroals.

\section{!Aussauern der Saaten.}

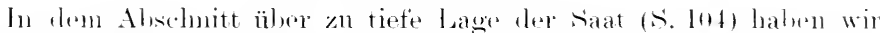

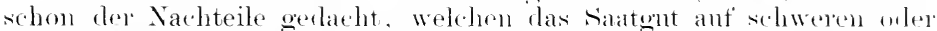
verkinsteten Böden bei grofisem Wassergehalt manehmal ansgesetzt ist. Anclı die aufgelanfene saat hat mit schwierigkeiten zu kämpten. di. von der phrsikalischen Bodenbeschatfonheit. nanentlich von dent

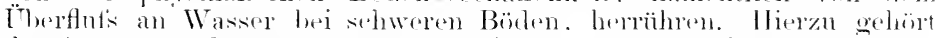
fas Anssanem der Saten, das allerdines anch hei leichten Bölen rin

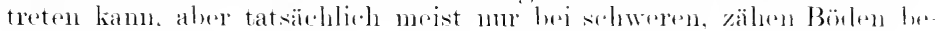
obaclitet wirl.

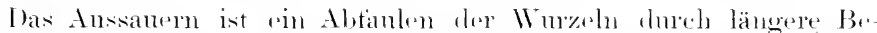
rïhrum mit strhenden IVasser in Genenwart oreaniseher Bestandteile. Lie meisten Wurzeln vertragen einen danernden Antenthalt in flietsen.

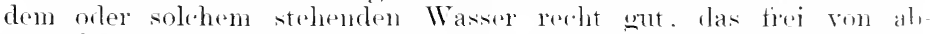
gestorbenen organischen substanzen ist. Was wir luei low Methoule der

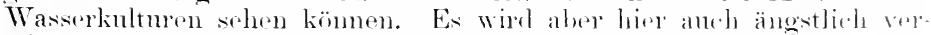

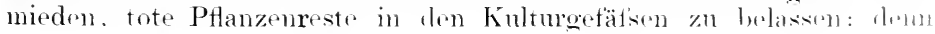

1) Junnks, W., Studier over Planternes periodiske Livs rttringer. 1: ait.

Bot. Jahresb. 1×97. I. S. 143.

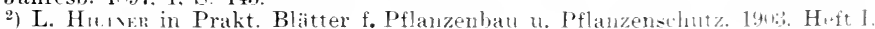


lie sich zersetzende organische Substanz heanspucht allen Sauestoff,

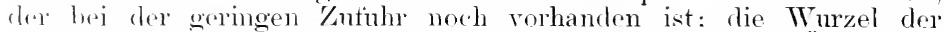
wachsonden Pflanze muls dam durch Sanerstoffimangel und Öberschuts an Kohlensäure zugmurle gehen. Auch in gewönlichen Verhältnissen kimmen saaten oft eine wochenlange Berühring mit Wasser aushalten, Wrm the Temperatur rine nierlrige ist. So herichtet FeIte ${ }^{1}$ ). dats Woizen. welcher tünt Wochen unter 50 C. kaltem Wasser gestanden, fronoch erhalten geblieben ist. Dagegen war ein Weizen, welcher arht Wochen moter Wasser war. lessen Temperatur bis ant' 7 "C. stieg, spulos verschwunden. Korn, welches vordem gesund war, vertrug vier bis fünf Wochen lang Wasser von $3^{\circ} \mathrm{C}$., war jedoch schon etwas angegritfener als der obenrwähnte Weizen. Lmzerne und Klee hielten phenfalls in Wasser lesser aus als Korn.

Durch Anssanern leirlet nach Köнn der Roggen besonders stark, während unter lenselbon Verhälnnissen andere Gräser, wie die Trespe, sich seh üppig entwickeh kömnen. Dieser Umstand hat den hier und la noch immer autretenden Irrolaulien hervorgerufen, dats Rogoen sich in Trespe rerwandeln köme. Hierher gehört nach unserer Auftassmg anch die "Arrabbiaticcio" des Teizens in den Maremnen und (rer römischen (ampagna. Peglos ${ }^{2}$ ) erklärt die Exscheinung als ein allwemeines Zurickgehen der Pflanzen durch Überwchermo seitens der Unkränter, die auf' dem mznträglichen Boden besser als der Veizen godeihen. In siiditalien bezeichnet man die Erkrankmug als ..calda firedila" und "secea molla".

An allerschädlichsten wird das Anssauern bei der Winterölsaat, spryiell bei fom Raps. I)ie Wmyeln desselben verfaulen bei anlanemuler Nässe rou der Spitze aus, so dats im Frïhjahr nur noch der. Wurzelhals mol die Blattrosette ïbrigbleiben, die so lange gesund rscheinen, als die feuchte Frïhjahrswittermo das Anstrocknen verlangsant. (iar hald indes werden die Pflanzen bram mol lassen sich an cinem Blatte aus dem Boden ziehen.

\%ır Erklärumg des Umstandes, dats bei danernder Bodemnässe die Veretationstecke sich ändert, dafs also Erscheimmgen eintreten, wie vorerwähnte Anshreitmo der Trespe bei Rogensaat, dient eine Untersuchung ron E. Freibeiri und A. Marer ${ }^{3}$ ). Dieselbe ergab. datis das sanerstoffherlüfnis bei den Wurchn der smmptptlanzen ein viel geringeres als bei denen unserer Kulturpflanzen ist. Damit zeigt sich, wie von vornherein zu vermuten, dafs die einzolnen Pflanzenspezies ganz rerschiedene Ansprüche an den Sanerstotfgehalt der Borlenlutt stellen mol sich demmach mit ihrer Ansiedhung nach den gebotenen Verhältnissen richten müssen. Aus den Versuchsergebnissen läfst sich aber noch sint Andentming entuchmen, die im aligemeinen zur Beurteilmo dor Ansmidche dienen kamn, welche die verschiedenen Pflanzen mit dem Lufthediurtinis ihres Turzelkönpers an die Borlenart stellen. Es zrigt sich nämlich. dats das Samerstotfbediurfnis der Pflanze für ihre

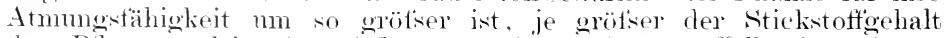
ler Pflanze. lie sumpifpllanzen zeigen einen auffallend geringen stickistoffgelatt und lockeren immeren Ban, der das sueichem grotiser

1) Aus Österr. landw. Wochenbl. cit. in Biedermann's Centralbl. 1877. S. 76.

2) Pecilox, V., Sull arral,biaticcio e calda fredda. Ammuar. d. R. Stazione di Patol. veget. Roma. Vol. I. 1901. S. 37.

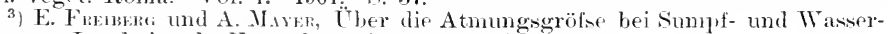
phanzen. Landwirtseh. Versuchsstationen 1879. S. 46:3. 
Inftquantitäton im Imem des Leibes gestattet mol anf eine Erleichtermo der internen Atmung schlietsen lätst. Die eigentlichen Wassemptlanzen atmen in geringerer Intensität wie die Landptlanzen, wie Böнu bei Versuchen in einer Wasserstoffatmosphäre durch Mesimg der intolge innerer Verbremmung webildeten Kohlensäure gofmulen $\left.{ }^{1}\right)$. Da man wohl annehmen kann. dats die Atmumgsomolso dor Pflanze von der Menge Eiweits bestimmt wirl, rie zm Verbemmug im Körper arlangt. so wird bei mseren stickstoftreichen Kultmptlanzen das sanerstoffbedürfinis des Wmyelk̈̈̈pers am grölsten sein mol diejenigen Bodenarten daher die reeignetsten, welche diesem Bediurtinis neben den anderen Anfordermmen am rollkommensten genïgen. Dies sinul die nährstotitieichen lorkeren odor gelockerten Ä.ker.

Denjenigen Ländereien also, welche duch Krustenbildmo bei Regen oder Verschlänmmmg hei ت̈bershwemmmoen immer wiedes. lem Samerstoftmangel ansesetzt sind, wird durch entsprechende Änderumg ihree physikalischen Eigensehaften anfgeholfen werden müssen. In denjenigen Fällen von Versanern dagegen, hei denen der Luttabschluts nicht dmoh die physikalische Beschatfenheit zur Notwendigkeit wird. sondern bei denen nu übermätsige Wasser"zutulu die an sich grotien Bodenuäume fïllt, wirr man an Entfermme des Wassels gehen müssen. Hier sind dam tiefe Inainage oder mindestens 120 cm tiefe Abzussorähen, die den (irmulwassersiegel so weit senken, die

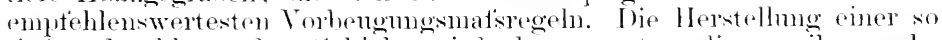
tiefen durchlasienden sichicht wird darmu notwondig. weil mancho Hölsentiöchte. wie Luzerne mol Esparsette. mit ihren tiefgehenden,

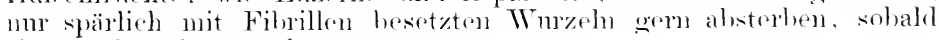
sir ant (ipmurlwasser liomment.

\section{Das Versauern der Topfgewächse.}

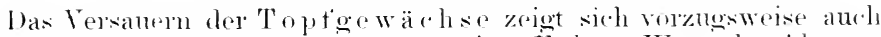
nur bei Anwendmug lehmiger orler mooriger Erden. Wrum das Abzugsloch des Blmmentoptis verstoptt ist und ïbermätiges Begietisen durch mgeubte Arbeiter stattfindet, sterben anch dir. Wureh der Toptgowächse vollständig ab, indem sie bram mel wrich werden.

Jie versanerte Frole läst sich durch ihren eigentumlichen Geruch sotort erkemmen: as tritt ein ganz anderer Zersetzmosurozels der reichlich vorhandenen organischen Reste. welche nahrhatte Topterden immer whthalten. ein. Es entstehen wahrscheinlich same Verbindumgen ans der immer noeh wenig gekamnten Reihe dor Hummsörper und jedentalls anch fire säuren. Ist Eisen im Boden. so kïmmen dir unschädlichen Eisenoxydsalze zu den schädlichen Uxydulsalzen reduziert werden, rla hei der İthertüllung der Bodemänme mit Wasser empfindlicher samerstoftinangel eintreten muts.

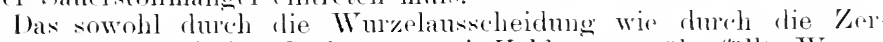
zetzmo der organischen Borlemeste mit Kohlensäme überfïllte Wassor. reicht bei rlanernder Einwirkmng allein schon hiu, die Pflanzen zu tötes. W. Wolf ${ }^{2}$ ) zeigte experimentell, dats gesmole Pflanzen, in kohlensämehaltiges Wassu versotzt. alsbald in ihrer Kohlensämoansscheinnu

1) Bunn. Über die Respiration von Wasserpflanzen. Sitzmgsher. 1l. Kais. Akat.

d. Wiss. zu Wien, 1875, Maiheft.

2) Tagehl. d. Naturf. Vers. zu Leipzig 1872, s. 209. 


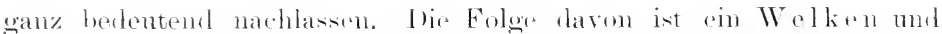
später ein Abstroben ler Blätter. Wem wir anch die Mechanik des hior stattfindemelen Welkens noch nicht mit sicherheit rrklären kömnen

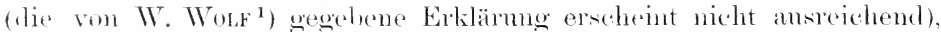
(s) werlen wir loch kamm fehlechen bei der Amahme, dats infolge (ter ähernuätigen Kohlensänreanläntung im Bolenwasser zunächst die

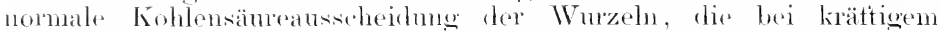
Wachstmm nicht unbeträchtlich, anforehoben wiol. Es muts im Imnern

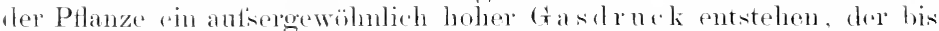
zum Anfreten pesitiver lonke in dru Gefatsen gesteigert, the Fähig-

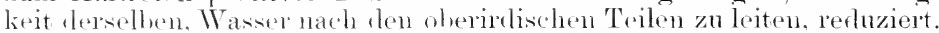

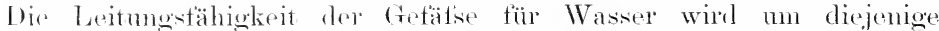

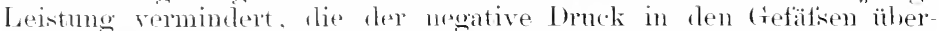
nimmt. Wemn somit fle /mleitmmg des Wassers weschwächt, olme dats ter Verbranch der Blättre vemindert wird. so ist das Welken die nächste Folge. ITemn, wie hei dru Versuchen von WoLf, die Pflanzen in destilliertes Wasser zuröckressetzt werden, stellen sich ein nomales Ansseluen mol normale Funlitionen wieder ein. Das destillierte Wasser ist in diesem Falle gleiehsam ein Schwamm, der die Kohlensänre und lie ührigen Wumelansscheishomgen mit Begierde anfinimmt.

För die Pflanzenwurzel wirf schliefich der Effelit derselbe sein. ob die Kohlensäure in Wasser gelöst orler gastörmig infoloc mangehnder Bodenabsorption die Wurzelfasern umspült. Bei len oberirdicchen Pflanzenteilen ist os allertings andors mol selu ins Gewicht tallent, ob sie mit kohlensäurereichem Wasser orler mit derartiger Inft in

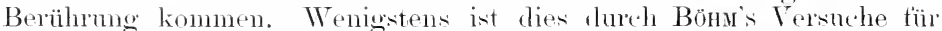
die Blätter grïner Landpflanzen anschanlich gemacht worden²). Вӧни tanchte Blätter verschieslener Landphanzen in kohlensäurehaltiges Wasser mul tand, dats die Sauerstoftalscheidung aufhörte. Wemn man fen Pflanzenteil verhinderte, sich erst mit einer Kollensäureatmospläro

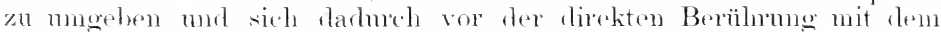
IVasier abzuschlietien.

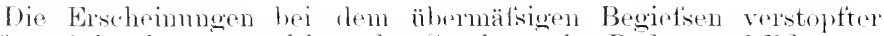

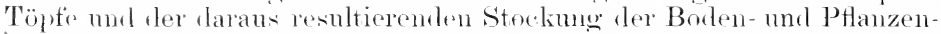
tätglieit lassen sich am bestron ennessen, wemn man eimmal den Boden eines mit riner gesmolon Pflanze vorselenen Blumentoptes während der Vegetationseit mikroknfisch hetrachtet. Was für ein reges Wirtschatten rntfaltet sich da im Boden. Tom der Krume ans bis (bei Laub- md Heiflecrlos anf' den 'Topt'mund hegegnet man Resten von Blättern und Sitengehn, an denen violfache Arten der sog. Schimmelformen in sterilen

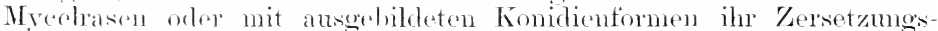
werk ansiiben. Jo natl der Natm der Pflanzenreste findet man al,-

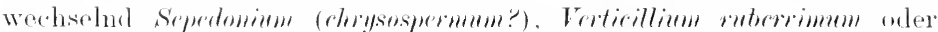

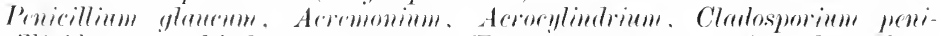
cillinides, verschiedene Arten von Fustrimm u. a. m. Anf der Ober-

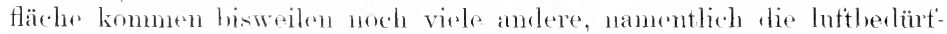

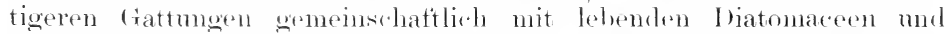

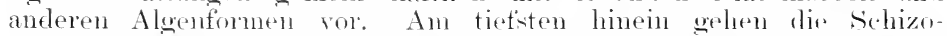
myceten. Man findet Stärkekïmehen und Plasmaroste von strablig

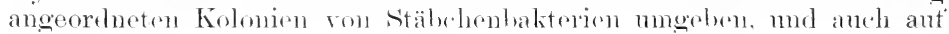


kristallinis hen sulitten sind manchmal Bakterienkolonien angesiedelt. All dies rege Leben arbeitet an der Kerstörmo der PHanzensubstanz mol befördert die samerstoft' heansinchenden Prozesse, die wir als Verwosnng bezoichnen, nnd all dies rege Lehen wird durch den Absehluts der Bodenporen mit Wasser entweder antgehohen oder in andere. schärlline Bahnen veleitet, die in die Reile der Fänln isrrschoinungen, also der Zersetzung bei Sanerstoffahschluts, gehören. Jeder Bodten hat antiser seinem Bakterienbestande auch seine mykologische Flora, die an der $/$ sersetzung der organischen substanzen arbeitet mol, wie os nach (bumass mod Koxw, i') scheint, ammähernd typisch für hestimmte Bodlenarten ist.

Man kann bej den 'Toptknltmen den Beginn einer Nitagnation schon voransictzen, wem man sieht, dats die Oberflächo des Bodens sich nit einer anch dem 'Toptrande tost ansitzenden, harten. weit'sen oder rïtlich gefärbten Kalkkmste äberzieht. I ats die Inkrustierung der obersten Bodensuhieht der Täpte und des Toptrandes vorugsweise durch kohlensauren halk erfolgt, ersieht man aus der mngemein reichen Kohlensänu-Entwicklung hei Kusatz von Essigsänre.

Auch kohlensame Magnesia mol kohlensames Eisenoxydul, das suater durch Oxvelation als Eisenoxylhydrat versehiedene Färlimngen der Kunsten erzengt, Werden angetroffen. Narh dem mikroskopischen Brfinnde scheinen anch sehwalbenschwanzförmige Kristalle des (iipses mol ()itaeder des oxalsaumen Kalkrs sowie in Essigsäne lösliche rhombische Formen von phosphorsaurem Kalke autzutreten. Diese letztgenamente salze sind nicht immer mol nie in grotsen Mengen nachwoishar: dagegen sind der kohlensame Kalk mol wohl aurh Tir kohlensame Magnesia

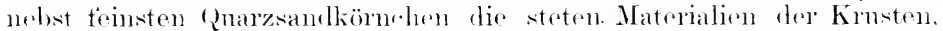
\%wisehen denen anfangs noch eine reiche Pilzvegetation mit Konidienhildmug aut den Hommshestandteilen wahmehmbar ist. Jie Entstehmog dieser Krusten ist darlureh zn erklären. lats das bei dem Begiefsen in gotsen ( wesmngsprozets reichlich erzengten Kohlensäme immerhall, der Bodenzwischenämme beladet. Dadmeh wird das Wasser ein ansorzeichnetes Iösmosmittel fïr den in Boden vorhandenen einfach lohlensamen Kalli mud dir Magnosia, für phosphorsames mol lieselsames "Eixen(axil n:m.

Je schnelley hri gutem Abzuge des Blumbntoptes das ähersehüssige Wasser ablanfen liam, desto wonger Mineralien werden gelöst und fortgeschwemmt. Bleiht dagegen das Wasser im Topfe, mol ist es einmal mit dem Kalk, der als doppeltkohlensaurer gelöst ist, reichlich

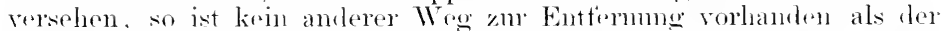
der Verdunstmug. Fs rerdunstet $11 m$ von der wasserexätigten Ober

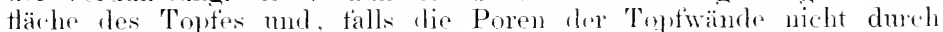
güne, schleinige Algenvegetation versehlossen, anch durch die Toptwandmogen himfureh langsam dieso Wassemasse, wohei sie die gelösten

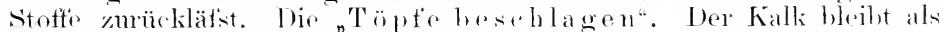
einfach liohlensamer Kalls zurït. wis am Pande eines Kochtoptes, in welchem kalkhaltiges Wasser zmm Kochen gebracht worden ist.

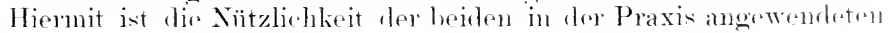

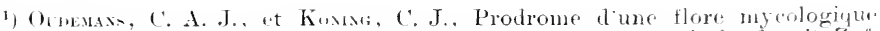
obtenue de la terre humeuse du Syanderswoud ete. Extr. Archiv. nérland.: cit. Z.t. Pflanzenkr. 1903, S. tif. 
Vorgänge des hänfigen Abwaschens der Blumentäpte und lw Auflockerms der Boilenobertläche erwiesen.

Man hat bei der zunehmenden sucht, alles durch loiugung zu elzielen. anch vicltach versucht. den in vergossenen Töpten stehenden PHanzen durch /uführung verschiedenartiger Inüngmosmittel wiederum ant'zuhelfen, ohne die Hauptaufgabe, nämlich di Herstellung genügenler Bodenventilation, zn erfïllen. Die Pflanzen haben sich dabei nicht verbessert. Umpflanzen der Gewächse zur Zeit der beginnenden Vegitation und Anregung der geschwächten PHanze zn erhöhter Produktion lurch Zuführung von Wärm zu den Wurzeh bleihen die besten Mittel.

Dals einc Düngmo bei saurer Erde, also bei Gegenwart freier Hummssänre, eher schädlich wie nützlich wirken kann, geht aus EıcH HoRs's Untersuchungen hervor $\left.{ }^{1}\right)$. Humusreiche Erden. sagt der Verfasser. welche freie Humussäuren enthalten, machen ans Lösungen nentraler Salze säure tivei. Die hierdurch entstehende Sänerung ist stärker als ohne die Mitwirkmng dieser Salze. Düngungen mit nentralen Salzen werden daher in solchen Bodenarten die Säuren vermehren. Dasselbe findet statt mit phosphorsaurem Kalk oder einem Phosphate ïherhaupt, wohei Phosphorsäure oder phosphorsaurer Kalk in Lösung gehen: Zusätze ron nentralen Kalisalzen. hesonders schwefelsamen Alkalien. begïnstigen die Zersetzung. Ist die Hummssäure an Basen gebunden, so tritt eine solche Säuerung nicht ein. Zutuhr von Mist, Janche usw. werden bei derartigen Aufschliessungen mur Nachteile bringen und sind ebenso zu rermeiden wie mergelige Erden.

In Rücksicht auf das häufige Absterben der Pflanzen bei der Zimmerkultur soll hier ant'

\section{Das unvorsichtige Begiefsen}

hingrewiesen werden. Ein übermätsiges Begiet'sen wird zum Teil dadurch veranlatst, dat's der Ungeübte jederzeit einen Wassermangel im Boden roranssetzt, sobald die Pfanzen welken. Bestärkt wird er in diesem Glauben durch die Erscheinung. dats häufig nach dem Gief'sen in Lanfe des Tages ein straffwerten ter Ptanzen eintritt. Folgt num diesem Zustande der Turgescenz wiederum ein Welken. so wird die Wassergabe ernenert. bis sich die Pflanze als danernd welk und die WVurel als verfault erweist. Solche Vorgänge zeigen sich namentlich im Herbst hei dem Einräumen zarterer Pflanzen in die Glashänser. die noch wenig geheizt werten. Der Grund des Welkens ist dann die Kälte des Bodens. Wir wissen aus einer Anzahl von Fällen, welche Stcos ${ }^{2}$ ) anführt, dats die versthiedenen Pflanzen eine bestimmte Temperatur tür ihre TVurzeln branthen, damit dieselben arbeiten, also anch Wasser aufnehmen können. Tabak und Kürbis welken in einem Boden von 3 bis 50 C.: wurde derselhe Borlen auf 12 bis $1 x^{\circ} \mathrm{C}$. erwärmt. war die Wurzeltätigkeit wiederhergestellt. WVemn, wie in dem angeführten Beispiele, nun begossene, welke PHanzen im Lanfe des Tages ihre Blätter hoben. wurde ties dem Eiutluts des Gief'sens zugeschrieben. Der wirkliche Grund aber war die während des Tages durch die Sonne veranlatiste Erhöhung ler Temperatur der Luft und somit les Bodens im Topfe. wodurch die Wurzehn zur IVasserautuahme wieder angeregt wuden. Bei Eintritt der Nacht und Sinken der Temperatur unter die Grenze. bis zu

1) Landwirtsch. Jahrbücher $1877,5.957$.

2) Lehrbuch der Botanik. 1. Aufl., S. 5.59. 
welcher die Wurzel überhaupt noch zur Anfinahme von Wasser tähin. wiederholt sich das WVelken. Die Pflanze kam also hei writster Boden. nässe demnoch verdursten. wenn der Boden zn kalt ist. Anderseits kamn die Pflanze in feuchter Lutt mit total fanlen Wurceln nocli lange Zeit leben, wie sich bei Wasserknltmen zeigt. lios ist and der brumb. dafs man bei Wrumelerkrankmgen meist erst selu spät symptome rom Störungen an oberirlischen Teile wahrnimmt.

Eine andere Ursache des Welkens macht sich in Hochsommen. bemerkbar. Wenn stark verdunstende PHanzen der heitsen Somm um bewegten Lutt längere Zeit ausgesetzt sind, beginnen sio trotz at nügender Bodentenchtigkeit zu welken, weil die WTasemnenge. welche

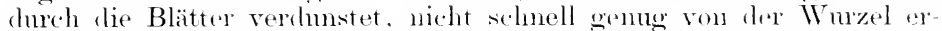
setzt werden kann. Zwar wirl dureh tie bei stärkerem Somnensehein gleichzeitig eintretende Temperaturerhömmg anch dic Wasserzutuhn' sich vermehren: es strigert sich nach le Vkiss ${ }^{1}$ ) die Imbibition der Zull wände und damit ihre Fähigkeit der Fortleitmug des Wasisers, aber die. erhöhte Zufuh: kann trotzilem nicht den Verfmustumsverhst decken,

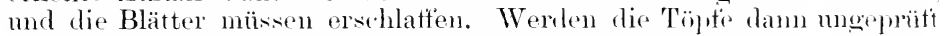
weiter gegossen, so versanert die Erole ebentalls.

Dasselbe Resultat zeigt sich hei den sogenamen Nonhollandro. und Capptlanzen ans den Familien der Epacrisleen, Eritanen, Pati lionaceen, Rutateen n. dol. Die lockere, foine. samblige, wenig zx's setzte Erde, lit als Ileiterrele im Handel ist, kamn zwar in lie Töpti.

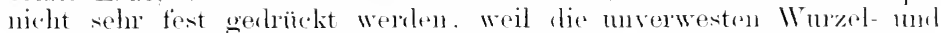
Blattreste aine selur lorkeres cietüge billun. Thureh zu seharties Br. siefsen werden aber dir feinen Sand- und 'Tonteilehen erst ant' pewirhelt und dam nach muten gespëlt, so dats mu lange. lockere.

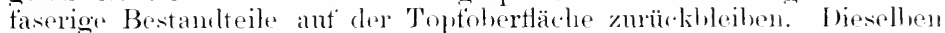

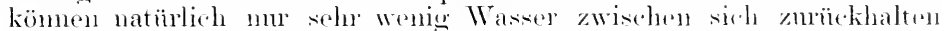
und lassen dasselbe schuell nach moten durch. Dio Toptoberfläche ist deshall, stets tast halhtrocken. Wrem sich mun ler (riatmer verleiten

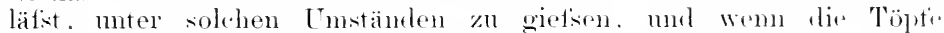
keinen guten Abzug habrn, dam fanlen die sehr teinen IVureh. (Nebenbei bemerkt soj, lat's bei den sogenamten versanerten Tüpten nicht selten alkalische Roaktion sich zeigt. Ich sah hei wuzeltaulen

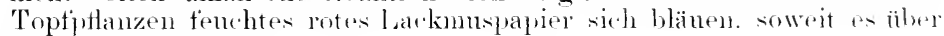
des. Topt'fläche lag.)

Als Hilfsmittel ist bereits oben das Terptlanzen in selm samberelus Erole und Einsenken der versanerten Pflanzen in Bretr mit Borlenwärme empfohlen worden. Iats hei dem Umptlanzen die Wurehn hiaut' die gesmulen Teile zurizekgeselmitten werdon mïssun, dart als selbstverständlich gelten. Als Vorbengmesnittel ist las Einfiittern drel Töpte in die Erde $n$. derọl. zu emptehlen. Dazn muls man siel abes' eines stockes orler anes kegeltärnig gedrehten Holzes hedienen. nu ein tiefes. trichtertormiges Ioch her\%nstellen. desion obeses Ramil gerade so grots wie der 'Toptrand ist. Iner 'Topt' hängt daun gleich-

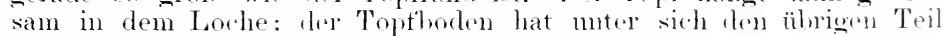
des kegelformigen Lowhes. wodurch das Einkriorhen der Reg+xu-

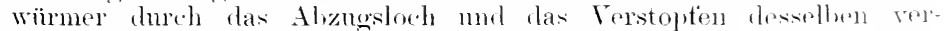
hindert wird.

Bei frei in Zimmer oder anf Tabletten stehenden Blumentiiptim

1) Bot. Zeitung 1s72, s. i=1. 
lant hei nu siniger Antherkisankeit kein Versanern vorkommen. Es lälst sich nämlich duxch Anklopten an den 'Topt mit ziemlicher Sicherheit der Wassergehalt der Errle beuteilen. Wenn diese reich an Fenchtigheit ist, befindet sich anch Wasser zwischen den einzehen Bodempartikelehen und der Wandung des Toptes, und der Ton desselhen ist ähnlich dem einer dichten Masise: hej Wascerarmut dagegen klinget der 'Topt hohl.

Nach dem Vorstehenden ist also nicht num zu erwägen, wieviel ge-

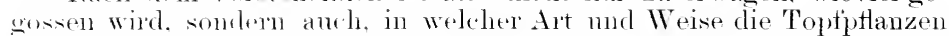
Tregossen werden. Un das Anfwirbeln rler feinsten Ton- und Sandpartikelchen mud damit die Krustenbildung oder das Verschlämmen der Abzurkanäl. des Toptes zu vermeiflen, wirl man also nie scharf aus drr' 'Tülle der' (iielskamne gietisen diüfen. Entweder bediene man sich bei beetweise grostellten, emgesenkten Pflanzon der Branse oder bei 'Tüpten ant' Stellagen in Glashäusem einer lang und eng ansgezogenen Tïlle, die nur pinen schwachen Wasserstrahl gibt. Anch vermeide man, den Wasserstrahl aut die Stammbasis zu halten. die nicht selten wanz weit's von Kalkinkuntationen ist.

\section{Gebrauch der Topfuntersätze.}

Bei der Zimmerkultur ist der trebranch von Toptuntersätzen allwamein. Betreft's Erhaltmo der Reinlichkeit der Fensterbretter und Blumentische ist der' Topfintersatz notwenclig: für die Kultur ist er' meistens schädlich. Gleichviel ol, man die Töpte von oben begietst orler sie durch Einfïllen von Wasser in den Untersatz von unten bewässert, so wird doch eine Ansammlung ron übertlüssigem Wasser fast strets lie Folge sein. Viele Liebhaber halten diesen Zustand sogar füu rsprieficlich. The Folgen aber sind ein Ersticken der Wureln am Boden les Blumentopfes. I) Wurzelfäulnis setzt sich allmählich nach oben fort und macht sich schliefich im Absterben dro Blätter rom Rande her kenntlich. Wenn diese Srmptome auftreten, ist in der Regel die Pflanze fïr den Liel,habor verloren. Der Gärtner kamn dio erkrankte Pflanze oftmals erhalten. Für den Liebhaber, der ein Wambeet nicht zur Vertïgnug hat, emptiehlt sich das Eimptlanzen des kranken stockes in reinen samel nud Anfistellen desselleen in warme, hallowhattige Lage.

\section{Der Abbau der Kartoffeln.}

Bei Besprechumg der Nachteile schwerer Börlen soi der in pralitischen Kreisen newordings wirlerm stark hervorgetreten Ansicht gelar.ht, dats unsere Kartoffeln sich, abbaurn". 1. h. ihre guten Eigenschaften almählich verlieren mnd hegenerieren. Nan will dies damit (skläron, dats bei der ïblichen Fortptlanzungsmethofle durch Anslegen von Knollen man rigentlich mansgesetzt ein eimmal ans samen erzogenes Individnmu ungeschlechtlich fortpflanze, und dats somit ein derart langlohiger Organismus doch anch endlich einmal die Schwächezuständr chs Alters zeigen müsse. Beweis dafür sei der Rückgang im Stärkegehalt hai mseren beliehtesten ältren Sorten, wie z. B. bei der I) aber'schen.

Thserer Ansicht nach liegt die Ursache des vermeintlichen Abbanes in der Unvorsichtigleit des Landwirts. Sorten, die anf leichtem Boden ontstanden sind, auf schweren Börlen zn linltivieren. Wir rerweisen 
in dieser Beziehmng anf eine Arbeit von Ehkenвek(i') ïber die Ergebnisse füntzehnjähriger Versuche der "Dentschen Kartoffelknlturstation". Der Durchschmittsertrag von sämthehen angebanten Sorten erwies sich von 1888 bis 190:3 heständig steigend. Betrettis der "Daber'schen" tallen die Erträge nm ant selwerem Boten, was erliälich wird, da in Daber sellst ein leichter, trockener Sandboden vorhersicht. Wurde nenbezogenes saatgut davon in schweren hindigen Boden geharht. liefirte dasselbe hessere Erträge, als die seit lange dort knltivierte Form. Dasselbe nene saatgut aber anf Sandboden wehracht, rogab meist ein minder gutes Resultat der eingebürgerten Rasse gegenüber. Wir finden in diesen Versuchen den llinweis, dafs nen aingefühtes saatnut zunächst den ('haraliter seines bisherigen Anzuchtsortes heibehält. IVenn also ein schwerer Boden den Stärkegchalt herabolï̈ckt, so we-

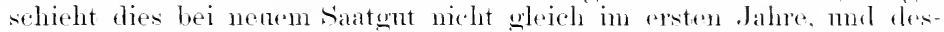
halb ist dasselhe stäliereicher als die emheimisedre Frucht. Anf śanclhoten aber hatte sich eme Rasse gezüchtet, die den fïr die Verhältnisse möglichen reichsten stärlegehalt besals: die Neneinführumgen mit ihren mitgehachten Eigensehaften aber hatten sich diesen Verhälnisisn noch nicht genügend angeratist, gaben also ome geringere Ansbente. Ein Abban orler eme Deneneration wird somit mu dort stattfinden, wo aine sorte nicht die voll ihr beanspruchten Kulturverhälnisse findet. Älnlich dürtte es sich mit allen Erscheinmeren anes vermeintdichen Abbanes oder ciner ldegeneration verlatten. Insere K n l $11 \mathrm{r}$ -

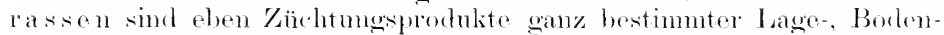
mel Wittermosverhälnisse nud erhalten sich nur roin, wems sie älnliche Bedingungen wie an ilnem Entstehumgsorte wiodertinden. Will man schätzhare Eigenschaften einer bestimmten sorte an einer andern Örtlichkeit verwerten, so geht dies mu durch äftere Emenomug des Saatwutes ans der Hemat dieser sorte oder ans ähnlich situirenten irgenclen.

\section{Die Empfindlichkeit der Süfskirschen.}

Die Klagen in einzehen (regenden, dats die süfskirschen alljählich zmehmente Beschärtignngen durch Frost, (*mmmithnts, Pilzbefall nsw. erleiden, heruhen vieltach anf Nichtbeachtung des Unstandes, dats die Kirsche linen schweren Borlen liebt. Dieser Umstand ist nenerdings von EwEr"2) besmulers hervorgehoben worden mid verdient den ohstzüchtern immer wieder vor Augen geführt zu werden.

Natürlich sind auch hier einzelne Kultursorten befähigt, sich schwereren Böden mehr anzmpasen: aber im allgemeinen gilt dir Regel, dats die süfskirsche pinen leichten, tictorrincligen Boden gerns

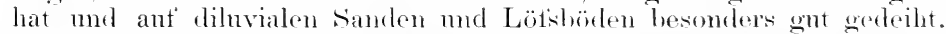
bor Nährstotfreichtmm des Borlens ist weit woniger amschlagorohend als die thrsikalische Bodenbeschatfenheit, mol zwar hesomelers dic Кӧrnumg:

Vieltach wird Kalkmangel als Trsache des schlechten crecleiheres angegeben, und wir erzielen anch Heilmosertolge durch halkzutinh. Die Ferbessermug im Warhstmu ler Bämne ist aber lahed nicht immer. auf tie Wirkung des Kalkes als Nährstoff' zurückzuführon, somrlem ant

1) Eurfanbrg, B., Der Abbau der Kartoffeln. Landw. Jahrb. Bd. XXXII: cit. Centralbl. f. Agrikulturchenie, 1905, s 2:35.

2) Ewrr, Das Gedeihen der Süfskirschen auf einigen in Oberschlesien häufigen Bodenarten. Landw. Jahrb. 1902, Bd. XXXI, s. 129.

Sorauer, Handbuch. 3. Aufl. Erster liand. 
die dadureh erzielte Verändermo der phrsikalıchen Bodenverhältnisse, nämlich ant die uröfsere Krömelmng mul dadurch gesteigerte Durchlïftbarkeit. Betrefts's des Kallies als Nährstoff erhalten wir dureh die EwErT'schon Angaben einen Einblick. Demmach gedeiht die Sütskirsche noch bei einem Kalkgehalt von 0.04 bis $0.15 \% 0$. Boden mit etwa

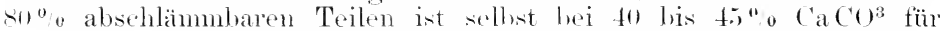
Kirschenkultur nicht geeignet, wenn der Kalk hamptsächllieh in absehlämmbarer

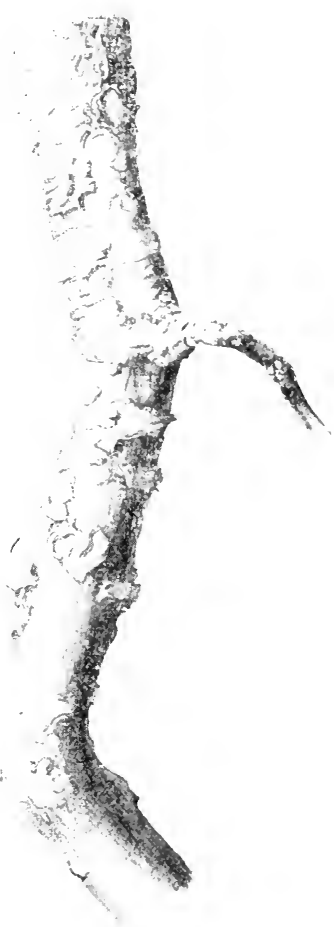

Fig. 2\%. Apfelwurzel mit aufgebrochenen Lohstellen, nat. Gr. (O) rig )

sirk bei Ulne'n und Rïistern Feinheit rorhanden ist. Gegen Grundwasser ist dir Kirsche sehr emptindlich, und ihr Anban renticrt am besten ant trockenen Böden in freien Lagen.

\section{Die Lohkrankheit.}

Vorzugsweise bei älteren Bäumen, die in nassem (irunde stehen. aber hisher krättiges Wachstmm gezeigt haben, leitet sich ein Rückgang in der Produktion dadureh ein, dats die stammrinde der alten Teile anfreifst oder nach $\mathrm{Ab}$ blätterung der äutseren Korkschichten blasige oder flach sthwielige Anftreibumgen zutage treten läfst, die später eine stanbig oder wollig anssehende Oberfläche crlalten. Wem die Strelle etwas trocken wird, lälst sich von derselben ein rotgelbes bis braungelles Pulver abwischen, das im Farbenton der frischen Lohe ähnlich ist und die Veranlassmng zur Bezeirhnung "Lohkrank heit" gegehen haben mag. "Ieh habe bei Einführmeng dieser Krankleeit in die Wissenschaft ten von den praktischen Züchtern gebranchten Namen beibelialten.

Ierselbe Vorgang stellt sich anch an Wurgeln mol jüngeren Zweigen ein. Junge "weige mit knötehenartigen Lohpusteh treten bei Kirsthen ant'. Die Erkrankinng der älteren Stamm- und Wurzelrinde ist bisher am häufigsten bei Äpfeln heobacthtet worden. Pflammen leiden seltener. Ähnliche Vorgänge, die ein Abplatzen grotiser Borkenschuppen zur Folge haben, Wachstmmstörungen der Moorböden abgehandelt werden.

In Fignr 로 selen wir ein Stück Apfelwurzel in natürlieher Grötse. lessen Rincle ist durch verschiedene grotse Querrisse mit zurückgresthlagenen Rändern zerklüftet, und die aufgebrochenen Stellen sind mit ockerfarbinen Pulver oder (bei frischem Heransnehmen ans der Erde) mit weichen, fenthten, bramen Massen bedeckt.

Figur "2t stellt den (Dnershmitt durch eine solche Sthwiele dar. 
Wir finden den Holzkörper ( $c$ ist die Cambimmzone) von meist normalem Bau, hurchzogen ron den Markstrahlen $(m)$, die der Mehrzahl nach keinerlei Abweichung zeigen. Nur bei enzelnen (mi) tällt es ant, dats sich dieselben in ihrem, jüngeren Teile zn verbreitrm begimen und dadurch einen lockerern Ban pinleiten. Dieser Lockermosvorgang findet aber erst in der Rinde seinen dentlichen Anstrnck, indem dont die Reihen der Markstrahlzellen äsenartig anseinanderweichen können.

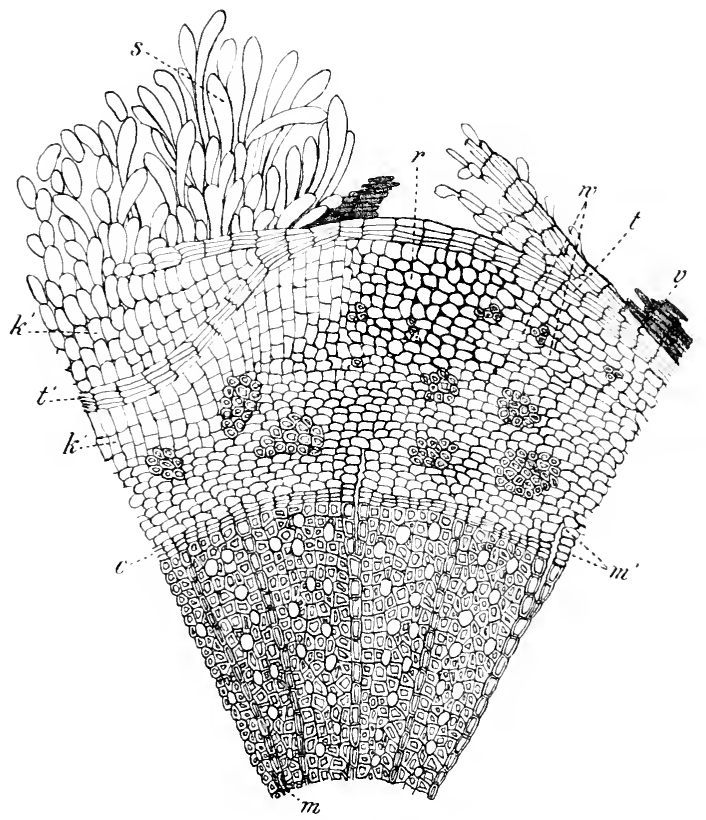

Fig. 24. Querschnitt durch eine lohkranke Stelle der Apfelwurzel. (Orig.)

Während die junge Immominde mit iluren Harthaststrängen noeh keine Ändermo des nom malen Banes zeigt, lassen die älteren schichten (anf der linken seite des Bildes) eine Verarmme des Kellinhalts und radiale streckung $\left(k^{\prime}\right)$ orkemen. Dir Öherverlängermng des Rindenparenchyms wird um so stärlier, je woiter rle tellen nach antsen liegen. nnd sie steigert sich immerhall, der Korkzone derart, dats die tiei an der (Oberfläche liegenden Zellen eine schlauchartige (rostalt $(s)$ annelumen um nur noch ganz lose miteinander in Verband stehen.

Wem die Wurzeloberfläche alstrocknet, schrumpten die Zall schlänche und lösen sich dabei in ihren änfseren schichtrn gänzhr.h voneinander. Dam bildet sich die lohfarbige pulverige Masie. welche mit dem Finger abwischlar ist. Auch die Lamellen von Tafilliork $(t)$. welehe an der Peripheris in dicken (bei normalem Vorhalten oleich- 
mätsigen) Schichten vorhanden sind mul von autsen her allmählich absterben und zertallen (r). werden an der lohkranken stelle in den Lotkerungspozets hineingezonen. Sie spalten sich, indem einzelne Mittelschichten ihre /ellen abrunten und die Neigmng zeigen, den Ban des Füllkorlis anzmelmen, wie später bei der Kirsche eingehender beschrieben werden soll.

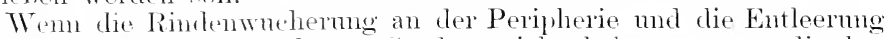
des Zellinhalts ihren höchsten Grad erreicht haben, treten die bekannten uhrolasömigen 'Tafelkorklagen ant' $\left(t{ }^{\prime}\right)$, welche das schliets-

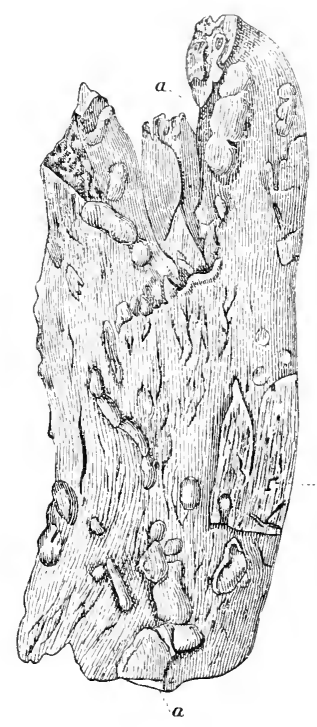

Fig. 25. Rindenstärk eines lohkranken Apfelstammes. " die Schwieken der Lohkrankheit. 1. Liest der trockenen. das franze iberdeckenten liorkenschuplen. (1) ris.) lich verlorkende hypertrophierte Rindenfarenthym abschneiden und zum Bestandteil der Borkenschupe werden lasson. Der Zellstrechungsvorgang schreitet mittlerweile seitlich mil nach inmen hin weiter fort. So sehen wir hei " bereits lie ersten Anfänge, indem die normalerweise tangential gestreekten Rindenzellen im (pressehnitt quadratisch werden und dureh Teilnng an Zahl zmmehmen. un sith nach der kranken seite hin mehr abzmmden, dureh Vergrötserung der Intercellularrämme sich zu Dockern (r) und schlietslich in rie Radialstreckung überzugehen, die bis zum schlauchartigen Auswathen sich steigert.

Durch dieses Zurückgreiten des ت̈berverlängerungsvorganges in immer jüngere Rindenparenchymlagen wird endlich die 'Tätigkeit der "Wn'zel an den lohkranken Stellen erschöptt.

An den oberirdischen Achsen ist die Besthädigmo nicht so intensiv. Bei stärkeren Stämmen wird man hisweilen ant die Erscheimmg erst anfmerkam, wenn man die Borke genamer betrachtet mud findet. dats einzelne Borkenschupen sparrig abstehen. Hobt man dieselben ab, was autfällig leicht vonstatten geht, clann bemerkt man, datis las noch sattige Rindengewelse in seinen äntsersten Lagon mogelmälsige, blasige Exhebungen bilitet. wolche später aufreitien mul in staubtönige, hei trockenem Wetter abwischbare Massen zerfallen. Figu 25 stellt die firische Rindenfläche eines Aptellanmes dar. die rumch Abhelsen der äutseren Borkenschmpren b blolingelegt wordin ist.

Ant der grionbramen sattigen Fläche treton num die halbkugeligen oder gestrockten, sehwielenartigen Erhebungen (a) deutlich hervor.

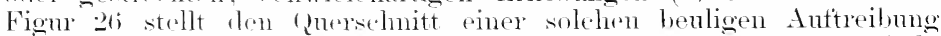
lar, bei weleher abre Iolzkörper, Cambinm und jüngste Fmeminde nieht gezeichnet worden sinc. Wir erkemnen anf den ersten Blick die C̈hereinstimmmo in Ban mit der Lohstelle dor Wurzel. An dem unteren 'Teil der' Figur finden wir das Rindenparenchym mit den drei Hartbaststrängen noch in normaler Ausbildung und Lagerung: aber schon dicht über den Harthastbündeln wird eine Unlagerung benerk- 
bar, indem die tangential gestreckten, chorophylhejehen Rindenzellen anfangen, sich radial zu verlängern $(r)$, sich zu teilen und in prarallelen, durch grolise Intercellularäume (i) gelockerten Längseihen sich anzuordnen. Ilats diese Gewebeveränderumg schon sebr tiüh, sogledeh bei dem Horansteten ans der c'ambimmone stattgefunden haben muis, geht daraus hervor. datis sich die l)anergewehroform des collenchrms. (a) nur einschichtig imerhalh des Wuchergewohes hat ansbilien

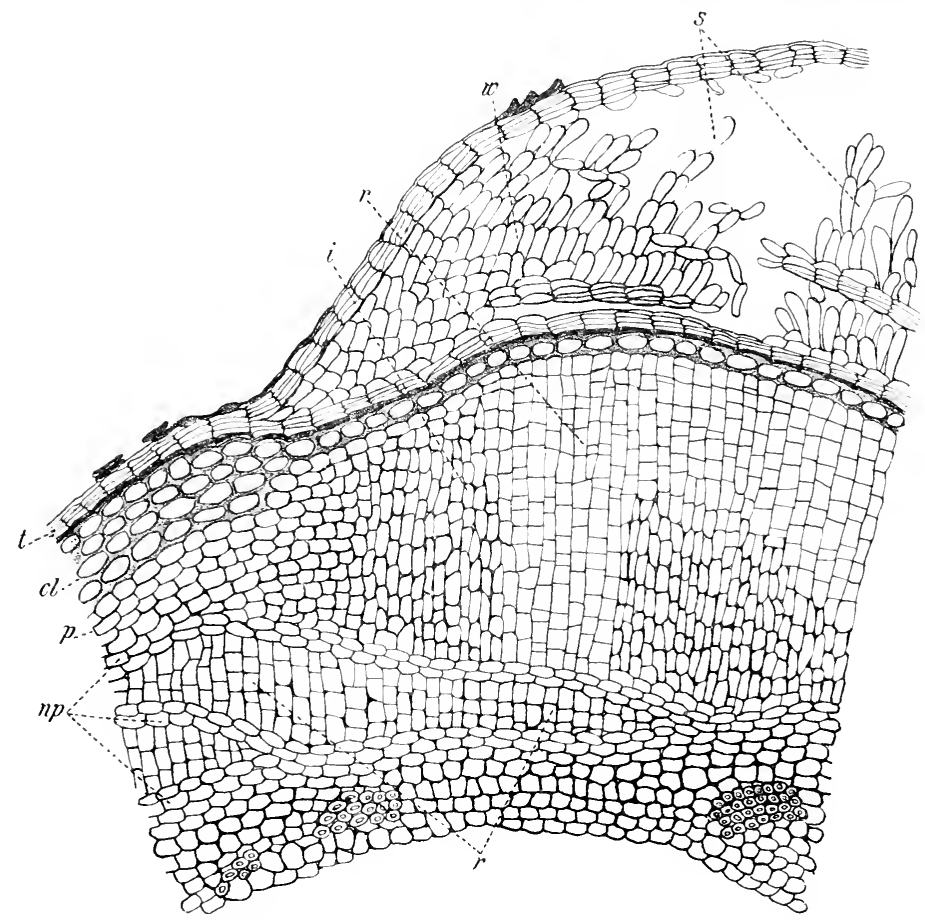

Fig. 26. Lohkranke Stelle an Apfelstamm. (Orig.) Buchstabenerklïrmg in Text.

kömnen. Den Hauptanteil an der Anftreibung aber haben die peripherischen sohichten, lie sich zu Polstern (w) westrockter, sthliefislich schlauchtörmiger (s) Zellen auscebildet und die tafolkorkartigen Zelllagen $(t)$ in die Höle geholen mol endlich zorsprengt haben.

Bei der Dentung diser krscheinmeg düren wir nicht vergessen. dats diese Lohstellen unterhalh der alten Borkensehuperen entstohen unt unter Ausbildung von Füllkork sellst wieler durd Vorkorkmng

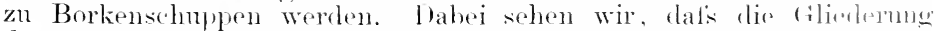
der Rinde in abgeschnürte und alschnürende Zelllagen. wis sir in ten Borken abwechehn, schon in jugendlichen Rindengewelo angelint wirl. 
Demn wir timlen, dats sich im jungen, trischen Rindengewebe Querbänder tafelfömiger, in Inhalt und Ban der Wandung abweichender bellen in geschwungenen Linien (m)). durch das hypertrophierte, anfangs stänctühnende Gewebe hindmohzichen.

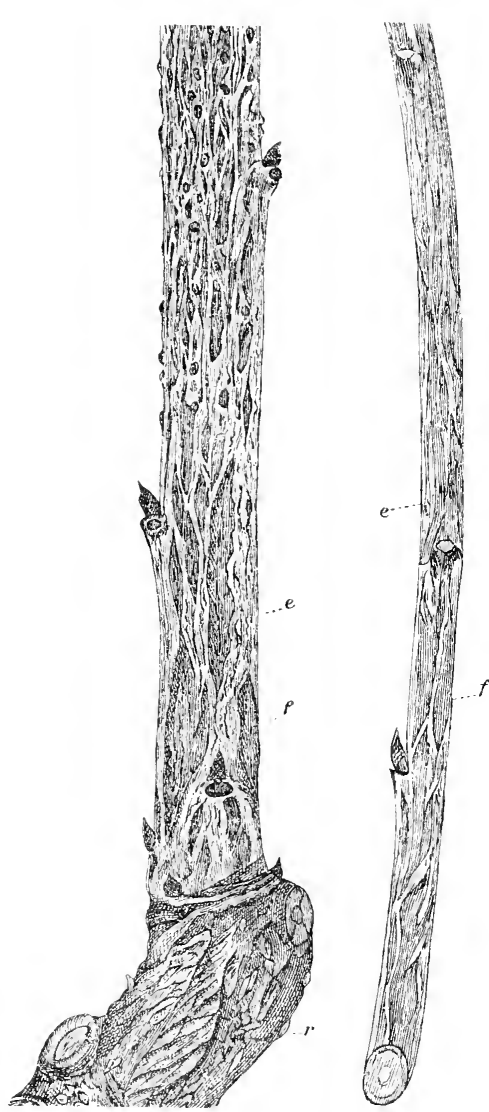

Fig. 27. Einjahriger and zweijahriger Kirschenzweig mit Lohpolstern zwischan den zerschlitzten Rindenstreifen. (Orig.)

Liese gestaltiche und fimktionelle, die Borliensehmpenbildme fredingende ciliedermo des Rindenparenehrms ist anch bei anderen Bamminden zu finden, tritt aber, soweit ich beobachtet, erst in ten alteren Achsen anf', bei denen das Rindemparenchym durch den Druck der autgelagerten Borkensehuppen bereits beeinflutst wird. Ith habe deshall, diese streifen tangentialer Zellen (np), ,lie später verkorken, manchmal anch noeh Tafelliork entwickeh mol die Borkensehuppen helansichneiden, als .. Druckbänder" bezeichnet.

Die Lohkrankheit an jungen Kweigen latte ich Gelegenheit, bei Kirschen zu studieren, mol zwar in einem nassen sommer an jungen, selır kräftigen Bämmen einer Bammsehule. Fig. 27 zeigt, dats an diesen Kinsehzweigen die Oberhant zerschlitat oder in loreiten, unregelmätsigen streifen (") autigerisen ist. An den aufgeplatzten Stellen war eine intensiv ockroell gefäbte Masio (f) exkembar, die bei stäkerer Ersehütterumg durch Ansehmellen pulverig

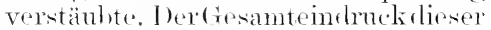
Triche war so, als ob dieselben äuliserst stalk mit einem Rostpilze bedeckt wären.

Dic ersten Anzeichen der Erkrankung traten im . Juli auf, indem mitten zwisehen normal wachsenden Stämmen rinzelne Exemplare ilme Blätter welle färlsten mol abwarfen. Trotzlem entwickelte die Endlinospe der \%weige einen kräftigen Angusttrieb, der bis zum Herbst den göbsten Teil soines Lambes behielt. Im September zeigte sirh, am ältesten Teil des Triebes begimnend und nach der Sipitze hin an Intensität abmehmend, das vorerwähnte Autplatzen der äul'seren lindemunkleilung und das Itervortreten der ockergelben sammetartigen Fläeluen. Bemerkenswert ist ferner der Umstand, dats fast nur die ïphigen Willlinge erkankt erschienen: hei veredelten Exemplaren waren die Frscheimmen der bohe nur spärlich bemerk- 
bar. Sodamn zeigte sich, dat's die Zweige, soweit sie noch ihre Blätter behalten hatten, wenig aufgerissene Rindenstellen. sondern nur geschlossene, schwielige Auftreibungen, also jüngere stadion besatsen. An ren zwei- und mehrjährigen Achsenteilen erkrankter Bäume kamen auforissene Rindenstellen $(r)$ seltener vor: meist traten dort die einzelnen Herde als sehr breite, querverlaufende, auffallend hoho, ockergelb getärbte Lenticellenpolster hervor.

Die Untersuchung dieser Polster und dor breiten, anfgerissenen, abfärbenden Flächen an einjährigen /weige licks sofort eine grolse Ïbereinstimmung mit den älteren erkemen: nur komnte nicht beobachtet werden, dafs die lenticellempolster stäul,ten. Die abtärbenden Massen erwiesen sich als hellbraune, zylinelrische, faltige Korkzellen mit abgerundeten Ecken, die einzeln oder in kleineren Gruppen sich ablösten.

Die stäubenden /weige zeiren sich mit wenigen Ansnahmen sonst gesund: nur ist ihre Primärrinde durch beträchtliches Anseinanderweichen der Parenchrmzellen sehr gelockert. Ehenso wie in der Rinde finden sich auth im Holzkörper strillen von gelockertem Bau. In der Region, die mgefähr gegen Mitte des sommers entstanden ist, bemerkt man Querbinden von getälslosem Parenchymholz, das mit siärke vollgepfroptt ist, währenf das normal geloute Holz mit Ansnahme ler Tarkstrahlen stärkelos ist. Innerhalf, der Querhinden sind die Markstrahlen erweitert mul zeigen hier frummilierfle.

Ije ersten Anfänge fer Lohbilflung findet man bereits dicht muter

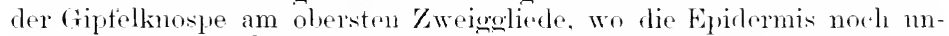
verletzt, abor doch sehon dmoh eine etwa füntschichtige Korklamello unterlagert ist. Diese aus verhältuismälsig diekwantigen Zellen bestehendo, dem Tafelliork entsprechencle schutzsehicht zeigt gleieh bei iher ersten Anlage stellenweise insofern oine Ändermg, als die mmittelbar muter ter Epirlermis liegenden \%ellen sich zu parallel gestellen Reihen zylindrischer, radial gestreckter, brannwandiger Füllkorlizellen ausgebildet hahen. Es lirgt also hier der ('harakter des Lenticellenbanes vor, den StraHL ${ }^{1}$ ) bei der Kirsche bereits eingehent beschrieben hat, mud der nur insofern von der STAHL schen Beschreibung abweicht, als hier die Füllkorkpolster selten unter einer spaltäffimm entstehen.

Tlats eine reichliche Fülliorkbildung bei der Anlage ciner Tatelkorkschicht mabhängig von den sipaltöffnumgen erfolgen kamn, sicht man hier, indem num mehrschichtige Lenticellen entstehen, bei denen die Korkbildung tief in die Primär- nur sogar in die Śekmelärrinde riickwärts hineingreift.

Mit dem Älterwerden des diesjälnjoen Triehes tritt ganz normal eine zweite Tafelkorklage ummittelhar unter der erstentstanclenen aut: sie ist ebenso stark (nämlich $5-7$ Kellen hoch) gefunden worden wie die erstangelente. deren /ellen alhmählich unter anscheinend woringer Quellung und Bräunung fler Membranen zusammensinken. Гourch diesen Vorgang erscheint die normale Korkhekleirlung des Kirschzweiges in zwei sehichten differenziert. Tie obere, ältere ist sehr dicht, da die \%ellen meist terart zusammengesunken sind, dats ihr Immenramn nur als finer Strich erkembar ist: diese sehicht geht allmählich in die zweite, nichgebildete Korklagre über. Bei letzterer sind die tafelförmigen /sellen sehr gleichartig und ihr weites Lumen mit wässerigem Inhalt odor anch mit

1) Stahl, Entwicklungsgeschichte und Anatomie der Lenticelle Bot. Z. 1. is. 
Luft erfüllt: sie grenzen an eine gebrännt erscheinende Zelllage mit deutlich plasmatischem Wandlolag, welche als Korkeambium die stellenweise eintretende Fortbildme der Korkschicht übernimmt. Die älteste, zusammengesunkene, hrame Korklage wird hei Behandlung mit Schwefelsiane deutlieher in ihrer Zusammensetzung erkennbar, da sich vielfach die Zellen dehnen und stellenweis ihre mrsprüngliche Höhe und Weite, hiswoilen fast quadratischen (pnerschnitt zeigen, während die Füllkorkzellen sich nicht verändern. Die später entstandene Schicht wölbt hei dieser Behandlung narh ' Kerstörung des Korkeambiums ilure jüngsten Korkzellen halbkinglig vor.

Bei der Anlage der mehrschichtigen Lenticellen wiederholt sich $n$ munterhall, des ersten Fïllkorkherdes die Bildung derartiger Elemente in der sekundären Korklage.

Her zweite Fall der Tenticellenbildung olne Zusammenhang mit Spaltöffhumgen ist hier in Fig. 28 abgebildet. Dieselbe stellt den Querschnitt einer Neubildung anf einem geschälten Kirschenstamm dar. Wir haben uns vorzustellen, dats das ganze hier dargestellte Gewebe in Form einer herindeten schwiele dem alten. von der Rincle entblötsten Holzzylinder antisitzt.

Intem wir hetreffs der anatomischen Vorgänge, welche zur Bildung dieses neuen (tewebes auf dem blotisgelegten Holzkörper führen, auf das Kapitel "Wunden" (Schälwunden) verweisen, erwähnen wir hier nur die Tatsache, dafs, wem man zu bestimmter /eit einem Bame die Rincle fortnimmt, das nummehr freigelegte, jüngste Splintholz wieder in Vermehrung treten und die Wundfläche mit einer parenchymatischen Gewebeschicht bekleiden kam. Dieser Parenchrmmantel vermehrt sich durch späteres Auftreten einer ständigen Meristemschicht im Innern, und diese wird zum normalen Cambium, das nach immen Holz und nach antsen Rindenelemente anlegt.

Fig. 28 ist eine mehrere Nonate alte Nenbildung, die in Form einer breiten, lappigen Schwiele auf dem Splintholz eines experimentell geschälten süiskirsehenstammes sich angesetzt hat. Der alte Holzkörper des geschälten Stammes ist in der Zeichnung fortgelassen worden : er würde an h.p anstotien. Das aus seinem splint hervorgegangene Gewebe hat sich durch Auftreten der Cambimmzone e scharf in einen Holz- und Rindenkörper differenziert. Der Holzkörper ist an der Stelle, an welcher er dem alten Stamme aufsitzt, parenchymatisch gebaut; erst später geht dieses Parenchymholz $h p$ in gefäfsfühlendes, Libriformfasern ausbildentes Neuholz $n h$ über. Entsprechend der erst allmählich zum normalen Bau relangenden Holzbildung ist auch der Rindenaufbau anfangs umregelmälsig, indem die llartbastkörper zmächst in Form einzelner, weitlumiger, kurzer Elemente $h b$ angelegt werden und erst später aus dem Cambium als zusammenhängende Gruppen faserartig gestreckter Elemente $h b^{\prime}$ hervorgehen ${ }^{1}$ ).

1) Nebenbei sei auf die mit der Lohkrankheit in keinerlei Verbindung stehende, aler in der Zeichung wiedergegebene Bilıung von Knollenmaseranfängen (B) hingewiesen. Es entstehen nämlich bei lokaler Anhänfung plastischen Materials, wie z. B. bei Neubildungen in der Nähe von Wunden bei verschiedenen Bämmen (Kirsche, Apfel, Birne, Kiefer) isolierte Holzkörper in der Rinde. Als Zentrum derartiger Holzbildungen von kuglig-schwielenförnigem Ban erkennt man sehr häufig eine oder mehrere Hartbastzellen.

Der Fall, dafs (namentlich erkrankte) Hartbastzellen umwallt werden, ist bei Verwmdungen des verschiedensten Ursprumgs ein sehr häufiges Vorkommnis. Die T'mwallung besteht meistens nur aus emem mehrschichtigen Mantel tafelförmiger 
Der Rindenkörper der Nenbilsmeg hat in seinon leripherischen Parenchymschichten pine schützende Forklage $k$ ancoliblet die allmählich zu grötserer Mächtigkeit gelangt ist. Antangs war nur Tatelkork angelegt worden: suäter haben sich an einzehnen stellen Fiillkorkmassen $7 \%$ statt der Tatelkorkzellen entwickelt. Welche die ans letzterer Zellform webildete Decke li zersurengt mul durch ihre rückwärtsgreitende Vermelnung das Korkeambinm kl tief nach innen gedriickt haben.

1. Der Beginn der Füllkorkbihdmeg fiel in die Keit, in der die ganze schälstelle zwecks anderweitiger Untersuchngen in einen Glaszylinder

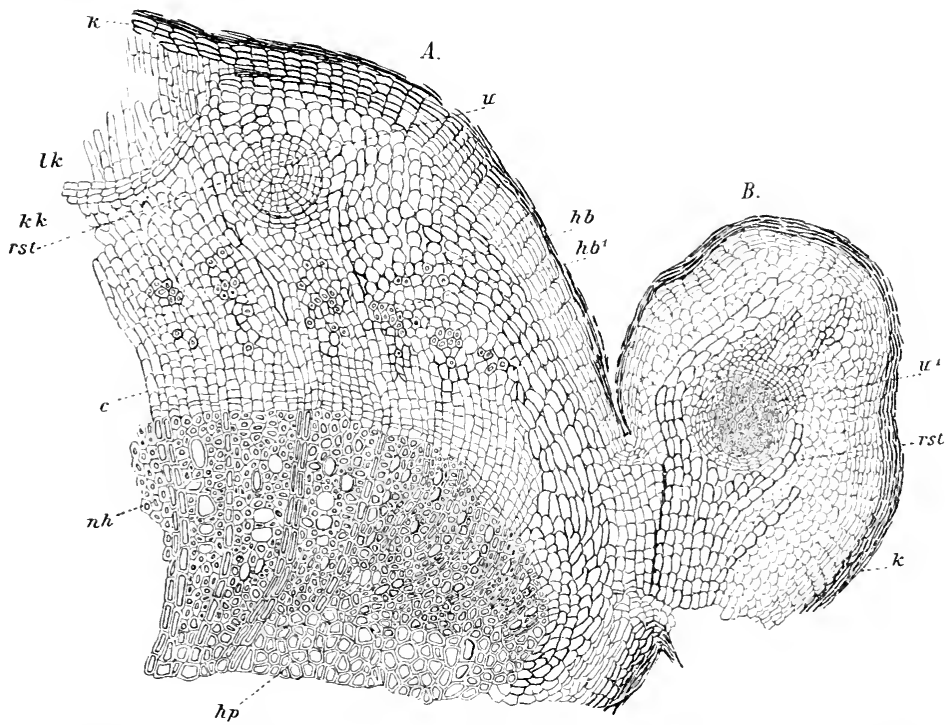

Fig. 28. Neugebildeter Holz- und Rindenkörper auf einer sichälwunde eines Kirschenstammes. Dir Rinde zeigt Lenticellenwurhermg. (Orig.)

mit Wasser eingeschlossen wurde. Während diese ans dem Phellogen hervorgegangene Lenticellenwucherum bei dem in der Inft belassenen Teile der sichälstelle nur schwath bemerkhar war, hatte sie muter

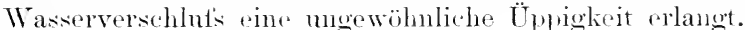

Die Lohkrankheit der Kirsehe ist also eine abmorme Niteigermen des normalen Lenticellenhilehmgsrorganges: es entstehen so zahlreiche

Korkzellen. In einzelnen Fillen aber bildet sich an Stelle eines bald erlöschenden Korkcambiums eine dauernd tïtige Cambiumlage aus, welche nach innen Holzelemente, nach aufsen Rindenelemente anlegt. Ein solcher vall ist in der schwielenartigen Gewebewuchermg $l$ bei $\|^{\prime}$ dargestellt, wihrend bei $"$ in linken Twil deFigur (A) nur eine Korkumwallung nm eine der erstentstandenen, isoliertin Hartbastzellen zu sehen ist. Im diese Neubihungen weichen di. Rindenstrahlen $r$ st wie um einen fremden Körper zu beiden seiten aus. 
und ansgebreitete Füllkorkpolster dicht nebeneinander, dafis dieselben miteinander versehmelzen, die Epidermis in zusammenhängenden, gröferen Fetzen abstotsen und als gleithmätsige, einen grotsen Teil des Zweigmntanges bekleidende, sammtige Fläche zutage treten. Die ändieren Lagen der Füllkorkpolster sind so locker, datis die peripherischen Zellen bei trockner Luft duch geringe Stötse aus ihrem Verbande sich lösen: daher das Alfü̈rben der lohkranken Stellen bei Berührung mit dem Finger und das stäuben der Zweige bei stärkerer Erschüttermg. Die Verstäubung ist um so grötser, je mehr Füllkorkzellen überemanterliegen, and es sind Polster beobachtet worden, die aus 20 \%elken hohen Paralleheihen von Füllkork bestanden. In diesem Falle hatte der Streckungsvoreang die primäre Phellodermschicht in ihrer ganzen Dicke erfatst, so dat's die später gebildete, zweite Füllkorklage sich unmittelbar darunter anschlots, also eine trennende Tafelkorklamelle zwischen den einzelnen Generationen nicht älrig blieb.

I ie Entstehmo der Lohkrankheit wird ant urotisen Wasserreichtum des Rindenkörpers züücknefüht werlen müssen. Dieser lokale Wasserübersehnfs wird einerseits threh reichliehe Wasserzutuhr zu den Wnrzeln besonders kräftig wachsender Individnen, anderseits durch geringere Verdunstungsfähigkeit der Rinde infolge grötserer Luftfenchtigkeit hervorgebracht werden können. Dafs solche Verhältnisse bei der Kirsche zm Lenticellenwndherung führen, beweist einerseits die experimentell erzengte Füllkorkanhäufung bei der unter Wasser zehaltenen schälstelle und terner eine Beobachtung an den natürlich erkrankten Exemplaren. Dort fand sich an den jüngsten, noch beblätterten Internodien, dafs gerade diejenigen Stellen, in denen die Rinde Falten bildete, bevorzugte Herde für die Korkwncherungen waren. solehe Falten entstanden z. B. an den Grten, wo die Gefäfsbündel für das Blatt ans dem Aehsenzylinder heranstraten und die Rinde bei dem T̈lbergang in den Blattstiel vorwölbten.

Es liegen antiserdem noch einige andere Beobachtmngen vor, welche für die Begünstignug der Lenticellenbildung durch grötsere Fenchtiglisit infolge verminderter Verdunstung sprechen. So erwähnt STAPF ${ }^{1}$ )

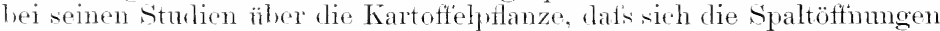
zn Lenticellen entwitkeln, wenn die Transpiration anfgehoben wird.

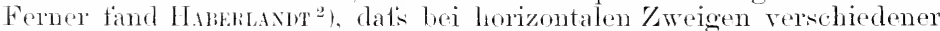
Bämme (Limle, Thone, (ileditschie n. a.) die Lenticellen an der Unterseite stets zahlreicher als an der Oberseite anftraten, obgleich eine Zählung der Sivaltöftinumgen anf beiden Seiten ammähernd dieselbe Menge arkennen lief's. The dem Erdhoden zugeneigte Zweigunterseite wird sicherlich bei der grötseren Nähe des Erdbodens und der geringeren Luftznfuhr eine geringere Transpiration als die olserseite besitzen.

Lie Lohpolster hei den Pflaumenbäumen stimmen im werentlichen mit den bri Kirschbänmen beobachteten ïberein. Sie sind bisher nur an alten, wnzelliranken Exemplaren beobachtet worden. Von Aprikosen sind mir nur Antangsstarlien bekannt geworden. Bei allen

1) StapF, Beiträge zur Kenntnis des Einflusses geänderter Vegetationsbedingungen usw. Verh. d. Zool.-Bot. Ges. Wien; cit. Bot. Jahresb., VI. Jahrg., Abt. I, S. 214.

2) Hanfraxid, Beiträge zur Kenntnis der Lenticellen. Sitzungsber. d. Akad. d. Wiss. in Wien, Bul. LXXII, Abt. I, Juliheft 1875. 
Steinobstsorten waren die Korkwneherungen von starken Lockerungsvorgängen in der Rinde, die zum Teil Versehiebungen ter Baststränge nach antien zur Folge hatten, begleitet. Im jungen Holz bemerkte man mehrfach anch ta. wo die Lohkrankheit nicht zum Anshruch gekommen, einen schwach ansgehildeten Holmring und Rechlition der Harthastliunclel ant einzelne weite, mit braumotem, gumnösem Inhalt rrfüllte Bastzellen. Spuren von Grmmosis fehlten nirgends: lisweilen fanden sich reichliche (tummiherde. Bei Kirschen liefs sich von nebeneinander gebanten vorschiedenen sorten eine besontere Neinmo rinzelner Sorten zur Lohliankheit erkemen, so z. B. Lei der ,Schwarzen Herzkirsche" und bei "Wnklek's weitser Herzkirsehe".

Sämtliche Fälle, die ich kemen gelernt, stammen von sthweren Böden orler moorigen Wiesen: bei einzelnen erklärten die Einsenter, dats die erkrankten Bämme eine Stallmist ofler Janchethingmmg rrhalten hatten. Diese Angaben in Vereine mit dem anatomisehen Befmute. veranlassen mich, die Lohkrankheit als eine Folge übermätsiger Wasserzutuhr ans rlem Boden zu erklären bei Bäumen, die, in krättigem Warlsstum begritfen, cine Störumg derart erleiden, lat's die Verdmstung der Krone zu Fortschattiong les Wasseriberschusses nicht meh amsereht. Eine Depression der Laubtätgkeit oder oin toilweiser Lanherhst dureh atmosphärische Einflüsse oder Bammsehmitt werden vorzugsworse in 13t.-

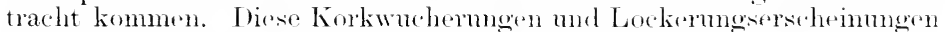
in Rinden- mel IJolzkärper treten anch bei gesmelen Bäumen in entspechenden standortsverhältnissen anf, steigern sich aber in dre lallkrankheit zom extremen Änkerumg.

Die regenmittel argehen sich von selbst. Hanptsäehlich wird ans-

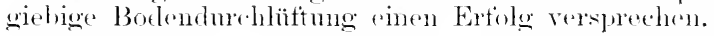

\section{Die Ringelkrankheit der Rotbuche.}

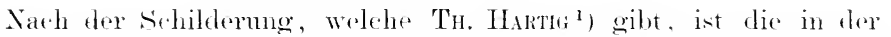
THhershrift gename Krankhreit. die ich aus eigner Ansehammg nicht kemne, hierher zu ziehen. In einem Buchenorto von ofjährigem Alter sah HakTu viele stangen von 1-2. m über dem Boclen bis zmm Gipfiel in Abstänflen von 30 his $160 \mathrm{~cm}$ mit einem fast ringfömigen, etwas spiralig ansemanderlanfenten Wulste von ter Dicke einer Federspule mogeben. Diese Wïlste erwiesen sich als T̈herwallungserscheinmogen von Wimrlen, welche msprönglich durch Lenticellenweherung veranlatst worden waren. Die Korkbilkmo hatte dabei rïckwärts immer tiefer in dir Rinde hinein $m$ sich genpitten, bis sie flen IJokkërper erreicht hatte. Darlureh war für ein bis zwei Jahre die Holzbildung an diesen stellen vollstäntig moterbohen worten. Ein erkembarer Sehaten der Krankheit. welehe mo in sehr sutwiuhsigen stangenorten mul dort wieder besonders an stämmen erstel und zweiter Klasse anfigetreten, lieds sich nicht konstatieren.

\section{Wurzelerkrankung der echten Kastanien. (Mal nero.)}

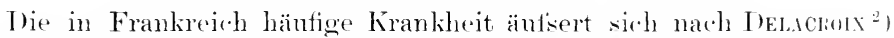

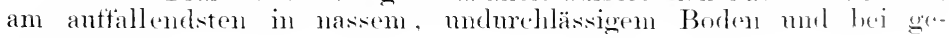

1) H xmor. Tu., Vollstandige Naturgeschichte der forstlichen Kulturpflanzen, S. 211. Berlin 1852.

2) Drincron, G., La maladie des châtaigniers en France. Pull. soc. myont. do France XIII, 1897. S. 242. 
I. Krankheiten durch ungünstige Botenverhältnisse.

ptroptten Bäumen. Lie Blätter verlieren ihre dunkelgrüne Farbe. und die Zweige beginnen an den spitzen zu vertrokknen. Die Frïchte werden nu mrollkommen reif und bleiben in der sich öttinenden C'upula sitzen. Desackox fand die Mykorhizen an den feinen IVurzeh krankhaft verändert. und zwar nehmen dieselben, wie er wlaubt, aus Mangel an Humus einen parasitären Charakter an. Das Mreel steigt dann in den stärkeren Wurzeln in die Höhe his zum Wurzelhals und in Stamm aufwärts lis zu den Zweigen. Aus den Wurzel- und Stammwunden ertolgt ein gerhstofthaltiger Austluts. In diesen schwächezustande biet $\rightarrow n$ die Bämme einen geeigneten Ansiedlungsherd tïr andere Parasiten, wie z. B. Polyporus sulficens und smillariu mellet sowie Splearerla maculiformis.

Der firmul, weswegen ich die Krankheit an dieser stelle einreihe, liegt in len Ergebnissen einer eingehenderen Untersuchmg, die ith mit Material aus Remnes anzustellen Gelegenheit hatte. In dem von Herru Chrt qesandten Begleitschreiben wirl mitgeteilt, dat's das absterbende Astholz beim Zerbrechen oder Ablosen der Rinde einen Gärmo anzeigenden feruch habe, und ex vormute eine Umsetzung des Tannins, wohei (Hykose und Alkoholgärmg antreten. Die eingesandten Zweigproben waren reich mit Flechten hesetzt, und die Blätter zeigten tief in die Interestalfelder hineingreifende. vom Rande anscehende Bräunmos.

Matsogend werden die Wurzeln, die ein holperiges Anssehen haben, da sehr zahlreiche, rersthieden grotse, abgetlacht halbkuglige, schwarze, harte Polster die Uberfläche bedecken. Nach Behandlung mit Kalilange, wobei das anstretende flockige Tamnin we in rot bis braun gefärbt wird, zeigen die Querschnitte, dats es sich $\mathrm{m}$ Rindenauttreibungen handelt, die noch von der normalen Korklage gedeckt sind. Die Primärrinde hat parenchymatische IV herungen entwickelt, deren in tächertörmigen Reihen angeordnete Zellen farblose, in Schwefelsäture anscheinend schwer lösliche Wandungen und einen bramen, sehr festen Inhalt hesitzen. Diese Rindenauftreibungen werden suäter von einer nhrolastörmigen, von der äuferen Korkschicht abgehenden Tafelkorklamelle abgeschnitten und durch die nachwachsende Imnenrinde ïher die Wurzeloberfäche ats schwiele emporgetrieben. Die gesunde Rinde ist vollgeptroptt mit stärke.

Bei dem eingesaniten Material hatten anch die Zweige etwa ${ }^{{ }^{1}} 4$ bis ${ }^{1} 2$ mm breite. algeflachte, hablingelige, nur sehr wenig hervortretende Erhebungen der Rinde. In diesen zeigte sich der Anfang von mehrshichtiger Lenticellenwehermg, wie solche in ausgedehntem Matie bei dion lohkranken Kirschen zu beobachten gewesen. Die an den Zweigen noch festsitzenden Blätter deuteten in ihrer Beschaffenheit hereits die Wurzelerkrankung an. sie zeigten eine rom Rande nach der Mittehrippe hin in den Intercostalfeldern fortschreitende Bräu mung und Vortrocknumg des Parenchrms. Dasselbe war schliefstich nur in der nächsten Nähe der Rippen noch grön. Die auf' den kranken Blättern auftretenden schwarzen, gelb umsämmten, zerstrent stehenden, rundlichen Flecke. welche verschiedene Pilzansiodlungen enthielten, müssen als seliundäre Erscheinmeren betrachtet werden. Der Befund an den Zweigen im Terein mit den Autreibungen des Wurzelköruers bringt die Krankheit, die uns ron Crís als . Mat nero" bezeichnet wurde, in die Gruppe der Lohkrankheiten. Demgemäfs wïrde die Auswahl faseriger oder gut gekrümelter Böten, welche beständig reichliche Bodendurchlüftung gewälıren. das heste Vorbengungsmittel gegen die Krankheit sein. 


\section{Der Wurzelbrand der Zucker- und Futterrüben.}

Als Wurzelbrand bezeichnen wir eine Gewebeerkrankung, die sich schon einstellen kam, wem die jungen Pflänchen die Kotvledonen entfalten ofler die ersten Blättehen auszulneiten beginnen. Es rescheint muterhalb der Keimbläter an stengelehen eine selnwarze stelle, die nach den Wurzolente hin (weniger nath den Kotyledonen zu) an Anstehmug gewimnt und einsinkt. Selbst wem die junge Keimptlanze noch nicht eimmal die Bodenobertä̈lie erreicht hat, kann die Erkrankung in den ersten Antängen bereits kemutlich werden. VАхн beobachtete dabei ein Glasigwerden des Gewebes, hevor dasselbe in Brämung äberging. Die Pflänzehen heginnen zn welken und knicken meist an der kranken stelle mm. Alshald erfolgt damn der Tou. Wenn die Krankheit ant eine kurze stengelstrecke iles hypokotylen diliedes beschränlit bleibt mel das PHänzchen nicht untält, liam sich die einresunkene stelle ausheilen und ein normales Weiterwachsen eintreten. TTegen der Schwärzung der kranken, oftmals fadendïnn zusammenschrmmfenden stelle miterhalb dre Keimbläter bezeichnen die Praktikir lie Erseheinme anch als .selewarze Beine" oder "Kwirn". Thie-

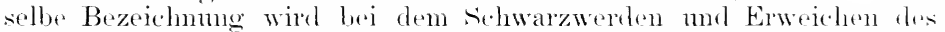
hypokotylen Gliedes unserer Kolilgewächse ohenfalls angewandt, berulit aber aut anderen Verhältnisisen.

Bennerlenswert ist, dats bei ansgelegten Rübensanen zwar oft ganze Böschel ron Pfïnzchen erkrankt sich zeigen, dats alser doch der Fall war nicht selten ist, dicht nelen ten erkrankten anch ganz gesumel. und gesmul bleibende sämlinge zu timden. Ferner ist hervorzmbeben,

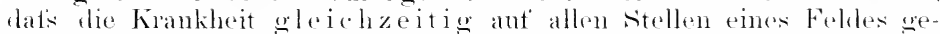

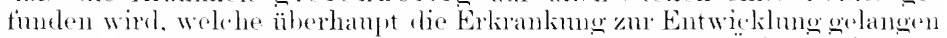
lasser, mul dats in der Regel mitten in risankten Äckom einzelne Flecke versehont bleiben. Mit dem Älterwerden der Ptlanzen härt der Wurzelbrand ant. Die answeheilten Pflanzen pflegen allorting gesenïher den gesmet geblicbenen an frötse mot Znckelgehalt nachansthen

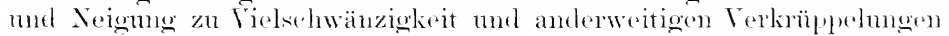

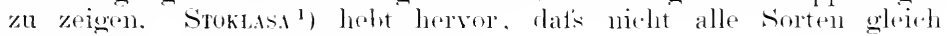
emptänglich tïr IVurelbranel sinel.

Die Krankheit kemnt man seit Ansbreitung des Rïbenbanes in den heitsiger Jahren des vorigen Jahrhmderts mu, nach stror ${ }^{2}$ ). begam tess bereits anf ciner Versammlmo der Rühenzucherfahrikanten des \%ollvereins die Disknssion ïber die Ersache der Erscheinmmg. Von sciten praktischer Rübenzüchter wurde damals die Ansicht ansugesurochen.

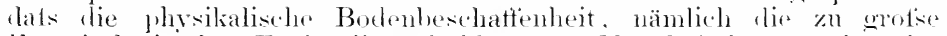
Festigkeit der Erde die Schuld trage. Man hoh hervor, dats der Wurzelirand nur da gefumden wird. wo der Boden obertächlich fiest geworken mud nicht gelockert womle: daher wäre Heitsiges Harken zn emptehlen.

Als die Wissensehatt sich der Frang hemächtigte. War die Parasiten-

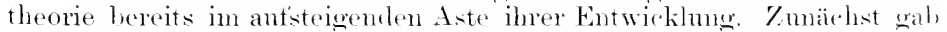

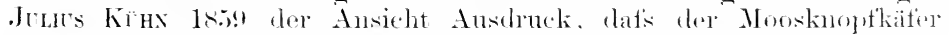

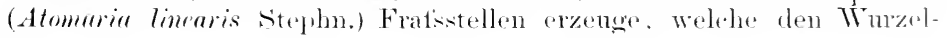

1) Srokisas, Jus.. Wurzelbrand der Zuckerrübe, Centralbl. fo. Bakteriologit. II. Abt., 1898 , ‥ $6 \times 7$.

2) Srrar, Axrox, Die Krankheiten der Zuckerrühe. Wien lono Verlag dus Centralver. f. Rübenzucherindustrie. 
brand einleiteten. Feh habe Ähnliches beobachtet ${ }^{1}$ ). Anch die Tausendfütsler und ähnliche Tiere wurden als Ursache herangezogen. Diese für eine längere Reihe von Jahren herrschende Ansicht wurde erst erschïttert, als Ifulderies fand, dafs die Krankheit ohne tierische Beschädigmngen entstehen könne um in vielen Fällen schon von den Knäuehn ausginge. Infolgedessen emptahl dieser Forscher ein zwanzigstïndiges Einweichen ler Rübenknäule in eine einprozentige Karbolsäurelösung²). Als eine spezielle Pilzkrankheit spricht zu ungefähr derselben Zeit KarLsox die Erseheinmo an und hebt dabei hervor, dats nur schwächliche Exemplare dem Wurzelbrande erliegen. Pflänzehen ans seln gntem Saatgut ofler dureh energisches Wachstum sich liräftigende sänlinge würden von den schon im samenknäuel mitgebrachten Pilzen nicht bewältigt ${ }^{3}$ ). Die antser mit Karbolsäure anch mit Kupfervitriol vorgenommenen Beizversuche liefsen eine Verminderma des Wurzelbrandes erkennen. Trotz slieser nicht ungünstigen Erfahrungen mit dem Beizen legt Kakssos doch das Hauptgewicht anf die Anzncht besonders kräftiger sämlinge und macht msere jetzige Kulturmethode, die nur anf die Trewimnmg grofser Mengen ron Samen hinziele und die Qualität vernachlässige, für die Ansbreitmo des Wurzelbrandes verantwortlich $\left.{ }^{4}\right)$.

Die Theorie der Samenlseize wurde von Wrnner, dem Mitarbeiter Heldrifier's, weiter ausgebildet. Ton den verschiedenen, zur Beizung benutzten Stoffen erwies sich die Karbolsäure am vorteilhaftesten, und zwar bei Benutzung einer eimprozentigen Lösmg des .Acidum carbolicum crudum 100\% Pharm. Germ. II." Auf einen Gewichtsteil Samen rechne man ungetähr of bis \& Gewichtsteile Flüssigkeit.

(tiinstig erwies sich anch eine Warm- sowie eine Kaltwasserbeize ${ }^{5}$ ).

Während Wrnmen die Frage betreffs des Einflusses von Witterung und Bodenbeschaffenheit mentschierlen läfst, tritt HoLbefLeIss entschieden dafür ein, dafs nicht Parasitismns, sondern Bodenbeschaffenheit den Wurzelbrand veranlasse. Bei den die Krankheit begünstigenden Bïden fand er meistens eine reichliche Menge von Eisenoxydul, aber verhältuismäfsig wenig Kalk. Dabei war eine Neigung zum Verschlämmen und Verkrusten der Böden mverkennbar, und dementsprechend war auch die Erfahrung, dats nach reichlichem Hacken der Wurzelbrand sich ansheilte. Daranthin empfiehlt dieser Forscher anfirer dem fortdanernden offenhalten cler Rübenböden eine reiche Znfuhr von gebramtem Kalk (12 bis 15 Zentner pro Morgen), der am vorteilhaftesten zu den Vorfï̈chten und nicht direkt zu den Rüben gegeben werde. Gute Erfolge einer Zufuhr von 7 Zentnern Ätzkalk pro Morgen sah anch Loris" "). Als weiteres begünstigendes Moment hebt HoLbeuxi eine niedere Temperatur hervor und gedenkt dabei des Umstandes, dafis die Wrurelbranderkrankung niemals über die Erddecke hinans ant die dem Luftznge ansqesetaten oberirdischen Achsenteile hinübergreife. Er tritt mit Entschiedenheit dafür ein, dafs phrsikalische und chemische

1) Zeitschr. f. Pflanzenkr., 1892, S 27 .

2) Hratumat, Ther dir Schädigung junger Raben durch Wurzelbrand usw. Deutsche Zuckerindustrie, Jahro. XV, S. 745. Biedermann's Centralbl. 1\$90. S. 647.

$\left.{ }^{3}\right)$ Auch Hotwex: fand bei Aussaat von grofsen Rübenknäueh einen geringeren Grad der Erkrankung. Dritt. Jahresb. d. Versuchsstat. f. Nematodenvertilgung. 1892.

4) Blätter für Zuckerrïbenbau, 1900, Nr. 17.

5) Hondu in Zeitschr. f. Räbenznckerindustrie i. D. R., Bd. 46, Heft 482.

6) Bericht d. Landw. Versuchsstation Posen. 1s91. 
Ursachen. welche bei kalten, luftahschliefsenden Äckem sich geltent machen. den Wurzelhrand veranlassen.

Die Ansicht, dats die Bëden, ant welehen die schwarzen Beine der Rüben sich einstellen, gern verschlämmen und ahbinden, wirl narh

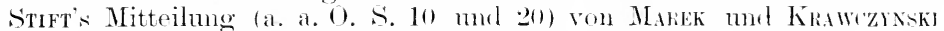
bestatigt: man fand in einem solelen Borlen 77.9.5 \% Feinsanul.

Diesen, noch von manchen anderen Beobachtern geteilten Anselanmogen gegenüber blieh die Parasitentheorie, die in Frowk ihren rifrigsten

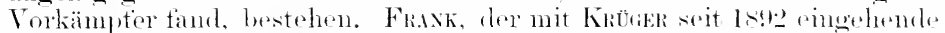

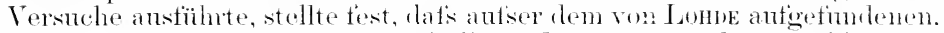
bei vielen Erkrankiungen von Keimlingspflanzen ans sehr verseloiedenen Gattungen vorliommenden Pythimm de Buryumm und antiser der von Em,

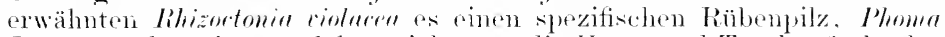
Is'tar Frank, äibe, welcher nicht nur die Horz- mod Troclienfäule der erwachsenen, sondern anch den Wurzellsand der jungen Rïlsen veruracht" 1). Die mamigtachen Erfahrungen bei Feldrersulhen liedien sellst diesen Forscher jedoch hald orkemmen, dats Wetter mol Bodenverhältnisse einen lestimmenden Einfluts ausiuben. .Es lileibt clalincestellt, ob daslurch das Pflänzchon tïr den Pilzhefall empfindlirher wird oder ob sich dies nicht genïgend dadurch erklärt, dats das Wachstmon durch das kalte Wotter verlangsamt und das PHänzehen ungerö̈hnlich

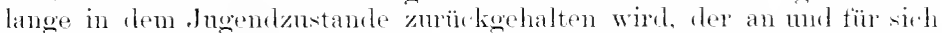
der krankheitsemptängliche ist, während eine Keimptlanze, dis durch

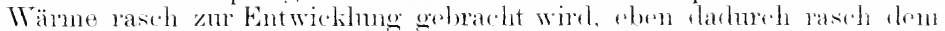
emptänglichen Kustande entwärhst mul der Gefale schmeller entereht."

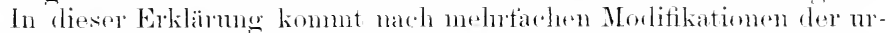

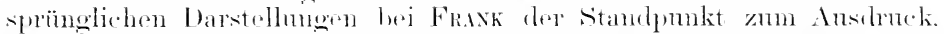
dats andiser diesem spezifischen Krankheitserreger, dem I'home, dorh

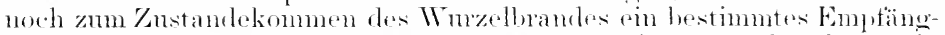
lichkeitsstadim des RübenpHänzchens gehört. l)ieser stamlpunlit wurk ron Sokalek schon trüher vertroten, wobei er nachwies, dalis Wurcellorand auch ohme das Vorhandensein des Phoma zu finclen sei. und dats statt dessen Bakterienvegetation die Krankheitserseheinungen begleite. Die eingehendsten Untersuchmgen über die Bakterien des Wruzelbrandes verdanken wir Hustek, auf dessen nene Studien wir in tolgenden besonders eingehen werden, nachrlem wir noch den standpunkt von

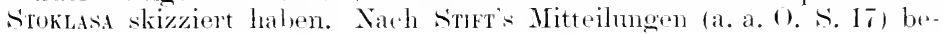
kennt sich auch Stoklasi zu der 'Tatsache, dats Bakterien den Wurzelbrand der Rüben zu crzengen vernögen. une er liält dazu folgende Arten für befähigt: Bacillus subtilis. B. liquefacions, 13. fluoressens liquefurims,

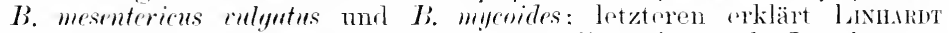
für den wesentlichsten S'chädiger. Nenerdings ist anch Psomlommos compestris genamnt worden. Die von den vorowannten Forsehern als schädlich hezeichneten Wittermos- mol Bodenverlä̈lnisse hält stokL.ssa für die Ursachen. Welche eine Prädisposition im Rübenpflänzchen erzengen. Er wendet seine Anfmerksamkeit spezirl] der Oxalsänre zu. die durch den Letrensprozets der Ptlanzo nomal gebildet wird mol als Kalimmoxalat vorhanden ist. Die giftig wirliendin löslichen Oxalate werden, wem Calcimmoxyd von den IVurelharen ans dem Boden antgenommen werden kam, zn den mulislichen

1) Fraxk, A. B., Kampfbuch gegen die Schädlinge unserer Feldfrüchtı. Berlin, Paul Parey, $18 \div \overline{7}$, s. 117. 
Calciumoxalat umgesetzt. J)meh diese Unschädlichmachung der Oxalsänce hört die lähmende Wirkmg dlerselben anf den Assimilationsfrozets anf, und die Pflanze gesunclet. Weun viel Salpetersäme im Borlen vorhanden oder gar im Ïbersehuts zugetührt wird (starke C'hilisalpeterdiingung), tritt allerdings eme Beschlemigung der Entwieklume, aber gleitheitig anch eine steigernng des oxalsä uregolialtes ein. In solehem Falle wird die junge Rübenptlanze, falls sie nicht genügerul halk aufnehmen kann, disponiert zum Wruzelbrancle.

I ie eingehendste Studie üher das Verhältnis der Bakterien zu der

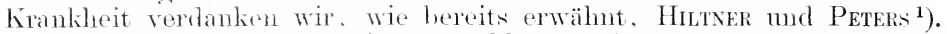

Die Tertasser haben eine Anzahl vou Versuchen angestellt und gefumlen, dafis es Erolen gibt, die tast niemals Wurzellnand anfkommen lassen und mugekelirt anch solche, bei denen die Krankheit kanm zu remmeilen ist. Sie sehlietien darans, dats manche Erden eine gewisse Sehutzliratt zu vorleihen imstande sind und erblicken diese schïtzende Eignschatt in der Fähigkeit der immmisierenden Erden, die Wurzeln (ler Rühenptlänzchen in ihren äntseren Zelhshichten mit solehen Mikroorganismen zu versehen, welche den Wurzelbrand erzengenden Pilzen und Bakterien das Eindringen verwehren. Diese schutzrcheide, die Hiltiner and PeTEss sehon trüher bei Erbsen ehenfalls beobachtet, nemen sie "Bakteriorhiza". Wurde die Bildume dieser Schntzscheide dureh sterilisieren der immmisierenden Erde und Abtöten der schützenden Borlenorganismen verhindert, so konnten die den Wurzelluand veranlassenden Pilze nud Bakterien, falls die samen nicht vorher geheizt wurden, anf die junge Keimptlanze übergehen und dieselbe zerstären.

Wie wenig aber die Organismen an sich zu fïrchten und wie die Hanptsache für die Erkranknng in den Umständen zu suchen ist, welche die Pflanze erst ampfïnglich fïr jene Kerstörer machen, greht am besten aus den eigenen Worten der gonannten Verfasser herror. Sie sacen (a. a. (). S. - 24!) von dem Resultat ihrer Versuche: . Dicses Erochnis aber lantet, datis die Eutstehums kranker Keime im Leimbett eine ziembich lomplizierte Erseheinmog darstellt. Sie ist nicht, wie man bisher fast allemein angenommen hat, anssehliefslich lara nt zurïclizuführen, dat's parasitische Pilze orler Bakterien den Kuäulen anhaften und von diesen ans anf die Wurzeln ïhergehen; lonn diese Oreanismen haben an sich nieht die Fähigkeit, die Rübrnw $n$ rednzur Erkranknng zubringen. Erst dadurch. dats die Wurzeln durch den Einflus bestimmter Stoffe, namentlich von () $\mathrm{x}$ alaten, in ihrer. Wirlestandstahigkeit geschwächt worlen, werdensiesonst harmlosen Parasiten zugänglich."

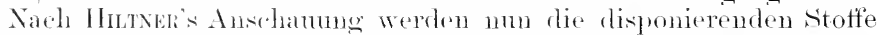
oder \%ustände durch Korsetzungen dor fewele an den Samenknäneh ontwoder anf dem Felde infolge nugiustiger Wittermo oder später auf Jem Lager durelı zu starke Erwärmung erzengt.

T̈her die Fördernug, welehe las Anftreten des Wurzellorandes da dureh tinclet, datis dis daboi vorzngwase beteiligten Mikroorganismen

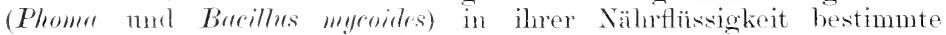

1) Hutxar, L., und Prthis, L., Intersuchumgen äher die Keimlingskrankheiten ler Zucker- md Runkelrähen. Arh. d. Biolog. Abt. f. Land- n. Forstwirtsch. am Kais. Gesundheitsamt, IV. Bd, Heft 3, 1904, s. 207. 
organische Verbindmugen vorfinden, berichtet eine Arbeit von sumn No ${ }^{1}$ ). Nachlem Verfasser hervorgehoben, dat's genamnte Parasiten a llein die Krankheit nicht zu steigern vermögen, erwähnt er, dals die \%ahl der kranken Rübenkeime aber erhöht wird, wemn (ilykukoll, Harnsäure, Asparaginsäne, Hippursäme, Lenem nsw. sich in den Xährlösmegen renamnter Mikroorganismen finclen mol die Räbenknänl. in diese Nährlösmgen eingequellt werelen.

Wir haben bei dieser wichtigen Kronkheit muächst die Ansehaumgen und Beohachtumestesultate, wie sie im lante der Zeit hervorgetreten, einfach registliert, $m$ zn zeigen, wio hei allen $B e-$ obachtern trotz ihres ganz versehiedenen Standpunktes doch eine Anwalce als roter Faten sich hindurehzieht, nämlich dor Eintluts des Bodens"). Dieser kommut am sehärtisten hei den schweren, abhindenden Böden zum Anschuck; er kamn sich anch bei anderen Äckern einstellen, wemn dieselhen durch irgemdwelehe Unstände verkinsten. Dere Faktor, der vor allen bingen nuter solchen Verhälnissen sich geltend maclen muts, ist der samerstoftinanged. Welde Voroünge in Borlen,

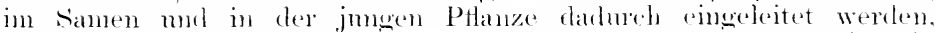
waren wir vorlänfig noch nicht zu präzisieren. Ehensowenge ist ein

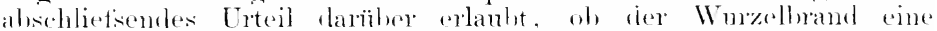
Konstitutionskrankheit, also eine zm Gewelezersetzmeng föhrende Ab-

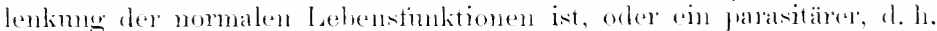

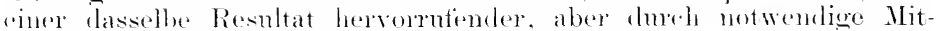

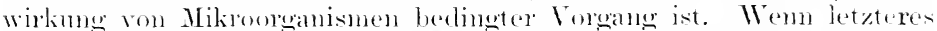

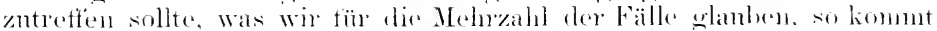

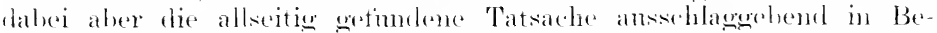

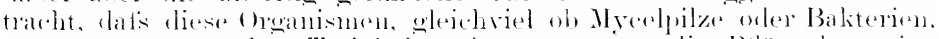

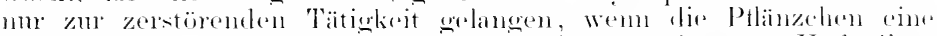

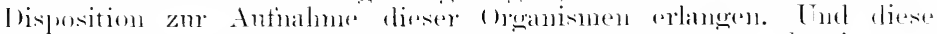
l) isposition ist rin Produkt des Stambortes muter bestimmten Wittermugrerhälnissen.

Also ist in rester hinie doch immer der Borlen dio nädeste Ver-

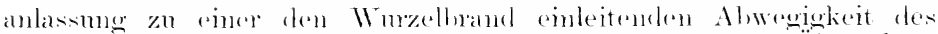

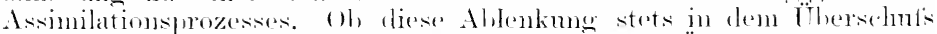

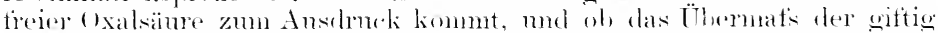

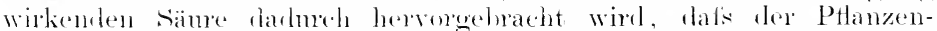

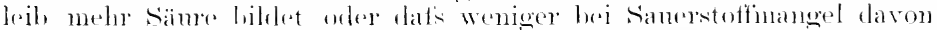

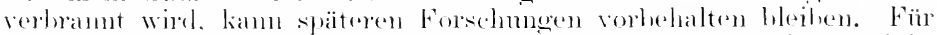

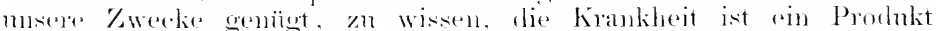

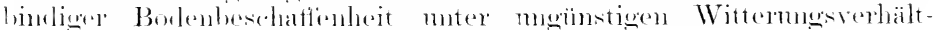

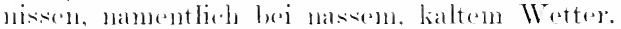

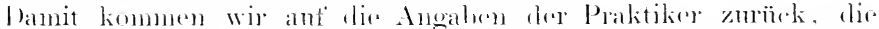

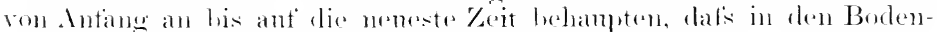

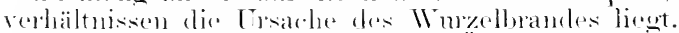

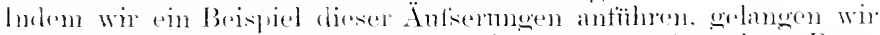

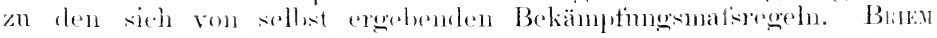

1) Wun. Stiman, Beitrïge zur Kenntnis des Wurzelbrandes der Rübe. Naturwissensch. Zeitschr. f. Lanu- u. Forstwirtschaft, 190.5, S. 212.

") Weiteres Material atis praktischen Kreisen findet sich in den Jahresherichten des Sonderausschusses für Pflanzenschutz. Dentsch. Landw.-Gescllsch. 1s!l2 his 1!nts.

Sorauer. IIandinch. 3, Aull. Er-ter liand 
berichtet ïher einen Fall ans den Jahren 1904 und 190:51). Anf einem kilargestiurzten Folde bei Prag wurden 1904 bei kalter, fenchter Witterung and langsamem Wachstmm die Fabrikrüben massenhaft wruzelhrantig, ohgleich bisher dort die Erscheinmo selten gewesen. Anch heilten sich später die Rühen vollkommen aus. Dasselbe Feld trug im folgenden dahre nach reicher Kali-, stickstoff- und Phosphorsäuredüngung wiederum Fabrikrïiben. Infolge der sehr nafskalten Wittermy ging die Saat erst nach 14 Tagen (am 24. April) anf. Die Befö̈rhtonng, dafs hei dem sehwächlichen Wachstmm infolge der kalten Nächte Wurzellsand wiederum sich einstellen würle, blieb wlïcklicherweise mbegrïndet, und die Anfang Nai eintretenden warmen Tage lirachten das arste Blattpaar zu schmeller, kräftiger Entfaltung. Als aleer am 20. Nai ein heftiger Regengnt's das Feld umgemein festgeschlagen hatte nur das Wasser nur langsam einziehen konnte, zeigten viele Pflänzchen nach fünf Tagen die Anfänge von Wurzelbranf.

Dieser Beispiel der Folgen des plötzlich eingetretenen Luftabschlusses in der rom Regen festgeschlagenen Erde zeigt, dat's in erster Linie das ständige offenhalten ier Bodenoberfläche durch Hacken gehoten ist. In zweiter Linie wird die Zutuhr von gebranntem Kalk empfohlen werden müssen, selbst wenn der Borlen kalkhaltig ist. Die Wirkmog des Kalkes wird nicht immer als Nährstotf in Betracht kommen. sondern als mechanisches Borlenverbessermusmittel, indem er die Krimelung erhöht. Anch superphos] hat hat unte Erfolge gezeigt ${ }^{2}$ ). Der Benntzmng eines möglichst lirättigen saatgutes ist in den gefährdeten Äckern erhöhte Aufmerksamkeit zuzuwenden.

Will man zur samenheize schreiten, was mserer Anschanme nach von zu geringem Vorteil ist"), so bediene man sich der Karbolsäurelösmng. '/um Beizen von 1/2 dz Rübensamen löst man 1,5 kg Karbol-

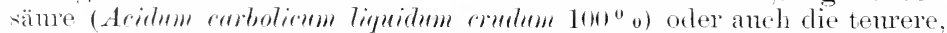
reine, kristallisierte in :3 hl Wasser. \%ur Prüfme der gewünschten Löslichkeit sthüttele man $0.5 \mathrm{~g}$ in 1 l Wasser wierlerholt durch: die bösmng muts in s his 10 Minuten arfolgt sein. Wenn nummehr die ganze Beiztlüssigkeit hergestellt ist, werden die samen hineingeschüttet und im Verlanfe der nächsten stumen wiederholt und liräftig nmcerührt. Sorlann heschwert man die Samen mit Brettern mil Gewichten, sn lats sie wänzlich von ter Flïssigkeit bedeckt bleiben. Nach etwa - St Stunden nimmt man die Samen herans und lreitet sie in dïnner sinhth in einem recht luftigen Ranme ans, wobei sie mehrmals mmzuharken sind. Sobalı das Saatgut wenügend abgetrocknet ist, kamm es gedrillt werten, kann aher anch, wem es vollkommen algetrocknet ist, lange Zeit liegen bleiben, ohne zu leiden.

Will man dir Beiztlïssigkeit mehrmals benntzen, brancht man nur den jeclesmaligen Vorhust dureh Nachgiefsen der greichen Lösmng zu ergänzen: dorh tut man hei der Billigkeit des Mittels gut, dieselbe l.oimg nicht zu oft zn verwendent).

1) Brun, H., Wurzelhrandentdeckung und kein Ende. Blätter f. Zuckerrülenbatu v. 15 . Juni 1905 .

2) Zeitschr. f. Pflanzenkrankh., 1896, s 54 u. 340. Landwirt, 1896, Nr. 15, 17 , 21. Jahresher. it. Sonderauschusses f. Planzenschutz, 1902.

3) Hurver in Mitteil. d. pflanzenphysiolog. Versuchsstat. Tharand. Sächs. landw. Zeit. 1904, Nr. $16-18$.

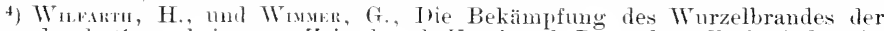
Rüben durch Samenbeizung. Zeitschr. d. Vereins d. Dentschen Zuckerindustrie, Bd. 50, Heft 529. 
Statt der Beize erscheint ms das Kandieren des saatsutes mit kohlensamem Kalk rorteilhatt.

Die Hanptsathe hleibt die Bodenbearlecitung: dem atch das rorsichtigst hehandelte, bei den Keimproben tadellos hofundene saatgut kam erlinanken. In dieser Brzirhumg gibt Howser in seiner vorerwähnten Arbeit sehr heachtenswerte IVinke. Es wirl bisher im Handel nach rereinbarter Methode die Gïte des Samens nach seinem Verhalten im Keimbett geprït. Num zeigt sich, dats die Menge der kranken Keime $n$ so höher steigt, je länger man die Knäule in Keimbett holätst. Die Versuche eroaben, dats wemn man z, B. lie Keime am nemten 'Tage dem Santkeimbett entnalnu, man oft meh. als zelmmal so viel hranke teststellen komnte als am sechsten Tage. Dazu kommt, dals wenn die Knäule dicht beieinander liegen, die gegenseitige Ansteckmng rine beträchtliche ist. Antserdem ist die Zahl der elkrankenden heime wanz verschieden, je nachdem man sie vorquellt orler nicht mol je nachdem man zum Vorquellen destilliertes oder kalkfieies oder kalkhaltiges Leitmoswasser benutzt. Zieht man sehliefslich in Betracht, dats die Bodenbeschattenheit ansschlaggebend fïr das spätere Verhalten der Keime wird, so kommt man zu drm sichluts, dats dir jetzt üblichen Methoden der saatontbenteilume kimen Sichntz mul

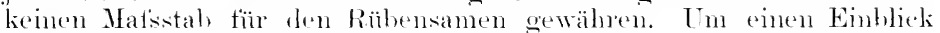
in lie Keinntähigkeit des saatentes zu erhalten, werlen die Rühenknänle in möglichst verschiedenen Keimbetten mil nach verschierlenen Methorden geprift werden mïssen $\left.{ }^{1}\right)$. Aber die hestril Kemmesmltate

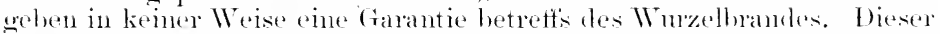
häugt in seinem Anftecten davon ah, ob die in den rertrockneten Blätenhüllen der samen vorhandenen Mikoorwanismen in Borlen (ielegenheit finden, sich derart zu entwickehn. datis sie die jumgen Ptlänzchen anzngreifin vermögen.

\section{Tropenkulturen.}

In Rüelisicht auf den von mir vertretenen Standpmukt, datis bei vielen muserer Kulturen den Borlenverhältuissen, namentlich der physikalisehen Bodenheschatfenhe it zo wenig Rechmmogengen wird, glanbe ich anch ant die Ansprëiche der tropischen Kulturptlanzen an die physikalischen Eigenschatten der Kulturländereien hinweisen zn müssem. Betreftes der tropischen Kultur stütze ich mich ant die Angaben ron Fesce 2), der mehrfach rigne Ertahrumgen mitzuteilen weifs, mel ferner aut die nenen Publikationen des Biologisch-Landwirtsehaftliehen Instituts: Amanil ${ }^{3}$ ).

1) Über Verschiedenartigheit der Keinung gleivhbehandelten riatgutes in sand und Erile vergl. die Miteilung von Mnk im Jahrb. d. Dentsch. Landwirtsch. Ges., 1-i.?.

2) Frsca, Der Pflanzenha' in den Tropen und Subtropen. Berlin, Süsserott. Bu. I, 1904.

$\left.{ }^{3}\right)$ Wie ohen gesagt, dienen die Angaben ibler die Krankheitserscheinungen tropischer Kultupflanzen hauptsächlich als Hinweis auf die Beachtung des Bodenund Witterungsverhälnisse als Krankheitsursache. Wir kömen ms bei ten Schilderungen $\mathrm{mm}$ so kïmer fassen, da eine reichhaltige Literatur spezielle titudien leicht ermöglicht. Aufser den bereits s. 6.5 bis 67 erwähnten /eitschriften bieten lie neuen Publikationen der Lsambara-Post wertvolles Material: .. Her Iflanzer", Ratgeber fuir tropische Landwirtschaft unter Nitwirkung des Biolowisch-Landwirtschaftlichen Institutes Amani, herausgegeben durch die Tsambara-Post. Tum. 
Wie wir sthen werlen, hamblet ss sich hei den schädigmoen,

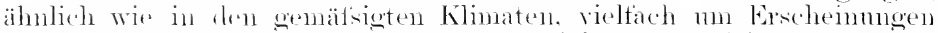
des sancestoftinangels, den schwere oder bei der Knltur sich verdichtencle Börlen zutage treten lassen. Nanche Ptanzen der Tropen sind in der

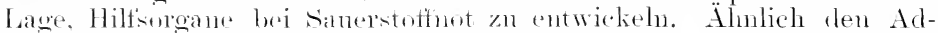
ventivwnzeln ans den stammorganen vershö̈teter oder verschlämmtel

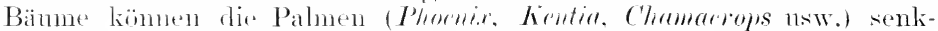
recht ans fer Ever hervorwathende Wuzelzweige entwickeln, die pine eigenartige Atmmugrorrielitung hesitzen (Pne umathoden): dieselle rischeint als ein mehliger Therzug, der von der spitze der Wurzel ans sich ant rine gewiste streclie ahwärts zieht. Diese mehlige Be-

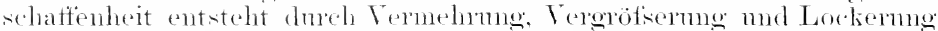

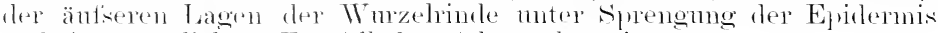
mul fast gänzlichem Forttall des sclerenchymringes.

Josti, stellte experimentell bei Phoenix fest, dats diese Pnenmathoden im Borlen rerbleiben, wenn dersello gnt dmelnlütet wird; dagegen erheben sie sich über die Toptobertiäche, wenn der Topt

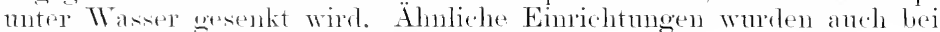
I'mulamis, Sactharmin num Cyporns getunden.

hie Wurzeltäule des ruckerrohrs.

Unter den zahheichen Krankheiten des Zuckerrohss spielt dio Tinzeltäule rine hervorragente Rolle. Auf' Java gilt sie als der schlimmste Feind der Zuckerrohrknltur. Es hat natürlich nicht daran erefehlt, die ant kranken Wn'meln side ansiedelnden Mikrooreanismen

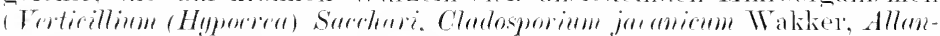

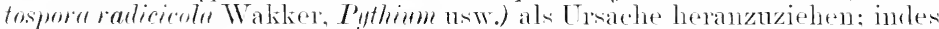

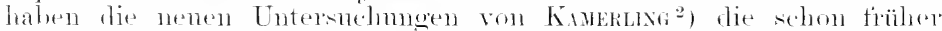

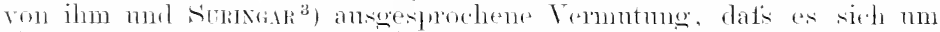

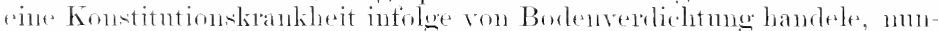

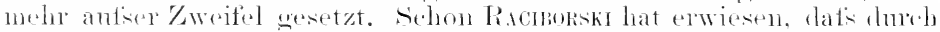

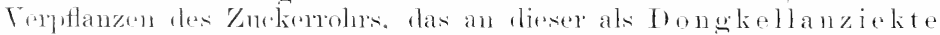

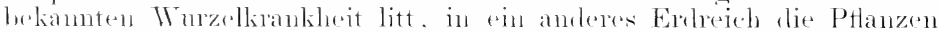
gesmul worden. Lie Krankheit tritt vorzngsweise anf schweren Ton-

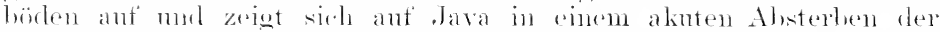

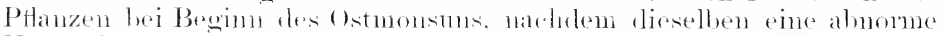

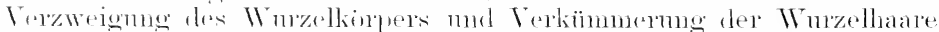

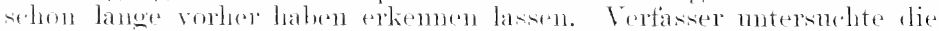

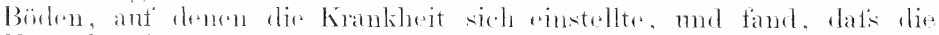

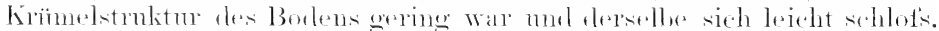

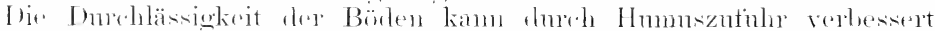

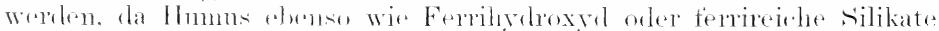

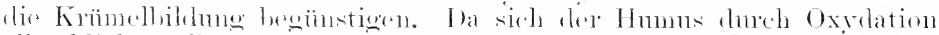

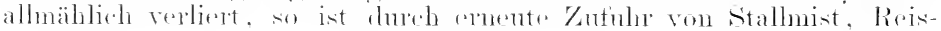

1) Josr, Ein Beitrag zur Kenntnis der Atmumgsorgane der Pflanzen. Bot. Zeit. $1>7, \mathrm{Nr},: 37$.

2) Kimburis, Z., Verslag van het Wortebot-lenderzoek, Noerabaia, 1903, 209 s. mit 19 Tafeln.

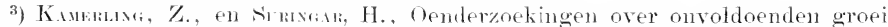
en ontijdig Afsterven van het riet als gevolg van wortelziekten. Iededeelingen van het Proefstation vor suikerriet en Wrest-Java, Nr. 4s; cit. Zeitschr. f. Pflanzenkr., 1901, s. 274, und 1904, s. st. 


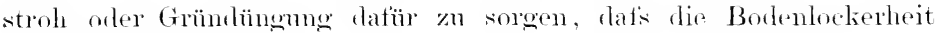
erhalten bleibt.

Nach den Stmolien ron W. Whek ${ }^{1}$ ) scheinen anch manche Blatt-

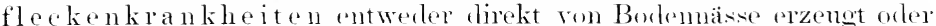
(bei parasitärer Natm) doeh dureh die Nässe herginstiot zu werlen. Der

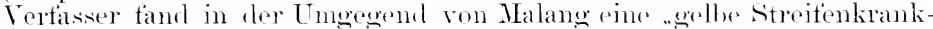
heit". .Rost", . Ringtleckenkrankheit", sowie lie rote mol gedhe Fleckenkrankheit. Während ex elie erstenenannten für parasitäre, durch die Nässe beginstinte Erseheimmgen ansieht, erklärt er lie gelle Fleckenkrankheit, bei der rlie Blätter etwas langogezogene, mitrinamble vershmelzemle, grïngelbe Flecke rhalton, tïr eine erbliche Konstitntionskrankheit.

\section{Krankheiten der Banmolle.}

Die Mehrzahl der Bammollkrankheiten ist zmrzeit nnter den parasitären Erscheimmoen zu snchen. Ob dies immer so bleihen wird, bezweifele ich. Mit der Überzenumg. dats viele der getmulenen Miliro-

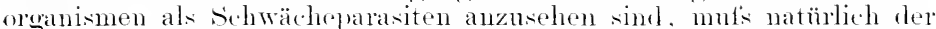
erst existierende Faktor als ausschlagoebend betrachtot werelen, nämlich

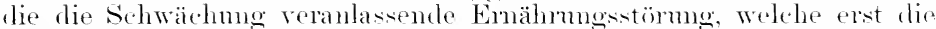
Möglichkeit für die Pilzansierllung bietet. Tnd rlese wirl in erster

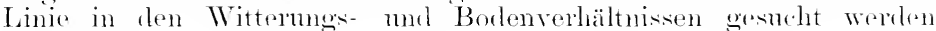
müssen.

Beispire von Krankheiten. hei denen der Borlen alloin hei dor nassen Jahreszeit als Ursache angesehen wird, werden ans museren ostatikia-

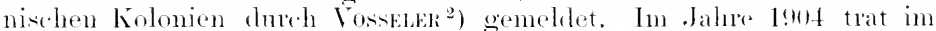

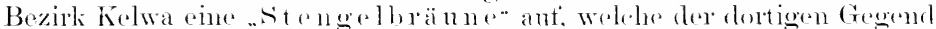

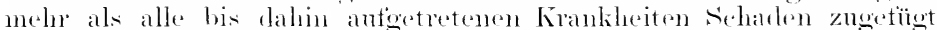

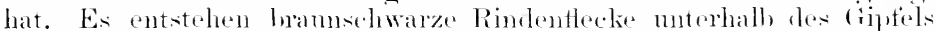

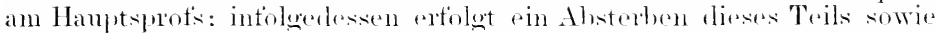
der oberen Nebensposien. Die Krankheit ersohien aber um anf sogenamtem samen Boden.

Eine zweite, längs der ganzen Käste verheerend anftretende Erscheinung war die Blattrotfleckenkrankheit. Die Blätter brkommen rinen blassen. mit zatchiger tirenze scharf gegen dir Imentläche abstechenden Rand. Dam rrhält das sanze Blatt erst dmbelpote Flecko oler gleichmälsige rote Färbmo. Womit oft rine Verkitionmmng der BlattHäche verbunden ist. Das Versehwinden des Ïthels hei cintretender 'Trockenheit dentet daranf' hin, dafs bei der herrschemelen nasien IVitterumg der Boden die Bammollknltur motinstig leseinflutst hatte.

Tosselek scheint anch zu vermuten, dats die getüirchtete . Wolkkrankheit" (Wilt disease) zu den klinutischen Krankheiten zu ziehen sei. mnd weist darant hin. daf's dureh Anzucht rom Pflanzen ans Samen gesunter stöcke in erkiankten Feldem immmne Rassen erzogen werden

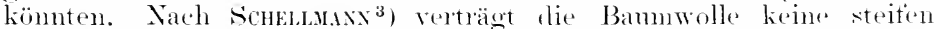
Tonböden und keine samren IInmusböden.

1) Wıккв, J. H., De Blalziekten te Malang. Archiev voor de Java-Śnikerindustrie, 189:, Aflevering 1.

2) Vonmar, Zwei Bammollkrankheiten. Immune Baumwollsorten. Mitteil. Biolog.-Landwirtsch. Institut Amani. 1904. Nr. 32.

Literatur.

3) Der Pflanzer. Usambara-Post 1905, Nr. 1. Daselbst atuch die altere 


\section{l)ie Ricinnskulturen.}

() bleich Ricinns in der smbtropischen und selbst in der gemäfsigten Zone noch gerleiht, kommt derselbe nach Zmmenuse ${ }^{1}$ ) doch als Kniturphanze betrefts fewimmm öreicher samen nur für die Tropen in Betracht, wo er von der Meeresküste bis zn einer llöhe von etwa

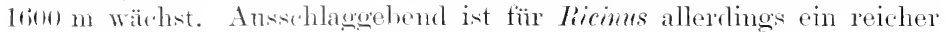
Nährstotfvorrat, da er solur starke Ansprüche an den Boden stellt. Demmächst verlangt die Pflanze grotice Wassomengen, solange sie in der vegetativen Periode sich befindet. Später aber spricht die physikalische Bodenheschatlenheit mit, indem alle Böden, die nicht drainiert sind und damerul fencht bleiben, die Knltur nicht godeihen lassen. Diese Beobachtmoen in den Tropen stimmen mit den Erfahrungen, die wir bei der Kultur von Ricinus als Kierptianze machen, überein. Kur reichen Entfaltung kommen die Pfanzen nur, wenn sie einen grotsen Bodenranm und lockere, nährstoffreiche Erde zur Verfügmug haben. Bei der Anzurht in Töpfen, denen man durch l)üngesalze viel Nahrung zutühren will, rerschlämmt die Erde, nud die Ptlanzen bleiben klein mol schwächlich.

\section{Der Tabak.}

Ein sehr lehrreiches Beispiel über den ansschlaggebenden Einfluts des Bodens liefern die Beobachtungen von Hunatr ${ }^{2}$ ) über die Entwicklung des Deli-Tabaks und sein verschiedenartiges Verhalten gegenïber der "Nosaikkrankheit", über welche in dem Abschnit ïber die enzymatischen Krankheiten ansführhcher berichtet werden soll.

Ein Boden ans weifsem Klei, sagt Huvier, der viel sand beigemengt enthält, ist bei gïnstigen Niederschlagsverhältnissen der beste für diinnblätterigen Tabak. aber zugleich anch für das reichliche Anftreten der Mosaiklsankheit in der Form des sogenamnten "Kopfbunt". Hier macht die PHanze den Eindruck des "Tberwa chsens": lange Intrmodien, gelbgrïnes Laub, nach hem Köpten zahlreiche seitenspossen, welehe sämtlich erkranken.

Fehlt dem Kleiboden jedoeh der sand mo wird er lehmartig, dam wird er für dir 'Tahakkultur unbranchbar. Der WVurzelkörper der PHanze ist gering entwiekelt mol häufig verkiömmt; die Blätter zeigen mnichtige Längenverhälnisse mul besitzen geringe Qnalität. Die Mosaikkrankleit tritt hier schon ein bis zwei Woehen nach dem Verpflanzen ant. Die roten Terwitterungshöden von Ober-Langkat sind zirmlieh test: die Pflanzen sind hier gedrungen; die ticht ïbereinanderstehenden Blätter sind nicht besonders dïm, und die Mosaikkrankheit kommt wonig ror: sie rseheint nur ansnahmsweise ant den

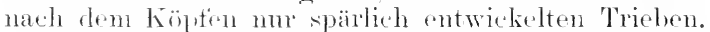

Ant den surarzon humuseichen Böden zeigt der Tabak eine enorme, wohl proportioniorte Entwicklung: die schr grofsen Blätter sind dunkelgriin mond dïmn. Mosaikkrankheit hänfig.

Auf drom torfähnlichem, poräsen, mit grofiser Wasserkapazität ver-

1) Zimmenux, A., Die Ricinus-Kultur. Der Pflanzer, Ratgeber für tropische Landwirtschaft muter Mitwirkung des Biologisch-Landwirtsch. Institutes Amani, heranse. durch d. Isambara-Post.

2) Zeitschr. f. Pflanzenkrankh., 1905, Heft 5. Hixicr hat als Botaniker der Tersuchsstation für Deli-Tahak (VIII. Abt. d. Bot. Gart. zu Buitenzorg) das um$f$ assendste Beobachtungsmaterial zur Verfügung gehabt. 
sehenen Paja-Boden tritt die Mosaikkrankheit tast gar nicht anf. Die enormen Blätter welken fast niemals in dem wasserhaltenden Boden, sind aber sehr dick mel ölreich, werden boi dom Fermentieren immer dunkelfarbig und sind daher nicht sehr preiswert. Ant nenem Paja-Boden kam iman anch duch Köpfen keine Mosaikkrankheit hervorruten.

\section{Kaftioe.}

Der am meisten Beachtmog verdienende Bam unserer Tropenkultur, der Kaffee, ist besonders empfindlich gegen extreme Borlenbeschaffenheit. Obgleich ihm Trockenperioden nicht zusagen mul or am liebsten in einem Erdreich steht, das anch zu Keiten der Dïrre sich firisch erhäl, so verträgt er doch Trockenheit noch hesser wie Bodennässe. Wenn er während der Regenzeit nur wenige Tage versmmpt, soll er nurettbar dem Tode vertallen. Himeichende Wasserkaprazität des Erdreichs rerbunden mit reichlicher Durchlïftung sincl somit llauptertordernisse. Ein frisch gerodeter Waldboden wird als besonders günstig tïr die Kaffeeknltur bezeichnet. Wahrscheinlich sind der selwarze Rost (sucute rost) und dic Krebskrankleiten (Natalkrebs und Javakrebs) (Djemer oepes) mit ihren Cambinm-Erkrankungen physiologische störumgen, die durch mpassende Boden- mud Wittermosverhältnisse eingeleitet werden und spätere Pilzansiedlungen zur Folge haben. Gegen undurchlässigen Borlen soll der liberiakaffer nitht so empfindlich wie der arabische sein mol noch dort gerleihen, wo der letztere versagt ${ }^{1}$ ).

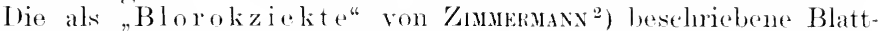
krankheit scheint mir auch hicrher zu gehören. Die Blätter hekommon wolkige, gelbe Flecke, an denen die Oberhant später einsinkt und der Zellimhalt sich bräunt. Die Bäume auf Java werken zwar nicht davon getötet, aber in ihrer Fruchtharkeit auliscrordentlich herahgedrückt.

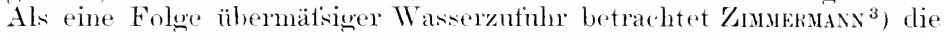
bei Coffor librica selten, hei $C$. arabira häufiger auftrotenden sogen. .Sternchen", d. h. vorzeitig sich öfnende, noch nicht vollkommen entwickelte und daher unfruchtbar bleibende Blüten. Dir Erseheimung ist nicht mit der mnter gleicher Bezeichnumg gehenden Sehwarzfärbung der Blïtenknosuen, die sehliefslich nugeöfthet abtallen, zu verwechseln. Tersehiedene Arten von Wuzelschimmel sind beschrieben und als Ursache von TV uxzeltäuls angesprochen wordent); ich elaube, dats man anch hier zu sturlieren haben wird, ob diese farasitären Pilzformen nicht erst dam schärllich eingreifen, wem die Wurzehn bereits rumeh moïnstige Emälımesserhältnisse geschädigt worlen sind.

\section{Kakao nud Toe.}

Betreftis des Kaliaolia umes sagt Fesca: „Extreme Bodenarten, sowohl magerer sand, wie zäher Ton sagen dem Kaliaobaume nicht zu. Hinsichtlieh Tiefoüurligkeit, Frische. ohme an Grunclwasser zu

1) Dunanor, G., Les maladies et les ennemis des caféiers. II édit. Paris, Chalamel, 1900 , s. 8.

2) Tersmannia 1901, s. 419.

3) Eenige Pathologische en Physiologische Waarnemingen over Koffie. Merledeelingen uit S'Lands Plantentuin. LXVII.

4) Bolletim del Instituto Fisico-Geographico de Costa Rica, 1901. 
leirlen, sowie an Humms mol Nähstoffgehalt stellt derselbe noch höhere Ansmö̈he als ler Kaffee." Über den Tee äutsert sich derselhe Antor, der in Japran selbst gnte Teebölen analysiert hat, dats er im gesetzterem Zustande derselhen 30 bis to\% Wasser bei kapilarer sätignng gefumlen hahe. ler Tee verlangt einen himeichend tieforiundign Boden, ler frei von stagnierendem Grundwasser ist: wegen letzteres ist ex seln empfindlich. Anch hier wird ein noch nicht näher bekamnter Pilz als Urachr einer Wnzelkrankheit beschieben: er soll, hesonders auf nassem Boden, rin fiühes Absterben der Sträncher zur Folge laben: jedoch versichert Fesca ${ }^{1}$ ), dats die Krankheit auf gut durchlüfteten B̈̈rlen nicht von ihn jemals gesehen worden sei. Anf unzusagenden standont möchten wir auch die von Zimmerunc ?) beschriebene Erkranknug junger Teeptlanzen zuriektïhren, obwohl ein mit gelappten Hanstorien versehenes Myeel in den Krankheitsherden beobachtet worten ist. Die Blätter erschlaffen und werden mifsfarbig: der stengel brännt sich an der Basis ofler an höheren stellen, während das Threlwerk gesund erscheint. Manehmal zeigen nur die Blätter, namentlich am Hamptnerv, hame Flecke. I ie von den kranken stengelteilen zur Entwicklun acbrachten Pilze (Nectrieen) komnten hei Imptrersuchen die Krankheit nicht hervornfen. Bei trockner Wittermo liets die Krankheit bedentend nach. Anch das Verptlanzen der Keimlinge von den diehten saatberten fühte zu rinem stillstand der Krankheitserseheinmoen. Wenn hier in möglichster Kürze der Bodenansprïche mserer hauptsächlichsten tropischen Kultuphlanzen gedacht worden ist, so mul's noch hinzugefügt werden, dat's natiurlich das Klima der ansschlagodonde Faktor bleibt. Unter diesen klimatischen Faktoren wird anch der Luftenchtigkeit hesondere Anfmerksamkeit gewidmet werlen müsisen, da dic Gïte der Ernte oftmals wesentlich davon abhängig ist. Bei den Kakaokulturen in Kamerm z. B. lätst sich beobachten, datis die quantitative Produlition der Bämme eine ungewöhnlich reiche ist, aber die Qualität der Frïchte infolge der grotsen Fenchtigkeit nur mittelmätsin ist. Hier leben sich die Bämme anch schnell ans.

\section{Anderweitige Tropenkulturen.}

Ton den Getredegräsern ist es zunächst der Ma is, der emen tiefgründigen, mürlhen, von (irmulwasser freien Boden verlangt und zähen Ton nicht vorträgt. Ebenso verhält sich Sorghmm, das noch empfindlicher gewen balte Nässo ist als der Mais und wegen seiner tiefen Bewruzelumg sehr widerstandsähig gegen Dürre sich zeigt. Daher der Anban in der tropischen mul subtropischen Steple. Ganz moeeignet füru feste Börlan, rorzüglich aber in lockeren Bodenarten an dürren (G)tlichkeitun ist die Neger-oder Pinselhirse (I'misetum spicatum). Die anderen Hirsearten verhalten sich ähnlich.

Die Lay minosen, die wewen ihrer meist knzen Vegetationsdaner zum Anlau als Nathifucht sich besonders eignen, dïrtten für die Tropen nud subtropen nicht num als Stickstotisammler mel als

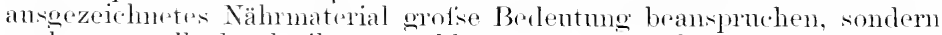
auch wertroll chrch ihur geschlosisene, vor Verhärtmos schützende

1) A. a. O. ค.. $27: 3$.

2) Zimmmix, Untersuchungen über tropische Pflanzenkrankheiten. Sonderberichte ibber Land- und Forstwirtschaft in Dentsch-Ostafrika, Bd. II, Heft 1, 1904. 
Bodenbeschattmog und als lockernde (rröndüngmesptlanzen werten. Ein gutes Gerleihen zeigen die Ptanzen in trocknen Böden. mul temgemä1s werden ihmen in Gegenden mit reichen Nichlersthlägen schwere Böden rerderblich. Eingehendere Studien ïber Sorghm-Krankheiten

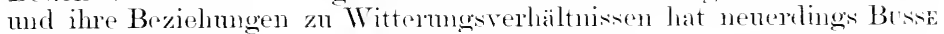
geliefer't $\left.{ }^{1}\right)$.

Von den Knollengewächsen beansprucht dic Batate etwa dieselben Kulturbedingmeng, wir hei uns die Kartoffel. Anch die Cassaven (Mamiok) verlangen ticforïnligen, losen, trocknen, aber

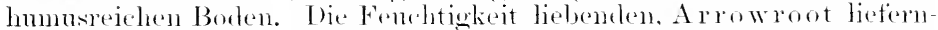
den Maranta-Arten beanspruchen ebenfalls Lockerheit des Borlens: daher erweist sich jungtränlicher Boten wegen seiner Festigkeit wenig geeignet. Sellst Taro, dir knollen der versehedenen ColorasiaArten, welehe schr viel Fenchtigkeit beansunchen, gerleihen dorh nur

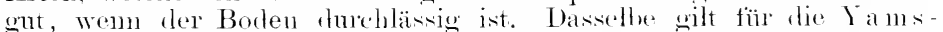
wurzel, die von rersehiedenen Arten der (iattung Dioscorea gewommen wird. Betreffes der Mohmkultur mol Opimmgewinmme sei ant die Aplest

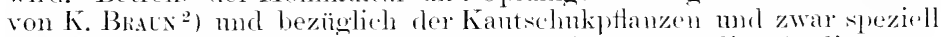
des Lianen-, Wurzel- nud Kränterkantsehnls ant die sturtien vom Zinukimano ${ }^{3}$ ) verwiesen.

\section{Mittel zur Beseitigung der Nachteile schwerer Böden.}

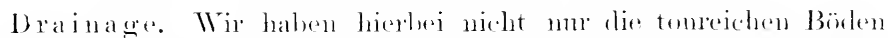

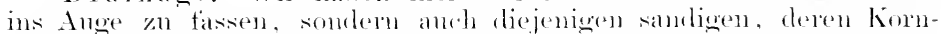

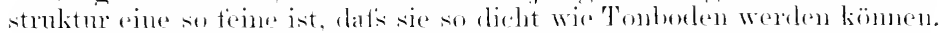

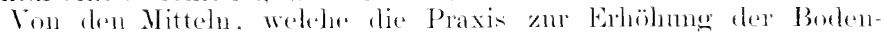

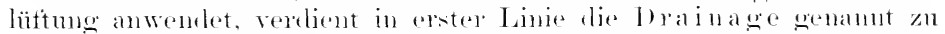

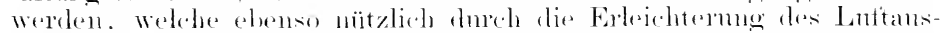

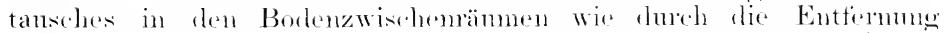
stagnierender Massermassen wirkt. Her Drainstrang wirkt nacle jedem Regen wie oin Luttiangapparat. Wem der Regen kommt muld die Bodemänmo anstïllt, nimmt er die gegenïber res Atmosphäres sanerstotfämere, alore kohlensänrereichere Luft fort. La aber der Regen

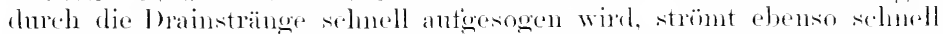

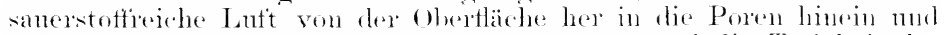
erhöht somit die Oxylationsvorgänge im Borlen mud die Tätiglieit dere

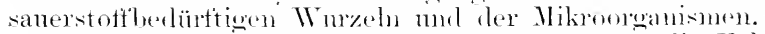

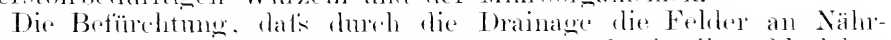
stoffen veramen, ist wohl nur selten zutrotfend, da die zahluedeluen

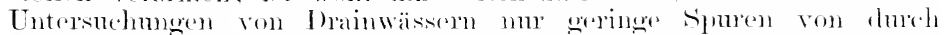
die Krmme alsonhiertem Kali mol Ammonials sowio ron Phorphorsäm

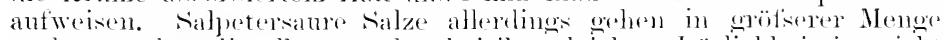

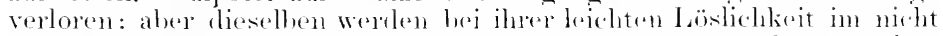
drainierten Boden ehenfalls trilwejs in den Entererund gewaschen werden.

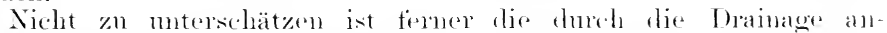
wachsende Erwärmbarkeit der Böden nud die dadurch erzengte lin-

1) Wantra Brsse, Cntersuchungen äher die Krankheiten der Sorghmm-HIirse. Arb. d. Biolog. Abt. f. Land- a. Forswirtschaft a. Kais. Cresumdheitsante, Bil. IV. Heft 4. 1904 .

2) Der Pflanzer, 1905. Ni. 11, 12.

$\left.{ }^{3}\right)$ Terselbe $1905, \mathrm{Nr} .-10$. 
bessermug der Emte, von welcher man im allgemeinen sagen kam, latis der nasse nud deshalb kalte Boden nährstotfärmere Produkte liefert. Warmm der nasse Boden ein kalter ist, ergibt die Betrachtmon, lats, wem das Wasser eine spez. Wärme = 1 hat, die höchste spez. Wärme, die ein Boden üherhampt zeigt, nur =0,5 ist, also höchstens die Ilältte derjonigen des Wassers beträgt. Entfernt man also durch lhamage den schwierigst zu crwämenden Körper, so nuts der Boden wärmer werden. Tor der Irainage bleiht der Boden im Frühjaln lange kalt, was ein suateres Erwachen der Vegetation, ein späteres Keimen der samen reranlatist. Ein kalter standort tïn die junge Pflanze wirkt doppelt störend, da er eine Verzögermog der Ausbildming gerade in einer fïr die wanze suätere Ptanze matsgebenden Entwicklmngs phase hervorntt. Ile Bewnzelung wird dïrtig, das Anssehen siech, und suatere gïnstigo Temperatmverhältnisse vermögen den schaden nicht melor anszubesiern. Als Beispiel mag einer der mit Winterroggen von

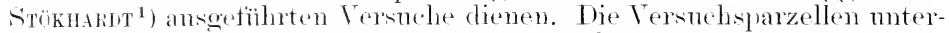
sthieden sich dmeh Lrainase und Bodenlockerma. Eine Parzelle

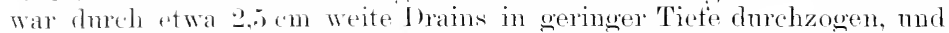
zWar drorat, dats an einem Ende des stranges die knieförmig gebogene Rïhre schomsteinartig nach der Bodenobertläche mïndete. Diese, sowie oine zweite Parzelle ohne Drains waren s() cm tiet gelockert, wähend eine dritte nm 20 cm tief gegraben und nicht drainiert war. In Bestäigung fröherer, mit Lmpinen, Ilafer n. derol. erhaltener Resultate roab die Ennte, obgleich die jungen PHanzen his zmm Frühjah keine Untersehiefle zeigten, pin erhebliches Plus ant der drainierten Parzelle. Pro Morgen berechnet, betrug die Ernte

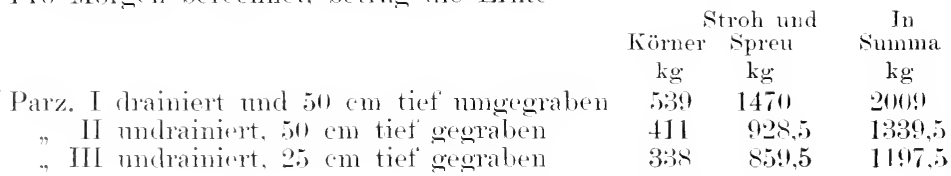

\begin{tabular}{|c|c|c|}
\hline & $\begin{array}{c}\text { löruergehalt } \\
\text { ro sicheffel } \\
\mathrm{kg}\end{array}$ & $\begin{array}{c}\text { Stickstoffgehalt } \\
\text { ler Körner } \\
\% \%\end{array}$ \\
\hline Parzelle I & $4(1,51)$ & 2,18 \\
\hline,$\quad$ II & $: 3(4,4,5$ & $1,8: 3$ \\
\hline III & $: 37,70$ & $1,6: 3$ \\
\hline
\end{tabular}

ت̈Her den Nutzen der I)rainage zur Entfernnng von Eisen ans Nonhröichen sagt Piтz"): "(rewöhnlich findet man das Eisen mmittellar muter der Ackrolkmme "mot zwar in ler Höhe des gewöhnlichen Grmulwascerstandes. Ilas cirmulwasser bringt das Eisen mit nach oben und verkittet in vielen Fällen in der gewönlichen Höhe des Grundwasserstandes die Sandkönehen im Boden derart, dafs man sehr oft bei Anstïhrmng siner I rainage sinen harten, steinähnlichen, roten Borlen findret. Inureh Ilerstellume ainer richtig systematisch angelegten Drainage. wobei die Horizontalen von den saughains rechtwinklig furchsehnitten, dio letzteren mindestens eine Tiefe von 1.2 $\mathrm{m}$ haben und die Entfernmo zwischen je zwei Drains anf das Zelunfache der

1) Chemische Ackersmann, 1859 , ร. 292 : 1861, S. $100 ; 1864$, S. 22.

2) Hannoversche landw. Keit. 1880 , Nr. 45; cit. Biederm. Centralbl. t. Agrik.('hemie, 1880 , S. 911. 
Tiefe angenommen ist, wird der Grundwasserstand his zur Tiefo der Drains niedriger gestellt und dem Boden oberhall, der stränge kein Eisen mehr zugefïhrt. Das bereits vorhandene Eisen wird rluch die atmosphärischen Niederschläge gelöst mul den Drainsträngon zugefïhrt, orler es verbleibt tem Boden als mochälliches oxyd."

Bodenbearbeit nng. Da, wo es sich nicht min die Fortschattiung ïberflissigen Wassers hamfelt, werden statt der Inainage das Rigolen nnd Tiefpetlïgen oft am Platze soin. Dabei wirl dam Vorsicht geboten erscheinen, wenn anf eine fruchthare Ackerkmm ein chrch das Rigolen oder Pflügen an die Oherfläche zu bringender toter Untergrmol in Ansicht steht. Anfser jeclesmaliger Löngung dart dam nur allmähliches Vertiefen der Krmme in Lanfe mehrerre Jahes statfinclen. Da mit einer Vertiefung der Krmme die Erweiternng des Wruzelnetzes jerler Ptlanze mul demgenäts die Erhöhnng der Ernte dintritt, also auch eine grölsere Ausmutzmer des Bodens stattfindet, so ist rime zunelumende Dinngerzufirh mit der zunehmenden Bodenlockerung gelonten.

Bei den zur Konstenbildung geneigten, sonst physikalisch nicht moïnstiog gebanten Böglen genïgt zur Erhöhnng der Bodenventilation las Hacken nnd Behänfoln. Diese dem Landwirt mel (iärtner kamm genng zn empfehlente Manipnlation, die anf jeden Borlen Verwenthug finden liam, reguliert die Bodenfenehtigkeit.

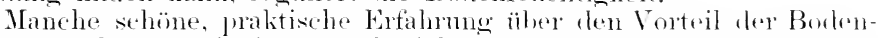

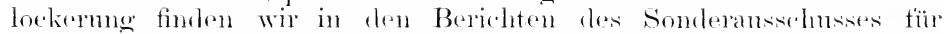
PHanzenseluntz bei der Dontschen Landwirtselafts-desollsehatt. Wir entnchmon ein einziges Boispied, das sich anf veroleicheme Versuchs-

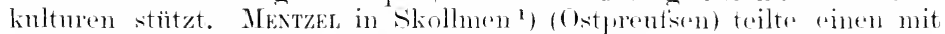
sehwedischem Weizen, Eppwizen nnd Koströmer Weizen im liemenge hestellten Adker in zwei Treile mol hiolt eine Hälfte dessolben durch Anfeggen nach jerlem Regen bez. dmeh Anfonblibem nit dem Federzinken-Kultivator welockert, während bei der andern Hältes diese

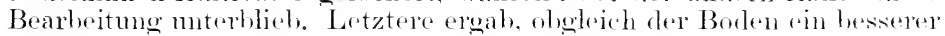
war, pro liektar $21^{3}$; dze erstere dagegen $26^{1}$ ? dz.

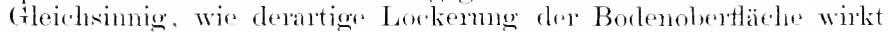

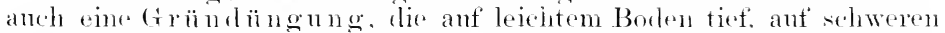

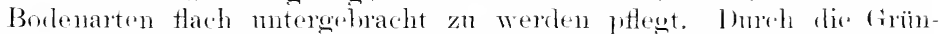
dïngung wird nämblich der kapillare Anfstiege des Wassers ans den darmenter liegonden Bodensehiehten mterbochen²). Einersats wirel die Erhaltmig der Fenchtigleit in den tieferen sichichten leichterer Böden 'rhalten: andererseits wird bej sthweren, nasson Börlen für eine Anssaat eine gut durchlüftete Krume geschatfen, so dats die samen normal keimen kïmmen. Die ans dem orfährlirhstrn Keimmessarlium horansgetretenon gekräftigten Pflanzen vermögen dam die nach $/+x^{3}$ setzung rles trïndungs wieder kapillar stärker anfsteigende Bodrunässe besser zu ïberwinden.

Dn rehfrieren. Von hörhster Berlontung für die Kultur schwerer Böden ist ihre winterliche Lockermo durh gehöriges Inmchfriren. Bedenken wir, dat's das Wassor beim Ühergang zu Eis eine Vermethrumg seines Volmmens mo nahezn ein Elftel erfährt. so wird mus kiar.

1) Jahresb. d. Sond.-Aussch. f. Pflanzenschutz. Arb. d. Deutsch. Landwirtseh Ges., Heft 107,1905, S. 64.

2) Kinc, F. H., Tenth Annual Report of the Agric. Exper, Stat. of Wisconsin, 1884 , s. 194. 
dats durch die Eiskristalle die dichter liegenten Bodempartikelchen anseinanderoedrängt werlen. I) a antsertem tie Gesteine von einem Netz teiner sualten $\ddot{i} h$ rezogen sind, in welche Wasser sich allmählich hineinzieht. so arbeitet der Frost andh heständig an dem Zerfall der festen Gesteine und zwar mm so intensiver, je ïter Auftanen mol Gefrieren in Lante des Winters miteinander abrechseln. Natürlich wird die Schnelligkeit der Wirkmng ron der Bodenbeschaffenheit, bez. dem Vissergehalt ahlöngen: ju geringer derselbe ist, desto schmeller und tiefer werden die Frostemperatmen eindringen. Somit werden die schweren mul die Humnshirlen am langsamsten gefrieren und anftanen. Welchen Torteil die Bodenlockerme dureh Frostwirkmng gewährt, zeigen die Versuche von Wobliy ${ }^{1}$ ). Wersellye liefs im Herbst von drei Parzellen

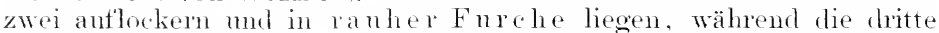

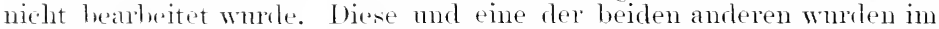
Frähjahr mmgegraben, wähnend die dritte blots oberflächlich bearbeitet wmole. Es zeigte sich nun, dats hei den verschiedensten KulturQewächsen lie Erträge der in Herbst nicht in rauhe Furche gelegten Parzelle am geringsten waren. während die im Winter in ranher Furche chrchgefiorene mol im Frïhjalı noch eimmal gelockerte die reichste Erite nab.

Berlecknng der Krome. Wir liommen jetzt zn den Vorteilen, welche schwere Böden durch das Bedecken der Krnme mit strenmaterialien elangen, nachdem wir früher des Schntzes solcher Bodenberlecknng bei leichten Böden bereits redacht haben. Der nächstliegende Vorteil ist der. dafs die Deckmaterialien dadurch. dats sie den Schlag der Regentropfen antfangen und das Wasser nm leitend der Bodenoberfäche mitteilen, das Znsammenschlagen der Borlenteilchen verhäten und infolgedessen die Krmme lockerer halten. In Banmschnlen keimt die saat anch gleichmätiger anf bedeckten Beetru. Das Unkiant wohert nicht so stark und kamn, da es oberflächlicher in lockeren Boden wmett, leichter und vollständiger vertilot werilen.

In dem porösen Material der Thecke erzengen die starken luftschwankmoren zwisehen Tag und Nacht starke Taubilibung: der abfliefsende Tan kommt dem darmuterliegenden Boden zugnte und beförlert seine Gare. Benntzt man Lohe in 1 his $1^{1}{ }_{2}$ Koll Höhe so bieter dieselhe in Winter den saatheeten eine Decke mol im Frülijahr Sehntz vor dem Eindringen der Fröste nnd ror dem Zerklüften des Borlens.

Bei samen- und kileinen Pflanzheeten wird man gut tun, im .Juni ofler Juli zu begietisen. In Angust wird behackt, mud wemn die Lohe zn tief unter die Erde kommen sollte, werken nachler die Blötsen mit nener Lohe bodeckt. Gegen die dabei nuremeidlichen Maikäter helfen Lockhantin ans antenchichteter, sich erwämender, fenchter Lohe. In diese Hanfen legen die Maikäfer ihre Eier, nnd diese Hanfen werden mit einem Tril der daruntreliegenden Erde anf den Wagen geladen nnd mit Bramkohlenasche. Kalk. Gips mol organiseheu Alfällen zn einem Komposthanfen verarheitet, ler nach sin lis zwei Jahren anch die Engerlinge zmm Absterben bringt. - Ein Verfahren, das schliefslich hier noch Frwähmmog finclen dürfte, ist rlas

1) Wouxr, E, Üher den Einflufs des Winterfrostes auf die Fruchtharkeit der Ackererden. Biedermann's Centrabl. 1902, s. 301. 
Anfeggen.

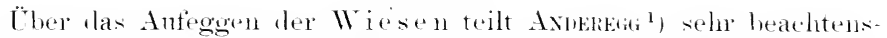
werte Ergebnisse mit. Eine IViese von gleiehmätiger Bomlenheschaftenheit mul Benarbung worde in vier gleich grotie Parzellen geteilt: dieselben ergaben

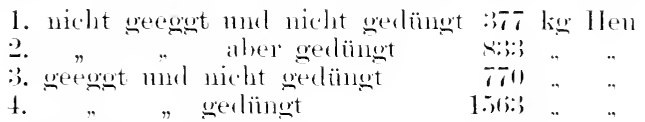

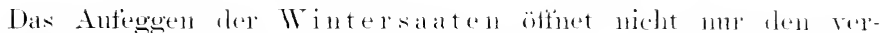
kinsteten Boden wieder, sondern erhöht anch wesentlich die Bestorknne.

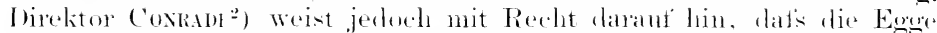
nm dann hranchbar sein wirt. wem die Kinste niedit allon diek ist nud der Borlen nicht zo hindig erscheint. Anch muts man. wem eine

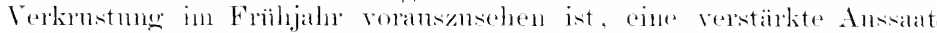

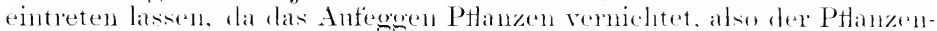

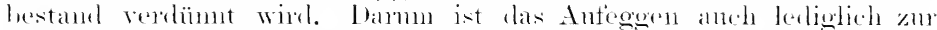

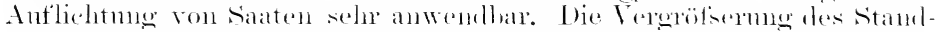
rammes für die strhengebliebenen Pflanzen bedingt eine erhöhte Licht-

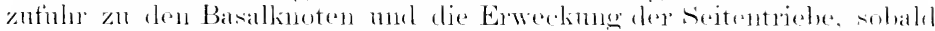

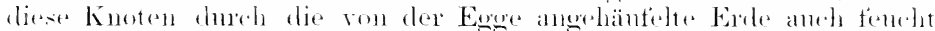

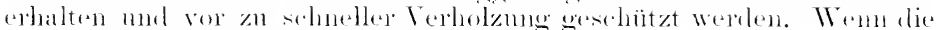

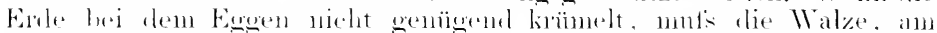

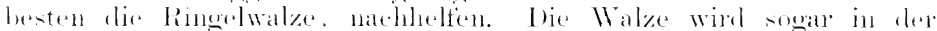

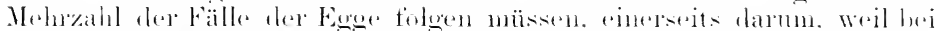

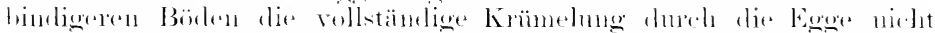

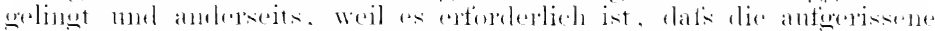

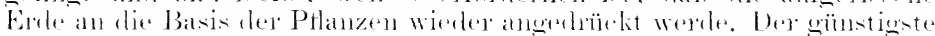

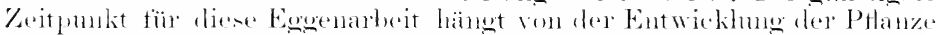

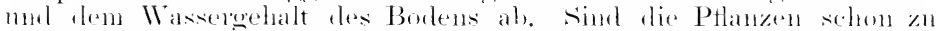

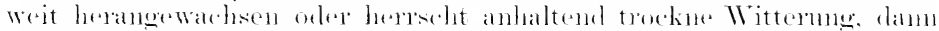

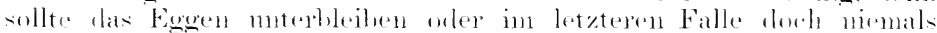
wher natehtolgentes Walzen ansegetïhnt werdent.

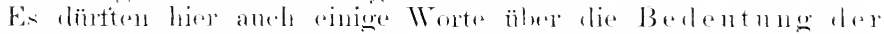

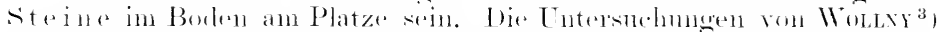

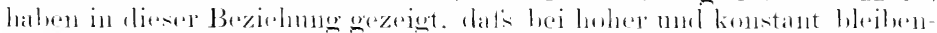

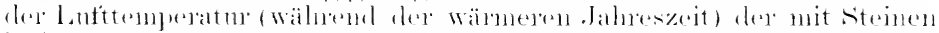

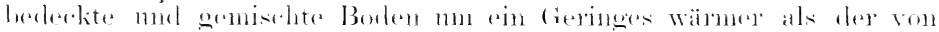

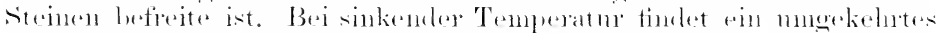

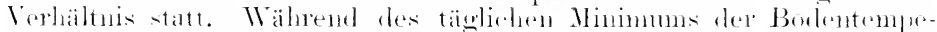

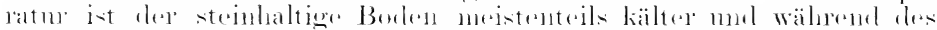

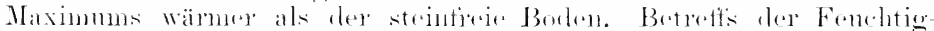

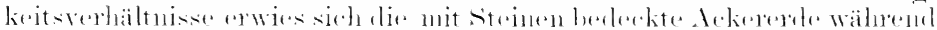

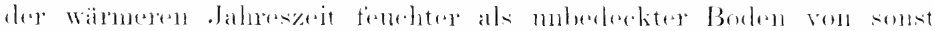

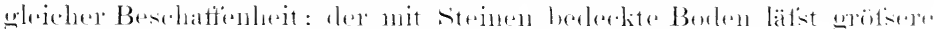

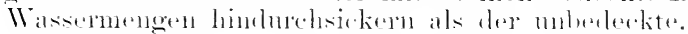

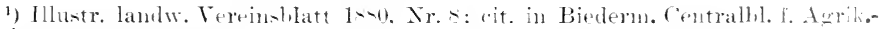
Chemie. 1-it) s. 69:

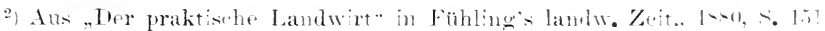

3) Winsw. Fühlings landw. Zeit. 1s=n, s. :31t. 


\section{Kalken. Mergeln. cripsen.}

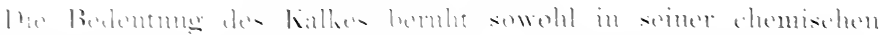

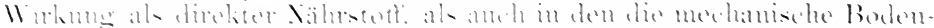

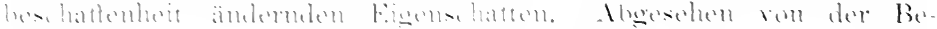

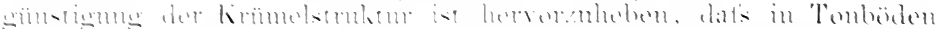

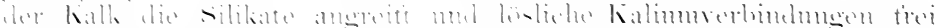

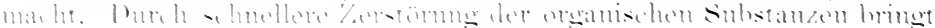

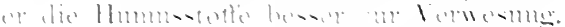

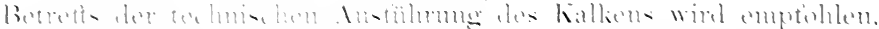

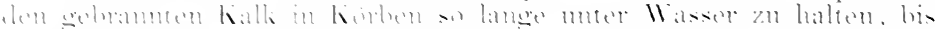

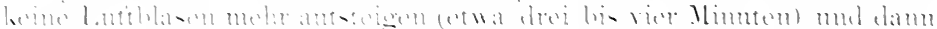

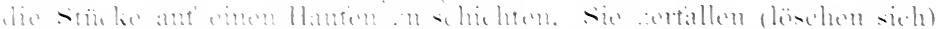

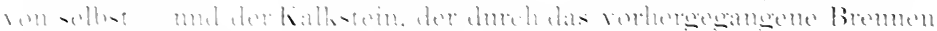

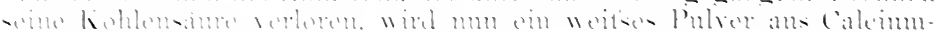
Solmovil (

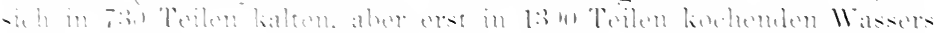

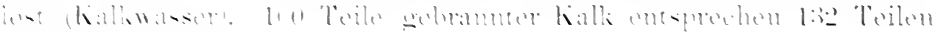
whlowing killin.

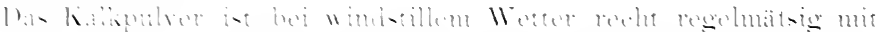

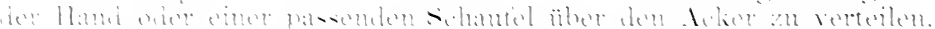

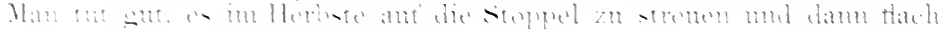

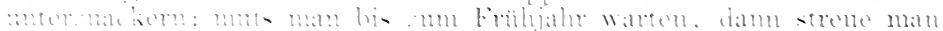

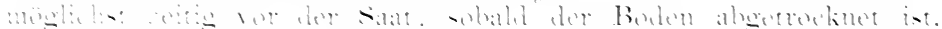

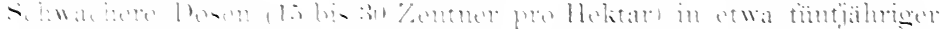

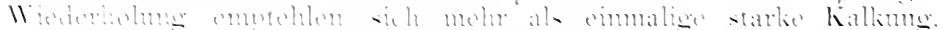

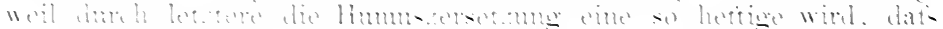

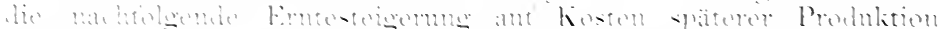

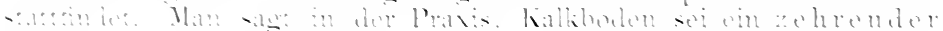

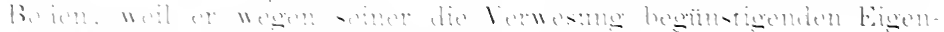

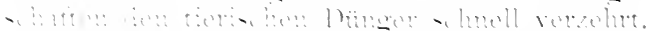

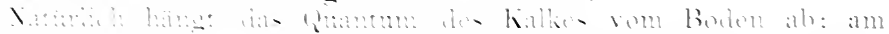

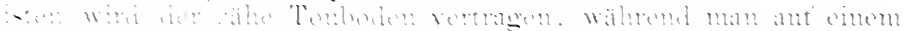

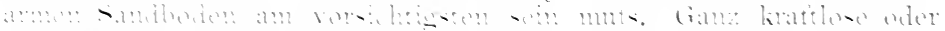

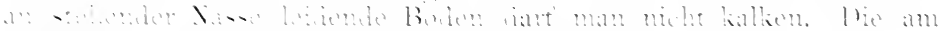

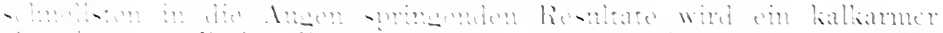

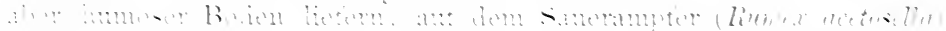

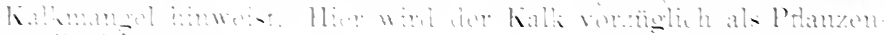
$\therefore$ ant 11 kin

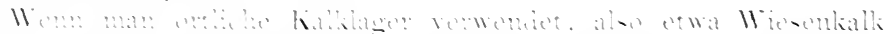

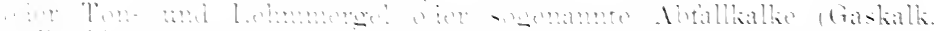

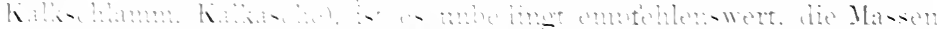

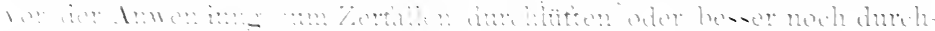

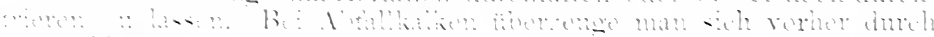

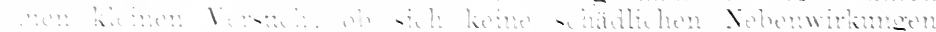

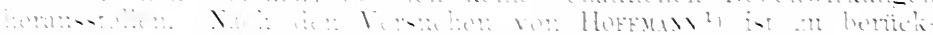

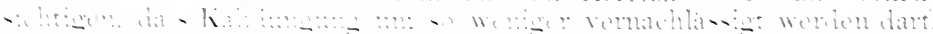

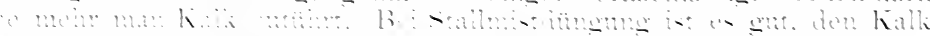

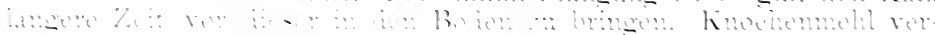

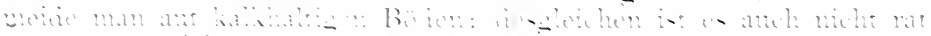

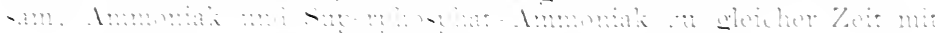




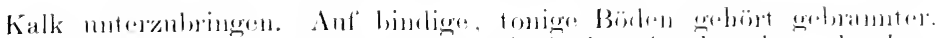

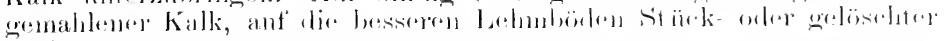
Kalk.

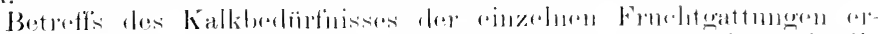

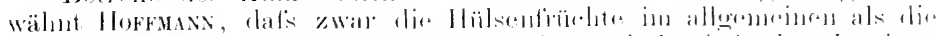

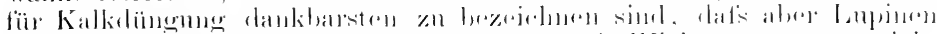

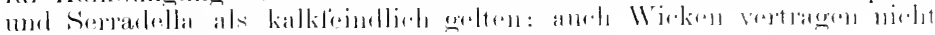

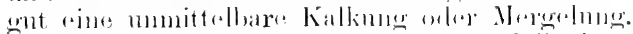

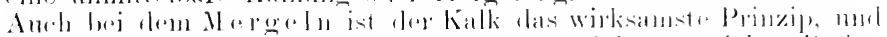

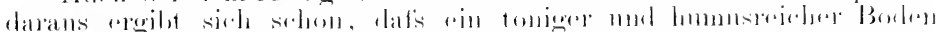

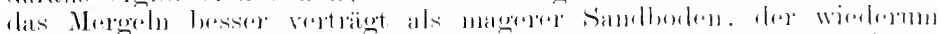

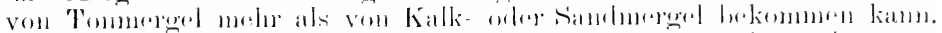

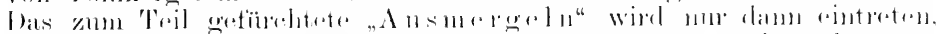

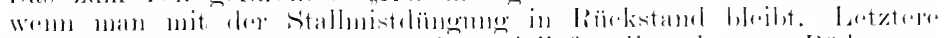

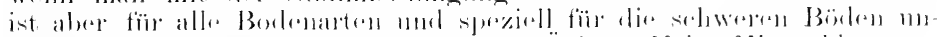

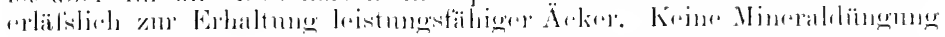
liamm stallmist ersetzroll.

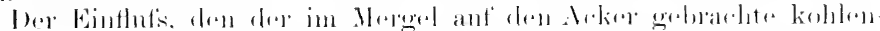

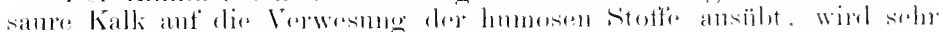

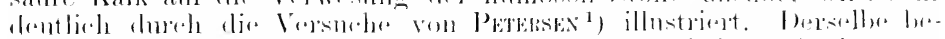

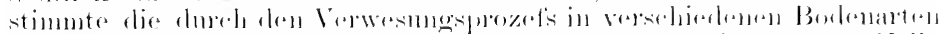

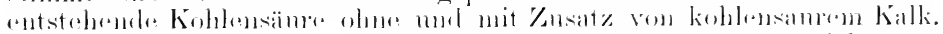

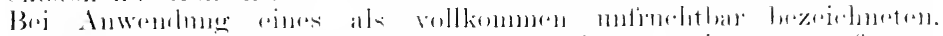

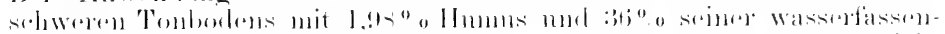

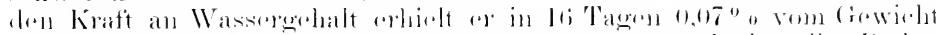

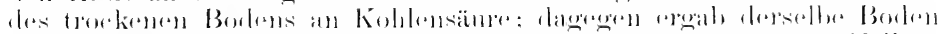

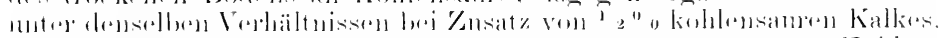

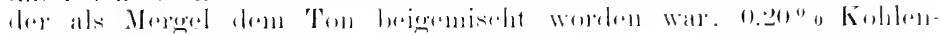
äint? orler

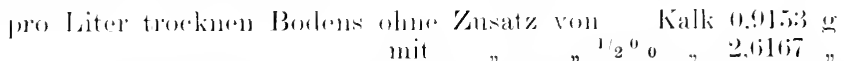

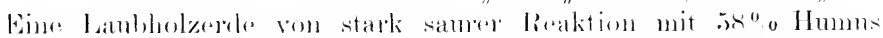

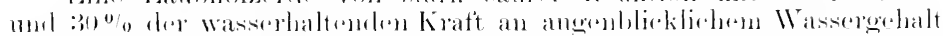

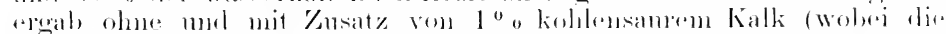

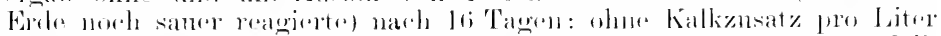

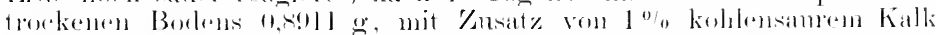

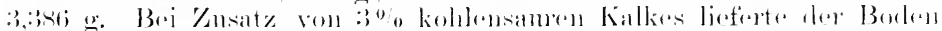

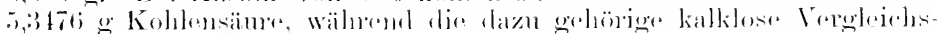

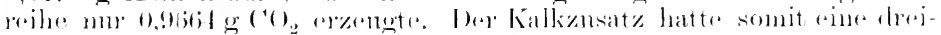

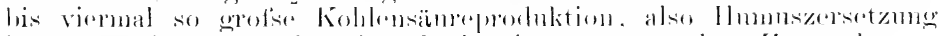

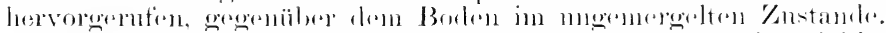

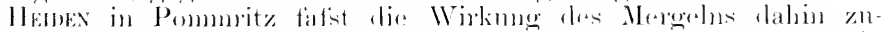

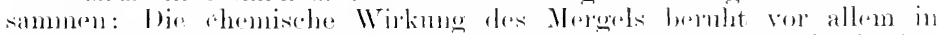

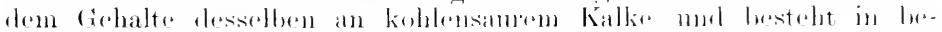

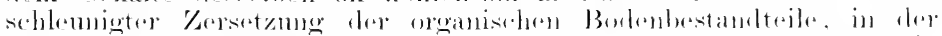

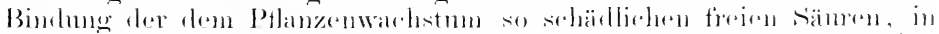

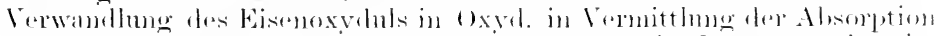

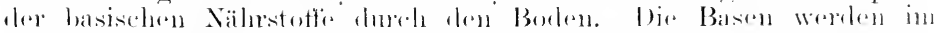

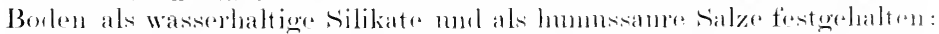

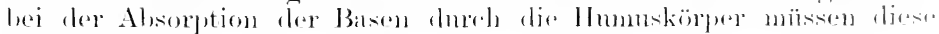

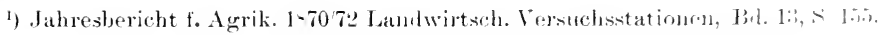


Basen an Kohlensäne gebnnden vorhanden sein. Die Vermittlung der Bilchue von kohlensatron salzen hewirkt der Kalk. Es werden ferner dir mineralisclen Bestamelteile des Bonluns zersetzt, wodureh die ba-

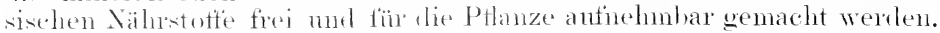

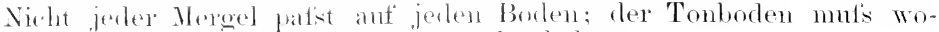

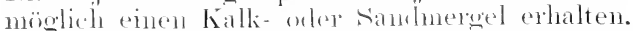

Gegeniibur diesen imblimken Vorteilen zeigt sich die direkte Wirkmer des Merogelns in der Kufuhr ron Kali, löslicher Kiesel-

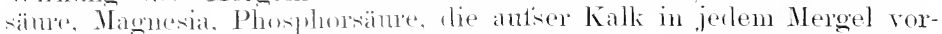
lintulen sind.

Einige IVonte seien lifer anch ïher das Gipsen angefüht. Bekannt

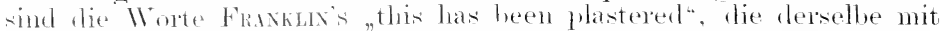

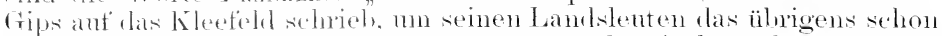

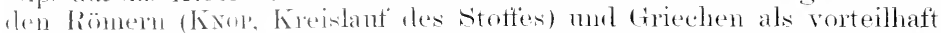
helannte Verahnen zu mupfehlen. Nath den Versnchen von Knop,

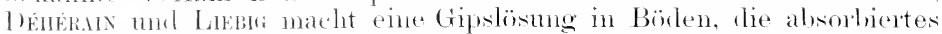
kali puthalten, dasiselhe als schwefelsames salz firei. währent sich Kalk nialershlägt. Die von der Praxis empfohlene Methorle, den

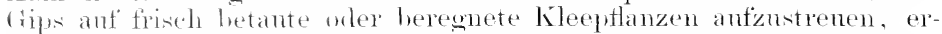
kliit sich daturch als vorteilhaft, dats anf clen nassen Pflanzen sehon

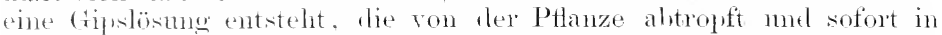
ler nädsten Nähe dex. Wurzehn wirksam werden kann. Sie wird lamm schnell fïr die Bakterientlona vorteilhaft, da die Untersuthmegen von

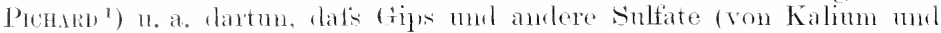
Natrimms anf den Nitrifikationsprozets einen höchst günstigen Einfluts ansïlen. (tips ist in nugeluanntem Zustande zu verwenden, nud zwar

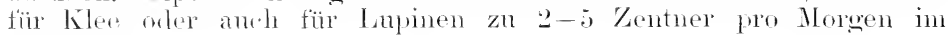
Frïilijalıs.

Viem oben von dem die Verwesmog begünstigenden Einflnsse des

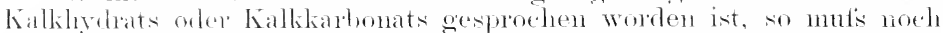

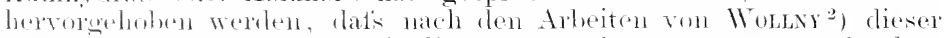

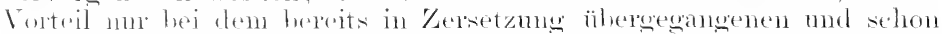

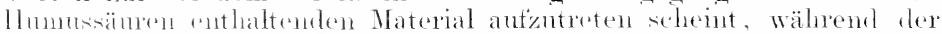
kalkzusaty anf unzersetzte oreanisehe sulstanz die Verwesmog eher

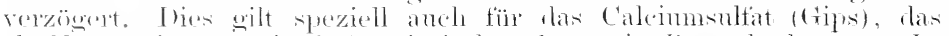

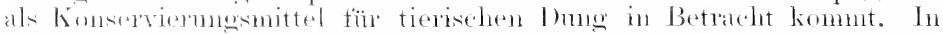

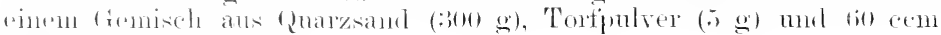

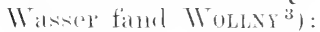

\section{Tolunen Kohlensiure in 1000 Volumen Bodenluft} ohne Gipszusatz nit

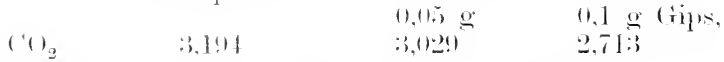

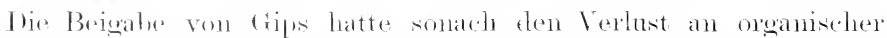

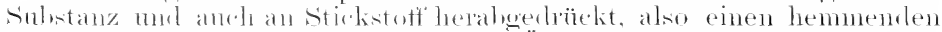

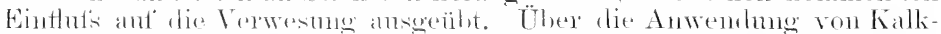

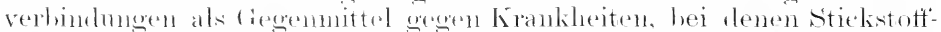

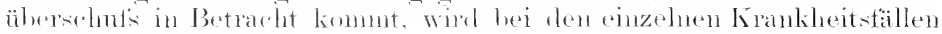
gerinochen werken.

1) Amales agronomiques $\mathrm{X}, \mathrm{F}$. 2302.

2) Worcx, E., Die Zersetzung der organischen Stoffe usw. Heidelherg, carl Winter, is: s. Sis:

3) Joumal f. Lamdwirtschaft, 1866 , s. 2653. 


\section{Die Nachteile der Heideböden.}

\section{Die Säuren im Boden.}

Als Heiden erklärt Ramax ${ }^{1}$ ) die Formationen fenchterer Gebiete der gemä1sigten Zonen, in denen nährstoffarme, saner reagrierende $B$ äden von zwerghaften stränchern, Halbstränchern, Gräsern, Moosen mul Tortinoosen, sowie Flechten bedeckt sind.

Es handelt sich hier um die freien Hnmnsänren, welche die saure Reaktion des Bodens verursachen. Bei der Zersetzmug der organischen substanz im Borlen, wobei antiver Baliterien anch Irveelpilze sicher.

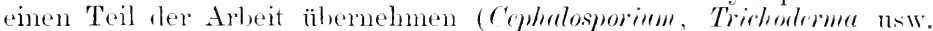

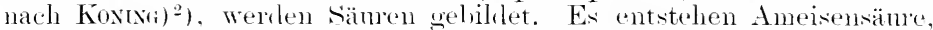
Essigsäure, Buttersänre nsw. die in gnt durchlüfteten Börlen hald wieder zersetzt werden. Antserdem aber bilden die Humnsubstanzen die noth wenig erkamte (quellsäure mit ihren Salzen (Krenate), die in Böden und Wässern reichlich verlneitet, eine gell, gefärl,te, stark sanere lösmug larstellt und zu einer amorphen Masise eintrocknet. Während die Salze der Alkalien mul alkalischen Erden löslich sinul, bleibt iln Eisenoxvilsalz unlöslich. Bei Luftzutritt entsteht ans iln Quellsatzsä ure (Apokrensäure), deren Salze schwer- orler mulöslich sind. Thesen säuren und ihren Verbindungen darf man einen grotisen Einflut's ant die Verwitterme und den 'Transport der' angreiflarm Nineralstofte zuschreihen ${ }^{3}$ ). Rohhmons, Tort' und andere stark saner reagierente Borlensulstanzen verlieren anch nach längerem Lagern an

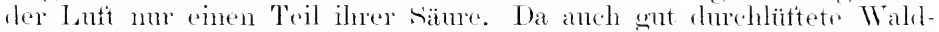
börlen oft same Roaktion zeigen, so gedit daraus hervor, dals cines

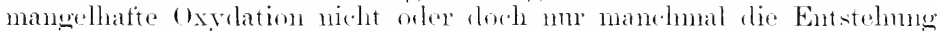
der Borlensäuren veranlatst. Wir werden wohl anch hier die Arboit hestimmter Bakterien als Ursache dirser sänehilhlmg anzmsehen halren. Freie sänen fehlen oft in reichen Börlen: ämmere Heilebörlen sind reich daran und verarmen noch mehr. weil durch die freiens sä̈nen weitgehente Answaschmugen und Verwitterungsprozesse fortwähreml stattinilen.

Betreffs der Empfindlichkeit mserer Kulturptlanzen wegen freje Sämen zitiert Ramox die Versuche von NAXWELL, ${ }^{4}$ ), der mit 1/10 mul ${ }^{1}$ so prozentiger Lösma von Citronemsäure experimentierte. Er fanıl, tats alle Cruciferen schnell, die Papilimaceen langsamer zumpunte gineren. Die Getreidearten litten stark: nur Perlhirse mul Mais widerstanten. Bezüglieh der Hummsänen liegen Erfahrungen von Touf vor,

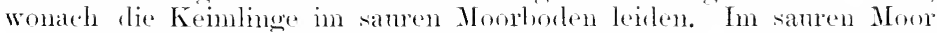

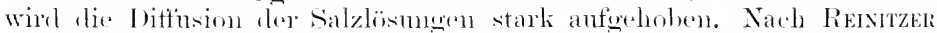

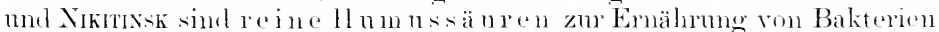
mol Farlenpilzen mugeeignet: dagegen vermögen die neisten höharen Pflanzen einen mätigen (iehalt an diren sämen zu ertragen. Aus unseren Kultmen von Eriken, Azateen. Rhodorlentron mud anderen Ericaceen in Ileideerle ertahnen wir, dats eine Anzahl ron Pflanzen an saure Böden sogar direkt angepalst erscheint.

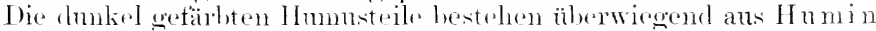

1) Rumsx, Bodenkunde, II. Aufl. Jul. Springer. 1905.

2) Kusisi, Arch. néerland. se. ex. et nat. 1902 II), 9, s. :34.

3) Rimis, a. a. O. S. 144.

4) Journ. amer. Chem. Soc. 189\&, 20, ‥ 103.

sorauer, Handbuch. 3. Aufl. Erster liand. 
mul Hnminsänle (Ulmin nach Mluner). Die Hummsstoffe muls man als ein fiemenge einamler nahestehender Körper mit und ohne stickstott ansurechen. dic man mach ihrem Terhalten zu Alkalien in

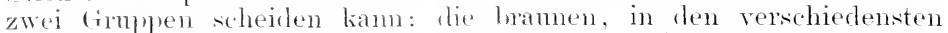
Lösmosmitteln mü̈slichen Huminstotfe quellen mit alkalischen Flïssigliriten ant nnd vehen allmählich in Humnsäumen ïher. Die in ihrer

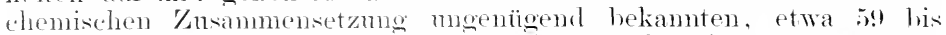

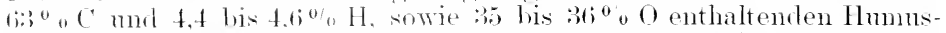
sämen lösen sich leicht in Alkalien und werden ans ihren Lösmngen curch stärtiere Nincralsinuen wiefler ausgefällt. Wenn man sie aus sanren B̈̈rlen (Moorlö̈len) mit Alkalien ofler Ammoniak anszieht mud mit salzsänre ansfällt, «hält man eine volmminöse gallertartige Masse. welche beim Trocknen brame oder schwarze, amorphe stïcke bildet. Beim Gefrieren werden die Humussäuren ans ihrer Lösmng als dunkelwefärbtes Pulver ahgeschieden, das allmählich wieder in Lösmmg übergeht. Rumax hetont, dats die Hummsämen in reinem Wasser etwas löslich sind, nicht alser in salzhaltigem. Die Salze der Alkalien und les Ammonialis mit den Hummsäuren sind in Wasser löslich, aber nicht die der alkalisehen Erden (Kalls und Magnesia): doch scheinen letztere bei Gegenwart ïberschïssiger säuren auch löslich zu werden. Hummsanrer Kalk wird schnell durch Verwesmog in kohlensanren Kalk übergeführt, der nene Mengen von Humussäuren zu binden vermag.

Der stickstoffgehalt der hmmosen Substanzen ist durchschnittlich in trockenen Gebieten grötser als in fenchten. Durch lie fortschreitencle Verwesmo wird ter in organischer Bindung den PHanzen schwer zuwängliche Stichstoff in leichter anfnehmbare Verbindungen ïbergefüht.

\section{Rohhumus.}

Torteillaft und mentbehrlich ist der Humus nur dann. wenn er in seinen reinen Lagern oder seinen Mischungen mit dem mineralischen Bodengerüst einer ständigen Durchlïftung neben genügender Befenchtung zugänglich ist. Seine Hanpteinwirlsung anf das Pflanzen. wachstum Gosteht nieht in seinem Nährstoffochalt nud der mineralienlösenden Kohlensäme bei seiner Terwesnng sondern in seinen physikalischen Eigenschaften.

Wenn man den Humms mit festen Bodenarten vermengt. Hockert man sie murl marht sie wärmer und leichter hearheithar. In Sandbïrlen wirkt der Hmmus festigend mot steigert die Wasserkapazität. wodurch dis Temperaturschwanknugen weniger sehrott werden. Diese

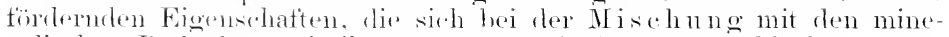
ralischen Bodenhestandteilen erochen, schwinden, solbald der Humns in einer geschlossenen selicht dem Borlen auflagert, also nicht flureh reichlicho Verwesmen mul die Arhrit von Mikrooreanismen geliömelt ist. In geschlosion anflagernelen Hummsecken ist der Gehalt an freien Sämon fast immer ein hrolentender. Diejunigen Waldböden sind die besten, in denen dis Humnsinlstanzen am solmedlsten zersetzt und verarbeiter worden. In wamen Klimaten geht die Aplueit am lebhaftesten vor sich.

Bei gïnstiger Hlmmuzersetzung sehen wir in Waldhöden die lockeren Waldabfäle, welehe dis strensehicht darstellen, won geringer Mächtigkeit und in mmerklichem Ïbergange zu einer gekrïmelten, stärker zersetzten, struliturlosen Itumuslage. Fehlen in einer Gegend 
die die Verwesmo begïnstigenden Faktoren, dann erhalten sich die

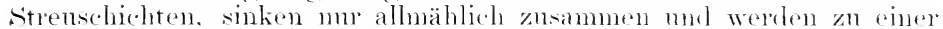
festen, faserigen, hmmosen Masse, die dem Thtophorlen anforelagert nud mehr ofler weniger seharf von ihm getrement bleiht. Solvihe Fälle lassen sich in armen, namentlich ortstrin fïhrenden sandlörlen besobachten.

Dieser Prozeds, bei dem also die oromische Sulstanz keine erelige Besehattenheit erlangt, wirl ïherall da anftreten, wo moünstige Verwesmosherlingungen vorhanden sind. also \%. B. hei Abschluts dor lanft

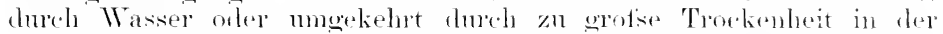

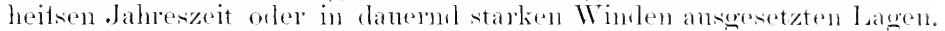

Am meisten geneight zm Bildumg derartig faseriger nul wenig erliger Ifumuschichten, deren matretzte Bestandteile in dichter Masse dem Boten sich anflagern mul anf diese Wrise den soge.

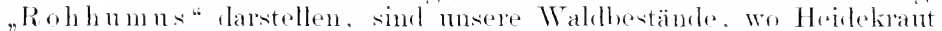

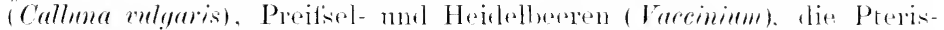
und Aspidimmbïsche nud die polstebliblenden Moose wathsen. Die obere sichicht solcher Roluhmmslagen zeigt noch die in ihrer struktur erhaltenen PHanzenabfalle miteinander vorweht: die tiefere Lago, bei der die Pthanzentede nur noch wenig im rinzelnen nuterseheidhar sind. stellt eine faselige, dunkle, von Wnrzeln dorelswomnene, hmonst substanz dar. In fenchten Buchen-. Kirefern- nud Fichtenheständen kamn soleher bohhmmms torfartig werelen.

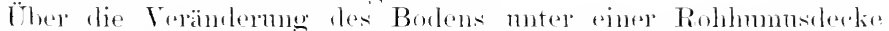

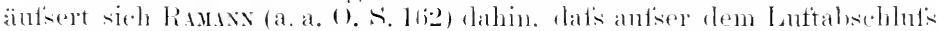

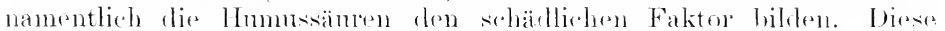

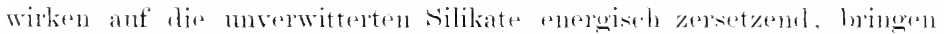

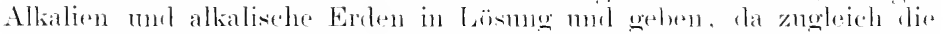

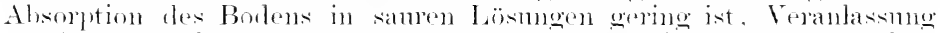

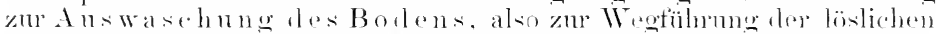

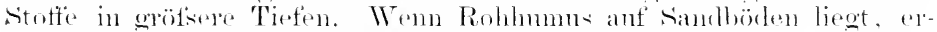

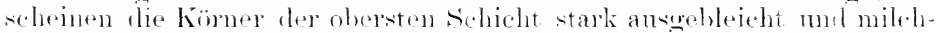
woits, dir eingemischten silikatgesteine stark verwittert mol meist in

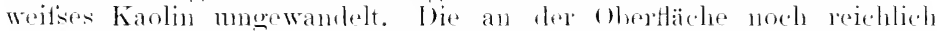
voshandenen humosen Beimischungen nehmen nach der Tiefe hin immer mehr ah, so dats der Borlen oine hellerane Farhe zeige mol nach dieser Färlumg als Grau-orler Blrisand bezeidnet wird.

Tnterhall, dieser hellegefirhten sehicht tindet man in scharfere Tresmmer von dersolhen einen gell, his bram anssehenden Boden, der allmählich in ten tieforen Lagen heller wirel. Ilier zeigen die sandkïrner Beimengungen von Eisenoxyd oder Eisenoxvelleylrat. Daranf

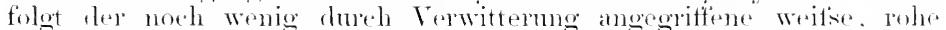
sand. Die oberste hmmose Bodenschicht erweist sich nun als die an

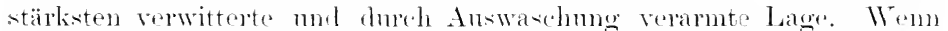
die Aurwaschung einer solehen obersten Bodenlage durch den Einthus

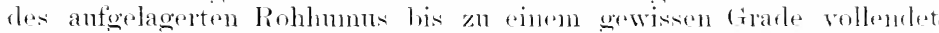

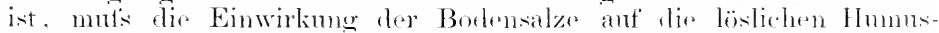

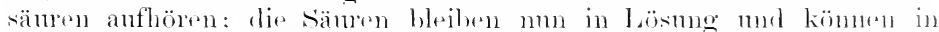
tiefere Bodenschichten vordringen. Kommen sie dann wieder in Bu-

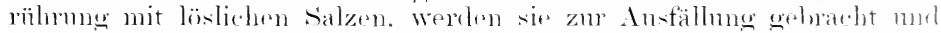
ïberziehen zunächst die einzehen Borlenkïmer mit einer strukturloxen Schicht organischer Stofte. Unter dem Nikoskop fand i.h dis sind körner mit haunen, landkartenähnlichen Keiclunungen bedeckt. W"nn 


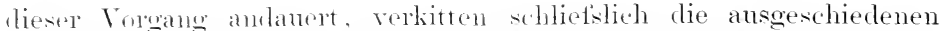

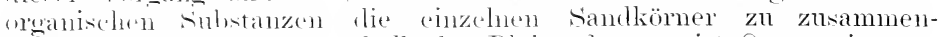
hängenden sichichtem muterhalh des Bleisandes: es ist Ortste in entstanklest.

\section{Ortstein.}

Sach der im rorigen Abrehnitt gegebenen Erklärmng Ramaxs's äber die Entstehune des (Jotsteins ist diester also ein Humusandstein. Dersellue kommt in reschiedenen Formen vor, und zwar zunächst als ..Branderale" oder "Orterde", die eine weiche, zerreibliche Form darstellt und grotisen fiehalt an organischen Massen anfweist: sie bildet sich in reichen Börlen, wellhe noch wenig mgünstig verändert sind. Der rigentliche (Hotein ist eine teste. stemartig harte Masse, die anf noch

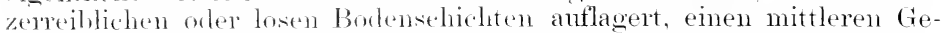
halt an organischen Stoftan und eine brame bis schwarze Farbe besitzt. Es ist dies die in Nordilentseluland verbreitetste Form (Lïnel,merer Heide). Antserdem giht es noch heller bram gefärbten Ortstein. der sehr test mul zähe ist mol num geringe Mengen von organischen sitotion lesitzt. Diere int die härteste, der Bodenhearbeitmox am moisten Widerstand leistende mol nicht selten in grofser Mächtigkieit antitretencle Form.

\%ur Bemteilnug der Anslangungsvorgänge diene eine Analy̌se,

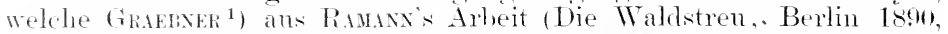
s. 30) (nthelnt hat. lur Ortsteinbolen in der Oberförsterei Hohenlnitck in Pommern enthielt in seinen verschiedenen schichten:

a) Bleisand, der 15 his 20 (cm Mächtigkeit besats und $1,050_{0}^{\circ}$ organischer stotfe enthielt ${ }^{2}$ ):

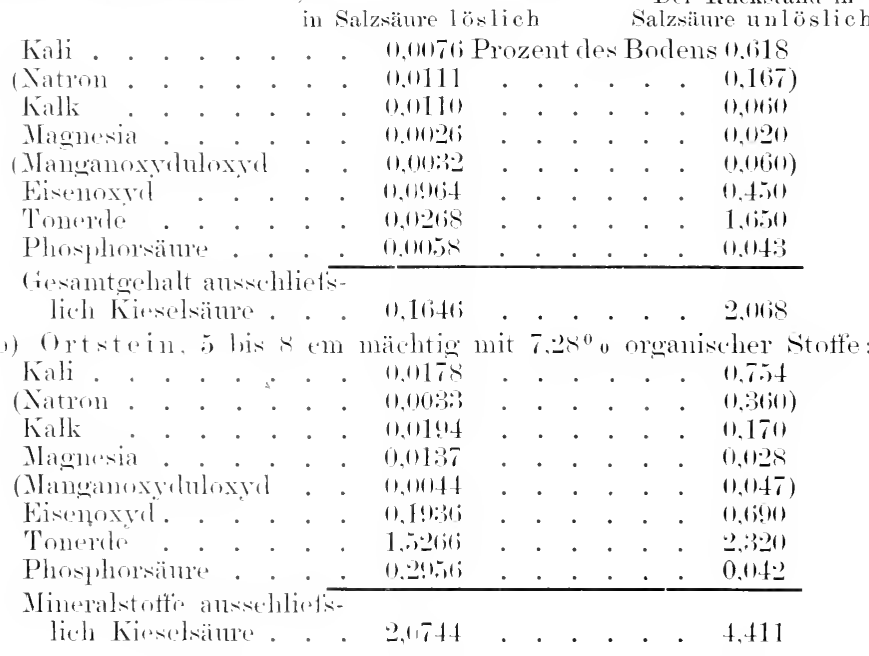

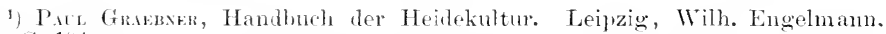
1904. S. 194.

2) Rumx giht in seiner "Bodenkunde" 1905, s. 166, dieselhen Analysen ohne die hier in Klammer gestellten Bestanlteile wieder. 
c) Der unter dem Ortstein liegente gelbbraune sand:

$$
\text { in salzsäure löslich Salzsiure unlöslic }
$$

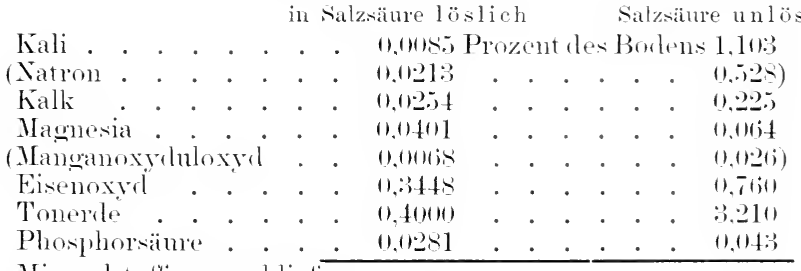

Mineralstotfe ansichliets-

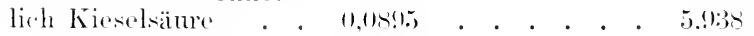

Wir ersehen aus vorstehenten Zahlen, dats der Bleisand nicht nur semen Gehalt an löslichen stotten furch Ausangmer vertoren hat, sondern dats anch der grötste Teil der ïberhaupt Nährstotte enthaltenden Gesteinsreste dimeh Verwitterung zersetzt unl abwärts gespült worden ist.

Es ist also Tatsache, dats gewisse Borlenschichten in Väldern und (den meist ans solchen Bodensehichten hervorwangenen) offenen Heirlen verarmen. Wirtschaftlich hedentmussoll wird dieser Vorgang. wem der Verammosprozeds die Nährstoffizufuh äbresteigt. Welehe

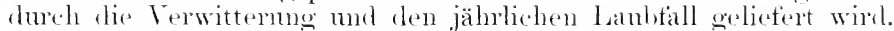

Vom eigentlichen Ortstein zu muterseheirten ist der Raseneisenstein; letzterer ist in einer säurelösmng. namentlich salzsäure, nulöslich. während 1 rtstein sich roichlich aut'löst.

Namentlich in den humosen Heirlebörlen, wo die Rohhumus-

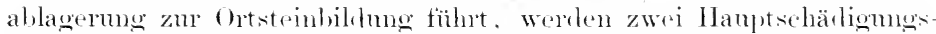
faktoren in Betracht kommen: der sanerstotfmangel dmeh die Boden-

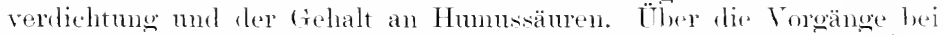
Sanerstoffabschluts ist bereits an anderer stelle (z. B. s. (!)! berichted worden. Hier haben wir mm noch die Humnsäuren in Betracht zu ziehen. Diesem Punkte willmet ( KAEBNER $^{1}$ ) die erwïnschte Autinerksamkeit. Anknïp,fend an die Untersuchungen von WoLF ${ }^{2}$ ), der das Welken der Blätter und deren schliefislichen Tod infolge des Anfenthaltes der Pflanzenwurzeh in einem mit Kohlensäure übermälsig bolarlenen Wasser beobachtete, citiert er die zn deithen Resultaten fïhrenden Versuche von Maxweld ${ }^{3}$ ) über dir Citronensäure und von Tot.f und Blask über die Hummsäuren: daran schliefst cine Äutserneg von Russws über die Ursache, weshall, eine verlangsante I Diffinsion in samen Börlen stattfindet. Es kamn nämlich entwerler die colloblate Beschatfonheit der Noorsubstanzen die Diffissionsfähigkeit herablrüeken, mul es werlen dureh Nentralisieren mit Kalk die colloblalen stoffe ansegefallt, orler es liegt eine direkte Wirkung der Humussäuren vor. Berlenkt man die Erfahrungen über den Eintluts veringer steigerunon von säuren anf das Protoplasma ${ }^{4}$, dessen strömmng dadureh sistiert wirel, so wird man als Hauptsache wohl die direkte säurewirkung betrachten müssen. Eliegen anch spezielle Beweise dariber vor, daf's die Transpiration durte

1) A. a. O. S. 228 .

2) Tagebl. Naturf. Vers., Leipzig 1872.

3) Journ. Ann. Chem. soc. XX (1\$98). S. 103.

4) Prafrar, Pflanzenphrsiologie II. Bd., 1904, s. 79-. 
Š̈̈nen ( Weinsäme. Oxalsänre. Salpeter- und Kohlensämre usw.) verlangsant. furch Alkalien (Kali, Natron. Ammoniak) beschlemigt wirel ${ }^{1}$ ).

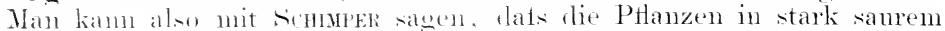
Buldo an hlysiologischer Trocknis leiden werden, selbst wem

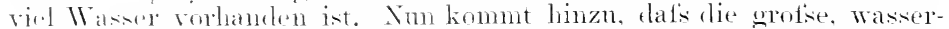
halteme hiatt des Humme das medhanische Abreiken des Massers von

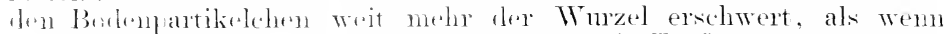

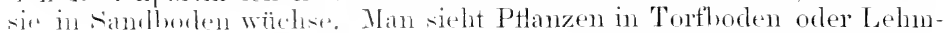

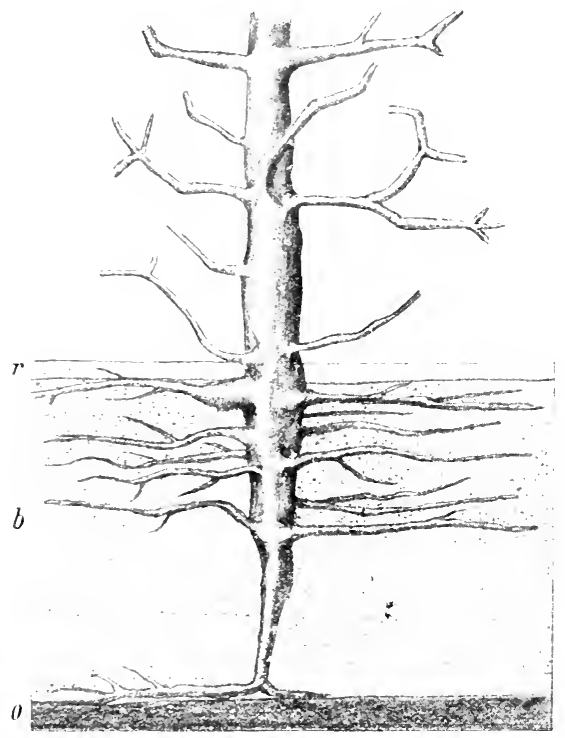

Fig. 29. Ortstrinkiefer aus der Lüneburger Heide, mach der Bildumg des Ortsteins erwachsen.

"Rohhumu, l, lileisani. "Grtstein. Cnterhall, des orttein. beginnt der welbe Sand. (Nach trakexer.) boden schon bei einem Prozentsatz an Wasser welken, hei welchem sie in Sandborlen unch vollstäntipfrisch bleiben, wie die Versuche ron sichs ${ }^{2}$ ) bereits darcretan haben.

\%um Ansilruek gelangen alle diese Bodenschädligmgen am meisten hei den Kiefernkulturen. welche Grafbar hesonders eingehend behandelt ${ }^{3}$ ).

Er sah in Kiefernsehonungen. welehe einige Jahre leidlich gecliehen waren. znnächst flen Maitriel noch normal sich ent wickeh. dam aber plötzlich bei Eintritt der sommertrocknis eine grangrüne Färbung annehmen. Wenn die Trotkenperiode anhielt, begannen die Triebe sich zu krümmen: anch die vorjährigen Narleh worden stumpt ind brann, und in vielen Fällen vertrockneten die Bäumehen in wenigen Wochen. Bei dem Nachgraben im Boden zeigte sich, daf's unter den Wrurzehn orler um die noch ziemlich dünnen Wuzch herum sich Ortstein gehildet hatte.

In Ergänzmng seiner Beschreihmug gibt GRAEBNEk in den beistehenden Figmren ein Bild der Wurzelentwieklung anf (ortstembörlen. Wir sehen bei der in Figur 2! dargestrollten Kiefer die kräftigsten und längsten Wurzehn mweit der Bodenoberflächr parallel zn derselben ansgebreitet, so dats die Ernährung durch den Rohhrmms und den nährstoffarmen Bleisand erfolgen mufs. Tie Folge ist - da in nährstoffarmen Lösmngen die Wurzelentwicklnng gröfer als in konzentrierteren ist - ein weites

1) Pffrfes, Pflanzenphrsinlogie I. Bd., S. 231.

-) Sucus, Handb. d. Exp.-Physiol., Leipzig 1ð65, s. 173.

3) Gramxr, R., Handhuch der Heidekultur, Leipzig 1904, W. Engelmann, S. 231 


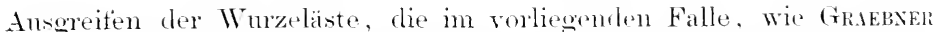
beobachtet hat, mehrere Meter lang mol wonig verzweigt erseheinen: die oherirdisthe Achse ist dabei kamm einen Jleter hoch. Die Nährstoffarmut in Verein mit dem in Bleisante leicht hoehorarlin

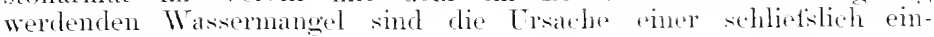
tretenden Gipteldiurre.

Fig. 30 zeigt das Wruzelwathstm einer Eiche. Die Eiche war.

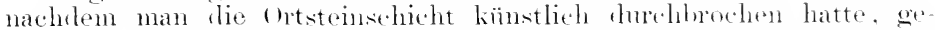
ptlanzt worlen. Aber die ortstembere hatte sich suäter wieder we-

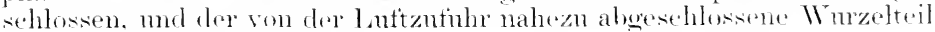
in a hatte sein Wachstuim tast eingestellt. An diesem Treile komiten keine orler fast keinu Mrkorhizen gefunden werten.

Ansolche Eriselieis. Hungen knïptt (iRAEBxer tolgente Betrachl-

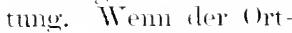
stein moterlall, der Wureln lagert, ist die iiber iln liegente Helschieht sellostrerstänllivh grotien F, nc l t igkeitsolewall-

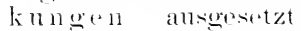
mul floret in Troelsenpriolen so starli alls. lats die Pflanzen ans

Wassermangel zusmucte gehen. In lexartigen Fällen zeigen aber die Ptlanzen. die sanz in tem Bleisande wirzoln, ein allmählich Inele kinrze, gelle.

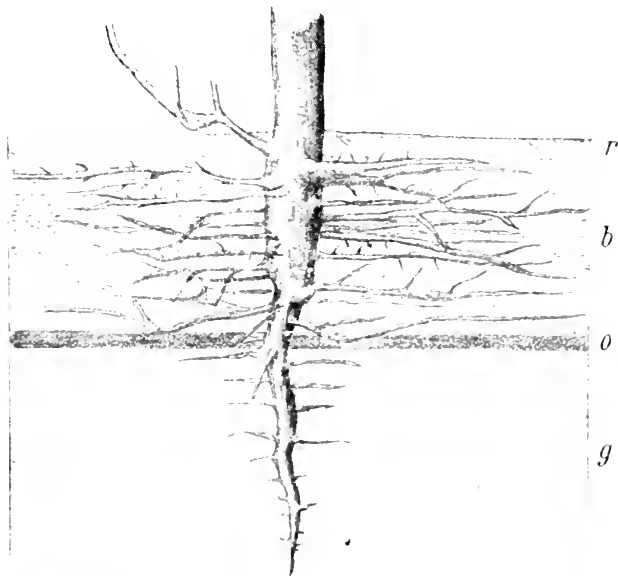

Fig. : :0. Eiche aus der Lïneburerer Heide nach Durchhrechung des Ortsteins gepflanzt. Die Ortsteinschicht hat sich spiter wioder geschlossen.

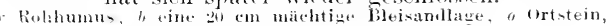
y) welher falld. (Nach firataner,

Narteh sich kemntlich

machendes, kimmmerliehes Wachstmm. Wenn sich ther ()rtstein aber direlit $10 \mathrm{~m}$ rie etwa stricknadolelicken Wuzeln, die in den besseren Boden einsedrungen waren, herumlegt, dann pretst er sie mel veranlatist knotige Anschwellungen. Jassellee findet statt. wenn die Wurzeln durch eine siralte in der Wrsteinlage in den besseren Untorgmul gelangen. Solehe mechanischen Einschnürungen stören das Weiterwathen dieser Wuzeln. Jer Baum ist also im wesentlichen ant den oberhalb der Ortsteinschieht liegenden Wurzelapparat angewiesen. Iterselbe arbeitet während rer Frühjahrsfenchtigkeit normal und gestattet einen günstigen Frïhjahrstrieb, muts aber seine Arleit einstellen. wom sin heifser Sommer den Boden austrocknet. Glisebsek sah die Wurzelspitzen schrumpfen und verharzen oder gänzlich ahsterben. Bei stärkeren Bämmen muls nach Wiedereintritt von Feuthtigkeit Zeit und Material zur Nenbildung von Wuzeln verwendet werden: dieser Zeit- und stoffverhnst macht sich hei dem Wathstum der oberirdischen Achse hemerkbar und reranlatist 
im Verein mit den Folgen der Trotkenperiode zum grofsen Teil das kïmmerliche Wachstum der Heidekiefern. Sobald die Fenchtigkeitsverhältnisse nicht mehr so extremen sthwankungen unterworfen sind, was schon durch ein Vermengen iles aufliegenden Rohhmmus mit dem unterliegenden sande geschicht. werden die Kulturen besser.

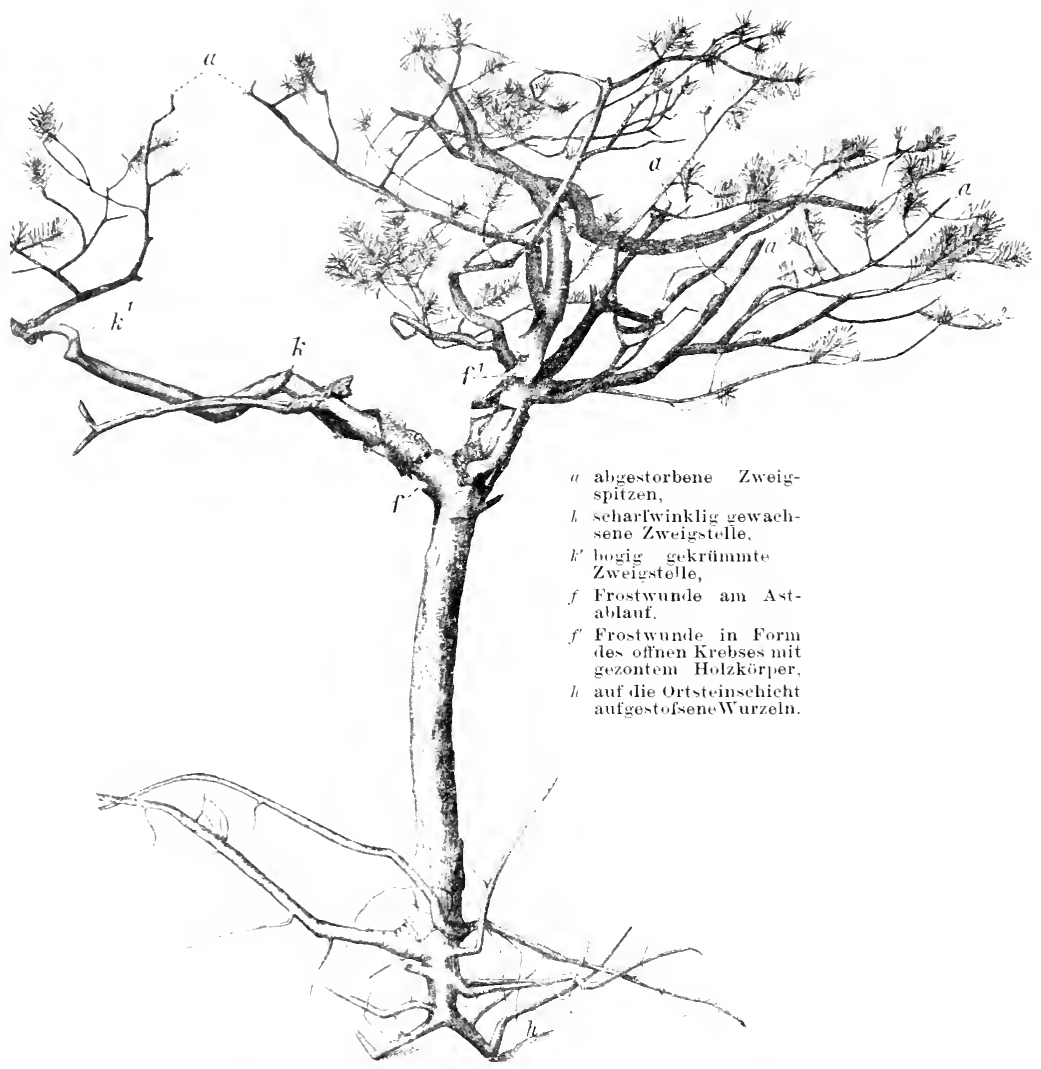

Fig. 31. Moorkiefer mit flachstreichenden Wurzeln ans der Lüneburger Heile. (Orig.).

Meist bilket sich bei Kiefern anf Hochmoorboden eine Krummschäftigkeit ans ${ }^{1}$ ). Doch geben diese Krüppelkiefern Samen, die nach Trockenlegung der Noore geradwüichsige Stämme liefern. Auch über Pims.

1) v. Simsars, Über die Vererhung von Wuchsfehlern bei Pimus silcestris. Forstl.naturwis.s. Zeitschr. 1896, Heft 5. 
montana änfsern sich Schkötek mol Kuchnek ${ }^{1}$ ), dats diesellse anf allzu nassen stellen des Ilochmoors in reduzierten Kriupelfomen (Kusseln) auttrete, aber nach Bolonentwässermes sich erholf. Solche "Kusseh" bildet unsere Kiefer anch ant nassen Tiesen. In flen von mir beobach-

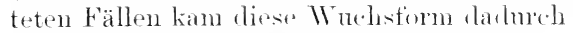
zustande. dats die Giptelknospe der Hanpttriebe unter Insekten-mul Pilzbeschärligmo verharzt and $n m$ nnterhall, dorselhen sich eine Anzahl linzhloibombler 'Triebe (zum Teil Rosettentriebe) antwiclielt.

Fig. 31 stell eine trjälnige Kiefer tar, welche ans der Lumelmroer lieide stammt

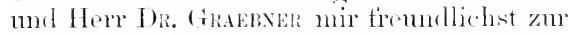
Verfügung gestellt hat. I je löhe des ganzen Bammes emschlietslich der hrone betrug. vom Wurzelhals remessen, $7+\mathrm{cm}$ : Stammlöhe bis zum ersten Astansaty :3! cm: Stammunfang minterhall, des moterten Astes s.: cm: durchselnnittliche hänge der Nadeln 르.

Die Benadelmog des ganzen Bammes ist eine äutserst spärliche. Es sind nur noch die Nadeln des letzten Triehes vorlamblen: die äteren sind alle abgefallen. lie zweige sind stellenweise stark verdiclit und infolge von Frostheschädigmen antopulatzt. Fie senkrecht absteigende Pfahlwurzel ist his zu ihrer horizontalen Tmbiegung s' cm. der stärliste horizontale Wurzelast 1s cm lane. I) er Astwuchs ist sparrig. nud dis \%weige zeigen scharfe hinckstellen (li) und vielfacl abgestorbene spitzen (a). Die Knickitellen oder bogenartigen Krömmmgen $\left(l^{\prime}\right)$ kommen dadureh zustande, dats die Aste sowie der Hauptstamm einseitig krebsartige Frostwunden erhalten haben, und diesen aut der Gegenseite vermehrte Holzbilimo und Streclimg entspricht. Intemsivere, mehr als halhen Achsenumfang nmfassende Frostwomben finden sich bei $f^{\prime}$ mol $f^{\prime}$. In der Figur 32 ist die stelle $f^{\prime}$ am llauptstamm in natülicher Grötse wiedergegeben, $1 \mathrm{~m}$ zu zeigen, wie. ont-prechend dem .. offnen Krebs", die IVundflicho aus violem, äntserst sehmalen, terrassenartion zurucktretenden T̈herwallingsrändern der cinzelnen .Jahr-

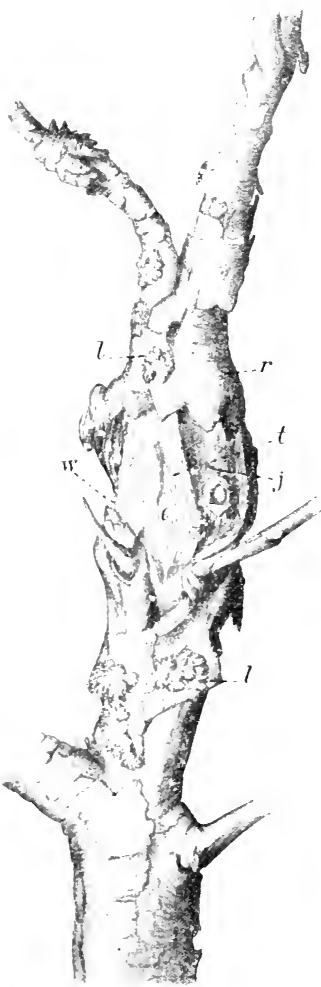

Fig. 32. Krebsartige Wundstelle der Moorkiefer.

a das (tiefstliegende) Wundcentrum t terasentörmig ansteigende Wundränter. Wobei die jünüsten, an starkstin gewnlstet sini und die sie deckende alte Rinde, $r$, in sparrigen stiicken alwprengen: "ah-

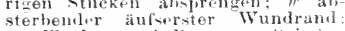
l Flechtenamsiedlungen. (Grig.) gänge besteht.

Dem sparrigen, dürtigen \%weigwnchs bei Fig. 31 entspricht ein ebenso sparriger Wurzelkiorler, der seinem natürlichen Streben, mit der

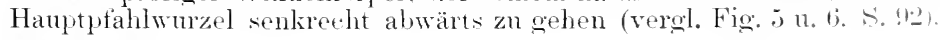

1) Lebensgeschichte der Blütenpflanzen Mitteleuropas, Heft III. 190.5, S. 22.2. 
nicht folgen komnte. sondern die Wirzeläste flach in den oberen Bodenschichten mal den Moospolstern ansbreiten mutste. Die untersten Wurceliste sind in scharten Knich zmm Teil anfwärts gebogen, wahnscheinlich weil sie anf eine Bodenshicht von Ortstein oder ähnlicher Tndurcholingharkeit sestolisen sind.

sehr interesiantr Ablikhmgen von Krïppeltomen der Kiefern. welche der Pims silmstris t. twifosn Willk. entspechen, gibt Weber ${ }^{1}$ ) in seiner eingehenden situdie iiber das Hochmoor von fugstumal im Memeldelta. Bei dieser (relegenheit werden anch die Krïppelbirken beschriehen. deren Wnrzeh wie diejenigen der Föhren stets eine vorzïnhich entwickelte Mrkorhiza erkennen lietien. Der gewöhnlich nm wenige ('entimeter dicke stamm ist meist knorrig verbogen und unten mit ciner rissigen Borke versehen, was bei so kleinen Bämmchen sehr antfallig ist. Lazn kommt, dats diese kleinen, meist mu etwa 1.: m hohen Birken eine gut abgesetzte Krone bilden. Die Hauptwourel dringt durchschnittlich nur $15-20 \mathrm{~cm}$ tief in den Boden ein und birgt Gamn zm Seite, mm parallel mit der Boclenoberfläche zu lanten. Die seitwäts ansstreichenden Wruzeh erreichen das Irei- bis Vierfache der Länge des stammes. Am besten gekennzeichnet wird das Wathstum auf dem Hochmoor duch ein Beispiel von Botulu fullesens, das W $\mathrm{EBER}^{2}$ ) hesehreibt. Der oberwärts weilsfanle Stamm war 1, m houh: der entrindete Holzkörper ïber dem Wurelhalse hatte etwa $34 \mathrm{~mm}$ Inuchmesser und zeigte 51 Jahresinge, von denen die letzten 11 zusammen nur 0,9 bis $2,6 \mathrm{~mm}$ breit waren. Das Bänmchen fing eben an, wipfeldürr zu werden, und war bis $30 \mathrm{~cm}$ hoch über dem Wurzelhalse mit Sphumum molinm und acutifolinm ïberwachsen.

Für die Knltur handelt es sich mu darm, nicht nm die Ortsteinschichten zu durchbrechen, sondern dieselhen anch an tie Bodenobertläche zn bringen. An der Lnft zerfallen sie zunächst zn einem bramen, durch Verwitterung der oroanischen Bestandteile allmählich heller werdenden siande. Dnrohtieren des Ortsteins heschlemigt diesen Vorgang autierordentlich. Der Zerfall pflegt mm so rascher einzutreten, je höher der (rehalt an organischen stoffen ist. Bramoefärbte (hmmusreiche) Ortsteine sind meist in Jahresfrist, hellgefärbte (hmmnsarme) dagegen oft erst in 2 bis 4 .Jahren zerstört.

\section{Die Bodenvergiftung durch Schwefelmetalle.}

Als Schädigmesfaktor für das Pflanzenwachstum kommt in erster hine las sehwefeleisen als sehwefellies (und rhombich kristallisiert als Markasit) in Betracht, da es eine cler verheitetsten Ansicheidnngen hei Moorbildmeg ist. In den Mooren selhst ist das selnwefeleisen weniger anzutreffen, als in tem nnterliegenden sande und an der frenze zwischen organischer Allagermo mi Tuterormel.

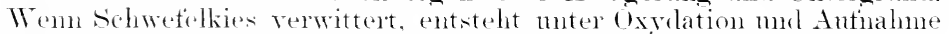
von Wasser sehwefelsaures Eisenoxyenl (Eisenvitriol) mul freie

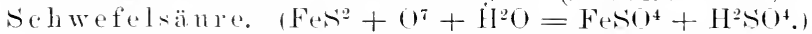

Der Eisenvitriol oxvliert meer Bildung hasischer Salze zn Eisenoxyd: hei Gegenwart gentigender Mengen fon kohlensamem Kall ent-

1) C. A. Wrass, C̈ber die Vegetation und Entstehung des Hochmoors von Augstumal im Memeldelta un. Berlin. Paul Parer, 1902, s. $40 \mathrm{ff}$.

2) a. a. O. S. 47 . 
steht schwefelsaurer Kalk (Gips). Wenn kohlensames Eisenoxydul auftritt, geht dieses muter Verlust der Kohlensänre und Anthahme von

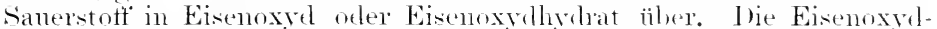

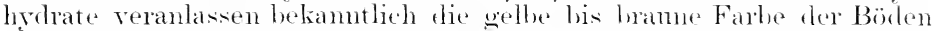
mind zejehnen sich turch eine starke Alsorption fïr Gase (Kohlensäure. Stickstott' usw.) aus. Ku ihnen gehört lor Brameisenstein. $\left(\mathrm{Fe}^{2}[\mathrm{OH}]^{6}\right)$, der den momliegenden siand verkitted $\left.{ }^{1}\right)$. In den Moor-

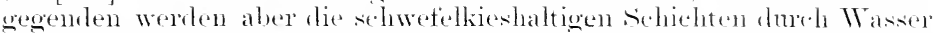
mid die stark reduzierende Wirkmer der Moorsubstanz ofturals gar nicht zum Oxylieren kommen. Weil sie keinen sanerstotf erhalten kimnen.

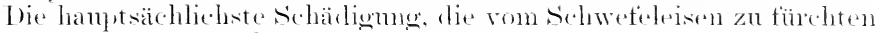
ist, wird darin zu suchen sein, dats die bei der Verwitterung sieh bilfende freie schwefelsäne dureh vorhandene Basen nicht gelmulen werden kann. In der Regel ist kohlensaner Kalk im Boden, so dats sich fije bilden kann: manehmal entsteht wohl aneh Alam oder schwefelsane Nagnesia. letztere im T̈hermats kömnen ehentalls schäıl.

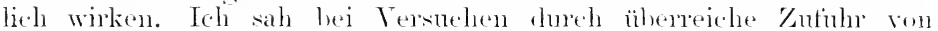
Alam die Fleckennekrose bei fresste antueten. Wem aber die Basen fehlen. wird die freie Schwefelsäne direkt als Ptanzengitt zor Wirksamkeit gelangen.

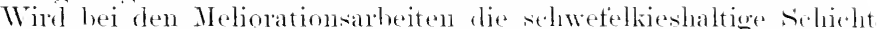

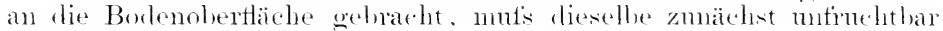
bleilien.

Bisweilen kömen anch schon die oleren lagen ter Noore sichwetel-

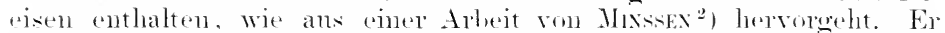
fand in einer Probe ans selulesien an wassorlëslieher siehwefelsäme F.2

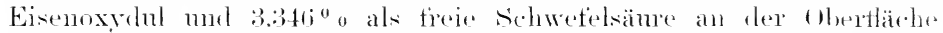
mol amähernd doppelt so viel in den tieferen sohichten, abgesehen ron groticen Mengen noch mverwitertem zweifach selowefeleisen. Die hier charakterisierte Fläche war später ant $(i 2$ em Tiefe alugetortt worden. so dats die reich mit sichwefeleisen durchsetzten muteren sehichten freigelegt wurlen. Die Oxydation des Schwetelkieses hatt: zur Bildumg so grotser Mengen pflanzenschädlicher Verhindmugen ge.

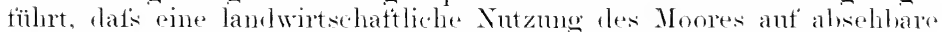
Zeit mmöglich ersehien. Fin soleher Fall mahnt zur Vorsicht bej Alsorfime ron Niedermesmoneren.

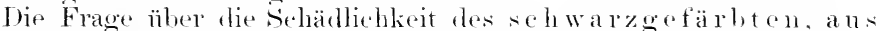
Ellorbrïrhen der Forsten aut die Viesen abtlietsenten Massers ist dureh $\mathrm{KLIFx}^{3}$ ) in eingehender Weise behandelt worlon. In einem spezicllen Falle, der zu Beschwerlen gegen den Forstiskus Teranlassmog gab, war das ans dem Forst kommende Wasser hame diekthïssig mal teilweis äbehiechent. Es enthielt in lonom Teilen :31.2s Teile organische Substanzen (Humusäunen usw.) nut 17,og Teile Mineralsubstanzen, darunter 7.51 Teile Kalkerde, 3,07 Teile Eisenoxyd nsw. Hier waren die Humnssämen der verelel,liehe Faktor. Es wird nm in

1) Rimsx, Bodenkunde, 190\%, s. . .

Nr. 1 .

-) Mitteilumgen d. Ver. z. Förderung der Moorkultur in Deutsch. Reich, 1904,

5) Kons, Die nachteilige Einwirkung des ans Eller-Brichen und Torfunoren kommenden schwarzen Wassers auf die Wiesen. Königsberger land- und forstwirtxchaftliche Zeitung 1E79, Nr. 2s: cit. in Biedermann's Centralbl. f. Asik.Chemie, $1<80$, S. 56:. 
ähnlichen Fällen daranf ankommen. anf wolche Bodenart solehe Bruchwässer abtliefsen. fielangen dieselhen anf eisenschüssige Böden oder solehe mit 'Tommergmul. werlen sie hesonder's schällich sein, während ein kalkrebler Boten dmoh lie ihm eigene beschlemigte Zersetzmng des Humns eher eine Üherthutmer ans den Erlenbrichen, wie solche im Frïhjahr bei Hochwasser vorkommt, vertragen kann. Immerhin sind solche Wasser als Berieselnug- nul Stanwasser zn vermeiden.

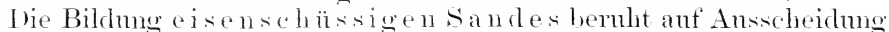
von Eisenoxylhyllat nud Eisensilikaten. Gemische von Eisenoxydhydraten mit wechsehnlen Mengen von kieselsamren und phosphorsamren Eisenoxten stellen anch das sogenannte Wiesenerz oder den Raseneisenstein lar. Die Terhindme entsteht in Mooren, stehenfen (rewässern und anderen Orten. wo eisenhaltige Wasser mit der Lnft in Berïhrung kommen, muter Nitwirkmng von Bakterien (Eisenbakterien nach Wixomansi ${ }^{1}$ ). Nenerdings ist man geneigt, die Mitwirknng von Nikroorganismen geringer anzuschlagen ${ }^{2}$ ).

\section{Die Frostempfindlichkeit der Moorbodenvegetation.}

Bei den in Knltur genommenen Noorböden ist die besondere Frostemptindlichkeit gegenïher den anderen Bodenarten dmrch vielfache Erfahrungen erwiesen. Dabei zeigen sich wesentliche Unterschiede, je nachdem der Moorboden eine Sandilecke erhalten oder mit sand gemischt ist. Wobly ${ }^{3}$ ) fand bei seinen Tersuchen, daf's letzterer bessere Produktion zeigte als ersterer, hei dem der Grmurasserstand höher war. Statt des saudes hat sich anch eine Bedeckmng mit Ton vorteilhaft erwiosen. Bei Wiesenkultmen empfiehlt FLerschFR ${ }^{4}$ ), falls zu starke Entwisserung eingetreten, eine Bedeckmng mit feldspatreichem sand oder Lehm oder Klei zm Vermeidmng eines allzmstarken Anstrocknens.

Juniser"s) führt mehrere Beispiele ans der Provinz Posen an bei denen solche Moortelder, die nicht mit tonhaltigem Boden bedeckt worlen waren, ein zweimaliges vänzliches Abfrieren der Kartoffeln und der Sommernng zeigten. wähend die bedeckten keinen besonderen Scharlen erlitten hatten.

Diese Ertahmug weist schon daranf hin, dats wir die Hauptschärligungsperiode hetrefts der Frosterscheimmgen bei Noorböden im Eriihjahr zn suchen hahen. Für Bammknlturen wirl dies erklärlich, weun wir berlenken, dats die Hummbörlon in der kalten Jahreszeit meist einen T̈herschut's an Fenchtigkeit haben. Der teimporige Hmms wird, mit Wasser gesätigt, sich im Herhst langsamer abkühlen als minder wasserreiche Börlen. sich aber im Frïhjahr anch viel langsamer erwärmen. Je länger flic ITnzeln aber ein warmes Medim finden, desto länger bleihen sie in Tätigkeit mol pressen mm so mehr Wasser in die oberirdische Achse. I)ic anf Moorboden mit ihrer verdïmnten Nährstott-

1) Wимивики, Über Eisenhakterien. Bot. Zeit. 1888. S. 260.

2) E. Rurn, IVie Moore der Schweiz, unter Berücksichtigung der gesanten Moorfrage, Leopoldina 190., Nr. S, S. 34 .

$\left.{ }^{3}\right)$ Towxy, Tntersuchungen über die Beeinflussung der physikalischen Eigenschaften des Moorbodens durch Mischung und Bedeckung nit Sand. II. Mitteil. Forsch. a. d. Geb. d. Agrik.-Physik. 20, 169798, s. 1>7.

4) Fr.schen, M., Lher die zwecknäfsige Behandlung von Noorwiesen; cit. Biederm. Centralhl. f. Agrik.-Chemie, 1885, s. 187 .

$\left.{ }^{5}\right)$ Zweiter Tahresber. d. Sond.-Aussch. f. Pflanzenschutz für 1904. Arbeit. d. Dentsch. Landw:-Ges, Heft 107, Berlin 1905, S. 61 . 
lösmng an und für sich schon schlecht wachsenden Bäume grehen mit grotisem Wassergehalt ihrer (iewebe in den Winter. Je wasserreiner und plasmaärmer die Gewebe sind, desto flostemptindlicher sind sie, gleichviel ob es sich nm die Wirkmgen von Wintertiost oder Frühjahrsfrost handelt. Daher die häntige und starks Frostheschädigmog hei Moorkiefern, wie sie oben bei dem Exemplar ans der I ïneburoer Heide sich dargestellt fimetet.

Für die kumbleligen Feldgewäehse werden diejenigen Frähjahrsfiöste am gefährlichsten. welche durch strahlume cntstehen, was man lejeht darmeh erkemen kam, dats die dureh die Kälte hervorowertenen Verfärbmoserscheinmogen an Blättern und stengehn schart ahschneiden, wenn ein solcher Ptanzenteil dureh darïberliegende Blätter trilweis gedeckt ist.

Es fragt sich num, wo die sitrahlungskälte am meisten sich entwickeh wirl und inwiefern dabei die Vertmistmeskälte mitspricht. Kommen heide Faktoren hochorarlig zur Wirkmng, werden die Luticchichten diclit oherhalh der Borlenohertläche merklich kälter als die durchschnittliche Temperatur sein. T̈her einer Sthneedecle hat PoLs ${ }^{1}$ ) eine solehe Tempratmerniedrignng der angenzenden Luftschichten nachgewiesen: dieselbe wird $n m$ so grofiser sein, je geringer die Lufthemegmer ist. Daher die Maifröste in windstillen klaren Näcliten. Lop moorigen mul ammoorigen Böden mit ihem Wasserveidentm werlen in ersten

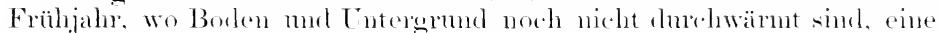
starke Verdunstung hahen, sellset weml sie als Knlturlanel bereits mit sand gemischt sind mul dementspechemel sich stänked ahkïhlen. Die

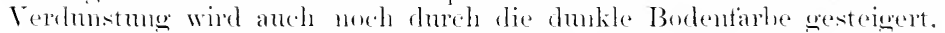

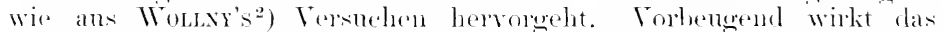

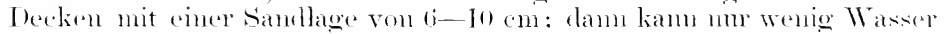
aus der Hommsschicht in den sand gelangen, mol es werden demgemäts mu peringe Mengen rerdumsten. Ans demsellen firmule wirkt die sianschicht a uch selö̈tzend gegen Trockenheit. Ein Nachteil

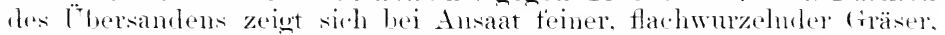
die loicht in dem nahrungsarmen sande verkïmmern ${ }^{3}$ ).

Wemn es sich mo Glsthammkultmen auf Moorbörlen handelt, dürfen als Frostsehutzmittel emptohlen werlen: 1. Bamphtanzmuen auf der Thest - mol südwestseite der (1)stanlage zur Mildermog der 'Temperaturdifferenzen im Fröhjahr. Die Rinde platzt fast ansmahms los ant den nach diesen Himmelsomgenden orientierten Flächen. mus andh die normalen Ahlömugserscheinmmen dre Borkenschuppen (z. B. Platane) hegimnen frïhre umd intensiver auf diesen Bammseiten. 22. Sitarke Kalkmo mul

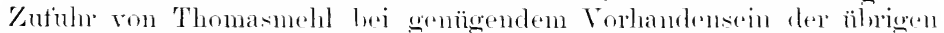
Nährstoffe. :3. Vor allem alure suche man die Uhsteorten herans, die

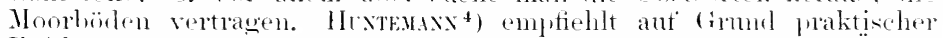

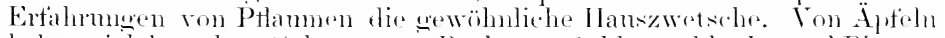

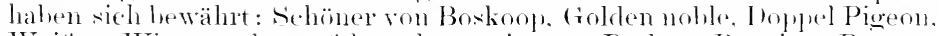

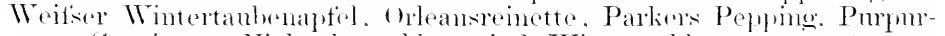
roter Comsinot. Nicht hamehhar sind Wintrogoldyamäne. Givensteiner. Prinzen- mol Alantaptel, da sie, zu fiostemptindlich, rom Krels

1) Meteorologische Zeitschr. 1s96; Hett I.

2) Blätter für Zuckerriblienliau, 1-99, Nr.9.

3) Mitteil. d. Ver. z. Förd. d. Moorkultur, 1×95, Nr. 5 11. 6.

4) Hrxpuns, Das Erkanken der Ohsth:iume auf Moorboden. Mitt. 1]. Ver. 7. Förd. d. Moorkultur, 1=9 . Nr. 7. 
leirlen. Nach den Erfahrungen des Herm Bammschulbesitzers Kumzini: eignen sich zum Anban anf Moorbörlen tolgende Apfelsorten: Roter Eiseraptel. Burchardts Reinette mul Clublins Herbstapfel. Von Birnen werlen empitohlen: Kästliche ron Charnenx, st. Germain und Nene Poitean. Will man Kirsehenkulturen äberhaupt versuchen, so wähle man eher noch sanerkirsehen als siöskirschen.

\section{Der Nutzen der Fichte.}

Betreffis der forstichen Kulturen auf Monrhoden wollen wir nur moere Ansicht wiederholen, dats die jetzt so beliebte Verwendung der Kiefor ein Milsoritt ist. Das s. sts vorgeführte Exemplar aus der Lüneburger Heide zeigt deutlich genug. welche Nachteile entstehen. Wenn tieselhen anch an anderen Orten nicht in der schroffen Weise bemerkbar sind, mnd namentlich die Frostheschädigmoen nicht so scharf hervortreten, so wird doch immer ein krippelhatter Wuchs eingeleitet, der frïher oder später zutage tritt.

Für das nomldentrohe Flachland ist anf die Fichte zurtelizugreifen. Vir sagen: .zurücligreifen": denn tatsächlich hat ('oNwestz ${ }^{1}$, nun nacherewesen. dats vielfach in moorigen Gegenden der Fichtenbestand der ursprüngliche, natüliche gewesen ist. Anch jetzt sind noch in Pommem und Hannover, selbst in der Lünebmore Heide mehrfach ursprüngliche Fichtenbestände vorhanden, und die von Conwentz speziell studierten Einzeltälle geben rortreffliche Beläge datür, dat's die Fichte noch in mrwallähnlicher Entwicklnng in Böden sich zeigt. wo weite strecken mit Torfmons bedeckt sind und die Nässe in gewöhnlichen Jahren einen Kugang mmöglich macht.

Bei dieser Gelegenheit sei der Senkerliblungen der Fichte gedacht, welche allerdings nur in den von der Forstkultur nicht bertuhten Wählern noch zu finden sein werden. mu es ist deshalb angezeigt, hervorragente Beistite einer Vermehrmo duch A bsenker in der Literatur zu erhalten. Doshall, sei hier noch Abbihlung mol Beschreibung einer Fichtenfamilie gegeben. welche in ler Nähe der Stadt Kragerö an der sürlöstichen Küste Norwowens heobachtet worlen ist (s. Fig. :33).

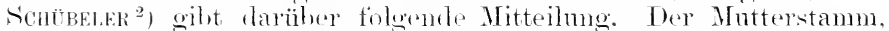
der am Futse eines IIügels steht, hat eine Höhe von ungetähr ! $4 \mathrm{~m}$

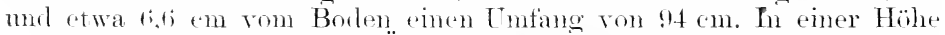
von 31 bis 34 cm gehen trei Äste rom Hauptstamm ab, die an mehreren stellen festownoelt sind. Ans diesen sind allmählich in einer Entfirnung ron 1,1 bis 2.; $m$ rom Mntterstamm sechs regelmäfige Fichten hervorewachsen, welehe rine llöhe von 2.5 bis $4.7 \mathrm{~m}$ hesitzen.

Die Fichte steht mit ihrer leichten Adventivknospenhildung, die zu Masertiörten Veranlassmng geben kann, und der schmellen Bewuralnustahigheit oberirdischer Achsenteile einzig da. Wwar hat

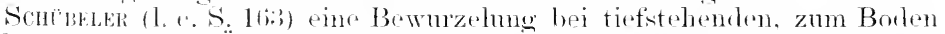

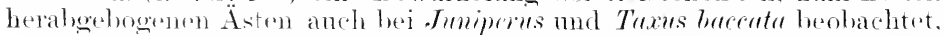
und sicherlich wirk anch hei anderen Coniferen, die gut dureh stecklinge wachsen, solrhe. Termehrung vorkmmen: allein derartige Fälle wertem stets vereinzelt bleiben.

1) Coxwrar, H., Die Fichte im norddeutschen Flachland. Berichte d. Deutsch. Bot. Gesellschaft 1905 , Heft 5, S. 220.

") Scmutran, F. C., Die Pflanzenwelt Norwegens. Christiania 1873-75. S. 164. 
Jic hier durch ein Beispiel erlänterte Vermelormgstähiglieit wewinnt eime erhöhte Bedentung in jenen Moorgegenden. Wo die Fichte als der einzig mögliche Vahlibldner zur hultur herangezogen werden muls.

Sur die wenigsten Narlelhölzer besitzen pinc solche Lejohtigkeit

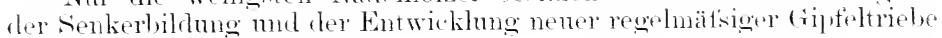

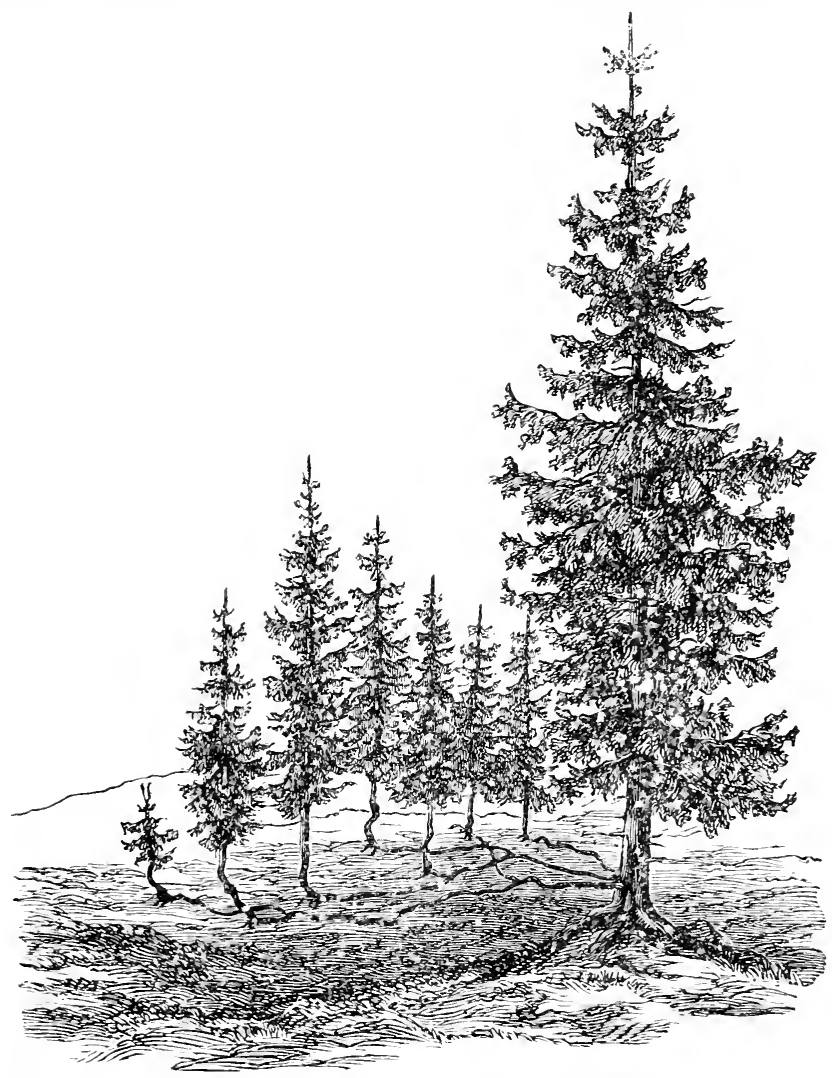

Fig. :3. Eine Fichtenfamilie, die durch naturliche Ableger entstauten ist. Drei an der. Stammbasis vorhandene Äste haben an einzehnen Zweigstellen sich nen bewurgelt und dort ihre Knospen zo seliundären stammen ausquebildet. (Nath S.Hi Het,ER.)

aus seitenswossen. biese Eigenschatt benutzen die fiartner reichlirh zur Anzucht junger Individuen ans Stecklingen. Bei anderen Conifien!

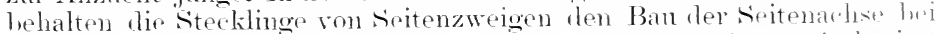

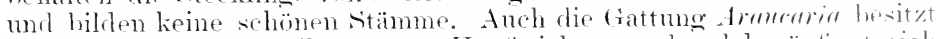
grotse Neigung zur Bildung von Kopttriehen, mol solvhe äulsert sich 
manchmal schon bei einzehnen an der Intterptlanze verbleibenden Seitenzweigen, wemn der Gipfeltrieb verloren gegangen ist.

In Anschlnts an diese anf nassen Böden herrortretende Senkerlibdung der Fichte geben wir in Figm it die Keichnmo eines nur eimmal beobachteten Falles von Wurzelhildmo ans einem Ast der Eiche.

In den achtziger Jahren des vorigen Jahrhunderts hatte ich Gelegen-

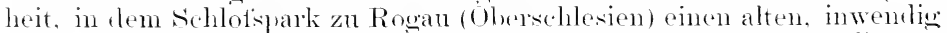
schon stark ansgehöhlten Eichenstanm zu sehen, der ant' einer tiefliegen-

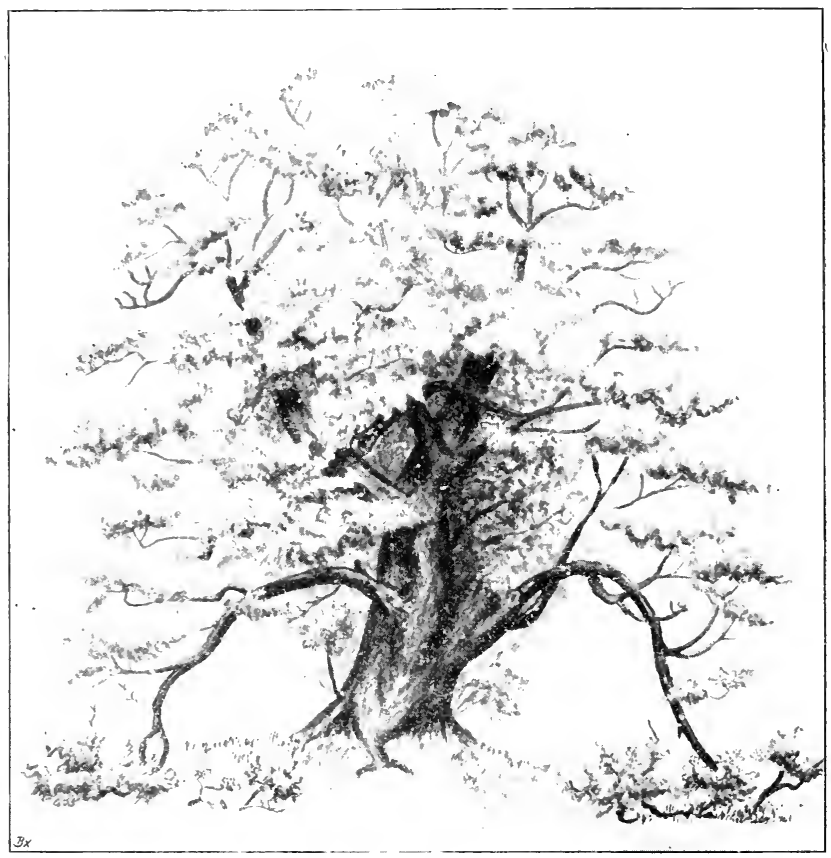

Fig. 34. Eiche aus Rogau (Oberschlesien) mit Senkerbildung. (Orig.)

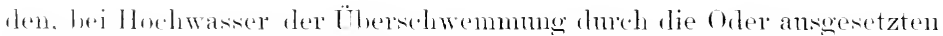

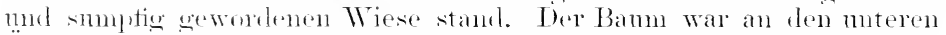
Ästen bereits lanbarm. Inie beiden mutersten, wahrscheinlich eimmal ahsiehtlich heraherehongenen Äste lagen mit ilnem oberen Teil tief im Borlen, mul ihre spitzen hatten sich anfwärts gerichtet. An der Krömmungstelle des Astes (rechte Sicite der Figmer war eine starke

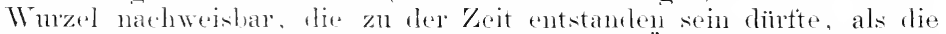
noeh jugendliehe \%weigspitze dureh die ersten Üherflutmoen von angeschwemmtem Boden ïherdedkt worden war. Die durch diese Wurzel herberigetührte Unterstätzung der Eruährung machte sich dadurch kemnt- 
lich, datis eine grötsere Anzahl von jüngeren \%weigen wie sellständiges Buschwerk sich entwiclielte. An den in einiger Entfenung stehenden kräftigen Fichtenptlanzmgen war mir nichts Besonderes autrefallen.

\section{Die Veränderungen im Moorboden durch die Kultur.}

Notwendig ist es schlietich noch, einen Einblick zu gewimen, inwiefern die schädlichen Faktoren der Hummbörlen hei der Kultur sich geltend machen mol dmeh die Kultur eine Äntermong erfahren. TTher die "Besandunge ist im Vorhergehenden bereits gesprochen

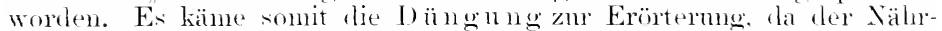
stoftgehalt, namentlich in Hochmons, so gerine ist, dats num spezielle. Pflanzen mit geringem Nährstottbedïrfins mul hoher Anpassmessähig-

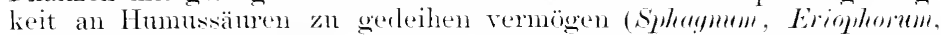
viele Carer-Arten, Culluna nsw.). Alle Dïngemittel mïssen zmmächst dalin wirken. die die Zersetzung übernehmenten Mikroorganismen im Moor zn vermehren: dem in dem hmmmsamen Boden ist die $B a k$ terienflora äufserst dürtig. Ïber den Einfluts der Kultmmatinalmen anf die /onnalme der Bakterienvegetation in Moorborlen finden

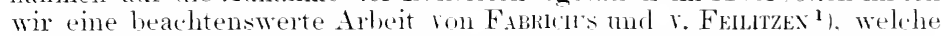

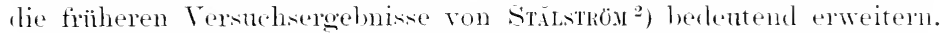
Letzterer stellte bereits test, dats der im natürlichen Znstancle an Bak-

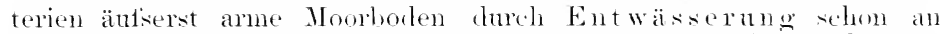
Mikroorganismen reicher wirl. Dies wirl hesonder's für Hochmone berlentungsvoll, da sie viel ärmer als Niedermosmoore an Baliterien sind, was wohl mit dem geringen stickstoftgehalt derersteren zusammenhängt. Die mit 'Ton gemischten ofler dureh Iöngumg verlesserten Moore haben höheren Bakteriengehalt. Lie Bakterientlora hält sich

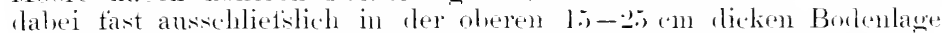

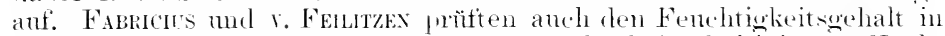
der oberen Bodenlage mud fanden, dats derselhe bei mbultiviertem Hoch-

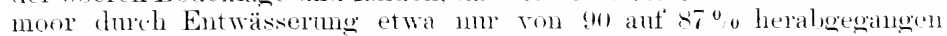
war, dagegen dureh andere Kultumalsnalmen lis anf etwa tit o o sinken komnte. Letztere hestanden in einer Mischnng der Krmne mit sand, infolgedessen sich ein anderer Ptlanzencharakter entwickelte. Die Bodentemperatur war auf dem jungträulichen Moor an niedrigsten. Blotise Entwässerung iibte wemg Einfluts $\left(+0.3^{\circ}(\mathrm{C})\right.$, aber die kultivierten Beete zeigten eine anhaltende steigerumg von beinalie 2 "C. Betreftis der chemischen Zusammensetzmog ergal, sich, wie zu erwarten, im natürlielen Hochmoor der Kalligehalt selne gering; ebenso war der stickstoftgehalt gering, während er in den Niederimgsmooren sich be

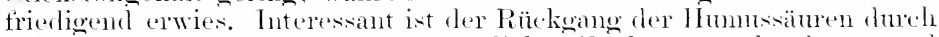
die Kultur: der Gehalt betrug im natiulichen Hochmoor mehr als : ${ }^{\circ}$ o mol

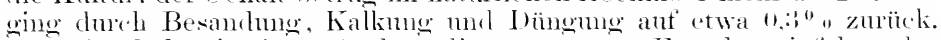

Die Bakterientlora fanclon die genamiten Forseher infolge der sauren Reaktion des Bodens im Hochmoor nur spälich entwickelt umi anch durch Entwässerung weng gehohen: dagexen zoigte sich eine

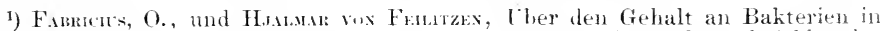
jumgfräulichem und kultiviertem Hochmoorboden auf dem Vesuchsfele des Schwedischen Moorkulturvereins bei Flahult. Centralbl. f. Batkeriologie ust: II. Abt., Bd. XIV, ז. 161. 1905. S. 44 .

") Om lerslagningens betydelse. Finska Mosskulturföreningens äsbok. 1-gk.

sorauer, Handbuch. 3. Aufl. Erster Iiand. 
grotse Steigerung durch Besantung. Kalkme und Iningme und die Clamit znsammenhängende Bearbeitung des Bodens. Sand führte nene Bakterien zu, Stalhwist gewährte eine derartig reiche Enährung, datder Bakteriengehalt so hoch wurke, wie in einem Niedermgsmoor bei denselben Kulturbedingmaen. In heiden steigt und fällt der Bakteriengehalt parallel mit der Bodentemperatur.

Bezüglich des Stalhlüngers gehen die Erfahrmnen der Praktiker sehr auseinanter. Es ist rielseitig ein Mitserfolg dabei beobachtet worden. Andererseits finden sich Berichte, welche selbst in Iooren mit grotsem stickstoffgehalt eine äntserst vorteilhafte Wirkmo des stallilüngers feststellen, wie (iRAF s'chwERIN ${ }^{1}$ ) berichtet.

Jan köunte sich diesen Wilerspruch folgendermatsen erklären: Scllset in Mooren. die Stickstoft im Überflufs enthalten, kann eine Stallmistelüngmeg von sehr günstiger Wirkung sein, wem das Moor wenig zersetzt ist, der stickstoff darin also wahrscheinlich noch in wenig aufnehmbarer Form (z. B. in organischen Verbindmgen) vorhanden ist. Anf zervetzten Mooren aher sind die Erträge nach stalldmg tatsächlich schwach, und das Unkiant wuchert in erdrückender Menge, weil dureh die Dmozufuhr vermutlich einseitiger Stickstottïberschuts ohne genïgentes Gegengewicht von Phosphat- und Kalkzufuhr sich geltend macht.

Bei der Monrkultur handelt es sich in erster Linie mm das Kali. Dies gilt auch für Moorwiesen, bei denen eine gute Henernte aber nach II. Flesscher ${ }^{2}$ ) antiser Kali anch Phosphorsäurezufuhr verlangt (Thomasphosphatmehl). (Verfasser warnt bei dieser Gelegenheit vor dem Übererdmgsverfahren, wemn das (trundwasser nicht tiefer als $2(1)-40 \mathrm{~cm}$ steht.) Ile Form, in welcher das Kali gegeben wird. dürfte auch in der Nehrzahl der Fälle matsgebend sein; denn TAckE ${ }^{3}$ ) erwähnt, rlatis er bei Kartotfeln den hesten Erfolg bei C'hlorkalinm erzielt habe. Kuollenmenge mud Stärkegrehalt waren dabei am höchsten. Während die Knollen ohe Kalidïngme 17.67\%, Stärke enthielten, besatsen sie bei Kainitdüngmg nur 17,020\%, bei Karnallitzufuhr sogar nur $16,48 \%$, dagegen bei Chlorkalimm $18.0 \% \%$. Die Dïngemittel wurden im Herhst gegehen: Fröhjahrsoüngung setzte (Quantität und Qualität der Knollen herab. Hexsele ${ }^{4}$ ) fand bei seinen Kartoffelanhanversuchen, dats Kanit auf Wiesenmoorboden den Stärkegrehalt rler Kartoffel bedentend zurückilrütekte. Bei Vergleichskulturen anf Mineralboden mol Moorboden waren die Erträge des ersteren grötser. mod der Stärkegehalt der Moorkartoffehn ereichte niemals den der Knollen auf Minerabodbon oder den des Saatgutes.

Bezïglich der Sohädlichkeit der Fröhljahrsoüngung sei auf clie Berichte der Generalversammlung des Vereins zur Fördering der Moorkultur verwiesen ${ }^{5}$ ). Dort findet man besomlers betont, datis Kainit und Thomasmehl im Herbst anf das Monr gestrent werten müssen, weil die Frühjahrseüngmo bei Hackfincht den " /ncker- und Stärkegehalt herabdrïcke. Für Thomasmehl sei die Herlstclüngmo anch tharum günstiger, weil die säme des Moores viel länger lösend einwirken kömne. Chili-

1) Mitt. d. Ver. z. Förd. d. Moorkultur, 189.; Heft 6.

2) Milchzeitung 18\$7, Nr. \&.

3) Mitt. d. Ver. \%. Förd. 1. Noorkultur, 189.5, Nr. 6.

4) Hrassic, J. A., Bericht ler Noorkulturstation „Erdinger Moos ${ }^{6} 190001$. Centralbl. f. Agril.-Chemie, 1903, Heft ::

5) Jahrg. I\$95, s. 1:3. 
salpeter hatte bei len Versuhskulturen den Znokergehalt der Rïben

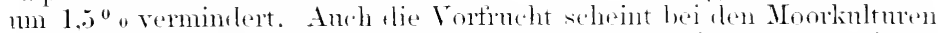
eine Rolle zn spielen, wie ein Fall ans der Provinz Posen zeigt ${ }^{\mathbf{1}}$ ).

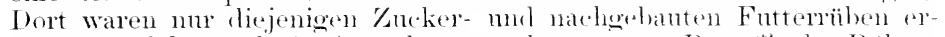
krankt. welehe nach sent angelsant worden waren. Botretfs fler Rüben-

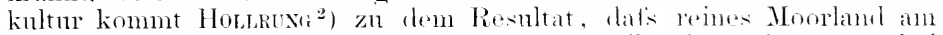
besten ganz vermieden werden mïse nud selhst hesandetes num bei orotier Forsicht verwendhar sei.

\section{Der Rindenmulm.}

Wenn wir hisher tas Charakteristisele des samen Heidebodens in der Produktion von Hungertypen kemuen gelent haben. zu deren Ent-

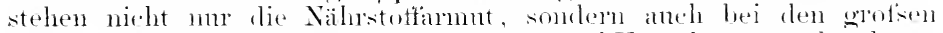
Fenchtigkeitssehwankmoen der Wassemangel Veranksimegelen kam,

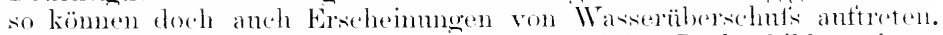
Dieselben äutsem sich an älteren Bänmen mit starker Borkenbildung dam, wemn Heidelirant mol Moos in hohen Polstern dis Stammbasis mongelen. Diese dichten Polster sind Wasserspeicher, die teils das Wasser des moorigen Borlens festhalten, teils das atmosphörische ansammeln mol anf diese Weise einen an der stammbasis stet höher hinanfwathenten fenchten Filz hilden. Solche fenchten Polster mindern dis Temperatm-

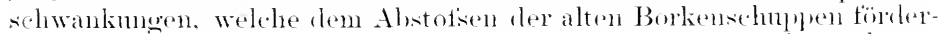
lich sind. Sie hindern aber anch wesentlieh den Lattzutritt umel ver-

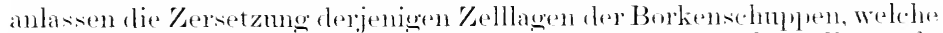

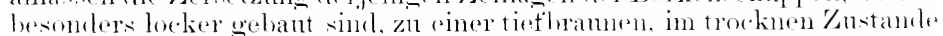
pulverigen, low stäkerer Fenchtigkeit schmierigen Masse, die als

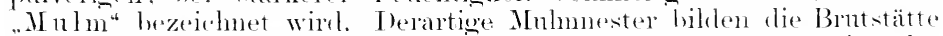

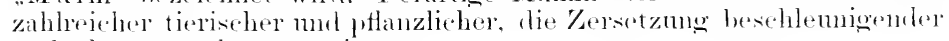
mol ïhertragender oromismen.

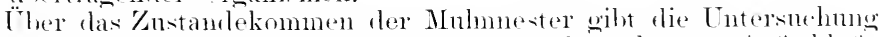
der jïngeren sichichten unterhalb der alten Borkensehmpen Anfichluts.

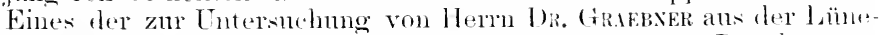

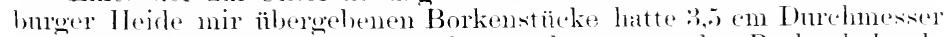
mil nuterschied sich von einer ebenso alten, gesmolen Borke dadurch.

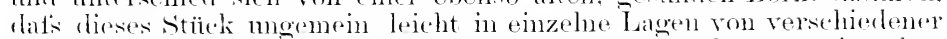
Dicke anseinanderbläterte. Die (bertläche der einzelnen anseinambrtallenden Borkenschichten war reliefkatenatig melon und stellenweise mit hreitlegelförmigen. his $2,5 \mathrm{~mm}$ hohen harten, oft kraterfömign vertieften holzigen Vorsprïngen versehen. solche Vorsurüge, ebenso wie die schwielig in weichen limien hervortretenten trewebejolster der einzolnen anseinanderbläternden Borkenlagen befanden sich stots

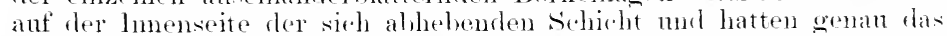

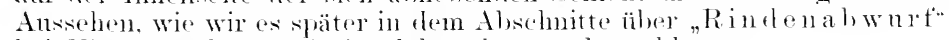
bei $T$ lmos abbilden. Ex ist daher dort nachznschlagen.

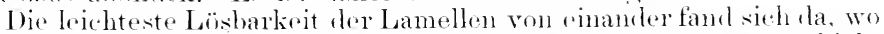
eine mulmige, fl.h. in Humitikation betindliche, zortallende Gewehesehieht die Tremnumgstläche bildete. Der Mulm bestand ans Korkzellen, wis in

1) Elfter Jahresher. d. Sonderausschusses f. Pflanzenschutz. Ari. d. Deutsih. Landw. Ges, Heft 71, S. 130.

2) Hon.mati, Die verschiedenen Bodenarten und ihre Eigung für den Rubenbau. Blïter f. Zuckerrübenbau, 1905, Nr. 14, s.. 217. 
beiliegenden (Snerschnitt (Fig. 3i) die obere Seite $(B)$ zeigt, während $H$ diejenige Borkenseite bezeichnet, wekhe dem Holzkörper näher liegt, also jünger int. rp ist verkorktes, festes, dagegen $k$ füllkorkartig gelockertes Rinclemprenchym, $t$ Tafelkork. I re Borkenschuppen setzen sich also aus immer tiefer nach der frischen Rinde mo dem Cambium hin fortschreitenden Alggliederungen von Rindenparenchym zusammen, tas von Tafelkorklagen algeschnitten wird und verkorkt; anfsertem finden wir Nester ron losen Zellen, die um so üppiger sind, je tiefer die Stammbasis im Moos gestanden hat. Die sehwammige Beschaffenheit der Unterseite der einzelnen Borkenlamellen rührt von der krankhaften

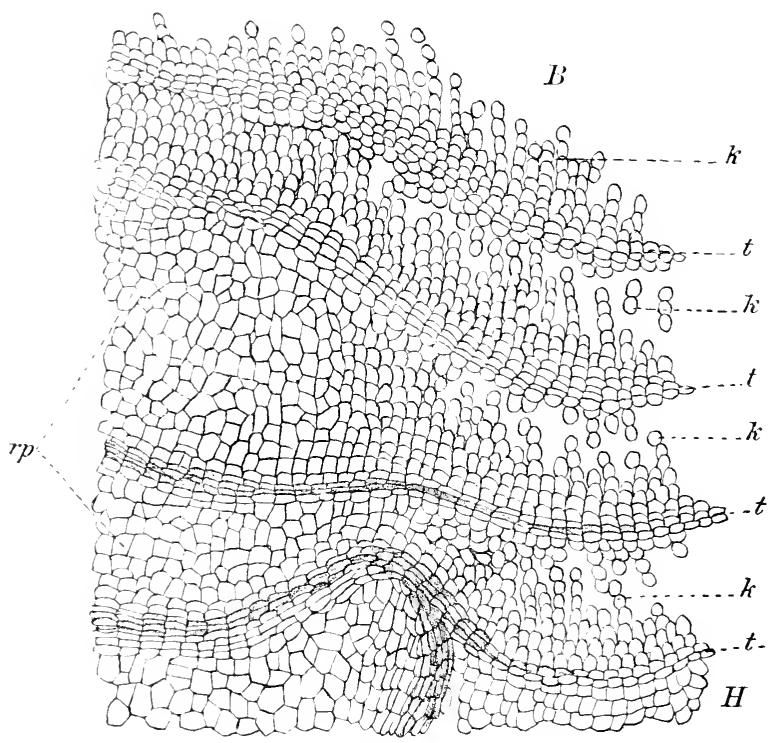

Fig. 35. Mulmige Borkenschuppe einer Kiefer aus der Lüneburger Heide. (Orig.)

Üppigkeit der Parenchrm- und Füllkorkmassen her. Infolge der Nässe und der geringen sanerstoffizufuhr werden diese Wuchergewebe humifiziert und bilden den die Tremnung der Lamellen erleithternden Mulm.

Die starke Beteiligung des abnorme Streckungserscheinmoen zeigenden Rindenparenehyms an der Borkenbildung setzt diese Mulmentwicklung bei der Noorkiefer in die Nähe des .R indenabwurfs" der Rüster mol mitersehejilet beide Fälle von der eigentlichen Lohkrankheit (s.s. 2010), hei der die Füllkorkbildung, wie bei den mehrschichtigen Lenticellen, die Oherhand behält.

\section{Die gärtnerischen Heide erdekulturen.}

Vermutlich durch die Beolachtung des natürlichen Standortes unserer Heidekrautgewächse angeregt, hat man bei der Kultur ter ans- 
ländischen Ericaceen denjenigen Bowen herbejgoholt, in welchom muere

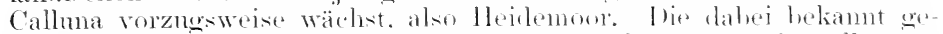

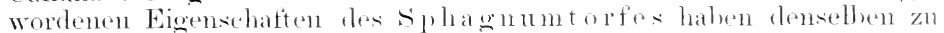

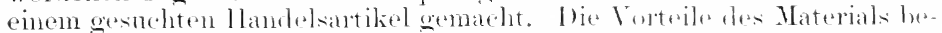

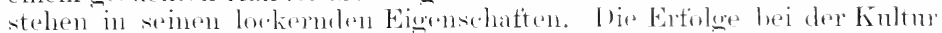

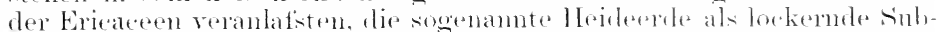

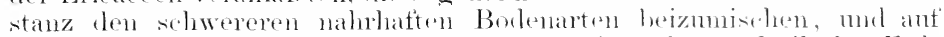

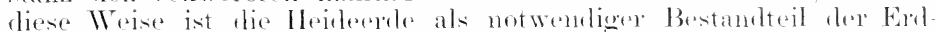

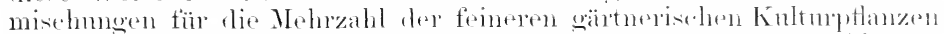

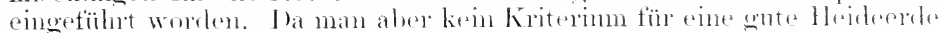
kannte. kamen bej dem wachsenten Bedarf viele Erelen in ren Handel.

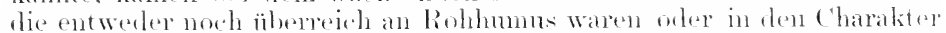
des IV iesenmoors shlugen. Dabei verfïhre die dunkle Farbe des

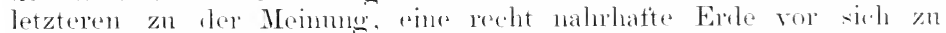

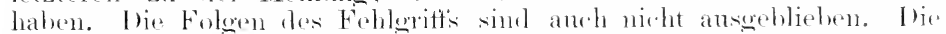

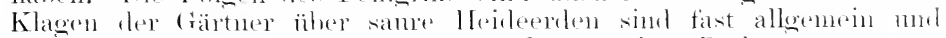

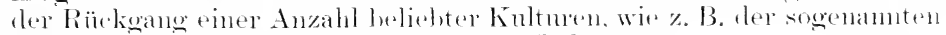
Nenholläneler ofler ..Kapptlanzen“" manthaltsann.

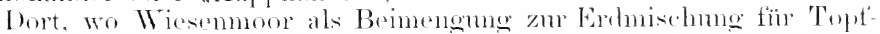

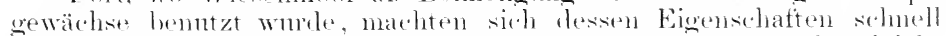

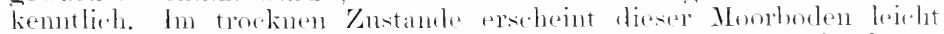

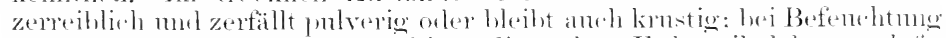

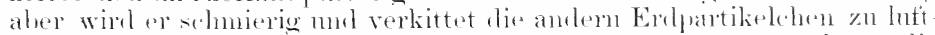

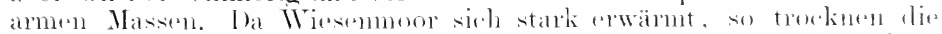

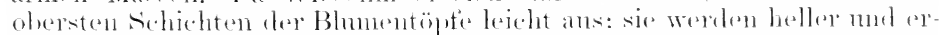

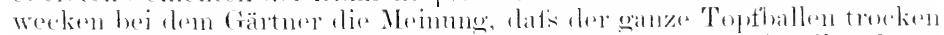

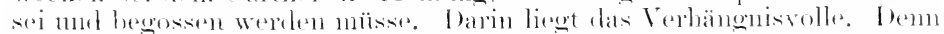

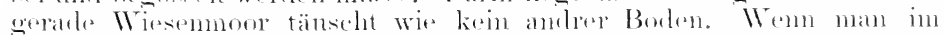

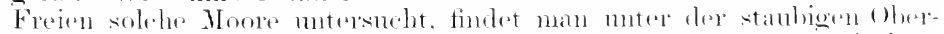

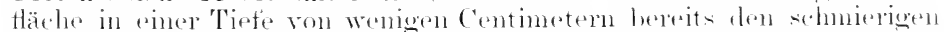

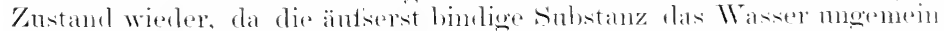
festhäl. Die Toptknlturen gehen deshall, sehom ans sanelstoffinangel

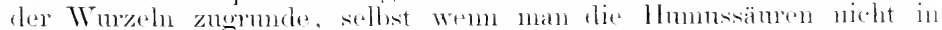
Betratht ziehen wollte. Letztere spielen aber eine verhänonisolle Rolle.

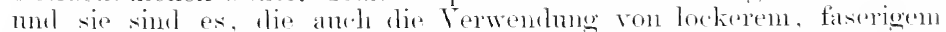
llevelemoor in vielen Fällen schädigenel wirken lassen. Am rorteilhaftesten ist sphagmmmtorf, weil der anatomische Ban des sphasmmm-

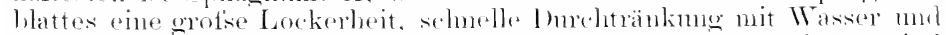

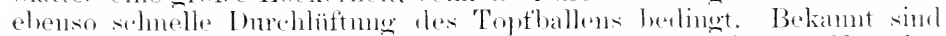

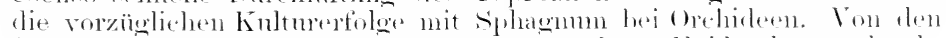

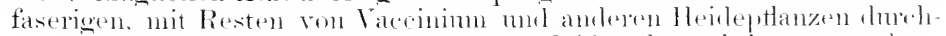

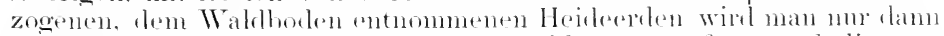

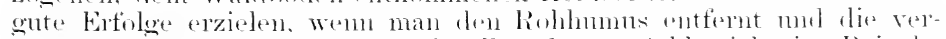

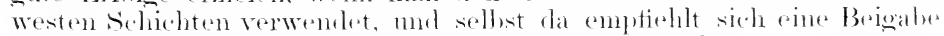

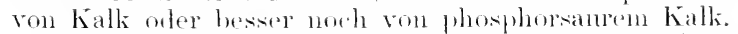

I.h habe in einem Jesomeleren Abselmitt die Mit'sotände der Hoblte

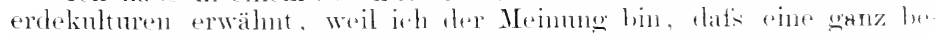
dentende Anzahl von Grankheitserseheinmegen anf die sänesn im Buten

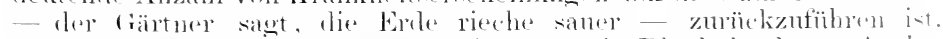

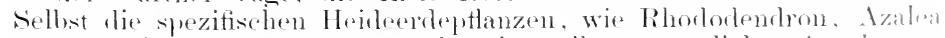

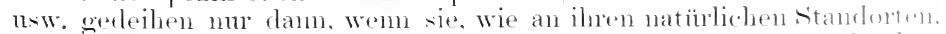
in taseriger Erde, die immer wieder leicht dnurhliaftet, stehen. In dren

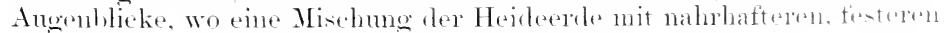


Errlen zur Toptknltur verwentlet wird, findlen wir Wuzelfäuhnis, die

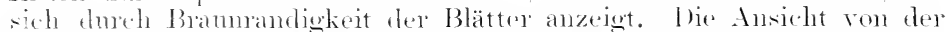
Notwentigheit ainer Beimengmes von Heideerde hei der Kultur der

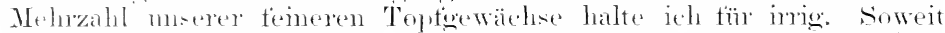

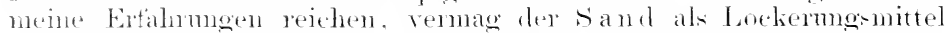

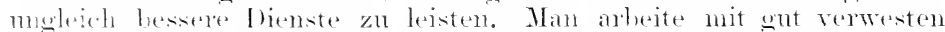

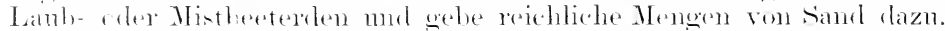

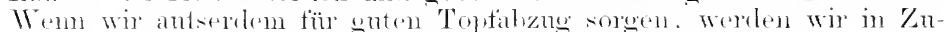

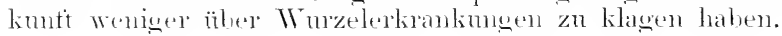

\section{Das Fleckigwerden der Orchideen.}

Eine speziell. Illustration der im vorigen Abschnitt geschileterten Vorteile der silhagmm- Terwentung finclen wir bei einer eigenantigen s.hwartleckinkeit der Blättor epiphyter orehileen. In mseren Glashänsern wilt es reichliche Blatterkanknngen, die häntig ant' Pilz-

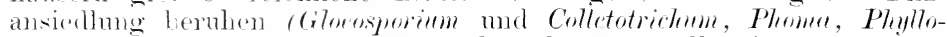
stictu nsw.). Wir haben al:er anch mehrtache Fälle, in denen Pilze nicht heteiligt simb oder erst sekmolär anftreten, mol muter diesen ist pin Vorkommnis lesonders berrorzuheben, das bei Cuthlyn.

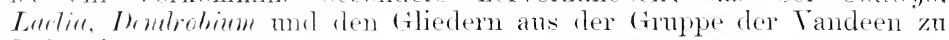
finden ist.

Der Erkrankmosvorgang wird am besten dureh Beschreibung eines speziellen Falles klar, der kïrzlich bei Platumopsis amabilis var. Rimenstadiuma genaner studiert worden ist ${ }^{1}$ ).

Die in duchbrochenen Töpfen in Lauberde knltivierten und mit Flutswasser begossenen Pflanzen zeigten alle Blätter mit Ansmahme des jüngsten gelb bis shwartleckig. Die Krankheit sthritt angenscheinlich von den älteren nach den jüngeren Blättern hin fort mol äntserte sich in ihen Anfängen duch das Auftreten mmegelmätiog kreismolor ofler ovaler. hleicher, durchscheinender Flecke. Dieselluen sind ïher die sanze Blattfäche verteilt, joflegen aber an der sivitze zuerst mul am reichlichsten anfzutreten. Wem derartige Blätter ab-

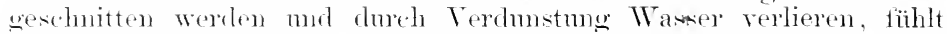
man. dats die hei Begim der Erlirankmo verbleichenden stellen etwas schwielig äber den gesmolen Blatteil hervortreten.

Bei dem Fortscheiten ter Krankheit aher ändert sich dieses Verhälnis, inflem alstald die gelben Flocke ein weitsliches Aussehen lo. liommen und schïsselfömig einsinken. Dabei sieht man, dafs einzelne henatharte Kronkheitsherdo miteinander versehmelzen und zusammenhängende dümne, schliefslich tief schwarzham sich färhende Flächen bilitur, fle mmmelu wallartig von dem gesmden Gewebe eingeschlossen werden. Nath der Brambäromg vergrötsern sich aber die Flecke nieht melur. Es sind also Kranliheitsherde, die in ihrer Anlage anf bestimmte fewhegrmpen buschänkt hleiben.

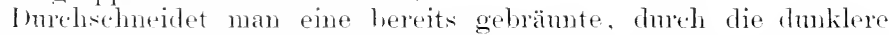
Nervatur mit länswstreiten versehene Sitelle, so finclet man, dats die

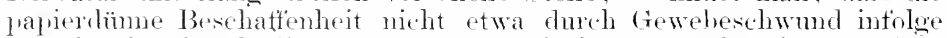
ron lnsektenheschärligmeg orler Bakteriosis entstanden ist, sondern lediglieh dureh Zusammentroeknen der ihos Inhalts fast gänzlich be-

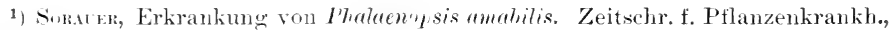
1904, Heft Y. 


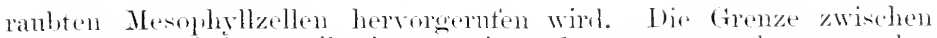
dem toten mol fom wallartig rorsumgenden, anguenzenden, gesmolen Gewebe ist schart, ohne T̈berwänge. Las zusamnengefallene bram-oder (meist) hellwandige Gewele zeigt mit Joel mu noch einzelue Flocken

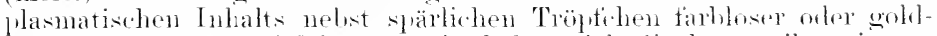

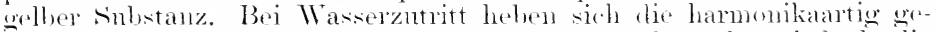
Eniterten Zellwandmegen etwas anseinander, olme dats jedoch die

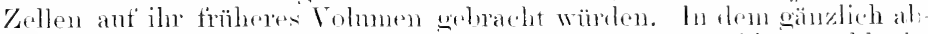

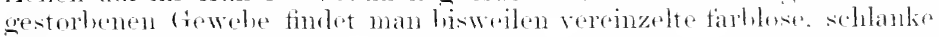
Mreeltädon.

Temn man anf die firischen sichnitte, dic ührigens anch an ten

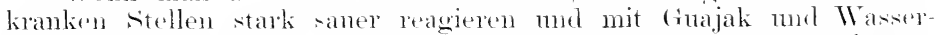
stottinperoxyd keine Oxydasen nud Peroxydasen erkemen lassen,

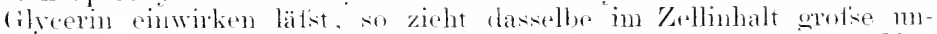
gefälote, mregehmäfige oler meist knglige Jassen zusammen. Man findet diese Erscheinume vieltach bei zuckerreichem, besonders saftigem Gewele. An dor Peripherie dieser Massen liegen die Chloroplastrn. ln dem stärer orkrankten Trike sind diese stoftempuen nicht meln

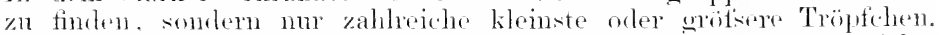

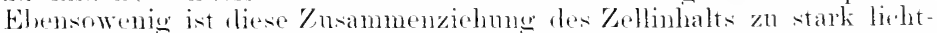
hechenden Tropten. die wir, weil se stellenweise hei der Tuonusk schen

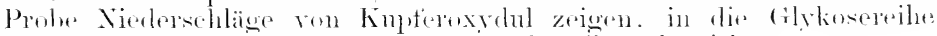

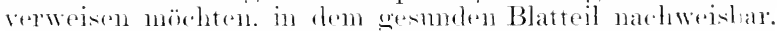

Hio weiteren anatomischen lintersuchungen fïhrten zn dem Er-

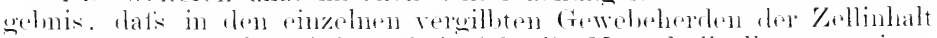
zon stark verbraucht wirl. wobei sich die Mesophyllzollen answeiten.

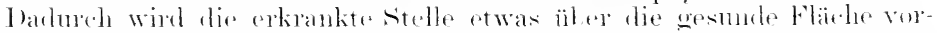

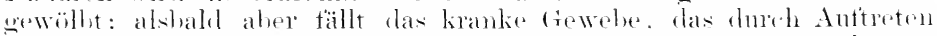

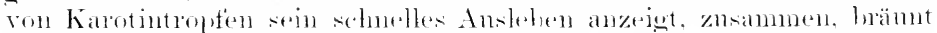

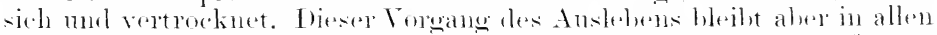

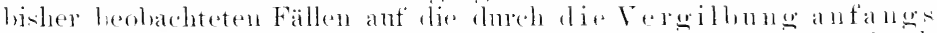

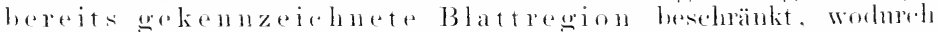

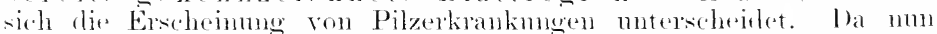

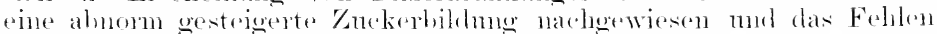

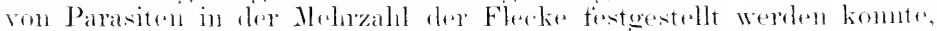
so hahen wir aine Konstitutionskrankheit ror mos, die dort sieh einstellt,

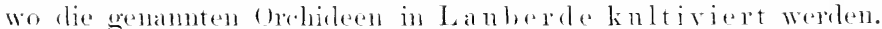

biese Kultumethode ist in den letzten . Jahen namentlied von

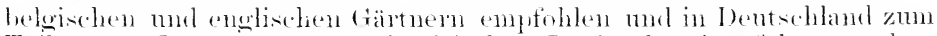

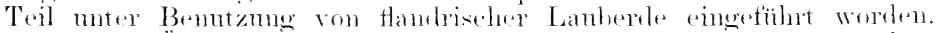

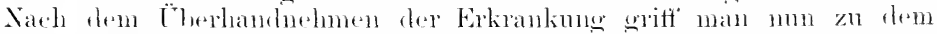

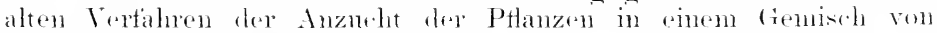
sphagmm mit Ileiderele-Brocken zuriek mol erzielte wieder die

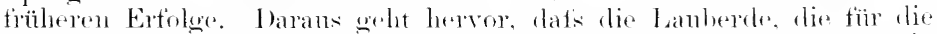
meisten anderen Ptanzen ein ändserst zosagendes substat ist mul in

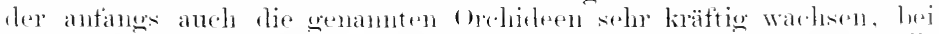

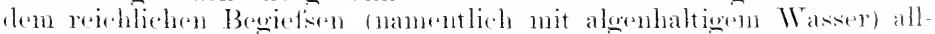

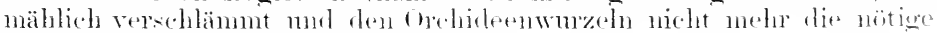
samerstotfzutiuhr zateil werden laitst.

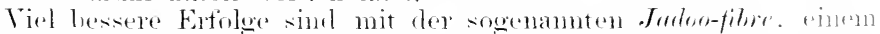
mit Nährsalzen durehtränkten, äutserst lorkeren Moostorf erzistt worelen:

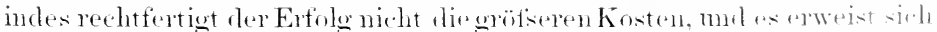

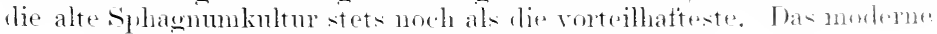




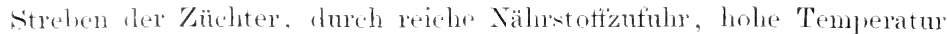
und grotise Fenchtigkeit die Orchideen zu schmellerer und ïprigerer Enttaltung zu bringen, hat nur tür eine heschränkte /eit wirkliche Erfolge: meistens stellt sich ein Rückschlag hei den ïherreizten Pflanzen ein, dem nur durch eine Ruheperionle an einem relativ kïhleren, trockneren standort vorzubengen ist.

Der kïhlere, trocknere stand ist in vielen Fällen anch das beste Nittel gegen die Pilzfäulen. Ein sehr lehreiches Beispiel beolrachtete Kumzing bei einer durch Glorosporimm hervorgentenen, jetzt ziemlich alloemein aut dem Festlande und in Ensland, sowie selbst im Vaterlande vorhandenen Fleckenkranklest von Tunda coorulea. Aus den Mitteilumgen des sammlers geht hervor. daf's diese Vanda im Himalaja aut Gordonion gefunden wird, die an mäfig warmen, windigen Standorten wächst. Hier in mseren (ilashänsern werden die PHanzen durchschnittlich mehr als $10^{\circ} \mathrm{C}$. wärmer kultiviert und in der geschlossenen fenchten filashanshuft jahraus. jahrein festgelıalten. Natürlich werden dadurch die Ptanzen zarter mil erliegen bei kïnstlicher Impfung dem Glopspminm bimmen wenigen Tagen. Während im Taterlande der Pilz beschänkt hleiht und die Pflanzen trotz seiner Anwesenheit sich weiter entwickeln mol remehren.

\section{Writter Kapitel.}

\section{Lnoinstige chemische Bodenbeschaffenheit.}

\section{Verhalten der Nihrstoffe zum Bodengerïst.}

\section{A. Bodenabsorption infolge chemisch-physikalischer Vorgänge.}

Die schädigungen der Vegetation können entweder dadurch erfolgen, dats das Nährstoftkapital im Boden quantitativ oder qualitativ mö̈nstig für die Ernährung der Pflanzen sich gestaltet oder daf's bei reichlichen Vorhandensein und normaler Kusammensetzung des Nährstoftmaterials lurch anderwitige Wachstumsaktoren die Aufnalmetätigkeit seitens der Pflanze irritiert wird.

Es kam rann Mangel oder Überfluts der Nährstofte sich geltend machen oder durch die modifizierten Aufnahmebedingungen ein einziger Nährstott in zu geringen oder zu wofsen Nengen zur WVirksamkeit gelangen und das fileichgewicht im Haushalt des Organismus stören. Dieser zweite Tril dre Ernährmestörmgen soll im folgenden Alschnitt behantelt werden, und zwar unter den Rulpriken . Wasser-mo Nährstoffmangel" und "Wasser- und Nährstoffüberschuds".

Dats in dirsen Bezeichmungen neben den Nährstotfen auch der Wasserzufuhr gedacht wird, rechttertigt sich durch den Umstand, dats das Wasier nicht nur loci siner Versetzung im Pflanzenleibe selbst Nährstoffe licfert, sondern anch als Transportmittel je nach der vorhandenen Nenge bald schwache, hald starke Konzentrationen der Nährlösmo veranlatist und darlurch den Ernährungsmodus vorteilhatt oder nachteilig beeinfluf'st.

In Rücksicht auf die beständig wechselnden Konzentrationen muls also auch hier bei der Betrachtmog des Verhaltens der Nährstoffe zum Bodengerüst der Wassereinflut's beritckichtigt werden. 
Die löslichen Salze, welche bei der Zersetznng der Mineralien entstehen oder durch büngung zugeführt werden, nuterliegon der Bodenabsorption. Das Festlalten und Abgeben sowis die andanernd im Boden sich vollziehenden Unsetzungen der sialze hat man anfangrorwiegend als physikatische Vorgänge angesporden, währent sie jetzt ter Hanptsache nach als chemische Prozesice anferefatst werden $\left.{ }^{1}\right)$. Allerdings ist es schwierig. die (ivenze zwischen phrsikaliseher (Arkorption) und chemischer Binchug zu ziehen.

Die Aelsorption wird nur dort von Bedentung. wo glotse Anzielnungfächen gehoten worlen, wie bei den organisehen sulstanzen und anch bei grwisen anorganischen stotten, zu denendie colloiblale Kieselsäme und las colloidale Eisenoxyd der tropischen Roterden gehören. An bs. dentungsvollsten tür musere Kultur erscheinen dir antipullharen llumusstoffe, Tie in nährstotfirichen Böklen wohl als salzartige Verhindmengen ansqefält werden, in reranten aber grotsenteils in liömng verbleiben. Betreftis der Ahsorption der llumusstoffe spielt ihre Anfuahmefähigkeit fïr freie Basen und deren Karbonate die prote liolle. Fiur das im Boden befindliche Ammoniak und kohlensaure Ammon sind namentlich die samen Humnstofte wirksam, mol wir verwerten diesen Lmstand beronders bei Anwendmug der Tortstreu.

Soben den eolloidalen stotten sind die teinverteilten Mineralbestandteile als Träner des Alsorption ins Auge zu fassen. Von Vineralien sime jedoch fuarz stots und Kaolin, wonn letzteres nicht mit Alkalisilikaten sich zu absobiomelen Doppelsilikaten etwat rephinder.

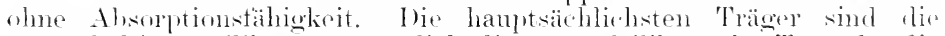
wasserhaltigen silikate, namentlieh die Doprelsilikate der'Tomerde, die kistallisiert sich als \%eolithe in den frestrinen fimlen, mul des Eisenoxyds. Sie rermitteh den im Boden zu beobachtendin Basenanstausch.

Lieser kommt bei ter Verarmung des Borlens an lïslichen Nährstotten zur Wirksamkeit. wie folgender von Lonberia (\%eitschr. d. fieol.

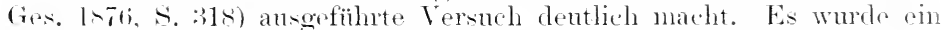
wasserhaltiges silikat drei Wochen lang mit kohlensänehaltigem Wasser in Verbindming gehalten und nach dieser \%eit gofunden:

I.

ursprüngliches

silikat

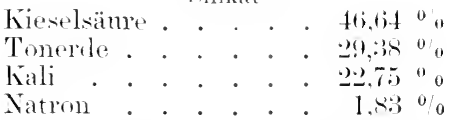

II. nach Behandlung mit kohlensäurehaltigem Wasser

$$
\begin{aligned}
& \text { i } 4 \text { (1):3 } 0 \\
& 39.6950 \\
& .5 .340 / 1 \\
& 0,1) 0 \%
\end{aligned}
$$

Wurde dieses ansgelanote silikat II wieder mit Kalilange behandelt. zeigte es folgende /nsammensetzung: Kieselsäum Hitio "o, Tonerde 3.5.67"0. Kali 17.73"0. E. war also in das silikatgeriist ter grölste Teil des Kaliums wieller antgenommen worden. so dats ein Zustand chemischen Gloichoewichts sich wierler heransgestellt hatte.

Tenn dem ursprünglichen Silikat I Chlorammonium zugetügt word. bekam es folgende Form: Kieselsätre sti,17 "0, Tonerde :34,s!" o, Kali 0.s! " o, Ammoniak ( $\mathrm{NI}^{3}$ ) $8.97 \%$ \% Würde statt des Ammonialis ein sehr grotiver Überschuts von Kalksalzen vorhanden gewesen sein. hätte

1) s. Rumsx, Bodenkunde, II. Aufl., S. 21. Berlin 1905. Jul. sirringer. Auch im übrigen Teile dieses Abschnittes stützen wir ms, falls nicht andere dutoren angeführt sincl. hauptsïchlich auf das genannte Werk. 
der Kalk das Kali aus dem Silikate gänzlich verhängen kömnen, wie

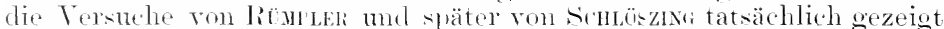
haben. Derartige Vorwänge sind num fortwähend vorhanden und zeigen, wir schmell ein Boden hei andanemden, reichen Niederseluägen answewathen werden ham oder hei einseitiger l)ïngerzutuh an anderen wertvollen Nährstoften verarmen liam.

Eine weitere Enttänchung zeigt sich bisweilen in dem Tmstande,

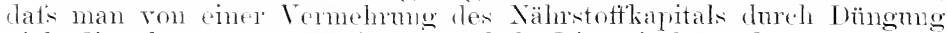
nieht die erhoflte Ertrassteigermug erhält. Dies tritt besonders bei reichen Böden manchmal hervor mud r riärt sich dadmeh, dats soleher Boden gerade infolor seines Nähstottieichtmms nicht mehr zu absolvieren imstande int. Namentlich tomanne Börlen mit ihrer geringen Absorptionskratt werden derartige Erscheinnoen bringen können.

Weitere schmeryliche İtherraschmoen, die mit der Absorption zusammenhängen, sind die Bodenvergiftungen durch Metallsalze. Alle seluwermetalle werden stark gobmelen. mol es ist daher $z$. B. in der Nähe vou Hütten der zn l eobachtende Mitswachs nicht immer der schwreligen sänre des Fenerung-matcrials allein zuzusehreiben, sondern manchmal auch den solisen Anhäufungen von Metallverbindmgen. Der Emstant, dats erfahrungsuemäts kleine Quantitäten von Kupfer, Blei, Zink n. Igl. in Boden von den Pflanzen schadlos rertragen werden, hat bisher verhindert, dieser Art ron Bodenveroiftumg die nötige Antmerksamkeit zu schenken.

Bei Kalimm und Ammon, die beide stark gelmunden werden, erfolgt die Absorption vielfach durch Austausch in äguivalenter Menge (:; Teile $\mathrm{K}^{2}$ () gegen 1 Teil $\left.\mathrm{NH}^{4}\right)$; dabei gehen Natrim, Calcimm und Iagnesinm in Lösmo ïler. Nur schwach absorliert wird das leiehtlösliche. Salze bildende Natrium und in noch geringerem Grade das als Humat, Karhonat oder Phosphat vorhandene Cateimm, das in don silikaten leicht durch andere Basen ersetzt werden kam. Ähnlich verhält sich Magnesium. Särien werden nur gebunden, wemn sie mlösliche salze bilden. Dies ist namentlich der Fall bei Phosphorsäne, die mit C'aleimm. Magnesimm, Eisen- und Tonerde mösliche Verbindmgen eingeht. Sehr schwach wird die schwefelsäme, gar nicht die Salpetersäme und das Chlor absorbiert. Letzterer Fall verdient Beachtung bei den Chlorvergittungen in der Näho der salzsänrefabriken.

I) meh die verschiedene Alsorptionstäligkeit und den steten Anstanseh der Nährstoffe erklärt sich die teils antschlietsende und damit die Pflanzenemährme tördernde, teils erschöpfende Wirkun maneher I öngungen. So ersehöpfen die reichen Zufuhren von Kalisalzen und Chilisalpeter die Böden an Kalk und Magnesia. Der Ansdruck na sogmergelter Boden" dentet darauf him, dafis der Mergel, thenso wie ter Gijs, durch seme anfschlietsende Wirkung das Nähstoff'kapital des Bodens fiühzeitig erschöpfen kann. In seiner anfschlietsenden Wirkung liest anch der Wert des Kochsalzes. In dem säuregehalte, namentlich in Reichtmm an Humusämren, die die Absorption starli schwächen und alle Bodenbestandteile zu lösen imstande sind, lient eine weitere Quelle mangelhatter Produktion. Dieser Gegenstand ist bei den Nachteilen der Moorböden und bei der Ortstembildung beroits cingehender behandelt worden.

Je weniger die vinzehnen Nährstoffe testgehalten und je löslicher sie in ihren Terbindungen sind, desto leichter erfolgt ihre Answaschmo: Im besten Falle gelangen sie in tiefere Bodenschichten: in Gegenden 
mit starken plötzlichen Niedersehlägen können sic fortgefühnt werken. Am leichtesten beweglich sind die wohl in den meisten Bäden in kleinen Mengen vorhandenen C'hloride: dann folgen die Nitrate, spätre die sulfate: langsam geht es mit den Karbonaten von Kalk mol Magnesia, um am dauerhaftesten sind die Phosphate. Getährlich fï̈ dis Kultur werden die Chloride in Gegenden mit sehr geringen Niedersehlägen. wo sie sich an tiefliegenden stellen ansammeln kömmen und hochkonzentrierte Bodenlösmoen erzengen. Unter denselben Bodingungen kommen durch die Karbonate und sulfate der Alkalien die sog. . Alkalibïden" zustande.

An schwerstwiegonden ist die stickstottfrage, nud bei der äulserst leichten Löshehleit der Nitrate kam eine Ausmagorung der oberen, Flachwurzler tragenden Budenschichten stattimben. wem der Unteround noch reichlich stickistoff enthäl. I)sien Nutzharmachmo kamn tann nur durch Tirfwurzler erfolgen. l)at's bei schlechter Düngerhehandlung auf dem Acker noth grofise Verhiste eintreten, kam der. Praxis gegenüber nicht genug hervorgehoben worklon. Betretts der Kalksalze kommt der Gijes als Träger der schwefelsäne in Betracht. Bei den Kalkkarbonaten kimn der Fall eintreten, dats in fenchten Klimaten selbst anf Verwittermoshöden der Kallogesteine der Boden kalkarm sein kann, weil das Karbonat langsam ansgewaschen wircl. Dagegen gehören die Kalkphosiluate sowie die Phosphorsäneverbindnugen iiberhaupt (mit Ausnahme der Alkalien) zu den widerstandsfähigsten Mineralien. Eine Ansnahme findet nur in ten Börlen mit fieien Hummsiämen statt. Hier werden Phosphate, anch Eisenvertinchmgen läslich, mol solbst die widerstandsfäligen silikate werden zossotzt murl in lïsliche Form ïbergefïhnt. Daher die moremeine Verarmmo an allen Vineralbestandteilen mit Ansnahme des Qnarzes hei den Moidehörlen.

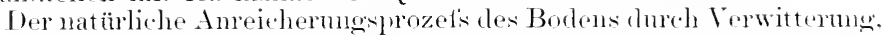
durch Anwehen nener Bodemmassen, durch Fäulnis der organischen Substanz u. dgl., welcher der Answaschung wirksm rntergenabeitet, diurte nur bei langlebigen Pflanzenbeständen ins crewicht fallen. Hier ist der Umstand. dats die tictgehenden Wruzeln das Nährstotfmaterial aus dem Untergruncle holen und der Laubfall dasselle den oberen Bodenlagen wieder zugänglich macht, sicher von wotser Wichtigkeit. Bei muscren Kulturen von ein- und zwejjährigen PHanzen finclen wir

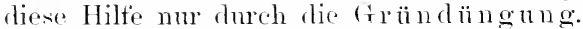

Nicht zu ïberohen ist schliefslich auch die Borlonverarmmong durch Irain a ge. So nützlich diesr Einrichtung ist, wie wir bereits früher bei der Bodendurchlöttung anerkamnt, läfst sich doch nicht vorkennen, dats sie auch ihre grotisen schattenseiten hat und stellenwoise sehädlich wirken kann. Dies bezieht sich namentlich auf die Anslaugmer des Borlens an salpetersauren salzen in Örtichkeiten, in donen intensive l)ïngerzufuhr nicht ausführhar ist. Dort natürlich, wo reiche stickstoffzufuhr rorhanden, strigert sich der Verlust zu bedentender Hähe. wie beispielsweise die Analysen lasy's von den Drainwässem der Pariser Ricselfelder beweisen ${ }^{1}$ ). In rinem liter der abtliefsenden Drainflüsiokeit waren enthalten an Ammoniakstickstoff $19, \leftrightarrow-11, ! 1$ mo, an salpeterstickstoff zwischen 1!,1-27.1 mg. Das zur Berieselmog verwendete Kloakenwasser enthielt 24,! Ammoniakstickstotf und 0,9 Salpeterstickstoff. Der Veroleich cieser Zahlen zeigt dabei, dats der in Form von

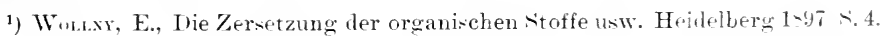


Ammoniak zugeführte Lüngerstickstoft bei seiner Durchwanderung des Bodens fast gänzlich zu Salpetersiume oxydiert wird. Die Untersuchungen von $\mathrm{W}_{\mathrm{Ar}}{ }^{1}$ ) zeigen, dafs dmohschnittlich von den Mineralbestandteilen sich keine sehr grotsen Mengen in Drainwasser nachweisen lassen. Er fand in 1000 Toilen an Kali nur bis zn 0,1003, an Kalk bis 0,180 , an Schwefelsiume bis 0,1:38, an Phosphomsäme bis 0,002 Teile nsw. Indes dïrfen wir aber nicht rergessen, dafs es sich um Tauende Vermindermogen handelt, die sich smmmieren, falls die Drainage reichlich läuft.

Eine übersichtliche Zusammenstellung 3.j jäniger Lysimeterversuche in Rothamsted und nenerer Untersuchungen in Holland ${ }^{2}$ ) lä1st erkemnen. wie schnell in der Regel die Nitrifikation von Düngemitteln, wie den Ammoniaksalzen ror sith geht. Selbst im Herbst und Winter ist die Nitrifikation so lebhatt, dals grotse stickstoffiverluste zu erwarten sind. weshalb es sich empfiehlt, Ammoniaksalze als Kopfdüngung in Frïhjahr zu verwenden.

Bei Terwendmo ron sulfaten mol Chloriden des Ammoniaks wird der Kalk in Verbindung mit der Schwefel- und Salzsäure in grofsen Mengen in das Drainwasser gespült. Dieser Vorgang ist die notwendige Einleitung zur Bindmo des Ammoniaks im Boden und der darautfolgenden Nitrifikation. Reicht der kohlensaure Kalk für diese Umsetzung nicht aus, so werden leicht die Ammoniaksalze den Pflanzen gefährich. Da anch die Sulfate nnd Chloride des Kaliums wie die des Ammoniaks Gips und Chlorkalk bilden, die nicht vom Boden absorbiert werden, so sieht man, wie notwendig eine periodische Kalkung ist.

\section{B. Die A rbeit der Bodenorganismen.}

Der 'Tätigkeit der' Tiere in bezug auf die Verändermng des Bodens ist im dritten Bande miseres Werkes Erwähnumg getan; hier handelt es sich in erster Linie $n$ die Arbeit der Bodenbakterien, deren landwirtschaftliche Bedeutung in sehr ibersichtlicher kurzer Zusammenfassme von Benress ${ }^{3}$, und Hutrser ${ }^{4}$ ) dargelegt worden ist.

Nach ihrer hauptsächlichsten Arbeitsleistung könnten wir bei den Bakterien von solchen, die die stickstoffivanderung auslösen, und anderen, welche die kohlenstoffhaltigen Verbindungen angreifen (wie z. B. die Pektin- und Celholosevergärer), und endlich von Humusbildnem und Humuszersetzern sprechen. Aber die Tätigkeit dieser Organismen an ihrem Nährsubstrat ist hier nicht allein zu wïrdigen, sondern, und zum Teil vorzngsweise, ilne gegenseitige Beeinflussung. Eimzelne Gattungen ofler Arten schliefsen einander aus, andere mterstützen einander.

Als ein hervoragendes Beispiel dient der Einfluts des s chwefelkohlenstoftes, von welchem man neben einer Giftwirkung auch eine direkt wachstumfördernde Reizwirkung angenommen hat. Letztere glaubte man in der Tatrache zu erkemen, dat's nach Verschwinden des Schwefelkohlenstoffes und seines wachstumhemmenden Einflusses eine deutlich erliemmbare Erhöhmg der Fruchtbarkeit eintrat. Hitrser gelang

1) Weitere Analysen bei A. Marsi, Agrikulturchemie. 5. Aufl. 1902 Bd. 2 Abt. 1 s. 11 \%.

2) Beleuchtung der Bodennitrifikation durch Drainwasseruntersuchungen. Mitteil. d. D. Landw. Ges. 1906 stück 13.

') Banmw, Die durch Bakterien hervorgerufenen Vorgänge im Boden und Dïnger. Arb. d. Deutsch. Laudwirtsch.-Ges. 1901 Heft 64.

4) Hurxa, L., İber nenere Erfahrungen und Probleme anf dem Gebiete der Bollenbakteriologie usw. Arl. d. Dentsch. Tandwirtsch.-Ges. 1904 Heft $9 \checkmark$. 
nun der Nachweis, dats der sichwefelliohlenstott hampträchlich dadurch die wechselnden Erscheinmgen bedingt, dats er den tileichgewichtszust and der Bodenbakterienflora stört. Inrch seine fottlösende Eigenschaft drängt er gerade die bis dahin vorherrschenden Bakterien plötzlich zurück, sowie or überhaupt die Vermehrung der sämtlichen Arten anfhebt, solange ex im Boden unverändert vorhanden ist. Verdunstet mum das Gift oder verschwindet durch Tmsetzung, damn steigert sich die so lange zurückgehaltene Vermehrung der Budenorganismen derart, dats z. B. in einem Falle eine Vermehrung von ? Millionen der auf Eleischpeptongelatine wachsenden Arten anf su Millionen in 19 Erde nachgewiesen wurde. Ton Moritz und schenes konnte dabei chemisch eine Erhöhung der stickstoffprodulition und damit der Kartottelernte festgestellt werden.

Tnter Hinweis anf das über die Bodenbakterion bereits in zweiten Bande (s. s!) geschilderte Virhalten der stickstoffbakterien ergänzen wir hier mu die dort angetïhrten Tatsachen. Nachdem nämlich Wswo-

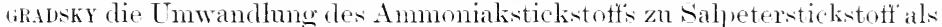
anfeinanderfolgende Arbeitsleistungen zweier vershiedener Bakterionoruppen (Nitrit- und Nitrathildner) nachgewiesen hatte, wurle ron UyELAxshy testgestellt, dat's der stickstoft' der oronisehen s'ubstanzen vorerst wieder durch andere Baliterien in Ammoniak verwandelt werden muls. Bei lieser trbeit kimnen num leicht sitörmogen eintreten, da die hier in Betracht liommenten Bakterien äntiverst ampfindlich wewen welöste stotte sind. So wird beispielsweise der salpetersäure bildende Organismus an seiner Tätigkeit vollständio gehindert. wom noch spuren von Ammoniali vorhanden sinul.

Lahlroichen anderen Bakterienarten (man kennt deren bereits mehr als zwanzig) kommt im Gegensatz zn obigen die Fähigheit der Lonitrifikation, also der Reduktion des Salpeterstickstofts lis zum treden in die Lut' entweichenden Stickstoft zu. Anf diesen Virgang hat man die Tatsache zurïckführen wollen, lats frischer stallmist miter Umständen im Boden enthaltenen salpeter schädigt und dats sitrolı d ̈̈ noun nachteilig wirkt. Jetzt erklärt man diese Erscheinmug haupt sächlich dadurch, dats eiweitsbildende orwanismen ren antirehmbaren Borlenstickstoff testgelegt haben (PFerforer mol Lemmenasx, sowie

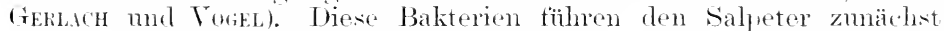
in Nitrit und damn in eiweitsartige Verbindungen über. Dats dazu abere bestimmte Nehenbedingungen wehören, zeigt ein Hutser'scher Versuch, bei dem die strohrüngmeg bei Toptkulturen ganz moemein sehällich sich rrwies, während sie in gleichen Gaben in freiem Landr eine gïnstige Wirkmg ausübte. Wahrseheinlich ist dieser Wiclersuruch darant zurïckzuführen, dats die entstandenen eiweilsartigen prodnlite im Freiland schneller in wieder aufnehmhare Produkte verwandelt werden kïnnen.

Für die Betrachtung dor Nährstoffwandernng und -wandhung durch die Borlenhaliterien kommt schlietislich anch moch der Voroang der sitickstoffsamm $1 n n \%$. l. h. der Assimilation des treien sitickstotfis dureh Bakterien in Betracht. Antiser dem von Wrowkask vor langer \%eit bereits f'estgestellten anä̈roben Clostrilinm I'astoriamum (Pustruirumum). das bei genügenden Mengen ron Kohlenhydraten den elementaren Luftstickstoff zu seiner Eruährung rerwenden kann, sind dureh IBr.JERIsck anch sauerstotiliebencle Arten. Wie Azotobuctor chroococcum. antgetunden worden. Diese in jedem Ackerboden vorhandene Art konstmiert äulserst groke Mengen on Kohlenhydraten bei ilner siticlistoft 
assimilation (nach GerLach und Toces s,9 mg stickstoff bei 1 g Traubenzucker).

Hierher zu rechnen sind auch die Verändermoen der Wraldstreu. bei rer die stickstoffanreithermg von HexkY ${ }^{1}$ ) berechnet worden ist. Er hoht hervor, dat's bei der auf fenchtem Boden im Sommer sehr lebhaften (im Winter kamm bemerkbaren) Zsrsetzmo abgestorbener Eichen- und Buchenblätter und Fichtemnadeln allein odler im (iemisch mit Erde Stickstoff gespeichert wirk. Nach seinen Berechumgen können abgefallene Eichenblätter bimen Jahrestrist 's $\mathrm{kg}$ Stickitoff pro Hektar sammeh. Auf trockenem Boden bereicherte sich das tote Lanb entwerler gar nicht (Rotbuche) orler doch nur ganz mbedentend (Weif'sbuche, Fichte). Ein stickstoffrerlust wurde jedoch in keinem Falle beobachtet.

Indirekt mitwirkend, und zwar speziell bei der Stickstotfanreicherung des Borlens, reihen sich hier anch die Knöllehenbaliterien an, die im Nitragin², als Handelsware eingeführt sind, während ein rein gezüchtetes Material von frei lebenden Stickstoffsammlern als "Alinit" verkantt wird. Die neneren Untersuchmoen weisen daranf' hin, dafs nicht blof's für einzelne Nährptlanzen angepatiste Rassen derselben Bakterienspezies anzunehmen sind, sondern dats verschiedene Arten zn mutesscheilen sind. Hutser hält hauptsächlich wegen ihrer morphologischen und phrsiologischen Terschiedenheit zwei Arten einander entgegen, nämlich Rhizulimm rodicicold und Rh. Brijorinclici. Dats die Knöllchenbakterien nicht ernährend für die Legmminosemptlanzen wirken können, so lange noch Salpeter im Boden den Wurzeln zur Verfügung steht, und die Wirksamkeit dieser Organismen erst hegimnt, wem die Legmminosen einige Zeit hindurch an stickstofth nnger leiden, sei hier nur nebenbei erwähnt, $m$ die Abhängigkeit des Bakterienlebens von den rershiedenen Faktoren weiter zu illustrieren. Als ein solcher Faktor wird anch die Wurzelanstheidung einer jeden Pflanze relten müssen. Ja anch rlie ganz gesmolen samen, welche in den Boden Fommen, und rie grïnen Teile gesmuder Keimpflanzen besitzen ihre spezifische Bakterientlora, die sich stark vermehren mol in den Boden ansschwärmen kamn. Dabei kömnen andere Mikronrganismen verdrängt werden ${ }^{3}$ ). Ans derartigen Ungleichleiten der Tegetationsbedingmgen im Borlen müxsen notwendigerweise bedentende Sehwankungen in der Indiviluenzahl jeder Bakterienart und damit in der Gesamtarbeitsleistung betreffs Herstellung des fïr unsere Kulturpflanzen zuträglithen Nährstoffinaterials rutstehen. Wem nun durch einzelne Umstände, wie z. B. chuch spezitische Wurzelausscheirlungen, einer bestimmten Pflanzenart Baliterienarten angelockt und zu starker. Vermehrung veranlatst werlen, welche einzehe Nährstoffe, vor allem aber den Stickstoff, in eine für die Kulturpflanzen mö̈nstige Form ïherführen, dam kam der Fall eintreten, dafs die Chemie den Gesamtuährstoffrorrat als genügend, ja rielleicht als ïberreich nachweist mul die Pflanzen doch in ihrer Produlition zurïcligehen. Wir stehen damn vor den Er-

1) Hexis, E., Uther dis Zersetzung der abgefallenen Blätter im Walde usw. (Amal. Se agron. fianc. VIII) cit Centralbl. Agrik. Chem. 1904 s. 793.

") Betreffs der Bodenimpfung mufs man herïcksichtigen, dafs die Bakterien, wie alle Pflanzon, nur gedeihen werden, wem der Bodlen so beschaffen ist, dafs er ihre Ver:lehrming beginstigt sie müssen, wie Rrw seln bezeichnend dies ansdrückt, ihr richtiges "Bodeuklima" finden.

?Diriar. M., "Die Bakterienflora gesunder samen usw. Centralbl. f. Bakt. II, 1904, Bd. XIII ڤs. 198. 
scheinmgen der Bod enm ï digkeit. Taranf hezïgliche Versuche erwähnt Hotrer, der bei Erhsen, welche im Lanto von drei Jahren siebenmal in derselhen. nur verschieden gedüngten Erds in Töpten erzogen worlen waren, in der dritten treneration answesposhone Anzeichen der Bulemü̈ligkeit wahrnahm. .. Die Ptlanzen kränkelten, neigten leicht zn Befall, vergilbten vorzeitig mul gaben schlechte Ernten," Ln ilus släteren

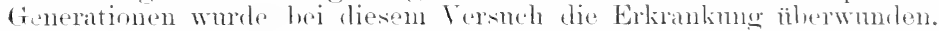
. Die Wruzeln der Erlsenptlanzen waren jetzt antfallend gebrämnt. imerlich aber ganz weits und gesmond, mol es liefs sich nachweisen.

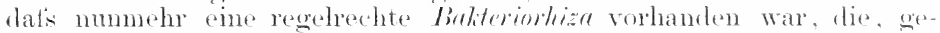
bihlet dmoh angepafste niitzliche Bakterien, las weitere Eindringen der schädlichen (Organismen verhinderte ${ }^{1}$ )."

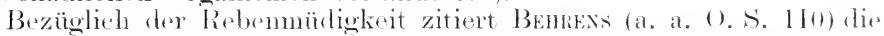
Beolachtungen von A. Koct, wonach dieselbe lureh eine Anhäntume sehällicher Aikroorganismen hevorgerufen wird. Nach dem sterilisieren des kranken Bodens (nicht des gesmolen) wurde das Rebenwathstm ein liesseres.

Trem ane soldhe Verschiebung in der Kusammensetzung der Baliterienflora nach der knltursthällichen Richtmog hin stattindet. dam erklärt sich anch die strigermng der Bodemmialigkeit dureh oine in kurzen \%wischenrämmen vor sich gehende Wiederholmng des Anbanes driselben PHanze anf rinem hestimmten Ackerstiok. Und diese Ansammlmus teindlicher Elemente wird nicht blots tïr die Bakterien ilne sijltigkeit haben, sondern an tö̈r andere phanzliche mol tierische Feinde. welehe Borlennïlierkeit veranlassen kïmnen.

Unter den Bakterien, welche bei mehmaligem Anban von Leguminosen im Borlen sich anhäuten, tand Hutrek, dat's die Pektinvereärer in Wirlisamkeit troten. Er tand, dat's in stark erbsemmïrlen

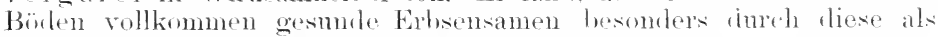
starke Säurebildner bekamnten Bakterien veriaulten.

Eine anderweitige Abweichme der normalen Bakterienarbeit im Boden ist die Vertortung des 1) öngers. Man findet in schweren Bölen oft noth nach. Jahren den eingebrachten I num ziemlich mzersetzt wieder. Ehenson vertort hisweilen eine zu tief mineroebrachte Grïndïngung. Ex vollziehen sich infolge des zu beschränkten Luftzutritts die Rohhmmusildmugen. Tho Herstellmg einer richtigen krimeligen Inmmslecke ist aber das Endziel mserer Bodenherabeituma dem durch den Humbs phalten wir die Answleichung der Hxtreme von llitze und Kälte, Nässe nnd Trockenheit mul den richtigen Nährboden, der don meisten Bolenhakterien erst die Existenzmöndichkeit liefert. Ist diese vorhanden, dam entwickelt die Ackerkmme ihr eigentliches Leben, las his zn einem gewissen Grade durch die Kohlensänreprodnktion metshar ist. Wie dabei die Bakterien mitwirken, zeigen einige An-

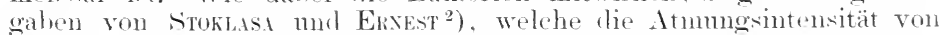

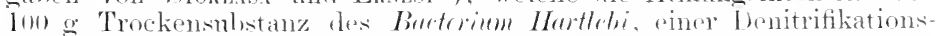

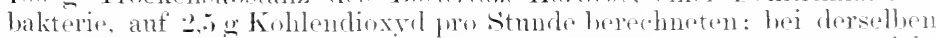
Menge Trockensubstanz von C'Tostridinm ghatimesem, oinem Ammoniak-

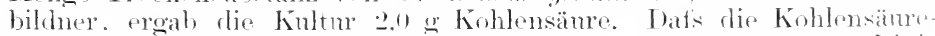
produktion eines Ackers wiblich vom Bakterienleben in erster linite

7) Bodenpflege und Pflanzenhau. Art. d. D. Landwirtsch-ties. Heft gs - it.

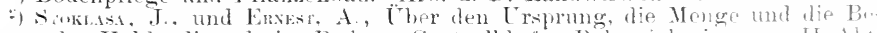
deutung des Kohlendioxyds im Boden. Centralh. für Bakteriologie usw. II Aht 190$.$) Bd. XIT Nr. 22.23$ ร. 725. 
abhängig ist, beweist der Umstand, dats nach Sterilisation des Versuchshodens keine Kohlendioxydprodulition zu beolathten war.

Über den Einflut's der Durchlüttung finden wir bei den genannten Antoren folgende Mitteihngen: Ein Waliboden aus tiefer Lage lieferte limen '24 stunden pro Kilo in Aërobiose 59, in Anaërobiose $0 \mathrm{mg}$, ein Tortboden in Aërobiose $41 \mathrm{mg}$ in Anaërobiose $7 \mathrm{mg}$ Kohlensämre. Natiirlich sprechen Wärme und Fenchtigkeit ansschlaggebend mit. Je reicher auf einem Acker die Kohlensäureprodultion, desto vollständiger vollzieht sich der chemische Prozet's der Bind $n \mathrm{ng}$ des fllï chtigen Ammoniaks, wie schnemewing ${ }^{1}$ ) beobachtet hat. Diese Frage kommt hier insofern in Betracht, als die Stickstoffrerhnste bei Zufuhr tierischen Dhuges eine Verarmung des Bodenkapitals darstellen. Wurde Stalldünger in gewöhnlicher Behandlung in einer Düngergrube belassen, $\therefore$ zeigte er nach dreimonatiger Lagerung einen Stickstoffverhust von :30,31\%0: lagerte er aber auf einer Unterlage von stark Kohlensäure produzierenden altem Dïnger, betrug der Verlust nur $16,94 \%$. Hier mutite also die reichliche Kohlensäure das flüchtige Ammoniak gebunden oder doch die Dissoziation des gebildeten kohlensauren Ammoniaks verhindert haben.

Zu den empfindlichsten, weil häufigsten Schädigmuen gehört der sogenamnte "ungare Boden ". Derselbe unterscheidet sich durch seinen Nangel an Elastizität von dem garen, der unter dem Einflut's der löslichen Bodensalze und Mikroorganismen die bereits früher besprochene Krümelstruktur amnimmt. In Rücksicht auf den vorwiegenden Anteil der Bakterien an den Zersetzungserscheinmngen können wir die Gare des Ackers als eine Arbeit derselben bezeichnen. Wenn wir auch noch lange nicht alle sich im gärenden Boden vollziehenden Prozesse kemnen, so wissen wir doch, dats wir die Gare bis zn einem hestimmten Grade als wirkliche Gärung auffassen dürten. Erimnert sei nur an die speziellen Pektinvergärer (Plsctridien), die bei der Keimung ter Leguminosensamen ron Bedentung erscheinen, ferner an die Cellulosevergärer mit rorwiegender Bildung von Wasserstoff und Methan (sumpitgas $\left(\mathrm{CH}^{4}\right)$. Weiter kommen die Streptothrix-Arten als Humusvergärer in Betracht, besonder's aber die säure bildenden Grannloseorgani:men ²), die vorwiegend Buttersäure und Kohlendioxyd produzieren, wobei die Plectridien die Hanptarlseit bei der Nineralisiermo der organischen substanz übernehmen. Der Stickstoffsammler (Bucitlus

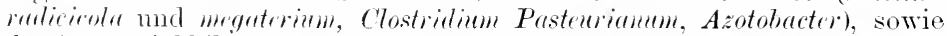
(ler Ammoniakbilidner (Bacillus ureae, albuminis, proteres vulgaris ${ }^{3}$ ), butyricus, mycoides, subtilis, mesontericus vulgatus, foetidus, Bacteriem coprophilum usw.), der nitrifizierenden (Burterinm nitrobacter nsw.) und denitrifizierenden Gattmgen (Bucillus myeoides, subtitis, liquidus, mbilus, venlgaris, coli, mordigiosus, liquefaciens, Bucterinme fuscum. Clostridium getatinosum nsw.) ist bereits gedacht worden, und num erimnere man sich noch an die spezifischen Fänhisorganismen. Alle diese biologischen Prozesse spielen sich im garen Borlen ab, ergänzen oder bekämpfen einander, je nach den jedesmaligen klimatischen Verhältnissen des Bodens.

1) Sonvanwax, Zur Frage der stalldüngerkonservierung. Deutsche landw. Presse 1904 Nr. 73.

¿) Limxis, F., Üher die Zersetzung des Kalkstickstoffs. Centralbl. f. Bakt. II 190.5 Nr. 34 s. 87.

") Sroks..., J., Über die schicksale des Chilisalpeters im Boden usw. Blätter f. Zuckerritbenbau 1904 Nr. 21. 
Autser den Bakterien hat man anch griine A lgen, deren Erscheinen als Zeichen einer guten Gare gilt, als Sticlistoffisammler angesprochen. Nach Koch ${ }^{1}$ ) ist aber dies wohl nicht der Fall, sondern ihr Wert darin zu suehen, elatis sie dureh ihre Chlorophyllätigkeit den stickstotibindenden Bodenbaliterien kohlenstotthaltige Nahrme liefern. Ton den blangrünen Algen behaupteten Berserisck, Śchlösini mud Lacrext die Fähigkeit, freien stickstoff zu assimilieren, mul ebenso sollen nach sisw ${ }^{2}$ ) eine Anzahl Sehimmelpilze (Aucor stolonifer und Asprogillus niger) diese Fähigkeit besitzen.

Vemn Tkeboux ${ }^{3}$ ) nenerdings hervorhebt, dat's die Tätigkeit der Nitrit- und Nitratbakterien häutig rersagen diurte, das's aber das im Boden zurückgehaltene Ammoniak den Pflanzen stets zur Vertügung ist und verarbeitet wird, so ist dies für viele Fälle zuzugeben. Auch andere Forscher haben die Nïtzlichkeit der Ammoniakernährung nachgewiesen. Aber schlietslich beruht die Ammoniakbildung im Boden doch anf Verwesmon, an der Baliterien beteiligt sind.

Das Wachstum der Mehrzahl der die Fruchtbarkeit des Bodens beclingenden Mikroorganismen ist an einen reichlichen IV echsel von Eeuchtigkeit und abtrocknender Durchlüftung bei genügender Wärme gebmelen, und diese Verhältnisse fehlen bei schweren Böden in nassen Perioden: der Boden bleibt ungar. Hier lätst sich die Ptlege der nïtzlichen Bodenbakterien nux chreh tortgesetzte Bodenbearbeitumg erzielen, und anerkannte Praktiker emptehlen möglichst schnellen Umbruch der Getreidestopueln auf Lehmböden zur Erzielung eines grötseren stickstoffgewimns durch fiöher beginmende Gare. In der Lauchstädter Versuchswirtschatt wurden nahezu dieselben Erfolge durch fröh zeitiges Pflïgen wie durch eine (irüntüngung erzielt. Ant' allen schweren Böden ist das Herbstptlïgen tür die Frïhjahrsbestellung das wesentlichste Vorbengungsmittel gegen mogren Boden.

Nenerdings wieder zu Ehren hommt die Brache ${ }^{4}$ ) bei schweren Bödlen. Bei leichten Bodenarten wird sie als Verschwendung anzusehen sein. Das Wohltätige der Brache ist ihre autischlictsente Wirkmu, über deren Zustandekommen ein endgültiges Urteil noch aussteht. IV glauben, dat's physikalische, chemische und bodenbakteriologische Vorgänge dabei ergänzend ineinander greiten. Der Winter wirkt un so besser lockernd, je ötter der Boden auttaut und wieder durchfiert; dadurch wird das Eingreiten des Verwittermosprozesses begïnstigt und der Boden für die nützlichen Arten der Bodenbakterien geöffinet. Zu welchen Gattungen dieselben gehören, ist noch nicht sicher festgestellt. Hiltsek hat zunächst nachgewiesen, dats es nicht die Alinitbakterien sind. In letzter Linie wird es stets darant ankommen, den Nitrifikationsbakterien die höchste Arbeitsleistung zu ermöglichen; dem nach REITsAIR $^{5}$ ) setzt in guten, milden Börlen bei gonügender Wärme gleich nach der herbstlichen Ente die Nitrifikation des Borlens sofort derartig

1) Kucn, A., Bodenbakterien- und stickstofffrage. Verh. d. Gesellsch. deutscher Naturf. zu Karlsbad. 190:3. Teil I s.. 18:.

2) s. Vucks, J., Die Assimilation des freien elementaren stickstoffs durch Mikroorganismen. Centralbl. f. Baktriol. II, 1905, Bd. XV \$. 174.

3) Trum , )., Zur sitickstoffernährung der grinen P'flanzen. Ber. d, botan. Gesellsch. 1905. s่. 570.

${ }^{4}$ s. Humuxx, Bedeutung der Agrikulturphysik nsw. Nachriehten atu dem Klub der Landwirte, $1902 \mathrm{Nr}$. 45:, und Mitteil. d. D. Landw-fies.

5) Rermur, O., Die sitellung der Brache und der Grindiungung in uneru modernen Fruchtfolgen. D. Landw. Presse. sond. 1903.

sorauer, Hanlbuch. 3. Aull. Erster lianl. 
wioler oin, dafs der Bedart einer folgenden Halnfincht an Nitraten

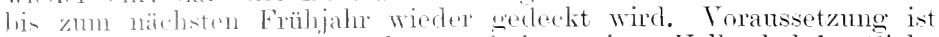

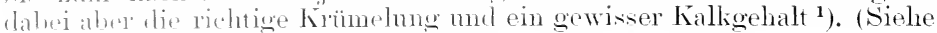

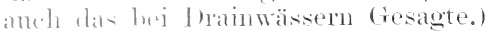

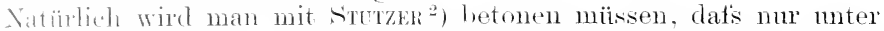
hertimmten [notänden die Brathe zur Anwendung gelangen kann. Wir shature, dats sic damn angelnacht ist. wenn es dem Landwirt rechnerisch an vorteilhaftesten erschoint, den Acker lieber für die lange Zeit der Brache zu cutheluen, als die schneller wirkende Grïndiüngung und stallnistzufuhr anzuwenden. Anf' diese allein ist wegen ihrer mechanisch lockinden Eigenschaften hei zu. Ungare neigenden Bodenarten Gewicht zu lewen und nicht anf ،lic Düngesalze. Der Stickstoff der organischen 1) nngmasien elseheint, wio PFEIfFER ${ }^{3}$ ) besonders betont, im Boden festgelent. whichsam kapitalixiret mul zeigt daher eine lange Nachwirkung. Dirser Antor ist ïbrigen ein Gregner der Brache, die er als Raubban

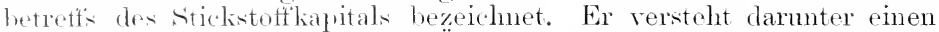
monllstandigen Ersatz der den Äckern durch die Emten entzogenen Nähstotfmengen. Die bei der Brachhaltung gewomenen löslichen Stickistotfrephindungen gingen nach PFEIfFer's Ansicht dem unbebanten Borkn wröstenteils durch die sickerwässer wieder verloren. Solche Bedenken sind unserer Ausicht nach vollständio gerechtfertigt für leichte Bülen, fallen aber bei schweren, durch Ton mit reicher Absorptionskraft versehenen, lurch die Ernten geschwächten Borlenarten tort.

\section{Verhalten der Nährstoffe zn den Pflanzen.}

l) Frscheinmogen, welche in diesem und dem folgenden Abschnitt zu bellandeln sind, dürten nur selten als alleinige Folgen eines Mangels order T̈hrschnsen des Nälnstoffkapitals im Boden anfgefafst werden. Sir sind meist das Erobnis des Zusammenwirkens zahheicher Faktor'm, moter denen der Feuchtigkeitsgehalt der Luft eine besonders matigelente liolle spielt. Wir wollen micht vergessen, dafir fast alle Krankheiten nu dureh eine $n$ passende Kombination der normakn Venetationstaktoren zustanke kommen und eine störmo des

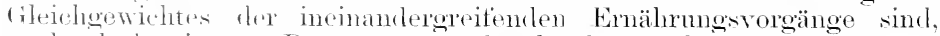
worlureh hestimntr Prozesse zurïckwedrïckt werden und andere in

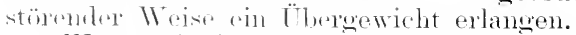

W'nn wir jetzt ron Krankheiten durch Wasser- und Nährstoff-

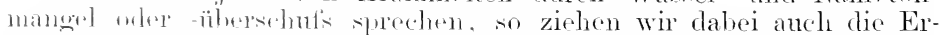

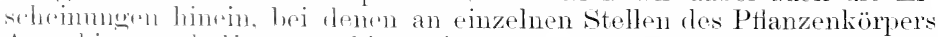
Atrohion und Hypertrohion eintreten. Diese branchen nicht ant

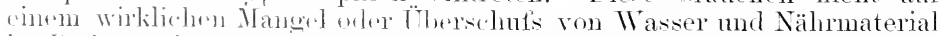

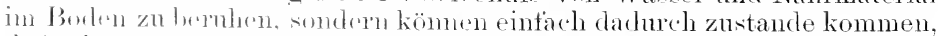

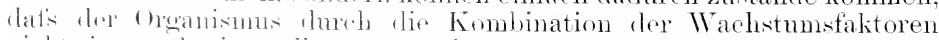

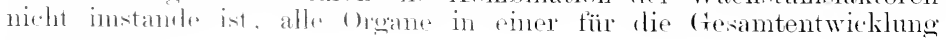

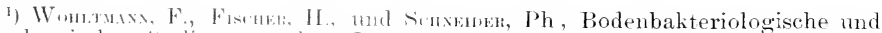
bondenchemische stublien aus dem Poppelsilorfer Versuchsfelde. Jomrn. f. Landwirtschaft $1904 \times 97$.

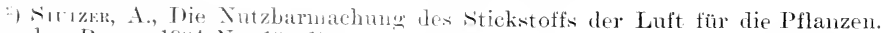
1). Landw. Presse 1904 Nr. $101 \%$.

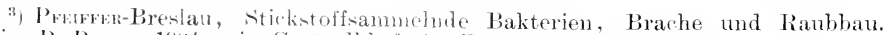
Berlin, P. Parey, 1901. cit. Cintralhl. f. Agrik. ('hem. 1905 s. 599. 
vorteihaften Weise zu ernähren. Zu den absoluten Mangel- und F̈berschutserseheinungen treten daher dis relativen in Firm vom störungen des lokalen Hleichgewichts.

\section{A. Wasser- und Nährstollmangel.}

a. Wassermanel.

\section{Einflufs der verschiedenen Vegetationsdecken.}

Nachdem wir bereits trüher der phrsikalischen Vorgänge. welch. zu Wassermangel im Boden führen, gedacht und cine Anzahl davon herrührender Kraukheitsorseheintmegen bespochen haben, müssen wir ergänzend noch des Einflusses gedenken, den die Togetationstecke selbst auf den Vassergehalt des Bodens ansïbt. Anf demselben Borten bei densolben Vitterungsverhältnisien findet (rine Kulturptlanze ant einem Teile des Ackers genügenden Wasservorrat zu ihrer Entwickhng und aut einem anderen Trile nicht, wem ant ersterem eine anspruchslosere Art kultiviert worden ist, welehe geringere Mromen Wasser dem Borlen entzogen hat. Also rie Vortrucht wird tür jerle Bestellums ron Bedentung.

Der Wassergehalt ist, wie Woblxi ${ }^{1}$ ) festgestrollt, in der Wurzelregion eines mit Pflanzen bestantenen tekers geringer als in der korrespondierenden sichicht des nackten Borlens. Jo üppiger der Ptlanzenbestand, je diehter mol langlebiger derselbe ist. lesto meln vorliort der Borlen an Wasser. Die Versuche lassen zwar lieine teste śliala des Masserverbranchs teststellen, doeh weisen sie darauf hin, dats dmehsehnittlieh die immerorïnen Nadelhëlzer die wrölsten Wassermengen bamsprnchen. Worant

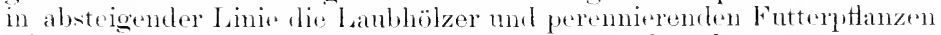
tolgen, während dic Hachwurzolnden Ackergewäehso den liesantrorrat an Wasier in Acker weniger in Ansponeh nehmen. Am nuisten stheinen ron letztrer cruppe die blattreichen, antrechtstohemben Schmetterlingsblätler, wie Acker- me Buschbohmon. Wasser in ihrer Hauptentwicklmoszoit $z u$ verlangen, während die bei weitem stande angebauten Trumel- und Knollengewächse an letzter Stell. zu nemnen sind. In sommer lonchen lie peremierenten Futterowäbse etwas grötsere Mengen als die Ackerptlanzen und Natelhölzer; im Frïhjahr imd Herbst ist es nugekchrt. Im Winter oleichen sich die Ansprürehe der verschiedenen Gewächse aus mit Ausnahme der Nadelhölzer, welehe bei milder Wittermo immer noels gewisie Mengrn Wasier tem Boten entziehen.

Denselben (iegenstand behantelt v. S'EELHoks ${ }^{2}$ ), ter zu dem sichlusio kommt, dats Rogren den A.ker in bezng ant die Fonelitigkeit bedentenul weniger rschöptt als IVeiz'n. Dieser Lmstand wird solur wesentlich für rine etwa nathfolgensle früntüngungspllanze: denn nach rem später das Feld rämmendrul Wrizen kommt dirse nicht nur später in

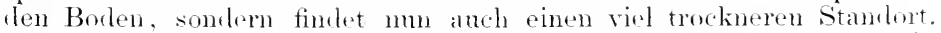
Der Kle erschöptt das Isunrl ändserst stark an Wassere, so dats in

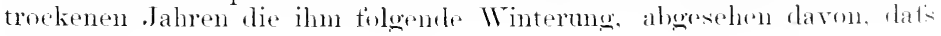

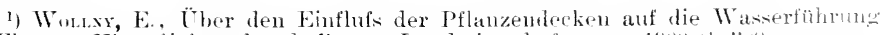
der Flüsse. Vierteljahrsichr. d. Bayer. Landwirtschaftsrates $1900-2 .:-9$.

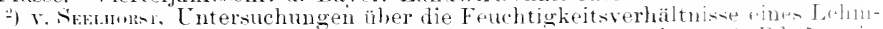

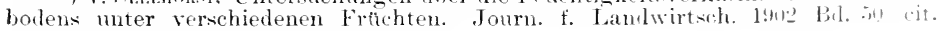
Centralhl f. Agr. Chemie 190:3 Heft 6 . 


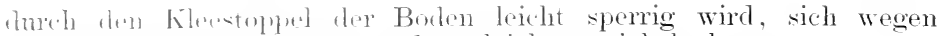

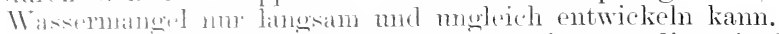

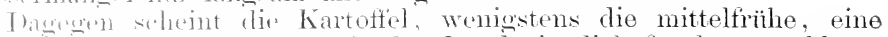
unt Vinfincht zn hilken, da sie das Land ziemlich fencht zurücklälst.

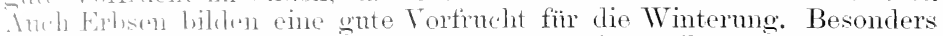

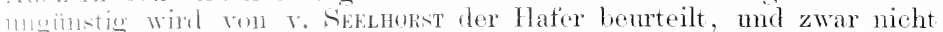

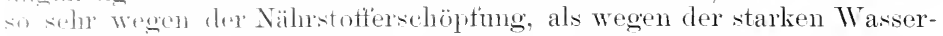
"ntziehmeg.

Im Anschlnts an lie Feldgewächse ist auch des schädlichen Eintlusses einer Rasennarbe zu gedenken. Dats eine geshlowen Narle den IVmzeh der holzartigen Gewächse, namentlich ler (1)stlämne, das Wasser wegfängt mul die Krume verarmen macht, ist leicht verstindlich: aber nenerdings hat man eine direkte (riftwhlung des Rasens lehamptet ${ }^{1}$ ), die vielleicht darin zu suchen sei, datis durch die (trasnarbe nützliche Bakterienarten unterdrückt mo schärliche boginstigt wïrden. In dem gemeldeten Falle waren die IInrzeh der Bänme (Apfellänme) lang, abnorm dümn und gebräunt, las Lanh war selur hell und fiel 14 Tage trïher ab. Die Belaubmo war sparlich, der Holzzmwachs gering. Sobald die Wurzeh oder auch mu sin grötserer Teil derselben in den nicht von Rasen gedeckten (irmul kamon, vershwanden die Krankheitserscheinmoen. Diese stimmen im wesentlichen mit den anf schweren, undurchlässigen Böden durch sanerstoffinangel erzengten überein, so dats es keineswegs notwendig ascheint, eine Giftwirkmg anzunchmen. Wir sehen, dak in vielen Fällen, namentlich auf leichten Böden, die Rasemnarbe nicht scharlet, wemm für Nährstoffe im Bereiche der Baumwurzeh sorge wetragen wird. Ant' schlietsenden 'Tonböden wird der Rasen sich von form kapillar anfsteigenden Wasser des Untergrundes lange grün erhalten und dem Thiteromude viel Fenchtigkeit entziehen, ohne ihm solde während der Tegetationszeit in nemenswerter Menge zurückzugulen, weil er die atmosphärischen Niederschläge für sich verbraucht.

\section{Das Welken.}

That's dio Erscheinmoen des Welkens anch bei Wasserreichtum im Boden eintreten kionnen, indem die Wurzeh mollkommen fimktionieren, ist hereits bei Berporhung des physiologiselen Welkens" erwähnt worelen. In Böklen mit holem Gehalt an löslichen salzen wird miter Thuständon das Tassel so festgehalten, daf's die Wuzel nur mülssam ihren Bordant ilecken kann. E.s troton damn die Erscheinmeen zntage, welche man hei Anwondum loxhlionzentrierter Nährstofflösmgen anch experimentell

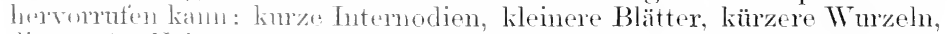

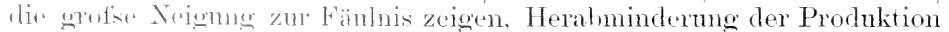
mol Transpiration. - Fine weitere Ursache des TTelkens ist die

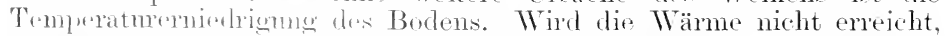

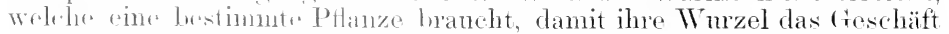

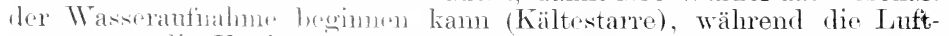
trmperatur dir Vortunstume soituns des Blattapparates zuläfst, macht sich diese Strirung des (ilcheherwichtes zwischen Wasserverbranch und

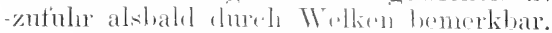

Ein srezieller nicht soltruer Fall ist das Welken ron Warmhans-

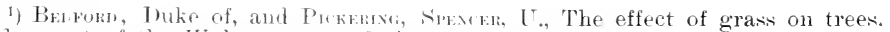
Third report of the Woburn exper. fruit farm. London 1908. 
ptlanzen bei Abkühlung der Töpfe wähnud des Tmarbeitens d’r Warmbeete oder bei from Verpflanzen usw. Unertahrene ciärtner gietsen damn hänfig und sehen einen Erfolg. Wenn das vorgewärmte Trasser die Wurclätigkeit weckt. Bei Wierlerholum der Albkïhlung wird dasselbe Experiment ausgetäht, bis schlietislich der Topf mit Wasser überladen ist und die Wurch dureh sanerstoftmangel zugrunde gehen.

Ein anderer Fall des Welkens der 'Topflitturen wurde von IELLHEsk beohachtet. Er fand, dats Pflanzen in wrotsen Töjten welkten, die einen mohr als dreimal so grotsen Wasservorrat führten als kleine Töpfe mit Pflanzen derselben Spezies, die nicht welliten. Dieser Unstand erklärt sich aus dem relativen Wassergehalt dor Erde, der in den kleinen Gefätsen noch 14-21"o betrus, während die absolut grötsere Wassermenge bei der grötseren Erdmasse der grofisen Gefätse so verteilt war, lats sie nur noch $11-1 ; \%$ o Borlenfenchtigkeit repräsentierte. In diesem Falle war durch die sehwierigere Bewegung des tester gehaltenen Wassers in den Bodenkapillaren den Wrrzeh in den oröseren trefäfsen die Antuahme erschwert, so dats die Verdunstung das Überowicht erlangte.

Gegenüber diesem physiologisehen Welken möchten wir die Welkerscheimmgen bei wirklichem Wassermangel im Boden als mechanisches Welken bezeichnen, weil der mechanische Wassertransport in don Gefäfsen nachlälst. Natürlich muls bei starkem Wasserverhanch dro. Blätter und veringem Nachsehnh, in den trefälsen der Lantgehalt steigen, und in dieser śtoigernng des Luftgehaltes über cin

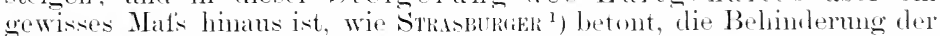
Trasserbewegung in den Achsenorganen zu erblicken. Wahei wird anch die Luft in den trachealen Elementen um so mehr verdiunnt, jo stäker an warmen Tagen Transpiration und Assimilation sind $\left.{ }^{2}\right)$, und die Folge. ist, dats eine Befenchtmm des Bodens mm so schneller zur Wirksamlitit velangt. In allgemeinen ïl,t das Begiet'sen einen $1 m$ so geringeren Einflutis aus, je turgescenter die Pflanze ist ${ }^{3}$ ). l)ie grofse tracheal. Luftrerdïmung komming auch bei der bekannten Tatsache in Betracht, dats die bei heifiem Wotter schmell welkenden Feldgewächse ron der Betaumg des Bodens in der Nacht schon Nutzen ziehen werden. namentlich da die Verdumstmo durch die Blätter zu dieser Zeit heral,gedrüiclit ist.

\section{Die Produktionsänderung durch Wassermangel.}

Auch des versehiedenartigen Ernteertrages intolge von Wassermancel ist bereits in frïheren Abschnitten gedacht worden, so dats wir hier nur erqünzend rinige weitere Fälle anzutühren lranchen. Am

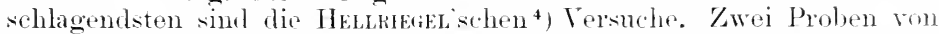
Kleeblätern wurden einem Folde entnommen, hei dem sich stellenweise ein Welken der Ptlanzen kunduab. Es wurle gefunden:

1) Srmsmata, Ed, Ïber den Ban und die Verrichtungen der Leitungshahmm

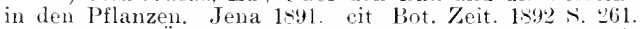

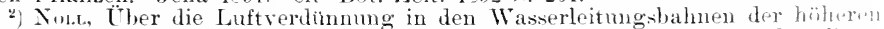
Pflanzen. Sitzungsber. d. Niederrheinisehen Ges. f. Natur- und Heilkunde. limm 189\%. II \$. 14 \%.

3) Chamberian, Hursos Srmand, Recherches sur la seve ascemlante. cit But. Jahresb. 1897 S. $7:$

4) a. a. O. 5. 544 . 


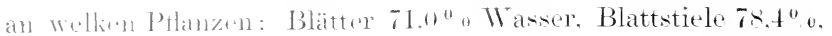

. $71.1^{\circ} \% \quad \% \quad$ "

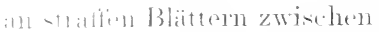

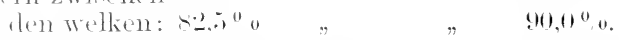

1. Thuthonhatanz hatten die welken Blätter in den Blattflächen 26" in don Blattstielen 19-20100: dagegen die straften Pflanzen

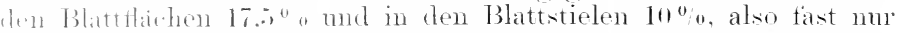

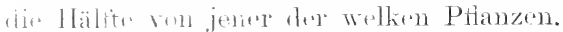

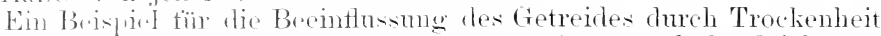

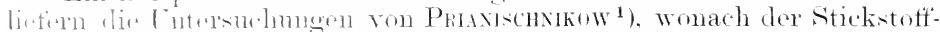
whlalt im Kurn zmninmt. Wenn die Fenchtigkeit sich rerringert. Ein anstïlnticheres Bihr iiher den Einflut's der Nälnstoffaufnahme und -rer-

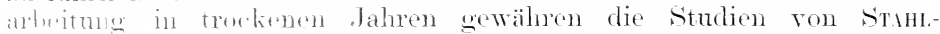

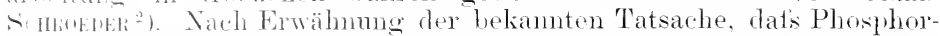

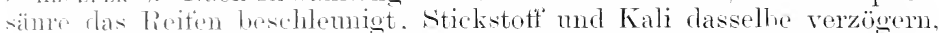

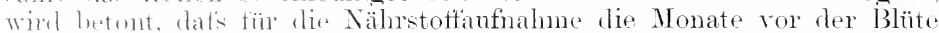
lie herhonngsollsten sinel. Herrscht in dieser Zeit Wassermangel im

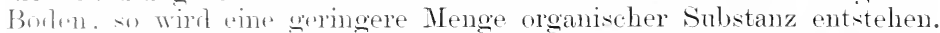

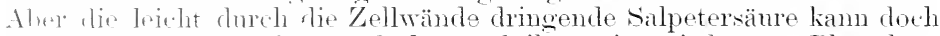
ihron Thes in dir. Ptanzen finden und ilnerseits wieder zur Phosphor-

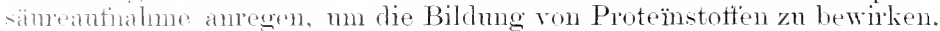
Ant liose IVeise fommen in trockenen .Jahren geringe Ernten mit hohem $\mathrm{T}$ - und P-(iehalt zustande. The Stickstoffsteigerumg tritt anch melr zutase, da hei der Trockenheit die Stärkefüllung des Korms sehr sthwert wird. Iler nongekehrte Fall Jälist sich bei den norwegischen Komproben feststellen, deren hohes absolntes Gewicht durch reiche stäkefinlagerung belingt ist. These erklärt sich durch das Wachstmm dos cotreites bei reichlicher Fenchtigkeit unter dem Einthlis der langu+n Tage.

In direkten talhlen ausgedrütkt finden wir das Sinken der Produktion

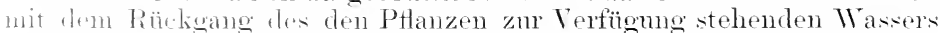

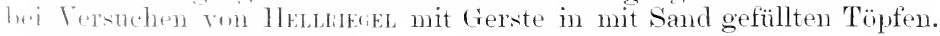

Isolenfenchtinkit

in Prozaten der

Wasterfasinden Kraft

(1)
(i) 111
(1) - $=11$

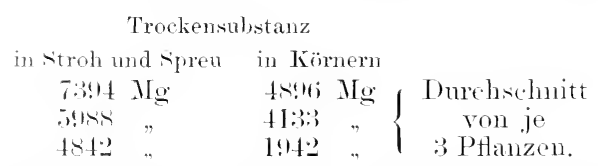

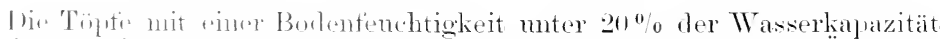

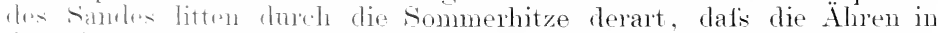

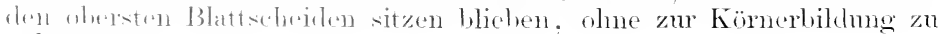

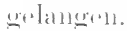

In scheinharm Wirlwsunch mit solchen Ergebnissen steht die

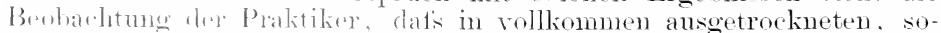

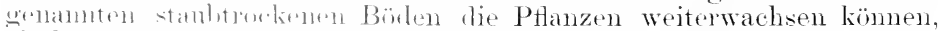

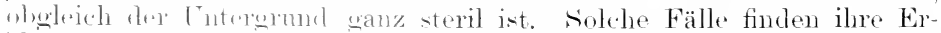
liärume. solnald der serile Unterorund nur wasserhaltig ist und die

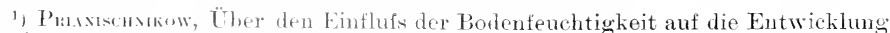
der Pflanzen. Jomrn. t. "xperins. Tandw. 1900 Bd. I s. 19.

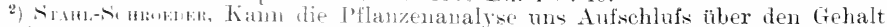

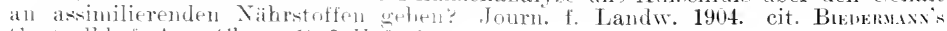
('entralbl. f. Awr. ('hen. len). Heft ?. 
Wurehn in der Fenthtgkeit bleiben. Experimentell hat diesen Fall

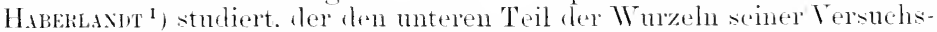
ptlanzen in destilliertes Wasser tanchen liefs. wäbrend die oberen Wuzeh in Boflenshichten verharten. die, wie Kontrollsersuche ercaben, so trocken Waren. daks die Pflanzen darin verwelliten. The mit ihren äutsersten Wureln in destilliertes Wassor tanchenden PHanz'n zeigten eine nicht mbeträchliche Zmuahme an Trocknsulstanz. Worams hervorgeht, dats die in Trockenen befindliehen Wurehn die Nineral. substanzen anfoenommen haben müssen. Ans dieser Arbsitsteilung der Wurzehn erklärt sich das Warhstum unserer Kulturptlanzen mit tief' in pinen sterilen, aber teuchten Unterormel hineinreichenden Wuzeln trotz troekener Ackerlinume.

Dieste vorzugswoise bri tietreide dargestellten Ändermgen in der Produktion erfolgen narh Hectalerief bei anderen Kultuptanzen gleichsimnier.

\section{Verfärbungen bei Gehölzen.}

Ias Typisehe bei Wassermangel mol reicher Bolichtung ist die kräftige Entwicklung der mechanischen frewobe. Wir haben num nötig, aut die Betunde in trokenen Klimaten hinzuweisen. Brispindsweise melilet Jössox") muter den ('harakteren der Wïstrmptlanzen. dats die

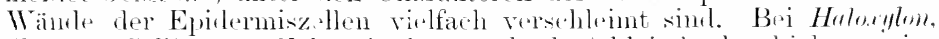

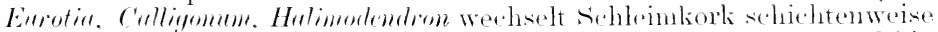

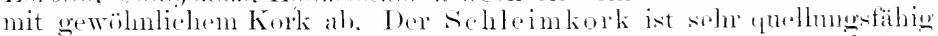

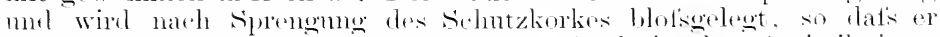
Wasser anziehen mul fisthalten kimn. Anch in flen Asimilations-

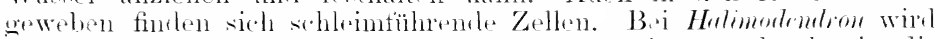

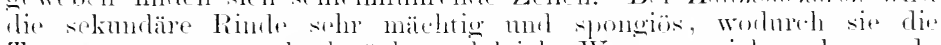

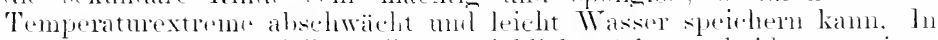

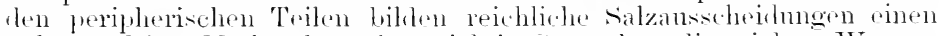

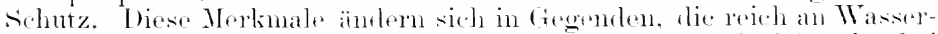
whalt in Boden med in der Lutt sind. So wordr beispielsweise hei Halimodemdrom in Kopenhagen kein schleimbork gefunden.

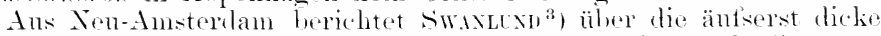
Antsenwand der Evidernen, die häufige Einsenkung der syaltïttinungen, die Einrollung der Blätter und dadureh bedingte Einschränkmog der Transpiration. Wir haben disen (regenstand schon fiöher in dem Alschnitt ïber horizontale Differenzen und bei den Fehlern der sandbörlen

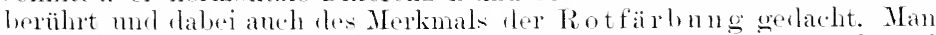
kamn auch durch liüstliche Eingrifte lokalen Wassermangel nud Anthocyanlildumg damit hervorutén. indem man PHanzen. welchen

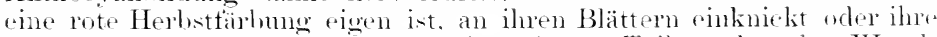
\%weige ringelt. Ex tritt Tann an den obxen Teilen über der Wumbstelle mitten im sommer Rottiirhmeng ein.

Betretts der durch Hitze nut Trockenheit hervorgerntenen Virfärlmngserscheinungen webe ich ringe Beobarhtumgen aus dem Jahw

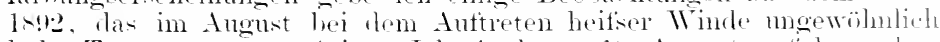

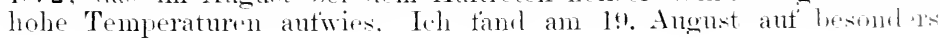

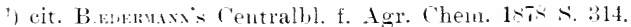

) Josson, B., Zur Kenntnis des anatomischen Baues der Wästmutianzen.

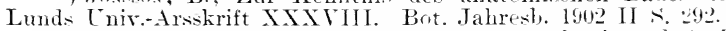

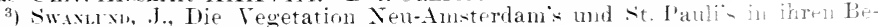
ziehumgen zum Klina. Dissert. Basel 1901. 
schweren l. hlmboden sine Temperatur von $5.27^{\circ} \mathrm{C}$. Sämtliche Gehölze wolliten wur die Mehrzahl antlanhte wich allmählich. Natürlich waren

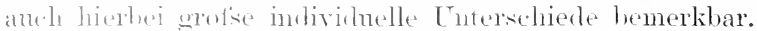

Vorfinbung mul Blattall vingen tast immer von den untersten

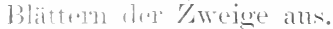

Bri der Erle fiolen die Blätter unter Erhaltung der grünen Farbe.

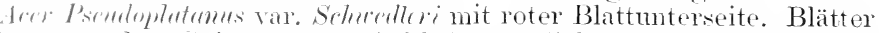
wnilen ron den spitzen der Zipfel her rötlichbram bis lederfarbig in den Intercostalfeldern. Antserdem auf der Blattläthe zerstrent mrongelmälsige tiefer gobrännte, vollkommen tiurre Brandflecke. Beselaciligte Blätter sitzenhleibend.

Aer Negmolo. Ohere Blätter etwas schlaff. Ränder der Teilhattchen nach oben wehoben. Wie nächst mteren Blätter bleich gedlogiin, die nutersten hellgell, gleichmälisig an den diirren Rändern nath oben gerollt.

Acer plitomides. Blätter zeigen mon schwacher Veroilloms unrogelmätige, kleine verfliefente, zwischen den Rippen verlantende Brandflecke: die rortrockneten spitzen biegen sich hakentörmig nach oben.

Fands silutica. Einzelne, aber nitht immer die untersten, sondem die rxponiertesten Blätter erhielten mregelmälsige, in den Intercostalfoldem antitretende, mit gelbem, verwaschenem Rande versehene, dïre stullen. Bisweilen ist die ganze Oberfläche gleichmä1sig leicht gebrämnt. Nicmals Randzeichnungen.

Titis rimiftr. Bei Begimn der Trockenheit zeigen sich einzelne, ganz moregelmälsig zwischen grünbleibenden stehende Blätter gelb. 1)ic citronengell:e. bei anderen Tarietäten rote Verfärbung begimnt an siner stelle des Randes und schreitet in den Intercostalteldern fort. lis nu noch die Rippen grün erstheinen. Trotz der Trockenheit tand irh lamals an einzelnen mnteren Blättern die den Rippen folgenden trockenen, exkisen Flecke der I'lasmonara ritionla.

Promer I'rrsicu. Säntliche Blätter etwas erschlafft: manche (aber nir.ht immor die motersten) ron der spitze ans vergibend. An einzelnen Bämmon schreitet die Verfärhmog an den Rippen schneller fort, st) dalis zuerst die Nervatur und dann die äbrige Blattfläche gelbrot lis. wrinest sich färben; darauf fällt das Blatt ab. (Eigenschatt der sir.t..)

I'rum,s drmestica. Sämtliche Blätter schlatt', Mehrzahl aber noch

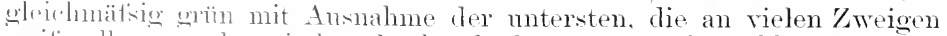
wrifigell, gownolen sinl und sehmale, brame, zurüekgeschlagene, dürre hamitlene hesitzrn. Tricht bei Wind sich ablösend.

l'rmms arim. Cnitro Blätter, namentlich der Kimztriebe, gleichmaitsige ritronemerelb mul abfallend.

Prmms Cormsts. Nur wrinige Blätter vergilbt, sonst die gesamte

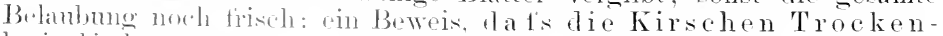
heit liejerls.

Pirms ammmis. Je nall Exposition meln oder weniger Brand-

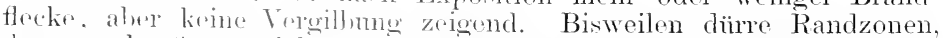

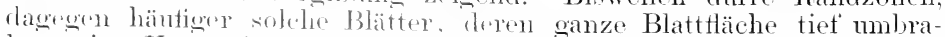

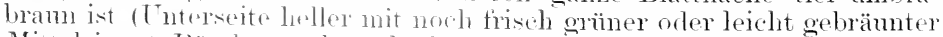
Mittelriples). Ründer stark nach oluen gerollt. Wegen der grün bleibenden Blattstiele fallen die heschädigten B]ätter nicht oder spät ab.

Aus diesen und zahlreichen anderen Beohachtungen ergibt sich, 
dats durchsehnittlich die von der Nervatur entfentesten Teile der Blätter znerst und an meisten sich verfärben mel vertrocknen: dabei Hebmo der Ränder nath oben. Bei schnell eintretenten Hitzeperioden mit starker somnenwirkmg traten die Brantfleck in den Vorderorme. bei geringerer Intensitat des sommenseheins herrscht die alloemeine fleckenförmige Vertärbung vor.

Hierher gehört anch die besonders brätige Entwitkhng von

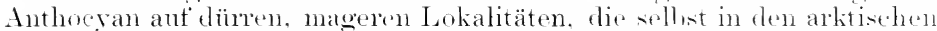
Regionen, wo die Rotfärbme bei der starkes Bolichtume eine vor-

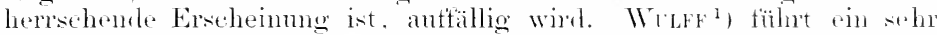
bezeichnentes Beispiel an. Er sah an Orten, die dureh Vogelexkrement. gedüngt waren, bei Ptlanzen, die in ariden fregenden in ihren regetativen Groanen stark gerötet ersehienen, stots iie Anthoeranbildme rersehwinderl.

sichlietslich sei anch noth an die Vermindermes der Bewerlichlieit der Klefblätrhen mol verwantter Orome bei anhaltendem Wastermangel gedacht. Bei Mimosa pulion geht die periodische Reizbarkit verloren, und die Blätchen bleiben offen stehen: "Troelienstarre".

\section{Röte des Getreides.}

Lir Rotfarbung des tretreides hei anhaltend trockenter heitser sommerzeit hat vielfach die Termutume hervorgernten. rats parasitare

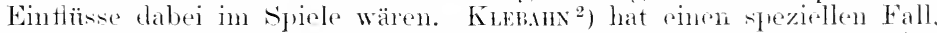
fer durch seine weite Verbreitung und Intensitä allgemein anfticl. senaner geprüt mol gefunden, dats der rote Farbstott allmählich an

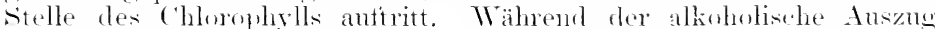

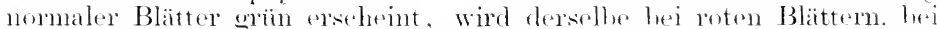

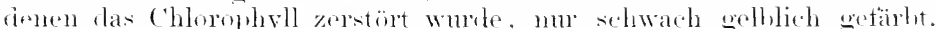

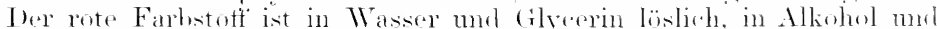

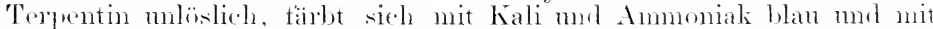
sänmen wierler rot. Er ist an ben Zellsaft welmurlen. morl zwar teils. in der Epidermis. teils im Assimilationsorewe. Bei Hafer erwes sich die Entwicklung der aeröteten Pflanzen und ilme Körnerproduktion geringer als hei den grünen Hahmen. Wir haben die Rötmo bei fietreide ebenfalls studiert ${ }^{3}$ ) und kommen in Übereinstimmung mit KLeвsнx

1) Wi11\%, Tumu1, Botanische Beobachtungen aus spitzbergen. Lumi. 1902. Betreffs der jet\%t herrschenten Anschanung, dafs das Anthocran eine Schutzvorrichtung für tas Chlorophyll gegen Lichtïberschufs bilden soll, macht Witrl (s. 67) auf die Cntersuchungen von Evimusix aufmerksam, woraus hervorgeht, dafs die Lichtaborytion des roten Anthocrans zu der des Chlorophylls komplementär ist und demgemäls die Kohlensiiurezerlegung nicht beeinträchtigt. „Diese Tatsache

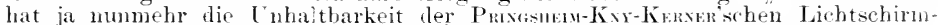
theorie $\%$ voller Evidenz daroetan." Wruw sieht den Vorteil des Anthocrans in seiner gröfseren Wärnespeicherung. Wie ich hereits früher erwähnt, vermag ich vorbedachte Nutzlichkeitseinrichtungen oder Äuf'sermgen einer „Finalität“ in Organismus nicht anzunehmen. Ich erblicke therall notwendige Folgeerscheinungen bestimmter Kombinationen der Wachstumsfaktoren. Iie Anthorrantildung erscheint mir als Folge von Lichthlerschufs auf einen an freien Siaturen reichen Zellinhalt, dem nicht genïgend stickstoffhaltige Assinilate zur Verfïgung stehen. Dieser Zustand kann, wie bei den Pflanzen der kalten Regionen durch Wirnumangel, in anderen Fällen durch Wassermangel, verringerte Nihrstoffzufulur usW. herbeigeführt werden.

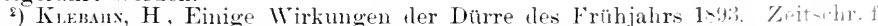
Pflanzenkrankh. 1<94 5.262.

3) Smatra, P., Beitrag zur anatomischen Analyse ranchbeschialinter Pflanzen. Landw. Jahrb. 1904 i. 596 , Taf. XV-XVIII. 


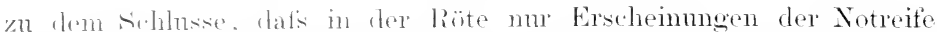

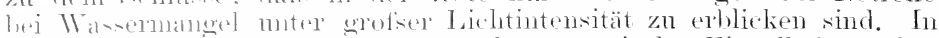

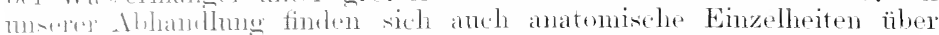

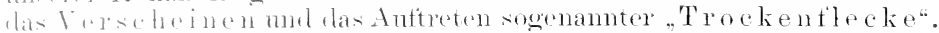

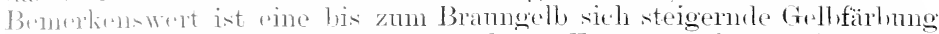
Hor Il andmenen der Baststränge mel das Erstarren des Zellinhalts in

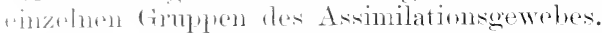

Tom den dmoh nomale semilität absterbenden Blättem nuterscherilet sich das durch pötzliche Ilitze und Troctemperioden zu-

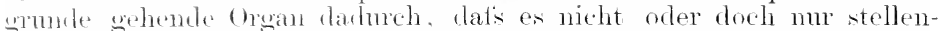
Weise so stark znxammenselnumpten kamn wie das normal ansoereifte, alse an testen Inhaltsstotten nahezu erschönte Blatt. Bei letzterem bremelen sich zwiselen dor Eprdermis dor Ober- mol Unterseite num lie sünzlids veromenten und daher zu einex welligfaltigen sichicht mosmmenfallenden \%ellen des Blattfleisehes, währent bei erstexen aren dere restierente reichlichere Inhalt durels sein Austrocknen die Wandmuen steift mul daturch das Zusammensinken mehr oder weniger rerhinelert.

In tamel dieselten Tertäromgsersheimmgen anch bei wilden

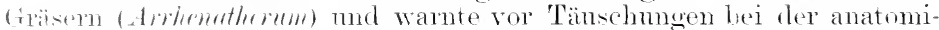
shon Intersuchnng. Es traten nämlich exige oder lingelige Inhaltsmasen ant, die ähnlich wie stätie mit Jod reagierten und somit den sehein ron noch vorhandener götserer Assimilationstätiokeit erwecken kionnen. Tie ïbrigon Reaktionen weisen indes nach, dats es sich nm "Restlïrper" von der chlorophyllzersetzmng handelt, welche in die Carotinguppe gohören. Man lömnte sie mit den Leichentett veraleichent.

\section{Die „Röte“ des Hopfens.}

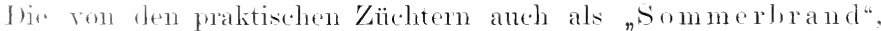
"Fnehs" ofler "Rot" Lohe" bezeichnete Krankheit besteht in einem von der Basis her fortschreitenden Fleckigwerden der Blätter. Die Flecke mfassm sowohl die Randpartien als anch die zwisehen den

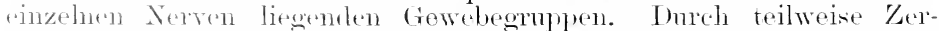
stïmug des ('hloroplirlls erseheinen die erlirankten stellen anfanes ondlich. srates rötlich mul endlich trocken und gebrämt. Das Blatt fänet nittlorweile an, immer länger im Kustande des Welkens zu verhloiben: schliefislich schrmmptt es und tällt anch wohl ab, während die

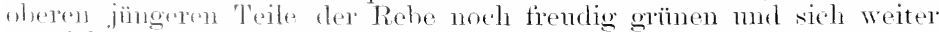

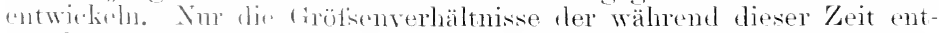

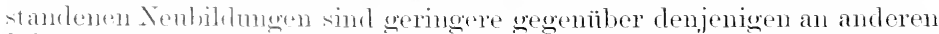
PHanzen, whele dron Verlnst der muteren Blätter nicht zu beklagen halen. Bloibt dir Linnliseit anf die unteren Partien beschränkt, so

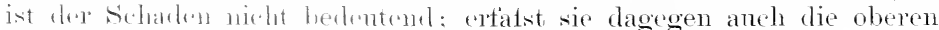

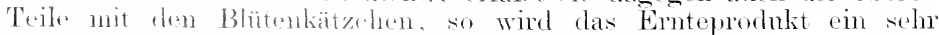
loichtes, nut os emptielelt sich clamm, alsbald zu ernten.

bie Kranliteit ist leiclit mit dem lurch die Webermillse ver-

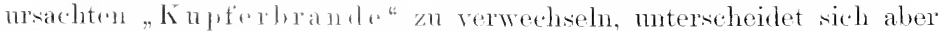

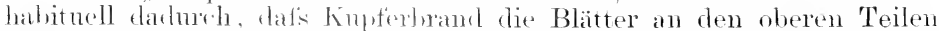

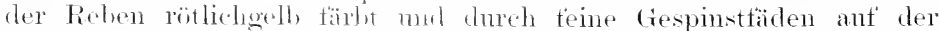
Blattunterseite erkannt wirk, wähend der Sommerbrand von der Basis der Rebe her ein Veroilhou mul Vertrocknen dor Blätter veranlatist. 
Es ist ein Ansiangen der äteren Organe durch die jüngeren, die zu ilner Fortentwicklune has vorhandene organische Material heanspruchen.

Dis sogenannte . stangen rot" scheint dem . Verseheinen" des Getreides zu entsprechen mol dis Folge plötzlinhen Eintritts einer Trockemperiote zur \%eit der Kätzehenanshihlumg zn sein.

Bei dieser und den verwandten Rötungskankheiten spielt ïlrigens der Wassermangel in der Lutt eine ansichlaggelente liolle: weil eine Botenbewässerung alloin selten Abhilfo schatft. Bosser ist. wem ein torteretztes abendliches Bupritzen stattinden kam. Alw hei grotsen Flächen ist schwerlide in praktischen Betrebe das nötige Arberterpersonal und die spotse Wassemasse zur Verfïgumg. An günstigsten sind die Vorbengungsnatsiegehn, indem man entwetre durch mätsige sichat ten an lagen für die IIoptenplantagen die exzessive Ver-

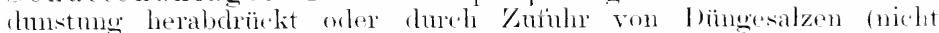
tierisehem Dung) die Wasserkapazität des Bodens rhöht. Ein Brispiel tür letzteren Fall tühnt Fr. Wraske ${ }^{1}$ an. Er fand hei seinen Kulturen, dafs die Hopfenptlanzen ohne Salpetergaben der Trockinheit sowie pflanzliehen und tierischen Parasiten weniger gnt wielerstanden mol die unteren Blätter trüher vergilht zeigten als hei den mit Chilisalperer

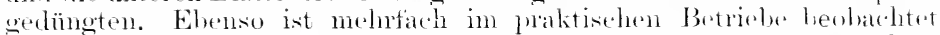

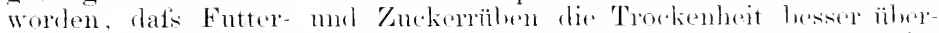
wnuden hatten. Wenn der Borlen mit Kalisalzen orlex ('hilisalpetor oder' anch mit reichlichem stalhnist gedüngt worden war (s. z. B. Jahnesh.

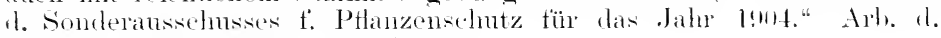
leutsch. Landw.-(ies. 19m.), s. (1).

Ähnliche Terfäbungen infolge von Wassermanged sind hei Lein

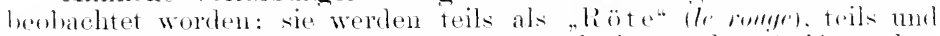
zwar bei vorzeitigen Veroiben der stengelspitzen als "rellisucht" (le jann') besthrieben.

\section{Der ,Laubrausch“ der Reben. ,Rote Brenner." „Seng."}

Hie obigen Namen sind Kollektivbezeichmmgen für eine fruple sehwer ansemander zu haltender Erscheinnugen, die das frememsane einer Rottärlome der Blätter haben. In der Regel folot der Vertärbmo stellenweises oder gänzliches Vertrocknen dos Laubes, das dam vor-

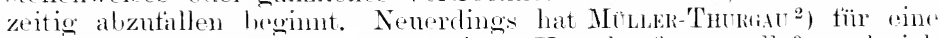
bestimmte Rötungstom eine parasitäre Troche fostgestellt ${ }^{3}$ ) und sich bemüht, die dem blotisen Ange wahrnelmbaren Morkmale, die diesen Erkankungsall von anderen nuterscheiden, hervorzuheben. Unter Hinweis aut die in zweiton Bande moers Handhueh bespochene. "lureh Psedelopeziza trachriphila vermsachte Form des ., Roten Brenners"

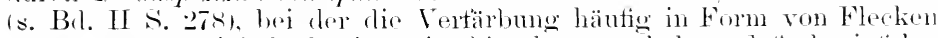
in den Norvenwinkeln bergint, ist hier hervorzuhelen, dats der infolge von Wassermangel hei starken somenschein sich kemtlich machend. Laubrausch in cer Regel mit einer vom Rande ausuchenden Vertärbung her Intercostalfelder anfïngt. Je nach sorte med standort weehseh

1) Whixen, Fr., Salpeterdügungsversuche des Hentschen Hopfruban-Vereins Wochenbl. d. Landw. Ver. in Bayern 1904 s. L'2.

2) Mintra-Tumiar, H., Der rote Brenner des Weinstocks. ('entralhl. f. Buks. II, $190 \%$, Heft $1-4$.

$\left.{ }^{3}\right)$ Eine andere, mit Botrytis-Vegetation verbundene Form vom Roten Br+ner

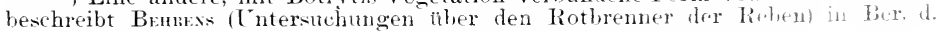
Grofsh. Bad. Versuchsanstalt zu Augustenburg 19u2 s. 4:3. 
dic Bileler nugenein. nud man finclet statt der Rötmog nur bisweilen sine lonelitenche cielbeärhme. Nanchmal trocknen die Blattränder ab.

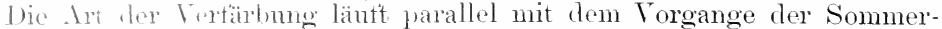
diinse he andren Gehölzen, wobei man meist beobachten kamn, wie liv manswhe Wasserzutuhy sich znerst an den von dem Blattstiel und lor Tittelrippe am weitesten entfernt liegenden Teilen bemerkbar matht mol nachlier fortschreitet, bis schliefslich nur die nächste Um-

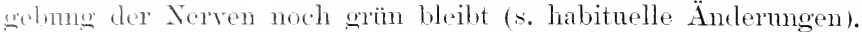

Betrefts ter phrsiologischen Arbeit hat M̈̈ller-THuktau schon trïher nachgewiesen, dats Stärkebildung und -lösung um so langsamer ror sich gehen, je geringer der Wassergehalt der Blätter ist ${ }^{1}$ ); bewossene Reben bildeten mehr Zucker.

Eine ähnlich dem parasitären Brenner sich äufsemde Erscheinung

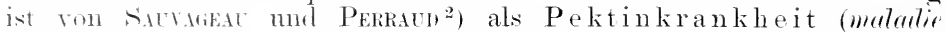
pretiqur) als Folge anhaltender Trockenheit beschrieben worden. Hier listen sich die Blattspreiten vom Blattstiel ab.

\section{Vergilbung durch die Veredlungsunterlage.}

Bei unseren Obstarten stellt sich ein Wassermangel manchmal dathreh ein, dats eine schnellwüchsige Sorte anf eine Kwergunterlage verelelt wircl, die nicht imstande ist, in Zeiten starker Verdunstung das nötige Wasser dem Edelstamm zuzuführen.

Anf gutem Boden werden manchmal Birnen, die anf Quitte veredelt sind. gelb, während die auf Wildling gesetzten Exemplare krättig wetleihen. Bei solchen Zwergstämmen sah ich in trockenen Sommern, dat's später in die Rinde eingespitzte, gut gewachsene Edelreiser kräftiqe, aber welbliche Triebe machten, während die ältere Krone orün war. Anch liferin sehe ich Erscheinmngen des Wassermangels durch sis (gnittemmterlage, die (namentlich wemn sie hoch gepflanzt ist) nicht las nötige Wasser beschaffen kam. Birnen anf hochgepflanzten Gritten reifon daher ihr Lanb sehneller und werfen es früher.

\section{Verfrüht€s Vertrocknen des Laubes.}

Wenn intolne der Sommerdürre das Laub alstirbt, wobei es meist woren des Frischbleibens der Blattstiele am Zweige hängen bleibt, ist dor sichaden, dron der Bam erleidet, ein weit gröferer, als man in fer Regel annimmt.

Man waulite, es bestehe vorzusweise die Schädigung in dem rorzeitign Anthörn der Blattarheit und der damit verbundenen geringeren Holitilitung ns. Es hat sich aber duch die Untersuchungen von Krots ${ }^{3}$ ) erwiesen, dats nelen diesem Mangel an Zuwachs anch ein positiver subsanzvelust cintritt, der viel grötser ist als bei einer nommal'n herbstichen Entlanhmo. Die clurch Dürre getöteten Blätter verhaltur sich nämlich nicht so wie die im Herbst aldallenden Organe. Letztere haben die Mehrzahl der für den Pflanzenkörper noch rerwentharen stotte allmählich an den Stamm abgegeben nud sich endlich durch eine rustzellige Tremnungschicht losgelöst; die verdorten Bläter, bei denon sich linine Tremmmgsschicht bildet, behalten ihre

1) III. Jahresher. d. Versuchsstat. Wülensweil. Zürich 1894 S. 56.

5) Suctiku, ('., et Prasu, J., La maladie pectique de la vigne. Revue de viticulture 1894 [. 9.

") Bot. Zeit. 1 73: Nr. 26 und 27. 
stickstotfhaltigen Bestandteile nebst der Phosphorsämre, uncl nu die Stärke samt dem Kali gelangt vor dem Tode des Blattes in den stamm zurück. Durch das verfrühte Vertrocknen des Laubes gehen den Pflanzen nahezu doppelt so viel Stickstoff' und Plnosphorsäure verdoren als durch den herbstichen Laubfall. Dies beweist eine von Makrkek ansgeführte Analyse von Blättern einer Syringa.

Es enthielten an Prozenten der Trockensubstanz

\begin{tabular}{|c|c|c|c|c|c|}
\hline & & Sion & erdürre & Blätter & Herbstliche Blatter \\
\hline stickstott . & .. & . & 1.947 & & 1.3711 \\
\hline Phosphorsäure & .. & . & $11,0.2 .2$ & & $11,37: 3$ \\
\hline Kali. . . . & & & 2.9918 & & 3.431 \\
\hline Kalk. . . . & & & 1,878 & & 2,416 \\
\hline $\begin{array}{l}\text { Lineralstoffe } \\
\text { (kohlensäuret }\end{array}$ & $\begin{array}{l}\text { iberl } \\
\text { (ei) }\end{array}$ & & 8,1198 & & 9,6330 \\
\hline
\end{tabular}

Obige Mengen in Prozenten der Gesamtasche ansgedrückt, würden sich folgendermatisen stellen:

\begin{tabular}{|c|c|c|c|}
\hline . & & Sommerdürre Blätter & Herbstliche Blätter \\
\hline Stickstotf & & . . $24,0^{\circ} 0$ & $14.11^{\circ} 0$ \\
\hline Phosphorsäure & & . . $\quad 0,5^{\circ} 0$ & 3.800 \\
\hline Kali. . & . & . . $37,3^{\circ} "$ & $: 39.7 \% 0$ \\
\hline
\end{tabular}

\section{Das Ausbrennen des Rasens.}

Bei dom Vertrocknen der Grasnarbe infolge sommerlicher Hitzeperioden kommt für Wiesen natiurlich der Virlust an Futtersubstanz schwerwiegend in Rechnmo. Wo Berieselung wanlagen fehlen, hat man keine Möglichkeit, den ścharlen zu verhüten. Bei Schmuchanlagen dagegen lätst sich der Schaden vermeiden, wenn man rechtzeitig durch Überstrenen ron Heu oder anderem leichten schattemmaterial die Lichtwirkung und damit die Verchmstung herabdrückt. Das sipritzen des Rasenflächen ist nur dort von Erfolg, wo dassolbe wiederholt am Tage ausuefïhlut werden kann. Andernfalls muls man zur Beschattums greifen.

\section{Milchglanz.}

Ku den Erscheinungen, die experimentell bezïglich ihrer Entstehungsursachen noeh nicht geprüft sind und daher nur vorlänfig cingereiht werden kömnen, achört der Milchglanz der Blätter.

Die Krankheit äutsert sich in der Weise an Fruchtbäumen, dats die sonst normal auscrebildeten Blätter ihr dunkelgriunes Ansehen verlieren und einen silberatio weilshichen Retlex zeigen. In der Regel leiden nur einzelne Äste und zwar etwa rom Juni oder Juli an. In folgenden oder im zweiten, höehstens dritten Jahre nach Anttreten des Milchglanzes stirbt der Ast ah. Bei den Exemplaren, die ich narh Jahrestrist wieder hesichtigen konnte, zeigte sich mehrtach nach Entfernung des abgestorlonen Astes die Erscheinumg an anderen Ä-ten. so dat's ich vorläufig mir tie Meinung gebildet habe, der Nilchglanz sei ein absolut sicherer Vorläufer des Todes eines /weiges.

An ausgebreitetsten liefs sich der Nilchglanz bei Aprikosen an spalier auffinden: autserdem begegnete ich der Erscheinmeg an Pflammen und Äpfeh.

Die Verändermo beginnt bei den älteren Blättern der Erïh.jalurs- 
triebs: die jïngsten hleiben öters rershont; ebenso die ans Proventivangen sich plitzlich am alten Holze entwickelnden spättriebe.

\%unädlot timblet man nur eine gewisse stmmptheit der Farbe, ein

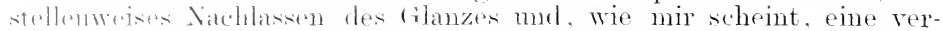
nelupe Inftnenge in den Intercellularräumen zwischen einzehen

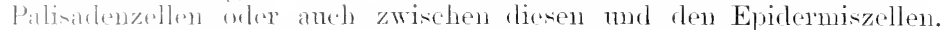
Alhuahlich werden die stumpten stellen weifslich, und zwar durch drïsige Loxkerme der Epidermi-zellen zwischen den grïnbleibenden.

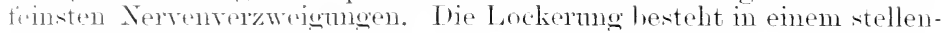
weisen Lören des Verbandes zwischen Epidermis and Palisadenparenchym.

AnekHown ${ }^{1}$ ). (lev die Krankheit anch an Kirschen beobachtete nud sah. datis the zellen der Epidermis sich gegenseitig lockern, liomute narloweisen, datis in der Löslichkeit der Intercellularsubstanz (Mittollanelle) sich boi den Mildhglanz zeigenden stellen Abweichungen rom wermelen Blatte zeigten. Daranthin vermutet er, dats die Inter-

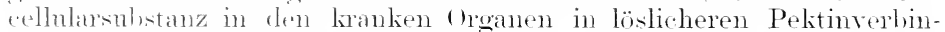
Jmen besteht als bei den gesmulen Blatte, mul da die Kalkverbindmen lor Palinsäme möisliche Zustände darstellen, so liegt die Vermutung mahe. datis Kallimanuel die Lrsache der Krankheit sei.

Anch nach dieser Anschanmg wörde llie Krankheit in die (iruppe der durch Wasser- mol Nährstoffinangel veranlatisten Erscheinmoen gehören: nur muts dabei hervorgehoben werlen, dats der Wasser- mud Nänstoftgehalt des Bodens hierbei nicht in Betracht komme, sondern nur in der Pflanze selbst sich lokal geltend macht. Und dieser Umstand dentet anf Stönmen im Zuleitmugssstem. Dafür spricht anch die Tatrache, das die /weige mit milchliranken Blättern vorzeitio absterluen.

Die ron mir beohachteten Aprikosen nud Pflanmen zeigten Gummoxis, mal die Aptellämme litten an Borkenkäfertiots. Es wäre möglich. dats man durch Vorjüngen der kranken Bäume und Kalkzufinhr

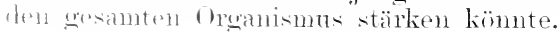

\section{Glasigwerden der Aepfel.}

Eluntiall ant lokials Leitmosstörmugen dürtte die Erscheinmmg

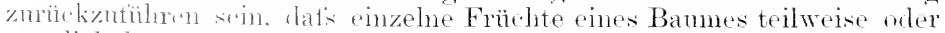

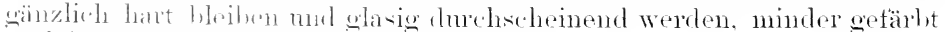

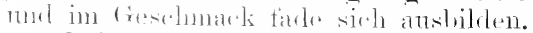

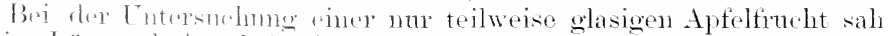

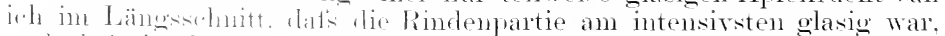

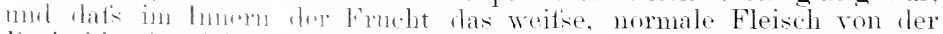

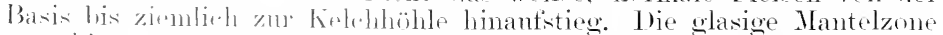

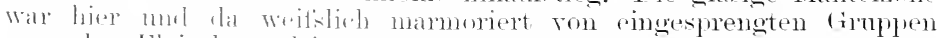

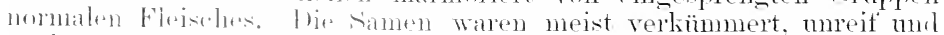

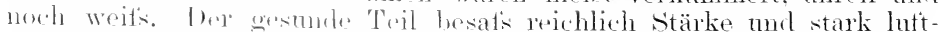

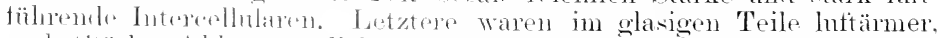
mol Stärk fohlo wainzlich mit Ansmalme einzeher eingesprengter

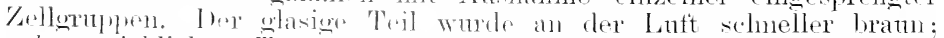

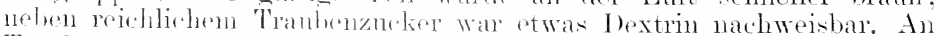
Troekensulstan\% regals:

1) Ankmn,l, R., Notizen üher einigo im vorigen sommer beobachtete Pflanzenkrankheiten. Zeitschr. f. Pflanzenkrankh. 1s:5 86. 


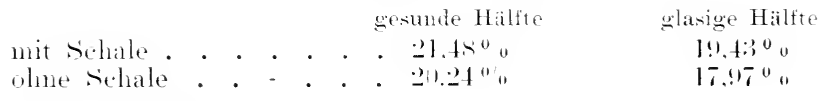

AnERHOLH', fand

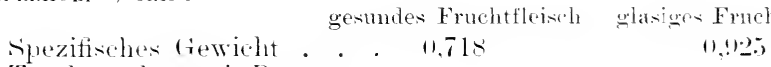

Trockensubstanzin Prozenten

des Frischgewiohtes. . . 14.4t"0 12,00"0

Asche in Prozenten der

in 100 cen sint an Apfel-

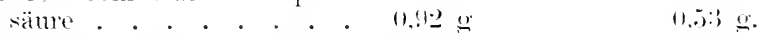

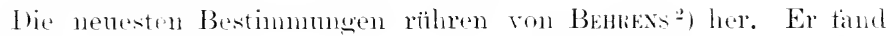
in 1101 e.c.1n von
Prefsisatt des nommalen Aptels
Pretsoatt des teilweis glasigen Aptels ston ".
$\therefore, 11 . ;$
11.51 i

Wasser

Invertzuck r siane

In ت̈bereinstimmmng mit meinen Angahen zeigen die vorstohen-

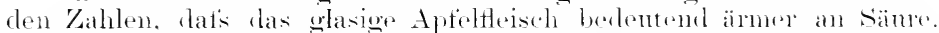

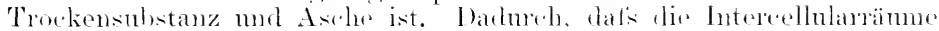

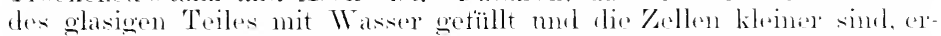

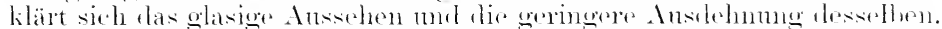

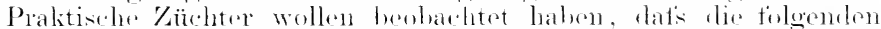

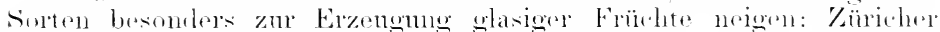

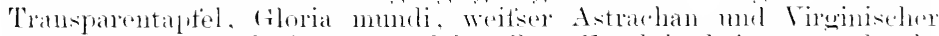

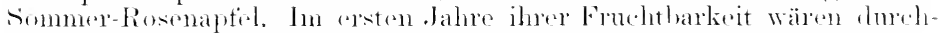

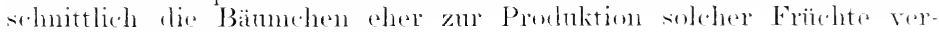
anlagt als in spätreren .Jahren.

\section{h. Produktionsändernng dureh Sitickstottmangel.}

\section{Hungerzustände bei Kryptogamen.}

Kann Hinweis des Parallelismms der Erscheinmuen bei niederen mul hochorganisierten Pflanzen mag zmächst ein Brisfied ans dem fithiete der Farlenpilze antgetährt werden. Flonow ${ }^{3}$ ) priite den Einfluts

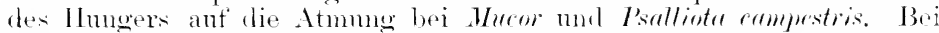
Wur sinkt die Atmmig sofort stark herab. weil bei diesen Pilz kein

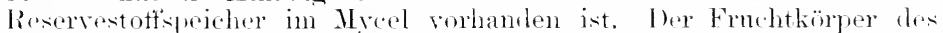
Intpilzes aber besitzt in seiner Körpermasse viel Reservematerial uml erwoist sich deshalh in hohem trate mabhängig von der Verarmmen des Nährsubstrates, so dats soine Atmmo beim IJuneern nur selir

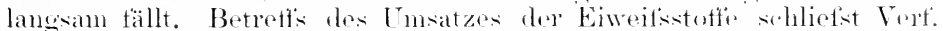

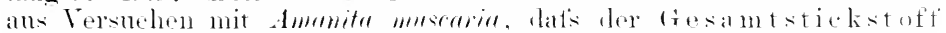
während des II nugerns prozentisehzunimmt, weil rorzug -

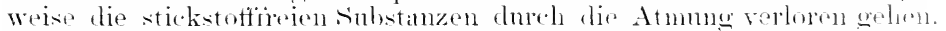

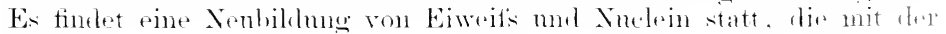

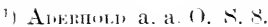

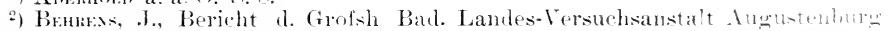
i. .J. 1904 ‥ 5:3. Karlsruhe 190\%.

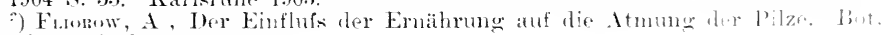
Centralbl. 1901 Bd. T $>$ i. 20t. 
Periode der siporenbildung und -reitung zusammenfällt. Sodann folgt schmollev Eiweitizertall.

Bti lem Hungern der Pilze gehen zwar Kohlensäureproduktion und cimopsoffantinalme allmählich zurück, aber in moleichem Verhältnis, wir P(rdewcz ${ }^{1}$ ) bei Aspryillus nigr beobachtete. Die Kohlensänreans-holidume sank schmeller.

schr shöne experimentelle Beobachtumgen lieferte Praxtu ${ }^{2}$ ) an Farnpothallien. Lie Ertahrung zeigt nämlich, dats bei Aussaaten von Farnsfuren die mannigfathsten Variationen unter den Prothallien anfreten. Ianche ron ihnen besitzen ain tortbildungsähiges Gewebe (Meristem), wïhend andere desselben entbehren, also "ameristisch" sind. Frïhere Tntersuchumgen"s) zeigten dem Forscher, dafs die Ameristie sowhlil bei zu geringem Lntzutritt als auch bei mangelhatter Wasserund wohl auch Nineralstoffzufuhr eintreten kann. Die Beobachtung, lat's muter den günstigsten Belenchtungsverhältnissen bei zu dichtem stancle der Prothallien ameristische Individuen erscheinen, führte zu dem Versuch. den Einfluts der sitickstoffzufuhr direkt zu pröfen. Es wruten simoren der schmell keimenden Osmmula ragalis und der Corrtopteris thulirtroiltes in verschiedene Nährstofflösungen ausgesäet. Dabei zeinte sich num, tats die in destilliertem Wasser gekeimten Sporen ampristische Prothallien hervorbrachten: sie bildeten Flächen von 15 bis "j Zellen von ziemlich gleicher Grölse und oleichem Inhalt: die chlorophyllkömer waren arm an Stärke. Dagegen zeichneten sich die in einer sonst normalen, aber sticlistoftfreien Nährlösmg erwachsenen Prothallien durch moemein grotsen stärkegehalt aus, glichen aber somst den in destilliertem Wasser gezogenen Individuen. Nur die in Nählösmo mit stickstoffleigabe (0 $104^{\circ}$ oo salpeters. Ammon) erzogenen Exrmplare waren meristisch. Wurden Exemplare von meristischen Prothallien in stickstofffiede Nährlösung äbertragen, so war nach 14 Tagen das Meristrm verschwunden, indem die Kellen sich sämtlich veroriolisert, al, mul zu sich anch geteilt und mit Stärke gefüllt hatten.

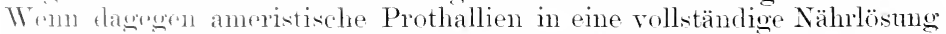
weharht worden, hildete sich alsbald am Vorderrande ein Neristem Gur.h wialerholt: Ttilms der Zellen, während die Stärkevorräte sich

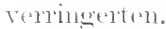

J، nach den Ernährmngsverhältnissen variiert nun auch die Ver-

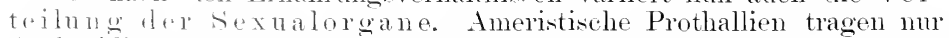
Anthribin, nimals Archegonien, welche an die Gegenwart eines Mlristems anbundur sind. Besonders wichtig ist num die Beobachtung Pkatris. dats amoristische Prothallien von Osmuma, welche vereinzelte Antherilins getragrn hatten, nach Stickstoffzufuhr reichlich Arehe-

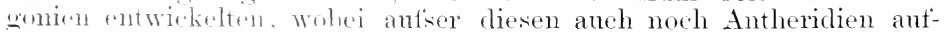
trateil.

Aus dirson. Anreh Nïhrstoffi herbeigeführten Veränderungen erlilät sich mugzmugen diw von verschieclenen Antoren hei manchen

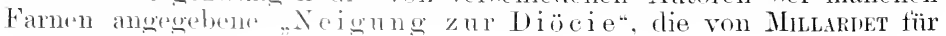

1) Prrs:w»\%, K., Physinlog. Entersuch. über die Atmung der Pflanzen. cit. Biederm. Centralbl. 1902 \&. 1 $1 \%$.

2) Prixrı, Beobachtungen ibher die Emährung der Farnprothallien und die Verteilung der sexnalorgane. Bot. Keit. 1x-1 s. 75.5.

?) Flora 187 s. 499. 


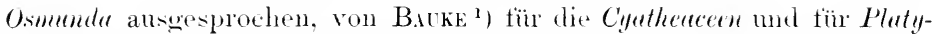
crvium $^{2}$ ), von Joskuns ${ }^{3}$ ) fïr die Marattacen angereben worden ist.

Weitere hierher gehörige Notizen citiert 11. Hofrunsw ${ }^{4}$ ) zunäuhst von llofukster, welcher ammimmt, dats bei Equistum die Prothallien an Lichte mat an trocknem Standort entsehieden mehr Antheridien produzieren, also (ta die Vorkeime fast ganz zweihäusig sind), melı männliche Pfanzen bringen. Bokodns tand, datis kimende sporen von Allo-

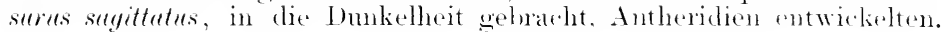

\section{Die Taubblütigkeit. Unfruchtbarkeit.}

Die Taubbhïtgkeit bei den Phaneroganen beruht vorherrshenel aut stickstottmangel. Derselbe kinn sich in seln verschienlener form äulsern. Wie bei dem "Verseheinen des (ietreides" bereits erwähnt, kam gen̈̈gender stickstoffvorrat in Boden sein, aber es felelt infolga Eintritts einer anhaltenden, intensiven Trockenperiode das Transportmittel, das Wasser, um die normal angelegten Sexualorgane zur waiteren Aushildung zu bringen. Andererseits kamm bei J)ichtsaat ein hampt mm den stickstoft" stattfinden, wobei die zuest vegetativ an krätigsten sich entwiekehelen Pflanzen den minder kräftigen das Nähmuaterial wegnehmen. Für die Enfrnehtharkeit kommen fermer die Fälle in Betracht, in denen das vorhandene Nähstoffinaterial nach anderer Richtung hin verbrancht wind, indem einsoitige strigermes oder Ver-

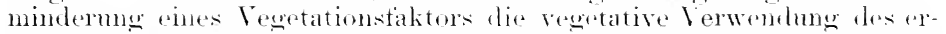

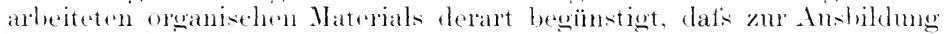

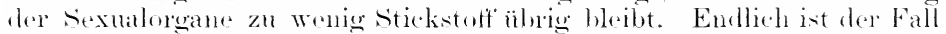
nicht selten. dats das Material in der Anlage der stickstoffansurnehs-

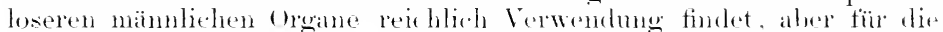

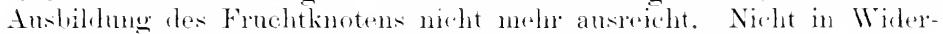
spruch tamit stehen die Fälle, dats bei den Phanerogamen Hungerzustände Veranlassun zur Blätenbildung sind. Bei mseren Gbstbäumen kommen Beisfiele vor, in denen kranke Exemplare mit hedentend zmiteligehender Triebbildurg .. sich tot blühen". In der gäirtnerischen Praxis lälst man Pfinzen alsichtlich hungern, mm Blïtenansatz zu erzielen (Kontua drpudens. Corna usw.). Kaktrenliebhaber reitsen liswrilen ihre Pflanzen in Winter ans den Töpten und lassen sie schrmution, danit sie williger blähen. Hier int nicht stickstotfmangel vorhanden, sondern eine Wasseramme, welehr die Pflanzen veramlatst, die Assimilate zur Blïtenbildung zu verwenden.

Bezinglieh einer Taubblätiglsit dureh mangehole Wasserzutuhr be-

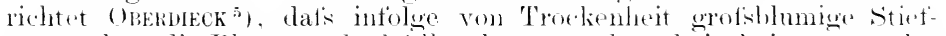
mütterchen die Blöten taub abtallen lassen. während sie bei genügender

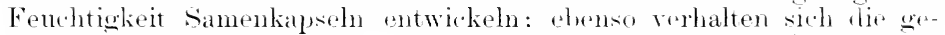

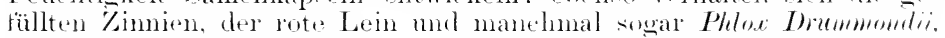
Auch Gartenbolnen setzen in trockenen .Jahren wenig an. Himberesen und Erelheeren gehen kloine, armsanige Fröchte. Bei der Monaterdbeere stellt sich hei fortuesetzter Trotienheit eine Ansartmme rin. welche dir Pflanzen den . Vierlander Erdbereren" ähnlich matcht

\footnotetext{
1) Pringsheims Jahrbücher X. s. 97.

2) Bot. Zeit. 187 5.757 .

3) Extrait des Actes du Congres international. Ansterdam 1-77.

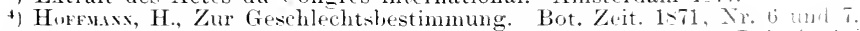

5) Ombneck, Deutschlands beste Obstsorten, s. 9, Ammerkung. Leifip 1>81. sorauer, Handbuch. 3. Aufl. Erster liand. 
inclem sio line truchtharen Bliten mehr entwickeln. Letztere Erd-

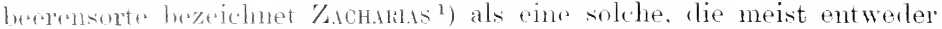

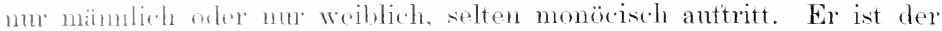
Ansicht, da ant din Feldern wenig männliche sogenamnte wilde

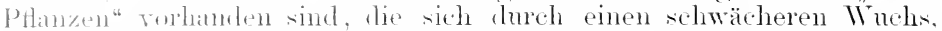

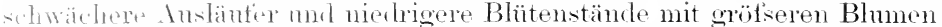
ansorichnen, so talle die Befruchtung unvollkommen aus. Es wird hervolghoben. datis stets wenig Pistille sich ausbilden, so dats sie nur sinen T'oil des angeschwollenen Fruchthortens bedecken. Wir legen ant letzteden Punkt las Hauptgewicht und raten zu Land- und sortenwechsel. Zachubas mutiehlt, mehr mämmliche PHanzen zwischen den weilichen zer erhalten.

Ahnlich Erstroinungen wie bei der Vierlander Erdbeere sind anch

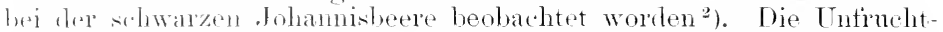
harkeit soll woder lnoh Bodentrockenheit noch schattigen Standort hedingt sein, sondern wirt ron den Praktikern als sorteneigenschatt angesporlen. Ehrnso liegen Klagen ïber mangelnden Eruchtansatz lwi den shattenmorellen vor. Der "Praktische Ratgeber" empfiehlt. lats man nm von ertahrmosgemäls grat tragenden Bäumen Edelreiser zur Verellung nehmen soll. - Es werlen ms noch vieltach solche Hinweis ant die Erblichleit mzweckmätsiger Eigenschaften entogenentreten.

\%ahheiche Angaben finden win betreffs des wachsenden Übergewichts der männlichen Blmnen gegenüber den weiblichen. Eine der trïhesten ist die von Kxight, dati Melonen mol Gurken bei hoher Temperatur ohne genïgende Lichtzufuhr fast nur männliche Organe hervorbringen. Mavz ${ }^{3}$ ) kommt bei seinen Versuchen zu dem Resultate, dats sowohl bei mon̈̈cischen als anch diörischen Pflanzen die Entwicklung des männhohen Geschlechts durch Trockenheit, dagegen die tes weiblichen durh Fonchtigkeit mol gute loüngmg begïnstigt wird. Auch sollen männliche Pflanzen hurh Alschneiden ganzer Äste in fruchtbare Zwitter verwantelt worlen kimmen. Letzterer Fall wäre dahin zu denten, dats

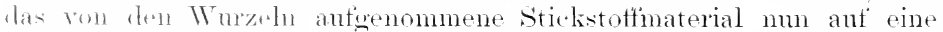
wringers Mange von Blïten sich verteilt mul daher diese besser ernährt.

AThulich ist ex nit mseren Obstbämmen, von denen die Mehrzahl win Rinhejahr. 1. 1. wins mit geringer Fruchtproduktion anfweist, bevor

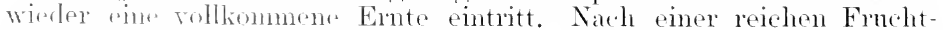
"rnte sind dir Bänmm meist so erschöpft. dats sie ein folgendes Jahr

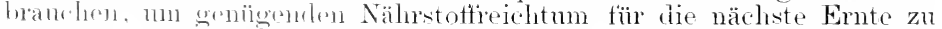

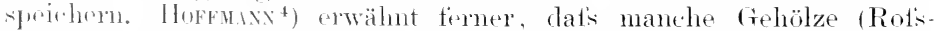
kastanis nul Kiofin) ainen normalen (reschlechtswedsel erkennen lassen, infom sio in sinem . Jahn männlich, im folgenden zwitteriog

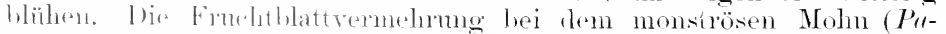

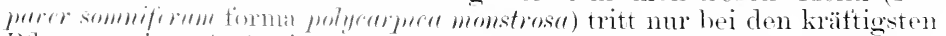
Pflanzen sin. Inf soinen Reisen fand Kanstes"s), (latis die in sümpten und tienchters Vïldern warhenden Palmen in der Regel Zwitterblumen tragen, aber chrel, Niblustottinangel polygam werten. Die an trockenen

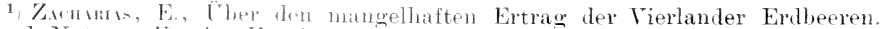
Verh. A. Natuw Leroins Itanlume log:3. 3. Folge. XI, s. 26.

2) Prakt. Raterober in ()hst- ind rartembau. Frankfurt a O. 1904 Nr. 10.

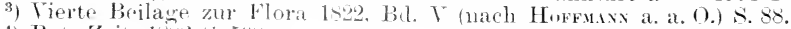

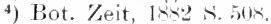

5) Limatea, $1 \times 57$ \&. 259. 
Abhängrn odter in wasseramen Ebenen wachsenten Gattumgen sind „regehmätig (nicht gesetzmälsig) getremnten (reschlechts" und tragen männlichr mel weibliche Blmmen in getrennton Ähren. Broi Becoinn der trockenen Jahresperiode tritt die viel Nibnstotimaterial linamspruchende Fruchtreite ein. nud es enttalten sich dann num männliche Bhmen, während nach der Rnhepanse am Anfang der Regenzeit vorherrsehenel die Anlage weilhlieher Blüten stattfindet.

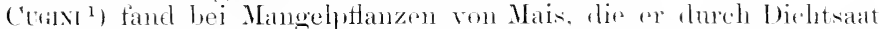
erzielte, datis rinzelue Exemplare nur noch mämliche Bliiton trugen.

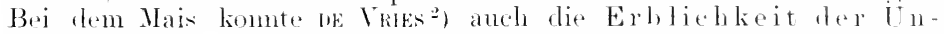
truchtharkeit nachweisen. Vom Ptlanzen, bes denen die weildichen Blütenstäncle ganz tehlten ocler änfserst schwächlich waren, nalnu es von einem Exemplar letztenenanter Art Samen zur Ansiaat. Er erlelt

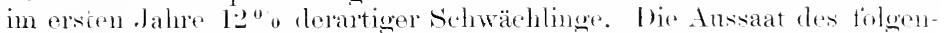
den Jahres lieferte bereits logoio steriler Pflanzen.

Lats , lie Untruchtharkeit antiser anf Stickstottinangel manchmal allein auf Wassermangel beruhen kamn, beweist ein von MóterThurg.t ${ }^{3}$ ) geschilderter Fall. Er fand die Naluen hei den Obstbämmen zu trecken, so dats die Pollenköner nieht anskemen konnten. Bui verofeichenden Versuchen mit Birnen zeigten die Bämue. wolehr während der Blätezeit reichlich begossen wurlen, eine deutliche Ertragssteigerung. An den nir.ht hewässerten Bämmen lësten sich nicht nur zalilreiche Blüten kur\% nach dem Abblïhen ab), sondern es fielen

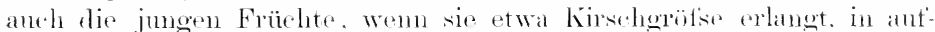

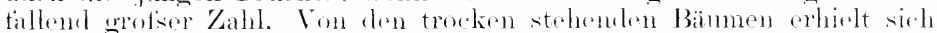
meist num eine Frucht an der Blätentolde, wählemel bei den bewässerten Bänmen turelschnittich deren hei sich woiter entwickelten.

Aler auch bej gutem Pollen nul gïnstigen Keimungsbedingungen aut der Narte kann sich Untinehtharkit einstellen. WATE*) hielt bei seinen Versuchen ïber Pear-blight hei Birnbinmen den Insektenlesuch von den Blïten ab und fand num den Frucitansatz fellent ofler tor h

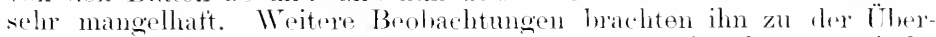
zengung. dats gewisse Birnen- mol Apfelsorten überhanht nicht

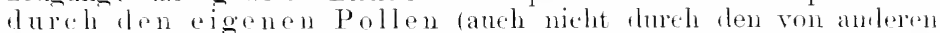
Individuen derselben Varietät befinchtet werten kömen, sondern dats ler Pollen einer aurleren Varietät dazu notwentig sei. Darans erliäre

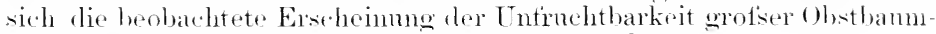
pHanzungen, tie ans einer rinzigen sorte bestehen.

Ewrkis) erkennt zwar an, (lats eine selloststerilität bei vielun

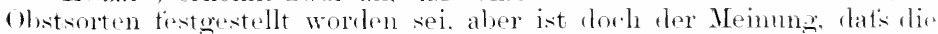
sortenreinen, orotisen Anptlanzmoen nicht hinter den ans gemisthten Sorten bestelenden zurickbleiben, weil die Fremolbestäubumg püuktlich von Bienen und Hommeln besoret werde. Nur wemn der Insektentlus

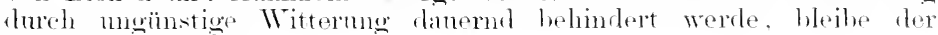
Fruchtansatz aus.

S. 1130 .

1) Crims. Intorno ad un anomalia della \%ea Mays cit. Bot. Centralbl. 1s-n

2) ne Vim, H., steriele Mais als erfelijk Ras. Bot. Jarbook II p. 109.

3) III. .Jahresber. d. Versuchsitat. Wädensweil. Zürich 1א94. S. .r.

4) cit. G.n.tuwr, B. T., Benerkenswertes Auftreten einiger Pflanzenkinklu it n in Amerika. Zeitschr. f. Pflanzenkrankh. 1×94 \$. 172.

5) Ewror, Welche Erfahrungen sind gemacht in bezug auf geringere Fruchtbarkeit usw. Proskaner Obsthan-Zeitung 1902. 
Nacll muserer Ansclummo muts hier anch der Wechsel zwischen

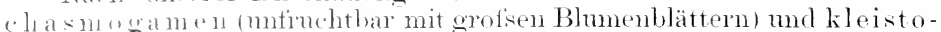
un and (finchthas mit rerkïmmerten Petalen) Blumen erwälmt werden.

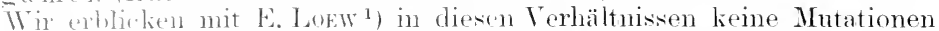
in time von ne Vhes. sondern eintache Variationen, welche von der Erudinnngstom ahhängen. (Goebre fand die kleistogamen Blüten fiüher angelont mul komute I eilchen. die rorher kleistogam geblïht hatten. dureh Trockenlatten and reichliche Besommong im .Juli zur Bildung der in dieser Jahreszeit ganz mgewöhnlichen chasmogamen Blüten

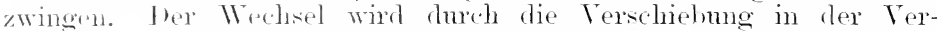
wendung des rorhandenen plastischen Materials hervorgeruten. Bei Wascemangel mul Lichtreichtum kam die Anlage der kleistogamen Blïte sich nicht aushilken mo es bleiben daher die plastischen Baustoffe den suïter sutstelırmlen Blüten zur Verfögma. Da bei diesen das weibliche sixualorgan mangelhaft ist und sich nicht ansbildet, wird las Material zm besonders irättigen Entwicklung der lichtberürftigen Blumenhlaitter frei.

\section{Kernlose Früchte.}

Im /usimmenhang mit der Taubhlütigkeit steht oft das Auftreten kernloser Früchte das chenfalls zur sorteneigenschaft werden kam.

Nan hat nonerdings diesen Umstand bei einer amerikanisehen Nenziichtum. einem Aptel, der als , the wonder of horticulture" bezeichnet wird als besondere Empfehlung der storte hervorgehoben²) und als wertroll betont. Iats die Blüten Frïchte bringen, olme befruchtet zu worden. I amit soien anch die ählen Einflüse ansgeschlossen, die bei anderen sorten dureh Frost. Nebel, Regen, Inurre, schlechten Insektenbesuch nsw. wähend der Blïtezeit drohen. Der nenen Sorte sollen ancle die Blumenhlätter felslen, und daran linïptt man die Hoffinme, dats Blitenstecher mol andere Inseliten, die durch die Petalen angelockt wiurlen, lerartige Blüten versehonen thïrten.

Kernlosi distsorten a. h. solche. bei rlenen man wenig gnt ausweliblente cannen finclet. sind schon von fröher her hekannt, wie z. B. die Birne . Rihas Krrulose" und der . Vaterapfel olme Kern". Bei Aussaten von Mostobst sull s mehrfach rorkommen, datikenfieie sorten

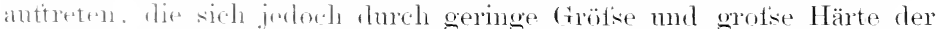
Frichte manerentelin anszeichmen.

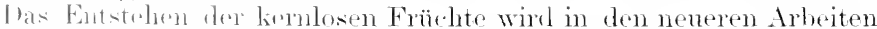

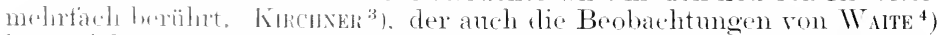

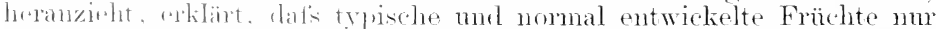
dureh Krenzume nut fom Pollen einer anderen Sorte exlangt werden:

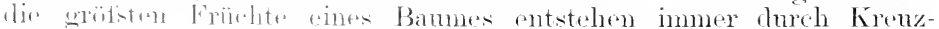

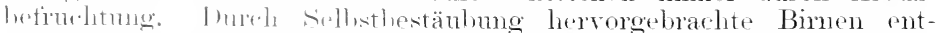

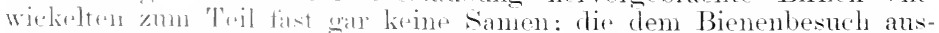

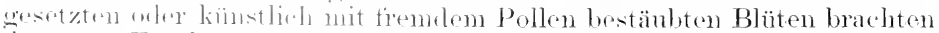

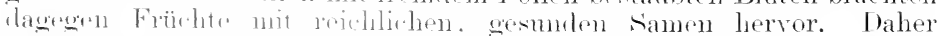

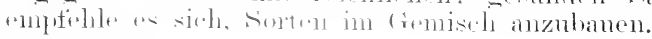

1) E Luw, Boncrkungen zu W. Burckis Abhandlung über die Mutation als

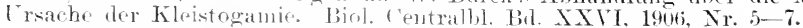

2) Jixin, A., Jier hermlose Apel. Gartenflora 1905 s. 490.

?) Kunnsta, (), Dats Blïhon und die Befruchtung der Obstbäume. Vortrag. Ref. Zeitschr. f. Pflanzenkrankh. 1964 is 297.

4) Wark, Mram, B., The Pollination of the pear flowers. Washington 1894. L. A. Def. Agrie. Bull. ., 
(iegenüber tieser Ansicht bleibt EwERT ${ }^{1}$ anch in seiner nenesten Arbeit ans praktischon fründen auf seinom stamblumkt stehen, den Massenanban riner einzigen Sorte zu befürwortru.

Betrettis der kernlosen Weinberen verweison wir ant die Unter-

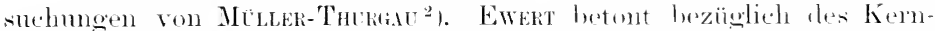

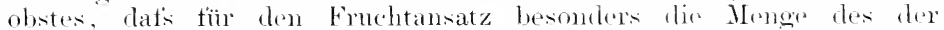
einzelnen Blüte zur Vertï̈mus stehenden orwanis-hen Bammaterials in Betracht komme. In einzehen Fällen kam man kïnstlich durch

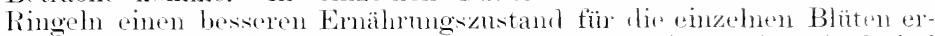

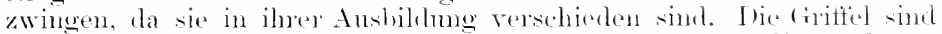
entweler stark entwickelt mol ragen his zol 1 am über die Antheren

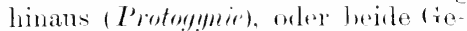
sehlechtsorame sind gleichlamg ( $H_{0-}$ morgamir), oder ble (iriffel sind kituzer wio die stanberefatioe (Protemdric). Der schluts, dats je stärlier die Protogrnie entwielielt ist, die Bliite desto mehr den Pollen oines anderen sorte verlanore, also selloststeril ist mol umgekreht, je nehr llomogamir mel Protandrie sich weltemel machen. desto mehr sellstfretioitä möglich sei, wirl flureh EwERT's Verstele nielit ausmahmslos bestätigt. Er-

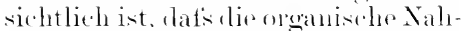
rumg zumärhst denjesigen Fruchtanlagen zuströnt, lud lonen Fremelbestänbum die Kernbildume ermö̈nlicht. In Iretthewerls mit liermhaltigen Frölehten hleiluen kemolose von ilemselben Bamme ann kleinsten und sind oft mitsosestaltet. Werden an einem Bamme clum Ablatten tremsten Pollens mu kemblose Früchte erzielt, so erlangen diese die gleiche (irötise wie kromerehe Frïchte. Wahroheinlich kïmon

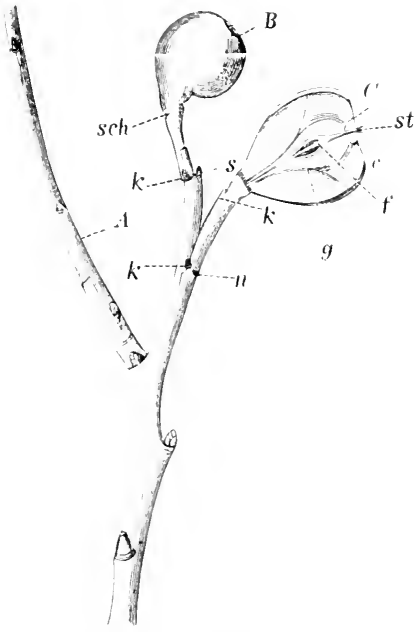

Fig. :36. Kernlose Birnt anch Frïchte ohne Einwirkmo von Pollen entstehen.

In einzelnen Fällen kamn man Früthte heobachten, bei denen sogar das Kermbans nicht vorhanden ofler cloch kam angelegt ist. In

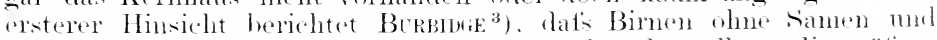
Sernhaus ganz solicle parenthynatische Frïchte darstollten, die grötser. wohlsehmeckenter nnd haltharer gewesen sein sollen wie die samentragenden Birmen.

Ich sellst erhelt vor Jahren einige Birnenzweige, vom denen ein Exemplar dureh Fig. 34 in halber Gröts wiertergegeben ist. Di, Früchte waren volliommen hart mol gestum bis anf Buschädiomegen.

1) Ewerr, Blütenbiologie und Tragbarkeit unserer Olstbämue. Lambirtach. .Jahrbächer 1906 S. 259.

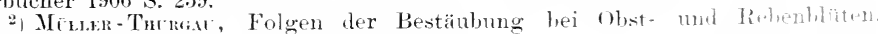
VIII. Ber. d. Züricher Bot Ges. $1904-190 \%$.

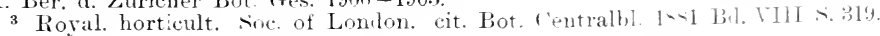


welche dis Hertstioiste reranlatist hatten. In a sehen wir einen monnalen Holzzwrig. in $B$ sinen \%weig, dessen Terminalknospe zm

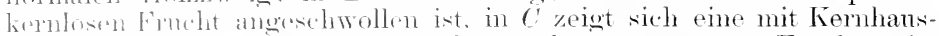

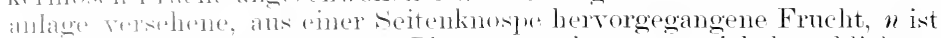
(li) Tartue sines aldertallenen Blattes, s eine montwickelt gebliebene

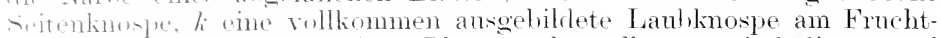
stiul. sh win schuppentömiges Blatt an demselhen: g sind die normal velantenden, num dio nit Eirudimenten versehenen Kernhansfächer $(f)$ sich hermmichemben (rö̈lsbindelstränge. Bei c sind vertrocknete Reste lep Kelchziptel nut hei st die tritfeläste sichthar.

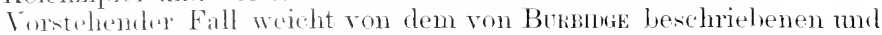
den meisten bishor abgebildeten Beispielen dadurch ab, dafs die Frnehtanshwelhmern hior nicht Prodnktionen vorjähriger, soudern liesjälniger Knospen sind. Bei Birnen ist es gerade nicht selten, dafs rimzelne llorsthlïten anftreten. Dieselben können wohl, wie manchmal angegehon ist, ans vorjährgen hnospen hervorgehen: indes habe i.h bisher nur solche Blïten zu beobachten Gelegenheit gehabt, welche an den disfibrigen, in sommer bereits answereitten \%weigen entstamlen warn. Was leicht ans dem Holzringe des firchtragenden

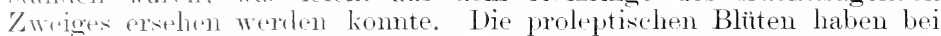
lem relativ geringen Nährorrat mod der kurzen Keit, die ilmen der Horlst noch zm Entwicklung bietet, natürlich wenig Gelegenheit, den Rindenköruer noch zu wohlschmeckendem Fruchtfleisch ansubilden, und daran erliart sich cincrseits die geringe Grötse und andererseits lie treschmacklosigkeit der hier beschrielienen Bimen. Wären die Fruchtinospen nicht durch die anfierordentlich gesteigerte Wasserzufuhr der damaligen Herlstperiode geweckt worden, hätten sie im

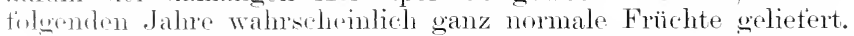

Tährond hier die Frucht kerntos geblieben, weil hei der proleptinchen Entwiclihng tie osespeicherten organischen Banstoffe nicht auslwichtent, kommon andererseits anch Fälle vor, bei denen Material genno volhamlen. alur dieses dureh Zerstörung der normalen Kernanlagen num

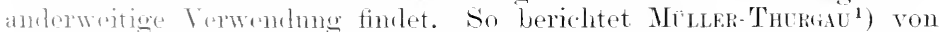

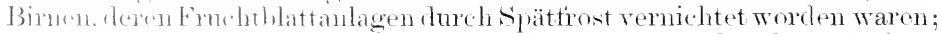
a motanton dam Fröhtr. die an stelle des Fruchtgehäuses einen

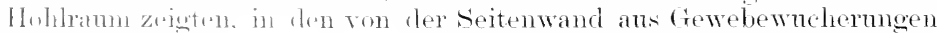
hineinwmelsine.

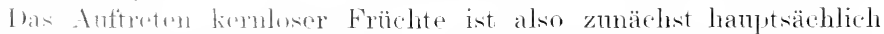

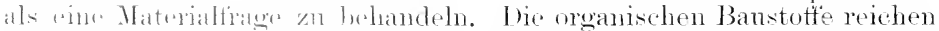

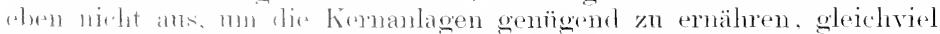

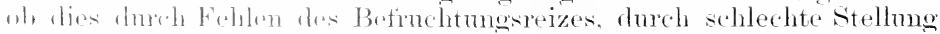

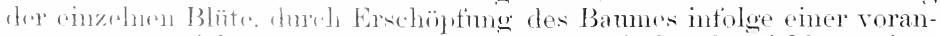

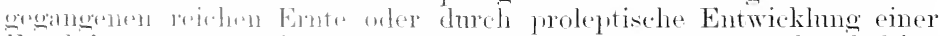

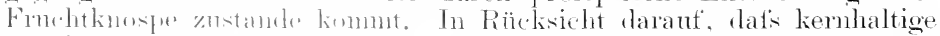

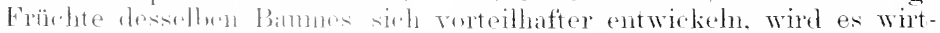

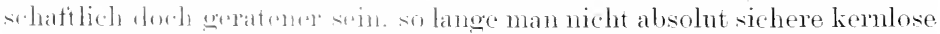

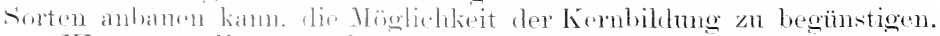

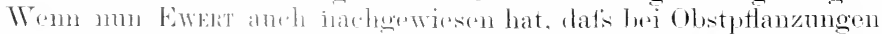

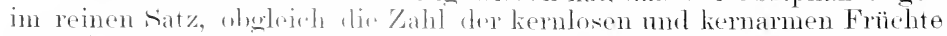

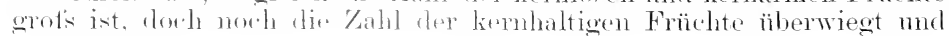

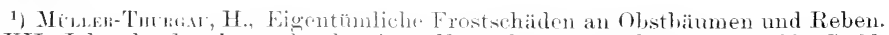
X.-XII. Jahresl. der leutsch-schweizer. Versuchsstat. Wiidensweil, 1902. S. 66. 
deshalb den ..reinen Satz" empifiehlt, so möchten wir doch dem gemisehten Satz vorläutig den Vorzmg geben. Die praktischen Nachteile betreffs des schntzes mul der Erote bei verschiedon wachsenden und roifenden sorten dürten sich darturch vermindern lissen, dats man streckenweise die gleiche sorte anhant. An Chanssen wirel jerlesmal diejenige sorte hesonders überwacht, wolche der heife am nächsten ist.

\section{Das Verhalten schwächlicher Samen.}

Die Ursachen. welehe bei den kernlosen Fröcliten ant las Fohl.

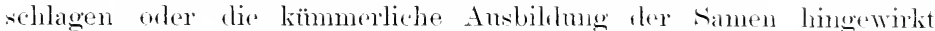
haben. werlen anch bei anderen hulturgewälssen mohr orlor wringer zur Geltumg kommen, so dats wir das Verhalten schwächlich ansgebileter samen ins Ange fassen müssen. Die mangelhafte Erü̈lum nuts sich im spezifischen Gewicht zeigen, mol in dieser Beziehmug

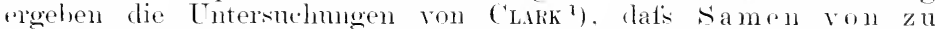
geringem spezifischen fewicht überhamt nicht keimen: tie etwas schwereren lieimen spärlich mol erzengen vielfach schwärlsliche Pflanzen. Die höchsten Kemprozente finden sich lei samen mit höchstem spezifischen Gewicht.

Nach den Versuchen von Hoseus ${ }^{2}$ ) kann man wohl ans un reifen, also spezifisch leichten samen mit vorichtiger Darbiotmes rechi gïnstiger Bedingmengen normale Ptanzen zichen: aber die strelblichkeitsprozente sind gexentiber denen ans nomalem saatgut bedentend

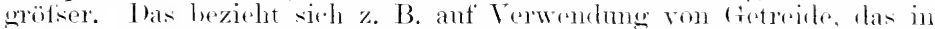
der Milehreife hat geerntet werten nü̈sen. Manchnal refahren die

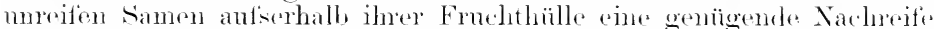

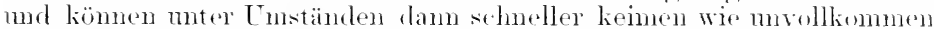
ausuereifte. Jieser Tmstanel tritt nach Kixzes ${ }^{3}$ ) hei unseren schmarotzenden seide arten oin mol ist selor heachtenswert hei deren Bukämptiung

Bisweilen hilft man sich hei schlechter samenbeschaffenheit durch vorsichiges Vorquellen. mu den Autenthalt des samenkorns im Borten bis zur Keimung möglichst ahzukürzen. Die mreifen samen faulen nämlich vicl leichter, namentlich in sehweren Börlen. Aler dieses Torquellen hat den Nachteil. dats die Saat, wenn Trockemperioden cintreten, länger liegen bleilit, als wenn von vornherein sie sich sellist ̈̈berlassen bleibt. Für Gurken hat dies Kawowst) exprimentell nachgewiesen. In dieser Beziehnug sei ant die frïler schon bespochene inreh Troekenheit nuterlnodene Keimmer verwiesen.

\section{Abwerfen der Früchte.}

Autser dem erwähnten Alwerfen der Birnen, das Mreter-Therene

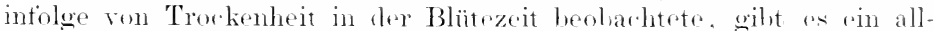
jährlich sich einstellemles . Reinigen " der fiuchttragenden Bämme da-

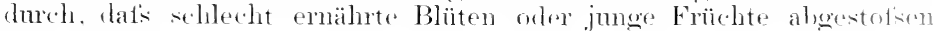

1: Cuns, A. Seed selection accorling to specific eravitr. New York Exprer. sitat. Bull. 256. 1904.

2) Deutsche Landwirtich. Presse 1:75 Nr. 4

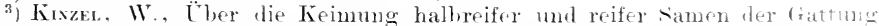
Cuscuta. Landwirtsch. Versuchsstat. 1900. Bel. 54. ․ 12.5. s. 236

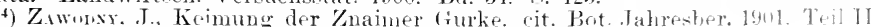


wrolen. Am maisten fintet dies hei den an den spitzen emes Blätensaukles znletzt zur Entwiklung gelangenden Blumen und den am Ende aine \%woings stehenden Blïtenbüscheln statt. Es ist nicht plastisches

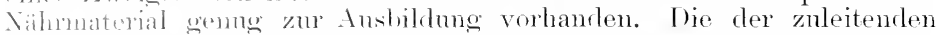
Stammarhss zmnäthst stehenden Frïchte heanspruchen die Nähstoffe anf Kuten dre melir peripherisch gestellten Grane. Bei der Spalier-

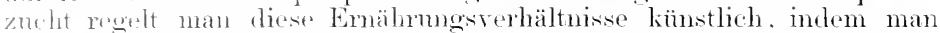

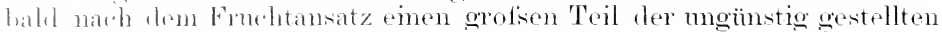
Eximplare mit ter Schere wegnimmt.

Bei her 'Treiberei ist aut das IVasserbediutnis der Friuchte be. sombles genan Rïtkicht zn nehmen, namentlich bei Pfirsich und Aprilose. TI'm der stoin zu erhärten beginnt, ist das Wasserbedürtinis am grötsten und das Abwerten manchmal durch eine einzige Trockenprickle roranlatist. Tor und nach dem bezeichneten Entwicklungsitadium liat man aber sparsaner mit dem Begiefien zu sein, da man sonst vorzoitige Triehe eryemot, welche das zur Ansbildumg der Früchte nötige Matrial an sich riehen. Dam kömnen noch in einer späteren Epoche lir Frïthe ans Nahrungsmangel fallen oder wenigstens rerkïmmern.

I)als alte Frïchte lureh spät eintretende Trockenperioden abwaweren werlen, haben wir bereits in fïhheren Abschnitten erwähnt, imd es ist mu noch daran zu erimnern, dats durch Frostwirkmo im Frïhjahr heschädiotes Obst manchmal nasienhaft am Erclborlen zu finden ist. Alle Urachen, die zur plötzlichen Funktionslosigkeit eines Organes fïhren. hewirken schliefslich ein Abstof'sen desselben.

\section{Das Vertrocknen der Blütenstände bei Zierpflanzen.}

Diese Erscheinung ist namentlith bei den Topfkulturen der Liellaber oft anzutreffion. Alogesehen ron dem Einfluts der trocknen Luft, ler suater behandelt werden soll, md der bereits erwähnten Bodentrockinlleit sincl as zwei Umstände, die hier in Betracht kommen. Brid. stellus ein Verhumgern der Blmmenanlagen dar. In einem Falle ist "s tatsächlich stithstotfinangel, der in den Töpten sich einstellt. wrme die PHanzen zu lange in denselben stehen: im andern Falle ist En Eälnumgsuangel tïr die Blütenorgane darlureh, dats andere Organe ihmen das Material wewnehmen.

Für den lotztron Fall dienen msere Azaleen und Kamelien al hänfigst. Beispicl. Liol,haher klagen ungemein hänfig, dafs sie Pflanzen mit grofisen Knospenroichtum nicht zur Blumenenttaltung im Zimmer konmm selen: hei Azaleon rertrocknen die Knospen, bei Kamelien

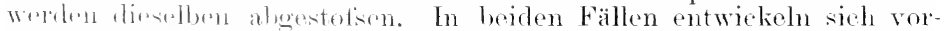
zatig mmittelbar mutro don Blätenknospen frische. selmell und kräftig Wartsent, Triole. In diesen vorzeitigen Hervorbechen junger Zweige

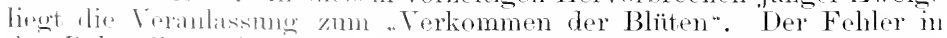

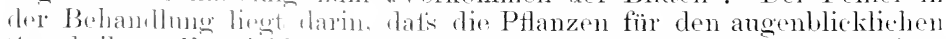

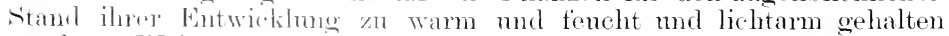
werden. Wälrent dir Blume zu ihrer Entfaltung zwar Wärme und luftfinchtigkeit hrancht, ist ihr wotse Bodentenchtigkeit schädlich. Letztere workt dagersun die nolen den Blumen stehenden Lanbknospen

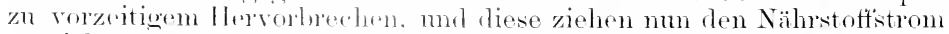
an sich mol tringen tir finktionssehwarhe Bliitenknospe ab.

soleler Vustainde des Verhmngerns einer Blïtenanlage infolge zu starker Entfaltumg der vegetativen creane finclen wir auch bei der 
Treiberei der Blumenzwiebeln. namputlich der Tulpen. Bei den neneren Kultursorten finden wir melufach, dats der Blïtensehatt nieht blattlos, somlern nit ein bis zwei Blättrem versehen ist. die ant dentlich ansgejö̈gten hnoten stehen. Bei dorartigen Exwmplaren ist die Blumenanlage so schwählich. dats se bei der Mintertredhered hurh

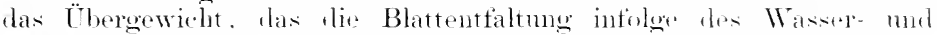
Wärmeüberschusses elangt. gar nicht zur Enttaltmug kumme somlom vertrockinet.

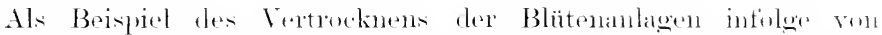

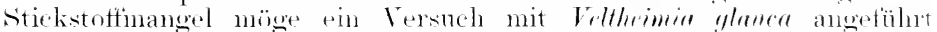

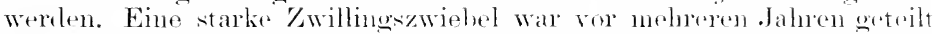

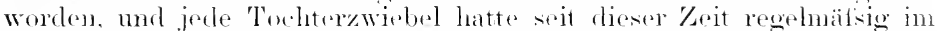

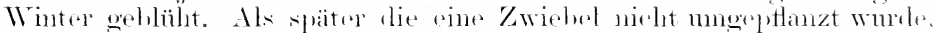
während die andere nene, krätige Erole bekan. entwirkelte sich les der ersteren der Blïtrustand zwar frïher und sclilankes, aber die Blmmen vertrockneten ror dor vollen Anshildumg. Dieser Pflanze wurden num Hornspäne als stickstoffipulle gegehen, ohne den krollumben im Topti.

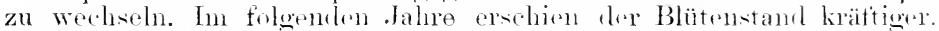

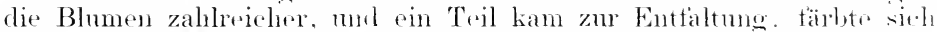
aher noch nicht so krättig. wie bei der alljährlich vorptlanztrn /wiolul.

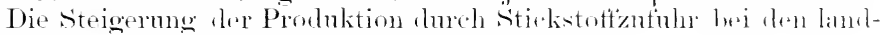
wirtsehaftlichen Kultuptlanzen ist bekamut.

\section{Die Dornenbildung.}

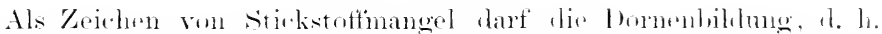

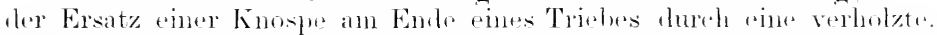

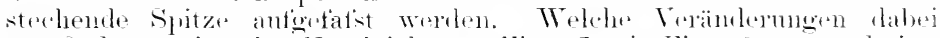

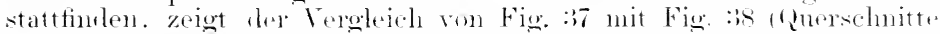

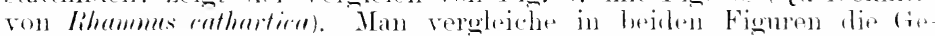

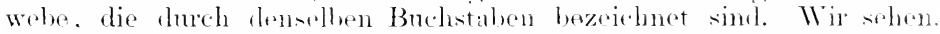
wie bei der Donenhildung die derbwandigen Elemente dis oherhand gewimnen und wie sellist die Parentelymzellen ler Rinde nud des

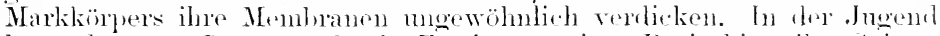
kam der zum Dorn werlende Zweig an seiner Basis bisweilen seitenaugen bilden. Wenn so viel Stickstoft noch zur Aulage ron Meristemherden vorhanden ist. Alwe aneh diese seitenathen pitlegen hakd nath ilner Anlage zu verelornen. So lange man Blattansätze an den Lornen

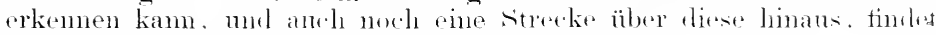

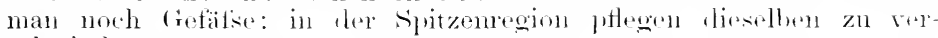
seliwinden.

Die Beseitigung der Dornen ist in Interesse des gärtheriselure

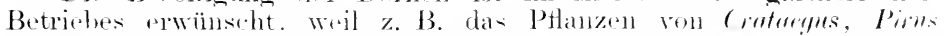
commmonis, Promes spimoser nsw. leicht zu Verletzmogen Viranlassmen

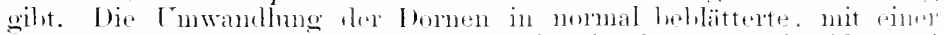

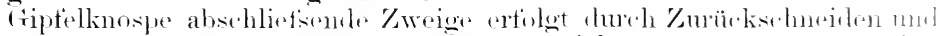

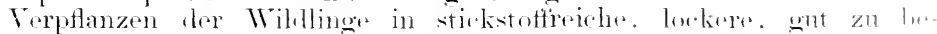
wässernde B̈̈rlen.

c. Produktionsänderung dur.h Ka liman̈r.

Einleitend sei noth eimmal darant hingewiesen. lat hillinangel in

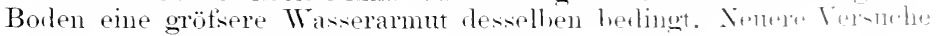




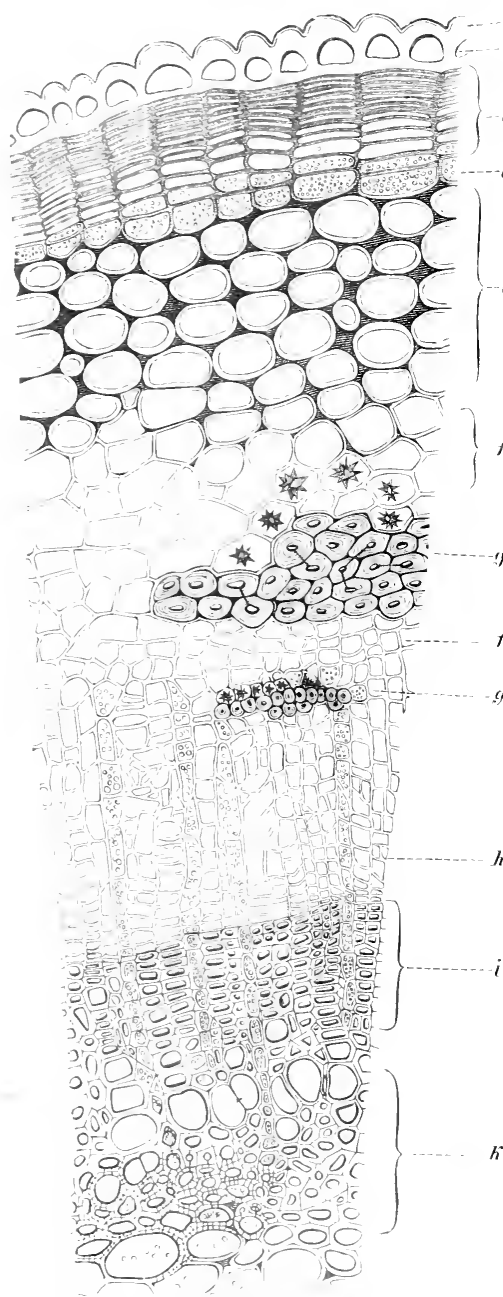

$m$

" von Hoblitio ${ }^{1}$ ) haben elwiesen, " lats rince Erde, welche mit Kalisalzen vermischt war, viel mehr Fenchtigkeit enthielt, als moler sonst gleichen Verhältuissen derselbe Borlen ohne Kalizusatz.

Jer Eintritt des Kalis in liv. PHanze erfolgt in der Form rou salpetersamem, schwefelmol phosphorsamem, salzsamem mol wohl anch ron kieselsaurem Kali. In der Pflanze ist es mit organiselon und anorganischen säuren verbunden anzutreften. und zwar vorzugsweise in den f Gewolin, in denen Kohlenhvdrate wandern oder gebildet werden. Hellieger und TiLFAkTH wiesen direkt nach, dats die Menge der als Reservestotfe niederoeschlagenen Kohlenliveluate (stärke. Zurker) bei

$t^{\circ}$ Kartofteln, Getreide morl Zuckerrüben lirekt abhängig von der $y^{\prime}$ gegebenen Kalimenge ist. Somit erkement man, dats Kalimangel sich in spärlichkeit der Reservestotfe amslrücken mufs: antirertem exlärt sich die beobaclitete Tatsache, datis die Triobbildmo nachläfst: denn die zom Anshildung des Parenchyms nötige (calluke ist foch abenfalls ein Kohlenhydrat.

(Hne Kalium ergriunt zwar lis Pflanze, wächst aber über das Matis des rom samen gelieferten Materials nicht viel hinaus. Alles übrige Nährstoft'material kam also nicht verwertet werlem (Gesetz des

1) Hot.lisxi. Tortrag im Anhaltinischen Zweigrerein für Zuckerrïbenkultur. Blätter f. Zuckerübenliau 1905, s. Ti.

Fig. 37. Quersehnitt durch den einjärigen /weig von likammes cathartica.

" Cuticulat. bejelermis, r Korksehieht, d) liellowen (Korkkambium), , Collenchym, fund $f$ lindemparenehym. o und $g^{\prime}$ liasthim.l.i, h stkumläre Rinde, i Ilolzköruer und an tescon l'eripherie die cambiale Zone, 6. Yarkkjene, m larkscheibe. (Nach DörnerNorBe.) 
Minimums). Nach den Situdien von Norbe riof ein Kusatz von Chlorkalimm, einer sehr gïnstigen Verbindmug. hei der seit Monaten rulsenden kalihmorigen PHanze wach zwei bis drei Tagen schon eine Kuwachs-

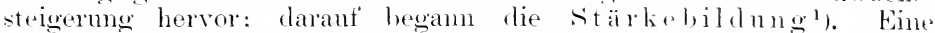
Kalizufuhr kommt aber erst zur vollen Wirlisamlent. Wemm sie nicht rlureh Kalli paralysient wirel. Ar. MEren ${ }^{2}$ ) helot die hesonders giinstige Wirkmor des ('hlorkalimms hervor, sah aber solche herlentend alogeschwächt, sobald slejehzeitio Bicalcimmphosphat vorhanden war. Bei /nckerriben wirkten sowohl C'hlorkalimm als anch Kalk in alleiniger Anwendoug sehr ont, aber nicht hej whingeitiger Zntiuhr.

Bei Getreite sah Hellategel. lats sich bei zu woringem Kalivorrat die wounen Teile aut Kosten dre Köner ansbileleten. Dies ist nicht so bej stickstotimangel, bej welchem sich die Pflanzen vollstänlig entwickeln, alee klein bleiluen. Bei Bänmon tïhrt ein anhaltender Kalimangel an immer schwählicherer Entwickhmo der Eneltriebe mol schlietslich zur

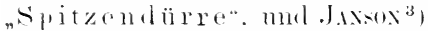
fiihlst an, dats er liese Krankhoit durch direlite /ufiuhr vou fo'o Salisaly geheilt habe. Natürlich bamu suitzendiure durels selur verschiedene Ursachen zustande kommen, mol namentlich ant lamborlen wird man in erstrer Linis nach anderen Ersachen snchen mïssen.

Tisiensehaftlich hearhtenswert ist die experimentell test westellt. Tatsachet), dats bej Kalimangel. wesenïber einer vollen

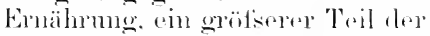
antigenommenen Nähstoffis mit

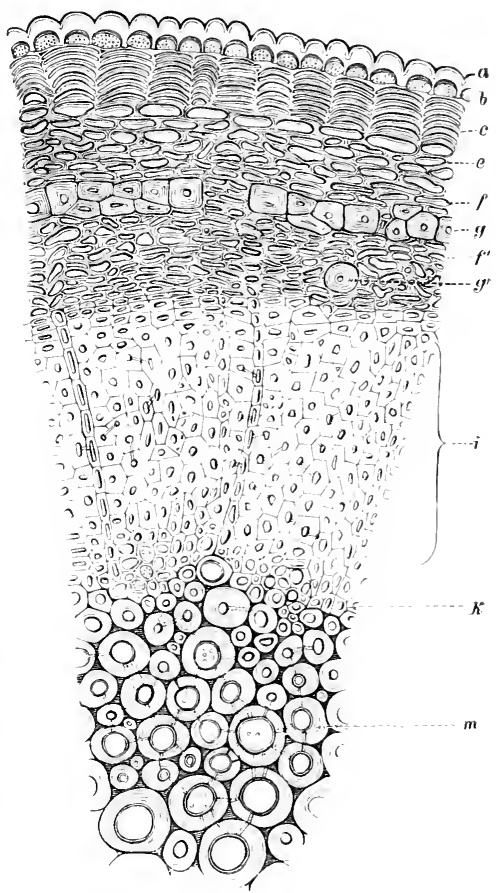

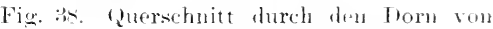
Rluammes rethertiare.

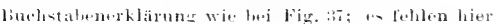

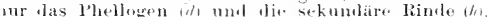

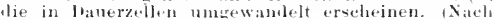
DUI:SER- NOLWH.1

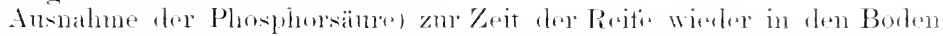

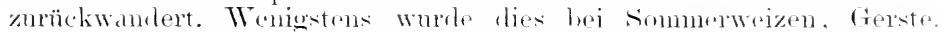

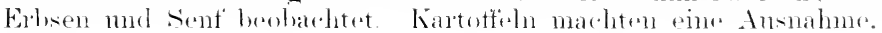

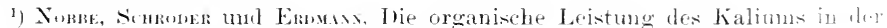
Pflanze. Landwirtsch. Versuchsiat. XIII - : :21.

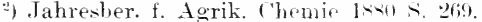

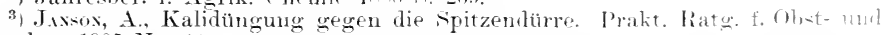
Gartenbau $1905 \mathrm{Nr}$. 38.

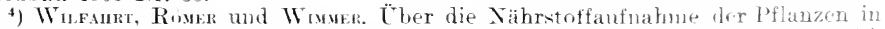

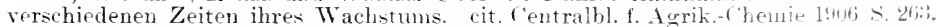


Interessant ist die Äntserme des halimangels bei Pilzen. Moubaro

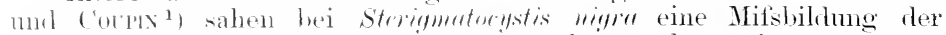
Kondienkïptiden. dir überhampt num now ansnahmsweise entstanden und sids unvolliommen aushildeten. Wiv bei anderen Hungerzuständen keimen the Kondien sofort. aber ihr hulalt wandert in eine Chlanydosurention.

Die wichtigste Frage töir die Kultur ist, ob sich äntsere sichere Irermale antfinden lasien. Welche den Kalimangel mit Bestimmtheit allzeigen?

Wie wesentliehsten darauf gerichteten Versuche verdanken wir

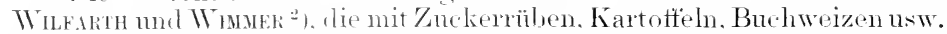
rergleichende Kulturen angestellt haben. Sie priften auch denstick-

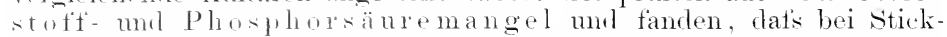

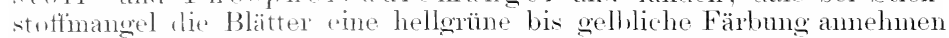
mul schlietslich mit haller, bräunlichoelber Farbe vertrocknen. Bei Phosphorsänemangel tärben sie sich entsprechend dem jeweilig vorlandenen stickstoftübershuts tief dunkelgrïn, und es bilden sich in pxtremen Fällen znerst an den Rändern. später über die vanze Blattflir he relnoitete shwarzhrame stellen, welche anfangs bisweilen rötlich gefarbt sind. Sibliefslich folgt Vertroeknen unter dunkelgrüner lis schwarzhanner Färhme. Steht derartigen Mangelptlanzen aber Kali genügend zm Vertïnung, so werden trotzdem reichliche Mengen rom Stälie mol /ncker gebildet, ja bei stickstotfmangel scheint lieser Prozets eher vermehrt als vermindert zu werden. TVem aber Kali hei sonst normalem Nährstoffvorrat fehlt, dam tritt bei Körnerfriichten rie oben erwähnte vermehrte Strohbihlung gegenüber der Körnerbildung zutase und bei Rïhen- oder Knollengewähsen steigert sich die Krautmenge gegenïher den Reservestoffhrhältern, die erheblich weniger Kohlenlivitrate als bei stickstott- mol Phosplossäuemangel besitzen.

T)a clip Pflanzen zunächst den Kalivorat zum Aufbau des regetativen Gerüstes verwenten, so behalten sie in ihrem Habitus länger das Anscehen der normal ruähren Ptlanzen, als bei Stickitotf-oder PhosHhorsänemangel: lann aber verkiurzen sich die Internodien und hrïmmen sich lie Bläter konvex nach oben. Es treten vorerst in der Nähr der Blattränder. später aber über die ganze Blattfläche

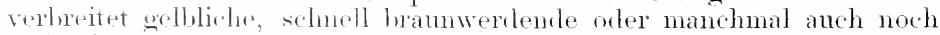

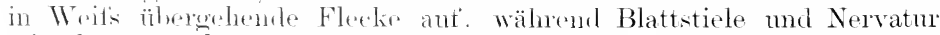
mit deren närhstr. I Tugehmeg grön bleiben. Endlich rertrocknen, moist rom Ranele lus, die Blätter nit dunkelbramer Farbe (s. neben-

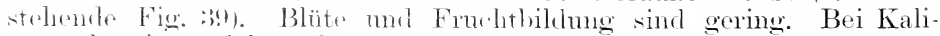

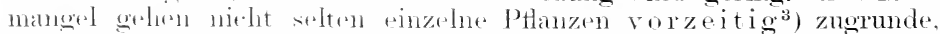

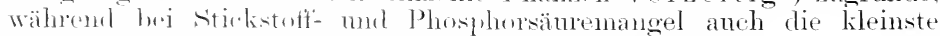

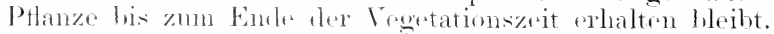

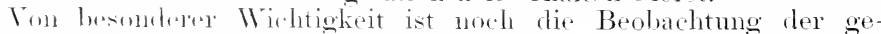
mannten Antoren, dats Kalimangelptlanzen sehr leicht in ihren Wurzel-

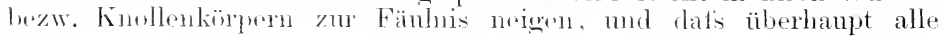

1) Munum et Cumx, siur les formes teratologiques du sterigmatocystis migra

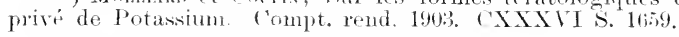

2) Wrman'm, H. W. und Wimse, G. (Ref.), Die Kemzeichen des Kalimangels an den Blättern der Pflanzen. Zeitschr. f. Pflanzenkrankh. 190: s. 82.

3) Vergl. auch: v. Simuons, Die dumch Kalimangel bei Vietsbohnen (Phaseolus volgaris nanus hervorgerufenen Ersheinumgen. \%eitschr. f. Pflanzenkr. 1906 s. 2. 

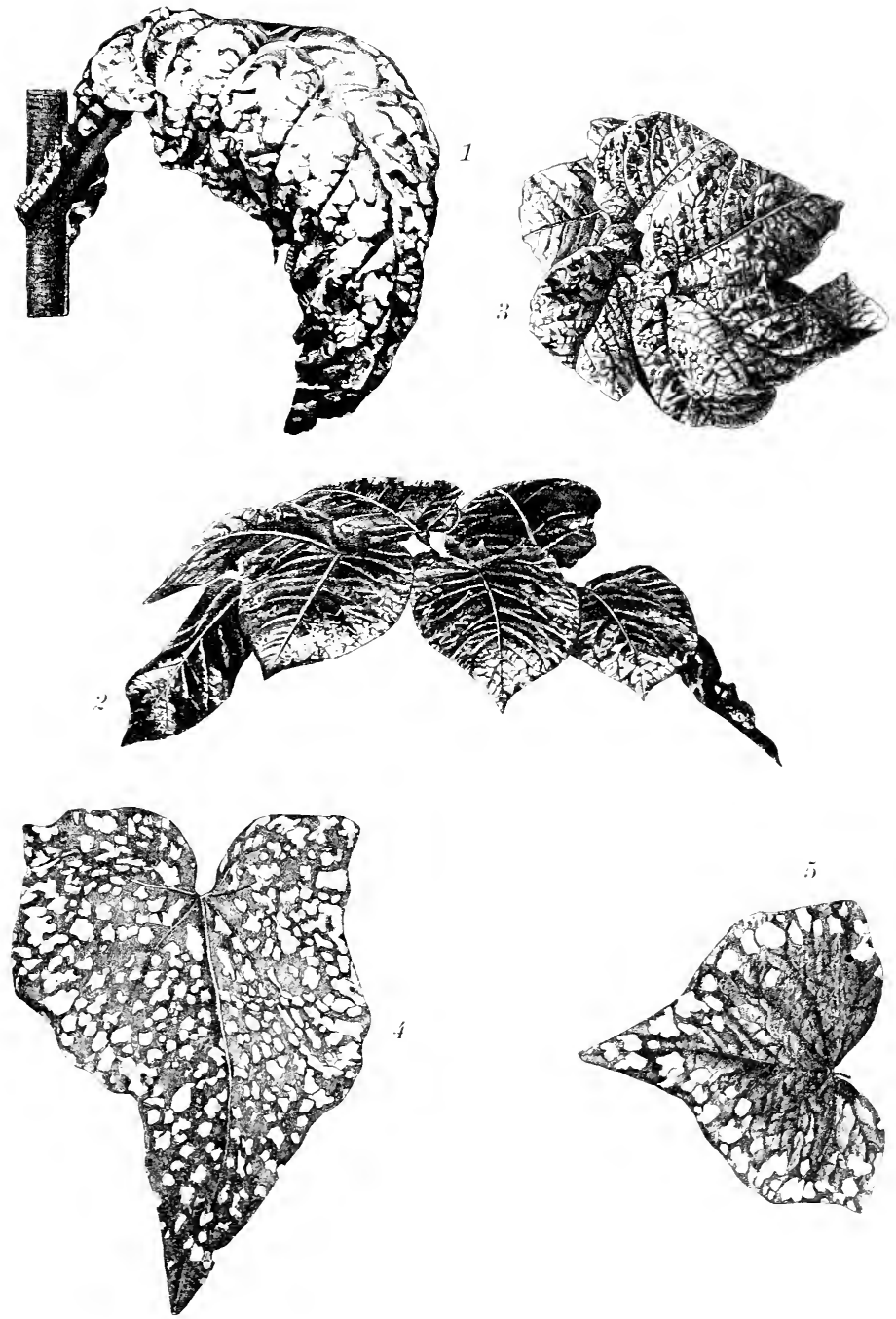

Fig. : S. Kalimangel.

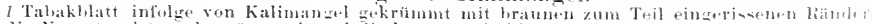

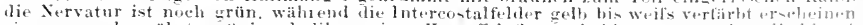

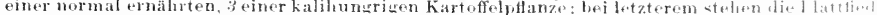

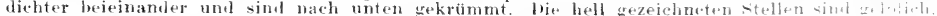

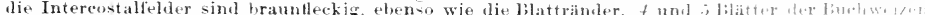

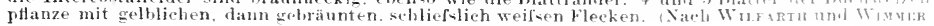




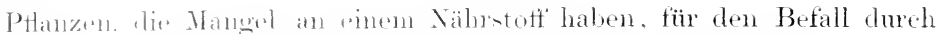

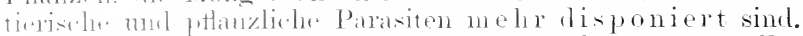

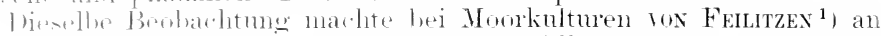

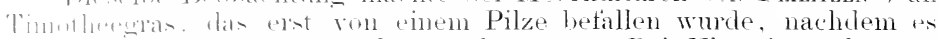

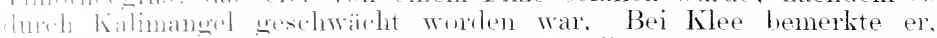

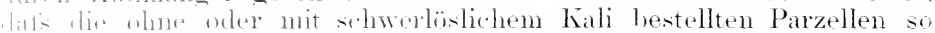
wethant" ansisahn. wie anf magerem sandborlen nach langen 'Troekenperiorlen.

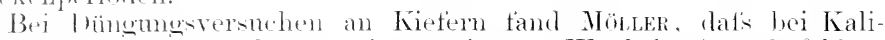

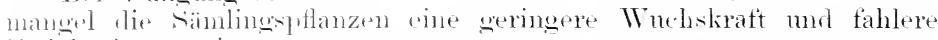

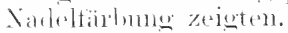

so sehät\%nswert die Bestrelmugen sind, habitutle siehere Merkmale für Kalinanes anfzufinden, so glaube ich doch. datis wir für lange \%oit hinans mele nit Vorsicht diese Nerkmale zur Liagnose benutzen

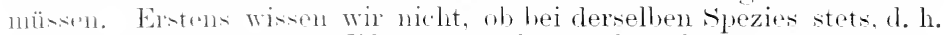
luj allen Variationen der Wachstmmstakoren dieselben Merkmale sichtlall werden. Zwoitens kemen wir noch viel zu wenig die Hunger-

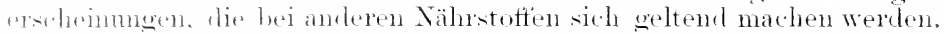
Inittrns tänsehen Einflüsse schällicher Gase hisweilen so ähnliche Biliker vor, alwesehen von parasitaren Eingriften, dats es schwer sein lïrtte. ans len hahituellen Veränderungen allein bestimmte schlüsse zu ziehen. Nan mutis nm berdenken, datis fast alle das Blattleben betreffinden sidudigungen an len ron den wasserleitenden Nervensträngen am tutturntrst liegenden Regionen zuerst sich äutsern. Daher der liantige Antang der Erkrankung vom Blattrande her orler in der Mitte ler zwishen len särleren Rijpen vorgewälsten Intercostalfelder.

\section{Kallina noel.}

bie Verwomlnow des Kalkes in der Pflanze als Festigungsmittel fiir li. Membranen mol als Bindmusmittel der entstehenden giftigen

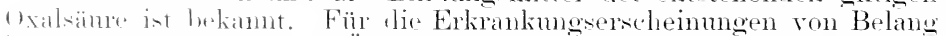

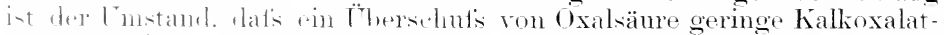
nexpen wielle lisen kann ${ }^{2}$ ). Ler entstandene oxalsame Kalli löst

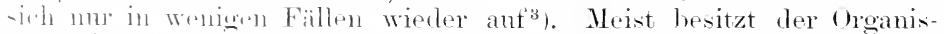
mus nieht dio Falngkeit, den schon anderweitig in alten Geweben

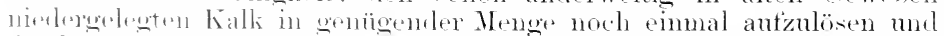

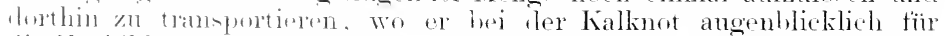

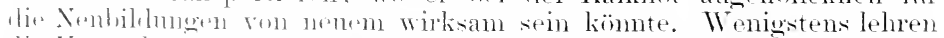

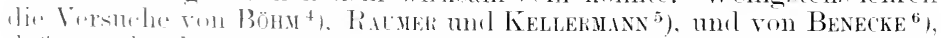

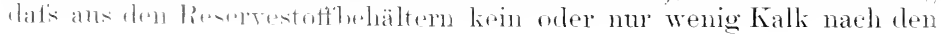

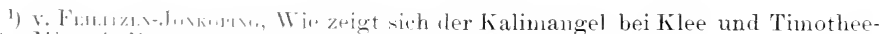

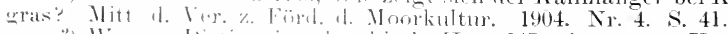

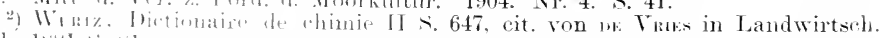
lahth. $18 \times 1<-<1$.

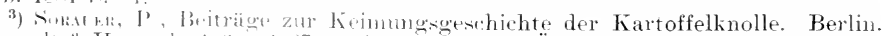

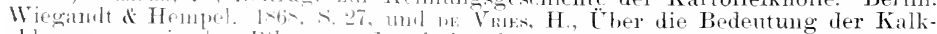
ablagerungen in ten Pflan\%en. lantwirtseh. Jahrb. v. Thiel. los s.80.

4) Bum. Ther dun regetahilischen Niahwert der Kalksalze. Sitzungsber. d. $\mathrm{k}$ Akad. d. Wissensch.. Bd. $71,1<7,-2,2<7 f$ ff.

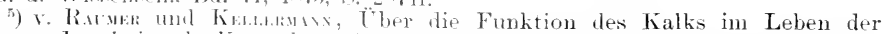
l'flanze. Landwirtseh. Versuchstationen XXV, 1sot. Heft 1 и. 2.

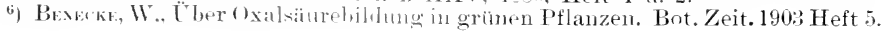


jugendlichen Geweben answantert. Wemn Pflanzen in destilliertem

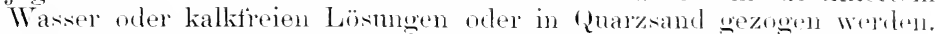
Zur Bildung der stärke sollost ist. Wie Bönn an stäketreien Primorial blättern mit schon schrmmptemelen stielen gozeigt hat, kein halk nötio. da diese sich ohne Kalkzutuh wieder mit Stärk muter somst ginustigen

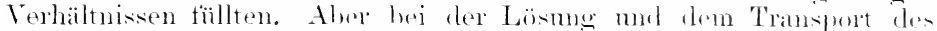

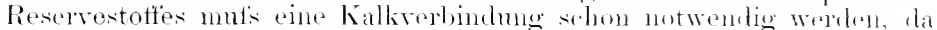

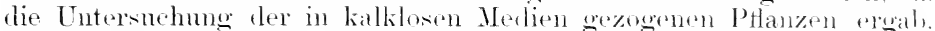

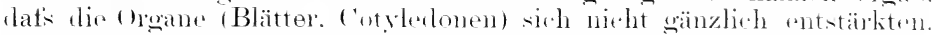

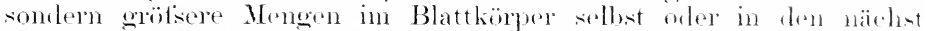

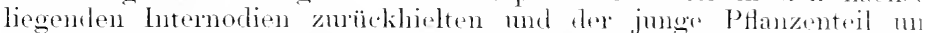

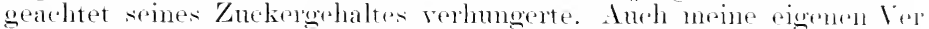

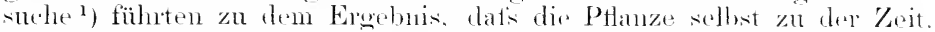
in der sie vorzugsweise das Reservematerial zu ('ollubse mul freml.

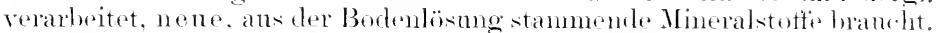

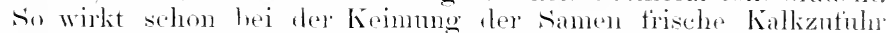
giunstig. ja sie erscheint manhmal notwemlig. Lie Angaben, dats Kalli

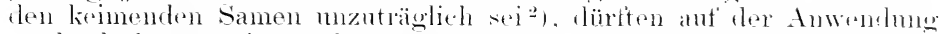

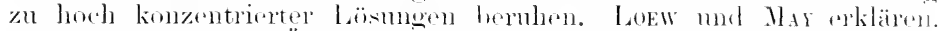

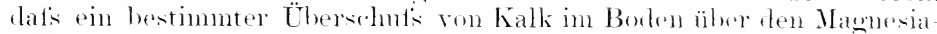

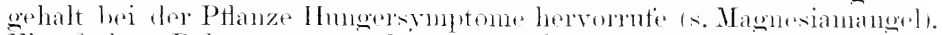

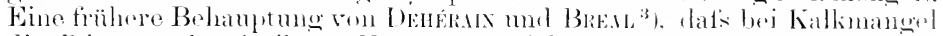
die Ptlanzen den in ihrem Körper gespeieherten Kalk heser verwemelen.

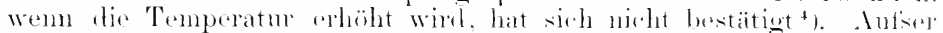

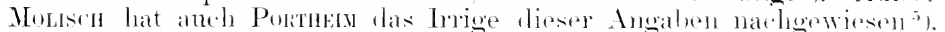

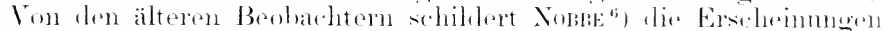

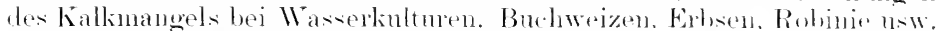

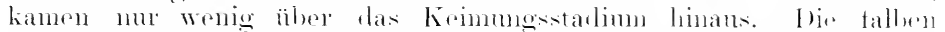

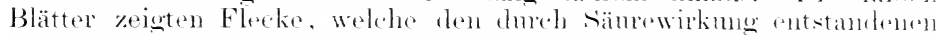
ähnlich waren und rortrockneten allmählich, wohed die Blattstiele häntio

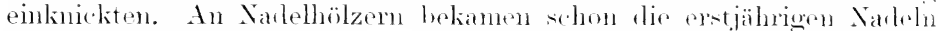
gelbe bis hame sitzen.

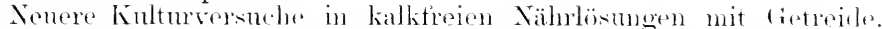

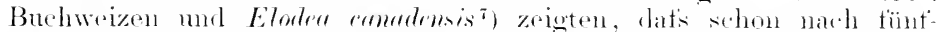

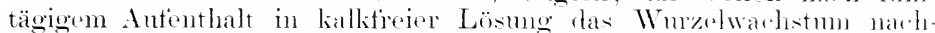

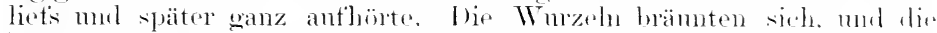
Wuzelhaule starh ah: ant den Blätteru, dis bald zugmure gingen. fanden sirh rigenartige. brämblehe Flecke. Der Gohalt an sancrem

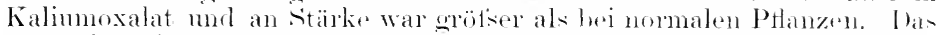

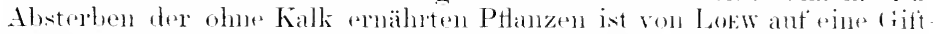

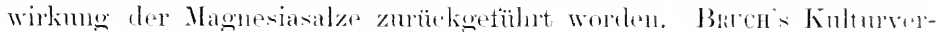

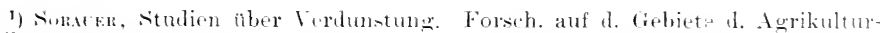
physik. $18 \times 0$, , $420 \%$.

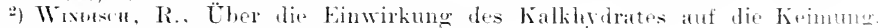
Landwirtsch. Fersuchstationen. 1900, - $2 \times 3$.

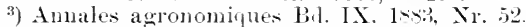

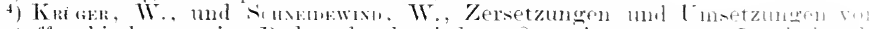
stickstoffverbindungen im Boden durch niedere Organisman usw. Latudwin-h. Jahrbücher 1901, s. 633 ff.

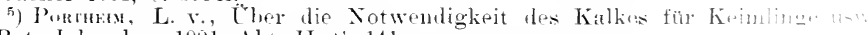
cit. Bot. Jahresber. 1901 , Att. II. S. 141 .

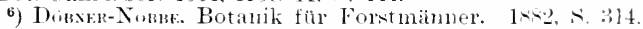

7) Bacu, P., Zur physiologischen Bedeuturg des calcium- in her l'tanzLandwirtsch. Tahrb. 1901. Suppl. II I, s. 127. 


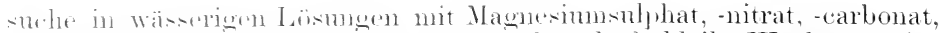

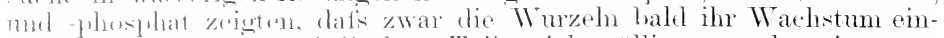

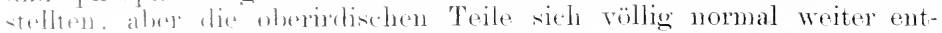

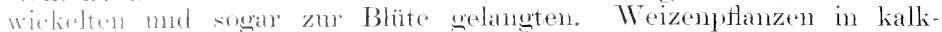

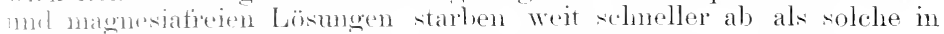
nur katktieiren läsmeren.

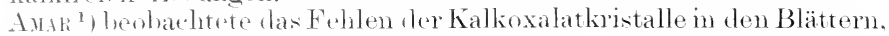
wellhe nath Einbringen der Ptlanzen in eine kallifreie Lösmng gebiliket warklen warem.

Einon writeren Einblick in die Wirkung des Kalkmangels geben

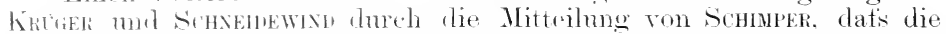
Folgen einer Kallintzichung alle symptome ler Vergiftung zeigen intolgr eines onom grotsen trehaltes an samem oxalsaurem Kali. Bei

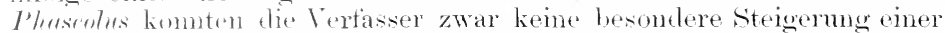
tarken orwanisclien säme nathweisen, aber es gelang ihnen, durch Bestreichede ahsterleneler Keimlinge mit einer Kalklösumg am hypokotylen Teilo ofter an der stelle. wo das Absterben zu begimen pflegte, lie Pflanzen his zmm vollstänligen Verham aller Reservestoffe zu mhalten. Dies bestatigt die Boenusche Beobachtumg, dats Keimptlanzen her Fentholm mittels dex therhant von Stengeh und Blättern aufer II ascier auch Kalk autinthmen.

Eine Bestätomg rorstehender Beobachtmgen bieten die Versuche

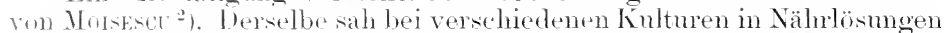
diejenigen Pfänzh hen an frühesten mol stärksten erkranken, welehe in

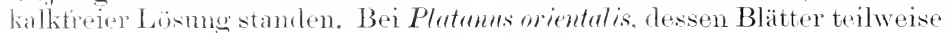
läng der Vervon hram und trocken wurlen. zeigte sich, dats die erkrankten gegrniilur den gesunden dinen dopledt so hohen Sänregehalt be-

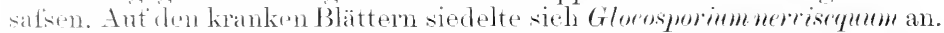
Ian muls deshalh, ammehmen, dats der cenannte Parasit nur geschwächte

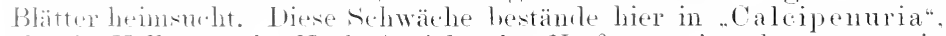
alse in Kallinangel. Nach Ansicht des Verfassers ist eben zu wenig Kalls dacewesen. mn das im T̈herschuts vorhandene oxalsaure Kali in oxalsamen Katli monzwanteln.

Antise deratign hulturersuchen liegon rine grotise Anzahl von prakticchen Erfahomigon vor. wolche ant die schädlichlieit einer Kalk-

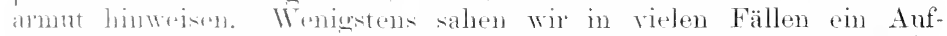

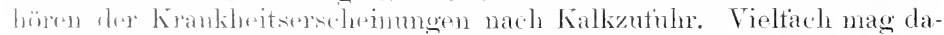

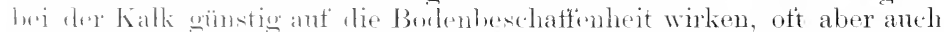

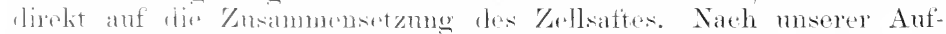

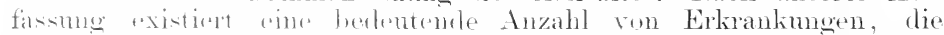

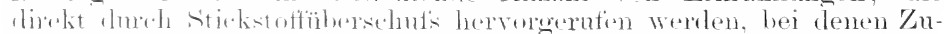

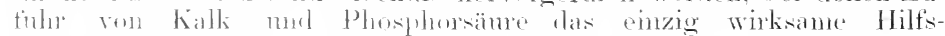
mittel bleiht. Ameh wrelen wir in dem Alschitt "Enzymatische

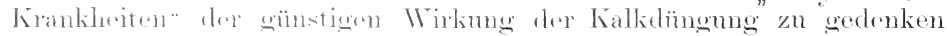

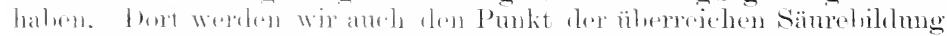

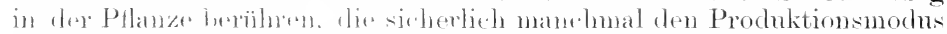

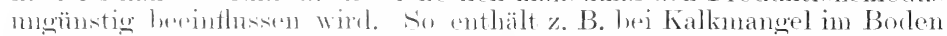

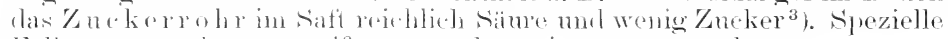

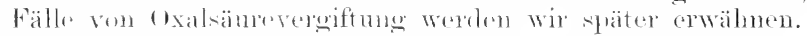

1) Amar, Moxme, sur le rôle de loxalate de caleium dans la nutrition des végétaux. Annal. se nat lont. 1944. XIX, s. 195.

2) Monser, N., Fin Fall ron (alcipenuria. Zeitichr. f. Pflamzenkr, 1905. S. 21.

3) Stemere, Tropisthu Agrikultur. I1. Aufl., :3. Bd. S. 2:3t. 


\section{e. Magnesiamangel.}

In Nïhrösungen olne Maguesia erzogene Getreidepflanzen zeigten mehrtach eine grötsere Langlebigkeit als bei Kalkmangel. Es wäre daraus zu schlietsen, dafis die Ptlanze imstande ist, ihre im frewebe bereits testgelegten Magnesiaverbindungen leichter zn romobilisieren und den jungen Organen wieder teilweise zugänglich zu machen. Wenn das Getreide langsan durch Magnesiahmuger erkrankt, zeigen die Blätter ein hellorünes, schlatfes, aber nicht direkt welkes Aussehen. Fin ganz bedentender Einfluts lätst sich von vormherein bei der Samenbiletung vermuten, wenn man bedenkt, dafs z. B. die in den Proteinkirnern eingeschlossenen rloboide als Kalk- und Magnesiaverbindung mit rino gefaarten Phosphorsäme anzusehen sind. Tatsächlich zeigte sich auth bei Magnesiamangel eine Verminderumg der Fruchtbildung, wie NobBe ${ }^{1}$ ) angibt. Er tührt folgende srmptome anf. I lie Blätter nehmen einen bläflichen, hier mol da durch gelbe bis orangerote Flecke muterbrochenen Farbenton an: die Blattentfaltung wird gehemmt, dis Internodien werlen verkürzt. Die Chlorophyllkörner sind blatsgelbgrün und enthalten in der Regel spärliche stärleeinschlüsse. In der Epidermis ist eine geringere Zellteilung bemerkbar. Mit den Pflanzen der stickstofffreien Nährlösungen fand NobBe die Magnesiamangelptlanzen darin übereinstimmend. dafs rotfleckige sitengel vorlanden waren und dats die Blatter vorzeitig von der Basis ans abfielen. Letzteres Merkmal diütte wohl bei allen Hungerptlanzen vorhanden sein, da tie jungen (Organs bei mgenügender Nährstoffzntulur dureh die Wurzel die älteren aussangen.

Eine orangerote Färhmeg komnte anch Mor.LeR ${ }^{2}$ ) bei seinen Magnesiamangelkulturen mit Kiefernsämlingen heobachten. Er sagt, datis die Narleln in oktober lenchtend orangegelbe spitzen zeigten mul weiter abwäts dureh ein lenchtendes Rot in das normale Grïn übergingen. Die Färbung verschwand, als die sämlinge im zwoiten Jahre Magnesia erhielten. Ramax hatte die orangespitzigen Narleln zweijähriges Kiefern

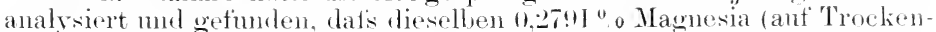
substanz herechnet) inthielten, während die danebenstehenden normal

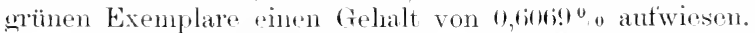

Betreffs der Magnesiawirkmog haben Loew und M. ${ }^{3}$ ) der Ansicht Anstruck gegebell. datis fïr ein gïnstiges Pflanzenwachstum rin bestimmtes Jengenverhälnis zwischen lösichen Kall- mul Magnesiaverbindungen notwendig sei (mogetahr tem molekularen (tewitht also) $\therefore$ zu 4 entsprechend). Nagnesia in einem Boden in grotisem löherschufs äher Kalk ist schädlich. Ptlanzen, dir insofern Magnesiamangel haben, als Kalli in Öthersehufs vorhanden ist, zeigen IInngersymptome. Ein kleiner Glersehutis an Kalk hebt die giftigen Wirkmingen der Magnesia ant. Bei Anrendung magnesiahaltiger Dïngenittel sollte zugleich mit Kalken voromangen werden. Diesor Rat ist sehr zu beherzigen. Wem anch die Pflanzen Magnesia sehr gut vertranen, ja notwenilig hauchen, so ist der T̈berschnts sicherlich schädlich, wi. die Dïngmeen mit Kalinohsalzen vielfach brweisen.

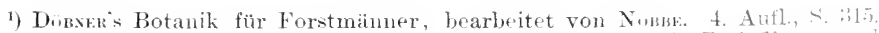

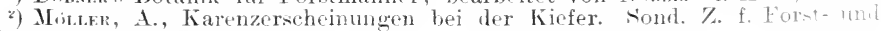
Jagdwesen 1904. ‥ 74.5 .

$\left.{ }^{3}\right)$ Lww, O., und Mix, W., The relation of line and magnesia to plant prowth. U. S. Departm. of agric. Bull. I. cit. Bot. Jahresber. 1901. II, S. 141. 


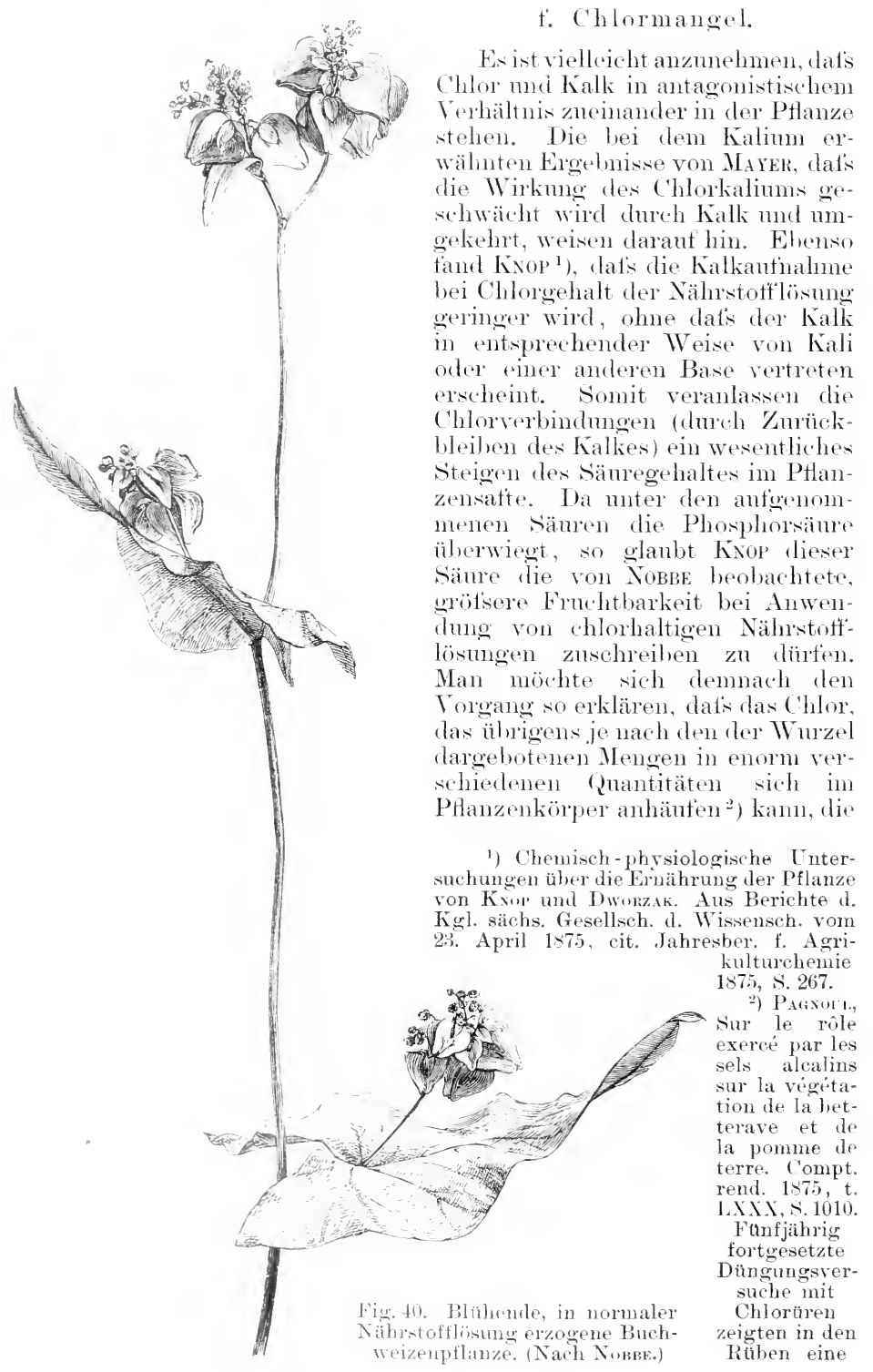


Transportfähigkeit der Phosphorsäure rhöht, indem es die Kalkanfinahme vermindert und dadurch verhïtet, dats dir Phosphorsäure in der sehwerlöslichen Form des phosphorsauren Kalkes anttrete. Kommt die bei der Bildung der Eiweitsitoffe mitwirkende Phosphorsäure sehr leicht in die meristematischen diewohezonen der fortwachsenden spitzen, damn tritt reiche Plasmalihlung mel Zellvormelnung und damit in Verbintung reiches Aboromen der Kohlenhydrate zur Eiweitsregeneration ein. Demgemäls werden sich stark tortwachsende Triebe und wenig gespeicherte Roservestofte in drin mit Chlor gediungten PHanzen finden müssen. Tatsärhlich zeigen die vielen Dïngungsversuche ein Herabgehen der stärke und des Reserveznckers in den üppig warhsenten Kulturpflanzen.

Antiser der wahrscheinlichen Erhöhmu der Transportfühigle it der Phosphorsäure hat das chlor nachweisbar einen betördernden Einthut's ant die Fortleitung der in den Blättern bereiteten stärke. Nach NobBe's Versuchen wächst die chlordarbende Pilanze unter ganz dunkel. grüner Färbung fort und zeigt eine beleutende Produktionstärkereicher substanz: aber es tritt früher oder später. jedenfalls vor der Blüte eine eigenartige fiestaltsänderung ein. Dits dunklen, abnorm lickHeischigen, stärkistrotzenden Blätter sah Noвbe (bei Eiche und Buchweizen) sich einrollen. brüchig und hin-

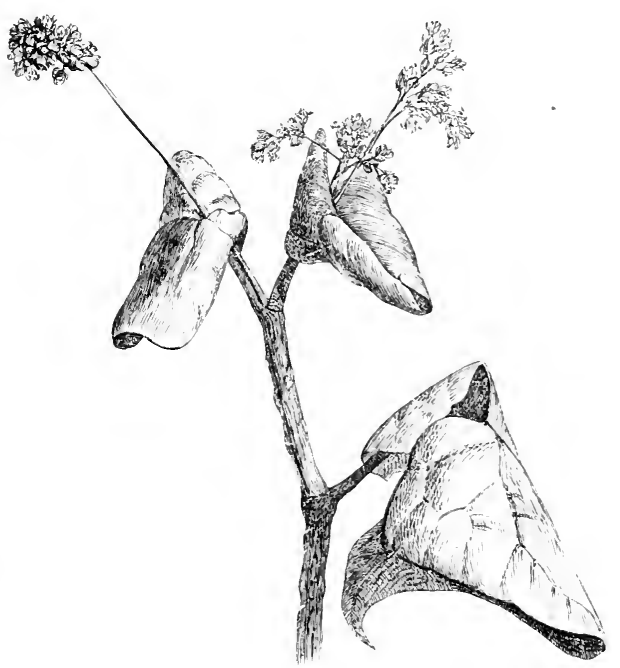

Fig. 41. In chlorfreier Lösung erzogene Buchweizenpflanze. (Nach Nons.)

fällig werden. Die Stengel und Blattstiele erscheinen wulstig dick, die Internodion der stengel immer kïrzer, und sehliefslich vertrocknen manche derselben ton der spitze aus. Wemn die Ptlanze bis zur Bläte kommt, entwickeln sich trotz des reichen stäkematerials in dru Blättern doch nur vereinzelte ungemein dürftige Früchtehen. I)e. Einthuts des Chlormangels wird am besten durch den Veroleich einer. normalen mit einer hei Chlormangel erzogenen Buchweizenptlanz. erkemnhar (Fig. 4 "l und 41 ).

Schwankung im Gehalt von 1-50. Bei Kartoffeln fiel der creringste Ertrar an Knollen mit der geringsten Nenge der Asche an kohlensauren Kali, aber Itr.n gröfstem Reichtum an Chlorüren zusammen. 


\section{4.. Eisonmangel und (tablosueht (Ieterns).}

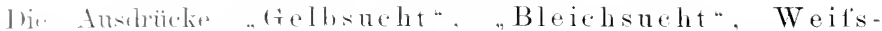
l, ättrigkeit". Panathure", "Chlorosis", "Albieatio", Etiolenent" sind die geläufigsten Bezeichnungen für die Zustände, bui hrum ein Blatt stellenweise ofler in seiner gesanten Flächenansidehnmm den grünen Farlsstotf verliert. Die Ursachen für diese Fartroündermg sind äntserst verstheden, stellen aber stets schwächezenstäncle dar.

Tm rinen T̈berblick äber die mannigfachen Erkrankungsfälle zu gewimnen, versuchn wir diselben zu gruppieren in

1. Nicht angeborene mnd nicht übertragbare Zustände.

a) Dic Verfärbung argreitt die gesante Fläche des im Lichte ansgewachsenen Blattes. Tasselbe nimmt, nachdem es in (ter Jugend grïn gewesen, in seiner ganzen Fläche einen nelblichen, gelben bis gelbweitien Farbenton an: Icterus urler Gelbsucht. Ursache: meistens Nährstoffinangel.

b) Lie bleiche Terfärbung ist im jugendlichen organ bereits vorhanden, und die Blätter verharren in einem der Jugend ähnlichen Zustande bis zu ihrem vorzeitigen Ende: Chlorosis, Bloichsucht oder Etiolement. Ursache: Licht-, bisweilen Wärmemangel (s. diese).

\section{Angehorene nurl ïbertraghare Kustände.}

hir Pflanzenteile zeigen gelbe bis reinweitse Flecke oder Streifen. Vorzugsweise leiden die Ptlanzen, bei denen rein weitse Blätter nehen grün gefleckten orler gänzlich grïnen antreten. Flecke meist nnit sharfor Alorenzmer: We itsblätterigkeit, Albicatio, Panachne. Nanchmal ühertragbar durch samen ofler dureh Veroflmeg. Trache: Wahrsehemlich Enzymatische störmgen (s. diese?

sullstrelstäudlich gibt es Mittelstuten zwischen den genaunten Typus, da mehrfarh sin Zusammenwirken der einzehen Ursachen stattimelet.

In vorlegenten Alschnitt fassen wir mur die ieterischen Zustände ins Ange nul tïhren sio unter Eisenmangel anf. weil man sich seit den

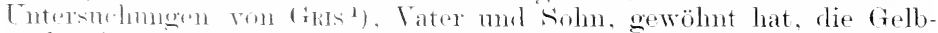
surht als wougsweise ant Eisemmangel heruhend zu betrachten. Die

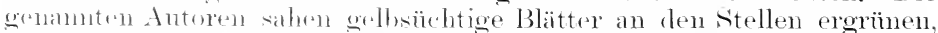
lie so nit rinem lïslichen Fisensalze hrstrichen hatten. Anch wemn

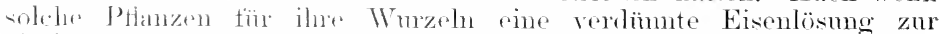

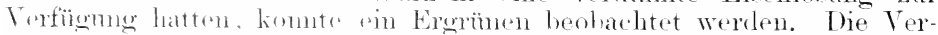

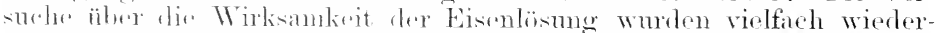

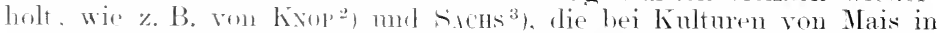

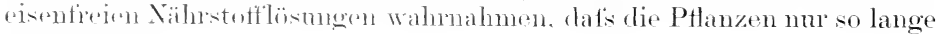

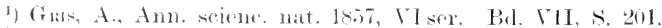

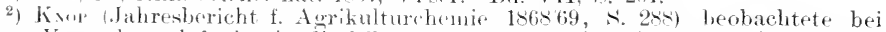
solchen Versurhon, dafs das in die Pflanze kommende Eisen in dem Zellsafte nicht nachgewiesen werden konnte, also in einer welnudenen Form vorhanden ist. Im

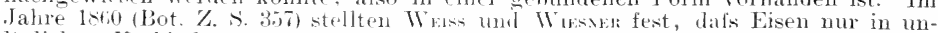
löslichen Verbindungen vorkommt. und zwar sowohl im Inhalt als anch in der Wandung äterer Zellen.

s) Experinentalphysologic $N$. 144. 
grün blieben, als sie rom Namen her noch Reservestoffe erhielten. Nach dieser Zeit entwickelten sich Blätter. die nur noch an der spitze grün und an ter Basis schon gelblich waren, bis die näthsten Blätter gleichmätsig icterisch erschienen. Ähnliche, zuerst stroifenwoise anteretende Verfäbungen zeigten erwachsene Pflanzen, die erst normal sich entwickelt hatten und dam in eisenfreie Nährösung gebratht wurlen. Es trat dabei Taubblïtigkeit ein, und die Prodnktion an Trockensubstanz war eine wesentlich geringere. FkaNk ${ }^{1}$ ) beobathtete bei Eisemangel die überall hemerkbare Hnngererscheimmo, dats die nen entsteluenden Blatter die älteren ausisaugten, die moner Entfärbung abstarben. Bei den icterisehen Organen sind die ('hlorophyllkömer von nomaler Gestalt, aber vielleicht an Zahl und Grötse etwas geringer; ihre Farhe aber int bleich. Wenn auch der Chlorophylltarbstoff' an sich kein Eisen enthält ${ }^{2}$ ), so wird doch durch das Fehlen desselben der ganze Ernährungszustand des Chlorophyllkorns geschwächt. Aher zunäthst ist der ('hloroplast normal geformt rorhanden und wird erst später zerstärt. Daclureh unterseheiden sich die llungererscheinungen von der enzymatischen Albicatio.

Um nun die durch ähnliche simptome zu Verwechslumg Veranlassumg gebenden Erseheinungen nicht trennen zu müssen, erwähnen wir hier noch den Icterus dureh Kälte. Wir sehen in kalten, nassen Perioden bei den meisten muserer Kultmptlanzen ein allmähliches Vergilben, das mit dem Steigen der Tenueratm som selbst versehwindet. Oftmals kommen im Frühjahr die Blattkegel mserer Blumenzwieledn gelb aus der Erde, uml erst, wem es wärmer wird, schieben sich die jüngeren Blatteile in normaler tirünfärbme allmählich nach.

Von dieser vorührogenden Gelbsucht ist die chronis he zu unterscheiden, bei welcher die gell, hervorgetretenen Blatteile anch gelb bleiben. Dieser Fall ist zu heobathten, wem eine plitzliche, stärkere Kältewirkmng die jugendlichen Zellen trifft und die Chloroplasten zerstört. Man sicht dann an Stelle derselben nur noch finkönige, gelbliche Grupen bisweilen neben gelben Tropfen, und diese Partien erholen sich später nicht mehr. An den Übergangsstellen in dic von der Erde gesthïtzt gewesenen erorïnenden Blatteile erkennt man farblose, verquollene und hellgrüne Chhorophyllkörner, die später zum 'Teil nachgrümen.

Bei Einwirlimo plätzlicher, mehrstündiger Kälte sah HaberLaxwe ${ }^{3}$ ) erst bei - 4 bis i $^{\circ} \mathrm{C}$. eine merkliche Verändermo und erst hei - 12 bis $15^{\circ} \mathrm{C}$. eine totale Kerstörung der Chlorophyllkömer (mit Ausnahme derer bei immerorinen Pflanzen) eintreten. Es entstand bei Vacuolenbildung eine Verzerrung der Form der entweder in die seitenstelhng (Apostrophe) ïhergehenten oder sich klumpig ballenden Körner, von denen ïbrigens die mit Stärkecinschlïssen versehenen schneller zerstärt wurlen als die stärkelosen. Bei den Blättern von Viola odoratu komnte ein dureh das Alter des Blattes erzengter Untersehied betrett's der Zerstörharkeit des Chlorophylls nitht wahrgenommen werden.

Wir werden diesen Gearenstand noch eimmal bei der Herlstfärbmo

1) Krankheiten der Pflanzen. 1895. I. S. 290.

2) Moms. Die Pflanzen in ihren Beziehungen zum Eisen. 1×92. ‥ $>1$

3) Haberlasin. Üher den Einflufs des Frostes auf die Chlorophrilkimer. Österr. Bot. Zeit.. cit. Bot. Jahresbericht 1\$76, s. 71s. 
berïhren. (ivblanbiekeit im Frïljahr als Nachwirkmg ron Froststïnugen timhot man in Bammschulen hänfig bei Birnen.

vilur wencigt zum Ieterus ist der Weinstock. Hier sind rer-

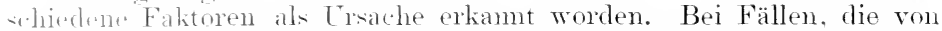

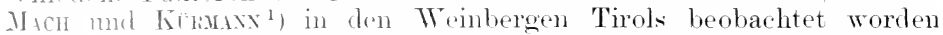
sinl. "roab die Analyse dicht nebeneinanderstehender grüner und interischer stöclie:

Wassergehalt der gelben Blätter . . $77^{\circ}, 90^{\circ}$

Wasserqualt ter grünen Blätter . 73.17\%

An organischer substanz und in dieser an stickstoff besatsen die grimen Bläiter einen grïlieren Prozentsatz der Trockensubstanz, an Asche lagegen einen betentend geringeren. In der Asche der gelben Bläter zeigten sich sechsmal so viel in Salzsäure mö̈sliche Minerallestantteile als in juer der grünen: ragegen war der Kaligehalt in den ersteren geringer. Ein Begiefsen mit Stalljanche wirkte günstig. Eimen ähnlichen Eall hesehreibt E. Schulze ${ }^{2}$ ). Blätter und Rebholz der kiranken stäglie enthielten nur halb so viel Kali wie die der gesmolen stircke. welde dagegen sieh ärmer an Kalk und Magnesia erwiesen. Autser dicem Icterus an $\mathrm{K}$ a limangel wird anch durch zahlreiche B.olrachtungen eine (iellowcht des Weines infolge von halküberschuf's festgestellt. Mir selieint, dats nieht die Kallimenge an sich der schäıligende Faktor ist, sondern hauptsächlich der Kalimangel, da Kalkbïlen in der Regel arm an Kali sind. Wir kommen ant diesen Fall im Abschnitt rom Kalkïberschnt's zurïck.

Eine häufige Erache ist ferner der stickstofthunger. Derselbe äntsert sich, abweichend ron Erscheinungen des Mangels an andren Nährstoffon. nicht im Alsterben der Ptanze im jugendlichen Alter, sondern mu in einer Terlangsammo des Wachstmms und lienhlition sämtlicher Organe anf ein Minimum.

lie vielfach wiederholten Tersmehe mit der Kultur von nichtshmettrhing blïtigen Pflanzen in Nährstoffgemischen ohne sitickstoff-

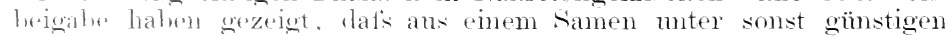
Toloiltnison hei einzelnen PHanzengeschlechtern eine nene, selbst bis

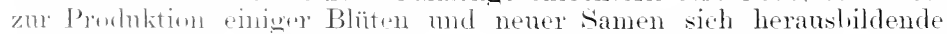
Miniatmptlanze entistelen liam. Der Gesantstickstoffgehalt dieser

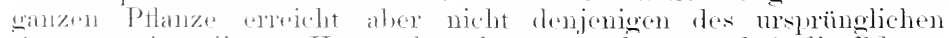
Sinnens. Ans diesen Unstinde geht erstens hervor, dats die Pflanze nicht imstande ist, hum ilne Blätter nemenswerte Mengen von Luftstielistuft zn repwerten. zwoitens ales erselsen wir darans, dats die in

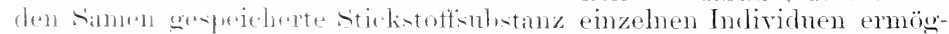
lieht. ihren ganzen Entwieklungezylus zu dmehlanten, also alle

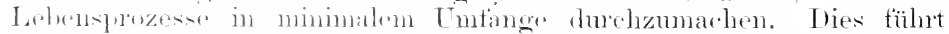

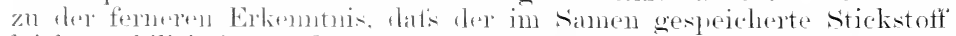

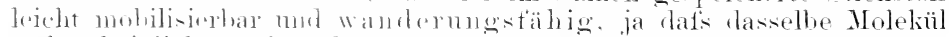

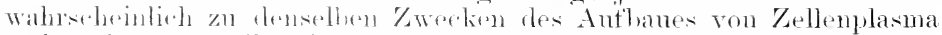

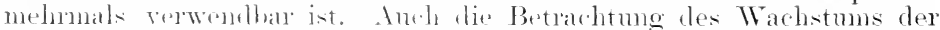
stickstoftinangelpotlanzen weist ant rin solehes Terhältnis hin: dem man sieht. dats in lom Matse als die stengelspitze weiter wäehst,

1. Biedermanns C'entrallil. 1×77, s. is.

2) Zeitschr. 1. landwirtsch. ('entralver. fior das Grolsherzogtum Hessen. cit. Centralbl. f. Agrikulturchem. 1872. \$. 99. 
die nutersten Blätter ansgesogen werten und vom Rande oder der Spitze her zu vertrocknen hegimnen.

Bei der schnellen Verwertbarkeit mol Wanderumgsähigkeit des Stickstotfs kam eben sehr schnell Mangel an diesem Nährsteft eintreten und sich durch Gelbsucht ankïndigen. Bei unseren Kultmen könmen auch solche Fälle eintreten, wemn roicher stickisoffrorrat noch im Boden ist, aber in einer für spezielle Anspriiche der bestimmten Kulturptlanze nicht zusagenden Fom existiert. Das hervorracendste Beispiel liefern unsere Zuckerräben, denen der stickstott antser in Stalhnist namentlich in Form ron C'hilisalpeter bishrer zugetührt worden ist. Die vielfachen, äntserst günstigen Erfolge der Düngme mit schwefelsaurem Ammoniak bei verschiedenen anderen Kulturowächsen haben nun auch zur Verwendung dieses Dïngemittels bei der Rübenkultur gefülhrt. Aher die Praxis hat dabei zum Teil üble Erfahrungen gemacht, da die Rühon in der Polarisation sehr sehlecht ausfielen.

In einer eingehenden Besprechung dieses Punktes ${ }^{1}$ ) heben Hows-

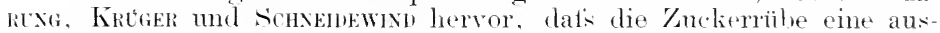
gesprochene Nitratpflanze sei; da das Ammoniak aber nicht so schmell und direkt durch die Mikrooronismen des Borlens zu Siabletersäure umgewandelt werde, kïmne Mangel an salpetersauren Vurbindungen

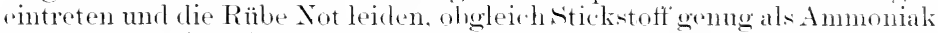
vorhanden sei. Etwaige Erscheinmeren der (ielblanbigkeit werden somit erklärlich durch sine för Rüben ungoeignote Beschaffenheit des stickstoftilüngers, lie aher für fetreide mol hartoffeh günstig sich rweist.

sichon rine älere Notiz weist anf don Untersehied der Wirkmug je nach der gebotenen Stickistoffform hin. Die Analysen ron Latikato ${ }^{2}$, nämlich rogahen, dats in den mit schwetelsaurem Ammoniali crorlüngten Rülon ein doppelt so wotiser Ammoniakgehalt nachweishar war als in den mit Natronsalpeter gediungten.

Dat's auch durch die Trockenheit allein sine cielbtäbung dor Rübenblätter verursacht werden kam, ist eine beliannte 'Tatsache, so dafs wir nur ein recht bezeichnendes Beispiel anzufïhren luatuchen. Im tahe 1n:ti litten (nach Trous: ${ }^{3}$ ) die Riiben in Frankreich, namentlich im nördlichen, in ausgerlehntem Matse an (ielhlaubigkeit. I) ie Erscheimung trat im .Jumi nach längerer Periode intensiver 'Trockenheit ant' und breitete sich besonders in somnigen Lagen mut aut' loichten Bölen ans. während fregenden mit fenchtem, maritimem Klima nm geringe Erkrankung zeigten. Der Kuckerwehalt des langsan wachsenden Rüben-

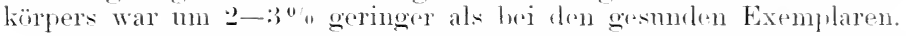

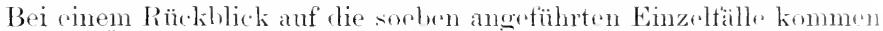

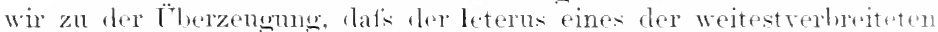

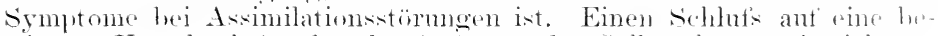
stimmte Ersache lälst alore das Anftreten der Gelbsucht zurzeit nicht zn.

1) Honnsis, Inwieweit ist eine bingung mit schwofelsaurem Anmmink

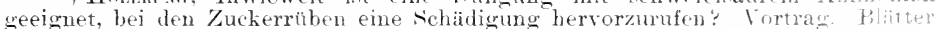
fiir Zuckerrỏbenbau 1906, >. 70 .

2) Bielermann 'sentralbl. 1876. I. ×. 25:.

s) cit. Zeitschr. f. Pflanzenkrankh. 1s97, s. 55. 


\section{h. Nangel an Phosphor und schwefel.}

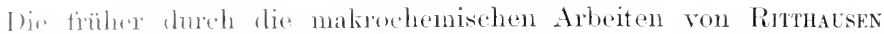
fistugestellte T'erteilung des Phosphors in der Pflanze ist später durch

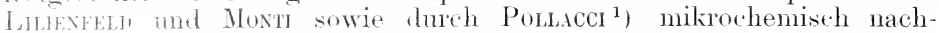
מntresen worden. Letzterer fand, dats im allgemeinen die Kellwände Frei rom Phosphor sint, dats dagegen das Protoplasma. namentlich aber der \%ellkorn sant den Chromatinkörvern reichlich dieses Elenent enthält. Hie Kristalloide und Globoicle der Aleuronkörner sind gleichfalls phosphorhaltig. Somit sind die Proteinsubstanzen ganz hesonders abhängig von den vorhandenen Phosphorsäuremengen, und deren Mangel wird sich namentlich bei der Blütenanlage und Samenausbildung zur (reltung bringen. Nach den NobBeschen Tegetationsversuchen ${ }^{2}$ erstheint der Phosphor hei der Bildung des Chlorophylltarbstotfis mbeteiligt: es zeigte sich bei Eichen, die seit drei Jahren in phosphorsäuretreier Nährlosmng standen, das Laub noch tiefgrün. Bei anderen Pflanzen sali NoBre schliefislich eine tief orangerote Farbe der Blätter und stengel eintreten. Eine Produktion von neuer Trockensubstanz finchet nicht oder nur äutierst minimal statt. An seinen Kiefernaussaaten bemerlite MöLLER ${ }^{3}$ ) bei Phosphorsäuremangel eine blaurote (stumpfviolette) Nadelfärbung. Bei zweijährigen Pflanzen war las Violett mehr zum ()livenbram neigend.

Bei den Mitteilungen üher Verfärbungserscheinungen, welche bei Mangel einzelner Nährstotfe sich einstellen, darf man nicht die bei riner Pflanzenspezies erhaltenen Resultate auf eine andere Spezies ïbertragen, da die Verfärbung nicht ïberall dieselbe ist. Betretẗs der Phosphorsäure sah ich bei Mangelpflanzen von Rüben, Erbsen und Serarlella, dafs sie in grangrüner Farbe vertrockneten, wobei sie vorher fahlgriin, aber nicht gelb geworden waren. Bei Stickstoffinangel verfärliten sich dieselben Arten rein quittengelb.

Bri dem Mangel an schwetel in einer Nährlösung sah Nobbe eine etwas bostere Entwicklung: doch erreichten seine Tersuchspflanzen kaum div Hältte dex normalen Ẅ̈he, und die gelbgrïnen Blattfläehen zeigten dementsprechend geringe Entwicklung. Stärke wenig und kleinkörnig. Lic \%elltwilnng wird wesentlich beeinträchtigt. Die Fruchtbildung kommt nicht odro nur sehr mangelhaft zustande.

\section{i. Sallerstoffmangel.}

\section{Allgemeine Erscheinungen.}

Als bekimnt voraususetz'n ist, dafs bei Aufhören der Sauerstoffzufuhr die Protoldasmahewroung alhmählich stillsteht (s a u e r st off-

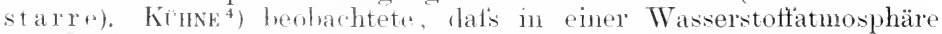
div Bewegung in den Stanbfarlenharen ron Tradescantia rirginica nach 15-20 Minuten authörte. Wortunn ${ }^{5}$ ) sah die Pflanzenteile in sauer-

1) Pondro, G., sulla distribuzione del fosforo nei tessuti vegetali. Malpighia. vol. VIII. cit. Zeitschr. f. Pflanzenkrankh. 1895, s. 299.

2) Dimskr-Nobl:, Botanik für Forstmämmer. IV. Autl. S. 317.

${ }^{3}$ ) Karenzerscheinungen usw. Zeitschr. f. Forst- u. Jagdwesen 1904, S. 745.

4) Intersuchungen über das Protoplasma. ls64, s. 89 und 106.

5) Wramax, Über die Beziehungen der intramolekularen zur normalen Atmung. Inauguraldissertation, Wür\%burg 1879. 
stofttreier Luft anfangs gerale so riel Kohlensäure aushanchen als die bei ungehinderter Sauerstotfzutuh: später machte sich ein Unterschied zugunsten der letzteren geltend. Hieser almähliche Kohlensäurerückgang bei Sauerstottabschlufs (intramolekulare Atmung) dentet wie das allmähliche Authören der Plasmabewegung daranf hin, Hals zmüchst noch der im Pflanzenleibe gespeicherte samerstott verluant wird. Ler Erst ickungstod erfolgt also langam, namentlich da die grüne Pflanze unter genügender Beleuchtung noch Kolnlensïme und Wasser zersetzt und sich noch sanerstotf' fïr einige leit selbst bihlet. Böнn ${ }^{1}$ wins eine geringe Menge sanerstott in tem (iasvolumen nach. Wrin er grüne Blätter von Landptlanzen bei genïgender Beleuchtung in Wasserstoftatmosphäre einschlots.

Abgesehen von den Fällen, welehe in den Alschnitten äber "Itehmboden " und das "Tiefe Pflanzen der Bänme" bereits besprochen worden sind, gedenken wir einiger Torkommmisse schlechter Durchlïtumg intolge Verstopfung der die Ilauptwasserleitung ausführenden Gefäfshmina. solche Verstopfiung ist besondes tür las splintholz getahrbringend ${ }^{2}$ ). Mit Böнм ${ }^{3}$ ) möchten wir uns den Inrchlüttumgsvorgang tolgendermatsen vorstellen. Es ist nicht hots eine Iruckilfferenz zwischen ler Autsenlutt und der verdünnten Lutt im Innern ler Gefäfse, somirn auch ein stottlicher Unterschierl. Die Bimnenht wird ilnen samerstotì bei den Respirationsprozessen schneller hergeben um die entstehende Kohlensäure antinehmen. Diese wird sntweder bei einer Füllung der Gefätse mit Wasser autigesogen und mit dem autsteigenden saftstrome fortgeführt oder aber, ta sie die tenchten Wandmeen ziemlich loicht durchtringt, durch Diffusion in radialer Richtumg nach autsen gesehaffit. Der nene notwendige sauerstott, der in geringerer M[onge wohl auch mit der im IVasser gelösten sauerstotfieicheren Luft durch dis: Wurzeln eintritt, wird jecfoch ter Hanptsache nach wnter mormalen Verhältnissen lurch transversale Leitmug nach imnen gelangen. Lerselbe diffundiert durch die feuchten Nembranen leichter als irer stickistoff der Luft, weil das Wasser tür im eine gö̈sere Absorptionstähiglieit hat als für den Stickstott. I) nun der Sauerstoff im Innern des Pflanzenleibes an meisten verbraucht wird, aber anch an leichtesten wanderungstähig ist, so wird wich ein vorherrschender Diffinsionsitrom von sanerstoffgas von autien nach innen in jeder Horizontalebene eines Stammes ergeben.

Weitere Beolachtungen äber den (Gasaustausch gibt Wiessek ${ }^{4}$ ). Derselhe zeigt, dats las Periderm, der Korkïberzug, selbst bri grotisen Drucklifferenzen für Lutt völlig undureholringlich ist; der Austansch finctet nur durch die awch im Winter durchlässigen Lenticellen statt. In gefätslosem Holze erfolgt der Ausgleich dureh die Membranen him lurch. namentlich durch die zarte 'Tüptollaut, wobei neloen der Efftusion anth

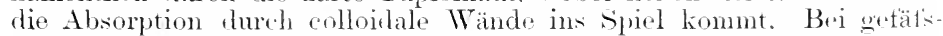
reichen Holzkörpern ist autserdem noch die Transpiration und thr

1) Binn, Über die Respiration von Landpflanzen. Nitzungsher. d. Kats. Akal. d. Wissensch. in Wien, Bd. 67 (1×73).

2) El.fusi, Cliar die Wasserleitmg im Holze. Bot. Z. 1502, Nr. 42.

3) Bum, .J., T̈ber die Zusammensetzung der in den Zellen und Gefilisen toHolzes enthaltenen Luft. Landwirtsch. Versuchsstationen Bd. XXI \&. 37.5

4) Wiesser, Versnche über den Ausgleich des Gasdruckes in den fitweh dent Pflanzen. Sitz. d. Kais. Akad. d. Wisensch. zu Wien am 17. Aprit, cit. in O-tert. Bot. Zeit. 1 189, s. 202 . 
Durhgang ler (ian dhureh die als Kapillaren fungierenden Gefätse zu berick-ichtione Axial findet ler Druckausgleich schneller statt als in den Surrolitmgen. Je stärker eine Parenchym-oder Holzzelle mit Traser imbibiret ist, lesto langsaner tritt Druckausgleich ein. Dieses Terhälnis krhet sich hei der Peridermzelle um; wenn dieselbe ihres witserigen Inhalts verlustig geht und sich mit Luft füllt, wobei die Wand eintrocknet. verliert die Zelle die Durchlässigkeit für Gase. In luftführendem Parenchym strönt bei Druckansgleich ein Teil der Luft durch die Intercellulargänge. ein anderer geht durch die geschlossenen Membranen. und zwar an leichtesten durch die mverdickt gebliebenen sitellen.

İher die Vorgänge. welche sich in den Bäumen bei sehlechter

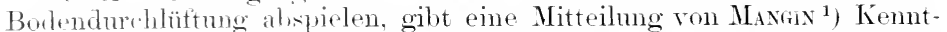
nis. Dersellue tand. dats die Gefätse bei Ailanthus sich mit Thyllen verstopten, mul crkiärt den Vorgang dadurch, dat's bei dem Luftmangel in Boden auch rlie Gefäse an ihrer Luftzufuhr Nangel leiden. Infolgelessen wird die frefätsluft über eine zulässige Grenze hinans verdünnt, und nun stilleen sich ans der Nachbarschatt die Thyllen in das Getätsmeh hinein und behindern ihrerseits wieder die VIasserleitung.

Bezïglich des Eintlusses ron Sauerstotfmangel auf Samen sei zunächst der Lntersuchmoen von BErT ${ }^{2}$ gedacht, wonach die Keimung un so langsanner vor sich geht, je weringer der Luftdruek ist. Den

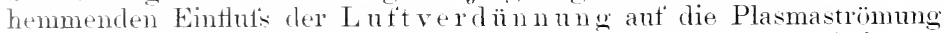
hat shon vor vielen Jahren Contr $^{3}$ ) beobachtet. Da aber bei normalem Luftdruck and nur vermindertem sanerstoffgehalt ebenfalls die Keimme langsamer erfolgt und umgekehrt bei enniedrigtem Lufthruck, alier erhöhter Sauerstoffzufuhr die Samen schmeller keimen, so ergibt sich. datis eben num der Partialdruck des sauerstoft's der matsgebende Falitur ist.

Anch hei den Erscheinmoen des sanerstottmangels bietet sich

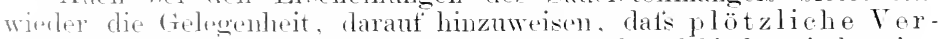

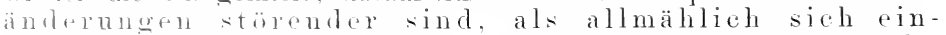

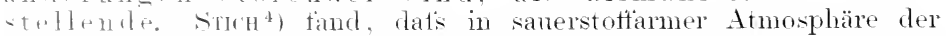
mornal. Atmmersuotiont sich wieder herstellt unter Terminderung lor abolnten simelstotf- mol Kohlensämemengen. Bei allmählicher Entzirhung des santestotfis wird die intramolekulare Atmung erst bei

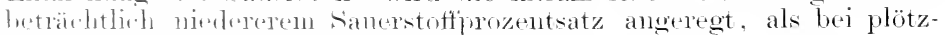
licher Torkloinermor desselluen.

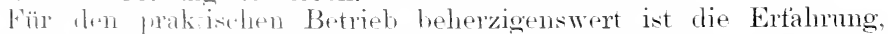
dats hei sanmen am Ersticknngserscheinumgen auftreten, wemn ihr

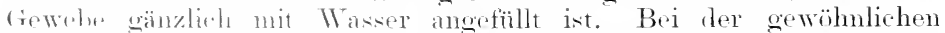

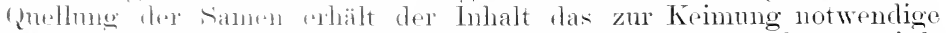

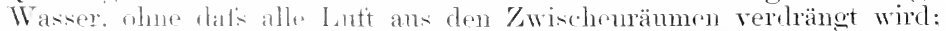
Wrm man tagenen die Samon zn lange \%eit im Wasser hehält, tritt

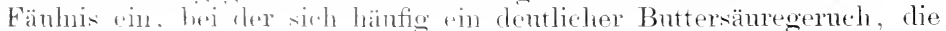

1) Maxis, Influfuce de la ratréfartion produite dans la tige sur la formation des thrlles gommensis.s. ('ompt. remd. 1!n1. II, s. 305.

2) Bent, Recherohes "xprimentales sur lonfluence que les ehangements dans la pression barometrique exercent sur les phémomenes de la vie compt. rend. LXXTI et LXXTII.

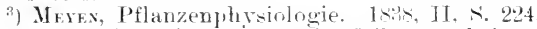

4) Sтrн, C., Die Atmumg ler Pflanzen bei verminderter siauerstoffspamnung und hei Verletzungen. Flora lstt, s. 1. 
Bakterientänle, in hohem Mafse gelteml macht. Ehrenso zrigen Versuche, wie z. B. die von J J $\mathrm{U}^{1}$ ), dats eine gänzliche Anfïllhng der Lut' fïhrendon Gewebe mit Wasser (durch Anspumpent der luft moter dire Luttemmer) die Keimprozente autiverorelentlich verringert.

Bei nats aufeinandereschichteten samen ist es nicht lex l̈berschuts an Wisser, der die Keimkraft so schnell zerstört, sondern ïbermätsige Erwarmmo und Kohlensäurobildung. W1EsNek ${ }^{2}$ ) tand äbrigens, dats die Kohlensänrebildung spätre als die Wärmeentwirklung anftritt: erstere kam also nicht die einzige Wärmequelle sein, sondern as ist eine solche anch in der Wasseranfuahne sellst zn stichen. Ifie mit Wasser in Berïhrung kommenden samen verlichten das in ihre fiewebe eintretende Wasser, wobei Wärme frei wird.

Dat's sanerstottülerschuts ebenso sehällich wie -nangel wirkt, ist natürlich. BERT fand, dats durch zu tohe spannme des Samerstoftis die Oxylationsvorgänge in den Ptlanzen gehemme worden. Bri (i Atmosphären starb eine Nimosa, welche hei sanerstoffunangel ihre Reizbarkeit verliert, in gewöhnlicher Inft. Wurcle die Inft sanerstoffreicher gemacht, genügte zur Tötmng schon din Irurk von 2 Amosphären.

\section{Die Brusone-Krankheit des Reises.}

Die dureh das Anfteten rostfarhiger Flecke ant den Blätern nelst Schwärzmon und Erschlattmeng ler Hahme sich kemntlich machencle all-

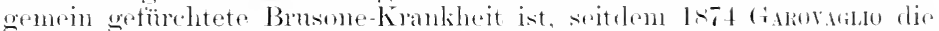
Entersuchungen begonnen hatte, vieltarh der fiegenstand eifriger

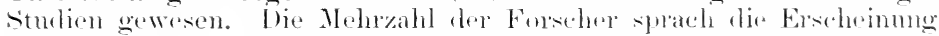
als parasitär an. Teils whanher man, Baliterien als Lrsache anmehmen

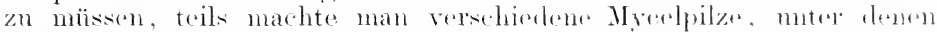

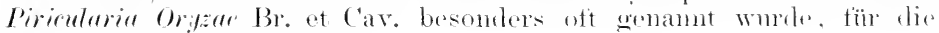
Krankheit verantwortlich.

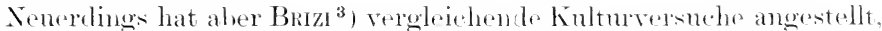
ans denen hervorgeht, dafs oin Luftabsehluts von den Wruzohn lwa hohen Trompreaturen in Wassoknltmen zur Erkankmeg der Ptlanzen mitre den Erscheinmengen der Brusone-Krankherit fülut. Mit dirsen Versuchsergehnissen stimmen die Erfahrnneren, die man in Italien mur Japan eremacht hat, sehr gut üherein. Es ist nämlich beobachtet

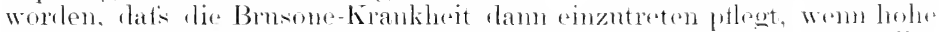

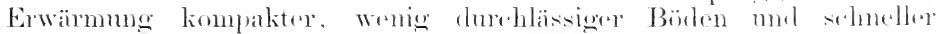

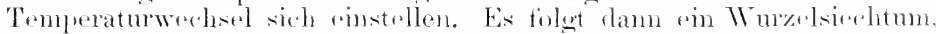

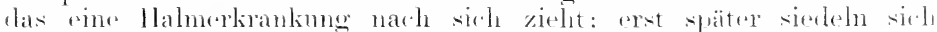
aut' den crkrankten Toilen parasitäe (hwanismen an.

Wir halten die Experimente Brizis fïr anssehlagorelend und

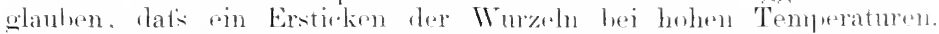

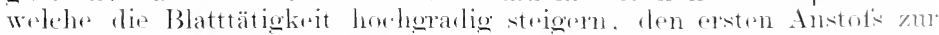

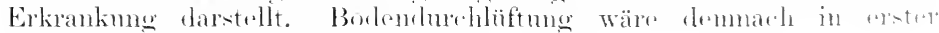
Linie ins Angur zu tasien.

1) Bot. Z. 1×-0, ‥ $14: 3$.

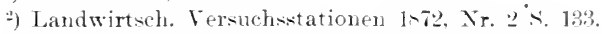

3) Bris, I.. Ricerche sulla malattia del riso detta Brusone. Anm. I-tituto agrar. Ponti. 1905. Milano. cit. Zeitschr. f. Pflanzenkrankh. 19uti. 


\section{Erkrankung der Gladiolen.}

Anf sinteroftimangel im Boden ist eine Krankheitserscheinung zmrïtczutïhren. dis in tiladiolenkultur'n auf sthweren Böden oder (irmulstïcken mit leichterer Bodenart, aber hohem Grundwasserstande in teuchten . Jahren nitht selten ist. Die Krankheit äutsert sich in einem oft plüzlichen Absterben der Pflanzen zm Zeit, in der der Blötenstand bereits entwickelt ist. Zunächst erscheinen (anfangs nur bei durchiallendem Lithte bemerkbar ) die nuteren Blätter gelb mamoriert. Der Chlorophyllkärper z+rfällt und lälst ölartig aussehende gelbe Tropfen zurück. Während lieser Vorgang in den oberirdischen Teilen der Blätter streitenweise zwischen den Rippen fortselueitet, zeigen sich an den in ter Erde befindlichen Blattbasen brame, eingesmakene stellen, die eine vänzliche 'Lersetzung des Blattparenchyms einleiten. Eigentliche Erweichung tritt nicht ein, sondern die Zersetzung stellt einen 1 lunitikationsvorang lax; in den humusartig sauer riechenden Gewehen finden sich stets Bakterien, häufig auch Mycelpilze, Anguillen, Milben usw. Die oberirdischen Blatteile trocknen schmell ab und bedecken sich mit schwarzen Tupfen von Cladosporimm und Alternaria.

Trotz des Reithtums an parasitären Organismen ist die Erkrankung doch nicht als parasitär zu bezeichnen. da die ersten Anfangsstadien, nämlich die Bramnfärbung der Gefätse und des dicht anstofsenden Parenchyms, mitten in einem gesunden Gewebe ohne Mitwirkmng von Grganismen entstehen. Später füllt sich meist eine Anzahl der trefätsöhren mit einer trüben, bramen, gummiartig fest werdenden Masse. Letztere Erscheinumg ist anch bei anderen Gewächsen, deren Wurzeln durch anhaltende Bodemässe und den dadurch kïnstlich hervorgerufenen sauerstoffmangel beschäıligt waren, beobachtet worden.

I) Gladiolen vertragen sehr gut eine starke Bodenfeuchtigkeit; aber dieselbe dart nicht ron langer Daner sein. In trocknen Jahren wird rielfath der Fehler begangen, die Zwiebel- und Knollengewäthse täglich zu bewäsiern. Dies ist falsch; man muls dem übermätsigen Austrotknen des Bodems lurch Bedeckmng mit stremmaterial vorbengen.

\section{k. Kohlensäuremangè}

Thotz des weringen frohaltes von etwa 0,036 - 0,040 Volumprozenten, den die aus amähernd 7! Teilen stickstoff und 21 Teilen Sanerstoft'1 bestehemde Luft an Kohlensämre besitzt, reicht dieselbe doch iiberall aus, wn eine lochgesteigerte Produktion zuzulassen. Wenn dieser wichtig. Nährstotf ä̈nzlich fehlt, wie man dies im Experiment durh Autstillumg rom firfätsen mit Kalilauge unter geschlossenen Glocken beobatiten kann, so nützen die ïhrigen Faktoren des Wachstums in gïnstigster /usammensetzmog nichts. Corenwinder ${ }^{2}$ ) sah, dafs Knospen und jung Blätter sieh in kohlensäurefreier Luft nieht weiter-

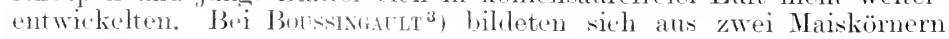

1) Nach den Intersuchungen von Just (cit, in Forsch. a. d Gebiete der A grikulturphrik 1879 , s. : $; 25)$ schwankt der sauerstoffgehalt der Luft nieht mbeträchtlich (zwischen 20,53-20.8600). Der sröste sauerstoffgehalt zeigte sich bei herrschendem Polarstrom und der kleinste unter herrschendem Äquatorialstrom

") Recherches chimiques sur la végétation. Fonctions des feuilles. rompt. rend. t. LXXXII, 1>76; Nr. 20, s. 1159.

3) Bulsiximis, Végétation du Mays. commencé dans une atmosphère excempte l'acide carbonique. Compt. rend. t. LXXX1]. Nr. 15, s. 7s. 
junge Pflanzen, deren Trockensubstanz, Kohlenstoff- und Sanerstoffgehalt geringer, fleren Stickstoffigehalt ebenso grots wie in den Samenkömern war. Wasserstoff und Asche hatten eine geringe Zmulime erfahren. B̈̈нм ${ }^{1}$ ) fand bei noch im Wathstum hegritfenen, abgeschnittenen Blättern der Fenerbohne, welche durch Imukelheit entstärkt worden waren, datis dieselben bei vollem Tagoslichte in liohlensäurehaltiger Atmosphäre nicht nur Wurzeln ans den Blattstielen bildeten, sondern sich anch im Querdurchmesser vergrötserten, selhst wrom sie blof's mit destilliertem Wasser begossen waren. Dawegen zeigten die in destilliertem Wasser gezogenen, mter dem Einflutis des vollen Tagestichtes mor (ilasglotken stehenden, aber übrr Kalilauge befindlichen Keimptlanzen der Fenerbohne mu eine Längenzmuahme bis $10 \mathrm{~cm}$, und dam verschrmmptten die stengel moterhall, der in der Regel ganz stärkefreien Primordialblätter. Keimpflanzen ron Fenerbohnen, die in hmmureicher (iartenerde gezogen, aber durch schwache Belenchtung ihrer stärle bis anf geringe Dengen beraubt worlen waren, hildeten bei suaterer intensiver Belenchtmo in einer ilurer Kohlensäure beraubten Atmosphäre keine nene Stäke mul gingen zugrunde. Es nützten ihnen also die Kohlensäure im Boden mud dir.

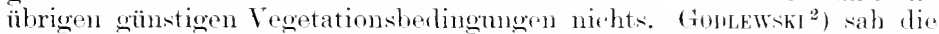
Stärle auch in den dem vollen Tageslichte answesetzten PHanzen vorschwinten, wemn denselhen die Kohlensäne der Int't genommen wurde.

Einen weiteren Einblick in den Warhstmmsmoins der Ptlanzen. denen die Kohlensäm der Lnft rntzogen, weben meine eigenen Ver-

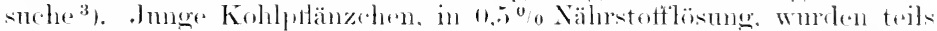

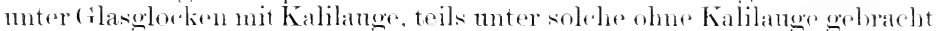

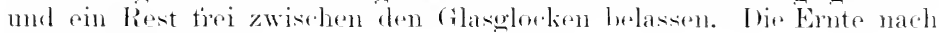
zelin Taugen eroal,:

Pflanze Nr.

Frischgewicht der

Wurzel ustengel

Frischgewicht ier

Bliatter. . .

Oberflache der

Bläter in rem.

(iesinttrocken-

substanz.

Prozentsat\% des

Frischgewichtes

an Trockensul,

stallz.

Gesant-

verelunstung in $g$

Verdunstung pro

Trockensulistanz

\begin{tabular}{|c|c|c|c|c|c|c|c|c|}
\hline \multicolumn{4}{|c|}{ Freistehende I'flanze } & \multicolumn{2}{|c|}{ Kalierlocke } & \multicolumn{3}{|c|}{ Kalilose Glocke } \\
\hline I. & II. & III. & $\bar{I} \bar{V}$. & T. & $\sqrt{1 .}$ & VII. & VII. & $\mathrm{IX}^{-}$ \\
\hline 0,457 & 0.367 & 0,414 & 0,4711 & 10,175 & 0,2305 & 0.297 & $0, ; 1: 3$ & 0,232 \\
\hline 1,598 & 1,494 & 1,564 & $1.6 \div 2$ & 0,765 & 1,011 & 1.736 & 1,712 & 1.550 \\
\hline 50.6 & 47,5 & 50,1 & 47,8 & 25,4 & 26,6 & $50, \mathrm{i}$ & 54,1 & 37,1 \\
\hline 0,2755 & 0,2510 & 0,2685 & 0.2760 & 0,0760 & 0,0985 & 0.1705 & 0,1740 & $0,176 \pi$ \\
\hline $13,4^{n} 0$ & 13.5 & $1: 3,5$ & $\cdot 12,-$ & 8,4 & 7.9 & $8: 1$ & 8,6 & 8.4 \\
\hline 69,3 & 74,4 & 82,5 & 75.0 & $2 \pi, 4$ & 34.4 & $4: \because, 1$ & 40,4 & $4: 3.3$ \\
\hline 2515 & 296,4 & 307,2 & 271,7 & 360,6 & $\therefore 49,2$ & 252 & 292,2 & $24 . ;,: 3$ \\
\hline
\end{tabular}

Die Tabelle zeigt, dafs die Protuktion an Friseh- mul Troulien. substanz in der Kaliglocke am geringsten war. Je nach der Menes von nen produzierter Trockensubstanz ist die absolute Veromstmens

1) B нu in Nitzungsber. d. Wiener Akad. 1466, eit. Bot. Zeit. 1-7i, s. wh.

2) Bibliographische Berichte uber die Publikationen der Akademie der Wiknschaften in Krakau. Heft I, cit. Bot. Zeit. 1צi6, s. \&2×.

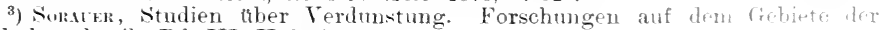
Agrikulturphysik, Bd. III, Heft 4.). 


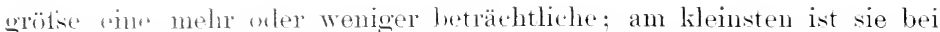
den Ptlanzan mnter der Kaliglocke. Natürlich ist der Einfluts der (ilorken. also die in denselhen herrschente Lutteuchtigkeit, in Anschlag zu hringen. Ileser Faktor macht sich gegenüber ten freistehenden Exemplaren Anrch einen geriugeren Prozentratz der Pflanzen an Prockinsubstanz, also durch lockeren Ban und längere Blattstiele. hemerkthar.

Veroleitht man blofis dir Exemplare ler Kaliglocke mit denen der anderen (ilocke, so ist das Resultat sicherer. Der Kohlensänremangel matht sich durch die seringere Gesamtproduktion, namentlich im Blattapprarat, am meisten kemtlich: die Uberfläche ist nur etwa halb so

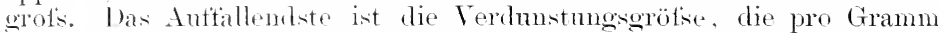
Tor vorhandenen Trockensubstanz berechnet wird. D)iese ist bei den der Kolılensäuroufuhr beraubten Pflanzen am grötsten: dasselbe zeint sich bei der Berechume der Verdunstung pro Quadratzentimeter Fläche von den unter den beiden (ilocken gewachsenen PHanzen. Diese Tatrache ist mit anderen Versuchsergebuissen in Verbindmo zn setzen, wonach sich erwibt, datis die relative Verdunstungsgrötse sich anch hei Ptanzen steigert, die andere Ernährungsmängel zn rrotulden haben. Stetzt man z. B. Pflanzen aus normaler, zusagender Nährstoftlösung in eine solche von zu reringer Konzentration ofler in destilliertes Wasser, so steigert sich die relative Verdunstung; ebenso wächst dieselbe bei sämlingen durch Entfornung der Reservestoflibehälter, der Kotyledonen. Man möhte ammehmen, dats die PHanze sich zu grötserem Wassertransport durch die Wurzel, also zu grötserer einseitiger Arbeitsleistung anstrengen mütste, um den Verlust der Reservestoffe durch vermehte Anfinahme aus dem Nurzelmedium zu decken.

Für the Praxis ergibt sich aus den vorstehenden Untersuchmoen Ar.r Wink, zu versuchen, durch vermehrte Kohlensäurezutinh die Protuktion zu hehen. Tatsächlich zeigen die Experimente, dat's man mit Vermehrum der Kohlensänue eine viel schnellere Stärkebildmog

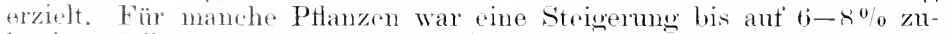
lïssig. Sollstverstäntlich ist für jede Pflanze und bei derselben für jerle antere Kombination ler Vegetationstalitoren ein anderes absohtes Nats von Kohlensäm nötig, mm eine optimale Produktion zu erzielen.

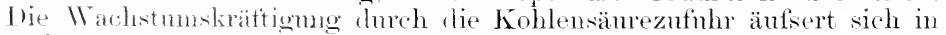

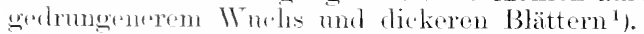

Währond dio hisherigen Versuche sich mit den Folgen des Kohlensänremangels fiir lie canze. Pflanze beschäftigen, hat Töchtrot ${ }^{2}$ ) das Verhaltru einzwher Zweige gepritt, die an ler normal wachsenden

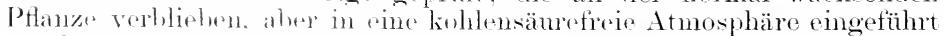
worlon. Fs zoigto sieh labei. wir jeder /weig und jestes Blatt sich

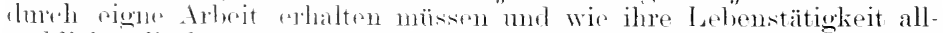
mählich rrliseht. Wenn sie lureh hohlensämremangel an dieser Arbeit verhimlert werten. Die PHanzo kamn ilore in cler kohlensäurefreien Atmosplä̈re befiudlichen \%weige wohl zu woiterem Wachstum bringen, aher die sirh entwickehnlen Bhäter sind fahlgrün und bilden keine

1) Fenwensw, E., Einflufs der Kohlensäure auf Form und struktur der Pflanzen. cit. Centralbl. t. Agrikulturchemie 1900. 5. 137.

2) Vömrxi, H., Uber die Abhängigkeit des Laıb,lattes von seiner Assinilationstätigkeit. Bot. Zeit. $1891 \mathrm{Nr}$. 
Stärke: sic erholen sieh anch nicht nehr. wenn dor Zweig in normate. Lutt zurütekrebracht wird, sondern gehen nach kurzer Zeit zuspunde. Daraus geht herror, dats jedes Blatt seine sefhständige Existenz hat uml eine störung derselhen nitht durch den fiesamtorganismus antsgeglichen werden kam. Das fimktionstos gewordene tran wird rom Körper abgestotisen.

\section{B. Wasser- und Nährstollüberschuls.}

a. Wasserüberschul's.

\section{Nässe.}

Der bei stamierender Nässe sieh einstellemlen Virollbung- und Zersetzmoserscheimmoen ist sehon bei Besprechume her Pachteile schwerer Bölen werlacht worden. Es hamblt sieh hier nur darmm.

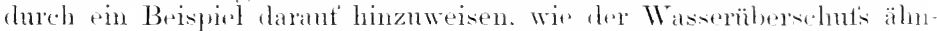
lich wie Wassermangol retardierend ant dir Prodnktion wirkt. So

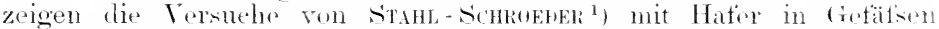
mit sterilem Dïnensande. dem Nährstoffllïmng zugesstot worken war. tolgentes Resultat.

Ex produzierten bei Wassraghen:

\begin{tabular}{|c|c|c|c|c|c|c|c|}
\hline $\begin{array}{c}\text { "o der vollen } \\
\text { Wasser- } \\
\text { kapazität } \\
\text { des randes }\end{array}$ & $\begin{array}{l}\text { Kör- } \\
\text { ner- } \\
\text { zahl }\end{array}$ & $\begin{array}{l}\text { Gewicht von } \\
\text { lowa hïrnern } \\
\end{array}$ & $\begin{array}{l}\text { sitroh-u. } \\
\text { spreu- } \\
\text { gewicht } \\
\qquad\end{array}$ & $\begin{array}{l}\text { Mittlere } \\
\text { Liinoran. } \\
\text { Pflanzen } \\
\text { cun }\end{array}$ & $\begin{array}{l}\text { Asche } \\
00\end{array}$ & $\begin{array}{l}\text { Phos- } \\
\text { phor- } \\
\text { siluer } \\
0_{0}\end{array}$ & $\begin{array}{l}\text { stick- } \\
\text { stoff } \\
{ }_{0}{ }_{0}\end{array}$ \\
\hline 33 & 84 & $1 . ; . ;$ (berechnet) & 6,2 & $4 !$ & $?$ & ? & 3,752 \\
\hline 50 & $172 \%$ & 21.6 & $7: 3,9$ & 102 & - $.97: 3$ & 1,144 & 2.915 \\
\hline 70 & 2074 & 18,5 & 101,2 & 140 & 2,712 & 1.090 & 2,501 \\
\hline 90 & 1827 & 16,3 & 115,0 & $15 \overline{7}$ & $: 3,007$ & 1.207 & 2,407 \\
\hline $9 . ;$ & 469 & 11,1 (berechnet) & $90,=$ & 162 & $5,-92$ & $1,-47$ & 3,444 \\
\hline
\end{tabular}

Es zeigten also mu die frefalse mit mittlerem Wassergebalt gute Körneremten. Bei grötserem Wassergehalt sinkt die Könerernte. während der strohertran weiter steigt. Bei Wasselmangel (3:;0) mol Wasserïberschuts (9:" o) in sande kamen die Körner überhampt nicht zur Reite. Je schlechter das Wachstmm der Pflanzen, desto grölsere ihr prozentischer Aschengehalt, ihr Phospuorsänre- mm sitichistottreichtum.

\section{Drainzöpfe.}

Ëberall, wo flahstroichende Drains sich dureh das IVurzelwerli

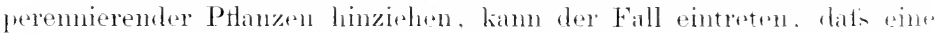

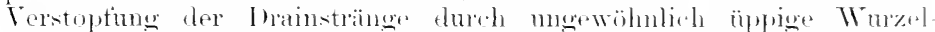

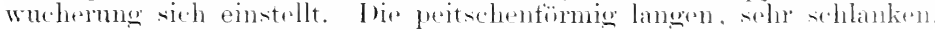

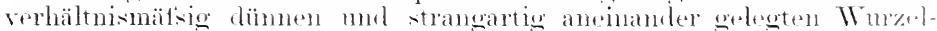

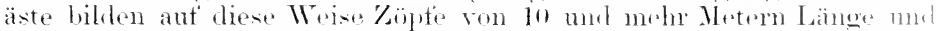

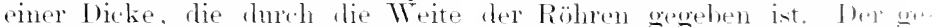
fährlichste Baum scheint die Weide zu sein: denn rom iln diüften ilf

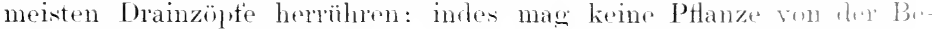

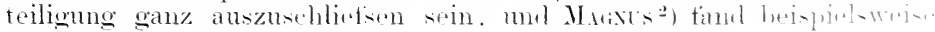

1) s. Biedermanns Centralbl. f. Agrikulturchem. 1905, Heft :'.

$\Rightarrow$ sitzungsber. 1. Bot. Vereins rom 26. Mai 1-it;, Bd. XVIII, ‥2 
sinmal sehr ïprig vegetierend das Rhizom rom sehachtelhalm (Equise -

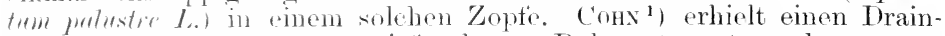
zopt. ler ans riner 1:25 cm tief gelegten Röhre stammte und ganz aus

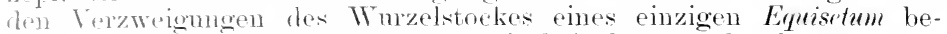
stamil. von dem ein 12 m langes stück freigelegt werden konnte.

I urch dic Versuche von JüLcks-Thurgau, der einzelne Wurzeläste derselben Pflanze teils in Nählösmo, teils in destilliertes Wasser tauchem liets mol in ersterer jedesmal ein stäkeres Wachstum wahrnahm, ist konstatiert, dat's eine lokale Wachstumsteigerung der Wurzel fort angeregt werden kann, wo dieselbe mit Nährstoffen bereicherte Lokalitäten trittit.

Praktisch emptehlenswert erscheint bei wiederholtem Auftreten von Trainzöpten das sorgfältige Entfernen der getahrbringenden Gehölze mit ihren Wurzeln. und zwar durch Ausoden und nieht durch Abhauen. Vïsicen Bämme stehen bleiben, so ist (namentlich bei Doppeldrainage) die Tertiofing der flach (in der Regel zwischen 80 - $90 \mathrm{~cm}$ ) gelegenen Stränge aut das Niveau des tiefer $(1,5 \mathrm{~m})$ lanfenden Sirangsystems ratsam.

\section{Ausgewachsenes Getreide.}

Bei den nummehr anzuführenden mit Wasserüberschuts zusammenlängenden Erscheinungen kommt eine Schärligung entweder dadurch zustancle. dafs Wasser zu ungeeigneter Zeit von aufsen mechanisch ant die fiewebe einwirkt, oder aber es kam das von der Wurzel autsenommene Wasier nicht in entsprechender Menge Verwendung und Ableitumg finden. Zm ersteren Grupe gehört das Getreide, das auf dem Felde durch Regen in der Emte zum Auswachsen veranlatst wird. [lor Nathteil ist nm so empfindlicher, da das answewachsene Samenkorn werler zu Nahrungszwecken, noch auch zur Saat taugliche Verwendung tinchn kann. sielbstrerständlich leidet die Keimfähigkeit bei späterer Verwentune als saatgut $\mathrm{mm}$ so mehr, je länger bereits die Körner

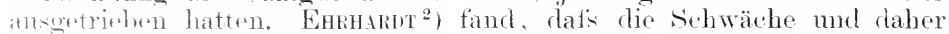
cho Storblichlieit der Ptänzchen in dem Natse zmmahm, in dem ihre Entwieklung hereit dmeh das vorzeitige Answarhen Fortschritte ge-

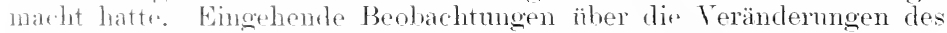

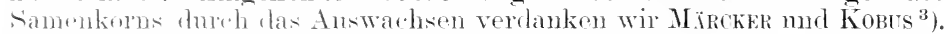
Fisteres mutersuble Gerste, welche bei der Ernte zur Hälfte un-

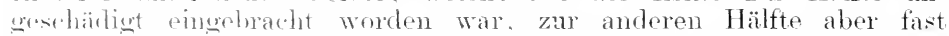
It Tilge ling dmelnätist infolge von Rogenwetter stehen geblieben war. Tru Thtershierle zeigten sich bei Bestimmmug der in Wasser

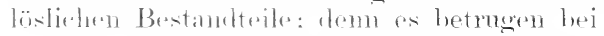
die lisklieles stäks. . $1.17^{0 / 0}$
loxtrin . . . . (1), . (1) .

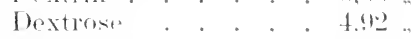

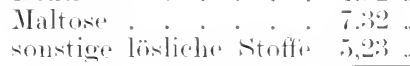
1ז. 6 . "

$1,71 i^{\circ} / 0$
$1,10 \%$
$1,00 \%$
$3,12 \%$
$5,64 \%$
$11,62 \% 0$
1) Verh. d. schles. (iesellseh. f. vaterl. Kultur, 25. Oktoher 1883.
-) Deutsche landwirtsch. Presie, 1st, Nr. 7ti.
3) Aus Bramschweiger landw. Z., 1, No, Nr.22, cit. in Biedermann's Centralbl. f. Agrikulturchemie, $188: 5,: 206$.

mul hei gut eingelorachter Gerste 
Wir sehen somit, (lafs sich infolge onergischer Jiastasewirkmng aus Stärke und Dextrin eino sehr reichliche Zuckerbildung eingeleitet hatte. Der Gehalt an stäkemehl war durch das Answachsen von 64.10\%;0 anf $57,98 \%$ gesmken. Die bedeutende Menge von Diastase wïrde nun, wenn man die Körner auf stärke verarbeiten würde, voranssichtlich beim Einweichen weitere Stärkequantitäten in bextrin mul /ncker ïberfïhren und empfindliche Fabrikationsverluste veranlassen. Dic grötsten Verändermugen haben aber duch das Auswachsen die stickstofthaltigen Bestandteile der Körner erlitten. Während nämlich der Ammoniakgehalt nnverindert geblieben war (s.'alpetersäme tiund sich in nennenswerter Menge in keiner von beiden Kärnersorten ror), hatte das lösliche Eiweils cine starke, das unlösliche eine etwas wenigrr grotse Vermindermug erfahren. Diese Vermindermug erklärt sich durch die relativ andserordentlich grotise steigermog des fiehaltes an Amilen. Es war somit hei dem Auswachsen zuerst das lösliche, später anch bereits ein 'Teil des mlöslichen Eiweifses zur Amilhildung verbrancht worden.

Zu denselben Resultaten kam Kobus bei der Untersuchnog von ausgewachsenem Weizen, dossen Klebergehalt heim Answachsen rine

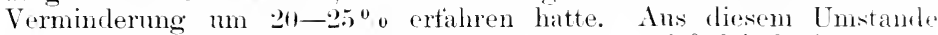
erklärt sich die bekannte Verringernng dor Backfäligkeit eines Mehles von auswewahsenen Kömern.

Die Keimfähigkoit war in den von Mïkcken ausgeführtrn Versuchen von $98 \%$ auf $450_{0}^{\circ}$ gesmben.

Man ersieht hierans, wie soln sich selbst die grötsten Kraftanstrengmengen belohnen, die eventuell zur trocknen Einbringmeg der Ernte gemacht werden mössen. Ähnliche Vorhste werden anch anderen Foldrïlehten. wie z. B. den Lupinen, Raps, Rumkeh drohen. Interessant, aber wirtsehaftlich bedentmoshos sind die Fälle, in denen innerhalh der Fincht und äutserlich nicht bemerkbar eine Keimmo der simen stattfindet. Jch sah solche Fälle bei Birne. Aptel, Melone und Kürbis. Andere Beobachter fanden derartige, in der Frucht keimende samen" antser bei Kürbis auch bei Orangen, und zwar sowohl bei solehen Früchten, die sehr lange auf dem Banme geblicben waren, als anch bei solchen, die sich kürzlich erst gefärbt hatten. Weitere anf dicsen Gegenstand bezügliche Mitteilungen finden sich in dem Abschnitt äber eine durch Trockenheit unterforochene Keimung.

\section{Das Aufreirsen fleischiger Pflanzenteile.}

Die Erscheinmer, dats fleischige Wrurzeln, Stengel mul Früchte klaftend anfspringen, ist in langen Fenchtigkeitsperiodon ain häntiges

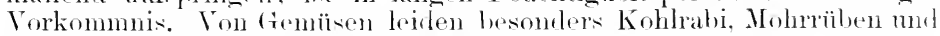

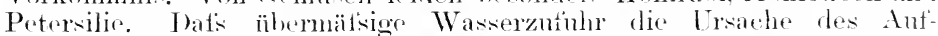
springens ist. bewies lIntuk ${ }^{1}$ ), indem er Petersilienwmzeln in Bromenwasser hing: nach drei Tagen fand er den ganzen in Wasser hefind-

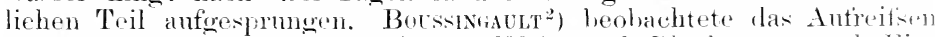
von Kirschen, Nirabellen, Birnen, Wein mol Blanheren nach Einhängen ver Früchte in Wasser: dureh Einbetten derselben in nassen sand erzielte ich die gleichen Erfolge. Von krantartigen stengeln platzen sern die des Rapses oft kurz vor der Blitezeit. Lmstehend. Figm

1) Hiller, E., Phytopathologie s. 87.

$\Rightarrow$ Tergl. Bot. Jahresbericht $1873 \mathrm{S.} 253$.

sora uer, Handbuch. 3. Autl. Erster hand. 


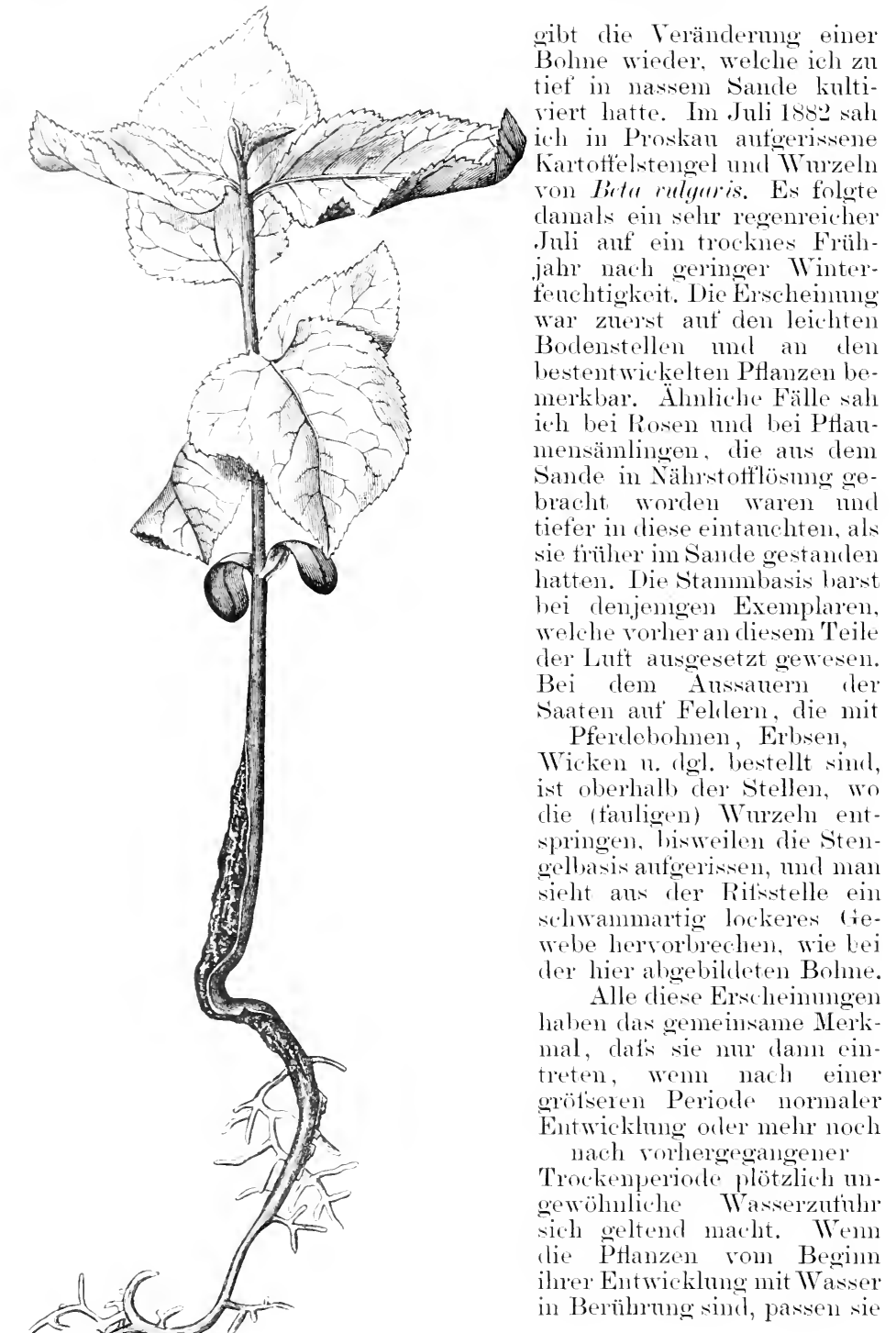

Fig. 42. Bohnenpflanze, die durch Wasseruberschufs an der Basis aufgeplatzt ist. Rifsitelle vernarbt. 
sich diesem Medimm an. Derartige Anpassmugerscheinmoen kamn man namentlich bei solchen Arten beobachten, Cie sowohl im Wasser als auch auf trocknem Lande sich entwickeh kömnen. Als Beispiel dienen die Untersuchumgen von LavakofFsi ${ }^{1}$ ) an Epilobimm hisutum, Lycoms. enopacus mol Lythrum. Der Vergleich von Wassor-mol I andexemplaren lehrt, dat's bei den IVasserptlanzen zwischen Cambinm und Rindenparenchym zwej Roihen farbloser, chlorophylloser /ellon, die:3-4 mal länger als breit sind, existieren, welehe bei den Landexemplaren tehlen. Dieser Untersehied schärtt sich nm so mehr zn, je ältere Pflanzenteilo man miteinander vergleicht. Unterhalh des Wasserspiegels werlen diese Zelheihen zu emem dicken, lakmösen Gewehe. Epirkernis mul Rinde gehen hier hald zugrunde. Die Zellen, wolehe dieses besondere Gewebe darstellen, bilden sich aus dem Cambimm.

Der plätzliche Eintritt von Wasserüberschuts, der das Aufspringen der PHanzenteile veranlalist, stört das tileichgewicht in der Ansdehmmó der Epirlermis bez. der statt dieser bereits vorhandenen Korklaue und des theischinen Parenchymkörpers. Namentlich aber nach voransgegangener 'Trockenperiode sind die Elemente der Oberhant derhwandiger und weniger strockmussähig geworten mol vermögen dem schwellenden Innengewebe nicht schmell gemmg zu folgen.

Findet das Autreitien bei saftigen (trgaten olne vorhergegangene Trockenperiode durch langandanernde Wasserzutuhr hei feuchter Unrebmo statt, dam sint die Rifsitellen in der Regel dadurch ron den Rissen dureh Trockenheit rersehieden, dats bei letzteren die WundHäche verkorkt onler dureh nen sich bildende Korklagen sich abschliedst; bei ersteren sicht man dawegen die durch den Rils blotsogelenten Parenchymzellen dïnnwandig hleiben, bisweilen sich sehlanehtöming

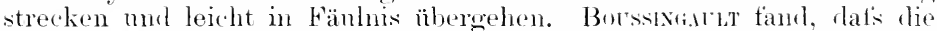
Früchte Zucker an das Wasser abgaben. Diese Abuabe nebst der vermehrten Aufnahme von Wasser mag ren wässerigon Geschmack der Früchte nach langem Regenwetter erklären. Einige untergetanchte Blüten liefsen ebenfalls Zucker austret'n: lagegen komnte hei Zuckervïben, Räbsen mul den Keimwuzeh von Veizen, Gerste und Mais keine Abgabe ron Zucker bemerkt werden, obgleich die fiewebe zuckerreich waren.

Es gibt eine sehr empfehlenswerte Anfluewahrumssmethode für Winteräpt't, nämlich das schichtenweise Einlegen der Früchte in sand. Wem man unvorsichtigerweise den sand zu nats wählt, verliert ein hisweilen grofiser Prozentsatz der Früchte seinen Verkant:wert durch Autieifien lor sichale.

MöLek-'Hoksid ${ }^{2}$ ) machte bei darauf bezügliehen Versuchen ähnliche Erfahrmgen. Nach achtmonatiger Lagerung ron Äpfeh in Kisten mit Frole fand er lie Frïchte nats und teils antgesprungen, teils mehlig und ihren š̈ure- und /uckergehalt stark zurückgegangen. I) Prozentsatz an fanlenden Apteh was aber geringer als hei din frei im Keller liegenden Frïchten.

Soweit das Autieitien von Früchten und (iemüsen an der Antbewalumosmethode liegt, wird man demselben duch einen trockntu, gut durchlüfteten Lagermgrsort ahhelfen kïnnen. Bei Früchten ant

1) Lnsmorsist, De l'influence de leau sur la croissance de la tige etc. cil. Bot. Zeit. 1875, S. 696.

Zurich 1896.

\footnotetext{
2) Fünfter Jahresb. d. deutsch-schweizerischen Versuchsstation zu Wädensweil.
} 
den Banme. namentlich bei Eierutlammen, die sehr emp,findlich sind, emplichlt sich hei Eintritt längerer Regenperioden das Abschïttehn des Wascer's ven den Bammlironen.

Shlitichich mutis noch daranf anfmertisam gemacht werten, dats dir Neigme zum Anfsuringen anch erblich werden kam. Es liert rine Beobathtme darüber bei Gurken vor $\left.{ }^{1}\right)$. Bei der Treiberei Wihlte der Besitzer stets die schönsten Exemplare einer sorte, die leicht anfilitzte. zur Simengewimmmg und mutste bemerken, dat's dieser Übelstancl ron Jahr zul Jahr reichlicher und früher sich geltend machte. Er bepflanzte mun die llälfte seines Glashauses mit der bisher benutzten Treiborte und dis amdere Hälfte mit einer Freilandsorte. Diese letztere ergal, sesmole Früchte his zum Herhst, während die mit der bisherigen Treiborte heptlanzte Hälfte von Mitte Mai ah anfgesprungene Frïchte zeigte. Solche Wahrnehmmgen gehen beherzigenswerte Winke für lic Anwahl der Samen ron Gemüsen, die zum Ant:pringen neigen.

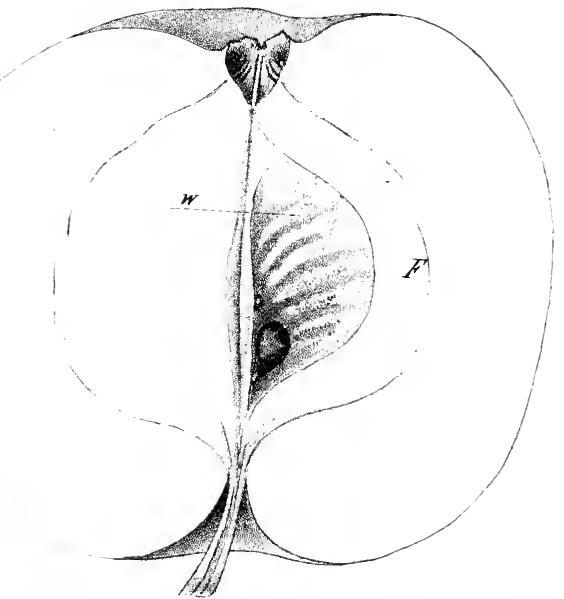

Fig. 4:3. Anfgeschnittener Apfel, dessen Kernhaus Wollstreifen (u) zeigt F'der fleinchige Teil am Fruchtblatt. (Grig.)

\section{Die Wollstreifen im Apfelkernhaus.}

Bui Beschreibungen der Apfelsorten finflet sich als Merkmal hier und da der Anedruek: .. Kernhanskammern zerrissen". Den beigetü̈gten Abbildungen nach soll damit ein Znstand der jergamentnen Fruchthläter angedenter wroden, hei wolehem die Innenwände der Kammern des Kernhames nidht eine gleichmälsig glatte und feste, sondern eine ron

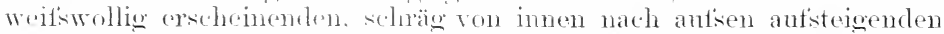
Streifen durchzogene Fläche darstellen. J)ie Erscheinmo ist hänfig und wird fïr sine normale waltem, welthe Ansicht ich jedoch nicht teilen möchte. Algesehen daron. dats unter Umständen bei derselben sorte 
nicht alle Früchte solche Wollstreiten zeigen, mut dats die verschiedenen Jahrgänge dieselhen in verschiedener llänfigkeit ontwickeln, ja anch veremzelt hei Sorten anftreten lassen. welche in dre Regel ein glattes Kernhans zeigen. ist tür die ahmorme Natur dioser streifen rorzusweise der mikroskopische Betund beweisend.

Durchschneidet man nämlich ein Fruchtblatt mit solchen streiten, wie sie in Fig. 4:3 hei " dargestellt sind. so hiet sich das in Fig. 4 gegebene Bild. In diesem ist die dum $K$ breichnote soite die Immenwand des Kernhanses. wogegen $F$ die an das Frublthrisch grenzendr. Autsenseite skizziort. Bei len Aptelsorten mit glattru Krruhans-

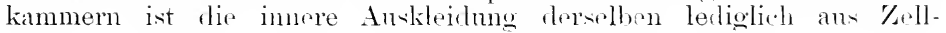

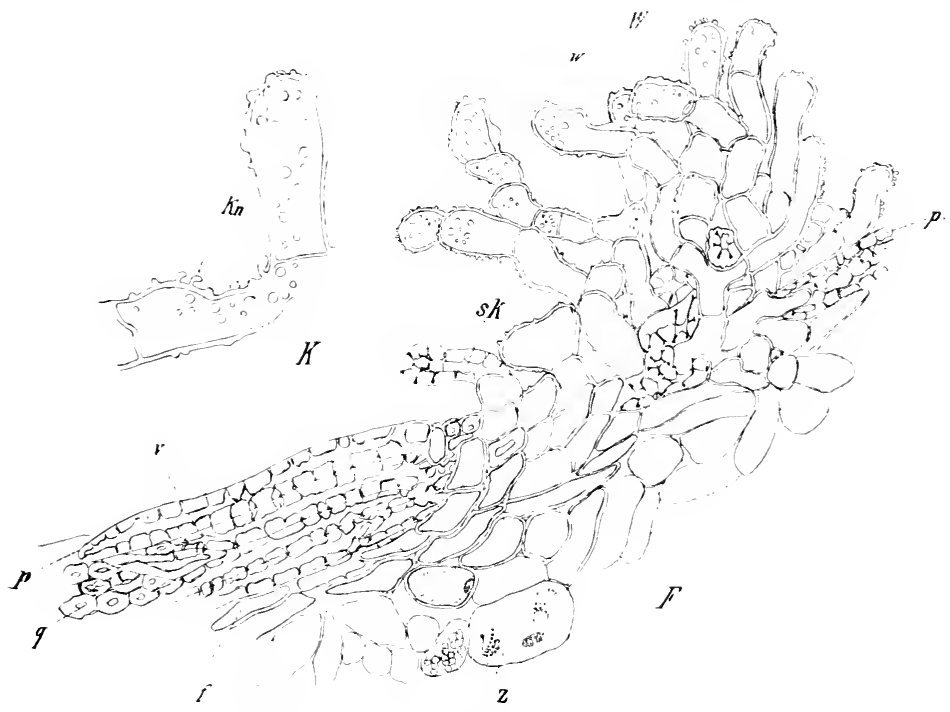

Fig. 44. Durchbruch des Wuchergewebes fines Wollstreifens durch die perganentartige Fruchtwand des Apfels. (Orig.)

elementen gebilflet. wie sie bei p dargestellt sind. Ex sind sehr langgestreckte. antiseromentich dickwandige. von volen, oft verzweinten Porenkanälen durchzogene. mit Chlorzinkjorl gell, werdende Zellen. deren einzelne śchichten eimen einander krenzenden Verlant zeigon. Infolgedessen weist derselhe Horizontalsehnitt nelun solehen Zellen. dir ihrer ganzen Länge nach kenntlich sind $(p)$. anch streiten ron qnerdurchschnittenen Elementen auf $(q)$. Es ist ersichtlich, dats chuch die dichte Lagermo der Kellen einerseits, dureh die selur starke Wantmng derselben anderseits eine sehr grotse Festigkeit des Kernhansower erzielt wird, welche noch dureh den sich krenzenden Verlant iler Zellen sich erhöht. Es ist ferner ersichtlich, datis hei ten Fritehtn mit weiter Kelchhöhle. durch welche ein Hineinwachsen von Pilz:n in 
das Kurnhans leicht stattfinden kamn, diese Fänhnis erzengenden Pilze eine (irenze ihrer Auslreitung an den pergamentartig-festen Wänden des Kernhanses finden.

Dieser sthutz des Fleisches gegen eine von imen heraus drohende Fänhis wird num durch die Wollstreifen (Fig. 44 W) zerstört, dem lieselben bestehen ans einem ganz lockeren Gewebe, das in wuchernder THurgheit die feste Wandung monterbricht.

TTir sehen, dafs diese Trollstreifen aus dichten Büscheh fadenartig verlängerter Zellreihen gebildet sind, die durch ihre dünnere Wandmog auffallend von der Umgebung abstechen und ganz allmählich in das Gewebe des Fruchtfleisches $(F)$ ïbergehen, während dasselbe sich miterhalb der pergamentartig verbliebenen Kernhansstellen ziemlich scharf and plötzlich ron den lickwandigen Zellen $y$ abhebt. Nnr an der Basis dieser Fadenbïschel erimem kurze, sklerenchymatische, vereinzelt ofler nesterweise beieinander liegende Zellen $s l_{i}$ an die in der nomalen Wand $z u$ findenden Elemente $p$. Obgleich num diese dümnwandigen Zellreihen sich ihrer Gestalt nach und durch ihre blane Fïrlung mit Chlorzinkjod mehr dem Gewebe des Frnchtfleisehes nähern, stimmen sie doch nicht ganz mit demselben überein. Der Untersehied besteht nämlich in einer warzenartigen Verdicliung der Zellwand $u$, die an den äudseren Zellen des Farlenbüsschels am stärksten entwickelt ist, bei den immeren Zellen oft nur schwach angedentet und bei den sklemchymatischen Elementen meist gar nicht vorhanden ist. Diese nach autien vorspringenden, knopfförmig erscheinenten Zellwandverdickmnen zeigen bei Chlorzinkjod-Einwirkung entweder eine mattblane Färbung, oder bleiben nngefärbt, oder erscheinen auch gelb. Letzterer Fall findet sich am deutlichsten bei den sehr dickwandigen Zellen $s k$, bei denen sich die ganze Nembran ebenfalls gelb färbt. Fig. It links ist ein stärker vergröl'sertes Stück einer Zellreihe des Fadmul,ïsthels; man erkemnt hier, dafs die warzenartigen Vorsprünge der Mtrmlnan, die ith übrigens für Quellungserscheinumgen einzelner Punkte einer feinen Zwischenlamelle halten möchte, manchmal gestielte Knöjffchen $7_{i}$ " darstellen ${ }^{1}$ ).

Es ist somit anzmehmen, dafs in der Periode des hauptsächlichsten schwellens der Frutht die Spammug der Gewebe in dem Fruchtblatte chreh plitzliche, starke Wasserzufulm eine so grofise geworden ist, dafs der Vrrband in der pergamentartigen (rewebelage sich streifenweise lodkerte mul lïste and tie mm von dem Druck befreiten, nicht dickwandigen Elmmente sich sthlanchförmig in die Höhle des Kernhanses hinein verlängerten.

Sirten, whelde zur Wollstreifigkeit neigen, werden in feuchten Jahren besonters leicht den Schimmelbildungen bez. Fänlniserseheinmen im Kemhanse ansgesetzt sein. Es empfiehlt sich daher, derartige Frichte bale zur verbramchen.

\section{Die Ringelkrankheit der Hyacinthenzwiebeln.}

I) fïr dio Zü̈hter von Iyacinthenzwiebeh bekanntlieh sehr gefährliche Krankheit äntwert sich dureh Bräunmo und Auflösung einer Sehupe mitten zwischen gresunden Zwiebelschalen: die Zersetzmg

1) (ileichartige oder ähnliche Erscheinumgen sind in letzter Zeit von verschiedenen Beobachtern erwähnt worden Ich fand sie auch an den haarartigen Zellen, welche das Innere hohl gewordener Rübenköpfe auskleiden, in Blattparenchrinzellen gelagerter Haferpflanzen икw. 
des Gewebes steigt vom Zwiebelhals ans abwärts in den /wiebelboden. Ist sie dort angelangt, gilt die /wiebel als verloren. Wie Krankheit geht anch oft auf die Brutzwiebehn ïber. Alle kranken Teile bekleiden sich mit Imicillimm, das hier tatsächlich parasitären Charakter anvenommen hat. Der (rrund für die äberans schnelle Anshreitung des Pilzes ist in der für ihn morewönnlich günstig sich gestaltenden Verändermg seines Mutterbodens zu sehen. Es ergahen nämlich die Analysen, dats die frisehe, gesunde Substanz der ringelkranken /wiebehn mehr Zucker besitzt als die der nicht erkrankten Exemplare: orstere gleichen darin den jüngeren sclmppen gegenüber den älteren. Da nun eine Abnalme des /uteliers mit /unahme der Reife der /wiebel stattfindet, so wird man ans dem grölseren Zuckerreichtum auf eine geringere Reife der erkrankenden Kwiebeln schlietsen müssen.

Tatsächlich läfst sich num nachweisen, dlats die Kulturmethoden mserer \%wiebelziichter vielfach die refahr in sich hergen, mreife Wwiebehn zu ernten. Man wartet einesteils mit dem Herausnehmen der \%wiebeln nicht, his deren Blätter vollständig im Sommer abgetrocknet sind. Dies gilt in erster Linie üherall dort, wo die Hyacinthen als schmuckpflanzen in Gärten und öffentlichen Anlagen dienen. Lort würde ein Beet mit verblühten Blmmen und langsam vergilbenden Blättern einen sehr mangenehmen Anblick bieten. Infolgedessen hebt man die Kwiebeln aus und lätst sie an rinem anderen Urte nachreifen. Die damit verlmudene hochgradige Verletzmng les Wurzellörpers hringt eimen vorzeitigen stillstand in der Vegetation der /wiebel hervor. Die Blätter vertroeknen, ehe sic normal answeleht haben, mol ihre Blattbasen, also die \%wiebelschmpen, bleiben mreif mul znckerroich und sind somit nm der erwïnsehte Herd zur beguemen Ansiedlmug des sthinmelpilzes.

Bei den grotien feldmätsigen Handelskulturen kommt die Düngerzufuhr ins spiel, da man recht käftige /wiobeh in müglichst kurzer Zeit erzielen will. Inr Dünger verlängert die Vegetationszeit so, dats manche Sorten zu der testgesetzten Erntezeit ihr Wrachstum noch nicht fertig abgeschlossen haben. Die noch orünen Blätter besitzen dam ebentalls unreife Sclimpen. und während der Autbewahrung der geernteten Kwiebeln anf den ,/wiebelböden“ bis zur /eit des herbstlichen Verkants hat das Penicillim \%eit, in die zuckerreich webliebenen schupen sich einzugrahen und tieselhen zu zerstören. Dafs besonclers suatreifende Sorten diesen Übelstand zeigen werden, ist selbstyerständlich. und darum sprechen auth die /ächtrr von ,ringelkranken sitämmen”.

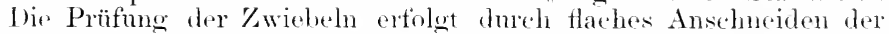
spitzen (des Halses) wälrend der kuheperiode. Keigt der Inerschnitt einen bramen Ring zwischen den weitsen Zwiebelschuppen, sollte eine derartige /wiebel nicht verkanft werden.

l) Heilung ringelkranker sitämme kam dadurch ertolgen, dats die Zwiebeh in sandigen, nicht triseh gedïngten Bodrn mit tiefliegendem irmulwasserspiegel crehracht werden, wo sie bei der Nährsteff- mud Wasserarmut früh ansreiten kïmnen.

/u erwähnen bleiht noch. dats man eine dem Habitus nach der eigentlichen Ringelkrankheit sehr ähnliche Erscheinmog mit lorselhen

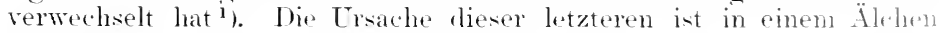

1) Joumal de la soc nat et centrale d'Horticulture de France. April lor Sonusk, Zur Klärung der Frage über die Ringelkrankheit der Hracinthem Wirner illustrierte Gartenzeitung 188\%. Aprilheft S. $17 \%$. 
(Tylemedus Hyacinthi Pr.) erkannt worden, das von den Blättern in die schupen himahwandern kann. Bei der Älchenkrankheit aber liommen gallenartige Zellstreckungen, inselartige Korkumwallungen und anclere Lnterschicile ror. wie wir in der zweiten Auflage unseres Handbuch ausführlicher besprochen haben.

\section{Rindensprünge.}

schon in der Abhildung der Bohnempflanze (Fig. 42) bemerken wir, dafs ans dem klaffenden Spalt des aufgeplatzten stengels eine weiche Gewebemasse hervorgetreten ist. Es sind dies Nenbildungen des lindengewebes, welche als eine Reaktion des Organs auf den ITundreiz und die verminderte Spannmog antzufassen sind. Nun kömnen aher anch Fälle eintreten, bei denen der Sachverhalt umgokehrt ist, nämlich dats die Gewebevermehrung in der Rinde der primäre und das Anfplatzen der sekundäre Vorgang ist. Eine solche Wachstumszunahme kann auf verschiedenen Ursachen beruhen. Als eine derselben betrachtet $H_{A R T}{ }^{1}$ ) die Zuwachssteigerung, die durch plötzliche Freistellung von Waldbäumen hervorgerufen wird. Er beschreibt Fälle von Hainbuchen in einem Buchenbestande, wo durch Freistellung der Zuwachs in Brusthöhe von 1,2 qem Querflächenzuwachs in wenigen Jahren auf $13,7 \mathrm{~cm}$ jährlich stieg $\left.{ }^{2}\right)$. Der Korkmantel wurde dadurch an zahlreichen Stellen gesprengt, und die Folge davon war ein Aufreifsen und sogar stellenweises Abheben des Rindenköryers vom Holzzylinder. Ähnliches fand H. bei Eichen und erklärte dies durch eine infolge der Freistellung eintretende gröfsere Bodentätigkeit und die rernehrte Lichtwirkung. (Unters. Bd. I. 1880 s. 45.)

Derartige Frscheinungen lassen sich auch bei anderen Bammarten namentlich in Garten- und Parkanlagen autfinden.

\section{Rindenabwurf.}

Während in dem von HakTa beschriebenen Falle das Reit'sen der Rind. durch gosteigerte Vermelumng des normalen /Juwachses erfolgt ist, wurle von mir ein Reifisen und Abwerten der Rinde intolge abnomer. Zellstreckmer des Rindenparenchyms beobachtet. Im Jahre 1904 fand in in einer Thmenallee eine Reihe neheneinanderstehender Bämme, an deren Basis cine grotse Menge kleiner oder anch handlanger Rindenschulden zerstrent lag. Bei genaner Besichtigung fand man am unteren Stammend, lowker hängende $25-50 \mathrm{~cm}$ lange Borkenstreifen, die mit Leichigkeit abgrnommen werden komnten. Der blotisgelegte Stammkörver war mit grïnliehen Gewebeinseln bekleidet, die sich als neue Rinelenhildungen rwiesm. Die abgelösten Borkenstïcke. Fig. 4i. zoigten ant ilirer Inmensite flache, hellbrame Polster in unregelmätsiger Vertrilung nud von varshiedener Grölse und Dicke: sie gaben bei ilrer schwammigen Beschattenheit dem Nageldruck leicht nach. Hier mot da benerkt man dazwischen kraterförmige, härtere, kleinere Erhelungen. Iid oberfliche der Polster war vorherrschend glatt: nur stellenweise way sie ranh und zum 'Teil wollig durch hervorragende haarartige Ansintulpugen. In an dem Bame verbliehene Rindenteil

1) Harru, R., Ias Zerspringen der Hainbnchenrinde nach plötzlicher Zuwachssteigerung. Entersuch. forstbot. Inst. Bd. III S. 14I.

2) Lehrbuch der Pflanzenkrankh. 1900, S. 261. 
erschien gelboxïn mol sattig: er hestamel ans Riblemparenclusm, das aus einem gesmelen ('ambium hervorgegangen war.

Die mostehende Figm ti gibt ein Bild von der zmm Alwortern

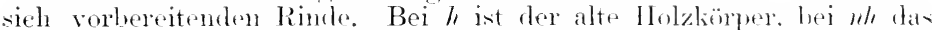

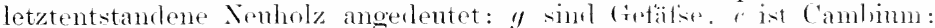
daran stötst die normale. Inngrinde, die allmählich nach antisen hin in dir.

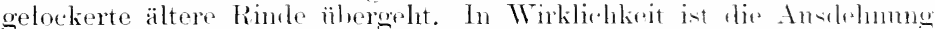
des velockerten 'Teiles in Verhältnis zn der normalen .Jumerinde vin

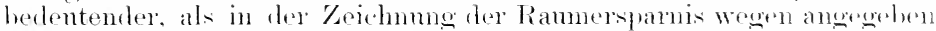

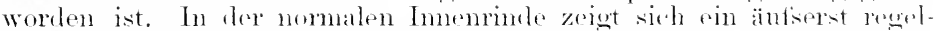
mäliger Ban, indem schichten von loekerem Rindemparenchrom recelmäfisio mit flachen Bäinlern schmaler Zellen (l), die wir als "Leistenzellen" unterscheiden wollen, als. werhseln. Es wiorlen diest. schmalzelligen Bänter ، l’n "Druckleisten" "ntsprechen, die wir hei der Lohkrankheit rrwilnt haben. Die \%ellen, wrolue diese Leisten bilden, rscheinen in Iängssolmitt ebrinso lang wie in (2nerschmitt, nahezn farblos mit eigenartigen weitmas shigen Wandrertickmngendid wie mmegelmätige lecisten ausisehen. I as zwischer je zwei solchen sohmaltrn Bändern von Leistenzellin liegende Parenchym ist rerhältnismätis grot:zellig. locker, stärliereich; in ihm eingelagert sind die grofisen Hartbastbinndel (b) mit iten sie berleitenden Rrihen von Kalkoxalatkristallen(o) nud die schleimzellen (s).

biese abwerliselucten Gewebolagen werlen von breiten. Verbogenen Mark-

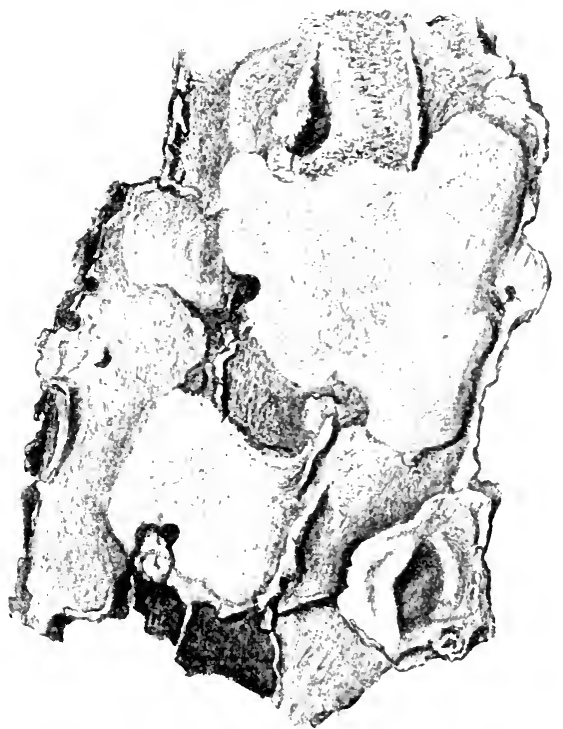

Fig. 45. Innenflaiche eines abgestokenen Borkenstiokes einer I Tme mit polsterartig vortretenden (iewebeinseln. (Orig.)

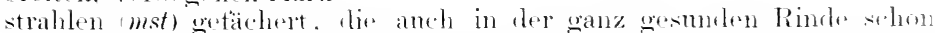
welligen Verlant \%oigen kïmen, in der kranken siel aber lis zmm

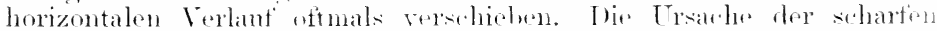

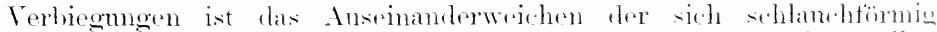
streckenden, zwish hen den schmalen Bändern von leeistenzellan

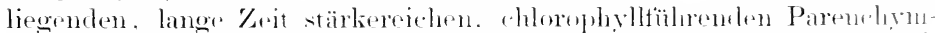

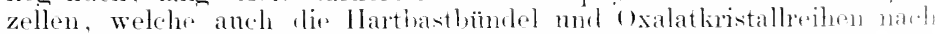

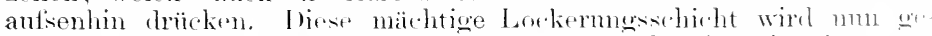

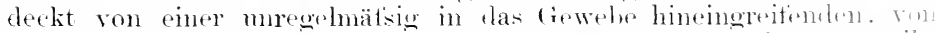

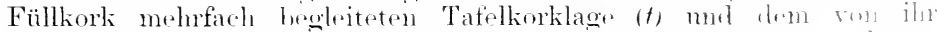
abgeschnittenen. number verkorkten Rindengewelse del tribleren 


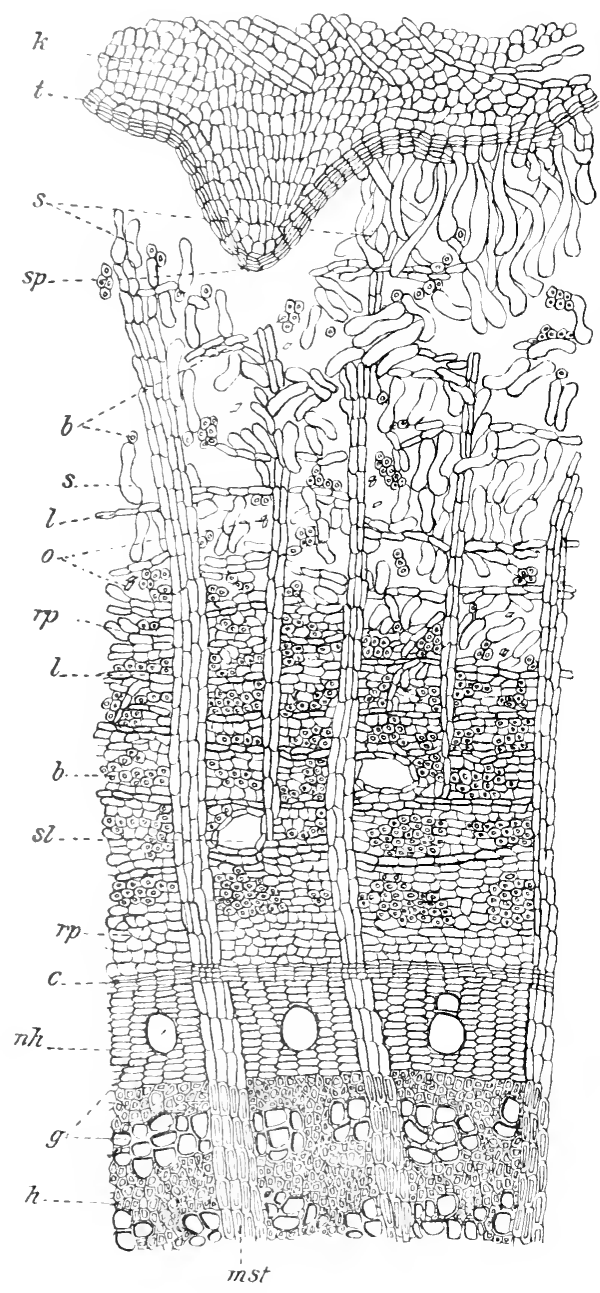

Fig. 46. Thuenrinde mit Rindenwucherung. (Orig.)
Vegetationsperiode $(k)$. Nanchmal wölbt sich die Korkschicht in kngelförmiger Gestalt in das schlanchartige Schwammgewebe hinein $(s p)$ und bildet die anfangs erwähnten, kraterförmigen, harten Spitzen anf der Innenseite der abgelösten Borkenschuppen.

An der Grenze zwischen dem harten Gewebe dervorjührigen verkorkten Borkenlage und dem weichen, schlanchförmigen Parenchym vollzieht sich der Ablösmngsprozef's des Rindenfetzens, und je nachdem noch an der Trenmmgsfläche schlanchartiges Parenchym mehr oder weniger festhaftet, erscheint die Oberfläche des Trennungspolsters wollig-rauh oder glatt.

Durch die Streckung des Rindenparenchyms miterscheiden sich diese Anftreibungen ron der Lohkrankheit, bei der es sich im wesentlichen um Korkwncherungen handelt.

Einen ganz ähnlichen Fall wie von Ulmus beschreibt $r$. Tubeuf ${ }^{1}$ ) von der Wermonthskiefer; nur komnte, der glatten Rinde entsprechend, ein Alowurf von Borkenschuppen nicht heobachtet werden. Iie Kiefer war krank und mit Polstern von Xanthoria paritina bedeckt. Unter diesen Flechtempolstern zeigten sich henlenförmige Anftreibungen, die teilweise anfgerissen erschienen und durch streckung des Rindengewebes entstanten waren. Die llarkanäle waren rorgrötsert und die tieferen Rindenparenchymzellon schlanchtörmig esestreckt und chlorophyllarm.

1) v. Trвerf, Intumescenzenbildung der Bamrinde unter Flechten. Naturw. Zeitschr. f. Land- u. Forstwirtsch. 1906 - 5.60. 
Dats wir in den geschilterten Fällen Wirkmgen lokalen Wasserüberschusses zu sehen haben, ist aus der Angabe ron r. Tubeuf zu entnehmen, datis er durch Anfbinden und stetes Finchthalten von Watte anf einen Zweig ganz ähnliche buckeltömige Anftreibungen erzengt habe.

Anch bei Trurzeln sind derartige Anftreibmuen der Rinde beobachtet worden. Ans der Umgebung von Lindan worle vor einigen Jahren von einer bedenklichen Krankheit der Weinstöck berichtet ${ }^{1}$, welche ähnliche Folgen, wie die dureh den Wurzelpilz verurachten, hatte. aher nicht parasitär sich erwies. Die mterirclischen stamnteile um dic älteren Wurzeln zeigten Iängsrisse von $1-3 \mathrm{~cm}$, ans denen anfangs weitse, später schokoladenbrame schwielen hervoragten. Die in der Nähe derselben befindlichen Seitenwmzeh starben ab. Die schwielen bestanden aus den in radialer Richtung abnorm verlängerten, kamm mehr zusammenhängenden Zellen des Rindenparenehyms. Mitten muter den erkrankten europäischen Reben fanden sich amerikanische sorten in bester Gesundheit. Bekanntlich verbranchen rie moremein ïprig wachsenden amerikanischen Reben viel grötsere Wassermengen.

Derartige Gewebeschwielen sind viel hänfiger, als man gewöhnlich annimmt, und kommen anch bei Kierptlanzen vor ${ }^{2}$ ). Site simel Reaktionen des Pflanzenteiles anf Wmalreize oder imnere Gleiehgewichtsstörungen in der Wasser- und Nährstoffzufuhr.

\section{Wasserreiser.}

Man versteht mter Wasserreisern, Wasserloden oder Räuberu ungemein kräftige, mit langen Internodien yersehene, sinkreelit antwärts strebende Lanbtriebe, die aus alten Ästen oder stämmen entspringen. Hänfig zeichnen sich die mit Flechten üherzogenen Stamme durch reichliche Räuberbildung ans. Da die Räuber in die Mitte der Krone hineinwachsen, so erzengen sie gerade an denjenigen stellen Holz und zwar unfuchtbares Holz, die man möglichst astfiei haben möchte, damit genügend Licht und Lnft dem Innern der Bammkrone zuteil werlen kömme. Räuber zu entfernen wird aber nicht ratsam erseheinen, wenn die Ursache dieser Bildmgen nicht gleichzeitig wohoben wird. Die Ursache wird in manchen Fällen in einem undurchlassenden Untergrunde zu suchen sein. Die Wurzeln des starken Bammes gelangen früher oder später anf diese molnrohdringliche schicht. die sich nicht selten als eine Ader eisenschüsigen. sehr fest verkittetrn sandes erweist. Dadmrch wird die Nahrumsautiuahme beschränkt; der Baum macht kurze Trielse, kleinere Blätter, trägt aber dabei noch Frïchte. In einem warmen mul feuchten Frïhjahr, in welchem alle Bänme starke Lanbtriele machen, erseheint die Eneroie des geschwächten Bames durch die gïnstigen Vegetationshedingungen ehenfalls gesteigert. Der starke Wasseranftrieb veranlatst Adventivknospenbildung oder reizt schlafende Angen und zwar solehe. die nicht allzuweit von der Mittellinie des Stammes ontfornt sind: denn der Wasserantiol, und damit die Ernährung ist in der senkrechten Richtmog viol ruergischer als in der geneigten Lage. Dirs weils der Gärtner bekamntich bei dor sipalicrzucht zu verwerten, indem er Horizontaläste anf der einen seite des

1) Kentemoxx im Jahresher. d. Sonderausschusses f. Pflanzenschutz. Arh. d. Deutsch. Landw.-Ges 189293.

2) Sorarer. P., Über Rosenkrankheiten. Zeitschr. f. Pflanzenkrankh. 1sy- S. 220. 
Stammes, die schwächer sind als die korrespondierenden aut' der anderen siaite. ein anzes. Jahr hindurch in eine senkrechtere Lage bringt und

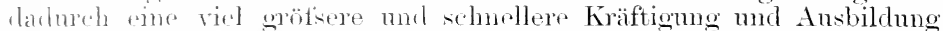
dersellyen erzielt. Mit der Aushildung ron Wassersehossen richtet sich allmailulich eine immer aröker werdende Ungleichheit in der Emährung anf hosten der älteren horizontaleren /weige ein. welche num Mangel leilen. Darans erkärt sich das bei dem Auftreten der Wasserloden berimende Absterben der '/weigspitzen älterer Seitenäste. Ein Teil des Banmes rerhungert bei iippiger Entfaltung eines anderen Teiles.

Wic gesagt, ist bei solcher sitörung im dilejehgewicht der Ernährung es kamm geraten, die Wasserreiser zu entfernen; viehmehr wird es vortoilhafter sein, hei älteren Bämmen die Wassorschosse mit wertrollen sorten zn veredeh und mit der säge gleichzeitig eine Partie älterer Ästr zn entfernen, so dats der Bam aut' diese WVeise verjüngt wird. W'mm man an Stellen, deren Untergrund sich ohne grolsen Kostenaufiand nicht öfthen läst, durch eine Düngung in einger Entfernung vom stamme dafür sorgt, lats der Baum seitlich eine nene kräftige Wurzelentwicklmo erlangt, so dürtte für eine längere Reihe von Jahren lindureh dem Übel gestenert sein. Junge Bänme wird man durch Verpflanzen gänzlich heilen kïnnen.

Ex mul's ührigens hervorgehoben werden, dafs von selbst die Räuberbilkmug an vielen Bämmen wieder nach einigen .Jahren verschwindet. Ijes ist nämlich dort der Fall, wo solche Wasserschosse durch unmäfsiges Zurückschneiden der Baumkronen oder plötzliches Ausputzen der Stämme hervorgelockt worden sind. Namentlich in Bammalleen, an stratien mit Telegraphenleitungen, in Baumptlanzmngen, durch welche eine Stratse oder Eisenhahnlinie hindmehgezogen worden ist, zeigt sich auf den dem Terkehrswege zugewandten Baumseiten sehr häufig eine starke Entwicklung von Räubern.

In solchen Fällen werden starke Äste an der stratisenseite oft einfach abuhanen. T)a der Wurzelapparat mbehelligt bleibt, so pumpt derselbe Twi begimender Vegetationseit ebensoviol Wasser in die Höhe wie ror der Terminderung der Bammkrone. Durch die Fortnahme der Äste ist aber ein kleincrer Verluamehsherd geschaffen, und infolgedessen werlen schlafende Augen wewerkt und zu so schlanken Trieben ansgelildet, datis dieselben zu Wasserschossen werlen, deren Seitenaugen manchmal noch in .Jahre der Entstehmo wieder anstreiben. Hats diese

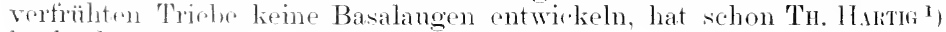
leoliachites.

Wem Ränber dureh plötzliche Entrahme starker Äste aus der Bammlirome prtstren. dann läfst sich ihre Ausbildung verlangsamen, wem man durch sichröten andere Ableitunssherde sehafft. Bei Ansästnngarbeiten in Fribljahr wird Sehröpfen sogar die Wasserlodenbilknng verhinlern liommon: chenso dürtte cin Einhauen in einen starken Wnzelast in der Nähr der stammbasis an der seite, an welcher die Bammkone stark ansegeriunt worden ist, den Wasserzutludis mindern und die Ränherbilıtung verliüten.

\section{Verbänderung (fasciatio).}

Ebentalls als cine lokale T̈heremährume ist der Kustand anfzufassen, lats eine zylindriseho Arhse lreit bandartig wird. Es sieht

1) Vollständige Naturgeschichte d. forstl. Kulturpflanzen, S. 176. 
dann so ans, als ob eine Menge Zweige mitrinandrr verwathsen wäre; indes ist dies nm solten der Fall, sonclern tast immer handelt es sich un einen einzigen /weig, der dureh Verbreitermug soines Vegetationspmuks an der spitze nicht einen Vegetationskerel besitzt, sondern eine kammartige Vegetationstläche ansililet'1).

In der leistehenden Abhildumg einer Fichtentasciation (Fig. 47) erkemen wir die Eimhoitlichkeit der verbeiterten Achse erstens in der fortlantenden Spiralc der Nadelstellumg. namentlich bei 1 und 2 und terner in den (querschnitten A und $B$ (Fig. tš), deren Mark-nul Holzkörper cine

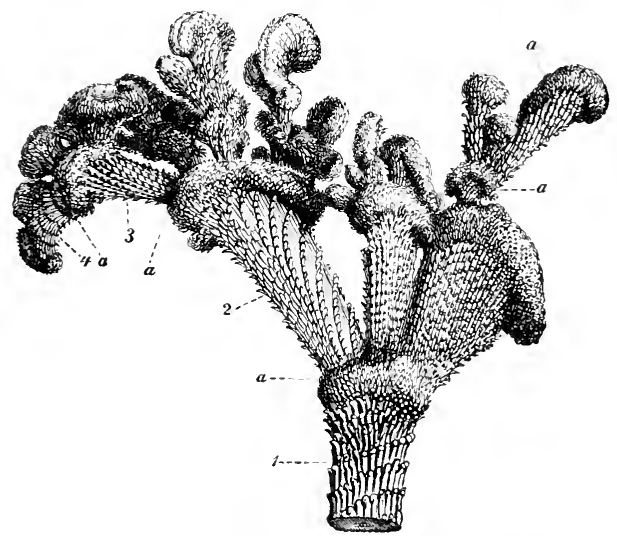

Fig. 47. Verbänderter Ast von I'ice rxerlsa.

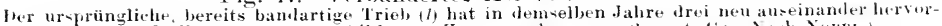
sprossende titagen $(?, 3,4)$ gebildet. It Knospenschuppen. (' 2 nat. (ir. Sach Xobre.)

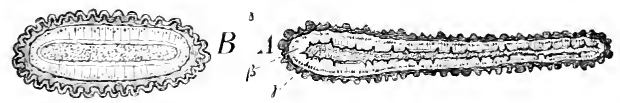

Fig. 4๖. Querschnitt der verbinterten Fichtenzweige, il aus den oberen. I) aus dem unteren Zweigteile.

« Rinde mit Blattkissen, 3 Ilolzkörper, $;$ Hark. Nat, tir. Nath Nozbe.l

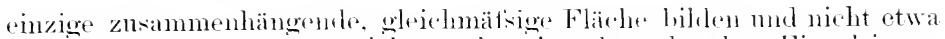
eine Verschmelzung von vielen neleneinanderstehenden Finzeldingen

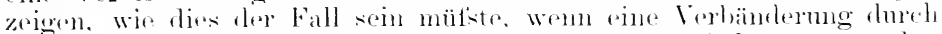

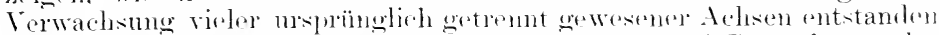
wäre. Diese Anschatume ändert sich anch nirht hei Betrachtumg der Fasciation der Frle Fig. 4!), bei der wir antiser der iiberall vol-

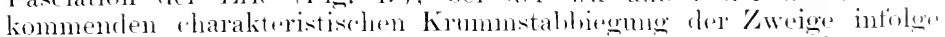
einseitiger Wachstmmsteigume anch die bei Lanbhölzern häutigeno

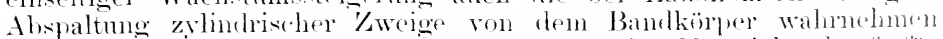
kömen. Es liegt oben in fascierten Strngel das Natrial gehäntt fiir viele Achsen, die sich isolieren kömen: aber er sellost ist rint Einheit.

1) Über Pflanzen-Verbanderung. Referat in Bot. Zeit. 1xtiz, s. 2:Y2. 


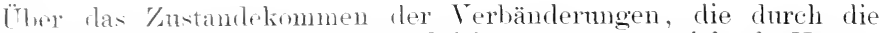
orotse Vormehrung ilner Bläter mol Blattspurstränge sich als Hypertrophic kennzeichnen, kömnen wir nur Vermutungen aussprechen. Lrsprünglich mus aine Achse, die später verbändert, eine Hemmung rrliten habon. Dats ein Iruck ron zwei entgegengesetzten Seiten die Achsc banchatic machen kann, haben wir bereits früher bei den zwischen Felssualten aingeklemmten Wurzeh sesehen. Unter Umständen kamn eine solche veränderte Wachstumsrichtung anhalten, weun die Ilemmung sellost hereits versehwmelen ist. So zitiert Trestanos eine Beobachtung'

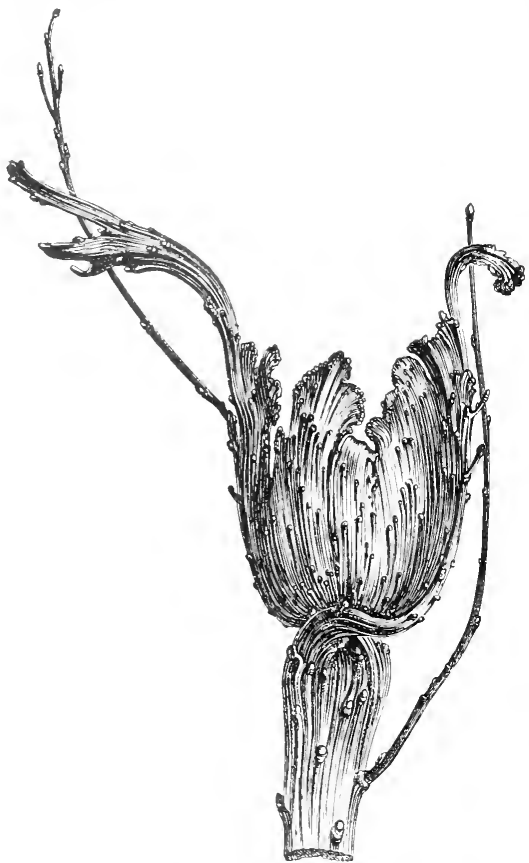

Fig. 49. Fasciation von Alums glutinosu. (1/2 nitt, Iir. Nach Nombe). äher einen durch Druck an der Naner bandförmig geworlenen Stengel von Teroma radicrus. der noch bandartig blieb, als er weit über lie Maner hinans gewachsen war. Dabei wurlen anch die weiter sich entwickelnden $\%$ weige noch teilweise bandförmig.

Autser solchem seitlichen Drucke kann in anderen Fällen anch ein vorübergebender Druck von oben eine Verbreiterung des Vegetationspmktes zu einer Vegetationsfläche wahrscheinlich veranlassen, und ein solcher Druck kann möglicherweise durch abmormes Verhalten der Knospensehuppen (verzögerte Lockerung dureh Verharzung. Vertrocknumg n. dol.) schon zustande kommen. Falls nicht almorme Drucksteigerung vorhanden, können direkte Verletzmgen der Tegetationsspitze Veranlassung zur Vermehrung der Vegetationspunkte geben.

Ist die Verbänderung einmal zustande gekommen, kam sie durch stecklinge fortge. pflanzt werden, ja unter Umständen samenbeständig sich erweisen, wie wir dies bei mserer beliebten (iartenpflanze Celosin cristuta, dem llalmenliamm, sehen. The Fähigkeit zur Faseiation ist bei allen PHanzen roransmsetzen, und wirklich beobachtete Fälle wurden schon ron MLstress ${ }^{1}$ ) in grofiser Anzahl (150) gemeddet. Wie erwähnt, ist von der eigntlichen Faseiation die fascierte Verwachsmug zn unterscheiden. die Anrch handartiges Verkleben isolierter Achsen zustande kommt. Lorkioke ${ }^{2}$ ) hat derartige Fälle bei Wurzehn künstlich hervorgeruten.

1) Mantaris, Vegetahle Teratologr 1stig, s. 20 (vergl. Paxzri und die Einzelfälle in den Bot. Jahresberichten).

*) Luprone, G., Die Anatomie bandartiger Wurzehn. cit. Zeitschr. f. Pflanzenkrankheiten 1904, s. .26. 
Zwangsdrehung (Spiralismus Mor.).

Mit obigem Namen bezeichnet A. Bkar ${ }^{1}$ ) diejenigen Stengelmitibilchungen. welche in tonnentörmig autgeblasenen stellen bestehen, an denen die Riefen, wolche von den Blïtern herahlanten mol die zu ihmen gehörenden Gefätsbündel darstellen, ein" "xtreme. spiralige" Windung zeigen. Bisweilen ist die tommentörmige Anschwellung so stark, dats der stenger in der Richtmog der spirithehmer reitst und sich an diesen liranken stellen in eine Anzahl spiralbändrer spraltet. Von Schuper ist die Wachstmmstörung .. St trophom a nie" genannt worden. Die meisten Fälle sind ans den Familien der Dipsacern, Compositen und Rubiaceen betiannt geworden. Einzelne Vorkommnise werlen auch von Labiaten, Scrophulariaceen, 'rinciferen mul unter den Nonskotyledonen von Asparagus, Lilium, Orchis, Triticum nww., autierdem auch von Equisetum beschrieben.

Wir glauben, dats es kein unzutreffentes Bitd ist, wem wir dir. Zwangsdrehumg als eine tomentörmig antopblasene Fareiation ansehen. Wirtschaftliche Berleutung kommt ien Fällen nicht zn.

Vou ihnen versehieden ist die verstärkte Spirahdrehung normal gebauter Holzstämme, die wir auf Hemmungen im Längenwachstmm (meist infolge von Wasser- und Nährstoffimangel) zurüclifïhren.

\section{Wassersucht (Oedema).}

a) Bei Beerenobst.

Seitem die Anzucht der hochstïmmigen stachel- nud Johamisbeeren dureh Veredlung ant krättige Triele von Ribs anmm weitere Verbreitung gefunden, Raben sich die Klagen über eine Krankheit der Unterlage, welehe das fielingen der Veredhung in Frage stellt, sehr vermehrt.

Diese Krankheit ist ron den Züchtern als, "Wassersucht" lezeichnet worden; sie besteht in dem Auftreten geschlossener, d. h. von der äntseren Korkschicht bedeckt blibender ofler aber anch antreitiender Rindenbeuten (Fig. io A). Die Rindenauftreibungen sind bald nur klein. bald erreichen sie eine Anstehnming von mehreren Centimetern Länge; sie stehen entweder einseitig an Stamm orler umgeben denselben, miteinander verflietsenul, ringsmm. Am häntigsten erscheinen sie an zweiund mehrjährigem Holze; doch können sie anch sohr intensiv an einjährigen Zweigen anftreten und leven Tod mmittelhar nach sich ziehen. wälırend das ältere /weigholz zwar liränkelt, aber nicht direkt abstirht.

Bei dem jetzigen Vertahren cier Frühjahrsveredlung ron Rilbs im Hause zeigen sich häufig anflorechende Benlen mmittelbar mer der. Veredlungsstelle, und in solehen Fällen wächst die Veredlung nicht. Aber anch weiter rïekwärts von der Veredlumgstelle sind in intensiven Fällen derartige Auftreibungen sowohl am Stamme zwischen je zwei Ang'n als anch namentlich dicht in der Nähe der Angen hez. der ans ihnen bereits entwickelten /weige zn finden. Man beobachter Fälle. in denen am zweijährigen Ilolze die Basis eines stehen gebliebenen Triebs tomenförmig geschwollen und an dieser stelle mit antgerisonen Rindenfetzen bedeckt ist. Der Zweig oberhall, dieser stolle ist ahgestorben.

1) Sitzungsberichte naturf. Freunde z. Berlin, cit. Bot. Zeit. 1=73, s. 11 u. 30. 


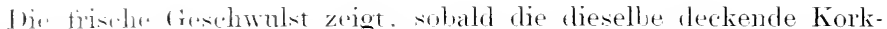
hïlle. wolche die (Herhant des Zweiges darstellt, entzweigesprengt ist, muter dieser llïlle hervorquellend cine gelbliche, schwammigweiche, callusihnliche fremebmasse ans sehlanchartig verlänerten, sehr inhalts-

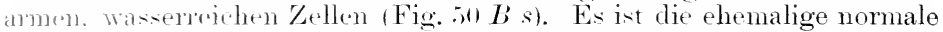
Rimbl. deren Zellen. in den Regionen zwisehen je zwei Bastzellgnupen (Fig. so $B h$ ) begimend, anf Kosten ihres sonst an grünem Farbstoff
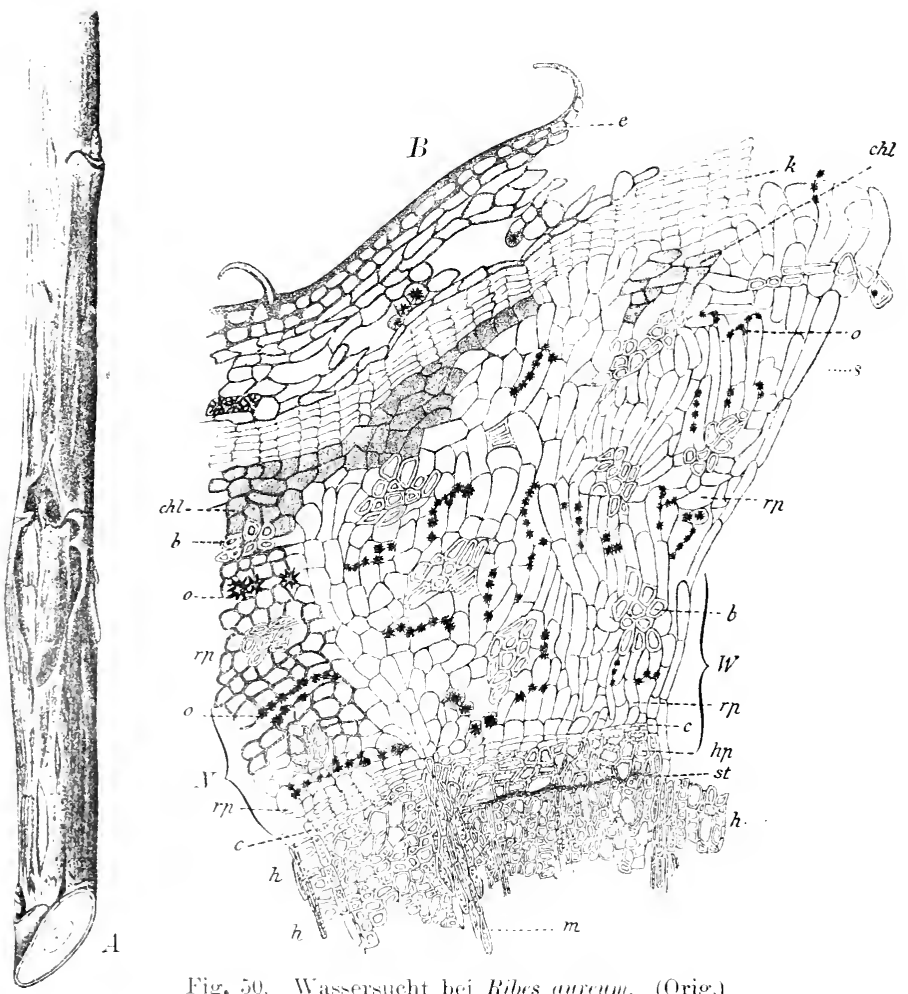

Fig. 50. Warmeracht bei Rilles anmem. (Orig.)

reichen luhalts sich in lex lichtmer des stammarlius antserordentlich

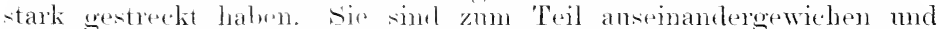

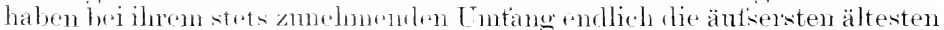

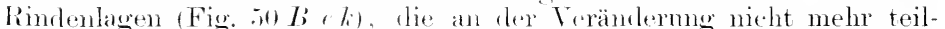
genommen und finhzeitie dmeh Korkichichten (hi) von den darunterlingemlen (iewohe abgotremt worlon sinel, entzweigespengt ${ }^{1}$ ).

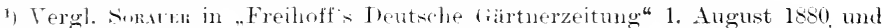
Griscmis in Monatssehrift d. Ver. z. Beförd. d. Gartmb., Oktober 1880, S. 451 
Nicht immer ist die Rinde in ihrem ganzen Qnerelnrehmesser von der schlanthtörmigen Streckung rgriffen: in sehr intensiven Fällen aber gewaht man schon eine Deformation der \%ellen in der C'ambialregion $(c)$. Dann ist anch das Holz nicht melur nornal; an stelle des bisher gebildeten, aus dickwandigen, langoestreckten Holzzellen und Gefätsen mit leiterartig durchbochenen Qnerwänden bestehenden, normalen Holzes entsteht ein ans kuzen, weiten, verhältnismätsig dünnwandigen, parenchymatischen Zellen $\left(h, l^{\prime}\right)$ zusammengesetztes Holz. Der Querschnitt (Fig. 50) B) stellt den Überang der gresmolen Zweigseite $N$ in die wassersüchtige $W$ dar: $h$ ist das nomale Holz. Zur Zeit, als die Lage st entstand, machte sich die Krankheit in der Cambiumregion bemerklich, und die Folge davon war, dafs von ra ab, auf der kranken Seite Parenchymholz $h l$ gebildet wurde, welches nach links bei einem Markstrahl m abbrach: noch weiter nach links entstand in derselben Zeit normales Holz. Ganz derselbe Unterschied macht sich in dem jüngsten Rindemparenchym $v p$ bemerkbar. Inrch die grofise, radiale Streckung der Zellen anf her wassorsüchtigen Seite $W$ werden die Hartbaststränge $b$ bogenförmig nach antisen wedrängt, und demgemäts sind auch die den Bastiörper begleitenden Zellreihen mit oxalsaurem Kalk $o$ in steil ansteigende, umregelmätsige Reihen verschoben: chl sind chlorophyllreich gebliebene Parenchymgrupern. Bei diesem lockeren. wasserreichen Ban des Gewebes, wolches die Geschwulst darstellt, ist es erklärlich, dat's es keine lange Daner hat. An trocknem Standort der Pflanzen und zmnehmender Iufttrockenheit brämnt es sich rasch. schrumplt, fällt zusammen und stellt cine mürbe, lraune Masse dar, die teils ant' dem Holzkörper anfgelagert bleiht, teils den äufieren, bei Trockenheit sich zurückrollenten, klaffent anseinanderweichenden Rindenlappen anhatet. Solche stämme erhalten ein brandiges Aussehen und sind von der Kultur am besten ganz anszuschliefsen. Bei der Leichtigkeit, mit der solche Intridagen auf kräftigem Boden wieder herangezogen werden können, wäre der Verlnst durch die Krankheit minder empfindlich, wenn er nicht gerarte die Topfexemplare, lie veredelt worden sind, beträfe und wemn nicht dalureh die Anzahl der Veredlungen bedentend verringert wïrde.

Ich bin nieht der Ansicht, die in der Praxis ausgesprochen wird. lats eine überreiche Emährmng der Pflanze die Schuli trage, sondern glaube, dat's an einzelnen Stellen der Achse ein Wasserïberschnfs sich geltend macht. Wäre hier gleichzeitig eine Anhänfinng von plastischem Material. so wünde sich dieselbe durch reiche Zellvermehrung vorzugsweise äutsern: das ist aber nicht der Fall. Zählt man die Zellen in derselben stammhöhe an der gesunden mol kranken seje. Ilam findet man nur ein mbedentendes Übergewicht an letzterer. Es handelt sich flemnach vorzmgsweise hier um eine abmorme Zellstredimng.

Dieselbe erklärt sich durch die Behandlung der Ribes-siammehen bei der Vorbereitung zur Veredlung. Em sehlanke, schnell in di Höhe gehende stämmchen zn erzielen, muls man die anderen, seitlich entspringenden Schötslinge wegnelmen und an flon jungen stämmchen selbst die Seitenzweige zurückschmeiden.

sind num die Stämmchen gut angewmzelt, worlen sie im Trarn. hause sehnell angetrielen und die durch das fröhere Zurtickischneiden schon spärlich vorhandenen Angen noch dachreh vermindert. datis man die ans ihnen sich entwickeluden Triebe einstutzt ofler äinzlich -ntfernt. Durch das Abschmeiden der Zweige steigert sich die durell den 
Tasserdruck amporotriebene Tassemenge in der Hauptachse nul macht sich in einer sulunchförmigen Terlängerung der jüngeren Rindenzellen und der Bihhug benlenartiger, schliefslich anfieitsender Anftreitmusen geltend.

Dirchte Tersuche, durch reiches Giefsen und schnelles Antreiben unt bewnrzeltor Exemplare im Warmhanse unter fortgesetztem Stutzen Ter sich entwickelnden seitentriebe die Wassersucht hervorzurnfen, ergaben mir änlserst ginustige Resultate.

Termeidung des zu schnellen Antreibens der Veredlungsunterlagen und vorsichtiges Einstutzen (nicht gänzliches Entfernen) der hervorhrechenden Triebe werden der Krankheit vorbengen. Maukek ${ }^{1}$, hat die Verwendung vom libes nigrmm statt $l i$. anrem als Veredlungsmiterlage empfohlen. Aber mir sind anch Fälle ron Wucherungen der Achse bei der schwarzen . Johamnisbeere bekannt geworklen, namentlich nach dem Terpflanzen solcher Stöcke, die zur Untruchtbarkeit neigen.

\section{b) Bei Kernobst.}

Es ist voraususehen, daf's hei mserer linlturichtung ähnliche Erscheinumen wie die bei Ribes beobachteten anch an anderen Obstarten anftreten werden. Denn durch die hochoradige steigermo der Nährstoffzutuhr werden unsere Obstwehölze immer weichlicher: die Masse der parenchymatichen Zweigsubstanz steigt beständig gegenüber den prosenchrmatischen (ieweben. Wwischen Wildlingen und Edelsorten sind in dieser Beziehmng sehon bedentende Differenzen. Direkte Messmengen haben mir gezeigt, dats die Zweige der Kultmrarietäten eine fleischigere Rinde bekommen und der Holzring bedentend an Dicke abnimmt ${ }^{2}$ ). Diese zunehmende Neigung unserer Obstbäume, weiche, reservestotfspeichernde, parenchymatische Gewebe anf Kosten der Ansdehnung des Holzringes zu bilden, habe ich als "Parenchrmatosis" hezeichmet.

In besomleren Fällen erreicht diese Bildungsichtmng so extremes Ïbergewioht, llaf's Krankheiten entstehen. Solche beobachtete ich besonders an Fruchtholz der Birnen, das sich zu tommenförmigen. Hrischigen Anschwellungen verkürzen kann, welche die Züchter als .Fruchtkurhen" bezeichnen. Die krankhaften störungen bestanden entwoder tarin. daks die Korklagen und äufseren Rindenschichten an eins 7 weigseite schildartig abgeplatzt waren und eine oriunlichgelbe callusartige (tewehemasse zum Torschein kommen lietien, oder dats fast an sanzen Zweignufang ringförmig, bei älnlicher Gewebeveränderung, die Rinde in steiten, hröckeligen Schuppen sich abhob. Im letzteren Falle waren alle oherhalh einer derartigen stelle befindliehen \%weine tot.

Wem die Erkrankung an dem minder ïppig entwickelten Fruehtholz, das als .Fruchtspief'se" von den Fruchthuchen unterschieden wird, sich geltend machte, sah man mehrfach eine vollständige Aboliedernue dieser \%weigehen, ähulich der von normalen Zweigabwïrten. wie sie bei flen Pappeln alljährlich beobachtet werden. Bei fem vorliesendsn almormen Abwurf der Birne war die Bruchtläche aber nicht wlatt, sondern uneben und wollig, dabei aber hellfarbig wie der Querschnitt dos gesmulon I Iolzes.

1) Der Obstgarten 1 1\$79, s. 1 152

2) Sormar, P., Nachweis der Verwolchlichung unserer Obstbäume durch die Kultur. Zeitschr. f. Pflanzenkrankh. 189:, s. 66. 
Der Qnersehnitt lurch eine im Antangstadinm ler Erkrankung befindliche /weigstelle zeigt, dats der Rimlenkörver einseitig eine starke Entwicklung, vorzugsweise immerhalb ler Primärinde ertahren hat. sein Parenchym ist diumwandig, teilweise blasig orter schlanehtörmig aufoetrieben iud nugenein gelockert.

Ein Vergleich der Markkïper zwisthen einem geplatzten mul gleich-

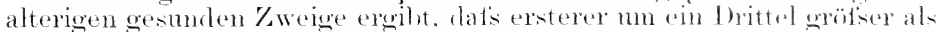
ter andere, der Holzring lageoen nur ein Drittel solmeit wie hei letzterom

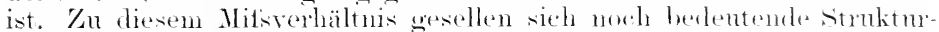
differenzen. Während ein wesunter Triel, die nomalen libriformfiasern und ein reichlich entwickeltes Getätssytem zeigt, int der Holzkörper

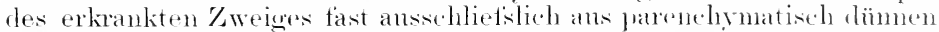
Zellen aufgehant, zwischen denen die Gefälistränge eingelagert sind. Bei normalen Bämmen kam muter Unständen die Sichwäche les Holzringes durch sklerenthrmatische Elemente in der Rinde answeglichen werlen ${ }^{\mathrm{x}}$ ).

Die wassersünhtigen Zweige der Birne mutersheirlen sich somit von denen bei Ribrs insofern, als hier der llobliörper mit in die Parenchymatose hineingezogen und gänzlich gelockert wird. Darlmeh, dals die parenchymatisch geworrlenen Holzzellen sich abmonden mol antblährn, werden die Gefälse allmählich verbogen, versehoben und schlietslich zerrissen. Sobald der Lockermospozedis den ganzen Unfane eines

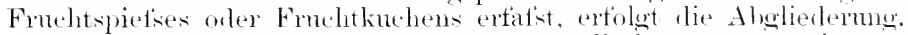

Die kranken /wrige stammten von spalierbänmen ans einem gut hewässerten, mit Kuhlung reichlich vesehenen fiaten.

VTemn anch deratige extrome Fälle zu den selteneren Vukommnissen gehören, so sind doch Antangsstadien, die in Erweiterungen und Wuchermoen der Narkstrahlen und Streckungsorgängen Trei einzelnen Rindenzellompen bestehen, gar viclfach zu beohachtende Erseheintmoen.

\section{Geschwulst an Johannisbrot.}

Manchmal treten Anschwellungen infolge ron hellstreckung uml Zellvermehrumg als Korrelationsvorgänge ant. So herielitet beispiels-

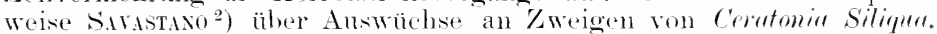
Es bilden sich tamminreiche, konische Anftreil,ungen an der spitze der Blütenachsen, worlureh die Blïten atrophieren. In einer früheren Arbeit beschreibt Sirastano ${ }^{3}$ ) das Zustanteliommen grötierer (íschwölste am .Johannisbrotbanm. An den normal angelegten Fruchtzweigen hemerkt man in solehen Fällen hei Beginn der Krankheit.

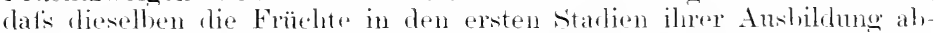
werten. und dats nummehr der zurückbleibende Batsalteil des Achsen-

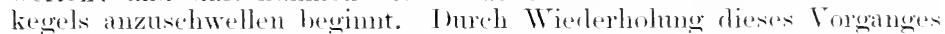
in den folgenden bahren entsteht eine knotige fieschwolst, die einen wanz beträchtlichen Unfang und eine llöhe von ti-lo ch erreichen kann. Diese hypertrophierte spitze des Frmelitzweiges hesitzt eine mohrmals dickere Rinde als das normale Fruchtholz. mond der Holzkörper bestelit aus gefätshem Holzparenchym. In der fast markigen Rinde erscheinen

1) Prexers, A., The influence of Fruit-bearing on the development of mechanical tissue in some Fruit-trees. Ann. of Bot. V. 10. London 1 K96 s. 511.

2) Sararax, L., Tumori nei coni gemmarii del carubo. Boll. ll. Socinti it. Naturalisti in Napoli. 1×x-. Yol. II, s. 247.

3) Sarastaxo, L. Hypertrophie des cônes à bourgenns (maladie le la loupe) du Caroubier. Compt. rènd. 12. Janv. 1885. 
die Bastiasern writhmiger mel vou mordentlichem Verlanf: die Mark-

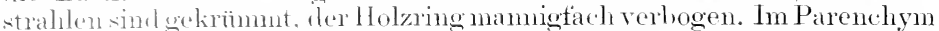
sind dinzelne Zellgnupen mit gefärbten Wandungen mol gmmosem Inlialt hemolich. Ton Begim ter Krankheit an steigert sich dor

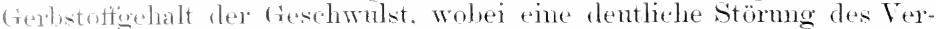
holzmespozesses in die Augen springt.

Hierler gethöt anch wahrsheinheh ein Fall, den Vöchting ${ }^{1}$ ) bei Solnhalipthanzon beschreibt. Nem alle Vegetationspunkte entfernt worden waren, schnollen die Blattkissen zu umfangreichen Gebilten an. In normalen Ilolzkörper dex Athse war, wie in den Blattkissen, das Cambium zur Entwicklmo dünnwandiger Sylemelemente angeregt worden. Bei ähnlichen Versnchen mit Holianthus ammus sah Verfasser an den Wnzchn kleine Knöllchen entstehen. Ich beobachtete an geknickten Trumeln von sï̈lskirschen tomenförmige Verdickmngen.

Anch die Anschwellungen, welehe Wakbukg*) bei dem Astkrebs der Kinabämme in fenchten Gründen beschreibt, dürften solche Korrelationserscheinungen darstellen.

\section{Die rückschreitende Metamorphose (Verlaubung.}

Wem die Organe einer morphologisch höheren Entwicklmngsstufe in eine niedrigere mongewandelt erscheinen, sprechen wir von einer rückschreitenden Metamorphose. Pathologisch in Betracht kommt nur die Tmwandhung der Blütenorgane insofern, als der Sexualapparat furch Verändernug in vegetative Organkreise seiner Bestimmmo entzogen und dadurch eine Unfruchtharkeit eingeleitet wird.

Dafs wir diese Fälle in die Gruplye der durch Wasser- und Nährstoffïherschuts veranlatsten Erscheinumgen eimeihen, beruht anf folgender Anschanmog. Die Ausbildung des ptlanzlichen Organismus hängt von zwei Falitoren ab: der Beschatfung des organischen Bammaterials mod der Art der Verwendung desselben. Unter der Voransisetzung, dat's liv erste Arlositsleistung des Organismms, die Assimilation, also die Bildung nener 'Trockensubstanz, in normaler Weise sich vollzieht, wird die Anshildnug des Ptlanzenleibes davon abhängen. nach welcher Richtung hin dieses organische Bammaterial Verwenchung findet. Dabei extemmen wir zwei Richtmoen, die wir als die vegetative und sexuelle Periorle anseinanderhalten. Letztere sehen wir meistenteils sich damit einleiten, dats dor Oronismms eine vielfach dentlich erkembare Ruheperiode in der Produlition semer vegetativen Apparate eintreten lätst. Nene Blätter werden zn dieser Zeit in der Regel nicht ansgebildet, mul das siritzenwahstum der Zweige ruht. Datür tritt der Torgang der speicherung vom Reservehaustotfen in den Vordergrund.

Liesen sipeichermugromang sehen wir eingeleitet mo beginstigt chuch ein Nachlasson in ter TTasseranfinahme hei zunchmender Belenclitmo mol Exwirmung. Tem sich Reservestefte z. B. in der Form

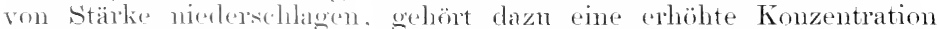
des Zellsaftes. Kamm eine solche durch irgendwelche Umstände nicht erzielt wertern mul bleiben die Banstoffe in einer dilnierteren Form, z. B. als Kucker. so berlant es num cines geringen Anstotises, nm die vegetative Tätigkeit winderznerwecken. Es herscht somit ein gewisser

1) Vicunxi, H., Zur experimentellen Anatomie, cit. Bot. Jahresb. 1902. II. S. 300.

2) Wannкr, O., Beitrag zur Kenntnis des Krebses der Kinabäume auf Java, cit. Bot. Centralbl. 1888, Bd. XXXVI, s. 145. 
Antagonismus zwischen diesen beiden Entwicklungwhasen, die wir als

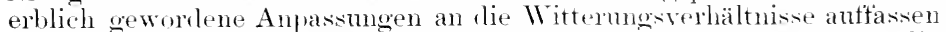
kömnen. Nach einer kühleren, wasserreicheren \%eit, in weleher die Pflanze vorzugsweise die Mineralsubstanzen des Bodens autinimmt und den Chlorophyllapparat in der Produktion ron Blättern zur möglichst reichen Aushildumg gelangen lätst, folgt eine wärmere, trockenere, den grölsten Lichtreichtum aufweisende Periode, in weleher die sexualorgane aus dem in den Blätern bereiteten, fertigen, plastisthen Ban material angelegt und nach kurzer obler längerer Ruhezeit weiter entwickelt werden.

Je mehr die Blätter plastisches Bamaterial ararbeitet haben, desto zahlreicher und vollkommener werden die scoxulorgane innerhalh rieser Ruheperiode angelegt werten. Wie diese Anlagen sich später ansbilden, hängt von der Art ihrer weiteren Emährmg ab. Nachen sich Einwirkmgen geltend, welche zur Ausbildung vegetativer Organt nötigen, dam entwickeln sich Laubblätter, und zwar entweder aus neu angelegten Herden oder aus den bereits vorhandenen Anlagen der Sexualsphäre. Es tritt .Verlaubung" ein.

Durch die Erfahrungen bei unseren gärnerischen Züchtungen wissen wir, dats reiche Nälnstoffzutuhr unter gleichzeitiger steigerung von Wärme und Feuchtiglieit, meist zu Zeiten geringerer lichtwirkmo, diejenigen Bedingungen sind, welche den Verlaubungsorgang einleiten und begïnstigen. Besonders dentlich tritt dies in die Erscheinmo bei der Entstehung solcher gofïllten Blumen, deren staubgefätse zu Blumenblättern umgewandelt werlen.

Da dieser Vorgang, wis alle Ändermenen in ler Wachstumsrichtmig. unter gleichbleibenden Bedingungen erblich wreden kam und Accumulationen erfährt, so ist es erklärlich, dats wir Beispiele finden, in denen die Neigung zum Rückgang der sexualorgane in morphologiseh niedrigere Aushildmostomen alle Kreise einer Blïte ergritten hat um damit vollständige Vergriunung eintritt.

Selbstrerständlich sind nur selten die Bodeneinflïsse direkt die Ursache einer Verlaubmon. Diese wird viehnehr durch bestimmte Kombinationen der gesamten Wachstumsfaktoren eingeleitet, wie wir bereits erwähnt haben, und tritt auch nicht selten als Korrelationserscheimung infolge Unterdrückung anderer Wachstumsvorgänge aut. so entstehen durch Verwundungen ler vegetativen Achsen, durch pflanzliche und tierische Eingritice (Milben) Vurlaubungen emzelner Blüten und Blütenstände. Beispielsweise hat C. Kkats ${ }^{1}$ ) PHanzen verschiedenen Alters von Helimithus ammus fortgesetzt entblättert und nur die Deckblätter ter Blätenkörbchen belassen. Bei älteron PHanzen trat num frïhzeitig an Zuriekkrïmmen und Vergrötsern der Deckblätter ein. Ton den jüneren Pflanzen zeigten 2:0 o eine wirliche Verlaubung. indem die Deckblätter mehr oder weniger die (iestalt von Laubblättern annahmen.

Die Cmwandlung ron Knospenschuppen zu kantigen, blattartigen Organeri nach Zerstörung des Vegetationskegels durch Front liahe ich bei meinen Erfierungsversuchen mehrtach heobachtet. Ähnliche

1) Krats, C.. Entersuchungen äber künstliche Herbeiführumg der Verlaubung usw. durch abnorme Drucksteigerung. Forsch. atuf d. (ieb. d. Agrikulturphysik. 1880, S. 32. 
Resultate whielt (FoEREL ${ }^{2}$ ) dureh Entlaubung und Entgipfelung junger PHanzen von T'rmmes Pudus, Aesculus, Rose, Syrimgu und cuercus.

Die "Tratologie hat die Vorkemmnisse systematisiert. Der cinfachste Fall ist die . virescentia", die Grünfärbung, bei der ein (1) ran ler Blïtmkroise im wesentliehen seine Gestalt behält, aber eine griune Färbung annimmt. Mit diesem Auftreten des Chlorophylltarbstoff's wirt in der Regel das Organ fleischiger. Bei der eigentlichen Terlanbung (Phyllodie. Phyllomorphie) nähert sich das Organ anch semer frestalt mach dem Laubhlatt. Brakteen werden zu normalen Stengelblättern, die Kelchbläter werden dureh wirkliche Laubblätter ersetzt. Die Blnmenhlätter werden grïn und fleischig, die Stempel werden zu stanherätsen (staminodie) oder Staubgeätse und stempel vehmen len Charakter von Blumenblättern oder grünen, fleischigen, laubartigen Gebilden an, wie z. B. hei der gefüllten Kirsche, den gefüilten Ranmkeln nsw. Bei der Reseda können dureh Phyllodie der (1)ula kleine be1) lätterte Achsen in dem mrnenförmig offenen Fruchtknoten gebildet werden. Bei den heliebten Knollenbegonien sah ich den Samenträger aus dem Fruchtinoten hervorwachsen und die Ovula ant die blumenblattartig mogebilketen Stempeläste übertreten usw.

Es gibt Fälle, in clenen sämtliche Blattkreise einer Blüte zu gleichartig nrïnen Blättchen mmgebildet sind, also vollständige Grünblïtigkeit (Chloranthie) entsteht. Eines der sthönsten Beispiele dieser Art ist die seinerzeit mit grotisem Enthusiasmus begriilste grüne Rose (Rosa chimensis Jaqu.), deren Umbildungsvorgänge von ('ELAkowshí ${ }^{2}$ ) eingehend gesthildert worden sind.

Sellst die in nenerer Zeit durch vielseitige Studien mehrfach als konstantes Torkommnis nachgewiesene Parth enogenese möehte ich hier anschlietsen. KinchNer ${ }^{3}$ ) sieht in ihr eine Einrichtung, welche in einer andersartigen Weise, als es die viel weiter verbreitete spontane Sulhsthestäubung tut, dazu dient, um die Ansbildung von keimfähigen Samon in solchen Fällen sicherzustellen, wo aus irgend einem Grunde der Eintritt rom Befmehtmo ungewifs oder sehwierig geworden ist". Man kann elven Samenanlagen von somatischem Charakter annehmen, bei denen zur '/ait der Entstehung des Embryosackes die Reduktionsteilung unterbliel, und die Eizelle einen vegetativen Charakter behielt.

Bei den krvptrgamen frewächsen entspricht die A pogamie dem Verlauhmosurozed ier Phanerogamen, inclem an Stelle der Geschlechtspromkte veretative Keime anftreten wie bei Athyrim Filix frmina var. cristutum. Aspridum falcutum und Pteris cretica. Bei letzterer Pflanze sollnu iiberlampt kine weiblichen Geschlechtsorgane mehr gehildet werten, sonclem das junge Pfänzehen gelıt vichmehr durch vegetative sprossmon genan ans drujenigen Stellen au Prothallimm hervor. wo die Arthegonien strelen miitisten $\left.{ }^{4}\right)$.

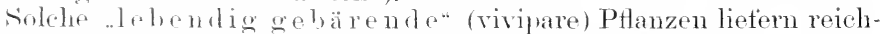
lich Materin zur Vormehmng ebenso wie z. B. die Zwiebeh mancher Liliaceen, die durch Thriandlumg einer Blïte entstehen.

1) Golma, Beiträge zur Morphologie und Physiologie des Blattes. Bot. Zeit. 1880, S. 803.

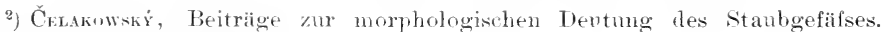
Pringsheims Jahrl, 1s7s, s. 124.

${ }^{3}$ ) Kircnxar, O., Parthenogenesis bei Blütenpflanzen. Ber. d. Deutsch. Bot. Ges. 1904, Bd. XXII. Generalversammhungheft. Hier auch die betreffende Literatur.

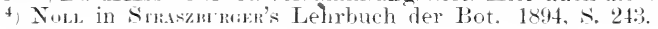



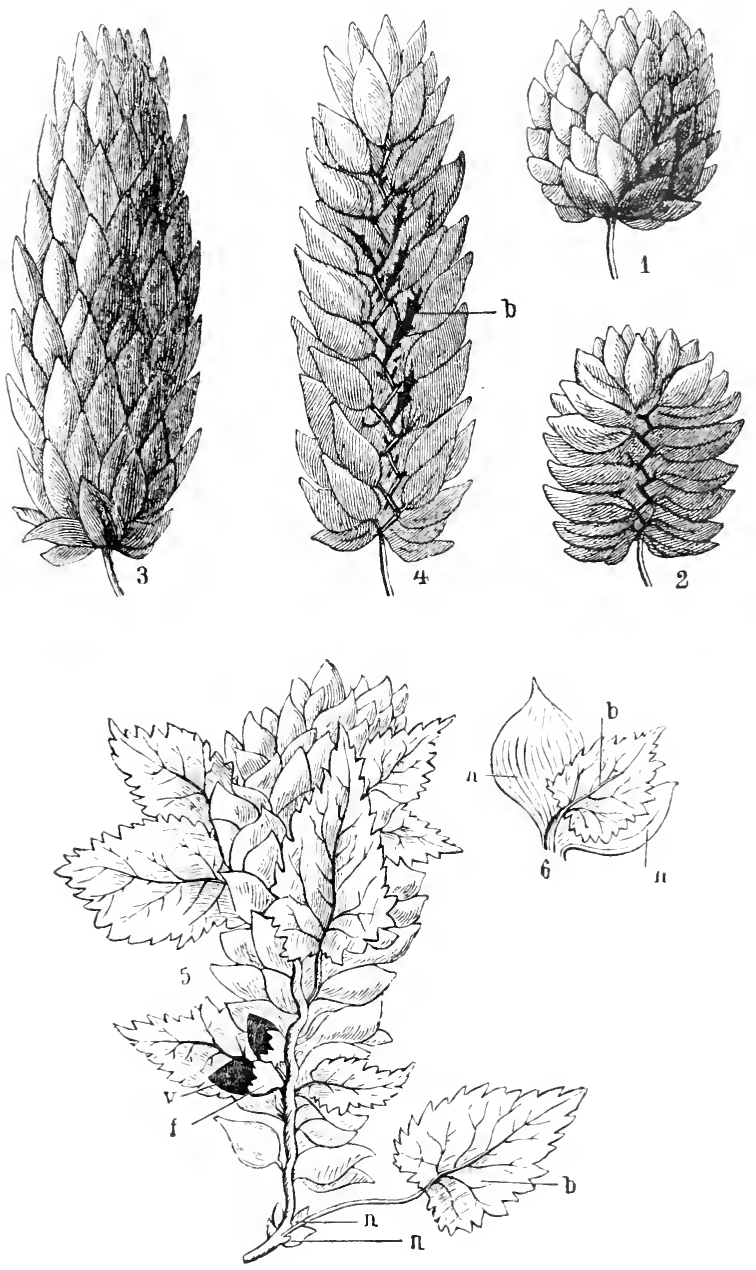

Fig. 51. Verschiedene Übergangsstadien der normalen Hopfenkätzchen in verlaubte.

\section{Die Gelte des Hopfens.}

Ein spezieller. für die Kultur hochhedentungsoller Torgang ler Verlaubmg ist die Gelte, das Blindsein, il is L mpel-oder Narrenkopfbildung des Hoptens. Die Namen bezeichnen mur ver- 
shiedene trate einer Mitsbildung, welche mit einer einfachen, abnormen Verlängermeng des lloptenkätzchens anfängt und sich bis zur Bildmeng thatterioer, Annkelorïner Fruchtstände entwickelt, aus denen vershifeden grofise Laubhläter in wechselnder Zahl hervorbrechen.

Die Hoptenzüchter wissen, dat's in dem Mafse, als das Kätzchen sich verläugert und die schuppen sich vergrötsern, auch die Qualität dis Hopfens sinkt. Die für den technischen Gebranch vorteilhafteste Aushilumg der Kätzohen ist an eine kurze, gedrungene Gestalt des ganzen Blütenstandes und an kurze, hreite, papierartig dïnne Beschaffenheit der schuppen gebunden, wie sie in vorstehender Fig. sl Nr. 1 und \& dargestellt sind. Nr.2 ist halb entblättert, um die kurzgeknickte sindel des Kätzehens zu zeigen. In $\mathrm{Nr}$. :3 und $\mathrm{Nr} .4$ ist die abmorme T̈berverlängerumg der Kätzchen dargestellt, die unter der Bezeichnung "bra usehe Hopfen" bei den Züchtern bekannt ist und als erstes stadim einer begimenden Verlaubmig gelten mufs. Solche bransche llopfen sind groh, weniger gehaltreich, etwas später reifend und in den schuppen krantiger. Von diesem Zustande ausgehend, steigern sich die Verlaubungserscheinungen bis zu dem Stadium, das in Nr. 5 vorgefïhrt ist. Die grünen, hier sichtbar gewordenen Laubblätter erlangen bisweilen die Grölse eines normalen Blattes; $b$ ist die BlattHäclie. die sich rïckwärts in den Blattstiel verfolgen lä1st. Am Grunde dieses Blattstiels stehen die zwei grünen Nebenblättchen n, ", welche im vorstehenden Basalteil des Kätzchens sehr klein sind, aber nach oben hin an Grölise zunehmen. Nr.6 stammt aus einer höheren Region des Blïtenstandes und zeigt die Nebenblättchen $n n$ von der Grölse der übrigen schuppen, dagegen den Blattkörper b schon viel kleiner. Die anderen Schuppen und Vorblätter sehen wir bei Nr. 5 r: sie mmschliefsen je eine Blume $f$ :

I ie Nebenblätter, welche in der Entwicklung dem ïbrigen Blattkïrper voranseilen und in dem normalen weiblichen Blütenstande des Hoptens allein entwickelt sind, besitzen dieselbe schmppenartige Beschatfenheit wie die Vorblätter, so daf's das ganze Kätzchen aus gleichmälicig gobildeten schuppen zusammengesetzt erscheint; alle Schmppen sind Fnmoluig nnd werden bald trockenhäntig, wobei sie fest dachziegelartig aufinander gelagert bleiben.

Die (ielte besteht also in der Ausbildung der sonst unterhüekten Blattflärhe zwischen je zwei schuppenförmigen Nebenblättern. Eine vielsoitige Erfahrung lehrt nm $^{1}$ ), dafs die fenchten Jahrgänge in stark mit stickstoffhaltigen substanzen gedïngten Böden es sind, welche das Auftroten der Gelte in grötserer Ausdehnung bedingen. Häufige Sommerregen, welche trïhe 'Tige im Gefolge haben, schädigen manchmal auch, ohme die fielte gerade zu przengen. Es strecken sich dam die Zellen des Laubkïrpers sowohl ak der Aehse, und sellst, wenn eine gïnstige Erntrwittermug sintritt, reifen die Kätzchen nur oberflächlich ab; sie gelangen mit viol mehr Vegetationswaser in die Aufhewahrungsräume und bedingen dadurh sin sehr sehnclles Erhitzen des ganzen Haufons. Infolgedesson tritt selhst bei den gut entwickelten Kätzchen ein schmeller Verlust des eigentümlichen Glanzes und der lichtgrünen Färbung und damit eine wesentliche Entwertung des ganzen Ernteproduktes ein.

$\left.{ }^{1}\right)$ Beobachtungen iber die Kultur der Hopfenpflanze. Heransgegeben vom Dentschen Hopfenbauverein, Jahrg. 1879-82. 
Als Mittel gegen die Gelte wird die Entternmo oder Lahmlegung der Ursachen zu versnchen sein, falls dieselluen in Form ron Wasseroder Stickstottäberschuts sich im Boden vortinclen. Ist die Ursache in trälser, feuchter Lutt zu suchen, dam sind alle diejenigen Mittel anzmwenden, welche eine möglichst starke Durchlïftmug mul I mrchlenchtung der Hopfenplantage betördern. Ist stickstoftüiberschuts im Boden, so empfiehlt sich eine Nachoüngung mit superphosphat.

\section{Gabelwuchs der Reben.}

In einzelnen Lokalitäten läfst sich bemerkon, dats verschiedene Rebsorten die Neigung zu ühermälsiger Verästelnng amnehmen und erblich behalten. Die Art der Verästelung erscheint in Form von Gabelung der Reben, und solche gabelsüchtigen Stöclie sind meist wenig oder gar nicht fruchtbar, wie R.tнAY ${ }^{\mathbf{1}}$ ), der die eingehendsten Beobachtungen darïber verötfentlichte, in Nieder-österreich vielfach gofunden hat. Die dortigen Winzer. Welche diese zweigsüchtigen Rebstöcke als "Gabler" oder "Zwiewipfler" bezeichnen, geben an, dal's die Gabelbildung in sehr verschiedenen Lagen sich einstellen liann. Die stöcke, die meist in gröserer Anzahl nebeneinander antangen, diese abnorme Wachstmmsichtmog zu zeigen, entwickeh zuerst einzeht. gabelige Verzweigmngen und stellen auf diese Weise ..mechte (rabler" vor, wie sie in üppigen Weinbergen allenthallien anzutreffen sein dürften. Dieses Anfangsstadium der Krankheit ist nicht gefährlich, da läufig die Stöcke wieder zur nomalen Produktion zurückichren. Dies Gefahr tritt erst durch die Aushreitmo der Zweigsucht über den ganzen Stock und die damit Hand in Hand gehende Erblichkeit der Erscheinung auf. Die Erblichkeit dokmmentiert sich bei stecklingen und $\mathrm{Ab}$ senkern gabelsiuchtiger Reben.

Eine Ursache dieser Erscheinung ist bis jetzt nicht mit sicherheit anzugeben. Riтна üherzengte sich, dat's Parasiten nicht vorhanden sind; die Meinungen der Praktiker gehen weit anseinander. Einzehe glauben, dats Bodenerschöptung durch intensiven Weinban die Ursache sei, während andere meinen, dats ein Anschwemmen von Erde durch heftige Regengüsse oder die Bearbeitung des Bodens während und kurz nach einem Regen einen verderblichen Einfluts ausüben.

Meiner Neinmng nach ist diese Krankheit eine Vergrünungserscheinumg, also ein krankhattes Überhandnehmen der vegretativen Wachstumsrichtung.

Für diese Antfassmng sprechen zunächst die Angaben von KAsERER ${ }^{2}$ ). dats die ersten Anzeichen der Krankheit in der Umwandlumg der Deckschuppe an der Ranlie zu cinem klemen Blatte, der höchste Grar in der Umbildung säntlicher Ranken zu belaubten sprosien sich liem zeichnet. Die Rauken beim Weinstock sind Achsenorgane, deren Ansbildung von der Nenge und Beschatfenheit des vorhandenen organiss.hen Bammaterials abhängt: hei jüngeren Reben werlen sie zum hrantartigen Triebe, bei älteren bilden sie sich an den unteren Augen zn Bliitruständen aus. Wenn num alle Ranken zu beblätterten Trieben werlen. muls die vegetative Bildungsichtung krankhat't überwiegen. Dan vor-

') Emerich Rituax, Über die in Nieder-Österreich als "Gablew" odter Zwiewipfler bekannten Reben. Klosterneuburg 188\%.

") Kaserer, H., Über die sogenannte Gablerkrankheit des Weinstocks. Mitteil. d. k. k. chemisch-physiol. Versuchsstation Klosterneuburg 1902. Heft 6. 
handene Bammaterial wird talsch rerwendet. Diejenige Konzentration hes hollsattes, walche fiur die Anlage der Sexualorgane notwendig ist, tritt ben nicht ain. Insofern kamm man Kkasses ${ }^{1}$ ) beipflichten, der rom 'iner Erkrankung des Protoplasmas bestimmter Regionen als Triale des, "Krautins" spricht.

Tremn Kkissek unter Berufung aut die Arbeiten von Kober und

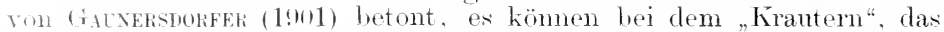
olvn nur ein Torlauben einzelner Knospen darstellt, keine lueitungsstommgen und liein Nährstotfimangel als Irsache angesehen werlen, sondern es sei eine ganz lokale Erkrankmng der Zellen einzehner linospen vorhanden, so widerstreitet dies gar nicht unseren Ansehammgen ïber Vorlaubung. Es ist selbstrerständlich, dats jede Grananlage unter bestimmten Ernährungsverhälnissen erfolot. Dafs dieselben beständig wechselnde und das Produkt der a ugenblicklichen Kombination sämtlicher Wachstumsfaktoren sind, haben wir schon in ten einleitenden Kapiteln zu dieser Autlage hesonders hervorgrhoben. Wir rermögen aber diese Kombinationen noch zu wenig festzustellen. Wir haben eben vorläufig nur einzelne Erfalnrungen larüber, dats z. B. Kali- und Stickstoffüberschufs im Terhältnis zur Trarbeitung der anderen Nährstoffe die vegetative Tätigkeit einseitig anf Kosten der sexuellen Periode steigern. WVasserüberschuts bei verhältnismälsig geringer Lichtzufuhr kam in ähnlicher Weise die Wachstumsichtung beeinflussen usw. Wie derartige Gleichgewichtsstïrungen für jede einzelne Organanlage zustande kommen, ob augenblickliche Hemmungen in der Nährstoffaufnahme oder -leitung die Veranlassung bilden, kömnen wir nicht präzisieren.

Wir kömmen daher oben nur ganz allgemein aussprechen, dafs die Vulaubungen durch ein Übergewicht der die grünen Blätter hervorrutonden Trachstumsrichtung gegenüber dem die Sexualorgane beguinstigenden Wachstumsmodus zustande kommen. Die sogenannten .. ITechslo " orler unechten (tabler sind stöcke, welche teilweise noch fruchthar sind. Unter den Tmständen, welehe die Neigung zur Verlanbmug begünstigen kömmen, führt KAsERER eine ungünstige Lage an, in wolcher Regunwasser aus höher gelegenen Grundstücken sich ansammolt. (iesumle letben in ein Gablemest gepflanzt, sollen sehmell zu galueh berimnen. Superphosphat seheint die Rückkehr zur Fruchtbarkeit zu vermitteln.

Alsmitehlonswertes Mittel betrachten wir den Ersatz der kranken stëcke dmoth wesmele von solchen Sorten, welche reichere Wasserzufuhr und schwrere Börlen reptragen. Die sogen. Gablernester wären

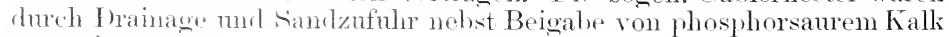
zil verbesseril.

\section{Der Blattfall.}

Der Blattfall, liese nomale Folge des Alters's), erlangt nur dadureh patholegische Berloutmug. tats er unter Umständen vorzeitig in die Erseheinumg treten katmo.

Ine Urachen, welehe soleh rorzeitigen Abwurf der Orane herbeiführen können, sincl rerschiedenartig, unt die entgegengesetzten Witterungsextreme kïmnen eine Veranlassumg bilden. Tomgemäts

1) Krasser, Frumax, Uther eine eigentümliche Erkrankung der Weinstöcke. II. Jahresb. d. Ter. d. Vertreter d. angewandten Botanik. 1905, S. 7.

2) Divater, H., Tersuche und Gedanken zum herbstlichen Laubfall. Ber. d. Theutschen Bot. Ges. Bd. X XIII (1905), s. 463 . 
könnten die Erscheinnugen auch in anderen Abschnitten des Buches behandelt werden. Indes ziehen wir vor, dor Ablösmssoränge in ihrer Gesamtheit hier zu gedenken, weil sie mit fewelseroünderungen verbunden sind, bei denen Turosenzsteigermotn auschlagelsend eintreten, nachdem die Organe ans irgend einer Trsach tinnktionssebwach geworden sind. Betretts der Abläsmwe der Blatter z. B. nuterscheidet $\mathbb{W}_{\text {Iesser }}{ }^{1}$ ) cinen Sommerlaubtall. Treiblanlitall, Hitzelanbtall und Frostlanbfall. Einen Einblick in die Verschiertenartigkeit der Ursachen wewährt uns PFerfek"): „Eine solehe Beschlemigung des Blattfalls wirl z. B. dureh unzureichende Belenehtumg, aber auch durch ungentigende Wasserversoromg mod dureh zu hohe Temperatur herbeigefïlnt. Nicht selten wird aber besonders dureh den plötzlichen W echsel der Antsenberlingmoen ein frühzeitiges Abwerten der Blätter hervorgerufen, das ans naheliegenden tründen znerst die älteren Blätter trifft." Als Beispiele für clen schädlichen Einfluts eines plötzlichen Wechsels in der 'Transpirationsorölse fülnt Pfeffer den plötzlichen Blattrerlust einer Anzahl ron Pflanzen an. sobald dieselben aus der fenchten Treibhaushti in sin trockenes Zimmer kommen; in gleicher Weise kömnen schrotfe Üherwänge der 'Temperatur, dor Belenchtung usw. wirken.

Die anatomischen Vorgänge bei den normalen Alugliederung:prozessen sind von v. MoHI ${ }^{3}$ ) sehr eingehend studiert worden.

Bei den Blättern erfolort eine Abgliederumg darlnrels, dats sith an ler Basis des Blattstiels, in der Regel noch immerhalb des Blattkissens. mol zwar meist dort, wo der Kork der Rinde in die Epidermis des Blattstiels äbergeht, im Imnern des Blattstielgewebes dureh nen anttretende Zellteilung eine quer durehgehende Parenchymschicht ansbildet, deren Zellen in einer Ebene vonemanderweichen.

v. MoH nemt die Kone, in welcher sich die Tremnngsschicht bildet, die "rundzellige sehicht", weil sie ans sehr kurzem, parenchymartigem Gewebe besteht, das nach dem Blattkörper hin allmählich in die langgestreckten Zellen des Blattstiels übergeht, nach der Rinde des Zweiges hin aber scharf abgegrenzt ist.

In sehr vielen Fällen ist die gröne, chlorophyll- und stärkereiche Rinde des Zweiges ron diesem kurzen, meist stärkelosen, chlorophyllarmen, an der Basis zur Zeit des Blattfalls sich hrämenden Parenchym der rundzelligen Schicht des Blattkissens durch eine ans tafeltörmigen Zellen gebildete Korklage getremnt. Diese Korkplatte. welche an den Seiten in die inneren Korkshichten der Zweigrinde übergeht, ist ron SichichT $^{4}$ ) als die Trsache der Abgliedermo der Bläter angesehen worden. In der Tat kann man rermnten. dals, wem sich eine Korkplatte zwischen das Gewhe der Rinde und das des Blattstiels einschieht, das Blatt in seiner Nährstoffzutuhr verarmt mol allmählich zugrunde geht. Democh ist die horkschicht uicht die Teranlassmng zum Blattfall; demn v. Mont hat gezeigt, dat's sie bei vielen Pflanzon mit abfallendem Laule sich gar nicht bildet. so z. B. ist keine Kork schicht zu finden bei den Farnkräutern mit abtallenden TVedeln (I'sly-

1) Wiescer, Jil., Ber. d. Deutschen Bot. Ges. Bd. XXII (1904), s. (it, :316, 501. Bd. XXIII, s. 49.

2) Pfeffel, Pflanzenphysiologie. II. Aufl., 2. Bd. (1904, s. 27-.

3) v. Mин, Über die anatomischen Veränderungen des Blattgrlenkes, welche das Abfallen der Blätter herbeiführen. Bot. Zeit. 1 60, $\mathrm{Nr} .1 \mathrm{n}$. ‥

4) Sснисн r, Anatomie und Phrsiologie, II, 136 . 


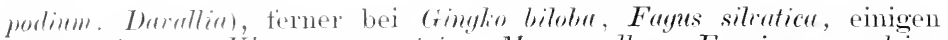
(Der)ens-Arten. Clmms compestris, Morms alba, Fraximus eacelsior,

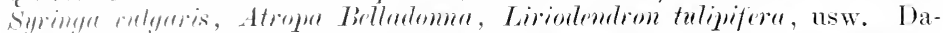
weron bildet sich die Korklage ans bei Popmlus canadcnsis und dilutata, 17mes glutinosa, Juglans nigra, Daphne Mezeram, Sambucus racemosa,

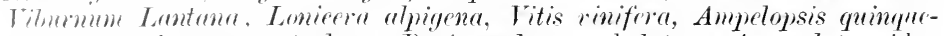
folia. Arsculus macrostachya, Paria rubra und lutea, Acer platanoiles, I'rmmes Patus, liobinir P'studucucia. Die Korksthicht ist also nur als eine schutzschicht des durch den Blattfall blofsgelegten Rindengewebes zu betrachten, die sich häufig schon ausbildet, bevor das Blatt abgefallen ist.

Die eigentliche Trennungsschicht hildet sich über der Korklage in dem tast isodiametrischen Parenchym der rundzelligen schicht und zwar auch noch nicht in tem direkt an den Kork grenzenden, braunwandigen, sondern in dem auf diesen folgenden, hellwandigen, gesmuden 'Teile. Dort zeigt sich kurz vor dem Blattfall eine quer vor dem Auge nach der Aufsenseite des Blattstiels verlaufende Zone jugendlicher, zartwandiger \%ellen mit weniger lufthaltigen Intercellularräumen und kleinen, soust im Blattstielwulste nicht vorkommenden Stärkekörnem. In dieser nengebildeten Gewebezone weichen die Zellen, ohne zu zerreitsen, lediglich rlurch Abrundung, wie schon INuAN ${ }^{1}$ ) beobachtet, auseinander. Ein Teil verbleibt dem abknickenden Blattstiel, ein anderer der Blatmarbe, an welcher er bald vertrocknet. Der Blattfall ist demnach ein vitaler und kein mechanischer Akt. An den Veränderungen, welche das Zellgewebe des Blattstielwulstes erfährt, nehmen die Gefäfsbündel vor dem Abfallen des Blattes gar keinen Anteil. Diese laufen, ohne ihre ()ganisation zu ändern, ja ohne sich zunächst braun zu färben, durch di" rundzellige Schicht und die Korklage hindurch. Der Bruch derselben tritt, nachdem der Rifs durch das parenchymatische Gewebe ertolgt ist, auf rein mechanische Weise ein.

Bei manchen Pflanzen (Nuhlıar, vielen Monokotyledonen, krautartigen Farnkläutern ${ }^{2}$ ), bei denen keine Korkbildung an der Blattnarbe vorkommt, gehen die äuseren, vertrockneten Zellkchichten der Blattuarbe umittelbar in das gesunde Rindenparenchym über und werden dureh Writerentwicklung desselben ebenfalls abgestofsen.

v. Bretfeli ${ }^{3}$ ) kommt zu dem Resultate, dat's der Ablösungsvorgang der Blattorwane hei clen Mono- und Dikotyledonen derselbe ist; nu der schluts der Ablösmngsfläche ist bei verschiedenen Gattungen ein vershiedener. Ein wesentlicher Untersehied besteht aber in der Zeit ler Bildumg der Grabezone, in welcher die Tremmungschicht entsteht. Während hei den Jikotrlen der Ablösungsprozets das Produkt einer kmrz vor dem Alifall rintretenden I cebenstätigkeit ist, zeigt sich dieser Vormang bei chen banmartigen Monokotrledonen, Orchideen und Aroideen als ein, llureh Anlage ciner hestimmten schicht vorbereiteter, mit der allgemeinen Gewohedifferenzierme fortschreitender Akt.

Von den Aurch Wasseriiberschuts veranlatisten Fällen des Blattalwwurfs wären die bei Glashauskulturen vorkommenden Entblätterungen ron krant- oler straurhartigen Begonien. von Cistus-Arten, sowie von manchen neuholländischen Myrtaeeen und Leguminosen zu nemmen. Der Wasserauttrieb wirl durch reichliches Begiefien der Pflanzen zu oiner

1) Bot. Zeit. 1850, s. 198.

2) v. Muн, Über den Vernarbungsprozefs bei der P'flanze. Bot. Zeit. 1849, S. 645 .

3) v. Bretres, Ül,er den Ablösungsprozefs saftiger Pflanzenorgane. Bot. Zeit. 1860 , S. 273 . 
Zeit minimalster Blatttätigkeit übermä1sig gesteigert. Die Bruchflächen der abfallenden Blätter sind hisweilen ganz melılig durch die gänzlich gelockerten Zellen der Trenmmgstläche.

\section{Die Schüttekrankheiten.}

Den bedentsamsten Fall vorzeitigen Blattabwurf hilden die sich üt te kranklieiten. Wir sprechen hier von ler Mehrzahl, obwohl man vorzugsweise einen plötzlichen Nadelabtall junger Kiefern als "Śchütte" zu bezeichnen pflegt. Es kömmen alle Pflanzen „schütten", welche überhampt ihren sterbenden Blattapparat alzugliedern imstande sind. Es handelt sich eben nur darum, ob der Blattkörper in seiner Gesantheit plötzlich tunktionsschwach oder funktionslos wirc. Nur weil bei der Kiefer der Fall so mgemein häufig und von schweren Folgen begleitet erscheint, hat man die $\mathrm{K}$ iefernschütte spezicll oft als "Schütte" angeführt.

Diese Krankheitsform äufsert sich am häufigsten und schwersten an zwei- bis vierjährigen sämlingen, deren Narlehn im Frühjalnr plützlich bramngelb oder brammot werden und nach kurzer Zeit abtallen. Die grötsere Verbreitung dieser Erscheinung datiert erst von einer allgemeiner gewordenen Änderung der früheren Kultumethode der Samenschläge und des Femelbetriebes, an deren stelle jetzt die Erziehung der Pflanzen in Saatbeeten getreten ist.

Seit dieser Zeit ist heobachtet worden, dafs in den Monaten März bis Mai manchmal binnen wenigen Tagen grotse Flächen von sämlingspflanzen wie verbrannt aussehen. Dabei aber kam man benerken, dats junge Pflanzen unter dem Schutze eines nicht sehr geschlosisenen Naclelwaldes oder gemischten Bestandes oder auf ron alten samenbäumen beschirmten schlägen nicht schütten, während kahle Flächen im Freien oder in geschlosienen Lagen von der Krankheit antiserordentlich heftig heimgesucht werden. Festutztwuzelige Exemplare leirlen mehr als solche mit langen, krättigen Wwzeln, mi Pflanzen ant nassem Boden an intensivsten. Gebirgslagen sind weniger heingesucht als die Ebene, und die Nordseiten scheinen fast vollständig verschont zn bleiben, während Süd- und Westseiten stark leiden.

Die Krankheit zeigt sich nicht alljährlich, sontern meist nur nach natskalten, schmeearmen Wintern mit abwechselnden scharfen Frösten. Am stärksten schütten die Pflanzen in trocknen Frühjahren, wo März und April durch helle, warme Tage und darantfolgende kalte Nächte ausgezeichnet sind. Manchmal tritt die Erscheinmo strich-oder fleckenweise ant. Es wurde ferner beobachtet, dats Ptlanzen, welche durch einen benachbarten Holzbestand u. dgl. vor cler Mittagssonne geschützt waren, meist nicht erkrankten. Saatbecte, welche bis über die /eit der Frühjahrsfröste hinans herleckt blieben, schütteten nicht, während nebenan liegende, schutzlose Saaten schütteten. Samenptlanzen, welehe zwischen älteren Ballenpflanzen oder zwischen Besemptriemen antwuchsen, selhst solche. rlie untrr hohem (irase geschützt standen, erkrankten nicht, wälnend sie da, wo z. B. die Besemptriemen im Friihjahr herausgehamen waren, von der schïtte betallen wurden.

Alle diese Tatsachen erklärt EBermarer ${ }^{1}$ ) ungezwngen duredl die

1) Eвғвматғ, Die physikalischen Einwirkungen des Waldes auf Linft mul Boden usw. Resultate der forstl. Versuchsstat. in Bavern. Aschaffenburg 1<is?. Bd. I, s. 251 . 
mahrjahrigen Beobachtumen der forstichen Versuchsstationen, dats im März nut April die Bodentemperatur bis zn $1^{1}+$ Meter Tiefe kam 4"R. heträgt. wähend die Luftemperatur im Schatten nicht selten 1111 1:5-18" R. höher ist.

1) im umittelhare Folge solcher Temperatmolitterenzen zwischen Luft und Borlen ist die, dats die oberirdischen Ptlanzenteile stark rerdunsten, während die Wureh. durch die Borlenkälte noth in Untätigle it zurückigehalten, nicht imstande sind, das Bodenwasser anfzunehmen oder doch nicht im gehörigen Mal'se autzunehmen. um den oberirdischen Wasserverlust zu ersetzen. Somit vertrockuen die jungen Kiefern selbst hei reichlicher Bodentenchtigkeit.

Je grötser num ler Tnterschied zwischen Boden- und Lufttemperatur im direkten sommenlichte, desto hänfiger und verheerender die schütte. J. mehr dacegen Umstände eintreten, welche die Bodentemperatur erhöhen. wie warme Frühjahrsregen, orler die stärkere Abkühlung vorher verhindern, wie lange liegenbleibende schneemassen oder Strenleckmug, desto weniger wird die Krankheit anftreten. Dasselbe wird stattfinden. wemn die Luftemperatur und die Intensität des Sommenlichts verminulert werden, wie z. B. durch hänfig bedeckten Himmel, Lage an Nordabhängen, muter dem Schntze von Oberholz, hohen Gräsern oler sträuchern oder bei künstlicher Beschirmung der Saatbeete während des Tages.

Daís ältere PHanzen von der schütte seltener leiden, erklärt sich eimmal aus dem stärker entwickelten Holzkörper, der für alle Pflanzen als Wasserreservoir anzusehen ist, zweitens ans dem reichlicher entwickelten, tiefer gehenden Wurzelkörper, welcher in der grölseren Anzahl Faserwurzehn mehr Aufnahmeorgane besitzt.

(iegen diese Ansicht hat sich HoLzNer ${ }^{1}$ ) mit dem Einwurf gewendet, dats die Terfärbung bei der Schütte bimen 2-3 Tagen eintritt, während hei rinem eigentlichen Vertrocknungsprozels die Kiefernadeln um allmählich sich röten. Er hält eine direkte Frostrirkung für die Ursache. balis Frost auch eine Veranlassung zul Schüte ahgeben kam, ist feststahend. Bsinst. ${ }^{2}$ ) hatte sämlinge durch Auflegen von Reisig auf $1 \mathrm{~m}$ von dor Borlenobertläche entfernte Rahmen geschützt. Die bis dahin gesmul gebliehenen PHanzen litten nach Entfermung des Schutzes durch ilie Aprilfroste.

Manclie Antoren schreiben anch schon den Herbstfösten einen schärtigenden Einflutis $z{ }^{3}$ ). Die zmzeit verbreitetste Theorie ist, die Krankfreit als rine parasitäe anzusprechen mol remgemäts mit fungieiden Mittehn zu behambleh. Lafs es anch parasitäre schütten gibt, ist nach

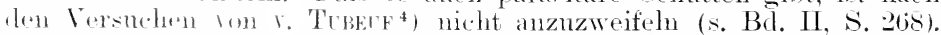
Nur ist dabei dir Tatsacho zu berücksichtigen, dal's die schüttepilze auf Kiefernarten. Tann’n, Fichten nmel Lärchen, an älteren Bäumen häufig

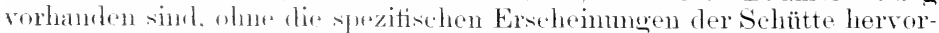
zurufen: es müssen also bei der so gefürchteten .Jugenderkrankmg

1) Honzra, (ifori, Die Beobachtungen uber die schütte der Kiefer oder Föhre und die Winterfarbung immergriner Gewähse. Freising 1<77. Hier Literaturnotizen von 145 Arbeiten iibar die sichïtte.

2) Centralbl. f. d. ges. Forstwesen VlJ, 1881, s. 362.

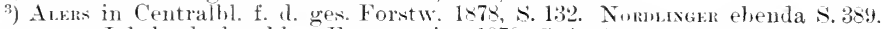
Dumss u. a., Jahrbuch d. schles. Forstvereins 1878 , s. $40 \mathrm{ff}$.

4) r. Tíығ, studien uber lie Schüttekrankheit der Kiefer. Arb. d. Biolog. Alt. an Kais. Gesumlheitsamt. Il. Heft. 1901. 
noch speziell heginstigende Unstände hinzntreten, ohne welche die Epidemie nicht zustamile lommt.

Die sämtlichen als Ursache der sohütte angwöhnten Falitoren stimmen darin äberein, dals die Nadeln darum fallen. Weil sie fimlitionsschwach geworden ofler infolge der winterlichen liule nomalerweise es moch sind. Num berulit aber der Abgliedermespromeds anf Aus-

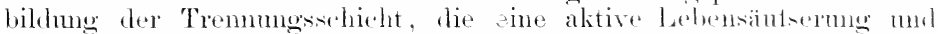
Turworsteigerumg vorausetzt. Somit ergibt sirh ein Antagonismus: Das Blattorgan ist zumeit anfserstante, als nomales Anziehumes- nul Verbrauchszentrum zu funktionieren. Nur der Basalteil, die Region der syäteren Tremumgsselicht, ist vernöge seines matomischen Bands erregbar und wird zur Ausbilımg dieser sclucht vorzeitig angeregt, weil die Turgorsteigerung, die dureh zeitige Besommong im Frïhjhar nen eintritt oder von fiüher noch erhalten ist, keinen Ansoleich finclet, indem eben der muätige Laminarteil des Blattes ihm das Masser nicht

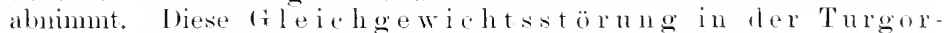
verteilnng ist die Urache alles vorzeitigen Blattahwurtis.

Im speziellen Fall der Kiefernschüte wlaube ieh, dats die von Ebermarek geschilderten Gegensätze mal zwal gerade die schrofted Gegensätze die häufigste Veranlassmg tür die sichüte darstellen. Nur in der Erklärung weiche ich insoferm vom ihm ab, als ith statt übermäsig gesteigerter Nadelverdunstum elen noch die winterlich Untätigkeit, die sich auch in der Besehatfenheit des C'hlorophyllkörpers zeigen wird, annehme. Nur die Nadelbasis wird erregt und hildet die Tremmmgsischicht ans, die, wie wir bei den Blumenblättern erwälnen werlen, unter Unständen in äutierst kurzer /eit entstehen kann. Ich meine, die Nadel verdurstet nicht. sourlern wird eben durch dir. Tremmugsolicht a us dem Betriebe a nsegenaltet. Latis nicht ein Vertrocknen der Nadeln infolge übermälsig westeigerter Verdmstmen

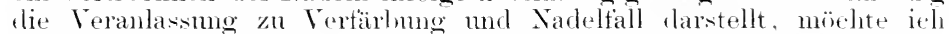
aus der absolut geringen Wasserabgabe der Kiefer in Winter ontnehmen. Ein Wasserkulturersuch mit einjälnigen sömlingen zeigte mir, dats eine Kicter an 17. November ihre Verdunstung einstellte. trotzdem noch Tage mit $+: ;, 4,7,90$ ('. foloten: sie verimnstete his zmm o.2. Dezember nicht ein einziges Gramm Waster melur obgleirl die Wurzel in Wasser stand '). Es ist also kaum anzmelnuen, dats die Friihjahrstemperatur in eingen Tagen einen glofisen Wasserverlust amegen sollte, zumal die Kiefer eine der am geringsten verduntenden Bammarten ist ${ }^{2}$ ).

Da zwar nicht ein Vertrocknen der Nadel, sondern der mangelnule Ausqleich der Wasserzutidn infolge des schotten (ienensatzes zwischen der assimilationsschwachen Nadeltläche und ilner bereits tätigen Basis mir als Ursache der sichütte erscheint, so mochte ich in dre Ver-

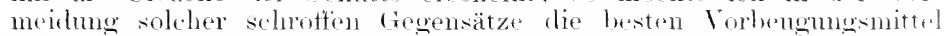
sehen. Ieh schlietse mich deshalb ten Vorschlägen von Exskrsser an. welcher empfichlt:

A. Erhöhmng der Bollentemperatur: 1. dureh Verhütung einer \%n starken Erkältung wälnend des Winters mit Hilfe von Lanb-. Fieisigoder Moosdecken: 2. bei nassem Boden dureh Entwässermun: :;. Lui

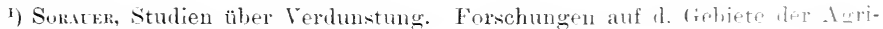
kulturphrsik, Bd. III, Heft 45 . \. 10.

?) Hinsel, v., a. a. O. Bd. II. S. 411 . 
fisten Boldnaten durch Lockermo und Beimischmo lmmmsreicher Erole. woluch die I antwäme leichter eindringen kamn.

B. Verminderung dersharfen Kontraste dureh Beschattmo: 1. durch Bestechne ler satheete mit Narleholzzweigen, die aneh an warmen Tag+n nichit zu entfernen sind: 2). dmeh Anlage der Saatheete an stollen. Welche ant der Mittagsite Schutz durch Holzbestand haben.

Bei den Kiefern-Verjüngungen im grotien wird das radikalste Wittul darin hestehen, von der ansgedehnten Kahthiebwirtschatt wieder mehr zm schlaywirtschatt zurïkzukehren, damit die jungen Ptlanzen hmch ()herholz (nätige Überschimmong) den nötigen Schutz gegen das direkte somnenlicht erhalten, aber doch so viel Licht emptangen kömnen, als zu ihrer liräftigen Entwicklmng nötig ist. Derselbe \%weck wircl erreicht durch die von No, nach sW. vorrïtkenden, schmalen Absämmmgen, welche gegenwärtig bei den Verjüngmoen der Kiefernhestände viclfach in Anwendung kommen. - Bei der Kultiviermo aussedehnter Blötsen kamn die Beschattmo anch erzielt werden durch den Torhan solcher. Ptlanzen, für deren Gedeihen der betreffende Standort giunstig ist, z. B. ron Birken usw. oder durch roransgehende Fichtenl, Hlanzung."

"In solchen Fällen, wo ein Vorban ans lokalen Grïnden nicht angeht, ist die Ptlanzmng der Saat vorzuziehen reinjährige Ptlanzen mit gntem Wruzelsystem scheinen sich dazu am besten zu eignen), immerhin werden aber die heiden ersteren Kultmmethoden weit sicherer zum Ziele führen."

Schliefstich wird noeh zu betonen sein, dats alle Aufmerksamkeit auf Erreichung eines guten Wurzelkörpers zu richten ist; demnach sind zu dichte saaten, schwerer, moelockerter Boden, bedentende Verletzmoen bei dem Verptlanzen n. derol. zn vermeiden.

Eine schüite bei älteren Bänmen kommt anch vor. Bei Pflanzen, die ant monrixem Borlen in Nebellächern stehen oder in extremen Frostlagen sich befinden, fallen vorzeitig die älteren Narlelbüschel. Aber diese hängen damn sehon vergilbend oder vertrocknend im Herbst an den Bännen mul muterseheiden sich dadurch von den spezifisch schüttekranken sänlinwstlanzen. Auf strengen Böden stirbt äberhanpt die Kiefer lejeht ali').

\section{Der Blattfall bei Zimmerpflanzen.}

Ln den sihnerzenskindern bei der Zimmerkultur gehören die Azaleen. weil sie in der Regel pötzlich im Sommer oder Herbst das lanb fallon lassen: di" hesenartig anssehenden Bäumchen bringen hörhstrns pinige liommerliche Blmmen. Anch hier handelt es sich um plïtzlich antrotumle schotfe tregensätze. Entweder werden im sommer eimmal die (meist in Iloikferde stehenden) PHanzen trocken im Ballen, and ss erfolgt damn eine sehr reichlicho Bewässernng, oder die Pflanzen weden im llerbst zn pïtzlich in das warme Kimmer gebracht. In beiden Fällon sind tio Blätter funktionsschwath mo erhalten num durch den erhöhtru Wasserantiel, einen Anstots zm gesteigerter Funktion. Wïrde der Öbergang allmählich erfolgen kömen, so dats die mntätigen Blattflächen \%eit fiäten, durch allgemeime langrame 'Turgescenzsteigermng ihren normalen Betrieh wieder anfzunehmen, wiorden dieselben Ver-

1) Roximaly, A., Das Absterben und die Bewirtschaftumg der Kiefer im stangenholzalter usw. Zeitschr. f. Forst- u. Jagdwesen 1\&92, s. 43. 
hältnisse schadlos vorübergehen: aher bei der Plötzlichlieit des Wasseranftriebs wird nur die Basalregion erregt und zor Anshildung der Tremmugsichicht veranlatist.

Bei den Blattbegonien, bei dem (immmibam, bei Kamellien und vielen anderen Gewächsen stellt sich im Herbst und Winter ein Ablösen der Blätter ein. Hier ist der Blattapparat in der natïrlich eingetretenen Vegetationsruhe. Reiches Begiefsen im warmen Zimmer veranlatist ein Zuströmen von Wasser, das die Blätter nicht zu verarbeiten vermögren.

Hier in Kürze noch einige eigene Erfahrungen. Begonin furhsiondes, die den Winter über im sehr warmen Zimmer getrieben hatte, kam Ende März in eine ungeheizte, aber somigere Stube und warf himnen wenigen Tagen sämtliche Blätter mit Ansnahme der jüngsten ah. Libonia floribumdu, die bisher sehr kalt gestanden, kam flötzlich zom Treiben schon im Dezember ins. Warmhans, und die Exemplare warten alle älteren Blätter, während bei den im Kalthanse verbhiebenen Pflanzen keine Entblätterung eintrat. Von einer gefüllten, weifsen Fuchsie waren einzehre Exemplare im Herbst ins Zimmer genommen worden, um fï̈̈hzeitig Triebe tüir Stecklinge zu erzielen: andere Exemplare dersollen Varietät verblieben im Keller und trieben bis Anfang März. Zu dirser Zeit wurden die spitzen sämtlicher Pflanzen als Stecklinge in einen Kasten mit 250 Bodenwärme gehracht. Nach wenigen Tagen waren die ans dem Keller stammenden Steeklinge bis auf die Spitze entlaubt, während die anderen noch nicht einmal clas Blatt an dor Sehnittlläclese abgestofien hatten. Die Spitzen eines wenige Tage spätor von einer Kellerptlanze abgebrochenen Astes wurten ohne besondere Rücksicht im Keller in Samil gesteckt und zeigten sich im Mai bewurzelt, während die von den Kellerptlanzen kommenden Zweigspitzen im warmen Kasten zugrumde gegangen waren.

Für die Zimmerkultur darf als Grundgesetz emptohlon werden, dats man die Pflanzen nur allmählich an andere Vegetationsbedingmeen gewöhuen soll und die Zeit der Vegetationsruhe, in die jede Pflanze eintritt, nicht durch Steigerme von Wärme- und Wasserzufiuhr unterbrechen dart.

\section{Der Ablösungsprozefs der Blütenorgane}

erfolgt in derselben Weise wie der der Laubhlätter ${ }^{1}$ ). Die zusammengesetzte Achse des Blütenstandes hei Aesculus und Pavin zergliedert sich hekamntlich in ihre einzehnen Teile, dir mit glatter Bruchfläche auseinanderweichen: ohenso löst sich oft, wemn viele Früchte angesetzt werden, eine Menge halherwathsener Früchte in einem Gelenke ab, welches sich im Fruchtstielehen befindet. Die mämnlichen Blumen der Cucurbitaceen lösen sich in einer Tremmungschicht ab, welche sich an der (irenze zwisehen Blütenstiel und Blüte hildet und die von Ririms. commmis in einer Tremungslinie, welche in einem, im unteren Teile des Blïtenstieles liegenden dielenke entsteht. Dir mbefruchtet w.

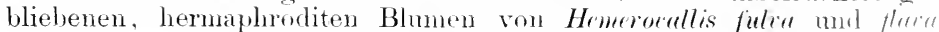
lösen sieh in einer Tremnungssehicht, die nnter dor Basis dor Bläte. durch den oberen Teil des Blütenstiels verlänft. Dis \%ollen ilen Trennungsfläche rumden sich ab und weichen anseinander. 1860 , S. 273 .

1) v. Мoнı, H., Über den Ablösungsprozefs saftiger Pflanzenorgane. But. Zeit. 
Auf oleiclue Weise zeigt sich eine lentlich ansgebildete Tremmingschicht zmzeit des Abfallens bei den Keldhblattern von Paparer sommifrmm. Livindembom tulivifora, bei dem abfallenden Teile des Kelches von Hirabilis. Jalaja, Matua Stramomim, bei den Blumenblättem ron Rosa camina, Paparer der einblätrigen Blumenkrone ron Lonicera Caprifolinum, Rihododendron punticmm. Latura Stramomiam, bei den Staubfäden ron Lilium bulbifermm und Hartagon, Dictamms Fraximellu, Liviodendrom, bei alem tritfel rom Lomieera Caprifolimm, Mirabilis Jalapa und Lilinm Martayon.

In den meisten Fällen enthalten hier die Zellen der Tremmungschicht keine ofler wenigstens nicht mehr Stärke als die Umgebung, während hei den Laubhlättern und bei den derben Kelch- und Blumenblättern von Livindmdiom reichlich stärke vorhanden ist. Dieses Fehlen der Reservenahrung erklärt sich durch die schnelle Bildung der 'Tremmmgsichicht bei den Blüten, tür die das augenblicklich bewegliche Nährstoffmaterial auswicht. Bei den Kelchblättern von Paparer sommiform entsteht die Trennmoss.hicht in einer einzigen Nacht, bei den Blumenblättern nicht gefüllter Rosen in den Nachmittagsstunden. Während hei den Laubblättern in der Tremmugschicht noch eine Zellvermehrma einzutretrn scheint, findet diese bei den Blumenblättern wohl kamm statt, sondern es bestehen die hier sichtbaren Vorgänge nu im Aut'treten einer reichlicheren Nenge ron Protoplasma, in Lockermo mo regenseitiger Tremmug mter Abrundmo und bisweilen schlanchartiger Tergröserung der Zellen, wodurch die Tremmungfläche das sammetartige Ansehen erhält. Je besser die Organe emährt werden, desto später tritt die Tremmungsschicht auf.

\section{Das Abröhren der Weinblüten.}

Unter ..Abrährn" oder "Durchfallen" verstehen die Weinbaner ein Ahtallen der Blïten bald nach der Blütezeit. In einzelnen Gegenden ist die Erscheinung eine jährlich wiederkehrende, während sie in anfleren Lokalitäten sich nu in einzehen Jahren zeigt, wie $z$. B. in solchen, in denen die Traubenblute durch natiskalte Wittermng gestört wird. Nach den Intersuchungen ron NüLLER-Thukfat ${ }^{1}$ ) zeigten sich bei niedriger 'Temperatur zur Blütezeit schon ror dem Abheben der Blütenhiille die Zallon lir Narbe in beginnender Brämmong, was auf ein Absterben oflu wenigstrus eine starke Belinderung des Befruchtungsvorganges hindontete. T'atsächlich wuchsen tie Pollenkömer aut solchen Narben gar nicht oder nur mangelhaft zu Pollenschläuchen aus. Das Abwerten der Blmmenblattkappe ging selu langsam vor sich oder muterblieh wänzlich. Iro Fruchtinoten solcher Blüten blichen zwar noch

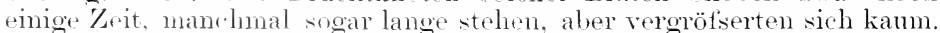
Da num aber nach Noberis Ertahrmgen das Ringeln der Reben gröstenteils hiltt. so int wohl meist nicht die niedrige Temperatur der

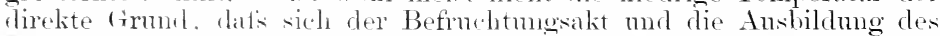

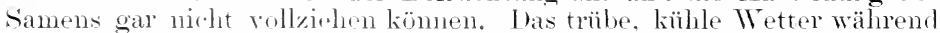
der Blïte ist hesonders gïnstig für das Wachstm der beblätterten Triebe, welche dahro das tü̈ die Ausbildung des Blütenstandes vorrätige Material für sich beanspruchen werden, so dats ein Nährstoffmangel tür die Blmmen eintritt. Ein solches Verlungeru der Blïtentraube

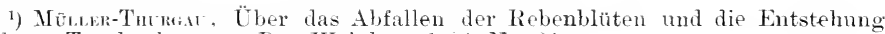
kernloser Traubenbeeren, Der Weinban, 18s:, Nr. 2.2. 
und demzufolge ein mehr oder weniger starkes Abröhren der Blüten wird auch bei günstiger Blütenwitterung eintreten, wrmm roiche stickstoffnahrung im Boden ist oder wenn überhaupt ein jungfräulicher Boden mit reichem Nährstotfrorrat und Wassergehalt zur Winkultur verwendet wird, wobei die üppige Entwicklung vegetativer (1) rane dis Weiterbilelung des sexualapparates einschränkt.

Tätsächlich liefert MöLlek Beispiele tür diese Fälle und teilt gleichzeitig Erfahrungen mit, dat's hald das Auslassen dre biingmug, bald ein langer Schnitt der Reben dem Ïbel abgeholfen haben.

Denselben Ursachen schreibt Mëstek anch das Aufteten kornloser Beeren an der Traube zu. wolches in dre Regel mit einem teilweisen Abröhren Iland in Hand geht. Die kernlosen Beeren sind grötser als die mbefruchtet gebliebenen, die bisweilen anch bis in den Herbst hinein an der 'Traube verbleiben: erstere sind aher nicht so grots. wie die kernhaltigen, normalen Beeren. obwohl sie wie diese sich färben und süts werden. Ja, es stellte sich herans, tats sie trüher reiften und sïfser wuden wie die Beeren mit ausgebildeten samfnkernen.

Da die Samenanlage in den kemlosen Beeren nicht viel gröser erseheint, als sie zur heit der Blüte bereits qewesen, so mul's man annehmen, dafs in fler Blütezeit schon rine Störung stattgetunden lat. Es ist wahrocheinlich, dats in solchen Fällen dir Befruchtung wohl vor sieh gegangen ist, dats aber entweder angenblicklicher Mangel an passendem Ermährmusmaterial oder eine andere störumg die weitere Entwicklung der Eizelle verhindert hat. Der Reiz, don die Befruchtung aut die Fruchtknotenwand ausübt, ist rorhanden, und demgemäls entwickelt sich anch die Berre: da dieselbe num nivhts von dem ihr zuströmenden Nahrumesnaterial zur Aushilımo der Kerms zu verwenden braucht, so schreitet sie den kernhaltigen Beeren antangs in der Entwicklung vorans. Dats der Same als Stotfanziehmoszentrum bei seiner Ausbildung funktioniert, beweisen die Wägungen kernloser und kernhaltiger Beeren. M(ULLer-Thukgat fand ${ }^{1}$ ) das Gewicht des Fruchtfleisches von 101 Beeren bei Riesting:

$\begin{array}{cccc}\text { kernlos } & \text { einkernig } & \text { zweikernig } & \text { normal vierkernig } \\ 25.11 \mathrm{~g} & 58,2 \mathrm{~g} & 7 \%, 2 \propto & 112 \mathrm{~g}\end{array}$

Als Beispiele für die Unterschiede in der stofflichen Entwicklung mag hier ein Untersnchungsergebnis von MünLer bei Riesling angeführt werden. Es hatten am 25. September 100() Beeren:

kernlose ein (rewicht ron $20 k, 9 \mathrm{~g}$, und /ucker 10,$6 ; 3^{\circ}$ o, säure $18,2{ }^{\circ} / 00$

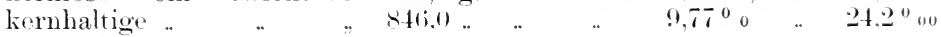

am 12. 1)itober:

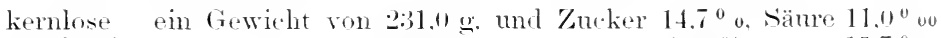

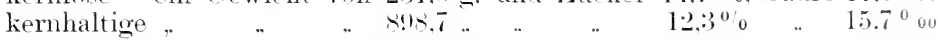

Betreffis des Einflusses des Ringehs lehrte ein Versuch, datis this nicht geringelten Reben nur mbetruchtete Beeren besatien. wolu

1) Mörlen-Thrrat, Einflufs der Kerne auf die Ausbildung des Fruchtileis hes bei Traubenbeeren und Kernobst. II. Jahresbericht d. Tersuchsist. Winlenswil. Zürich 1893. S. 52. 
hald abtielen. während diejenigen Tragreben, welche kuz vor der Blïte serinselt waren, verhältnismätsig lange Tranben mit einer übermä1siog grofsen lahl kernloser Füchte licferten, zwischen denen nur vereinzelt normale Beeren sich betanden.

Diese Bildumg kernloser Beeren ist für msere Verhältnisse eine scotse suärligmen, da die vorzeitig reifen Beeren bis zur allgemeinen Treinlese schrmmpfen und abfallen oder faulen, also keine V'erwendung finden. Wem dagegen diese Ausartung allgemein wird, lälst sich dieselbe als ein Torteif hezeichnen. Wahrscheinh(ch sind msere Korinthen und sultanminen, bei fenen anch Beeren mit Kernen vereinzelt vorkommen. die Prodnkte solcher Stöcke, an welchen die Kernlosigkeit der Beeren zur Regel geworden ist. Setzholz ron Korinthen soll in anderen regenden kernhaltige Beeren lieferm.

Einen she heachtenswerten Rat erteilt EgEk ${ }^{1}$ ), der vielfach Studien über die Inrlivirlualität bei den einzehnen Weinsorten gemacht hat. Er fand dats rinzche Stöcke derselben sorte rlie Trauben stets fiüher zur Reite bringen und manche unter sonst gleichen Bedingungen eine geringere Neigung zum Inuchfallen der Blüten zeigen, was namentlich bei Riesling sehr in Betracht kommt. Demgemäl's mul's man in jeder schule mó jerlem Weinberg die einzehen alljährlich durch günstige Entwicklumg hervorragend bleibenden Individuen bezeichnen und nur von diesen das Setzholz zur Vermehrung wählen.

Andere Vorgänge zeigen sich bei unseren Steinobstgehölzen während der Treiberei. Wemn das Holz zu viel a usoed ünnt wird, d. h. zu viel Laubzweige weggeschnitten werlen, mn den Blüten und jungen Früchten Licht zu schatfen, dam kömen Knospen, Blüten und junge Früchte ahgestolsen werden. Durch die plötzliche Verminderming der verdunstenden Blattfïche stellt sich ein erhöhter Wurzeldruck für die anderen Orwane ein. die die vergrölserte Wassermenge nicht anfnehmen kïmnen. Es lockert sich infolgedessen die Tremmngsschicht. Das Abwerfen wird natürlich auch durch andere Ursachen eingeleitet werden kömmen ${ }^{2}$ ).

\section{Das Abstofsen junger Blütentrauben bei den Hyacinthen.}

Bei llyacinthenzwiebeln haben mir mehrfache Einsendungen ans verschiedenen (tärtnereion gezeigt, dats der Fall einer Ablösung der ganzen noch montwickolten Blïtentraule nicht selten ist. Aus vollkommen gemmlon Ywielseh mit bereits weit entwickeltem, ja häufig ühermätivg gestrecktem Laubkörper lätst sich die noch ziembich kurze ungetänte, ebenfalls ganz gesunde Blütentraube heraushehen. Bei der sehr ïfrrigen, ans Holland stammenden Sorte Baron van 'Thuyll fand ich die sonst normal entwickelten Blätter stellenweise gelblich und an diesen sitellen sehwach geschwollen, ja hier und da sogar geplatzt. Lie Blütentranle war stark, vollkommen gesume, etwa s'cm lang, mit einem dernso langen, wanz pesundem Sehaft versehen und fast noch vollkommen timblios.

Der Schatt hatte sich rom $/$ wiebelboden losgelöst: die Kellen desselben crwiesen sich melir odex weniger sehlanthförmig anfgetrieben, und diese Auftreibung liefs sich von der Bruchstelle aus in wechselnde

1) EaEk, E., Uutersuchungen über die Methoden der Schädlingsbekämpfung und äber neue Vorschläge zu Kulturmafsregeln für den Weinbau. Berlin. P. Parey. 1905 , S. 63.

2) The Dropping of the Buds of Peaches. Gard. Chron. XIII, 1893, S. 574. 
Tiefe hinein verfolgen. Anch die moeambial’n Zellen der Getätsstränge waren blasig erweitert.

Die Gefätive an den Bruchflichen waren sinfach ahgebrochen und besatien zunächst ebenso wie die übrige Bruchtläche vollkommen mgetärbte Wandmngen.

Der Begimn der Jösma zeigt sich tarin, dats einzelne zellen im Basalgewebr des Blötenschattes meist in geringer Entfirmung vom Zwiebelbolen anfangen, sich abzumnden mul vorzmoillen. irleichzeitig mit der beginnenden Wölbung ist eine Quellnng der Mombranen

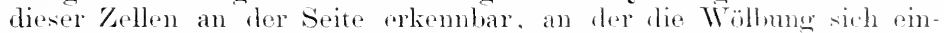
stellt; es ist eine streitige Mittellamelle der Mombranen, welehe in Qnellung gerät. Anch retolgt die quellumg nieht in tor ganzen Membranschicht gleithmätsig. sondern an einzelnen stellen in höherem Grade als an anderen, wodmreh lir gequollene Mombranstreifen einen knotigen, stellenweise Einschürmmgen zeigenden Verlauf erhält.

Bemerkenswert ersheint noch an den der Bruchtläthe naheliegenden Zellen eine häufig antretende, perlig mregehnäsige Besthatfonheit der Autsenfläche der \%elmembranen. Die halblingeligen his zitzentörmigkugeligen Auftreibungen entsprechon denjenigen hei der Wollstreifigheit der Aptel und zeigen mit ('hlorzinkjod eins rein voldgelle Färbmo. während die übrige Membran intensiv ban wird. Liess stiormng stellt sich ein, wenn bei Begimn der IIvacinthentreiberei die tawabeh zn früh hohe Wärme und starke Beräisermng erlalten. Die noch nicht in streckung begriffene Blïtentrambe kann das dmol gesteigerten Wurzeldruck znefïhrte Wasser nielit verarbeiten mol anfinelmen. Danit kommt ein Wasserïhersehuts an der Basis des J3litenschates zustande, dessen Kellen sich strecken und aus ilnem Verbande läsen. Langsames Antreihen der Hyacintlen dïrte dem T̈relstame rorbengent.

\section{Zweigabsprünge.}

Als ..Absurünge" werden diejenigen libinen /woige hezeichnet. welehe sich durch einen manischen Prozeds meist samt ihror ausgelibleten Belanbmo von fler Mntterachse abeliedern. Die Ahgliederung ertolet rorzugsweise im Herbst: doeh liegen anch Beobachtnngen von einem Abwerfen von /weigen im sommer (.Juh) vor. und wir haben werade ebenso wie hei der sidnöte verschiedene Ursachen für dasselbe Phänomen zu berïcksichtigen. Nicht alle frehölzo. zeigen diese Eigentïmlichkeit, mol dir.jenigen. hei druen sie anftritt. wrifen nicht alle Jahre ${ }^{1}$, nud nieht in allen Exemplaren. Jnnge. kräftige Bämme zeigen manchmal kein Alswoüne. Während älter

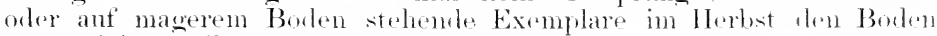
unter sich mit ihren Kwrigen bedecken.

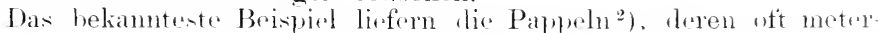

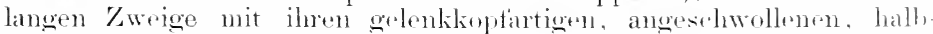

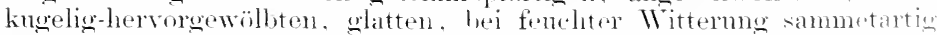
schillemden Brnchtlärhen am dentlichsten anch zeigen, datis der Zwoin

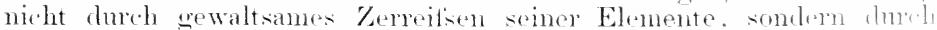

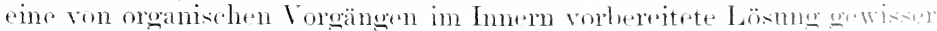
Gewebezonen sich ablöst.

1) Burkutsex, Forstbotanik I, s. 2!4t

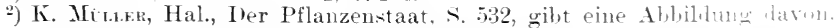


Neben den Pappeh werden vorzugsweise die Absprünge der Eichen ${ }^{1}$ ) erwähnt: hei den Fichten kommen autser den häufig zu tintenden. von den Eichlömchen abgehissenen Zweigen ${ }^{2}$ ) (Abbisse) wirliche Alsprïnge wahrschemlich nicht vor.

Benhachtet ist ferner noth eine Ablösmg der Zweige (Phyllocladien) les Xylophylla und Ihyllorladus ${ }^{3}$ ), bei allen Dammara-Arten, vorzüglich schoin nach A. Brann hei Dammara anstralis, bei mehreren PodocarpusArten, hei Guajaceen, Piperaceen, vielen stranchartigen Acanthaceen, bei Lanres Camplora, Corssula arborescens, Portulacaria afra, Tarodium distichum ${ }^{4}$ ), bei Tilia ${ }^{3}$ ), bei ITmus pendula, Exomymus, Prumus P'udus, Ericu. Sali.i usw. $\left.{ }^{4}\right)$.

l)icen thsnüngen vertanken die Bämme teilweise ihren charakteristischen Habitus. Aluer der Ablösmosvorgang weehselt nach standort, Witterumg und anderen Einwinkmgen. So hebt Röst beispielsweise hervor, dats bei anhaltender Inüre die Absuninge bänfiger sind, dats in der Mehrzahl der Fälle seitentrielse abgeworfen werlen, bei manchen Pfamzen aher anch der (xipfeltrieb. Letzterer Fall wird am häufiosten hei jumgen, in finchtharem Boden erwachsenen Bäumen beobachtet. NönuLINiER ${ }^{5}$ ) heht hervor, dat's vorwiegend schwachwüchsige /weige sich aligliederm.

sowie win emen sommerlaubfall haben, finden wir bisweilen anch sommerliche Absprünge. Gymmocladus, Catalpa bignomioides, Gileditschia, Titia und hesonders Ailanthas glandulosa zeigen die sleiche Bildumg siner Tremmugschicht mol das Ansemanderweichen der zellen wie lie Blätter. Bei den jumgen Triehen von Aitanthes läfist sich gut beolachten, dats an der Bildmo der Tremmosschicht neben dem Paranchrm anch tie noch nicht verholzten \%ellen der Gefätshïndel sich heteiligen. Kork ist $\mathrm{mm}$ diese heit weder in der Nähe der Ahlismmstelle noch an der Obertiäche der Zweigninde entwickelt, wolumeh wir wiederm bestätigt sehen, dats der Ablösmosprozefis nicht ant dor Billmo einer Korkschicht berulte diese ist nur als eine lald

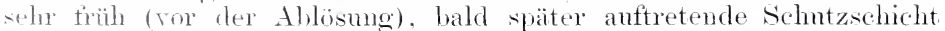
des firigelesten, parenchymatischen Gewebes zu betrachten.

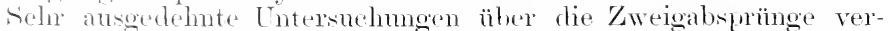
danken wir i. Hönet $\left.{ }^{6}\right)$, der besouders anch Coniferen in den Kreis

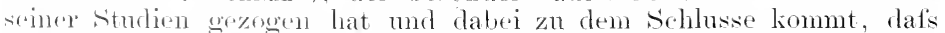

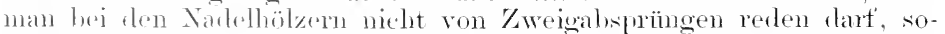
hald man damuter das Abwerten lebensfrischer und saftiger Zweige versteht. Bei den ('omiferen stirht nämlich der abzuwerfende Lweig

1) Tu. Hanmi, Naturereschichto d. forstl. Kulturptlanzen, S. 119. Pғи, Deutsche

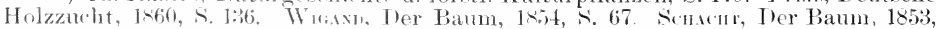

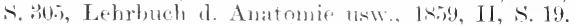

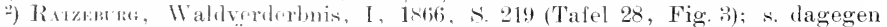

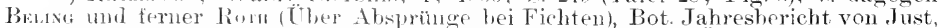

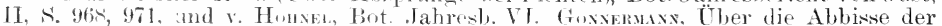
Tammen und Fichten. Bot. Keit. von v. Nohl und śchlechtendal, 1865, Nr. 34. Ruiss, Bot. Zeit. 186.5, Nr. 41.

3) v. Mum, Ther den Ablismosprozefs siftiger Pflanzenorgane. Bot. Zeit. 1860, s. 274 แ. 275 .

4) Ruse, Üler die "Absprïnge" der Bäume. Bot. Zeit. 18tin, S. 109 (Nr. 14).

5) Ninnuxies, Deutsche Forsthotanik. 1874, I, s. 199.

6) v. Hinst., Uler den Ablösmmgsorgang der Zweige einiger Holzgewächse und seine anatomischen Irsachen. Mitteilungen aus dem forstlichen Fersuchswesen Österreichs von v. Seckendorff, III, 187., 5. 25.5. Weitere Tntersuchungen ïler den Ablösungsvorgang von verholzten Zweigen. Bot. Centralbl. 1880, S. 177. 
zunächst am stamme ab und wird gelb oder hram : erst nachdem er schon tot ist, wird er anf gesetzmätige Weise mul immer dureh Vermittlung einer Korkschicht abgeworten. woled ler Holzkörper an einer bestimmten stelle bricht. Die Kweigabspünge der Lanhlı̈̈lzer werden im lebenden und saftigen Zustande durch Vermittlung einer den dicken Holzkörler quer durchsetzenden Parenchymzone ohno Mithilte einer Korlischicht abgeworfen.

Das Alter iler normalen Abwürfe ist sehr verschioden. Bei Turndimm sind sie immer einjährig, bei L'mus Strobns immer dreijälrig. bei

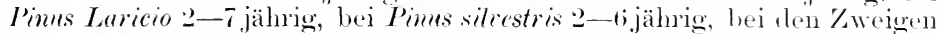
von Thuja accidentalis 3-11,jährig. Dafs Fichte mal Tame keine Al.sprünge machen sollen, ist bereits anfangs erwähnt worten. Indes erinnere ich mich, anch rimmal trische Fichtentriebe mit gelenkloptartiger Abgliedermo gesehen zn haben.

Bei den Laubhölzem kam man dentlich brmerken, dats meist die ans seitenknospen oter Adventivangen hervorgegangenen, oft sehwächlichen Triebe abgestotsen werclen, lie sich blotis zu Irurztrieben entwickelt haben. Langtriebe werden nur reichlich bei Papjeh und Weiclen, bisweilen anch bei Eichen abgestotisen, mu zwar ältere bis dijälnige Äste). In seltenen Fällen beobachtet man den Vorgang anch hei Prumes I'udus and Exomymus rntopura, während bei den anteren Gehölzen meist nm einjährige 'Triebe aboeworten werden.

Für ms beachtenswert ist die Beobachtmo von v. Hönxel hei Thuja occidentalis, dats der Holzkïrper an der späteren Abschmörmnssstelle berlentend schwächer entwickelt ist als ober- orler muterhall, derselben. An der suateren Bruchstrlle ist derselhe besonders stark eingeschnürt. Die Zellen tes Rindentarenchrms rergötsom sich stark. so dats eine namhafte Lockermo entsteht. Bei Thujn orimtulis fehlt das theischige Zweighissen, mn es zeigt sich hier kein regelmätsiger Abwurt. Bei Ampropsis quinquefolia sah IEenax ${ }^{1}$ ), dat's las hasale luternodimm stelien bleibt ma im nächsten Jahre nene Triebe bringt, welche sich bei Eintritt kalter Wittermg wiederm aloliedern.

Für die Zweigabsprünge ergibt sich dasselbe Gesetz, das wir für ten Laubfall anfoestellt haben: her Terbrauchsherd, also hier der \%weig, bildet ans ingend einer Ursache nicht melir das mormale Anziehungszentrum fïr das mgeschwächt zuströmende Wasser, mnd es tritt infolgedessen Wasserüberfïllmg in der noch reaktionsfähigen, anatomisch abweichend gebanten Basalzone ein. Entwrder sind die /weige von vornherein schwächlich angelegt, oder sie hommen durch moinstigen standort zu geringer Entwicklme oder werken durch grotse sommertrockenheit vorzeitix reif oder sincl dureh Kälte alitionsmüahg geworten nsw. Erst aut das lebenssehwache Organ macht sich der relative Wasserüberschnts an dessen Basis geltend. Entwickelt sich dasselle von Anfang an hei orofiser Wasserzutuhr, erfolot kein Alwurt. Fenchte Jahre zeigen wenig orler lieine Absuringe. Dir bej Forstmämern vorhandene Ansicht, dats . Jahre mit viel Absprünen gute Samenjahre rinleiten, hat eben ihre Begrïndmer darin, dats ites

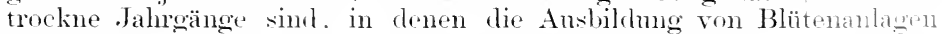
begiinstigt wirl.

Tenn die Absprünge in Forstbetriehe auch wenig wirt-chattliche.

1) Meshox, On disarticulating branches in Ampelopsis. Aus .. Proceet. of the americ. Acad. of Philadelphia. Part. I, 18>0, im Bot. Centralt,1. 1.- \$. 1005. 
Bedentmo hahen. so erlangen sie bei dem Gartenbau aber eine Wichtiglieit als symptom. Namentlich zur Herbstzeit gliedern sich bei vielen mserer tilashankituluren dic stengelgheder ab. wie namentlich bei den stranchartigen Begonien, Melastomateen, Acanthaceen usw. Das sind richere Anzeichen von Wasserüberschufs, und ein scharfes Trockenhalten der Töpfe allein ist imstancle, die Pflanzen vor Erkrankung zu bewahren.

\section{b. Erhähung ler Nährstofflonzentration.}

Unter den in diesem Abschnitt zu hesprechenden Krankheitserscheinungen müssen wir anch noch einige Fälle behandeln, bei denen ein Wasserïberschuts im Pflanzenleile nur stellenweise zum Ausdruck gelangt. Die Wurzeltätigkeit brancht dabei keine erhöhte zu sein; die TVasseranhänfung kommt viehmehr dadurch zustande, dats die Verdumstungstatigkeit der Blätter herabgedrückt wird. Es müssen Turgorsteigermeen in einzelnen Organen oder Organteilen sich einstellen, wie man solche anch künstlich an algeschnittenen Blättern durch gesteigerte. Wasserzufuhr exzengt. Mithin bleibt zu beachten, dafs vieltach die Inftenchtigkeit ausschlaggebend mitspricht. Umgekehrt ist in anderen Fällen, bei denen es sich um Nährstotfüberschuls handelt, darant antmerksam zu machen, daf's derselbe nicht immer eine absolute Anhäufung im Boden voraussetzt, sondern anch dann eintritt, wem das Lösmingsmittel, das Wasser, vorübergehend in zu geringer Menge vorhanden ist und dadurch eine schädlich hohe Konzentration der Bodenlösmo zustande kommt.

Gemäts den verschiedenen Mengenverhältnissen, in wehchen die einzehen Nährstoffe und äbrigen Wachstmmstaktoren bei der Herstellung von 10 Trockensubstanz einer Pflanzenspezies beteiligt sind, erscheinen anch die Ansprürche jeder spezies an die Borlenlösung verschieden. Bei Pflanzen z. B., die zur Herstellung ihrer Substanz viel Kali oder viel Stickstoff' verlangen, wird der Wurzel eine hochprozentige Lösmg dieser stotfe notwentig sem. Die Pflanzen sterben nicht, wemn ihnen die gewïnschte, hohe Konzentration nicht geboten wird, aber sie ändern ihren Trachstmmsmorhs; sie beanspruchen dann, wie frïher gezeigt worden ist, viel mehr Wasiser, gleichsam als ob sie bestrebt wären. durch vermehrte Aufnahme der verdümnten Lösung das nötige Quantum eines hestimmten Nährstoff's dennoch herbeizuschatten. Trotz des vielen Wassers und der sonst gebotenen Stoffe ist die Gesamtprodulition eine ämliche. Ein gleicher Wachstumsstillstand zeigt sich, wemn die Pflanzwn in wine zu hod konzentrierte Bodenlösming gebracht werden. Die Wassoraufinahme ist relativ gering, die Aschemmenge aber grofs mol die Produlition an Trockensubstanz eine kleine. Es kommt dam der T̈bersehnts wohl zur Anfnahme, aber nicht zur Verwemlung; die Mineralsubtanzen werden einfach in Pflanzenkörper abgelagert und sind teilweise wieder mit Wasser auslaugbar. Bei Wasserkulturen mit hohen Nährstoftkonzentrationen kamn man hisweilen wahmehmen, dafs die kurzen, knorrigen Wurzelhare mit kristallinischen Blättchen bedeckt sind. So kann beispielsweise salpeteranläutimg in der Pflanze stattfinden. wenn übermälig mit Kalisalpeter gedüngt wind. Für die dabei stattfindenden Vorgänge gibt EunERLin: ${ }^{1}$ ) duch seine Versuche eine

1) A. Emmantixa, Beiträge zur Kenntnis der chemischen Vorgänge in der Pflanze. Landwirtsch. Versuchsstationen, Bd. XXX, Heft 2, 1884, s. 109. 
sehr acceptable Erklärung. Er zeigt nämlich, dats grarts so, wie hei der Verwendung von salpetersamen Kalk anch das Kalimmitrat dureh Oxalsäure selbst in sehr verdümuten Lösungen drartio zorsetzt wirl, dats oxalsames Kali und freir Salpetersäme entstehen, während Oxalsäure den kohbensauren Kalk nicht stark angreift, da sie denselben mit einer undurchdringlichen, dïmen sehicht von Calciumoxalat iibrezieht. Wenn nun in Verhältnis zm Quantitït der sänre, dis eine Pflanz’n spezies zu bilden rermag, sich sehr viel salpeter in Boden finclet. so wird derselbe zwar aufgenommen, aber nur in Verhätnis der vor handenen Oxalsäme zersetzt werden und lie fieie salperssiime zu Bildung der Eiweitistoffe Verwendung finden: des äbrige Salpester hänft sich nuzerlegt in der Ptlanze an.

Für msere Kulturptanzen gilt sicher das fresetz, dats sie alle dassellse Nährmaterial beanspruchen, aber in versehiedener honzentration. und dafs anch ihre Fähiglieit, Anhäutmonen einzelner Stotfi zu crtragen. ausschlaggebend für das (ielingen der Kulturen ist. I)abei ist nicht zu vergessen, dats weder die absolute Menge eines Nährstottes, welchr ïberhampt schadlos ertragen werden kam, noch anch diejenige (2uantitï eines Nährstoffes, wolche sich als die fïr die Produktion heste (optimalo, erweist, für eine bestimmte Pflanze absolut feststehende cröben darstellen. Vielmehr ist anzmohmen, lats je nath der Kombination, in welcher die übrigen Vegetationshedingmoen angenhlicklich rorluandru sind, das Bedürfinis nach einem bestimmten Nährstoft sich hestämlig ändert. Inaher gibt as immer nur relative Optima nul Maxima tör jedan Vegetationstaktor. Je narle der angenblieklichen Kombination der Vegotationsfaktoren ändert sich der Produlistionsmodus und das Prodult, nämlich der Ptanzenleib: daher argibt die morphologiscle. anatomische mul chemische Analyse tür jedes ludivionum andere $\mathrm{VF}_{\text {erter }}$.

Jede Konzentrationsänderung in remsellen Nährstoffoemisch ändert schon den Wachstumsuodus und spricht sich mor Tmständen direlit im Verhalten der Wurzelhärchen ans, wie S'TtELER ${ }^{1}$ ) angiht. Bei den noch im Wachstum begriftenen Wurzelhärchen sah er hei jedem Wechsel der Lösung eine Veränderung (Verstärkmo') der Vemlnan an dor Kupje der Wuzelhärchen; unter Umständen kann sogar Wachstumstillstan eintreten. In wässerigen Lösungen der Elektrolvte bilden bei manthen Phanzen die Wurzelhärohen hasenartige, mmegelmälige Erweitermugrn, ja sie kïmen selbst an der Kuple ofler (selten) an der seitr zerplatzen. Die Nichtelektrolyte äben nur dann einen schärllichen Einflutis aus. wenn sie giftig wirken ofler in zu hoher Konzentration vorhanden sind, wohei Plasmolyse eintritt. Besomelers heachtenswert ist die Buolachtmen. dats konzentrierte Nagnesinmverbindungen sich direkt wifti erweisen kïmen, was hei anderen Nährsalzen sefbst bei hoher Konzentration nicht wahrzunehmen war.

Es finden durch diese Tntersuchungen moine ejgenen Boshar.homeren eine Bestätigung, dats lui hochkonzentrierter Nährstoftlösmes .. linorivion

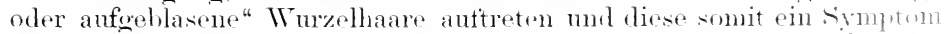

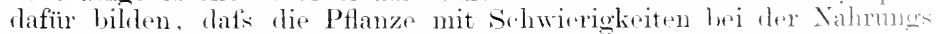
aufnahme zul kämpten hat.

Betreff's der Gotreidearten weisen dis Versuche daraut hin. dals

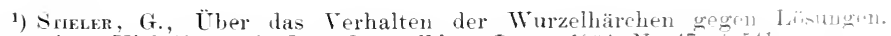
Dissertation. Kiel 1903. cit. Bot. Centralbl. v. Lotsy 1904. Nir. 4\%, $3.5+1$. 
ъ. B. Hafer schon durch Nährstoffmengen leiden kam, die für Weizen erst eine volle Produlition zulassen. Daher versagt manchmal der Hafer auf' Parzellen, die allmählich in zu hohen Düngmaszustand gelangt sind. Die Messungen der Transpirationsgrötse zeigten, dats die Pflanze zur Produlition von 1 g. Trockensubstanz in konzentrierteren Lösmugen weniger Wasser als in sehr verdiumten brancht. I larans ergibt sich, dats bis zu einem bestimmten Grade die Düngung eine Tisserersparnis bedeutet ${ }^{1}$ ).

Entsprechend der erwähnten Veränderung der Wurzelhaare ändern sich durch dis Konzentration allmählich anch der Ban und die Henge des ganzen Wurzelapparates. Sehr bezeichnend sind dafür die Versme vom Schwarz ${ }^{2}$ ) mit Kiefern. Es zeigte sich anch bei dem Naclelholz eine bei anderen Pflanzen schon trïher festgestellte allmähliche Almahme des ITurzelumfangs bei Steigermng des Salzgehaltes im Borlen. Damit rerschiebt sich das Verhältnis zwischen oberirdiseher und mnterirdischer Achse. Während im mogedüngten Sande das Gewicht des Wurzelsystems der Kiefernsämlinge grötser als das der oberirdischen Teile war, betrug bei reichlicher Nährsalzzufuhr das Gewieht des Wurclkörpers mur ein Fünttel ron dem der oberirdischen Achse.

Selbst bei den Kohlgewärhsen, die man durch die Kultur allmählieh zur Verwertung der hö̈hst zulässigen Konzentrationen gewöhnt hat, findet schlietslich eine Übertütterung und damit ein Rückgang der Produktion statt. So erwiesen sich die Kohlrabipflanzen besonders empfintlich gegen starke Phosphorgaben, während sie hohe Stickstoffund Kahidüngung noben der entsprechenden Kalkgabe geradezu haben müssen ${ }^{3}$ ).

\section{Veränderungen der Wiesen.}

Die Methode, saure und sandige Wiesen durch Düngung zu verbessern, beruht im wesentlichen auf einer Erhöhung der Nährstoffkonzentration. Es fliehen dam die sauren Gräser otler die des sterilen Bodens, die nur sehwach konzentrierte Lösmugen vertragen, und es siedeh sich musere guten Futtergräser mit höherem Nährstoff'bedürfnis und reicherer Produktion an Trockensubstanz an. Sehr instruktive Versuche über permanente Wiesen liegen von Lawes und Grbert ${ }^{4}$ ) vor. Wir entuehmen darans num ein Beispiel, $m$ zm zeigen, wie die einzelnen (irasspezies in denjenigen Nührlösungen, von tenen sie eine höhere Konzentration vertragen, allmählich an Übergewieht gewimnen. Es fand sich bei nachstehenden Düngungen folgender Prozentsatz der einzelnen (rrasarten low 100 Pflanzen Hon (s. die Tabelle anf folgender Seite).

Ans dır umstehentlon firäsertabelle sehen wir, wie die auf sterilem Sandhorlen schmell sirh anshreitende Festuct dirimscula verschwindet, wemn die komzentration der Stickstottlösmo und gleichzeitig die der Nineralsulstanzen zunimnt. l assolbe Verhalten zeigen Ayrostis mugris und Anthorcuthum odwirtum, währent mmgekehrt die Mastptlanzen

1) Sund en, P. Über Mifsernten bei Hafer. Österr. Landwirtsch. Wochenblatt Nr. $20.1 \times 8$.

2) Scnwarz, F., C̈ber den Einflufs des Wasser- und Nïhrstoffgehaltes des Sandbodens auf die Wurzelentwicklung von Pinus silvestris im ersten Jahre. Zeitschr. f. Forst- 12. Jagdwesen. Jantuar 1892.

\%) Oro, R., Vegetationsversuche mit Kohlral,i etc. Gartenflora 1902. S. 393.

4 Nach "Journal of the Royal Agric. Soc. of England" und . Proceedings of the Royal Hort. Soc. 1870", cit. in Biedermann's Centralbl. 1876, II, S. 405. 


\begin{tabular}{|c|c|c|c|c|c|c|c|}
\hline $\begin{array}{c}\text { Bezeichnung der } \\
\text { Grasarten }\end{array}$ & $\stackrel{80}{\Xi}$ & 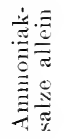 & 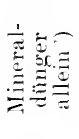 & 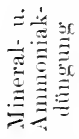 & 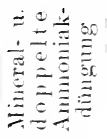 & allein & $\begin{array}{l}\text { mit An- } \\
\text { moniak- } \\
\text { dinggung }\end{array}$ \\
\hline Festuca duriuseula. & 13,114 & 21,42 & 12,00 & 2.9 & 0.79 & $0, \underline{2}, 2$, & (),19 \\
\hline Agrostis vulgaris. & 8,62 & 21,29 & 2,76 & $11,5,5$ & 9,$1 ;$ & 1,38 & 0,78 \\
\hline Lolium perenue. & 8,62 & 2,39 & 0,$0 ;$ & 11.89 & $-6,60$ & $2.5 !$ & 2.73 \\
\hline Holcus lanatus. & 4,97 & $9,6<$ & $4, \diamond 6$ & 11.06 & 8,82 & 2,17 & 2,01 \\
\hline Dactylis glomerata. & 1.76 & 2,27 & 2,79 & 5,04 & 23,5 & 4.45 & $16,-6$ \\
\hline I'oa trivialis.. & 1,511 & 1,61 & 5,77 & 12.00 & 15.47 & $27.4: 3$ & 29,34 \\
\hline Bromus mollis . & 0.08 & 0,15 & 0,63 & $2: 21$ & $0,9:$ & 9.64 & $12,5: 3$ \\
\hline $\begin{array}{l}\text { Anthoxanthum odo- } \\
\text { ratum. . . . }\end{array}$ & $: 3,29$ & 2,41 & 0,00 & $0,4 !$ & 0,10 & $0,1 !$ & 0.06 \\
\hline
\end{tabular}

mserer Rieselwiesen, Dactylis glomorata und Pon trivalis, in den ; Versuchsjahren, deren Ergebnis die Tabelle darstellt, sich immer reichlicher aut den stark mit Śtickstotf' gedüngten Parzellen ansiedeln mul die anderen verhängen. Das Gras der Lorfistration. Biomms mollis, beteiligt sich in hohen Prozentsätzen nu dort, wo Stallnistdüngung statt gefunden hat, während Lolium percme und Holrus lomotus zwar ïberall vorkommen, aber da, wo reiche stallmistrlingmeg ist, nur wonig sich ansbreiten.

Toi den iibrigen, interessanten Beobachtumen der Verfasier mag noch angeführt werden, dats die Wiesenparzelle, welche nugediungt geblieben war, oine grotse Mannigtaltigkeit in don darant vonetierenden Familien nud Arten zeigte. Das (iras war kurz stengellos nud bei der Sehnittperiode verhältnismätsig sehr grïn. Bej Mineralı̈̈̈nger gewimen die Legminosen die Oberhand: bei den tramineen, die älrigens nicht eine hesonders vorherrehende fattung orkennen lassen, ist die Neigme zur Blütenentwicklung mehr ansgespochrn als im moredïngten Lande. Ungekelnt schlietsen tie ohne ander Beiliongme verabreichten Ammonsalzo die Leguminosen fast gänzlith ans mol dir framineen werden herrschender, Frstuca und Agrostis arreichen ihren hörhsten Prozentsatz: üppig gedeihen Rumfe. ('armm und Achillea.

TVem Chilisalpeter allein angewentet wurl., zeigte sich im allgemeinen derselbe Ettekt wie hei den Ammonsalzen: indes war bei

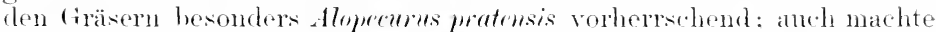

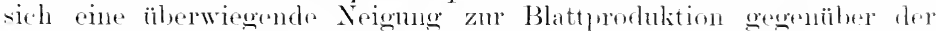
Entwicklung der Blätenstengel hemerklich. Nehen den sich atwas bessel entwickelnden Leguminosen fand sich eine iijploge Entfaltung des wenio

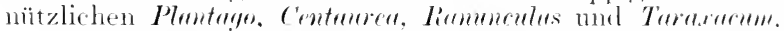

Die hächsten Erträge mul heste Entwielinmg der froiser sah man bei stallmist mit stickstotthaltigem Beidünger. Lie locemminosen

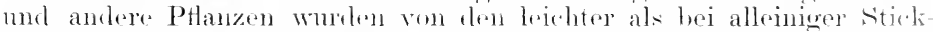
stoffzutuhr reitenden brisom ïherwuchert mul versehwandon. I)

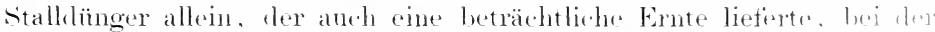

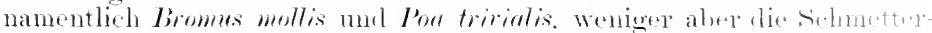

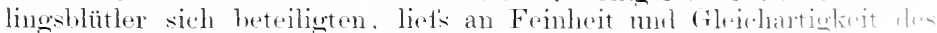
Henes zu wiinschen ïhrig.

1) Cnter Mineraldingung verstehen d. Verf eine Mischung von supurphopliat mit schwefelsaurem Kali. schwefelsaurem Natron um schwefelsarm Magresia. 
Wrenu mosige Wiesen in Kultur genommen werlen, so findet sich, datis das Noos eben gar keine konzentrierten Nährstoftlösungen verträgt oder mindestens keine hohe Konzentration einzelner noch näher zu erforwhenter Nährsalze. Iarans erklärt sich das Verschwinden des Mooses von Wiesen nach Kalidüngung. Insselbe Verhältnis wird fïr den sehachtelhahm Gïltigkeit haben, welcher nach Chlorealcimmläsmng mhedingt versehwinden soll und deshalb gegen hohe Kalkkonzentration hesonders empfindlich zu sein scheint.

I ex extremen Ansmagerung der Wiese, die sich durch die Moosvegetation ankïndigt, steht die ïbermächtige frasentwickhmg an den sog. Geilstellen gegenïber. Es tritt durch das Harnlassen der 'Tiere eine vorzugsweise reiche Stickstoftioungung ein. und dieselbe macht sich durch üppigere Lambentfaltung geltend. Die Pflanzen hatten nach Weske ${ }^{1}$ ) nahezu (loppelt so viel Prote von stickstofffreien Stotfen als die daneben stehenden, nicht überdïngten Pflanzen. Demgemäl's fanden sich in der Asche der ersteren mehr Alkalien, Magnesia und Schwefelsäure. Die PHanzen solcher (reilstellen bleiben trotz ihres grötseren Volumens in einem zu jugendlichen /mstande und wïrten bei grotser Ansdehnung solcher überdüngter stellen mehr soharlen als Nutzen gewähren. Darin gleichen sie dem Bestande der Rieselwiesen.

\section{Rieselfelder.}

Die Ausdehnumg der Rieselfeldwirtschaft in der Nähe grofser Stäite erfordert, dats wir lie hei diesem Betriebe mvermeidlichen schädigmngen spoziell besprechen. Eнkenbek ${ }^{2}$ ) hat kïrzlich seine Erfahrungen betrett's der Berliner Ricselfelder mitgeteilt.

Abgesehen von der durch sehnell sich wiederholenclen Anban der Kohlarten hochoradig gesteigerten Entwicklung der Plasmodiophora Brassicre finden sich anch Tierschäden mogemein begïnstigt. Am meisten trat dis antiergewöhnliche Vermelirung von Sitpha atrata hervor, wodurch grotse Räbenflächen vollständig zerstört worden sind. Der sehädling findet in den faulenden organischen Stoffen der Syäljanche äberreichliche Nahrung und in den Dämmen und Kanälen willkommene Schlapfwinkel gegen Kälte und Feinde. Der grofse Nährstoffvorrat zieht anch die Krälen ans weiter Umgehnng nach den Rieselfeldern, deren Saatgut wie z. B. Mais und Weizen reihenweis ansgewïhlt wirl. Eine fermere Plage bihlen dir Ratten.

Yut dioson pflanzlichen und tierischen schädigern gesellt sich der Wind, der hier verterlicher als anf anderem Ackerlande wirkt. Anf' den Berliner Riesclfollern wmole cine grotse Anzahl völlig belankter Ulsthänme trotz ihrer starken Bammptähle umgeworfen, weil dis durchnälst. Erob den olmehin nicht tieforehenden Wurzehn zn wenig Halt crewährte. Beoliahtet wurde dieser Fall besonders dann, wemn ein Feldstück mit den mmonenden ()hstbanmalleen durch spouljanche ïbersthwemnt worde.

Bei den Brriesehngen während der Tegotationsent hemerkte man bei den herangewachsonon Exemplaren von /ucker- mol Futterüben sowie von Mohrrïhen und ähnlichen Wurzelgewächsen, dats dieselben

1) Annalen d. Landwirtsch. 1871. Wochenblatt, S. 310.

2) Eimenuma, Pát, Einige Beobachtungen über Pflanzenbeschädigungen dureh Spüljauchenberieselung. Zeitschr. f. Pflanzenkrankh. 1906. 
es nicht vertragen, wenn die Spüljauche ainigo \%eit am Trumelhalse steht. Es trat nach wenigen stunden ein Welken der B lät er und gegen Abend sogar ein Erschlatfen der Blattstiele ein. Hahmfrüchte, Gras, Hülsentrüchte mol andere (iewällse ohne fleischigen Wnrzelkörper zeigten die Erseheinmo nicht. Wahrscheinlich handelt es sich hier um ein physiologisches Welken, inclun der bei jeder Heisehigen Nurzel spärliche Wurzelfaserapparat aus der hoehkonzentrierten Bodenlösung nicht imstande ist, erenügend Wasser loszureifisen, $u m$ den Verdunstungsverlust zu decken. Wem dureh die Absorption der Erete die Bodenlösmo an Konzentration verlor, verschwand das Welken wiederm.

Zur Vermeidung dieses Übelstandes wirl der Anbau ant metribreiten Dämmen vorgenommen, oder man liäufelt die Rüben mit fortschreitender Entwicklung an mol rieselt in clen dadurch entstandenen Furchen.

Anf die Verändermo des (rraswuchses ist schon an anderer stelle aufinerlisam gematht worden. Ant den Berliner Rieselteldern hamblelt es sich vorzugsweise mm Lolium italicum, das namentlich bei Winterberieselung vieltach gänzlich answintert.

Die Weichlieit des Grases, die sich sehon tureh tas leichte Faulen anzeigt, wird vorzugsweise auch durch den sitickstoffübersehul's

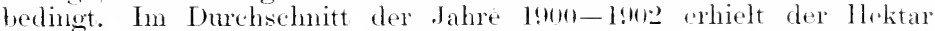

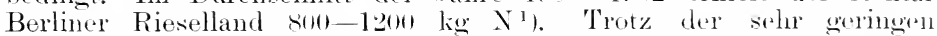
Aussaatmengen und des weiten standes neign die nastigen fictreide.

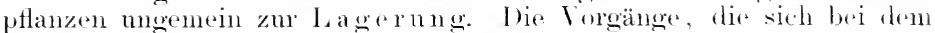
Lagern absfielen, hahe ich (xelegenheit wehabt, bei Hafer von Berliner Rieselfeldern zu studieren ${ }^{2}$ ). E- ist dabei einn eigenartige /ermürlumg des Blattgewebes intolge vom Bakterienarbeit auttällig. Botrefts des Verhaltens junger Saat bei T̈berdüngmg beobachtete ich hei rerste. dats, gegenüber den normal ernaihten Pthanzen, die äberdüngten dunkles grün Wurden, aber in Wathstum zurürkblieben. Dann bekanen die Blattspitzen graugelbe Flecke und verfärbten sich schlietshich gänzlich grau, wohei eine Anzahl der Sämlinge nukniclite. Bald nach dem Umknicken hegamn der oberhalb der Knickstelle befindliche Teil zu vertrocknen. Während aber normal vertrocknende Ptlanzen schliefslich eine strohtarbe annehmen. war dies hier nur bei den unteren Blättern der Fall: die oberen vertrockneten in hengrüner Fäbung. Wichtig ist labei auch die Erkrankung der frefatsbiundel und die grotise Neigume der Pflanz'n zur Verpilzung ${ }^{3}$ ).

Autser der bekannten Terzägerung der Reite des fietreiles auf Rieselfoldern erwähnt EHrexberg aneh das Mifserhälnis zwischen stroh- und Könerernte. Bei berieseltem Hafer war das Verhälnis von Korn zu Stroh wie 1 : 3,33, hei mberieseltem wie $1: 2.85$.

solehe ..strolew iachsiglieit" stellt sich alhählich als typische Eigenschaft heraus: drun as rgaben sieben nen hezogene fierstensorton ein Verhälnis ron Korn zu Stroh im Hurehsehnitt $1: 1,75$, wiln

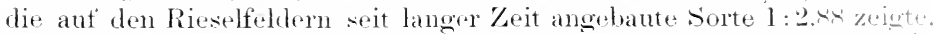

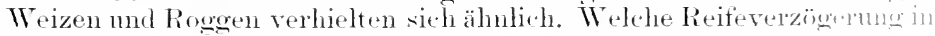

1) Backinss, Landwirtschaftl. Versuche auf den Rieselgütern ler vitalt bertin im Jahre 1904 .

2) Sorarear, P., Beitrag zur anatomischen Analyse rauchbeschadigter l'tharen. Landw. Jahrbücher von Thiel. 1904 \$. 593.

3) a. a. ค. . . 646 . 
extremen Fällen eintreten kann, fand man bei Rotem Gebirgsweizen, ler am 1!? April auseresät worlen war und anf dem berieselten Felde am 13. September, anf dem unberieselten am 224. Augnst reif war; es eroal, sich also ein Unterschied von 20 Tagen.

l)ats die Chlorverbindungen anf den Stärkegehalt der Kartotfeln unt anch anderweitig nachteilig einwirken, finclet sich an anderer stelle erwähnt.

Als die bedentsamste Schädigme anf den Rieselfeldern ist die "Verschlickung" zu bezeichmen. Wie śpüija uche rnthält neben den grotsen Mengen von Kochsalz und anderen Salzen sehr viel organische substanz, besonters Papierreste, Kaffeesatz und dergl. Im I)urchschnitt ergahen sochs Intersuchungen der Berliner späljauche in .Jalne $1910 \cdot 2$ :

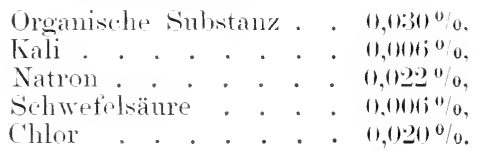

Ife Papierreste mit der organisehen Substanz trocknen aut den Felılem zu zähen, dünnen Fladen zusammen, welche wegen ihres Fettgehaltes sich nur shwer zersetzen, und mit den sialzen und organischen Stoffen durchtränkt, den Schlick darstellen, der hodenverschlechternd wirkt. Der hohe Gehalt an salzen wird durch Basenaustansch leicht ein Auswasthen des Kalkes verursachen.

Dals auf verschlickten Rieselfeldern tatsächlich $\mathrm{Kalk}$ in die Tiefe wandert, bestätigen die Analrsen ${ }^{1}$ ). Es betrug der Kalkgehalt in
hei normalem Boden

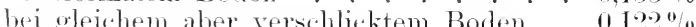
$(0,1): 31^{\circ} 0$,
$0,048 \%$.

Oberkinume

Untergrund

Kalkzufuhr ist also bei verschliektem Boden erwïnseht, da er phrsikaliseh verbessornd wirkt.

Die Beseitigung drr erwähnten papierartigen Fladen, durch welche junge Ptanzen, namentlich die Grasaat, ersticken können, wird man zmü̈chst durch Aufegoen, Kerreitsen und Fortschaffen der Fetzen in Angriff zn nehmen haben. 'Trotzdem kommen bei der Ackerbestellumg' reichliche Mengen in die Erele und ähen dort einen schädigenden Einthuls ans. The Anreichermeg an organischer substanz durch den Sehlick lälst sich ans dem tilühverlust erkennen.

$$
\begin{aligned}
& \text { Normaler Boden enthielt in der Krmmo. 1,994\%, }
\end{aligned}
$$

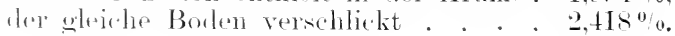

Vegetationstrsuche in Töpten erwiesen, dats die sehlickbeigabe stets hemment anf las Warlistnm wirkte mol eine Zufuhr von Ätzkalk die Wathstmmstorägernug nicht zu heseitigen vernochte. Die Hemmung in der Entwicklung hestand nicht in dem Anftreten positiver Krankheit:svmptome, somlelu nur in verspätetem Anfoang des Samens mol allgemeiner Depression des Warhstums. Die Erlä̈rung der Erscheinmong

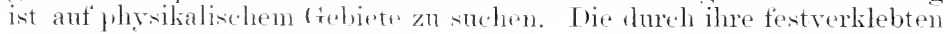

1) B.ekilis a. a. O. S. 69 11. 114. 
Bestandteile und ihren Fettgehalt für Wasser nnd Lnt't sehr undmehlässigen sichlickstïrke hemmen die Wurzeln in ihrer Anshreitung und biliten grotse Himlernisise tï̈r das herabsinkende und antsteigende Wasser.

\section{Die Schorfkrankheiten.}

Tou den vielen Krankheitsformen, in deren Ursachen wir noch keinen geniigenden Einblick haben. reihen wir die schorte hier muter die Überschutskrankheiten ein. Der (irund dafür ist die vielseitig gemachte Wahrnehmung, dats nach zutuhr von stotten. welehe die Alkalität eines Bodens zu vermehren vermögen, die Sehorterscheinungen in reichlicherem Mal'se anfintreten ptiegen.

Bei dem schort oder der . R ä nde" bilden sich volznosweise Hach ansogebreitete, borkig zerklüttete, korktarbige stullen ant den Heischigen, unterircliselhen, rïhenoler knollenartigen

Reservestoftbehältern. śolange eine solehe horlienartige Zerklüftmig oberflächlich bheibt. spricht man voll Oberflächen sehort. Erfolet rageren eine selnell. Tertiefing der Vimdstellen.sodats dirselhen zu truben oder Lörhern werden, hezeichnet man die Erkrankung ats Tirtselort', hei rem in gewissen Fällen warzenartige Wu hermengen die

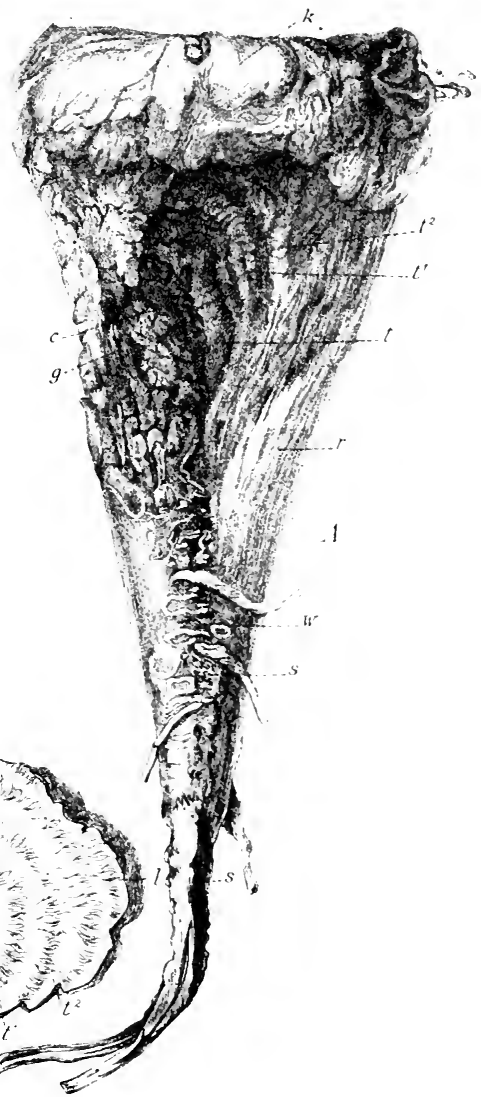

Fig. 52. Tiefschorfkranke Rübe von der stiirkist erkrankten seite der Wurzelrillen gesehen.

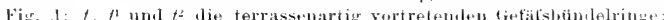
g frewebeticken mit zunterigen limern: l. knollige Parenchym-

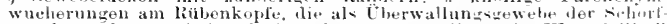
wunde zu deuten sini: s flache Schordintanze, die an ler Wurzelrille. II abwärts sich ziehen: raulserster Rant der selurlmulde; , tielste - tell. dersellsen. Fig. $B$ : Riäbenquersehnitt in d..r Nähe des Tiefschorfzentmu-

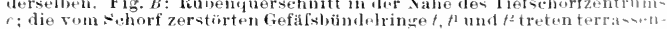
artig von der tiefsten Wundstelle au zurick: / zeiut die whith.

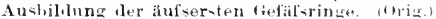

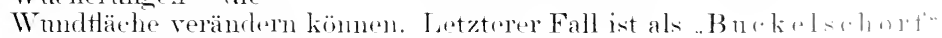
unterschieden wordin.

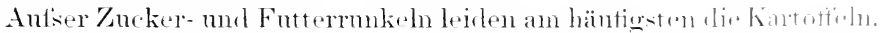

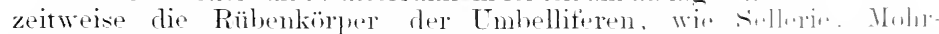

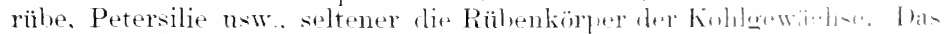


('harakteristische ist die Kerstörme von Korklagen. die sich aus den

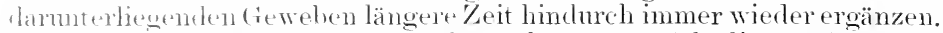
Ton sich rine Vorstellmo von der schwersten schädigungstom der chortkrankheit machon zu kömen, geben wir die Abbildung einer

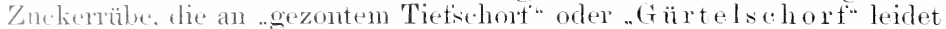
(Fin. 52). Lie Rübe hat am Kopfende eine Ilicke von $7-8 \mathrm{~cm}$, ist "ther nur oben liveistund, zeigt dagegen an den beiden seiten, welche lin Wuzelreihen tragen, eine beträchtliche Abtlachung, welche sich nach dem schwanzende hin wieler verliert. Die abgeflachten seiten sind mulfenartig vertieft, und das Zentrum der Mulde ist etra 6 cm von der sichnitfläche am Rübenkopte entfernt. Die Oberfläche der Mulde ist dadureh wellig, dafs über einem tiefstlicgenden /sentrum sich lic einzelnen Ringe des Rübenkörpers, terrassenartig nach antsen ansteigend, in mehroder weniger dentlich hervortretenden Zonen erheben.

Die Beschaffenheit des Gewebes der Nuldenränder ist zunderigschorfig, 凡. h. zerklüftet, und lie Klüfte von röhrenartigen Gängen durchsetzt, welche einen faserigen Zerfall der substanz einleiten. Die Anskleirtung der gangartigen Klötte besteht ans bramen, verkorkten, zarkenartig voripringenden Grweberesten, deren Oberfläche einen eigenartig könnigen Zerfall erkennen lä1st. Trotz des tiefgehenden Zerfalls an der schorfstelle sehen wir, dats der Rübenkörper seine Reaktionsfähigeit behält: denn die Ränder der einzehnen Gefätsbündehinge wälien sich nach der Verletzung durch Neubildung von Zellen wallartig rol.

Dats der Rübenkörper an den schorfigen stellen schon vorher eine Wachstumshemmmg erlitten haben diurte, geht daraus hervor, dats an ler heschädigten sowohl wie an der gegenüberliegenden Rübenseite live einzelnen Geweberinge schmaler als an den anteren Rübenseiten sind. Bei Behandhung von Querschnitten der erkrankten Stellen mit Schwefelsämp sioht man, dafs muterhalh der hramnen, spröden, allmählich zerfillmolen (iewebelagen, die verkorkt sind, im anscheinend gesmolen Rizhentleisch olic Intercellularsubstanz einen gellolichen, weimoten bis louchtent karminoten Farbenton annimmt. Manchmal erscheinen auch cinzuln (iefätigruppen mit festen Ballen orler Pfropfen versehen, welche diesclle Färbung mit schwefelsäme annehmen. Die Intercollukasubstanz oxweist sich später gelockert und beginnt schliefslich, kïmig-sidulumig zu zerfallen. Dem blotisen Anse erscheint der ganze Vormang als cill trokener Kersetzmngspozeds.

Wir wähnt, ist dirse Schonfform, welche so tief in das Fleisch

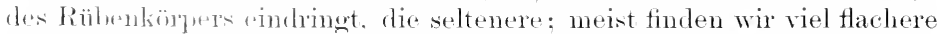

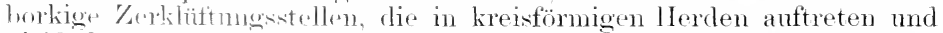
vielfach rekmon lasson, fats sie in einer ziemlich fröhen Entwicklungsphase der lizib antigetreten sind und später an Anslreitung nachwolassm haleen. Brmertinswert ist, dats bei dem gezonten Tiefschorf

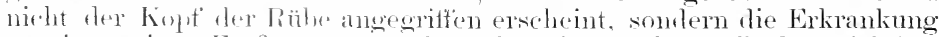

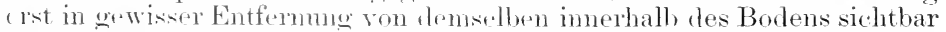
winel. Boi tiefoeflanzten Rïhen finclet man manchmal schorfanfänge an den Blatsticlhasen. (Gauz ähnliche Erscheinmogen bemerkt man anch bei den Kartotfeh. Molmö̈len nsw. Bei der Kartoffel ist der Ausgang der schorfhildung von den lenticellon ans beobachtet worden, und es ist mschwer ersichtlich, wie loicht schädigende Einflüsse einen Angriff'spunkt finden. wom wir rine solehe lenticelle betrachten. Hier sehen wir moter dex ans tafelfömigen Korlizellen anforbanten schale li (in 
mutenstchender Fig. i3) die ersten Antänge der Lenticellenbilelumg muterhalh, der sipaltöftinumen in Form uncegelmäsiger, inhaltsamer

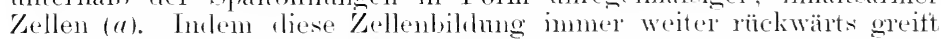
und die zuerst gehildeten Kellen Wasies anfuelmuen, quellen und dadureh die Korkrimle sprengen, entstelit die num zm sidhorfbildung Veranlassmo gelende Lenticelle, ans weleler die sich lockernden Fïllzellen $(f)$ in Form eines weifslichen, fenchten Mehles hervortreten.

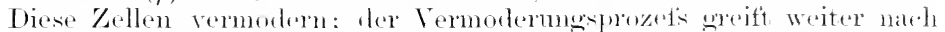

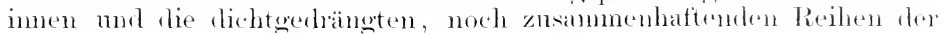
jugendlichen Füllzellen (1) sind immer tiefer im Innern des Fleisehes zu suchen, wo fortoesetzt die stärke (st) aus dem die Füllzellen mugebenden Gewebe verschwintet. Ganz ähnliche Vorgänge spielen sich muter dem Einfluts anhaltender Fenchtigkeit andh bei anderen muterirclischen Pflanzenteilen al. Ler hisher schützend wirkende Korkmantel erfährt somit eine arefährliche Lockerme.

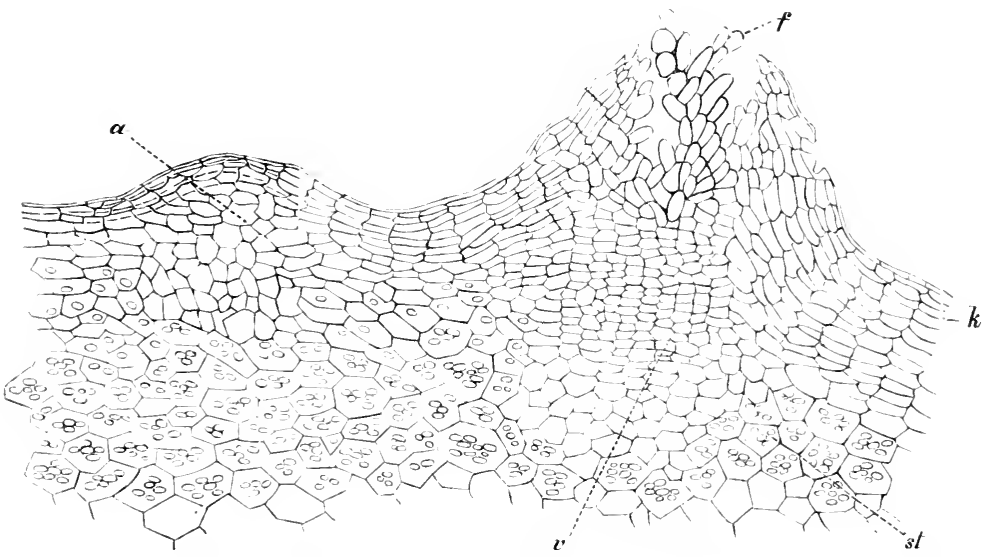

Fig. .33. Lenticellenbildung an ier Kartoffelschale. (Orig.)

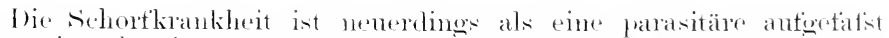

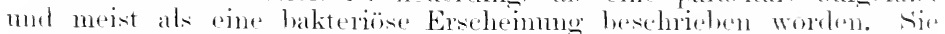

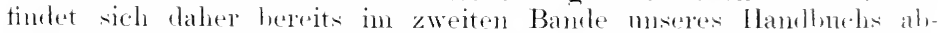

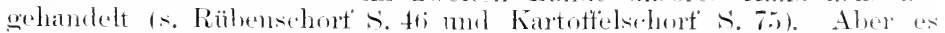
ist dort sehon hervorechoben worden, dats als Tratehe pecht ver-

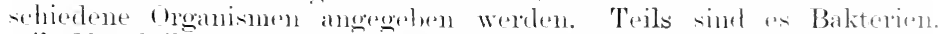

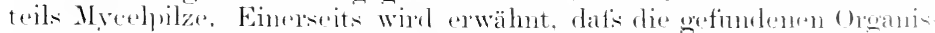

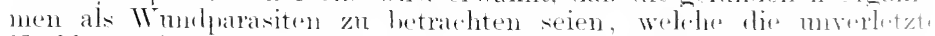

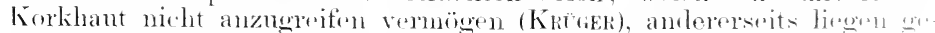

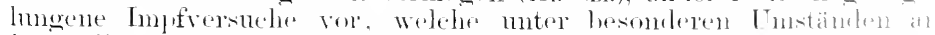

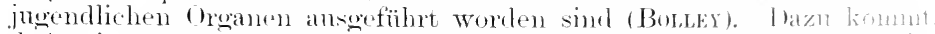

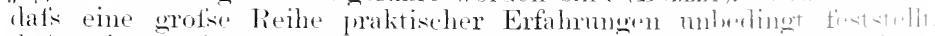

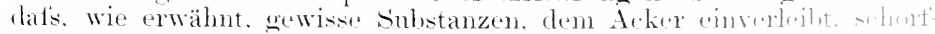

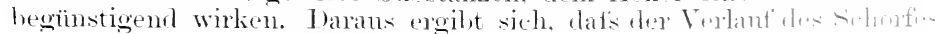

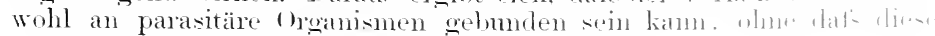

Sorater, Handbucli. \& Aufl, Erster bandi. 
aber spezifische schorforganismen wären. Viel wahscheinlicher ist es, dats in den Rübenböden meist vorhandene saprophyte Arten dureh hestimmte Änderumgen der Bodenbeschattenheit den geschwächten, alten oder zarten jugentlichen Rübenkörper anzugreifen imstande sind. Dats der Rübenkïrper zur Zeit der Schortirankheit schon eine Hemmung erfahren hat, zeigt der Umstand, dats die gesunden Gefätsbiundelringe lort, wo der sehorf einsetzt, sehmaler sind, also ihr Dickenwachstum beschränkter gewesen ist.

Gestützt auf die BoLber'schen Impfrersuche ${ }^{1}$ ), welche den Rübenund Kartotfelschort auf gleiche Ursachen zurïtifüluren, wenden wir uns der Hamptfrage zu, welche Umstänle als schorflegünstigend oder -veranlassend durch die praktische Ertahrmg testgestellt worden sind. Ganz bekannt ist mnter Landwirten, dat's das Me reeln des Ackers die hänfigste Veranlassung zum Schorfigwerden der Kartotfeln darstellt. Besonder's soll es der gellye Mergel sein. welcher Eisenoxyduloxyd enthält. Frank ${ }^{2}$ ) hat hetreft's dieser Frage direlite Kulturversuche angestellt. Aut msterilisiertem Borten entstand schorf und unterblieb auf sterilisiertem, anch wenn demselhen Lehmmergel zngesetzt worden war. Erfahrungsemäts wirken ferner als schorfhegïnstigend Raseneisenstein, Stratienkeluricht, Klobkenkot, frischer tierischer Dung, Jauche und Chilisalpeter, so dats man zu der Vermutung gedrängt wird, die alkalische Reaktion sei die hauptächlichste Ursache ler Begünstignng der Sohorforganismen. \%u diesem Schlufs lisommt anch BuLLEY $\left.{ }^{3}\right)$, dessen Versuche ergeben, daf's seine Schorthaliterien sich am schnellsten anf neutralem oder hasisehem Nährboden entwickeln. Dat's die Nässe fördernd wirkt, hahen Frank's vergleichende Tersmche erwiesen, mut Botler hebt hervor, dats leichte sandige Böden in der Regel glatte Knollen liefern. Frank's Resultate scheinen der Ertahrung zu widersprechen, dat's man in heifien, trockenen .Jahren stellenweise viel sichort finden kam.

Die Viderspriche lösen sich, wenn man die Tntersuchungen von Thuxter ${ }^{4}$ ) herbeizieht, der für Tief- und Flachschorfformen rerschiedene cranismen unterscheidet und hervorheht, dats für den von ihm kultivirrten Organismus nentrale Reaktion am förlerlichsten, leichte Alkalität aher wie leichts Ansänernng verzögernıl zu wirlien seleinen. Bei seinen I'restehen wurten junge Knollen an jeder stelle, älere noeh mit Erfolg an $\mathrm{I}^{+}$molstellen mol namentlich Lenticellen angegriften, während annähernd reife Knollen gänzlieh rersagten.

Die Shohortorganismen excheinen also in ihren Anspriehen nicht ühereinstimmend. Nur das ist ihnen gemeinsan, dats sie die lenticellen hevorzugen; antserdem sind die jugendlichen organe mit zarter Korlibelideidnen und bei Rüben die Stellen, wo die ITürzelchen ent-

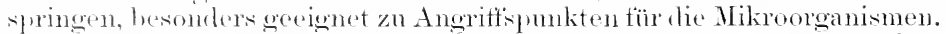
Dirse stellen werden aber wesentlich gelockert durch nassen Boden, mul daher wird dis Behauptumg erklärt, dats Nässe die Solnorferkrankung beginstigen liann. Aber nasse. sehwere Böden sind anch ler Durchlüftung schwrer zugänglich, und wenn sich im Boden suh-

1) Border, H. L., A disease of beets, identical with Deep scab of potatoes. (Gov. Agric. Exp Stat f. North Dakota. Bull 4, 1891.

2) Kampfluch gegen die richädlinge unserer Feldfrüchte. 1897, S. 177.

?) Zeitschr. f Pflanzenkrankh 1901, S. 4:3.

4) Tinxier, Romxi, The Potato Scab. Fourtheenth Annual Report of the Connecticut Agric. Exp. Stat. 1890. 
stanzen befinden, welche bedentende sanerstoffinongen beanspruchen, so nehmen sie, wemn derselbe von autisen hor dom Boden nicht genügend zugefühnt wird, ihn ron der lelendigen Pflanzensubstanz. Als solehe stark sanerstoft heanspruchende Massen mïsten die Alifallstotte,

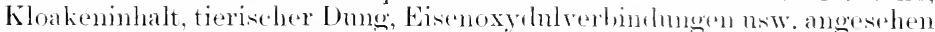
werden. Wir finden Beispiele, dats ein gedïngtes Ackorstäek schorfige Kartotfeln brachte. während die olne stallehmg geldichene l'nechmo schorftreic Ernteprodukte lieferte $\left.{ }^{1}\right)$.

Bei der Zersetzmong des Kloakeninhalts mol anderer tierischer Abfallstoffe entstelen aber schäbliche Sehwefolverhimbmeen im Boden. mol diese werden selbstreständlich giftig ant den Wrurzelapharat, fördernd aber anf gewisse Bakteriengruplen wirken können. Solabl solche Vorwänge sich einstellen, kïmen die schorfbakterien, die nentralen orler alkalischen Borlen bevorzugen, besonders gerteihen.

Nun diurten solehe Vorhälnisse in Tombëden auch bei intensiver

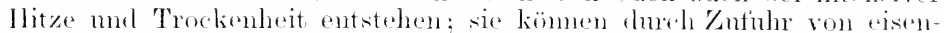
haltigem Nergel sich liklen, und ramit wïrde sich das Erscheinen nul oftmals alljähliche Wiederholen des sehorfes erklären, dre nach Nergeh eintreten kann, alser nicht immer sich einstellt. Alle die genannten schorfhegünstigenten Faktoren kïmnen in bestimmten Fällon wirklich s.horf hervorlningen mul in anderen Fällen nieht. Die gute Wirkmng des Kalkes, die bei mehreren Anbanversuchen beobachet worken ist²), wirl sich dureh seine flockencle Eigensehaft, die er ant seluliefige

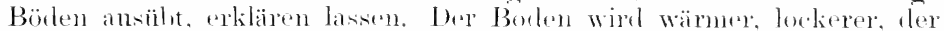

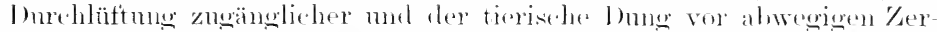

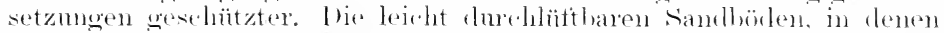
sich hochlonzentriede Botenlïsmenen nicht lange halten kïmnen, sind meist selonffied. Also die einzelnen sogenamntan selorftördernelen substanzen an sich sind nieht schädlich, somelern erst gewisse Kom hinationen. die die Borlenzersetzmeg in mogesmele Bahnen leiten.

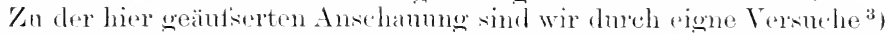
gefühnt worlen. welche rlie Frage heantworten sollten, ob der sichorf sich stets im Acker erhalten und ansbreiten kam. Das Ergelonis war ein negatives. In zwei anfeinambertolenden Versuchsahren waren nämlich nicht mor die vom gesundem Satgut kommenden. sondern anch die von sehorfigen hartotfirn stammenten Knollen nit ganz geringen Ausnahmen gesund. l)arans geht hervor, dats tïr die Anshreitum der schortkrankheit in treien Felde dio Beschaffenheit des Saatontes weniger ansschlaggehend ist mul die vieltach rmp, fohlenen Beizvertahren ïbertlïsig sint. Hic Bekämpfungsmatsnahmen mïssen auf eins.

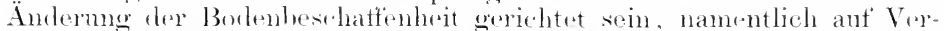
medelune ler schorfberginstigenden subtanzen. Betretts der oft behaupteten sichällichlieit dre Kalles haben meine V'ersuche eroeben.

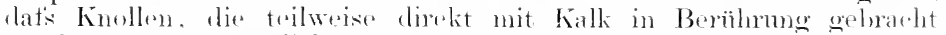
worden waren, günzlich glattsohalig und gosund geblieben sind. Hn

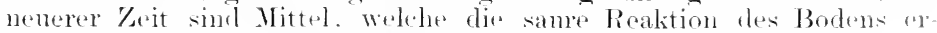
höhen sollen, in den llandel gehracht werlen (z. B. sulfarin.

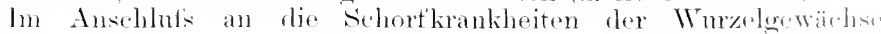

1) Arb. 1. T. Landw-(ies. Jahresbericlit d. Sonderausschusses f. Pflan\%nschutz 1904.

2) Kürk, Fr., Inntersuchungen über den Gürtelschorf der Zuckerrüben. Zeitschrift d Ver. d. Deutsch. Zuckerindustrie Nov. 1904.

$\left.{ }^{3}\right)$ Zeitsehr. f. Pflanzenkrankh. 1899, s. 182. 
möchten wir ant ähnliche, noch nicht stutierte Erscheinungen an glattrindigen, jungen Bämmen anfmerkam machen. Linden, Uimen, Eichen nsw. zeigen anf' gewissen Bölen (z. B. hei moorigem Untergrund), in der Umgebmog von Adventivangen ofler-trieben mude, sich veroröbernde, horkig zerliütende Rinflenstellen. Dieser Rindenscliort ist in der Umgobmg grotser sitädte, wo die Bämme häufig Banschntt und Abfuhrstotfe im Unterorunde finden, nicht selten.

Eine andere in diese Gruppe zu ziehende Erscheinmo bei Gerstenund Weizensaat ist die "Fleckenneklose", d. h. Clas Antreten tief dunkelrotbanner, absterbender Flecke an ter suitze und am Rande der Getreideblätter. Ich habe die Krankheit an intensivsten bisher ant schweren, tonigen oder moorigen Ätkern, dic danernd reiche Kalitüngung erhichten mol in Flugaschemegionen sich hefanden, angetrotfen.

\section{Die vorschreitende Metamorphose.}

Während wir bei then bisher in diesem Abschnitt besprochenen Fällen mehrfach dentlich das Gemeinsame der Erscheinungen darin erkannt haben, dafs es sich im wesentlichen 1 m den Einflufs ron unzweckmätsiger Konzentration der Bodenlösmng handelt, dmeh welche der Organismm leidet, wollen wir jetzt der Fälle gedenken, bei denen die plastischem Banstotte mzweckmälig resteigert werden. Anch hier brancht nicht immer ein übermätsiger Torrat von Nährstotfen im Boden die Veranlassmog zu geben, sondern os kam auch dureh versehiedene Ursachen nu eine (Heichgewichtsstörmg in der Bildmosichtmo des Individums, eine Veränderung der Verwend ung des plastischen organisehen Materials eintreten.

Beispiele datür sind diejenigen Erscheimningen, welche als vorschreitende Metamorphose angesprochen werten. Es handelt sich hier $n$ m den T̈bergang von Blattorganen in eine morphologisch höhere Ansbildumstom. Die Teratolowie klasifiziert solcle Tmbildmoen miter den Namen "Petalodie" nnd "Pistillodie", 1. h. in Fälle, lei denen die Deckblätter oler der Kelch hlmmenblattartio werken oler Teile der corolla dem Charakter der Staubgefäse sich nähern oler diese sowie wirklich dem stauhblattliseise angehörige (Hogne sich in Fruchthläter mmandeh. Für die Petalodie bieten die Kulturtormen muserer Primeh mol Ranunkeln zahlieiche Beispiele. Für die Pistillodie finden wir die schönsten В3rläge bei unserem IInhn (I'opueser sommiforum), ter als eine alte Kulturptlanze, ähnlich msern Kohlgewächsen, in seinen morphologischen Bangesetze schon derart rrschüttert ist, dat's a zu Umbildmoen seiner oroane sehr leicht neigt. ber interessanteste Fall dürften soluhe Mohnköpfe sem, die kranzartig an ihrer Basis viele kitrine verholzende Anlagen von Köptehen (in Frucht-

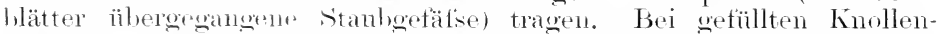
begonien. Thlpen und anderen Liliacepn wurden Exemplare gefunden. bei denen die Stanhgefalse zu Fruchthlätorn mit Samenknospen sich umgewandelt hattrn. Terwandt damit sind dit Erscheimmgen der "Zapfensutht" hei den Nadelhölzern, namentlich ten Kiefern, wie nebenstehencle Figm it roranschanhicht.

In der Mehrzahl der Fälle stehen die Zapten am (irunde eines Jahrestriebes dicht gedringt mol hleiben kleiner als nornale, liefern aber keinfähige Samen. Ihro Entstehmo an Stelle von mänulichen Blüten deutet anf einen lokalen ت̈thrsehutis an konzentriertem, plastischem Material. 
Es spricht dafür anch eine Be. obachtung von Bokgikete ${ }^{3}$. der nach dem Verptlanzen mehrerer etwa 15 jähriger Fichten in dem Botanischen Garten zu Bom fand, dafs im tolgenden Jahre der Trorminaltrieb sich in einen weitslichen Blïtenstand nmgewandelt hatte.

Wemn der Übersehuts an plastischen Banstoffen sich darin betätigt, dats zwar die einzelnen Blattkreise emer Bliite in ihrer Gestalt erhalten bleiben, aber rlie Achse sich verlängert, sprechen wir von Anseinanderhebungen (apostasis) der Blïten. Es erscheint damm \%. B. der Keleh rlureh ein lamges Internodium ron der Blumenkrone mul diese von den Stanlgefäfisen getremut, n1*w.

Die vollkommenste Form Ir. Öherermährma der Bliiten tritt mus in den sonen. ., Rosenkänigen" "entgegren, d. h. Thei solkhen Rosen, hei denen ans der Nitte einer Blume eine nene hervorsprietist orler seitlich nene Blmmen heranstreten. Wir bezeichenen dorartione Fälle als Übersposon oder Proliferatio. Es entstehen immerhalb ciner Bliite oder eines Bliitenstandes antisergewölnliche Knospen.

solehe Knospen kïmnen nun bald zn Blöten. hald zn beblätterten Trichen sich entwickeh. Steht eine solche Arlventivknospe im Zentrum einer Blume, so dlatisladur.h deren Achse geschlosien und erst durch Entwicklnng dieser Kinospe tortgesetzt erscheint, so nemen wir eine

1) Forstliche Bliitter 1\&80. Bd. 17 , s. 245 .

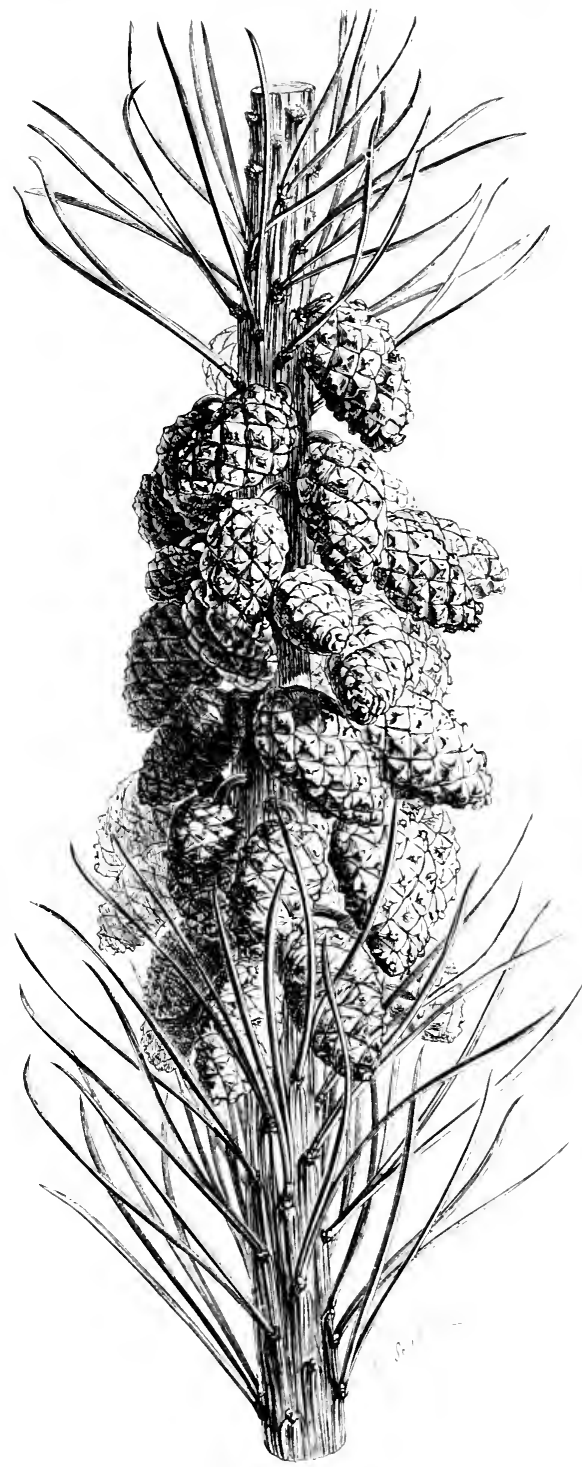

Fig. 54. Zapfensucht bee Kiefer. (Xitul Xonbs.) 
solehe Proliferation eine Durehwachsung (diaphysis). Erscheinen dagegen die Adrentivknospen in der Achsel irgend eines Gliedes der Blätenkreise oder der Deckblätter, tührt die Bildungsabweichung den Namen Achselversprossung (echlastesis). Die mittelständigen

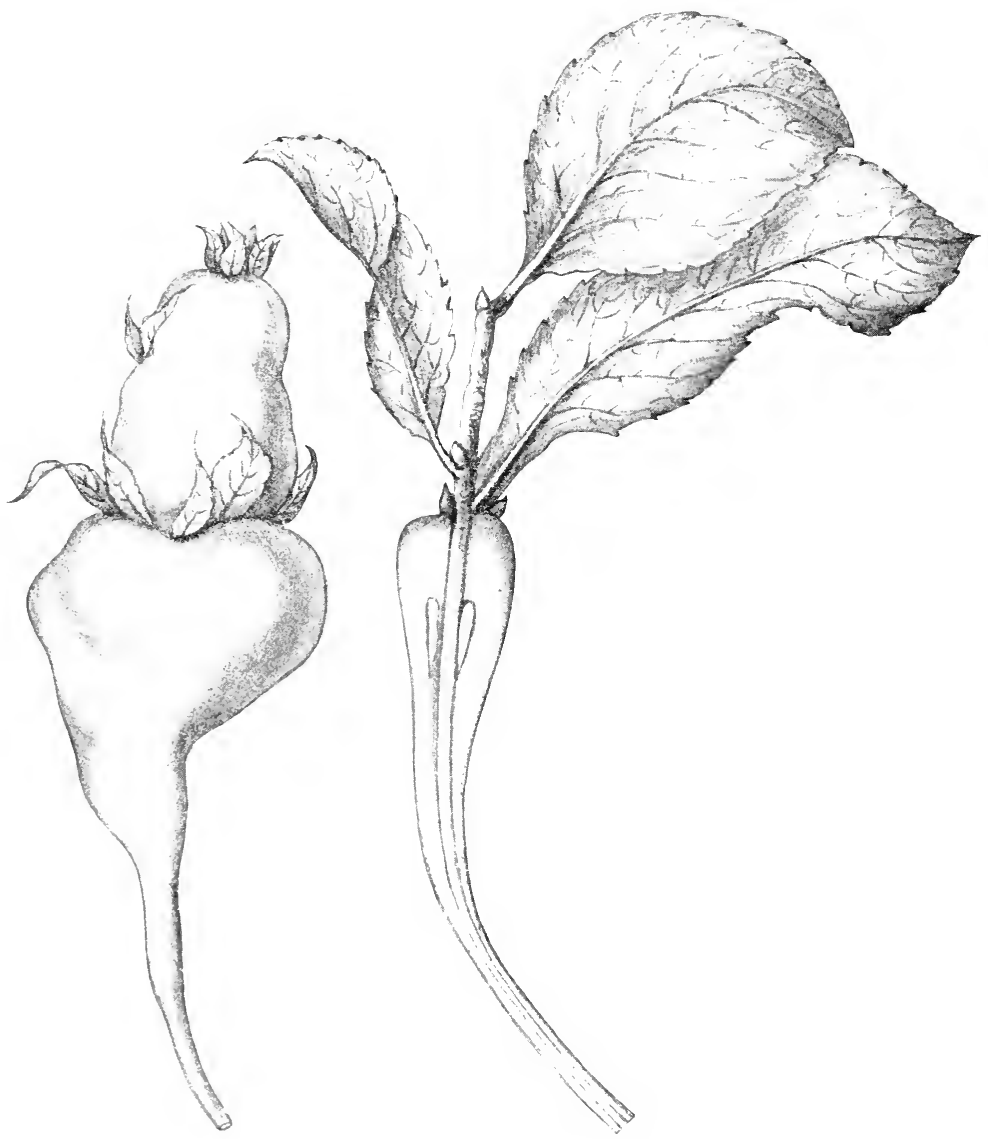

Fig. 5.5. sprossende Birnen.

Versprossungen sind hänfiger als die achselständigen, was wahrscheinlich mit dem Umstande zusammenhängt, lat's alle Triebe, welche die direkte Fortsetzung der aufsteigenden Achse bilden, leichter Wasser- und Nahrungszufuhr erhalten als die seitlichen Verzweigmoen. Hierfür spritht anch das äufserst seltene Vorkommen von Proliferationen bei Bhmen, die einzehn in der Achsel von Blättern stehen. 
Die Füllung der Blumen bei Compositen besteht bekanntlich hänfig darin, dats die normal röhrenförmigen scheibenblumen zu lenchtend gefärbten Kungrnblumen werlen. Eine Proliferation bei Compositen ist vieltach in der. Weise beobachtet worden, dats an Stelle dos einzelnen Blïtchens sich vom allgemeinen Blütenboden ein ganzes Köptchen erhebt. So berichtet Mands ${ }^{1}$ ) äber Exemplare von Bellis permmis, die an der Peripherie ihrer Köptehen zahlreiche, gostielte Sekmdäköpfchen besatisen. Dieselbe Erscheimmo worte bisweilen antser an Crmis birmis L. anch noch an Cirsimm arense Scop. beobachtet. T̈herall waren die einzelnen Blïtchen derart durchgewachsen, dats sie zn einer mehr oder weniger langgesticlten, oft mit trockenhäutigen Blättchen versehenen. von einem ganzen Blütenköptichen gekrönten Achse wurden. An der Peripherie eines jeden Sekundärköpfchens können sogar 'Tertiärköpfchen und mehr Generationen sich entwickeh.

Sprossungen von phanerogamen Frïchten sind ebonfalls keine Seltenheiten. The bekanntesten Beispiele finden wir an unseren Kernobstfiüchten, nnd zwar bei Birnen mehr als hei Äpteln. Wir geben in Fig. 5s eine Abhildung sprossonder Birnen. bei denen ans einer Frucht eine andere oder anch melnere hervorbrehen. Die Erklärmo dieser Erscheinmo ergibt sich von selbst bei der Betrachtung, dafs die Frocht moseres Kermobstes ein roweig ist, dessen Rincle antserowewhulich stark sich entwickelt. Fewöhnlich ist der \%weig dureh die Fruchtbläter an seiner syitze abgeschlossen: diese entwiekeh sich zum Kernhanse mol trasen in dessem Innern dis Samon. Dabei wölbt sich die Rinde des /weiges, an dessen Gipfel die Blume eingesenlit ist, immer mehr über den samenanlagen znsammen mol wird durch stoffliche Veränderumgen mol streckungen ihrer Zallen zum Fruchtfleisch. Wie bei den Durchwachsmgen der Rosen kam mu anch eine Birnenblüte durchwachsen, indem der kleine Achsenscheitel zwischen den Fruchtblattanlagen sich wiedrer streckt, die Fruchtbätter anseinanderdrängt oder gar nicht zur Entwicklumg kommen lätst und sich zu einem ans der ersten Birne hervorsprossuden /weige ansbildet. l)erselbe entwickelt an seiner spitze entwerler sine Blïte oder sehwillt anch ohne eine solche kreisolfömig anf und stellt so eine zweite Birne in der orsten dar. Entwieleh diese \%weige keine Geschlechtsolgane, damm zeigen die monströsen Birnen im Imern gar liein Keruhans. WTenn sich die durchwachsend. Achse der Birnenfincht verzweigt, dam spossen neben der zentralen Birne noch seitliche, kleinere Birnen hervor.

Bei Äpfeln erstreckt sich manchmal die Sprofiskratt nur anf einzelne Gefätshïndeläste in der Frncht; es wöllt sich dam ans derselben seitlirh ein Buckel, der sich bis

1) Sitzungsber. d. Bot. Ver. A. Prov. Brandenburg XXI. 1\&i9, Sitz. 5.28. Nov.

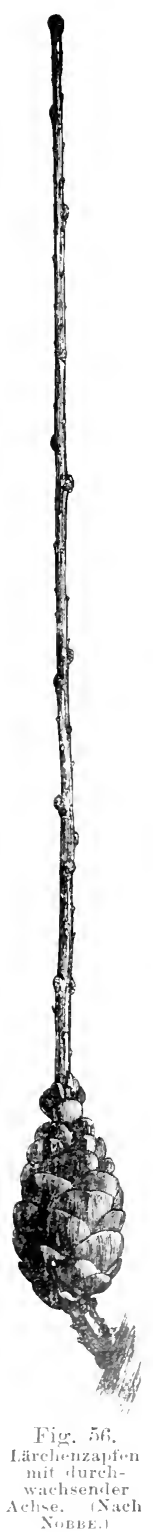


zn einer kleinen Nehenfrucht steigern kann, hervor. Bildet sich die seitensprossung bis zur Prodnktion einer wirklichen Knospe aus, so erhalten wir zwei schräg überemanderstehende Kerngehänse. Der Fall hat dann grofe Ähnlichkeit mit den Doppelfrüchten, welche durch Terschmelzung zweier getremter, seitlich stehender Blütenanlagen entstuen. Ein einfacher Fall ist die Entwicklung einer ruhenden Lanbknospe am noch unverdickten Zweigteile der Frucht, nämlich am Fruchtstiele.

Bei den Nadelhälzern zeigt sich die Proliferation in Fortwachsen der Zapfenachse zu einem beblätterten /weige. was am hänfigsten hei den Lärchen (s. Fig. sti) zu finden ist.

lan den Erscheinnngen, bei welchen sich ein Ïthersehuts von plastischem Naterial geltend macht, gehört auch das Auftreten von Blattorganen an Stellen der Achse, die normalerweise blattlos sein sollen (C'horise) und die Vermehrung der Blattorgane in einem Knoten (Verdopplnng, Wédonblement), sowie die Vervielfältigung der Teile eines zusammengesetzten Blattes (Pleophyllie). Das hänfigste Beispiel tür letzteren Fall sind die vierblätterigen Kleeblätter, ïber welche eine nene Studie von TAMmes ${ }^{1}$ ) zunächst erwähnt, dat's DE VRIEdurch fortgesetzte Selektion bereits eine Rasse geschaften habe, deren Individnen selır reich an vier-bis siebenscheibigen Blättem sind. Es liegt hier wieder ein sehr hübsches Beispiel vor, wie eimmal zutällig entstantene Üherernährmngserscheinmngen erblich werden können. Wir haben anf diesen Punkt anch bei den Verbänderungsvorgängen hingewiesen. Bei dem Klee arscheinen einzelne Nervenäste kräftiger und gespalten oder anch der Mittelnerv, und zwar bisweilen über den Blattstiel noch hinans. Dann trägt jeder 'Teil des gespaltenen Blattstiels an seiner' Spitze einige Blättchen. An den Zweigen zweiter, dritter und vierter Ordnung, bei denen die Nährstoffzufuhr sehon nachlätst gerenüber den erstentstaudenen. kräfigen Achsen, läfst anch die Pleophyllie nach. Weniger in die Augen springende Beispiele finden wir bei allen Ptlanzen: ̈̈berall zeigen sieh in den für die Nahrungszufuhr am siunstigsten gestellten /Wweigen solche Bläter, die besonflers stark entwickelte Blattfächen und damn Gabelnngen einzelner Rippenäste erkennen lassen.

Am hänfigsten hegegnet man solch üppig ansgebildeten Blattormen bei dem sogen. Stotkausschlag, also den aus schlafenden und arlventiv gebildeten Angen hervorgehenden Trieben an den stimpfen gofällter Bänme (z. B..Pomulus nud Mors). Die Grölsenverhältnisse pflegen weit über das Dnchschnittsmats hinanszugehen, und die Blattformen weichen lis zur Tukenntlichkeit oftmals rom Typus ab. In diesen Fällen haben die nenentstehenden Triebe das gesamte gespeicherte Reservematerial des Banmstumpfes zur Verfügung, und daher die enorme steigerung ihrer Produktion.

Als verwandte Frscheinmngen nemnen wir hier anch die Hexenbosen, die wir als , $/ 4$ weigsucht "ansprechen können. Die Häufung des plastischen Materials an einzelnen Aststellen, die sich allmählich durch proleptische, nestartige /wweighildnug zu verwerten sucht, dürfte in der Meluzahl der Fäle dureh parasitäre Reizung zustande kommen.

1) Tamass, Tro, Ein Beitrag zur Kenntuis ron Trifolium matense quinquefolium de Tries. Bot. Zeit. 1904, Heft XI, s. 211. 
In der Reged weichen die ahnorm gebildoten Athen in ihrem Ban von den normalen ab ${ }^{1}$ ).

Hierher wehört turner der R ïckgang auf die Ingendtormen²) bei frehölzen. dic nach starken Verlotzmnoen frisch und krättio austreiben. Auch die sogen. Rosettentriefr, wir sir Fig. st ron der Kiefer darstellt. sind Folgen lokaler C̈beremährung. dir daclureh zustande kommt, dats die Bämme äntserst starke Verluste an ihom Laul,körper (meist durch Raupenfiats) rorher erlitten haben. Hir mobilisiertru

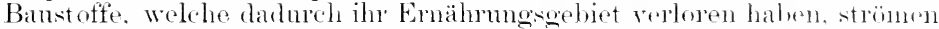
nun den ruhenden Augen, die zwischen den mormalen Nablebüscheln angelegt ofler in Form schwäthlicher Quirlinospen dentlicher rekembar sind. zu und reranlassen dieselben zum Austreiben. An Stolle von Narlelbüscheln entstehen damn eintache, hreit schwertförnice Narlehn mit gezähntem Rande; in deren Achseln kïnnen damn, wie msere Figm es zeigt, wieder normale Kurztriebe (Narlelbüschel) gehildet worden.

Betrachten wir die geschilderten Fälle in ihrer Gesamtheit. eroilst sich sofort der ïbereinstimmende /ug in fenselben. Es ist überschüssiges Banmaterial in einem Teil der Achse rorhanden. Und zwar ist durch Überernährung wirklich neu rom Blattapparat gebillote orwanische substanz rinem Achsenteil zur Verfü̈mung gestellt. oder es kommt eine Anhäufunu her Banstotte lokal dadurch zustande. lats nobilisiertes Reservematerial nicht sein hisheriges Verbranchsobiet findet, indem dassolbe durch Verletzungen (Raupentiats, Verbifs, selmeidelung. Stmon nsw.) verloren gegangen ist. Wirtt sich dieses überschïssige Material auf bereits vorhandene Organanlagen, kommt tasielbe

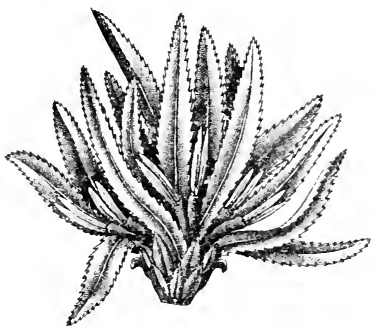

Fig. 57. Rosettentricb ciner Kiofer. In ler Achel der einfachen schwertförmitren Nadeln zeigen sich die kuratriebe mit lopuelnateln. (Nach RATELtrat.) (Vergrïlsert.)

in erhöhter Aubildung der normalen Form oder im Rahmen dir vorsehreitenden Metamorphose in anderer Organform zum Ausiluck. Gelangen dis Banstotfo an einen Vegetationspunkt. werten meln organ. angelegt. Joder Vogotationsmukt ist stets das Produkt der ihm zu Gebote stehenden Nahrmos: or häl sich nur so lange innerhalh seiner morphologischen Gesetzmälsigkeit, als der Eruährungsoreang der hisher üblithe war. siteigert sich die Nenue der Banstoffe. hildet er melm Oroananlagen. unel lamit können sich die erlich gefestigten Blattstrllungsgesetze ändern und abnorme newe Vegrationspunkte in Forn

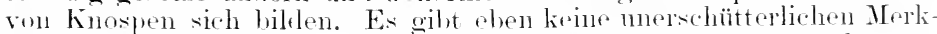

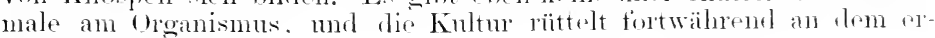
erliten Bantyums.

\section{Knospendrang (Blastomania A. Br.).}

Es ist bereits in rorigen Ahschnitt des sogen. . Stockansichlates gedacht worden. Hiv Erschoinmoen sind überall zu heohathten, ww

1) Vergl Zwa, Wum., Cntersuch. über die Eutstehung des Kieferuhexenbuspts. Ber. d. Kol. Lehranstalt $\mathrm{f}$. Weinban usw. Geisenheim 1905, s. 2.:5. Ferne bietet die naturwiss. Zeitschr. f. Land- n. Forstwirtschaft neuerdings reichliches Matrial.

") Diecs, L., Jugendformen und Plïtenreife im Pflanzenreich. Berlin 1906. Gehrr. Bornträger. 
alte stämme von Pappeh, Eichen, Buchen, Kastanien usw. gefällt worten sind. An der Schnittfläche des Stammstumptes erhelot sich aus der cambialen \%one ein Überwallungsand, in welchen zahlreiche Adrentivknospen gebildet werden. Datis auch an Wundflächen krautartiger stengel und Blätter neme Knospen entstehen, zeigen die vielfachen Vermehrumgsvorgänge durch "Blattstecklinge" von Begonien, Gesnerien usw. Als ebenso bekannt vorauszusetzen ist die Eigensehaft der "Vivipar it ät", d. h. der Entwicklung nener vegetativer Knospen aus einer muverletzten Blattfäche innerhalb des normalen Entwicklungsganges (Aspleminn, Bryolhyllum usw.). Oft beobachtete, nicht nomale Fïlle sind solehe Knospenbildungen bei Cardamine fratemsis, Mrosen intermelia, Arabis momila usw. DUchartre sah ans den Blättem von Solamm Lycoporsicum kleine beblätterte Zweige hervorgehen. Brate beobachtete an den Blättern und namentlich an den Stengeln der Kulturformen von Calliopsis tinctoria so überreiche Adventivknospenbilkung, dats er z. B. auf einem etwa 20 cm langen stengelstück gegen 300 zählen konnte ${ }^{1}$ ). Anch bei anderen Ptlanzen sind derartige Fälle beobachtet worden²), und ich sah Exemplare von Prlaryominm zonale und phtutum mit kuchenfömigem, fleischigem stengelanswuchs an cler Basis, der gänzlich mit kleimen Knöspchen bedeekt war. Einzelne kräftigere Exemplare derselben entwickelten sich so weit, dats man äufierst kleine Blättchen unterscheiden konnte: die Mehrzahl der Knospen ging zugrunde durch gegenseitigen Druck. Ein gleiches Heischiges Polster bildete einmal Dahlia varialilis, die im Vermelmungskasten angetrieben worden war, um aus der Stengelbasis neue Angen zu entwickeln. Die Triebe wuden sofort zu Steeklingen abgeschnitten, worauf ans den Basalangen der krautigen Zweigstumpfe sich nene seitentriebe entwickelten, die immer zahlreicher, aber anch immer schwächlicher wurden. Es entstand aut diese Weise eine krautartige K ropfmaser.

\section{Die Kropfmasern der Bäume.}

An die vorerwähnte, selten vorkommende Knospenhäufung bei krantartigen Pllanzen schliefst sich naturgemäls die Kropfmaserbildung bei Bäumen, die (nnit spärlichen Ausnahmen) dadurch zustande kommt, dat's normale /weiganlagen verhindert werten, ihr kängenwachstum fortzusetzen und statt desien nene Seitenangen austreiben. Die aus solehen hervorgehenden 'Trielse stehen $1 \mathrm{~m}$ so dichter, je näher sie der Basis des Mutterzweiges entspringen, weil dort die Luternodien am kürzesten sind. Wenu derartige //weiganlagen durch Verwuntungen oder andere Ursachen, wie z. B. gegenseitigen l)ruck, in ihrem spitzenwachstum eine Beschränkung finden, treilien anch sie wieder seitliche sprosse.

Als Beispir einer answozeichneten Kroptimaserbihlung, deren Holzkïrper nach Entfermung for auffallend dicken Rinde die spietsigen Fortsätze abgestorbener Knospenkegel zeigt, geben wir die Abbildung (Fig. So ) eines Stammstiotes von Acor campester; bei a finden wir die Flächenansicht, hei $b$ den Querschitt der spiefsigen Holzkegel, deren Markparenehym durch die dunkleren Fnnenkreise angedentet ist.

1) Brarn, A Über abnorme Biłdung von Adventivknospen am krautartigen Stengel von Calliopsis tinctoria Dec. Verh. d. Bot. Ver. d. Prov. Brandenburg, XII, S. 151.

2) Marixts, P., Verh. d. Bot. Ver. d. Prov. Brandenburg, XII, ‥ 161. 


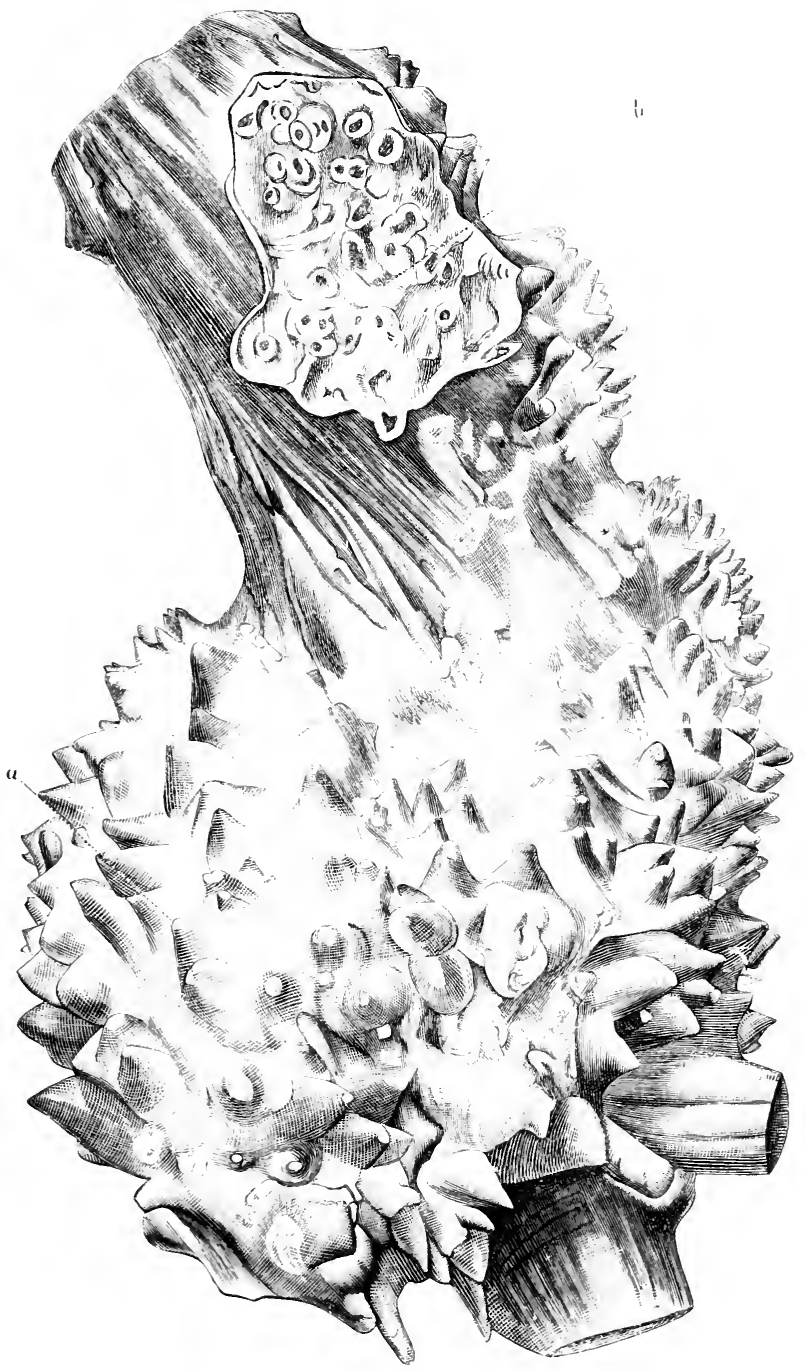

Fig. 58. Entrindete Kropfmaser von Ahrm 
Ähnliche Bildungen treten bei sehr verschiedenen Baumgattungen anf. mul zwar sowohl an beliebigen stellen der oberirdischen Achse als anch, obwohl viel seltener, bei Wurzelstockknospen. Besonders bevorzugt sind diejenigen Stellen, an denen Äste abgeschnitten worden sincl. Hier beginnen dann die am Astgrunde gehäntten Proventiv- und Adrentivknspen sich zu klemen Trieben zu entwickeh. Die aus dem Cambium des Dutterstammes hervorgehenden Holzelemente nehmen durch die vieltar hen Ifindernisse, welche diese durchbrechenden Knospenkegel bicten, einen $\mathrm{nm}$ disselhen herum sich schlängelnden Verlant. Darlurch muts eine Verlangsamung in der Leitung des plastischen

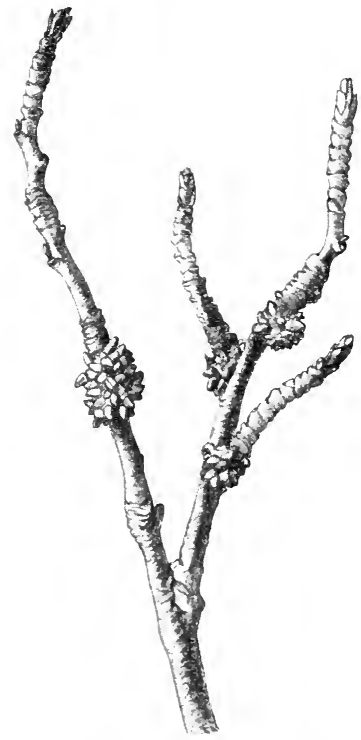

Fig. 59. Maserbildung an Zweigen voll Malus sinensis. (Nach Kisina.)

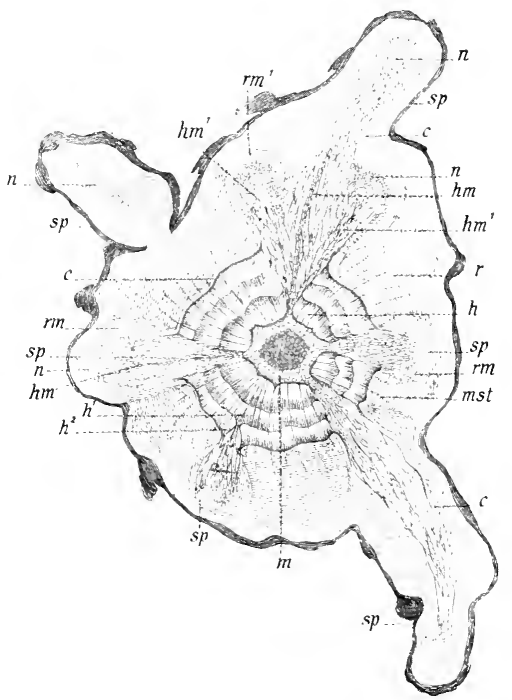

Fig. 60. Querschnitt durch ein Maserpolster. Man sieht, dial's die tentralpartie der einzelnen Maserspielse aus einer. Markstrahlerweiterung der Zweigachse lievorgeht. (Nach KissA.)

Materials nach der Stammbasis stattfinden. Da aber die Masergeschwulst meist oinseitig an der Achse anftritt, so dat's the gegenüberliegende Soite frei nud der normalen Emährmg danernd zugänglich bleibt, so leirlet die Clkonomis des Bammes wenig.

Nicht immer jedoch ist rine normale Zweiganlage als der Ausgangspunkt von Kopptimasorbildungen vorauszusetzen. Es gibt auch Fälle, bei denen die Maserspiefse aus Markstrahlwuberungen hervorgehen. Einch solchen Fall behandelt eine unter meiner Leitung entstandene Arbeit von Krsisal) äher Maserbildung bei Malus simensis. Ine beistehende Fig. jo zeigt eimen Kweig mit Maserpolstern, die

1) Kiss, N. W., Kropfmaserbildung bei Pirus Malus sinensis. Zeitschr. für Pflanzenkrankh. 1900, s. 129. 
vorzugweise aus der parenelymmeichen Basis likiner Fruchttriebe hervorgesprotst sind.

In Qnersehnitt erkannte man, dats die kecreltörnigen sipietse Holzzylinder darstrllen, deren Kentralkörper aus verlmeiterten Markstrahlen hervorgegangen sint. Iteratige Markstrahlen (Fig. (io) sint entweder primäre oder entspringen rest ans einem suateren oahresinge. Der Holzmantel des spiesses besteht ans der Fortsetzmug des llolzringes des Mutterzweiges. Wir hei einer normalen seitenadise ist ler Maserspiets mit einer eignen Rinds momeben mol weist anch einen gut ans-

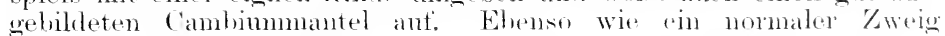
verästelt sich der Maserspiefs (Fig. bohm') mol verlängert sich durch sipitzenwachstmm: aber lieine dieser Achsen zeigt jemals die Anlage von Blättern orler Knospen.

Die Differenziermug der. trewebe des Maselspiedises erfolgt sehon in den ersten Entwicklongsstarlien innerhalb der Rinde des Mntterzweiges. der zmuätehst $11 m$ otwas angeschwollen orscheint. Diese Ansehwellums wired ladureh hervorenolnaclet, dats die Rinde Turrh eine Anzalil hesomeler's stark entwickelter, mit me ristematischer halle. versehener Markistrahlenantwetrieleen wird. Durch das weitere spitzenwachstum dieser Nentildmugen wird dir Rincle des Mntterzweiges schlietislich durchbrochen. Nim tritt dier Maserspiefs. mit eigner Rinde lekleirlet. als selhständiges rebilde lervor. Aber las Längen-

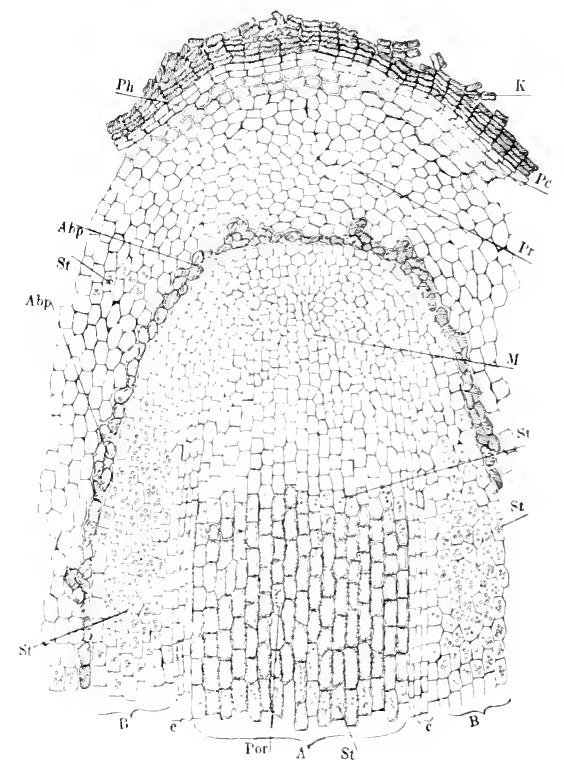

Fig. 61. Längsschnitt durch einen Maserspiefs. (Nach Kism.) wathstum desiellew timelet seinen baldigen Abschluts. da die Rindenkapene und die darmuter lienente Meristemschicht vertrelinen. Statt des spitzenwarhstums tritt $11 m$ eine basale seitonspossmng bei den einzelnen Maserspintisen im Innern der Rinde des Mutrawariges ein.

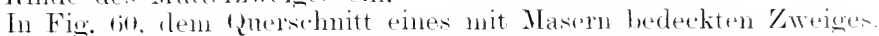
sehen wir, dats die den Markkärper des Maserspietses hildendon Markstrahlen meist primälr simb. also vom Markkörper des Mutterzwoiges

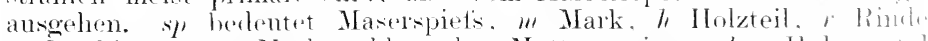
c Cambium, mst Markstrahlen des Mutterzweiges, him, Holznnantel.

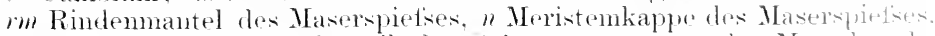

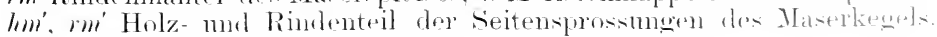
l' zweiter, li" tritter .lahresting. 
Fig. 01 ist der stark verorötserte Längsschnitt durch einen Maserspiets, der noch immerhall, der Rinde des Mntterzweiges sich befindet. $7 \%$ ist Phellogen, $k$ Korkschicht, Pc collenchrmatisch verdickte Zellen, I'Parenchym der Primärinde des Mntterzweiges, welches sich in seinen immeren Lagen mit Stärke zu fïllen beginnt, St Stärke, $A b p$ ahgestorbene Lage von Parenchymzellen der primären /weigrincle, $M$ meristematische spitze des Maserspicfises, A Zellen des ILolzmantels des Maserkegels mit ihren Poren $\left(P()^{*}\right)$, Cambium, $B$ Eigenrinde des Maserspiefses.

Also der Kegehmantel $A b p$ ans schratfierten

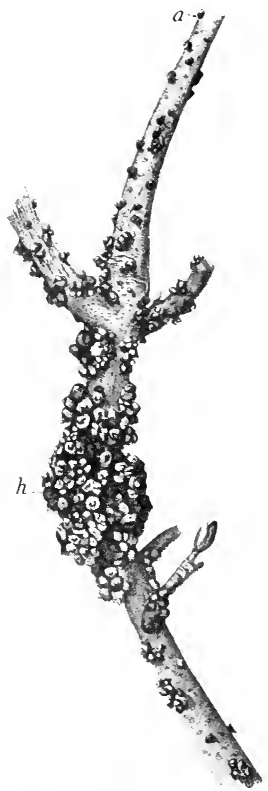

Fig. 62. Perlartige Naserbildung bei der sichwarzen Johannisheere. (Orig.) Zellen bildet die (trenze zwischen der Maserspiefianlage und der Mutterinde des Zweiges. Erstere gibt sich deutlich als Achsenzylinder zu erkennen, indem ein Holzmantel $A$ bekleidet ist mit eignem Rindengewebe $B$, wobei zwischen beiden sich die C'ambiumzone - keuntlich macht. Der Holzzylinder zeigt sich vorzugsweise ans stark porösem Parpuchrmholz zusammengesetzt (Por). Das Rindengewebe ist reichlich mit Stärke angefüllt. Der junge Maserspief's rerlängert sich durch spitzenwachstm mittels seiner Meristemkappe und pretist allmählich die angrenzenden Zellen der Mutterrinkte zu einer welhlichen verquollenen schicht (AbJ) zusammen. (Herhalb dieser abgestorbenen Lelllage ist die Mutterrinde noch ganz gesund; erst wemn der Maserkegel durchbricht, wird rie ahgetïtet.

Wenn wir im vorhergehenden der struktur des fertigen Maserkegels besondere Antmerksamkeit geschenkt haben, so wenden wir ms jetzt ergänzend zu den Vorgängen der Markstrahlerweiterung. Welche dir Maserkegelbildmo einleitet. Ein solcher Fall ist von mir bei libes nigr $m m^{1}$ ) stmiliert worlen.

Fig. id h zeint die gehänften, perligen bis $1 \mathrm{~mm}$ hohen Maserbildumen neben- mol zum 'Teil überemander. In (puerschnitt Fig. 6i:) bemerlit man, wie der IJolzing des Kweiges in fächerartiger oder fiederiger Verästehmo in den Maserkïrper ausstrahlt, der hier nicht, wie bei Malts simensis kegelfömig. sondern kngelig-warzenförmig erseheint.

Fig. (i) stellt in $B$ die Längsansicht, in A den Qnerschnitt einer Maserwarze dar. I) ist die normale /weigachse mit ihrem Markkörper m. mod Iolzringe 7. der mu dureh wnchernde Markstrahlen mst geklüftet erscheint Diese Markstrahlen bilılen den Anseangsumkt für die sich fächerartig verzweigenden Maserbilinugen (sp), die bei weiterer Ansbildung einen centralon Holzkörper $(k /$ ) mol dentlichen Rindemmantel $(r)$ crliennen lassen.

Der (2merselmitt durch den \%weig an einer solchen warzigen stelle lätst erkemnen (Fin. ift), dats die Warze eine kegelförmige WVuchermo (li) der immeren línulw dastellt, welche die äufseren Rindenschichton

1) Soratel, P., Krebs an Ribes nigrum. Zeitschr. f. Pflanzenkrankh. 1891, S. 77. 


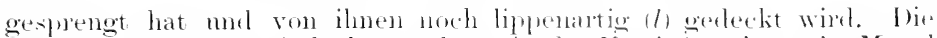
Ränder der Lipren sind abgestorben: in der Vortietume ist meist Myerd

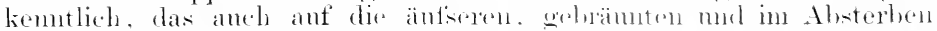
bewrittenen ofler bereits toten \%ellen dis primäron Mrserkegels (p) überweht. Verfolgt man das Wnehersewebe das nach seiner Basis hin einen aus sehmalen, netzartig vesdickten Gefätizellen bestelendens in den nomalen Ilolzring ïlerexelenden Holzmantel hesitzt. riulkwirts, so hemeskt man, dats mass rine einfache Markistrahlwuehermer vor sich hat. In Fig. 64. die eine ann weitesten forteresehittene Narkistrahlwallermne ann Encle des ersten (Entstehmes-) Jahres eines /weiges darstellt, zeigt die linke sieite noch den nommalen Rintestrau: ali sind die verkorkten Reste der in Laufe des Entstehmegjalmes bereits abbläternelen, äntser-

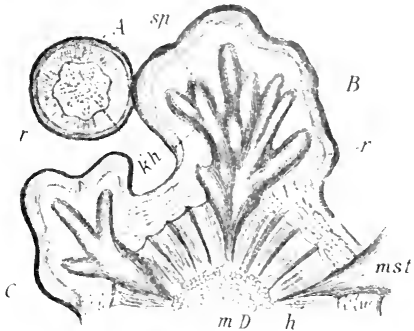

Fig. ti3. Querschnitt durch einen mit Masern bedecktan /weigteil. (Orig.) stron Rindenlagen mit rinzelne+1 Kalli-

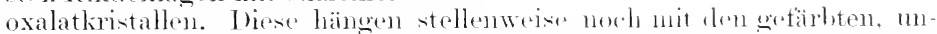

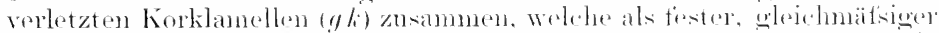

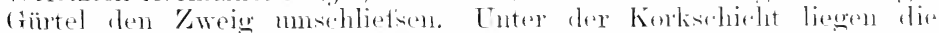

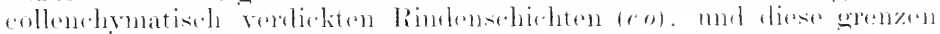

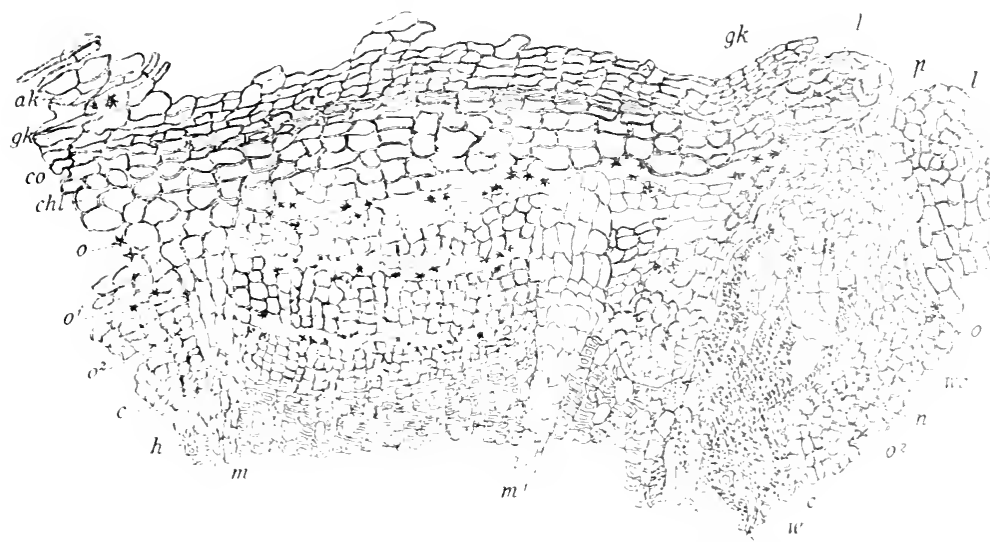

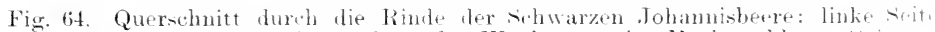
gesund, rechte seite mit zumehmender Wucherung der Markstrahlen. Hrig.

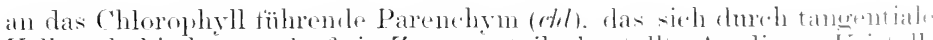

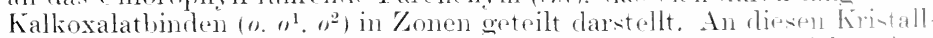

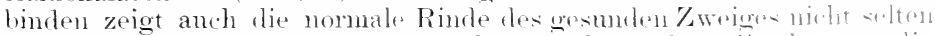

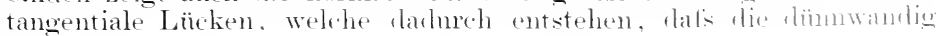


bleibenden \%ellen, welche die klemen Drusen von Kalkoxalat fühnen, selur leicht zerreitsen, so dats die Kristalle zum Teil freiliegend an den Rïndern der Lü̈lie auttreten.

In Herlst des ersten dahres sicht man die Phloëmstrahlen his an die erste Uxalathinde (o) reichen. In diesen Strahlen wölbt sich, wie dies bei unseren Holzgewächsen die Regel ist, die Cambiumzone (c) math autsen und sinkt über dem Holzkörper $(h)$ vieder bogenförmig zurïck. Daraus läfst sich erkennen, dat's der Markstrahl als schwellkörper für die radiale Ausdehnme der Achse timktioniert, sowie der Narkzylinder sellst die longiturlinale streckum unterhält.

Der normale Markstrahl (m) behält immerhall, der Rinde seine in Iolzkörper zuletzt elangte \%ellenzahl duchschnittlich bei, und seine

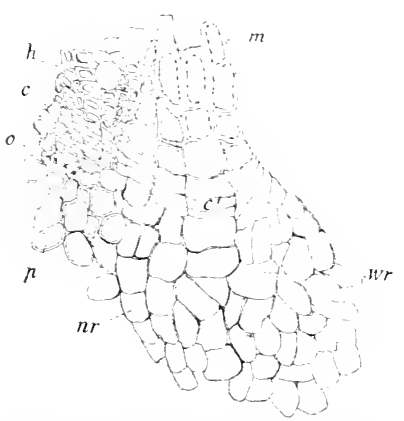

Fio. 6.5. Markstrahl in den Anfangsstadien der Maserbildung. (Orig.) Verloreiterung in ter Rinde hervht dam nur anf der grötiveren Ausdehnung der einzelnen rellen. In der Nähe der Wucherme dagegen findet man nicht selten schon Markstrahlen, deren Zellen an \%ahl gewachsen sind $\left(m^{1}\right)$, aber im wesentlichen noch ihre radiale normale Längsstreckung bewahrt baben. Im Wucherstrahl endlich tritt eine autiser. ordentliche Zellvermehrung ein, und die Cambiumzone wölbt sich steil nach antisen.

Man sicht dies am besten in den verhältnismätiog seltenen Fällen, in flenen Markstrahlen einseitio mit der Wuchergewebebildung anfangen, wie dies in Fig. 65 dargestellt ist. In dieser Fig. (is dentet mie Marlistrahlzellen imnerhalb des Holzkörpers an, $c$ ist die Cambinmzone, die an der rechten seite ansteigt, linkerseits ïber dem Iolz h züücksinkt; $n r$ ist die normale seite des Rindenstrahls, der an das derbwandige Rindenparenchym f' anstäst und sich in Kalilauge duch die gelhere Färbme deutlich von der Ungelnung abhebt. In o sind die sehr zartwandigen, klemen /elleihen mit oxalsaum Kalk angedentet; schon hier, in der Nähe der ('ambimmone, lassen tie Wandumgen dieser \%ellen eine eigentümliche kömige Beschatfonheit als Zeichen ihres

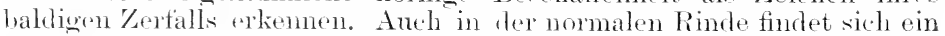
soleher hörnigschleimiger \%erfall dieser Kellbinden und das Heranstreten lor Kalkdruson an die Ränder der entstehenden Lücken. In der worhernden reite ( Kalilange morh dumkler geth als die anf der nomalen Seite werden mul nicht solten eine dentlich knötchenartige Aufpuellung der. Wandumg zoigen, richtet sich die ('ambiumzone stril auswärts, r', und deutet schon an, dats sie kapprnartign in fertigen Wuchergerwe sich vorwölbt.

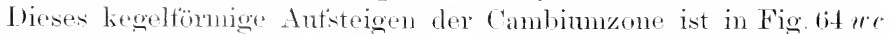
ersichtlich. Jïrer erlirme man, dats sie sich zu einer Spitzemegion himzieht, die aber nicht am äutsersten (Xiptel des Wuchergewebes liegt, sondern immer gedeckt vom Rindengewele bleibt; dasselbe stirbt von andien nach immen fortscheitend ab. bis anch die meristematisehs spitze des Wucherkerels erreicht ist. 
Die Meristemzone des Masorkegels begimt im nächsten .Jahre sowohl in der sjpitzemegion als anch im hasalen Teile siprosimgen

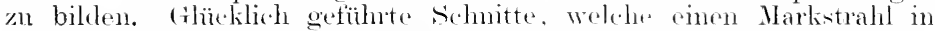
seinem ganzen Verlante blotislegen, zeigen, dats dic Bildnug der sekmudären Achsen wiedermm in derselben Weise erfolgt, wie lor primäro Maserlegel entstanden ist, nämlich durch Wnoherme des in der Rindo verlantenden Marlistrahlteils.

Terfolgt man von einer bereits dentlich als Mascranlage kinutliehen stelle aus den Ban der Tnteruodien nach immer jüngeren Trilen des \%weiges hin, so sieht man schon in dem noch ganz selwarle angelegten Holzringe der Achse, welche die zur diesjälrigen Vordangermme des

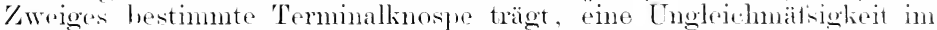
Markstrahlban. An der Basis der diesjälnigen Knospen, in denen der jugendliche Ifolzzylinder erst die Syrralgefätise der Marklirone und einige Libriformfasem nebst vereinzelten notzömmigen oder por̈isen Gefäfen besitzt, bemerkt man hier mul da einen Markistrahl, der dumbls die etwas gröfsere Weite der Kellen, etwas stäkere Lirhthrechmo seiner \%ellwände, sinen answerägteren, goraden Verlant und seme tiefere Fortsetzung in die Rinde hinein von don anderen strahlen abweicht. Dabei ist hemerkenswert, dats die an weitesten in die Rinde hineinragende Endzelle des Phlö̈nstrahls nieht, wie leei den anderen. schmäler als die vorhergehenten, sondern breiter mol zwar an hreitesten ron allen den strahl zusammensetzenden /edlen ist. Während also die gewöhnlichen Markstrahlen doutlieh krgelformig endigen, hat dieser soine hreiteste seite nach der Peripherie arithtet. Hs ist diesellue Wachstumstendenz, die sich hed den älteren. Tereits als ansegerpochene Tueherstrahlen anftretenden statien kemtioh macht. Fine solehe Differenzierung im jüngsten /wejgstaflim zeigrt, wiי diese Art der Kroptimaserhildume schon in dru ersten ongendphasen dor Achso vorbereitet ist.

Autiser den Markstrahlwotherungen giht es noch andere Faktoren fiir Rindenauttreibungen, die bei der Einkalpselung erkankter Gowebeherde entstehen. Wir kommon in dem Abschnitt über dic ,Knollen maser". die besser bei den Wundheihngsvorgängen abgehandelt wird. anf diese Punkte zuriick.

Kropfinaserhildmoen mit hexenhesenartiger Serzweigmng hatte ich cielegenleit an Prumes Pudus zu beobatehton. Ähnliche rebilde fand ich hei stachelheren $\left.{ }^{1}\right)$. Warzenartige, den beschriebenen bei Ribs ähnliche Masem sah ich bei Cydomia vulguris²). Anch hei stachelbeerstränchern in les Nähe von Komposthanfen liomte ith später Naserbildungen in ähnlicher Form wie bei dor schwarzen Johamnisbeere feststellen ${ }^{3}$ ). In einem erst lï̈rzlich mir bekannt gewordenen Fall. hri der roten Kirschjohannisbeere entwickelten sich ans einem kroptartigen Maserknoten lange belnäterte Trielse, flie in den Blatt achsehn keine ausowbildeten Augen besatien. An den Stcllen, an dentr die Markbrieke in Zweinnodus sonst zur Knospe fïhrt, war entwedr. war keme Mrristomlage zu finden, oder diselbr blieh von einer Rinden kappe bedeckt mol gestaltete sich zu einem kleinen Masersjiofi. An

1) Jahresbericht des Sonderausschusses für Pflanzenschutz. Arb. d. I lentsi. $I_{1}$ Landw.-Ges. 1898. S. 145.

2) Ibid. 1899, s. 188.

3) Ibid. 1900, ‥ 213.

Sorauer, Handbuch. $\because$ A A th. Erster liand 
stelle les fipofolknospe fanden sich Maserspiofsanlagen gehäuft und wurden wioderum im nächsten Jahre zur wirklichen Kropitmaser, aus welcher, wie bei Acer und Tilia, später schwächere. beblätterte Zweige hervorspotsten.

Soweit man aus der Beschreibung ersehen kamu, dürten auch die merkwördigen "Kylindermasern" (chichi, nipple) an Ginglio biloba zu den Kropfmasem zu rechmen sein. Nach KExnko Fun ${ }^{1}$ ) zeigen sich diese chichi oder Zitzen als zrlindrische oder kugelförmige Auswüchse, welche in drr hegel von älteren /weigen ans senkreckt naeh unten wachsen. Thre Grötse wechselt von der Länge eines Fingers bis zu $2 \mathrm{~m}$ bei 30 cm Iticke. Sie gleichen normalen \%weigen, denen die Blätter f'ehlen. Am Boden angelangt, schlagen sie Wurzeln, und lamn vermögen sie auch Blätter zu entwickeln. Anch an den Wurzeh sollen ähnliche Bildungen auftreten.

Ich habe derjenigen Form der Koptmaserbildung, hei der nomale Augenanlawn nicht beteiligt sind, eine eingehendere Darstellung gewidmet, weil sie die Wichtigkeit des Markstrahlgewebes in einer Richtung dartut, die bisher nicht die geringste Beachtung gefunden hat. Dankenswerte Hinweise finden wir aller(ings hei Fkask ${ }^{2}$ ), der anch die trüheren Beobachtungen über Naserhildmogen bespricht; aber es handelt sich hier vorzugsweise um die Erklärung des wimmerigen Verlautes der Holzfaser bei gemasertem Holze. Wir legen das Hauptgewieht anf die Ursachen, die eine Verlmeiterung der Markstrahlen bedingen. Die letztgeschilderte Kropfmaserform ist nur das Extrem einer Neigung zur Markstrahlwucherung, welche uns zu gewissen Krebsgeschwälsten hinüberführt. Bei diesen handelt es sich aber m Vorgänge, die durch Wunden veranlatist sind, während wir hier keine äntseren Eingriffe autfinden kömnen, sondern anf immere Störungen im Gleichgewicht der Wachstmmsvorgänge hingewiesen werden.

Wir haben as mit lokalen, durch den Ernährungsmodus eingeleiteten steigerungen der Druck- und Turgorverhälnisse zu tun, und in dieser Beziehmog geben uns die Untersuchungen von $\mathrm{KNY}^{3}$ ) einen erwünschten Hinweis. Dersellye fand hei Einwirkmog mechanischen [ruckes, dats in den Markstrahlmeristemzellen die Teilungswändo eine andere Richtung anmelmen und zweireihige Markstrahlen zustande kommen. Was hier ein mechanischer, von autsen zugeführter Druck tut, mut's nach unserer Anffassung auch der gegenseitige durh Turgorsteigermo zustande kommende Druck der Gewebe aufeinander veranlassen kömnen. Da aber der Turgor - genügende Wasserzufuhr vorausgesetzt — von der Beschaffenheit des Kellinhalts, von seinem Reichtum an wasseranziehenden Verbindungen abhängt, so wirt jede gesteigerte /ufuhr an plastischem Material eine Turorsteigerung und Verschiebming der bisherigen Druekverhälnisse dor emzelnen Gewebeformen zueinander veranlassen.

solche vermehrte Zufuhr von plastischem Material stellt sich ein. wemn in der nomalen Ölionomie des Pflanzenteils eine Störung durch Entfernung von V'erbranchsherden stattfindet. Bei den Kropimaserbildungen liandelt es sich vorzugsweise $m$ das Abschneiden von Kweigen, was bei dem Ausputzen der siämme und der mamnig-

1) Krxnn Frn, (1) the nature and origin of socalled .chichi" (nipple) of (ringko bilolua. Bot. Magazime vol. IX, No. 105.

2) Fraxk, A. B., Die Krankheiten der Pflanzen. II. Aufl., I. Teil, s. 82.

3) Kxr, L, Über den Einflufs von Druck und Zug usw. Pringsheims Jahrb. wiss. Bot. 1901. Bd. XXXVII, S. 55. 
tachen Arten des Kulturschnittes zur Notwendigkeit wird. Beredte Beispiele datür finclen wir bei mseren linden, Paplehn, Ahom nsw. in den Alleen in den immer mehr sich veronotsernden Angenkolonien an denjenigen stellen der stämme, an tenen ehrmals /weige fortgeschnitten worden waren. Stehen solche Masertolonien an besonders bevorzugten, tür die Assimilationsarbeit hervorragend gragneten stellen, dam erlangen einzelne Schossen ans diesen Polstern ein Öheruwicht und nähern sich den Wassereisern.

\section{c. Eintlut's vonstickstotföberselunt's.}

Wie wir gesehen, sind die stömmgen der gestaltlichen Entwicklung des Ptlanzenkörpers durch lokale Anhänfime des fertigen Bammaterials zwar wissenschattlich interessant, aher ohne grotice wirtschaftliche Nachteile. Ja, wir fimen sogar, dats die Kultmr derartign Bildungsabweichmngen, wie die Füllumg der Blumen, absichtlich zn fördern bestrebt ist. Anders aber liegen die Virhälnisse, wem durch das Rohmaterial die stoftlichen Vorgänge einseitig beeinflutst werflen. Hier kommt die Düngnngstrage in erster Linie in Betracht, mol ror allem handelt es sich mm die störmugen, welche dureh stickstoffüherschnts mol einseitige steigerung der halizutinle hervorerenten werlen.

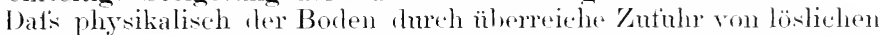
Düngesalzen schädlich beeinflutst wird, haben wir sehom erwähnt. Womn anch die Salze den Boden fenchter halten, so lange atmosphärische Niederschläge ausreichend vorhanden sime, so bihten sie doeh cine stete Gefahr tür die Ptlanzen zu Zeiten der Trockenheit, weil leicht eine zu hoch konzontrierte Bodenlis nn w entstehen kam, welde den ت̈hertritt des Wassers in die Ptlanzonwurzel erschwert'). Der Einthnts aut die Pflanzenentwicklmg kam nicht anshleiben. Eine'n Eimblick gewährt die Arbeit von (Ekneck ${ }^{2}$ ), der bei Triticum beohachtete,

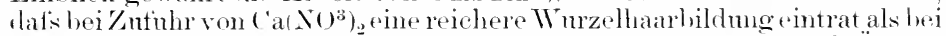
$\mathrm{KN}^{3}$. Bei der Ernährmo mit Nitraten fand die Hahn- und Ährenbilelumg spät, dagegen mit chloriden mol Phosphaten früh statt; bei letzteren ersthienen die Wurzelzellen stärker verklickt als bei ersteren, bei denen auch die Ejidemiszellen und las Blattederenchym am wenigsten verholzt waren.

Wir hesprechen $11 m$ einige Einzeltälle:

\section{Überdüngtes Saatgut.}

Die irrtiumliche Anschammer, dats man dmeh reiche loüngung die Pflanzen zu mulegrenzter Vervollkommmmng tühren kïme, hat das Bestreben erzengt, dem samen schon bei der Ansiat eine Nachlilte lureh Dünger zu gehen. Nan hat entweder den Weg des . Kandierens" der samen, d. h. des T̈herzirhens der einzehnen Samenkërner mit ciner Nährstotfkruste gewählt oder sich des Einguellens in mehr oder wening. hochkonzentrierte Nälrsalzbömngen bedient. Hierbui liets sich dim

1) Wouxr. L., Tntersuchungen über den Einflufs der salze anf dis Budrontenchtigkeit. Vierteljahrsschr. d. Baver. Landwirtschaftsrates 1899. Erö̈nzmustheft S. 437 .

2) Genхкк, R. ̈̈ber die Bedentung anorganischer Salze für die Entwichlung und den Bau der höheren Pflanzen. Göttinger Dissertation. cit. Jisr, Bot.,Jahrenher. 1902 , II, s. 301 . 
alsbald die Erfahrung machen, dafs solche Unterstiitzung teils nutzlos, teils schädlich ist.

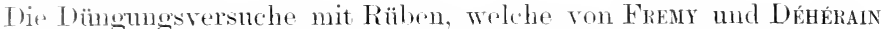
ansoetührt wurden, gehen schon einigen Aufichluk über diesen Punkt. Es zeiote sich. dats schwefelsames Ammoniak und die Katisalze einen schädlichen Einfluts aut den Keimungsorgang ausüben. Schon bei einer Konzentration von 20\%00 sahen die Fersuchansteller die Keimung ganz anshleiben. Nit Bohnen, Erbsen, Mais, Raps, Roggen und Weizen vorwenommene Einquellungsversuche von Tactphöss' ${ }^{1}$ ) ergaben als Resultat, dats die in destilliortem Wasser eingequellten samen an besten keimten und dak die Keimfähigkeit $1 m$ so mehr herabgedrückt wurde, je konzentriertor die Salzlösungon (Chlorkalium, Chlornatrim, Natronsalpeter, schwefelsames Kali, phosphorsames Kali und salpetersaurer Kalk in Lösung von $0,5-5,0 \% 0)$ wurlen. Raps keimte in einer $2 \%$ igen Lösung fast noch ebenso gut, wie in lestilliertem Wasser, während die übrigen samen schon in einer $0.5 \%$ igen Lösmng wesentliche Beeinträchtigung zeigten. Anftallenderweise war die Entwicklung der Keimpflänzchen in $3 \%$ iger Kochsalzlösung eine bedentend ïppigere als in destilliertem Wasser.

FleIscher ${ }^{2}$ ) beriehtet über einen in Ostprentsen ausgetührten Saatlüngmngsersuch mit Kainit und superphosphat bei Kartotfeh, ron denen ein bedentender Prozentsatz nicht ansgetrieben hatte, sondern noch als unverändertes S'aatgut zur Zeit ler Ernte im Boden zu finden war. Lie Analyse dieser Knollen ergab im Verhältnis zu den in den WobfFschen Aschen-Analysen gegehenen Durchschnittswerten einen mehr als coppelt so grotsen Gehalt an Reinasche; das Kali verhielt sich anf tansend Teile Trockensubstanz bei den nicht gekeimten wie 37 gegenüber 22 bei den normalen. Während der Kalkgehalt fast gleich in den kranken und normalen Knollen war, erschien die Magnesia in ersteren doppelt so grols, die Phosphorsäure fast doppelt so grot's und der Chlorgehalt dreizehnmal so hoch, als in ten nommalen Knollen. Auch die Schwefelsäure war auf das Vierfache in tausend Teilen Trockensubstanz gestiegen, so dafi man sieht, dat's gerade die Bestandteile des Kainit's (Kali, Natron, Magnesia, Schwefelsäure und (Chlor) in der Asche der nicht gekimten Knollen eine ungewöhuliche Zunahmo erfahren hatten. Im vorliegenden Falle war die Dïngums im Frühjahr mmittelbar vor dem Legen der Kartofteh erfolet, statt dafs nach Vorschrift der Kainit längerer /eit vor der Einsaat in den Boden gebracht worden wäre.

In den Fitrbotiex'schen Feldversuchen ${ }^{3}$ ) mit Hafer, der vor der Anssaat in simperphosphathei eingerihht worlen war, zeigte die Parzelle mit kandicrtem stamen weniger Ertrag als die ungedïngte Parzelle. Wurde dagroen das Superphosphat mit Sägespänen verdünnt, ergab sich die höchste Ernte. Wahrscheinlich wirkt bei der direkten Berïhrung mit dem siuperphosphat nehen dem Phosphorsäurehydrat anch das nicht selten auftretende schwefelsäurehydrat schädlich. Auch BröganN ${ }^{4}$ ) berichtet äber die schädliche Wirkmog der mit Schwefelsänre aufgeschlossencu Ilüngemittel; diese Wirkmo war in trockenen

1) Tantriös, v., Die Keimung des Samen bei verschiedener Beschaffenheit derselben. cit. Bot. Jahresber. 1876, II, S. 117.

¿) Beobachtungen über den schädlichen Einflufs der Kainit- und Superphosphatdüngung auf die Keimfähigkeit der Kartoffeln. Biedermann's Centralbl. 1880, S. 765 .

$\left.{ }_{3}\right)$ Deutsche landwirtschaftl. Presse 1877, Nr. 81.

4) Hannover'sche landwirtsch. Zeit. 1881, Nr. 12. 
Frühjahren recht ersichtlich und zwar sowohl bei Wiesen- als hei amberen Kultmptlanzen.

Bei samen wird sich der sehädlicho Einthlis do .. Kandierens" 1 m so wenger geltend mathen, je längere \%eit dirselben im Borlen liegen müssen, bevor sie anforohen; tem dam kam win öfterer Regen das Dungsalz in clen mogebenden Erdboten hesser abspïlon, wio schon bei älteren Versnchen in salzmünde') gefmolen wombr.

\section{Überdüngte Rüben.}

Bei der bekamnten Intensität des Rühenbanes ist dio Erfahmung eine allgemeine geworden, dats gesteigerte stickstotfzufuh zwar die Emtesmbstanz bedentend erhöht, aber den /uckergohalt herab. drïckt. Wir hegnügen ms deshalb mit einem Hinweis, dats es anch keinesweges gleichnültig ist, in welcher Form lor Stickstoff gegehen wird. PAgnorL ${ }^{2}$ ) analysierte drei Räben, von denen die erste (H) mit einer Lösmng von Natronsalpeter. die zwoite (J) mit schwefelsamem Ammon mehrmals bexossen wurde, während die dritte $(\mathrm{K})$ eine qleichzeitig geemtete momale Rühe darstelle.

Es betring

das Erntegewicht

saftdichtigkeit

Zuckorprozent der Rübensubstanz

Kohlensäure mol ('hloralkalien aut'

100 Teile Rüblonsulstanz

es kommen davou auf' 1001 /ucker
11.

414.2

1.1126

$: 3 . !$

$1,(9 ! 91$

$2 \times 11$
. $\mathrm{J}$ $2671)$

1,11411

(i,:)

(1.). 1).4

$14.1 i$
K. 78.50

$1 .(1+4 i$

s.:

11.814

1.8

Man sieht, dats die Erntequantität an Frischsubstanz dureh die stickstoffdüngme um 3,5 bis 5.0 mal so hoch geworlen als bei normaler Kultur, aher der Zuckergehalt anf dir Hältte gesmenten ist. Besonders interessant ist der Vergleich der Wirlime Tes salpeterstickstoffs mit dem Ammoniakstickitott: dats letzterer einen bedentent grötseren Ammoniakgehalt in der Rübensubstanz veranlatst, ist bereit, erwähnt worilen.

Nenere Versuche von Mülder-Thukgad ${ }^{3}$ ) ergaben, dats dio stickstotfjplanzen eine erhöhte Atmmng hahen, was wohl die Folge eimer erhöhten Umwandlumg von Rohrzucker in direlit reduzierenden sein diurfte. Es enthislten je a Rüben im Inurelscehnitt

$$
\text { direkt reduzierenden Zucker }
$$

die stirkstoffieichen

lie stickstoffämeren
(1). $3+4^{\circ} 0$
$11.114^{0 / 0}$
$8.27 \%$
14,3900

Rohrzurker

Eine Vorstellme ïler die Vorgänge, lie sich hei überreichen Stickstoffoaben einleiten, erhalten wir dureh die Angahen von Presters-

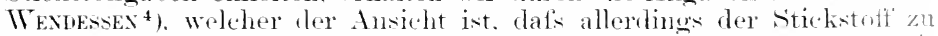
Eiweits umgearbeitet worde, dats classelle aber in Verbimdme nit

1) Jahresber. f. Agrikulturchemie 1863, s. 60 .

2) Annales agronomiques $1 \varangle 76,5$. ::21.

3) s. Überdüngte Kartoffelı. \$. 390 .

4) Bericht über die Generalversammlung d. landwirtschaftl. Centralver. f. il. Herzogtum Braunschweig. Blätter f. Zuckerrübenbau 1๖96, Nr. ‘. 
Kalk in Asparagin, Glutamin und entsprechende organische Säuren zersetzt wirl mol lats diese mit Kalk lösliche salze bilden, die sich in der Melasse wierlerfinden. Schultze bezeichnet auch die nicht vollständig verarbeiteten, intermediären stickstoffverlindungen als wesentliche Melassebildner, welche die Kristallisation des Zuckers heeinträchtigen. Tie bei der Fabrikation diüften anch in der Pflanze selbst die genannten Verbindungen das Niederschlagen des Zuckers verhindern, so dafs sich dadurch der /ustand der Tn re ite mol /uckerarmut der äherdïngten Rüben erklären lietse. Aufser der Verzögerung der Reife kommt noch die geringe Haltbarkeit der Rïben in den Mieten in Betracht. Phosphorsäure wirlst qualitätsverbessernd; der Saft von Rïben, die souar mit Phosphorsäme ïberdüngt waren und schlecht polarisierten, zeigte aber doch die wenigsten die Kristallisation des Zuckers verhindernden Bestandteile.

Üher die Kopflüngung mit Chilisalpeter stehen gute und schlechte Versuchsesultate einander gegenïber. Diese Erfahrung machen wir fast bei allen Tersuchen. T)as Resultat hängt eben aufser vom Dïngerquantum auch von der Form der Verarbeitung durch die Pflanze ab, mel dieser Albeitsmodus ist je nach Varietät, Bodendichtigkeit. Bearbeitung, Lage und Wetter sehr verschieden. Immerhin mul's betreffs der Kopfdüngung auf die Bemerliung von Kuntze-Delitsch ${ }^{1}$ ) hingewiesen werden, dats der Boden leicht verkrustet und junge Rüben aus Sanerstoffimangel dann stellenweise ganz absterben, ältere aber sich schlechter entwickeln. . Tedenfalls sollte nach Ausstremen von Chilisalpeter ummittelbar die Hacke folgen ${ }^{2}$ ).

Anch die Frage der Stickstoffdüngnng der samemrüben erhält widersprechende Beantwortung Während einerseits behanptet wird, daf's die (qualität der Nachliommen leide, widerspricht WiLfarth ${ }^{3}$ ) anf Grund seiner Versuche dieser Ansicht.

\section{Überdüngte Kartoffeln.}

Die Folgen ïberreicher Stickstoffzufuhr bei den Kartoffeln sind mit den bei flen Rïben gefundenen gleichsinnig. Dio Resultate, welche Mílder-Thurgud ${ }^{*}$ ) erhalten, lassen sich für beide Feldfrïchte dahin zusammenfassen, dat's bei reichlicher Stickstoffnahrung eine stärkere Entwicklung der Blattflächen und ein grötserer Chlorophyllgehalt sich einstellen. Damit verhmolen aber ist eine Erschwermg der Stärkebildung mur schmellere Aufläsung derselben in len Blättom, sowie verminderte speichermg in don Reservestoftbehältern. Die Organe zeigen grötseren (ilyliosegehalt, raschere Lösung der Reservestoffe, ausgiebigeren Umsat; der stickistrffrerbinhmgen, erhöhte Atmung nud gesteigertes Wachstum.

Mit dem geringeren Vorrat an Reservestotfen und ler schnelleren Veratmung lerselloen wird anch die geringere Haltharkeit der Knollen in den Vieton zusammenhängen. Aber for sticlistoffäbersehuts wirkt direkt anch fänhnisförlernd, während phosphorsaurer Kalk das Gegen-

1 cit. Zeitschr. f. Pflanzenkrankh. 1×96, ऽ. 310.

2) Auf die Perchloratwirkming bei Chilisalpeterverwendung wird im Abschnitt der schädlichen fraso und Flüssigkeiten eingegangen werden.

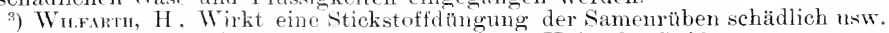
Zeitschr d. Ver. Deutsch. Zuckerindustrie Bd. 50, Heft 52ヶ, s. 59.

4) Míler-Thrast, Iritter. Jahresbericht des fiflanzenphrsiol. Laboratoriums $d$. Versuchsstat. Wädensweil. Zürich 1894 . \. 52. 
teil hervorutt. Ich legte von drei möglichst raschiedenen siorten in abwechsehden Reihen Knollenstücke gesmuler Exemplare und soleher Knollen, die an der schwarzen Troekenfä $\mathrm{Tl} \mathrm{e}^{\mathrm{I}}$ ) littrn, in sandigen Acker. Derselbe wurle in zwei ganz gleich bestellte llältten weteilt, von denen die eine in sämthehen Reihen starke Gahen von ('hilisalpeter, die andere von Thomasmehl erhielt. Bei dem gesmelen saatgut machte sich in der C'hilihälte ein lückenhattes Aufgehen der Knollon benerkbar: von dem kranken saatgut war fast alles vertault. (ianz scharf abgeschnitten zeigte sich aber, dafs genan dasselbe liranke saatgut in dem Augenblicke, wo es in tie Thomasmehlparzelle cintrat, eine'n ganz gleichmäligen Bestand an gesunden stauden geliefert hatte.

Gesuntes wie krankes Saatgut sämtlicher Sorten hatte in ler letzt genaunten Parzelle kürzore stamlen mit hellerem laabe mul fiüherer Reife entwickelt. mul die Ernte war nahezu doppelt so grotis als bei der Chilisalpeter-Parzelle ${ }^{2}$ ).

Hierher zu rechnen dïrtte anch die Erscheinung sein, welche in don praktisthen Kreisen als Eisenfleckigkeit oder Buntwerden der Kartotfeh bekaunt ist. Änlserlich normal aussehende Knotlen zeigen aut dem frischen (dnersehnitt brame orler bramgraue Gewehestellen. Dabei kamn das ïbrige Fleisch vollkommen gesund sein mul weits bleiben oder aber auch schmell an der Luft eine rostrote Färbme annehmen. Die ursprüglich schon vertärbten stellen zeigen brame, abgestorbene Kellwände mud vichtach noch Stärke. Manchmal mml zwar lam, wom die śchnittläche nachträglich sich an der Luft rötet, kam man an den

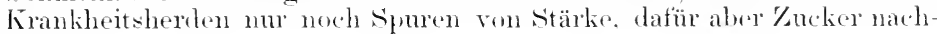
weisen.

Währond sinzehne Beobarhter glauben, die Eisenfleckigleit anf einen Reichtmm des Bodens an sauren Eisenverhindmngen zurïckführen zu müsien, sind andrere reneigt, der Nässe die sidmld heizmmessen. Nun liegon aber mehrtach Erfahrungen vor, tats starke stallmistdüngmo hestimmte Sorten eisenfleckig gemacht hat, dic in demselben Jahre bei Mineralküngug gesund geblieben sind ${ }^{3}$ ). Anch hegognet. man den bei dem herschneiden sich rötenden Knollen werade dort am häufigsten, wo weiche Stickstoffliünung zur Anwendming kommt. Infolgedessen ist man bereehtigt, im Buntwerden des Fleisches Anzeichen einer Überdüngung zu rrblicken. Eisenfleckige Kunllen geben übrigens in rler Regel im nächsten Jahre gesumde Pflanzen.

\section{Chilisalpeter bei Holzgewächsen.}

Ein Versuch ron Jaxonschest) kemzei,hnot die Erseheinmogen fïr den Fall, chats ,lic stickstoffzufuhe ohne Beigalw von Kalli mul

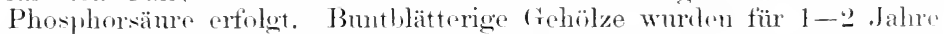
grïnor. Bei /werobst trieben die /weige fast ohne Unterbrechmes his Angust und noch länger, wodureh der Ansatz der Blïtenknospens

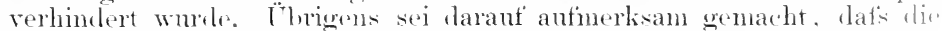

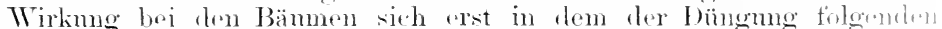
Jahre bemerkbar macht, aber dann auch bis zum dritten . allie nath-

1) Zeitschr. f. Pflanzenkrankh. 1894, s. 126, und 1×95, s 98 .

2) Zeitschr. (1. Landwirtschaftskammer f. d. Prov Nichlesien 1s.9.

3) s. Jahresberichte des sionderausschusses för Pflanzenschutz, herati-g then

$\checkmark$ d. Dentsch. Landw.-Ges.

4) Zeitschr. d. Latudwirtschaftskammer f. Schlesien 14: Nr. 34. 
wirlst. Nach eignen Vorsuchen, bei denen l,atrinendïnger gegeben war, möchte ich eine erhöhte Neigung der Früchte zm Fänhnis, namentlich einer vom Kernhanse ansgehenden, sowio eine grötsere Frostempfindlichkeit als Folgen einseitiger sticlistotfüberdüngmg bezeichnen. Phosphorsaurer Kalk arheitet diesem ubel entgegen. Versuche mit Aptelbänmen, die reiche Salpeterdïngung erhalten hatten, zeigten, dats die gedïngten Bäume stärker von der Blutlaus zu leiden hatten wie andere Exemplare ${ }^{1}$ ).

Ein anderer Fall ist mir bei Ailanthus glamdulosa in wohlgepflegten Anlagen vorgekommen. Die Bäume wurden gelblanbig und zweigdïrr. An den schnittfächen frischer Äste entwickelte sich reiehliche Penicillimmvegetation. Hier fand sich in Gewebe ein anftälliger \%uckerreichtum.

Bei den Orangenliulturen neigen die gedïngten Bäume zur (tummosis, unt die als "Lic-back" hezeichnete Krankheit in Florida wird direkt anf Ḧherfüttermng mit organischen Stickstoffrerbindungen zurïckgeführt. Anch sollen derartige Orangenbäume mehr den Insektenangriffen answeretzt sein ${ }^{2}$ ).

\section{Überdüngung bei Gemüsen und anderen Feldgewächsen.}

Trotzdem unsere Gemüse sämtlich in ihrer jetzigen Form Produlite hochgradiger Kultm sind und reicher Dïngmg sich angepatst haben, finden wir doch vielfach Fälle von Erkrankung, namentlich bei Anwendung von Fäkalstoffen. Es läfst sich dann eine Vermehung der leicht oxydablen, an der Luft sich brämenden Substanzen beobachten. Dabei tritt stets Bräumung der Gefälswandungen, nicht selten anch Ausfïllung einzelner (Kefälse mit tintenartiger Flüssigkeit auf. Gerade bei ïberdïngten Ptlanzen ist hakteriose Fäulnis eine häufige Erscheinung. Am wenigsten vertragen den Stickstotfïberschnts die Erbsen und andere Hülsenfrüchte: dagegen sehen wir ein hohes Anpassungsrermögen bei eingen Umbelliferen, wie z. B. bei stellerie. Aber auch hier wird, namentlich bei den Rieselfeldkulturen, häufig genng das zulässige Mats ïberschritten. Wem die fleischigen Wurzellinollen bei dem Lurchschneiden ihre schmittfläche schmell und intensiv rostfarbig werden lassen, sind sie schon in der Regel weniger wohlschmeckend. Das stärkere stadimm, das in der Marktware grof'ser Städte häufig zu finden, hestelit in der vermelnten Schwammigkeit des Gewebes und reichlicher Bramflexhigkeit drssellen. Selbst bei den an die höchsten Konzentrationen dor Nährläsmg gewöhnten Kohlgewächsen lassen sich hisweilen soleho Kustände und damit in Verlindung bakteriose Fäulniserseleinmogn anffinten. Hicr erweist sich neben der Zufuhr von phosphorsanrem Kalk ther fortwähoude Gebranch der Hacke als besonders empitehlenswert.

Der zunehmencle Verluatch der Blattstiele von $R$ habarber zu Friilijahssompott hat den Anban der Pflanzen anf Rieselfeldem veranlatst. Foh komute dabei Fälle beobarhten, bei welchen ungewöhnlich dicke stiele gänzlieh farle im (tesehmack sich erwiesen. Es hängt somit hier eine mangelhatte Produlition orler ein völliger Aufhranch der organischen Säuren mit der. Üherdüngmng zusammen. Meiner Amahme nach ist

1) Fünfter Jahresher, d. Grofsherzogl. Olstbauschule zu Friedberg i. d. W.

2) Webrer, H., Fertilization of the soil ete. Yearbook U. S. Depart. Agric. for 1894. Washington 1895. S. 19:3. 
dieser Rückgang der säuro hei stickstoftëhberschufs auch anderweitig zu finden und dis. Ursache des schucllen Eintritts hakterieller Fäulniserscheinumgen. (s. Wirkmog der Oxalsinme s. 3il.)

Bei den C'nembitareen (curken nuel Molonen) kinn eine an sich

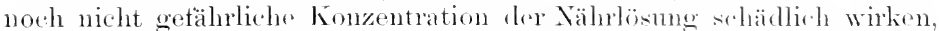
wenn die 'Temperatur danernd nicht genögend hoch ist. In diesen Falle sind gummost Erseheinmoen in den foüchten am hänfigsten. und man bemerkt dabei sehwäizung der frefailise.

Bei der Tabakkultur macht sieh Stickstotfïberselents dureh rauluere Blätter und grötseren Nikotingehalt kemutlich $\left.{ }^{1}\right)$.

Dafs bei Getreide die Fäkaldiungme Lagerung mol, namentlicl bei Hafer, Taubheit veranlassen kam, ist bereits trïher erwähnt worden.

\section{Stickstoffüberschufs bei Zierpflanzen.}

Hier liegen änferst zahlreiche Fälle vor. Noben Fäkaldiunger mul Chilisalpeter orler schwefolsamem Ammoniak kommen, hesonders bri den gärtnerischen Kultmen, die Horns löue in Botracht. Wir kömnen natürlich nur einzelue Beispicle antïhren. Von riner Reihr Pflanzen der Begonia semperflorens gab ich einigen sohwotelsames Ammoniak im Überschuts. Vier Tage nach der Iöingme womben dir jumgen Triebe an ihrer Basis mifstarlig mol begannen sich schlatf momegen. Ile Blattränder fingen an, sehmutzig griüse, später ham wordendo mul

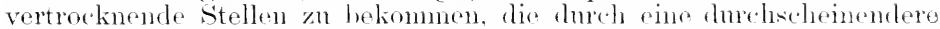
Ühergangszone mit dem gesunden mittleren Blatterewbe repbumben waren. In der somne trat schnolleres Wellen pin. Mark nud Rintw rwiesen sich mit Kalkoxalat hrusen durehsetzt, deren Einzelliristallo nitht so schartkantig wie hei len gesmelen Exemplaren. sondern mohr knollig

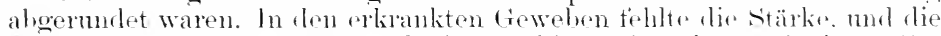

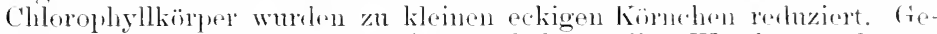

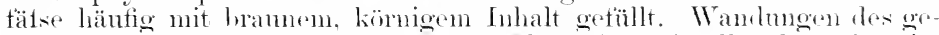
sammten frewebes hram. Luhalt der Blattepidermisollen lramkömig. Vor dom Zerfall der chlorophyllköner zoigten sich in Inhalt der Mesophyllzellen oftulals hrame Tropfen.

Bei Begonien sowohl wie hei Prlargominm amale, dessen Blätter sich ebrnso verfärbten mud leicht nach dem Vertrocknen abfielen, fand ich in der Achse der erlirankten Pflanzen in Mark und der Jumgrinde antfällig viel Kristalle von Kalkoxalat. Wie Stengel der kranken Polar gonien zeigten durchgängig spärlichere mol kleinere stärkekörner: sie fehlten in Rindenparrenchyon tast wanz, während die nieht überdüneten Pflanzen riesolben seler reichlich hesatison.

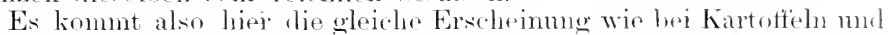
Rïben zum Ansdruck, nämlich die Armut an testen Kohlenhrolrator.

Bei eben bewmonten Pelaremiensterklingen verusachte pin chilisalpetergabe, die an und tïr sich kloin war, aber durch ilne häufige Wiederholung verhängnisvoll workle, zunächst ein äntisors iippiges Blattwachstmm: dam aher senkten sich lie Blätter abwäls mol an der Achse entstanden, stets dicht iiber dem Blattansatz. Lram

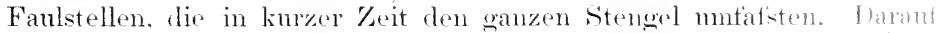
fielen die Blätter. mud die ganze oberirdische Achse stall his ant winen kurzen Basalstmmet' ab. Ans diesem begamen nene kitmmerlich

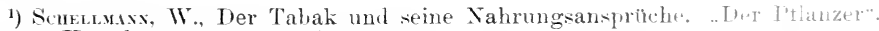
Herausg. [sambara-Post 1905, Nr. 5 
Triebe hervorzubrechen. - Wir haben dieses Beispiel angeführt, um darant hinzuweisen, dats die Wirkmog der Üherdïngmng, obgleich dieselbe rom Boden ansgeht, sich nieht an der Basis der Achsen zuerst bemerkhar macht, sondern an den peripherischen Teilen, den Blättern.

Bei vergleichenden Kulturen mit Fuchsienstecklingen ${ }^{1}$ ) ergab eine fortgesetzte Dïngung mit schwachen Gaben von schwefelsaurem Ammoniak eine merkliche Wachstmmsteigerung und wesentliche Vergrötsermng der Blätter; aber dieselben besatsen Epidermiszellen mit dïmnerer Wandung, und der Holzring der \%weige war schwärher ausgehildet. stärkegehalt geringer, ('hlorophyllgehalt grölser, Vegetationszeit verlängert. Nachrlem die Fuchsien durch Öbertïhrung in ein Glashaus vor den Herbstfrösten geschützt worden waren und Keit gehabt hatten, ihre Entwicklung normal abzuschlicken, verschwanden die Unterschiede gegenüher den ungedüngten PHanzen, und die gedüngten hatten nummehr den Vorteil der gröfseren Produktion für sich Hier haben wir einen Erfolg, wie in die Landwirte namentlich bei den Futterrïbenkulturen wahrnelmen. Die Wirkung der starken Stickstoffgaben macht sich in einer Terzögernng des Reiferorganges bemerkbar. Finden misere Kulturen noch vor Eintritt der Frostperiode Zeit genng. ihren Entwicklungxgang abzuschliefsen, so dafs die Blätter sich normal ansleben kömnen, damn haben wir den gewünschten Vorteil ron der Jöngmug durch Erzielma gröserer Substanzmengen mit normalem Reservestoffvorrat. Aber in cler Regel verbieten die klimatischen Terhältnisse den Abschluts der Tegetation, und die Organe gelangen in mreifem Zustande in den Winter.

Der Nachteil, den das Eimbringen moenügend ansgereifter Organe in die Winterquartiere hat, ist bei den landwirtschaftlichen Erntepodukten bereits hervorgehoben worden: sie besitzen gröfsere Neigmng zur Fänlnis.

Dasselle Resultat zeigte ein vergleichender Düngmosversuch bei Erica. Rotblühende Arten entwickelten in den Versuchsreihen mit einseitiger Stickstoffilïngund weniger lebhaft rote, fast blaurote Blumen : ihr Habitus war schlaffer und ler Blütenansatz spärlicher. Die gedünoten Exemplare litten im Winter so stark von Botrytis cineru. dats sie meist zugrunde gingen, während die nicht getüngten Pflanzen derselben sorten an demselben standort schadlos duch den Winter kamen. Ein anderer Versneh, der den Einflufs hochkonzentrierter Lösmng der gesamten Nährstoffe dartm sollte, wnrle von BLCTH ${ }^{2}$ ) ansgeführt. Die im zwciten Knlturjahr befindlichen Eriken erhichen in fortgesetzten Gaben Wannksehes Nährsaly in 10\%o iger Lösmng. Nach 10-12 Tagen trat dunklere Lanlfärbmg und stärkeres Wachstum ein, aber jetzt schon zeigtrn diese Pflanzen eine grötsere Empfindlichkeit gegen sonnenwirknng nnd Trockenheit im Vergleich zu den vielen hundert nugedïngton Exomplaren derselhen Sorte. Gewisse weiche sorten (E. hirmalis, comysta nsw.) 'ntwickelten ihre nenen Seitentriebe schlaffer und mannigfach verlongen. Hartnadelige Arten (E. blanda, maditerramea, ireticilluta, mammosa) behielten zwar ihren anfrechten Habitus, aber der K nospenansatz war anffallend gering oder blieb ganz ans, während dic /weige weiter wnchson. Anch hior starben die gedüngten Pflanzen

1) Sonalke, P., Einflufs einseitiger Nitickstoffdüngung. Zeitschr. f. Pflanzenkrankheiten 1897, s. 247.

2) Zeitschr. f. Pflanzenkrankh. 1895. S. 186. 
während der Winterzeit dureh Botrytis grölstenteils ab. Bei anderweitig mit Hornspänen durehgetührten I inngungrersmehen komnte ebenfalls eine üppige Laubentwicklung ant hosten les Blïtenansatzes der Eriken testgestellt werden: aber es zeigte sich lieine gröfsere Hinfälligkeit der gediungten Pflanzen währnd des Winters.

Nach den mohrfach gemachten Erfahrungen mot's iob die sich häufenden Klagen übrr "Versagen der II ablumen" hei der Treiberei anf Stickstoffïherdüngung zurückführen. Bei cler zweijälnrigen Anzucht der Pflanzen ant dem Felde wird jotzt vieltach ('hilisalpeter oder schwetelsames Ammoniak angewendet.

Die Pflanzen wachsen ïppiger und bestechen durch ihre sehr starken (meist blanspitzigen) "Keine" (Knospenkegel) den Känter: aber die Blütenstände sind in der Anlage schwach. Solche Pflanzen lassen sich schwerer treiben und geben hänfig Blätentrauben, hei denen einzehe Glocken nicht zur Ausbilelung kommen. Vergleichende Versuche von Koopmaxs ${ }^{1}$ ) lieferten sehr interessante Unterschiede hei der Treiberei. Bei Anzuelıt der Ptlanzen mit Kainitdüngmeg entwickelten sich zuerst. die Blütentrauhen und die Blätter folgten sehr langsam: daugegen war durch Ammoniakdüngung die Blattregetation so iupig, datis die Blitentrauhen ganz in Laub versteckt safien. Im alloemeinen wirl man für Maiblomen eine Kalilüngme emptehlen dïrten.

Eine weitere schälliche Wirkung konnte bei hosan festuestellt werden. Es liegen mir Beobachtungen vor, dats Teerosen, darunter Marechal Niel und Nyphrtos in den Glashäusern nach starker l)üngmeg ihre Knospen abwarten oder an der Thergangsstell. des Kelehbechers in den Blumenstiel ahtanlen liefsen. Ein Ferptlanzen von eingesandten kranken Toptexemplaren in eine sandige, nährstoffarme Erde hatte zur Folge, dats in nächsten Jahre sich normale Blmmen entwiekelten. Almliche Fänlniserscheinnugen beobachtete ieh hei Bombon- und Remontantrosen in freien Lande nach Fäkaldiungme. Hier hatte das Unterhacken von Gips ein allmähliches Nachlassen der Krankheit zur Folge.

Anch bei anderen gärtnerischen Kulturpflanzen, ia selbst hei Efem hatte ich Gelegenheit, Fäuhniserscheinungen nach sitickstoffüberschutis (meist in Form von Fäkaldünger, Janche, Chilisalpeter und schwefelsamrem Ammoniak) zu heobachten. Ich habe dam in der Mehrzahl der Fälle das Unsetzen der Ptlanzen in reinen sand oder sehr sandige Lauberde tür ein Jahr empfohlen mol mehrfach selhst mit Vorteil erprobt.

\section{Die Kräuselkrankheit der Kartoffeln.}

Wir reihen hier diese in den Kreisen der Kartoffelzüchter so wohl

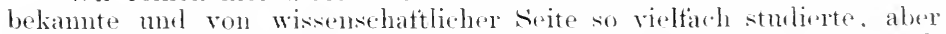
in ihren Ersathen noch nicht erkannte Krankheit ein. Iter firund, weshalh wir der hränselkrankheit an dieser sitelle gedenken. ist die aut eigne Beobachtmog georündrate Anschammg, dals , Tie kränselkranken Triehe die Nerkmale einseitiger stickstoffilüngme erkemen lasten. Nur handelt es sich hier nicht mu die direkte Folge derselben, somblern nm die Nachwirkmg im folgenden Jahre. I) Monterknolle ist entweder gänzlich oder in einzelnen Angen nicht vollstänilig ancereritt und zeigt num bei ter Entwickhng im folgenden Jahre oine Erkrankmo

1) Zeitschr. f Pflanzenkrankh. 1×94. ‥314. 
sämtlicher orler auch nur einzelner Triebe. Hieser Punkt ist zu betonen, weil die bisherigen Beobachter lisweilen besonders hervorhelen, daf's a lle stengel an einer Knolle erkranken, also die Krankheitsursache in der ranzen Knolle liegen muls. während meine eigenen Beobachtungen mit sitherheit das Resultat ergeben haben. dats die Erkrankmng auch an einzehne Augen webunden sein kam.

Lie Krankheit, welehe nach KüH') znerst im .Jahre 1770 in England, 1770 in Dentschland epidemisch auttrat und antiserorlentlichen Scharlen verursachte, besteht zmächst in einer Tertärbung des Laubes, das nicht mehr das frische Aussehen wie an der gesmonden Pflanze besitzt. Der Haupthlattstiel zeigt sich meist nath unten gebogen oder vollständig eingerollt: die einzehen Blattalschnitte sind gefaltet. wellig hin md her gebogen. mit bramen, meist länglichen Flecken versehen. Letztere dehnen sich aut die Hamptripe des Blattes mol endlich ant den Stengel aus. Zuerst sind nur die obertlächlichen Zellen der Flecke bram: später geht die Erkrankmng des newebes tiefer ins Innere und im stengel bis ant den Markkörper. Labei ändert sich die stengelbeschaffenheit ron der normalen Biegsamkeit bis zur glasartigen śprörligkeit. Dazu zeigt wich nach sंснаснт ${ }^{2}$ ) eine sehr reichliche Znckerbildung in den kranken Zellen. Wenn sich solehe Pflanzen bis zur Ernte wirklich lebendig erhalten, haben sie doch gar lieinen oder höchst spärlichen Knollenansatz.

Betreff's der triiheren Literatur, in der die versehiedensten Ursachen (auch parasitäre Pilze) angegeben werden, verweisen wir auf die vorige Auflage unseres Handbuches. Nenere Anschaumnen finden wir bei FRaNk ${ }^{3}$ ), der eine Anzahl verschiedener Formen der Krankheit mnterscheidet und in Übereinstimmung mit mir ansspricht, dats die ersten Anfänge der Erkrankmng eine Beteiligung von Pilzen nicht erkennen lassen. Die Ursache des Absterbens Tes Protoplamas in den einzelnen lramen Gewebeherden ist nicht bekannt. Abweichend von meinen Beobachtungen betont aber Frask, ,dats alle Triebe einer stande zusammen erkranken." (Kamptimch s. 2.2.).)

siveziell anf die Kränselkrankheit gerichtete ansgedehntere Anbanversuche mit mehreren sorten zeigten mir, dafs die Krankheitserscheinmoen antangs bei einer Sorte (Eurly Puritan) allein anfgetreten waren. Die kranken vereinzeit zwischen den gesmnden stehenden Pflanzen besafsen nu ein Drittel der Höhe der gesmolen Exemplare und wiesen die bokamnten Merkmale, besonders das Knacken der gekräuselten Blätter, aut. An ten Blattstielen tanden sich mehrtach verkorlite klome Ritsstellon. Iie erston Erkrankungsanfänge an den stengeln fand man an rimem der mnteren in der Erde befindlichen Internodien, wobei stets sine Schwäzung der Grofitiwandung festzustellen war. Dieses Merkmal lätst sich rïckwärts mehr oder weniger tief ansstrahlend in die sonst gesund anssehende Mntterknolle hinein verfolgen. I)as zeigt, dats nicht die Knolle dem Triebe das Krankheitsmaterial gebracht hat. sontlern umgekehrt. Ebenso strahlt die Getätsbräunung ans dem er-

1) Kins, Jut., Krankheiten d Kulturgewichse. 1858. \$. 200. - Ber. aus d. phrsiolog. Laborat. d. landwirtsch. Instituts zu Halle. 1872, Heft I, s. 90.

2) Bericht an das Kgl. Landesökonomiekollegium über die Kartoffelpflanze und deren Krankheiten. 18.54. s. 11.

3) Fraxk, A. B., Dif pilzparasitären Krankheiten der Pflanzen. Breslau 1896. ․ 300. - Kampfluch gegen die schällinge mserer Feldfrüchte. Berlin, Parey, 1×97. ร. 217 . 
krankten Stengelinoten in die clort entspringenden Wuzeln aus und ist im ganzen äu1serlich noch grün ersehemonden Arhsenteil bis zu den Rippen der jünssten Blätter hinant zu timblen.

Besonders autfällig ist das saftstrotzende der ganz gesmul aus-

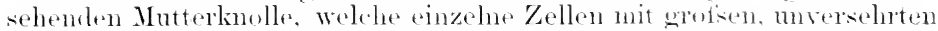
stärkekönnern aufweist. Lie stärketührenclen (inmpen lieson zorstrent in tem äuferst turoescenten. aher kam spumen tester Inlabltsstofte antweisenden, wotse Zellkerne besitzenden, übrigen Parenchym ler Kinolle.

Bemerkenswert ist temer, dats. obenso wir gesmile mul liranke Triebe ans einer Mutterknolle entspringen kïmon, anch die Krankheitsmerknale an remselben stengel manchmal aut' bestimmte Regionon sich beschränken. Man sieht ans kranken stengeln wesunde Angen sich entwickeln mol finclet kranke stengel, Jei llenen num eine llälft. des refälsbündelringes geschwärzt ist.

sio wie andere mit Gefälshämung vertmulene Krankheiten hegimnt auch die Kränsolkrankheit die ersten s'smptome an der Peritherie zu zeigen. Es s.hwärt sieh zumeist die cinticulardeclie dere Epidermiszellen. fleren lnhalt dam sehwach tintenartig sieh zu rerfärben begimnt, his Wandung und Inhalt gleichmätsig bram geworden sind. nud num die Epirlenniszelle zusammensinlit.

Ihort, wo die Epidermis an das collenchymatische frewele grenzt, sieht man die Vertärbme in den Vandungen desselben tortschreiten:

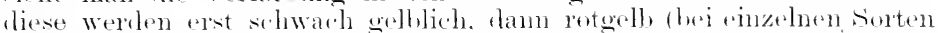

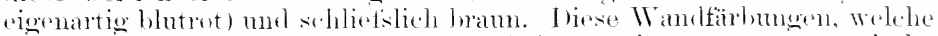
tangential sich sehnell auszulehnen scheinen, erimern an enzymatische linfliisse.

Jer weitere Verlatut der Krankheit stimmt bei den rinzelnen sorten nirht ïberein. weil wahrehenulich die Zellwandungen hald lockerer.

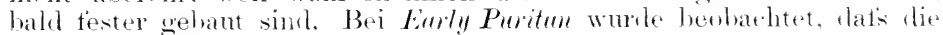
gebräunten Zellwandungen in kïnngen Zertall geraten können. wobei wahrshemlich stabehentörmige Bakterien zur Mitwirkmg gelangen. In

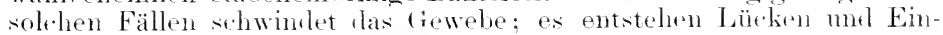
senlimuen in Rindengewebe des stengels, und nummehr finclet man meist Mreel. Die Einsenkungen vertieften sich bei obengonamter sorte hisweilen his ant den Holzring und waren im späteren stadium der Krankheit auch schon an den moch wrïnen stengelspitzen nachweishar. Ton ihmen aus geht aber die Gefälibäunme nieht: dieselbe begimn an der stengelbasis und ptlanzt sich num im Röhrensystem selbst fort. An den Rifistellen lemerlit man manehmal Heilungsvorgänge durch schlauchartiges Vorstrecken benachlarter. assumter Rindenparenchymzellen.

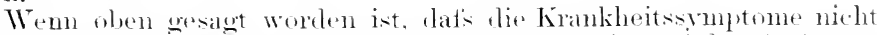
überall gleich erseheinen, so bezoht sich das z. B. anf das Auttreten bramer stiplether" an nieht gekrämeltw Blätern. Diese Blätter aber besitzen in ihren Blattstiolen genan dieselbs schwach tintentarbige. in rinigen Fällen schloinig-kïmig sich verdichtemb Anstüllume i (refäse, deren Wandung anch gebräunt erseheint.

Die hier geschilderten Merkmale kommen einzehn anch bei antirin Pflanzen mit Sitickstottïherschutis vor. Hält man 11 m liese Merkmale zusammen nit don Ergehnisin früherer Beohachtumgen, so charakterisient sich die Kräuselkrankheit tolgentermat'sen. Die Frlirankmug tritt hesonders gern mol stark an zarten, frïhen sorten ant. Fernir besitzen die geernteten Knollen den Charakter der Jugendentwicklnus. inden 
sie sich durch glattere stchale, schwächeren Stärkegehalt und einen bedentend höheren Kaligehalt anszeichnen. Hierzu kommt noch eine geringere firitse mol ein geringerer Gehalt an Trockensubstanz. Ans Terartigen Knollen sind mehrtach unter giunstigen Unständen wieder gesmule Pflamzen gezogen worden.

Unter den angegebenen Merkmakn haben wir die lange I aner dor saftstrotzenden, noch stärke tührenden Nutterknolle hervorgehoben,

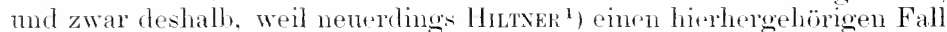
rou Erhaltung, ja sogar teilwciser nachträglicher Verwötserung der Mutterknolle zur sprache gehracht hat. Ton rerschiedenen Seiten sind dieselben Erfahrungen gemacht worden. In dem von Hintwer beschriebenen Falle kam hinzu, dats diese aus prall gebliebenen Mutterknollen entstandenen Stäke gar keine unterirdischen, an Stolonen hängenden Knollen entwickelt hatten, sondern solche direkt an den unteren fnternodien der griunen stengel trugen. Diese Stengel waren aber mu die Hälfte kïrzer als hei normalen PHanzen und trugen zusammengerollte Blätter, die Hunver an die Kräuselkrankheit erimnerten. Er glaubt, dats diese Vorgänge eine Folge davon sind, dat's man umeife Knollen als Saatgut benutzt hat. Diese Saatknollen haben. nachdem sie stengel entwickelt, das vom Blattkörper erarbeitete Material zunächst dazu benutzt, $1 m$ selbst noch weiter zu wachsen. Natürlich sei damm zu wenig organische substanz für die diesjährigen Knollen übrig geblieben.

Wemn wir die Anschanung von Hntwer über das Zustandekommen solcher stratfbleibenden Knollen acceptieren, werden wir darauf hingewiesen. in der Kräuselkrankheit eine Folge mngeeigneten Saatguts zu sehen. Die Mntterknollen sind im Vorjahr nicht genügend ausgereift. Dieser Umstand muts anch in fer Ausbildung der einzelnen Augen zur Geltumg kommen. Während die Mehrzahl derselben noch Zeit gefundon, sich normal zu entwickeh, kömen emige im Jugendzustande zum stillstand gekommen sein, und werden demnach den. Jugendcharakter bei dem Anstreiben im folgenden. Jahre beihehalten. Somit wïnde sich erklären, daf's man manchmal nur einzehe Triebe kräuselkrank findet. ber ('harakter der. Jugend ist das Vorherrschen des Kalis und der sorotsere Reichtum an stickstoffverbindungen bei geringen Niederschlagen ron Kohlehybaten als Reservestotfe. Derartige Zustände sehen wir begtinstigt, wem frischer Dung bei tiöhen sorten zur Anwendung gelangt mo Trockenheit dem Knollenwachstum ein vorschmelles Enrle hereitet.

Wum die Kräuselkrankheit dre Kartoffeln, ähnlich der Schrmmptkrankheit der Nanheerhäume und in Übereinstimmmng mit anderen Fällen, di, wir bei den .enzymatischen Krankheiten“ erwähnen werden, anf einem Ïberwiegen von stickstoffierbindungen, die nicht nomal verarheitet werden, beruht, dam wiurlen sich auch die gefundenen symptome der Schwärzmng der Gefäfse und der schmellen Ansiedlung von Baktrien loitht erklären lassen.

Diese Anschammg rhält eine weitero sitüze lurch eine studie ron AppeL ${ }^{2}$ ), der muter dem Namen "Bakterien-Ringkrankheit"

1) Hutxer, I., Zur Frage des Abbaues der Kartoffeln. Prakt. Bl. f. Pflanzenbatl und Pflanzenschutz 1905, Heft 12.

$\left.{ }^{2}\right)$ Arrut, O., Die Bakterien-Ringkrankheit der Kartoffel. Flugblatt 36 d. Kais. Biolog. Anst. Dahle'm. 1906. 
Erscheinungen beschreibt, die vieltach an die Kränselkrankheit erinnern. Er macht fïr die Ringkrankheit Bakterien rerantwortich, und „zwar ist es, ehenso wio hei cler schwarzbeinigkeit, nicht eine einzelne Art, sonctern einige sich verwandtechattlich nahestehente Formen". . Diese Bakterien sind in manchen Böden zwoitellos normalerweise vorhanden ..." Nach diesen Äulsermgen möchte ich die Bakterien-Ringkiankheit anch in den Kreis derjenigen Erscheinmmen ziehen, hei denen der Parasit nieht das Ansschlaggebende ist, sontern die Beschatfenheit der Mnttrentlanze. die den Bakterien den erst zn ihrer Anshreitung hesonder's ginstigen Mutterboden bereitet. Tnel solehe Zustände werden ähnlichr sein lï̈nnen. wie die bei der Kränselkrankheit gesehilderten, bei weh.her ich ebentalls einen weiteren \%ertall der Gewche durch Bakterien beobachtet habe.

Es scheint somit, dats wir eine ganze Girmpe von Kartottelkrankheiten vor uns haben, die das gomeinsane Merkmal der sehwärzme der fretätse besitzt mol clarant zurückzntühren wäre, dats muvollkommen verarbeitete stickstoffierbindmuen bei ungenügender Ansbilcme der Kohlehydrate ihren Eintlut's geltend machen.

Diesen Mangel werden wir nach Mäglichlieit vorzubengen snchen. indem wir alle ITat'sregeh durhtïhren, welche oine allmähliche vollkommene Reife der Knollen am sitocke zulassen.

\section{d. Kalk- nud Magnasiäberselhul's.}

Unter llinweis ant die in frïheren Absehniton bereits ïbor dio Wirkmog des Kalkes erwähnten Beobachtnmen hehen wir hier zunärhst die Mahnumg von () RTH $^{1}$ ) hervor, an stelle einer cinzigen seln starken

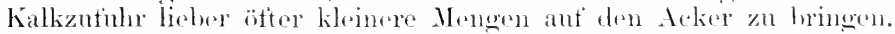

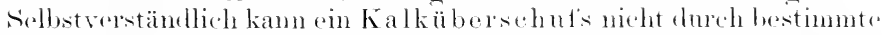
Zahlen präzisiert werden, da jede Ptlanze und jeder Arker ein anderes Kalkbediüfnis haben. Anch liomme es gar nicht ant div ahsolute Menge bei der Kalkzntuhr an, sondern ant Tas Verhälnis zu den anderen Nährstutfen, welche durch den Kalk in ihrer Löslichkeit mol Wandermusifähigkeit beeinflutst werlen. Entlich kommt aber anch die Wittermog zur Keit des Kalkens in Betracht.

Fïr die Praxis namentlich beherzigenswert sind the Marmmngen.

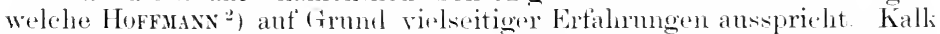
wirlit sehällich. wem er in grötseren Nengen anf krattesen Bärlen zur Verwentmng gelangt: auf humusarmen, leichteren. tätigen Bärlen erweist er sich in trockenen Friihjahren zn stark lockernel mud anstrocknend und stärt die Bakterienarbeit. Kommt ar als Meroel zur Verwendung. ist daraut zu sehen, dats dieser vorher an der louft gnt zertallen ist. damit etwaige schälliche Bestandteile rechtzoitig oxydiert werden kïmen. Ebenso wie hei anhaltender 'Trockenheit wird Kalk anch bei stanenter. Nässe gefährlich, namentlich wenn wr als sogen. W Wsscrkalk" mit viel Kieselsäme. Eisenoxyl mul Tonerde vermischt ist. Derselhe wirl hei fenchtem Wrtter leicht zementartig hart.

Aber anch muter normalen Verhälnisien kam der Kalk geföhlorlich werden: man dart nicht rergessen. dats bei seiner erwiunschten Leistung der Zersetzung der organischen stickstotthaltigen substanzin

1) Orтu, A, Kalk- und Nergehlungung. Anleitung, im Auftrage d. Leutscle. Landw.-Ges. Berlin $1 \$ 96$.

2) Hoffuxis, M., Jüngungsverstiche mit Kalk. Arb.d. D. Landw.-lies. Heft lofi. 
mel der Tmformung des entstehenden Ammoniaks in salpetersauren Kalk auch Ammoniakverbindmogen verflüchtigt werden. Kommt salzsames oder schwefelsaures Ammoniali mit kolilensamem oder phosphorsaurem Kalk zusammen, entstehen das äutserst leicht lösliche ('hlorcalcium und Gips und andererseits kohlemsames bez. phosphorsaures Ammon. Bei Versuchen von Warser ${ }^{1}$ ) (Darmstadt) beobachtete man einen durch Ammoniakverdunstmog entstandenen Stickstoffierlust von $30 \%$ gegenüber einer Salpeterdïnomg. Besonders leicht entstehen derartige Verhuste, wenn der Boden reich an kohlensaurem Kalk ist, wemn das Ammonialisalz nur flach motergebraclst ist und some und Wind reichlich Zutritt haben; dann kann das durch die Umwandlung des nicht flüchtigen schwefelsamen Ammoniaks entstehende flüchtige kohlensamre Anmon sehr schnell dem Acker entführt werden.

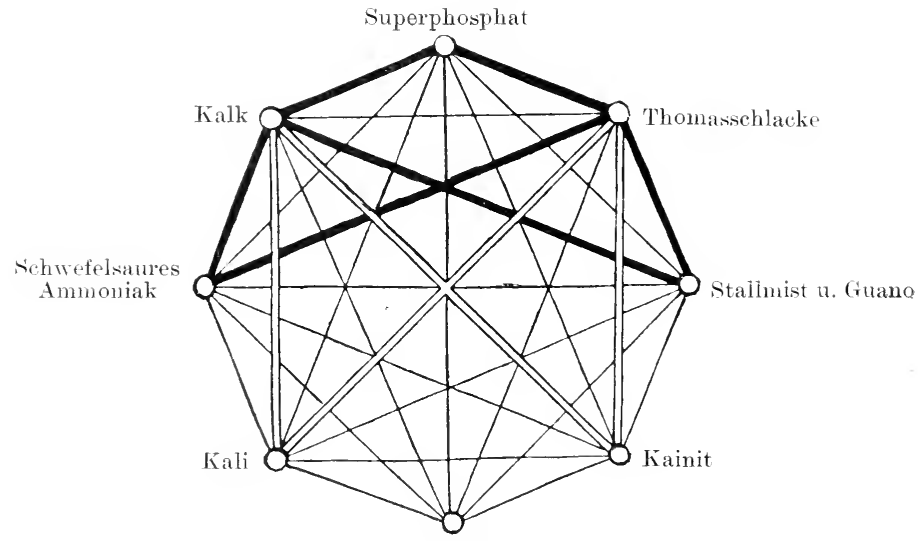

Chilisalpeter

Fig. 66. Schematische Larstellung der günstigen und unginnstigen Beziehumgen der Irïngemittel zueinander.

Sandige und zugleich kalkreiche Böden werden deshalb nicht für Ammoniakilüngung, namentlich nicht fïr Koptilingme. geeignet sein. Autserden wird jetzt verständlich, warum man nicht Ätzalk direkt mit stallmist oder auderen ammoniakhaltigen Inumgstotfen in Berührung bringen soll.

Anfser den orenannten Bezichmeen hat der Kalk auth seine nicht zu monteräzente. Wirkmg anf die Phosphorsäme. Die wasserlösliche Phosphorsäure in simperphosphat wird duch gleichzeitige Kalkme in ihrer Wirkung lesintrichtigt, allerlings nicht so sehr wie die der citronensäureläslirh@n Thomasmehlphosphorsämre: an stärksten ist die Behindermog bei der des Knochenmehls.

Es dürtte hier der Ort sein, auf die Beziehungen der Dünger zueinander hinzuwrisen, $n$ zu vermeiden, lats sie gegenseitig emander schädigen, d. h. in ilırer Wirlimng heeinträchtigen. An Stelle längerer

1) Zeitschr. der Landwirtschaftskammer f. d. Prov. Schlesien. 1904, s. 168 :. 
Beschreibungen geben wir eine dem .Pratischen Ratgeber im Obstund Gartenban" $1906 \mathrm{Nr} .17$ entlehnte Figm wierler.

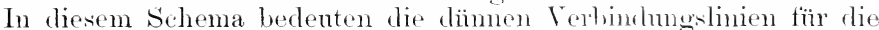
einzelnen Düngerarten, daf's man diesclben immor znsammenmischen darf. Die Dünger, welche mit Doppellinien verbunden erscheinen, dürfen nur kur ror dem Ansitrenen miteinander gemengt werlen: daregen darf man niemals diejenigen I)ïnger miteinander mishen. welche in der Figur mit dicken Strichen verbunden sind.

Der Fergittungserscheinumgen durch Magnesiäiberselon l's und ter daran sich lin̈̈ptenden Theorie von hoew üher ein bestimmtes Menernverhältnis zwischen Kalk und Magnesia im Boden zur Erzielumg enter Ernten ist schon in dem Ahschnitt üher Kalkmangel (S. 30) E wordacht worden. Nenerdings hat Low ${ }^{1}$ ) seine frïheren Nitteilumen erwänzt. indem er daraut antinerkism macht, dat's das günstige Mengenverhältnis zwischen Kalk und Magnesia im Boden dureh keine hestimmten /ahlen stets fixiert werden liamn; es ändert sich, sobald die beiden Basen der Antinahme durch die Pflanze in verschielenem Grade zugänglich sinf.

Gegen die Low'sche Anschammg sprechen die Versuche von MEYER ${ }^{2}$ ), von denen wir hier nur hervorheben, dats sowohl starke Kalkals auch Magnesiagaben die Ernten sehr beeinträchtigen. Natürlich verhalten sich die verschiedenen Pflanzenaten zn derselben Döngme ganz verschieden: bei derselben Magnesiagabe zeigte heispielsweise Hater schon einen Rückgane in der Körner- mol strohernte. währencl hei Rogren dies nicht der Fall war.

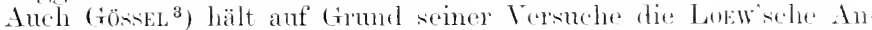
sicht fïr nicht richtio: indes wauben wir. dats trotzdem dieselbe be achtenswert bleibt. Tan darf'sich nur nicht an lestimmte Kahlen hinden, weil jeder Kulturversuch andere Verhältnisse bietet. Dir. Paralysierung der mit den Döngesalzen massenhaft in den Boden. gebrachten schädlichen Magnesiaverbindungen wird man stets im Augu behalten müssen. Vor allem handelt es sich mo die grofisen Nengen von Chlolmagnesium, die mit den sogenamien . Aloranmsalzen" flem Acker zugetöhrt worden und die den Zuckergehalt der Rïhen, den Stärkegelalt der Kartoffoln usw. herabulïcken. Unser Bestreben mufs sein, das nicht absorbierbare ('hlor an eine Base, also namentlich an Kalk zu binden, durch die es leicht in den Tnterommel gewaschen werden kamn.

Sichlieflich muts daraut antimerksam gemacht werden, dafis dieselbe Kalkmenge eimmal schädigend, ein anderes Mal förternel wirlit, je nachdem dieselbe als kohlensanrer oder schwefelsaurer Kalk gegeben wird. So fand z. B. Suzrist) hei Vegetationsersuchen mit Bergreis, dafis durch eine übermätige (iabe von kohlensamem Kalk d das Verhältnis ron Kalk zu Magnesia war :3:1) die Ernte beträchtlieh herabgedrizckt rumde, selbst wemn dic Phosphorsäure in leicht löslicher Form vor-

1) Lnw, O., und Aw, K., Ïber rerschiedene cirade der Aufnahmefähigheit von Pflanzennährstoffen durch die Pflanzen. Bull, College of Agric. Tokro, Imp. ['niv. vol. VI. No. 4, cit. Centralbl. f. Agrik.-Chemie 1905, s. 594.

*) Merki, D., Lntersuchungen über die Wirkung verschiedener Kalk- und Magnesiaformen. Landw. Jahrbücher Bd. XXXIII, 1904, s 371.

3) Gusst., Fro, Bedeutung der Kalk- und Magnesiasalze für die Pflanzenernährung, Tortrag auf d. 75. Naturf. Vers. (s. Chemikerz. 190:3, Nr. T‘)

$\left.{ }^{4}\right)$ Suzr Bodens. Bull. College of Agric. Tokpo, Imp. ['niversity vol. II. cit. Centrallit. f. Agrik.-Chem. 1905, S. 588.

Sorauer, Handbuch. 3. Aufl. Erster Banil. 
hanrlen was. Hagegen zeigte die Zufuhr sinn äquivalenten Menge a ips eine ungwwöhnliche Erntesteigerung namentlich an Körnern. Ans direm Versuch aber ergiht sich auch, dats die schädliche Wirlimng den Kalkïhersehusses nicht immer in einer Verminderung des Aufschlietsugsermögens eines Borlens wegenïber schwer läslichen Phosphoximreverbindungen zu smohen ist, sondern wahscheinlich anch ilren Gruml in der Nentralisierung der Wuzelsäuren lat.

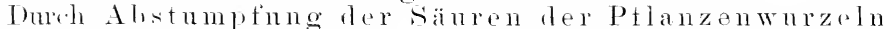
kann die Antinalıme ler verfügbaren Phosphorsäure heeinträchtigt werden. l) grofe Unterschiod zwischen der Wirkung des Calciumkarbonats und derjenigen des tripses erklät sich leicht fladurch, flate der Gips aus dem Boflen nur so weit. als er in Wassel löslich ist (also in änfiserst geringer Menge), aufgenommen wind. während die Aufnahme des Karbonats durch die Pflanzen hauptsächlich von der säure der Wruzeln abliängt.

\section{Der Kalküberschufs bei dem Weinstock.}

sceit dur Einfüilnung des Weinbanes mit veredelten amerikanischen Reben sind die Klagen über fie Gelbsucht des Weinstockes besonders in don Vorderoment getreten. Buschicben wird die Krankheit meist als .. Chlorose"; nach nuserer Anschanung müfste sie als .. Ioterus" bezeichnet werden.

Selhstrerstänflich sind die Ursachen für die Gelblaubiglieit, wie bei den anderen Pflanzen, äufserst verschiedener Art: sehr häufig spielt dabei die mit oder ohne Mrcelpilze sich einstellende Wurzeltäuhnis ant schweren Böden eine Rolle. Namentlich Fitis Riparia und rupestris mit ihrem feineren Wurcelsystem erwoisen sich gegen solehe Büden empfindlich, während Sorten mit starken Wurzeln (Jucques, Herbemont usw.) sich hesser ampassen ${ }^{1}$ ). Besoncless schwer aber ist es, dif amerikanischen Reben anf' solehen Böden zu erziehen, die viel Kalk in leicht anfinehmbarer Form enthalten und nicht sehr reich an Nährstoffen sinf. Die meisten Erfahrungen dariiber hatte man in Frankreich (ielegenheit zu sammeh. Luenecke ${ }^{2}$ ) gibt dic Resultate ron Bodennutersuchungen wioler, welche der landwirtschattliche Terein zu Cadillac 1s!n vomehmen liets. Es enthielt der Borlen, der

keine Gellsucht mol der, welcher Gelbsucht der stöclie zeigte

\begin{tabular}{|c|c|c|}
\hline & & \\
\hline Kali & 0,10 & $\begin{array}{l}1,106^{\circ} 0, \\
0.370\end{array}$ \\
\hline $\begin{array}{l}\text { Kall } \\
\text { Kalk }\end{array}$ & $1,, 39^{0} 0$ & $0,370 \%$ \\
\hline Kalk & $1,81 \% 0$, & $18,93^{\circ} \%$ \\
\hline Fisenoxyd & $5,910^{0 / 0}$ & $3,112 \%$ \\
\hline Sticlistolf & $(1,10)^{0} / 0$ & $0,10^{0 /}$ \\
\hline
\end{tabular}

Der frehalt der Böden an Stickstotf, Kali mol Phosphorsäure ist also gleich, Eismoxyd in heiden hoch, aber cler Kalkgehalt des Gelbsucht erzengenden IBorlens nahezu zehmmal grötier. Bei den nummehr vorgenommenen Iöngumssersuchen mit Chilisalpeter, Ammoniak,

1) EGai, E., Untersuchungen über die Methoden der Schädlingsbekämpfung usw. Berlin, Paul Parer, 1905.

2) Lubuecke in Zeitsehr. f. d. landw. Yer. d. Grofsherz. Hessen 1892, Nr. 41, $1 \varangle 98$, Nr. 2 . 
superphosphat, Chlorkahm, schwetelsumer Mannesia mul Eisenvitriol zeigte mur der letztere einen hervornterhamlen Erfolo. Ant

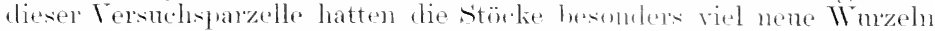

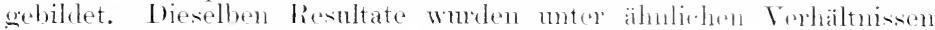
anderweitig ant Boiden erzielt, die ebentalls soh reich an Eisen von vomherein waren, bei denen also die Eisenvitroldiongme in ilner giunstigen Wirkmg nicht einem vorher dagewescum Fisommangel znateschieben werlen liomute.

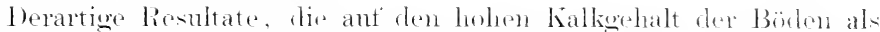

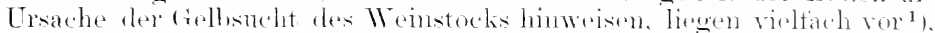

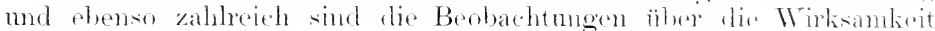
des Eisemvitriols.

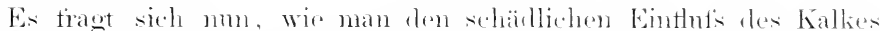

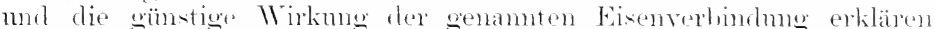

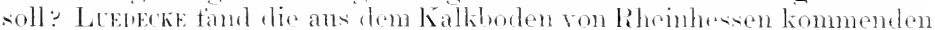
Wäsor alkalisch reaciremel mel sah hei Lnsaty anes Eisensalzes

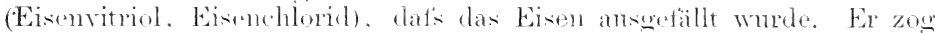

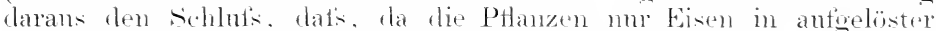

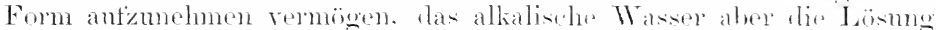

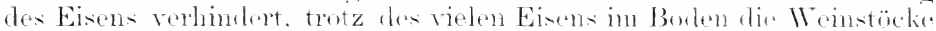

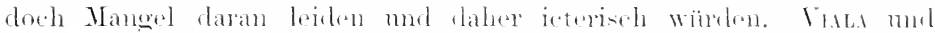

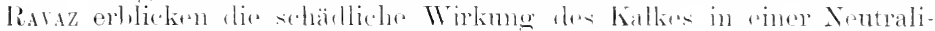
sation des Zellsattes der Wurehn (s. Eith).

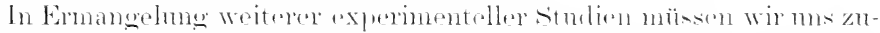

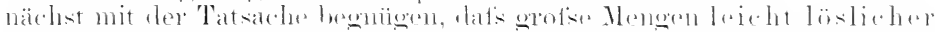

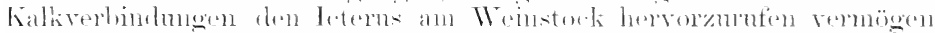

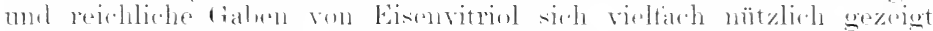

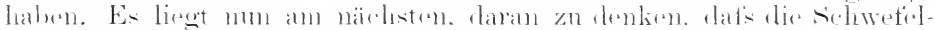

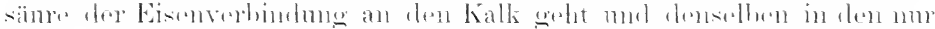

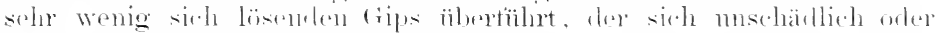
sogar warhstmonsörlermel prweist.

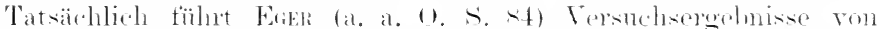

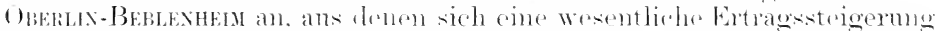

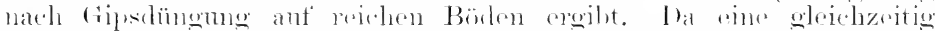

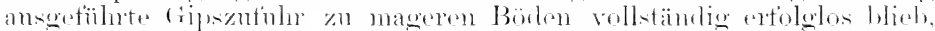

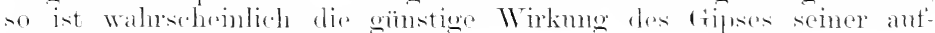

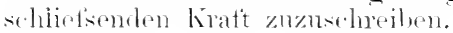

\section{c. Kalinhersolentis.}

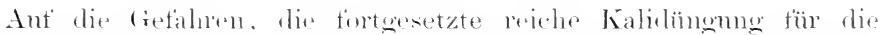
Bodenheschatfenheit hat, ist schon hingewiesen und hahei hesont worden.

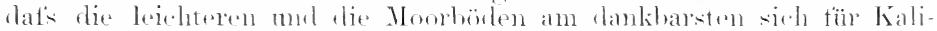

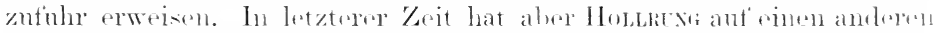

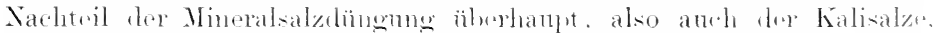

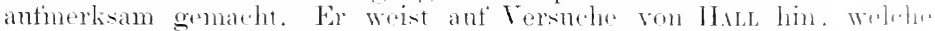
ergeben haben. dats sich der Masserbestanel in den Börlen röllie

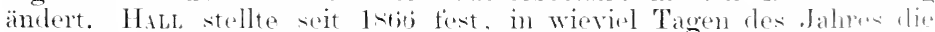
Drainage aut' einem moediingten gegenüher einem fostamlig mit ('hili.

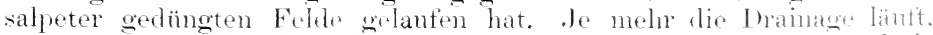

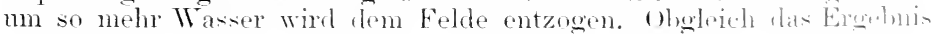

1) s. v. B.ı, u. M.ın, Hanthuch des Weinbanes und der Kellerwirtschaft (s. Eimis). 
in den einzelnen füntjährigen Perioden, die zum Tergleich kamen, ein schwankendes war, tentete das Gesamtresultat fïr den ganzen Zeitraum doch daranf hin, dat's der wesalzene Boden" weit grötsere Mengen TTasser dureh den Untergrund in die Drainage entlassen hatte, was anf eine mö̈nstige Ungestaltmog des Borlens schliefsen lälst.

Bei dem Einthl's der Kalisalze ant den Pflanzenliörper kommt es daraut an, in weheher Form mol anf welchem Boden das Düngesalz zur Anwendung gelangt ${ }^{1}$ ). Denn es handelt sich wesentlich mm die Wirkungen der Nebensalze, die bei der Kalizufuhr dem Boden einverleibt werden. Zurzeit finden der Ka in it mul das to" oige Kalisalz die reichlichste Terwentung. Bei Kainit brancht man $3^{1}+$ Zentner, wenn man so viel Kali zufïhtren will. wie in einem Zentner 40\% oigen Kalisalzes enthalten ist. Unter den im Kainit zugetührten Nebensalzen spielt das Kochsalz eine hervorragende Rolle. Antiserdem kommen s.hwetelsame Magnesia mui Chlormagnesimm in Betracht. Die emzelnen Ptlanzen verhalten sich num sehv verschieden zum Kochsalz: während Znckeriuben dankbar sich erweisen, ist die Kartoffel sehr empfindlich ${ }^{2}$ ). Allerdings ist anch bei den Znckerrüben rer Erfolg ein ziemlich trïgerischer, da zwar (nach ten Versuchen von ADecco und Wohumans) die Masse der geenteten Rïbensubstanz vergrösert wird, aber der Reinheitsquotient und her Zuckergehalt zurückgehen.

Wegen der Nebensalze püften Schnemewisd und Ringlebex ${ }^{3}$ ) die Kalirohsalze gesenïher den hochkonzentrierten Formen bei verschiedenen Kalligaben. Bei Kleegrasgemisch, Hafer, Znckerrïben und Kartotfeln zeigte sich, dats der Kainit sich dem Chlorkalimm und schwefelsamen Kali überlegen zeigte, wenn ansreichende Mengen von kohlensaurem Kalk vorhanden waren: fehlten diese, trat der entgegengesetzte Fall ein. Nahm man den sthwerlöslichen Gips statt des kohlensauren Kalkes. erwies sich der Kainit schädlich, besondlers für Kleegrasgemisch, weniger fïr Hafer. Bei Kartoffeln war die Wirkmo gïnstig. sofern die Böclen kaliarm waren : hei grötserem Kalireichtum derselben kam die Überschutiwirkmng. nämlich Ernichigmog des Stärkegehaltes, zum Torschein. Die, durch die (hloride bewirle stärkederression, die mit einem gö́tseren Wasserreichtum verbmolen ist, fand szoldems ${ }^{4}$ ) bei den stärkereichen Kartofficonten etwas grölser als bei den stärkeärmeren.

Bei den Pflanzen, welche gegen die ('hlorverbinchugen der Kalirolssalze, wie z. B. des Kainits, sehr empfindlich sind, erweist sich manchmal der Nachteil, dats das Kali während des Herbstes mul Tinters ans drm Boden teilwoise ansowaschen wird, insofern als vorteilhatt, als dabei auch reichlich die gefählichen Nebensalze (Kochsalz mo ('hlormagnesimn) ansgewasehen werden, also dem Boden zwar absolnt weniger Kali verbleibt, aber dassellue in reinerer Form zur Geltmug komment. Das Answasehen von Kali tällt ïbrigens blof bei Böden in die Wagschale. Welche nur geringe Mengen Kalk und der-

1) Blätter für Zuckerräbenhau 1905, S. 62.

2) Blïtter für Zuckerrübenbau 1905, s. 89 .

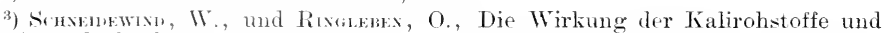
der reinen Kalisalze bei verschiedenen Kalkformen. Landwirtsch. Jahrl, 1904. Bd. XXXIII, S. 353.

4) Szon fas, D., Über den Einflufs von Chlor- und anderen in den Stafsfurter Rohsalzen vorkommenden Verbindungen etc. cit. Centralbl. f. Agrikultur-Chemie 1901, S. 516. 
artig absorbierente Bestandteile besitzen, wie z. B. bei leichten Sandund Noorböden ${ }^{1}$ ).

Ton den nachteiligen Wirkungen der Kalibïngnug boi andern als den hereits genannten Kulturptlanzen erwïnnen wir noch diejenigen die Benress ${ }^{2}$ ) bei $\mathrm{T}$ abak beobathtet hat. Seine Virsuche ergaben nämlich, dats der Wassergehalt der Blätter beträchtlich stiog. wem schwefelsames Kali als Beidiunger zu stallmist rewolon wurlo, unt dats clamit rine gröscre Leichtigkeit des Fanlens der an dre Lutt schwerer trocknenden Blätter verbmulen war. I)ies hängt wahrschoinlith mit der von ('opelane beobachteten 'Turgorsteigrume dureh Kalisalze (Pottasche) zusammen ${ }^{3}$ ). Natronsalze (Socla) zeigton dirse phrsiologisehe Wirkmug nieht.

Beachtenswert ist die Klage dor Lamdwirte, dafis hei fortucsotatrer Kalirlüngung die ( 1 a litä der Wirsenptlanzen so rerschlechtert werde, dats die mit dem IJen gefïtterten Tiere abmagern. Wemn anch diese hochgratige Wirkmme noch anzmzweifeln ist, so steht toeh fest. dats hänfig eine geringere S.'nmarkhaftigkeit des Ienes soleher Wiesen beobachtet worden ist, welche mit Kainit oder Kainit num Thomasselilacke wiederholt gediungt worken sind ${ }^{4}$ ).

Die hei verschiedenen Feldfriithten uml Obsthämen hier amb lat

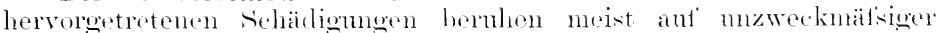
Anwendung der Kalisalze und äutsern sich damn vieltach anch in Niu.hwirknngenö). Man wirl denselhen am hesten rorbengen durh Ver-

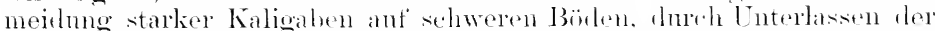

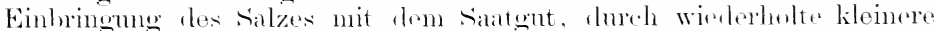
Kalkgaben nut bei den hesonters chlorempfindlichen Ptlanzen wie z. B.

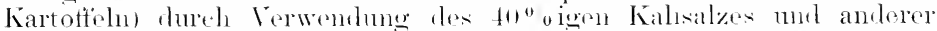

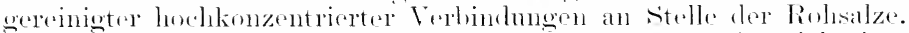

Jie wiederholte Zutuhr kleiner Kalkmongen opweist sirlo larmm nützlich, weil der Kalk in kohlensänehaltigen Boldenwasser mon so

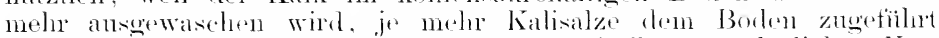

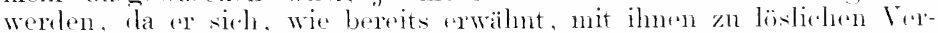

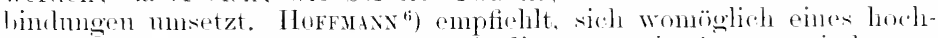
prozentigen Handremerogels zu bedienen mul davon mindestens

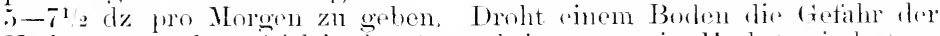
Verkinstung (das . A hbinden"), so hringe man im llerbst mindestens

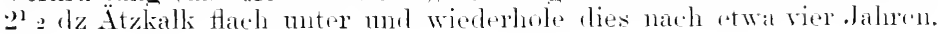

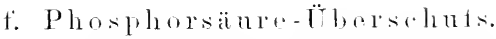

Schätiomoen dureh einen ت̈herselutis an Phosphorsäure sind selten. sie kïnnen wohl num dort exwartut werklon. wo reichlich superphosphate

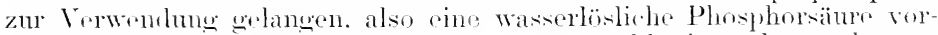
handen ist. Die citratlösliche tes Thomasmehls ist sehon solowerer

1) Sinvunwar, duswashen des Kalis im Winter. Zeitschr. d. Landwirtschaftekammer 1. Sihlesien 1904, Nr. 14, si. ti1.

„) Bamar. J., Weitere Beitrige zur Kenntnis dor Tabakspflanze. Lamiu Versuchstationen 1899, s.214.

3) Bot. Jahresber. 1897, I. S. 72.

4) Mitteilungen d. Dentich. Landw-Ges. vom 11. März 1905.

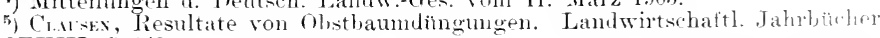
Bd. XXXIII, S. 939 .

6) Horrmins. M., Die Kalisalze. Anleitung. Heranog. v. d. Dentath. Lindw Gesellsch. III. Aufl., 1905. 
heweglich. Aber anch die wasserlösliche Phosphoräure geht alsbald wieder in den mö̈slichen Znstand dachreh übere, dafs sich im Boden Diphosplate des Caleims, Magnesims, Aluminims und Eisens bilelen, die nur langsan von der Kohlensäme des Bodens und den sauren Ansicheidmngen der Wruzeh gelöst werden. Eine Schädigung durch superphosphat wirel daher selbst bei reicher Gabe nu auf Böden zu befürchten sein, die arm an kohlensanem Kalk, Eisen und Tonerde sind. Tersuche liegen nu in reringer Anzahl vor. Die sorgfältigen Untersuchungen der Versuchsitation Bernbmo nit Zuckerriben ${ }^{\mathbf{1}}$, die einbasisches Calcimmhosphat, also wasserlösliche Phosphorsäme im Überschuts exhalten hatten, haben wezeigt, dats ein Rückgang im Zuckergehalt nicht eingetreten int mol anch die Mengen der Rübensubstanz mol des Nichtznchers dieselben wie in normal gedüngten Rïben geblieben sind.

soweit meine eigenten Erfahmongen reichen, liann sich der Phosphorsäureäbershuts in siner Verkürzung des Wruzksstems äufsern, wie dies hei allen hochkonzentrierten Lösmoen ainzutreten pflegt. Anlserdem wird ein vorshnellor Abrhlud rler regetativen Periode (Frühreife) eingeleitet. Dit. Pflanzen liommen nicht zur vollstänligen Ausmutzung ihres Laubapparates, der vorzeitig zu vergilben ptlegt. Dementsprechend ist die Ente weniger ansgiebig.

\section{Kohlensäure- ̈̈berschnts.}

Die Tersuche äber den Einfluts eines Gehaltes der Luft mol des Bodens an Kohlensänre, der weit üher das unter den gewöhnlichen Wachstumsverhältnissen vorhandene Mafs hinaus geht, führen zu widersprechenden Resultatrn. Während ein Teil der Beobachter nur schädigende Wirkmoen erkannt hat, berichtet ein anderer' Teil iiber' vorteilhafte Entwickinng. Diese Gegensätze dürtten ihe Erklärmmg dadureh finden, dats bei der Kohlensärue wie bei allen anderen Nährstoffen die Wirkmo davon abhängt, wie gleichzeitig alle sonstigen Wachstumsfaktolen in Tätigleit sind. Die PHanzen sind im allgemeinen ant den geringen normalen Kohlensänregehalt der Luft in ihrer Tätigkeit abgestimmt ${ }^{2}$ ). Sie werlen eine stäkere steigermo bald chureh Hemmmngerseheinmodn, bald dureh Wachstmofürlerme beantworten, je nachdem die steigermo plötzlich oder alhöhlich eintritt und je nachlem der Roichtum an Ificht mol Wäme, an Wasser und anderen Nährstoftion dem Individum gestattet, dis reroüberte Kohlensäuremonge noch zu voratheiten. Experimentell tinclen wir diese Ansehammg llureh GOLLEWSKI ${ }^{3}$ ) hestätigt.

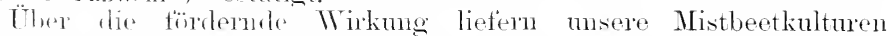
reichliches Bureismaterial. Nach den Tntersuchmen von E. Denouss ${ }^{4}$ ) ist es nicht nur die orhöhte Wärne, somblern tatsäehlich auch die Steigerung dos Kohlensänuegehaltes der Lutt in den Mistbeetkästen,

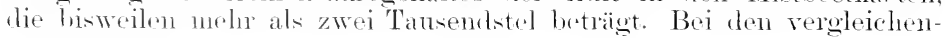

1) s. Tortrag von 11. Romate; eit. Bläter f. Zuckerribenban 1905, S. 229.

2) Brows, F.. u. Finns, F., Tex Einflufs wecliselnden Kolnensänregehaltes der Luft auf den photosynthetischen Prozefs ler Bliitter und auf den Wachstums-

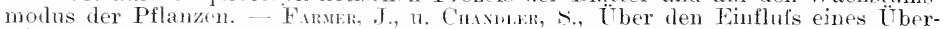
schusses von Kohlensiume in ler Luft auf die Form und den inneren Bau der Pflanzen. Proceed, li. Sioc. I.XX. cit. Centralbl. f. Agrik.-Chemie 1903, S. 586.

) s. Surr. Arbeit, 1. Bot. Instituts zu Wiurzbure. Heft III.

") Compt. rend. de l'Acad. d. sciences 1904. vit. Centralb]. f. Agrik.-Chemie 1904 , Heft 11, s. 745 . 
den Kulturen hatte die Mistheetlutt, die nach surefialtiger Prüfung licin Ammoniak erkenuen liets, nahezu tas dreifach kintexewicht wegenüber den in gewöhnlicher Lutt muter sonst wleirhen Lnntänlen elwachsenen Pflanzen geliefert.

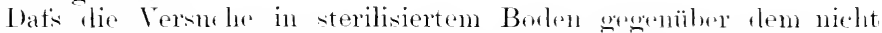
sterilisierten viel geringere Entemengen erkennen fassen, whreiht der Verfasser der Abtötung der Mikroorganismen zu, dir durelo ilıe 'Tätiskeit bei der Zersetzmner zur Kohlensäureprodulition beitragen. Tud es ist auch wahrseheinlich, dats die dicht an Boden bleihendon fienärhse eine Wachstumsberiunstigung durch die ans ler Evele bestäntie entweichende Kolnlensäne crtahren, da mehrfach festgestellt ist, dats die Luft an der ohertläche der Erele mehr als drei zelmtansendstel Kohlensïure enthält.

In einer Lutt, in tler die Kohlensäme eine fïnfmal höhere s'jammung als nomalerweise hatte, nahmen cine grotise Anzahl versehiestener Pflanzen $n$ etwa (i) ${ }^{\circ}$ mehr an Gewicht $z u$ als in wewöhnlicher lant' anch blühten dieselben fï̈her und reichlicher' ${ }^{1}$ ).

Vermögen die Ptanzen, die selbstverständlich je nach dit nut Indivishalität sich verschieden verhalten, dis gebotene Kohlensänre. menge nicht meln zu bewäligen, muts Funlionstocknng eintreten.

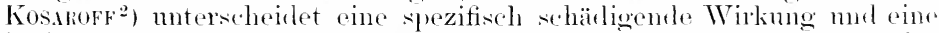
indirekte dureh Vermindermng des Partialdruclies bezw. Entziehnug des Sanerstoftes. Infolere der Tepression des Transpirationsstromes zeigt sich ein Welken der Pflanzen. Böнu ${ }^{3}$ ) heobachtete ohemso wie Sarsink

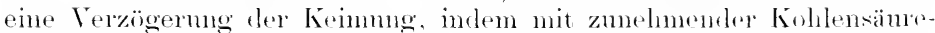

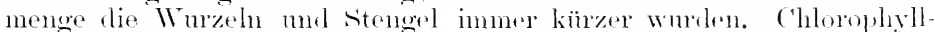
anshililung mol Asimilation waren wesentlich vermindert.

In riner Kohlensäneatmosphäre kann bei Golenkptanzen (firami-

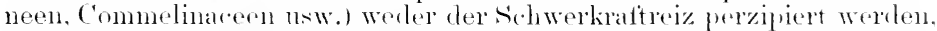
noch vermag cin in lutt perzipierter Reiz eine Krïmmmg oinzuleiten $\left.{ }^{4}\right)$.

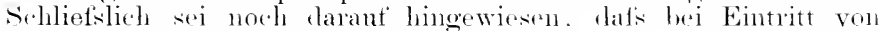

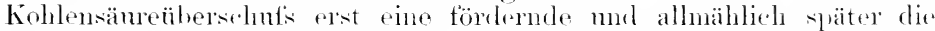
störende Wirkmos sich oinstellen kamn. In dieson simne sinel diw

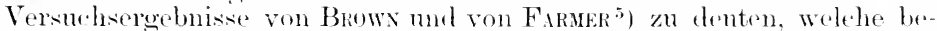
obachteten, dats bei vermehrtem Kohlensämegehalt dor Luft sich narh acht bis zelm Tagen in meluren Fälen eine tiefor griine Färtung aller Chlorophyll füluremen Pfanzenteile geltend machte mul der Stärke-

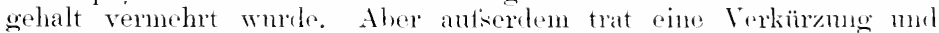

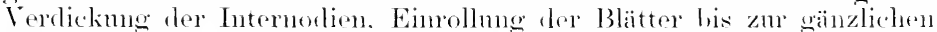

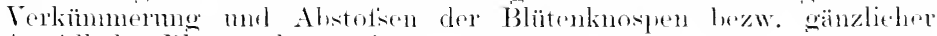
Anstall der Blïtenamlagen ein.

In der Praxis sind derartige Verhälnisse. wio sie in Experiment geboten worlen sint, kamm jemals zn fiircliten. An hïntiosten diirften

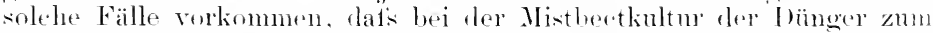

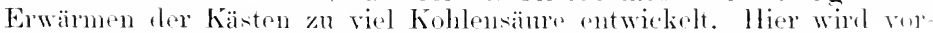
sichtiges Lätten (anch bei Frostagen) die (iefalu boxitigen.

1) Dexussy, E., Sur la vegétation dans des atmospheres riches en aride carbonique. Compt. rend. ('XXXIX, s. so:?.

2) Konmer, P., Die Wirkung der Kohlensänre auf den Wassertransport in den Pflanzen. Bot. ('entralb). 1900, Bd. \&:3, S. 138.

3) Sitzunguber. d. Wiener Acad. 1873 vom 24. Juli.

4 Kon., Die paratonischen Wachstumskrimmungen der Gelenkpflinzen. Bin. Zeit. LVIII, 1900, \$. 1 .

5) a. a. $\mathrm{O}$. 


\title{
Zweiter Abschnitt.
}

\section{Schädliche atmosphärische Einflüsse.}

\author{
Viertes Kapitel. \\ Zu trockene Luft.
}

Die Knospenbeschädigung.

Der Mangel einer genügenten Lnftenchtigkeit ist ein bisher antserst wenig berïcksichtigter Faktor bei der Entstehung ron Krankheitsersehcinungen, trotzdem wir demselben z. B. bei den Zimmerliulturen beständig begegnen.

In welcher Richtung sich eine anhaltende, grotse Amut der Luft an Fenchtigkeit goltend mathen wird, ersieht man ans den Eigensehaften der xerophilen Gewächse. Als Beispiel erwähmen wir die Beobachtungen von (ikeviburs'), der bei den Pflanzen eines bamlosen Kalkplateaus fand, dafs sich namentlich eine Verdickung der Epidermis mit ihrem ITachsüberzuge oder als Ersatz eine stärkere Behaarung bemerkbar machten. Diese Merkmale treten an den Blättern mm so stärker hervor, je höher dieselben am stengel stehen. Die Epidermiszellen sind gegenüber den Normaltormen gewöhnlich etwas kleinlmmiger, die Palisaden breiter und lichter aneinander geschlossen, Intercellularränme geringer. Die mechanischen (tewebe in Achsen und Blattstielen sind stärker entwiekelt, Markkörper minder krättig, kleinzelliger, aber stärkereicher. Diese Verändermgen treten freilich fast immer in Verbindmo mit grotsem Trassermangel im Boden auf, wodmch das Urteil dariiber, welchen Einfluts die Trockenheit der Luft und die dadurch bedingte übermäsige Transpiration allein ausüben, sehwer zu fällen ist. Einzelne Vorgänge aber sehen wir sich einstellen, wenn hei genïgendem Wasservorrat im Borlen die Luft anhaltend heits nud trocken ist, mol diese werden hier zn erötem sein. Es sind teils Hemmungerscheinmoen im Knospenleben oder in den Keimmonsuänden, teils störmgen in ansgewachsenen Blättern, welche zum sommerlichen Laulifall führen.

Betrefts des Knospenletens haben wir zwei Zustände ausemanderzuhalten: die ̈̈ffinung der Knospen und terner das Hervorbrechen des jungen Triebes kurz nach Entfaltung der Knospen. S'szt eine längere Trockenpreriole im zeitigen Fröhjahr ein, wo sie in der Regel bei andanerudem Gstwind sivh erhält, so wirl der aut abwechselnder Wirkmng von Somnenseluein und Regen beruluende Öffinmessorgang der Knospe behindert. Thie in dem Knospenschuppengewebe vieler Bammarten meist Aurch Mombranselnolzume entstehenden Gummimassen müssen zur Erleielitermo der Knospenentfaltung durch Regen erweicht sein, während die harzartigen und teilweise halsamischen Sichmelzmosprodulite in den Knospenselmpen, durch den sounensehein erwämt und erweitht, dem Druck der schwellenden Knospe gleichzeitig nachgeben. Bei anhaltend trockner, meist windiger Früljahrswitterumg wird die Knospenentfaltung

1) Greviluts, Morphologisch-anatomische studien üb. d xerophile PhanerogamenTegetation der Insel Oeland. Englers Jahrbucher 1s97, XXIII, s. 24. 
nun dadurch gestört, dats die Innenseite der Knospenschuppe an ihrem notwendigen IVachstum verhindert wird und sich nicht genügend zurüekschlagen kann.

Bei der zweiten Art der Schädigme wirt die hervortretende, junge Trielspitze pötzhelh den sthartin somenstrahlen mol der hochgradigen Verdunstung in ahmorm trockner Lutt ausoesetzt, nachrlem sic bereits den ror zu starker Verlunstung schützenclen Mantel der Knospenschuplen ahgestreitt hat. Z/um Verstänlnis dieser Vorgänge gehen wir nach Gröss ${ }^{1}$ ) einige Ablildungen.

In Fig. it finden wir den (suerschnitt durch die Knospendecke der Eiche, bei Fig. tis den von l'ims Mughus. Man mitersicheidet leicht die einzehen s'chuppen, die test übereinandergeschachtelt arscheinen. an der stark entwickelten Fpidormis der Autsenseite und findet bei Vergleich der beiden Knospenhüllen die Steigermong der schutzrorrichtungen bei dem Nadellaum douch Finlagerung der llarzmasisen (h). An dem Rnerselnitt der einzelnen l)oekschupe bemerkt man, dats ihe Autien- oder suatere Unterseite besonters starli verdiclite Elemente besitzt. Bei P'mes sind die Epideloniszellen in lohem cirarle. sklerenchrnatisch rerlickt. Bei der Wintereiche, deren huospendecke im vorliegenden Falle ans acht einzelnen s.huppen zusammengesetzt ist, sind die unterhalb der Epidermis befindlichen \%elllagen die stark repdickten, so dat's das Lumen fast ganz verschwindet. Die Śmmereiche (s"r. podunculata Ehrh. verhät sich etwas abweichend. Infolge ter sklerotischen Elemente in lon loceksehupen hehalton dieselben, wenn sie in Fröhjahr sich tureh Basalwachstum reroüforn, eine gewiste siteifheit mul bleiben dem hervorbrechemlen Triehe länger angelegt. Dadurch beschützen sie ihn länerer vor den gefalnhichen Temperaturschwanknowen. Dit Eiche in den wärmeren Mittelnesläntern, Querexs Ile. L., hat die sklerotisthen Element.

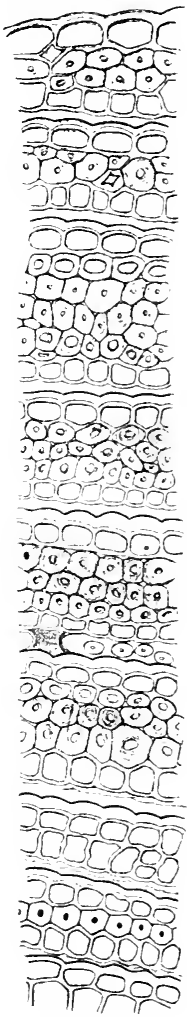

Fig.67. (2uerselnitt durch die Knosyendecke von (Jirter.s sessiliflora sin.

(Xach (isit....)
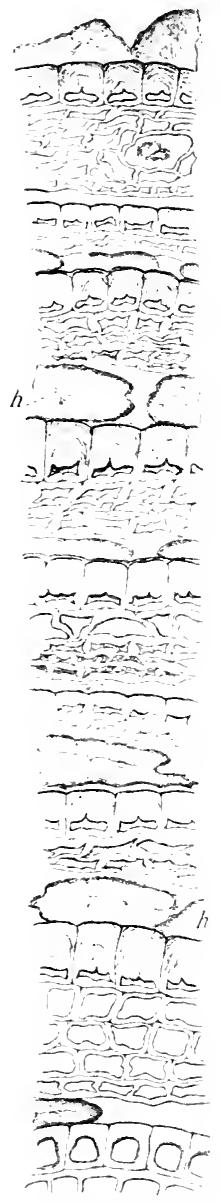

Fig. 6s. (2)rerselnitt

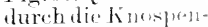
decke rou l'imes

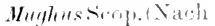
(itit -...)

1) Gmos. J., Beitrige zur Biologie der Knospe. Pringheins .Jahrb. f. wissenschaftliche Bot. Bd. XXIII, Heft 4, S. 6:37 ff. 
in ihren spärlicheren Knospendecken nicht oder kanm angedentet. Hier handelt es sich mn sichutz gegen die sommerliche Trockenperiode und dazu dienen ein Haaraprarat, der sich ans der Epidermis, und eine Korktage, welche sich aus dem subejidermalen frewebe entwickelt.

\%ur \%eit des Laubansbruchs wäthst nun die Innenseite der dachartig bisher zusammengeneigten schupum, die bekamntlich nichts anderes wie reduzierte, anf ihren Stipmlarteil beschränkte Blätter sind, an der Basis weiter, während die sklerotisicrte Antisenseite dies nicht tut. Folglich winl die Basis der nmmehr rom Rant her vertrocknenden schuppe Heisehig, polsterfïmig und thïclit sie somit gespreizt nach autsen. Dies ist der \%eitpmbt der fiefahr: dem num ist der zarte Tegetationskegel nahezu sthntzlos den Temperaturshwankungen ansgesetzt. Daher finden wir in Frïhjah bei Eichentrieben bisweilen ilureh Frosteinwirkng hervorerutene imnere Kerklüttungen (siehe Kapitel Frostwirkmoen) oder schrumptimeserseheinungen dureh Trockenheit infolge anhaltendor scharfer Ustwinde.

Gleichviel ant welche Weise bei den einzelnen Bamnarten der Schutzapparat der Knospenschuppen gelililet wird, ob ans sklerotischen Zelllagen oder aus Korkschichten, Haarfilzen oder Harzmassen, so steht die eine Tatsache fest, dats diese Apparate je nach der Witterung und Nahrungsutuhr zur /eit ihrer Anlage sich in den versehiedenen Jahren verschicden aushithen und demnach im folgenden Frühjahr von verschiedener Schutzkratt sind. Wenn z. B. der Sommer fencht und trïhe gewsen, neigen die Deckschupen in ihrer Entwicklung mehr zur Natur tes grünen Laubblattes, und dic Zellen werden gröker, aber weniger verdickt; sie reagieren im Frühjahr schneller aut die 'Turgescenzsteigerung der Gewebe und werden schneller anseinanderweichen. Damit wird der Vegotationskegel frühzeitio den Unbilden der Frïhjahrswitterung ausgesetzt und dabei zu schnell seines Transpirationsschntzes beraubt.

Jieser Faktor ist nicht zu muterschätzen; dem (iküss (l. e. S. 64!) berichtet, daks, als or von einer Eichenknospe die äutsèren stärkeren Deckschupen entfernte, ex fast regeluäfis ein Kugrundegehen der Knose bemerkte, selbst wemn die Temperatur nicht simli und Fenehtigkeit in genügendem Matie vorhanden war. Anch die inneren, zarthäntigeren Tesmente vertrockneten, da sic an die Transpirationssteigermng nicht grwöhnt waren. Die nnter gleichen Berlingungen (aut abgeschnittenen \%weigen) gehaltenen, mverletzten Knospen entwickelten sich weiter.

Hor Virsud hei Buchenknospen, denen tie ganze Knospendecte aemommen worden war, zeigte, dats die jumgen, blotisgelegten Blätter viel länger trisch bliehen als bei ler Eiche, und man darf dieses Verhaltrn from Unstante zuschoiben, daks die jungen Buchenblättehen furch ihre Buharumg vor zu starker 'Transpiration und dem Vertrocknem geschützt werelen. Lafür spricht auch die Beobachtmig von Gritss, datis bei Assulus Hinpocastamm die jungen, bekanntlich änfserst dicht behatrten Blättor nath der Entfernumg der Knospendecken sich doeh noch normal "ntfalteten. Die Wirksamkeit des Harzchutzes erwibt sich ans einem Beispiel hei Abies P'insopo Boiss. Hier vertrockneten diejenigen Knospen, doren I Iarz durch Schwefelkohlenstoft' entfernt worden war.

Es fragt sich nun, inwieweit man in praktischen Betriebe solehen Tnegelmäisgkeiten in der Knosprnentialtung entgegenarbeiten kann? iie Anstililung der Knospendecken kann man nitht beeinflussen. 
und die getähliehen Schwankmoen in dor Tempreatm mel dem Fenchtigleitsgehalte der Lutt während der Frühjahrseit kann man nicht heseition. Dennoch glauben wir, lietse sich sugat bei dem Waltban ein vorbengndeos Verfahren einschlagen. mu ilis Transpirationsextreme zu mildern. In elster linie muts dem Bostrus seme natioliche Moos- bezw. strendecke rhalten bleiben, wril damit die Borlenfenchtigkeit geschont mul eine fouchte Atmosphäre ludingt wird. Ans

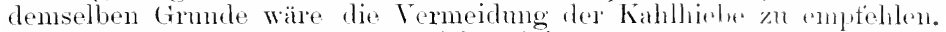
Endlich aber, und zwar namentlich bei jüngeren Kulturen, dinfte das Stehenlassen ron Walımänteln an den Seiten, an denen die fonnt im Frülijahr besonclers stark anf die stämme wirkt, sich vorterlhatt prweisen. Wir denken bei derartigen schntzbämmen besondors an dir schnellwüchsige mul locker sich authanende Birke.

Bei Gartenkulturen hat man natülich tie Vorbengme besser in der Hand. Es sei in dieser Bezirhung vorlänfig hier nur darant antmerksam gematht, dats man nicht verstehen soll, den ïbernälisid starken Transpirationsverhst durch gesteigerte, reichliche Wnrzelbewässtrung zu ersetzen. Dies geht nicht, mol man siht Pflanzen rertrocknen, die Wasserïherflut's an den Wmzeln haben. Las eimig rationell. Mittel bildet kï $n s t$ liche $B(x)$ hat $t u n g$.

\section{Der Hitzelaubfall.}

Die Beobachtung zeigt, dats alljählich rom Frïhjahr an hei museren sommergrünen Bämmen Ianh, alegeworfon wirel. Bor stältischen Anptlanzmngen fällt dies namentlich an Acr. Negunde ant: antiserelem gesedlen

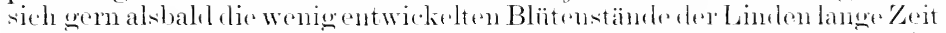
vor der .. Lindenblüte" hinzu. Weniger antfällig, aher stets vorhanden ist

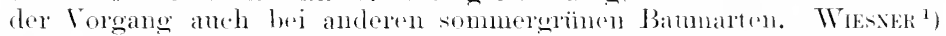

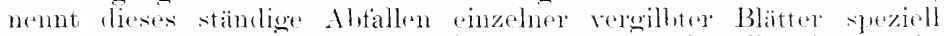
den „sommerlanbiall" mel sieht die Ersache dreselben in der Abmahme des hëchsten somnenstandes. Ich glanles, dafs auch andere Lrsachen dabei wirksan scin liönen: dem während nach Wresser's An-

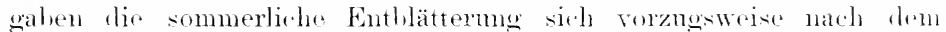
21. Juni einzustellen pthert, lehrt die Beolatelitmog, dats z. B. bei dor Negundo, Acer ealifornicum und verwanden Arten sehon im Mai nus Jumiantang ein Abwertion der erstgebildeten Blätrer stattfinden kann.

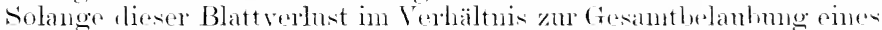

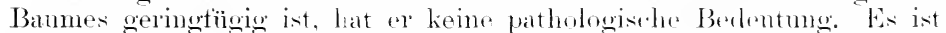

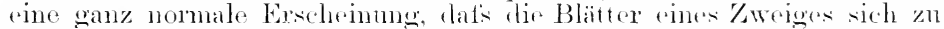

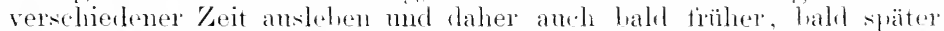
fallen. Dio erstentstelenden im Frölejalı sind ilnor ganzen dulage

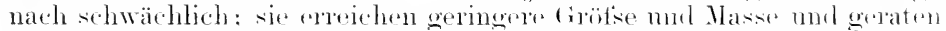

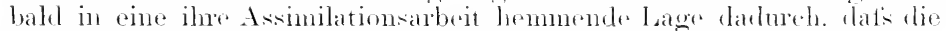
später entstehendon liäfigeren Bläter ilmen das licht entziehen. Als-

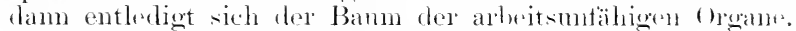

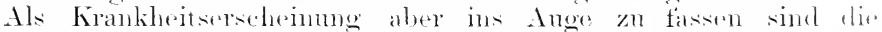
sommerlichen Enthlätrougen, welche massenhatt mol pötzlich sich

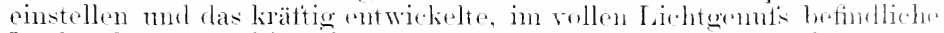
Laub erfassen. Dahin gehören als Ersarho die siätfrïste, an häutigsten

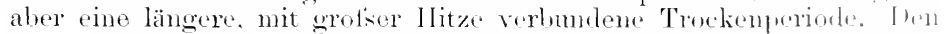

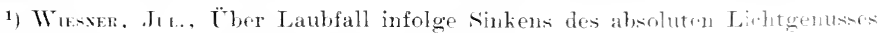
(Sommerlaubfall). Ber. d. I: Bot. Ges. 1914. S. 64 . 
hierdurch eingeleiteten Blattabwurf unterscheidet WiEsser als ., Hitzela ubfall", "offenhar in erster Linie infolge einer übermälsigen Transpiration, mit welcher die Kufuhr des Wassers rom stamme her nicht melır gleichen schritt hält."

Eimen derartigen . Hitzelaubfall" sal ich in den Stratienpflanzungen, namentlich bei Linden eintreten, trotzdem reichlich bewässert worden war. Daraus geht hervor, lats tatsächlich die trockenc Luft bei reichem somenschein als der schärligende Faktor anzusehen ist. Bei alleinigem Wassermangel im Boden stirbt das Laub an Sommerdiure, aber bleibt meist am $/$ weige hängen.

Wegen der besonfleren Empfindlichkeit der Linden sind diesolben als stratienbäme trotz ihrer sehönheit nicht zu empfehlen. Die Sommerlinde leidet frïher und stärker als die Winterlinde und zeig't sich nach Eintritt der sommerlichen Hitze fast ansmahmslos mit den feinen spinntäden der Wrermilbe (Triramychus tolarins) bedeckt. Bei vielen Gehölzen treten die Blattlänse in Ummengen anf. Wit der Entlanbung. von der nu die Kreigspitzen ansgenommen sind, tritt eine vorzeitige Ruheperiodo bei ten Bänmen ein. Sobald das Wetter kühler wirl - oder bei reichlicher Stratsenbewässermng anch noch innerhalb der heifsen Keit -) beginnt (in zweiter Trieb, wobei die sich entwickelnden seitenknospen anch noch etwa sitzengebliebene Blätter abstotisen kömen (Treiblaubfall nach Wiesser). Dieser zweite Trieb erlangt bei nassen Herbsten nicht die gehörige Holzreife und leidet dam leicht durch winterliche Fröste.

Tm allon diesen Folgeerscheinungen vorzubeugen, empfiehlt sich bei Strafisenpflanzmoen der Ersatz der Linde dureh die Ulme. Handelt a sich um ältere Afllcen, die geschont werden müssen, so dïrtte aufser den möglichst häufigen stratsenbesprengungen ein Überbransen der Bäume mit scharfem Wasserstrahl zur späten Abendzeit sich besonders nützlich erweisen. Ich halte die komsequente Durchführung dieser Matisegel anch tïr das wirksamste Mittel gegen das Ungeziefer.

\section{Der Honigtau.}

Nach den bisherign Beobachtmoen muts eine Krankheit hierher rezogen werten, die unter dem Namen, Honigtan" (Molligo, Mel reris, lios mollis) mehrtach ${ }^{1}$ ) heschriehen und dabei anf sehr verschiedene Ursachen zurïckgetüht worken ist. Sie besteht in Auf-

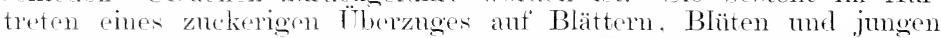
\%weigen holziger und krantiger Pflanzen bald als wanzender, wheichmätiger Firnis, hak in Form gellolicher, zäher Tropfen, meist die ober-

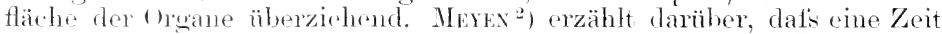
hindurch die von PLinus answespochene Ansicht Geltung gehabt, wonach der Inonigtan als wirklicher ans der Luft fallender 'Tau anzusehen s.i, der besomdirs in den Hundstagen antrete und nicht blok die Ptlanzen, somblem anch die Kleidrer der Nunschen überziehe. Dieser Ansicht

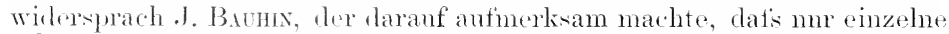
Pflanzen ofer Arten in einer Gegend krank wïrden. Nachdem man die Abscheidung eines siztsen Saftes ans dem After oder ans den Hinter-

1) Saccharogenesis diabetica; Uxtwk, Exanth. p. 3. - Honning Dugen, Fabricius Kiohenh. 1774. - Le Givre, Adans, cit. bei Skrtzex: Sistematarum generaliorum de morbis plantarum. Göttingae 1789.

э) Pflanzenpathologie, 1841, ‥ 217. 
leibsröhren der Blattläuse beobathtet hatte, wurlen diese als die Ursache der Krankheit angeschen, zumal man lemerkte, dal's Blattläuse und Honigtan schr häntig gemeinschaftlich gefimden werelen. Dem wurde aber zunächst entgegengestellt, dats die Blattläuse meist nur aut der Unterseite der Bläter, der llonigtan dagegen vorzugswos ant der Oberseite auttrote: jedoeh ist dies allerding liein she sicherer Beweis, da die Blattläuse von der Unterseite des närhst höheren Blattes die Oberseite des darmuterliegenten bespritzen liönnen. Aber almählich mehrten sich die Beobachtungen von lloniptan an isolierten Pflanzen im Freien und in $/$ immer, an denen lieine Blattläuse sich vortanden oler doch erst einige Zeit nachher auftratrin. In dieser Beziehmng interessant ist cine Beobachtung von Hatui im . Jahre 18:34. Ein Rosenstock, der nicht ans dem Zimmor wekommen, sonderte aut' ler unteren Evidermis ler Bläter kleine 'Tröpfohen ab, aus denen der Kucker in rantenẗ̈̈migen ofler kubischen hristallen sich ausschier. Dahei veränderte sich die grüne Farbe des Blattes in eine grane, was dureh Verseluwinden des Chlorophylls in Mesophyll der secemierenden Stellen und durch Auttreten heller Tropten in den Zellen bedingt wurde. Therinases' ${ }^{1}$ tand ebentalls mehrfach solele zuckerige dusscheidungen bei warmer, anhaltend trockner luttheschattenheit, sowohl im Freien wie in Gewächshäusern. an Weitspapteln, Linden. Orangen-

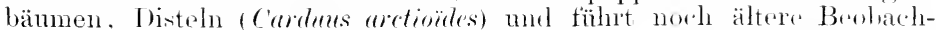
tungen von Lobel, Pres. 'Tochisefort u. a. an, womach llonigtan ant Glbäunen, thornarten, Wahüssen, Wriden, Chnen und Fichten vorkommt. Er nud nach ihm Nerse haben sich äbrerengt, dats die zuckerhatigen 'T'ropton direkt von den Epidermiszellen ansogschieden werden, wobei der erstere Beobathter noch hinzutïgt, dats die spralt-

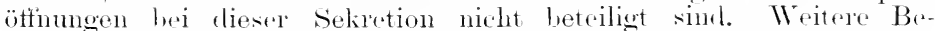
merkungen äler Honigtan aut sehr versehiedenen Pflanzen, nannentlieh

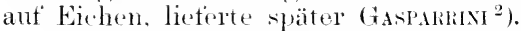

Der Honigtan an den Linden ist von Borssintidurt nud bei der Traubenkirsche (Prumes Pedus) von KöLLes $\left.{ }^{3}\right)$ themisch untersucht

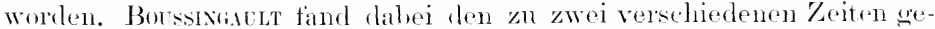
sammelten Honigtau in den Mengenverhälnissen der einzehnen stoffo versehieden, woraus ersichtlich ist, dats das sekret nicht immer gleiche prozentiselue \%usammensetzung hat. Aber anch tie Natur cler stotte seheint sich zu veränrlern: denn während Bousswiault mu Rohrzucker (4r-5.50\%),

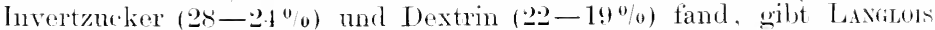
in Honigtau der Lincle autserdem noch Mannit als Bestandteil an. Die Resultate nenerer Untersuchumen wurden ron CzAPEK ${ }^{4}$ ) gesammelt. Es geht daraus hervor, dats bei den versehiedenen Pflanzen die Kusammensetzung des Honigtanes verschieden ist.

Eine İbereinstimmmo der Ansichten üher die Ursachen der Erseheinung hat sich bis jetzt nicht exzielen lassen. Während Büsies") in eingehenden studien üher das Einstedhen der Blattläuse in den

1) Physiologie der Gewiichse, 1 \&3. Bd. II, Teil 1, s. 35-37. S. 324.

2) Sopra la melata o trasudamento di aspetto gonmoso etc. Bot. Keit. 1sit,

3) Ökonom. Fortschr. 1572, Nr. 2, s. 39. s. 408

4) Czıьк, Fı., Biochemie der Pflanzen. Jena. Gustar Fischer. 1905. Bu. I,

5) Bëstiex, M., Der Honigtau. Biolog. Studien an Pflanzen u. P'flanzenlaiusen. Sond. Biologisches Centralbl. Bd. XI, Nr. 7 u. $8,1 \diamond 91$. 
Ptlanzenteil nathweist, dats die Tiere dureh den Atter viel grösere Nengen Homigtan ansseheiten dourch die Hinterleibsöhren wird nur (in wachsartiges sekret weliefert) als man owohnlich ammimmt und dalyer zu dem Schlusio lommt, datis echter Honigtau nur von Pflanzenlänsen herrüht, hahen wir von Boxwek ${ }^{1}$ ) Versuche über künstliche Herrorrutume der Erseheimme ohme Mitwirkme von Tieren.

Biscies sagt: "Die Eigursehaten der Cuticula westatten weder ein Auschwitzen von Zuekersäten aus dem Kellimnern. noch, wie Wrson amuahm, ein osmotisches ILerausingen von Flïsigkeiten durch ant der Blattfäche befindliche Znckertröptchen, wie solche die Blattlausexliremente darstellen." Dieser Aussuruch lätst aber die Tmstande unberücksichtigt, dats die Cuticularglasur surünge bekommen kam, und dats Auscheidungen in eimzelnen Fällen doch wohl dureh die spaltätthungen ihren Weg finden kömnen. Bewris für letzteren Fall bieten die von Boxwsti erhaltenen Resnltate. Blätter, die gröferen Temperaturditterenzen ansogetzt waren (Nadellölzer, Eichen, Ahorn ete.) liefsen bei antiallendem Lichte muter dem Mikroskope das Hervortreten von nektarähnlichen Tröpt 'hen ans den spaltäthungen direkt erkemnen.

Meine eigenen Beolachtungen bestätigen das Auttreten ron Ilonigtan ohne Mitwirkung von Blattlänen. In einem Falle sah ich bei ITasserkulturen auf älteren Blättern von Birnensänlingen, die nugeschützt der heitsen Julisomne ansgesetzt waren, reichlich Honigtaubildung. liese Beohachtung zeigt. dats der Wassermangel im Boden nicht mitzurirken brancht. Ith glaube, dats dann Honigtan zustande kommt, wenn hei hrättion regetierenden, nicht zn alten Blättern eine plötzliche, ïhermätige Transpirationssteigermo hei starkem Lichtreiz wich einstellt und eine zu hole Konzentration des Zellsattes herbeiführt. Danert die Störung über rin gewisses Mals hinaus fort. leislet das Blatt dauernd und tällt vorzeitig ab. Im anderen Falle wäscht dèr Regen alhmählich den zuckrigen Überzug, der zm Ansiedelung von sichwärzepilzen (Rutistan) leicht Veranlassmugulit, wiederab. Es handelt sich bei der Entstehung des Honiotanes nicht immer nm ahsolut hohe Wärme- und Lichtreize, sondern mehr um eine plötzliche grotie Diflerenz, die z. B. sich einstellt, wemn nach shehr kïhlen Frühlingsnächten das in seiner Tätigkeit heralgedrückte Gruan pötzlich den Reiz der intensiven Norgensonne bekommt.

Beschattung würde das beste Vorbengungsmittel, häufiges Bespritzen ein wirksames Heilmittel sein.

Wahrscheinlich gehört hierher die gefürehtete Mafuta-Krankheit der Sorghum-Hirse (Ambrongon Sorghum) in Deutsch-Ostafrika. Auf Blättern und stengeh zeigen sich honigartige Ausschwitzungen (Matuta heifs (i). die zur Entstehmo rutsartiger Öbrezüge Veranlassung (reben²). Anch andere Pflanzen leiden, namentlich bei Dürre.

\section{Die Herz- und Trockenfäule der Futter- und Zuckerrüben ${ }^{3}$ ).}

Als eine dem Honigtan ihren Triahen nach repwandte Erscheinung ist die Herztäule der Zuclierriben zu betrachten. Sie zeigt sich meist in rer heitirn . Julizrit in regenlosen Perioden und äutisert sich in cinem

1) Boxinn, G., sur la miellée des feuilles. Compt. rend. 1896, p. 335, cit. Zeitschrift f. Pflanzenkrankh. 1ष96, s. 347.

") Buss, W., Weitere Intersuchungen über die Mafuta-Krankheit der SorghumHirse. Aus ...Tropenpflanzer", cit. Zeitschr. f. Pflanzenkrankh. 1902, S. 82.

$\left.{ }^{3}\right)$ s. Bd. II s. 240. 
Alsterben der Herzhlätter, soweit diesellsen noch nicht ihr hallw Giötse erroicht haben. Das absterhened. Lauh wirl tast plötzlich schwarz. In schweren Fällen sieht man den gesamten Blattapparat zngrunde gehen: aber in der Regel sterben die Pflanzen nirht winzlich, sondern treiben in rer nächsten Regenperiode wieder nemes Lamb. Nolun der Er-

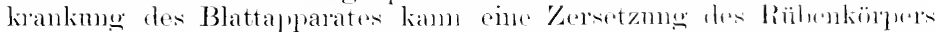
sich einstellen (Trockentänle). Dersolbe bekomme in der Nähe des

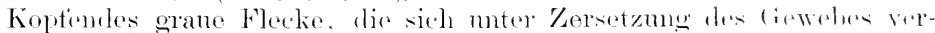

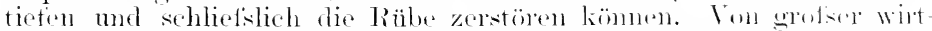

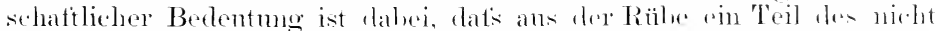

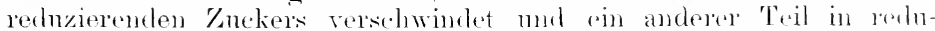

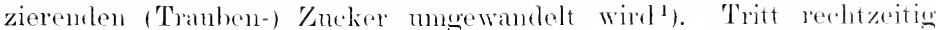

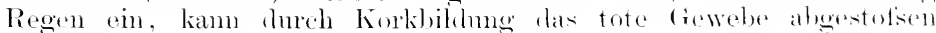
werden.

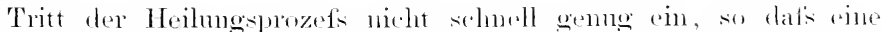
lange Herhatfenchtigkeit ihren Einthuts ant die Fanktolle ansïhru liam,

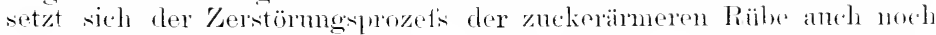
imerhall, der Mieten tort.

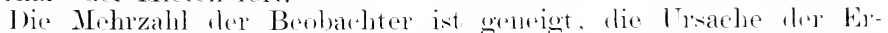

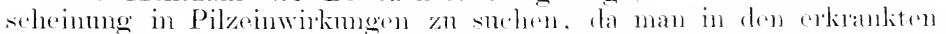

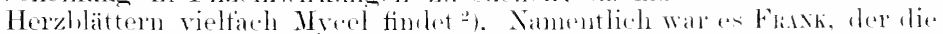

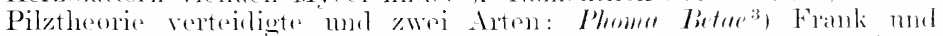

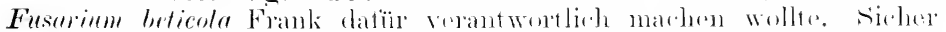

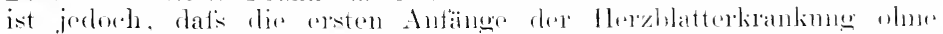

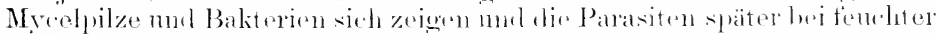

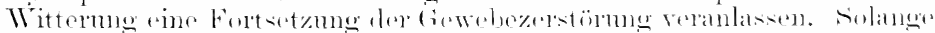

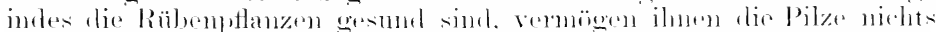

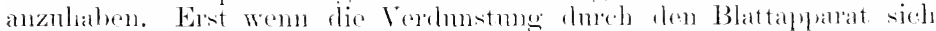

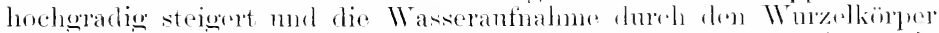

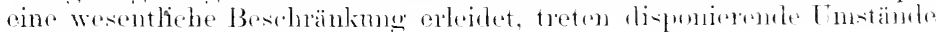
tïr rine Pilzansiollung ein.

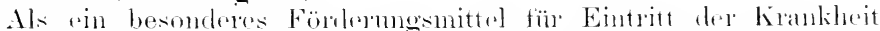

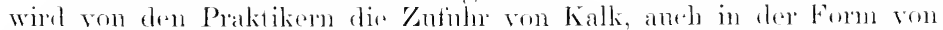

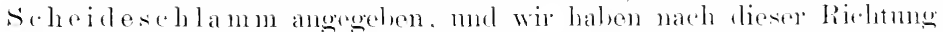

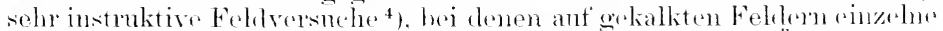

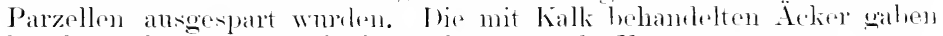
kranke Rïben. div megkalkten aber gesmol. Ernte.

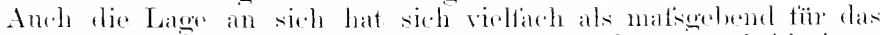

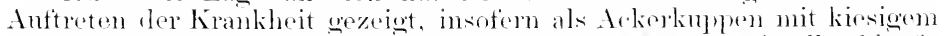
Unterermel orler Ablänge, von denen das Wasser schmell abläuft.

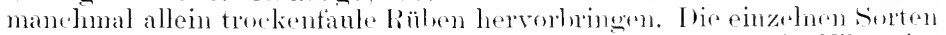

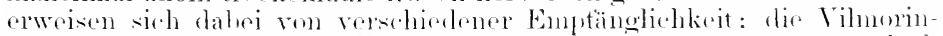

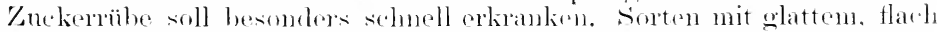

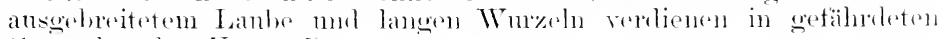
(regenden den Vormusing).

1) Fњхк, A. B., Kampfbuch. 1897, S. 131.

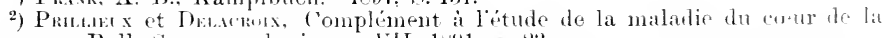
Betterave. Bull. soc. mycologique. VII, 1sy1, p. 2:?.

") sin. Phoma sphairosperma Rostr., Phoma Retre Rostr., Phallosticte tabifien Prill. et Del.

4) Zeitschr. f. Pflanzenkrankh. 1-95, s. 250, 1896 \&. 399.

5) Barros, W., Einige Beobachtungen ther die Herz- und Trockenfäulu, cit Centralbl. f. Bakteriologie 1899, s. 562 . 
s'ehr eingehende Feldversuche hat SAsE ${ }^{1}$ ) angestellt und dabei sefunden, dafs die I dampfticfkultur den Ausbruch der Trockenfäule zu verhindern instande gewesen ist. Betrefts des Einflusses der Düngung wehen die Meinmeen weit anseinander. Dies kommt unserer Meinme mach daher, dat's die Wirkmng desselben I momittels aut verschiedenen Äckern und je nach der Wittermng verschieden ist. Betreffs der Trockenfäule werden diejenigen Düngungen gefährlich erscheinen, welehe leichte Böden noch mehr lockern, ihre Erwärmbarkeit vermehren und ihre wasserhaltende Kraft vermindern, wie dies bei Scheideschlamm (eintreten kann 2). Dieselben Mittel sind bei schwerem Boden günstig. Am meisten streitig ist der Punkt der Kalidüngung. Es wird betont, daf's eigentlich der Boden durch die Salzdüngung das Wasser besser zurücklialte, also dem Einflutis der Trockenheit grötieren Widerstand leiste, und dennoch fände man nicht selten bei reicher Kainitdüngmng gerade dort zuerst herzfaule Rüben.

Ein solches Ergebnis findet nach unserer Anschaumg aber seine naturgemätse Erklärung: die Kainitdïngung befördert antserordentlich die Entwicklung der Blätter, und es ist erklärlich, dafs bei Eintritt einer anhaltenden Trockenperiode der unfangreiche Laubapparat dem Rübenkörper am schmellsten Wasser entzieht und eine schädliche Konzentration des Zellsaftes veranlatist. Analysen haben gezeigt, dat's bei hohem Kaligehalt in dern Blättern die Trockenfäule um so stärker auttrat, je geringer in Verhältnis dazu der Gehalt an Phosphorsäure war.

Feboten sind also hei dieser Krankheit als Torbengungsmatsregeln die Vermeidung solcher Lagen, die schneller und starker Austrocknumg aurgesetzt sind. Bei leichten Böden werden die den Boden hitzenden Materialien (Kalk, Scheideschlamm) nicht direkt zu den Rüben gegeben werden dürfen. Bei Eintritt geführlicher Trockenperioden suche man die Drainage zu vermindern, da in den meisten Fällen eine Bewässerung der Rüben nicht austülırbar sein dürfte. $/ 2 u$ erwägen ist, ob man lum h Abschmeiden der älteren Blätter oder dureh Beschattung mittelst Überstrenen von Langstrol dic Terdunstung der Pflanzen herabdrücken kamn.

\section{Mangelhafte Blütenentfaltung.}

Tiel häufiger, als man allgemein annimmt, machen sich die Folgen grotier Luftrockenheit hei den Blumen, und zwar namentlich den gefüllten, bemerlibar. Wenn man dio Entwicklung von Exemplaren derselben spezies mit einfachen und gefüllten Blïten an demselben standort vergleicht (Fuchsien. Petunien, Knollenbegonien, Rosen u. dol.), so wird man ausnahmslos eine sclmellere und leiehtere Entfaltung der nicht gefüllten Blumen heobachten. Das langsamere und schwerere

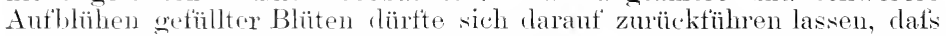
die durch fon Blütenstiel zugetührte Wasser- und Nährstotfmenge sich auf ein weit hedententeres Blattmaterial verteilen muts. Der dureh die vermehrte Kahl der Blumenblitter hervorgerufene Transpirationsverlust ist ein gewaltiger, und lerselbe ist keineswegs duch Begiefsen der Wurzeln zu ersetzen. Infolgedessen leben sich die Organe schmeller aus: sie werden motreif und sterben in ihrer Wachstmmsregion schon

1) SAns: Orw, Einige Beobachtungen aus dem praktischen Betriebe betreffs Auftretens der Herz- oder Trockenfäule. Zeitschr. f. Pflanzenkrankh. 1894, \$. 359.

") Richrer, W. Über die Beziehungen des Scheideschlamms zum Auftreten der Herzfäule der Räben. Zeitschr. f. Pflanzenkrankh. 1895, s. 51. 
ab, heror die Blume sich noch vollständig entfialtet hat. Daher tindet man hei grotser Trockenheit der Lutt vielfacl win Ahtallen halbgeöffucter Blüten, das nicht zu verweehseh ist nit lem Abwerfen der Blüten bei Wasserübersehuts. In letzterem Falle läfst sich melnfiach beobachten, dats die Blüte samt ihrom stiol sirle aloglierlert, während bei übermälsiger. Transpiration in einer äntisest trockenen Atmosphäre die Blumenblätter an der Ansatzstelle an Blïtenstind sich lösen, nachdem sie sich dort grebrïunt haben.

Wem bei gärtnerischen Gilashanskulturen oft versucht wirel, durch reichliches spritzen fler ganzen Pflanzen kïnstlich eine fonchte Atmosphäre zu erzeugen. so hilft dies nur dam, wemn die Blumentëpti. anf siner Eroltläche stehen und nun die verdamptende Fonchtigkt ans dem Erdboden eine beständig fenchte Atmosphäre schafft. Strhen dir Pflanzen dagegen ant stellagen von Holz, Eisen oder Manerwerk, damm verkïmmern die Blïten trotzdem, und es findet sich dabri an ler Ablösmosstelle der Blütenblätter leicht Botrytis-Vegetation rin. Diese führt nachher zu irrigen Schlüssen, da Botrytis-Erkrankmugen rorherrschend bei grotser Luftenchtigkeit sich einzustellen ptlegen.

Eime der anffälligsten schädigungen durch übermätige Lufttrockenheit ist das Abtallen der gefülltrn männlichrn $\mathrm{B}$ lumen bei Knollenbegonien. Hier heobachtete irh dir Erseheinme virelfach in dem trockenen sommer 1904 an stellen, die nienals direlites somnenlicht erhielten. Dats die Trockenherit der lutt tatsächlich der schädigende Faktor war. "roab sich ans lem Umstame, dats solele Pflanzen, die ilne Blumen gerade währent ilnes Erschliefsens abtallon lictien, dieselben hehielten mul entfalteten. wemn sie äber weitr. mit Wasser gefïllte Bassins gestellt wurlen.

Das Abtallen der männlichen Blïten (die weihlichen kamen stots

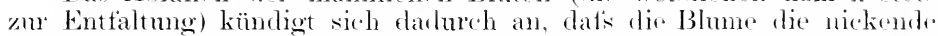
sitellung der Krospe Jeibehäl. Nit der Lupe erkennt man an der Ansatzstelle der Blütenblätter einen schmalen, bramen Ring. Dort erweist sich das jugendliche trewebe in Wandumg mol Inlate tief lnam und zusammengofallen. \%wischen eler Basis der Potalon mud der sie tragenden Achse bilden sich grotise Lücken lurch Selnmmpten mol \%erreitsen des Gewebes dor Petalenbasis, his schliotslich dir Blumenblätter nur noch an wongen Gewrberesten festhängen. In den cinzelnen Petalen esscheinen die Gefäisbïndel anch an den stellen, dic noch unverfärbt und anscheinend trisch sind, bereits tief relnämnt. Thas Alsterben des Basalteils erweist sich als ein vorzeitiges Ansleben: lem man findet in drom frewebe nur noch spärliche plasmatisch. Flocken als \%ellinhalt. In der Nachbarschatt der abgestorbenen (tewebe zeigt sich cine ahnome Hänfung vom teilweise schlecht ans rebildeten) Einzelkristallen des oxalsamen Kalkes als letzte Reste der reratmeten organischen substan\%.

Eine zweite Art mangellatier Blïtenentfaltung infolge der lanft trockenheit wude bri Liliaceen und Amaryllideen beobarbitet und le stand darin, dats dic Perigonziptel an den spitzen rerklebt hivbru. Während der übrige Teil ler Blume normal gestaltet und getäilit War. vargilhten die verkleht hleibenden Prrigonziptel, schminutten mul trockneten zu einer schliefslich brüchig werkenden Mass zm-annmpr. ber wirtschaftliche schaden ist num dam ron Bedentmo. wam wich hei der Blumentreiberei um die Entfaltung grof'ser Einzell,litur wir bei Lilium aurem und longiflorum und Hipueastrem robustum Diots. etc. hanele.lt.

Sorauer, Handbuch. 3. Aufl. Erster Rand. 
An letzterer sipezies, die bei den Gärtnem anch als Amaryllis Totturi hed liannt ist und wegen ihres leichten Blühens als Zimmerptlanze vieltacl, kultiviert wird, beobachtete ich die öftinungsmechanili und deren movllimmenes Funktionieren bei Trockenheit rtwas eingehender.

Die drei äutseren Zipfel des ziegehoten Perigons Jeginnen am vorletzten 'Tage vor der vollen Entfaltung der Blumn an iluren Basalteilen sich vonemander zu tremnen, so dats die grothe liegeltömige Blumenknospe zunächst drei Schlitze zeigt. Die S̈pitzen dieser drei äntser'n Bhunenblätter aber bleiben noch fest miteinander verklebt, selbst wenn der Vorgang des Auseinanderweichens sich dureh bevorzuntes Wachstum der Tumenseite der Perigonhasis so verstälst, dat's dieselhe bauchartio nach autsen vorgewölht wird. In dieser immer stärer werdenden Konvexität hegt eine grofise Federkraft, welche die

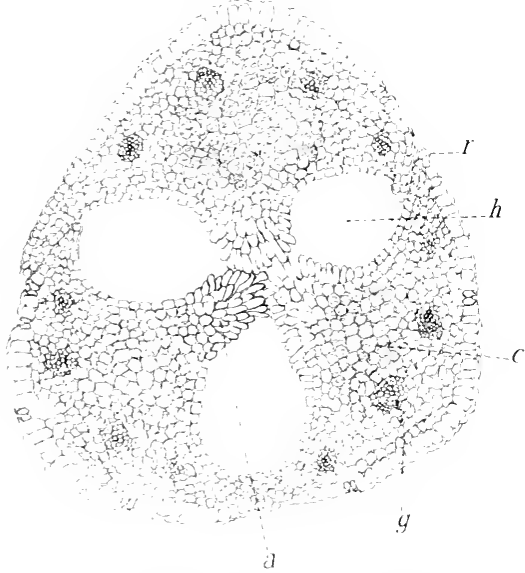

Fin. 6\%. Querschitt dureh die Sitzenregion finer noch nicht entfalteten Blume von Hiph'"strum rohustwm. (o)rig.) Buchstalienerkiärung im Text. verklehten spitzen voneinander tremmen möchte unel in normalen Fällen anch tatsächlich endlich voneinanderreifst. Wie grots diese tedrende, rumch basale Epinastie des einzelnen Perigonziptels erzengte Kraft ist, zeigt sich. wenn man tie noch verklebten spitzen der drei Zijutel musefähr ts stunden vor der normalen ïttinungszeit abschmeidet. Es sind dam himnen 10 Minnten die einzelnen Ziptel mm 1,5 bis $2 \mathrm{~cm}$ auseinandergewichen, d.h.die Blumenkine hat sich so weit geöfthet. Der Aprarat, weleher imstande ist, einer so stark ferlenden Kraft derartigen Widerstanel zn leisten. besteht darin, dats die noch rollstänlig arinen spitzen der drei äulseren Perigonzipifel zn einem festen, bisweilun fingerhutähnlichen

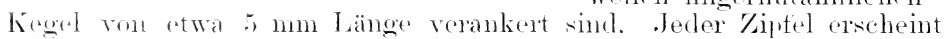
nämlich ant dre Innenseite dicktteischig durch starkes Wachstum des

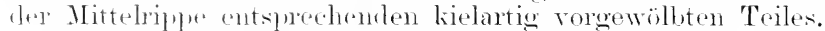

In der vorstrhenden Fign. be sehen wir, wie die droi Perigonziptel in

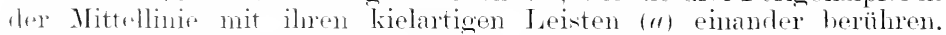

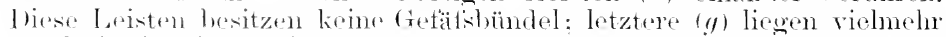
zu drei his vier jeripheriseh in tem eigentlielen Lammarteil. Die

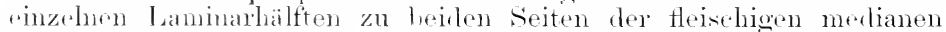
leiste sind nach immen werïmmt und berïhren die benathbarten Perigonziptal mit den Rändern (r): diese sind grïn, während die Heischigen, im Kentrum (c) dit weitesten Parenchymzellen hesitzenden Polster tarhlos aseheinen. Die Polster weisen nur spärlich grotie stärkekörner goxenüher den zahlreichen kleinkärnigen stärkemengen im äbrigen Gewe aut. Die Epirtermis ist nomal Hachwandig an 
den Antsenseiten der Perigonziptel: die [nutuseit derselhen zeigt unter heginnender Entwicklumg ron rotem Fallstotf ein papillöses Auswachsen der Ephilermiszellen. Während diesthen shon zu dentlichen. zahnuadartig gesenseitig inemanterereitumlen Papillen an den polsterartigen Erhebungen ausgewachsen siml (a). \%ignen sie an dem Hachen Laminarteil noch kamm eine streckmng.

In diesem diehten Inemandergreifen der Paprillem sines Perignnziptels zwischen diejenigen der anteren ist die l roithe zu "rblicken, weswegen diese hiptel so fost miteinamber vermbert bleiben. Ihre

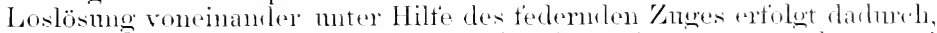
dats diese Papillen sehnell zu kenlenförmigen Haaren answarhsen mul

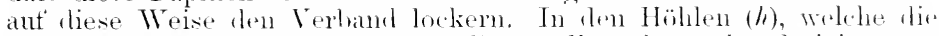
änseren Perigonbläter frei lassen, liewen dio syitzen der drei imeren, deren Epidermis aleer tiöher zu Papillen answähst, als dies hei den äudseren der Fall ist. Diese imeren Perigonziptel werden jedentalls durch das gegensertige Aneinanderstemmen ihrer answahsenden Papillen das Anseinamlerweichen, also das Aufblühen begïnstigen.

Bei trockner Luft bemerkt man mon zwar die Anlage der Papillen, aber nicht ihr Answahsen zu kenligen Haaren, mol leshall, bleiben die spitzen der Perigonhlätter vereinigt mul sthrmution allmählich.

\section{Die Zimmerkulturen.}

Jas typisele Bilıl. das uns hei den Zimmerpthanen entgegentritt. ist die Bramnfäbung und das Abtrocknen der Blattopitzen. In den Nohmungen. in wellehen fas gehrannt wirl. ist mant in der Regel

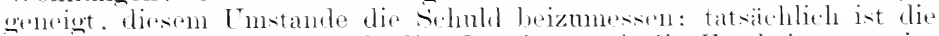

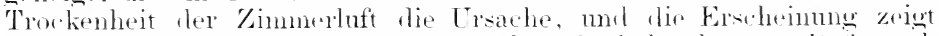
sich ahenso intensiv in Wolmumgen ohne Gasbelenchtumg. Dats nar.h diesen Anzeichen lor Erkrankung so häutig der Tod der Gewächse, namentlich der somenamenten Blattphamzen dintritt, hängt nicht mehr mit ler 'Trockenheit fir Lutt, sondern dem Bestreben der Blmmenliebhaber zusammen. dureh resht häutiges Begietsen sine grötsere Lufteuchtigkeit zu rrzencen. Die Pflanze hat aber rom dieser ellöhten Wasserzutuln keinen Vorteil: sie kam nur dam meln Nasser verbranchen mul aushanchen. Wom sie stälier neme Substanz produziert, also kräftiger assiniliert und junge Blätter bildet. Die Troekenheit der Luft aber lnhinert gerade die Blattenttaltme.

Bringt man Blattptlanzen tropisches Klinate (manche Blatthegonien, lloffmamien, Ruellien. Maranten usw.) aus lom fenchen Warmhause in elenso warne Vimner. bemerkt man alshald pinent sillstand in der

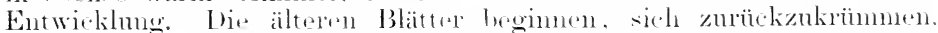

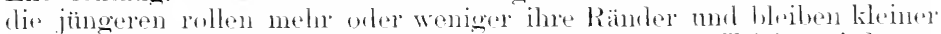

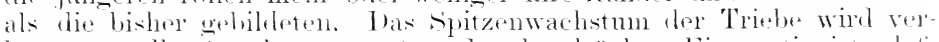

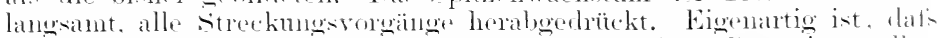

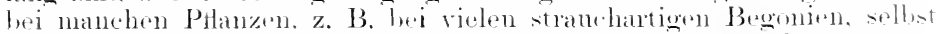
die in der trocknen lanft entstandenen Blumen nicht oder nur mu-

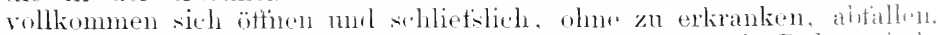

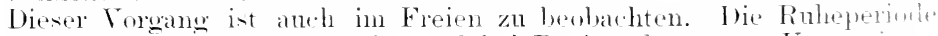

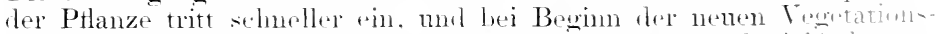
epoche wirl das Anstreiben der Knospen verzögert und vidtath wats verhindert. Wem hei riner derartigen Lntätigkeit der oherirdi-chen Achsen die Turehn zu reich begossen werden. vertauln six. 
Man hat verschiedene Mittel vorgeschlagen, um den schädlichen Einflutis der trocknen Zimmerluft abzuschwächen, wie lıäufiges Überbransen oder nächtliches Überdecken der Pflanzen mit fenchten Gazetüchern mol deroleichen; indes laben sich derartige Hilfsmittel nicht anspeichend erwiesen. len besten Erfolg sah ich in Waruschen Kästen odre bei dem Aufstellen der Pflanzen über Wassertlächen. Nenerdings hat man Blmmentische, in denen die Pflanzen anf einem mit Wasser gafïllten Zinkkasten stehen, dessen obrer Boden reichlich durchläthert ist. Dadureh steigt fortwährend Wasserdampt zwisthen den Ptlanzen in die Höhe.

\section{Hartschaligkeit der Leguminosensamen.}

The Hartschaligheit der Leguminosensamen nnd zwar nicht nu die der Papilionaceen. sondern auch der Mimoseen und Caesalpiniareen ham als eine natürliche Schutzvorrichtung der im Quellungsstadium hörhst anfälligen samenkörner gegen Mikroorganismen angesehen werden. Alle unsere wildwachsenten Schmetterlingsblütler zeigen dasselbe Banprinzip. mul erst bei unseren Kulturen wird die Hartsehaligkeit zum schädigenden Falitor, soluald sie das Keimen des saatguts verhindert.

I) Hartschaligkeit beruht auf der besonderen Terstärkmg der Palisadenschicht des samenkou'ns, welche mit ihrer Cuticula die äufserste Lage der samenschale hildet. Diese säulenförmigen, äufserst dicht ancinandergefïgten Palisaden zeigen im (nuerschnit stark lichtbrechende Querlinien (Lichtlinien) von besonders diclitgebanter Substanz. Der Zellinhalt enthält jene Stoffe. welche die Färbung der Samenschale veranlassen und denen als schutzstofte gegen parasitäre Angriffe eine hervoragende Bedentmg zugeschrieben wird. An die von NobBe als .Ha rtschicht" angesprochene Palisadenschicht schliet'st sich nach immen eine Lage von sogenamnten Sanduhrzellen, worauf dïmmandiøe Zallagen mit grotisen Intereellularen folgen, die bei der quellung des samens besonder's beteiligt sind. Entsprechend der kleberschicht bei dem (ietreideliorn finden wir bei der Melnzahl der Leguminosensamen mit Ausnahme der Phaseoleen und Tieieen nut einiger anderer Arten nach Hirz (Landwirtschaftliche samenkunde) ein Enilosperm in Form einer harten, hornigen, im Wasser schleimig werdenden Lage. In der Nabelgrgend pflegen Palisaden mul runde sanduluzellen zweireihig anfzutreten.

Dats die Hartschaligkeit. Welche die sehnelle quellung des Samenkoms verhindert. wirklich einen schutz gegen Miliroorganismen bildet.

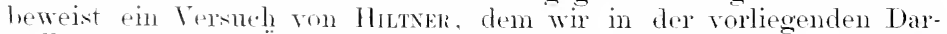
stellung tolgen ${ }^{3}$ ). Älere Lmpinensamen, die nieht absolut hartschalig. sondern nur schwes quellhar waren, wurden in Wasser zum Aufquellen grebracht. lie an jeden Tage antgequollenen samen wurden gesondert in den Krimaprarat gelegt, und os liets sich feststellen, dat's die zuerst aufgeruollenen, also gar nicht hartschaligen Lupinenkörner tast sämtlich verfaulten, wäln'mel der Prozentsatz der zur Keimung gelangenden samen um so höher wurle, je später die Aufquellung erfolgte, je höher also der Grad der Hartschaligkeit war.

1) Hutxan, L., Die Keimungsverhältuisse der Leguminosensamen und ihre Beeinflussung durch Organismenwirkung. Arbeiten d Biolog. Abteil. f. Land- $\mathrm{u}$. Forstwirtsch. am Kaiserl. Gesundheitsante. Bd. III, Heft 1. Berlin 1902. 
Ans Versuchen mit achtjährigem Klessumen, fler dureh das Alter teilweise schon nachorelunkelt, ja selbst bisweilen hram und gesehrmmptt

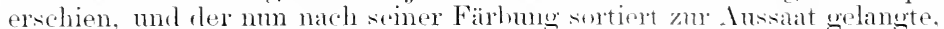

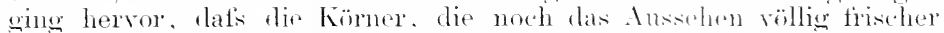
Sirat zeigten. dir höchsten Keimprozente antwiesen. Vim len bereits rertärbten Samen waren die hramgewordenen die schlechtesten mul zeigten mehr als moo taulige Körner. Bei den mur loicht nach-

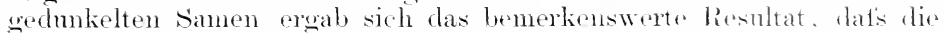
hellen Körner emen hedeutend grölseren Anstall durch Fäulnis ant'wiesen als die violetten samen. was zu der Anselhanme fïlnte, in dem violetten Farbstott' der samensehate einen sintzstotf gegen balitericlle Angrifte anzuerliennen.

Dats die Hartschaligkeit von der Wittromg abhängig ist. geht ans dem verschiedenen Prozentsatz von Keimlingon, den eine lestimmte Art in den einzelnen Jahrgängen liefert, dentlich hervor. [nutele welche Art ter Witterungseinflüse diese moliebsame Beschattenheit des saat-

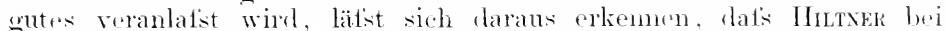

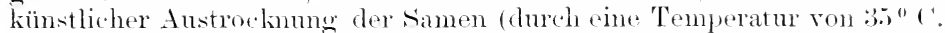
oder ïber schwefolsäure) den Prozentsatz an hartschaligen Körnern erhöhen konnte. Es wird also ählich wis hei dem tilasiswerden des Getreides sein: je schnoller der Trocknumgrormang hei der Reite sich vollzieht, desto meln hartschalige simen diunten sich hililen.

In der Praxis zoigon sich num aber mannigfach sinander widersprechende Erfahrmeren. Bei trockener Lagerume heohathete man, rats die Samen von Luphen. Wieken. Inkarmat-mil Wunfklee mit dor

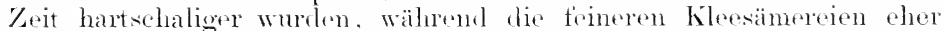

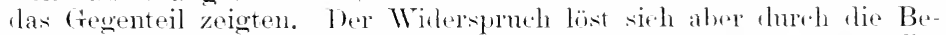

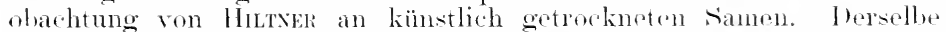
Einfluts, der hei dickwandigen samen eime erhöhte '/ähigkeit der schale hervorrutt, bewirkt dies zwar anch bei den dïnwandigen: abor bei tiesen treten infolgedessen spaltungen in der schale ant, welche die Unquellbarkeit vermintern. Übrigens soll anch rlie Kälte. wie Ronewalu meltet, eine Vermindermog der Hartschaligkeit bei Legmminosensamen herheifïhren.

Wenn man sich veroregenwärtigt, dafs tie seler stark hartschaligen samen jahrelang im Bofon liegen kömen. ohm zu keimen, und sellst die minder quollungsunfähigen so spät zur Keimmogelangen, dats sir zwei- und mehrwüchsigen Bestand veranlassen, so wirl nan einselien, lat's der Landwirt zur kïnstlichen Beseitigung der lartschaligkeit greiten muts. Es sinel num im Laufo der Jahre vielfacle Vlitel empitolilen worden. So sollte man heispielsweise die samen in sine 1 bis 20 oigo Iösmng von kohlensaurem Satron legen, um die Kieselsäno in del schale in Lösme zu hingen. Son anderer seite wurle der Vorschlag gemacht, die hartschaligen samen einfach ahzusioluen, woil sie etwas Fileiner wis die quellharen betumden worden sind. Anch die Hoitiwasserbehandlumg ist, und zwar mehrtach mit Erfolg. zmm Teil aber anch mit Mifsertolgen zur Anwendmeg gebracht workm. Eintanchen in

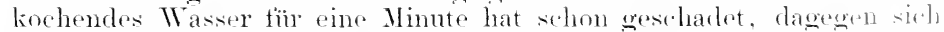

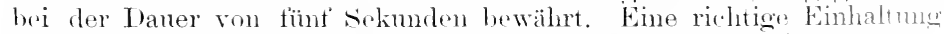
so kumer Zeitperiorlen aber dart man den Arheitern nicht zutram.n.

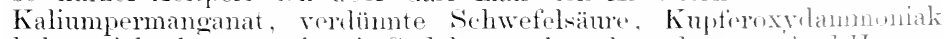

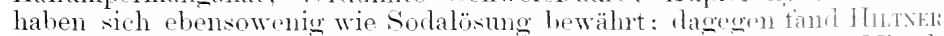
in der konzentrierten schwefelsän ein wirkanes Mittel. 
Dieselbe hat sellist hei längerer Einwirlinng sich nur tïr solche samen schädlich erwiesen, die Verletzmoen ater sehale beim Drusch erlitten hatten. Im allgemeinen wire ${ }^{1} 2$ his 1 sitmole Beizlaner himreichend scin. wenn die Samen durch oin Rïhrwerli auch tatsächlich alle benetzt werten. Nach vollendeter Beizung entferne man zunächst die säure durch Nachspölen mit Wasser mol setze dam möglichst bald rotwas Kalkmileh zu, die ;-20 Mimnten lang einwirken muts. Die milisoskopische Untersuchung derartig geheizter samen ergah, dats (bei Acacin Lophenta) die schwefelsäme nicht nu die Cuticula, somdern anch den grölsten 'Teil der Palisadenzellen wegrenommen, aber vor der Lichtlimie Halt gemacht hatte. Jeeloch erst. wem diese Lichtschicht sellost an eingen stellen von der säme dmehbrohen war, wnolen die samen in Wasser quellähion $\left.{ }^{1}\right)$. Es ist deshall, diese in der samenschale sämtlicher Legmminosen vorlandene Kellsehicht, die nach Matrikoto²) ans einer besomders dichten ('elhnlose besteht, welehe den samen ror sehneller Wasteranfnahme mul -abgalse schïtzt.

An die angehorene Hartsehaligkeit schlietist sich das Verhärten der samenhant während der Keimung. Bei solchen sämereien, welche in Keimprozefs die Kotyledonen üles die Erde emporheben, streifen diese allmählich die kappentörmig anficitzende samenschale ab, wem diestbe die autgenommene Fenthtigheit lange genug behält und lehmbar bleibt. Tritt dagegen plötzlich cine heitie, regenlose Periode ein. trocknet die Kapre anf den Kotyledonen zusammen und verhindert deren Entfaltume, sowic das Hervorbrechen des jumen stengelchens. Dasselle zwängt sich, falls es nicht erstickt, sthlietslich minter Verkrümmnng seitlich hervor. Loprose ${ }^{\sigma}$ ) erwälnt hierhergehörige Ershoinmeen bej keimenden Bohnen: ich beobachtete sie bei Gurken, Kürbisen, Melonen und steinolsstsaaten. An störendsten erwies sich das sitzenbleiben rer abgetrorkneten Steinfiuchtschalen bei sämlingen von Ptlammen. Pfirsichen und anderen Amyodalaceen. Ein Überbransen dre saatbeete zur Abendzeit ist daher eine nicht zu umgehende Vorsichtsmatisegel.

\section{Fiinftes Kapitel.}

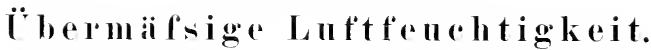

\section{Der Wachstumsmodus bei anhaltender Lufteuchtigkeit.}

Ätere Arheiten haben daranf hingewiesen, dafs Ban und Funlitionen der Individuen turch den Einfluts hochoradig fenchter Luft in dem scichen sime alteriert werlen, wie dien durch Lichtentziehmo geschieht. Nach den Versuchen von Vesude und Viet") haben die in f'enchter Lnft erzogenen PHanzen längere, weniger verzweigte Wurzehn, schmäclitigere stengel, Blätter mit längeren Blattstielen mul kieineren

1) Harmas und Kixza, Über die Trsachen und die Beseitigung der Keimungshemmungen bei verschiedenen praktisch wichtigeren Samenarten. Naturwissensch. Zeitschr. f. Land-u. Forstwirtschaft 1906, s. 199.

$\left.{ }^{2}\right)$ La linea lucida nelle cellule malpighiane degli integumenti seminale. Torino 1885, eit. von HuTNer und Kivze..

$\left.{ }^{3}\right)$ Berichte d. Deutch. Bot. Ges. 1904, Heft 5, S. 307.

4) Vesirz et Vur. Influence du Milieu sur les végétanx. Annales des scienc. nat. Sixième serie. Botanique t. XII, 1s81, p. 167. 
Flächen. Die Wanlungen der Epidermiszellen sind weniger unduliert, die Zelheihen des Mesophylls etwas minder zahlreich und ohme Differenziermo zu Palisadenparenchym. Üherhampt war das ganze Gewehe des Blattes ans fenchter Lutt gleichnalsiger. wähend man in trockner Lutt die Interschiede zwisehen Palisaten- und schwamm-

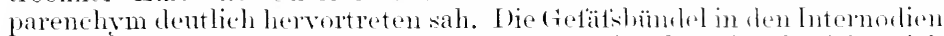
sind in der trockmen Luft riel stärkes entwickelt: lies bezielet sich nicht blots auf den Hurehmesser des ganzen Bündels, ant die Zahl der Gefalse und deren Inuchmessel, sondern vorzugsweise ant die Harthastfasern, die in trockner Luft rejehlich vorhanten und in der fourhten

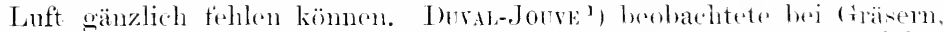

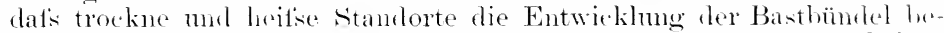
gïnstigen, während in Fouchten diese Entwicklung zurülkwehalten

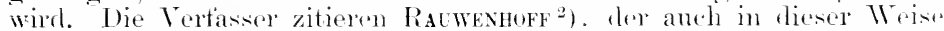
die etiolierten Pflanzen aharakterisiert. Bei veroleichenden Versuchen in trockner und feuchter Lutt, sowohl unter heller als chukler filocke, zeigte sich, dats in der Dunkelheit, aher in trockner I att, die Pflanzen weniger verspillert waren als diejenigen, welche bei Belenchtung in fenchter Luft gewarhsen waren, woraus die Verfisser sehliefon, lats die restalt der ctiolineten Pflanzen in erster Linie durch don Mangel an Transpiration helingt wird.

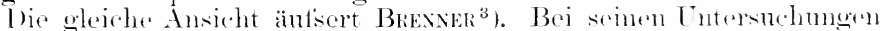

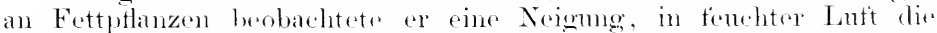

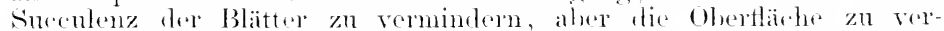

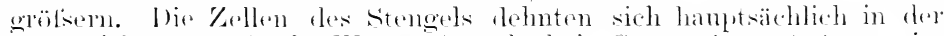

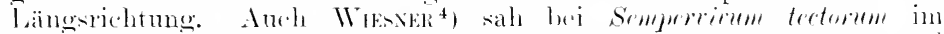

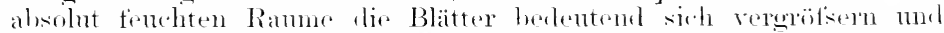
stark epinastich werlen. Inic Blattrosetten lösen sich dabei anf. mutem

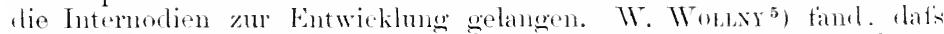

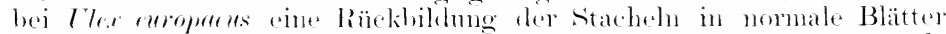
infolge danerneler Inftemeligkeit eintrat. Er beohathtete aber anth.

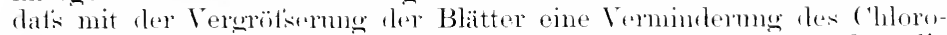

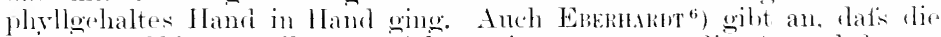

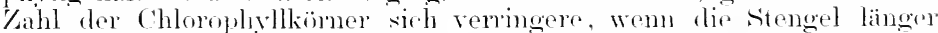
unt die Bläter wribser werden. In einer spateren Arbeit ${ }^{7}$ tats dieser Forscher die Ergebnisse seiner Versube dahin zusammen, dats die fenchte Luft mit der Streckmo der Blätter mol Stengel eine Abuahme in den Diekendimensionen dieser Organe verbintet. Die Haarliklmen wird verringert, die Blïten- und Fruchtbildung worden rerzögert. Epidermis-, Rinden- mnd Markzellen werden länger, dir Intereellularrämme grötser, the \%ahl ron Sokptionskanälon geringer und die Entwicklmo iles Holzos weniger stark. Am Wurzelkïrper hemerkt man eine geringere Produlition ron Nebenwurzeln.

1) Botan. Jahreshericht 157.) ... 4:32.

- Anmal. d. science nat. is sér. $r$, p. $26 \pi$.

3) Buxsa, W., Intersuchungen an einigen Fettpfanzen. Just 's Bot. Tahrent. 1900, S. : : 306.

4) Wraxer, Tri., Formverändermgen von Pflanzen bej Kultur in aheolut feuchten Rämmen. Ber. d. Deutsch. Bot. Ges. 1891, s. 4t.

5) Worsx, Wr, Intersuchungen über den Einflufs der Luftionchtigheit aut das Wachstum der Pflanzen. Inangural-Dissertation. Iall. Isg-.

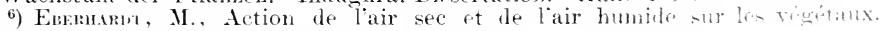
Compt. rend. 1900. t. 131. p. 114.

i) cit. Centralbl. f. Agrik - hem. 1904, Heft \&. 
Die Trrägerung der Blüte- und Reifezeit wird anch von E. WoLLny $\mathbf{1}$ ) angegelen, der den roransusehenden Tmstand durch zahlreiche Versuche bekräftigte, dat's die Verdunstung ron Pflanzen und Boden unter sonst gleichen Tmständen um so geringer sich erweist, je grölser der Fenchtigkeitsgehalt der Luft ist. Daf's in zahlreichen Fallen bei Herabdröckung der Transpiration reichliche Wasserauscheidung in Tropfenform stattfindet, und zwar bei den einzelnen Pflanzen durch verschiedene Torrichtungen, sei nur kurz erwähnt $\left.{ }^{2}\right)$. Wir finden die Erscheinung häufig bei Toptgewächsen, welche im Herbst in noch ungeheizte Glashäuser gebracht werlen oder als Zimmerpflanzen mit ihren Blättern die stark sich abkïhlenden Fensterscheihen berühren.

Schliefslich erwälne ich noch die Resultate eigener Versuche ${ }^{3}$ ).

Bei Bämmen (Birnen) fanden sich dic gesanten Triebe und ebenso deren einzelne Internorlien in trockner Luft kïrzer, die Blattstiele ebenfalls kïrzer, die Blattfächen schmäler als in fenchter Luft. Bei Getreideaussaat erwies sich in fouchter Luft die Bestockung etwas geringer; die Blattzahl war darin etwas vermindert, aber die Gröse der einzelnen Blätter vormelirt, und zwar in der Längenausdehnung, während sie in ler Breite etwas alogenommen hatte. Dieselbe Dimensionsänderung zeigten anch die einzelnen Zellen des Blattes. Der Einfluts der fenchten Lutt reranlafiste ganz hesonders eine Streckung der Blattscheiden und auch der einzelnen Halmglieder sowie selbst der Trurzeln, obgleich die sämtlichen (auch die der trocknen Luft ausgesetzten) Pflanzen in Nährstofflösung standen.

Dafs anch die Substanz neben der Form der Pflanzen bei verschiedener Lufteuchtigkeit sich ändern wird, ist von vornherein zu vermuten. In der Tat ergaben meine Versuche, dafi in fenchter Luft eine geringere Menge von Frischsubstanz produziert worden ist, und dafs von dieser Frischsubstanz bei den Pflanzen in feuchter Luft ein gröfserer Prozentsatz auf die Wruzel entfiel. Daboi waren die oberirdischen Teile anch wasserreicher. Betreffs der Funktionen liets sich feststellen, dats die Verdunstung in feuchter Luft eine absolut geringere ist: sie ist aber auch pro Gramm produzierter Frisch-und Trockensubstanz rine geringere, $\mathrm{d}$. h. die Pflanze brautht zur Herstellung von 1 g substanz in feuchter Luft weniger Wasser, und dies dürfte daher kommen, dats sie unter diesen Unständen ihre Substanz mit weniger Mineralstotfen anfhaut.

Ein woiterer Versuch mit Erbsen ${ }^{4}$ ) beweist, dats wirklich die nemproduzicrte Suhstanz prozentisch ärmer an Asche ist. Die durch stärere Verdunstmo in trockner Luft vermehrte Wasseranfinahme der Pflanze zur Folge hat, daf's lieselbe in der reiteinheit nur eine halb so konzentrierto l, äsung aufnimmt als die mit geschwächter Verdunstung in fenthter Luft stehende Pflanze.

Ans diesen Rosultaten eroibt sich zur fienüge eine Erklärung, weswegen Pflanzen in fenchter lutt den Krankhoiten hänfig leichter erliegen als die in trockncr Atmosphäre gewachsenen Individnen. Man sieht,

1) Wousy, E., Untersuchungen über die Verdunstung und das Produktionsvermögen der Kulturpflanzen bè verschiedenem Fonchtigkeitsgehalt der Luft. Forsch. anf d. Geb. d. Agrikulturphrsik Bd. XX, 1895, Heft 5.

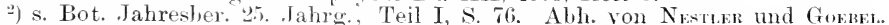

3) Soraver, Studien iaber Verdunstung. Forsch. auf d. (reb. d. Agrikulturphysik, Bd. III. Heft 4/5, s. $5.5 \mathrm{ff}$

4) a. ล. O. S. 79 . 
dats die Exemplare schmächtiger, wasserreicher mul ascheärmer sich anfbanen. Und moch haben wir keinen Einblick in die Verschiedenartigkeit der organischen Bestandteile des Pflanzenloilues: es ist sehr wahrscheinlich, dats die in tenchter Atmosphäe erwathonen Pflanzen zuckerreicher, stärkeärmer sowie reicher an Anfaragin mol ämor an wirklichen Eiweit's sind.

\section{Einflufs feuchter Luft auf durch Trockenheit beschädigte Pflanzen.}

Man wird der Meinumg sein, dat's man Ptlanzen, die dureh intensive Trockenheit gelitten haben, am schnellsten wieder zur frührom Tätiokeit zurücktühren kamn, wem man sie zmuächst in eine recht fonchte Atmosphäre bringt. In dieser Beziehung erhalten wir durch tolgenden Versuch eine Warmmo.

Kirschbaumsämlinge, welche bei sandkulturen eine lange lourstperiode ansgehalten hatten, zeigten abbald eine Akkomodation an die verminderte Wasserzutuhr zu den Wmzehn. Sie verehmsteten, zunächst ohne ihren Hahitus zu verändern, allmählich ahnehmende Mengen von Wasser, bis der sand etwa nur noch $t^{{ }^{\circ} / 0}$ seiner wasserhaltenden Kiaft an Feuchtigkeit besals. Ton da ab hegannen die Pflanzen zu welken; dabei hörte ihre Verlunstung aber anch fast ganz ant. Beispielsweise verdunstete bei einer 'Temperatur von $30^{\circ}$ C. mo reirhlicher sommbelenchtmug cin Ptänzchen, das bisher etwa $x g$ Wasser täglich vorbrameht hatte, mu noch ein Decigramm. Nath geeigneter Vasserzutuhr steigerte sich auch wioder langsam die Vertunstmo. Wenn dagegen der Durstzustand zu lange anhielt, vertrockneten die Bläter, anfangs ohne sich zu verfärben, von den spitzen herab.

TFurden nun die Pflanzen, nachdem sie begossen, in teuchte Lutt gehracht, so erholten sie sich nicht, wie ich antänglich geglaubt, während die meter der trocknen Glocke ihre oberen auscebileleten Blätter wieder hoben und auch die noch nicht ganz vertrockneten Basalteile der älteren Blätter ron nemem turgeseent werden liefisin. Die Verdunstung richtete sich auch wieder langsam ein.

Bei Toptkulturen der Gärtner wird diese Beolachtung nützliche Anwenrlung finden. Man muls ïhermätisg trockne Töpfe nach dem Begietsen an ihrem Standort helassen und nur etwas besehatten, aber nicht die Pflanze durch T̈Therführung in eine mit Fenchigkeit fast gesättigte Luft zu gänzlicher Untätigkeit herabstimmen.

\section{Korkwucherungen.}

Ïberall da. wo hork als normale Gewebeform gebildet wird, kamn durch hesondere Umstände eine abnorme steigerme, also Wuchermmg auftreten. Auch die renuläre Korkbildme ist in den verschiedenen Jahreszeiten in wechsehnler Stärke zu beobachten. Erimnert sei an lic gewöhnlichen Rindenporen mit ihren abgerundeten, durch fntercelhnlaren getrennten Füllkorkzellon: diese Zellen, welche lange ('ellulosereaktion hehalten, werken während der Vegetationszeit ans einer Verjüngungsschicht stets nen erzengt. Im Winter, wo der Gasaustausch der ruhenden Rindr. ein minimaler ist, wirl die Produktion des Füllgewebes sistient: es hat sich im Herbst aus der Verjüngmossehicht statt der rmullichrn Füllkorkzellen ein Verschlut's von normalem Tafelkork gel,ildet. Bei dem Erwachen der Rinctentätigkeit in Frähjahr hildet Gas Korkiantimm 
wieller Fïllkork, der die winterliche Verschlutsschicht der Lenticelle sprengt, gerarle so, wie or bei der ersten Anlage der Rindemporen die Epirlemis gesprengt hatte, muter iler er zuerst gebildet worden war. Je fenchter die Luft wird, desto mehr treten die wasseranziehenden. sich streckenden Füllzellen über die (berfläche der Rinde herror. Bekamnt sind die strichförmigen, mehlartigen, abwischloren, weifsen Polster, die an fenchten standorten bei westeigerter Luftenchtigkeit und Terminderung der Transpiration der lanblirone an den glattrindigen stämmen der Kirschen mol Erlen hervorquellen.

An der Basis starker Blattstiele von Juglums regia, Sambucus nimpr, Ailanthus glumbulosa, Poulon'mia imprialis und anderen Bämmen lassen sich im Herbst den Lenticellen äntserst ähnliche Gehilde beobachten: nur fehlt bei ihmen die Terjüngmosschicht (STAHL) ${ }^{1}$ ). Spätere Untersnchmoen ${ }^{2}$ ) haben gezeigt, datis nicht mm die Blattstielbasis, sondem bei manchen Phanz'n die Nerven ant'der Blattunterseite (Ficus stipulutu), ja schlietslich anch die Blattfächen, Korkpolster entwickeln kömnen.

Obgleich num diose Korkbildunu ant der Blattfläche eine fast ebenso verbreitete Erscheinmo wie die ant den Blattstielen ist, mit welcher sie in Ban und Entwicklmg sehr viel Übereinstimmendes hat, so ist trotz der weiten Terbreitung doch in diesen Bildungen ein pathologisches Honent nicht zu verkemnen.

Man kamn bei dieven Korkwnhermoen auf Blättern zwei Typen unterscheiden ${ }^{3}$ ). Entwerler liegt die Korkfläche mit ihren Teilungswänden mol ihrem meist emschichtigen Phellogen parallel zur BlattHäche in derselben Ehene, und damn erhelen sich die Korkpolster äher die Blattfäche in Form von Schwielen nsw.; oder aber die Korkschicht und speziell ilu Phellogen liegt in Form einer uhrglastörmig eingesenkten, meist sich immer mehr verticfenden \%one im Blattimnern. Nanche Pflanzen haben beide Bildungen anf' demselben Blatte. (regenüber der Konstanz, die sich in betreff rles ortes seiner Entstehmog und seiner Ausbildmo bei dem stengelkorke geltend macht, int hirer bei den Blattkorkwnchermagen das /ufällige hervorzuheben. Algesehen davon, dats die beirlen vorerwithnton 'Truen anf' demsellen Blatte rorkommen kömmen, gibt es anch zwischen beiden Typen noch Übergänge: ja die Korkwnchermgen kömmen ant' demsellien Blatte in rerschiedenen Schichten entitehen (meist beginnen sie in der subepidermalen Lage) and verschiedenen Entwicklungsgang haben (Bichuns).

Das äntiser: Anssehen dieser Korkbildmgen anf Blättern, die bei Gymuospermen, Mono- mul Likotyledonen auftreten kömen, ist sehr verschirden. Bald simd es likeine Ḧ̈̈gel, balıl Korkplatten oder Streiten

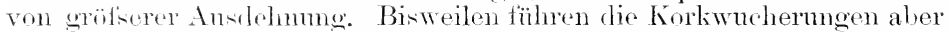
anch zur Bildung von Lïehern, dio das ganze Blatt durehbohren

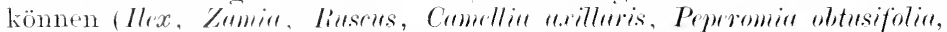

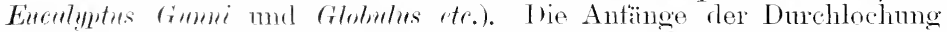
zeigen sich in Forn welhlicher Punkte. Bei Blättern mit grotinen

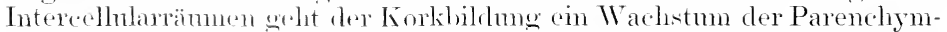
zellen vorher, dorat, dats die Intercellnlarrämne dureh die Zellwandansstïlpungen answerüllt wroten. Wenn Kellen mit etwas rlickeren

1) Snm, Entwicklnngsgeschichte und Anatomie der Lenticellen. Bot. Zeit. $1873, \mathrm{Nr} .36$.

2) Po[ısix, Om liorkdamelse paa Blade. Kjöhenharn 1875.

3) Bucmux, Über Korkwucherungen auf Blättern. Pringsheim's Jahrb. 1880, Bd. XII, Heft 2, s. 1!11. 
Wandungen dureh wiederholte Teilungen in Korkellreilen mmgewandelt werlen, so verlieren die Zellwände ilnt urspoungliche Dicke. Häng erfahren anch die Korkzellen, wenn sie erst die kpirlormis cresprengt haben, noch eine nachträgliche streckmng: dic äntieren streckon sich zherst.

Bei Znmin integrifolin sieht man brame, den Xorren paralled verlautende Streifen auf den rinzehen Fiederehen. die suater in dirsen Streifen stückweise oler dor ganzen länge nach cimpeitsen. [)ie Streiten sind Korkgewebe, die nicht etwa nach dem Korroition der Fiedern entstehen mul also Wundkork darstellen, somlern sio sind sehon im jïngeren Blatte angelegte Bihlumgen. Anf älteren Blätern rom

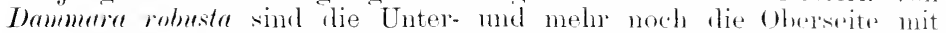
Korkwohermoen ledeckt, welche in der liegel klein und nichrig heiben. In . Jugendzustande stellen sie kleine, rote Fleckr anf ler grïnen Blattläche clar mol werden später, wemn sie sich hïgolartig erhehen, bram; zulotzt finden in der Epirlermis und den nächstfolgenden

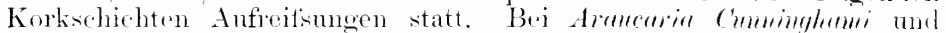
seltener hei $A$. Bidrilli finden sich an älteren, vorjährigen Blättrun kleine Korkhügel. die zu Leisten miteinander verschmelzon bïmnen.

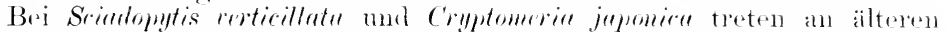
Blätern auch bisweilen kleine Korkwärzehen auf; häufiger (aluer nueist nm anf der Tnterseite) lassen sich solche Bildmonen an dru hroiten

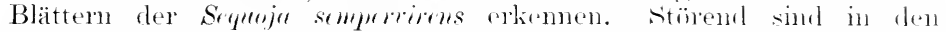

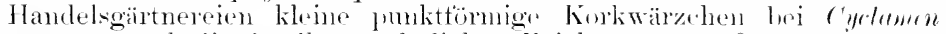

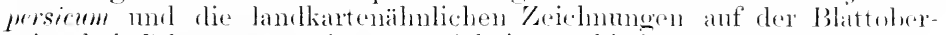

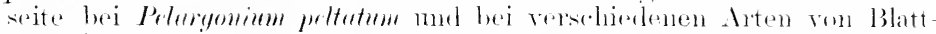
hegonien nsw. Alle diese Korkweherumen halen sich his jetzt nur in den feurhten Marmhäusern mul Mistlectkästen antfinden latson.

Von den Monokotylen zeigen Korkhihtungen. die in das Blatt hinem-

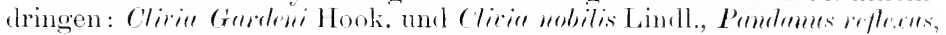

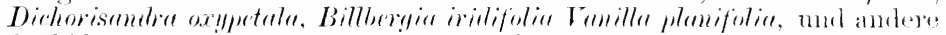
Orchideen. Ile heobachteten Korkwoherumen anf den Blattern finden sich nicht bei allon Exemplaren in oloicher Menge, nicht aut allen Blätern dorselben Pflanze in wedoher Anstehnutw und nicht in allen Jahren in dersellen Entwicklung. Man muts daties selolietson. dats besondere Enstände derartige Korkbildmoron veranlassen. Soweit die Erfahrung reicht. ist as ein Ühersehnts an Fenchtiglieit in der lont hei anhaltender hocheradiger Wasserzufuhe dureh die Wureh und ahmehmender lichtintensität. Eimen Einblick in das /ustandekommen dieser Erscheinumen finden wir hei der

\section{Korksucht der Kakteen.}

Diese Grankheit. die lexi importierten Kakteen manehmal zu finclen ist, leei den in Europra gezogenen Pflanzen aher zur ständigen sorwe der. Züchtre geworden ist. lestoht an den verschiedensten halitusalton in

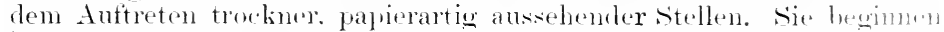

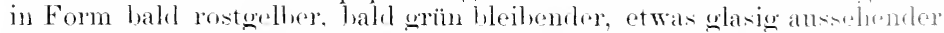
Flecke und breiten sich ontwroler zu grotion, korkfarbigen Flaidun ans oder werden zu Vertiefungen, die wie vernarbte Fratsistellen arscheinen. Speziellere studien maehte ich zmächst an Corms flumllifwmis. Bui schwerer Erkrankung ersehienen zwar die stengelspitzen moh frisch

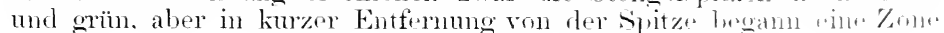




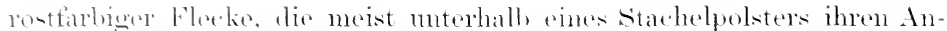
fing nahm. Wir Flecke verschmolzen allmählich zu einer rostigen

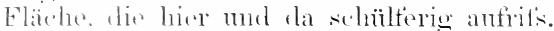

An dem wesmelen Teil bestand das obrohantowebe ans zwei

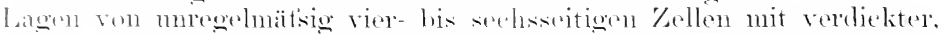
stark cuticulanisierter Antsenwanel. Tuter dieser loppelschicht lag sine einzige lieihe tangential gestreckter. oblenehymatiseh verdickter

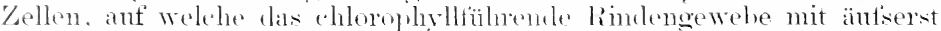
zahlreichen Kristallen von oxalsamem lialk tolgte. An den rostfarbigen

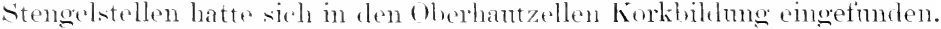

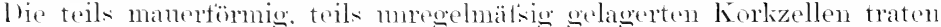

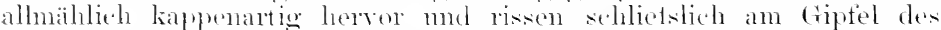
llïgels entzwei. wobei die cutienlarisierte Anfsenwand der oberen Epilemislage enespenet wourde.

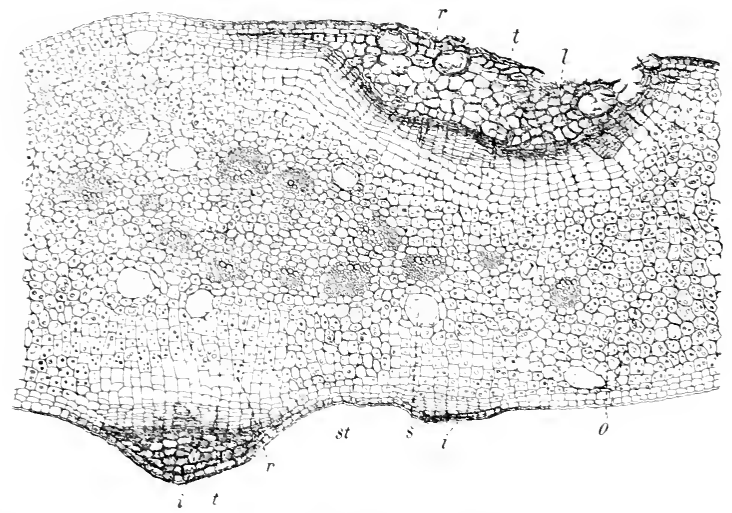

Fig. 7u. Stammst huck eines Plullourtus, das unterseits Korkwucherungen in schwielen zeigt, withrend auf der Gegrenseite der Durehlöcherungsprozefs beginnt. orig.)

Bei amlern ('erensarten exshienen einzelne seiten des stengels anf grötseren strecken weilsheh und trocken. Hier hatten sich in den an den Stengelkantrn papillï vorgezogenen, an den Stengelfäthen ehenen Enilemisonllen Korklawen gehildet. An jungen Flecken bemerkte man cint Veränderung des hindemparenchrms: die äntseren Yellen waren nicht mehr answoriant collenehrmatisch und tangential gestreekt, sondern meln in ratialor Richtung verlängert, dümnwandig. ehlorophyllarm und

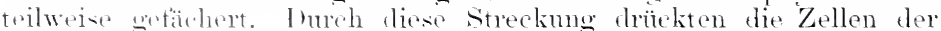

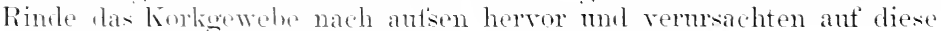
Weine weit'slich answhencle Blasen oder sichwielen.

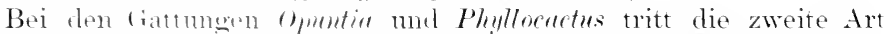
her Korkwuhermen. Woldhe zur Bildung vertiofter stellen oder

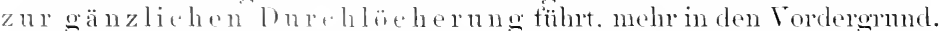
Tie beistehende. von rinem Phyllocartus stammende Figur Go läfs beide Vorounge der Korkwohermer erkennen. Anf dor Enterseite sehen

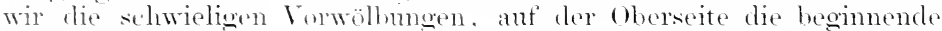
l)meliëchermong. 
Ler flache stengel zeigt in Querschnitt antserhall, des Getaisbündel-

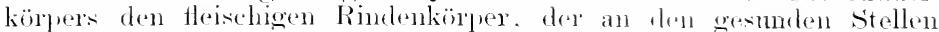

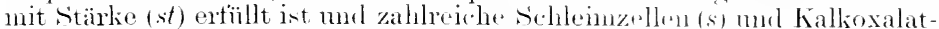

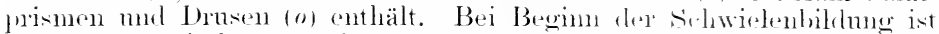

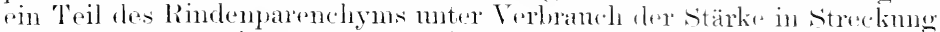

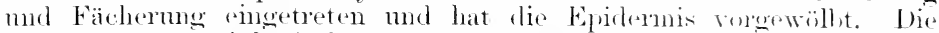

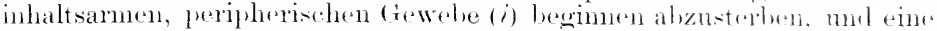
Tatelkorklage (t) grenzt das tote, in den Intereellndanen stark lufterfïllte

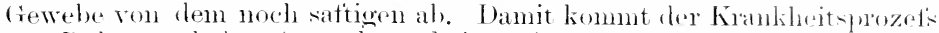
zur Ruhe, mol der Stengel erseheint mit papierartig-trenden Flecken

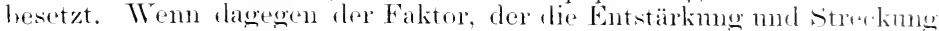
des Rindenparenchyms einleitet, nicht in semer Wirksamkeit "rlischt

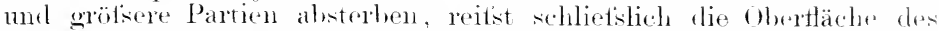

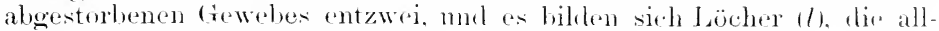
mählich sich immer mehr verticfen, indem die Tatelkorklilume (t) immer weiter nach innen zu fortschreitet. Bei $r$ ist die Vexänderume des Inhalts der Rindenzellen, lie zur Korkbildum Veranlassung gergeben hat, am frïhesten mal intensivsten aufretreten mel selureitet rlort anch an schnellsten in las Blattimere hinein fort.

ber Korkhildmespozets an sich ist bei den Kalitern ein normaler Vorgane. wem die Stengel pin awisses Alter erreicht haben. An rer Basis alter stämme zeigt sich eine Borkenbillung wie bei mseren (rehölzen. Das Pathologisthe ist die in jugendliehen Treile bereits sich einstellende Bildumg von Tafelkorklagen aut Kosten les Rindengewabs. Unel die

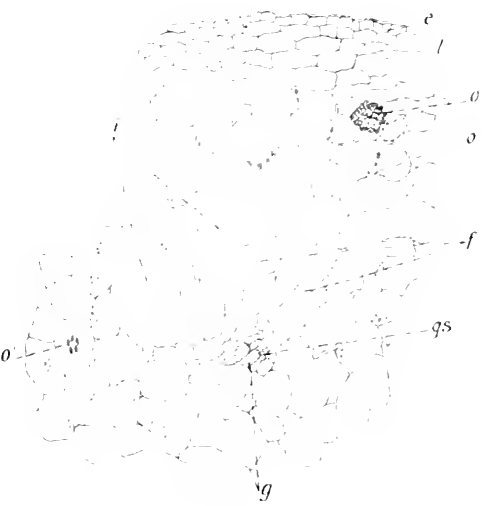

Fig. 71. Anfangsitalium der Korkwucherungen bei Phyllocurtus. (Orig.)

Veranlassme dazn wirel in flem Vorgang zn suchen sein. datis sich

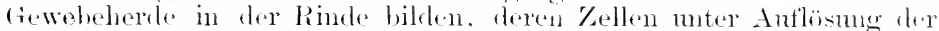

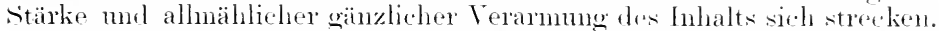

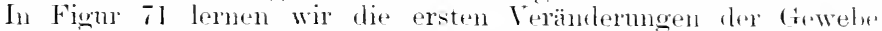
kennen. welche sowohl die Korkischwielen als anch rlin I Burchlëcherungen einleiten. Wir haben ein Stück Rindengewelse von Plydloractus vor ums. das sich durch eine kam merkliche Verfärome ins felles nus äntserst schwache Vorwölbung rom der gesmolen Lngebung mntre

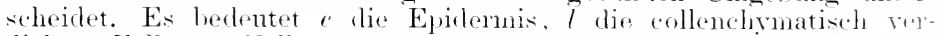
dickten Zellen. o Kallsoxalatliristalle. Die Veränderumg begimnt in d.r. mmittelbaren Nähe der (iefäl'se g an drum zarten Nervenstrange. welcher

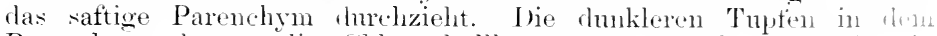
Parenchyon denten die Chlorophyllkörner an, welche entwerler in

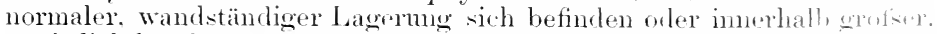
stark lichtbrechender Inhaltstropfen (o') zusammengezogen linen. [b

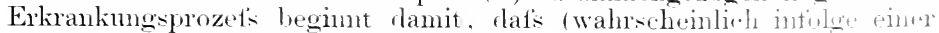


Hänfing abbanenter Enzyme und steigerung des säuregehaltes) die

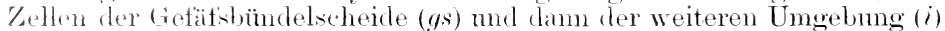
an Inhaltsstotfen verarmen und dabei sich strecken. Es entsteht somit eine ,innere Intumuscenz", die, wemn sie bis in die Nähe der Ubertläche fortgeschritten ist, die Korkbilinng einleitet. Greift die Veramung des Zellinhalts weiter nach rückwärts in die imnere Rinde hinein, so vird immer mehr Kork gebildet. Da derselbe bei dem Wachstum des Grgans der Streckmng nicht folgen kamn, so muls er zerreitsen. Bei der Bildumg obertäthlicher schwielen werten dieselhen schlietslich gesprengt. Bei der nach der 'Tiefe fortschreitenden Korkbildung aber reitst der Korkzylinder lochartig ant und es entstehen tiefe truben, wie bei dem Tiefschort der Kartofteln, die zur vollkommenen Durchlöcherung führen können.

Eine ertolgreiche Bekämpting der den Kakteenzïchtern unangenehmen und zu Verhsten tührenden Erscheimmo wird dureh Nathlassen des Begietsens und reiche Luftzufuhr eingeleitet. Unter Umständen, namentlich bei mehrjähriger Wieclerholung der Erkrankung, mulis sin Trockenhalten der Pflanzen his zur Schrmmpting eintreten.

\section{Zerfressene oder gefensterte Blätter.}

Sowohl bei krautartigen Pflanzen als auch bei Bäumen ist in dinzehen Lokalitäten dor Umstand befiemalich, dats die Blätter vielfach durchlöchert sind, als ob ein Tier die substanz zwischen den Ripfen heransgefressen hätte, ohne dats aber ein tieriseher schädiger antzutinden wäre. Die Beohachter werden in der Regel $1 m$ so ängstlicher, je länger der Vorgang anhält, weil er sich in seiner Intensität zu steigern pflegt. Es kömen dam derartig extreme Fälle eintreten, dats einzelne Blätter tensterartig durchbrochen erscheinen, indem nu das Ripremetz mit schwachen s̈̈̈mmen von Blattparenchrm noch übrig lileibt. Derartige Blätter sind nicht selten verbogen nud gekränselt, sterben aber nicht rorzeitio ab. Die Triebe selbst lassen keine Erkrankmo erkennen und entwickeln häufig in den Achseh der gefonsterten Blätter nemo sposse mit normaler Belanbmo.

I) extremste Fall, den ich zu heobachten Gelegenheit hatte, betraf' Kartotfeln, deren Triebe zu Anfang des Monats Juli an einzelnen stauden nur durehlökherte Blätter zeigten (s. Fig. 7.2). Während meist dic unteren nur verenzelte Löcher besatsen, waren die oberen in den Intercostalfelelern lang zerspalten mul dureh \%erstörmo der Randpartien mannigfach zerschlitzt. Manchnal sahen die jüngeren Blätter federartig ans, tha die einzehnen Teilhbätchen nur ans den Ripuen mit ganz schulem samm bestanden.

\%wisehen den Durhlöcherungen bemerlite man in den Blattflächen bei durchifllendem Lichte vergillite Punkte, mol diese erwiesen sich als div Anfangstadien rines Ferkorknngspozesses, der mit Durehbohrung der Blattfläche endete. Die Forklildnno ertolote in der Art, wie sie im vorherohenden alloweinen Absehnitt beschrieben worden ist. Sie erwies sich alber nitht als das Primäre, sondern war erst eine Folgerscheinung. I lie arsen Anzeichen der Erkrankung bestanden in den Verblassen einzeher Mesophylloruppen, meist in der Nähe teiner Nervenäste. Das Palisalenparenchym war häufiger als das Schwammparenchym beteilint. In einzehen Fällen benerkte man an stelle des Vorldeichens eine Bramntähmmg des rellinhalts, begleitet von Ver- 
korkung der Wandungen. Tie Epidermis folgte in iluen Verändermgen

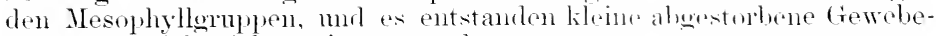
herle, die sich nicht weiter veränderten.

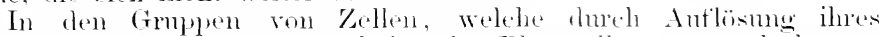
Chlorophyllkörreds die durehscheinenden Blattstellen vermeacht hatten.

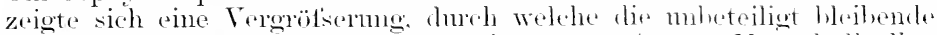
Epidermis vorgewälbt wurle. In den vergüsertrn Mesophyllzellen stellte sich num Korkhildung ein. Dabei lorach die rerkorlite stelle anf. Durch das Fortschreiten disser Vorgänge rülekwäts in las Blattfleiseh hinein vertietten sich die Korkherde his zur vollstandigen Lurchlöcherung. Diesolbe wird verstänollich, da es sich mm jugentliche Blätter handelt. die durels ihr Wachstum alle fowelne spannen mul

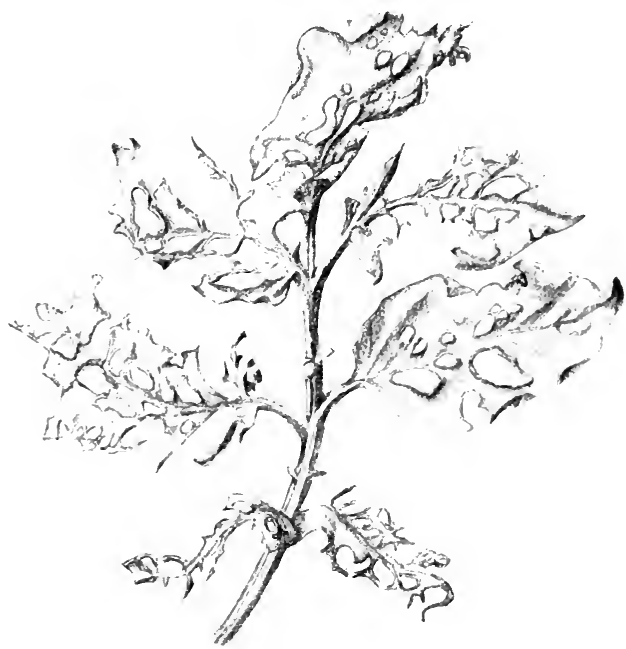

Fig. 72. Kartoffublatt infolge krankhafter Korkbildung durchlöchert. (0)rig.)

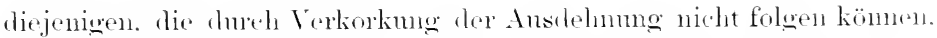
zum \%erreilisen relanlisisen.

Der Vorgang ist also in Prinzip dersellu wie hei len stämmon dis Kakteen.

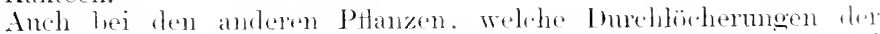
Blätter autweisen, lasson sich als Anfangsidadien dir Verarmme num

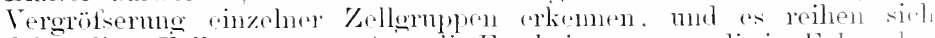
daher diese Fälle natmogenäs an die Erscheinumen an, die inn Folgenden als Intumeszenzen heschiehen werlen sollen. lont wind ande ant die Trachen noeh eimmal näher eingegangen werchon.

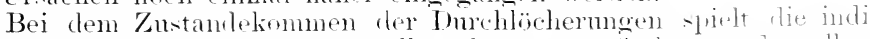
viduelle Ernährumg eine thaptrolle: fom man findot an hemstben

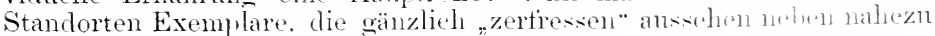


nommal bleibenten Pflanzen. Bisweilen leiden num einzelne Arten. So sah ich heispielsweise in Gruppen ans rerschiedenen Ahornspezies nur aine einzige shr krätig wachsend, mitten zwischen anderen gesund sich entwickehden Arten erkrankt.

\section{Korkbildung an Früchten.}

Bekannt sind die sogenamten Rostzeichnungen auf Äjfeln und Birnen, d. h. hraune, stmmpte. nicht selten schülterige Fleckchen oder Linien anf der glatten Fruchtobertläche. Einzelne sorten zeigen die Erscheinmo alljälulich, sodats sie in die Beschreibung des Sortencharakters aufgenommen worden ist. Ex sind Korkbildungen, die in der Regel von spaltöthnungen ausgehen. Abnorm wird der Torgang in einzehnen Jahren dadurh, dats nicht nu die ,rostfleckigen Sorten", sondern anch gewöhlich glattschalig blejbende Frïchte zur Hältte oder wänzlich eine liorlitarhige Oberfläche erhalten und vielfach später Flaffend anfinpringen.

Es lingen hier Terletzungen der Epilermis zur Zeit der ersten

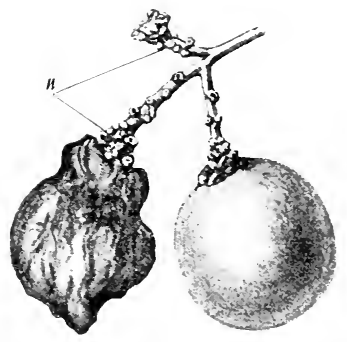

Fig. 7:3. Neinheeren mit liorkwarzen( $\mathrm{W}$ ) am Fruchtstiel.(Orig.) Schwellungsperiode der Frïchte zugrunde. In den mir bekamntgewordenen Fällen (Äpfeln, Birnen, Pflamen, Weinbeeren) liet's sich nachweisen, dat's ein leichter spätfrost clie Cuticulardecke der jumgen Frucht durch unzählige kleine Risse zerklïftet hatte. Unterhalb der mikroskopisch kleinen sprünge bildete die Frucht sofort Korklagen ans. Stellenweise rertrotknen die Epidermiszellen und bleiben nebst den erstgebildeten Korkzellen als schülfern anf der nummehr stumpf lederfarbigen Fruchtohertläche sitzen.

Überall da, wo die rerkorkten stellen eine zusammenhängende Fläche bilden, wird der fortschreitende schwellungsprozeds der Frucht behindert, und die Folge ist. dafs die Frucht lilaffende Sprïnge bekommt. In diese wandert besonders gern die Monilia hinein und mmmifiziert die Früchte.

Allein diese Erscheinmgen gehören, streng genommen, nicht hierher: sie haben nur insofern einen Zusammenhang mit Wasserübèrschnfs, als die \%erklüftungen $\mathrm{mm}$ so leichter auftreten, je schneller bei anhaltender Fenchtigkeit die Schwellung der Früchte erfolgt.

Dagegen möchte ich las Anftreten ron Korkwarzen an Beerenstiolen der Wrintranben als einen nur bei fenchter Luft sich bemerkbar mathemen Vorgang bezeichnen. In Fig. 73 finden wir zwei Beeren, deren stiels ein gebränntes, holperiges Aussehen durch das Anftreten vieler korkturliger, dichtgestellter Wärzchen zeigen. Die Erscheinung tritt shom ant, ehe die Beeren ihre normale Grötse erreicht haben.

Die Warzen sind an der Ansatzstelle der Becren am reichlichsten entwickelt: stärkere Äste der Fruchtspindel pflegen glatt zu bleiben, nurl es zeigen in der Rogel anch nur einzehne Trauben eines Stockes die Erkrankung. Dieselbe ist, rolange warme, trockene Witterung herrscht, bedentmoslos: sie wird erst gefälnrlich, wem bei anhaltend 
fencht-warmen Wetter Parasiten sich einnisten. Folgt dann eine seharfe Trockenperiode, schrumpten vinzelne stark wawige stielehen und die dazu gehörigen Beeren.

In Fig. Tt sehen wir den Querschnit dur.h oinen warzigen Beerenstiel, der den gewöhnliehen Ban der Achse zoigt. alw rinzelne anttällig weite Markstrahlen (ms) hesitzt. die don Molzring (h) zerkliutt(rn.

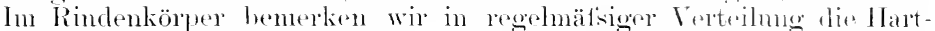
hastgruppen (b) mol vor ihnen die siebelemente (s) mit oftmals diek verquollenen Tandmogen. Bei o sind fie reichlieh vorhandenen Kallioxalatkristalle angerleutet: dieselhen treten teils als kloine Lrusen, toils als Raphidenhündel auf. Die verschiedenen Statien der Korkwarzonbildung sind mit Wr hezeichnet. Die warzigen, den lantionllen ähnlichen Auftreibungen entstehen datureh, dats einige direkt unterhalb der Epidermis oder etwas tiefer liegende Rindenparenchymzellen sich radial vergröfsern mol die (Herhant leicht vorwölben. Durch steigerung dieses Vorganges, wobei Fächerungdergestreckten/ellen nicht ausgeschlossen ist, entsteht ein Gewebehïgel, lessen verkorkende Kappe sich soluliefslich hrämut mol entzweireifist. Durch die Vermehrmo des Rindenparenehyms mol Absterben der iinfieren bramen. verkorkten Elemente entstehendie arölseren Warzen, deren peripherische \%ellagen schatentömig auseinanderweichen. Es bildet sieh dabei ein deutliehes Korktamhium aus, das mit dem Absterben der äuliseren Schichten rückwärts immer tieter in lie Rinde des Becrenstiels hineingreitt. Bleibt die Witterung dautrul trübe, warm nut foucht, ofler

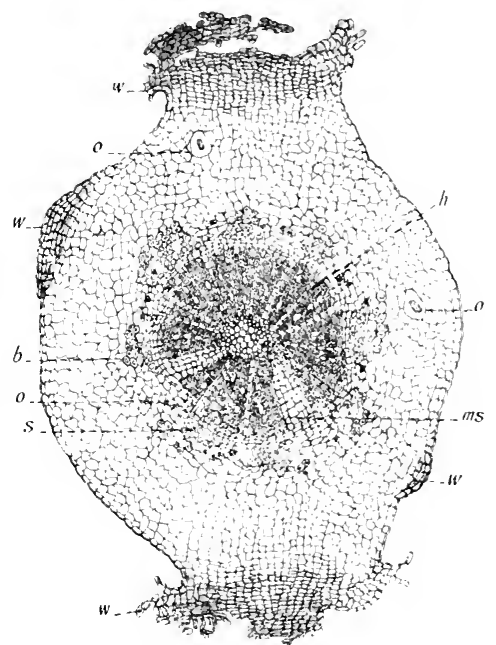

Fig. 74. Querschnitt durch den warzigen Fruchtstiel einer W'einbeere. (Orig.)

simd die Trauben zu stark miter den Laube versteckt, so ist füir die Ansiedlung von Mreelpilzen, unter denen Botrytis aimera in erster Linie bemerklar wird. die giunstige Gelegenheit geschatfen.

Die Erscheinumg ist nanentlich in den 'Treihhänsern zu finden. umel

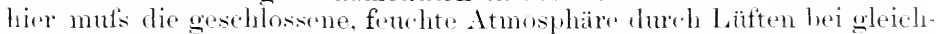
zoitigem Heizen verlussert werden. Zeigen sich warzige Berrenstiele in Freien, lichte man das vol den Tranben lefindliche Laubwerk stärlior aus und sehüttle nach jedem Regen das von demselben festgehaltum. Wasser sorofältig ab.

Als Begleiterseheinung der Korkwarzen beobaclitete ich rimmal hei jungen Weinblätteru am (irunde zwisehen stärkeren Seitemiplen liputuartig einander gegenüberstehende Flügel der Blattflä $\mathrm{Bl}$ e. Iles.

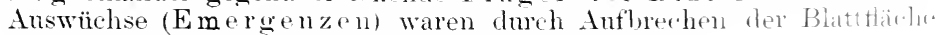
(meist über einem Gefäfsündel) entstanden. 
Anhangweise sei hier noch das Charrinieren der Rosenstämme angeführt. Die hochstämmigen Rosen werden bekanntlich ïber Winter niedergelegt und mit Reisig oder Erde zugedeckt. An jungen, noch glattrindigen stämmen findet man bisweilen im Frühjahr bei dem Heransheben ans der Erde dieselben mit kleimen Warzen hesät, von denen eine Anzahl in der Regel mit einem bleichen oder brammoten Hot nmsänmt ist. Die Warzen sind Lenticellenwncherungen. Dieselben beginnen unterhalb der Spaltötfinmeng und treiben die Schlietszellen auseinander. Dort. wo ein verfärbter llof sich vorfindet, ist Mycel nachweisbar.

\section{Gelbsprenkelung (aurigo).}

Bei Monokotyledon'n mehr als bei Dikotyledonen erscheinen die Blätter bisweilen mit gelben oder rötlich-brannen Fleckchen übersät. Die Sprenkelung begimnt von der Spitze aus, und die Zahl der Flecke, die in der Regel durch eine blasse Rantzone in tie sonst normal grünbeibende Blattläche übergehen, kam sich bei Beginn der Krankheit dadurch rermehren, dafs zwischen den erst entstandenen noch nene kleine Fleckchen sich ausbilien. Ein Verschmelzen derselben ist seltener. Bisweilen ist mit der Verfärbung eine Auttreibmo des Gewebes verbunden, und es zeigt sich dam ein deuthicher Übergang zu den eigentlichen Intumescenzen ${ }^{1}$ ).

Die Gellsprenkelung tritt besonders bei Glashans- und Kimmerpflanzen auf', und unter diesen begegnen wir der Erscheinmug am hänfigsten bei Dracänen, Palmen mnd Pandanusarten.

Um ein Beispiel zu geben, wie diese Flecke sich ausbilden und unter Unständen bis zur Blattdurchlöcherung fortschreiten können, führe ich einige Beobachtmogen an Pandams jacanicus an.

Die Flecke entstehen stets in einer zwischen zwei Rippen liegenden Mesophyllpartie, die nach der Blattoberseite hin den Charakter des Palisadenparenchyms, an der Unterseite den des Schwammparenchyms anfweist, in der Mitte aber ans sehr zartwandiøen, nahezu isodiametrischen. mit tarblosem. Wässerigem Inhalt erfüllten, etwa sechsseitigen /ellen besteht.

Von dieser inmersten, farblosen Gewebegruple begimnen die peripherischen, also dem chlorophyllführenden Mesophyll angrenzenden Zellen sich nach der seite des geringsten Widerstandes, d. h. nach dem Zentrum hin, ïbermälsig zu strecken, wobei sie häufig die centralen \%ellen zusammendrürkien. Nicht selten erfolgt die Streckmng nur in den direkt nach oben und nach unten gerichteten, aber nicht in den seitlichen Zellen der zartwandigen (zruppe, und es entsteht dadurch eine eigentïmliche Lagerung. Die tentrale Partie des fewebes besteht dam aus radial gestellten, schlanchfömig ausgezogenen, oft durch Quellung dickwandiger gewordenen, inhaltslosen Zellen, die später braun werden und verkorken. Bui zunehmender Intensität wird das Schwammparenehym unter Auflösung seines Chlorophyllkörpers in diesen streckungsprozets hineingezogen: sein Inhalt zerfällt zu hraunkörniger Substanz, und damit wird die gellue Färbung intensiver. Mit dem Hineinziehen des chlorophyllreichen (rewebes in den abnormen Streckmosprozefs erhelot sich die Blattoberfläche oft schwielenartig.

1) Sornutr, P., Ïber Gell,fleckigkeit. Forsch. auf d. Geb. d. Agrikulturphysik Bd. IX, Heft 5 . 
Hänfig bleibt mit der Vurkorkmo der gastreckten Kellelemente der Krankheitsprozets stehen, and wir haben ham elen nur aelbe, im jugendlichen stadium sogar erst bei furchtallentem lichte erkembare Flecke. Der ganze Erkinkungsherd kam dabei durch eine /one wirklicher Korkzellen rom gesmiten trewebe abgeschitten werlen. Bei

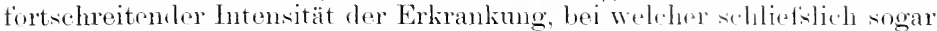

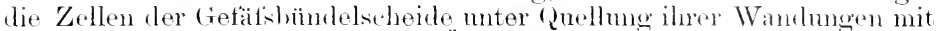
nachfolgender Brämmug an der Überverlängremg teilnohnen kömnen, sprengen die sich streckenden Mesophyllzellen die dariberliegente Epirlermis. Es folgen dam die Vorgänge, welehe bei den Durdnöcherungserscheinmoen bereits beschrieben worlen sind. Antiserlich ähnlich aussehente Pilzerkrankmngen lassen sich bei Pandanus leicht unterscheiden, da dahei dis Zellstreekmoen tehlen. Boi Mracana rubra und Inraco beschänkt sich der Krankheitsprozets bisweilen nur aut' den zertall des Chlorophylls in den imneren zellgruppen: hier wmen mehrtach Membranen mit perlig in das zollimere vorspringenden Quellnngsstellen wahrgenommen. Bei linarom indirisu beobachtete ich während der Vertähnug der Krankheitsherde, dat's bei der Auflösmug des chlorophylls reichlich Zucker in den Zellen nathweishar war, dor im gesunden (rewebe sich nicht zeigte und in dem Krankheitsherde verschwand, sobald Bräunmog und Verkorknog der Wandmogen eintrat.

Die Gelhsprenklichkoit erweist sich somit in vielen Fällen als Vorstalimm der eigrntlichen Intmmescenzen, in andern aber, wie z. B. bei den Inacänen, bleiht sie neist als sollständiges Krankheitslibl

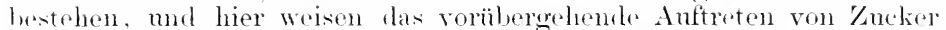
und die perligen Membranquellungen ant dieselben Ursachen hin, wolcho hei lex Öherverlängermng von Zellen zur Wirkmo gelangen. Bei der praktischen Behandlung hat man sich zu vergegenwärtigen. dats die Pflanzen, welche Amrigo zeigen, mner einer Wasserzutuhr leirlen, die sie nicht bewältigen kïnnen. Die Wassergalon branchen gar nicht stäker wie frïher zu sein: abor sir werden den Pflanzen in der Ruheperiode verabreicht, in ter ihre Assimilationstatigkeit herabgedrüekt ist und dic änfsern Verhälnisse nicht dazu angetan sind, dieselbe zu heben. Die Flecke troten nänlich vorzugswoise in Iterbst mol Winter anf. wem die PHanzen in warme Rämme gehacht werden. Sie haben damn wohl Värme mel Wasser nebst mineralischen Nährstoffen, aber nicht Licht genng. Man mul's deshall, die dinseitige Reizmog entfernen und die PHanze Rïlle's, trockner mol möglichst hell stellen.

\section{Intumescenzen.}

Noch nicht genügend von den praktischen Pathologen gewüreligt sind die meist mpupenweise anftretenden, knötchenfümigen onter pustelartigen Gewebeantreilumgen, die irh seinerzeit als , Intmmescentia" eingeführt habe. Sie sind vorherrschent an Blätern getunden worten. sint aber anch an stengeln nicht selten: spärlich waren bisher dis Beobachtungen äber Intmmescenzen an Blumen mul Früchten.

Den besten Finblick in die Entwicklmo solcher trebilde dorn Wert in ihrer symptomatischen Bedentung liegt, erlangen wir dureh Betrachtung eines bestimmten Falles. Bei Cassia tomentosa fand inh im Januar 187! in einem Warmhanse die jumgen Triebe mit Blättern hesetzt, deren Fiederchen nach mten gekrïmmte Ränder anfwiesen. Die Krümmung erschien durch ein gesteigertes Wachstum der Oberseite 
hervorwernten, welche pustelartige Anftreihmoen bemerken liets. Je weniger Anttreibmgen, desto flacher das Blattfiederchen und desto mehr fanten sich die Erhabenheiten in der Nähe der Nittelrippe: wenn dieselhen sehr reichlich und gleichmätsig über die ganze Fläche verteilt waren, erschien das Blatt fast hasig. Wirklich blasig konnte man es aber nicht nemen, weil den Anftreibungen der Oberseite keine sleichorotse Vertiefung der Unterseite ent-prach.

Die Anftreibung ist kegelförmig, anfangs mit derselben Färbung und matten Oberfläche versehen wie das ïbrige Blatt: später wird die spitze des Kegels heller, straffer und glänzender. Noch später wird die Spitze gelb. verhreitert sich, reitst (Fig. .5 zo) endlich anf (wem nicht vorher (las ganze Fiederchen vergilbt), und die Auftreibung erscheint nm in der Tritte trichterförmig vertieft und gebrämnt.

Die Ursache der Erscheinmo ist das stellenweise schlanchartige Answachsen des Palisadenparenchyms ( ${ }^{\prime}$ ) der Blattoberseite, das an

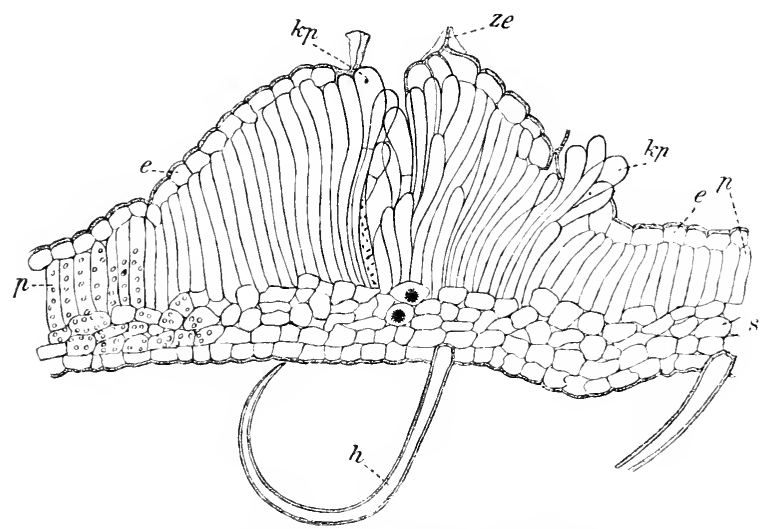

Fig 75. Blattintumescenz bei ('assia tomentosu. (Orig.)

den nomalen Stellen chlorophyllreich, dicht ameinandergelagert und nur nach dem S'chwammparenchym (s) hin mit schmalen, spaltenförmigen. lufterfüllten Intercellnlarräumen versehen sich erweist.

Sobalı die Ansehwellmo beginnt, fangen die Chlorophyllkömer an, von der Spitze der Zelle ans zu verschwinden, und die Zellen verlängern sich derart, daf's zuerst nur wenige die Streckung begimnen, allmählich aber die Umgehmng mit in den Streckungsprozets hineingrezogen wird. In dem Matse, als die Verlängerung fortschreitet, wird immer melır Chlorophyll gelöst, so dats schliefslich die schlauchförmig gewordenen Palisadenzellen fast ganz farblos oder mit wenigen kleinen, gelhlichn, in „anzen Zelhaum zerstrenten Körnern versehen erscheinen. Mit der Verlängerma der Zellen, die die Epidermis in die Itöhe stülpen, ist anch eine geringe Breitenzmahme verbunden, wodurch rlie Yellen seitlich sehr fest aneinandergepretst erscheinen und nur nach dem schwammprenchym hin noch schwache Intercellularrätme zeigen. Sobald der Drutk des sich vorwölbenden Gewebes die 
Epilermis (f) an der höchsten Stelle der Anftreibmo entzwoigesprengt hat (z), schwellen die nun freigewordenen Enden des Palisarlenparenchyms

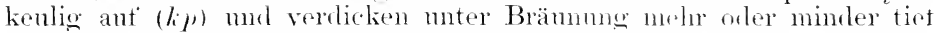
abwäts ihre Wandungen. An der Durblunelstelle und deren Tmgohmog brämen sich auch die Epidermiszoll'n mut fallen teilweise zusammen.

Derselbe Vorgang der Anttreibung kamn and ant der Unterseite des Blattes eintreten: labei werden die direkt moter der mit Haaren (h) rersehenen Epidermis liegonden, sonst atwa isodiamotrischen \%ellon des selowammparenchyms anch lang-zylindrisch.

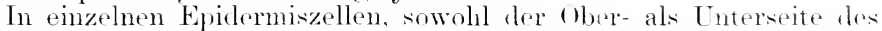
Blattes mol auch in manchen der schlanchtömig answewarhsenen Parenchymzellen zieht Glycerin rinzelne grotse orler mehrere kleine Glykosetropten znsimmen.

Ähnliche Blattantitreilumgen fand ich hei golbtleckigen und auch bei noch normalorïnen Blättern von Acacia lonerifolia und mierobotrya.

Als Beisjuel für das gemeinsame Vorkommen der Intumescenz mit Korkblattern führs ich $\boldsymbol{M} y \mathbf{y}$ mecodia erhinata an, deren Blätter die Intumescenz'm meist anf der

Blattunt reite, dis Korkwuherungen aber vorherrsehend anf der Oberseite entwickeln. In Fig. Ti erkennen wir, dat's hauptsächlich an der Bildung der zartdrïsigen Gewoheantroibung die beiden der Evidermis zunä̈hstliegenden Parenchrmschichten beteiligt sind. I)ie Epidermis mit ihren unverändert gebliebenen Spaltöffinmoren (c) ist in die Höhe getrieben wind an der firenze des normalen Gewebes abgesprengt

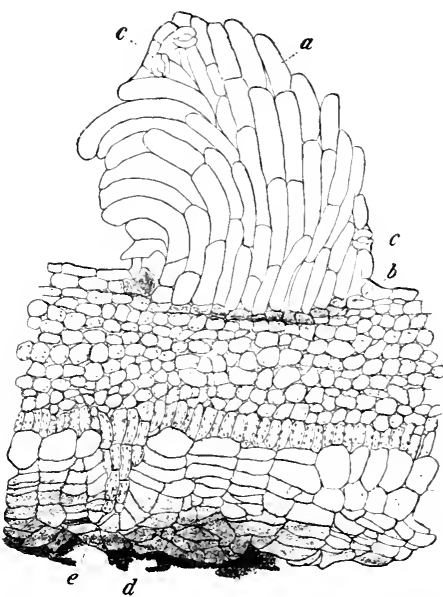

Fig Ti. Blattstück von Myrmer orlin erlimata mit autbrechender Korkwarze auf der()herseite und drüsiger Intumescenz auf der Cuterseite. (Orig.) worlen: sie erscheint aber. was bemerlienswert, nocls moebrännt und tmgescent, also wie die schlancliförmigen Mesophyllzellen (a) noch vollstänliy anspedehend emährt. Erst in einem weit rorgeschrittenen Alterstarlium des Blattes sal ich dir Antreibungen znsammentrocknen und durch Bildume riner Tafelkorklage an ihrer Basis (b) vom gesunden Parenelyom abgesclmitten.

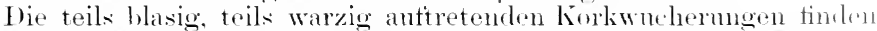
sich an häutigsten olne die Berleitmo von Intunescenzen. sie sind mregelmälsig über die ganze Blattflache als rostfarbige, hisweilen sillverig glänzende Fleckchen verteilt. Bevorzugt ist die Gegend der Nittelrippr.

Die Korkbildung begimnt hier innerhall, der Eliderniszellen 1 mul schreitet ron da ans in das Mesophyll hinein fort. indem zundellet lio zwei anstofenden Lagen les aus t-; Reihen farbloser. inhaltsanum, sehr weithmiger Zellen gebildeten Hypodorms ergriften weribn (d). Das darmerliegende Palisadenparenchym, das in kegeltömigen strebe- 
pfeilem (e) in das Hypoderm himeimeicht, wind meist nicht imitiert, zeigt aber, ebenso wie das chlorophyllarme Schwammparenchym, zu. Zeit der Korkbildung in jeder /elle einen stark lichtbrechenden, oft grïn crefärliten Tropten.

Nanchmal ähneh derartige Korkpolster in hohem Grarle gewissen Pilzcrkrankungen, wie ich Gelegenheit hatte, an Pflaryomimm somale zu beobachten.

An dieser Pflanze waren die Blätter unterseits mit einzelnen oder zu grötseren Gruppen vereinigten. weitsen, crstopusähnlichen Polstern bedeckt. Dieselben erwiesen sich als halbkugelige, später manchmal tächerig auseinandergehende, lufterfüllte Korkwuherungen. Letztere begamen mit einer Vergrötserung des Schwammparenchyms, wobei alle Intercellularrämme auscefüllt wurden. Die Epidernis blieb in der Regel mverändert, während die daranstofienden Mesophrllzellen sich senkrecht zu derselben streckten und unter allmählichem Verlust des Chlorophylls sich durch Korkwände fächerten. Die Korkzellen verloren teilweise durch unregelmälsige Vergrölserung ihre parallele Anordnung und wölbten sich stark in die Höhe, bis die Epidermis rifs. Dieselbe machte aber vorher ihren hemmenden Einfluts dadurch geltend, dafs sie die Korkzellen drückte, wodurch die Wandmgen zerknittert erschienen. Der Streckmgs- und Korkbilkmgsprozeds griff immer tiefer rückwärts in das Mesophyll hinein, wodurch die Wucherungen bis zur vierfachen Ausdohnung der Blattdicke bisweilen gelangten. In die Spaltötfnungen und später in die Wunden der anfieifsenden Korkwucherungen wuchs ein brames gewundenes Hrcel (vichleicht ein Cladosporium) hinein.

Reichlich von Intumescenzen hat der Weinstock zu leiden und namentlich die Exemplare, die in Glashäusem behuts Frühtreiherei im freien Grunde ansgepflanzt sind. Es wurden autser den Blattauftreihungen auch an den Beerenstielen Knötchenbildungen bisweilen beobachtet, und da diese eine von den vorher geschilderten War"zen abweichende Baurt zeigen, mögen sie hier eingehender beschrieben werden.

Beistehende Fig. 75 ist der Querschnitt durch ein solches Knötchen. Die den Holzring des Beerenstiels hildenden Gefätsbündel sind mit $l$, bezeichnet; $m$ ist der Markliörper, $/ 6$ der Hartbast, bis zu welchem die abnorme T'eränderung des Rindenparenchrms zurückgreift. Dieselbe zeigt sich in einer Ausweitung mol schlietshchen radialen Überverlängerumg des mutchalb der collenchrmatischen Elemente liegenden Parenchrms, dessen \%ellen sich nachtrïglich grefïchert haben. Durch diese Überverlängertung wird das Collenchrm (c) zusammengedrückt und, ohne vorher an der Streckmng teilgenommen zu haben, samt der Epidermis zum Absterten gelsacht. l)ie normale Epidermis erkennt man bei '; $l$ ist die an drer firenze des absterbenten Gewebes sich bildende Korkzonc. Letztere ist ïbrigens nicht immer zn finden; manchmal geht das absterbende unmerklich in das sehr dïnnwandige, noch lebende Gewebe üher, das an der ت̈bergangsitell schwach verkorkte Wandungen zeigt. c g nomales, hier gruplenwrise mol nicht in zusammenhängendem Ringe auftretendes Collenchym. I) Fe Fächermo nud Überverlängermng des Rinclenparenchyms und das Felılen von Korkwncherungen unterscheidet diese knötchenförmiøen Intumescenzen von den früher geschilderten Korkwarzen, die im . Jngendstarlium grofse Ähnlichkeit mit jenen haben. 
Die anf den Weinblättern bemerkbaren Intmmssenzen erscheinen anf der Unterseite in Form drüsiger Erhabenheiten, die oftmals zuxammenfliefsen und aut der Blattoberfläche dureh welhlich verfärlote, bisweilen auch etwas rrhabene stellen angedenter wrelen. Sie entstohen durch schlanchförmiges Auswachsen des monter ter Eprlermis liegenden Schwammprenchyms, dessen Zellen sch verarmt an fosten Inhaltsstotten mud durch Answeitung dicht aneinandergeprefst exscheinen. Mit ihrer zmehmenten Überverlängermo wird die sie checkende Epiclermis gebräunt uncl entzweigesprengt.

Anfangs sind nur die direkt unter der Epidermis liegenden Kallen irritiert: aber kurz nach Beginn der Anftreibung wirel anch die nächstinnere Zellschicht rroriffen, nud diese ist es in der Regel, welche später die grölste Streckung erfährt, und deren /ellen sich nicht selten durch nachträgliche Querwände teilen. Die das Zentrum der Anttreibung eimnehmenden Zellen sind am längsten mol sthmälsten mol

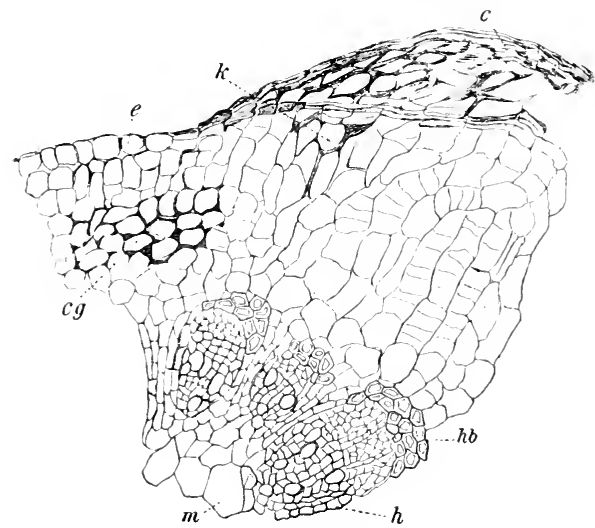

Fig. T. Teil einer knötchenförmigen Intumescenz am stiel einer Weinbeere. (Orig.)

stehen genan senkrecht zur Oherfläche des Blattes, währent die seitlich anstofisenden schief fäeherformig gelagert sind, an Iänge ab- und an Breite zunehmen. Stärke ist nicht nachweisbar. In den extremsten, zur Beobachtung gelangten Fällen sind sämtliche Zallen des Mesophylls bis zum Palisatenparenchym der Oherseite hin in dir. streckung hineingezogen: das letztere sellist jertoeh sah ich nicht ereriffen.

Tie gesagt, sind diese Erscheimmgen bei der Wointreiberei gar nicht selten, mel lierbei finden sich Fälle, welche auf die Lrsachron der Intmmescenzen mit grotier Ientlichkeit hinwoisen. Ans dom in Lanfe der Jahre mir hänfig zur Vertïgmng gewesenc'n Material greje ich als Beispiel eine Mitrilung des Herrn Hoföirtmer Rosse herans.

Derselhe hatte ein Wrinhaus, das mit 14 stïcken besetzt war: von diesen gehörten i Stürk der Sorte Blark Hamlmrgh (Blaner Frankenthaler' an, und einer derselben stand an derjenigen Seite des Crlathamses. an welcher die Wasserheizungsöhren ans dem Vorhanse eintraten. Hier war also erhöhte Wärme bei reichster luttfenchtigkejt vohanden. 
mud dieser stock allein entwickelte derart Intumeseenzen, dafs die Blätter moterseits nahezu filzig ansishen. Ein gegenïber, an der andern Trand des Glashanses, angepflanzter Stock vom Royal Muscardine vermischte in den oberen Regionen des Hanses sein Lanb mit dem des befallenen stockes, ohne eine Spur ron Erkrankmng zu zeigen.

Dieser Fall läfst erkemen, wie verschieden sich die einzehnen sorten an demselben standort verhalten und wie bei derselben sorte individuelle Erkranknngen ilıe Erklämng findlen.

Betreffs des vershicdenartigen Terhaltens der einzelnen Reben ist auf eine Studie von Fr. М tтh $^{1}$ ) zu verweisen, der das Entstehen von Intumescenzen nach der Kupternng der Blätter beobachtete. Während beispielsweise Frïhroter Veltliner und Muscat St. Lament keine Auftreibungen erkemmen liefsen, waren Morillon panaché, Madeleine Angevine mol blanes Ochsenange äutserst stark erkrankt.

In einem dem obigen, von mir beobachteten, ähnlichen Falle sah No.ıck ${ }^{2}$ ) die Frkrankming nachlassen, als in rlem Weinhause nicht mehr so viel gespritzt wurde.

Das beschriebene Vorkommnis ist nicht mit den Erscheimmoen, die an Amplopsis hederacea gefunden wurden ${ }^{3}$ ), ïhereinstimmend. Bei dieser Pflanze sah Tomascher an jungen /weigen, Blattstielen und Blattnerven, besonders aber an der Autisenseite der Nebenblätter perlenartige Bildungen. Die Perlen, die bei Lichtmangel besonders grol. waren und im Herlst rertrockneten, bildeten sich unterhalb einer Spaltöftinng, schon an ganz jungen Teilen, indem die eine Atemhöhle nmgebenden Zellen in dieselbe hineinwuchsen und bei ihrer fortschreitenden Termehrung die Epidermis auftrieben. Im Herbst und Winter zeigten sich an Stelle dieser Auswüchse wirkliche Lenticellen mit Korkbildung.

Während die hisher geschilderten Fälle ebenso wie die später noch zu erwähnenden nur Glashauskulturen betreffen, möchten wir num iiber ein im Freien und zwar bei einem Grase beobachtetes Vorkommnis berichten.

Bei äufierst starkwïchsigem Hafer von der Insel Rïgen fanrlen sich Pflanzen, deren unterster, von der Erde gedeckter Halmknoten im Querschnitt das nebenstehende Buld (Fig. 78) anfivies. Der zentrale 'Teil des Halmknotens zeigt den bekamnten wirmen Verlauf der Gefät'sbïmlel $(g)$ und die Anlage einer Wrurzel (u), welche im Begriff ist, die autoetriebene Rinde des Halmknotens zu durchbrechen. In diesem Rindenmantel bezeichnet $r$ den normal gebanten Teil, während bei $r$ die subepidermalen Parenchymzellen bereits beginnen, sich radial zu strecken. Die Überverlängerung steigert sich bei s zmm ansgesprochen schlanchförmigen Charakter und eroreift in der Nähe der durchbrechenden IVurel alle Schichten des Rindenkörpers. Die dadurch übermätsig gespannte, an dem Streckungsvorgang nicht aktiv beteiligte Epidermis begimut schliefslich an einzelnen Stellen $(c)$ entzweizmeifsen. Der Halm zeigt bei s eine starke Fratsbeschärigmo, deren Einfluds tief in ten Halmknoten hineimeieht, in dem eine starke Gewebebräummg

1) Muтn, Fk., Über die Beschädigung der Rebenblätter durch Kupferspritzmittel. Mitteil. d. Deutsch. Weinbau-Tereins 1906.

2) Noak, Fr, Eine Treibhauskrankheit der Weinrebe. Gartenflora 1901, S. 619.

?) Tоминск, Über pathogene Emergenzen auf Ampelopsis hederacea. Österr. Bot. Zeit. 1879 , S. 87. 
mit zum Teil gummös ausgofüllten Gefäsen sich his zur Mitte des Knotens hinzieht. Es liegt num nahe, diese V orwn lung als Veranlasinng zur Int umescenzhildung anfzutasson, zumal henachbarte andere, nicht angefiessene Halme die fowebrweherung nitht zeigen. Man wärde sich dann den Zusammenhang in d.r. Weise vorstellen kömnen, dat's hei der reichlichen Wasser- nud Nährstotizutuhr durch die Wurzeh nut der geringen Verdunstumg des Knotens innerhalh der Bodenkrmme die Fntfermung eines Teils des fowobes dureh den Tiertials hingereicht hat, den Turgor im resticrenten fiewele bis zur Intumescenzbildung zu steigern.

Ähnliche Korrelationserscheinumgen heobachteto ioh hereits friihre bei Einwirkmng ron Kupfermitteln ant die Kartoftelbläter ${ }^{1}$ ). Bui stark-

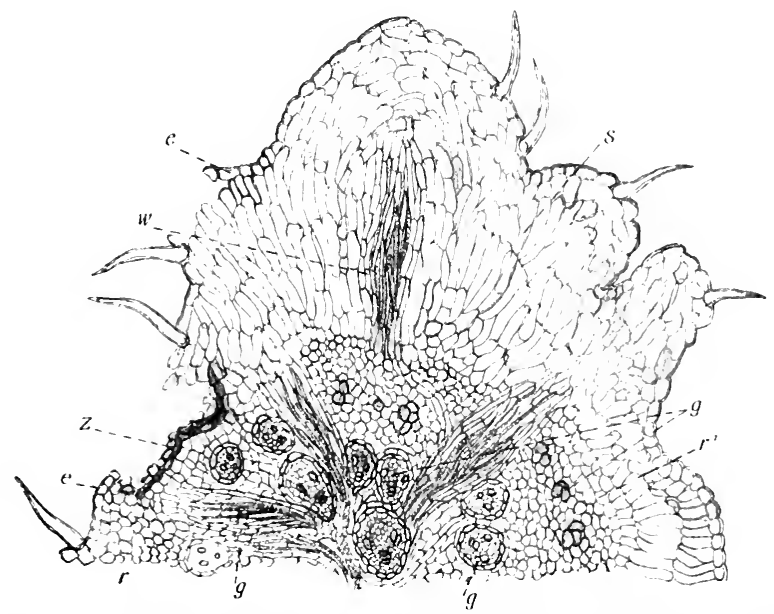

Fig. 78. Intumescenz an lem unteren Knoten einer Haferpflanze. (Orig.)

wïchsigen Sorten erwies sich eine Anzahl von Blätern durch das Bespritzungsmittel heschädigt; in der Nähe der abgestorlenen Gewebetlecki ersehienen später Intmmescenzen. Dafs anch andere Ursachen dergleichen Erscheinmoen veranlassen kïnnen, eroibt sich aus dem Lmstandx. dats Wärzchen anf Kartotfelblätern schon zn emor Keit heobachtet worden sind, als die Kupterbehandlung noch nicht eingefüht worktur war ${ }^{2}$ ). Nenere Resultate in dieser Richtmos hat v. Schresk ${ }^{3}$ ) goliefirt. An Kohlpflanzen, die in einem Glashanse mit Kupter-Ammon-Cartonat bespritzt worden waren, zeigten sich nach wenigen 'Tagen anf der Blattunterseite blasse, almöhlich fast weils werdende Knötehen, die sich als

1) Sonalsr, P., Einige Beohachtungen bei der Anwrndung ron Kupfermitteln gegen die Kartoffelkrankheit. Zeitschr. f. Pflanzenkrankh. 1<9:3, s. 3:2.

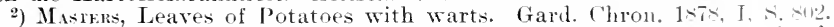

3) Surexk, H. v. Intumescences formed as a result of chemical stimulation. Sixteenth ann. report Missonri Bot. Gard. May 1905. 
Intmmescenzen ilnem anatomischen Ban nath erwiesen. Auf ungespritzten Pflanzen in demselben Glashause waren keine Anttreibmgen zu finden; wohl aher entstanden solehe durch Bespritzung der Blätter mit schwachen Lösmgen von Kupferchlorid, Kupferacetat, -nitrat und -sulfat. $\checkmark$. Schrenk betrathtet aber diese Intumeseenzen nicht als Korrelationserseheinmgen, sondern als Realitionen des Blattgewebes auf den chemischen Reiz der Gifte.

Hierher rechne ich ferner den Fall, welehen HabErLand ${ }^{1}$ ) bei einer Liane, Comoceplulus, beschreibt. Er schildert die Bildnng von ErsatzHritathoden nach Veroiftung der nomalen Organe an den Blättern.

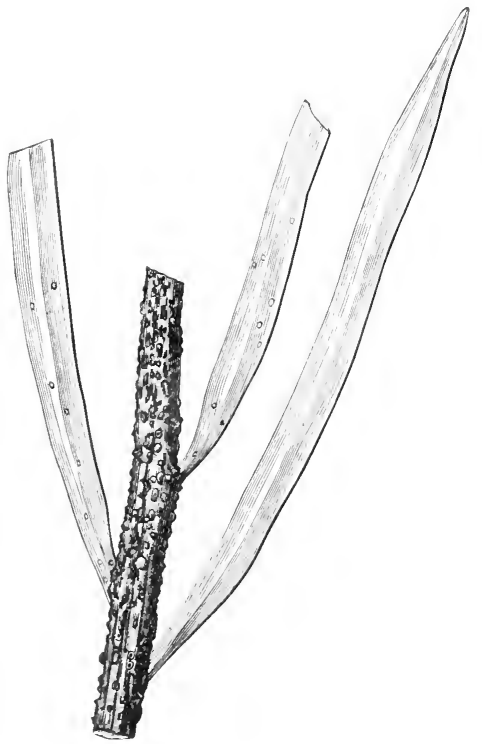

Fig so. Intumescierter Zweig von Aratia pendulu. (Orig.)

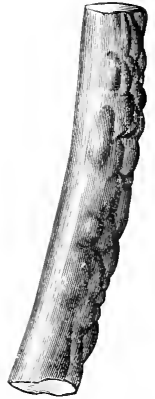

Fig. 79. Intumescierter Stengel von Lacatera trimestris. (Orig.)

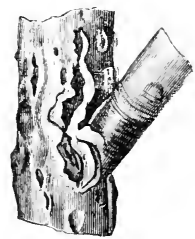

Fig. 81. Vergröfsertes Stlick von Fig. 80. (Orig.)

Die marmein reiche nächtliehe Wasseransscheidung erfolgt am Grunde

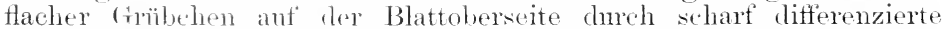
Epithem-Hrulathoden mit Wasserspalten, die stets über den Treffpunkten von Gefäfsbinndehn liegen. Nach Vergiftmo dieser Organe durch Bepinseln des Blattes mit 1),5 prozentiger alkoholischer Sublimatlösmng

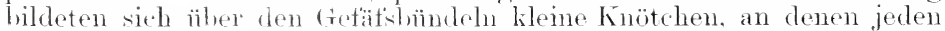
Morgen grotse Wassertroptinn antraten. Diese Knötchen, welche also die Funktion der getötren Iydathoden übernommen hatten, erschienen

1) Haberdane in .Festschrift für Schwendemer", eit, in Naturwiss. Wochenschr. 1899, s. 287. 
aus langen schlauchartigen Zellen zusammengesetzt, die in ihrem unteren, durch Querwände gefächerten Teile lückenlos aneinanderschlossen, am oheren, keulentörmig angeschwollenen Ende aber pinselartig auseinanderwichen. Sie waren durch Streckung der Leitparenchrmzellen, oft anch der Palisadenzellen entstanden und hatten die Epildimis durchbrochen.

Als Beispiele wuchernder Zellstreckung an sitengeln gebe ich die Habitusbilder eines Stengelstückes ron Larat ra trimstris Fio. 7! und von Acacia pendula Fig. so, deren autgerissene Rinde in der Vergrötsermug Fig. S'l noch teutlicher zu sehen ist.

Bei Malope grambifora unel Laratera trimestris bemerkt man stenerel und Zweige anf der Sommenseite dicht mit Längssehwielen besetzt.

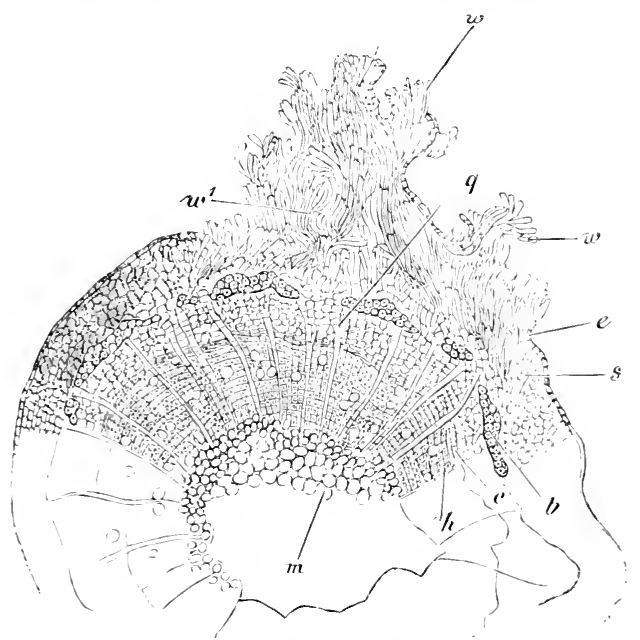

Fig. 82. Querschnitt durch einen intumescierten einjährigen Zweig von Acarian pendula ${ }^{1}$ ). (Orig.)

Diese Schwielen werden durch bedentende Längs- und Querstreckung der zellen des Rinden- und auch des Ilokkörpers veranlatst. Wimn die Schwiele noch jung ist. leitet sich der Vorgang meist dadurch ein, dats in der Höhe der primären Hartbastbündel die zwischen zwei Bündeln liegenden. chlorophylltährenden Parenchymzellen sich radial und stärker noch tangential strecken und hei dieser Vergötsermug sich hogentörmig nach autien wïlben. Der merhanische Ring erscheint dadurch gelockert. dats die Bastbïndel weit anseinandergerüclit werden und dic collenshrmschichten weniger entwickelt sind. Bei stärkeren Intmmescenzen arwejt sich die gelockerte stelle tiefer gehend, indem anch der Holzkörper seine prosenchymatischen Elemente und Markstrahlzellen zu einmm weitmaschigen Parenchym umändert. S. 4.58 .

1) Sorackr, P., Über Intumescenzen. Ber. d. Teutsch. Bot. Gies. 1 ag9, B1. X VII 
Ïber die Vorgänge, die sich bei der Bildung der moosartig zusammenstehenden Intumescenzen bei Acurin putula abspielen, gibt die beistehende Figur $* 2$ hinreichend Aufichluts. Es bedentet m Markkörper, " Holzring, $c$ Cambinm, "Hartbastgrnpen, $o$ Epidermis, $s$ heginnende Streckung imnerhalb der Primärrinde, $w^{\prime}$ die in gewundenen Parallelreihen aufisteigenden, schlauchförmig gewordenen Rindenparenchrmzellen, welche bei "r nach Inrchbruch ier Epidermis garbenartig anseinanderweichen.

In Fällen hochgrarliger Intumescenz greift der Vorgang der Überverlängerung rückwärts in die Sekmdärrinde hinein und weitet die

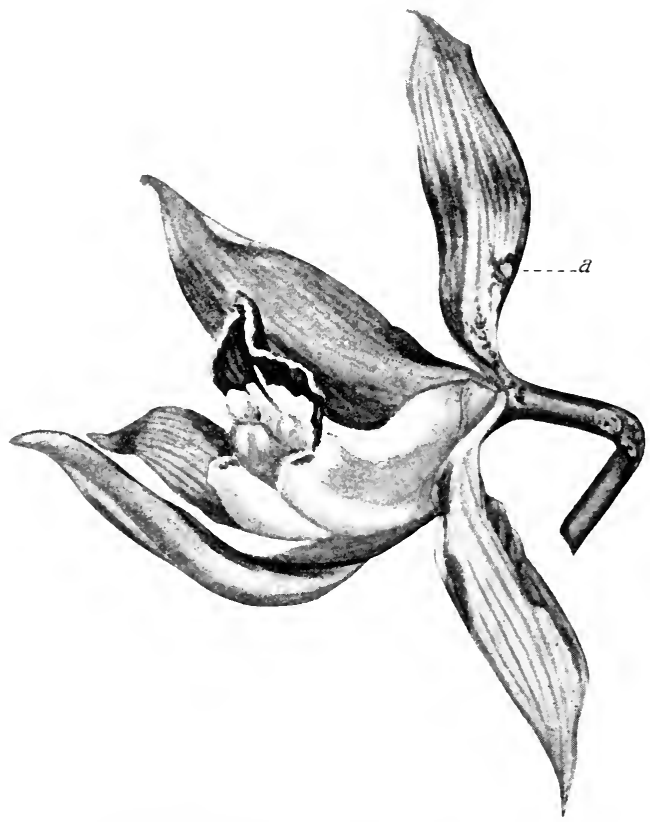

Fig. 83. Blume ron Cymbidium Lowi mit drüsenartigen Intumescenzen (a auf den Perigonzipfeh. (Orig.)

Zellen der Phlö̈mstrahlen (q) aus. Ja es kommen sogar Fälle vor, in denen der Holzring in seinen letztgebildeten Lagen irritiert erscheint, inclem die äutsersten Sulintschichten aus Parenchymholz sich anflinen. Nicht selten beobachtet man, ebenso wie bei Intumescenzen an verschiedenen Arten von Euculyptus, das Vorherrschen und bisweilen ausschliefsliche Anftreten der Intmescenzen auf der dem Lichte zugewandten Zweigseite. Nach den in trüher angeführten Fällen gegebenen Erklärungen erübrigt sich hier eine eingehendere Besprechung.

Am seltensten sind die Intumescenzen an Blütenorganen. Ich beolrachtete einen derartigen Fall bei Cymbidium Lour. Die normal 
grofien, sonst gnt ausgebildeten Blüten zeigton an den Porigonblätern

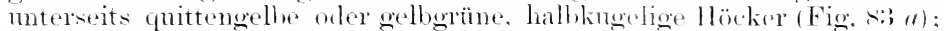
ebensolche (iebilde waren auch ant dem Frubthonten zu fimten. In ler. Jugend besatsen sip eine glatte Obertläche, später platztrn sie in rer Giptelregion und vertieften sich triehterartig. An drin alten Knötehen

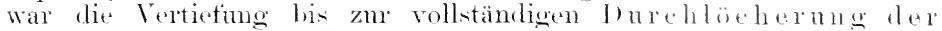

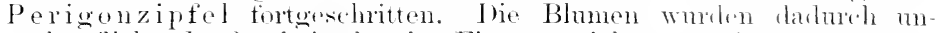
verkänt'lich. In der beistehenden Figur st sieht man dir mortall, der

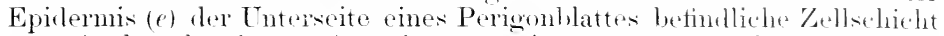
zu autiechtstehenden, antangs kupenartig zuammengeneigten, kenligen schlänchen ansoewachsen $(s)$, die zunächst von dor an der strecking mbeteiligten bramwandigen, verquollonen Epiclermis zurammengolualten werlen. Narh sprengmo der olserhant weichen die nummelne selist derhwandig, tiefbram mo inhaltian werlenden S.hö̈nche garbenartiog
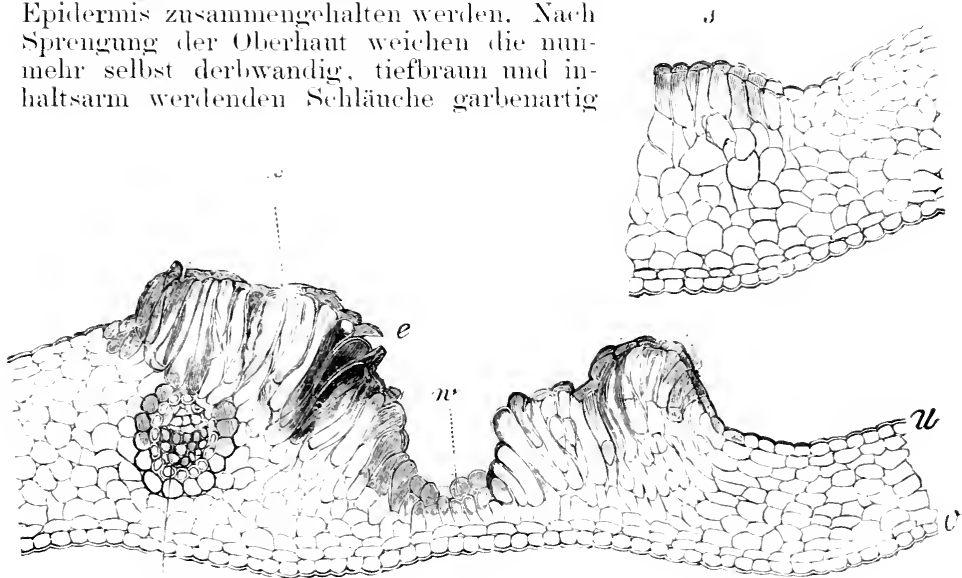

\section{9}

Fig. 84. Querschnitt durch eine Intumescenz des Perigonziptels von (ymbirlium Lour.

Olere Figur Jugendstadium, untere Figur ausgewachsener Zustand. (Orig.)

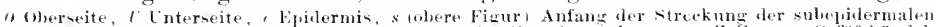

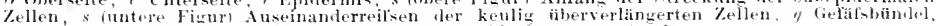
fortzeschrittener burchlöcherungsuntantl.

anseinander. Der Vorgang der T̈hervorlängermng ergreift allmählielı immer tieter liegende /tellpartien und kam sich schlietslich bis direkt

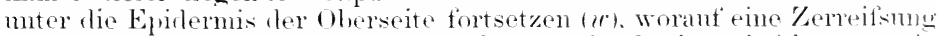
dieser Epidermis und eine Durchlöchermng dos Perigonziptels zustande kommen ${ }^{1}$ ).

Die Anfangsstadien der Intmmescenzen wurden am Finchtinoten studiert. Man Tremerkt zmächst, dats an einer stolle eimige Oburlatut zellen eine gelhbrame. rerquollene Wandung bekommen mul ganz numerklich äber die Ohrifläche hervortreten. Enterhall, derarticer st llen ist das Gewebe noch vollkommen farblos. aber dichter gethängt mul

1) Sorncr, P., Intumescenzen an Bläten. Ber. d. Deutsch. Bot. dien. 1901, Bd. XIX. ล.. 115 . 
rejehlicher mit Plasma und älig anssehenden Tropfen erfüllt. Bei einigen dieser \%ellen hat bereits eine rarliale streckung stattgefunden, die his zur steilen Aufrichtung und einer truerfächerung derselhen sieh steigert. Der Vorgang greift allmählich ant die Umgebung, namentlich auf die dieht unterhalb der Epidermis liegenten /ellen über. Die sich überverlängernde schicht wird anffällig dickwandig und färbt sich kaffeebraun, während die zusammensinkente, verquellende Epidermis eine hell gelbbrame Kappe bildet. Tie Verfärbmo ist von einem Verkorkungsprozesse hegleitet, und diesem ist es wahrscheinlich zuzuschreiben, dafis an den noch nicht vollständig entwickelten und daher noch in streckung begriftenen Organen die spröde gewordenen Zellpartien zerreitsen mul abbrökeln. Dadurh wird die trichtertörmige

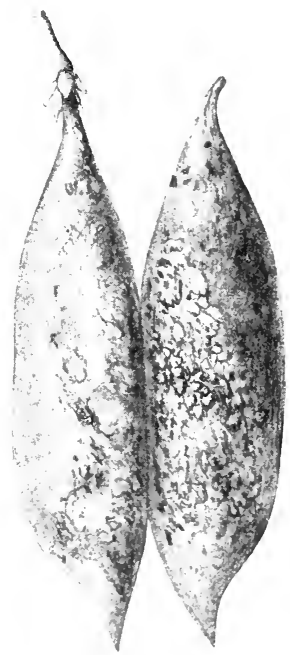

Fig. 85. Erbsenhälsen mit dräsig-aufgetricbener Aufsenflache (Orig.) Vertiefung am Gipfel der Intumescenz eingeleitet.

Ton den aut Früchten auftretenden Intumestenzen sind mir an häufigsten solche auf unreifen Hülsen ron Bohmen und Erbsen zugegangen mud zwar melnfach mit der Bemerkung, dals reiche Pilzrasen sich auf den Hülsen angesiedelt hätten. Die Früchte erscheinen, namentlich wenn sic in der Nähe der Erdoberfläche sich befinden, stark mit Warzen bedeckt und erwecken den Verdacht starker Verpilzung, wie beistehende Erbsenhülsen (Fig. 85) erkennen lassen.

Auf puerschnitten gewahrt man an einzelnen, dem bloticen Ange noeh glatt erscheinenden stellen, dats einige Epidermiszellen sich hereits zn strecken beginnen. Dieselben liegen oftmals nmmittelbar nehen einer Spaltöffnmog, ohne dat's aber sonst dieser Apparat bei der Entstehung der Intumescenzen mitwirle. Allmählich beteiligen sich auch die darmenterliegenden Parenchrmzollen an dem streckungsvorgang. Die gestreckten Elemente fächern sich durch Querwände, und es entstehen num feste, ans anfangs oft säulentörmig aneinandergereiliten Kellreili'n golildete Warzen, die über $1 \mathrm{~mm}$ Hïhe erreichen. Sic werden später durch Alsterben der peripherischen Schichten braun. und ihre /ellreihen weichen nach Zerklüttung der Decke garbenartig anceinander.

Das starlinm der höchsten Entwicktung stellt sich in Fig. 8ti dar. Es bezeichnet $f^{\prime}$, den noch normalen Teil der Fruchtwand; $e$ Epidermis, $y^{\prime}$ sind die $z$. 'T. sich kieuzenden Lagen dickwandiger Elemente der innelen perwamentartigen Fruchthant. Im Kentrum der Wucherung (w) erkennt man die langoestreckten, säulenartig gestellten Parenchymzellen, die nach autsen hin umregehnätsig fächerartig auseinandergehen. I) in ier Zeithnung dunkel gehaltenen Randzonen $(z, z)$ denten das in Absterben begritfene Gewebe an. Die Wandungen lieser zusammengesunkenen, zu sich kräuselnden Kipfeln oftmals verschumpfenden Parenchymgruplen erscheinen gelb bis bram und verleihen den IVarzen eine erlartige Färbung. Furch die vielfache 
Zerkliuftume der Intmmestenzen, die manehmal so dicht stehen. datis nur wenige normale Epidermiszellen sic tremon, erhält die anze Fruchwand stellenweise eine mosartige Olurbiähe.

Auch die pergamentartige Innenwand der llïlsen kann intumeseieren, und zwar ist dies sogar häufiger der Fall als bej der Antienwant. Bei manchen Erbsensorten mit sehr markigen Hailsul finflet man fast alljährlich anf rler testen, olatten lmmensoite wrifie, wie schimmelrasen ausehende (iewebefilze. In rimem falle fand ich in intmescierten Gewelse zahlreiche Oosporen, die vermutlich zu Irommospma Viciar gohört hahen.

Aus den bisher angetührten Beispicelen ergibt sich. dat's ant' allen oberirdischen Organen der Ptlanze die Intmencenzen antereten kïnnen. Sie biklen nur ein Glied in einer Kette ron Erscheinmoen, die z. 'T'. gemeinsam miteinander antreten, z. 'T. songr ineinanifer übregehen. Die rinfachsten störungen hahen wir als .Amrigo" angesporden: sie charakterisierten sich ilureh VerarmugeinzeherGewehesruppen im Blattimem unter Zerstörung des Chlorophyllapparates meist unter /uriucklassume von Carotinkïrpern. Während des Versohwindens des ('hlorophylls bemerlit man ein Bestreben der Zellen sich auszudehnen: sie füllen clie Intereellularen ans. wober sie aut die Umgebme einetl Druck ausiiben, und sterben schlief'sliel unter Verkorkume der Zelliwandungen. Man kamn lerartige Fester iiherverlängerter Zellen anch als "innera Intumescenzen" bezeichnen. Bei don eigentlichen Intumescenzen be-

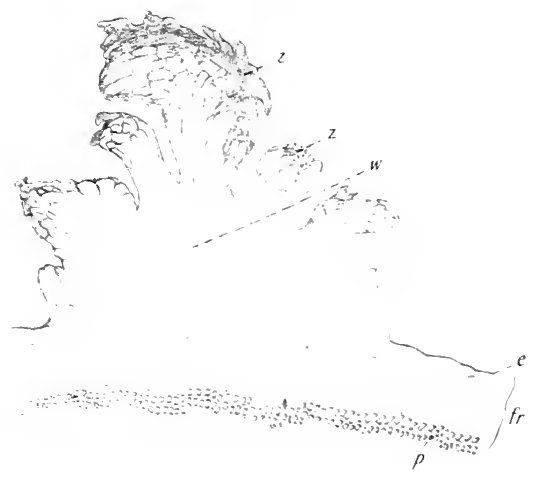

Fig. 86. (querschnitt durch die intumescierte Aufenseite einre Erbsenhälse. (1)rig.) ginnen tie Vorgänge der Ver-

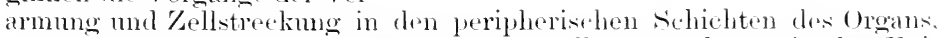
und zwar meist in den subepidermalen /elllagen. seltener in der Epidermis sellst. Der Vorgang der Öborverlängermo ist hier unbehinderter. und häufig schreitet er in lie tiefer liegenden fiewebeschichten fort. so dats wir Fälle von Intumesernzen haben. die an der Tntersoite dex Blattes begimen and allmählich das gesamte Nesophyll bis zur obrern Epidermis nunfassen. Wenn sich in dem intmonesierenden fervebe Korli hilkung einstellt, sehen wir schwielige oder grubige Korkherde antireten.

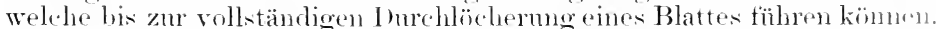

Am Aehsenkörper intsert sieh die Intmuscenz in Ilypertrophio. tes Rindenparenchyms. das in abgeschlossenen Einzelherden in Form

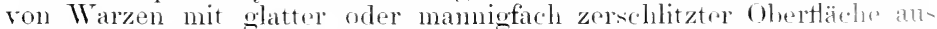
der Rinde herrorbricht. Bleiben die Vorgänge der c berverlängrmu nicht anf kleine, isolierte Einzelherde beschränkt, sondern ergroifin thparenchynatische fewehe in grotisen, zusammenhängenden Flärhen. su reifsen die Organe aut" und stellen dann jene Kustände dar. dir wir bei der "Wastersucht" kemnen welernt haben. 
Obgheich somit die genamnten Erscheimungen immerlich zusammengehören, haben wir sie doch getrennt behandelt, weil zu ihrem $/$ ustandefiommen bald die eine, bald die andere Ursache vorwiegend sich seltend macht. Für die Intumescenzen erweist sich das Vorhandensein ciner mit Fenthigkeit reichlich verselienen Atmosphäre als ausschlagsehend, wie sich ans den Beobachtungen zahlreicher Forscher ergibt.

Indem ich betrett's meiner eignen und anderweitigen älteren Untersuchungen anf die Literatmangaben in K'stek's pathologischer Anatomie ${ }^{1}$ ) verweise, tühre ich hier mur einge besonders eingehende Arbeiten an. Ein Teil derselben beschäftigt sich mit der Frage des Lichteinflusses bei dem Zustandekommen einer Intmmescenz. In dieser Bezichung erklärt Atrinson ${ }^{2}$ ), dats eine Erhöhmg der Tmoescenz in den Blättern curch dic herahgedrückte Transpiration zustande kommen wird, wemn die Glashänser schwach belenchtet sind. Tatsächlich fand ich in der Mehrzahl der Fälle Intmescenzen zm Herbst- und Winterzeit, wem die Glashänser nach der Überführmng der Pflanzen aus dem Freien bei (rm kïhlen. trülen Wetter geheizt werlen mulsten. Trottek ${ }^{3}$ ) spricht rinekt ans, lats llalbdunkel die Bildmng von lntmmescenzen begünstige, ja STEINER ${ }^{4}$ ) sah solche sogar im Dunkeh entstehen, aher nur in den ersten Tagen der Terdunkelmng, so dak man eine Nachwirkmng der vorangegangenen Lichtarbeit vermuten clarf. Dieser Autor beobachtete anch bei Rincllin und Aphotandia, dats dis Pflanzen bei gleicher Lnftfenchtigkeit nach einigen Wochen anfhörten, Intumescenzen zu bilden, sich also der hochoradig feuchten Atmosphäre angepatst hatten. Dats ler schroffe Übergang von trockner zu fenchter Luft wirklich ansichlaggebend ist, geht daraus hervor, dats die genamnten Pflanzen wieder anfingen, Intumescenzen zu biklen, nachdem sie drei Wochen hindurch in trockner Luft gehalten und dann in die fenchte wieder zmrïcligebracht wurden.

Unter Wasser sah S'TEnse keine Intumescenzen entstehen, wohl aber konnte Küster") solche an Pappelblättern wahrnehmen, die er auf Wasser oder Nährlösmgen schwimmen liefs, und zwar im Dunkeh wie im Licht. Nur hei allzu intensiver Belenchtung unterblich dieser Vorgang, wahrscheinlich intolge der geförderten Transpiration. Im (iegensatz hiren stehen die Angaben von Viald und Pacottex ${ }^{6}$ ), welche bei der Beschreihung von Intumescenzen anf Weinblättern in Glashäusern angelien, sie hätten durch direkte Versuche festgestellt, dafs die Intumcscenzen durch Lichtïberschnts in fouchter Atmosphäre erzengt werden. Nur mmittelbar mter dem Glase sind solche entstanden. Dieselle Beobachtung wird aus dem Missoni Botanical Garden gemelilet.

Die eingehendsten experimentellen Studien finden wir in den Ar-

1) Kisma, Euxr, Pathologische Anatomie. Jena 190:. Gustar Fischer.

2) Afrinsix, (7. F, Dedema of the tomato. Bull. Cornell Agric. Exp. Station 1893, No. 53.

3) Trotran, A., Intumescenze fogliari di Ipomea Batatas. Annali di Botanica 1904, No, 1 .

4) Srkisk, Rinur, Über Intumescenzen bei Ruellia formosa und Aphelandra Porteana. Ber. d. Deutsch. Bot. Ges. 1905, Bd. XXIII, s. 105.

$\left.{ }^{5}\right)$ Kistre, E., Üher experimentell erzeugte Intumescenzen. Ber. der Deutsch. Bot. Ges. 190:3, Bd. XXl, s.. 452.

6) Viala et Pasuter, sur les verrues des feuilles de la vigne. Compt. rend. Acad. d. sciences 1904, No, 138 . 
beiten von Mifs $D_{A L E}{ }^{1}$ ), welehe lei Hibiscus ritifolims brobachtete, dats die gelben und roten Strablen hesonders wirksm zur lIervorrufung von Intumescenzen sich erweisen. Betrett's der Wirkung der plätzlichen Änderungen in den Vegetationshedingungen sind ihre Versuche mit Kartotfeln sehr lehrreich. Die Pflanzen wurden im Kalthanse herangezogen und dam im Warmhause bei nugefäh "21 ${ }^{\circ}$ ('. muter einer hell belenchteten (ilasglocke antgestellt. Bereits nach fis stunden waren der stengel und fast alle Blätter auf ihrer Oberseite mit einer Unmenge von blatsorünen Erhahenheiten hedeckt. Wmalen die Pflanzen daraut in trockne Luft gebrarht, schrmmpten the Bläschen zn schwarzen Flecken zusammen, ofer es entstanclen Iturhlöcherungen ler Blätter. Fielen bei längerem Aufenthalt mor der teuchten dilocke rinzelne Blätter ab, so entstand an der Blattnarbe ein wrotses Polster von Intumescenzen, das Ähnlichkeit mit Wundkallus hatte. Ältere Pflanzen entwickelten unter gleichen Bedingumgen nicht so sehmell und auch nicht so zahlreiche, ganz alte Blätter ïberhaupt lieine Intumescenzen. Blattstucke, ant feuchte Bammolle gelegt, waren nach etwa zwei Tagen dicht mit Auftreibungen bedeekt. Schnell gewachsene Pflanzen reagierten am leichtesten auf den Reiz des plötzlichen Fenchtigkeitswechsels.

Die angeführten Beobachtungen stützen misere Anschammgen, dats die Intumescenzbildumg die Reaktion des organs anf rinun Stofis ist, den dasselbe duch pine plötzliche Erhöhmng dor laftenchtigkeit erhalten hat. Nur das jugrnolliche Organ ist reaktionstähig. Wenn ältere Blätter, wie wir dies \%. B. bei Solamm Warsenviozii zu heobachten (ielegenheit hatten, nach dom Transport aus dem Froien in ein femchtes (ilashaus noch mit Intumescenzbildung antworten. so sind rlies Ansnahmofälle von besonderer Erreglbalkeit der spezies. Suldhe Fälle kommen hei rerschiedenen Pflanzengattumgen vor.

Abweichend ron andern Forschern exblicken wir in der Intumescenzbilklung stets die Folge einer Hemmmng in der Aximilationsenergie. I) ieselbe kann sowohl durh lichtmangel als duch lielitiberschuls herbeigetührt werden: sie äntsert sich aber stets durch geringe Neubildumg tester Reservestoffe, meist sogar durch Lösung der vorhandenen geformten Inhaltskërper der Zellen. Die Abwegigkeit in der Assimilationsarbeit kam seln gut, wie DALE amimmt, mit einer steigerung des $1 \mathrm{xals}$ äuregehaltes in den Zellen zusammenhängen und in der abnormen Turgorsteigerung zum Anseluck kommen. Ebenso kann der Wurzeldruck dabei answesehaltet sein, wie die Experimento mit einzelnen Blättern und Blattstüclien beweisen.

I) von mir behanptrte Unzulänglichkeit der Asimilationsarbeit. dio sich in der Intumescenzenhildung kumdgibt, kann sellstrerständlich durch verschiedene Kombination fler Vegetationsfaloren eingeleitet werlen. In der Mehrzahl der von mir beoluachteten Fälle glaubo ich die Veranlassung in einer siteigermog von Wärme und Fenchtigkeit wälnend einer Periole dre Ptlanze zu erblicken, in welcher sie in natülichem Ruhezustande sich befindet oder durch äul'sere Umstainde zu einer Assimilationsinhe arzwungen worden ist. T̈her Verhitumesmatsregeh gibt der folgende Absehnitt Anfischluts.

1) Date, E., Investigations on the abnormal outgrowths or intumpsefnees on Hibiscus vitifolius. Phil. Trans. R. Soc. of London. ser. B. 1901, vol. 194. Dis.E, E., Further experiments and histological investigations on intunciseners. with some observations on nuclear division in pathological tiscues. Phil. Trans. R. Soc. of London 1906, ser. B. vol. 198. 


\section{Die Knötchenkrankheit der Gummibäume.}

Die Blätter zeigen anf der Unterseite zahlreiche, selur kleine, drïsige òder knötchenartige, halbkugelige Auftreibungen. Dieselben werden dureh schlauchförmige Streekung (Fig. si int) ron Zellen des Blattfleisches hervorgerufen, welche im normalen Zustande Gestalt und Gefïge wie auf der mit $m$ bezeichneten Seite des Bildes besitzen, also durch mehr oder weniger grofse Intereellularräume (i) gelockert sind. Das krankhaft ïberverlängerte Gewebe (int) der Blattunterseite nähert sich somit dem normalen, aus Palisadenparenchym ( $p$ ) gebildeten Blattfleisch der Oberseite, die mit einer dreifachen Epidermis ( $e^{\prime}$ versehen

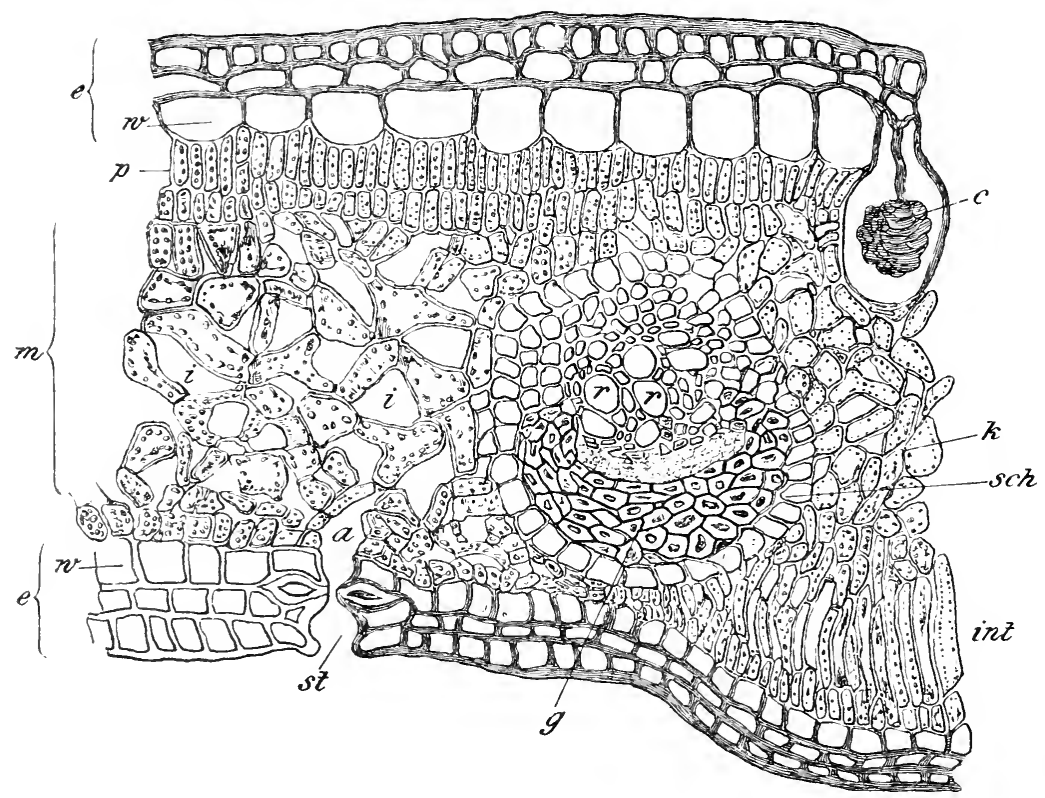

Fig. 87. Querschnitt durch ein Blattkn̈̈tchen des Gummibammes. (Orig.)

ist. Von diesen dlee Sohichten ist die äuferste kleinzellig und mit einer selır starken Cuticularglasur versehen. Die immerste Zelllage der Oberhant zeigt dünnwandigeve, verhältnismälsig sehr weite Zellen $(\boldsymbol{w})$. welche als wasserspeiehernde Schutzschicht angesprochen wird. Einzelne sackartig ausgeweitete /sellen dieser Schicht bergen jene eigenartigen traubenförmigen mit Kalk inkrustierten Zellstoffliörper $(c)$, welche al Cystolithen bekannt sind.

Der feste Abschluts der Blattoberseite mufs ungünsti@ für den T) urchlüftungsprozefs des Blattes sich erweisen; aber dafür besitzt die Blattunterseite die förderlichen Einrichtungen. Das Schwammparenchym \%igt grofse Intercellularen (i), deren Binnenluft durch die Atemhöhle $(a)$ 
und ten Spaltöftiumgskanal (st) nach aulsen entweichen und frisch eintretender Aufisenluft Platz machen kamn. Die Wasserzuleitung erfolgt lureh die Blattnerven, von denen einer bei g durchsehnitten zu sehen ist und bei $r$ die grotien Gefälsröhren zeigt. I)er Weg für die im Blatte erzengten, nath dem Stamme abtlielsenden orwanisierten Banstofte ist in sch, der (Gefätsbündelscheide, angedentet; $F_{i}$ bezoichnet die stelle, bei der die Zellen durch übermälsig gesteigerten Turgor sich zu vergrötsern begimnen und damit die Intercellularräume ausfüllen, also zunächst „innere lntumescenzen" bilden. Der überreiche Wassergehalt kommt noch mehr in dem peripherischen Gewebe zum Ansdruck, da dasselbe, nur miter den Druck der Epidermis stehend, sich schlanchförmig verlängern und samt der Oberhaut emporwölben kamn (int).

Tatsächlich ist also die Knötchenkrankheit des Gummibaumes eine regelrechte Intumescenz, die in den vorigen Abschmitt gehört. Wir haben die Krankheitserscheinung aber deshalb abgegliedert, weil sie bei der Anzucht ron Ficus als Marktptlanze eine wesentliche praktisthe Bedeutung erlangt.

Die Krankheit tritt seltener bei den gärtnerischen Kulturen als bei denen der Liebhaber auf und führt zur vorzeitigen Entblätterung. Sie kommt, wie ich experimentell nachweisen komnte, dadurch zustande, dal's die Pflanzen zur Zeit, in der sie ihren Trieb abgeschlosisen haben. und ihre Transpirationsgrötse zurückgeht, dureh ïbermäfsige Wärme und reichliche Bodenfenchtigkeit zu emeuter Tätigkeit gereizt werden. Ich erzielte die Intmmescenzen dadurch. dats ich einen Gummibaum. der im sommer kräftig getrieben hatte und dann in normale Ruhe ïhergegangen war, im Wintor nicht kïhler und trockner histt, sondern in einem stark weheizten Zimmer am Fenster aufistellte und reichlich begots. Die älteren Blätter fielen daranf ab. während auf don jüngeren sich Intumescenzen einstellten. Nachdem der Baum hell, aber kïhler acstellt wurde, blieben die intumescierten Blätter bis zum nächsten Sommer an stamme, und derselbe trieb wieder gesund, wenn auch schwächlich, weiter.

Diese Erkrankungsart und ihre Heilung dürften als Norm für alle derartigen Fälle anzusehen sein. Die Intumescenzen sind also hoch. bedeutsame symptome einer abnormen Turrescenz bei allen Kulturen. Sobali sie sich zeigen, ist es \%eit, die Pflanzen möglichst hell, aber kühler zu stellen und mit rlem Bewässern nachzulassen.

\section{Die Hautkrankheit der Hyacinthen.}

Unbeachtet, obgleich sehr häufig ist die Erscheinmong, die in Fig. xi sich darstellt. Anstatt daf wis bei gesmnden /wiebeh die äufiseren Schuppen glatt sind und, dic /wiebel fest umsthlietisend. bis an den \%wiebelhals hinaut zu reichen ptlegen, erscheinen bei der Hautkrankheit die äutsersten Schuppen kurz und mit vertrocknenden Rändern zurïtksterbend. Nicht selten sind derartige Iyacinthen geplatzt und besonders in der Nähe der Rif'sstelle mit trocknen Blattern dicht besetzt. An don noeh Heischigen äutseren /wiebelteilen sind Ansiedlungen des blanorïnen Pinselschimmels (Penicillium glaucum) ein häufiges Vorkommmis.

Die einzeh stehenden oder miteinander verschmolzenen Blattrut sind oberseits abgeflacht und nicht selten spaltentörmig angerisen. Anch in dem getärbten Teile normal abgetrockneter Zwiebelschuppen sieht man oft reichlich solche geschwïrartig anfoetriebenen. gelben 
Stellen, welche fast immer Mycel erkennen lassen; dasselbe erweist rich bei der Kultur als zu Pinicillinm gehörig. Das Gewebe solcher stellen unterscheidet sich ron dem gesunden Teile der Schuppe durch tie gelben, maemein spröden, in schartkantige Stücke zerspringenden Wandungen und durch das weite Lmmen ier Zellen, während diejenigen des gesunden Teiles mit ihren etwas gequollenen, dicken, farblosen Wandungen bis zum Verschwinden des Lmmens zusammengesunken sind. Die Stärke ist nicht nur in dem gelbwandigen, bisweilen quer die Schuppe durchsetzenden, verkorkten und durch nachträglich entstandene Korkzellen antgetriebenen Gewebe, sondern auch in der farblosen Umgebme bis ant spuren verschwunden.

Nach Entfernmng der erkrankten trorknen Zwiebelwchalen bemerkt man auf den noch rollständig weitsen, saftigen, bis an den Zwiebelhals normal hinaufreichenden schupen oin ron oben her begimnendes Abtrocknen derselben. Hier verliert das Gewebe den natürlichen Glanz

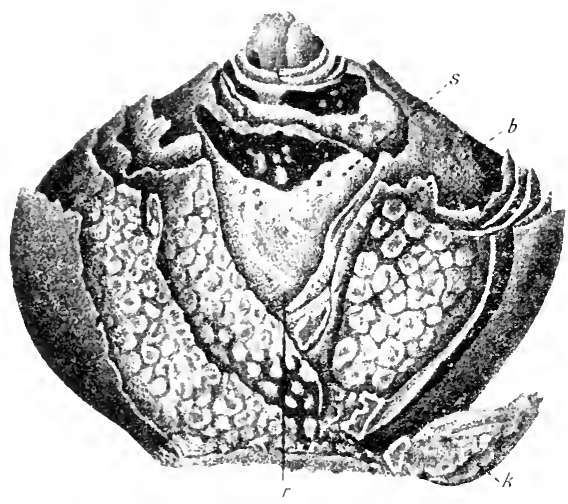

Fig. 88. Hracinthenzwiebel mit den Blattern der Hautkrankheit behaftet. (Orig.)

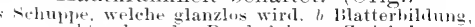
abtro-knender Rand, $k$ junge Zwiehel. und den Turgor, so dat's allmählich der schuppenteil durch Zusammensinken der Zellen zwischen den nummehr dent licher hervortretenden Gefä1'sbündeln ein faltiges Aussehen bekommt. Autserdem pflegt der Rand gelblich zu werden. Dabei erscheinen an tieferen Stellen des fleisehigen, weitsen, yor Straftheit glänzenden Schuppenteils kleine, längliche, glasig durchscheinende, gelbliche, schon schwach über die Oberfläche hervortretende

Flecke. Dieselben vergröfsem sich in wenigen Tagen und werden durch einen lehmgelben, saftigen

Rand alsbald mehr in die Angen springend. Dann aber schreitet die Veränderung langsamer fort. inden die Anftreibung nur allmählich dentlicher hervortritt und ihre Vitte weitslich. trockenhäntig und längsfaltig wird. Mit zunehmendem Alter sinkt die Mitte ein, und schlictilich erscheint sie durchlocht. Bei Behandlung mit Schwefelsäure sieht man die obere, numittelbar miter der Cuticula liegende Lamelle (Fig. s! /) dor ctwas mehr verdicliten Epidermiszellen sehr stark aufquellen. und dann erkennt man darin bisweilen Mycelfäden.

Der Querschnitt turch die erkrankte Schuppe (Fig. 89) zeigt bei b eine ältere, linkis davon eine jüngere Blatter. Man erkennt, dafs in der verfärbten Epidermis die Wandmgen verquollen sind, und dieser (Qnellungs- mud Terkorkungsprozefs $(r)$ sich in der älteren Blatter bereits durch die ganze Diclie der schuppe fortgesetzt hat. Dort ist das Heischige, stärkelose Parenchym, das anfangs $(p)$ noch farblos und in normaler Lagerung sich zrigte, sehon strangweise zusammengesunken nnd hildet erhärtende Stellen mit unregelmälsigen Lücken $(z)$. 
In den \%ellen ummittelbar unter der antwetriehenen Epitermis sieht man keinen \%elliern mehr, während dic när-list imneren denselben noeh besitzen, aber bramgefärbt zeigen. In wor Hidermis entstehen Korkzellen, während das darmerliegend. Parneliym mit der Trommersehen Probe Zneker erkemen läkst. In dirsen zuckerreichen Gewebe schreitet die Korkbildung fort. mul da diw vorkorkten rellen nicht zusammenfallen, erhehen sie sich allmählich mehr mol mehr über das andere fiewolse der Zwiebelschupe, descen Wandmogen tie Cellnlosereaktion behalten unel zusammensinken.

Die Analysen eroaben an Trockensubstanz

gesunde $Z$ wiebeln

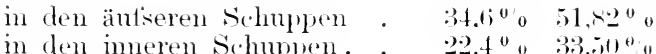

kranke \%wieheln

2iti, $7^{\circ} 0 \quad 55,43^{\circ} 0^{\circ}$ $\left.\because ; .00^{\circ} 0 \quad+1\right) .110^{\circ} 0^{\circ}$

Demnach sind tie kranken Zwiebeh reicher an Trockensmbstanz, was nicht antiallen kam, da bei ihnen der Abtroeknungsprozets der äulseren Schup'en viel weiter fortgeschritten ist.

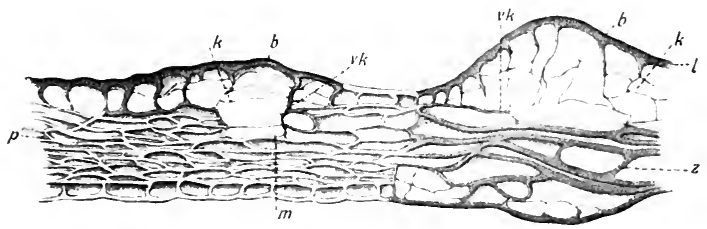

Fig. 89. Querschnitt durch eine hautkranke Zwiebelschuppe der Hyacinthe. (1)rig.)

Es enthielten nach Entfermmg aller hranngefürthto schuppen an Zucker (als Traubenzucker bestimmt und aut' Trockensubstanz berechnet)

gesunde Zwiebeln kranke Zwiebeln

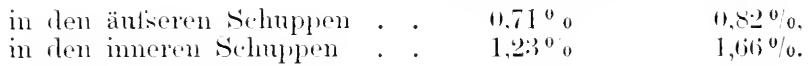

Das heitst, es sind die /wieheln in ten inneren jüngeren sehmppen zuckerredeher als in den äleren, und bei der Krankheit simel innere und äutsere stehupen zucherroicher als im gesmelen Kustande.

Wir erhalten somit dieselhen Resultate, welche bei dor Ringrelkrankheit getimulen worden sind. Tatsächlich hommen beifle Krankheiten häufig vemeinsan vor, und diese Blattron, die als Intumescenzen zu bezeichnen sind, erweisen sich als Symptom für eime geringere Reite ter Zwiebehn, das grate bei sehr üprigen, geplatzten Exemplaren zn finden ist. Dats sich das Penicillium auf solchem Boden sehnell mud häufig ansiedelt, ist selbstverständlich. Die Hantkankleit rertient daher als symptom eine grotse Beachtung und weist daraut hin. dats die Zwiebeh in einem sandigen, nicht zu hmmspoichen mul zu feuchten Boden kituliviert werelen sollen. 


\section{Das Glasigwerden der Kakteen.}

An verschiedenen Kakteen beobachtet und an Corms mycticalus Lk. näher von mir mntersucht wurde ein Krankheitszustand, der sich dureh das Anftreten glasiger, später sich schwärzender Stellen charakterisiert. Bei den weicheren Cereen führt eine grölsere Ausdehnung dieser Gewebeveränderung zum Absterben des darïherstehenden Stammteils. Der Tod erfolgt entweder durch Znsammentrocknen des geschwärzten, in seiner Struktur verbleibenden Gewebes oder (bei Mitwirkmug von Bakterien) durch Eintritt eines breiartigen Zustandes, wohei die Oberhant dmreh geringen Fingerdruck sich ablösen lätst. Bleibt der Krankheitsherd anf eine Seite des Stengels beschränkt, vermag sich derselbe mnter Zurüclilassung tiefer schüsselartiger Wundstellen anszuheilen.

Das Habitusbild anf Seite 456 stellt ein Stammstück von Cercus mycticalus dar, das am oberen Ende geschwärzt und breiartio erweicht ist. Ton dem erweichten Teile ist durch schicten Druck des Fingers ein Oherhantfetzen abgelöst worden. An der Basis des Stammstückes befinden sich ansgeheilte Wundstellen, die bis anf den Holzring des Achsenzylinders reichen.

Bei Dmrehmustermo' sehr stark erkrankter Exemplare bemerkt man, dats eine Anzahl glasiger Stellen sehwielig über die Oberfläche hervortritt. Der Querschnitt zeigt, dafs zwar die änfsere Rindenpartie des Stammteils noch dmkelgrïn nnd normal gebant sich erweist, aber die darunterliegenden Rindenschichten chlorophyllos und stärkearm sind und stark vergrötserte Zellen besitzen, welehe die Ursache der schwieligen Anftreibung sind. Im Gegensatz zn den gewöhnlichen Intmmescenzen, bei welchen die schwielige, oftmals berstende Gewebewucherung durch Streckung der subepidermalen Lagen eingeleitet wird, habe ich die abnorme Vergrölserung der tiefer im Gewebe eingesenkt liegenden Zellnester als, innere Intumeseenzen" bezeichnet. Damit reihen sich diese Vorkommnisse an die Erscheinmngen der vorher beschriebenen Gelbsprenklichkeit an. Anch hier bestehen die Anfangsstadien der Erkrankung in dem Anftreten inhaltsarmer, sich brännender und verkorkender /ellnester mitten im grünen Gewebe; nur leiden bei den Kakteen die Stengel, während bei Pandanus die Umänderungen in den Blättern sich abspielen.

Die Nester der meist nach einer Richtung hin sich vergrötsernden Zellen fallen zusammen, während numelr in der Kalitusrinde die hellwandig bleibenden \%ellen in der Ungebmo dieser Nester sich schlanchartig zu strecken pflegen und stemartige Anordnungen bilden. Von diesen inneren, erkrankten Gewebeherden greift der Vorgang der Verarmmng und Ïberverlängerung d@s Rindenparenchrms rückwärts nach dem Holzring und seitlich in der Richtung des Rindenumfangs beständig weiter $\mathrm{mm}$ sich, bis ein grötserer Teil des Stengels gebrämnt oder gesehwärt ist. Schliefich werden anch die äufsersten Zelllagen von der Verfärbmug croritten, olme clafs dabei eine Überverlängerung noch einzutreten pflegt, und nummehr erseheint der Stengel anch dem blotsen Auge tief tintensehwarz.

Der Schwärzungsvorgang tritt schon an den glasig erseheinenden Krankheitsanfängen fast angenblicklich nach Ausführung des Schnittes ein, so dafs man anfangs an das Vorhandensein übergrofser Mengen von Gerbsäure glaubt, die mit dem Eisen des Messers sieh verbinden. 
Da aber die Verfärbung anch bei Verletzungen durch ein Hormmesser oder einen Platinspatel sich einstellt, so muts man eine empfindliche, lusch den Samerstoff der Luft sich schnell verfärbende Substanz voraussetzen. Aber Guajaktinktur allein oder mit Wasserstoffsuperoxyd gehen keine Blaufäbung. Auf Lackmuspapier zeigt das gesamte Rindenparenchym seharf saure Reaktion.

Als Falitor, der die Überverlängerung der /ellen einleiten dürtte, ist eine Glykoseanhäufung anzusehen; denn bei Behandlung der Schnitte nach der Trommen'schen Zuckerprobe erfolgt in dem gresamten glasigen fewebe ändsert reicher Niederschlag von Kupteroxydul, das in dem Mafse spärlicher wird, als man sich dem gesmuden vivebo nähert. Umgekehrt verhält sich der Stärkegehalt, der in dem schwersterkrankten Gewebe gleich Null ist, während die gesündere Umgebmng reichliche Stärkemengen zeigt. Auffällig ist das Verhalten des oxalsauren Kalkes, der nebst dem Inhalt der Schleimgänge ungemein reichlich auftritt. Im gesunden noch grünen Rindengewebe zeigt er sich vorwiegend in Form von Raphiden, während er in dem erkrankten Teile meist als kurze Oktaederform und bisweilen in langen Säulen zn finden ist. Wahrscheinlich sind verschiedene Mengen von Kristallisationswasser ansschlagorebend.

Über den Heilungsprozefs belehrt uns die obere Figur der umstehenten Abhildung 90; sie stellt ein Stück des Quersehnitts lurch einen Zweig mit vertiefter Wunctstle dar, wie solche an der Basis des Habitushildes zu sehen ist. $M$ ist der Markkörper mit seinen schleimzellen, $H$ das normale alte Holz, $R$, ler Rindenkörper. An fler Wundstelle erkennt man, dats der Gewebeschwund ursprünglich die gesamte Rinde ( $I_{i}$ ) ertafist hatte. Der Iolzzylinder $(H)$ war aber nicht angegriffen worden. Die Wundränder $(u \%)$ des Rindenkörpers waren abgestorhen und dureh eine Tafelkorklage $(t)$ rom gesunden, seitwärts belegenen Rindenparenchym getremut. In lem stehengebliebenen Rindenteil war nenes Dickenwachstum eingetreten, das sich durch die Anlage nener IJartbastbïndel $\left(b^{\prime}\right)$ kemntlich machte. Die alten Hartbaststränge in der Wundnähe waren erkrankt und erwiesen sich durch einen Korkmantel eingekiapselt (b).

I)ie ganze Gewebezone $b^{\prime}-b^{\prime}$ ist nachträglich nen gebildet worden, und zwar an den 'Teilen, welche vom Rindenkörper bedeckt geblieben waren, durch eine normale C'ambialtätigkeit, dagegen an der Wuntstell selbst durch eine Vermehrung des jüngsten Silintes. Denn in der Wunde war das Cambium zerstört, mind daranfhin ist die letztgebildete noch cambiale Holzlage in ernente Kellvermehrumg eingetreten und hat callusartiges Gewehe gebildet. Die zur Keit der Nenbelebung der jüngsten Splintschicht bereits derbwandig gewordenen Gefätsanlagen hahen aber an der Vermehrung nicht teilgenommen, sondern sind passiv von dem neugebildeten Callus nach aulsen geschoben worden. Man erkennt dies daran, daf's diese Gefälsanlagen ( $\left.g^{\prime}\right)$, die im Querschnitt den Gefälsen $(g)$ im normalen Holzkörper $(H)$ gleichen, sich nun isoliert in dem callösen Gewebe vorfinden.

Genaner kenntlich wird der Heilungsvorgang in der untenstehenden anatomischen Figur, die ein Stück Gewebe aus der Lücke dos oberen Querschmitts darstellt. $H$ bedentet wiederum den alten Holzkïrper mit einigen Gefäfsen $(g)$. Dort, wo die dickwandig gezeichneten Elemente aufliören, war die tiefste Stelle der Wundfläche. Fs verblieben ant' derselben die jumgen Elemente des Splintes, welche narh Authïren der 

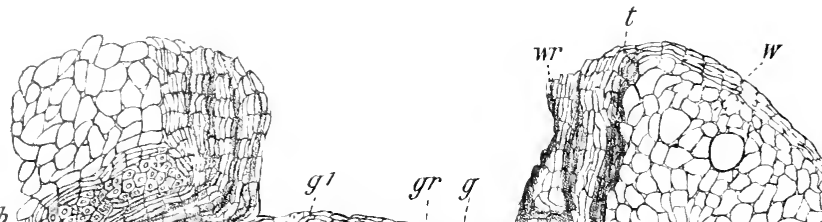

b.

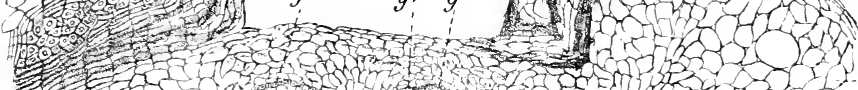
Py $b, 5$ -

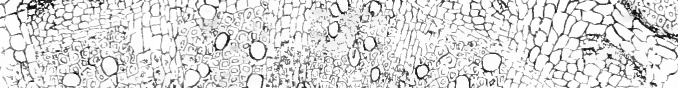

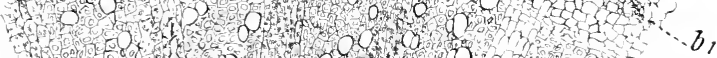
W Her.

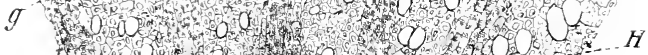

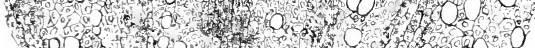

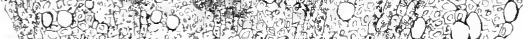
on to n

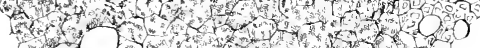
(n)

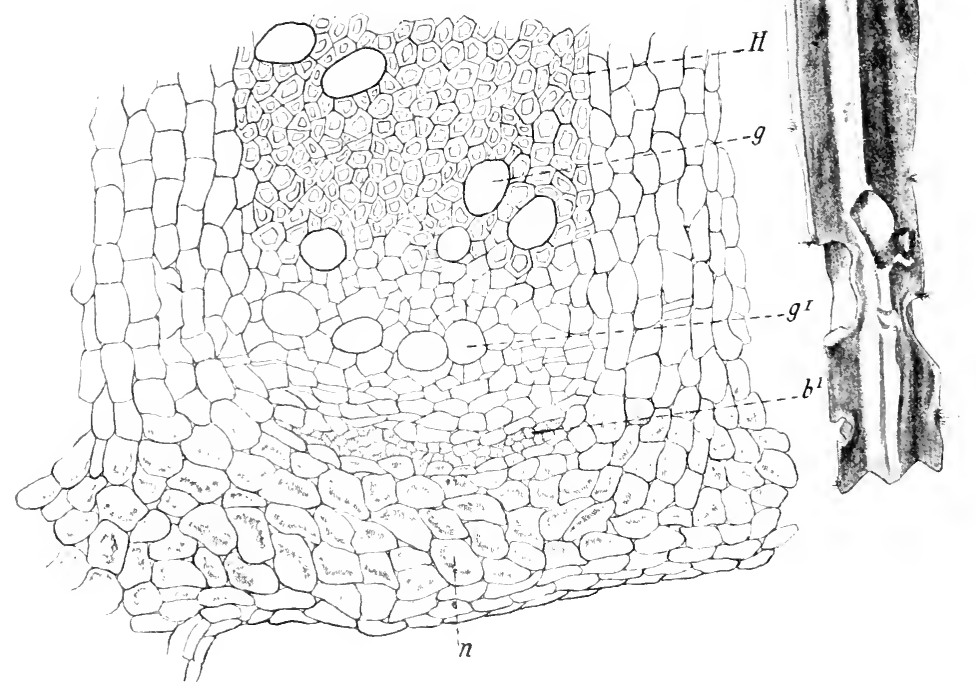


Fig. 90. Das Habitusbild auf der rechten Seite ist ein verkleinertes stammstiick von Cereus myticalus, das, an der spitze geschwarzt und erweicht, einen durch Fingerdruck abgelösten Rindenfetzen zeigt; an unteren Teil befinden sich verheilte, tief schüsselartige Wunden. Das obenstehende anitomische Bild gribt den Querschnitt einer schüsselartigen, verheilenden Wunde wieder. lie untere anatomische Zeichnung stellt die Neul,ildungen und Gewebedifferenzierungen dar, welche bei den Heilıngsprozefs der IVunden sich einstellen.

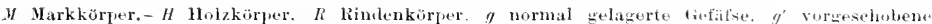

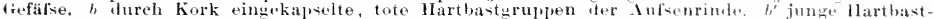

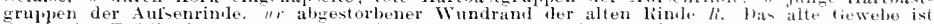
iurch eine Tafelkorklaqe $(t)$ vom gesunden algegrenzt. " mal "aus dem Wumb'allus ditlerenzierte newe Rimite. (Hrig.)

Fänlniserscheinungen sich vergröserten und vermehten. Ther hereits differenzierte jugendliche splint bildete seine Elemente in lockerer, diumwandiger Form weiter aus. und daher kommt es. dats man dümmwandige Gefätise $\left(g^{\prime}\right)$ in einem zarten Parenchrmbolz wiederfindet. Das ganze mit $n$ bezeichnete Gewebe ist Neubildung, deren Entstehmog mit der Neuberindung geschälter Banmstämme ïhereinstimmt. Das neue, aus Callus hervorgerangene (iew be weist bereits eine Differenzierung aut. welche anzeigt, dats der Stamm eine nene Rincle an drer Wundstelle zu bilden im Begriff ist: denn wir finden in der Region unmittelbar vor den dümnwandigen Gofätsen $\left(g^{\prime}\right)$ die ersten parallelen \%ellteilungen, die ant die Ausbildung einer nenen Cambiumzone hindenten. Aniserhalb derselben erkemnt man bereits die Anlage ron sekundären Hartbastelementen $(b)^{\prime}$ in einem zwar plasmatischen Inhalt, aber noch leine Chloroplasten tührendun parenchymatischen Gewolse. das später zur normalen Rinde wird.

Dieser Heilungsrorgang ist aber nur dann beobarhtet worlen. wom die Pflanzen direktes Sommenlicht umel frische, bewegte Lontt zugetïhrt bekamen. Die ganze Erscheinumg habe ich bis jetzt nur als eine Krankheit in Gewächshäusern kennen gelernt, und zwar in solchen, die wegen der Kultur anderer (iqwächse wärmerer Zonen eine geschlossene, sehr teuchte Luft behalten mutsten. In einem speziellen Falle sah i.h die Krankheit Anreh reichliche Läftung des fiewächshanses zum sitillstand kommen und im tolgenden Jahre bei nener Besetzung mit Blattpflanzen und demgemäf gesteigerter Luttenchtigkeit in verstäktem Matse wiederum auftreten. Daher möchte $i c h$ die Erscheinung als eine direkte Folge ïbermäsiger Luttfeuchtigkeit ansprechen.

Die Bekämpfungmatisegeln ergeben sich vom sellst. In einem Falle hat neben der gesteigerten Licht- und Luftzufuhr anch eine B.igahe von Gips zur Erde sich vorteilhaft erwiesen.

Wir hahen den Intumescenzen und rerwandten Erscheinungen einen bedentenden Ram gewiomet, um darlurch aut deren Bedentmo hinzuweisen. Vorzugswe kisemmen die (ilashanskulturen in Betracht. und vielfache Beobachtungen haben mir gezeigt, latis äulserst zahlreiche Krankheiten daraut zurückzufïhren sind, datis man die nat ïrlichr Ruheperiode der Pflanzen nicht beachtet und sie durch hohe Wämo und Fenehtigkeit zu mzeitiger und daher abwegiger Produktion reizt. 


\section{Sechstes Kapitel. \\ Nebel.}

In den gemäfisigten Klimaten hört man selten über Beschärligungen durch Nebel klagen. Im Gebirge hat sich sie Vegetation den reichen Niederschlagsmengen angepalst, und der Verzögerung in der Reife der Halmfrüchte und im Trocknen der übrigen pflanzlichen Produkte hat man durch Kultumatisregeln nach Möglichkeit abzuhelten gesucht.

Daf's in der Ebene sogenamnte "Nebellöcher", anch .Frostlöcher", sind, welche durch starke Flechtenvegetation an den Baumstämmen sich auszeichnen, llürfte bekannt sein.

In den warmen Gegenden wirl der Nebel bedeutungsvoller als schädigender Faktor, weil er hier als wesentlicher Förderer saprophyter und parasitärer Pilze sich geltend machen kam. Den häufigsten Klagen hegegnen wir bei den $\bar{B}$ a n mollkulturen, und eingehende Schilderungen liegen ans Ägvpten vor. DAvID ${ }^{1}$ ) schreibt ans der Baumwollversuchsstation zu Zagazig, dafs an jedem Morgen im Oktober in Unterägrpten der Boden von schweren, dichten Ausdünstungen oder niedrigen Nebeln bedeckt erscheint. Eine allgemeine Folge ist zunächst die, dafs die Kapsehn sich nicht öffnen, weil die Fruchtb)ätter zu zähe bleiben. I) Laubblätter bekommen rote Flecke, die man der Einwirkung der Sonne auf die Tautröpfehen zuschreibt; letztere wirken als Brennlinsen. Die Baumwollhaare in den Kapseln faulen oder werden durch die Einwirkung eines Schwärzepilzes entwertet. Neben der Baumwolle leiden anch Hibiscus esculentus und cumabimus, ja selbst junge Maispfflanzen. Die wesentlichste Veranlassung zu dieser verhängnisvollen Nebelbildung, die von den englischen und Gebirgsnebeh vollständig verschieden ist, gibt das Einsickern des Wassers vom Nil her und die während der Brache erfolgende Unterwassersetzung des Landes, so dafs der Boden nats, dicht und schlammig wird.

Die Empfindlichkeit der Baumwolle erklärt sich aus ihren speziellen Ansprïchen an Boden und Klima. Dieselben werden besonders eingehend in der Spezialartheit von Oppes ${ }^{2}$ ) geschildert. Danach verträgt die Baumwolle als Tietlandyflanze keinen steinigen Boden und keine schroffen Temperaturübergänge; sie verlangt in ihrer sechsmonatlichen Wachstumszeit $18-20^{\circ} \mathrm{C}$ Jittelwärme und ansgiebige Fenchtigkeit, aber erweist sich gegen anhaltende Regenzeit sehr empfindlich. "Hohe Luftwärme, grofse Bodenwärme, heiterer Himmel bei Tage und reichlicher Taufall bei Nacht sind I Iauptberhingungen." Nach Autbrechen der Blïten mufs trockenes, warmes Wotter herrschen. Sandiger Boden ist besonders zusagend: auf humusreichen Böden schiefst die Pflanze zu sehr ins Kraut. Tonloden ist gänzlich untanglich, da er die Feuchtigkeit nicht durchlä1st.

Ührigens liegen auch Beispiele von Anpassung an das Klima vor. So berichten Wriber and Besser ${ }^{3}$ ), dafs die Baumwolle bei ihrer Überführung von Bahamas nach feorgien anfangs zugrunde ging, doch allmählich sich dem gemälsigten Ḱlima anpatste.

1) Inwro, Nebel und Erdausdänstungen und ihr Einflufs anf ägyptische Baumwolle. Zeitschr. f. Pflanzenkrankh. 1897 , s. 143.

2) Opper, Die Bamwolle nach Geschichte, Anbau usw. Leipzig. cit. Bot. Jahresber. 1902, I. S. :374

$\left.{ }^{3}\right)$ Yearbook of the Ilepart. of Agricult. 1899 , p. 463. 
Aber anch die Nebel von der Art der anglischen kömmen verhängnisvoll werden, und zwar in grotsen Stäilten mit vielen Fabriken. Die umfassentsten Studien ïber Londoner Nebel hat auf Veranlassung der Royal Horticultural Society in London F. IV. ()trek ${ }^{1}$ ) veröttentlicht. Die lästigste Beimengmug ist der R a uch, dessen Bestandteile als rufsige T̈berzüge nicht nur die Pflanzen, sondern anch dir šcheiben rsw. ïberziehen. Eine Analyse dieser Rutsüberzüge ergal):

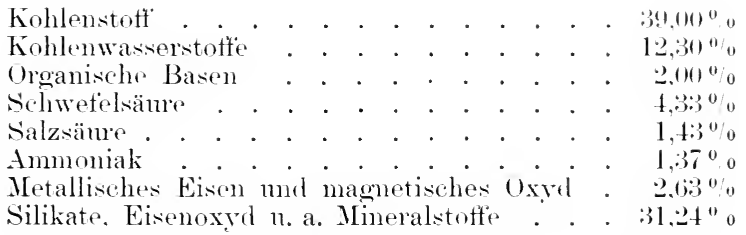

Je nach der Emptindlichkeit der einzelnen Arton sind die Beschädigmngen der Pflanzen entweder nur Verfärbungserscheinmegen orter führen zum Blattahwort. Bei ersterer Art sind Blattspitzen und -ränder gebräunt, aber die ïlrige Blattfläche noch arbeitstähig (Ptris, odontoglossum etc.). Blattabwurf unter gänzlicher Vergillung und Brämung oder aber anch ohne äntsere Zeichen einer Buschädigme ist der häufigere Fall. Als Ursacho der Blattzerstömmg wird dir Schwefelsäure angesehen: anfisertem schreiht OLIVER anch flem metallischen Eisen eincn schädigenden Einfluts zn. Bei den hattahwrefenden Ptlanzen, die äbrigens vor dem Abtall eine Entleernms der Blätter an stärlie premen lassen, dïrtte tie schwetelige säne in erster Linie verantwortlich zu machen sein. Die Versuche, welehe ein schmelles Herabgehen der Transpration feststellen. eraben jedoch erst dam ähnliche Wirkmgen wie bei dem Nebel, wem alodichzeitio eine Vermindermg des Lichtes dintrat. Diesem Lichtmangel mörhte ich auch die Entleerung der Zellen zuschreiben: dem bei alleiniger Einwirkung der Säure sah ich bei meinen Tersuchen den wesanten Kellinhalt. schmell sterben und der Wandung auftrocknen.

Von Teersubstanzen war namentlich Pyridin in wrotser Menge im Nebel enthalten. Bei Versuchen mit Dämpfen von diesem Körver zeigte sich, daf's die Blätter nach einiger Zeit schlatf mol dunkler urün wurlen. Die Zellen erwiesen sich als plasmolysiert: las Plasma cler Epidermis wurde gebräunt, das Chlorophyll aber nicht verändert. Wo Bramfärbung eintrat, war in der Regel Tamnin in den \%ellen. Das Eindringen des Pyridins erfolgt ähnlich dem der schwefeligen säure vorherrsehend durch die spaltöttiungen. (tanz ähnliche Wirkungen zeigten anch die dem Prridin verwandten Körper, wie Picolin, Lntidin. Nirotin. Thiophen etr.

Sohr heftig griff Phenol sowohl in wässeriger Lösmng als anch namentlich in Damptiform tas Laul, an : starke Plasmolyse. Bramfärtmon des Plasmas mol der Chloroplasten.

Die Blüten verhielten sich dem Nebel gerenüber ungrmein varschicden: bisweilen zeigten sich wesentliche Untorschiede hei zwei

1) Oliner, F. W., On the effects of urban fog upon cultivated plants. Journ. Hortic. Soc. Vol XVI, 1\&93; cit. Zeitschr. f. Pflanzenkrankh. 1\&93, 5.224 , und Gard. Chron. XII, 1892. ล. 21, 594, 64× usw. 
Arten dorselben Gattung und sogar bei den einzelnen Petalen derselben Blüte. Tulpen, Hracinthen und Narzissen waren sehr widerstandsfähig. Tom luteresse ist es, dats infolge des mit dem Nebel verbuntenen Lichtmangels, wodureh die Assimilation, Transpiration und Respiration zuritckgertrückt werden, sich manchmal eine eigenartige Gelbfleckigkeit eimstellte. Dabei schien eine Häufung des säuregehaltes (weil bei der verminderten Atmmng weniger organische sämen verbrement einzutreten und eine damit verbundene Turgescenzsteigermug zu Zellstreckungen im Mesophyll zu führen (amigo).

Wir haben somit bei dem Nebel in den Städten zwei schärligende Faktoren ins Ange zu fasisen: die Lichtverminderung und die Git'twirkung der beigemengten stoffe, wehle $u m$ so getährlieher ist, je lichthediunttiger dis Ptlanzen sind. Die einer geringeren Lithtzufuhr angerafisten (tewächse (Farne) haben sich weniger empfindlich erwiesen.

Eine Verminderung der sthädlichen Wirkungen derartiger Nebel wird nur bei (ilashansknlturen möglich sein und ist in England anch erzielt worlen. Man bediente sich spezieller Reinigungsapparate (Fogannihilator), hei denen die in die (tlashäuser eintretende Luft über stark absorbierende substanzen (tholzkohle) geführt wrole. Für Freilandpflanzungen kann nur die Auswahl widerstandsfähiger Arten in Betracht kommen.

\section{Siebentes Kapitel.}

\section{Reg e II $g$ ii s s e.}

Ton den schädigenden Einwirkungen, die sogenannte Schlagregen anf den Boden ansïben, indem sie die Uberfläche desselben festschlagen oder grofse Erdmengen zusammenschwemmen, ist bereits früher gesprochen worden. Die nächstliegenden Folgen sind die Erstheinnngen des sanerstoffmangels für die WWrzeln. Betreffs der Einwirkmng der Regengüsse direkt auf den Pflanzenkörper kommt zunächst die mechanische Wirkung in Betracht. Dat's nicht hänfiger Pflanzenblätter von Platzregen zerschlagen werden oder bei anhaltend santiem Regen durch eine zu grol'se Wasseransammlung leiden, exklärt sich darans, dats vicle PHanzen Eimblitungen zeigen, durch welehe sie befähigt werden, derartigen Sohädignngen auszureichen. Eine eingehende Darstellung solehor Verhälnisse finden wir bei STAHL ${ }^{1}$ ) und JuNtineR ${ }^{2}$ ), welche aut lie Anslilduug von Träufelspitzen, aut' die stellung und vieltache Teitung ler Blattfläthen usw. aufimerksam machen.

Weniger in Betracht gezogen sind bisher die mittelbaren Folgen des Regens, die dureh Vermindermng der Transpiration in Verbindung mit der starken Wasseraufnahme durch die Wurzeln zustande kommen. Dahin gehört das Anschwellen dos Holzkïrpers bei den Bäumen. Nach ilen Untersuchumen von Friensich ${ }^{3}$ ) findet dureh die Herabmindermog der 'Transpriration während der Nachtzeit ein ständiges An-

1) Sтми, E., Regenfall und Błattgestalt. Ein Beitrag zur Pflanzenbiologie. Annal. de Buitenzorg.: cit. Bot. Jahresber. 1893, I, S. 49.

2) Jrxicen, J. R., Om regnblad, daggblad och snöblad. Bot. Not.; cit. Botan. Jahresber. 1893 , ‥ 49 .

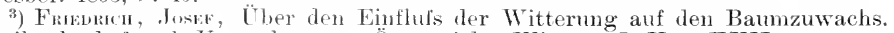

Mitteil. üb. d. forstl. Versuchswesen Österreichs, Wien 1897, Heft XXII. 
schwellen des Baumstammes (abgeschen vom iireliten /uwachs) dureh Qnellumg des Holzkörpers statt, während tassibres ain Absehwellen sich cinstellt. Die Differenzen werden zur \%eit ler grëtsten $/$ uwachstätigkeit an stärksten sein mol flic quellung des llolzkïrpers bei Eintritt von Regen nach längerer Trockenheit besonders shant hervortreten. Rincle murl Borke simel dabej mehr passiv heteiligt. Kuwates unel

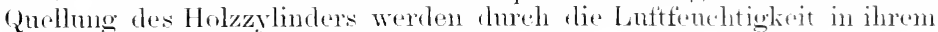
Einflutis ant die Bammkrone geregelt.

Es ist mum leicht ersichtlich, lass hei Bämmon, solange sis glattrindig sincl, dureh starke und plötzliche schwollumgs- mond howachssteigermongen die Rinde stellenweise platzen wirel. Derartige Wmulen können in Lagen mit reicher Boten- und Luttenchtigkeit zu oftenes Wunden werden, die, wie irh glanbe, durch Baliterienansiedlung sich danernd veroüstem. Es entstehen dam jene ririndstellon der jugendlichen Banmstämme, die man z. B. bei linden, Chnen. Eschen, thern usw. an nassen Gräben mol borfteichen beobachton liann.

Mehr noch als bei den holzigen äutsert sich hei den krantartigen Gewächsen der Einfluts einer längeren Regenperiode in Erscheinumgen des Aufilatzens von Früchten mid stengen. Las bedentsanste Forkommnis bei unseren Genüseknlturen nach dieser livhtung ist das

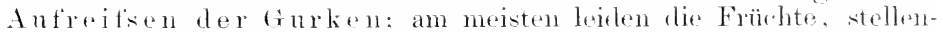
weise anch die stengel. lie mit anhaltend regnerischem Wetter vielfach verlmulene Depresion der Temperatur ist nicht selten die Tratehe gänzlicluer Mitsernten, da die timken dam an firmmosis und verschiedenen schwärzepilzen leielen.

Langer, kïhle Regenperioden können ferner anch vorzeitigen Blatt-

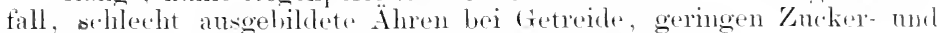
siärkegehalt an Rïben unf Knollen usw. hervorrufen.

Mit Recht fürchtet man den Einfluts wiederholter Regenschaner zur Blïtezeit der 01 stbämme und der zur Samengewimung angebanten Feldgewärhse. Erstens werden die zur Bestänbung notwendigen Insikten ron roichlichem Fhng abgehalten und zweitens auch tlas Antspringen der staubbentel mid Festhatten der Pollenliömer anf der Narte ersehwert.

Ingegen ist die Ansehaumng, dafs die Vermehrumg der Balitrin und Mycelpilze stets aweh Regenzeiten getörlert werde, nicht durchgängig zutreftent. Nu wrm die Regenperioklen von Wäme begleitet werden, steigern sich meistens lie parasitaren Erkiankungen: dagegen hält kalte, nasse Witterme das Wachstum der hervorragendsten Parasiten (Roste. Falscher Meltau etc.) zmoïck.

In don Tropengegenden erweisen sich die regenreichen .Jahroüng laher meist als Beginstigre der Pilzkrankheiten, mel um wenigstems ain

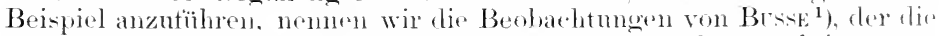

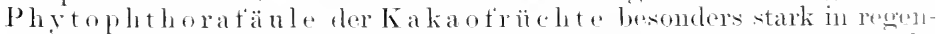

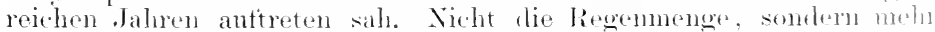
die Form der Wiederholung der Regen ist ansschlaggebend. Ir nelition

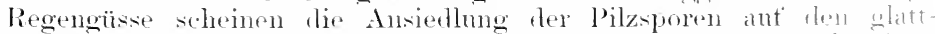
schaligen Früchten eher zn verhindern; aber die teinfren hantingu

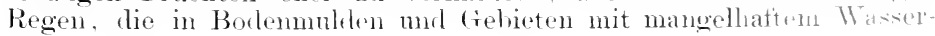

1) Bisse, W., Reisebericht der pflanzenpathologischen Experlition d. kolonialwirtschaftl. Komitees nach Westafrika. Tropenpflanzer 1905, s. 25. 
abthts stagnierende Fenchtigkeit leicht erzengen kömmen, erweisen sich pilzbegiustigend. Weniger leiden die Gegenden, in denen die trisehe Seebrise oder überhaupt der Wind mgehindert /ntritt hat.

Auch für unsere Kulturen ist in regenreichen Zeiten der Wind ein bisher unterschätzter Bundesgenosse im hampfe gegen Parasiten, und in dichtgepflanzten Obstgärten sollte man namentlich in warmen Regenperioden die Baumkronen rurch öfteres schütteln von dem ïberschüssigen Wasser befreien.

\section{Ichtes Kapitel.}

\section{Hage $\mathrm{l}$.}

Alle Hagelschäden stellen Wunden mit Substanzverlust dar; eine 'hemische Eimwirkung infolge der Kälte des Hagellorns ist nicht nachweisbar, sondern nur eben der mechanische Schlag, der entweder tinzelne Partien des Gewebes quetscht und durch Vertrocknung zugrunde gehen lätst oder der Blätter und Achsen zerfetzt, indem er mehr oder weniger grotse Partien abschlägt.

Un einen Einblick in die verschiedenen Wirkmgen des Hagelsehlages zu erlangen, sei hier ein kleines stück eines Roggenhalmes vorgeführt, der an den stellen $g, z$ und $v$ vom Hagel getrotten worden ist. Bei Betrachtung eines solchen Halmes nach einem Hagelsehauer, der nicht so stark gewesen. dafs Blätter oder Ähren abgeschlagen oder gar die ganzen Halme geknickt worden wären, bemerken wir bekanntlich weitsliche oder weif'se Flecke aut der grünstreifigen Oberfläche. Die sitreifung entsteht durch abwechsehnde Lagerumg von dunkelgrünen Furchen und helleren Linien. Im Qnerschnitt erkemnt man, dats diese Furchen ans einem weichen, Chlorophyll führenden Rindenparenchym bestehen, währent die helleren streiten ans dickwandigen, faserartigen Zellen (j) zusammengesetzt sind. Diese Faserstränge geben dem Halme seine Festigkeit: je dickwandiger dieselhen. desto widerstandsfähiger und weniger zum Lagern geneigt zeigt sich der llalm. In vorliegender \%eichmmg (Fig. 91) erweisen sich dis grünen Particn am meisten verändert. Während hei g die Zellen mversehrt crscheinen, zeigen sich bei z nur noch woriistartig mutereinander verbmulene, trockene Zellhäute, die weiter nach der inneren Halmwandung zn in noch grïnes, lebendes Gewebe " ïborgehen. Hier hat also der Schlag des Hagelkorns in der Weise gewirkt. dat's die Oberhant des Halmes $e$ gar nicht zerstört worden ist, wohl aber hat clas weichere, darmterliegende Rindemparenchym terartige dnetschmoen clavongetragen, dats ein Teil der Zellen allmählich ahgestorten ist. Las dahinterliegende, ehlorophyllhaltige fewebe zeigt aber, dats der Schlag hier an ilieser Stelle nicht so heftig war wie bei $r$. Hort rerblieben nur noch wenige Reste von Zellwandungen dos ehomaligen saftigen Rindengewebes, und an dieser stelle hat das Hagelkom solehe Gewalt gehabt, dafs es die derbwandige zähe Oberhaut bei " entzwoigeschlagen hat. Durch die dadurch entstandene Offinm ist dio Lntt in die Wunde wetreten, mo infolgedessen erscheint ein solcher Hageltteck für das blofse Auge weits, wärend bei u immer noch ein griinlicher Farbenton bemerkbar sein wird. 
In ähnlicher Weise wird sich der Gewohererhst hei anderen parenchymatischen Pfanzenteilen gestalten, und je nach der Grölse dieses Verhustes wird die assimilatorische Tätigleit sinken. Indes dürte dieses Herabdräcken der Lebenstätigkeit nur dam von hervorragendem Einfluts werlen, wenn las Hagelwetter zu einer /ait sich cinstellt, in welcher die Bildung des vegetativen Apparates hereits herudet worden und die Pflanze in die Reproduktionsepoche eintritt, in weleher sir dir plastischen Stoffe aus den Blättern herauszieht.

I)en Einflut's des Hagels auf die Getroideähren schildert (. Knats ${ }^{1}$ ) nach Beobachtmoen, die er hauptsächlich hei fierste angestellt hat. Er fand viele Ähren stark abwärts gekrümmt und gedreht, weil os den wenigsten Ähren gelungen war, ihre Grammenspitzen aus der obersten, von Hagel getrottenen Blattsheide loszmachen. I)ie direkt getroffenen

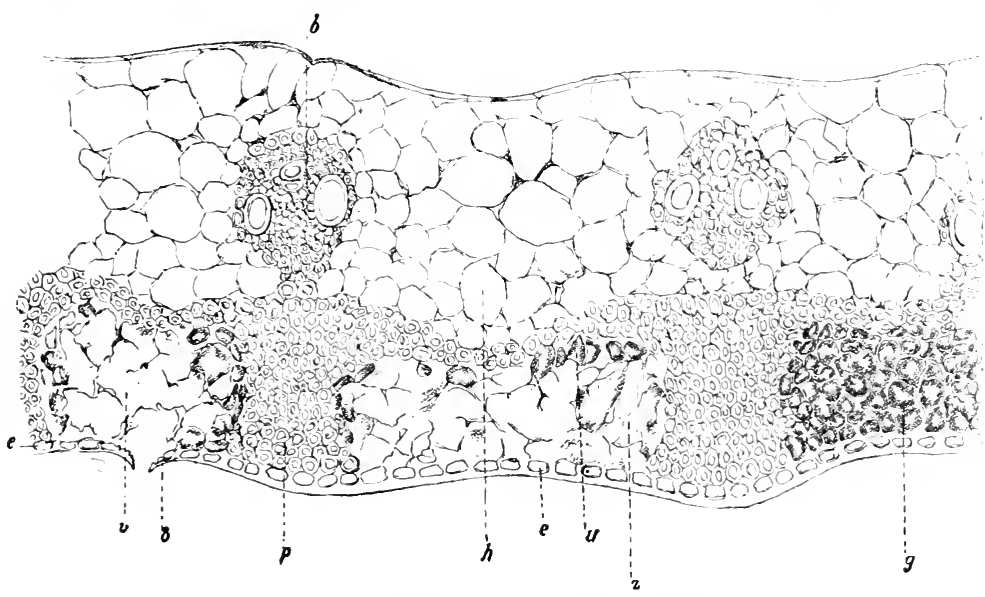

Fig. 91. Hagelschlag am Roggenhahm.

g gevmiles, grünes fiewebe, z von einem Hagelkom verletztes, "anstofsentes gesundes Parenchym.

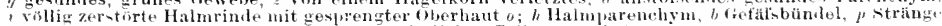
bastfaserähnlicher Zellen. (Orig.)

Ähren blieben in ihrer gesanten Ausbildung züiık. Hie Körner erwiesen sich leichter, moleichmätsiger mul violtach schwarzspitzig.

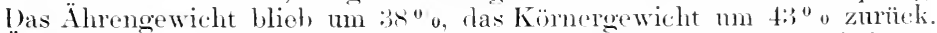
Ämliches fand Krous bei zwei umbegramenten Weizensorten, bei flento sich aber wegen des Fehlens der Gramen div Ähren leichter ans del. obersten Blattscheide hatten heransarbeiten kömen. Demgenäis war laAhrengewicht der verhagelten Weizenhahe num um at bes. 1so o, da

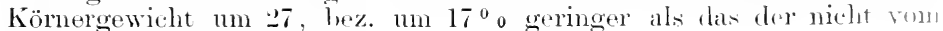
Hagel getroffenen Pflanzen.

Wem zeitig im .Jahre, also etwa im Mai, Hagelschlag eintritt. be merkt man später nicht selten zwischen den von llagelflecken bedeckten

1) Kracs, C., Wirkung von Hagelschlägen. Deutsche Landwirtichaftl. P'resme $1 \varsigma 99$, Nr. 1415 . 
reifenclen, autrechten viele kürzere, grüne, an der Basis gekniete Halme. Hier hat wahrocheinlich das Hagelkorn die Pflanze geknickt, und der

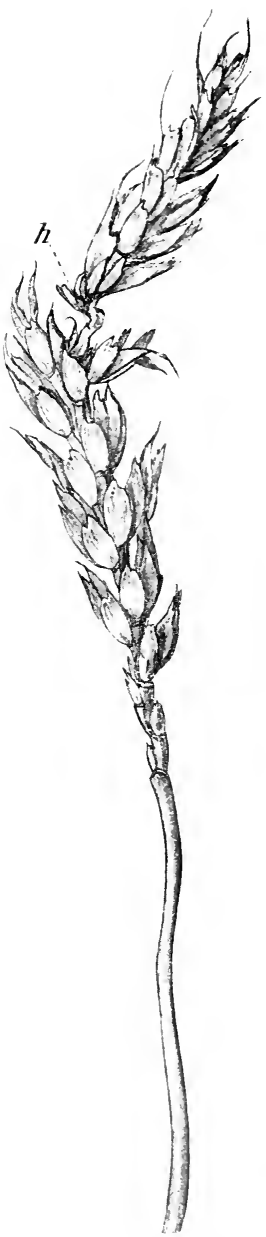

Fig. 92. Weizenähre durch Hagelschlag geknickt. Knickstelle kahl. (Orig.) Ährenverkrümmungen durch tlas sangen von Thrips habe ich bei Gerste in manchen Jahren häufig gefunden. Schr instruktive Abbilıtugen

Halm hat zum Emporrichten mehr 'Zeit gebrancht, was die Reife verzögerte.

Der Weizen scheint am robustesten zu sein. Ich beobachtete nach einem Hagelwetter im Juni 1!\%5, dat's die Roggenhalme, die in Fig. !1 dargestellten Beschädigungen anfwiesen, während in den entsprechenden Zellgruppen bei Weizen das innere Gewebe nur durch einen Rifs zerklüftet oder unbeschädigt war. Die Epidermis war nicht zerrissen, sondern nur in Wandung und Inhalt gebräunt.

Sehr auffällig war die Knickung der Ähren, von der die beistehente Fig. 92 nur eine milde Form darstellt, bei der die Spindel einen stmmpfen Winkel macht (h). Bei len stärkst heschädigten Ähren war die Spindel zwei- bis dreimal derartig geknickt und an den Knickstellen fast gänzlich kahl.

Fig. 93 gibt ein Bila von der Beschatfenheit der spindel an der Knickstelle. Es hezeichnet y die Gefälse, z das zerrissene Parenchym, $r$ die Stelle, an der ein Gefälsbündel zum Alsterben gebracht worden ist. Seitlich davon, bei $l \%$, erschien das gesamte Gewebe tief gebräunt. An anderen Ähren fand man an der Schlagstelle die Epidermis aufgerissen, das angrenzende fiewebe zusammengefallen, verzerrt und gebräunt. Einzelne Gefälsbündel erwiesen sich fast gänzlich isoliert, indem das gerissene ofler gezerrte Parenchym abgeplatzt war. Es dürfte dies eine Folge der Spanmung sein, da die noch grüne Ähre später weiter wächst. Je nachrlem das Hagelkorn aufschlägt, variieren die Beschädigungen sehr mamigfar:h. Stellenweise konnte auch das von C. Kraus gemeldete Torkommnis beohachtet werden, dafs nach dem Aufschlagen des Hagelkorns auf Ähren, die noch in der Blattscheide gesteckt hatten, die Grannen sitzen blieben. Dadmeh kam die Ähre bogig verkrüummt zum Torschein. An der Ansatzstelle der Ährehen waren die Beschädigmngen meist intensiver als in den spindelinternodien zu finden.

Schwere Schädigungen liann der Hafer erleiden, wenn die Rispen noch in der oberen Blattscheide zur Zeit des Hagelwetters eingewhlowen sind. Es können gänzlich taube Ährchen entstehen, und die Pflanzen ähneh dam zum Verwechseln den durch Blasenfüfse beschädigten.
urch dlas Sangen von Thrips habe ich bei Gerste 
liefert PlPpeL ${ }^{1}$ ), der auch mehrtach versucht hat, dir Wirkungen mechanischer stölse zu studieren. Er liels z. B. ein situck noch nicht gescholsten Winterroggens mit einer schweren wlatten Walze niederwalzen. Bei dem Ausschossen der Ähren fand or ein ähnliches Bilıl wie nach IIagelschlag.

Eine eigenartige Erscheinmer zeigte sich bei Weizen, der am 4. Jumi verhagelt war. Autser den bekannten Hagelwmilen an allon Halmen tanden sich, zerstreut im ganzen Felde, Pflanzen ron grïnerem Aussehen mit fast kömerlosen Ähren. Was an Körnern vorhanden war, erwies sich im Juli noch grün und milchig. Die Ähren in ihrer. tresamtheit ersehienen hell lederbram fhrch Brämmng fast aller suelzen. Zwischen diesen sah man kurze, tirisch orüne spelzenspitzen hervortreten. welche d n rehwachsenen Ährchen angehörten. Diest cnthielten li-s Blütenanlagen, von denen keine einzige ausgebildet wa.

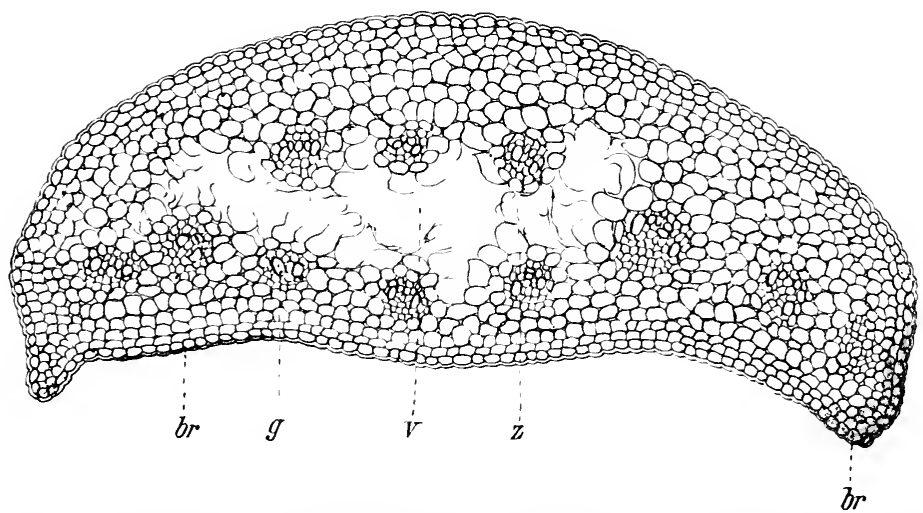

Fig. 9:. Querschnitt durch die sindel der Weizenähre an der Hagelschlagstelle (h) der vorigen Figur. (Orig.)

und die obersten nur noeh Antänge ter Staubbentel ersemen liefsen Iic sipelzen waren lanzettlich, dunkelgrïn nucl krantartie weich, so dats ein deutlicher T̈bergang zum Laubliattcharakter erkemmbar war. In einem andern Falle waren tatsächlich junge Pflänzchen ans drm cirmul. einzelner Ährehen hervorgesprotst.

Etwas Ähnliches beobachtete Benkess a) nach einem am 1. Juli eingetretenen Hagelwettre hei Hopfen. bei dem hereits vier Wochen später die Blütenkïzchen vollkommen verlauht waren. Lats diese Embildung der Blïtenständs wirklich mit der Yorstïrung der Blätter durch den Hagel zusammenhängt, geht ans des Verfassers Versmlum hervor. Er erzielte nämlieh be fortgesetzt liünstlich entlanbton Rankin

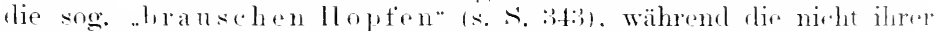

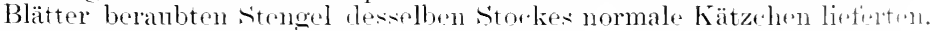

1) Prppis, Mix. Hagel- und Insektenschïden, to Tafeln nach originalphotographien. Perlin 1 $\$ 04$. P. Pares.

-) Zeitschr. f. Pflanzenkrankh. lig6, s. 111. 
Bei den K a rtoffeln ist ein Rückgang in stärkegehalt der Knollen durch Verhageln des Krantes beobachtet worden $\left.{ }^{1}\right)$. Bedentenden Schaden liam der Raps dureh Verletzmeg der Schoten arleiden, und es ist selbstrerständlich, dats bei allen msern krautartigen Kulturgewächsen die Zerstörung des laabkörpers einen Ernteanfall bedingen muls. Ein Fehler wäre es aber, das rom Hagel zerfetzte La uli zu entfornen. Versuche bei Kohlpflanzen zeigten, datis man hessere Köpto anf derjenigen Ackerparzelle erhielt, bei welcher man das zerschlagene Laub helassen hatte gegenüber ciner solchen, ant welcher don Pflanzen die verletzten Blätter fortgenommen worden waren.

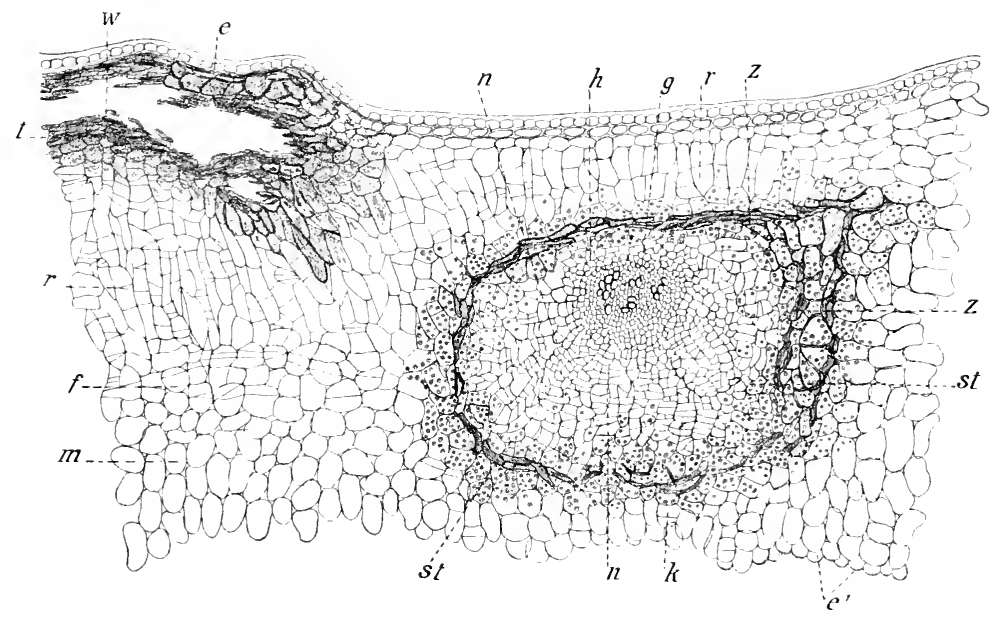

Fig. 94. Querschnitt durch die Fruchtwand einer vom Hagel getroffenen Tomatenfrucht. (Orig.)

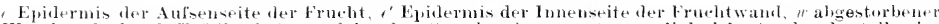

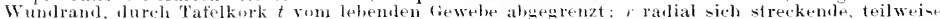

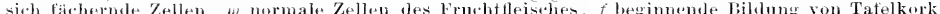

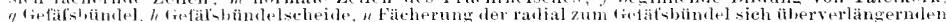

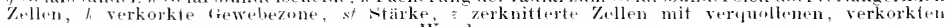
itanduneren.

Interessant sind die inneren Beschädignnem, rie nach Hacrelsehlag an sattigen Frïchten vorkommen. Fig. 94 stellt den Qnerschnitt der Fruchtwand einer rom Hagel getroffenen Tomate dar. Wir erblicken links die eigentliche schlasstelle in Form einer trocknen, harten, dunkelbramen Auftreibung nit nicht zerstöter Epidermis (e). Durch den S'chlag des Hagellorms ist das zartere subepidermale Gewebe tödlich vequetseht worden und infolgedessen gebräunt und vertrocknet $(t)$. Infolge des weiteren sehwelhngsunzesses der noch nicht ansgereitten Frucht ist das Gewehe zerrissen und zn einer harten Blase mimebildet worden.

Neben dieser äntserlich schart in die Augen springenden Vorletzung aber zeigt sich mitten im saftigen Fruchtfleisch eine zweite harte stelle

1) Jahresber. d. Sonderausschusses f. Pflanzenschutz 190:3, S. 94. 
im Umkreise eines (refätsbündels (»). Die llärte des fiewebes kommt hier von dem Terkorkmosvorgange, dem tie canze stelle verfallen ist, nachdem sich zunächst eine reichliche Zellstreckimg und fäichermg in der Ungebung dos Bündels eingestellt hatte. Diese wird wahrscheinlich dadurch eingeleitet worden sein, dats durch den Hagelschlag oder dessen Nachwirkmo eine ringförmige Zone $(z)$ in einer bestimmten Entfernmo vom Gefäisbündel sich verändert hat. Einzehe \%ellen sint miter Verquellung und Verkorkung der Wandungen zusammengefallen; andere hahen nur verquollene Wandungen bekommen und die anstolsenden Zellwände sind ohne sonstige Änderung mur verkorkt. Zu der \%eit, als der Hagel fiel, war die Frucht noch grïn und stärkereich, mut durch die Gewebeverkorkung ist die stärke in der irritierten (iewebezone erhalten geblieben, während sie bei der nachträglieh fortschreitenden Reife ans dem ibrigen Fruchtfleisch verschwnnten ist. Deshalb sehen wir einen Ring aus tief gebräuntem, mit Stärke (st) angefülltem Gewebe um das Gefätisbündel gezogen.

Inuch die Abtötmng und das teilweise /usammenfallen dieser \%ellen haben die direlit an dem Gefätsbündel liegenden und von diesem noch reichlich mit Wasser versehenen \%ellen Ram zur Streckmng bekommen. Sie haben sich, von der Gefälshïndelscheide $(h)$ begimend, in annähernd radialer Richtmo äberverlängert mel dur parallele querwäncle (n) gefächert. Anch autserhalh der eigentlichen Wundstelle hat das Parenchym der Fruchtwand an der radialen streckung (r) sich beteiligt, und nur das Imentruchtfleisch $(m)$ ist normal ceblieben. An der (irenze zwischen dem normalen und itberverlängerten Gewebe begann zur Zeit der Untersnchung eine Tafellorkbildung $(f)$ sich einzustellen, die, sich an die verkorkte Innenstelle anschlietsend, eine zusammenhängende zäle Nasse bildete.

Ähnlichen Korkstellen begegnen wir bei den Früchten von Kernobst, namentlich bei Äpfeln. Auch hier macht der Hagelschlag vielfach keine offenen Wunden, namentlich bei mreifen Früchten. Wir finden nur vertiette, teilweise später sich lrämnende Stellen. Die Vertiefing kommt dadurch zustande, dats das unter der moverletzt bleibenden Epidermis liegende Parenchym aler Apfelrinde gequetscht worden ist, infolgedesien vertrocknet und, meist in ratlialen Rissen, zerklüftet. Anch hier hleilst, wie bei der Tomate, die stärke in dom rerkorkenden Gewebe der Timgebming der Hagelwmide erhalten, falls der Apfel zur Yeit rles Hagelschlages noch mreit war. Es bilden sich in diesem Falle später oftmals anch mregelmätsig uhrolastörmige Zonen von Korkzellen ans, welche flie gesamte immere Hagelwumle vom gesunden Fruchttleisch abgrenzen.

Hoch bedentsam sind die dureh Hagelschlag hervorgernfenen Rindrnwunden, welche, an sich in ler Regel von geringer Ansdehnung, turch ilıre Häntigkeit aber wesentliche schä̈ligungen repräsentieren. Soweit ich derartige Verletzmgen an obstbäumen zu sehen (ielegonheit hatte, habe ich gefunden, dats die stärung im Gewele sich nitht blofis ant die IIagelstelle selbst erstreckt, sondem anch seitlich noch sich fortptlanzt. Bei Hagelwunden an den dienjährigen Zweigen, an denen sie relativ den beträchtlichsten s.haden vermsachen, lfflanzt sich die störung rom der eigentlichen ITmulstelle in der Form einer Rinclenlockermos seitlich tort. In Folge davon selen wir im (querschnitt ron der toten Zone ans Streifen von meist stärkgefülltem Parenchromholz sich in das normale Holz einschiebur um 
dasselbe lockern. Es wird dadurch spröde und brüehig, mo dies dürtte besonders bei solehen Bamarten ins Gewicht fallen, deren Zweige als Bind- und Flechtmaterial Verwendmg finden (Weide, Birke). Unterscheiden lätst sich die Hagelwunde von der Frostbeschädigung oft durch ihre Lage im .Jahresringe. Da Hagel meist in der heifsen Zeit auftritt, so liegt die Wunde nahe dem Absehluls des Jahresringes, während die Frostbeschädigung in der Frühlingsholzzone sich vorfindet. Auffallend ist, dafs nnter den Hagelstellen diesjähriger Zweige, aut welche ein Frost überhaupt noch gar nicht eingewirkt haben kamn, man bisweilen in dem Radius der Wundstelle die Markkrone gebräunt, namentlich aber den Spiralgetätsteil des Gefäfsbündels stark vertärbt findet. Da das zwischen der Wundstelle und der Markkrone liegende Holz des Gefäfsbündels gesmond ist, so bleibt nur der Sehlut's. dat's (vielleicht durch die Markstrahlen) eine Fortptlanzung der Störung nach dem Narke hin erfolgt.

Oftmals lassen wich anch die Hagelwunden von Frostwunden dadurch nuterscheiden, dats bei ersteren sehr bald wieder geradlinig gefächertes, gefälsreiches, normales Holz anftritt, während bei den verheilenden Frostrissen durch die grötsere Ansdehnung der Überwallmngsränder breitere Zonen von Parenchrmholz zn finden sind. Bei schwachem Hagelschlag erfolgt die Tötming der Rinde innerhalb der schlagfläche nicht gleichmätsig, und das Cambium wäehst lückenhaft weiter.

Bei der Unregelmätsigkeit der Heilung löst sich an den Wundstellen die Rinde schlecht und unregelmätsig vom Holze, und dies gibt im Eichenschälwaldbetriebe Veranlassmg, dal's die verhagelten Eichenschossen sich schlecht schälen lassen.

Vielfach sind die Hagelwunden Ansgangsstellen fïr andere Krankheitserscheinungen. Wemn tenchte Wittermng längere Zeit nach dem Hagelschlag anhält, zeigen sich nicht selten Anfänge von Wundfäule. Pilzfäule und dergleichen. Bei Amygdalaceen bürgert sich leieht Gummifluts ein. Solehe Folgekrankheiten können nachler Veranlassme zum Absterben von Zweigen geben. Betrifft dieses Absterben die Gipteltriebe junger Bäume, so sind verkrüppelte Kronen oder (bei sämlingen) krïppelhafte Stämme die nicht seltene Folge.

In Obstbaumsehulen wird nach heftigem Hagel, der die glattrindigen Stämme stark beschädigt hat, sich oft als das beste Nittel das Zurückschneiden derselben über der Teredelungsstelle empfehlen, um einen ganz nenen Stamm zu erzielen. Anch bei älteren Stämmen mit stark verhagelter .Krone, die ja oftmals auch noch durch die vom Sturm abgerisisenen Äste deformiert ist, wird man im folgenden Frühjahr durch zweckmätsiges, tiefes Zurückschneiden die Krone zum Teil neu zu bilden suchen müssen. (M)gleich die Reproduktionskraft zur Zeit der Hagelschäden in der Regel eine grotse im Bamme ist, so dats die Wunden leicht überheilen können, so wird man doch bei glattrindigen Stämmen, die mötsere Partien von Rinde durch die dicht nebencinander aufgeschlagenen Kömer losgeplatzt zeigen. zmm Verschliefsen der Wunde durch eine Baumsalbe schreiten müssen. Nachdem die quetschwunden der llagelköner durch Ansschneiden mit einem scharfen Yesser in leichter heilende Flachwunden umgewandelt worden sind, verwende man eine Nischung von Lehm und strohtreiem Rindsdung mit Asche oder Schieferstanh. die zur Salbenform znsammengeknetet sind. 
Bei der augenblicklich herrschenden Manie, alles durch Düngmng kurieren zu wollen, ist es nicht zu verwundern, dats auch bei starken Beschädigungen mit sulstanzverlust, wie Sturm und llagel hervorbringen kömnen. sofort zum Iüngen geschritten wirl. Wir laten aber tavon ab: selbst aut magerem Boden dünge man erst dam, wem der Bam bereits wieder nene Triebe gemacht hat. (irötsere Wundfächen, die längere Zeit zur Öherwallung branchen, schliefst man am besten durch T̈herstreichen mit kaltflüsigem Bammachs, also einer Harzmischmo, welche dem Wasser den Eintritt verweht. Billiger ist ein Üherstreichen der Wunde mit heilsem steinkohlenteer.

Der Warumg, welche wir betreffs Erhaltung des verhagelten Blatt. apparates hei den Gemüseptlanzen ausgesprochen, schlietst sich Mubsk'THukfat auch in Beziehming auf' die Obsthäume und den Weinstock an ${ }^{1}$ ).

Bei dem Weine wird ron einem.. Hagelgeschmack" gesprochen ${ }^{2}$ ): dies ist vermutlich eine Folge ron Pilzansiedlung an den Wundstellen der durch Hagelschlar beschädigten Beeren. Es ist empfehlenswert, dieselben auszuschneiden, obgleich die Arbeit sehr mühsam ist. Die gelockerte Traube schlietst sich wieder vollkommen, ta die stehenwebliebenen Beeren um so gröser werden Wenn man die verhagelten TTeinstöcke durch den schnitt regulieren will, fange man frïhestens eine Woche nach dem Hagelwetter mit dem schmeiden an, um zu sehen. wie weit die Stöcke sich erholt haben: dabei muts soviel als möglich von dem diesjährigen Holze erhalten bleiben. Besonters wichtig ist es, die unteren, Früchte rersprechenden Angen an den Reben in Ruhe zu lassen, d. h. sie ror vorzeitigem Austreiben zu bewahren. Dies geschieht dadurch ${ }^{3}$ ), dats man mindestens noch eimmal soviel Angen, als man im nächsten Jahre nötig hat, ïber den eigentlichen Fruchtangen an der Rebe stehen lätst.

Unter dien Vorbengungsmitteh gegen Iagelschädenist weiterer Prüfung ein in Piemont üblich sein sollendes Terfahren zu emptehlen. Es werden nämlich Netze von verzinktem Eisendraht über die Stöcke gespannt ${ }^{4}$ ).

In nenerer Zeit hat das. Hagelschief'sen" zu zahlreichen Ver. suchen getührt. Die Theorie, welche zur Anwendung des Mittels führt, wird ron NoLibors ${ }^{5}$ ) entwickelt. Die von der Erde anfsteigenden Wasserdämple verdichten sich zu Wolken, deren dichteste Lagen am tiefisten liegen. Wemn diese untersten Schichten, veranlatist durch die starke Wärmeausstrahlung des Erdbodens, sehr stark verdampfen, wird die ummittelbar darïber liegende Wolkenschicht in hohem Matse abgeliühlt und gelegentlich sogar bis unter den Nullpunkt. Irgendein Anstofs genügt nummehr, mm den ïberkälteten Nebel zum Gefrieren und Niederfallen zu bringen. T)er Prozed's setzt sich unter beständiger Abschwächung der Kältewirkung in die höheren Wolkenschichten fort und gelangt endlich bei der Regenbilomo an.

Nach dieser Theorie wären Abhänge dem Hagel mehr ausgesetzt als Flachland, kalkiger und sandiger Boden mehr als fenchter Alluvial-

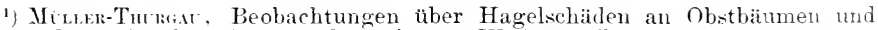
Reben. VII. Jahresber. d. Versuchsstation zu Widensweil.

•) Chronique agricole du Canton de Vaud rom 10. August 1895.

3) Tngarische Weinzeitung 1×96, Nr. 34.

4) Ruo, G., Le reti metalîiche a difesa delle viti dalla grannuola. Bollet. d. Soc. dei Viticoltori. Roma 1892; cit. Zeitschr. f. Pflanzenkrankh. $1 \ll 94$, S. 16ঃ.

5) Nubroms, P., Théorie de la formation de la grêle: cit Hollrungs Jahresber. f. Pflanzenkrankh. 1904, S. 73. 
boden, nackter Boden meln wie bewaldeter, das feste Land meln wie die seen oder das Meer. Wemn man num die ïbereinanderlagernden Wolkenschichten mitemander vermengen kïnnte, so dats eine grötsere Temperaturausgleichmo erfolgte mol eine Überkältmng verhindert würde, so diurte der Hagelbildung vorgebengt werden können. Eine solche Bewegung der den Wolken benachbarten Luftschichten sucht man num durch die Erschütterumg infolge von Kanonenschïssen herbeizuführen.

Eine andere Theorie, die von der Entstehung von Wirbelstürmen infolge Nachfliefsens kalter Luft von den Bergen in den heifs anfsteigenden Talstrom ausgeht ${ }^{1}$, kommt ebenfalls zur Emptehlung des Hagelschietsens. In Italien haben sich bereits zahlreiche Schiefistationen gebildet; doch lanten deren Meldungen sehr widersprechend; gïnstiger wird über das Wetterschiefisen ans Frankreich berichtet ${ }^{2}$ ).

\section{Neuntes Kanitel. Wind.}

Bei den plötzlichen Beschädigungen durch stark bewegte Luft begegnen wir in den Wäldern entweder dem. . Windwurf oder "Wind bruch". Unter ersterem verstehen wir das Stürzen des Stammes mit einseitigem Ansheben der Wurzelkrone. Windbruch, der wirtschaftlich schädlicher ist, zeigt den stamm in einer gewisisen Höhe abgebrochen.

In welcher Weise sich die Sturmwirktung äul'sert, hängt von Baumart, individueller Stammfestigkeit und vom Standort ab. Betreffs der Bamart lätst sich bemerken, rlats zähholzige Gattungen, wie Birke, Fichte, Hain- und Rotbuche ofter geworfen als gelorochen werden; Kieter und Eiche brechen lieber. Anch die Art der Bruchwunde dürfte je nach den Gattungen verschieden sein: es scheint, als brächen die Kiefern kürzer ab, wogegen die Eiche länger einreit'st und die sprödle Akazie von der Bruchfläche aus tiefgehende Längsklïftungen des Stammstumptes oft zeigt. Inbezug anf die individuelle Stammfestigkeit immerhalb derselben Art bemerkt man leicht, dats kernfaule Bäume am leichtesten brechen. Der individuelle Ban der Baunkrone, die den Hauptangriffspmkt am Hebelarm des Stammes bildet, ist ebenfalls sehr herückichtigenswert. Die Lage und rie lokalen Standortsverhältnisse, welche den Ban des hier so wesentlich in Betracht kommenden Wurzelkörpers beeinflussen, sind rom weitgehendsten Einfluts. Auf tiefgrindigem Terrain werden gesäte Bäume in der Regel besser aushalten als geptlanzte, denen man zwecks leichterer Verpflanzbarkeit die Pfahlwurzel abgeschnitten hatte, und die deshall flacher stehen. Bei Hachoründigem Boden tällt der Vorteil der Pfahlwurel weg und tritt die Ausbildung der Krone in den Vordergnund. Je höher dieselhe am sonst glatten stamme beginnt, desto höher rückt der Schwerpunkt, lesto gefährdeter wircl der Baum. Pyramidale Kronen sind darum wahrscheinlich güustiger als dicht kugelfömige. Die selbstverständliche Erscheinung, dats the Gefahr der Beschädigurg nm so grötser,

1) Bortrga, O., Grandine e spari. Atti del R. Istituto d'incorraggiamento, Napoli, vol. II, 5 ser.

•) Praktische Blätter f. Pflanzenschutz, herausg. von Hurxen, 1905, Nr. 11. 
je exponierter die stellung des Banmes, erleilet Ansnahmen. An Gehirgsabhängen lemerkt man manchmal, dat's der stumsehaden, mamentich der Windwurt. an der Windseite weit geringer ist, als an den Abhängen, an denen der stmm abwäts woht. Ferner werden nanchmal miten in einem gleichmätigen, alten Bestancle ganze Kom-

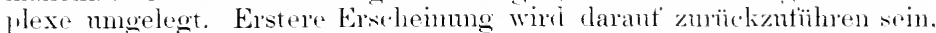
lats der Wind, der herganfwärts weht, farlureh mehr in seiner Wirkung welorochen wirl. dats er die Krone eines stammes immer nur zmm kleinen Teil fassen kann, weil lavor eine andere ler tictor am Ahluange stehenden Bämme sich befindet. Dieses etagemmälsige Ansteigen dor Baumkronen kamn man anch manehmal an bewaldeten mol ebenen Kïstengegenden wahmelmen. Nu wird hierbei die Terassiermer dre Bammkronen nicht rlurch tie Borlemmebenheit bei gleichhohen sitammen hervorgenfen, sondern lunch die Verschiedenheit ler stammhöhe liei weicher Bodenebene. Man wird bemerken, dats die Küstenminde da. wo der Bammwnchs ihnen entgegentritt, die ersten Bänme nicht anfkommen lassen, sondern luschartig niederhalten. Frst in einiger Entfernmo dahinter strecken sich, mit der Entfermmo zmehment, die ctämme bis zum Hochwalel. I)as Umstiirzen ganzer Bammkomplexe im lmnern eines gleichmäfigen Bestancles ist ant Wirbelwind zurïckzutïhren. Eine andere Form des natïrlich sich ansbildenden Windschntzes

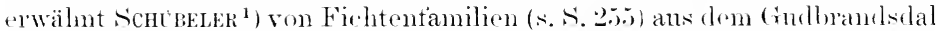
in ciner Höhe über dem Mrere, wo lie Fichte sich bereits ihrer Höhensrenze nährert. Jie Bämme ordnen sich dort an exponierten sitcllen sern in Reihen, und zwar so. dats der Mntterstamm anf der Seite zn strhen kommt. welche gowen den herschenden Wind gerichtet ist. während die dmelı Absenker der Äste entstambenen Tochterstämme rine zienlich gerarle linie hinter dem Mnterham hilıen. Also nur soweit der letztere den Wind abgelualten. War die Mänlidhkeit ror. hanclen. dats tie jungen sentierstämmehen in die Höhe kommen komnten.

Tnter den mannigtachon Tindbeschädiomeren in den Tropen hat man bei der Kakaokultur vielfach mit Winclbruch zu tm. Abgesehen von indirekten Verhuten dureh stme der Schattenbämne. bricht anch Irr Wind direkt die Gahelmoen der Hauptäste anseinander. Nath den Bericliten von L. Kinor hat man mm versucht, ans dem Rest der windheschärligten Buschformen 11 ochstämme zu erziehen, indem man rinen dor vielen sich libtenden $\mathrm{W}$ assersthossen in die Höhe gehen liefs mul dam durch Köpten zm Astbildung zwang. Dieses Verfahren ist teilweise als voüüglich sich bewäbrend hingestellt worlen, wirl

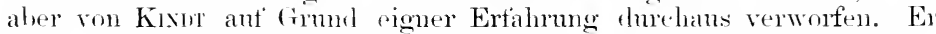
fand. dats bei derartiger künstlicher. der Satur des Bammes zuwider. lanfenter Stammhildung nur eine spärlichr, aus kmzen, wagrecht abstehenden Ästen welililete. schwachbehätterte Krome entsteht, hei der vorzeitig reifende Frïthte nu am stamm gebildot werden. Ije Ernto ist nicht mur in ersten . Jahr, sondern anch in den folgenden . Jahren quantitativ mul qualitativ mornügend.

Berücksichtigenswert sind die Zeitdaner mel der Yeitumkt der Stumwirkmo sowio die herrschende Wittermo. In Regenperioden wird durchweichter Boden leichter nachgeben und zum Windwort disponieren (s. Rieseltelder), während Frïhjahrsstürme äbor geforenem Bomen drn Baum viel fester verankert finden mol bei zmohmenter siatis mohr Windbruch veranlassen.

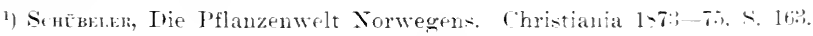


Anfser diesen gröbsten, angenblicklich eintretenden Besehädigungen sind aber anch sole he zu registrieren, welche die Existenz des Individnums nicht vernichten, sondern nur vorübergehend oder danernd schwächen.

Zu diesen Windwirktungen gehört dir sehiefe Richtung der stämme. Die anffälligsten und hänfigsten Erscheinmngen bieten die Stratsenpflanzungen, namentlich dam, wenn Gräben zu beiden Seiten der Chansseen oder Landwege lauten. Es lätst sich dort die antfällige Ertahrung machen, dafs, wemn sich die Strafse senkrecht zur herrschenden Windrichtung (bei uns meistens West) hinzielit, diejenige Batmreihe, welche dem Windeinflusse zmächst steht, ziemlich geradestehende Stämme behält, währent die andere Seite mehr oder weniger tiet geneigte, über den Graben überhängende, manchmal säbelwuchs zeigende Bämme besitzt. Man ersieht darans, wie ungleich die Wurzelstintze wirkt. Auf der Windseite einer solchen Stratse, wo der Vind bei seinem Angriff zmächst die (irabentläche trifft, ist der Wurzelapparat in anderer Weice entwickelt: anf dieser Seite kann sich das Wurzelgeflecht weniger ausdehuen, dagegen ist ss innerhall, des Stratisendammes stark befestigt. Wer Winddruck findet durch diese Stütze ein genïgend starkes Gegengewicht. Aut' der anderen Seite der Strat'se liegen die Verhältnisse umgekehrt; dort sind zwar auch die Wurzeln anf dem Stratienteil besser entwickelt als am Grabenteil, aber diese ersteren bilden hier die verankernden Apparate, welche den $\mathrm{Zug}$ des sich neigenden Stammes anszuhalten haben. Die stïtzende Seite ist hier die nach dem Graben zu liegende Wurzelseite, und ihre schwache Entwicklung veranlafist das Überneigen des Bammes nach dieser Richtung. Es scheint daher, dafs der wirksamste Schutz bei Obstbäumen der gegen die Windrichtung schräg gesteckte Pfahl, der den Batm stützt, sein wird; die ,jetzt häufiger in Anwendung liommenden Drähte vor der Windseite, welche also den Zug des Bammes anszuhalten haben. möchten wich als minder gut erweisen.

Der ..s äbelwuehs" wird verständlich, wemn man bedenlit, datis der Baum alljährlich in der Frühjahrs- und Sommerzeit, in weleher die Triebe sich ausbilden, durch den Wind geneigt wird. Die zu dieser Zeit fortwachsende spitze des jungen Stammes strebt, sich immer iu der Senkrechten zu erhalten, und krümmt sich um so mehr, je schneller der Baum zur Horizontalen gerlrückt wird. Was hier von der Hauptachse gesagt ist, bezieht sich auch anf' alle ' $/ w c i g e$, welche in scharfen Windlagen tat*ächlich einseitig fahnen artige Kronen darstellen.

Der fahmenartige Charakter liegt nicht nur in der Biegung der Äste nach der Seite, whin der Wind weht (bei mn nach Ost), sondern anch in der Verzweigung, welche bei grötserer Länge der Haupttriebe spärlicher zu sein scheint. Die Zweige, welche dem Wind entgegen wachsen müssen. bleihen kïrzer und sterben bisweilen ab.

Sehr instrulitive Beispiele liefert Lowwir KLesN ${ }^{1}$ ) in zwei Fichten rom Weidfeld obrihalh, des Weges Haldenwirtshaus-Wiedenereck. Die Bänme sind auf der Windseite nahezu ilırer Äste beraubt, geradeso als ob eine llälfte der Krone mit der Schere abgeschnitten wäre (scherende Wirknng des Windes). Dieses Abtöten der Äste sehiebt KuEIN aut dir austrocknende Wirkung des Windes. Unterstützt wird die Windwirkmg durch eine erheblich stärkere Erwärmme und dachurch gesteigerte Transpiration.

1) Kı.s, I.. Tie botanischen Naturdenkmäler des Grofsherzogtums Baden usw. Karlsruhe 1904, Fig. 26 
Bei den Obstbämmen tragen die fahmenartigen kionen nanchmal nm. an der Peripherie Früthte, weil das Innere der Krone le.icht zu dicht wird. sobald der stamm in holem tirade ans der Lothine heransoredickt ist. macht sich eine Ermährmesclitterenz zwisehen der ( )her-mol Untersoite der Achse geltend, welche in der Erzengung üppigor Latubtride aut der

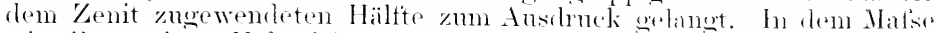

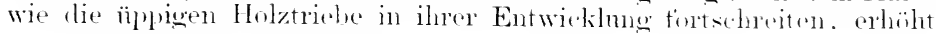

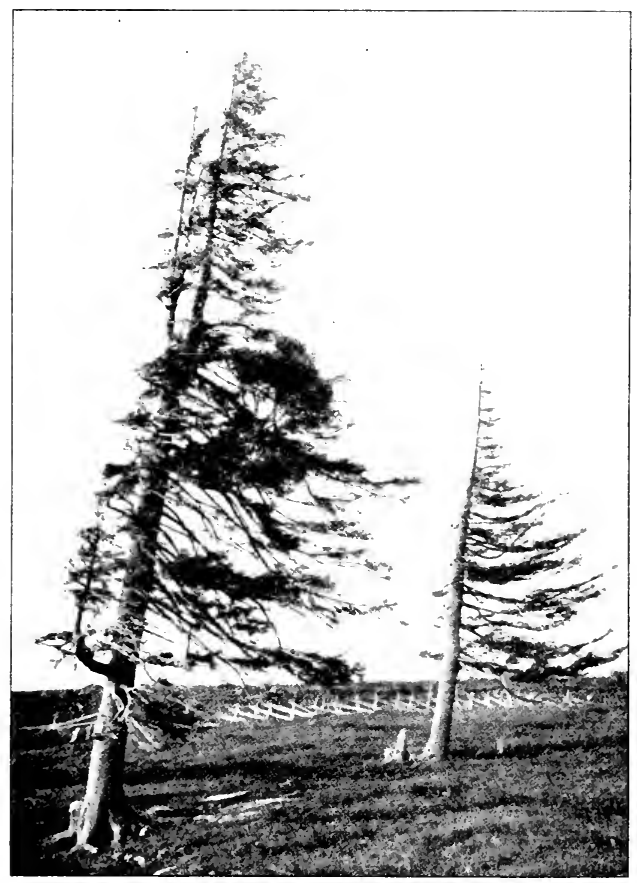

Fig. 95. Zwei windgedrückte und windgescherte Fichten. Die linke Pflanze besitzt zwei Hexenbesen und drei Sekundärwipfel. (Nach KLFix).

sich ihre Matht als Anziehmosherd für das rohe Borlennährmaterial.

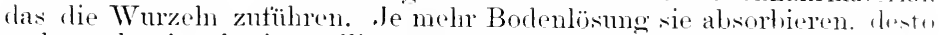
mehr geht der horizontalliegenden Partie der Bammkrone von dienes. Lësmg verloren, und einzelne, alwärts gedrüblite Äste berinnen infolwe. dessen abzusterben, wähend dic nenen Laubachsen senkieclit anfwärts schietien und sich zu Wasserreisern ansbilden. Imanit ist eine langjährige Unfmelitbarkeit angebahnt. Anch hei Waldptlanzungen in der Nähe der Kästen ist die rinseitige Kronenentwirklung lumbringr. Das Tertrocknen der Zweige wird zum Teil jedentalls ant' dis stete 
Reibmo durch den Wind zurïckzufïhren sein. Die schwierigkeit in fer Nenbewaldung von Küstenstrichen ist nicht, wie wohl vielfach anwenommen ${ }^{1}$ ), durch den salzgehalt der seewinde, sondern einfach durch leren mechanische WVirkung zu erklären.

Die Kr ïppelformen der Bämme an den Kïsten und an den Höhegrenzen des Bammwohses vordanken in den meisten Fällen auch flem IVinle ilme Entstehmg. Die Wiptel werden zmm Teil vertrocknen und vom Winde abgebrochen: ein hier wesentlich mitwirkender Faktor dürfte allerdings schneebuch sein. In der nächsten Vegetationsepoche versuchen die Bämme eines der obersten seitenangen zu einem nenen Gipfeltriebe anszubilden, was hei Narlelhölzern selbst mier geschützten Verhältnisen um einigen Gattungen gelingt, in Stumgegenden aber noch weniger vorkommt. Die Folgen der Entspitzmo machen sich duch vermehres Wachstum ron seitenzweigen hemerlibar, welche, oft gut henadelt, schlangenartig im Gestrïpl' des Bodens dahinliriechen. Ein schönes Beispiel schildert Prens ${ }^{2}$ ) von der livorneser Kïste. Autser den schief sestellten stämmen der Kiefernarten mol der stecheiche sieht man . Jomiperes phomirea and Tamarix gallica schlangenartio verbogen und die Zweige von Phillyma mul anderen stränchern miteinander verstrickt am Boden entlang kriechen.

Eine äntserst ähnliche Schilderung entwirft Hansex ${ }^{3}$ ) ron der Insel st. Honorat bei Camnes.

Bershakm ${ }^{4}$ ) bezeichnet für Dentschland gewisse Gegenden als besonders oft heimgesnchte Stumherde. Beispielsweise seien Schwedt a.0., las schlesische Gebirge, der bavrische und Oberpfälzer Wald, der Frankenwald und in beschränkter" Weise anch das norddentsche Küistenland (Mecklenburg, Holstein) zu nemnen. In diesem Küstenlande herrschen im allgemeinen Nordoststürme ebenso häufig wie WVest- und Nordweststürme, während für Süddentschland West- mnd Südwestwinde, im ganzen Norddentschland aber. West- und Nordwestwinde ein ansaesprochenes Übergewicht besitzen.

Dats die Terteilung der Pflanzen sich den TVindverhältnisien anpassen wirl, ist sicher, indem die windtesteren Arten am besten aushalten werden. ScHRöTER und Kirchser ${ }^{5}$ ) zitieren beispielsweise eine Erklärmng von NüLcer über die Verbreitung der baumartigen Bergkiefer (Pinus momtana) in den Alpen, die trïher einen grötseren Verbreitungslrezirk gehabt hat, aber durch ihr langsames TVachstum, ihr Lichtbedürtnis und ihre Genügsamkeit sich anf Stellen züückgezogen hat, wo eine andere Waldvegetation sich nicht mehr entwickeln will, nämlich an die windgefegten Stellen mit geringer Lnftenchtigkeit oberhalb der Höhengrenze des Waldes. Diese TViderstandsfähigkeit der Kiefer gegen Wind hänst wahrscleinlieh mit llem anatomischen Bau der Nadel zusammen. \%/xi erblielit mit ScHert in rem sogenannten Transfusionssewebe der Gefäfsbündel (s. Sirnert, die Tracheödensämme im Blattbündel

1) Axwnıмn, Lw, Bericht üher die Wirkung des Salzgehaltes der Luft auf die Seestrandskiefer (Pinus Pimaster). Forstl.-naturwiss. Zeitschr. 1897, Heft 6.

2) Prfar, L., Effeti del libeccio etc. Bollet. Soc. Bot. ital. 1901; eit. Zeitschr. f. Pflanzenkrankh. 1902 , s. 160 .

3) Haxs: A.. Flora oder Allgen. Bot. Zeitung 1904, Bd. 93, Heft I, S. 44.

4) Die Waldbeschädigmoen Wurch Sturm und Schneebruch usw.; cit. Forsch. auf dem Geb. d. Agrikulturphrsik 18s0, S. 527.

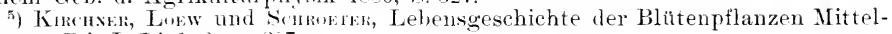
europas. Bd. I, Lief. :?, ר. 207 . 
der Coniteren. Jenaisehe Keitschr. f. Natmwiss. XVI. lss:3) eine Vorrichtmo, welche durch ihren steten Wassergehalt die Existenz der Nadel in anlialtend trockner Luft ermöglicht. 'Trotzden dart' natürlich eine cewisse Grenze nicht ïberschritten werden, mul als IVindheschärligmeg gibt Zax: ${ }^{1}$ ) ein Virwilben mul Vertrockinen der Narlelspitzen an.

Sicherlich erhöhen bei den Comiferemnadeln die starke Vachserlasur (ler Epidermis und die sclerenchymatische, sulepidernale Zolheilie ähnlich wie bei Kakteen, sukkulenten Emphorbiacoen mul c'rassulaceen die Widerstandskraft gegen den Windeinfluts. Für dis Kaptlora letont (FERHARI ${ }^{2}$ ) als weitere Sohntzmittel die Rerluktion der Inter.rllularen und Einsenkung der spaltötfinnom. Als eine mechanische Wirkmu des Windes, die sich trotz der Bodenfenchtigkeit zeigt, heht der Verfasser die Ansbildnng von sclerotischen Hypodermfiasern und die Verstärkmug der Blattränder durch Collenchym oder Bastbündel hervor.

Für die Erklärmng des säbelwnchses und anderer threh Wind belingten Banmformen sind die sehr interessanten Untersuchmosergolmise von G. Lkass ${ }^{3}$ ) von Wiehtigkeit. Sehüttelt man nämlich einen tirischen. wachsenden Sprot's einer krantartigen oder holzigen Pflanze, so dats cr sich schlietslich bogenförmig mit üherhängender śpitze krümmt, clam ist sofort die Konzentration des Zellsaftes anf der konkaven und konvexen ścite nicht mehr oleich: der saft ant der lonvexen seite ist konzentrierter geworden. Die höhere Saftionzentration der konvexen seite ist mit einem wesentlich höheren /uckergehalt verliü̈ptt. Dicser /ucker ist eine Nenhildung im Nomente der Erschüttermg. Die hemorkenswerte Eigentümlichkeit hezicht sich num nicht blots ant die Achsenurgane. allein. sondern anch die halbwïchsigen und ansocewachsonen Blattstive zeigen das gleiche Verhalten. I)ie /uckerbildmog ist ïlurigens nicht an die Krümmmg gebunden, somblem von der Bewenme an sich ahhängig, mnd mit der Zuckerbildmg geht hänfig ein Ferschwinden der freien Säure Hand in Hand. Dafs Ersehütterungen die Transpirationsgrötse vermehren, beobachtete Frenuzi ${ }^{4}$ ) an Palmen und sulkulenten. nachdem schon frïher WIEsxer ${ }^{5}$ ) und EBERoT ${ }^{6}$ ) gezeigt hatten, dats der Wind eine Transpirationsbeschlemigung veranlatist. Dal's selbst selur geringe Erschüttermngen schon die Verdunstmugsoüse steigern. wurde von Koн ${ }^{7}$ ) und Bakanfazis ${ }^{*}$ ) gefunden. Betreff's der weiteren Literatm sei aut Bunciersteix velwiesen ").

Da man mm ans der örtlichen Vertalunü des /ucker's in den rewehen schlietsen kamn, dats er in dem Stoffwechselprozesse des Pflanzen-

1) Zww, W., Die Anatomie der Kiefernadel usw. Dissertation. Giefsen 1904.

2) (ismom, G., Beitrïge zur Blattanatomie usw. Dissertation, Basel: cit. Bot. Tahresber. 1902 , II S. 29:3.

3, Kinats, (;., Uher die Wasserverteilung in der Pflanze, II. Der Zellsaft und seine Inhalte. Sep.-Abur. aus d. Abbandl. d. Naturf.-Ges. zu Halle, Bd. XV: cit. Bot. Zeit. 1 $8 \times 1$, s. 389 .

4) Frmazi, G. Sulla traspirazione di alcune palmi etc.: cit. Bot. lahresher. 1899, II, ऽ. 124 .

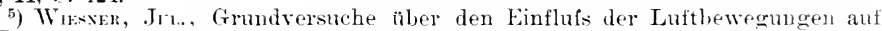
die Transpiration der Pflanzen K. K. Akad. d. Wissensch., Wien, 1s<. Bit. XCTI.

$\left.{ }^{6}\right)$ Eввиьт, O., Transpiration der Pflanzen und ihre Abhingigheit ron änfoeren Bedingungen. Marburg $1<-9,8.82$.

i) Koн., F. G., Die Transpiration der Pflanzen. Braunschweiq lati.

9) Baraxerzo, C̈bes den Einflufs einger Bedingungen auf die Transpiration der Pflanzen. Bot. Zeit. 15i2.

$\left.{ }^{9}\right)$ Brmansteix, Transpiration der Pflanzen. 1904 
leibes eine (wenn anch nicht ummittelbare) Vorstufe der Cellulosebildung ist. so wird man sich sagen müssen, dats mit der Erhöhmmg der Zuckerbildmg im windbewegten Pflanzenteil die Cellulosebildung und Zellwandanshildmg beschlemnigt werlen. Es ist verhältnismätsig selten, dafs Pflanzenteile anf' der Zuckerbildmgsstute in ihrer Entwicklumg stehen bleiben; viel hänfiger ist der Prozef's, namentlich am wachsenden Sprofs. dats der Zucker in dem Matse verschwintlet, als die Zellen dickwandiger werden. Wir werden also in der Deutme kamm fehlgehen, daf's die Krtimmmogen durch den Wind schneller incofern fixiert werden, als die konvexe Seite der Krümmma leichter Zucker und Cellulose bildet und mit ihrem Wachstum schmeller fertig wird, als bei einem nicht rom Winde bewegten Achsenteil. Bedenken wir, dat's für Licht- und Wärmewirkmng sich die Biegmngsstelle gïnstiger stellt, so ist das frühere Abschliefsen der Zellstreckmosperiode eigentlich selhstrerständlich. Der Zweig erliärtet früher mo wird nicht so lang; daher also der gedrungene Ban anf der Windseite mol die schlanke bis peitschenförmige Zweigbildmg der windgeschützten Seite.

Tat: Saatbeete und junge Pflanzmngen bei leichten Bodenarten bisweilen rerweht werden kömmen, dats flache Ackerkrumen durch plötzliche unvorsichtige Entfernung schützender Waldstreifen manchmal abgeweht und unfruchtbar werden, und datis man gegen alle die verschiedenen Windbeschärligungen am besten durch den Verhältnissen angepatste Schutzpflanzungen vorbanen wird, bedarf keiner eingehenderen Besprechung.

Wir kommen nummehr zu den Blattbeschädigungen, die durch Wind hervorgerufen werden. Dat's dort, wo der WFind sich häufig zum Sturm steigert, Blätter zerfetzt werden oder teilweise vertrockinen und dürr an den Zweigen hängen bleiben, ist eine, namentlich in Küstengegenden so hänfige Erscheinmug, dats hier nicht darauf einzugehen ist. Ebensowenig branchen die Verletzungen weiter berührt zn werden, die bei der Reibung der vorstehenden Blattkanten ${ }^{1}$ ) an sich eben entfaltenden Blättern entstehen. Besonder's häufig sind derartig durchgeriebene Stellen bei den gefaltet aufbrechenden Blättern der Rolskastanie und Buche zu finden. Anch jugendliche Zweige leiden durch Reibung, wie man dies bei jungen Trieben von Birnen und Tranerweiden (Salix bubylonica), nach Sturmtagen im Sommer beobachten kam. IHierher gehört ferner das Peitschen der Hopfenranken, wodurch die Hoptenkätzchen bisweilen notreif und rot werden ${ }^{2}$ ). Wichtiger, und bisher wenig beachtet, sind die dürren Blattränder. Ian muts dabei, weil viele Trsachen Blattranddürre hervorzurufen vermögen, unterscheilen, ob der vertrocknete und verfärbte Rand nur cine zusammenhängende orler anch stellenweis unterbrochene Saumlinie bildet oder ob noch von der abgestorbenen Randpartie diurre, verfürbte Stellen (häufig keiltörmig zwischen den Hauptnerven) in die Blattfläche hinein sich fortsetzen.

Nur dic trockne, sich lrämnende oder schwärzende Sammlinie ist als reine Windheschärligung anfzufassen, wie Hassen experimentell

1) Cuspan, Bot. Zeit. 1869, Sp. 201. - Mnsis, Verh. d Bot. Ver. f. d. Prov. Brandenburg. XVIII, s. IX.

2) Beobachtungen üher die Kultur des Hopfens. 1s\$o. Herausgeg. v. Deutsch. Hopfenbauverein. 
festgestellt hat ${ }^{1}$ ). Dieser Forscher hat sich einen eignen Apparat zur Erzengung von Wind konstruiert ${ }^{2}$ ), $u$ die bei don im Freien anttretenden Windbeschädigungen mitwirkenden Nehenfaktoren (Licht umd Wärmeüberschuts. Troukenheit) auszuschalten.

Aus den Versuchen ergab sich zunächst als Resultat, daf's das

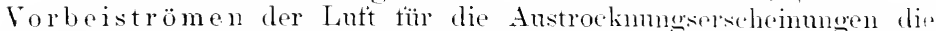
gionstigste Bedingmg ist. Blotser Stot's des Windes ant eine an fester Trand wachsende Pflanze ist häufig mschädlicher, mter Unständen sogar wirkmoslos, weil die ITand den Windstrom sofort zuriekwirtt

Bei den mit dem Apparat durchgeführten Versuchen kam eine Tas. und Nacht anhaltende Winctstärke zwischen 1 und 2 der Bestfortschen Skala zur Anwendumg. I)ic in Töpfen stehenden Tabalipflanzen zeiuten an einzehen Blättern bereits nach 24 Stmolen leichte Bränmmoen drr Ränder, während der übrige Teil der Blattspreite völlig gesumd bliel, und keine spur von Welken erkemnen lieds. Durchsehnittlich litten die ansquebildeten Blätter eher als die jüngsten. Stets begam die Vertrockmmo der Gewebe in der Nähe der dümsten Rambnerven. Das Mesophrll collabierte, wurle aber nicht lufthaltig. sondern sah vielmehr durchsichtig "wie injiziert" aus. Der Zellinhalt war deformiert : die C'hlorophyllkörner waren nicht mehr dentlich zu erkennen. In manchen Zellen zeigte das Protoplasma schwach häunliche Kömnchen. Ire Lacitbïnclel rwiesen sich stark oehrämut. Tie Grenze zwisehen vertroeknetem und gesumdem Gewebe war schart und

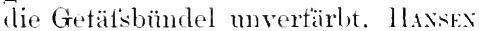
rrklärt sich das / hustandekommen der Beschädigmo in ter Weise, .. dats die diumen Getälshindel durch
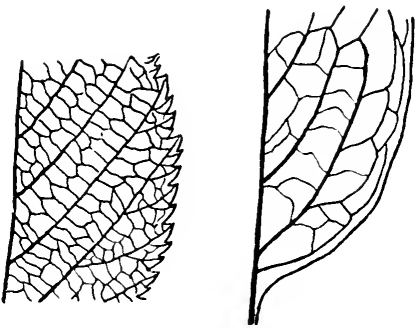

Fig. 96 .

Craspedolrome Camptodrome (Nach Bнгск). den Luftstrom zuerst ihres Massers beraubt und dadurch so verändert werden, das sie das Wasser nicht mehr leiten. Dadurch rertrocknet an dieser Stelle das Mesophrll". I)ies wäre also der sekmuläre und das Absterben des Leitumgsstranges ler yrimäre Vorgang, während man bis jetzt wohl meist das Vertrocknen des Randrarenchrms als direkte Wirkung antgetatist hat. Jemgegenïber sagt Hossex: . Wollte man annehmen, dor Wind gritfe das Mesophyll direkt an, dann wäre nicht zu verstehen, warmm der Vertrocknungprozels nicht anch mitten ant rer Lamina hegimen sollte".

In derselben Anschammoswerse bewegt sich die Arbeit von Broch ${ }^{3}$, welcher beobachtet hat, dats im allgemeinon nur diejemigen Bläter di*

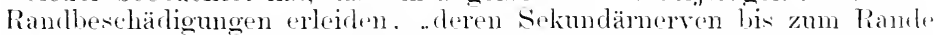
verlauten, sogenamute (rasperlodrome oder cheilodrome (randläntiene)

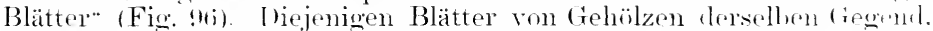
welche die Beschädigmo nicht zeigten, hatten ,mehr odr.r wenigrer

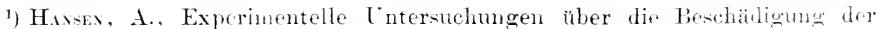
Blatter durch Wind. Flora ofer Allgem. Bot. \%eit. 1904, Bul $93, \mathrm{H} \cdot \mathrm{ft} 1$.

־) Ber. d. Deutsch. Bot. Gies. 1944. Bd. XXII, Heft 7, s. :izl.

?) Britk. W. F., Kur Frage der Windbeschädigungen an Biattem. Boihefte z. Bot. Centralbl. Bd. XX, Aht. '2. 'iep. 
camptohlome, resp. brochidodrome Nerratur: sie verlanfen bogenläufig oder schlingläufig, ohne im Blattrande zu cneligen." In letzterer Anordnung der Nervatur erblickt Bruck einen entschiedenen Schutz der Blätter vor Austrocknung durch Winde. Wie Braunfärbung der Gefätsbïndel ist der durch Frost hervorgerufenen sehr ähmlich.

Nach den Studien, die ich üher das Entstehen dürrer Sammlinien an Blättern infolge der Einwirlsung saurer (tase gemacht habe, wäre der Vorgang rles Sterbens labei ein anderer. Bei Einwirkung der Ranchwase wird das Gewebe nicht rorher durchsichtig, und es färben sich die Trandmgen der Bastelemente gell, his lram : der /ellinhalt trocknet als nahezn gleichmälisige Substanz in seiner Gesamtheit zusammen. Die Getätsbündel der Randzone sind anch alteriert, aber ich erkläre mir das frühere Absterben des Blattmesophylls an den Rändern dadurch, dat's selbst, wem die feinen Gefätíbündelendigungen noch Wasser in der normalen Menge zuführten, dies doch nicht genügte, den durch die Säurewirkung gesteigerten Wasserverlust zu decken. Ebenso dürfte es bei den trockenen saumlinien der Windbeschädigung sein. Es kann sehr wohl die bei Wind gesteigerte Verdunstung des Mesophylls der prinuäre Vorgang sein. Am Blattrande ist der. Wasserverlust darum relatis grötser, weil im Verhältnis zur Gewebemasse die Oberfläche zu grots ist und das wasserleitende Srstem aus zu wenig Elementen besteht. also zu gering ist. An den stellen, wo las Blatt dicker mo die Nervatur stärker entwickelt ist, werden die Gewebe erstens mehr Wasser empfangen und zweitens mehr behalten, da hier dieselbe verdunstende Oberfläche wie am Blattrande viel mehr sattiges Parenchrm hinter sich hat. Daher sehen wir die (tewebestreifen dicht an den stärkeren Blattnerven zuletzt sich verfärben und vertrocknen.

Nachdem man den Windbeschädigungen gröfsere Aufinerksamkeit zuwendet, erhelıen sich auch Stimmen, welche eine Anzahl auffälliger. bisher nicht genügend aufgeklärter Erscheinmogen als Windschaden bezeichnen. So führt beispielsweise Lüstsen $^{1}$ ) die sogenamute Mombacher Aprikosenkrankheit anf den Einfluts des Windes zurïck. Die in Mombach hei Mainz endemische Krankheit äufsert sich darin, lats die Blätter der Aprikosenbäume ron der spitze oder dem Rande her vertrocknen und abfallen. Bisweilen wird der allein vertrocknete Blattrand abgestotien und der Rest des Blattes bleibt am Bamme. Brick ${ }^{2}$, fatst die Krankheit als Folge von sommenbrand aut.

Bei Gartenkulturen ist of der Schutz gegen die raule n Frïlnjahrswinde notwendiger als gegen Frost. Beispielsweise beobachtete man in April 1905, dat's junge Rhabarberblätter, die den Frost vertragen, wenn sie umberührt langsam auftanen, sich stark heschädigt zeigten, soweit die gefrorenen Blätter vom Winde getrotfen worden waren. Ebenso wurden junge Rosentriebe nur dort verletzt, wo der WVind sie hatte fassen lönnen. Während in windstillen Lag®n junge Gemüse und Blmmenpflanzen tadellos standen, waren sie dort rerdorhen, wo der Wind freien Zutritt gehabt ${ }^{3}$ ). Ant'ser der Steigermo der Verdunstungsorötse spricht hier sicherlich die gegenseitige mechanische Reibung der noch zarten Organe auschlaggebend mit.

1) Listixa, Beobachtungen über die sogen. Mombacher Aprikosenkrankheit.

Ber. 1. Kigl. Lehranstalt zu Geisenheim am Rhein. Berlin 1904, S. 222. Paul Parer.

-) Bик а. а. O. s. 74 .

3) Bimsis, Jum., Rauhe Winde. Prakt. Ratgeber im Obst- und Gartenlau 1905, Nr. 8 . 
Als bedententer sichädiger wirkt ferner dor Wind durch Abwehen der śchmeedecken. Saaten der verschirdensten Art whalten sich in Furchen ant der dem Winde abgekehrten sirite, sollst bei minimaler schmeebedeckung, während sie ant der Windseite zugrumb gehen.

Zur Milderung dor WVindschäden kamn nur oine rivhtig anfgebante schutzpflanzmog dienen. Unter dem richtigen Anflan meinen wir erstens die Nachalmmng des Systems, das clie Natur an den sitranlgebieten selbst befolgt, und zweitens die richtige Answahl der (rehölze.

Ias natürliche System besteht darin, dats hei IJechen die niedrigst bleibenden Gestränche nach der Windseite hin gepflanzt werden: sir kïmmern oder sterben zwar anch in ilnem //weigwerk anf der Angritt seite al): aher diese dïrren Äste brechen dam schon die Gowalt dx Windes nud lassen die abgewendete sicite zur Entwicklung kommen. Wem num dahinter höhere Sträucher gejflanzt werden, so bleiben dieselben schon so lange geschützt, als die Höhe der ersten Vorptlanzmng reicht. Kommen sie darüber hinaus, wird ihr Wacistum liümmerlich und einseitig, aber immerhin erheben sie sich etwas höher und gewähren einer dahinter gepflanzten Bammart wiederum Schntz, his hohe Bäums endlich zur Entwicklung kommen kömnen.

Dort, wo Versand ung mit in Betracht gezogen werlen muls.

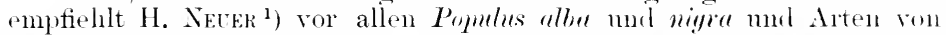
Salis. Als Zwischenptlanzen gedeilien noch Ailonthus glamelulosen mul lihus Cotimus. Von Stränchern sind besonders Lignestrum vulyur,

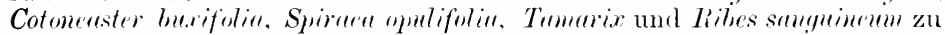
emptehlen. Von Zierptlanzen verwende man in erster Linie Pelargonien, Cluyanthemen mul Lakoyen.

\section{Zehntes Kapitel. \\ Elektrische Entladungen.}

Blitzschläge.

Trotz zahlroicher Beschreibungen von Kerstörungen der PHanzenwelt durch Blitzschläge sind wir zu einer genauen Konntnis über die Wirliungsweise des Blitzes noch nicht gelangt. Wir werden, wie bei den Frostheschädigungen, mit denen die vom Blitz hervorgerufenen Verletzungen vielfach Ähulichkeit zeigen, eine mechanisclue nud eine chemische Wirkung auseinander zu halten haben, und hei dem Blitzschlag diurte die mechanische Wirkung die weitans rorherrschende sein. (Cons ${ }^{2}$ ), dem wir eine /usammenstellung von 41 Blit schlägen und reiche Literaturangaben verdanken, ist der Meinumg. dat's. wem der Blitz in einen Bam gelangt ist, der Itauptstrom der Elektrizitä nach Durchbrechung der Rinde in der gut leitenden Cambialschicht weitergeht: die ,hierdureh sich entwickelnde Erwämmung virdamptt augenblicklich die in den ('ambiumzellen enthaltene Fläs-ighit gavz ofler zum 'Teil: der gespannte Dampt wirt' die Rinde mit der

1) Ntrut, H., Neue Erfahrungen über Aulagen und Pflanzungen an dor Nordsefküste. Die Gartenwelt 1904, Nr. 49.

2) Conx, Ein interessanter Blitzschlag. Verh. d. Katis. Leop. ('arol. Akan. il Naturf. Tol. XXVI, P. I. - Üher die Einwirkung des Blitzen atlif Bitumt. Denkschrift a. schles. Ges. f. vat. Kultur $185 ;, 2.267 \mathrm{ft}$. 
laran hängenden Bastschicht ganz oder in einzelnen Fetzen oder Streifen ab". Die Bruchstüclie findet man häutig ant wrofe Entfernungen him fortgeschlendert. Neben diesem Hauptstrome wäre ein Nebenstrom lureh den schlechter leitenden Holzkörper die Veranlassung der Holzspaltungen, die an den Orten der geringsten Festigkeit und zwar infolge einer plötzlichen Austrocknung durch Terdunstmog des Saftes entstehen. scomit wären nach der CoHs schen Anschanmg weder Holzspalt noch ler abgelöste Rindenstreiten als \%eichen für die Balm des Blitzes anzusehen, sondern lediglich als die Region der geringsten Widerstände zu deuten. Ich möchte dagegen mit Cassilir glauben, dats der schmetterstreiten die tatsäthliche Blitzspur ist.

Die Vermutung von Cons, datis eine starke, plötzliche Iampfbildung durch Verdmstumg der vom Blitz getrottenen Gewebe das explosive Fort. schlendern der Rinden und Holzsplitter veranlasse, war ihm durch man-herlei Erscheinnngen nahe gelegt worden. Zmü̈chst findet man wirklich stark ausgetrocknete Splitter: sie gelangen nur darum wohl selten zur Beobachtmo, weil die frewitter in der Regel von Regengüssen begleitet sind, die die ansgotrotkneten Späne sofort wieder nässen. Anch die Erscheinung, dats Bämme durch den Blitz entzïndet werden, spricht für die austrocknende. Wirkung dessellxen. Es muts hierbei jedoeh wleich bemerkt worden, dats bisher kein Fall mit sicherheit konstatiert worden ist ${ }^{1}$ ). in welchem durchaus gesunde Bäume in Brand qeraten wären; viehmehr zeigen die meisten Beobachtungen, dats eine Entzündung nur bei kernfanlen stämmen zustande gekommen ist.

Für die Art und Weise der Blitzl,eschädigung ist neben der Intensität des stralıles jedenfalls die Individualität des Baumes von grofsem Einfluts. Man findet, dats die einzelnen Bammarten vielfach übereinstimmende Verletzungen zeigen, und dats gewisse Arten ganz besonders, andere sehr selten dem Blitzschlag ausgesetzt sind.

Betreft's der Charakteristik der Verletzmngen läbit sich zunächst angrehen, dats zwar dip Mehrzahl der Fälle eine Blotslegung des Holzkïrpers durch abgesprengte Rinde zeigt, las aber bei gut leitenden Arten und jumgen Exemplaren Blitzschläge vorkommen, die gar keine sichtbare Verletzung hinterlassen. Bei len Pyramidempappehn schlägt ler Blitz in der Regel nicht in die spitze, sondern tiefer abwärts am stamm ein, so dats der grötste Teil der Krone mverletzt bleibt, und geht in einem graden oler nur wenig spiralig gewundenen schmetterstre if en stammabwärts. Holz- und Rindensplitter werden abgesprengt; an den Rändern des schmetterstreifens ist die Rinde vom Holze abwehoben, die Ränder sellst sind unverfärlst. Bei den Eichen dagegen wird öfter der. Wiptel getrotten, und es werlen häufio ans der Krone starke Aste getötrot mul ahgeschlagen. Der Schmetterstreifen zeigt meist stark spiralige Irehme:- am Stamme, dessen Holzkörper eime mehr rimenartig ansgehöhltr Blitzsum zeigt, während bei der Pappel scharfkantige sialten don Virlant des strahles andenten. Namentlich bei Eichen rzengt der Blitzschlas neben radialen auch viele tangentiale rerkiöttumgen in dor Richtmug des Jahresinges. Jedenfalls hängt die Riclitung and trestalt des schmetterstreifens rom Holzban ab. Jo

1) Caspar. Mitteilungen ïbor rom Blitz getroffene Bäme und Telegaphen-

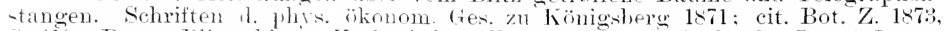

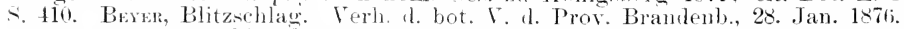

$\because$ Bunexu, Alhanill. A. naturwis. Ter. zu Bremen, Bd. VI. - schriften d. Leopolil. Akad. d. Naturf, Bil. XXYIII. 18ti7. 
spiraliger der Verlaut der Holzfaser, desto mehr dreht wich auch der streiten. was sich taraus erklärt. dats der Blitzstrahl tem Wege ter besten Leitung tolgt. Bei der nebenstehenden. von E. Bromexat beoluachteten.

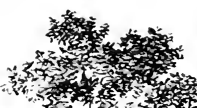

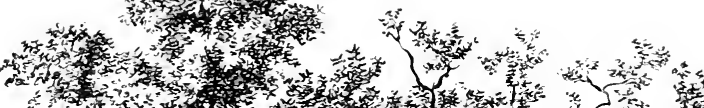

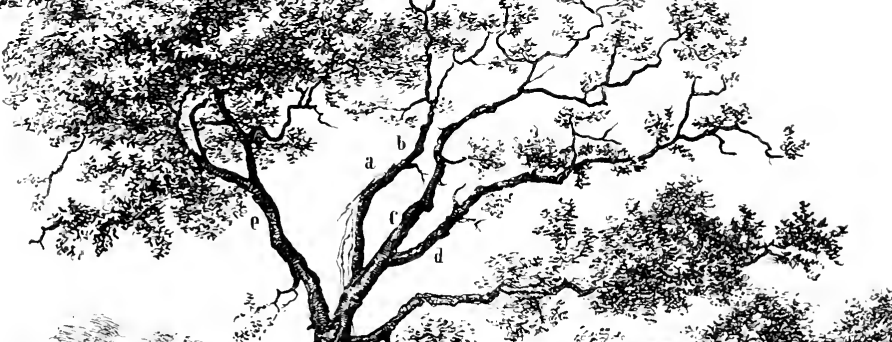

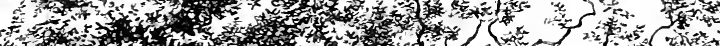

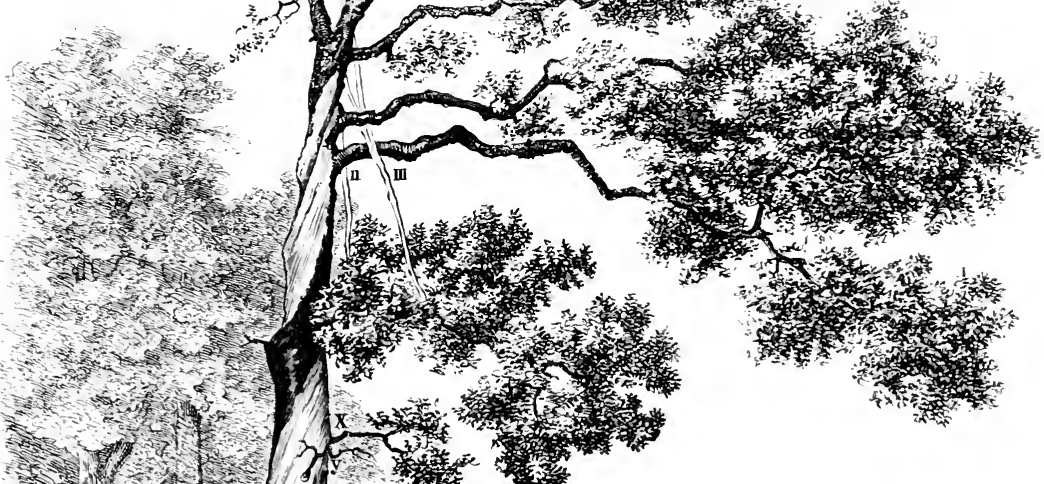

Fity

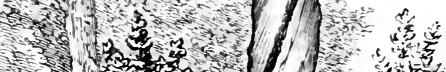

f.

ntw (3)

A

Fig. 97. Vom Blitz getroffene 2:3 $\mathrm{m}$ hohe Eiche.

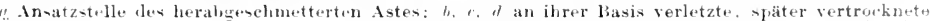

Aste: , unverletzt grebliebenter A-t: $/ I$ und $/ I /$ herabhäugende Holzfetzen: it und "f in sillint l,

shäliute Astehen. (Nach NoBzE.)

von Nobbe ${ }^{1}$ ) wiederogentenen Eiche (Fin. 97) zeigt sich der spiralin

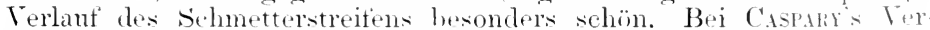
suchen über die Wirkung des Entladungstunkens einer mit on Tm-

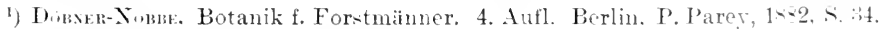


drehungen geladenen Leidener Flasche bestätigt sich die von Viluaki gefundene Tatsache, daf's der elektrische Funke im Holz in longitndinaler Richtung eine viel längere Strecke durchschlägt als in transversaler. Aufserdem zeigt sich, daf das Holz in tangentialer Richtung lem Funken gröfseren Widerstand leistet als in radialer. Das Verhältnis der Schlagweite in longitudinaler, radialer und tangentialer Richtung betrug nach CASPARY bei frischem Lindenholz 19: 2: 1, bei trocknem Fichtenholz $7: 2: 1$. Immer zerrits das Gewebe in der Bahn des Funkens und wurde eine weitgehende Zerstörung des Zellinhaltes infolge der Hitze wahrgenommen.

Diese Folge des Blitzschlages dürfte überall nachweisbar sein, und in den Fällen, in denen änfserlich keine Verletzung erkennbar, dürften doch eng begrenzte, leicht übersehbare Eintrittsstellen des Blitzstrahls niemals fehlen. Colladon ${ }^{1}$ ) beobachtete auch z. B. bei einer Pappel und Fichte anf den von der Rinde entblötsten Flächen besonders charakteristische, kreisrunde Stellen, die infolge sehr starker lokaler Anstrocknong des jungen Holzes entstanden zu sein schienen und durch konzentrische, dunkelgelbe und brame Ringe gefärbt waren. Es sind anch noch eine Anzahl anderer Fälle bekannt geworden, in denen kreisrunde, kleine Flecke anf Eintritt- oder Austrittstellen des Blitzstrahls hindenten.

Besonders anschauliche Abbildungen der verschiedenen Arten der Blitzbeschädigungen gibt $R$. HarTia in seinem Lehrbuche ${ }^{2}$ ). Er führt die Terschiedenartigkeit der Blitzspuren auf die moleiche Leitungsfähigkeit der Gewebe und anf den Grad der vorhandenen Befenchtung derselben zurück. Wenn ein Baum beregnet ist, „dringen schwache Blitze gar nicht in dessen Inneres ein, sondern reifsen nur Borkenschuppen, Flechten und trockene Äste ab. Bäume, die eine ganz zarte Korkhaut haben, wie z. B. die Weilstanne, lassen nur in den äufseren Rindengeweben zum Teil höchst merkwürdige Blitzspuren erkemnen. Es werden oft nur kleine, rundliche, isolierte oder in Zickzacklinien

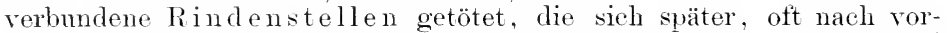
gängiger Korkbildung, von der lebenden Rinde des Banmes loslösen." Bei Bäumen mit starker Borke muls der Blitz erst diese schlecht leitende Hülle durchschlagen, um in die gut leitende Rinde zu gelangen; als besonders gut leitend sieht HarTig die äufere Rindenschicht an, die .. arm an Fett ist", während das protoplasmareiche, in der Regel viel Fett enthaltende Gewebe der jüngsten Rindenlagen, wegen seines Fettgehaltes sehr schlecht leitet und oft rom Blitz ganz verschont bleibt. Das beste Leitmngscewehe ist das nur noch sehwachen Plasmabelag zeigende Jungholz, das auch gegen Frostbeschädigung sehr empfindlich sich erweist. Wenn (bei kräftigen Entladungen) der Cambiummantel mit geschädigt wird, erfolgt eine "innere Überwallung“.

Die Anschanmg von der Beeinflussung der Leitungsfähigkeit der Gewebe durch ihren Fettgehalt stützt sich auf die Arbeiten von .Jusescu ${ }^{3}$ ). Dieser fand, dats der elektrische Funke durch frisches Holz

1) Contum, Die Wirkung des Blitzes auf Bäume; cit. Biedermanns Centhl. 1873, S. 153 . Bot. Z. 1 s.. S. 686.

2) R. Hanti, Lehrbuch d. Pflanzenkrankheiten. III. Aufl. 1900. Berlin, J. Springer.

3) Joxescr, Dmmme, Über die Trsachen der Blitzschläge in Bäumen. Tahresb. d. Ter. f. vaterl. Naturkunde in Wirttemberg. 1892. Schweizerbartsche Verl. Weitere Untersuchungen üher die Blitzschläge in Bäumen. Ber. d. Deutschen Bot. G. 1894 , S. 129 . 
um so schlechter durchschlng, je reicher dasselbe an tettem öl war. Die Unterschiede z. B., tie sich auf gleichem standort zwischen der selten vom Blitz getroffenen Buche und der äutserst häufig heimgesuchten Eiche ergaben, erklärte der mikroskopische Befund: die Holzzellen der ersteren waren mit öl versehen, die bei der Eiche nahezu ölfrei. Andere ..Fettbäume* thei denen sich im Winter und Frühjahr dif gesamte stärke in (i) verwandelt), wie z. B. Juglans regiu,

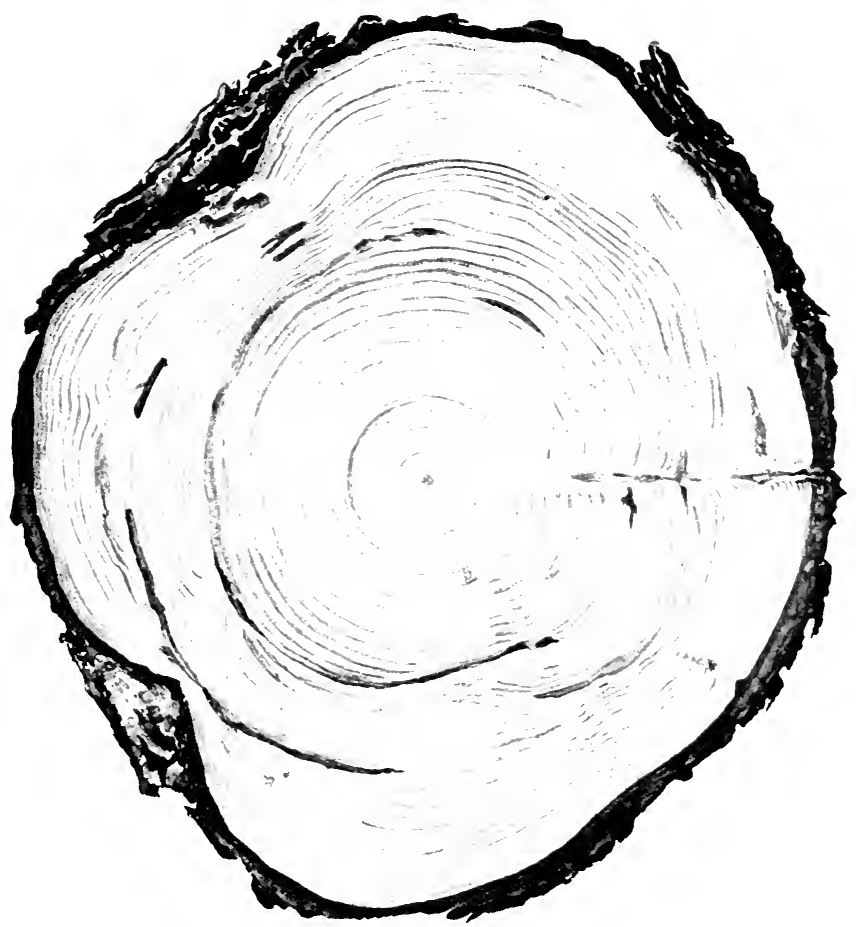

Fig. 95. Querwhitt durch eine Fichte mit zahlreichen äberwallten Blitzwunden. (Nach R. Hiktir.)

Tilin purvifoliu, Brtulu. Pinus erwiesen sich auch als schlechto Leiter

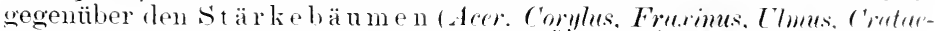
gus usw.). Wurle ans Fettbänmen das iil mit Äther ausgezogen. so durchschlug der Funke die trishen Holzstionder elenso leicht al bei trpischen Stärkeläumen. Man dart bei der Bemetrilune dieser Verhälnisse aber nicht veroesen, dats der ölgehalt hei den einzehen Bammarten je nach der.Jahreszeit sich ändert: darans roilht sich, dati anch die elektrisehe Leitungtahigkeit wechselt. Bui glocherotsen 
Stammstücken ron Tilia parvifolia fand Josesce, dafi im Februar, wo Holz und Rinde ölreich sind, eine viel höhere elektrische śpanmung nötig war, als Ende März, wo das junge Holz mit Stärke mol Glykose angefüllt sich zeigte. Umgekehnt war as bei der Buche, die im .Januar his April stärkereich, im Mai dagegen öheich sich erwies, ebenso wie Kiefer, Rottamme, Hainbuche mol stieleiche. Die Kiefer wird bei unsern Sommergewittern ziemlich oft getroffen; sie enthält zu dieser Zeit in Holz, Rinde mol Mark Glykose, in den Markstrahlen stärke. Aber im Winter besitzt der Bam viel fein zorteiltes Ö) und es zeigt sich, dats in Ländern mit Wintergewittern (Irland, Norwegen) der Blitz fast nie in Kiefern einschlägt. Diese Differenzen in der /usammensetzung des Zollinhaltes aber treten in den Hintergrund, wem der Stanclort eine hohe elektrische spammng veranlafst, wie z. B. wemm ein Bam auf molurchlässiger Bodensehicht steht, wo sich Wasser angesammelt hat, oder an Flufsufern, Teiehen usw.

Dem Wassergehalt des Holzes ist nu wenig Bedentung fï̈r dir Häufigkeit der Blitzrchläge beizmmessen.

Der elektrische Funke sucht bei hoher Spammng sich den kürzesten Wog mud sehlägt damn anch dmoh schlechtere Leiter.

Manchmal wird ein Bam in Lanfe der. Jahre wiederholt vom Blitz getroffen, und es kommen damn Fälle vor, dats ein Stamm ant der ganzen Aut'senseite ringsherum kleine, rundliche oder längliche Blitzspmen zeigt, so dats man Hagelschlag vermuten kömnte. Hartir (a. a. 0. s. 241) meint aber, dafs die charaliteristische Gestalt der Blitzsewebe im . Jungholz jerlen /weifel heben kam. Ein solches Bild wiederholt erfolgter mil geheilter Blitzwnuden zeigt die mostehende Fig. !s. Eine ähnliche stammbeschaffenheit kömnte anch anf Frostwunden hindenten; nur fehlen hier die vorspringenden Frostleisten. Sionst zeigen aber auch die anatomischen Gewebereändermoen, die hei der Heihmo von Blitzwnden im splinte sich einstellen, eine äntserst grotse Ähnlichkeit mit jener Parenchymholzbildumg, welche nach Frostheschädigung sich einzustellen ptlegt. Indem wir bei letzterer näher claranf eingehen werden, geben wir hier nur für späteren Vergleich die Kopie einer von R. Haktri gezeichneten geheilten Blitzwnde, welche v. Tubeuf nenerdings reproduziert hat ${ }^{1}$ ). Tir erblicken in der untersten derbwandigen 'Trachë̈lenschicht (Fig. (!!) den Abschluts des vorjährigen Jahresringes. Ler nene Jahresing hat mit der Bildmng diunnwandiger Elemente lragomen mol ist zurzeit, als die zelmten bis zwältten Sommertracheïlen angelegt worden waren, vom Blitzstrahl getroffen worden. Die Wirkung desselben bestand darin, dafs die jüngsten Holzelemente, wie durch eine tangentiale Zerrung, schief verschoben, zusammengedrückt und zmm Teil getötet worlen sind. während die lebensfähig gebliebene Zelllage sich zu Parenchymholz ausgebildet hat mol erst allmählieh wieler in kleinzelliges normales Holz übergegangen ist.

lieselben Torgäng zeigen die verheilten Frostwunden: nur findet sich in der Regel die abmorme Parenchymholzlage näher am alten .Jahresting. Ileser Unterschied ist erklärlich, da die Störmm durch die Spätföste schon zu einer Keit aufzutreten pflegt, in welcher die Bämme noch wenig nenes Holz gebildet haben, während die Blitzheschädigmgen erst später im .Jahre durch die sommergewitter entstehen.

1) v. Trmer, Über sogenannte Blitzlöcher im Walde. Naturw. Zeitschr. f. Land- U. Forstwirtsch. 19i6, s. : 449. 
R. H.sтui betrachtet das Zustandekommen des zusammengefallenen (iewebestreifens nicht als direkte Folge der Blitzwirkmo: dem er sagt ${ }^{3}$ : , Wenn der Blitz seinen Weg in Jungholz ganz oder teilweise genommen, so erkennt man dies daran, dats die Zellon muerholzt heihen und durch die später entstehenden Gewobsbildnugen znsammengedrückt

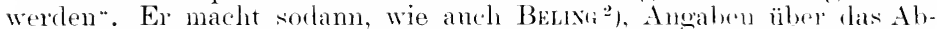
sterben ganzer Bammormpen mol fand ${ }^{3}$ ), dats an den rom Blitzstrahl getroffenen Kiefern mud an zahlreichen Nachbarstämmen der Bast lï̈rper getötet erschien. Derselhe Beobachter rrwähnt and rincn Fall, bei welchen in einem gemischten Fichten- und Eichenforsts mit rorwïchigen Firhten nur die unterdrücliten (12) Eichen Blitzwhlïge er-

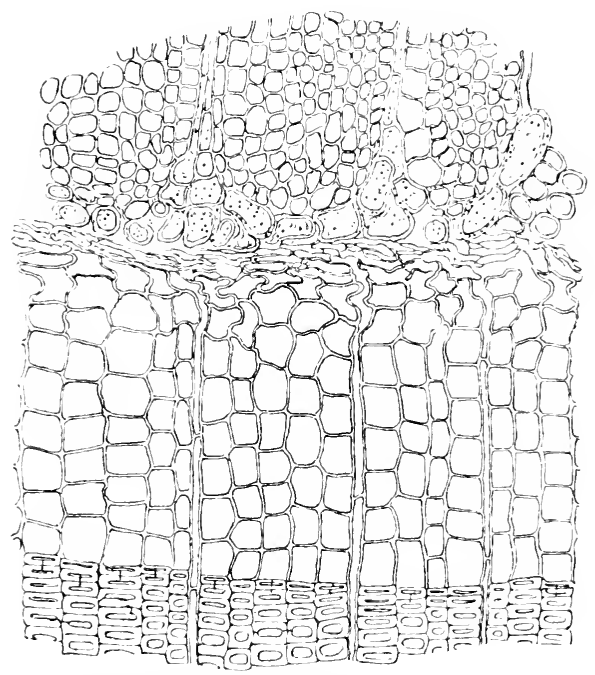

Fig. 99. Querschnitt durch den Jahresring des Blitzjahres bei einer Fichte.

Oie zerknitterte Zellschicht zeigt die Blitzwirkung. (Nach v. Tolstr.)

kemen lietsen, während die Fichten vällig verschont gehibehen waren. Tafis in gemischten Beständen die Eichen hesonder's häntig rom Blitze leiclen. ist öfter ausgespochen worden: chenso datis anch andere, nicht

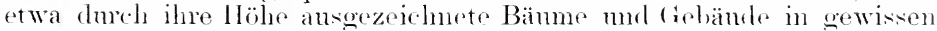
Lokalitäton dem Blitzstrahl vorzugsweise zmm (0,tior fallen ${ }^{4}$ ).

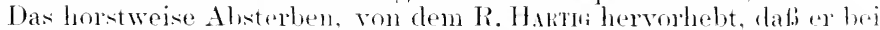
Kiefernbeständen im Lante von tïnt Jahren oin radiales For tse hre it en der Erscheinumg heohachtet hahe ist nenerdings von v. Trbect stuliert

1) R. Honn, Lehrbuch der P'flanzenkrankheiten. III Aufl. 1900, s. ㄹ⒉

2) Zeitschr. f. Forst- u. Jagdwesen, Nov. 1-7:3. ‥ 191 .

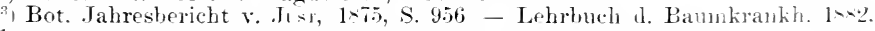

4) Landwirt 1>75, s. 400 u. 513. - Gard, Chronicle 1-7- II, \& if6i. 
worken $\left.{ }^{1}\right)$. Er heschreibt einen Fall, in welchem nur eine Lärche sichtlich vom Blitz getrotfen worden war und democh eine gröfsere Anzahl der sie umgebenden Kiefern und Fichten abzusterben begamn. Die Lärche zeigte einen am Stamm herablanfenden, morbrochenen schmetterstreifen, die Krone blieb grün. Die Bäume der Ungebung wiesen keine örtlichen Verletzungen auf, waren aber in einem Halbkreis ron 25 an abgestorben. Derartige Fälle sind rielfach bekannt geworden. In einer früheren Veröftenthichung s) spricht v. Tuberf dic Termutung ans, dats ein solches Absterben grotser Bammgrupen durch .streublitze" veranlatst werde, also durch Zerstremug des Blitzes in

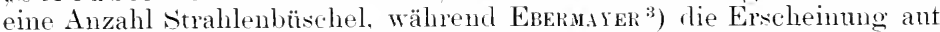
das Zustandekommen eines in neren B litzschlages durch plötzliche Vereinigung getrennt gewesener Elektrizitäten zurïckfülnt. Die Gewitterwolke trennt durch Influenz die entgegengesetzten Elektrizitäten im Baume: die nngleichnamige zieht in den oberen Teil, während die andere (gleichnamige) in die unteren Teile hinabdringt. „sobald num der Blitz einschlägt, fällt die Ursache der Scheidung beider Elektrizitäten innerhalb der in der Nähe befindlichen Körper weg, und es verbinden sich diese in demselben Augenblick plötzlich wieder miteinander". Auf Grund seiner künstlichen Blitzversuche rermag r. Tubeuf sich dieser Ansicht nicht anzuschlietsen. Bei der Untersuchung ron Bämmen ans Blitzlöchern fand er doch an einem oder dem anderen Stamme "grobe Blitzverletzungen", und da andere Ursachen des Absterbens (tierische und pilzliche Feinde) ausgeschlossen sich erwiesen, kam er eben zu der Anschaumng, dats "Streublitze" existieren müssen. Eine Zweiteilung des Blitzes wurde von dem Forstmeister Petzoli im Forstamt sachsenried beobachtet ${ }^{4}$ ).

\section{Gipfeldürre der Nadelhölzer.}

Im Jahre 1!n: beschrieb v. TrberF ${ }^{5}$ ) mter Beifügung zahlreicher Abbildungen einen Fall von sehr ausgedehnter Wipfeldürre bei Nadelhölzern in Öberbayern. Die Beobachtming tährte zu dem Schlusse. dafs nur eine einmalig wirkende Ursache im Winter 190102 vorhanden gewesen sein kann, und dat's sie in dem elektrischen Ausgleich bei Wintergewittern gesucht werden muts. Das charakteristische Merkmal ist die Art des Absterbens. In der oberen Region des Bammipfels sind Rinde, Bast und Cambium tot. weiter abwärts nur Rindenteile autserhalb iles ('ambiums abgestorben, so dats dieses wälnend des Sommers noch Bast mul .Jungholz bilden kounte. .Der weilse, weiche Bast liets sich demmath leicht rom saftigen Holze ablösen wie an gesunden Bämmen. An den neugebildeten Bast schlof sich die tote Rindenzone, und autserhalb derselben war die orïne Rinde wieder lebend. In dieser grünen Rinde verliefen vieltach von Kork eingekapselte streifen toten frewebes. Noch weiter nach miten waren die

1) v. Trumf, Über sogenamte Blitzlöcher im Walde. Naturwiss. Z. f. Landu. Forstwirtseh. 1906, s. SH.

2) Absterben ganzer Baumgruppen durch den Blitz. Naturwiss. Z. f. Landu. Forstwirtsch. 1905, s. 493. Dort auch weitere Literaturangaben.

3) Emermarer, Wall und Blitzgefahr Naturwiss. Rundschau. 1889.

4) Beobachtungen ïber elektrische Erscheinungen im Walde. Naturwiss. Z. f. Land- u. Forstwirtsch 1905, s. 308 .

$\left.{ }^{5}\right)$ v. Tumst, Die Gipfeldüre der Fichten. Naturwiss. Z. f. Land- u. Forstwirtschaft. 190:3. No. 1. Fortsetzung iljid. No. 7, ४. 
getöteten Bast- und Rindenteile nicht mehr stammumfassende Bänder. sondern sie zerteilten sich in Streifen; endlich fanden sich nur noch tote Flecke, und einige Meter unter der Bammitze rerlor sich jedes Krankheitszeichen, der freie Stamm und die Wurzel waren vollkommen gesmud." (Fig. 100.) In der beistehend ahgehildeten scheibe einer gipfeldürren Fichte ist die Rinde sehlietslich blof's an einiom Stellen in zusammenhängenden Streifen von antsen herein getötet. Sonst finclen sich im Rindemmantel nur noch zerstrent kleinere Herde von gelräuntem (iewebe. Da dieselben mitten in der lebenden Rinde liegen, sind sie ringsum von einem weitsen Korkmantel eingekapselt. Der Bastring erseheint gebräunt, aber an einzelnen Stellen von gesundem trowebe unterbrochen.

Die Übereinstimmung dieser Merkmale mit den von R. Hortur als „Blitzspuren" beschriebenen Verändermgen begründeten bei r. Trвer'F die Ansicht, dat's diese weitverbreitete, plötzlich an vielen Individuen anfoetretene Wipfeldürre eine Folge elektrischer Einwirkmng sein müsse. Das Bedenkliche, anf das der Antor selbst aufmerksam machte, ist, dat's die Blitzschläge meist unterhalb der Krone einsetzen und den Stamm verletzen, aber die Krone unverletzt lassen: in anderen Fällen hat man wohl ganze Bäume absterben gesehen, aber niemals die Krone allein. Gegenüber den anderweitic erhobenen Einwendungen, dat's diese Wipfeldürre durch Borken-

käferfrats oder Wicklerrampen (Grapholithe pactolana) veranlatist worden sei ${ }^{1}$ ), betont v. Tubeuf, dafs die Bäume die Krankheitsmerkmale anch ohne Borkenkäfer zeigen und diese. wohl angelockt durch den Terpentingeruch, erst sekundär anf-

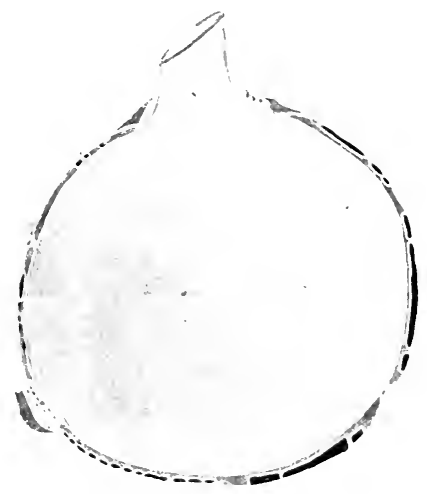

Fig. 100. Querschnitt durch eine gipfeldurre Fichte aus dem Forstamt Stamberg. (Nach v. Tentr.) treten. Einzelne Kiefern und Lärchen verhielten sich wie die Fichten. Das bei den hlitzbeschädigten Fichten anftretende Ansstrahlen des Absterbens in Form branner Pindenstreifen mit Korkmmwallmngen innerhalb der sonst grün mond frisch bleibenden Rinde muterhall, des abgestorbenen Wiptels. komnte $v$. Truel's' weder an Bämmen finden (Fichten und Kiefern). die mechanisch algelmorhen. geknickt oder abgebissen. noch an solchen, die erfroren oder von einem Insekt getötet worden waren.

Weitere Untersuchungen ${ }^{2}$ ) ergaben die Identitat der anatomischen Derkmale der wipteldüren Fichten mit denen, welche bei Bämmen gefunden werden. an denen der Blitz äusere Verletzungen hervorgerution hat. Die Hauptstiitze aber liegt in der Tatsache, dats v. Tirser mul

1) s. Mirt.er in Zeit.schr. f. Forst- u. Jagdwesen. 1904, Heft S.

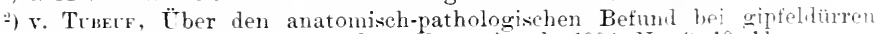
Nadelhölzern. Naturwiss. Z. f. Land- u. Forstwirtsch. 190:3, No. 9, 10, 11. 
ZEHXER ${ }^{\mathbf{1}}$ ) durch experimentell erzengte Funkenströme imstande gewesen sind, sowohl die äutsere Erscheimmg tler Wipfeldürre als anch ganz die gleichen anatomiseh-pathologischen Folgeerscheinungen, namentlich die toten "Rindenangen", die von einem weitsen Korkmantel eingeliapselt sind, am lebenden Stamme hervorzurufen. So lange also nicht nachwewiesen werden kamn, dafs andere Trsachen dieselben Symptome erzengen, wird man daran festzuhalten haben, dats die beschielene Art der Gipfeldüre eine Folge elektrischer Entladungen ist. Dieselben dürften an und für sich schwach sein.

Dagegen zeigten Laubhölzer (wie Herr v. Tıвғь mir vorläufig brieflich mitteilte), weder in der Natur noch bei seinen Tersuchen jene weit in das gesunde Gewebe hinein ausstrahlenden Beschädigungen. Bei dem künstlichen Anblitzen starben sie oben nur bis zu einer bestimmten Stelle ab.

Zur Erleichterung der Vorstellmng elektrischer Ausgleichmngen erinnert v. Tubevf an die $\mathrm{Elmsfeu} \mathrm{er}^{2}$ ) und hat dieselben anch experimentell hervorgerufen. Er verweist dabei auf die früheren Versuche von MoLISCH ${ }^{3}$ ), der (angeregt durch die Beobachtungen von Linné's Tochter und Sohn über ein Blitzen der Blüten) ein Büschellicht, also eine lenchtende, aber stille elektrische Ausgleichung erzielte.

Bei den v. Tubeuf'schen Tersuchen wurden Topfexemplare anf einen Wachsklotz gestellt und dadurch isoliert. Thre Erde wurde durch einen Kupferdraht mit der einen Konduktorkugel einer Influenzmaschine verbunden, und an der Kugel des anderen Konduktors wrole ebenfalls ein Draht befestigt. Sobald die Influenzmaschine in Bewegung gesetzt wurde, lud sich der Blumentopf nebst der Pflanze mit Elelitrizität. .. Bringt man den anderen Draht in die Nähe der Pflanze, dam sieht man ein Ausströmen der positiven und der negativen Elektrizität, welche ich in den beiden Konduktorkngeh und demmach in den beiclen Drähten getrennt hatten. Die positive Elektrizität strömt in Form eines Lichtbüschels ans, die negative erscheint wie kleine Lichtperlen an den Spitzen." Die Versuche mit Fichten und Kiefern ergaben, dafs an den negativ geladenen Pflanzen bei Amnäherung des positiv geladenen Drahtes eine gröfsere Zahl ron Nadelspitzen die Elektrizität in Form von Lichtperlen ansstrahlen liefs. Lädt man aber positiv, so strömt die Elektrizität aus den Nadelspitzen lich los aus. ${ }^{4}$ )

Bei zarten Pflanzen (Begonien) wrude beobachtet, dafs, wem man den positiv geladenen Draht so hoch über die Pflanze hielt, dats am Rande der Blüten kleine Lichtperlen sich zeigten, oh ne daf's ein Funke ïbersprang, eine schädliche Wirkmng sich nicht einstellte. Wurde diese Vorsicht nicht beobachtet, trat schon nach wenigen Minuten ein Welken der Blumenstiele und darmer befindlicher Sprofsteile ein; diese ersehienen dunkelglasig wie nach Frostwirkmng. Es ist ans diesen

1) v. Tuber u. Zenxum, Über die pathologische Wirkung künstlich erzeugter elektrischer Funkenströme auf Leben u. Gesundheit der Nadelhölzer. Sonderabdruck.

$\left.{ }^{2}\right)$ v. Truex, Elmsfeuer-Tersuche. Naturwiss. Z. f. Land- u. Forstwirtsch 1905, Heft 5.

3) Mousch, Leuchtende Pflanzen. Jena 1904, G. Fischer.

4) Über die Unterschiede in der Wirkung der positiven und negativen Elektrizität. Vergl. Ptowms, Elektrotropism of roots. Americ. Jouru. Sc. 1904. cit. Bot. Centralbl. 1905, No. 40, s. 342. 
Versuchen zu folgern, dats stille elektrische Ansgleichungen (Büsehellicht) eine direkte Beschädigmo nicht hervor'uten, jecloch eine solehe sich sofort geltend macht, wenn eine Funkenentlarmm eintritt.

\section{Unterschied zwischen Blitz- und Frostwunden bei Nadelhölzern.}

Bis jetzt fehlt den von v. Trbeuf veröttentlichten Elgelmisisen seiner experimentellen studien eine Abbildung des anatomischen Befimdes jener Blitzspuren, die sich als augenförmige Flecke in der Rinde zeigen (s. Fig. 100). Obwohl wir in den am Anfang dieses Ahrehnittes erwähnten Arbeiten von Colbanos mul von R. HakTa ebentalls Angaben

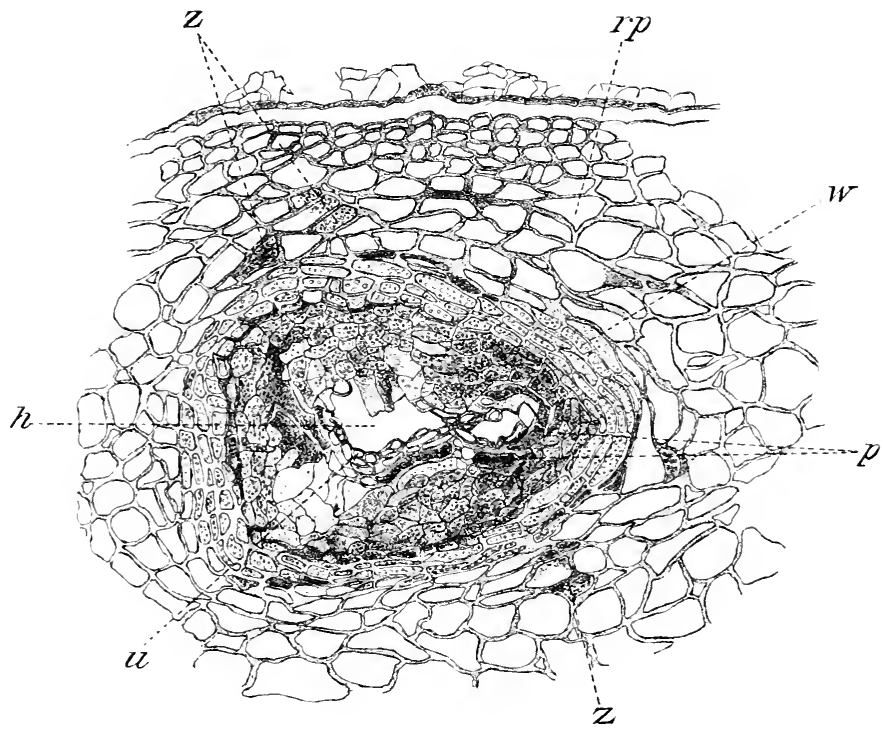

Fig. 101. Kiefer, künstlicher Frost. (Orig.)

z Einzelne abgetijtete Rindenzellen mit braunem. gleichmälsigem Inhalt: " Höhlung 1 m abgestorbenen frewebchern: " wenig gefible oder fast farliose Umkleidung ler zentralen Höhlung. Welche in Bau und Lagerung deutlich noch die struktur der Auskleidung eines Harzuanges erkennen lalst: ${ }^{\prime}$ vollstänlig verharzte. branne Rinlenparenchym-

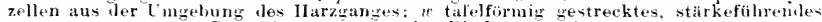
Parenchym: ri normales Rindenjarenchym.

äber isolierte, ringfömige Blitzspmen finden, ersehien es mir toch notwendig, die Frage zu priten, ob nicht derartige Beschädigumen dureh Frost hervorgeruten sein liönnten. I)er Verdacht lag um so näiler. als ich bei Laubhämmen $n$ trostbeschädigte Bastgruppen in ler Nähe von Angen ähnliche Erscheinungen zu beobachten lielegonheit wahaht hatte.

Un zuverässiges Veroleichsmaterial zu bekommen, eriat ir h von Herm v. Trberf Proben seiner künstich angeblitzten Fir.hten mul lu. schaffte mir Frostwmelen dadurch, dats ich eine sesmole füntjährige

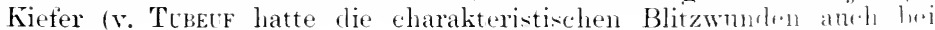




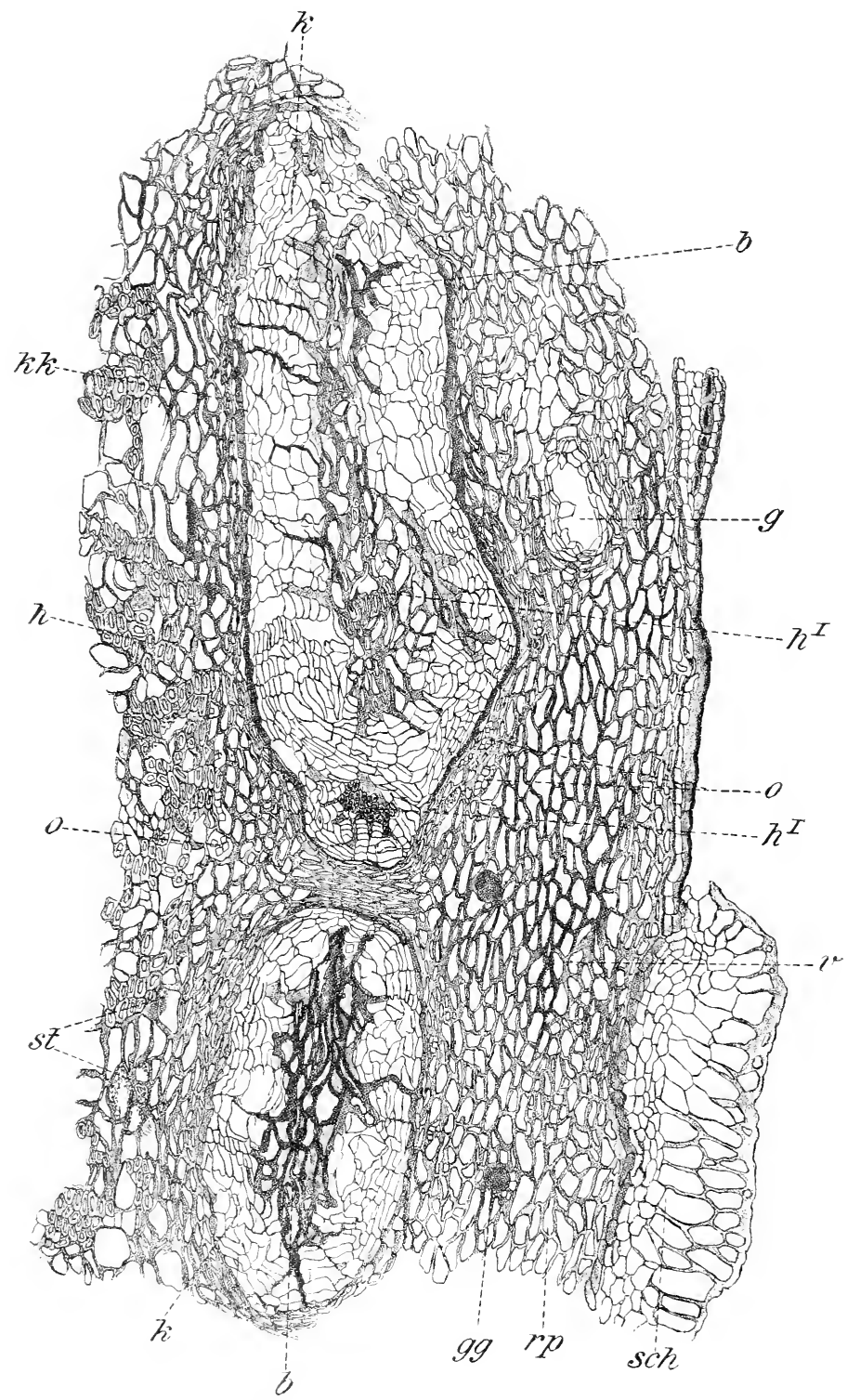

Fig. 102. Fichte, kïnstliche Blitzspur. (Orig.)

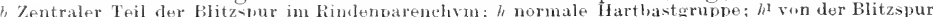

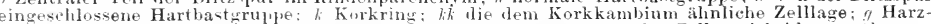
yang in der gesunden Rinde, aus desien normaler Auskleidung einzelne Zellen sich blasenartig vor

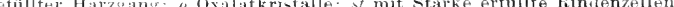

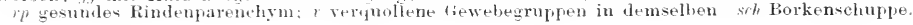


Kiefern und Lärchen gefunden) im Mai währent einer Nacht im (iefrierzylinder einer Kälte bis zu $-7^{\circ} \mathrm{C}$ anssetzte. lor anscheinend $u n-$ besehädigt aus dem Gefrierapparat hervorgegangene Bam kam Ende des folgenden Jahres zur Untersuchung, mm ihm \%eit zu lassen, etwaige innere Beschädigmngen auszuheilen, wie dies bei den Blitzwunden ebenfalls stattgetunden haben mulste.

Innere Beschädigmngen zeigte die Kiefer nur an einer seite der Stammbasis im Rindenteil, mol zwar teils in Form rinzelner abgestorbener Zellen mit bramem, rerquollenem Inlialt mitten im gesmuren Parenchrm, teils in testalt grötserer toter Zellormpen, die ringförmig von einem lebenden, manerförmig angeordneten Parenchrm umschlosien waren und dadurch eine angenähnliche Figur darstellten (s. Fig. 101). Das Kentrum dieser augenförmigen Figur wurde häufig durch eine Höhlmng (h) gebildet, welche von schwach gebräunten, bisweilen fast farblosen Zellen (u) ausoekleidet war. Bei Vergleich der mit jerlem schnitte wechselnden Bilder kam man zu der Überzeugung, dats diese den Hohlraum umschlietsenden Zellen der Auskleidung eines Harzanges entsprachen und bisweilen blasig in denselben himein vorgewölbt gewesen waren. Daran grenzte nach antsen ein abgestorbenes Rindenparenchym (l)), dessen Vellen nur selten zusammengefallen waren und meist in ihrer natürlichen Gröfse in Inhalt und Wandung verharzt sich erwiesen. Bei Authellung der Schnitte erkannte man in dem abgestorbenen Parenchym noth einzehe Oxalatgruppen und zellen mit hörnern, die als verharzte stärkekömer anzusehen sind. An das tote (rewebe grenzte nach autsen jene oben erwähnte ringtörmige /one tafelförmiger /ellen, die ihrer Anordnung nach einer Korkumwallmo olichen, aber mit ('hlorzinkjod /ellulosereaktion in ihren Wandungen zeigten und vielfach reichlich mit stärke und Harztröpfchen angetüllt waren ( $u$ ). Diese Unwallung des toten Gewebekernes. welche das aunentörmige Aussehen (ler Frostwunde beflingte, ging dam in das normale Rindemparenchym (ry) über, das hier und da noch Spuren von stärke erkennen liefs.

Der Querschnitt durch die Rinde des von kïnstlichen Blitzen beschädigten Fichtenstämmchens ergab das in Fig. 10:2 vorgeführte Bild.

Die Blitzsjur (b) zeigt zunächst einen zentralen brannen, streifenartigen Kern aus verquollenem Parenchym. Derselbe wird von einer breiten, hellen Zone $\left(l_{i}\right)$ umgeben, die aus radial angeordneten Reihen sehr dïnnwandiger, nahezu inhaltsloser, oft luttführender Zellen bestelit.

Nach autisen stötst diese Zone an einen Gewehering $(k /$ ) aus tatelförmigen, plasmareichen, in ihren Wandungen die Kellulosereaktion zeigenten tellen, die allmählich in das normale. wotslumige Rinclenparenchym (rp) ibergehen. Die autserhalh, aber ziemlich nahe der Blitzspur liegenden Harzgänge $(g)$ sind in der Regel nicht verändert: die bisweilen blasig in den Harzgang hinein sich vorwöbenden Zellen der Anskleidmo sind hellwandig. Anch diese blasige Anftreilung dor Wandungszellen ist eine normale Erseheinmo: demn man tindet an Zweigen gestuder Fichten im Winter manehmal die Haryänge voll kommen ausgefïllt rum thrllenartige Erweiterumgen der Wambungzellen. Vereinzelt treten in mmittellarer Nähe her Blitzspm anch Harzgänge ant', bei denen die anstüllenden Zellen zu lraunen. vorpullenen. harzigen Masien umgewandelt sind.

Der tote (zewebekern im /entrum der Blitzspur hestelit häutig nur

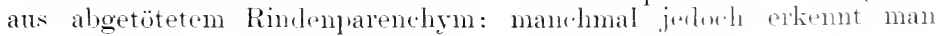


auch, dats einzelne Bastgruppen $\left(h^{1}\right)$ dabei beteiligt sind. Herrorzuheben ist der Umstand, dafs die ahgetöteten Parenchymzellen vielfach uanzlich zusammengefallen und vertrocknet erscheinen. Dieses Zusammentrocknen erkläre ich mir als die Ursache fïr die Entstehung der hellen Ringzonen ans weitlumigen, dïnnwandigen Zellen, welche sich als wirkliche Korkzellen erweisen nud den Unterschied ron der Frostwunde bedingen.

Ich mache mir num folgencle Vorstellung von dem /anstandekommen dieses Unterschiedes in den beiden Wundformen. Der elektrische Funken bedingt ein schnelles A ustrocknen des abgetöteten Gewebes. Da er ehenso wie der Frost kein langsam verlaufendes, nachträgliches Absterben des anstotsenden Gewebes veranlafst, so grenzen an die abgetöteten Gewebeherde ummittelhar lebenskräftige, reaktionstähige Zellen. Eine Reaktion auf den Wundreiz stellt sich sofort ein, wem die regetative Tätigkeit in der Rinde sich geltend macht. Das Parenchym an der Grenze des toten Gewebes antwortet ant den Wundreiz durch Zellstreckung und Zellvermehrung. Die durch den Blitz zusammengetrockneten Zellpartien bieten der Umgebung Raum zu bedentender Strecking and Fächerung. Je schncller der Vorgang stattfindet, desto mehr Material wird verbraucht. Ist dasselbe zurzeit nicht in genügender Menge rorrätig, findet nur Korkbildung statt, und damit rrklärt sich, dat's nach der elektrischen Entladung das die zusammentrocknende frewebeinsel umgebende Rindenparenchym, welches eine viel schnellere streckung und Fächerung zur Ansfüllung des gröfseren Rammes erfahren muls, mit Korkbildung antwortet.

Bei der Abtötung einer mitten im Rindenparenchym liegenden Geweheinsel durch den Frost erfolgt zmächst kein Vertrocknen des Gewebes. Die abgetöteten, verquollenen /ellen behalten ihren Umfang infolge der noch vorhandenen Turgescenz. Somit wird anch der Iruck les frostbeschädigten, sterbenden Gewebes anf die gesund und reaktionstähig gebliebene Ungebung nicht wesentlich vermindert. Damit tällt aber tür die momgebenden \%/ellen auch die Teranlassung fort, sich so stark zu verlängern und zu fächern, wie dies beim Vertrocknen der Blitzspur notwendig war. Es wird also mo den toten Kern der Frostwmole die infolge des Wundreizes entstehende Nenbildnng in Form einer Ringzone ans spärlicheren und kleineren Zellen anftreten. Das zuströmende plastische Material kann nicht mehr zur Zellremehrung verbrambht werden, da der Bedarf gedeckt ist, und wird daher in Form von Reservestoffen sich niederschlagen. Daher die direkt $\mathrm{mm}$ die Frostwunde hemerkbare stärkeanhäufung.

Als positives Ergebnis der Untersuchung wäre anzufïhren, dats bei den Nadelhölzen ein hestimmter Unterschied zwischen kïnstlich erzengten angenförmigen Blitz- ma Frostwunden besteht. Bei der Bitzwunde trocknet das algetötete Rindengewebe schmell zusammen und wird zunächst von einem lockeren Forkmantel umgeben, der einen hellen Andsemring darstellt. Bei der Frostwunde behalten die abgetöteten Zellen im Innern des Rindenparenchyms zunächst ihren fiüheren Unfang: sie werden zwar ebenfalls eingeschlossen von einer Ringzone nengebildeter Kellen, aber diese entwickeh wich nicht zu einem lockeren Lorkmantel, sondern bilden eine schmale \%one enghmigen Parenchyms, las reicher an Reservestotfen wie das normale Rindenparenchrm zu scin ptlegt. Diese \%one stellt sich bei der Blitzwmile erst nach der korkzone ein. 
Hinzu kommt noeh der von v. 'Tuber angewehene Untersehied, dats lei der Blitzwunde der abgetötete Rintenring in immer schmalur werdrnden Bändern abwärts in tas gesmule Gewebr hinein ansstrahlt. während eine derartige langsame Abmahme der Frostwirkmo nud ein streifenartiges Ansstrahlen der toten Gewebezone in lie sesumb Rinde hinein bei Nadelhölzern bisher nicht beobachtet worden ist.

Betretts der Theorie der Blitzwirkmos stellen dir vorstehendon anatomischen Beobachtungen fext, dats der elektrisclur Funken in erster Linie ein Vertrocknon des fewebes hervorrutt.

\section{Die Beschädigungen der städtischen Baumpflanzungen.}

Bei der Zmahme der elektrischen Anlagen in len stälten ist aut die Gefährdung der Bampthanzmngen hinzureisen. Nach den Lnter. stehmogen von strove ${ }^{1}$ sind es die Werehsel- mul direkten Ströme. welche dureh ätliche Verbrennmgen schaden. Bei troeknem Vietter ist weniger zu fïrehten. wesentleh mehr aher, wemm die Rinde nats ist. Ekommen hier namentlich die direkten ströme der stratsenbahnen in Betracht. Antser der Alotötmog des fewelos ist anch die Reizwirkmug schwather strömo ins Ange zn tassen. Frontlarlumen bei Gewittrum sind nach Soove's Beobachtungen häufiger als man rermutet mol erklären

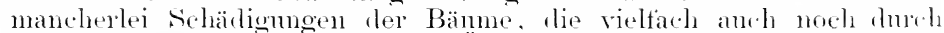
rïcksichtsloses Ansschneiden der Aste zur Isoliermug der loühte mitishandelt werden.

\section{Wirkung von Streublitzen an Weinstöcken.}

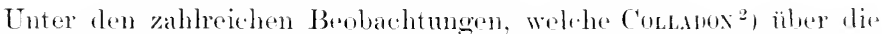
Blitzwirkmo veriffentlicht hat, findet sich eine Angabe dats in einem Weinberge clie gotrottene Bodruobertläthe einen reselmäbigen schart

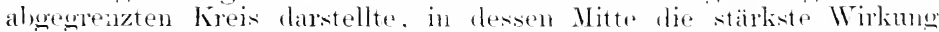
wahrmuehmen war. Die Weinstüelse zeigtrn anf den Blättern einw Menge Flecke, die anfangs clunkler grïn ersehicnen mud erst nach eingen Tagen sich ziegolnot tärbten. An den jüngeren, saftigrn Stengeln war namentlich ras C'ambimm gebräinnt, wälnend der llols kïlper unversehrt sich erwies. In den verletzen feweben bliehen dit. \%ellwantungen unverändert, aber das Protoplasma war zusammen. groggen mil getoitet. Die gleiche Beobachtumg von der Ansbreitumg

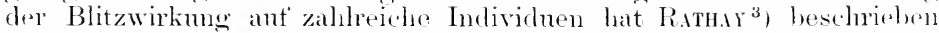
und nach Erwähmung frïherer Fälle auch darant hingewieson, dats dirselhe Erscheinmur der Anshreitmor des Blitzstrahls bei den sichafherden zu heobachten ist, wo ebenfalls stets molnere Individuen getrottion werden.

Ebenso wie Coldabos nahm Rathas andh ein Rotwerden der Blättre an getroffenen Reben wahr, soweit die Sorten rote Ilerbsträpung zeigen. Die Endon der Kweige starben gänzlich ab. Der Vorgang dre

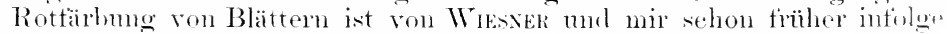
von Ringelungs- mul Knickungsversuchen festoestellt worden. Rathis

1) Sinse, G. E., Injuries to shade Trees from Electricity. Hatrh Exper. stat. Massachusetts Agrie. ('oll. Bull. 91. Amherst, 1903.

2) Confanos, Dxina, Effets de la fondre sur les arbres et les plantes lignenses. Mém. de la soc. de phys.. et dhistoire nat. de Cienéve $1 \times 7: 2$, s. its $4 . ; .3$.

a) Rirнı, Eмmm, Über eine merkwärdige durch den Blitz an Vitis vinifera hervorgerufene Erscheinumg. Denkschr. d. math.-naturwiss. Kilasede d. kais. Akat. 1. Wissensch. Wien 1s!1. Hier anch reichliche Literaturangahen. 
ergänzt diese Tatsache durch die Beobachtung, dat's die geröteten Blätter viel weniger transpirieren als die normal grünen. Die nach Blitzschlag geröteten Blätter gleichen in allen geprütten Beziehungen den durch Ringehng der Zweige sich rotfärbenden, und tatsächlich ähnelt die Blitzbeschädigung in vielen Punkten der mechanischen Ringelung, da hier die aufserhalb des Cambiums liegende Rindenschicht getötet wird. .. Das Cambinm der vom Blitz getroffenen Lotten bleibt lebend und erzengt innerhalb der getöteten Gewebe nach antsen einen ron Wundkork umhïllten Callus und nach innen einen Holzring, der von dem älteren Holze durch eine dïnne gebrännte Schicht geschieden ist." Die Trauben an den rom Blitz getroffenen Reben vertrocknen vollständig.

Einzehe Punkte ron Wichtigkeit, welche einen Parallelismus zwischen den Blitzwirkungen am WVeinstock und an Nadelhölzern erliemen lassen. finden wir in einer Arbeit von Ravaz und BonseT ${ }^{4}$ ). Nachdem darauf aufmerksam gemacht worden, datis das Blitzloch, welehes :1)-100) Stöcke umfatiste, gerade die kräftigsten Pflanzen am meisten beschädigt zeigte, wird hervorgehoben, dafs infolge des am 20. Mai erfolgten Blitzschlages die Spitzen der Triebe sich zn Boden neigten und vertrockneten. Die Knoten blieben längere Zeit grün, während rie Internodien schon wie verbrüht anssahen. Nach unten nahmen die Krankheitserwcheinmngen allmählich ab. Unterhalb der vertrockneten spitze war in den beschädigten jungen Trieben der Markkörper zerrissen und dem Holzringe angeprefst. Wurzehn blieben unbeschädigt. Einige Wochen nach dem Blitzschlage erschienen die getroffenen Internodien rotbram, geschrumpft und der Länge nach aufgeplatzt. Die Risse zeigten Vernarbungsgewebe. Die dazwischen liegenden Knoten schwollen auffällig an. Z Zweige, deren Spitzen nicht getroffen wurden, wuchsen weiter, behielten aber sehr kurze Internodien. Das junge Holzgewebe erschien bram, seine Zellen entleert und mit unverdickten WVandmngen. Die beschädigten Rindenpartien waren von Kork in selartig eingeschlossen (vergl. Fig. 102). Das Cambium bildete zunächst ein mnregehmätiges Gewebe, das erst allmählich wieder in normales Holz ïbergegangen war (vergl. Fig. 99).

Wir gelangen nach diesen Angaben zu der Anschaumg, dafi der Blitz (wie der Frost) wesentlich auch durch seine mechanische Wirkung schädigt, und zwar infolge plötzlicher übergrofser Spannmosdifferenzen. Je nach dem Alter der blitzbeschädigten Achse reagiert dieselbe in rerschiedenem Grade. Dort wo die Rinde nicht mehr in ihrem ganzen Umfange geschädigt wird, kapseln sich die toten Stellen durch einen Korkmantel ein. Wird das Jungholz nicht mehr gänzlich getötet, sondern nur noch geprefist und gezerrt, bildet sich später ein Paren(-hymbolz ans, das langsam nach aufsen hin in normales Holz übergeht, so clats falsche Jahrestinge entstehen können. Alle Erscheinmugen strahlen nach der Basis der Achse hin allmählich ans, d. h. sie verschwinden schlieflich.

Daf in Blitzwunden sich hänfig Mikroorganismen ansiedeln, ist selbstverständlich, und es ist daher leicht erklärlich, dafs man derartige Fälle als parasitäre Krankheiten beschrieben hat. Ein Beispiel bietet die "Gelivmre" des Weinstocks, welche als Bakteriose be-

4) Roviz, L. et Buxwr, Effets de la foudre sur la vigne. Extr. des amnales de l'école nationale d'agricult. de Montpellier; rit Bot. Jahresb. 1900, II, S. 417. 
schrieben worden, aber nach Ravaz und Boxwer nichts anderes als eine durch Bakterien besiedelte Blitzwunde ist ${ }^{1}$ ).

\section{Streublitze auf Feldern und Wiesen.}

STErLICH ${ }^{2}$ ) beobachtete im Juli einen Blitzschlaw in Kartotét acker. Der Blitz schlng an zwei Stellen ein, nnd dic Pflanzen wurden infolgedessen gelb und starben ab: die stengel erschienen antgeschlitzt und durchbohrt, wobei die Wundränder ein zerrissenes Aussehen hatten.

v. SEELHorst ${ }^{3}$ ) beschreibt Rübenbeschädigmugen durch Blit\%. In einem Falle bildete das Blitzloch eine Kreisfläche von ca. $15 \mathrm{~m}$ Inurhmesser. In der Mitte des Kreises waren die $\mathrm{R}$ üben total ahgestorben: bei den peripherisch angrenzenden Pflanzen erschienen die Blätter welk und vertärbt. Manchmal standen zwischen stark verletzten Pflanzen einzelne Exemplare von geringer Beschärligms. Im Rühenkörper waren hisweilen kleine Hohlrämme bemerkhar, namentlich im Kopfteil. In andern, von Praktikem beobachteten Fällen wirl von Verfärbung und Erweichung der Rübenköpfe und ähnlichen Erscheinungen gesprochen, indessen dürften hier schon sekundäre, parasitäre Einflüsse sich geltend gemacht haben. Auch CoLbubos ${ }^{4}$ ) berichtet von einem Blitzloch auf einem Rübentelde. Die heschärligten Ptlanzen hatten Blätter, die rötlich verfärbt, geschrmptt oder stellenweis zerrissen waren und deren Randpartien teilweis vortrocknet arshienen. Aut' einem Kartotfelacker tand sich die Mehrzahl der Pflanzen in der aufgewïhlten Erde gesmul: nur an einer stelle sah die Basis der Kartotfelstengel zerrisen und wie rerbrannt ans. In dem in Durehmesser zeigenden Blitzloch einer Wiese waren die höchst empor. ragenden Distelkïnte abgetötet. während die niederen Teile mol dir. Grasnarbe gesund geblieben waren, olwohl hier und da die Erde antgewiihlt gefunden wurde.

Zur Erklärung des Lmstandes, lats stets auf gleichbestellten Iändereien viele Individnen getroften werden, weist RathA auf dio photographischen Blitzanfinahmen hin, aus denen sich ergibt, dats der Blitz meist keine einfache Entladung zwisehen zwei Punkten ist, sondern sich zerstreut und in vielen Punkten endet. Kommt dann (bei Weinstöckenl) hinzu, dals die Stöcke in Drahtanlagen erzogen werden, so bildet der Draht eine noch besser leitende Verbindung. welche die Ansbreitung der Schädigung begïnstigt.

Ton Bedeutumg sind anch die Angaben von v. Bezout $\left.{ }^{5}\right)$. dafs nach den Akten der Brandversicherungsanstalt in Bavern die Gefährdung dureh Blitz von 18:3:3 bis 1<82 sich geradezu verdreifacht hat. Vermutlich spielen die ausgedehnten Entwaldmugen und Entwässerungen und die rapide Vermehrung der Schicuen und elelitrischen Drahtleitungen dabei eine Rolle.

1) Rowz, L. et Buswa, A. Les effets de la foudre ot la gelivure. compt. rend. 1901, I, S. 805 .

2) Jahrb. d. D. Landw.-fres. 1\$92.

3) v. SEennors, Rübenheschädigung durch Blitz. D. Landw. P'rene 1904, S. .15.

4 a. a. O. S. 555 .

5) v. Brzont, W. Über zündende Blitze im Königreich Bavern wihrend des Zeitraums 1s:3 his 1s82. Abh. d. K'gl. Bayer. Akad. d. Wist. II. 1'1., Bd. XV. 


\section{Nachteile bei der Elektrokultur.}

I) as anerkennenswerte Bestrelven, clie Elektrizität bei der Pflanzenkultur direkt zu verwerten, hat nach drei Richtungen zu Versuchen gefïhnt. Einesteils will man durch Belenchtmo mit elektrischem Licht die Asimilationstätigkeit vermehren. Andernteils hat man begonnen, einen elektrischen strom durch die Erde gehen zu lassen, indem man zwei Netallplatten in den Boden versenkte und dieselben mit einer Stromquelle verband. Irittens hat man versucht, einen strom dureh eine Pflanze (Bamm) direkt gehen zu lassen.

Die Resultate sind hisher sehr widersprechender Natur, so dafs ein Urteil sich nicht fällen lälst. Grotse Hoffnungen setzt man mehrfach auf den Einfluts der dunklen elektrisehen Entladnng. Dieselbe kommt zustande, wenn man z. B. ein Netz von Drähten über ein Felt zieht, ohne dafs es den Erdhoden berührt, mul einen Pol einer Elektrisiemaschine mit dem Drahtnetz mol den anrlem mit dem Erdboden verhinclet. In solehem Falle dienen die Pflanzen als Leiter, unct durch sie hindureh wird vermittels der dunklen elektrischen Entladung ein Ausströmen der Elektrizität aus den Spitzen der Kulturgewächse erfolgen. Ein derartiges Anströmen muls eigentlich fortwährend in der freien Natur stattinden, da der Erdboden eine antere elektrische Ladung zeigt als die darïber befindlichen Luftschichten. Die bekamntesten Fersuche diurften die von Lemström ${ }^{1}$ ) und von Pringshem ${ }^{2}$ ) sein. Ältere Arbeiten über Versuche, bei denen der elektrische Strom flureh die Erole geleitet wird, finden sich von WoLlNy ${ }^{3}$ ) zusammengestellt mol dureh eigene Versuche erweitert.

Die Resultate der Prinashemischen Versuche, bei denen die Elektrizität durch Influenzmaschinen erzengt wurde, lanten ungemein günstig. da hei Kartoffeln, Zuckerriben, (Ferste, Bohnen, Erdbeeren eine quantitativ und pualitativ hessere Ernte erzielt wurde. Da, wie gesagt, andrerseits aher viel moünstige Erfahrungen vorliegen, so ist vorläufig dieses frehict als noch nicht genug reklärt hier nicht weiter zu berücksiehtigen. Wohl aber muts hier einer Arheit von LöwenHerz ${ }^{4}$ ) gedacht worten, wril dieselbe mit wissenschaftlither Genanigkeit durchgeführt ist und neme Gesichtspunkte eröffinet.

Ilie Versuche wurlen mit Chevaliergerste angestellt; zur Anwenchug gelangte ein Gleichstrom, der durch die Erde geleitet wmde. Die Körner wurden sorgfältig derartig ansogelegt, dafs bei der Hälfte der Versuchsöpfe die Samen mit ihrer Längsachse parallel zur Stromrichtmer lasen und taher der Länge nach vom Strom durchflossen wmolen. wähend bei der anderen 'Topfreihe die Körner reehtwinklig zur Stromithtung lagen. Es zeigte sich nun, dats die versehiedene Lage der Kömer zur stromrichtme einen ganz merwartet grotsen Untersehied in der Wirkmo der Elektrizitä zur Folge latte.

Bui der angewandten Stromstärkr (1),1)15-1),(130) Ampère) war überall eine Benachteiligung des Keimungsorganges bemerkbar gewesen; aber es war stets zn rerennen, daf's die Körner, welche der länge nach

$\left.{ }^{1}\right)$ Lkmsmin, Elektrokultur. (Thersetzt von O. Pringsheim. Berlin 1902, W. Junk.

2) Prixishen, Orтu, Nene Elektrokulturversuche. Österr. landw. Wochenbl. 1904, No. 24: cit. Centralbl. f. Agrikultureh. 190.), Heft 6.

3) Forschungen auf dem (iehiete der Agrikulturphrsik. Bd. 11, 1888, s. st.

4) Löwaxmenz, Ricunat: Versuche über Elektrokultur. Z. f. Pflanzenkrankh. 1905 , s. $1: 37$. 
vom Strom durchflossen wurden, schlechter keimten als die. bei denen rler strom quer hindurchging. Doch auch in der erstgenamnten Abteilung machte sich ein Unterschied insofern geltent, als hei den parallel zur Stromrichtung liegenden Körnern diejenigen am schlechtesten sich entwickelten, bei denen der positive Strom an der spitze der Körner eintrat und an dem Ende, wo der Embryo liegt, austrat. Wem innerhalb 2t Stunden die Stromrichtung zwei- bis dreimal mugelielirt wurde, konnte eine Ändermog des Resultates nicht erzielt werrlen: dagegen wurde eine solche dentlich sichtbar. Wenn der strom zweimal pro Minute wechselte. Die reehtwinklig zur Stromrichtumg gelegton Köruer waren dam ebenso gut, wie die nicht elektrisierten Samen antwegangen und bei den der Länge nach von der Elelitrizität durehflossenen machte sich der Nachteil nur noch dadureh bemerkbar, dats die kïrner etwa 12-24 stunden später lieinten. Dieser beachtenswerte Versuch zeigt dentlich, wie mannigfache Bedingungen bei der Elektrokultur bearhtet werden müssen.

Anhangsweise sei hier noch der Bestrebungen über dic Elektrisierung von Wurzelreben und Blindholz des Weinstods durch ströme hoher. siammo gedacht ${ }^{1}$ ). Im Auftrage des Kais. Landwirtschaftrereins zu Moskan wurden, angeregt durch Berichte über Bekämpfung der R ebla us durch elelitrische Ströme, Versuche eingeleitot. indem man Kisten mit Wurzelreben und stecklingen 10 Minuten hindurch einer elektrischen Entladung anssetzte. Einige Wurzelreben wurlen dan anch noch rureh Funkenentladung elektrisiert. Es wurde getunden, dats ströme von hoher spannung eine fiöhere und ginstigere Entwicklung der Reben veranlassen. Wurzhehen aber, welehe direkt durch Vuphinlumg mit dem Induktor elektrisiert worden waren, zeigten Beschädigungen, indem die oberirdischen Teile nicht anstrieben: es waren nur bei clen unterirdischen Knoten Triehe zum Vorsehein wekommen.

\section{Elftes Kapitel.}

\section{Wä r me ma n gel.}

\section{A. Allgemeiner Teil.}

\section{Lebensäufserungen bei niedrigen Temperaturen.}

Weit abhängiger als von der Temperatur der Ackerkrmme ist die Pflanze von der Luttemperatur. Ehe noch der Boden den Schwankungen der Luttwärme folgen kann. hat die letztere hereits das Pflanzenleben geweckt und bisweilen schon zu bedeutender Entwicklung gebracht. Die einzelnen Pflanzenteile folgen natürlich mit verschiedener Solmelligkeit den Temperaturschwankmgen. Während Blätter mol dïme Stengel in kïrzester Zeit ihre Wärme parallel derjenigen der Lutt steigern orfer vermindern, werden dicke stämme einer berlentend längeren \%eit dazn hedürfen, zumal da alle Pflanzengewelse schlechte Wärmelciter sind. Aus diesem letzteren Umstande erklärt es sich, dats dicke stämmo balk wärmer, bald kälter als die momgebende Lutt sind, und zwar sind sie

1) Nach einem Referat der "Weinlaube“ 1904, No. 34; cit. Centralhl, für Agrikulturchemie 1905, s. 394 .

Sorauer. Handbuch. 3. Autl. Erster Band 
durchsehnittlich am Tage kälter, in der Nachtzeit wärmer als die Luft. Aber anch die dïmen Pflanzenteile, die in tie Lutt hinausragen, sind am Tage kälter. Ilie Abkühlung der Blätter rühnt von ilner Ausstrahlumg her' solche wird um so grötser sein, je mehr Obertläche der Pflanzenteil im Verhältnis zu seiner Masse besitzt. Als weitere Ursache ler Abkühhlung ist aber anch die Verdunstung zu betrachten, welche auf Kosten der Wärme des Pflanzenteils vor sich geht, und diese beiden Ursachen erklären die Erseheinung, dats in hellen Nächten das Thermometer ummittelbar zwischen dieht stehenden Pflanzen mit dünnen Blättern, wie im Rasen einer Wiese, eine um mehrere Grade geringere Temperatur anzeigt als in der Luftschicht über denselben. Ist die Luftwärme selbst nahe dem Gefrierpunlite des Wassers, so kömnen durch strahlung die Pflanzenteile selbst schon unter oo erkiltet sein und infolgedessen zugrunde gehen orler wenigstens einzehe ihrer Funktionen zeitweilig einstellen. Nach den Beobachtungen von SAcH(Lehrbuch III. Aufl. S. (i3) kömmen die Fenerbohne und der Mais (Phaseolus multiflorus und Zare Mays) nicht ihre Chlorophyllkörner grün färben, wemn die Temperatur nicht wenigstens $+10^{\circ} \mathrm{C}$ beträgt. Ebenso verhält sich der Raps. Die Pinie (Pimms Pinca) braucht wenigstens $7^{\circ}$ C. Die Kohlensäurezersetzung zeigt sich bei Potamogetom erst zwischen 10-15" C; dagegen bei Vallismeria schon oberhalb 4 " $\mathrm{C}$, bei den Blättern der Lärche bei $0,5-2.5^{\circ} \mathrm{C}$ und bei den Wiesengräsern hei $1,5-3,5^{\circ}$ C. Die Bewegung der Blätter der Simmptlanze (Mimosı pudica) tritt erst ein, wemn die Temperatur der momgebenden Luft 150 C übersteigt usw.

Wie versehieden die Wärmeansprüche der einzelnen Pflanzen sincl, zeigen am hesten rie Beobachtungen, welche über das Keimen der samen in Eis gemacht worden sind. ULoTH ${ }^{1}$ ) fand beispielsweise, dats samen von Weizen und Ahorn (Accr platunoides) in Eis keimten und sich tief in das Eis eingruben, das sie durch die bei der Keimung zunächst entwickelte Wärme anftanten. Die feinen Nebenwurzeln des Weizens hatten Eisstïcke von ${ }^{1}, s$ m Dicke durchbohrt. Spätere Verstrehe ${ }^{2}$ ) zeigten demselben Beobachter, dats anch mehrere Cruciferen (Lepridium rinderale und sutirum. Sinapis alba und Brassica Nopus). Hafer. Gerste, Roggen sowie antlere Gräser, in grotsen Prozentsätzen gekeimt hatten. Bei Gerste und Hafer waren die Keimprozente aber merklith geringer als bei Weizen und Roggen. Ton Schmetterlingsblütlern hatten im Eiskeller Erbsen zu $80 \%$, Linsen zu 12\% gekeimt. Ton Petersilie zeigten $(60 \%$ der ausgesäten Kömer eine Feimung. Angeregt durch diese Beobachtungen, mnternahm später Haberianit ${ }^{3}$ ) weitere Versuche mit Aussaat der gebräuchlichsten landwirtschaftlichen sämereien in Kästen, welche durch Eis konstant bei einer Temperatur von $10^{\prime \prime}$ bis $1^{0}$ C gehalten wurden. Nach $1^{1}{ }_{2}$ Monaten zeigten Roggen, Hanf, Leindotter, Rotklee, Luzerne. Wicke, Erbsen und Bastardklee einen Anfang der Keimung; eine weitere Entwicklung der Würzelehen aber lief's sith nach vier IIonaten nur bei Senf, Leindotter, Bastardklee, Rotklee und Luzerne konstatieren, während Weizen, Gerste, Hafer, Raygras. Buthweizen, Runkelü̈be, Raps, Mohn, Weitsklee,

1) Fintaxi's Neue landwirtsch. Z. 1871, S. 875.

2) Flora 1875 , S. 266.

$\left.{ }^{3}\right)$ Wissenschaftl. praktische Tntersuchungen auf d. Gebiete d. Pflanzenbanes. Wien 1875, I, S. $109 \mathrm{ff} ., 117$. 
Bohne 11. a. mar nicht zum Keimen gelangt waren. Am günstigsten von allen Pflanzen hatte sich auffallenderweise die Luzerne gezeigt.

Diese Resultate stehen betreffis der Getreidearten in sehr anffallendem Widerspruch mit den Unoth'schen Erobnissen und ebenso mit den Resultaten von Versuchen, welche HeLfrientis ${ }^{1}$ ) veröftentlicht hat. Hier zeigte der Winterrogoen sich entschieden als dic anspruchsloseste der gepröiften Pflanzen betreft's des Wärmehedürfnisses. Er entwickelte bei ciner fast konstanten Temperatur von o (nur wenigo kurze Überschreitungen bis $+1^{\circ} \mathrm{C}$ kamen imerhalb der sechswörhigen Versuchsdauer vor) Blatt- und WVurzelapparat ganz normal. Sichon etwas wärmebedürtiger erwiesen sich durch die geringere trö̈tse der Keimptlanzen der Winterweizen mol, übereinstimmend mit Usorn, in noch höherem Matse die Gerste mul der Hafer, welche bei " " nur "lie Wïrzelchen zu einiger Entwicklung brachten, den Blattlegel aber nicht aus dem Korne hervorzutreiben vermochten. Bei + " " dagegen war die streckung shon eine reeht vollkommene. Mais regte sich bei $+5^{\circ}$ ( noch nieht und keimte selbst bei $+8,7^{\circ} \mathrm{C}$ sehr träge und u1vollkommen. Bei $0^{\circ}$ waren noch gekeimt und zu nemenswerter Entwicklung des Blattkeims gelangt die Wicke und der Rübsen, währent Erbsen in grölserer, Lipinen und Bohnen in geringerer Anzahl zwar den Wurzelkörper gestreckt, aber den oberirdischen Achsenteil nicht entwickelt hatten. Von den bej +20 ( gekrimten samen war der Lein emptindlicher als der Rübsen, der bei nahezu o" noch lieimte, aber in der Entwicklung stehen blieb und erst bei merklich höherer Temperatu (8.70 C) erwähnenswertes Wachstum zeigte. Den Wicken am nächsten stehend erwiesen sich Erbsen und Klee, welche bei ciner Inuchschnittwärme von + ${ }^{\circ} \mathrm{C}$ den Wurel- und Blatteil hervortrieben, während Bohnen und Lupinen dazn mindestens + $3^{\circ}$ (' brauchton. Der syörgel entwickelte sich bei $+2{ }^{\circ} \mathrm{C}$ anch langsam weiter. Für die Mohrrïbe scheinen zur Keimung ungefähr $+: 3^{\circ}$ ( : und für die Runkelriibe sogar etwa +50 C nötig zu sein.

Es gehört nicht mehr hierher, daranf einzugehen, daf's nat ürlich die Länge der Keimdaner in dem Grade zunimmt, als die Temperatur von dem Keimungsoptimum entfernt ist: wohl aber dürfte darauf anfmerksam zu machen sein, dat's solche Keimungsversuche bei möghichst niederen Temperaturen dazu führen kömnten, frost harte Varietäten zu züchten. Bei allen Aussaatversuchen zeigt sich ein mngleichmätsiges Antrehen. Es wäre möglich, dat's diejenigen Samen, welche zuerst bei so nierlerer Temperatur keimen, Pflanzen ergeben, welcho für alle Lebensprozesse ein geringeres Wärmebedürtinis haben als andere Individuen derselben Art.

Dat's nicht blot's die ersten Stadion der Keimung bei so niederen Temperaturen normal verlaufen, sondern auch ein weiteres Längenwachstum ermöglicht ist, zeigen die Versuche von Krachner ${ }^{2}$ ), d(י Sent, Rogren, WVeizen, Erbsen und Hanf als Keimptlanzen längere /seit bei Temprraturen, die wenig über $0^{0}$ lagen, vegetieren sah. \%war weisen auch Pflanzen mit einem höheren Wärmebodiurtinis bei [Thesführum in niedere Temperatur noch Tängenwachstum aut': aber das-

1) Beiträge zu den naturwissenschaftl. Grundlagen des Ackerbaues. Braunschweig, Vieweg 188:3, \$. $284-304$.

2) 54. Vers. deutscher Naturforscher u. Ärzte zu Salzburg, S. 75 d. Berichtes. 
selbe ist nur als das allmähliche Anspendeln der muter den früheren günstigen Verhältnissen erhaltenen Wachstumsenergie zu deuten.

Bei Alpenptlanzen ist von Kerser ${ }^{1}$ ) beobachtet worden, dat's solche bei " " auch blühen können. Das von den Schneefeldern in den Boden einsickernde Schmelzwasser vermag bereits die Lebenstätigkeit solcher Pflanzen derart anzuregen, dal's ihre bei der Atmung erzeugte Wärme die oft $2-5 \mathrm{~cm}$ dicke Eiskruste zu schmelzen imstande ist, so dafs die grünen Organe ins Freie gelangen (Soldamella).

\section{Die Herbstfärbung.}

Die Verfärbumg der Blätter im Ilerbste ist bei derselben Bammart nicht immer dieselbe. Es scheint, dats die Verschiedenheit durch den Standort eines Individnums bedingt wird. Im allgemeinen kann man zwei Typen unterscheiden. Entweder zeigt sich ein ganz normal rom Blattrande ans beginnender Vergilbungsprozef's, dem, nach der Blattmitte fortschreitend, eine Vertrocknming des Gewebes folgt. Oder Vergilbung und Vertrocknmng gehen nicht parallelen, sondern entgegengesetzten IVeg. d. h. der Fergilbungsprozefs geht rom Blattstiel und den starken Blattrippen aus und schreitet nach der Peripherie hin tort, so dafs der Rand zuletzt verfärbt wird, aber democh nachträglich zuerst vertrocknet. Letzteren Gang beobachtete ich besonders schön bei Acer platanoides, weniger konstant bei Acer Psouloplatamus. Die Nittelfläche wies ein gleichmälsiges, lenchtendes Quittengelb anf, während die Randzone noch grün war. Bei fortschreitender Temperaturelniedrigung zeigten viele Blätter ein Bramwerden und Absterben deäufsersten Sammlinie der noch grünen Randpartie, während das gelbe Wittelfeld noch keine toten Gewebestellen erkemen liefs.

Dieser Fall kamn anch bei Tilia eintreten, und zwar meist einseitig, indem nur eine Blatthälfte den Vorgang zeigt; jedoch ist bei der Linde die vom Rande nach der Mitte hin fortsclureitende Verfärbung hänfiger. Die Untersuchung zahlreicher Fälle lehrt, daf's die Unregelmäl'sigkeiten der Verfärbung mit dem ungleichmälsigen Absterben der Gefä1sibüudel zusammenhängen.

Die normale Antolyse im Herbst stellt sich ein, wenn der gesamte Gefäfsbündelkörper seitens der Wurzel in seiner Funktion noch erhalten wird und nur langsam von den feinsten Nervenendigmngen des Blattrandes her abstirbt. Dam verfärbt sich und rertrocknet das Blatt an der Randzone zuerst, und die Verfärbung schreitet in den Intercostalfeldern zwischen den schwächeren und schlietshich auch zwischen den stärkeren Nervenästen nach der Blattmittelrippe und dem Blattstiel hin allnählich fort. Wird dagegen die Gefäfsfunktion im Achsenkörper oder den Blattstielen vorzeitig gestört, was man aus der Bräunumg der Bündel ersehen kann, dann beginnt die Verfärbung am Blattstiel oder den stärkeren Rippen und breitet sich num unregelmälsig nach der Peripherie hin weiter ans.

Das Absterben durch andanernde sommertrockenheit gleicht in seinem Gange insofern der herbstlichen normalen Autolyse, als anch hei jener die am wenissten Wasserzutiuhr erhaltenden Partien des Blattes sich zunächst verfärben. Nehen der Randtrocknis tritt aber hier mehr das Anstrocknen der Mittelregion der gröf'seren Intercostal-

1) Berichte d. naturwissenschaftl.-mediz. Vereins zu Innshruck, Sitzung vom 15. Nai i 873 , eit. Bot. Z. 1873 , S. 438 . 
felder in den Vordergrund, weil diese von den starken /uleitungssträngen am entferntesten liegen und durch den Licht- und Wärmeüberschuts besonders stark in Anspruch genommen werkn.

Die Herbsttärbung beginnt mit einer Veränlerung des Chlorophyllkörpers, welche vielfach ron dem Auftreten eines ruten Farbstoffs begleitet wird. Zunäehst bemerkt man eine Verändermug der Latge der Chlorophyllkörner und ein Bestreben, miteinander zu verschmelzen. Bei der Fichte sah ich, dats das einzelne Chlorophrllkorn strahlige Fortsätze bildet, die sich mit denen des Nachbarkörpers vereinigrn. Die Rottärbung wird durch das Auftreten ron Substanzen ans der ( stoffreihe und damit verwandten Körpern bedingt. Manche immergrïnen Pflanzen werden schmutzig braungrün. Sach Kkat's ${ }^{1}$ ) kommt diese Färbung dadurch zustande. dats im Palisadenparenchym feinkörnige, lebhaft rotbram bis kmpferrot gefärbte Protoplasmamassen an Stelle der verschwundenen Chlorophyllkörper anttreten. .Je weiter die Kellen des Blattfleisches von der bramen Oberseite entfernt liegen. desto mehr bemerkt man Übergänge von diesen geröteten Plasmamassen zu den normalen Chlorophyllkörnern.

Alle diese Verändermgen lassen sich in vielen Fällen wieder anf normale Fürbung zurücktï̈hren, wem man abgeschnittene Zweige in die Wärme bringt. Dabei wird aber die Lichtintensität nicht erhöht. und es ergibt sich daraus, dats nur die Temperaturemiedrigung als die Ursache der Herbstfärbung im allgemeinen angesehen werden muts. Ein weiterer Beweis liegt darin, dat's bei den herbstlichen, nächtlichen Reifen nur die bereiften, also die durch strahlung am meisten abgekïhlten Stellen sich verfürben, während die im Innern der Krone befindlichen, irgendwie dureh andere Blätter gedeckten Teile lieine Farbenänderung zeigen.

Was num die Verändermug des Chlorophyllfarlstoffes anbetriftt, so ist durch $\mathrm{FraNK}^{2}$ ) und $\mathrm{WIESNER}^{3}$ ) nachgewiesen worden, datis bei der herlsstliehen Verfärbung das Chlorophyll in eine von Princishem ${ }^{4}$ ) ..Hrvochlorin" genamnte Substanz übergeht. Es ist dies ein meist dunkelgetärbter, ölartiger Körper, der bei Einwirkmng anorganiseher und organischer Säuren auf das Chlorophyllkorn entsteht und schlietislich in nadel- oder peitschenartigen, bramen Kristallen anschiefst. Ton diesem Hypochlorin hat um Tschrec ${ }^{5}$ ) nachgewiesen, datis es mit dem ..Chlorophyllan" von Hoppe-SErLer identisch ist. und dafs es als das erste Oxydationsprodukt des Chlorophylls (und zwar nur eines Teiles des Rohchlorophylls, nämlich des Cranophylls von (ł. Krars) aufzufassen ist, welehes auch schon von selbst sich bildet. wemn eine ('hlorophyllösmg längere Zeit stehen bleibt ").

Die Bildung des Chlorophyllans orler Hypochlorins fand Tschrren in dem Maße zunehmend, je nehr Säure (dureh Nomalalkali titrimetriseh

1) Krstr, Über die winterliche Fürbung inmergrüner Gewächse. Sitzmugher. 1. phrs.-merl. Soc. Erlangen: cit. in Ökonomische lortschritte 1Ni2. Nr. 1 u. "2.

s) Sitzm gsher. d. Bot. Ver. d. Prov. Brandenburg XXIII, v. 24. Febr. 1sce.

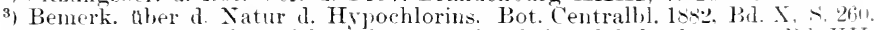

4) Entersuchumgen üher Lichtwirkung. Pringsheims Jahrbucher 1sent, Bd. XII.

5) Sitzungsber. ‘. Bot. Ver. 1. Prov. Brandenburg XXIII, v. 2-. April 1<-2.

6) Konzentrierte Salzsäure spaltet das Chlorophyllan in einen in salziaure mit blaner Farbe löslichen Körper, das "Phyllocranin" der Autoren und einen in dieser unlöslichen, in Äther lïslichen, bratuen Körper, das "X a n th in" won C. Krar. (Tscmicu, Entersuchumgen über das Chlorophrll III. Ber. d. deutschrn Bot. Ges.. Bd. I. Heft 3 und 4: cit. Bot. Centralbl. 1 83, Bd. XIT, Nr. 2.. s. 856. 
bestimmt) in den Pflanzenteilen nachweisbar war. Anßer Wasserpflanzen diurten nur wenig Pflanzen existieren, deren Zellsaft nicht dentlich saner reagiert. Bei Gattungen, welche wenig säure enthalten, wird dic Chlorophyllanbildung eine geringe sein, mol der gemachte Auszug wird lange stehen müssen, während bei stark samren Pflanzen (Aesculus, Rumex) die Oxydation so schmell vor sich geht, datis man ïberhaupt keinen rein grünen Auszug machen kam, da derselbe sofort die Eigenschaften des modifizierten Chlorophylls zeigt und schon bei dem Erkalten Chlorophyllan absetzt.

Für nnsere Betrachtung erwähnenswert ist, dals nach 'Tschinch selbst schon die Kohlensäure imstande ist, das Chlorophyll in Chlorophyllan umzuwandeln. Auch die Substanzen der Gerbstoffreihe, mit welchen der rote Farbstoff sicher verwandt ist, werden wir zn den saner reagierenden, das C'hlorophyllkorn angreifenden Körpern zu rechnen haben, und es fragt sich jetzt nur, woher es kommt, dafs erst im Herbst dieser entfärbende Einflut's des sauren Kellsaftes anf das Chlorophyllkorn sich geltend macht. Dies kann num entweder darin seinen (rrund haben, dat's im Laufe des Sommers so wenig freie Säure im Terhältnis zum ïbrigen Material in der Blattzelle disponibel ist, dafs das zur Chlorophyllanbildnug verbrauchte Chlorophyll stets und schnell durch den iiberwiegenden Assimilationsprozets ersetzt wird und wir daher in gewöhmlichen Fällen nichts von einer Gelbfärbung der Chlorophyllkörper merken, oder zweitens könnten auch die C'hlorophyllkörper durch eine Substanz, welche die Säuren nicht durchläfst, geschützt sein und erst im Herbst diesen Schutz allmählich verlieren. Es könnten aber anch beide Vorgänge stattfinden, und dieses ist nach den vorliegenden Untersuchmoen das Wahrscheinlichste.

Auf das tatsächliche Vorhandensein einer Schutzvorrichtung der Chloroplasten gegen die Angriffe der Säuren des Zellsaftes weisen Frank und WIEsner hin, welche betonen, dafs die grümen Körner im fïr Sämren undurchdringlichen Protoplasma eingebettet liegen. Anch hat Tschirch erwähnt, dats jedes Chlorophyllkorn von einer farblosen Plasmamembran (Hyaloplasma-Schicht), die namentlich bei Wasserpflanzen leicht nachweisbar, momeben ist und anf diese Weise einen speziellen Schutz gegen den sauren Zellsaft besitzt.

Wemn nun die Blattzelle im Herbste ihrem Lebensende sich nähert, ist das Protoplasma in derselben nicht mehr sehr reichlich vorhanden. Aber selbst da, wo es noch reichlicher sich vorfindet, erleidet es bei der Herbstkälte eine (durch Wärme wieder reparierbare) Alteration, vermöge welcher es permeabel für Sämren wird. Frank sah die durch Sänrewirknng erzengte Gelbfärbmug des Chlorophyllkorns bereits eintreten, wem dasselbe nebst dem Zellkern noch dicht in der wandständigen Plasmaschicht eingebettet lag. Eine solche Ändermo in den diosmotischen Eigenschaften des Protoplasmas läbt anch in den wintergrümen Gehölzen die säure zur Wirksamkeit kommen. Die organischen Säuren vermehren sich aber im herbstlichen Blatte, und anf diese Weise ist die Verfärbung eine um so leichtere.

Betreff's der Rotfärbung ist ron C. Kkaus ${ }^{1}$ ) nachgewiesen worden, dats das von Gorvp-BEs.sNEz ${ }^{2}$ ) in wilden Wein zuerst anfgetindene Brenz-

1) Über die Herbstfärbung der Blätter und die Bildung der Pflanzensäuren. Biedermanns Centralbl. 1\&74, I, S. 126.

2) Amnalen der ('hemie und Pharmacie 1872, Bd. CLXI, Heft 2 und $?$. 
caterhin (0xyphensäure) in allen sich lorlstlich verfärbenden Blättem, ja anch (soweit die teilweise Untersuchmo reichte) in allen nfel kräftig vegetierenden Blättern vorliommt. Diese sulstanz wird durch Eisenchloril grün, mit Phanzensämen schön rot. Ilie Extrakte der Blätter geben die Reaktionen der Oxyphensäure, mul es ist deshalh der Sichluts nahe gelegt, dat's der rote Fasbstofl bei den jumen mol herbstlich gefärbten Blättern aus der durch gestrigerte sö̈mebildum vermehrten Einwirkmo auf das Brenzeatechin lervoreht.

Tlas bisher fresagte zusammentassend, kimnen wir dren Voruane der Herbstrerfärbumg als einen gegenüber dom Assimilationsprozeds gesteigerten, anf Lichtwirkung angewiessnen Ixydationsprozets antitassen.

Derselbe änbert sich ant die in den rellen der verschiedrenen Phanzen quantitativ sehr verschieden vorhandenen stotfe derart, dal.j ans dem Chlorophyllarbstoff das C'hlorophyllan entstelit unl darlureh das Blatt gelb wird. $\left.{ }^{1}\right)$ Wem das kïnstlich ans Kohlehydraten herstellbare, in opalisierenden Tropten wahscheinlich vorluardene Brenzrateehin durch die herbstliche, reiche säurebildumg in einen roten Farbstoff' nugewandelt wird, tritt neben der Gelbtärbung die Römme der Blätter auf. Überwiegt dagegen die nuter Formzerstïrmog der chloro-

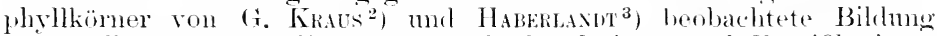
hramgelber Massen, die C'. Kkows als Oxylations- mol Humifikations-

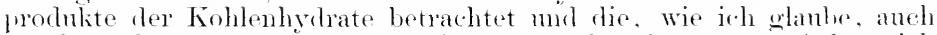
hureh \%erfall dor Chloroplasten direkt entstehen kïmon, so färben sich die Blätter bram.

Jie hänfigste, aber durchans nicht dir einzige Irsalche der Rottärbung ist die 'Temperaturemiedrigmug, wodureh die Lichtwirkmo in relativen Öberschulis gelangt. Ex sind nicht dio absoluten licht- mol Wämewerte, wolehe hierbei ansiohlagrehend sind, sondern die relativen, also in Beziehung zueinander in Betracht kommenden Werte. lie Temperaturemiedrigung wirkt herahstimnend ant den ('hlorophyllhildumgspozets, während sie noch den Brenzatechin bildenden, etwas mehr Licht beanspruchenden ${ }^{4}$ ), die Rotfärbmeg einleitenden (Exylationsvorgang in voller Tätigkeit muterhält. Tem die Tätigkeit des ('hlorolhyllapparates erhöht, also mehr Kohlelivelrate gebihlet worden, reicht der zugängliche sanerstoff zu so hocherarliger oxvation nicht mehr ans, mul der Prozels der Rotfärbmo miterbleibt. Wem man aher dir (hlorophyllarbeit dureh Nangel an Nährstotf'- und Wasserzufuhe künstlich herabstimmt, dam kam der in der \%elle dispemible sautrstotf genügen, das sfärlicher gewortene Material wieder hochgrarlig zn

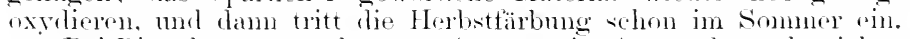

Bei Ringelungsversuchen an Cortacgus in August hemerlite jedr, wir.

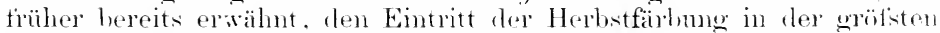
sommerhitzo, und liswoilen gelingt es. an etwas lionsistenteren Blättern durch Einbrechen der Mittelriple an dem an Bame helassenen Blatte die

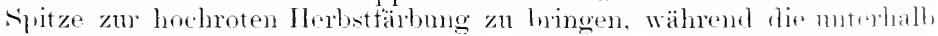

1) Der ('hlorophyllanauszug herbstlich toter Blitter zeigt dirselhen .. bandes

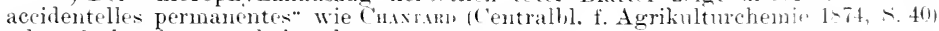
schon frither hervorgehoben hat.

2) Ökonom. Fortschritto 1872, No. 1 und 2.

3) Biedermamn: ('entralbl. 1-76, II, \& 40.

4) Burma, Über dif Einwirkmo des Lichtes auf die Bildung des rotrm Pigmentes. Acta Hort. Petrop. VI. 
der scharfen Knickungsstelle gelegene Blattbasis ihre normale, tieforiune Färbung behält. Anfserdem sehen wir im Lanfe des Sommers bei vielen Pflanzen die erstgebildeten Blätter des Jahrestriebes, die schnell sich ansgelebt haben, im heifsen Sommer die Herbstfärbung annehmen (Ampelopsis). Bedeckte Stellen an jungen, roten Blättern bleiben grüner. Wir kommen auf diese Verhältnisse bei dem .. Frostlaubfall" noch eimmal zu sprechen. Auf die winterlichen Vorbereitungen der immerwrünen Pflanzen wird in dem Abschnitt über die Theorien der Frostwirkung eingegangen werden.

\section{Gefrieren und Erfrieren.}

Betrefts der Bezeichmmg. .Erfrieren" finden wir in der Literatur verschiedene Auffassmoen. Teils erklär man jerles Absterben. das allmählich sich bei einer Pflanze einstellt, weil sie zur Durchfïhlumg ihrer normalen Funktionen nicht die nötige Wärme erhält, schon als ein Erfrieren: andererweits will man nur den plötzlich eintretenden Tod infolge des Eingriff's einer unter die Minimalgrenze der Wärmeansprüche herabgehenden, in der Regel mit Eisbildnng verbundenen Temperaturerniedrigung als „Erfrieren“ gelten lassen.

Wir können diese Differenz am besten dadurch überwinden, dats wir die erstere Art der Wirkung des Wärmemangels als phronische schäden" von dem plötzlichen Tode als einer akuten Schädigung bei der Betrachtung tremnen.

Beispiele für chronische Schäden bieten vielfach zarte Pflanzen der Tropen, die in mseren Glashänsern nicht danernd die Wärme füir alle ihre Entwicklungsphasen finden. Bekannt sind die Mifserfolge bei der Kultur der indischen Anoctochilus-Arten und anderer zartlaubiger Orchideen, Begoniaceen, Gesneriaceen, Marantaceen usw., deren Blätter ich bramfleckig werden, sich krümmen und absterben sah, wenn sie längere Zeit einer Temperatur von $+3-50$ C ausgesetzt waren $\left.{ }^{1}\right)$. In nassen kalten .Jahren erkranken auch Freilandkulturen von Melonen, Gurken, Tabak und Bohnen bei anhaltendem Wärmemangel.

Bei den akuten Schäden ist man unwillkürlich geneigt, dieselben der Eisbildung zuzuschreiben. Dat's dieselbe an sich nicht totbringend ist, beweisen in vielen Fällen unsere winterharten Gewächse, die oftmals steif gefroren und spröde wie Glas sind und doch nach dem Verschwinden des Frostes wieder fortwachsen.

Über die Eisbildung im Gewebe machen wir uns folgende Vorstellung. Ist die 'Temperatur des Pflanzenteils auf den Eispunkt oder etwas tiefer gesmken, dam schiet'sen ant' der Aut'senseite der Zellhant kleine Eiskristalle an. Diese, wohl zuerst ans dem Absorptions- suäter ans dem Imbibitionswasser der Zellhant entstandenen Kristalle werden immer grötser, indem sich an ihrer Basis immer mehr Wasser ans den Micellarinterstitien der Zellwand herans zn Eis verwandelt. Schlietslich sind rlie sämtlichen f'einen Eisprismen zu einer Eiskruste vereinigt. Die \%ellwand hat den erlittenen Wasserverlust zu decken gesucht, indem sie aus dem Kellinhalte nene Wassermengen autnahm.

so wird der Protoplasmakörper der Zelle wasserärmer, und es beginnen stoffliche Umlagermugen, die endlich eine solche Intensität

1) Vgl. auch: Mnum H, Han, Das Erfrieren der Pflanzen bei Temperaturen über dem Eispunkte. Sep, sitzungsber. d. K. Akal. d. Wiss. Wien. Mat.naturw. Klasse, Bd. CV, Abt. 1: cit. Z. f. Pflanzenkrankh. 1897, S. 23. 
erreichen, dats die einzehnen Micellen der Zellwand mul des Protoplasmas ,lanernd in ihrer Gleichgewichtslage gestïrt, sich anf eime Weise verändern, die keine Lebenstätiglieit mehr gestattet. I)ie chuch Frost getötete Zelle zeigt dam, dats ihre Wandmu lieinem Widerstanl gegen den Truck des Zellsattes leistet und lätst lotzteron allmähliw austlietsen. In ummittelbarer Berïhrung mit der I,utt arelit derselhe in Zersetzmng ïber, und die Zolle sellst fällt zusamment "Lur erfrorene Pflanzenteil sieht welk ans mul vertrocknet oder vertault schnell. Dieser heraustretente Kellsaft, welcher die Fäulnis einleitet, dringt furch die Micellarinterstitien und nicht etwa dureh Risise ller \%ellwanl. welche durch den Frost entstanden wären. Wohl kam in einem gefrorenen Pflanzenteile das Gewebe durch das Eis in einzelne fruplen zersprengt werden und, was häufig zu beobachten ist, kömen die (berhantzellen von dem darunter liegenden Parenchym sich abgehoben haben: aber ein Zerreilsen der einzehnen Zellen durch das Getrieren de Wassers ist bisher selten beobachtet worden. Es fällt somit die frïher allgemein und jetzt anch ron Praktikern häufig gemug ansgesprochen. Ansicht, dals der Frost die Pflanze durch /erreitien der /ellen tötr. als haltlos zusammen.

Derselbe Kältegrad kamn bei derselben Ptlanze cinmal mschädlich. ein andermal tödlich sein, je nachdem das A u t't a ne n eimmal alhmählich und ein zweites Mal plötzlich erfolgt. Dieser letztere Fall lälst sich beobachten. wenn man gefirorene Blätter oder krautartige stengel von weichlaubigen Pflanzen mit der warmen Hand anfatst. Jie Berührungsstellen werden hänfig nach dem Auftanen schwarz und sterben ah. Wir kommen im folgenden aut diese Erscheinmngen zurück.

Auch schmelle, starlie Temperaturschwankungen inmerhall, einer sikala über " " werlen nicht wirkmbslos bleiben. SAcHs ${ }^{1}$ ) hat nachowiesen, dats jeder schnell eintretenden llobung oder senkmm der Temperatur auch eine Hebung oder Herahstimmmg der Wachstmmsgeschwindigkeit folgt. Während IE ThIEs keine nachteiligen Folgen von derartigen Schwankungen beobachten konnte, sah ich in extremeren Fällen Blattabwmf eintreten, namentlich wenn die Schwankungen in einer Skala stattfanden, die mehrere Grade unter $1^{\circ}$ begann und bedentend äber $0^{\circ}$ stieg. Dieselben Pflanzen sterben sogar, wemn sich in kurzer Zeit der Temperaturwechsel mehrmals wiederholt, wie ans

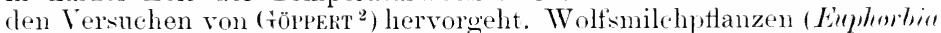
Lathyris) wurden aus einer 'Temperatur von - to $^{\circ}$ in ein Zimmer vou + 180 gebracht. Die dureh den Frost mit ihrer syitze abwärts nebogenen, an den stengel angelegten Bläter crhoben sich alsbald mul nalmen ihre normale. wagerechte Stellung wieder ein. Derselhe Vorgang zeigte sich bei einer immerhall zweier Tage stattfindenden fiintmaligen TViederholmug des Versuches. Am dritten Tage begann daAutichten der Blätter nachzulassen. und nach acht Tagen waren hip Pflanzen tot. I)ie Pflanze war hier also infolge wiederholter Einwirlinm. geringerer Frostgrade remichtet. wänend sie im Freien in muledectitrim Zustande I0-120 Kälte längere Zrit hindureh schadlos erträgt. Ähi. liche Resultate ergahen dieselben Versuche mit vieln anderen Ptanzon.

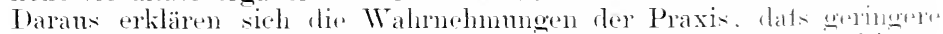
Kältegrade an manchen orten Pflanzen töten. Welche sholdiz+itic an

1) Lehrbuch a. Bot., :i. Aufl., ‥ 638 .

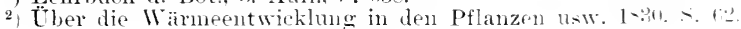


anderen Grten mit konstanteren Temperaturen eine viel gröfsere Kälte vertragen.

(röppERT matht noch aut einen anderen Umstand autimerksam. welcher zur Erklärung der vielen Widersprüche dienen kam, die sich bei Beobachtmngen über die tötliche Wirkmg geringer Frostgrade an solehen Pflanzen ergeben, welche stärkerer Kälte gewöhmlich trotzen. Es kommt nämlich anch darauf an, in welchen Verhältnissen sich die Ptlanzen vor Eintritt des Frostes befunden haben, wie ein Versuch mit dem wewöhlichen Krenzkrant (Srnecio rulguris) und dem Stratsemrispengras (Poa amua) zeigt. Töpfe mit diesen Pflanzen, welche bereits eme Kälte von 90 üherstanden hatten, wuden tür 15 Tage in ein Gewächshans ron 12 180 Wärme gebracht. Nach dieser \%eit erfroren sie schon bei einer Kälte von "0, wälnend andere Exemplare derselben Arten, welche während dieser /eit im Freien geblieben waren, sich hei schnellem Anftanen vollkommen mversehrt erwiesen. Die getöteten Pfianzen waren durch den Anfenthalt im Warmhanse verzärtelt worden. Zn demselben sehlusise kommt anth Könxicke ${ }^{1}$ ) bei der Beobachtung, das tranzösische Getreidevarietäten durchschnittlich weit mehr dem Froste erlegen sind als sorten, die ans den Provinzen Prentsen und schlesien stammten. Die längere Knltur in einem Lande mit mildem Winter hat die Tarietäten weniger widerstandsfähig gemacht.

Bei sonst gleichen Verhältnissen fand HabrkLsisur ${ }^{2}$ ), datis die im Warmhanse bei $204^{\circ}$ C erzogenen Sänlinge von Ackerbohne, Futterwicke. Möhre, Gerste, Erbse, Raps, Mohn, Rotklee, Luzerne und Lein schon bei - i" C', Roggen und Weizen bei - 10 bis $12^{\circ}$ ertroren, während gleichzeitig im Kalthause erzogene Pflanzen derselben Arten erst bei - ! bis 120 C zugrunde gingen, ja Roggen und Weizen erst hei - 20 bis 240 C erfroren.

Am wenigsten leiden durchschnittlich diejenigen Pflanzen und Pflanzenteile, deren Wachstmm in eine Ruheperiode eingetreten ist, und es ist bekannt, dats trockene samen bedentende Kältegrade schadlos ïberdanern, während sie im angekeimten /ustande bei viel geringerem Frost zugrunde gehen.

Während der vegetativen Entwicklung ändert sich die Frost. empfindlichkeit mit ren einzelnen Phasen des Zelllebens

In anfbrechenden Blütenknospen von Apfelbäumen, die durch einen Frïhjahrsfost gelitten, fand ich nicht die jüngsten, plasmareichsten Zellen beschädigt, sondern die etwas älteren, im stadium energischer streckung befindlichen gebrämnt, während noch ältere Parenchymzellen wiederum gesmud erschienen.

Aus den bisher angetührten Fällen ersieht man, dats es schwierig ist, lestimmte Thermometergrarle als die festen Minimal- und Maximalgrenzen tïr die Entwicklungsfähigkeit einer Spezies angeben zn wollen. Im grotsen mol ganzen ist gewits jede Pflanze an eine bestimmte Wärmeskala gelmuten, aher $m$ einzehe Grade sind die Grenzmoll optimalwerte verschiebbar, je nach der Kombination ler übrigen Vegetationsfaktoren, welche angenblicklich rorhanden ist mul frïher zmm Antban des Individums beigetragen hat. S. $286 \mathrm{ff}$

1) Annalen d. Landw: cit. in Neue landw. Zeitung v. Fühling 1871, Heft \&,

2) Honerasur, Über die Widerstandsfähigkeit verschiedener Saaten. Wissensch. praktisch. Entersuchungen, Bd. I. 
Andererseits ist daran festzulalten, dats trotz aller die Frostempfindlichkeit steigernden Vegetationshedingmoen viele Pflanzen (namentlich zahlreiche Flechten sowie Monse und Alpinen) niemals Frostbeschädigmigen erkemnen lassen. Wir haben diese Erscheinmo damit zu erklären. dafs das Wärmebedürfnis soleher Ptlanzen ein derartig geringes ist, dafs die grösten Temperaturerniedrigungen nicht imstande sind, jene molekularen Tmändermgen der freweb hervorzuruten, welche cine Wiederantuahme der normalen Lelensfunlitionen verhindern.

\section{Theorien über das Wesen der Frostwirkung.}

Nachdem wir bisher die Umstände besprochen haben. die lei dem Ertiferen der Pflanzenteile modifizierend wirken, möchten wir dor Theorien gedenken, welche über das Wesen der Frostwirkun aufoestellt worden sind.

Dahei kommen nicht mehr die $L$ ähm ung serscheinungen der chronischen Kältewirkungen in Betracht: demn diese sincl zunächst doch normale Funktionen, die nur allmählich durch Wärmemangel sich verlangsamen, bis das Leben erlischt ${ }^{1}$ ). Anders liegt die sache bei den akuten Fällen, bei denen wir den Tod der kältewirkung umittellar toloen sehen.

Bei den alinten Frostersheinmogen wird die Eisbiltung ein wesentlicher Faktor. Dieselbe tritt aber nicht bei der 'Temperatm ein, bei welcher das reine Wasser getriert. sondern erst unterhall, " weil der Zellsaft eine Salzlïsung tarstellt. Anfserelem ergahen die Beobachtungen, von denen namentlich die von MïLLer-Thrkist 2) anzutühren sind, dats Eis erst nach einer bestimmten Überschroitung des Gofierpunktes, einer Überkältum ofler Unterkühlun en enteht. Als Beispiel, wie manchmal der Unterkïhlmospunkt arheblich tiefer als dor Gefrierpunkt liegt. mögen einige Angahen des rorgenamuten Forschers dienen.

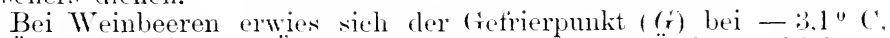
der Überkältungspmkt $(\ddot{C})$ bei - $i, c$ bis $7,{ }^{\circ} \mathrm{C}$, bei Äpfeln und Birnen

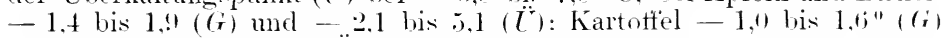
und - 2, $5^{\circ}$ bis $5,6^{\circ} \mathrm{C}(\ddot{l})$ usw.

Die Eisbildumg tritt plötzlich ein: es erfolgt also in den Fällen, wo eine Überkältung stattgefunden hat, ein plötzlicher 'T'emperatursprung. Dats die Eisbildumg nur bei bestimmten Pflanzen tötlich wirlit, zeigen unsere winterharten Pflanzen. welche, nachdem sie spröde von Eis gewesen, doch später mgehindert weiter wachstn. In anderen Fällen aber ist beobachtet worlen, dats Pflanzenteile unter bestimmten Umständen auf eine tiefere Temperatur abgekühlt werden kömnen und am Leben bleiben, währent sie bei geringerer Kälte sich erfroren zeigen, sobalil Eisbildung dabei stattgetiunden hat.

Dieser Eisbildung, deren Authau wir eingangs bereits gescliblert

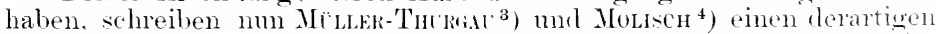
Tasserentzug aus der Zelle zu, dafs diesolbe daran zugrumb gelit.

1) Vgl.! Kixiscu, H., ̈̈ber die tötliche Wirkung niederer Temperaturen auf die Pflanzen. Inauguraldissertation. Breslau 1>80. - Sirus, Landw. Versurhstationen 1860 , ‥ 196 .

$\because$ Landwirtschaftl. Jahrbächer 1×6. s. 490.

3) A. a. O. s 534 .

4) Mon.soin, Über das Erfrieren der Pflanzen. Jena 1,47. 
Es wäre demgemäts der Frosttod ein einfacher Vertrocknungsvorgang. Die Forscher stïtzen sich dabei anf den physikalischen Prozets, daf's heim Gefrieren gequollener Colloide reines Wasser auskristallisiert und das dadurch stark anstrocknende Colloid erstart.

Obiger Anschaumg gegenüber'steht unsere Ansicht, daf's der Frosttod kein spezifischer Austrocknungsprozets ist, sondern in einer molekularen, irreparablen Zertrïmmerung des Protoplasmagefïges zu suchen ist; disselbe änfsert sich sowohl in mechanischer als auch in chemischer Form. Die Zertrümmerungstemperatur ist für jede Art, jedes Individnum, jeden Pflanzenteil und jeden Wachstumsmodus eines Pflanzenteils srezifiseh. hängt aber mit der Eisbildung nicht direkt zusammen, was wir bereits ans der Menge derjenigen Pflanzen ersehen, welche Eisbildung in ihren Geweben scharllos ertragen. Man nennt diese Gewächse eisbeständig", und diese erfrieren erst, wenn ihre steitgefrorenen Teile unter das spezifische Minimm abgekïhlt werden.

Dieses spezifische Minimm ist keine feste Grötse, sondern steigt mit der Menge des Zellsaftes, d. h. der Kältetod tritt bei höherer Temperatur ein, und umgekehrt wird der Wasserverlust eine Steigerung der Resistenz gegen alle Faktoren zuwege bringen ${ }^{1}$ ), also bei Frost den Tod erst bei niedrigerer Temperatur eintreten lassen.

An diese Vorgänge schliefst $\mathbf{M f z}^{2}$ ) folgende Betrachtungen an: Jede Lösmng einer Substanz in Wasser muts unter den Gefrierpunkt des Wasser's abgekühlt werden, bevor sich Eis ausscheidet. Für verdümnte Lösungen, wie sie unter normalen Umständen im Zellsaft existieren, ist die Erniedrigung des Gefrierpunktes proportional der molekularen Konzentration (RAoult'sches Gesetz: cit. NERnst, Theoretische Chemie, 4. Anfl., 19013, S. 152). Betreffs der Lösungen osmotischer substanzen, welche mehrere Stofte gelöst enthalten, gilt das Datron'sche Gesetz, wonach die Gefrierpunktemiedrigung gleich ist der Summe der Emiedrignngen, welche jeder Stoff für sich allein erzengen würde.

Da num jede Zelle in demselben Pflanzenteil einen von dem der anderen graduell verschiedenen Inhalt haben dürfte, so wird anch der Unterkältungspunkt des Zellsaftes ein stets wechsehnder sein. Da die Zusammensetzung des Zellsaftes innerhalb der Breite der für jede Pflanzenspezies spezifischen Grenzen je nach der Ernährmis schwankend ist, so wird verständlich, dats die einzehnen Individuen verschiedene Resistenz lesitzen. Auch erklärt sich damit das verschiedene Verhalten trockener Pflanzenteile gegenüber den sehr saftigen. Dafs der Tor hei den anstrocknungstähigen Samen nm anch durch die Wasserentziehme erfolgen soll, erklären sich H. MöLlek und MoLIsch in der Weise, dats se anmehmen. es erfolge die 'Tötung durch die plötzliche Eisbilrtung in der ïberkälteten Pflanze, indem hierdurch eine seln schnelle Wasserentziehung stattfände Gegen diese Hypothese spricht bereits PFEFFEI ${ }^{3}$ ). bei dem wir die betreffende Literatur sehr eingehend behandelt finden, seine Bedenken aus. Unterstützt werden diese \%weifel durch die bereits erwähnten studien ron Maz. Denn die Untersuchmgen desielhen führen zu folgenden Resultaten. Der die Beendigung cler Kristallisation anzeigende Temperaturabfall lag bei

1) Prefrer, Pflanzenphrsiologie, 2. Aufl., S. :is, Anmerk.

2) Mrz, C.r.. Nene Cntersuchungen über das Erfrieren eisheständiger Pflanzen. Siond. Flora oder Allgem. Bot. Z. 1905, Bd. 94, Heft I.

3) S. das Kapitel über" .Die Krachen des Erfrierens" in ".Pflanzenphrisiologie", II. Bu., 1904, s. 314 . 
keinem der geprüiten Objekte unterhalb - ¿ $^{\circ}$ C. (Die Versuche wurden mit Blattstielen von Helleborus, Saxifiaga mnel Strelitzia, mit

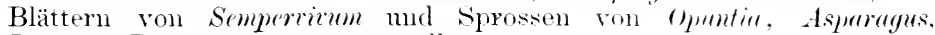
Begonia, Peperomia usw. angestellt.)

"Aller erstarrungsfähige (nieht absorbierte) \%ellsaft erstart zwischen $11^{\circ}$ und $-0^{9} \mathrm{C}$. Dementsprechend tritt bei - 30" krine stärliere Aus. trocknung der Protoplasten infolge von Wasserentziehnug bei der Eisbildmo ein als bei - ${ }^{\circ}$. Eine Pflanze, welche die Eishilimmo in ihren Geweben überlaupt erträgt, stirbt also nicht infolge von Anstrocknung der Protoplasten, sondern infolge der Ablïllhme unter das spezifische Minimm."

Wir sehen somit unseren frïheren stanchmlst bestätigt, dals nicht ein einfacher Wasserausscheidungsprozets. sondern eine stottidisoziation durch die Kältewirkung hervorgebraeht wird, welche die Funlitionen des Lebens unmöglich macht. Es sind aber neben diesen wesentlich mechanischen Vorö̈ngen vielfach chemisehe Zersetzungen im sipiele. Diese werden bald nach Unterkältming. bald ohne eine solche eingeleitet. Es braucht nicht jede Pflanze erst unterliältet zu werten, um zu gefrieren: sie erfiert aber" wahrscheinlich rascher, d. h. wirel zu ultraminimaler Temperatur abgekühlt. wem clas (iefrieren mit Unterliältmmg eintritt. Wenigstens ergibt sich dies aus Versmehen rom Mkz mit Stammstücken von Impations parriflora. Aus diesen Versuchen erfahren wir auch, wir solm die Unterkühlumg von der Beschaffenheit des Zellsaftes abhängin ist. (iase. gelöste Luft verhindern ofler vermindern elenso wie emmgiertes (i), fimmi oder Planzensehleim die Unterkühlung. Anch sieht man, ratis in Wasser abgeliühlte Pflanzenteile stets ohne orler wenigrtens olme wesentliche Unterlizhlumg erfieren. Es liommt vor, dats man Phanzenstengel, die teilweise im Wasser stchen, so weit erfioren findet. als sie in die Lntt hincimagen. Mossch prütte die Frage experincentell.

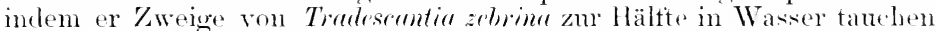
liets: ïber Nacht wirliten $; " C$ ' Kälte ein. Nach langsamem Autanen im kïhlen Zimmer erwies sich die in der Lutt befindliche sprolshälfte erfroren, während die untere, in Eis steckende mbeschädigt geblieben war. Dic obere, von Luft momgebene Hälfte wird sich mit Unterkältung raseh abgekühlt haben und cladurch erfioren scin. Soweit die Pflanze dagegen im Wasser steclite, ging wegen der hohen spezifischen Wärme desselben die Ablïhlung langsam vor sich, und sowohl durch das gefrierende Wasser ringsum wie anch dum thas Eis in den bereits getrorenen, in der Luft befindlichen Geweben wird die Unterkïhlumg verhindert worten sein.

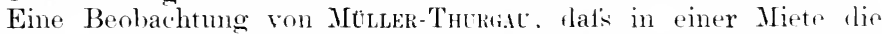
äudseren gefrornen Rüben die immeren vor dem Gefrieren schützen, leitet die Autmerksamkeit auf den spezicll gïnstigen Einfluls ler Eisbild ung. Dieser Punkt wird von Mtz hervorgehoben, indem er allgemein ausspricht, dats der C̈bergang des Zollsattes in den feston Aggregatzmstand ohme weiteres die in fer Pflanze noch erhaltomen Enervien vor allzu raschem Ahströmen schützt. Die Wämeleitmug in Eis ist eine viel langsamere als in Wasser, in welchem sich die Wämo dureh strömung verbreitet.

Die Gefahr des Erfrierens, also einer Temperatmerniedrigme ant

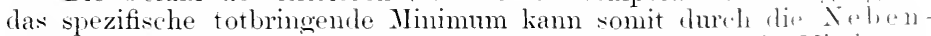
$n \mathrm{mstände} \mathrm{teils} \mathrm{gefördert,} \mathrm{teils} \mathrm{gemindert} \mathrm{werdon.} \mathrm{Wio} \mathrm{Mindermn}$ liegt in der Benutzung der spezifischen Wärme drs Wascers. Wie wir 
bei den Frostschntzmitteln noch erwähnen werden, ferner in der Eisbildung selbst, welche doch schon heim Nullpunkt oder dicht unter demselben eintritt, währent der 'Tod erst bei tieferer Temperatur sich einstellt, endlich aber in der Änderung des Zellsaftes, indem ein wötserer Reichtum an (̈), Gummi und Schleim verzögernd wirkt.

I) Steigerma der (tefahr des Erfrierens liegt in allen Umstänclen. die das Eintreten der tötlichen Unterkïhlung heschleunigen.

So lamn beispielsweise der von der Kräftigkeit der Ernährung abhängige anatomische Ban des Individums schon mitsprechen. Bei sehr üppigem Wachstum sind die Lumina der Kellen und Gefatie weiter und die Intercellularen gröker. Je weitre aber ein Gefälsroh gebant. desto mehr kommt die Getierpunkterniedrigung durch die Kapillarität in Tregtall. Ifiesen Umstand finden wir von BRrmsing ${ }^{1}$ ) hervorgehoben. Derselbe fand, dats Taxusblätterextrakt in engen Kapillaren seinen

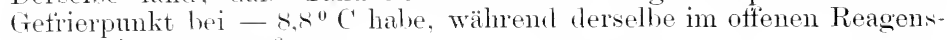
glase bei $-1,3^{\circ}$ getror.

Antser dem gritseren Wasserreichtm des Gewebes kommen noch die Luttbeschatfenheit (Fenchtigkeitsgehalt) und Luftbewegung in Betracht. In letzterer Beziehung sei an die vielfache Erfahrung erimnert. clats in geschützten Lagen (geschlossenen Tälern, waldumgebenen Feliern usw.) Pflanzen erfirieren, die in der windzugänglichen Ungebung unbeschädigt bleiben.

Zur Erklärung dieses Umstandes werden wir daran zu denken haben. daf die bewerte Luft die Vertumstung steigert und den 7ellsaft konzentrierter macht. Bei stärkerer Verdunstung wird schneller Eisbillung eintreten, also die Unterkältung vermieden und gleichzeitig der Schutz des freien IVärmerestes in den Geweben herbeigeführt.

In der Verhindermo der Unterkühlung durch anfgelagertes Eis diurte auch der Vorteil der "ra uhen Furche", die den Schnee länger hält, für das Wintergetreide zu suchen sein.

Auch Nebel werden schützend wirken. Ein neneres Beispiel dafür finden wir in der Beobachtung von Thomss ${ }^{2}$ ), der in Thüringen aut den in Nebel gehüllten Höhen das junge Buchenlaub unbeschädigt fand, während dasselbe in den Tälern infolge der Frostwirkung sich gebrännt und welk erwies. Es war in diesem Falle eine dentliche Grenzlinie lemerkbar. Die Wolkenbedeckung in den Bergwäldern ist ein nicht zu unterschätzendes Frostschutzmittel.

Wir wollen num noch eimmal daranf zurückkommen, dafs in manchen Fällen ein schnelles A uftauen gefrorener Pflanzenteile den Tod herbeiführt, während eine langsame Erwärmung das Leben erhält. Über die Richtigkeit dieser Behauptumg wirl vielfach gestritten. Spricht man dieselbe als allgemeine Regel ans, so erscheint sie mzutreffend, beschränkt man sie lagegen auf gewisse Fälle, damn hat sie sicherlich ihre (rültigkeit. Ein älteres, sehr lehrreiches Beispiel liefert KAnstes ${ }^{\mathbf{3}}$ ). Eine grötiere S'onrlung von Baumfarnen (Bulantium) hatte auf der Reise 200 Kälte zu ühorstehen. Die bei der Ankmutt in noch gefrorenem

1) Bromaxici, F. F., Zur Kemntnis der Crsache des Frostschadens. Sond. Wollny's Forschungen auf dem Gebiete d. Agrikulturphys. 1896; cit. Centralbl. f. Agrikulturchemie 1898, s. 173.

2) Tним. , Fk., Scharfe Horizontalgrenze der Frostwirkung an Buchen. Thüringer Nonatsblätter 1904, 12. Jahry., No. 1 .

3) Über die Wirkmng piötzlicher bedentender Temperaturänderung usw. Bot. Z. $1861, \mathrm{Nr} .40$. 
Zustande ins warme Haus gebrachten Pflanzen wallen qetötet, während die zuerst in kaltes Wasser zum Auftanen gelegton stämme, die nachlier in ein kaltes Haus kamen, fast alle am Leben blieben. Daraus welst hervor, dat's nicht der Frost. sonderu das schnelle Anftanen die Todesursache gewesen ist.

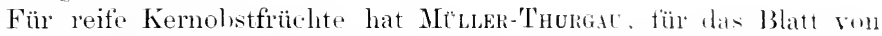
Agare americana hat MoLssich erwähnt, dats diese (1)jelite nach nätigem Gefieren bei sehr langsamen Anftanen am Loben erhalten worden sind. während sie bei raschem Autamen ahsterben kïmm.

Getiorene Blätter der lirantigen Cinerarien faste ich mit der lland derartig an, dat's nur die Fingerspitzen anf der Blattläehe lagen. Onu an ihrem Standort belassenen Ptanzen zeigten nach dem Anftauen mu. die Fingerdruckstellen extroren. Nach den Erfalnmengen der Gärtnis sind es besonders die zartlaubigen, sattreichen, in den tiashäusern herangezogenen Frïhjahrsblïher (Cinerarien, krautige Calceolarien usw.). welche mach einer Frostnacht durch möglichste Verlangsammog dre Auftauens gerettet werden kïmen.

Bei völlig eisbeständigen Ptlanzen scheint ragegen die schnellig-

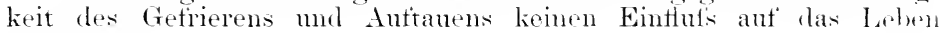
anszuiiben.

'/ur Erklärung des Sachverhaltes werden zwei Punkte heranzuziehen sein. Erstens werden bei dem schnellen Auttanen sich dieselhen Vorgänge abspielen, die z. B. bei dem Verdunsten der flüssigen Kolılensäure eintreten, wobei beliamutlich die Bildung fester Kohlensäure stattfinclet. Die schmelzwärme wird bei schnellem Auftanen nicht nur der Lmaebung, sondern anch den tieferen Sehichten des Pthanzenteils entnommen, wud diese werden dadurch noch mehr abgekïhlt. Bri solehen Gewächsen, bei denen der kritische Punkt, l. h. das spezifische Minimm, nahe unterhall, des trefrierpunktes liegt, kann dieser bei schmellem Autauen westeigerte Wärmeentzug den Tod herheiführen.

Der zweite zu berücksichtigende Vorgang besteht in der Ummörhchkeit der \%ellmembranen, ans denen Eis herauskistallisiert ist, die plötzlich durch schnelles Auttanen entstandenen grotien Mengen von Schmelzwasser autzusangen. Das Wasser bleibt in den Intercellnaren und verdunstet, ohne dals es der Zelle des Blattes velingt, den nötion Turosecenzzustand wieder zu erlangen. I)aher die Methode der Gärtner. die rom suätfiost getroftenen Pflanzen vor der autgehenden somme zu schützen.

Betrachten wir schliedslich rom standpunkt der hier vorgetragenen MEzschen Theorie die natïrlichen Vorgänge der herbstlichen Stuttumwandlungen. Wenn sich die Pflanzen fïr den Winter vorbereiten, sammeh sie die grölste Menge der Reservestoffe mul ereichen, je nach ihrer Individualität, zu verschiedenen /eiten ein Maximum. Bei P'inu. anstrinca fand beispielsweise LACLER Id SARLos', dasselbe in Nai. bei dem früher wieder austreibenden Spindelbaum in März: bei den laubabwertenden Gehölzen ist das Maximum bereits im Herhst vorhanden. Bei den immergrünen Ptlanzen rerbleiben die Reservelinhle.

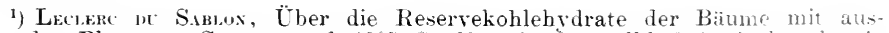
dauernden Blättern. Compt. rend. 190.), S. 1608: cit. Centralbl. f. Acriculturchemif: 1906, S.322. - Fanricts, L., Untersuchungen uber Stärke- und Fettgehalt der Fichte usw. Naturwiss. Z. f. Land- u. Forstwirtschaft 1905, S. 1:3. 
hydrate reichlich in den Blättern ${ }^{1}$ ), deren Tätigkeit auf ein Minimum reduziert erscheint. da ihre spaltöttinnngen danemd sich schlief'sen. Diese Reservestoffe werden tunlichst gegen Frostgefahr geschützt. Teils wandert die Stärke in die geschüitzten zentralen Teile der Achse (Markkörper, Markstrahlen, Parenchymholz), teils verwandelt sie sich in Zucker, orler es tritt fettes Öl an ilue Stelle. Bei den Fichtemnadehn im Gebirge sieht man die substanz der Chloroplasten verflietsen, und der Zellinhalt bildet in Winter eine gleichartige plasmatische Masse mit reichlichen Öltröpfchen. Wiese Umwandlung hat Libforss ${ }^{2}$ ) für alle grünen Zellen wintergüner ( iewächse nachgewiesen; im Frühling erfolgt Rückbildung der Stärke.

Dieses Fortschaffen fester Kïrper aus der /elle bei Eintritt des Winters stellt sich nach MEz als eine vorteilhafte Eimichtung bei den eisbeständigen Pflanzen dar. Er nennt die flüssigen Stoffe ,thermisch aktive", denn sie lassen bei der Kristallisation Wärme frei werden. Die festen Bestandteile dagegen folgen retardierend der Temperatur der Flüssigkeiten; sie sind "thermisch passiv" und wärmezehrend, da sie bei Eintritt der Eisbildung, die durch den Temperatursprung rom Unterkïhlungspunkt nach dem Nullpunkt hin angezeigt wird, ihre Wärme relativ rasch abgeben. Dieser Umstand bewirkt, dafs bei Anhäntiung fester Körper in den '/ellen die S'chmelztemperatur des '/ellsaftes nach stattgehabter Unterkïhlung nicht erreicht werden kann. Eine grotse Menge thermisch passiver Bestandteile bildet daher eine Gefahr tür die Pflanze, während die flüssigen, thermisch aktiven Körper als Wärmeerzenger sich vorteilhaft erweisen. Wir nuterscheiden seit den Untersuchungen ron A. Fischek (Jahrb. f. wiss. Bot. 1891, S. 155: cit. von PFeffer a. a. (.. S. 317) ()l- nund Stärkebämme, je nachdem dieselben ihre stärke in öl verwandeln oder sie in das Innere ihrer Achse wandern lassen und in fler Rinde in Zucker umsetzen. Das fette (̈) (ler Fettbäume (Nadelhölzer, Birke), das wir durch Jonescu als Schutzmittel gegen Blitzschlag kennen gelernt haben, wirkt neben seiner Eigenschatt, die Tnterkühlung zu vermindern, ebenso wie der Zucker. thermiseh aktiv, d. h. als Wärmespeicher für den Fall der Kristallisation. Die Bänme, welche nun ihre gesamte Stärke in öl umsetzen, dürften höhere Kältegrade zu ertragen geeignet sein (Nadelhölzer) als die, bei denen ein Teil Stärke zuritckbleibt und nur in der Rinde zu Zucker wird (Mehrzahl der Laubhölzer). Dieser Umstand spricht sicherlich bei der Erscheinung mit, dat's Nadelhölzer und Birke am weitesten in die kalten Regionen hineinreichen.

\section{Störungen durch Erkältung.}

Bei dlen Topfkulturen in den Gewächshäusern kommen Fälle vor, dafs Pflanzen durch den Transport aus einem Glashanse in ein anderes leiden, falk sie dabei eine kurze Zeit, bisweilen nur wenige Minuten, einer 'Temperatur unter Null ausgesetzt worden sind. I) praktischen Gärtner behaupten, dals ,die Pflanzen sich exkältet haben“.

In nenester Zeit ist Moeburs ${ }^{3}$ ) dieser Angabe näher getreten und

1) Simox, Der Ban des Holzkörpers sommer- und wintergrüner Gewächse usw. Ber. d. D. Bot. Ges. 1902, s. 229.

2) Libfonss, Zur Physiologie und Biologie der wintergrünen Flora. Bot. Centralbl. 1896, s. 33.

$\left.{ }^{3}\right)$ Miныs, M., Die Erkältung der Pflanzen. Ber. (l. D. Bot. Ges. 1907, Bd. XXV, H. 2, s 67 . 
hat durch Versuche obige Behauptung bestätign këmnen. Er nahm z. B. eine Begonia metallica aus dem Warmhanse, trus dic Pflanze 1 bis 2 Mimuten im Freien bei einer Temperatur von - j" ('. mmler mul stellte sie dam wieder an ihren fribleren Ort. Noch an demselben Tage bemerkte er auf einigen älteren Blättern nenentstanclene brame Flecke; später bekamen diese Blätter .ein glasiges dunkles Anssehen, hingen herab und vertrockneten". Junge Blätter litten nicht. Derartipe Verfärbungs- und Welkerscheinungen wurden hei andoren ähnlichen Versuchen beobachtet und sind anch im wesentlichen rie Merkmale, welche von den Praktikern als Folgen der Erkältung angegelen worden sind. Dats es sich hier nicht um eine Eisbilingng in den Geweben handeln liam, hebt Мoebus bereits hervor. Ich kamn den Beweis rafür durch einen Versuch erbringen, den ich mit Begoniu argyrostigmu amgestellt. habe: von derselben wurde ein Topt aus dem IVamhauso erst ins Freie gebracht, nachdem die Temperatur aut 0,:" C über Null westiegen war. Bimen kurzer \%eit sah ich anf einigen Blättern olasige Fleclie anftreten.

Nach den im vorliegenden Kapitel an verschiedenen stellen niedergelegten Versuchsergehnissen sehe ich in tem Welken und Glasigwerden einzelner Blätter hei scharten Temperaturspüngen die Folgen pötzlicher stramnungsifferenzen in den Gewehen. Die Kusammenziehung der 'bellen infolge der starken Abkïhlung wird stellonweis rin Heranspressen von Traser in die Interellularäune veranlassen:

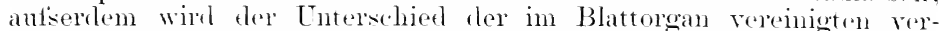
schiedenen kewebeformen zur freltumg kommen. Wir verweisen in dieser Bezichung anf den suäteren Abschnitt äbrr Frostblasen, wo Eyidermisabhebmgen nud fieweheablosmoen vershierlener Alt beselurieben werden.

Der pralitische Züchter hat jetenfalls im Ause zu behalten, tats hei cinem Transport von Ptanzen ans wamen Häusen die Möglichlirit einer Erkältmog selbst dam gegeben ist, wem die Pflanzen nur wenige Minnten einer Frosttemperatur dabei ansgesetzt werden. I) a der schrofte Temperaturwechel vermieden werden muls, so wirf eine Umhüllung ter 'Töpfe mit Leinwand oder Papier für alle Fälle anzuraten sein.

\section{B. Spezielle Fälle der Frostwirkungen.}

\section{Sürswerden der Kartoffeln.}

Bei der belamnten Erscheimmg. dats Kartoffeh bei Eintritt schwacher Kältegrade sïts werden, heobachteten bereits (GöPPElT ${ }^{1}$ ) und Esnно ${ }^{2}$ ), dats sich individuelle Verschiedmheiten geltend machton. Unter denselben Verhältnissen wurle nur ein Teil der Kuollen siits, und diese hlieben weich. während die antleren erstarten. Brachte man Kartoffeln schmell in grötsere Kälie (etwa 10"), so gefroren sie säintlich, ohne Zuckerbildmo zu zeigen. Nur bei Temperaturen, die wenis miterhalh des Gefrierpmktes Jagen, liets sich ein Sütswerden beohathten.

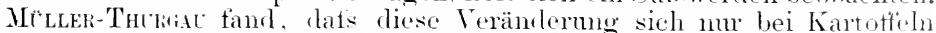
einstellte. die schon mindestens einen Honat ans der Erde wemommen worden waren: hei frisch geenteten Knollen liets sie sich nicht hervor-

1) Wärmeentwicklung, s. : 3 .

2) Neues allgem. Journ. f. Chemie. Berlin 1 105 , S. 473.

sorauer, Handbuch. Autl. Erster lanil. 
rufen. Wahrseheinlich ähnliche Erfahrmgen führten Parex ${ }^{1}$ ) zu dem Schlusse, dats schon vor der Frosteinwirking die Knollen bereits wieder in Vegetation eingetreten sein dürtten, wemn sie Zuckerbildung auf. weisen.

I lie von Eınhof und Göppert gefundene Tatsache, dats bei höheren Kältegraden die Kartoffeln erfrieren, ohne süis zu werden und die sïts gewordenen weich geblieben waren, erklärt sich nach den Experimenten von Mondi-Thurtial ${ }^{2}$ ) in einfacher Weise. Dieser Forscher fand, dat's die Kartoffelknolle erst bei - : 3" erfriert. Allerdings liegt ihr eigentlicher Gefrierpunkt schon etwa bei $-1^{\circ} \mathrm{C}$ : aber die Zellsäfte müssen erst bis auf " $2-3^{\prime \prime}$ unter den Gefrierpunkt abgekühlt, $d . h$. . überkältet" werden, bevor zwischen den Zellen die ersten Eiskristalle sich bilden kömnen. Natürlich aber wirkt eine Tomperaturerniedrigung auf ") bis - 2" auch schon lähmend auf riele Lebensprozesse ein. Unter diesen sind es zwei, welche hier wesentlich in Betracht kommen, nämlich ein Vorgang, bei welchem Stärke in Zucker umgewandelt wird und ein Zuckerverbrauchsprozef's. Man kamn ammehmen. daf's der Zucker von dem Protoplasma der Zelle teils veratmet, teils (während der Vegetationszeit) zur Regeneration des Plasmas und zur Stärkerückbildung verbrancht wird. Méluer-Thurgat fand in der Tat $^{3}$ ), dat's suif'se Kartoffeln nach einem Aufenthalte in Temperaturen von $20-30$ " ihren Stärkegehalt auf Kosten des verschwundenen Zucker's erhöht hatten. Bei einer Temperaturerniedrigung auf $10^{\prime \prime}$ bis herab anf $-2^{\circ}$ nimmt der Veratmungsprozets (und höchstwahrscheinlich anch der Regenerationsprozets des Protoplasmas) ab, während die Umwandlung der Stärke in Zucker nicht so schmell zurück geht. Infolgedessen wird der Zucker in der Knolle angehänt' und diese Ansanmlung anch durch den Geschmack bemerkluar: sie beträgt etwa $2,5 \%$ der Frischsubstanz; doch sind verhältnismätsig grotse Schwankungen hei verschiedenen Individuen derselben Varietät vorhanden. Ein höherer Wassergehalt der Knollen begünstigt das Süfswerden. Dieser Zuckerzunahme entspricht eine Stärkeabnahme: jedoch ist nach den Analysen von $\mathrm{Czcbata}^{4}$ ) kein entsprechendes Verhältnis zwischen beiden Vorgängen nachweisbar. Nach Czubata geht ein Teil der Eiweifistoffe ans dem unlöslichen Zustande in den löslichen während des Gefrierens über. HöLter nimmt an, dats das betreffende Ferment bei niedriger 'Temperatur sich vermehrt.

Werden Kartoffehn, welche süls geworden sind, einige Tage in einen Raum gebracht, der mehr als 10" Wärme hat, dam hebt sich der Atmungsprozets, und der Zncker wird verbrannt, d. h. die Kartoffehn werden entsüfst und auf diese Weise für den Hanshalt wieder branchbar. Andere vorgeschlagene Mittel, wie z. B. das Auslangen der Knollen durch Wasser, führen nicht zum Ziel. Autserdem ist aber noch hervorzuheben, dats man süts gewordene Kartoffeh anch unbesorgt zur Anssaat benutzen kann. Siifs gewordene Kartoffehn ertrieren erst bei höheren Kältegraden als nicht süls gewordene Knollen").

1) s. Czsıк, Fr., Biochemie der Pflanzen. Fischer, Jena, T. I, S. 371. Dort auch Notizen über ältere Literatur.

2) Miture-Thurgau, Ein Beitrag zur Kenntnis des Stoffwechsels in stärkehaltigen Pflanzenorganen. Botanisches Centralbl. 188\%, Nr. 6.

3) Landwirtseh. Jahrb. 1883, s. 807.

4) Czriata, Die chemischen Teränderungen der Kartoffeln beim Frieren und Faulen. Öster.-Ungar. Brennerei-Zeitumg 1879; cit. in Biedermanns Centralbl. 1880, I, s. 47:.

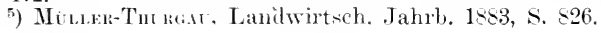


Anhangsweise möchte ich hierbei noch eine mir mündlich gemachte Hitteihng anschlietsen, dat's in Reinerz ein im Gestein liegender Keller existieren soll, in welehem die Kartoffeln auch ohne Frosteinwirkung suits werden. Man schreibt diese Erscheinung einer starken Exhalation ron Kohlensäure zu. Experimentell ist es mir nicht gelungen, binnen zwei Tagen eine Zuckervermehrung durch Autenthalt der Knollen in einer Kohlensäure-Atmosphäre nachzuweisen; indes wäre es wohl möglich. dat's nach längerer Zeit sich erst ein Einfluts geltend mathen dürtte. Die Angabe gewinnt an Wahrscheinlichkeit dureh eine Arbeit ron BACHET ${ }^{1}$ ) und SAvaLLe, wonach durch die Anwendme von Kohlensäure bei etwas erhöhter Temperatur und grölserem Druck stärkemehl schell in Dextrin und Traubenzucker umgewandelt wurde, namentlich wenn man den Prozefs's der Saccharifikation durch Beigabe ron Kleber erleichterte. Man kam annehmen, daf's durch reiche Kohlensäurezufuhr zu den Kartoffelknollen in dem vorerwähnten Falle aus Reinerz der natürliehe Atmungsprozets ebenfalls wie durch niedere Temperatur herabgedrüekt worden ist und der nach Müluer noch bis zu einer 'Temperaturhëhe von + 10" nachweisbare Znckerbildungsprozets eine langsame Anhäutung des Zuekers verursacht hat. Die Entstehung ron Saceharose bei der Keimming nach einer Temperaturerhöhung beweisen die Versuche von Marcaccl ${ }^{2}$ ) mit Kartoffelscheiben, die an der Sonne und im Ofen getrocknet wurden. Bei dem Anstreiben der Knollen findet sich in den jungen Trieben und später in den Blättern Saccharose (wahrscheinlich durch Hydratation der Stärke).

Dafs die Verwendungsmethoden für sütse Kartoffeln, die im äutseren Ansehen von den gesunden, nicht süfsen selten muterscheidbar sind, durchans nicht anf gefirorene, also vereiste anzuwenden sind, ergibt sieh aus dem Vorstehenden von selbst. Eine Knolle, die einmal hart gefioren gewesen, ist tot und täll bei dem Auftanen sofort hochgradiger Zersetzmng anheim. Die Knolle wird weich, läfst Wasser anstreten, wird an der Schnittfläche sofort bram, falls dieselbe nicht alsbald mit einer Säure überstrichen wird. Die Schale löst sich bald blasig unter Gasentwicklung rom Fleische, dessen Rindenzellen unterhalb der Korksehale durch Auflösung der Intercellularsubstanz sich lockern. Das Plasma ist bram und körnig und ron der Zellwand zurückgezogen, die Prote inkristalle sind dunkelbram; der Saft ist stark sauer.

\section{Scholsrüben.}

Mit diesem Namen bezeichnet man solche Exemplare von Zuckerund Futterrüben, welthe bereits im ersten sommer in Samen schietsen. Die Erscheinmng ist in manchen Jahren sehr häufig und bei der Ernte und Verarbeitung des Rübenkörpers störend, da der Wurzelkörper holziger als bei den zweijährigen Rüben ist. Über die Ursache der Erscheinung gehen die Meinmen anseinander. Sie bewegen sich in zwei Richtungen. indem einerseits die Beschaffenheit des Saatoutes. andrerseits die Wittermasserhältnisse und namentlich Frühjahrströste dafür verantwortlich wemacht werden. In Rücksicht daranf, dat' man tat:ächlich in Jahren, in denen Spätfröste die jungen Rübenpflanzen getrotfen haben, besonders viele "Schosser" oder "Trotzer" findet.

1) Nach Compt. rend. 1878: cit. in Biedermanns Centralbl. 1<79, S. 5.54.

2) M.rnc.sci, A., Sui prodotti della transformazione dell' amido. cit. Bot. Jithresb. 1891, I, S. 47. 
und gestuitzt anf die nachher zu erwähnenden Versuche von AderhoL, mit Kolhlrabi, reihen wir vorliegenden Kulturrückschlag an dieser stelle ein.

Aus der reichen Literatur über Zuckerrüben führen wir nur eine Arbeit an, da dieselbe nenere wissenschaftliche Untersuchungen bringt und kurz referierend die älteren Erfahrungen aufzählt. Axdruk und Mrsik ${ }^{1}$ ) kommen auf Grund zahlreicher Analysen zu dem Ergebnis, dats das Gewicht einer Schotsrïhe bald kleiner bald grötser als das der normalen Rübe sein kann. Die Wurzel der Schofsrübe ist ärmer an Kali, Phosphor- und Schwefelsäure sowie an Ammoniak- und Amidstickstoff. Der Saft ist reiner. Ton der durch die Schofsrübe gebildeten organischen Substanz betrug der Zuckergehalt nur $4 . ;-5, \% / 0$, bei der normalen Rübe 54-69\%. .. Der grötste Teil der zuckerfreien organischen Substanz entfiel auf das Nark, also die das feste Gerippe der Pflanze bildenden Bestandteile . . . .". „Die Markbildung erfolgte wahrscheinlich auf Kosten des Zuckers."

Wir ersehen, dat's die Rübenpflanze ihren angezüchteten Wachstumsmodus, im ersten Jahre nur Reservestoffe im Wurzelkörper zu speichem und dieselben im folgenden Jahre zur Samenbildung zu verwerten, geändert hat und die durch den Blattapparat erarbeitete organische Substanz sofort weiter verwendet.

Dieser Umstand weist daranf hin, dafs der bei der Kulturrübe normale Vorgang der mansgesetzten Bildung neuer Blätter eine Störung erfahren hat. Die Vegetation hat für einige Zeit einen Stillstand erlitten, gleichsam eine Ruheperiode durchgemacht, die der winterlichen Ruhe eines normal ansgereiften Rübenkörpers entsprechen würde. Das neu mobilisierte Reservematerial wird hier wie dort nach dem Wachstumsstillstand zur Produltion des Bliitenstandes verwendet. Daf's Spätfröste einen solchen Wachstumsstillstand hervorzurufen vermögen, ist wohl begreiflich; sie werden $u$ so mehr eine Samenstengelbildung amregen, je später im Jahre sie eintreten, und je mehr die nachfolgende Witterung die Ausbildung eines Blïtenstandes begünstigt. Ist das der Frostnacht folgende Wetter dagegen ganz besonders für die Laubentwicklung geeignet, kann die begomnene Streckung der Achse zum Stillstand kommen und die Ausbildung des Rübenkörpers fortschreiten. In grofsen Zuckerrübenfeldern findet man in der Regel Schof'ser und derartige Mittelformen. Sicherlich kamn diese Neigung zum Schossen durch Samen vererbt, vielleicht anch schon im Saatgut von normalen Rüben vorbereitet werden, wenn dasselbe nicht genügend ausgebildet, also z. B. unreif geerntet worden ist.

Den experimentellen Beweis über die Bildung von "Schossern" infolge von Frostwirkung hat AпекноLо ${ }^{2}$ ) bei Kohlrabi geliefert. Er hatte Sämlingspflanzen in Töpfen 8-12 Stunden in einen Gefrierraum gebracht und dann dieselben mit anderen nicht vom Frost beeinfludisten ausgepflanzt. Bei einem Versuch erhielt er z. B. von 18 unbehandelten Pflanzen zwei Schosice und ron derselben Anzahl ron Exemplaren, welche im Mai 10 stumden hindurch einer Kälte von $-2{ }^{\circ}$ bis - 6,5" C ansgesetzt gewesen war, sieben Schoser. In beiden Fällen überwanden S. 374 .

1) Schofsrübe und normale Rübe. Blätter f. d. Zuckerrübenban 1905, Nr. 24,

2) Anerhons, R., Über das Schiefsen des Kohlrabis. Mitt. d. K. Biolog. Anst. 1906, Nr. 2, S. 16. 
später einzelne Kohlrabi den Stol's der Frostwirkmo und setzten noch einen Rübenkörper an.

Dats solche vorzeitige Blitenstengelentwicklnng anch bei anderen. Heischige Revervestottbehälter bildenden Ptanzon (Sellerie, Mohrrïben. Rettichen) in manchen Jahren reichlich anftritt, ist bekannt. Dats dabei nicht immer der Frost, sondern anch andere Ilemmungsvorgänge wirksam sein können, ist sehr wahrscheinlich.

\section{Frostgeschmack der Weinbeeren،}

Die Vorgänge, welche bei dem Süfswerden der Kartofteh eintreten, vollziehen sich auch bei den Holzgewächsen. PFEFFe' ') erwähnt in dieser Beziehung die Untersuchungen von Frscher ${ }^{2}$ ) über die Schwankungen zwischen Stärke und Zucker bei den sogenammten Stärkebämmen wie Linde und Birke ${ }^{3}$ ). Bei der Überführmo von Zweigen im Winter aus dem Freien in das warme Zimmer biletet sich bimen wenigen Stunden in den Rindenparenchymen Stärke ans, welche in der Kïlte wieder in Zucker ïbergeht. Eine ähnliche Zuckerbildnng rerbunden mit Almahme der organischen sämren sehen wir nach Frostwirkung bei den Weintrauben eintreten.

Sielbst solche Trauben, die noch nicht ausgereift waren, und die zwar in ihrem Hauptsticl vom Frost angegriffen, aber im Kamm noch grïn und in den Beeren noch klar waren, zeigten eine bedentende Säureabnahme und steigen des /uckergehaltes ${ }^{4}$ ). Betreffs der Verminderung der Sämren ergab eine Untersuchung von Rieslingtrauben am Stocke, die rom 1!. Olitober bis !. November einer Kälte bis zu : "C ausgesetzt gewesen, eine Sämeabnahme um 4 \%. Abgeschnittene, halbreite. vom Frost stark beschädigte Trauben zeigten vom 1.-11. Oktober einen Verlust ron $4,5 \%$ an Sämre.

Der Frostueschmack scheint aber nicht ant der /uckerzunahme und säureabnahme allein zu beruhen, sondern es werden vielleicht noch Stoffrerhindungen aus den Beerenstielen diffundieren, die das Protoplasma der Zellen ohme die Frostwirkmng nicht hindurchgelassen hätte. Es dürtte durch diese Teränderungen die Empfänglichkeit der Trauben für den Treitsfäulepilz gesteigert werden, da VuL. und PAcotrer ${ }^{5}$ ) nachgewiesen haben, dat's dieser Pilz nur bei hohem Zucker- und geringem Säuregehalt die Beeren zu infizieren rermag. Der Black-rot verhält sich gerade mingekehrt.

\section{Veränderungen an Blütenorganen.}

Bei der Einwirkung des Frostes treten bald die chemischen. balı die mechanischen Vorgänge in den Vorderorund. Bei den ersteren ist es schwierig zu entscheiden, inwieweit dieselben sich schon während des Gefrierens emleiten oder erst bei dem Anftanen begimen. so hat beispielsweise (iöp'skT' hei den Blumen von Phajus und Calanther

1) Phrsiologie. 2.. Aufl., I, S. 514.

2) Jahr?. f. d. wiss. Bot. 1-91. Bd. 22.

3) C̈ber die Periodizität der Stärkezu- und abnahme in den Biimen. Vergrl. Mre, E. in Bot. Jahresb. 1891. I. s. 46.

4) Biedermanns ('entrall, 1879, I, S. 23:\%

5) Vinil, P. et P.cotiki, Sur la culture du black-rot. Compt. rend. 1904. CXXXVIII, S. 306 .

6) C̈ber Einwirkung des Frostes auf die Gewächse. Sitzungaber. d. Sichles. Ges. f. vaterl. Kultur 1\$7t cit. Bot. Zeit. 1875, S. 609. 
ein Blauwerden derselben beim Gefricren beobachtet und diese Farbenänderung dadurch erklärt, dat's durch die Frostwirkung eine Oxydation des in den sonst farblosen Zellen enthaltenen, namentlich im die (refätsbündel herum reichlichen Indicans zu Indigo stattfinde. Prilliecx ${ }^{1}$ ) gibt an, dat's diese Veränderme erst bei dem Auftamen eintrete. In ähnlicher. Weise schwankend sind anch anderweitige Angaben über das Verhalten der Blütenfarbstofte, und man kam im allgemeinen uur sagen, dats der rote Farbstoff zu den widerstandsfähigsten gehört, ja nach (GöpperT ${ }^{2}$ ), der viele Beobachtungen über die durch Frost hervorgerufenen Farbenerscheinungen gesammelt hat, sich an Blättern und Blïten durch schwache Frostwirkmgen noch steigern kann.

Am hänfigsten und darnm am bedeutsamsten sind die Froststörungen an den Blüten unserer Obstgehölze. Für die Praxis ist es allerdings qleichgültig, in welcher Weise der Verfärbungsvorgang verläuft. Wissensehaftlich aber dïrtte es von Interesse sein, die Frostwirkung genaner kennen zu lernen. Da wir aber bei den natürlichen Frühjahrsfrösten nicht feststellen kömnen, welches die ersten Frostwirkungen und welches nachträgliche Veränderungen sind, habe ich künstliche Fröste auf Apfelblüten einwirken lassen.

Nachdem ein blühender Apfelzweig während zwei Stunden einer Temperatur von - $4^{\circ} \mathrm{C}$ ausgesetzt worden war, ergab die sofort nach dem Abheben des Gefrierzylinders vorgenommene Untersuchumg, dals die sämtlichen Blumenblätter wie einzehe Stellen der Laubblätter eine glasige Beschaffenheit angenommen hatten.

Bereits nach wenigen Mimuten (die Lufttemperatur betrug $+11^{\circ} \mathrm{C}$ ) begann ein Erschlatfen und Bramwerden der glasig gewesenen Teile. Die Bramnfärbung der Blattorgane ist also nicht direkte Wirkung der Kälte, sondern eine erst bei dem Auftanen sich geltend machende Erscheinung. Die in ihrer natürlichen Färbung unterseits rötlich anwehauchten Blumenblätter wurden braunadrig und fleckig. Der Rand fing alsbald an zusammenzusinken und zu vertrocknen. Der (vnerschnitt zeigte, dats die Verfärbung weniger auf einer Bräunm der Zellwandungen als des \%ellinhaltes beruhte, indem dieser rotgelbe bis braungelbe, zusanmenhängende, meist in der Längsrichtung der Zellen sich lagernde Massen ausscheidet, die an Karotin erimnern. Die einzelnen Zellschichten des Blumenblattes zeigten ein verschiedenes Verhalten. Die ausgeschiedenen gelben Massen waren namentlich reichlich unterhalb der farblos und in ihrer natürlichen Höhe verbliebenen Epidermis zu finden. Autserdem zeigten die Parenchymzellen, welehe die Gefät'sbündel der feinen Nerven begleiten, diese Ausscheidungen besonders ausgeprägt. Durch letzteren Umstand kam es, dals gerade die Aderung des feimen Blumenblattes dem blofsen Auge auffüllig bram erschien. Bei dem schnell fortschreitenden Vertrockimungspozesse sanken die Zellen des Mittelfleisches zusammen, während die Oberhautzellen in ihrer natïrlichen Höhe verlulieben.

Fig. 103 gibt ein Bild von einem Teile des Blumenblattes bald nach dem Herausnehmen aus dem Gefrierzylinder. Wir sehen das Blatt noch in seinen natürlichen Dimensionen mit den grotsen Intercellularräumen (i) zwischen den äut'serst zartwandigen Blattfleischzellen und

1) Bot. Zeit. 1\$71, No. 24. - Bull. de la Soc. bot. de France 1872, s. 152.

2) Kınхs' H., Über die tödliche Wirkung niederer Temperaturen auf die Pflanzen. Inauguraldissertation, s..29. Breslau 1880 . 
mit der unveränflerten Epidermis (e). Die Verfähmm dureh die gelbbramen, zusammengezogenen Inhaltsmassen (b) ist am intensivsten in rer Umgebung des Gefätsbündels (g) mol zwar besonders ant dor Unterseite des Blmmenblattes. Im trefälsbundel sind die engen stiralgefätse gebräunt.

In anderer Weise war der Bränmugsorgang hei den Stanbertaitisen verlanfen. Nach dem Heransnehmen ans dem Gefieryylimder crhielten sie sich noch anscheinend mverändert, als dio Bhmenblätrer schon zu welken anfingen. Erst später wurlen die Stanbtärlen gelhbram mul die Stanblientel heichgelb. Ler quersehnitt dureh den Stanhfarlen zeigte, dats die Bramnärbmo wesentlich durch die inhaltseiche Epidermis bedingt wurde. \%war ersehien in allen feweben der /ellinhalt tropfig bis khmpig zusammengezogen nud bram, aler die substanz. menge in den imneren \%ellen war so gering, dats die Färbmo des resanten (rewebes cine mattere blieb. Hie Spiralgefätso waren wie bei den Bhmenblättern leicht hramwandig. Bei den stanbbontrh hing die Verfärbmo elenfalls von der Menge des Zellinhaltes ab. Derselbe fand sich im comnektiv am reichlichsten, und fioses orschien

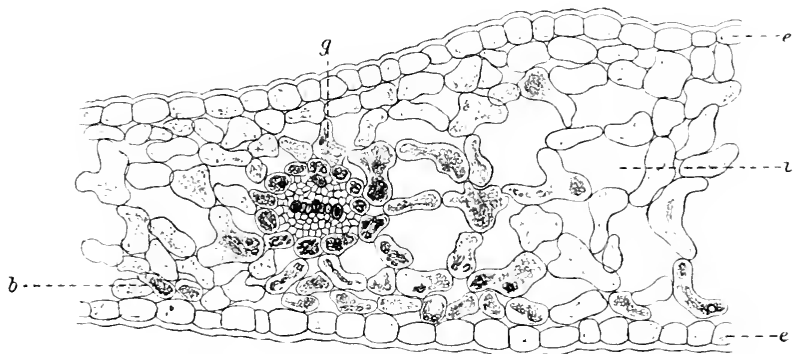

Fig. 10:3. Durch künstlichen Frost beschädigtes Blumenblatt eines Apfels. (Orig.)

laher am tiefsten gebrämnt, während die staublientel solbst in ihrer Epidermis mod den darmer liegenden palisadenartig geordneten Faserzellen nur äufserst spärlich feste Inhaltsmassen antwiesen und daher nahezn farblos erschienen. Die Reste des (irmongewelies in drer Nähr les Commelitivs waren etwas dunkler.

bie schwersten Beschärligmgen zeigten die Griffol, die schon bei rem Verlassen des Gefrierzylinders tieflram und verbogen ansisaben. Ein /usammensinken des (iewebes war zunächst nirgends bemerklual. Die Narbenpapillen erschienen straff und mit gebrämntem, plasmatischem Inhalt angefïllt. Sie hielten anch noch, wie im trisehen Kustande, dir. etwas gequollenen mol daher vorschieden gestalteten, mit trülwem, gleichmätsigem Inhalt erfïllten Pollenkörner fest. Am Griffel waren wie bei den stanhfäden die peripherischen schichten am inhaltreichsten und rlaher in Inhalt und Wandung am tietsten bram gefäbt.

Von mechanischen störungen bemerkte man hier umd da in firittelwie im Staubfadengewebe tangentiale Lüclien, die teils dmolı Anscinanderweichen, teils aber auch duch Zer reits nu vom Zellen entstanden waren. Nach dem behaarten (iriffelfuls hin. desen inhaltsarme Haare eine Bräunmo der Wandung erkemmen liefisen, nahm dir Kalıl 
und frobse der Gewebelücken zu. Ilier erweitert sich das Gewebe des ciritfelfutses bereits zu fünt anseinanderwoichenden. mit ihrer spitze nath dem Zentrum gerichteten, stmmpt kegelförmigen, parenchrmatischen Gruppen als T̈bergangsitelle in die fünt Fruththatter. Jedes derselben lätst eine epidermale Umkleidmo nut cin parrnehrmatisches Imnenfleisch mntersheiden. In dem Fig. 104 dargestellten Qnerschnit eines Apteltiuchthechers sehen wir das zukiunftige Aptelfuchtfleisch bereits von zahlreichen. regehmälig gestelltu (refäbliündeln (g) hurchzogen. Ter mit einer fisten Epidermis (e) moleidete Fruchtbecher sotzt sich

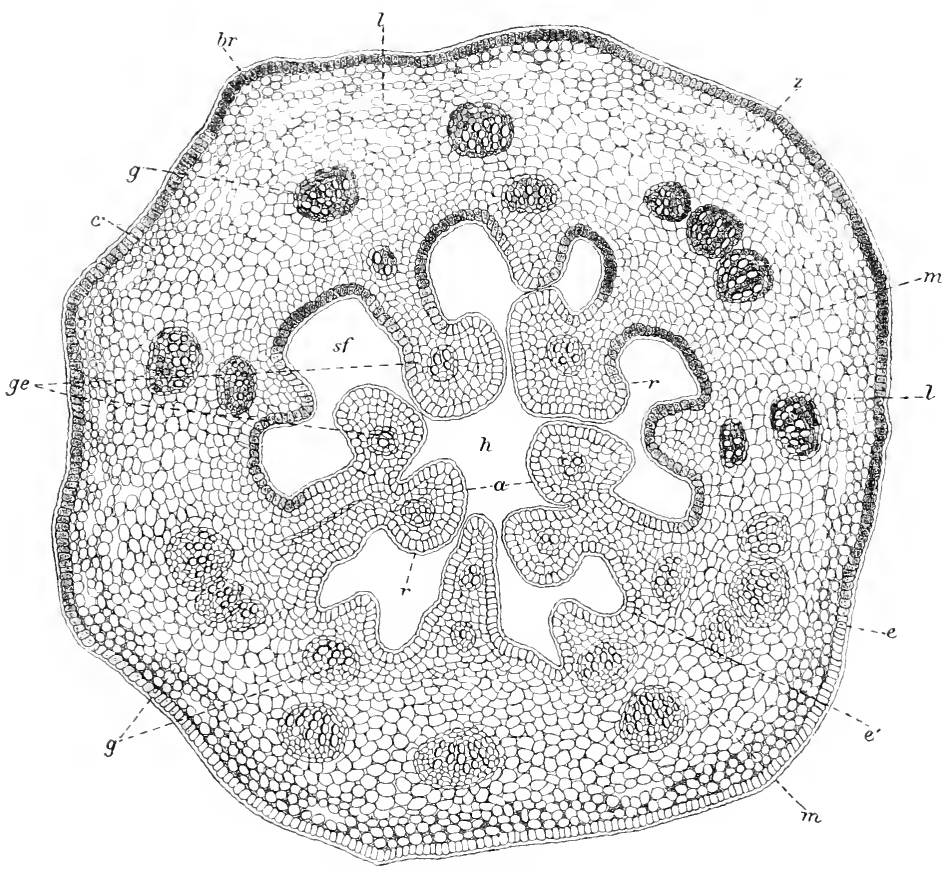

Fin. 104. Querschnitt durch einen jungen, frostbeschädigten Fruchtbecher des Apfels. (Orig.)

nach innce in tïnf ankerförmige Äste (a) fort. E- sind dies die fünt Fruchthätter. zu welchen sich die Griffel erweitern: an ihren umgeschlagenen Rändern, die im (2nerschnitt wie Ankerame erscheinen $(r)$. bilken sich in nutren Tril des Frneluthechers die samenlinospen, die ihre Emährmo dnoh dir crefätsündel (ge) finclen. I)ie Samenfächer (sf) mut der Hohlram (h), der in der Nitte durch die nitht verwachsenden Fruchtblattränder fiei gelassen wird, finden sich mit regelrechter Epidermis answelifeidet (r). Die Kellen der Epidernis erweisen sich sowohl an der Achsenseite $(h, \%)$ als anch immerhalh des Frucht- 
bechers am inhaltreichsten und daher an tief-sen gehräunt, während die zentrale, zunächst noch meristematischr Partio jedes Fruchtblatter nur schwach vertäirbt ist.

Eine Zerklïftung des Gewebes, dic sich im Auftreten tangentialer Lücken (l) durch Trenmmg der eollenehrmatischen sehichten (c) rom

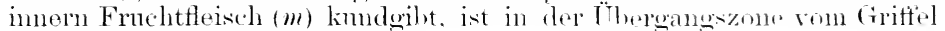
zum Fruchtknoten schon bei schwachen Verolöserungen bemerkbar. Es ist hervorzuheben, dafs dabei tatsächlich anch, wie in den Staul,gefätsen ein herreition ron Zellen $(z)$ stattfinclet, währent bei derberen (rewelen nur das gewöhnliche Anseinamlerweichen der Zelllagen vor wich geht. Diese mechanisehen Störungen. die hei den vegetativen Oroanen, wie wir später sehen werden, so bedeutungsvoll sind, haben bei den Blütenorganen geringe. ren Einfluts. Die Bliiten sterben schen dureh die chemisthe Veränderung des bellinhalts nud werten mur schneller abgeworten. wemm gleichzaitig Zerklüttungen vorhanden sind. Der experimentelle Befund deckt sich mit den Erscheinungen nach natürlichen Früh,jahrsfiösten.

Wie selur ron der Beschattenheit des Zellsattes die Frostempfindlichkeit abhänot, mag die nebenstehende Abbildume einer jumgen. von schartem Frost getroffenen Apfelbliite zeigon (Fig. 111.). Die dasolbst einseitig ansqefïhrten sehattiermugen n. sonstigen Bezcichnmogengeltensolistverständlich tür beide Hälten. Alle schratienten stellon

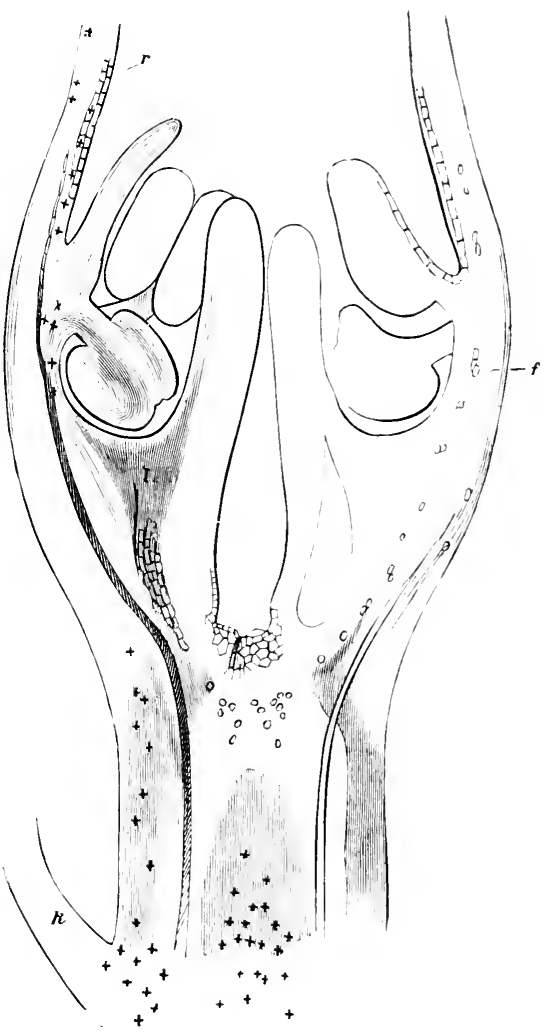

Fig. 105. Die in der Knospe durch Frost beschidigte Anlage einer Apfelblüte. Inrig.l

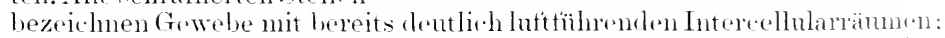
bei, ist durch die Glyzerineaktion Zucker nachweisbar: die Krenze he-

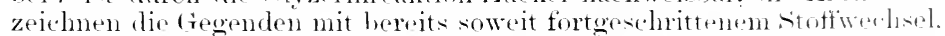
dats reichlich oxalsaurer Kalk alegelagert wird. Die Ringe $f$ sollen die einzelnen frostgebrännten Zellen andenten: alle jünguren. plasmareicheren Innenteile sind gesund geblieben: dis dunkle lanis in sin Getälibündelstrang. 
Dats auker den beschriebenen akuten Kältewirkungen auch thronische, nur anf Verlangsammo der normalen Lebensvorgänge beruhende störungen des Blïtenlebens rorkommen, sei hier nur anhangsweise erwälnt. Das bekannteste Beispiel diurfte tas Unterbleiben des Öthnens der Blüten von Crocus rimus und Tulipa Gesnorima sein. Durch die niedrige Temperatur findet kein qenügend starkes Wachstum der Innenseite der Perigonblätter statt, so dats ein Heransbiegen (terselben, also ein Aufblühen muterbleibt. Ähnlich, aber sehwächer reagieren äie Blumen von Ornithogahum umbellatum, Colchicum autumale. Adomis vanulis n. a. Dafs auch grïne Blätter durch Einflut's niederer Temperatmen thermonastisch reagieren, beweisen die Vorgänge bei Mimosa pulica, Oxalis acrowa usw. Hierher gehöriges Material findet sich noch in den späteren Abschnittrn, welche die mechanischen Frostwirlingen behandeln.

\section{Die Rostringe an Früchten.}

Als Folgen leichter Frostbeschädigungen an jungen Früchten treten die sogenamnten Rostringe aut. Man versteht darmter verschiedenartige, namentlich bei Kernobst in ringfömigen /onen sich ansbreitende Korkbildungen der Fruchtschale. Bei manchen sorten ist das Erscheinen korkfarbiger Zeichnungen ein ganz normaler Vorgang. Unsere Reinetten besitzen beispielsweise vieltach sternförmige, kleine Rostpunkte. Die sogenannten ngestrickten Reinetten " zeigen linienartige Korkzeichnungen aut "der Fruchtoberhant, und manchmal erlangen solche Korkbildungen auch eine tläthenartige Ausdehmung, wie z. B. bei der französisthen Reinette, Parkers granem Pepping, bei der granen Herbstbutterbirne, der Mispel nsw. Krankhaft ist nur die in manchen Jahren (z. B. 19u(1) hocharadig gesteigerte Ansdehmung der Erscheinmng aut viele sonst glattbleibende Sorten und die Ansbreitung der Korklillumg über den gröfsten Teil der Frucht. Die Anfangsstadien zeigen sich in trüher. Jugend. Man bemerkt zunächst nach Eintritt selm später Maifiöste, dafs einzelne Grupuen von Oberhautzellen bramen Inhalt bekommen und ahzusterben beginnen. Unterhalb solcher stellen bildet sich Tatelkork, wodurch die absterbende Epidermis etwas vorzewölbt wird. Während des Schwollungsprozesses der jungen, grünen Frucht schreitet die Korkbildung rückwärts in das Fruchtfleisch hinein weiter fort, so dafs grösere Gruppen von parallelen Reihen senkrecht zur Obertläche angeordneter Zellen entstehen. In einem speziellen, bei ..Amanlis Butterbirne" beobachteten Falle zeigten diese reihenweis anweordneten Kellen diescibe Anstohmmg wie die Oberhantzellen; sie erwiesen sich aber nur in ihren peripherischen Lagen wirklich verkorkt, wäluend die hellen dicken Wandungen der tiefer liegenden Zellen Cellulosereaktion zeigten Je stärker die Nenbildung ist, desto meln werden dic über ihnen liegenden, absterbenden Zelllagen zersprengt, und die Fruchtoberfläche wird sehmpig-rauh.

Bei flaschenförmigen Birnen erscheint manchmal der die Kelchzipfel tragende, banchige Teil rer Frucht rostig-grauschuppig und die stielhältte wlatt und grïn. In anderen Fällen zeigt sich ein breites liorkfarbiges Band in ler Nähe der Kelchhöhle usw. Bisweilen ist mit diesem Einreitsen der Wachsolasm und Absterben der Oberhantzellen eine Ausbildung des neu darunter entstandenen Gewebes zu Steinzellen verbunden, und diese treten später in kreisfömigen Herden an die Fruchtoberfläche, $\therefore$ dats die /nstände entstehen, die wir bei der ..Lithiasis" (S. 171) 
beschrielven haben (.,Diels Butterbirne" .. frute Lnise von Arranches"). Da solche Veränderungen sich meist einseitig zeigen, so bleibt die korkfarbige, steinzellige Fruchtseite vieltach im Wachstum zurück, und es entstehen Krüppelfïichte.

Nachdem es mir gelmogen, durch Einwirknus kïnstlither Fröste clas Zersprengen der C'nticularlecke bei derben Blättern hervorzuruten, stehe ich nicht an, anch die Beschädigme der Warchsolasm an jumgen Früchten auf Frostwirkmng zurïckzuführen, zmmal dio Bildung solchor .Rostringe" bisher nu in Jahren mit spätrösten beohachtet worin ist. Die frostempfindlichen Birnen leiden am häufigsten und stäristru und zwar meist an einer Seite und in bestimmter Höhe dos Jammin.

\section{Das Verhalten älterer Laubblätter bei akuter Frostwirkung.}

Während des Frostes sind Ändermgen an den Chlorophyllkörnern insofern bemerkbar, als sie sich in den sattärmer gewordenen \%ellon meist klumpig zusammenballen. Eine chemische Verändermeg des C'hlorophyllarbstoft's durch den Frost allein wird, soweit Angalien ïber gefrorene Chlorophyllösungen vorliegen, von der Mehrahl der Forseher nicht angenommen. Bei einer Temperatur von - 30 $0^{\circ}$, der eine chlorophylllösmng in Olivenöl ansgesetzt worden, fand WiEsske ${ }^{1}$ lieinen

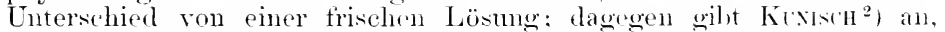
dats der allioholische Chlorophyllansing von lue $-7 "$ gefirorenen Hrazinthenblättern sich abweichend von dem der nicht getrorenen Biätter gezeigt habe. Manthmal sieht man beim tictrieren der Blätter stumpfweitsliche Flecke anftreten, die von Eisdrusen herribren kïmsn. welche in die Intercellularräume ansschiefisen. Hoffuss sah bei Corotomiu. Landes und Camplora blasiges Abheben der Epidermis und hezeichnet diese Erscheinmng als „Frostblasen"3). Bui starken Frösten werch die gänzlich durchfiorenen Blätter glasartig sprö̈le und durchscheinend. Bei dem Auftanen derartiger Blätter hängt dio Farbenändermng davon ab, ob das Protoplasma der Zellen getötet ist oder nicht. Im ersteren Falle ist es für die säuren in der Kelle durchlässig, und diese dringen an die Chlorophyllkörner, deren Zersetzung sie einleiten (Chlorophrllanbildung): das Plasma brämnt sich: der Zellsatt tritt sehnell nach autisen, das Blatt trocknet zu ciner spröden, bramen Masse zusammen. (iöppert ${ }^{4}$ ), der die verschiedenen Färbungen der Laubblätter beschreil, erwähnt auch noch einen überaus starken Krautgeruch bei erfiorenen Pflanzen, und bei Farnkräntern erhält sich der der ganzen Familie eigentümliche Geruch in den erfrorenen und getrockneten Exemplaren in ungewöhnlicher Intensität. Bei kïnstlich rrfrorenen Sülskirschenzweigen fand ich ausgesprochenen Bittormandelgerueh. Es sind dies Folgeerscheinungen des Chemismus, der sich boi dem Auftauen sofort enererisch aeltend macht. Eine andere Wirlsung hat FLteklite ${ }^{5}$ ) an erfrorenen Kirschlorbeerluattern beobachtet. I)ieselben gaben bei der Ilestillation

1) Whsser, Die natïrlichen Erscheinungen zun schutze des Chlorophylls etc Festschrift d. k. k. zoolog.-bot. Ges. zu Wien l-76, s. 2:3

") Krsiscu, H., Über die tödtliche Wirkung niederer Temperaturen auf lif Pflanzen. Inauguraldisertation. Breslau 1880 .

3) Kexisen a. a. O., s. 2.2.

4) Göprenr, Über Einwirkung des Frostes auf die Gewächse. Sitzung-h, a schles. Ges. f. vaterl. Kultur 18it: cit. Bot. Z 1875, S. 609 .

5) The effect of intense cold on cherry-laurel.; cit. Bot. Centralbl, $1 \cdots 0, \mathrm{~S}_{\mathrm{T}}$ 
ein von dem der frischen abweichendes (̈) und keine Blausäure, während mit Eis hedeckte, aber nicht erfrorene Blätter beide Substanzen im normalen Zustande lieferten.

Wichtig ist es, ant das Verhalten der Nineralstotfe in den durch Frost getöteten Blättern hinzuweisen, weil wir dadurch einen Einblick in die Stotfiverluste erlangen, welche eine Lanbzerstörung durch Frühjahrströste veranlatist.

Schrofder's $\left.{ }^{1}\right)$ Analysen ron Rothuchenlaub, das ein Maifrost getötet hatte und das vier Wochen später im vertrockneten Zustande der Untersuchung unterzogen wurde, ergaben Folgendes: In dem erfrorenen Laube ist der ganze Stickstoffgehalt $(3,5,0 \%)$ der frischen Maiblätter vorhanden, währent in den Herbsthlittern nur etwa noch 1,33\% vorhanden sind so dafs also der Pflanze durch den Verlust des Mailaubes tast dreimal soviel Stickstotf' verloren gelit als durch den herbstlichen Lanbfall. Die 'Trockensubstanz ergab 3,10100 Asche. Von dieser Asche waren 20 "Phosphorsäure, also soviel wiederum, wie in frischen Maiblättern, während die Juliblätter nur ; \% besafsen. Von Kali waren in den Maiblättern normal etwa $310 \%$, in den ertiorenen dagegen nur $\therefore$ " o vorhanden. Kalk war natürlich im jungen Laube noch wenig $\left(1,78^{\circ}\right.$. im gesunden, $4.70^{\circ} 0$ im erfrorenen Laube) vorhanden, während die vegetierenden Juliblätter schon dreimal so viel $\left(20,34^{\circ}{ }^{\circ}\right)$ besafsen. die abgestorbenen Novemberblätter sogar $37,60 \%$ anfwiesen.

(iegenüber der Neinmo, dat's das vom Frühjahrsfrost abgetötete Laul am Baume hängen bleibt und somit dessen wertvolle Nineralhestandteile Zeit zur Rückwanderung in die Achse finden, ist auf die Untersuchmgen von R.mans ${ }^{2}$ ) zu verweisen. Derselbe zeigte, dafs das von der Kälte getötete Blattwerk bei Eiche. Fichte und Tamne allerlings zunächst dieselbe Zusammensetzung besafs, wie das frische Laub. sofern es noch vor einem Regen analysiert wurde, aber durch den Regen eine sehr wesentliche Veränderung erlitt; demn Ramann fand, dat's bimmen 72 Stumden Wasser nicht weniger als 19,219\% der Gesamtasche der Rotbuchenblätter und bei der Eiche sogar $26,46^{\circ} \%$ auszog. Dat's diese leichte Diftusibilität der Aschenbestandteile nicht etwa als eine Folge späterer Zersetzung angesehen werden darf', geht daraus hervor, daf's die grötsten Mengen, nämlich bei der Buche 15,4:\% \% bei der Eiche 19,66\%. r.hon in den ersten 24 Stunden ausgelaugt worden waren. Diese letzteren Mengen ergaben an Reinasche für cie Buche $11.15 \%$, für die Eiche 14,18"\% des Anszuges.

Wie sehr der Lanbverlust den Achsenkörper schädigt, ergibt sich ans einer andern Arbeit von Schroener ${ }^{3}$ ) über . die Wanderung des Stickstoffis mul der Mintralhestandteile währent der ersten Entwicklung der Tricbe in der Frühjahrsperiode". Die Erschöpfung der Achse durch die Produktion der jungen Triebe ist am weitestgehenden bei der Phosplnorsäure. nämlich 4i\% Sticlistoff' mud Nagnesia gehen etwa zu $26 \%$ aus der Achse herans. Dafüir treten bis zu Ende dieser Periode 1.200 Kalk und 84\% der Anfangsmenge an Kieselsänre hinzu. Ton der (iesamtmenge des in die jungen Triebe einwandernden Stickstoffs, Kalis und der Phosphorsäure

1) Srulomwa, Entersuchung erfrorenen Buchenlaules. Forstchemische $u$. pflauzenphysiologische Intersuchungen, Heft I, 187, Dresden, s. 87. S. 1274

2) Rimax, Aschenanalysen ertrorener Blätter md Trielse. Bot. Centralbl. 1s४0,

3) a. a 0., S. 8:3. 
stammt etwa ${ }^{1}, 5$ aus der oberirdischen Achse, ${ }^{4}{ }_{5}$ aus der Wurzel und dem Boden. Diese Verhältnisse sprechen datür, dats der Wurzelkörper in noeh höherem Grade als die oberirdischen A.hsenorume von seinem aufgespeicherten Vorrat an stickstoff, Phosphorsäme und kali abgiht.

\section{Mangelhafte Ergrünung jüngerer Blätter.}

Eine besondere Form der Äntserung niederer 'Trmpleratmen anf' die Färbung des Pflanzenkörpers ist clas Gelbbleiben wachsender Organe ans Mangel der nötigen Erorïnmgstemperatur. Bei verspillerten Keimptlanzen, die, limze Zeit dem Lichte auscesetzt, geller. wurden als die in Dunkelheit verbliebenen Exemplare, tand Elfrisig'). dats sich Etiolin gebilıtet bei Temperaturen, die für die ('hlorolhyllbildung noch zu niedrig waren. Im ersten Früljahr, wenn Pflanzen ihrer Schutzdecken entledigt worden, finden sich zahlreiche Beispiele. datis die muter der Declie entstandenen, etiolierten Triebe trotz der hisweilen reichen Beleuchtung ihre gelbe Farbe nicht oder mu lang und mregehmälisg, nämlich stellenweis verlieren. Das häufigste Beispic] lietern die Hyazinthen in den (räten. Wenn dieselhen zu zeitig in Frühjahr aufgedeckt werden, und ler Frost die jungen, noch nicht rroünten Blattkegel überrascht, entwickeln sich wohl sjäter die Blätter in normal grüner Färbmy weiter, aber ilne jungen spitzen luleiben weils oder well.

In den gelb erscheinenden Teilen sehen wir meist die chlorophyll-

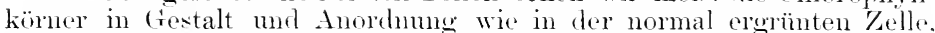
also den fireiliegenden oder an Intercellulareänge grenzenden Teilen der \%ellwand angelagert (Epristrophe): jedoch ist der Farbstoft' nur ein melu oder weniger intensives (ielb. "Ton diesem Stadium bis zum vïlligen Fehlen der Körner in der wänzlich gebleichten spitze des Blattes tinclen sich alle möglichen Überginge: liese sind aber keine läsungszustände, sondern Hemmungsbildmngen. In den weifsestan Partien des Mesophylls erscheinen die Zellen mit wässrigem Zellsaft erfüllt, der ron Plasmasträngen durchzogen ist, ohme dafs im plasmatischen Wanrlbelage irgendwelche Chloroplyyllkörper angelegt wären. In anderen Zellen der gelblicher aussehenden Partien ist die Differenziermng des Inhalts bis zur Anlage der ('hloroplasten fortgeschritten: aber diese erscheinen weifslicher, weicher, ich möchte sagen, bisweilen wolkiger. minder dicht und minder scharf konturiert. In den nach der Frostwirkung aus der Erde herausgetretenen Teilen der Blätter findet man endlich normal ausgebildete, intensiv grïne Chloroplasten. Bisweilen ist der Erorünmosinangel mit Auftreten von rotem Farbstotf rerbunden.

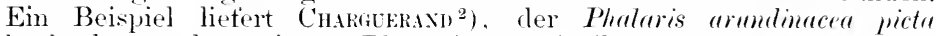
beobachtete, deren junge Blattspitzen mit ihren bekannten, weif'sen Streiten fiostgerötet hervortraten: die rosenrote Färbung verschwand bei Eintritt warmer Wittermng. Eine Bestätiomng für den Eintritt der Rotfärbung hei Kälte liefert ScheLL ${ }^{3}$ ), der im Erïhjahr Pflanzen mit rotgefärbten, jungen Blättern in drei Partien in verschiertenn Temperatmen brachte mol heobachtete, dats die im Zimmer bei + 15" " befindlichen Exemplare bimmen 1s stunden grün wurden, wälmend di

1) Arbeiten d. Bot. Instituts zu Würzburg. Bd. II. Heft 3; cit. Bot. Centralbl. $1880,5.835$.

*) Revue horticole. Paris 1\&i4, S. 249.

?) Botanischer Jahresbericht 1×76, S. 717 . 
1, i +5.50 ( gehaltenen Individuen erst nach 5 'Tagen ergüunten uncl die im Freien bei einem Maximum ron etwa $+4^{\circ} \mathrm{C}$ belassenen Pflanzen erst nach 20 Tagen grün wuden, als die Lufttemperatur sich crhöhte. Es sprechen diese Beobachtungen für die von mir geänlserte Ansicht, dafs die Rotfärbung durch ein Überwiegen eines an die Lichtwirknng gebundenen Oxydationsprozesses über den Assimilationsprozets hedingt wird. Bei gleicher Lichtmenge steigert eine Temperaturerhöhung die Assimilation derart, dats der Eroriunmgsprozet's ïberwiegt.

Zur Termeidung einer Fixierung des krankhatten, gelblichen Aussehems trostgebleichter Blattspitzen ist anzurmptehlen, die Winterdecke a $l \mathrm{~m}$ ählich wegzmehmen orler cine leiehte Reisigrchicht für die ersten 'Tage üler' dlie PHanzen auszubreiten.

\section{Der Frostlaubfall.}

Das plötzliche Abtallen des Laubes während und nach Eintritt der ersten Herbstföste ist nur eine Form des herbstlichen La bufalls. der (im Gegensatz zu den bereits beschriebenen Fällen abnormer Entblätterung nach ïbermä1siger Hitze, 'Trockenheit, Lichtmangel, Wassuäberschuts und anderen, eine plötzliche Funktionslosigkeit des Organs herrormtenden Ursachen) als seniler Tod zu bezeichmen ist. Das Blatt hat sich eben ansgelebt und ein derartig normaler Tod desselhen hat fïr die lebendig bleibende Achse die wenigst nachteiligen Folgen. Aus dem senilen Blattapparate wandern allmählich viele plastische sowie wichtige mineralische Stoffe in den Stamm zurick und kommen bei der nächsten Vegetationsperiode zu nener Verwendung. Das bei den plötzlich im Jugendzustande sterbenden Blättern so nachteilige Verbleiben reichlicher Nengen organischer Bausubstanz, die dadurch für die Achse verloren gehen und ras Auswaschen leicht böslicher Nährstoffe durch Beregnen sind bei dem senilen Ausleben nu von geringer Bedentung. In letzterem Falle ist, wie nenerdings. B. Schultze ${ }^{1}$ ) wiederum hervorgehoben hat, bis zum letzten Augenblicke noch die Assimilation von Kohlensäure. wem anch natürlich mit erlahmender Kraft nachweisbar. Durch das Überwiegen der Vorgänge des Zertalls über diejenigen des Anf'banes verarmt das Blatt namentlich an leichtlöslichen Eiweitsstoffen. Mit der zunehmenden Verlickung und Verkalkung der Membranen wird die /uleitumg neuen Nährmaterials stets schwieriger, so dat's dadurch sehon die nachweisbare Abnahme ${ }^{2}$ ) von Stickistoff, Phosphorsäme und Kali erklärlich wird. selbst wenn man nicht einen bedentenden Ruickwanderungsvorgang amnelimen will.

Nach dem. was hereits in früheren Abschnitten über den Einfluti von Lage, Bodenbeschaffenheit und Wittermg gesagt worden ist, braucht hier nicht noch hesonders betont zu werden, dats die Lebensdaner cler Blättrr bei derselhen Pflanzenspezies ganz verschieden sich erweist und somit der Frost auch stets auf ganz verschieden alte Blätter wirkt. Demgemäls ist der Vorgang des Blattabwurfs nicht immer derselbe. Der häufigste Fall besteht in der Ausbildung einer Gewebe-

1) Scur tze, B., Studien über die Stoffwandlungen der Blätter von Arer Negumo L., 76. Versammlung d. (ies Deut sh. Naturf. : cit. Centralbl. f. Agrikulturchemie 1906, S.:.;.

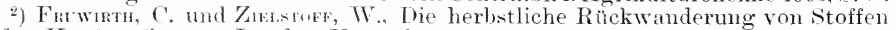
lei der Hopfenpflanze. Landw. Tersuchsstat. 1901; eit. Bot. Jahresl, 1901, T. II, S. 161 . 
zone am Blattgrunde zu einer charakteristischen Trennungsschicht. Wir welsen hier die Abbildmo der herbstlichen Tremmossolicht eines Blattes ron Aesculus Hippocustumum wieder (s. Fig. lowi). I) as Bild stellt einen sichnitt dar, welcher in der Richtung der Länge des Blattstiels durch die Gelenkstelle an der Basis geführt worden ist. " ist clas Rinden-

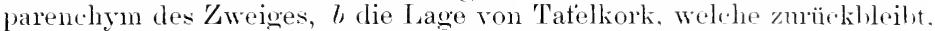
wem der Blattstiel sich abgegliedert hat und den Schutz fïr das Rindengewebe bildet. $c$ sind die Zellen des Blattstielormdes, die hri a in das festere, mit reichlichen Kalkoxalatdrusen versehene Parenchym der verbreiterten Blattstielbasis überohen. "Wwischen $c$ mud " findet der Lockerungsvorgang statt, indem bei d die Zellen sich abrundrn mul auseinander zu weichen begimnen. Wem num die Hebelwirknng dis windbewegten Blattes sich geltend macht, linckt der Blattstiel in der. gelockerten Kellschicht ab.

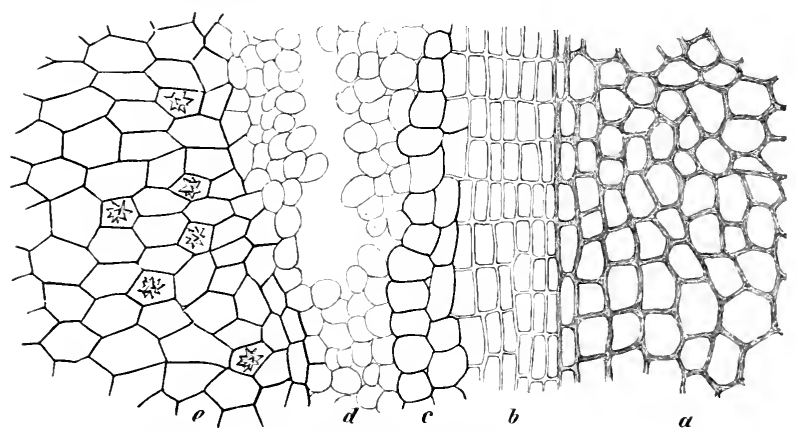

Fig. 106. Herbstliche Trennungsschicht eines Blattes der Rofskastanie. (Nach Diimseri-Nenise)

Je reifer das Blatt zur Zeit der erston Herbstfröste ist, desto leichter tällt es ab; daher sieht man die alten Blätter der Zweige im Herbst zuerst rom Winde abgeknickt. Die gröfsere Lebensenergie, der grölser Reichtum an plastischem Material lassen das jugendlichere Blatt bei Frostwirkmoen, welche nicht tödlich sind, widerstandsfähiger erscheinen.

Treten tötliche Frostgrade im Herbste zu einer Keit auf, in welcher das Blatt seine Trennungsschicht noch nicht weit genug ausgebildet hat, der Baum also von seiner Vegetationsruhe noch weit entfernt ist. dann bleibt clas tote Laub über Winter an den Zweigen (Buche, Eiche). Die Buchen, bei denen das Laub hängen bleibt, belauben sich vieltach später in Frühjahr, als normal anvgereitte Exemplare. ')

Zur Zeit des ersten Nachttrostes wieht man frühmorgens, wem der Reif noch liegt, sellst bei windstillem Wetter, sobald die sonne herautkommt, rlie einfachen Blätter der Bäume abbrechen und die Fiederchen zusammengesetzter Blätter sich von der gemeinsamen spindel lösen. v. МонL ${ }^{2}$ ) fand in solchen Fällen die Blattnarben der abgetallenen oder gerade in der Ablösmng begrift'enen Blätter bei einer Anzahl von

1) A. me Canome in Centralbl. f. Agrikulturchemie 1879 , I, ז. 159.

2) Bot. Zeitung 1860, S. 16 . 
Pflanzen mit einer dünnen Eisschicht bedeckt. Paulounia z. B. zeigte eine besonders dicke Eiskruste. Manchmal waren die Blätter nur noch durch die Eiskristalle mit ihrer Narbe verbunden. Diese Eiskristalle haben sich in der Trenumngsschicht der Blätter gebildet. Die säulentörmige Beschatfenheit der Kristalle, ihre über den Giefälsbündeln durch Luftbläschen hervorgebrachte Trübung, ihre scharf mit der Umgrenzung der Blattnarbe abschneidende Antlagermo sprechen dafür, dafs nicht mötsere Mengen etwa ausgeflosicnen saftes gefroren sind, sondern dats kleine Partien Wasser durch clie Zellwände genan am Orte, wo sie beobachtet wurden, ansgetreten und zu Eis erstarrt sind.

Die Eisbildung kamn manchmal sehr fiüh auftreten und dadurch Ursache werden, dafs Blätter, die sonst noch längere Zeit am Bame verblieben wären, ja bisweilen noch ganz güu sind, bei dem Auttanen abfallen. Antier dieser Wirkmng der Eislamelle kamn ein vorzeitiger Herbstlanbtall dadurch eintreten. dats das Blatt gänzlich oder teilweis ertriert, also plötzlich funktionslos und damn abgestolsen wird.

Bei dem Frostlaubtall erfolgt die Ablösmig res Blattes stets in der Tremmungschicht, die nach Wiesser's ${ }^{1}$ ) Beobachtungen nicht immer ans einem Folgemeristem hervorgeht, sondern manchmal sich anch als ein Rest des nimären Meristems darstellt. In anderen Fällen von Blattabwurt kamn der Ablösungsprozets in versehiedenen Geweben sich vollziehen.

Betrachtet man den Abgliederungsvorgang innerhalb der Tremmungsschicht im allgemeinen, so findet man nach Wiesser ${ }^{2}$ ) folgende Modifikationen: Es kamn in den Zellen der Tremmngsschicht ein so starker osmotischer Druck zustande kommen, dats die Gewebe mit glatten Wänden auseinanderweichen. Dies finden wir bei einer Entblätterung infolge von Wasserüberschufs auch in den Fällen, wo derselbe nur durch reichliches Begiefsen nach langer Trockenperiode sich einstellt. Die bei den Gärtnem bekannte Erscheinmo des Abwerfens der Blätter bei Azaleen, Eriken und Nenholländern nach Ballentrocknis gehört hierher, sowic die sommerliche Entlanbung bei Eintritt von Regen nach langer Trockenheit.

Bei dem herbstichen Laubfall kommt nach WIEsser ganz besonders die mazerierende Wirkmng organischer Säuren in Betracht. Er nimmt an, dats die Trennmosflächen beim Frosttod in der Regel sauer reagieren und erklärt sich diesen Umstand dadurch, dats der Frost das Zellplasma töte und es dadurch durchlässig für die im Zellinhalt vorhandenen sämren mache, die sodann auf' die Membranen wirken können. Wahrscheinlich dürtte dabei die Oxalsäure eine grofse Rolle spielen. Genamnter Forscher legte Stengel verschiedener sommergrüner Gewächse in eine 2,5 prozentige Oxalsäurelösung und sah bimnen wenigen Tagen die Blätter sich ablösen. Auch Stengel ron Pflanzen, die an den Internodialgliedern Tremnungsishichten anlegen, zerfielen schon binnen kurzer \%eit in ihre Glieder.

Wemn die Blattfäche durch Frost beschädigt wird, aber die unterhalb der Trennungsfläche gelegene Partie des Blattes, also der Blattstumpf, lebendig geblichen ist, dann wird der erfrorene Blatteil zusammentrocknen, aber die Blattbasis intakt und turgescent sich

1) Wiescer, Jinu, Über Frostlaulfall nebst Bemerkungen uber die Mechanik der Blattablösung. Ber. d. I. Bot. Ges. 1905, Heft I, S. 49.

2) a. a. 0. , s. 54 . 
erweisen. Zwischen letzterem mul dem vertrockunden Teile müssen spannungstifferenzen entstehen, the zm Ablismmg ites Blattliörpers fïhren.

Wie schnell die vom Frost getrotfenen Teile anstroclinen, zeigen die Versuche von Prunk' '). Ein angefrorener Rohwaweig mit vier Blättern, in Wasser gestellt, verdunstete während zwei simmien 475 mon Wasser: sein Gewichtsverlust betrug dabei 14.46"\%. Tnter demellien Bedingungen verdunstete ein nicht dureh Kälte beschädligter ähnlicher \%weig nur 1:32 mgr Wasser mel hatte wegen der stattgetumben Wasserabsorption 0 m $0.26 \%$ seines kewichtes zngenommen.

Experimentell hat WIEsNER auch gezeigt, wie bei Ptlanzen, die ihr erfrorenes Laub lange, of über Winter, festhalten, dies lenliglich im sehmellen Vertrocknen legrïndet ist. Er nahm /weigr von Ligustium oculifolium mit erfiorenem Laube und stelle sio im Warmhause derart ant, dat's die Sprosse beständig Wasser anfsangten. Iiese lietisen nach 6-12 Tagen die Blätter fallen, während an den nicht mit Wasser vorsorgten Sprossen lie Blätter test sitzen blieben. Bei den im Freion vorkommenden Fällen festsitzenden toten Laubes an den /wweigen wird die Ablösmng erst durch Zersetzmng des Gewebes erfolgen. Es wird die Vermodermo der Membranen innerhalb der toten Tremmingsshicht allmählich so tortschreiten, dats Wind oder andere mechanische Trsalehen schliefslich das Blatt zum Abknicken bringen. Bei dem Vernodernugprozesse werden Mikroorganismen zweifellos sirh brteiligen.

Aus dem Gesauten regibt sich, dat's die Mechanik lex Ablösmer bei dem herbstichen, senilen sowohl wie bei lem Frostlanbtall manchmal selbst bei demselben lndividum versohieden sein liam je. nach dem Alter der Blätter und den vorhandenen Nebenmmständen. Antser der Abgliederung des ganzen Blattes von der Achse kommt anch bei manchen Pfanzen (WVeinstock) ein Ablöson der Blattfläche

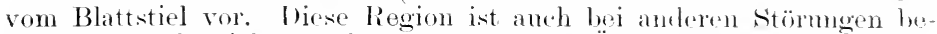
sonders empfindlich mol kemzeichnet ihre Ämlirhkeit mit der Blattstielhasis bisweilen durch gleiche Verfälonng. Isei Pappeh z. B. kamn man beobachten, dats im ITerhst Basis und spitze des Blattstieles rot werden, während der ganze übrige Teil gell, bleibt.

ber Unterschiod in ler /eit, in welcher diese Prozesse hei verschiedenen Individuen und bei demselben Individum in verschiedenen Höhen des einzelnen /wviges sich einstellen, hängt mit dem physiologischen Alter jedes Blattes zusammen. Je jünger dasselbe ist. desto später fällt es unter sonst gleichen Verhältnissen rom Kweige, wie experimentell von DiNiLeR ${ }^{2}$ ) durch Schneidelungsversuche testrestellt worlen ist. Derselbe beobaehtete eine grötsere Widerstandsfähigkeit der jungen Blätter speziell gegenübor den Ilerbstfï̈sten. Die jumgen Blätter von Curpimus Brtulus erfroren nicht nat tagelang währenden Frostperioden, dic äleren hatten gelitten und vertrockneten schliefslich am /weige. Ähnliches sah ich bei Platanen, bei dentn sich in gleicher Weise das Alter der Bäume weltend machte. B. i strafienptlanzungen waren zwischen alten Bämmen junge Exemplare

1) Provet, A., Sur les modifications de l'absorption et de la transpiration, qui survienment dans les plantes atteintes par la gelée. Compt.-Rend. d. I'Acal. des sciences 1892 , II, S. 964 .

2) Dixglem, Hexmax, Versuche und Gedanken zum herbstlichrn Laul,fall. Ber. d. D. Bot. Ges. 1905, Heft 9, s. 463. 
angepflanzt worden. Letztere hielten, obwohl nicht unter dem schutze der älteren Bäume stehend, ihr hedentend krättigeres Laub noch fest, als das der alten Stämme zum grötsten Teil schon am Boden lag.

\section{Verhalten der Rüben und Kohlgewächse bei Frost.}

Bei der Aufbewahrung ron /uckerrïben kann man uu durch möglichst kïhle Temperatur den Zuckerverlust, der durch die Atmung des Rübenkörpers imnerhall, der Micten eintritt, vermindern ${ }^{1}$ ). Bei Zuckemïlen, die wirklich gefioren gewesen, zeigt sich durch das Ausfrieren des Wassers sogar eine Erhöhmng des Zuckergehaltes, der von Ninger auf $0,39 \%$ berechnet worden ist $\left.{ }^{2}\right)$.

Eine Neubildung von Saccharose aber findet ebensowenig wie eine Zerstörung dorselben dureh den Gefrierprozet's statt. Auch die Menge der Stickstoffsubstanzen und das Verhältnis von Eiweits zum Nichteiweifs bleiben dabei unverändert. Sobald aber das Wiederanftanen beginnt, scheint letzteres auf Kosten des ersteren sich zu vermehren. Die Bestandteile der Rohfaser (C'ellulose und verwandte Stoffe) werden schon lurch den Getrierprozets tür sämen und Alkalien löslicher³, und teilweise auch wasserlöslicher. Daduch wirl eine Erhöhung des Nichtzuckers im Safte hervorgebracht. Tch beobachtete bei dem Gefrieren der Rüben teilweise Membranguellungen. was als der sichtbare Ausdruck der chemischen Veränderungen der Cellulose gedentet werden darf. STroнukr und strmt fanden eine auffallende Zunahme des säureyehaltes.

Der grölsere, durch Wasseraustritt hervorgebrachte Zuckergehalt and der ladureh konzentrierter gewordene Zellsaft werden übrigens das wirkliche Erfrieren dos Rübenkörpers verzögern. Anfserdem werden in Nieten die äufseren, gefirorenen Rüben die imneren vor dem Gefrieren schützen, worauf namentlich MüLLER-THuRgut hingewiesen hat, und was $\mathrm{MEZ}^{*}$ ) dadurch erklärt, dats der Übergang des Zellsattes in den festen Agoregatzustand die in der Zelle noch vorhandene Energie vor allzu schnelem Abströmen bewahrt. Die Wärmeleitung in Eis vollzieht sich viel langsamer als in Wassor, in welchem sich die IVäme durch strömung verbreitet.

Die Angaben der Gemüsegärtner, dat's Brannkohl (Brassica olvacea acepluala) erst nach Frösten die gewünsehte Sülsigkeit erlangt, dürfte in der /uckeranhänfung durch die niedrige Temperatur ihre genügende Erliärung finden. Nach den Analysen von Mirkek und PAcés) liefs sich aus crfiorenen Kohlpflanzen eine $68,60 \%$ der Pflanzenreste betragende saftmenge abpressen, während der gleiche Druck bei den nicht erfrorenen Exemplaren nur $7,1^{\prime \prime}$ " Saft ergab. Es enthielten 100 cem Saft vor

1) Hвхту, Atmung der Rübenwurzehn. Zeitschrift d. Ver. f. d. Rübenzuckerindustrie d. dentsch. Reiches 1873, Bd. XXIII; cit. Bot. Jahresb., I, S. :355.

2) Bot. Jahresber. 1880, S. 6655 .

3) Srruman, F., u. Stri, A., Über den Einflufs des Gefrierens auf die Zusammensetzung der Zuckerrübenwurzel. Österr.-[ng. Z. f. Zuckerindustrie und Landwirtsch. 1904. Heft I'I.

4) Mrz, Can, Nene Innternchungen ïber das Erfrieren eisbeständiger Pflanzen. sond. Flora od. Allgem. Bot. Zeit. 1905, s. 109.

5) Міккек и. PArik, Über den Einflufs des Frostes auf Kohlpflanzen. Biedermam's Centralbl. 1877, Bıl. XI, s. 26: -66. 


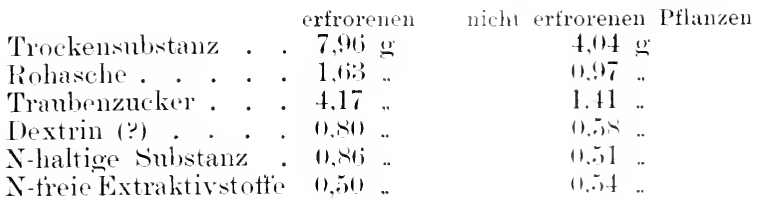

Man sieht, dats die lëslichen Bestandteile im Satt eine ertudeliche Vermehrung erfahren haben, nud dats an dieser Vemehrung dir 'Tranben-

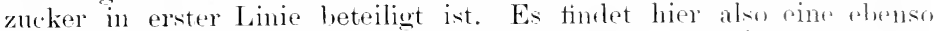
bedentende Zuckerbildung wie bei der Kartotfel statt, die ron sinum anf $21,650 /{ }^{1}$ ) angegeben worten ist.

\section{Frostblasen.}

Von geringer wirtschaftlicher Bedentmo, wohl aber wissems hattlieh beachtenswert in Rüeksieht aut das Kustandekommen mochanischer

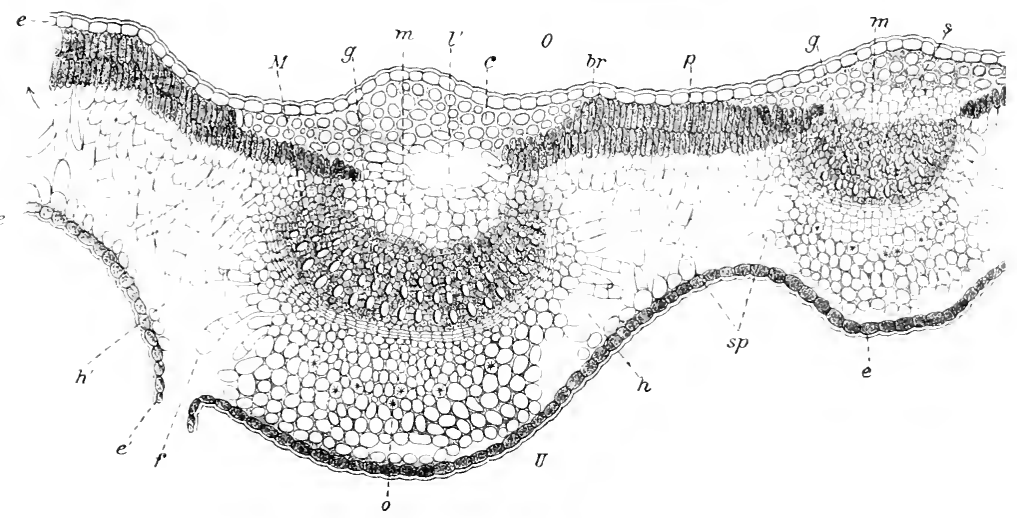

Fig. 107. Querschnitt durch eine Frosthlase an Apfelblatt. (O)rig.)

Gewebestörungen in Imern lehend hleibesuler orome sind die Frost

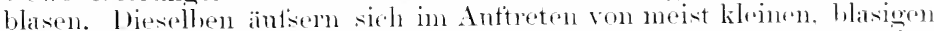

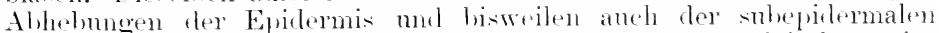
schithten von dem zartwandigen Parenehym des Blattfleisches oder lem derberen der Blattrippen. An stello einer weitlänfigen Besthreihmus

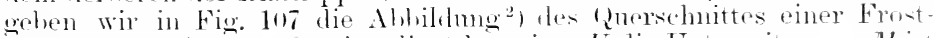
blase an Aptwhlatt. O zeigt die (Bberseite, $I$ die Tnterseite an. $M$ ist

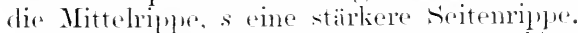

In der Rippe bildet der balbmondfömige Holzkërper mit seinen

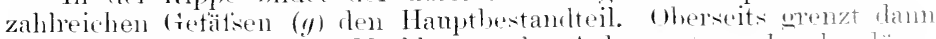
eine chlorophyllose, dem Markkïrper der Achse entspreederude, diinnwandige Parenchymsehicht $(m)$ an, welche ron derlwandigen. coll-

1) Nach Rurнus s. s. .Der Landwirt” 1×75, . . 501.

2) Sornck, P., Frostblasen an Blättern. Z. f. Pflanzenkrankh. 1902. S. 44. 
enchrmatischen Zellen $(c)$ gedeckt wird: diese sind $n$ so reichlicher cutwickelt, je stärker dio Rippe ist. Las collenehym tritt als feste Leistr über den nur ans Blatttleisch bestehemen Teil der Blattfläche fotws hervor. Das Blattfleisch zeigt die wewöhnliche Gliedermo in Palisaden- (p) und sichwammparenchron (s/1). Von diesen ehlorophyllführenden schichten reicht das Palisadenuarenchrm nicht ïber das (tefälsbindel oberseits hinweg. sondern keilt sich beiderseits ans, so dats (s in kurzer, einschichtig werdender /selllage $(b)^{\circ}$ zwischen dem collenchym und Parenchym des Rippenkörpers ansmündet. Das Schwammparenchym lagegen länt anf der Enterseite über lem Gefätsbindelkärver fort nind hildet den Rindenteil der Rippe, in woldhem, wie in der Zweigrinde, Oxalatlinistalle (o) in halbmondformiger Reihe zu finden sind. Die Epidermis (o) deckt zunächst gleichmälsig das ganze Blatt.

Die mechanischen Flostwirkungen zeigen fich hier in der für die Mehrzahl mserer Pflanzen typischen Form, indem anf der Blattoberseite über tem Gefätsbündel der stärkeren Ripuen das collenchymatische fewelse vom farenchrmatischen sich abhebt, und dadurh eine Lücke (/') gebildet wirl. Anf der Blattunterseite hat sich an den Böschungen drs stark hervortretrnden Rippenkïrpers das Sohwammparenchrm von lem Rindenkörper dex Rippe abgeläst, so dats zn beiden Seiten derselben luftführende Hohlränme (h) entstehen. Wir erklären nus die Bildnng der Hohlrämme dadurch, dats das jugendliche noch hyponastisehe, mit den Rändern nach oben gehobene Blatt bei der Frostwirkung sowohl von oben nach mten als anch tangential sich zu beirlen Seiten der Mittelrippe zurammenzieht. Wem das muldenförmig nach oben gehogene Blatt sich zusammenzieht, muts die muldenförmige Krömmung stänker, d. h. die Spannung der Unterseite grötser werlen. Dieselbe äulsert sich in einer Kerrmo nach den emporgehobenen Rändern hin, siche die Pfeihrichtmog in (ler Abbildung). An den Böschungen der Rippen muts die Zerrung am stärkten sein mol kann unter Umständen his zum Zerreiftsen der Epirlermis (e') führen.

Wemn nun das Antanen stattfindet, bleibt die Folge der Frostwirkmo in einer Ïberverlänerung der wezert aresenen Gewebe hestrhen. Dem die frewbe sind wohl dehnbar, aber nicht vollkommen plastich: sie ereichen nicht wieder ihre frühere Gröfse und Lagerung. Namentlich die am meisten grespannt gewesene montere Evidermis ist länger seworden und ïht mun nicht melı den Druck anf das darunter liegende S.hwammparenchym in dersellen stäne wio fröher ans. Dor EpidermisIruck ist gelockert. mul das sehwammparenchym antwortet sofort anf diese Lockermo darhuch, dats es sich schlanchförmig strockt. Wenn die Epridermis zm Keit der stärsten spanmmg entzwei gerissen ist, bilden die überverlängerten Rishänder (f') eine liraterförmige öffinmg, nach woleher hin dis tarknartig sich anshildenten Schwammparenchymweihen (f) wachsen.

Weitere Thtersuchmesen ïber Frostblasen finden wir in einer Arbeit von Nodck '), der zir rem schlusice liommt, dat's die Erostblasen darlurch entstehrn, , dats sich ans den Zellen Wasser in dic Intercellularränme ergiefist mol dort zn Eis erstarrt, sobald die Temperatur bis zn einem gewissul für dir sinzelnen Pflanzenarten verschiedenen Grarle moter den (iofrierpmlit sinkt". Das Anschietsen der Eiskristalle

1) Noxk, Fr., Üher Frostblasen und ihre Entstehung. Z. f. Pflanzenkrankh. 1905 , s. 29. 


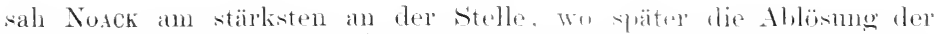

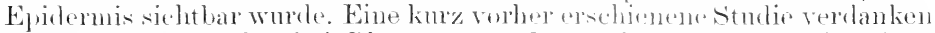

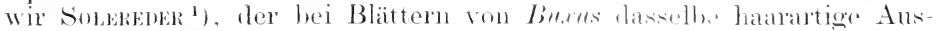

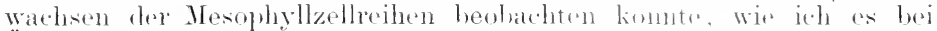

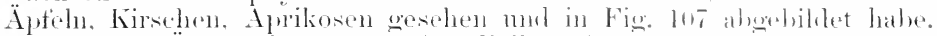

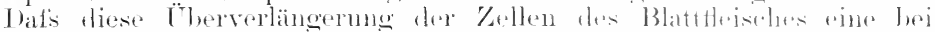

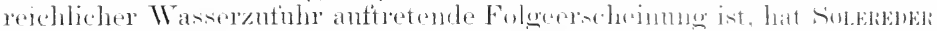
experimentell bewiesen, indem er die Blattunterseite entfornte mul

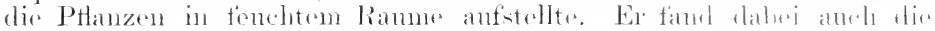

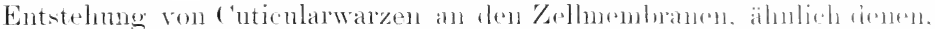

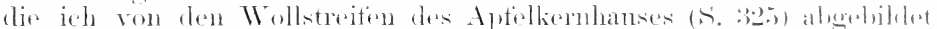

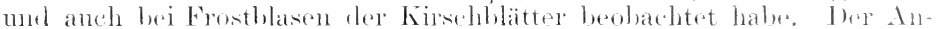

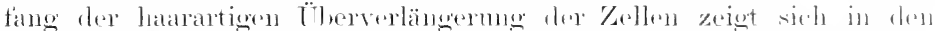

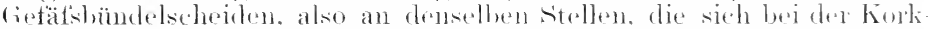

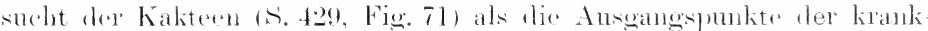

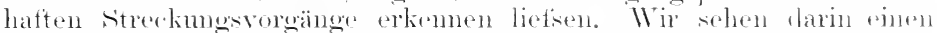

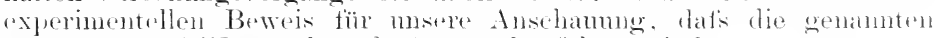
störmuen auf Wasserïhorsehnfs zurïckzuführen sind.

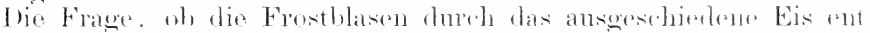

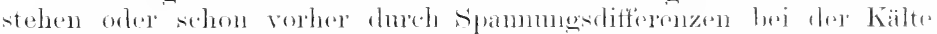

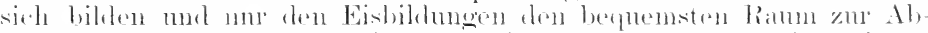

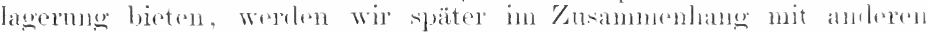

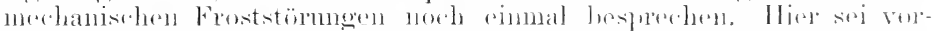

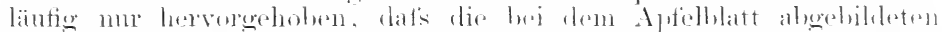

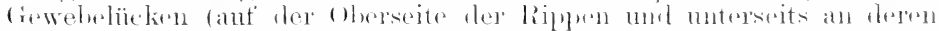

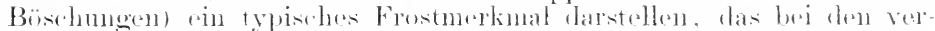

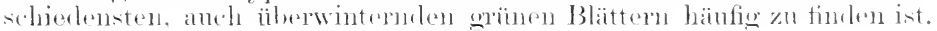

\section{Kammartige Zerschlitzung der Blätter.}

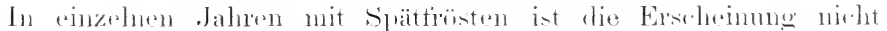

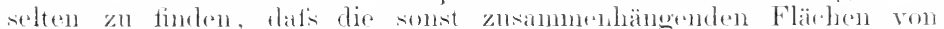

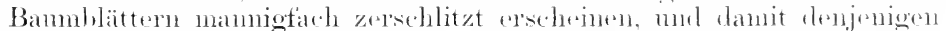

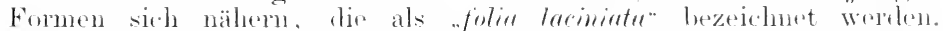

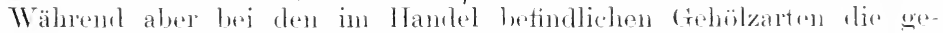
schlitzte Blattform pin in Entwieklungseanes des Indivinlumes fixierter.

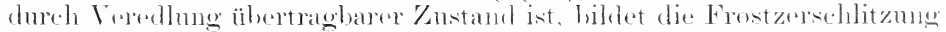

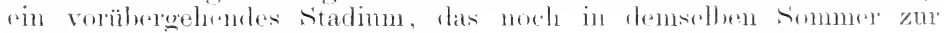
normalin Blatter'm zuriickkelert.

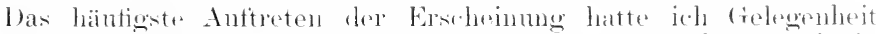

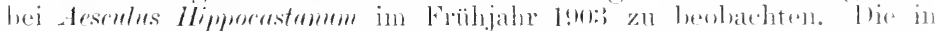

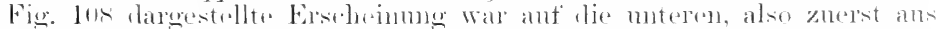

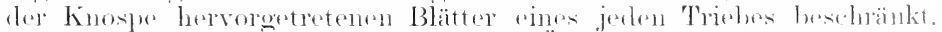

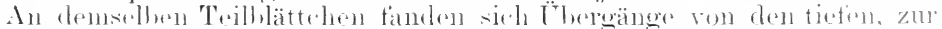

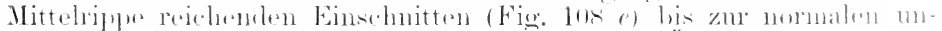

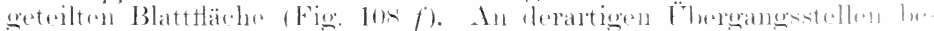

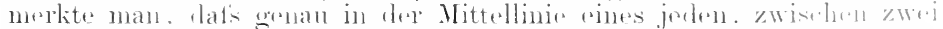

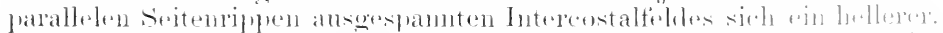

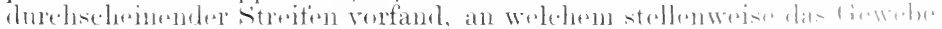

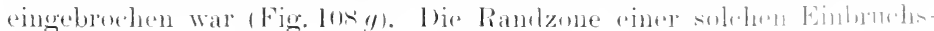

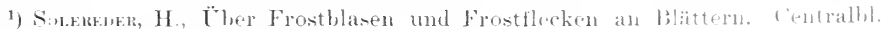
f. Bakteriol., II. Al,t., 131. XII, 1904, N⿴囗68.

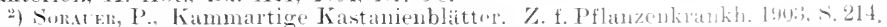


stelle zeigte henso wie der Samm der einzehnen fiederigen Schlitzzipfel vieltach eine etwas gelbliche, härtere, manchmal ein wenig schwielig hervortretende Linie. Dieser schwielige saum bestand ans tafelförmigen Korlizellen, dmen nacli autisen hin nicht selten Fetzen von abgestorbenen Jesophyllzellen anhafteten. Man ersieht darans, datis die kammartigen Einsehnitte nicht bereits in dor Knospe angelegt gewesen, sondern erst suäter entstanden sind.

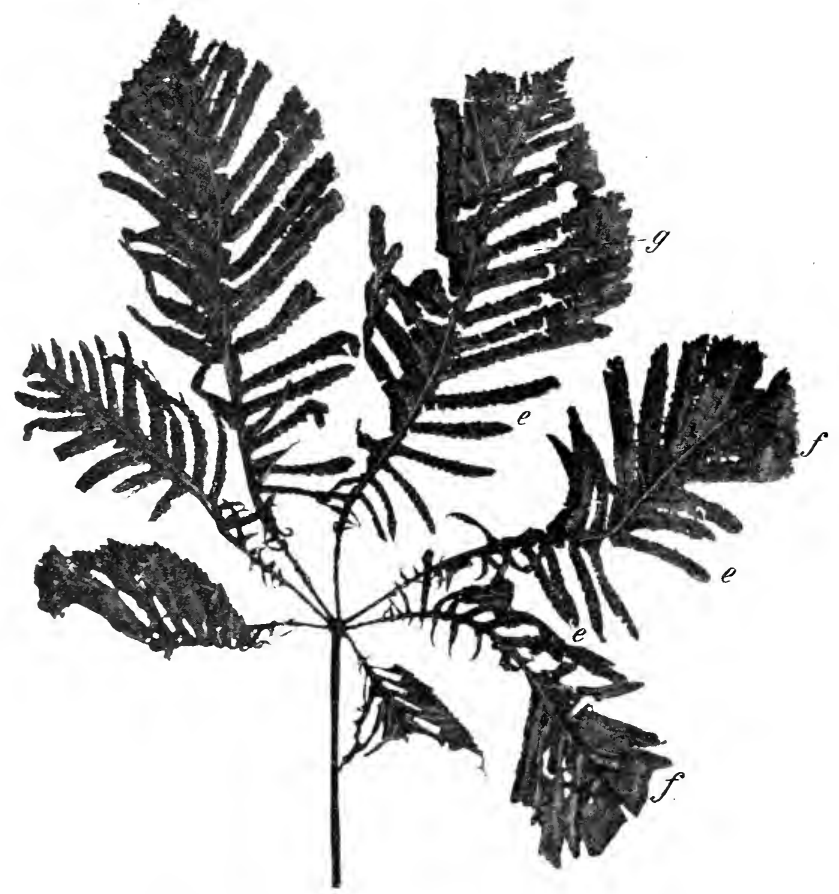

Fig. Ior. In der Knospenlage durch Frost beschädigtes und bei der Streckung kammartig zerrissenes Blatt der Rolskistanie. (Orig.)

In don vorerwälnten durchscheinemlen Linien, die erst stellenweise eingebrochen waren, fand man an muverletzten Teile das Mesophyll abgestorben. Der Kollinhalt war nowh reithlich vorhanden, aber bram

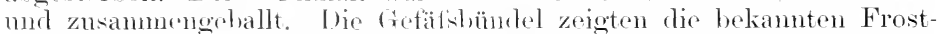
hräunmogen. Trafs gerade stots die Mittellinie der Intercostalfelder vom Frost beschädiet worken ist, orklärt sich dureh die eigenartige Faltung der Blattflächen in der Knospenlage.

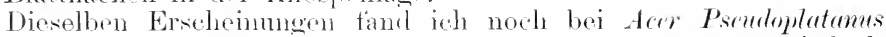
mur einzolnen derbbläterigen anderen Ahornarten, hei letzteren jedoch 
nur in Form umegelmälisiger Durchlöchelumgen. [a.l'BERT ${ }^{1}$ ) beobachtete fiederige Zersehlitzung bei Blättern von Birks und Weilsbuehe. Thomas") dentet die Schlitzblätterigkeit hamptsärhlich als eine Folgo der Windwirkung. Es ist seit A. Braun mol ('Aspar hinlänglich bekamnt, dafs Kastanienblätter dureh gegensoitigo Roibmeg ler Blattflächen durchlöchert und stellenweise zerschlitzt worlen fiommen: abor die hier geschilderte Erscheimung hat nichts mit der Windwirkmo zu tum. Ich habe die Antänge der Sehlitzblätterigkeit loi Bämnehen entstehen geschen, wolche bald nach der Frostwirkung ins Zimmor gebracht worden waren ${ }^{3}$ ).

\section{Das Aufziehen der Saaten.}

Abgesehen von den sichädigungen, welche die äberwinterndrn lirant artigen Pflanzen durch ein zu langes Liegenbleiben der sirhneedreke erleiden können, indem sie vielfach crsticken, haben wir eine andere Erseheinung in Betracht zu ziehen, welche namentlich dem retreids. verhängnisvoll wird, nämlich das Aufziehen der jungen Ptlänzchen.

Grade die stark wasserhaltenden Bodenarten sind es, welche das Autziehen der Saaten durch Frost zeigen. Nach mbestandiger Winterwitterung, bei welcher auf nasse Tage scharte Fröste plötzlich folgen. sicht man im ersten Fröhjahr nicht selten eine Menge junger Pflänchen mit blotsgelegten Wurgeh ant der Oherfläche les Arkers. Ein Teil der Wurzeln ruht anch wohl noeh mit soinen spitzen in der Erole und fristet den Pflänzchen ein kümmerlichos Dasoin, während andere Würzelehen, vollkommen trei, mit abgerissenen Sirtzen dem Vertrocknen durch Wind mel somne entgegengehen. Die Erklärmu des Vorganges liegt sehr nahe. Der schwere Borlen hält grofise quantitäten Wasser zurürk: dieselben gefrieren, sehiefson als lange, nardelförmige Eiskristalle an und heben dadmreh dic oberen Bodenschichten sannt der jungen saat in die Höhe. Wenn ein 'Tril der feinen Wurzeh bereits in grötsere Tiete gegangen ist, wroten diese abgerissen. Bei dem nachfolgenden Auftanen kam sieh zwar der Boden sotzen, die jungen Pfänzchen aber können nicht mehr zurürck. Wie Wiederhohng hes Vorganges hringt endlich obiges Resultat und, wem man mit der Ililfe nieht schmell hej der Hand ist, namhatto Verluste zuwege. Dic Ililfe beruht hier wohl meist in der Anwentumg einer schweren Walze zu einer \%eit, wo das Feld schon ringermatien abgetrocknet ist, aber die Pflanzen durch die wenigen, im Boden befindlichen Wurzeh sich noch frisch zeigen. Inreh fas Andrïcken einer in Be-

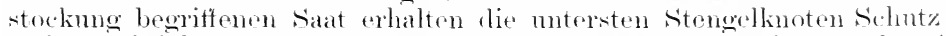
und Fenchtigkeit woumg, mm nene Adventirwumeln zu treiben und aut diese Weise den Sr.haden an Befestigungs- mol Ernälnmosoromen wirder allmählich zu resetzen. Namentlich hei fretreideptlanzen wirel das Walzen günstig wirken. mot es lassen sich hri fomchter Frïhjahrswittemug aus solchen autgezogenen Pflanzen nowh dirattige llalus heranzichen.

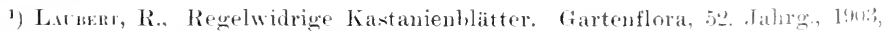
Oktober.

2) Tuoms, Fu, Die meteorologischen Ursachen der Schlitzhitterigheit von Aesculus Hippocastamm. Mitt. d. Thüring. Bot. Ver. 1904, II.ft XIX, S. 10.

3) Siche Z. f. Pflanzenkrankh. 1905. S. 2:4, Anmerk. 
Als Torbengungsmittel wird solbstverständlich lie Thainage wirken. Giinstig mas sich anch ein Loekern mooriger Erde durch Öberfahren mit sand zeigen. KüнN ${ }^{1}$ ) fand autseldem in dieser Beziehung die Drillkultur wirksan, indem man hierbei die saaten behackt. Zwisehen diesen entstelien dadurch ,kleine Rillen, in die sich die Nässe vorzugswoise zicht, und so beobachtet man nuter den angetührten Umständen in ten '/wischemräumen cin Autzichen des Boflens, während die Pflanzemreihen selbst mberührt bleiben". Henwa: $\left.{ }^{2}\right)$ empfiehlt frühe Bestellung der Saat, um mögliehst reichlich recht tiefgehende Wurzeln zu azielon und dadureh die Pflanzen mehr im Boden zu befestigen.

EkKERT ${ }^{3}$ ) empfiehlt eine flache saat, hauptsächlich abex die Anzucht kräftiger Pflanzen. '/ur Befünwortung der flachen Saat scheint Ekк EkT durch den Ausspruch des Grafen Pinto-MetTka bewogen worden zu sein, welcher angiht, dats nur tirfliegende saaten aufgezogen werden und bei diesem Autziehen an der Basis des primären Internodiums ruitisen, also an dem nur bei tiefor Saat sich stark streckenflen Stengelwhede, wolches den Bestockungsknoten in die Nähe der BodenoberHitche heht. Diese Ansicht wird anch von Bresmon ${ }^{4}$ ) geteilt. Die Untersuchmon von Eккект über die Festigkeit und Elastizität dieses mntersten Stengelgliedes und der Wurzeh sprechen dafür, dats die Wurzeln bei (lem Aufriehen elier reitsen werten als das Internodium. Bei der Hachen saat ergibt sich die Möglichkeit, dats nur die Wurzeh abreitsen und das thathliegende Korn also mitgehoben, der verletzten Pflanze somit als möglicher Reservestoffluehälter noch erhalten bleibt. Die Beschädigung wïrde somit geringer und bei Nachhilfe durch eine schnellwirkende Früljahrsdüngumg leichter zu überwinden sein

Als willerstandsfähige Art ist der Johannisroggen empofohlen worden. Unter den Weizensorten findrot sich eine russische sorte, der Urtoba-Weizen, als besonders wilerstandsähig angegeben. Ïbrigens werden werler Sorte noch Saattiefe den Ausschlag geben, sondern wohl vorzugrweise die Beschaffenheit des Bodens, flessen wasserhaltende Kraft dabei besonders ins Gewicht fällt.

Bei den jungen Gehölzkulturen kommt bei B arfösten anth ein Aut'zichen der Saaten vor. Die mit kräftigen, langen Ptahlwurzeln versehenen Kieftrn- und Eichensämlinge leiden nicht, wohl aber die flachwuzeligon Fichten und Tamen und von Laubbämmen die schwarzerle in monrigen Bürlen.

\section{Innere Verletzungen bei jungem Getreide.}

Thlearlitet ist es lis jetzt gellichen, dats die Getreidepflanzen bei Bartiösten, auch wenn sie nicht ans dem Boden rezogen werden, innere Vuletzungen weiden, die bei anhaltend nasser Witterung bequeme Einfallspforten für parasitäre Pilze bilden. Aufser den gewöhnlichen Schwïzepilzen finden wir den schneeschimmel, ten Rogoenhalm-

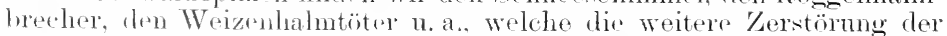
Pflanze ühromehmrn. The für Pilzerkankmngen disponierenden Frost-

1) Krankheiten der Kulturpflanzen 1859, s. 11.

$\Rightarrow$ eit. bei Cunners, Wïmeentwicklung usw. S. 2:36.

3) Eкkнtr, Über Koinumg, Bestockung und Bewurzelnng der Getreidearten ete. Inanguraldissertation, Leiprig 1N74; cit. in Biedermann's Centralbl. 1875, S. 204.

4) Über das Auswintern des Weizens, des Rapses und des Rotklees. Biedermann's ('entralbl. f. Agrikulturehemie 1×81, s. 829. 
beschäligmgen bestehen antser in einer Brämmug lor Getätsbündel innerhalb des Bestockungsknotens namentlich in dem hasigen Abheben der Oberhant an bestimmten sitellen des tietrebleblattes. Solche Abhehungen zeigen sich sellst an ganz jugendichon, nuh in dor hnospenlage betindlichen Blättern, wie die heistehent. Fin. 10! mus verführt.

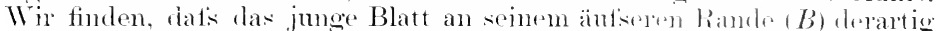

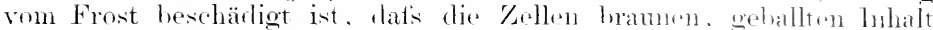
bekommen haben und zusammengesimken sind, also in km\%er \%eit ah.

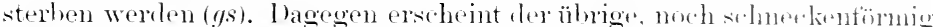

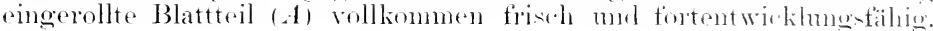

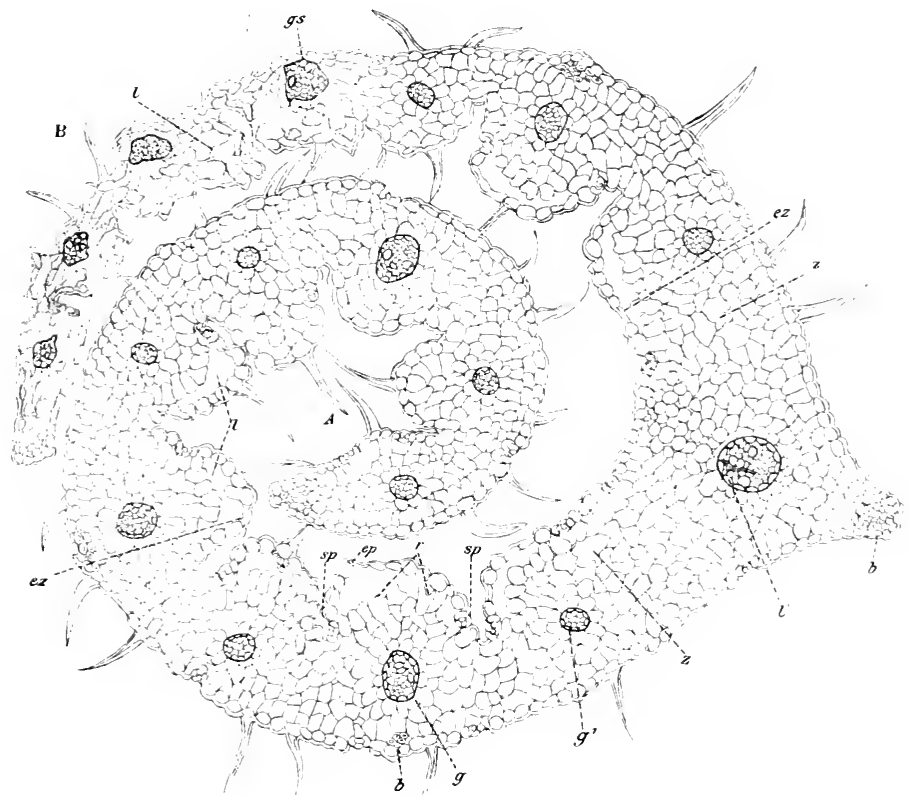

Fig. 169. IJ Junges. frostbeschäligtes Roggenblatt mit Abhebungen der Epidermis. (f)rig.)

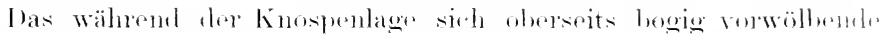

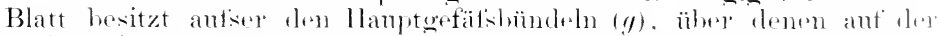
Anfsensede Harthaststräno (b) angelent sind. noch die orst in dep mittleren, hroiteren Blattregion zur Ermährme des vermeluten Men phylls sich abzweigenten schwächren B̈̈mblel $\left(g^{\prime}\right)$. Von den durch

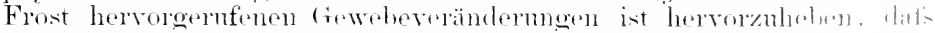

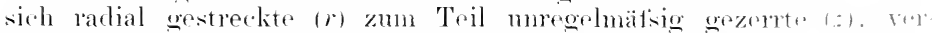

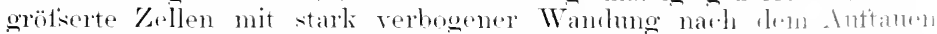

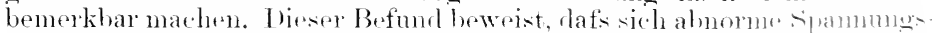
verhältnisse entwickelt hahen müssen. Diosen ist anch liv am moisten

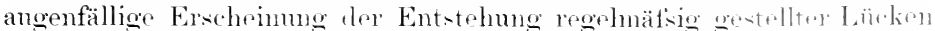


(7) zuzuschreiben. Die Lücken entstehen durch die blasige Abhebung ler Epidermis rom eigentlichen Blattfleisch meist anf der Oberseite zwischen den spaltötfinungseihen (sp). Die Blattunter- oder Autsenseite zeigt nur spärliche Lücken von geringer Ausdehmmg. Für das Zustandekommen der.Lücken bieten dio stellenweise bemerkbaren tangentialen Stredkungen einzelner, dabei zusammenfallender Epidermiszellen ('l) und ('z) cinen bedentiamen Hinweis. Der Epidermisbogen ist länger geworden, als er vor der Frostwirkmg gewesen ist, und diese Verlängerung erfolgte durch die Zerrung einzelner Zellen. Aufser diesen Blattabhebungen ist eine boi l' angedentete radiale Zerklüftung des Gefäfsbündels ein sehr charakteristisches Merkmal für Frostheschädigung; dieselbe wird im Achsenkörper hesonders bedeutungsvoll.

Betreffs einer Unterschridung der Lückenbildung durch Frostwirkmo von den senilen Gewebezerreifsungen geben wir in Fig. 110 den 'puershnitt des ersten scheidenförmigen Blattes emer Roggenpflanze wieder, dessen Innengewebe im Lante der normalen Entwicklung bei dem Ableben zerreitit: die dadurch entstehenden Lücken $(h)$ sind stets tangential.

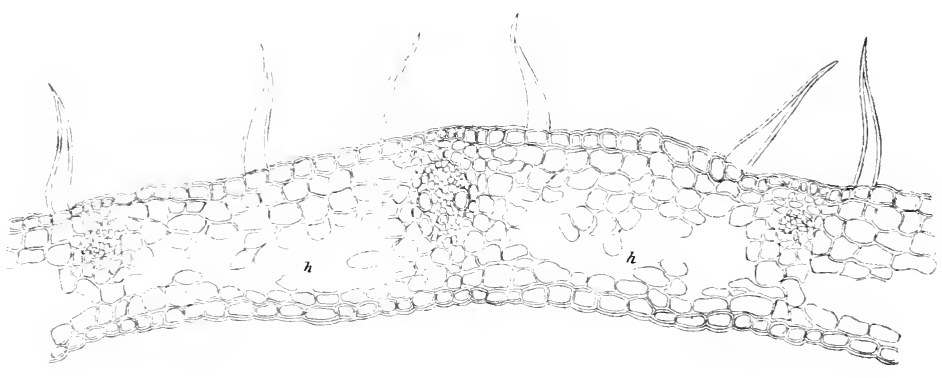

Fig. 110. Natürliche Lïckenbildung im scheidenförmigen Roggenblatt bei zumehmendem Alter. (Orig.)

\section{Innere Verletzungen im Getreidehalme.}

Viel wichtiger aloer, als die Blattbeschädignngen sind die Frostwirkmugen in Halme, von denen wir meist keine Almung haben, da mit blokem Ange eine Veränderung an der Pflanze nichit hemerkbar wird. Fis. 111 wilst die Albildumg eines frostbesthädigten unteren Halmkmotens vom Rogeen.

Das Gewche les llahmes $(H)$ ist fest unschlossen von der s'cheide $(S c h)$, deren äntisue Epidermis mit e, deren innere mit $f^{\prime}$ bezeichnet ist, während," dio ohrohantzellen des Halmes zeigt. Die bei allen Frosterscheimunen anftretend. Bränmung der trefäse in den einzehnen Bïndeln ist bei "l mol "i angedentet, wo zwischen den weiten Ringgefätien die engeren sprirahöhren am meisten aeschädigt erscheinen. Bei hr befinden sirl Nester gebrämnter Parenchrmzellen in der Scheide, hei $6 r^{\prime}$ solche in Halm selbst; hei $r$ und $r$ zeigen sich gebräunte Zollpartien in der scheile und im IIalm, deren WVandumgen äutserst stark antgequollen sind, so dais die ganze helle zn einer gleichartigen welben. gummiähnlichen Masse umgebildet erseheint. An anderen 


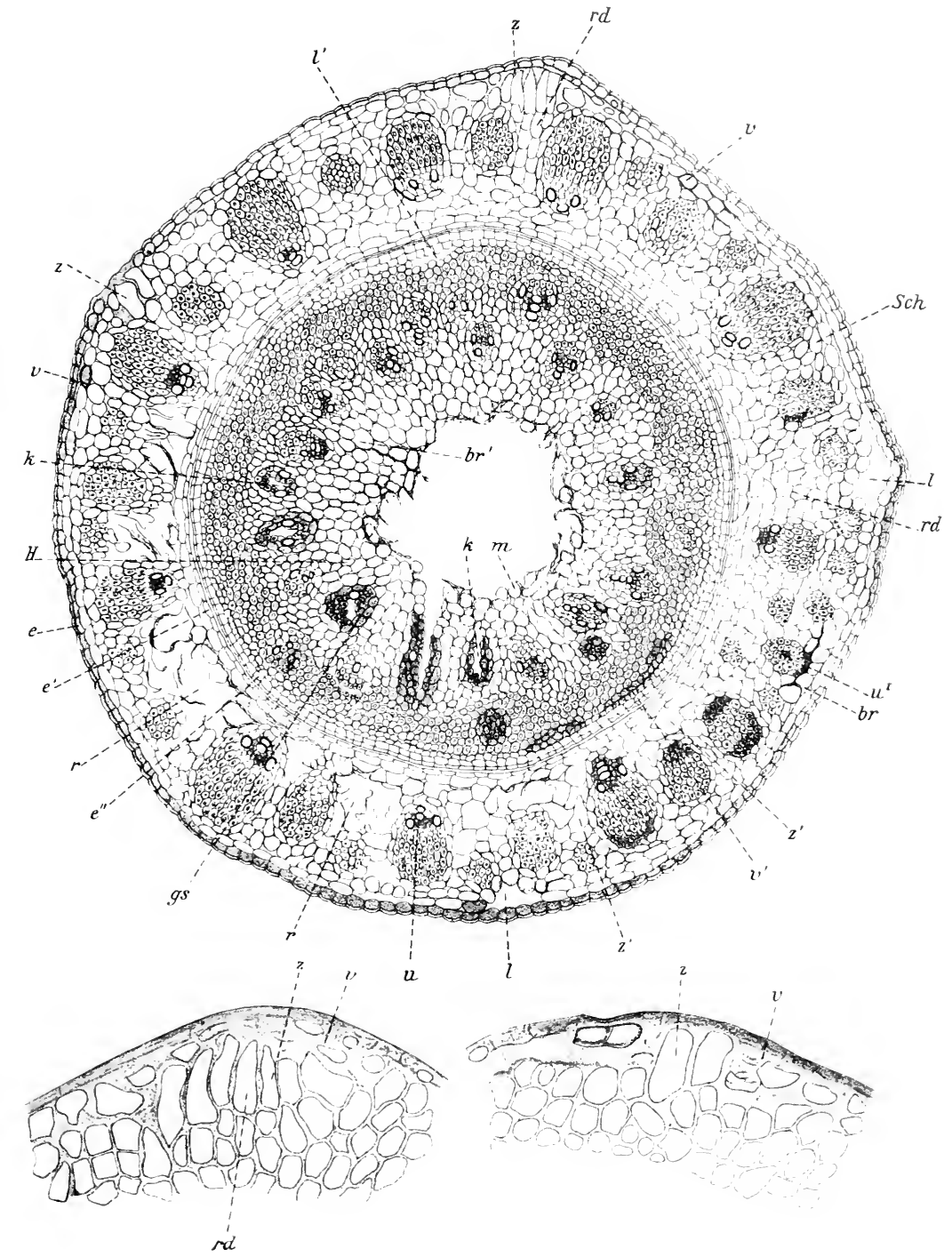

Fig. 111 tobere Figur. Halmknoten aus einer frostbeschädigten Roggenpflanze. Fig. 112 iund $11:$; (untere Figuren). Terquellungen der Membraneril an frostbeschädigten Blattscheiden eines Roggenhalmes. (Orig.) 
Stellen (r) ist das Parenchym im Imenteil der Scheide zerrissen oder dureh Abheben der Epidermis mit periphrischen Lücken rersehen. In der Nähe derartiger Lücken oder manchmal an Stelle derselhen treten gostreckte \%ellen anf, welche daranf hindenten, datis bei dem Gefriren sich der Hahm überwiegend in tangentialer Richtung zusammengezogen und die Epidermis gezert hat. Dadurch, dals die Epidermis, micht so dastisch wie das übrige Rindengewebe infolge der Zerrumg danernd verlängert bleibt, muts sie lei dem Nachlassen des Frostes sich stellenweise al,heben (I und /') oder doch lockem, so dats das damuter liegende Parenchrm durch den reminderten Epidermisdruck nm schlanchförmig sich streckt $(\boldsymbol{r})$. Die vergötserten Zellen, die meist unter der änfiseren Ejidermis liegen $(z)$, seltener auf der Innenseite sich finden $\left(z^{\prime}\right)$. besitzen manchmal stark verbogene oder gezerrte Wantungen.

Diese 'Lustände sind in Fig. 112 und 113 vergritsest dargestellt. Hier. erscheinen die (Quellungsvorgänge an den Wandungen so stark, dats man nur undentlich die Genzen der einzelnen Kellen noch zu unterscheiden rermag and manche Zellhmina fast ginzlich verschwinden $(r)$. 1) mit den (quellungserscheinmeen im vorliegenden Falle rortmudene Lockermo los Epidermistruckes hat nun die Überverlängermo des darmer liegenden Gewebes zugelassen, so dafs teils grötsere Gruppen ( $/(d)$, teils vereinzelte verbogene, abnorm verorofserte Zellen (z), sich ausbilden kominten.

Höchst heachtenswert sind endlich die Kerklüftungserscheinungen innerhalh der Gefätsbündel und um dieselben. In den Gefatsbünteln findet die ZerkJüttung meist in radialer Richtung (Fig. 111 li) statt, und zwar derartig, dats das zartere frewebe zwischen ilen beiden weiten Gefaitsen zerreitst. Tlie Umaebung der Gefätsbündel kamn stellenweise so stark zerrissen sein ( $r)$, dats das Bünrlel halbinselförmig in der Lücke liegt. Diese Erscheinmo macht den Eindruck, als hätte sich das Parenchym infolge der Frostwirkme so heftig znsammengezogen, dats es rom den nicht nachgebenden Bündeh algeplatzt ist. Falls derartige spannumgrifferenzen weniger extrem sich geltend machen. wirc das Parenchrom in der Umgebmg der Bündel mu stark gezerrt, so dafs nachher verorötserte Parenchymzellon mit verbogenen Wandmigen entstehen $\left(z^{\prime}\right)$.

Von hervorragender Wichtigleit tür das Leben der Pflanze sind lie Beschädigmoen des (refätibündel, deren Elemente unbedingt an Leitungsähigreit einbiotsen müssen. Es ist daher erklärlich, dafs frostheschädiote Pfanzen in ihrer Entwicklumg zuröckbleiben, und dats sie, selbst olme Mitwirkmg parasitärer Groanismen, die besonders sern geschwächte saten aufsuchen, weniger stroh und namentlich schlecht ernähre Köner lirfern. In der Regel kommt aber noch eine farasitäre Beschäligme durch Rost, Schwäropilze und andere Blattund spelzentewohner hinzu. Temn da niomals alle Ptlanzen eines Felles gleich stark loilan weil autser der individuell rerschiedenen Widerstandsfïhigkrit dis Bodrnmebenheiten bald frostfördernd, bald frostscluäzend wirken). so ist anch die Entwicklung der Halme eine mmelmäsige. \%wischen krätig forwachsenden Exemplaren stchen the stärker Feschädigten in S'chatten und Iruck der ersteren. Lichtmol Luftmangel nud steigernng der Fenchtigkeit zwischen den unterdröickten Pfanzen liegimstigen dir Ansiedlung und massenhafte Anshreitung der Pilze. 


\section{Halmknicken.}

Die vorstehend geschilderten Verändermuen in firstheschädigten Halmen haben nun, je nach den stellen, wo dre Fustangritt am intensirsten war, versehiedene Folgeerseheinmgen antznweisen. I) häufigste Fall ist, dat's bei spätfrösten die llahmbasis angencitten wird. Meistens treten diese Schädigungen nesterweise in Achire ant. Wril die kalte lonft sich in tiefliegenden Bodenmulden anhänft. His simnnelt sich aber anch an meisten die Fenchtigleit von den atmosphairischun Niederschlägen, so dafs zu den Froststörmogen die parasitäe Ansiedlun kommt. Die Hahmbasis kann dann vermorschen mul der Ilahm min-

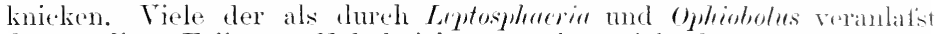
dargestellten Fälle von Halmknicken erweisen sich als kombiniorte Erseheinungen, zu denen der Frost clie erste Veranlasimm gegehen lat.

Es lommen aber anch andere Fälle vor, hei rlenen dir. Hahne nicht an ler Basis, sondern in verschiedener Höhe nmknicken. Die Erscheinumg tritt nicht immer in einzelnen Nestern ant, sondern ist lisweilen streifenweise zu finden und zeigt sich so, dat's gesmule mul liranko llalme gemischt stehen. Derartige Fäle geben nicht selten zu streitioxkeiten Feranlassung, indem sic grotise Ähnlichleit mit Hagelse hä̈lon haben. Eine Entschädignng wird aber dam seitems der llavelversicherungsesellschaften ahgelehnt, da sich heine Anschlagsitellen der Hagellörner nachweisen lassen.

Bei dem hasalen llahmbruch erweist sich der Hahngrund hram. und die Bestockmngstriebo simel tast säntlich abgestorlene vielfarle sogat "rweicht nud stets von Mreelpilzen, bei anhaltender Fenchtiglieit anch

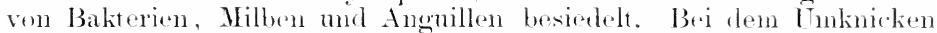
in höheren Ilahmregionen erscheint der Ilalmgrmul text num grön: die Bestoclimmgstriebe sind nur vereinzelt abgestorben mol mehrfach whor Verpilzung. Am hänfigsten zeigt sich lie enhmale huickstelle am zweiten oder dritten Internodium oberhalh der Budenoberfläche mul charakterisiert sich als teik emseitige, teils ring sherum verlantencle hrane Zone, deren Färhung nach dem nächst höheren Knoten hin an Intensität zunimmt. Demmach exseheint die dicht muterhall, eines Lnotens belegene Region eines Halmes als die am meisten emptindliche. Dennoch vormag der an das tietgebrïunte (iewebe oberhalb anstolisene Kuoten häufig noch eine Aufwärtsbiegung des mmgclegten Halmes anszuführen, so dafs derselbe mit einem Knie wiecler antrecht zn stehen kommt. Aber die Ähre an solehen Pflanzen ist sthwarh und lïckjy. Die Wurzah erscheinen gesund, der gehräunte Halmteil tiast stets ohni irgencleine Pilzvergetation.

\section{Die Kahlährigkeit.}

Die scheinbar an wenigsten mit Frostschäden Berirhmeren hesitzoncle Erlirankmo ist die $\mathrm{K}$ a hla hrigleit, wie sie in Fig. 114 . 1

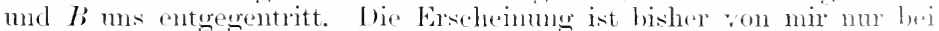
Roggen gefimden worden. und ich schilifere mmmele sinen siperialtall, den ieh im Jumi Imo zu beobachten (relegenheit hatte ${ }^{1}$ ). IIin. zeigten sich die Halme meist von normalex firötse und kräftigem IV ntels. aber besalsen im obersten orler nächstunteren Gliede bleichgellus sräter

1) Sonater, P.. Über Frostbeschädigungen am Getreile und danit in Verbindung stehende Pilzkrankheiten. Landw. Jahrbücher 190:3. s. 1. 

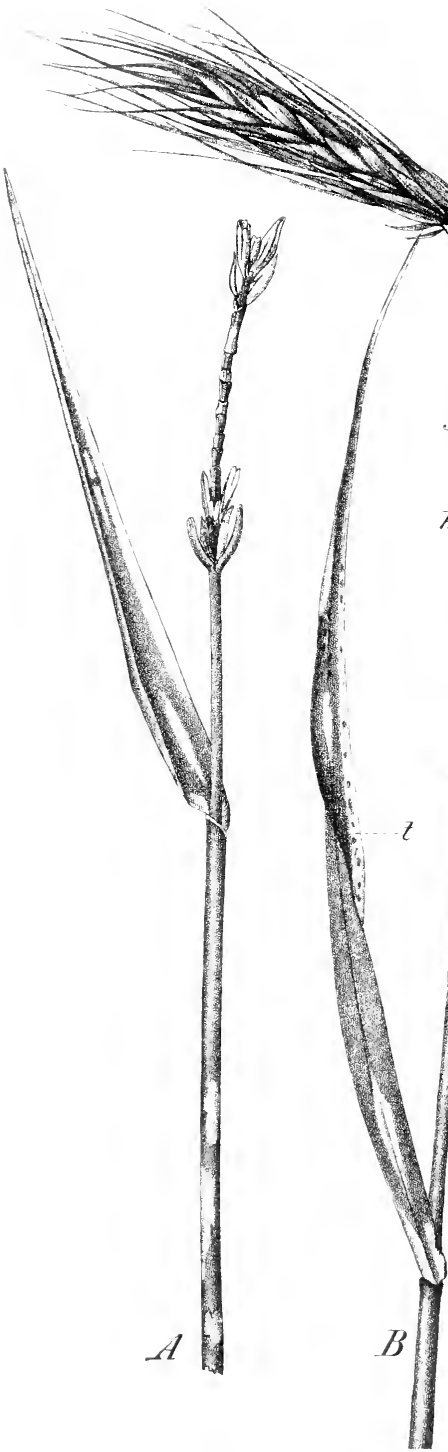

Fig. 114. Verschiedene Fomen der Kihlährokeit. (Orig.) strohfarbige lis loraungethe, oft dunkler umäumtr Flecke, die oft zu einer den Halm umfassenden Binde sich prweiterten. In anderen Fällen erwies sich der Halm bis zum obersten Internodium ganz gesund. (Oherste Blattscheiden und Blätter aber waren strolifarbig gefleckt

(Fig. 114 Bt) oder getuptt; höchster Teil des llahmes nebst Basis der Ärenspindel rötlichstrohtarbig, Ähenspindel selbst hraungliedrig, lachstarbig punktiert, am Girunde ganz kahl (k) und weiter autwärts mit anfangs färligen. später etwas breiter werlenden papierartigen spelzen beleckt (sp). Die Spitze der Äre kann dabei noch zur vollständigen Entwicklnng kommen, wie

Fig. $114 B$ zeigt, mol in dem Matse, wie man sich dem grïnen (rip,telteil der Ähre nähert, sieht man.

wie die fadenartigen, weitsen spelzen derbor und grötser werden mol sich in ihrer Beschatfenheit dem normalen Zustancle nähern. Bisweilen findet man (iruppen bereits eroriunter nud

Hrischiger spelzen im Verlaute des kahlbleiben(len Spinclelteils (Fig. $B g$ ).

In Fig. $A$ ist ein Fall clargestellt, bei welchem die unteren spelzen normal und wrïu, die obersten zwar normal in Grölse und Gestalt sind. aber ein rosa-

strohfarbiges Anssehen haben. Wwischen Gipfel und Basis ist die Ähren- 
spintel nackt. In den intensivsten Fällen der Beschädigmng ist an Stelle der Ähre nur eine kahle, bramgliedrige lachsfarbig pmbtierte Ährenspindel ïbrig. getblieben. Die lachatabigen Punlito sinel die Ansatzstellen der Ährohen, die dureh ïprig entriche Pilzrasen gefärbt sind.

Fast bei allen Formen der Kahlährigkeit hient sich dureh Vertroeknen des kahlen śpindelteils die Ährenachse krummstabtömmig Fig. $114 B_{1}$ ). An den im Bilde vorgeführten Beispielen erkennt man dentlied, watis die Kahlährigkeit wanz lokal wirkenden Ursachen ihre Entstelume rerdanken muts. Wem man diese Erscheinungen anf oinem Felde stmilierte. auf welchem besonders zahlreiche Pflanzen an Kahlähigkeit litten. Wemerkte man, dats die Beschädigungszonen in annähernel wheicher Fntfermung rom Boden zu finden waren. Es mutste somit dic sehädiognde. Ursache für dir Kahlährigkeit in einer Inftschicht sich hefunden halen. die ansschliefslich in einer gewissen Entfernumg rom Borlen vorhanden gewesen ist. Jo nachlem num die nach ihrer individuellon Entwicklmos

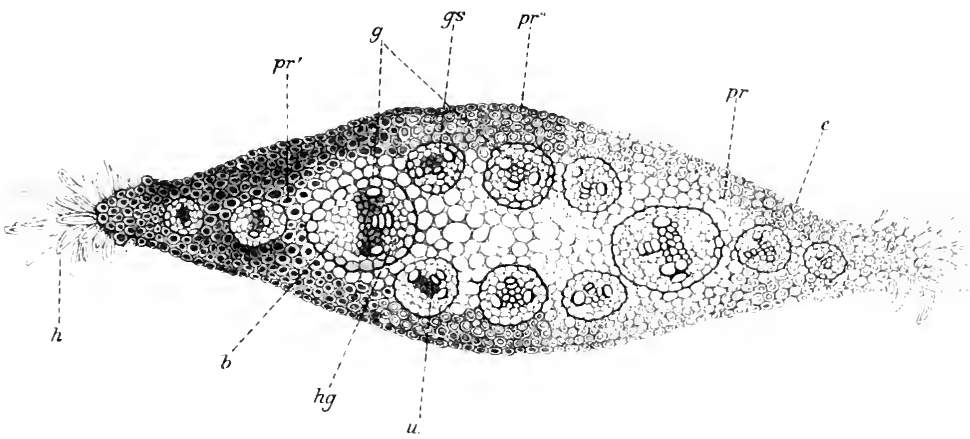

Fig. 115. Quershutt durch ein Internodium der Ihrenspindel eines an Kahlärigkeit leidenden Roggenhalmes. (1)rim.)

in versthedenen Stadion befindlichen Rogerenthanzen in diese schäli-

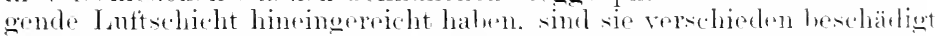

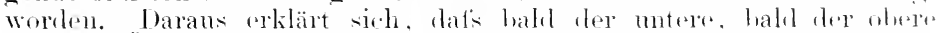

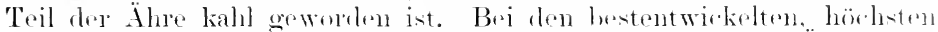
PHanzen. bei donen die anf den längston Halmen steluenden Älnen sirh

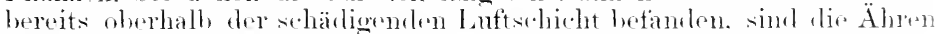

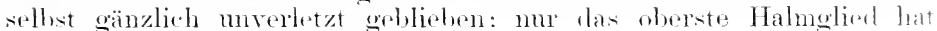
eine bleiche Bint, erhalten.

Bei Erwägung der Trsache der Kahlährokeit liegt die Vormutume am närhsten, dats der an don Binden mud namentlich an der Ähenspindel erkembare mul an den Ansatzstellen der Bläten in lan horrat Räschen anfretente Pilz die Krankheit veranlatist habe. Ihen Annahme ist jedoch irrig, da auch schwere Beschädigmoen tex stimbl beobachtet worden sind. ohme dats die fregenwart rom Pilzen malhgewiesen werden komnte. Es ist fleshall, dieser Pilz. dor zut liattmug Acremominm gehört, als eine sekundäre Ansiedlung. olwnson wis das selten fehlende Cladosponimm anzusprechen. 


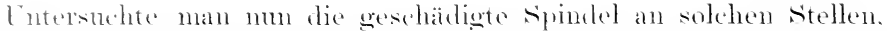
an denen feremonimm sich nicht angesiedelt hatte. so bekam man div Bilder. die in Fig. 115 mol 116 darestellt sime Fig. 115 stellt den

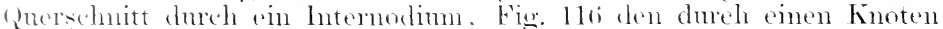
dere Ahrenspindel dar. Mit, ist die Eprelermis, mit he deren Hare

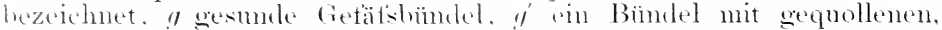

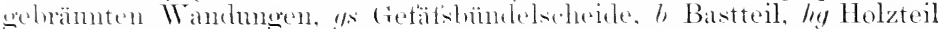

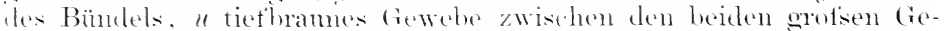
fätsen. Wolehes an emptindlichsten ist mul bei rerschiedenen anderen

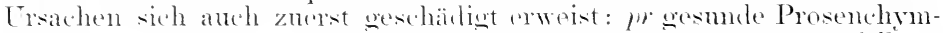

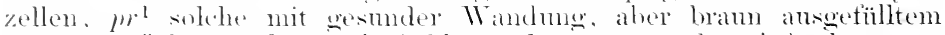

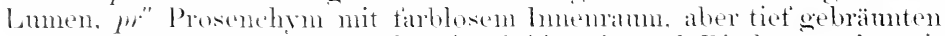
Mandungen. Parenchymallen in Epidemis mol Rindengewebe mit

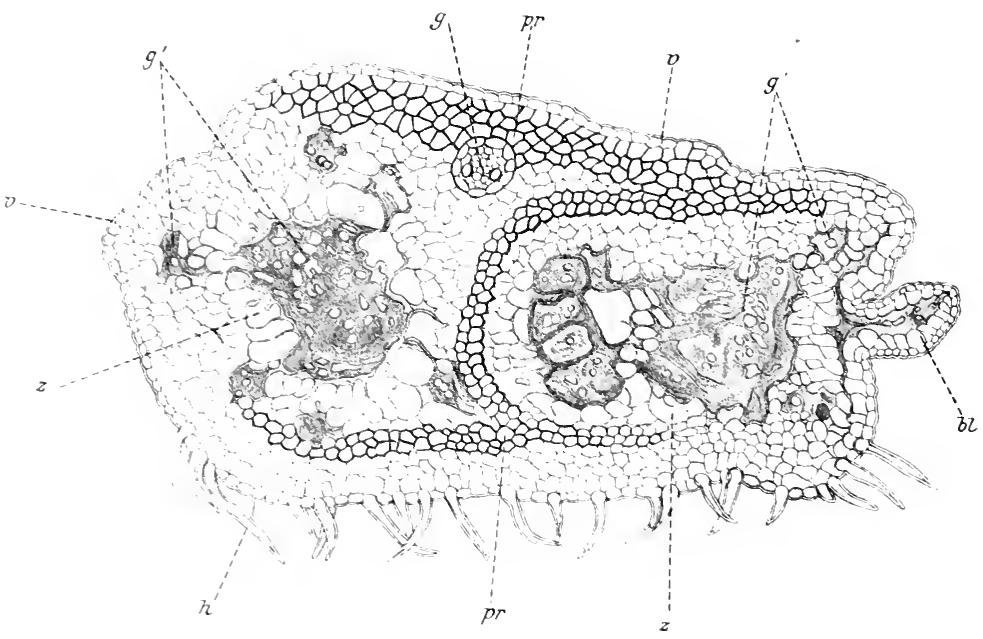

Fig. 11\%. Querschnit durh den Nodus einer kahlïhrigen spindel. (Orig.)

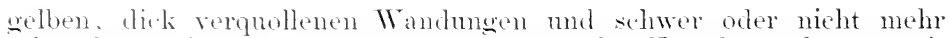

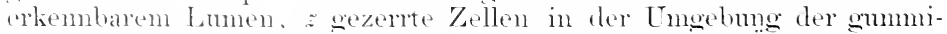
ämlich veryunllenen fiewebeherde. 6,1 Basalteil eines Ahrehens. das hier vom kinoten aligeht.

Man timlet somit an den kahlen stellen der Ährenspinclel alle diejenigen Beschädimustomen wieder. die in then moteren Hahmknoten trostbeschädieten fretreides hemerkbar sint: num sind an stelle der

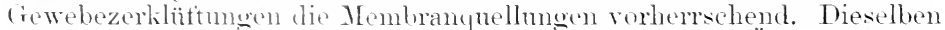
sind besembers answoduht an den Ansatzstellen ker Ährehen, weil tort viel reichlicher parenchrmat isches. also frostemptindliches frewebe rorhanden ist. Tue solde grimmiählich verouollenen Gewebeherde liegen tief im Innern levespindel. Inwh diesen anatomischen Befund mitershodet sich die Kahlahrigkeit dureh Frost ron den ähn-

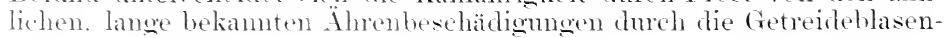


fïtse (Thrips), deren Saugstellen oberflächlieh bleiben. Alleplings findet man anch nicht selten an den frostheschädisten Änen Blasonfïitie, da

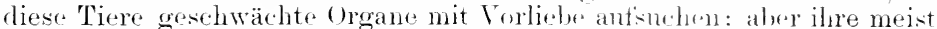

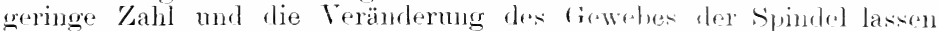

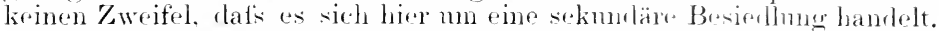

Ausselnlaggebend ist fler Cmstand. dats es mir gelungen ist. durele lïnstlichen Frost alle hier gesehilderten Blatt. Halmund Ährenbeschädigungen hervorzuruten. Anr all. var. schiedenen Formen der Könerschrumpfung konnten exp+rinfitell "rzenut werden.

Die Kahlährigkeit dureh Frost tritt nur in oinzeluen .Jahrou mul in gröfserer Ansdehnme blots an bestimmten Lokalitäts ant.

Der Gedanke. datis nur einzelue Rogionen dos Halmes durch Frost beschärligt werden. wie dies bei der Kahlährigkeit voran-gesetot worlon mufs, hat anfänglieh etwas Befiemolliches. Aber man wirl sofont vertranter damit, wenn man die Regromen ins Ange fatist. die welitten haben. Entwerter ist es der zuletzt aus der brheide heranseretretus Basalteil der Ähre. samt dem anstotisenden obersten Teile des Hahnos. oder es ist der mmittelluar unter einem Knoten belewene Tril eines Internodiums. der dam die Frostbinde zeigt. Dies. genanntran Rerpionen sind aber die weichsten und empfindlichsten am ganzen Halure, mud analoge Erschrinmogen finden wir anch bei dikotylen fowächsest. lex

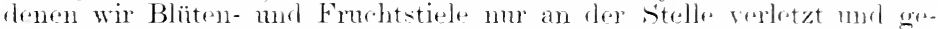
schwärzt sehen, dis monittelhar an don Blütrngmud anglenzt. Währond der ältere Teil gosud hleiht.

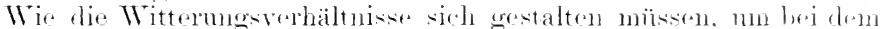

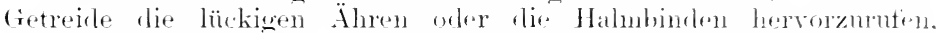

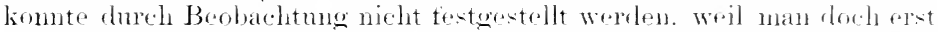
längere \%oit nach der Frostwirkmeg ant die Erscheinung antinerlisan

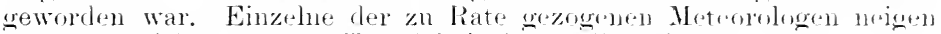
zu der Ansicht. dats der Tan dabei rine Rolle spiele.

Die Frostnächte in Mai sind meist windstill, und rlie Beschädignne der Pflanzenteile erfolgt durh Ablïhlumg der Grone infolge vom stralihmen.

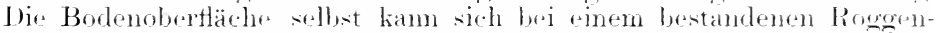
felde niclit sehr stark alkühlen. la sis ihre Tageswärme durch den Mantel. den die zwischen den Halmen befindliche. shwer hewrelielse luft bildet, lange behält. Die stärste. Ahkühlumg durch strahlung kann nur in den oberen Halmegronen erfolgen. Jores sind aber von dem näelitlichen Tau berleckt. Teem sich nun pötzlich der Morgenwind hei sonnenanterang erheht und schnelle Vorlmustung des Tanes

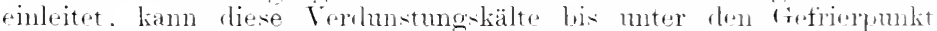
kommen. Alle stellen mit geringerer Tammengesowie die Teile. die durch vorliegende andere Hahne geschützt werden. bleiben dann sor dieser

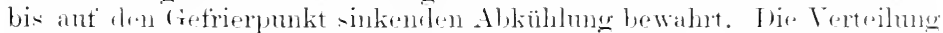
des Taues anf denselben Pflanzenteil wird atber anch verechierlen - win

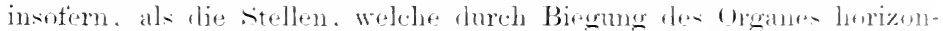
taler als andre weneigt sind. grötsere Tammengen testhaltwn werlen.

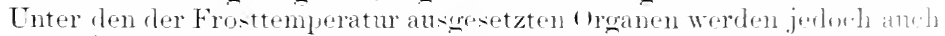

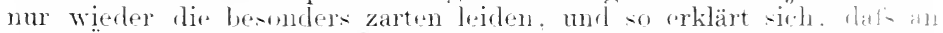

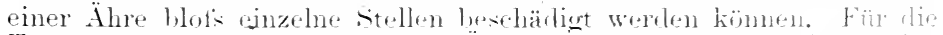

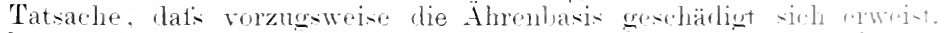

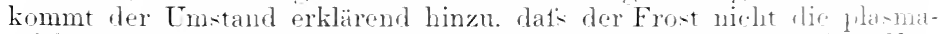

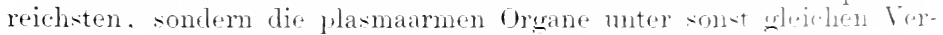

Sorauer, Handbuch. 3. Autl. Erster Band. 
hälnissen zuerst beschädigt. Die Ährchen an tler Basis der Ähre sind aber die schlechtest ernährten und plasmaämsten, wie jede gesmole (retreicleähre erkemnen lälst.

lnfolge einer Unterhaltung mit drm Direktor der Deutschen Secwarte, Herrn Admiral Inerz, liets mir derselbe in liebenswürliger Weise später folgende Erklärung zugehen. .In Pfanzendickichten, sie mögen hoch oder niedrig sein, wird einerseits der Boden dmeh Beschirmmng gegen die nächtliche Ausitrahlung geschützt, andrerseits geht diese Ansstrahlumg von dre Oberfläche des Dickichts kräftig mo, wegen der schlechten T"Tarmeleitmog, sehr wirksam vor sich. Aler die an den Blättern erkaltete luft sinkt in das sieb des Dickichts herab, wie sie an den lä̈ngen in die Mulden des Bodens hinabsinkt Es ist deshalb sehr wohl denkbar, dat's lie nicdrigsten Luftemperaturen etwas unter der Oberfläche eines solchen Dickichts sich einstellen, hesonders wenn einerseits seine l)ichte nach miten zmimmt mol andererseits die Wipfel anch duch rinen leichten Wind vor allzuweit gehender Erkältung geschützt werden."

In welcher Weise tatsächlich im Freien sich dic Vorgänge abspielen, welche die schädigende Abkühlung einzehner horizontaler Lnttschirhten in wölserer Entfermm von der Bodenolerfläche zuwege bringen, bleibt weiterer Beohachtmo üherlassen. Aber dat's Kahlährigkeit dur derartige Frostwirkmgen hervorgerufen wird, zeigt eben das Experiment, bei welchem ein IJohlzylinder mit einem dic Kälemischung enthaltenden Mantel ïber den obcren Teil blühemler Roggenhahe gestülpt worden war. Bei der Unmöglichkeit für die enzehnen horizontalen Luftschichten imerhalb des fofrierzylinders, sich schmell zu vermischen, erwies sich auch mu eine bestimmte /one derart algekühlt, dats sie clie geschilderten Ährenbeschärdigungen zuwege brachte.

Dats anch bei Wahlbämmen sich Beschäthomgen einstellen, welche anf las Torhandensein einer den Frosttod herbeiführenden Luttschicht oberhall, der warmen Bodenoberfläche hinweisen, schliefsen wir $z$. B. aus den Beolachtungen von Nörousnties ${ }^{1}$ ). Er sah im Jumi 186:2 im llohenheimer (Hheren Walde junge Schosice von sale, Eichen und Aspen, im Angust 18s:; mehrere Wejdenarten, namentlich Salia fragilis. am frunde der Blattstiele erfroren, ohme dats eine Frostnacht eingetreten gewesen wär'.

\section{Bewegungserscheinungen durch Frost.}

Bei manchen den Frost iiberlebenden Pfanzen erfolgen bei lem Gefirien eigentümliche Bewegungserscheinungen, welche bei dem Anttanen wieder verschwinden. Göprert (Wärmeentwicklung in den Pflanzen S. 12) erwähnt die Beobachtung von limmé, dats die Blätter einer Wolfsmileh (Euphorbia Lathyris) sich mit der Spitze abwärts neigen, lis das Blatt dem Stengel anliegt. Die Blätter vom Goldlack (Cheiranthus Cheivi) sehen im gefrorenen Zustande wie verwelkt und mamigfach gekrömmt aus und erlangen naeh dem Anftanen wiedre ihre trïhore Buschaffenheit nnd stellumg.

WiтTRock ${ }^{2}$ ) erblickt in den Bewegungserscheinmogen einen Schntz gegen Winterkälte. Beisfickweise biegen sich die immergrünen Wurzel-

1) Nombingicr, H., Lehrbuch des Forstschutzes. Berlin, P. Parey 1884, S. 347.

2) Bot. Ges. zu Stockholm. Sitz. v. 24. Oktob. 1883; cit. Bot. Centralbl. 1883, Nr. $50, \mathrm{~s}, 350$. 
blätter zahlreicher Kränter rörkwärts mol ahwärts, so dats wenigstens

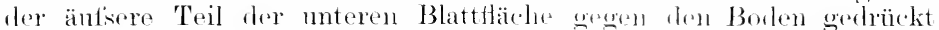
erseheint: in sommer stehen sie schräg anterelit. Busonders dentlich

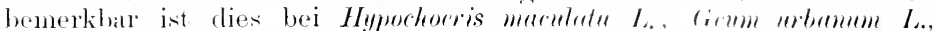

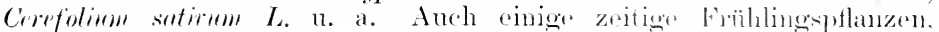

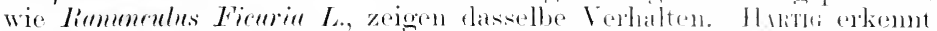

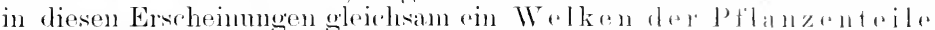

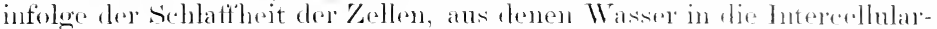

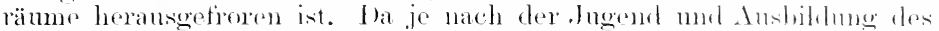

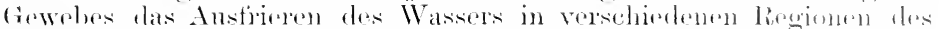

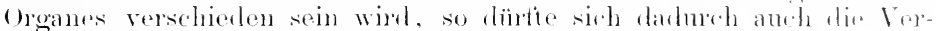

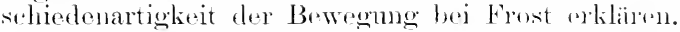

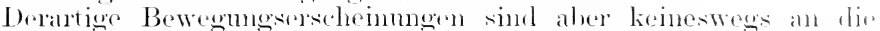

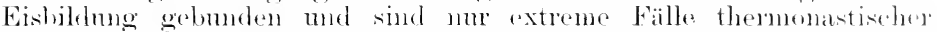
Reaktion, die, wie PrefFen ${ }^{1}$ ) erwilnt, schom in den abroullehen

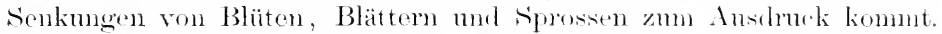
Vöntwi: ${ }^{2}$ ) beobachtete an Nimmlus Tilimgii Rogl., datis in Fröhling sprosse bestimmten Alters bei hoher Temperatm rmporwallsem, hei niedriger dagegen eine horizontale Richtmog hehalten onler, falls sio hereits antrecht sich ontwickelt haben, die horizontale wieder ammohmen. Belenchtme und laftfouchtigkeit sind dabej olme Einflufs. Fr meint,

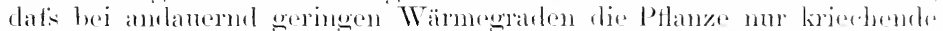

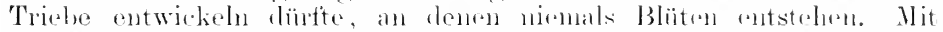

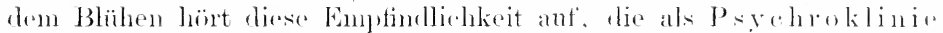

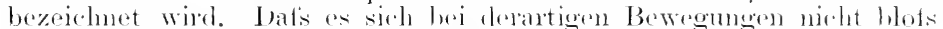

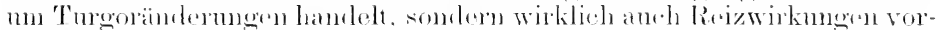

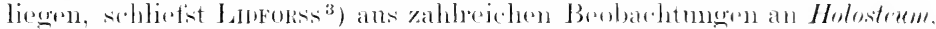
Lamium, Fromica nsw. mit lenen anch Klinostatenvelsuehe angestellt worden. Bei höherer 'Temperatur sind die strugel negativ gootropiseh, hei Temperaturen moter $+4{ }^{\prime}$ dagegen diageotropiseh mol epinastisch. Hire wirkt aher das Licht moditizierend, indem bei Lichtabschluts dir. stengel trotz der niederen 'Temperatur nicht mehr dia-, sondern negativ geotropiseh sind.

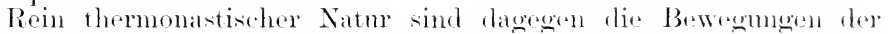

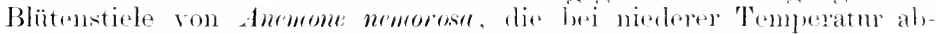
wärts gekrönmt sind, boi höherer aber anfirecht stohen.

Bei den Blattstielen mol Blattflärhen lemert man vielfach die Amahme eiser llorizontalstellomg oder, an höheren anfiechten Aclisen, das 'buriekhiegen moter die Horizontalebene. Ilervorheben möehten wir dabei aber den Unstand, dats die Bewromeren sich meist in den Gelenlicu vollzichen mut hei derselben Pflanze nicht immer olejchsimnie siel zeigen. Es kam vorkonmen, dafis hei znsammengesetzten Bläten'n cin Teil der Foliola nach oben enesehlagen ist, während dir Mehrzahl nach unten sich zurizckliegt, dats also eimmal die mor hologische oberseite der trelenkpolster sich vorkïrzt, ein andermal die Intersita. Tnter den Krimmumgen, die bei Eisbildung besonders dentlich in die Erscheinme treten. ist das Rollen der Blattläihon hervorzuhalen. Ein sehr leicht zn heobachtendes Beispiel lieten mser winterhanten

1) Prtrits, Pflanzenphysiologie, II. Aufl., 2. Bd. (1904), S. 495.

2) Bot. Jahresh, 1898, I. S. 582 .

3) Lumus, Baxt, C̈ber den (ieotropismus einiger Frühahrsplfanzen. Jahrb. f. wiss. Bot., 38 Bd., 1902, s. 343. (Z. f. Pflanzenkrauk., 190:3, s. 277.) 
Rhododendron. Harshbentier ${ }^{1}$ ) beschreibt einen Fall bei Rihododendron matimum, bei welchem sich die Blattstiele bis $10 \mathrm{~m} 70^{\circ}$ senkten und die Blattränder sich stark rückwärts rollten, so dats die Oberseite vorgewölbt ersthien. Wurlen die Pfanzen ins warme Zimmer gebracht, hatten schon nach 5 Mimnten ihre Bläter in normale Stellung sich begeben. Als Grund dieses Vorganges vermutet $H$. eine cigenartige Reizbarkeit des Plasmas, während ich Spammngsdifferenzen zwischen den verschieden gebanten Geweboshichten annehme.

Bei mehreren holzigen Pflanzen wieht man eine Bewegung der Zweige und Äste und zwar proportional der Kälte. Nach (Aspaki ${ }^{2}$ ) richten Acer Negumdo numl Ptrocarya cancusica ihre Beastmng auf, während Larir, P'imus Strolus sowie Titia parvifolia die Äste senken; Acsculus Hiprocastamm und rubra sowie Carpims Botulus senken die Äste bei goringen Frostgraden nud richten sie hei stärkerer Kälte wieder ant. Bei dieser Hebmo oder sienkung vollzieht sich gleichzeitig eine seitliche Bewegmng, die bei einzehnen Arten nach rechts, hei anderen nach links hin erfolgt. An Cormus sumfumon sah Fronk ${ }^{3}$ ) die ein-bis dreijährigen Ästchen stark wellenförmig geschlängelt und mmeinander wewunden. Die meisten Krümmungen zeigten sich dentlich nach einer ind derselben Himmelsgegend orientiert, so dafs ron Frask anf die Wirkung eines aus bestimmter Richtung kommenden lialten Luttstromes weschlossen wurde.

Die Ursache fïr die genamnten Bewegungsvorgänge an Blättern und Blattstielen sowohl als anch bei /weigen möchten wir, wie gesagt, in Siannmosdifterenzen suchen, welehe teils durch Turgescenzänderungen, teils durch ungleiche Zusammenziehmo verschiedener Gewebeformen immerhalh desselben Organs bei Eintritt der Käle zustande kommen.

Dats eine steigerung der 'Turgescenz der yarenchymatischen Gewebe hei der "Frostwelke" der Blätter unter Umständen die Straftheit derselben wieder herstellen kann, beweist ein Versuch, den ich bei Asculus Himnowstumum ausgefühnt habe.

Ein Areijähriges Toptexemplar wude in Februar in ein Warmhans gestellt. Es entwickelte sich sehr kräftig his Mitte März, so dat's der Terminaltrieb bei 14 cm Länge sechs Blätter zur Entwicklung brachte. Das gröfiste Blattfiederchen der beiden jüngsten Blätter besaf's eine länge von 2,5 cm und bei den unteren, älteren ron $5 \mathrm{~cm}$ bei $9 \mathrm{~cm}$ Blattstiellänge.

Die Pflanze liam am 14. März ins Freie. In der folgenden Nacht sank die Temperatm auf - 2,5" C, nnd am nächsten Norgen bemerkte man an rier der ältesten Blätter ein scharfes Einknicken der Blattstiele etwa in ilner Mitte oder etwas nnterhall, derselben. Die Knickstelle war flach zusammengediötst und begann alsbald schlatt zu werden. I ie Syitz'n der Teiblättchen, die sonst kein welkes Anssehen hatten, waren an den geknickiten Blättern schlatf und fingen an, sich bram zu verfärlen.

Da ein solches Knicken der Blattstiele bisher nicht beobathtet worden war, wurde dieselbe Pflanze in der Nacht vom 21.-2.2. März wiederum ins Freie gestellt. Die Temperatur sank bis $-7^{\circ} \mathrm{C}$, und

$\left.{ }^{1}\right)$ Hanmumain, Jomix, Thermotropic movements of the leaves of Rhododendron maximum: cit. Bot. Jahresb. 1899. II, s.. 141

2) Teport of the international Horticultural Exhibition etc., London 1866; cit bei Nirrdlinger, Forsthotanik, I, s. 201.

3) Fraxk, A. B., Krankheiten d. Pflanzen. Breslau 1895, Bd. I, s. 187. 
am nächsten Morgen hingen die Fiederchen säntlicher Blätter im scharten Winkel abwärts. Die jün 2 sten Bliittren zoigten dio kr-

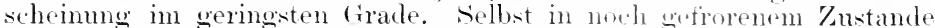
erschien kein 'Teil ter jungen Triebe spröl. orler von glasiger Be-

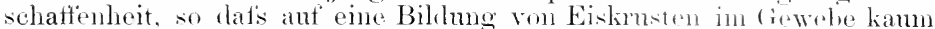
geschlossen werden liomte. Hie Blätchen waren wohlh mel schlatf und von grangrüner Färhmog, und die Blattstiele, solang die Ptlanze im Freien stand, im starken Bogen nach alswärts gerichtes, aher unch nicht geknickt. Die Knickmo trat erst nach ainigen simelen in bimmer ein, und zwar, wie bei der erst heoharhteten Beschädipune, wiederum etwa in ter Mitte der ganzen Länge. Ilese Stolle selormufte alsbald und bräunte sich. (ileichzeitig begannen sämthiche Teilllättchen mit Ausnahme der jüngsten, von ihrer Ansatzstelle aus sich zu sehwär\%"n, wohei die spitzen sich nach oben krümmten mod trocken wurlen.

Die Knickungsvorgänge mïssen anf Helelwirkung bei verminderter Turgescenz zurückgetïhrt werden. Dem sobald man einzehne der bej der schwachen Frostwirkmg eingeknickten Blätter abschnitt mul in Wasser stellte, verschwanden trotz der Kinckstelle dio Wellierscheinmoen. mol es trat eine grotse straftheit der (tewehe pin. Wwar behielten die Teilblättehen ihre dem . Jugendstadinm oigrne Abwärtsneigung, aber ihre Intercostalfelder wölhten sich stark zwisehen den Rippen hervor, und ihre seitenränder begammen sich nach unten zu richten.

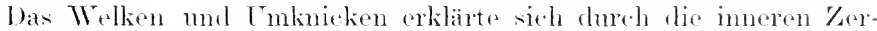
klïftungserscheimugen im Markkärper des Blattstieles. Bei der Kastanie hat der Blattstiel insotern eine der Achse ähnliche strulitur, als (re

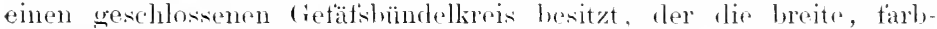
lose Markscheibe vollständig gleichmälisg moibt und in einer der Markkrone ähnlichen Abstufing in diesclbe ähergeht. sichon nach der schwächsten Frostwirkmo bemerkte man an den Blattstielen. dir moeh nicht eingelinickt waren, aber doreh Erschlathing der ontsprechenden stelle als zur Einknickung vorbereitret sich rewiesen, datis dort der Markkïrper L ï eken in meist radialer Riehtme besat's. Jasselbe zeigte sich an der Blattstielbasis. Dadurch, dats der hier in \%entrum der Narkscheibe verlantende, ans ein his zwei Bündrhn be-

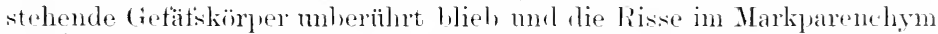
allseitig radial verliefen, fiund man hisweilen eine rigenartige, storntörmige \%erklüttungsfigur. Bei den Blättern, welehe orst nach der zweiten, stiakeren Frostwirkmo eingeknickt waren, ersehen dis \%erklüttung der Marliseheibe bisweilen so stark, dats der zentrale Gefätihiindelstrang nu noch dureh einen sehmalen Parenchynstreifen mit den peripherischen Gotalsbïnteln zusammenhing, und die ganze iibrige Markscheibe sich losgelist hatte. Die lï̈ckn setzten sich nicht solten

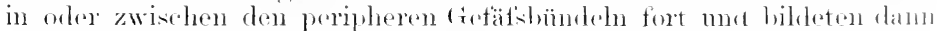

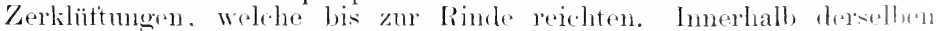
kömen sich noch tangontiale Abholnmgen der zwei lis vier äntiseren eollenchrmatiselon Zelllagen rom zarten, inneren (iewebr hinzunesellen. Lotzteres erwies sich ahlorophrlheich und zeigte bisweilen som nom geformte Chlorophyllkörper. Ähnliche störungen liefsen sieh anch in den Mittelippen stäker geschädigter Teilblättchen nachwיis's.

Hier wurden Brämmungerscheimungen zuerst an den fiofialswandungen wahrgenommen und dam traten sie in einzelnen Parenchrmentypren der Rinde aut. 
Bei der Frostwelke im Freien kann natïrlich eine so gesteigerte Trasserzutuhr, wie hier im Versnche durch Einstellen der abgeschnittenen Blätter in Wasser erzielt wude, nicht Platz greifen, und deshalb bleiben die welken Organe lange Zeit oder anch danerud im Welkzustande, namentlich wemn Gewebezerkiüftungen und Veränderungen ler Gefäfse die Leitungstähigkeit herabdrücken. Dies kann nicht nur bei den cinzelnen Arten und Individurn, somlern selbst an den einzelnen Zweigen desselben Exemplares verschieden sich gestalten. Ein Boispiel lieferte eine Ulme, die in einem Topfe stand und im Winter in einem Warmhanse zum Anstreiben gehracht worken war. Das Bäumchen, das einer Frostnacht mit mu $1^{\circ}$ C Kälte ansopetzt worlen war, hatte an seiner Spitze vabolartig zwei Triebe entwickelt, welche in Länge, Blattzahl nud Blatgoritse nahezn übereinstimmten In der Frostnacht hatte aber

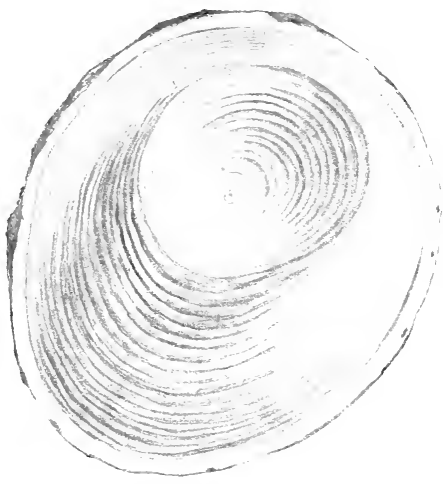

Fig. 117. Querschnitt durch einen Fichtenast, der das feste Rotholz im inneren Teile der Holzscheibe auf der Zweigoberseite, in den äufseren. Jahresringen aber auf der Zweigunterseite zeigt. (Nach R. Hiniti). nur ein Trieb zu welken angefangen und zeigte anch einzelne welkende, aber kine Farbenänderung aufweisende Blätter. Die erschlafften Organe erholten sich bei mehrtägigem Autenthalt im limmer nicht mehr, verrieten aber auch kein Fortscheiten im Welken. Es geht daraus hervor, tafs die Frostwelle eine ganz lokale mit dem Wasseranftrieb seitens der Wurzel nicht in direkter Bezichung stehente Erscheinmog ist.

Bei den Bew egungserschei nungen der $/$ weige wird sich die Vershiedenartigkeit der Bewegungen leicht erklären lassen, wenn man den Bau der einzelnen Achsen genaner betrachtet und sieht, wie die Ausbildung der Jahresinge betreft's der Menge des dïmnwandigen Frühlingsholzes (Fig. 118) zum derbwandigen, englumigen Herbstholze stänelig wechselt. Man vergleiche in dieser Bezirhmo die Sturlien von R. Hartig ${ }^{\mathbf{1}}$ ) ïher den Wrehsel von dickwantigem Rotholz zum hellen lockeren Zngholz imerhall, desselben Quersehnittes eines Fichtemastes. In beistehender Fig. 117 zeigt sich das Rotholz in clen ersten Jahresperioden anf der Oberseite des Astes besonders stark auscebildet; die spätren .Jahngänge weisen dann einen plötzlichen Wechsel auf, inclem nummehr lie Astmnterseite dmokel durch die dichte Rotholzbildung erseheint. Wie versdieden die Elemente von "Rotholz" und "Zugholz" gebant sinfl, "rsehen wir ans den anatomischen Bildern (Fig. 1 s nund Fig. 11!1).

T̈ber clas /ustandoliommen derartiger Versehiedenheiten erlangen wir von R. H.ıтTi sehr beachtenswerte Mitteilungen. Er gibt an, dafs z. B. hei stämmen mit exzentrischem Wuchse die Jahresinghildnng anf der boasteten Seite besonder's stark entwickelt ist. Die Retholzbildung erweist sich vielfath von der herrschenden Windrichtung ah)

1) R. Hanti, Holzuntersuchungen. Berlin, springer, 1901, \$. 50. 


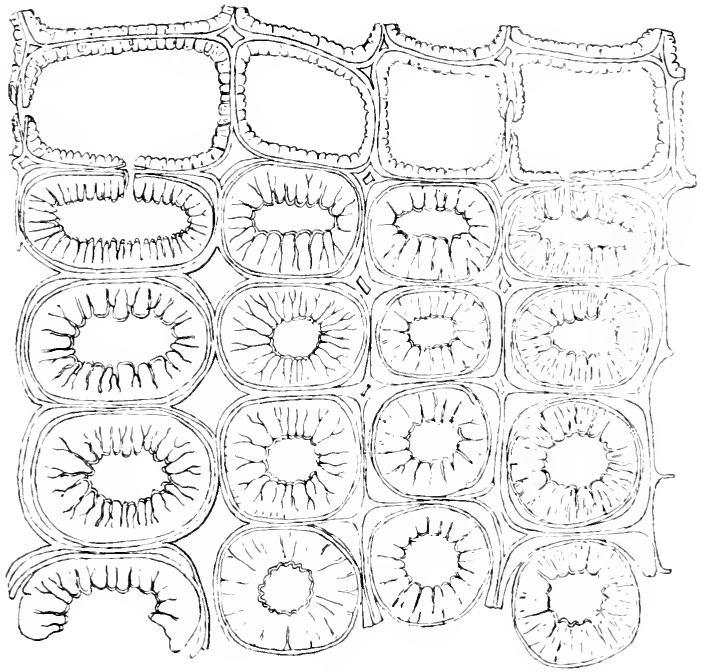

Fig. 118. Rotholz von der ['nterseite eines Fichtenastes ((querschnitt).

Die oberste Zellreihe gehört noch dem Frühjahrsholze an, die unteren vier Reihen sind Rotholz, das linksseitig grofse Intercellularräume besitzt. (Nach R. Hummi.)

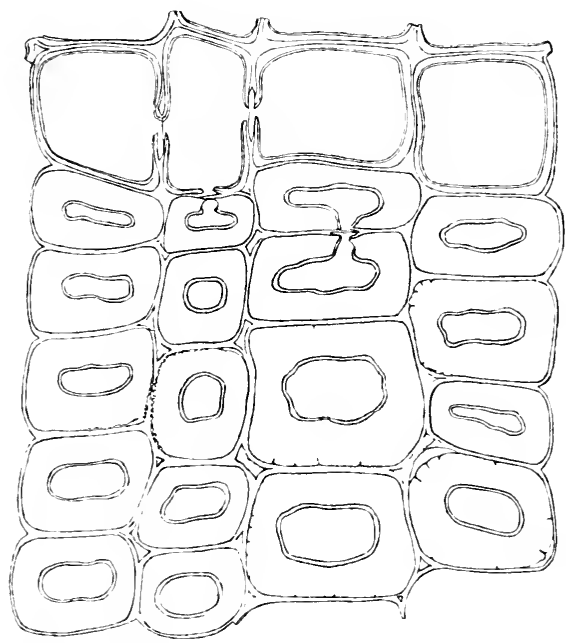

Fig. 119. Querschnitt durch Zugholz von der Oberssite eines Fichtenantes. (Nach R. H.rmi.) 
Winde abgekehrte Seite in der Rotholzhilhung begïnstigt wird. Hier wird, wenn der Westwind beispielsweise danemd eine Fichte fafst, die Westseite gezogen und die Ostseite, nach welcher hin der Baum gebogen wird, stärker geflückt und zur stärkeren Rotholzhildung veranlafist, während die hei der Biegung des stammes gedehnte Windseite /ugholz produziert. Jeder Ast wirl eine ebensolche Differenzierung anfweisen, denn durch das Gewicht der Benarllung wird der Ast nach unten gezogen; seine morphologische oberseite steht also miter einem fortwälrenden Zuge, der einen Reiz auf das Cambium ausübt, welches infolgedessen dïmn wandigere, weniger verholzte, aber längere Tracheïden ausbildet, die das "Kugholz" darstellen.

Abgesehen von der Windwirkmg wird die Holzausbildung eines jeden Astes durch seine Ungebung beeinflutst: die Beschattung durch andere Bäume, die Nähe von Felsen oder Manern, die einseitige Wirkung gröfserer Fenchtigkeit, teilweise Entlaubung durch Tierfials oder sonstige einseitige Änderungen in der Ernährung der Achse werden Ungleichheiten in der (vuantität und Qualität des Jahresringes herheiführen. Daraus ergibt sich, dats bei Kältewirkung die Zusammenziehnug der Gewebe eine sehr' wechselnde und die Senkumg der Äste je nach Verteilung von Zug- und Rotholz eine sehr mamigfache sein muts, also die von den einzehen Forschern gemachten Beohachtungen keine allgemeine Gültigkeit haben kömnen, sondern nur als Einzelfälle vorläufig zu registrieren sind.

Anf die Spamnungsdifferenzen kommen wir in dem Abschnitt über die inneren Zorklïftungen eingehend zu sprechen.

\section{Abfrieren älterer Zweigspitzen.}

Fast so regehmälsig wie der Blattabfall zeigt sich bei einzelnen unserer Holzgewächse ein A b frieren der Z W eigspitzen. Maulbeerläume, Akazien und Himbeeren liefern die häufigsten Beispiele hiervon. Genanere studien über diesen Punkt verdanken wir v. МонL ${ }^{1}$ ), der faranf hinwies, in wie versthiedenen Starlien sich unsere Holzgewächse bei Eintritt des Winters befinden.

Bei manchen danert das Wachstum der /weige mugestärt fort, so lange die Bedingungen für die Weiterentwicklumg überhaupt giinstig sind; dasselbe erleidet nur durch die Frostperiode einen Stillstand und fährt sogleich wieder fort an der Stelle, wo es im Herbst anfgehört hat, solnald die Temperatur os gestattet. Dies ist bei dem Efen (Hodera Helix) und beim Sarlobaum (Jumipress Sabina) der Fall. Bei vielen Bämmen schlietst die Entwieklungsperiode eines Zweiges gegen Ende des sommers ron sellst dadurch, dat's sich eine Endknospe bildet. welche im nächsten Frïhjahr die ummittelbare Fortsetzung des Zweiges übernimmt, wir hei den Olstbäumen, bei Eichen, Eschen. Fichten und Tamnen. Bei mseren Kulturen tritt sehr häufig der Fall ein, dats ein zweiter Trieb im Jahre, der Joh an $n$ istrieb, hervorgeloekt wird; derselbe gibt num nicht selten mmeifes Holz, welehes im Winter leicht erfriert, während das Holz des Fr ïh jahrstrielos stets vollkommen ausreift. Eine dritte grotise Gruppe läist im Lanfe des Sommers bei einer ganz normalen Entwicklung die mitten in ihrer Entfaltung begriffene Spitze des Wweiges auf eimmal abfallen. Die Fortsetzung des Zweiges übernimmt

1) Eot. Zeitung 184s, S. 6 . 
damn im nächsten Jahre die oberste Seitenknospe. wie rlies Crymmocluhus camalonsis und Ailunthus glamblosa zeigen. Weitre Brispiele lieten die Linde, Ulme, Platane, Haselnuts. Nun wies v. Mont nacl, dats die Bänme, deven \%weigspitzen fast regelmätsig bei uns artionen. zu dieser letzten (irupe gehören, deren Vertreter z. 13. in Thom im 1)ktober

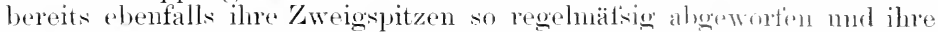
Vegetationsperiode damit faktisch berndet haben, wir bei ms die Linde. Bei den Bämmen dieser (imppe, die wir in dren Anlagen kultivieren, erfolgt ein solcher normaler Vegetationsabschluls in ter Melnzahl der Fälle nicht, und dies zeigt, dats mnsere tommnor für sin zu kurz und zu kalt sind, mo sie ihre vollständige Entwicklnug berenten zul lassen.

Der Frost trifft deshall, immer nn reife Triebe. Hierher ge-

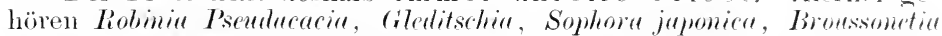

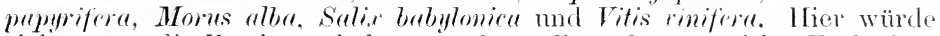
sich, wenn die /weige erhalten werlen sollen, das vorzeitige Entlanben derselben emptehlen. So sint beispielsweise nach den Beobachtungen von Lawrexce ') im Winter 1708-! unter allen Fruchtbänmen nur die Maulbeerläume erhalten worlen, weil man ihre Blätter schon längero Zeit vor Eintritt der Kälte zu Futter für die Seidenraupen abgeptlückt hatte.

Bei unseren Obstbänmen pflegt man das Absterben der Kweigspitzen infolge der Winterkälte als .spitzenbrand" zu bezrichnen. Damit in Verbindung steht aber nicht selten eine Folgeerscheinmo, die erst im sommer sich geltend marht. Wem nämlich bei nanchen \%weigen der Fall eintritt, dats nu die besonder's empfindlichen basalen Astringe beschädigt werden, treiben in der Regel diese $/$ weige noeh aus und die angelegt gewesenen Blïten entwickeh sich. Aber mugefahr im Juni zeigt sich Vereillom no des I a nbes. Abwerfen der otwa angelegt gewesenen Früchte mi Vertrocknen der Zweigr. Infolwe der Beschädigmng des Astringes ist die Leitmmg des Nälnmaterials gestört. Die Kweige sellst leben noch, solange Reservestoffo vorhanden sind. Nach Verbranch derselben stirbt die Achse.

Bei Weinstöcken verdient der Fall, dafis die Stöeke his auf das alte Jlolz herabfrieren, besonderer Erwähnung. Es entwickeln sich dann ans der Stammbasis ungemein üppige Roben, von denen man fiöher meist amnahm, dats sie unfruchtbar im tolgenden . lahre wären und erst im zweiten Jahre Fruchtholz trïgen. Dieser Ansicht grepen-

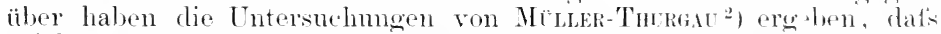
solches 1lolz doch schon im 1lerbst (Angust) seines Entstohungsjahres Fruchtangen anlegen kann, mol dats demgemäts dir Behandlung des sitockes einzurichten ist.

\section{Das Kirschbaumsterben am Rhein.}

Als cinen speziellon Fall dor worhergehend geschilderton Erscheinungen betrachten wir die seit Ende des vorigen Jahrhmolorts viel besprochene Erkrankmng der Sïtskirschen in den Kreisen st. (inar. st. Goarshausen und Unterlalm.

I) Göprert, Wärmeentwicklung, S. 5.

2) Mümen-Turm, Über die Fruchtbarkeit der aus den ailterm Treilen der Weinstöcke hervorgehenden Triebe, sowie der sog. Nebentriebe. I)er IN inhau 1 Nr. 2ช. 
Nach den mir ans dortiger Gegend zugegangenen Material ${ }^{1}$ ) und nach anderweitig von mir beobachteten Fällen äntsert sich die Erseheinum in der Weise, dats ziemlich plotzlich ein Gelbwerden des Laubes sinzehner '/weige oder der gesamten Krone sich einstellt und, meist unter Auttreten reichlichen (Fummiflusses, die /weige oder selbst der ganze Stamm alsterben. Nanchmal treiben auch die Kweige noch an der spitze weiter, während sie am übrigen Teile kahl bleiben. Die mikroskopische Untersnchung stellte hochgradige Gummosis fest ; selbst in den jüngsten Trieben waren bereits Gummilïcken zu finden. Im Holzund Rindenkörper fanden sich vielfach jene Bräunmoserscheinungen, die wir später bei der Bescheibung der Wirkungen kïnstlicher Fröste noth schildern werden, und zwar waren dieselben selbst bei anscheinend noch gesmden Trieben, Blättern und Fruchtstielen nachweishar. In älterem Holze sah man mehrfach bestimmte Formen von Gewebezerklüttungen, die mit den durch kïmstliche Fröste hervor. gerufenen ïboreinstimmen. Ant Grund dieses Befundes bin ich der Ansicht, dats nicht nur bei dem "Rheinischen Kirschbaumsterben", sondern anch bei den vielfach, aber meist in geringerer Ausclehnung sich zeigenden ähnlichen Fällen eine Frostwirkung zu Keit des Frühlingstriebes als hauptsächlichste Ursache anzusehen ist.

Für die am Rhein belegenen Lokalitäten sehildert GöтHE ${ }^{2}$ ), der mserer Ansicht beitritt, die Wittermosverhälnisse im Jahre des Erscheinens der Krankheit folgendermatsen: Die Kirschen standen schon in Blüte, als sie an 22. März von einer Kälte von $-9,7^{\circ} \mathrm{C}$ ïberrascht wurden; es zeigten sich im Laufe des Frühjahrs abnorm starke Schwankmngen zwischen strenger Kälte und hohen Wärmegraden. Solche Witterungskontraste halte ich füu die Ursache äufserst zahlreicher Fälle von Nachwirkmoskrankheiten, die bei den Steinobstgehölzen fast stets mit starker Gummosis verbunden sind und von der Ansiedlung ron Wund-oder Schwächeparasiten begleitet werden. Auch für den speziellen Fall an Rhein hat man anfangs einen derartigen Pilz, Talsa lencostoma, verantwortlich gemacht ${ }^{3}$ ). Bald darauf wies aber schon Wenvek ${ }^{4}$ ) darauf hin, dat's dieser Pilz, der von Fraxk als Cytospora rubescens zunächst beschrieben worden war, nicht imstande sei, rie Krankheit hervorzurufen, sondern nur ebenso, wie das gleichzeitige Auftreten von Bakterien, als sekmoläre Erscheinmo zu betrachten sei. Den experimentellen Beweis datür, lats die Valsa nicht imstande sei, in gesundes Gewebe sofort einzudringen, führte zmächst ADERHoLD ${ }^{5}$ ). Dieser Forscher fand hei seinen kïnstlichon tefrierversuchen, dats eine Mitwirkmng von Spätfiösten fü̈ das Wuchern des Pilzes unverkembar wäre.

Betreffis des genamnten Pilzes ist Anenholo der Ansicht, dafs, wemn ler Pilz anch zunächst die lurch Frost oder andere Ursachen hervorgerutene Trommlung nötig habe, $m$ sich anzusiedeh, er später aber

1) Sorntr, P., Das Kirschbaumsterben am Rhein. D. Landwirtich. Presse 1900 , S. 201.

2) Grims, R., Das Absterben der Kirschenbäume in den Kreisen st. Goar, st. Goarshausen u. Unterlahn. D. Landwirtsch. Presse 1899, s. 1111.

${ }^{\circ}$ F Frisk, A. 13. in D. Landwirtsch. P'resse 1899, Nr. 83, S. 949.

4) Wenmer, Zum Kirschbaumsterhen am Rhein. D. Landwirtsch. Presse 1899 , Nr. 96.

5) Amprim, R., Über das Kirschbaumsterben am Rhein, seine Ursachen und scine Bekämpfung. Arb. d. Biolog. Abt. f. Land- u. Forstw. am Kais. Gesundheitsamte. Berlin 190:;, P. Parey и. J. springer. Bd. III, Heft 4. 
sich so kräftigen kömno, dats er parasitär sich weiter ausbreite. Diese Anschanung deckt sich mit der von Vulbemis ${ }^{1}$ ) betrett's der 1887 in Lothringen beobachteten Kirschenkrankheit, die wots. Ähnlichkeit mit

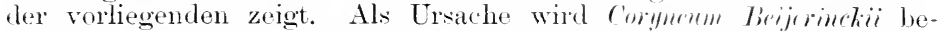

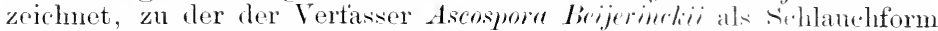
zieht. Als Ansicht der genamnten Forscher wiirle sirh also rroplen, dat's klimatische Ursachen den Krankheitsboden geschattin lablen, aher ,ler $\mathrm{Pil}_{z}$ immerhin die Krankheit erzenge. Dengemäts müsis bei dor Bekämptiung alles mit Iralsa oder deren Konidientorm, dor Cyptospora. besetzte Holz sorgfältig vernichtet werden.

Über das richtige Verhältnis dieses Pilzes zur Krankheit crlangen wir aber erst einen Einblick duch die nenesten Impfrersuche wolche

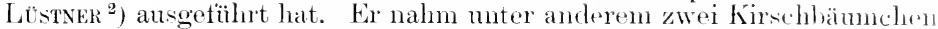
von verschiedenen sorten und knickte ihnen die Kronen ab. Las al. acknickte Ende und das stehengebliebene Stammstück wnden mit don Konidien des Pilzes geimptit und aufserdem nachher noch mit lionidienhaltigem Wasser bestrichen. Da die Krone infolge der Kuickung nicht absterben wollte, wurde sie später abgesehnittron mol an ihron Stamm angebunden. Bis Eude Olitober hatte sich der Pilz, wie Fig. 1:0 an den mit $>$ bezeichneten stellen zeigt, über das abgeknitkte und abgestorbene Giptelende ansgebreitet, während dur übrige Teil des stammes. obgleich in desselben Weise geimptt, vollständig gesnns l, lieb und wieder austriel. Die Tmpfwunde war dort normal ansareheilt.

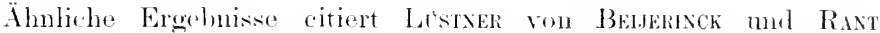
(C'entralblatt fïr Bakteriologie und Parasitenkumele. II. Alit. B3l. XY.

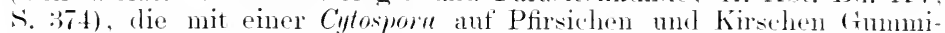
fluts nicht hervorruten komnten und nichts über oin Eingehen der veimptien Äste berichten.

Gestützt auf diese Versuche und meine eigenen Boolnachtungen betrachte ich nicht nur die vorliegende Erkrankimg, sondern anch die anderen durch Valsa-Arten bzw. deren Pyknidentomen hervorgerntenen Erkrankungen als Torkommnisse nnter Nitwirkng von súchwächeparasiten, bei denen num das Krankheitshild diuch den Pilz hrstimmt wird. Die Pilze kommen erst zur Ansiedlung, wemn ter Ast infolge von Ernährungsstörungen durch Wittermes- oder Bodeneinflüsse u. clel. erkrankt oder mindestrus geschwächt ist. Anf solehem Mutterboden bedart es nachler gar nicht mehr einer Wunde zm Eimwanderung der Pilze: diese kam anch dureh die Lenticellen erfolgen. Die zur Ansiellung derartiger Schwächeparasiten notwendig vorher vorhandene Ernährungsstörung brancht durchans nicht immer dureh Frost verursacht zu werken: es können ebenso nugergneter standort. Wasseräbersehuts. Trockenheit u. dol. den erstem Anstotis geben. Letztgenannten Faktor

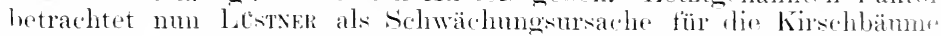
am Rhein, während ioh an der Ansicht festhalten möehte. dates in der Mehrzahl der Fälle Frostbeschärligmeng und zwar soleler, dir in Frühjahr znstande limmen, lie erste Teranlassung dastellen.

l)emnach sehe $i c h$ in einer ängstlichen Vernichtung der pilz-

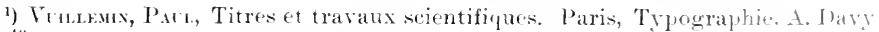
$1890,4^{\prime \prime}$

2) Listare, (4.. Beobachtungon ibber das rheinische Kirschbaumsterben, Bericht d. Kgl. Lehranstalt für Wein-, Obst- und Gartenbau zu Geisenherin a. Rh. f. d. Jahr 1905, von Prof. Wortmann. Berlin, Paul Parey 1906. s.. 122. 


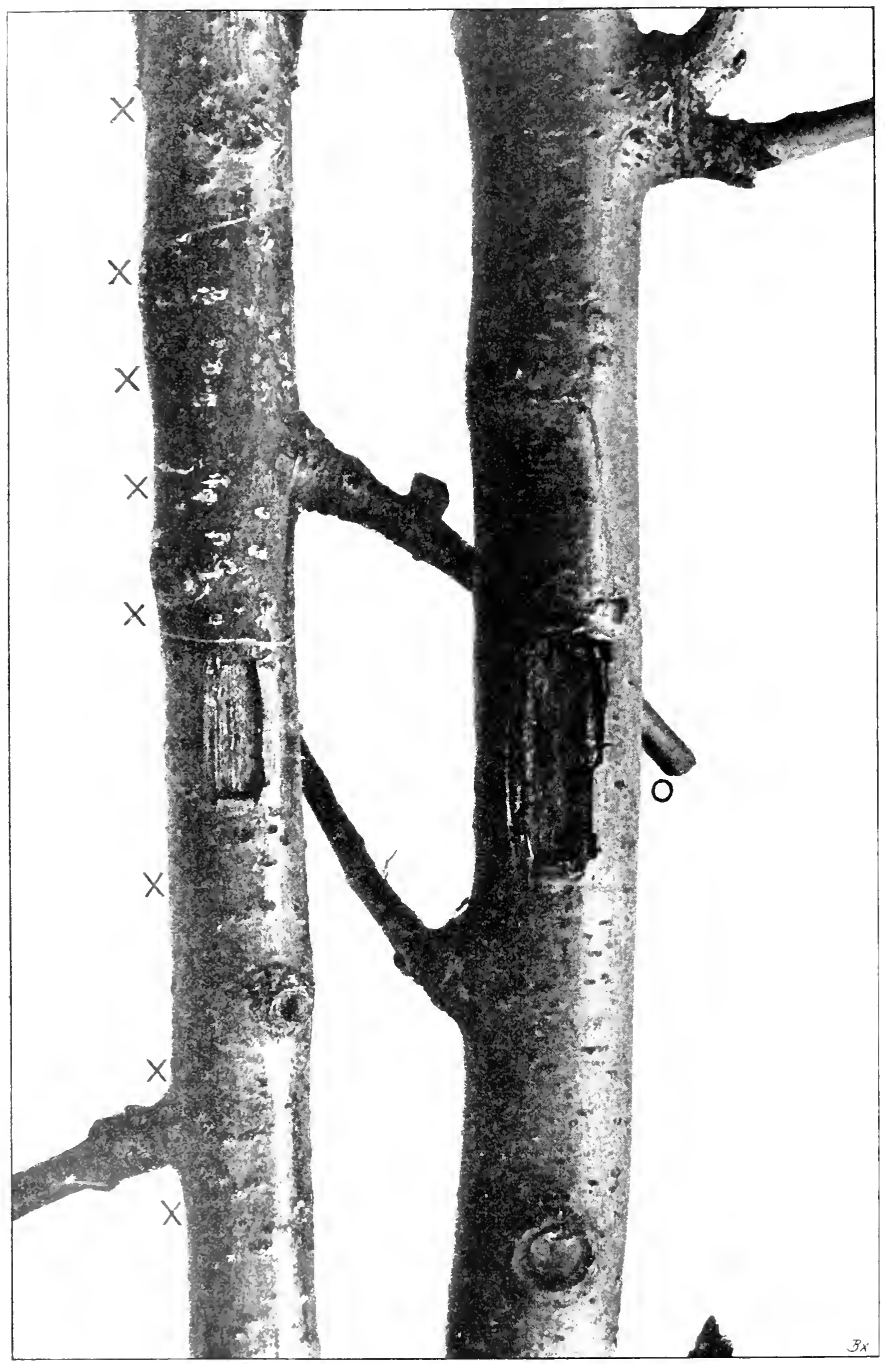

Fig. 124. Mit den Konidien ron Ialsa lemostoma an zwei Stellen geimpftes Kirschenstammchen, dessen Krone nach der Impfung unterhalb der oberen Impfwumle ahgeschnitten wurle. Bei $O$ die normal geheilte Wunde, bei $>$ Prkniden der Valsa leucostoma. (Nach Listxer.) 
befallenen Teile nur einen sehr schwachen 'Trust. Man vergesse nämlich nicht die Ubiquität der C'ytosporeen mul ähnlivher Pilzoruppen. Die Hamptsache ist der Anbau ron Sorten, lie rincr hestimmten Lokalität sich angepat'st haben. Anferem abre ist zn versmehen, ob die Frostempfindlichkeit nicht dureh Kalkzufinh in lnmmsroblen Böden vermindert werden kïme.

\section{Zweigbrand bei Waldbäumen.}

In derselben Weise wie das Kirschensterben hentejle ich eine Grankheit, die Fuckel bei Aprikosen mol Pfirsichen beohachtet hat. Das charakteristische Vergilben und Verwelken des Laubs mit nachfolgendem Absterben einzelner Äste begann im Juni. Als Crsache sieht Fickes Cytespora rubeserns an, zu der als reiti Fruehtform von ihm Valsa prunastri Fr. angergeben wird.

Ton den bekannteren Vorkommmissen descellen Krankheitseharakters reihe ich hier noch an den . Sehwarzen Brand ler Rotbuehentriebe". Nach Wiblomm ${ }^{1}$, soll die Ursache des Absterhens der an der Basis sich schwärzenden Triebe in einem Pilz zu suchen sein, der eine Konidienform wie Fusisporium comblidum I.k. entwidielt und zu Liburtella faginca Desm. zu ziehen sei. l)ie vollkommone Fruchttom wäre demmach (Puaternaria Persomii Toul. ${ }^{2}$ ).

Viel von sich reden machte zu Anfang dre arhtziger Jahre des vorigen . Jahrhunderts das Abstarben der Pyramidrolpapelu, das in versehiedener lutensitä dureh Nord-mel Mitteldentsehlamel zu

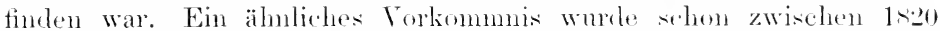
his lsto in England heobachtet ${ }^{3}$ ). Jüngere /weige hatten gelräunte

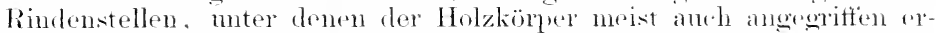

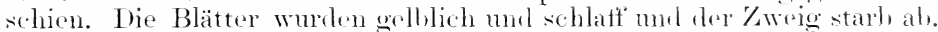

Unter den verschiedenen Theorien, die zur Erklärumg der Erseheinumg herangezogen wurlen, spielt die Degeneration iler Art dureh fortgesetzte moeschlechliche Vermehrung eine llamptrolle. Ol,wohl von vielen seiten von Anfang an darant hingewiesen wurle, datis cin spätfost als Ursache anzusehen sei, der die im Vorjahr wenig ausgereitten Zweige beschäligt habe ${ }^{4}$ ), siegte schliefsheh dic Anschammg.

1) Wиккмм, Die mikroskopisehen Feinde des Waldes. 1ษ66, Heft I, S. 101.

-) Selecta fung. carp. II, s 10.5 .

3) Biolog. Centralbl. XI, 1\&91, S. 1:9.

4) In nenerer Zeit hat die Frklïrung dieser Krankheit als eine Folge von Frösten eine wesentliche stïtze durch die Beolachtungen des Grafen vux si nwm erhalten (Gartenflora 1905). Heft 15, S. 400). Bei einer Reise nach Italien liefs sich feststellon, dafs südlich der Alpen keine Erkrankung der Prramidenpappeln rorhanden war, also in der jetzigen Heimat des Baumes von einer Legeneration niehts zu bemerkent war. Das in Deutschland strichweise hervorgetretene Absterben erklïrt sich einfach als Folgeerscheinung der Ende der iver Jahre wiederholt nach langen, feuchten und milden Ilerbsten auftretenden Frinhjahrsfröste. Ton den früherm

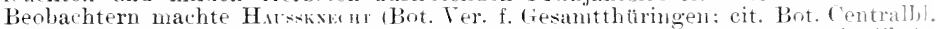
1s4. s. 275) bereits daranf anfmerksam, dafs das Absterben sich fast nur in linlistiilern und Niedermgen zeigte, höhere Lagen aber verschont llieben. Eine andure beachtenswerte Notiz finden wir von Prersu in Petersburg (Deutsche Giirtnerzeitung 1884, Nr. 10). Dersellhe sah bei einer Reise durch Nord- West- und Mitteldeutschland, dafs die Limge der abgestorlienen Zweigspitzen immer geringer wurde, je mehr er nach siden kam. I af́s gerade l'opuhes mommilulis frost omptindlicher ist als die meisten anderen Pappeln, geht daraus hervor, dufs diesellue in

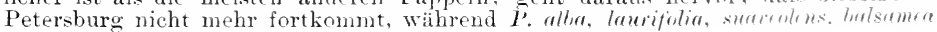
u. a. sehr gut dort noch gedeihen. 
datis ein Sicheibeupilz, Dothiora spharenides Fr. das Absterben herrorrute $\left.{ }^{1}\right)$. Anderwäts machte man einen Kermpilz, Didymospleaeria populina, dafür verantwortlich ${ }^{2}$ ). Vullewis ${ }^{3}$ ) tïhrt bei cinem Zweigabsterben der. Ha inbuchen Maminia fimbriata und als Lerstërer von TTe idenanlagen Dhibmosporium saticimm an. Schlietslich erimern wir noeh einmal an das ron Aper ${ }^{4}$, beschrobene Absterben der Roterlen durch Talsa orystoma, welcher Pilz sein Kerstörungswerk nur bei den durch Emährungstörmngen geschwächten Exemplaren vollziehen kann.

\section{Abfrieren von Frühjahrstrieben.}

Wemn die suäfröste den Bam zu einer Zeit äberaschen, in welcher die Laubluspen sich zu strecken begomnen oder anch zu kurzen Trieben sith schon entwickelt haben, damn treten mamigtache Beschädignngen nnd Regenerationserscheimmgen ein. Ein bei Kirschen mir melintach rorgekommener Fall stellt das Alsterben des jüngsten Tegetationskegels in der sich erschliefsenden Lanbknospe dar. Antangs ist der Schaten nicht hemerkbar, da die sämtlichen Knospenschmppen intakt geblieben sind: nach einger Zeit aber gibt eine eigentïmliche spreizung, hervorgeruten durch Rückwärtsschlagen der sehr turgescenten Schuppen mul das Ausbleilen des Triebes Teranlassmo zur Untersuchung. Syäter kommen ans den unverletzt gebliebenen seitenangen schwählichere Nebentriehe und hisweilen gerade nach solchen Frïhjahrsrerletzungen auch verbänderte Triebe.

Es ist mir mlängst gelungen, derartige störungen durch kïnstliche Frostwirkugen hervorzurufen. Fig. 121 stellt einen Kirschenzweig dar, an welehem die drei Angen durbh den Frost ihren Vegetationskegel verloren haben. Die im Frühling so äntserst energische vegetative Täigkeit hat sich bei den beiden oberen Augen in der Weise geltend gemacht, datis die schmppenartigen Erstlingsblätter grötser, dumkelgrüner und fleischiger geworden sind und sich nahezu wagerecht ansemander wespreizt haben. Am mutersten Auge beginnt sogar eine Bildung von zwei seitlichen Ersatztrieben.

In Fig. 121 $B$ findet sich der /oustand einer Knospe mit erfrorenem Veretationskegel genaner dargestellt. Der Vegetationskegel a ist geschwärt mul reptrocknet mol wird dmedh eine Korkschicht innerhalb des angrenzenten, lebendig gehliehenen Gewebes abgestofisen. In dem low wolig gebliebenen Teile des Achsenzylinders aber zeigen sich anch noch Frostwirkungen in Gestalt horizontaler Markzerklüttumgen (Fig. B, l) mul -brämnngen, welche notwentigerweise die Funktion des Markes als Schwellkïruer beeinträchtigen müssen und die Ursaehe sind, dats dic Achse sich nicht so bald wieder in die hänge streckt. Die Spiralwröalive (9). Welche in die Blätter $(b, 7)$ abgehen, erstheinen ebenfalls stark geträment: lagegen ist das Parenchym (p) des Rindenkörpers wenig bescliadigt mol von ungemeiner Strattheit. Hier und da fanden sich zur \%eit fler Untersuchumg (21. Jmi) beroits Spmen von Stärke. Es ist erklärlich, dat's der fast fleisehige Rindenkörper einen Überschut's

1) Rosmir, Prramidepoplens Undergang. Tillaeg til Nationaltidende 13. November $188: 3$.

2) Vrimin, P., Remarques étiologiques sur la maladie du Peuplier pyramidal. Rerue mycol, $1 \varangle 92, \mathrm{~s} . \mathrm{2}$.

$\left.{ }^{3}\right) V_{\text {unf }}^{2}$ max, P... Titres et travaux scientifiques. Paris 1890.

4) Aprec, O., Über hestandweises Absterben ron Roterlen. Naturwiss. Z. $f$. Land- u. Forstw. 1904. 
an Wasser und Nährmaterial erhält mul drmestmäs eine erhöhte Arbeitsleistmo ïbernehmen wirl. Der hocherarliu cuesteigerte Wasser-

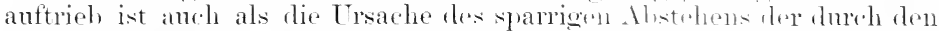
Chlorophylgehalt ihrer inneren fewebeschichten langholiger gewordenen Knospensehmpen (bs) und schuppenartigen B3läter anzuselirn.

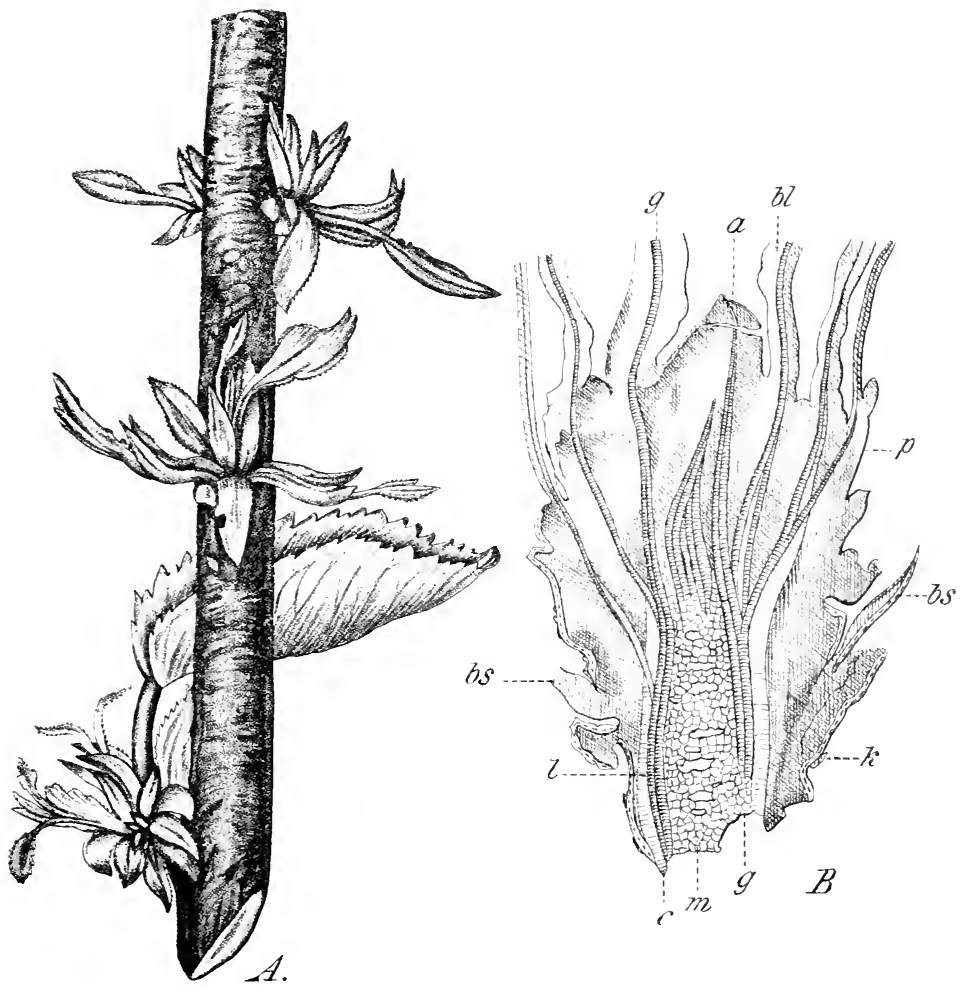

Fig. 121. 1: \%wrig einer süfskirsche. Die durch künstlichen Frost heschialigten Augen zeigen ihre Schuppenblitter fleisehig verdickt und vergröfsert und spreizent auseinander gebogen. B: Längschnitt furch eine frostheschädigte linnsue des inebrnstehenden Zweiges. (O)rig.)

Bed des in manchen Jahren innerhalh oinzelnex Lokalitäten hö̈tienen Torkommnissen dieser Art hemerkt man, dats in der liegel dis lwroitam weitesten in der Entwicklung fortgeschrittene (iipfelkmospe m-

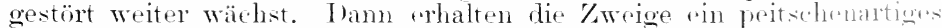
Ansehen, indem ilure spitze reich belanht ist, währemel die mutron Jutrenodien kahl bleiben. Eine andere bei älteren Birnentriobur mir hokannt gewordene Erscheinumg bestand in dor Sohwärmu num tem 
Absterben der Basalpartie der jungen Triebe, die im übrigen noch grïn ershienen und erst später vertrockneten.

Eim spezielles Studium hat Porosit den Erscheinungen des Wiedereratzes der durch Frost verlorenen Früllingstriebe gewidmet ${ }^{1}$ ). Die einzehnen Baumarten verhalten sich verschieden. Bei manchen Arten scheiren ans den unverletzt gebliebenen Basalangen der erfrorenen Zweige seitliche Triebe hervorzuliommen, wie z. B. bei Castamu sutiva Mill. sowie bei Catis- und Platams-Arten. Wem der junge Trieh ganz zerstöt ist, erfolgt hei vielen Pflanzen rie Neubelaubung dureh Anstreiben accessoriseher sprosie". Manche Holzarten legen nämlich bei zunehmend kräftiger / wrigernährung in der Achsel eimes Blattes nicht eime, somlem durch sprossen des immeren Knospen. stammes mehrere Knospen in einer Längseihe an ("Unterknospen“). Diese Unter- oder "Beiknospen“ kommen nuter normalen Verhältnissen nu bei kräftigen Trieben einzeher Gehölze (Coris) zur Entwicklung: bei Störungen aher, wie z. B. bei starkem Beschneiden, bei Terbeitsen und bei Frost, der den aus der Hauptknospe entstandenen Trieh vernichtet, bilden sie auch bei anderen Gehölzen das Ersatzmaterial, wie z. B. bei Calycanthus floridus, Coreis Siliquastrum, Gymmoclatus, Liviodemlion tulipifira und Robinia Psonlacacia, welche bis vier in der Blattstiellasis versteckte Unterknospen entwickelt. Andrerseits kamn auch der Ersatz aus andern, ebenfalls schon vorjährig angelegten, den sogenamuten „S ä um a ngen" beschatft werden. Es sind dies in den Achseln hasaler Knospenschuppen bisweilen regelmä1sig zur Ausbildung gelangende Augen, wie man bei manchen Weidenarten dentlich wahrmimmt. Wenn die aus zwei Schuppen verwachsene Knospendecke abtällt, sieht man jeder Schuppenhälfte entsprechend eine Achselknospe, die bei Vermglïcken des Hauptzweiges zmächst Ersatz bilden kann.

In andern Fällen greift der Bam zum Ersatz auf seine schlafenden Augen vorjähriger Triebe zurück, wie sich bei Rhus, Carya glabra Mill. und Juglans rupustris Engehm. vorzugsweise beohachten liefs, während C'arya amara Wich. und Ptrocarya firamifolia Lam. vorwiegent Unterknospen zur Entfaltung brachten. Die Koniferen pflegen die erfrorenen surossen sowohl durh ein Erwecken bisher schlatender Augen als auch sellst lureh Nenbilutung von Knospenanlagen in bisher knospenlosen Blattachseln, namentlich ans den Achsehn der Schuppen an der Basis les .Jahrestriebes zu ersetzen.

Eine hesondere Bowrenzmng in der Art des Ersatzes erfrorener Triebe lue den einzelnen Bammarten lälst sich aber nicht ziehen, da die Stärke der Frostheschädligmo einerseits und der bisherige Ernälnungszustand des Bammes andrerseits im Verein mit der jeder Art charakteristischen, grökren oler geringeren Leichtigkeit der Adventivknospenbildung in verschiedenen Fällen auch vershiedene Ersatztriebe hervorufen. Je ïpliges rine Banmart wächst, desto mehr neigt sie zur Bildung von Unterknospen, wis man bei Stockansschlägen hänfig beobachten kann.

Bei Weinstïcken rfolgt die Regeneration, wemn der Frost das Hanptange getötet hat, ans ien Nebenangen. Hier kommt es num sehr anf die Zeit der Frostwirkung an. Ist der Tod des Hauptauges sehon so) frïh im Jahre afolgt, dats os zu seiner streckmo noch sehr wenig Reservestoffe verbrancht hat, dam reicht häufig das in der Rebe vor-

1) Pornit, Über den Ersatz erfrorener Frihlinestriele durch accessorische und andere sprosse. Sitzmingher. d. hot. Ver. d. Prov. Brandenb. XXII, 1880, S. 81. 
handene Reservematerial noch ans, die Nebenangen lerartig zu liräftigen, dats noeh Blütenknospen angelegt werden kïmnen. Stirbt das Hamptange jedoch erst chrch Maifröste, dann entwichln sich llie Triebe ans den Nebenaunen zwar kräftig, aber ohne Blütenansatz nul kïmen erst im näehsten .Jahre allentalls zur Frnchtbarkejt gelangen.

\section{Das Erfrieren der Wurzeln.}

Nach schneelosen Wintem finden sich. namentlich in nasind Lagen, nicht selten hei den versehiodenartigsten Gohölzen dis ITnzoln erfroren, während die oberimbsehen Achsenteile am Lebon wablishen sind. Lie Erscheinmeg erktärt sich dachurh, dats las Wmzolholy weicher und lockerer als das stammbolz gebant ist. Wis Wrichlorit liegt emerseits darin, dats zur Zeit, in wreher die Käle am tiefisten in den Boden dringt, das Wachstum dor Wurzel noeh nieht ahgesehlossen ist, also der Frost noch junge, muerdiclite Elemente trifft; andrerseits aber sind auch die fertig ausgelildeten Elemente des Holzkörpers nicht so dickwandig wie die entsprechenden Lagen des oberirdischen Ardsen-

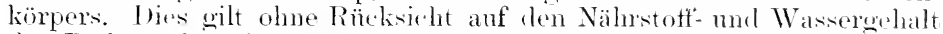
des Bodens für alle Lagen. Dat's der trad der üprigen Entwioklung anch einen Einfluts ant die Frostempfindlichkeit ansibben wirl, ist nicht in Abrede zn stellen: allein dieser Einfluts äulisert sich nach den 1. Монь'schen Untersurhungen ') in anderer Weise.

Betreftis des ersten Punktes, des Eintreffens der Frostrolle anf noch nicht in Rolse hefindliche Wirzeln. Wirl eine Butrathtumg des

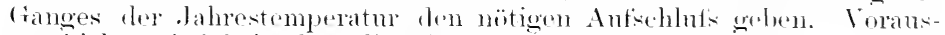

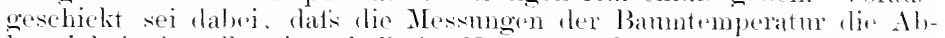
hängigleit derselhen imnerhalh der Krone von den IVämeschwankingen les Luftmeros nachweisen, dats aber die stammtemperatm, natmentlich an der Basis mol hei dickborkigen Bamnaten, sehr wesentlide von

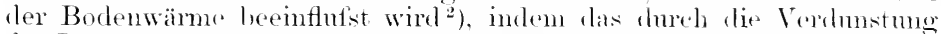
des Lanhes notwendig narlsteigende Wasser die Temperatur der Bonlenschichten mitbringt ${ }^{3}$ ). Einen seln in die Angen springenulen Beweis

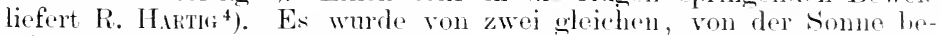
schienenen Bämmen der eine mitästet, so dats der Verdmotmosstrom

1) v. Mrnm. Einige anatomische und physiologische Bemerkungen äber das Holz der Baumwrzeln. Bot. Zeit. 1862, Nr. 29, 33:34 if.

2) Brrtextonser und Bunn (Sitz. d. Kais. Akad. d. Wiss. zu Wien, 17. Mai 1N77) fanden, dafs die Temperatur der unteren stammpartie ganz unter dem Einflufs der Bodenwäme steht; wem aber die Transpiration aufgehohen ist, hängt die Baumtemperatur lediglich von der Lnftemperatur ah.

3) Eвекмитк, Die phrsikalischen Finwirkmoen des Waldes anf Luft und Boden. I, Aschaffenburg 187:, S. 119-139. - Die Nessmgen zeigten, dafs zwisthen der Temperatur der Bäume (in Brusthöhe) und des Waldhodens kein wesentlicher Interschied besteht. Mit zmehmender Bodentiefe und Baumhöhe aler werten the Interschiede grofs. In allgemeinen ergibt sich, dafs vom Oktober l, is Miar die Waldbäume kälter sind als der Waldhoden., "Die WVurzeh sind in dirser Periode die wirmsten Teile des Bammes; mit steigender Höhe nimmt die mittere Bamntemperatur stucessive al, und ist am tiefsten an len Ästen uml Zweigen." "Im Sommerhalhjahr (vom April bis inkl. September) sind umgekeh"t dio $\mathbb{V}_{\text {ithl- }}$ bäume wärmer als der Boden, d. h. die Temperatur der Bäume nimmt von. olwn nach unten ab und ist wihrend des Tages am höchsten in den Zweigen und İsten, am tiefsten in den Wurehn." Die mittlere Jahrestemperatur der Biimme whinkt

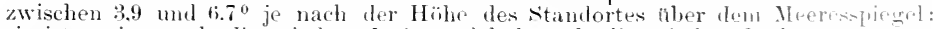
sie ist geringer als die mittlere Luft- und höher als die mittlere Bohluting ratur des Waldes.

4) Lehrbuch der Farmkrankheiten 1882, ‥ $17 \%$.

Sorauer, Hamlbuch. 3. Aufl. Frster Pand. 
fast ranz zum Stillstand kam. I)as Thermometer wies num in dem belanht welassenen Exemplare eino nm 100 niedrigere Temperatur auf als in dem entästeten. Nach Entfermmg der Äste bei diesem zweiten Exemplar stieg dessen 'Temperatm alsbald mo $10^{\circ}$.

I) a sich nun im Frühjahr das Luftmeer sehnell erwärmt, unterstiotzt es schr hakl die direkte Einwirknng der sonnenstrahlen auf die Zweige ${ }^{\mathbf{1}}$ ) und erhält dieselben auf der 'Temperatur, bei der sie wachsen können. Je intensiver und länger anhaltend die Luftwärme, um so mehr geht das Erwachen des Cambiumringes mol seine Produktion nener Holzund Rindenelemente ron der Krone aus stammabwärts, his es im April und Mai die Wurzeläste ereicht und dort mm endlich anch die Produktion eines nenen Holzringes einleitet. I)ie Zeit des Erwachens, die Dicke des nenen Holzringes und seine Ausbildung sind bei den einzelnen Bammarten und Varietäten versehieden. Ja, es zeigt sich anch oft eine individuelle Verschiedenheit insofern, als nieht alle Exemplare alljährlich imstande sind, soviel plastisches Material in der Bambrone zu produzieren, dats dasselbe noch zur Ernährung des Cambiummantels der Wurzel ausreicht. Es tritt dam der Fall ein dafs sich der Verdickmosing in einen solchen Mangeljahre von der Krone nur bis zur stammbasis erstreckt und sich dann anskeilt, so dafs die WVurzeln in diesem. Jahre gar nicht dicker werden.

In derselben Weise, wie die Wärmewelle und damit die Tätigkeit des Cambimmringes ron oben nach unten fortschreitet, erlischt sie anch im Herbst. Da der Boden länger warm bleibt, hat aneh die Wurzel noch Gelegenheit, ihr wenu auch nicht mehr sehr intensives Wachstum fortzusetzen, und somit wird die v. MonL'sche Beobachtung erklärlich. dat's die Wurzeln im Dezember, Januar und Februar noch an der Verdickung der /ollwände ihres letztangelegten .Jahresringes arbeiten.

Positive Zahlen werden hierbei das anschanlichste Bild geben. v. MonL fand im Winter $1861 / 62$ an einem sütskirschhamme die Bildung des Wurzelholzes an 4. April noch nicht beendigt. Dabei hatten sich die Zweigknospen hereits his über $2 \mathrm{~cm}$ Länge entwickelt, und der nene Holzring an dem Mutterzweige hatte schon nene Gefälse soweit ansoebildet, dafs ihre Tüpfelung erkembar war. Die zwisehen den Gefätsen liegenden Holzzellen waren noch dünmwandig und besalsen erst die Hälfte ihrer typischen rröse. An der Wurzel waren aber the äutsersteu Ilolzzellen des rorjährigen lahresringes noch nicht einmal verdickt. Nachdem der Bam am 11. April bereits geblüht hatte, zeigte die Untersuchung zu dieser \%eit noch immer keinen vollständigen Abschluts des vorjährigen Jahresringes in der Wurzel, und erst an 26. April war fü̈ die Wurzeln die Ruhe eingetreten.

An den vorjährigen /weigen war zu dieser Zeit der nene Jahresring hereits vollkommen verholzt und schonso dick, dats man in radialer Richtung sechs (xofätse hintereinander zählen konnte. Im morsten Teil des Stammes war dagegen erst eine einzige Reihe von Gefälsen ausgebildet, und es zeigten sich nur die innersten Holzzellen verdickt. In (ier Hauptwuzel war der vorjährige Jahresring fertig und das Cambium anch gleich zu neuer Tätigkeit vorbereitet, da die Rinde sich leicht vom Holzk̈̈per trennen liets: jedoch von einem nenen Holzringe war

1) Vergl. Knn rscm, Untersuchung über die Temperatur der Bäime etc. Jahrb. d. Kigl. sächsischen Akad. zu Tharand, Bd. X, 1854. 
noch keine spur zu sehen. In den Nebenwnysu von der Dicke eines kleinen Fingers löste sich die Rinde noch nicht; hire war also vollkommene Winterruhe. Sie verharten auch an :31. April noch in diesem Yustande, als die Blätter zum Teil hereits ansgewachsen waren und an

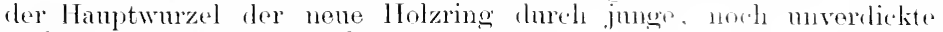
Gefätse seine Ausbilinng hegann.

Betretf's des zweiten der oben erwähnten Punkto, nämlich der eine geringere Widerstandstähigkeit bodingenden, anatomisch abweidhondru Banart der Wurzeh, werten wir anen Einblick gewinnen, womn wir uns erimnern, zu woleher Zeit die Jahresringe im stamm gerentiblor denen der Wurzel ansegebildet werden.

Bei der stammproduktion wird der fertige Alschluts des daluresringes $n \mathrm{~m}$ so frïher in das .Jahr fallen, je höher er in der hrone liegt. mithin wird dort seine Ausbihlung überwiegend ans Frïhjahssul\% hostehen. Ehe die Herstellung des .Jahresinges bis zur Stammbasis tort. schreitet, ist es schon sommer weworden mol daher nicht mehr videl \%eit zur Aushildung von Frïhjahrsholz. Somit muls die Ditferenzierme des Jahresringes in der Weise vor sich gehen, lats (gleichviel ob ein

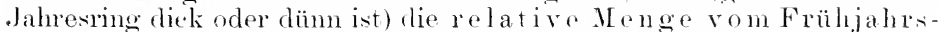
holz zum Herbstholz von oben nach unten ahmimmt, also relativ das Herbstholz immer nach der stammbasis hin zunimmt. Diese Voraussetzung ist durch direkte Messme ron v. MoHL ${ }^{1}$ ) sowohl als ron

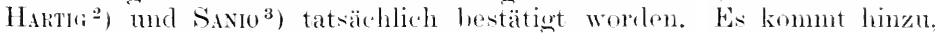
dat's der Bannteil, je dicker or ist, ein desto höhores IVärmemaximm (rreicht $\left.{ }^{4}\right)$.

Ant der äherwiogenden Ilerhstholzbildnong heruht die Festigkeit der stammbasis.

Fïr die Ansbildung des Wurzelholzes kommt der Charakter der Holzart in Betracht. Bei den Koniferen mit ilnem frühen Abschlufs des Wurzelwachstums fällt die Ausbilolung noch in die Zoit gröberer Bodenwärne und Trockenheit, und demgemäts wird sich meistens Herbstholz bilden. Ist viel Material da, also der Jahresing breit, (lam ist ein starker l Lerbstholzring vorhanden (v. NoHL). Bei den Lauh)häumen, bei denen sich die Aushildung des Wurzelholzes bis zum nächsten . ahre hinzioht, ja, wie oben gezeigt worden, manchmal erst zur Blütezeit des neuen Triebes abschliefst, sind alle I)ifferenzierungen schwächer und die Grenzen der Jahresringe verwaschener. 1) as in den Bodenschichten erst Frühling wirl, wemn es oben sehon sommer, ist die Bildumg von Frühlingsholz immer vorhanden. Bei weiterem Fortschreiten iles Jahresinges hängt dessen Ansbihlumg von dem Gradr. und ter l haner der Bodenwärme mol Trockenheit ab. Bringt ein .Jahrgang eine lange trockene Prriode, wird sich Herbstholz vorfinden: ist dies nieht der Fall. hesehränkt sich rlie Anshildung ant' das Fröhlingsholz und zeigt nur eines soliwachen Ansatz von IJwhstholz. Iraher der lockere Bau bei schmalringigen IV nzoln.

In kimzer Wiedrrholung des Dargestellten kïmnen wir den Unterschied zwischen Wurzel und stamm bei den Laubbäumen dahin

1) a. a. $\mathrm{O}$.

2) a. a. $\mathrm{O}$.

3) Jahrbücher f. wissensch. Bot. IX. S. $115 \mathrm{ff}$.

4) Inx:, Über Baumtemperatur unter dem Einflufi der Insolation. Bot. Centralblatt 1883. Nr. 34, S. 2:34. Voxmarsis, Lntersuchungen uber den Rindenbrand. Allg. Forst- und Jagdzeitung 187:3. 
zosammenfasien, dats erstens alle Jahresinge in der Wurel weit schmäler als dio entsprechenden des stammes sind, mol dat's bei der stoten Anshilkmo des porösen Frïhjalursolzes diese schmalen Schichten ̈̈horwiegend porös sind. Bei den Koniferen finclet sich betreftis der geringen Breite der Jahresinge derselbe Tutrischied zwischen stamm imd Trurzel, und ehenso nimmt, je dïnner dor Jahresring ist, desto mehr das Herbstholz im Verhältnis zum Frïhlingsholz al, Überall sind die 1Lolzzellen länger und weiter und deren Wandmogen dümner in der Wruzel als in ven entsprechenden stammteilen.

bem Erfieren der Wrurzeln ist larmm eine grökere Anfmerksamkeit zn wilmen, woil dafurch zahlreiche Falle sommerlichen Absterbens einzelner Bammindividnen oder -nupjen mitten muter Alterswenosien derselben Art ilne Erklärme finden. Lie Bämme mit erfiorenen Wurzeln pflegen nämlich. wie die gusunden, im lröhjahr anszutreiben und entwickeln anch noch nomale, wem anch in der Regel mit kleineren Blättern versehene Triobe. Erst im sommer, mol dam allerdings schnell tortschreitend, tritt Vergilbung des Lanbes mol Vertrocknen der / wreige ein. Wer Wasservorrat der Achse ist dann durch die Transpiration der Blätter anfigelsancht.

Sulbst in tregenden und bei Varietäten, wo eine Beschädigmo der oherirdischen Arhse durch Winterfröste nicht zu befürchten, wird man, in Rücksicht anf die Empfindlichkeit der Wurzeln, Topfolstbäume in geschützte Ränme zu bringen haben mol bei Freilaurlinlturen den natülichen schutz durch Laub nnd sichnee nicht nur belassen, sondem womöglich erhöhen. Bei Anlage von Gehölzkomplexen wird man nur

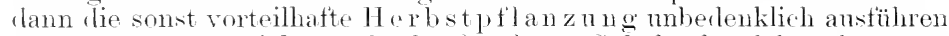
kïmen, wemn es sich $m$ absolnt frostharte Gelölze handelt, otler wenn man so frïl im Herlste mit der Pflanzung vorgeht, dats tïchtiges Einschlämmen der Trurzeln voransesest, man noch ein Anwurzeln und dichtes Aulegen der Erde amehmen dart. Thats eine Billums. feiner Haarwurzeln noch im Winter stattfinden kamn, heobachtete schon

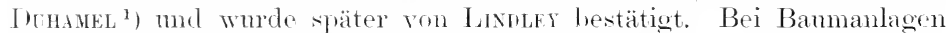
von geringerer Ansiehmmg wirl sich durch Bedecknng des gelockerten Bodens das tiefere Eindringen der Kälte in denselben abschwächen lassen. Dats frisch verpflauzte Bämme durch Winterfrost an ihren Wnyeh leichter leiden als auf ihrem Standort belassene Exemplare, ist eine viflach gemachte aher nicht ansmahmslose brfahrung.

\section{Frostspalten.}

Die 'Temperatur im Innern starker Baumstämme kamn nur langsan der Autsentrmperatmr folgen, und darum ist das Stamminnere rom Morgen his Mittag kälter, am Abend aber wärmer als die mogebende Lutt ${ }^{2}$ ). bie \%nammenziehmo der (iewebe bei Eintritt von Kälte wird somit in den äntiveren stammshichten sich schon geltend machen, während der Kern nocl seine trühere Ausdehmmg beibehält. Auf diese Weise

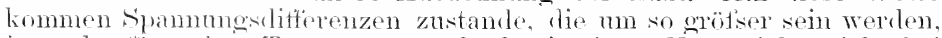
je schroffer der Tempresaturwechsel pintritt. Nm zieht sich hei 'Temperatmerniedrigmes der IIolzkïrper in der Richtmo' des Umfanges, also tangential starker zusammen als in ratialer Richting, so dafs der peripherische Mantel för den noch wärmeren stammkern eigentlich zu

1) Des semis et plantations des arbres. S. 15.5.

2) Rur IV. Squmes, Nimmesota Bot. Studies. Bull. 9, 189.. 
eng wird. Er muls demgemätis tangential guspannt werten, wenn er den Kern noch vollkommen monschlosicen halten soll. Kanm or sich bei zunehmender Kälte nicht mehr genügend dehnen, so muts el reitsen. Anf diese Weise müssen Risse in der Bamminde znstande kommen, die nm so tiefor in das Holz sich fortsetzen werden, jo strencer die Kilte

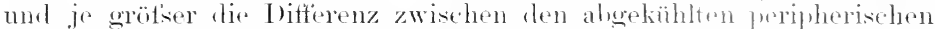
und den wärmeren zentraten freweben des stammes ist. Bsei poitzlieh sich einstellender starker Kälte hat man mun wahroenommen, dals muter beträchtlichem Knall einzelne Bammstämms dor Länge nath pinın tief

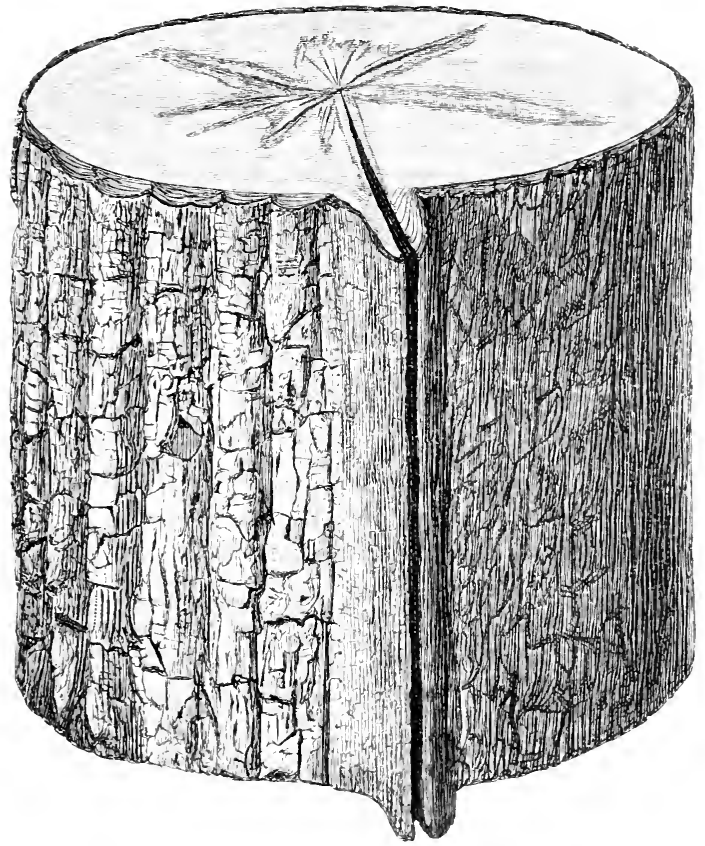

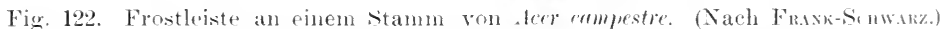

klatfenden, der Inohmes dor Molzfasire tolgenden sipalt bekommen. Einzelne Bammanten zeigen diese Ersehrimme lesomeles häntie. In

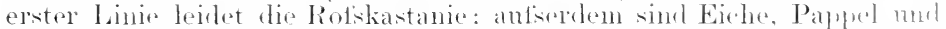

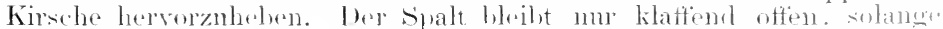
die strenge Kälte anhält. Bei Eintritt wärmepen Wotters werlen diw

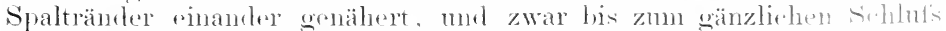
der Wunte. wolche aher kamm jemals ont verheilt und mejs in dou

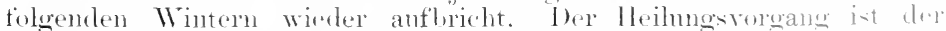

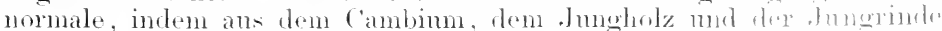
Überwalhungswitste gebildet werden. die miteinander zu verliletesn bestrebt sind. Diese hervoryuellenden Überwallmosünder finden aber 
nicht, wie bei jeder anderen Verletzung mit freiliegender Wundfläche, den notwendigen Ram zu ihrer Anshreitung, sondern sint gezwungen, steil gegeneinander zu wachsen und sich ïber die spaltwunde emporzuheben. Sie bilden daher duch den gegenseitigen lonck nach ant'sen vorspringende, in der Nitte lippenartig vertiette Wülste, die als „Frostleisten" bezeichnet worden.

In Fig. 122 sehen wir eine derartige Frostleiste an einem starken Stamme von Arer compestre, der eine Anzahl radialer Zerklüftungen zeigt. Einer dieser radialen Risse hat ten Stamm in seiner ganzen Jicke zersprengt, so dats ein äuferlich sichtbarer, anfangs weit klaffender, bei Eintritt wärmerer Witterung sehr eng gewordener Spalt entstanden ist. Als der Bamm im Frühjahr von seiner C'ambiumschicht ans den Spalt schlietsen wollte, fanden die Überwallungsränder keinen Platz, sich in den spalt hineinzulegen und mulsten daher nach antsen sich biegen. Daher die lippenartigen Vorsprïnge, die der Querschnitt erkemmen lätst. Ein derartiger IVundheilmgsrorgang ist bisher bei keiner anderen Stammverletzung beobachtet worlen, so dafs sein Anftreten als mulingt sicheres Merkmal für Frostwirkmng bezeichnet werten darf.

(Aspak ${ }^{1}$ ) ist dieser Erscheinung experimentell näher getreten. Er wies durch direkte Messung nach, dats der Ansdehnungskoetfizient des frischen Holzes sowohl in der Richtung des Umfanges als anch les Radius den aller festen Körper, auch denjenigen des Eises, beträchtlich übersteigt und nur von der Luft übertroffen wird. Dies erklärt die plötzliche Entstehung tiefer Spalten.

Wie weit der Spalt sich öffnet, ist bei derselben Baumspezies und stammstärke inclividnell verschieden; aber darin stimmen alle Fälle überein, dals, wenn die Frostspalten eimmal entstanden sind, nach ihrem Zusammengehen bei Tauwetter ein sehr geringer Kältegrad hinreicht, um sie wieder zu öffnen. Dies erklärt sich daraus, dats zur Entstehmng der Spalten eine Kraftmenge nötig ist, welche die Kohäsion der Yellelemente in der ganzen Länge des Stammradins zu überwinden hat, während hei dem Eintritt erneuter Kälte zum Wiederöffnen des sipaltes in demselben . Jahre nummehr gar kein Widerstand und im nächsten Winter nu der des letztjährigen, nengebildeten Wundschlusses zur ïberwinden ist.

Alle im Winter entstehenden Frostspalten gehen meist tief in flas Stamminnere hinein. Im alten Holzkërper aber ist ter Bam unfähig, nenes Ternabungsgewebe zu bilden; infolgedussen stellt jerle Frostspalte eine dansmde, woll äutserlich zu üherdeckende, aber im Innem stets unverlepilte Wumde dar. Dieselle wird um so bedentungsvoller, jo mehr zu dem radialen, grotsen Froststpalt sich noch seitliche tangentiale sprünge gresellen. Diese lanfen meist in den Lagen des

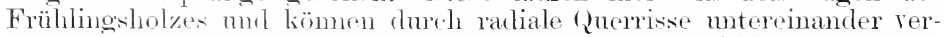
bumden worlen. Es tritt dann eine gefelderte Kerklïftung ein, welche den Holzkïrper technisch rollkommen unlorachlor macht und durch Erleichterung dor Anstreitung holzzerstörender Pilze den Tod des Bammes beschlemigt.

Wir erhalten dann Bilder wie in Fig. 12:; welche den quersehnit eines Eichenstammes darstollt, der durch Polyporms sulfurus von einer Astwunde aus besiectelt unt zorlibuttet worden ist.

1) Carinr, Nene Untersuchungen über Frostspalten, Bot. Zeit. 1857, No. 20-22. In einer früheren Abhandlung, Bot. Keit. 145.5, S. 449, hat Verf. anch die ältero Literatur angegeben. 
Während die Zerklüftumgen dor stämme durch lan ne, den grötsten Teil des Bamschaftes durchziehende spaltin vielfach beschrieben worden sind ${ }^{1}$ ), ist der Entstehmig kmzer. Wringer tief yehender und leichter sich schliefsender Spalten nicht genügend Btachtung areschenkt worlen. R. Hintig ${ }^{2}$ ) gedenlit derselben bei der Wrilstanne. wo sie oft nur ganz kur sind, in den höheren schafteilen anftroten und meist sehr bald rerwachsen, ohne Frostloisten zu bilden. Anch sie verlatufen in der Richtung der Holzfaser, also meist etwas sehridg. Antiser hei ler 'Tanne rah ich derartio linrze Frostepralten, mul zwar oft mit

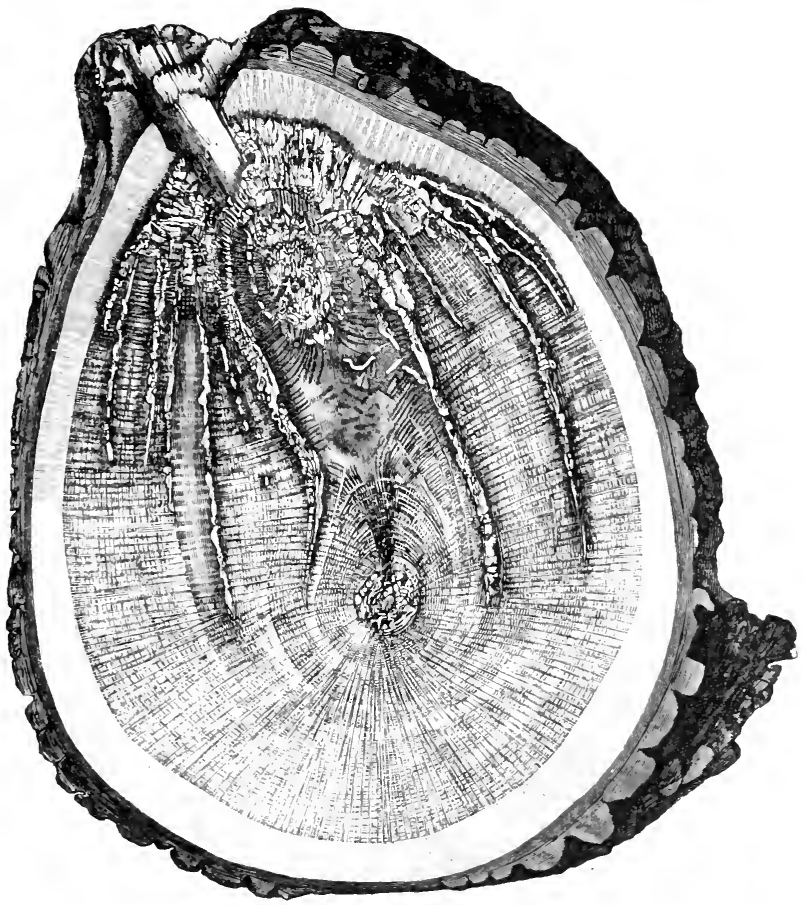

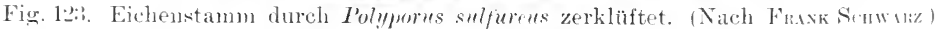

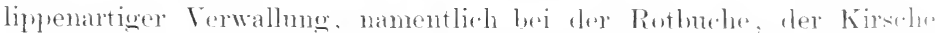

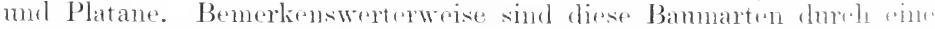

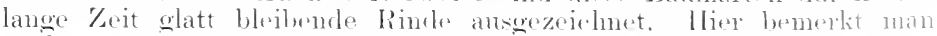
anch am leichtesten die Bovorzmomne wewisser Bammsoitun lud der

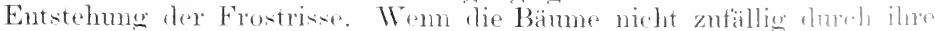
Nachlouschaft enesthützt sinel, somelern trej stehen, wirl man lui der

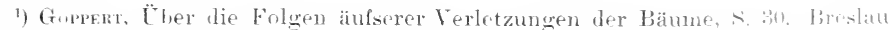
1 73. Verf. hat an 76 versehiedenen Gehölzarten Frostrisso kennen zelernt.

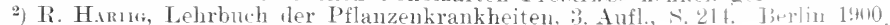
Julius springer. 
Mehrzahl derselben feststellen kïmmen, dat's die West- und Südwestspiten die reichlichsten Frostverletzmoen zeigen. Wie verschieden sich die inzelnen Baumseiten verhalten, lehren z. B. die Strat'senpflanzungen ron Platanen. Zur Keit, wemn das bekamnte normale Abschmpen der stämme begimnt, wird man sehen, dats die meisten Borkenschuppen zunächst auf' den zwischen West mol süd gelegenen Stammseiten abgestofsen werden.

Bisweilen werden "Trockenrisse" als Frostrisse angesprochen, woraut Nörolinfier ${ }^{1}$ ) besonders aufinerksam gemacht hat. Die Trockenrisse, welche namentlich boi kräftion Bämen sich einstellen, die auf eine undurchlassende Bodensehicht gelangen oder sonst plötzlich starken Wassermangel zu erleiden haben, charakterisieren sich dadurch, dafs sie entweder in ihrem radialen Verlant wiederholt absetzen, also in den älteren . Jahresringen in einem anderen Radius verlaufen als in den jüngeren, ofler üherhaupt nur km\% mitten in der Holzscheibe einen oder zwei .Jahresringe radial spalten. Derartige immere spalten erscheinen dann in Form einer Lanzenspitze, d. h. in der Mitte am meisten verhreitert. Da bei den bis zur Rinde gehenden Spalten die Wunde otfen bleibt, neigen sich anch die Überwallungsränder in den Spalt hinein, hilden also keine vorspringenden Leisten wie die Frostspralten.

\section{Frostbeulen.}

Im Anschluts an die Frostspalten wäre der sogenamnten ., inneren Frostrisse" zu gedenken, welche R. Hartig ${ }^{2}$ ) an Eichen und Tammen beobachtet hat.

. Wemn hei starker Kälte der Baum schwindet ${ }^{3}$ ), sagt er, so kömnen zwar im Holzkörper in der Spaltungsfläche Risse entstehen, die aber nur bis zum Rindenmantel verlaufen, ohne letzteren zu zersprengen. Die Rinde, welche ja kine radialen Spaltflächen besitzt, hält den Holzkörper zusammen. Allerdings wird die elastisch dehmsame Tanneminde da, wo innerlich ein Frostrifs mündet, anseinandergezogen und verliert dadurch einen Teil ilurer Elastizität. Wem dam in der Folge der Bam dicker wird, so ül,t die Rinde hier einen veringeren Druck auf das Cambium aus, und der Zuwachs wird dadurch Iokal gesteigert. Der Stamm erscheint äufserlich nicht rund, sondern mit leistenförmigen Vorsprïngen versehen."

Einen ganz ähnlichen Vorgang nahm ich bei der Entstehung der Gebilde an, welche ich als Frostbeulen bezeichne. Es sind dies breitkegelfömmige, aber meist abgeflachte, bisweilen l cm hohe Auftreilmugen an glattrindigen zwei- bis mehrjährigen stämmen oder lweigen.

Niclit zu verwochseln sind diese Benlen mit den bei üppigen Kulturvariotäten gar nicht selten vorkommenden, kegelförmigen Buckeln, die mer dor Rinde sofort einen harten, holzigen Kern erkemen lassen, während dir Frostheulen zum Teil stets, zmm Teil wenigstens in Jahre ihrer Entsteliung aus einer weichen, mit dem Nagel leicht zerdiziclibaren (iewebenasse bestehen.

1) Nimnixam, Trockemisse (falsche Frostrisse) an der Fichte. Auch ein Grumd der Rotfäule. Centralbl. f. d. gesamte Forstwesen. Wien 1878 , Heft 6.

¿) R. Hirie, Innere Frostspalten. Forstl-naturwiss. Zeitschr. 1896, S. 48:.

3) Lehrbuch der Pflanzenkrankheiten 1900, S. 214. 
Die ron Anfang an hart verholzten Erlwhmeren, fiur welche ich

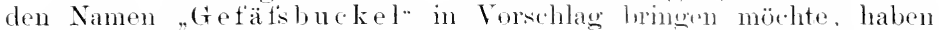
fast immer eine bestimmte stellumg zum fuge, währoul die Frostbenlen an beliebigen stellen des jungen sitammes whe des zweig. internodiums sich zeigen. Wie .Getätsheliel" simb "inspitzige oder zweispitzige, berindete Holzanschwellungen, wolehe wie Maselanfänge

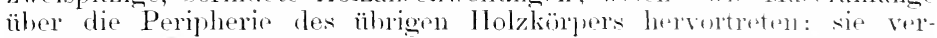

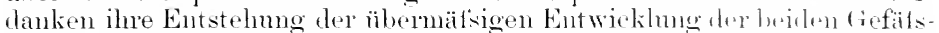
bündel, welche normalerweise in jedes Angenkisten gehen mul sieh mit dem zentralen, stärksten Bündel zur Bihlung des firfailshiumelelkörpers in Blattstiel vereinigen.

Bei den (weichen) Frostrenlen fimlen wir keine Brzinhmeen zn den Blattspursträngen. Sie zoigen sich an belieligen stellen und mitstehen durch blasenartiges Abhehen des Rindenkörpers rom llolzzylinder. Das aut letzterem stehen gebliebene Jungholz tritt da die Abhebungen mu beis sätfösten, also zur Keit reicher regetativer Taitiglieit

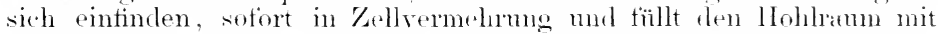
zartwandigem Parenchymholz, das an der Peripherie allmählich in normales Holz ïhergeht.

Der ganze hier stattfindende Prozetis ist derselbe, welcher hed der Nenberindung einer künstlich hervorgerntenen sehälwunde eintritt. l)er Unterschied liegt bei der Butenbilduner nur darin, datis dir Rinde nicht abgeschalt, somclern nur stellenweise dureh Frost abeghoben mol dats somit die vom Holzkörper ansegehenele Nemporluktion drem Ange zmöchst nicht sichtbar wirl. Man kamn sie bisweilen in ilnere un-

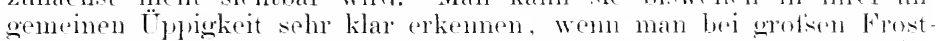

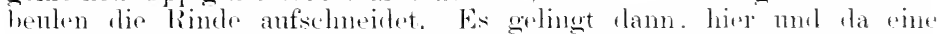

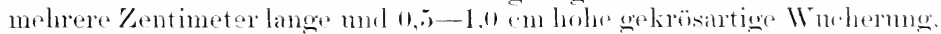
the gar nicht mit der alten Rincle zusammenhängt mul mur ant drm Holzkörper rulit, blotizulegen. In eimem Falle (hei drer Birne Bome Lomise dAramche) hatte die Wuchermog den Rindemmantel pesprenent und war als mregelmätig konturierte, etwa liegolformige Masse mit warzig-kïmeliger Ohertläche weit üher den stammuntang hervorgetreten.

Altere zustande verheilter Frostbenlen lionute ich bei Ahorn. Kirsche und Apfel heohachten. Bei Ahorn sind sie hisher am schönsten anzutreften gewesen, mol zwar an zweijührgen, ïher $1^{1}$ 2m Länge hesitzenden Trivben. Manthe dersellen zoigten in ihrem ganzen Verlanfe mit Ausnalme der spitzenregion kleine, Hache. etwa ${ }^{1} \mathrm{~mm}$ hohe. allseitig sanft verlanfende, vollkommen berindete Buckel. wele he mehr

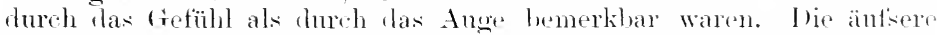
Rinde ersehien dmehans normal mul als dir direkte Fortsetzmone der

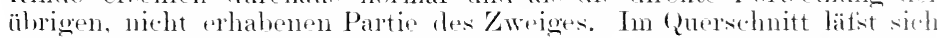
die Ersache der Rindenantereibme in einer Anschwellumg des 1101\% kërpers erkemen. Welcher im Anfange des zweiten Jahrescinges ein Nest holzparenehymatiseher, sehr weiter. stärkereicher \%ellen ged,ililes hat. In der Regel finclet sich rin solehes Parenelymholzmest genan zwiselum zwei Ilarkstrahlen, so dats der seitliche Ïbergang von diesem libuli-

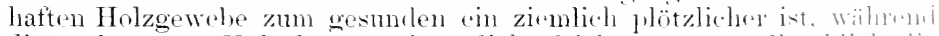
diese abmormen Holzelemente in radialer Richtumg ganz allmaililich di. normalen Dimensionen und Verdickmgen amehmen. Xn zalgen sieh noch in dem radial angrenzenden sowohl wie in then soitlieh an-

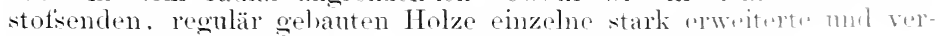
kïrzte, mit Stärke (im März mutersncht) erfüllte Holzzollen. 
In dem Holzparenchymneste finden sich umregelmäfsig verlanfende gelbe Streiten : die gelbe Färbung rührt von gequollenen Zellwandungen her, die bei Frostschädigungen allgemein vorkommen. Anch andere Merkmale einer bestimmten Gruppe von Frostschäden sind vorhanden, wie z. B. die Zerrung der Markstrahlzellen an der Froststelle nach einer seite hin and die tomnenförmige Elweiterung des Markstrahles bei seinem Eintritt in das Parenchymnest. Diese tomnenförmige Erweiterung des Markstrahles wird weniger oft durch Vermehrung seiner Zellen hervorgerufen als durch Verhreiterung derselben auf Kosten ihrer Länge; dabei hemerkt man nicht selten eine in die Angen springende Verdickung der sekundären Membran. Eine \%ellvermehrung zeigt sich am hänfigsten bei den einzolligen Markstrahlen, die von der Froststelle aus zweizellig werden. Je weiter sich ein soleher Markstrahl in das Parenchrmnest hinein fortsetzt, desto breiter und kürzer erscheinen im Qnershmitt seine einzelnen Zellen und mit desto schiefer stehenden Wandungen greifen sie keilförmig ineinander, anstatt stumpf aneinander gefïgt zu bleiben: endlich werden alle Zellen in dem Parenchrmneste, dessen Elemente im Zentrum des Nestes am weitesten sind, gleichgestaltet, so rlatis man überhaupt eine Iifferenzierung der Narkstrahlen nicht mehr erkennt.

Dem gelb- bis hraunstreifigen Neste von Parenchymholz entspricht in demsellien Radius eine ehemals damit zusammenhängende, jetzt alser durch dazwisehengescholsenes, nenes Holz getrennte, brame Rindenzone, die tangential gestreckt ist.

Bei dem Färben der Sehnitte mit Campecheholzextrakt zeigten sich oft schr hübsche Bilder, wem konzentrierte Chlorzinkjodlösung hinzutrat. Die Holzzellwandungen in ihrer versehiedenartigen Verdickung traten deutlicher hervor. Einzelne Gruppen von Holzzellen färbten ihre Wandungen intensiver gelb und zeigten sich mehr gequollen: ss waren dies die Wände der die Gefälise umgebenden. stärkeführenden, gefäeherten Holzzellen ${ }^{1}$ ), welche somit

1) Aus diesen gefïcherten Holzzellen kann man zur Zeit des Erwachens der Tegetation bei Behandlung der Schnitte von Acer, Salix riminalis und anderen

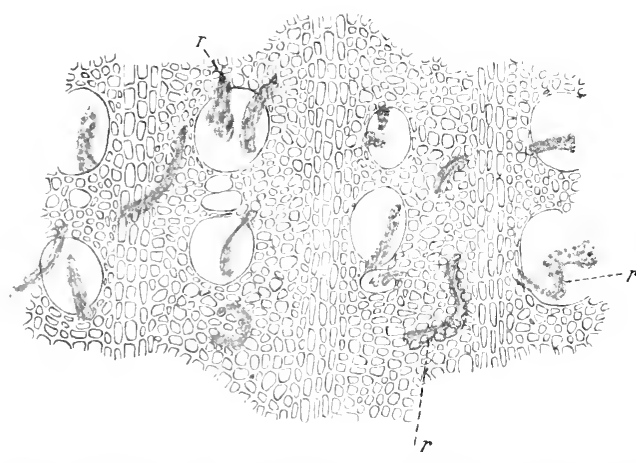

Fig. 124. Stäkeranken bei Bohandlung der Schnitte junger Weidenzwoige mit Chlorzinkjod. Tie Ranken treten ans den angeschnittenen gefacherten Holzzellen hervor mo krìmmen sich vielfach in die fiefafslumina hinein. (Orig.) Gehölzen mit stark saurer, konzentrierter Chlorzinkjodlösung grofse, dunkelblaue St i r k era n keu austreten sehen (vergl. Fig. $124 \%$ ). Die Struktur der Ranken ist verschieden. Bald erkemnt man ihre Zusammensetzung aus den rinzeluen, unregelmäl'sig gequollenen sitäkekörnern noch sehr deutlich, inden ein fester gehliebener Kern der Körner über die Oberfläche der glatten, durch Verschmelzumg der peripherischen schichten der stäkekörner entstan. denen Wandung der schlanchförmigen Ranke höckerig hervortritt: bald jedoch ist die Substanz der hohlen Ranke 
empfindlicher sein dürften als dic anderen Elemente des Gefätsbündlels.

Bei Frostbeulen der Kirsche, die in Fig. 12: mol 126 skizziert sind, zeigt sich das anatomisehe Bild insofern "twas ahweichend von den Frostbenlen des Ahornzweiges, als hier meist der ( immuthnts intolge

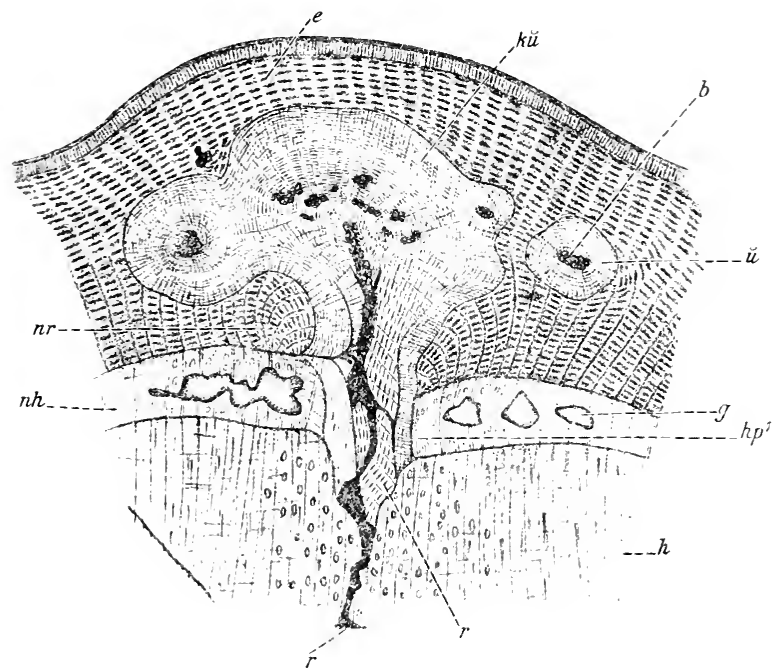

Fig. 125. Frostbenle am Zweige einer süskirsche. Medianer sichnitt. (O)rim.)

der Verletzung sich hinzugesellt. Fig. 125 ist der Quersehnitt aus den Zentrum einer Beule, Fig. 120 ein seitlich der Mediane der Wunde antnommener Längssohnitt. , ist der hrame streifen aus totem frewebe, welcher den die Benle veranlassenden. inneren, feinen Rifs zunächst.

gleichmäsig hautartig und die Oberflähe glatt: die sitze erscheint oft zackig. Bei älterem Holze treten die stärkeranken in Herlstholze des letzten mul rorletyten Jahresringes am zahlreichsten auf. (Hycerin hellt die kauken oder, besser gesigt. Stärkeschliache auf, die übrigens sowohl auf der Oberseite als auf ter Cnterseite des sichnittes hervortreten. Alkohol laifst sie schärfer konturiert und dunkler erscheinen: Kalilange entfürbt sie und zeigt dic kimnigen Bestandteile der Wandung besice. Ile Bildung der Ranke scheint zu erfolgen durh Quellung der Stäkekirmer, di. dann platzen und ihren Inhalt mit dem Reagenz zn einer Jembin unformen, an der man bisweilen helle kreismude stellen rekennt, gleichsam als of Vakuolen hi der Bildung angelegen häten. Die zackige Beschaffenheit der spitze wirl durlt

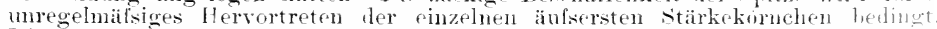
Hiese Ranken möehte ich für Traubasche Zellen halten: stark sumes Chlorzink mit hali allein zeigte hautartiqe Niederschläge. Zinnchlorid (nentral) und Fi-nchlorid (sauer) erzengen keine Ranken, die ubrigens durch schwefolsiure onter. ral\%-

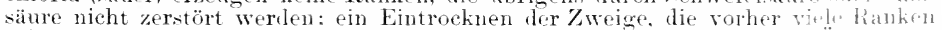
zeigten, vermindert die Ausbildung derselben oder hebt sie ganz auf. Therhauit ist diese Erscheinung nicht immer hervorzurufen; wie scheint an pine hemmlcre. Beschaffenheit der Stäke kurz vor ihrer Auflösung im ersten Frühjahn gehnuln zu sein. 
begrenzte. Dieser Rils war äntserlich gar nicht sichthar; dem die änisersten Rinclenschichten s sind mverletzt geblieben, obwohl die Trunde riemlich tief war und bis in das alte Holz $h$ hineinreichte: sie nutis aber von Anfang an seln eng wewescn und zu einer /seit entstanden sein, in der eine Überwallnng sofort möglich war, demn es senkte sich das übrewallende Gewebs alshald in die Wunde $r$, ohme dats erst wälsere Gewebepartien zum Absterben gekommen wären. Dieses junge, weiche T̈berwallungsgewebe sowie die an die erkrankten Partien der Rinde angrenzenden Zellen erzengten alsbald dicke Korklagen $l_{i} u$, welche das tote Gewebe vollständig cinhüllten mol von dem gesumden isolierten. Die Hartbastbündel b, welehe mitten im gesunden Rindengewebe in der nächsten Nähe der Wunde erkrankten, smol dure h isolierte Korkumwallungen (Fig. 125 "1) eingeschlossen, so dats v on ihnen aus eine writere Zersetzung des ungebenden chlorophyllhaltigen Rindenfarenchyms nicht stattfiuden kamn.

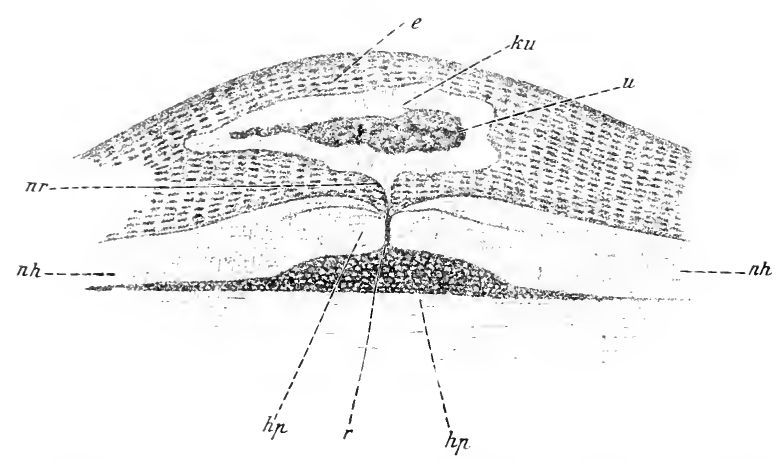

Fig. 126. I)ieselbe Wunde wie bei Fig. 125 dargestellt. Seitlich geführter Schnitt. (Orig.)

Bei dem lleilungsvoruange bemïhten sich nm das neue Holz $n$ h und rie nene Rimale $u r$, die WTunde von den seiten her zu überdecken. In der Mitte der Wunde, wo die klatfenden Ränder am weitesten ahstchen, Fig. 1:5 $n h$, ist ein Schluts noch nicht erreicht; dagegen ist an den seitenfartien dieser Fall bereits cingetreten; es haben sich von othen ma untru lier dio beiden nenen Holzlagen Fig. $126 n h, n h^{\prime}$ mit ilnen Rändern vereinigt nud das tote Rindenstück, Fig. 126 u, von dem toten llolzteil suhom getremnt. Je älter und dicker die nenen Ilolzund Rimdenlawen werden, desto mehr wirl die tote Rinde nach antisen gexlrängt mul endlich ganz abgestotsen. Das abgestorbene Holz $h p$, welches farenchymatischer Natur war und die angenblicklich noch frischen T'undränder. Fig. 125 $h p^{\prime}$, die ebenfalls ans Parenchymholz gebililet sind, gelen erst wanz allmählich in festeres, nomales Gewebe ïber. Das erst celilhete, zur Therwallung sich anschickende Neuholz trägt in der mittleren Wrundgegend den Todeskeim schon in sich, indem zahlreiche (tummiberde (Fig. 125 g) sich gebildet haben, welche das wenig widerstandsfähige Gewebe in kurzer Keit anflösen werden.

Poi älteren ÏHerwallungen an einem durchaus nicht üppigen Ahornzweige wude anch eimmal eine spaltung des Jahresinges be - 


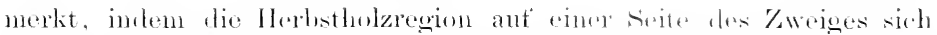

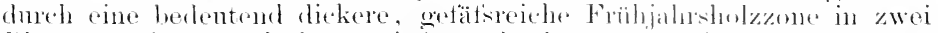

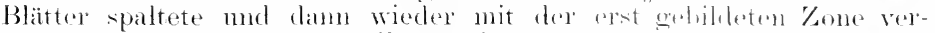

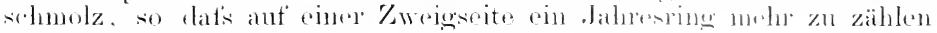
warl als aut der anderen.

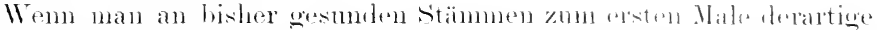

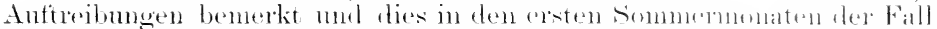

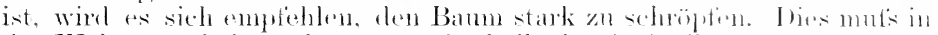

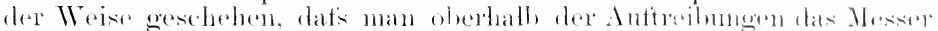

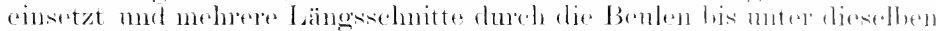

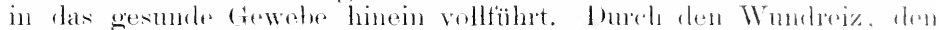

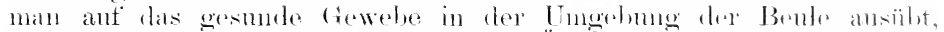

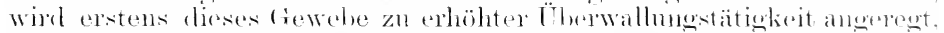

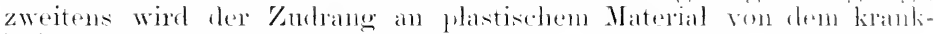

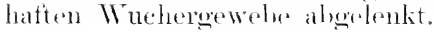

\section{Frestrunzeln.}

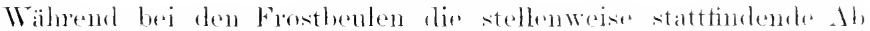

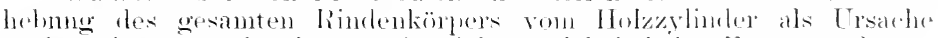
nachowiesen werden komite, handelt es sieh hoj ilon frostrumzeln 1 m

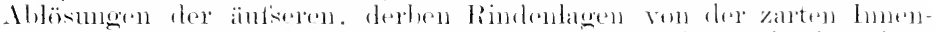

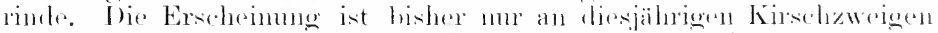

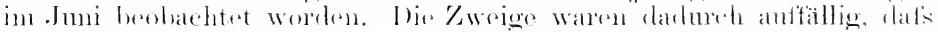

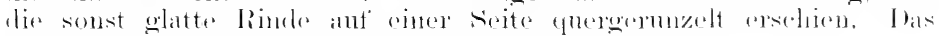
('ambium War nicht westört, das Mank etwas gehrämut.

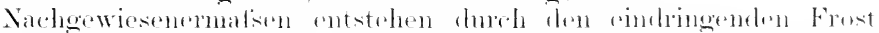

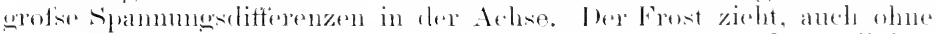

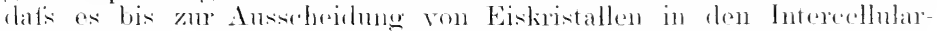

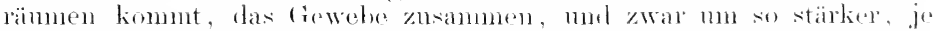

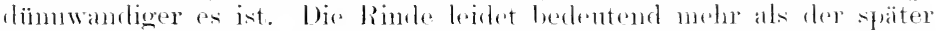

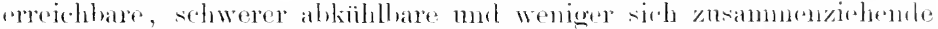

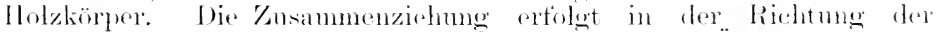
Tangente stäler als in rarlialer Richtmog. Dieser Überschuls wirkt wie ene alleinvorhandens, in der Richtume des stammmutanges statt-

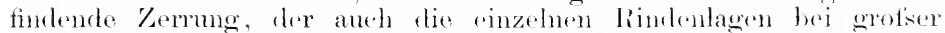
Jugend der ganzen Rinde in versehiedenem Matse folgen werdon. Bei

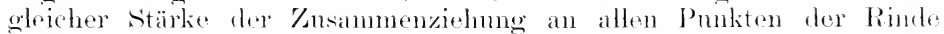
werten diejenigen Zellen, welehe der Peripherie am nächsten liegon

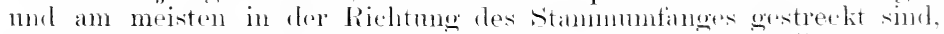

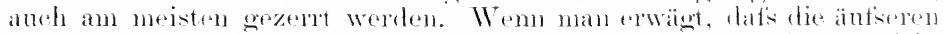

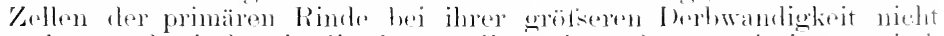

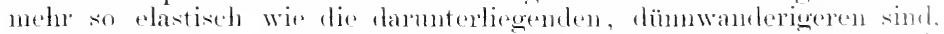
$\therefore$ sieht man ein, dats nach Authören der \%errumg bej ihnen die dureh

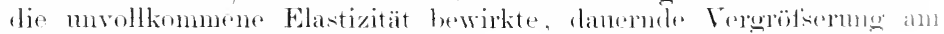
hedentendston sein wirl.

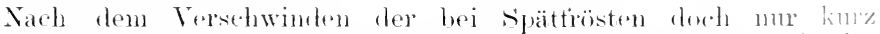

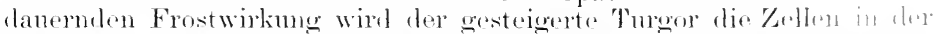

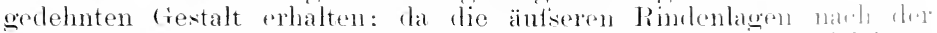

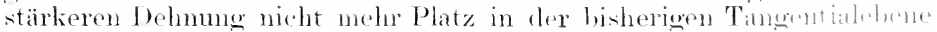

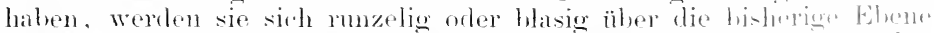

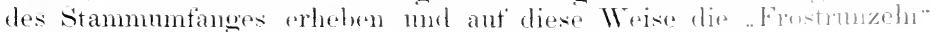
bilden. 
Antiver der tangentialen und rarlialen /usammenziehung fommt hei ten jungen, noch krantartigen Zweigen die longitudinale Veränderung hinzu, die bei der durch die Frostwirkung bedingten Krümmung des Achsenkörvers entstehen mut's. Man kann künstlich an einjährigen Trieben durch Biegen leicht (querrunzeln erzeugen. Betreffs der bei

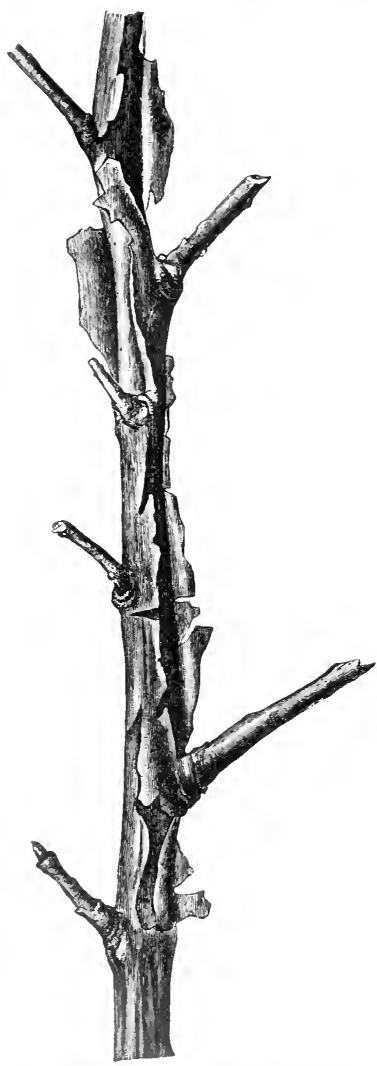

Fig. 127. Flatterig aufgerissene Korklamellen an frostbeschädigten Zweigen. gebogenen, krautartigen Stengeln sich entwickehden spammosverhältnisse sei aut die Arbeit ron Ursprus: ${ }^{1}$ ) verwiesen.

\section{Frostlappen, Korklocken.}

Viel häufiger als die in Form von Frostrunzehn und Frostbeulen anftretenden Abliebungserscheinmgen im lebenden Rindengewebe sind die Ablösmngsvorgänge, die sich durch Vertrocknen der äutseren Gewebelagen einstellen, wemn Zweige durch den Frost getötet werden. In Fig. 127 sehen wir eimen Zweig mit lockenartig zurückgerollten, flatternden, trockenen Rindenfetzen von der Herbstsylresterbirne. Anch bei weichholzigen Äpfeln (Morgenduftapfel) wurde an Wweigen und jungen, noch glattrindigen Bamnschulstämmen im Mai und Juni die Erscheinung aufgefunden. Man sieht zunächst das Periderm blasig abgehoben: später reifsen die Blasen durch einen Längsspalt auf. Das gesamte Rindenparenchym erscheint unterhalb des Risses geschwärzt und trocknet schmell zusammen. In dem Matise, als sich der Rits erweitert, schreitet das Absterben des Rindengewebes weiter fort, indem es zmächst gelbgrün und weich wird, dam nachdumkelt, zusammensinkt und schliefislich vertrocknet.

Mit der /eit werden diese toten stellen anch ganz blotsgelegt, indem der Längsrifs in ter Peridermblase sich verlängert und neu auftretende (vnerrisse die ganze abgehobene Korkhaut in mehrere Lappen teilen. Bei dem Zusammentrocknen rollen sich tamn die einzelnen Lappen rückwärts ein mol enthlïtsen dadurch das bisher bedeckt gewesene Rindenparenchym. Es bleibt zu bemerken, datis werade an der Basis der jungen, noch glattrindigen Stämme am meisten derartige Korklappen zu finden sind, während die jüngeren Zweige äufsclich mversehrt erscheinen und anch frisch anstreiben, aber allerding nach einiger Zeit gelbe und wellie Blätter erhalten.

1) Crispris, A., Beitrag zur Erklärung des exzentrischen Dickenwachstums an Krantpflanzen. Ber. d. 1. Bot. G. 1906, Heft 9, S. 498. 
Von der Ausdelmung und Häufigkeit solcher Korklocken, die immer wieder durch gestund gebliebene stell 'n voneinanter getremt gefunden werten, hängt es ab, ob der Bam am I.oben bleibt. Meist stirbt derselbe, da das Cambium nnter den grsthwiryten Rindenstellen

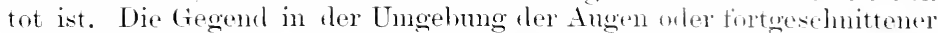
Zweige erscheint zu derartigen Frostbesehädignugn hesonders geneigt.

\section{Die Verfärbungserscheinungen im Achsenkörper.}

Die Obstzüchter phlegen, wemn sie in Frühjahn ilne Bämm. schmeiden, ans der Betrachtung ter Schnittfläche Schlïsse zu ziehen. ob eine Ubstsorte frosthart tür eine bestimmte Gegend sich erwiesin hat oder durch die Kälte beschädigt worden ist. Man urteilt danath. ob die schnittfläche gleichmälsig weits oder stellenweise gobrännt arscheint. Die Bräunme tritt teils in ringtömigen \%onen, teils in Hächenartiger Ausbreitumg auf. In ersteren Falle ist coft einseitig an Kweige) die cambiale Region oder die Peripherie der Iarkscheibe, ali. sogenamnte Markkrone, wo die imersten Gefätse des IIolzringes in das Markparenchym hineinragen, der Herol der Vertäbmug. Bei flächenartiger Bräunung pflegt ein Teil der Holzfläche nehst Markiärper an derjenigen /weigseite ergnitten zu sein, an welcher die dazugehorige Knospe sitzt. Die Bramntärbung ist ein Zejehen eler Humitiliation. Welche allmählich bej dem Anftrocknon des \%ellinhaltes an dir Wandumgen sich einstellt. Bei den lnamnen Kellwänden bemerkt man nielit selton vallungserseheinumgen.

Wenn einzelne Ftammteile ertroren sinel, sielnt man lisweilen von denjenigen Trilen, welchs in ganzen querdurchnssser velorant sind, braune streifen im Holzköper bis zn verschiedener Tiefo sich stammabwärts ziehen, und diese streifen haben manehmal cine symmetriselu. Anorelnung, so dats ein (quersehnitt durch den halb gesmolion stammteil cine regelmälige, gebräunte Figur aufweist. An bekanntesten ist das "Landwehrkreuz" bei Acer: bei Cytisus unel Fraxims kommen ähnliche Bilder vor. Cytisus und andere Papilionaceen zeigen zuweilen selnr ansprechende Buntfärbung derartiger Qnerscheiben, welche wohl eine technische Verwendung verdienen. Ile Buntfärbme ist dnuch den verschiedenen Grad der Brämmong in den Konen des Kornholzes und des splintes bedingt.

Doch sind derartig regelmälsige flächenartige Verfärtungen seltane Vorkommnisse. Die häufigste Erscheinmog besteht in muegohnatsiger. Bräunm@ derjenigen Rinilonpartie, die ein Ange mogibt, und derjenionen Markansbuchtumg, welche nach dem Ange finführt. Her cirad dor.

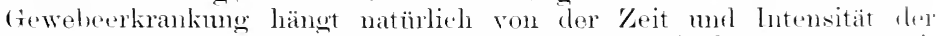
Kältewirkmo sowie der sperifischen Empfindlichkeit der Bamart mul. hei gleicher Intensität, ron dom Alter der Achse al, Je jünsw win

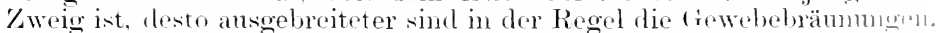

Einen Einblick in die Verschiedenartigkeit der Frostbrämmun lin on der in Fig. 128 wiedrogebene quersehnitt pines dureh kïnstlichen Frot beschädigten Birnenzweiges. Hier bedentet $m$ den Marklionper, m/: bie

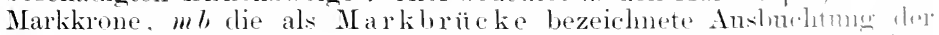

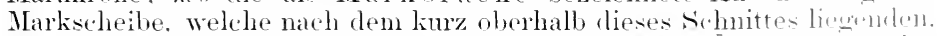
also hier noch nicht sichtbaren Auge tïhrt. An der vitulle. Wo das Auge (die Knospe) sitzt, ist jeder Zweig mehr oder wenigor verdickt und baucht sich aus zum . A ugenkissen". In diesen verlautun dic 
Crefitibuindel if und $g^{\prime \prime}$, welche in den Blattstiel abgehen, in dessen Achrel das tuge sich befindet. Die Gewebekappe, welche ither dem zentralen Blattspurstrange dem Rindenkörper des Zweiges in der

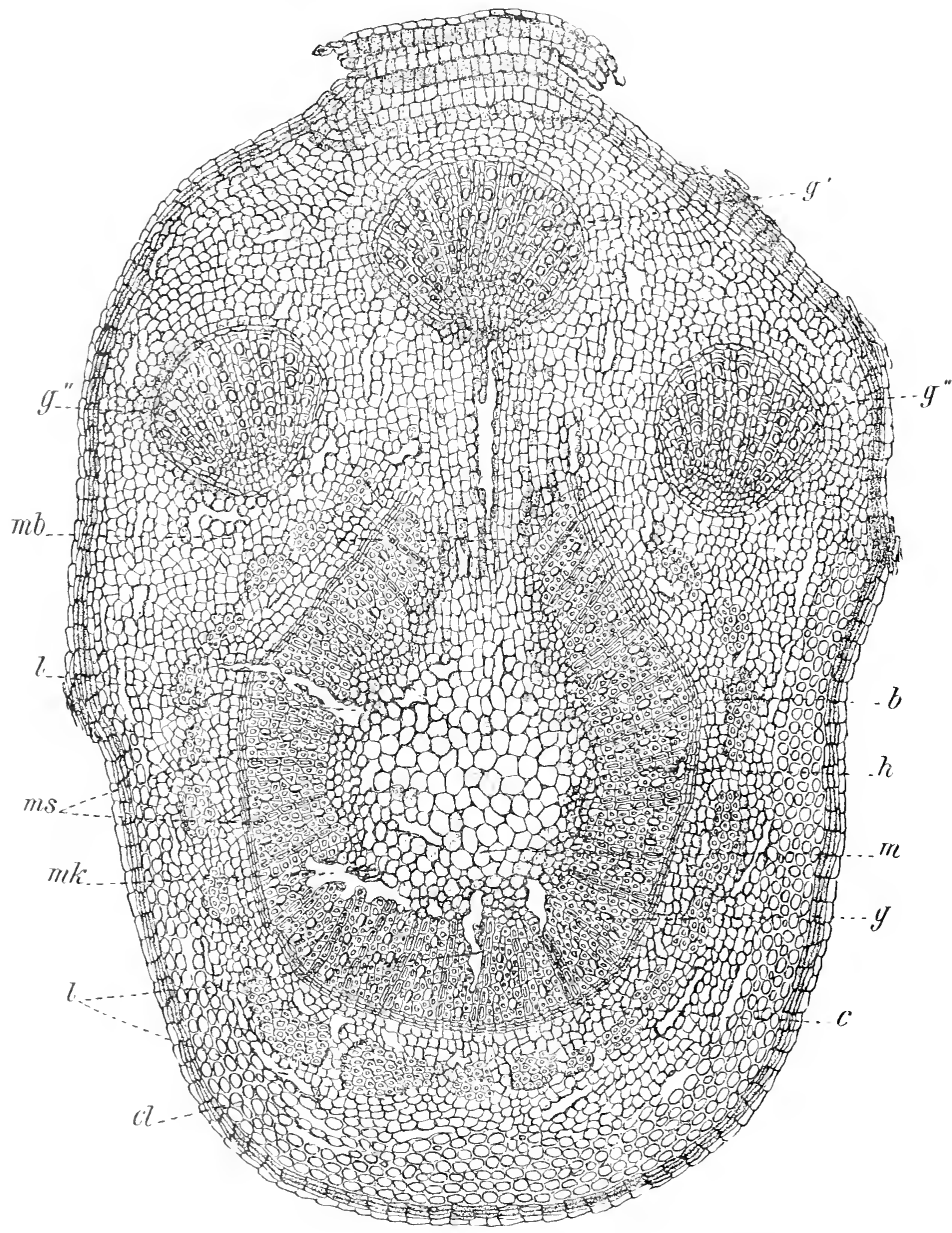

Fig. 128. Durch känstlichen Frost hervorgerufene Bräunung und Zerklüftung der (iewebe eines Bimenzweiges. (Orig.)

Zeichnung anfoesetzt erscheint, stellt das V'ernarbungscewebe dar, das nach dem Abfallen des Blattes im Vorjahre sich gebildet hat. Die einzelnen Gefätise in den Blattspursträngen und im Holzringe sind mit $g^{\prime}$, 
$g^{\prime \prime}$ und g bezeichnet. Der Holzring h mit den Markistrahlen ms zeigt mamnigfache, vorherrschend radiale Zerklüftungen, während die (rewebelücken / im Rindengewebe meistens tangential rellunfen. Bemerkenswert ist die durch einen klaffenden Längsspalt gesprengtr Markbrücke, die durch die stärke der Verwundung erkennen liikt, das sie die frostempfindlichste stelle des Zweiges darstellt.

Bei vielen Laubhölzern gilut es noch eine zweito Reuion unotser Frostempfindlichkeit, nämlich die Ilartbastzellen mul deren äutsere parenchymatische Unkleidnng. Bei meinen künstlichen Erficrungsversuchen zeichneten sich dadurch mamentlich Kirsehe, PHatume. Rítbuche und Affel aus, während die Birne grötsere Widerstandsliratt anfwies. Auch im vorstehenden Bilde zeigen sich die Bastbümtel (b) nicht angegriffen, ebensowenig wie das Collenchym (rl). Die Cambiumzons c, welche den Bammzüchtern bei dem Frïhjahrsichnitt der (b)stbäum dureh ihre Bramfarbung anzeigt, dafs die Zweige dureh den Frost beschädigt worden sind, ist hier nicht durchgängig gebräunt. Bei der mikroskopischen Untersuchung zeiert sich, dafs am meisten das noch cambial zartwandige Jungholz und die gleichalterige, innerste Jungrinde rebräunt sind, während hie zwischen beiden Regionen liegende plasmareiche Meristemlage farblos mol unversehrt erscheint.

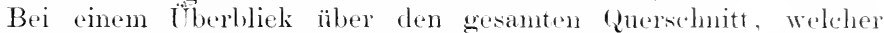
betreff's der Frostverfärbungen als Beispiel fïr alle Gehölzo welten kann, sehen wir also als die emptindlichste stella dos W weiges die Region des Angenlissens, in weleher der Zwoig don schmalsten llolzring und die meiste Parenchymanhänfung besitzt. I)ie in der \%eichnumg dunkel gehaltenen \%ellen stellen die gentännten Partien dar. Sodann folgt hetrefts der Frostempfindlichkeit die Markkrone mit den Markstrahlen. Der Markkörper selbst leidet moist erst später und wird um so weniger beschädigt, je älter der \%weig ist. Im vorliegenden Falle war der Versuch gexen Mitte Mai ansqefïhrt worden, zu welcher Zeit in Mark und Rinde bereits stäkespeicherme stattgefunden hatte. Die Markbeschädigung beschränkte sich hier anf eine schachbrettartige Zeichnung der Markscheibo, indem einzelne der stärkefïhrenden Zellen ihren Inhalt gebräunt hatten. Die Untersuchung zeigte, dafs nicht die stärkekörner selbst, sondern ihre plasmatischer Einbettungsmasse verfärbt war.

Die unregrelmäfsige Verteilung der vom Frost gebräunten Vellon in allen Geweben kamn nur durch den verschiedenen \%ellinhalt erklärt worden. Wahrscheinlich sind die zuckerreichen Zellen die empfindlicheren. Der plasmatische Inhalt leidet bereits, wenn die Zellmemlman noch hell ist. Bei den Besehädigmgen der Markkrone zeigen sich zuerst die engen spriralgefäíse gebräunt.

\section{Die Frostlinie.}

Es ist in vorigen Abschnitt erwähnt worden, dats die olstzïchter.

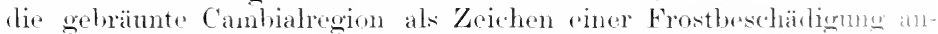
zusehen pflegen. Man findet num vielfach diese \%one als "Frostlinie" bezeichnet. Selbst sinfache Walkarbeiter zeigten mir cinnul die

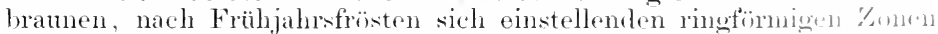
zwischen älteren .Jahresingen, die wir später bei der Besprelnug der "falsehen Jahresringe" und ..Mondringe" näher krnnen lernen werlen, als Frostlinien. Wir verstehen unter diesem Ausdruck die lue miliro- 


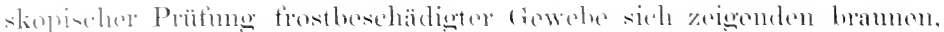

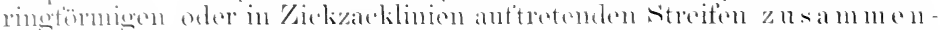
yos hïntig vorkommen, aber bisher kimm beadehet worden sind. Genanev

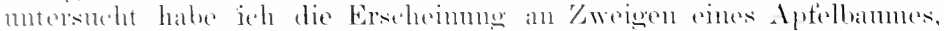

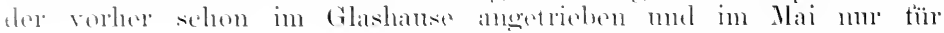

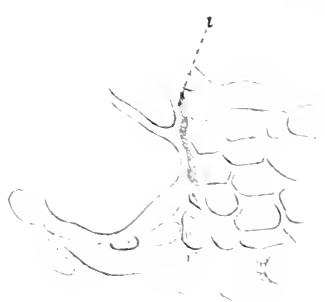

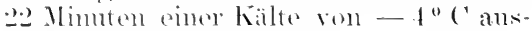
mesetzt worden wall.

Bri der Mitte dumi anserefühlutem

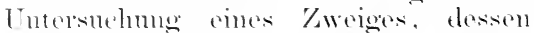
sitze erfiomen war, zeigte sich änlserlieh oine scharte tirenze zwischen dem

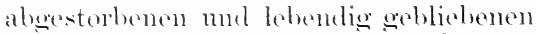
Tribe. Liese Walumelmmug macht man bei allon Frostseläilen. Fis macht sich nielit eine allmähliehe Auselehmung cler sehädigmeszone nachträglich bemerkbar, wenn nieht sekmuläre Faktoren, z. 13. holzzerstörende Pilze, zmr Mitwirkme gelangen. Wohl aber kam die Frostwirlmere selbst in das gesmude Gowobe hinein dureh Abtöten bestimmter Gewoheration ansstrahlen. wie dies in vorlierenten Vorsuche der Fall war. berschnitt man nämlich den an seiner spitze erforenen mul abgestorbenen Kwore mmittelbar neben dem an das tote fiewele anstolsenden gesund geblicbenen nud anstrobenden Ange, so sale man sinen bramen, scharf abaeneruzten streifen von den toten stellen ans in den gesmulen Achsenteil hinein an drei resmulen Angen rorbei sich fortsetzen. Er durehlief die Achse ron

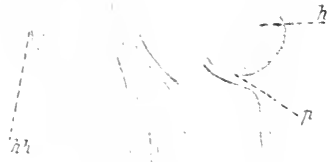
antsen nach imen in cliagonaler Richtung.

Die seharfe Umerenzung, welehe der brame streifen zoigte, und sein diaronaler Verlant erkiarten sich bei der mikroskopisehen Betrachtmong. Welehe nachwies, dats wir es mit dem Ilaupt-

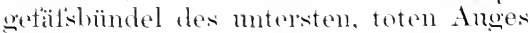
der erforenen spitze zu tum hatten. Ewar also hier der Fall eingetreten, dats der Tod des A $\mathrm{T}$ ges allmählich amole das Absterben des im ar. sunden nnd wesund bleibenden Gewebe verlanfenden Zuleitunes-

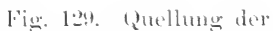
Zellmeinturanen wach kïnstlicher Frostwirkung. (() rig.) stranges (Gefätshüudels) nach siel zos. Dies wäe also die einzige Nachwirkmug, die bei Frostheschädigmeen eintreten kamm, falls nicht nachtrïglieh Parasiten eingreiten.

Tm zu erfahen, welches wohl the allererste Frostwirkung auf tas Fewehe des Bames sein mögre. also welehe Beschäclinmo bei dem Auftreten anz geringer fröste sich einstellt, wurde eine ganze An- 


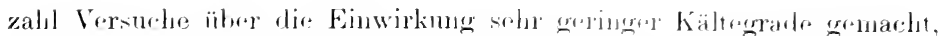

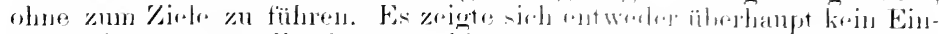

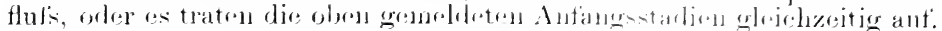

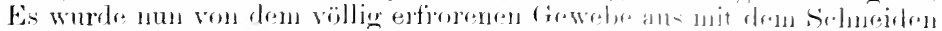

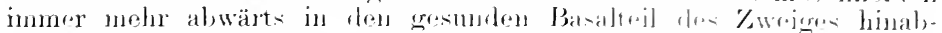

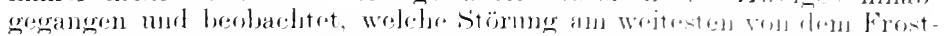

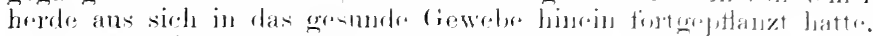

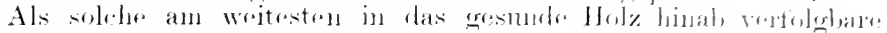

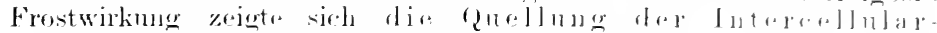
substan\% b\%w. Nittollandelle (Fig. 129. i).

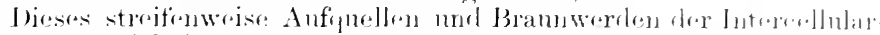

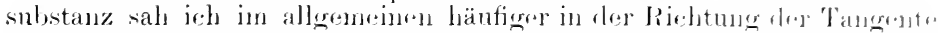

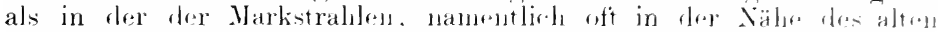

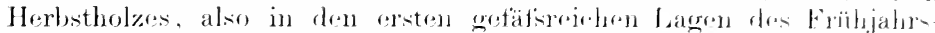

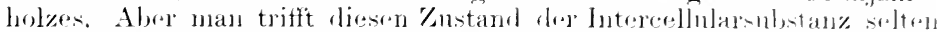

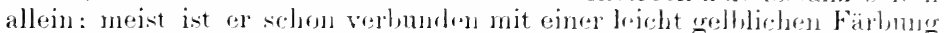

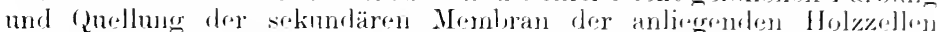
(Fig. 12!, h). Jiese Vorändermug wird in einzelnen Fälen derartio

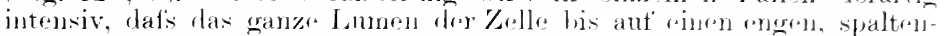
förmigen Hohlram ansorefïllt wird $(/ / h)$.

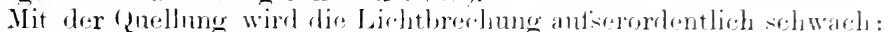

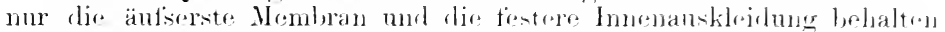

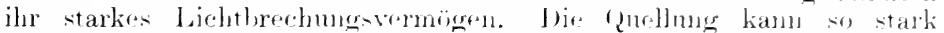

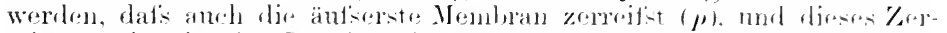

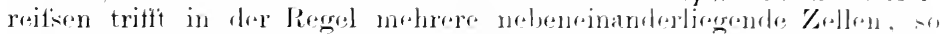

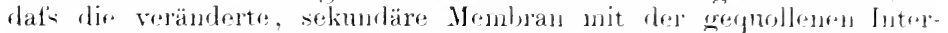

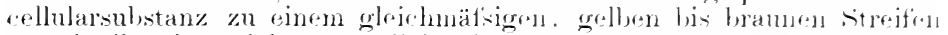

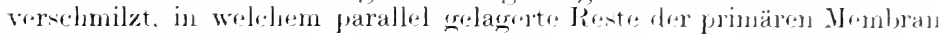
himutlich bleiben (st).

Es ist somit reperinentrll erwiesm, dats durell den Frost

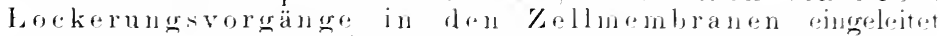

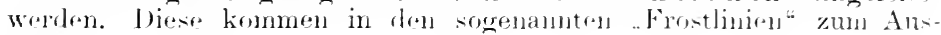
divick.

\section{Innere Zerklüftungen des Achsenkörpers.}

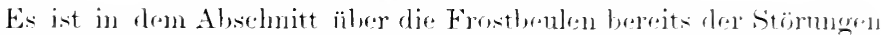

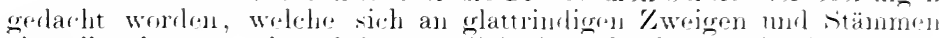

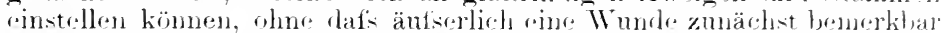
wäre. Erst in näehsten Jahre narh ror Entotehmeg der Brulen hanu

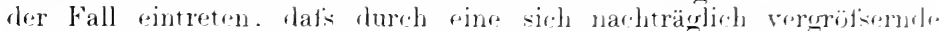
Beulo die sie deckenden primären Rindensehichton platom und als

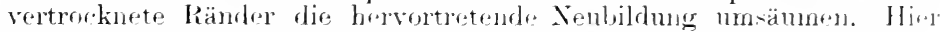

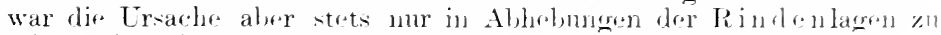
sehen, ohne dats Iror Holzkïrper zoryprengt wordon wäre.

Wrenn man aber die Vortommuise in Frojen, in sogenanusten

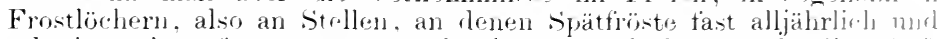
sehr intensiv auftreten. genaner durelmmustrort. findet man luenlige Anf-

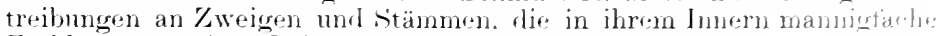
Zerklititungen des Holzringes erkenmen lasien.

Fs ist num zufällig gelungen. auch drerartige Beules biinstlinh hervorzurufen. indem ich $/$ weige, an denen rer diesjälrige Holzring schon eine namhafte Breite erlangt hatte einer kurzen. -chartin frostwirkung aussetzte. Die beistehende Fig. 1:30 stollt rins varbilto inders 
\%erklittungswunde an einem Kirschenzweige dar. Die Frostwunde ist durch einseitiges Abheben der Rinde rom jmingen Holze entstanden; " ist das alte Holz des Vorjahres, l, das diesjährige, bis Juni gebildete Frühlingsholz. $g$ ist die splintregion mit der normalen Cambiumzone. Um diese Zeit wurde der Zweig in den Kältezylinder gebracht, und bei der Untersuchmo zeigte sich, dat's tie Rinde im weiten Bogen ( $s p)$ vom Splinte losgeplatzt war, und dat's auch das junge $\mathrm{Holz} b$ radial zerklüftet erschien. Die Kerkiüftung erfolgt entlang den Markistrahlen d, welche seltener selbst zerreitscus, als vielmehr sich an einer Seite von den prosenchymatischen Zellen mol Gefätsen loslösen und dann teilweise zusammentrocknen. Eine in der Zeichnung bei o dargestellte ratiale Erweiterung der Lürcke stellt sich in einzehen Fällen durch

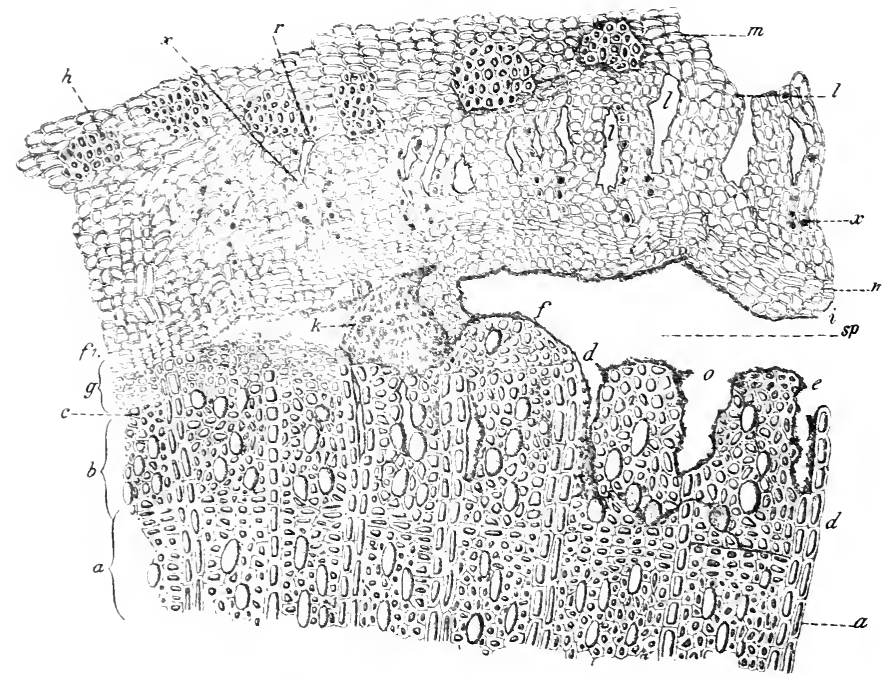

Fig. 130. Durch kinnstlichen Frost erzengte innere Zerklüftung bei einem Kirschenzweige. (Orig.)

weiterwreifendes Vertrocknen der prosenchrmatischen, noch teilweise dïmwandigen Splintelemente ein. Doch bleiben im allgemeinen die ratialen Holzspalten schmal, und es brämen sich nur die Wandungen der auseinanterweichenden Elemente tief.

In der Nähe der turchbrechenden Angen, bei denen also eine Markbrücke den wanzen Holzkörper rom Mark bis zur Rinde durehzieht, ist hei allen Bänmen das (iewebe weicher, die Zahl der schon dickwandigen Holzzellen geringer; es hahen sich erst die den Markstrahlen zunächst liegenten Ekmente zu Holzzellen mit stark lithtbrechender Wandung ansegebildet, während die weiter entfernt von zwei Markstrahlen befindlichen Zellformen noch dïnnwandiger und inhaltseicher sind, anch zwischen with noch keine woiten Gefätie erkennen lassen. In solehen, einem Ange nahe liegenclen splintichichten zeigt sich als Fortsetzung 
radialer sprünge bisweilen auch eine tangentiale fiewebezerklüftnng an der Grenze des vorjährigen und diesjährigen Holzes.

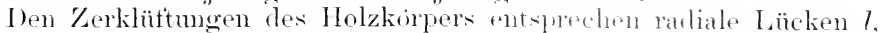
im Grewebe der sekundären Rinde $n$, während dir primärs, m. mit ilıren Hartbastbündeln $/$ keinerlei Zereitsungen, smmern mo toilwrise Brännung des Inhalts mol der Wandungen einzelner Ilarthast- mol Rindenparenchymzollen erkemen lätst $(i)$ Anch hier sutstehen dir I ücken vielfach durch Anseinanderweichen der einzehen fewolokmmlexe mol weniger durch Zerreitsen der Membranen der einzelnen Kellen. Es tremnen sich nämlich die zartwandigen \%olgruppen, welehe in tre sekmndären Rinde dem Bastparenchym der Primärrind, entsprechen, von den in ihrer Entwickhmo bereits weiter fortaesehrittenen nus deshall, dickwandigeren Rindenstrahlen, an deren Seiten die die Hart haststränge begleitenden Reihen von Zellen mit oxalsanen Kalk, $x$. in die Angen springen.

bie radialen spalten und Klüfte sind aber mu nebensächliche Exscheimmgen gegenüber der grotsen tangentialen spalte sp, wolch dio Rinde vom Holze tremt. Die Tremmoslinie verläuft nmegelmälsig bald in den noch cambialen schichten der Rinde, bald in denen des splintes. Da man ammehmen kam, dalis an allen stellen des (rewroes

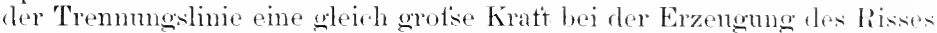
tätig war, so geht ans der Tnregelmälsigkeit dor Tremmugshinie hervor. dats das frewebe in demselben radialen Abstande rom Mittelpunkte des /weiges nieht überall dieselbe Festiglieit besitzt. Eine solehe Tnrowelmäsigkeit ist durch den auf dem splinte sit\%en gehliebenen und später abgestorbenen Gewebelappen li neben dem Ifolzvorspunge $f$ angerlentet.

Mit Ansuahme dieses Lappens finctet sich in der Ritsstelle wenig zusammengetallenes Gewebe: selbst die Zellen der jüngsten Rinde, $n$. sincl zum 'Teil zwar tief gehräunt und inhaltsarm, aber nicht zusammengesunken, sondern steif und in ihren Wandungen regen sichwefelsäm viel widerstandstahiger geworden (i).

Die Heilung solcher Wunden erfolot in der Regel nicht dur.h seitliche Überwallung. Man sieht bei ähnliehen Stellen viehmeln $z$ nächst eine streckung des älteren Rindenparenchyms in rarlialor. Richtung: suater entstehen in der Rinde zwischen den Rindenstralilen antangs isolierte Meristemherde, welche nene IIolzelemente hervorgehen lassen. Das Neuholz drängt allmählich die in diesem Falle nicht veränderten (ieweheschichten " wegen den zerklüfteten splint in

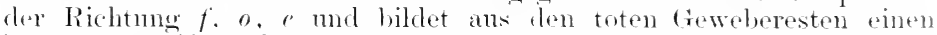
bramen streifen, der $n$ so sehmäler wirl, je mehr Holz sich äber der Rifsitelle anhäuft, also der Druck anwächst. Die isolierten Meristemzonen der in lem abgehobenen Rindenlappen ent

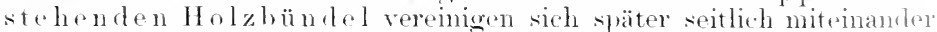
und schliefistich anch mit der cambinmzone $f$ " an der nuverletzt wr. bliobenen Zweigseite. Fine solehe durch tangentiale Abhelmug num radiale ltolzringzerlibïfung hervorgerutene Beule bleibt tïr molner. Jahre änferlich kenntlich.

\section{Offene Frostrisse.}

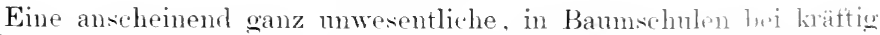
waehsenden Exemplaren an leichtesten aufzufindende Er-cheinung ist das Auftreten kleiner ïberwallter Rifstellen. Ijiesollon tretrin anch 
meist mehr oder weniger beulenartig etwas über die glatte Rinde hervor. mnterscheiden sich aber von den bisher beschriebenen Beulen dacurch, dats sie an ihrer Oberfläche eine Längsturche zeigen. Darans ergibt sich, dat's sie durch Verwachsmg von zwei lippenartig hervorgetretenen TIundrändern entstanden sind. Diese Erhebungen gleichen sich bei späterem Wachstum meist wickler ans und haben dann für das Leben der Achse keine weitere Bedentming.

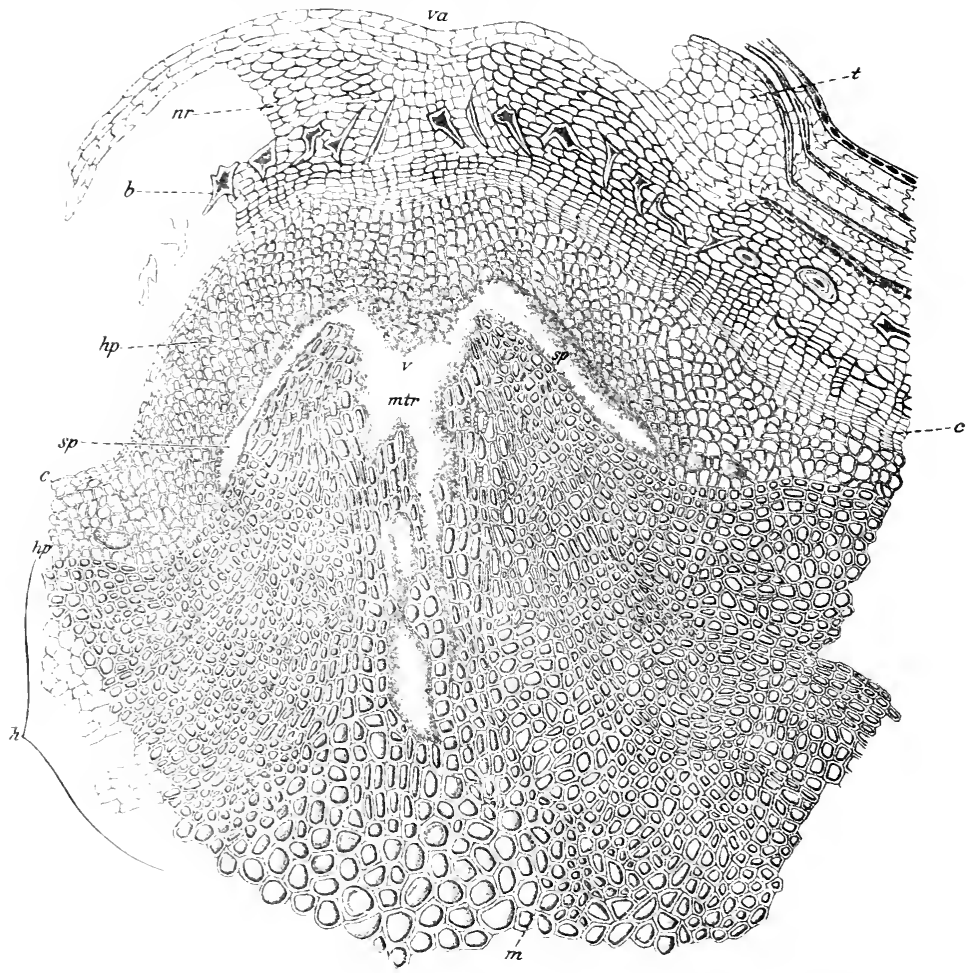

Fig. 131. Qurrechnitt durch dis Augenkissen eines Lärehenzweiges, welehes durch künstlichen Frost beschädigt worden ist. Orig.)

Aler sie erlangen eine moeneine theoretische Wiehtigkeit für die Erklärmug der Entstehmeg der als Frostkrebs später vorgeführten (x)webewncherungen. Somest meine Tntersuchungen reichen, stätzen sie die Anschanmo, dats die Gesthwölste des Frostkrebses ilren Anfang ron derartigen kloinen Rissen nehmen, die zur \%eit der ipprigsten cambialen Tätigkeit der Arhse in Frühjahr entstehen. Man findet solche Risse meist in mmittelbarer Nähe der Angen und kam mm zunäthst deren Auftreten anf lokale Kuwachssteigerung zurückführen. 
Es ist anch nicht zu leugnen, dafs dies die nächstliegende Erklärmo ist, aber der. Wumbefund in manchen Fïllen wies doch aut Frostwirkung hin.

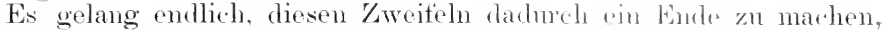
dats bei künstlichen Erfiermasversuchen solehe Frostrisse pryolt wurlen. Fig. 131 stellt das anatomische Bild einer solchen Mimele dar, div dureh die Einwirkung kïnstlicher Kälte anf einen $1^{1} 2_{2}$ Jahr altril I ärrhen-

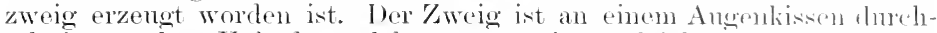
schnitten. Ilas Holz $h$, welches sonst einen gleichmäligen Ring mu las Mark m bilden wïrle, erscheint durch die hreite parenchymatische Markbriicke m-mtr unterbrochen.

Dieses (tewebe ist durch don Frost wetötet worden mul hei dem Zusammentrocknen zerrissen. Das in der Richtung v-r"l liegent. Parenchym war zur Zeit der Frostwirkung (am 18. Mai) noch niclit vorhanden, sondern der spalt der Markbrücke setzte sich dureh die Rinde nach antien fort. Letztere war in der damaligen Cambiumzone anch tangential zu beiden s'eiten des Risses rom Splint abgeplatzt mul bildete die spalte $s p$. Aber nur die unmittelbar an den W Wundränitern liegenden Zellen sind abgestorben und teilweise zusammongetrocknet. Die ursprünglich getremnt gewesenen beiden Rindenseiten ïber des spalte sy bildeten sofort in der bei allen Überwallungsvorängen sich einstellenden Weise durh Vorwölben der peripherischen, wesmolen Zellen und Teilung derselben die Anfänge von T̈Therwallmussändern. die gegeneinander hin sich immer weiter ansbildeten und in limzer /oit miteinander verschmolzen.

Die Verschmelzungsstelle der T̈̈berwallungsänder $n r$ ist an der

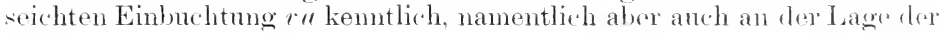
Hartbastzellen b, welche gegenemander geneigt erscheinen. I as wanze trewebe, welches die spalte deckt, ist im Lanfe von sechs Wuelun (die Wunde wude am 4. Juli motersucht) nen gobildet worlen. Die alte Rinde, welche der Frostritis gespalten hatte, ist dnch die lippenfömig hervorgewölhten Überwallmgsünder zurickgedrückt worden mul mm-

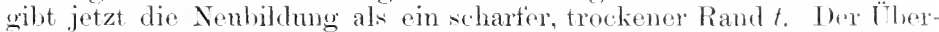
wallumgsand hat in dieser Zeit anch schon Holz gebildet; die ganze derbwandige Zone $h \prime$ ist Nenholz. Dasselbe ist aber muter pinem so geringen Rindendrucke entstanden, dats es parenchymatiseh knzzellig geworden ist. Erst später würde die Cambimmzone c-r, die dureh Vershmelzmo der in beiden Hälften isolinet gewesenen $/$ on ist, normale Holzelemente gebildet mol immer festere schichten über tie Frostwumde golagert haben.

Ämlich der Beschärligmng an drer Iärohe ist die an pinem Apter

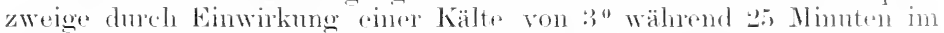

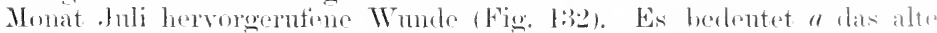

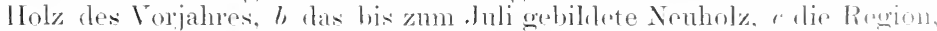

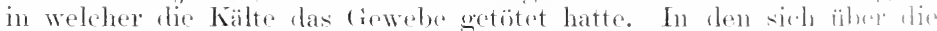

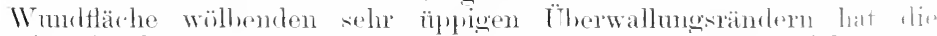

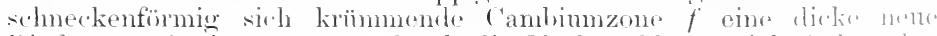

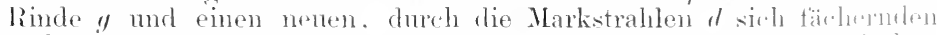

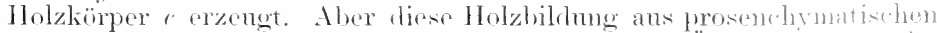

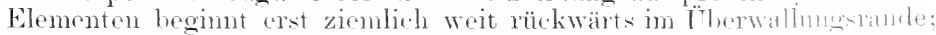
der davorliegende lippentörmige Teil dieses Rander hestrit an Parenchymholz, an dessen Peripherie sich allmählioh ainzelum fos enchymatische Vellormpen / kemntich machen. In demsellon liarlius. 
in welchem die ersten derbwandigen Iolzzellen anftreten, erscheinen in der Rinde die Anfänge von Hartbastzellen l, l.

l)ie T̈berwallmosränder treten als Buckel mit anfangs lippentiomiger spalte über die Rinde hervor. I)asselbe Bild gewähren nun natiurliche Anschwellungen, die hisweilen an Aptel-, Buchen-, Eschenund Kirschenzweigen krebsiger stämme angetroffen werden, und die ich tüir die Anfangstarlien der geschlossenen Krebsgeschwülste halte (s. Fig. 13.s im folgenden Abselmitt).

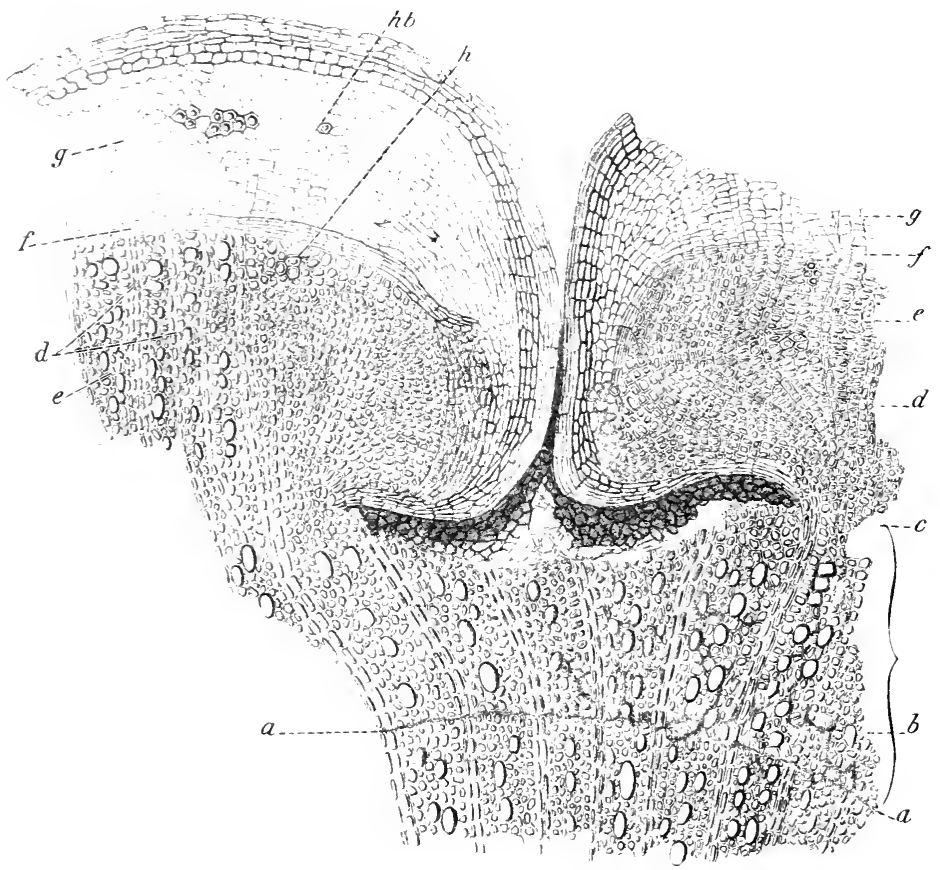

Fig. 132. Turch künstliche Kälte erzeugter Frostrifs an einem Apfelzweige.

In Utberwallung. (Orig.)

\section{Der Krebs (carcinoma).}

Als "Krols" spreche ich solche Wrunden an, deren Überwallungsränder zn wruhernden Holzgeschwïlsten sich ansbilden. Der Charakter der Wncherung liegt in der ausschliefslichen oder äberwiegenden Bildung von Parenchymlolz an stelle der normalen prosenchymatischen Holzelemente. Die Krelsceschwïlste haben für jede Gehölzart typische (testalt.

\section{a) Der Aptelkrebs.}

Der Krebs an den Apfelbäumen tritt in zwei Formen auf, von denen dic eine, länfigere sich durch eine breite zentrale, blofisliegende 
Wundläche, gebildet aus dem frei hervortretrnlen, seschwärzten Holzkörper, auszeichnet, welche von wulstigen, sehr starken, nach antisen terrassenartig alljährlich zuriicktretenden Überwallnngsän tern nmgeben wird. Im Mittelpmkte der Wunde ist hänfig der hest rines kileinen Wweigstmmptes kemntlich. Derselbe ist in Fig. 1:3:3 mit $a$ bereichnet, während der nächste Überwallungsrand durch $u^{1}$ kenutlieh eremacht worden ist. Wir sehen, wie die Wundtläche sich allmählirh veroritsert, indem der erstgebildete, noch ziemlich flache Überwallungsand alstirbt und sich schwär\%t, während der nächstjährige $1^{2}$. terrassentë̈rnio zurïcktretende zur Ausbildmug gelangt. Der Forgang wirlerholt sich von Jahr zn Jahr (s. $\|^{3}$ und $\left.n^{+}\right)$, his die Achse nahezn in ihren ganzen

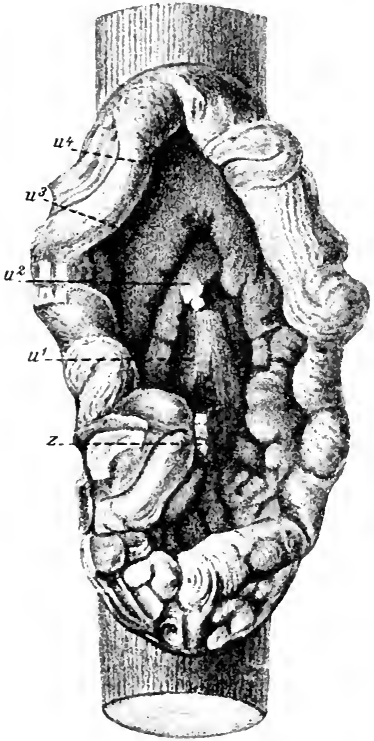

Fig. 133. Offener Apfelkrebs. (Orig.)

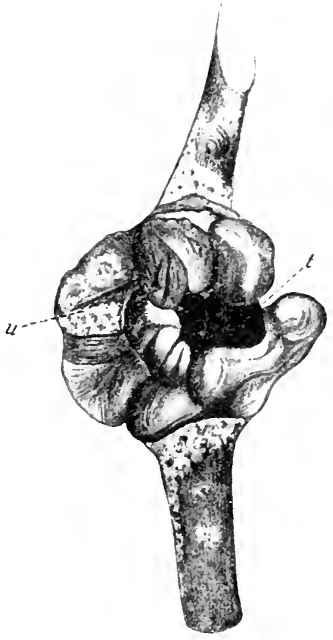

Fig. 134. Geschlossener Apfelkrehs. (Orig.)

Umfange von der Krolswnchermeg erfatist wird und abstirlst. Solvele stellen mit offenlicuenter, immer breiter werdender Wundtläche les zeichnet man als offenen Krebs.

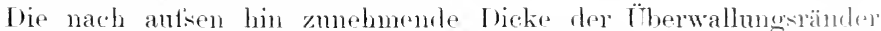
erklärt sich darlureh, dafs das von oben herablommende plastiselio Material des noch lobenden belanbten /woiges in jedem folgrmbrn

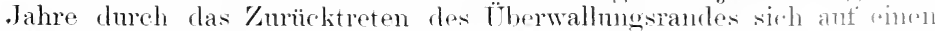
kleineren Teil des /weig-orler Stammumfanges zu verteilen hat und demgemäls die immer lï̈zer werdende Cambimmzone mit ratativ reichlicherer Nährstoffmenge zu Neubildungen versieht.

Der geschlossene Krebs (Fig. 1:34) stellt bei vollkomuenor Ansbildung annähernd eine kugelige, hisweilen den /wreigdurbmesier mu 
das I rei- bis Vierfache übersteigende, knotige, meist vollkommen berindete Holzwncherung dar $(u)$, welche an ihrem (iiphel ahgeflacht und im $\%$ entrum ter ( iipfelfläche trichterfömig vertieft ist $(t)$. Im Gegensatz zu dem offenen Krebs umfatst diese feschwnlst einen viel geringeren Teil der sic tragenden Achse, ersetzt aber die geringere Breitenausdehnm durch bedentend grötsere radiale Frholome, also grötsere Höhe.

An denselben /weigen und Ästen, an denen Krebsgeschwülste anftreten, lälst sich hänfig auch Brand konstatieren. Bei allen drei Arten von Verletzmeen trifft man in Winter nicht selten in den abgestorbenen, zerklüfteten Wundrändern die lenchtend roten lis bramen, stmmpfkegelfürmigen oder anch ovalen Kapsehn der Notria ditissima.

Macht man einen Quersehnitt durch die (roschwulst des geschlossenen Krebses, so zeigt sich nngefäh tolgendes Bild. Wir sehen (Fig. 135)

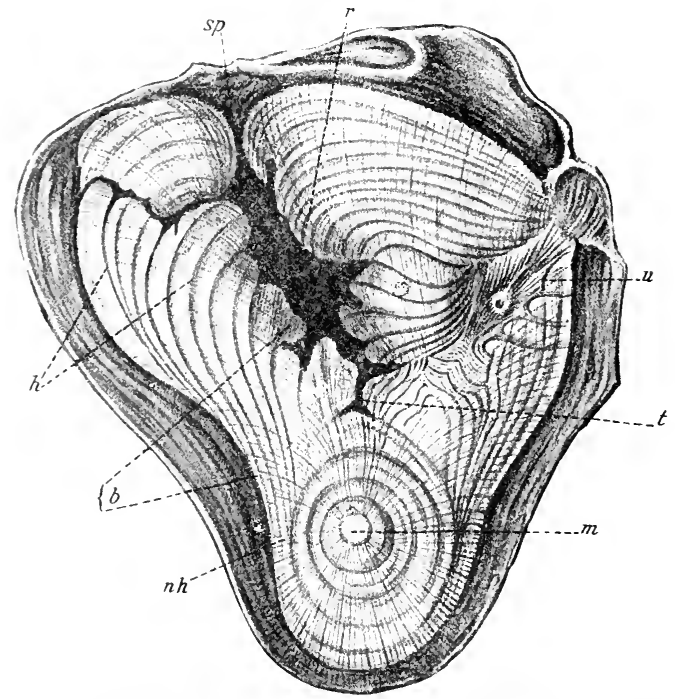

Fig. 1:5. Querschuitt durch einen Apfelzweig mit einem Knoten des merehlossenen Krebses". (Orig.)

div ganze grotise Anschwellung radial in zwei (rmplen zerliuftet durch rinen syatt (sp) mit wulstigen Rändern, der die innere Fortsetzung der anticelich erlemnharen. trichterfömigen Vertiefung am abgeflachten (iipfel ter Krebseschwntst bildet (Fig. 134 und 1\%, t). Am (irunde des spaltes lient meist ano hrame, mehlartige oder kittartige Masse, die sich als ans humifizierton Vellestem bestehend erweist. Die Ränder $(r)$ des S fraltes simel ehenfalls stark gehränt; sie werden durch bramwandige, mit totem, bramem Inhalt versohene, parenchrmatisch gestaltete, derhwandige, por̈̈se \%ollen gebildet. Je weiter man von diesen im Absterben hegriffenen spalträndern rïckwärts nach dem gesmelen Teile des stammnmfanges hin fortschreitet, desto meln verliert sich die branue Färbmo. Las fiewele wirl weits; es ist ans Parenchymholz gebildet, das anfser- 
ordentlich viel stärke besitzt. Allmählich treton (ripupen stark lichtbrechender Zellen in diesen Parenchymholzmassen ant: rlies sind bereits deutlich langoestreckte, dickwandige Holzzellen, die hisweilen verainzelt oder in kleinen (iruppen, anscheinend unregelmisig verstrent im parencliymatischen Holze erscheinen (Fig. 135, h: vernl. din in Fig. 1:32 dargestellten (Querschnitt durch einen kïnstlich erzengten Frostrits am Aptelzweige). Mit dem Autroten der ersten Itolzzellen farallel weht dis

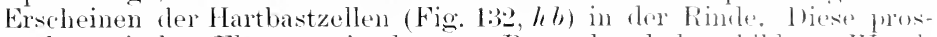
enchymatischen Elemente in dem ans Parenchymbolz sobildeten II mulrande sind die ersten Antänge normaler .Jahressinghildung nul lauten von dem Wundrande aus nach rü̈ckärts immer näher zusammen, his sie sich in einem normalen Jahresringe auf der gesunden soito rereinigt haben. Wenn wir von der normalen Jahresringzone der gesmultin Stammseite ausgehen, kömmen wir diese Bildung so anffassen, als ol, das prosenchymatische Gewebe eines gesunden Jahresringes (Fig. 1:3, " h) sich innerhalb der Krebsgeschwulst, die der Hauptmasse nath ans hirr und da grotse Kristalle von oxalsaurem Kalk fülnendem, stärkerelebem Parenchymholz besteht, in mehrere, tächerartig auseinandergohencle Äste spaltet (Fig. 135, h). (Fäeherung des Jahresringos.)

Die Wundränder selbst findet man nicht vereinigt, den syalt also trotz seiner Enge niemals ganz verwachsen, da die änlseren, den sipalt begrenzenden Zellen immer wieder absterben.

Im Verhältnis zu der ungemein üppigen Neubildung ist die Masse

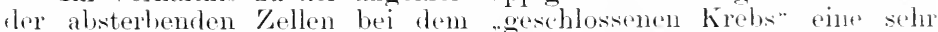
geringe; daher bildet hier die tote stelle immor nur cinen engen, gewundenen spalt, während bei drum offenen krebs" das uspriuglich getötete fiewebe eine derartio breite Fläche darstellt mol das Absterben dor Wundränder ein so weitgreifendes ist, dats nicht mu die gleich antangs abrestorbene Holzfläche moredeckt bleibt, sondern anch jerler Iitrerwallungsand dureh den folgenden nicht mehr vollhommen gedeckt wirl.

Dis charakteristische Fächerung bzw. Spaltmo eines Jahresinges (Fig. 135, wh. h) imerhalb der holzparenchymatisch(n Incherränder ist bei dem offtenen Krels minder dentlich nud kann in dem Falle vällig rorschwinden, dats der wanze, resmol webliebene Achsenteil in tre Höhe der Krebswurdr an der exorbitanten Verdickmo teilnimmt, also eine rinseitige Hryertrophie der Achse aussehliefist.

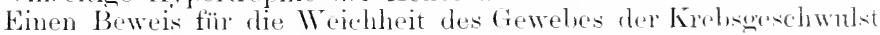
gibt die Trockensubstanzhestimmung von normalem mol krofiskinkem

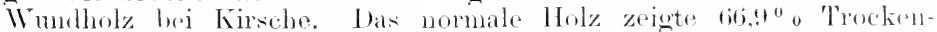
substanz, das dariblerstehende Krebsholz 11 ur $45,1^{\mathrm{o}} \%$.

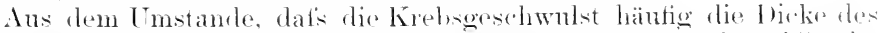

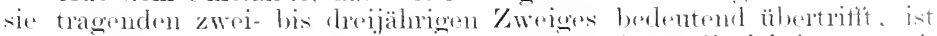

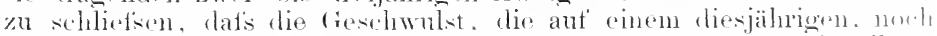

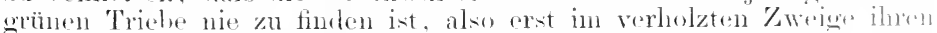

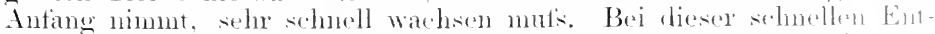

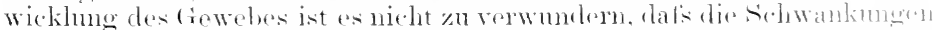

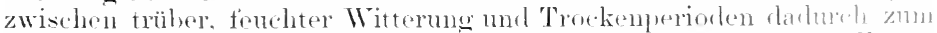

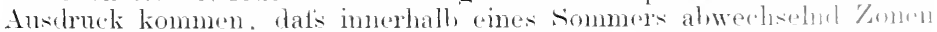

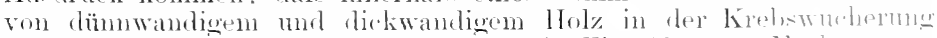
entstehen. liss sieht man. wenn man in Fig. 1:35 vom Mark m ans-

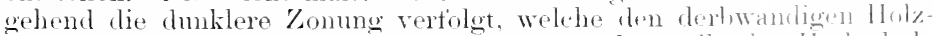

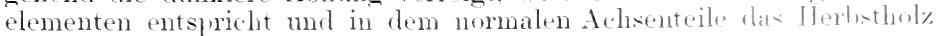


gegenüher dem reichlicheren Frïhjahrsholz, innerhalb der Krebsgeschwulst aber überhampt Prosenchym gegeniiber dem Parenchymholz antentet. Lie Figu zeigt, wie die letztgebilduten, dunklen Ringe im gesunden Teile nach dem kranken hin sich fächerartig teilen. " bedentet einen schräg angeschnittenen, abgestorbenen Ast.

Diese Üppigkeit des Wachstums,

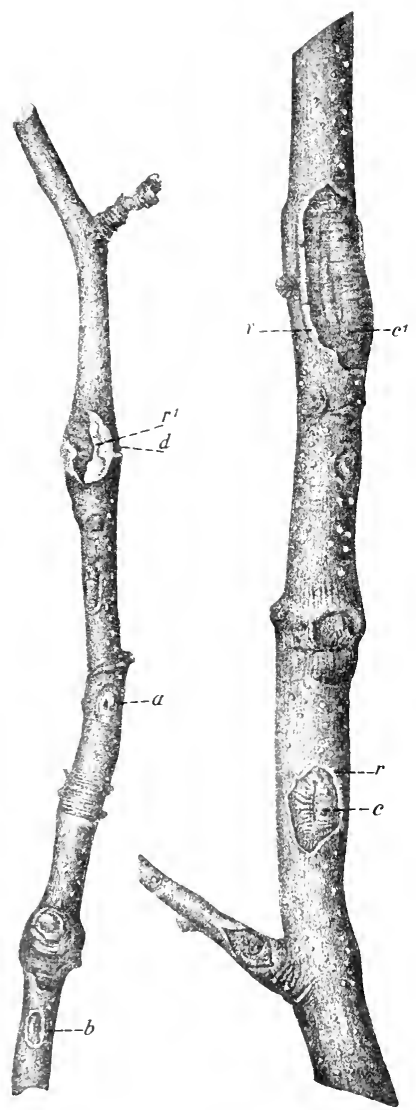

Fig. 1:36. Jugendzustände des Apfelkrehmes. (()rig) welche sich turch Bildung der getacherten Krebsgeschwulst kundgibt, dart aber durchaus nicht zu dem Schlusise fïhren, daf's das Wachstum des ganzen Baumes stets ein üppiges sei: man findet im Gegenteil bei mageren, schmachtenden Bäumen an gewissen Öthchkeiten ein regelmälsiges Auftreten von Krebsknoten.

Die krebsigen und auch brandigen Bäume zeigen meistens cine sehr iiplige Flechtenvegetation. An der zentralen Hattstelle eines solchen Flechtempolsters lälst sich oft konstatieren, dats die Korklagen des \%weiges schief aufgeblättelt sind und tie 'Thallusstränge sich dazwischen geschoben haben. Ja, ich komnte Fälle beobachten, in denen der Flechtenthallus die ganze schützende Korklage eines /weiges durchsetzte und anf den teilweise noch Chlorophyll fïhrenden, collenchymatischen Rindenzellen angelangt war. șo scharllos also, als man im allgemeinen rie welhen und granen Flechtenkolonien erklärt, diurften dieselhen nicht sein. Wie sehr aber die Ausbreitung der Flechten von einer uns noch unbekannten Beschaffenheit des

Baumes (wahrscheinlich einer grölseren Weichheit, Lockerheit und Rissinkeit der Rinde) abhängt, beweist eine Beobachtung an veredelten, älteren stämmen von Frasims. I)ie etwa I bis $1^{1 / 2} \mathrm{~m}$ hohe Unterlage erschien nur sparsam mit Flechtenpolstem bekleidet, während ler anfresetzte Edelstamm, der bisweilen schon eine 12-15,jährige Krone trug. mit Flechtenvegetation dicht ïberzogen war. Krebsitellen an alten Eschen auf nassien Boden sind in der Regel mit Fleehtempolstern ïberdeckt.

Betreffis der .Jugendzustände der Krobsstellen ist bei den Frostrissen bereits erwähnt worken, dats ich derartige kleine Rifswunden für die Ausgangspunkts ar Krebswuherungen halte. In nebenstchender 
Figur gebe ich die Abbildung zweier /weige in natürlicher Grötse, wie ich sie an einem krebskanken Aptelbaum gefmeten labe. Bei Fig. 13ti, a fintlet sich eine ovale, eingesunkene Rintenstell, in dor Näho eines

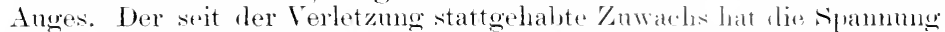
an fler toten Stelle so vernehrt, dats in der Mitte dersellum sich ein sprumg in der anfgetrockneten Rinde eingestellt hat. Bui lo selusu wir ein otwas fortgesehritteneres Stadimm: die tote Rincle in ter Mitte der Wunde wird bereits dureh seitlich hervorgetretene mul selon mitrinamer verschmolzene Überwallungsänder emporgehoben. Lis in Fin. lint,

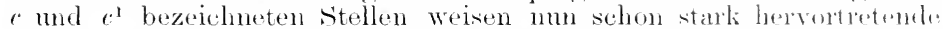
Höcker mit gleichmätsiger nener Rindenbekleidmug ant: , sins ,lic trockenen, schorfartig etwas vorspringenden Rändw dex prinniren \%wrorinde, welche dmeh den Frost anseinandergeborsten war. Hier simbl die Stellen nicht in der numittelharen Niihe des Anges: $c$ ist mitten in Internotimm nucl $r^{\prime}$ anf der entgegengesetztrn seite pines Anges. Bei Fig. 1:30, d hat die Wunde das frewcbe ring mo ein Ange erfatist. Das Auge ist gestorben und die Ungebung cingesmiken.

Die Wunclfäche ist hier sohr grots: die Rincle $r^{1}$, unter welche Intt ringutreten, ist mit ter gesmuden Ungermmg noch im /nsammenhang, mol die Nemprodultion an der Erenze der toten stelle hat eine Verbreiterume des /weiges hervorgernten, wie sie hei Brandwumlen sehr häntig ist.

Die Abhildungen des offenen sowohl als des geselolossuren Aptelloboses zeigen. datis die rirgend der Achse, in wolcher Augen oder jugendliche \%weige sitzen. zm Krebshildmen bevorzugt wird. Eine solche Bevorzugnum der Region muterhalh eines kuren /weigehens zeint die Abliblung des nelienstehenden Birnenästehens (Fig. 137). Unmittelbar mer dem limzen \%weigelsen bei a sehen wir einen tireten, hereits ïberwallten Frostrits: hei b, her Gegend les sogenamuten Astringes mit seinen kurzen Internorlien und vielen sehwachen Angen ist tic Rinle dmeh viele kleine sprönge zer-

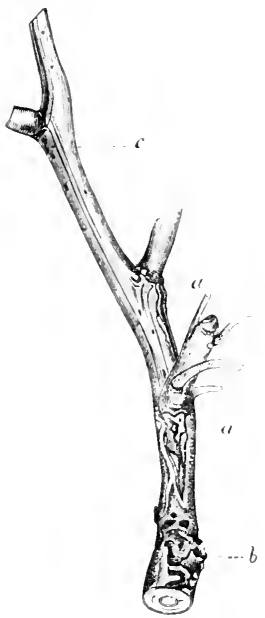

Fig. 1:3. Bevorzugumer der Z $Z$ weigbasen scitens des Frostes. (Orig.) kiätret und schmprenförnig anfuetrocknet. (ie-

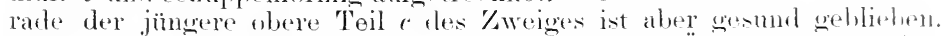
Bei solchen Rindenspalten findet nan dir stärksten Überwallungsünelen, lie manchmal einen einzigen. geschlossenen, nit gleichmätsiger Rinte bekleideten Buckel, ott abse zwei einameler herïhrende lippenfümige,

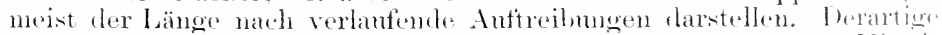
Wundränder arscheinen hisweilen faltig nach iler gewmolenen Mitialspalte, dem ehemaligen Rindenisse, hin abtallend mol almont iann die Krebswnde nach. Aber nicht immer stellen dis limelentiser.

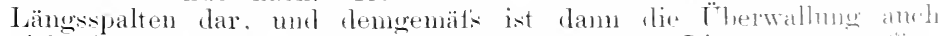
nicht in Form voll zwei wulstig antgewortenten Liplen anzutreffin.

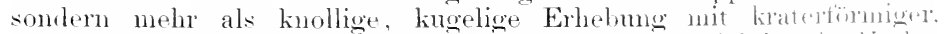

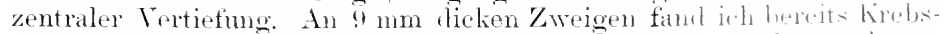

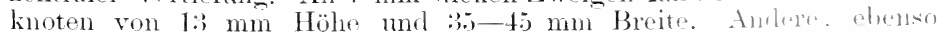


dicke, zweijährige Zweige zeigten aher anch bisweilen nur sehr schwache, schwielige, mit neuer Rinde versehene, gleichmätsig geschlossene Auftreibmgen, welche ans einem spalt ler alten Rincle herrorbrachen.

Die hier vorgeführten studien stellen fest: Jede Krebsstelle zeigt als Anfangsstadium eine Wunde, welche als schmaler radialer Rits bis auf das Cambium geht und dasselbe in geringer Ausdehmung zu beiden seiten des radialen Risses aliötet. Diese Wunde muls kurz vor oder zu einer Zeit entstanden sein, in welcher der Baum seine höchste vegetative Tätigkeit in der Achse entfaltet, da die Wundfläche sofort durch äulserst ïppige Überwallungsänder zu decken gesucht wird. Ilie Üppigkeit der Überwallungswïlste gibt sich dadurch kund. dats, namentlich bei der geschlossenen Krebstorm, rine Fächerung des Jahresringes, der rorzugsweise an seinen Randpartien aus Parenchymholz besteht, einzutreten pflegt. Hieser gelockerte Bau macht die Wunträndler äutiserst hinfällig, so dat's sie schädlichen Eingriffen mit Leichtigkeit erliegen.

Als Trache dieser Erkrankungsformen müssen wir den Frost ansehen, weil es gelungen ist, durch Einwirkung künstlicher Fröste solche Anfangsstadien zu erzengen, wie sie bei den Krebswunden gefiunden werden.

Eine Anzahl sehr zurerlässiger Beobachter hat andererseits aber festgestellt, dafs man durch Tmpfung eines Kapselpilzes, Nectria ditissima, Wunden zu erzengen imstande ist ${ }^{1}$ ), welche den Formen des oftenen Apfelkrebses vollkommen gleichen. Diese Angaben kam ich dirch eigene Tersuche bestätigen. Man hat wohl ein Recht, von einem Pilzkrebs zu sprechen, aber der genannte Parasit ist nicht imstande, eine unverletzte Achse anzugreifen; er vermag nur lann zerstörend weiter sich auszubreiten, wem er in eine Rindenwn nde gelracht wird. Darin stimmen sämtliche Impfrersuche überein. Andererseits triftit man dieselbe Nectria anf Apfelbämmen, auf Buchen und anderen Laubholzarten an, ohne dats der Pilz iroendwelche krebsige Wucherungen reranlatst. Als spezifischer Erreger von Krebsgeschwïlsten kamn er daher nicht bezeichmet werden, sondern wirl nur gelegentlich dazu Veranlassung geben, wemn ganz bestimmte Nebenmmsände gleichzeitig mitwirken. Antser dem Torhandensein einer tivischen Wundfläche ist es die spezifische Eigenart der Bammspezies bzw. der Kultursorte, welche die Fähigkeit besitzen muts, mit schmell sich anshiklenden Überwallungen von grotser Üppigkeit auf den Wundreiz zu antworten.

Dieso Fähigkeit ist so typisch, dafs man in der Praxis von ..krebs süchtigen sorten" spricht. Antserdem hat die Erfahrung aber anch gewisse Lagen und Bodenarten kemnen gelehrt, in denen die Bäume leicht krebsig werden. Es sind dies sogenannte Frostlagen, eine moorige Bodenbeschaffenheit, undurchlässiger Untergrund usw.

Dies sind feststehende Tatsachen. Wenn man num im Auge behält, dass die Nectiva ditissima unbedingt eine Wunde zur Ansiedlung brancht, so mufs man fragen. woher denn die Wunden kommen. Nach den Beobachtungen im Freien und den Ergebnissen der künstlichen Erfrierungsversuche mul's man zu der Üherzengumg gelangen, dat's die häufigste Gelegenheit die Frostbeschädigungen liefern werden. Für

1) s. Literatur im zweiten Bande dieses Handluchs, S. 209. 


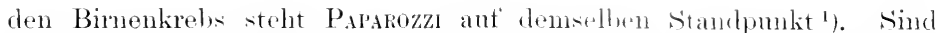
die Frostwunden flächenartig ansgobreitet. wis wir sir suater hei dem "Brand" kemen lernen werden, so siedelt sich div Nectria an, ohne dats der Baum üppige Überwallungsänder bildet. Wenn aber ('nge, his anf' das Cambinm gehende Frostrisse entstehen, mul die Nertria findet Eintritt in dieselben, dam antwortet der Bamm, falls w dureh Wittrume. Standort ofter sortencharakter dazn befähigt ist, mit der Bildmus von Krebswoherungen.

Demmach erscheint auch der Pilzkrebs im wexentlichen abhängig von den Frostbeschärligmegen, und seine Bekämptung onler Vormedimng wird äbereinstimmend mit der Frostgefahr zu hehandsh sim.

\section{b) Astwurzelkrebs bei Obst- nud Waldbä nmon.}

Als eine besondere Form des Krebses wird der wAtwnyel. krebs" genamnt, der bei Walı- und Obstbäumen eine häufige Erscheinumg ist. Er besteht darin, dat's /weige und Äste an ihrer Basis Frostwmlen zeigen, welehe in die rruple der oftenen Krebse gehören und aus verschieden grofsen, schwarzen, toten Holzflächen mit ïppigen, mroelmälsigen Überwallmosrändern gebildet werden. Gerade der Astwinkel ist bei manchen Baumarten besonders heimgesucht, mol bei den sogenamten ..\%wieseln" oder trabelungen, bei denen also der Unterschied zwischen llamit- mol Nebenachse resschwindet mol zwei gleich starke Äste von einem Punlite ans abgehen, zicht sich tic enthölste und geschwärzte Holzstelle meist an beiden Seiten in lie Höhe, mul der Ïberwallungsand wird demgemäts durch das Material beider Äste gebildet (s. Fig. 1:3). Abgesehen von den empfindlicheren, eingeführten Ilölzern sind nach NöruLriser ${ }^{2}$ ) anch msere einheimischen Walıbüme den Astwurzelschäden answesetzt, namentlieh in der. Jngrend. so z. B. die Buche in schattigen lagen mol schlechten Böden. wobei sich übrigens sehr hänfig anch die von den

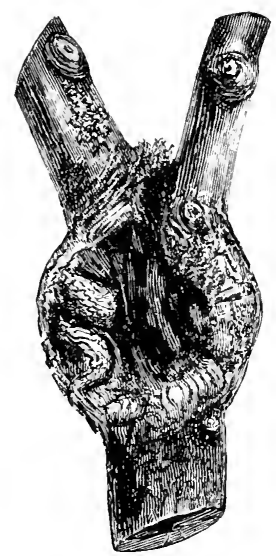

Fig. 1:38. Astwurzelkrebs. Astwrmeln entfernten Internodien mit Frostplatten berlecken: auch die jährigen Anschläge der Eichen anf mageren Bodenarten leiden, ma hei Eschen zeigt sich die Beschädigme. wemn die Bänne in Einsenkungen mit strengem Tonhoden stehen. In solchen nassen Lagen sah ich the Überwallumg antserordentlich üppig, abor durch dicke, rissige, mit Flechten überzogene Borke bis zur Tukenutlichkeit verdeckt.

Entgegengesetzt der ron IIARTu; vertretenen Ansicht, dals iro Astwurzelkrebs chuch Frühlingsföste bedingt sei, meint Nöruraviti. dat's die Fröste im Vorwinter die Trsache wären. Es stïtzt sich lalei auf die Untersuchung der Holzringe und auf den Umstame dat's der Astwurzellirebs in Tausenden von Fällen hoch in ter Krone und in

1) Paparuzzi, G., Il cancro del pero. Roma, Offizina poligrafica: cit Bot. Centralbl. 1904, Bd. XXVIII, s. 94.

2) Die Septemberfröste 1877 und der Astwurzelschaden (Astwurzelkrebs) an Bäumen. Centralbl. f. das ges. Forstwesen. Wien 1>78, Heft 10. 
schattigen, also den Frühjahrsfrösten weniger unterworfenen Lagen so liäufie ist.

Dat's die Astbasen ganz besonder's frostempfindlich sind, erklärt sich ans dem Umstande, dafs wegen der dort ursprünglich angelegten grötiseren Anzahl von Knospen mehr prarenchymatische den Holzring durchquerende Markbrücken vorhanden sind. Das parenchymatische Holz ist aber weicher und stärkereicher. Diesem Umstande ist anch zuzuselureiben, dafs Borkenkäfer sich gern an Astwurzeh ansiedehn, und daf's Waldmäuse, wie NörulıNike angibt, bei Pappelabsprüngen (Popmlns monilifra) häufig nur die Basis der seitenzweige befressen. Der Frost, anch der Frühjahrsfrost, tötet also am leichtesten die Kweiglasen.

Bei alten, schwachwüchsigen Stämmen vermindert sich die Üppigkeit des Überwallungsrandes bedeutend, und sie kam in der Weise herabsinken, dafs wir üherhaupt nur schmalringige, langsam unter die tote Rincle sich hinschiebende Überwallmgsränder des Brandes erhalten, mit dem der Astwurzelscharlen als offener Krels darin iibereinstimmt, dat's die erste Anlage kein spalt, sondern eine einsinkende, auftrocknende, tote Rindenfläche ist. Paher der bei manchen Praktikern geläufige Anstruck "Zwiesellirand".

\section{c) Der Kirschenkrebs.}

An süfskirschen zeigen sich meist hallseitig tomenförmige Auftreibungen der Zweige oder älteren Äste. Die Rüickseite der oft mehr als fanstdieken Anschwellungen erscheint nicht selten brandig eingesmlien, wobei die tote Rinde von dem geschwärzten Holzkörper abgeplatzt und teilweise abgeblättert ist, teils aber anch in gröfseren Platten mit aufwärts gerollten Rändern noch festsitzt (s. Fig. 139).

I) tonnenförmige Zweiggeschwulst stellt sich als eine abnorme Ausbildung von Ïberwallungsräudern (" und $u^{\prime}$ ) einer sich nicht gänzlich sehliefsenten Wunde (sp) dar, wie dies bei dem geschlossenen Ap,felkrebs" ebenfalls gefunden wird. Bei diesem ist aber das Überwallungsgewebe cine plitzliche. in mugemeiner Üppigkeit auftretende Erweiterung des Jahresringes, während bei der Kirsche die Anschwellung der normalen Zwrigseite zum wuchernden Überwallungsrande einen alhnählichen Übergang erkemnen lätist. Daher stellt sich der geschlossene Apfelkrebs als Knoten, der vollkommen ausgebildete Kirschenkrebs als sant ansteigende tomnenförmige Verdickung dar. Neben dieser typischen Form findet man die verschiedenen T̈bergänge einerseits bis zum geschlosienen Krebsknoten, andererseits bis zu den Flachwunden, welche als Brand von uns bezeichnet werden.

Bei älteren Zweigen lirebsliranker Bäume erkennt man bisweilen an ihrer Basis kegeltörmige Anschwellungen, die alle Ïbergangsformen bis zur typischen Krelsgeschwulst biefen kömnen. Hie Anfangsstadien zeigen sich an einer Tweigseite in Form einer kleinen Frostwunde am rrsten Jahresringe. Was hier hesonders hervorgehoben zu werden verdient, ist, daf's man las enorme Überwallmuggewebe oft von einer Markbrücke aus sich entwiekeln sieht. Dies weist also anf eine direkte Beschädigmo riner Knospe hin. I ie Ausbildung der Überwallungsänder setzt sich in den nächsten Jahren fort, wobei stets nur Parenchymholz angelegt wird, in welehem sich schnell und reichlich stärke ahlagert. Wem die Krelsgeschwulst einen gröfseren Unfang 
erreicht hat, stirbt in der Regel oberhall, dersellun der Ast ab, wobei stromabilılende Pilze (meist aus der Familis dre Valseen), die in Form kleiner Wärzchen hervortreten, reichlich mitwirken.

Wem man jugendliche (ein- und zweijährige) \%wwige lirebskanker Bäumo durchmustert, findet man hrandartige, oft mehrere c'entimeter lange stellen, an denen statt der einzehen Angen lippige T̈brewallmgen sich zeigen, währenel an den daröber mol darmorre befindlehen \%weigteilen die Augen sich zu kurzen Trieben entwickelt haten. Inrans geht hervor, daf's die Beschädigmo des Kweiges vor drm Anstreilien der Augen erfolgt sein muts.

Da man aber in dem .Jahre, in welchem der \%weig gebildet wirk, keinerlei Beschädigung wahruehmen kann, solche jedoch im näehsten Frühjahr gefunden wird, so muf's sie im Winter oder Frühjahrsanfang entstanden sein. Es ist also das Nächstliegende, zu vermuten, dat's das sich zum Austreiben äflinencle Ango vom froste getötet wirl und num das gehäufte plastische Material zur Bildung wochernder WVundränder Verwendmog findet. Da das (iewebe dieser Überwallungsänder parenchymatiseh weich bleibt mel fast stets vollgeptiopft mit Starlie gefmelen wirl, so ist es erklärlich, dats es im folgenden Winter der Frostbeschäligmeg an seinen Rändern shr leicht wliegrt und aus den gestund bleibenden tiefer liegenden Zonen nene Wneherungen produziert.

Der ganze Vorgang wird bei Betrachtung der Querschnittfläche von Fig. 139 deutlieh. Man bemerkt hier, dats die /erklüttung der Achse in kurzer Entfernumg vom Markkörper (mi), und zwar in zweiten. Jahresinge begonnen hat. Der dritte Jahresring hat schon ïppige Überwallungsränd(r. (f) geliefert, die im folgenden .Jahre wiederum zerklüftet sind $\left(s p^{\prime}\right)$. Diese sekundären spalten veranlassen sekundäre Überwallungen ( $\left.f^{\prime}\right)$. I) ie tonnentörmige Krebs-

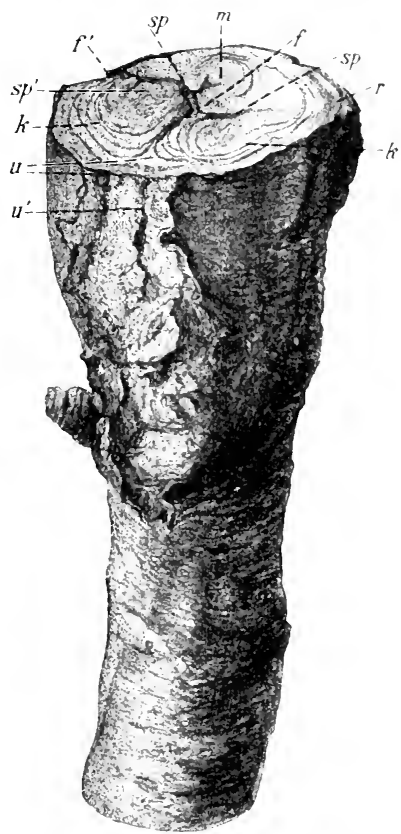

Fig. 139. Kirschenkrebs. Frostspalt mit Überwallungsrändern in Längsansicht und Querschnitt. (Orig.) anschwellung aber wird hamptsächlich dureh die wethemelen Wruetränder des Hauptspaltes geliefert, die in facherfömiger roume (li) autreten. Es teilt sich somit ain Jahresing imerhalh der Krebsgesehwnlst in mehrere, wie bei dem gesehlossenen Apfelkrehs. 1) nentsprechend wuchert anch der Rindenkörper $(r)$ mol bildet stellonwaises dicke Borkenschuppen ans.

Wie bei allen Krobserkanknngen, findet man aneh bei dem Kirschen-

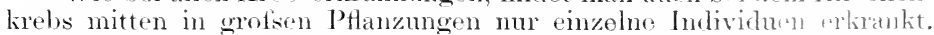
Bei diesen krebsï̈.htigen Exemplaren tand ich in gesmeton Trielwn vielfach abnorm verbreiterte Markstrahlen, eine Erscheinmo, die anch bei 
anderen Bammarten zu beobachten ist. Ich habe daher die Vermutung, dat's die Anlage zur Krebssüchtiglieit in der individuellen Neigung mu Mastrahlerweiterungenzu suchen ist.

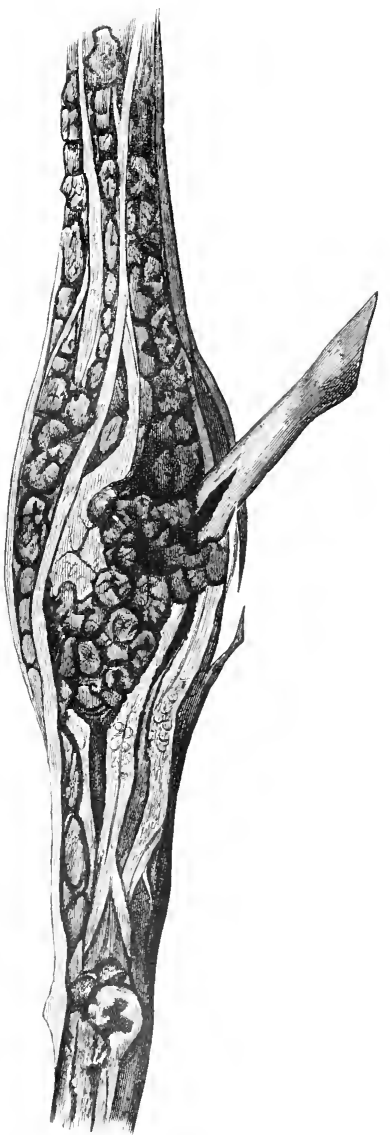

Fig. 140. Krebswucherungen an der Weinrehe.

\section{d) Der Krels (Grind) des Weinstoekes.}

An älterem Rebholze sieht man in der Nähe des Erdbodens, ungefähr 10 bis s) cm ron der Bodenebene entfernt, einzelne kleine, kugelige oder grofse, tonnenförmige Holzautreibungen von perlartig muregehmäfsiger (Oberfläehe aus der der Länge nach faserig zerschlitzenden Rinde hervortreten. Fig. 140 zeigt zwischen den weils gezeichneten Rindenstreifen die perlartigen Krebsgeschwiilste. Bei kleinen, isolierten Wncherungen erkennt man dentlich, nach (†öTHE's Untersuchnugen ${ }^{1}$ ), ihre Entstehmng als Überwallungsgewebe von längsverlaufenden Holzspalten. Es erscheinen die spalten an der Grenze eines Jahresringes, so dats darans geschlossen werden muts, sie seien zur Zeit der beginnenden Bildung des nenen .Jahresringes durch stellenweises Abtöten der Cambimmzone im Frühjahr entstanden. Betreffs der Entstehung der Wucherungen habe ich einige abweichende eigene Beobachtungen bei der folgenden Krankheit, dem spiraeenkrebs, niedergelegt.

Die Beschädigmo, welche das Cambium getötet, hat aneh den alten $\mathrm{Holz}$ körper in einem grötseren Kreisa usseln uit tief gebräunt. Die von den gesunden Stellen her oingeleitete ÏTberwallung, welche die Spalten manchmal schnell schliefist, zeichnet sich durch wuchernde Üprigkeit des Holz- und Rinclenkörpers aus. Die sich regensinander vorwölbenden Holzränder bestehen aus weichem, gefätslosem Parenchymholz ohne eigentliche prosenchymatische Elemente, zeigen also den charakteristischen Ban des wuchernden Wundholzes. Wemu die Überwallungsränter sich zn einem zusammenhängenden J aluresringe wioder vereinigt haben, wächst derselbe in der Weise weiter, datis er sich aurh wieder durch Markstrahlen fächert, und zwar bilden diese Markstrahlen in ihrer Richtung die Fortsetzung derjenigen des

1) Mitteilungen über den schwarzen Brenner und den Grind der Reben. Berlin unil Leipzig, H. Foigt, 1878 , s. 28 ff. 
vorjähigen Holzes: dasselbe hat also durth las hrame, getötete Gewebr nur eine vorïhergehende Unterbrohnus prlitten.

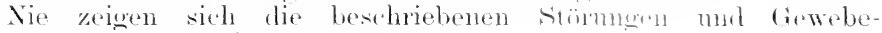
wotherungen am diesjährigen Holze.

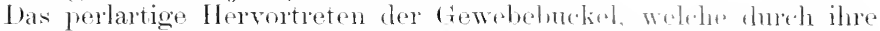

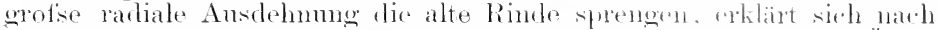

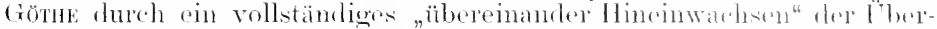
wallungswïlste, die am ïppiosten an denjongen liolstellon siels vor-

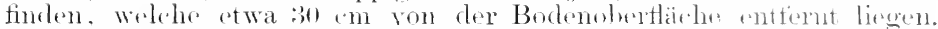
Ton da ab sieht man in der Regel sowohl nateh oben als nateh der

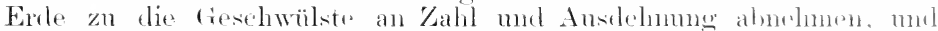

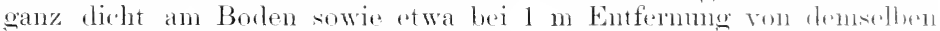
sind sie nur nech selten zu fincten. Bei geringer Fntwielilung dex

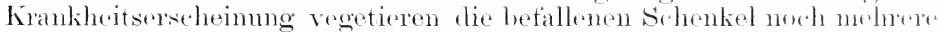
. Jahre und kömnen auch noch Thagholz produzieren. Bei stäkeres Entwiekhmg der Krebsqeschwïlste stirbt das Ilolz olerhall, derselber ab.

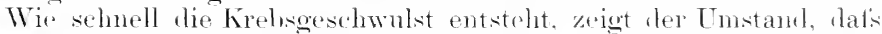
man einmal am 8. Angust stëek gefumten hat, hei denen das Ver-

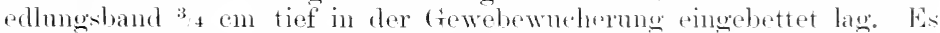

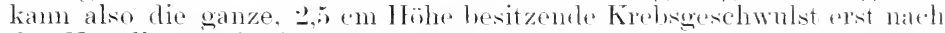
der Verellungseit (im Mai) entstanden sein, la man nicht ammelmmen

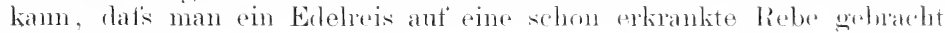
haben wird.

l)ats die Beschädionngen des ('amhimmringes im Frïhjahl statt-

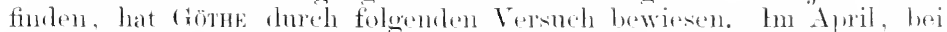

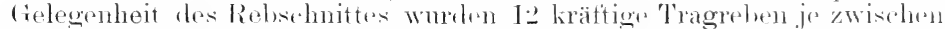

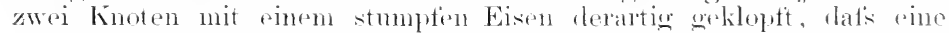

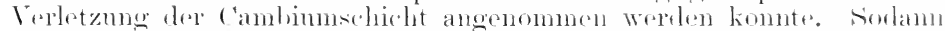

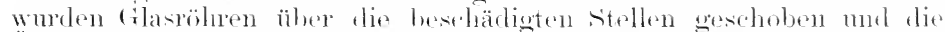

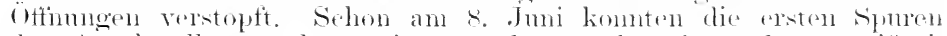
der Anschwellnugen konstatiert werden. während an den sperifisels

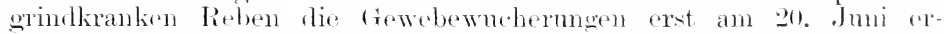

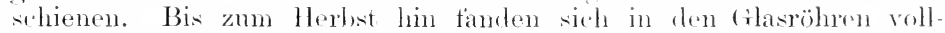
kommen normale frinderseheinmogen ein, dis anth tenselben anatomiselien Ban wie die natülich gebildeten Wueheränder zeigten.

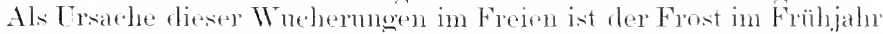
anzusehen. Es sprechen datïr tie meisten literatmangaben, welche sin Anftroten des Weinkrebses nach Fröhjahrsfösten konstationen.

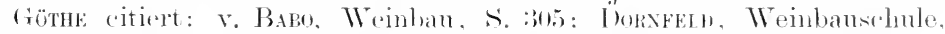

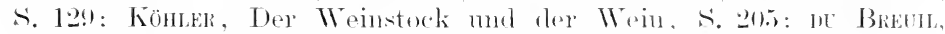
Les Vignohles. Ferner spricht fïr diese Amahme die Erfalmum,

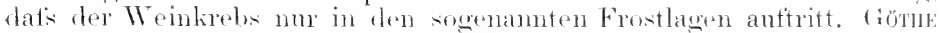

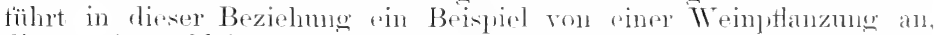
dic an einem kleinen Alhange herann, sich domeh eine Mnlde linzon

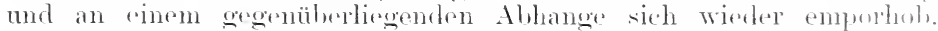

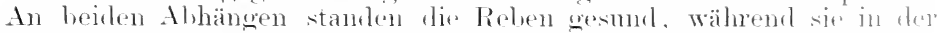
Mulde vom Krels betallen ersehienen. Bei piner weiteren Pritinn sall der Beobachter anch noch an 20 anderen Rebsö̈ken, die in Bodentiefen standen, dats Erkrankung anfgetreten war.

Die Tatsache, dat's der Weinkrebs in bestimmter lliblu and dor

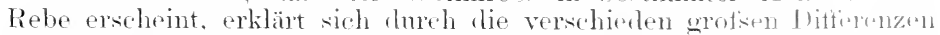
zwisthen Wämemaximum und -minimum, denen die Rel, in ihn's verschiedenen Höhen zur Zeit der Frühjahrsfröste vieltach an-grestzt ist. 
Bodenentwässerung dürfte sich als das wirksamste Mittel erweisen. Gimstige Resultate davon meldet bereits KöHLer in seinem vorerwälnten Werke. Thaneken wird man vorzugsweise ant die Anpflanzung härterer Sorten Berlacht zu nchmen haben und namentlich richtige TVeinlagen (mätsig teuchte, lockere und warme Bodenlagen) zur Anpflanzung auswählen müssen.

Dats der Grind anch ohne Frostwirkung, lediglich durch Stanung des plastischen Materials entstehem kamn, wie BLankenhorn und MühtHïuser infolge eines zu kurzen sichnittes beobachtet haben wollen (s. Wïrzburger Weinbaukongrets) ist nicht unglaublich. Sicher ist, dats die in Form von Markstrahlwuchernugen sich zeigenden Anfänge der Geschwülste an Reben anftreten können, bei denen im Frühjahr eine stellenweise Abhobung der Rinde vom vorjährigen Holz stattgefunden hat. Solche krebsartigen Wucherungen mögen, wie gesagt, ohne Frostbeschädigung sich ausbilden können, ebenso wie man bei üppigen Kernobstsorten krebsartig wuchernde Überwallungsränder findet; allein es fehlt in diesen Fälen die tiefgehende Bräunung des Holzkörpers.

\section{c) Krebs an Spiraea.}

Eine von anderer Seite noch nicht beschriebene, mit dem Weinkrebs grotse Verwandtschatt zeigende Krankheitserscheinmo existiert an ten Stengelbasen von Spiran opulifolia. Die Krankheit scheint nur in Gegenden mit sehr kalten Wintern luänfiger vorzukommen; mein Beobachtungsmaterial stammte aus Ostpreutsen.

Älteres, mindestens zweijähriges Holz mit starken .Jahresringen zeigt an der Basis antiserordentlich zahlreiche, isolierte oder perlartio aneinandergereihte oder anch gehäutte, weiche, halbkugelige Holzanschwellungen (Fig. $1+1 \mathrm{~A}, \mathrm{l}, \mathrm{k}_{\mathrm{i}}$ ), deren (iröke von wenigen Millimetern bis zu 1,5 and $2 \mathrm{~cm}$ Durchmesser schwankt. Die Anschwellungen sind gebräunt, dunkler als die von ihnen durchbrochenen, Hatternd sich ablösenden, äutseren Rindenlagen, manchmal zerklüftet oder in der Mitte trichterförmig vertieft und mit gnob chagrinierter, rissiger Oberfläche versehen. Eine Rindenlage ist nicht abhebbar, da die Substanz der (Geschwulst bröckelig ist und in stücken leicht ausbricht.

Bei dem Zerschneiden einer gröfseren Geschwulst oder, wie man mit aller Berochtigung sagen kann, eines Krebsknotens, sieht man, dats Lamellen festeren Gewebes fächerartig ron einer mehr oler weniger breiten Basis ansstrahlen; jedoch sind die Lamellen weder durch die ganze Breite sines Krebsknotens gehend, noch anch scharf von dem zunderartig mürben, dunkleren Grundgewebe getrennt. I)ieses selbst ist als ein nach der Peripherie hin immer weicher werdende, wucheruda Fortsetzung des letzten Jahresinges anzusehen.

In Fig. 141 l; welche den Quersehnitt des Krebsknotens $k$ von Fig. 141 A darstellt, liedentet m den Markkörper, a den mverletzten Jahresring des ersten. b den gespaltenen des zweiten Jahres, $c$ das zur Krebsaeschwulst $l_{i}$ answuchemde Holz des dritten Jahres; $i$ sind die festeren frewbeinsoln und streifen in der zunderartig mürben Grundsubstanz.

In den bisher zur Beobachtung gelangten Fällen erwies sich der Krebsknoten seiner Hauptmasse nach als die Produktion eines einzigen Jahres, und zwar als eine einseitige Holzwuchermo über einer stelle, welche schon in vorhergehenden Jahre eine keilförmig nach imnen 


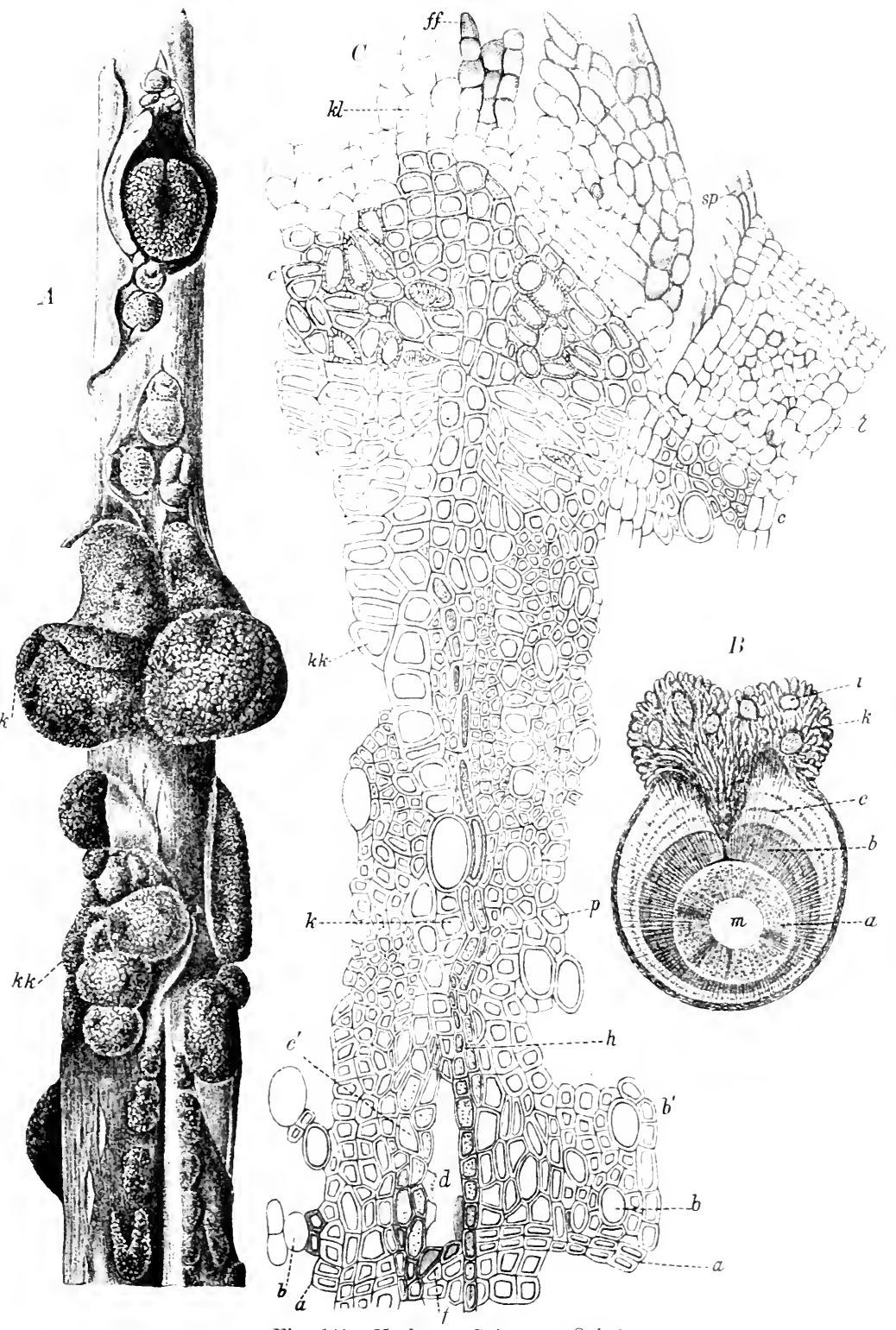

Fig. 1+1. Krebs an Spiraea. (Orig.) 
zunspitzte \%one von gelockertem, parenehrmatischem Holzgewebe wobildet hatte. Insofern gehören allerdings zwei Jahre zur vollkommenen Herstellung des Krebsknotens. Verfolgt man rlie erwähnte, keiltörmige Zone tes Torjahres rückwärts, bis auf den vorhergehenden Jahresring, so wieht man, dats sie ihren Ursprung von einer gebrännten, schmalen Stelle in ersten Frühlingsholze nimmt.

Das beigegebene anatomische Bild, Fig. $1+1 \mathrm{C}$, wird die Darstellung erleichtern. Die ganze Fig. (' ist ler radiale Ausschnitt aus dem zweiten Jahresringe eines śpiraeastengels und enthält die die eigentliche Krehigeschwulst vorbereitende Gewebezone. Die Linie $f$ bis $f f^{\prime}$ stellt don streiten reränderten Gewebes lar, welcher bei seiner Weiterentwicklung im tolgenden .Jahre zum vollkommenen Krebsknoten geworden wäre. Das Gewebe nnterhalb a dentet das Herbstholz des ersten Jahresringes an. Im Holzlïrper dieses ersten Jahresinges ist nie eine störung beobachtet worden, gradeso wie bei dem Weinkrebs der erste Jahresing ebenfalls ganz normal gebant ist. Das Holz des zweiten Jahresringes b fing zunächst auch mit normaler Entwicklung an und setzte sich in derselben Weise bis $b^{\prime}$ fort.

Zn dieser Zeit kam eine störumg, welehe den spalt d erzengte und dessen Ränder $c$ häunte. Die Entstehungszeit dieses Spaltes mul's die der kräftigsten Neubildung gewesen sein; denn schon wenige Zellreihen später, bei $h$, sehen wir den Spalt geschlossen und den Jahresring unter Bildung von Gruppen normaler Prosenchymelemente $p$ weiter wathsen. Nu eine einzige Zelheihe $l$ bildet einen radialen Streifen aus kürzeren, weithmigeren Holzzellen. Anstatt dafis nun mit dem Älterwerden des Jahresinges und dessen zunehmender Dicke sich der abnorme Holzstreifen verlieren sollte, nimmt derselbe an Breite zu, indem immer mehr Zellen an der veränderten Banart teilnehmen lil. So schreitet die Störung bis zum Abschluts des zweiten Jahresringes fort und beginnt in rerstärktem Mafse in der Frühlingszone des dritten Jahresinges $c-c$.

Schon bei Abschhutis des zweiten .Jahresringes sieht man den Streifen der Krebsanfanges als schwachen Hügel über die Peripherie des übrigen Holzringes hervoragen. Im Frühjahr des dritten .Jahres ist die Nenbildung an dieser Stelle eine so üppige, dafs der schnell anwachsende, durch eine ebenso wuchernde Rindempartie lil verstärkte Krelsknoten die normale Rinde $r$ durchbricht (bei $s p$ ) und num als gleichsam fremdes ( als tertiger 1-2 em hoher Krebsknoten sein Wachstum zu beschlietisen.

Bei dem Woinkrebs zeigen sich ähliche Bildungen. Nu habe ich lisher refunclen, dafs die zu Anfang des zweiten Jahres sich einstellende sitörmg, der Lütke $d$ entsprechend, in einer breiteren, tangentialen Abhebung von ringtörmiger Gestalt bestelit. Es macht den Eindruck, als ob bei Begimn der Vegetationsperiode die Rinde rom Holzkörper ant eine grötsere Strecke hin abgehoben worden sei. Meine vielfachen Versuche mit künstlichen Frösten zeigen, daf's dieser Torgang tatsächlich eintroten kann und sogar bei den verschiedenen (Fehölzen ziemlich häufig anzutreffen ist. Infolge dieser Abhebung entsteht hei dem Wein meist an der Stelle, wo bei Spiraea die schmale racliale spalte sich befindut, eine tangentiale Lücke. Die abgehobene Rinde bildet zunächst Holzparenchrm, und dieser weiche Holzkörper geht ganz allmählich in Laufe dos tolgenden sommers in normales Holz über. Hier wind es aber einzehne der breiten Markstrahlen über 
der abgehoben gewesenen stelle, welche eine hevorzunte Entwicklung zeigen und am Ende des Jahres als weiche (inwehelinfmen vorpringen.

Bei Wein wie bei spiraea müssen es also hri lur Krobshildung nicht notwendigerwoise Ubberwallnugsänder sein, wis dies bei dem Aptelkrebs stets der Fall ist; bei ersteren kömm violmelu unverletzt

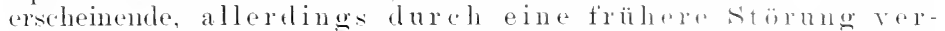
anlafiste fiewebepolster eines parenchymatisch wowolomen Holzkörpers zu Krebsknoten sich ausbilden. Damit erkiait sich die rom

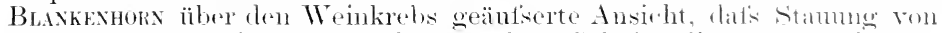
plastischem Material (z. B. nach zu starkem Sehnitt) die Krehsueschumbt veranlassen kitnn.

Die Bildung der Krebseschwulst erleidet insofern manthmal eine Modifikation, als die schon im ersten Jahre der Vorbereitmo entstandenen Krebspolster durch den Frost teilweise getötet werden; es loilet dam die zentrale, weichste Partie, die nun einen schwarzen, vertrockneten Kern darstellt. Im folgenden Frühjahr wachsen tlann nur die Randpartien nach Art der ÏTberwallumgsänder wuchernd weiter und umkleiden einen spalt, wie er in Fig. 141 l dargestellt ist. E- ist wesagt worden, dats die Randpartien des angehenden Krebsknotens .nach Art" der Überwallumgsänder fortwachsen; wirkliche T̈therwallungsiänder mit schneckenförmig äbergebogenen Rändern sind nu selten zu finden (auch hei rlem WVeinkrebs).

Wie Fig. 14l IB zeigt, geht der Ilolzring des dritten Jahres mmerklich in die Krebseschwulst ïher. Tatsächlich ist also der Krehsknoten rine Holzbildung: aher dieses llolz ist bei der enornen schuelligkeit der Gewobebilitung ein so weiches, lem ebenfalls wuchornden und von antien her leicht absterbenden Rindengewebe so änliches (iebilde, dats es manchmal schwer fällt, die (xrenzo zu finten. Dieses lockere, mir in solcher Weichleit nur noch bei dem Rosenkrebs vorgekommene Holz bildet in der fertigen abgestorbenen freschwnlst die brame. zunderartige Grundmasse, von der anfangs die Rerle war: die festeren, helleren Teile sind die an der Peripherie an Breite und stärk zmmehmenden Inseln von dickwandigen Holzzellen mul Gefätisen (Fig. 141 B, i). Bei Krebsknoten von verschied ner Stärke finden sich dio Gefäfsoruppen i bald in Form keilförmiger, nach antien dickerwerdenter Lamellen. bald (wie in Fig. $141 B$ ) in Form kugeliger Gruppen mit schalenförmiger Anordnung ihrer Elemente. Die Gruppen verschmelzen nicht selten miteinander and bodingen auf diese Weise cine wrösere Festigkeit: aber ein zusammenschlietsender Holzring ist nie beobachtet worden. Diese isolierten Prosenchym- unt Gefätsentupen sint es, wolche bei tem Zersehneiden dem Messer einen so grotsen Widerstand entgegensetzen, dats sie sich schon aus dem Verbande mit dem iibrigen

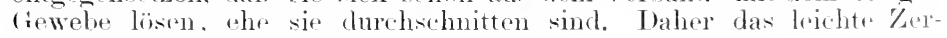
bröckehn des trocknen Krolisknotens.

\section{f) Der Rosenkrebs.}

Durch die Kultur der neneren Rankrosen, die (nach ('kérx-Brïstel) ans einer Kreuzung von Rosa indica $\times$ multiflora hervorgegangens sind und als Polyantha-Arten bezeichnet werden, sinel wir mit aner Elscheinung bekannt geworden, welche in das Gebiet der Krelswnelwangen

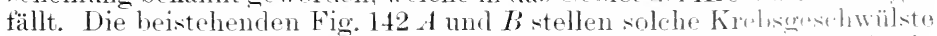
dar, wie sie an der Basis der starken Stämme von Crmmson linmblor in 
Dentschland aufgefunden worden sind. Ihr Auftreten am unteren Teile dieser hekanntlich auch bei uns änfserst ïjpig wachsenden Rosenstämme erimert an die gleichen Vorkommnisse bei lem Weinkrebs. Wie bei allon Krebsbildungen finden wir auch hier diejenige Region der Achse levorzugt, an welcher Zweige $(A, \|)$ entspringen, und an diesen selbst die Basis stark verdickt oder in gekrösartigen Wucherungen anfgebrochen $(b, \ddot{\prime} b)$. Yor Erklärung dieser Erscheinung tlarf man sich nur
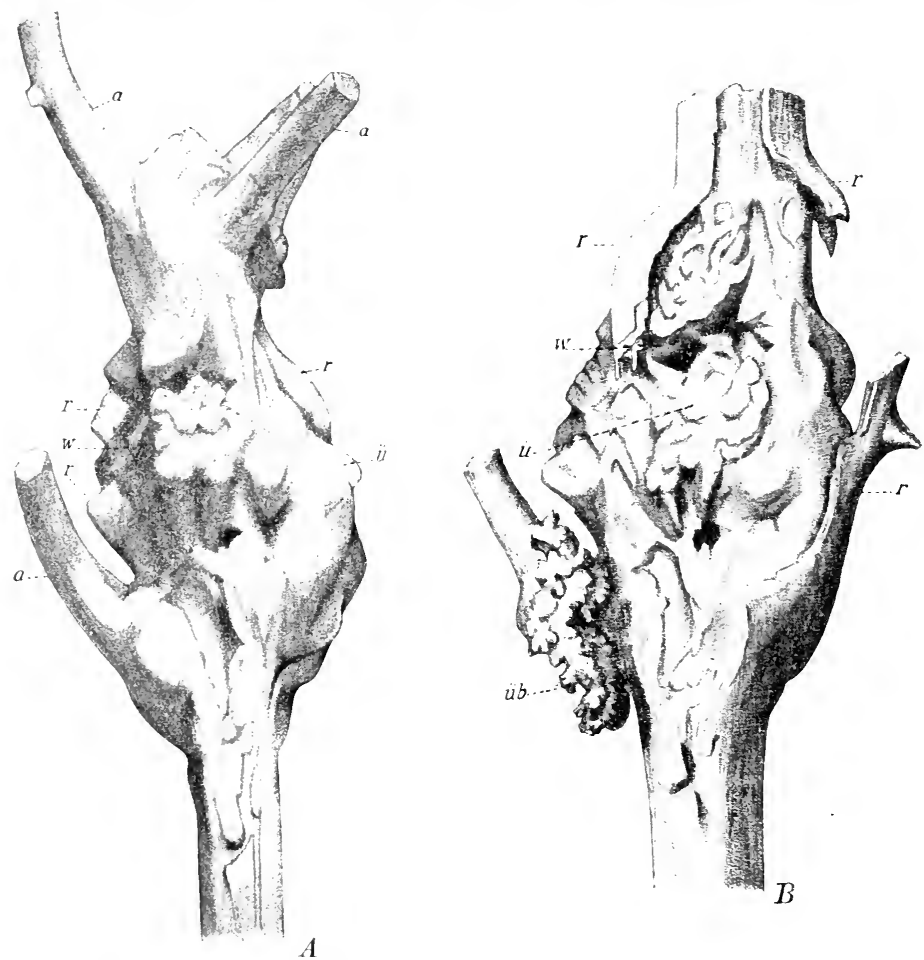

Fig. 142. Rosenkrebs. (Orig.) Man erkennt terrassenförmig nach aufsen ansteigende konzentrische Uberwallungsränder um eine zentrale tote Holzfläche.

daran erimnern, datis an jeder Stelle der normalen Achse, von welcher ein \%weig abgeht, for Holzring gelockert und für Störungen besonders empfindlich ist. Dem der Markkïrper erweitert sich an den Zweigansatzstellen zu einer den Holzring quer durchsetzenden Markbrücke, die in die Seitenzweige abgeht. An jedem sich entwickelnden Aste stehen die Augen an der Basis am engsten beieinander; sie sind zwar oftmals wenig ansgebildet, weil anch dic Blätter noch schuppenförmig oder doch mvollkommen sind, alser die parenchymatischen Markbrïcken, welche den Holzring durehqueren, sind vorhanden. 
bie Komstelle an der Hanptachse läst in voldegenden Falle wie

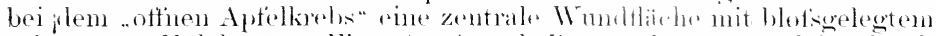

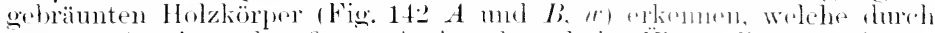

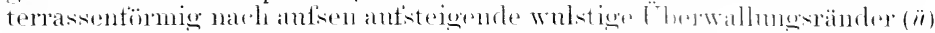

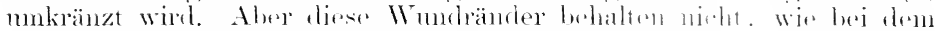

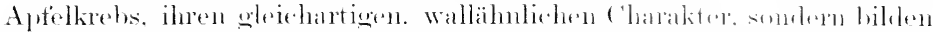

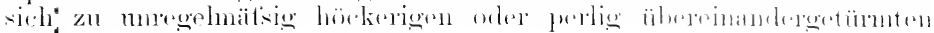

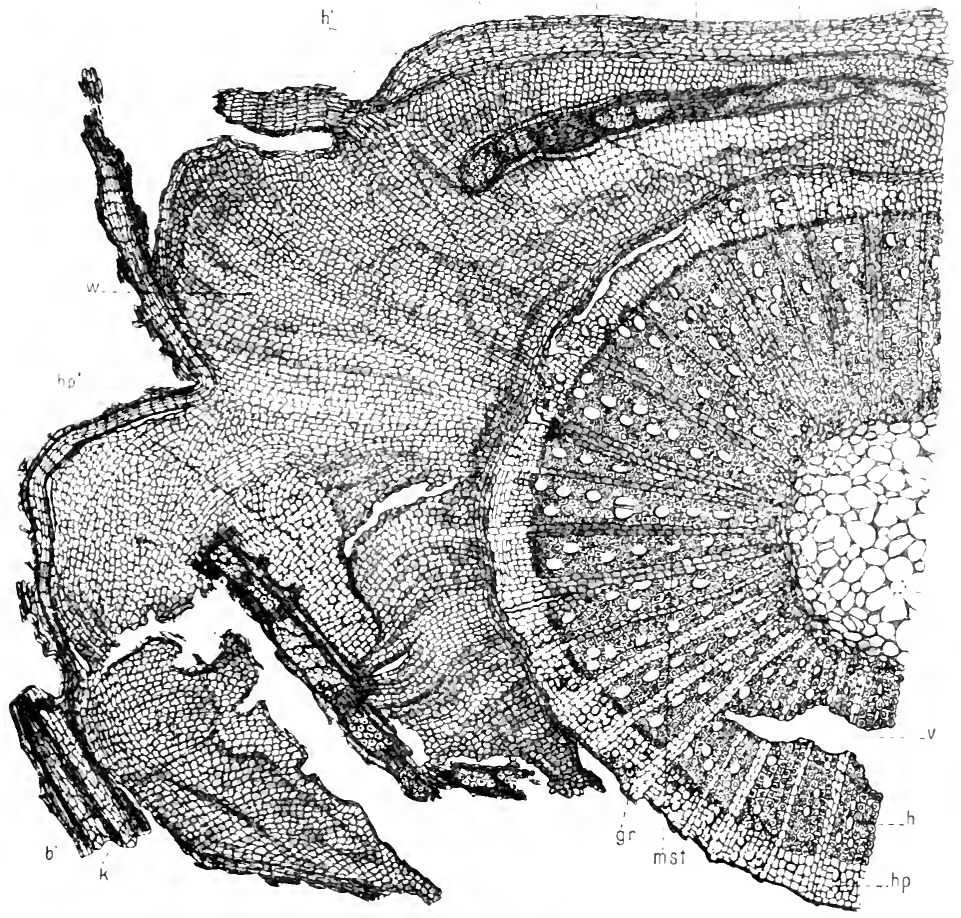

Fig. 14:8. Anfangastation des Rosenkrobses. (O)rig.

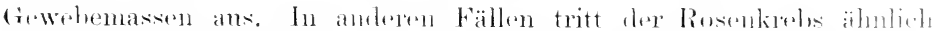

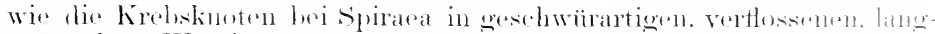

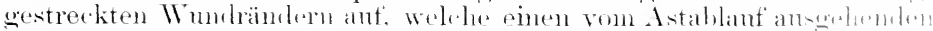

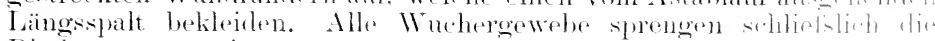
Rinde (r) entzwri.

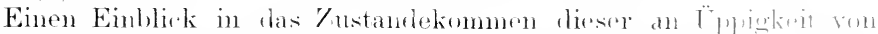

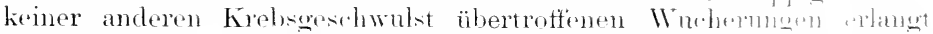

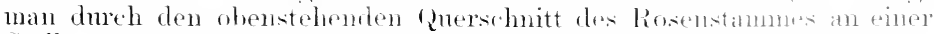
Stelle, wo er eine kleine, isoliert hervortretende, perlartig. Finduenheit 
gebilitet lat (s. Fig. 143). Wir erkennen, dats der Stamm im ersten Jahre seine normale Ausbildung erlangt hatte: um den Markkörper ist ein normaler Holzring $(h)$ mit breiten Narkstrahlen (mst) vorhantlen, der später zerklüftete $(\imath)$. Im zweiten Jahre, als die ersten Zellreihen $(g \circ)$ des nenen Holzringes in der Ansbildung begriften waren, muls sich eine Störung in Form einer Lockerung geltend gemacht haben, dem der neue Holzring (hy) hat zum grotsen Teil den Charakter des Parenchymholzes angenommen und nur stellenweis (li) den hureh Ansbildumg von Gefätsen und dickwandigen Holzzellen crekemzeichneten nomalen Holzhan beibehalten. Ihie Ursache dieser Lockermo ist ein Rindemit's gewesen, dessen spmren man in der lippenförmigen Einbnchtmg am sheren Teile der Figm erkennt. Die deckenden Korkschichten $\left(k_{i}\right)$ der Rinde sind entzwei gesprengt worden, und das beiderseits hervorquellende Überwallungsgewebe $(u)$, das sich wielerum mit einem Korkmantel bekleidet hatte, ist zu einer geschlossenen Masse in ummittelbarer Nähe des nicht gezeichneten) Risises verschmolzen. Wenn man von der üppigsten stelle des Wuchergewebes (u) ausgehend dasselhe rückwärts nach der gesunden (oberen) Zweigseite hin verfolgt, sieht man, dafs es sich allmählich anskeilt und imerhall der Rinde normalen Charakter $(f g)$ anzmehmen begimnt. Hier ist die Lagerumg der Hartbaststränge (b) noch nahezu normal, aber ihre Beschaffenheit ist stark verändert. Die Mehrzahl der Bastzellen zeigt gelben, verquollenen Inhalt und leicht gebrännte Wandung. Democh aber treten sie als leuchtend helle Gruppen aus dem tiefbram gefärbten Rindemparenchym hervor, das dmoh eine nachträglich entstandene Tafelkorklage $\left(l^{\prime}\right)$ von den äntiseren collenchymatischen Rindenschichten abgegrenzt ist.

Die /eichmmo zeigt aber, dats der Ring ron Bastzellen (b) in rem Malse sich weiter vom Holzzylinder entfernt, als er weiter in das Wuchergewebe eintritt; er ist also durch die Termehrung desselben vom Holzliörper abgedrängt worlen. Gleichzeitig sieht man, dats der Bastring anch von den äulseren, collenchymatischen Schichten weiter abgerïckt ist. Es mufs deshalb anch eine Zellvermehrumg in der Primärrinde eingetreten sein.

Es tragt sich num, ob das Gewebe, welehes den Bastring vom Holzkönper abrlängt, anssehliefslich ein Produkt der sekundären Rinde ist, orler ob anch der Holzzylinder selhst dazu beigetragen hat. Die Antwort erhalten wir durch die Gewebegruppe $\left.\left(h^{\prime}\right)^{\prime}\right)$, welche Parenchymholz darstellt. Wir finden derartige Giruppen parenchymatischen Holzes imnerhall, eines weichen, dïmmwandigen (xewehes bei der Heilung von śchälwnuden, hei denen sich ans den jüngsten anf dem Holzkörper strhengebliebenen splintlagen nenes Gewebe bildet. Wir lemen ferner bei dem studimm der falsthen Jahresringe (s. diese) und bei den Heilungsvorgängen der inneren Frostrisce die Bildung ron Parenchymholz aus der relockerten siphintholzschicht kemmen. Anch bei den V́eredlungsvorgängen, namentlich der Olinlation mol dem Rindenpiropfen, sehen wir Vernarbungsgeweloe rom jüngsten Splintholz nen gebildet werden, wemn die eigentliche Cambinmzone verletzt worden ist. Bleibt das Cambium bei einer Verwundung erhalten, so entwickelt sich dieses im Falle einer Lockerung dos Korkgürtels der Rinde durch einen Rits zu einem zmächst parenchrmatischen Gewebe, las an seiner Peripherie alimählich in den normalen Holzban in dem Mat'se übergeht, als sich her normale Rindendruti wieder herstellt (s. Wundheilung).

Alw dieselben Nenbildungen kömnen anch ant der Innenseite der 
Rinte entstehen. wenn man dieselbe vom llolyzxlinder abhebt, ohne dats ihre Ernährung gänzlich unterbunton wirl. Iol hale die Versuche bei hirsehen in der Art ansgeführt, dats ich die noch glate Rinde jugendlicher stamme in streifen ablöste. Woll he an ihesm oberen

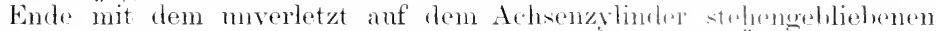

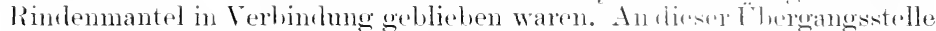

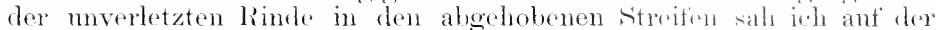
Innenseite desselben ('allns sich bilden, der sich spator in Rinden- mul Holzkörper differenzierte. Es ist also experimentull fostgestollt, dat's ein blofsgelegter llolzkörper none línde nud rin abgehobener, aber am oberen Ende ant dem llokliorper noch fextsitzender Rindenlappen nenes Holz orzengen liann.

Ladmeh wird mos der Vorgang bei dem Rosenkrels verstämllich. $1 m$ ersten Frühjahr entstand ein Rindemrits, der bis anf das bereits in einzelnen Vellreihen angelegte Frïhjahrsholz des nenen Jahresringes reichte und anch seitliche Abhebungen fler Rincle vom siplinte zur Folge hatte, wie die Lücken (l) orkemnen lassen.

Durch diesen rarlialon spalt war der schnörende Einfluts, den der Korkgürtel ( $/$ ) auf Rincle und Jumgholz auszuïben ptlegt, zunächst gänzlich anfgehoben, und die Folge war num die lnxmrierende Vurmehrung des Jungholzes (auf der mnteren seite der Fingur), dort wo die cambiale Kone nicht gestört worden war, mul andererseits dir ïppige Vermehrung des Parenchyms der Imneminde dort, wo theselbe vom Jumgholz abgehoben worklen war thej / anf der oberen seite der Fignr). Die Noubilılmeren sint, gleichviel ob vom abgehobenen Rindenlappen oder vom .Jungholz ansoghend, gleichmäfige callnsartig und versohmelzen unmerklich miteinander. Sie sind as, welehe den ehemaks zusammenhängenten Bastring $\left(b, b^{\prime}\right)$ entzwei gesprengt, den stärkstbeschädigten Teil desselben $(b)$ nach auben gedrängt und nach sciner Abklïtumg von der Antseminde zmm Alsterben getorath haben.

Die Hauptfrage ist, ant welehe Weise tis erste ratiale Yerklïftung znstande gekommen sein mas! Und darant kam die Antwort nur lanten: durch den Frost. Denn wir finden jene Brämnung der Markkrone. jene Zerrungen und Erwoitermeen der Markstrahlen, jene Abhebungs-

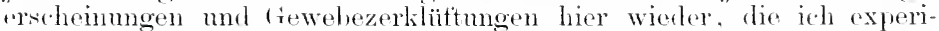
mentell durch Einwirlsurg kïnstlicher Fröste habe erzengen können. Nur die Folgeerseheinmoen, nämlich die luxuriferende Gewebevermelnung habe ich künstlich bisher noch nicht hervorzurnfen vermocht. Es liegt dies wahrscheinlich darin begründet, dat's ich noch nieht den richtigen jugendliehen Entwieklungszustand bei der Einwirkmo der künstle.hen Fröste getroffen habe. Es muts dies die Zeit sein, in welcher die cambiale Tätigkeit eben beginnt, wie man ans den wenigen \%ellagen ersieht, die der nene. Jahresring erst aebililet hat. Treten die Störungen suater ain, so ist die Reaktionsfähigkeit dor Gewehe geringer, mol die wnelerme Zellvermehrung unterbleibt. Wie sehr der Zeitpmkt der Virletzme ausschlaggehend ist, heweisen die Versuche von Göths, Woldher, wit bereits erwähnt, lumeh fortgesetztes Klopten an einer Wrines, in ersten Frühjahr Wuchermngen erzengt hat, die dem Weinkwhe wirlen: der Weinkrels ist in seiner Entwicklmo dem Rosenkrels nalustomel.

$$
\text { (2) Dor Brombeerkebs. }
$$

Es ist eine bemerkenswerte Erscheinmo, dats mit Ansualnme dos Weinkrebses alle übrigen Krebswucherungen in itr Familie 
der Rosaceen gefunden werden. Bei dem Brombeerkrebs entstehen am älter'n Holze blumenkohlartig gehänfte, harte, weilshich schimmernde Gewebemassen mit perlartiger warziger Oberflache (s. Fig. $144 k$ ), die

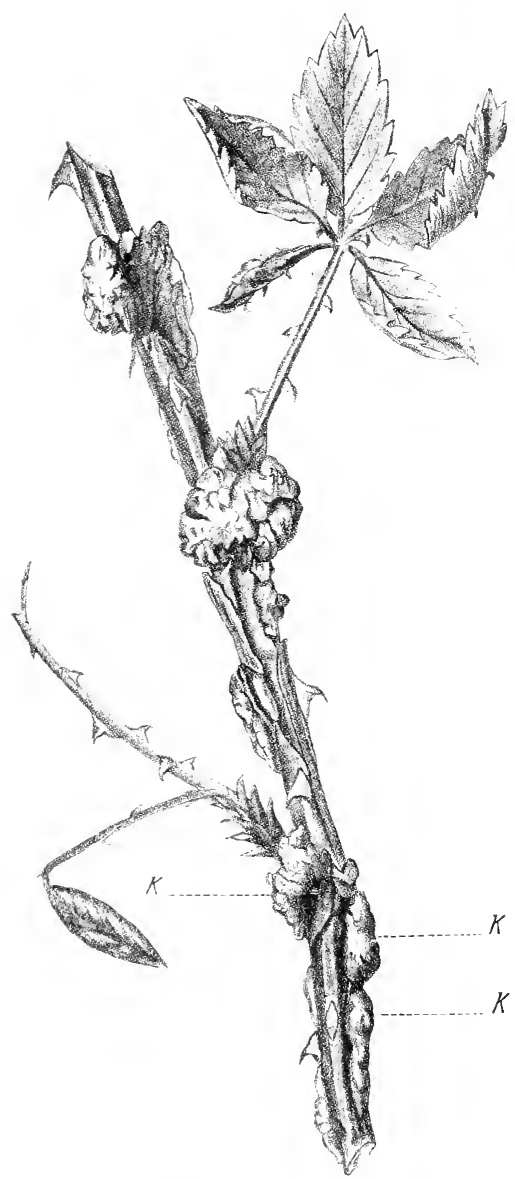

Fig. 144. Krebs bei der wilden Brombeere. (Orig.) bald einzelne Kugehn, bald, wie bei spirata, wallartig gehäufte, langgestreckte Polster bilken. Die Angengegend ist der hevorzugte Entstehmonsort. I) ie Rinde wird gesprengt mul teilweise flügelartig znrückigeschlagen.

Bei reichlichem Vorhandensein der Krebsgeschwälste vergilbt zumächst das Lanb; damn beginnt langsam der Stengel von den gebräunten Angenstellen ans abzusterben. Bis Juli sind in der Regel die erkrankten Zweige, die an temselben Stocke neben frendig grünenden rorkommen, gänzlich abgestorben.

Wenn man an den gesunden Trieben solcher kiebsig erkrankten stöcke machsuclit, finclet man entweder kleine. rötliche oder brame Längsichwielen oder anch bis 1 cm lange, klaffende Rifsstellen. Dieselbe Erscheinumg bemerkte ich anch an manchen Blattstielen. I) Be Böschmgen derartiger Rifswunden sind mit Kork bekleidet. An diesen Böschumgen treten stellenweis kleine, perlige Wncherungen hervor, die ans Parenchym bestehen und dicht an iler

Aufsenseite der Hartbaststränge von der Primärrinde gehildet werden.

Diese Geweberegion erweist sich bei den Rosaceen als eine sehr leicht erregbare. Nach den verschiedenartigsten Rindenbeschädigmaen, die nicht lis an den Hartbast reichten, sah ich kräftige Zweige

dureh Parenchymvernehrung dicht anfserhalb der llartbaststränge anf den Wundreiz antworten. Anch bei dem Brombeerkrebs bemerkt man eine Voranlawe für die Krobshildnug; dem an den Stellen, wo eine warzenartige Wucherung herrorgetreten war, erwies sich schon bei der jugendlichen Zweiganlage der ans Hartbaststrängen mo deren 
derbwandigen Verbindungselementen gebilute mechanische Ring m. verdickt, indem zartwandiges Parenchym an strlle der prosenchymatischen und sclerenchymatischsn Gewebe gotroten war.

Das parenchymatische Wuchergewebe in der Primärinte vermehrt sich äulserst schnell und durchbricht die deckenton nomalen Rinden-

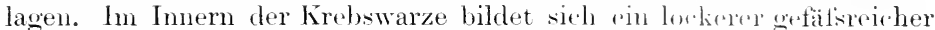
Holzkörper; die Bildung von Ilolzelementen wirelreholt sich in den peripherisehen Parenchymlagen des erstentstandenen Wrucheregels, indem Meristemherde entstehen, aus denen tracheale Ifolzedomente in schalenfërmiger oder muschelartiger Anordnung hrrvorgehen.

Bei dem Brombeerlirebs ist also ter Antang eim Parenchrm. wucherung im primären Rindenkörper, tie in limmenkohlartiger íer zweigmo nach antien wächst. Erst später greift lie Neigmng zm Hypertrophie rückwärts in die hmeminde hinein und ertatst schlietslich auch den Holzring, der anfangs vom normaler Ausbildmo erscheint. sobald die Geschwülste älter werden und ler Holzkörper sich an deron Bildung beteiligt, rrstärkt sich dieser um das Inri- bis Viertarhe seimr normalen Ausdehmung. Wir haben ähnliche Voroüngre bei der Wassersucht, bei der Knollenmaserbildung usw. Trer Krels bei Rubus ist selten; ich habe ihn bisher nur in vier Fällen liemnen gelernt und zwar strets in engbegrenzten Lokalitäten.

Die übereinstimmenden Momente bei den Krobsgeschwälstru.

Bei einem Ëberlolick äber das gesante Beobarhtmngsmaterial botreftis der geschlossenen Krobse fler ottene Krebs" hilket eine Ëberangstorm $z x m$ Brande and scheidet hier aus findet man ïlereinstimmencle Zïge. Üherall bildet die Entstehme einer kleinen Rifimmele den Antang; ïberall lätst sich erkennen, dat's die Verwmelung im zeitigen Frühjahr stattgefinden haben muts, und dats das reichlich mobilisierte Material die Umgebmog der Wunde zu äutserst schnell zustandeliommonden, enomen Wucherungen befähigt. Durch den frarmchomatischen Charakter der Nenbildungen wird eine grotise Emptindlichkeit gegen schädliche Wittermosemflüsse mod namentlich dem Frost gegenüber berlingt. Geringe Frostorate sind daher imstande, das Krobsgewehe in der nächsten Wachstumsperiode zu verletzen. Der verlotzte (rewebekomplex kam darum wiederum mit Wuchergewele antworten, weil ex bei seiner parenchymatischen Natur in der vorangerangenen Vegetationsperiode reichlichst Reservestotte in Form von stärke gesperichert hat.

Die Krebsormen bei den einzelnen fattmoen dor Rosaceen unterscheiden sich nur dureh die Art der Reaktion auf den Wundreiz. stimmen aber darin wieder ïberein, dats sie das Augr und dessen nächste Lmgebung als Eutstehungsort bevorzugen. Der Grund datün ist in der Loekermer des Achsenkörpers an der Ansatzstelle einer Knospe zu suchen. Hier ist stets der Holzring sclmaler mut wirel schlielsheh von der parenchymatischen Markbrücke quer chreksetzt.

Die bisher boobachteten Anfangsstadien dor Krelshnoten, nänlicl) die kleinen, meist in der Nähe der Angen entstehenten Rifirmunton, haben sich dureh künstliche Fröste erzengen lassen; lie üpligen Ïlurwallungserscheinumgen aber noeh nicht. Dieser Umstand diutte daranf zurückzuführen sein, dlatis ein zu später Zeitpmbt in Friilıjaln für die Einwirkung der künstlichen Fröste gewählt worlen ist.

Bei krebsigen Bämen ist in den gesunden /wejuctn mehrtarch 
eine ahnorm gesteigerte Ausbildnmo der Markstrahlen beobachtet worden, und dies diurte ein Fingerzeig sein, mm die Neigmng gewisser Kultursorten od er einzeher Individnen an bestimmten standorten zu Krebswuherungen zu erklären, indem derartige Exemplare, fleren Markstrahlen bzw. Rindenstrahlen schon im resunden Zustande luxurieren. am leichtesten durch Iryertrophie anf einen Itundreiz antworten werden.

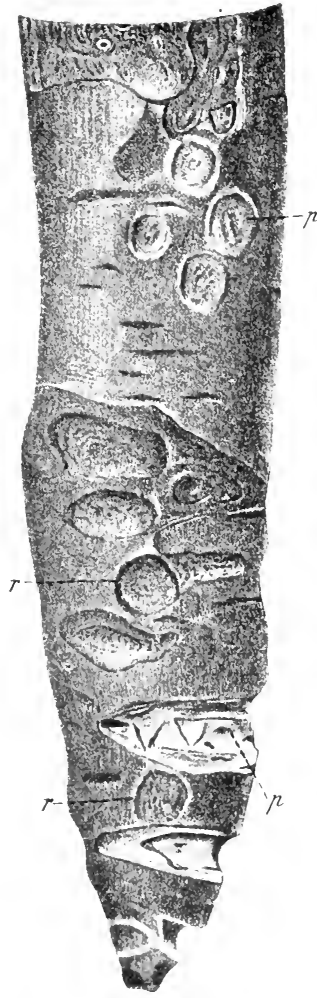

Fig. 14:. Frostplatten an Birmenrinde. (1)rig.)

\section{Der Brand (Sphacelus).}

Im Gegensatz zur Bezeichnung "Krebs", welche in den Kreisen der Praktiker für die heterogensten Erscheinumgen einer allmählich sich ansbreitenden Erkrankung Verwendung findet, versteht man unter "Brand" ziemlich allgemein das Anftreten toter, schwärzlich verfälbter, dem Holzkörper aufgetrockneter Rintlenstellen von grötserer Ausrlehnumg. Bei glattrindigen stämmen bemerkt man anch an Stelle grötserer zusammenhängender Brandflächen oft cinseitig am Bam erscheinende kleine, zahlreiche, eingesunkene, einem Fingereindruck ähmliche Rindenflecke. die man als "Frostplatten" zu bezcichnen pflegt. Diese Beschädigungen sind je nach der Frostempfindlichkeit der Bammarten und den Standortsverhältnissen bald häufig, bald spärlich. Branderscheinmegen dürten rom steinobst am hänfigsten bei Kirschen und Pflanmen zu finden sein: bei den emp,indlicheren Pfirsichen mul Aprikosen pflegt meist der Achsenkiirper in seiner Gesamtheit zu leiden.

Bei dem Kernobst sind unzweifelhat die Birnen zu Brandloschädigmngen am leichtesten geneigt. Von den Waldbänmen gelten als Desonders empfindlich Buche und Fiche, an fenchten stanclorten auch Esche und Akazic. Erlelkastanie erhält sich üherhaupt im mittleren I eut schland nmr an einzelnen Lokalitäten. Unter den Nadelhölzen ersheint die Tamne frostempfindlicher als die Fichte. Lärche leidet, soluald sie nicht genïgend Licht und Luftzirkulation hat. Selten beschädigt zeigen sich Lincte mol Ahorn. Am wenigsten findet man Brandstellen bei Erle, Birke, Ulme, Weide, Paprel, Hainbuche und namentlich Kiefer.

Das Absterten der linde ist als direkte Frostwirkmng anzusehen, welche bis zu verstherlener 'Tiefe cindringt und demgemäts ein verschichlenartiges Aussulen der Brandwunden hervormfen kam. So erareitt z. B. häntig der Frost nur die jüngsten Rinden- und splintschichten einschliefich des eigentlichen Cambiums; die älteren, äntseren Rindenlagen sterben dam nur aus Nangel an Ernähmug ab. Da die rom Frost getötete Rinde sich kurze \%eit nach dem Auftanen dunkel 
verfärbt, so sehen wir in Fröhjahr (besomelors oft hei Birnen) zmächst

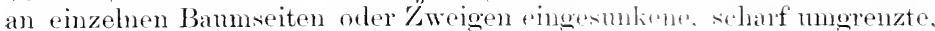
oft nur sehr geringe Anstehmmo besitzende sinllen. die bald trocken werden mol dem Holzkïrper fest anhatten (Fig. 14.1'). Es sind dies dir oben erwähnten "Frostplatt " 11 " mancher Obstbanmzïchter. Im Lanfe des siommess entsteht an der (irenze zwisehen dem antigetrocknetrn mul dem gesunden, dureh das Dickenwachstmm des stammes sich hebenden 'Teil der Rinte eine Ritsstelle, dureh welehe der algestorbene Teil num von der Umgebme isoliert wirl mul seinen hemmentum Einfluts verliert (Fig. 145, r).

Die Ilemmmn, welche eine solehe tote Rindenstelle ausïbt, liegt in ler Iruckerhöhung des ïhrigen Rindenmantels. so lange derselhe mit dem toten, trockenen, dehmugsmbihigen frewebe noch verbmoten ist. In der Nähe der toten stelle wird der Rindendrutk am grösten, die Kahl der nengebildeten Elemente am geringsten sein.

Dies sehen wir bei Beginn der Heihngsvorgänge. Der Banm sucht die tote stelle dureh Bildums ron C̈berwallungsrändern von den gesmnden Rindenteilen ans zu derken. lies kam mun je nach der Art des Brandschadens in zwei Fornen geschehen. Wenn nämlich dor Kwoig zu \%eit des Frosteintritts schon äleres Holz besitzt, las anf der Brandseite wohl gebrännt, aber nicht erespalten wird, dam schioben sirh oftmals die fiherwallmesönder allmählich zwischen rlie tote Rimble nurl ren Holzkïrper und heben la 11 s. a m die schortartig trockene, branne Rindrmmasse ab. Mit jeflem folgenden Jahre rïcken dis Überwallungsiänder von den Seiten her anfeinander mehr und mehr zn. bis sie sich endlich rereinigen, die geschwälzto Holzstelle decken mol dabei dio ehemals anfgelagerte Rinde narh ant'sen drängen und alstol'sen.

In Fig. 1ti, die oinen brandigen, jungen Birnenstamm darstellt, schen wir ohen fen alten, geschwärten, blotigelouten Hokkörper. weleher

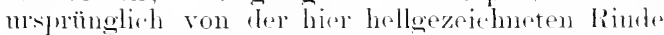
in trisehen Knstante hefeckt war. Die Rimele ist an der ganzen Bammseite vom Froste getötet, anfuretrocknet mel fureh die nach tem Fost hervorgekommenen Therwallnussänder von den gesmolen Bammteilen algeplatzt worlen. Die hekittïmmige Erhöhung an ter Basis der Keichnung zeigt dir. bei Brandstellen hänfige Verheitemug des abgeflachten Stammes duroh vermehrte Holzhilume

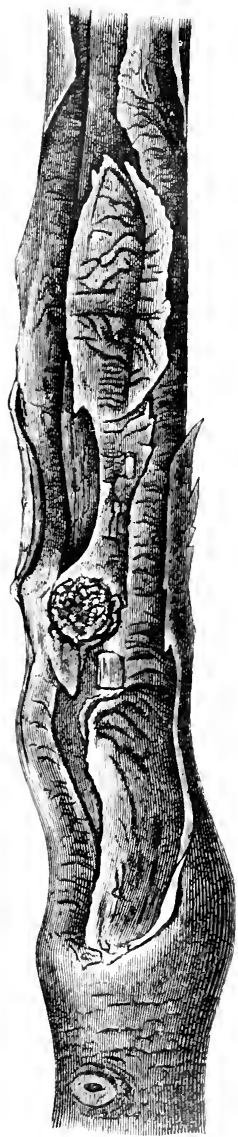

Fig. 1tit. Jumger.

Birnerustanm mit vil sehiedenartinen brandstr.]1 11 . der unbeschärligten Tmgehmo.

An dümen Kwoigen hosizen die Frostplatten mandunal eim num geringe Ansidehmme; dafïr aher zeigt sich der Ilolzhiorper muter der

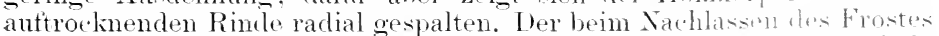
sich schlietsende spalt wird nm schnell überwallt. dir eqetietere Rinde 
alshalu abgehoben, und die Ïberwallmosänder verschmelzen miteinander. Hierbei erfolgt nun die Vereinigmm nach Art der Frostleisten, l. h. die Ränder springen leistenartig über clie normale Jahresringebene hervor, während sie bei den breiteren, nu langsam sich sthliefsenden Wunden den Achsenzylinder an ter erfrormen stelle abgeflacht erscheinen lassen.

In beiden Fällen aber zeichren sich die Öberwallungsränder daAnrch ans, dats sie unter dem hohen Inuck ter toten Rinde entstehen, daher an ihren äutsersten Enden am sehmakten sind, sich also keilförmig zuspitzen. Diese keilförmige Verjüngung der sich ïber die tote Fläche ansbreitenden Ïberwallungsiönder ist das charakteristische Merkmal des Brandes im Gegensatz zum Krebse, dessen Überwallungsiänder narh der Wnndstelle hin an Ilicke zunehmen und sich wulstartigin den offenen spalt, der den Krebsantang bildet, hineinsenken.

Dat's die Gewebe der Ïberwallungsränder je nach den Druckverhältnissen, muter denen sie entstehen. verschierlen sind, ist leicht zu ermessen mol ist bei dem hrebs ansführlicher besprochen worden.

In der Fig. 147 entspricht die dumkle stelle 13 einer Frostplatte 1' in Fig. 145: t ist ein Rest der toten Rinde, deren gesmuder Teil $l i$, durch die weifoglänzenden IJarthastbïndel hl, kemtlich, von drm toten Gewebe durch eine schrägr verlanfende, sich an die normale Korkbekleidmo $K$ bei $B$ anlegende liorkzone getrement ist. Wher nach dem Frost entstandene , balnesing ist mit.$J$

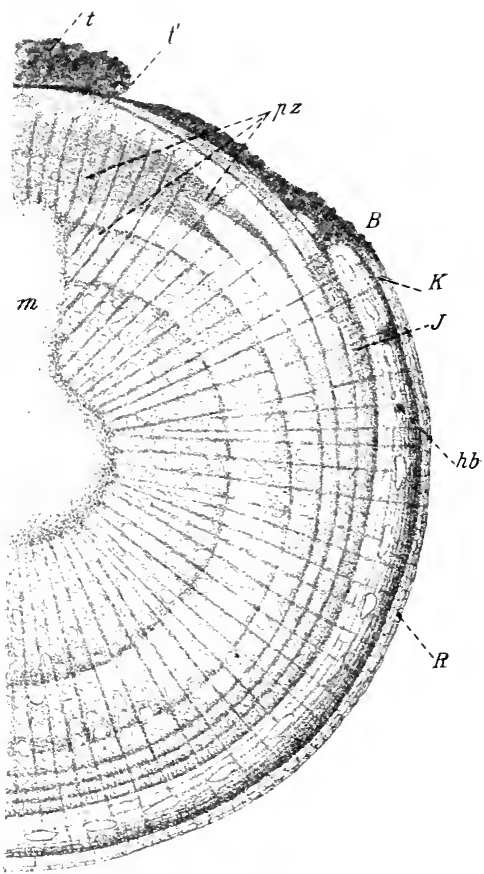

Fig. 147. Querschnitt durch einen Birnenstamm an einer durch Frost erzeugten Brandstelle. (Orig.) bezeichnet. W'on man renselben nach ter Wumlstelle lin verfolgt, sieht man, wie er sich spitz anskieilt und mter der antegetrockneten, toten Rindenstelle $t^{\prime} t$ noth ganz fehlt. Erst der nächstjährige Ring würde sich dazwisehenschieben. Der Ban dieses zngespitzten Ïberwallmostandes ähnelt durch das nur sehr gering ansgebildete Parenthymolz und die balı antretenden, dickwandigen Holzzellen nebst refief'sen viel mehr dem normalen Holze als die lippenfömig sich antwulstenden, holzparenchymatischen Überwallungsränder des Krebses (s. . offenen Krebs").

Wir sehen in beistehender Fig. 147 ïber der Narkbrücke $(m)$ die 
normalen .Jahresringe durch minder helle, hier wran erscheinende, sichelförmige Zonen $p z$, die fein keilfömig nach flon seiten hin ansstrahlen, unterbroehen. Diese Zonen bestehen ans lïmwandigerem, bisweilen getälslosem. verkürzten Prosenchyn, hisweiln sogar der Hauptsache nach aus stärkereichem Holzparenchrm. Lie hier veraden Radien der Markstrahlen erscheinen bei ïprig wachsomen sorten geknickt und die longitudinal gestreckten liolzzellen und rivtaitice diagonal bis horizontal verschoben.

Es ist vorhin gesagt worden, dats die Frostplatten als enghegrenzte. in allen Richtungen relativ geringe Ausdehnmog zeigende Brands leärlen anzusehen sind, die bis zu grotsen, ganze Bamseiten umfassentin Brandflächen alle Übergänge aufweisen. Autser bei Birno lassen sirls anch bei Rotbuche leicht solche Frostplatten autfinden. An reichlich mit derartigen Platten besetzten Zweigen einer Buche liets sich als die in das gesunde Gewebe am weitesten hineingehende, letzte Ausstrahlung der Frostwirkung die Brämmo des Inhalts einzeher, durch das Mark zerstrenter Zellen nachweisen; diese Zellen haben unzweifelhatt einen anderen Inhalt als die ïbrigen, farblos gebliobenen Markzellen und nähern sich betretts des Zellinhalts watnstheinlich denen der Marklirone, die ebentalls leicht gebräunt wird.

Die Bräunumgteiltsichnicht, widbei ler Wundtäule, der Lmebung mit: dem die schon vorhandenen sowohl als die sich später noeh bildenden Zellen in der nächsten Nähe der frostgebräunten Gewebe bleiben hellwandig und gesmed. Die gebräunten Irarkzellen enthalten ebensogut stärlie wie die nicht angegriffenen. so dats die brame Färbung nicht von veränderter stärle, sondern von einem anderen Stotte herrähren muls. Nicht in allen Fällen leiflet clas Mark. Manchmal ist bei zwei- bis dreijährigen Zweigen der Holzkörper in der Wrise gebräunt, daf's die golbe, grmmiartig aussehende Ansfüllung der Getätse bis zur Markkrone hin stattgefunden hat und auch die Markstrahlen bis nahe zum Zentrum gebräunt erscheinen, der Markkörper selbst aber ohne jede lirankhatte Verfärbung ist. Solche Differenzen finden in demselben Zweige an verschiedenen Internodien statt. Incles bleibt als Regel. dats die ersten Anfänge der Brämmmg sich durchschmittlich an einzelnen Zellen des Markes, namentlich anch dex Markkrone zeigen, dats zmächst mur der Inhalt und später erst dio Wandung sich verfärbt, und dat: diese Inhaltsfärbung auf einer Bräumung und Erstarrung der \%ellflüssiglieit zu beruhen scheint. Die gummiartiy festgewordene Masse kann beim Schneiden schartkantig brechen. Ebenso glaube ich. die Ausfüllumg der Getätse zum Teil auf clas Erstarren des tlüssigen bereits vorhandenen Inhalts zurückführen zu müssen und daduch mit Leichtigkeit die oft troptenartige Formierung der Ausfüllungsmasse erklären zu liönnen.

Der Bräunmug im Markkörper tolgrt bei zumehmender Kältewirkmng in der Regel die Verfärbmo einzelner Markstrahlen und einzehnre Bastparenchrmgrupen in der Rincle. An den Rotbuchenzweigen lietis sich auch eine aut einzelne Grefäsbiundel heschänlite Frostwirlimes manch. mal erliemnen: die Verfärbung hält sich dann immerhalb zwoier llanytmarkstrahlen, ergreift zunächst den Markkronenteil des Bündels mul schliefst oft plötzlich mit einer Jahresringorenze ab.

Man sieht bisweilen eine fretälswand noch gar nicht ocler cinseitig gebräunt, wenn der Inhalt schon gänzlich verfärbt ex'scheint. Es wurde erwähnt, dat's an der Ausfüllung der Gefäfse und Holzzellen sich anch die 
sekundäre Membran beteiligen kann: diese quillt zunächst ant, und zwar zureilen bis zur Ausfüllmig des Lmmens einer Holzzelle oder eines engen (iefätses, welche damn noch farthlos und gleichmätsig lichthrechend ercheinen. Daneben findet man Zellen und (Gefälse in tiefer Brämmng; ihre anskleidende Masse liegt oft tropfenfömig der Wand an oder int ringartig und scharf' von der Nembran abgegrenzt. In anderen Fällen ist zwischen der Auskleirlmgsmasse und der '/ellhant keine Grenze und hierbei die Beteiligung der Iembran zweifellos. Es kommt anch vor, dats nur eine innere Lage der Zellmembran sich bräunt und quillt und schliefslich erstarrt. Diese gesmollene Lage hat dam am Innenumfange der Zelle orler des frefälises nicht mehr Platz und faltet sich nach immen, so dats ein farbloser Hollyaum zwischen der nach innen ansqestülpten. Lramen Membranlamelle und dem äutieren. unverändert gebliebenen Teile der Wandung sich zeigt.

Bei der meist einseitig rorhandenen Bräunung des Cambiums ist in geringeren Stadien auch nur der Inlalt gebräunt und erst nachträglich verfärbt sich die Wandung. Las direkt an das Herththolz angrenzende Frïhlingsholz scheint am empfindlichsten zu sein. Im Rindenkörper erkennt man, dafs die bogenförmig von Rindenstrahl zu Rinclenstrahl sich spannenden, in der streckmo voraneilenden Parenchrmzellen weniger leiden als das von ihnen begrenzte kleinzellige Innengewebe.

The hier erwähnten Beohachtungen repräsentieren hänfige Einzeltälle. aber nicht durchgängig anzutreffende Erscheinmoen. Erwähnt sei schliefich ein Fall bei süfsirsche als besonders bemerkenswert. Ier Markkörper des einjährigen /weiges erschien an einer Seits bis ïber die Nitte hinaus zerklinftet, und in die entstandene Lücke wucherten fadenartig. wie bei den Wollstreifen des Apfelkernhanses. die Zellen der Markperipherie. Gummosis war nicht vorhanden. Dor Fall wurle bei den sogenamten .Frostrunzeh" heobachtot: er ist deshalb interessant, weil er die nachträglich im Mark wieder erwachte Wachstumstätigkeit zeigt. was im allgemeinen nur hei wrichen Hölzern (Titia) rorkommt.

Anch bei den obenerwähnten Branderscheinungen findet sich als Regel. gerade so wie hei Krebs, mit der Kmahme der Parenchymmassen (Fig. 147, pat zwischen den normalen Teilen des Jahresringes anch eine \%mahme der (immmiherde bei den Amroxlalaceen und der Harzherde bei den Coniferen. Bei dem Krehs kann man andserdem wahrnehmen, dafis der Lockermo des llokkörpers durch Parenchymholy eine Lockermo des Rindenkïrpers in demselben Radins durch schwächnnщ des mechanischen Ringes entspricht; es fehleu nämlich die Ifartbastbündel in der Rinde der Überwallnugsoünder so weit, als im Holzkörper der letzteren die eigentlichen diekwandigen Holzzellen fiehlen.

\section{Parenchymholznester.}

Bei den Krobsuchermngen haben wir gesehen, wekche Weichheit und Hinfälligkeit der Inolzring erlangt, sobald er zur Bildung des Überwallungsrandes einer engen spaltwinde zurzeit der grölsten Znwachstätigkeit im Frïlijahr plützlich ühergeht. Bei der Schmelligkeit der Entstehung derartig grotser Gewebemassen hat der Holzring nicht Zeit, prosenchymatische Elemente auszubilden, sondern baut sich anfangs ans parenchymatischen, dïmwandigen Elementen auf, die als 
speicherungsewebe tür Reservestofte zwar Vurteile bieten, aber den Parasiten und Wittermgseinflïssen regenüher seln weringe Widerstandskraft zeigen. Es ist daher lejeht verständlich, dats anch bei gosmulen Bäumen das Auftreten parenchymatischen lloloss an sitelle des prosenchymatisehen rom pathologischen standpunkt ans rine besomelere Antmerkamkeit verdient. Derartige fälle sind überall zu fiurlen.

Die llerde von Parenchrmholy kömen in Fom einestrenter Nester oder in ringtörmigen Binden von versehiedenes läinge unil Breite in stammkörper anftreten. Nie sind mamninfarh henannt worken.

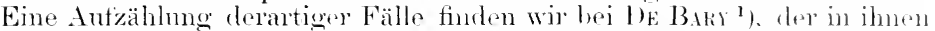

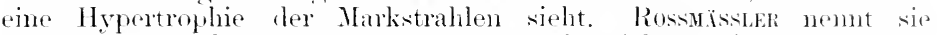
. Markwielerholungen". Nörmbntier bezeirlmet so als . Mark-

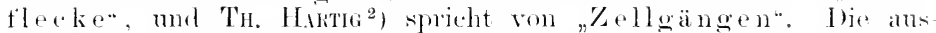
gebildetste Form finden wiv bej den sog. „Mondringen". Es sint dies brame oder weitie, meist ringtömig nm einen Teil oder anch mm den ganzen stammumfang hermmeichente Binden von Parenchronhol\%, das hisweilen schon zunderartig zemiirlst erscheint. Diese miirhen fewehemassen zeigen nicht selten bereits lie C'ellulosereaktion. Vielfach findet man dieses trewebe von Mrcel durchzogen. 'TH. IlakTis

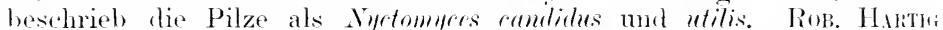
zox das bei Eichen heobachtete Mreel zu Stromm hirsutum Milld. ${ }^{3}$. Bei anderen Bammattungen finden sioh andero holyzstionente Pilze,

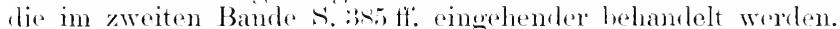

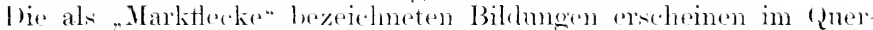
schnitte des IIolzkïrpers als isolierte, zerstrent anftrotende, schart bowenzte, etwa hallmondtomige, wehramtr, mübe stellen, welche sich gangartig anf vorschieflene fänge hin stammalwärts vortolgon lassen.

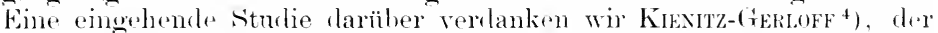
als Entstehmesursache bei Wejlen, Ehereschen mud Birken den Frats einer Insektenlarve beobachtete. Nach eimem Referat vom Karsch") soll ss sich um Timulı suspectu Rtzh. hameleh. I)jese Larve nährt sich . vou den Zollen des Cambiums mul des .Jungzurachses zur Keit der Jahringlildmo". Die Fratisänge werden in tolgender Weise geschlosien: . I) den Wuntrand durchbrechenden \%ellen wachsen schnell mol teilon sich weiter durch zarte qnerwände; gleichzeitio findet eine vollständige Schlietsung des cambialen Ringes statt, mul von num ah wirl wieder normales Holz nurl normale Rincle äber der Wmittäche gehildet, während ganz mabhängig von drom nenen C'ambium ter Hohlraum durch die Kellenwucherungen geschlossen wird." (Bot. Jahresber.

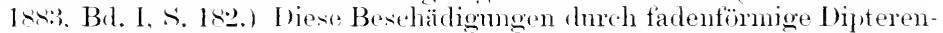
larven. welche in der Cambiumzone, namentlich an Stammbasis nut Wurclhals. hisweilen aurh an höheren schafteilen mol Wasserreisern im Mai und .Juni ihre Gäng gralın. werden zunächst nur für die wr.

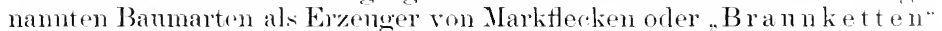
anzusehen sein. Kitstr sellst bemerkt, dats älmbiche Bildungen bri anderen Bäumen, namentlich hei Narlelhëlzern. nicht von don riädinten 1)jptrenlarven herribren.

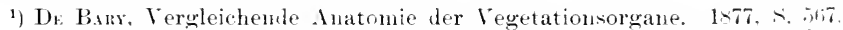

2) Tи. Hsku; Follstandige Naturgeschichte der forstlichen Kulturplan\%n. 18.2, S. 211.

3) Rus. Hanri: Zersetzungserscheinumgen des Holzes. s. 129.

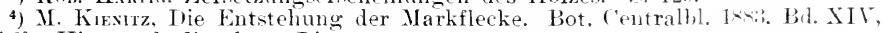
S. $21 \mathrm{ff}$. Hier auch die ältere Literatur.

$\left.{ }^{5}\right)$ Bot. Jahresbericht. Jahrg. XI, Teil 2, s. 518. 
Betretts der Markflecke der Birke bestätigt v. Tubeur ${ }^{1}$ ) die Unter-

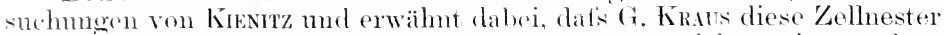
sogar für normale Bilflungen erklärt. In B.sis spricht, wie erwähnt, von Ilypertrophien der Markstralilen, und hei dem ersten Öberblick gewimit man anch den Eindruck, dats die Markflecke dureh eine Erweiterung der Markstrahlen hervorgehacht werden. Man sieht wirklich letztere, bevor sie in die Pareneliymholznester eintreten, allmählich breiter werden mel ihre zellen das polvedrische, derbwandige, stark getïptelte Anssehen der mit stärs nud hramem Gerbstotf hisweilen erfüllten \%ellen der Markflecke anmelmen. Ja, man sieht sosar manchmal, dat's die Markstrahlen bei dem Eintritt in den Markfleck sich erweitern und seitlich zusammenfletsen; aber ich halte trotzden, gestützt auf meine "sichälversmehe", das nengebildete Füllgewehe tür ein Produkt piner Zellvermolnmes, an der nicht nur die Markistrahlen, sondern samtliche den .Jahresing anf andenden fewebeformen sich beteiligen liönnen. Die Nark- bezw. Rindenstrahlen eilen nur bei allen

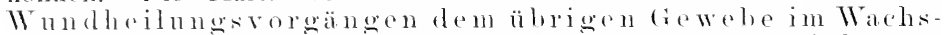
t 11 m vorans nut erlangen dadureh einen überwiegenden Einfluts.

Anch wemn man bei den oben erwähnten , Iondringen" die

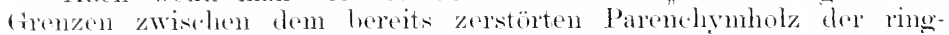
fïmigen Binden mol dem resumel geblicbenen Gewebe mitersucht, findet man nicht selten eine hervoragende Erweitermg der Markstrahlen, namentlich bei Fichen.

Bui Nadelhölzern und besonders bei Kiefern begegnet man einer noch extremeren Form rom Zerstërmo, der sog. Ringschäle. Bei dem spalten der stänme läst sich nämlich hisweilen ein Vollzylinder, ans dem gesunden, zentralen stammteil hestehend, von einem ebentalls gesund erscheinenden peripherischen Holzmantel, wie ans einer Hülse,

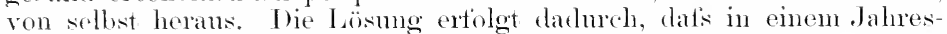
ringe, mul zwar nur in diesem einzigen, das Gewohe zerstört, mulnig mel moceldurelizogen ist.

T)iese Forn der Ringschäle unterscheidet sich durch ihren festen,

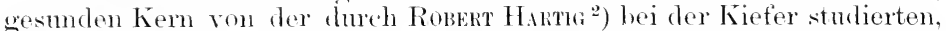
bei welcher ein Wmmlparasit, Trametes P'ini (Brot.) Fr. die Zerstërme des ranzen Kernes veranlatist, aber nieht in das gesunde splintholz übergeht. HakTi besehreibt das schnelle Fortschreiten des Mycels in den Markstrahlen mul saut, nachdem er die dureh das Mrcel verursachte Holzzerstörmng, das Aut lösen ter inkrustierenden Substanzen und Zurieklibloiben dre cellulose in den Holzfasern dargelent hat: "Intolge der '/usammenzichung des Holzkïrpers, welehe mit der Fäulnis und dem Wasterverhst desselhen verhunden ist, hilden sich nicht allein radial verlanfende Sualten, sondern es lösen sich seln oft die äulseren Jahresschichter als Mantel von einem diekeren oder sthwächeren Kerne. Es entstuhen so Ringspalten, die wohl den Namen der Ringse hä le veranlatist laben mögen." Wir haben es also hier mit einer Form der selur verbroiteten Rottäule oder Kernfä nle zu tum. Der Pilz tritt narle v. Trbetr anch an Fichten anf und ist aufserdem an Lärchen mel Weifstamen und in Amerilia an longlastamnen beobachtet worden. Hervorzuheben ist der Lmstand, dat's sein Myeel sich ,besonders leicht

1) v. Tıbrf, Die Zelloinge der Birke und anderer Laubhölzer. Forstl. naturwiss. \%eitschr. 1897, s. 314.

2) R. Howru, Wichtige Krankheiten der Waldbäume. Berlin 1874, s. 55. 


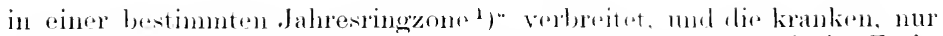

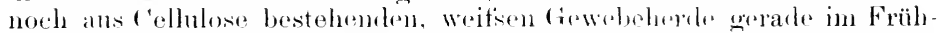
jahrsholz reichlich zu finden sind 2). Lles schoint mir anzulenten, dats

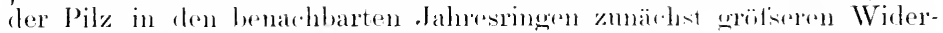
stand findet, also der befallene. Jahresping von vomberein lockerer

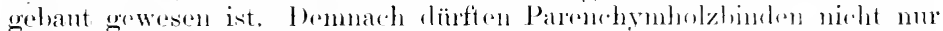

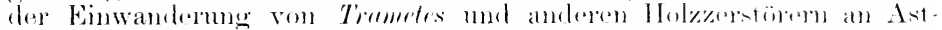

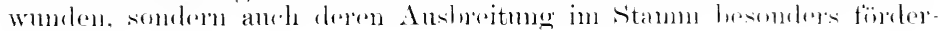
lich sine

\section{Falsche Jahresringe, Doppelringe.}

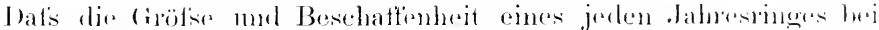

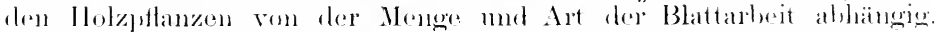

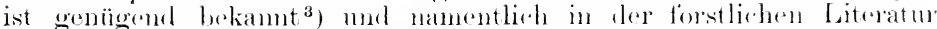

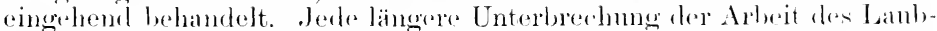

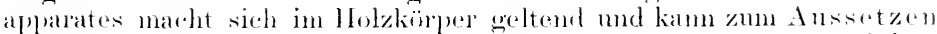
dor IIolzbildnme an einer Bammseite oder an der Stammbasis mol dem

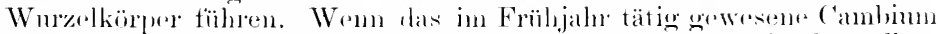

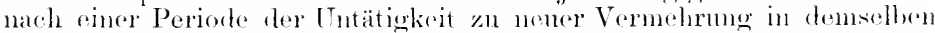
Jahre angeregt wird, legrime es mit der Bildhng rines menen brïhlings-

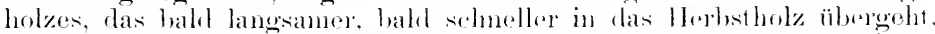

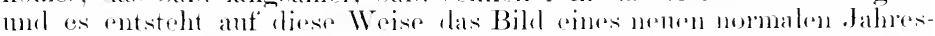

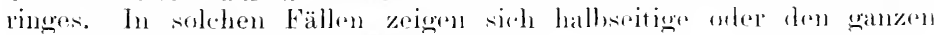

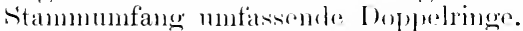

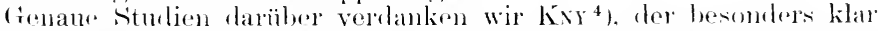

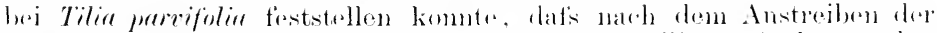

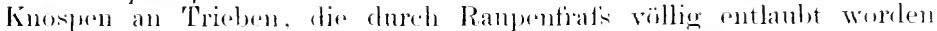

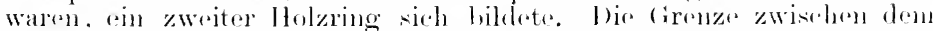

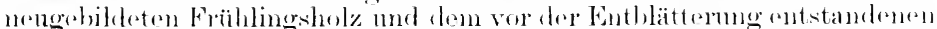
Holzringe war seharf. Mehrfache Brispiole ïber die Abhängigkeit der.

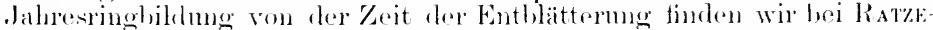

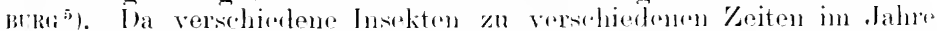

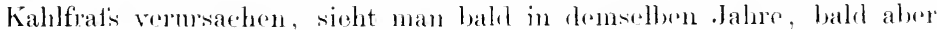
anch erst in folerenden (bei mangelhafter Ablagerumg der Reservestoftio) die sichwächmog im llolzzuwaths.

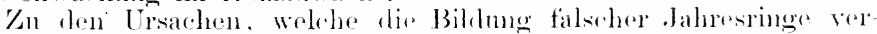
anlassen kömmen, komnte irh in Jahre lsti die Frostwirkmogen hinzu-

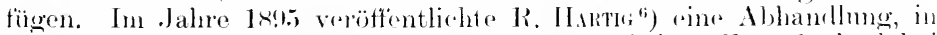

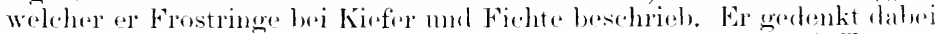
auch einer anderen merhanischen Wirkung. nämlich einer fureh Throwe

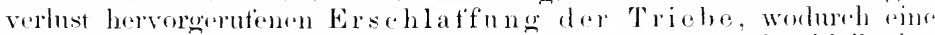

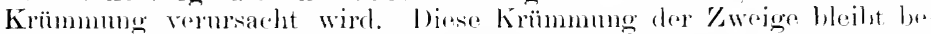

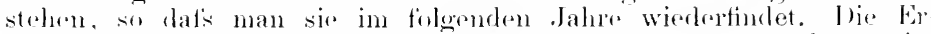

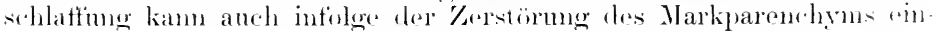

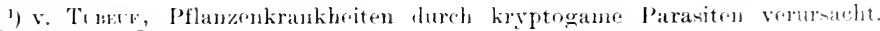
Berlin 1895, s. 471.

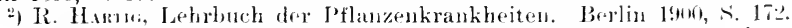

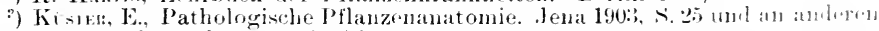
Orten. Hier auch die boneffende Literatur.

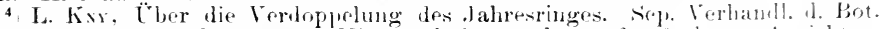

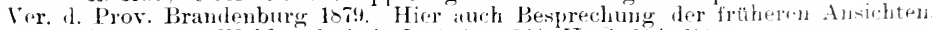

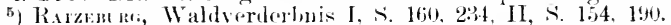

6) Harm:, R.. Doppelringe als Folge von spätfost. Fortl. naturw. Zeitschrift 189.5. S. $1-\div$ 
treten. In der letzten Anflage seines lehrbuches' ${ }^{1}$ ) wird von ihm ein Frostring aus dem Holze einer Kiefer und einer Fichte abgebildet und dazu bemerkt: „An älteren Stammteilen der Kiofern zeigte sich, dat's in jedem spätfrostjahre ein sogen. Dop pelring entstanden war. Ich habe später anch an Fichten mol anderen Nadelhölzern dieselhe Tatsathe konstatiert, dats ein spätfrost nicht die jüngsten Triebe allein schädigt, sondern oft noch in den zehnjährigen Stammteilen . Joppelringbildung hervorruft."

Eine gleiche störung im Bau des lahresringes beschreibt und zeichnet O. G. Petersex²) ron Buchen, die am 17.18. Mai 1901 in Mittel-Seeland stark rom Frost gelitten hatten. Schon fröher hatte Nörblnger ${ }^{3}$ ) eine ringförmige Unterbrechumg in der normalen Holzbildung als eine rötliche frewebelinie beobachtet. Auch anderweitig finden sich entsprechende Nitteihngen und Beobathtungen, die nene Gesichtspunkte aber nicht enthalten. Eine Erweiterung unserer Kenntnis der Starmugen in der Jahresringbildung brachten die Studien äher die Krebserscheinungen. Bei dem Apfelkrebs habe ich nachgewiesen, dats ein Jahresring, der ant der gesumlen Zweigseite eintach und normal ist, auf der krebigen sich fächerfömig in mehrere Ringzonen spaltet. Wie solche Lockerungen zustande kommen, heweison meine neneren situdien bei Eichen.

\section{Experimentelle Erzeugung von Parenchymholz durch Frostwirkung.}

Die in den vorhergegangenen Kapiteln als „Markflecke“, ..Parenchymholzbinden", "Ringschäle" nsw. beschriebenen Fälle einer Bildung von parenchymatischem Holzgewebe an Stelle normalen Prosenchyms beruhen auf mamigtachen Ursachen, die aber sämtlich darin äbereinstimmen, dats das Cambium an einzelnen Teilen oder am gesanten Unfang eines Jahresringes vom Jruck des darïber gespamnten Rindengürtels mehr oder weniger befreit wird. Dat's der Frost und namentlich der Frühjahrsfrost einc der wesentlichsten und hänfigsten Trsachen solcher Lockerungen des Rindengürtels abgibt, dïrfte ans nachstehenden Beobachtungen hervorgehen.

Im Jahre 1904 hatte ein Maitrost die jungen Eichentriebe am Rande einzelner Waldkomplexe —, dort wo dieselben an Wiesen grenzten derartig stark beschädigt, dats eine Anzahl Zweigspitzen gänzlich erfroren war, während andere nur geschwärzte, vertrocknende Blätter aufwiesen, aher an den spitzen später weiterwuchsen. Nachlem derartige 'Triebe imnerhall einiger Wochen wieder nene Blätter webildet hatten, wurden sie zur Untersuchung abgeschnitten. Sie lieferten in verschiedenen Höhen sehr verschiedenartige Bilder und mnter diesen auch das in Fig. 14s dargestellte.

Wir erkennen cinen mregelmälsig fünfseitigen Markkörper (m), mmgeben von cinem schmalen, einseitig stärker ansgebildeten Holzringe $(h)$. Dieser Holzring schlietst aber nach autsen hin nicht mit einer regelmäfsigen Cambimmzone ah, wie rles im normalen Zwoige der Fall ist, sondem geht plïtzlich in oin lockeres, weitzelliges Parenchymholz $(, h)$

1) Lehrbuch der Pflanzenkrankheiten. Berlin, Springer 1900, S. $220,221$.

2) Petersex, O. G.. Natterfrostens virkning paa Bögens ved. - Sep. Det forstlige Forsögsvaesen, I, 1904.

5) Nombntikn, Die fetten und die mageren Jahre der Bäume. Kritische Blätter f. Forst- und Jagdwissenschaft $1 \& 65$, Bd. 47, H. "2." 
ïber, das nach der Rinde zu derbwandiger wird und nur selten eine cambiale Grenzzone zwischen sich und der Rinde erkennen lätst. Dats dieser ans Lockerungsgewebe gebildete Gïrtel ( $\left.\eta^{\prime}\right)$ wirklich zum Holzring noch gehört und von demselben ausgegangen ist, beweisen die in der

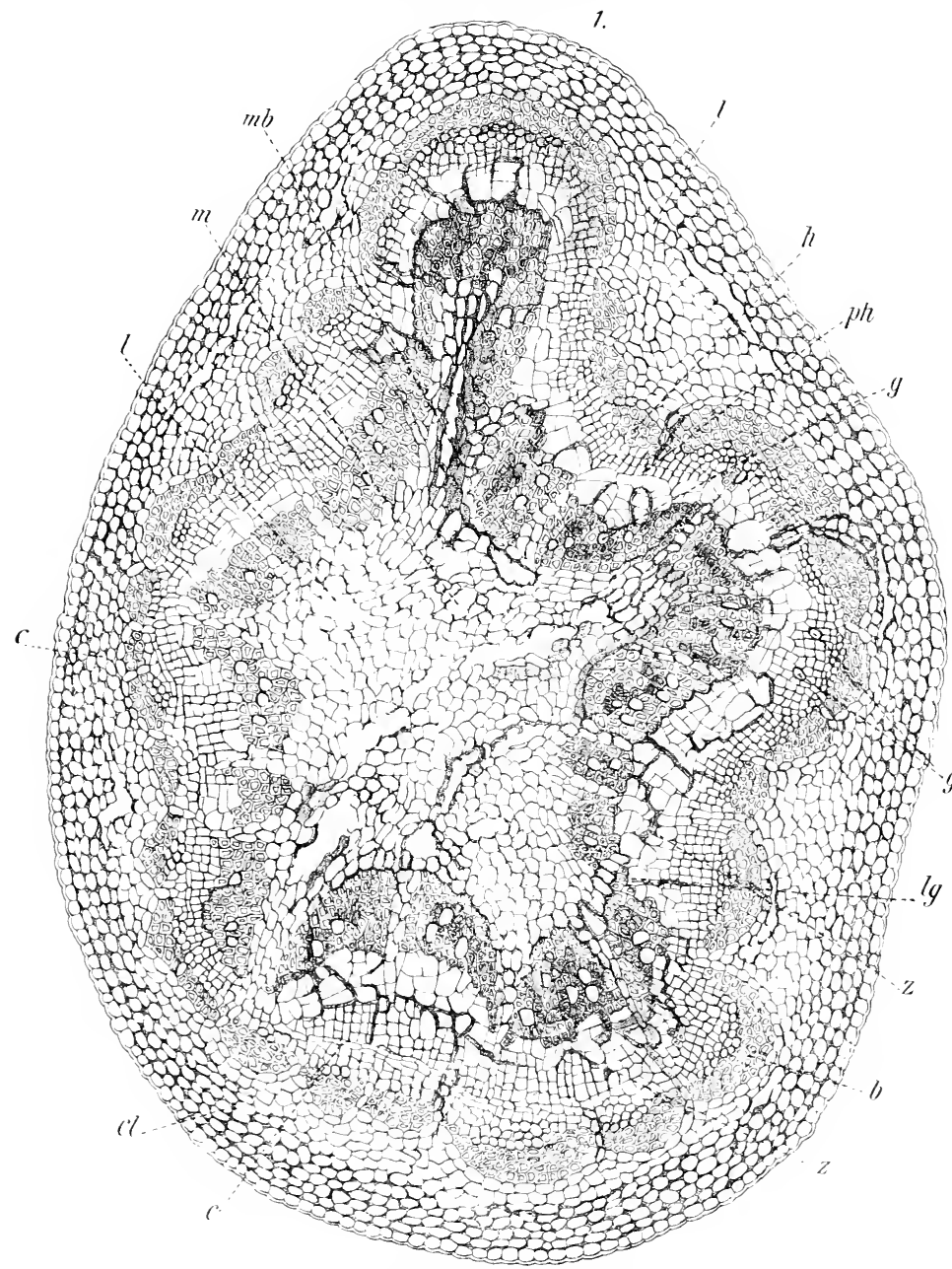

Fig. 14:. Ausheilung einer inneren Frostwunde an jungen Eichenzweige nach Maifrostbeschïdigrung. (Orig.

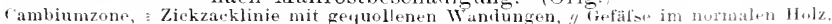
Erkitirung der übrigen Buchotaben befindet sich im Tost 
Lockerungszone zerstreuten kurzzelligen Gefätielemente $\left(g^{\prime}\right)$, die im Bau ihrer Verdickungsshichten denen der Gefälse im normalen, erstgebildeten Holzringe ähnlich sehen oler wloichen. Dieses Vorhandensein kurzer Gefälse oder Gefäfszellen und die Verdichtung der ganzen Lockerungszone an ihrer Peripherie durch Auftreten von derbwandigen, den echten Holzzellen ähnlichen Elennenten zeigen somit, dats dieser frostbeschädigte Zweig kurze Zeit nach Authören der Frostwirling und Bildung des Parenchymholzes sich angesclickt hat, zur normalen Holzringbildung zurïckzukehren.

Wir wïrlen, wem dieser Zweig Gelegenheit gehabt hätte, bis zum Herbst fortzuwachsen, dam einen zweiten (falschen). Jahresing erhalten haben, wie er von früheren Forschem bereits beobachtet und in vorhergehenden Kapitel besprochen worden ist.

Der Bastring (b) ist wenig irritiert worden; nur der Inhalt der jungen Bastzellen erweist sich meistens gebräunt, entsprechend der Ausfüllung einzelner (iefätse des Itolzringes mit rotgelber, gummiähnlicher substanz. Das Rindenparenchym besitzt einzelne gelräunte Gruppen. Die collenchrmatische Anlisenschicht der Rinde (cl) zeigt lieine besonderen Verfärbmgserseheinumgen, wohl aber ist dies hei der Markkrone der Fall, welche gänzlich gebrämnt erscheint. Diese Brämmmg lätst in lem Matise nach, als die Schnitte nach der gesünderen Zweighasis hin entrommen werden: dort finden sich nur noch einzelne Zellen mit gellem, rerquollenem Inhalt.

Bei den reichlich rorhandenen Zerklüttungen macht sich ein Unterschied in der Richtung der entstandenen Lüclien bemerkbar. Imnerhalb der Markscheibe ist die gröste Ausdelmmng der Lücken in der Richtung des Radius zu finden. und wir sehen, dats dies mit der eigenartigen strahligen Ausbildung des Markkörpers zusammenhängt. Derselbe zeigt sich fünfeckig ausgebuchtet. und die Ausbuchtungen kommen ladurch zustande, dats die den Holzring zusammensetzenden Gefätshündel sich teilweise anschicken, aus dem Ringe herauszutreten. Wie vorher angedeutet, liegt der Grund tü̈r dieses Answeichen einzelner Bündel darin, dats an jeder der tünt Ecken der Markscheibe die für die fünf nächsthöheren Blätter bestimmten Leitungsssteme im Begriff sind. nach aufsen ihren WVeg durch die Rinde zu dèn Blättern anzutreten. Für das der hier abgebildeten /weigstelle nächstliegende Blatt ist der Markkörper natürlich schon am weitesten ausgebuchtet und schickt sich an, als Markbrücke $(m b)$ in die nächste Knospe überzngehen. Dir beiden höheren Blätter, die nur ein und zwei Internorlien ron unserem (querschnitt entfornt stehen, haben ihre Bündrel noch innerhalb des geschlossenen Holzringes: aber dieselben lilden bereits merliche Ausbuchtungen des friten Achsenzylinders (rechte Seite der Figur). Für das der Blattstellungsspirale folgende vierte und fünfte höherstehende Blatt liegen die Bümdel noch ganz innerhalb des Holzringes und denten ihren späteren Anstritt nur durch schwache Vorwölbung nach autien an (linke seite dr.r Figm). Zwischen ilnen ist der Markkörper nur in Form eines verbreiterten Markstrahls fortgesetzt und noch nicht zu oiner wirklichen Markliriok erweitert.

Wie durch Vureifsung des Gewebes entstandenen Lïiken (l) entspechen num in ihrer Grötse der Mächtiglisit der Markaushuchtungen: je breiter dieselben sind, je näher sie also schon den ihnen zugehörigen Knospen stehen, desto stärker erweist sich die radiale Zerklïttung. Im (iegensatz zum Marklïrler sehen wir die Lücken $\left(l^{\prime}\right)$ in der Rinde sich 
tangential hinziehen. Sie entstehen teils dureh Ahlwhen der peripherischen collenchrmatischen schichten von dem chlorohylhoichen Parenchrm. teils aber auch durch Zerreitien einzeher Parenchymzellun. Bomerkenswert ist, dat's sowohl die Lückenbildung in ler limele als anch die Ars-

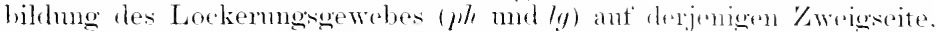
welche die weitest herausgetretenen Bändel anfwoist. viol märhtigel sind als anf der Gegenseite. Nummehr erklärt sich anch der Fmstand. dats man bei der Untersuchung frostbeschädigter toweige in der liegel eine śroitestärker angegriffen findet als die anderen. Wer

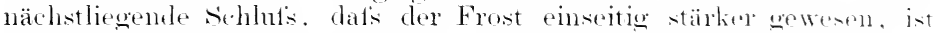
meist irrtimlich. Dem wemn man in Serienselmitten oine Anzahl älwe. einanderstehenter Internodien untersucht, wirl man sich älmpongen. dats bald die eine, bald die andere sieite desselben / weiges starline

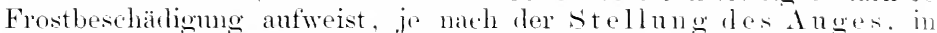
dessen Nïhe der Selnnitt ausgetührt worken ist. Je näher einom Anger. desto stärker die Frostwirkmug in der Achse.

Die im Vorstehenden geschilderten Gewehestïrmagn und Heilungvorgänge komnten nach mehrtach vergeblichen Versmehen endlich im Frïhjahr l!wi; anch kïnstich darmeh hervorgeruten werlen. dat's 'Toptexemplare von t-5.jährigen Eichen in einen Glashanse schon im April zum Austreiben gebracht worden mol these weichen Triobe im Mai in rinem (iefrierzylinder wähend einer Narht einer hälte his

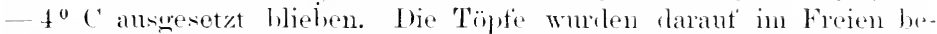

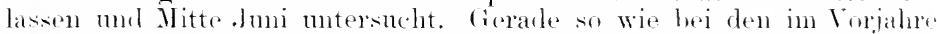
urmachten Beobachtungen an natiolich erforenen Eichen zeigtrna anch

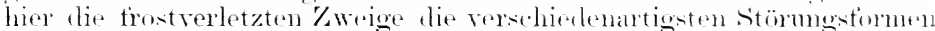

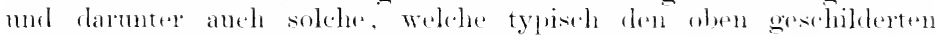
matülichen Beschäligmgen glichen. Nu waren die Heilmosvorgänge. die hier dentlich von den Markstrahlen ans ihren Anfang nahmen. von viel geringerer Mächtigkeit. was wohl darant zuriekzutühren ist. lats

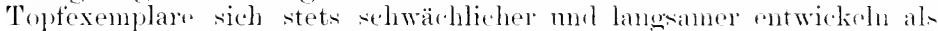
im fieien firmede wathsende Waldhänme. Anch worde die Benbachtme

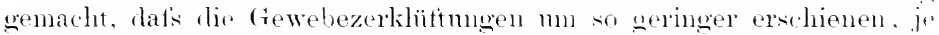
äler mol stärker der \%weig bereits zur \%eit der Frostwirkme war.

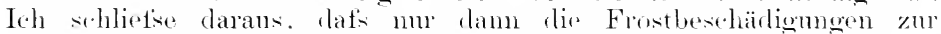
Parenchymholzbildung imerhalh emes Jahresringes tïhron, wenn sit ganz jugendliche. weiche Kweige zur \%eit des kräftigsten längen wachstums treften: antserden muls nach der Frostnacht gïnstige warme

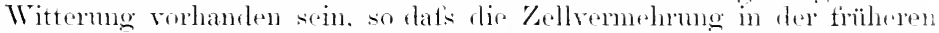
lutensitä vor sich gehen kann. Das Bammaterial in Form der molili-

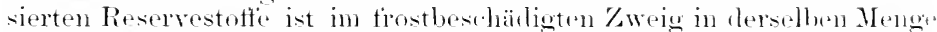

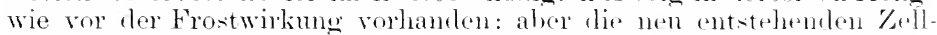

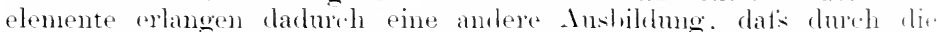

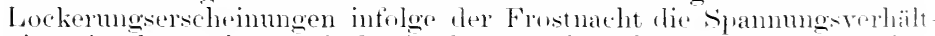

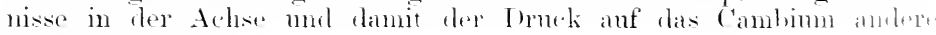
geworlen sind.

\section{Die Theorie der mechanischen Frostwirkung.}

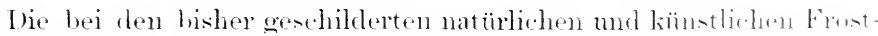

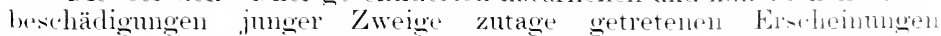
lassen. so weehselvoll sie sind, sich aut eintache muhanisch. lom-

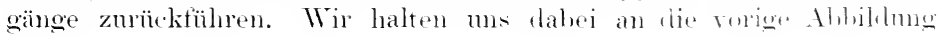


des Eichenzweiges, an der wir seluen, dats der tüntseitige Holzring, der die Markstheibe mmkränzt, plötzlich in eine helle \%one weichen

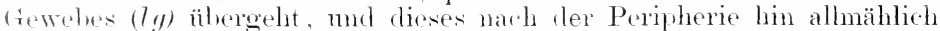
wieder derhere Ellemente bildet, die den Charakter des mormalen Holzes (h) hesitzen.

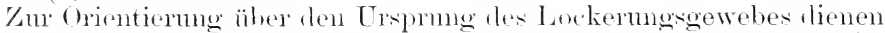

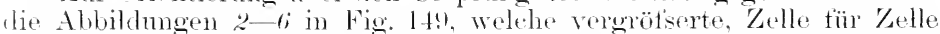
gezeichnete Partien ron ter rechten Seje der vorigen Figm (148) ans der zwischen 7! und lo gelegenon Region dess sehnites darstellen. Bei allen Bildem ist die obere Kante die markwäts gerichtete, die untere ist dis nach der linde hin gewrutete mol teilweise sogar (Fig. 149, Alb. ¿, 4, 6) schon Rindenelenente selbst anfweisenle. Die obersten, teilweise mit / bezeichneten Kellgruppen bilden die (trenze des vor der Frostwirtmg vorhandon gewesenen Holzringes, mol diese gehen nuvermittelt in das dïmnandige Gewebe (lg) des Lockerumgstreifens über

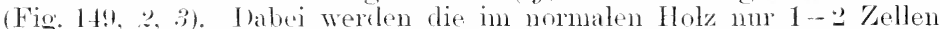
breiten Narkstrahlen (Fig. 14!, $5 \mathrm{~ms}$ ) ansoeweitet mol muegelmälsig vielzellig und ziehen sich erst wieder zu ihner frïheren Breite zurammen, wemn das lockere (rewebe in das sekmudäre Ilokz (Abl. :2, 3, li) mit regulären (iefätsen if übergeht. I)am bildet sich anch wieder eine normale ('ambinmzone (Fig. 14!, 2c) ans, welehe in der Zeit, in der die Markistrahlen whehernd sich verbreiterten, unkemtlich geworden war, da die \%ellteilmgon vänzlich umregehätig in versehiedenen Rogionen des Lenkermosringes stattfanden. Sobald wieder eine reguläre Cambiumzone sich einzurichten hegimnt, differenziert sich anch das gelockerte Rindengevebe derant, tats nun jugendliche Bastgrupen (Fig. 14!) \& b, mul $;$ i, li') wieder erkembar werden.

Thuth den Umstand, dats zwisehen dem vor der Frostwinkmo ansgefildeter Holze (h) und dem Lockermosgewebe (lg) keinerlei tote (iewebestellen sich rortinden, wirl bewiesen, dats das jugendtiche llolz, der siplintring, direkt in las Parenchymholz des Lockerunesringes ïherwegangun ist. Lieses Parenchym hat also immerhin seine Kugehörigleit zum llolzkörper bewaht, nud daher ist es nicht erstamlich, dat's nath lem Anthören der Ursachen, welche diese parmehrmatisehe Holzbildmeg veranlatst hatten, das Gewebe allmählich

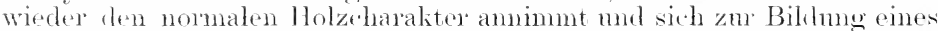

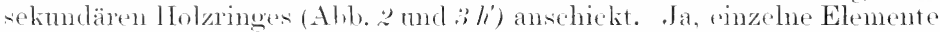
des riplintes, die zurzeit der hroimenden Parenchymbolzhilinug schon in ilner Verdicknus etwas weiter voreselniten waren. haben ihre Wandverdiclime weiter fortgesetzt, mot daher finden wir einzehe tracheale Elemente (Fig. 14!), f tr) nitten in dem Parenchymbolze.

Die Locliernngszone (ly) im quersehnitt des Eichenzweiges (Fig. 148) ist also nur ein mo lit'izierter Holzring, der in übermälsig

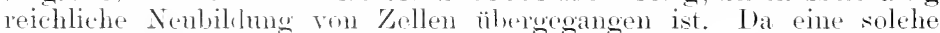
\%ellvermehrung lediglieh von Elenenten ansegehen kann, die noeh ihre cambiale Natur busitzen, muts notwendip geschlosen werden, dats die allerjüngsten cambialen Holzedomente, also der Splint, das Parenchymholz hervorgehracht haben. Selbstverstiandlich haben das eigentliche anatomische ('ambinm nebst der Jungrinde an dieser /ellvermehrmg teilgenommen, und ant liase Weise ist ein so profuses fiewebe entstanden, bei welehem man nieht zu nuterscheiden vermag, wo der Überwang vom Holz zur Rinde sich befindet.

Tir fragen num, was die Veranlassme zu Bilfmug dieser profusen 


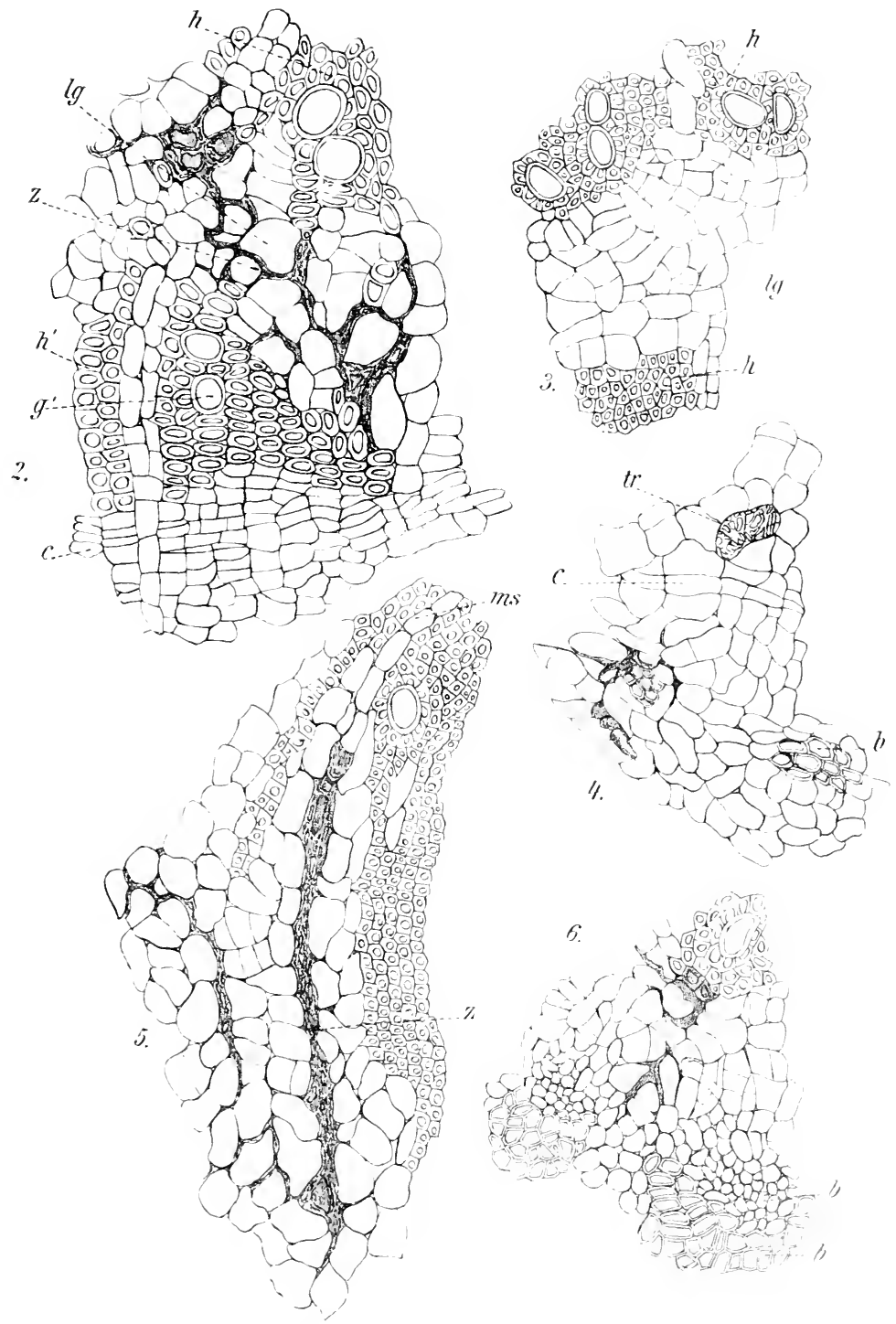

Fig. 149. Zellgruppen ans der Übergangsregion des normalen Holzringrs in den durch Frost hervorgerufenen Lockerungsistreifen aus Parenchrmhul\% litnommen aus der Zone l $g-b$ von Fig. 14. $z$ in Abb. : und ; zeigt die Zirkzallilinien mit ihren verquollenen Zellwandungen. inrig.) 
Gewelsezone gewesen sein mag: Iie Antwort kann nur lanten, das der schnürende, pressende Eintluts. den der Rindengürtel in seiner Gesamtheit ant die jüngsten Gewebe, ako die cambiale Region normalerweiste ausïben muls, durch irgendeine Ursache anfoehoben oder doeth äuliserst gesehwäeht worden ist.

Anf diese Ursache werlen wir durch die Lücken im Rindengewebe (Fig. 148 l', rechts) hingewiesen. Solche tangentiale Lücken im gesunden Gewelse kommen dadurch zustande, rats das oberhalb der Lücke liegende Gewebe sich von dem muteren abgehoben hat. Es kam sich aber nur ahheben, wemn es anf diesem darunter befindlichen Parenchym nieht mehr Platz hat, also tangential eine gröfsere Ansdehnung wie früher erlangt hat. Mithin hat in diesen äulseren Gewebelagen ein stärkerer tangentialer $/ \mathrm{mg}$ stattgetiunden, als in den nächst inneren Rindenschichten.

Nun erinnere man sich an die Casparschen Messungen beim Gefrieren. Es ziehen sich die peripherischen schichten fribler und stärker zusammen als dis zentralen. Dieses Zusammenziehen bei der Kälte ist in der Richtung der 'Tangente stärker als in der des Radius und in dem weichen Parenchym stärlier als im posenchymatischen Holzkïrper. Mithin muls bei der Frostwirkung ïberall imnerhalb einer holzigen Achse ein Überwiegen des tangentialen Zuges über das radiale Zusammenziehen stattfinden und unter Umständen sich bis zur radialen Zerklïftung des Gewebes steigern.

Wem der Holzring zunäthst isoliert gedacht wird, so mufs dieses überwiegend tangentiale Zusammenziehen notwendig an den Stellen des geringsten Widerstandes zu solchen Zerklüttungen führen, die den Flaffenden Frostspalten an alten stämmen entsprechen. Es müssen also ans rein mechanischen Grïnten innere radialo Zerklüftungen zustande kommen, und zwar in den Narkstrahlen und Markbrïicken. solche zeigt tatsächlich die Abbildmo des durch natiorlichen Frost heschädigten Eichenzweiges (Fig. 14s).

Betrachten wir jetzt den primären Holzring in seinem Verhältnis zn dem ihm anliegenden Rindengiütel, so haben wir anf die 'Tatsache zurüclzuweisen. Clats der Rindengürtel, dessen peripherische Zellen schon an sich in der tangentialen Richtung grötser sind als in der rarlialen, sich nun tangential anch stärker zusammenzieht, also in dieser Richtmo während cler Frostwirkmostark gezerrt wird. Läfst der Frost nach, hört zwar diese Kerrung anf, aber ihre Folgen bleiben. Demu das frewelse ist zwar dehmbar, aber nicht absolut elastisch, mol weht taher nicht vollkommen auf sein fï̈heres Volumen zurïck. Daîrch hinterlälst jede Frostwirkung eine Öberverlängerung der peripherischen Gewebelagen gegenüber den benachbarten mehr nach innen liegenden schichten. Der Rindenkörper in seiner Gesamtheit ist also linger geworden und hat entweder anf dem Holzzylinder nicht mehr Platz und hebt sich stellenweise von demselben ab. oder aher er wölls sich wenigstens mehr nach antien ror. d. h. vermindert seinenschnörenden Einflutis anf die tambialen Elementedes 110 lzzylinders.

Darauf antwortet die rambiale Zone durch Parenchymholzbildung, wie wir bei jeder Wunde sehen, bei der dio Rinde gelüftet wird. schlietst sich der Rindengiurtel wieder zu einer zusammenhängenden Schicht, hat anch der Cambinmzylinder des Kweiges bei seinem Dickenrachstum den schnürenden Einfluts der Rinde wieder zu iberwinden mol bildet laher wielerm normale Holzelemente. 


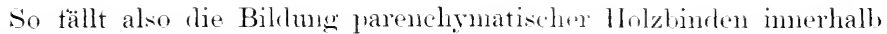
der jugendlichen Achse muter dasselbe Gesetz der mgleichen Zusammenziehung, das bei alten stänmen zur Entstehmé der kilaftenten Frostspalten führt.

\section{Die Cuticularsprengungen.}

Bei den in vorigen Abschnit erwähnten Versuchen mit 'Tont'exemplaren rom trüh angetriebenen Eichen wurde die bishor muckamnt. Tatsache festgestellt, dats an oberflächlich lejeht gehrämutru wher aurh noch grünen, also sicherlich noch wenig irritierten Blättern muterseits eine vielfach unterbrohene, schwarze, antiserst zarte sammlinie sich einstellt, die den Eindrnck macht, als ob stellonweise feinsto Rutstrilchen sich angesetzt lätten. Bei stäkerer Vergö̈sermug erkenut man nun, da1s diese sammlinie ans kleinen Abschülfirmeng der äutsersten cuticulardeclie besteht, welche durch ihren kömigen Kertall dis Lutt festhält mel darlurch schwarz erscheint. Wurle das Blatt durch Schwefelsäure zerstört, wohei es wurmförmig sich krömmte und dis Epidernis der (B)erseite sich stellenweise hlasig ahhob. dam bliebru die körnigen Häufchen zuräck.

Es stimmt dieser Befund mit den Walunehmmoen ïherein. the wir bei der Buche frïher nach natürlichen siätiösten boubachtet hatten mel anch hej Eichen in Froien nachweisen liosmten. Zum Zustandekommen derartiger liamm meklarer ('uticularsprengumgen müssen ïbrigens noch fresondere Tmstände mitwirken. die hier in Versuch zutällig vorhanden gewesen, aber bei anderen Versmehen mul in der freien Natur nicht immer wirksam zu soin scheinen. I) manchen Lokalitäten komnte man hald nach siätfösten solche verletzte Eichenblätter finden, in anderen aber nicht. Wahrscheinlich wehört ein bestimmter Turgescenzzustand des Blattes dazu. und dieser wird wieder von der jedesmaligen Beschatfonheit des Zellinhaltes ahhängig sein.

Einen Begrift ron den feinen Unterschieden, welche bei Frostheschädigmngen ausschlaggebend sind, erhält man schon durch die Beobachtung, dats mitten in dem sonst weng odes nicht erkembar beschädigten Mesophyll eines Blattes sich frostverletzte, absterbende Gew reinsehn bisweilen vorfinden. Dats in Versuch num anf cler Unterseite der Blätter diese Cuticularbrïche autgetreten, ist vielleicht auf eine abweichende Beschaffenheit gegenüber der oberseitigen Cuticulardecke zurückzuführen: demn man sah hei Einwirkmo von s'chwefelsäure rlie obere Decke sich lenchtend zitronengelb färben. während dieser Farhenton bei der unterseitigen Cuticula liam wahrnehmbar war.

Ich möchte der Entrleckung, datis durch leichten Frost muter Emständen Sprengungen der Conticularglasur entstehen liömen, emen besonderen Wert zuweisen. Bei anderweitigen Brïchen der c'nticula (an Kernobstfiüchten) sah ich in der Bruchturehe Pilzsporen lingen, und es dürte daher selir nahe liegen, anzumehmen. dafs solche Pilzsporen in dieser geschützten Lage an besten Gelegenheit hahen, zu keimen und ihre Feimschläuche in das Organ einzusenlien. Ant rliese Teise würde sich also erklären, wesweren uäuzlich gesund aussehende Blätter und Früchte nach leivhten Frühjahrsfrösten später einer Pilzinfektion anheim- 
tallen. Hierher zu ziehen wären Mitteilmuen von Voriso ${ }^{1}$ ), der 19!): nach Apriffösten gerade an den tiostbeschädigten Pflanzen die pilzlichen Parasiten in besonders starler Ansclehumg auftreten sah.

Es erklärt sich nun anch lie Esscheinung der sogenamnten Rostzeichmmgen in zusammenhängenden Ringen und nmregelmätigen Flächen anf unserem Uhise. Ex sind Korkbildungen. welche infolge der Heilungsvorgänge bei c'nticularbiuchen sich eingestellt haben, während die normalen Korkzeichnmen der Frïchte von den siraltäftinungen bzw. Lenticollon anszugehen ptlegen.

\section{Frcstschutzmittel.}

a) loie sichneedecke.

Das allgemein angewendete Vertahren, PHanzen gegen Frost zu schützen, besteht darin, dats man dieselben mit möglichst schlechten Wärmeleitern umgibt. Man hedeckt die Weinstöcke, Rosen nsw. mit Erde oder Lanb oder bindet die stämme in Moos, Strol n. dol. ein. Alle diese Mittel sind gut. Man versämme aber nicht, in kalten Wintern mit märigem schneetall auch den schnee aus den Wegen anf die eingebunlenen Pflanzen zu werfen. Es ist allseitig bekamnt, dat's eingebmudene stämme, z. B. von Rosen, oft erfirieren, und dieser Umstand wird erklärlich. wemn man mit einem 'Thermometer die Temperatur. muter dem Deckmaterial mutersucht: diese ist mu wenig von der äufseren Lnfttemperatur abweichend. Untersucht man dagegen den Boden muter einer vielleicht nu is cm hohen schneedecke. so findet man denselben ganz bedentend wärmer. (iöplerT : Untersuchungen²) geben anch über diesen Gegenstand die schönsten Belege. Im Februar 1870 war die Temperatur selu niedrig: das Thermometer sank an 4. ant chrchschmittlicll $-12,6^{\circ}$, und dabei war die Temperatur mter einer $10 \mathrm{~cm}$ hohen schmeerlecke - :". Ther Luttemperatur

$$
\begin{aligned}
& \text { von }-14,7^{\prime \prime} \text { am 5./2. entiprach eine Temperatur unter dem schnee von - 4,6" }
\end{aligned}
$$

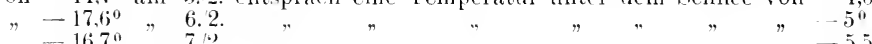

$$
\begin{aligned}
& "-16.7^{\circ}, 7.0 . \\
& " \text { - } 10,70.2 \\
& " \quad-15,4^{\prime \prime} ", 9.2 . \\
& \text { " - } 14,9^{\circ} " 10.2 \text {. } \\
& "-15,{ }^{\circ} " 11.2 \text {. } \\
& "-5,7^{\circ} " 1,2.2 . \\
& \therefore-2,8^{\circ} " 16.2 .
\end{aligned}
$$

Her Boden selhst war unter der Schneedecke 30 em tief getioren, aber die Temperatur desselben selbst an dem kalten 5 . Februar in 5 con Tiete nul - 1".

sprechendre Beweise fü̈r den Nutzen der Schmeedecke dürften liamm zu findsu sein. Es erklärt sich darans die Möglichkeit der Polarvegetation. Die höehsten his jetzt beobachteten Kältegrade der Polarzone (- $\left.4^{\prime}\right)$ bis $4^{\circ}$ ) wirken nu anf die ïher den sclmee hervorragenden Stämme der Bämme, nicht ant die Wurzeh dieser Stämme und ebensowenig aut die perennierenten, krautartigen frewächse. Diese befinden sich im Borlen in einer nm rinige Grade unter $0^{\circ}$ betragenden Temperatur ler schneedecke. welchr zwar nicht das Gefrieren, wohl aber den

1) Vurixn, P., Liazione del freddo sulle piante coltivate, specialmente in relazione col parassitismo dei funghi. Atti Accad. di Torino XIVI.

2) Bot. Zeit. 1<71, Nr. 4, S. it. 
Wärmeverhust dureh Strahlung, das Eindringen hoher Kältegrate mul

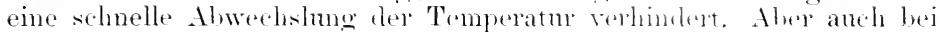
mos ist öfter, als wir denken, die Existenz manclur Kulturen an die

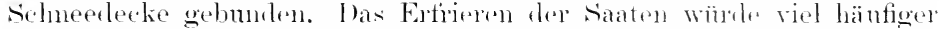

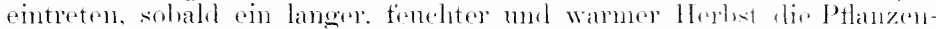

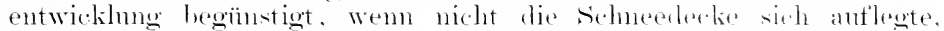
welehe die strahlung mol die in mseren Breiton so hänfigen stakken Temperaturschwankimgen ahlält. Wir sehen oft wenne, wit hicht die

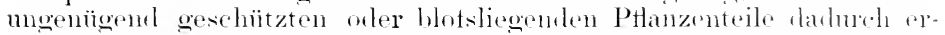
frieren, dats plötzlich anftretender starker sommenchein sio trittit. In

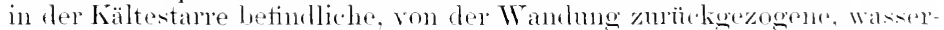

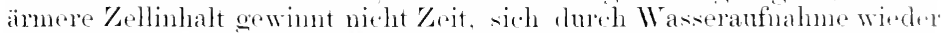

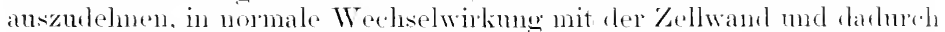
mit der Ungebmog zn treten, nud damit ist die Ibsorganisation der Zelle eingeleitet. Das sind die Vorgänge, die namentlieh bei Frühjahrs-

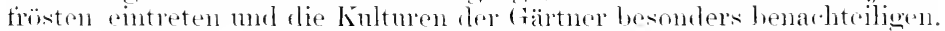

\section{h) lige Verwendnug des Wassers.}

Namentlich bei lisantarticen froüchsen, die plötzlich rom Frost überraseht werden, hiltt man sich lurch Begietsen ter hantwefinenen Pflanzenteile mit recht kaltem Wasser mol Eimrichtung einer Brseluattung. I)as Wasser ant den Ptlanzen erefiert damn zu einer Eiskinste; hier-

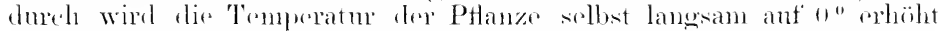
und kann num von dieser. 'T'mperatur an nach dem Anftanen der Konste sich alhmählich weiter erwärmen.

Anf demsolben Prinzip der allnählirhen Erwärmme bermht das Einsehütten angetrorener Kartoffeh nul Rüben in Bottiche mit kaltem Wasser mol das Zusammenwerten gefrorener Kohlkëpte in Hanfen, die mit strohmatten heeleckt werden.

Geren die Naehtfroste im Frïhling und lleplest. wo es vorkommen liam. tat's die Luftemperatm gar nicht bis ant "s" sinkt, die Pflanzen

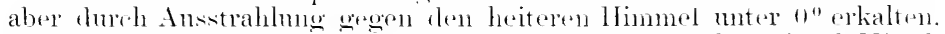
sich mit Roif' bedecken mud erfrieren, schützt man dieselhen durch Mittel. welehe die strahlung hemmen. Man spannt Deelien unf Matten iiber

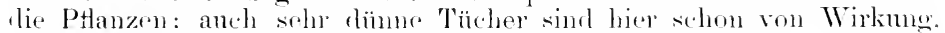
und bei Mangel an I leckmaterial ist das diime Belegen mit Reisin hier ganz an Platze. Anch senkrechte Wände erweisen sich häufig als vortreftliches Frostschutzmittel sie wirken einerseits daclureh, dats sie die Winde ahhalten nurl andrerseits datureh. dass sie dio Ansstrahlumg der Ptlanzen vermintern. Bei śpalierläumen an Manern oder Holzwänden kommt ans der ganz bedentend verminderten Aus-

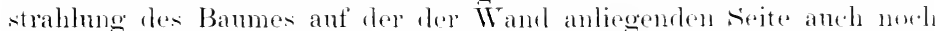
hinzn. dats die Wand selbst ihre opespeicherte Ẅ̈̈mo alhuählich alggiht.

Weniger wirkam, jeloch nicht ganz zn verwerfoul ist ein von alten sichritt-tellern emptohlenes. boj Gartenkulturen anwendhares Fontschutzmittel im Frühjahr. Der stamm von Bämmen wird mit cinem strohseil nmwickelt. dessen eines Encle in Wassor tancht. Fbur Burte blühenter Frïhjahrsblumen werden kreuz mol quer in eininer Ent-

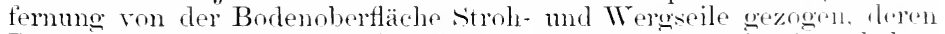
Enden in einem Gefäts mit Wasser dum cimon stein tixtgerhahten werden.

Zur Erklärung einer gïnstigen Wirkung diesen Vortalurens wird 
man an die grotse latente Wärme des Wassers denken müssen. Wenn las Wasser in den vollgesogenen strohseilen gefiert, wird Wärme trei, die den darunter liegenden Pflanzenteilen insofern zm Vorteil vereicht, als dadurch das Tordringen der Kälte zu den Pflanzen verzögert wird. So gefieren auch die Pflanzen in der Nähe grötserer Wasserflächen weniger leicht. Ein Nittel. welches Gärtner mit Erfolg bei Topfkulturen zur Keit, wo Nachtfröste zu befürchten sind, anwenden, hesteht in der Terminderung des Giefsens, damit das Gewebe der Pflanze weniger wasserreich dem Frost ontgegentritt. Eine reichlichere Tertumstung entzieht der Pflanze mehr Trärme, und somit werden stark begossene Pflanzen sich mehr abkïhlen als weniger turgescente.

\section{(.) Iid Windwirkungen.}

Anch Winde kömnen günstig wirken, insotern als ein Stum bei warmer Witterung hegimnt, somit die Verdunstmos sehr stark beschlemigt mind das frewebe wasserärmer macht. Umgekehrt werden wimlarme Regemperioden die Gefahr des Erfrierens steigern. Experimentelle Beweise liefern die von Anerhou, ${ }^{1}$ ) ansugefühten Versuche mit künstlicher Beregnung. Ton je sechs Exemplaren von Birnen, die mehere Monate im sommer in einer Regenzelle anfgestellt waren, erwiesen sich nach einem Wintertiost fünt Exemplare vollig und eines teilweise erfioren, während bei den Vergleichstöpfen, die in einer Trockenzelle gestanden hatten, nux zwei erfroren und vier unbeschädigt waren.

Indes lassen sich betreffs der Windwirkung keine allgemeinen Regeln autstellen. Jede Lokalität hat ilne besonderen Ansprïche. Wemn beispielsweise gesagt worken ist, dafs Winde gïnstig wirken. so bezieht sich dies nu auf solche Fälle, wo es sich nicht mm dauernde Windwirkmg handelt, wie sie an sandigen Küsten auftritt. Dort wird das Terhalten der Wurzeln ansschlaggebend, die, selbst wem sie nicht erfieren, doch kein Wasser mehr aufnehmen, wenn die oberirdischen Teile noch stark verdunsten. Es kömnen dann Gehölze geradezu vertrocknen. In dieser Beziehung sind die Ertahrungen von Hörker-Dortmund ${ }^{2}$ ) sehr beachtenswert. Derselbe schützt weniger die oberirdischen Teile, aber bedeckt den im Herbst um seine Gehölze gelockerten Boden mit Dïnger oder teuchtem Torfmull und begietst sogar die immergrünen Sträucher an sompigen Frosttagen. Durch die Deckschicht tritt dex Frost nicht tief em, und die Wurzeln kömnen den oberirdischen Teilen stets Wasser zuführen. In Schmuckanlagen, wo man reichlich die feineren Coniferen verwendet, scheint es in stark windigen Lagen vorteilhatter zu sein, die blangrünen Formen zu verwenden anstatt der remgrünen Stammarten. Es wird nämlich behauptet, dats erstere widerstandstähiger sind.

Ferner weute man seine Aufinerksamkeit dem Unstande zu, dafis lie Basis der (Fehölze, die vielleicht durch Moosvegetation, Laubanbäufiung, Waldstreu und dergl. das ganze Jahr über geschützt gewesen ist, nicht im llerbst durch säuberungsarbeiten und dergl. fireigelegt wird. Man hat nämlicin gefunden, dafs Pflanzenteile, welche

1) Aıеrнor, R., Versuche ïber den Finflufs häufigen Regens auf die Neigung zur Erkrankung von Kulturpflanzen. Arb. aus der Kais. Biol. Anst. f. Land- u. Forstwirtschaft. Bd. V, Heft fi $(1907)$

2) Hirker, Windschutz mul Winterschutz. Prakt. Ratgeber i. Obst-u. Gartenbau 1907, s. 61 . 
geschützt (chrch Boden oder Laubwerk) erwachsen sind, säfte besitzen, die leichter erfieren als die von dauernd in dre l nut lufindlichen Teilen.

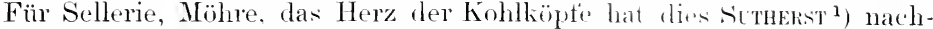
gewiesen. Anferdem wird, selbst wenn die Burhattenheit des /ellsaftes nicht mitspricht, mindestens der Wassertransunt in den ihrer schützenden Umgebung beraubten and daher schneller sich ahkïhlenden Wurzel- mnd Stammkörpern vermindert mel die Gedahe des Vertrocknens erhöht²).

Das Belassen toter PHanzenreste (Laub, Grasbiuschel, vorjälrige Blütenstiele und dergl.) anf Saatbeeten mol standen bis zm späten Frühjahr hin ist eine Matsregel, deren Wichtigkeit nicht wentiond gewiüdigt wird. Es handelt sich nämlich daboj nicht num nn ilien Einfluts als Frostschutzmittel, sonclern auch als Sehntz geven das Ter trocknen durch Frühjahrswinde. Wir kömmen fast alljährlich die Erfahrung machen, dats Ptlanzen gnt durch schwere Winter gekommen sind und wintergrüne Gewächse ihr Laub hehalten haben. Wenn aber wenige Tage nach der Entfermmng des Schnces windiges, helles Wetter eintritt, vertrocknen die bis dahin noch saftig gewesonen Blätter. Möglicherweise tritt bei dieser schnellen Anstrocknung der Gewebe cine ähnliche Veränderumg der Eiweifsstofte in Protoplasma ein, wie sie nenerdings (GokkE ${ }^{3}$ ) als Frostwirkmg nachgewiesen hat. Die Folge ist bei manchen Gewächsen eine vollständige śch üt to. krankheit, die tort unterbleibt, wo durch vorjährige Vexetationsreste ein Schutz geboten wird. Unsere gewöhnlichsten ïberwinternten Blïtenstanden, Getreidesaaten, Gehölzsaaten usw. gehen manchmal erst im Frïhjahr durch Vertrocknen zugrunde.

\section{(1) Die sehmauchfener.}

Alle diese Vorbengungsmethoden lassen sich in dor I sandwirtseluaft im grofien nicht anwenden, wohl aber dïrtte das Wittel noch mehr Beachtung des Landwirts verdienen, welches M.MER ${ }^{4}$ ) ans der Vergessenheit hervorgezogen hat, nachdem es trïher von GörpenT ${ }^{5}$ ) und MEYEN ${ }^{6}$ ) sehon wiederlolt anempfohlen und durch Beispicle grestützt worden war. Man zïndlet nämlich mehrere Fener, die recht viel Rauch entwickeh, auf' den Grundstücken, bei denen man Frostheschärligungen türchtet,

1) Simbrs, W. F., Der Gefrierpunkt von Pflanzensäften. Biedermanns Centralbl. 1902, s.' 401 .

2) Kosnory, P., Einflufs verschiedener äufserer Faktoren anf die Wasseraufnahne der Pflanzen: cit. Just's .Jahresbericht 1897, I, S. 75.

3) Grikf, H., Tber chemische Vorgïnge beim Erfrieren der Pflanzen. Landwirtschaftliche Versuchsstationen LXV, 1906, s 149; cit. Bot. Centralbl. 1907, Bd. 104, S. 35x. - Der Verfasser sieht die Ursache des Kältetodes darin, dafs durch die Eisausscheidungen der Zelle der Saft eine so konzentrierte Salzlösung alhnibihlich darstellt, dafs eine Aussalzung der löslichen Eiweifskörper erfolgt. Er stintzt stines Ansicht auf Versuche mit Prefssäften aus gesumden und erfrorenen Pflanzenteilou. Frischer Pflanzensaft enthielt wesentlich mehr filtrierbare Eiweifsstoffe als gefroren gewesener. Der Kältegrad, bei dem in Prefssaft eine Eiweifsfälung eintritt, ist bei den einzelnen Pflanzenarten ungemein verschieden; bei sommergerste und -roggen schwankt er zwischen - 7 bis - 9", bei Wintergerste und -rogeren zwischen - I0 bis $-15^{\circ}$, bei Narleln von Picen excelsa beträgt er -40\%. Auch Reaktionsänderungen können beim Erfrieren mitwirken. Die Phosphorsäure beispielsweise ist als säure schwächer bei höherer Temperatur, stärker bei Abkuhlung.

4) Lehrbuch der Agrikulturchemie 1871, I, S. 382 .

5) Wärmeentwicklung 1830, S. 2:30.

6) Pflanzenpathologie 1841, S. 323 .

Sorauer, Handbuch. 3. Aufl. Erster Band. 
an. Das Verfahren, das nach Boussinciault in Oberperu von den alten Lnka's eifrig ansgeübt worden sein mol bei den alten Völkern mehrfach ansgedehntere Anwendung gefunden haben soll, wird jetzt auch wieder mehr zum Schutz der Weimptlanzungen benntzt. Nach Göprert bestrebten sich Olivier de Serres im Jalure 1639 und später Peter Hogstroin im Jahre 1757 die Wirksamkeit des Verfahrens durch Versuche festzustellen. In Württemberg existieren Verordnumgen bereits vom Jahre 1796 und in Würzburgischen von 18(1);, nach welchen im Herbst bei eintretender Frostgefahr für die Weinberge Ranchfener angezündet werden müssen. In Sehlesien wurde längere Zeit hindureh in Grünberg von diesem Mittel Gebrauch gemacht; es wurde aber, trotzdem es 20 . Jahre hindurch von einem Besitzer mit Erfolg angewendet worden, aus Mangel an allgemeiner Beteiligung wieder autgegeben. Die allgemeine Beteiligmng einer Gegen,l ist aber nötig, da somst häufig ein einzelner dem Nachbar, aut dessen Felder der. Wind den Ranch hintreibt, einen Dienst erweist, ohne Gegendienste zu erhalten. Besondere Torschriften für diese sichmanchfener sind nicht nötig. In klaren Nächten, namentlich gegen Morgen vor Somnenanfgang, werden die Feuer angezündet und durch fenchte Abfälle, Moos, Stroh usw. genährt, wobei man eben Sorge trägt, dat's möglichst dichter Ranch über die Felder himziehe.

Natürlich wirkt hier nicht die durch das Eener erzeugte Wärme, welche schon in geringer Entfermung vom Herde der Flamme nicht nachweisbar sein wird, wohl aber wirkt der Ranch, wie bei dem Gärtner die über die Pflanzen gebreitete Bastmatte, oder wie eine Wolkendecke, indem er die zu grofise Abkïhlumg dureh Strahlung verhindert. Dureh Trnoal's Entdeekungen wissen wir, dat's eine Anzahl Stoffe, wie Kohlenoxydgas, Kohlensäure, Sumpfgas, Ammoniak, Schwefelwasserstoff und ätherische Öle in änt'serst f'einer Verteilumg in der Luft die Fähigkeit derselben, Wärmestrahlen durchzulassen, ant ein oft selm geringes Mat's reduzieren. Diesell,e Fähigkeit besitzt num aneh der Wasserdampf ${ }^{1}$ ), von dem Trndal teststellte, dats er eine 15 mal grötsere Wärmemenge auffing als von der ganzen (umreinen) Luft, in cler er verteilt war, anfgehalten wurde. Der Vorgang ist also folgender: Am Tage sendet mns die Somne ihre Wärme in leuchtenden und dmblen Wärmestrahlen, die der Boden teilweise reflektiert, arösenteils aber absorbiert und so lange hält, bis die Luft kälter wird wie er selbst. Tritt dieser Zustand ein, sucht sich das Gleichgewicht der Wärme dadurch herzustellen, dafs die Erde num ihre Wärme in der Form dunkler Wärmestrahlen an den kalten Luftranm ahgibt. Sind nm aber die meren Luftschichten mit einem der obenerwähnten Gase oder mit Wasserdampf stark beladen, so nimmt der Wasserdampf die vom Boden ansstrahlende Wärme in sich auf, anstatt sie durch sich hindurch in die oberen Regionen der Luft zu leiten. Wie grof's diese Wärmemenge ist, die von den unteren Luftschichten aufgetangen wird, zeigt TrNDAL: „Betrachten wir die Erde als eine Wärmequelle, so werden zum wenigsten $10 \%$ ihrer Wärme imnerhalb zehn Fut's von der Oberfläche aufgetangen." Dureh diese Absorption der dunklen Wärmestrahlen bilden die unteren, wasserreichen Luftschichten einen schïtzenden Mantel um die Erde, die infolgedessen nieht so tief erkaltet. Der durch das Fener erzengte Rauch ist somit ein künstlicher Mantel voll Wasserdampf, der in Terbindung

1) Trxwal, Die Wärme betrachtet als eine Art der Bewegung. Deutsche Ausgabe von Helmholtz und Wiedemann 1867. 
mit zum Teil noch unbekamnten Destillationsprodukten die Durchlässiokeit der Atmosphäre für die ron der Ackertläche answestrahlte dumkle Wärme vermindert.

Eine spezielle Aufzählung der in nenerer Zeit zmm /wecke der Raucherzengung bei Frostgefahr zusammengesotzten käntlichen Räncherkerzen und-ziegel übergehen wir, da mit der tortichneitenten Technik immer neue Kombinationen auftreten werlen. Es genüigt der llinweis auf die Existenz derartiger Artikel. Erwähnt werelen mag nur, datis neuerdings bei den Räncherungen der Weinberge man zur Termerilmng des Fortziehens der Rauchschlangen bei plötzlich mmschlagentem Windo das Räuchermaterial auf Karren packt'). Am ausgelereitesten soll die Anwendung der Räucherkarren in der Stadt Cohmar sein, dis cinen seit 1s84 wohl oromisierten Räucherdienst ausogehildet hat. ('olmas liegt in einer Ebene, und in Ebenen ist die Frostgetaher mötser als in den höheren Lagen, wie sich beispielsweise 19m3 bei den Frïhjahrsfrösten in Florenz gezeigt hat, wo Passerisi ${ }^{2}$, in to $m$ Mrereshöhe Ohstbäume mol spargel stark beschäligt, aber $100 \mathrm{~m}$ höher ganz womml fant. In Colmar werden eiserne Karren mit rtwa li Liter flïssigem Teer beschickt mod der Karren nath Anzünden des Teors ant den Feldwegen bis zum nächsten Posten (etwa li, m Entfernumg) hin und her gefahren. Bei $+1^{\prime \prime}$ wird die Ränchermamschatt alarmiert und bei

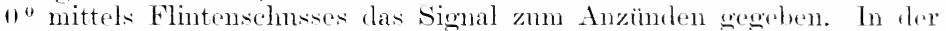
Regel wirl nachts zwischen 2 ind :) Uhr begomen. D)ie allerdings hohen Kosten, welche dor Stadtrerwaltung dureh den Räncherdienst erwachsen, werden durch eine Abgabe von den geernteten Tranben gerleclit.

Wir haben diesen speziellen Fall angetührt, woil wir olanlen, dat's nur rine derartige Organisation durchoreifenden Erfolg hatien kimn.

\section{Die Voraussage der Fröste.}

Bei der Kostspieligkeit der Erzengung von Sehmanchteneru zum Schutze der durch Spätfröste bedrohtrn PHanzungen ist es natiurlich von grölster Wichtigkeit, amähernd vorher beurteilen zu können, ob Nachtirost eintreten wird.

Es empfiehlt sich daher die Benutzung der von Lavi (Mïnchen) lionstruierten Nachtfrostkurve, die auf Pschrometerbeobachtumg beruht (s. Fig. 150). Wem in den Nachmittagsstunden im Frïhjahr dic Temperatur sinkt und bei Windstille der Himmel klar wird, steigert sich die Nahrscheinlichkeit eines Nachtfrostes. Zur Benutzung beistehender Figur sind zwei empfindliche, gena übereinstimmende Thermometer notwendig. Die Quecksilberkngel des einen wird derart mit tiaz' momickelt. dafs das untere Ende der Umhïlhung in Wasser tancht, also die Kugel stets eine nasse Decke hat. Dieses 'Thermometer wird infolge der stïnligen Wasserverdunstung tiefer stehen als das daneben befindiche Instrument. welches die gewöhnliche Luftemperatur anzeiot. Ans der Diffinuz dieser T'emperaturen kann man die relative Feuchtigkeit unt die Lage des T a u pu ktes berechnen, d. h. derjenigen Temperatur, hei lisen Eintritt der in der Luft zurzeit enthaltene Wasserdampt' als 'T'un, Nebel

I) Brnikn, Räucherkarren. Prakt. Ratg. im Obst- u. Gartenlau 1996, ‥ 128.

2) Passemixi, N., Sui danni prodotti alle piante dal ghiacciato dei giomi 1920 aprile 1903. Bull. soc. botan. ital. 1903, S. 30 s. 
oder Regen ansgesehieden wird. Damit aber diese Wasserdampfniederschläge als ein schützender Mantel gegen die durch Ausstrahlung erzengte Frostgefahr wirksam werden, muls die Tau-und Nebelbildung bei Temperaturen über Null erfolgen, also der Taupunkt über Null liegen. Ist dies nicht der Fall und die Luft trocken, so ist Nachtfrost zu erwarten.

Die mechanische Handhabung würde also folgende sein. Man lese zunächst den Stand des trockenen Thermometer's ab und berechne den Unterschied desselben ron dem mit der nassen Kugel. Der Stand des trockenen Thermometers wird auf der wagerechten Linie und die gefundene Differenzzahl auf der senkrechten Skala anfgesucht. Schneiden

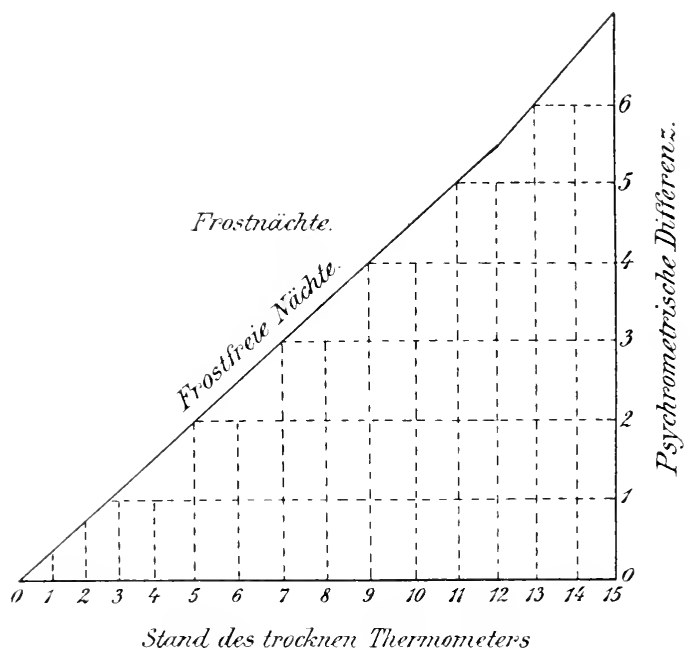

Fig. 150. Nachtfrostkurve nach Dr. Lixı, München.

sich nun die beiden von den betreffenden Skalenpunkten ausgehenden Linien rechts von dem gebogenen Strich, welcher die Nachtfrostkurve darstellt, also noch immerhalb des Gitterwerks der Skalenlinien, so ist kein Nachtfrost zu befürchten. Wenn aber der Schnittpunkt erst links von der Hypotenuse des Dreiecks, also ant'serhalb des Gitterwerkes auftreten würde, ist mit Bestimmtheit Nachtfrost zu erwarten, falls nicht plötzlich die Witterung umspringt und warme Luftströmungen, Nebel- oder Wolkenbildung veranlassen. Finden wir beispielsweise nachmittags am trockenen Instrument $8^{\circ} \mathrm{C}$ und am feuchten Thermometer $4^{\circ} \mathrm{C}$, so ergibt sich eine Differenz von $4^{\circ}$. Der Schmittpunkt der senkrechten Temperaturlinie (8) mit der wagrechten Linie der Differenz von 4 würde autserhalb des Gitterwerkes, nämlich links von. der Nachtfrostlinie liegen, also wäre Nachtfrost wahrscheinlich. 


\section{Frosthärtere Obstsorten.}

Je mehr wir erkennen, wie mamnigfach die oft äuficrlich unbemerkbaren und erst in ihren Nachwirkungen zur Geltung welangenden Froststörungen sind, desto grötseren Wert erlangt die Frage nach trostwiderstandsfähigen Obstsorten. Wenn wir aber die Erfahrungen der Obstzüchter miteinander vergleichen, stellt sich die 'T'atsache herans, dafs die klimatischen Verhältnisse der einzehen fegenden den Charakter der sorte derart zu modifizieren imstande sind, datis cine hier als fresthart empfohlene sorte dort durch frühere Entwicklung oder geringeres Ausreifen ter Zweige frostempfindlich wird. Deshalb ziehen wir vor, die als frosthart empfohlenen sorten fü̈ einzehe Gegenten zn nonnen, wobei wir die Gegenden derart answählen, dat's sie teils unter kontinentalem Klima stehen, teils vom Meere beemflutst werden. Ausichlaggebend ist für diese Aufzählung die Blütenbeschädigung durch dio Iaifröste, weniger das Verhalten des Holzes, weil letztere Beschädigungen meist nur bei den selteneren strengen Winterfiösten in Betracht kommen, während die Blüten alljährlich der Gefahr des Erfrierens ausgesetzt sind.

Fïr die deutschen Kulturen beachtenswert ist der Untersehied zwischen Nordost- und Nordwestdeutschland. Im Osten macht sich der Einflut's von Ruf'sland durch die hereinlnechenden suätfrostperioden ganz besonders in der Provinz Posen und in Oberschlesien geltend. Demnoch haben wir Erfahrungen zu registrieren, welehe dartun. datis sellst die emptindlicheren Birnen in gewissen sorten noch in Posen gutes Tafelobst liefern. R.nowski ${ }^{1}$ ) nemint ron Winterbirnen, die sich selbst in ungünstigen .Jahren noch bewährt haben: Josephine von Mecheh, Rilars Kernlose, Madame Verté, Winter Nelis, Nene Fulvie, Winter William unel Dechantsbirne von Alencon.

In Oberschlesien haben sich bewährt 2): Amanlis Butterbirne, Williams ('hristbirne, Giute Lonise v. Arranehes, Rote Bergamotte, Englisehe Sommerbutterbirue, Köstliche v. Charnen. Esperine, Napoleons Butterbirne, Neue Poitean. Pastorenlirne met Diels Butterbirne.

Von Apfelsorten, die im Kreise Rybnik gut gediehen sind, wreten hervorgehoben: Roter Astrachan, Charlamowsky, Kaiser Alexander, Weitser Klar-Apfel, Danziger Kantapfel, Hawthornden, Winter-troldparmäne, Landsberger Reinette, Baumams Reinette, London Pepping und trotse Kasseler Reinette.

Ganz besonders warm emptohlen werden aus der. Umgegend von Kosel die englischen Züchtmigen: Lord Derby, The Qneen, Lord Grovenor, Lane's Prince Albert, sowie Cellini, Hawthornden und Bismarck-Apfel. Geeignet für rauhe Lagen und sandboden sind der Bramschweiger Milchaptel, Rote Astrachan und Charlamowski. Für die klimatischen Verhältnisse Mitteldeutsehlands gut geeignet sind narch Mismer: Weitser Astrachan, Charlamowski, Roter Eiserautel, Kaiser Alexander, Roter Kardinal und in zweiter Linie: Roter Astrachan, Prinzenapfel, Baumanns Reinette und Boikenapfel. Bewährt haben sich rom Birnen: Winter-Apothekerbirne, Barons B.. Punktierter Simmertorn, Grüne Magdalene, Kleine lange Sommermuskateller, Römische Sichmalz-

1) Raиш:кі-Schrimm, Winterbirnen für den Osten Deutschlands. Prakt. Ratg. i. Obst- u. Gartenb. 17. Dez. 1905.

2) Lavier, G. A., Die Bedeutung der Olstsortenwahl für dit örtichen und klimatischen Verhältnisse. Deutsche Gïrtnerz. 1905, Nr. :S. 
birne, Nparbirne, Gute Grane und Erzherzogsbirne ${ }^{1}$ ). Obgleich bei Birnen die Gefahr der Frostbeschädigung besonders grots ist, so darf man nicht nach einem Maifrost, der in die Blïte tällt, sofort verzagen. Die Erfahrung lehrt, dafs noch gute Ernten trotzdem manchmal erzielt worden sind, weil nur die offenen Blmmen zu leiden pflegen und damn die suäter sich entwickelnden $u m$ so schönere Früchte bringen. Bei der Uhstblüte ist antser dem Frost ein anhaltender Regen besonders zu tiurchten.

Im dentschen Klima durchschnittlich am besten sich bewährende Pflammensorten sind: Königin Viktoria, Gelbe Mirabelle (von Metz), Toppelte Mirabelle von Nancy, musere gewöhnliche Zwetsche und die Grüne Reineclande.

Ton Kirschen kommen trotz der frühen Blüte gut durch die Frosttage des Frühjahrs: Unsere gewöhnliche Sanerkirsche, Ostheimer Weichsel, Doppelte Glaskirsche, Grotise lange Lothlirsche und die Rote Matikirsche.

Für das fenchtere Klima dürften in erster Linie solche Sorten in Betracht lommen, die in Schleswig-Holstein sich bewähren. Als solche werden genannt: der pfirsichrote Sommerapfel, Degener Apfel, Schöner r. Bath, Roter Juniapfel, Sommer-Gewürzapfel, Weitser Sommerkalvill, Williams Liebling, der aus den Ostseeprovinzen Rut'slands stammende Weitse Klar-Apfel und die englischen Züchtungen Mr. Gladstone und Irish Peach (Sommer-Pfirsichapfel) ${ }^{2}$ ).

Die Melirzahl der genamnten Sorten gehören zu den Frühäpfeln, und wir glauben, dafs wir für die norddeutschen Verhältnisse besonders die Kultur der frühen Sorten empfehlen müssen. Sie stellen zwar meist nicht erstklassiges Obst dar, aber sie haben bei ihrer kürzeren Vegetationsdaner den Forteil, ihr Zweigwachstum schneller abzuschliefsen und mit reiferem, also frosthärterem Holze in den Winter zu gehen. Bei der Nenanlange von Obstpflanzungen berücksichtige man vor allen Dingen diejenigen Sorten, die im verwandten Klima und ähnlichen Bodenverhältnissen sich bereits bewährt haben. Man vergesse z. B. nicht, dafs die für trocknes Klima passenden Sorten sich in solchen Gegenden schlecht zu entwickeh pflegen, welche unter dem Einflut's der See stehen, und umgeliehrt.

Betreffs der Bodenverhälnisse ist darauf hinzureisen, daf's solche Sorten, die sowohl auf' leichten als auf schweren Böden gedeihen, doch am vorteilhattesten ans Baumschulen bezogen werden, welche dieselbe physikalische Bodenlieschaffenheit haben wie die Örtlichkeit, anf welche die Bäume danemd zu stehen liommen. Eine grotse Differenz zwischen dem Anzuchtsorte und der definitiven Auspflanzungslokalität bedingt leicht einen Stillstand im Wachstum, bis das Exemplar sich an die newen Bodenverhälnisse gewöhnt hat. Am schwierigsten liegen die Verhältnisse für Moorböden, selbst wenn dieselben bereits durch Kalkung und Zufuhr von Asche oder Kainit und Thomasmehl verbessert worden sind. STOLL ${ }^{3}$ ) empfiehlt von Steinobst unsere gewöhnliche Sauerkirsche und (bei guter Kalkung) die Hanszwetsche. Ton Äpfeln gedeihen: Schöner von Boskoop, Gelber Edelapfel, Doppel-

1) Jahresbericht d. Sonderausschusses für Pflanzenschutz 1900. Arb. d. D. Landw. Ges, Heft 60, S. 247.

2) Suraurr, Schutz der Obstbäume gegen Krankheiten. Stuttgart, Eugen Ulmer, 1900.

$\left.{ }^{3}\right)$ Srot., Obstbau auf Moorboden. Proskauer Obstbauzeitung 1906, S. 182. 
pigeon, Weilser Wintertaubenapfel, Boikenapfel, (rleans Reinette, Grane holländische Reinette, Parkers Pepping und Punumoter C'onsinot.Gravensteiner, Prinzenapfel und Groldparmäne qudeilen wohl, aber neigen sehr zum Krebs.

V́n Birnensorten wären nur zu nemen: die finte firaue. Köstliche von Chamen und Grofser Katzenkopt. Von Beerenolist findet man Anptlanzungen ron Stachel- und Johamisberen ant Nowhorten.

\section{Schneedruck und Eisanhang.}

Wie es bei dem Hagel gewisse Gegenten gibt, die besonders häntig heimgesucht werden, so existieren anch, wenngleich aus anderen Ursachen, namentlich in Gebirgen, bestimmte Gürtel, in denen Verletzmngen durch Schneedruck fast alljährlich sich einstellen. Autierdem werden einzehe Lokalitäten in allen Gogenden mit reichlichem schnectall als besonders gefälndet betrachtet werden müssen: es sind dies die Bodonsenkungen, in welehe der schnee von olsen oder den seiten hineingeweht werden liann. Die gleichen sichneemassen wirken aber anch verschieden, je nach der Witterung, bei welcher sie fillen. Ist es sehr kalt und windig, dann sammelt wich selten so viel bchnce in dem (rezweige, dats er Schaden bringen könnte: die Kristalle sind zu tein und kalt. $n$ m sich aneinander zu kitten. Wenn dagegen bei weichem, windstillem Wetter der schnee in grofsen Flocken fällt und leicht zusammenballt, dam haftet er in grotsen Massen in den Bammkronen und biest oker bricht die Äste.

Temn die Bäume auf Abhängen stehen, bemerkt man zahlreichere Schäden aut den der Windseite entgegengesetzten Abhängen, in denen dann ganze streifen von Bäumen geworfen werken können. I)ies zeigt sich als einfache Folge des Schneedruckes, namentlich bei mildem Winterwetter und noch weichem, offenem Boclen, während bei stärkerer Kälte der sprögle stamm eher gebrochen wird (Schneebrueh). Verpflanzte Bäume mit flacher Wurzelkrone werden leichter als gut durch Pfahlwurzehn verankerte Exemplare geworfen. Torzugsweise der (iefalir des Brechens ansgesetzt sind die wintergrünen Bämme. und unter diesen, wie es scheint, die Kiefer ganz bosonder's: die zäh'ren Holzarten, wie Tammen und Fichten, biegen sich meln unter der Last und richten sich später wieder auf. Günstiger stehen die Laubhölzer dam da, wemn dler Schmee zu ciner Zeit massenhaft eintritt, in der sie ihr Laub verlor'n haben: Eiche und Buche, welche oft das Laub den ganzen Winter über halten, sind gefährdeter wie die anderen Hölzer, vorauscesetzt, dats letztere nicht durch einen vorhergegangenen nassen und liülen Sommer verhindert worden sind, in die Ruheveriode einzutreten mul das Laub zu werfen. Anch hier wird die Sprödigkeit des llolzes tür die Art der Beschädigung matsgebend. Bei der Akazie sieht man an älteren Bäumen fast immer Ast- oder Stammbruch; auch Birk uncl

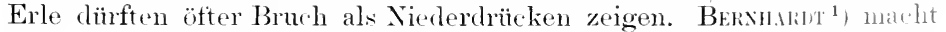
anch darauf aufmerksam, dats sich die Widerstandsfahigkeit der Bamm arten ändert, je nachdem sie einen ihren Ansprüchen angemessenten Standort haben. Für unsere Obstbäume kommt auch die Kronenbilchung sehr in Betracht: namentlich bei Äpfoln mit iloren flarlen, ausgebreiteten Ästen findet man ein förmliches Auscinandrrsualten der

1) Waldbeschädigungen durch Wind-, Schnee-, Eis- und Ibuftbruch. Centralbl. f. d. gesamte Forstwesen 1-is, s. 29 . 
Kronen. Da, wo der natürliche Habitus des Baumes eine pyramidale Kronenbildung nicht zeigt, wird es sich empfehlen, durch künstliche Einwirkmg die Entwicklung eines starken Mittelastes anzubahnen.

Bei dem in Hochgebirgen häufigen Lawinensturz ändert sich das Bild nach Baumart und Alter der Stämme. Dort, wo nur altes Holz steht, wird dasselbe in verschiedener Höhe gebrochen und wild und regellos durcheinander geworten. In Waldungen mit Stämmen verschiedenen Alters werden die jungen Bämme teilweise nur niedergedrückt und eine Zeitlang im schmee vergraben. Nach der Schneeschmelze richten sich derartige Bäume wieder etwas in die Höhe, bleiben aber in talabwärts geneigter Stellung und wachsen langsam weiter; sie haben meist nur noch anf der nach dem Tale hin gerichteten Seite fortwathsendes Gezweig, da die der rollenden Schneemasse entgegenstehenden Äste abgebrochen werden. In Laubwäldern entwickeln sich durch Wurzel- oder Stockansschlag krüppelige Büsche, welche das Aussehen haben, als ob sie durch Wildrerbils entstanden wären.

Des Einflusses der Schneedecke und des dieselbe begleitenden Frostes anf die Saaten ist in den frïheren Kapiteln bereits Erwähmmng geschehen; bezüglich der Temperaturänderungen des Bodens ist auf die Arbeiten von ITIL und von WoLLxy ${ }^{\mathbf{1}}$ ) zm verweisen. Das bei der Schneeschmelze entstehende Eiswasser wird, sobald es bereits ergrünte Wiesen und Saaten trifft, nicht ohme Einflufs bleiben können; denm KÜster ${ }^{2}$, hat beispielsweise nachgewiesen, daf's bei Blättern ron Fumaria infolge Abkühlung durch Eiswasser eine Takuolisation in den Chlorophyllkömern eintritt, wobei die grüne Pigmentsubstanz in mondsichelartiger Form an die Peripherie der Taknole zu liegen kommt.

Eisanhang. Die Schärligungen durch Eis, das sich an den Bäumen ansetzt, sind seltener. Eine schnell vorïberochende Inkrustierming durch Glatteis wird meist für ungefährlich gehalten; indes sincl in der Praxis manche Stimmen laut geworden, welche der Auflagermng von Eis auf glattrindigen Zweigen und Stämmen die Entstehung von Brandflecken zuschreiben. Wenn man sich mit Noues die Entstehmng des Glatteises in der Weise vorstellt, dals Regen, dessen Tropfen bereits muter $0^{0}$ abgekühlt waren, bei dem Auffallen anf die Bäume durch die Erschütterung erstarren, so wird man nicht amnehmen können, dats die Kältewirking des Eises störend wirkt. Nach den bei kïnstlichen Frostversuchen gesammelten Frfahrungen bin ich der Noimung, dats der Glatteisibberzug durch Spannmngändermngen im beeisten Gewebe schädlich wirken kann. Bei ganz leichten Frïhjahrsfrösten lälst sich konstatieren, dats bei den krautartigen Trieben im Rindengewebe Spalten entstehen, ohne dat's tiefogehende Bräunmo der Zellen stattgefunden hätte, also olme dats die chemische Wirkung des Frostes zur Geltung gekommen wäre. Solche Gewebererletzungen sind anch bei Glatteis möglich, wenn dasselbe längere Zeit am Pflanzenteil fest haften bleibt und namentlich die bei Eintritt von Glatteis häufigen Temperaturschwankungen ïberdanert.

Von den gewöhnlichen (ilatteisbildungen dürften zu unterscheiden sein, weil aut verschiedenen Bildungsprozessen beruhend, der Eisund D $\mathrm{fttanh}$ ang, der mit dem Schneedruck zu rergleichen ist. Zur

1) Bot. Jahresber. 1898 , I, S. 5\&4 u. 5×5.

2) Kóster, E., Beiträge zur Physiologie u. Pathologie der Pflanzenzelle. Z. f. allgem. Physiologie 1904, Bd. 4. 
Charakteristik der Erscheinung halten wir uns an eine Darstellung von Breitenlohner ${ }^{1}$ ), der eingehendere Beobachtmgen wemacht hat. Am 27. Januar 187! stellte sich im Wiener Walele be rilliger Wimdstille und nebligem Wetter zur Mittagseit unter zunehmemelem Lutteruck und negativer Temperatur bei Wien ein Niederschlar oin. der dio Mitte zwischen Spröhregen und Nebeheit hielt mol der halıl zu dilatteis erstarte. An den Bämmen, deren Temperatur in allen 'Tuilen muter Null lag, entstand ein einseitiger Eisbelay von :;-; mm loilke. Wie Periorle des stillen Frostes währte im Wirner Walı. i ti l'are: der Eisanhang blieb "Tage und rermehte sich derart, dats die diumsten Zweige zur Dicke eines Sehiffstanes heranwuhsen und lie Buchenstämme brachen, während die Stangenhölzer zu Boden gebonen waren. Da der Boden nur oberflächlich gefroren war. wurden auch Bäune waworfen. Bei Koniteren war die Benadehng der Eisablagerung besonders

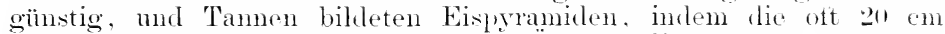
Länge messenden Anhänge der oberen Äste an die unteren angefioren waren.

In den Tieflagen war der Besatz wirkliches, transparentes Glatteis: anf den Höhen dagegen bestand die Hauptmasse mehr ans cincm Gemenge von Eis und Intt. Ebenso nahm die Eispartir vom Walchand. nach dem Immern hin allmählich ab, wo der Beschlas weder Eis noch Duft war und ein testes, strahliges Gefüge besals, mm endlich noch ticfer im Walele als typischer lonftanhang anfzutreten, der immer kïrzer wurde, jo tiefer man in den Walel hincingring. $\mathrm{Lm}$ sich einen Begritt von der so entstandenen Eisbildme zu machen, welche gledehzeitig auch in D antsehlanel und Frankreich auftrat, bestimmte man das fiewieht des Eises, das an rinzelnen Kweigen hing, mol es erobles sich dabei. dats anf einen Gewichtsteil eines bhattosin Zweiges an bis bei

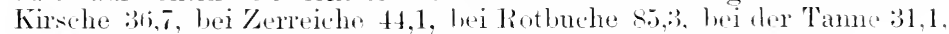
bei Fichte $; 1, \because$, bei Kiefer sogar !!!1) Gewichtsteilo kamen.

Breiterionser macht betreffs Erklärming der Erscheinmog darant anfmerksm, dafs die Beobachtmoen der meteorologischen Stationen zur Zeit des Eisanhanges dir Wirksamkeit cincs Föhnw indes konstatierten: es lief also ein feuchtwamer Äquatorialstrom äber einen kalten, die Täler austïllenden Polarstrom. Dieser Kontakt der äquatorialen mit den polaren Luftwellen führte zu der a uffallenden Niederschlagsform, die mur flarum flüssig blieb, weil der untere, kalte latitstrom eine sehr geringe vertikale Ausdehmmg besats, so clatis der ans dem warmen strome kommende Niederschlag nur einen kurzen Weg furch die kalte Lutt zu machen brauchte.

Da, wo die kalte Inftschicht eine wrötsere vertiliale Erhobmo zeigte, nahm anch der Niederschlag bereits eine teste Form an mul setzte sich als Raulreit' ( 1 a a r frost) test.

Der Nebel, der nach Berührung zweier nach Temperatur nul Fenchtiokeit verschiedener Luftschichten sich bildet, kam anch muter $0^{0}$ seine Konstitution als tropflar flïssiges Wasser beibelialten, da feuchte Winde ausgezeichnete Caloriferen sind und in Wasserilumst. eine Nenge Wärme latent mit sich tühren, welehe bei der tort währnelen Kondensation entbunden wird. Erst wemn das erkältende An ein gewisses Maf's übersteigt, verwandelt sich der Nebel in Frostiampt.

1) Bretrexionxer, Der Eis- und Duftanhang im Wiener Walde. Forsch. auf d. Gebiete d. Agrikulturphysik 1879 , S. 497 . 
indem die Dunstausscheidung num aus Eisnadeln besteht. Die dem freien Luftzuge ausgesetzten Randbäume wirken als Dunstfang, während im Innern der Schläge die stockende Luft blot's den typischen Dunstanlıang sich ansbilden läfst.

Dies wäre also eine Analogie mit dem bei Spät-oder Frühfrost auftretenden Reife, der also nicht als gefrorener Tau aufzufassen ist. Tau ist das kondensierte Wassergas, das sich an den unter dem Taupunkt der Luft durch Strahlung abgekïhlten Ptlanzenteilen in zusammenfliefsenden 'Tröptchen niederschlägt. Das Wassergas ist meist schon reichlich in der Luft vorhanden; es kam zum Teil, wie Stockbrinie ${ }^{1}$ ) nachweist, während der Sommermonate aus dem in der Nacht wärmer als die Luft sich zeigenden Erdboden ausdampfen. Ist einmal ein starker Taü̈berzug vorhanden, so kann derselbe eher als ein Schutzmittel gegen das Erfrieren der Pflanzenteile angesehen werden. Gefriert dieser Tau, so entsteht eine kristallinische Rincle, die identisch mit dem Eisanhange ist. Der Reif dagegen entsteht, wenn der Taupunkt der Luft bereits mer $0^{0}$ liegt und dieser Temperaturgrad durch Strahlung und Verdunstung der Pflanzenteile erreicht wird. Es fügen sich also die Dunstmoleküle schon in fester, kristallinischer form aneinander (Boden- oder Sommerreif'). Der Duttanhang oder Winterreif entsteht durch Einströmen des Äquatorialstromes in den langsam weichenden Polarstrom, und dieser Kampt ist darum so gefährlich, weil bei langer Daner so viel Duftanhang erzengt werden kann, dafs unter seiner Last die stärksten Bäume brechen.

In den Baumgärten wird rechtzeitiges und vorsichtiges Anschlagen mit Stangen an die Äste einer solchen schädlichen Anhäutiung des Duftes vorbengen; im Walde ist dieser Schutz natürlich nicht durchzuführen.

Betreff's des Sommerreifes werden hänfig die Kulturverhältnisse von ausschlaggebender Bedeutung. Bei bestelltem Boden ist zu berücksichtigen, dafs die Abkühlmng des Pflanzenkörpers schneller vor sich geht als die des Bodens, der während der Nacht als ausgleichende Wärmequelle dient und mehr oder weniger die Reifbildung verhindert. Diese Wirksamkeit wird um so grölser sein, je grötser der die Abkühlung verlangsamende Wassergehalt des Bodens ist. Auf fenchten Feldem bildet sich auch der die Abkühlung der Blätter mälsigende Tau früher und reichlicher als auf trockenen Böden. Alle Kulturmafsregeln, welche das Aufsteigen der Wärme aus den tieferen Bodenschichten vermindern, wie Bodenlockerung oder strohiger Dünger, werden dagegen reifbegünstigend wirken ${ }^{2}$ ).

\section{Zwölftes Kapitel. W ä r me ii bersehufs.}

Der Hitztc d.

Gestützt auf zahlreiche physiologische Arbeiten ${ }^{3}$ ) kommen wir zu der Anschauung, dafs bei der Beurteilung der durch Wärmeüberschufs hervorgerufenen Beschädigungen dieselben Gesichtspunkte wie bei

1) Journal of science vol. 1, p. 471; cit. Naturforscher 1879, Nr. 32.

2) Perit, M., Einflufs einiger Kulturverfahren auf die Bildung von Reif. Annal. agron. 1902 Nr. 7 ; cit. Centralbl. f. Agrikulturchemie 190:3, S. 577.

3) Prefrer, W., Pflanzenphysiologie, 2. Aufl., Bd. II. Leipzig 1904. 
Wärmemangel gelten. Wir stehen bei mseren Kinlturpflanzen fortdauernd wechsehden Organisationen gegenüber. Nicht nur jede suezies hat ilne besonderen Ansprüche betrett's der ihn zutrüglichen Wärmemenge, sondern anch imnerhalb der weiten Wämmsliala der sipezies verhalten sich die einzelnen Individuen, ja sellst dir eimzolnen Entwicklumgsstadien ganz verschieden. Die indivistulle Empfindlichkeit gegen eine das Optimalmats übersteigende Wiime sthwanlit jo nach dem Standort, der. Wasser- und Nährstoffizutuhr mul der Ein-

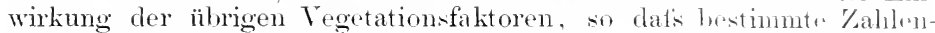
angaben über zulässige Temperaturwerte immer nur loslingte (ioiltiglivit haben können.

Wir ersehen dies daraus, dats bei unseren kulturen sich dis Pflanzen bis zu einem gewissen Grade an höhere Wärmestmmnen vewöhnen kömnen: ihr Aufbau wird ein anderer, ihre Entwicklumg eim. beschlemigtere, aber ihre gesamten lebensprozesse vollzichen sich noch innerhalb der Breite der Gesmolheit. Betreft's der verschiedenen Empfindlichkeit der einzelnen (1roane je nach ihrem angenhlirklichen Entwicklungsistadium vertreten wir die Anschanung, datis der Pflanzenteil nm so widerstandsfähiger gegen Wärmeüberschuts ist, je plasmareicher und relativ wasserärmer noch dic Gewelue sind. Der Hitztod kommt ebenso wie der Frosttod dadurch zustande, dats dir Moloknlarstruktur des Plasmaleibes irreparahel zertrümmert wird. In welcher Weise dies stattfindet und wie weit dabei an fierinnen gewisser Eiweilskörper mitspricht, wissen wir nieht. Je lockerer dre Plasmaleib innerhall, seiner spezifischen Zusammensotzmy gobant ist dadmeh, datis schon reichlich Wasser eingelagert ist, desto leichter wird eine solch.

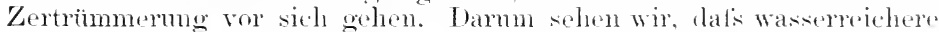
Organe schneller an Hitztod zugmude gehon. Vicltach geht dem Hitztod eine "Hitzestarre" voran, ans der die Pflanzen hei Nachlassen der supramaximalen Temperatur heranstreten mol iln Waehstum wieder begimen kömnen. Je länger die Pflanze im starrezustand verblieben ist, desto langsamer erlangt sis ihre Tätigkeit wieder ${ }^{1}$ ). Weitere Momente ïber die verschiedene Empfindlichlieit werden wir bei den folgenden praktischen Torkommissen kimnen lernen.

\section{Mangelhafte Ausbildung unserer Gemüse in den Tropen.}

Bei Übertragung der Kulturpflanzen aus der gemätsigten \%one in die Tropengegenden machen sich bisweilen sehr mnliebsame störungen im Entwicklungsgange der Pflanzen bemerkbar, die den Kulturzweck $\arg$ schädigen. Es liegt dies in der merwünschten Abkïrzung der einzelnen Fegetationsphasen, namentlich in der Verkürzmng der Period. der Blattentwicklnmer und der Produlition der Reservestoffe, weleh zn fï̈h zur Ausbildmo-des Reprodultionsapparates verwendet werclen. E. leiden darmer namentlich diejenigen (rewächse, bei denen wir inm

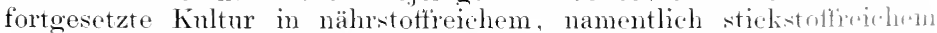
Boden die vegetative Periode verlängert mod den Blattannarat zur üppigen Entfaltung gebraclit haben (Kohlarten, Salate nsw.). Faill. dieser Art finden wir bereits in älteren Arbeiten. So fïlnt lutisuls.

1) Hunrit, H., Über den Einflufs supramaximaler Temperatur auf das Warhstum der Pflanzen. Inauguraldissertation. Leipzig 1900. Cit. J - , Bot. Jahresber. 1901 , II, S. $20: 3$. 
Wrise solche Drthe aus Saharampur') an, dessen Anbauversuche fin Indien mit wenigen Ausnahmen eine zu schnelle Samenreife europäischer Gerächse ergaben. Während die Runkelrübe z. B. in England zm Durchlaufen ihrer Entwicklungsstadien 1s Monate nötig hat, brancht sie in Indien nur \& Monate. Bei den Kulturformen der dentschen Astern äutwert sich der Klimawechsel darin, dafs kein Same reift. Broclugcomc und Petunia verändern ihre Blumen und erhalten dieselben in weitser Farbe. Der Vorgang scheint mir den Gegensatz zu dem Prozels der Rötung der Pflanzenteile im Frühjahr bei Wärmemangel darzustellen.

Über ähnliche Erscheinungen wird ans dem tropischen Amerika berichtet: LeHunN ${ }^{2}$ ) fand im westlichen Kolumbien, (lat's Kohl, salate, Zwiebehn, Mohrrüben sich in einer dem Kulturzweck nicht genügenden Weise ausbilden. Während die aus Emopa bezogenen samen im ersten Jahre in entsprechenden Örtichkeiten ansgezeichnete, zarte Gemüse in gew ïnschter Ausbildung liefern, bringen die nun ron diesen Individuen geernteten samen Pflanzen hervor, die bei Kolıl mol Salat nur noch Spuren von Kopfbildung zeigen und bei Zwiebeh zu fingerstarken Strünken ohne Zartheit und Schmackhaftigkeit sich ansbilden. Die Pflanzen kommen hier in keine Ruheperiode.

In den Hachen Äquatorialgegenden tritt diese Erscheinmng schneller und stärker anf als in den höheren Bergregionen und bei $10-15^{\circ}$ Breite.

\section{Die Verschiebung der gebräuchlichen Saatzeiten in unseren Breiten.}

Hierher zu rechnen sind die bei uns nicht selten zu beobachtenden Erscheinmogen, daf's Gemüsepflanzen, welche zu spät im Jahre ausgesäet werden, mit ler Entwicklmo ihrer vegetativen Organe zu schnell in die heilise, trockne. Jahreszeit kommen. Ier Laubkörper wird hart, und die rühenartigen Anschwellungen werden schmell holzig. Annuelle Samenträger (cetreide, Sommerblumen) werden notreif. Erbsen werlen bei zu später Aussaat sehr leicht vom Rost (Uromyces) überwältigt. Laf's die Turescenz der (tewebe bei zu hoher 'Temperatur abnimmt, hat hereits Kraus ${ }^{3}$ ) ausgesprochen.

Für don Einflut's der 'Trockenh it ant' den Befall der Ptlanzen durch Pilze hat Haberdare bei seinen Versuchskulturen ein schönes Beispiel beigebracht. Ton drei mit Weizen besäeten, während der wanzen Vegetationszeit dicht beieinander strhenden Töpfen war derjenige, dexisen Pflanzen nur gerade so viel Wasser empfingen, um sich am Leben zu erhalten, vom Meltan (Erysiphe graminis) derart hemgesucht, lats dem Pilz jedenfalls ein grotser Teil der Schuld für die gänzliche Mifsernte zugeschrieben werden mutste. Der danebenstehende, reichlich bewässcrte 'Topt' war fast gänzlich von dem Schmarotzer versehont ${ }^{4}$. Noch schlagender ist ein von mir beobachteter Fall mit Podospluara lemetricher Sahm. Ton riner Anzahl junger Aptelbäume in Töpfen stand die llälfte in einem Glashause, die andere hinter demselben im Freien. Alle Exemplare hatten ïber Winter ihre Oidienform vom Vorjahre behalten. Dio im (ilashaus der Sommerhitze ungeschützt ans-

1) Gardener's Chronicle 1ஷr1, I, S. $6 \% 2$.

2) Lrumx, Über eine physiologische Erscheinung bei der Gemüsekultur im tropischen Amerika. Deutsche Gärtnerzeitumg 188:3, s. 260.

$\left.{ }^{3}\right)$ Molekularkonstitution des Protoplasmas. Flora 1s77, s. 534.

4) Biedermann's Centralbl. 18r., II, S. 402. 
gesetzten Pflanzen verkïmmerten dureh die Übrhandnahme des Meltaues, der sich bis zur Kapseltrucht entwickelte. Wie hinter dem Glashause in Halbschatten und in bewegter Lutt stelunden Apfelbämme verloren den Meltan. Wie sehr anch olne Mitwirlime parasitiseher Feinde die Produlition der Ptlanzen bei falscher Ansisatzoit leidet,

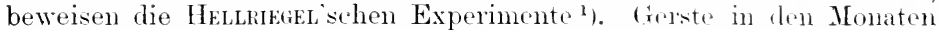
April, Mai, Juni, Angust und september in Töjpr mit aleicher

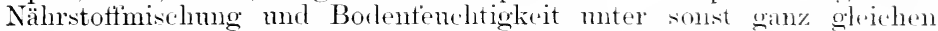
Terhältnissen ansgesäet, verhielt sich vollkommen verschirilin. Dio Aussaat im April brachte sehr gleichmätsig ansgebililete, vorziigliche, reife Samen tragende Pflanzen nach s8 Tagen. Die zu Enilu Mai vollzogene Anssaat zeigte Pflanzen, die anfangs anch seln lirittip sich entwickelten. Als aber gegen Mitte Juli, zm Zeit des Hervortreibens der Ähren aus den obersten Blattscheiden, eine danemde Hitzeprioule eintrat, blieben die Hahne im Längenwachstum zurïck. Die Kömur erreichten bis zu dem verfiühten Alsterben der Pflanzen (nach 77 Tagen) nur eine unvollkommene Ansbildung und blieben flach, waren also notreif geworden. Die späteren Ausiaten zeigten eine steigende Verlängerung der Vegetationsperiode (die Septemberansiat lranchte z. B. 240 Tage) und ergaben sämtlich mvollständig ansoereifte Kïner.

Betretti der forstlichen Kulturen liegen anch Eifahrungen vor, dats die Verluste beim Verptlanzen der jungen Waldhämme je nateh der \%eit der Ansführung schwanken. Dis Versuche in Mariabrum ") zoigten den greringsten Ausfall hei der Frühjahrsverptlanzme. Bei der Fichte steigerte sich die Zahl der absterbenden Exemplare von der April-bis zur Juniptlanzung, nm dann bei der Herbstpflanzmng (september, Oktober) wieder wesentlich zurüclizugehen. Dasselbe Verhalten zeigte sich bei der Kiefor, die noch bedentendere Verhustrozente anfwies. Bei den Laubhölzern wird belianntlich dic Herbstptlanzung mit Tortiebe angewendet.

\section{Das Verbrennen der Blätter im Freien.}

Ian bezeichnet damit den Tod der Gewelse infolge der Einwirkmng der somme. Dahei wirken aber Licht und Wärme zusammen. Wieviel bei den Torleserscheinmoen einem jeden Faktor zugeschrielen werden mufs, wissen wir nicht. Die Meinme bedentender Forscher, dats das gesante Licht in der Pflanzenzelle in die Kraftform der Wärme ülsergehe und in dieser Form wirksam sei, ist nicht wahrseheinlich; vielmehr deuten meine Verdunstungsversuche hei Lichtrormind rung monter gle zeitiger 'Temperaturerhöhmo an, dafs clas Licht als solches mindestens zu einem Teile wirksam soin und den Assimilationsprozets beeintlussen wird: ein Teil wird zweifelsohne anch in Wärme umgewandelt mol derart verwendet werden. Tnter dieser Toraussetzmer ist as amed wahrscheinlich, dat's eine Pflanze sich quegen dieselbe Wärmemenge verschieden verhalten wird, je nachtem sie dieselbe in dumbeh orlid im erlenchteten Ramme emptängt.

Im allgemeinen sind Temperaturen zwischen fo und in" (" tödlich; doch ist bei Fettptlanzen von Askexass ${ }^{3}$ ) beobachtet wortin,

1) Grundlagen des Ackerbaues 1-x:3, S. :3:.).

2) Deutsche Forstzeitung 18:1: vom 1:\% November.

3) Askmasr, Über die Trmperatur, welche Pflanzen in sonnemlichte anehuen.

Bot. Zeit. 1875, s. 441 . 
dats dicselben solehe Wärmemengen sehadlos ertragen. Askenasr überzengte sich im Hochsommer, dats Semperrirm bei einer Luttemperatur ron $: 31^{\circ} \mathrm{C} \mathrm{im}$ Schatten eine Erwärmmg im Innern bis 48 und $51^{\circ} \mathrm{C}$ erlitten hatte. Die Wärme im Immern der Ptlanzen war bei einigen Arten etwas höher, bei anderen etwas niedriger als an ihrer Oberfläehe. Die Temperatur an der Oberfläche des Blattes stand in keinem direkten Verhältnis zur Luftemperatur an verschiedenen Tagen. Es zeigte z. B. Semperivam arenarium

$$
\begin{aligned}
& \text { bei } 31,0^{\circ} \mathrm{C} \text { am } 15 \text {. Juli } 10 \mathrm{~m} \text { 3 Uhr nachmittags } 48,7^{\circ} \mathrm{C} \text {, } \\
& \Rightarrow \quad 28,20 \mathrm{C}, 16 . \quad . \quad, \quad 3 ., \quad, \quad 46,0^{\circ} \mathrm{C} \text {, } \\
& " 28,1^{\circ} \mathrm{C} " 18 . " \quad " \quad, 12,30 " \text { Uhr mittags } 49,0^{\circ} \mathrm{C} \text {. }
\end{aligned}
$$

Dicht danebenstehende, dümmblättrige Pflanzen besafsen eine viel niedrigere Temperatur.

Am hänfigsten zeigen sith die Erscheinungen des Verbrennens bei Glashansptlanzen, die im Frühjahr ins freie Land gehracht werden. Nicht immer wird das Blatt getötet, sondern manchmal nur gerötet oder gebrämnt. Bei gewölbten Blättern ist oft nur die Völbung an der Uberseite verfärbt, und anstatt grün ist sie kupferig gerötet (Rosen). Im Lante einiger Wochen kam sich eine solche Pflanze selbst unter Verbleiben an ihrem standort wieder ansheilen.

Experimentell prüfte ich einen derartigen Fall bei Topfexemplaren von Camma indica, von denen dic grölste Anzahl bei trübem WVetter aus dem Glashanse, in welchem sie bis zur Entfaltung der ersten Bhmen angetrieben worlen war, ins Freie gebracht wurde. Einige Töpte blieben zwei Tage länger im Glashanse und wurden dam in der Mittagsstumde neben die früher freigestellten Exemplare eingesenkt. Die oberen Blätter erschienen num schon am Nachmittag weifsstreifig, indem die von den wasserleitenden Nerven am weitesten entfernten Partien eines jeden Interestalfeldes abgestorbenes Gewebe zeigten. Am hreitesten waren die weitsen Streifen am Blattrande und keilten sich nach der Mittehippe hin almählich ans, so dats man dentlich wahrnehmen komnte, wie das Verbrennen des Blattes in denjenigen Regionen am frïhesten und stärksten auftrat, die von dem Wasserleitungssystem der starken Gefäfibündel am weitesten entfernt lagen.

An den weitsen Stellen erschien die Epidermis nicht wesentlich alteriert. wohl aber das Palisademparenchym, das keine Chloroplasten mehr besat's, während eine Übergangszone nach dem mit grofsen wandstänrligen Chlorophyllkörpern versehenen gesunden Gewebe hin zwar noch grïngefärbten, aber wolkigen Inhalt zeigte. In dem weifsgewordenen Gewebe, dessen Zellwandungen hell verhlieben waren, zog Glyzerin nur noch geringe Inhaltsmassen zusammen, so dats man schliefsen muste. dafs ein grofser Teil derselben in der kurzen Zeit veratmet war. An den stärkst besehädigten Stellen war die Epidermis vom Blattfleisch hier und da blasenartig abgehoben (Brandblasen), und die Zerstörung des Chlorophyllkörpers war bis zur Blattunterseite vorgedrungen. Nach einigen Woehen komnte man bei den verbrannten Blättern in den oben erwähnten Übergangszonen übrigens eine $R e$ generation der Chloroplasten beohachten. Es hatte also gerade so wie nach sehwächeren Frostbeschädigungen ein Ansheilungsprozefs stattgetunden. Unterhalb der Brandblasen, bei denen die Epidermiszellen teilweise zusammengesunken erschienen, war nummehr Pilzmycel nachzuweisen. 
Ein Kollabieren der Epidermiszgllen beobachtete RowteE ${ }^{1}$ ) anch nach achtstündiger Einwirkung von elektrischem Bogenlicht, das in einem Meter Entfernung anf Bläter ron Helintron wirktr. Andere Pflanzen (z. B. Ficus elastica) blieben muter gleichun Tmständen unverändert.

Bei fleischigen, langlebigen Blättern grenzt sirh das gesmure frewebe von dom verbrannten dureh eine Korkzons al, Wie dis beistehende Abbildung eines im August dureh Fomnenhrand heschädigten Cliviablattes zeigt. Man konnte beobachten, wie die Latere des Blattes den Ausschlag für den Ort der Entstehmng der Brandfleclir gah, indem nur die senkrecht zur Wärmequelle orientierten Stellen sich gellygum verfärbten und zusammensanken. Am folgenden Tage war der Brandfleck vollständig bram und brüchig. I ie jüngsten Blätter hatten nicht gelitten. Die Grenze zwischen totem nud lebendem liewels ist. solald der Brandfleck durch die ganze Blattdicke hindurchweht, sthart: wem aber nur die Blattoberseite beschädigt ist, zeigt sich eine rerwaschene Übergangszone. In derselben bemerkt man, dats die Chloroplasten

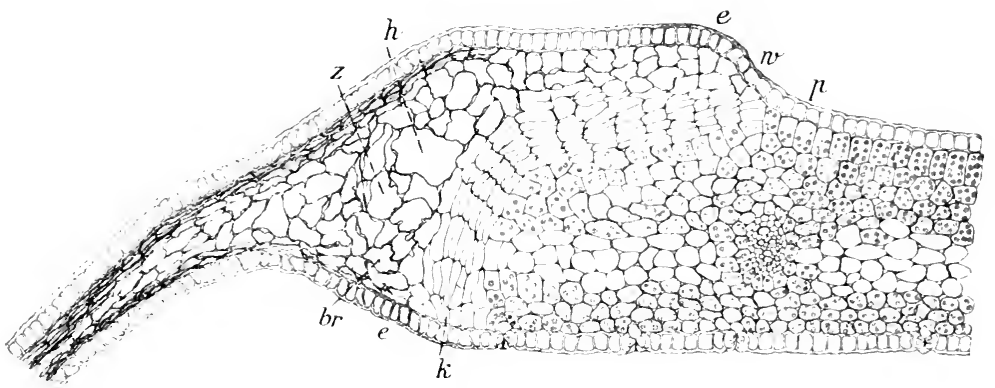

Fig. 151. Durch Sonnenbrand abgetötete Stelle eines Blattes von Cliria nobilis. (O)rig.)

spangrün werden, während der übrige Zellinhalt gellygün erscheint: es dürfte hier zunächst also ein Austritt des Xanthophylls erfolgen. während das Cyanophyll an den Chloroplasten gebunden bleibt. Sortamn wird die anfangs gloichmälsig stark lichtbrechende Masse des Chlorophyllkorns in ihren Konturen weniger scharf, mol eine grotse Menge feinster Körnchen geben demselben eine sandige Beschaffenheit. Sehliefistich bilden die Chloroplasten schmntzig-teegrïne bis schwargurine (irmpl;n. die dadurch eine strangartige Gestalt amnelmen, dats die Zalle znsammensinkt. Diese Inhaltsmassen, welche einer Wand anliesen. bleichen ungemein schnell durch flie Somne aus und veranlasson mmmehr die gelbgraue Färbung der Brandflecke. Die Zollwandnum verlieren nicht ihren Cellulosecharakter, wie die Prüfung mit ('lılurzinkjod zeigt.

Das gesunde Gewebe begimt alshald, sich durch eine Kortizone (li) von dem beschädigten abzuschliefsen, wobei auch die inhaltsreir.h rerbleibenden Zellen der Übergangszone $\left.(b)^{\circ}\right)$, die sich zun̈̈rhst nuch

1) Rowrf., W., Effect of electric light upon the tissues of leutes. Just's bot. Jahresber. 1900, II, S. 287. 
etwas unter Welhung ihrer Membranen vergrötsern $(h, z)$ und grölsere Intercellularräume aufweisen, allmählich sterben.

Trenn der Brandfleck etwas älter wird, rertärbt er sich tiefer bram, wobei auch die nicht zusammensinkenden Epidermiszellen $(e)$ bis an clas gesunde Gewebe heran beteiligt sind. Die Korkzone $\left(k_{i}\right)$ entsteht durch Fächermng der an der (rrenze des Brandfleckes lebendig bleibenden, sich streckenden Mesophyllzellen, deren rückwärts anstofsende normale Zellen (1) etwas ärmer an Chlorophyll zu bleiben pflegen. Bemerkenswert ist das schwielige Hervortreten der Randzone $(\boldsymbol{w})$ des nommalen Blatteils an der Grenze der Branclstelle; dieses Verhalten erklärt sich rlurch die Streckung der die Korkzone liefernden Zellen und des davorliegenden, beschädigten, aber nicht sofort getöteten (h) Mesophylls.

\section{Die Brennflecke in den Gewächshäusern.}

Namentlich im Frühjahr häufen sich die Klagen über die Entstehumg von Brandflecken auf den Blättern zarter Pflanzen in den Glashänsern. Über die Entstehung derselben gingen die Meinmngen auseinander. Teils machte man die Blasen im Glase der Gewächshausscheiben dafür verantwortlich, teils glaubte man, dafs die Wassertropten, die beim spritzen der Pflanzen an der Blattoberseite haften bleiben, als Bremnlinsen wirken oder sich durch Insolation so stark erwämmen, dats sie dadurch das Gewebe schädigen. Durch die Experimente von Jössox ${ }^{1}$ ) ist nachgewiesen worden, dats tatsächlich die Blasen in Glase die Ursache sind. Er beobachtete tas durch solche Blasen anf dem Blatte hervorgebrachte Lichtbild der Sommenstrahlen und das Fortschreiten desselben infolge der veränderten Somnenstellung. Darans erklärt sich auch die nicht selten wahmehmbare Erscheinung, dafs solche Bremnflecke in reihenförmiger Anordnmg auftreten.

Dats das spritzen aber anch getährlich wirlien kam, geht aus einem Tersuch hervor, hei welchem ein Wassertropten an der Unterseite eines in einiger Entfermung ron der Blattfäche aufgekitteten Deckglases hing. Hierbei lietsen sich anch spuren von Bremnflecken erzengen, während direkt anfliegende Wassertropfen keine Beschädigung hervorbrachten.

Zur Termeidung derartiger Tnzuträglichkeiten wird man im praktischen Betriebe wenigstens in denjenigen Gewächshäusem, welche wertrolle Blattpflanzen bergen, zur Bedachung bessere Glassorten wählen müssen.

\section{Entlaubung.}

Hier handelt es sich nicht um Terbrennungserscheinungen, sondern um ïberstürztes Ansleben der Gewebe. Bei den in der freien Natur zu beobachtenden Fällen pflegt sich der direkten Somnenwirkung eine grofse Bodentrockenheit zuzugesellen: bei speziellen Tersuchen mit Bremnlinsen aher erkemnt man, dak auch in feuchtem Boden die stärker durch Brandflecke beschädigten Blätter abgeworfen werden. WIEsser ${ }^{2}$ ) fand, dafs bei dem..Hitzela ubtall" von den Baumkronen weniger die peripherischen Blätter als vielmehr die im Innern der Krone befindlichen abzufallen ptlegen und meint, dat's die ersteren infolge der

1) Juxisu, Bexcr. Om Brännfläkar pa växtblad. Botaniska Notiser 1891. Zeitschr. f. Pflanzenkrankh. 1s:2. S, 35:

$\Rightarrow$ Wiester. Ju1. Über den Hitzelaubfall. Ber. d. D. Bot. Ges. 1904. Bd. XXII, S. 501 
grölseren Wärmeansstrahlung sich veht so selur erhitzen wie die in geschlossener Lage befindlichen Blätter. Wir mïrhten den frund in der verschiedenen Kräftigkeit der Organe suchen. Die der grötsten Lichtzufuhr ansgesetzten Organe poduzieren nelur sulstanz, wud ihre Zellen sind reicher an plastischem Material: sie haben taher bei abnorm gesteigerter Verdunstungs- und Atmmngstätigkeit mehr Reservestoite and sind daher langlebiger gegenüber den im Innern einer Bammlirene befindlichen gleichalterigen Blättern. Die jungen Urome simb an mul für sich wiclerstantstähiger.

Bei den im Freien vorkommenten Fällen spricht ler sitandurt mit seiner Wasserzufuhr ansschlaggebend mit. Man sieht dies bei Wallbämmen am besten an Eichen und Lärchen in Sehommeren, wo zwisehert aränen unbeschädigten oder doch wenig alterierten Pflanzen strots einzelne Exemplare zu finden sind, die bereits vëllig rertrocknete Lanberuplen antweisen.

In einer Lärchenschonmg sah ich tie stärlist geschädigten Exemplare im oberen 'Teil tast völlig entuadelt: nu die ganz jungen 'lvieles, deren spitzen gekrïmmt und fuehsot erschienen, trugen noeh Nadelu, die wie rote gefärbte quasten abwärts hingen. Die allerjüngsten Nareln erschienen tahl mol papierartị flach zusammengotrocknet: ihr äutivest spärlicher Zellinhalt billete einen farblosen. mit Jod sich gelb färbend n Ballen frei im Zellinmern. In den älteren Nadeln, deren Zellwandmorn gänzlich farblos geblieben waren. erschien der reichliche Kellinhalt in Forn l, lat's gramötlicher oder wolblnamer, wleichartion Massen, den Wandungen anliegend. Die Bilder ähnelten den bei Einfluts samer Gase entstehenden. Auch bei Fichten sind die clureh intensive sommer-

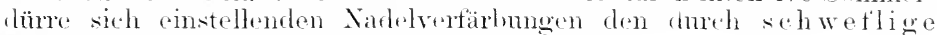
š̈ure erzengten mogmein ähnlieh.

Ähnliche Hitze- mud Trokkenschïten dürtten anch, namentlich nach plötzlicher Freistellung, hei anderen Natlelhölzern nicht selten sein. Betreft's des Entnadelungsorganges zeigten mir Versuche bei Fichten, dafs die an ihrer Basis dmrch den strahlenkegel einer Linse getroffenen Varleln sich bei geringem Druck sofort ablösten, auch wem sie keine Vertärbung wahmehmen lietsen. Bei Beschädigmngen an höheren Stellen der Nadeh blieben dieselben sitzen. In den Brandflecken hatte sich dor Zellinhalt zu einer bandartigen grïnen his braungriinen Masse in der Mitte zusammengezogen, wobei man mehrfach noch die Körnerstruktur wahmehmen konnte. Die zusammengezogenen Inhaltsmasien lagen in den einzehen Zellen meist gleich. sinnig, nämlich in der Richtung des grotisen Querdmchmessers der Nadel.

Verhältnismälsig selten sind Knospenbeschädigungen durch sonnenbrand. Es wirt dies teils aut ten schutz der vielfach durch Haarfilz, Gummi, Harz, Korklagen oder dgl. besonders zweckmätíig sich erweisenden Knospendecken, teils ant den plasmareichen, also schwrer. zu alterierenden lnhalt der jugendlichen Gewebe zurückzutülırm sein. In den Tropen sind noch lesondere Schirmvorichtmgen manchmal wahrzmehmen. Nach Potтek ${ }^{1}$ ) werden z. B. bei Artocripmes. Heptrpleurum, Canarim ceglanicum u. a. die Nebenblätter der ältrem Blatt-

1) Porrer, M. C., Observations on the Protection of Buts in the Tropics. Journ. Linn. Soc XXVIII, 1s91, s. :34:3. 
organe als schutz der jugendlichen Blätter bis zu deren Erstarling verwendet, oder das ganze ältere Blatt hildet zmächst ein Selnutzdach füir das jüngere (Uraria mupnorea, Gossyminm usw.).

In England ist ein Abwerfen der Pfirsichlinospen hei der Treiberei heobachtet worden. Iort, wo ein genälistes Tuch gegen die sinnnenwirknng ïber die strecke gespannt worden war, wurde kein Knospenabwurt wahroenommen ${ }^{1}$ ).

\section{Sonnenbrand an Blüten und Früchten.}

Ku Beschädigmegen an Blumen bedart es häufig gar nicht absolut loher Wärmegrade, sondern ss kinnen lei mginstigem standort die gewöhnlichen Temperaturen schon schattenliehenden Pflanzen schädlich werden. Die bekanntesten Beispiele bilden die Knollentegonien, deren Blïten leicht hamne Sammlinien belommen, wenn dis PHanzen nicht die Verolunstung des fenchten Erdbodens geniefsen können.

Bei den Frïchten macht sich nngewöhnlicher Wärneäberschuts in zwei Richtmogen geltend. Einerseits erzengt er Notreife, d. h. dat: Eintreten der Reiferorgänge zu einer \%eit, in welcher die Frucht eigentlich noch Reservestotte speichem sollte. Die Folge ist die, datis die nur moenigend mit Reservematerial ansgestatteten \%ellen des Fruchtfleisches sich vorzeitig ansleben, was stippfleckigkeit und rorschmelle Lagerfänle zur Folge hat. Bei Getreide bewirkt ein vorzeitiges Abreifen der Hahne eine empfindliche schädigung des Kornes dmoh moenügende stärkebildung ${ }^{2}$ ).

I ic andere Beschädignngstorm besteht in einem direkten Abtäten der Gewobe durch fommenbrand an den exponiertesten stellen sattiger Fritchte. Solche Brandflecke ähneh hänfig den Hagelschlagstellen, weil das ahgetötete fiewebe während des schwelhmgsvorganges der Frucht sich nicht entsprechend dehnen kam und entzweireitst. Bei der zunehmenden Tomatenkultur finden wir jetzt reichlich Beispiele, die nur daduch verdeckt werden, dafis sich an den Brandstellen der. Früchte Mycelpilze anzusiedeln pflegen. Die Fälle werclen dam als prarasitäre Erkrankmngen Jeschrieben. Ton wirtschaftlicher Bedentmug ist

\section{die Beschädigung der Trauben durch Sonnenbrand.}

Eine Beschädigung der 'Trauben wird nach den Beobachtungen

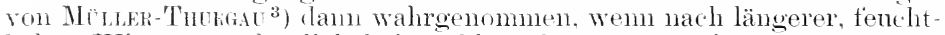
kalter Witterme poutzlicl heife, klare somentage eintreten; es zeigt sich dann an treihängenden Trauben fast regelmätsig, dafs die den tirekten somenstrahlen ansgesetzten Becren ilire grüno Farbe verlieren. bleich werden, dann sich brännen und schliefishich zu schrumpfen besimen. Anch der 'Traubenstiel kam an solchen Stellen, an denen 'r' direkt von der somne getroffen wird, leiden, mul es schrmmpten dann lie dazn gehörgon Boren ebentalls ein, verlieren jedoch in riesem Falle nicht ihre griun Farbe. Bei blanen sorten werden die von der Sonne getroftendr, noch grïnen Beeren tunkler als die der weilsen sorten und nolmon oine fast schwarze Färbung an. In einzelnen . Jahren

1) Gardener's ('hronicle 1st\%, XIII, si. 698.

2) Dennax et Dn rox, Über den Ursprung der stärke des Weizenkorns. Cit. Biedermann's Centralbl. 190:2, \&. 324.

3) Der Weinbau 1ss:?, Nr. $: 5$. 
findet man ganze Trauben wie Rosinen versolnomptt, und tadmeh wird

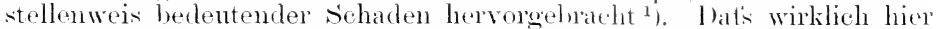
es Wärmeäberschuls ist, der die Beeren tötrt, wht daras hervor, dats

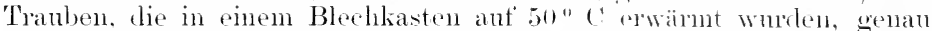

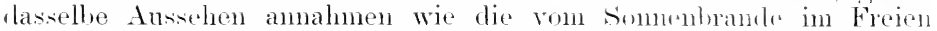
botroftenen Exemplare. Ant' das Verbremmen ïbt der lieifinustand sowie äberhaupt der. Wassergehalt der Grgane mul anch der Fenchtiglieitiwehalt der umoebenten Luft einen matigebenden Eintluts ans. Unreif: Beeren ven Riesling und Sylvaner wurden durch pind zwei stmuden

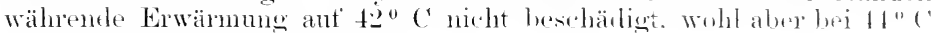
nach gleithlanger Einwirlimg.

Dats die besomnten Beeren wärner sind als dir mmgebende latt. zeigten direkte Messumgen. Währent ein Lufthermometer in s.chattın $24^{\circ} \mathrm{C}$, ein anderes in ter Somne $3 i^{\prime \prime}$ " zeigte. stien in are besomnten Weinleere tie Temperatur anf f10 ('.

Es zeigte sich terner, dats Rieslingsheren aus guter, wamer laser. welche nachgewiesenermat'sen an Wasser ärmer waren als soldse aus geringen Weinberwen. weniger vom stomenbrande litten als lotzter. Teben dem geringen Wassergehalt ist die fortgesthrittene Roife der Beere ein Umstand, der seluätzend geven den Somnenbrand wirkt. I)

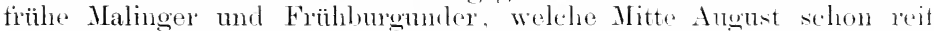
sind, zeigten heispielsweise hureh die heilse Angustsome keinerlei

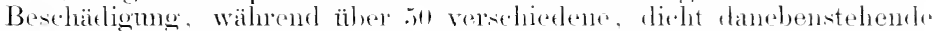

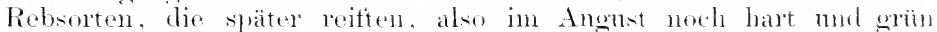
waren, mehr orler weniger gelitten hatten. Eine Temperatumessmes in grïnen, unreiten, harten Beeren ven Risling, sylvaner, Ell, ling mul

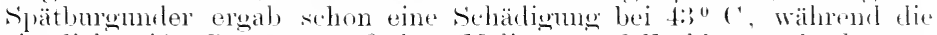

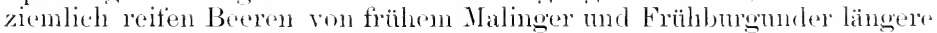

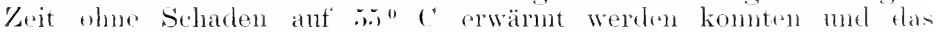
Fruchtfleisch der Malinger Trauben erst bej ctwas äher lig" ("getöted wime.

Die Erfahrung der Praktiker, dats Somnenhand an neisten dam sich zeigt, wem natiskalte Wittermg den heitsen Tagen vorhergelit, rrliärt sich einerseits durch den wö̈seren Wassergehalt der Bucron mul andererseits dureh die geringere Verdunstmo mud dengenüls aurh geringere Abkïhlumg in fenchter laft. Betreft's des Einflusses der Trockenheit wurle ein Versuch von Mǘlek mit zwei Rieslinsstrandon angestellt. vou denen die eine in einem mit fenchtem Flietspapier anstapezierten Glase. die antere in einem mit Chlorkalcim versehrum Gilase in den heizharen Blechkasten gebracht wude: bei 41.500 war die in feurhter Inft hetindliche Traube vollständig getëtet, währent die in der mit Chlorkalciun aetrockneten Lutt befindliche Tranbe kamm beschädigt war. Kwei Themometer, von denen der eine frei hing. ir. andere mit seiner Kugel in eine Weinbere gesteckt worten war. Finnent

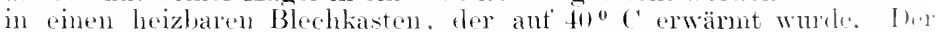
mit der Beere mmkleitlete Thermometer stand sowohl les drum latme samen steigen der 'Temperatur als anch bei dem sinken dersellum stets etwa fo tiefer als der andere. Was wohl nur durch tie Vortumstmen der Beere bedingt sein komnte.

Als Folge von sommenbrand këmnen anch die Erscheimnngen do

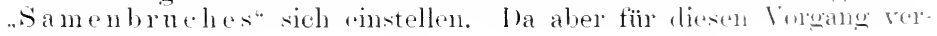

1) Jahresber, d. Sonderausich. f. Pflanzenschutz 14:92. Arb. 1. 1). Jandw. (r. 
schiedene Ursachen existieren, so ist es besser, ihn später gesondert zu betrachten.

Bisweilen findet man sog. "rostige Beeren", d.h. solehe, deren Hant feime Korklamellen gebildet hat. Mau hat darin ein Schutzmittel gegen somnenbrand ${ }^{1}$ ) erblickt.

Das beste Vorbengungsmittel wird der Schutz der Tranben durch Blätter sein, und es ist irrig, zn glauben, man nütze den Trauben, wenn man die Blätter vor denselben entfernt.

\section{Sonnenrisse.}

Bei Wald- und Obstbämmen reitst im Frülijahr bisweilen die Rinde anf. Diese Erscheinmo ist ron DE Joxine als somnemisse (smotrokes) hezeichmet worden, währent sie CAspARY ${ }^{2}$ ) als Frostwirkmgen ansieht. Flächenförmiges Absterben der Rinde wird als Sonnenbrand von den einfachen Rilswunden unterschieden. Abbitdungen finden wir bei

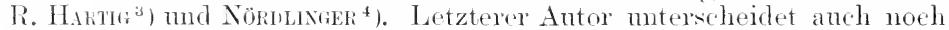
einen. W W in tersonnenbran $\mathrm{d}^{5}$ ), bei welehem die stammbeschädigmng. nur an der Basis zu finten ist und man den Reflex der somnenstrahlen von der Bodenoberfläche als Ursache amnimmt. R. Hatrir bililet das montere Stammende eines Rotbuchenstämmchens mit Sommemits ahti). I) a diese Erscheinmugen bisher nur im Nachwinter beolachtet worden sind mol strikte experimentelle Beweise noch fehlen. so halten wir an mserer früher geäntserten Meinung fest, dats Risse duch Spannmgsdifferenzen entstehen, die bei plötzlichem starkem Temperaturwechsel zustandekommen, ohne daf's eine Erwärmmng des Gewebes durch die somne bis zum Absterben desselben nötig wäre, wie dies bei den Somnenbrandstellen der Fall ist. Wie sehr sich die Pflanzenteile über die Luftemperatur erhitzen, zeigt eine Messung von Haktu; ${ }^{\top}$ ) an einer Fichte im Angmst. Er fand bei einer Luftemperatur von $37^{\circ}$ ( $^{\circ}$ in der Cambialregion der Südwestseite $55^{\circ} \mathrm{C}$, auf der Südseite nur $45^{\circ}$. auf der Ortseite $39^{\circ}$, ant der Nordseite $37^{\circ}$ C. Die Messungen fanden nachmittags nach 4 Uhr statt.

\section{Einflufs zu hoher Bodenwärme.}

Sthon Sichs ${ }^{8}$ ) liefert reichliches Material betreffs der Bestimmung der Temperaturansprïche einzehner Pflanzen und bezüglich der Erhaltung der Keimfähigkeit von samen, die einer hohen Temperatur in Luft oder Wasser ansgesetzt worden sind. In letzterer Beziehming ergibt sich, daf's trockene Samen höhere Tempcraturen vertragen, ohme Schaden zu nehmen, als bereits angekeinte, und dats wahrseheinlich das Pflanzengewebe (imnerhalb der für die Spezies zulässigen Grenzen) ïberhampt $m$ so widerstandsfähiger gegen Hitze ist, je geringer der Wassergehalt der Zellen sich erweist. Bestätigende Arbeiten lieferten

1) Zeitschr. f. Pflanzenkrankh. 1902, S. 111.

2) Bot. Zeit. 1 $\$ 57$, Nr. 10: .Bewirkt die Sonne Risse in Rinde und Holz der Bäume? ?*

$\left.{ }^{3}\right)$ Lehrbuch der Baumkrankheiten, I. Aufl, S. 188.

4) Lehrbuch des Forstschutzes, 14st, S. : 302.

5) Baumphysiologische Bedeutung des kalten Winters 187980 . Cit Illustrierte Gartenzeitung $1 \times 81$.

6) Lehrbuch der Pflanzenkrankheiten, 3. Aufl., 1900, S. 2:30.

7) Ibid. S. 22:

8) Experimental-Phrsiologie S. tit ff. 
Haberlandt, Wiesner, Fiebler, Krasax, Jest, Nobbe, 1 hofhnel mol nenere Autoren, betretts deren auf PFkfFer's Physiolouie rerwiesen werden muts.

Dat's man durch Erhöhumg der 'Temperatur iiber das tïr eine bestimmte Art gegebene Optimum hinaus schon lei heimenten Samen üble Erfahrungen machen kam, zeigen beispielsweise dio Versuche von Jusc ${ }^{1}$ ), ans tenen sich ergab, dats, ähnlich wie hei sinnen von zn hohem Alter, anch durch zu hohe Temperatur eine Verlingerung der. Keimzeit und langsamere Entwicklung der Keimlinge horvorgeruten wirl.

Betreft's der anatomischen Verändermuen ist oine ältere situdi. vom Pribleux ${ }^{2}$ ) von Bedeutung. Bei Samen von Bolnen uml hïrlisicen. die in Töpte gesäet wurden, welche durch erhitzte Hrähte cine hoh. Bodenwäme erhielten, ergab sich folgendes Resultat. Dis jungen Keimpflanzen verlängerten sich nur wenig und schwer, erhielten aber ein geschwollenes Ansehen. Dort, wo die Schwellung des stengelehens am intensivsten war, zeigten sich klatfende, bis aut das Mark gehende. meist horizontale Risse. Gegenüber den qleichalterigen, momalen Phanzen waren die des überheizten Bodens num halb so lang, aber vom nahezu drei-bis viertachem Dickendurchmesser an der Stelle der stälisten schwellmo. Dort waren auch die Epidermiszellen zwei- bis dreimal breiter als bei den normalen Pflanzen; die spaltötfimngen zeigten den. selben Unterschied, nur in geringerem Natse. I) Haare waren nicht verschieden. Las Rindenparenchym war zwar viermal dicker: cine Vermehrung der Zellen hatte aber nicht statgefumlen. Noch orötsere. radiale Answeitung zeigten die Zellen des Markparenehrms: nur im Bastparenehym liefs sich wirliche Zellvermehrmenachweisen. Prinder tührt terner an, dats die Zellierne sich dabei ähnlich den Zellon selbst verhalten; sie hypertrophieren mol vermelnen sich forart, dats oft drej his vier in einer anzigen /elle zu finden sind. Die Kernteilung erfolent dureh Fragmentation. Nan nimmt rine solehe Kellvermehrung auch in den kurzen, gebogenen unl verkiümmten, aber nicht rescliwollenen Wurzeln der alterierten PHanzen wahr. l lie grofisen, deformierten /ellkerne zeigen meist auch ganz umregehnäsige und zu mehreren anftretronde Nucleolen, welche durch sichwarzfärbung mit 0 smimsäure nicht sclten Vaknolen erkemnen lassen. Bei der Fragmentierung der Kerne erschoint meist einseitig vorher eine Falte, welche den Kern einzuschnüren sucht: später bildet sich eine Plasmawand zwischen zwei Nucleolon; die beirlen entstandenen Hälften blähen sich aut und suchen sich zu separioren. welche 'Trennung sich aber nicht immer wirklich vollzicht. Ubrigens scheint es, dats the Kernzerklüttme innerhalb einer dem ursprünglichen Kern angehörenden, sthon vorhandenen Plasmahülle stattfindet, die rrst später zerreit'st.

In dieser Vermehrung der Zellkerne mol der Wrobhbastelement: kann man wohl eine Andeutung sehen, in welcher Weise rine lem Optimum näherstehende Erhöhung der Bodenwärme begïnstigend wirht. Es dürfte die '/ellvermehrmo und die Zuleitung des plastivelien Materials beschlemigt werden. Ien wohltätigen Einfluts shoiihter Bodenwärme nutzt die Gärtnerei bekanntlich in hohem Mals. dureh die Nistbeetkästen aus. Aber gerade dort lä1st sich anch dir Beobachtung machen, dat's manchen Pflanzen kühlorer Klinate ein. zu

1) Conx's Beiträge zur Biologie der Pflanzen. Bd. II, S. :'11.

2) Prutrax , Altérations produites dans les plantes par la culture dans un sol surchauffé. Ann. sc. nat. ser. VI Botanique t. X, p. :it7. 
hohe Boclenwämne nicht zusagt; sie wachsen nicht schneller, sondern taulen leicht. Die Assimilationsenergie lätst nach, und der geschwächte (1) ganismus wird jetzt von Spalt- mal Mreelpilzen besiegt.

Wie sehr die Assimilation sinkt, wenn die Bodentemperatur zu hoch wird, zeigen die Helnabtistishen Versuche ${ }^{1}$ ). Vergleichende Kulturen in ansogeöhtem Quarzsande ergaben als Emteresultat bei

\begin{tabular}{|c|c|c|c|c|c|c|c|}
\hline \multicolumn{8}{|c|}{ Roggen: } \\
\hline be & $8^{\circ}$ & $10^{\prime \prime}$ & $1.0^{\prime \prime}$ & $20^{\circ}$ & $2.0^{\circ}$ & $80^{\circ}$ & 40" C' konst. Bodentemp. \\
\hline Frischgewicht & $191, \pi$ & $17 t ;,: ;$ & 269,4 & 4 titi, & 涪 & $4(1)<, 0$ & 240,1 \\
\hline Trockensubstanz & $2: 3$ & 28 & $: 32,4$ & $49,-3$ & 42,4 & 47,0 & $: 11,2$ \\
\hline \multicolumn{8}{|c|}{ Weizen: } \\
\hline Frischgewicht & 9 & $1: 30,8$ & 241,0 & $260, ;$ & $: \because+2,0$ & $40 \div, 2$ & $2 ! 96,0$ \\
\hline Trockensubstanz & 15, & $20,-7$ & 29,5 & 30,4 & $4: ?, 9$ & $46,1)$ & $40,: 3$ \\
\hline \multicolumn{8}{|c|}{ Gerste: } \\
\hline Frischgewicht & 151,9 & $151 ; 0$ & $: 33,4$ & 408,5 & $4:, 1,2$ & $3(i, 5,1)$ & $2: 30,5$ \\
\hline Trockensubstanz & 17,1 & $1<, 0$ & $: 34,4$ & $: 36,7$ & 42,0 & $: 3.5,0$ & 26,3 \\
\hline
\end{tabular}

Die Resultate beziehen sich anf jugendliche Pflanzen mol zeigen dentlich, wie von einer Optimaltemperatur für die Wurzehn ans nach einer oberen und mteren (irenze hin die Produktion abmimmt. Gleichzeitig geben die Zahlen aber anch einen Anfschlut's über die Verschiedenartigkeit des Wärmebedürfnisses der verschiedenen Getreilearten. Die höchste Borlentemperatur (wenigstens in der Jugend) beansprucht sonach des Weizen. Die energischste Assimilationstätigkeit entwickelte der Weizen bei $30^{\circ} \mathrm{C}$ Bodenwärme, während Roggen sich hei 201", Gerste bei 25" ( am besten entwickelten.

Anch in diesem jugendlichen, der Akkomodation zugänglichsten Lebensalter zeigten die Pflanzen deutlich den störenden Einfluts zu hoher Bodenwäme. Abgesehen von einer Terzögerung der Keimmg zeigte sich im Habitns der Pflänzthen ein wesentlicher Untersehiea clarin, dats dieselben bei hohen Temperaturen in Stengehn und Blättern dümm und schmächtig worden, während hei niederer Bodenwärme die Exemplare limz, dick mol fleischiger erschienen.

Die Versuche ron v. Bulobrocki ${ }^{2}$ ) ergalon dieselben Resultate und zeigten anch namhafte Unterschiede in der Ansbildmog des Wrmzelapparates. Die Gerstempflanzen, welche konstant bei $10^{\circ} \mathrm{C}$ Bodenwärme wachsen mutsten, hatten ihre Wurzehn aus wenigen grotsen, antfallend starken, schön weitsen Ästen erster und zweiter Ordnmug sebildet, von denen die letzteren moewöhnlich kn's mol mit kleinen. warzentörmigan Erhöhmoen (Zweiganlagen dritter Ordumng) bedeckt waren. Dis in einem Boden von :30" konstanter 'Temperatu' stehem len Individuen hatten fadendïnne, antserordentlich reichlich verzweigte mol zu einem dieliten Nest rerfilzte, hraune Wurzelfasern getrieben. Bei 4"0 C war der Charakter des Wurzelballens derselbe, aber die Ansdehnung desselhen überhanpt moemein gering; es war ein kleiner Filz in den oberen Bodenlagen vebildet worden.

Anch Totsk ${ }^{3}$ ) tam bei Hafer die Entwicklnng der einzelnen Wurzeh

1) Beitr. zu den naturwissenschaftlichen Grundlagen des Ackerbaues. Bramschweig 188:\%. Vieweg \& sohn.

2) Landwirtschaftliche Versuchsstationen 1871, Bd. XIII, S. 4\%4.

3) Jomn. f. experim. Landwirtschaft 1901, S. 790. 
bei niederer 'Temperatur stärker, mel nenerding bestätigt Kossowsten ${ }^{1}$ ) diese Resnltate. Hic schnelligkeit des Eimbringens der Maferwmzehn in den Boden wird flabei verlangsant. Eine Bodenselicht vou mugefäh

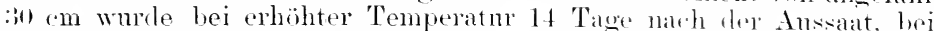
nierlrigen Wämmegraden erst nach 30 Tagen imelelmugen.

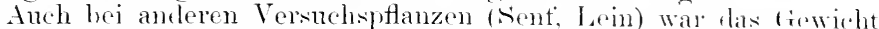
der luftrockenen Wurzeh hei niedriger Bodentrmperatm am hörds-ten.

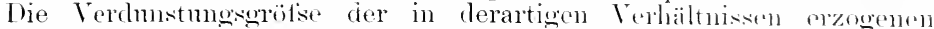
Ptlanzen war geringer als hei den Exemplaren vongledelur Eutwicklme, die bei normaler oder erhöhter Temperatur erwar.fsen warem.

\section{Fehlschlagen der Ananas.}

Der Umstand, dats die in Europa in Gashänsorn knltiviorten Ananas durch das grötsere Aroma die importierten Frïelite ïbertreffor. rrhält die Kultur in vornehmen Privatgärtnereien in einzelnen Gegenden (\%. B. Schlesien) noch in namhatter Ansichmmg. Die grötste (infahr hei dieser Kultur liegt in dem .. Lmehtreihen", il. h. dem tortgesetzten Blattwathstm zu ener Zeit, in der die Ptlanze in ene Ruheperiode treten muts, mo rinen Fruchtstand anzulegen. l)ie Trsache liegt in dev unzeitigen Wärnis mol Wasserzutuhr während der Ruheperiorle

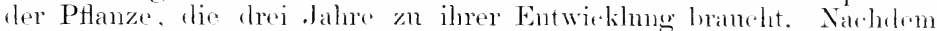

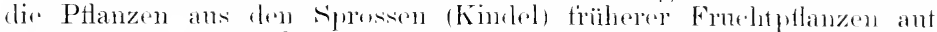

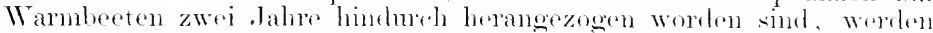

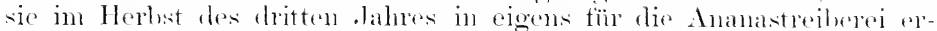

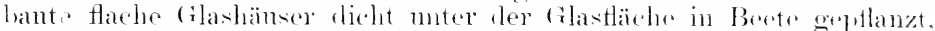

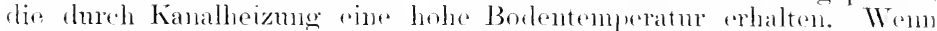

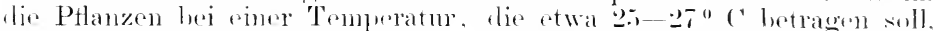

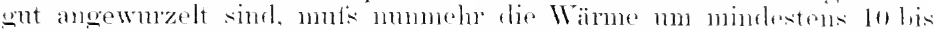

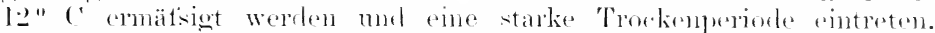

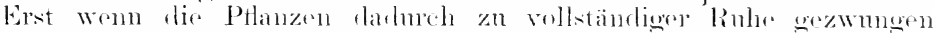
worden sind. darf im Folpuar das Antreiben beriment indern man sofort die frïheren Wämegrarle in Boden wierler einwirken lätst nurl bald darant die Erele stark mit warmen Wasser begiefist. IVemu nach vier his sechs Wochen die Blätter der Pflanzen sich anszulneiten bewimnen und im Herzen sich tärben. dart man schliefisen, datis der Frunchtstand dorehbrieht. Ans Besorgnis, dats die Temperaturemiedrienng

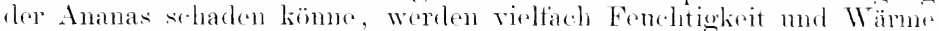

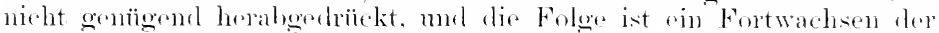
Ptlanzen nuter ansichliofislicler Blattproduktion.

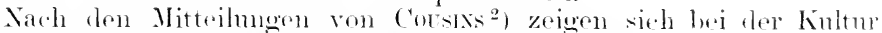
der Ananas in droll Tropen dieselhen Erseheinmoen.

\section{Das Glasigwerden von Orchideen.}

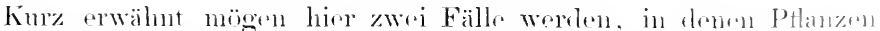

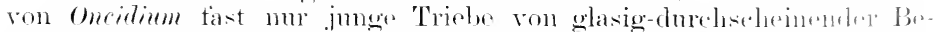

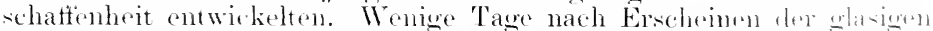
stellen an dor Basis ter Bulben fielen die Triehe mu mul verjandelent.

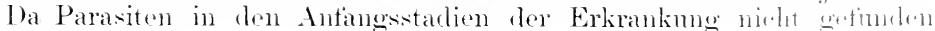

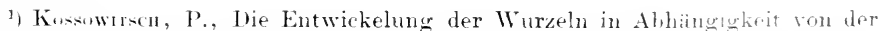
Bodentemperatur in der ersten Wachstumsperiode der Pflanzen. Trurn. f. xperin. Landw. 190:3: cit. Centralhl f. Agrikulturchemie 1944, s. fil.

$\Rightarrow$ Revue cult. colon. 19y2, No. (y.). 
werden komnten und die Schlankheit der älteren Triebe aut grofse Tärme und Fenehtigkeit hindentete, so wurden die Pflanzen ohne jegliche weitere Behandlung in ein kïhleres, helleres Gewächshans vebracht. Nach einigen Wochen war die Erscheinung verschwunden.

\section{Fehlschläge bei der Blumenzwiebeltreiberei.}

Nach sehr heitsen Sommern klagen in manthen Jahren die (tärtner, dafs, entgegen allen Erwartungen, die Blumenzwiebehn sich sehlecht treiben lassen, dat's bei Anwendmug der ïblichen Wärmegrade die Blumen sich nur ungenïgend ans ter Zwiebel hervorschieben und letztere zu faulen beginnt. Dieselben Zwiebehn später als gewöhnlich zur 'Treiberei anfgesetzt und bei geringerer Wärme kultiviert, geben aber volliommene Blumen.

Aus den mir hekannt gewordenen Einzelfällen habe ich folgende Anschammeg gewonnen. Wenn eine heifse Wittermosperiode bereits im Frühsommer eintritt, wo die Blumenzwiebelfelder mitten in der kräftigsten Entwicklumg sich befinden. wird das Lanb durch die Hitze vorzeitig abgetötet und die rwiebel notreit. Unter diesen Unständen seheint das Material, das später bei der 'Treiberei die stärkelösenden Enzrme liefern soll, in ungenügender Menge gebildet zn werden. Wenn num bei der Treiberei der Zwipheh im TVinter die ïbliche hohe Temperatur zur ïblichen Zeit zur Anwendung gebracht wird, so ist bei diesen notreifen Zwiebeln der Wärmereiz zu grof's, da sie diesmal langsameres, allmählicheres Antreiben bei geringeren Wärmegraden verlangen. Wird diese Forderung nicht berïckichtigt, so findet das Reservematerial nicht die normale Verwendmo zur Frnährung des Blïtenschaftes, und die $\%$ wiebeln faulen.

Ein anderer Fall, bei welchem ebentalls die gewohnte Treibmethode dadurch versagt, dats die sonst ïblichen und bewälnt befindenen Temperaturen sich als zu hoch erweisen, besteht in dem, Um fallen der Tulpen". Bei bestimmten trühen Sorten (rosablühenden) wurde beobachtet, dafs die Blïtenschäfte vor der Entfaltung der Blume umknickten. Unterhalb des Knotens, aus dem bei diesen Sorten mehrere Zentimeter ïber dem '/wiebelhalse) die Blätter entspringen, zeigte sich eine glasige, 1-2 cm lange Stelle, die durch iln allmähliches Einschrumpten das Unknicken veranlatiste.

Die Untersuchung ergab reichliche Stärkefüllung des gesamten Zwiebelkörpers bei mngewöhnlicher Menge von Peroxydasen. Bei der Treiberei erwies sich aher, dats bei der hohen Wärmesteigerung die Stärke nu ungenïgend gelöst, alio zu wenig Bammaterial den aufgeschossenen oberirdischen Teilen zugeführt wurde. Das inhaltsarme Tarkgewebe des schattes war hei der schnellen streckung an den glasigen Stellen zerrissen, und somit hatte der Schaft seine Steifung verloren. - Zwiebeh derselben Sentung, welche einige Wochen später. also dor natürliehen Entwicklungszeit näher, nuter denselben Wärmegraden zum Treiben auforestellt wurden, entfalteten sich normal. Man sieht also, wie je nach der Witterung des Vorjahres und der Beschaffenheit der ' Wwiebeln dieselbe Treibhanstemperatur einmal gïnstig, ein anderes Mal ungïnstig wirken kann, und es empfiehlt sich, zu Anfang rer 'Treibperiode zunächst kleinere Proben warm zu stellen.

Bei Maihlumen änfsert sich derselbe Zustand ungewöhnlich reicher Stärkeschoppung hei mzulänglichem Vorrat an stärkelösenden Enzymen in mangelhafter Entfaltung der Blïtentrauben. Es entwickeln sich zu- 
nächst nur einzehne der untersten Blumen der Blütrntranbe. und erst wenn diese verblüht sind, entfalten sich dis olwren (ilocken. Dadurch werden die getriebenen Maiblumen als Marktptlanzen mrerkäuflich. Für derartige Fälle empfiehlt sich das ron den (iarteninspektor Wrake ${ }^{1}$ ). spindlersteld angewendete Verfahren, die Maiblnmenkeins vor den Eimptlanzen mit Wasser von 3.50 R zu begietisen. Jedentalls wired dadurch die Lösung der Reservestotte beschlemigt.

Man ersieht aus diesen Beispielen, dats zum Gelingon dor Tresiberei der rolhende PHanzenteil einen bestimmten Reifoznstand erreicht habun muts, der durch einen hinreichenden Vorrat von stärküisendru Enzmen sich kemmzeichnet.

\section{Saatgut, das durch Selbsterhitzung gelitten hat.}

Ohne ant die Streitfrage einzugehen, ob die Selhsterhitzung ron mureif oder fencht anf Lawer gebrachten samen durh Oxvelasewirkmn oder durch Mikroorganismen. wie bei dem Iten ${ }^{2}$ ), oder durch heide Vorgänge zugleich erfolgt, letrachten wir hier mu len frobranchswert des erhitzten Saatgutes. Wir erwähnen als Beispiel rine Beobatehtme ron Boller ${ }^{3}$ ), der sowohl bei dem in s.hoher (stack burned) als anch

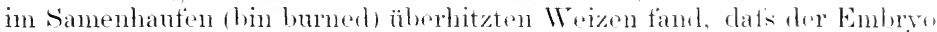
gebräunt oter gänzlich algestorben war. Entwickehn sich die Körnor überhanpt, so pflegen die Blattspitzen abzusterben mol die Wureh

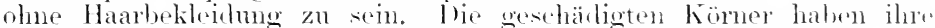

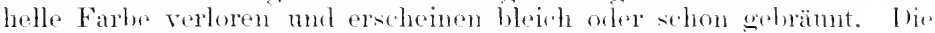

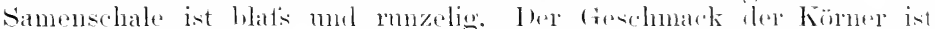

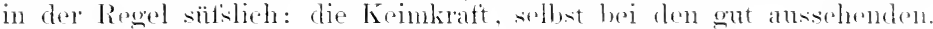
reschwächt.

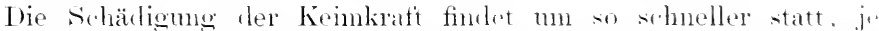

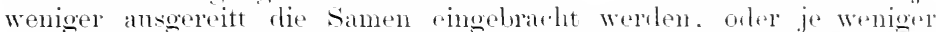
Luttzug an den Autbewahrungsorten herrseht, der den Wasserdampl entfernen könnte. Nach den Fersuchen vom Joms ${ }^{4}$ ) erweist sieh dix. Anwendung eines austrocknenden Nittels (qebramter halk) als vorteilhatit.

\section{Dreizehntes Kilpitel.}

\section{L i c h t m a II $\cong$ el.}

\section{Das Verspillern.}

Die Krankheit, welehe durch mangelhafte Belenchtmog oder gänzlicho Fehlen des Iithes hervorgerufen wird, heifst das Verspillern futiol.. ment). Die einzelnen stengelglieder der Mehrzahl der arimen Ptlanzen werden monein lang und schwach. Die Blätter werden je nats des PHanzenart, der sie angehören, rntweder ebenso wio die Sitengelinter nodien sehr lanes. sehmal unel schlatt (Mehrzahl der Monoentrindoment.

1) .Gartenflora", Berlin 19u7, Heft 2, s. :26.

2) Mistr, H., Tber dhe selbsterhitzung des Henes. Arh. d. Jentsh. I,andw. (i.s. Heft $111,1905,5.76$.

3) Bor.fy, H. L., Conditions afferting the value of wheat for send. Anrit. Exp. stat. North Dakota; eit. Zeitschr. f. Pflanzenkrankl. 1-4t. S. …

4) Jons. V. Sim la résistance des graines aux temperatumes fletes. ('ompt iend. 1899 cit. Bot. Jahresber. 1900. II. S. 4:0. 
oder aber bilden sich überhamt nu sehr wenig ans und bleiben ihr ganzes Leben hindurch in einem ähnlichen /nstande, wie sie in der Knospe gewesen (die meisten Dicotyledonen).

ILit der Gestaltsänderung ist eine Verbleichung der griunen PHanzenteile, also verhinderte Ausbildung oder Kerfall vorhandener Chloroplasten verbunden. Ausnahmen finden wir nur bei den Gymmospermen, von denen die Nelnzahl antserordentlich wonig empfindlich gegen Lichtentziehmng ist. Allerdings erfolgt nach Burciesters ${ }^{1}$ ) die Absorption des Endosperms langsamer, die epinastische Ansbreitum der Cotylen träger und mvollkommener als im Lichte, aber - mit Ansmalime ron Ginglio biloba und Eyhrdia - ergrimen die Keimlinge doch. Cyous und Zamia dagegen kömmen anch bei gïnstiger Temperatu kein Chlorophyll in völlger Dunkelheit bilden. Unter den Coniferen sind die Larixarten die lichtbedürftigsten, da sie nur schwach bei Lichtabschluts eroriunen, während dies rollständio bei den Cupressineen eintritt.

Die verschiedenartige Ansbillung der Blätter von verspillerten Pflanzen wird erklärt durch den Umstand, dafs das Blatt sich selbst wotsenteils ernähren mufs und dats das Collulosematerial, welches es zur Neubildung und Ausbildung der Blattzellen braucht, sich nur durch die Einwirkme des Lichtes an Ort und Stelle bilden kann. Wemn die Emälnme mnterbleibt, so werden sich die in der Knospe angelegten Blattzellen durch Wasseraufinahme strecken und das Blatt wird sich fladurch etwas vergrötsel'n lïmmen: aber jedes weitere Wachstum, das anf Zellvermehrung bernht, wird unmöglich sein. Je mehr ein Blatt hei seiner späteren Vergrötserung an Licht ant die Kellvermelnung angowiesen ist, um so kleiner wird es bei Lichtabschluts hleiben. Es wird sich ferner $m$ so weniger entwickeh. je weniger Zellen msprïnglich als Blattanlage an der Stengelspitze sich bilden; ein stengelumtassendes Blatt wird sich darum mehr entwickeln können als ein quirlständiges. weil bei der Anlage des ersteren der ganze Stengelumfang tätig ist, bei Anlage des zweiten sich die Zellen in wleicher Stammhöhe auf so viel Blätter verteilen mïssen, als der Quirl solche zählt. Ein weiterer Punkt. der auf die Ausbildung fes Blattes auch in Finstern von Einfluts sein muts, ist die Entfernmo der Blattanlage von der Reservestoffquelle. Die erst entstehenden, emem Reservestotthehälter zmnächst liegenden schöpten reichlicher ans dem Vorrat, werden daher wrötser als die später am rerspillerten Stengel höher hinauf entstehenden Blätter. Ex wird somit die Entwicklung des rerspillerten Blattes ron der individnellen Anlage und son dem in mmmittelbarer Nähe befindlichen Nährmaterial abhängi@ sein.

Die Anlage der Monocotyledonenblätter erfolot in der Mehrzah] fler Fälle als stengelunfassender Wulst unter dem Vegetationskegel und zwar dort, wo Reservestoffbehälter rorhanden sind, in ummittelbarer Nähe dieser Behälter, ans denen das celïste Bammaterial nur kurze Wege duxh lie verkïrzte Achse zu machen hat (träser).

Sach flen Erörterungen ïber dic Verspillerungserscheinungen des Blattes bleibt die moewhinlithe Streckmo der etiolierten Stengelglieder zu erklären. Wir folwen hierin den Angaben von Krats ${ }^{2}$ ). In der Regel sind die verspillerten Stengel dünner als normale, was von einer

1) Burianstrix, A., Üher das Verhalten der Grmnospermen-Keimlinge im Lichte und im Dunkeln. Just's bot. Jahresb. 1900, II, S. 250.

2) Krass, C., Üher die Trsachen d. Formverinderungen etiolierender Pflanzen. Pringshein's Jahrb. f. wiss. Bot., Bd. VII, Heft 1 ı. 2, S. $209 \mathrm{ff}$. 
geringeren Anzahl von /ellen herrührt, und dirse mangehde Tätigkeit im Cambium des Stengels wird ihre Erklärmng in dr Annahme finden, rats die vom Blatt erarbeiteten Nahrungsstuffo, die durel den Blatt-

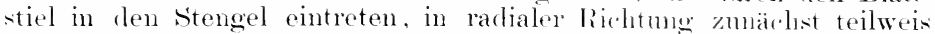
weiterwandern mol das C'ambium tes stongelintrinotimus omähren helfen. Fehlt diese Nahmmgsquelle. d. h. ist das im Finstern sthmpen-

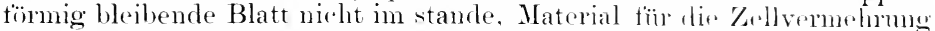

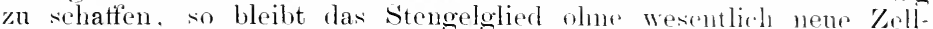
bildung. Aber anch die Verdickung der Kellwandmen wirel nuterbleiben. Im normalen Stengel verdicken sich dir. Panenclivmzellen der Rinde und die Prosenchymzellen des Holzes wälmend ihrer Längsstreckung. I)ie Markzellen tangen aber erst an, sich zu rerliclien, wem ihre streckumg nahezu beendet ist, also am spätesten. da sio von dem aus dem Blatt in radialer Richtung nach dem Stamminnern wanderneten Cellnlosemicell erst dam erreicht werden, Wem dassellor nicht meln zur Verdickung der Holz- mol Rindenzellen verluancht wird. In rerspillerten Stengel ist ans Nahrmosmangel die Vopolickmne der \%ellen nur angedentet, so rats sie oft hei /ellen, wolche zwiseluen

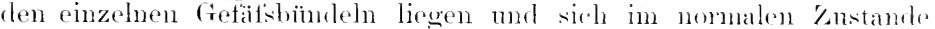
zu Holzzellen ausbilden, fast fehlt: daher finder man in etiolierton PHanzen häufig nicht eimmal einen gesehlosinen Ilolzring. Was solehen

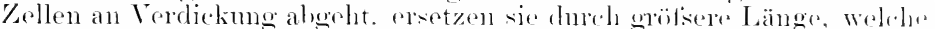
the der normalen Zelle mu das Zwei- his Vielfarhe älersteigt. L)ieso

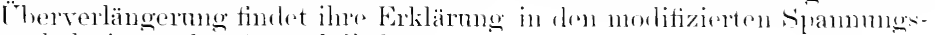
rolhältnissen der stengrelglierles.

Wem man von einem noch fortwahsenden stengeloliede den hinulen kïrper ahlöst, rerkïrzt sieh derselbe; der isolierte Marklïrper daugenen verlängert sich bedentent. Man sieht darans, dats in stengel has Mark rigentlich der streclinute Faktor ist, wälrend das iibrige fieweh. den zurïckhaltenden Faktor darstellt. Nur wom res stengel noch ganz jung ist, kam das Mark sein Ansdelmungstlehen betriedigen, weil die

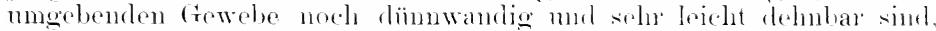
also der Zugkratt, welehe das Mark ansïht, leideler passiv tolgen kimmen. Almählich aber exlischt die Dohmbarkeit der äutsoren fiewoles wänzlich, mol das längere Mark wird jetzt durch dio nummehr, diekwandigen Rinden- mol Holzolemente zurijckgehalten. Im lotzteren Entwicklumgstarlimm, kurz bevor das stengelglied zu wachsen anthört. gleicht sich der

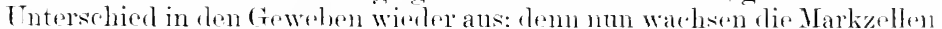
moln in die Breite als in die Länge infolge des zurïrkzielenden Einflusises der Rindensehichten, mel in dieser Form werden die Markzellen

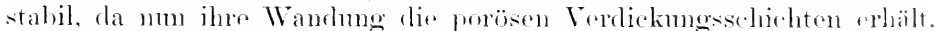

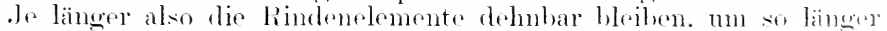
kann das Marli seinem Streben nach Verlängerung folgen mul tis ïhrigen tewebe mit sich in dir Jöhe ziehen.

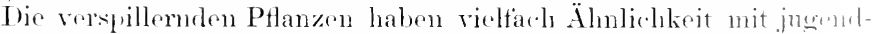
lichen Organen, mol man kann den Kustane? des Verspillerne his zu einem gewissen Grade als permanente Kindlueitsform brzaichnen.

Nach der Besprechung der westaltichen Verändermonen hahns wis

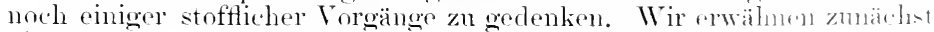

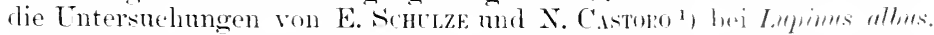

1) E. Suntzr: u. X. Cistun, Bejträge zur Kenntuis der Zu-ammensetzung und des stoffwechsels der Keimpflanzen. Zeitschr. f. phrs. ('hemin He MXIVIII: rit Botan. Centralbl. 1944, Nr. 47. 5. 540. 
In verspillerten Keimlingen nimmt der Gehalt an Proten̈stoffen beständig ab, der Gehalt an Asparagin zu; Tyrosin und Lencin nehmen ab. Allerding bewahren auch die am Licht erwachsenen Keimpflanzen lange einen hohen Asparagingehalt, enthalten aber sehr wenig Aminosäuren.

Die Versuche von Paldanc ${ }^{1}$ ) lassen erkemen, dafis der verminderte Transpirationsstrom bei etiolierten Pflanzen eine zu geringe Aufinahme ron Mineralbestandteilen, namentlich Kalk, veranlatist. Der Mangel an Kalksalzen läfst aber selbst bei eiweifsreichen Blättern keine weitere Entwicklung zu.

Dats im Dunkeln erwachsene Pflanzen weniger widerstandsfähig gegen atmosphärische Einflüsse sind, hat W1EsNEk ${ }^{2}$ ) durch mehrfache Tersuche rezeigt. Er fand beispielsweise, dats im Lichte erzogene Keimlinge der Einwirkmo des Regens und ïberhanpt des Wasser's gegenüber viel resistenter sind als die im Dunkeh entwickelten Keimlinge.

Wie diese stofthehen Verschiedenheiten zum Ausdruck beim Wachstum kommen, zeigen die Beobachtungen von $\mathrm{HAtiE}^{3}$ ) an Ampelopsis und Gilechrma. Ditfuses Licht befördert die Bildung der Laubtriebe und kann sogar die Umbildung einer Infloreszenzknospe in einen kletternden '/weig veranlassen. Lirektes Sonnenlicht bewirkt das Gegenteil.

Besonders wichtig für die Pathologie und namentlich den ron uns vertretenen Standpunkt, datis eine ganze Reihe von Krankheiten durch Terschiebung der enzymatischen Funktionen zustande kommt, sind die Untersuchmogen von (GREEN $\left.{ }^{*}\right)$. Derselbe bestätigt die Beobachtungen von Brown und Morks, dafs nach einer Periode heller Belenchtung der Vorrat an Diastase in den Lanbblättern vermindert wird. Besonders sind es die ultravioletten und anstodsenden sichtbaren Strahlen, dir eine solche Enzvmverminderung hervorruten. Eine solche Enzymzerstörung durch das Licht ist mit der bekamnten Bakterienabtötung lurch Licht zu vergleichen.

\section{Die Beschattung.}

Im wirtschattlichen Leben sind die schäden, die durch direktes Verspillern hervorgerufen werden, viel seltener und daher bedentungsloser als die minder hochgradigen Vorkommisse, die durch ungenügende Lichtzufuhr, also zu starke Beschattung entstehen und in einer Verminderung der Produktion an nutzbarer substanz sich geltend machen. ت̈ber dlen Lichtentzug, den verschiedene Bämme ausüben.

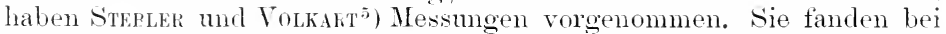
bedecktem Himmel eine Lichtverninderung bei der Kiefer mm $50 \%$, bei der Birke 5i, bei der Kirsche 7s, bei Eiche, Birne und Apfel s.2. bei der Buche sogar um $1 \% 1 \%$.

1) Pundrx, W., Eiweifsgehalt der gränen und etiolierten Blätter. Ber. d Deutsch. Bot. Ges. Bd. IX, s.. 194. - Ergrünen und Wachstum der etiolierten Blätter. Ibid S. 299.

2) Wirsxer, J., Der Lichtgenufs der Pflanzen. Leipzig 1907, W. Engelmann. S. 260.

3) Mritik, Influence de la lumière etc. Compt. rend. 1898, p. 420; cit. Bot. Jahresber. 1898, I, S. $5 \div 7$.

4) Grem, J. Rexporns, On the action of light on diastase. Phil. Trans. of the

R. Soc. of London. Ser. B., vol. 188; cit. Bot. Jahresber. 1×97, I, S. 89.

5) Sinater, F. G., u. Torkar, A., Der Einflufs der Beschattung auf den Rasen. Landwirtsch. Jahrbücher d. Schweiz. Bern 1904; eit. Bot. Centralbl. 1906, Bd. 101, S. 60. 
La jede Pflanze ihr bestimmtes Lichthediurnis hat. so liommen auch Fälle vor, bei denen die Kultur Lichtïbershuls bictet. währent der natürliche standort nur gedämpftes Licht den Pflanzen zuteil werden lätst. Dieser Fall zeigt sich bei vielen muser Hontentelder mul bei manchen nuserer Erdbeorknturen ${ }^{2}$ ). In solden Fïlen brirlit der schatten eine Produktionsteigerung, aber in der Mehrzall d,re Fäll. drïekt er die Menge der Troekensubstanz herah mol schwächt dis Färbmg von Blatt und Blïtenorganen. För msere Kolomiallinltmen dürte die Beschattungstrage eine besondere Wiahtiglieit r.rancen. Aut' Java sowohl wie in mseren ostafikanischen Kolonien ledilen nämlich

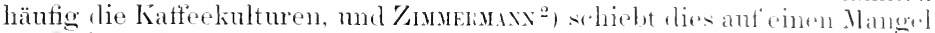

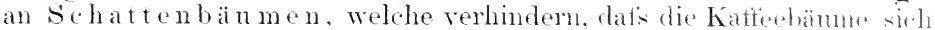
übertragen, was z. B. in Lsambara schon gloftsen seharlen anereliehtet

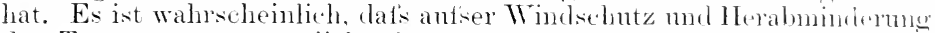
der Temperatur namentlich eine geringere Lichtstärke dem rixleihw des Kaftoes förderlich ist.

Die verminderte Ernte bei mseren lichthedürtigen Kulturen mntr. dem Einfluts des Baumschattens leruht niclet num ant der beschänliten Lichtzufuhr, somelern anch ant geringerer Bodenerwärmmug.

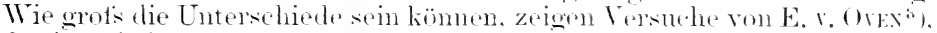
der imerhalh von 10 Angustagen morens : The in tieibesomenten Boden

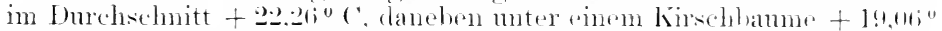

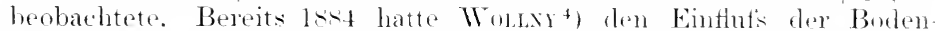
beschattmug durch die Enkräuter hei einem Kartotleltelde wemessen

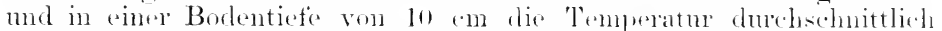

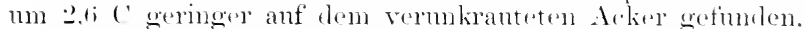

Nächst der Temperatur spricht der Wassorehalt des Borlens mit. Wie sehr die Bodententhtigkeit die Blattoratse herinflutst, zeigen die Messungen von $\left(\mathrm{i}_{\mathrm{A}} \mathrm{N}^{5}\right)$, der. die Länge der (1rane anf troclienem stantort $=100$ gesetzt, die Inmensionen ant fenchtem Boden bei cierste

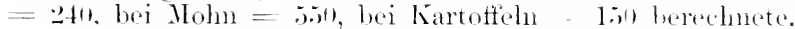

Wemn die Pflanzen danernd zu wenig Wasser haben, wirl ihr Ansleben verzögert und natürlich anch ihre Produlition wesentlich herab. gedrückt. In dieser Beziehung sind die Versuche von Bank ${ }^{6}$ ) zu erwähnen, der bei Kartotteh in einem Borlen mit fol bis 300" dor Wasserkapazität die Reile der Standen um 8 Tage, bei :30 bis $10 \%$ mm 1s Tage sich verspäten sah gegenüher den Standen mit reichlicher Bodenfenchtigkeit (so) \% der. Wasserkapazität). Bei demselben hohrn Fenchtigheitsgehalt des Bodens erntete Wouxy bei Toptkulturen su "r an Knollen, während er bei dem halben Wassergehalt der Erde num $39 \mathrm{~g}$ und bei $20^{\circ}$ o der Wasserkapazität nur 1!,5 $\underset{g}{g}$ an Knollengewicht erhielt.

Bei der Kultur krantartiger Pflanzen mit flach streichenden Wurzeln wird der Ertrag durch die tiefer liegenden $\mathrm{Ba}$ a w w $\mathrm{meln}$ mprich

1) Tигик, O. M., и. Cикк, V. A, An experiment in shading strawberries. New York Agric. Exp. stat. Geneva Bull. '-46. 1944.

2) Zismensixs, A., Einige Bemerkungen zu dem Aufsatze von Fr. II m asw. Berichte äber Land-u. Forstwirtschaft in Deutsch-Ostafrika. Bd. I. Haft 5. 194.3.

${ }^{3}$ ) v. Ovw, Über den Einflufs des Baumschattens auf den Ertrag der hätoffelpflanze. Naturw. Zeitschr. f. Land- u. Forstwirtschaft 1914, s. 4694

4) Wow..xy, Forschungen auf dem Gebiete der Agrikulturphrsik Bu. VII, s. : : 49

5) Bot. Centralbl., Beihefte, Bd. IV, s. 418 .

6) Busr: in Biedermann's Centralbl. 1-is, S. 154. 
werchmälert. Bei den v. Urischen Versuchen betrug der Wassererelualt unter einem Kirschbam $20.24^{\circ}{ }^{\circ}$, in der mbeschatteten Nachbarschaft aber $21,78 \%$. In (nach WoLcxy) $2,80 \%$ Wasser mehr entzogen als durch die Kartofteln allein.

Den Einflutis des schattens aut die Pflanze selbst schildert 1. ()w: nach eignen und andoren Beobachtungen. Die Stengelglieder werden länger, die Blätter schmäler, das Auseiten wird verlangsamt. Epridermis, Gefätibünlelscheide, die Wandmeen ter Ringgetätse und des Jarkparenchyms sind weniger verdickt und tie Terholzmo geringer.

Die Ursache der verlängerten Vegetationszeit der Sthattemptlanzen muts in der geringeren Intensitä des stotfwechsels gesucht werden, die sich durch die schwächere Atmung kund gibt. Da unseren Versuchen nach, unter sonst gleichen Verhälnissen die Grölse der Assimilationstätigkeit die Höhe der Transpiration bestimmt, so erklärt sich auch die wesentlich geringre Terdunstung und daher ein höherer Wassergehalt der sichattempitanzen.

Von den zahlreichen Untersuchungen, welche eine Depression der Ernte durch die Beschattung feststellen, und die v. Orex ant'ser seinen eigenen antïhrt, interessiert die von Wersk an einem Weizenfelde. I ie Pflanzen, die einen grotsen Teil des Tages dur'h Obstbämme bes.hattet waren, zeigten einen $u$ m $30 \%$ verminderten Körnerertrag und

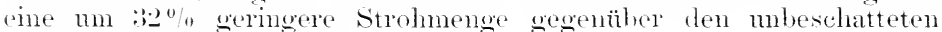
Pflanzen dessellien Feldes.

Besonders bemerkenswert sind die Ergebnisse, die Parour ${ }^{1}$ ) erziclte. Er fand bei Tersuchen mit /uckerriben einen starken Rüclgang des /uckergehaltes unter Anwachsen der Blattmenge pro Gramm Riilenkörper und bei Kartotfeln einen geringeren Knollenertrag mit bedentendem Rückgang an Trockensubstanz. Autserdem aber wies er nach. dat's der Nitratgehalt in den unter geschwäztem Glase kultivierten Rüben und Kartoffeh in Blättern mol Wurzeln mehr wie zelnmal so grofs als bei den in treiel Besonnung erwachsenen Pflanzen wal. life physiologische Arbeit wurde also in schatten geändert, intem die saljetersauren șalze nicht genögend verarbeitet wurden.

Einige der v. (1wishen Versuche beschäftigten sich auth mit del Messung der Lichtstärke, die nach Durchgang der somnenstrahlen unter ciner Baumkrone noch vorhanden war. Es stellte sich nach der BunswRoscoeschen Methode heraus, dats das Terhälnis des vollen Tageslichtes zur Lichtmenge muter den Obstbämmen etwa wie $1: 1,3$ sich erwies. Der sehatten der Apfelbäume setzte die Lichtintensität durchschuittlich von 1 aut o,2:34. der Schatten der Birnbäume von 1 auf 1,2:3:3, derjenige der Kirschbämme von 1 ant 1,34 , herab.

Für den pralitischen Betrieb diurte ans den vorliegenden Beobachtungen sich die Johe ziehen lassen. dats der so vielseitig empfohlene gemischte Anlau von Obstbämmen zwischen Feldlulturen t'ür die nördlichen Gegenden mrentabel ist. Für südliche Länder, bei denen ein Licht- und Tärmeäberschuts zeitweise die Kulturen schädigt, wird die Methode vorteilhatt sein. Bestätigt sehen wir diese Ansicht dadurch, daf's Italien seino Felder mit Streifen von Maulbeer- und

1) Annales agronomiques Bd. V'II, lsol (cit. v. Ova). 


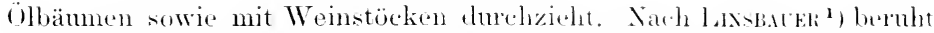
die Kultur des Weinstocks in Italien (Peroulations mul in den iosterreichischen Ländern (niedrige Ptahltornt ant dor Anpasinne an dis.

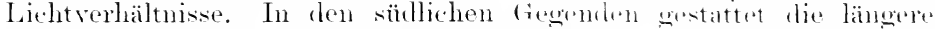
somenscheintaner die schattige Kultmonethorle in Lanhen, wälneml

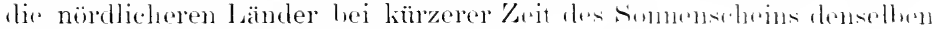
mehr ausnutzen müssen.

ت̈ber die Struktur der Sichattenblätter lienen dir hekinnten simelien

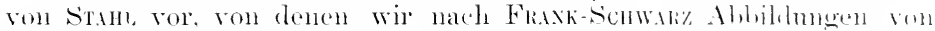

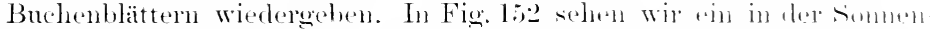

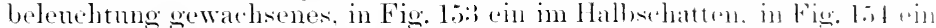
in sehr starkem Schatten erwathenes Buchenhlatt. Wir arkemmest dis

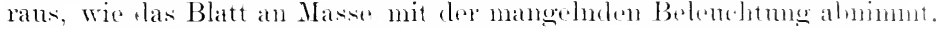

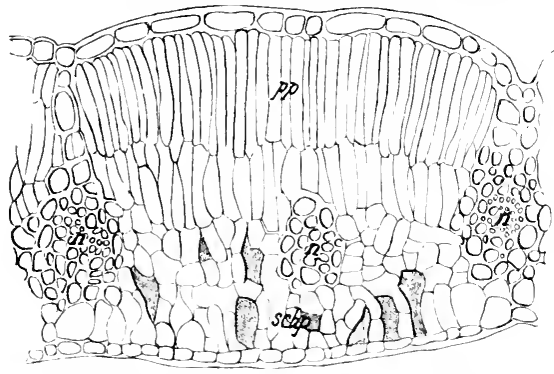

Fig. 15.2. Querschnitt durch ein in der some erwachsenes Buchemblatt. (Xach si:.ни..)

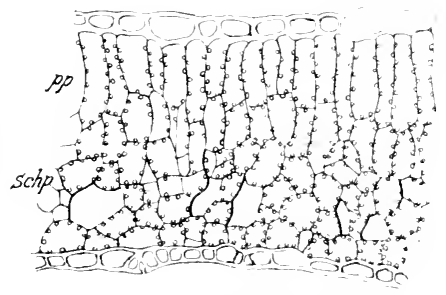

Fig. 1sis. Querschnitt durh pin Buclienblatt atls halbachattigur Lage. (Nach Simul.)

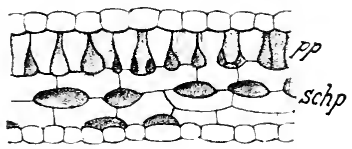

Fig. 1.j. Querschnitt durch ein Buchenblatt von sehr schattigem stantort. (Nach siratil..)

1" Patisartenparenchym, shl schwammparenchym.

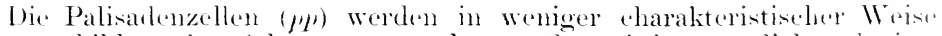

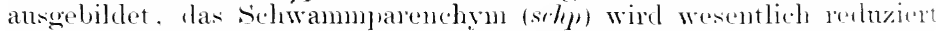
und dir Giefafisthündelstränge werden schwächer. Der woringeren Blatt "ntwicklmug entspricht eine schwäehlichre Knospe.

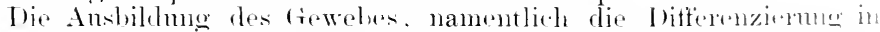

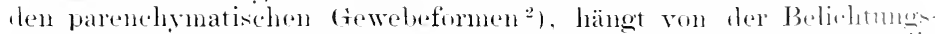

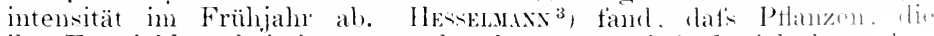
ihre Entwicklnng bei einem stets herabgesetzten, jerloch nicht hwander

1) Wrankli, Lichtgenufs der Pflanzen. 1907.

") Mar Dorar, F. F.. The influence of Light and Darknesis etce; cit. Bot. Centralbl. 1913, Bd. XCII, s. $2 \%$.

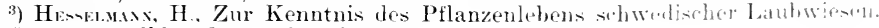
Beih. Bot. ('entralbl. Bd. 17, 1904, s. 311. 
niedrigen Lichtgenufs vollziehen, eine weit geringere Ausbildung des Ascimilationsgewebes anfweisen, als solche Exemplare, welche im Frühling viel Licht geniefsen, im Sommer aber stark beschattet sind. Bei gleicher Grötse der Blattfläche transpirieren die Somnenpflanzen mit ihrem ansgebilketen Palisadenparenchym hedentend stärker als die schattenpflanzen ${ }^{1}$ ). Nach Ricone ${ }^{2}$ ) sollen die Palisarlenzellen höher, aber enger, die Gefätshündel in ren Blattsticlen zahlreicher sein. Derselbe Untersehied besteht zwischen Exemplaren im Freien und in (rewächshänsern ${ }^{3}$ ).

Betreft's der Arheitsleistme von Licht- und Schattenblättern ge-

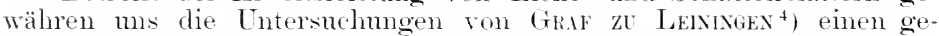
nügenden Einblick. Er fand bei Buche anf dieselbe Blattfläche berechnet den Gehalt an Reinasche (mit Ausnahme der Kieselsäure) bei den somenblättern bedentend geringer als bei den schattenblättern: thenso rerhiclt sich der stickstotfgehalt. Wir erklären uns den Sachverhalt folgendermatsen. Der Wurzelapparat versorgt die Blattanlagen mit gleichen Nengen von Wineralstoffen. Es kommt num darauf an, wie clieselben ansemutzt werden. Je krätiger eine Pflanze vegetiert, desto mehr organische Substanz produziert sie pro Gramm Aschenbestandteile. Es wird also jedesmal anf eine geringere Assimilationstätigkeit geschlossen werden müssen, wenn die Analyse einen in Beziehung zur Trockensubstanz hohen Aschengehalt nachweist. Im vorliegenden Falle ist die geringe Lichtmenge der die Produktion herabdrïckende Faktor.

Die Schattenempfindlichkeit ist für jelle Pflanzenart allerdings anch an bestimmte Grenzwerte gebunden, aber diese Werte sind, wie bei allen Wachstmmsfaktoren individuell bis zu einem gewissen (Hrade verschiebbar, so dats es innerhalb derselben Suezies schattenempfindlichere Rassen gibt, bei denen, wie Nordhauses ${ }^{5}$ ) meint, gewisse Redultionserscheinmoen erblich werden.

Jedes Blatt an einer Pflanze hat seine besondere Schattenempfindlichkeit je nach den Belichtmosverhältnissen, nuter denen es entstanden ist, und je nach seiner Stellumg an der Achse. Am meisten spricht dabei die Beschattmng mit, welche darüberstehende Blätter ausüben. Assimilations- und Atmungsgröfse sowie die Transpirationsgrötse werden dadurch bestimmt. Bei den Versuchen von GrufFon ${ }^{6}$ ) beispielsweise zeigte sich, dats ein so dickes Blatt wie das von Prums Laurocorasus noch nicht imstande war, bei direktem Somenlichte die Kohlensäurezersetzung eines Blattes von Ligustrum ovalifolium gänzlich zu verhindern. Hinter zwei solchen Blättern dagegen fand mur noch Ent-

1) Brikgex, J., Transpiration of sun leaves and shade leaves of Olea europaea and other Orval-leaves evergreens. Bot. Gaz. Bd. 38, 1904, S. 285.

") Rrôse, R., Action de la lumière sur des p'antes étiolées. Rev. gen. de Bot. 1902 , t. XIV, p. 26.

3) Küsme's Referat über „Bíntux, Influence de la culture en serre etc." in Hollrung's Jahresber. über Leistungen auf d. Geb. der Pflanzenkrankh. Bd. VII, 1905, S. 7. (Weitere Notizen über Somnen- und Schattenblätter s. Küsrer, E., Pathologische Pflanzenanatomie 190:3, S. 24 usw.)

4) Whnem Graf z Laxixiex, Licht- und Schattenbläter der Bnche. Naturw. Zeitschr. f. Land- u. Forstwirtsch. 1901., III. Jahrg., Heft 5.

5) Nommarsex, M., Üther Sonnen- und Schattenblätter. Ber. d. Deutsch. Bot. Ges. Bd. XXI, 190:3, s. 30 .

6) Griffox, El., L'assimilation chlorophyllienne dans la Immière solaire, qui a traversé des feuilles. Compt. rend. CXXIX, Paris 1899, s. 1276. 
wicklung von Kohlensäure statt. Unter solehen Verhälnissen war also der Assimilationsprozetis bereits derart herabereluitekt, dats der Atmungsprozefs ihn ïbertraf.

Es kommt natïrlich anch darauf an, wit. dis lieselattenten Ptlanzen-

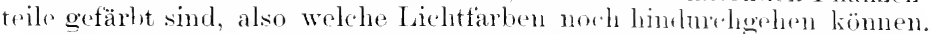

Nach Teonoresso ${ }^{1}$ ) entwickeln sich die Blattgewelue am schleshtesten im grüuen Licht; im roten Licht zeigen sie frsisere, im hlanen abor

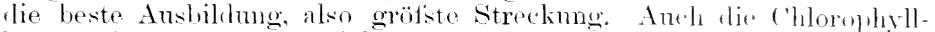
kömer sind im grünen Licht kleiner, weniger zahlrejoh uml nicht so regelmälsig verteilt als im roten und hlanen licht.

Entsprechend der Ausbildung der Chloroplasten arwist sirh anch

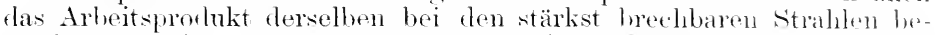

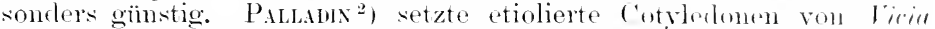

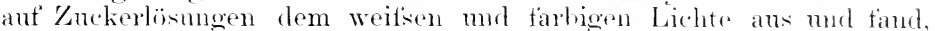
dat's sowohl die Assimilation des Zuckers als anch die Bildung alitiver Proteäle turch dir stärker hrechbaren Lichtstrahlen am wirksamsten vor sich ging; anch die Atmung war intensiver.

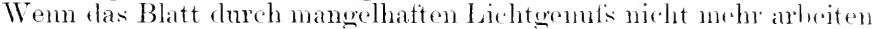
kamn, tällt es ab, wie bei Einwirknng aller anderen Faktoren, die seine Assimilationstätigkeit anfheben ${ }^{3}$ ). Darans erklät sich ter regehnätige

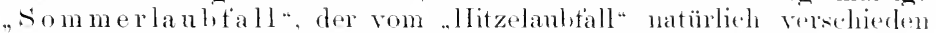

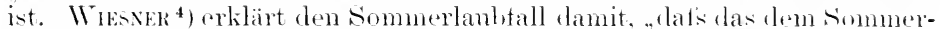
hegim tolgende sinkon der tägliehen Lichtstärke sin sinken des absoluten) Lichteremsses der betreffenden Pflanze nuter das Minimmm herbeidührt, woturch alshalıl ein Losläsen der Blätter herbergefïlnt wirl'".

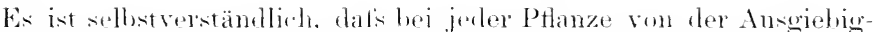
keit aler Kohlenstoffassmilation die Jume der Blïten abhängig ist, also beschattete Exemplare weniger hïhen. Anscoliledslich diffuses Licht verzögert die Blütezeit mol kam die völige Reife der Fräelite verhindern, so dats die samen wänzlich atrophieren können 5).

Es liommen nun auch Fälle vor, wo Ptlanzen mit hisheriger reichlicher Assinilation vor ihrer Blïtenbildung verelumkelt werden. Im Inmklen erschenen die Bläten in der Regel später, ihre Farbe wird blasser, bisweilen weils. ihre Grötse und Sulstanzmenge geringer, die Blütenstiele nicht selten länger"i). Wem aber die Bläter in Licht verweilen mo nur die Blütenkusspen tragenden Äste verfunkelt worlen. lann entwickeh sich nath Kkacsi ${ }^{7}$ mit wenigen Ansnahmen die Blmmen vollkommen.

Win haben bereits im vorhergohenden Abschnitt der Iömmandiokeit cler Zellelement, bei ctiolierten Pflanz'n geflacht.

1) Tenuntaso, E., Influence des differentes radiations etc; cit. Bot. Jahresher. 27. Jahrg, 1901, TI. II, s. 13:3.

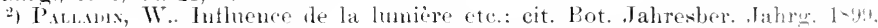

II, s. $1: 34$.

3) Vientrw, H, Üher die Ahhängigkeit des Laubfalls von seiner Assinilationstätigkeit. Bot. Zeit. 1s.91, Nr.

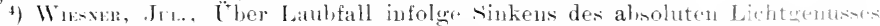
(Nommerlaubfali). Ber. d. Weutsch. Bot. (ies .Jahrg. XXII, Iloft I. 190t, it.

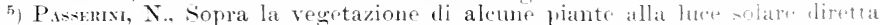
e diffusa. S. Just's Jaliresber. 1902, II, S. 62:

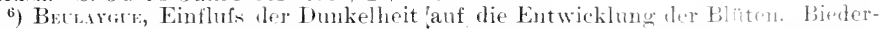
manns Centralbl. 190:2, s. 10:.

i) Krus, Über die Crsachen der Formveränderungen etiolixender Pflanzen. Pringsheim's .Jahrb. f. wiss. Bot, B 1 . VII, S, 209.

Sorauer, IIandbuch. : A Autl. Erster Band 


\section{Das Lagern des Getreides.}

Halusenkungen von längerer I)aner bewirken einen Rückgang in (n)antität und (qualität der Ernte. Sic sind un so gefährlicher, je meln die Biegmo des Halmes in eine wirkliche Knickung äbergeht. Man war fiüher geneigt, eine einzige Ursache tes Lagerns anzmehmen, bis die späteren Beobachtmoen teststellten, dats seln verschiedenartige Faktoren dabei zur Wirlisankeit kommen kömnen, und je nach diesen Ursachen das Unlegen der Halme bald an der Basis im Erdboden oder dicht äber demselben oder in einer höheren I Halmregion erfolgt.

so wissen wir jetzt, dafis vielfach Frostschäden schwächungen des Halmes lierbeiführen, die ohne oder (meistens) mnter späterer Nitwirliung von Pilzen ein Umknicken einleiten. Ferner sind Insektentrats, Windbruch, Hagelschlag, lang andauernder Regen nicht selten Veranlasismo zu einem direkten Tunkicken ter Halme.

Während aber die Mehrahl der genamiten Faktoren ein grtupenartiges Tmlegen des Getreides veranlatist, so datis dazwischen anfrechtstehencle Halme verbleiben. ist das eigentliche, vom Landwirt am meisten gefürchtete Lagern ein in zusammenhängenten Flächen anftretendes Tnnkicken infolge zu schwacher Ausbildung der Halmbasis.

Dats dasselbe durch Lichtmangel hervorgerufen wird, hat L. Koch ${ }^{1}$ ) experimentell genan nachgewiesen, indem er liumstich die Erscheinungen des Lagerns dadurch zustande gebracht hat, dats er die Halme heschattete. Es werden dadurch die bereits fiüher von Gronemerer ${ }^{2}$ ) gemachten Angaben hestätigt. Die Schwäche des Halmes, die das Kniclien bei dem hagem bedingt, zeigt sich wesentlich in den unteren stengelgliedern, mud besondirs ist es das zweite Internodimm (von der Halmbasis ans gerechnet), welches dem Einknicken am meisten mnterworfen ist.

Das rste, nuterste stengelglied ist zwar ebenfalls schwach, aber in der Regel zu kurz: dagegen ist das zweite am meisten gestreckt und an wenigsten verdickt. Die Zellen dieses Internodimm zeigen heim lagergetreite im Verhältuis zu ten entsprechenten des nomalen Stengels eine bedentendo Ïberverlängermg und mangelhafte Terdickmn. Letztere int besonters bei denjenigen \%ellen in die Augen springend, welche am Hahm den Ramm zwischen Oberhant und fictätisbündelscheide eimelmen und im wesentlichen durch ihre Verdickung die Festiglieit des Halnes hedingen.

Das Iagergetreide entsteht alio, wem bei dichtem Stand der saaten rine centigende Belenchtung der miteren Internodien unterhleibt. Die zn starke Beschattumg wirkt anch in ganz frühen Entwicklungsistadien der Pflanze sthon nathteilig durch Ï̈berverlängerung der /ellen unt geringe Verdickmng der Wandungen, was, wie gesagt, vorzugsweise im zweiten Internodium vom mnten stattfindet. l)iese C̈belstände werden an derjenigen stelle drs Internodiums $1 \mathrm{~m}$ so tärker auftreten, wo die Blattscheide den Hahn am dichtesten mmschlietst: dies findet in der Nähe fer Basis des Stengelgliedes statt. und hier zeigen sieh dem anch die Verpillermesserseheinmong am klarsten und intensivsten.

Früher wurde als (irund für das Lagern des Getreides Mangel an hieselsäme angenommen: dies ist jetzt als irrig zu erläaren, da sich bei

1) Lı пw Kon, Abnorme Ändermuen wachsenter Pflanzenorgane durch Beschattung.

") (imoviman in Agronom. Zeit. 1\$67, Nr. 34. 
den Wasserkulturen der tietreideptlanzen horatsintelle, datis tie hiesel sänre in minimalen Mengen genitgt, eine normal. Pflanze zu erzeugen,

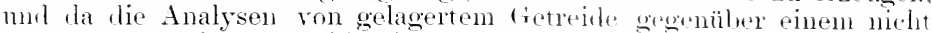

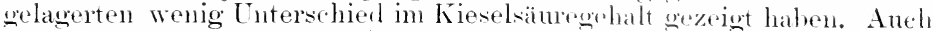
in den nom

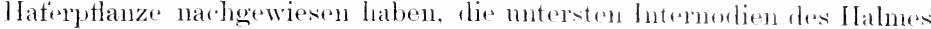

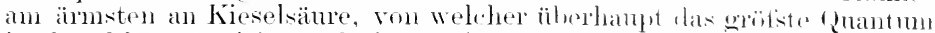

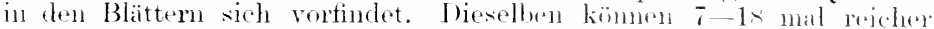
an Kirselsäure sein wie die unteren Stengelglieder.

In Verbindung mit dem Lifhtmangel stelit der zwrite als firmut

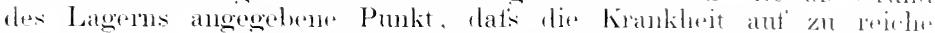

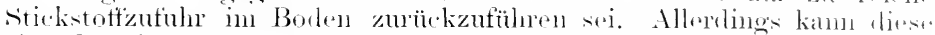

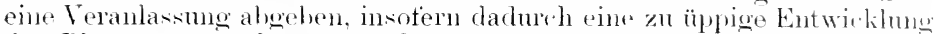
des Blattapparates hervorwerufen und dir Beschattmog wesentlich ver. mehrt wird: eine ebensolehe Veranlassmer wirl aber iiberhante jeder Unstand geben, der zu diehten Stand der Saaten bedingt, alson z. B. zu starke Ausisat, reiche Wasserzutuhr usw.

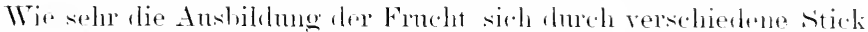

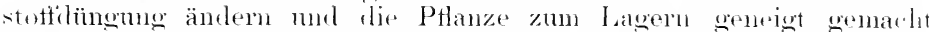

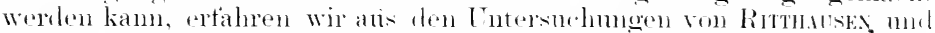
Potr $\left.{ }^{1}\right)$. Während dir Körmer des sommerweizens hei rojeher sitiek

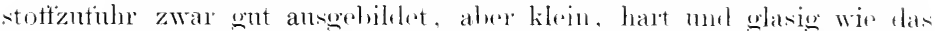

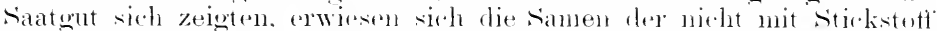
gediungten Parzellen grötser, halbmehlig und hellfarhig. Die Pflanzen

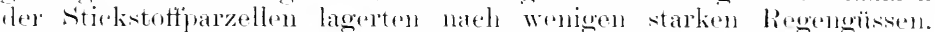

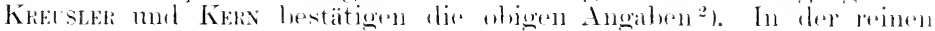

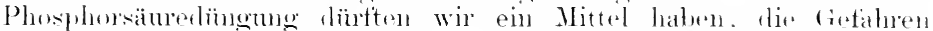

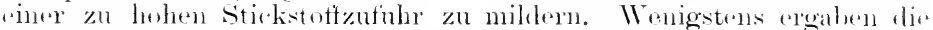

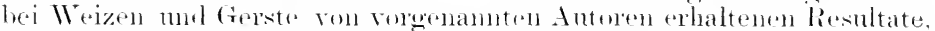

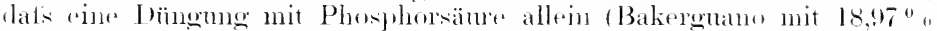

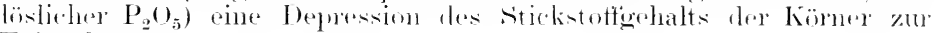
Fologe hatte.

Alwr abgesehen von der Kusammensetzung der könure, dir dureh erhöhte stickstoffzutuhr geändert wird, muts doch auch die (iesant menge dre Ernte in Betracht wozogen werlen, welehe hej zu ïppigen

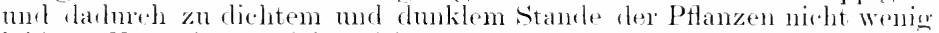
leislet. Vorsuche, welche sich an dic in praktischen Betriebe vorkommenden Verhälnisse an meisten anlehnen, indem sie den binfluti

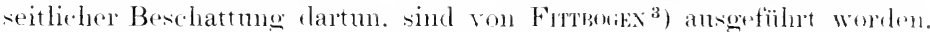

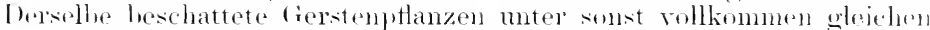

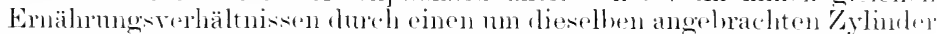
rom nebeneinander betistigten Rogoenhalnen, der in dem Matis: in die

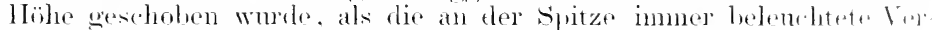

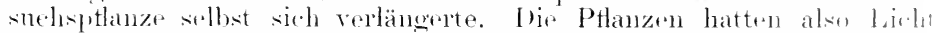

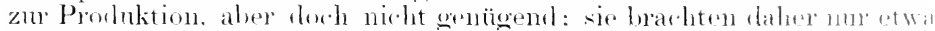

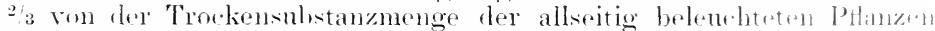

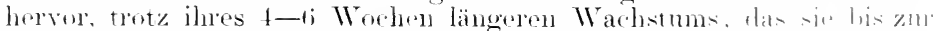
völligen Reife hranchten. Lie Trockensubstanz war abre andh luwh

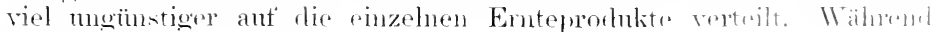

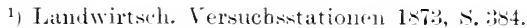

2) Centralbl. t. Agrikulturchemie 1>i6, I, S. 401.

?) Vortrag aus dem Kluh der Landwirte an 14. I, 1.\%, 1-7.;. 
nämlich unter nornaler Belenchtung bei der kleinen Gerste von der Gesamttrockensubstanz $47 \%$ anf die Körner mol $53 \%$ ant stroh und spren kamen, wurden bei den beschatteten Pflanzen anf 61 Gewichtsteile Stroh mo siren nur 39\% Kömer reentet, die anch qualitativ geringer waren. Betrefts des Wasserverbranchs ergab sich, dats die seitlich beschatteten Pflanzen trotz ihrer minclestens i Wochen längeren Vegetationszeit innerhalb der heifsesten Monate. Juli und Angust doch nur etwa 1, 10 mehr. Wasser verbrancht hatten: in lerselben Keiteinheit also verdunsteten sie absolut bedentend weniger als die normal belenchteten Exemplare, entsprechend der geringeren Produktion an Trockensubstanz. Relativ dagegen wird die Pflanze viel Wasser verdomstet haben: so sehen wir dem bei den beschatteten Pflanzen über soo a Wasser pro Gramm Trockensubstanz verbraucht, während die normal belenchteten Exemplare nur etwas über $300 \Omega$ ant dieselbe Trockensubstanzmenge ansgehancht haben. Also anch bei diesem Tegetationsfaktor sehen wir denselben Einfluts ant che Transpiration wie bei den anderen (Bodenlösung, Kohlensämregehalt der Luft nsw.). Eine unterhall, des Optimnms beharrende $Z$ ufuhr eines Tegetationstaktorserhöht den relativen Wasserverbranch po framm poduzierter Trockensubstanz.

Der durch Lager hervorgernfene Sehaden wird in vielen Fällen bei Getreide dadurch remindert, dafs dasselhe die Fähigkeit besitzt, sich wieder anfzurichten. Der Torgang des Anfichtens beruht in der Fähigkeit der Hahmknoten, noch zu einer Zeit Wachstumserscheinnngen zn zeigen, in der die Zwischenglieder bereits verholzt sind. Nach der Erklärumg von ne VRIEs ${ }^{1}$ ) erfolgt dadurch, datis der Halm mit seinen Knoten mun zur Horizontalen geneigt ist, auf der der Erde zngewendeten Hältte des die Biegmo anstïhrenden Knotens durch den Einfluts der Schwerliratt eine Neubildung von osmotisch wirksamen stoffen in den Parenchymzellen. Diese ziehen Wasser an. dehnen sich mehr ans nnd heben auf diese ITeise das über dem Knoten sitzende Hahnglied.

Wir möchten aber auf (irund der Forselmngen von (G. Krats ${ }^{2}$ ) ammehmen, datis nicht eme grotsere Neubildme ron osmotisch wirksamen Stoffen (Sämron), sondern ein längeres Verbleiben derselben ant der konvexen Seite infolge verminderter Verbremung der organischen säuren zu Kohlensänre erfolgt. Wenigstens konstatiert Krats bei Eintritt geotropischer mol heliotropischer Krïmmmogen anf der konvexen seite ebensoviel sänre wio ant der konkaven.

Las einzige. winklich erfolgreiche Vorbengungsmittel liegt in diunnerer Saat, deren Qnantm nach der Borlembeschaffenheit aber modifiziort werden muts. Anf sandigem Boden wind dichter gesät werden müssen als ant lehmigem. mul bei magerer Düngme dichter als hei reichlicher stickstotizuting. Tor allem nützlich wird sich das Inillen erweisen. weil dadurch ein möglichst lockerer stand der Pflanzen arzielt wird.

Wem aber die Ansisat hereits geschehen ist mol ein dichter Pflanzonbestand, iippige Wntwicklmo mel fenchte Wittermg ein späteres Lagern befürchten lassen. dam mut's man, durch scharfes Egeren, Walzen oder vorsichtiges Abweiden mol schöpten einen Teil des

1) иe Vurs, Über dif Aufrichtung des gelagerten Getreides. Landwirtselaftl. Jahrlücher von Thiel, IX, 18st, Heft?

2) Sitzungsher. d. naturf. Ges. zu Hallo 1880: cit. Bot. Centralbl. 18s2, I, S. 107. 
Blattapparates zu entfernen suchen, mm dem Lichte möglichst genügenten Zutritt zu versehatfen.

Betrettis der Kulturmatsnahmen mïsen wir ant diesoehen erschienene, lö̈hst eingehende, ant experimentell, situdien gestïtzte Arbeit von C. Kraws' verweisen, weil nach den hier erwähnten verschiedenen Ursachen des Lagems anch die Vorhümmosmatsegeln mamigfaltig sein müssen. Im Prinzip handelt es sich nicht allein tarm, liräftige, regen Gleichgewichtsstörmoen möglichst widerstanchtähigu. PHanzen zu züchten, sondern auch datür sorge zu tragend dats die ober- und moterirelisch mechanisch gut ansgebildeten PHanzen immhalb der Erde durch einen zweekmätsig entwickelten Wurzclapvarit ihre unentbehrliche Stützung finden. Nach diesen beiden liichtungen hin wirl jetzt anch die Zucht a uslese betrieben. Selbst das Wetter bei der Saatzeit wirkt schon bestimmend für die Lage des dir Terankerung der Pflanze im Boden vorzugsweise regehden Bestoclimngr knotens mit. Nach Śchellexbeki ${ }^{2}$ ) liegen die Bestockmosknoten höher. wem die saat hei trïbem Wetter sich entwickelt: es ist daher vorteilhafter (anch fïr die Überwinterung). wenn die sat bei hellem Wretter antigeht.

Bei an und fïr sich zum Lagern geneigten, schwachstengeligen Pflanzen tritt hisweilen nehen dem Lagern ein Faulen der dem Licht gänzlich entzogenen Partien ant', was besomders verhsthingend bei Clem Lagern ler Futterwieken ist. Als Vorbengunsmittel wird angeraten. etwas Pferdezahmmais mit anszusäen, an dessen stengeh sich die Wicken hinanfwinten kömmen und dessen Blätter ein gutes Futter darbicten.

Gegen das Lagern der Erbsen. Wicken n. derol. wird anch emp fohlen, lseindotter (Camclina sutira) etwa di l pro llektar zwisehenzus äen. Diese ganz frostharte Ptanze wirel mugefäh gloichzeitig mit den Erbsen reif, mul die hïner lassen sich leicht durch sicbe von den Erbsen trennen. während das in der Regel dazwischen gebante tretreide (Sommerroggen. Hater) viel schwieriger anszuscheiden ist mul den Boden tür die folgende Winterfincht mehr anssangt.

Auch hier, wie bei dem tretreide, richtet die Zïchtung jetzt ihr Augenmerk ant die Lagertestiglieit. Sohr vorteilhaft erweisen sich nach dieser Richtung die ron der Dentschen Landwirtschatts-desellschatt heransgegebenen Flugblätter ${ }^{3}$, welche die neusten Eruebnisse vom Anbanversuchen mit den einzelnen sorten unserer Kulturptlanzen ent halten.

\section{Lichtmangel als Krankheitsdisposition.}

VTenn es sich mm die Einwanderung von Parasiten handelt. so wird der mechanische Widerstand der Membran bei den verspillerten Phanzen ein geringer sein. Es werden aber anch alle atmosthäristhen Einflüsse leichter und deren schwankmuen ummittelbarer zmm plasmatischen Zellleibe gelangen und dessen Funktionen stören kïmmen, sollsi wem eine verspillerte Pflanze ganz in derselhen Weise mul nit duselhen Energie wie pine genïgend belenchtete arbaiten wiundr.

Letzteres ist nm aber keineswegs der Fall.

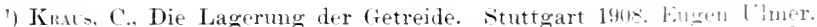

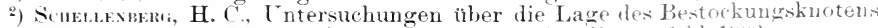
heim Getreide. Forsch. auf d Gebiete d. Landwirtsch. Franenfeld 1:Huz.

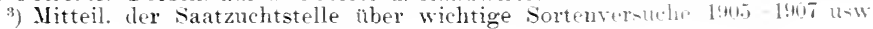


Die erste Andeutung fïr eine Veränderung der Funktionen finden wir schon in einer Wanderung der Chlorophyllkörper an die Seitenwände bei Terdunklung. Gleichzeitig leitet sich anch eine andere bedentungsvolle Änderung, nämlich las sichliefsen dor Spaltöffum gen, ein. Diese schon frïher bei vollkommener Dunkelheit beobachtete Erscheinmo stellt sich aber nach ScHwExwener ${ }^{1}$ ) auch schon bei plötzlicher Abuahme der Belenchtungsintensität ein. Und das ist nicht etwa eine Folge der mit der Lichtabnahme verbundenen Wärmeerniedrigung; dem eine Temperaturerhöhung innerhalh der gewöhnlichen schwankmgen bewirkt kein Ötfhen dieser Apparate. Das eine längere Tnterdrückmng oder doch Herabminderung des rasamstansches Teränderungen des Zellinhaltes durch sauerstotfmangel, also z. B. Neigung zur Alkoholbildmo, herbeiführen kann, ist nalieliegend. Diese Störungen werden um so leichter eintreten, je intensiver die Wachstumsfähigkeit und je grötser das Durchlüftungsbedürtis ist. Also gerade junge Organe werden dies empfinden, während alte, mehrjährige Blätter mit ihrem geringeren Lichtbedarf länger eine Beschränkung im Gasanstansch ertragen. Dies deutet die Natur anch schon durch die mit zunehmendem Alter sesteigerte Wandrerdicknng der schlietszellen an, welche nach

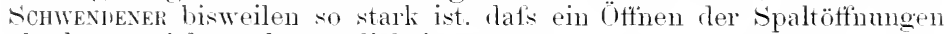
iiberhampt nicht mehr möglich ist.

Betreft's der geringeren Transpiration fand ich bei jungen, ant ihre cotyledonen angewiesenen Keimpflanzen von Pluscolus den Tnterschied zwischen etiolierten und normalen Pflanzen derart, dat's erstere pro (vuadratzentimeter Blattfläche $0,21 \mathrm{~g}$, letztere $0,29 \mathrm{~g}$ im Durchschnitt in derselben Zeiteinheit verdmsteten ${ }^{2}$ ). Parallel mit der Verdunstung veht nuter sonst gleichen Verhältnissen die Produktion von Trockensubstanz einer Pflanze. I) Untersuchung ergab, dafs nicht nur die absolute Produktion der jungen Pflanzen eine wesentlich energischere am Liclite war, sondern dafs anch der (knadratzentimeter Blattfläche substanzreicher sich aufbante. Ähnlich wie Lichtentziehung durch Verdunklung. wirlit anch Lichtschwächung durch Anwendung von gefärbten Medien. welche die Lichtstrahlen passieren miissen. Im gelben Lichte sincl Assimilation und 'Transpiration energischer als im blanen Lichte: wenigstens spricht die Mehrzahl der Yersuche dafür ${ }^{3}$ ).

Die Produktionsenergie und auch der Produktionsmotus der Ptanzen ändern sich mit der Lichtabnahme, und diese Veränderumg äutsert sich nicht blots in der gestaltlichen, sondern anch in der stoff'lichen Zusammensetzung.

Der hekamnte Tersuch, belenchtete Blätter durch eine Schablone zu bedecken, lie irgendeine etwas grotisflächige Figur zeigt, diese Blätter nach einigen Tagen dureh Alkohol zu entgrünen und dann mit Jodlösmg zu begiefsen, ist das einfachste Beispiel für die Teranschanlichung der Lichtarheit. Man sieht damn die belenchtet gebliebenen Blattstellen blan durch die gefärbte stärke, die im Lichte gebildet worden ist. Dieser Tersuch ist anch insofern von Interesse, als er zeigt. wie örtlich beselnänkt zunächst die Belenchtmng wirkt. Nur der

1) Sonwexnskn, Über Bau und Mechanik der spaltöffnungen. Monatsher. 1. Kgl. Akad. d. Wiss. zu Berlin. Juli 1881: cit. Bot. Zeit. 1882, S. 244.

2) Sonukn, Studien üher Verdunstung. Aus IVolluy's ,Forschungen auf dem Fehiete der Agrikulturphysik". Bd. I, Heft 45, S. 116.

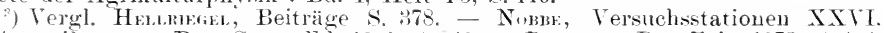

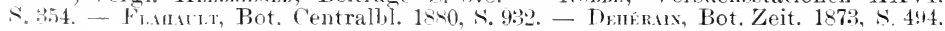


beleuchtet gewesene Toil hat stärke gehililet, mul ant die verdunkelte Umgebung ist keine Stärke übergegangen. Man sirht tarans, dats grüne Pflanzenteile sich ihr Bammaterial der Hauptsalle narh selhst erarheiten müssen, wenn sie dauernd bestehen sollon.

Dats ans Kuollen und Samen die molilisiontrul Roservestotte his anf eine gewisse Länge in die jungen. wänzlich roplunkeltrn Triebe wandern, ist fröher hereits erwähnt worden. Bri zn langenn Wege wehen schlietslich aber doch die Triebe zugrume, weil sir verhmern: sie veratmen melur, als sie Atmmngsmaterial in Form von /urkep nur

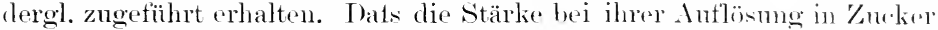
ïbergeht und dieser teils zum Aufbau, teils zur Interhaltung der Atmung Verwentung finclet, lehren beispielsweise ainigo Vorsude von

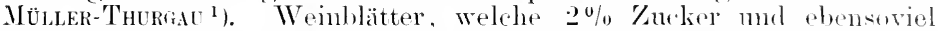
stärke enthielten, wurlen abgesthnitten und mit dem sitiel in Masire gesetzt: das Gefäts kan in einen Ramm von $1^{\circ}$. Nach ! Tauen wall clie stärke bis aut spuren versehwumben. In die Atmung des Weinstocks jedoch bei o $^{0}$ eine sehr geringe ist, so konnte flor furch Lösmo ler Stärke in der Dumkelheit entstandene Zncker nicht veratmet werden und mufste sich demgenätis in Blatte anhänton. Tatsärhlich stellte tie Untersuchung num $4^{\prime \prime}$ " /ucker in den Blättern test.

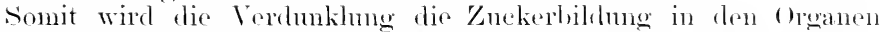

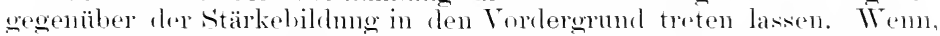
wie dies bei drem Wachstum der Pflanzen im Froien hänfig der Fall ist, mit der Lichtahmahmo oleichzeitio eine wesentlicho 'T'emperatur-

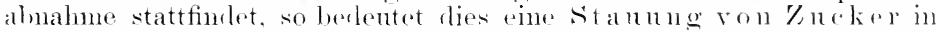
len assimilierenclen tieveloen.

Jerler, der sich mit Knltur von Pilzen in Nährlïsmugen beschättignt

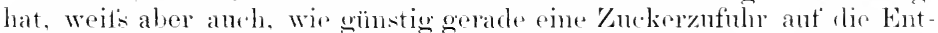
wicklung mancher parasitisther Pilze wirkt.

Trübe. kühle Tạe werden also nicht num die Ascimilationsarbeit der grimen Pflanzentrile schwächen, sontern gleicharitig dureh Herabdrücken des Atmungsprozesseseine Yuckeranhäutuno in den Blattzellen herlueifülren nudsomit lie Her. stellung eines günstigeren Muttorlodens för Parasiten r rmögliehen.

Auch rer säuregohalt der Ptianzenteile ist bei Verdunklumg ein wesentlich anderer als hei zusagender Belenchtung des Organs.

Die Beobachtung ist schon alt, dats manche Pflanzen (Crassuluecen) in der Nacht saner schnorken 2 ). währemel dies an Tage nicht benerkhar ist $\left.{ }^{3}\right)$. Bei verspillerten Ptlanzen komnte Wiessek erkemen. dats lie Blätter vieler nonocotyler frewächse äntserst reich an orwani-

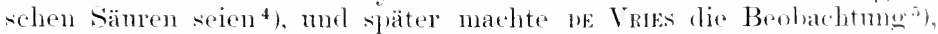
dats auch rie stengel etiolierter Dicotylen stark saner sind Bu Bu-

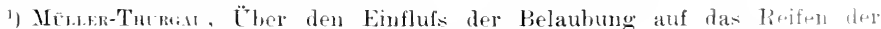
Trauben. Weinbaukongrefs zu Dtorkheim a. d. H. 18*2.

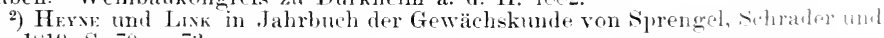
Link, 1819, S. 70 u. 73 .

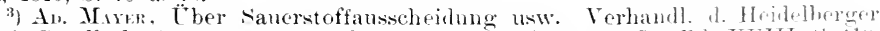
naturf. Gesellsch. 4. 177. - Landwirtsch. Versmehsstat, 1×75, P,1 XVIII \&. 411 , Bd. SXI, s. 277 .

4) Wiesxis, Sitzungsher. d. K. K. Akad. d. Wirsensch. I, April 1-it. BAl. ti9: cit. Bot. Zeit. 1874 , S. 116

5) De Vriss, Über die Bedentung der Pflanzensäuren für den Turgor der Zellen. Bot. Zeit. 1879, S. -52. - T̈ber die periodiche Säurebildung der Fettiflingen. Bot. Zeit. 1884 , Nr. 2.2 u. $2: 3$. 
leuhtung verschwindet der reiche Säuregehalt, was wenigstens speziell für die Crassulaceen nachgewiesen worden, bei denen in der Nacht von IE VRIEs nur damn eine reiche Säurebildung konstatiert werden komnte. wemn am Tage reichliche Beleuchtung der Pflanzen stattgefunden hatte. Var die Lichtzufuhr am Tage nur auf einige stunden beschränkt, so war auch der säuregehalt in der Nacht entsprechend niedriger.

Steigerung der Wärme steigert auch die säurezersetzung im Dunkeh. Kühlere Nächte führen zur Säurespeicherung.

Direkt nachgewiesen wird dies durch die Versuche von le VRIEs ${ }^{1}$ ). Es geht aus dem mit jedem folgenden Tage der Terdunlinng sich steigernden Geringerwerden des Säureverlustes aber auch hervor, dats das Terschwinden der Säure an den Tonrat des im Lichte erarbeitet gewesenen Materials zur Säurebildung gebunden ist.

Die Pflanzen produzieren also fortwährend Säuren und zwar um so energischer, je wachstumskräftiger ihre Organe sich erweisen. Bei Beleuchtung werden die Säuren in dem Mafse, wie sie entstehen, verbrannt; im Finstern speichern sich die Säuren, und verspillerte Pflanzen sind darm relatir säurereich. Die Unterdrückung der Inflorescenzen vermehrt den (tehalt an flüchtigen Säuren in den Blättern. Auch der Säuregehalt in den Wurzeh ist grotsen schwankungen unterworfen und soll nach Chakıвот²) bei Pflanzen, die im Schatten kultiviert werclen. sogar gröfser als in den Blättern sein. Im allgemeinen ist er in etiolierten Pflanzen grötser.

Diese Anhänfung von sämre kamn an und für sich schon solchen Pilzen, die Säuren zersetzen, die Möglichkeit der Ansiedlung und üppigen Entwicklung bieten; es kann aber anch noch eine übermäfsige Turgescenzsteigerung des Gewebes hinzukommen, da nach DE Tries die Pflanzensäuren es vorzugsweise sind, welthe die Turgorkraft der Zelle bedingen.

Wie sehr der sämregehalt manchmal mafsgebend sein kann, beweisen die Untersuchmoen von TiAla und PAcotter ${ }^{3}$ ) über den Black liot (Guignardia Bidnellii). Die Impfrersuche ergaben nur Erfolg bei jungen Beeren, solange der Sämregehalt den Zuckergehalt überwiegt. Nicht blofs der Gehalt an organischen säuren steigert sich, sondern auch das indifferente Aschenmaterial wird durch veränderte Nährstoftautinahme ein anderes. Dies geht aus den Versuchen von ANuse ${ }^{4}$ ) hervor, der etiolierte Pflanzen durch erhöhte Temperatur (300) zu besonderer Tätigkeit amregen wollte. Er fand aber nur eine autserordentliche Steigerung der Kieselsäureautnahme unter Ausschlul's anderer Mineralbestaniteile.

Im engsten Zusammenhange mit den geschilderten Vorgängen der Bildung und Verbremmung der Kohlenhydrate steht auch die Eiweilis -

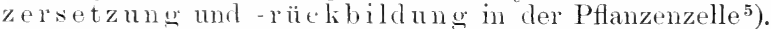

Bei der Keimmo und bei dem Austreiben der Knospen an Zweigen, Wruzeln und Knollen sehen wir die Prolukte des Eiweifizerfalles.

1) Bot. Zeit. 18ธ1, S. 340.

2) Cuarabot, E., et Hmar, A., Recherches sur l'acidité végétale. Compt. rend. 1904, CXXXVIII, p. 1714.

$\left.{ }^{3}\right)$ Viala, P., et Puormal, P., Sur le développement du Black Rot. Compt. rend. 1904, CXXXIX, p. 152.

${ }^{4}$ ) Axiné, G., Wirkung der Temperatur auf die Alsorption der Mineralstoffe bei etiolierten Pflanzen. Compt. rend. 1902; cit. Biedermann's Centralbl. f. Agriknlturchemie 190:3, Heft. 2.

5) Prefren in Jahrb. f. wissensch. Bot. 1\$72, Bd. \&. s. 54s. - Tagebl. d. NaturfVers. z. Wiesbaden. 


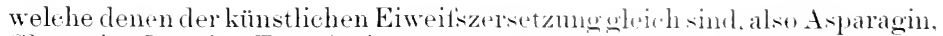
Glutamin, Leutin, Trrosin in grëtster Menere anftreten. Nich Borons's Untersuchungen ${ }^{1}$ ) treten diese Amidoverbindungen 1 m nm so reichlicher aut, je weniger stickstofffreie Bestandteile namentlich wolnl Traubenzucker) vorhanden, welehe zur Rücklikdung von Eiweits rerwendet werden können.

Da nun bei verspillerten ebenso wie bei belenchtetrn, abes in hohlensäurefreier Luft erzogenen Pflanzen die Nemprolulition vom Lolilenhychaten unterbleiht und dieselben dureh Veratmung von Taly zu Tas mehr verbrautht werden, so wird num eine Anhäufung des Asprarain

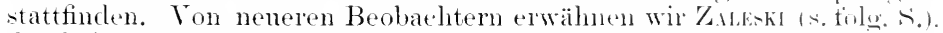
der bei Keimlingspflanzen von Allium Crya Vermehrume des Asparacrin wahrnahm. Namentlich aber ist die schon erwälnte Arbeit von ficmetz: und (Astoko 2) zu beachten, aus der hervorgeht, dats z. B. hei etioliorten Keimpflanzen ron Lupims allus der (Fehalt an Proteünstotten ab-. der Asparagingehalt aber beständig zumimmt. Trrosin und Lenein nehmen ab.

'Tatsächlich fand E. Sichloze mehr als die llälfte des Gesantstickstoff's bei zwanzigtägigen, verspillerten Lupinenkeimlingen in del Form von Asparagin wieder ${ }^{3}$. Wenn um fortanernel der $\mathrm{N}$-tireir Teil des Eiweit'smoleküls veratmet wirel und keine nenen N-losen Bestandteile vorhanten sind, $u$ normales Eiweils im Protoplasmakörper autzubanen, so wird der Zellenleib lie tieforehendsten störungen ertahren: es ist wahseheinlich, dats ein weiterer herfall num Fänlniserscheinmgen einleitet. welehe den ïpligsten Nährhorlen tïr Parasiten und saprophyten herstellen. Ihas Asparagin wird ron Pilzen hei Gerenwart von Zucker sehr gut verarbeitet. Bei heimung von angefeuchteren Kressesanen sah Vorbl ${ }^{4}$ ) im lounkeln sehwefelwasserstoti entstehen. während in den Parallelversuchen mit lelenchteten Flasehen das Bleipapier nahezu keine Veränlermg zeigte.

Bei tlen Blättern kann im Blattparenthym ein anderer Vorgang herrschen als in den Blattnerven. Bei juigen I ahliaptlanzen wies Boroms ${ }^{5}$ ) in den Blattnerven und im Blattstiel salpeter nach. in dem Blattparenchym aber grofise Mengen von Tyrosin und keinen salpeter. Es mag hier das Tyrosin kein spaltungsprodukt, sondern ein sinthetisches Produkt soin: dem wenn die jungen Triebe der Dahlia etiolieren. bildet sich kein Tyrosin, sondern Asparagin, das bei Wachstmm unter Beleuchtung nicht zum Vorschein kommt.

Bisweilen findet man allerings noch eine zunahne an Eiwoils stotfen in Inukeln, aber dam liegt die Ursache darin, dats sehr reich lich Kohlenhydrate in Reservestotfbehältern zunächst noch zur Ver. tögung stehen, wie z. B. hei Allimm Com von Lwavof $\left.{ }^{6}\right)$ angegehon wirl. sind Kohlenhydrate vorhanden. so kïmnen selbst Blätter im Imulieh.

1) Bot. Zeit. 1*78, s. $802 \mathrm{ft}$.

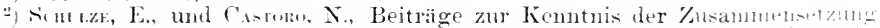
u. des stoffwechsels der Keimpflanzen; eit. Bot. Centralbl. 1944. Bu. Xil > itu.

3) Srmt.z, E., Über den Eiweifsumsatz im Pflanzenorganisnus. Latulwirts.]. Jahrbücher $18>0$, ‥ $1-60$.

4) Voras, Ein auffäliger Lnterschied zwischen Keimen an Tatgeslicht und im Dunkeln; cit. Bot. Jahresber. 147. S. 675.

$\left.{ }^{5}\right)$ sitzungsber. d Bot. Sekt Petersburg. Naturf. (ics. 1-l: cit. Botan, Zeit. $1 \diamond \times 2,5.5<9$.

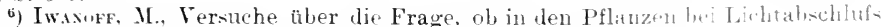
Eiweifsst offe sich bilden. Landw. Versuchsstationen 1901. . . . 


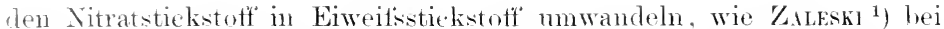
Helianthusblättern fand, die in eine Nährlösmo mit Nitraten und Zucker eingesetzt worden waren.

Wir haben hier einfach eine simme von Tatsachen vorgefïhrt, welche die stofflichen Änderungen in Pflanzenleibe bei Lichtmangel dartuu. Diese erklären zur Genüge die geringere Wirlerstandskraft der verdunkelten Pflanzenteile gegenübor atmosphärischen Einflïssen als auch parasitären Angriften.

\section{Vierzehintes Kapitel. L i c lı t ii be l s c ll 11 Is.}

Nach den Ertahrungen, die äber den Einfluts der Wäme ant die •inzelnen Vegetationsvorgänge in grofiser Anzahl bereits vorliegen, ist von vornherein zn vermuten, daf's anch für die Lichtwirlinng nicht num eine Minimalgrenze vorhanden ist, sondern dats anch ein bei jeder PHanze für jeden Vorgang und für jede Kombination der Tegetationsfaktoren besonderer Belenchtungsgrad existiert. der als der optimale hezeichnet werden kann und dessen Überschreitung einen Produktionsrückgang einleitet. In der Tat ist bereits bei einer Anzahl von Pflanzen die Beobachtnng gemacht worden, da1s, wenn das Licht über ein gewisses Ma1s himans gesteigert wird, die Assimilation. Kenntlich dureh die sanerstoffansscheidung, nicht mehr fortschreitet, sondern stehen bleibt ${ }^{2}$ ) oder sogar zurückgeht ${ }^{3}$ ). Voransgesetzt ist dabei ein normaler Kohlensäuregehalt der Luft; denn anch hei einem zu hohen Gehalt der Luft an diesem Bestandteil geht die samerstoffansicheidung zurizck, wie schon Boussingaver und rach ihm PFEFFe ${ }^{4}$ ) dargetan haben. Ein optimaler Belenchtungszustand macht sich in Anssehen der Pflanze kenntheh, indem dieselbe eine tieforiune Färhmog erhält, welche sie bei grötserer Steigermo der Lichtintensität über las Optimm linans verliert und dafür einen gelben Farhenton annimmt.

Bekannt ist die Erscheinmo. dats die dunkelgrïnen Blätter der Kamelien nach dem Transport ans dem Glashause ins Freie an somnigen Stellen (telblanbigkeit zeigen. T)ie Kamelie ist eine japanische Interholzpflanze, die mit geringeren Lichtquantitäten schon zufrieden ist und bei flen grellen strahlen unserer Sommersonne mehr Chlorophyll dureh Oxydation verliert, als durch den Roduktionsprozets gehildet wirl. Die /ersetzung des Chlorophylls dureh Sanerstottaufinalme (die ïbrigens auch hei Gegenwart von Köpen, die leicht Samerstoft aus der Lutt aufinelmen mol ozonisieren ['Terpentinöl] in I'mnkeh stattfindet) ist hekanntlich an bestimmte strahlengatmongen gebmolen. Nach Whesser zaigen die gellon und die beiderseits benachbarten grïnen nud orangen stralilen die grölste Energie in der Zerstörung des c'hlorophylls am lichte.

1) Zanskn, Wr Die Bedingungen der Eiweifsbildung in den Pflanzen. Charkow 1900 (russisch); cit. Bot. (entralbl. 1901, Bd. 87, S. 277.

") Renks, L. Intersuchungen über die Einwirkmgen des Lichtes anf die sanerstoffausscheidung der Pflanzen. Bot. Zeit. is83, Nr. $42 \mathrm{ff}$.

3) Fimntzin, Effet de l'intensité de la lumière etc.; cit. Bot. Centralbl. 1880, S. 1460.

4 PFerfer, Arbeiten d. Bot. Instituts zu Würaburg, herausgeg. v. Sachs. Heft I. 
Ein anderes Beispiel von Gellolanbigked hei hoher Lichtintensität bieten einzelne grelhbunte Coleusvarietäten. Wolchr sich anfangs griun antfaltende Blätter produzieren, die erst hrin Älterwrilen linchtend gelbe stellen amnehmen. Ebenso werlen nandhe gollhmute (iarten-

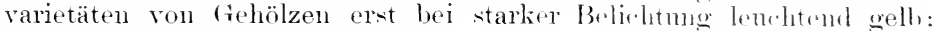
im Schatten bleiben sie griner.

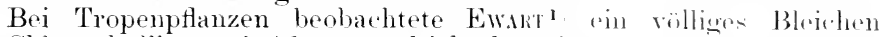

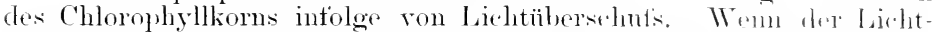
reiz über dlas spezifische Optimm sich steigert, hält zunächst morh die optimale mol maximale Gasentwieklong kn\%e \%eit an: alwe damu trit

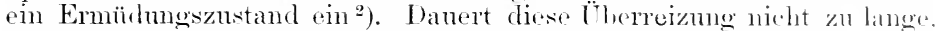
kann die Pflanze wieder ihre normale Tätigkeit zmö̈ckrrhaltru. Wir

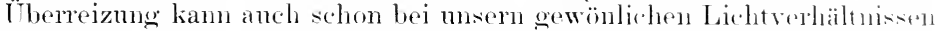
eintreten. Wenn eine Pflanze ihrer Natm nade zn den siehattruptlanzen gehört. Ein hübsches Beispiel dafïr hringt WEss ${ }^{3}$, hei I"yly-

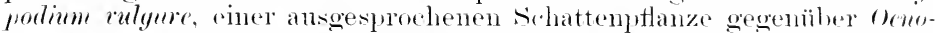
there birmis, die eine ansegerägte sommenptlanze ist. Isetztere produzierte hei gïnstiger 'Temperatur im direliten siomenlicht mugefälu dreimal so viel Kohlensänre als im diffusen licht. während restere im diffusen Lieht eneroischer assimilierte. Für dic Nurzeln. die an l lunkelkeit gewöhnt sind. wird ditfises Tageslicht schon wathstmushemmenel wirken können, wie dies Kxy hei Lnpinen, Sanbohnen und Brmuen-

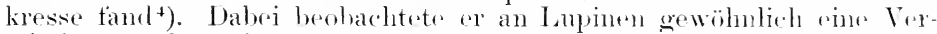

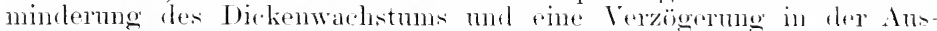
biklung des Zentralzylinders, wrom das I ängenwachstum sich steigrete.

Eine sehr auscesprochene Tachstmmshemmung hei Anwridnung von Röntgen - und Radiumstrahlen geht ans den Arbeiten von

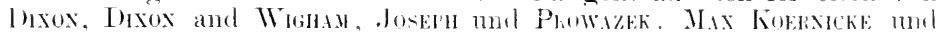
von Hass Mobisch hervor"s).

Bei Erbsenwurzeln wurle eine ahmormo Verdiclime nud eine rumzliche Oberfläche beobachtet, die angenstheinlich ant imnere Sipanmugdifferenzen zurückzuführen sind. Es kommen Kontraktionen dadurch zustande, dats die zellen des imneren Rindenparenclisms ihren radialon I)uchmesser vergü̈sern, während sie in longitudinaler Richtnug küuzer werten. Bei anderen Versuchen mit Wieken nud Siaubohnen sah man die Wuxzeln sich bram färben mel anch im Warhstm still stehen. Aher nach $8-10$ Tagen wolsen sir weiter, narhelem sie die äuliserste spitze in Form einer bramen Kappe abgestolisen und umittelbar flahinter eine neue Wurzelspitze geliblet hatten. T)arant entstanden normale seitenwurzeln. An den chlorophyllü̈hrenden Organen sind dir. Warhstmmshemmungen geringer: es ist hei Keimpflanzen ein stillstant in der Verlängerung, aher kim Absterben heobachtet worden: dir Blätter wurlen etwas kleiner als hei nomalen Exemplaren. Holiotronisc.

1. S.

1) Ewsk, A. J., The effects of tropical insolation: cit. Just s Jahreher. I w

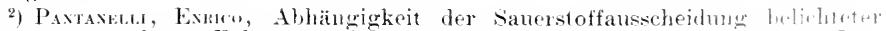

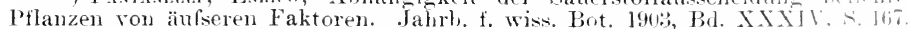

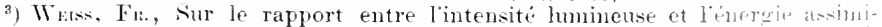
latrice chez les plantes appartenant id des types biologiques différente. ('inut. remol. Paris CXXXVIl. 1903, p. $>01$.

4) Kir, L.. Über den Einflufs des Lichtes auf das Wachstmm der Bubenwurzh. Jahrb. f. wiss. Bot. 1902, Bd. :3৮. S. 421 .

5) Skckr, Has, Die Wirkung der Röntgen- und Radimnstrablet1 ant lie Platnze. sammelreferat. Naturwiss. Wochenschrift 1906, Nr. 24. 
Krïmmungen konnte Dxох ${ }^{1}$ ) bei jungen Kressenkeimlingen in $1 \mathrm{~cm}$ Entfernung von einer Glasröhre mit $\lesssim \cong$ Radimmbromid nicht wahrnelmmen.

Bei greller Somnenbelenchtung sehen wir die Pflanzenteile manchmal nicht blotis vergilben, sondern anch sich brännen und absterben ${ }^{2}$ ). Dats dieses Absterben eine spezifische Lichtwirkung und nicht eine Folge zu grofser 'Temperaturerhöhung ist, geht daraus hervor, dat's Chlorophyll unverändert ${ }^{3}$ ) bei Temperaturen von - 30 bis + $100{ }^{\circ}$ bleibt und andrerseits, dafs die Zerstörung stattfindet bei Strahlen kürzerer Wellenlänge, welche auch ant die Wachstumsrorgänge und Protoplasmabewegungen am meisten influieren.

Die durch Kupferoxydammoniak gegangenen strahlen eines konzentrierten sonnenbildes töten manchmal schon nach wenigen Minuten, während dasselbe Lichtquantum nach dem Inrchgange durch eine (nur das äuf'serste Rot durchlassende) Lösung von .Jod in Schwefelkohlenstoff kaum oder erst sehr spät eine Störung hervorbringt ${ }^{4}$ ). In diesem roten Lichte aber tritt gerade eine intensive Erwärmung hervor, in dem blanen niclit.

Y $/ \mathrm{u}$ den aut Lichtüberschut's beruhenden Erscheinungen gehört auch die Entstehmo der śchattenbilder, d. h. von intensiv grünen Zeichnmoen beschattender Organe auf einer grell belenchteten BlattHäche. Es braucht hierbei keine Zerstörung des Chlorophyllapparates stattzufinden, sondern es vollzieht sich nur eine Veränderung der Lage der Chloroplasten.

Die Beobachtungen von Böhm, Famstzin, Boroms, S'Tahl und Frank beweisen, dafs bei einer für das spezielle Bedürfnis einer Pflanze zu hohen Somnenbeleuchtung eine Wanderung der Chlorophyllkörner von der der Oberfläche des Blattes parallelen Zellwand nach den rechtwinklig dazu stehenden IVänden sich einstellt. Die Chloroplasten gehen von der Epistrophe in die Apostrophe über und bewirken dadurch die lichtere Färbung des zu stark besomten Teiles.

Eine weitere, leicht zu machende Beobachtung ist das Auftreten einer Rotfärbung bei zu starker Belichtung, wenn man grüne Blätter von Pflanzen mit roter Herbstfärbung, z. B. Süfskirschen mit der Unterseite nach oben kehrt. Ebenso sieht man bei vielen Pflanzen, namentlich solchen mit fleischigen Blättern, eine ausgeprägte Brannrotfärbung auftreten, wemn sie im Frühjahr aus den beschatteten Glashänsem an einen freien, sonnigen Standort gebracht werden. Mousch ${ }^{5}$ ) hat solehe Fälle nntersucht. Bei Alor und Solammlla wies er nach, dat's nicht etwa Anthocyan in den Zellen ausgebildet wird, sondern dafs die Chloroplasten selbst sich rot färben und bei Verlunkelung wiedler grün werden. Bei selaginellaarten wmolen ebentals durch Carotin gefäbte, rote oder rothrame Chromoplasten beobachtet, namentlich oberhalb einer Knickstelle.

Der wirtschaftlich wichtigste, tür die Hygiene bedentsamste Tor-

1) Dixux, Hran, Radium and plants. Nature, London LXIX: cit. .Just's Bot. Jahresber. 190:s, II, s. 567 .

:) Binn, Versuchsstationen 1877, s. 46i3.

:) Wissin, Die natürlichen Einrichtungen zum schutze des Chlorophylls. Festschrift; cit. Bot. Jahresber. 1×76, s. 72ک.

4) Priscintmely, Jahrb. f. wiss Bot. 1879 , Bd. 12, s. 336,

5) Mursn. H., Über voritbergehende Rotfärbnng der Chlorophyllkörner in Laubblättern. Ber. d. Deutseh. Bot. Ges. 1902, Bd. XX. s. 442. 
gang aber besteht in der zerstörenden Wirkmng les sionnenliehtes auf pathogene Pilze und namentlich aut Bakterisll. Prifrke ') sagt: „es scheint, dats sämtliche pathogenen Bakterion lureh rine genïgente Insolation retötet werden."

Dats ähnlich dem somnenlichte anch das kïnstlichr licht wirkt.

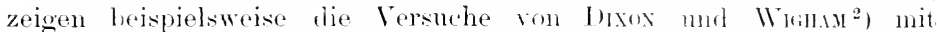

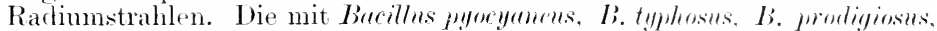

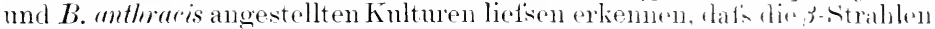
les Radiumbromides eine dentliche Wachstmmshemmmg hervoriefin. Nachdem ; mo Radimbromid t Tage hindureh in der Entformun ven $4^{1 / 2} \mathrm{~mm}$ ant dic Bakterien eingewirkt latten, War ihr Wathimm anfgehoben, wemn sie anch noch nicht getötet waren.

\section{D) ritter Alsschnitt. Enzymatische Krankheiten.} Fiinfzehutes Kapitel.

\section{Verschiebungen der enzymatischen Funktionen.}

Allgemeines.

Die jetzigen Forsehmegen drängen zn der Anschammeg, in der

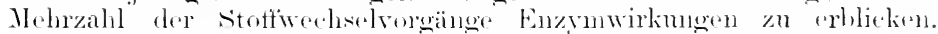

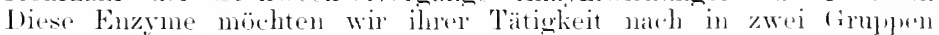
gliedern, die sich als anthanente mut abhanente bezedehen lassen. In

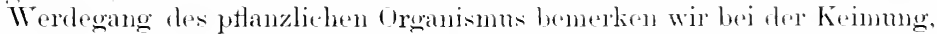
also bei der Vorhereitung zur vegetativen Entfaltung, das Vorherrseden der abbanenden Tätigheit, indem die Reservestotto gelöst nud in moist

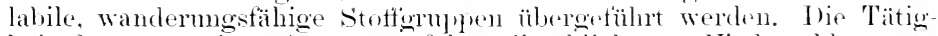
keit des regetativen Apparates führt allmählich zum Niederschlage von Reservestoffen, mol diese Tätigkeit sprechen wir als anthanende an; diese lätst ihren Endpunkt in der Aushiletung des Samens erkennem.

Darans ergibt sich ein Antagonismms in Anfteten der hauptsächlichsten stofformplen, der sich in der Weise präzisirren lätst, dats bei reichem Stärkeniederschlag der Zuchergehalt sowie die Menge des

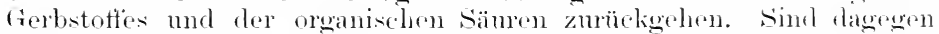

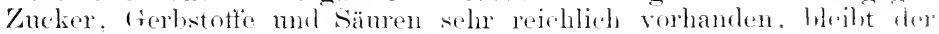
stärkeniederschlag gering. Wenn der stärkereichtum rin hoher ist,

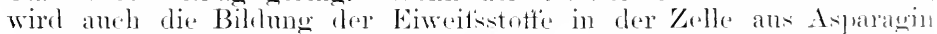
oder anderen sitickstofverbintmeren eine reichliche sein. Bui irn

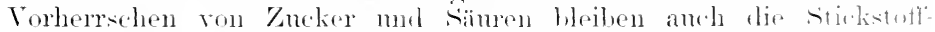

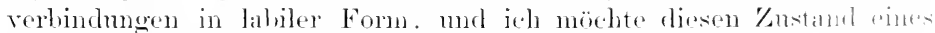

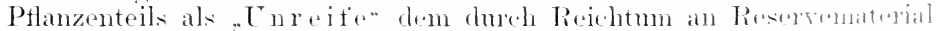
ansogeichmeten .Reifezustand" gegenïbersellen.

bie einzehnen Wachstumsfaktoren heeinflussen num hestindig den

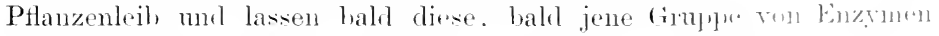

1) Pflanzenphrsinlogie, 2. Aufl., II. Teil. s.:319.

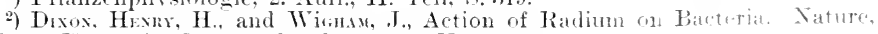

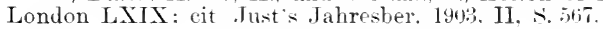


zur Vorherrschaft kommen. E- ist dabei nicht nötig. datis Enzyme zerstort werden: sie kömmen auch in iher Wirkmng nur vorïbergehend gehemmt werden. Ein Beispiel liefert Pozz-Escot') bei Gelegenheit Ter Besprechung des Philothion. .Red uktasen", meint er, die bei hroll Phanzen mit Losw's Katalase identisch. sind ebenso wie die Oxydasen ïberall verbreitet und wirken antagonistisch. I'E REY-Panhane hat gezeigt, dats Recluktasen schnell durch eino Oxydase bei (regenwart von freiem sanerstotf zerstört werlen, und umgekehrt weist nun PozziEscor nach, dafs unter bestimmten Umständen bei grofsem Überschuts an Redulitase eine Oxydase in ihrer Wirknng "paralisiert" werden kam. So kam in rortibergehenden schwankungen des Kellinhalts eine Reduktase die oxylase angenblicklich mwirksam machen und mmgekehrt. I)ie wichtioste Rolle der Reduktasen erlickt Pozzi-Escot in ihrer Wirksamkeit auf $\mathrm{H}_{2} \mathrm{O}_{2}$ sowohl in den Prozessen der Respiration als auch bei der Photosynthese.

In anderen Fällen treten Antifermente ant. wie beispielsweise (zaper ${ }^{2}$ ) gefunden hat. Er sah eine Hemmung in der Weiteroxydation der aus flem Trrosin stammenten Homogentisinsänre in geotropisch oder heliotropisch gereizten organen durch Antreten eines Antifermentes.

In allgeneinen erkemen wir ans den Ergebnisien der Kultur und einzehnen experimentellen Forschungen, dat's Licht und Wärme die aufbanende Tätigkeit, also den Niedersthlag fester Reservestoffgruppen begünstigen. während Dunkelheit und Kälte die kolloidalen Yustände im Zellenleibe rhalten oder vermelnen.

Bei normalem Wittermosver]ant liegen tatsächlich dic Perioden des vorherrschend kolloidalen Zustandes des Zellinhalts, der die abbauende Tätigkeit charakterisiert, in der kälteren Jahreszeit; wir finclen die Keimmngsorgänge namentlich im Herbst und Frïhjahr, dagegen die antbanente Wirksamkeit, also den Niederschlag der Reservestoffe, in siommer.

Die notwendige, regelmätsige Folge dieser Perioden hängt aher nicht nur von rex Witterung ab, sondern anch von allen Ernährungsfaktoren. wic z. B. der Masserzufuhr, der Menge und Besthaffenheit des Nährstoffmaterials und aulserdem von den vershiedenartigen Knltureingriffen, wie z. B. dem künstlichen Beschneiden. Betreffs des letzteren Punktes bietet eine Anzahl ron Krankheiten uns Beispiele, wie durch die plätzliche Entfernmo einex grötseren Menge von Gliedern des Pflanzenleihes (̈̈str und Blätter) der Grganismus zu einer Zeit, in der die Periode der stoftispoicherung bereits vorherrsehend ist, nummehr gezwungen wirl, das wespeicherte Naterial wieder zu nobilisieren und dureh Bildung nom Ersatztrieben in die vegetative Periode zurütkzutreten. Bezüglich drs Nährstoffzufuhr sehen wir beispielsweise, dats ïlermätsige stickistottaben dic Periode rler Reservestottispeicherung hinauschieben, indem die Neubildung regetativer (1rane über die normale \%eit hinaus fortwesetzt wirl.

Darlurch wird tie snzymatische Arbeitsleistung verschoben; es herrschen num dio mohilisierenden Enzyne vor. und die Pflanze tritt

1) Pozz-Escor, E., The Reducing Enzymes. American. Chem. Journ. Vol. XXIX, 1903 . p. 517 ; cit. Bot. Centralbl. $1 £ 04$, Nr. 49.

$\rightarrow$ Crapk, F., Antifermente im Pflanzenorganismus. Ber. d. Deutsch. Bot. Ges. $190 \%$ Bu. XXI, ร. 229. 
mit jugentlichen Oromen in eine Wittermusperioted die in nomalen Verlanf ausgewachsene, reservestoffleiche Teilo ertoridert. sic wirl cladureh tïn parasitäre und nichtparasitäre Angritfo emptänglich.

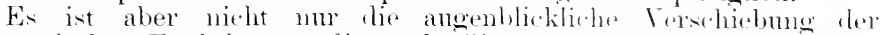

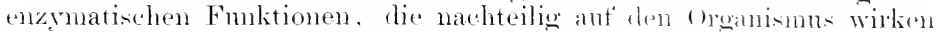

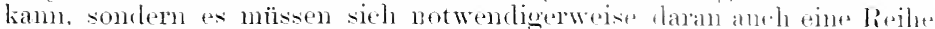
ron Folgeerseheinmogen knüpten, die in der näthsten fiencration sich

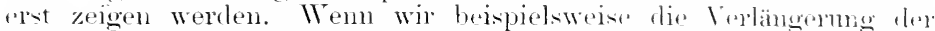

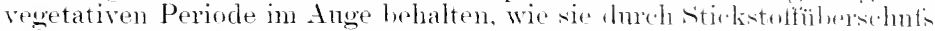

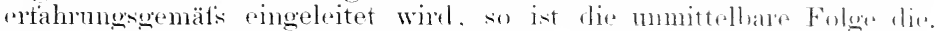

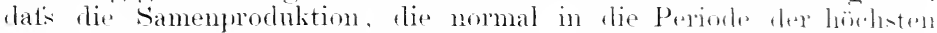
Wärme- mod Lichtzutuhr tallen sollte, in eine kïhlere, lichtaintere. \%eit hinausquerielit wirl. Das entstehende samenkorn hat also ni.hit mehr die genügende \%eit und entsprechende Wittermg. $1 m$ alle Pro-

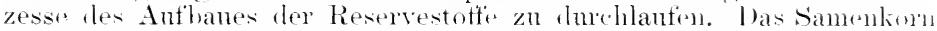
wird in anem Zustamele geentet, in welehem die mobilisierenten Enzyme noch in grötseler Tätigkeit sind. und es wirel datureh tüis Parasiten angritfifahig. tie ein vollsommen reites Korn nicht anzngreifen vermëgen. Es ist experimentell erwisen, dats mmeites satgut schneller dureh sichimmolpilze zugrumele weht

Aber sellst wem das weniger ausgereifte saatgut nireht zugrumele weht, somblern in der närlsten Vegetationsperionle sich entwielielt, wind

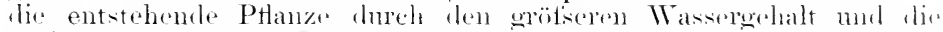
geringere Menge von Reservestottin des samens zunäehst in der olugenul

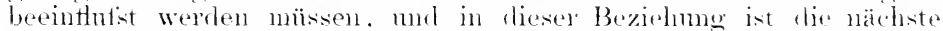

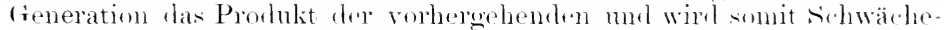
zustände dureh Erhlichleit fortphtlazen.

Was von den samen wilt, muts anch tïr alle anderen ansdancrublen

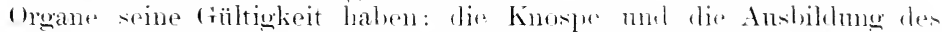

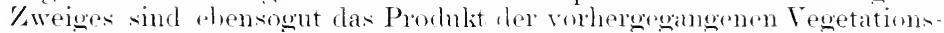

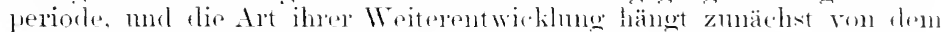
Reifezustancle ab. don sie im Vorjahn rlangt haben.

Vershiobungen in den enzrmatisehen Finktionen setzen sich also von einer legetationsperionte aut die andere tont. mel die nachfolgenel

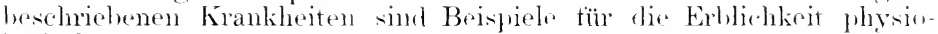
lowischer stïrmugen.

\section{Die Albicatio (Panachierung).}

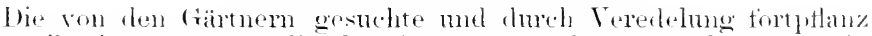

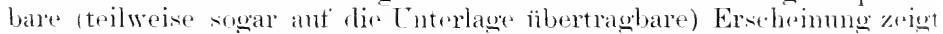

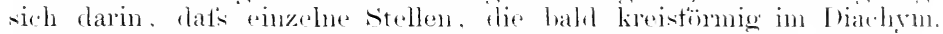

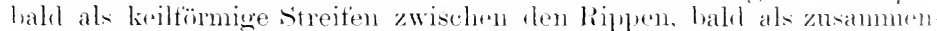

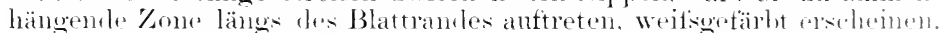

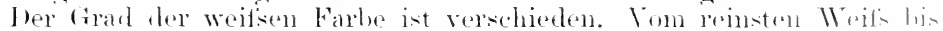

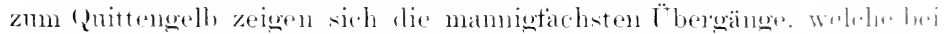

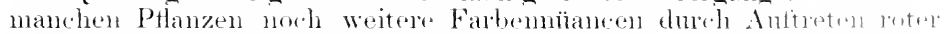
Farbentöne liefern: darlurch wird lanm die eigentliell. Bunt 1.lätterigkeit (coloratio. Chomatismus) er\%enot.

Ein sehr bekamntes Beispiel tür die Weifstrekigkeit in lat Bumb-

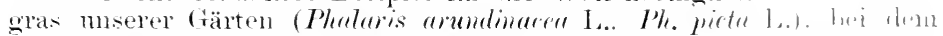
die weitsen Partien abwechselnd als streifen zwischen dru Rillwn ant-

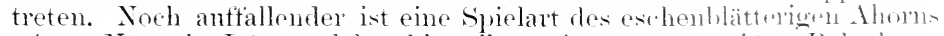

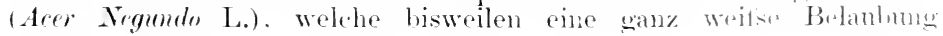


zeigt. Als Beispiel tür das Auftreten der Buntfärbmg sowie der Teilsfärbung sei die Familie der Aroideen genamt: unter diesen zeigt der häutig im Zimmer linltivierte Aronskelch [Zuntedeschia /Calla] urthiopica) Blätter, die of so blendend weils sind wie die diutentörmige Blïtenseheide: an rie Zantedeschia schliefisen sich die bunten Caladien, tie Lieblinge nuserer Warmhänser an, von denen einige nur weifsgefleckt, andere weits und rot und endlich manche nur rotgefleckt sind.

schwerlich zu tremnen ist davon die Weifsfleckigkeit der Blüten und die seltenere Panachierung der Frïchte, von denen Durour ${ }^{1}$ ) interessante Fälle bei Weintrauben heschreibt.

Es herrschen teilweise noch namentlich in praktischen Kreisen emste Bedenken gegen die Anschanmog, in den weifsbunten Blättern Krankheitserscheinmoen anzusprechen: indes glanben wir doch, diese Meinmng verteidigen zu müssen. Wenn wir eine grölsere Anzahl von huntblätterigen PHanzen untersuchen, so finden wir in den Zellen alle Abstutungen rom normalen (hlorophylliorn bis zm gänzlichen Verschwinden der gehallten Träger des Chlorophylfarlstoffes. Die gelbarscheinenden PHanzenteile zeigen häufig noch die Chlorophyllkörper als gelbe, schwammig aussehende Ballen oder Scheiben in den Zellen; je remer weits die Pflanzenteile erscheinen, desto weniger ist selbst vom ungefärbten Chiorophyllkömem noth zu entdecken und desto mehr nimmt las Plasma die Beschaffenheit einer weichen, gleichmätricen Wandauskleidung an. I) Intercelnlarränme sind lnftreicher nnd bisweilen gröfser.

Mit dem Schwinten des Chlorophyllkörpers hört anch die Kohlen-

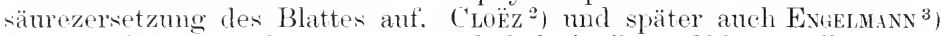
fanden, daf's die Blätter mu im Verhältnis ihres Chlorophyllgehaltes Kohlensäme zersetzen. Wie verschiedenen Abstufungen der gelben Panachiermo beruhen auf geringeren Quantitäten derselben CThorophylline und Xanthophylle, wie sie im normalen grïnen Blatte vorkomment), und dementsprechend wird anch ihre assimilatorische Tätigkeit sein.

Bei den reinweilsen Blättern kommt es vor, dats der /ellinhalt überhanyt nicht bis zur Bildung des Chlorophylls gekommen ist, sondem dat's das Material des Chlorophyllkoms im jugendlichen Entwicklumgsstadium stehen geblieben ist. Bei den gelben Formen findet man ('hloroplasten zwar mindestens noeh in der Knospe, vielfach anch später, aher in dem Matie, wie sie der reinweifsen Zone sich nähern, schwinden die geformten Inhaltskörper der Kelle. Die ron ('Hukci") ansgetöhrten Analysen können als eine gute Bestätigung dienen. '/ur Verwendmo kamen weitsfleckige Varietäten von Maple

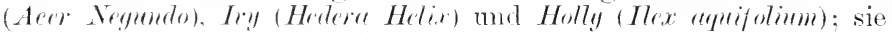

Aici

weifshl. grinbläterig weifsbl.

$42,30 \% 07 ., 70^{\circ} \%$

15. 1 . "24.22 .

$2,112, \quad 3,0,1$,
Ilex

$74,14^{\circ} \% \quad 6 ., 8,3 \%$

$2:, 66 ;$

30 " 24,4
Healera

weifsbl. griunlil. $7 \times, 8^{\circ} 0 \quad 66,13^{\circ} \%$ $18,74, \quad: 31,6: ;$ 2,38 " 2,24 " organisehe vulstanz

Asche.

1) Drrorn, .., Panahierte Trauben. Extr. C'lronique agric. du canton de Taud: cit. Zeitschr. f. Pflanzenkrankh. 1904, S. 28ti.

2) compt. rend. LVII, 1) 8:i4.

3) Extermux, Farbe und Assimilation, Bot. Zeit. 1883, Nr. 1 11. '3.

4) Kinixzıx, G., Anatomische und farbstoffanalytische Tntersuchungen an panachierten Pflanzen. Inang.-Diss. Berlin 1908.

5) Curni, Tariegated leaves. Gardeners Chronicle 1877, IT, s. 586. 


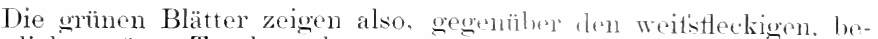
trächtlich grötsere Trockensubstanzmengen, mol liw Archenhestandteile bilden bei letzteren (wie äberall wo Einähnngstionmen sich geltend

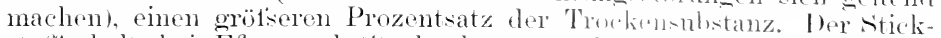
stoffgehalt bei Efen und steehpahne war bei den weitien Baittern reicher im Verhältnis zur 'Trockensubstanz. Anch dionss liesnltat ist exklärlich; dem wenn der ('hlorophyllapparat. dreson Notwemliekert.

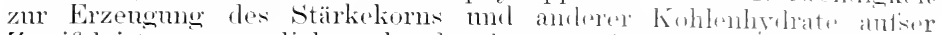

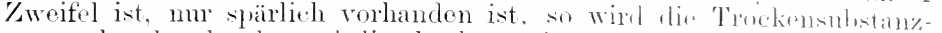

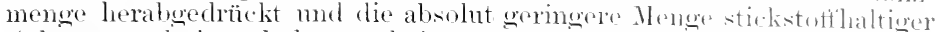
Substanz relativ erhöht erscheinen. Thats dir in Alliohol und ither. löslichen substanzen bei den weitsen Blätern von Eition mut sionhpalme nur megefär die Hältte der Menge betrugen, als bei den mizinen Blättern, dart ebenfalls nicht wumdernehmen.

Sehr wichtig ist die prozentische Konsammensetzung der Asche: as fand sich hei

\begin{tabular}{|c|c|c|c|c|c|c|c|}
\hline \multirow{4}{*}{ an } & & \multicolumn{2}{|c|}{ Acer } & \multicolumn{2}{|c|}{ Ilex } & \multicolumn{2}{|c|}{ Hedere } \\
\hline & & weils & grïn & weifs & grim & weils & errion \\
\hline & Kali & $4 ., 050$ & $12,61^{\prime \prime \prime}$ & $35,8,300$ & $16,2020 \%$ & $47,20^{\circ} \%$ & $17,91^{\circ} \circ$ \\
\hline & Kalk . . & 10.89 & $: 39,93$, & 21,30 & $: \because 4,4: 3$, & $12,9: 2$ & $48,5,7$, \\
\hline & Magriesia. . & 3,95 & $4,7.5=$ & $3,2: 3 \ldots$ & $=4: 3$ & 1,11 & , \\
\hline & $\begin{array}{l}\text { Phosphorsiture } \\
\text { Eisenoxyd. }\end{array}$ & $\begin{array}{c}14,57, \\
?\end{array}$ & $\begin{array}{c}-, 80 \quad . . \\
?\end{array}$ & $\begin{array}{l}9,51 \ldots \\
3,11 \ldots\end{array}$ & 7,299 & $\begin{array}{c}10,65 " \\
2,6 \%\end{array}$ & 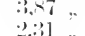 \\
\hline
\end{tabular}

Ans diesen Zahlen ist ersichtlich, dats die rein albiliaten oreane sich dem . lugendzustand der grönen Blätter nähern, also whelchan ant jugendlichem Entwicklmosstarlim stehen geblieben sind. (ikfrox') kommt zu dem schlusse, clats panathierte Pflanzen sich im allowneinen wie etiolierte verhalten, die wir auch nit dim permanenten Jug(sudzustande verglichen haben. In den gelleen frbergangsstadien ist der Befund sehr verschiedenartien. Bei Alutilon Thompsomi fand ich in manchen Bättern den Zellinhalt noch derartig gruppiert wie in rein grïnen Teile, ‘. h. mit C'hloroplasten versehen, die in ihren Unrisien rundlich-eckig, in ihrer Lagermong normal wandständig sich erwiesen, aber blatsgelb oder farblos waren und stark gekörnelten Inhalt tïhnten. In anderen \%ellen war die substanz der Chloroplasten zu mregelmälsigen, körnigen Ballen vereinigt, die mit Jodglveerin und teilweise auch mit Schwefelsäure sich blan färbten und als ('arotin anzusprechen sein diüften. Anch Kont, ${ }^{2}$ ) gilst bei der Untersuchung goldgelber Blätter neben $\beta$-Xanthophyll ume Phyllofuscin das ('arotin (Etiolin) an.

Der Unterschied im Diclindurchmesser des Blattes, d. h. dir anttällig geringere Dicke der reinweitsen Teilo gegenüber den reingrinn Blattstellen, nimmt $\mathrm{mm}$ so melir ab, je mehr sich der Farbenton vom reinen Weils entfernt, dic Blattstellen also golber werden. linsurn Umstand heht anch 'Tines ${ }^{3}$ ) hervor und betont, dafis bei Pflanzens mit

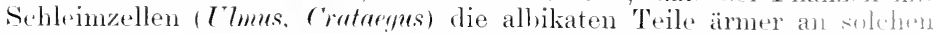
Zellen sind. Dagegen erwies sich der Gerbstoffgehalt in den wojlens

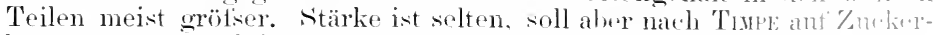
lösung ron den allikaten sitellen oftmals reichlicher als ron dex wiinen

1) Gruffox, Eu., Lassimilation chlorophyllienne et lit colorition les planters. Annal. se. nat. VIII, 1飞99: cit. Bot. Jahresber. 1\&99, I, ‘. 151.

2) Kon, F. G., Lntersuchungen über das Carotin und seme phrarologitiche Bedeutung in der Pflanze. Leipzig. Bornträger, 1902, IX.

3) Tıмr, H., Beiträge zur Kenntuis der Panachierung. Dissertat., (rijttingen 19m. sorauer, Handbuch. 3. Aull. Erster liand. 
webilket worken. Monocotyledonen speichern ant Zuckerbismg keine Stälie.

Ton anderen Antoren wird angegeben, dats die reinweitsen stellen livine stärke tühren, da sie nicht asimilieren. Die Widersprïche erlikiren sich durch die Übergangsstufon zm goldgelben Färbung, welche zwar kein Chlorophyll, wohl aber ein Xanthophyll und Carotin enthalten und im Liehte (wie etiolierte Blätter) Sinerstoff ansischeiden (KoHL, l. c.).

Interessant ist die Tatsache, dats bei manchen Pflanzen die reine Albicatio duch Veredelung ant die Unterlage ïberzugehen vermag. Versuche dieser Art mit positivem Erfolge meldet bereits Meres ${ }^{1}$ ) ans

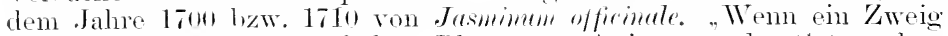
des Jasmins mit gesprenkelten Blättern anf ein gesuncies stänmohen desselben Jasmins geptropft wird, so bekommen anch die übrigen, oberhalb und mierhalh des Pfroptreises sitzenden Zweige gleichtalls gesprenkelte Blätter." Später haben besonders Lindenuth 2 ) numd nener(lings auch B.rmi ${ }^{3}$ sieh mit der Frage beschätigt. Letzterer hat die Theorie anfoestellt, dats die gelbbunten Formen als spielarten oder Nutationen, die zum Teil samenbeständig sincl, zu betrachten wären. die reinweitien aber als durch Infektion erkrankte Exemplare davon ahzutremen seicn. Allerdings sei dor Infektionskörper kein Lebewesen. sondern ein mhliekamntes stotfliches Etwas, ein Virus, das innerhalb der kranken Ptlanze an Nenge zunehmen kann. Dieses Virus kam ein Stotfwechselprodukt der kranken Pflanze sein, das imstande ist, die jungen Chlorophyllkörner so zu affizieren, dafs sie sich nicht zu nomalen Oroanen entwickeh, sondern zu Milsbildungen, in denen dam dasselbe Firms immer nen gebildet wirl. Oder aber es kann ein Stoffwechselprodukt der kranken Pflanze sein, das in gewissem Sime die Fähigkeit des Wachsens hat, d. h. Stotfe, die mit ihm identisch sind, aus anderen Verbindungen abspalten oder Stotfe dieser Art synthetisch nen antbanen kam ${ }^{*}$ ).

Dieser Gedankengang ist bereits früher von Pantaneldis) in präziserer Form zum Ansdruck gebratht und später ergänzt worden. Genannter Autor sagt "): "Der Albinismus ist krine Intektionskrankheit, sondern eine konstitutionelle Krankheit, deren erste Zeichen als abnorme Anhäufing von abbanenden, vor allem von oxydierenden Enzymen anftreten." .Durch die Leptombündel rerbreiten sich die zerstörmgbringenden Stofte, sci es duch energetische Bceinflussung benachbarter und konmmizierender Protoplasten, sei es dmoh materiellen Transport durch Siebröhren und analoge Elemente äber den ganzen Körper und gelangen in die sich streckenden Blattstiele, dam in die llamptrippen

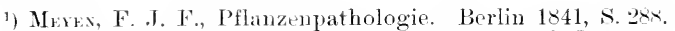

2) Linimin, Vegetative Bastarderzeugung durch Impfung. Landwirtschaftl. Jahrlücher 1878, Heft 6. Gartenflora 1901, 1902, 1904.

") Bar, Enwx, Zur Ätiologie der infektiösen Panachierung. Ber. d. Dentsch. Bot. Ges. 1904, Bd. XXII, s. 4.3. - Weitere Nitteilmgen über die infektiöse Chlorose der Nalvaceen un über einige analoge Erscheinungen bei Ligustrum und Labumm. Ber. d. Deutsch. Bot. Ges. 1906, Heft s, s. 416.

4) Burr, E., Über die infektiöse Chlorose der Malvaceen. Sitzungsber. d. Kgl. Preufs. Akad. d. Wiss. 11. Januar 1906.

5) Puxmanci, E., studii su l'abinismo nel regno vegetale. Malpighia.

Bd. XY-XIX (1902-0.5).

6) P.xmast., E, Ïber Albinismus im Pflanzenreich. Zeitschr. f. Pflanzenkrankheiten $1905, \mathrm{~s}, 1$. 
der Blätter. Hier heeinflussen sie alle Parenthrmzllon. Womit sie in Verbindung treten, offenbar mehr energetisch onlen durh s.hlechte

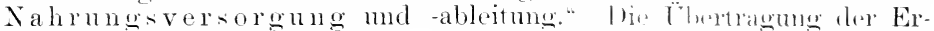

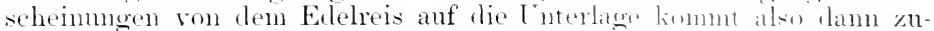

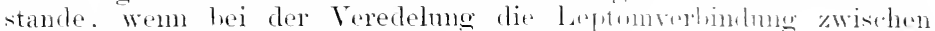
bejilen ('omponenten sith hergestellt hat.

Liese Anschamme beruht ant experimentellen sturlinn. Es ist

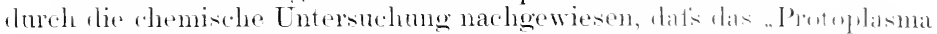

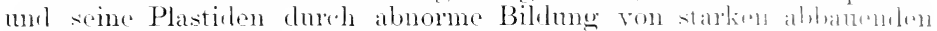

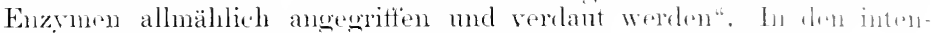
siveren Fällen von Albinismus ist überhante keine Anläntume vol

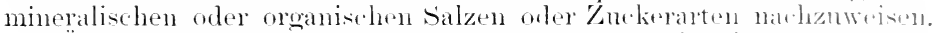

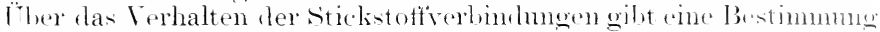

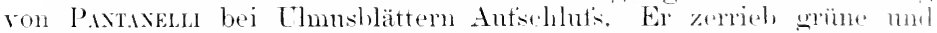
panachierte Blätter mit den nötigen Vorsichtsmatserehn mul liets don Brei in einem Kolben acht Tage stehen. I)er ursprüngliehe Wasser-

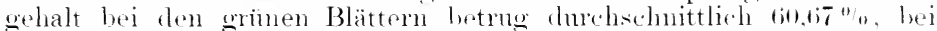
den panachierten Blättern desselhen Bammes zu derselben Zeit $7: 3,{ }^{\prime \prime} /$.

(irüne Blätter enthielten (in Prozenten des Trockengewichtes):

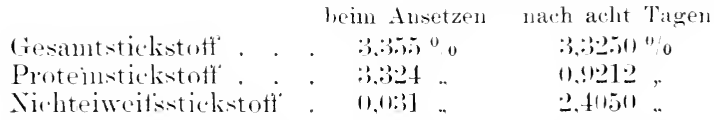

Panathierte Bläter ('nthielt'n (in Prozenten des Trockengewichtes): beim Ansetzen nach acht Tagen

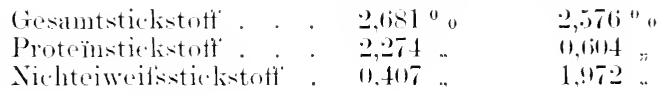

lie Autolyse im Satt von panatherten Blättern ist also verhältnismätig tiefergehend als in grïnen. Der Stickstotfgehalt ist in albikaten Granen berlentend geringer, aber dor prozentische Golualt an nichteiweitsartigen stickstotforbindungen gölser. Dabei kam die reichlich vorhandene Phosphorsäme doch in ciner Form gebmolen sein, dats sich leevithin nicht hilden und der chloroplast sich nicht anfhan'm kamn. Anch ein stairliespaltentes Enzym seheint nach Paxtoxedus Tnternchnngen in den panachierten Blättern reichlicher als in den griönen vorhanden zu sein, wenigstens in der Jugenul.

Ich labe bereits in der zweiten Antlage dieses Handbuches (s. I!n) auf dir stotfarmut der albikaten Teile lingewiesen und foldente Ansin.lit ansosespochen: Boi der nomal ernährten Blattzelle ist soriol Pla-ma

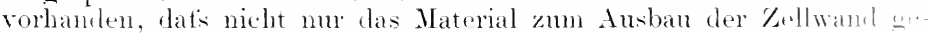

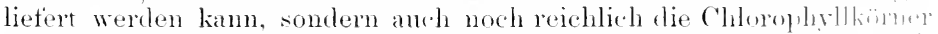

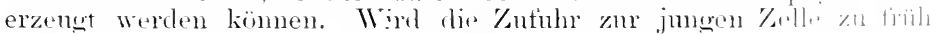
abgeschniten, indem das das Protoplasma vermehrende Matorial zon

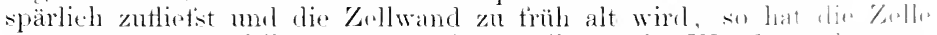

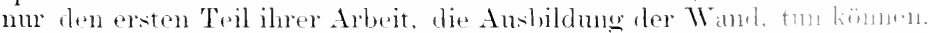

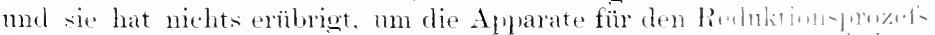
und die Vermelurung der Trockensulstanz herzustellen whe zon whaltent.

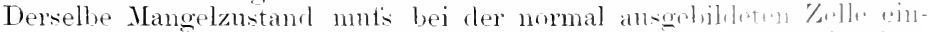

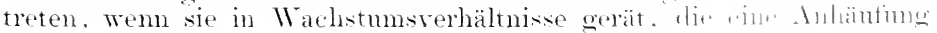


abbanemder, namentlich amylolytischer Enzyme bedingen, wodurch sie den . Jugendstadien wieder näher gerückt wird. Bringt man die Pflanzen in Terhältnisse. welehe die nornale vegetative Tätigkeit begünstigen (Schatten, Fenchtigkeit und Wïme), so werden die albikaten Achsenteile geneigt, grine Blätter zu produzieren. Diese Beobachtung wird durch eine Erfahrung von Lisdenctu gestätzt, der eine wesentliche Begünstigung ter Weifffleckigkeit durch intensive Lichtwirkmng lionstatierte. ERxs'1) in Saracas erwähnt, dats das in dortiger Gegend gewöhnliche Solamm ulinmm schlecht. sich nicht selten buntblätterng findet. Diese Erscheinumg tritt jedoch nur ant magerem Boden aut. stark buntblätterige Exemplare in besseren Boden verpt'lanzt, wurden grün. Bei Litica dioica komnte BeInenisck ${ }^{2}$ ) schon in einem Jahre aus der hunten Form wieder die grüne durch sitecklinge zurückerlangen.

I) Gewebe aber mit geringer konzentriertem Zellsaft sind weniger widerstandsfähig. Tatsächlich sind die weilsblätterigen Pflanzenteile empfindlicher gegen Hitze, Frost und Trockenheit und sterben früher ab. Die häufigsten Beispiele finden wir bei dem weilsblätterigen Acer Nrgmmlo, hei dem anch die Rinde der Zweige albikat wird. Sommenbrand im sommer und Winterfrost töten fast alljährlich die exponiertesten Zweige. Auch bei Koniferen kommen derartige Fälle vor ${ }^{3}$ ). Ebenso gehen sämlinge mit weitsen Cotyledonen und Plumularblättern sehr leicht zugrunde: ich habe hei grölseren Aussaaten von Obstsorten verschiedener Art nicht selten rein weifse oder weitse mit rötlichem Anfluge versehene Sämlinge gefunden: dieselben wurden stets mit besonderer Autmerksamkeit behandelt, gingen aber nach einiger Zeit zugrunde, falls sie nicht anfingen, grime Blattteile zu produzieren. Dergleichen Beobachtungen liegen auch von anderer seite vor, wie z. B. bei Phommem tenax (DE SMET), Passiflorn qualrangularis, sowie bei Dahlin raviabilis, Dianthus Caryophyllus und Liliaceen (Lrnueneto). Bei dem Mangel an Reservestoffen in den albikaten Zweigen ist auch die weitere Beobachtung erklärlich, dat's deren Stecklinge schwerer wachsen als die von den grünen Teilen desselben Individuums: man denke beispielsweise an Hortensien mit reinweilsen Blättern, an Pelargonien ans der Gruppe der "Mils Pollack".

Linemicth beobachtete auch bei Abutilon, dal's albikate Blätter meist kleiner und von kürzerer Lebensdaner sind. Wir erimnern in dieser Beziehung an die auch bei unseren wilden Pflanzen nicht selten vorkommende Erscheinung, daf's da, wo die eine Blatthälfte weifs, die andere grïn ist, die erstere kürzer bleibt und die letztere deshalb in grölserem Bogen um die weitse Hälfte sichelförmig sich herumkrümmt (Cichorium, Brtu). Bei marmorierten Blättern erscheinen die weit'sen Felder eimes Blattes oft gespannt, die grïnen runzelig bis blasig: anch die Achsen zeigen bisweilen im albikaten Teile eine Terkürzung, wie die bunte Koria japonian boweist, deren grüne Triebe desselben Stockes und Alters bisweilen um emen Meter höher sind als die weilsbunten : ebenso verhalten sich Sombucus, Weigelia u. a.

Die Albicatio ist meiner Auffassumg nach eine Hemmungsbildung,

1) Botanische Miscellaneen. Bot, Zeit. 1\$76, S. :37.

2) Велькаск, М. W., Chlorella variegator, ein bunter Mikrobe; cit. Bot. Centralbl. (7. Fischer, 1907, s. :

3) Zeitschr. f. Pflanzenkrankh. 1×96, S. :361. 
die bei wilden Ptanzen seltener, bei der Kultur in zmnhmender Menge

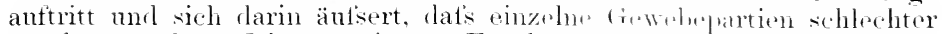
ernährt werden. Diese geringere Emährung hat zmr Folge, dat's entweder der Chlorophyllapparat gar nicht zur Anhilhme kommt oler

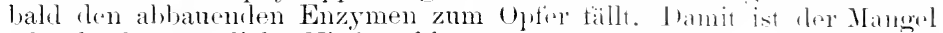

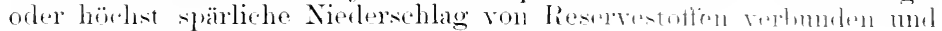
die grösere Hintälligkeit der Gewebe uklärt.

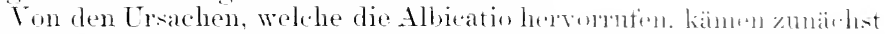

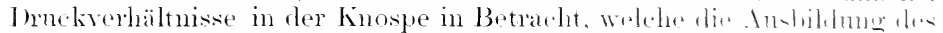
leitenten strangsystems hemmen und damit die genëgrnte fiillmus ifor

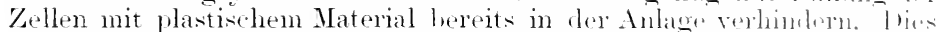

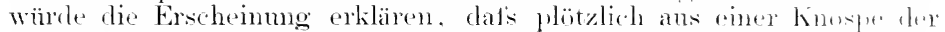

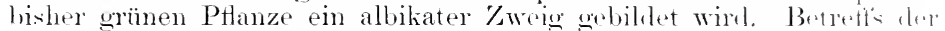

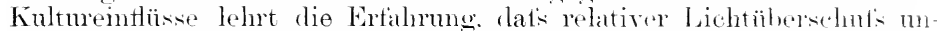
berlingt begünstigend wirkt. [Jenn wir sehen, rlak vielfach die roine Weiliblatterigkeit hei direkter starker Belonehtmer am intensirsten anttritt mol am längsten sich erhält, lagegen aber zuriuckocht, wom

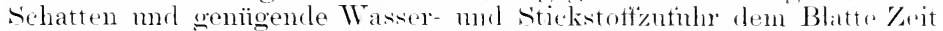
zu langsamerer Entwicklmng und längerer Betätigmng soiner venutativen Funktionen belassen, also das vorschnelle Ausloben verhindern.

Eine experimentell wiederholt geprïte Erschrinmu tïhrt Trup: ',

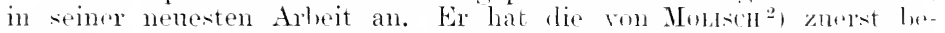

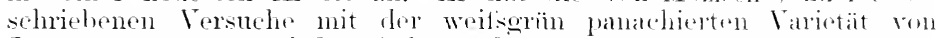

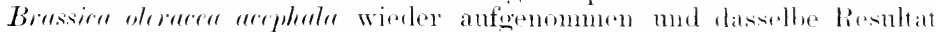
getunden, nämlich dats dic leuchtend weitse Färbung der Blattllärhen. die in Winter im Kalthanse bis Februar ihre höehste Anshildung erhäl. alshald nachlätst und schliefslich verschwindet, wrom tie Ptlanzen in

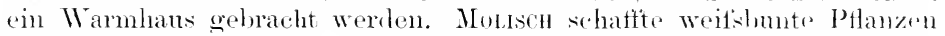
ans einem halthanse mit $+4-7^{\prime \prime C}$ in ein Wamhans von $+1215^{\circ}($ ' Dort eroüuten die sehon vorhandenen Blätter nach s-14 Tagen: dir neu gebildeten erschienen sogleich grün. Alemals ins Kalthans celoracht. bileteten die Exemplare wierler weilsbunte Blätor. Hierler gelört

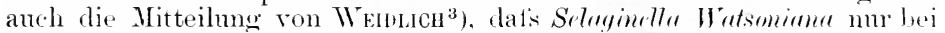
+100 C knltiviert werten dart, wemn sie weitse spitzen hildan soll. In diesen Fällen ist also dio den Verlust her Allicatio hervorruteme steigernng der vegetativen Funktionen durch die Frhöhmo der Wärme bedingt, während die albikaten Blätter je nach der Natm der Pflanzen und ihrem lokalen Ernälnmoszustande in anderen Fällen durch Licht- und Wärmeabnahme, durch die die Vegetationszeit vorlängernde s'teigerung der siticlistoft'- oder Kalizufuhr wierler ant das optimm ihrer Funktionen und zur normalen Chlorophyllbildung znriitk geführt werden kömnen.

Mangelhatte Stottionfuhr, hänfig zum Ansibuck kommend lureh Steigerumg von Gerbstoffen und Abwesenheit von Stärke. Kleinwerilen der Zellen und Vergröserung der Intercellularen. betont ancli Tinp: bei seinen sorgtälig ausgetührten Fersuchen. Eine Erschoimme, ili. ihm sellst befremdlich rorkommt, aher gerade der heste Buw wis tiin

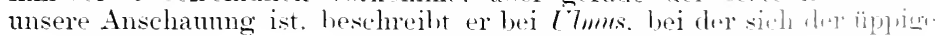

1) Tinne, Hesruen, Panachierung und Transplantation. Jahrbuth 1. Hamblum. wiss. Anstalten XXIV, 1906, Beiheft 3.

") Ber. d. Deutsch. Bot. Ges. IIX, 1, s. :;:

3) Gartenflora 1904, s. . is:. 
Frïhjahrstrieb weitsbunter Reiser nach dem Auspflanzen des Bames välig grïnblätterig entwickelte, der Hochsommertrieb mit seinem Thassermangel und Licht- und Wärmeälerschnt's aber wieder dic richtige Panathiermo zeigte (l. c. S. (is).

Wenn nun die Albicatio in einrm vorshnellen Ansleben, also in einer Unterdrïknng orler Hemmung der Arbeit des Chlorophyllapparates hesteht, dann werden die alhanenden Enzrme, selbst wem sie in ihrer absoluten Menge gar nicht gesteigert sud, doch ein Ühergewicht in der Kelle erlangen, weil die die Resrrvestotte niederschlagenden ans Mangel an Chlorophyllätigkeit zu weng entwickelt werden. Das sonst ïbliche in der chlorophyllführenden /e.lle sich einstellende Gleichgewicht ist gestürt.

Wir hrauchen also gar nicht die A nuahme eines.. Virus", einer giftig wirkenden Stoftgrmpe, dio sich in der Pflanze erzengen nurl vermehren muls. nm die Albicatio und die mit ilne verwandten Krankheitserscheinnugen (Mosaikkrankheit, Schrmmptkrankheit nsw.) zu erklären. Es ist cinfach eine Abwegigkeit der Funktionen, also eine andere Richtung in der molekularen Bewegung, ant wolche wir doch alle Stotfwechselvorgänge zurïckfühıren müssen. Wenn lie abwegige Stoffhillung eine Bewegung ist, so wird sie sich so lange fortptlanzen, his eine andere molekulare Bewegungsform ihr stillstand gebietet. Der albikate Pflanzenteil ist also der Träger einer abnormen Stotflbewegung, und daher ist es nicht autfällig, wenn diese Bewegung sich fortptlanzt, sobald die Wege, also die Gefätsbündel (nach Pantanelu die Leptomteile) zweier getremnter Individnen sich vereinigen. wie es bei der Veredelung der Fall ist.

Betrachten wir die Albicatio nicht als eine ans dem Rahmen der iibrigen Erscheinnmgen der Butblätterigkeit heranstretende, sondern nur als den extremston Fall eines die Verminderung der Chlorophyllmenge repräsentierenden Vorgangs, so kann es anch nicht mehr auffällig erscheinen, dats die gelbbunten, also minder irritierten Pflanzen es noch zur Produktion von Samen bringen, in denen dieselbe Bewegungsichtung des Stottwechsels fortclanert, d. h., dat's die samen wiederum gelbl,unte Pflanzen liefern k̈̈nnen.

\section{Die Mosaikkrankheit des Tabaks.}

bie neneren Antoren, welche ïber die Albicatio geschrieben haben, erwähnen bereits die Verwandtschaft dieser Erscheinnng mit der Mosaikkranklesit res Tahaks.

Dieser Name stanmt von Aborf Marer, der im Juli 187!, zu welcher Zoit die Krankheit in Holland bereits in besoroniserregender Weise aufortroten war, kranke Pfanzen vom Verein tüir Landwirtschaft (Abteilung Wijk lij Dumstede) zur Untersuehme zugeschicht bekam and 1885 seine Untersnchmessoebnisse in einem holländischen Journal, im folgenden .Jahre in den .. Tamelwirtschattlichen Versuchstationen"1)

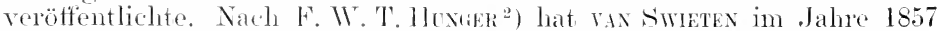
die Anfmerksamkrit anf dis mosaikartige Buntblättrigkeit des Tabaks in den holländischen Knltmen znerst velenkt, erwähnt aber bei seinen späteren studien der. Tahakkultur' in C'ula die Krankheit, die damals

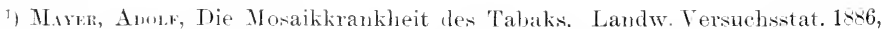
Bd. XXXII, s. 450, Taf. III.

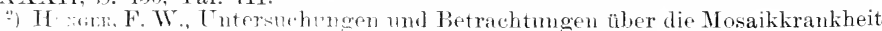

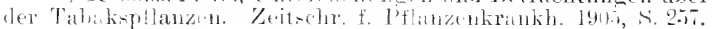


. Rost" genamnt worde, noch nicht. Jetzt diirtte die Erscheinmo in allen tabakbanenden Ländern vorhanden sein mol hat demgemäts eine Menge Namen erhalten. So erwähnt Hrokr, dats sio in Holland nicht nur als . Rost", sondern stellenweis als, „Bunt" onler .. Fä ule” bezeichnet wird. In Dentschland gilt der Name .. I osalkkrankheit ": stellenweis geht sie als .. Ma nehe": in Frankreich hrifist sir .. I a Mosa-

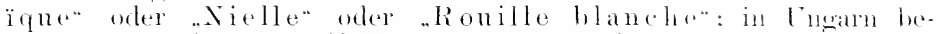

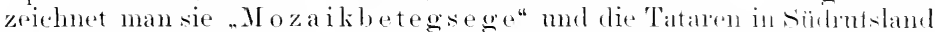
nemnen sie .Bosnch". In Italien wird sie heschieben muter den Namen "Mal de Mosaico" ofler "Mal della holla". In Amerika heifst sie in den nördlichen staten , C'alico" oder "Frenchine disease", in den Sürlstaten dagegen .Brindle" oder "Monerel discase". Schwer leiden anch dic Kulturen in Java, Borneo mel sumatra. Die Javaner nemen dir Krankheit .Poetils", währent sie in Deli muter dem chinesischen Namen .Peln-sem" bekamnt ist ${ }^{1}$ ).

Man darf die Mosaikkrankheit als rle zurzeit getährlichste Er. krankmng der Tabakptlanze bezeichnen, mol daraus crklärt sich. dak sie in nenerer Zeit von mehreren Seiten eingehend sturliert worlen ist. Aber die Ergebnisse sind einander vielfach widersprechend. Während einzelne Forseher, mit grofiser Zähigkeit der alten Throric folgend, dureluans Mikroben finden wollen mul gefunden zu haben glatuben. rer. teidigen andre die Ansicht, dafs lies eine anstedende Kranklopit vorliegt, deren Ursache in mowecknnäsiger enzymatischer l'ätiglient gesucht werten muts.

Diese Verschiedenartigkeit rler Ansehanmugen erklärt sich trilweise daraus, dats man als Mosaikkrankheit rersehiedene Erschoinuneren zusammengefalst hat, die nicht zusammengehören, andererseits kame aluer die Krankheit anch tatsächlich unter werhsehulin Formen anftroten.

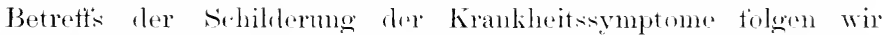

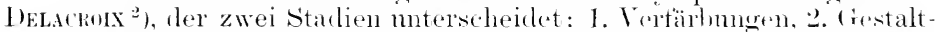
ändermgen der erkrankton Blätter. Bei den ersten Sirmptomenkomplex zeigt rer Blattrand selart abgegrenzte rerschiedenfirbige Flecke von

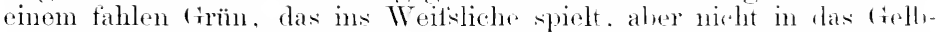
grüne wie bei der ( homese. Die blatsgrönen Rogionen sind ramistht mit Flecken von donkelgrïner Farte, und dieses friön ist dmoliter als das des normalen Blattes. Bei durchtallendem Lichte worlen die Farbenmerschiede noeh rentlicher mol hei dom Bufühlen des Blattes benerkt man, dats die dmnkelgnünen stellen etwas dicker als dio hleichen

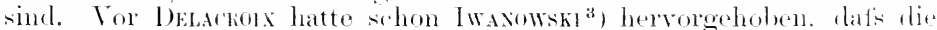
seitentriobe, die sich ans don Achsehn erlirankter Bläter entwickeh, wiederm mosaikkrak worden. Dieser Unstand ist sehr wichtig mul

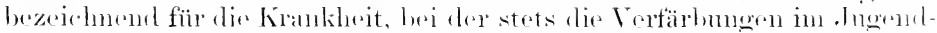

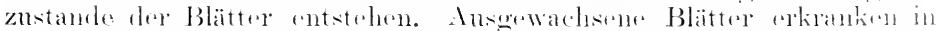

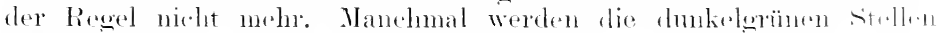

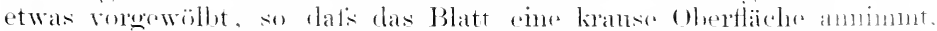

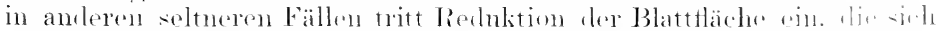

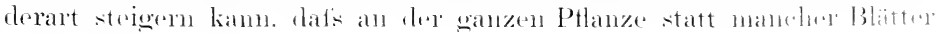

1) Hritil: al. al. (1).

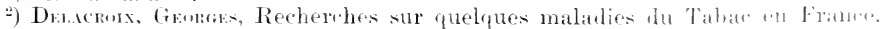

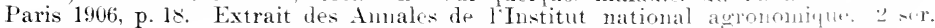
tome $\mathrm{V}$.

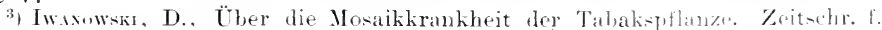
Pflanzenkrankh. 190:, s.. $1 \mathrm{ff}$ 


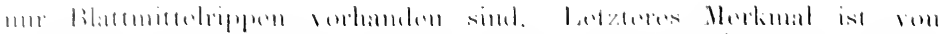

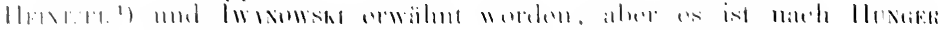

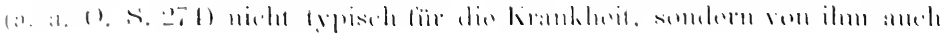

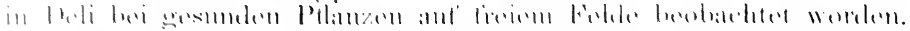

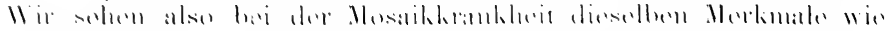

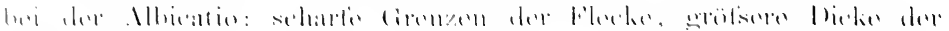

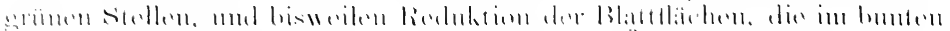

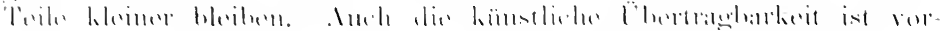

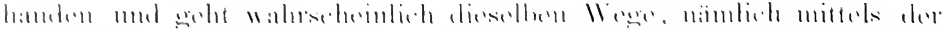

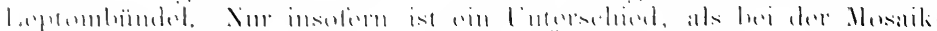

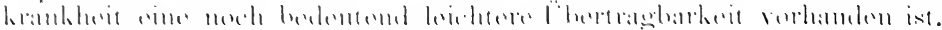

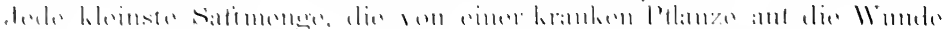

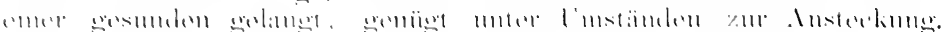

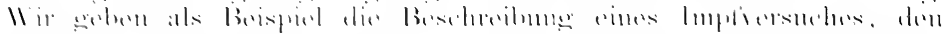

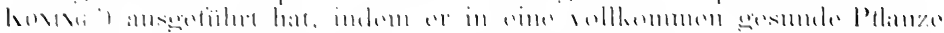

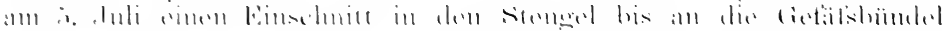

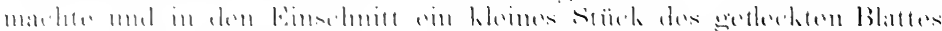

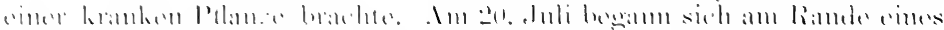

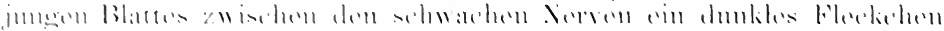

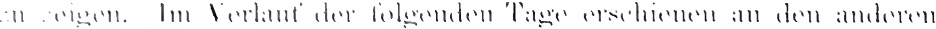

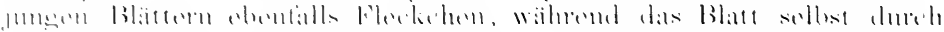

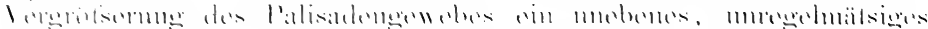

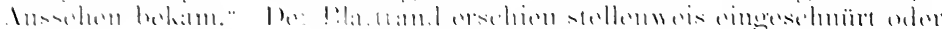

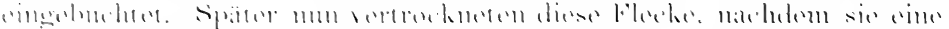

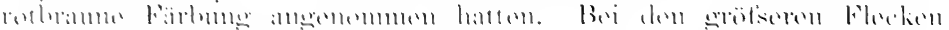

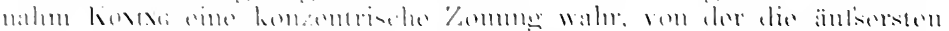

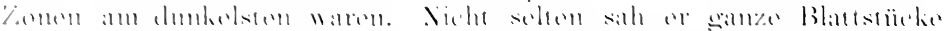

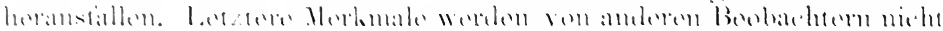

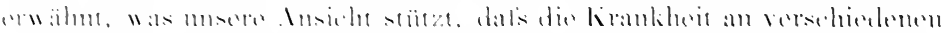

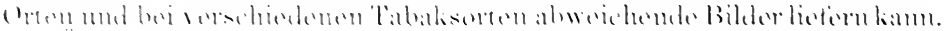

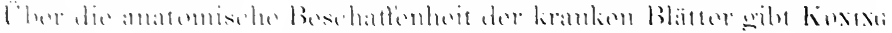

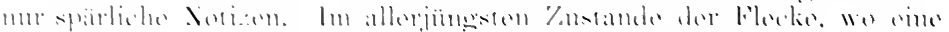

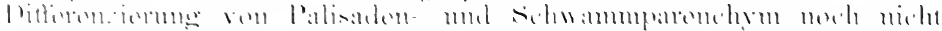

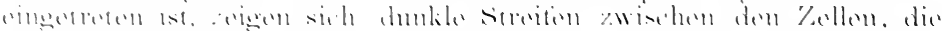

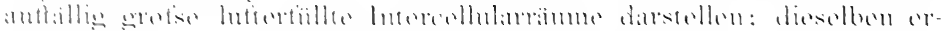

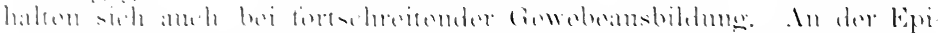

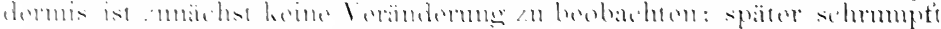

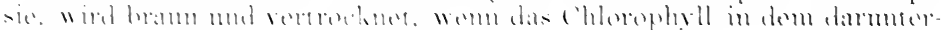

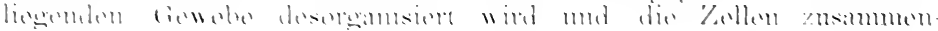
ninklline

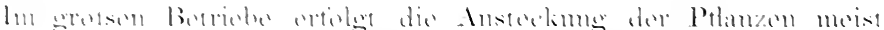

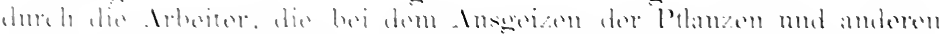

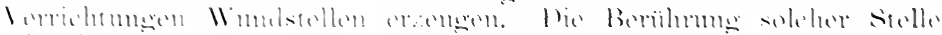

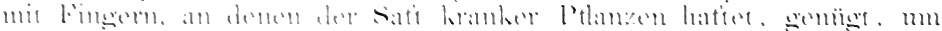

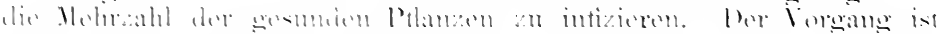

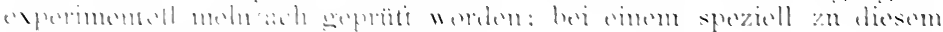

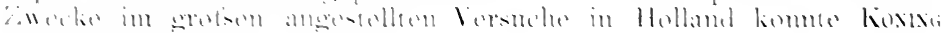

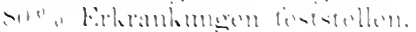

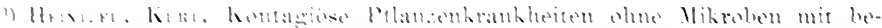

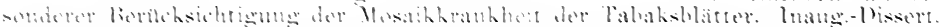
Frimeron ling

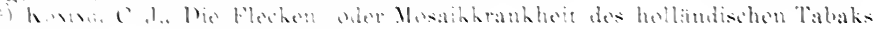

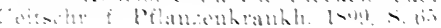




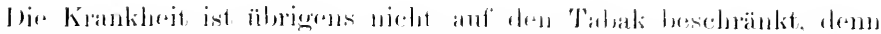

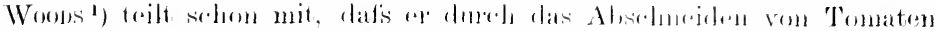

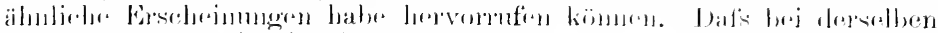

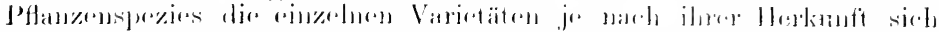

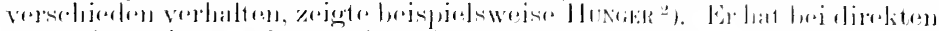

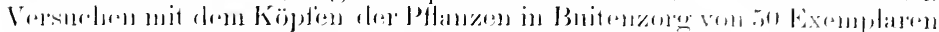

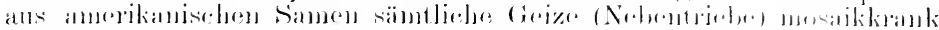

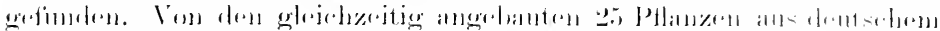

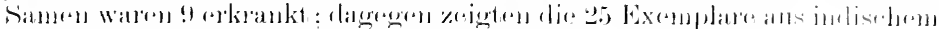

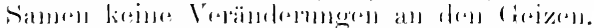

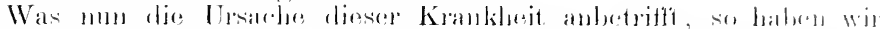

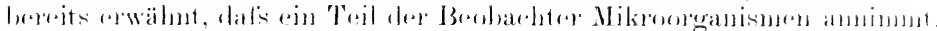

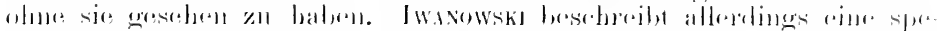

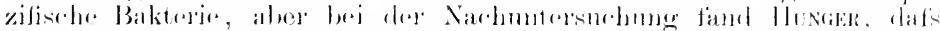

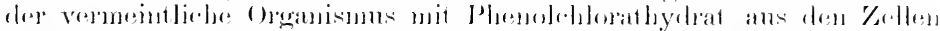

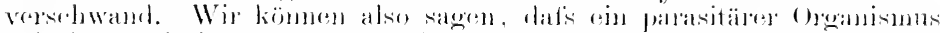

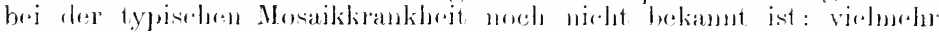

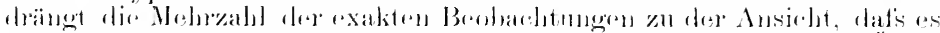

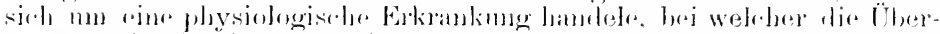

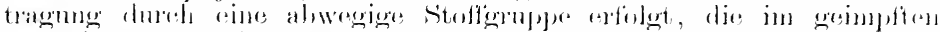

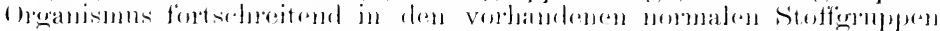

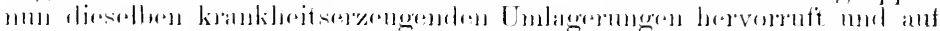

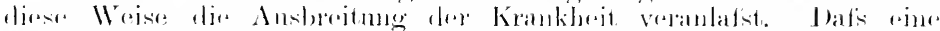

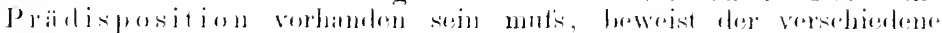

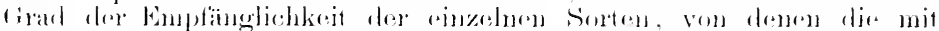

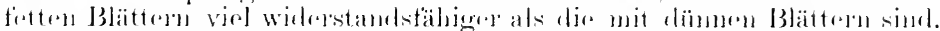

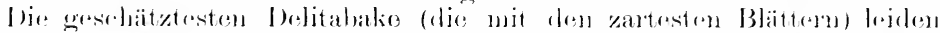

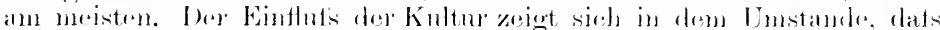

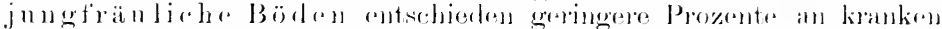

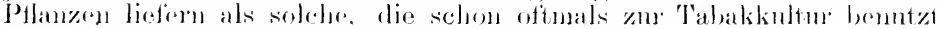
worden sind (s. Anbanversuche von Honeres).

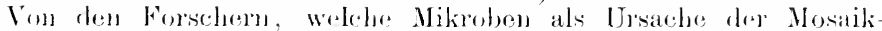

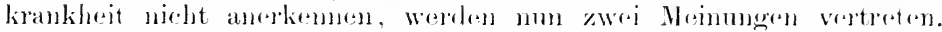

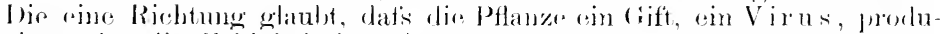

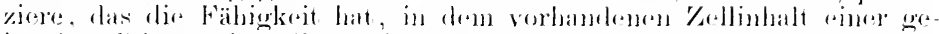

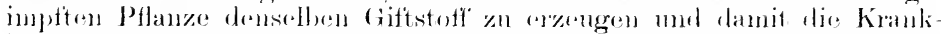

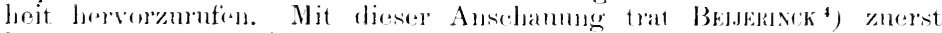

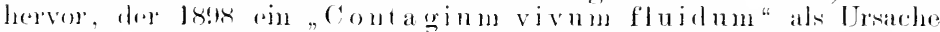

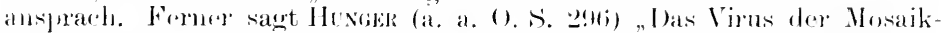

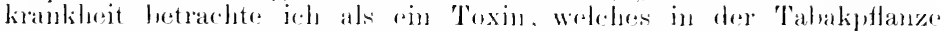

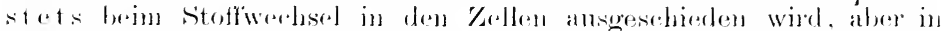

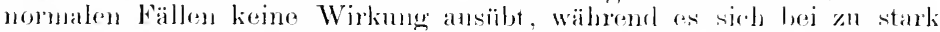

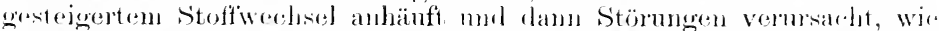

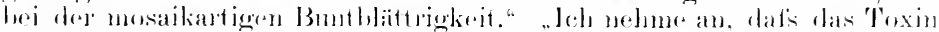

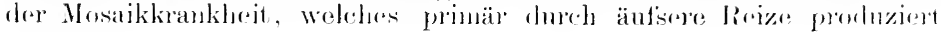

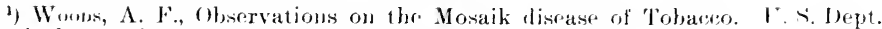
of Agriculture. Bull. No. 1X, May 1902.

a. a. O. S. 287 .

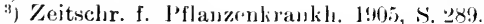

4) Bromosis, M. W., Over ren contagium vivum fluidun als romaak vas de Vlekzickte der tabaksblaten. Koninkl. Akad. van Wrotroschappen te Amstromam.

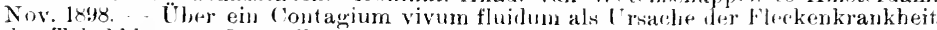

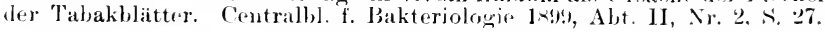


wird, fähig ist, beim Eindringen in normale /ellen eine physiologische Kontaktwirkmo anszüiben mit dem Erfolg, dat's sich tort sekmndär dassellue Toxin billet, mit andern Worten, das Mosaikkrankheitstoxin besitzt die Eigenschatt, physiologisch-antokatalytiseh zu wirken." Auf diese Weise kam das Virus selbständig einen Weg durch die Tahakpflanze mathen unl anf die Bahnen gelangen, die nach den Meristemen führen, nm dort seinen Einflus anf die jungen Bildungen auszü̈ben. Ind zugleich erklärt sich darans die Vermehrungstähigkeit des Krankheitsstoffes, "welche nicht ant aktiver Reproduktivität des Virus sellist leruht, sondern blots ans der passiven reproduktiven Kraft der belcbten Zellensubstanz hervorgeht."

(iegenüber der Gifthlheorie vertreten wir eine zweite Richtung, indem wir an die Untersnehmgen ron Pantanelu n. a. erimnern, die eine Verschiebung in den Enzymmengen und -wirkmoen nachgewiesen haben. Hesntzed ${ }^{1}$ ) sagt (1899 5. 45) , das Enzym, welches die Mosaikkrankheit verursacht, ist demuach als eine Oxvdase anzusprechen." Iemgemäls wäre also die Ursache der Mosaikkrankheit in der gesmulen Pflanze vorlanden, und kïme nur durch besondere Umstände zu abnormer. Wirkmg. (Genan dieselbe Ansicht spricht Wooss ${ }^{2}$ ) ans, indem er meint, es handle sich nur nm gewisse Bedingungen, unter denen die oxydierenden Enzyme wirksam werden: ,either become more active or else are protncer in abnormally large quantities." Genaner anf die Verhältnisse einzugehen, verbietct die angenblicklich noch mngeklärte Sachlage; tüu die von mns vertretene, im ersten Abschnitt dieses Kapitels ansgesprochene Ansicht lommt es weniger in Betratht, ob eine Vermehrung der Oxydasen tatsächlich stattfindet, oder eine Terminderung der die Oxydasen stets begleitenden reduzierenden Stoffe (n. a. Gerbstoft) vorhanden ist, woturch die gleiche Nenge Oxyclase eine erhöhte Wirksamkeit erlangt. Tatsächlich hat Huxner nachgewiesen, dats das mosaikkranke Blatt weniger rednzierende Stotte, anch Gerbstott, enthält als gesunde Tabakblätter ${ }^{3}$ ). Entsprechend dem Chlorophyllmangel ist anch weringerer Znckergehalt im lianken Blatte nachgewiesen worden: autierlem finden sich weniger treie organische säuren ${ }^{4}$ ). Es tehlt demgemäts dem mosaikliranken Teile an der Möglichkeit, genügend Reservestoffe zu bilden, mol lamit gliedert sich rie Mosaikkrankheit, die nach Hoxfer ${ }^{5}$ ) anch ohme Terwundung, allein schon durch die Beröhrung mit der Hand ïbertraghar ist, und durch Verellung sich anch auf die Unterlage tortphlanzt, der Albicatio an.

Während wir hei letztgenamnter Erscheinmng noch keinen (trund zur Einschänkmug derselhen haben, weil die weis sunten Gehölze trotz ihrer grötroren Empfindlichkeit wesuchte Artikel tür unsere Gärten liklen, $s$ ist bei clor Mosaikkrankheit die Notwendigkeit ernster Bekämptimgsmatsnahmen mberlingt geboten und sind diese anch vielfach

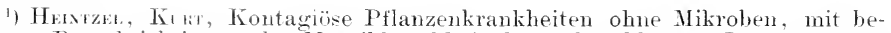
sonderer Berückichtigung der Nosaikkrankheit der Tabaksbliitter. Inaug.-Dissert. Erlangen 1900 ; eit. v. Hixtes a. a. (). s. 269.

of IVin, A. F., The destruction of chlorophyll by oxidizing Enzymes. ('entrall, f. Bakt. 1-99, Abt. II, Bd. I, Nr. ㄹ.. S. 745.

3) Hixim, F. W. T., Bemrtimgen zur Wood'schen Theorie über die Mosaikkrankheit des Tabaks. Bull. de l'Inst. Bot. de Buitenzorg 1903 No. XVII.

4) Hoxis, De Mozaik-Zickte bij Deli-Tahak. Deel I. Mededeelingen uit s'Lands Plantentuin LXIII, Batavia 192.

5) Hixise, On the spreading of the Mosaik-disease (Calicol on a tobaccofield. Extr. Bull. de l'Institut Bot de Buitenzorg 190:; Nr. XVII. 
versucht worden. Als das beste Mittel hat sich nach Konso die Kalkzufuhr zum Borlen erwiesen. Husiek konstatiorte anch einen guten Erfolg bei der Düngmy mit Knochenmohl und warnt vor allen Dingen vor ïbertriebener chemischer Ioungme. Nach meiner Anschanme ist die Krankleit ein Ergebnis der Hochzucht, der dhul Verminderung der Stickstoffzufuhr und Erhöhung des Kalkens strilgrench entgegengearbeitet werlen kann.

Woons sagt (Observations on the Mosaic discase of 'Tobaces, Washington 19(2). S. 24): "Orerfeceling with nitrogen tavors the development of the disease, and there is some evilenep that rxcess of nitrates in the cells may cause the excessive develomment of the ferments causing the disease."

Besondere Beriicksichtigung verdient anch die Auswahl des Samens. wie aus den Angalien von Bourgeres und Perreal ${ }^{1}$ ) hervorgeht. Iniese Forscher entnahmen von einzelnen Pflanzen, die mitten in einem versenchten Felde bis zur Ernte von fler Mosaiklirankheit frei blieben. das Saatgut und erhiclten $98 \%$ gesunde Pflanzen: dieselben waren allerdings wieder ansteckbar von Wunden ans, die mit mosaikkranken Teilen in Verbindung gebracht wurden. Vor allem ist ant den Boden besondere Rücksicht zu nehmen. In Erde, die schon länere /uit Tabak getragen hat, erkrankt gesunde Saat sehr leicht ${ }^{2}$.

\section{Die Pockenkrankheit des Tabaks.}

Wir erwähnten bereits bei der Mosaikkrankheit, datis andere Verfäromgserscheinmoen vielfach zu Verwechslumgen Veranlassung woveben haben. Ein Beispiel für letzteren Fall bietet die Pockenkrankheit, anf deren Verschiedenartigkeit ron der Mosaiklirankheit Iw.swWsk und Poloftzoff ${ }^{3}$ ) anfmerksam machen. die im Auttrage des russischen Ackerbanministeriums die Krankheit drei Jahre hindurch in Bessarabien studiert hatten. Die Krankheit äutsert sich nach IFunsek ${ }^{4}$ ) im Auftreten zahlreicher, kleiner, weitser Fleckchen zn \%eiten grofser Trockenhoit. während in Deli die Mosaikkrankheit gerade nach Eintritt scharfor Regengïsse zu beobachten ist. Die Ursache wird in ähnlichen Tnständen wie hei cler Mosaiklirankheit gesucht.

\section{Weisser Rost des Tabaks.}

Ferner ist mit der Mosaikkrankhoit eine Erseheinme verwechselt worlen, die als Weitser Rost bezeichnet wird. IELckors", hat darant aufmerksam gemacht, dals hierbei nicht die jungen, sondem die answewachsenen Blätter znerst erkranken, die Flecke anch zahlreicher. aber kleiner sind und sich scharf ahthehen; schlietshich werten diosellon

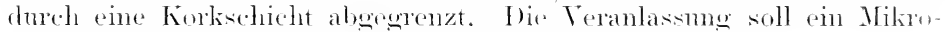
organismus, Bacillus maculivola, sein.

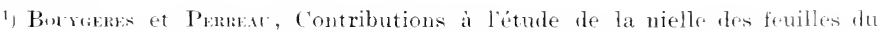
tabac. Compt. rend. 1904, CXXXIX, p. 309 .

$\Rightarrow$ Bant:x.. J., Weitere Beitrïge zur Kenntnis der Tabakpflanze. Landwirtsch.

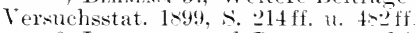

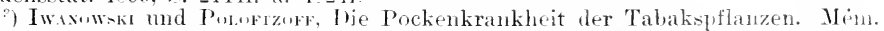
de l'Acad. Imp. de st. Petersbourg lesı. sér. VII, t XXXVII.

4) Hoxibl. Zeitschr. f. Ptlanzenkrankh. 1905, S. 297. Hier auch die betreffende Literatur.

5) Desarnix, G., La roulle blanche du tabac et la nielle etc. Compt. rencl. 1905. CXI, 1. 675. 


\section{Erkrankung der Erdnüsse in Deutsch-Ostafrika.}

Nach Katosek ${ }^{1}$ ) ist Arachis hypogaen, eine der wichtigsten KulturpHanzen der Kolonie, im allgemeinen nur wenig von Kranklieiten heim-

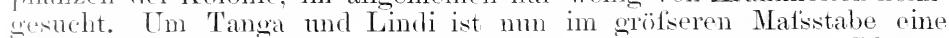
Errcheinung anfgetreten, die an die Mosaikirankheit erinnert. Blätter, Blüten und Friichte bleiben klein, der Fruchtansatz gering. An den Blättern zeigen sich weitsliche, mregehnäsige Flecke, wodurch das Blatt etwas verkrïppelt. Die Blätter werden schliefislich bram und sterben ab. Pilze sind nicht gefmulen worden. Nährstoffmangel ist ausqeschlossen.

\section{Die Schrumpfkrankheit des Maulbeerbaumes.}

I) durch ganz Japan jetzt verbreitete Krankleit, welche in Europa sicherlich anch zu finden sein wird, ist erst seit vielleicht 20 bis 30 Jahren genanerer Beobachtung gewiurdigt und erst im letzten Jahrzehnt ernstem Studium unterzogen worden. Nach Suzukr ${ }^{2}$ ), dem wir in der Darstellumg folgen, heitst die Krankheit in Japan Jshikub yo oder shiknyohyo. Gerade so wie die Mosaikkrankheit tritt anch die schnumptirankheit am intensirsten bei den zartblättrigen und schnellwïchsigen sorten auf. Imerhalb derselhen Kulturvarietät leiden die Individuen am stärlisten, welche zu viel flüssigen Dünger erhalten, während die in magerem Boden oder in Berogegenden angepflanzten Bäume beinale frei ron der Krankheit sind.

Ton besondrrer. Wichtigkeit ist, dats die Krankheit mgefähr gleichzeitig mit der allgemeinen Einführung der sogenamnten selinit ILethode in Japan sich bemerkbar machte. Diese besteht darin, datis die Stämme oder / weige zur Zeit der üppigsten Blattentwicklumg (Mai. Juni) kurz über lem Borlen abgeschnitten werden, wenn die Pflanze Hrei Jahre alt ist. Darauf produziert der Nock sofort wieder neue ïpplge Triebe, die bis september noch fünf bis sechs Euts hoch werten. Diese Zweige werlen in folgenden Sommer wieder geschnitten und zwar entweder kurz üher dem Boden oder mehrere Fufs über der Bodenoberflä،he. Die lang geschnittenen Exemplare leiden weniger von der Krankheit, und in denjenigen Gegenden, in welchen die Pflanzen nach der alten Kultumethorle gar nicht geschnitten werden, ist die Irankheit ïberhaupt mbekannt, so dats man mit sicherheit behaupten clart, dats es sich anch hier wielerm un eine Folgeerscheinumg der Hochlunltur handelt. Für die Ansicht, dat's namentlich dieses Schneiden während der Triebzeit die Ursache der Schrumptkrankheit ist, spricht anch der Umstand, dats die im Herbst oder ersten Frühjahr vor dem Lanbansbruch gesclnittenen Pflanzen gesund bleiben. Kranke Pflanzen kömen geheilt werden, wenn sie einige Jahre vom Sehnitt verschont bleiben.

Das erste /eichen der Krankheit erscheint gewöhlich an jumgen, aus dem Stammstumptc hervorbrechenden /wweigen, wenn dieselben etwa einen Fnfs llöhc erreicht haben. Zunächst schrumpfen die obersten Blätter oder zeigen andere śchwächeerscheinmogen, und diese Ver-

1) Karmsk, A., Eine neue Kranklueit der Erdnüsse in Deutsch-Ostafrika. Gartenflora 1904, S. 611 .

2) Stzuki, U., Chemische und physiologische studien über die Schrumpfkrankheit des Maulbeerbaumes, eine in Japan sehr weit verbreitete Krankheit. Zeitschr. f. Pflanzenkrankh. 1902, s. 20:3. 
ändermo schreitet allmählich abwärts fort, wohei llie Blätter sich gell,lich oder schmutziggrün färben oder aber anch ihre normale Färbung behalten kömen. Neist finden sich diese Verändrungen langsam ein, indem im ersten sahre nur die oberen Blättex einzolner 'Triebe erkranken und der Znstand sieh im Lanfe der Jahne derart anshreitet, dats der Baum abstirbt. Es gibt aber anch alinte Fälle. in denen alle Blätter gleichzeitig in einem Jahre schrumpten. Die Äste der rrkinaliten Pflanzen sind gewöhnlich sehr dümn und entwickehn sehr zahhreiche Seitenzweige und Blätter; die Zweige erschlatten bisweilen mud verlieren ihre Festiglieit: die Wurzeln begimen zu faulen.

Ian hat natürlich vielfach Parasiten für die Erkrankmng vrrantwortlich gemacht und namentlich die Erscheinme als Folge einer parasitären Wurzeltäule hingestellt: aber nachweislich sind die Wurzin in den ersten Stadien der Erkrankung der oberirdischen Teile noch gesmol; antiserdem erscheint es von vornherein sehr bemerkenswert. dats ein Parasit immer nur die nach der Sehnitt Nethode behandelten Bäume aufsucht.

Unter Berücksichtigmng der vorstehenden Tatsachen wird man zn dem schlut's gedrängt, dats hier eine fortgesetzte Störung des tileichgewithts in den Ernährmgssorgängen die Ursache sein muts. Dies wird dureh die zahlreichen Analysen Suzukri bestätigt. Er fant z. B. im Durchschnitt ron zehn Untersuchungen bei den Blättern der schrmmptkranken Pflanzen, wemn der (iehalt der gesmonden Blätter $=1$ (n) gesetzt wirel:

Wassergehalt $94.7^{\circ} 0$, Trockensubstanz $116 \%$. In hundert Teilen der Trockensmbstanz sind enthalten

(normal mit 100 in Ansatz gehracht):

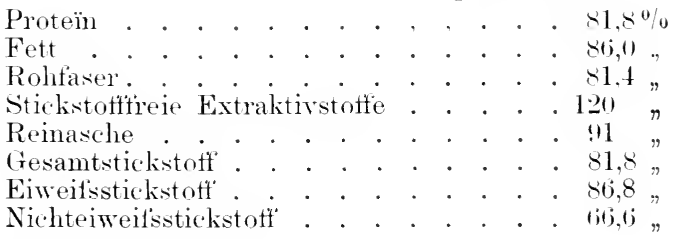

In 100 Teilen Asche sind enthalten

(normal mit 100 in Ansatz gebracht):

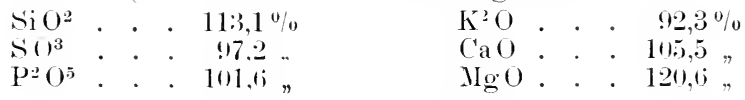

Also: grofiser Aschereichtum im Verhältnis zur produzierten organischen substanz, wie wir dies als typisch für alle Nangelpflanzen bereits betont haben.

Was num die Schrumptkrankheit der Maulbeerbäume charakterisiert, ist eine Anschoppung von Stärke in den kranken Blättern und eine sehr mangelhatte Ausbildung des Holzkörpers. namentlich der stotfleitenden Bahnen, des Siebröhrenkörpers. Inrch die geringe Zahl und Lumenbreite dieser Elemente kann nur eine langsame Wegführung der Assimilate (hier speziell des Zuckers) stattfinden; infolgedessen 
wirrl die weitere Lösmng der Assimilationsstärke gehindert ${ }^{1}$ ). Neben diesen anatomisthen Verhältnissen weist nm die Chemie eine abnorm Enotice Quantität rom Oxydasen und Peroxydasen nach. Nach Woous ist ex sehr wahrscheinlich, das die Oxydasen nicht mu Chlorophyll zerstören, somblem anch die diastatische mol protoolytische Wirkmig verhindern, mul deshalb wïnden sie die Ursathe der Verzögermo in der Wanderung der stärke und der Stickstoffrerbindmogn sein können. Allerdings be-

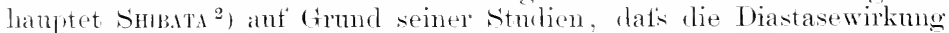
nicht durch die Oxvdase verhindert wird mul dals die Mehrprodnktion der Enzrme durch die gesamte Entlecrmm der Assimilate hervorgernfen wïrde. Welche von diesen Ansichten die richtige ist. müssen spätere Untersuchungen klarstellen. Tns qenügt hier die Tatsache dats die Gesamtmonge ler Reservestoffe hoi len kranken Pflanzen erschöpft wird (Suzuki a. a. O. S. 276). Dies kommt anch in der mangelhaften Füllmng der Zweig- und Wurzehinde und der ruhenden Knospen mit stärke zum Ansiluck mol äntsert sich anfsertem im Nachlassen des Wurzeldruckes mod der Transpirationsintensität (Mroshi). Es ist num erkärlich, dats, wenn eine Pflanze durch Fortnahne ihres Laubköpers fortgesetzt gezwungen wird, ihr Reservematerial zn verbranchen, sie nicht Zeit hat genügend die Ersatzorgane answmeifen, 1. h. himeichend stärke, Eiweits mul cellulose in ihnen niederzuschlagen.

Die Heilung der Krankheit wird in der Rückkehr zum normalen Herbstschnitt bestehen. Sobald man Äste erkrankter Pflanzen inrch Absenken zn selbständiger Bewurzelmng bringt, entwickeh sich dieselben normal, wie Suzthi experimentell gezeigt hat.

Ührigens kommen ganz ähnliche Krankheitserscheimmgen anch hei dem Teestra ne h vor, sobald das Abpflücken der Blätter mmationell betrieben wird.

\section{Die Serehkrankheit des Zuckerrohres.}

Die ant Java zuerst in den achtziger Jahren des vorigen .Jahrhunderts aufgetretene und ron Westen nach Osten fortschreitende Sereh ist zur Zeit wohl dir gefürchtetste Krankheit des Znckerrohres; rie ist jetzt anch auf Rémnion, Sumatra, Borneo, Malakka, den maskarenischen Inseln und in Anstralien beobachtet worden ${ }^{3}$ ). Der Name stammt

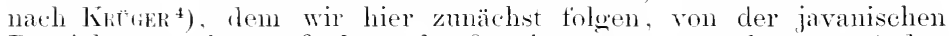
Bezeichnmo des anf Java häufig in Gärten angebanten Andropoym Schormanthus (jar. Sorih). Welches (ras antiserordentlich reich verzweigte Büsche bildet. In ihrer ansgebildetsten Form tritt num die Krankheit des Zuckerrohrs anch in einer übermäfsigen Bilimm kmrer Seitentriebe. wrolse die Ptlanze buschig machen, ant. Der Wruzelkörper zeigt geringe Ansilehmmg, weil nur wenig schlanke Äste sich im Borlen anstneiten; die Mehrzahl der Wurzeh bleiht limrz und buschig, la ilne spitzen absterben mol die Nenbildmengen

1) Mrusu, M., Tntersuchungen über die Schrumpfkrankheit („Ishikubyo") des Maulbeerbaumes. II. Journ. Coll. Sc. Tokio 1901, vol. XV.

") Snmsta, K., Die Enzymbildung in schrumpfkranken Maubeerbiiumen. The Botanical Magazine XVII, I!N (13.

3) Cit. Zeitschr. f. Pflanzenkrankh. 1901 s. 297.

4) Kut abs, W., Über Krankheiten u. Feinde des Zuckerrohrs. Ber. d. Versuchsstation f. Zuckerrohr in West-Java, Kagok-Tegal. Dresden, Schönfeld's Verlag, 1894, ‥ 126. 
demsetben schicksal vertallen. In dem alnestorlenm fiewebe finden sich reichlich Parasiten, unter denen anf davat Tylenchus sacchari soltw. am meisten rorhanden ist. I ie Internodien dej stengel bleiben linæz. die Angen in den Blattachseh schwellen hallswgelig an. während sie (mit Ansmahme einzeher sionten) bei dem nomalen Rohr flach

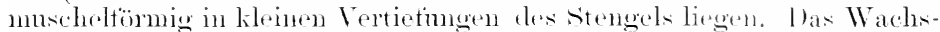
tum des llanpttriebes bleibt zurtick nur tatür entwickeln sich sehmell

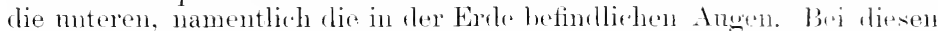
nenen Trieben aber wiederholt sich alsbald derselhe Vurwang des

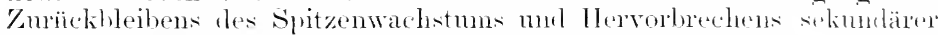
Achsen, wodurch der ganze Stock eine abnome Buschliblume erhält. Thas jaranische Material, das ich zur Untersuchmg zugeschirkt hekommen habe, zeigte an oberen, hochgelegenen Punkten des stengels bisweilen eine derartige Verästelung der seitenachsen, dat's sich hexprhesenartige Nester bikleten. Kwischen dicser bïschelartigen Verzweroung und dem schlanken nomalen Zustands finden sich in den verschiedenen Krankheitstarlien alle möglichen Öthergänge.

Intolge der starken Verkïrzung der Intemodien stehen die Blätter fächerartig heicinander: die Blattscheiden sind wie ineinander weschachtelt. Ihr Alsterben erfolgt in vielen Fälen nicht, wie nomal, vom Rande ans nach dem Mittehner hin fortschreitenel, sontern umgekehrt, und die Folge ist, dats sie lange an stengel sitzen bloiben und Xiststätten für Mikrooroanismen bilılen. Ilure Farbe ist meist dumkler als die der normal abgestorbenen Blätter, mol während diese zähe sind, zeigen sich jene suö̈ler mel mterliegen leicht dem \%ertall.

In den (Qnersinnitt In'ch einen Knoten des kranken Rohres fallen sotort die intensiv rotgetärbten Getälsbiundel anf, deren Farbstoft' mit Alkohol ansziehbar ist. Die Kellmemlranen sind hänfig verquollen und teilweis zerstirt.

Diese Rotfärbung der Bündel tritt schon in Stecklingen nud bei älteren Pflanzen in den ersten Krankheitsstadien ant, so dafis man glanhte, sie als ein hesonders beachtenswertes Morkmal horvorheben zn mïssen.

Wir haben die Rotfärbung der \%ellmembranen bei vielen niedst parasitären Erkiankungen von Monocotylen beobachtet, und Brsse ${ }^{1}$ ) hat dieselhe hei der Sorghm-Hirse in Dentseh-0statika kïnstlich dadureh hervorntin kïmnen, dats er die Blattspreiten mit Vaselin oler Paratinoil bestrich. l)e Färbme leitete sich in den Stereombelägen der Getätsbündel weiter fort und wird ron Busse ant eine Störung des Atmungsprozesses zurieligeführt. Wir halten die Rotfärlomg für eine Oxvationserscheinmo. die bei den rejschiedensten Ursachen, namentlich aber bei Wruzel. erkrankungen eine Funlitionstörmo in Leitmngssytem anzeigt. Seln deutlich tritt sie anch bei der Ananaskankheit, einer parasitären, dureh

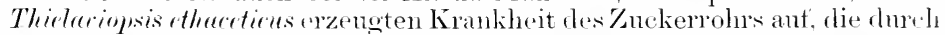

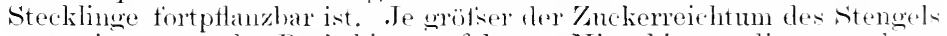
- er nimmt von der Basis lis mgefähr zur Mitte hin ständig zu - ilesto leichter erkanken die Stecklinge lureh den Pilz ${ }^{2}$ ). Die Rotfarmum erscheint hei der serehkrankheit hisweilen ganz isoliort in rinzehern

1) Buss. Wurfik, Cutersuchungen über die Krankheiten der sormhum-Hirse. Arb. d. Biol. Abt. f. Land- 11. Forstw, an Kaiserl. Gesundheitsante 19n1. Bd. IV, Heft 4, S. 319 .

2) Cons, X. A., Fungus Maladies of the Sugar Cane. Rep. Exp. Stat. of the Hawaijan Sugar Planters Association. Bull. 5, Honolulu 1906. Pl. 1, p. :Lls. 
Knoten, während das darunterliegende Internodium noch unverfärbte Fibrovasalstränge besitzt. Dies lälst darauf schliefsen, dats die hrankheit ein Allgenteinleiden, eine Konstitutionskrankheit darstellt, die ihre resten sichtbaren symptome bald hier bald dort an hesonders gesehwächten stellen in die Erscheinung treten lätst.

Nan hat die Ursache der Kranliheit in den verschiedenartigsten Einflüssen gesucht: Bodenerschöptung, Degeneration durch fortgesetzte moeschlechtliche Vermehrumg, abnorme TVitterumgsverhältnisse, unpassende Düngung, namentlich nit Erdunfkuchen (Bungkil), zu tiefes Pflanzen bezw. zu hohes Anerden, zu frïhe oder zu späte Pflanzumg und endich Parasiten. Von letzter'en liommen Nematoklen, Fadempilze und Bakterien in Betracht.

Nun widersprechen die Untersuchungen des einen Forschers denjenigen eines anderen. So gibt heispielsweise KRïgkr an, dats er als steten Begleiter der Krankheit Bakterien in den (refäsen gefunden habe, während Tschnch ${ }^{1}$ ) die Bakterien als Krankheitsursache für ausgeschlossen hält und die ersten Anfänge in einer Wurzelrerletzung erblickt. Benecke ${ }^{2}$ ) steht auf der Seite von KkÜGE; MöbIUs ${ }^{3}$ ) wendet sich gegen die Behauptung einer vorliegenden Degeneration und sucht rie Ursache auch in parasitären Organismen. OHL ${ }^{4}$ ) sieht die Ursache der serehkrankheit und der Blattfallkrankheit des Kaffeebaumes in Java in der Entwaldung derBerge und der daraus hervorgehenden Trockenheit. Ebenfalls aut Wassermangel führt JANSE ${ }^{5}$ ) die Krankheit zurück, insofern als er glaubt, dats die gummiartige Verstoptung der Getätse die Leitumg behindert. Die Bildung der g'ummiartigen Substanz bringt er mit Bakterien in Verbindung (Bacillus Sacchari). "WENT ${ }^{6}$ ) betrachtet die Sereh direkt als eine Gummose, die durch das Kusammenwirken einer parasitären Wurzel- und Blattscheidenerkrankung zustande kommt und sich durch stecklinge fortpflanzt.

Als nicht parasitäre (rummose falst $\mathrm{W}_{\text {AkKER }}{ }^{7}$ ) die Krankheit auf, die damit zusammenhängt, dal's die während des trocknen Monsuns entwickelten stecklinge in der folgenden Regenzeit Wasserüberschut's bekommen.

So wogt der Kampt der Meinungen bis in die neuste Zeit fort ${ }^{\star}$ ), ohne dats er zu positiver Einigung getührt hätte. Der Grund ist wahrscheinlich darin zu suchen, dat's die bei der Serehkrankheit angegebenen Merkmale auch bei anderen Krankheitserscheinungen vorkommen, wie beispielsweise der folgende Abschnitt zeigen wird, und dat's daher ver-

1) Tscnum, A., Über Sereh, die wichtigste aller Krankheiten des Zuckerrohres in Java. Schweiz. Wochenschrift t. Phammazie 1891.

2) Bexecke, Fraxz, Proefnemingen ter Bestrijding der „Sereh“. Samarang 1890. Weitere Abhandlungen desselben Autors s. Zeitschr. f. Pflanzenkr. 1891, S. 3.4, 361.

$\left.{ }^{3}\right)$ Möни, M., Over de gevolgen van voortdurende vermenigvuldiging der

Phanerogamen langs geslachteloosen weg. Mededeelingen van het Proefstation „Midden Java" te Simarang. 1890.

4) On., A. E., Eene Waterstudie. Batavia 1891 ; cit. Zeitschr. f. Pflanzenkranlih. Bd. I, s. 365 .

5) Cit. Zeitschr. f. Pflanzenkrankh. 1893, S. 298.

6) Wexr, F. A., Die Serehkrankheit; cit. Zeitschr. f. Pflanzenkrankh. 1894, S. 235 und 1901. S. 297.

7) W.ккик, J. H., De Sereh-Ziekte S. A. Archief voor de Java-Suikerindustrie. 1897 ; Afl. 3.

s) Hzix, A. S. A., Hypothesen en Ervaring omtrent de Sereh ziekte. De Indische Mercuur. Amsterdam 1905; cit. Jahresber. f Pflanzenkrankh. v. Hoturdxi, Bil. VIII, 1906, S. 245. 
schiedene Untersucher auch verschiedene Krankheitsformen unter den Händen gehabt haben dürften.

Von den positiven Ergelnissen hehen wir einign 'Tatsachen herans, nämlich, dats gesundes Rohr mitten in serehkranken Ptlanzmugen sich gesund erhalten kam, und dat's zweitens krankes Rolur in gesunden Feldern krank bleibt. Es kommt ferner hinzu, datis manchmal tiete Feldränder zuerst orler allein erkrankt sich zeigen, mud hals das stark zur Erkrankmug neigende ('heribon-Rohn im ciebirge angeptlanst, wesunde stecklinge ergeben hat. Bekannt int autiverdem, dats rinzelne Varietäten nahezu immun, anclere sehr: hinfällig sincl. Ja, Ntrellinge derselben Varietät aus serehfieien Örthichkiten halten sich anch in infizierten (regenden zmächst gesmol. Darans geht hervor, dats die Krankheit sehwerlich parasitär ist, somblem in die Gruppe der Gimmmosen fällt. Es wird tabei gar nicht bestritten, dafis anch bakteriöse Gummoseznstände bei der Sereh existieren, ähnlich wie bei der sichwanzfänle unserer Znckerrïben, aber anch diese Formen hängen von gewisinn Schwächezuständen des Pflanzonleibes ab, die wir al Verschiebungen der enzymativchen Funktionen bezeichnen.

Wir erblicken in der räeksichtslosen Kultur des Zuckerrohrs bei gesteigerter Dünger- und Wasserzufuhr anf schwerem Boden in greschlosisenen Lagen usw. die Ursache, dat's das Rohr nicht genügend ausreifen, 1. h. Reservestoffe, also hier Rohrzucker ablagern kam. 'Tatsächlich ist der Rüekgang im \%nterergehalt hei der sereh mugenein grols.

Wir sind nicht in der Lage, den Vorgang zu prizisieren, der den

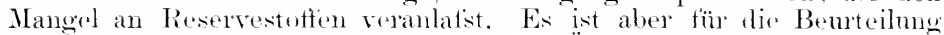
der Krankheit gleirhgültig, oh, dabei ein Übersehntis ablanender orler eine Lähnung anfhanenter Enzyme vorhanten ist. Ilir Stoffwechselvorgänge, welche zu diesem Rohrzuckermangel fühn'sn. sins natürlich in der ganzen Pflanzer vorhanden, gleichviel wo sie sich simptomatiseh geltend machen. Also jeder kleniste Teil des kranken Rohres, anch wenn er keine symptome von sereh erkemnen lälst, ist tatsö̈chlich prällisponiert mul enthält eben die abwegigen stoffwerlswelvorginger. Mithin ist jeder Bibit (Steckling) einer serehliranken Pflanze ein Todeskandiclat. sobald er in Verhältnisse kommt, wolche dor krankheit gïnstig sind: er heilt sich alner aus und kommt zu normalur Enzymtätigkeit zurück anf' Läntereien, wo Seseh nicht zum Anshroneh komnnt.

Daraus ergibt sich als bestes Nittel dic Answahl serelitester sorten oder wenigstens die Anzucht von Bibits in freien Gobiroslagen und sonstigen Grtlichkeiten, welche die Krankheit nicht anfliommen lasisu. Wahrseheinlich wird eine Kulturäntermeg in der Richtmmg, dats mur

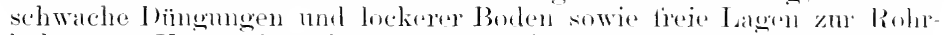
kultur zur Vorwendung liommen, anch in ansgesprochenen Krankiseit: herden dir sioreh zmm stillstant liommen lassen.

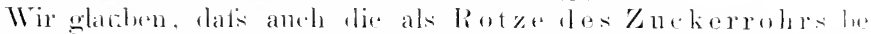

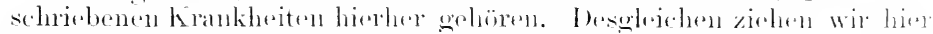

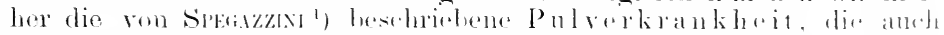

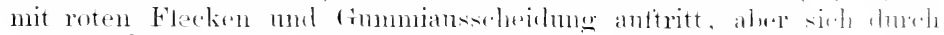

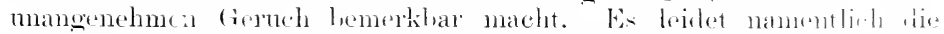

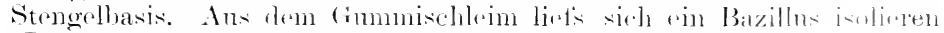

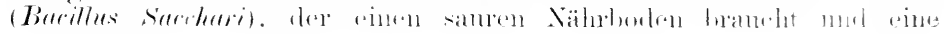

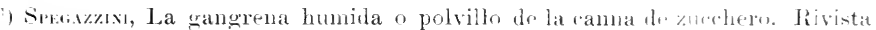
azucarera 1 $1 \% 9.5$. 
Eireifstäulnis hervorruft, welche die Veranlassung zu dem ekelhaften (remeh des kranken Rohres gibt. l)ieselbe Krankheit kommt anch bei - Imelropoyom mitams vor. Betreftis des Zustandekommens der Rotfärbung der frefätsbündel und des fimmis beim Kuckerrohr durch Mikroorganismen ist eine Arbeit von Grist surt') ron lesonderer Wichtiolieit. Fr fand rote Gefäfshïndel sowohl an sonst gesundem Rohr als auch an len von Bacillus rusularum Cobb gummos geworkenen Stengeln. Die rote Färhmo war durch die Anstüllung der grotsen Gefäfse dureh ein lotes Gimmi entstanden, wie bei der Sereh und anderen Zuckerrohrkankheiten. Er tand ferner einen Fadenpilz, der aut Nährmedien mit Dextrose eine olänzenrle, hoch scharlachrote Färbmo, aher kein Gummi erzengte mul in den erkinkten Gefätien Gummi-

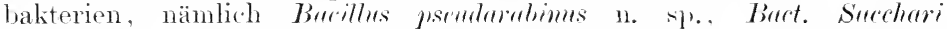
(..diese Art bewolnnt normalerweise (las Zuckerrohr") und autserdem Burt. rascularum. Auf Platten von Nährasar mit Laevulose produzierta, ler Pilz keinen Farbstoff, aber in Kombination mit Burt. psendumbims worde ein lenchtend scharlachroter, mit Bact. Succhari ein rosthramer erzengt.

Aus diesen Beispielen ersieht man, wie die Beschationheit des Mntterhodens die parasitäre Tätigkeit zu modifizieren imstande ist, und aut weleh. Weise daher wechselnde Krankheitsbilder entstehen. Torberlingung füir das Zustandekommen der Krankheit ist aber cine Abwegigkeit der normalen stoffwechselvorgänge im bisher gesunden Rohre, welche die Vermehrung ron (wahrscheinlich stets vorhandenen) Bakterien begïnstigt und die bei den verschieden empfänglichen Rohrsorten balı trïler, bald später eintritt, bei den immunen sorten aber unterlleibt.

\section{Die Cobb'sche Zuckerrohrkrankheit.}

Nach Erwn SurrH ${ }^{2}$ ) hat die Serehkrankheit viel Ähnlichkeit mit der von ihm beschriebenen Cobl'schen Krankheit des Znekerrohres in Australien (und wahrscheinlich anch anf' Mauritius, Java und Brasilien). Die letztere charakterisiert sich anch chrch Zwerghaftigkeit des Wuchses, Vorkürzmo der Internodien, Albicatio, vorzeitiges Aussprossen der Knospen und Fortpflanzmog durch infizierte stecklinge. Sie muterscheidet sich aber wesentlich dadurch, dats das Herz des Rohrstengels rotzig wirl mul dafs beständig in den (hlutroten) Bündeln des Stammes massenhatt ein gelber Schleim (gum) anftritt. Durch sorgfältige Impfrersuche ist nachgewiesen, dals dic Ursache der Erkrankung Psendomomas ( $B a-$ rillus (COBB) rascularmm ist.

Die Rottärbung der Bündel (rntsprochend der Braunfärbung bei anderen bakterïsen Gummosen) hält s. fïr eine Reaktion der Pflanze.

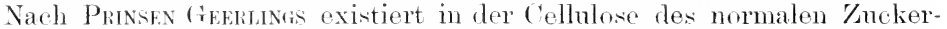
rohres ein nentraler, schwer löslicher ungefärbter Stoff, welcher bei Einwirkung von Alliali ins Gellse übergeht (wie Gerbstoffe, Ref.), aber bei Tourchlïftung rot und später bram wird.

Das interesiante Resultat ist der Nachweis, daf's bestimmte Rolurvarietäten (Common Green Canc) bei Impfrepsuchen eine anfserordentlich grot'se Empfänglichkeit zeigten, während andere Varictäten

1) R. Grew Smrn, Sidnev. Batiteriolog. Laboratorium der Limean Soc. of Now South Wales. Centrallil. f. Bakt. usw. 1906, Bd. XT, Nr. 25, s. 733.

2) Surn, Enwax, Trache der Colb'schen Kranklieit des Zuckerrohres. Centralblatt f. Bakterioloyie usw. 1904, Bd. XIII, Heft 22:?. 
(z. B. Common Purple ('ane) num ganz leicht erkinkten. Letztere zeigten nahezn den doppelten säuregehalt des saftes, ma sum vermutet, datis die hohe Emptänglichleit für den Parasiten ,nur auf der schwachen Aciditat oder dem minimalen Antroten einer suezifisch hindernden s'äure" beruht. C'obB berichtet, dat's dort. wo solthe widerstandsfähigen sorten angebaut wurden, die Krankheit versolwwulen sir.

Zn derselben Kranklieitegruppe gehört die von mir als . halit er jöse Gummosis" zuerst heschriebene, später als . Rïldenselowanzfäule" bekannt gewordene Krankheit der Kuckerrüben (s. II. Teil des Handbuches s. 42). Soweit Versuche erkennen lasien, enclangen die Bakterien nur ram zur epidemisehen Ansbreitung, wem hei rescher

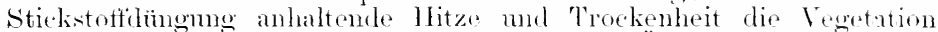
der Räben schwäclen. Tritt bei lerselben Überdïngnus fenchtes Wetter ein, weht zwar der Zuelierertras be lontend zurieck, abor bakteriöse (Gummosis bleibt ans ${ }^{1}$ ).

\section{Peach Yellow.}

Seit 188 ist eine Krankheit der Pfirsichen in den Ver. Staten von Nordamerika dem ernsteren Studimm nuterzogen worlen, welehe den ausgedehnten Kulturen ungemein grotsen schaden zutïnt. Es handelt

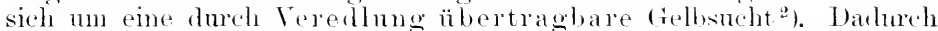
unterscheidet sich diese (ielblaubigkeit vou den älmblichen. durch Nährstettmangel, Frost nsw. veranlatsten Erstheinmong. Bei der Krankheit, die seit zwanzig Jahren in steter /muahme begritten ist mul in manchen Landschatten (Dolaware nud ('hesapeake Region) den Pfirsichban mlohnend gemacht hat, gilt als charakteristisch zmächst rine eigrnartige Rotfleckigkeit mul vorzeitige Reife ler Fröthte. llierzu liommt die vorzeitige Entwicklumg der Winterknospen und reichliche Proventivund Arventivangenanshildmo. Also krankhafte Verzweigung wie boi der sereh. Während die hisweilen anch im Fleiseh rotstreifigen Früchte im ersten . Jahre noch normale (irötse haben, verkloinern sie sich in den folgenden Erkrankmus jahren und werden geschmarkhs orler gar bitter. Dre Erscheinmor ist zunächst anf einiqe Aste bsebränkt, breitet sich aber allmählich über den ganzen Bamm aus. Dabei tängt das Laub an stellenweis gollogiin zu werlen, und scliwächliche, bleiche

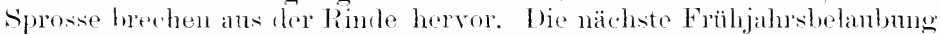
tritt damn schon gell, oder rötlichoriun horans: die nenen Trinbe verbutten und ihre Blätter rollen nul verkiömmen sich. Bisweilen zeigen alle gesunden schlanken Triobe plötzlich an ihrer spitze eine sich fortwähend wiederholende Bildung von immer schwächlicher wrelemten seitenachsen. nud es antstelen (meist im Ilerbst) ranzo Sprodsnester. Früler oder später tritt der Tod ein. Bei Olinlation von gesmolen Augen erliranker Bämme zeigte sich ain grotier Prozentsatz der (Oknlanten erkrankt, und zwar nicht blots der ans dem Ange sich entwickelusle Trieb, sondern auch dir Unterlage. ähnlech der Panachiernog in der Allicatio.

Zmäelst als eine Varietät der greschilderten Krankheit walt dio Peachrosette, die anch an Phammen antitt nut nummelr von sum

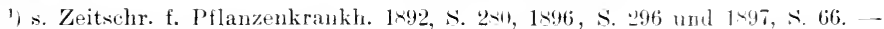
Blätter f. Zuckerribenbau $18 .+4$, s.. 1.

") Sun, E. F., in Report of the chief of the section of lencetable Pathology. Washington 1890. - Sum, Enws F., Additional evidence on the communicability of peach rellows and peach rosette. Washington 1<91, Bull. 1. 
als besmolere Krankheit angesprochen wird. Hhr Verlant ist mogemein schnell, so dats schon in demselben oder spätestens im tolgenden Jahre der 'Tod eintritt. Auch hier entstehen Blattrosetten durch antiallig reichliche Entwicklung sehlafender Augen und Ansiprossung normaler Seitentriebe, die aber kam ein Sechstel der Iänge gesmoler Triebe erreichen und sofort wieder seitensposse entwickeh, die wiederum sich rerzweigen. Solehe /weignester (nthalten manchmal g(m) bis $4(n)$ kleine Blätchen und mificgestaltete Nobenbläter. An der Basis der Triebe sind die Blätter gröfier und hesser ausgebildet, aber eigentïmlich an len Rändern eingerollt und durh eine gewisse startheit der Mittelripe anflälig steif. Diese Blätter werten schon im Frühsommer gelb mut fallen ab: im Lanfe des sommers trocknen die wanzen Rosetten ein. Inie Blumen an den erkrankten Trieben entwickeln sich hier aber micht fiüher, sondern eler ctwas syäter als hei den gesmolen; dagegen fallen dic gummos werlenden Frïchte ab, wem sie noch grün sind mol zeigen niemals die roten Flecke, wie bei der Peach YellowKrankheit. In beiden Krankheiten erweisen sich die feinen Seitenwrmzeln geschrumptt und ahgestorben, und die Rosettenkranklieit ist vielfach mit reichlichen fummiherden vergesellschattet getunden worden. Anch die Rosettenkrankheit ist durch Okulation anf die Unterlage ïbertragbar. Nur entwickeh sich in der Regel viel mehr normale seitenancen an einem /weige zu Rosetten, und daclurch wird die Büschelbildmo eine dichtere als bei der Peach Yellow.

Betreffs der Ursache sind dis Meinmoen geteilt; doch kommt hier die Bakterientheorie weniger zum Aurdruck, nachdem anerkanut worken ist, dafs Mycel und Bakterien in vielen Fällen nicht zu finden gewesen sind. Nan kommt also hier viel allgemeiner zu der Anschaumg; fats es sich $\mathrm{mm}$ eine Konstitutionslirankheit handelt, hei der die abwegigen Sitoffgrulven, wie bei der Allieatio mol der Mosaiklirankheit sich dureh Veredlung ïbertragen lassen; hier ist sogar die T̈bertragmo durch den Pollen wahrscheinlich, da Mokst ${ }^{1}$ ) heobachtet hat, dats von (trei Pfirsichsorten zwei erkrankten, eine dritte aber, White Magdal'ne, gesund blieb. T)iese liets sich mit anderen nicht kremzen.

Von den antierordentlich zahlreichen praktischen Versuchen, die namentlich smтн ${ }^{2}$ ) angestellt hat, kann als Resultat nur gemeldet woden, dals darlmoh kein Hinweis aut die Ursache erlangt worden ist. Nährsteffmangel nud - ̈̈berschnfs kïmuen in gewöhnlichen Jahren nicht als frumel einer Erkrankung angesehen werden: loeh läts sich beobarliten, datis regenreiche und kïhle sommer eine Abnahme, grofise Thockenperioden wine Kmuahmo dor Erkrankmogen zeigen. Boi der Rosetten-

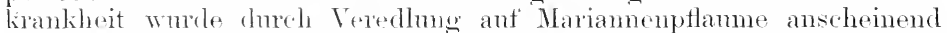
rin Schutzmittel gefunden, la dis rom kranken Pfirsich stammenden Angen sich zn gesmolen Trichen antwickelten. Infektionsversuche mit stwa 20 versthofenen Bakterien- mol llefearten ans dem Gewebe

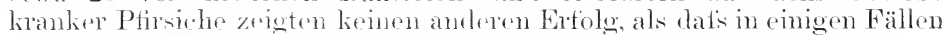

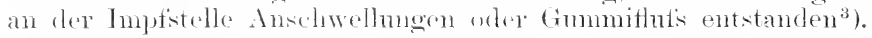

1) Monts, E. W., On the power of some peach trees to resist the disease called nellows." Bull. Bussey Instutution, Cambridge 19ul; cit. Zeitselur. f. Pflanzenkr. $130+2,5.5$.

$\Rightarrow$ suru, E. F., Experiments with fertilizers ete; cit. Zeituehr. f. Pflanzenkr. 1094, ค. $17 \%$.

) Sunn, E. F. Additional notes on feach rosette. The Journal of Mycology. Tol. VIl, N1: :, 1-!):? 
Mandelbäume leiden von beiden Krankheiten. von der Gellsweht auch die Aprikosen und die japanische Pflamme ${ }^{1}$ ).

Unserer Anschammo nach handelt es sich hier anch mm Schäden, die durch intensive Kultur und Nichtberïcksichtignng der Bodenansprüche des Pfirsichbames hervorgebracht werden. Alle schworen und sehr

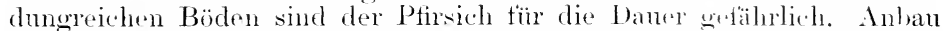
aut fockeren Bodenarten und frejer Standort diurten bei lex Bekämpfumg in erster Linie zu herücksiehtigen sein.

\section{Der Gummifluss der Kirschen.}

Der (immnifluts ist als eine weitrepheitete Erscheinmug, namentlich in der Familie der Steinobstgehölze hekannt, fie durch sehr versehirelenartige Ursachen hervorgernten worden kann.

Hanpträehlich sind es bei uns die Kirschen und Pfirsiche. weldhe am häufigsten an Gummiflus leiden. Wir sehen bald hellgelbe, durehsichtige, hald brame, trübe, teste Massen üher cinen Teil rler Rinde eines Zweiges, oder Stammes eroosien. Diese Massen sind in kochentem Wasser lïslich, in Weingeist mböslich, mbristallisierbar, woben mit verdümnter Sehwetekäure gekocht einen gärmngsähigen /ucher mol liefern, mit Salpetersäme behandelt, Schleimsäure, sinel also ein Glied jencr Gruple, welche dic organisehe Chemir mit (immi bezeichnet. Jo nate ihrer Quellhaticit im Wasser hat man ressehiedene Arten ron Gummi mnterschioglen: das in kaltem Wasser vollständig lösliele (timmi hat man

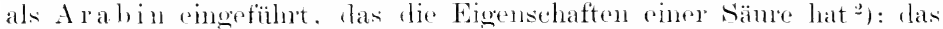
in Wasier zn einer lilehenden tiallerte antignellenle Tragantgmmmi ist ein Repüsentant der Bassoringrupe, mol als Cerasin wurte die Modifikation des Bassorin angesprochen, die in kochenden Wasser löslich ist. Das (immmi der Kirschen mol Pflamnen ist pin fiemisch vom Arabin mul cerasin. Wir dürfen ammehmen, dat's das bei der bummose geliblete frummi je nach der /eit seiner Entstehumg mud je nach Charaliter der (rewebr, ans denen es entsteht, in seiner Kusammensetzung weehselt. Es dïrtte Verwandtschaft mit den Pektinsubstanzen besitzen. Das arabische Gummi trägt den Charaktry eines organischen Kalkialzes.

Den besten Einblick in das Wesen der Krankheit orlangen wir hei Betrachtung eines jungen, stark gummosen Kirschenzweiges, wie er in Fig. 15. 111 . 2 dargestellt wirl. Hier zeigen sich zunächst mitten im normalen Holzkörper einzelne Gefät'se, welche gänzlich mit frmmi angefïllt sind (Fin. 15.) \& a), und zwar hat sich ilasselbe zum Teil sehom aus der sekundären Gefätsmembran evebildet. Durch Behandlung nit

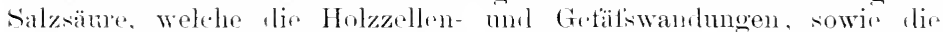
eigentlichon Bastollen lenchtend liamiurot förbt. erkennt man den

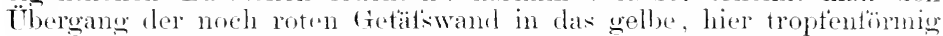
aufsitzende (inmmi sehr laicht. Diese Erseheinumg ist hänfig nur Vor-

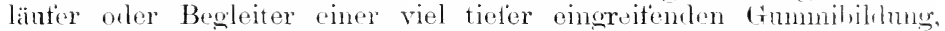
woduch protse frummitrusen in Holz und in dre Rinde antstelentl.

schon an einjährigen \%weigen gelingt es, die ersten sumron dos Gummifluses zn entrlecken. Bei Durehmustermug von querschnitten jugentlicher Zweige, an donen sich lie (rummosis nur durch Anftreten eines äufserst kleinen, sehwarzen Punktes dem hlotsen Ange liemutich

1) Cit. Zeitschr. f. Pflanzenkrankh. 1×96, S. 156 .

2) Czipk, Fr., Biochemie d. Pflanzen. Leipzig 1905. Bil. I, S. 5.j. 
macht. zeigen sich hisweilen hellere stellen im Holzkörper, die bei genanerer Untersmehmo ans parenchymatischen anstatt ans prosenchymatischen Zellen zusammengesetzt sind. Dieses abnorme Holzparenchym (Fig. 15, $2 l^{\prime}$ ) ist meist von dem normalen Holzliörper eingeschlossen, der es anch rom Cambinm (\&) abgrenzt. In der Regel sind diese helleren stellen, welche parallel der Peripherie und meist getrennt durch diume, radiale streiten nomalen Holzes nebeneinander gelagert sind, in verschieflenen Entwicklmosstadien. Einige sind vollständig unversehrt, andere zeigen bereits die Zellen in der Mitte zn Gimmi nmgewandelt: in einzelnen Fällen ist schon das ganze abnorme Parenchym nud ehenso das festo. normale Holz in vollständigem T̈bereange zu (immmi (Fig. 15.) 2d). Es wird dabei die Intercellularsubstanz znerst aufgelöst : damn folgt die primäre mol endlich die sekmndäre Membran der Gefäfse mol holzzellen. In solchen mrötseren Gummilückin tritt ein rigentïmlicher Vorgang von Wachstm einzelner Zellelements nehen der gleichzeitigen Auflösmo der ülrigen ein. Während nämlich die Holzzellen und Gefätice der Gummifiziernng unterliexen, wachsen zmüchst einzelne Markstrahlzellen etwas in die Länge: die stärlie. wolche sie enthalten, wird anfgelöst; in einigen hemerkt man hier und da zwei nene Kellen, die sich in divergierenden Richtnugen verlängern. Die mehr nach imm liegenden, vom fimmiherde etwas enttirnteren Markstrahlzellen runden sich ab mol verlängern sich ebentalls. nnd so entstehen zahhoiche Fäden, welche Ähnlichlieit mit manchen Algen (Trentepolitia) haben (Fig. 15. m) und welche frei in die Gumminasse hineinwachsen. Allmählich vertallen auch diese Fäden der Grmmosis: anch sie werden von auf'sen nach immen autgelöst, was jedoch nicht in bestimmter Reihentolge stattfindet. Manchmal sieht man die Zellen an der spritze des Fadens bis anf cinen diumen Überrest der Wandung verflüssigt; in anderen Fälleu sind Zellen an der Basis aufgelïst, ind es liegt dam das treigewordene Fadenstïck isoliert in der Gumminasse.

Ganz ähnliche Toränge zeigen sich in der Rinde, deren dickwandige Bastzellen (Fig. 1, b) sehr leicht der Gummosis unterliegen. Die Gummiherde sind in der Rinde hänfiger anzutreften als im lIolze; in seltenen Fällon halse ich die ersten Anfänge nur im Cambium selbst gefunden. mul zwar bei Pfirsich mehr als bei Kirsche.

Wo alwer anch inmer die ersten Antängo sich zeigen mögen, stets ist dat Übel hei weiterem Umsichgreiten gefählich. Im Holz entstandene Gummifizierme trilt sich bahl dem cambinm und der Rinde mit; bei grötserer Ansdehmmg in der Rinde, dis wohl den grötsten Teil des mach antisen tretenden (immmis liefern mag, bleibt tioir die Folge auch das Cambinm nicht morerseht. Die Behamptung, dat's die Gimmose stets im Cambinm beginne, ist num damn richtig. wem damit die Anlage nuvollkommen a usgableter Kellen, die später der Schmelzung verfallen. Eemeint ist. Iler Verflizsigmosprozets selbst kam an jeder Strlle dro Achse mol viel später begimmen, als die Anlage dieser Gewohe statterfunden hat. Daher sehen wir Gummilücken miten im Holzlioinger.

Das Endresultat ist im wesentlichen dasselbe. An einer stelle des stammmonfanges ist schliefslich das Cambimm vernichtet und der schon gebildete Folzkïnper mehr orler minder krank. Eine sich weiter amsbreitende Wunde ist vorhanden: liesolbe ist aber äntserlich nicht immer kenutlich: dem nicht immer wird oine kranke Stelle durch nach 


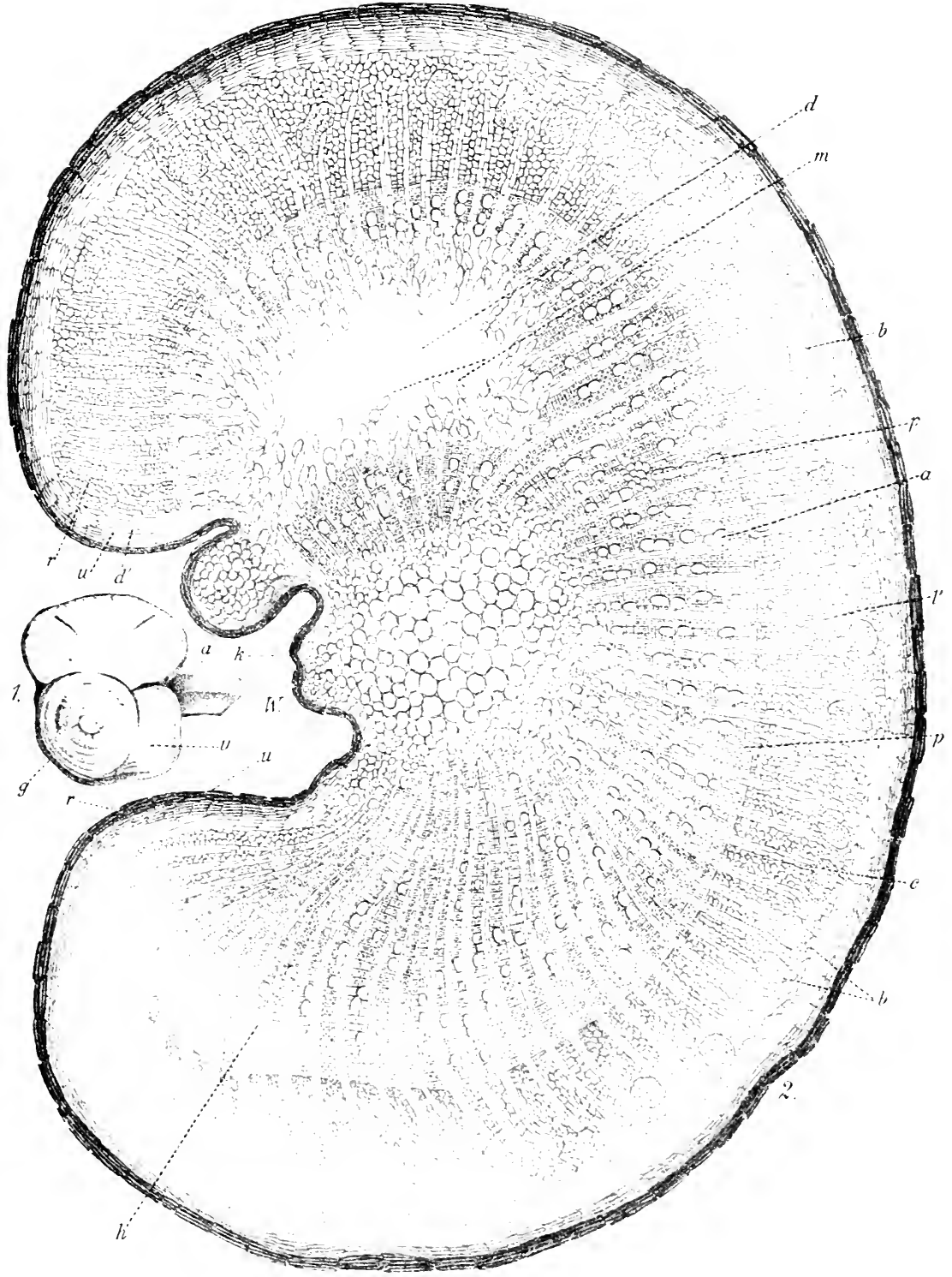

Fig. 15. Einjührign Zweig einer Sibskirsche mit ausgebildeter timmmintrue und

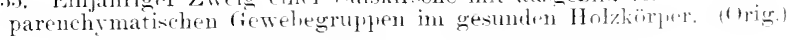


autsen getretenes Gummi bezeichnet. Selten oder doch erst sehr spät tritt fimmmi nach anf'sen, wemm das ('ambium zuerst von der Gummosis eroritten ist. Es stirlut dam das teste, vorhes gebildete Ilolz nur langsam ab, und zwar allmällich mehr nach der Tiefe des stammes, nach dem Markliörer (Fig. 155 2k) him, als in der Richtme des Stammmontanges. was ron den gleichzeitig mit der Krankheit anftretenden T̈lerwallungsostrebungen herkommt. Ein Fall, der in der Zeichnung (Fig. 1,s 1 1, dargestellt worden ist mel nicht selten vorliommt, besteht darin. dafs der Rindenkïrper mit Ansnalnme siniger Bastbündel über lem gnmmosen Holze nicht anfugelös wirl, sondern znsammentrocknet. Dort ist der in der Fin. 155: mit II markierte Ramm durch die Rindenelemente (Fig. 2r) B̈berspant. Ine timmibilelung ist dann keine sehr reiche: aber 10 so rejoles tritt das strehen des Bammes hervor, flie Wuncle zu heilen, was am einjährigen /weige schon dentlich wahrnehmbar wird. Fig. 15. 1, die einen älteren ommosen Stammteil darstellt, zeint in "die mohrjälrigen Überwallmusvasuche des Bames: " ist ein abogenter $/$ weig.

Reichlichere Holz- mut Rindenbildung an den der Wunde zmnächst liegenten gesmeten Stammteilen (Fig. 15\% $2 /$ ) machen ten stamm an der Wundseite dicker als an der cresunden seite $l^{\prime}$ und ober- mul mterhall, ler Wunde. Wenn die Rinde über der Wunde rhalten bleibt, heben die Überwallungsänder Fign. 15.j u) die trockne Rinde von dem kranken Holzkïper ab, und es bildet sich ant diese Weise eine Höhle, deren hintere $\mathrm{IV}$ and von dem der (immose teilweise anheimfallenden Holz- mol Markkörper, deren vordere Wrand ron der vertrockneten (in unserer Figm nicht rezeichneten) Rinde und deren seiten von den frischen Überwallungsändern I) dadurch entstehende Höhle ist ein Anfenthalt von Insekten mul Pilzen.

Aber anch die nengebildeten Überwallnngsänder bleiben selten intakt. In den meisten Fällen sieht man in flem ülpig entwickelten, nenen (iewelue kleine Gmmmiherde (Fig. 15.5 $\left.2 d^{\prime}\right)$. Ywar sucht die lelrendige Rinde die kranke Stelle durch Sehichten von Lederliork einzuschlichen: allein eine Heilmo habe ich nicht bemerken liömen. Inuch dieses Anftretru nener Grmmiherde im T̈borwallungsgewebe elklärt sich fas schwere śchlietien fer Wumde.

Ans der Betrachtum des abgehildeten gummösen Kirsehenzweiges lablen wir folgende Punkte hervorzuheben: 1. die Entstehmo parenchy-

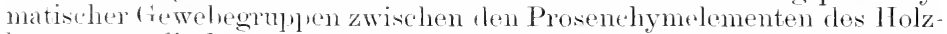
kïrpers: 2. die Lage tieser (imppen zwischen zwei Markstrahlen, welehe mu dixe Parenchymnester hermmliegen kömnen nud (seltener) sich anch an deren Bilflimg zn beteiligen vermögen; :3. die Entstehmng dieser Gruplen unahhängig von Wunden: t. die schmelzmng dieser Gewebenester zu (inmmilidien, in welehe dir resistenten Markstrahlzellen fadenartig hineinwalhen. lestzterer Unstand erklärt sich dacheh, dats in derselben ambialen Ringzone rincs tweiges oder Stammes die Markistahladhen dem zwisclien ihmen liegenden Gewebe in der Entwhklmug roranseilen, also rarlial schon weiter in den Rindenkërper hinein vorlänert sind mul als s'chwellgewebe finktionieren. Zur Zeit des Antangs tes schmelzmesprozesses sind somit die Markstralılzellen

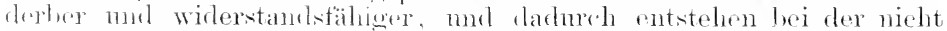

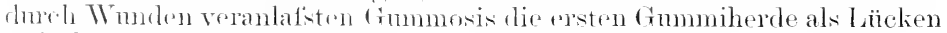
zwiselen zwei Markistralilen. 
Die neueren Erklärungsversuche üher tas Zustandekommen des Gummiflusses - über dis ältren Anschanmogen vergleiche man die zweite Autlage dieses Handbuchs - gehen von den Erscheinmogen der Verwundung ans. In einer sehr austïhrlichen Arbrit behannten BeIJERINck und Rave ${ }^{1}$ ), dats der Gummifluts ,aut einer durch Wn nolreiz verursachten ahmormen Entwicklung des embryonalen Holzw welos" beruhe.

Berserinck stellt sich die Sache so vor: Die normal. Ptlanze bildet cytolytische Substanzen, welche sich an der (retäts- und Trache ïlenbildung beteiligen. Das dabei elzeugte physiologische (immmi wird zwar gewïhnlich gänzlich resorbiert, bleibt jedoch nutr. Luständen als solches selbst in der Höhlung der erwachsenen (iefälise nachwoisbar. Der ,Gummithuts beruht num auf abnormaler steigermer der. Wirkung jener cytolytischen substanzen unter dem Einfluts abstrobender \%ellen, vielleicht dadurch, datis bei dor Nekrobios eine besonders grots. Menge davon elzengt wird. Unter Nekrobiose ist die /elltätiqlirit zu verstehen, nach Tötung des Protoplasma, aber hoi dem Aktivbleiben der enzrmartigen Kïrper".

Gegen diese Anschanmo wondet sich Ruhusn ${ }^{2}$ ), (ler zunächst darant autmerksam macht, (lats (iummifikation in Samen. Früchten ${ }^{3}$ ), Blättern und, worant' pr besonders Gewicht legt, auch in Phellowen stattinden kamm. Er tand im jüngsten Phellogen bei Promus crosus hedruteme Gummimassen und glauht, dat's es sich .hei der gummosen Autlösmo um eine allocmeine Eigensehat embromaler \%ellen hamlelt, die aber in nornalen Leben ni.ht zur Ans lösming kommt, sondern erst anf rinen

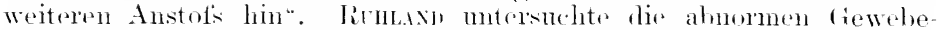

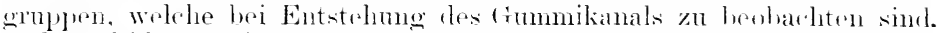
und fand hlasenartie vergöbliserte Kollon mit zwoi ansgebildeten Kernen. ohne dats zwischen ihmen eine tellwand golibldet worden wäre. Ier Vorgang wird durch the motehende Fig. 1.iti rrläntret.

Also die Zolltäden, wolche in ein timmidruse hineinragen, kommen dartureh zustande, dats ,eine nicht kranke, an der Basis drs Fadens liegende \%olle sich wiederholt teilt, die entstehenden Tochtr. zellen aher mur noch sich vergrötsern, ohne sich zu teilen." Es wirl der nomale Wandhildungsvorgang in den embryonalen \%ellen gehemmt und die zur (2nerwandbildumg bestimmten Kohlenhydrate in Gummisubstanz'n übergefülnt. Die Trsache dieser Anderung sei darin zn suchen, dats dureh eine Verwund rong die embronalen Gewobe dem Samerstoff' der Luft zugänglich gemacht werden: dir eigentlich zur (zuerwandhiklung hestimmten Kohlenhydrate (also Pektine) werden dann in

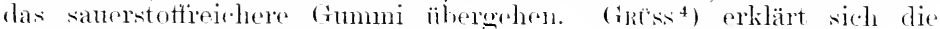

1) Betmaxes, M. W.. und Rixr, A., Wundreiz, Parasitismus und (iummiflufs bei den Anygdalaceen. Centralbl. f. Bakteriol usw. 190., XV, Nr. 12. - Rixi, A., Die Cimmosis der Amygdalaceen. Dissertation, Ansterdam 19oti.

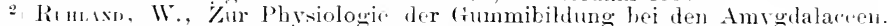
Ber. d Deutsch. Bot Ges. 194iz. Bd. XXY. s. :302.

3) Besonders bäufig kommt in nassen Jahren der Gunmifhufs bei den Früchten der Pflaumen zum Vorschein. In der Regel sind es wasserklare Gummitröptehn, die an dem Fruchtfleiseh ans Wunden, die von lnsekten herrühren, hervortroten. Nanchmal kamn man keine Insektenverletzung erkemen: es sind dam hiorter gehiebene. meist etwas abgeflachte stellen. welche ein fimmitröpfchen tragen. In Innern der Frucht erkemint nan unter der Abflachung eineu gröfseren (immnimerd. Bei Pflaumen sah ich anch Gummifikation des Steines an der Xiahtfliche auftreten, so dafs bei geringem Truck die Hïlften auseinanderfielen.

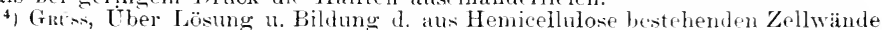
und ihre Beziehung \%ur (rummosis. Bibl, bot. Heft 39, stuttgart 1s!ti. Erwin Naegele. 
Oxrration durh o-ت̈berträger, welche sich bei dem Austreiben im Gewole bilelen. Schon frïher nahm Wissise ${ }^{1}$ ) ein Ferment an, das, glejell der Ibistase, die Guajakemulsion blänt und dureh Koehen zerstöt wirk. Bei der Behandlung mit Orein mul salzsäme tritt nach limzem Kochen rine rote oder violette Färbung auf, und es scheidet sich ein blaner Niederschlag ans. In Anfingstadinm der Gimmose sieht nan mu die Inhalte der Parenchrmzellen sich derart färben, worans zu sehlief'sen ist, dat's das Ferment im Protoplasma seinen sitz hat. Das Ferment ist in Gimmi dor stein- mol liernobstbämme, in arahischen und anderen (immmianten nacherewiesen worden. Dat's die sauerstoffzufuhr ein muberlingtes Erforlernis zu sein scheint, zeigen

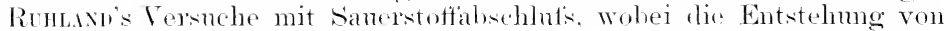
Gmmiheren miterblieb.

Nach muserer Anschammg ist dio Banenasck-Rostsehe Theorie von

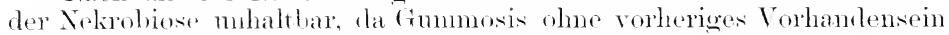
toter \%ellen in ganz jungen Zweigen und einjährigen sämlings flanzen

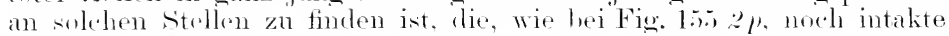

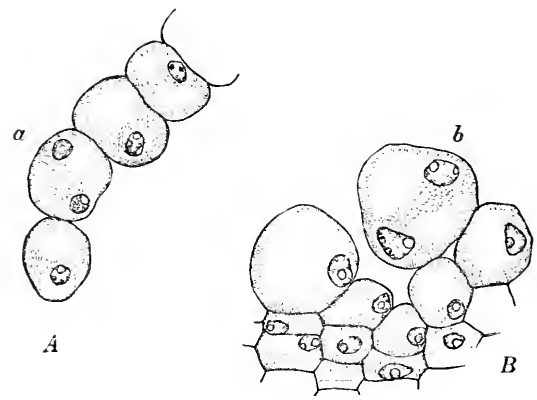

Fig. 156. Schnitte lurch las gummibildende Gewebe tf:xient mit Chromessigsäure.

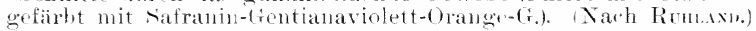

1 ein konfervenartiger Zellfalen, $k$ eine junce dimmilicke; bei " untl be eine zweikernige Zelle.

Cellemnester darstellen. Also der Wundreiz kommt hier war nicht ins spiel. Wir glanben violmehr, dats alle emlnyomalen mol ansorwachsenen Vellen

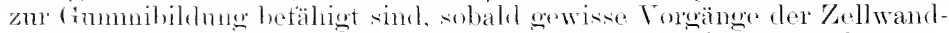

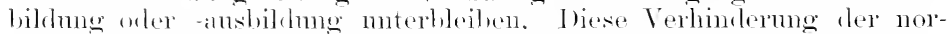

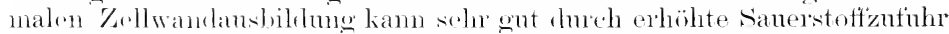

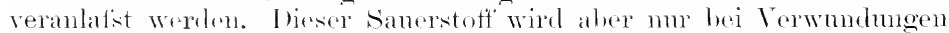
ler atmosh härische sanerstoff direkt sein kïnnen, aber wahrscheinlich mrselten tatsällich seriu, sondern durch sancrstotfïhertragende sub-

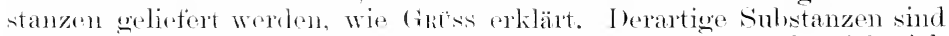
hei drom nomalen Anstroiben der Bämne vorhanden. Es handelt sieh bei dom trummithnts nur mon eind abnorme Staigernng in der

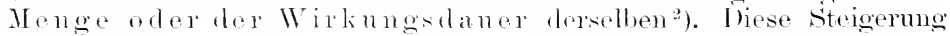

1) Wrasts, İber ein Ferment, welohes in dor Pflanze die Umwandhung der

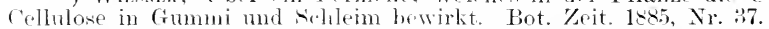

") Diese sulstanzen sind in wechseluder Menge je nach Individum, Standort, Jahreszeit usw. in Bamme zu finden: daher erklairt sich der verschiedenartige Frfolg bei der Hervorrufung des fimmifluses durh Verwminng. So sind bei- 
kamn durch den Wundreiz stattfinden, sie kam anch durch verschiedene Parasiten hervorgerufen und endlich dureh anorganischr (iifte erzengt werden. In letzterer Beziehung erwähne ich nu-in. Versuch. ïber Eintïhrung einer sehwachen Oxalsämelösmng mter dir Rinde ganz gesunder Kirschbämme. Es entstanden frofuse (xmmnierwiosso im lante des sommers, welche alhöhlich durch das Erläschen der Gxalsämewirkme antheirten und sich z. B. nicht ant Wunden fintsotzten, die statt der Oxalsäme nur destilliertes Wasser zugeführt erhaltrn hatten.

Betrefts dor Art und Weise, in weleher finmmitluts sich antwidielu

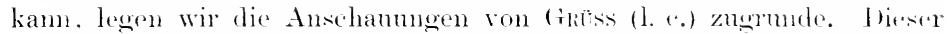
Forscher liommt bei seinen [Tutersnehmeren zu dem Ergebnis, dats dis Hemicellulosen Mamman, fralactan mul Araban direkt oder indirekt als Reservestotfe angelegt worden. Inokt woschieht dies in Form von

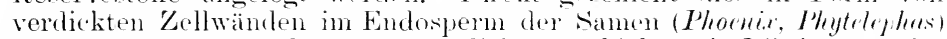
oder in Form von sekmolaren Verdickmesschichten in Tibritom- ofler Holzparenchrmzellen (Astragalus. Pranus-, Acreria-Arten u. a.). Als indirekte Reservestotfe kömen sie gelten, wem sie, wio im Endosperm ter Gramineen, dir \%ellwände der stärketïhrenden Zellen zusammensetzen. Die Hemicellulosen Galatan mol Araban werden durch Enzyme

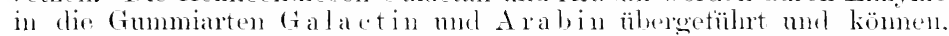
noch bevor sie in die Zuekerarten (ialaktose und Arabinose mogewandelt sinul, im tiewebe wandern.

Nun sind die gmmmibildenden sanerstotfïherträger in der Form von Enzymen, die bei tem Anstroiben dre Kuospen entstehen, tatsächlich nathgewesen. und zwar sind diesellen nowh vor der Diastase vorhanden. Die letztere wird dam die llemicellubsen oder deren

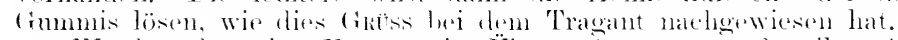

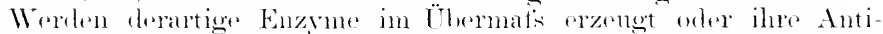

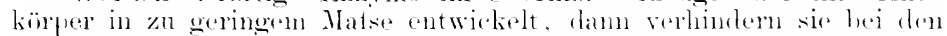

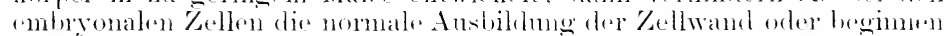
bei den fertigen Zallen des anserewarhenen Holzes den sehmelzung:-

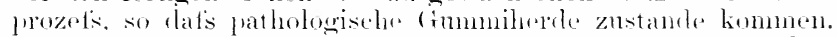

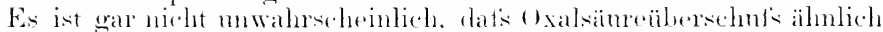
der hydrolisierenden schwetelsäure mul auderen Mineralsäuren so wirkt.

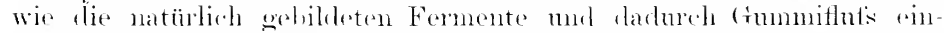

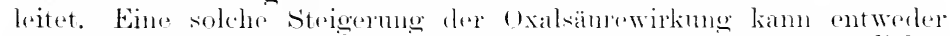
darlureh zustande kommen, dats sie reichlicher gebilifet onder spärlicher dureh kalk golmuden wirel. so math beispielsweise Mrosent) dar-

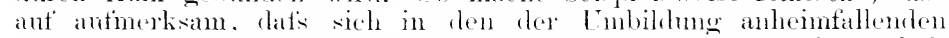
(rewelen fast gar keine Kalkoxalatkristalle vorfinden. Dats der (ichalt an diesen Kristallen mit der Emährme zusammenhängt, weht ans den Arheiten von Baxecke ${ }^{2}$ hervor. dre Thei seinen Kulturen fand, dats Kufuhr von Nitraten die Kallowalathildmug betördert, Ernährme mit Ammon diesclbe verringert.

spielsweise nicht die jüngsten \%weigspitzen die gefiihrdetsten, sondem die Region. in der das Gewele sich am meisten streckt, also die unterhalb der (iipfelregion. Betreffs les Eintlusses der Bammeiton und Jahreszeiten fand ich dureh almonatlich ausgefinhte Einschitte, dafs die Ze it des spïten Fröhjahrs und dis sullichen bis westlichen Baumseiten am tördrrlichsten für die Ausbildung der Gummose sind.

1) Мия⿻и一, K., Intersuhungen über die Entstehung des Kirschgumni. Sitzungsber. d. Akad. d. Wis. Wien: eit Bot. Centralbl. 190\%, XXVII, No. 27.

-) Bexers. W. Üher Oxalsiurebildung in grimen Pflanzen. Bot. Zeit. 190:;, Bd. LXI; cit. Bot. Centralbl. (Lotsr) 190:3, Nr. 2: s. 11\%. 
Von den Parasiten, welehe Gummifluk erzengen, ist in erster Linie

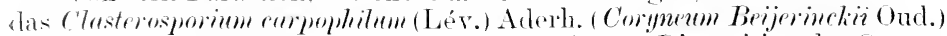
zn nemmen. Indes gehört selbst hier eine bestimmte Disposition des Organs (azn, wemn der Pilz wirksam sein soll; demn Arkrhold ${ }^{1}$ ) fand bei seinen Impfiersuchen an Blättern, dals Pilzflecke olme fimmibildmng antitraten, wie auch umgekehrt Wunden mit reichlicher Gummibildung in der Mittelrippe des Blattes und im Cambinm der /weige zu finden waren, bei denen der Pilz tehlte. So verhalten sich anch die ïbrigen Parasiten:

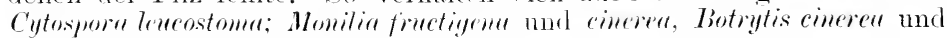
mancherlei Bakterienarten ${ }^{2}$ ).

Bei einigen rter genannten Parasiten ist as sehr wohl möglich, dafs Oxalsäme das vom ihmen produzierte Gift ist. welches die Gummose veranlatist.

Beror wir die Frage nach der Heilung des Gummiftusses berïhren, ist es nötig. die Anfmerksamkeit auf die Berlingungen zu richten, unter denen die Krankleit aufritt. Am hänfigsten findet man in der pomologischen I.iteratur die Ansicht [DH.nnes's bestätigt, dat's Kirschbänme, welche in eine zn kräftige Erde gepflanzt sind, am meisten der Krankheit unterworten scheinen. Beweise finden wir namentlich bei Pfirsich und Kirsche. wenn man unter einer zu kräftigen Erde eine tonige verstehen will: ant lockeren, warmem Boden, der sehr reich sein kam, findet sich fiummifluts seltener. Reichlich begegnen wir ferner der frummibilkmg bei wötsoren, mongshossenen Astwunden. Ebenso sehen wir dieselbe namentlich bei jungen Pfirsichzweigen anftreten, deren Rinde Amreh Quotschmng oler Reibung stärker vorketzt worden ist.

Bei meineri Tersuchen, bei denen von einer gröliseren Anzahl von Kirschbänmen in Frühjahr die sämtlichen Angen entfernt worden waren, trat mit sehr wenigen Ausmahmen Grmmiftuts ein. Bei anderen Tersuchen. bei welchen die Stämme auf eine grölsere Länge geschält worden waren, erschien an denjenigen oberen Ringelschnitstellen, an frenen sich lieine Neubildnnen in Form von Überwallungsrändem gebildet hatten, dir timmmosis in der Rinde. Bekamnt ist endlich, dats starke WTurel- odru Kronenbeschädignng bei dem Verpflanzen sowie anch schlechto Teredlung Veranlassung zur Gummibildung geben.

Alle diese Verwmulumen wirken mnserer Ansicht nach nicht durch Nekrobiose, sondern durch einfachen Wumlreiz, der ein ïbermätsiges Zuströmen ion Bamnaterial veramlatist, welehes nicht normale Terwendung finden kam. Es stellt sich gleichsam eine Überstïrzmg in der Neubildung von Kellen ein, die sich in der Anlage parenchrmatischer Elemente ani stelle prosenchymatischer Kellen limolgiht, wie bei allen sonstigen

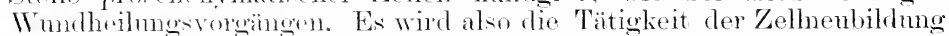
ïbermärio cefortert zn einer \%eit, in welcher hereits die antbanenden Enzrme vorlindschen mul die Wandverdickmgen sowie das Ablagern von lieservestoffirn äbrimchmen sollten. Dieses Vorherrschen der Enzyme des Jusendzustandes fühnt zur V'erflüssignng der abwegig gebilileten rewebegruplen. Eine solehe Terschiebung der Enzymtätigkeit ist in ihrer Wirkmng wie rine Wello antzufassen, die sich im Bamme so lange tortptlanzt, bis ihr clurch pine andere Bilelungsrichtung Halt geboten

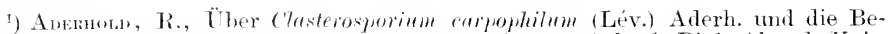
ziehungen desselben zun Gummiflufs des Steinobstes. Arł. d. Biol. Abt. d. Kais. Gesundheitramtes 1902, Bil. II, Heft $\mathrm{V}$.

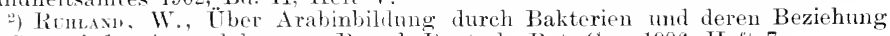
zum Grummi der Anygdalaceen. Ber. d. Teutsch. Bot. Ges. 1906, Heft 7. 
wirl. Nach den Erfahrumgen der Praxis wird ihr ein solehes Halt geboten durch alle diejenigen Faktoren. Welche nomale Holzreite und rechtzeitige Niederschlagung reicher Rescrvestothmengen bedingen: lockerer Boden, somniger treier Standort und Kalkzufuhr, Vermeidmus ïberreicher stickst oftdiüngus.

Kur Behandlung der gummiflüsigen Wturlen wirl von mehreren Seiten die Anwendung von Weinessig warn emptohlen: mir tohlen clarïber persönliche Erfahrungen.

\section{Der Gummifluss bei anderen Gewächsen.}

(*ummithluteder Akazien.

Dats die Bildung des Akaziengmmmis ant ähnlichen Metamorphosen wie die des Kirschgummis beruht, bestätigt MöLser ${ }^{1}$ ), der ganz alluermein ausspricht, dats das Gummi der Akazien immer lunch Lmwandhumg der Zellmembran, von autisen nach imen fortschreitend, entsteht. \%un̈̈chst sind es die Membranen des Parenchyms nnel der siebröhren, wetehe der Autlösmog verfallen. (1)ie zusanmengesunkenen siebröhren biliten Whasu's Hornplosenchym). NörLer beohathtete das (xummi stets

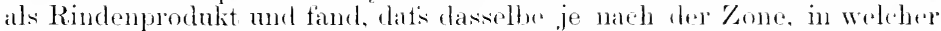
es entsteht, verschieden ist. Durch die Lösmog der Imenrinte entsteht Arabisehes Gummi, wähend rine lem firschemmi ähnliche, weniger lösliche Form in der Mittehinde anftritt, was wohl von dem

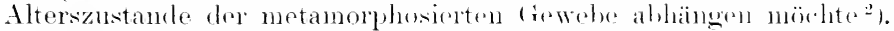

Als eine der Irsachen, welehe den Ansthuts von senenglemmmi ans

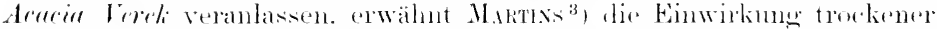
Wïstenwinde, welche im Herhst und Winter wohen mel die dureh dir. Angust- und Septenterrexen erelockerte Rimele der Aliazir zum Aut-

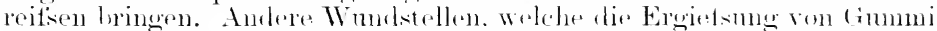
\%ur Folge haben. werelen dureh einen Sehmanotzer, den Martas als

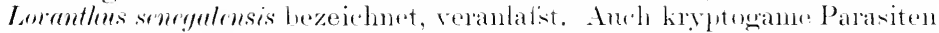
werden imstande sein ein ständiges lttenhalten von IFunden zu veraulassen unel damit cinen Roiz zu (immonibildumg auszuïlen. Wie

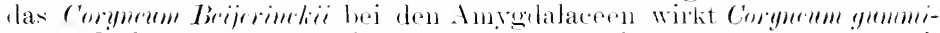

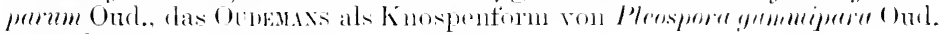
hetrachtet.

\section{(iummifllut's der Poneranzent).}

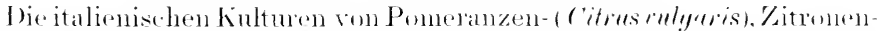

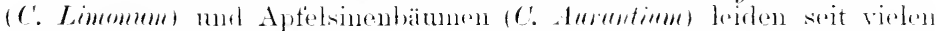

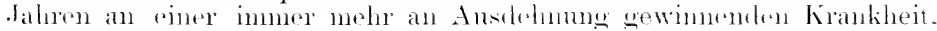

1) Maina, Uher die kntstehung des Acacien-fimmi. Sitzungsber. d. Akad. 1. Wissensebaften. Wien 1<7, Juniheft.

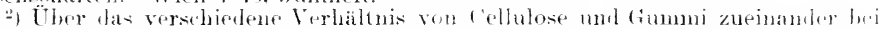

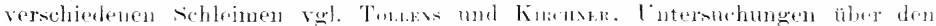

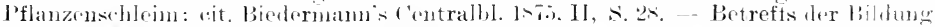

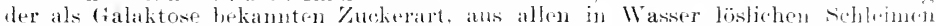

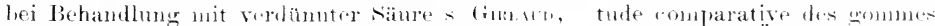

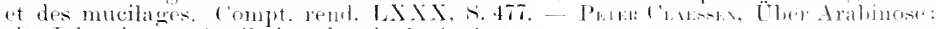
cit. Jahresher. f. Agrikulturchemie lsist, s.

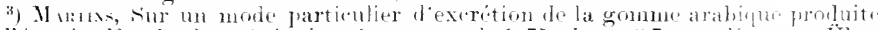

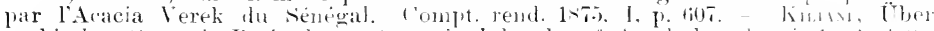

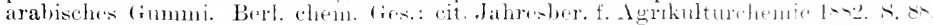

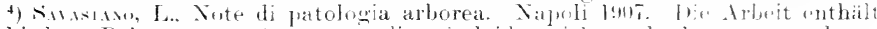

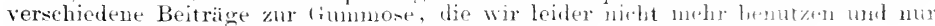
bei der letzten Korrektur noch erwïlnen künnes. 
dem ..mal drllı gomma" der Italiener, welcher derartige Beschädigungen

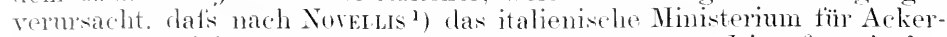
ban und Handel vor Jahren eine Prämio ron 2500( Lire für ein bewährtes Heilmittel atsonesetzt hatte.

Die Krankheit begimnt mit dem Auttreten sehwarzer, sehmell sich verorötsernder Rindentleckchen an stamme und an den Ästen, namentlich an den Gabelenden. Nach einger \%eit platzt die geschwärzte Rimdenstelle, und ans der Wundfäche eroiefst sich eine gelblichweitse Flüssiglieit, die allmählieh komsistenter mid klebriger wird und sehlietslich zu gelben Perlen oler einem glasmartigen T̈berznge erstart. Das Holz mier der Rindenöttinumg ist hram nol im Zustande gummöser Autlösung. Wenn das Gummi ant andere Regionen des Bammes dureh den Regen gesthwemmt wird, soll es nene Krankheitsherde rrzengen. Ähnliche Behanptungen finden wir anch betreft's des Akaziengummis. und es ist gar nicht mmöglich, datis solche Fälle vorkommen. Si. würden sich, wie boi der Mosaikkrankheit des Tabaks, in der Weise erklären lassen, dats die ahwegige Enzymkombination, die in der Gimmibildume ihren Ansdruck findet, den Anstots zu ähnlicher Umlagermon in disponierten gesmolsn Exemplaren gibt und sich wie eine Wellenbewegmes weiter fortpflanzt.

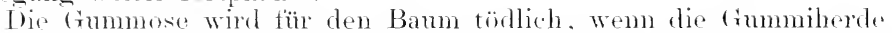

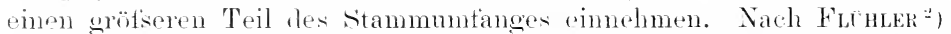
leiden die Zitronen am meisten, die Poneranzen am wenissten. Stecklinge scheinen die Krankheitsanlage heizubehalten und ebenso veredelte Exemplare einen göbsen Prozentsatz an Kranken zu geben als mveredelt gebliebene sïmlinge. Reichliche Düngmo, starke Bewässermg, toniger Borlen vormehren das Übel, das auch zunehmen soll, wenm Kwischenfrïchte, wio Kürbis, Bohne, Liebesapfol, Tabak u. derol., welcho starke I) ïngme vorlangen, wehant werden.

Nach dem mir bisher zugänglich gewesonen Material halte ich die Krankheit der Agrumen tür genau dieselbe Ersheinmo wie den (xmmmifluts bei den Anyralabreon. Als eme dex angenblicklich häntigsten Trsachen. welche anch in Dentschland bei den Steinohstfïchten in den Bammshulen rins grofie Rolle spielt, sehe ich die äbermäkige \%utuler stickstoffrejehen Dimerers an.

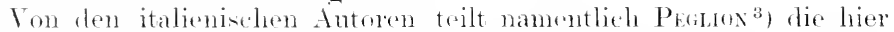
geänterte Ansicht. Er macht daranf antinerksam, dats der Unterhau fon Pflanzen. die eine reiche lö̈ngme leslïnten, schädlich sei. stall-

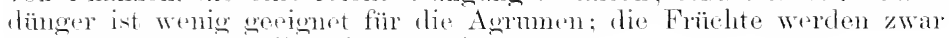

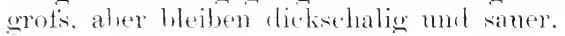

\section{Die Dintenkrankheit der echten Kastanie.}

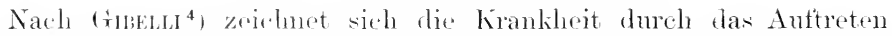
welker, gellorr Blättre mul kleiner, zurkerimmerer Früchte ans. An jungen Bäumen vertrocknet die Stammbasis unter Brauntäbung der

1) Novel,is, Errone in, Il male della gomma degli agrumi; cit. Bot. Centratblatt $1<50$, s. 469.

2) Fumns, Die Krankhrit der Agrumen n ricilien. Bientermam's Centralbl. 1874 , .. 368 .

3) Perion, V., La concimazione o lo malattia nella coltura degli agrumi. Boll. di Entomol. agras. ets lonl in Bot. Jahresber. 1501, I, S. 479.

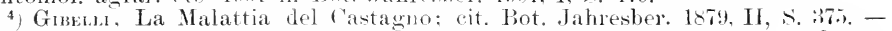
Grber.1 ed G. Anfoxible, Sopra una nuovil malattia dei Castagni, ibid. - Cugsi, Sopra una malattia che devasta i castagneti italiani, ibid. 
Rinde, deren fewebe bis stecknadelknfigrotise 'T'aminkonkretionen antweist. Die Analysen zeigen das charakteristilimn schlecht wachsender Pflanzen, nänlich grotsen Aschengehalt in Verhältnis zur Trockensubstanz: in rer Asche erkemnt man Mangel an hali mol Phosphorsänre und bedentende /mnahme an Eisenoxyd.

Betretfis der kngeligen Abscheidmeen, welche 'Tammintralition zeigen, scheint mir die Krankheit verwandt mit einer Form des $1 /$ al mon bein Weinstork (s. S. 219). Hiese Form wird ron Cones') direlit als (imm-

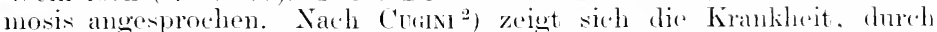

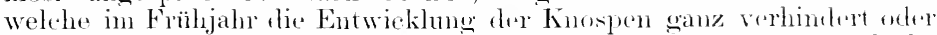
doels gestönt wird, durch das Erscheinen schwarzer Streiten mul Flerke an Zweigen, Blattstielen mol Rippen, Ranken mol Tranhenstielen an. bie Flecke erstrecken sith anf das Imere ther Grone, mol zwar im stamme sogar bis auf das Kernholz. Antsordem charaktrisiert sich die Krankheit dureh das in den parenchromatischen Elomenten des

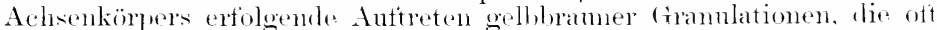
das wanze /elllumen anstïllen und weder ans eiweilshaltioger sulstan\% noch aus Colluluse hestehen. Cocise, der älnigens die Erscheinung doeh für parasitär lä̈lt, konstatierte anch das duftreten von Vereriummeren der Bläten und bringt liese Erscheinungen mit ter hrankheit in /nsammenhang. Unter inen Pathologen, welehe Parasiten gefunden

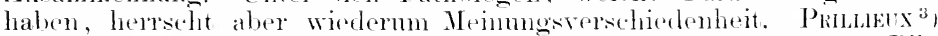

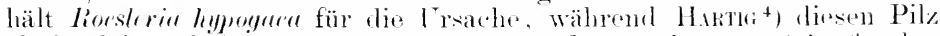
als Begheiterseheinmer mol einen anderen, Itematophona mecotrix, fïr den eigentlichen Parasiten erklärt.

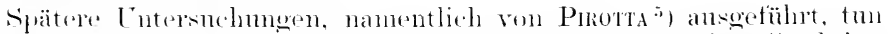
dar, dats die angegrobenen Körnehen in den Kellen de Gerhstotfreaktion

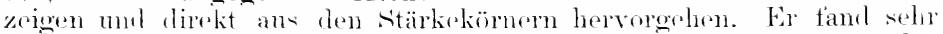
häufig, aber doch nicht immer. Rhizomorphen an fon lisanken Irurzeln: democh glanht or diese Tatsache nicht zwingend genne, mo die Krankheit als Pilzerkranking ansprechen zu müssen. Comes zeigte, dats dio fraglichen Körner keine Gerbstottanhänfimgen darstellen, sondern ans riner anderen (irundsulstanz (fimmi) bestehen, lie nur mit 'Tannin getränlit ist.

\section{Die Gummose der Feigenbäume.}

I) schon seit den \%eiten des Theophrast bekannte Krankheit des Feigenbaames (.. II a reinme dol Fieo" ther Italiener) hat dureh Sira staso") rine eingehende Bearbeitung erfahren nud ist von diesem $B$ o. obachter als fine Gummosis erkannt worden.

1) Conm. Il Mal nero della vite. Portici 1882. - Primi risultati degli experimenti fatti per la cura della (iommosi o Mal nero della vite. Portici 18s.. Sul preteso tannino scoperto nelle viti affette da Mal nero. Bot. Jahresher. 1si...

2) Cirax, Rieerche sul Mal nero della Vite. Bot. Centralbl. 18x1, Bu. VIIl, $\therefore$ 147. - Nuovo indagini sul Mal nero della Vite. Bologna 188.2. - Il Mal nero della Vite. Firenze Iš?.

3) Prumax, La pourridié des vigues de la Hante-Marne, produit par lo Roesleria hypogaea. I'aris 1

4) Hanirg. R. Rhizomorpha (Tematophora) necatrix. Der Wurchil\% des Weinstocks. Intersuchmoen ans dim forstbotanischen Institute $\mathrm{zm}$ Munchen.

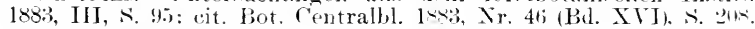

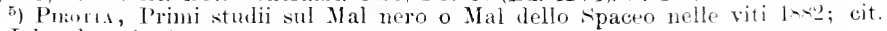
Bot. Jahresber. 1>-2.

6) Sarntaxo, L.. Il Marciume del Fico. Annuario della R. Simola sup. d'Agricult. Portici, Vol. III, fasc. $\mathrm{V}$, lsist con t. tav. cromot. (nach brieflicher Mitteilung). 
Am deutlichsten zeigt sich die Krankheit, der die alten Pflanzen mehr als clic jungen ausqesetzt sind, in den Monaten onli bis September, wo die Bläter gell, werden und abfallen, ebenso wie die Früchte. Obgleich man ant den welken und toten Blättem zahlieiche Pilze und auch Insekten findet (Fumago salirima Tul., Treto Firns ('ast., Phyllostirta sycophila Thüm., Sporodesminm. Coccus raricur Fab.), so sind diese Parasiten doch nicht als die Ursache der Krankheit anzusehen. An den Stämmen und Ästen findet man meist keine Veränderung. wohl aher an der Wurzel, in welcher der Hauptsitz der Krankheit zu suchen ist. Im hochoradigen Stadium erscheinen die Wurzeläste his an den Wurchals selowärzlich, teilweise anfoespalten oler schon geradezn vertanlt.

An den dureh sinosisen erzogenen jungen Pflanzen bemerkt man, dafs der sitz der Krankheit in clen Wurzelzweigen der Mntterptlanzen zu finclen ist, von wo ans die weitere Verbeitung allseitig, besonders aber in antisteigender Richtmo, stattfindet. T)ie meist erkrankte sehicht ist die änfiserste: nur zuweilen ist das Immere hochgradiger zerstört. Hat die Zersetzmug den Wurzelhals erreicht, geht rie Pflanze unbedingt, dem Tode entgegen.

Bei dem ersten Erscheinen der Krankheit findet man zellen und Gefätse mit einer siubstanz erfüllt, welche antangs zitronengelb und später dunkelhernsteingelb erscheint. Zuerst sind die Kellwände damit tapeziert und später das ganze Lumen ausgeföllt: mit der Kumahme dieser Füllmasse vorshwindet die stärke. Schon bei sämlingen beobachtete sirastaxo die Entstehmo von Gummiherden an der Öbervangsstelle der jungen Wïrzelchen in dio obcrirdischen Achsen. Ähnliches sah ich bei sütskirsthen, welche äutserlich keine spm von Erkrankmus autfinden lictien.

Auch an stamm und /weigen sah salastano die Gummosis auftreten: in deren fimmi fand er eine substanz, die ähnlich dem bei der Gummose des ölba nmes auftretenden Ulivile zu sein scheint. Die Gummose der oberindischen Achse wirl von den schon bei sämlingen in den Wnzeln sich rorfindenden Gmmirlusen abgeleitet. Erst nachdem die Pftanzen smmmikrank geworden, liefs sich die Rhizomorpha. die von anderen Forschern fïr die Urache der Erkankung angestrochen wird, nachweisen. Unter Rotfärhung der Wandmngen gehen die Parenchymzellen der Nruzeln einen Humitikationsprozefis ein, bei dem durch Verschwinden der organischen substanz das spezifische Gewicht des Gewebes immer geringer wirl.

Eine sätere Arbeit von SAdstano ${ }^{1}$ ) gibt die Resultate vergleichender

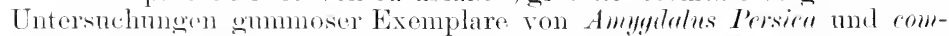

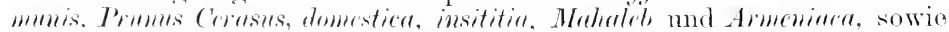

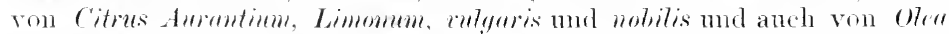

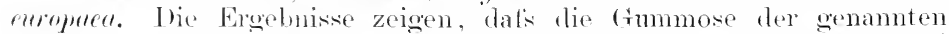
Pflanzen mit der ron Ficus Carion viel femeinschattliches hat. Bei allen erfolgt die Bililung der (immmiherde entweder infolge von Ver-

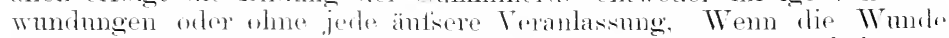

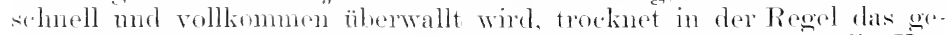
bildete Grmmi zn spröden Nassen zmsammen und bleibt fï̈ die fimwebmes shadlos. Tritt dacegen Fenchtigheit an die Wundstellen, dam wird das Gommi weich allatten, leicht in die Umgebung der Wumd-

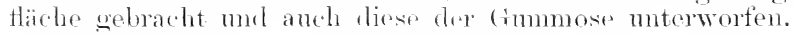

1) Gommose caulinaire dans les Aurantiactes, Amygdalées, le Figuier, l'olivier of noircisement du Noyer. Compt. rend. I, I lecembe 1xit. Separatabug. 


\section{Der Mannafluss.}

An stelle des Gummi treten bei manchen Pflanzen zuckerhaltige, erhärtende. helle Massen aus der Rinde junger stamme und Zweige, die als.. II anna "im Handel rorkommen. Das ausumende Verflüsigumgsprodukt enthält Mamnit, der durch Ausziehen mit Weingeist in feinen. schwach sütsschmeckenden. weitsen, seideglänenrlen hristallen erhalten werden kam und auch kïnstlich sich aus "inzehen /uckerarten darstellen lä1st. Untersuchmoren über Mammathuls rïhren licreits ron Merex', her. Nach diesem Forscher werclen die grotien Mringen Manna, welche aus Italien kommen, künstlich einer Eschenart, der Manna-Esche entlockt, indem man gegen Ende .Juli Einschnitte in rlie Rinde macht. Aus diesen Einschnitten fliefst allmählich rlas Mama als dicker, sülser, an der Luft erhärtender satt aus.

\section{Der Harzfluss.}

Das, was der Grmmifluts bei Amrgdalaceen und der Mannafluts bei Oleaceen. ist der Harzhuts ( $R$ esinosis) hei den Koniteren. Derselbe tritt bald im Holzliörper anf. bald ergreift er Parenchym und Bastzellen der Rinde. Die ersten Zustände der Krankheit zeigen sich im K i en ignwerden des Holzos: der ausceliblete Znstand besteht in Bildung grotier Mengen gleichmä1sige Harzmassen in verschieden grotien Hohlräumen ler Achse, die gewöhnlich 11 arzbeulen genannt werden. Bekannt ist. dat's Harz nomalerwrise als Zellinhalt in Troptenform ofler, wie hei den Leimzotten mancher (rehölzknospen. in Gestalt von Zwischenlamellen der Zellwand oder endlich. wie lei unern hieftrn und Fichten. in bestimmt verteilten, eigentümlichen Harzängen vorkommt. In der Lmoegend des Harzonges zeigt der Inhalt vieler Parenchymzellen Harztropten mor stärkekïrner. von renen nicht selten einzelne mit Harzïberzug rersehen sind. Das Material zur Fïllung der grotisen Harzhehälter muts notwendig zunächst die Lmgebung lietern. (1) dieses Material in Form von Harz wandert, wie X. J. C. MrLLER ${ }^{2}$ ) annimmt, oder in Form einer anderen Verbindung und sich dort erst zu Harz umlildet. wo es als solches autgefunden wird. wie HAsses. ${ }^{3}$ ) anzmehmen peneigt ist. das fällt fïm mnsere Betrachtung wenig ins fiewiclit, ra wir festzuhalten haben. dat's die Bildung gö̈tserer Harz- und Gummimassen nur möglich ist durch Umwandlung zuströmender plastischer Sahrung zu ren orten. Wo rlie Verflïsigung stattindet, also positiver säftevrlust ist. I lazu liommt für die Resinose wie bei der (iummose, dats auch tie getornte PHanzonsmlstanz in fiestalt von Holz- und Rindengewebe und ron stärkehörnorn rler Vorflïs-some verfällt. und rat's aut

\section{1) Pflanzenpathologie $\therefore$.2.}

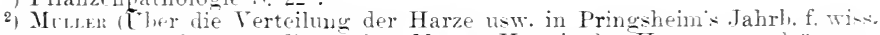

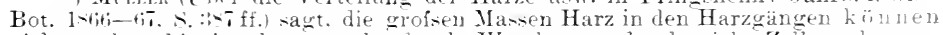
nicht anders hineingelangen als durch Wanderung durch vifle Zellmembranen.

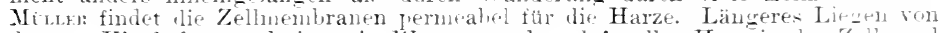
dünen Kienholzquerschnitten in 11 asser macht, dafs alles Harz in ler \%ellwand durch Wasier ersetzt wirl.

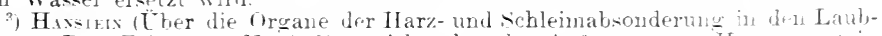
knospen. Bot. Zeit. 1ori-. Nr. 4:3ff.) spriclit uber das Anftreten von Harz zuerst in den Fugen von solietionszellen als schmales Band zwischen riticula und Cellulonehant Dies sind muwrifelhaft gewichtige frounde für die Anuahne...dals auch das Harz, welches zuerst in Gestalt von Zwiochenwaul-chichten auftritt. seine eigentliche Natur erst annimmt, nachdem es noch in anulerer fiestalt dir Zellwand durchsetzt hat und als Zwischenschicht abgelagert ist".

sorauer. Handbuch. 3. Aut. Erster Eand. 
diese Teise hedententes Material verlorengeht. Nach den Untersuchungen

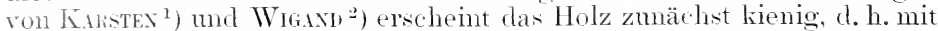
Harz mnd Balsam durchtränlit. Innerhalb der meisten Zellen dieses harzoetränkten Gewebes zeigt sich das llarz als Wandbekleidung oder in Tropten zusammengeflossen, während andere /ellen schon vollständig mit dieser Nasse angefüllt sind. In dem Natse, als der Harzreichtum im Innern der Zelle zunimmt, werden die mrsprünglich dicken Wandmngen der Zelle immer dünner, bis schlietslich nur noch eine feine Umgrenzung übrig bleibt, die sich in die Harzmasse allmählich verliert.

Vie bei dem Gummiflut's erscheinen anch hier die Narkstrahlen länger widerstandsfähig, da man dieselben noch dentlich in die gleichartige, sie umgebende Harzmasse der aufgelösten Holzzellen hineinragen sieht; es fehlt zur vollkommenen Analogie beider Vorgänge nur der Nachweis, dat's bei dem Harzthuts anch ein abnormes Holzparenchym gebildet werde, das unbedingt der Verharzung verfällt.

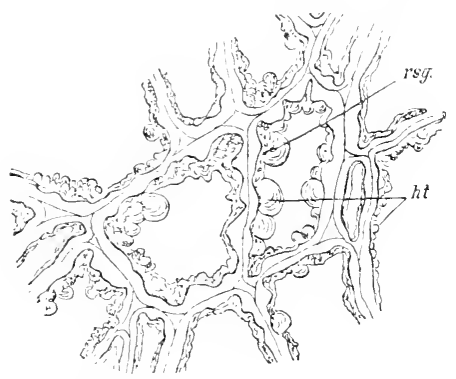

Fig. 157. Zellen des Trachë̈dalparenchyms von Pims Strolus mit der resinogenen Schicht rsif; lit Harztröpfchen. (Nach NuTruetici.)

Dat's, gerarleno wie bei der Grmmosis, die stärkekörner bei der Resinosis der Verflüssigung erliegen, ist melrfach beobachtet worden. Stärke liefert sicherlich einen grofsen Teil des Harzes bei dem Harztluls. WIEsxer (Sitzungsbericht d. Akad. d. Wissensch. zn Vien, B(1.51) gilit z. B. an, dafs im Innern der Markstrahlzellen der Laubbäume sich Harzkörper vorfinden, die den Ban des Stärkemehlliornes besitzen. Dieselben werden selten durch Jod allein blan, ötter durch .Jod und Schwefelsämre. Mit Cnoxam zeigen sie die /ellstoffreaktion; gegen Eisenchlorid reagieren sie wie Gerbstotf. Daher schlietst Wiesxek aus seinen Untersuehmogen, dats oine grotise Nenge des in der Natur vorkommenden Harzes aus stärkekörnern oder aus in Gerbmehl sich umwandelnden stärkekörnern besteht. Er hält den Gerbstoff für das Kwischenglied zwischen Cellulose und Harz.

Den Beweis, datis auch bei dem Harzfluts ein abnormes Parenchymholz gebildet wird, das der Verharzung und Schmelzmo verfällt, finden wir in einer seln eingehenden Studie von Notтьвк ${ }^{3}$ ) über die Harzgallen. NotTBERt weist nun nath, dals infolge irgendeinor Verwundung, die bis auf das Cambinm weht, lieses mit der Prodnktion eines . Tracheïdalparenchyms" antwortet, las allmählich zu den normalen Tracheüden wieder übergeht. Die infolge der Terwundung mit der Autsenwelt in Berührung kommenden Tracheiden des Splintes verstojfen ihre Lumina

1) Kanstex, H., Über die Fntstehung des Harzes, Wachses, Gummi und Schleims durch die assimilierende Taitigkeit der Zellmembranen. Bot. Z. 18.57, S.316.

2) Wrisxn, Über die Desorganisation der Pflanzenzelle. Pringsheim's Jahrb. f. wiss. Bot. Bd. III, S. 16.).

3) Nuтruek, P., Experimental-C'ntersuchungen über die Entstehung von Harzgallen und verwandter Gelilde bei mseren Abietineen. Zeitschr. f. Pflanzenkr. $1 \triangleleft 97$, S. $131 \mathrm{ff}$. Hier auch weitere Literatur. 
mit einer wundgummiähnlichen Masse, welch" in Weingeist mö̈slich ist, aber nach der Behandlung mit dem Schnltzechen Fremisch sich löst. Gleichzeitio tritt im Holzkörper meist Verkienmng ein. Die einzelnen Zellen des pathologischen Parenchyms heginn numittelbar nach ihrer Entstehumg im Innern lfarz zu bilden (Harzadlen). Dio Membranen der Zellen des Trachë̈alparenchyms verholym sehr trüh-

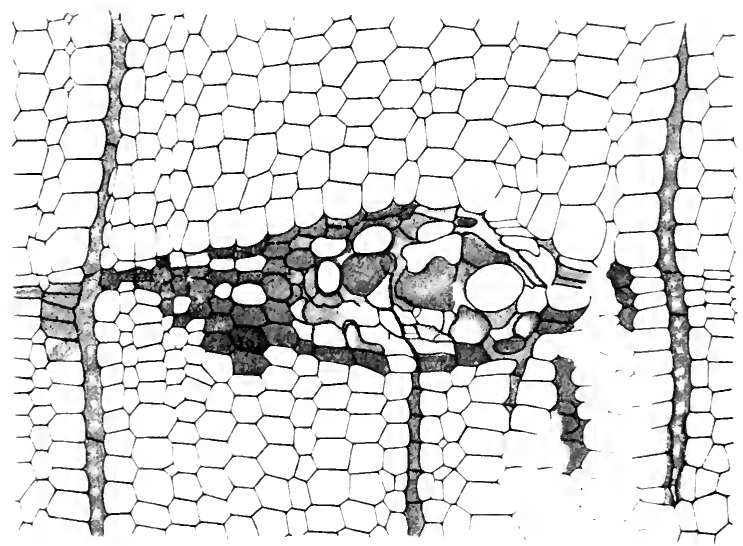

Fig. 15. Terkienungsprozefs, beginnend mit der Bildung eines lrsigenen Harzganges im Holz. 20.): 1. (Nach (inwextz.)

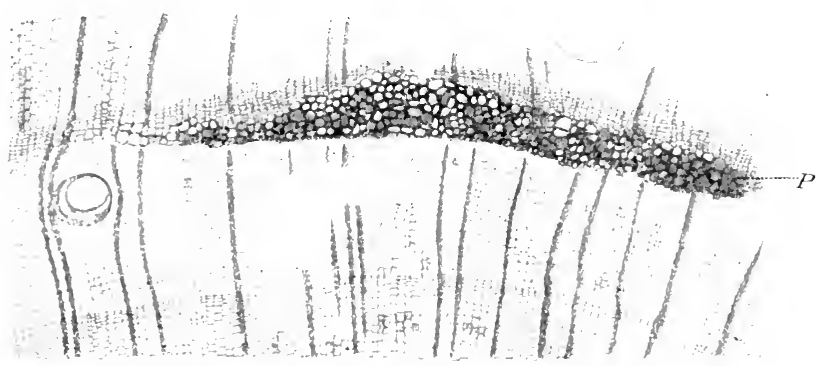

Fig. 159. Horizontalschliff. Im sommerholz eines Jahresinges liegt eine fruppe von abnormem Holzparenchrm ('). 56:1. Die Lücken im Gewebe sind dur'h

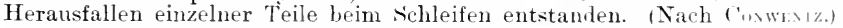

zeitig: die unverdickten Elemente dagegen zeigen, solange sie erhalten bleiben, stets nu die Celhulosereaktion. In den Harzzellen erkennt man eine bestimmte schicht, in weleher sich das Harz billet (rosinogene Schicht) (Fig. 157). Nottbeli; dem wir dis genannte Figur ontnehmen. lä1st es unbestimmt, ob diese resinogene Schicht ein .. Bildung sprodult der Nembran oder des Plasmas ist". 
Die bathologische Harzbildung darf als der von jeher verbreitetste Terflissigmngsvorgang bezeichnet werden, den wir im Pflanzenreiche kemnen, und der in der Tertiärzeit ebenso vorhanden war wie jetzt. Denn CoNwExtz gibt in seiner durch vortreffliche Abbildungen ausgezeichneten Nonographie der baltischen Bernsteinbäume (Pims succinifera (onw.) an: "Es gab kam einen gesunden Bam im ganzen Bernsteinwald - das Pathologische war tie Regel, das Normale die Ausnahme." 1) Wir können die Vorgänge der Resinose gar nicht besser zur Darstellumg bringen als durch die Kopien von Bernsteinschliffen, die Conwentz abgebildet hat (Fig. 158-16il).

Wie in der Jetztzeit sehen wir den Verkienungsprozel's in der Weise begimen, dafs Verharzung und schmelzung der Membranen und schliefslich der ganzen Zelle samt Inhalt an einzelnen Gruppen zwischen zwei Markstrahlen sich einstellt (Fig. 158). Hier brancht noch kein anatomisch abweichendes Gewebe zu bestehen; aber in der Mehrzahl der Fälle ist solches vorhanden, und zwar in Form von

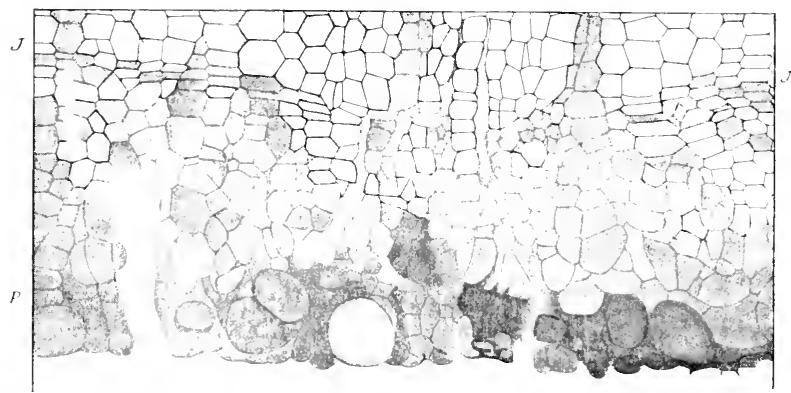

Fig. 160. Horizontalschliff mit abnormem Parenchymholz $P$, das in Succinose begriffen ist. Dus abnorne Gewebe liegt im Sommerholz. $J$ ist die Grenze des Jahresringes. 210:1. (Nach Coxwexrz.)

Parenchymholz, das in tangentialen Binden angelegt wird. Coswentz beschreibt diese Binclen (Fig. 159) im Sommerholz. Ich habe sie bei unseren Hölzern bisher vorherrschend im Frülyjahrsholz gefunden, so dat's der nene Jahresring sofort oder nach wenigen Zellreihen mit dem alnormen Holz begann. Die Entstehmng dieser Binden fïhre ich anf vorübergehende Lockerung in der Rindenspannung zurüek (s. Frosterscheinungen). Dieses abnorme parenchymatische Holz zeigt sich in vollständigster Vorharzung in Fig. 1tio. Die entstandenen Harz- bzw. Bernsteinmassen können die Rinde gänzlich rom ältesten Holzzylinder abrlrängen. Solche Rind melemente fand Coswestz noch so gut erhalten, dat's er die \%ellkerne nachweisen komnte (Fig. 161).

Bei der Verflïssigung des festen Tracheïlalparenchrms sah Notrbers: die tertiäre Membran am längsten erhalten, wie dies bei der Ausbreitung der Gummiherde der Kirsche elenfalls zo beobachten ist.

Je nachdem eine Wuncle alsbald ansheilt oder ständig weiter um sich greift, unterscheidet Noтtвевi gutartige und bösartige Wunden. Bemerkenswert ist noch, dats anch die Bämme, welche normalerweise

1) Cuxwext, Monographie der baltischen Bernsteinbäume. Danzig 1890, S. 145. 
gar keine Sekretbehälter im Holze führen (Eleltamne) nach Verwundungen reich an Harzgängen, namentlich in den ت̈horwallmosiandern, sich erweisen. Diese Untersuchmogen werden von v. FubEr ${ }^{1}$ ) bestätigt, der noch hervorhebt, dafs die pathologischen Harzlianäle schizogen gebildet werden: sie anastomosieren in der Tangentialebene, hilifn ein znsammenhängenrles Netz und ragen mit ihren offenen Enden in dir. ITunde hinein. Oberhalb derselben sind die Harzkanäle zahlreicher nurl länger als unterhalb derselben.

Gegenüber den Angaben, dats die Veranlassung zur Rexinosis stets in Wmilen zu suchen sei, mus ich, wie bei der Gummosis, behampten, dat's der Vertlüssigmesprozet's anch antochthon, ohne Wundreiz entstehen kanı. Ieh beobachtete dies bei sämlingsplanzen ron Kirfern ans starkgedüngten Bammschulen; ebenso fand ich rlerartige Torkommmisco bei älteren Pflanzen ron Psendotsugn Momglasi. Abies Fraseri und Abirs comcolor, welche Rindenauftreibungen zeigten, die sich als eine lysigene Erweiterung schizogener Harzaänge erwiesen. Die Bämme standen aut feuchtem, moorigem Borlen, der in Intervallen ron 2 bis :3 Jalnen kräiftig gerlïngt worle.

Nenerdings habe ich die Resinose als Fonstitntionskrankheit, also als Äulsermo einer in gesamten Pflanzenkïper sich verbreitenden Neigung zur übermäfigen Harzbilimug anch an alten Bänmen zu brobachten Gelegenheit geluabt. Diese Allgemeinerkrankung habe ich als "chronisehe Resinose" ron der örtlich infolge von Wuntreiz entstehenden unil lokalisiert bleibenrlen, mit Austritt profuser Harzmassen verbmolenen, ak $u$ ten Resinose" unterschierlen ${ }^{2}$ ). Dementsprechend wïrle man in

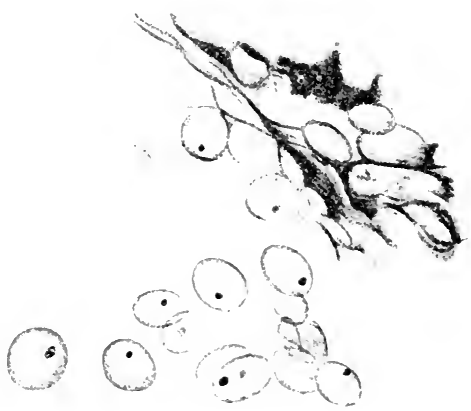

Fig. 161. Gruppe von Parenchymzellen der Aufsenrinde, welche durch Verharzung einer ringförmigen abnormen Holzparenchrmzone vom zentralen Holzzylinder vollständig getrennt worden ist. In den Rindenzellen erkennt man noch die Zellkerne. (Nach Coxwrizz.)

Zukunft anch eine chronische mut aknte Gummose anseinanderzuhalten haben, und bei letzterer kömnte die emptohlene Wunbehandlumg mit Essig auch Erfolg haben.

\section{Harztildung bei dicotylen Gewächsen.}

Parallel mit den in vorigen Abschnitt geschilderten Vorgängen zeigt sich anch die Entstehung von Harzen und Gummiharzen bei den dikotylen Gewächsen. Svexusex ${ }^{3}$ ) fand, dafs die Gummiharze hei styru. . Liquidambar, Toluifera u. a. pathologische Produkte sind, die infolge

j) v. F.ввен, E.. Experimentaluntersuchungen über die Entstelıng d. Harzflusises bei Abietineen. Dissertation. Bern 1901.

2) Landwirtschaftliche Jahrbitcher 190s.

3) Sresisex, Cart. Juhix, Z̈ber den Harzflufs bei den Dicotrlen, speziell bei Styrax, Canarium, Shorea. Toluifera und Liquidambar. Archif for Mathematik og Naturvidenskab. Kristiania 190., Bd. XXVI, Nr. 13. 
von Terwmunngen entstehen. Nach jeder bis an das Cambium gehenden Trrletzmng bildet sich ein Wundholz, das sich durch seinen tracheïlalparnchymartigen Charakter anszeichnet und allmählich wieder in normales Ilolz ïbergeht. Die Vorgänge simb ïberall also dieselben, wie wir sie bei den Frostwnden heschrieben und abgebildet haben. l)er Thudreiz macht sich im Altholz durch Verstopfung der Gefätse mit Thyllen oder Bassorinverschluts geltend. Das um die Wunde sich bildende zunächst prarenchymatische Nenholz weist schizogen entstehende, lrsigen sich erweiternde Harzlianäle aut; die Verharzung eroreift dam das Parenchrmholz mit Ausuahme grötserer Teile der Markstrahlen und setzt sich später ant lie Rinde fort, wo sie, was hervorzuhelen ist, immerhalb der Rimlenstrahlen bemerkt wird. Wie bei den Nadelhölzem ist anch bei den Dikotylen die pathologische Harzbildmo von der Anwesenheit normaler Harzkanäle vollständig mabhängig. Bei dem Pern- und Tohnbalsam scheinen die Verhältnisse komplizierter zn sein.

Also, soweit wir die pathologische Harzbildung überschanen kömnen, entspricht sie rollkommen der Gummose, nnd somit gelten für die Resinose dieselben Gesichtspmkte, die wir früher ansgesprochen: nicht der Wundreiz an sich ist das zur Verflüssigung der festen Gewebe anregende Prinzip, sondern enzrmatische WVirkungen, die wir vorläufig nicht präzisieren kömnen, die aber im Erfolg sich darin äut'sem, dat's einzelne Gewebegruppen im jugendlichen Zustande verharren und durch Oxydation selmelzen. Diese Vorgänge liömnen durch Wunden eingeleitet werden, aber auch selbständig durch abwegige Emährung entstehen. Sie sind abhängig von einer gewissen Entwicklungsphase, namentlich der Zeit des Austreibens der Gehölze. Vorhandene schmelzungsherde vermögen durch Übertragung ihrer Enzyme auf nomales Danergewebe sich zu vergrötsern.

Anhangsweise ziehen wir noch eine Anzahl von Erscheinungen hierher, die teils direkt zu gummosen Entartungen gehören, teils darm sich hier anschliefisen, weil wir sie als Folgen enzymatischer Gleichgewichtsstörmongen auffassen.

Tem Gummiflufs analog ist das namentlich an Wundstellen eintretende Ansfliefsen durchsichtiger, gummöser Massen bei Elacagms crumulensis, das Frank genaner beschrieben hat. Ich sah Gummibildung bei Palmen, (*urken, Kakteen, Hrazinthenzwiebeln ${ }^{1}$ ).

Enzrmatische Abwegigkeit nelme ich an bei der Kernfäule und schwarzringigkeit des Meerrettichs (s. Zeitschr. t. Pflkr. 1899, s. 132), dem (Flasigwerden der Kakteen, Orehideen, Nelken usw. Es werden darlureh Schwächezustände geschaffen, welche die Pflanzen tür parasitäre Angriffe empfänglich machen. Anf diesen Punkt hat Woors mit besonderer schärte hingewiesen: "J called special attention to the fact, that plants rich in oxidizing enzyms were more seusitive to mfavorable conditions of temperature, moistmre, and especially to insect enemies than plants foor in these enzyms" (l. c. S. 2.2).

1) Nach Cous ist die "Brusca der Oliven" eine ausgesprochene Gummosis. 


\title{
Vierter Abschnitt.
}

\section{Einflufs schädlicher Gase und Fliissigkeiten.}

\author{
S'echzehntes Kapitel.
}

\section{Die Rauchase.}

\section{Schweflige Säure.}

Bei der beständio zunehmenden Ausbreitung aewerlicher Betriebo sind die Beschädigmngen der Vegetation durch Rauchgase so zahlreich und vielseitio geworden, dats das sturlium derselben einen eignen Zweig der Pathologie zu bilden beginnt, an welchem Chemie und Botanik in gleicher Weise beteiligt sind. Es ist daher erklärlich, dats dieser Wissenszwein spezialwerke erfordert. Die untassendste Bearbeitung hat der fiegenstand in einem Buche von Haskenof und LINDAU ${ }^{1}$ ) und später von WIELEk ${ }^{2}$, gefunden; wir müssen bei der Fïlle des Materials bezüglich der Ranchschärlen ant diese Werke verweisen und könmen nur solche Punkte eimgehender hier noch hehandeln, welche in den genannten Werken nur geringere Berücksichtigung finden komnten.

Lange \%eit ist man im Unklaren gewesen, weleher der schädliche Bestandteil des Rauches sei, bis durch die Untersuchungen von Morkes ${ }^{3}$ ),

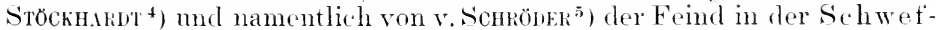
ligen säure erkamnt worden ist. Die metallischen (iifte, wie Arsen, Zink und Blei, die man trüher vorzugsweise hei der Beschädigmng durch den Rauch der Hüttenwerke im Auge achabt hat, sind experimentell als minder schädlich für unsere Kulturptlanzen nachgewiesen worden, während die schweflige säure schon in sehr geringer Beimengung zur Luft den Tod der Versuchspflanzen herbeizufïhren imstande ist. WVie gering eine solche Beimischung zur Luft zu sein brancht, geht aus den Beobachtungen von Morkes ${ }^{6}$ ) hervor, der die charaliteristischen spuren der Zerstörung an den Blättern schon wahrnehmen komnte, wemn die Lutt nur 1/5000 ihres Volumens an Schwetliger säure enthielt. schröner ${ }^{7}$ ) wibt an, dats schon ein Millionstel sich schädlich erweist, sobald eine längere Einwirkmg stattfindet. Und so geringe Bei mergungen enthält sicherlich mancher Rauch, der durch die Ver brennung schwefelhaltiger steinkohle gebildet wird. I) aber schwefe

1) Hinflumr, E., und Lisns, G., Ile Beschädigung der Vegetation durch Rauch. Berlin 190:, (rebr. Bornträger. 412 S. mit 27 Textabb.

2) Wulk, A., Intersuchungen äber die Einwirkmg schwefliger Nïure auf die Pflanzen Berlin 19\%, Gebr. Borntrïger.

3) Récherches expérimentales pou déterminer 1 influence de certains gaz industriels, spécialement du gaz acide sulfureux, sur la végétation. Extractel from the Report of the International Horticultural Exhibition etc. London 1stiti.

4) Cntersuchmgen über die schädliche Einwirkung des Hütten- 11. Steinkohlenranches auf das Wachstum der Pflanzen. Tharandter forstl. Jahrb. Bul. 21, Heft :3.

") Die Einwirkung der schwefligen sïure auf die Pflanzen, in Landw. Versuchsstationen lei:.

6) a. a. O. S. 2.24 .

i) Scurimer, J. v. und Ras s, C., Die Beschädigumg drr Vegetation durch Rauch usw. Berlin 1.s. P. Pares. 
in der Form ron Schwefeleisen ein häufiger Bestandteil der Steinkohle ist. so ist anzunehmen, dat's wir, wie Мокикx sagt, mit jedem schornstein die Anlage zu einem Vergiftungsherd der Pflanzen errichten.

Nun darf man allerdings auch nitht zu weit in den Befürchtungen gehen. Die Experimente, welche zum Nachweis der Nehädlichkeit so peringer Gasmengen angestellt worden sind, bestanden in der meist mehrstündigen Einwirkmng des Gases in cinem durch eine Glasglocke abgeschlossenen Ramme.

Diesem Znstande entspricht im gewöhnlichen Leben nur etwa die Luftbeschaffenheit in ummittelbarer Nähe eines industriellen Etablissements, wie einer Hätte, eines Koksofens u. rgl, in geschlossenen Tälern, in denen der Rauch in grotsen Massen Tag und Nacht sich über die Vegetation lagert. In der Mehrzahl der Fälle dienen die Luftbewegung, namentlich der WVind und die Eigentümlichkeit der Sehwefligen säure, in Berïhrung mit Wasser zu Schwefelsäure zu oxydieren, als Schutzmittel gegen die extremsten Wirkungen des Giftes, gegen das baldige Absterben. Jedenfalls aber wird man guttun, in denjenigen regenden, wo mit Steinkohlen oder 'Tort'1) gefenert wird, bei der Anlage von viel Ranch produzierenden Etablissements solche Orte zu wählen, die möglichst entfernt von grotsen Kulturen, namentlich ron Bamanlagen, sind.

Die gastömigen Produkte, welche bei der Verbremmo einer schwefelfreien Steinkohle erzengt werden, sind für die Vegetation unschädlich 2). Enthält dagegen die Kohle einen Teil schwefel und entweicht die schweflige säure in die Luft, so wird dieses Gas von den Blattorganen der Nadel- und Laubhölzer aufgenommen; dabei wird es (nach v. S'HRöıER) in diesen Organen grötstenteils festgehalten und nur zu einem geringen Teile in den Holzkörper der Pflanze geleitet. Aneh die von Frestas ${ }^{3}$ ) in dieser Beziehung direkt angestellten Versuche denten darauf hin, dats wir die Blätter als die Hauptorgane zur Anfnahme des Giftes anzusehen haben. Nitht alle Blätter aber nehmen gleichriel von dem gebotenen Gifte anf, und in dieser Beziehumg unterscheiden sich die Nadelhölzer merklich von den Laubhölzen. Erstere nehmen unter sonst gleichen äulseren Terhältnissen mit der gleichgrotsen Blattfläche weniger schweflige säure auf als letztere; jedoch ist mit dem Nachweis einer grötseren Menge aufgenommenen Gases noch nicht gesagt, dat's dadurch anch eine Pflanze mehr leidet. Die Widerstandsfähigkeit hängt viehmehr von der speziellen Organisation der Pflanze ab. In dieser Beziehung lag die Termutung nahe, dats der anatomische Bau, namentheh die Zahl der Spaltötfinmgen, für die Emptänglichkeit einer Pflanze mat'sgebend sein möchte; diese Vermutung, welehe ron Mokren wiederholt ausgesprochen worden, hat sich aber als irrig erwiesen, da ScHröser gefunden hat, dats die Schweflige säure nicht mu durch die Spaltöffinngen, sondern gleichmäfsig von der ganzen Oberfläche des Blattes aufgenommen wird. Er sah von der spaltöffinm slosen Oberseite eines Blattes ebensoviel Gas

1) Nach Srïкиин ist auch Braunkohlen- und Torfrauch schädlich, wemn dieses Feuermngsmaterial Schwefelkies enthält. Der Ranch der Kalköfen zeigt sich am mindesten nachteilig, weil der Kalk die gebildete Schweflige Säure zurückhält, ebenso wie bei Ziegelöfen der häutig vorhandene Magnesiagehalt des Tones durch Zurückhalten der S'chwefligen Siiure günstig wirkt. Chemischer Ackersmann 1872, Heft II, s. 111 u. f.

2) Nachgewiesen an Pflaumen- und Birnbäumen.

3) Mitteilung der landwirtsch. Akad. Poplelstorf. Bd. II, 1\$69, s. :34: cit. bei Schröder a. a. O., s. : ::21. 
anfnehmen als von der an Atmungsorganen roichen Unterseite; nur war die Wirkmng des von letzterer Seite oingulrungenen Gases viel schneller mol energischer. Diese Erscheinmo finclet ihre Erklärmo in dem Unstande, dals die Schweflige säure Gegierip rom Wasser absorbiert wird und sich in Berührung mit demselluen leicht oxydiert; da num durch die locker gebante, an Spaltöftinnng roichere Unterseite die Wasserabgabe des Blattes an die Luft rorzusweiso ertolot, so macht sich hier die Einwirkung des Giftes $u m$ so mohr goltend. IVird das Wasser in den Micellarinterstitien der Zellwände ron der säure in grötserem Maf'se gebunden, als ein Zuströmen erfolgen hann, lam werden die Zellwände wasserarm, werden endlich anstrockmen mul somit ihre Fähigkeit für die Wasserleitung verlieren.

Es werden damn nur noch diejenigen \%ellpartien, welehe direlit an dem schnelleitenden Gewebe der Gefälsbündel liegen, stark wasserhaltig bleiben und ihre normale Färbung behalten, währond der trockene Teil zwischen den (Gefätsbündeln (Gen Blattnerven) eine tahle. brämliche Färbmng annimmt. Tiese Erseheimmg einer hellgrïncin Nervatur in der fahlen Blattmasse ist als ein Merkmal für die Erkennung einer Vergittung des Blattes durch schweflige sämre bezeichnet worden. Später ist von HarTw ${ }^{1}$, behauptet worden, datis die Rotfärbung der Schlielszellen der spaltütfumngen bei Nadelhölzern ein sicheres Merkmal für Säurebesehädigung sei. Diese Angabe aber hat alsbald seitens anderer Beobachter ihre Widerlegung getimden. WiELkR $^{2}$ ) mul Sonuter ${ }^{3}$ ) hahen nachgewiesen, dats ein langsames $\mathrm{Ab}$ sterben muter dem Einfluts des Lichtes bei Einwirkmo sehr verschiedener Faktoren die Rotfärbung veramlatst. Unmittelloar im /usammenhang mit diesem für das Ange erkenubaren Merkmal steht die dureh Wägung von v. Schröber gefundene Tatsache einer verminderten Wasserver hmstmo der vergifteten Blätter. Die Transpirationsgrötse lälst sich aber als Ausdruck der Produktion gebrauchen, und somit lälst sich schliefsen, dats das Blatt weniger assimiliert. Die allgrmeine Wirkung der Vergiftung anf den Pflanzenkörper wird also ähnlich der einer frühzeitigen Entlaubung sein, und zwar wird die Wirkmng 10 so schneller eintreten, je grölsere Mengen von schwefliger säure vorhanden sind, je troekner die Lnft ist, je höher die Temperatur und je stärker die Belenchtung ist, durch welche Faktoren das Blatt zu intensiverer Tätigkeit angeregt wird. Durch dicse experimentell festgestellte Tatsache wird die Fermutmg nahe gelegt, dats der Iüttenund Steinkohlenranch in der Nacht weniger schädlich als am Tage wirkt. und wir werten diese Vermutung später bestätigt finden.

Betreftis des Merkmals der grünbleibenden Nervatur bei vertrocknenden Mittelfeldern eines Blattes ist aber Vorsicht bei der Beurteilmug geboten. Fast alle schädlithen Einflüsse des Luftmeeres äutsem sich in der Weise, dats die ron den wasserleitonden Nerven am woitesten entfernt liegenden Partien eines Blattes, also die /wischemippentider (Intereostalfelder), am ersten und stärksten leiden (Frost, sionnenbrand usw.). Bei Einwirkmng ron Säuren in Ranch sind aber die

1) Hartu, Rıв., Über die Einwirkung des Hütten- und Steinkohlenrauches auf die Gesundheit der Nadelholzbämme. Munchen 1s96, Rieger'sche Buchhandl.

2) Wrater, Über unsichtbare Rauchschäden bei Nadelbäumen. Zeitschrift für Forst- u. Jagdwesen 1 897 , Sept.

3) Sormen, P., Über die Rotfärbung von Spaltöfnnugen bei Picea. Notizbl. d. Bot. Gart. Berlin 1s98. Nr. 16. 
Grenzen zwischen totem und gesundem Gewebe meist scharf, bei EinHht's der Witterungsfaktoren dagegen mehr verwaschen durch allmähliche T̈borgangsstadien.

Anch sind in ausgesprochenen Ranchbezirken die Schädigmesbilder verschieden, weil neben der Schwefligen säme anch andere Säuren, wie Schwefelsäure, Salzsäure, Fluorwasserstoff́säme usw., zur Wirksamkeit gelangen kömnen. Diese stark wasserlöslichen (hygrophilen) Sämren beschränlien sich aber in ihrer Wirkung ant die nähere Umoebung der Erzengungherle, wo sie allerdings auch viel intensiver und ant das Gewebe schnell abtötend wirken, während die schweflige sämre, die in gastörmiger Gestalt sich üher weite Gebicte ansbreitet, langsam aber fermanent von der Pflanze eingeatmet zu werden pflegt. Erstere, schmell und ätzend anftretende Wirkmoen unterscheidet man als , akute" von den langsam rergiftend sich geltend machenden Erscheinmoen, die als "chronische Rauchschäden" bezeichnet werden. Selbstverständlich müssen letztere sich schon im Innern einer Pflanze geltend machen, wenn äulsere Merkmale noch nicht vorliegen. Der ChLorophyllapparat wird schon alteriert (was spektroskopisch ron Wricenus ${ }^{1}$ ), mikroskopisch ron Sorauer nachgewiesen wurde), wem anch die Pflanzen noch ganz normal aussehen, und man spricht dam ron "unsichtbaren Rauch schäden". Natürlich sind derartige Störungen anch am leichtesten zu beseitigen, und die Pflanze ist nachgewiesenermafsen in der Lage, nach Fortfall schwächerer Raucheinwirkmgen sich selbst auszuheilen ${ }^{2}$ ).

Solche Fälle werden anch im natürlichen Forstbetriebe vorkommen, wenn Situationsänderungen eintreten, welche eine Rauchschlange ablenken oder bis zur Unschädlichkeitsorenze verdïmen. Wisucesus ${ }^{3}$ ), (lem wir besonders eingehende, gewissenhafte Untersuchungen nenerlings verdanken, gibt die Unschädlichkeitsgrenze auf 0,0005 Tolmmprozente an.

Dieser Autor heht auch hervor, dat's, abgesehen von der äufserst verschiedenen individuellen Empfindlichkeit, das Entwicklungsstadim der Pflanze ron ausschlaggebender Bedentung ist. Die Zeit der Enttaltung der nenen Blätter und Nadeln ist die gefährlichste: hier leiden die Pflanzen am meisten, wel die Cuticulardecke der Epidermis noch nicht genügend ansgebildet ist. Der schon oben erwähnte, von r. Śchröner und HARTi beobachtete schädlichkeitsfördemde Einflut's des Lichtes ist experimentell von Wrisucesus ${ }^{4}$ ) geprüft worden. Er fand, dats sichtbare Beschädigmoen bei jungen Fichten im Dumkeln und im Winter nicht auftraten, obgleich eine Steigerung des Schwefelgehaltes nachweisbar war. RAuAxs und Sokduer haben ebenfalls beobachtet (s. a. a. (1.), dats die Menge des nachweisbaren Schwefels in einem Organ nicht ausschlaggebend für den Grad der Schädigmng ist, und Graf zu Lesnivies ${ }^{5}$ ) macht ant einen Faktor anfmerksam, der bei

1) Wisticfirs, Resistenz der Fichte gegen saure Rauchgase bei ruhender und tätiger Assimilation. Tharandter Forstl. Jahrbücher 1 $89 \varsigma$, Sept.

2) Sorater, P., u. Rimıx, E., Sogenannte unsichtbare Rauchbeschädigungen. Bot. Centralbl. 1899, Bd. LXXX. - s. anch Brizı in Zeitschr. f. Pflanzenkrankh. 1904 , ‥ 160 .

$\left.{ }^{3}\right)$ Wistrexus, H., Mafsuahmen gegen die Ausbreitung von Hüttenrauchschäden im Walde. Referat 5 der Sektion VIII d. interuat. landw. Kongresses in Wien 1907.

4) Tharandter Forst. Jahrbücher $189 \div$, s. 152.

5) Graf zr Lemingax, W., Licht- und Schattenbläter der Buche. Naturwiss. Z. f. Land- u. Forstw. III. Jahrg., Heft 5. 
der Probeentnahme behuts Begutachtmur von sämeschäden von ausschlaggebender Wichtigkeit ist, nämlich ant den ganz verschiedenen Gehalt an Schwetel und Chlor bei s'chat tenblät trrn vegenüber den sonnenblättem. Bei Buche fand er aut je 1 qm Blattsubstanz

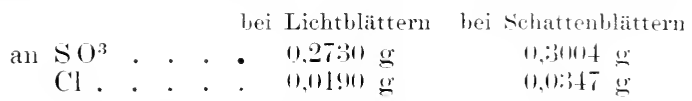

Also je ungenïgender die Produltion an organischer substanz, desto höher wird relativ der Gehalt an schwetwänre mol chlor. Gleichsimnig verhalten sich die Angaben von Wisterses. „Geringe Bodenbonitäten, d. h. phrsikalisch und chemisch minderwertige Bodenbeschatfenheit, für die Pflanzengattung spezifisch movergneter Boden, vor allem aber moenügender, ibbermätsiger oder abnorm wechschnder Wassergehalt des Bodens, schatfen eine Prädisposition tür Raucherkrankun $\alpha$, darunter am meisten der Wassermangel."

Dats der Habitus des Waldes durch Entnadelumo und Absterben der Zweige ein anderer wird, ja dats anch in Laubwäldern sich das Aussehen dadurch ändert, dats die stämme fast gänzlich firei von Flechten werden $\left.\left[\mathrm{Lindat}^{1}\right)\right]$ und bei den Buchen die Stamminde einen eigenartigen granen Farbenton amimmt, sei nur nebenbei erwähnt. Direkt aut die Änderung der Bodenbeschaff̈enheit weistn dic Angaben von v. Schröner mul Reuss hin, dats eine Anbäufung mzersetzter Nadeln minter den chroniseh beschädigten Fichten stattfindet und, soweit die Traufe des Baumes geht, anch eine gänzliche Entblösung von jeder lebenden Vexetation bemerkbar ist. Dieser Umstand deutet aut "Bodenvergittung”. Bewiesen wird dies durch das Revsische Experiment, bei welchem Boden aus einer Ranchgegend in eine ranchfireie Zone übergeführt und bestellt worden war. Nach drei Jahren betrug der Verlust an ein- und zweijährigen Sämlingen von Esche

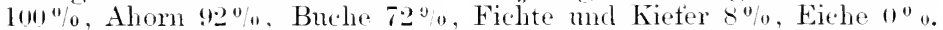

Wieler ${ }^{2}$ ) hat num speziell die Frage der Bodenvergittung in die Hand genommen und nachgewiesen, dats sich in Ranchgegenden mit anhaltender Ranchüberflutung menter Umständen noch sehweflige säure in $30 \mathrm{~cm}$ 'Tiefe nachweisen liefs, diese also noch nicht in Schwefelsäure übergegangen war. Letztere wird anch nur so lange mschädlich sein, als sie an Basen gebunden werden kamn. Wemn aber diese Basen zur Nentralisation verbraucht sind und durch Regen ansgewaschen werden, findet die vorhandene $\mathrm{Humus}$ üure kein Bindemittel mehr. Tatsächlich zeigten alle von W'teLER untersuchten Bodenproben aus Ranchscharlengebicten grofse Mengen von Hummsämre. Es fehlte diesen Böden also an Kalk, mm die entstehende llumussäure zu binden. Es mulsten aber auch die anderen Basen, mit denen die Humussäure lösliche Verbindmoen eingeht (Magnesimm und Eisen), ans dem Boden versehwmilen sein. Damit verschlechtert sich natmoemäts das Absorptionsvermägen des Bodens für andere mineralische Nährstotfe; dies bezieht sich anch auf die mit Hmmussäure lösliche Verbindungen eingehenden Alkalien, welche gleichtalls in den Untergrund wandern. Der Kalkmangel erschwert die Zersetzung der Humusstoffe, und der in ihnen eingesehlosicne

1) a. a. O. S. 1:0.

2) Wifter, Neuere Untersuchungen usw. s.:;14. 
Stickstoffhleibt dem Pflanzenbestande unzugänglich, zumal die BakterienHora in dem samen Boden gering ist. Die freie Schweflige Säure und die schwefelsäure werlen anch anf tierische Organismen, wie z. B. die Regenwïmer, schädlich einwirken künnen. Durch alle diese Faktoren wird der Rauchboden ansgemagert bzw. vergiftet werden.

Der geringeren Wasserkapazität des durch schwefelsäure (oder anch (lureh Salzsäme) rergifteten und auscemagerten Bodens schreibt num Wieler das Absterben der Bestäncle und überhaupt die chronisehen Beschädigungen zu. Er geht sicherlich darin viel zu weit; demn alle Tersuche lehren, dat's der direkte Rauchangriff die Hauptursache des Absterbens der oberirdischen Organe bildet; auch ergeben die vergleichenden chemischen Analysen von Laub und dem dasselbe produzierenden Boden durchaus nicht immer eine Verarmung an Basen. sondern bisweilen sogar ein starkes Anwachsen von Kalk und Magnesia ${ }^{1}$ ). Aber immerhin bleibt diese Seite der Wirkung der samren Rauchgase höchst beachtenswert, und die Aufmerksamkeit der praktischen Kreise ist auf eine periodiseh sich wiederholende $\mathrm{Kalkdüngung}$ zu lenken.

Betreffs des Einflusses der Luftströmungen und ihrer Beschaffenheit. namentlich ihres Wassergehaltes, sowie betreffs des Nachweises der säuren in der Luft und der Mat'smahmen zur Abschwächung der Ranchschäden müssen wir auf die Spezialwerke rerweisen. Erwähnen möchten wir nur, dats $\mathrm{Ost}^{2}$ ) eine einfache Methode zur Bestimmung des Gehaltes der Luft an Schwefelsäure eingetührt hat. Es werden nämlich kleine Zenglappen mit Ätzbarỳt getränkt und getrocknet; sodann werden sie an den Untersuchungsorten in exponierter Lage aufgehängt und nach einer bestimmten Zeit anf ihren schwefelsäuregehalt untersucht. Auch die reine Gebirgshft zeigte bei dieser Methode als normale Beimengung noch einen gewissen Gehalt an Schwefelsäure, der in der Nähe von Dörfern sofort bedeutend anstieg. Eine Zusammenstellung der Forderungen des Forstmannes zum Schutze des Waldes gegen Rauchbeschädigungen finden wir nenerdings in einem Tortrage des Oberforstrats Reuss ${ }^{3}$ ). Derselle weist darauf hin, dats es notwendig sei, da, wo viele Fabriken beisammen liegen. Schadenersatzgenossensehaften zu errichten.

Nicht autiser acht zu lassen ist, dats bei den Schadenersatzforderungen nicht selten der Einwand seitens der schädigenden Hütten und Fabritien gemacht wird, dal's Insektenfrat's die Hauptursache abgäbe. In dieser Beziehung macht (GERLACH ${ }^{4}$ ) darauf aufmerksam, dat's die rauchkranken Fichtenbestände von den Harzrüsselkäfern bevorzugt werden. Nicht nur I'issodes Horciniac und scabricollis, sondern anch andere Insekten, wie Grapholitha pactolana und Chrmes zeigen in rauchbeschädigten Forsten ein rerheerendes Anwachsen.

1) Die landwirtschaftliche Versuchsstation in Munster i. W. Denkschrift ron J. Küsig. Münster $1 \triangleleft 96$, s. $191 \mathrm{ff}$.

2) Os, H., Die Verbreitung der Schwefelsäure in der Atmosphäre. Die chem. Industrie 1900; cit. Zeitschr. f. Pflanzenkrankh. 1901, S. 24.

3) Rerss. Kan, Mafsnahmen gegen die Ausbreitung von Hättenrauchschäden im Walde. Internat. Landw. Kongrefs zu Wien 1907, Sektion 8, Ref. 5.

4) Gertich, Beobachtungen und Erfahrungen uber charakteristische Beweismittel bzw. Merkmale von Rauchschäden. Osterr. Forst- u. Jagdzeitung: cit. Bot. Centralbl. 1907, Nr. 40, S. :360. 
Salzsäure, Chlor.

Die steinkohlen enthalten neben dem selnwetel anch Chlor in Form von Chloruatrium ${ }^{2}$ ): der Chlorgehalt sehwankt zwischen 0,1 bis

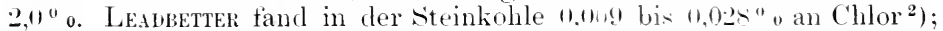
dasselbe war aber in der Asche nicht mehr nachweisbar, mutste also mit den flüchtigen Substanzen ausgetrieben worden sein: Meskcke hat num auch in den Hochofengasen , las ('hlor direkt nachoewiesen ${ }^{3}$ ), mol Swith ${ }^{4}$ ) macht aut den Chlorgehalt von Regenwasier in (regenden antmerksam, wo Steinkohle in Menge gebrannt wird. Nach diesen Angaben mïssen wir also nicht einen einzigen schädlichen Faktor im śtcinkohlenrauche, sondern mehrere in verschiedener Kombination amelmen. Die Terschiedenartiglieit wird auf der Zusammensetzung der siteinkohle einerseits und anf ihrer Verwendung im technischen Betriebe andererseits beruhen.

B.i dem schnellen Ühergange ron Chlor in Salzsäure in Gegenwart ron Fenchtigkeit und Licht müssen beide Faktoren qemeinsam abgehandelt werden. Über die durch fortgesetzte Einwirkmg ron salzsäure im Boden möglicherweise entstehende Verarmung ist bereits bei der schwefligen säure gesprochen worden. Von der Wirkmog direkter Löstmgen von Chloralkalien wird bei fielegenheit von Kochsalz noch die Rede sein. Das Terhalten der Ptlanzen ist je nach spezies, Jahreszeit, Standort und individueller Entwicklung verschieden. Im allgemeinen erfolgt Ausbleichen und Vertrocknen der Blattränder oder auch der Intercostaltelder, wobei Chlordämpfe schneller wirken als salzsaure Gase. Gegenüber der schwefligen säme herrschen aber hier dio trocknen Blattränder (s a umlinien) vor. Bei den vou Rumax mul

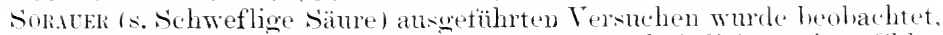
lats die mit Wasser besprengten Fichten duchsehnithlich weniger Chlor absorbierten als dic nicht lienetzten Pflanzen.

Die bisherigen Arbeiten über die anatomischen Verändermugen haben zu widersprechenden Resultaten gefïhrt. So beobachtete Lixbal (a. a. O. S. 24t) bei Alies bei den Sipaltötfinmgen und deren Nachloarschatt

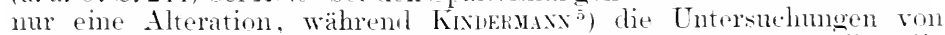
LeITies und von Molson bestätigt, dats gerade die s'chliefszellen die grötste Widerstandsliraft gegen alle schädlichen Einflïsse (damunter anch salzsäme) besitzen, was wahrscheinlich ant einer besonderen Konstitution des Plasmas beruhe.

Bei der Unsicherheit der bisherigen Resultate wobe ich hier kurz die Ergebnisse eigner studien ") am (retreide mnd bei der Fichtr wieder. /unächst wurle der grotiv allgemeine Produktionsiöchuang. welchen die Pflanzen iureh die Salzäuredämpte erleiten und der sich in den frölsenverhältnisien und der Kornansbildmng kemzeichnot, in

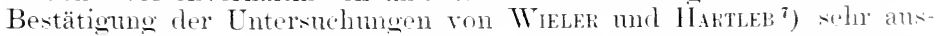

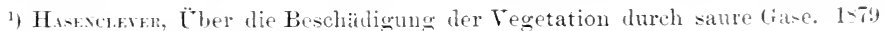
S. 9. Berlin, springer.

2) Chemical News 1<60. No. 4t;

3) Dingler: . Journal 1-is, 217 .

4) Bericht uber die Entwicklung der chem. Industrie von A. W. Human, 1- is.

5) Kixmmux. V. T̈ber die auffallende Widerstandskraft der schlicfscellen

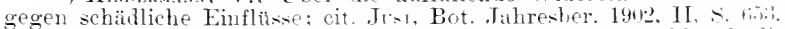

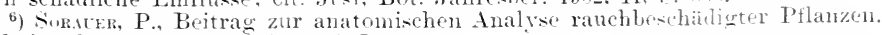
Landwirtsch. Jahrbucher 1904, s. $\therefore \div$.

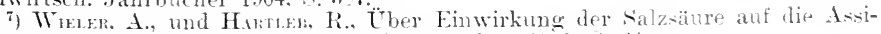
milation der Pflanzen. Ber. d. Deutsch. Bot. Ges. 1900, s. : 4. 
geprägt gefunden. Eine solche Wirkung kamn eintreten, ohne dats auttälige äutsere Merkmale die Wachstumstörung anzeigen. In der Regel aber ist dieselbe von einer Enttärbung mit nachfolgender Ballung der Chloroplasten begleitet, Es tolgt dann eine Zusammen. ziehung des Primordialschlanches nud schumpfung der Chlorophyllkünner. Je nach Stärke und Daner der salzsänregaswirkmog hat das so geschädigte Blatt bisweilen noch die Mäglichkeit eines normalen Auslebens; meist aber stirbt es teilweise ofler gänzlich rorzeitig ab. Im letzteren Falle umfalst das Absterben vorzugsweise diejenigen Blattteile, die vermöge ihrer Lage und ihrer geringeren Mesophyll- und Gefälsbündelentwicklung eine schwierigere und geringere Wasserzufuhr haben, und dies sind die spitzen und Ränder der Blätter. Daher die trocknen, verfärbten Blattspitzen beim Getreide und die schmalen trocknen Sammlinien zu beiden seiten des noch orün verbleibenden unteren Teiles der Blatttläche. Als Folge des schnellen Todes zeigt sich dam in diesen abgestorbenen Teilen ein verhältnismälsig bedeutender Bestand an Zellinhalt. Das Zusammentrocknen unter Festhaltumg der Luft im Gewebe erfolgt unter Schrumptimg der Zellen. jedoch so, dafis die Wände einer jeden Zelle einander nicht berühren. Der natürliche Vertrocknungsprozels dagegen, der erst nach vollständiger. Terarmung des Zellinhaltes eintritt, charakterisiert sich durch ein gänzliches Zusammenfallen der Mesophyllzellen, wobei die Oberwand anf die Unterwand sinkt und das ganze ehemals grüne Blattfleisch einen matt-strohgelben, dichten Gewebestreifen aus wellig verbogenen, schichtenweise aufeinanderliegenden Wandungen darstellt. Das Zusammensinken der Zellen erstreckt sich bei den Getreidearten mit Ausnahme der Gerste während des natürlichen Vertrocknungsprozesses fast nur ant das Mesophyll, während die Epidermiszellen nahezu in ihrer natürlichen Höhe verbleiben. Bei der - schon von den Praktikem als "weich" bezeichneten - Gerste sinken allerdings auch die Epidermiszellen bei dem natürlichen Tode zusammen, wobei aher einzelne der weitesten Oherhantzellen nach autsen hin eine Falte bilden. Dieselbe erscheint bei einem (querschnitt durch das tote Blatt als kegelfömige krhebung, die einem Haar gleicht und dem ganzen Querschnitt das Anssehen eines dünnen, knotigen und stacheligen stranges verleiht.

Bei der Wichtigkeit der Untersheidung eines Blattes, das natürlichen Todes gestorben, von einem durch saure Gase vorzeitig zugrunde gegangenen Organe geben wir nebenstehend die Abbildung eines säurebeschärligten mul eines normal gestorhenen Blattes. Fig. 162, 1 ist der Qnerschnitt durch eine unter dem Eintluts ron Salzsäzure bzw. Chlordänpfen ahtrocknencle Randpartie eines Haferblattes. Man sieht, das Gewebe schrumpft namentlich in der Zwischemrippenregion (Intercostalfelder) scharf zusammen, ohne daf's das Mesophrll Zeit gehabt hätte, sich zu entleeren. Ler Zellinhalt erscheint schmutziggrün bis branngrïn und mamnigfach gehallt. Die Membranen der Bastbeläge an der Blattkante $(B)$ und unterhalb der Gefätsbündel $(b)$ sind, wie die der Epidermis, rotgell, bis branngelb gefärbt, und die Epidermiszellen stellenweise $(s)$ derart zusammengetrocknet, dat's die Oberwand die Unterwand berïhrt. Fig. 162, 2 ist cine verorölserte noch den reichlichen Zellinhalt zeigende Zellowppe ans Fig. 162, 1.

Fig. 16:, 3 stellt den Querschnitt durch ein normal vertrocknetes Haferblatt aus rauchfreier Gegend dar. Das Blatt erscheint im Quer- 


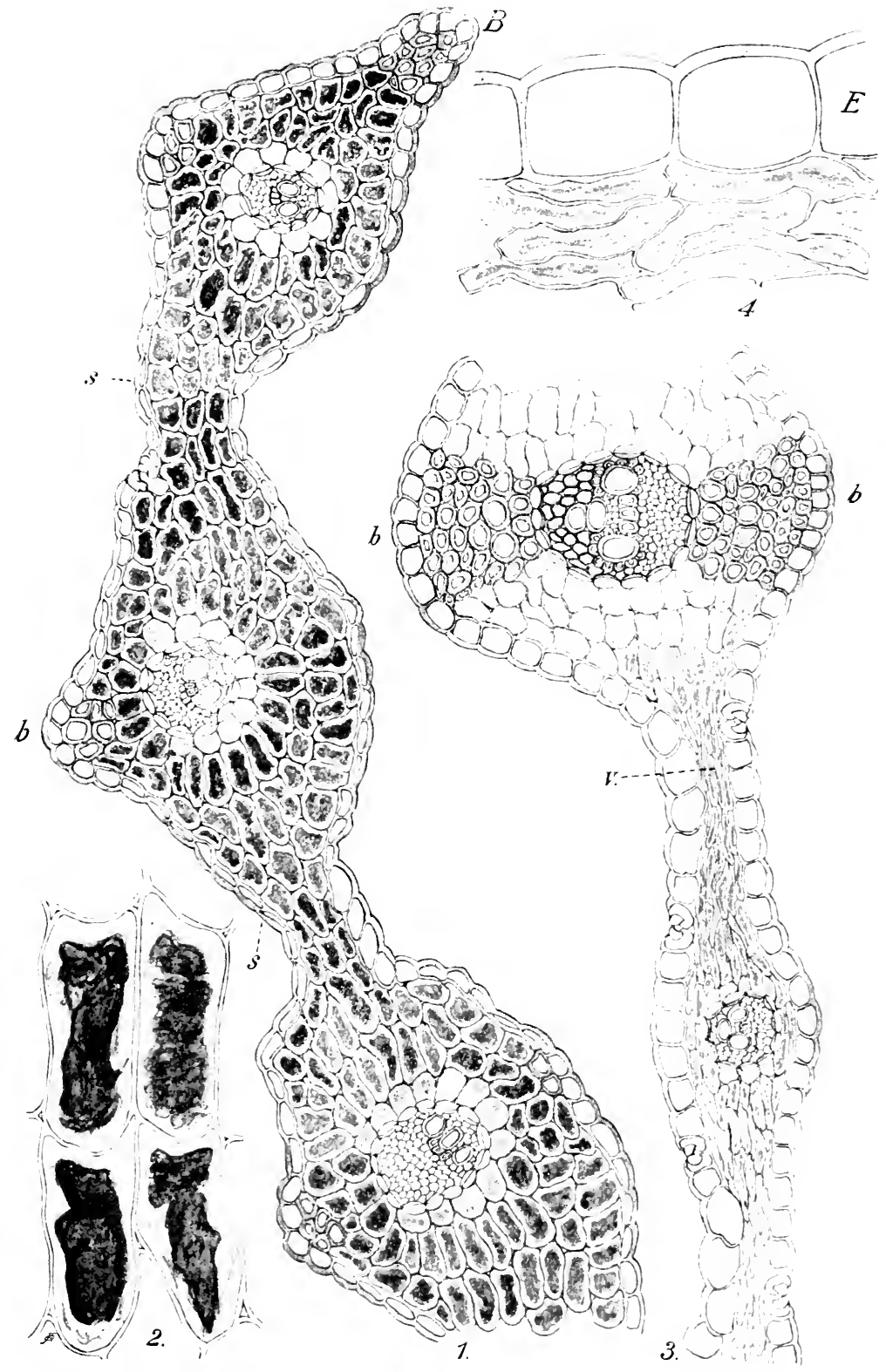

Fig. 162. Unterschied zwischen einem durch Salzsäure- hw. Chlordiimpte abtrocknenden und einem natürlichen Todes gestorbenen Haferblatte. (Orig.) 
cchnitt strangartig dünn, weil das Mesophyll ( $T^{*}$ ) nahezu ganz entleert ist nnd die Zellwände anfeinander gesmken sind. Nur nm die stärkeren (iefätibündel herum vermag das Blatt nicht derartig zu sehrumpfen, weil die starken Bastbeläge als Steifen dienen und als Knoten in der Strangform stehen bleihen. Trotz der seharfen Vertrocknung des Blattes bleibt die Epidermis in ihrer natürliehen Höhe und wird höchstens

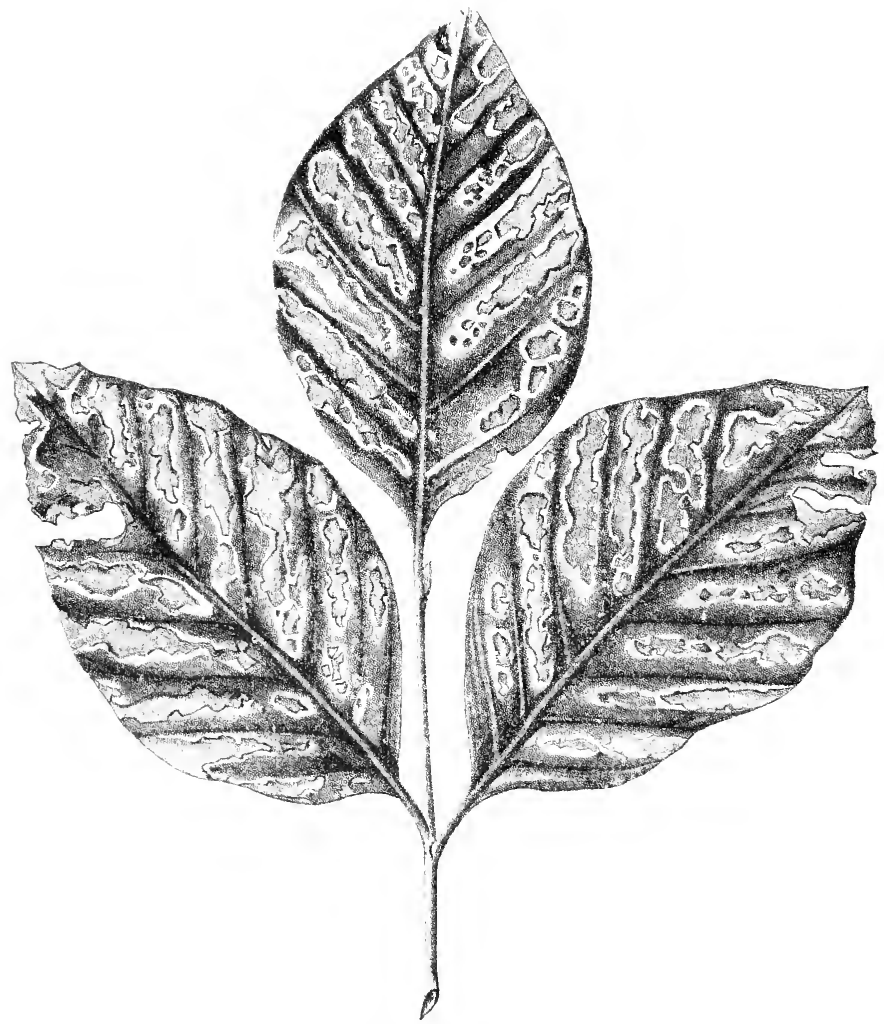

Fig. 163. Durch schweflige Säure angegriffene Blätter einer Rotbuche.

(Nach Scmociner und Reris.)

matt quittengelb gefärbt, wie die Baststränge, wodurch sie sich von der sämrebeschädigten ehenfalls unterscheidet. Fig. 162, $f$ ist eine vergrötserte Zelloruppe ans Fig. 16: $\because$. E' bezeichnet die Epidermis, darmenter cie zusammengefallenen Mícsophyllzellen, bei denen durch Einlegen des schnittes in Wasser die spärlichen plasmatischen Inhaltsreste kemntlich semacht worden sind. Anch yon einem bei danemd nassem Wetter langsam ansreifenden Ilaferblatt muterscheidet sich das säurebeschädigte 
in der Farbe, da ersteres in den Wandungen soiner Bastleläge und Epilernisedlen eine citronengelle Farhe ammimnt. Wie Intensitat

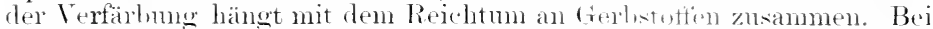
der Beobarhtung der Farbenuntersehiede muls natn sehnell vorgehen, da der Farlstott in Wasser löslich ist.

IVas hier vom dietreide beschrieben worden int, läkt sich nicht ohme weiteres auf andere Pflanzen ïbertragen. Nul tas ist als all-

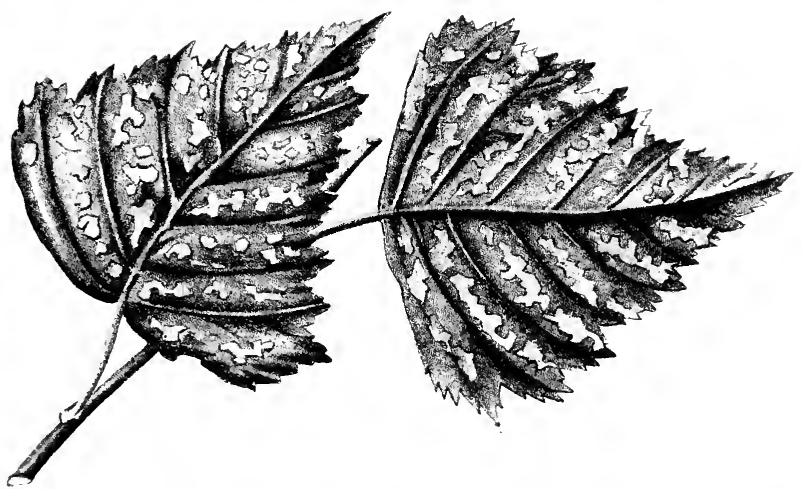

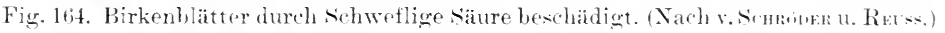

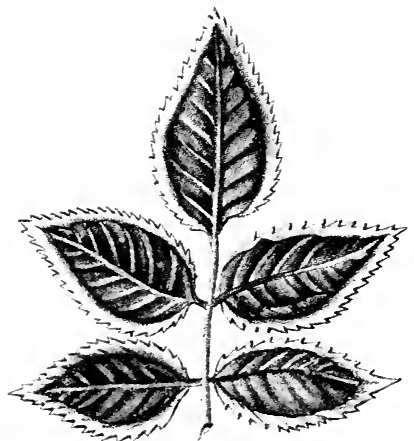

Fig. 16is. liosenblatt

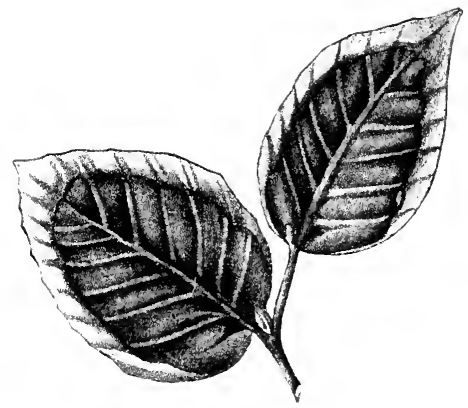

Fig. 166. Buthenblätter

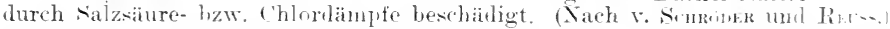

geneines Vorkommmis zn hetrachten, daks hoi allen platzlinhwn

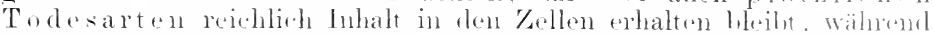

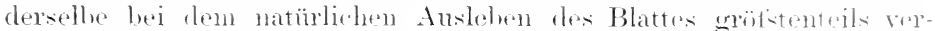
atmet wird.

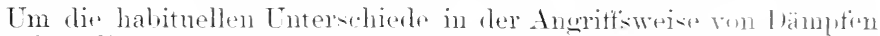

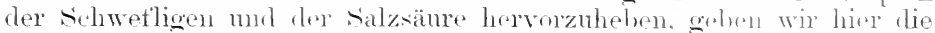
Kopien beschärligter Blätter ans dem mehrfach citienten Wirke von v. Śchlö̈ner und ReIs.

Sorauter, llandbuch. :. Aufl. Er-ter liand. 
In Fig. 163 sehen wir das durch $\mathrm{sO}^{2}$ angegritfene Blatt einer Rotbuche ans der Nähe einer Silberhütte. Fig. libt ist ein von $\mathrm{SO}^{2}$ geschädigtes Birkenblatt aus der Nähe einer Kupferhammerhütte. Das gemeinsame Merkmal besteht in mehr oder weniger scharf umschriebenen gebräunten Flecken in den Intercostalfeldern. Die Flecke sind meist mit einem Rande umgeben, der bald dunkler, bald heller bram sein kann. Bei manchen Gehölzen (z. B. der Rotbuche) findet man anch noch hänfig um die Randzone einen durchscheinenden gelblich-grïnen Samm ron erkranktem aber noch nicht abgestorbenem Gewele.

Fig. 165, 16it und 16i sind Blätter einer Rose, einer Buche and einer Birke, die kïnstlich durch Salzsäure beschädigt worden sind; sie zeigen die düren Sammlinien, die man meist nach Einwirkung reiner Salzsäuredämpfe beobachten kann. Indessen ist zu betonen, daf's man

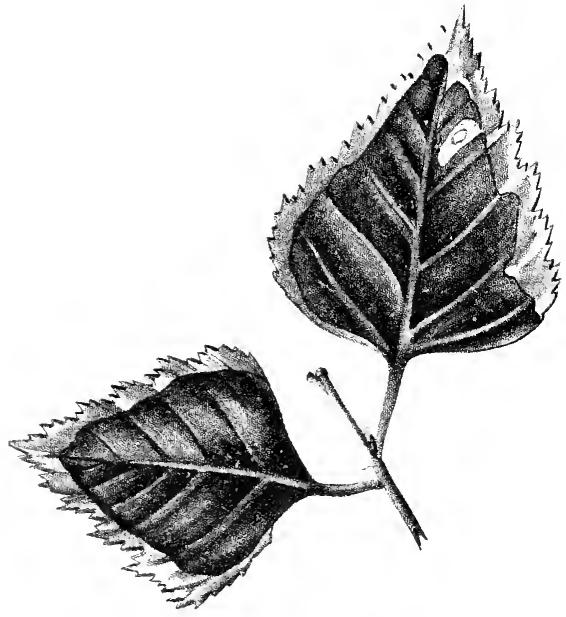

Fig. 167. Durch Salzsäure bzw. Chlordämple heschädigte Birkenblätter. (Nach v.Scurïnk u. Retss.) bei der Rauchexpertise aus solchen Habitusibildern keine sicheren Schlüsse ziehen darf, weil einerseits je nach dem individuellen standort und Entwicklung des Baumes die Beschädigungsformen wechseln und weil andererseits anch andere Faktoren ähnliche Bescliädigungen hervorzubringen vermögen.

\section{Flufssäure (Fluorwasserstoff- säure).}

Viel mehr als man früher vermutet, hat sich die durch den Betrieb ron Superphosphat-, Glas- und chemischen Fabriken erzeugte Flufsäme als Feind der Vegetation entpuppt. Durch sie ist der anfangs rätselhafte Befunt geklärt worden, dafs Rauch ans Ziegeleien und Tonwarentabriken manchmal hochoradig schädlich, in anderen Fällen unschädlich sich erweist. Dies hängt eben von dem Vorhandensein und der Menge der Fluorverbindungen ab, welche in den Tonen und Rohphosphaten vorhanden sind. Nach 0 s äntserte sich die Wirkung in dem Auftreten kleiner, bramner Ätzflecke, welche bei manchen Pflanzen mit einer gelblichen Kone umgeben waren. Von anderen Forschern ansgeführte Räncherungen liefisen bei der Eiche schmale, gelbbrame, schart abgegrenzte Randrerfärbungen erkennen; ähnliche Randzeichnung zeigte ein Spitzahorn, dessen Blattfläche später aber ebenfalls sich brämnte. LINDAU ${ }^{1}$ ) beschreibt den anatomischen Befund bei der Eiche. Er tand die beiden Epidermisschichten intakt und den Inhalt der Mesophyllzellen leicht gebrämnt; die einzehnen Chloroplasten sind noch erkennbar, , aber der übrige Inhalt hat ein öliges Aussehen erhalten“.

$\left.{ }^{1}\right)$ a. a. O. S. 250 . 
Über den am meisten in Betracht kommenden Waldbaum, die Fichte, finden wir die Notiz, da1's dieselbe bereits einen Tag nach der künstlichen Räncherung einzelne Triebe mit weit-lich-graner Terfürbung zeigte, die sogar welkten. Nach einer zweiten Ränchermo wuden die Bäumchen ins Freie gestellt, und nun ging der antangs weitsliche, gelblich-graue Farbenton durch alle Abstufimgen von Gelh met Gelb. rot in .das charakteristische Rot der säurebeschälligmng äher”.

so wie die Fichten sah man in der Nähe einer Phosphoritfahrik, die durch Antschlietisen des Fluorcalcinm enthaltenden Phosphorites mit Schwefelsäure Flufssänredämpte entwickelte, anch Kiefern. Lärchen und Akazien sich verfärben ${ }^{1}$ ). МАгкноғек ${ }^{2}$ ) komnte einen auttallend hohen

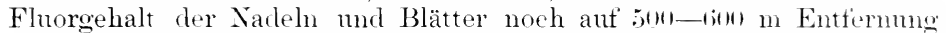
von der Fabrik nachweisen. Anf das Getreide kann die Wirkmg einer solehen Exhalation geradezu rernichtenrl sein. So beobachtete RHow: ${ }^{3}$ ). dat's Roggen auf einzehen Parzellen gar keine oder nur verkümmert. Körner entwickelt hatte.

Meine eigenen Untersuchungen erstrecken sich nur anf Spiritusmaterial ron abgestorbenen Fichtennadeh, das ich von Herm Protessor Rumsx erhalten hatte, und bestätigen der Haup,tsache nach die Übereinstimmmo des Befundes mit den bei sehwefliger säure erhaltenen Bildern. Fur fand ich bei den Flnorwasserstotfnadeh noch eine (rewebefaltung. die anf' einem Sichrmufen der Zelhmembranen beruhte. Man muls darans sehliefsen. dats das bei schwefliger Säure so schnell eintretende Austrocknen der Nadeln hier erst erfolgt. nachdem die tirekte Säurewirkung bereits eine (iestalt veränderung der Gewebe hervorgernfen hat. Anch war der Inhalt den Wandmigen nieht fest angentrocknet. wie bei Wirkung der Schwefligen säure mud konnte deshalb nicht zur steifung der Wandmaen beitragen.

\section{Stickstoffsäuren.}

C̈ber den Einfluts von Salpetersäure (bzw. Untersalpeterwäure) haben wir nur eine Notiz ron Köswi ${ }^{4}$ ) gefunden. Er sah bei jo Stickstoffsäuren (auf Untersalpetersäure berechnet) auf longm l Luft' oder 0.15) $g$ Untersalpetersäure in 1 cbm Lntt bei Bämmen Merlmale auttreten. die denen glichen, welche bei schwefliger säure und Salzsäure sich einstellen. Ile gewöhnliche Luft enthält nur $0.000013 \underline{\underline{n}}$ Salpetersäure im Kubikmeter.

\section{Ammoniak.}

Weit über den gewöhnlichen Gehalt der Luft hinansgehend, der höehstens zn $1,0,4$ ing pro Kubikmeter anzmehmen ist erweist sich das Ammoniak und kohlensaure Ammoniak als wachstumstördernd. Nur bei Fabrikbetrieben (Ammoniak-Soda-Verfahren u. dol.) kommen so grolise Mengen ins Freie, dats Schäden entstehen, obgleith the Pflanzen sich im alloemeinen sehr widerstandsähig erweisen. Dir

1) Allgem. Forst- u. Jagdzeitung 1sy1, s. 22:0.

2) Marnofrer, J., C̈ber Pflanzenbeschädigung, veranlafst durch den Betrieb, einer Superphosphatfabrik. Freie Vereinigung d. Bayr. Vertreter für angewandte Chemie. Bd. X, s. $12 \mathrm{~T}$.

3) Rune, A., Schidigung ron Rogrenfeldern durch die einer superphosphatfabrik entströmenden Gase. Zeitschr. F. Pflanzenkrankh. 1 $5 \%$. . 13.;.

4) Kinsis, Denkschrift 1s96, s. 202. 
Emptindlichkeit der einzelnen Arten schwankt moemein, aber die Art der Beschädigung zeigt grotse Übereinstimmmo, nämlich vorzugsweise eine fleckenartig oder flächenfömig anftretende šchwarztärbung.

Die Versuche von Bönner, Haselhof mal Könd ${ }^{1}$ ) ergaben bei der Eiche das Auftreten dunkler Flecke odrr vollständige Schwarzfärbung der Blätter. Bei der Kirsche ist anfangs Braunfärbmg und später Schwärzung beobachtet worlen. Die trerste zeigte nach limzer Zeit der Einwirkung an der der somne zugewendeten seite Blätter und Halme weils gefäbt, Roggen und Weizen bekamen rostfarbige Flecke und Ränder.

Zu den in der Literatu lereits bekamten Fällen füge ich hier einige eigne Beobachtungen. Bei Gerste sah ich die Blattspitzen weils werden. Bei jungen Kastanienblättern wurden zuerst die Intercostalfelder dumkel, am nächsten Tage schwarz und später dün' Ähnlich verhielten sich die Laubblätter von Azalea indica bei einzelnen rotblühenden sorten, während eine danebenstehende weilsblühende Varietät nur Bräunung der Blattspitzen und ränder erkennen liet's. Die Blume der roten Varietät zeigte auf tem samme der äntseren Zipfel weit'se, nahezu kreisrunde oder keilförmige, eine natürliche Panachierung nathahmende Flecke, während die weilse Varietät innerhalb derselben Zeit die Blumenkrone mit Ansnahme vereinzelter kleiner brauner Tupfen unverändert liets. Eine Nachwirkung nach Entfernmng der Pflanzen aus der Ammoniakatmosphäre wurde nicht wahrgenommen, wohl aber eine Gegemreaktion bei dem Blütenkörbchen einer Cinerarie; die roten, durch das Ammoniak blan gewordenen Randblumen erschienen einige Zeit nach Verlassen der Ammoniakatmosphäre wieder rot gefärbt.

Über den Einflut's des Entwicklungszustandes auf die Stärke der Beschädigung liefert die Fichte ein Beispiel, deren alte Nadeln eine pechschwarze Färbung annahmen und danernd behielten, während bei den jungen, weichen Nadeh der anfangs schmutzigorüne Farbenton später in ein fahles Rotgell äberging. Äulserst scharf kam bei einem Versuche die individuelle WTiderstandskraft der einzehen Nadeln zur Geltung, da man an allen Zweigen zwischen den pechbramen Nadeln anch solche beobachten konnte, die lieine Verfärloumg oder höchstens ein dunkleres Grün zeigten. Die sehwarze Färbung rührte hauptsächlich ron dem pechbramen Farbenton her, den das Protoplasma der Epidermis- mol Desophyllzellen angenommen hatte. Die Membranen waren nur leicht gebrännt. In den intensirst geschädigten \%ellen war der Inhalt eine zusammenhängende, körnig-teigige Masse geworden, die sich bisweilen von der Wandmo zurtickgezogen hatte. Der Inhalt der schlietszellen der spaltöffinmeren war ebenfalls pechbram, niemals rot, wie bei Sämebeschädigmoen. An den Übergangsstellen zwisehen gesund geblebenem mul geschwärtem fewebe bemerkte man, dats die protoplasmatische Einhettungsmasse für die Chloroplasten sich bereits schwärzte, wähend dirse selbst in Gestalt und Lagerung noch mverändert erschienen. Erst syäter fand man den grünen Farbstoff' in das Plasma ïbrogetreten und schmntzig bramgrïn geworden. Dam

1) Zeitschr. f. Pflanzenkrankh. 1\&9:3. S. 100. - LixuAt (a. a. 0. S. 2ه6) beschreibt die Wirkung des Ammoniakgases lei starker Konzentration auf die Pflanzenzelle: Im Innern des Blattes zeigen die Zellen meist sehr starke Plasmolyse; die Inhaltsstoffe werden undentlich, und bisweilen werden Oltropfen ausgeschieden. Dabei wird ein brauner lis schwarzer Farhstoff abgesondert. der den ganzen kontrahierten Inhalt gleichmilsig tingiert. Derselbe erweist sich später als Gerbstoff. 
verschmolz auch die Grundsulstanz der C'hloroplasten nit dem äbrigen Zellinhalt anseheinend mer Zurïcklassung kioniner Reste.

Das Ammoniak düfte eine spezifisthe tiftwirknn ant den \%ellinhalt ausäben und nicht nur lie säme hinden. wie anderweitig an-

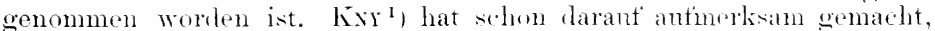
dats nach den in der Literatur vorliegenden Angabre das Protoplasma in den verschiedensten Ptlanzenteilen alkaliselue Ruaktion hestzt, ohme datis die Chloroplasten beeinflutst werden. Derselbr Autor zeigte anch,

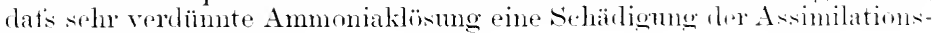
tätigkeit hervorrutt.

Auf welche Weise manchmal Ammoniakveroiftung zustanele liommt, zeigte mir ein Fall, wo die Maner eines Pferelestalles als Riirliwand fï̈r ein Gewächshaws benutzt worden war. Als in flerhst das IJeizen begam, entwickelte sich aus dem Manerwerk kohlensanres Ammoniak, das bimen kurzer /seit die Blätter von Amruba. Tibumm Timus, Prums

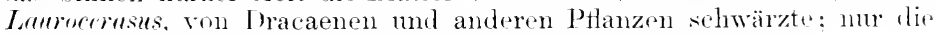
nächste Tmoghmo der Nervatur der Blätter blieh noch griun.

\section{Teer- und Asphaltdämpfe.}

Diø Ertahrungen äber die schänllichleit von Teer- und Asphaltdämpfen haben sich erst in nenerer Zeit geklärt, seitdem das Beolachtungsmaterial reichlicher geworden ist. Abgesehen von den Einwirkmngen. die das Asphaltioren der Straken bisweilen an empfindlichen Pflanzen hervorruten kann, sind lie Fabriken. welche Kohlenstifte für clie elektrische Belenchtum antertigen, als wesentliche Uriach ron Frkrankungen zu betrachten.

Als Leitptlanzen für Besehädigungen durch Asphaltrlämpfe ${ }^{2}$ ) sind die rerbsäurereichen Rosen. Eribeerblätter, wilder Wein und Kastanien zu bezeichnen. Bri den Rosen leiden die einzelnen Arten in sehr rerschiedenem (irarle. indem beispielsweise Tee- und Bengahos'n weniger. Remontantrosen und deren Hybriden aber meistenteils sehr stark angegriffen werden. Die Gherhant wird stellenweise wher über die ganze Blattfläche stumpt schwarz. Wem nicht die ganze Oberfläche verfärbt ist (Fig. lis, 1 a), pflegen die geschwärten Stellen als mnterbrochene oder zusammenhängende Bänder zwisehen den stärkeren Seitemnerven, also in len Intercostalfeldern, aufzutreten. Wrem dir Kelchblätter von den I ämpten getroffen worden sind, liommen die Blütenknospen nur zu mangelhafter Entfaltung. Bald nach Eintritt der Schwärzung findet man den Inhalt der oberseitigen Evidermiszellen tiet geloräunt, kïmig-klumpig und meist einer Horizontalwand angelagert. Die C'uticula ist nicht gebräunt und anscheinend unverändert. Bei stärlierer Erkrankung ist die Epidermis der Unterseite in gleicher Weise eroritten und sinkt später zusammen; dagegen wirl das Mesophyll nur wenig imitiert. Die Dämpte ätzen nur an den Organen die exponierte Flärhe. alle gedeckten Teile (Fig. 16s, 1 h) bleiben unvertärbt. Wird die Mittelpartie eines Blattes beschädigt, heben sich die Rändler liahnförming nach oben.

Beiläufig ist darauf aufmerksam zu machen, dats manche Rosin (z. B.

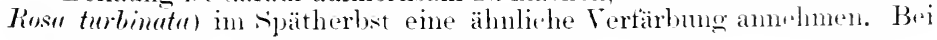

1) Bot. Centralbl. 1s!ł, Bu. LXXIII, S. 4:30.

2) Sumter, P.. Die Beschadigumgen der Vegetation durch Aiphaltämpfe. Zeitschr. f. Pflanzenkrankh. 1s.7, s. 10. 


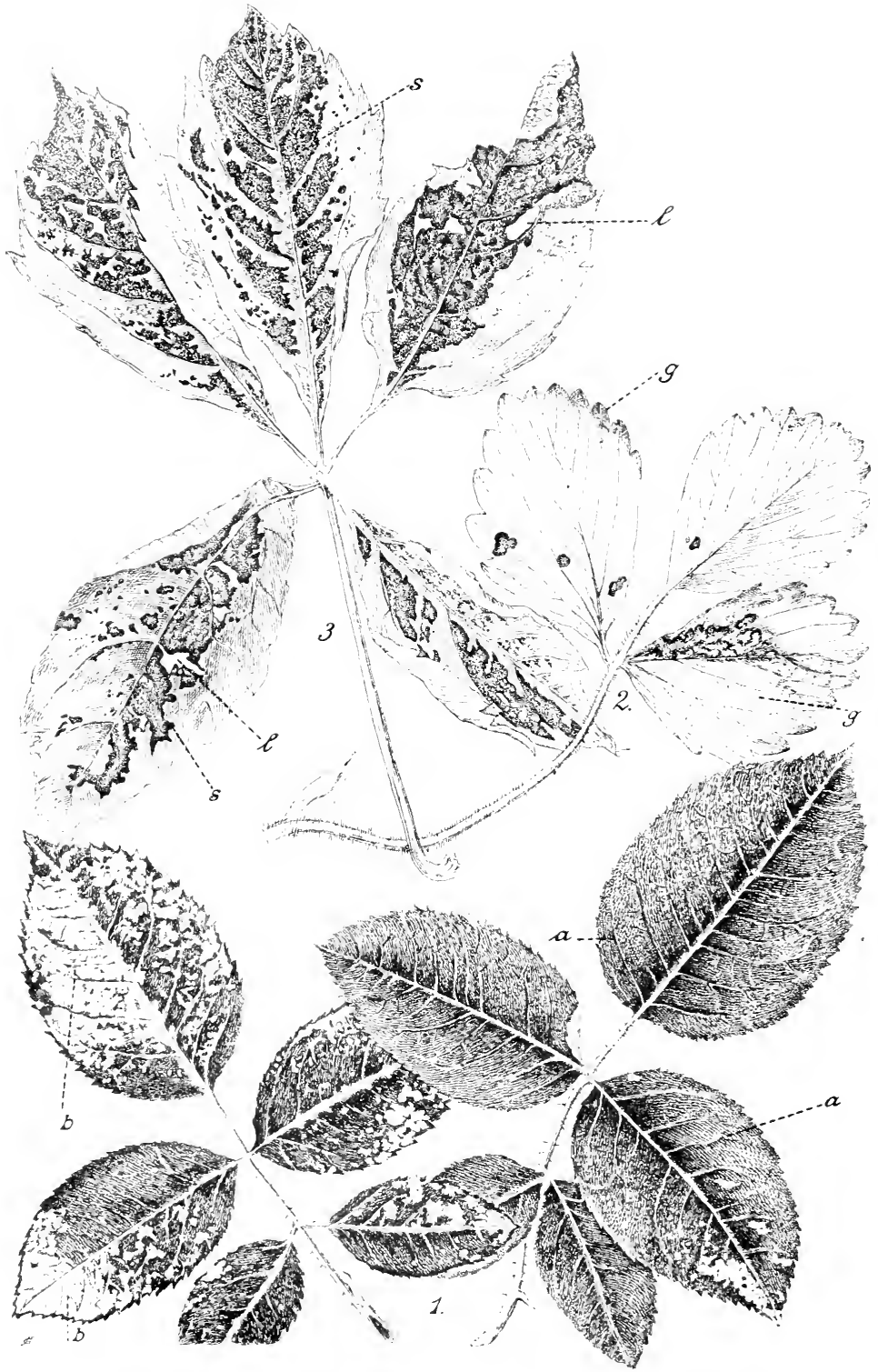

Fig. 168. Wilder Wein, Erdbeere und Rose durch Teerdämpfe beschädigt. (Orig.) 
der genamnten Rose beispielsweise tand ich, dat: die noch testsitzenden älteren Blätter ohne vorhergehende Rotfärhmg stmmpt schwarzfleckig wurden, was ant einer Balhung und Bräumung des Inhalts der Epidermiszellen berulte. Letztere aber blieben dahei in ihrer natürlichen Turgescenz und Höhe, während sie nach der Wirkmng von Asphaltdämpfen zusammenzusinken beginnen. Hier hält sich auch der Inhalt des Mesophylls lange Zeit in normaler Beschattenheit mul latgerung, während er hei der Herbstärbung alsbald sich hallt mol zu gleichartigen, anfangs orünen, später sich bräunenden Massen ungewanclelt wird. Parasitäre Schwarzfärbungen (Astroma rullosum usw.) wird das Mikroskop leicht von Asphaltätzmgen unterscheiclen kömnen.

Vor Beginn meiner Untersuchungen hatten hereits Altw und Jisxicke ${ }^{1}$ ) die Schwarzfärbung von Rosen und Erdbeeren infolge der Einwirkung von Asphaltdämpten beschrieben. Sie betrachten clas in diesen Dämpten nachgewiesene Eisen als eigentlichen Schädigungstaktor, indem dasselbe sich mit der Gerbsäure der Zellen verbindet, und stützen diese Ansicht durch Versuche, bei welchen sie durch Bespritzen der Blätter mit Eisenchlorür und Eisensulphat schwarze Flecke, die mit den Asphaltbeschädigungen übereinstimmten, erhalten haben. Eisenchlorid ergab diese WWirkung nicht.

Ich habe diesen Ertolg nicht erzielen kömnen, und anch diejenigen Beobachter, welche als Mittel gegen Chlorose mul Icterns das Bespritzen mit Eisenlösungen angewandt haben, berichten nichts von einer śchwärzung.

Bei dem in Fig. 168, 2 abgebildeten Blatte der Erolbeere (Kulturform von Fragaria chilusis) zeigt sich bei g eine nu teilweise schwärzmng der Oberseite, weil nur dieser Teil des Blattes freigelegen hat. Sonst waren die Erscheimmgen wie bei den Rosen: Hebmng fler Blattränder, teilweises Ilürrwerden der Blattzähne usw.

In Fig. lis, 3 sehen wir ein Blatt von Ampelops is quinquefoliu einige Wochen nach der Wirkung von Teerdämpten, welche einer Fabrik von Kohlenstiften tür elektrische Lampen entströnt waren. Die minder erkrankten Blätter erwiesen sich noch grün, aber nicht melır flach ansgebreitet, sondern an den Rändern muldenförmig in die Höhe gezogen und innerhalb der spreite rumzelig durch Hervortreten einzelner Gewebepartien zwischen den feineren Nervenverzweigmnen. Bisweilen fanden sich in der Nähe der Mittehipue kleine Stellen mit korkfarbiger Obertläche. Bei intensiverer Beschädigung sind derartige Stellen stets vorhanten und gehen teilweise in dïrrwerdende, miteinander vertlietsende Brandflecke üher. Schliefslich kann jedes Blatt ganz regelmätrige Zeichnungen durch das Dürrwerden der Intercostalfelder erhalten (Fig. 1tis, 3s). Durch die gegenseitige Reibung der Blätter bröckeh die dürren stollen vielfach heraus, so dats eine witterartige Inrchbrechung zustande kommt (Fig. 148. :37).

Junge Zweige werken an der Angriffsseite korkig und teinrissig. Etwaige Luftwurzeln schrumpten.

Wem die Wirkmm der Asphaltdämpte authört, zeigen sich die Heilungsbestrebungen des Blattes. Falls das Palisadenparenchym nicht oder nur wenig angegriffen worden ist, streckt es sich etwas mul wölbt die bis zur Unkenntlichkeit zusammengesmnkens Epidermis

1) Altwx, H., und Jixiıк, W., Eine Schädigung von Rosenblättern durch

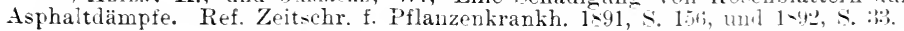


cin wenio vor. Wenn aber die Palisadenschicht mit abgestorben ist, (ntwickelt das darmnter liegende gesunde Mesophyll eine ganz reguläre Tafelkorlilage. An den stengeh ist derselle Vorgang zu bemerken: lie gebräunten, abgestorbenen, abgesprengten äntieren Korklagen und Rindenparenchymschichten samt den bisweilen in die Nekrose einhezogenen Harthastbïndeh werden dureh ein breites, in extremen Fällen bis an das Cambium reichendes Forkband rom gesunden Gewebe abgetrennt.

Bei Titis vinifera, der schneller und stärlier wie Ampelopsis leidet, so dats die Blätter bisweilen qänzlich verhänselt und durchlöchert werden kïmnen, wurde leobachtet, dats an don licht angegriftenen Stellen die schliefisellen der Spaltïftimmgen zuerst gelitten hatten. Andere Ptlanzen zeigten ein anderes Verhalten, hetretts dessen aut' meine Originalarteit verwiesen werden muls. Als allgemeines Merkmal aber darf die C'orrosion der Epidermiszellen bezeichnet werden.

Wie hei allen Boschädigmnen durch gastörmige höruer wirlit ausschlaggebend der Unstand, ob chronische orler akute Beschärligung eintritt. Im ersteren Falle, bei langsamer Einwirkung, kann das anregrittene Organ durch fiegenreaktion sich lange am Leben erhalten mind langsam ausleben. Dam sind die Merkmale andere als bei dem Einfluts hochlionzentrierter Gaswellen, die ein schnelles Absterben zm Folge hahen. So wurde heispielsweise hei langsamem Absterben der Fichtemnarleln in dem noch wrünen Teile eine starke Rotfärbung des plasmatisthen Inhalts der sichlietszellen und später sogar der Wandungen derselben wahrgenommen, bei akuter Beschädigmo aber nicht. Im ersteren Falle verfärben sich auch die Wände der Gefälshiundelelemente. wie üherhaupt durch Asphalträmpte die /ellwände hesonders schnell leiden. Man wieht dies namentlich schën an den metalliseh olänzend werdenden älteren Tannemnadeh.

\section{Brom.}

Bei dem gewöhnlichen wewerblichen Betriebe, in welchem Brom entwickelt wird, kamn man schwerlich von reinen Bromschäden sprechen. weil in der Regel die Schweflige Säure heteiligt ist. In grötserer Entfernung der Fabriken kann man wohl das Brom noch durch den Geruch wahnchmen, aber man findet dam ïberhaupt keine ausgeprägten sämreschäden mohr. Es ma@ deshalb hier von der Besehreibung natürlicher Vorkommnise in der Nähe von Bromfabriken abgesehen und das Verhalten der Pflanzen nath kïnstlicher Einwirkung intensiver Bromdämpte ceschildert werden. Ile Tersuche wurden in der Weise von mir ausgeführt, dats kleine, gntdurchworzelte 'Topf bäumchen der Fichte vier Tage hindurch täglich mehrere stumden dem verdamptenden Brom ausgesetzt wurden und in dar /wischenzeit in Freien verbheben. Die der Bromquelle zunächst befindlichen /weige litten natürlich am meisten und waren vollkommen brammadelig. Bei den weniger geschädigten \%weigen fanden sich viele Narlaln ron iter Spitze herab teilweise gebrämnt, und an den der Bromqualle ternst stehenden /weigen sah man mu einzelne Nadeln mitten zwischen gesmelen bram werden. Das anfangs lebhafte Rotbram ging alshald in (iraubram ïber. In diesem Farbenton erhielten sich die Nacleh bis zum Abfallen, das mogefähr nach zwei Wochen hegann, aher nur die starlibeschädigten Kweige umfal'ste. An den vertärbten Stellen sthwach heschädigter, am Zweige verbleibender Naleln erkannte man, dat's die Wandungen einzelner Gruppen von 
Mesophyllzellen in der Nähe ler Epidermis talnlgelb bis rotgelb geworden waren, wähenel der Inhalt sich entrïrth hatte und unter wänzlicher Desorganisation schliefich der Wandmo anfoetrocknet war. Dabei durehlief er nicht selten ein stadim sthammiger Boschatfenheit.

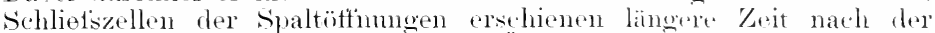
Einwirkmo des fiases num an den Übersangszonen in das gesmule Gewebe gerötet, wobei ihne Wandmuen bramgell, sich verfarht hatten.

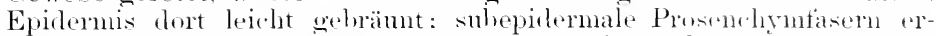
wiesen sich farblos. Das Mesophrll in der Nachbarsehat vler wehränuten stellen blieb grün und hatte entweder flockigen. grïnen Inlablt onler klumpig rereinigte ('hloroplasten. T)aran stiets alsbald gesumber fiewole.

An stäker geschädigten Stellen war anch las frefaitsbiunlel angegriffen mol in dersellen Weise vertärlst wie hei der schwetligen Säure. Aler der Farbenton der gesehädigten Nadeh war nur seiten ein Rotbram: meist erschienen dieselben gelhbram mol wenger hart.

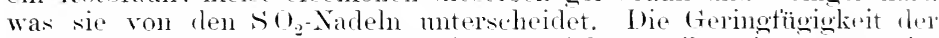
Unterschiede fällt hier weniger ins Gewicht, weil, wie gesagt, in praktisehen Betriebe Brombesehädigung in ler Regel mit der dinch sichweflige säme angerichteten gemeinsam antritt.

\section{Sielyehntes Kapitel. \\ Feste duswuristoffe der schormsteine und mitgefïhrte Destillate.}

Den besten Überblick ïhre das Material, welehes dureh die Ranchschlangen auf die Vegetation zur Einwirkme gelangt, gewährt ms ein.

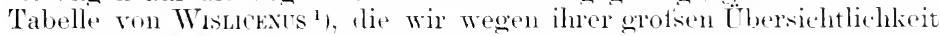
hier (s. 7:30):31) unverändert wiedergeben.

Ïber tie in der beistehenden Tahelle anfoeführten stotfe läkt sich ein allgemeines Urteil nielit fällen: sie kömnen nnter Unständen schädlich, sogar äufserst schädlich wirken, aber in anderen Fällen zu nemnenswerten Ernteverlusten keine Veranlassung geben. Es hängt dies nicht nur von der aröseren oder geringeren Exposition der Pflanzenteile ab, sondern von lokal ress.hiedenen Nobenumständen. Abgesehen von der individuellen Empfindlichkeit der einzehnen Pflanzenarten kommen hier, nanentlich bei Flugasche, die Bodenbeschattenheit und Wittermo, bisweilen ansichlaggebend, himzu.

Betretts der schädlichkeit ler Teernebel ist zu erwähnen, dats dieselben bei Kalkäten in Betracht kommen. Wem bei dem Brennen des Kalksteins das Calcinieren, also die Abspaltmog der Kohlensäure, beginnt, helarlet sich der Raurh mit orotsen Hengen der in der Tabell. angeführten Destillate, wolehe je nach der Eigenart dex PHanze ähnliehe Atzwirkmoen herrorbingen. wie sie bei den Asphalträmpten geschildert worden sind.

Die Schädlichkeit les R u tses ist früher durehgängig ïherschätzt worden und wird es jetzt noch toilweise. Die neneren Gntersuchungen

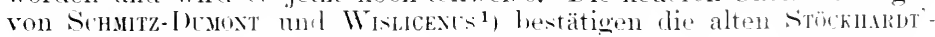

1) Wistexs's, H., Zur Beurteilung und Abwehr yon Rauhschiaden. Vortrag in Dresden am :31. Mai 1901. Zeitschr. f. angewandte Chenie 1901, Heft 2:, Taf. I? 
Chemische Beschaffenheit Die Zahlen bedeuten

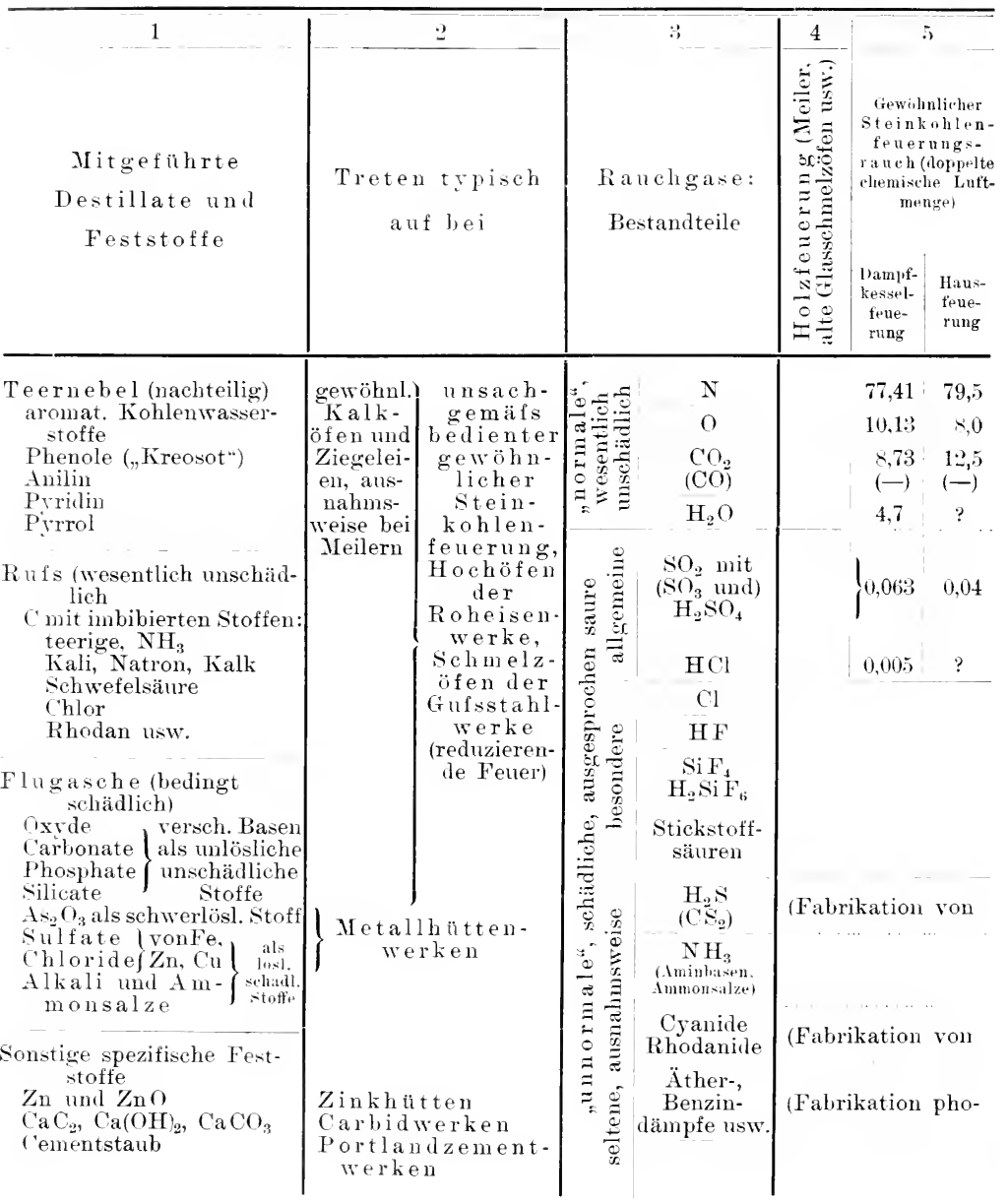

schen Erfahrungen, dats Ruf's meist unsehädlich wirkt. Zartere Pflanzen kömnen durch die mitgeführten Phenole nsw. Ätzerscheinmoen aufweisell.

Die Theorie von der Verstopfung der Spaltöffnungen muls fallen gelassen werden. Nach meinen Untersuchmoen bernfster Pflanzen sind Fälle, bei denen Rutsteilchen in den Vorlof einer spaltöffinung 
der Raucharten.

Volumprozente.

\begin{tabular}{|c|c|c|c|c|c|c|c|c|c|c|c|c|}
\hline bj & 7 & 8 & 9 & 10 & 11 & 1: & $1: ;$ & 14 & 15 & 16 & 17 & 18 \\
\hline 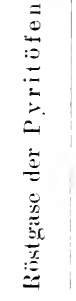 & 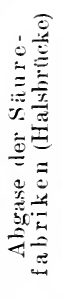 & 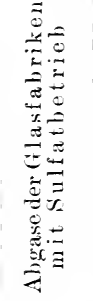 & 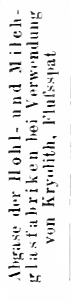 & 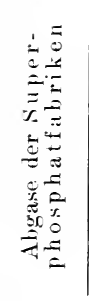 & 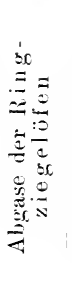 & 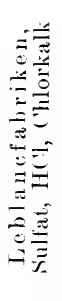 & 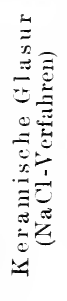 & 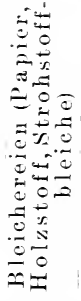 & 10 & 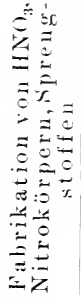 & 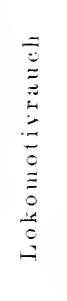 & 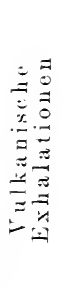 \\
\hline$\unlhd 1$ & & & & & 68,44 & & & 1 & & & 49,39 & \\
\hline 10 & & & & & 8.96 & & & & & & 6,3 & \\
\hline & 2,5 & & & & $\begin{array}{l}7,77 \\
(-)\end{array}$ & & & & & & $\begin{array}{l}5,41 \\
(-)\end{array}$ & \\
\hline & & & & viel! & 15,7 & & & & & & $40,-6$ & \\
\hline \multirow[t]{4}{*}{$\begin{array}{c}8,5 \\
\text { genut } 2 t: \\
0,45\end{array}$} & 0.26 & $\begin{array}{c}\text { heim An- } \\
\text { heizen } \\
0,08 ! \\
\text { bein } \\
\text { schmolzen } \\
0,44: 3\end{array}$ & & & $\overline{0,074}$ & & & & $\begin{array}{l}\text { Tltra- } \\
\text { marin- } \\
\text { ofen } \\
3,0 \ldots, 0,-\end{array}$ & & $\overline{0,0: 39}$ & \\
\hline & & & & & 0,023 & & & & & & 0,004 & \\
\hline & & & ! & $\begin{array}{l}\text { haupt- } \\
\text { satchlich } \\
\text { fluorhalt. } \\
\text { iligats. }\end{array}$ & $: !$ & & & & & & & $\begin{array}{l}\text { Bor- } \\
\text { säure }\end{array}$ \\
\hline & & & & $\begin{array}{l}\text { Hxugau- } \\
\text { der ham- } \\
\text { mersiture }\end{array}$ & & & & & & & & \\
\hline
\end{tabular}

Leuchtgas, Blausäure. Blutlaugensalzen usw. $u \rightarrow w$.

tograplincher Papiere usw.

gelangen oder denselben gar verkitten, äulsorst selten, und selbst in diesen Fällen habe ich eine Veränderung an den umgebenden Zellen nicht wahmehmen können. Es mïssen aber erst grölisere Mengen von Extraktstoffen (Sulfate und Phenole) ausgelaugt werlen, the eime Schädigung sich naehweisen lätst. Dies zeigen die Versuche von Wisurexts mit Steinkohlen-. Bramkohlen- und Benzimruts sowie mit 
Rufextrakten. durch welche Blätter von Hainbnche und Linde und später anch Fichtemmadeh leichte Ätzwirkmngen durch die Extrakte erhielten. Wahrscheinlich bewirken die eintrocknenden salze eine osmotische Wasserentziehung und Anstrocknmg. Dieselben Versuche ergaben auch die Nichtbestätigmng der Befömehtmo, dats dicker Rutsïberzug das Licht absorbiert und in Wäme mmwandelt und dadurch nachteilig wirkt.

Dats die im Ranch mitgeführte Kohlensäure schädlich wirken kann. ist eine theoretische M̈̈glichkeit. da die Versuche mit extremer Steigerung dieses Gases über die normalen 0.04 bis $19,100^{\circ} 0$ hinans die Behinderung der Assimilation ergeben haben. Aber im praktischen Betriebe wird kamm davon die Rede sein kïmnen. Dasselbe gilt für das Kohlenoxyd.

Die metallisehen Bestandteile des Hüttenrauches (s. momstehende Tabelle) kommen bei der Flugaschenfrare zur Geltung. Nach Freytar's ' ${ }^{1}$ Untersuchmoen erweisen sich reine Metalloxyde meist muschädlich. Als Futter tür Tiere wird natürlich Laub mit derartigen Oxyden nicht zu verwenden sein, da leicht Entzündungskrankheiten auftreten kömnen.

Als mö̈sliche Oxyde, als Karbonate und Silikate sthaden die metallischen Bestandteile des Hüttemranches den oberirdischen Pflanzenteilen kaum mehr als etwa Strat'senstaub. Lösliche Terbinlungen dagegen, wie arsenige sämre, Sulfate und Chloride (es handelt sich hier vorzugsweise $m \mathrm{~K}$ h p fer, Z in k und Blei), erzengen durch Korrosion des Gewehes lrame Flecke, sobald sie auf vorher benetzte Blätter gelangen. Auf trocknem Laube sollen sie nicht schaden, und eine nachfolgende Benetzmng durch Regen wäscht leicht den Überzug wieder ab. Quecksilberdämpfe wirken oberirdisch stets schädlich. Die durch Regen in den Borlen himabgewaschenen Verbindungen werden rom Boden absorbiert und dadurch meist msehädlich. Eine grot'se Anhäufung von Arsen (ron 0,1\% ab) ist nachteilig. Die Experimente von?. PHILLips ${ }^{2}$ ) bestätigen, dats gesunde Pflanzen durch Anfinahme ron Blei und Zink keine Wachstumsstörungen erleiden: dagegen wirkt Kupfer ebenso wie Arsen giftig, wobei die Wurzelansbildnug gestört wird. Einen Nachweis arseniger säure in Pflanzen liefern KLiss ${ }^{3}$ ) und zahlreiche neuere Beobachter. Solche Vergiftungen des Bodens kömmen z. B. in der Nähe von Kupferhüttenwerken eintreten, nnd in einem Prozesse gegen die Mammsteld-Hettstädter Kupferhüttenwerke weist Grovres auch speziell anf diesen Punkt hin ${ }^{4}$ ). Neine eigmen Erfahrungen in derselben Gegend zeigen, dafs zurzeit grofse Ackerflächen vergiftet sind und trotz reichlichster Düngmo sehr mangelhafte Ernten liefern. Daf's hier nicht Ranchuse die schädigenden Falstoren allein mehr sind, sondern der an Kupfersalzen reiche Boden, beweisen die Versuche, bei denen der unfuchthar gewordene Boden ans der Nähe der Kupferwerke

1) Frexra: in fahrh. für das Berg- und Hüttenwesen im Königreich Sachsen 1873, S. 24 u. :36, cit. hei Hasenclever. - Landwirtsch. Jahrb. 1882, S. :315-357. Verfasser weicht betreffs der Rauchwirkung insofern von schröder ab, als er nicht die schweflige säure als solche, sondern erst die aus ihr sich bildende Schwefelsïure für das schädigende Agens hält.

2) Phrmirs, The absorption of Metallic Oxides by plants; cit. Bot. Centralbl. 188:, Bd. XIII, Nr. 11, s. 364 .

$\left.{ }^{3}\right)$ Chemischer Ackersmann 1875, Heft 4.

4) Fühling's neue landwirtseh. Z. 1871, Heft 7, s. 5934. 
ausgehoben und in rauchtie Gegend gebracht worken war. Auch am letzteren Orte waren die Pflanzen $($ Pluscolus rulguris) crlirankt, während die daneben gesäten auf dem an Urt und stelle grewatisenen Boden der rauchfreien fregend gesund und krättig sich woitu entwickelten. Wieviel die Ptlanzen während einer Vegetationsprode an Metallen aufnehmen kömnen, zeigrt eine Analyse von hartofleh, deren Kraut von dem metallischen Flusstanb ans einer Nielielfabrik hestrichen wure. Gesundes Laub enthielt (in Prozenten der wassur- mol sandfreien silustanz):

$\begin{array}{llllll}\text { Kupteroxyd } & \cdot & \cdot & \cdot & \cdot & 11,1198 \\ \text { Zinkoxyd } & \cdot & \cdot & \cdot & \cdot & 11,11469 \\ \text { Nickeloxyd } & \cdot & \cdot & \cdot & \cdot & -\end{array}$

Krankes Laub enthielt (in Prozenten der wasser- mol sandfreden Suljstanz):

$$
\begin{aligned}
& \text { Kupteroxyd . . . . 1,1171:; } \\
& \text { Zinkoxyd . . . . 11,172 } \\
& \text { Niclicloxyel . . . (1,11,251 }
\end{aligned}
$$

Ihe zugehörigen hnollen aber zeigrten gar kein Zink- und Nickel-

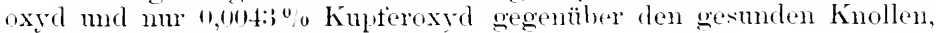
welche $0.10141^{0 / 0}$ besatisen ${ }^{1}$.

Neben Kuptorvergiftumgen ragen wegen ihrer Sthädlichlieit dic Arsenverbindungen hervor, die (mach v. Schkönek) schon in Mengen unter $1,1 \%$ im Boden die Vegetation beeinträchtigen.

Indes sorgt die fortschreitende Technik tatüur, dats sowohl Arsenili wie anch die löslichen Metallsalze des Ranches in den Flugstaubkanälen immer mehr zurüchigehalten werden, so das im jetzigen praktisehen Betriehe neue Metallvergiftungen des Borlens weniger zu befürehten sind.

Democh beanspruthen tie Flugaschena us ürte eine erhöhte Aufinerkamkeit. Eine Reilue eimer Versuche hat gezeigt. dats man mit manchen Flugaschen, die dem Boden beigemengt werten, eine, sichtliche Wachstumsfördermog erzielen kann. während aus anderen Betrieben stammende Proben eine vergiftende Wirlime ausüben. Dicselbe ist weniger of cine direkte Beschädigung der oberirdischen Pflanzenteile, sondern häufiger eine indirekte, dis in dem Einfluts ant gewisse, schwere, wasserreiche Bodenarten sich geltent matht. Bei den oberirdischen Beschädigmoen kömen sichwefeluatrium und schwefelcalcinm Ätzwirkmgen an einzelnen zarteren Pflanzen hervornten, bei den indirekten Schädigmngen ist die Wirkmngsweist noch nicht genügend aufgeklärt. Meiner Ansicht nath handelt es sich teilweise um Reduliomserseheinmoen im Boden, hei denen Seluwetelwasserst of 't entwickelt wird.

In den durch Flugasche stark übershoutteten schweren Börlen. namentlich wemn diesclben reiche Kalkdüngung erhalten haben, tritt hei Gerste eine hrankheitsersheinmo, die ich als ..Fleckennelirose" bezeithnet habe. so hochradio ant, rats die Ernte rine antierordentlich starke Einluntse erfäht. Alle Teile der Ptanze bis zu den trammen der syelzen erscheinen dicht brampmbtiert. lit loamen Punlite stellen abgestrobene frewebeinseln dar, hei lenen Parasiten bestimmt nicht die Trache sind. Es kömen später sich schwäzepilze

1) Kinsı, J., Denkschrift der Landwirtschaftl. Versuchsstation Münster i. W. 1896, s. 204 . 
ansiedeln, und man hat dann diese Komplikation als "HormodendronKrankheit" beschrieben. Die Fleckennekrose ist jedoch nicht spezifisch für die Flugaschengebiete, aber mzweifelhat't dort am intensivsten. Gemildert sah ich diese Erkrankung nach krättiger Kalkdüngung.

Die meisten Hinweise anf die schädigende Wirkung von Schwefelwasserstoff finden wir in den (tutachten von STEFFEck ${ }^{\mathbf{x}}$ ). Dort wird anch der vielfachen Entwertung der Feldfriehte durch mechanische Überschüttung gedacht. Auch mir sind Fälle bekannt geworden, in denen eine Einlagerung von Asche in Gemïsepflanzen, namentlich Kohlarten, so stark war und so wenig sich entfernen liels, daf's die Pflanzen minderwertig oder ïberhampt unverkäuflich wurden. Nach starker Überschüttung ron Futterrunkeh und /uckerrüben, deren Blattköpfe später verfüttert wurden, gingen einzehe Stücke des Viehbestandes ein. Man fand bei diesen Tieren im Magen ganz unglaubliche Nengen ron Asche.

\section{Schwefelwasserstoff.}

In Rücksicht ant unsere Anschaumg, dafs bei Flugascheeinlagerung in gewissen schweren Bodenarten sich Schwefehwasserstoff bilden kann, habe ich einige Tersuche mit Gerste ausgeführt. Es wurden die Kalimmpolysulfide der Schwefelleber benutzt, die teils in Stücken zwischen die junge, in Töpfen erzogene Gerstensat gelegt, teils in Wasser von Untersätzen gebracht wurden, in denen Töpfe mit Gerstensaat standen. Ein zwischen die Pflänzchen ausgelegtes Bleipapier bräunte sich langsam. Nach sechs Tagen begam eine Teroilbung der Blätter, und zwar meist in der Mittelregion, seltener von der spitze aungehend. Die verfärbten Stellen sahen saftiger und durchscheinender aus als bei der durch andere Ursachen hervorgerufenen Tergilbung ${ }^{2}$ ). Der Gelbfärbung folgte cine Erschlaffung der Gewebestelle und ein Vertrocknen der darüber liegenden, noch grïnen Blattfläche unter Annahme einer graugelben Farbe.

Das erste Srmptom der Erkrankung ist hier stets die Bleichung. des Chlorophylltarbstofts, der alsbald in den plasmatischen Zellinhalt iiberzutreten beginnt. Es geht nicht, wie bei anderen Vergiftungen, ein Kusammenziehen des Primordialschlanches oder Schrumpten der Chloroplasten voran oder nebenher. Dafür aber ist ein stellenweises Übertreten des Zellwasser's in die Intercellularräume bemerkbar, und rarans ist das durchscheinende Aussehen der vergilbten Stelle erklärlich. Sodamn folgt ein Verschwinten der Grenzen der einzehen Chloroplasten bis anf einen körnigen Rückstand, der in der Mitte der gesamten wolkig-trïben, bleich gelloriunen Plasmamasse zusammengezogen ist. Man hekommt den Eindruck, dals hier der gesamte Zellinhalt zu einer gleichartig teigigen Masse verquillt, während bei Chlorund Salzsäurewirkmg man sehrmm,fungserscheinumgen, bei Schwefliger Säure aber Auftrocknungsrorgänge des differenziert bleibenden Inhalts wahmimmt. Bei Hafer war lie Bleichung des Chlorophyllfarbstoffs eine langsamere und weniger intensive. Infolge eintretender WVurzelerkrankung wurden die Gefälibindelelemente tief bramwandig.

1) SrkfFeck, Die durch gewerbliche Einwirkungen hervorgerufenen Flurschäden und Terumreinigungen von Wasserliafen und Teichen. Magdeburger Zeitung 1907, Nr. $: 39$ u. 331.

2) Silitri, P., Beitrag zur anatomischen Analrse rauchbeschädigter Pflanzen. Landwirtsch. Jahrb. 1904, S. 64:). 


\section{Sodastaub.}

Über die Schädlichkeit von Natrondämpten herichtet EBERus ${ }^{\mathbf{1}}$ ). Bei der Gewimmong (ler Cellulose wird Natronlauge unter erhöhtem Druck auf zerkleinertes Kiefernholz einwirken gelassen. Behutis Rückwewimmung des Natrons wird die benutzte Lauge eingedamptt mul der Rückstamil zur Zerstörung der organischen Stoffe rerbramnt. Halei quangt viel kohlensaures Natron in rio Umgebung. Obstbäume in der Nähe soleher Fabriken zeigten die Blätter bram oder schwarz gefärht mul in kurzer Keit abgestorben.

Dieselbe Färbung nalmen Blätter an, die in eine veroümnte sockalösung von 1,01 spez. (Gewicht getaucht wurden. Aptelblätter erschiencn etwas weniger widerstandstähig als Birnen und Pflammen.

Betreff's des Sodastaubes sind bisher nur Fälle bekannt geworden. wo Soda aus Ammoniaksorlafabriken durch ene unzulässige Ventilation der Fabrikräume verstäubte. Die durch Tau oder Regen gelöste soda ruft durch Absterben der Blattränder oder auch durch einzelne Ätzflecke leicht bei manchen Bäumen das Bild einer Beschädigung durch saure Gase hervor.

In zweifelhatten Fällen hilft dem Experten aber hier die Beschatfenheit der willen Gräser und namentlich der Getreidchalme, welche eine citronengelbe Färbun@ einseitig amehmen. Je nach der /eit und Intensität des Entweichens des Sodastaubes kamn Getreide taub werlen und die Bammvegetation allmählich durch eine alljährlich sich wiederholende Blattbeschärligung zum Absterben gebracht werden. Übrigens sind die einzelnen Pflanzenspezies in sehr verschiedenem Mat'se empfindlich und verhalten sich manchmal widerstandsfähig gegen Sorla und empfindlich gegen saure Ranchgase und umgekehrt. Künstlich von mir vorgenommene Bestäubungsversuche an Getreille und wilden Gräsern (Agronyrum repens, Agrostis milgaris, Lolium etc.) in betautem Zustande ergaben das Auftreten derselben (ielbfärbung auch an den Spelzen, wie bei den natürlichen Beschärligmoen ${ }^{2}$ ), die bis auf 2 Kilometer Entfernumg ron der Fabrik nachweisbar waren. Kösı: ${ }^{3}$ ) beobachtete, dats Gerstenblätter weits gerändert wurlen: Rotklee soll zuerst kleine schwarze Flecke auf den Blättern zeigen, später werden einzelne ganz schwarz und fallen ab; ehenso bei Kartotfeln. Bei Eichen wie bei Kirschen fand Könu neben den bramen Blatträndem anch Löcher vor. Weitstamnennarleln sollen gelbspitzig werilen und abfallen. Auf Grund seiner Analysen sieht genannter Autor die WVirkung der Soda nicht nur in einer Humifizierumg der Blattsubstanz, sondern in ler Aufualmme ron Soda durch die Blätter, von wo aus tieselbe bis zur WVurel wandert. Mit rler Steigerung der Natronmenge erfolgt gleichzeitig eine Zumalme an säuren, namentlich Kiesel- und s'chwefelsäure ${ }^{4}$ ): vielfach nehmen auch Phosphorsäule und Chlor zn. Diese Gegenreaktiondes Pflanzen-

I) Ein Beitrag zur Pathologie der Obstbäume. Tagebl. d. Naturf.-Ters. zu Hamburg, cit. Biedermanns Centralbl. 187\%, II, S. 31\%.

2) Zeitschr. f. Pflanzenkrankh. 1892, S. 154, Anmerk.

3) Bärser, Hasphmfr und Körig, Über die Schädlichkeit ron sodastaub und Ammoniakgas auf die Vegetation. Mitgeteilt von Kösi, Landwirtsch. Jahrb. XXI cit. Zeitschr. f. Pflanzenkrankh. 1893, s. 95.

4) Nur bei Roggen fand Kixia (Denkschrift 1 $>96$ \$. 207) trot\% hïheren Gehaltes an Natron weniger Asche, namentlich weniger Kieselsäure. Es scheint ihm, dafs durch die Soda im Halme Kieselsïure gelöst und ausgewaschen wird. 
kïrpers zeigt sich im mogekehten sime auch bei den Beschälimngen durch same Gase, bei denen die noch nicht über ein gewisses Thas hinaus heschädigten Blätter mehr Basen enthalten als die gesmnden.

\section{Fangpfianzenmethode.}

Über die technischen Mafsnahmen zur Vermeidnus oder Verminderung der Rauch- und Flugaschebeschädigungen muls aut die technischen Handbücher verwiesen werden. Wohl aber möchte ich hier eine Methode behut: Klärung der Frage angeben, ob rle wahrgenommenen schärlen mit der Bodenvergiftung zusammenhängen oder rein oberirdische Wirkungen der säurehaltigen Gaswellen sind. /n diesem $/$ wecke bediene ich mich des.. Fangptlanzenbanes". Diese Methorle besteht darin, dats in die klägerischen Äcker Holzkästen von mindestens 1 clom Inhalt eingestellt und mit einer Erde angetüllt werden, welche vor Zengen ans rauchfreier Gegend entnommen worden, ist. Andererseits kommt die ans dem klägerischen Acker ansgehobene Erde in ebensolche Kästen, tie aber ant emem Acker in ranchfreier Gegend eingegraben werden. Beide Kästenkategorien werden dam in ganz gleicher Weise mit Bohnen (Phaseolus inlyaris nums) besät und gleichzeitig nach einer Reihe von Wochen geerntet. Die Ernte wird mikroskopisch und chemisch untersucht.

Eine Bodenvergiftung wird ladurch bewiesen, dat's die Pflanzen in dem aus dem klägerischen Acker stammenden Boden in den in rauchtreier Gegend eingesenkten Kästen unter denselhen Nerkmalen wie die vor der Rauchquelle erkranken. Wemn dagegen die in der Nähe des schädigenden industriellen Etablissements auf dem klägerischen Acker eingesenkten, mit Errle aus rauchfreier (Gegend angefüllten Kästen an ihren Bohmen die Merkmale der Ranchvergiftung erkennen lassen, so ist der Hinweis gegeben, dats die gefährliche Ranchschlange allein schon hinreicht, das Pflanzenwachstum zu schädigen.

Diese vergleichenden Kulturen haben den Vorteil, den streitenden Parteien schon einen dem Laien erkennbaren Einblick in die s.chädigungsart zu geben und darturch eine gïtliche Einigung anzubahnen und den langwierigen Prozetsweg zu vermeiten. Betrefts der Prozesse ist die Bildung statlicher Rauchkommissionth anzustreben. Wir verstehen darunter hestimmte Personen aus den Kreisen der Botaniker, Chemiker, Land- und Forstwirte, welche zu Sachrerständigen-Kommissionen zusammentreten und für dic einzelnen Bezirke stets dieselben sind. Durch die Beibehaltung derselben Persönlichkeiten erhalten diestluen einen genaneren Einblick in die sveziellen Verhältnisse ihres Bezirlies und rin gesicherteres Urteil in diesen schwierigen Fragen.

\section{Leuchtgas und Acetylen.}

Man hatte dem häufig im Leuchtgase vorhandenen Schwefelwasserstotf den schädlichen Einfluts zugeschrieben, den das Lenchtgas anf die Pflanzen ansïbt. Dis allemige Ursache ist er nicht, da Kxy ) nachgewiesen, dats anch das sorwältig von schwefelwasserstoft gereinigte Gras den Wurzeh schärllicli ist. Aus der violettoramen Färbung vieler Wureh bei den rum Lenchtgas geschärligten Bämmen schlietse ich, dat's mitretührte stotte ans der 'Teerreihe bzw. Ammoniak die schädigenden Faktoren sincl. Diese violette Verfärbung der Wurzeh

1) Sitzungsber. a. Ges. naturforsch. Frounde zu Berlin in Bot. Zeit. 1871, s. 869. 
ist rorläntig als das beste Merkmal zu bezeichnen. wenn es anch keine

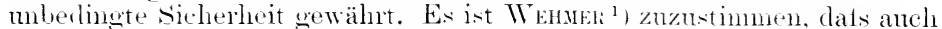
bei anderen Todisarten derartige Wurchertälumen vorkommen, und rats lei Bämmen, die durch Lenchtgas in Boten zngmude gegangen sind, manchmal das Merkmal mur spärlich zu finden ist. lutzterer Fall ist sehr erliärlich, da nur diejenigen Wurzeläste, die direkt mit dem schärligenden Agens in Beriihrung kommen, sich vertiatsen und das Absterben der Bämme veranlassen; die selumelä sterlenden Wurzeläste lleiben ungetärbt.

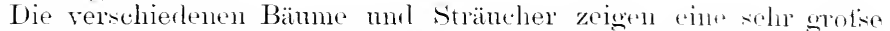
Mamngfaltigkeit hinsichtheh der Widerstandstähigkeit wegen den EinHut's des Gases. Während \%. B. in den Kxy schen Versuchen dio Uhme selne hald einging, hat Comms somemined olne wahmehmbaren sichaden die Veroiftung mit Lenchtyas überstanden. Wie weit rer Eintlutis einer (iasleitungsö̈he sich erstreckt, zeigt eine Analyse ron (imatins²), wonach der Boclen noch in eincr Entfermung von 1 m brenzliche öle, schwetel- und Ammoniakverbindungen autivies.

Ein weiteres Beispiel für tas rersehiedenartige Verhalten der Pflanzen gegen Lenchtgas föhrt Lackiser ${ }^{3}$ ) an, dessen Beolathtmngen sich aber aut den Einfluts beziehen, den (ias bei seiner Vellnemung im Zimmor ausüben soll. Den Kamolien und Azaleen ist ein Antenthalt im Kimmer,

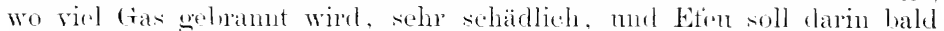

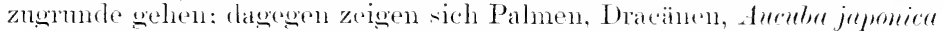
mind andere PHanzen war nicht empfindlich.

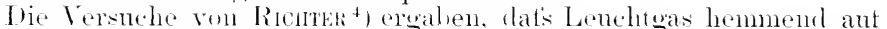
das Längen- mel törelernel anf das Dickenwachstm bei heimlingen rou Bohmen mel anderen Pflanzen wirkt. Dats der bed der Ver-

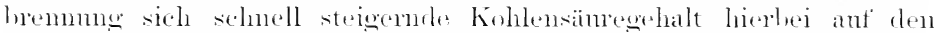
PHanzenkörper so schällich wirke wie ant den 'Tirkärles. wie man fiüh+1 anzunelmen geneigt war. ist nieht der Fall's) es ist cher zu vermuten, dats einzehe Prouluktr der unvollkommenen Verberemung les Leuclitmateriak die sichulet tragen.

1) Whms, C. T̈her einen Fall intensiver shädigung einer Allee durch aus-

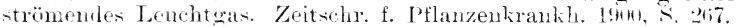

2) Jahrester. über Agrikulturchemie Jahrg. VII, 1sic; S. 19:.

Donatsohrift d. Ver. z. Beförd. d. Cartenbanes in d. Kol. Preufs. Staaten Januar 1sir, s. '2.'.

4) Risure, O., Pflanzenwachstme uml Laboratoriumsluft. Ber. 1. I). Bot. (ies. 19m:?. Hoft :3.

") Wir wiederholen, dafs bei sonst günstigen Wachstumshedingungen bis zu

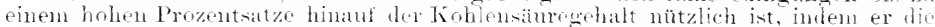
Produktion von Pflanzensulatanz hefördert, Was durch die vernehrte sinferstofl-

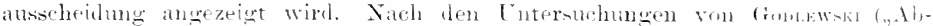

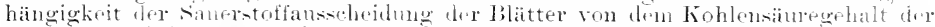

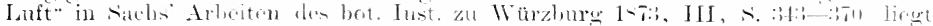

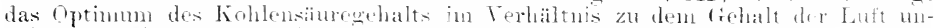

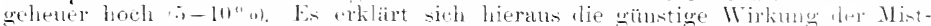

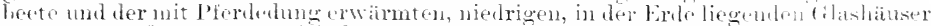

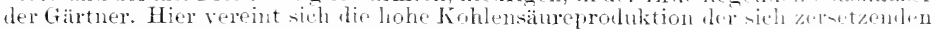
organischen substanz mit ruchlicher. Wömeentweklung, abgeshwichten Licht mil feuchter Luft, also den wesentlichen Faktoren eines nippigen libattwachstums. Aber anch die Blütenentwicklung wird in der Weise gefördert, thafs ba pasteigertem

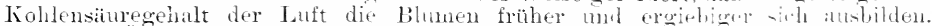

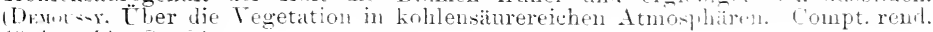
19404 , t. $1: 34$, s. $(3: 3$. 
Nach meinen Erfahrungen ist bei den Zimmerkulturen in erster Linie die Trockenheit der Luft die llauptursache des Absterbens, das sich dann in einem Vertrocknen der Blattspitzen und Blattränder geltend macht.

Betreffs des Einflusses ron Lenchtgas auf die Wurzeln zeigten Вӧнм's $\left.{ }^{1}\right)$ Versuche mit Weidenstecklingen in Flaschen mit Wasser, welchem Leuchtgas zugeführt worden, dat's die Wirkung eine langsam tötende war; die nach drei Monaten absterbenden Stecklinge hatten auf Kosten der gespeichert gewesenen Stärke neue, kurze Wurzeln gebildet. Die Wirkung war dabei weniger intensiv, als wem das Wasser Kohlensäure zugeführt erhielt. In diesem Falle waren alle Neubildungen an dem im Wasser befindlichen Stengelteile unterblieben, während der obere Teil, der Thyllen in den Getälsen bildete, noch krankhafte Triebe entwickelte; der Tod trat nach zwei Monaten ein. Bei anderen Versuchen, in denen Wasserstoff zum Wasser zugeführt worden, war die Entwicklung nahezu normal. Vergl. d. Abschnitt über Kohlensäureüberschul's.

Die Pflanzen starben anch, wemn Leuchtgas der Erde ihres Topfballens zugeleitet wurde. Samen, welche in Erde gelegt wurden, durch welche fast $2^{1} 2$ Jahr lang Lenchtgas hindurch gegangen war, kamen nur zu einer höchst mangelhaften Entwicklung. Wurde durch solchen Boden während längerer Zeit ein Strom atmosphärischer Luft geleitet, so verlor die Erde ihren schädlichen Einflufs durchans nicht, so daf's man diese Wirkung wohl, wie bereits gesagt, vorzugsweise den teerartigen Produkten zuschreiben darf, welche sich im Boden in flüssiger oder fester Form absetzen.

SP̈̈тн und MEYER ${ }^{2}$ ) fanden, dafs schon eine verhältnismätsig geringe Gasmenge (25 Kubikfufs auf 14,19 qm Fläche bei 1,25 m Tiefe täglich verteilt) die mit dem Gas in Berührung kommenden Wurzeln tötet. Weniger schädlich zeigte sich selbst ein grölseres Gasquantum, wenn dasselbe die Bäume in der Zeit der Winterruhe bestrich. Auch hier erwiesen sich die verschiedenen Baumarten von verschiedener Widerstandskraft

Am zweckmäfsigsten erscheint vorläufig das durch BöHм empfohlene Verfahren von J Jergers, die Gasröhren der Straf'sen usw. in glasierte Tonröhren zu legen, welche Ausmündung in die Belenchtungskandelaber haben, so dat's innerhalb der Tonröhren eine danernde Ventilation stattfinden kann.

Bezüglich der Acetylenvergiftung hat Brizi ${ }^{3}$ ) Versuche angestellt, der in einer italienischen Stadt cin Absterben von Quercus Ilex an einem Leitungsstrange dieses Gases wahrnahm. Krautartige Pflanzen gingen in den Töpten, welche Acetylen zugeführt bekamen, unter Vertrocknungserscheinungen zugrunde. In den Palisadenzellen von Coleus waren die Zellkerne verschwunden; die Wurzeln hatten ihre Haare verloren; die Seitenwürzelchen erschienen welk, gequetscht und braun; die Rindenzellen entbehrten jeder Flïssigkeit. Bei Evonymus japonica

1) Über den Einflufs des Leuchtgases auf die Vegetation. Sitzungsber. d. k. Akad. d. Wissensch. zu Wien, Bd. LXVIII B.

2) Spätil und Merer, Beobachtungen über den Einflufs des Leuchtgases auf die Vegetation von Bäumen. Landwirtsch. Versuchsstat. 1873, S. 336.

3) Brizi, U., Sulle alterazioni prodrotte alle piante coltivate dalle principali emanazioni gasose degli stabilimente industriali. Staz. sperim. agrar. ital. XXXYI; cit. Zeitschr. f. Pflanzenkrankh. 1904, S. 160. 
erwiesen sich die Pflanzen in trockenem Boden nach sieben Tagen noch normal, während sie in fenchter Ercle nach sechs Tagen bereits die Blätter abwarfen und die meisten jungen Wurzeln abgestorben zeigten. Lorbeer und Weinstock verhielten sich ähnlich. Brizi sieht die Wirkmng der im Acetylen enthaltenen Gase und Beimengungen in einer Entziehmo der normalen, sauerstoffhaltigen Luft, so dats die Wurzeln ersticken, und meint, dats Lenchtgas ganz analog, aber noch heftiger wirken werde. Die Feuchtigkeit des Bodens fördert darum die Schädlichkeit, weil sie seine Durchlässigkeit für die Gase herabdrückt.

Die Ansicht Brizi's ron der erstickenden Wirkung, die Lenchtgas in seinen mitgeführten Produkten anf die Wurzehn ausïbt, findet insofern eine Stütze, als ich bei Gasvergittungen von Linden in Berlin beim schneiden der Wurzeln dentlich einen Buttersäuregeruch wahrgenommen habe und bei Wurzeh von Bäumen, die dureh stagnierende Nässe zugrunde gegangen waren. violettbrame Membranvertärbungen feststellen komnte.

\section{Achtzehntes Kapitel.}

\section{Abwisser.}

\section{Kochsalzreiche wässer.}

Von allen Schädigungen, die durch Abwässer veranlat'st werden, sind die durch Kochsalz hervorgerufenen die häufigsten. Besonders begegnet man denselben in solchen Gegenden, in denen eine grofise Steinkohlenförderung stattfindet. Aus den Analysen, welche Kons: ${ }^{1}$ ) in (remeinschaft mit STORP ${ }^{2}$ ), BöHмER ${ }^{3}$ ), S'TOOD ${ }^{4}$ ) und HASELHOFF $^{5}$ ) veröffentlicht hat, geben wir einige Zahlen über die Znsammensetzung ron Grubenwässern, die zur Genüge zeigen, um welche Mengen von Chlornatrium und anderen Salzen es sich bisweilen handelt. Es enthält pro 1 l:

\begin{tabular}{|c|c|c|c|c|c|}
\hline Name der Zeche & $\begin{array}{l}\text { Chlor- } \\
\text { natrium }\end{array}$ & $\begin{array}{l}\text { Clor- } \\
\text { calcium }\end{array}$ & $\begin{array}{l}\text { Chlor- } \\
\text { magnesium }\end{array}$ & $\begin{array}{l}\text { Kalium- } \\
\text { sulfat }\end{array}$ & $\begin{array}{l}\text { Magnesium- } \\
\text { sulfat }\end{array}$ \\
\hline$x$ & $65.949 \mathrm{~g}$ & $11,1956 \mathrm{~g}$ & $3,736 \mathrm{~g}$ & $0,659 \mathrm{~g}$ & 一 \\
\hline as S'ti & 33.2440 & $3,631 \mathrm{~g}$ & $1,735 \mathrm{~g}$ & - & $0,1142 g$ \\
\hline Saline Königsborm & $45.413 \mathrm{~g}$ & $4,061 \mathrm{~g}$ & $0,189 \mathrm{~g}$ & 一 & $1,2,0100$ \\
\hline
\end{tabular}

Man kamn ans diesen Beispielen leicht ermessen, welchen Einflnts Berieselungen oder gar Überflutungen mit derartigen Lösmgen ausüben werden. Die Wirkmng wird sowohl eine direkte, als anch eine indirekte durch die Veränderungen sein, welche der Boden erleidet. In letzterer Beziehmmg kommt zunächst der Umstand in Betracht, dat's die Borlemnährstoffe (Kali, Kalk, Magnesia, unter Umständen anch Phosphorsänre) in erhöhter Menge gelöst und ausgewaschen werden. Der Auswaschungsprozets hegimnt schon bei $0,5 \mathrm{gr}$ Kochsalz pro Liter: mithin sind alle Wässer mit grötserem Gehalt schon zur Berieselung bedenklich. Dem Nährstoffverlust des Bodens entsprechend zeigrten anch Topfversuche mit Wiesengräsern einen wesentlichen Rückigang der geernteten Substanz.

\footnotetext{
1) Die landwirtsch. Versuchsstat. Munster i. W. Denkschrift 1\&96, S. 1.i3.

2) Landwirtsch. Jahrbücher 1883 , XII, S. 795.

3) Ebend. S. 897 .

4) Landwirtsch. Versuchsstat. 1889, S. 113

5) Landwirtsch. Jahrbücher 1 $\$ 9: 3$, S. 845 .
} 
Ein zweiter Nachteil der Berieselumg mit kochsalzhaltigem Wasser ist das Dichtschlämmen des Bodens; es genügen schon $0,41 \%$ Kochsalz im Boden, um denselben infolge Verdichtung mfruchtbar zu machen. In der Nähe von Salzwerlien sah saxa ${ }^{1}$ ) ein Überwiegen ron Feinerde gegenïber den groben Bestandteilen und macht darauf aufimerksam, dafs durch die rerminderte Luftzufuhr die Arbeit der Bodenbakterien aufgehalten wird. Solche Büden müssen umbedingt vor Winter in rauhe Furche gelegt werden, damit sie durch den Frost wieder eine Auflockermo erfahren. Endlich aber ist noch ein Punkt, auf den Perilox ${ }^{2}$ ) aufinerksam macht, zu verzeichmen. Er studierte die eigenartige Ährenverkümmerung, die mit "Garbin" bezeichnet und der Wirkung der Seewinde zugeschrieben wirl. Nach dem genamnten Beobachter trägt aber die physiologische Trockenheit die Schuld daran. Der Salzboden hält das Wasser so fest, dat's die Wurzeh dasselbe nicht in genügender Menge anfzmmehmen vermögen.

Bezüglich der direkten Wirkung ist zu berücksichtigen, dals sich die Pflanze je nach ihrer Eigenart dem kochsalzhaltigen Wasser teilweise ampassen kam und demgemäfs ihren Habitus ändert. Bei Wiesengräsern hat Hösterusмх ${ }^{3}$, nachgewiesen, dat's dieselben Xerophytenstruktur annehmen: sie werden likiner, gedrungener, die Internodien liüzer und die Blätter kleiner: die Bestockung ist gering und der Wurzelkörper schwach entwickelt. Iie Transpiration geht zurück and die Assimilationsenergie wird schon bei 0,0.; \% gehemmt. Betreffs der Keimkraft der Samen wrurle beobachtet, dats schwache Konzentrationen $(1) .5-(0,7,5 \%$ ) förderlich wirlen, dats aber darüber hinans eine Schätligung eintritt.

Andere Anpassungserscheinungen erwähnt Areschoct $\left.{ }^{4}\right)$, indem er als Schntz gegen die Anhäufung ron Chloriden das Festhalten von Wasser in Geweben (Speichertracheïden, Schleimzellen) ansieht, die direkt nicht mit der Arimilation zusammenhängen. Anch scheinen die Hrdathoden chlornatrimultiges Wasser auszuscheiden. Die Struktureimrichtmaen zur Hemmung der Transpiration sah Diels ${ }^{5}$ ) sich steigern, je salzreicher der Standort der Pflanzen sich erwies. Darans wäre zn schliefsen, dats die Strandregetation an Wasserhecken von verschiedenem Salzgehalt anch abweichend sich verhalten wird. Anf diesen Punkt macht Rostrite") auch tatsächlich aufmerksam. Die Kiefer leidet am meisten. die Birke am wenigsten. Ans den von der ökonomischen Gesellschaft des Amtes Naribo nach den Überschwemmumgen in den

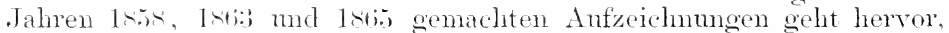
dats die Wirlimng des Salzwassers um so schwerer war, je lehmhaltiger der Boden sich erwies. Ton den ïherschwemmen Winter-

1) Sixx, A., Eintlufs des seesalzes anf die Pflanzen. Staz. sperim. XXXVII; cit. Centrallol f Agrikulturchenie 1904, S. Som.

2) Pramox, T, J er salzgehalt des Bodens und seine Wirkung auf die Vegetation des Getreides. Staz. sperinent. agrar. ital. 190:3: cit Centrallsl. f. Agrikulturchenie

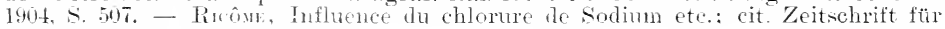
Pflauzenkrankh. 1904. ㅅ...2....

3) Hrisfamix, Einflufis hes Kochsalzes aut die Tegetation von Wiesengrisern.

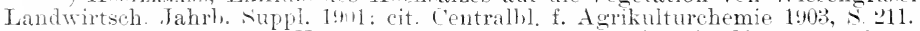

4) Anmon q, F. W., Intersuchumgen über den Blattbau der Mangrovepflanzen.

Bibl. hot. 1902; cit. Bot. Taluesher. 1902, II. S. 29.

5) Dis.s, L., Stoffwechel und struktur der Halophyten; cit. Bot. Jahresber. $1>9=1$, s. 6 inti.

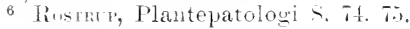


saaten litt der Roggen mehr wie der Wrizen. Bri len Frühjahrsaaten auf dem durchsalzenen Boden wuden Gerstr mul Erbsen an meisten geschädigt. Runkelrüben, Kartotteln. Weitikles mul Rargras selienen nicht sehr unter der Einwirking des salzhodens zu lebilen, dagenen war

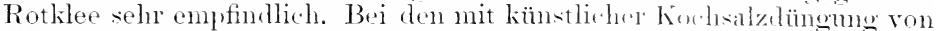

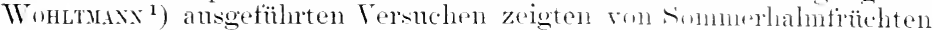
Gerste und Weizen spotise Emptindlichkeit, wähnom Winterweizen noeh bei selu starken (tahen ron Kochsalz leillich gedich. Eilsen versagten bei starker Düngmng gänzlich. Hafer war willerstandstïliger. An wenigsten empfindlich erwies sich Winterrogow. Boi len hartoffeln war der Stärkegehalt sehr herabgegangen, der Proteingehalt nieht lw-

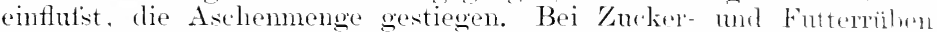
wurde das Erntequantum erhöht, ohme datis der /ncliergehalt zurïcliging. Man merkt hier die Abstammung ron der Strandiflanze.

Bei Bämmen macht sich die Wirkmng des salzhorlens erst weltomil, nachdem sie längere \%eit das Salz gespeichert haben. So fand ITrenen ${ }^{2}$, der übrigens die Ansicht vertritt, dats in manchen Fällen nieht der Salzüber'schuts, sondern die Versumpting die Trache des Alsterbens sei, bei vergilhenten Zwoigen von Salir rimimalis im Lahntale bei Bersenbrück, wo die trubenwässer von Evershme eintlietien, dats die Blätter

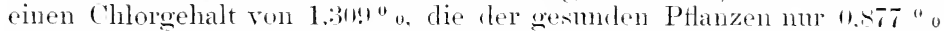
besalsen. Betretts des Verhaltens von Kierptlanzen finden wir reichliche Angaben in einer Artheit von $\left(\right.$ Tro $\left.^{3}\right)$, der als alloemeines Merkmal ein Rotspitzigwerden der Ptanzen vor dem Ahsterfen ansibt.

Abgesehen von den Grubenwässern macht sich der hohe Kochsalzgehalt hesonders ant den Rieselfoldern goltend. Namentlich in Sommer wird die Konzentration der spëljauche rolativ grofs, mnel man sicht viele frewächse "verbrennen", wie der Rieselwirt sagt. selur emptindlich hat sich der Tabak erwiesen, so dat's man mit der Tabakkultur lisher

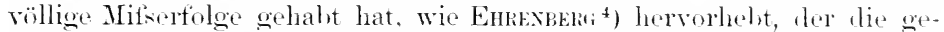
samten sehädigungen durch sipüljauche sehr eingehend lohandelt.

Neben ,lem Chlornatrium kommt auch vieltach ter Chlormagnesimgehalt in Betracht. Lie answaschende Wirkmog ändert sich in ihren Resultaten, wir die Untersuchmoen ron Fricke. HAskehoff mul Koxw ${ }^{5}$ ) ergeben haben. Währent die Rieselung mit kochsalzhaltigem Wasser eine erhöhte Ausfuhr von Kalk. Magnesia und Kali zur Folge hat, treten bei chlormagnesimmaltigem Wasser Kalk, Kali und Natron aus, und Magnesia wird testwehalten. Bei chlorealeiumhaltiger Berieselung wird der Kalk von Boden und Ptlanzen zurïckgehalten, und es treten grötisere Mrenen von Magnesia. Kali und Natron aus.

In ten grotien siälten kommt aher die Kochsalzfiage nech nach anderer Richtung hin in Betracht, nämlich hei dem Auftanen der stratienbahnen. Antierdem wirl von vielen Hansbesitzern anch Viehsalz aut die Bürgersteige gestrent. In Berlin ist dies zwar verloten. alwer man

1) Wontrax, F., Die Wirkung der Kochsalzalügung auf unsere Feldfrüchte. Landw. Zeit. f. d Rheinprovinz 1904, S. 4 ti.

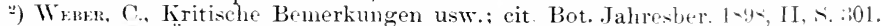

3) Orro, R., Eber durch kochsalzhaltiges Wasser verumachte Pflanzenschïdigungen. Zeitschr. f. Pflanzenkrankh. 1904, S. 13:5

4) Enrexbera, Paı, Einige Beobachtungen ther Pflanzenschädigungen durch Spüljauchenberieselung. Zeitsehr. f. Pflanzenkrankh. 1906, S. 19:.

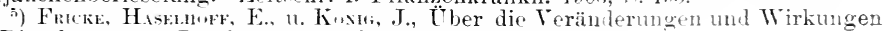
des Rieselwassers. Landwirtsh. Jahrbucher 1-4:3, s. - -01. 
tänscht die Polizei dadurch, dafs das Salz mit Sand vermischt wird ${ }^{1}$ ). Das zur Beseitigung des Schnees verwendete Salz schmilzt und dringt dort in den Boden, wo die Strafse nicht asphaltiert ist. Im Frühjahr treiben die Bämme zwar ans, aber im Laute des Sommers gehen sie zugrunde. Auch hier verhalten sich die einzelnen Baumarten in verschiedenem (irade widerstandstähig ${ }^{2}$ ). Übrigens ist die Wirkung einer Kochsalzlösung verschieden, je nachdem sie ständig die Wurzeln bespült oder der Boden zeitweise austrocknet; letzterer Fall ist der gefährlichere.

Beschädigungen im Grotsen hat man auch in der Umgebung von V u lkan en durch den Eintlut's der ausbrechenden Dämpfe wahrgenommen. Die in dem Dampfgemisch in wechselnden Mengen vorkommende s'chweflige Säure, sowie Salzsäure und Schwefelwasserstoff mögen wohl die Hauptursachen der Vergiftung sein. Sie dürften anch vorzugsweise die zerstörenden Wirkungen des Aschenregens veranlassen; doch werden diese ihrerseits von einzelnen Beobachtern auch dem reichlich gefallenen Kochsalz zugeschrieben. Nach den Mitteilungen von $\mathrm{P}_{\text {Asquale }}{ }^{3}$ ) gehen die roten und violetten Blütenfarben teils in Blau ïber (Papaver, Rosa, Gladiolus), teils bleiben sie unverändert (Viola tricolor, Convolvulus, Digitalis). Bei dem zurzeit des Austreibens der Bäume pingetretenen Aschenregen wurden die grünen Pflanzenteile bram, wie nach Verbremmung oder Vertrocknung, aber nicht nach Verbrühen. Sukkulente und lederartige Blätter hatten nicht gelitten. Mechanische Einwirkungen des Aschenregens, wie etwa Verstopfung der Spaltöffnumgen, lietsen sich anfangs nicht konstatieren; nach einigen Tagen schienen sie sich aber geltend zu machen.

Dieselbe Ansicht wie Pasquale vertritt neuerdings auch Sprenger ${ }^{4}$ ), der die Folgen des Vesuvausbruches im April 1906 beschreibt.

\section{Chlorcalcium- und chlormagnesiumhaltige Abwässer}

sind reichlich in den Steinkohlen-Grubenwässern, in den abflietsenden Mutterlaugen von Salinen und Bädern, in den Fabriken für Bereitung von Chlorkalium und Kalisalzen, in den Äbwässern der Ammoniaksodafabriken usw. enthalten. Welche Mengen dabei in Betracht kommen, zeigt beispielsweise die Analyse von einer neutralen Flüssigkeit, welche aus den Kesseln abflief'st, in denen das bei der Ammoniaksodafabrikation erhaltene Chlorammonium zersetzt wird. Kösıg ${ }^{5}$ ) fand im Liter 80,06 $\mathrm{g}$ Chlornatrium, 56,00 $\mathrm{g}$ Chlorcalcium, 1,02 Magnesiumsulfat. In anderen Proben, die stark alkalisch waren, fand sich ron den genannten Stotfen weniger, aber dafür Natriumsulfat und 3-5 $\mathrm{g}$ freier Kalk. Der Umsetzungen im Boden ist bereits im vorigen Abschnitt gedacht; aber es soll hier noch hervorgehoben werden, dats bei vorübergehenden schwachen Gaben (bis $2,0 \mathrm{~g}$ pro l) günstige Wirkungen beobachtet worden sind. Das Keimen von Samen wurde befördert. Himbeeren und Erdbeeren sah man auf einem mit Chlorcalcium durchtränkten Boden sehr grof's und hellfarbig werden; jedoch schmeckten die Frïchte nach Chlorcalcium und hielten sich nicht lange ${ }^{5}$ ).

1) WeIss, A., Zeitschr. f. Gartenbau und Gartenkunst 1894, Nr. :37.

2) Riтzema Bos, Schädlichkeit des Auftauens der Trambahnlinien mit Salzwasser für die in der Nähe stehenden Bäume. Tijdschrift over Plantenziekten 1898, S 1 .

$\left.{ }^{2}\right)$ Pasqcale, Di alcuni effetti della caduta di cenere etc. Bot. Zeit. 1872, S. 729.

4) Sprexries, C., Vegetation und vulkanische Asche. Österreich. Gartenzeitung 1906, Heft VII.

5) Denkschrift S. 161 


\section{Chlorbarium}

ist ein verhältnismälsig minder wichtiger Bestandteil, der nur zuweilen in den Abwässern von Steinkohlengruben getunden wirl. Seine Giftigkeit ist durch Wasserkulturen von Mais mol Pferdebohnen seitens HAselHofF $^{\mathbf{1}}$ ) erwiesen worden. Die PHanzen wurden im llöhenwaehstum gehemmt; die Blätter welkten und fielen ab. In der Natur wird aber eine direkte Schädlichkeit wohl nur selten autreten, weil die überall im Boden und in flietsenden Gewässem enthaltenen schwetelsamren salze schnell eine Unsetzung zu mlöslichem und mschädlichem Bariumsulfat bewirken werden.

\section{Zinksulfathaltige Abwässer.}

Mit der Untersuehmo solcher Gewässer aus Zinkhlendearuben hat sich Köxir eingehender beschättigt ${ }^{2}$ ). E- zeigte sich, dals die Bäche, welche das Abflutswasser aufnahmen, schwetelsames Zinkoxyd in Lösmng enthielten. Auf den bewässerten Wiesen bemerkte man einen deuthichen Rückgang des Ertrages und stellenweise eine nur noch kümmerliche Vegetation. Die auf derartigen Fehlstellen gewachsenen Gräser, sowie die verkümmerten Sträucher von Buche und Ahorn enthielten bis $2.78^{\circ}$ o ihrer Asche an Zink, während die Asche gesunder Wiesemptlanzen dieses Metall nicht besals. Da, wo Zinkerze zufällig verschüttet worden, erlosch die Vegetation; nur eine spezifische Zinkpflanze (die .weilse Erzbhme“) erschien noch. Die erwälnte .Erzblume" hatte nicht weniger als 11 bis 15\% Zinkoxyd in ihrer Asche. Man sieht. wie verschieden wiederm sieh die einzehnen Pflanzen verhalten. und welche hohen Konzentrationen manchmal vertragen werden. Die Beschädigmoen erscheinen erst nach eimer längeren Reihe von Jahren. nachdem sich das im Bachwaser in absoht geringen Mengen vorhandene Zinkoxyd zu grötseren Massen angehäut hat. Aus diesem Tmstande folgert Köxi; mit Recht, dats die den (iruben bei der Konzessionserteilung auferlegte Verpflichtung, nur klares Wasser abHiefsen zu lassen, nicht ausreichend zum sichutze der Wiesenbesitzer sei.

Eine Erweitermo der erwähnten Erfahrmgen liefern zwei Arbeiten, ron denen die eine von A. Barmax ${ }^{3}$ ) ansschliedslich den Einfluts von Zinksalzen anf Pflanzen und Boden behandelt, während die zweite von Norbe, Bisster und WILL ${ }^{4}$ ) neben dem Zink sich anch mit den durch Arsen und Blei hervorgernfenen schädigungen beschäftigt.

Aus den Resultaten der Bdraxs schen Versuche ist hervorzuheben, dafs das schwefelsaure Zink in gelöster Form für die Pflanzen sieh viel schädlicher erweist, als man bisher annahm: kleine Mengen (etwa 1\% / Zink, also $4,4 \mathrm{mg}$ Zinkvitriol in Liter) haben sich bei allen Versuchsptlanzen (1:3 spezies aus 7 Familien) mit Ausnahme des Rettichs als vollkommen unschädlich erwirsen. Die Koniferen sind sehr widerstandsfähig: sie vertrugen noch eine Lïsmng von $1^{\circ}{ }^{\circ}$ Zinkgehalt, während

1) Landwirtsch Jahrbücher $1 \times 95$, \& $9 * 2$.

-) Kinis, Entersuchungen äber Beschädigungen von Boden u. Pflanzen durch ndustrielle Abflufsw ässer mu fiase: cit in Biedermann's Centralbl. 1-79, S. sfit.

3) Barmsx, A.. Das Verhalten von Zinksalzen gegen Pflanzen und im Boden. Preisschrift 1st. Landwirtsch. Versuchsstat. Bd. XXXI, Hoft I. 1o-t, s. 1.

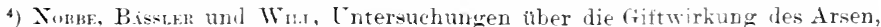
Blei und Zink im pflanzlichen Organismus. Landwirtsch. Versuchistat. Bd. XXX, H. it 5 is. ij 
die Angiospermen schon bei $5 \mathrm{mg}$ Zink pro Liter zugrunde gingen, und zwar starben ältere Pflanzen im allgemeinen schneller ab als jüncrere.

Kenntlich macht sich die Giftwirkung durch eine auffallende Farbenänderung der kranken Pflanzen. Anf ilen Blättern erscheinen einzelne kleine Flecke ron metallglänzender oder rostgelber Farbe, die schliefslich sich über die ganze Blattfläche ambreiten. Dats das Zink ganz speziell den Chlorophyllapparat angreitt nud damit die Assimilationsarbeit behindert, wird durch die Beolachtmo nahe gelegt, dats Keimlinge mit noch nicht ausgebildeten Chlorophyllkörnem sowie Dunkelpflanzen und Pilze sich gegen relativ hochkonzentrierte Zinklösungen indifferent verhalten.

Auch in den Borlen gebracht ïben Zinkkarbonat und Zinksulphid eine schädliche Wirkmng ans. An sich selbst schaden sie zwar nicht, obgleich sie in kohlensäurehaltigem Wasser in ziemlich beträchtlichen Mengen löslich sind, wobei das Zinksulphid sich zuerst in Zinkkarbonat umwandelt. Aber ihre verhängnisvolle Wirkung liegt in der Umsetzung, die das Zink in der Form von Titriol mit den Kali-, Kalk- und Magnesiumsalzen eingeht, wodurch diese Nährstoffe löslich und auswaschbar werden. Auf armen Sandböden kann recht wohl dadurch Unfrucht. barkeit erzengt werden. und in dieser Entführung von Nährstoffen liegt besonders die Schädlichkeit der Berieselung mit Abwässern aus Zinkhïtten.

Die schädigende Löslichkeit des Zinks im Boden hängt wesentlich ron dem Gehalt desselben an kohlensaurem Kalk ab. Bei Anwesenheit dieses Minerals in etwa vierfacher Menge des Schwefelzinks wird überhaupt kein Zink mehr in Lösung gebracht. Ein durch Zinksulfat verdorbener Boden wird durch Zufuhr solcher Stoffe, welche die löslichen Zinksalze unlöslich machen, zu verbessern sein. In dieser Hinsicht hat sich Humus ausgezeichnet erwiesen, und man wird deshall, eine Düngung mit Moorerde empfehlen können. Bei Mangel derselben wird reichlich Stalldünger. Ton oder Mergel zu verwenden sein. Mergel oder Kalk wird unter allen Umständen gegeben werden müssen.

Betreffs der Beschädigungen durch Bleisalze erwähnt Tschirch, dats eine eigenartige Terzwergung zustande limmt. Die Pflanzen, welche $1 \mathrm{~kg}$ Memnige anf ") qm Bodenfläche erhalten hatten, blieben klein und schmächtig und kamen nicht zur Blüte [Blei-Na n ism us $\left.{ }^{1}\right)$ ]. DEvaux ${ }^{2}$ ) fand, dats Bleilösungen in $1 / 10000000$ Verdümmung schon vergiftend wirken. Las Metall wird durch Membran und Zellimhalt fixiert.

Kur Reinigung ron zinksultathaltigen Abwässern wird sich die Einrichtung von Filtrierschichten ron Kalksteingrus und Moorerde empfehlen; es bilket sich in diesen dann unlösliches kohlensamres und humussaures Kinkoxyd.

\section{Eisensulfathaltiges Wasser.}

Die Abwässer ron Schwefelkiesgruben, Schwefelkieswäschcreien und Steinkohlengruben, das Sickerwasser aus Steinkohlenschuthalden, die Abwässer von Drahtziehereien enthalten meist Eisensulfat. Nächst-

1) Tsemuch, A., Das Kupfer rom standpunkt der gerichtlichen Chemie usw. Stuttgart 1893, F. Enke.

2) Derarx, De l'absorption des poisons métalliques très dilués par les cellnles végétaux. Compt rend. 1901 ; cit. Just's . Tahresber. 1902, II, s.. :5:5: 
dem ist der Gebrauch des Eisenvitriols als Desinfelitionsmittel in Senkgruben zu herückichtigen, wobei grotse Mengon von shwefeleisen entstehen, die durch Oxydation an der Lutt in kisonvituin und sehwetelsaures Eisenoxyd sich musetzen.

Ähnlich wie das Zink bei dem Zinksulfat wimt das Eisonoxydul rom Boden festgehalten mol zu Oxyal verwandelt, wähemel eine mtsprechende Menge anderer Basen, wie Kalk, Magnesia mol Kali, an die Sehwefelsäure herantritt und leicht ausgewaschen wirl. Antser dirsem Verarmmosprozesse des Bodens länt dessen Amreichernug mit Eisenoxydoxydul nebenher, die Versanermo und Verschlammung finloiter. Sobald lieine Basen mehr zur Unsetzung des Eiscusmltats vorlanden sind, bleibt Eisenvitriol mzersetzt, oder es tritt anch tires sirelofelsäure aut.

So nützlich kleine Mengen [his $150 \mathrm{~kg}$ pro Hektar nach Kövu: ${ }^{1}$ ] anf reichem Boden sein worlen, indem die freiwerdende schwetelsum antschliefsend wirken muts, so schädlich wird die fortgesetzte Kufuhr ron Eisensulfat hei ständiger Berieselmo von Wiesen sich gestalten. Ilie Versuche zeigen, dats. wenn den Nutzptlanzen anstelle der ihmen allein zusagenden hasischen Salze same Verbindmoen - Eisensulfat ist stark saner - geboten werlen, eine Verschlechterumg des llenes mud Verringermo des Nilchertrages die Folge ist. Tom solchen WViesen relschwinden allmählich die Kleearten und sütsen Gräsor vielleicht mit

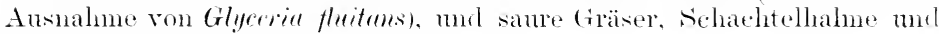
Moose nehmen rom Boden Besitz.

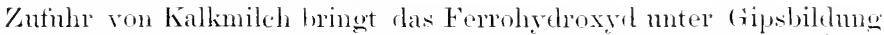
zur Abscheidung. und man wird dureh Verwemelung von Kalk die eisensultathaltigen Abwässer reingen kömmen.

\section{Kupfersulfat- und kupfernitrathaltige Abwässer.}

Es wird sich hier $n \mathrm{~m}$ Abwässer ans silberfabriken und Mesinggiefsereien handeln. Einen Einblick in die Zusammensetzme derartiger Abflüsse gibt rine Analyse von Alfalllange einer Messingoielserei, tie

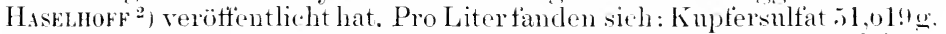
Kupternitrat 5.2! g. Zinksulfat 14,045 g, Ferrosulfat 2,42.2 g, Caleim-

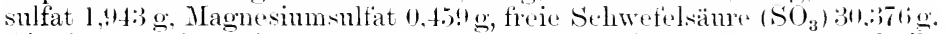
Dies ist allerdings ein ganz exorbitanter Fall, der für einzehe Bestantleile. hundertmal grötser ist als der Gehalt der WV̈̈sser. die aus Kupterwerkm und Silbertaloriken abtliefsen. Für das IVesen der Sehädigung ist aber die Menge der Bestandteile gloichë̈ltig, da geringe Mengen flurch andanernde Berieselung denselben Eftekt hervorrufen. Die Art, wie Sultat und Nitrat der Kupfersalze aut den Boden wirken, ist lieselbe wir bri den Zink. unt Eisensalzen. Kupferoxyd wird im Boden festonglialten und bleibt hauptsächlich im Obergrund der Wiesen: die fireiwrelente. Schwefelsäur tritt an Kalk, Magnesia und Kali heran. mud diese ralze gehen beim Berieseln in den Tntergrme. Abgesehen von der Verarmung an basisehen Nährstoffen wirkt das Kuptersulfat - PHanzen, wir z. B. Gräser, nehmen ziemlich bedontende Jengen ron Kunter- und Zinksalzen auf - schliek sich auth als rirektes (rift, soweit die hinlturversuche in Nährstotfläsungen gezeigt haben $\left.{ }^{3}\right)$.

1) Denkschrift S. 17\%.

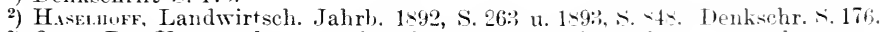

") Orr., R., Tntersuchungen über das Verhalten der Pflanzenwurzeln gegen Kupfersalzlösungen. Zeitschr. f. Pflanzenkrankh. 18!3, S. 32:. 
Masarasu Kanda ${ }^{1}$ ) fand, daf's bei Wasserkulturen von Erbsen sich schon bei $0,000000249^{\circ}$ Kupfersulfat Schädigungen zeigten, dagegen in millionenfacher Verstärkung dem Boden zugetührt als Reizmittel wirkten. Bei Kulturen im natürlich gewachsenen Boden liegen eben die Verhältnisse günstiger. Nach Tschikch ${ }^{2}$ ) besitzen fast alle Pflanzen etwas Kupfer, da wohl alle Ackerböden Spuren davon enthalten dürften. Selbst ans reichlich gekupferten Böden nehmen die Gewächse meist aber nur wenig auf, so dats die Gefahr einer Vergiftung keine drohende ist. Diese Anschaumng findet auch in dem Umstande ihre Bestätigung, dafs bei dem überaus häufigen Gebranch des Kupfervitriols als Spritzmittel gegen parasitäre Krankheiten eine starke Amreicherung des Bodens fortwährend stattfindet, ohne dals Schäden mit Sicherheit bis jetzt nachgewiesen worden sind. Wir persönlich glauben allerdings, dats eine Zeit kommen wird, in der sich eine stete Kupferzufuhr lähmend auf den Pflanzenwuchs geltend machen wird.

Ähnlich wie die bisher genamnten wirken die nickel-und k obalt. haltigen Abwässer, die in der Nähe von Nickelwalzwerken gefunden werden. Anhangsweise mag hier erwähnt werden, dafs schon $1819 \mathrm{JoHN}^{3}$ ) in seinem Buche „Über die Ernährung der Pflanzen“ sich mit Sand- und Wasserkulturen beschäftigt hat, denen verschiedene Metallsalzlösumgen zugesetzt worden waren. Er konstatierte dabei, dat's Somnenblumen Kupfer, welches ihnen in der Form von unlöslichem Kupferkarbonat geboten wurde, nicht anfnahmen, dagegen Erbsen und Gerste grofse Mengen aus einem Boden speicherten, der tropfenweise salpetersaure Kupferlösung zugeführt bekommen hatte.

Auf die einzelnen Fabrikbetriebe näher einzugehen verbietet der Umstand, daf's lokale Verhältnisse bald nützliche Verwendung der Abwässer zulassen, bald schädigende Faktoren sich geltend machen. Hier spricht in erster Linie die entgiftende Eigenschaft der Erde durch ihre Absorptionskraft mit, woranf betreffs der Kupfersalze speziell HaTTORI ${ }^{*}$ ) aufmerksam macht.

Die Schäden der städtischen Spüljaucheberieselmng sind bereits in dem Abschnitt „Rieselfelder" S. 36it erwähnt worden.

\section{Neumzehntes Kapitel.}

\section{Schidlliche Wirkungen von Kulturhilfsmitteh.}

\section{a. Anstreichmittel.}

1. Teer. In Glashänsern der Gärtner findet sich vielfach das Gebälk anch im Innem mit Teer angestrichen. um die Widerstandsfähigkeit gegen den Einflut's der starken Feuchtigkeit zu erhöhen. Wir begegnen nun einer ganzen Reihe von Klagen, daf's nach dem Einräumen der Pflanzen in die geteerten Glashäuser Schwärzung und Abfallen der Blätter sich einstellt. Ich bemerkte dieselben Erscheinmngen in der Nähe frisch geteerter Zäune. Der Befund stimmt im wesentlichen

1) Masayasu Kaxin, Journ. College of Science. Tokyo, Vol. XIX, art. 13

2) Tscunci, A., Das Kupfer vom Standpunkt der gerichtlichen Chemie, Toxikologie und Hygiene. Stuttgart 189:3, Fr. Enke. 80. $1: 38 \mathrm{~S}$.

3) Mülafe, Carr, Zur Geschichte der Plirsiologie und der Kupferfrage. Zeitschrift für Pflanzenkrankh. 1894, s. 142.

$\left.{ }^{4}\right)$ Just's bot. Jahresber. 1902, Alsch. Krankh. Ref. 277. 
mit dem schon hei den Asphaltdämpten geschilderten überein und erklärt sich aus den Exhalationen des fristhen Teeranstrichs. Die schädlichen Folgen kommen nicht zum Vorsehein, wenn man das Teeren einige Monate vor dem Einräumen der Ptlanzen in die (ilashäuser vornimmt. Ein Verfahren, das sich sehr gut bewährt hat, sah ich in der Umgebung von Berlin. Die Bretter und Balken wurden mit Steinkohlenteer behandelt und nach dem Trocknen des Teers mit Zementmasse ïberstrichen.

Nenerdings hat man mehrfach versucht, die Wege in (rärten und öffentlichen Schmuckanlagen durch eine dünne Schicht von Teer staubfrei zn erhalten. Das Verfahren wird sehr empfohlen ${ }^{1}$, wnd die in Frankreich und ltalien ansgeführten Versuche haben ergeben, dats man auch fertig gepflasterte Stratien vorteilhaft in dieser Weise behandeln kann. Dieses Verfahren macht aber notwendig, daf's an den Kanten der Wege eine Einfassung, etwa ein s-10 em hohes Band ron verzinktem Eisenblech, eingelassen wird, da die schädlichen Bestandteile des Teers sonst die Vegetation angreifen. Das Vertahren, das sich trotz seiner jährlich notwendigen Ernenerung doch billiger als das Asphaltieren und weniger lästig als das ölen bzw. Behandehn der Stratsen mit Westrumit stellen soll, wird doch noch durch weitere Versuche zu prüfen sein.

2. Nach Nitteilung ron Herrn Kurtzini hat man in Ludwigslust auf Sandboden zur Wegefestigung Abfall aus Gasanstalten aufgefahren. Derselbe veranla1ste ein Eingehen von Alleebäumen.

3. Als Anstrich für Glashäuser wurde in einem mir bekannt gewordenen Falle Bleiweil's benutzt, und, da kurze Zeit nach dem Anstreichen die Häuser mit Topfgewächsen bestellt werden mulsten, hat man die mangenehme Ertahrme gemacht, dafs die Ptlanzen die Blätter abwarfen.

4. Bleioxyd verwandte KonfF²) als Zusatz zu kochendem Leinöl, um experimentell den Einflut's von öldämpten zu pröfen. Veranlalst wurde er zu den Versuchen durch Schädigungen, welche in der Umgebung einer L e in öl - und Firnissiederei anfgetreten waren. Wie bei der Zersetzung der Fette durch Alkali ein Gemisch von fettsamren Alkalien, die Seife, entsteht, so bildet sich bei der Zersetzung ron Fett mit Bleioxyd ein Gemisch entsprechender Bleisalze, das Bleipflaster. In beiden Fällen tritt als Nebenprodukt Glyzerin auf: bei starkem Erhitzen von Glyzerin oder von Fetten bildet sich der scharte Dampf des Akrole ins, der nach angebranntem Fett riecht und durch Oxydation schnell in die durch stechenden Geruch sich bemerkbar machende Akrylsäure äbergeht. Je nach der Natur der Pflanze entstanden bald in den Intercostalfeldern, hald an den Randpartien der Blätter gell,e, rote oder brame Flecke, die sich bei längerer Einwirkmng vergröiserten und auch wohl zusammenflossen. Die Zellen des Blattmesophylls, namentlich des Schwammparenchyms waren durch Turgorverlust gröstenteils zusammengesunken : der Zellinhalt war von der Wandung zurückgetreten, und die Chloroplasten bildeten grünlichgelbe lis brämnliche ITassen. Schlietslich wurden der strukturlose Zellinhalt und lie Wan-

1) Das Teeren von Fufs- und Fahrwegen in Gïrten und Parks. Der Handelsgärtner, herausgeg. von Thalacker, Leipzig-Gohlis 1906. Nr. 5i.

2) KonfF, G., Über Einwirkung von Öldämpfen auf die Pflanzen. Prakt. Bl. f. Pflanzenbau u. Pflanzenschutz 1906, Heft 5. 
dungen lram. Besonders auffällig war die Abscheidmo von Gerbstoff in den Epidemiszellen, deren Kellinhalt mit Eisenchlorid eine blauschwarze Färbmng ammahm. Das Fruchtfleiseh ron Äpfeln und Bimen, die vier stmnden lang den Öldäm,fen ansqesetzt gewesen waren, zeigte einen ölig ranzigen Geschmack.

Da durch Kochen von Glyzerin erhaltenes Akrole in dieselben Erscheinmoen herrorrief, so dürfte die schädlichkeit der Öldämpte in wesentlichen diesem Stoffe zuzuscheiben sein.

¿. Über den Einflus ron Terpentindämpten luat MoLz ${ }^{1}$ ) Untersuchungen angestellt. da ihm ein Fall zur Begutachtung vorlag. in welthem Rebenblätter durch den frischen (O)anstrich eines Traubenhauses geschädigt sein sollten. Die Wirkmg der Terpentindämpfe machte sich bei TVeinhläter'n hereits nach einer halben Stunfle durch seliwache Randverfärhmo und zmehnende Verkränselmmg bemerkbar; Apfellhätter zeigten nach einer stuncle eine schwache rötliche Brämung, nach drei stunden eine tief dunkelrotbrame Vertäbung der Oberseite; Rebenbläter wurden olivenhram. Bisweilen fanden sich einzelne orine Inseln innerhalb der gebräunten Fläche, so dafs die Blätter gänzlich scheckig anssahen. Rosenblätter färhten sich olivengrün-bram, Birnenblätter glänzend schwarzgran. Nouz rermutet als Ursache einen Oxydationsorgang, hervorgerufen .. hurch das Torhandensein von Terpentinozon und dessen Wirkmo anf hradoxydable Stotte der Zelle".

i. K a rboline un dient einerseits (ähnlich wie Teer) als Anstreichmittel tür das Gebälk in Glashäusern. Mistbeetkästen, fïr Ptähle u. derogl., um die Widlerstantskraft des Holzes gegen Nässe zu erhöhen, andererseits als Heilmittel bei Bammwnden und Vertilgungsmittel gegen schädliche Insckten. Die Urteile ïber die Wirksamkeit sind autserordentlich geteilt, mol dies kommt einerseits von einer unzweckmätsigen Handhabmo, andererseits daron, dass "Karholinem" ein sammelbegriff ist; die einzehen Sorten sind je nach der Falrik. welehe das Produkt liefert, von verschiedener Zasammensetzung und Wirksankeit.

In alloemeinen gilt für die Benutzung des Karbolinemms als Anstreichmittel dasselhe, was bei dem Teer gesagt worden ist. Wemm man Pflanen in Rämne mit nicht genïgend ausgetrocknetem Karbolinemanstrich bringt, leiden dioselhen, und zwar hisweilen unter symptomen, die den hurh Asphaltdämpte hervorgerufenen gleichen. So berichtet beispielsweine Zons' ${ }^{2}$ ) in Hotheim ('Tamms), dats bei ihm pikierte Erdbeerptlanzen in den Mistleeten, die nur äutserlich mit Karbolinem gestrichen worden waren, cigenartig hrame, stark glänzende, verkïmmernde Blätter erhalten hatten. Bezüglich les Bestreichens der Spitzen ron Weinpfählen macht die . Chronique agricole“ ${ }^{3}$ ) daraut aufinerksam, dats selhst, wenn solche Ptähle in Winter gestrichen werden und die jungen Triebe des Weinstorks in Frïhjahr bereits über die aestrichene Zone hinansgewachsen sind, doch immerhin noch unliebsame Erscheinmoen autreten können. Es wurlen an den Trauben, welche dicht den getränkten Pfahle anlagen, einige Beeren mit schwarzbramen Flecken gefunden, und diese Breren zeigten einen leichten Teergeschmack. Anch erwiesen sich die getränkten stellen des Pfahles weniger wider-

1) Bericht der Kgl. Lehranstalt für Wein-, Obst- und Gartenban zu Geisenheim a. Rh. 1905.

2) Praktischer Ratgeber im Obst- und Gartenkan 1905, Nr. 51.

$\left.{ }^{3}\right)$ Chronique aqricole du cinton de Vaud 1892, Nr. 16. 
standsfähig gegen Pilzmycel als die mit Kuntervitriol behandelten. Bei einen im Herbst gestrichenen und den ganzen Winter über der Witterung frei ansgesetzt gewesenen Pfirsichsplicr lunerkte man trotzlem im Frühjahr, dats nach jedem Regen dic jünssten 'Trielspitzen wie verbrannt aussahen. Derartige Vorkommine sind koineswegs selten. Es sind die verdampfenden Phenole mor ähnlichen Körver, welche den schaden amichten.

Seit dem Jahre 1s!n! ist das Karbolinemm als Ileilmittel in direliter. Anwendung anf den Ubstbam zu verbreiteter Anwendung velanot. Über die Erfolge lesen wir teils antserorlentlich lobende'), teils välie absprechende Urteile. Der frund liegt einerseits in der versehienten-

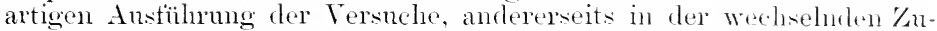
sammensetzung des Mittels, das ein ans den Produkten der steinmul Holzkohlentecrerabeitung hervorwehendes Gomiseh ist. Wemn der Teer, der bei der trasbereitung nehen Lenchteas, Kols mul Ammoniakwasser aus der steinkohle entsteht, noch einmal in tiasioten erhitzt wird, so erhält man bis zu einer Temperatm vom $1500^{\circ} \mathrm{C}$ sog.

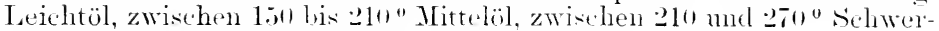
öl und zwischen 270 mel tisto Anthracenöl 2).

In Uten bleibt das Pech zuriek. Cranz älnulich verhält sich ter Holzteer. Bei der Karbolinembereitung liommen num die genamten öle zur Verwentung, inclem sie in bestimmten Prozentsätzen gemischt and mit Kolophonimm, Asplualt, Leinoiltirnis usw. versetzt weren.

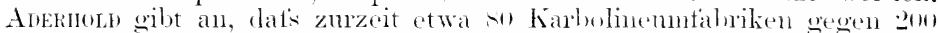
bis :3on sonten in len Handel bringen. Hie in dor Biologischen Anstalt

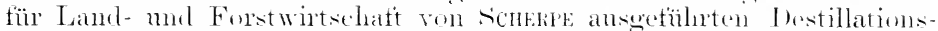

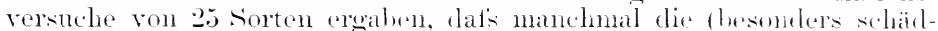

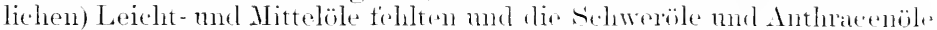

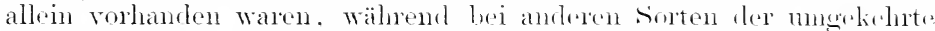
Fall sich zeigte. Ilementsprechend war anch der Exfole hei dor Be-

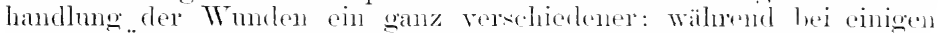
normale Überwallung eintrat, zeigte sich loi anderen wine wesentliche

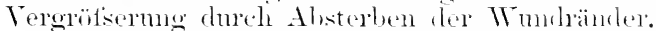

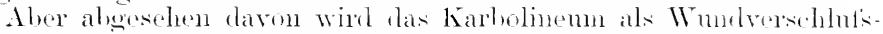
mittel selhst in den zähflüsigen, pech- mut asphaltreichen sorten ilen

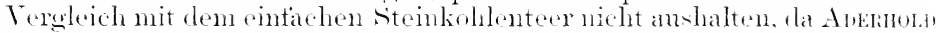
beobachtet hat, dats wenige Wochen nach dem Bestreichen sich ant der Karbolinemutläche bereits wivler Pilzräsehen angesiedelt hatten. I) mon die bestrichene Fläthe aneh meter den Einfluts der Atmosphärilien

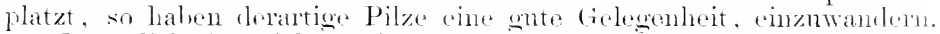

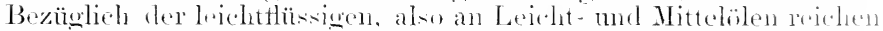

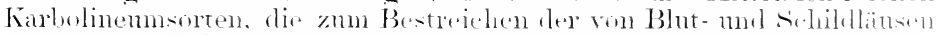

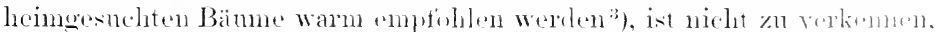

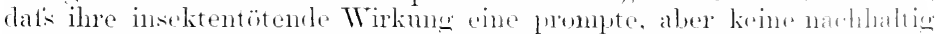

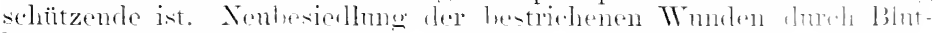

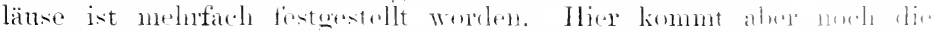

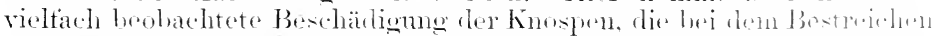
oder Bespritzen der Bämme nicht zu verneiden ist, hinzu. nurl dir lw-

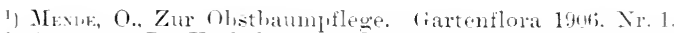

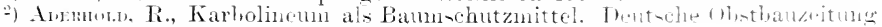
(C'lmer-stuttgart) 1!mi, Heft '2.'.

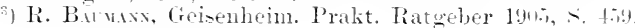


sonflers den Ausdünstungen und direkten Einwirkungen der Leichtöle zuzuschreiben ist. Es wird also bei dieser Art der Verwendung eine Terdümnung des Mittels eintreten müssen. Empfohlen wird, sich der bereits im Hantel befindlichen, in Wasser löslichen Karbolineumsorten zu bedienen und sie der Kalkmilch zu etwa 201"0 zuzusetzen ${ }^{1}$ ); günstig wirkt auch schon ein Zusatz von $10^{\circ} 0_{0}{ }^{2}$ ).

Man will auch eine direkt wachstumsfördernde Wirkung bei bestrichenen Stämmen beobachtet haben ${ }^{3}$ ) und hat eine Zunahme des Chlorophyllgehaltes der bestrichenen Rinde bei Anwendung einer bestimmten Sorte aus Braunschweig mikroskopisch festgestelltt ${ }^{4}$. Wir glauben, dafs der Erfolg darin liegt, dat's bei dem Bestreichen glattrindiger Stämme hänfig Risse in der Rinde entstehen, die nachher überwallt werden müssen. An den Überwallumgsrändern ist eine gesteigerte Rindentätigkeit auch bei gewöhnlichen Schröpfwunden erwiesen.

Die Verwendung des Mittels als Anstrich für Bäume wird nur während der Ruhezeit derselben zulässig sein, und zwar mit einer erprobten Sorte, als welche "Schacht's Obstbaumkarbolineum" (20) bis $30^{\circ}, \mathrm{ig}$ ) wiederholt genamnt worden ist ${ }^{5}$ ). Eine Sommerspritzung würden wir niemals amraten. Als Wundschlulsmittel werden wir den Steinkohlenteer vorziehen, weil nicht num die ADERHowdschen Erfahrungen, sondern auch die in Hohenheim ron ScHweINBEz ${ }^{6}$ ) ausgeführten und unsere eigenen Versuche keinen Vorteil des Karbolineums gezeigt haben. Die Emptehlungen als Heilmittel gegen chronischen Gummiflufs beruhen mindestens auf Selbsttäuschung, wem nicht auf Reklamebedürfnis.

Dasselbe Urteil fällt SchweInbez über die verwandten Mittel „T uv", "Dendrin", „Baumschutz", "Neptun".

7. Lysol. Ähnlich wie jetzt das Karbolinemm hat früher clas Lysol seine begeisterten Anhänger und Zweifler gehabt. Das Lysolum purum von Schülke \& Mayr in Hamburg, das ungefähr zu Ende der achtziger Jahre des vorigen Jahrhunderts in den Handel kam, ist eine durchsichtige, braune, sirupartige Flüssigkeit, die vollständig klar in reinem Wasser löslich bleibt und als Desinfektionsmittel die weitgehendste Terwendung gefunden hat. Bei der Ankündigung wurde gesagt, dafs nach Versuchen schon eine Menge von $3 \mathrm{~g}$ Lysol auf einen Liter Flüssigkeit hinrelcht, „um in Zeit von $15-20$ Minuten Spaltpilze in allen Entwicklungsformen, wem sie in Flüssigkeiten suspendiert sind, zu vernichten". Wir haben es hier mit einer Lösmg von Teerölen in nentraler Seife zu tun, und zwar mit den leichten Teerölen (Kresolen); denn sie gehen fast vollständig zwischen 187 und $200^{0}$ über $\left.{ }^{7}\right)$. Gegenäber den anderen Handelsprodukten, wie Creolin, Kresolin, Littles soluble Phenyle, welche als Lësmngen von Harz- oder Fettseifen in Teerölen mit Wasser nur Emulsionen bilden und beim Verdünnen das Kohlenwasserstofföl grofsenteils wieder abscheiden, hat das Lysol allerdings den Torteil der vollkommenen Wasserlöslichkeit,

1) Praktischer Ratgeber im Obst- und Gartenbau 1906, Nr. 49.

2) Praktische Blätter für Pflanzenbau und Pflanzenschutz, herausg. v. Hiltner.

1906, November.

3) Gartenflora 1906, Nr. 3.

4) Graff, Über Karbolineunversuche im Jahre 1906. Prakt. Blätter f. Pflanzenbau und Pflanzenschutz 1907. Heft 3.

5) Strafrex in Prakt. Ratgeber 1906, Nr. 23.

6) Tom Karbolineum. Gartenflora 1906, S. 20.

¿) Zeitschr. f. Pflanzenkrankh. 1891, S. 185. 
teilt aber mit den vorgenannten Präparaten seinen schädlichen Einfluts auf das Gewebe der Pflanzen. Es kam im Gartenbau am meisten als Spritzmittel gegen Blattläuse, Thrips, schwarze Fliege und dgl. tierische Schädlinge zur Verwendung. Schon die bald nach der Einführung des Mittels von OTто ${ }^{3}$ ) ausgeführten Kulturversuche ergaben, (lats die tüntprozentige Iyysollösung, die gewöhnlich zur Desintelition benutzt wird, im Boden sich als schweres Gift tür die Pflanzen erweist, auch wem es nicht direkt mit den Samen oder Keimptlanzen in Berïhrung kommt. Bei direkter Einwirkung auch in viel verdïnnterer Form grift es die Wurzeh der WVasserkulturen moemein schart an. Als schutzmittel gegen Blattläuse kam es in 0,25 und $0,5 \%$ iger Lösung zur Verwenchug. Dabei tötete es aber nu einzelne Blattläuse, und erst bei „20\% iger Lösmo erschien die Mehrzahl der Tiere getötet; aber auch die Ptlanzen waren derart geschwärzt mel beschädigt, dats sie als nicht mehr lebensfähig angesehen werden konnten.

8. Karbolsäure, Amylokarbol und Sapokarbol. Das Amylokarbol ist eine Mischung ron Schmierseife, Fuselöl und reiner Karbolsäure; das Sapokarbol ist verseifte Karbolsäure.

Alle Karbolsäure enthaltenden Wittel sind gefährlich und meistens: die PHanzenteile direkt tötend. In FleIs('HER's ${ }^{2}$ ) Versuchen war von den vorstehenden Präparaten clas Sapokarbol in 1\% iger Lösung gegen Blattlänse wirksam, ohme dat's die Blätter, mit wenigen Ausnahmen, durch das Bespritzen geschädigt wurden. In Verdümmungen, welche vollständig die Blattläuse töten, wirken auch $\mathrm{Pinosol}$ und Creolin, da beide in Wasser nur emulsiert werden, schädlich. Das Antinonnin, das Kaliumsalz des Orthodinitrokresols, ist nach Frask's Versuchen ${ }^{3}$ ) den PHanzen mehr schädlich als den Blattläusen und anderen tierischen schmarotzern.

9. An diese Beschädigungen schliefsen wir einen Fall, den wir der Mitteilung von Herrn KLITzis:-Lndwigslust verdanken. Er bemerkte, dafs die Rückstände aus einer Fabrik, welche Milchsänre zur Behandlung des Leders aus Mais und Kartoffeln herstellt, ein Eingehen der Pflanzen verursachten.

11. Die Arsenikbrühen, die als Insektenbekämpfingsmittel immer mehr in Aufnahme kommen. werden in der Regel in Form ron Schweinfurter Grün oder Kalkarsenik gegeben. Sowohl bei den Lösungen in Wasser als auch in Kalkwasser oder Bordeauxmischung oder Soda-Arsenik-Kalkbrühe sind Schädigungen der Blätter beobachtet worden. Im übrigen verweisen wir anf die Sipezialwerke ${ }^{4}$ ).

11. Bl a us ä ure. Als modernes, namentlich in Amerika ausgebildetes Bekämpfungsverfahren gegen tierische Schmarotzer an den PHanzen ist neuerdings die Räucherung mit Blausäure in Aufnahme gekommen. Gegenüber vereinzelten Klagen über Beschädigungen der PHanzen lä1st sich im allgemeinen sagen, dal's diese von dem Gebrauch des Mittels

1) Orт», R., Über den schädlichen Einflufs von wässerigen, im Boden befindlichen Lysollösungen usw. Vorl. Mitt. Zeitschr. f. Pflanzenkrankh. 1-!y, S. $70 \mathrm{ft}$.

2) Flesscher, E., Die Wasch- und sipritzmittel zur Bekämpfung ler Blattläuse. Blutläuse u. ähnlicher Schädlinge usw. Zeitschr. f. Pflanzenkrankh. 1891, ... 3.5.

3) Krankheiten der Pflanzen 189.;, Bd. I, S. 329.

4) Hollrex, M., Jahresbericht auf dem Gebiete der Pflanzenkrankh. Berin, Paul Parey. Erscheint seit 1§98. - Holnrwi, M., Handbuch der chemischen Mittel gegen Pflanzenkrankheiten. Berlin 1898. Paul Parey. 
niclit abhalten sollten. Für trockene Samen stellte Towssexu ${ }^{1}$ ) fest, dati die Keimfähigkeit nicht leidet. wenn die Einwirkung der gasförmigen Blansänre nicht länger dancrt als zur Abtötung des Tierlebens noitig ist; längere Behandlung schädigt allerdings heträchtlich. Fenchte samen leiden schneller und verlieren ihre Keimkratt.

12. Die Kupferbrühen. Dieselben kommen hier nur soweit in Betracht, als es sich mm ihre Schällichkeit handelt. Ihre Nützlichkeit als Fungicid, die im zweiten Teile dieses Werkes gewiurdigt wird, beruht unserer Anschaumg nach hauptsächlich darauf. dats die Pilze Fermente ausscheiden, welche das ant den Pflanzenteilen angetrocknete Kupfer:salz lösen und sich dadurch selbst vergiften. In erster Linie steht die Bordeauxmischung, die als Pilzbekämptimgsmittel unzweifelhaft grotse Bedentung hat, als wachstumstördernd, wie ihre begeisterten Verehrer nachweisen wollen, aber nicht anerkannt werden kainll.

Han ist sich noch nicht einig, ob das Kupfer durch eine normale Cuticula bei allen PHanzen hindurchdringen kamn. Nach Bourgues²) soll dies nicht der Fall sein. Rum ${ }^{3}$ ) konnte auch kein Kupfer in den Gewehen bespritzter Bläter nachweisen und glaubt, eine giunstige Wirkmng nur aut einen cliemotaktischen Reiz zurückführen zu müssen. Die infolgedessen antretenden elektrischen Ströme sollen dam im Blatgewebe die gïnstigen Wirkungen veranlassen. Die Frage, ob und whe das Kupter in das Innere eines Pflanzenteils gelangt, lälst sich nicht allgemein entscheiden, sondern muls von Fall zu Fall in Betracht gezogen werden. Eine alte, mit starker Wachsglasur versehene Cuticula wird vielleicht nicht angegriffen werden, wäluend das junge Blatt leiden kann. Aber auch bei älteren Blättern können in einem Falle Beschädigungen auftreten, in einem anderen Falle nicht, weil manchmal durch Witterungseinflüsse (Spätfrost) die Cuticulardecke Risse bekommt, in denen sich Kupferlösmo lange \%eit halten kann. Endlich kommt die spezifische Empfindlichkeit der Phanzenart ausschlagoebend hinzu, wie wir an spaiteren Beispielen zeigen werden.

Die ersten /weifel an der wachstumstördernden Eigenschatt der Kuptermischungen hatten wir anf (irund von im Jalue 18.11 ans getührten Bespritzmigsversuchen zu erkennen gegeben ${ }^{4}$ ). Wir komnten eine Ifemmung in der bintwicklung der Kartoffelpflanze gegenüber gesundbloibenden mberpitzten Phanzen nachweisen. Der als Wachstrms-

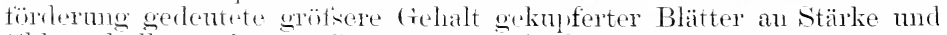
Chlorofhyll wurde von ScHoxus ant die schattenwirling des Kupfer-

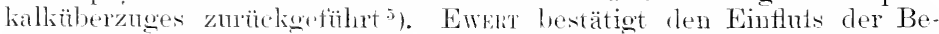
schattung, aber macht daraut aufmerkism, dats dies nicht der einzige hemmende Falitor sei"i). Es kommen durch den Einfluts der Kupfer-

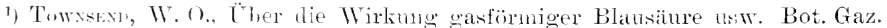
XXXI; cit Bot. Jahroblur. 1902, I, s. 3:4t

¿) Bonvatrs, H., La chiticule et les sols de cuive I; cit. Centralbl. t. Bakt. usw. 191.5, Nr. 24.

3) Rrm, C., Zur Frage nach der Wirkung der Kupferkalksalze usw. Ber. d Tleutrch. Bot. Ges. 1st:; s. 44.)

+) Sontrer, P., Einge Beolachtungen bei der Anwendumg von Kupfermitteln

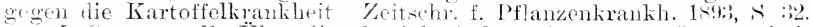

5) Simstas, E, Über die phrwiologische Wirkmg der Kupfervitriolkalkbrühe. Inaug.-Diss. Berlin 1904 und Landwirtach. Jahrbücher 1904, Heft 45.

6) Ewert, Der wechelseitige Einflufs des Lichtes und der Kupferkalkbrühen auf den Stoffwechsel der Pflanze. Landwirtscn. Jahrbücher 190\%, s. 2:3. 
mittel, speziell der Bordeanxmischmor, sitannugen in der Abf̈̈hrung der Assimilate zustande; die heobathteten orölseren Stäke- und Eiweitsmengen sind nicht Folgen einer westeigerten Assimilation, die nachgewiesenermatien netst der Transpiration und Atmung herabgedrückt wird, sondern die Wirkmus stockender Ableitmos. Diese Anschammo, der wir beitreten, setzt allerling voraus, dais Kupfer tatsächlich in die PHanze eintritt, mol diest Amsicht findet darin ihre Bestätigmng, dats anch Forscher, welche ein Eindringen des Kupters nicht annehmen, doch bei einer Anzahl iner Versuche die Kupferreaktion fanden (Frask mol Krïser). Antserdom lat EwerT in hordelasierten PHanzen anch Kupfer nachgewiesen. Öber den Vormang der Autinahme bringen wir suater noch Notizen aus der Arbeit von S'CHANILR.

Meiner Anftassung nach wird bei den gekmptiorten Ptlanzen das durch Wunden oder durch die Epidermis eintretende Kupfer sofort von den Eiweilsstoffen des Protoplasmas gebunden und drüclit damit das Zellenleben herah. Da die Bes]ritzmgen keine vollständigen Benctzungen der ganzen Blattfläche darstellen, so heiben zwischen den geschärligten Blattpartien stets gesmule stehen, und diese mïssen nun eine resteigerte Wachstmotatigkeit zeigen. I)icselbe äufert sich bei reichlicher Zutulur von Licht mu Fenchtiokeit bisweilen in der Ausbildmer von Int umestenzen. Der erstr derartige Fall wurde von mir bei Kartoffeln besehriehen ${ }^{1}$ ). Sinäter hat $v$. S'chresk ${ }^{2}$ ) an Kohlptlanzen Intumescenzen infolge ihrer Behandlung mit Kupferammonimmkarbonat, Kupferchlorid, -acetat,

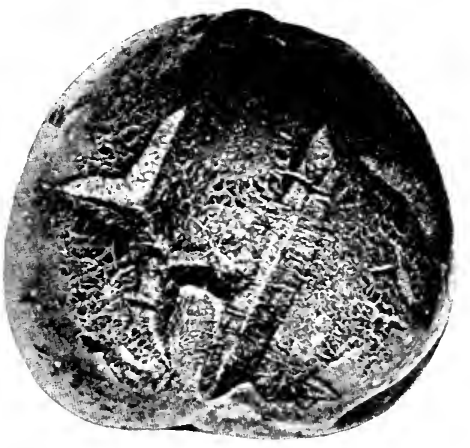

Fig. 169. Ältere Frucht von Apfel mit bramen Flecken und Rissen. (Nach HE1MiI K.) -nitrat mol -snlfat beobachtet. In neuester Zeit hat $\mathrm{MUTH}^{3}$ ) sehr starke Intumescenzhildmo bei Weinblätern nach Kupfermog getiunden.

Durartige Wirliungen kömnen zustandekommen, wemn sich das Gewhe partiell vergittet, ohne direkt zn sterben: sie treten aber anch ein, wemn eine Abtätung wirklich stattfinder, wobei die abgestorbenen Gewebstellen bei manchen Pflanzen ans dem Blatte heranstallen, sn dats eine I) urehläeherung sich geltent macht. Solche Fälle sind nenerdings von sindist (l. e.) beschrieben worden. Es wird dabti erwähnt, dats Fuchsid mut Orwothera säure ausscheiden. Wolde geringo Mengen von Kupterhydroxyd lïst. Es kömen aber anch alkalische

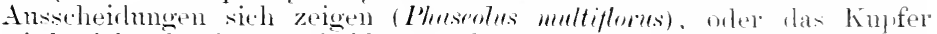
wird nielit durch Ansscheidmoren des Blattes, sondern entiach inuch die Atmosphärilien, namentlich bei anhaltend feuchtem Wotter, arelist.

1) Zeitschr. f. Pflanzenkrankh. 1‘9:3, s. 1*2.

2) Sicurax, H. r., Intumescences formed as a result of chemical -timulation. Sixteenth ann. report Missouri Bot. Gard. Nay 1905. Sonderablruck.

$\left.{ }^{3}\right)$ Mr ru, Frax, Über d. Beschädigung d. Rebenbläter durch Kuferepritzmittel. Mitteil. d. Deutsch. Weinbauvereins I. Jahrg. Nr. 1, s. y. 
Ruhlani ${ }^{1}$ ) erklärt dagegen, daf's die Annahme ron einer Lösung des Kupfers durch austretende Blattextrakte keine Berechtigung habe, sondern nur den Atmosphärilien zuzuschreiben sei.

Die Nachrichten über die Beschädigungen des Laubes durch Kupferbespritzungen liaben schon begonnen, nachdem das Verfahren eine allgemeinere Ausbreitung gefinden hatte. Im Jahre 1891 wurde bei der Bekämpfung des Peach rot beobachtet, dat's nach der Anwendung ron Bordeauxmischung nicht nur Blätter und Blumen ahfielen, sondern anch das junge Holz beschädigt wurde ${ }^{2}$ ). Die Amygdalaceen und namentlich die Pfirsiche haben sich auch in der Folge als besonders
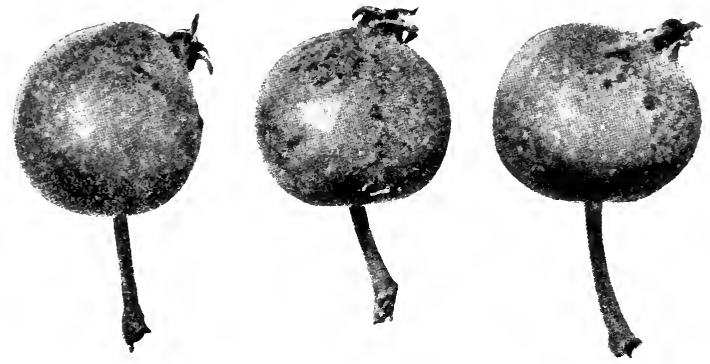

Fig. 170. Junge Apfelfrüchte mit einseitig behindertem Wachstum infolge Bespritzung mit Bordeauxmischung. (Nach Hedick.)

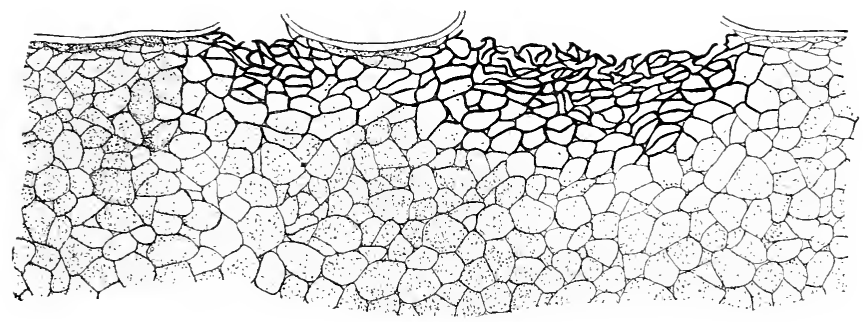

Fig. 171. Querschnitt durch die Randpartie eines von Bordeauxmischung: beschädigten Baldwin-Apfels. (Nach Henнск.)

empfindlich erwiesen. $B_{A N}{ }^{3}$ ) zeigte bei seinen Versuchen mit Apfel-, Wein- und Pfirsichblättern, dat's dies mit der spezifischen Empfindlichkeit des Protoplasmas zusammenhängt. Das Pfirsichblatt, sagt er, hat die Fähigkeit, durch eine an der Oberfläche ausgeschiedene Substanz Kupferoxyd zu lösen. .Junge Blätter leiden am meisten. Die be-

1) Ruhlaxw, W., Zur Kemntnis der Wrirkung des unlöslichen basischen Kupfers anf Pflanzen usw. Arbeiten 1. Biol. Abt. f. Forst-u. Landwirtsch. beim Kaiser] Gesundheitsamt Bd. IV, 1904, Heft ?2.

$\left.{ }^{2}\right)$ Report of the Secretary of agric. for 1s91. Washington 1892 , p. 364 .

3) Bux, S. M., The action of copper on leaves ete. Agric. Fxp. Stat. of the University Tenessee 1902, vol. XT. 
schädigte Blattstelle wird durch Kork ahgentenzt und ausgestofsen (Schrotschutskrankheit), was AnERHuL, ${ }^{1}$ ) an h Twi hir.hen beschrieben hat. Stark verletzte Blätter werden ahgeworfen, wänend das Apfelblatt, ebenso wie das Weinblatt, die Fähigheit hesitzt, mit dem Rest seinel Lamina weiter $\mathrm{zn}$ assimilieren.

Nach den nenen Studien von Hennck ${ }^{2}$ ) sinul Ptirsich. Aprikose und Japanische Pflame die empfindlichsten Obstgehölze. Wälnend die gewöhnliche Pflammenicht stärker wie Birne, Aptel oder ruitte angegriften wird. Wie cinzelnen Varietäten verhalten sich verschieden: die bestgeptrogten Exemplare mit den sattinten Blättern leiden an stärkisten. Von hervorragendem Eintluts: sind die Witterungserlualtnisse, ron denen dic zartere orler lerbere Ansbildung der Blätter und namentlich deren Cuticula abhängt. Ten besten Berreis lieferte in sitaate New Sork das dalu 1!m.), dessen warme, neblige Eräljahrswittermon clas Laul, seln zart bleiben liets. Viele Aptelzïchter erkärten. sie häten in diesem .Jahne mehr sicharlen wie Nutzen rom Beyritzen mit der Bordeanxmischumg gehabt. Hentis tülnt Beispiele an, bei fromen ein Spritzen bei darautiolender anhaltond fenchter Witterung moemein grolse sichäden hervorgeruten hatte, wälmend acht Tage später, nachilem trocknes Wetter eingetreten war, die Bespritzmo gar keine ühlen Folgen ochaht liat.

WVir entlehmen oluengenamntem Autor einige Abfildumgen von Früchten und Blättern, die durch das s pritzen beschädigt worden sind. Auf den Früchten erscheint der

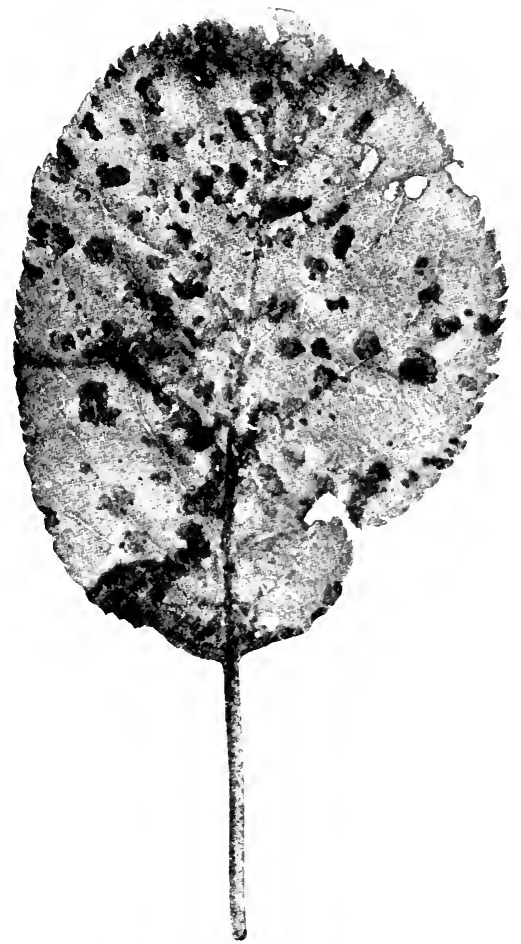

Fig. 172. Apfelblatt. das infolge von Bespritzung mit Bordeanxmischung tote (icwebestellen und Durchlöcherung zoigt. Nach Нвинак к.)

Schaden zuerst in fiestalt

kleiner bramer Fleckchen. div sich zu ansgedehnten Ro-tz.ichnmgen erweitern (Fig. li9). Tem diese Oberhantverletzmong wibrembl der Schwellungsperiode eintreten, ham das Wachstum der Frucht mregel-

1) Aıremor, R., Über Clasterosporium carpophilum usw. Arb. d. Biolog. Abt. d. Kais. Gesundheitsantes 1902, Hett 5.

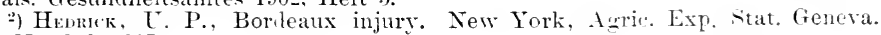
Bull. Nr. 287, 1907. 
mätsig werden (Fig. 170), oder es künnen bei jungen Äpfeh selbst klaffende spalten entstehen. Derart beschädigte Frichte werden mehlig und taulen leicht.

Die mikroskopische Untersuchung der braunen Flecke zeigt, dal's die Cuticulardecke mit ihrer Wachsolasur zerstört ist (Fig. 171). Die benachbarten Epidermiszellen und das blotsgelegte Fruchtfleisch bekommen stark verdickte Wände von korkartigem Aussehen; sie kömmen der Schwellung der Frucht nieht mehr folgen, und die Frucht reilst nummehr ein. Der in den Rissen gebildete Wundkork nebst dem dureh die Bordeauxmischung abgetöteten Gewebe bilden clann die eigenartigen „Rostfiguren“, welche unsere Abb. 169 zeigt. Die Grölse der Verletzung steigert sich mit der Zartheit der Schale, die die ersten Anfänge der Brätnung in der Regel um ein Haar oder eine Spaltöffinmo herum erkemmen läfst. Bei zunehmendem Alter der Früchte werden normalerweise die Haare abgeworten und an Stelle der Spaltöffinmgen entstehen Lenticellen; dabei verstärkt sich die Wachsolasur, und damit tritt eine Immmität der Früchte gegen das giftige Kupfer ein. Anch auf den Blättern entstehen brame Flecke, die bisweilen ausbrechen (Abb. 172). Am schwersten leiden natürlich die Blüten. Nan kam mit Sieherheit ammelmmen, dals bei diesen das Kupfer sich mit dem Zellinhalt verbindet. Betreffs der Herstellung der Bordeauxmischung, die im zweiten Bande mnseres Werkes (S. 521) eingehender behandelt worden ist, wird die Bemerkung HenRich's beachtenswert, dat's eime grötsere Beigabe von Kalk die Beschädigungen kaum verringert.

Was von den Kupferkalkmischungen gilt, bezieht sich in erhöhtem Mafse auf die A z ur ine, bei denen zur. Neutralisation des Kupfervitriols das Ammoniak benntzt wird. Je naeh der Menge des benutzten Ammoniaks entstehen reine tiefblane Lösungen, wie die „Bonillie Céleste" und das "Azurin Siegwart", oder"es bleiben, namentlich bei stärkerer Verdümmung, basische Kupferverbindungen als Niederschlag wie bei dem "Kristall-A zurin Mylins". Je mehr Ammoniak verwendet wird, desto näher rizckt die Gefahr des Verbremmens der Blätter ${ }^{1}$ ).

\section{Anaesthetica.}

In Rücksicht auf die sog. „Äthertreiberei“, d. h. das Verfahren, die Pflanzen zur Beschleunigung ihres Austreibens Ätherdämpfen auszusetzen, müssen wir ms auch mit den Anaestheticis beschäftigen. Der günstige Erfolg, der namentlich bei der Frühtreiberei von Flieder bei richtiger Anwendung des Verfahrens erzielt werden kamn, steht aufser Zweifel; aber bei anderweitiger Verwendung machen sich nachteilige Folgen bemerkbar. Die durch mehrfache Versuche nachgewiesene Wirkung von Äther, Chromäther, Chloroform, Stickstoffoxydul, IIorphimm, Cocainn usw. besteht in der Iähmung der vollen Entfaltung der protoplasmatischen Tätigkeit. Erleidet dabei das Protoplasma in seiner physikalischen oder chemischen Struktur eine dauernde Schädigung, so folgt der Tod; im anderen Falle kehrt die Pflanze allmählich wieder zu ihrer normalen Tätigkeit zurïck²). Natürlich hängt die Wirkung

1) Krtisn, P., Über die Verwendung der "Azurine“ zm Bekämpfung der Peronospora. Landwirtsch. Z. f. Elsafs-Lothringen 1907, Nr. 26.

2) Kitraxix, C., Über die Einwirkung der Anaesthetica auf das Protoplasma und dessen biologisch-physiologische Eigenschaften; cit. Just's Jahresber. 1900, II, S. : : $: 01$. 
davon ab, in welchem Zustande sich das Protoplasma hefindet. So hat Corrs ${ }^{1}$ ) nachgewiesen, daf's selbst eine mit ('hloroform und Äther gesättigte Atmosphäre keinen Einfluds auf clas Protoplasma von Samen, die sich im Ruhezustande befinden, auszuïhen rermas. Ist dagegen die Lebenstätigkeit derselben durch Anfenchtum erweckt, wenügen schon sehr kleine Dosen $\left({ }^{37} / 100000\right)$, um Scharlen zuzutïpen. Doch ist die hier angeführte Zahl nicht als Norm anzusehen; demn abgesehen von der Indivielualität der Pflanzenspezies, kam anch dieselbe spezies durch Anpassung eine rerschiedene Widerstandsähigkeit entwickeln. So gibt beispielsweise Towssexu ${ }_{2}^{2}$ ) an, clafs sporen ron Muror und Penicillium, die in einer starken Ätheratmosphäre zur Reife gelangten, ebenso schnell keimten und nene sporen hervorgobracht haben, als wemn sie in einer ätherfreien Atmosphäre gekeimt wären. Dersellw Beobachter erwälnt, das hier und bei anderen Giften, selur schwache Dosen anregend und die Keimungstaner abkïrzend wirken, währent stärliere Dosen sehaden.

Über die Art der Einwirkmo erhalten wir einen Einblick durch die Beobachtungen von Maknowse ${ }^{3}$ ), der aus seinen Versuchen den Schlul's zieht, dats bei einer längere Keit anhaltenden Wirknng anästhesierender Dämpfe die Atmung beträchtlich gestei $\varrho$ ert wirl. Unter dem Einflut's ron Alkoholdampt sah er die Atmung etiolierter Pflanzen sich $u m$ das Anderthalbfache erhöhen; noch stärlier wirkte Äther.

Wir dürfen also hier eine spezifische Reizwirling ammehmen. Diese Ansicht wird ron BrHness ${ }^{4}$ ) vertreten, der anch die beschlemigte Keimfähigkeit der samen nach mechanischen Verletzungen, welche HuLtwer der erleichterten Wasseranfnahme zuschreibt, als Reizwirlimo auffassen möchte. BrHrexs stützt sich dabei anf Versuche mit verletzten Samen, bei denen die Wundstelle sofort mit Kolophonimmachs rerklebt worden war. Obwohl die Wasseranfuahme dieser Körner im Vergleich mit normalen Körnern nicht gesteigert erschien, ergab sich democh eine erhebliche Wachstumssteigerung. Die Versuche mit dem Anfeilen und sonstigen absichtlichen Verletzungen hartschaliger Samen beweisen jetoch, dats anch die mechanische Erleichterung des Wassereintritts an sich keimungstördernd wirkt.

\section{Schädigungen durch Düngemittel.}

1. Chilisalpeter. Bei dem Gebrauch ron Chilisalpeter sind vielfach unangenehme Nebenwirkungen und Nachwirkungen beobachtet worden. Die Ursache wurde zum Teil in dem Torhandensein von $\mathrm{Ka}$ li um perch lo rat gefunden. Die zahlreichen Kulturversuche stellten fest, dats namentlich Getreide sich empfindlich erweist und hei 2." Perchlorat schon autfällige Schätligungen erkennen lätst, wälırenıl Luzerne. Erbsen und Senf diese Konzentration noch vertragen liönnen. Bei Roggen wurde sogar noch ein Verkümmern der Pflanzen leobachtet.

1) Cor prx, H., Action des rapenrs anesthésiques sur la vitaliti des graines sèches et des graines humides; cit. Just's Jahresber. 1900, II, S. : 211.

-) Towrexn, C. O., The effect of ether upon the gemination of seeds and spores: cit. Just's Jahresber. 1s99, II, S. 142.

3) Mикоwine, N., Recherches sur l'influence des anesthésiynes sur la respiration des plantes: cit. Just's Jahresber. 1 199 , II, S. 143.

4) Brнmss. Bericht d. Grofsherzogl. Badischen Landwirtsch. Versuchsanstalt Augustenberg f. d. Jahr 1906. 
wemn derselbe als Nachfrucht gebant wurde $\left.{ }^{\mathbf{l}}\right)$. Hackfrïchte, Zuckerrïben wurden durch 2\% Perchlorat auf $200-; 00 \mathrm{~kg}$ Salpeter pro Hektar nicht geschädigt ${ }^{2}$ ). J JxGNer und (EERLAcH ${ }^{3}$ ) beschreiben die Formveränderungen bei Weizen- und Roggenkeimpflanzen folgendermatien. Ias Primordialblatt bleibt längere Zeit teilweise zusammenverollt und hält das zweite Blatt zmü̈chst so fest mmschlossen, daf's dasselbe nur schwer mit seiner Spitze sich lösen kann und infolgedessen eine Öse oder Schleife bildet, wobei es querfaltig wird und sich m seine eigne Achse rollt, schlietslich wohl anch zerreist. Gleichzeitig erfolgen ein Vergilben der Blattspitzen und bedeutendes Nachlassen der Streckung der ganzen Pflanze. Je nach der Menge des vorhandenen Perchlorats wird sogar schon eine Verzögerung der Keimung eintreten kömen; bei schwachen Dosen ist dieselbe nicht beobachtet worden. Die Schleifenbildung der Blätter durch Steckenbleiben der Spitzen in der Scheide des nächstälteren scheint ein beachtenswertes Merkmal des Getreides bei Perchloratrergittung zu sem. Charakteristisch ist es jedoch nicht, da ähnliche Erscheinmogen bei Tylenchus devastatrir auftreten ${ }^{4}$ ).

DAfERT und HALLA ${ }^{5}$ ) beschreiben einen Fall vom Auftreten von freiem .Jod im Chilisalpeter, der dadurch einen Geruch nach Jodoform erhielt. Der salpeter enthielt $0,31 \% \mathrm{KClO}{ }^{4}$ und $10,11 \% \% \mathrm{~K} . J 0^{3}$. Die Gefahr für die Praxis ist aber in solchen Fällen gering, da man die säcke mit Chilisalpeter nur längere Zeit zu lüften braucht, damit das Jod verdampten kamn. Daf's die Jodide von Mangan, Kalium, Natrium und Lithium schädlich wirken, während die Oxyde sich als günstig erweisen, hat u. a. TóLkER ${ }^{6}$ ) gezeigt. - Anknüpfend an seine früheren Versuche, aus denen die Schädlichkeit grölserer Mengen von Jod- und Bromnatrium und Chlorlithium, dagegen eine Förderung der Keimung bei Befeuchtung der Samen mit schwächeren Lösungen hervorgeht, schliet'st MAzÉ ${ }^{7}$ ), dat's die Zelle zur vollen Entfaltung ihrer Funktionen der Anregungen durch solche Salze bedarf. Ähnliche Erfahrungen ïber Schädigungen durch stärkere und Förderung des Wachstums durch sehr schwache Konzentrationen von Fluornatrium haben Asos, und betreffs des Jodkaliums SuzukI ${ }^{9}$ ) gemacht und sind anch anderweitig mehrfach beobachtet worden. Ebenso meldet MIANI ${ }^{10}$ ) für Kupferlösungen fördernde Wirkungen.

1) Thimax, Mantix, In welchem Grade ist Kalimperchlorat ein Pflanzengift? Die Regelung des Verkehrs mit Chilisalpeter. Meffe 1901. Cit. Centralbl. f. Agrikulturchemie 190:3, Heft 7.

2) STokLasi, Beiträge zur Kenntnis des schädlichen Einflusses des Chilisalpeters auf die Vegetation. Z. f. d. landwirtsch. Versuchswesen in Österreich 1900, S. : $: 5$.

3) Jusiser und Gericici, Versuche mit Kaliumperchlorat. Jahresber. d. landw. Tersuchsstation in Jersitz bei Posen 189798, S. 29.

4) Kríger, Fr., и. Bн:л, G., Ein Beitrag zur Giftwirkung des Chilisalpeters. Centralbl. f. Bakt. II, 1898, Bd. IT, s. 674.

5) Differr, F. W., u. Hill., Av., Über das Auftreten von freiem Jod im Chilisalpeter. Z. f. d. landw. Versuchswesen in usterreich 1901.

6) Vorıker, A., Utber den Einflufs von Mangansalzen sowie von Jodiden und Oxyden von Mangan, Kali, Natrium und Lithium auf Gerste und Weizen. Journ. Roval. Agric. Soc. of England, vol. 64 u. 65; cit. Centralbl. f. Agrikulturchemie 1905, S. 715 .

i) Maze, Einflufs der in den Pflanzen in geringer Menge enthaltenen Mineralstoffe auf das Pflanzenwachstum. Biedermann's Centralbl. f. Agrikulturchemie 1902, s. 686.

s) A $=0$, Bull. Coll. Agric. Tokyo: cit. Bot. Jahresber. 1902, S. 353.

9) Srzrki. S. ibid.

10) Yux, D., Üher Einwirkung von Kupfersulfat auf das Wachstum lebender Pflanzenzellen. Ber. d. Deutsch. Bot. Ges 1901, Heft $\mathbf{i}$. 
2. Superphosphat. In Kürze zu gedenlien ist des Zurückgehens der Phosphorsäure im Superphospliat mod Thomasmehl in manchen Böden, die reich an Kalk und Eisenoxyd sind. In saurem Moorboden und humusreichem, saurem Wiesenboden überwiegt der die Phosphorsäure löslich erhaltende Prozets; dem Wasser, Kohlensäıre, Hummssäure und einige Salze wirken lösend. Im limmnshaltigen, nicht sauren Sandboden halten der lösende mul der die welöste Phosphorsäme wieder in schwer lösliche Formen übertührende Prozedis einanter ungefähr das (ileichgewicht. Aber in kalkhaltigen und eisenhaltigen

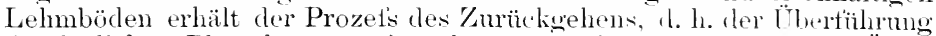
der löslichen Phosphorsäure in schwerer lösliche Phosphate das Ühergewicht. Unter solchen Umständen wäre eine Frühjahrsverwendung von Thomasmehl nicht anzuraten.

3. Gasphosphat. In den Gasfabrikationsabfällen findet sich in verschiedenen Mengen Rhodanammonim vor. Dasselbe hat eine erhöhte wirtschaftliche Bedentung dadurch erlangt, dats man durch Reinigung des Leuchtyases mit Superphosphat ein stickstoffhaltiges Düngemittel hergestellt hat, welches als .trasphosphat" in den Handel gebracht worden ist. Das saure Phosphat hat aus dem Lenchtgasstrom das Ammoniali aufgenommen, aher dabei zugleich auch das Rhorlanammonium behalten. Bei der vielseitig nachoewiesenen (riftigkeit dieser Verbindung hat man versucht, dureh Waschen des (rasphosphats mit einer konzentrierten Lösmg von Ammonimmsulfat, in welehem die Rhodanverbindmgen leicht löslich sind, das I)ïngemittel zu reinigen. Nan komnte dadurch den tiehalt desselhen bis auf $0,90^{\circ} 0$ Rhodanverbindungen herabmindern mol hat infolgerlessen die direkte Anwendmo dieses Düngers, der sich in der Tat dureh hohen Phosphorsäure- und stickstofficehalt auszeichnet, emptohlen.

Die Versuchsresultate waren einander widersprechend insofern, als aut Sandboden günstige Ergebnisse, ant lehmigen Börlen nachteilige Wirkungen beobachtet worden sind. Dies legte die Vermutung nahe, dat's im sand eine schnellere Zersetzung des Rhodanammoniums in Ammoniak bzw. Salpetersäure und schwetelsäure eintritt mol darlurch die Giftwirkung anfgehoben wird. Die Vermutung wird durch andere Versuche bestätigt, welche dartun, dats bei dem Einbringen des I büngers mehrere WTochen vor der Aussaat sich keine Schädigmuen. bei gleichzeitiger Saat aber arge Verluste zeigen. Dasselbe Ergebuis stellte vich bei Benutzung eines Staubes aus Hochöfen heraus, der 1 " Rhodlan enthiclt.

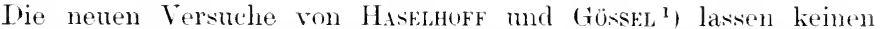
Zweitel an der (riftigkeit des Rhodanammonimms, dessen Zersetzmo selbst in einem Sandheden nicht so leicht vor sich geht. wie frühere Versuche zu ergeben schienen. Schon so geringe Dengen, wie 0,00:-5" o, ruten eine erhebliche Verzögermo der Keimumg hervor, und da anch das gereinigte Gasphosphat noch immer 1.71;" "Rhordanammonium entlält, so möchten die genannten Forscher dasselbe, zmal bei der schwerlöslichkeit der Phosphorsäure, als Düngemittel überhaupt nicht emptehlen.

4. Schwetelsaures Ammoniak. Im Anschlntis hieran sei

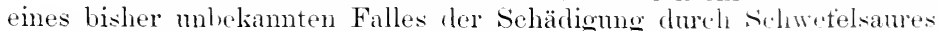
Ammonlak gedacht. Ein Waggon roll Pflanzen (Azaken) zeigte beim

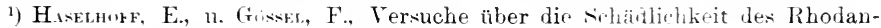
ammoniums für das Pflanzenwachstum. Zeitschr. f. Pflanzunkrankh. 1904. \& 1. Hier anch die frühere Literatur. 
Öffinen, daf's die Blätter teilweise gesthwärzt, wie nach Ammonialdämpten, waren. Die Nachforschungen ergaben, dats vorher der Waggon zum Transport ron schwefelsaurem Ammoniak benutzt worden war. Die daraufhin angestellten Versuche zeigten, dat's bei Vorhandensein ron Kalk sich freies Ammoniak entwickelt. Ebenso wird frisches schwefelsaures Ammoniak, das nicht genügend getrocknet und neutralisiert ist, Ammoniak entwickeh kömnen, das ähnlich dem in dem Abschnitt über Ammoniakdämpfe geschilılerten Falle in den Wänden hatten and nachträglich schädigen kamn.

5. Kalkst i ckst off. Dieses junge Produkt unserer Düngerindustrie gibt augenblicklich noch zu mannigtachen Klagen Veranlassung. Das zunächst zur Herstellung eines sehr hellen Leuchtgases, des Acetryens, rerwendete, aus der gegenseitigen Einwirkung von Kalk und Kohle im elektrischen ofen gewomnene Calcinmkarbid wird in hermetisch verschlosienen, eisernen Wuffeh bei intensiver Hitze der Einwirkung von Stickstoff ausgesetzt und liefert dam den Kalkstickstotf als ein verumreiniotes Calciumcyanamid mit etwa $20-24^{\circ}, 0$ N. Dieser Kalkstickstoft oder das Calciumcyanamid hat die Eigenschaft, durch Erhitzen mit IVasser unter Druck seinen ganzen Stickstoff in Gestalt von Ammoniak abzugeben. Durch Einleiten des Ammoniaks in Schwetelsäure ist die Möglichkeit gegeben, den wertvollen Dungstoff, das schwefelsaure Ammoniak, herzustellen. Der "Kalkstickstotf" (CaC N2) entliält ungefähn 20-21\% Stickstoff, $40-4.2 \%$ Calcium und $17-18 \%$ Kohlenstoff neben Terumreinigungen von Kieselsäure, Ton, Spuren von Phosphorsäure usw. Durch Entfernen des Kalkes entstehen Cyanamyd (C N, $\left.\mathrm{NH}^{2}\right)$ und das homologe Dicyandiamid $\left[\mathrm{C}^{2} \mathrm{~N}^{2}\left(\mathrm{~N} \mathrm{H}^{2}\right)^{2}\right]$.

Der in dem stark alkalisch reagierenden Kalkstickstotí vorhandene Kalk existiert teils in gebundener Form als Calciumcyanamid, teils ist er frei. Aus diesem Grunde darf er nicht mit Superphosphat zusammengebracht werden, da die Phosphorsäure dadurch unlöslich gemacht wïrde. Die Vorschriften tür den Gebranch sind etwa folgende ${ }^{1}$ ). Das pro Hektar anzuwendende (zuantum beträgt je nach der Beschaffenheit des Ackers 1:0-301) kg, entsprechend 30-60 kg Stickstoff. Zur Termeidung des Staubens remischt man den Kalkstickstoff mit der doppelten Menge trokkner Erile. Das Ausstrenen soll 8-14 Tage vor der Anssaat erfolgen, und dieser Inngstoff mul's sogleieh 3-5 \%oll in den Boden gebracht werden, damit derselbe das durch die Einwirkung der Borlenfeuchtigkeit freiwerdende Ammoniak anfinehmen und nitrifizieren kann.

Die Ammoniakentwicklung aus dem Kalkstickstoff geht durch Bakterienarbeit ror sich ${ }^{2}$ ).

Die in Vegetationsgefälsen ausgeführten Düngungsrersuche haben die Möglichkeit wezeigt, dieselbe Düngewirkung durch Kalkstickstoff wie durch Salpeterstickstotf und durch Ammoniakstickstott zu erzielen; bei den bisherigen Foldversuchen hat der Kallistickstoff etwa $74 \%$ der Wirkmng des salpeterstickstoftis entwickelt ${ }^{3}$ ).

1) Bunn, Der Kalkstickstoff und seine Verwendung in Gartenbau und Landwirtschaft. Gartenflora, Berlin 1906, Heft 10.

$\left.{ }^{2}\right)$ Lrimsis, F. Über die Zersetzung des Kalkstickstoffs. Centralbl. f. Bakt. 1905, II, Bd. XIV, s. 87 . - Bumax, J., Versuche mit Kalkstickstoff. Bericht der Grofsherzogl. Bad. landw. Versuchsanstalt Angustenberg 1904, Karlsruhe 1905, s. 36.

$\left.{ }^{3}\right)$ Gintacn u. Whixen, P., Gewinnmg u. landwirtschaftliche Terwendung des Salpeterstickstoff's. Verhandl. d. Winterversammlung 1904 d. Deutsch. Landwirtsch. Ges. Jahrb. d. D. I. G. Bd. 19, s. :3:39. 
Die herbsten Schädigmgen erleidet der Landwirt, wenn er bald nach dem Ausstrenen des Kalkstickstoft's die Anssaat vornimmt; von Getreide pflegen damn nur meist diejenigen Körner anfzugehen, die an der Wegkante der Felder liegen. Ist dieser erste Stof's überwunden, pflegt sich bald die reiche Ammoniakzutuhr turch hesonders dunkles Grün der Ptlanzen kenntlich zu machen. Die Sthädlgung bestcht in einer Austroeknung des Blattparenchyms und kïmmerlicher Wurzelentwicklung $\left.{ }^{1}\right)$.

So wenig man den Kalkstickstoff direkt vor der Answaat woben darf, so wenig bewährt er sich als Kopfdüngme. Ungünstig wirkt dieser Körper auch aut gewisse Böden, selbst wenn er rorschriftomialsig untergehackit wird. RenY" ${ }^{2}$ fand die günstigste Wirkmng ant tomreichen Börlen; auf Sandböden dagegen ist seine Wirkmongesthwindigleit erheblich geringer und die direkt schädliche Becinflussmng der Koimmo viel anhaltender. Er sah erst drei Donate nach der Düngung die sehädliche Wirkung auf Sandbëden ganz versehwinden. Alle Böden. welche zur Säurebildung neigen, beeinträchtigen die normale Bildung von Ammoniak. TAcke hat nachgewiesen, dats aut saurem Moorboden die Umwandlung in Ammoniak derartig gehindert wird, dats dort eine Kallsstickstoffdïngung unterbleiben muts. Andererseits kam bei viel Kalk im Boden die Ammoniakbildung so sehnell ror sich gehen, dats namhafte Verluste durch Ammoniakverdunstung entstehen. Auf' Hochmoorborlen zeigen sich Giftwirknngen, die nach GEkLach darauf zurückzuführen sein dürften, dat's bei der Zersetzung des Calciumcranamids unter Abspaltung von Kalk bimen wenigen Tagen grötsere Diengen des giftigen Dicyandiamicls entstehen.

Die solehe Nachteile umgehende Übertïhrung des Ammoniaks in Schwefelsaures Ammon verbietet sich aus wirtichaftlichen iründen. da der Stickstoff dadureh zu tener würde.

Zu diesem neuen Düngemittel, dem "Kalkstickstoff", ist bereits ein noch neueres getreten, nämlich der . St ickstofflialk", der trei von Cranverbindungen ist und der 2.2 ${ }^{\circ}$ o Stickstoft', $19 \%$ Kohlenstoff, $6 \%$ gebundenes Chlor und $4.5 \%$ Calcium enthält. Die Vegetationsversuche von Böттснек ${ }^{3}$ ) haben ergeben, dats hierbei aber dieselhen Vorsichtsmatsregeh geboten sind wie bei dem Stickstoffkalk. Er darf anch nieht kurz vor der Anssaat und nicht als Koptelïngung gegeben werden, weil er dann schäeligt*t).

Betreffis des Ammoniakstickstoff's möehten wir nicht vergessen. darauf aufmerksam zu machen, daf's anch dieser unter Verhältnissen, in denen die nitrifizierenden Bakterien nitht genügend arbeiten, sthädlich werden kann. Für schwere Böden, die mehr Wasser halten, also das Ammoniak reichlicher in Lösung bringen, liegt keine (iefahr ror, aber bei Sandböden kann die behinderte Lösliehkeit zu direkten Ätzerscheinumgen fülnren ").

1) Penrth, R., Über die Ferwendung des Calciumeranamids zur I lingmug. Staz. sper. agrar. Ital. 1904, Bu. XXXVII; cit. Centralbl. f. Agrikulturchenie 190;, S. 814 .

2) Blätter f. Zuckerrübenbau, 31. Mai 1906.

?) Deutsche landw. Presse 1906, Nr. 34.

4) Blätter f. Zuckerrübenbau 1906, Nr. 10.

5) Miź, Cntersuchungen über die Einwirkungen des Salpeterstickstoffs und des Ammoniakstickstoffs auf die Entwicklung des Tlais. Amal. agron. t. 26; cit. Centralbl. f. Agrikulturchenie 1901, s. 5\%5. 


\section{Fünfter Abschnitt. Wunden.}

\section{Zwanzigstes Kilpitel. \\ Wunden des Achsenorganes.}

\section{Allgemeines.}

So verschiedenartig die zufällig oder absichtlich dem Baumstamm zugefügten Verwundmegen auch sind, so übereinstimmend im wesentlichen ist bei allen der Heilungsprozel's.

Wir sehen, dats in allen Fällen, in denen die Verwundung der Achse so weit geht, dafs der Holzkörper an der Bildung der WVundfläche beteiligt ist, das zwischen Holz und Rinde liegende Cambium, welches bei mosestörter Entwicklung das Dickenwachstum des Stammes vermittelt, sowie die aus dem Cambinm unmittelbar hervorgegangenen, jungen Gewebeelemente (- die wir im folgenden mit in die Bezeichnung "Cambium" hineinziehen -) es sind, welche die Heilnng der Wundfäche des ausgewachsenen Stammteils allein übernehmen. Bei krautartigen Stämmen oder noch krautartigen Entwicklungszuständen holziger Achsen kömnen auch andere Gewebeformen sich an der Wundheilumg beteiligen, wie bei Besprechung der einzelnen diesbezüglichen Fälle später gezeigt werden wird.

Die Bildungen aber, welche ans dem Cambium bei der WWundheilung hervorgehen, weichen in ihrem Bau wesentlich von dem des normalen Holzringes ab. Die Ursache dieses abweichenden Banes des Wundholzes ist darin zu suchen, daf's die Druckverhälnisse, unter denen das zur Wundheilung dienende Gewebe entsteht, gänzlich andere als bei der Bildung des normalen Holzkörpers sind.

Anlehmend an die Untersuchungen von G. Kraus mag zunäehst daran erinnert werden, dafs jeder stamm und Kweig dureh das verschiedene Wachstum seiner einzelnen, mit einander verbundenen Gewebeformen bedentende Spannmgen in seinem Innern besitzt. Die von Hofuesterer ${ }^{1}$ ) begonnenen, von SAchs ${ }^{2}$ ) erweiterten mud von Kraus ${ }^{3}$ ) besonders mmfassend durehgeführten Experimente über die Gewebespannung haben bewiesen, dat's das Längenwachstum jedes Achsengliedes (Internodium) unserer Bäume von zwei Falitoren geregelt wird.

Das zentrale Gewrhe des Sprosses, speziell das Mark, ist der streckende Faktor ${ }^{4}$, das in die Höhe treibende Gewebe des Sprosses;

1) Hofmastm, Über die Bengung saftreicher Pflanzenteile durch Erschütterung. Ber. d. Kgl. sächs. Ges. d. Wissensch. 1×59, s. 194.

") S.ucus, Experimentalphysiologie, S. 465-514.

3) Gretion hiars, Die Gewebespannmg des Stammes und ihre Folgen. Botan. Zeit. $1867, \mathrm{Nr} .14 \mathrm{ff}$.

4) Schon Halrs adoptiert nach Kr.ws (a. a. O. S. 141) the von Bonent in seinem Buche ,de motu animalium" geäuscerte Ansicht, wdafs der junge Sprofs wächst und sich streckt durch Ausdehnung der Feuchtigkeit in dem schwammigen Mark." 
es wird in seinem ganz bedentenden. bei der Trennm von dem äbrigen Gewebe recht dentlich hervortretenden streben, sich zu verlängern und das umgebende Gewebe mit in die Höhe zu ziehen, gemäligt mud zurückgehalten durch den Zug, den die sehr elastisch gewordenen. peripherischen Gewebepartien des Rindenkörpers ansïhen. Diese verkïrzen sich, wenn man sie isoliert: sie verkïrzen sich anch in inrer natürlichen Lage am Bame regehälsig des Nachts dmeh rarliale Schwellung infolge einer Autinahme von Wasser ${ }^{1}$ ).

So lange der sprot's also wächst, entwickelt sich eine berlentende. Längsspannung dureh ten Kampt der streckenden rewalt des Markes mit dem Bestreben der Ungebmo, zmmal des Rindenkirrpors, sich und das umliegende Gewebe zusammenzuziehen. Dor Erfolg des Kamptes dokumentiert sich anch in der Länge der Markzellen immrhalb eines Internodimms. Die Zellmessmgen haben gezeigt, dats die Markzellen anfangs länger sind, als später mol dats mit ihrer suäteren Verkürzung eine sehr starke Verbreiterung verbunden ist. Diese Verbreiterung ist die Folge des endlichen Überwiegens des peripherischen Zuges. Mit der Vollendune des Iängenwachstums des Internodiums tritt die Querspannung in den Vordergrumd.

Es ist leicht verständlich, dats nach Beendigmng des Längenwachstums eines Pflanzenteils andere Syannmgen eintreten müssen, wem man bedenkt, dats der fertig gestreckte Stammteil sich jetzt danemd verdickt und dats diese Verdickmng von der Umwandlung der zwischen Rinde und Holz liegenden Cambimmzellen zu nenen Holz- und Rindenelementen herrïhrt.

Wenn im folgenden .Jahre der einjülnige sprots nene Holzlagen aut die vorjährigen schichtet, müssen diese nenen Holzlagen sich Platz muter dem Gürtel, den lie Rinde und deren äufsere Korkschichten bilden, zu verschaffen suchen. Platz ist aber nur zu gewimen durch Auseinanderpressumer des Rindemmantels, der jedoch nieht widerstandslos nachgibt. Dieser Widerstand macht sich geltend als Truck, mol so finden wir währenrl des Dickenwarhstums eines sprosses das zarte Gewebe des Cambiums gepretit ant der einen Seite durch das Ausdehmmgsbestreben des fertigen und jungen Ilokkörpers, gedrückt anf der Anfsenseite durch den schnürenden Einflut's des nur sehr starken Kräften nachgebenden Rindemmantels.

Unter diesem zweifachen Drucke bilden sich ans dem Cambium die Elemente des Holzkörvers, nämlich die langgestreckten, dickwandigen, inhaltsarmen orler schlietslich inhaltslosen Holzzellen sowie die Gefä1se und gefätsähnlichen Zellen.

Durch die Untersuchungen von ne VRIFs ${ }^{2}$ ) ist num experimentell festgestellt worden, das das Holz um so engzelliger (und getäliämer) wird. je grötser der Rindendrnck ist. DE VRIEs erhöhte rlurch Tmlegum eines festen Bandes den schnïrenden Einflut's des Rindemmantels und lockerte bei anderen Exemplaren kïnstlich den Druck der Rinde durch Längseinschnitte in dieselbe. Dadurch gelang es ihm, wie sehon s.schs ${ }^{3}$ )

1) G. Krats, Über die Verteilung und Bedentung des Wassers bei Wachstumsund spannungsvorgängen in der Pflanze. Bot. Zeit. 1877, s. 595.

2) Hrio ne: Triss, Über den Einflufs des Rindendruckes auf den anatomischen

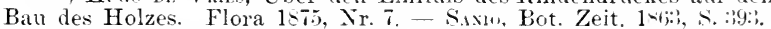

") Sucus, Lehrb. d. Bot., I. Aufl. 1=65s, S. 409. 
remutete, die Entstehung der. Jahresinge durch den im Laufe des .Jahres regelmätsig wechselnden Rindendruck zu erklären ${ }^{1}$ ).

Der Rindendruck ist im Frülijahr zur Zeit. wo das Holz durch Trasseraufnalme am stärksten gequollen ist, sehr grof's, wie durch die m diese Zeit stattfindende Entstehmg nener Rindemisse und die Erweiterung der schon vorhandenen bemerkbar wird. Während der Blattentfaltung verliert das Holz einen grolisen Teil seines Wassers durch Terdmintung: es zieht sich mehr zusammen und der Druck der num einmal schon erweiterten Rinde wird geringer, mithin die zu dieser Zeit kenntliche Bildmng weiterer Holzzellen erklärbar. Je mehr sich aber num im Lanfe des Sommers nenes Holz unter der Rinde bildet, desto grötser wird dessen Immendruck auf dieselbe: gleichzeitig verlieren die Rindenschichten durch Trockenheit einen Teil ihrer Dehmbarkeit, und ihr Widerstand gegen den Innendruck des Holzes wird um so gröfser. Unter solchen erhöhten Druckverhältnissen sehen wir das eng- und breitzellige, dickwandige Herbstholz entstehen.

Ein anderer Punkt, den ich bei liüstlichen Schüustellen zu beolachten Gelegenheit hatte, ist die durch Vermeh ung des Rinden druckes bedingte Steigerung der spiraligen Drehung der Holzelemente, welche bei endlich überwallten Drahtemschnürungen sich derart gesteigert erwies, dats in einer gewissen Zone des Überwallungswulstes die sonst längsverlaufenden Holzzellen fast horizontal lagen. Ein Radialschnitt zeigte mmittelbar über dem ïberwallten Drahtringe eine Zone von Holzzellen quer durchschnitten statt längsverlaufend. Diese horizontal celagerten Fasern nahmen allmählich wieder ihren vertikalen. normalen Verlauf da an. wo die Geschwulst sich abschwächt und in den normalen Stamm überging.

Die vermehrte Drehmng der Holzelemente durch erhöhten Rindendruck erklärt jetzt auch die bekamnte Erscheinung der nicht parasitären D rehw ïchsigkeit, die besonders in trocknen, armen Bodenlagen (namentlich bei Syringu und Craturyus) auftritt und bei sehr verschiedenen Bammarten beobachtet worden ist. Die Ursachen der Erhöhmo des Rindendruckes werden in den einzelnen Fällen verschieden sein.

Die so bedingte, regelmälsige sehichtung des Holzkörpers aus weitem Frühja hrsholz und engem Herbst holz ist mur ein spezieller Fall des durh le Vrits bewiesenen Gesetzes, dafs Erhöhung des Rindendruckes engzelliges, Lockermo der Rinde dagegen weitzelliges Holz erzengt.

Wie man sich aber durch Zählung der Zellen nach kïnstlicher Lockerung leicht überzengen kam, wirkt diese Lockerung nicht nur anf die Ausbildung, sondern auch auf die Termehrmg der Cambiumzellen. Je geringer der Rindendruck ist, desto gröfser ist die Zahl der Zelltoilungen in der Richtung des Stammradius, desto grötser ist anch die streckung der einzelnen Zellen und Gefätse in radialer und tangentialer, desto geringer aber in longitudinaler Richtnng. Diese Ver-

1) Die später veröffentlichten Untersuchungen von Kuns: isitzungsbericht d. Akad. d. Wissensch. z. Berlin, 14. Dez. 1852; cit. Bot. Zeit 188:3, S. 399), Uber die Beziehungen der Rindenspannmg zur Bildung der. Jahresringe und zur Ablenkung der Markstrahlen, kommen zu dem Resultate, dafs dem radialen Rindendrucke wegen seiner Geringfügigkeit kein Einflufs auf die Jahresringbildung zuzuschreiben sei. Mir scheint indes die gehandhabte Methode nicht vorwurfsfrei, so dafs ein Zweifel in die Richtigkeit der Resultate wohl berechtigt ist. 
änderung in den Dimensionen steigert sich in dem Mafse, dafs wir endlich an solehen Stellen, an denen der Rindendruck fast ganz aufgehoben ist, die dickwandigen. langgestreckten llolzzellen in kurze, parenchymatische Zellen übergehen sehen. Dabei fällt die Diff'erenzierung des Gewebes in Zellen und Gefätse fort; es bildet sich nur noch ein gleichmätsiges Parenchymholz.

Eine Arbeit ron (iғницснEк ${ }^{1}$ ) beschäftigt sich mit dem Einflut's des Rindendruekes auf den Bau der Rinde selbst. S'cine Untersuchmen führen zu dem Schlnsse, dats, je grötser der Druck, destro weniger Korkzellen gebildet werden und umgeliehrt : ebenso wechselt der radiale Durchmesser der einzelnen Zellen. [lie Zellen des primären Rindenparenchyms crscheinen nicht nur radial, sondern auch seitlich zusammengedrückt, also eckiger, während die unter geringen Druck entstandenen kugeliger sind und hedentend grötsere Intercellnlarrämne (die bei starkem Druck ganz verschwinden kömnen) zwischen sich haben. Dic Bastfasem sollen bei Druckverminderung an Zahl hedeutend zumehmen (was ich nicht beobachtet hahe) und bei Erhöhmng des Rindendruckes bis zum Verschwinden alnehmen.

$\mathrm{Als}$ eine Folge des Rindendruckes sieht NörnLINtikr ${ }^{2}$ ) auch die Entstehung der wellenförmigen statt der regelmä1sig kreisrunden Peripherie des Holzkörpers an. Da, wo der Holzkörper eingebuchtet ist, erscheint die Rinde häufig dicker. Vorzugsweise sollen es die stark entwickelten Steinzellyruppen sein, welche von der Rinde auf das Cambinm geprefist werden und die ihnen gegenüberliegrende Stelle des Holzkörper's im Wachstum hemmen.

Wenn wir jetzt dem Umstande, auf (den Kkacs's) aufmerksam macht, Rechnmo tragen, dats ans dem unter grofsem Rindendruck stehenden Zellgewebe ein Teil des Zellinhalts schneller hinansgepretst werden dürfte nach jenen Regionen, in denen der Rindendruck geringer ist, dam dart es uns nicht Wunter nehmen, wem in dem lockeren Parenchymholz, das infolge des aufwehobenen Rindendruekes sich ans dem Cambium gebildet hat, einc grotise $I[$ enge Reservestoffe sich a ufgespeichert tindet. Auch für das neu zuströmende Baumaterial ist die weithmige. dïnnwandige Parenchrmholzzelle der am leichtesten erreichbare Ablagermosherd. I arum sehen wir dort, wo der IIolzcrlinder statt der prosenchymatischen Elemente parenchymatisches Gewebe bildet, meist (mit Ausnahme der jungen Calluswülste) dasselbe eine grofse Zeit des Jahres hindurch reich mit Reservestoffen, und zwar bei mseren Bäumen mit stärke ertüllt.

Die sämtlichen Wunden des Baumstammes schliefsen eine Rindenlockerung ein: mithin muts das Holz, das bei der Heilung der Wunde wel,ildet wird, in seinem Bane mu so mehr von dem normalen Holze abweichen und $u m$ so mehr den Charakter des Parenchymholzes annehmen und behalten, je geringer bei der Verwundung der Druck des Rindengürtels auf das Cambium semacht wird und je länger tliese Lockerung erhalten bleibt.

Wir haben bei den Krebswnden gesehen, wie dieser lockere Bau des Wundrandes immor wieder Ursache zu nener Lockerung der

1) Aus Sitzungsber. a. Wiener Akad. d. Wissensch., Bu. LXXXVIII, Abteil. I; cit. in Botan. Centrall, $1 \times 3, \mathrm{~N}_{\mathrm{r}}, 4 \overline{\mathrm{i}}, \mathrm{s}, 22 \mathrm{~s}$.

2) Nimmixier. Wirkung dor Rindendruckes. Centralbl. f. d. gesamte Forstwesen. Wien, Oktoberheft $\mathbb{1}=0, s, 407$.

${ }^{3}$ ) a. a. O. S. 138. 
Rincle, zu neuer, wuchernder Produktion lockeren Gewebes und zur endlichen Erschöpfing des Astes durch diese Produktion wird.

Jeglicher Überwallungsand, der sich bei einer offenen Wunde des stammes bildet, beginnt also mit der Bilrlung knrzzelliger, weitlumiger (mit weitem Imnenram versehener) Holzelemente, die sich, schart abgegrenzt, auf das normale, blofingelowte Holz lagern. In dem Maf'se. als die Überwallungsränder sich verorëtsern, der Rindendruek somit stärer wird, gehen auch die Holzelemente allmählich in den normalen Bau über, und wem endlich die Überwallungsänder mit einander verschmelzen und die Rinde wieder zu einem gleichmälsig zusammenhängenden Gürtel am Stamme oder \%weige wird, stellt sich anch die

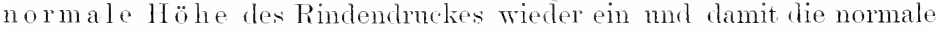
Richtung der Holzzellen und Gefätse: Es lagert sich num wieder alljährlich normales Holz über die geschlossene Wunde.

\section{Die Schröpfwunde.}

Jas nächstliegende Beispiel für die Gewebeändermgen bei dem Wundheilungsprozesse finden wir in der Vernarbung der schröpfirmule. Man versteht mter "S ehröp f'en" bekanntlich das Einschneiden in die Rincle in der Längsrichtung des stammes bis anf den Holzkörper, olme dats Substanz entfernt wird. Wird ein Bam in dieser Weise geschlitzt, so weichen die Wundränder auseinander (Fig. 173). Natürlich ist am Ende des Sehnittes (Fig. 173, (1) die Entfermmo der beiden Wrundränder am geringsten; der Heilungsprozets vollzieht sich dort am sehmellsten. Fig. 174 stellt den (Querschnitt dmreh eine geheilte Schröptistelle eines Süfkirschbanmes am Encle der Schlitzwunde, also aus der Gegend von a dar. Wir selien in $h$ das alte Holz, das hei $u$ von dem Messer getroffen worden und durch die Einwirkmo der Luft einen Teil seiner Gefäfise nul Holzzellen abgestorben zeigt. Die Cambinmzone $c$, die zur Zeit der Austührung des Schnittes ant 7 antlag, hat bei dem Heilungsprozel's nene Rinde $m$, und nenes $\mathrm{Holz}$ nh rebildet. Die nen rebildete Holzzone ist aber weder in ihrer Lagerung noch in ihrem Bau dem normalen, unter der mverletzt gelbliebenen Rinde entstandenen Holze oleich: sie bildet eine nach aufisen dreieelig vorspringende Partie, deren höchster Punkt am meisten der dimch den ehemaligen Schnitt gebildeten Rimne (s) genähert ist. Bedingt wird diese dreieekige Vorwölbung durch die dem weiter seitwärts gelegenen Gewebe voraneilende Entwicklung von Parenehymholz 7 . Diese Holzproduktion war die erste Tätigkeit der beiden durch den Schnitt $s$ geteilten ( ambiumränder. Hier war der Rindendruck am schwächsten, die Kellrermehrung die reichste, die Zellenlängsstrecknng die geringste. Erst nachdem die aus der jungen Innenrinde und der Cambiumzone hervorgegangene Neminde in $s$ eme grötsere Mächtigkeit und durch die neu entstandene Korkschicht derselben (l') grötsere Widerstandsfähigkeit erlangt hat, ist der Rindendruck allmählich mäthtiger, sein Einflufs anf die Holz produzierende Cambiumzone energischer und die Gestalt der Holzelemente allmählich der normalen ähnlicher geworden. Die Partie $h p$ geht allmählich in das viel dentlicher durch Narkstrahlen (iil) gefächerte, regelmälsige Holz über. Über die der Änderung der Holzelemente parallel gehende Umformung der Rindenelemente wird bei dem Ringelwulst ausführlicher gesprochen werden. 
Bei weiterem Wachstum des Stammes layert dic Cambiumzone $c$ immer neues, normales Holz und nene Rinili. nit Hartbast $h$, ïber die Wundtläche, und wenn endlich die durch den ehemaligen Schnitt getrennten, alten Rindempartien ar mit ihrer Korkzone li and ihren algestorbenen und durch eine Korkzone rom lehendinn Gewehe getrennten Wundrändern $(t)$ der Borkenbildmng verfallen und abblättern. ist äntiserlich die Wundstelle ansgoglichen.

Wemn wir etwas ausführlicher auf die Anfänge des Vernarbnngsprozesses eingehen wollen, haben wir Fig. 175 zu hetrachten. Dieselbe stellt den (knerschnitt durch einen einzigen Wundrand einer sichröj,tstelle (Fig. 17:3, b) hei einer Sütskirsche dar zu einer \%eit, in wolcher dieser Rand sich mit dem gegenüberliegenden. von der anderen Wuntseite kommenden, noch nicht vereinigt hat, die Wmultläche sellost (Fig. 17.; , w) also noch nicht redeclit ist. Es berdentet h anch hier

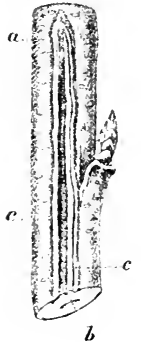

Fig. 17?. Schröpfwunde. (()rig.)

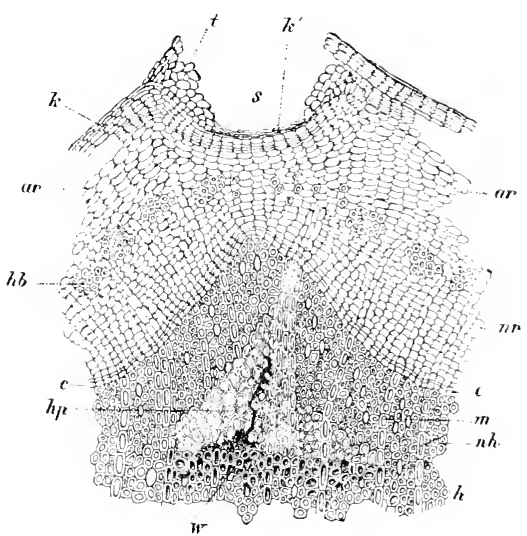

Fig. 17t. Verheilte Schröpfirunde.

(Orig.)

das alte Holz, dat's bei "durch den sichröptischitt blotisgelegt worden ist. Der Zug des Messers zur Zeit der Ansführung des Schröptens ging von s nach $w$. Ton dieser Elene des Schnittes hat sich die alte Rinde (ar) seitwärts zuriickgezogens es entspricht dieser Teil tem gleichbezeichneten in Fig. 17. Ther obere Teil dieser alten Rindenpartie, sowie der infolge des schnittes algetrocknete Rand (Fig. 174,t) sind in Fig. 17.; durch die mit $t$ bezeichneten Konturen angedentet und nur ein Hartbasthündel $h l$ ist in das Rindenparenchym ar eingroeichnet worden. Zur Zeit der Austührung dos Schnittes lasen die Cambiumzonen $c$ und die junge Inmenrinde ir dicht am alten Ilolze $/ 1$ : die Zellen, welehe an die Schnittebene $s$ bis ar grenzten, reagirten mun verschieden auf den Wundreiz: das Parenchym der alten Pinde trockinete auf eine kurze Strecke rïckwärts zusammen und bilklete den hraunen, trocknen Wundrand, der, dem blotien Ange kemntlicls. jede Schlitzwunde einsäumt (Fig. 173. c). I as noch rermehrungsähige in seinem Wachstum noch nicht abgeschlossene Parenchym der inneren Rinde $i$. 
folgte am Wundrande sofort der Gelegenheit, sich nach derjenigen Seite auszudehnen, an der der Druck weggefallen war, d. h. iiber die Ehene $s$ bis $u$ hinans. Diese Zellen wölbten sich also vor; die ans der Cambiumzone folgenden sehoben die ersten Rindenzellen weiter hinans und bildeten sich in der später nachwachsenden Zone selbst zu Chlorophyll füln'enden Rindenzellen $r^{\prime}$ ans, und anf diese Weise entstand zuerst der weiche, parenchymatische Wundrand $r^{\prime} i r$. Die Randzellen $r$ des vorgewölbten Wundrandes bräunen sich später und trocknen zusammen: in den unmittelbar darunterliegenden Zellen entsteht Kork $l_{i}$ und diese, den ganzen Wundwall einhü̈llende Korkzone $F_{i}$

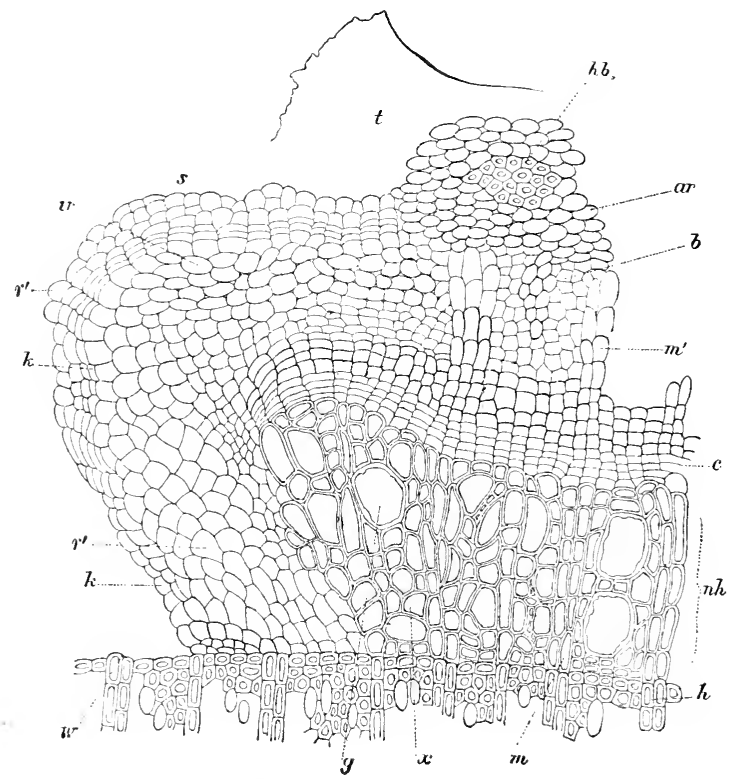

Fig. 175. Entstehender Überwallungsrand bei einer Schröpfwunde. (Orig.)

bis li legt sich an die äufsere Korkbekleidung der alten Rinde an, so dafs die ganze Neubildung von einem schwer dehnbaren und daher auf das darmnterliegende, schwellende Gewebe drüickenden Korkgürtel umgeben ist.

Dadurch ist anch der Rindendruek interimistisch hergestellt. Der Einflufs dieses Rindendruckes auf die nächsten Produkte der vorn schneckenförmig gekrümmten, aber nicht bis auf das alte Holz $h$ reichenden Cambiumzone $c$ macht sich durch die Bildung dickwandigerer Elemente geltend; es entsteht Nouholz $n h$, welches nach der Wundseite zu parenchymatisch kurz, weithmig $(x)$ und von vereinzelten, kurzen, weiten Gefäfsen $(g)$ durchsetzt ist. .Je weiter das Neuholz vom Wundrande entfernt ist, desto regelmälisiger, eng- und langzelliger wird es, 
desto schärfer treten die Markstrahlen m und deren Fortsetzmug m' in der Rinde hervor. Je mehr sich allmählich Nenholz hildet, desto strafter wirl die äuliere Korkzone $l$ his li des ت̈berwallungsrandes gespannt. Hänfig reitst sie stellenweis infolge las Immentruckes, so dafs das Rindenparenchym blotiliegt und sich in die Ritistelle hineinwölbt. In diesen sich vorwälhenden Zellen hilden sich aluer in kiurzester. Zeit none Korkzellen, die sich an rie mugehenden anlegen mul ant diese Weise den Korkgürtel wieder schlietsen.

Falls num ein Sichröptischnitt so broit ist, dats dor Tlbrwallumesrand des essten Jahres ihn nicht decken kam, wiol das Nonholy iles folgenten .Jahes sich lippig äber die Wundfä̈he lanern. In diexer lippentörmigen Vorwälmong, die durch den Verlant der dexkenden nenen

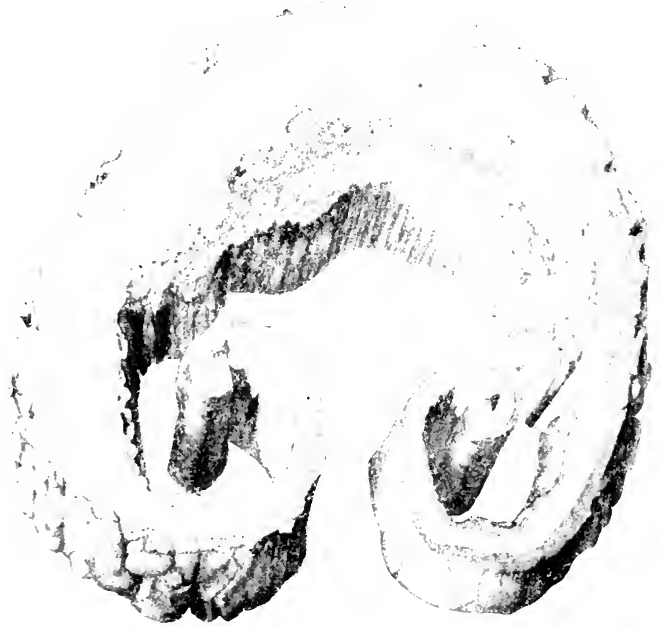

Fig. 176. Querschnitt durch einen hohlgewordenen Kiefernstamm, beis den die mehrjahrigen Überwallmusründer allein noch die Ernährung des Stammes übernehmen. (Orig.)

Korkzone li bis li Fir. 175 am hesten gekommoiclnot wirl, nimmt

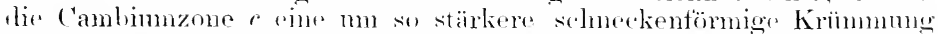
an, je tiefer lie Wumlfäthe liest. Wenm num der Fall pintritt, dats bei altrn stämmen an stolle des schröptsehnittes rine hreite Längs-

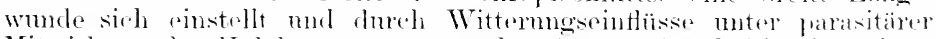
Mitwirkmog der IIolzkinger zerstört, der Stamm also hohl wirel, dam können schlietslieh nur noch die ت̈herwallmngsö̈nder ïlnig hleiben. Einen solehen Fall stellt Fig. 17i dar. Dieselbe ist fer Emerselmitt

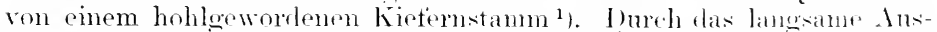
fanlen der jünoren Holzringe haben die Therwallungsäinder eine selten schöne sohneckentörmice fiestalt angenommen. nurl anf den verhältnismätigig sehmalen Holzstreifen der letztom Jahre beruht num

1) Das Original befindet sich in Botanischen Museum zu Berlin.

sorauer, Handbueh. 3. Aull. lirster lind. 
dir Ernährung des Stammes. In mincler ansgeprägter Form zeigt sich der Torgang bei allen hohlgewordenen Bänmen, namentlich oft bei Weiden mon Pappeln. Bei den Nadelhölzern ist das Ansfanlen des stammer infolge von Längswunden der soltenere Fall, weil sich die Wundfläche mit Harz zu bekleiden pflegt oder wenigstens die blofsliegenden Holzelemente kienig werden. Dieser Selbstschutz nach Längswunden kommt am dentlichsten bei der Harznutzıng der Bäume zum Ausdruck, wie Fig. 177 zeigt.

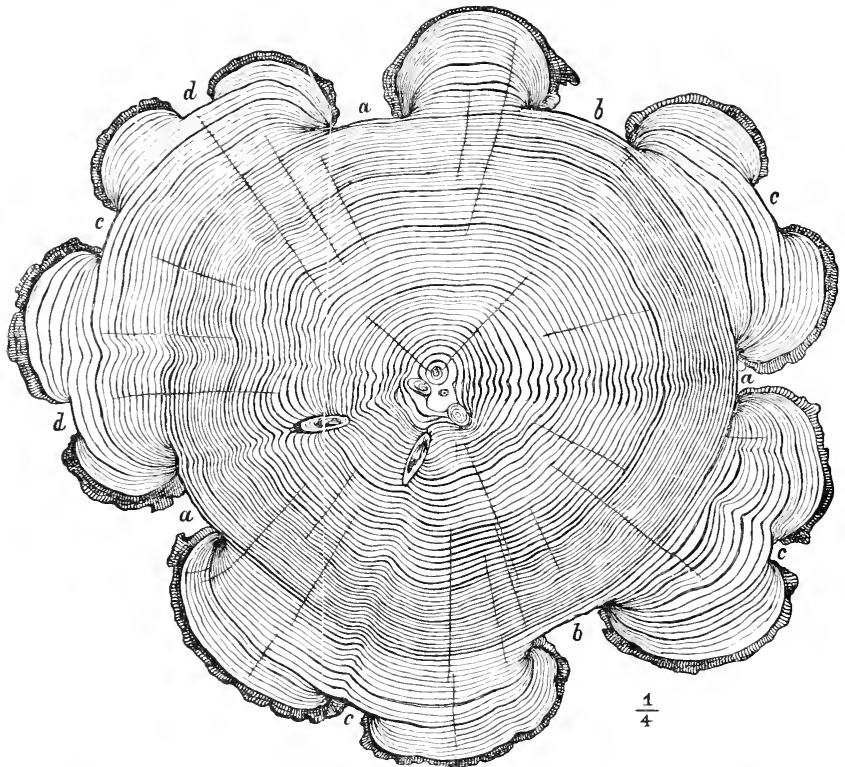

Fig. 177. Stanmseheibe von P'icen culguris mit Überwallungen von Harznutzungslachen. Das Gesamtalter des Baumes beträgt 70 . Tahre. Die erste Nutzung $(a)$ fand statt im Alter von 50 Jahren. die zweite $(b)$ von 51 , die dritte (c) von 62 , die

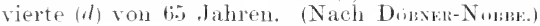

Dip church Ilarznutzmug entstehenden Wunden, welche meist

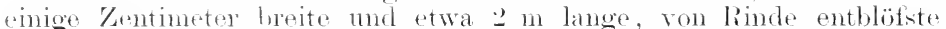
Stammstreifen darstellen, sterben erst nach längerer Zeit ab. Bei Fichten sah R. HakTu; den Trrpentin ans den in den Markstrahlen liegenden Harzkanälen bald nach der Terwmehng in Troptenform levvortreten. Oboleich bei der oftentur Terbindung, welche die vertikal im Stamme verTanfenden Harzkanäle mit denen der Markstrahlen haben, eine grotise Mrnge Ilarz der Wonde zu trebote steht, so hört doch der Austritt fles Teichtflïssigen 'Terpentins in der Rogel sehen im ersten Jahre ant: In 'Trerpentin wird hureh Vertlüchtigung des Terpentinöls and dureh Verharzung (1)xydation) dirlier. Nach tem Abscharren des Harzes zu

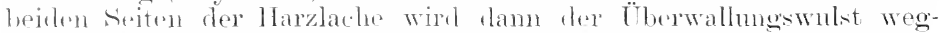

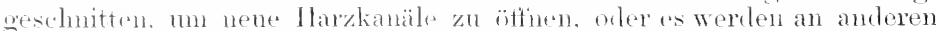
Barmseiten nene Rindenstreifen forterenommen. 
Inschritten.

Als spezielle Fälle einer gewöhmlichen. mit sulstanzverlust verbundenen Längswonde, die bis in das alte Holz hinmin sich crstreclit, sind die in sitamme eingeschnittenen schritt- mol \%ahlenzeichen zn erwähnen, sowie die mregehnäsigen Nage- uml Bifistellen, welche durch Verberitsen des Wildes in Winter rntstelen.

Bei den sichrittzeichen hat las Messer berlenteme. Mongen alten Holzes entfernt, ist also tiefer in den stamm cingedrmugens: fatïr aber hat dic Wnmle oine geringere Ansdelmmog in dic Breitr. Dir. Ver-

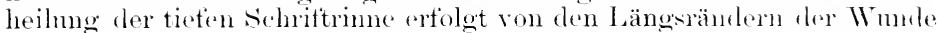

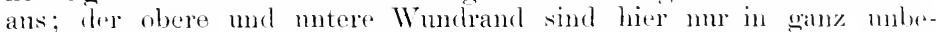
dentendem Mafse beteiligt. I) ie ans der ('ambiumzone horvortrotenulen, mit ejgener Rinde versehenen Wundränder legen sich alljälnliel schichtenwejse äber einander in dis Wundrime hinein, diesellor nach und nacle ansfüllend, ohne sich natïrlich mit dem alten Holze, dessen äutserste, die Wunde begrenzenden Zellschichten sich bräunen und absterben. jemals zn vereinigen : sie billen nur eine text anlogende Masie, wie das Metall in einer Gutiform. Mit dem Angenblicke, wo die beiden contergengesetzten Wumbänder eines jeden Schritzedehens mit cinander verscimelzen. also ihre (ambiumzonen mit anander sich vereinigen,

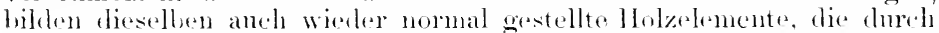
die alljährlichen /uwathsonen immer stärles werden nud damit die

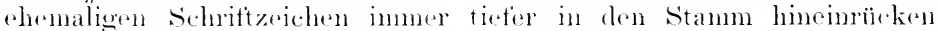

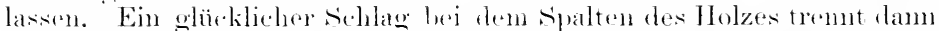
dir nicht verlatzt gewesenen /wischensehichten zwischen den anzelnen

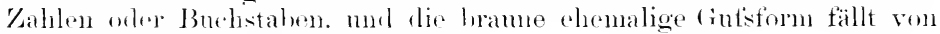
der hinoinergossenem Holzmasse ab.

\section{Wilalsellaten.}

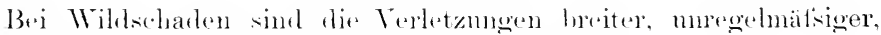
aber in der Reged num bis in den sprlint reichend.

Wird der Stamm an seinem ganzen Untange der Rinte und des

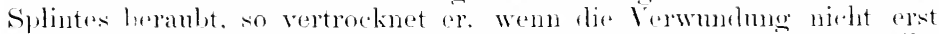
gegen das Frïhjaln hin oder im sommer weschielst, nach einer Roihe von Jaluen. In der Regel aber tindet date Verheifsen mul sebälen des Wildes nur an einzelnen stellen des Stammmmfanges statt und

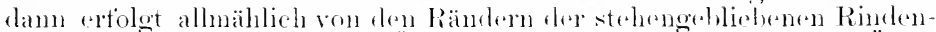

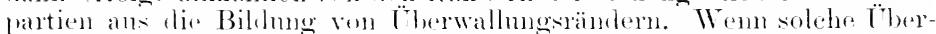

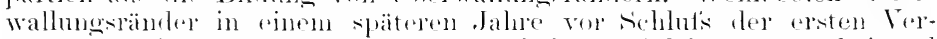

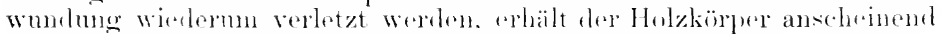

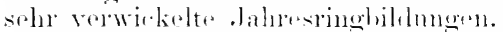

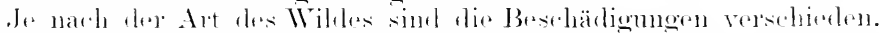

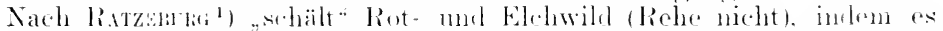

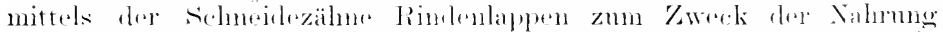

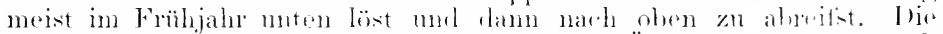

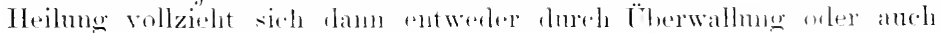

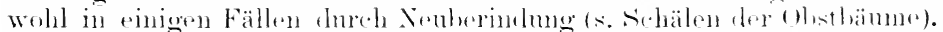

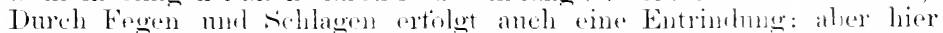

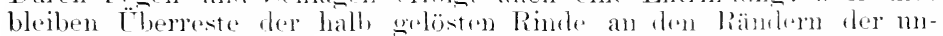

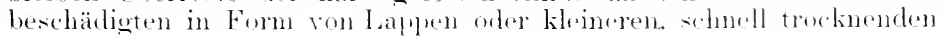

1) Waldrerderbnis I. s. i, ff. 
mol daher gekräuselten Fetzen stehen: anch tehlen selten die spuren von Haaren an der Rinde. Da Hirsche und Rehböcke während des Fegens mit dem Gehörn anf und nieder fahren, nm es vom Bast zu leinigen, so sind auch die Fegewnuden länger mol gehen hänfiger als schälwmuden rings um rlen Stamm. Nun schlägt das Reh den Bast im Februar und März ab, der Hirsch $10 \mathrm{~m}$.Johannis, das Dammwild vier Wochen später. Letztere Wmuden fallen also in lie Periode, in welcher der Bam seine gröliste Menge plastischen Materials disponibel hat: ihe Terheitung wird daher weit schneller erfolgen, als die der Winter- und Frïhjahrswunden. Hier kommt es auch vor, dats die Wunde gar nicht einmal das ('ambium erreicht, somdern nur die äulseren Rindenschichten wegnimmt. Bleibt die Inneminde stehrn, so entwickelt sich mnter derselben der Jahresing aus dem Cambium tast normal weiter, wenigstens soweit dies die Anortnme der Holz- und retäselemente betrift. Dit Holzzellen sinel aber meist dïmwandiger und weithmiger, die Gefälse häufig zahlreicher, der ganze Jahresring breiter. Ist die Wittrung fencht oder der standort der Bäme ein schattiger und firchter, dam entwickelt sith ant der Antrenseite aus den stehengebliebenen Zellen dre jüngsten Rinde manchmal ein Callusgewebe, das zu neuer Rindenbildmng, bei ïppigen Bämmen in seltneren Fällen zur Bildung isolierter Holzkörper in der Rinde tühlıt.

Ilas sichlagen mol Anflulatzender Rinde kommt anch autiser der Fegezeit und Brmstzeit ror, im Nachsommer. Hicr stellt sich oftmals eine andere Wundheilumg ein, indem sich anf dem vom ab. gehobenen Rindenkörper befreiten Holzkörper ans den jüngsten splintschichten callöses Gewebe bildet, das die Lücke ansfüllt, ähnlich wie bei okulierten sitämmen (s. Oliulation).

Ferner halen wir noch der $\mathrm{Nagew}$ nden zn gedenken, wie sie dmrch Mäuse, Kaninchen, Biber und Hasen hervorgebracht werden. Letztere schmeiden mit ihren Zähnen zwar lieber junge 7weige oder schwache Pflanzen ganz ab. Das eigentliche Nagen, das besonders mnern Obstbäumen so verterbentringend ist, erfolgt meist num bei hohem schnee. Tie Wunden gehen bis auf das ältere Holz, an dem man die Zahmspmen erkemt. Entstehen sie rings um den Stamm in zusammenhängender Fläche, dam ist der Bam verloren; bleiben daorgen einzelne Rindempartien stehen, so erfolgt von diesen ans eine Uberwallmo:

Nach r. Bers; soll das Fällen ron Aspen und salweiden, die rom Wilıle alshalı geschält werden, die äbrigen Bämme vor Verletzungen schützen. Achlieflich dürtte sich als das beste Nittel überhanpt die Anfuhr von Futter während des Winters heransstellen. Wir streifen dieses Kapitel des Wildschadens nur durch Hinweis ant die anatomischen Vorgänge der Wumlleilung. Der Gegenstand findet sich in einer neveren Arheit von Eckstex') seln austührlich behandelt.

An denjenigen Urten, wo Weidevieh in die Forsten getrieben wird, verursacht dasielbe hänfig mehr suchaden als clas Wild. Wurzeh werden blotisgetreten in dem Matse, dats Bämme an den Triebpfaden vingehen. Schafe mol Ziegen verbeisen Lärchen. Tammen und Fichten nsw. Wie 1. MoHL andentet mol Ratzebliti bestätigt, vertragen die Sarlelhölzer weit weniger stanmverletzungen, die bis anf das Cambinm wehen, als die Laubhölzcre

1) Ecksmax, Die Technik des Forstachutzes gegen Tiere. Eerlin 1904, Paul Parey. 
Zahlreiche mnd sehöne Abbildungen von Bänmen, die durch Weidevieh verbisien worden sind, liefert KLEx in seinem nemesten forst botanischen Merkbuche ${ }^{1}$ ).

\section{Überwallung der Querwunde mehrjähriger Achsen.}

Wem Äste oler stämme quer algeschnitun worlen, müssen die-

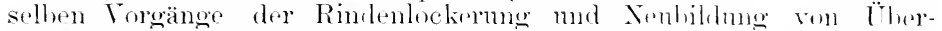

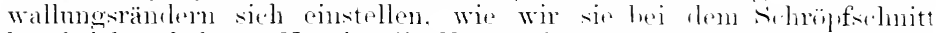

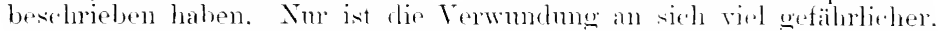

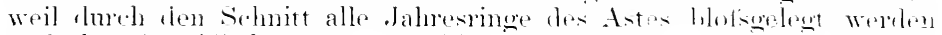

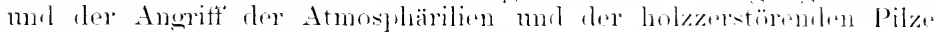
ungemein erlei,htert wirl.

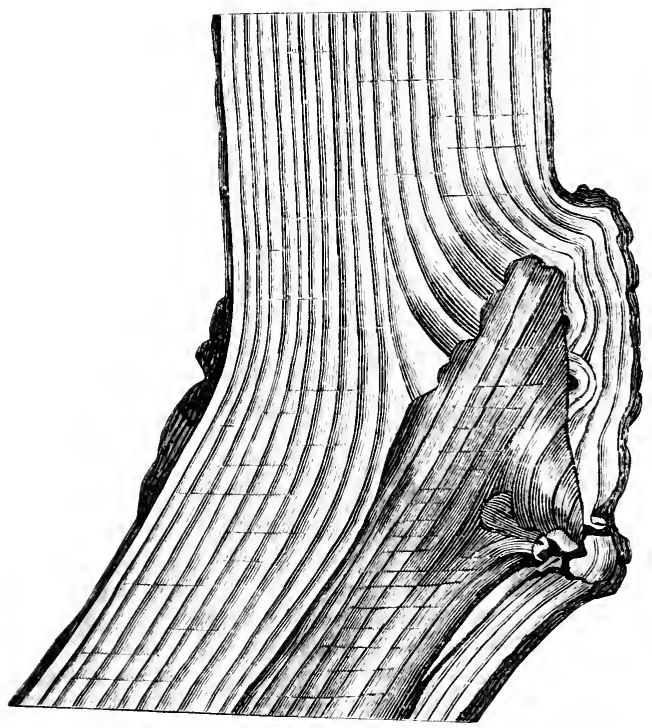

Fig. 17. Rest einos abgesägten, von der simittflia ho ans abgestorbenen Antes. der durh die Chorwallumgräncles der folgenden Jahre kappenartiggedorkt worlen ist.

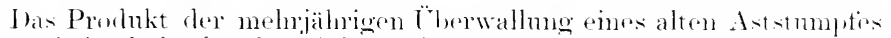

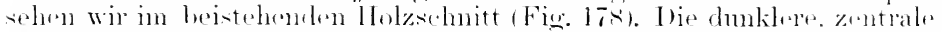

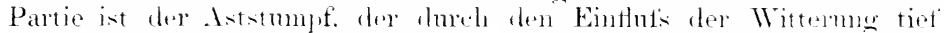
in len stamm hinein abgestonlen ist. Sieit tünf Jahres halwe sieh

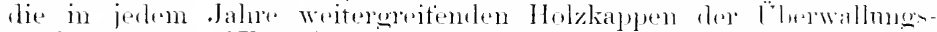

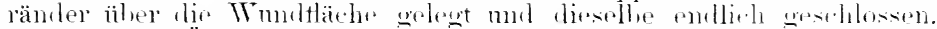

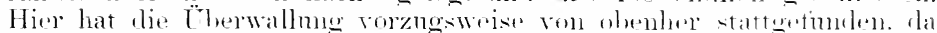

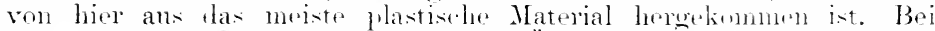

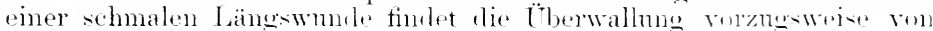
den Seiten ans statt.

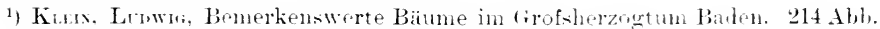
Heidelberg 19us. Winters Iniveritätsuchhambung. 
Derselbe C̈berwallumgsprozel's, der an den Ästen der Bämme sich einleitet, verursacht auch den Wundschluts der Schnitt-oder Hiebfläche an den zurückgebliebenen Baumstumpt'n nach dem Fällen der Bäume. Der Vorgang vollzieht sich nur verhältnismätsig langsam, da der den Überwallmossand erzengende Cambiumring eine sehr grotise Wundfläche zu decken hat. Die Folge davon ist, dats lange, bevor der Überwallungsrand nach den zentralen Partien der schnittfäche rorrückt, diese durch Fäuhis zerstört, der stammstumpt daher in der Mitte hohl geworden ist. Non senken sich die Überwallungsmassen in den verschiedensten Formen and bisweilen in zoptähnlichen Strängen in die Höhlung hinein, wobei sie hervorstehende Splitter oder steme umhüllen und dabei zu grof'ser Massenansdehmung gelangen kömnen ${ }^{\mathbf{1}}$ ).

Es liegt nun die Frage nahe, woher das Material zu derartig massenhafter Neubildmo kommen mag. Meist wird die Ansicht ansgesprochen, dats die in dem Baumstump rorhandenen. vor dem Fällen des stammes gebildeten Reservestotfe clie einzige quelle tür alle die Neubildungen abgeben müfsten; in anderen Fällen rieht man die nicht selten rorkommenden Wurzelverwachsingen zu Hilfe, indem man annimmt, dafs durch ein Verwachsen der WVurzeläste des Baumstumpfes mit stärkeren Wurzeln henachbarter Bäume, welche ihren Stamm mit Krone noch besitzen, eine Ernährung des Banmstumptes stattfindet.

Sicherlich werden derartige Fälle in grötseren Bammbeständen nicht selten sein ${ }^{2}$ ) und solch ein Nährstamm tatsächlich eine wesentliche Unterstützung für den Zehrstamm darstellen. Allein es liegen anch Beispiele vor, bei denen vollständig isoliert stehende Bäume nach dem Fällen o grotse Überwallungsmassen an den Stïmpten gebildet haben, dats die Annahme der Entstehung so massiger Nenbildungen lediglich aus den Reservestoffen des Baumstumpfes zur Erklärung nicht ansreichend erscheint.

Es existiert aber meiner Meinmng nach überall in solchen Fällen ein Hilfsapparat, welcher nen assimiliertes Material herbeizubringen imstande ist. Wenn man die jungen Ï̈berwallungsränder mntersucht, wird man in der Rinde derselben mehr oder weniger Chlorophyll finden, je nach dem Grade der Belichtung der Bämme, und es ist gar nicht einzusehen, weswegen dieser Chlorophyllapparat nicht ebensogut assimilieren sollte wie die grüne Rinde des Stammes. Welch reiches Leben in der Überwallungsinde herrscht, geht daraus hervor, datis man 'Zweige aus älteren Überwallungsrändern hervorbrechen sieht ${ }^{3}$ ).

Die Bildung von Zweigen aus dem Cambiumringe ron Baumstumpfen ist eine ganz gewöhnliche Erscheinmng, die bei getällten Pappeh allenthalben vor die Augen tritt mul ant der Entstehung von Adventivknospen in dem parenchvmatischen Überwallmngsgewebe beruht. Grade bei den Pappeln erhebt sich ein ganzer Kranz grüner, kräftiger Zweige an der Peripherie des Holzköriers. Derartiger "Stockausschlag" geht nach einigen Jahren in der Regel zugrunde, weil er nicht imstande ist, an seinem Entstchungsherde zwischen Rinde und Holz nene Wurzeln, welche die Erde erreichen können, zu bilden.

1) Schöne Abbildungen derartiger Fiille bei Giipresr, Nachträge zu der Schrift über Inschriften und Zeichen in lebenden Bämmen. Breslan, Morgenstern 1870.

2) Gïprert, Beobachtungen üher das sogen. Überwallen der Tannenstöcke. Bonn, Henry \& Cohen, 1>4:.

?) v. Trincur in Lampersilorf bei Frankenstein in seiner Anzeige der Göppertschen schrift (Über die Folgen äufserer Verletzungen der Bämme nsw.) rom Mai 1874. 
Wem durch Überschüttung oder vorzeitige Zerstörmg von Rindenpartien Erde an die Basis des Stockausschlages gelangt, kann sich der Stockausschlag durch Wurzelbildung von dem Nährstamm befreien und langlebige, selbständige Individuen bilden.

Die Eähigkeit zur Produktion neuer Triebe ans dom Bammstmmpf, die bei don verschiedenen Bammattmgen antiorordentlich rorschioden ansgebilklet, bei den Nadelhölzern reradezu solten ist, beruht nicht immer ant der Bildung von Adventivknospen, sondem anch auf ter Weckung von schlafenten Augen (Proventivknospen), wio bei den Koniferen. Hierbei ist aber oftmals die harto Borlie des stammstumptes ein Hindernis fïr die weitere Ansbildmng.

Wemn man äberhaupt anf eine Weiterentwicklung des sitockansschlages rechmet, wie im Waldbetrielse ofer in Parkanlagen, muts man die Bäume mögrlichst tief' abhauen, m den newen Trieben reeht schnell die Gelegenheit zu eigner Bewurzelung zu hieten.

Die nicht selten anzutreffende Manier, Bammflanzungen dadurch zu verjüngen. dats man stammstmmpte his 1 m Höhe stehen läfst, ist durchaus zu verwerfen. Die an solchen Resten von stämmen sich entwickehden. nenen Triobe sind durchschnittlich viel schwächlieher mel werden von don Ansichlägen an der Boclenobertläche vieltach äberholt.

\section{Überwallungsvorgänge bei einjährigen Zweigen.}

Bei unseren Kulturbäumen macht sich die Notwendigkeit geltend, die Kronen zn schneiden. weil wir entweder in Rürksicht ant den Fruchtansatz die Lanbtriebe stutzen orler bei dem Verpflanzen die Krone in Einklang mit tem verletzten Wurchlïrper bringen müssen. Der Sohmitt erstreckt sich rorzugnweise anf die einjährigen /weige und erfolgt entweder in Herbst oder in zeitigen Frïlijahr. Intolgedessen vergeht ein längerer \%eitram. hevor die Vongänge des Wmolschlusies durch Nenbilumg von fiewebe sich rinleitrin. Man sieht daher nicht selten, dats derartige junge Zweige vom der sohnittfläche aus aut eine kleine strecke hin absterben.

In Fig. 17! sehen wir die Siptze eines einjährigen Kirsehenzweiges, der von rer Sehnittläche aus etwas zurïckgetrocknet ist. Fig. 180 zeigt denselben der Länge narh durchsehnitten; ss ist die mispoungliche Schnittläuhe, $t$ ist die Grenzschicht. lis zu weleher der $/$ weig alugestorben ist, " eine dabei häufig sich hildende Anschwellung. I)as anatomische Bild liefert Fing. 181. In dieser ist s bis s' die sebmittebene, al das letzte, poripherische stückehen des rom sichnitt getrottenen alten Holzes, ar die alte Rinde mit ihren äutseren nomalen Korkschichten li. Von dieser Rinde ist das mit $t$ hezeichnete fewelne zurticheretrocknet, mul zwar ist das Alsterben des fieweles in dej Umgebung der llarthaststränge l, an tief'sten nach abwärts gedrungen: Ger Baststrane w wht ist ebentalls tot mol ragt nebst fen anch nur wenie znsammenschmmptenden änferen Korkschichten der Rinde aus lim rortälten

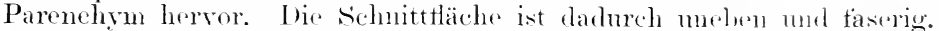

Der nächste Vorgang, der sich nach der Verletzmo mul dem Absterben des oberen Rindengewebes einleitet, hesteht in tro Aligrenzme des abgestorbenen (tewelses von dem gesmelen durch Bildumg einer Korkzone (lí. l'). En die Basis des Bastbündels bilflet sich die Korkzone stärker aus und stellt eine fächerförmige Unwallmug (li") dar. Daranf legimnt die Zellvermehrumg in den der sichnittlär.he zunächst liegenden Schichten der Cambimmone $c$ und der angrenzenden immeren 
Rincle, welehe zur Zeit der Ausfïhrumg des sinnittes dicht auf dem Holzkiiper al auflagen.

Genau wie die Vorwölbung des Längswulstes an der Schröpfwunde in Fig. 17:; baut sich eine vorgewölte Rindenzon $n$, ans den Produkten der Cambinmzone mod ter jungen Rinde ant, und diese Vorwölbung mmkleidet sich in derselben Weise mit rinem Korkgürtel (li"). Die"

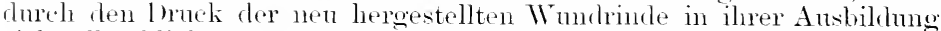
sich allmählich änderuden Holzprodulitionen der Cambiumzone stellen
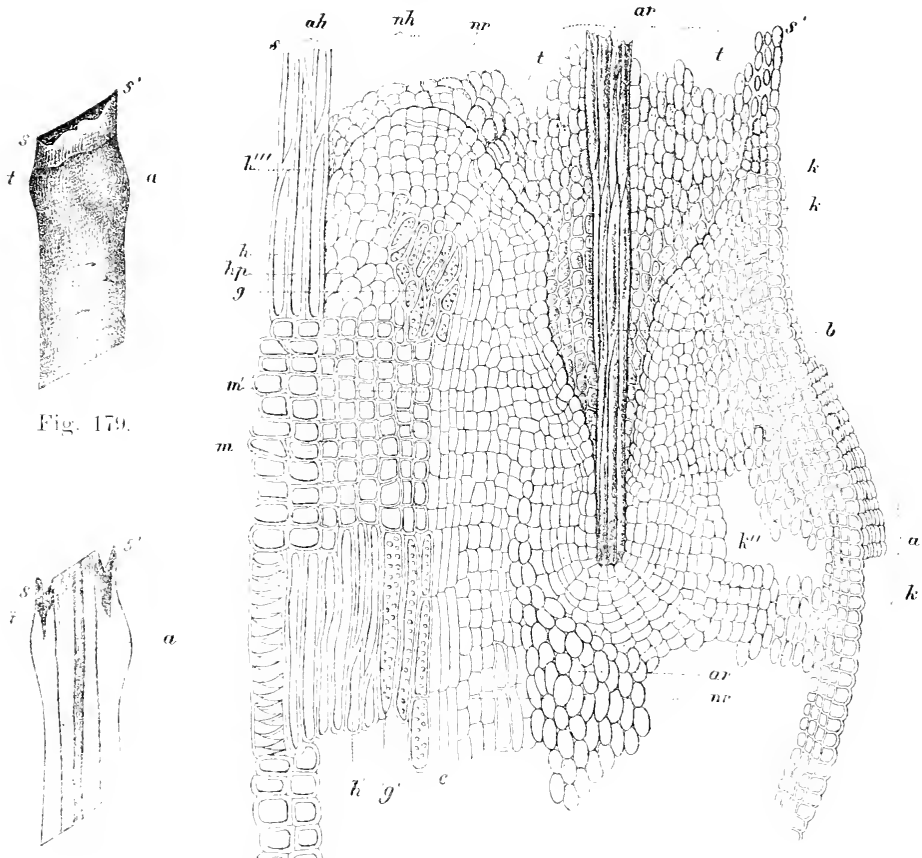

Fin. 100 .

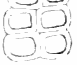

Fig. $1-1$.

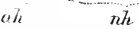

Quer abgeschnittener cinjähiger siul-kirschewzweig mit eingetrockneter sichnittfläche.

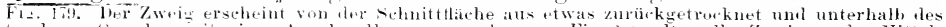

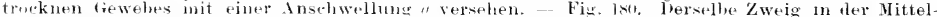
linie durehsehnitten. - Fig. lat. Anatmisches bild der hegion "bis s' von Fig. lé(). (Orig.)

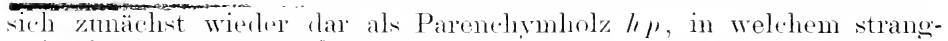

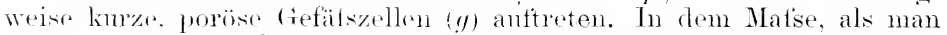
ron fer schnittfläche ans alwärts die Bildmug des nenen, nach der Terwundung entstandenen Holzos verfolet, findet man, datis die Elenente descellen immer melir den normalen, gestrecliten, derbwandigen ähnlich werden ( $\left.j^{\prime}, l^{\prime}\right)$. In der Keichmung int ter Ühergang von den kumprn (rotatsolementen zn den langen unterbrochen durch die Fortsetzung eines alten Markstrahls (m) zu dem Markstrahl (mi) des Neuholzes. 
Autser tlieser Neuholzbildmg macht sich. mabhängig von dieser, noch eine andere Zellvernehrung in ter hind in dor Nähe des lartbastbündels geltend. Die Parenchrmzellen teilen -i.h mol vermehren

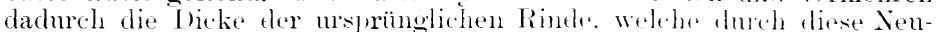
bildung autgetrieben wird und den äntsertich sichtlaten Buckel

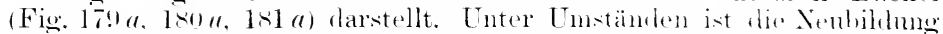
in der Rinde derartio intensiv, dats daselbst eine lange /ent in Tätie-

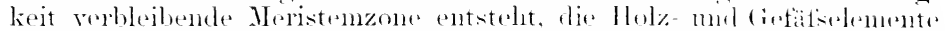

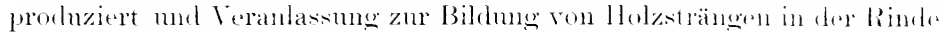
gibt. wie bei der Entstehmig ler Knollemmaser gezedgt werten soll.

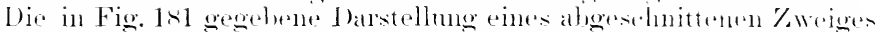
stimmt nicht ganz mit der Vorstellumg, die wir fon der iiberwallendere

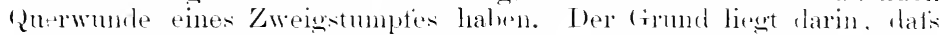

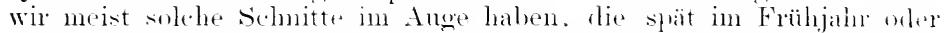
sommer an äteren \%weigen ansigetïlnt worlen sind. In diesen Faillen

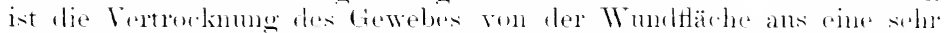

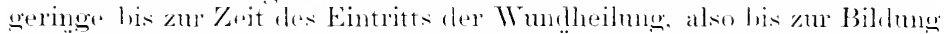

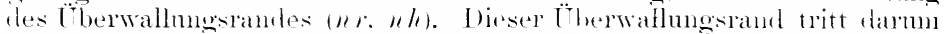

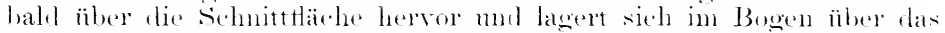

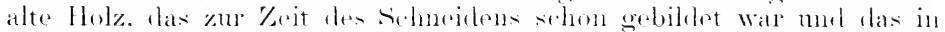

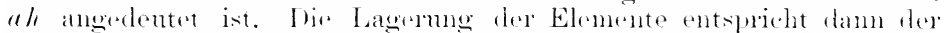

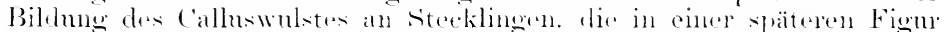

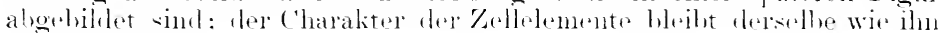
Fig. I-1 zeigt.

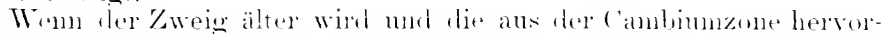

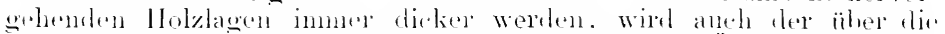

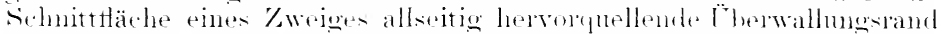

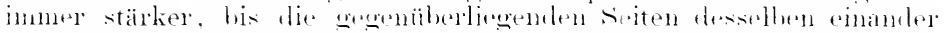

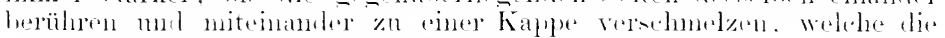

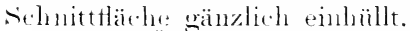

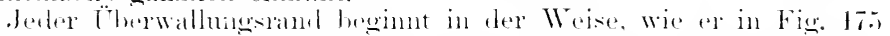

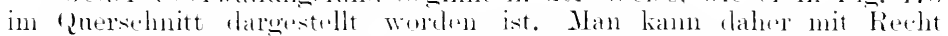

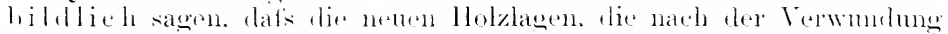

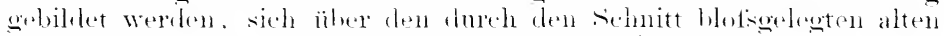

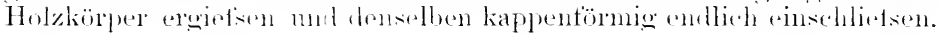

\section{Der Ringelwulst}

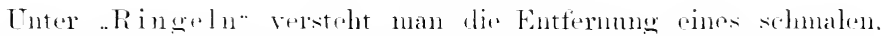

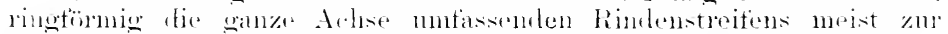

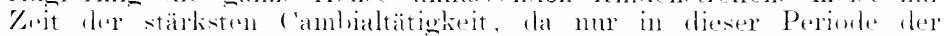

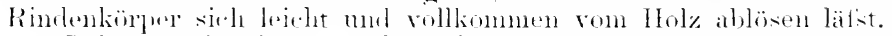

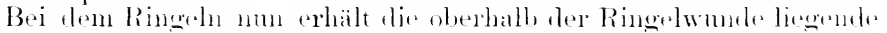

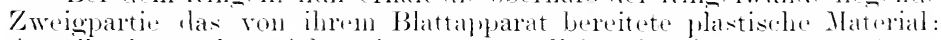

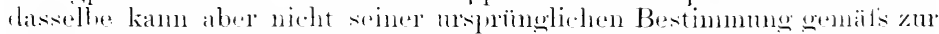

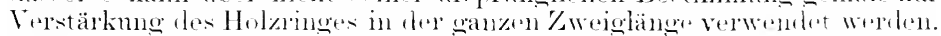

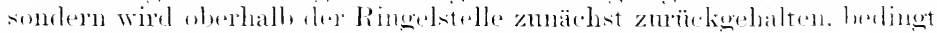

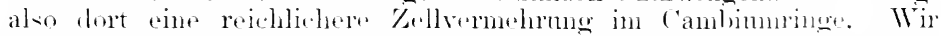

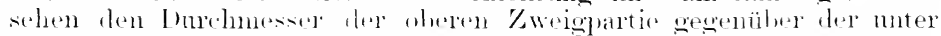

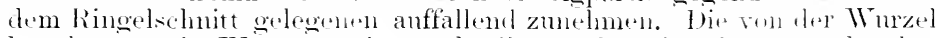

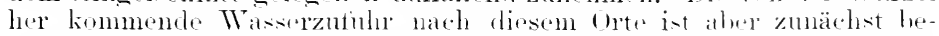
dentend remindert. Erstens ist die in der Rimble antwints steigrende Thassermenge dureh den Ringelsehnitt an weiteren Anistrigen ver- 
hindert: ferner verliert der im Holzkörper anfsteigende Hauptstrom lurch die Verdmotmo an der durch den Ringelschnitt blofisgelegten stelle in der ersten Keit nicht nuwesentliche WTassemengen. In der oberen \%weigpartie vermindert sich also der Hamptstreckmosfaktor der Zetlen, der 'Turgor, durch die geringere Wasserzufuhr von unten. Die Zellvermehrung ist zwar reichlicher, die Zollstreckung geringer als im normalen Zweige. Während das Inckenwarhstum des oberhalb der Ringelstelle belegenen Achsenteils gesteigert wird, bleiht das spitzenwathstum des Zweiges gemäsigt: lie Internodien werden weniger verlängert. Verkiurzung der Internodien bei reichlichem Vorhandensein plastischen Materials ist die erste Finloitung zu Fruchtholzbildumg; somit wird dureh den Ringelsehnitt die Fruehtbarkeit des \%weigesschneller herbsigetührt. Nachweishich ist der oberhalb der Ringelstelle liegende /weigteil wasserämer: seine ebenfalls wasserärmeren Blätter gehen fiüher in die Herbsttärbung ein, seine Früchte werden in der Reife gezeitigt.

Die Behamptung, dats lumch das Ringeln anch grötsere Früchte erzielt werden, findet nu in bestimnten Fällen ihre Bestätigung Die Weinstöcke z. B., und zwar namentlich die amerikanischen sosten, scheinen nach dem Ringeh noch eine so bedentende Partie ron Wasser in den oberen Zweigtoil zu bekommen, dats eine Verlangsammng des Spitzenwachstums nicht bemerkbar ist. In diesem Falle hängt also die Anshildung der Frïchte wesentlich von der Menge des plastischer. Materials ab, und dieses wechselt in den einzehnen .Jahren je nach den herrschenden Wittermosbedingmoen. Ebenso ist der sortencharakter ron Einfluts. Beispielsweise beolachtete Psmock ${ }^{1}$ ), dals die Weinsorte Empire state durch das Ringehn ilure Früchte 2l Tage früher wie gewöhnlich reitte, dagegen reagierte Delaware kamm und gab sogar cine geringere Qnalität cler Trauben.

Man wendet den Ringelschnitt bei dem Weinstock anch als Heilmittel gegen das Verief'sen oder Reeren der Tranben, r. h. gegen das Abwerten der jungen Beeren an ${ }^{2}$ ). Aher als eine ständige. reguläre Manipulation des Kulturschnittes wird das Ringeln nie Eingang finden; es wirl immer nur als drastisches Ansmahmemittel in besonderen Fällen zur Anwendung gelangen dürton, dessen schädlichlieit hänfig den Nutzen ïherwiegt.

Selbst hei dem Treinstoek, bei dem wohl am hänfigsten geringelt wirl, nuts die Anwondung eine beschränkte bleiben. In den . Amnalen

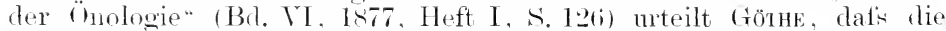
Hottinumen für eine allgemeine Anshreitung des Verfahrens bei Weinstöcken sich nicht realisieren dürtten. Der Torteil der Beschlemnigmng der Reiťe sei nicht zu verkennen: man kann auf diese Weise späte Sorten noch zum Ansreifen bringen, aber die Trauben der geringelten Relien geben einen gehaltloseren Wein. Tas über der Ringelstelle befindliche stück der Rebs stirht (wenigstens bei den emropäischen Reben) leicht ab, das nuter derselben hefindliche wird mangelhaft ernährt, so dafs die Angen unfruchtbar bleiben mol bej dem Sehnit

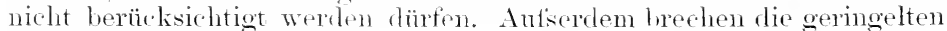
Triebe sohr gern ab.

1) Pumuk, II., Experiments in Ringing Grape Vines. New York Agric. Exp. Stat. Bull. No. 151, 1segs

2) Jises. Ohstban 1856, S. 125. 
Anch bei manthen Gä̈lzen zeigt sich häntig dic Beschlemigung in der Entwicklumg der mter dem Ringalschint stehenden Laubknospen, die sich bis zur Ausbildung von Wassorschosicen steigem kam. Bei Aptelbänmen ist les Fall häutiges als hei Bimhämmen.

In nenerer '/eit ist das Ringeln anch bei lirantartigen Pflanzen

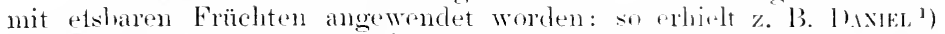
hei Solaneen gö̈sere Früehte dureh diess Manipmation. Andere

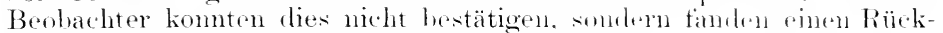
wang in cler Entwieklung der ganzen Pflanze²).

Wenn wir jetzt zum Studium der anatomiseluen Verhälnisse, die durch den Ringelschnitt orlur . Pomologiscinn Zanbering hervorgerntion werden, an der lland der beistrhenden Abbildungen ïlergehen, so glauben wir, dadurch am besten las Verständnis zu fördern, dats wir zmächst eine all-

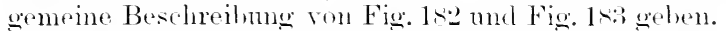

Fig. 1s. stellt eine geringelte Weimelie dar: " ist der mitere, $u^{\prime}$ der obere Therwallungsand, hl die hotisgelegte stelle dis Holzkïruers.

Fin. 183 ist der längsishnitt dmeh den muteren, schwächeren T̈therwallungsand (Fig. 1s2, "1). S. S' ist die Ebene, in der der mone Messersehnitt beim Ringeln

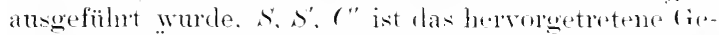
webe des l̈berwallungsrandes. II stellt die äntserste Lage des holinglegten Holzkïrpers dar: in diesem bedenten !. g' Gofatise mud h, li poröso IJolzzellon. Ii ist. wie in Fig. 1s.), die hei dom limedn durehsehnittene Rinde, die vom llolz dureh das hervorquelleme T̈led-

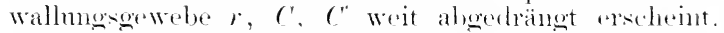
Dasselise lient bei $z^{\prime}$ eng dem Holzkörper an mon wirel nach antien hin chreh eine Korlischicht, li l'. eresehützt. Dieser hervortretende Fberwallumestand von parmelematisehom firwele wird lureh die bogio verlanfende Cambiumzone $r, r, c^{\prime}$ differenzicrt in das par-

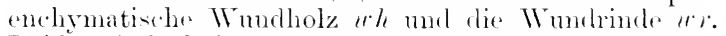
Beilie siml färherartig durelizogen von den Markstrablen $m$.

Wie ein soleher Ïberwallungsand in tuersehnit erseheint, zeigen die Fig. 1st minl los. von lonen die

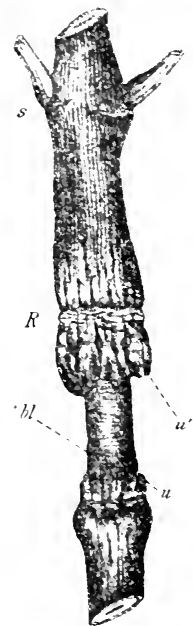

Fig. 1-2. Ringetwinde an einer Weinrebe mit dem oberen, stirkrentwickelteni" u.dem shwidher auscebildeten unteren ت̈herwallung:rande (u). (I) rig.) crotere ans fom oberen Wumblwall dicht an fer sitelle entnommen worden ist. Wo dersellue ans der Rinde levortritt, wähend Fig. Is. ans einer loreiteren, entfernteren Region stammt.

Wir seleen bei Botrachtmeng ron Fig. ls:?, dats ans dem Wumbande. ein massiges fiewele hervorectroten ist. das durch drej-bis viertidehe

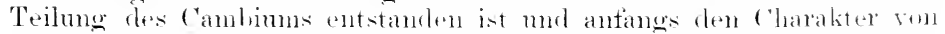

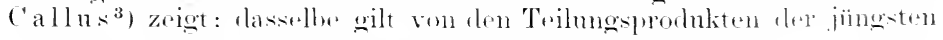

1) Dixum. Lanx. Efferts de la décortication anmulaire chez quelques plantes herbacées. Compt rend. laris 19h!, s. 125\%.

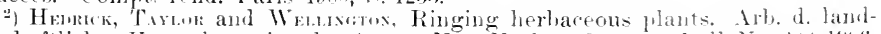

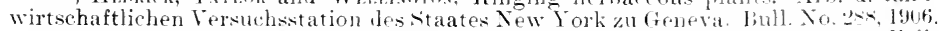

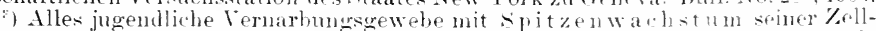
reihen, gleichviel ob es an einer sichintfläche itber ouler in dor Erile entsteht, ist als "Callus" zu bezeichmen. Der berindete, verholzende durchein innere dl eristemzone fortwachsende ('allus wird von uns als Clberwallung-rand ange-frochen. 
Rink die mit dem ('ambinmeallus vereinigt den späteren Überwallungswnlst bilken.

\%ur \%eit der Ringelme (im .Jnli) war der alte Holzkörper (Fig. 18:3. $H$ ) ler Rebe sthon stark entwickelt. Wir erkennen langgestreckte, diekwandige, in der mmittelbaren Nähe der Gefälse (g) vorzugsweise mit horizontalen Querwänden versehene (h). sonst meist licilfürmig zugespitzte

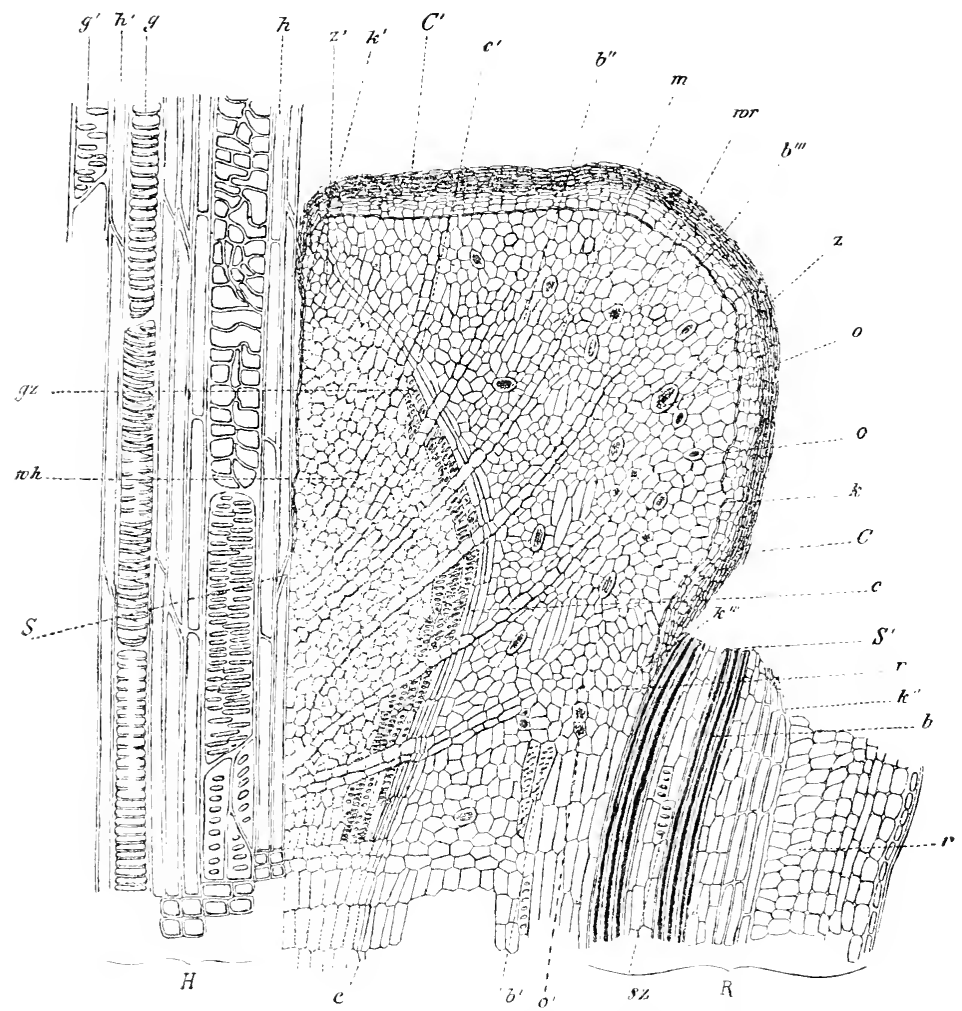

Fig, 1s:. Längsschnit durch den C̈berwallungswulst, der aus dem unteren Rande der Ringelwund. (Fig. 1,2, n) sich entwickelt hat. (Orig.)

Holzzellen mit femen Pornkanälen (li). Ilie engeren Gefätse sind

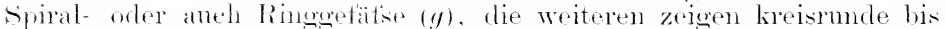
sualtenförmige. gehöfte Tiïutel ( $\left.g^{\prime}\right)$ : die weitesten haben eine leiterförmigofler netzartig-porön. Wantung. Iis leitertörmige Anordnung der Tüpfel pntepricht den reiluenweis gelagerten Poren der die Gefätse umgebenden Zellen. deren Wanthng anf dere cieföt'swandung abgedrüekt ist.

Der nutere Ringelsehnitt, lureh den die Ringelbliotse (Fig. 182, b) hergestellt wurde, wird in Fig. 18:; durch die Ehone SS' hezeichnet. In 
diesem Längssehnitt erstreckt sich also die Ringellibilse von s aufwärts. an den blotsgelegten Holzzellen entang. Bu. $S^{\prime}$ selnen wir. wie das Messer senkrecht zur Längsichtmog der Rehe ten Rindenkïrper (Ii)

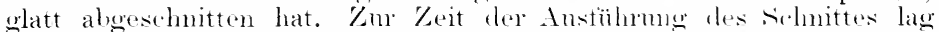
die Rinde $l i$ dicht an dem Holzkörper $H$ : das dazwischenliegende.

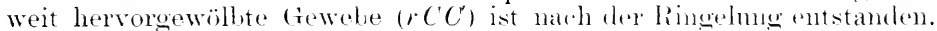
Und zwar tritt dureh die mit der Entternung der Rinde vortmolene moremeine Verminderung des Rindendruckes in der selnittedene SS mot den darangrenzenden Teilen in den /allen des canbiums sownhl als auch in denen des jüngsten l Lolzes sowie der jïngeren mol jiinesten

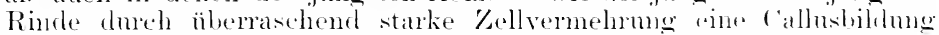
ein, indem die Endzellen der genamenten fiewebe mol div mmittelbar daranstotsenden sich nach antsen wölhen, sich teilen, sich strecken mud ihr hinteres Ende durch eine (knerwand von dem vorderen bute al,grenzen. In diesen vorteren Enden wierlerholt sirh das strecken mul Abschmören mehrere Male. Auf diese Neise wölbt sicle rings an sehnittrande ein Calluswall $C^{\prime} C^{\prime}$ herror, dessen Innemand bei $z$ ' ene dem Holzkörper anliegt, ohme jedoeh je mit ihm zu verwarhsen.

Allerlings ist dieser Calluswall zunäthst nitht ron der Anselehmmng und dem Bau, wie ihn die Zeichmmo zeigt: diese stellt vichnehr oinen ans dem Callus hervorgenamgenen VTmolwall dar, welcher duch die

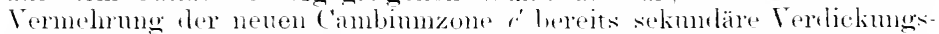
elemente gebildet hat. Eisprünglich hesteht dieser ('alluswall nur ans

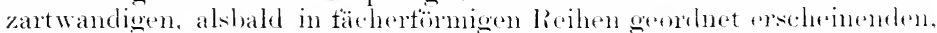

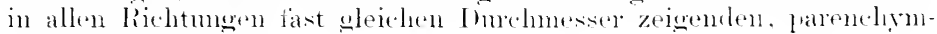
atischen $/ 2$ ellan $z z^{\prime}$.

In einem solehen jugendlichen. sich bald ditterenzienemelen ('allus-

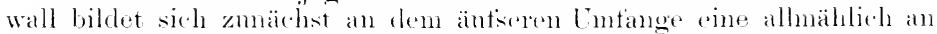

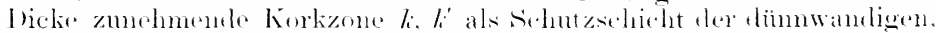

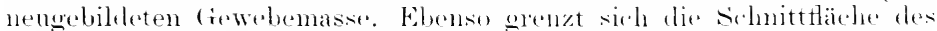
alten Rindengewebes $R$, das durch das nene Wnulgemele weit rom Hokkörper entternt worden ist, durch eine Korlisehicht li" nach autson ab. Wie rom sichnitt getrottienen alten Harthastzellen b sind von der sichnittläche aus bis tiet in das gesmule (iewele hinein fram mol ahgestorben. Das hinter diesen Bastzollen nath men gelegene, chemals jiungste Rindengewele, hat an der tellvermehrung mol c allushildmu teilgenommen: nur in den, dem Ilarthast zmnärhstliegenden Zellen dè rinstigen jüngsten linde hat sich rine dir tote stelle isolierendr. Horli-

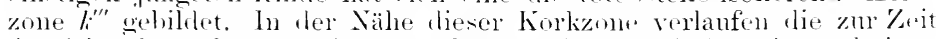

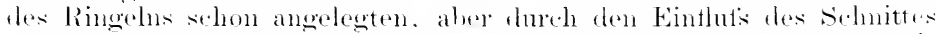

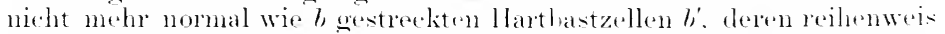

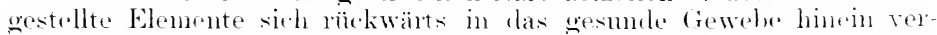

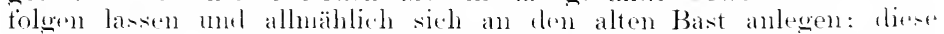

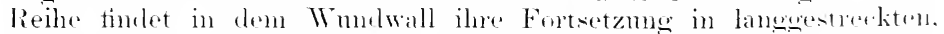

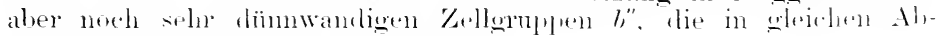
ständen von der ('ambiumzone liverent.

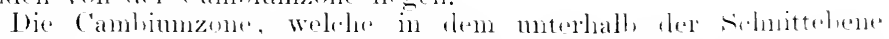
liegenden 'Teil der normal entwiekelten Rebe dieht and den fors-

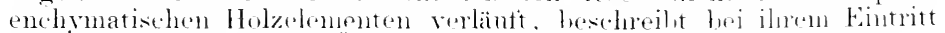

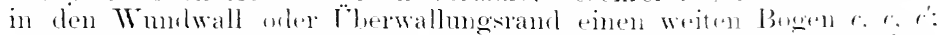

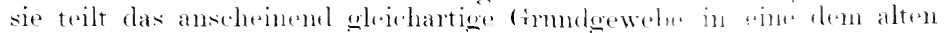

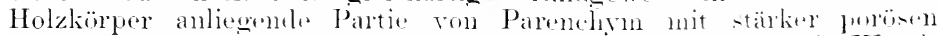

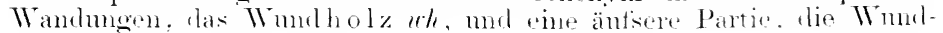


rinde $x \%$ In der dentlich markierten, fächerartigen Anordnung der einzelnen \%ellenreihe erkennt man dise Reihe als sekmndären Nachwachs der schon sehr frïh in dem c'alluswulst antretenden Cambinmzone. Die Elemente, welche ans dieser ('ambimmzone hervorgehen, haben nahezu in derselben Horizontalfläche dieselbe parenchymatische Gestalt: nu mutersheidet sich, wie gesat, das parenchymatische Holz wh von dem Rindengewebe durch seine porösen Wandungen, die stärker verdickt und dichter, also anch schantkantiger aneinander gelagert sind; es hat sich hier bereits ein stärlierer Hruck geltend gemacht.

Aber anch in dem Rindengewebe selbst ist eine deutliche Differenziermo bemerkbar. Zwischen den etwa ovalen Zellen, welche die firundmasse der Rinde bilden, finden wir länger gestreckte, stmmalere. etwa prismatische \%ellen in bogiger, der Cambiumzone amähernd paralleler Anordnung $b "$, welche die ersten Anlagen der Hartbastzellen darstellen: sie simb reicher an Inhalt und begleitet von Schlanchzellen, die in ihrer Längsichtung meist parallel dem jungen Baststreifen lanfen und Raphiden von oxalsaurem Kalk " enthalten, wäluend das Rindengewebe, das ans der zur Zeit des schnittes schon vorgebildeten jüngsten Rinde entstanden ist und deutlich dickwandige, wenn anch noch kmze und weite Harthastzellen enthält, den oxalsauren Kalk in sternförmigen Drusen oler grotsen, die Zelle austïllenden Einzelkristallen enthält. wie er vorzusweise in der normalen Pinde vorkommt (o'). An der Öbergangstelle sind Raphiden und sterndrusen of nur durch zwei Zellen getremnt. Hier hat also nu das locker gebante Gewebe Raphiden.

Am besten gewahrt man die mit den Baststrängen parallele Lagermog der oxalsauren Kalk führenden schlauchzellen anf' 'Tangentialschnitten an Kirschen; dort sieht man die vielfach netzfömig aneinandertretenden Stränge des Bastes begleitet von dichtanliegenden, in die Längr gestreckten parenchymatischen /ellen, von denen fast eine jede eine Druse von oxalsamem Kalk anfzuweisen hat. Bei dem Wein ist dies weniger scharf ansgeprägt und wird in lem Matise molentlich, als das Gesamtgewebe im Therwallungsande seine Differenzierme nahezu verliert. In diesem wenig differenzierten Teile erkennt man schon Grupen dickwanligerer Elemente, ohne dafs in der Umgebmg lereit oxalsaurer Kalk algelasert wäre. Der Kalk tritt in den friiher mit Stärle erfüllten \%ellen ant. was daranf hinweist, dafs bei der Lösung der Kohlenhydrate oxalsaner Kalk eines der Endprodulite des Löimngeprozesses ist.

Yan findet in den äntsersten peripherischen \%onen des Üherwallungsrandes darmu licinen oxalsauren Kalk, woil dirse \%onen aus dem erstgebildeten fiewebe des ïler die sichnittläche hervorquellenden, schnell warhenden, undifterenzierten Callus bestehen. in lenen das Material wänzlich zur zellvermshrung verbrancht wird und sich nicht sehlietslich als lieservestälie ablagert. Aber os bloiben im ganzen nur wenige

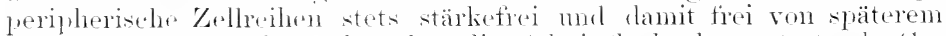
oxalsamem lialk: dem das ïher die selmittläche bervortretende (xewebe, das nur so lane den Nanen "'allus" verdient, als es vollkommen molitterenziert ist, litist hald eine Verschiedenartigkeit in seinem Ban exkemen mol tritt somit selus schnell aus dem Calluszustand in den \%onstand des T̈herwallmnesandes. Bald nach der Bildimg der peripherischen Korkmhöllune ersheint anch im Inmern des callösen Geweles dine Meristemzone. Welche die Fortsetzme des Cambiumringes des normalen Rebenstiockes innerlall, des Überwallnugsandes 
darstellt. Autserhalb dieser Meristemzone skennt man damn auch schon die ersten spmren eines Bastkör] wrs in cinzelnen, dicht unter der Korkzone zerstrent liegenden parenehrnatisehen \%ellen mit etwas stärker lichtbrechender. wie es scheint, leicht pnellharer Wanchug l,"'. Bei einigen dersolben glaube ich eine ähnliche viohporenzeichmmg erkannt zu haben, wie sie in der tangentialen Wanmmo nomaler Rindensiebzellen sz opfunden wird, so dats man schlietisen liann, dats die erste Difforenziermog des Callnswewohes. welche fast ghrehzeitio mit der Bildung der neuen Cambimmone antritt, inmerhalb der Rinrli. in der Ausbildming von viebzellen besteht.

Das aus der Cambinmzone hervorgehende freweler erstheint in der Fig. 1s:3 der Länge nach vefüchert durch die in ihrer radialen strockmon bevorzugten, in ihrem Inhalt helleren Markstrahlzellen m. wolche, wie das äbrige tiewebe, an ler Peripherie des C̈berwallungsiandes klom. zelliger sind, immerhatb des T̈berwallongsandes eine der Sentirechten genäherte Richtıng haben und erst allmählich in dem Matse zur normalen horizontalen Lagerung übergehen, als sie in das normalo Gewhe des morletzten Rebenstürkes rintreten.

Das zwischen den helleren Markstrahlen liegende Holy ist in der Jugend des C̈berwallungsrandes, wo also erst das dem Korkrande zunächst liegende frewebe entstanden war, kurz, sohr dïmnwandig, parenchynatisch. Es erscheint, je weiter man es nach dem nomalin Gewobe hin mutersucht. desto länger und drewandiger und geht ans

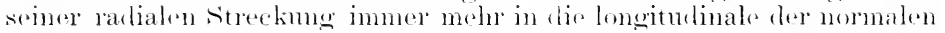
Holzelemente äber. Je trïher in Jahre die Ringelung vorgenommen worden ist, je länger also die nempebildete ('ambiumzone des Öber-

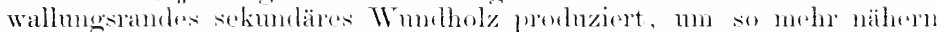
sich die später arobildeten Elemente schon in ihrer Länge mul fiestalt dem nomblen Holze.

In diesem zatwantigen parenchymatischen IIolzo treten als erste dickwandige Elemente limze, treppenartig poüse Getialszellen gz aut:

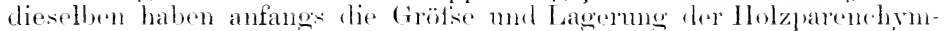
zellen ihrer Lmgebmng und nehmen, je mehr sie sich dem unverletzten Holzteile nähern, immer mehr tie (irstalt unl Lagerung normaler Gefälise an. Im Gegensatz zu DE Vkits muls ich behampten, dats die kurzen frefülszellen nicht immer die ersten dirkwandigen Elemente sind. Bri sche sehwach entwickelten monteren Ringelwïlsten peht

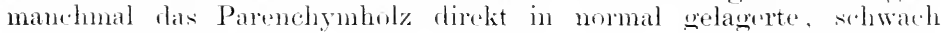
verdiclite llolzelemente ïber, ohme dats kmos Gefälszellen rorher antitreteris.

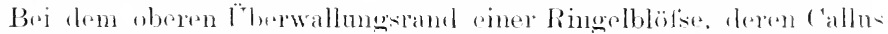
in dersolluen \%eit meist sehon meln als doppolt so stark sich entwielselt.

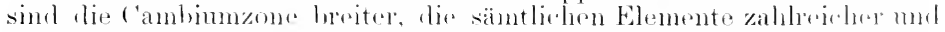

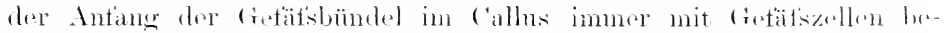

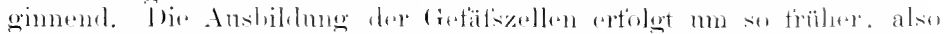

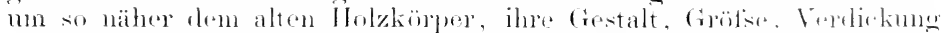

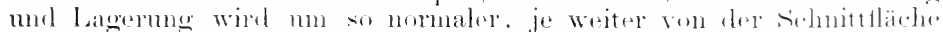

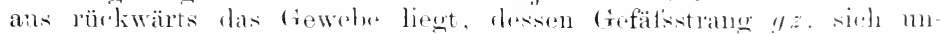

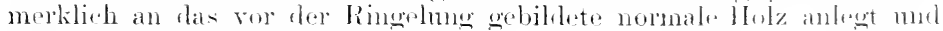
dosien weitere Vordickmo ansmatht.

Wir kömen nach dean in Fig. 1s:3 dargestedlten anatrmischesu Be-

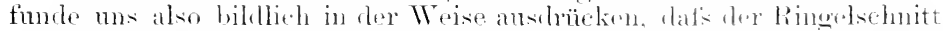

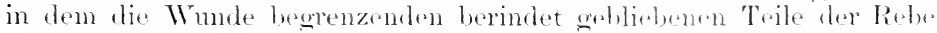




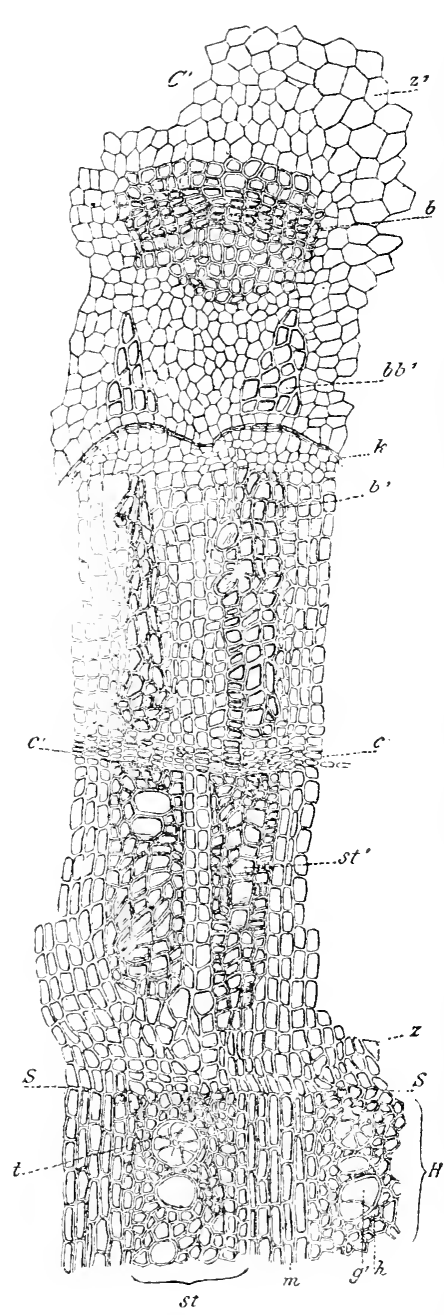

Fig. 1st. Querschnitt dureh den RingelWulst dicht an seiner Austrittsitelle in der Ebene shis s' ron Fig. 1 r.: (Mrig.)

eine ungempine Lockermo des Holzkïrpers hervorgebracht hat. Dadmeh sind lie fiefarisbindel, welche aus dickwandigen Holzzellen mol Gefätsröhren einerseits und aus dickwandigen llartbastzellen und siebzellen jenseits des C'ambiums bestehen, mol welche im normalen Holzkörper in konzentrischen Kreisen dielit anemander gelagert sind, auseimandergerïlkt min in einzelne durch Parenchrmmasien getremnte Nitränge aufolöst. Diese stränge y z' (tiefailsstrang) und $l^{\prime}$ (Baststrang) setzen sich, an Elementen immer ärmer werdend und immer melur wich verändernd, in den als Calluswnlst msprïglich ïher die schnitttläche hervorbrechenden Überwallumesand fort.

Dats der Getätsbïnlelköryer. welcher in ten muerletzt gehliebenen Teilen ver Rebe den nu durch wenigzellige Narkistrahlen gefächerten Holzlïrper mol Bastring bildet, gleichsam dureh das infolge der Ringelung entstandene parenchrmatische Gewehe in einzelne, immer dïmer werdende, wollig in radialer und tangentialer Richtung verlaufencle, untereinander anfings noel dorch Anastomosen netzartig verbundene, endlich aber isoliert und in tächerartig auseinandergehtude stränge zertasert wird, seben wir am besten an (puerschnitten, die in varseliedenen Hähen durch den Ringelwulst getüht werden. Wegen der götserom Lentlichkeit sind die Querselmitte Fig. 1st und Fig. 1s: ans dem oberen, analog gehauten aber stäker entwickelten Überwallumgsrande dorselben Weinrebe entnommen worden, die den Jängsschnitt Fig. 1t:3 eqeliefert hat.

Fig. 1st zeigt den Ringelwulst querdurehsehnitten in der llïhe, wo derselbeansderalten Rinde heranstritt, also mogetäh bei $S$ bis $S^{\prime}$ in Fig. 1s:3: Fin, 1s: ist ein quersehnitt durch die Mitte des heranswetretrmen Teiles des Throwallmusandes, also etwa in

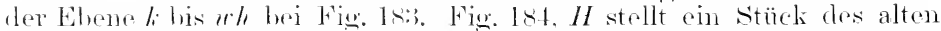
vor der Ringrome gebildeten l Jolzes dar: if bezeichnet die weiten, leitertormigen orler spaltenfömnig-porisen Gefäke, von denen diejenigen, 


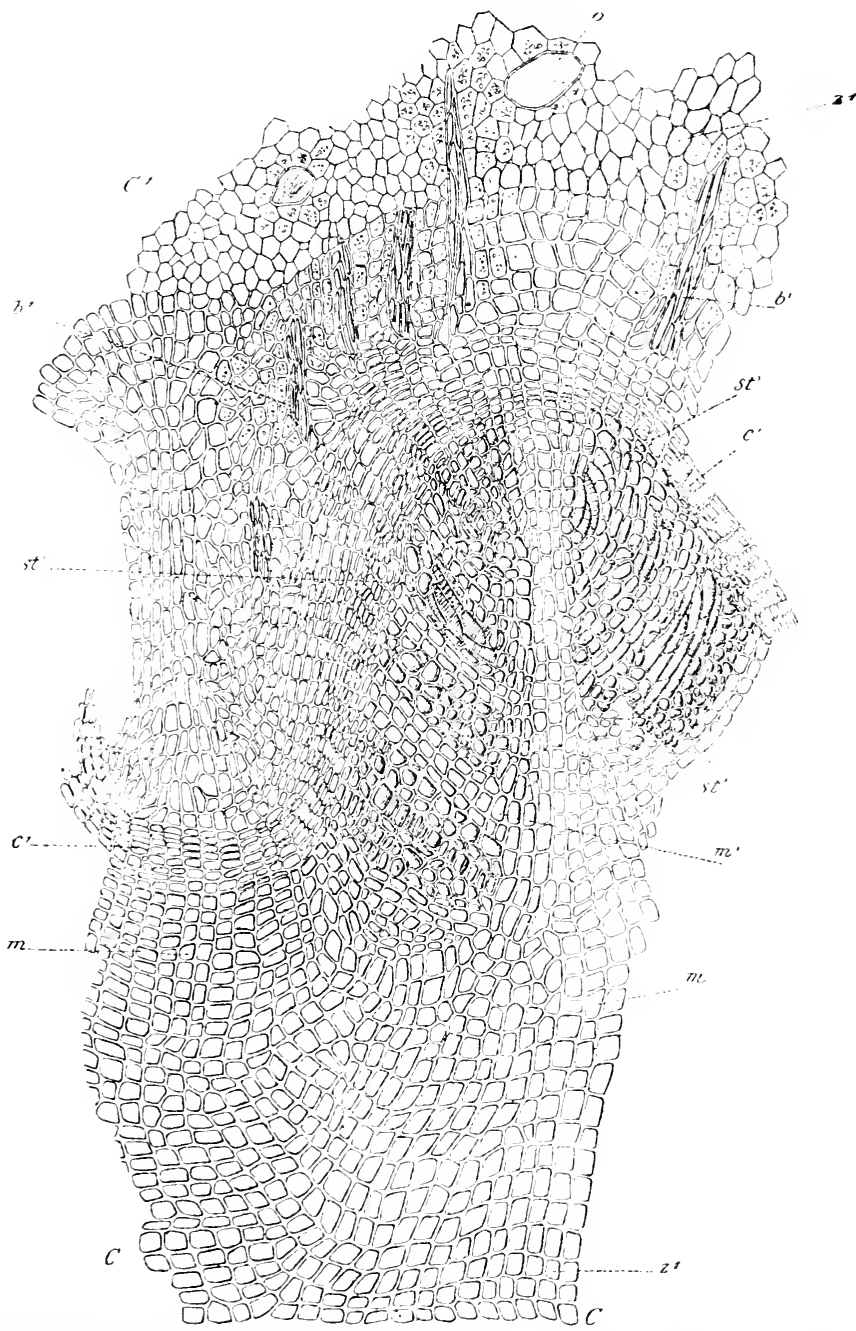

Fig. 1x. Querschnitt durch den Ringelwulst in gröferer Entfornumg von der Austrittsstelle, also in üppigerer Entwicklung, wic or in Fig. lo:; it wa in der. Ebene li-wh zu finden wire. (orig.)

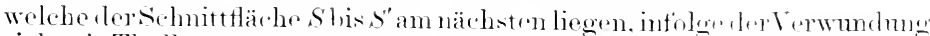

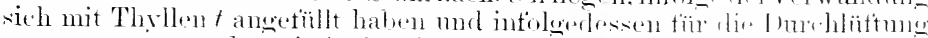
mwegsam greworden sind: le zeigt die querdurehsohnittenon Holzzollen.

Soraver, Handiuch, :A Aufl. Erster Fand. 
Slis (" (bei Fig. 185 ('bis $C$ ) ist die infolge des Ringelschnittes entstantene Nenholzbildung des Überwallungsrandes. In diesen Überwallungsrand hinein. der ans dem Callus hervorgegangen ist, sehen wir ans dem nomalen Gewebe $H$ die Markstrahlen m mit kurer Unterbrechung: sich fortsetzen. Die Marlistrahlen werden immer breiter, die Gefälsbündel, deren Holzkörper im normalen Holze dicht aneinander gelagert sind, werden nun durch die stets breiter werdenden Markstrahhpartien immer weiter anseinandergerückt; die Bündel werden dabei ämer an Elementen, und normale Holzzellen sind nicht mehr vorhanden. Der Strang st besteht nur noth aus kïrzeren, weiten, runden und engeren mehr abgeplatteten Gefäfsen, nebst weiten, meist schon stumpt auteinandersitzenden weniger dickwandigen Holzzellen.

Der eine Strang Fig. 18t, st im normalen Holze hat sich im Gewebe des Ringelwulster hereits in zwei stränge st' gespalten und diese hahen sich in der noch weiter von der Schnittebene entternten Region (Fig. 185, st') wieder in je vier stränge gefäehert. Dabei sind dureh die Bildung nener Markitrahlen (Fig. 18.5, mi) die nenen Bündel ans ihrer bisherigen Anordnung herausgedrängt worden: sie rücken jetzt in einzehen Gruppen weiter nach der Peripherie des immer dicker werdenden Ringelwulstes. Indem auch die tertiären Markstrahlen immer breiter werden, erscheinen num anch diese dünnen, sich im Längsverlanf verästelnden stränge ron Gefäfsen (Fig. 185, st') immer weiter auseinander gerückt, bis sie endlich in der Nähe des Anfsenrandes des Ringelwulstes ganz verschwinden. Die letzten Auslänfer dieser Elemente sind kurze, weite, poröse Zellen ron Parenchymholz.

Es ist bekannt, dals zu jedem Gefätsstrange des Holzkörpers ein Baststrang gehört. Das $\mathrm{Hol}_{\mathrm{z}}$ ist mit der Rinde Gesehwisterkind ${ }^{\mathbf{1}}$ ). In Fig. 184, b sehen wir das Hartbastbündel, welches zu dem Holzstrange st gehört; $l$ ' und $h l ;$ stellen die in ihren Zellen analog den Holzelementen weiter gewortenen Bastkörper dar, welche zu st' gehören; die radiale Terdickung der Weichbastzellen ist in der Zeichnnng nicht gut wiedergegeben.

In Ilerbst, wem die Weinrebe ihre primäre Rinde turch eine Korkzone aberenzt, hat die wellig verlaufende Korkschicht $l$ hier im Ringehwulst die Bastbündel in zwei Teile (Fig. 184, b' und bl') zersehnitten: $e^{\prime} \varepsilon^{\prime}$ bedentet bei Fig. 184 und 18.5 die C'ambiumzone, Fig. 185, o ist eine schlauchzelle mit oxalsanrem Kalk in Raphidenform: bei einigen Schlauchzellen lassen sich scharf zackenartige, sehr kleine Vorsprünge anf rler Innenseite der Membran wahrnehmen.

I ic erste Differenzierung in Calluswulst läfst sich anch nach Ïbbergang desielben in den fertigen C̈berwallungsrand oder Ringelwulst noth erkennen. wemn man. von dor äntsersten Korklage begimend, (vuerschnitte dureh das Wulstgewebe macht, wenn man also bei Fig. 18:3 von der am meisten nath unten vorgewölbten Partie beginnt und nach oben hin fortschreitet. Bezcichnen wir den dem alten Holze anliegenden Tril (Fig. 1s:3, $z^{\prime}$ his $S$ ) als lessen Imnenseite im Gegensatz zu der knerelig gewöbten Antienseite: es zeigt sich nach den ersten Querschinitten lereits das mmittelbar unter der Korkzone liegende parenchrmatische frewehe des Innemrandes durch Jod dunkler gefärbt als die entsprechente Partie der gegenüberliegenden Autsenseite. Ebenso erkennt man liei Anwendung ven Jod anch eine radiale Fächerung des

1) Rotristri, Waldverderbnis I, 70. 
Gewebes, indem streifen von anfangs nu 1-:; Zellen Mächtigkeit durch Jod dmkler gefärbt werdon als diw breitren zwischen ihnen liegenden Partien. Auch in der Gestalt for \%ollen lätst sieh schon in den ersten Quersehnitten ein Enterschied finden, inchu dir dem Autsenrande näler liegenden Zellen rmullicher als die diehtren, drm lnnenrancle wenäherten Zellen erscheinen: auch sind rlir simtlichen, dirckt unter der verkorkten Autsenschicht liegenden \%ellen kleiner als dio im Zentrum liegenten. Die helleren streiten enthalten /allen von maliserer radialer streckmo: die erste Andentmo der Markstrahlen. Dio Zono der erneuten Zellteilumgen zmm Zwecke der Anlane des stäteren Cambimminges liegt zmäelst dicht an der Imenseite des ( 'alluswolstes, sich an die Region von Zellen anschlietsent. Wolde zur Virstälimg der peripherischen Korlizone zuletzt in Teilung gotretru ist: vom la ans rückt sie in den folgenden (querschnitten immer weiter von rem alten Holzkïrper tort rol. den bogigen Verlanf in Längssolnitt Fig. 1s:3, c bis $r^{\prime}$ ), erreicht noch andserhalh, der Ehene, in welchrer der Ringelschnitt ansceführt worden ist. ihre grötste Entfernmo rom alten Holzkörper und nähert sich immerhalh der alten Rinde wieder dem normalen Holze, his sie als normales Cambium anch wioder ihre gewöhnliche Lage rimnimmt.

Was hier speziell vom Weinstock guzeigt worlen ist, findet im Prinzip hei allen Ringelmogen statt: der spezielle Authan ist natürtich je nach der Pthanzenart rersehieden.

Betretis der anatomischen Elemente. woldhe die stottleitmo ijher-

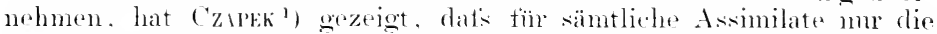
Siebrohren nusl Cambiformzellen in Betracht kommen kïmmen. und zwar sind die stofteitemelen Bahmen im Leptom selbst geratlinig. Das Leptomprenchym dient ahnlich den Markstrahlen als spe ichermesgewehe. Ile Reservestotite werlen in ihrer Ahlagerme insotim be-

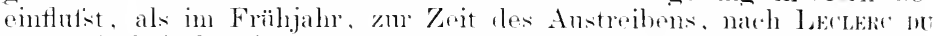
S.ıptox-2) bej den in der Nähe des Wurzolhalses geringelten Bämmen die Wnreln reicher, die Ntämme ärner an Rescrestotten sind als bei dיn nicht geringelten Bämmen. I)ie Blätter der ersteren sind zwar weniger grïn, aher enthaltm viel mehr Reservestotte. als die der mgeringeltin Exemplare. mol gehen nach meinen Beobachtmoen viel früher in lie llerbstfäbme ither.

\section{Die Schälwunde.}

a. Geschichtliches.

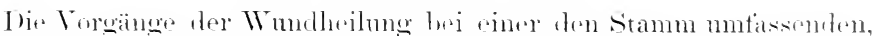

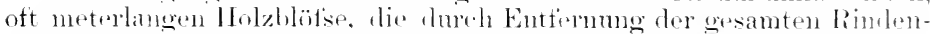
elemente entstamben ist, sind schon soit meler dem hmolert dahrem

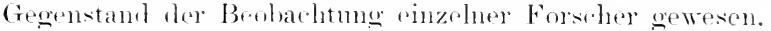

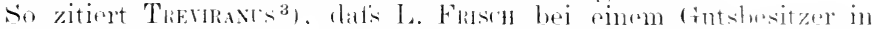
der Mark mehrere Aptol- nud Bimbïmm sah, denen man die wanze Rinde rom Ansatze der monterten \%weige lis zur Wury+l in wanzen

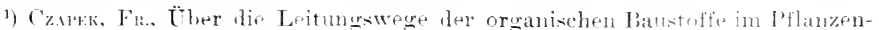

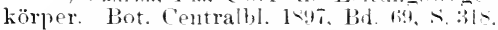

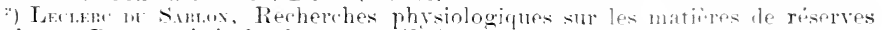
des arbres. Rerue générale de Bot. t. XVIII: cit. Bot. ('antralb]. L. Lotsy, 1!n6, Nr. $4: 3,+47$.

3) Travmax, Physiologie der Gewähse Br. II. Abt. I, 1-32, ‥2.2. 
Tnutinge des Stammes so genommen hattr, dats überall das weilse Holz zu sehon war. Die Bänme waren wieder mit nener Rinde bekleiclet. Frisch rersichcrt, dafs dieses Experiment immer gelinge, wenn man nur die \%eit der Sonnenwende dazu benutze und die entblöfste Ubertäche, anf weleher man den saft mit einer Feder gleichmäsig ansbreiten soll, durch Leinwand oder Rohrlecken gegen Sonne md IVind schüitze (Miscell. Berolin. (Contin, II $|17.27| 26$ ).

Der herühmte Experimentator Duнnusu ${ }^{1}$ ) nahm in der Saftzeit von mehreren jungen Stämmen von Ulmen, Pflamen usw. einen etwa 7-10 cm breiten Ring bis aufs Holz weg und mmab die Wunde mit einem Glaszrlinder, (Ter oben mul mien an mverletzten Stammteil mit Kitt mil Blase verschlossen wurde. Er sah auf der Holzfläche zarte, gallertartige Wärzchen sich bilden, welche zwischen den Holzfasern des Splintes hervorbrachen (des mamelons gélatinenx qui sortaient d'entre les filmes longitudinales de l'aubier): diese Wärzchen, welche der Mehrzahl nach muter äntserst zarten, wahrscheinlich stehengebliehenen Bastlamellen sich emporhoben, waren erst weit's und halb durchscheinend, später gran mol nach 10 Tagen (am 1ヶ. April) grün. Diese Nenbildmgen breiteten sich im Laute des Sommers aus und exzengten durch Vereinigung eine narbige Rinde, unter welcher zarte Holzlamellen erkennbar waren. "Ainsi il est lien prouré que le bois pent protuire de l'écorce et que cette écorce est des lors en état de produire des fenillets ligneux ..."

Ähnliche Versuche machte Kxicht und erhielt ähnliche Ertolge. Einnal beobachtete $\mathrm{er}^{2}$ ) an Clmus montana eine Reprodultion der Rinde, ohne dats die Wunde bedeckt war; der Bam hatte einen schattigen standort. An alten geliappten Eichen mit mrollkommen eintretenter Neuberindmo fand KNont, dat's die gallertartigen Wärzchen aus dem parenchrmatischen Zellgewebe hervorquellen, und ..in vielen Fällen woule nur ant deren Oberfläche eine nene Rinde in kleinen und getremten Portionen erzcugt".

MErex ${ }^{3}$ ) zitiert die Brobachtungen von WErseck, nach welchen die Wiedererzengung der Rinde nur dam gelingen soll, wenn das Abschälen um .Johanni geschieht, wem die stämme noch jung sind und dic verwmote stelle ., sehr sorofältig durch einen hohl und dicht anliegenden Verband gegen Anstrockinumg geschüitzt wirl."

Ifrex ${ }^{4}$ ) derene Ansicht finden wir bei Wiedergabe seiner Versuche in seiner Plıtopatholocie. Er schälte am :30. April 1839 während eines warmen somenscheins Stämmchen und wrotise Äste von Haselnuts, schneeball, Srringa mul Weide, umsthlots die Schälstellen nach Art

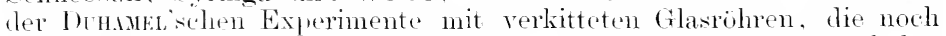
mit Papier momiclielt wurden, olgleich er die Versuche an stark behuschten stellen ansfülute. Anch hier wurlen gallertartige Tröpfehen answeschwitzt, "welehe stets an denjenigen stellen hervortraten, wo die Markstrahlen ant der ()berflärhe des Holzes zum Vorschein kommen".

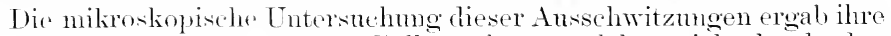
Zusammensetzmg ans zartem Kellgewehe, welches si.h duch den nenen, gummihaltigen satt immer mehr und mehr verorötserte, der lumeh ilie Markistrahlzellen ansgeschieden wome".

1) Domina, Phrsique des arbres 1758. II, s. 42, t. VIIff. 63 und a. a. O. S. 4t, t. VIIIff. $66,6 \overline{6}$.

2) Trevilixis a a. O. s. 22:3 (Beytr. 22:3).

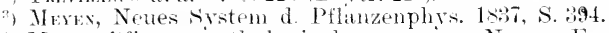

4) Mrsm, Pflanzenpathologie, heraungeg. v. Nees v. Esenbeck. Berlin 1s41, S. 14. 
Die gränliche Färbung. welche diese Xenliblungen annehmen. rübrt von ('hlorophyllkörnern her. Diese Nenhildmugen erhielten im

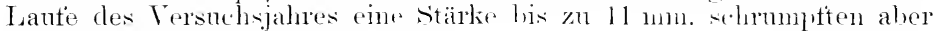
bei dem Vertrocknen stark ein.

Mrsex kann diesen neuen Protulitomon, dir ïhrigns anch im

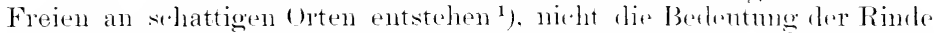

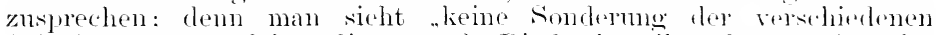
Schichten. ans welehen die normale Rinde dessellen Banums lesteht. und es findet sich in derselben anch keine sijum vom Baströhren, wolche offenbar besonters wichtig sind . . . "

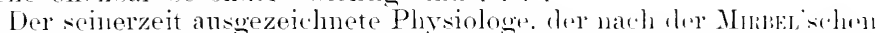
Anschanmeg das ('ambium tür einen strukturlosen Saft anspricht, der solche Zellbildungen hervorbringt wie die, ans denen er heranswetroten. hat zwar das Verdienst, das Miliroskop bei Tntersuchnng dere nemen. bei Heilung der schälwunde auftretendon Prodnktionen angewendet zu haben, allein es ist ihm nicht geglïglit, die Holzprodulition muter den Nenhildmeren zu beobachten nud die Anabogie dieser Bitelungen mit der normalen Rinde nacluznwejsen.

Wahrseheinlich waren die fonchte Luft unel starke Beschattmos seiner Zy-linder schuld, da diese Faktoren. wie wir selsen warlen, den Charakter der Neubildung wesentlich bereintlussen.

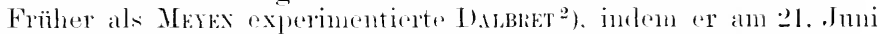
eine Esche nnd einen Nulshamn schälte, die sichälstellen in rylinder

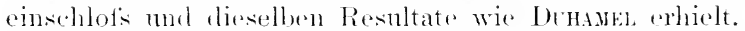

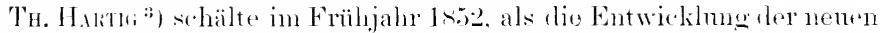

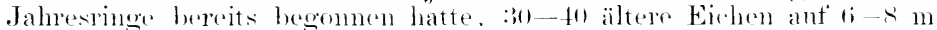

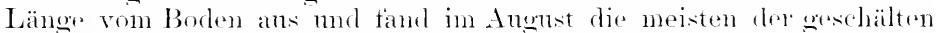
Bäume elenso dicht belanlit als die danebenstehenden. nicht antrindeten

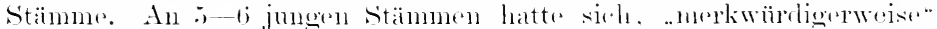
fast mor anf cler Sommenseite, ein aus den Markstralulen des llolzes

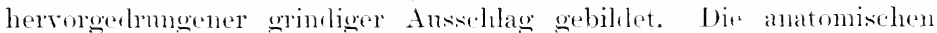
Untersuchungen zeigten. dals der Ausschlas, ganz mabhängie vom Baste nud Cambium, allein ans dem Holze hervorgegangen mud ein Probukt der Markistrahlen sei.

Dio Nenbildmo beginnt mit dem Auftreten einer Korlizellenlage an der Peripherid des gesumblen Markstrahlgewehes, dureh welche eine ändsere, alogestorlene Partie abeegrenzt wirl. Der lebendige Teil des Markstralils entwickelt num in seinem Unfange mehrere Lagen par-

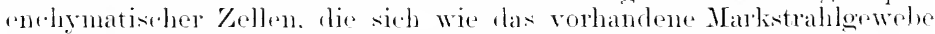

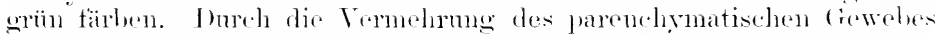

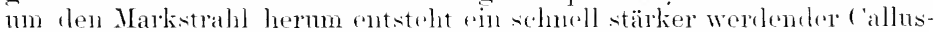

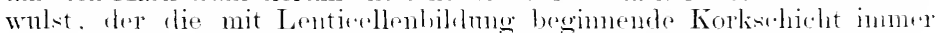

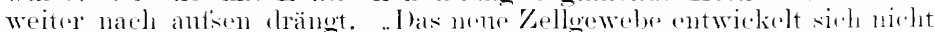

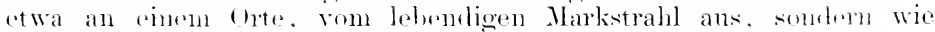

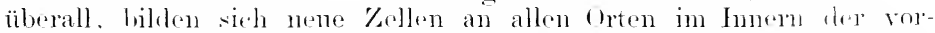
gelibdeten \%ellen. diese resorlieren die Mntterzellen, erwallsen zur

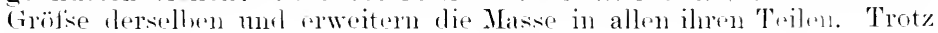

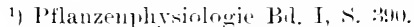

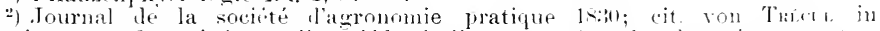
Aceroissement des vergitanx dicotylidonés lignenx". Anmalen des reiences natur. III. Série, $t$ XIX, Paris 1>53.

3, Tr. Hurm, Vollst. Naturgesch. d. forst. Kulturpfl. Teutshlands. Berlin 18.i2. Figurenerklärung Tafel 70 , Fig. 1-:3. 
der Erweiterung des ('alhs durch das heranwachsende Zellgewele behält daher der lebendige Teil des Markstrahls stets denselben Umfang, dieselbe Grötse, Kahl, Form und stellumg des ihn konstitnierenden Zellgewebes."

"Hat der Callus eine gewisse Ausdelmung erreicht, so werden einzelne Partien ungemein dickwandig, wie dies auch im normalen Terlanf des Rindenlebens der Fall ist (Steinzcllennester). Weiterhin entwickelt sich an jeder Seite des lebenden Markstrahls, untern der Spitze desselben, im Zellgewebe zwischen ilm und der Korkschicht ein Faserbündel, bestehend aus getïpfelten Holzfasem und Holzröhren." Durch Verschmelzung der einzehnen gleichnamigen Gewebezonen der bisher völig isoliert gewesenen, warzenartig hervortretenden Nenbildungen entsteht eine zusammenhängende, mit Korklage versehene Rindenschicht, welche nur durh die radiale Anordmung ihrer Zellelemente im querschnitt ron dem Bau der normalen Rinde abweicht. .An den Seiten der Markstrahlspitze schreitet die Entwiclilung des Holzkörpers lis zur Bildmo einer zusammenhängenden, von Zellgewebe des alten wie ron nen gebildeten, kleineren Markstrahlen durchsetzten Holzschicht vor. Die einzehnen Holzbïndel bestehen aus Holzfasern und Holzröhren. Eigentliche Spiraltasern fehlen. Mit vorschreitender Entwicklung des Holzkörpers bildet sich anch eine Tremnumgsinie zwischen ihm und dem Rindenkörper (Meristemzone Ref.) immer schärfer ans, obgleich weder von Bastfasern noch von Saftröhren sine Spm zu entdecken ist."

Die emen bedentenden Fortschritt darstellenden Beobachtungen von Th. Hınт́ elgehen also, dafs die Entwicklung der nenen Rinde auf einer Schälwmole auf Kosten der in Holzkörper vorhandenen Nahrmesstoffe geschicht und mit der Bildnng eines Callusgewebes um die Markstrahlspitzen beginnt.

Welehe Zellen den Anfang der Callusbildung hervorrufen, geht weder aus der Beschreibme noch ans den Keichmingen hervor.

liese Lücke füllt Thécud ${ }^{1}$ ) mit seinen eingehenden anatomischen Untersuchmoen ans, die gleichzeitig die Beteiligung des wesamten, a uf lem gesehälten Holzstamm verbliebenen jungen Gewebes und wicht nur der Markstrahlen an der Callusbilumng nachweisen. Allerdings können muter besonderen Verhältnissen die Markstrahlzellen die Callusbildung allein veranlassen: jedoch tritt ebensogut anch der Fall ant, dat's ron den jungen Holzzellen allein die Callusbildmg ringeleitet wird.

An der Callushildumg beteiligen sich dir jungen Holzzellen, Markstrahlzellen und die engen Gefälse dureh Umwandlung in Parenchymzellen, die sich num weiter vermehren ${ }^{2}$ ).

Dic jünsten ant' dem Holzzylinder stelsengebliebenen Zellen weiten sich aus: sie verlängern sich, nind in ihrem Imnern bilden sich scheidewände; die Endzelle der jungen Calluszellreihen wird am onölsten und weitesten, oft kugelrumd. dlann liculenförmig gestreckt, nnd in diesem Zustande entsteht wewionlich eine noue (juerwand. Die jetzt durch

1) Tharı. Accoissenent des végétaux dicotrlédonés ligneux. Annales des scienc. nat. XIX. S. 16.5

2) ..Les fibres ligneuses, les rayons médullaires et les vaisscaux d'un petit diametre eux-mêmes sont métamorphosés en tissu cellulaire proprement dit; car il y a une métamorphose réelle de ces organes élémentaires en tissu utriculaire ordinaire, et ensuite nultiplication de ces utricules nonvelles. 
die (querwand hergestellte nene Endzelle wiederholt diesen Prozets. Die darmerliegenden älteren Zellen strecken sich anch in die Länge und teilen sich.

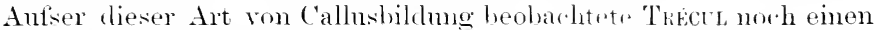
anderen Fall. Während bisher die änlsersten dror stohengebliehenen Zellen sich durch Answeitmo und Alschnörmy zmun (allnswewebe entwickelten. kommt es anch vor, dats die antsersten '/ellen nur cine geringe Entwicklung zeigen, und dats die un ter lonsollown liegenten

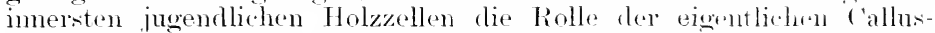

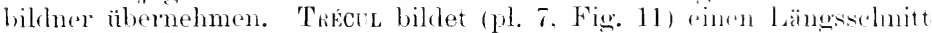

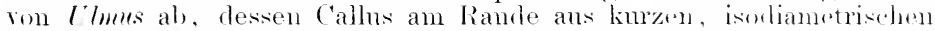
Zellen hesteht. Diese almä̈hlich rertrocknente schicht ist vom llolz-

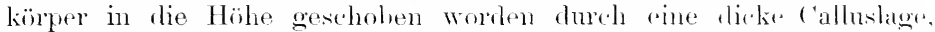
deren älere Zellen jetzt dem Holze anliegen, deren jüngstr Zollen im weitesten rom alten Holze entfernt, mmittelhar unter der munwgehobenen, absterbenden sichicht liegen, sich ling radial gestred lit haben und bereits rarlial parallele Reihen bilden.

Beide Fälle der ('allusbildung kämen oleichzeitig an demsellon Exemplare vorkonmen. Wahrsheinlich durch Vertrocknng der äutseren schichten des blotsgelegten Cambialkärpers werden die innersten zur Vermehrung angeregt.

Wie sirh ans meinen eigenen Versuchen rergilt, kïmen die sämt-

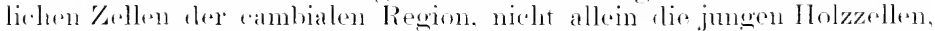
wie ns: Vkiss meint, sondern anch die jungen Rindenzellen an der

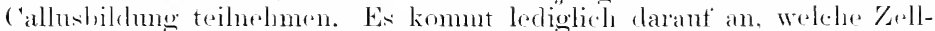
schichten bei dem Abschälen der Rinde stehen bloiben. läst sich die Rimde deratt dats mu einige diesjährige sulintzellen, dir moli ver-

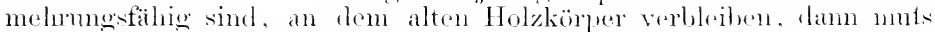
von ihnen die ('allusbildung ansgehen: wemn dagregen die allerjüngsten, cambialen Rindenzellen nocls stehen bleiben, so übernehmen diese die Callusbildung, währent der darmuterliegende jugentliche splint sich sciner Anlage gemäts zu differenziertem Holz mit crotiitsen anshildet mol num darin sich verändert, dafs alle Elemsnts kürzer, radial weiter und diimnwandiger werden.

Das treftlichste Beispiel tür diesen Fall gibt Trécld ${ }^{1}$, in seiner Fig. $\therefore$, p. :3 von einer Linde. Wir verwenden diese (s. Fig. Isti) zur Bestätigme unserer Ansicht. $B$ berlentet das junge. shon ror drer

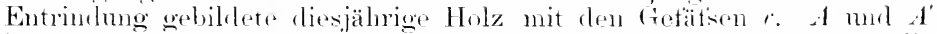
ist nach Trece das alte Holz des vorigen Jahres ${ }^{2}$ ). Der Rif's, der die

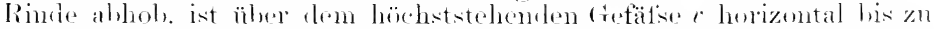
der mit í bezeichneten strelle verlanfen, hat sich von dort rechts ahwäts gesenkt his nahezn anf die dïmwandigen, letztgebildetrn Zellen

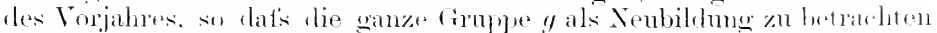

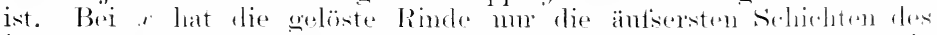
jüngsten llolzes wrogenommen wer vielleicht gar nur dir zentrale

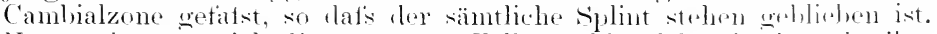
Nun verlängern sich dis äutsersten Zellen schlanchförming ils mel teilen

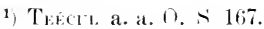

2) Es könnte auffallend erseheinen, dafs der. Jahresing bei l' mil wanz dünwandigen Friblingsholze abschliefst Es kommen aber in der Tat srilchr Faille vor. Teh erhielt aus der Eifel krebskranke Lärchen im . Ianuar. dren Jahresing nach dem Herbstholze noch sechs Zellen starke Lagen von dïmmandigem Fruhjahrsholz gebilulet liatte. 
sich. fortwachsend ( 7 '), durch eine scheidewand. woraut die abgeschnürte obere Zell. $r$ jeder Reihe den Verlängermasurozef's wiederholt.

l as junge Holz (splint) hat sich durch die Verwundmo. also durch die Anfhehung des Rindendruckes, ratial westreckt, ist kurzzelliger und weithmig geworden, ist dünmwandiw verblieben, und die bereits angelegten (refälise haben sich ansqebililet.

Nach $x^{\prime}$ hin ist mit der abgelösten Rinde anch der junge Splint fortgenommen worden. und aut den Itolze des vorigen Jahres sind nur wenige, junge Holzzellen dieses Jahres stehen geblieben; diese haben nun die Callusbiltung ïbernommen uni natïrlich gefätslosen Callus gebildet. der weitzelliger geworthn mul schneller ein grötseres Volmmen

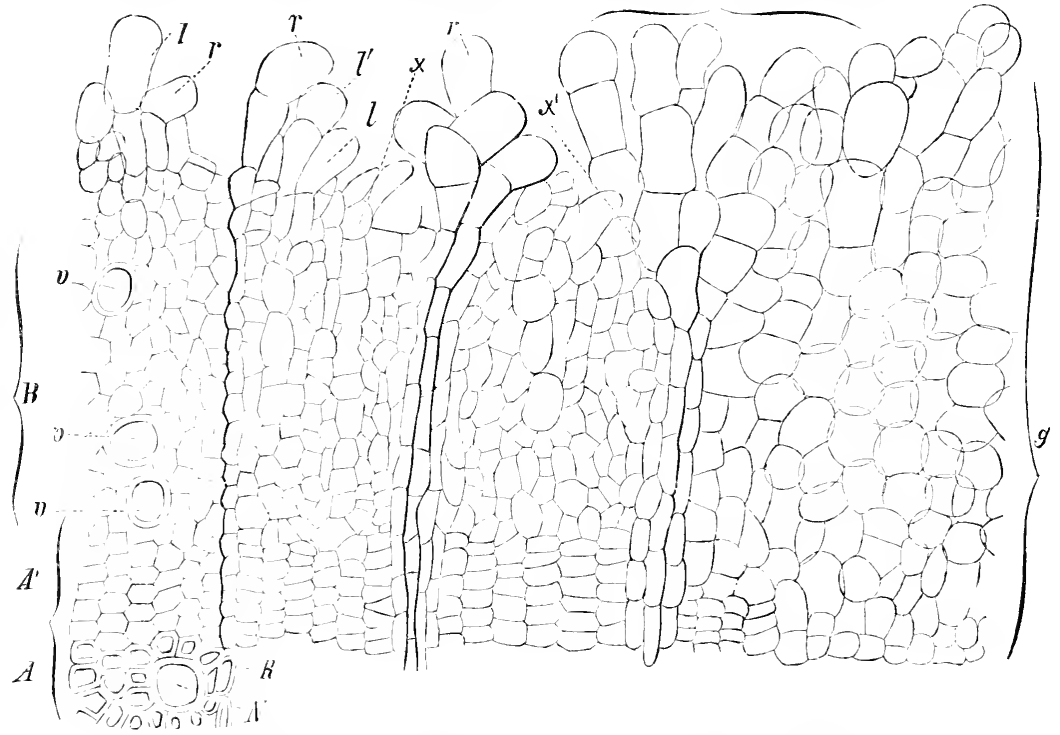

Fig. 1 1 G. Callushildung aus jungen Rindenzellen bei einem geschälten Stamme. (Nach Trist 1.).

angronommen hat als tie anliegende Partie, deren Tickenansilehnmng er aut liese Neise reresicht hat ${ }^{1}$ ).

Betreftis dor Ixhemslaues geschälter stämme gehen die Meinmoen weit auseinander.

1) Wir geben zur ('harakterisierung der Trorrischen Anffassung dessen Figurenerklärung 1. ‘. l. 191: $A$, $A^{\prime}$ hois de l'année précédente $V$ vaisseaux de ce bois: $I$ rayons médullaires - $I$ jeume bois formé au printemps avant la décortication. Tous les éléments de re jeune bois, et la partie la plus externe $A^{\prime}$ de celui he l'année précédente. ont subi un amincissement dans leur membrane. Les cellules rxternes des rayons médullaires $R_{i}$ ont donné lieu à une multiplication utriculaire, guel fuefois abontante, en $r$. La multiplication commence aussi en $l$. l' dans les Gements du tissu ligneux. En y, cette multiplication s'etend ì tonte la conche de l'annee "t meme anx fibres ligneusen les plus externes ${ }^{\prime}$ ' de l'année précedente. Les vaisseaux qui existaient primitivement dans la conche de cette amée, comme en $B, r$, sont disparu en $\%$. 
I) hervorragendste Beispiel ungewöhnlich langer Lebenstaner von Bäumen, die ihren Rindenkörper anf grotse surecken hin verloren und nicht ersetzt hatten, mul deren blotslienomler Holzhörper infolge-

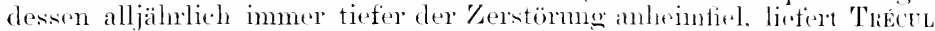

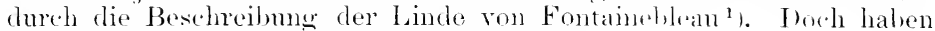
wir anch noch viel fiöhere Brobachtumgen.

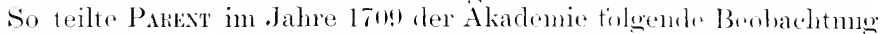
mit: Eine Rüster in den Tuileries, welelle hei Bromm des Frölijalns 17us in ilner qanzen böhe der Rincle beranht worice, antwickelte trotz-

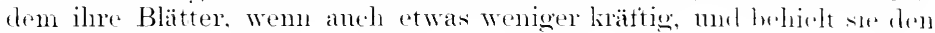
ganzen sommer ïber.

Drmanke ${ }^{2}$ spricht sich in dieser Beziehumg tahim ans. datis der Batum mit mbedeckt heibeneler schälwmele allmählich (\%uweilon erst nach vier Jahren) zugrmole gehe.

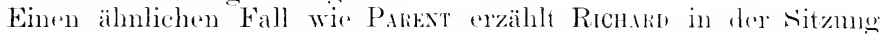

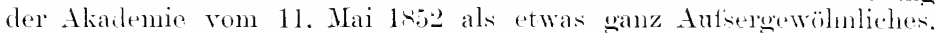
da in der grälsten Zathl der Fälle die Bämme nach solehen Beschäılienneren alshald sterbrin.

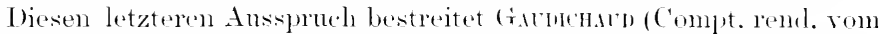

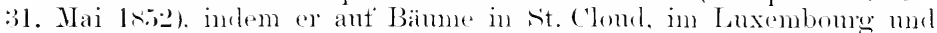
in Fontaineblean hinweist. welehr nach solehen Verletzmeren nor.h eine

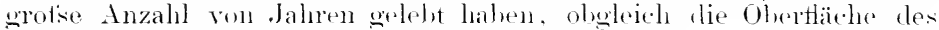
entblöfsten Ntammes sohon toilweise zerstört war.

Derselhe Botaniker kommt in der sitzmng der Alialomie rom

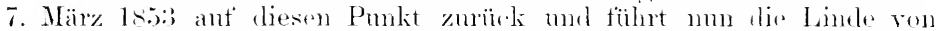
Fontaineblean an. Narh Treere ist dieser Bam gegen das dahe 17 הo

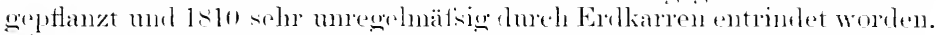

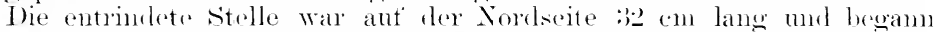

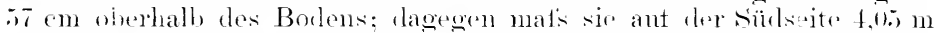
and bexamn gleich an der Bodenoberfläche. Dis Entrindung war am ganzen Stammumtang eingetreten, mol trotz lessen hatte dor Bam noch 44 .Jahre welebt (er ist im Jahre lsit gestorben): der Inurehmesser oberhalb der Wundstelle betrug 20 cm, untorhall, derselben 1s cm. Die (Ohertläche des rntrindeten Holzkörpers, der in dor Mitte der Wundstalle am meisten substanz durch die Erdkaren verloren

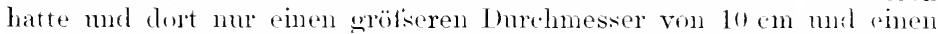

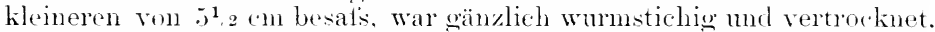
Sach Entfermung des toten Holzmantels craah sich die lehendig acbliebene zentrale Partic nur noch von 21/2 'm Dicke: sie war sehr saftreich und machte den Eindruck jungen Holzes. Iturh diesen

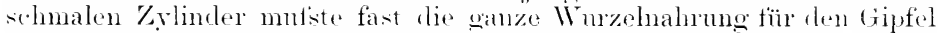
des alten Bamnes anfwäts wandern, nni loch entwickelte sich rlerselbe

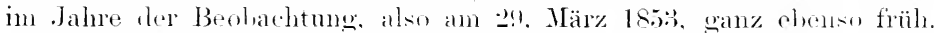
war ebenso reich mit I3läitem mul Blüten versehen wic die anderen Linden. Nur entaubte sich der Bamm, ler übrigens an soinre Basis

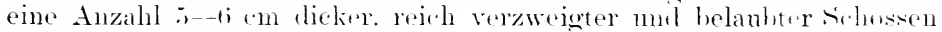
getrieben hatte, schon in Angust.

Jiesen sichossen schreibt 'Tuscre die Erhaltung des moterlally der Entrindung belegenen basalen stammteiles zu: sio bereiten ihm das

1) M. A. Torre, Linfluence dos cortications anmulaires sur la végétation des

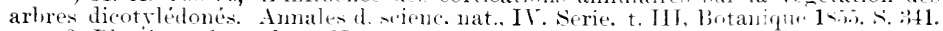

2) Physique des arbres II, p. th. 
plastische Material, das ein normaler Stamm durch den Rindenkörper ans der Banmkrone emptängt.

Eimen analogen Torgang bei einem Birnenaste, ler nahe seiner Ursprungsstelle vollständig der Rinde und des splintes beraubt worden war mol democh mehrere Jahre fortgelebt hat, beschreibt Linnuer ${ }^{1}$ ).

TII. H.nTt; sah eine ringtörmig weschälte Lincle auch noch ! Jahre nach der (operation leben und in ihrer Fruchtharkeit sogar vermehrt ${ }^{2}$ ).

Hotgänther Resneckes in treiz berichtet ïber einen $10 \mathrm{~cm}$ starken Ulmenptiöptling, der mit seiner Unterlage seit 6 . Jahren nicht dureh die Rinde, sondern nur durch rlas llolz in Terbindung geblieben war. Garteninspektor Roth in Muskan sah ferner eine ${ }^{3}{ }_{4} \mathrm{~m}$ starke Rotbuche von 2:; Futs Höhe, welche während ihrer fijälnigen Lebenszeit mit dem Mutterstamm niemals durch die Rinde (wie ( nur durch die Holalanen in Terbintung gewesen ist und democh krättio wuchs: sie wurte schlietslich durch den Wind abgebrochen. In botanisthen Garten zn Breslan blähte alljährlich sine 14 m hohe und ${ }^{1 / 3} \mathrm{~m}$ dicke Linde, die in einer Länge von $1 / 3 \mathrm{~m}$ gänzlich und

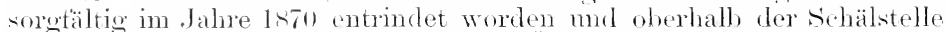
nur in den ersten zwei Jahren eine Überwallmosschicht von kamm - em Längo getrieben hatte ${ }^{3}$ ).

Die Folgen des Schälens lassen sich im voraus nicht bestimmen. Lie Lebensianer der grochälten stämme hängt wesentlich von der Bamart ab. Am lichtesten vertragen schmellwüchsige Lanhhölz+2x derartige tiefoehend, Verwundungen. Ther das Verhalten der Narlelhölzer liegen genügende Erfahrmeren noch nicht vor. Hartig ${ }^{4}$ ) fand keine Nenbildung von Rinde an der Schälstelle und sah das Astutück muterhalb der Schälstelle bis zum närhstunteren Aste in schönen „Speckkiehn" ver-

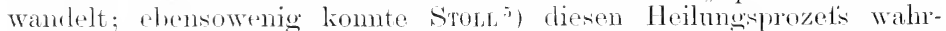
nehmen: er cribt jedoch an, dats Nönuncer eine Neubildung beobachtet, aber dabei die Neimmo geäutsert habe, datis die nengebildete Rinde nicht imstancle sei, den alsteigenden satstrom zu leiten.

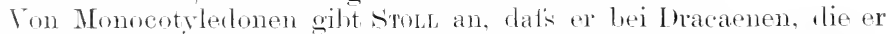
in Gewäh hanse ihrer Rinde beraubt hatte, eine Vernarbong des IVundHäche gefindern habe.

Antser von der Ptlanzenspezies hängen dir Folgecrscheinmoen noch ron der zeit der Anstührung der Manipulation und der Leiehtigkeit les Individums al, sich Hilfsoreme in Form von Adventivknospen und - worzeln zu sehatten. Bei der (1)stkultur kommt las Verfahren nur als extremstes Hiltimited zur Fryichng von Fruchtansatz bei Bämmen zur Anwentmug, die sich in zu üppiger Holzbildung erschöpten.

\section{Eigene Beobachtungen.}

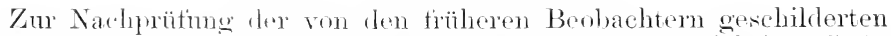

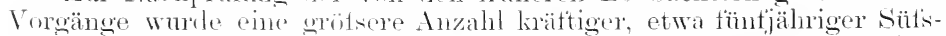

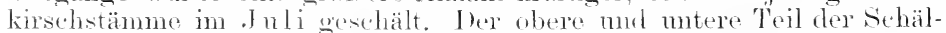
stelle woule ant einc länge rom $20-4$ cm mit dem Ilesser zur Vel-

1) Gardener's Chronicle vom 1:2. Nov. 1852, s. 726.

2) Th. Hum Folgen der Ringelung an einer Linde. Bot. Zeit. 186:3, S. $28 \%$.

3) Ginpur, Ther das saftsteigen in mikeren Bimnen. 57. Jahresher. d. Sichles.

Ges. f. vaterl. Kultur lest. st. 2y:i.

4) Folgen der Ringelumg an Xadelholyisten. Bot. Zeit. 186;: S. 202.

5) Über lingehmg. Wiener (Hst-med Gartenzeitung 1sit; s. 167. 


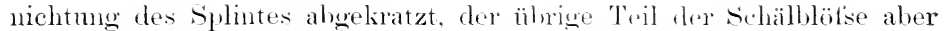
mberïhrt gelassen (s. Fig. 1st). Ein Toil der in treien lande erwachsenen Versmehsbämehen wurle ans seincr natiirlichen vertikalen stellung dureh Bänder in eine zur Erdoberfläclut geneigte Lage herabgezogen.

Die Neuberindmo ertolgte nicht bei allen Exemplaren, bri einigen aler in vorzüglichem Malise. Unter letzteren zeigten sich stänmehen, div allseitig neme Rinte rebilatet hatten mit Ansnalme der gänzlich ahgetrockneten, alegeliratztro stellen in dex Nähe des oberen mol mteren Schnittrantes. Die nene Rinde stant also antier jeglichem Zusammenhange mit dre alten. Die Antänge hatten sich allscitig zu wolcher

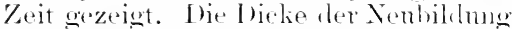
war aber in dem miteren Teil der sihälblïtse mehr als doppelt so grots wie am oberen Teil, ja, am moteren Rande war dir neme limele stollenweiss in limzon, troptenatios sich rerdickenden streifen ant die abockratzte muter. Inolierstelle gesmlien. Bei rinem wemoigten stämmehen hate sich lev Rindenfortsatz rom der aligeliratzten stelle algewendet und nach des Erow hin zu wathern versucht. wie Fig. 1st, zeiet.

In Fig. Ist ist 11 der montere di der

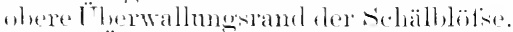
Dieser ت̈lerwallmesand. der in Ban

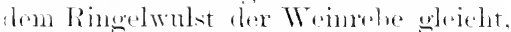
ist hies nicht an wanzen Lmtange answeblitet worden, da cin Teil der Rincle in Iappen l und l'stelen gelasson worden ist. Ant diesen Lalpen hat sich stellenweise ant kurze butfernmor ron der Ansatzstelle her Nenholz mit Rincle

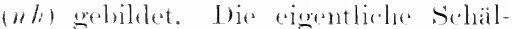
höftse des stammes int larlureh ven

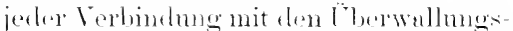
rändern 11 "i abgeselnitten worelen, dats bei i mud ídas junge IJolz. wio hereits erwähnt, rings am Stammuntange al, gekratzt mul auf diese IVeise (rin Folierstreiten herestellt worlen ist. Anf der

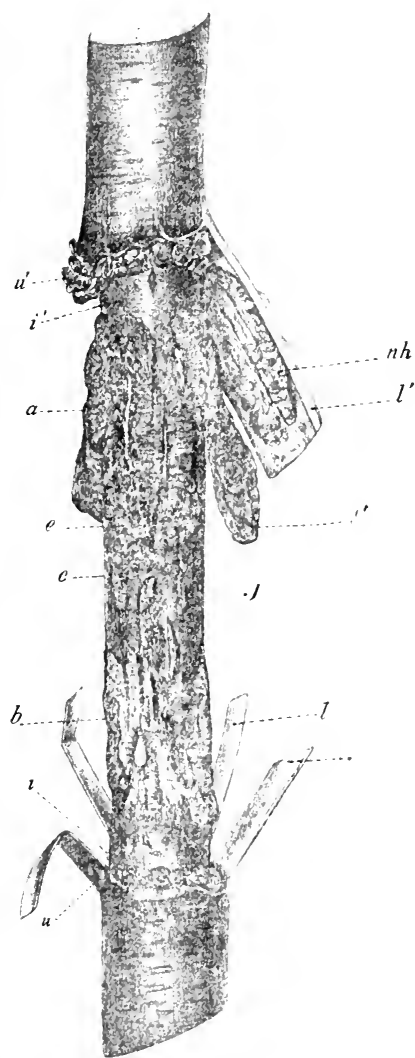

Fig. 1st. Geschïter sitamm einrr cualskirsche, dessem sidhilstelle am oberen und unterin Teile alles jugendlichen fiewries heraubt worden ist. (1) rig.) von jeder Ferhindmen mit den limelen-

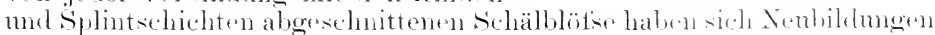
von Rindenelementen mit IIolzantängen eingestullt. Welche keinen

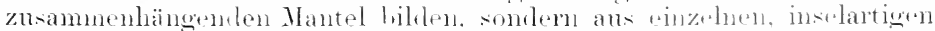

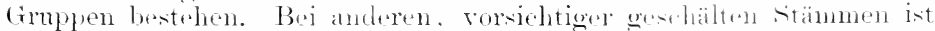

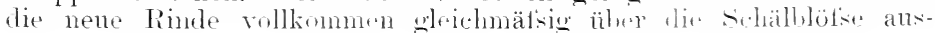


qubeitet. In der Mitte der Schälblöse ist hier eine wellige Zone des holkgelegten Holzkirpers ohne jerte Neubildung geblieben. Die nene Produktion b hängt also mit der oberen " war nicht zusammen; die ohere " ist bedentend dicker. Beiden gemeinsam und hei allen ähnlichen Nembildungen auf anderen stämmen elenso dentlich erkembar ist die von oben nach unten zmehmende loicke hei jedem einzelnen Gewebstreifen, der in seinem Ansolen durchans die Erscheinung nachahmt. welche die herabrinnenden Masson einer schlecht bremenden Kerze darstellen. In der Tat ergietst sich das nutere, im Bau dem Ringelwulst gleichende Ende der Nenbildung troptentörmig über die nackt gebliebenen stellen des Holzkörpers "': ja, an den absichtlich

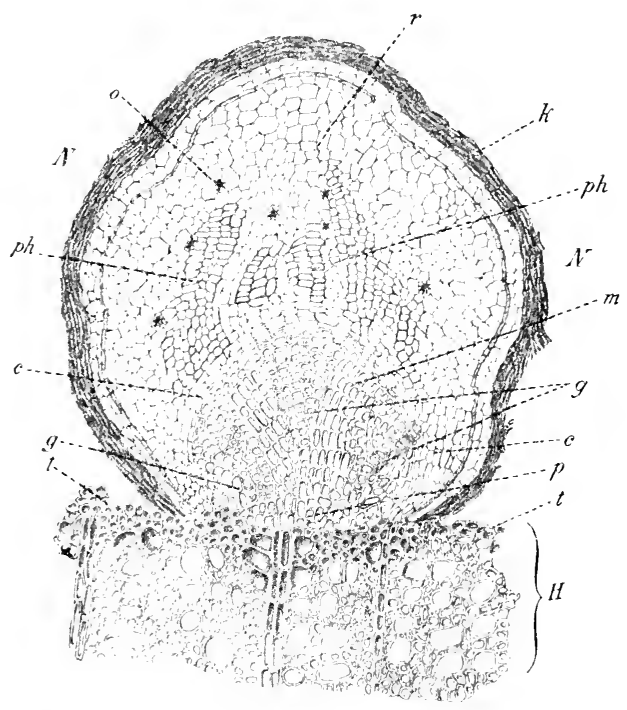

Fig. 1ss. Quershnitt durch eine neu entstandene Gewebeschwiele auf dem blofsgelegten Holzköruer eines geschälten süfskirschenstammes. (Orig.)

schräg gehaltenen stämmen läst sich lis Neubilılung, wie bei oiner schräg gohaltenen, brommenten Korze das Paraffin, von der Achse los mol wächst, der silhworkratt folgend, als isolierter Zopf senkrecht alwäits ( $\left.6^{\prime}\right)$.

Tm nun zu zoigen, dats die einzelnen kleinen Inseln, wie solehe

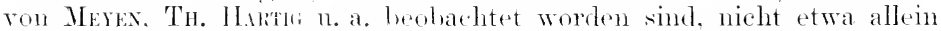
Markstrahlproduktionen sint, ist pine solehe inselartige Nenbildme in Fig. 18s im Quersehnit. in Fig. 1s! im Längsithnitt dargestellt worden. Fig. 1st, $H$ zoigt das alte Hollz, dessen schälfäche t-t zum Toil abgestorlen ist: nur dor mittlere Teil hat sich zu einer nenen Prochlition $\mathrm{N}-\mathrm{N}$ angesehickt.

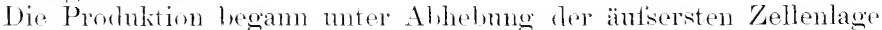
durch die schnell entstehenten Teilprohnke der nächstimmeren splint- 
schicht, und zwar sowohl der jumgen Holzzellun sant den Getä1sen als auch der Markstrahlzellen.

Nach haldiger Umgrenzung der verhälnisnailsig spälichen Neubildung aus parenchymatischem Gewele $(r$ his $/ 1)$ durch die dicker werdende Korkzone $l_{i}$ erscheint seln frïh. mul zwal arst stranwrise, dam zusammenhängend eine imnere Meristemzone, das nen ('ambium (c bis c), das num das sekmoläre Wathstum des nenen Rindenkïrpers ïbernimmt.

Dadurch unterseheiden sich auch solu wesentlieh die beidem Wachstmusvorgänge, die hei der Neuberindung von sichälstellen ein-

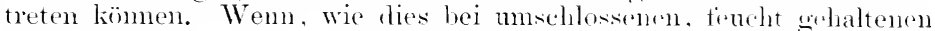

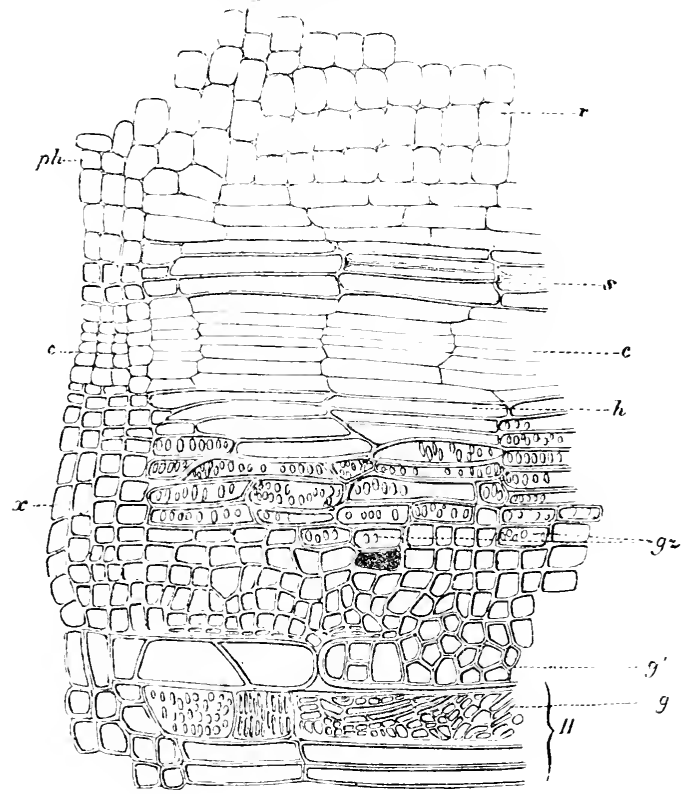

Fig. 189. Längsichnitt dureh die Basalpartie von Fig. 1ss, etwa in der ron " bis p befindlinhen Zone. (Oriw.)

Wunden der Fall ist, dir nene Rinde mit mächtioner callusporluktion

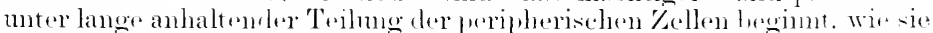

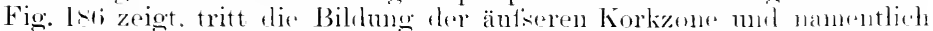
die Entstrhumg der inneren Meristemzone sehr spät ein. Im tienenteil hiervon zeigen, wie in vorlingenelen Falle, die der heitsen sommer.

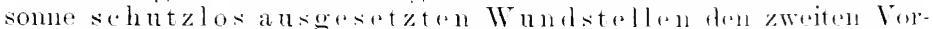
gang. indem die autsersten der stehengelliebenun \%ollen ilur Aulsenmembranen schnell verlicken. Wobei sie zusanmensinkm nud ant diese Weise den nächstiumeren Shehichten den nötiens sidrut\% vor Austrocknmog gewähren: hior findet nur weringe Panenehrmbildmeng and sehr baldiges Auttreten der Cambiumzone statt. Es shorint somit, dats 
die innere Meristemzone sich in einem Callus nmso schneller ausbildet, jeschnellersich durch Verkorkung ein genïgender Rindendruck herstellt.

Die nächste Produktion der newen ('ambiumherde Fig. 188, $c-c$ besteht in der Anlage isolierter, nener (iefatshündelstränge, die, mit einzelnen kurzen Getätszellen $(g)$ begimment, mit zumehmendem Alter die Zahl und Grölse ihrer Elemente schnell vermehren und so eine lieilförmige Gestalt erlangen, welche die anfänglich moemein breiten Markstrahlregionen (m) immer mehr verengen, bis Ban und Lagerung der Elemente das normale Stadinm des moeschälten stammes erreicht haben. Zu jedem Xylemteil wehört ein Phlö̈mteil ( $/$ h), in dessen Nähe zahlreiche Zellen mit oxalsamrem Kalk $(o)$ erscheinen.

Wir sehen, dats das Auftreten der Gefätsbiundel in dem parenchrmatischen Grundgewebe dasselbe wie in lem RingelwuIst ist. So ist es überall, wo eine parenehrmatische Grundmasse von gröfserer Ausilehnung gebildet wird. Durch Querfächerung einer Anzahl zunächst in der Form ron der Grundmasse nicht verschiedener oder wenig radial und longitudinal gestreckter Zellen bilden sich Meristemherde, von denen aus die Anlage dickwandiger trewebeelemente erfolgt. Bei von Anfang an sehr üppiger, callöser Kellvermehrung können im Innern der älter werdenden Gewebemassen gleichzeitig zwei parallele Zonen von Meristemsträngen entstehen, die zwei isoliert tortwachsende Holzkörper erzengen, welche erst bei gröfserer Dicke miteinander verschmelzen. Die Bildung isolierter (retätsbündel in der Rinde unserer Bäume ist keine anfiserordentliche seltenheit, wie bei den Knollenmasern gezeigt werden soll.

Die ersten Vorgänge im splint des geschälten Kirschbaumes erkennen wir in Fig. 189, die einen Längsschnitt ans der Basis der Randpartie von Fig. 188 darstellt. $H$ ist flas alte, durch den Schnit nicht mehr alterierte Holz mit längsmaschigen Netzgefälsen (!). In der mach autisen folgenden Splintschicht hat der Schnitt schon derartig ant das in der Ausbildung weit rorgeschrittene Gefäis g' gewirkt, dats der Innenram desselben sich mit Thrllen fiullte und diese zu nener Zellbildung verwendet mid zu parenchrmatischem Holze mmgewandelt wurden. Die nene Lage von Parenchymholz besteht nur aus wenigen Zellen und zeigt alsbald die ersten Anfänge dickwandigerer Elemente in fiestalt knzer, poröser Gefätizellen $g z$ als erste Produlition der nen gebildeten Cambiumschicht c-c. Jede folgonde spätere, aus dem Cambium hervorgegangene Gewebeschicht zeigt schon längere Gefälse; bei / finden wir bereits dünnwandige, zwar noch verkïrte, aber den normalen Holzzellen unverkenmbar ähnliche Elemente, denen entsprechend bei s die Weichbastelemente in der Rinde $r$ antreten: $t$ ist Xylemstrahl, 1'l, Phlö̈mstrahl.

Während im ersten Frühjahr, in welehem sich die Rinde leicht löst, in der Regel am ganzen Stammuntange durch das Abschälen die gleichnamigen Zellen zerrissen werden und somit eine etwaige Wiederberindung, von gleichartigen Elementen ausgehend, auch gleichartio wird, sehen wir zur /eit der Blattentwicklung his zum .Juni hinein die Schälwunden immer unegelmäfiger werden. Es bleiben an einer stelle des Holzzylinders mehr Zellgrupen stehen, wie ant einer anderen, und demgemäls sind die Neubildmgen verschieden. Es kommt damn vor. dats gefätsführende Stücke des diesjährigen splintes durch ein darunter entstandenes, callöses Gewebe in die Höhe getrieben werlen. 
Wem man die Schälwunden ganz unbedeckt lä1st. wird der Eintritt einer Nenberindung in manchen Fällen zweifelhattur: sie gelingt nach meinen Erfahrungen besser im .Juli unl. Wei manchen Bäumen, im Angust wie im April, Nai und Juni. Ahorn mol Erle nïssen frïher geschält werden: zahlreiche Versuche mit dieson Bänmen im Angust waren sämtlich ohıe Erfolg.

Untersucht man eine Sichälwumle, wolche in der heitsen Mittagstunde bei intensiver sommenbelenchtung gemarht nurl ohne jeden Schutz gelassen worden ist, nach einigen Stunden tzm Virsuche wurden Süfskirschen benntzt). so findet man zmnärdst die Farbe des ursprüglich weifsen Holzzylinlers in (ielb ïhergegangen. I) jese Färbmy verdankt die Wundfläche vorzngsweise den IIarkstrahlzellen, dern Wandung sich gebräunt hat.

Die Brämmug ist aut der südwestseite intensiver als an der Nordostseite.

Die Markstrahlen kemmzeichnen sich leicht dadmrch, dafis sir sotort nach Entfernmg der Rinde üher die schälfäche etwas hervorgewölht erscheinen.

Dieser Umstand deutet daranf hin dats die Markstrahlzellen in derselben radialen Entfernmog von der Mittellinie des Stammes schon fester in ihren Wandungen geworten als die jmngen Holzzellen, also in der Entwicklung tortgeschrittener als die gleichalterigen Zellen des Gefätsbündels sind.

Ein solches Voranseilen der Markstrahlen wird sie zum Schwellgewebe stempeln, welches dem nen entstehenden Holzgewebe in der Richtung des Stammrallius Raum schatit.

Znm Teil kommt dieses Hervortreten der Narkstrahlgruppen anch durch das in der Regel nach der Sochälmanipulation ertolgende schnellere Hervorwälhen ilner änt'seren Wandmug zustandr, die (schntzlos) sich sehr schnell verdickt und brännt.

In den Markstrahl- nurl jugendlichen IIolzzellen, die nmmittelbar unter der Wundfläche liegen, vermehrt sich der Zellinhalt: es treten Plasmamassen und später Stärke anf'; erstere ballen sich bei Glyzerinzusatz zu einzehen, gelben Kugeh. Unter der äntsersten Zellschicht. welche alsbald znsammensinkt und nun einen schiitzenden Mantel für das larmuterliegende junge Gewche darstellt. beginnt rlie Neubildung von Zellen durch Auftreten von kuerwandmgen. In den Markstrahlzellen, welche anch hiterbei in der Regel voranseilen. wird durch diw Nenbildung hänfig der Markstrahl verbreitert. indem seine seitlichen Zellen sich fächerartig ïher die angrenzenden Holzzellen anwzulreiten surhen.

Es ist hereits gesagt worden dats aber manehmal anch die Mark-

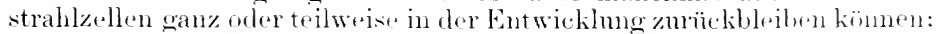
damn legen sich the parenchynatischen. hier nie rundlichen, somelern stets

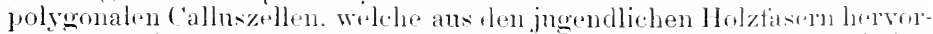
gegangen sind. ïber lir Markstrahlgrupern hinüber. In der Rogel aber beteiligt sich das gesante liewebe gledehmätsig an der Bildnug winer

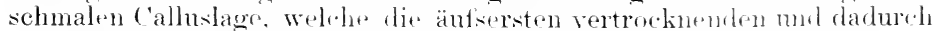
eine sichntzochicht darstellenden Zellen rom alten In, ze abheht.

Während hei den in fenchter Luft unter -chiity gehaltenen schälstellen die Callushilfung durch whohrudes spitzenwachstum der einzelnen Zellreihen eine sehr ledentunde ist. crreicht 
sie hier bei den mosehützten schästellen nur geringe Dimensionen. Tuter der vertrockneten äulieren \%ellsehicht tritt alsbald Korkbildung aut, welche nun oinen schmürenden, fest schützenclen Gürtel für das darmertiegende junge ergrïnende Gewebe darstellt.

Bei der Noubermilumg einer Schälstelle kommt anch noch ein dritter Fall vor. Wem nämlich die schälwmole in der Weise heroestellt worden ist, dats junge Rindenzellen die äntsersten Lagen des blotsgelegten llobkörpers darstellen, dam leiten diese zmächst die Callusbildmo ein, und the eigentliche Cambimmschicht er leidet nu weringe Störungen.

Der ت̈bergang des callus in las normale trewebes findet in allgemeinen in der Weise statt, lats nach Beginn der Korkzellenbildung am Untange des Callus zmächst tiefor im Immern descelben vereinzelte, kurzzellige Gefätsstränge anftreten. Etwa in derselben radialen Richtmo, aber mehr in der Nähe der Randzone. findet man nm diese Zeit knrze, dickwandige. schwach por̈̈e, muegelmätsig gestaltete orler anch polygonale \%ellen, welche die crsten Spuren einer Bastbildmg andenten. Bei manchen Bämmen finden sich vereinzelt oder bald zu Gruppen vereinigt die ersten Bastelemente in Form ron Steinzellennestern. In einer Zone zwischen den Bast- und den Gefälselementen findet man \%ellen mit trïberem, dichterem Inhalt. In diesen treten eine Menge parallelwandiger, in der Richtmo der Längsachse des Stammes etwas gestreckter Kellen ant. Wolche die erste Anlage des nen sich bildenden Cambiums sein dürten. Ton diesem Cambium aus entstehen alluählich die langgestreckten Elemente, die sich endlich zn normalen Holz und Hartbastzellen ansbilden. Nur lange, enge Spiralgefä1se scheinen nicht mehr angelegt zu werden.

Mit der Ansbildung dieser spätest erscheinenden normalen Harthastzellen diurte sich die nene Rincle anch in ihrer Funktion der unverseht gehliebenen angeschlosien haben.

\section{Eas Biegen der Zweige.}

Als oin spezielles Hiltsmittel sler Obstkultur kommt das Biegen der \%weige vieltach zm Anwendmug. Die Erfahrmo zeigt nämlich, lats Triobe, welche senkrecht in die Höhe wachsen, am schmellsten

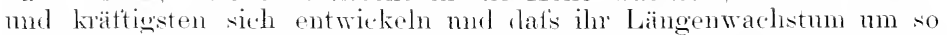
mehr verlangsamt wirl, je mehr der Zweig von der Vertikalen nach der Horizontalen hin geneigt wirl. Dieselbe Terlangsammo des spitzenwachstums zrigt sich aber anch, wenn /weige ans natiulich gegehener Horizontallage mehr zur Senkrechten hin kïnstlich gebogen werden, worans zn ertennen ist, lats die Biegnow an sirh den hemmenden Einflutis ansiulit.

Eine änferlich wahrnolnmbare. Wumble entstelit hei vorsichtiger Ausführme der Manipulation nicht: man gewaht num an der Oberseite eine

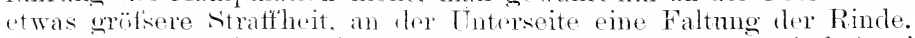

1)ureh das Biegen wirl die Anstildnug dre Angen beeinflutst, inlem die miterhall, , ler Biegungstell. stehonden Knospen stärlier anschwellen mul nicht selten vorzeitig austreiben. Der Erfolg hängt davon ah, wann und in wolcher llöhe ein /weig gebogen wird. Je näher sich die Biegungsstalle der /weigspitze befindet, desto geringer die inners Verwmilmus, desto wringer aber anch der gewïnschte Ertolg. Es werden sich dam die moterhall, der Biegmog befindlichen 
Augen zu schlanken Laubtrieben entfalten, währond bei einer Krümmung des Zweiges an seiner Basis die zur Streckung angeregten Augen nur Triebe von geringer Länge entwickeln werlen: letztere aber zeigen dam Neigung, sich zu Fruchtholz muzuwandehn.
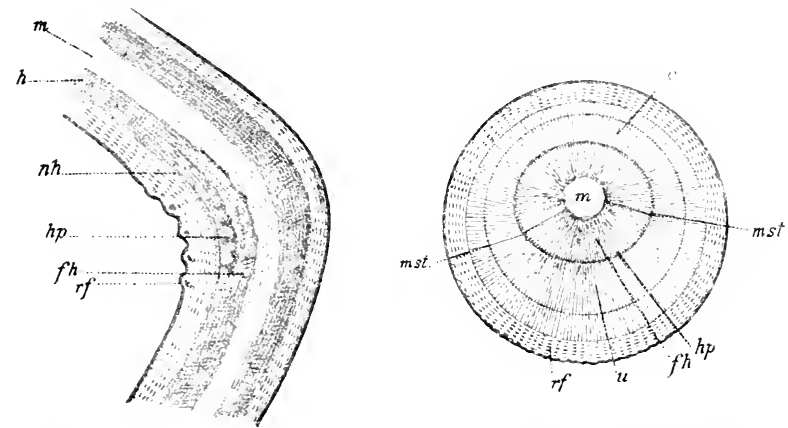

Fig. 194 u. 191. Künstlich gebogener Apfelzweig im Längs- und Querschnitt. Orig.)

Wir strachen ohen von einer inneren Verletzmer der Achse auch hei sorgfältiger Biegung. Diesc lemen wir am hesten an einem bestimmten Brispiel kemen. wie es in ren Fig. 19n-194 von einem Aptelzweige vorgeführt wird.

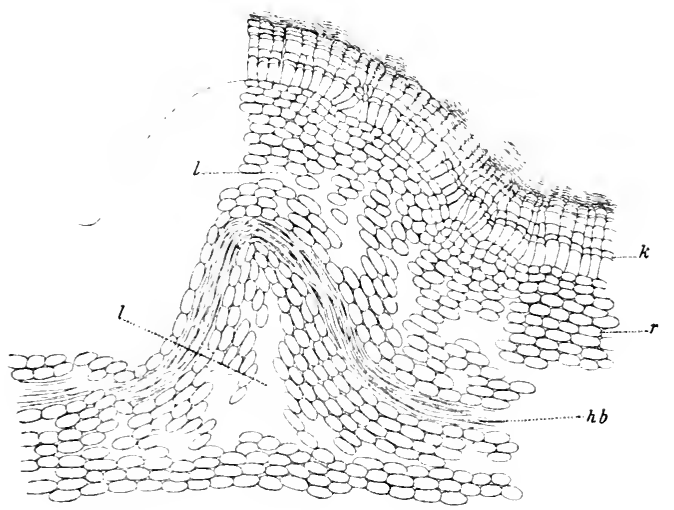

Fig. 192. Rindenfalte von der Lnterseite der Biegungsstelle. (Orig.)

Die Faltung der Rinde ist anf Fig. 19. rf und Fig. 191, if angedentet. Man findet zunächst schon hei der Betrachtmng mit blotisem Auge im Längsschnitt (Fig. 19!1. h) und im Querschnitt (Fig. 191. ") eine Holzanschwellung auf der Lnterseite unterhall, einer mattbräunlichen, an der Biegungsstelle verbreiterten Zone (Fig. 1!n und 1!1, h p). Der Rinden- 
kïrper zeigt antser der Faltung keine so wahruehmhare, gleichmätsig zumbhmende Verdickinng.

las Dickenverhältnis der Unterseite zur Oherseite der Rincle ist hri dem hier gezeichneten Aptelzweige wie ., : : 4., während die Unterseite les Holzkörpers sieh zur Oberseite verhält wie 2:1. I)er Markkärver (m) erscheint im Längsschnitt, hesonders in der unteren Hälfte,

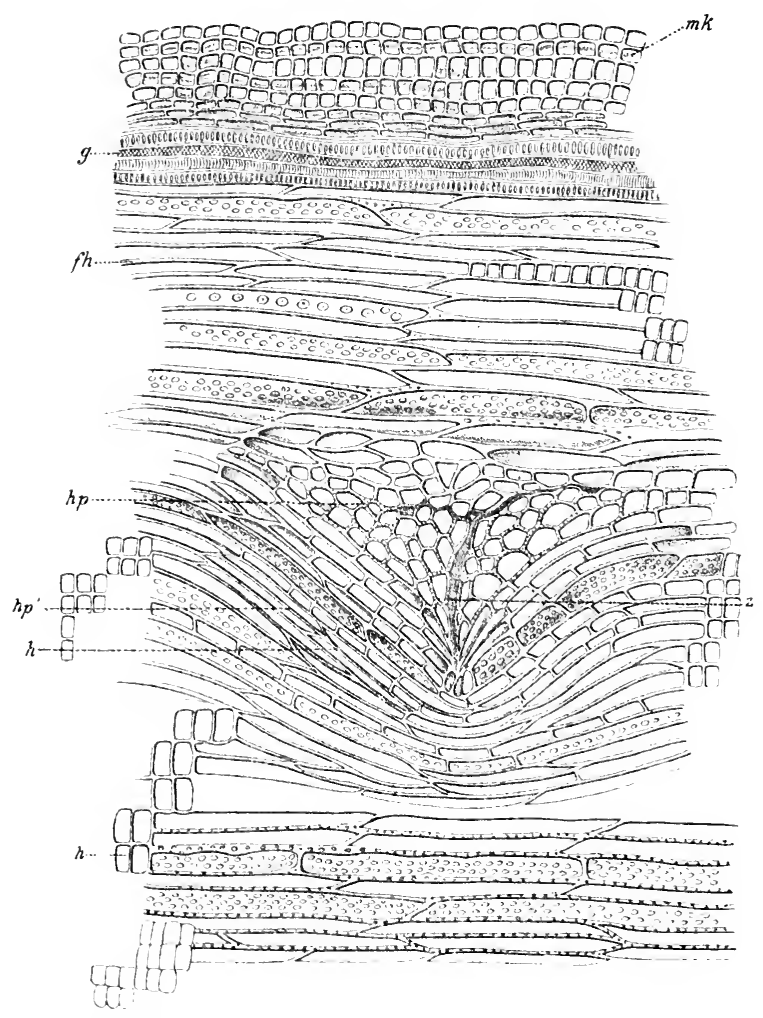

Fig. 193. Längsschnitt dureh den Holzkörper innerhalb der Biegung. (Orig.)

schwach bräunlich grestreift. Unter dem Mikroskop erweisen sich vicle der oft in wellige Reihen geordneten Zellen des Markes und der Markkrone mit bränulichem Inlialte und geblöunten Wandungen, welche bei sinzelnen \%ollen, die der Markunterseite angehören, hier und da einweknickt sind mol an diesen knickstellen dureh nen entstandene InterCellularränme voneinander getrennt sind (Fig. 194). Dieselbe Lockermg zeigen diese Zellen auch im truersehnitt. 
Die störungen der Rinde lassen sich an leichtesten in den vorspringenden Falten ler Unterseite (Fig. 1!n und 1!1, \%) erkemmen. In solehen, durch das Biegen vom Holzhörper ahweplatzten Falten zeigen die Bastbïnclel ( Fig. 1!2, $h b$ ) in der Regel eine starke Krömmmmg nach autisen, entsprechend den peripherischen, durch ils quotschon der Epidermiszellen in bedeutender Dicke entstandenen korklagen (k) samt dem Rindemparenchyon $(r)$, das durch zahlrejehe lä̈cken $(/)$ in moregelmäfige Partien auseinandex gerïclst ist. In dieson liärhen finden sich einige reit nach der Biegung einzelne Brïelen radial pestrecliter

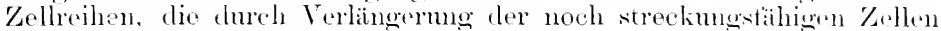
der jungen Innemrinde entstanden sind.

loie Biegumg ist an vorliegenden Apfelzweige zu Anting des

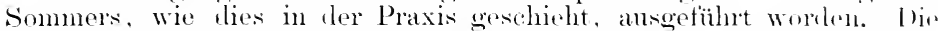
Rinde hat sich an den oben beschriebenen Falten in der ('ambialregion rom Holzkörper abgehoben. Ile Betreing des Holzkörpers an diesen Stellen rom Rindendruck hat die Bildung eines reichlichen,

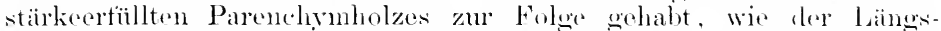

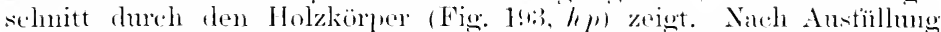

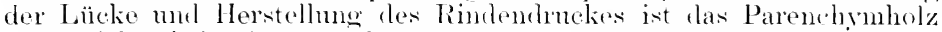
allmählich wieder in mormales llolz (Fing. 19!3, hli) äbroregangen.

Die Austüllumer der Lïclie arfolote hior nach Verschmelzum der beiden anfeinander zu wachsenten Parenchympartien, die sich in der Mittelzone (z) vereinigt halhen. Diese gell gefäbte \%one löst sich leei starkir Veroriofiserung in einem streiten stark zusammengepretster Lellen auf. In anderen Fïllen entsteht die Austüillum der Lïeke anch dureh parenchymatische Nouhilklumgen sowohl vom der aberehobenen Rindenzone als anch - wie

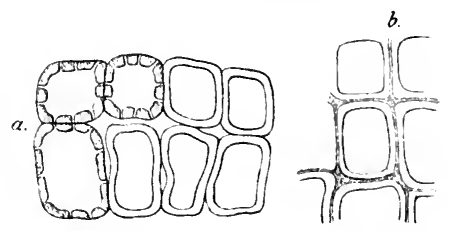

Fig. 194. " Markzellen, welche durch die Biegung gelockert, bolche, die unversehrt geblieben sind. (1)rig.)

bei schälwumlen - von dem stehengebliebenen jungen splintgewebe aus. In allen Fällen begimnen nach der Anstüllung zunächst Trefül'se in Parenchymholz aufzutreten, die allmählich ihre nornale läinge nud Ansbildung erhalten, von antangs lï̈zeren, dämwandigeren, später normal langen und dickwandigeren llolzzellen benleitet werden und so die normale Holzbildung einleiten.

Nach der Schliotsumg dieser Biegungswunden ist der Eintluts der Biegumg aber immer noch weiter duch eine anf der Unterseite stälier als anf der Uherseite stattfindencle IIolzproduktion bemerklan. Das nengebildete 110lz (Fig. 19:3, h) folgt auf der Unterseite in soiner Lagerung der Wellenform. Welche ilurch den Parenchrmbolzkingel hol

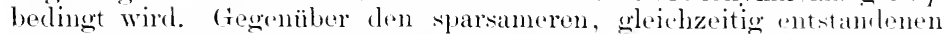

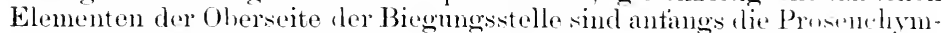
zellen auf der Unterseite kiirzer und stmmpt mit breiten IV andmigen anfeinander stehend. Ferner finden sich ant der Untersede zunichst reichlicher gefächerte, mit stärlse erfällte Holzzellen mul Paronchrmholzreihen $\left.(h)^{\prime}\right)$ zwischen den derbwandigen, prosinchrmatischen Elementen.

In der Zeichnmo sind des beschänkten Rammes wegen grötsere

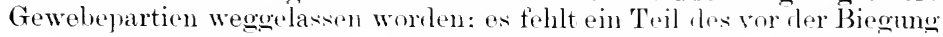


gebildeten. normalen Holzkörpers sowie ein Teil des nach der Bildung des Parenchrmholzes entstandenen, die Biegung ansoleichenden Übergangsgewebes. In Fig. 193 bedentet $f$ l das diesjährige Frühlingsholz, a die den Markköruer mli begrenzenden Spiralgetätse. Fig. 194 sind a die Markzellen, die durch die Biegung gelockert. b solche, die unversehrt geblieben sind und aus der oberen Hälfte des Markkörper's stammen.

Wem man den gekrümmten Zweig von der Biegungsstelle ans aufwärts und abwärts untersucht, so findet man, dafs im vorliegenden Falle der Einfluts der Krümmung sich durchschnitlich auf etwa if bis 8 cm Länge erstreckit.

Die IIessungen des zur Zeichnung gewählten Zweiges ergaben folgendes:

Lie Dicke des Zweiges betrug 4,6.5 mm unterhalb der Biegungsstelle, $5.511 \mathrm{~mm}$ innerhalb und $5 ., 06 \mathrm{~mm}$ oberhalb der Biegungsstelle. Die Rinde zeigte nach der Spitze hin eine bedentende Dickenzunahme. Die Dicke des Holzkörpers vor der Manipulation betrug

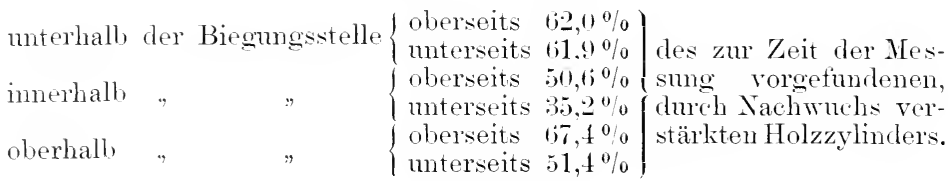

Der Zuwachs ron der Zeit der Biegung bis zur Zeit der Untersuchung betrug

an Herbstholz an Frühlingsholz

\begin{tabular}{|c|c|c|c|c|}
\hline unterhalb & der & Biegungsstelle & $\begin{array}{l}\text { oberseits } 31,0^{0} 0^{0} \\
\text { muterseits }: 31,9 \%\end{array}$ & $\begin{array}{l}8,11 \% \\
6,1 \%\end{array}$ \\
\hline & & & oberseits $39,0^{\circ} \%$ & $10,4^{\circ} \%$ \\
\hline mnerhalb & $"$ & $"$ & unterseits $51.8 \%$ & $\mathrm{~J} 3,+4 \%$ \\
\hline oberhalb & $"$ & $"$ & $\begin{array}{l}\text { oberseits } 28,1 \% \\
\text { mnterseits } 27,2 \% 0\end{array}$ & $\begin{array}{r}5,9^{\circ} / 0 \\
21,9 \% / 0\end{array}$ \\
\hline
\end{tabular}

Also der Holzzuwachs ist trotz der grofsen Spannung, die durch das Biegen des Zweiges an der konvexen Seite imnerhalb der Biegungsstelle herrschen dürfte ${ }^{\mathbf{1}}$ ), doch auch an der Oberseite verhältnismälsig höher als ober- und unterhalb der gebogenen Stelle. Die Gewebelockerming, welche sich an der Biegungsstelle geltend macht, ist anf der Oberseite nicht mehr weit hinaut kenntlich; dagegen lätst sich dieselbe anf der Unterseite noch bis anf $6 \mathrm{~cm}$ nach der Spitze hin verfolgen.

Die Holzzellen sind innerhalb der Biegungsstelle am weitesten; oberhalb derselben sind sie noch weiter als unterhalb. Auf' der Zweigmuterseite erschienen sie hier weiter als anf der Zweigoberseite.

Je nach der (Arötse des Bogens, den der Zweig bei der Krümmung. beschreibt, sowie je nach der Zeit der Ausführumg der Biegung und nach der Spezies, ja selbst je nach der Individualität des Zweiges sind die anatomischen Verändermengen quantitativ wechselnd.

1) Über das Zustandekommen der Druckspannung vgl. Unsprcxi, H., Beitrag zur Erklärung des exzentrischen Dickenwachstums an Krautpflanzen. Ber.d.Deutsch. Bot. Ges. 1906, Heft 9, S. 499. Ferner: Bicner, H., Anatomische Veränderungen hei gewaltsamer Krömmung und geotropischer Indnktion. Jahrb. f. wiss. Bot. 1906 , Bd. 13, s. 271 . 
Man hat also in dem Biegen der \%wroge ein einfaches Mittel, den Längstrieb zu mälsigen nnd die Wasserzufuhr auf Augen zu lenken. Welehe ihror Lage und Anlagenach wenigzur Weiterentwicklung betahigt sind.

Weit energischer und nachhaltiger als das "Biegen wirkt in derselben Richtung

\section{das Drehen der Zweige.}

Ein weiteres Kulturhiltsmittel der Obstzüchter behnts Ändorung des Wachstums der Zweige stellt das Drehen derselben dar. Während der Vegetationszeit wird nämlich ein zu üppig wachsender \%weig in einer schon verholzten, kuzen Region zuerst durch halhseitiges Drehen der Gewebe milne Längsachse in diesen Partien gelockert, meist dabei auch schon gequetscht und der Länge nach gespalten mol dam an dieser gelockerten stelle mit seiner Spitze schleitenartig nach min gebogen, so dat's die spitze des /weiges in einer nach der Basis gerichteten Lage verbleibt. An der Irehmosstelle gelangt dadurch die Unterseite des Zweiges nach oben, die frühere Oherseite hildet die Imnenseite der scharfon Biegung, in welcher der IJolzkïrper bis zum Mark einbricht.

Ein möglichst übersichtliches Bild der durch die Drehmng entstandenen Verändermogen liefert der Längssehnit durch die linotige. vorwachsene, ein Jahr alte Drehmngsitelle Fig. 19.). Darin ist "' der Markkörper, der durch den beim Drehen erfolgten Bruch des Holzes mit gestïrt worden ist. $h$ ist das

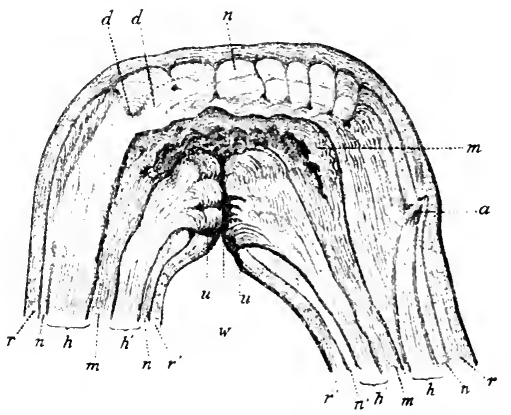

Fig. 19.5. Ein nit seiner șitze abwärts gebogener und an der Biegungsstelle um seine Läingsachse gedrehter Zweignach Verwachsung der inneren Verwundungen. (Orig.) Holz der jetzigen oherseite. an dem hei a cin Auge sitzt. Durch die Umolrehung der Unterseite zur jetzigen Oberseite ist der Holzkörper vieltach längsspaltig geworden. und tie dureh die Risse entstandenon Lamellen sind in spiralige Drehmng gekommen, was durch dd angedentet werden soll. Die Risie werilon zunächst durch Parenchym ausgetüllt, und die allmählich sich wiodor schlietsende Cambiumzone lagert welligr Nenholaschichten $(n)$ älur die Wunden unterhall, der autserordentlich gespannten, nicht selten durch spiralige Längsisse hier und da weklïtteten Rinde $(r)$.

Die nach der Trehmon zur Unterseite gewordene organiselo olserseite zeigt noch grösere Störungen. Der in " zerbrochene. rom Mark teilweis abgespaltene Holzkörper $(h)$ hat sich durch sehr mreg.elmälsig bogig gelagerte Partien ron Parenchrmholz zu einem uroten Kuoten u geschlossen, der hoi tortgesetztem Wachstum dur.h die Neuholzbildungen $\left(n^{\prime}\right)$ stetig an Untang zunimmt.

Dats duch eine derartige Gewebeverletzung die Spitzenernährung des Zweiges gestärt werden muls. und dats das als stärke sichtbare Reservematerial in den parenchymatischen T̈berwallungspartien der 
Wundränder den nächstliegenden Angen zum Torteil gereichen muls, ist leicht einzusehen. Dats neben dieser stärkeren Ernährung auch die ummittelbar unter der Drehungsstelle befindlichen Augen von dem vermehrten Wasserdrucke profitieren werden, geht ans dem früher Gesagten ebenfalls zur Genïge hervor.

Die Manipulation des Drehens ist, wie bemerkt, ein energischeres Mittel zur Lähmmng des Spitzenwachstums eines Zweiges zu gunsten der stärkung basaler Augen, ohne aber dabei das mnter der Verwundung liegende, höchste Seitenange zum sofortigen starken Austreiben zu veranlassen. Nur wemn durch die Drehming die Verletzung der Gewebe so stark ausgefallen ist, dat's die Triebspitze auch das notwendigste, durch Verdunstung entweichende Wasser nicht mehr erhalten kann und schnell vertrocknet, namentlich wenn die Manipulation zu frülı im Jahre ausgefïhrt wird, wächst das zunächst unter der Trehmngstelle befindliche seitenauge zu einem neuen, liäftigen Laubtriebe ans. Dieser Erfolg wird natürlich vom Obstzüchter nicht beabsichtigt. Eine zu spät im Jahre ausgeführte Drehung würde zwar nicht melır die genügende Wirkung hervorbringen, basale Angen zu Fruchtangen vorzubereiten, aber doch das Längenwachstum des Zweiges hemmen und das Holz mehr zur Reife bringen, so dats es dem Winter besser widersteht.

Bei der Senkervermehrung der Quitten dreht man auch gern einmal den abzusenkenden Zweig um seine Längsachse an der Stelle, an welcher er in der Erde Wurzeln bilden soll. Die Art der störung ist ähnlich wie bei dem vorerwähnten Falle; der Ertolg insotern ein anderer, als das gehemmte, absteigende, plastische Material volzugsweise zur Bildung ron Adventivwurzeln verwendet wird.

Die deutschen Weinbauer in der Umgegend von Tiflis sollen die Stiele der reiten Weintrauben drehen und daduch einen besseren Wein erzielen. Die durch diese Manipulation eingeleiteten Vorgänge werden folgendermatsen ineinander greifen. Durch das Drehen des Stiels wird die Wasserzufuhr aus der Rebe in die Traube gemätsigt; infolgerlessen erlangt die Verdunstung ein grölseres Übergewicht über die Zutuhr, und der Satt der Beeren wird concentrierter. WVas an Stärlie etwa noch in den Stielen ist, wird als Zucker nach den Beeren gesthickt. Dieselben veratmen dabei anch einen Teil der organischen sämren. Dieselben Prozesse finden bei tem Nachreifen der abgeschnittenen Trauben statt.

\section{Wirkung des Einschnürens der Achse.}

Das .Einschnüren" besteht in dem dichten Umlegen eines nicht nachlassenden Bandes (aus Bindfaden, Draht u. dol.) um einen Stamm oder Zweig. Dit Folgen dieser Manipulation eroben sich aus der einfachen Betrachtung, dats dieses Einschnören einer Achse nichts anderes ist, als eine lokale, künstliche Vermehrmng des Rindenrruckes. Nur findet hier alsbald der extremste Fall von Rindendruck statt, indem die Neubildungen unter der geschnürten Stelle allmählich his ant ein Minimum reduziert werden und endlich gänzlich anflıören. Die Holzelemente in der Nähe des sehnürenden Bandes kommen dabei aus ihrem senkrechten Terlante und nehmen eine schiefe, ja selbst bis zur horizontalen sich steigernde Lagermng an, so dats ich glaube, dafs anch im normalen Banme die mehr oder weniger spiralige 
Drehung der Holzfasern bei den verschiedenen Bämmen mit dem grötseren oder geringeren Druck zusammenhängt, den die Rinde ausübt.

Endlich wird dic Verdickung des Baumes olerhall der geschnürten Stelle so grots, dats die Rinde oberhalb und später auch unterhalb des Bandes reilst, also nun der Rindendruck fast gänzlich aufgelıoben wird. Die Folge davon ist eine ïppige Bildung von Parenchrnoliolz, das mit dem Älterwerden des Pflanzenteils in den späteren Jahreslagen allmählich in normales Holz übergeht und das Band, bzw. den Iraht gänzlich überwallt. Eine solche ïberwallte Schnürstelle hat dann äutserlich wrotse Ähnlichkeit mit einer Veredlungsstelle, im inneren Ban natïrlich nicht.

In der umstehenden Fig. 19; sind zwei verschiedene stadien des Einschnürens dargestellt. Fig. 196, 1 ist ein einjähriger thornzweig, der eine Schnïrstelle von wenigen Monaten besitzt. Fig. 196, \& zeigt cin älteres Aststück, das eine mehrjährige Überwallmng eines Drahtringes anfzuweisen hat. Fig. 196, 3 ist der Längsschnitt von Fig. 19;, 2 , und im ersteren ist $d$ und $d^{\prime}$ der Durchsehnitt des Drahtringes, $u$ der Überwallungsrand, welcher an der einen Seite (u') durch die erhöhte Nälnstottzufuhr seitens des überstehenden /weiges z stärker entwickelt ist und den Draht früher überwallt hat als an der Gegenseite.

Die anatomische Untersuchumg des in Fig. 19t, 1 dargestellten stadiums ergab, dats das schmüren anfangs nieht sehr durchgreifende Veränderungen hervorzurufen vermag. Den wesentlichsten Nachteil hat die Rinde erlitten, und zwar sind es vorzugsweise die in der primären Rinde nach auken hin zwischen den Iartbastzellen, respelitive den Steinzellnestern und der Epidermis liegenden Zellschichten, welche zusammengedrückt worden sind. Am stärksten zusammengeprefist erscheinen die dem Hartbast am nächsten liegenden /elllagen: weniger schart ist der Einflut's anf die nach aulsen folgenden, oft sehon collenchymatisch verdiekten Iagen: ihre Kellen werden aut die Hälfte bis aut ein Viertel ilires normalen Querdurchmessers zusammengedrückt, und es scheint, als wïrden sie labei anch etwas verlängert gegenüber den entsprechenden, an einer ungeschürten stelle liegenden Kellen. Die subepidermalen, fast quadratischen /ellen werden auf etwa die Hältte ilıres (Querdurchmessers zusammengeprelst; am wenigsten leidet die Epidermis.

Wem, wie hier in Fig. 1!H, 1 das schnürende Band mehrmals mm den Zweig geschlungen ist, damn machen sich zwischen je zwei Umschlingungen scheinbar weit vortretende Wülste bemerkbar. In diesen ist die erwälnte Rindempartie in der entgegengesetzten Weise wie an der Schnürstelle ausgebilulet. Die im normalen /weige in der Läng:richtumg gestreckten, dem Hartbast angrenzenden Zellen sind radial bedentend erweitert, ja kommen sellst lang cylindrisch in einer senkrecht auf die Harthastzellen verlaufenden Richtung vor: daturch wird das ïber ihnen liegende Rindengewebe, das weniger an der radialen Erweiterung teihimmt, in die IIöhe gehoben. Ërigens sind die zwischen zwei śchnürstellen liegenden Aufwulstungen gar nicht absolut grots: sie erscheinen nur im Gegensatz zu den Vertiefungen besonders auffallend. Den Anshuchtungen und Pressungen der primären Rinde folgen, wenn anch mit weit geringeren schwankmngen, die sekundäre Rinde und der Holzkörper. Der Druck. Welcher sich ant die Gewebe geltend macht, wirkt nicht nur so weit, als gerade das Band aut der Rinde anfliegt. sondern anch noch ctwas ober- und unterhalb der eigentlichen Schnürstelle: man merkt dies an dem Quer- 
durchmesser der Zellen. Diese zeigten im Mittel aus zeln Messungen ein gegenseitiges Verhältnis

$\begin{array}{ccc} & \text { in der Rinde } & \\ \text { Normale } & \text { Wulst } & \text { geschnürt } \\ \text { Fig. 19t;, } 1 u & \text { Fig. } 196,1 w & \text { Fig. 196, } 1 g \\ 11,2 & 11,8 & 9,4 \\ 7,3 & \text { im Holz } & \\ & 1,9 & 4,6\end{array}$

Nach diesen Mittelzahlen, deren Glieder übrigens bedentende Schwankungen darstellen. gibt sich also nur in den rundlich und weiter erscheinenden Rindenzellen eine Tergrötserung liund; die Holzzellen dagegen erscheinen etwas enger als im normalen Holze, wobei jedoch zu betonen, dat's dieselben grifisten Breitendurchmesser der Holzzellen im Wulst wie in dem normalen von der Schnürstelle entfernten Zweigteile angetroffen werden und nur die Häufigkeit des Torkommens den Ausschlag gibt.

Wenn die Schnïrstelle jedoch älter wird, ohne dafs das Band gelockert oder gelöst werden kann, wie dies bei der in Fig. 19t;, 2 und 3 dargestellten Drahtumschlingung der Fall ist. dam nimmt endlich durch das Dickenwachstum des Holzkörpers des Stämmchens der Druck des Drahtes auf die Rindenschichten derartig zu, dats dieselben getötet und in eine braune, krümelnde Masse verwandelt werden. Schliefslich reitst die gesunde Rinde ober- und unterhalb des Drahtes ein, und nun beginnt der Einschluts des Drahtes durch Überwallmng. Dadurch, dafs die ïberwallenden Schichten des Jahresringes in Holz und Rinde bedentend dicker als an den rom Draht entfernten Stellen sind, tritt die ehemalige schnürstelle als bedeutender Wulst hervor.

Fig. 196, 4 zeigt den in Fig. 194, 3 bei a angerlenteten Ausschnitt wesentlich vergrötsert. Wir sehen hier im Längsschnitt einen kleinen 'Teil des alten Holzes des /weiges $H$ vor der Anlegung des Drahtes d und gewahren die Neubildungen des Überwallumgsrandes zunäclist in der engsten Ungebung $U$ des Drahtes und daranf eine Fortsetzung dieses Gewebes aus ciner älteren Jahreslage $U^{\prime}$. Die Übergänge sind aus Mangel an Raum fortgelassen worden; ebenso fehlt die Darstellung der. über $U^{\prime}$ hinausgehenden Verschmelzung dieses ganzen oberen Überwallungsrandes mit dem unteren und die Darstellmo des Überganges von den wirr verlautenden Holzelementen des Überwallungsrandes zu dem normalen Holzbau, wie derselbe in den späteren Jahreslagen über der Drahtstelle wieder allmählich zustande kommt.

Wäre das Holz ohne die Behinderung durch den Draht normal weiter gewachsen, lann lätte der Bau derselbe bleiben müssen, wie er in $H$ vor der schnürung sich darstellt; es wären in regelmäfsiger Aufeinanderfolge Holzzellen $/$ mit Getälsö̈hren g gebildet worden, und dieses weite Holz wäre durh radial verlanfende Markstrahlen $m$ regelmälsig gefächert worden. Statt dessen sehen wir nun durch den Einfluts des Drahtes ein Holz an der Schniirstelle und oberhalb derselben, $h^{\prime} h^{\prime \prime}$, entstelien, das fast nur aus Holzzellen ohne Gefä1se zusammengesetzt ist. Diese Holzfasern lagern sich auch num noch im Anfang bei $h^{\prime}$ genau in der Längsrichtung des Zweiges: je meln sie sich in der Richtung von $h^{\prime \prime}$ und $h^{\prime \prime \prime}$ befinden, 10 so schräger verlanfen sie, um so gedreliter erscheinen sie. I as nach dem Umlegen des Drahtes gebildete Holz ist 


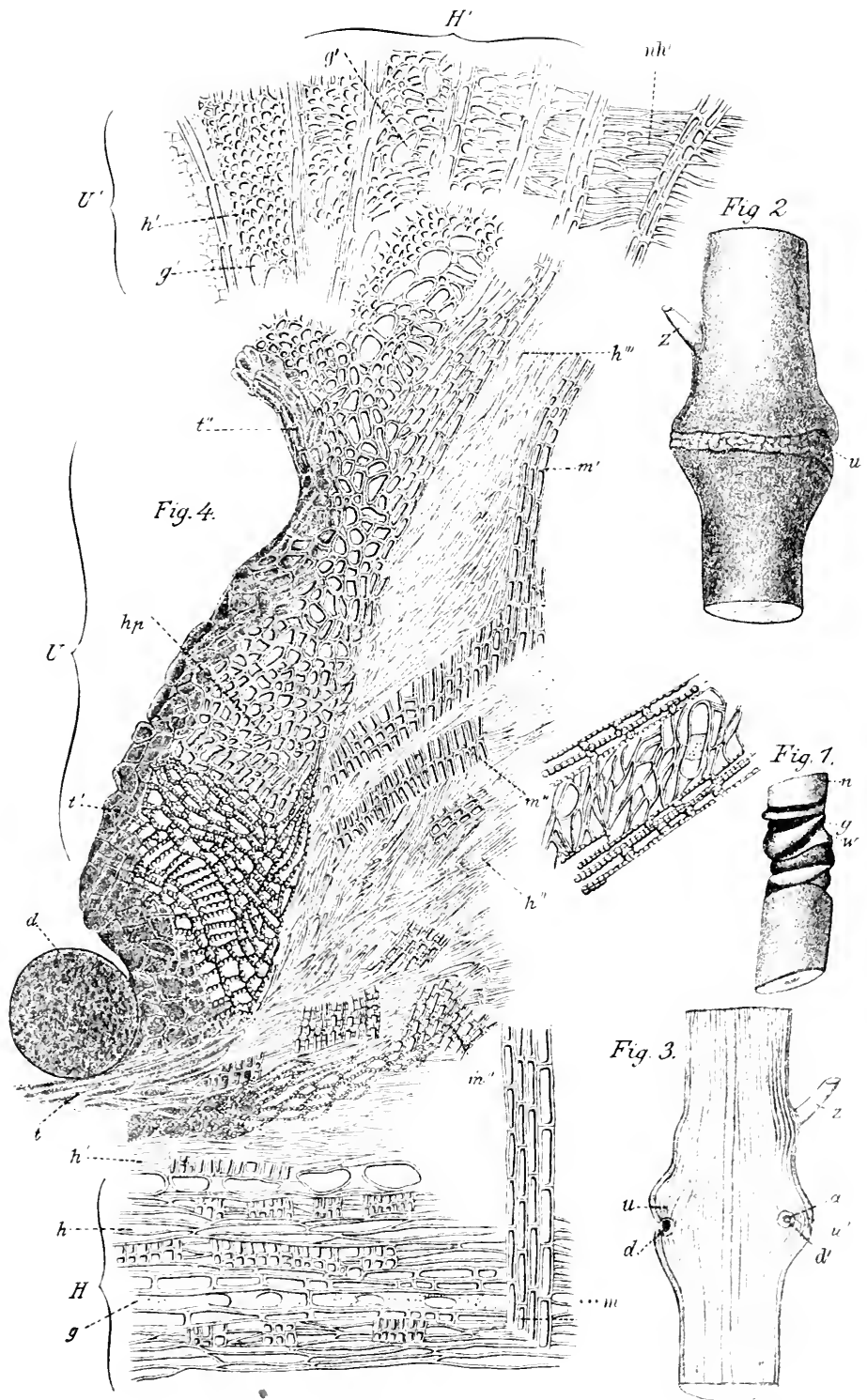

Fig. 196. 1 ist ein einjühriger geschnürter. " ein mehrjihriger \%welg nit thberwalltem Drahtring. :3 Lïngssehnitt durch Fig. ?', $t$ anatmisches Bild eines Längsschnittes aus der Fig. :, a stammenden Zone. (Orik.) 
also dichter, getälsärmer und gedrehter geworden. Die Markstrahlen, welche sonst als grade radiale Bänder vom Marke nach der Rincle hin verlauten, machen dieselbe Drehung und das Answeichen nach oben mit. wie die Holzzellen, so dat's ein genau in der Richtmng des Stammradius geführter Schnitt verschiedene der gebogen verlantenden strahlen $m^{\prime \prime}$ anschneidet.

Den Unterschied zwischen Holzzellen und Markstrahlzellen bemerlit man aber erst in einiger Entfernung von dem Drahte. In dessen unmittelbarster Nähe finden wir ein fast gleichmälsiges parenchymatisches Holz hl, dessen Randpartie abgestorben und schwarz ist und den dunklen strich darstellt, den wir in Fig. 196, 3 vom Draht $d$ aus eine kleine Strecke aufwärts verlaufen sehen. Die schwarze Furche geht nicht mehr ganz nach autsen, da die späteren. Jahreslagen (Fig. 196, $3 u^{\prime}$ ) schon miteinander verschmolzen sind. Diese zu einer gemeinsamen, zusammenhängenden Holzlage miteinander verbundenen Überwallungsränder sind in Fig. 196, 4 durch das Gewebe $H^{\prime}$ angedentet. Hier finden wir die Gefätse $g$ und die Holzzellen $n l i$, wie im normalen Holze (nur kiirzer) gebildet: aber ihr Verlaut ist in der Ebene. welche in gleicher Höhe mit dem Draht liegt, horizontal statt vertikal. Erst wenn man ich etwas ron der eigentlichen Schnürstelle nach oben oder unten entfernt, fangen diese Elemente an, allmählich in den senkrechten, normalen Verlant überzugehen. Fig. $196,4 g^{\prime} h$. Die gebräunte respektive geschwärzte Zone $l l$ setzt sich nicht mehr bis $U^{\prime}$ fort.

Nicht ohne Grund ist die Bezeichnmo ,gebräunt beziehungsweiso geschwärzt" gewählt worden; denn die Färbung ist von $t$ bis ' $t^{\prime}$ vollkommen tintenschwarz, von da aus nach $t$ " braunschwarz. In der Tat ist es anch Tinte, welche den geromnenen Zellinhalt in der Nähe des Drahtes färbt. Die Gerbsäure des Gewehes hat sich mit dem Eisen des Drahtes verbunden und damit den Zellinhalt der nächsten Umgebung getötet. Diese Verbindung ist num anf weitere Strecken diffundiert, and zwar in dem Markstrahlgewebe weiter in das alte Holz hinein als quer durch die Holzzellen hindurch. Dafs der Draht direkt am alten Holze liegt und eine Zone dessellen schon getötet hat, darf nicht in Erstamnen setzen. wemn man bedenkt, dats der immer stärker werdende Druck des sich ansdehnenden Stammes auf den nicht nachgebenden Draht dazu führt, die weiche Rinde und das Cambium zusammenzudrücken und zu töten. Das tote Gewebe ist nur noch in schwachen Resten am Draht erkennbar.

Wie diese versthiedenen Gewebeformen zustande kommen, haben wir bereits ohen dmch clen erst bis auf das Äutserste gesteigerten und rann durch das Platzen der Rinde nm den Draht herm nahezu vollkommen ansgelösten Rindendruck erklären können. Die fast vollständige Lockermig der weplatzten Rinde lälst ans der Cambiumzone zunächst Parenchymholz hervorgehen: später, wem durch Verschmelzen der Wundränder äber dem dadurch eingeschlossenen Drahte sich der Rindendruck einstellt, treten auch echte Holzzellen und Gefälse wieder ant; aber die Lagerung dieser Elemente ist noch lange Zeit hindurch die horizontale oder spiralige, schiet antsteigende, die sich durch den starken Druck des Inahtes zu der Zeit eingeleitet hat, als die Cambiumzone des Stammes noch hinter dem Drahte lag.

Physiologisch interessant bleibt die extreme Drehung der Holzfasem, die in geringerem Matse bei sehr vielen Bäumen normalerweise 
zu konstatieren ist und bei Individuen derselhen Art in rerschiedenem Grade zum Ausdruek kommt. Aut trockenem staudort ist der Drehw uchs angenfälliger. Wahrscheinlich ist die mincler lange dehubar bleibende, weniger leicht zerklüftende und darum lï̈leren Inuck ausïbende Rinde solcher Exemplare auf trocknem stantort die Ursache der stärkeren Drehung der Holzfasern.

Der praktische Zweck des Schnïrens ist dersclle wie der des Ringelns, aber ohne die Gefahr, welche eine gänzliche Fortnahme grötserer Rindenpartien mit sich bringt.

\section{Zweigstecklinge.}

Als Steckling bezeichnet man jedes von der Nutterptlanze ab. gelöste Glied, das vermöge seiner Reservenahrung cinzelne, vorzngsweise in der Nähe dor Schnittfläche gelegene Kellwrupen zu nener vegetativer Vermehrung anregt, so dats sich meist Ternalbungsurewo einstellt; das abgelöste (ilied entwickelt sich durch Bildung nener If urzeln schliefislich zur selbständigen Pflanze. Über die anatomischen Verlältnisse und die Abhängigkeit der (kewebedifferenzierung von äutseren Faktoren gibt eine Arbeit ron Snox') Autsehluts, die während des Druckes erschien und nicht mehr berïcksichtigt werden lionnte.

Man dart beham,en, dats eine derartige ungeschlechtliche Vermehrung bei allen Klassen des Pflanzenreiches zu finden ist und von den verschiedensten Organen ausgehen kann. Wir erimern an das Fortwachsen abgerissener Mrcelfïlen, zerschnittener sclerotien, abgetrennter Fruchtstiele von Laubmoosen. vonBlatt-und Blütenteilen hei Phanerogamen. Autser den reichlich vorkommenden Wurelstecklingen sind sellst Fälle von Wurzelbildungen aus Frücliten bekannt geworden.

Uns beschättigen hier vorläutig nu die Zweigstecklingr, deren schnittfläche anf den Wundreiz zunächst dureh Callusbildung reacriert. Im Ansehluts daran crörtern wir dann die Vermehrung dureh Wrizelstecklinge, deren Vernarbmg ebentalls mit Callusbildumg begimnt. Die Umwandlung des Callus zum eigentlichen ए̈berwallungssande durch Bildumg einer peripherischen Korkzone hat sehr viel Ähnlichkeit mit der Bildung der T̈berwallungsänder an weringelten oder quer abgeschnittenen holzigen Zweigen. Nur macht sich bei den Stecklingen der Eintluts des fonchten Mediums, in welchem die schnittfläche sich befindet, modifizierend bemerkhar. Anch ist ein Unterschied testzustellen, je nachdem der den steckling liofernde \%weig sich bereits $\mathrm{im}$ verholzten Zustancle befindet oder noch krautartig ist. An stelle weitlänfiger Auseinandersetzungen geben wir hier die Abbildungen cines noch krautartigen Fuchisiensteclilings und eines bereits verholztun Rosenstecklings.

Die Basalpartie eines Fuchsienstecklings (Fig. 197) ist der Länge nach durchschnitten. s bis s bedentet die ursprüngliche Sclmittläche: die unterhalb vortretenden Elemente sind nach dem Alschneiden gobildet, oberhalb s bis s liegen die urspünglivhen Gewelo des stecklings. desisen eine Hältte nur gezeichnet worden ist. m ist der Markliörer, l, der IIolzkörper, $r$ die Rinde, in welcher die IIarthastzellen l, verlanten; rliese sowie ein Teil der Holzzellen $l$ ' sind an der Schnittläche gebräunt und abgestorben: anch die äufsere Rinde $r^{\prime}$ ist in der (iegend der schnitt-

1) Stms, s., Experimentelle [ntersuchungen über die Differenzierungsvorgänge im Callusgewebe von Holzgewächsen. Leipzig 190s, Gebr. Bornträger. 
fläche zusammengetrocknet. Die jüngeren, imneren Rindenschichten dagegen und namentlich der Markkörper halen durch reichliche Zellvermehrung ilne Wundfläche vernarbt. Der äntsere Teil dieses Vernarbungsgewebes ist verkorkt, und diese Korkschicht $l_{i}$ hat eine bedentende Ausdehnung durch die Tätigkeit les Korkcambiums lis erlangt, welche num für das zartere, imnere Rindengewebe den Abschluf's bildet. In der Callnsinde sehen wir die quergestreckten schlanchzellen o mit oxalsaurem Kalk in Raphiden: in der Nähe derselben einzelne Zellgruppen mit dickeren Wandungen l', welche den Bastkörper der Gefälsbündel darstellen. die hereits im Callus sich gehildet haben und deren Holzkör\}er durch Stränge kurzer. netzartig verdickter Gefätszellen g' angedentet ist. Diese legen sich an dic Frefätse im Holz-

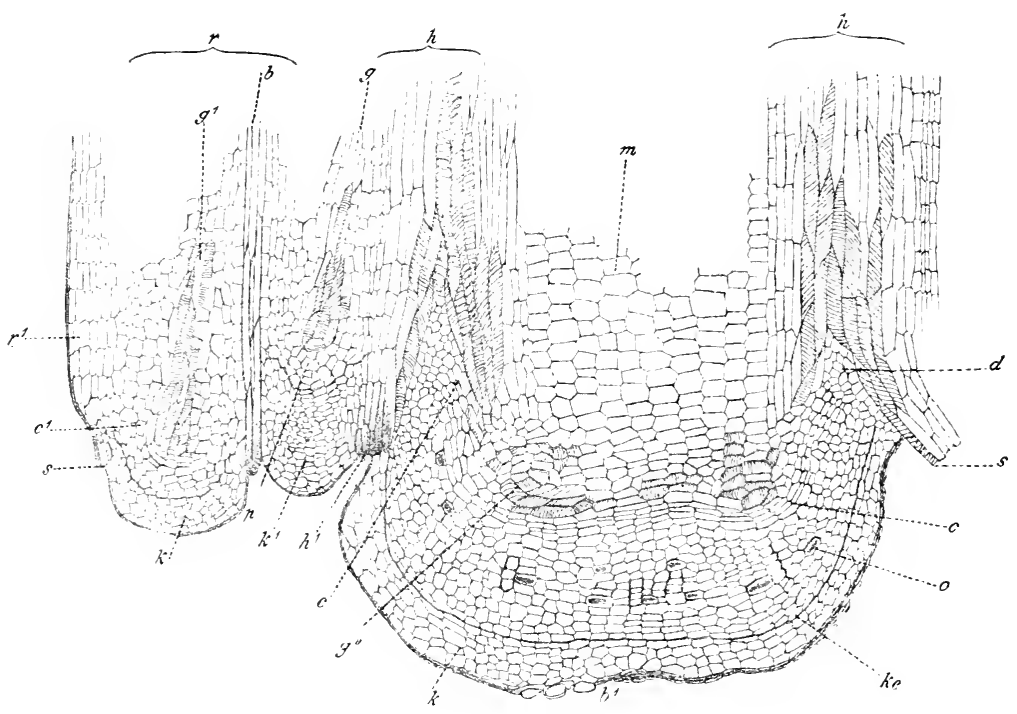

Fig. 197. Fuchsiensteckling. (Orig.

körper des Stecklings an, dessen dünnwandige. stärkereiche, an den Markkörper grenzenden Holzzellen an der Callusbildung teilgenommen haben. Der alte Holzkörper des Stecklings ist bei rem Schneiden eingerissen. Die Ritsstelle d ist ausgefïllt mit Callus, und bis in diese Ritistelle hinein lä1st sich die Cambinmzone $c$ bis c verfolgen, die in einem zusammenhängenden Bogen sich durh den Callus himzieht. Das normale Cambium des Stecklings lag anf der Autsenseite des Holzkörpers h. Hier ist durch das Abschneiden des Zweiges zum Steckling genan diesclbe Veränderung wie bei dem geringelten Zweige eingetreten. Ans dem Cambinm hat sich zunächst gleichmäfsiges, parenchrmatisches Gewebe $\|$ gebilılet, in welchem allmällich kurze, netzförmig verdickte Gefäliselemente "s auftreten. Nach der Schmittläche 
hin haben sich diese Gewebepartien durch eine starke Korkschicht $k^{\prime}$ abgegrenzt. Aber anch in der äntseren Rinde hat eine Zellremehrmng und in dem nenen Gewebe eine Bildung von kuren Getälszellen g' stattgetumden, anf deren Autsenseite cine Meristemschicht \& orkemubar ist.

In dem vorliegenden Beispicle hat neben den Cambimm der Ma k kkörper den llauptbildumsherd fïr den Callus daresesteflt.

Ganz untätio dagegen bleibt das Mark in dem folgenden Falle, bei einem Rosenstecklinge, Fig. 19s.

Auch hier bedentet s bis s dir schmittlinie: alles untwhalh dieser schnittlinie Liegende ist Callushildnng, die in dicken Wïlsten aus dem

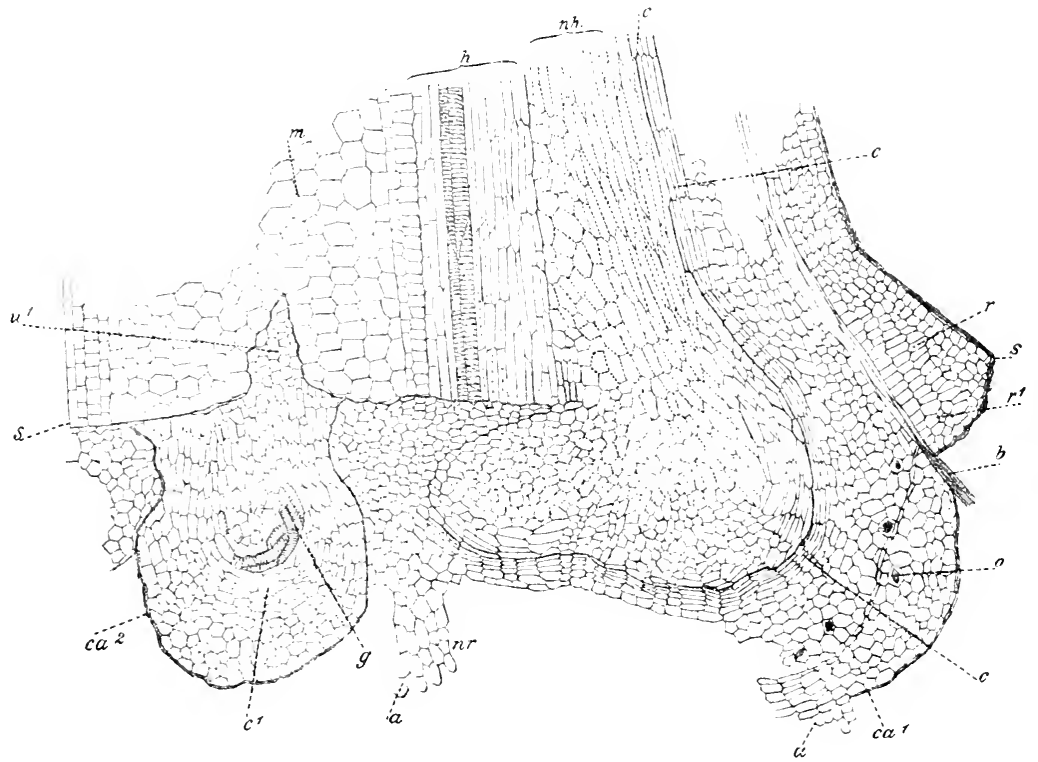

Fig. 19r. Rosensteckling. (Orig.)

ursprünglichem ('amhim hervorgehochen ist und sich vom Rande her ïber die schnittfäche ausbreitet. Wir muterscheiden in den rlurel die Figm dargestellten Längsichnitt einen radial geschnittenen Wulst ca' und eimen von der IInterseite her sich vorwölbenden nud daher quergeschnittenen Calluswulst $\boldsymbol{r}^{2}$, dessen Rinde bereits mit dem seitlich sich herumwölbenden ca' verschmolzen ist. So wird bei diesem äteren Rosenstecklinge allerdings anch rer Markkörper gedeckt: allein dies geschieht hier durch Verschmelzung der vom Rande nach der Nitte hin sich vorwölhenden Ränder, während bei dem ahgebildeten Fuchsienstecklinge die Hauptcallusmasse vom Marke selbst gehildet wirt.

Die Bezeichmung der einzehnen Elemente stimmt im allgemeinen mit der der vorigen Zeichnung. "' Markkörper, ler hier durch den 
Schnitt eingerissen ist. Der Ril's $u^{\prime}$ ist ansgefüllt durch den vom Hinterande her sich vorwölbenden Callus; $h$ ist das alte, vor dem Abschneiden des Zweiges zum Steckling gebildete Holz; $n h$ das während der Stecklinssperiode gebildete Neuholz, das in seinem Charakter genau dem Nenholz des Ringelwulstes bei dem Weinstock entspricht; es begimnt mit kmrzen, weiten, porösen, dickwandigen, stärkereichen Zellmassen, in denen ebenso kurze, netzförmige Gefälse auftreten. Diese Elemente werden nach autsen hin immer enger und gestreckter, dem normalen Holze immer ähnlicher, je später nach dem Schnitt sie angelegt werden, je näher sie also der Cambimmzone $c, c$ liegen. Diese Cannbiumzone geht im weiten Bogen um die Schnittfläche des alten Holzkörper's herum und ist anf ihrer Autsenseite von der nengebildeten Rinde $n r$ bekleidet, die in der Zeichnmng nicht rollständig wiedergegeben ist. Am äntisersten Rande der Rinde bemerken wir noch die jetzt verkorkten und bereits im Absterben begriffenen, zuerst über die Schnittlläche hervorgetretenen weiten, reihenweis geordneten, an den Enctgliedern ans abgerundeten, kugeligen bis birnenförmigen Kellen gebildeten Callusanfänge $a$. Diese Zellreihen vermehrten sich zuerst an der spitze, indem ihre änfsersten Zellen sich vergrölserten, durch eine Qnerwand sich teilten und die dadmeh verkleinerte Endzelle den Prozefs im Heranwachseu wiederholte.

In dem von hinten hervorkommenden, quergeschnittenen Calluswulst $c a^{2}$ bedeutet / die kurzen, netzigen Gefäfse, welehe die Anfänge des nenen Holzkörpers sind; $\mathrm{nm}$ dieselben zieht sich die Cambiumzone $c$. b ist der alte, vor dem Abschneiden des Zweiges zum Steckling gebildete Baststrang; er ist an der Schnittfläche durch die wuchernde Neuholzbildmng weit von dem alten Holze abgedrängt worden und an seinem treien Ende abgestorben. Die zu beiden Seiten dem Hartbast anliegenden Zellen dagegen haben sich, vom Rindendruck durch den Schnitt befreit, quergestreckt $r$, während sie im normalen Zustande längsgestreckt sind. Der übrige änfsere Teil der alten Rinde $r$ hat sich nicht verändert und seinen Wundrand durch Kork abgeschlossen. o rhombische Einzelkristalle und sternförmige Drusen von oxalsamrem Kalk.

Je nach der Pflanzenspezies treten bald aus dem Callus selbst, bald aus der oherhalb desselben belegenen basalen Region des Zweiges die nenen Wurzeln hervor.

\section{Verwendung verschiedener Achsenorgane zu Stecklingen.}

Die Callusbildmo selbst, sehen wir, ist also der einfache Vernarbungsprozel's einer querwunde. Die Ansbildung des Vernarbungsgewebes an der Basis des Stecklings wird von besonders günstigen Umständen begleitet. Tie Reservestoffe im Steckling finden aulser in der Terheilung des oberen Wundrandes augenblicklich keine andere Verwendung als bei der Vernarbung der moteren Wundfläche, da der meist sehattige Standort des Stecklings einem Erwecken der Knospen nicht günstig ist. Wo durch Unkenntris die dem Steekling gebotenen Tegetationsbedingungen eine schnelle Entwicklung der Angen veranlassen, bleiben die Callus- und Wurzelbildumg zurïck oder schlagen ganz tehl. Kweitens wirken der feuchte Standort und die in der Regel erhöhte Bodentemperatur dahin, dals die Zellvermehrung an der unteren Schnittläche begünstigt wird, das Vernarbungsgewebe also einen sehr üppigen Charakter annimmt. Unbedingt nötig ist für den Steckling 
die Callnsbildung nicht. Pflanzen, welehe she leicht Arventivknospen entwickehn, reduzieren ihr Callnsgewehe anf yanz yeringe Mengen; sie grenzen ihre sichnittfläche durch Korkbildmng ab, mul verwenden ihre Reservestoffe sofort zur Bildmng und Weiterentwicklung nener Wurzelanlagen. Dabei tritt eine reiche /ellvernelurme häntig nur in der der Schnittfäche zunächst liegenden Cambiumzon ein. Worlureh die Basis des steeklings bedentend ansehwillt (Begomia). Lir Callusbildmug

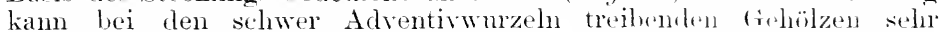
sthädlich werden, indem sie dureh ihre besonders reiche Anshildmng das Ifaterial für die Bildung nener Wureh in Beschlas nimmt. Wir sehen dam bisweilen enome, knorpelige Calluswiilste, ohne datis der Steckling. WWrzeln macht (Coniteren).

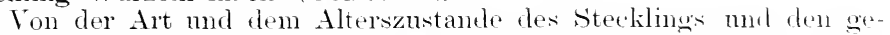
botenen Vegetationsherlingmengen hängt es ab. Welche (rewebe an iler Callusbilimng teilnehmen. Stets ist fas C'ambinm dabei beteiliegt. Ia. wo es nicht ansischlietslich den Ternalomgsprozedis ïbernimmt, wird es von dem Parenchrm der Inmenrinde oder autserdem von rinem Teil oder sämtlichem Parenchym les Markkärpers unterstützt; firmer kömnen sellst das Parenchrm des Holzhöruers und das der älteren Rinde sich beteiligen. Bei krantartigen, sehnell wachsenden PHanzen tritt sogar in diekwandigen Elementen eine /sellvermehrung in der Näle cler sंehnittläche ein dureh Thyllenbillung in Gefätsen und durch Nenbilrung von Querwänden in collenchym der älteren Rinde, wobri beobachtet worden ist ${ }^{1}$ ), dats die verdickten Wandmuen dor ('ollenchrmzellen und der Gefätse in der mmittelharen Nähe der Throllen sich anfyuellent hokern und teilweis resorbiert werden.

Jo melur lebenskräftiges Parenchrm vorhanden, desto schneller mul reichlicher ist die Callusbileme. Man schneidet die sitecklinge wern am Knoten, ummittelbar nnter einem Anoe. Man kann bei einem Guerschnitt durch ein Augenlisisen sehen, datis hior die Parenchrmmasse an meisten entwickelt ist chreh Abgang der Markhrïcke in die Knospe. Am Knoten ist anch hänfig das gesante Markparenchym noch

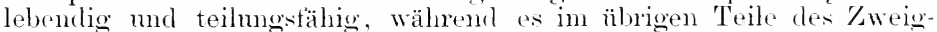
gliedes schon algestorluen und teilweis zerrissen ist.

Zu bemerken ist aber, dafs sich lirine stets gültigen Regehn ïber die Art der Callushildung geben lassen. Nanchmal machen (namentieh bei krantartigen Pflanzen) die Stecklinge nur sehr geringen oder keinen Callus an der konvex sich vorwölbenden, durch Kort abgeschlosienen Wundfläche, und in einem anderen Falle liefern die PHanzen lwdentende Callusmassen. Die ganz krantartigen Sommersteckling von Vitis, namentlich den amerikanischen Arten, liefern must geringen Callus, manchmal aber grotse Massen davon. Ebenso ist es lue Rosenstecklingen, wem diesellsen in krautartig weichem /ustande von abgetriebenen stöcken im ersten Frïhjahr entnommen und in warme Sandbeete gesteckt werlen. (irotser Nährstoffiorrat und langrame Verwendung dosselben erwecken die Neigmng zur Callnswelnermug.

Die mit eingehenden Litrraturnachweisen verschene Arbeit von J. Haxsten ${ }^{2}$ ) beschäftigt sich mit geringelten Stecklinern. Er sah.

1) H. Crärn auf Trinilad: Westindische Fragmente. XII. Einigus über die Gewebsverinderungen bei der Fortpflanzung durch stecklinge bei l'ortulaca deracea. Bot. Zeit. 1860 , s. 371 .

") Jumwe Haxims. Über die Leitung des Saftes durch lie Rinde. Pringsheim's Jahrbücher für wissensch. Botanik Bd. II, 1 60, s. $89:-46 \bar{i}$. 


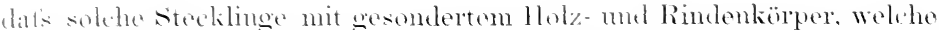

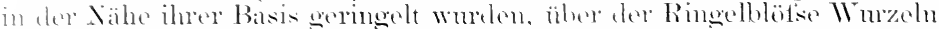

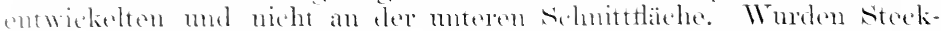

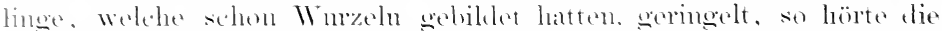

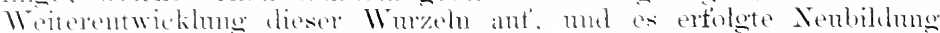

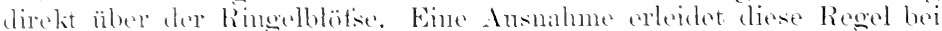

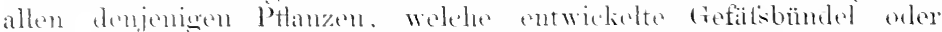

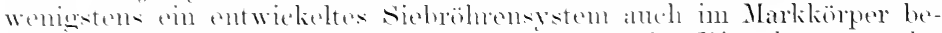

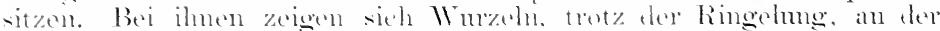

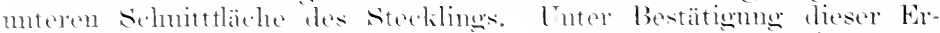

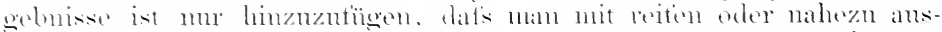

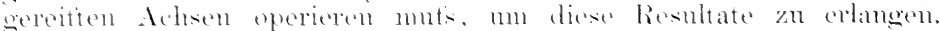


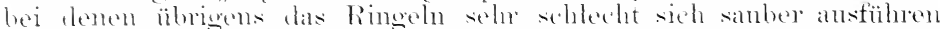

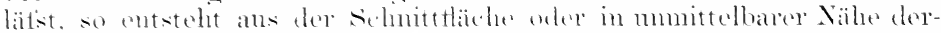

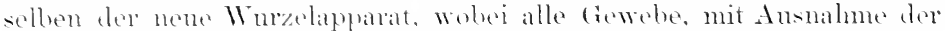

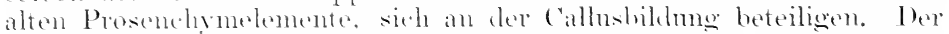

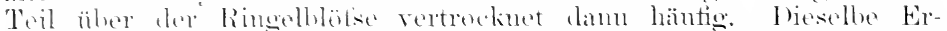

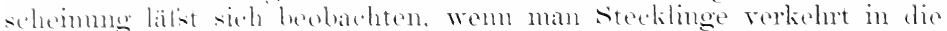

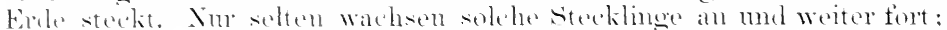
meist sterhen sie. natehlem sie an dem in der Erde hetindlehen, organiseh

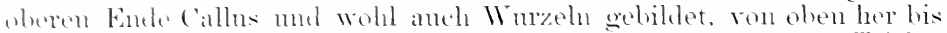

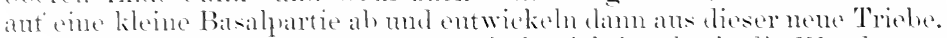

lie liesultate sind insotern praktisch wiehtig. als sie die Mandermen des plastisdem Materials. das zu allen Noubildmenen notwentig ist.

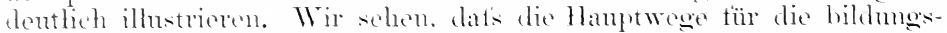
tïlige substanz in dem der Rinde singetügten siebröhrenssstem zu

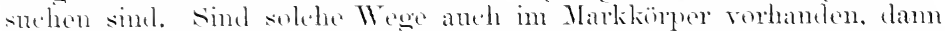
findet in demselben elentalls eine Mandermer der plastisehen substanz

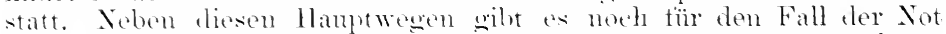
bedentungsvoll werdente Xebenwere. Es werden anch die Parendehrmzedlen der Rinde mel des Markes plastische Materialien ant mol abwäts

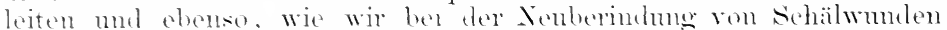
wahmehnen, die Markstrahlzellen in der Achse gelöstes Reservematerial

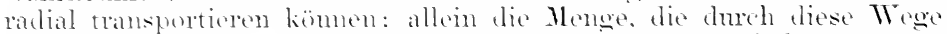
wandern kinne ist nur gering und laher mzmedehenel für nemens-

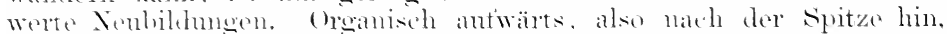
wandern die plastisehem stotte viel sehlechter als organiseh abwäts.

Wie wir ans den verkeht geptanzten stedklingen selen mol anch

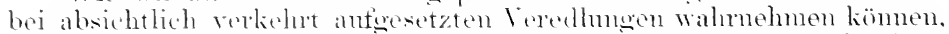
ist monter gïnstigen Vehöiltuisson eine Wandermng des gesamten flüssigen Materials in der Ptlanze. sowohl der rolen Bodenlësmug als aneh der plastisehen, organisierten Baustotte nath allen Richtungen hin möglich.

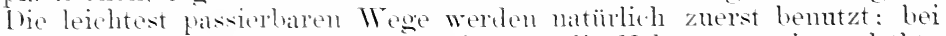
bort cintretenden Hindernissen erlangen die Nebenwege eine erhöhte Bedentung. Bei sitecklineren kanm sibh an jeder Wundstelle Callus

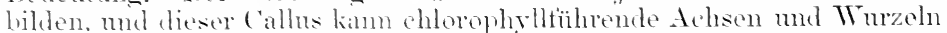

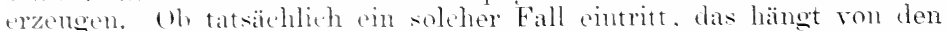
äntseren Verhälnissen mul, lom jeder PHanze imewohnenden, typischen, nur shwer irritierharen Entwieklungsesetz ab. Viele Pflanzen machen so schmell Adrentirwurzeln ans dem Internodimm, dats die Callus-

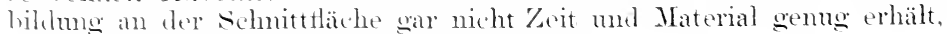
mo zu namhatter Entwicklume zu wolangen. 


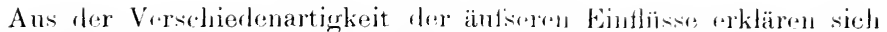

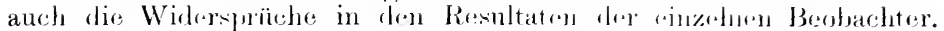

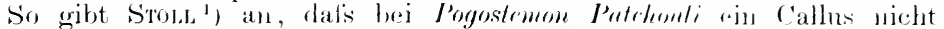

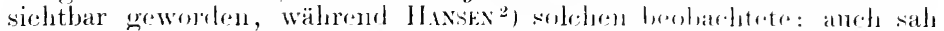

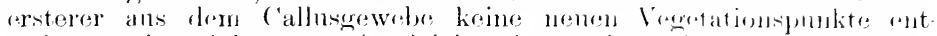

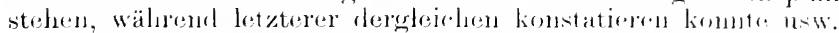

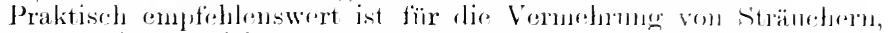

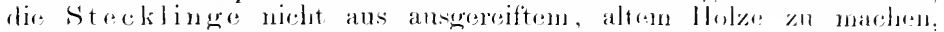

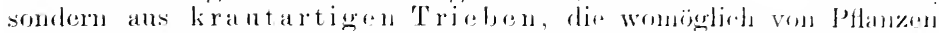

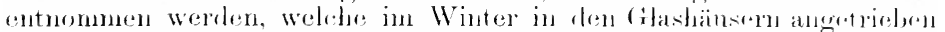

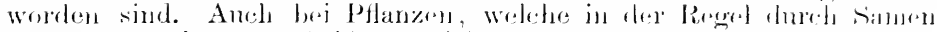

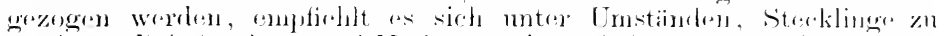

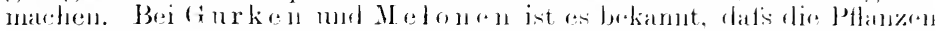

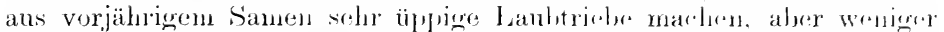
gern roichlichen Fruchtansat\% zeigen. Alte Samen mit wasseraimenem

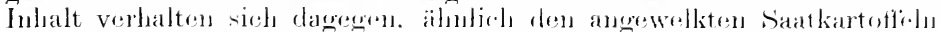

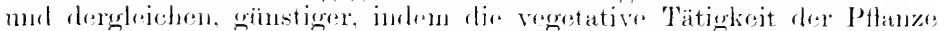

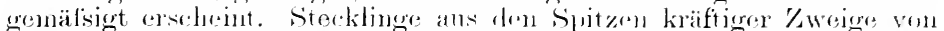

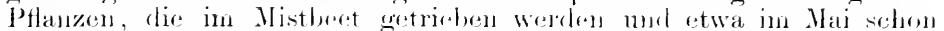

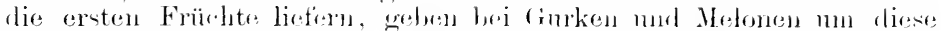

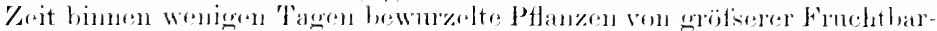
keit als dir Somenjeflanzors.

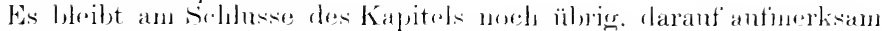

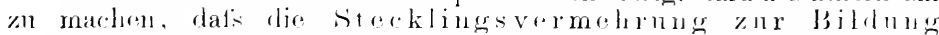

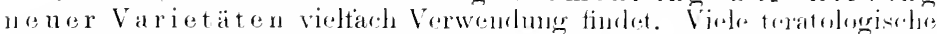
and pathologische \%ustände, dis an einzetnen 'Teilen aines Pflanze

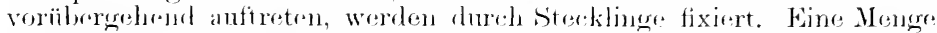

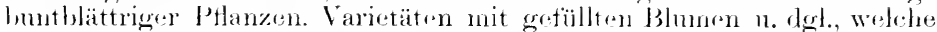

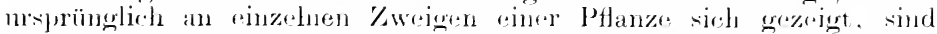

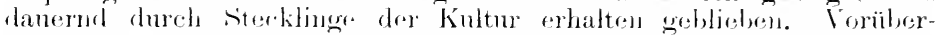
gelende, in Habitus alweichende. Jugendzustände les Konderen sind flum Stecklinge weiter vermeht mod als nene Formen orler Arten

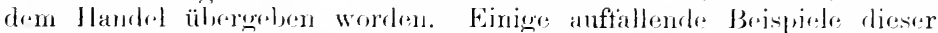
Art bilden beachtenswerte. Winkr für woitcro Versuche ant dieserm

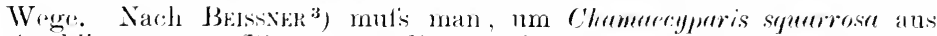
Stecklingen von Biota orimlalis zn erlangen, mur die kloinen \%woigachson mit krenzständigrn Blättern, welche sich dicht ïber don

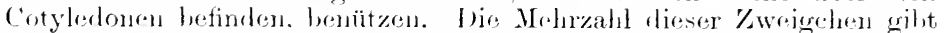

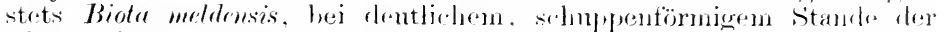

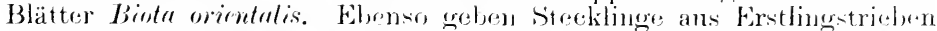

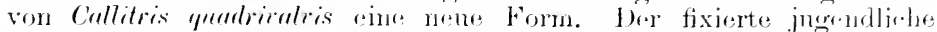

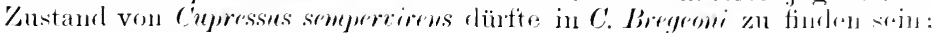

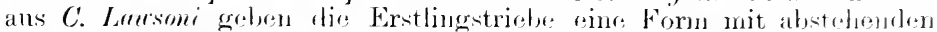

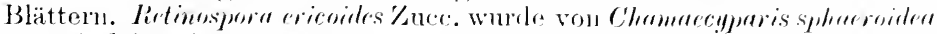
rar. Andalyensis gewromen.

Bekamnt ist die Verschierenartiokeit dor Pflanzen. die man bei

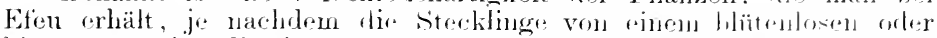
blütentragenden \%weigr entuommen werden. Alugeshen von der oft

1) C̈̈ber die Bildung des Callus bej Sterklingen Bot Zorit. 1×7t. No. 46 u. 47.

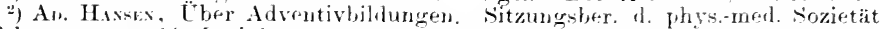
zu Erlangen vom 14. Juni $1 \times<0$.

") Brissies, C̈ber Formveränderung von Koniferensänlineren. Regel's Gartenflora $1 \times 79$, \$. 172 ; cit. Bot. Jahresher. 1×79, II, \$. ๖.

sorauer, Handbuch. Bulf. Erster liand. 
cintacheren Bhattorm der letzteren, die sich ant stecklingspflanzen gern ïlerträigt, sehen wir anch den Habitus hei diesen zwergartiger und

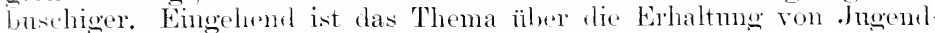
formen nenerdings rom DieLs ${ }^{\mathbf{1}}$ ) behandelt worlen.

Noch wenig ansgenützt, obgleich bei vielon Gehölzen sehr vorteil-

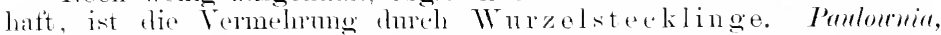

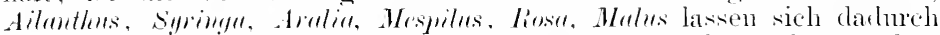
vermehren, dats man vor dem ersten Triehe im Frïhling oder vor dem zweiten Triebe im Juli stärkere Wurzoläste ablïst, in etwa 5 cm lange stücke schmeidet und reihenweis in don Boden flach hinlegt. Durch Adrentivknospenbilelmog entstehen an verschiedenen stellen des Wurzelstückes nene, sich durch eigne Wurelbildmo bald sellständig

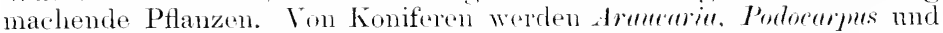
Gimmlio als durch Wurzolstecklinge vorteilhatt vermehrbar angroührt, mamentlich wemn sic in rin warmes Beet gosteckt werken. Stärkere Wurzelstöcke vertragen es anch, wenn sie der Länge nach gespalten werlen; jede Hältte entwickelt dann Adventivknospen.

Einzelne Gehölze lasien sich auch dureh Auslegen von Augen ver-

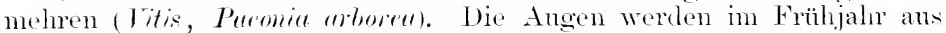
dem alten Holze derat ansoeschnitten, als ob man lange Okulationsangen mit Holz schneiden wollte, mond diese A ugenstecklinge werten Hach auf' die Erelobertlache in 'Tüpten niederocelent. Es ist aber erforlerlich, dats ein schnelles Vachstum durch Bodenwärme angeregt werde.

Man kann terner auch ron Knollenstecklingen sprechen, da ein Verfahren existiert, die Pflanzen daduch zu vermehren, clat's man aus fleischigen Knollen die Angen mit einer Partie reservestotthaltigen Knollengewebes ansboht (Kartotfeln, Caladien). Meist bildet das ausgeschnittene Knollenstück an seiner freien Wurdfläche auf Kosten der Stärle Kork nul behält die übrigen Reservestotte für die erste Ernährung der Angen, welche durh Entwicklung von Adrentirwmzeh sich hald selbstänflig zu machen suchen. Im Anschluts hieran ist das Zorschneiden der Saatkartottoln zu besprechen. Die Praxis beobachtet in der Regel die Vorsicht, die Stücke der Knollen nicht gloich nath dem /erschneiden der Erde zu übergeben. Diese Vorsicht ist ganz gerechtfertigt, da bei dem Legen der frisehen stücke ein Fanlen derselben leicht cintritt, sobalıl ant sehwerem Boden nur einigermatsen viel Fenchtigkeit vorhanden ist. Beläist man die zerschnittenen stücke daseren einine Tawe in der Lutt, so bilden sich moterhalb der schnittfächen Korklagen aus, welche das Knollenstück schützen. Wem man die Knollen zu triil vor dem Anstreilsen schmeirlet, kommt bei einzelnen sorten dor. Fall vor, dals die stücke lange Zeit in der Erde scheinbar unverïnlurt hleiben, olne dafs die Angen aber austreihen. Bei zarten sorten emptiehlt es sich daher, die Knollen vor der Saat an einem hellen, warmen Grte auszulneiten, his die Angen sich zu strecken beginnen, mul dann erst das /erselmeiden vorzmelnmen.

Die Wichtigkeit der Korkbileme an der schnittläche zeigen die

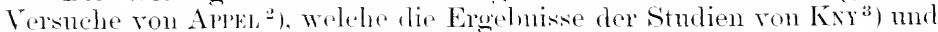

1) Drvis, L., Jugendformen und Blütenreife im Pflanzenreich. Berlin 1906, Gebr. Bornträger.

2) Apro., ()rw, /ur Kenutnis des Wundverschlusses bei den Kartoffeln. Ber. d. Dentsch. Bot. Ges. 1906, s.. 11s.

3) Kry, L., ت̈ber die Bildung des Wundperiderms an Knollen in ihrer Abhängigkeit von äufseren Einflüssen. Ber. d. Deutsch. Bot. Ges. 1\$99. s. 154. 
OLUFser ${ }^{1}$ ) ergänzen. Wähend die letztgrnamten bedelen Forscher in dem nach limzer \%eit unterhalb der Schnittlläche sieh hildenden WVundperidrum das llamptschutzmittel der Knolle genen dic Einwanterung von Parasiten phlicken, weist Arpen nach, dats sich die Kartotfin schon zu schützen imstancle ist, che der Wumcliork entstelit. Er fimclet, dats in giinstigstru Falle die Poridermbilemeg erst am dritten 'lane nath der Terwmelumg sich einstellt nud damn nach zwri weiteren Tagen beenclet ist. Für die nachweislich äntserst schnell eindringenden fänhnisbakterien läge also die Wundstelle so lange sthutzlos ila, wrom nicht alsbald die Membranen der direkt unter der Wumeltäehr liegranten murersehrten \%ellen an der von dre Wundtläche abgewandten suite verkorkten. Sogar für Bucillus phytophthorus erwies sich diese nateh 1.) Stunten bereits vollendete Korkeinlagerumg in rinem Teil der \%ellwand dre ersten und zweiten \%ellawe unter der Wundfläch" als vollständig ausreichend, um die Infelition zu verhindern.

Veniger gut kommt der Verkorkmgsponzels zur Ausbildmug, wrm die Knollenstücke sofort trocken mus warn (z. B. im Kimmer) anfbewaht werelen. Die änfiersten \%ollagen dor Schnittfäche trocknen damn so schucll zusammen, dats die beilen zur Verkorkung nötion Faktoren, nämlich Samerstolf mnd Fenchtiglieit, nur ungenügend zu den in Betracht kommenden fieweleschichten /outritt haben.

In gleicher oder ähnlicher Weise vollzieht sich der WVundschluts boi allen fleischigen Pflanzenteilen²).

\section{Die Veredlung.}

Die Voredlumg bestoht in der kïnstlichen Ablösung riner orlor melnerer Knospen mol deren Einfïgumo in einen lobenden Pflanzenteil behut's weiterer Ernährung und Ansibilumg. Dio ineinander wetügten Teile werden meist clurch ein Band festerehalten mol dureh Bammachs vor den störenclen Eingritten der Atmosphärilien geschützt. In übertragene Troil kam im allogmemen als .. Edelreis" bezeichnet werlen. während der ernährende Stamm als . Unt er lage" angesprochen wird. Das neu entstehende, teils von der Unterlage, teils rom Fdelreis gelieferte Gewebe, welches die Verkittung der beiden künstich verbundenen Glieder hewirkt, wird .K it schicht" ocler, nach Göreklit, .intermediäres (i e webe" genamnt. Das Elelreis ist entwoler ein einziges, mit einem Teil der momgebendun Rincle abgelöstes Auge odru ein 7woigtril mit mehreren Aneren. Je nath dem Kulturzweck kian das Eolelreis an die stelle seiner Ablösmo orler an eine andere stelle desselleen Individums oder (was an hänfigsten) anf ein andrese Individum gebracht werden. Im ersteren Falle wirl nur dio Wirkmng der Verwudmog allein in Betracht kommen, in letzteren Fallo wirel anch der Einfluts der im Charaliter versehiedenen Untrrlage anf das Edelreis zu beriülisichtigen sein.

Das Teredeln wird zuächst als Wundheilungsprozel's zu hetrachten sein; in zweiter Linie wird cler betörternde oder hemmend. Eintlutis ins Auge gefafist werlen mïsisen, der ans einer grenseitigen Ein-

1) Ourwix, Untersuchungen aber Wundperidernbildumer an Kartoffe'knollen. Bot. Centralbl. Beihette. Bi. XV (190:3) s. 269 . S. $185 \mathrm{ff}$

2) Küsrir, Eıxsr, Pathologische Pflanzenanatomie. Jena 199:, G. Fischer, 
wirkung der beiden kïnstlich ancinander gefügten PHanzenteile etwa (entspringen könnte.

Unter den diese Punkte eingehend behandehden Autoren ist zunächst GöplekT ${ }^{1}$ ) zu nemmen, der durch anatomische Studien der Frage näher getreten ist. Eine sich an diese mit Abliblungen versehene Arbeit ankniipfende zum Teil bestätigende, zum Teil berichtigende Notiz hat Verfasser ein Jahr nach Erscheinen der Görestschen Arbeit veröffentlicht ${ }^{2}$ ). Ton den früheren Physiologen sind die Angaben von Haxstein ${ }^{3}$ ), von de (ANbolle ${ }^{4}$ ) und vom Trivikdxus ${ }^{5}$ ) besonders beachtenswert. Eine systematische Bearbeitumg aller nur möglichen Variationen des Teredhugsverfahrens lieferte Thoun ${ }^{6}$ ), der sich auf Dunanel ${ }^{7}$ ), La (2untinye $\left.{ }^{8}\right)$, Roziek $\left.^{9}\right)$, Cabanis ${ }^{10}$ ) und die älteren (Gartenschriftsteller stätzt und duch reiche Literaturangaben das Studium der Geschichte der Veredlungskunst unuemein erleichtert.

Ton den 120 verschiedenen Veredhungsormer, die Thous in seinem Buche beschreibt, mit besonderen Namen belegt und meistens anch abbildet, haben sich nu einige wenige einer allgemeinen Verbreitmm zu erfrenen. Alle die jetzt üblichen Arten der Veredlung werden vom pathologischen Standpunkte aus am besten in ihrer Wertigkeit nach flem irade der Verwundung abgeschätzt werden, den die Unterlage crleidet mol nach der grötseren oder geringeren Leichtigkeit, mit welcher die Wunden reheilt worden kömncu. Unter sonst gleichen Umständen wird der Erfolg der Manipulation um so sicherer sein, je schneller das Gewele des Edelreises mit dem der Unterlage in feste Verbindung tritt, und da diese Verbindung durch das nen entstehende Vernarbungsgewehe der Wunde hervorgebracht wird, so wird die schnelligkeit des Wundschlusses den Malsistab für die Verwertbarkeit der Veredlungsart hauptsächlich. wemn anch nicht ausschliedslich, abgeben kömnen.

I ie bei den Veredlungen überhaupt möglichen V'erwachsungserscheinmugen lassen sich auf die Heilungsvorgänge von drei Wmaklassen zurïckfïhren, die ich Schälwunden, Flachw unden und Spaltw wnden genamnt habe.

Als Schälwmolen sind (wie ans den früheren Kapiteh ersichtlich) diejenigen Verletzmngen bezeichnet worden, welche in einem vollständigen Entfernen des Rindenkörpers bestehen, so dats der Holzkörper blotingelegt wird, ohne dats derselbe aher einen substanzverhst erleidet. Die Teredlungsarten, bei welchen der Schälprozefs den hauptsächlichsten Teil der Verwundung bildet, gehören zu dem Typus ker Okulation. Hier wird zur Keit grötster, cambialer Tätigkeit die Rinde anf eine gewisse Strecke von dem Holzkörper der Unterlage abqeloben, und auf die entblölste Holzstelle das Edelreis eingeschoben. Letzteres besteht entweder ans einem einfachen Auge mit einem Rinden-

1) Güprst, Über innere Vorgïnge bei dem Veredeln der Bäume und Sträucher. Kassel $1 \geq 74$.

2) Surarkn, Vorläufige Notiz äber Veredlung. Bot. Zeit. 1875, S. 201.

3) Haxsmis, Dr. J., Das Reproduktionsvermögen der Pflanzen in Bezug anf ihre

Vormehrung und Veredlung. Wiegandt's Volks- und Gartenkalender 1865, S. 190.

4) $\mathrm{D}_{\mathrm{E}}$ Caxmons: Phrsiologie végétale II.

5) Thmonis, Physiologie der Gewächse 1s:B, II, S. 647.

6) Tuoris, Monographie des Pfropfens, ïbers. von Berg 18:4.

7) Dunima, Physique des arbres 1758, II, S. 75.

6) DE LA Quncise, Le parfait jardinier. Paris 1695 .

9) Rozns, Cours complet d'Agriculture, t. V, s. :346.

10) Camans, Principes de la Greffe, p. 105. 
schildchen (Okulieren mit $R$ inde), oder ans einem Auge, das mit etwas Holz aus dem Mutterzweige herausgeschnitten war (O kulieren $\mathrm{mit} \mathrm{Holz}$, oder ans einem vollständigen /woigstïcke, das in verschiedener Weise zugeschnitten werlen kann und unter die Rinde des Wildlings mit der Schnittfläche aut den Holzcylinler geschoben wird ( Rindenp fropfen).

Unter der Bezeichnung "Flachwnde“ sind alle diejenigen Verletzungen zusammengefatist, bei welchen neben gänzlicher Entfornmo eines Teiles der Rinde anch rom Holzkörper rin stïck wrugenommen wird. Je nachdem die Wundfäche durch einen länss- onler Qnerschnitt entstanden, präsentiert sich nud verhält sich div Flachwmo verschieden. Wem ein Span der Länge nach von der Arhss abgeschnitten worden ist, liegen die Elemente des Rinden- mnd HolzFörpers in ihrer Längenausdehmung trei zutage. Es läutt das Regenwasser von dieser Längsflachwmle mit Leichtigkeit ab, wowegen es auf einem stammquerschnitt in kleinen Mulden meist sich ansammelt und viel leichter die Fäuhnis des Holzkörpers cinleiten lann. Dio horizontale Flachwonde ist immer viel gefährlicher tör die Achse als die vertilial verlantende. An stelle fler Horizontalwunden werden daher im praktischen Betriebe meist Diagonalverwmolungen ausgeführt.

Die Veredlungsarten, bei denen die Flachwmolen hamptsächlich oder ansschlietshich ins spiel kommen, gehören zum Typus dre .Ko. pulation". Wie eintachste Form derselben besteht in ilem Aufsetzen eines Erlelzweiges ron derselben Dicke wie die Unterlage anf deren diagonale, durch das sehräge Alschneiden des fiptels entstandene Schmittläche. Am nächsten verwamlt clamit ist das einfache und doppelte Sattelschäften. Man kann auch Edehois und Willling durch wirlich longitudinale Flachwunden miteinander verlinden, indem der Vildling nur an einer stelle seitlich angesehnitten wird, ohne seinen friptel zu verlieren. Das Edeheis bleibt entweder an seiner Mntterptlanze und wird ebenfalls nur seitlich angeschnitten (Ablakticren), orler es wird in Form eines abgeschnittrnen /woigstïclies. wie bei den anderen Veredlungsarten. durch seitliches Anschneiden passent zum Anlegen an len Willling gemacht. Damit das Edelreis in seiner seitlichen Iage fester sitze, wird es am unteren Ende kurz keilförmig zugespitzt und mit diesem Ende in eine spalte am Grmole der Flachwunde des Wildlings eingezwängt. Bei manchen Pflanzen (Kamelien) schmoilet man nicht selten das Erlelreis ïberhaupt nu kurz keilförmig und zwängt den Keil in eine seitliche durch einen kmzen, schräg abwäts in das Holz geführten sclunitt entstandene spalte der Unterlage (Einspitzen). Bei dem Milslingen der Veredlung ist die Unterlage dam am meisten geschont und kam in kurzer Keit zu nener Verellung buntzt wrien.

Diejenige Verletzung, bei wolcher der Stamm am mistril leilet, ist die spaltwunde. Die Veredhugsart mit solehen Wunden ist das spaltpfropten, das in Dentschland wohl zuerst answialst worden

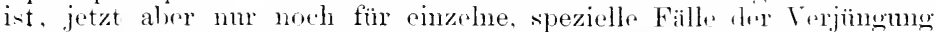
älerer stämme in Anwondung gebracht wird. Das spaltperiopten besteht in einem Einsehieben cines von zwei seiten keilfömin zuneschnittrnen Erlalreises in den entweder dureh Klüftung oder dureh Ansichneiden eines Holzkeiles entstanden'n spalt des quer abgeschnittemen Willlings.

Bei Betrachtung der Heilmosvorgänge, also des Verwachsungsprozesses bei den verschiedenen Feredhungsarten int zunächst zu unterscheiden, ob eine Veredlung durch krautartige odre mit ansgereiftem, 


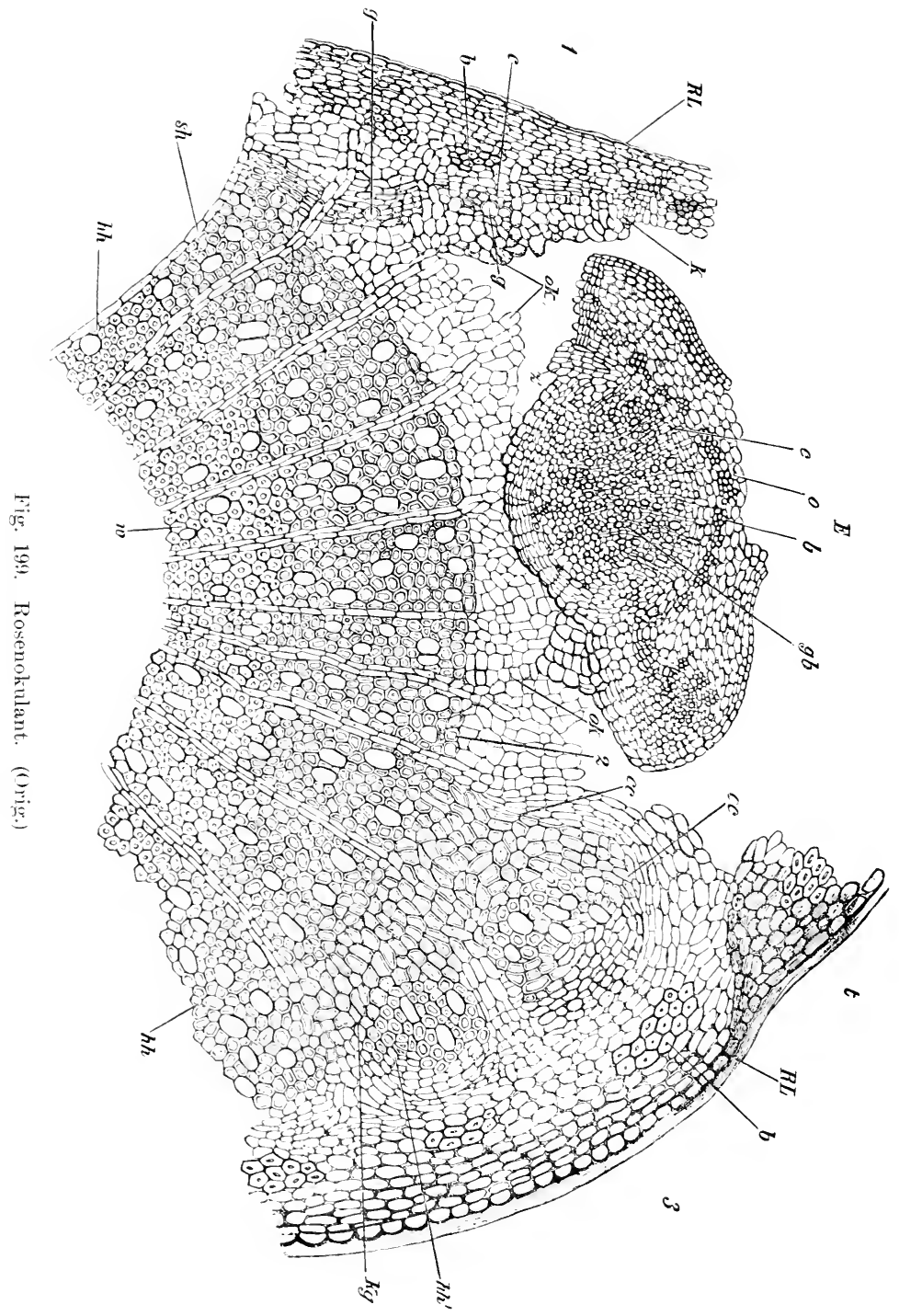


fertigem starken Holzkörper versehene /weigr ausortïlnt wird. Im ersteren Falle nehmen hänfig an der Buldumg der .Kittrchicht " mehr Gewebe teil als im letzteren Falle, bei welchen as sich rorzugweise mm eine ron der ('ambiumzone (bisweilen anch noch von der Markkrone) ausgehende (rewehemasse handelt, welehe sich in den twischenramm zwischen Edelreis und Wildling hineinzwängen orlor, bildlich genommen, die Fugen zwischen den beiden aneinanterdirnenden Teilen ansuictisen muti.

\section{I) (I) knlation.}

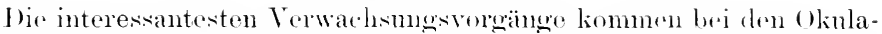
tionen vor. Anf der heigegehenen Tatel ist ein Rosenolinlant dargestellt, dessen cine IIälfte (rom 1 bis ¿) die Wundheilmugsvorgänge mach sechs Tagen und die andere Hälte (von $\approx$ bis 3 ) die trewebe-

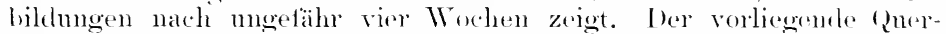

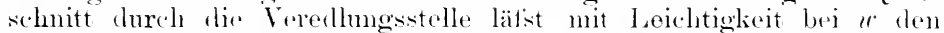
Wildling, bei $E$ das Edelange erkennen. An Wildline ist h h das alte Holz des Vorjahres, sh das diesjährige bis zur (1kulationszeit gebildete Holz. RL sind lie dureh den T-Schmitt abgehobenen Rindenlapsen, in drenen b dir Hartbastzellen, t das abgestorbenc Gewebe des sichnittrambles bedenten soll.

\%ur \%eit als die Rindentappen durch das Einschieben des Anoes $E$ anseinanderospreizt wmolen. War die Pfluze in grotiser cambialer 'Tätgkeit: clie Abhebung dre Rinde erfolgte hies im Splinte derart, dats schon die jünosten fiefoitianlagen of und die davor liegenden c'ambiumschiehten r aut' dem Rimdenlappen verblicben.

Vielfach hels sich nur der Rindenköryes ab, ja, unter Umständen bleibt stücliweis die ganze cambliale Region mit den jüngsten Rindenzellen aut dem Holzkiinger haften. Eime fiesetzmälisiglicit ist nicht erkanmt worlen. Es solueint, dats stets die angenblicklich zarteste

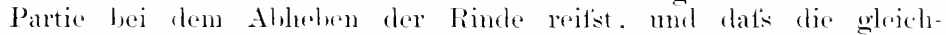
namigen fiewele zu lersolhen \%eit bei denselben Varietäten sich individnell verschieden verhalton. ja, dats sollost dir einzelnen stammseiten eine verschiedene Iäsbarlint der Rimle lesitzen. Es sind daher dir Ileilungsvorgänge bei derselhen spezies nnd Varietiit, ja selbst an derselluen Feredlume in versehiedenen Höhen merleich.

Schon nach zwölf Stmolen lätit sich an den Wmobändern sowohl dre Rinde als des Holzkërpers eine Veränderung der pripherischen

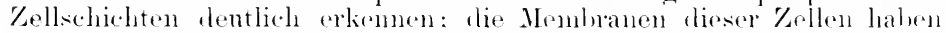
sich entweder $11 m$ an drer fireilienenden Anlisenseite obler an wanzen

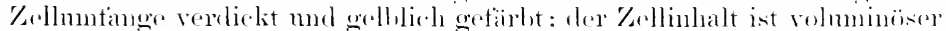

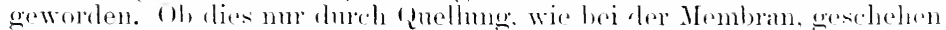

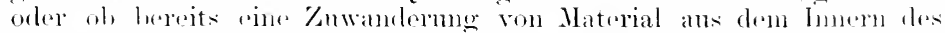
Holzhöpers nath les Peripherio hin statgofunden, lätst sieh nicht entscheirlen. Wie närhsten Entwicklnugstadion ditterieren jutzt schon

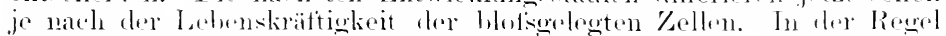
sind nicht alle sitellen am antblitsten llokkörper nit vermelnmes-

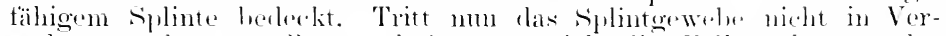

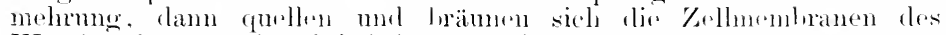
Wunclrandes sant len luhalt immer mohr, sinken anch of was zusammen

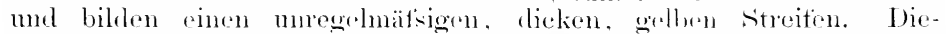
jenigen Zellgruplun, welehe sich zur Vormolimmg anschicken, brämen ihre Mombranen moist nur sohr schwach mul tamen häufig nach seln 
kurzer Zeit an, Wundcallus zu bilden. Das zartwandige, allmählich in parallelen Reihen fortwachsende Gewebe oli ist das bei den Schälwunden in seinen Wachstumsterhältnissen hesprochene Wundgewebe, das heisplelsweise bei Frarmus nach zwei Tagen einmal in einer Mächtigkeit von lit Zellen Höhe bereits beobachtet werden konnte. Terhältnismätsig selten ist die Lagerung des Schälcallus so regelmätsig, wie in der Zeichnung. Dadurch, daf's einzelne Stellen des Molzkörpers nicht Wundcallus bilden, legen sich die henachbarten Zellreihen fächerartig anseinander und überdecken die untätig bleibenden Stellen. Bei rer schmelligkeit dieser Callusbildung ist ein Decken der Fehlstellen und imniges Verkitten der von verschiedenen seiten kommenden Elemente sehr natiirlich.

Die Rindenlappen gehen durchschnittlich mit der Bildung von Wundcallus weniger schnell vor; anch sind die Produkte der Neubildung verwehieden. Zwar wölben sich die plasmareicheren, peripherischen Zellen auch bald nach der Operation etwas hervor $\left(l_{i}\right)$, aber treten nicht immer in Zellvermehrung oder, talls sich eine solche einstellt, ist das Produkt derselben nur Kork, weleher die Wundfläthe sehützen kamn. Meist erst weiter nach dem immeren Winkel zu, an welthem der Rindenlappen auf dem Holzkörper festsitzt, sind die Neubildungen energischer und bis zu reichlichem Wundcallusgewebe gesteigert (oli).

Die schmell gebildeten Wundeallusmassen von Rinde und Holz sowie eventuell anch noch vom Edelreise vereinigen sich und bilden in kürzester Zeit einen vorläufigen Schlut's der Veredlungswunde. Wir sagen ,einen vorläufigen Schlutis": dem tatsächlich bleibt das bisher neu entstandene Gewebe meist nur kurze Zeit. Sobald nämlich das Callusgewebe eine grötsere Ansdehnung erlangt und einem sich steigernden Drucke ausgesetzt erscheint, bildet sich in ihm in einer gewissen Entfernung von der bisweilen durch Korkzellen getestigten Peripherie eine Meristemzone, deren Ausbildung von der Weite zwischen Wildling und Edelauge abhängig ist. Bei sehr geringer Entfernung sind bisweilen nur wenige seitliche, isolierte Herde kemntlich, bei grofsen Zwischenrämmen und ïlpiger Ansbildung des Wundcallus kam man dagegen kontinuierliche Zonen entdecken. die manchmal nach schleifenartigem Verlauf eine Verbindung mit der mittlerwile scharf hevortretenden Cambiumzone des älter gewordenen Überwallungsgewebes des Rindenlappens $c c, c c$ finden.

In dem jungen Wundeallus ist die Meristemzone nicht wezeichnet, weil sie erst später anftritt.

Lieses Callumeristem liefert in Gemeinschaft mit der Cambiumzone des Rindenlappens $c$ r num zmächst das eigentliche Kittgewebe, bestehend ans Parenchymholz in Form derbwandiger, isodiametrischer oder etwas radial gestreckter, unregelmälsig vierechiger, nicht selten mit etwas verlogenen Wandungen anftretender Zellen $\left(l_{i g}\right)$. Diese stellen die Anfänge eines unter geringem Druek sich bildenden Ilolzkörpers dar; sie pressen bei ihrer Vermehrung almählich alles zartwandige, erstuebildete, den Charakter ron Rindenparenchym bewahrende Gewele (oli), das den ersten Wmdichlufs darstellt, zusammen. Bei sehleifenartiger Anlage der Neristemzone entstehen kreisförmige Figuren von Parenchymholz, welche noch braune, tote Zellnester des ursprïnglichen Gewebes eingeschlosien haben. Almählich ist zwischen 1 und ? das ganze (iewebe oli durch stärke speichernde Zellen vom Charakter lig verdrängt. 
Das Edelreis nimmt im gïnstigen Falle ebenfalls am Wundschlut: teil. In der vorliegenden Zeichnung stellt es ein Auge mit Rindenschild, also ohme Holzkörper dar. Der s.chitt $E$ ist der (Querschmitt mur dureh das Rindenschildehen; die dazn grourige Knospe, welehe in der Richtmng ron o redacht werden muts, Lient oferhall, der schnittebene, in welcher nu das zum Ange führencle. zentrale, orotse fiefätsbïndel $g l$ und ein seitliches, kleineres gezeichnet sind. Pas in jerlen unverletzten Angenkissen vorhandene, die Zweigathse ebenfills schrän durehsetzende, fritte, kleinere Bïndel anf' der anderen sieite des zentralbïndels ist bei dem Abheben des Rindenschildehens hier abgeschmitten worlen, was für das Anwachsen des Anges mwesentlich ist. Dagreren ist das Fohlen des zentralen Gofäsloündels, gleich. bedeutend mit dem Fehlschlagen der Voredlung. Das Rindenschildchen mit der schnell vortroeknenden Knospenhïlse ohne Gefälskörper ham anwachsen: es ist mir aber nicht rorokommen, dati etwa ein übermätsig üphiges Überwallumgsowebe von Seite des Erlel. auges Adrentivknospen gelildet mol anf liese Weise Ersatz für das getötete Ange reschaflt hätte. Es findet zwar Adventivknospenbildmu bri manchen Feredlungen statt, wie die umstehende Fig. on riner krautartig ansegetührten Rindenpfroptung vom Aesculus inbirmude ant

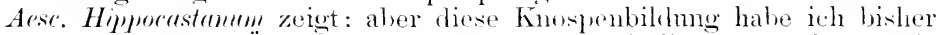

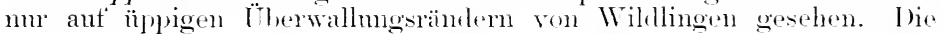
Rindenlappen $n$ l halen eine derartig starke Seubilimug erzengt, dats sie dadmeh flïgelartig vom Edelreise ahgerlüngt worklen sind. Anf dem Rande stehen mehrfach Ailventivknospen (a).

Bei rem Rosenolulanten Fig. 1!!! hat hereit die wanze Homentäthe des Rindenschildchens E nenes Wmolgewebe produziert, mul zwar je nach dem Alter der Mutterzellen halel melne bald weniger. l)ie miterhath des Hartbaststranges l, liegende Cambiumzone des Bünulels hat am reichlichsten nene Zellen geliblet, wie dre vorspringende Kiptel : zeigt. Die Nenhildmur anf der hmenseite des fichildehens tränt den Charakter des Rinelenerwebes mol ist hereits durch reichliche kistalle von oxalsamen Kalli ausogeichnet. Während die C'ambiumzone $c$, wolche nene Ilolzelomente zu hilden leginnt, in späteren stadien der Verwachsmo in Verlinumg mit der Cambimmone a des Rimlen-

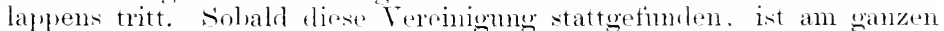
Stammuntange wieder din zusammenhängender Cambimming geliblet, von wellhem die Cambiumzone des Erlelanges rinen integricurenten Bestandteil dastellt. Ilis Kone r zeigt sich, wem man sie rüelwäts vertolent, als die mmittelhare Verlängerung des cambialen Ringes bu dem morletzten dilisenteile.

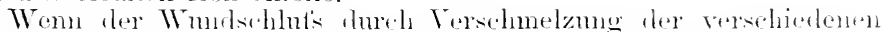

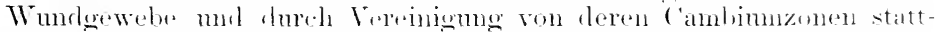
gefunden, ist das dïmmamlige fiewebe des Wmulcallus oli fast rel-

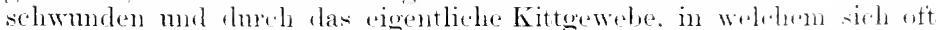

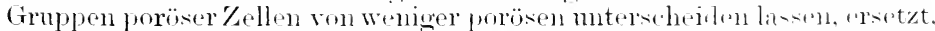
wie oben bereits gesant worlen. Wie der Rindenziptel $2-3$ zeigt,

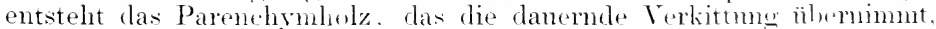

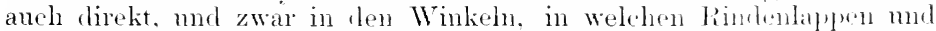
Holzkörper wieder znsammenstolisen, also da. wo hro Kaigerstrieh rom kg endet. Wem man num sieht, dats der Rindenlapjen $\because I^{\prime} L$ derart durch das Okuliermesser abuehoben worden, dats nicht nur die ganze Cambiumzone, sondern anch noch ganz junge, aler in ihrem Charakter 
shom bestimmte splintelemente anf demselben sitzen geblieben sind, so erkennt man darans, dals dieses Kittgewele ein Produkt von schon dwas älteren (nicht mehr den jüngstgelildeten) splintzellen ist. Es geht nicht ans Wundeallus hervor ider sich in den inneren Winkeh nie bildet), sondern aus Teilung der schon zu Holzzellen und Getätisen veranlagt gewesenen Zellen.

Wir haben also drei rerschiedene Faktoren, welche ein gleiches Produlit, nämlich das als Kittgewebe angesprochene Parenchymholz, lietern, das die Verbindmng von Edeleeis und Wildling übernimmt. Der erste Faktor ist der Rindenlapuen des Mildlings, der zweite der Schälcallus des entblötsten Holzköruers der dritte ist das Eelelreis.

Thelther von desen drei Falitoren bei einer anwachsenden Teredlung die Verkittung tatsächlich übernimmt, hängt ron der angenblicklichen Krättiglieit der einzehen Faktoren ab. Die zu beobachtenden Variationen sind autserordentlich grots. Wesentlich für das Gelingen der Veredlung ist die möglichst schmelle Bildung von Wundeallus, der den vorlänfigen Wundschluts übernimmt. Danernden Halt gewinnt die Veredlung aber erst dam, wemn die Cambinmzone $c c$ der Neuholz bildenden Rindenlapyen $R$ L. die ich gelegentlich .den be we glich hn IV nndwa ll" genannt. mit der Cambimmzone c des Edelreises in danemele Verbindung tritt und in zusammenhängender schicht verbleibente Holzelemente bililet. Ther bewegliche II undwall, der dureh seine schmeckentörmig an der treien s'ate eingebogene Cambiumzone schon den Charakter des gewönlichen Überwallmngrandes zeigt. mnterscheidet sich ron diesem, dem ..stehenden Ti nndwalle". durch die grotse, zwischengesthobene Zone ron Parenchymholz (fig), welche dem stehenden Wundwalle abgeht. Die Verschmelzungsstelle der Cambiumzonen von Wildling und Edelreis macht sich nicht nur im Terwachsungsiahre. sondern noch viele. Jahre später immer lienntlich durch den Verlanf der Holzelemente. In der Terbindungslinie, welche sich also zwischon $c$ mel $c c$ herstellt, sind die Elemente meln oder weniger stark tangential gestreckt, während sie im Inmem des Wundwalles bereits nomale vertikale Lagerno angenommen haben, also lurch den tonershnitt anch tatsäthlich yner durchschnitten erscheinen (hli) und so dem normalen Holze hl, gleichen. Wemn dureh Herstellung dieses Verbindmmestückes die ('ambiumzone $c$ des Edelreises mit der des Wildlines co zu einem znsammenhängenden Ringe verhunden ist. sieht man. dats dieser Ring nicht wie am unveredelen stamme vom Zantrum ïherall annähernd gleith weit entfernt ist.

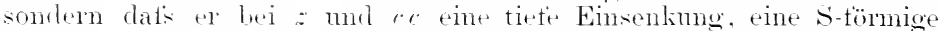
Biegnng zeigt. Sohon das hlots. Ange erkennt diese gebogene Terbindmeslinie, die llemarliationslinie Göpert's, welche anch in ter Rindenbelieidung anttaillt ${ }^{1}$.

1) Das Abweichemie dur vorliegenden Eutersuchungen ron den bisherigen Arbeiten liegt in den Nachwois des versbiedenartigen [rivrunges des Kittrewebes

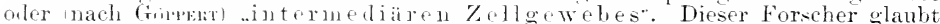
die Entstehung des Gewebes, das in Groneins haft mit dem Cambinn die Verwachsung

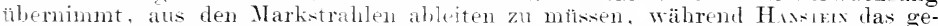
sante Kittgrwebe für Produktionen des Cambiums allein hält. Tatsächlich können alle noch zu Neubildumgen fähigen Elemente an der Bildung des Wundeallus und Kittgewebes sich beteiligen. Bei manchen Biimuen erhält man heispielsweise ausgezeichnete Bilder von Wundeallu, der auch aus dem Markkörper, namentlich der Markkrone. hervorweht tTilim. 
Die Heilungsvorgänge bei der zweiten ïblichen Art der Okulation, bei welcher das Eclelauge mit einem sitüclichen daranhaftenden Holzes ron dem Zweige alogrelnitten und in den Wildling eingeschoben wird, sind von den beschiebrinen etwas abweichend. Der Nachteil bei dieser Verodlumemethorle mit Holzschildchen ist eine Verlangsammig der Verwachsums der Vorteil besteht aber in einer grötseren sicherheit der Erhaltmon des Exlanges. Bei dem Abplatzen des Rindenschildehens vom Ilolzkïrper zwecks Oliulation mit Rinde wird nicht selten bei zu starlior Verholamo des fuir das Auge bestimmten Getätsbiundelzylinders der eigentliche Knospenkegel aut dem '/weige helassen. Das Ange aut dem Rindenschildehen hat dann auf cler Immenseite eine Grube nud treibt nicht mehr ans. Ungeübte iibersehen dieses (irïbchen mul olinlieren somit nutzlos.

Dersclbe Heilungspozeds, der bei dem Oknlieren mit Holz eintritt, findet bei dem Ptropten in die Rinde statt. Nur wirl hicrbei der Wildling mehr beschädigt. indem er zumächst quer abresclmitten werlen muls: clamm wird die Rinde an einer seite anforespalten mol zu Antinalime des Edelreises wie bei der (1) klation etwas abgehoben. An stelle des einzelnen Anges tritt hier ein melirknospiger, schräc zuceschnittener /weig. Die schräg abwärts gehende schnittfläche dessellen Dilclet einfache Überwallungränder. also stehende TIunclwälle, die mit den beweglichen TVundwällen der Rindenlappen des Wildlings mol dem Kittgewebe ans dre blotsgelegten Inolztläede desselhen verschinelzen. Bei dem Rimelenfifopten (.. Pelzen") liat d.

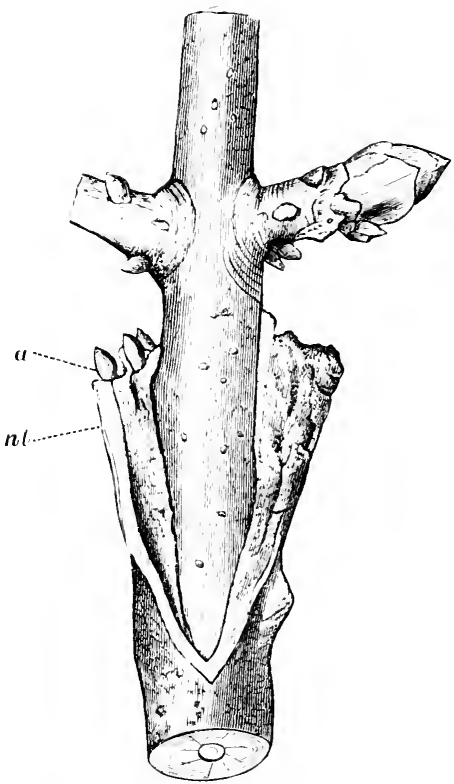

Fig. 201. Rindenpfripfling von deserlus mit Adrentivknospen. (1)rig.) Wildling aler meler Arlus mit

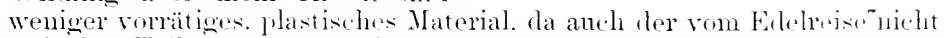

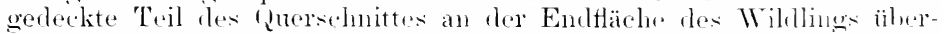
wallt werten muls.

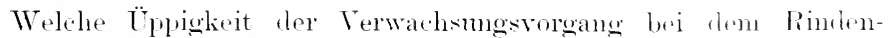

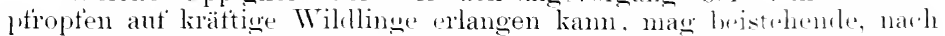

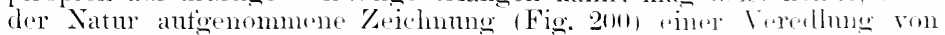

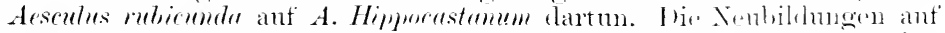
der Imnenseite der Rindenlappen nl tes Wildling waren wenige Wochen nach der Veredhung so stark, dats sie flizgulartig rom Erleleris

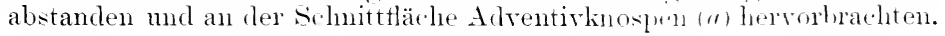




\section{Kopulieren und Ptropfen.}

Bei der Kopulation werden das Edelreis an unteren Ende, die momöglich ebenso starke Unterlage am oberen Ende schief abgeschnitten. Lie beiden Sihnittflächen werden derart anfeinander gepatst, dafs die gleichnamigen Gewebepartien einander decken. Ifier haben wir also einfach zwei Flachwunden; dieselben werlen an ihrem Umfange Überwallungsränder bilden, die sich zwischen Edelreis und Wildling hineinschieben. Der Verschluts ist bei gut ansgetührter Manipulation und sehr geringem Zwischenraum zwischen den Wundflächen ein so dichter, daf's selbst das Mikroskop keine Lücke zwischen dem alten Holze der Schnittflächen und dem eingeprefsten Kittgewebe erkennen kam. Göperer findet, dals gerade bei der Kopulation dieses Kittgewebe schon im jugendlichen Zustande bald abstirbt, ohne zu verscinwinden, während es nach Olinlieren und Ptropfen bei vollständigem s'chlusse lange in organischer 'Tätigkeit verbleibt. Nir ist eine solche, vom Veredlungsmodus abhängige Differenz in der Lebenslaner des Kittgewebes nicht aufgefallen. Wohl hemerkt man hei älteren Veredlungen Lücken oder brame, mürbe Nassen abgestorbenen Gewebes; es schien mir aber, als ob dasselbe bei allen Veredlungsarten ohne Unterschied dann aufträte, wemn der Wundrchluf's bei sehr dichtem Aufeinanderpassen von Edelreis und Wildling nur dureh den erst entstehenden Wundeallus stattgefunden hat, ohme dat's sich nachträglich in der Fuge das holzparenchymatische Kittgewebe gebildet hätte. Die Kopulation darf laher wohl den WVert und tie allgemeine Terwentbarkeit behalten, welche sie bisher gefunden. Die einfachste Form halte ich aber tür die beste; das sogenannte englische Pfropten, sowie die von Thous angetührten Methoden (Mrluer, KǘfFner, FerRari nsw.) halte ich für mnvorteilhafte oder gar schädliche spielereien.

Als die gefährlichste Operation ist das spaltptropfen zu erklären. Im gebränchlichsten Falle wird der Wildling quer abgeschnitten und ein- oder mehrfach bis tief in das Holz hinein gespalten. Das Edeheis wird ron zwei Seiten keilfömig zugeschnitten und derart in den spalt eingeklemmt, dat's die Cambinmzone desselben das Verbindungsglied zwischen den beiden durch den spalt retrennten Teilen des Cambinmringes des Wildlings ansmacht. Das keilförmig zucespitzte Edeheis wird, falls es nicht krantartig ist, ans dem stehengebliebenen Teile seines Cambiums allein Wundwälle beiderseits hervortreiben; dasselbe geschieht an den beiden spalträndern des Wildhings. Die verschmolzenen Kittmassen werlen versuchen, den spaltram im alten Holze auszutüllen. Hurchschnittlich gelingt dies selten vollkommen; von der Querschnittfäche des Wildlings ilringt trotz des Bammkittes Fenchtiglicit in die spaltwunde und veranlatst leicht Wund-oder Pilzfäulnis.

Der Veredlungsmozets ist natiulich nicht an die Existenz einer bestimmten Cambiumzone gehmelen, sondern wird auch bei Monocotyledonen möglich sein. Beispiele dafür lietert I)Ané ${ }^{1}$ ), der bei Va nille und bei Philodendron Ptroptversuche mit Erfolw ausührte.

Es ist am Schlut's dieser Betrachtung der Wundheilungsvorgänge noch eimmal zu betonen, lats das Urteil über die Wertigkeit der Teredlungsarten sich hier nur ant mindestens ein .Jahr alte, mit ausgebildetem Ilolzkörper versehene Achsen bezieht. Bei Veredlungen krautartiger

1) Dixirı, L., Greffe de quelques Monocotrledones sur elles-mêmes. Compt. rend. $1899, \mathrm{II}, \mathrm{p} .65 \mathrm{~s}$. 
Triebe von Holzptlanzen oder krautiger Pflanzen äberhaupt kann die Wahl der Veredlungsmethode nach rein praktischen (iesichtspunkten stattfinden. Es nehmen bei der Verwachsmon moist so viel Elemente der schnittflächen (ältere Rinden- und Holzelemente, Markkörver) an der Bildung von Wundeallus teil, dats eine innige Verbindmng unter allen tlem Pflanzenkörper ïberhaupt zuträglichen Imständen stattfindet, voransgesetzt, dat's eine genügende Verwandtschaft zwischen Edelreis und Unterlage existiert.

\section{Die Lebensdaner veredelter Individuen.}

Ein Einfluts des Veredlungsorganges ant die Entwicklung des Individnums wirk, ganz algesehen von etwaigen Einwirkmgen rinzelner Eigenschatten der beiden veredelten Teile anteinander, nicht abzulengnon sein. Jerlenfalls werden, wie Drнanel bereits hervorhebt, die dewebeverïndermugen an der Veredlmngsstelle eine Verändermo in der Laitmosfähigkeit veranlassen. I) Kittschicht wird sowohl in der Partie, in welcher sie ans stärkereichem Parenchymholz besteht, als anch später, wo sie ans gewumdenen Prosenchymelementen gebildet ist, eine Verlangsammo der Wasserleitumg und eine leichtere sijeicherung des al)wärts wandernden. plastischen Materials hervorruten. Die Folgen dieser Veränderungen sind früher hereits besprochen worden.

Die bis jetzt wenig belannte (irenze, bis zu welcher verschiedene Individuen miteinander zu einem danerud normal fimktionierenden Urganismus verbunden werden këmen, läts sich mugefähr dahin jräzisieren, dats im allgemeinen mu Pflanzen derselhen natiolichen Fanilie mit Aussicht ant Ertolg anteinander veredrlt werden kömmen. Dies wïrde nach den hisherigen Erfahrungen aber anch die äutserste Grenze darstellen. Es liegen Beispiele in gentigender Mengo dafür vor, dats tieschlechter derselben Familie sich nicht danernd vereinigen lassen, ja Arten desselben Geschlechtes kömmen tür einige Jahre verhunden bleiben und lösen sich schliefslich doch ans dem Verhande. wobei in rer Regel der Tod des einen Teiles eintritt. Es ist wahrscheinlich, dats autser der stotflichen Verwandtschatt namentlich eine gleichartige, biologische Entwicklung der zu vereinigenden Individuen notwrendig ist. Sio glaube ich, dals der verschiedene Eintritt und Abschlut's der Vegetationsphasen (Blattbildung. Fruchtansatz usw.) mnd der verschiedenartige Wasserbedarf der Individuen soln matsgebent für die Daurer selbst solcher Veredlumen sind, die anfangs gut miteinander verwatelsen. Manchmal halten sich Teredlmoen viele Nonate hindurch trisch, ohne dat's sie miteinauler überhaut fest verwachsen. Bei krautartioen Veredlungen heterogener Arten oder lerartiger Organe sieht man. dat manchmal das Erlelreis weiter treibt und sich kïmmerlich bis zm Blïtenbildung entwickelt, schliefslich aber abstirbt. Soweit ich Einblick rrlangte. war überhampt keine Verwachsung eingetreten. Beide Teilo kïmen dabei ihr Bestes getan habon: ihre sämtlichen forthldmngsilhigen tie. webe kömnen Neubildungen produziert, ja stellenweise namhatten Wmulcallus hervorgebratht haben, aber es zieht sich zwischen liesen fiewehemassen der beiden Teile cin bramer Streifen hindurch. der sofort erkennen lä1st, zu wolchem Individum das fragliche frewelo gelört. Der brame streiten ist entweder nur durch die gequollene. Wandung der äufsersten Zellen gebildet oder auch durch /nsmmenfallen granzer Zellen der Wundränder verbreitert. Meist hat sich an der firenze eine 
Korkschicht durch Verkorkmng der Menbran der peripherischen Parenchrmzellen odor antserdem noch durch Erscheinen wirklieher Korkzellen eingefunden.

Auch bei Gattungen, welche schliefslich tatsächlich miteinander verwachsen, wie z. B. Iresine auf Altrmonther. findet man an ganzen Strecken der Veredlungsflächen ein Nebeneinanderwachsen der Kittgewebe, von denen jedes dureh eine Korkichicht abgeschlossen ist.

Ähnliche Fälle liefsen sich bei IV urzelveredlungen (Bignonia) nachweisen, mol bei spaltptröpflingen won Pormin whor an fleischigen Wurzeln der P'armia officimalis liets sich beobaehten, dats die Wurzelunterlage nur als Aufbewahrumsort tïr das Edelreis gedient hatte. Letzteres hatte IVuzeh gemacht, ohne irgendwo mit der Unterlage verwachsen $z u$ sein.

Die Wurzelveredlung ist im allgeneinen eine seln gute Methode. Auch hei unsern 0bstbänmen ist sie schon von Sicklen zu Ende des vorvorigen .Jahrhunderts geäbt worken, und später hat namentlich SeIgerschum in Mako sich sehr empfehlend darüber geäufsert ${ }^{1}$ ). Wurzelstïcke von der Dicke eines Federkiels bis zu der eines Dammens erweisen sich, wenn sie mit feinen Wurzeh versehen sind, geeignet; sie werden in $8-12 \mathrm{~cm}$ lange Stüclie geschnitten, durch Kopulation oder mit Geitstuts veredelt, und die Veredlungsstelle wird mit Erde bedeclit, so dafs 2-3 Angen ïber der Erde bleiben. Alte Kern- und Steinobststämme, welche entfernt werden müssen, gehen ein reichliches Material zu Unterlagen. Sellstverständlich müsen die Wurzeln sehr gestund sein. Noch mehr in Aufnahme ist bereits das Vertahren, die Rosen anf Wurzelstïtke im .Januar oder Februar zu veredeln; anch bei Clematis und manchen andern Holzpflanzen bürgert sich diese Veredlungsweise immer mehr ein.

Dat's minter Unständen, die eine mangelhatte Verwachsmng bedingen, die Lebensdaner einer Veredlung eine geringe sein wird, ist von vornherein zu vermuten. Ob aber der Veredlungspozets an sich die Lebensdaner einschränkt, wie THow und GöpPEn ausprechen, bleibt dahingestellt. Dat's reredelte Obstbämme durchschnittlich kurzlebiger sind als wurzelecht weiter wachsende sämlinge, ist nicht zu lengnen. Man kamn auch zugeben, dats ein Absterben der Bämo, wie Gör'ent beobachtet hat, in der Demarkationslinie durch allmähliche Verrottmng der Verbindungsitellen sich einleitet; aber es ist nicht zu glauben, dats dieser Verrottmussmozets eine reguläre Todes-oder auch nur Krankheitsursache der veredelten Bäume sei. Man sieht im Gegenteil, dass selbst schlecht verwachsene, ja anfangs blols einseitig zusammengelikebte Kopulanten ganz gesunde dauerhafte stämme geben können. Die alten Veredlungsitellen haben das festeste Holz: der Stum dreht die Bämme an jeder andern stelle wohl leichter ab als gerade an der Veredlungsstelle. Nur bei alten stänmen, die später umgepfropft werden, mögen die Beobathtungen Göprent's vielleicht als Regel gelten. Den durchschmittlich fröheren Torl der veredelten Stämme erkläre ich mir darburh, rlafs man eben nur bessere. aber anch gleichzeitio weichere Kultursorten veredelt, die, abgesehon von den störungen, welche sie durch den Kulturschnitt erleiden, an und für sich emptänglicher gegen Wachstumsstörungen und atmosphärische Unbilden sind, wie die ans Samen erzogenen, fast immer mehr oder weniger der härteren Wildlingsnatur sich nähernden Exemplare.

1) Wiener Obst- und Gartenzeitung 1s7i, s. $5 \leqslant 7$. 
Gegenseitiger Einfluts von Edelreis und Untorlage.

Betretfis der Einwirkmo des Mutterstammes ant das Edelreis liegen

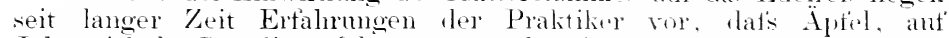

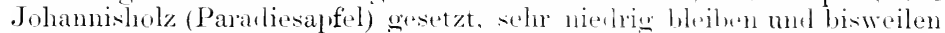
schon in dem ant rlie Veredhum foldemlen Jahre truktitiziesen. Ant

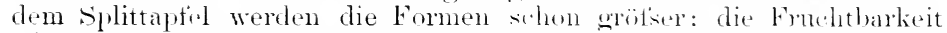
tritt nach wengen Jahren ein, wähend das Edeheis ant einer Enterlage

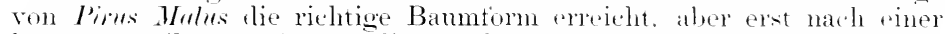
längeren Reihe ron Jahren die Fruchtbarkeit erlangt : bei Birnen biliten

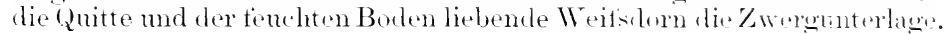

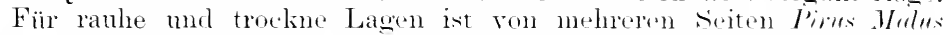

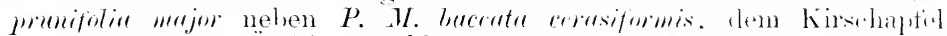
als Unterlage für Äptel emptohlen worlen ${ }^{1}$ ). P. M. In'mifolin, ,ler anSibirien stammt, ist hart und anch als stratsenham zn verwendell: rr unterscheidet sich durch seinen, in dic Angen tallenden, stehenbleibenulen Kelch ron der Art $P$. M. barrata, zu weleher crasiformis crehört, lie den Kelch zur Reifezeit abwirft.

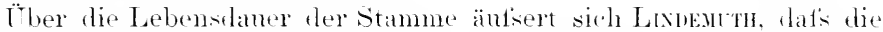

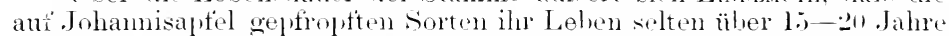
bringen, während die aut sämlingen eller, baumartiger sorten ron Mulus reredelten Exemplare 150-20n Jahre alt werden liömen. Von somstigen Literatmotizen erwänen wir noeh tolgende:

Sanerkirschen anf Süklinschen gedeihen woniger wut als fliese ant'

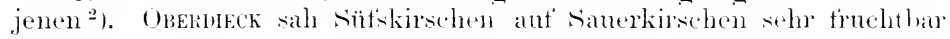
tragen.

Tlevhasis") zitiert: Nutshäune mul hastanienbämme von den slätansschlagenten Varietäten sollen aut frühtreibenden niemals weraten

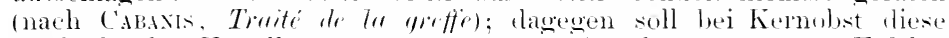
Methode cler Veredlumg später sorten aut frühe von gutem Erfolge begleitet sein mul cine trühere Reife (dor Früblate hodingen ${ }^{4}$ ). Bux Pfirsichen seheint die Veredlung an sich, also sowohl ron firühen at späte Sorten und umgeliehrt, von gïnstigem Erfolge zu sein. Grotulk teilte der Pariser soe dété cont. dHortienlture"s) mit, dats er Pfirsich in Angust oder September ant ' Lapten (comsomes) wie aut' die Verlängermugtriebe ptropfe und zwar späte Sorten anf frïhe und umgekelirt. Tho Frïchte sollen dadurch wrötser werden, dats bei einem Bamme, der mit spät reifender Sorte veredelt, die Frïchte der Unterlage znerst geerntr.t werden kömnen, und dats damn der Baum seine ïbrige Kraft ant die Aushildung der Früchte an den Ästen der anfgesetzten, späton surt. verwenden kamn. Im mmekehrten Falle einer Veredlung ant spaite Sorten werlen die ganzen Bänme krättiger, da späte Varbeläten in allgemeinen einen ïpligeren Wuchs haben.

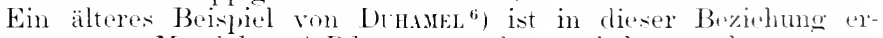
wähnenswelt. Mandel anf Ptaumen und umgekehrt Watheren zurist

1) Lnz, Pyrus Malus prumifolia major. Pomolog. Nonatshefte 1-79, - 1: 134.

2) Lixnemin, Vegetative Bastarderzeugung durch Impfung. Landwirtsich. Jahrbitcher 1sis, Heft is.

3) Trimmins, Physiologie der Gewächse II, 18:3, s. tit-ff.

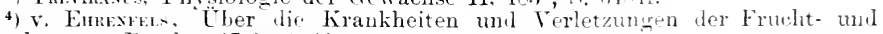
Gartenbäume. Breslau 179.5, s. 10s.

5) Oniris, Vorteilhaftes Pfropfen ron Pfirsichbäumen. Pomolog. Monatshefte v. Lucas 1879 , S. 61 .

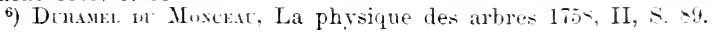


sehr gut an, aber gehen meist nach einem ofler einigen Jahren zurück. live Tandel hat ein viel üppigeres Wachstmu, treibt frïher in Jahre ans mol bildet als Edelois einen starken Wulst an der Veredhmosstelle. Fs ist daher wahrseheinlich, dats ein solches, tiouher mol danernd mehr Wasser heansprnchendes Foleheis so lange anf einer minder ïppigen Untrilage gedeihen wirl, als diese im stande ist, ans ihrem grespeicherten Vorrat im stamm dem jungen Reise zn genigen. Wird der Edelzweig mehrjähig, werlen seme Bedïnthisse grötser mol kamn er sich nicht, was häntig (Wwerostamme von Kermolst) der Unterlage akkomodieren, so geht re aus Nahrmogsmangel allmählich zngrunde. Boden, Bewässermo, sorte varieren die Erfolge selur wesentlich. Tongeliehrt wircl eine zu frïhe mol ïppige Unterlage cinem mit weniger Ansprïr.hen auftretenden Edeheise mehr zuführen, als dieses antuehmen kam. las älorsehüssige Material der [nterlage orecht sich mm in schmellen Noubildungen. sind viel. Knospenherele da, dam macht sich der l̈berschuts in der Produlition langoliederiger schossen Lnft. Wem aber, wie bei den Veredlungen, dir meiston Seitenzwoige und Angen unterchëlelit sind, damm bleibt das Material dem Verdicknngsinge des stammes zur Verfï̈mme. Es lilden sich statt der Prosenchymelemente Nestor aus

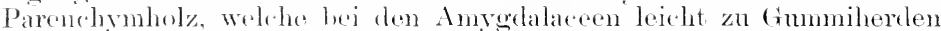

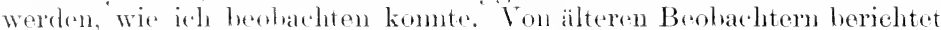
[) Honel, dals dir mit Pfanmenreisern besetrten Mandelunterlagen an den Veredlnugsitellen surch fimmosis zugrmole gingen.

Aneh bei den wanz allgentin durchgetührton Veredlumgen der Birnen anf Qnite mol der Apfed ant Paraliesaptel hat die Erfahrme geleht, dats der 'Tod fïr' schmellwïchsige Edelreiser mu so schmeller rintritt, je trockner der Boden mol jo wenigre Wurch die Unterlage

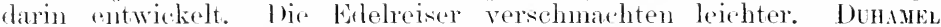
zitiert anch Fäle, dafs bei solehen Mitsverhältnissen zwischen Edelreis mel Willling betreft's der Wasseransprüche selon das einfache Verpflanzon don Tod dnreh Versehmaehtnug zur Folge hatte (Mandel anf Pfanmen), während die in der schule stehen geblicbenen Stämnchen dersellen sorie gesumel blithen. Das Abschneiden der Wurzeln bei dem Verptlanzen hate die angenhlickliche Fähigkeit der Wasseryntulı hei der Tutorlage zu selur verminelert. Anch Pfirsieh auf / wwetschen sollen keine besonders haltharen Verbindumgen liefern (Pomolog. Momatsliefte 187!, S. 370): das Ehlehris soll rotgefärbtes

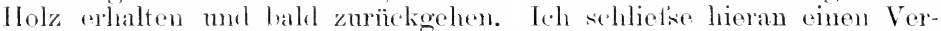
such mit. Veredelong von llimbeeren anf liosa ramimat $\left.{ }^{1}\right)$. Von den dureh Kopulation anfersetzten linbuseisern salı ich anf einem Exemplar zwei Tweige sich entwickeh, von denen der oine vier normale llimbeeren trug. In Herlst aber starh das Edelreis ab, wnd bei der Untersuchung fand ieh, dats die Verwachsmer dine selor mangelhatte gewesen war. Am oberen Teile des Kopmlationsschnittes hatte nm der Wildling Vernarbmosgewehe geliefert: lagegen war an mutern Teile sowolil von lioser als anch vour liubus reichlich Wundeallus gebildet worden, der die nomalen Verwathonusvoreginge zeigte.

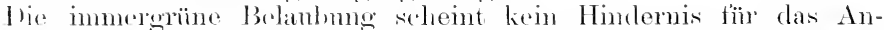
wathsen anf lambabwertenden Tuterlagen zu sein. Reiser von l'rums

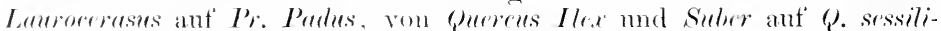
flowa, von ridrus Libani anf Larid mopara sollen gedeihen, wälrend

1) Sнвики, P., Ruhus auf liosil. Keitschr. f. Pflanzenkrankh. 1898, ‥ 2227. 
äber ein Gedeihen laubal,wertender fiehölze auf immererünen noch nichts herichtet wirel. 'Tnotsx ${ }^{1}$ ) widerspleht orsteres Bohamptung.

Von den hemerkenswerten Ergebnissen der Donduks schen Versacho sei hier erwähnt, dats z. B. die Frucht der Winterehristbirue ant quitte ein zarteres, saftreicheres Fleisch und einc feinere, intensiver gerähte

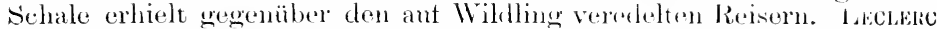

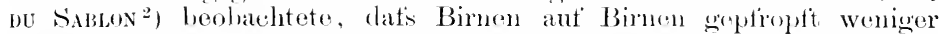

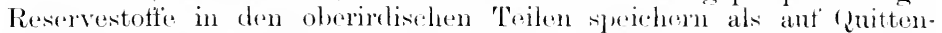
untrelage, deren Wruzehn abre ärmer an Reservenaterial wïrlen.

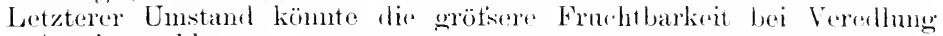
ant' (2uitte crkläron.

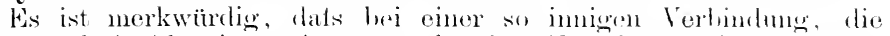
Birne und Aptel mit entfernter stehenden Unterlagen angehen, sie

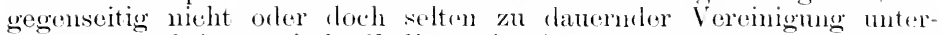
einanter zu bringen sind. Es lingen in dieser Bezichung schon zuemlich zahlreiche Versuche vor. So beriehtet Kxanti3) von einem Aptel ant Birne, der ein Jahr lang eine reiche Ernte brachte, aber in IVinter daraut einging. Die Früchte sollen auch ein schwarzes Kerngehäuse ohme einen einzimrn samen besessen halen. Von den späteren Beobachtern wird die Tatsache in allgemeinen lostätigt, aber hervorgeholen, rats gïnstige Ansuahmefälle rorkommen. So herichtet Direktor STOLL $\left.{ }^{4}\right)$, dats Aptehreiser auf Bimbäumen ganz gut angehen, auch sohr hald tragen, aber kleine Fröchte bringen mal meist in vierten Jahre absterben. (1)ergärtner SkIfElit in seugeberor (llolstein) beschreibt eine fünfjälnige Apfelveredlung anf Birne als Unterlage, welche in vierten Jahre sechs gut ausgebilkte Aptel getragen hat (RibstomPepping). Die Früchte waren won gutem (reschnack, aber die Krone sehr schwachwïchsig. Von Birnenvererllungen anf Äpteh sind mir mehrere günstige lirsultate lekannt geworlen. In Czerwentzitz boi Ratibor fanclen sich vicle Exemplare von Birnen, welche aut Äptieln veredelt waren. bas Verfahren war seit zehn .Jahren in Anwentung. Bei dem ersten Versuche (foilshirtenbirne anf Apfel) zeigte sich, das die Früchte vom zweiton Jahre der Veredlumer an aut der Aptelunterlago un vierzohn Tage firiher reiften als anf dem eignen Mutterstamm. Das Edeheis hielt sich acht Jahe. Schwächore Unterlagen lieferten kein gutes Resultat; die moisten Sorten gingen zwar an, wuchsen aber nicht von der Stelle. Bei Wiedorholung derseilern Veredhung in mittlere Kronenästo gingen cine Anzahl Exemplare nach

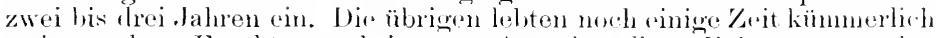

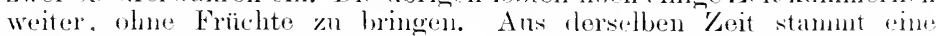

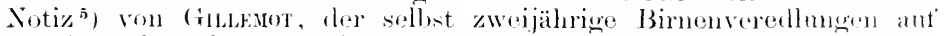

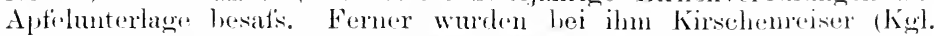

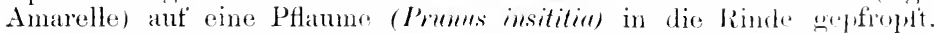
Die Reiser entwickelten sehr lange Triobe und in zweiten lahre anch verhältnisnälsig viele nue schöne Früchte, starben ales nach den Fruehttragen säntlich ab.

1) Tuors, Monographie des Pfropfens. Deutsch von Berge 1-2.t, s. 11 t.

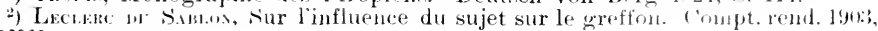
CXXXY, p. 6ie?

3) Hort. Transact. II, p. 201.

4) Srron., Das Veredeln von Birnen auf Äpfeln. Wiener (1)st- und Gartenzeit. 1876, s. 10.

5) Grimsor, Beitrag zur Veredlung versehiedenurtiger (iewachse aufeinander.

Wiener Obst- แ. Gartenzeit. 1๕if, s.. 121.

Sorauer, Iandbucl. 3. Aull. Erster liand. 
Bis in die neneste Zeit hinein sind derartige Versuche von verschiedenen seiten wiederholt worden; es haben sich jedoch bis jetzt keine weiteren emptehlenswerten Resnltate erorlien als die, welche seit langer Zeit betreffs der Terwendung der 'Zwergunterlagen bekannt sind. In einigen Fällen hat sich herausgestellt, dats die Art der Veroflumg ansichlaggebend tïr das felingen derselben ist. So berichtet beispielsweise (AnRtene ${ }^{1}$ ), dats die Birnenvarietaten Rom chritien liams,

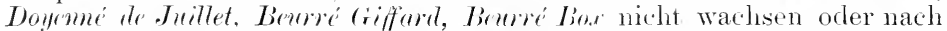
Produktion schwächlicher Triebe bald zugrmde gehen, wem sie auf Quitte oknliert würden (greffé en ismsom); dagegen ist der Erfolg ein ganz wesentlich günstiger, wenn man in den spalt pfropft und namentlich als Edeheis eine Zweigspitze benützt. Die Fruchtharkeit ist ungemein grots. So soll auch Lignstrum orulifolinm als Unterlage für die einzelnen Arten des Flieders sich versthieden verhalten. Nur Syringa Josiliea soll als Okulant (greffé $r n$ écussom) fortkommen, während $S$. Emodi, persicn n. a. nur durch Pfropfen in den Spalt (greffé en fonte) sich gut entwickeln.

Die Neuzeit hat dieser Frage eine besondere Anfmerkamkeit bei der Weinveredlung im Kampte gegen die Reblaus zugewendet. Lie $/$ ahl der daräber erschienenen Arbeiten ist moemein wrots, so dats wir nur aut einige hervorragende aufmerksam machen kömnen. Zunächst stellte Couterc ${ }^{2}$ ) durch eine Unfrage bei etwa 450 fianzösischen Weinbanern fest, dafs durch das Ptropten selbst die Resistenzfähigkeit einer amerikanischen Unterlage gegenüber den Reblausangriffen gewöhnlich etwas herabgedrückt werde; aber auch die verschiedenen als Edelreis sebrauchten Sorten üben einen verschieden starken Einfluts aus.

Doch kommen auch Fälle vor, in denen ein sehr zusagendes Edelreis die Resistenztähigkeit erhöhen kamn. Dals die Unterlage das Wachstum des Edelreises und namentlich auch seine Fruchtbarkeit beeinflutist, hebt u. a. RAvaz ${ }^{3}$ ) besonders hervor Präzise Zahlen äber die Änderung der Trauben durch den Einfluts der Unterlage verdanken wir HotTER ${ }^{4}$ ). Derselbe untersuchte verschiedene Traubensorten, welche sowohl von den anf Ripuria veredelten als auch von wurzelechten Rebstöcken derselben Sorte stammten. Ton nem Traubensorten waren $70^{\circ}$ o der Moste bei den veredelten Stöcken säurereicher als die der unveredelten stöcke, ron denen (i.; "'o mehr Zucker als die aut Amerikanerunterlage besalisen. Dicse Angaben stehen allerdings in Widerspruch

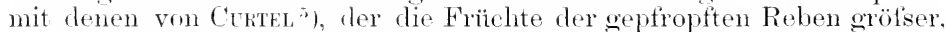
ihre schale dümner und die samen weniger zahlreich, aber dicker fand. Der Saft war reicher an Kucker wie an Säure, ärmer an Aschenbestandteilen, besonders Phosphaten, reicher an stickistotfhaltigen Bestandteilen, ärmer an tierbstoft. Wir haben absichtlich beicle Beobachtungen angeführt, $u$ zu zeigen, wio verschiedenartig die Unterlage wirken kann. Treitere Erfahrungen finden wir in den Denkschriften iles Kaiserlichen Gesundheitsamtes zu Borlin. So bestätigt beispielsweise die fünfund-

1) Cunner, Quel fues olservations à propos de la greffe. Revue hort. 1876, II, p. 208 .

2) Aus dem Weinban-Kongrefs vom 16. bis 19. August 1894 in Lyon; cit. Zeitschr. f. Pflanzenkrankh. 1\$5, s. 11

$\left.{ }^{3}\right)$ Raraz, L, Choix des porte-greffes. Rerue de viticulture 189., Nr. 100, 10.5, 106.

4) Hotrse, E., Der Einfluts dor amerikanischen Tnterlagsreben auf die Qualität des Weines; cit. Centralbl. f. Agrikulturchemie 1905, S. 625 .

5) Corris, (t., De l’influence de la greffe sur la composition du raisin. Compt. rend. 1904, t. CXXXIX, p. 491. 
zwanzigste Denkschrift die bereits erwänte Buobachtnng. dats die amerikanische Rebe an Widerstandskint gegen die Reblans, Gelbsucht u. a. verliert, wem sie gepfropft wirip).

Betreftes des technischen Verfahrens, das hei der Weinveredlumg

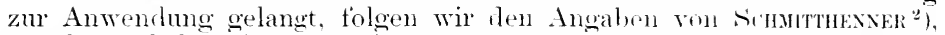
der herrorhebt, dat's zurzeit der sogenannte Engliseho Knn wen. selunitt fast allogeme Anwendung finclet. Es ist lies eine Form der Kopulation, bei der der Ijagonalschnitt nur reringe Länge hat, dafïr aber die schnittfäthen von Edeheis und Willling noch einen axilen Einschnitt erhalten. Nun schieht man das Reis mit rinem siraltteil in den s'palt der Unterlage, so dats Reis mol Unterlage mit Genenzungen ineinander greifen. Der anatomische Befind zeigt, dats lei der Rebenveredlung mehr als bei jedre andern die Tätigkeit des C'ambiums herabgedrückt wird: der nach der Veredlung entstohente Jahresring ist viel schwächer als der normale. Der Einfluts der Wunde ist viel bedentsamer als bei der Veredlung anderer Gehölze und erstreclit sich bis zum nächsten Knoten, indem sämtliche Grefäse mit verkorkten Thyllen ausgefüllt sind, welche Wundgummi enthalten.

Schon frïher hatte Toups ${ }^{3}$ ) ïber das Veredeln ler Reben im krantartigen Zustande eingehende anatomische Daten weliefert. Übrigens wirl die Weinveredlung erst damn zur vollen praktischen Wirksamkeit gelangen. wenn man als Unterlagen nicht die amerikanischen Arten, sondern deren Hrhriden henutzt, lie den einzelnen Örtlichkeiten angepalst sind ${ }^{4}$ ).

Seit dem vorigen Jahrhmolert ist man der Bastardhildung durch Verollung näher getreten. Das bekamnteste Beispiel ist Cytisus Adumi. der ans einer Veredlung von Cytisus purpuress ant Laburmm rulgar herrorgegangen sein soll und zeitweise num seit ls.ti in einzelnen Zwoigen hald die Blïten dre einen oles anderen Sitammart produziert. Nach A. Brals"s) soll sich der Rückschlag zuerst li .Jahre

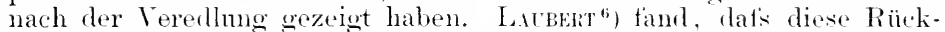
schlagsbildung als eine Knospenvariation anzusperhen sei, bei der tie den Cytisus jurpurus repräsenticrende /weigform anch in anatomischer

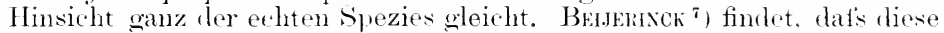
Knospenvariation sich häufig durch Wundreiz wecken läl'st.

Ein antleres Beispiel wircle 1s\% veröttentlichts). In einem Wrinhanse in England wurle ein Stock, dor mit Blacli Alirante bereits verelelt worden, nach längerer Zeit noch rimmal mit drei siorten auf len Black Alicante veredelt. Eine lieser drei Sorten wurde später samt

1) Finfundzwanzigste Denkschrift hetreffend die Bekimptung dor Rehlannkrankheit. Bearbeitet in Kaiserl. Gesumbleitsamte bis 1. Oktober 1st);

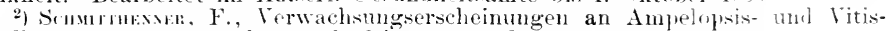
Veredhungen. Internat. phytopath. Dienst 1908, Nr. I.

3) Tumi, A., Fondure de la greffe herbacée de la vigne. Aunal. Iustit. ampélologique hougrois. 190m, t. 1, Nr. 1.

4) Trikk, Avmi, Die Rekonstruktion der Weingärten usw. IJ. Aufl.. Wien und Leipzig, Hartlebens Virlat. $190 \%$.

5) Bot. Jahresber. $1>7:$, , S. $5: 37$.

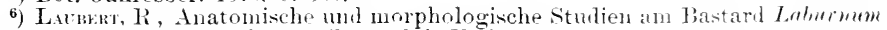
Allami Poir. Bot. Centralbl. Beihefte Bd. X, Heft 3.

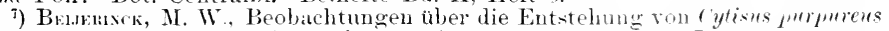
aus Cytisus Idami. Ber. 1. Theutsch. Bot. (ies. 19us, Heft 2, S. 1:3.

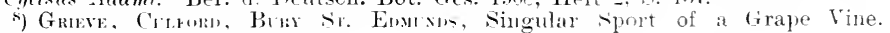
Gard. Chron. 1875. I, s. 21. 
einem kleinen Stücke der Unterlage fortgeschnitten. Tharanf zeigte ein mitten in dem Aste der zweiten aufgesetzten Sorte (Trbbirmo) stehender sprots einen Sporn mit Trauben, welche gänzlich der fortgeschnittenen Sorte (Golden Champiom) glichen. Unterhalb und oberhalb des abmormen spornes trug die Trebbianorebe wieder ihre charaliteristischen Früchte. Es bleibt somit keine andere Amnahme ïbrig, als dafs die weggeschnittene Championsorte nach rückwärts hiı einen Einflut's auf die Unterlage (Bluch Alirante) und durch diese auf die seitlich veredelte Trebbianosorte ansgeibt hat.

Ein anderer, sonderbarer, älterer Fall ist durch LAckNer ${ }^{1}$ ) bekannt geworden. Im Garten Palavicini bei Gemu sah Lackner unter dem Namen Mararilla di Spana eine Orange (Bigaradia bizarro Riss.), die auf der Oberfläche zum Teil wulstige Streiten zeigte und anch dementsprechend im Innern teils einer Citrone, teils einer Apfelsine und C'edrate glich. Diese Form ist nachweislich um 1tift) entstanden, wo ein Gärtner in Florenz einen Wildling veredelte, ohne dafs das Edelreis anwuchs. Unmittelbar unter der Teredlungsstelle entstand a!er ein Zweig, welcher diese höchst merkwïrdigen Früchte brachte. Die Blumen sind ebentalls verschieden; einige erscheinen weits, andere rot.

Im Jahre 1873 veröffentlichte die Revue horticole einen Fall, in welchem ein Herr ZEx durch Veredhung nene Rosenvarietäten gezüchtet habe. Die Varietäten blieben konstant.

FockE ${ }^{2}$ ) erwähnt eine weil'se Moosrose, die anf eine rote Centifolie gepfropft worden war. Ein solcher Stock entwickelte ans der Basis Triebe, die teils weilse Moosrosen, teils Centifolien und auch Moosrosen mit zum Teil rotgefärbten Petalen trugen. Aufser bei den hier besprochenen Rosen werden noch Pirus. Begomia, Oxyria und Abies als Genera genamnt, bei denen Pfropfmischlinge vorgekommen sind.

Eine Rückwirkung des Edelreises anf die Unterlage sieht DANIEL in einem Falle, in welchem alte, auf Quitte veredelte Birnen $2 \mathrm{~m}$ über dem Erdboden abgesägt worden waren. Aus den gänzlich entasteten Stumpfen entwickelten sich teils Zweige mit normalen Quittenblättern, teils solche mit Mischformen zwischen Quitte und Birne ${ }^{3}$ ). Derselbe Autor beschreibt in Gemeinschatt mit Junic ähnliche Beispiele an gepfropften Reben, von denen RAvaz ${ }^{4}$ aber nachweist, dal's derartige Variationen auch an nicht geptropften Reben auftreten. Solche Fälle von Verwechshng kommen mehrfach ror: man ist sehr leicht geneigt, Formenunterschiede auf den speziellen Einflul's der Veredlung zurickzuführen, die in der Tat nur Tariationen an üppigen Zweigen sind, wie solche nach starkem Zurückschneiden älterer Achsen sich geltend machen. Wir erinnern nur an die mannigfachen Blattformen des Stockansschlags bei Morus, Populıs n. a. nach dem Absägen der Stämme.

Die meisten Irrtümer kommen bei den Pfiopfrersuchen mit krautartigen Pflanzen vor. Anch hier haben wir Versuche von D.sNIEL ${ }^{5}$ ), der Kohlrïben auf Alliaria und diese auf Grünkohl pfropfte und bei den

1) Lackser, Einflufs des Edelreises auf die Unterlage bei Orangen. Monatsschrift d. Ver. z. Bef. des Gartenbaues v. Wittmack 1878, S 54.

2) Focks, Die Pflanzen-Mischlinge. Ein Beitrag zur Biologie der Gewächse. Bot. Centralbl. 1880, S. 1428.

3) Dixibr, L., Un nouvel hyluride de la greffe. Compt. rend. 190\%, t. XXXVII.

4) Ravaz, L., Sur les variations de la vigne greffée; reponse à M. L. Daniel. Montpellier 1904 .

5) Daxier. L., Creation des variétés nouvelles au moyen de la greffe. Compt. rend. $1894, \mathrm{I}$, p. $99 \%$ 
aus den Samen der gepfropften Exemplare entstandenen Pflanzen morphologische und anatomische Unterschiede gefunden hat. Hierher gehören auch die Kartoffelyfropfrersuche und dic Veredlungen von Solamm Lycopresicmm auf Kartotfeln. Es liegen geral. hutretts der Veredlung verschiedener Solaneen aufeinander äntserst zahlreiche Versuche vor, die wir bereits in der zweiten Autlage dieses Iandbuchs

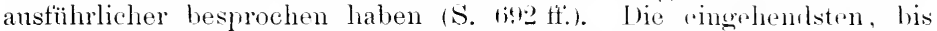
auf die neueste Zeit fortgeführten Versuche verdanken wir IsNumuru, dessen Untersuchmoren wir bereits in dem Absehnitt iblere Albiatio

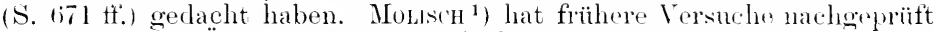

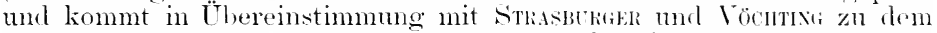
Resultat, dat's eine Entstehung von Ptropthybriten zwar theoretisch wohl erklärlich wäre, aber tatsächlich nicht genügend nachgewirsen sıi, da er und die genannten Beobachter gefunden hätten, dats Reis und Unterlage stets ihre Natur in morphologischer Hinsicht beibehiclten.

Wir remögen diesen Standpunkt nicht zu teilen, da namentlich die nenen Lixnemthschen Versuche ${ }^{2}$ sowie die ron E. Bark eine Beeinflussung der Unterlage durch das Erlelreis genügend feststellen. Allerdings laufen in rielen Fällen Knospenvariationen nebenher, die mit dem stofflichen Einfluts des Edelreises anf die Unterlage nichts zu tun haben, sondem wahrscheinlich auf' den Wurlreiz zurückzuführen sind. Henmmosersheinmogen der verschiedensten Art. wie z. B. Drucksteigerung in der Knospenlage, kïmnen schon eine andere Entwicklung einer jungen Achse einleiten.

Der Einthuts der Unterlage ant das Edelreis ist bei der (olstzucht eine bekannte Tatsache. Wir erimmern nur an die verschiedene Wirksamkeit der Unterlage auf ein und dieselhe Apfelsorte. Ant Inucin zeigt sich starker Holztrieh und spätere Fruchtharkit, anf Paracliesstamm geringer Holzwuchs und frïher Fruchtansatz. Allgemene Regeln lassen sich nicht autstellen. Dor Erfolg hängt nicht nur von der Pflanzenspezies, sondern anch von den Febenmmständen (Alter. Standort. Ernährungstorm nsw.) ab.

\section{Die natürlichen Verwachsungsprozesse.}

Am häufigsten treten uns in Hecken die Versehmelzungen zweier Äste entgegen, die von don rerschiedensten Richtmogen her anfeinander zu gewachsen sein können. I)asselbe lä1st sich in dichten Banmbeständen an Wurzeln beobachten.

Die Wuzelverwachsungen lionnen in jugentlichem Alter der oroane stattfinden, in welehem die Epidermis noch teilungstähig ist. Fath

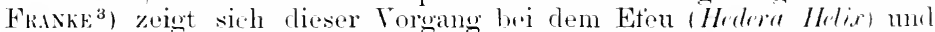
der Wachsblume (Hoyn camosa), bei denen die Epidermiconllen zweier benachbarter Wuzeln papillenartig anfeinander zn wachson mul rer-

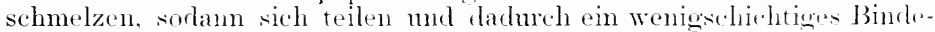
gewebe darstellen. das allerlings nicht die Festiglieit hesitzt wie das ans der Cambiumzone hervorgehende Kittgewohe hei zwei mit Borke versehenen Wurzeln älerer Holzptlanzen. Hier strllt sich derselbe

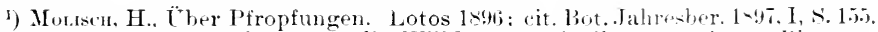

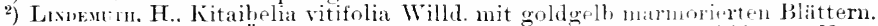
Gartenflora 1\$99. s. 4:31. - C̈ber Veredlungsversuche mit Ilalvacen. Ibid. 1901. Nr. 1

3) Fraxk, Beitrïge z. Kemntnis der If urzelverwachsm wn. Beitrige z. Biologie der Pflanzen von F. Cons, Bd. 111, Heft 3: cit. Bot. Centrall,1. 1482, Bd. X, Nr. 11, S. 401 . 
Torgang wie bei der Terschmelzung oberirdischer Organe ein. Die Rinde an den Berührungsstellen wird teils nach aufsen gedrängt, teils inselartig eingeschlossen; das Cambium produziert dort nicht mehr, wo der Druck an der Berührmgsstelle sich geltend macht, und rerschmilzt zu einer gemeinsamen, beide Wurzeln umfassenden Schicht, die alljährlich bei genügender Emährung neue Holzlagen über die

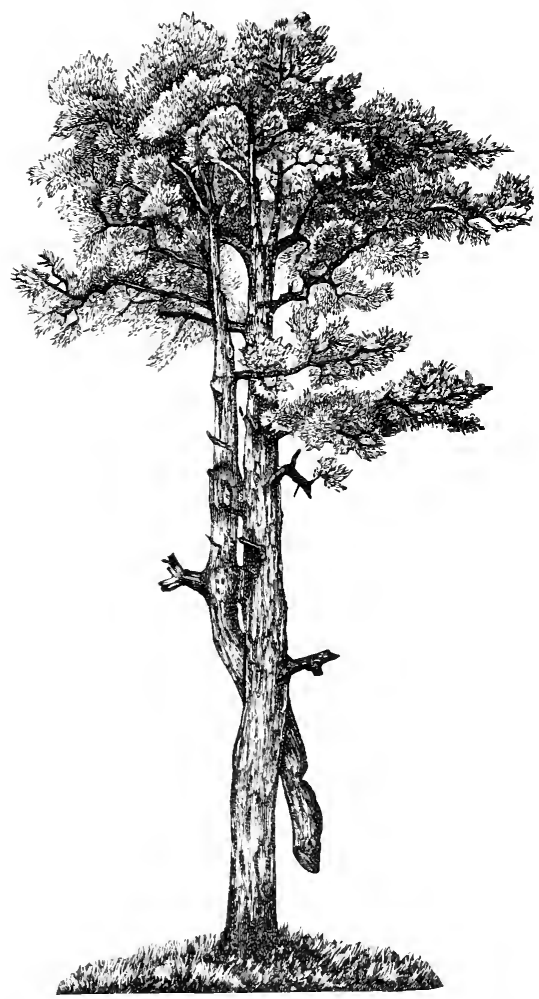

Fig. 201. Kiefer aus dem Ellguther Forste, bei der ein stamm einen zweiten durch naturliche Ablaktion verbundenen, wurzellosen Stamm dauernd mit ernährt. (Orig.)
Verwachsungsitelle legt.

Bezïglich der anatomischen Verhältnisse bei der Verwachsung von Stämmen verweisen wir ant die Arbeiten von $\mathrm{Ki}^{\prime} \mathrm{sTEF}^{\mathbf{1}}$ ) und erwähnen hier nur noch einen von mns selbst beobachteten seltenen Fall. Derselbe fand sich im Ellguther Forste bei Proskau an einer Kiefer, an deren kräftigem Stamm ein zweiter, dïmmerer Stamm an mehreren Punkten durch natürliche Ablaktion festgewachsen ist.

Die Basis des schwächeren Bames ist vor vielen Jahren abgehanen worden, so dats derselbe seme Nahrmo ansschliefslich von der älteren Kiefer beziehen muls. Beide Stämme waren zur Zeit der Beobachtung vollkommen gesund und bilden eine gemeinsame Krone: nur wollte mir scheinen, als ob der ablaktierte. wurzellose stamm etwas kürzere Nadeln besessen hätte.

Ton einer anderen Kiefer besitze ich ein stammstïck, bei welchem die spitze eines etwa 5 cm dicken Astes in die Hamptachse hinein sich gebohrt hat nnd in derselben gänzlich verschwunden ist. Es ist dies ein Beispiel für die sogenannten ..gehenkelten sitämme*.

Sämthehe Vorgänge dieser Art beruhen ant der Fähigkeit des cambialen Gewebes, Verkittungsshichten zwischen vershiedenen Achsen zu bilden. Lie Prozesse unterstheiden sich von den Ver-

1) Köriz, E., Über Stammverwachsungen. Jahrb. f. wiss. Bot. Bd. XXXIII, Heft 3. - Pathologische Pflanzenanatomie. Jena 1903, Gustar Fischer, s. $173 \mathrm{ff}$., Abschnitt Wundholz. 
edlungen nu dadurch, dat's die später miteinander verwachsenden Cambialschichten zunächst duch die Rinde der PHanzenteile voneinander geschieden sind. Diese muts erst durch allmähliche Reibme entfernt werden. Ist die Verschmelzung der Arhsen vor sich gegangen, dann lagert sich allährlich ein zusammenhängrencler llolzmantel über die Verwachsmgstelle. Manchmal liegen möisere, brame Partien abgestorbener Rinde mitten in der Verwachsmestläche, was sich dureh die unebene Beschatfenheit der miteinander in Brrïhrum trotenden Achsen erklären lätst. Wem zwei mit Borkensehuphen bekleidrete Stämme einander berïhren, so reiben sich zunächst die hervorragendsten Stellen gegenseitig ab und verwachsen miteinandre znerst, Währembl tieterliegende Furchen gar nicht an der Verwachsmer trihnehmen, sondern von dem nenen Gewebe eingeschlossm werden.

In Wäldern, namentlich Eichten- und Kiefernwaldungen, begegnet man hänfig Zwillingsstämmen, welche ant verschieden lange Strecken von der Basis ans miteinander verwathen sind. Soltener sind die Fälle, in denen stämme isolierten Ur'sprungs in den häheren Regionen ihrer Hamptarlsse miteinander verwachen.

Manchmal zeigt der Quersehnitt der Basis eines Zwillingstammes drei Centren. Bei Koniteren ist rer mittelste. drittr stamm in der Regel verkiehnt. Hier ist jedentalls in der Jugend der Giptel der Hauptachse abgebrochen worden, und zyei Soitrnangen hahen das Wachstum übernommen. Anstatt wagrechte Äste zu bilifin, haben sich diese zu zwei Gipfeltrieben entwickelt, walche nach einer längeren heihe von Jahren die absterbente Ilamptachse vedrïckt und endlich muwallt

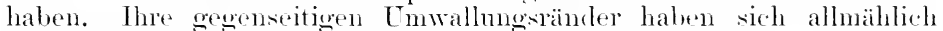
miteinander vereinist, und sehlietich ist ein einziger, zusammentgedrïckter Cylinder ans den droi Achsen geworden.

Dats die Terwachsmo anch zwischen Teilen von Individnen verschiedene' Arten vor sich gehen kam, int nach den hei dem Vereflungspozese erwähnten Tersuchen als teststehende Tatsache anzumehmen. Fichten und Tammen, Äptel und Birnen und diese mit (suitte, Mandel mit PHamme u. dol. diurten als bekannte Beispiele welten. Es ist jedoch auch hier sicherlich eine Grenze in ler Verwandtschatt der Ptlanzen vorhanden, über welche hinaus eine wirkliche Verwachsung trotz innigster Berïhrung und starker Reibung nicht statthaben wircl. E- finden sich zwar in der Literatur eine muze Anzahl Mitteilungen üher Vorwachsungen schr heterogener Pflanzen, indes heruht arowts ein 'Teil dieser Angaben ant' irrtümlicher Boblachtung ${ }^{1}$ ), inden

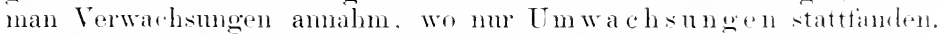

Nach den bister so anstïhrlich darestellten Voroängen rler Mundheilung diinfon wir hice wohl, ohme mifserstanden zu werelen, anssprechen, dats sich der sehrinbar so starer Holzkörper eines Banmes in alle möglichen Formen bringen lätst, wemn das ans don ('ambimm-

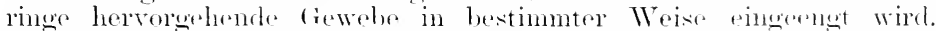
Jan kamn anch hildlich recht wnt sagen. dats sich der Holzstannm num

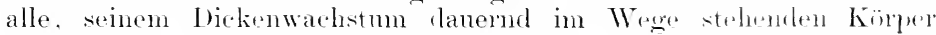

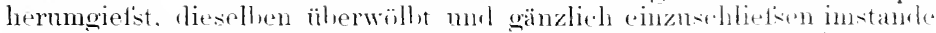
ist. Beispicle von sog. cingewachsenen stringn, Fichtenzapfen, ja selbst Tiermumien sind mehrach heobachtet worden.

1) Munix Tixm, Pflanzen-Teratologie, deutsch von sichatuer 1st2, s. 27t. Masters, legetable Teratologr 1 1 f59, s. .). 
Trir kömnen um so mehr die Anfzählung von einzelnen Beispielen mnterlassen. als wir jetzt eine ganze Anzahl äulserst amregend geschriebener Bücher über merkwïrdige Bänme und andere botanische Naturdenkmäler aller Art fbesitzen. Das lehrreichste dürfte zurzeit das Werk von Liwwir KLein ${ }^{1}$ ) sein, das durch mehr als 20 () nach photographischen Naturantinahmen angefertigte Abbildungen besonders berufen erscheint, die Liebe für die Bammwalt zu wecken und zu tördern.

\section{Wundschutz.}

Vom natürlichen Wundschutz haben wir teilweise schon gesprochen, insofern er durch Korkbildung hervorgerufen wird. Bei dem Holzkörper der Bänme aber findet sich keine die WTundfläche schmell deckende Korklage, sondern es füllen sich die Gefätso an allen den Stellen mit Thyllen oder einer gummiartigen, in kochender Salpetersäure meist leicht (bei den Correen schwer) löslichen Substanz ( Wundg $\mathrm{gmm}$ i), wo gesundes an abgestorbenes Holz grenzt. Die Thyllen sind in der Regel von etwas Gummi begleitet. Beide Austïllungsarten machen das Holz der Aststumpte tür Wasser und Luft röllig undurchdringbar und bilden imnerhalb der Vegetationszeit einen schnellen Verschluls. Aus dieser Beobachtmog ergibt sich, dafs wir gut tum, im Winter kurz vor Begimn der cambialen Tätigkeit die Bäume auszuschneiden²).

Bei einer grötseren Anzahl ron Holzgewächsen füllen sich die Getätise und häufig auch einzelne der anderen Holzelemente mit kohlensaurem Kalli ${ }^{3}$ ). Derselbe zeigt sich in (ler Regel im Kernholz und denjenigen Gewebepartien, deren Zellen dem Kernholz ähnliche chemische und physikalische Beschattenheit haben wie das rom Kernholz umschlossene Mark und das tote, verfärbte Holz in den Astknoten und an Wundstellen. Diese Ansfüllung ist eine meist so rollständige, dat's man nach dem Verbremen solcher Holzteilchen solide Kalkabgïsse der Zellen sieht, welche den Kalk enthalten haben. Der Vorgang läfst sich so erklären, datis überall da, wo sich tür das die Holzzellen und (ietälse durcheilende Bodenwasser, das den Kalli als doppelt kohlensamen enthält. Gelegenheit findet, Kohlensäure abzngeben, sich der num nicht mehr gelöst bleibende Kalk als Niederschlag anf der Innenseite der Gefätse absetzt. Im lehendigen Kernholze, das nicht wie der Splint noch das Kalkisalz schmell verarbeitet, wird cine jede Temperaturerhöhmo ein Entweichen von Kohlensäure veranlassen und einen Niederschlag von Kalk einleiten. Bri den Wunden wird durch das Freilegen des Gewebes ehenfalls die Kohlensämre verschwinden. Während mu der splint, der liemen Kalk ablagert, durch die Thyllen- resp. Gummilildumg (wahrscheinlich infolge des Eintritts von Luft in vorher safttährende Getälse) sich ror dem Eintritt der Atmosphäre schützt, sehen wir bei Kernholz dic Kalkablagerung als s.chntzmittel auftreten.

Im normalen stamm tritt die Kernholzbiloung erst in fortgeschrittenen Altersistadien auf: nach Verwmdungen aber leitet sie sich

1) Kı⿻上丨, Lrıwix, Pemerkenswerte Bäume im Grofsherzogtum Baden. Heidelberg lins, Winter's Universitittsbuchhandlung.

$\because$ Binn, Über die Fumktion der vegetabilischen Gefälse. Bot Zeit. 1879, S. 229. - Die äufserst reiche Literatur äber Thyllenbildung findet sich bei E. Kïrsme, Pathologische Pflanzenanatomie, 1!n: S. S ff.

3) IIouscin, Über die Ablagerung von kohlensaurem Kalk im Stamme dicotyler Holzgewächse. Sitzungsber. d. mathemat.-naturwissenschaftl. Klasse d. k. Akad. d. Wissensch. zu Wien, Bd. LXXXIII, Nr. 1: (1ø81). 
sofort ein und gibt Veranlassung zur talschen Kernbild $n n g^{1}$ ), die durch die Mitwirkung ron Pilzen und Bakterien zum Faulkern ${ }^{2}$ ) sich umgestalten kann.

Dieses Eingreifen von Mikronrganisum hat zur Antistellung einer Reihe parasitïer Krankheiten gefülnt. (lie aher in wesentlichen auf Störungen im Wundheilungsprozef's beruhen. Wir nemen in "rster Linie den

\section{Wundgummi.}

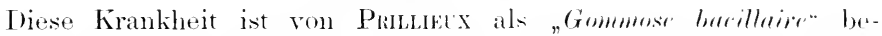

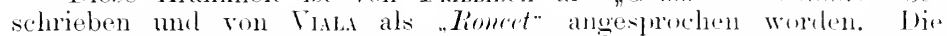
Blätter bleiben zwar grün, aber sind mregeimälsig tief eingeschnitten und vermstaltet. Das Holz zeigt im Querschnitt schwalrze Punkte und Flecke, die sich vergrötsern mut seine Lonsistenz lockern. suater lösen sich die Bastlagen rom Holze. An dru sichnittläehen, ron denen die Kranliheit an:geht. entstehen Risce, die ron Silprophyten besiedelt werden, und nach 3-5.; Jahren sah Priblatex den Towl des Stockes eintreten.

Die schwarzen Punkte in Holze rühren von einer gmmmosen Veränderung her, indem die Getätse und die Zellen des Folzparenchyms mit bramem (xummi, das von Bakterien (brwegliche Stäbchen) wimmelt. erfïllt sind. Ine im Mai im Laboratorim vorgenommene Impfung liefs Priblew die charakteristischen Merkmale der Krankheit wieder

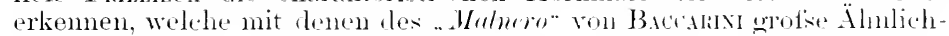
keit haben.

Vhate und Fö̈x sowie Maxils sprachen sich im Gegensatz zu Priblect dahin ans, dats die geschilderten krankheitserschemmoen durch die versehiedensten Trachen reranlatist weren kïmen mut anch an gesunden stöcken nicht tehlen.

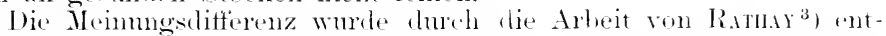
schieden, der zmü̈chst nachwies. dats (rommi in ganz gesunden Reben rorkommt. Bei gesumten einjührigen Trieben ron libs ripuria sah Rathar aus den Getätsen gallertartige Fäden hervortroten, die aus Gummi bestanden. The mit firmmi augefölltun Röhren f,tinmmigefälse") sind in Fig. 2012, 1 zu sehen. Dassill gab die Farben-

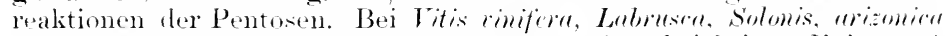
u. a. konnte die Reaktion erst in zwei- und mehrjährigen flolze antgefiunden werden. Wo dieser Vorgang schon in jungen Reben anftrat, komnte ar nicht vor Juli beobachtet werden. Las Gimmi wird threh Druck herrorgepretist. In den Wurzeh ist der Vorgang spärlielwer.

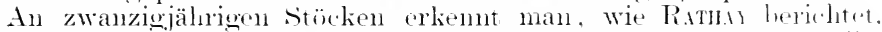
dats anch beim Wein eine normale Kernholzhildmes wirh endlich einstellt: nur ertolgt dieselha unregelmailsig. indem einzelne stellen der inneren Splintholzes in dir. Veränifermeng dintreten und dadureh die bramen Fleetse

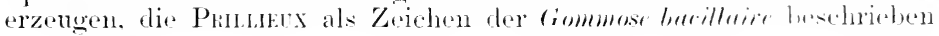

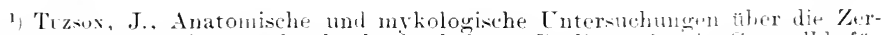
setzung und Konservierung des Rotbuchenbolzes. Berlin 194s: cit. C'ntralbl. für Bakt. 1905, II, Bd. $\mathrm{XV}$. 4 .

a) Henmax, Uber die Kernbildung bei der Buche. Naturf. Gre. lanzig: ait. Bot. Centralbl 1905. Bil. Xi'1S.

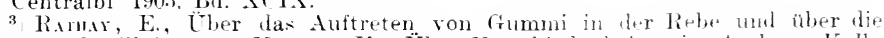
„Gommose bacillaire". - Krevi... H., Ther Verschiedenleeiten in Aschen-, Kalkund Magnesiagehalt ron splint-. Wund und Wumlkntum der Rebe Jahresber. d. k. k. önolog. u. pomolog. Lehranstalt in Klosterneuburg. Wien lagk. 
hat. Prüft man nämlich cine solehe fadenartig im splintholz abwärts sich ziehende brame stelle (Fig. 202, 3), so sieht man tie weiten Gefäfse erfïllt nit diner bramen Gmmmimasse und in lerselben liristallinische Niederschläge von kohlensaurem Kalk (f): die Inhalte der un das Getäts gelagerten TLobparenchym- md Markstrahlzellen sind ticf bram, und die benathbarten engeren Gefätse $(t)$ sind mit Thyllen ansgetüllt. Stärke war nu im splint: an deren stelle waren im Kernholz brame Körner, welehr mit Eisenchlorid blanschwarz women. Gefaisverstoptimgen fanden sich nicht im splint, sondern nur im Kernholz: sie wm den verursacht zunäthst durch Thyllen, die im inneren Kernholz sogar ansschlietslich antraten, während in dem äufseren Kornholzringe die Verstoptimg durch fimmi und Kalli vorhersehte. Manchmal erwiesen sich ganze Reihon ron Gefätsen des Herbstholzes mit (neistens kohlensamem, hisweilen oxalsaurem) Katk erfïllt (Fig. 202, 4). Ler in den jüngsten Teilen des Kemholzes abgelagerte kohlensame Kalk wird später wieder anfuelöst. Ebenso rersehwinflet der grotse Gummireichtum des splintes bei dessen Übergang zu Kernholz.

An einer querwunde stirlst das der Wundtäche anstotiende Gewebe mehr oder weniger tief ab. In dem darautifolgenden lebendigen Gewebe erfolgt zunächst die Gefätsverstoptimg dmeh Grmmi, weiter abwärts dureh Thyllenbitdmg. Dats es die Holzparenchymzellen sind, welche das Gmmi ansischeiden, geht darans hervor, dat's die Getätse nm an den an diese /ellen anstotsenden Teilen fimmitröptchen mnd Gmmmibeläge haben, während dort, wo sie an Nachbargefälse anstotsen, das (immmi tehlt. An den Wundflächen begimmen die Veränderungen, welche das Kernholz charakterisieren, viel tiïher als im nomalen mnverletzten stamme, gehen aber nur so weit abwärts, als eben der Wundreiz wirksam war, und ist deshall, als. "Wundkernholz", das von auderen Beolachtem als .Falscher Kern" angesprochen wird, vom eigentlichen Kernholz zu muterscheiden. An den von der Wundfläche answehenden Einzelherden der Kermholzbildmo, die als brame Gewebestreifen sich im splint alwärts zichen, findet man in der Nähe der schnittfäche viele Bakterien, aber nicht in den tieteren Regionen. bas Krankheitshild stimmt also mit der crommose bacilloire, nud diese ist deshall, nur als eine mmittelbare Folge der Verwundung älterer stammteile antzutassen. Lieser Wundreiz dürte vorzugsweise ant das Protoplasma der dic Gefätse mogebenden Holzparenchymzellen wirken, sich wegen der Contimität des Protoplasmas benachloarter Zellen mithin fortptlanzen und die llolzparenchrmzellen zn einer verfiühten Thrllenbilkme anregen: diese Killen altern und sterben deshalb vorzeitig ab. Wit der Thyllenbilenng hört die anfänglich sehr reichliche normale (inmmiseliretion ant. Ler besclubebene Torgang wird bei Vergleithmo der beistehenden Figmen äbersichtlicher.

In Fin. 20.2, : Alkoholoräparat ans einem zelmjährigen Aste von Iit is rifurin) zeigt j lie (irenze zweier Jahresringe: m, m Markstrahlen,

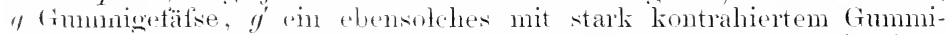
inhalt. Rechts (Fig. 1) sind zwei fimmigefätie ans einem einjährigen Triele von litis rimifra (hlaner Trollingtr) dargestellt; sie zeigen in der Jitte den kontrahierten Gmmminhalt. Fon den Gefätswandnngen ist nur

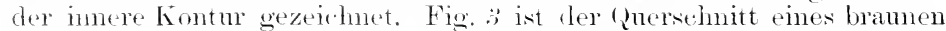
Ilolztadens ans dens splinte eines selu alten Relstamnes. j, j, j, jorenzen Lre Jahresingo. $l_{i}$ ein radialtaseriges, kristallinisches Aggregat von kohlensamem Kalk, eingelsettet in der bramen fummimasse eines weiten 
Wunden des Achsenorganes.
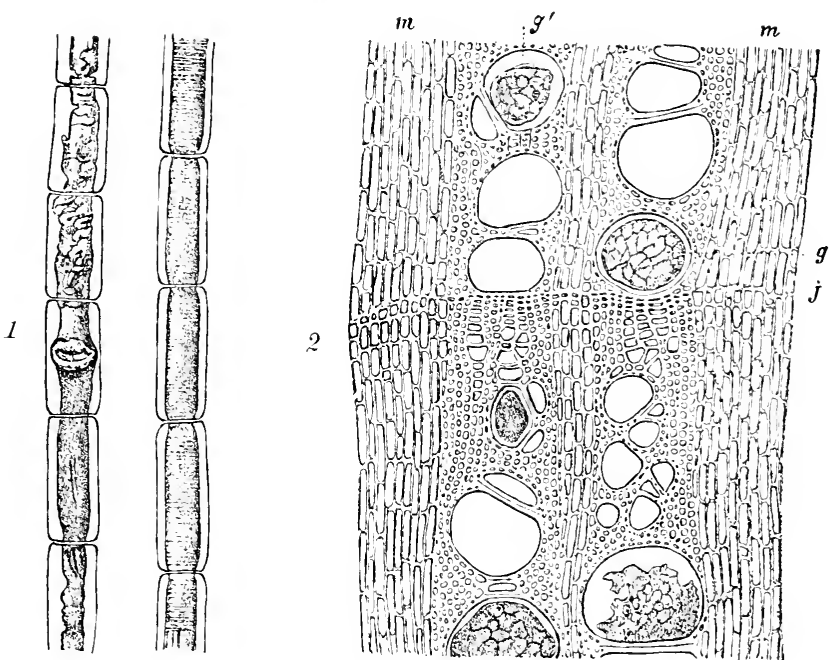

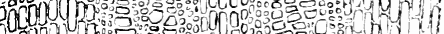

nOTn f 1. Th:

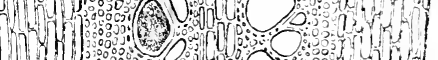

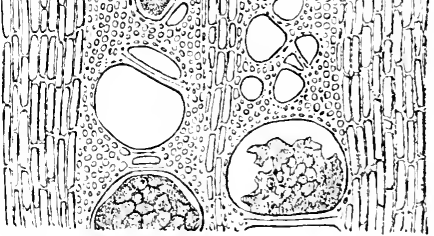

in

$g$

$m$
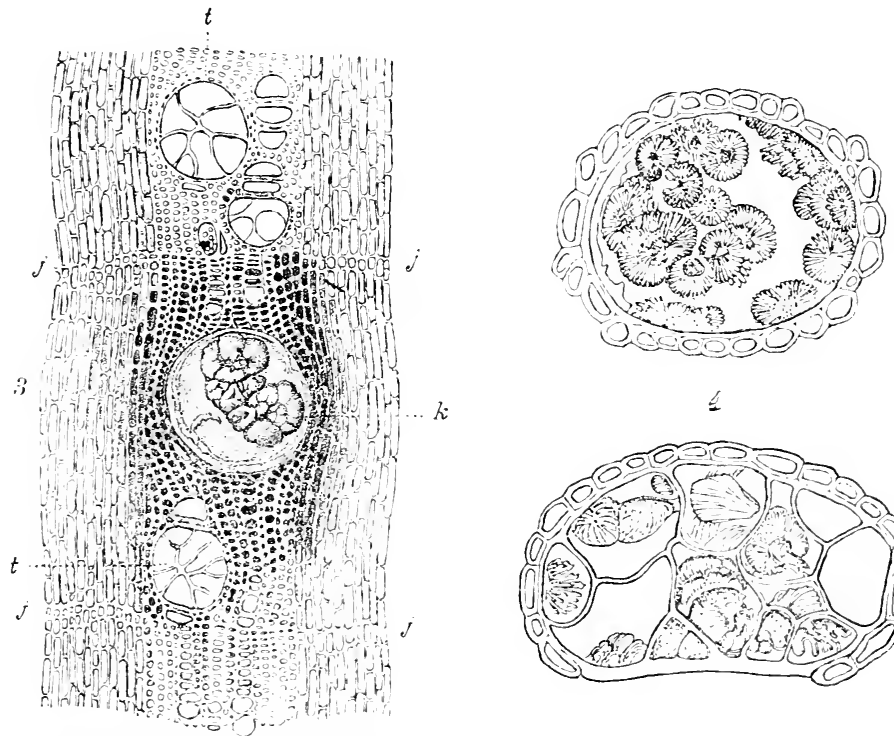

hi

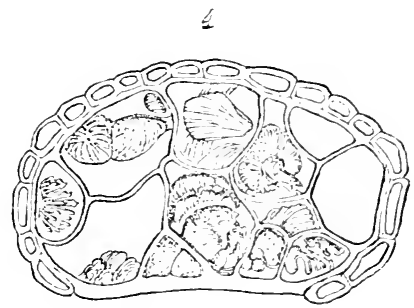

Fig. 202. Gefäsverstopfungen bei einem an Wundfanle leidenden Weinstort. (Nach Rumix.) 
Grofitses: der Inhalt des angrenzenden Holzparenchyms, der Libriformfasern und Markstrahlzellen ist tief gebräunt, und die nächst gelegenen Gefälse $t$ sind mit Thyllen erfüllt.

Fig. 202, 4 ist ein Gefäl's mit zugehörigen Holzparenchymzellen aus dem unter der Entgipflungswunde eines einjährigen Triebes befindlichen abgestorbenen Holzteil im Querschnitt. Es enthält neben farblosem Gummi rarlialstengelige Aggregate von oxalsaurem Kalk. Die untere Fignr ist ein Crefäis mit umgebendem Holzuarenchym aus dem Kernholz eines sehr alten Robstammes. Das Getät's ist mit Thyllen angefüllt und enthält in diesen kristallinische Aggregate von kohlensaurem Kalk (nach RathaY).

Wir haben diesen Fall hier vorgeführt, weil er als Typus für viele andere Fälle die (immmibildung als Folge des Wundreizes veranschaulicht und gleichzeitig zeigt, wie leicht hrankheiten als absolut parasitär hingestellt werden, bei denen es sich nur um die nachträgliche Ansiedlung von Wundbewohnem handelt.

Dies bezicht sich ganz besonders auf krautartige, fleischige und saftige Organe, und in dieser Beziehung ist eine Arbeit von SPIEckerMaxN ${ }^{1}$, hervorzuheben, der besonders darauf hinweist, wie bakterienfest eine verkorkte Memloran ist, wie notwendig ein bestimmter hoher Fenchtigkeitsgehalt der momgebenden Luft und auch der Wassergehalt des Gewebes selbst, abgesehen von dessen spezifischer Empfänglichlieit, sich erweist, damit selhst von einer Wundfläche aus eine bakterielle Zersetzung sich einleiten kamn.

\section{Die Schleimflüsse der Bäume.}

Im Anschluts an das bei der "Gommose bacillaire" erwähnte Verhältnis der parasitären Besiedhng" von Wundfächen erwähnen wir die Erscheinmong. dats sehr häufig bei einzelnen Exemplaren der verschiedensten Bämme eine auch im Sommer oft feucht bleihende abweichend gefärlote, meist schleimig bis gallertartig. bisweilen lehmartig aussehende Rimne bemerkbar ist.

Unserer Auffassung nach handelt es sich um ein abnormes Bluten der Stämme aus Wunden, die sich nicht schlietsen kömmen. W[oLssch ${ }^{2}$ ) hat nachgewiesen, dats lei jeder Wuncle, die zu ïberwallen begimnt, sich ein lokaler Bhutungsdruck geltend macht. Infolge der Verwundmng werden das Cambimm sowie die parenchymatischen Elemente des llolzes und der Rinde zu erhöhter 'Tätigkeit und Zellteihmg angeregt. Damit vertmulen ist eine solehe Thoorsteigerung, dats aus der TWunde oft unter ganz enormem Druck (bisweilen bis zu "Atmosphären) Wasser ansgepretst wird.

Wenn man die Analyren cles Saftes, der bei dem Tränen des Weinstocks austliefst ${ }^{3}$ ), zugrunde legt, so darf man in den Blutungssäften

1) SPвскинах, A., Beitrag zur bakteriellen Wundfäulnis der Kulturpflanzen. Landwirtsch. Jahrbücher 190.', S. 15.).

״) Mous . H., Über lokalen Blutungsdruck und seine [rrachen. Bot.Zeit. LX; eit. Just's Jahresber. 190:. II. s.. 618.

") Rurzz, F., Über las Thränen der Weinrebe usw. Staz. sperimentali 1s8s; cit. Biedermann's Centralbl. f. Aqrik. 18st. S. 541. Nach den Tutersuchungen von Nerbarki und v. Caxsmen (Ammalen der Önologie, Bd. IV, 1s74, Heft 4, S. $499 \mathrm{ff}$.) enthielt der im frischen Zustande wasserhelle, neutrale, aber leicht durch Bakterienvegetation sich trübende und dam alkalisch reagierende Rebensaft (gesammelt im trocknen Jahre 1874) pro Liter $2,1204 \mathrm{~g}$ fester Substanz; davon waren 0,7408 $\mathrm{g}$ 
autser geringen Mengen organischer substanz anch Stickstott, Phosphorsämre und Kali als vorhanden ansehen, also eine Nährlösmng vorans. setzen, die zur Ansiedlung und Vermehrung von Mikrooranismen sehr gut geeignet ist. Diesen hat num Loww: ${ }^{1}$ ) an ringehendes studium gewidmet. In einer Reihe von Veröttentlichmpen heschreibt er cinen TTeitson Sehleimflut's bei Eichen, Birken. Salicineen u. a. durch Lenconstoc Lagerheimii Ludw., dem sich versehiedent Alkohol erzengende Pilze hinzugesellen (Saccharomyces Ludurgii Ilans. nsw.). Ein hei Apteln, Birken, Pappeln, Rotskastanien und andern Obst-mel ('hansicebämmen

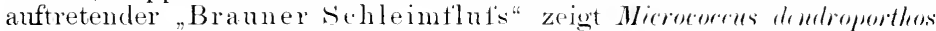
Ludw. dem sich Tornla momilioides Cord. zugesellt. Einen .Roten Schleim" fand Lruwn im Siätsommer ant den Stïmpten alter, wesmuler Buchen und beobachtete dahei eine fädige Bakterie (heptothrix?) und Fusarium moschatum. Demselhen Fadempilz begegnete er in einem gelblichweilisen Blutungssaft von gallertartig knorpeliger Konsistenz bei der I inde und vereinzelt bei der Birke. An frischen Astwumden von llainbnchen fand Luww gegen Mitte April einen wie Mileh anssehenden schleim, der Endomnces ermulis Ludw. neben Alkohol erzengender Hete enthielt. Von tierischen Begleitern derartiger Ansiedlungen, von Bakterien und Pilzen finden wir in einer sräteren Arbeit Lcuwris's) Milben (Hericiu) und Älehen (lihablitis) erwälnnt. Eine Liste sämtlicher Bewolmer der s'chleimflüsse, die nicht nur bei uns, sondern auch in den Tropen nachgewiesen worden sind, finclen wir in der Zeitschrift für Pflanzenkrankheiten 1 s!!!, S. 1:3. Es ist selbstverständlich, dats diese Liste immer wieder ergänzt werden wirk, je nachdem die einzchen Lokalitäten spezitisch angehörenden Mikrooranismen Gehenenheit erhalten, an Bhtungswunden der Bämme sich anzusiedeln.

Die genamnten Organismen dürten nur insofern fïr die Bäume als Schäeliger anzusirechen sein, als sie durch ihre Ansiedlung den IVundschluts verzögern oder verhindern. Die erste Veranlassmeg der sichleimflüsse sind eben Wunden, die lurch Frost. Blitzschlag. Tiere usw. veranlafist worden sind und periodische Blutumen einleiten. Sollte es wirtschaftlich notwendig sich erweisen, diese Schwächungsursachen zu heben, so kömite nur ein sorgtältiges Ausschneiden der kranken stellen und Verschluts der frischen Wundränder durch Anstrich mit steinkohlenteer zn emptehlen sein.

\section{Wurzelverletzungen.}

Nachdem wir eingehend die Üherwallungsvorwänge der oberirlischen Achse nach den verschichensten Verletzmoen hesprochen halren, kïmen

Mineralbestandteile und $1.3796 \mathrm{~g}$ organische Substanz. Fine Aschenanalyse ergal,

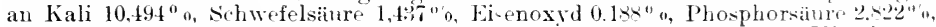

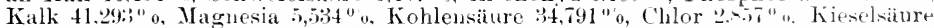
$0,810 " \%$ der Rohasche. Aufserdem fanden wich ein organisches Magnesiasalz, Gummi, Zucker, weinsteinsaurer Kilk, Inosit, Bernsteinsiure, (1xalsiiure uml tu-

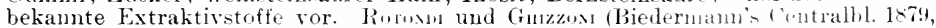
S. 527) geben neben Stäke anch Zucker an, den die Numn'schen l'ntersuchungen im frischen saft nicht anfgefunden haben. Frst der eingedunstrot saft, welcher unter Abgabe von Kohlensäure und Ausscheidung von phosphorsiurem kalk unter Gelbfärbung eine schwachsaure Reaktion annahm, zeigte alle Zuckerreaktionen.

1) Lriwati, F., Der Nilch- und Rotflufs der Bäume und ihre I'rheber. - C̈ber das Vorkommen des Moschuspilzes im raftflufs der Bäume: cit. Zeitschr. f. Pflanzenkrankheiten 1892. \$. 159. 160.

^) Linwa, F., Über die Milben der Baumflusse und das Vorkommen des Hericia Robini Canestrini in Deutschland. Zeitschr. f. Pflanzenkrankl. 1906, s. 137. 
wir uns betreffs der Heilung von Wurzelwunden kurz fassen. Sie entsprechen denen der oberirdischen Achse uncl erleiden nur insotem Modifikationen, als das umgebende Medium oft störend in den Überwallungsvorgang eingreift. Bei grolser Borlenfenchtigkeit beispielsweise ist das Stadimm der Callusbildung ausgerlehnter, die Umbildung des Callusgewebes zum testeren Überwallungsrand eine langsamere und die Möglichkeit einer Infektion durch holzzerstörende Pilze eine grölsere. Diese Falitoren verlieren aber an Bedentung, wemn die Wundtiäche offen zutage tritt. Der Einflufs von Licht, Wärme und Trockenheit erleichtert damn den Wundschlufs und lätst selbst grolse Wundflächen

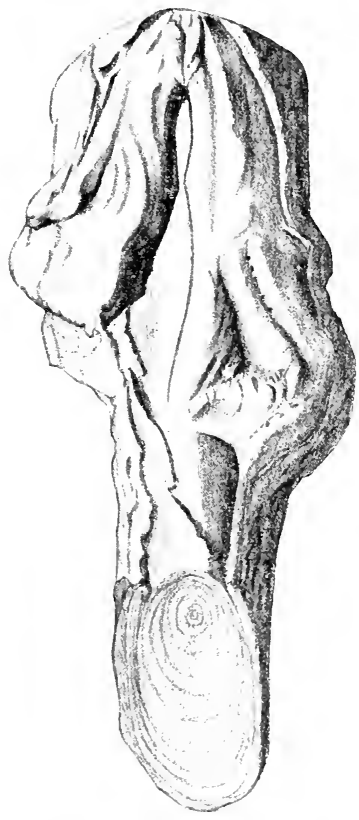

Fig. 20:3. Flachstreichente Erlenwurzel, durch Fufstritte abgeschliffen. (Orig.) ohne weitgreifenden Einfluts auf den Gesundheitszustand der ganzen Wurzel. Den besten Beweis lietern die rom Publikum stark besuchten Wälder in der Umgebung grofiser Städte, wo die flachstreichenden starken Wrurzeläste durch den Fulstritt der Besucher oberseits beständig abgeschliffen werden und trotzdem Gelegenheit finden, die Wundflächen immer noch dureh Überwallumgsränder zu umgrenzen. Beistehende Figur zeigt eine derartig abgetretene IVurzel, bei der nur noch die erstgebildeten Jahresinge oberseits intakt sich erweisen. Im Querschnitt ist angedentet, dats von der verletzten Stelle aus eine parasitäre Wundfänle nicht eingetreten ist; der untere Teil der WVurzel zeigt gesundes Holz.

Am meisten Beachtung verdienen die Wunden, die bei dem Terpflanzen der Bäume entstehen. Das Verpflanzen ist eine notwendige, nicht zu nmgehende Arbeit hei jedem Baumschulbetriebe; denn derselbe läuft darauf hinans, dem Käufer Bänme zn liefern, die nach dem Transport an ihren definitiven standort eine möglichst grotse Fähigkeit zeigen, bald wieder anzuwachsen und sich kräftig weiter zu entwickeln.

Bei dem Verpflanzen älterer Bäume mit hoch entwickelten Kronen und woitverzweigtem Wurzelwerk ist das Abhacken stärkerer Wurzeläste nicht zu umgehen, daher die Grefahr des Eintritts einer parasitären Wurzelfänle, die allmählich in den Stamm hinein sich fortsetzt, eine sehr naheliegende. Aber sellst wem diesor Gefahr dadureh vorgebengt wird, dats die Hieb- oder Sägewunden sofort mit Teer bestrichen werden, bleibt das Terpflanzen alter Bämme immer eine gefährliche Operation, weil der Wurzelapparat bis zur Bildung nener Wurzelfasern antiser Tätigkeit gesetzt wird und die Krone während dieser Zeit von dem im Holzköper gespeicherten Wasservorrat zehren muls. Bei der gegenseitigen Abhängigkeit der unter- und oberirdischen Achsen von- 
einander ${ }^{-1}$ ist es notwendig, dat's die Krom the verpflanzten Bammes entsprechend der Verändermog des Wurzelalplarates anch zuriuk-

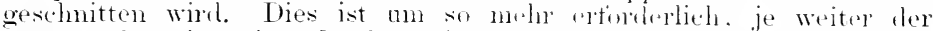
Bamn schon in seiner Lambentwicklung tortumehittrin ist. In prak-

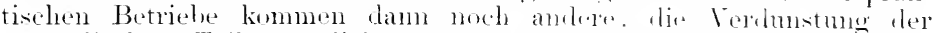
oberirdischen Teile mögliehst heschränkende Miltinittel hinzm, wie z. B. das Einbinden der stämme, das hänfige Bespritzen der kronen. kiinstliche Beschattung usw.

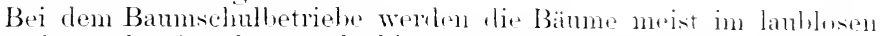
Zustancle verkautt: aber auch hier beansurucht der hadel sich int-

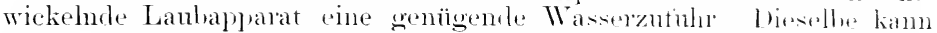

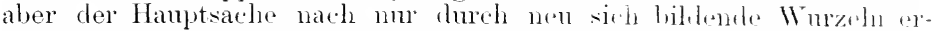
möglicht werden: deshall, ist es von der grodsten Wiehtigliegt, dis Bäume so an liefern, dats sie sehmell und rejehlich nene Wureh bilden. Dies hängt aber von der hisherigen Erzichmosweise des Bannts und der Art des Wurzelsehnittes ab. Je älter ein Wumelast ist, drsto spärlicher ist die Entwicklung nener Faserwuzeln an der schnittläche. desto grobiser ist diese selbst. lesto langsamer ihre T̈lwrwallumg. mul desto näher liegt die Gefiah des Eintritts einer Wurabianle, die

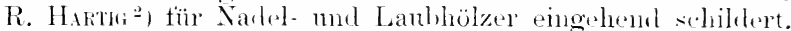

Daher wilt als rste Regel, die Stämme so zu erziehend dats lange sich weit himziehende stäkre Wmzoläste. wie sie die Bämme hei mgestärter Entwicklung ant dersellen stelle zn hilın pHegen, möglichst rermieden werden mol das Wurzelsystem in Form eines Nestes dicht

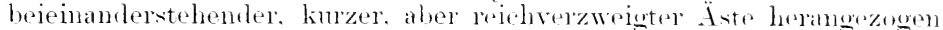
wird. Dies geschieht duch wienlerholtrn Wmyelschnitt in den ersten . Jahren der Entwicklung.

Man hat melutach tie Methote empfohlen, die jumen Bammsehnlhämme an ihrem langen Ptahlworzelkörles zur Vermeirlung der Wuml-

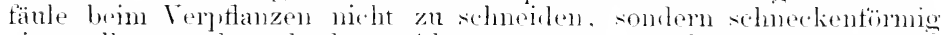

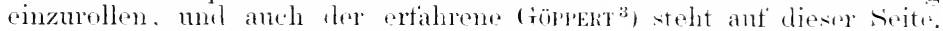

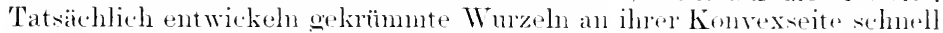
Nebenwureh"). Bei den von mir in Proskan ausuefühnten Wasserknlturen der Olstbäume erlitten pinzehe sämlinge ron Apfel. Birne. Kiefer, Ahorn u. a. Krïmmmogen der Ptahlwurzel dadmelh, dats diese den Borlen der kleinen Gefätse erreichte und pinige Zeit in dieser Lagne rerblieh; andere Pflanzen waren bei dem Aushelen aus dem siante an ilnrer Wnzelspitze verletzt worlen. Beirle Arten von sämlingen entwickelten in der Mehrzahl der Fälle viel frühr seitenwm\%n al: die unverletzten, fribzeitio in sobtsers cietäse versetzten Versuch

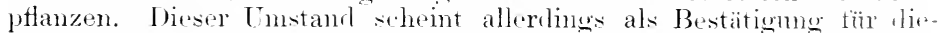

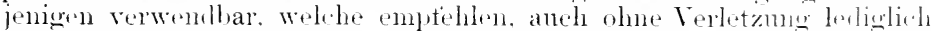

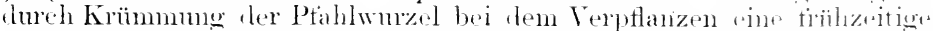
Wurzelverästelung zu erstreben. Wir kömmen dieser Nothordo judor h nicht das Wort reden: in sehwerem Borlen namentlin. Wo wir ver-

1) Kx, L., On correlation in the growth of roots and shoots. (Necond praper.t Anmals of Botanr. vol. XV. No. fit, Di.z. 1:ml.

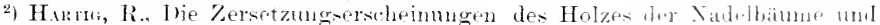
der Eiche. Berlin lor. - Lehrbuch d. Pflanzenkrankh. III Auflage, Berlin lym, springer, s. 263 .

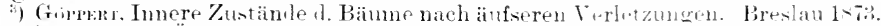

4 Non., Fs. Uber den bestimmenden Einflufs von Wurm,krimmungen atuf

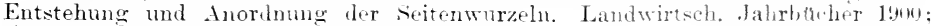
cit. Zeitschr. f. Pflanzenkrankh. 1!n!2, s. 5.5. 
suchsweise Aptelsämlinge mit gestutzten und mit unverletzten, aber spiralig eingerollten Wurzeln pflanzten, war das Herausnehmen zur zweiten Herbstrexpflanzung bei den gerollten Exemplaren ungleich gefährlicher. Es wurde an den Pflanzen zur Erleichterung des Herausnelmens etwas gezogen, und hierbei zeigte sich, dats die gerollten Exemplare an der ersten Krümmmosstelle der Wurzel sehr leicht ahrisien.

Es empfiehlt sich daher, die Sämlinge gleith bei dem ersten Verpflanzen zu schneiden, so dafs sich am Wurzelhalse mehrere Wurzeläste bilden, die in der Nähe der Schnittläche im zweiten Jahre nene Seitenachsen entwickeh.

Es wird dadurch nicht nur eine Vermehrung der Anfnahmeorgane erlangt, sondern anch die Herstellung eines die Erde zwischen seinen zahlreichen Ästen gut haltenden Wurzelballens erzielt.

Die anatomischen Veränderungen, welche bei der Verletzung jüngerer Wurzeln, namentlich aber bei Keimwurzeln, eintreten, sind zunächst von PRANTL ${ }^{1}$ ) eingehend studiert worden. Er zeigte an Gemüsepflanzen (Erbsen, Pferdebolnen u. а.), dafs der Verlust der zarten Wurzelspitze durch Neubildung derselben mter Beteiligung aller Gewebesysteme vollkommen ersetzt wude, sobald die Verletzung dicht an der Spitze der Wurzel stattfand. Schnitt er eine Keimwurel etwas weiter hinter dem Sclieitel ah, rlann trat auch eine Regeneration ein; aber es beteiligten sich nicht mehr alle Gewebe, sondern nur die jugendlichen Gefätsbündelstränge. Der Schnitt endlich, der fast ausschliefslich in der Praxis angewendet wird, nämlich der das fertig ansgebildete Gewebe verletzende, bringt keine Regeneration der Wurzelspitze mehr zuwege, sondern es tritt Callusbildung von dem Rindenkörper her ein, wodurch die Schnittfläche ïberdeckt wird.

Noch umfassender und vielseitiger ist die Arbeit von NĚMEc ${ }^{2}$ ).

Gegenüber der Annahme, dats echte Regenerationen, bei welchen ein vom Individum abgetremter 'Teil direkt in seiner ursprïnglichen Form und mit seinen msprünglichen physiologischen Eigenschaften neugebildet wird, im Pflanzenreiche selten wären, zeigen die Versuche zunächst für die Wurzeln das Gegenteil.

Es handelt sich nur darmm, dats die Verletzung an möglichst jungen Organen stattfindet. Bei den Wurzeln leibt die Restitution eigentlich anf' die Zonen beschränkt, wo an der ganzen Wundfläche (vielleicht mit Ausnahme der Epidermis und der autsersten Rindenschichten) die Zellen noch meristematisth sind. Sobald sich die Zellen der äutisersten Rindenschichten samt den zentralen Skleromreihen dem Danerzustand nähern, beteiligen sich an der Regeneration nur noch die meristematischen, dem Pericambinm anliegenten Zellschichten. Es zeigt sich fernex, dats der Vegetationspunkt einer Wurzel, dessen meristematische Zellen äuferlich recht gleichartio erscheinen, doch bereits eine gewisse spezialisierung besitzt. Die Zellen sind nicht äquipotentiell und kömnen nicht unter williürlich veränderten Bedingungen anch veränderte Gewebe erzengen. Solche ganz pezifischen Differenzierungen liegen in den "Statocyten" vor. I) Be Beweglichkeit der Stärkekömer bei denselben setzt ganz spezifische Eigenschatten des Protoplasmas voraus;

1) Privru, Untersuchungen aber die Regeneration des Vegetationspunktes an angiospermen Wurzeln. Würzburg 1873.

2) Ň̌sc, B., Studien über die Regeneration. Berlin 1905, Gebr. Bornträger. 
dem in vershiedenen callusartig hypertrolhierten \%ellen werlen ebentalls stärkekörner gebildet, welche zuwoilen now gritiser soin kömen

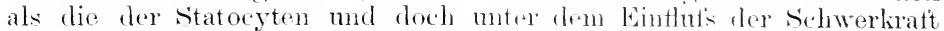

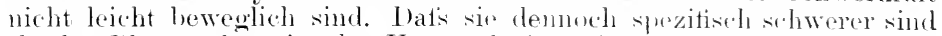
als clas Plasma, beweint der Umstand, dats sie muter Einwirkmer einer genügend starken \%entritugalkraft sich zentritugal hewexpll. Es muls somit das Plasma der Statoeyten ein geringes sporifische fiewieht labm

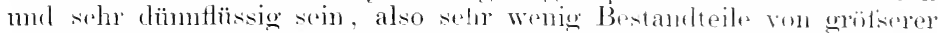
Konsistenz enthalten. Auch entelectito Nente pigenatigo Platsmaansammlungen in den statocyten der Wurzelhanhen. dis sirherlich rine besondere Reaktion vorstellen.

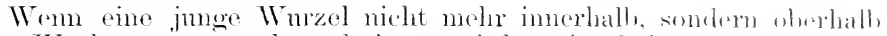
ihrer Wachstumszone abseschnitten wird, tritt keine Respenerition,

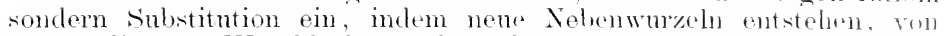
denen die der Wundtäche närhststehenden durch ihre geotropische. Sensibilität veranlatist werken, mehr senkrecht abwärts zu wachses. als sie bei moreletzter Hanptwmzel gewachsen wären. Es ist clatureh

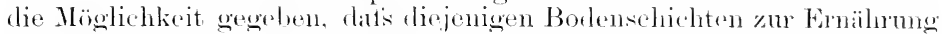

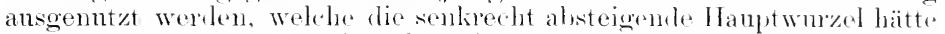

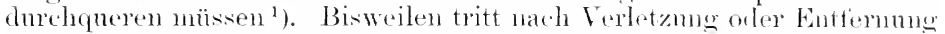

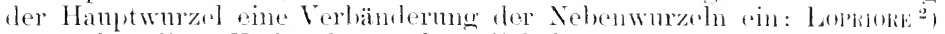

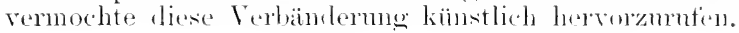

\section{Maserige Überwallungsränder.}

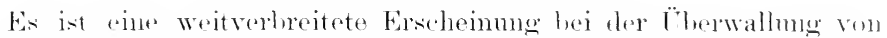

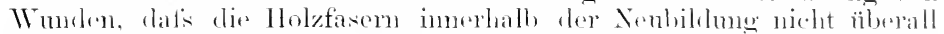
parallel mitemander verlanten, somelern mannigtach sich verbingen und

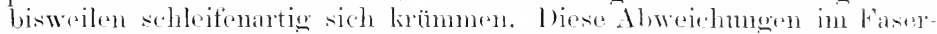
verlant bezejehnet man als ,maseriges llol\%". Jen lesten Fin.

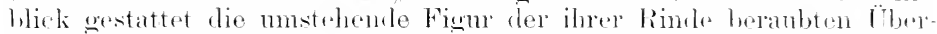

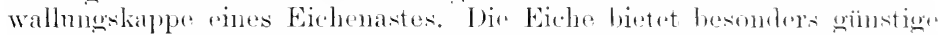

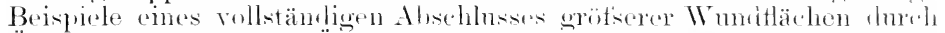

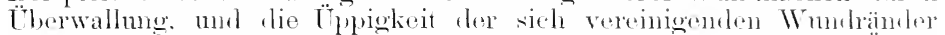
hedingt dabei nielit selten, lats \%. B. bri abexägten stärkeren Ästun

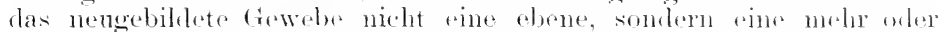

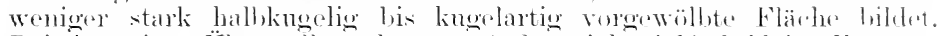

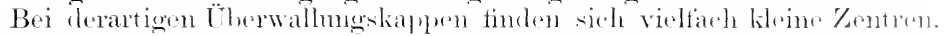

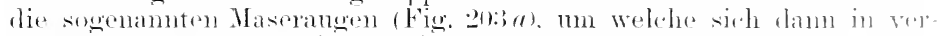

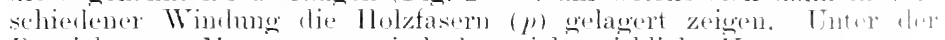

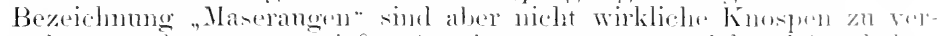

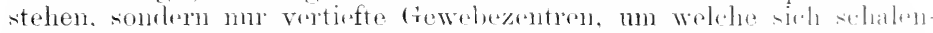

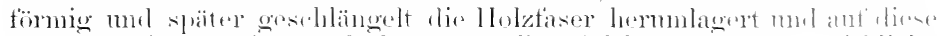

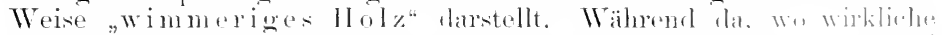

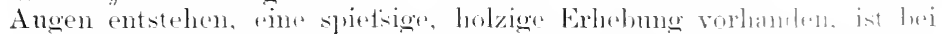

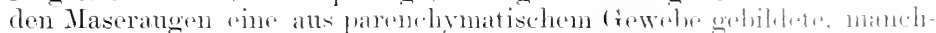

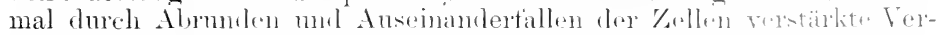

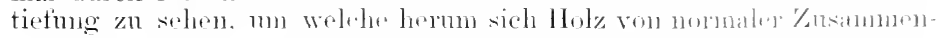

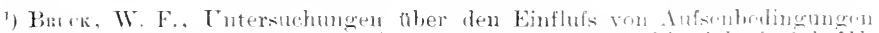

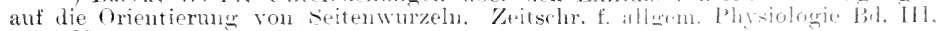
1904 , Heft 4 .

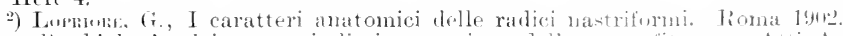
Note sulla biologia dei processi di rigenorazione dello comolite ate. Atti Aral. Gioenia. Catania 1906, vol. XXl. 
sotzung ans Holzzellen, Markstrahlzellen und Gefäfsen lagert. Abnorm nur ist die schalenförmige, an die Knollenmaser erinnernde Lagermng und dlas häufige Anftreten von sehr stark erweiterten, den Markflecken ähnlichen Markstrahlgebilden, welche bisweilen zu einem zweiten Zentrum sich ansbilden kömnen.

Wir betrachten das wimmerige orler maserige Holz nur als einen extremen Fall ganz normaler Vorgänge des Ausweichens der Holzfaser, wemn sie bei ihrem Bestreben, sich in der Lingsrichtung des Pflanzenteils zu lagern, auf Hindernisse stötst. Derartige Hindernisse kömnen in der verschiedensten Form anftreten. Jede normale Zweiganlage bildet die Ursache einer Ablenkmug des Holzfaserverlanfes in der Umgebung derselben. Die bei den Rindenknollen besprochene Nenbildung

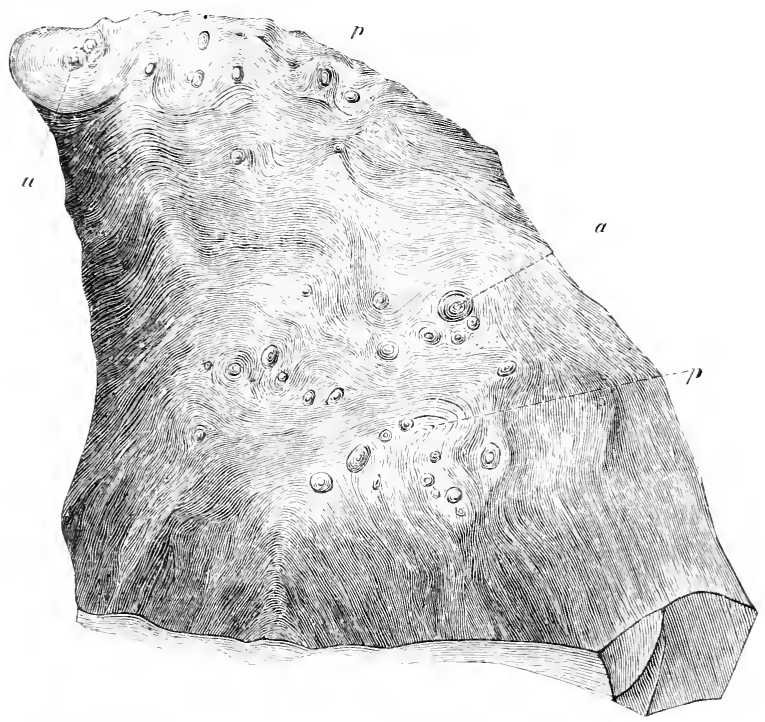

Fig. 204. Maneriger Holzbau der Überwallungskappe eines Aststumperes der Eiche. (Orig.)

von Holzkörpern inmerhalh, der Rinde stellen eine weitere Ursache dar. Endlich aher finden wir die mamigfachsten Ifemmmgserstheinmgen in der Ansbildung eines Jahresinges, hervorgerufen dureh spammosdifferenzen in der fortwachenten Achse. Und solche spannungsdifferenzen sind fortwihrend vorhanden und wrorden vielfach dureh änlsere Einflusse verstärkt. Tom hervorragender Berlentung sind z. B. die Frostwirkmgen, welche die Anlage ron Parenchymholzbinden bedingen. Eine andere änficere Trsache ist die Berührmg einer Achse mit einer anderen. Antser dem mechanischen Drucke sprechen die Liehtverhältnisve mit, wrolde Ahwrichungen in der Ernährung der verschiedenen Sxiten des Canl,imminges bedingen. Es kommen imere Wachstmmstorgänge hinzn, wie z. B. das Vorauseilen von plötzlich 
sich verbreiternden Markstrahlen, welch" di* Rincle höckerartig auttreiben kömen und dabei die benachlnaten llolzlagen in Wachstmm zurübkbleiben lassen mul dgl. Alle derartigen Sï̈rmugen müssen Änderungen in den Druckverhältnissen ansülexn. div der Rindengürtel in seinel Gesamtheit auf das Cambium ausïht mul die Anshildumer des aus ihm hervorgehenden Holzringes heoinflussen. Wir sehr der Verlauf der Holzfaser schon im nomalen stann durh dis Iruckrerhältnisse beeintlutst wird, sehen wir an drer spiraligen Drehnug des llolzkörpers eines jeden Stammes; wie die Holztaser ans dem longiturinalen Verlanf in eine nahezu horizontale Lagermo lureh frock veloracht

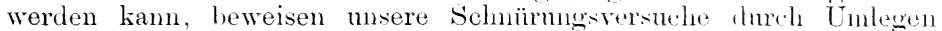
eines Drahtringes $n$ die wachsende Achse.

Es ist also der verschiedenartige Druck, den der Rindengintol fortwäluend erfährt und ausübt, welcher die Entwicklnum mul ,len Verlauf der Holzfaser bedingt. Wir brauchen daher zur Erkiärume dis maserigen IVundholzes nicht die Theorie von der Polaritat der \%ellen und dem Alstofsen der gleichnamigen Pole zu Hilte zu nehmen, wie sie Voschisic und Mäus: ${ }^{1}$ ) vertreten.

\section{Rindenknollen.}

An Schluts des Kapitels äber die Wundhrilumgsrorgänge haben -wir noch der Entstehmug kugeliger, verholzter Anschwellungen odre knollentörniger Answïchse der Rinde an Bämnen und (seltancr) kraut -

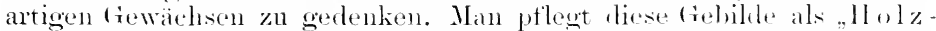
knollen" oler "Knollenmaser" zu bezeichnen. Ihr Ban und ihro Entstehung sind verschieden und berlingen sine spätre 'Tremmung in einzelne (iruppen. Das fremeinsame ist ihr tharakter als korrelative Hyperplasien. Sie sind als fregemratition des fromismus ant vorher-

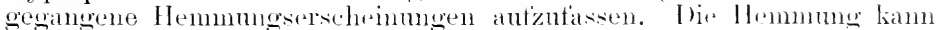
in einem stillstandr in der Fortentwicklung riner linospenanlaue bestehen oder, mabhängig von jeder Knospe. durch Alsterben rinz huer Gewebegruppen immerhalb der Rinde hervormaten werten. Der Tod einzeher Zelloruppen in lindunkërper holziger Achsen ist eine woit-

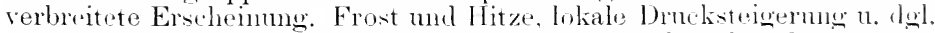

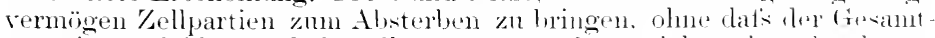
orvanismus leidet, mul derselhe antwortet dann nicht selten durele relstärkte Neubildungen in der Nähe der Hemmmersherde. Io nach \%oit

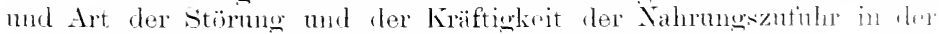

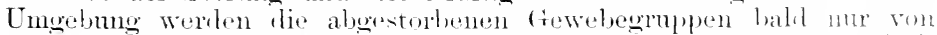

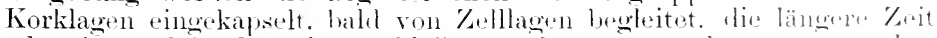

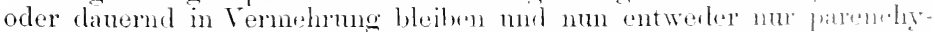

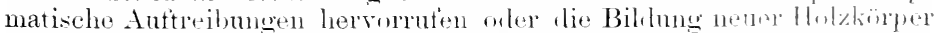

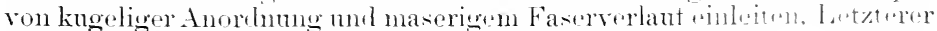

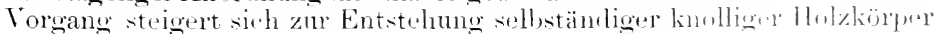
immerhall, der Rinde.

Über die crste (irmppe von Rindenknollen, lenen Entstrhme ant in ihrer Fortentwieklung wehemmte Knospenandagen zuritigefuiht wirel.

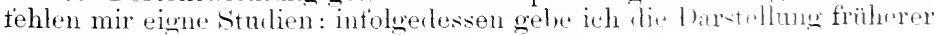

1) Mirtw, C.. Der Faserverlauf im Wundholz. Bibliotheca botaniea Heft 33. Erwin Naegele. Stutgart $1 \triangleleft 96$. 
Autoren. Ton diesen wäre zunächst Trécur, ${ }^{1}$, zu nennen. Derselbe hesclreibt einzelne Fäle (Eiche, Hainbnche) der Knollenbildung einwehend und kommt zu dem schlusse, dats die Knollen immer ihre Entstehmo einer Knospe verdanken, die zmächst in direkter Gefälsverbindung mit dem Holzkörper des Astes oder Stammes steht. Eine solche Knospe kamn mehrere Jahre vegetieren, ohne mehr als ¿2 mm (wenigstens bri der Hainbuche) ïber die (Obertläche der Rinde hervorzutreten. Nach einigen Jahren dieses Zustandes von Lethargie kann sich der Fibrovasalkörper nen beleben. sich zu einer kugeligen oder ovalen oder selbst quergestreckten Holzknolle ausbilden.

Das Absterben der ruhenden Knospen erfolgt, wenn äutsere Ursachen nicht beitragen, nach einer grötseren Anzalil von Jahren von selbst, indem der Zusammenhang des in der Rinde befindlichen Knospenteils von dem in Holzkörper befindlichen dadurch autgehoben wird, dat's sich der Holzmantel dos die Knospe tragenden Kweiges zwischen beide Teile schioht. Der mit schuppen versehene, der Rinde antsitzende äntsere Teil der Knospe bleibt noch lange an seiner stelle; er vertrocknet sehr allmählich und wird endlich abgestotisen.

Diese ursprünglich an dem Holzkörper befostigt gewesene Knospe kann sich also loslösen durch Abreifien ihres Fibrovasalkörpers vom Holzkörper des stammes. In der Regel stirlbt darauf die Knospe in ihrem äntseren, über die Rindenoberfläche hervorragenden Teile; dagegen tährt der in ter Rinde jetzt isoliert liegende Knospenfibrovasalkörper tort, nene Holzlagen mil eigene Rindenlagen zu bilden, ohme die Mitwirlinng von Blättern: er muts also sein plastisches Material aus der umgebenden oriunen Stammrinde beziehen. Dieses Wachstum kann viele. Jahre hindurch andanern; die Autsenseite der Holzknollen kann der Kerstörung durch die äutseren Agentien anheimfallen und trotzdessen kömmen diese noch aut der Innenseite fortfahren, neues Folz zu bildon. Diese Knollen entstehen bei der Rotbuche sowie bei der Hainbuche aus Adrentivknospen.

Lie Entstehung der Knollen hei der Rotbuche ans Proventivknospen beschreibt Th. HAkтi ${ }^{2}$ ). Die schwachen Basalknospen (Kleinknospen) sterben bei der Rotbuche etwa nach 20. Jahren insofen ab, als der in der Rinde befindliche Knospenstamm von dem im Holzkörper befindlichen Teile durch \%wischenlagerung einer vollkommen gleichmätsig zurammenhängenden Holzshicht des die Knospe tragenden Zweiges getrennt wirl. Der in der Rinde liegende 'Teil der Proventivknospe Fiann sich aber noch lange Zeit lebendig erhalten mol, gleichsan ein parasitisches Leben tührend, furch fortchamemde konzentrische Holzbildme zu jenen erbsen-bis haselnutiorotisen, äber die Rinde hervortretenden Holzknollen horanwachsen, die üppig gewachsenen Buchenstämmen in mittleren Nlter so eigentiumlich sind.

I) wurzeltheorie verwandten Anschaumngweise die knolligen Answüchse als Knospenentmyonen (mirithulles), die sich nicht, wie dies bei Her-

1) Thur, Mémoire sur le developement des loupes et des broussins, envisagés au point de vue de l'accroissement er diametre des arbres dicotyledonés. Annales des science nat. ?. serie. Botanique t. XX, 185;, S. 65.

2) Hinrm, Tr., Vollständige Xaturgeschichte der forstlichen Kulturpflanzen Deutschlands, S. 17\%. Berlin 185\%.

3) Observations sur la forme primitive des embryons gemmaires des arbres dicotyledonés, 1837. (Nouv. Mém. du Mus. d'Hist. nat. IV.) 
stellung der Achse normalerweise der Fall sisin sollte, auf einander und zwischen einander einptropfen, sondern die olne Verbindmng mit den übrigen Knospenembryonen mul deren (iefäsisträngen bleiben, also nicht dem Achsenzylinder sich einverleiben. Sio linge ein solcher Embryo, eine Atrentivlinospenanlage, isoliert in dem anderen fiewebe verbleibt, entwickelt er kein Blatt mul keine Knospe: (re hehailt soine lingelige Form und wächst, indem er immer nenc linzentrische, mit

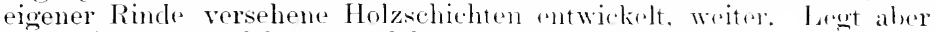
dieser isolierte Holzkörper solcher Arlventivknosenanlage sich endlich an den Achsenkörper an, versehwindet seine eigene Rinile durel lornek, und num bildet der IIolzknoten eine wirkliche Knoser, lie Blatter pnt-

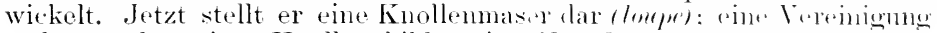
mehrerer derartiger Knollen bilelet eine Krophuaser (bomsim).

Liese Anschammg weicht insotern von den frïher entwickelten Ansichten ab, als hier die Knospe das Emdproululit der Kundlenhilinus.

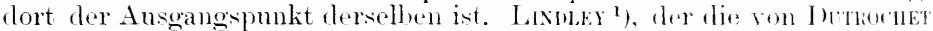
erwähnten Knollen bei Buchen. Kedern und Pappeln bespricht und bxi einer Pappel ${ }^{2}$ ) anch Kweine ans ihnen hervorbrechen sals. betrachtet sie als ans Atventivknospen entstanden mol zählt einen weitopen. von Maxetr erwähnten Fall hei alten ölbämmen hierher. Boi diesen sollen die Knollen (Gmanrs) mit einem stück Rincle ausereschnitten mud geptlanzt werden: diese von Maxerts als Voroli lezeirhneten knollen sollen dam junge Ptlanzen geben. Trevtsists, dem Knollen riner

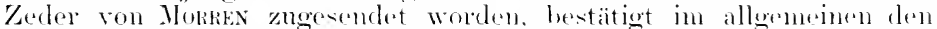
Ban der von Introchet heselpiolenen Knollon: tre zioht in dieselbe

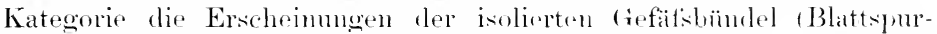

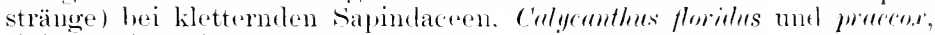
einigen Bignoniaceen u. a.

Sconche ${ }^{3}$ ) erklärt die Knollen in der Rinde eler Pappel, linde, Buche nsw. für verkümmerte toweige, die nicht in lie länge. wohl aber im Umfang gewachsen sinel. Während Hontri die erste Anlage

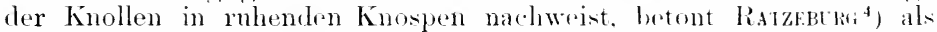
Entstehmosherd derselben Buchenknollen hestimmt dir. Rinde und sant ausdrürklich, dats sie nicht his anf den Jolzkörper reichen. Ehenso

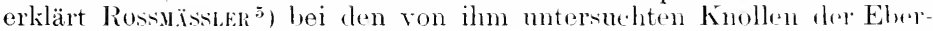
exche (Sorlus ancuparia), dat's diese nur in der Rinde sitzen mol nicht mit dem Iolzkörper zusammenhängen: dagegen besthreiht Korscur ") wiedermm 10-15 em grotise Rindenknollen an den alten stämmen der Libanonzeder als knorrige, fest in ler Rimle sitzende Inolzanswïrlsse. welche mit dem Muterstamm durch wenige Getälshïndel volmmelen

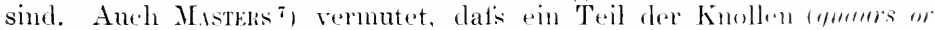
burs) bei Uhmen usw. sowie hei manehen Aptelvarietäten llantion von Adventivknospen sind.

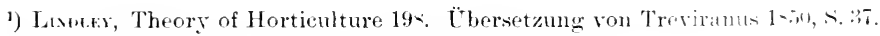

$\because$ a. a. O. . . 2.24.

3) Sсниян, Der Baum, 1-5;3, s. 1:34.

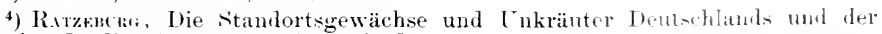
Schweiz. Berlin 1859, ‥ $24: 3$, Anmerk. I.

5) Rossüssisk, Versuch einer anatomischen Charaklevistik des Holghörpers der deutschen Waldbäume. Tharandt. Jahrb. 1847, Bd. lV, s.

6) Korstur, Reise in den eilicischen Taurus. Gothat 14., t. 26it.

i) Masmas. Vegetable Teratology 1\$69, S. :347. 
Die Lösung der Widersprüche bringt eine Arbeit von KRIck ${ }^{\mathbf{1}}$ ), weleher foststellt, dats die Rindenknollen (Sphaeroplasten) der Rothuche sich sowohl im Anschluts an Präventivknospen (Proventivknospen) entwickeln, die sich von der Holzachse des Stammes trenmen oder sich selbständig in der Rinde entwickeln. Im letzteren Falle besitzen die Knollen im Zentrum einen Holz-, Kork- oder Bastkern, aber niemals echtes Mark.

Die letztere Art der Knollenbildung, die autiserhalb der primären Harthastbïndel im Rindenparenchrm stattfindet, führt uns himüber zu der zweiten Gruppe der Rindenknollen, bei der bestimmt keine Knospenanlage beteiligt ist. Hier haben wir zunächst die Untersuchmgen von (iERNer ${ }^{2}$ ) über die Knollentildung bei Sorbus ancuparia zu erwähnen. Dieser Autor fand die toten Knollen so locker in der Rinde sitzend, dats man sie leieht mit den Fingernägeln heransheben konnte: hingegen safsen die lebenskrätigsten anscheimend fest im splint. Demnoch erwiesen sie sich als . voll diesem vollständig getrennte und schon durch das äutserlich rötliche, mit rem Bastteil äbereinstimimende Kolorit ihres glatten mnteren Endes als möglicherweise jenem angehörige Körper". Die meisten durchschnittenen Knollen zeigten mehrere Mittelpunkte, um die sich vollständige, mit Gefälsen und Markstrahlen versehene, in ihrer \%ellenstruktur mit dem Stammholz übereinstimmende Holzlagen in 1:3-1; Jahresschichten angesetzt hatten. Der Verlauf der Holzlagen war maserig. Fast immer waren die Jahresringe in der dem Stamm zugewandten unteren Hälfte der Knollen breiter als in der oberen, aus dem Stamme herrorstehenden. Ein Kusammenhang mit einer Knospe liefs sich nicht nachweisen: selbst da, wo eine Knolle dicht neben einer Kroptimaser saf's. lief's sich kein '/usammenhang mit einem der zahlreichen Knospenkegel der letzteren erkemmen.

Leider hatte GEKNET noch keine Gelegenheit, die ersten Anfänge der Knollenentwicklung zu studieren; die jüngsten stadien semes Materials waren Knöllchen von $0,5 \mathrm{~mm}$, die noch vollkommen in der Rinde eingesenkt waren, ohne äntserlich irgendeine Anftreibung veranlatst zu haben. Sie lagen autserhalb der Hartbastzone, waren lingelig oder ellipsoidisch und zeigten benfalls bereits mehrere Kerne, mm die sich der Holzkïrper gelagert hatte: derselhe bestand aus parenchrmatisch gestalteten Kellen, in denen auf dem Längsschnitt eine Ditferenzierung von Markstrahlzellen kemntlich wurde. Einige mit aröserem Lmmen verschenr, aber noch mit fast horizontalen, molmehbrochenen Wänden aufeinander sitzendle, stärkärmere oder anch stärkelose \%ellen dürften die ersten Andentungun von Gufäfen darstellen. Je weiter vom Zentrum die sämtlichen $\%$ ellen entfernt waren, desto dentlicher wude eine Verringermo ihrer ratialen und eine Vermehrung ihrer tangentialen Ausdehnung bemerkbar; ihr puerschnitt näherte sich also dem des Herbstholzes. Bei älteron Knöllchen fanden sich zuerst einzelne getïptelte Gefälise nur ein leutlich kemntlicher, zentraler, parenchymatischer, stärkereicher Kern seharf unterschieden. Der Holzkörper war rings umgeben von einer ('ambinmzone und einer eigrnen Rinde. In der oberen Hälfte her Knollen stellte sich bisweilen in der Innemrinde Korkbildung ein. Diese nen entsteliende Korkzone rereinigt sich nieht

1) Кнкк, Fr., Über die Rindenknollen der Rotbuche. Bibliotheca botanica 1\$91, Heft 25: cit. Bot. Zeit. 1s92. S. 401.

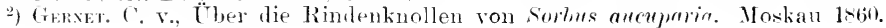


selten auf der Aulsenseite mit der Korkzone des Stammes. Die von solcher Korkzone (Korkdamm GEkxers) abgeschnittene Rindempartio verliert ihr Stäkemehl, wird lufthalti $\underline{\sim}$ und stirbt allmählich ab, so dats der Knollenkörper an seiner Antsonseite totes fieweles erluält. Das Auftreten dieser Korklagen leitet and in clur Regel den nach einigen Jahren extolgenden Tod der hnolls sin. Tlie untere Hiilte slerartig erkrankter sowie die der vollkommen gesumbleibendru binollen behalten ihr lebensfähiges Rindengewebe, in welehem die Ansbilelume des Batstkörpers mit der des Holzkörpers fortschreitet. Daraus ist zul schlietisen, dat's die Knolle nach unten fortwächst. wotureh ihr oberer 'Teil allmälilich über die Oberfläche der Stammrinde hervorkommt, inclem el disidbe durehbricht.

Nach diesem Befiunde kommt Grenet zu der Ansicht, dats. wemm ihm auch die Anfangsstadien der Knollen mbekamnt greblicben. cr iloch bestimmt einen Zusammenhang derselben mit dem llolzlöruer des Stammes in Abrede stellen mufis und die Entstehmeg der Knollen werler von Proventiv- noch Adventivknospen herleitru kam.

Diesen Ausspruch num kann ich nach meinen Untersuchungen an Knollen der Aptelbäume vollkommen bestätigen. Kur Untersuchung lagen mir Knollen von der Grölse cines Hirselions bis zu der einer Erbse vor: dieselben stammten rom der Stammbasis cines jungen, etwa 8jährigen Aptelbaumes. I)ie Kuollen satsen in der Antsominde und brachen leicht ans derselben herans: sie waren obersoits entwedre vollkommen glatt (Fig. 20.), 1 a) herindet ofler zeigten eine lirimuliche, trockene, etwas vertiefte, rindenlose (iiptelpartie $(1 / \mathrm{l})$, die ven rinem grünen, kreisförmigen Rindenwalle mogelun war.

Den zentralen (2uerschint einer hinolle letzterer Art stent Fig. 2015, ¿ dar.

In demselben gewahren wir einen mittelstandigen, ans zwei. durch wenig Parenchym getremten Ilartbastbündeh bostohenden Korn (2l);

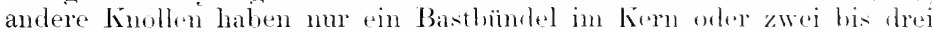
entferntere Kerne. Un das Bündel hermm lasern sich /ollon parenchy.

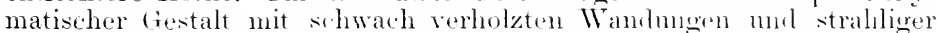
Lagermo: man sicht, lat's sie moweitillatt nach Art dre Korlizellem entstanden sind. Bisweilen findet man in ter Mitte der kinollen mur eine (irupue dickwandigen, stärkereichen oder anch stärkelosen, bramen Parenchyns ohne Hartbastzellen: doeh ist dies der seltenere Fall. Endlich sieht man anch dam und wam Knollen mit einre zentreten. kleinen Höhlumg, die mit bramen Zelhesten angrefüllt ist.

Die strahlig gelagerte, ringtörmige Kone parenchymaticeher. verholzter \%ellen geht almählich ïber in enge, dorbwandigere. hereits

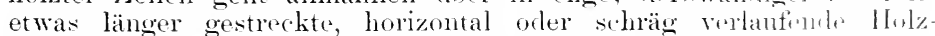

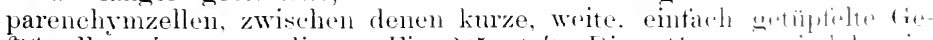

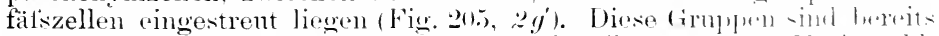

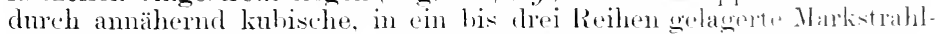

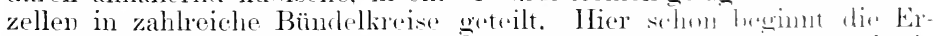
scheinme. welehe sich in alweehselnden tonen his an die Peripheri.

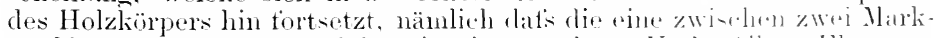
strahlen vorhandene Bündelpartie einen anderen Vulant iluer Elenente

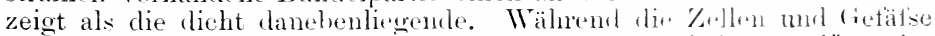
des einen Bündels tast ganz quor durohschnitten ersolumen (:l"). zeigt die danebenliegende Partie die Fasern in ihrer l, ingsichtung. Hies.

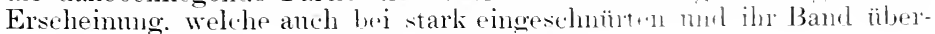


wachsenden Stämmen sich zeigt, lätst sich nur dadurch erklären, dats die einzehen Cambiumpartien des un den Kern sich schalig herumwölnenden Holzköpers gleichzeitig verschiedanem Drucke resp. Znu ansgesetzt sind. Tha der junge Knollenkïrper keine genane Kugel-

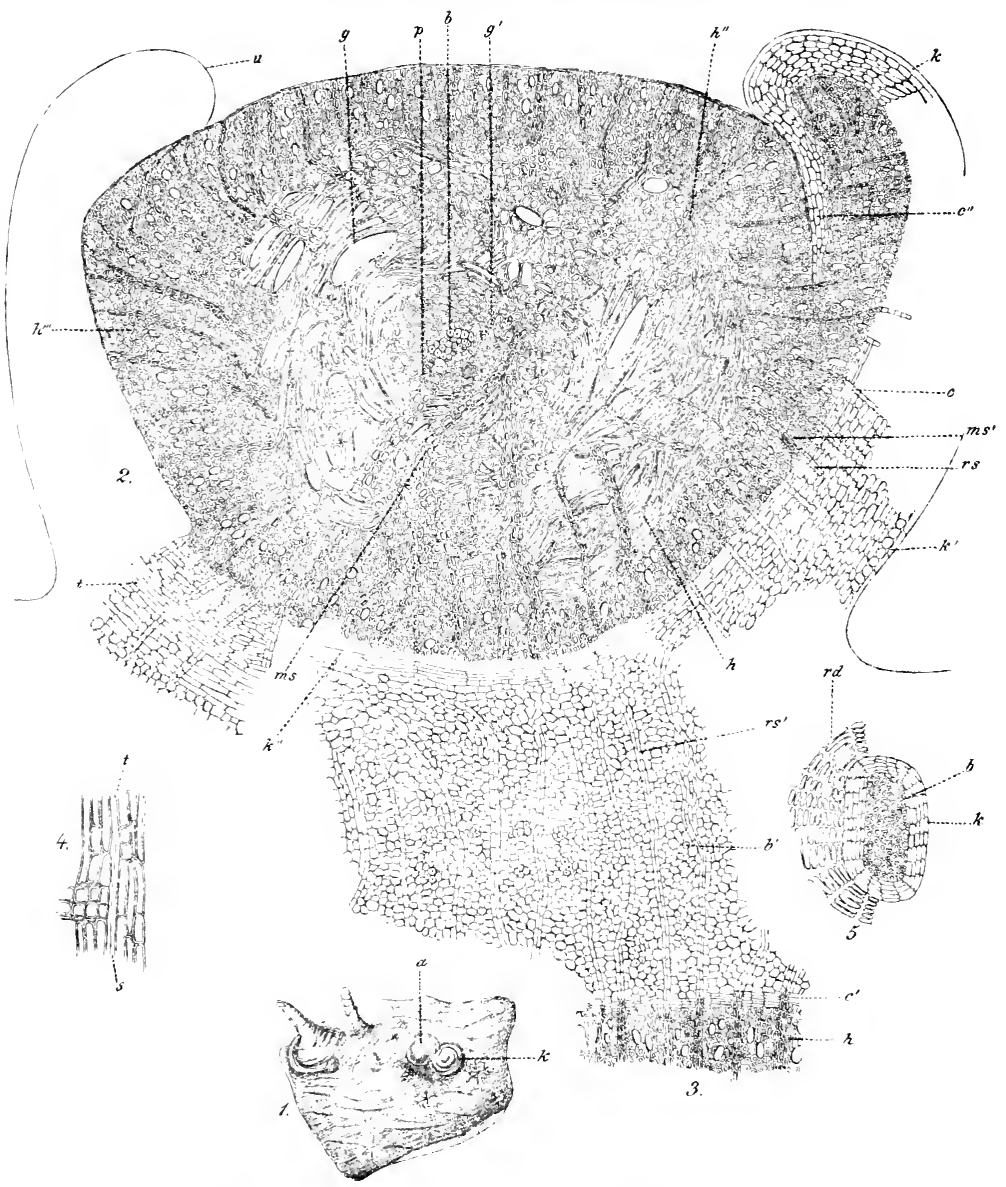

Fig. :0.5. Rindenkuollen ans finem Apfelstimm. (Orig.)

gestalt besitzt, sondern nur annähernd kngelig ist. so strecken sich die Partien, welehe die vorhandenen Kanten zu überwölhen haben, in der. sellon teit stärker.

Jo weiter man in dem linollenkïrper nach aufisen geht, um so choce und gestreckter und mo so dirbwandiger werden die Elemente, 
his sie die Länge und Gestalt und teilweis anch die Lagerung des normalen IIolzköıpers annehmen.

So wie bei diesem erliennt man anch innerhall, der Kinolle eine Differenzierung der Jahresinge in Friblingsoly mol llerbstholz, so laf. man sieht: I)ie Knolle ist ein mit charakteristischen Eigenschaften der speries versehener, in der Rinte isolierter Holzhöruer, dessen Ele-

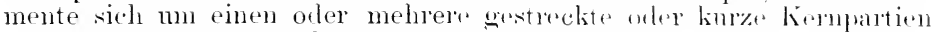
nach allen Richtungen hermmwiblien.

Diw rings um then Holzkörper sich hinzielenele ('anblimmzone (: a)

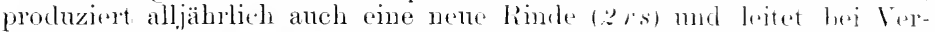
letzungen dieselhe Wundheilung wie an einem nomalen stammliorpur ein. Eine solehe Verletzmog ist auch bei Fig. 2014,2 oingetreten, in

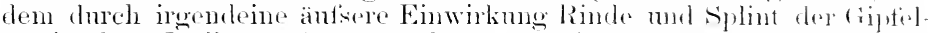
partie der Knolle entfernt worden sind: infolgedessen hat sith rin

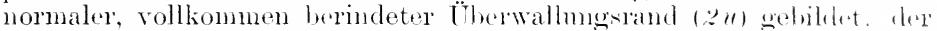

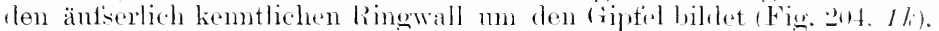

Der zuerst antfallencle Umstand, dat's in /entrum eines loblziörus's sich Harthastelemente vorfinden, fïlnt zu dem Sidnluse, datis die [ngebung der Hartbasthïndel die Staitte ist, von der die Bildnung des Hokkörpers begomen hat. Noeh mehr bestälst wird dieser sichluts

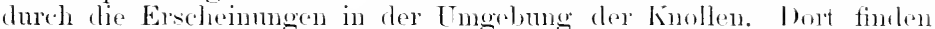
sich sehr häntig jüngere, ja hisweilen jüngster müngst ans der ('ambiumzone heransgetretene Bastbïndel, mit rigentïnlichen, strahlig angeorl-

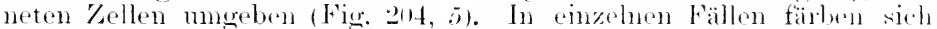

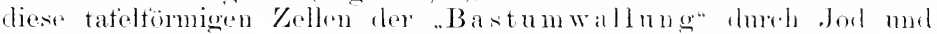
śchwetelsäme blau, in den meisten Fällen velh. Man sielst darans, dafs

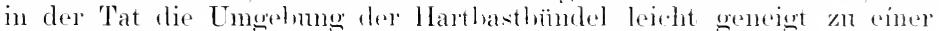
Kellvermehrung ist.

Die Bastmmallumeren ans Korkorwebe sind aber lieineswess ant" die Umoelung der Maserknollen beschränkt: sie tinclen sich äbrall bei allen bisher von mir motersuchten Bäunen an rinzelnen Sitollen nath manehen Verletzungen. Hierbei haben aber die Zellen in der Tat stets den (harakter der Korkzellen nud dienen vorzugweise dazu, oin exliranlites Basthïndel von dem gesmolen foweln abzugrenzen. Wer viel mit kranlien llölzer'n geasheitet hat, weils, wir amptintlich dit scheinbar so resistent geluanten Bastzellen sind. An ilnen lälst siell dureh die brame Färbung mor das dentliehere Hervortreten ihror Schichtung hänfig die Erkiankung tiefer in das gesunde fiowohe hinein verfolgen als an dem Rindenparenchym der Tmonbung.

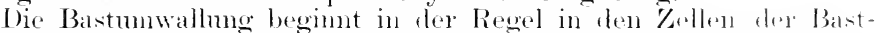
seheide, bloibt hisweilen halbseitio oler ist wenigstens an der Antisen seite stäker entwickelt. Ähnliche Erscheinmogen, wie die Lmwallnng der Bastbümlel finden sich anch hei einzelnen Parenchrompation. wolde

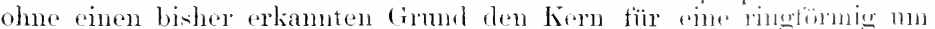
dieselle sich bildende Meristemzone in der Rinde alurelen mul dianit

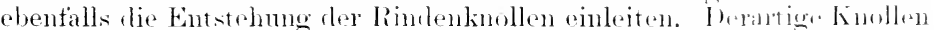

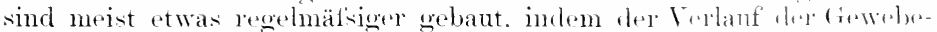
elementr für melnere Jahresinge lieselbe Richtmo heiheloalt. Man tintet

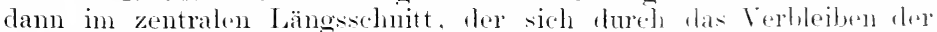
Markstrahlen in annähernd clerselben Ebene linutlich nacht, hiv ring-

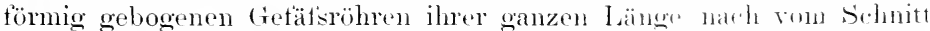
getroffen, so dafs diese als helle konzentrisehe Ringlation die dunklen. parallellautenden Holzzollzonen nuterbrechen. 
Einen interessanten Beitrag und Schlüssel zur Knollenbildung liefern dit Keichnumgen (Fig. 206) ans der Rinde eines gesunden, einjährigen Birnenzweiges. Wir sehen in Fig. 2m, 1 den Basalteil eines sehr kräftigen, emjährigen Birnentriebes, dessen Knospen a nicht in der normalen $/$ weifïntelstellung angelegt sind; $b$ ist die mitten ion Internodimm lefintliche einseitige Anschwellumg, tie in Fig. 206, 5 an der tiefsten, ler Zweigbasis zugewandten stelle, in Fig. 200,3 in der mittleren Region mol in Fig. 2ox. 4 in der höchsten Zone quer durchschnitten dargestellt ist. In den Fig. 2om, 3, 4, ; bedenten dieselben Buchstaben ameh dieselben Teile; ${ }^{2}$ Rincle des Kweiges, $g^{1}, g^{2}$ usw. sind die Rindengefäfsbündel in den verschiedenen Entwicklungsstadien; es zeigt sich, dafs diejenigen, welche znerst angelegt sind, auch zuerst nach ihrem Eintritt in die Achse kleiner werden. m der Markkörper, mb die Markl,rücke eines zentralen Blattspurstranges, dessen Begleitsbündel sich nngleichmätsig entwickelt haben, m st Markstrahlen, hl Hartbastbündel, welehe den zentralen Kern der in der Rinde gebildeten Holzstränge ausmachen. Fig. 20ri, $4 \mathrm{rt}$ ist die durch Druck getötete Rinde, welche dmrch die in die Achse des \%weiges eintretenden Holzstränge in den Stamm hineingepretst worden ist. Fig. 2ot; $5 y^{\text {s }}$ zeigt einen IJolzstrang mit den ersten Antängen der Umwallung; man sieht dieselbe anf der Ant'senseite bereits stärker entwickelt. Fig. 20ri, $3 g^{\prime}$ ist ein Holzstrang, weleher noch nicht völlig zun Holzcylinder geschlosien ist: seine Bildung erfolgte in der Weise, dafs anf der Anfsenseite des Harthastbündels in der Bastscheirle die /ellvermehrung begann, welehe die Ansbildmng von Gefäfselementen und Holzzellen zur Folge hatte. Dieser einseitig entstandene Holzkörper schlielst sich durch allmähliche Versehmelzmng der beiden gegeneinander wachsenden, nach innen gewendeten Ränder. Fig. 201, je die Cambinmzone eines bereits anf der Innenseite geschlossenen, an der Versthmelzmngstelle aber noch nierentëmig eingedrückten Holzstranges. Fig. 206, ¿ stellt

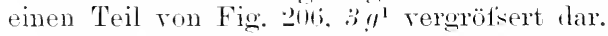

Man erkennt in Fig. 201; 2 eine vollkommene Übereinstimmmng mit dem Zentrm der hnollemmaser rom Aptel. hl Hartbastkörper, 1' Holzparenthyn. "f Gefatizellen, it kurze, quergeschnittene, $t^{\prime}$ in der Horizontalrichtmm verlantende Holzzellen der nach imnen gewendeten Wölbung des Holzstranges an der Stelle, wo die beiden Ränder sich vereinigt haben. m die wie Fangarme verlaufenden Markstrahlreihen, c die rings den strang mmebende Cambimmzone, $r$ jüngstes Rindenparenchym der sporiellen strangrinde.

Die Holzstränge (Fig. :206, 5) entstanden also an ter Basis der Anschwellmng durth aufergewohnlich reiche Ernährung der Bast. seheiden; ihr Anfang liegt in ungleicher Höhe. Bei ihrer Ferorötsermg

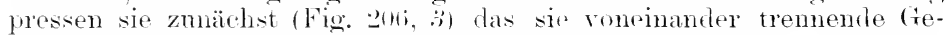
webe der Rinde zusammen mol endlich anch das vor ihnen liegende, sie bisher vom Achsencolincler tremente Gewebe, das als brame Masse im Immern des Holzkïrpers (Fig. 2mi, 4rt) wiedergefunden wird. Bei dem Eintritt in den Achsenerlmbler ändert sich die Form der Rindenholzstränge: ihr Kern ist exzentrisch geworden und entlich an die spitze des keilfömigen Stranges qerütkt, wie Fig. 206; $4 g^{1} \cdot g^{2}$ mol $g^{3}$ zeigen. Es ist also genan die nmgekehrte Formveränderung von drorjenigen, welche ein normales, ans dem Aclsencylinder in die Rindo tretendes ( iefäisbündel erleidet. 


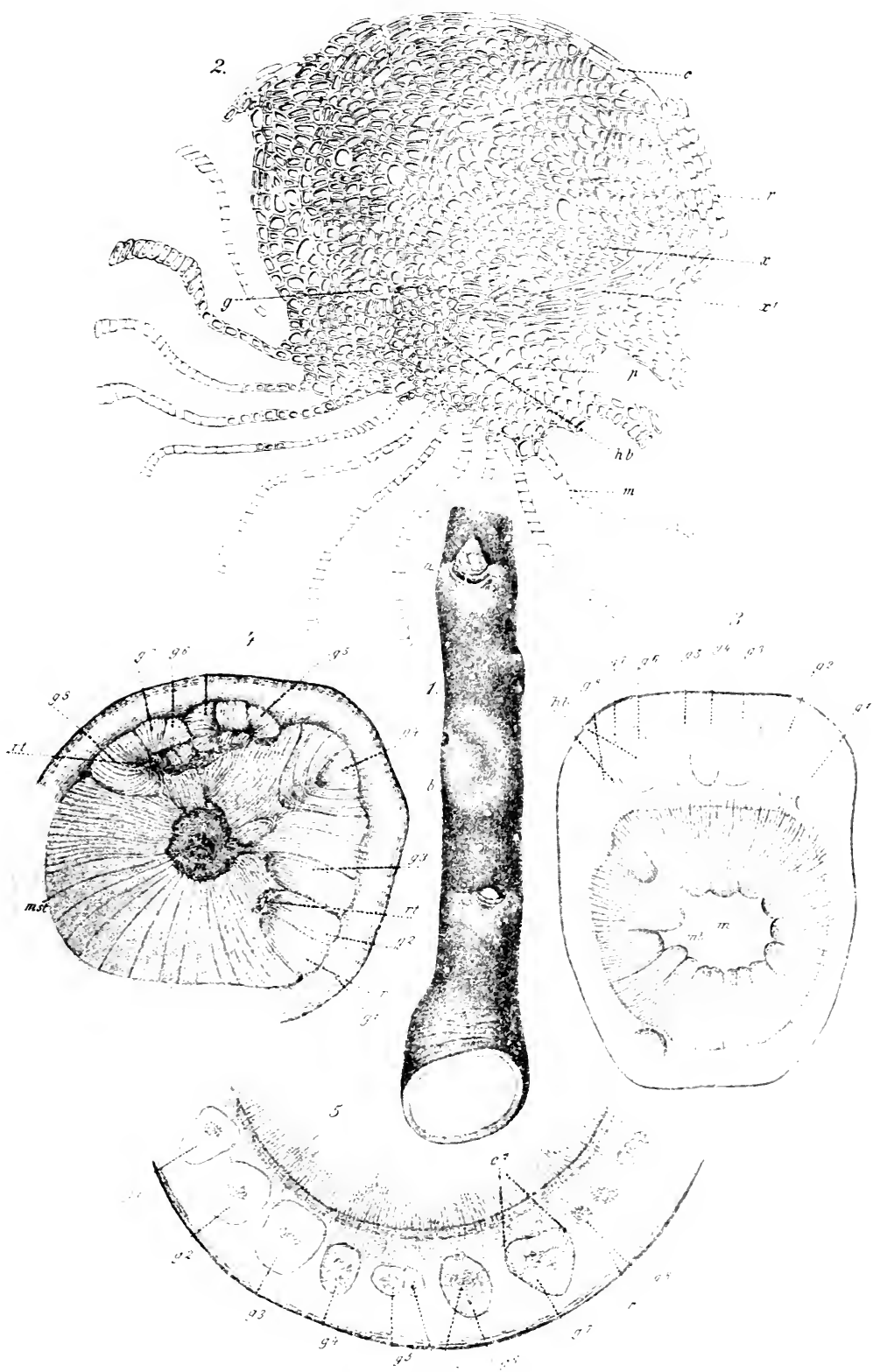

Fig. 206. Entstehung isolierter Holzkörper in der Rinde eines einjärigen Birnenzweiges. (Orig: 
TTeiter aufwärts war der Zweig normal ${ }^{1}$ ).

Das Vorkommen rindenbürtiger Holzstränge legt somit die Entwicklung fler Knollenmaser in folgender Weise klar. Die fertige Maser ist eine in Rindenkörper isolierte Holzkngel, deren Oberfläche von einem Cambimm- nud Rindemmantel gebildet ist, welcher seine Nahrung ans dem magbenden Rindengewebe empfängt. Nach den noch zu wiederholenden Untersnchmoen der oben genamnten Forscher kömnen diese Maserknollen oder Knollemmasern ans einer ruhenden Knospe sich entwickeln und daher ursprünglich im Kusammenhange mit dem Holzkörper des /weiges stehen. In vielen Fällen entstehen sie aber auch als schalenförmige Holzmmlagermngen $u$ ein Hartbastbündel oder eine andere Rindengewebegrupe ohme Zusammenhang mit dem Holzzylinder oder einer Knospenanlage. Die Knolle wird allmählich durch Hinamsrïcken in dic äufiseren, der Borkenbildung verfallenden Rindenregionen abgestofisen: die der Knollenbildmng verwandten, aber longitudinal gestreckten Holzsträngo der Rinde können in den Achsenkörper hineinrücken und zum Bestandteil des normalen Holzcylinders eines Zweiges werden. Äutsore Wunden an dem Knollenkörper heilen durch uberwallmng wie bei dem normalen Zweige, und es liegt kein Grund vor, zu bezweifeln, dats ans dem Überwallungsrande sowie ans der normalen Lnolleminde sich Arlventivangen entwickeln können, wie dies bei den ()lbämmen angegeben wirl.

Zn erwähnen ist noch, datis die grotsen, kugeligen Anschwellungen, welche bei C̈berwallung der Ansatzstellen von Loruthus curopurus auf Eichenästen entstchen, anch als Maserknollen oder -köpfe angesprochen werden. Es sind nach unserer Einteilumg keine eigentlichen "Masern", sondern maserige Ïberwallungsränder.

Als almorme ت̈berwallmngen beschreibt Tine Tammes ${ }^{2}$ ) eigenartige zapfenfömige, meist einseitig sich lappenartig ansbreitende Fortsätze an Fagus siliatica. Ihe Untersuchmog ergab, dats es sich m Zweigstmmpfe handelt, die mit maserigen, hypertrophierten Wmärändern geschlossen waren. Die Hypertrophie war dadmeh reranlafst worden, dafs die Bämme sehr stark beschmitten worden waren, und deshalb Überschuts an plastisehem Material an den übriggehliebenen Wachstumsherden sicli eingestellt liatte.

Eim Beispiel ron Rindenknollen an krantartigen Pflanzen liefert Peters dureh seine Beobathtmogen an Holianthes amme und Polygonum cuspidatum ${ }^{3}$ ). Die in der Mittelrinde entstehenden Knollen sind als Reaktion der Pflanzen auf Wundreiz anzusehen. Es starben einzelne Zelgruppen in der Rinde ab und vertrockneten. Der dadurch ent. stehende Hohlraum molkleidet sich mit einer cambialen Zone, die nach immen Holz, nath antiven Rindengewebe hildet.

Beispiele für die Knollenbildme an Wurzeln erwähnt bereits Тн. Haнткі ${ }^{4}$, bei Besprechmo des Dmstandes, dats junge Zitterpappeln in grofiser Meng. an abretriebenen Beständen auftreten, wo seit langer Zeit keine samentragenden Bämme gestanden haben. Diese klemen

1) Über die Ähnlichkeit dieser Bildıng sekundärer Holzkörper mit der bei den Sapindaceen. Vergl, Soratrk, Die Knollemmaser der Kernobstbäume. Landwirtsch. Versuchsstationen 1878 .

״) Tive Timss, Über eigentümlich gebildete Maserbildungen an Zweigen von Farms silvatica L. Recueil des travaux bot. Neerl. No. 1. Groningen 1904.

3) Cit. Zeitschr. f. Pflanzenkrankh. 1905. s. 26.

4) a. a. O. S. 429 . 
Pflänzchen verdanken, wie Th. H.ıти; erklärt, ihr Dasein der fortdanernden Vegetation der Wurzehn längst ahgestorlnener' und oberirdisch verschwundener Aspen-Intterbämme.

Die Basis der Wurzelbrut ist in diesen Fällen stets rine linollen-

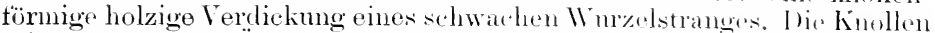
selbst sind etwas Ähnliches wie die Kunllon am maseriun Fulise alter Eichen oder Linden und wie the Knollen an ter Rinde der Ruthurhe; sie sind der holzige Stamm eines schlatenten Anges, dr.r, vollständio

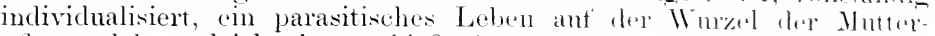
pflanze lebt ,gleich dem schlafenden Ange an dron annrikinnischen

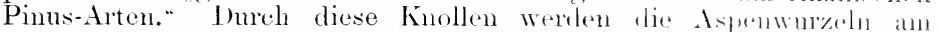
Leben erhalten, ohne dats das ernährende Wurzelstiicle sellist fint wïchse. In der Regel zeigt sich das knollentragende Wurclintstiick schon wenige Zentimeter von der Ansatzstelle der Kindle alderestomben

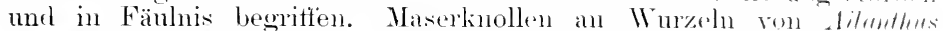

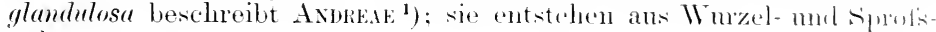
anlagen.

In Anschluts hieran mag einer Erscheinmog Erwähnmeg geschehwn,

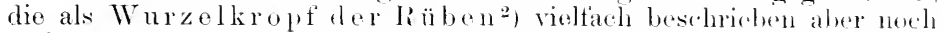
nicht genügend anfgeklärt ist. Es zeigt sich. moist in trocke+ment Böden, in der Nähe des liübenkoptes ofler etwas weiter abwärts rines kugelige, mit borkiger (Bhertläche versehenr (ieschwnlst, die in Ban dem Räbenkörper ähnlich, ihrer Kasammensetzmen naeh aber dureh grötseren Wasser-, Asche- und Protëngehalt von ihm ahwricht. Dar

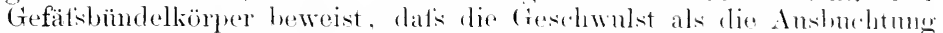

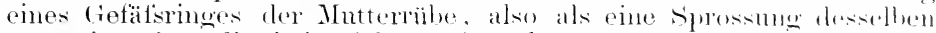

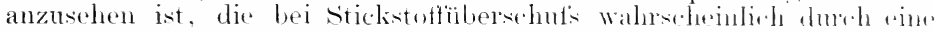

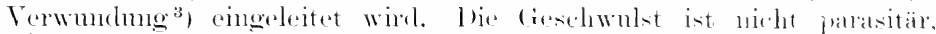

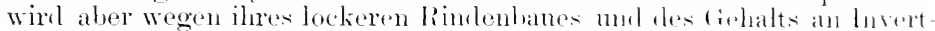

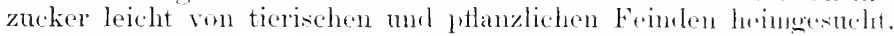

\section{Blattverletzungen.}

In Rücksicht tharat, dats gerade bei Blättern und andron tleischigen Pflanzenteilen dir Folgen der Vorwumbungen dentlicher herventretent

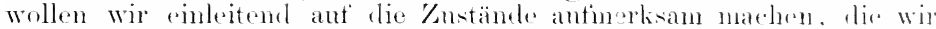
als Wundreiz bezeichnen. Die arste Folge des Reizes, den jerle.

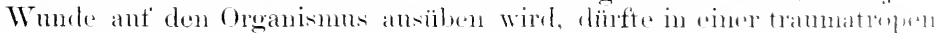

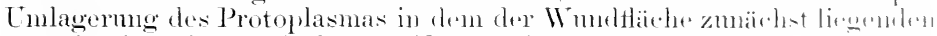

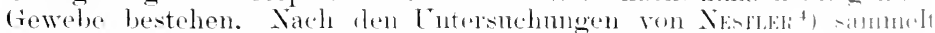
sich in den unverletzten Zellen das Protoplasma an in IImularit.

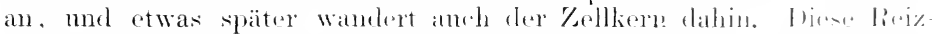

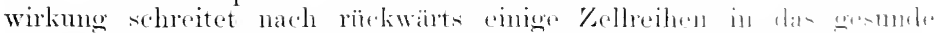

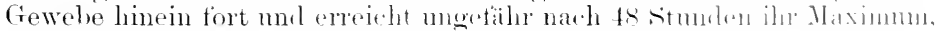

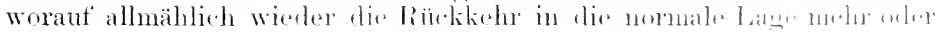

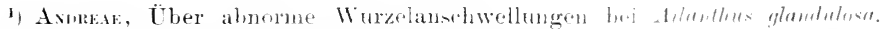
Inauguraldissertation. Erlangen 1<!l

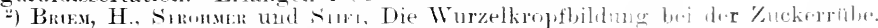

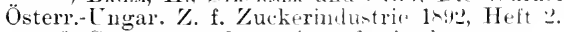

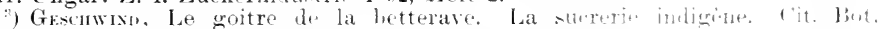
Centralbl. f. Bakt. II, ]! 15,5 , s. 4ti.

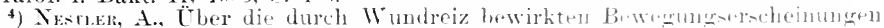
des Zellkerns und des Protoplasmas. S. Alial. Wien ('Tll, 1, 1-g, 
weniger vollkommen sich einleitet. Die Umlagerung scheint im Licht schmeller als im Dunkehn stattzufinden.

Ebenso erleidet der Chlorophyllapparat oftmals eine wesentliche Umlagerung ${ }^{1}$ ). Gleichzeitig ist in vielen Fällen eine Steigerung der Atmungstätigkeit bemerkbar; namentlich bei fleischigen Pflanzenteilen komnte auch eine Temperaturerhöhung nachgewiesen werden, die man als Fieberreaktion bezeichnet hat ${ }^{2}$ ). Bei verletzten Blättern soll die Kohlensäureproduktion besonders gesteigert werden, wenn dieselben arm an Kohlehydraten sind ${ }^{3}$ ). Je nach dem Grade der Verletzung: treten die Reaktionen früher oder siäter ein. Nach Townsend ${ }^{4}$ ) zeigt sich die Wachstumsbeschleunigung boi geringen Verletzungen bereits nach 6 -24 Stunden; dagegen fülmen sehwere Verletzungen zunächst eine Hemmung herlei, bevor die Besthlemigung eintritt, die je nach der Pflanze in 12-9" st stunden ihr Naximum erreicht, um dann allmählich anf den normalen Zustand zurückzugehen. KrasssosseLskY ${ }^{5}$ ) führt die Steigerung der Atmung auf eine Vermehrung der Atmungsenzyme zurück. Er geht von den Versuchen Korchorr's ans, welche ergeben, dafs nach einer Verletzung eine Zunahme der Gesamtmenge der Eiweifsstoffe und namentlich der Nucleoproteïle stattfindet, und weist dann (bei verletzten Zwiebehn) nach, dats der Saft derselben mehr Oxydasen als der von nicht verwundeten Exemplaren besitzt. Ähnlich verhalten sich Kartoffeln.

Die weiteren Reaktionen der Blätter nach Verwundnngen sind num ungemein versichieden je nach der Art der Pflanze, dem Alter des Blattes und der Keit der Verwundung. Wir begnügen uns mit der Darstellung der beiden Extreme, nämlich der Realition eines derben, lederartigen und eines Heisthigen Blattes. In ersterer Beziehung repräsentiert Prums Lanrocerasus einen Fall, bei welchem, wie wir bereits bei den Folgen der Kupferbespritzungen erwähnt haben, mit der Verwundung ein Abstotsungsprozet's der verletzten Zellenkomplexe verbunden ist. Nach Bbackinan und Мitтhani ${ }^{7}$ ) sterben je nach der Stelle des Blattes, wo die Verletzmngen stattgefunden haben, entweter nur die betroftenen Zellen oder auch noth deren ummittelhare Ungebung ab. Es entsteht um die Wunde eine brame Zone mit einem helleren Hote. In dieser hyalinen Region reitst die Epidermis auf, und es wachsen aus dem benachbarten Mesophyll farblose, sehr zartwandige Zellen hervor, die lintikularisieren und einen vollständigen Versehlut's der verwmoten Blattfläche darstellen. Wenn dieser Versthlufis fortig ist. wird das tote trewebe ausgestolsen. Vorausgesetzt int lahei das Vorhandensein feuchter Luft; andernfalls bilctet sich ein normales Periderm ans mehreren Kelllagen, das vollkommen ansreichend das gesumde Blattgewebe schïtzt.

Der zweite Fall der Heilnng von Blattwmelen, nämlich dureh

1) Prafer, W., Pflanzenphysiologie. II. Aufl. 1904, 2. Bd., S. 819 . Siehe auch hier die Literatur üher die Wirkung des Wundreizes.

2) Ricnuss, Hensma Miris, The evolution of heat by wounded plants. Annals of Bot. XI: cit. Bot. Jalresher. 1sy. s. 99.

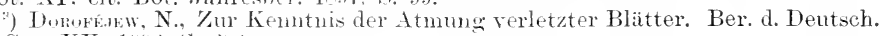
Bot. Ges. XX, 190: s. :3:6.

4) Timssern, C. O., The correlation of growth under the influence of injuries: cit. Bot. Jahresber. 1897 , I, s. 98.

5) Krissunsuskx, Billung der Atmungsenzrme in verletzten Pflanzen. Ber. d. Dentsch. Bot. Ges. 1905, Bil. XXIII, S. 143.

6) Ber. 1. Dentsch. Bot. Ges. 1908 , s. 16i,

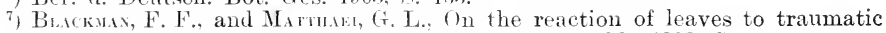
stimulation. Ann. Bot. XV; eit. Zeitschr. f. Pflanzenkrankh. 1902, S. 61. 


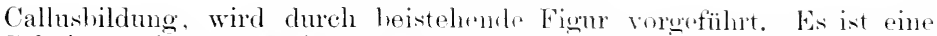
Schnittwunde an Leucojum ermmm. D) We Wusle war dureh den zwisehen

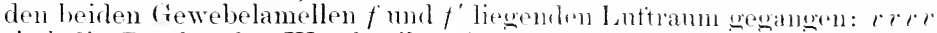

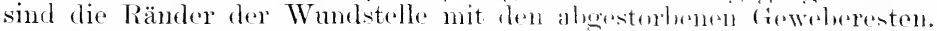

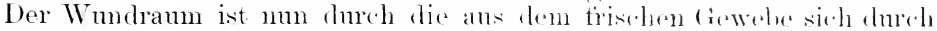
Stroekung entwickehnden rhlorophyllosen ('alluszellen answetïllt, derent Waudungen verkorken. Her normale Kustand des Blattes ist ant der

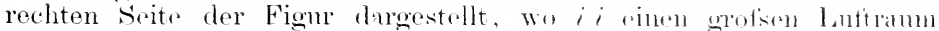

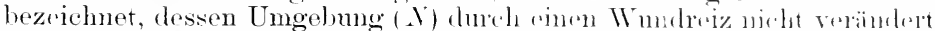
worden ist: o ist die Oberseite, "die Tutersoite des Blattes. Niteh

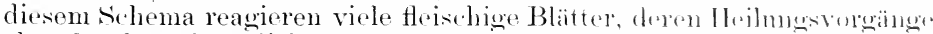

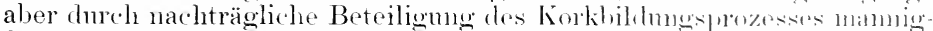

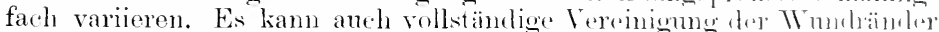

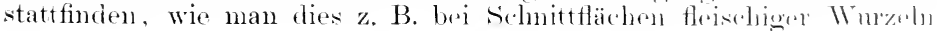

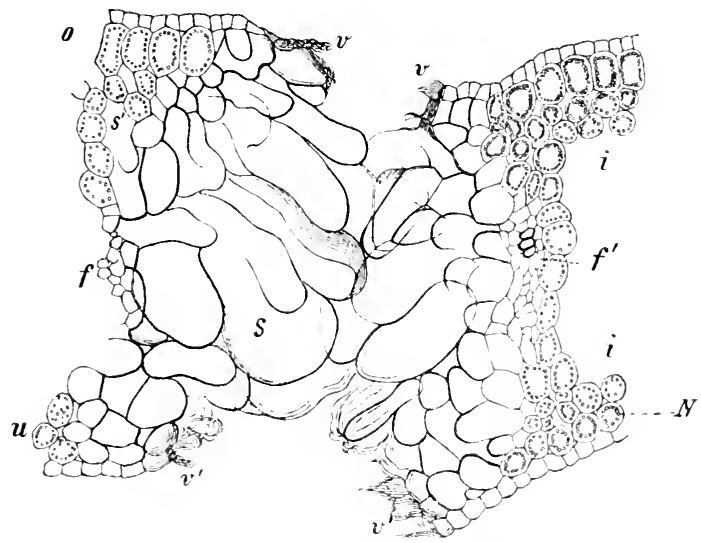

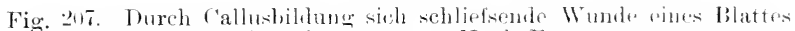

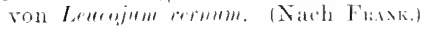

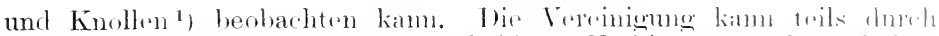

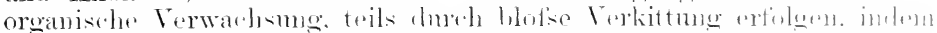

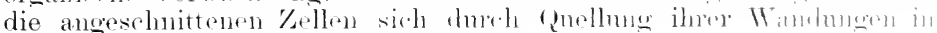

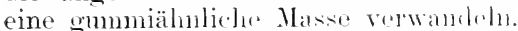

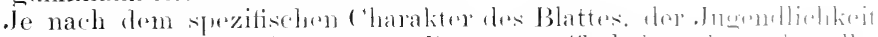

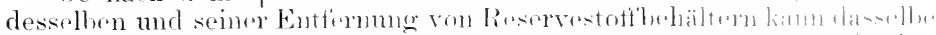

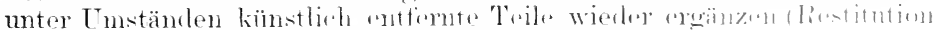

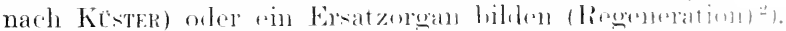

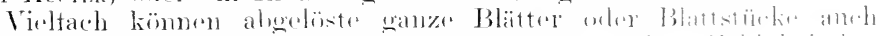

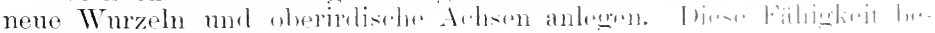
dingt ihre Benutzung als

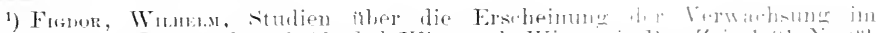

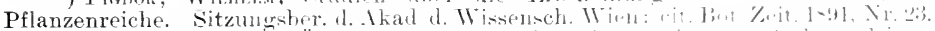

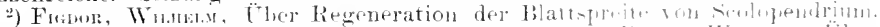

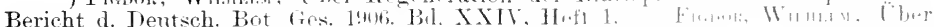

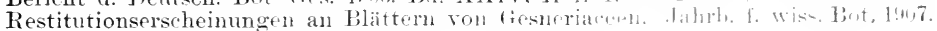
Bd. XLIV, Heft 1 . 


\section{Blattstecklinge.}

bie hekannteste mol am meisten angewandte Vermelirung durch Blätter ist die bei den Begonien. Bei der in den verschiedensten spielarten vorhantenen Brgomia liex erscheinen nach Hassen ${ }^{1}$ ) die mittelst Durchschneidung der Nerven am horizontal anf die Erde gelegten Blatte entstandenen Wunden alsbald durch Callus geschlossen. Es entsteht auf diese Weise ein knolliges (rowebe am Mutterhlatt, aus welchem sclbst oder dessen nächster Umgchmo die Wruzelu zuerst hervorbrechen: später bilden sich anf diesem Gewebe anch die sprossen aus, die aber keme eisenen Wruzeln bilden, sondern durch die vorgenannten des Überwallungswulstes weiter ernährt werden. Diese Sprossen entwickeln sich aus einer oder wenigen Zellen der Epidermis in der Nähe des durchschnittenen Blattnerven bald nahe, bald fermer von der Verwundungsitelte. In solchen /ellen entsteht zunächst eine horizontale scheilewand und allmählich durch weitere Teilmug das Meristem des jumgen Sprosies, ans dim sich ein Wulst als erstes Blatt differenziert.

I) Wurzeln bilden sich seitlich aus wenigen Zellen, welche neben der cambialen Kone der Getäbbündel liegen. Diese somit „endogen” angelegten Wruzeln durchbrechen in kuzer /aeit das vor ilmen liegende Gewebe. Bei den \%weigstecklingen der Begonien können die Wurzeln auch aus dem Interfaserenlarcambium hervorgehen, wie Fr. RecieL ${ }^{2}$ ) angibt. Dieser Antor, der antser $B$. Rir mehrere andere Begonien mit rhizomartigem, niederliegendem Stengel, wie z. B. noch B. imperiulis und xanthima mntersucht hat, erwähnt, dat's ant der Blattspreite an eingeschnittenen Stellen die Bildung von Knospen ebenso stattfindet. Fachrlem die Epielermiszellen sich geteilt, werden auch das darunter liegende Collenchron und das trundgewebe in die Nenbildung hineingezogen, mol dieso helfen den über das Blatt an der eingeschnittenen Stelle entstehenden Hïgel von Vernarbungsgewebe bilden, welches sich rom dem der \%woigstecklinge nur dadurch unterscheidet, dats hier die Evilermis sich an ter Kellyermehrung boteiligt.

I iese Epidermistätigkit kann gleich in ler ersten \%eit nach dem Einsclmitt in las Blatt ron ganz hesonders hemerlienswerter, physiologischer Wichtigkeit werden, indem sich in der Nähe der Wundstelle einzelne ()berhantzellen haarartio streclien (Psento- Wuzellaare) und zweitelsohne eine wurchähnliche Tätigkeit ontwickeln, bis echte Wurzeln sich gehildet hab'rn.

In der beistehenden Fig. 2us sehen wir die Neubildungen an der schnittfäche einer stälieren Blattriple von ciner Hybride der RexBenonie. A berlentet den alten Blatteril, D) die entstandenen Nenbildungen. Ans tor schnittlä̈lue war zunächst cin reichliches Callus-

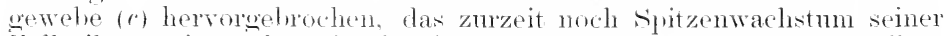
Zellreihen zeigt, alwr durch die antretenden parallelen Korkzellenwände andentt, dals os im ÏThergang znm Öherwallungsande ist. An der Grenze zwische'n dem ('allus mol alten Blattgewehe Indelit mnterseits die andogen angelegte nene VTuzel (w) hervor, wähend oberseits sich bereits zwei nene Knospenambgen gebilklet haben. Die eine, jüngere,

1) An, Haxsex, Vorläufige Mitteilung. Flora 1<79, S. 254.

2) Fr. Raris, Die Vermehrung der Begoniaceen aus ihren Blättern usw. Jena ische Zeitschr. f. Naturwiss. 1876, s. 477; cit. Bot. Jahresber. 1876, S. 42:3, 4\%9, $4.2 \mathrm{usw}$. 


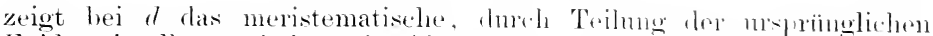
Epidermiszellen und des subepidermalen fiewales motambine fiewebe der jungen Knospe mit ihrer Epirlemis (6). Jir zwoite Knospe ist

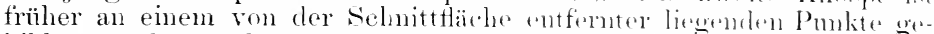

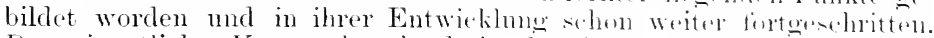

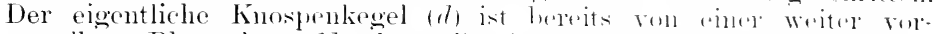

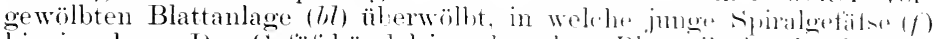

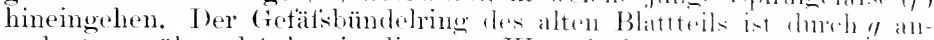

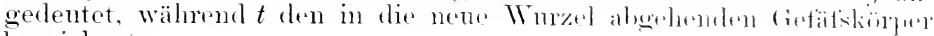
bezeichnet.

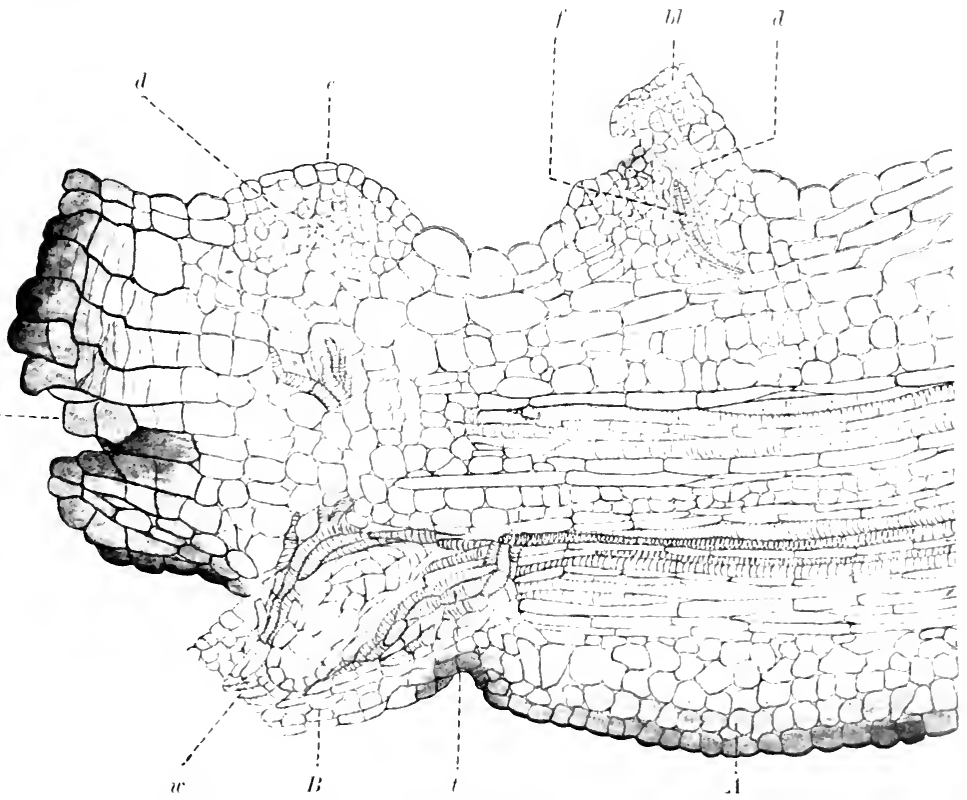

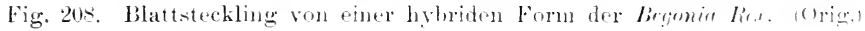

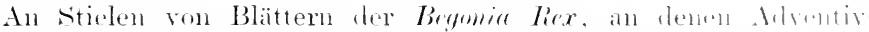

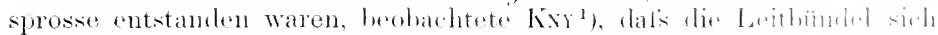

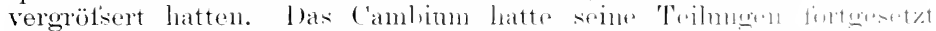

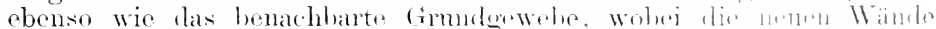

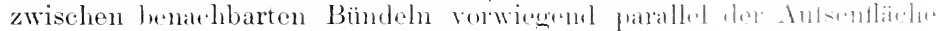

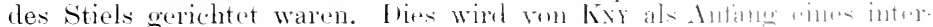

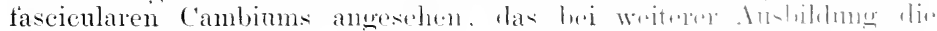

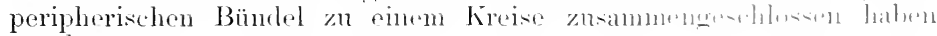
wiirde.

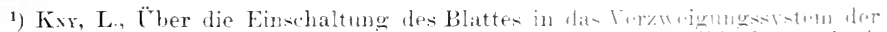

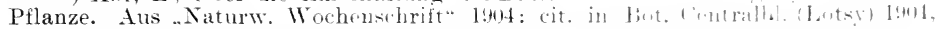
Nr. 50, S. 61:. 
Nach den mehrseitigen Beobachtungen, welche über Blattstecklinge bereits rorliegen. ist tie Ammahme gerechtfertigt, dats die oben bei Bryonir heschriebenen Vorgänge sich hei viclen Blattstecklingen vorfinden. Aus mehr oder weniger oberflächlich gelegenen Zellen entwickeh sich die Laubsprossen; ans den der ('ambialzone angrenzenden Zellen entstehen die Anlagen der Wurzehn, welche entweder das alte Gewebe des Stecklings durchbrechen oder ans dem Wundvernarbungsgewebe hervorkommen. Die Unterschiede bei den einzehnen Gattungen sind meist nuwesentlicher Natur, und die Meinungsverschiedenheiten der einzelnen Autoren erklären sich oft daraus, dafís dieselbe Pflanzenspezies nuter verschiedenen Terhältnissen und in verschiedenem Alter, hei den einzelnen Individnen nicht immer genan dieselben Vorgänge zeigt. Aus den Untersuchmgen von BeInLin: ${ }^{1}$ ) ist beispielsweise zu entnehmen, dafis die Gattung Pepromia keinen Callus bildet, sondern die schnittfäche durch Wundkork abschlietst. Er sah iubrigens die Knospen aus dem Gruntparenchym des Blattstieles oder der spreite, nicht ans der Epidermis, nud immer mabhängig vom Gefäfsbündel entstehen. Dagegen beschreibt $\mathrm{H}_{\mathrm{ANsEN}}{ }^{2}$ ) bei Achimenes und Peperomia ansführlich die Vorgänge der Wurzel- nnd Sprofsbildung ans dem Callns. Hier entstehen nur die ersten adventiven Wurzehn ans den bereits rorhandenen Giewebeelementen. Nachdem das Callusgewebe einige Zeit hindurch sich vermehrt hat, zeigen sich im Imnern desselben zahlreiche, procambiale stränge, die nach allen Richtungen gegen die Oberfläche hinstreichen und deren Zellen sich bald zu Tracheen umbilden, so dats der "Callus"3) mit einem verzweigten System von Leitbündehn versehen wird. Bald darauf erscheinen peripherische Kellen dieses Gewebes reich mit Protoplasma angefüllt, teilen sich und erzengen ein Meristem, das sich wie bei den normalen Vegetationspunkten gliedert und namentlich dentlich bald eine Epidermis erkemnen läfst.

Bei den Blattstecklingen der Monocotrlen sind die Vorgänge der Knospenbildung wie bei den Dicotylen. Dagsus $\left.{ }^{4}\right)$ beschreibt Blattstecklinge von Hyacinthen. Aus der Bauchseite bilden sich an der Schnittfläche zahlreiche Adventivknospen, die, falls das Blattstïck noch jung war, ans einer Epidermiszelle oder bei älteren Blattstïcken ans dem darunterliegenden Parenchym entstehen. Ans den sich teilenden Gewebezellen formen sich zmächst zarte (iewebehöcker, die mit diver-

1) Baxusa, E., Entersuchungen äher die Entstehung der adventiven Wurzeln und Laubknospen an Blattstecklingen von Peperomia. Inanguraldissertation. Breslau $1878 . \mathrm{S.} 2: 3$

2) Hixss, As, Über Adventivbildungen. Sitzungsber. d. phrs.-med. Soc. zu Erlangen vom 14. Jumi 18,0: cit. Bot. Centralbl. 1880, s. 1001.

3) Es bietet sich hier Gelegenheit, darauf aufmerksam zu machen, dals die Autoren zwei verschiedene /ustande mit dem Nanen "Callus" bezeichnen.

Callus wird dasjenige fiewehe genannt, das aus den ersten Zellteilungen hervorgeht, einige Zeit hindurch reilsenweise Anordnung besitzt, namentlich an der Spitze der Zellreihen fortwiehst und ohne alle Differenzierung ist.

\%weitens verstehen darunter die Autoren nach dem Gebrauche in der Praxis aber auch das aus dem C'allus durch Entstehung einer Korkzone, Anlage imnerer Meristentherde und Anssheidung eines frmudgewehes differenzierte Gebilde, das schon dem Gewebeteil ïhnlich geworden, aus dessen Wunde es entstanden ist. Von diesen Dauerzuständen sind ither die durch Spitzenwachstum ausgezeichneten Jugentzustände zu tremsen, und ich schlage deshalb die Bezeichnung "Callus" nur für diese Erstlingsbildungen ror, wïhrend die späteren Zustände als "Vernarbungsgew ebe" angefuhrt werden können.

4) Mnise. Hracinthenbiatter als stecklinge. Sitzungsber. d. Ges. naturforsch. Freunde vom 16. Juli 1878: cit. Bot. \%eit. 1878, S. 765. 


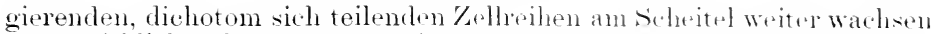
(also wirklicher Callus). An weiter entwiokelten lläckron tritt rin ring-

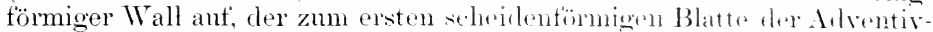

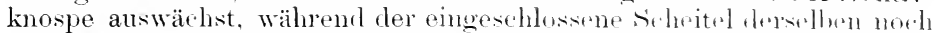
das Wachstum mit divergierenden Kollreihn zeint. Andh an den

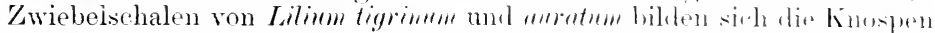
am äufsersten Rande der Immenseite: die ant dre Autsomsejta ans der

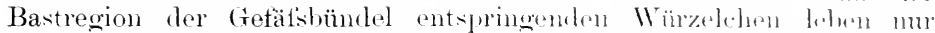
kurze Zeit, da die junge PHanze alshald sellstämlin Wmosh mar.ht.

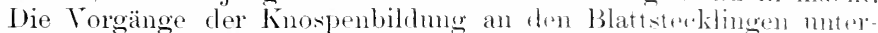
scheiden sich auch nicht wesentlich rom der frowilligen Futstehume

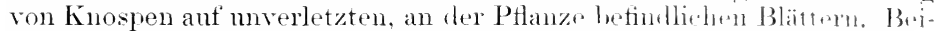
spiele sind zahlreich bekannt geworden ${ }^{1}$ ): sie sind hej \[m⿻n mul

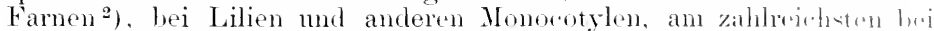
Dicotyledonen, beobachtet worden. Für letztere nanentlinh stollt.

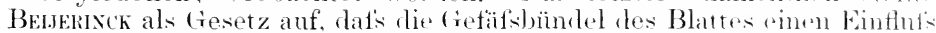
auf die Anlage der arlventiven Oreane haben. Ila, wo dre Holzteil der Gefälsbündel nach der Blattoberseite gekeht ist, fimden sich dir

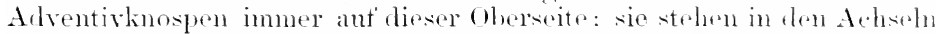
der Nerven und sind meist mo so stälere entwickelt, je dieker dic

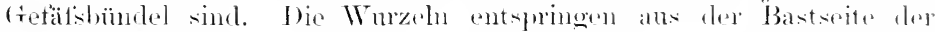
(ietälsibünclel.

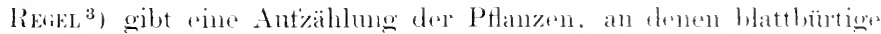

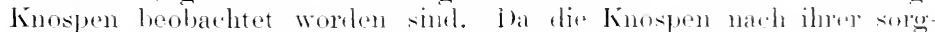
fältigen Ablösmeg eigene Wurceln anstreiben mol drshall, fïr dir

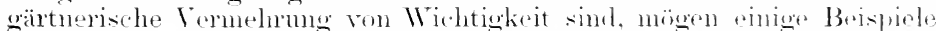

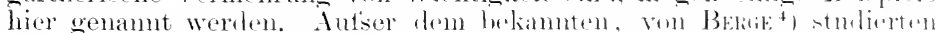

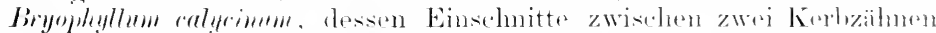

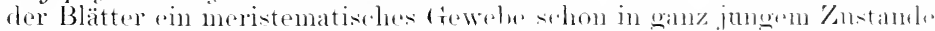

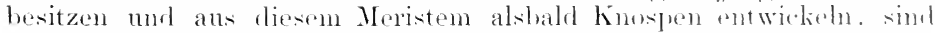

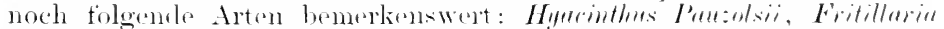

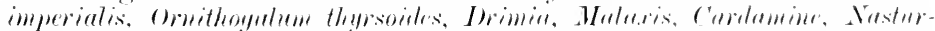

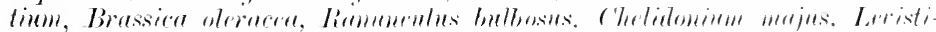

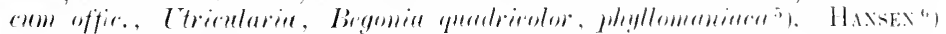

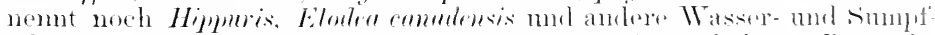

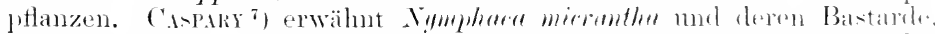
Letzterer Autor tührt anch Beispinde ant, lei denen sieh statt di..

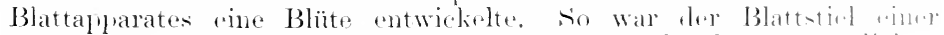

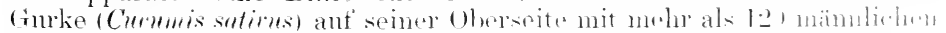

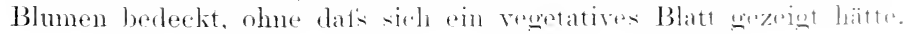

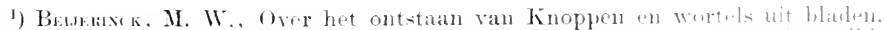

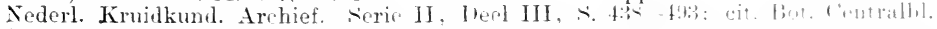
$1 \times 3, \mathrm{Nr}, 17$, s. 112.

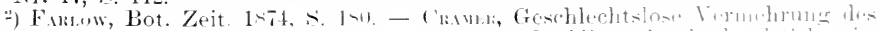

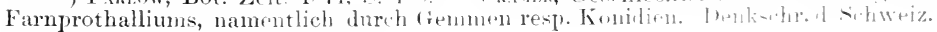
Naturforsch. Ges. XXIIII, 1 w-

3) a. a. 0.5452 .

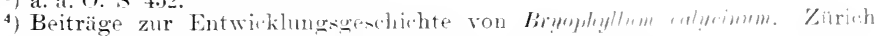
$18 \pi$; cit. Bot. Tahresber. IV. 4 .

5) Iom. Ëber die Cambimnschicht des stammes dep phantoganen und ihr Verhältnis zum Dickenwachstmm desselhen. Bot. Zeit. 1-i, S. 194;.

6) a. a. O. S. 100 ?

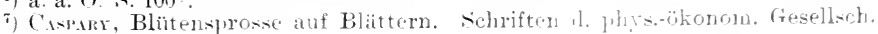
XV, 1874. \$. 99 . 
1)as (ielingen der Vermelumng durch Blattstecklinge wird autser von der PHlanzenspezies auch von der Blattindividualität abhängen. ( ianz jugendliche Blätter werden wegen der Unfertigkeit ihrer Gewebesrsteme, sehr alte wegen ihrer geringen Lebensenergie und Abreifung ilires C'hlorophyllapparates auszusehliefisen sein.

Bei solchen Gattungen, deren Blätter überhaupt zu Stecklingen benutzbar sind, sollen die daraus hervorgehenden Pflanzen nach

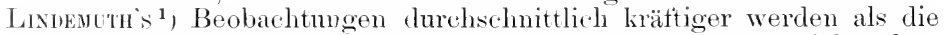
aus sprotistecklingen. Sobald ein Blatt einige Wurzeln getrieben hat, ist es schon als ein nenes Individuum zu betrachten, auch wenn es nieht einen sprof's zu entwiekeln imstande ist. Es geht dies aus der grötseren Langlebigkeit der Blätter gegenüber unbewurzelten hervor, und GOEBEL ${ }^{2}$ ) liomute auch noch ein vermehrtes Dichenwachstum (bei Bryophyllum) nachweisen. Dats bei Blattstecklingen an stelle eines Laubtriebes sogar direkt ein Blïtensprots gebildet werden kann, beobachtete anch Linnenuth an einer Begonie. Dieser Umstand würde daranf hindenten, dafis die Blätter in verselicedenen L ebens altern und stellungen an der Achse verschiedene Assimilationsprodukte liefern; meist werden die Assimilate die am Blattsteckling entstehenden Knospen nur zu Laubsprossen befähigen, manchmal aber diejenige Konzentration besitzen, dals eine Blütenknospe angelegt werden kamn.

Statt der Blattstücke bedient man sich in der Praxis bisweilen auch des Blattstiels zu Stecklingen, falls das Blatt selbst zu zart ist. Ein neneres Beispiel ist die Vermelurung der als Winterblïher hochgeschätzten Kulturform von Begomia stmperflorens, die als Gloire de Lorraine im Handel ist ${ }^{3}$ ). Es werden hier im Februar die kräftigsten Blätter sthart am Stengel abgelöst und mit dem Stiel $1-2 \mathrm{~cm}$ tief in sand mit Torfmull gesteckt. Bei einer 'Temperatur von $18-2.20 \mathrm{C}$ machen diese Blattstiele bis walnukgrofise Wurzelballen. Andere Begonien, wie z. B. die Iitr-Formen, machen zwar auch aus dem Blattstiel Wurzeln, aber wohl haum jemals kräftige Knospen. Ebenso verhalten sich Blattstiele von Kolıl, Sellerie und anderen fleischigen Pflanzen.

Blütenstiele sind bei Primmla sinemsis mit Erfolg als Stecklinge benutzt worden. Bei derselben Ptlanze verwendete ('iAMER ${ }^{4}$ ) verlaubte Blüten, bei denen Knospen in der Achsel der Fruchtblätter entstanden waren. Dat's auch Frïchte selbst als Stecklinge benutzt werden kömnen, zeigt ein Fall, den Bulcon beobachtete; hier brachen Wurzeln aus einer Kaktusfrucht hervor ${ }^{5}$ ). Derselbe Forscher durchschnitt anch den Fruchtknoten der Jussinu sulicifolia, welcher nngefähr in der Mitte zwei Blättchen hat, während mul nach dem Anf'blühen quer über der Basis, so dat's man imen die Eichen sehen konnte, und setzte diese Stecklinge in einen Topf. Nach drei Wochen wurden die reichbewruelten stecklinge verpflanzt. Im Winkel eines joden der Fruchtknotenblätter erschien ein kleiner Zweig mit Schuppen. Die oberen

1) Liximutu, H., Weitere Mitteilungen äher regenerative Wurel- und sprofsbildung auf Laubblïttern (Blattstecklingen). Gartenflora 190:3, S. 619.

2) Flora 190:, S. 1:3:

3) Knis, Vermehrung der Begonie ,Gloire de Lorraine". Prakt. Ratgeber im Obst- u. Gartenibau 1906, Nr. 5

4) Bildungsabweichungen, s. 37.

5) Vegetable Teratologie, S. 160 . 
Blumenteile starben ab, und es bildete sich oine ringtionige Narber ${ }^{1}$.

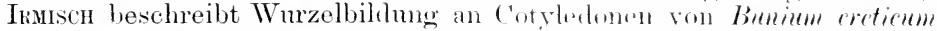
und ('arum Bulbocustamm ${ }^{2}$ ). Verfasser sah solehe hei abowhochenen Cotyledonen von Bohnen (Phaseolus rulgaris). ('anktekt fand Wurzeln an Früchten von Lilium lameifolimm. BEswas; ${ }^{3}$ ) sals Blïtenstiole von Echereria im fenchten Sande mit Wnrzeln vorsehen.

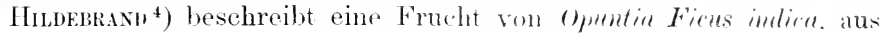
der eine zweite hervorgesprolst war: beille Friichte ontwichelten nach

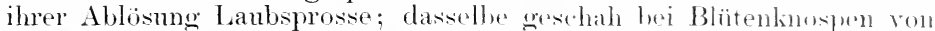

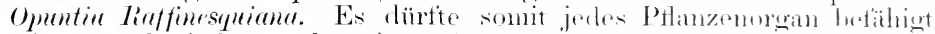
sein, durch Anlage adventiver Augen Laubsposism zn "nitwiekin,

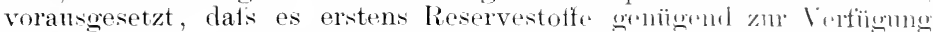

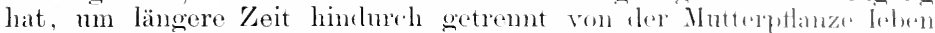
zu kömnen. und zweitens, dats die äntseren Budingungur sich ginstin erweisen. Weitere Ausühmugen mit den Ansiduten von Kurs.

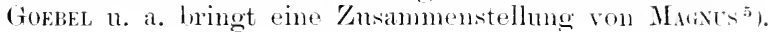

\section{Beschädigung des Laubapparates.}

Die Folgen einer teilweisen ofur gänzlichen Ent lan l, nn w müssen natïrlich in der Menge der produzierten Trockensulstanz zun Ansdruck liommen. Iner Effelit ist verschieden je nach Menge mul Alter der entfernten Blätter mul je nach der Mändichlieit eines bisaltzes de fehlenden Laubapparates ans vorhandenen Knospen nud dou in der Achse gespeicherten Reservematerial fö̈ lren Entfaltung.

Betrefts der Waldbämme bringen die , Jahloucher für Furstwirtsehatt genügende Beispiele, ant dir hier darmm nirht näther eingergangent zu werden brantht, da jedrer Einzeltall besomelers bemtrilt werolun muts. Bei den zahlreiehen Buschärligmeen doreh Rampen hängt lwispiels-

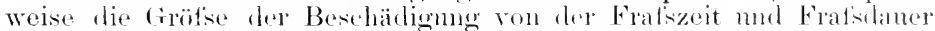

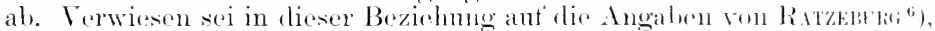

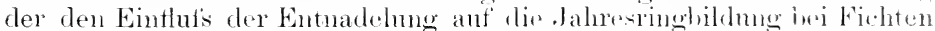
und Kiefern eingehend hespricht nud spater anch die Laubhöber bohandelt $\left.{ }^{\top}\right)$. Dats anch der anatomische Bat eines nach starker Eutnadelung entstelıenden Holzringes geändert (viel zarter) wird. zom

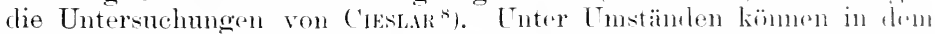

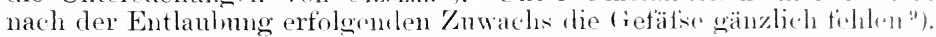

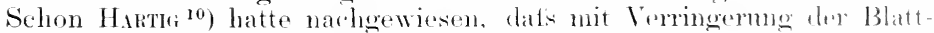
menge eine Verminterung fler (iefätizahl Hand in lland solit. Wals

1) Bot. Zeit. 1×65, S. 527 , aus Adansonia t. I, ‥ 1<1

2) Flora $1 \times 5,5,32,4: 3$.

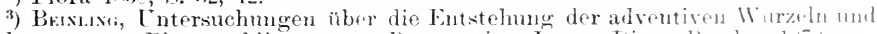
Laubknospen an Blattstecklingen vou Peperomia. Inang.-Tisis, limalan l-

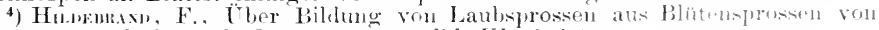
Opuntia. Ber. d. Deutsch. Bot. Ges. Ixst, Bd. VI, si. 109.

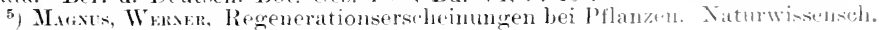
Wochenschrift 1906, Nr. 40.

6) R.тzени:, Waldverderbnis. I. s. 160, 2:34 u. a.

i) A. a. O. II. ค. 154. 190, 2:3:3.

8) Cissum, A, Über den Einflufs versehiedenartiger Entnadelung anf fröhe

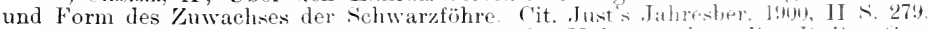

") Li\%, K. G., Beitrige zur Phrsiologie der Holzewachse. Ber. D. Bot. (ies. 1895, S. 185.

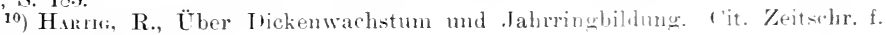
Pflanzenkr. 18:2. S. 29:2. 
unter Tmständen doppelte Jahresringe entstehen können, hat $\mathrm{KNY}^{\mathbf{1}}$ ) bereits erwähnt. WIELER ${ }^{2}$ ) zeigt durch Versnche, dats man durch Verschitbmgen in der Ernährmg die Grenzen zwischen Frählings- und Herlitholz ganz verwischen könme.

Inrartige Folgen werden anch bei den obstbäumen eintreten und häufig in der Fruchternte zmm Ausdruck kommen. Nur in wenigen Fällen kimm eine teilweise Lambentfermmg sich wirtschaftlich empfehlenswert erweisen, wie $z$. B. beim Weinstock, wenn dorselbe beständig nene Laubtriebe produziert, welche die zur Ausbildung der Trauben nötige Nahrungszutuhr fïr sich beansuruchen.

Ton den ein- und zweijährigen Kulturptlanzen kommen besonders die Rüben in Betracht, weil man in Jahren der Futternot im Lanfe des Sommers die älteren Blätter abbricht und zu Viehfintter verwendet. Dats der Rübenkörver dadmeh veranlatist wird, mehr wie sonst nenes Lanb zn bilden, mnd dats dadurch die sueichermo der Reservestofte leiclet, beweist ein Beispiel aus Böhmen ${ }^{3}$ ). Hier zeigte sich, datis nach der Entblattung nicht nur der Rülenkörper selbst kleiner blieb, sondern dafs namentlich der /nckergehalt $u m$ 10\% geringer als bei den unversehrt gelassenen Rüben war. Gleichlantende Resultate erzielte Anerholo ${ }^{4}$ ) bei seinen Versuchen mit Rïben und Getreide. Bei letzterem zeigte sich, dats besonders die Ährenlänge, abgesehen von der ReInlition der gesamten Erntemasse. stark beinflutist wurde.

Indes darf man mit semen Befürchtmgen auch nicht zn weit gehen und geringtügige Verluste an Blattsubstanz zu hoch bewerten, wie dies nenerdings von seiten mancher Pathologen bei Abschätzung von schäden durch Pilzbefall in ,lie Erscheinung tritt. Man darf nämlich nitht vergessen, dats bei noch kräftig vegetierenden Blättern, die einen Teil ihrer Lamina verloren haben, der zurïckbleihende Teil zu erhöhter Arbeitsleistming angeregt wird, wie ich durch Versuche nachgewiesen habes). Borrivant ${ }^{5}$, fand sogar, dats nach Entfernumg der Blattspreiten sich die Blattstiele und Stengel in höherem Matse als bisher an der Asimilation beteiligen, mnd dats ihr parenchmatisches Gewehe in streckmng und Temehrmg eintreten kamn.

1) Terhandl. d. Bot. V. d. Prov. Brandenburg 1879.

s) Wirts: A., Utber Beziehumgen zwischen dem sekurdären Dickenwachstum und den Ernährungsverhältnissen der Bäume. Tharander forstl. Jahrb. 1892 Bd. 42.

") Blätter f. Zuckerräbenbau. $1905 \mathrm{Nr}, 20$.

4) Anmm., R., İber die durch teilweise Zerstörung des Blattwerkes der Pflanze zugefügten 'schäden. Prakt. Blätter f. Pflanzenbau u. Pflanzenschutz. III. Jahrg. 1905 Heft '2.

5) Sinner, P., Studien über Verdunstung. Forsch. a. d. Gebiete der Agrikulturpliysik. Bd. III. Heft 4\%. R\%. s. 109 .

6) Buminr, A., Nur le tissir assimilateur des tiges privées de feuilles. Just's Bot, Jahresh. 1*98. II s. 2:?1. 


\section{Nachträge.}

Zu seite :3os. Nenere Untersuchungen über die ('hlerose liegen

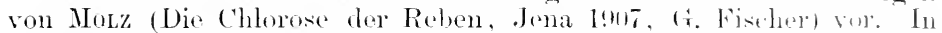

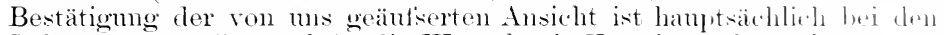
Reben Sanerstoftimangel för die Wurehn als Ersache zu betrathten. An gefährdetsten sind laher tiefe Lagen, in denen sieh das von den llängen abfliefsende Wasser sammehn kam. In schweren Bërlen leislet darmiter die Ansbildme des Wurelsistems. Der Kalk allein er\%engt krine Chlorose, aber, da kallireiche Bödren auch öfter sehr loinkërnig sint musl eine alkalische Realition hervorbringen kïmnen, so bieten sie besonters leicht (xolegenheit zmm Alsterben ler Wimzeh. Darmm kam man von einer Kalk-chlorose sprechen. Aber anch anhaltende

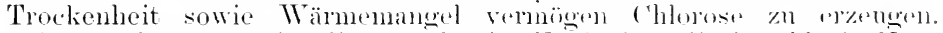

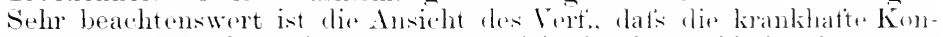

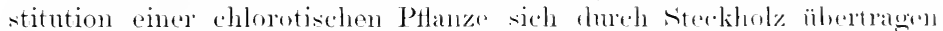
lassen wird. Diesen Stecklingen kamm entweder von Anfung an die

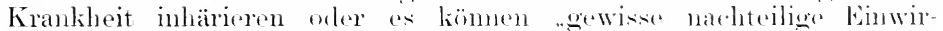
kmngen von antisen infolge einer ähernommenen starlinn Präilispusition das iliterische Phänomen und dessen Folgeznstionde entstehen laxsent".

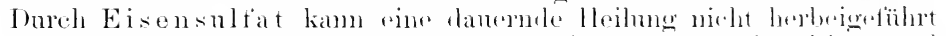
werden: es worden in hesten Falle nur die symptome besitigt, mot

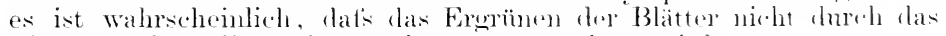

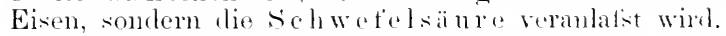

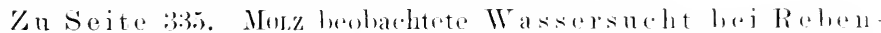

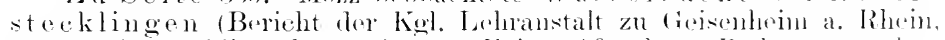

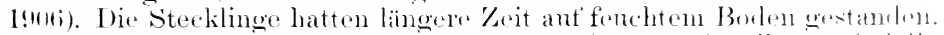
Sir zeigten sich an cinzehen stellen tomenartig angeschwollen, wehe die

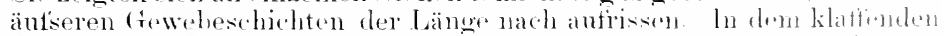
spalt wurde ein meist weitses. sehwammiges frewehe sichthall. das ans hypertrophierten Rindenzellen bestant. Ifolz hält die Krankilucit, dir in fenchten Weinbergen nicht selten ist, fï̈ iclentisch mit hel ron

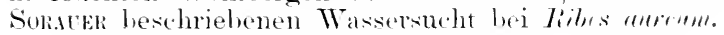

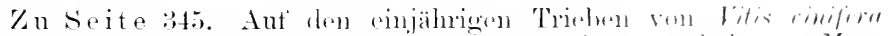

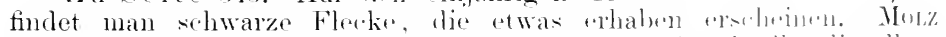

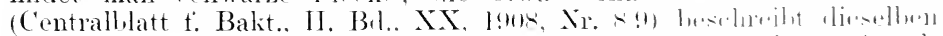

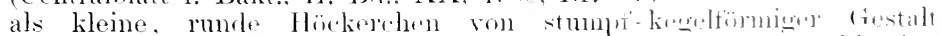

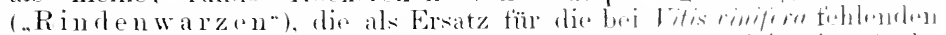
Lenticellen anzusehen sind. Sie tragen ant ihron (iiptiol je eine sipalt

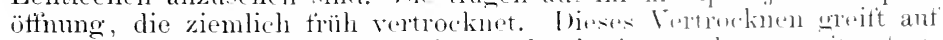
die benachbarten Zellgrupen B̈her mo sedreitut sn langw weiter tort.

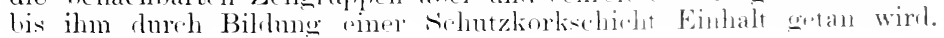


Je kräftiger und besser ernährt das Gewebe ist, desto sehneller wird der Sehutzkork entstehen. Sehlecht eruährte Triebe erzengen keinen schutzkork, und daher werden auf diesen die Rindenwarzen besonders orot's und zahlreich. Diese schwarzen Flecke geben also einen Maf'sstab für den Grad der Holzreife und Gesmontheit der Rebe; je zahlreicher und grötser sie sind, desto weniger ist in allgemeinen das Holz ansgereift.

Zu seite:378. In Geisenheim beobachtete JuLE Jürer eine Kropfmaserbildung am Apfelbaum (Zeitschr. f'. PHanzenkrankh., 1908). Die Ursache ist noch nicht genügend festgestellt, ist aber wahrseheinlich in einer Ernährungsstörung zu suchen, die sich in einer Erweiterung der Narkstrahlen auss]richt. Einzehe Markstrahlen zeigen schon bei ihrer Anlage eine grölsere Zellvermehrung und Erweiterung der cinzelnen Zellen. Der Vorgang schlietst sich an die von uns beschriebene Bildung von Maserspiefsen aus Markstrahlwucherungen bei Ribes nigrum und Pinus Malus chimensis an.

Zu Seite 391 und 395. Eisentleckigkeit der Kartoffeln ist in nassen .Jahre 1907 moemein verbreitet gewesen und damit vergesellschaftet eine gelbe bis brame Verfärbung im Gefäfsbündelringe aufgetreten. Diese Verfärbung in Gemeinschaft mit einer häufigen ErFrankung des Nabelendes, bei der bisweilen ein Fusarium beteiligt war, hat APper bewogen, die sogenamnte Blattrollkrankheit, eine Form der Kränselkrankheit, als Pilzepidemie zu erklären. Appé behauptet, das am Nabelende zu findende Fusarium wüchse während des Winters durch den Gefätsbündelring in die Angen der Knolle und verursache im nächsten Jahre ein erhöhtes Auftreten der Krankheit und allmählichen Aboan der Kartoffeln. Die gleiche Theorie ist ron Reinke und Haluiek aufgestellt worden; nur haben die genannten Beobachter andere Pilze dafü̈r verantwortlich gemacht. Sorater woist num (Internationaler phytopathol. Dienst, Stiuck 2, 1908) nach, dafs das Fusurim zwar mehrtach zu finden sei, dat's aber ebenso oft anch andere Schimmelpilze vorkämen, sämtliche Pilze aber niemals im Gefälsbündelringe der Knolle bis in die Angen weiterwachsend beobachtet werden komnten. Ton einer Pilzkrankheit und deren Öbertragung dureh die Knollen in das nächste Jahr hinein sei nitht die Rede. Die Verfärbmaserscheinungen in der Knolle seien viehmehr durch Steigerung von Enzymen zu erklären, welche Professor GRC̈ss am Nabelende besonders angehäuft nachgewiesen habe. Infolgedessen sei relativ grotser Zuckerreiehtum vorhanden, der für zahlreiche Mikroorganismen einen besonder's gïnstigen Mutterboden schaffe.

Zu Seite tmi. Der Einflufs der Elelitrizität anf das Pflanzenwachstum wurde in der Hatch-Yersuchsstation des Massachusetts Agric. ('ollege (cit. Z. f. Pflanzenkrankh., 1918) gepruift. Als Versuchsptlanze diente Raplumes sutirus. der eine Wachstmmsbeschleunigung und Gewichtszunahme an Blattwerk und Wurzehn zeigte: doch waren die Blätter von hellerem Girin und neigten zur Blattdürre. Der elektrische Reiz scheint in ähnlicher Weise wie Lichtmangel anf die Organe zu wirken.

Die im Text erwähnten Tersuchsresultate ron Löwenherz kamn

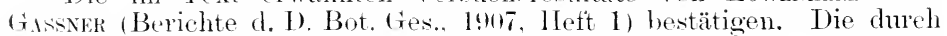
Einwirkung des Stromes entstehende hrömmung, die bei allen Pflanzen zu beobachten war, hleibt nicht immer dieselbe: zuweilen ist sie dem negativen, in andern Fällen dem positiven Pol zugekehrt. 
Gegenüber den von Löwexhek, frïhre verïtiontlichten und von Gassner bestätigten Kulturversuhen mit frerste, lis einen shädlichen

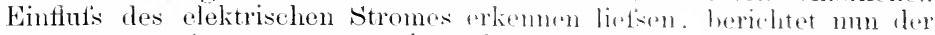
erstgenamute Autor von gïnstigen lisultatru (\%. 1. PHanzonliranlili.,

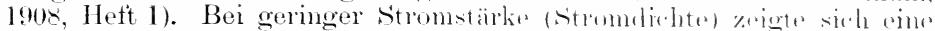

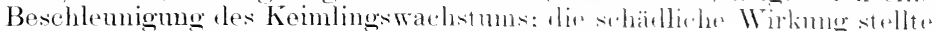
sich erst bei Erhöhumg der Stromstäliw rin.

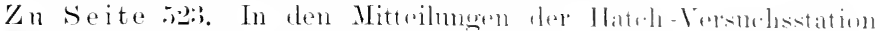

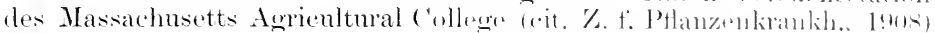

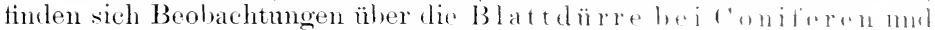

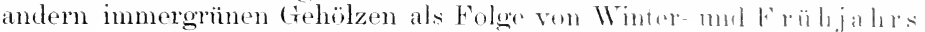

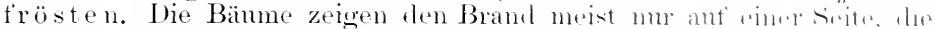
mit der vorhersechenden Windrichtmog ïheroinstimnt. Winm \%n wink

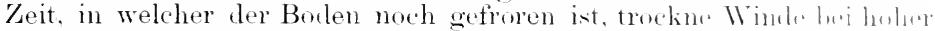
Temperatur wehen, kamn die gesteigerte Transpiration der PH:t1\%+n in lem getiorenen Boden keinen genïgenden Ersatz finden, mul dir Blätr. vertrocknen. Es ist dies dieselle Ansehamme. wolehe zm Erlitirmme

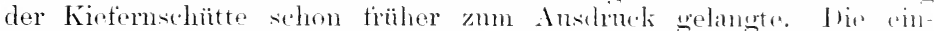
heimischen Coniteren litten weniger. falls sie nicht etwal ant monsagendem Boden standen, gegenüber den oingetühten Arten von l'irar.

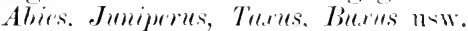

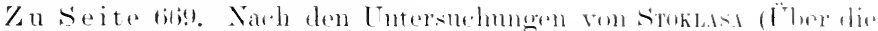

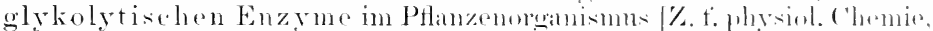

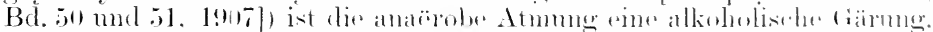

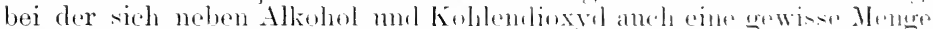

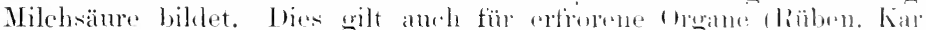

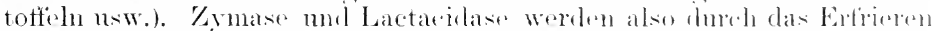

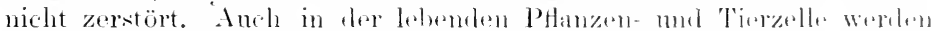
Milchsäure, Alkohol, Kohlendioxyl. Escig- mul Ameisensäm dmol

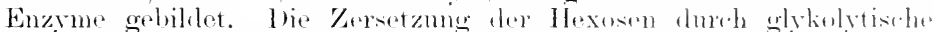
Enzyme vollzieht sich normal ohne die Mitwirkme rom Baktorinn. In

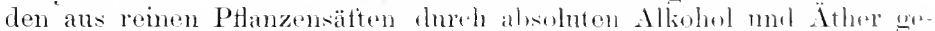

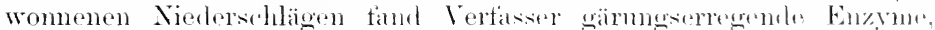

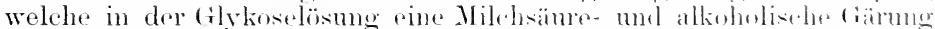
hervorriefen, hei welchem Prozets unter vollem sauerstoftytrilt si.h

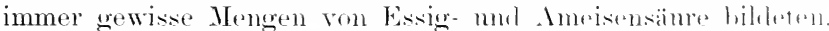

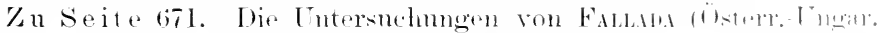
Zeitsehr. f. Zuckerindustrie n. lamelw. Iloft V. I!nT) iilwe lie Wi il

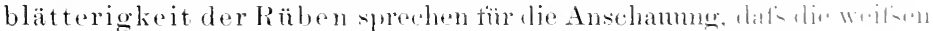

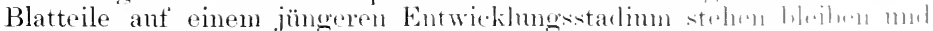

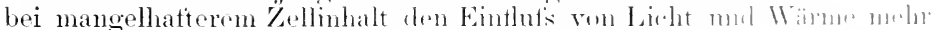

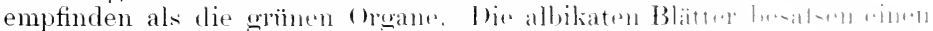

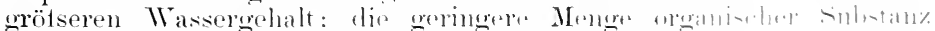

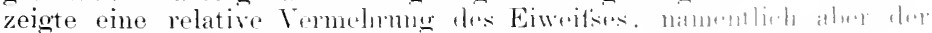

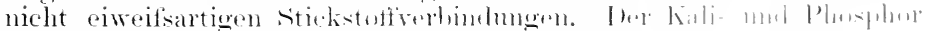

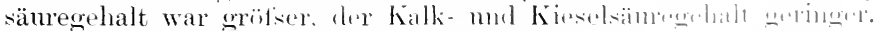

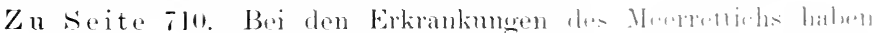

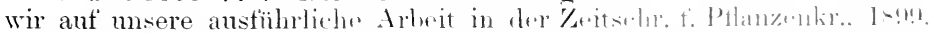

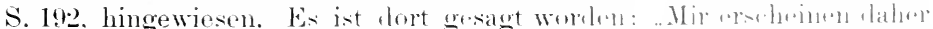

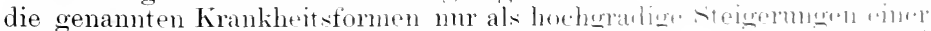

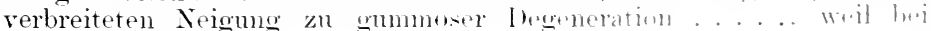


der Entstehmng der Füllmassen der Gefätse auch die schmelzung der sekundären Membranen in gevissen Fällen mitwirkt." Diese Anschanmo wird nenerdings von A. Schlerer (Der Anbau des Meerrettichs usw., cit. Biedermamns Zentralbl. f. Agrik., Heft \&, 1!ns) geteilt. Er sagt: "Das Sehwarzwerden aber wird nach meiner Ansicht dadureh bedingt, dats die Pentosane und der Zucker im Meerrettich gummiartig degenerieren." Auch die Ansicht, dats Kalk als Ileimittel (da oft im Boden Humussäure vorhanden) anzuwenden sei, wurde durch den Versuch bestätigt. Wurden Pflanzen in Nährlösmngen kultiviert, die, eimmal mit Kalk, das andere Mal olme diesen angesetzt waren, so liets sich an der kalklosen Ptlanze sehr bald die gummiartige Degeneration "des Zuckers" nachweisen.

Zu Seite 711. Das Gebiet dex Beschädigumgen durch Ra ueh gase und andere industrielle Auswurtistotte beginnt jetzt als gesonderter TVissenszweig sich von der allgemeinen Pathologie abzuzweigen und wird durch an gesondertes Publikationsorgan vertreten. Seit 1908 existiert eine .Sammlung von Abhandlungen ïber Abgase und Ranchschäden", heran-grageben von Prof. Dr. Wistackus, der im ersten Hett eine zusammentassende Darstellung "T̈ber die Grundlagen techniseher und gesetzlither Matsnahmen gegen Rauchschäden "bereits geliefert hat.

Über die Einwirkung der S'chwefligen säure anf den Boden liegen von Haselhoff nenere Untersuchungen vor (Z. t. Pflanzenkrankh., 1908). Die Versnche zeigen, dats die Tegetation nicht reschädigt wird, wemm der Boden solche Mengen zersetzungsfähiger Basen (namentlich Kalk) enthält, dats die aus der zugeführten Sichwefligen säure gebildete Schwetelsäme gebunden wird. Der von Wrecer geschilderte Fall der Bodenverarmmo bei Vorhandensein fieier säme im Boden dürfte höchst selten (vielleicht in Waldböden) anzutreften sein. Wenn dagegen während des Wachstums der Pflanzen Schwetelige Säure in den Boden geleitet wurle, so dats derselbe cine same Beschaffenheit zeigte, waren Tachstumsstömngen deutlich bemerkbar. Bei kupferhaltigen Böden wird durch die schwetlige säme das hupter in leicht lösliche Verbindungen ühergetührt, und dieses gelöste Kupter kann damn für die Vegetation schällich werden. Aber anch hier wird kohlensanrer Kalk helten, inden el die lösende Einwirkung der säme aufheht.

Ku seite 752. Die von mo zuerst heobachtete Erscheinmog einer nachteiligen Wirkung der Bordeanxmischung auf den Ernteertrag wird drurch nenere Versuche von v. Kinchnen (\%. t. Pflkrankh., Heft II, 19us) bestätigt. Der Antor beriicksichtigt auch die ältere Literatur. Wahrscheinlich ist die s'ehattenwirkmng der Brïhe für die Erntedepression verantwortlich zu machen; dieselbe würde auch das freudigere Ergrïnen ler Blätter bei starkor Somnenhestralılung erklären. Der grötsere Stärkereichtum ist nicht chöhhter Assimilation, sondern verringerter Altuhr der Assimilate zmzuschreiben.

Zu Seite riti. T̈ber cinge fresichtspunkte bei der Ilerstellmmg

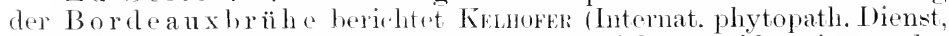
1!)8, Heft :). Die Wirksamkeit der Brühe ist nicht nur abhängig von der qualität der verwandten Materialien, soudern anch von den Mengenverhältnissen der beiden Bestandteile und yon der Zubereitungsweise.

Was zunächst die Mengenverhältnisise anbetrifft, so ist zu betonen, dats der Kupteniederschlag seine voluminöse Beschaffenheit 1 m so 
schmeller verliert und die Gefahr des Ahwaschens durch Regen um so grötser ist, je mehr Kalk zur Herstellnug der Brïhe verwendet wird. Nach Kenhofrks Versuchen ist ex temer arforderlich, datis die Kuptervitriollösung und die Kallimileh in der Kälte, mul zwar in mäglichst

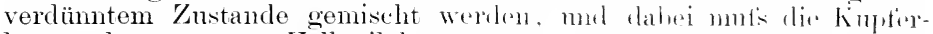
lösung langsam zur Kalkmileh pegosisen weleten. Andrintills nimmt der Niederschlag eine pulverige Form an, dir schmell zusimmmusintut. Obgleich der /uckerzusatz im Prinzip zu "mutchlen ist, mmls man sich doch davor hüten, zu grotse Mengen zu momen, dal dies Alwashlarkeit der Kupterlösung dadurch getörlert wirel. Allerling in ale zme Haltbarmachung der Mischmng nötige /utekermenger vom Kalliculhalt

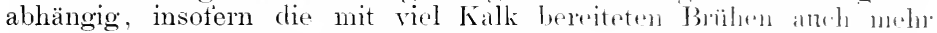
Zucker bedürten. So haben sich beispielsweise luei Vinwentules von

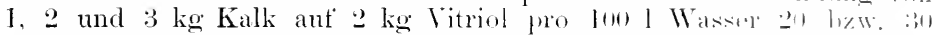

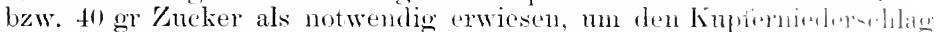

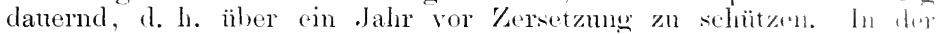
Praxis, wo in der Regel reichlich Kalk zur Terwentmo kommt, ist

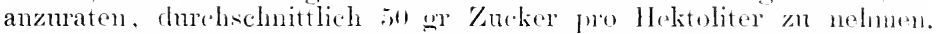
Bei diesem /usatz kann der ganze Bedart an Bordeanxhrïh which bei Beginn der Sarson in Frïhjaln angefertigt worlen: die Mis.hmm hält sich dam den ganzen śommer ïber.

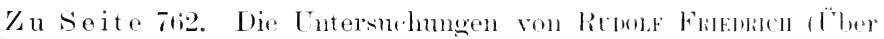

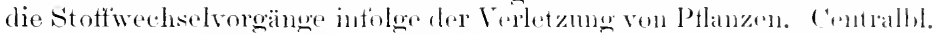

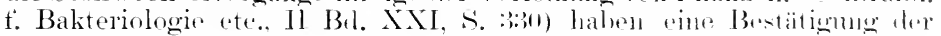

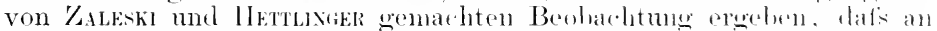
der Wundstelle eine Eiweifsumahme stattimlet. Aufserdem alue find

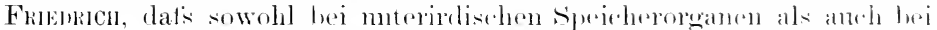

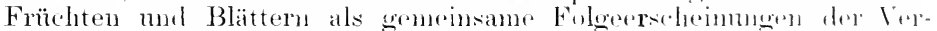

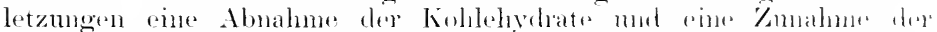

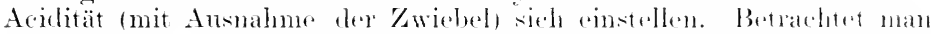

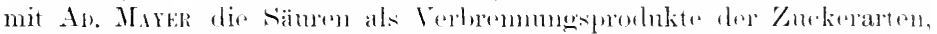
so erklänt sich die gesteigerte Aciditä dom das lebhattere Atmmmes-

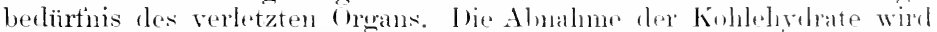

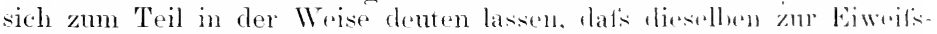
synthese verbrancht werlen. Als fermere Roalitionen anf don trammati. schen Reiz dïrte anch eine ent-pirechende Almahmo der Amisto haw. der Amidosänren anzuschen sein, die zum Anflan des Eiweitsmolokials

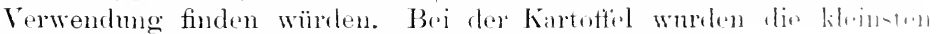

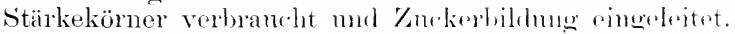

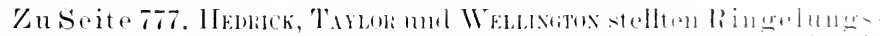

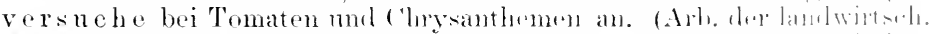

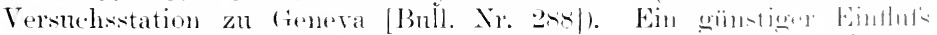

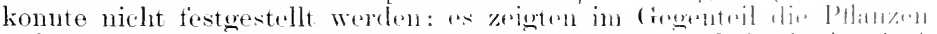

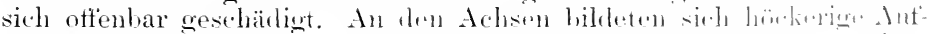

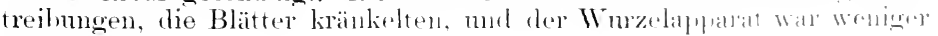
entwiclielt.

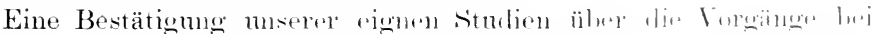

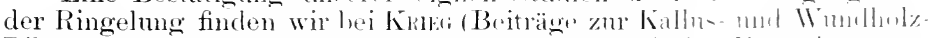

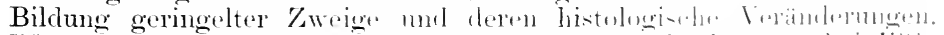

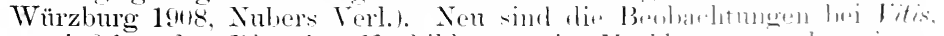

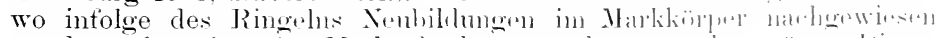

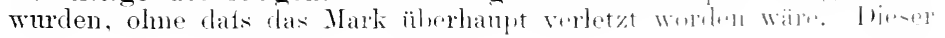


Umstand ist dadurch wichtig, weil er zeigt, dafs der WVundreiz oder die bei jeder Verwundung sich einstellenden Änderungen in der Gewebespamung sich in Regionen geltend machen, die von der Wundfläche weit entfernt und durch feste Holzzonen von derselben getremnt sind. Nan versteht nummehr auch besser die Veränderungen im Markkörper bei solehen Frostbeschädigungen, bei denen der Holzring keinerlei Störungen erkennen läfst.

Die von Kreag beolsachtete Wundholzbildung im Mark von Vitis, die der Vertasser der Einwirkung von Zersetzungsprodukten des bei der Ringelung abgestorbenen Holzteils zuschreibt, bestand aus markfleckenähnlichen, parenchymatischen Nestem. Diese waren von einem ringförmigen Cambium nmschlosien. Der innerhalb der Narkscheibe liegente Ring entrickelte nach innen Holz mit zahlieichen Gefätsen, nach autsen den Siebteil. Der andere, der Markkrone benachbarte Markfleck bildete ans seinem Cambinmringe nach innen den siebteil und nach autsen Holz. Die entsprechenden Gewebe der beiklen Nenbildungen vereinigten sich später mit den gleichnamigen Partien des Ïberwallungsrandes. Die Pflanze hatte mithin den beim Ringeln abgestorbenen Holzkörper durch Anlage nenen Holz- und Sielggewebes im Mark ersetzt.

\% u Seite 814. Vielseitige und sorgfaltige Versuche verdanken wir Elsie Kupfer (Studies in plant regeneration. Dissert. d. Columbia Universität New York, 19(1). Wir heben darans zunächst die Versuche mit Wurzelstecklingen von Rorim Armoracin hervor. In den Boden eingelegte Wurzelstïcke bildeten nene Triebe ans dem Cambium der oberen und unteren Schnittfläche. Wurden Rinde und Cambium fortgeschnitten, so entwickelten sich nach vorangegangener Callusbildung Sprosse an versehiedenen Stellen in der Nähe der Gefäfsbündel, und zwar häufiger am oberen wie am unteren Ende. Die Fähigkeit zur Sprotibildung, die sonst dem Cambium eigen ist, geht also in diesem Falle anf das, als Reaktion auf den Wundreiz nen entstandene Callusgewebe ïber. - Längsschnitte von Wurzeln der Pastinaca satira, die horizontal in sand eingelegt wurden. entwickelten an beiden Schnittflächen nahe dem Cambium nene Sprosse. Bei isolierten Rindenstïckchen entstanden an der Innenseite sprosse, an der Auf'senseite nene Wurzeln. Der isolierte Zentralzylinder bildete nur Wurzeln.

Sehr instruktiv sind die Versuche mit Kartoffeln. Wenn von oberirdischen Trieben eine heliebige linospe mrerletzt gelassen wurde, entwickelte sich diese zu einer oberirdischen Knolle; wurden alle Kunspen entfernt, fand nur Wurzelbildung statt. Stütelichen von Kartotfelknollen, an denen die Augen nebst dem anstolisenden Knollenparenchym herausgeschuitten waren, bildeten an diesen Schnittflächen nene Angen. Bei Kartoftelhlättern zeigte sich am unteren Encle des Blattstiels entweder einfache Wurzelbildung oder eine linollige, stärkehaltige Anschwellung oder beirles vereint oder sogar eine regelrechte kleine Knolle mit Angen.

Als Gesamtresultat der zahlreithen Versuche, zu denen auch Blütenund Fruchtstiele mit Erfolg herangezogen wurden, kam man erkennen, dats für die Regeneration zumächst das Vorhandensein reichen Reservematerials notwendig ist. Rein weitse Sprosse verschiedener Ptlanzen bildeten keine Wurzeln. Verdunkelung oder Entzug der Kohlensäure verhinderten die Regeneration. Da gewisse Pflanzenteile nicht fähig sind, cin oder das andere Organ zu regenerieren, auch wenn alle 
Bedingungen günstig sind, wird man zn dro Insieht grefïhnt, dats bestimmte Substanzen vorhanden stin mïssen, welehe die Bilulung eines bestimmten Groms bedingen. Solehe substanzin sind in der Gestalt vou Enzymen zu denken, die nicht in allen /ellen vorhanden, sondern an bestimmten Stellen des Ptlanzenleilus lokalisiont sincl.

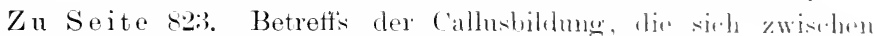

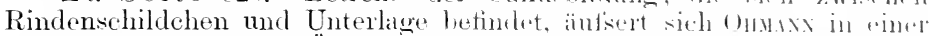
ausführlichen Arbeit (Über die Art unt das /ustandrommman der

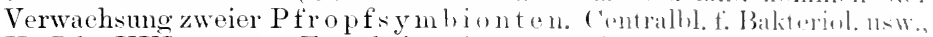

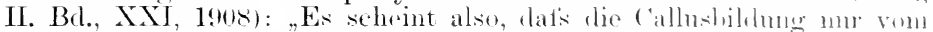

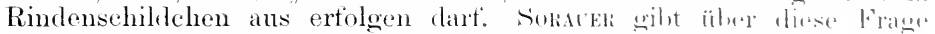

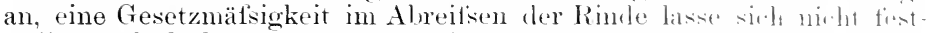

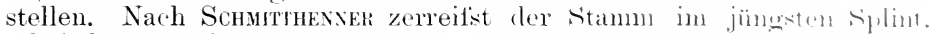

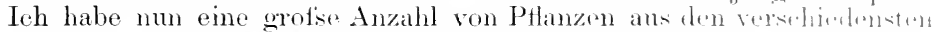
Familien aut diese Frage hin motersucht. Es ergah sich, dalti das Cambium vollständig anf der Rinde verbleiht, In ganz vereinzeltell Fällen bemerkte ich, dats wenige Cambiumzellen an jüngsten Hol\% körper hängen geblieben waren. Jedoch habe ich dies so selten

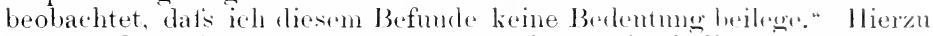
wäre zu bemerken, dats der Vert. zn ainer \%eit okuliert fiat .. Wo din. Cambiumtätigkeit in vollem (iange ist". Für dieseri Fall hat der Iutor Recht; wird aber zu einer späteren \%eit olinliert, dam mohren sich die von Soratrk beobachteten Fälle.

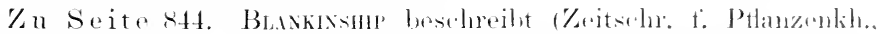

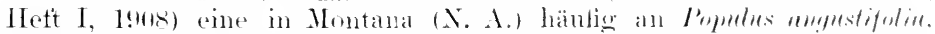

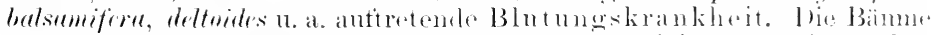
zeigen ein äbermätsiges Bluten ans Wunden, hergleited von oinem ler-

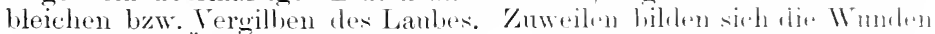

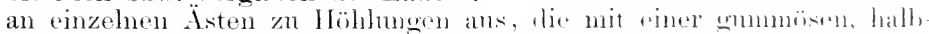

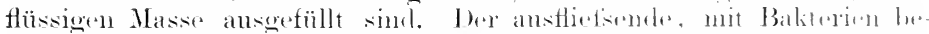

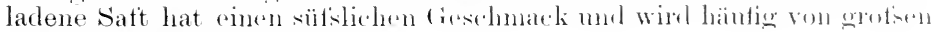
bramen Aneisen anfigesucht.

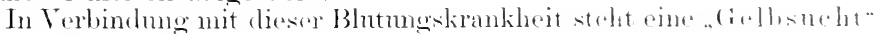
der Pappeln, bei der Bluten eintreten kam, aber and habliger am

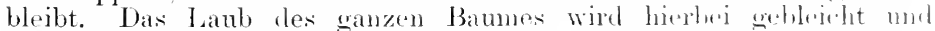

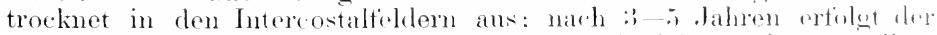
Tod. Die erkrankenden Bämme stehene gewöhnlieh an tieften strolten.

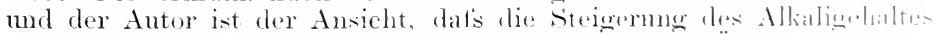

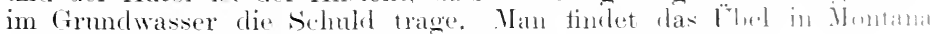

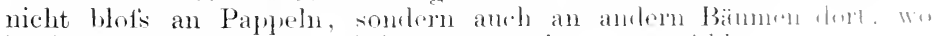
Berieselung angewendet wirk. I)ränge ist zu 'mptihlen.

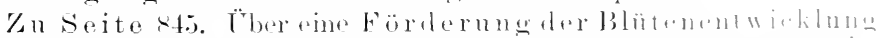

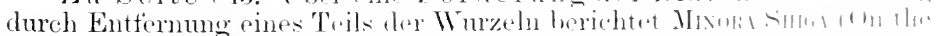

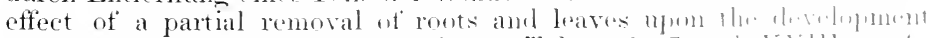

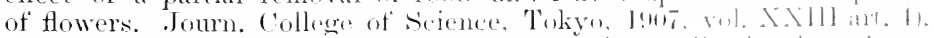

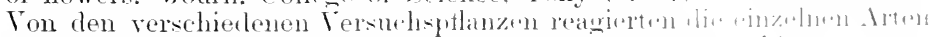

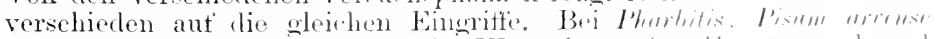

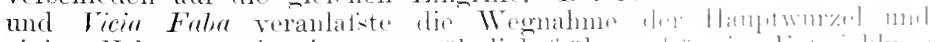

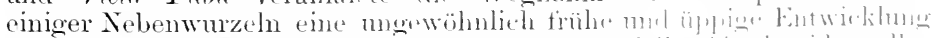

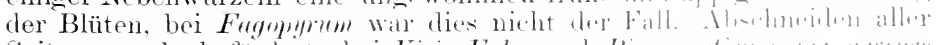

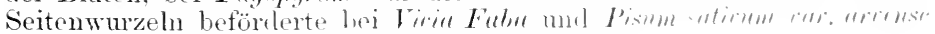
die Blütenbildung, bei T'sum mrense aher nicht. 


\section{Register $\left.{ }^{1}\right)$.}

Abban der liartoffeln 208. Abbinden des Bodens 405.

Abgliederung, Fruchtspiebe 338 .

Abies $10: 3$.

Ablakticren 821 .

Ablösung der Blüten 353.

Abraumsalze 401 .

Abröhren der Weinblïten 354.

Absterben der Frlen 150.

- der linospen 85\%.

Abstocken der 'Triebe 1:32.

Abwässer 7:39.

- chlorcalcium- und chlormagnesiumhaltige 742 .

- eisensulfathaltige $7+4$.

- kupferhaltige 745 .

nickel- und kobaltbaltige $74 i$.

- zinksulfathaltige 743 .

Alowaschen d. Blumentöpfe 206.

Abwerfen der Frichte 295.

- der /weige 358.

Acacia longifolia, Intmmescenz 437.

- microlotrya, Intumescenz 437.

- prendula, Intumescenz 442.

Acer 93.

- caupestre lireufmaser.378. Am

- oltusatum 158 .

- italum 158.

- Negunlo, Verfarbung 280.

- falmatum, Nanismus 141.

- platanoides 152.

- l'seudoplatanus var.Schwedleri, Vertarliung 280 .

- Ilitzelaubfall 411.

Acetylen 7:36;. 760 .

Acetylenvergitung $7: 38$.

Achse, Einschnüren 806 .

- Zerliliuftung 579 .

Achselversprossung 374 .

Acremonium 204.

Kahlährigkeit 543.

Acrocylindrium 204.

Acrospermum 51 .

Aeseulus 152 .

- macrostacliya 103 .

Aethertreiberei 756 .

Aetiologie 4.

Agaricus 50 .
Agaricus campestris 97 .

Agathosma 1:32.

Ageratum 144.

Agropyrum repens 87 .

Agrostemma Githago 71 .

Alinenplasma 28.

dilanthus 100 .

Akazien, Gummifluß 701.

Alklimatisation 37 .

Akkumulation 35.

Akroleïn 747.

Aliute Ranchschäden 714.

- Resinose 709.

Albicatio 33. 308.671.691. 837 .

Alinit 270.

Alkaliboden 194. 267.

Alkaligras 195.

Alkalitit des Bodens 367.

Allantospora radicicola 228 .

Allgemeinerkrankung d. I'Hanzen 6.

Allium ('epa 27.

Alnus glutinosa 9:.

- - tasciatio 933.

- incana 8.

Altersschwäche 31

Amanita muscaria 287.

Ammoniak $72: 3$.

- Bindung des 272 .

Ammoniaksalze, Koptlïngung

$$
268 \text {. }
$$

- Wiesen $36: 3$.

Ampelopsis hederacea, Emergenzen 440 .

Amygualus, Nanismus 141.

Amylokarbol 751 .

Anabaena 7 .

Anatesthetica 756 .

Ananas, Fehlschlagen 647.

Anastatica hierochuntica 175 .

Andropogon nutans, Jiotz 690.

- Schoenanthus, Seréh t8ø.

- Sorghum, Mafuta-lirankheit 414.

Anpassung der Wurzel 75.

Anstreichmittel 746 .

Antibiose 7.

Antifermente 670.

Autinomnin 751 .

Apera spica venti 7.

Aptel, Fliegentlecke 169 .

- für trockene bülen 174.
Apfel, Glasigwerlen 286.

Aptel-Kernhaus, Wollstreifen 324.

Apfel-Krebs 584.

- Kropfmaser 872 .

- Lohkrankheit 210.

- Stippflecke 166.

Aphelandra, Intumescenz 448.

Apogamie 342.

Apolsrensäure 241.

Apostasis der Blïten $37: 3$.

Apostrophe 668.

A prikosenkrankheit, Mombacher 478 .

Arabin 699

Arabinose 166.

Arachis hypogaea 684 .

Arancaria 91.

Arrabbiaticcio 202.

Arsen 733. 743. 751.

Arundo arenaria 87. 147.

- baltica 147.

Aschenregen 742.

Ascophora 51.

Ascospora Beijerinckii 555 .

Aspergillus 9. 50.

- niger 14. 97. 273.

- - Inngerzustand 288.

Asphalttämpfe 725 .

Asphaltieren der Straßendämme $10: 3$.

Aster alpinus 81.

Asteroma radiosum 727 .

Astwurzelkrels bei Obst- und Waldbäumen $5: 1$.

Atmung, intramolekituare 97 . 313.

Atomaria linearis 221 .

Aufhewahren der Winteräpfel $3: 3$.

Aufeggen der Wiesen 237.

- ler Wintersaaten 2:37.

Autieißen der Gurken 461.

- von Pflanzenteilen 321.

- der Tonböden 188.

Auftauen 505.

- schnelles 108. 510.

Augenstecklinge, Vitis, Paeonia 818.

Aurigo 4:34. 460.

Ausbrennen, Rasen 185. $2 \$ 5$.

- Saaten 185.

1) Von den zahlyeichen Platnzenuamen sind nur diejenigen in das Register aufgenommen worden,

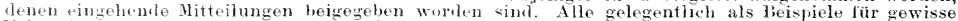
likrankungsialle angefihrten Pflanzen häten das liogister nutzhs besehwert. 
Aussauern der Saaten 201.

Bastumwallung -.77 .

Ausscheidungen des Wurzel- Batate, Boden 2:3.:

körpers 136.

Auswachsen des Getreides 320. - Gindstellen 4til.

Auswaschung des Bodens 146. - Kropfmaser 37.

243.

Auswächse der Wurzeln 191. - Remigen 295.

Auswurfst offe, Schornst eine729.

Azaleen, Blatifall 3.52 .

Azolla caroliniana 7 .

Azotolnacter 272 .

- chroococeum 269

Azurin 756 .

- Siegwart 756 .

Bacillus albuminis 272 .

- anthracis 669.

- Berestnewi 14.

- Betae 25.

- hutyricus 272.

- coli 272 .

- coli communis 25 .

- Horescensliguefaciens 20:3.

- foetidus $27 \%$.

- liquedaciens 202:3. 272.

- liquidus 27.2.

- maculicola 683.

- megaterium 272.

- mesentericus vulgatus 272.

- mycoides 223. 272.

- mulilis 27.2.

- phytophthorus s19.

- prodigiosus 272. 6699.

- proteus vulgaris 272.

- psendoarabinus 690.

- pyocyaneus 6tis.

- radicicola 272.

- ruber balticl's 14.

- Sacchari tisce (is!)

- subtilis 11. 22:3. 272.

- typhosus 669t.

- urear 27.).

- vascularum 690.

- vulgaris 272 .

- vulgatus 10 .

bateviorrbiza 7. 224. 271.

bacterium coprophilum 272.

- tuseum 272.

- Hastlebi 271.

- nitrobacter 272.

- psenlarabinus 690.

- Sacchari 690 .

- vascularum 690.

Bakterientlora des Bodens 257 . 269.

Bakterien-Ringkrankheit, Kartoffiel :39s

Bakteriöse Gimmosis der - Korkwulderungen f2it. Zuckerruben 691. - Verbremun dia 6iv.

Ballentrocknis der Fricaceen - W(1knn :;65.). 180.

Bambus, Nanismus 141

Bassolin 69:.

Bastaribildung d. Veredlung 8.3.5.

Bedecken iler lirmue sisti.

- der Samen 107. :3.). zell 36 .

Bullis permis 124.

Berberis 10:;

Berieselusg 181. 195.

Beschattung 411, 65.5.

Beta 47.

- Autreilien :3:2.). boulens 1 lit.

betula pulescens 950.

Bewaldung odi.

Bewernug-erselorinnngen furch lirost ifti.

Biegen der \% wige sia).

liomen 2!).

Biologische liassen 126.

biota 141 .

- orientalis 10\%. 817 .

- meldensis 817 .

Bimen, Jithiasis 16i9.

— Steinigwerden 16:4.

Black liot bits

blast 44 .

B]astomania $: 37 \%$.

blatt, amige 4:34.

- limergen\%en 4:3:?.

linosiel ant :-

- Windhesebaligme titi. is:is.

Blattfill : :Hij, :351

- der Azaleen :352. biattiall der begronia fuchsioides :

- les Lihonia thoribunda :3.iv. bei Kimmerptlanzen 305.

battheckenkrankheit des

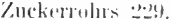

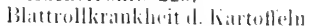
$(72)$

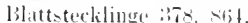

Bhatterletemeren -fil.

Blatsolure 751

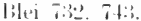

bhei-Nomismus Tht.

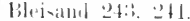

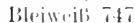

limelsein dis Ilopleds :it:

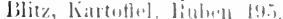

Blitzordalage, 17,

Bererenstiele, Korkwarzen 432. Bhitsplaren 4ri.

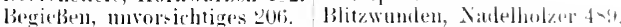

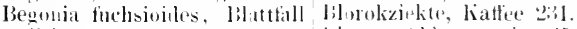

Behacken des Bodens l-:3. - apostasis 373.

Beharrungsormagenderl'tan- - Vertrocken 296.

Bebäuleln 2:35.

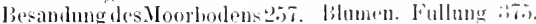

Blitenbilelung der Jlungerzustiull. "2xy.

- mamegellatite 416.

Bilutenveranterung dimeth lirost . 17 .

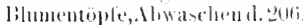

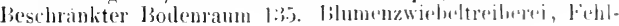

Betaumestihigkeit des siand- Bhotungskrankheit bei l'appeln

- tiir trocliene boilen 174.

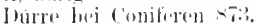

- Inrchlocherung 126. 1:30.

- Yerachlitameng durch liost

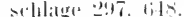

blutall, : : $-7 \%$

Boden, dhbinden 40.\%. Alsopption :bit. Alkillut 3 isi.

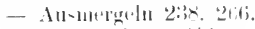

Allswarchung 243.

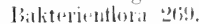

liearbetung 1,2. 2.27. 2035. bedectimne 1 1 -

belatken lan 1-i.

Butiestumg 1-1.

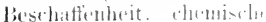
264.

- - ungumstiga lin.

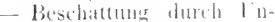

kratuter (joi:)

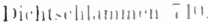

Hurblutture 24:

birnon 1 - : :

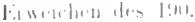

lialin $-1 ;$.

litelimes 1:2

tul औ)

$1,11.110,1: 1$

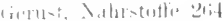

kitum lingle l:is.

lilimat ile: $=20$.

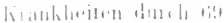

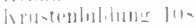

l.tere les lit. -6. 4.5. 
Bolen, leichter 145.

- Lockerung 102.

lobsung, hochkonzentrierte :is.

- Mastkulturen 138.

- mechanische Widerstäude $1: 38$.

Mosaikkrankheit 681 .

Miidigkrit 270 .

- Nachrutschen 88.

- Oberfläche, Neigung der 8:3.

- Organismen, Arbeit der 268.

- Raum, beschränkter 135. Säuren im 241.

- Schälen des 18:. schwerer, Nachteile 233. Struktur, unpassende 145. lingarer 272 ungünstiger, Tabak 2:30. - Banmwolle 229

- Kaffice, Kakao, Tee 2:3l. - Tropenkulturen 225.232. - Zuckerrohr 228.

- Verarmung 265.

- Vergiftung 266.

- _ durcl Rauch 715.

- - durch schwefelmetalle 250.

- Verhagern des 150.

- Verkrustung des 1:32.

- Vernagerung 89.

- Verschlammen des 190.

- Volumen 136. 138.

Wärme 70 .

- hohe 644 .

Wassermangel im 181. zehrender 238.

Pohne, Intumescens 446.

boletus 50 .

bordeauxmischung 75\%. 874 .

- nachteilige Wirknng 874 .

horosma 102.

Borronia 132.

Botanischer Jahreshericht 57 .

Botrytis 10.24 . 50 .

- cinerea 20. 394. 4\%: 700.

Boullie Céleste 756 .

Brache 187. 27:3.

Brand 38, 606 .

- I)isposition 49.

- schwarzer, Rotbuche 557.

Bramblalasen (j3'.

Branderde 244.

Braunketten 611 .

Bratsche Ilopfen 344.465.

lireite des Libens 5 .

- der ciesundbeit 5.

Bremia Lactucae 21.

Brennflecke $6: 40$.

Brenzcatechin 50:3.

Bizopyrum 195.

Brom 728.

Brombereratis tio3.

bomus mollis 143 .

- Nanismus 141.

Bronssin (5):
Brusone-Krankheit des Reises (horise 376.

315.

Butkelschorf der Riulsen :367. Buntblatterigkeit 671

Buntwerden, liartoffel 391.

Caeona 56.

- cerealium 56.

Calcipenuria 304 .

Calciumkarbid 760 .

Calda fredda 202.

Callitı is quadrivalvis 817.

Calluna $25 t$.

- vulgaris 144. 243 .

Callus 779 .

Calycanthus 103 .

Canibiumbräunung, Frost 610.

Campannla 144.

Cancer 50.

Cannabis 145.

Caragana 10:3.

Carcinoma 584.

Carex 254.

- arenaria 147.

Caries 46. 53.

Carotin 282.

Cassaven, Boden 28:.

Cassia tomentosa, Intumescenz. $4: 5.5$.

Castanea 7.

Cattleya, Fleckigworden 262.

Celosia cristata $\$ 30$.

_ _ fasciatio 3:34.

Centaurea Cyanus 71.

Cephalosporimm 241.

('urasin 69:?.

Ceratopteris thalictroides 288 .

Cereus flagelliformis, Korksucht 427 .

- nycticalus 454 .

Chagrinieren d. Rosenstämme $4: 34$.

Clamaecypais Lawsoniana 157.

- splateroidea var. Andalyenis 817 .

- squarrosa 817 .

Chemische botlenbeschaftenheit 264 .

Chemotropismus 9.

Chermes 716.

Chilisalpeter 2:4. 311.757.

- Koptiliungung 390.

- 1lolzgewäclise 390

thlor 717 .

Chloranthie :34:

Chlos barium $7 \mathrm{t:}$

chlorcalcium- und chlormagnesiumhaltige Alowasser 742 .

('hlormagnesium 741.

chlormangel 306.

(hlorophyllan 5ol.

(1) horosis 305.871 .

Chlorosis, Tabak 679

- Weinstock 402.

('lavus 47.

Cyathis 51.
Chorizema 132.

chronische Rauchschäden 714 .

- Resinose 709 .

Cladosporium 10.438. 543 .

- javanicum '28.

- penicillioides 204.

Clasterosposium carpophilum 700 .

('livia nobilis, Sonneubrand 639 .

('lostridium gelatinosum 271 . 272.

- Pastenrianum 269. 272.

Coccus caricae 704 ,

('offea arabica 2:31.

- liberica 231.

Colletotrichum 262.

Coniferen, Harzflub 705.

- Frostbeschätligung 879 .

Contagium vivum fluidum 681

Convaliaria majalis $13: 3$.

Cornus alla 103 .

- mascula 103.

- sanguinea 103 .

- sibirica 103.

Correa 192.

Corylus 7. 10:.

Coryneum Beijerinckii 555. 700.

- gummiparum 701.

Crataegus 105. 125.

Creolin 750 .

Cupressus 141.

- Bregeoni 817.

- Lawsoni 817.

- sempervirens 817 .

Cuticularsprengung d.Frost 621 .

Cycadeae 7.

Cydonia vulgaris, Maser 385.

Cymbidium Lowi 444.

Cytists 103.

Cytospora lencostoma 700 . rubescens 5.54 . 557 .

Dasyseypha Williommii 80 .

Iédoublement 376 .

I) generation 31 .

Dematophora necatrix 703 .

lendrin 750 .

Jendrobium, Fleckigwerdu 262.

I) nitrifikation 269.

Diaphysis 374 .

Dic-back der Orangen 392.

Dichtsaat 144.

1)iclitschlämmen d. Bodens 740 .

Dicotylen, Harzbildung 709.

Didymosphaeria populina 5.58 . Didymosporium salicinum 558 .

Digitellus 50 .

Dintenkrankheit, Kastanie 702.

Jiöcie b. Kryptogamen 288.

I)ioscorea 283.

Diospyros, Nanismus 141. 
Disposition 24. 59. 125. s. l'rädisposition. tür Brand 49.

- erbliche 80.

- d. Nährstoftmangel $30^{\circ}$.

Ijamoer oepas, liaffee $2: 31$.

Dongkellanziekte, Zuckerrohr 228.

Doppelfrüchte ::76.

Doppelringe, Frost 613.

Dornenbildung 297.

Dothiora sphaeroides 5.5.

Dracaena, Gelbsprenkelung 435.

Drainage 197. 233. 267.

Drainzöpfe 319.

Irehung der Crataegus 176.

- der Stämme 176.

- der Syringa 176. der Zweige 805.

1)rehwuchs 764.811 .

Iünen 147.

Düngenittel, Schädigungen 7 is. I)ünger, Vestorfung เl. 271.

1)ïngesalz 192.

I)üngung, Fisenvitriol 41::3.

- erschöpfende Wirkung $266 t$.

- d. Moorhodens 257. 258.

I)ürre bei Feldfrüchten 153

- Kalidüngung 154.

- Notreife 154.

Duftanhang 632 .

Durchfallen d. Weinblüten :,.54.

Jurch frieren 2:35.

Durehlöcherung, Blätter 419.

Durchlüftung des Bodens 24:3.

I)urchwachsen d. Kartofteln Ltil.

l)urehwachsung 374 .

- Ähren 46.5.

Evllastesis 374 .

Echte Kastanie, Inintenkrank-

Eggen 18:?

heit 702 .

Binflul' v. Stickstoftuberseluut? 387.

- des Waldes 13:2.

Einquellen des saatgutes 1-it. Exoascus $14:$

Einschnüren der Achse 806.

Einspitzen 821 .

Eisanhang 6:31.

Eislildung, günstiger Eintlut 509.

Hisenfleckigkeit b.Kartoffel:391. 872.

Eisenmangel 308 .

Eisensehüssiger sand 2.it.

Fisensulfat 871 .

Eisensulfathaltiges Wasser 7 tt. Fanguflanzenbau $7:$ it.

Eisenvitriol, Düngung 403 .

Eiweißzersetzung, Lichtmangel 664.

Elektrische Entladungen 179. Farne, Apogamie :3.2.

Flektrizität 488.872 .

- städtische Baumptlan\%ung 493.

Elektrokultur, Nachteile 49ii.

Elektrolyte 192.
Elymus arenarius 7.117.

Embryonales Plasma 2.

Emergenzen $4: 3$.

- Ampelopsis hederacia 110. Endemie 15.

Engliseher Zongensingitt $8: 3$,

Entlauhnng durch Warmeuberschul 640.

Entwisserung des Ioorboden. 257.

Entwicklungsmechanik 61. 6:3.

Enzymatisthe lirankheiten tir:9.

Enzyme 877. glycolytische 873.

Epidemie 15.

Epilobium hirsutum, Anpassungsfahigkeit :32:?.

lepistrophe 66r.

Erbliche Disposition 2๖. ๙ 6 .

Erhlichkeit der línkheit 28.

Erbse. Intumesenz 446.

Frolnüsse, Erkratilkung 6\&4.

Erffieren 504.

Figrunungsmangel, Frost i2:

Erhöhumg der Nibrstotikonzentration :860.

Ericacen, Ballentrocknis 180 .

Erineum 17.

Firiphorum ets.t.

rialtumg si:"

Frien. Misterlen 150.

Filenliruch, Watsere 251.

Ernteverminderung d. Bammschatten tisi.

Ersticken durel Saluerstoflmangel :31\%.

Erysiphe 50. Faluricii $41 \%$.

- graminis 6:3i.

Ftiolement :?08, 64t?.

Etiolierte I'tlanze 4:3:

Eucalyptus, Intumescenz 414.

Evonymus, Nanismus 141 .

Fatenlildung d. Liatofieln 1.is. Fïkalstotle 392.

Fagn: 7 .

silvatica, Verfirlume $2 \times 0$.

Falsehe dilhresringe, Frost 61:?. licmbildung $\times 41$.

fiames io.

Familiola 50 .

Firben, rote 124

- wirmende 1.4.

$$
\text { I riöcie } 288 \text {. }
$$

- lebendig gehirende :;42.

Fasciatio $30.93: 2.3: 3:$.

Faulkern 811 .

Felier, Streublitze 49.5.
Feldfuchte, Dime lo:

Therdimgung 392.

fegewunden 7 i.:.

Feigrulatume, finmmose $70:$.

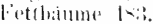

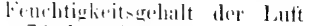
7.3. 1.0. 10.

- vihermaliger 102.

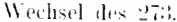

Firlite, (iipfoldare

Nitzen der 20.1.

Senkeghildmer 20 .

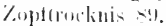

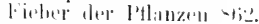

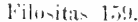

Fiklimankin 17.

Flathomiten -20 .

Flechten an stammen :3:31.

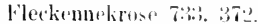

Flerkigwerden der orchideren $26: 2$.

licigenflecke, Aptel lis.

lilockung 192.

Fittlehm 19\%.

Fogische, Zusammensetzung 730.7.;

Flugsind 147 .

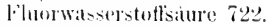

Flulisature 7.2 .2 .

Föluwind 6:i:

Formae speciales 1:.

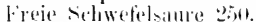

lreintellung der Waldhamume : :

Frost, dehsenzerkliultung si: Autzichen ler Sataten sis. Augenlisisen 577

liarfirost 5iats.

-heulen it6\%. 571

bewegungserscheinungen itit.

- hasen $82: 3,531$.

bliitenverinderung

('ambitumlrimumer tifil.

Cuticularsprengungen li2l.

loppelringe 61:5.

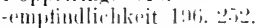

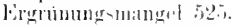

Ersaltzlumepen itfor. falsche latheringe bils.

- Fulijalostrible sis. - gefalle bei samdlonden 146;

- 17

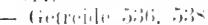

- llahmlinichen sill.

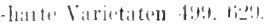

hahblatirigkeit .ill.

liwhl .j:31.

- litelis 5ice.

lathungerseheinumgen

i.17.

- lappen its.

- lamblall : 247 . 506.

- leisten stitj.

- linie 577.

f́orauer, Handbuch. :3. Aull. Erster liand. 
Frostlocher 197.

- Lockerung der Membranen 5) 79 .

- Markflecke till.

Markstrahlzerrung 570 .

Mondringe 611 .

Parenchymholzerzeugung 614.

-platten 606.

- Reif 634 .

- Ringschäle $\$ 12$.

-risse, innere 568 .

- - offene 581 .

Rostringe 52.

Rüben 5:30.

-runzeln 573.

schnclles Auftauen 10s

- SchoBrüben 515.

-schutzmittel 62:5. 62:3. 624. 625.

- -spalten 5tit.

- Sipannungsdifferenzen 513.

- Überkältung 507.

- unreite Triebe 553.

- Interkïhlung 507. Verbänderung 558.

- VerfärbungenderAchse 575.

- Vergilben 55:3.

- Voraussage 627.

- -welke 548 .

- -wirkung, mechanische 617.

- Theorie 507.

-wunden, Nadelhölzer 489.

Wurzeln 561.

Zellgänge 611 .

zerschlitzte Blätter 5:3.:.

- Zweigsterben 152.

- an Zweigspitzen 552.

Friuchte, Abwerfen 295 .

- liernlose 292.

Itorkbildung 4:-2.

Sprossung $\$, 75$.

- Wässerigkeit :2:?.

Fruchtkuchen $33 \%$.

Fruchtspiebe, Abgliederming 3:3.s.

Frühjuhrsfröste 873 .

Frülj̣ahrsholz 764 .

Frühjahrstriebe, Abfrieren 5ss.

Fuäjahrswinde, rauhe $47 \ll$.

Fuchs des Hopfens 24:-

Fuchsige Pflammen I6t.

Füllung der Blumen, Kinnpositen 375 .

Fuligo vagans 5:.

Fumago salicina 704 .

Fungus marinus 50 .

- panis similis 50 .

Fusarium 204.

- moschatum 845 .

Fusicladimn 170 .

lusisporium candidum 557.

Futtervihen, Herz- u. Trocknfäule 414.

- Wurzelbrand 2:1.

Futterwicken, Lagern 661.
Cabelwachs der Reben 345 .

(iabler, Reben 345.

Galactin 699.

Galaktose 166.

(iallimaceus 50 .

(rare des Ackers 194.

Gasanstalten, Abfiall $7+7$.

Gasaustausch $31: 3$.

Gasphosphat 759 .

Gefißiruckel 569.

Gefrieren 504 .

(ielneukelte Stämme s.3.

Gehölze. Verfurbungen $279: 20$.

Gehölzsamen, Behandlung 156.

Gribtellen der Wiesen $\$ 64 t$

G(mblauligkeit 191. 196.

- Kimclien 66il.

- Lichtiberschub ri66.

Gollisprenkelung 4:it.

- Dracaena 435.

- Jandanus javanicus 4:34.

(ielhsucht 35.008.

- durch liallïhliersehuß :30.

- (le jaune) des Lein '25:

- hei Pappeln 877 .

- lurch stickstofíhunger $31 \%$.

- durch Trockenheit ::11. übertragbar 691.

Weinstock for.

Gelivïre des Weinstockes 494.

Gelte des Hopfens $34:$.

Gemmulae 28.

Gemüse, Tropenklima $6: 35$.

- Therdiungung 392.

Genista 147.

Geoponika 40.

Gerlistofte 14!.

Geschichte der Pflamzen 37.

Geschlossener Krelos 55.5.

(ieschwülste an Jolimmisbrothamm 339.

Gesmulleit, Breite 5.

Getreide, Auswachsen :20

- Fleckennekrose 372.

- Frostrerletzung 536. 5is.

- Ilagel 462 .

- Lagerung äti.), (isß.

- lieifererzögerumg :66.5.

- liöte des 281.

- Strohwüholgkeit :36is.

- Trockienfleclie 2-2.

- Vorscheinen Iss 2so.

(ietrudekorner, glasige 126.

- Wurzeln aus spitze 113.

fiewohnheit der Pflanzen : $: 6$.

Gingko bilola, Zylindemas'r : 36 .

(iipteldiurse 89.150 .

- der Niadelhölzer 48ti.

- ans Wassemangel 18!)

Gips 195. 251. 402 .

Gipsen 238,

Gladiolen, Erkrankung: :16. Glasige Getreideliörner l2ti.

Glasigwerden der Äpfel ¿86.

- der liakteen 454. 710.
Gilasigwerden d. Orchideen 647.

- Zierpflanzen 710 .

(iloeosporium 26:. 264.

nervisequm $: 204$.

Guaphalium Leontopodiun $\$ 1$.

(iommose bacillaire 841 .

Grapholitha pactolana 716 .

Gas, stickstoffïberschub 345.

- Rotfiubung 282.

- Verschwinden $36 \%$.

(irausand 243.

(irind an Weinstock 594 .

firindstellen an biamen 461.

(inunblutigkeit $: 42$.

(iründïngnng 2:55. ㄴ67. 271.

Grundwasser, Moorbolen 25.

(irundwasserspiegel 14 .

- Senkung 10:?.

Guignardia Bidwellii 23. 664.

fiummilaum, Kuötchenkrankheit 450 .

Gummifluß der Akazien 701.

- der Feigenbämme 70:3.

- ler kirsihen 693.

- Gllaum 704.

- der Ponneranzen 701.

Ginmmigefäbe $>+1$.

Gunnera 7.

Gürtelschorf der Rülıen :36r.

Gurken, Aufreiben der 161.

Gymmosporangium 50 .

- Sabinae 59 .

ILarfrost $63: 3$.

llackien $23 \%$.

Hagel 46:.

- durchwarhsene Ähren 465.

- Getreide 462.

- Hopfen 46.5.

- liartoffeln 466.

- liaps 466.

- Rindenwunden 467.

- Tomate 46i.

llagelgeschmack bei Woin 469.

Ilagelschießen 469 .

Halmknicken durch Frost $5+1$.

- durch IIagel it1.

11 irfenbäme 91 .

llartschaligkeit d. Samen 1 I3. 420.

Jlarzbildung h. Jicotylen 709 .

IIarzbeulen 70.5.

llarzfluk der Coniferen 705 .

IIarznutzung, Wunden durch 770.

Iautlirankheit der Hyazinthen 451 .

IJeidehöden, Nachteile 241.

Ileideerdekulturen 260.

Heilmittellebre 4.

lleliantluus annuus, Verlaubung $\$ 41$.

Ilelichrysum 132.

llelotium 51 .

llemisaprophyten 8.

Hemiparasiten 8 . 
IIerbstfarbung 124. 500.

llerhstholz 764 .

Herlistlaubfall 520 i.

Herbstpflanzung i64.

Ilericia 845.

Ilerzfäule d. Futtoriulien 414.

llerz- u. 'Trockentïuls: Jurb Seheideschlimm 194.

Ilexenbesen 14:3. :376.

lliliscus vitifolius, lutuneseenz. 449.

Ilieracium alpinum 81.

Ilippeastrum I\%:).

IIippophä̈ rhamnoides 87.147.

Ilit\%elaubfall :34. 411.641 .

Iitzestarte (i;i).

Ilitztod $6: 34$.

lloloparasiten \&.

Holosaprophyten

Holz, maseriges rit9.

- wimmerige's 819.

Holzgewächse, Chilisal poter:3yl.

IIol\%knollen sts.

Ilolzkörper, Anschwellen d. trio.

Ilolzphanzen, Achse der 73.

- Anpassungen 75.

Ilomogamie 293.

Ilonigtau 412.

llopten, Blinksein 343.

- brausche :: 4 t. 46.5 .

-- Erhitmen :34.

- Fuchs 282.

- Gielte les :i, $4:$.

- IIagel titi.

- Limpiellrand 282.

- Lupelbildung :34:;.

- Narrenkopflitelung :34:?.

- liöte 2s.2.

- Rote Lohe 282.

- Schattenanlagen 2s:i.

- Sommerhanil 282.

- Stangemot 28:3.

Hormolemelron-lirankheit $7: 34$.

llornprosenclyim (i) I.

llornspäne $39: 3.395$.

Hülsenfiüchte, Verscheinen lis.

Hülsenwuchs 90.

IIïttenrauch $7: 2:$.

Hüttenwerke, liancherzengmy 730.

IHumea 132.

Humin 241 .

Huminsäure 242.

Humussäture 241. 715.

llumussandstein 244 .

IIumussulistanzen 14.9.

Hyazinthen, Alstolien Blüten 356.

- Hautkrankheit 451 .

- Ringelkrankboit :326. 4i3.

Hypochlorin $50 \mathrm{I}$.

Hypocrea rufa 14.

- Sacchari 228

Hypoplasie 176.

Hypoxylon 50 .

Hysterium 51 .
Leterus :30s.

IV (instock :il1). 40.2.

lioplasma 2s.

Igniarius 50.

lommunisierumg, kinstliche

Immunitait 2:?. 12:5.

Inschritten, Wumden dureh 7 î.

Intramolekulare 1 tmming 97 . :31:3.

litumescenz f:il. 4:i:.

- Acicra longitolia, micresbotryal 197.

- Acariar pendula 4t:i. Apluelandia 44 s.

- Bolme ftti.

- Cassia tomentosa fiki.

tymbidim lowi 411.

- Hirse 446.

- Encilyptus 44.

- Ilibiscus rititolins If!. - innere 145.

- Kaliteen f:20. fit. Myrmecodiar echinata 1:37.

- I'elaroonium zomalo fi:

- Linedliar 4ts. durch Verwumdung $\$ 11$. Weinstock $4: 3$.

loribe 75:?.

Ishikuluso tict.

lsopyrum bitermatum s.

-Daloo-filore: som.;.

dabresringe, Fintstedung 7(il.

Iabresringtacherung isti.

Johamishrothamm, fieselewal-to :?:?!).

Ingendformen, liüliganer ant die : :76.

Iuglans 10.5.

Juniperus, liewurelung 25t. (ommunis lit:? phoenicear $4 \mathrm{i} . \mathrm{l}$

- Salinar Jo:3.

Iílte, loterus durch :30!!.

liattee, lilorokziclite 2:31. l)jamoer onpats $2: 31$. livels 2:il. schwarzer liost 2yl.

- Imgtinstiger lionlen 2:31.

- Wurzelfaule :2:1.

iiafleckulturen, schattembatme (i.i).

liablalurigkejt dured Fost ifl. der liainit 404.

kakao, l'lytophthorafaule 4til.

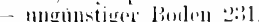

- Wimllarteh til.

Kaktern, (ilasigwerden fit.

$$
\text { - imi. }
$$

- liorksucht 4.27.

kialidüngung 1:27. 1:it.

lialimangel $29 \%$. lialimangel loei siterigmato(yotis nigrat 3010.

Killiuberschul; 40:3. 10:5.

Kalimmerehlorat 7.5 .

kialk-flulorose si.

lialkthumeng, loi lianchverviftume $71 \%$.

kithen 191. 2:89.

kitkmanew :30. :30:3, :301.

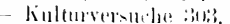

Kallimamgel, Milchelan\% 2-4i. J'hasrolus :iol.

l'latamus :30.

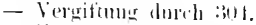
\%uclicroule :;01.

kallicition, Tereneled 7.?!

labliubersehuli :309. Gellisucht lured :ilo. Wininstock 40 .'.

kalkumg, periodische 26 ir.

Kitlistickstotl 760 .

kialte, nasse Wittermng 1Ł.

lianelien, fielblauhiglieit titit.

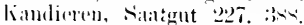

linlulinem 74 .

liarholsallu 2.24, 7.il.

Kartoftiol, Aufreiben :32.2.

Darchloclarimg der Blatter $1:: 0$.

Kartuffilknollen, olerirdische lii:?.

Kartotiln, Ahlou 201.

- Rakterien- Linnkrankbeit :39:-

- Buntwerden :3:11.

- Inrchwarelisele lib.

- Eistenfleckiglieit :39l.

- Fadembilalmo 1.5!).

II aunel titis.

- Kindelloildung $16 \mathrm{l}$.

- linollenbildung olme Lanl, lii,

- Kräusellinanklueit : :ir.

- liulturrassen 204.

- Lenticallen :3is!.

- Notreite lis!r.

- l'rolepsis div.

- schwalle Troclienfanle :39s. stipptlecke :3:1\%. siliwerdens ilis.

- 'Tieforeholt' l:30. uberlumete :ish).

Vererolinemer der Motter-

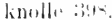

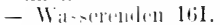

liastanie enlatt, Wurzelerkankillug 22l!?.

liatala-tion.

lieinklialt 10\%, I:2:

linuplasmal 2 .

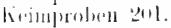

livinmor, liolilen-ame 11\%.

lockendeit 1.il.

Kernfinle tile.

liculose finchte :-2!). 
Kernlose Weinbecren 35...

Kernobst, Wassersucht 3:3r.

Kiefernschütte 349 .

Kienigwerden 705 .

Kirschbaumsterben 152. 553.

Kirschen, Emptindlichkeit 209.

- Frostbeulen 571 .

- für trockene Böden 17t.

- Gummiflub 69:3.

- Krebs 592.

- Lohkrankheit 210.

- Trockenheit 2\$1.

Klee, Pleophyllie 376.

Klima, Kontinental-12x.

- See- 128 .

Klimatische Sippen 131.

Knick 192.

Knollenbegonien, Blütenabwurf 417.

Knollenmaser 851 .

- Anfainge 216.

linollenstccklinge, Kartoffeln, Caladien 818 .

hötchenkrankheit, (iummibaun 450 .

Knospen, Absterben 852 .

- auf Blättern 378.

- Beschädigung durch sonnenbrand 641 .

- - durch trockene Luft 40s.

Knospendrang 377 .

Knospensucht 144.

linospenvariation 149. 144.

Koclisalz 266.

liochsalzdiungung 192.

Kochsalzhaltige Alwwässer $7: 39$.

Kochsalzgehalt der Rieselfelder 741 .

höner(Getreide-), Schwarzwerden der 69 .

liohl, Frost 5:30.

Kohlehyllate, liosung 782.

liohlensäure 7:32. 7:38.

- lieimung 107.

- Mangel 316 .

- Uberschul; 107. 406.

Kommensalismus 7 .

liompositen, Füllung der Binmen 975 .

Konstitutionskrankheiten der I'flanzen 6.

liontinentalklima 128.

Kiopfiüngung, Ammoniaksalze 268.

- Chilisalpeter 390 .

liopulation 821.828 .

Korkbildung an Früchten 4:32.

lorklocken 574 .

Korksucht d. Kakteen 427. 428.

lorkwarzen an Beerensticlen $4: 32$.

Korkwucherungen 425 .

Krados 39.

Kröhen, Rieselfelder 364 .

Kräuselkrankheit, Kartoffeln 394.872 . lirankheiten, absolute :3.

- durch Boden 69.

- Entstehung 4.

- Frblichkeit 28.

- Frreger 24.

- Konstitutions- 6.

- parasitäré 10 .

- relative 3.

- spezielle 78 .

- Umgrenzung 1.

- Wesen 1.

lirautartige liropfmaser $: 378$.

Krautern, Reben : 76 .

hirels, 584.

- Apfel 584 .

- Brombere 60:3.

- Aurch Frost 582.

- geschlossener 5.5.

- Kaffee 231.

- Kirsihe 592.

- offener 585.

- Rosen 599.

- Spiraea 596.

- Weinstock 594. 59x.

Krelswunden 765 .

lixesolin 750 .

Firistall-Azurin 756 .

liroptimaser 853 .

- an Apfel 872.

- Acer campestre 378.

- der Bäume :378.

- krautartige $: 378$.

- Prunus P'adus 385.

liruppelformen der Bäume 474.

Krume, Bedecken 2:36.

Krustenlildung des Bodens 108.

Kryptogamen, Itöcie 288.

- II Ingerzustände 287.

- Sexualorgane 28׳.

Kuhbüsche 144.

liultur der Lürche 78 .

- des Moorbodens 257.

fulturhiltsmittel, schädliche Wiıkung 746 .

Kulturstand der Pflanzen i2. Linum usitatissinum 105.

Kiulturversuche, halkmangel Lithiasis 169. $: 30: 3$.

liulturzweck des Organismus 2.

Künstliche Beschattung 411.

liujter $7: 32$.

Kiupferbrand bei Hopfen 282.

Kupterbrühen 752 ; s. Bordeauxlirühe.

Kilpterhaltige Abwässer 745

Kiup)irung, Wrinstock 440.

Laclia, Fleckigwerden 262 .

Larche, Rückgang 78 .

lage, horizontile 11 s.

- steile 86.

- südliche 85 .

Lagern 129.

- des Geitreides 365. 6.5.

- der Futterwicken, 661.

Laub, Vertrocknen $2 \triangleleft 4$.

Laubfall, Hitze 640 .
Laubtall, sommer- 657 .

- Treib- 347. 412.

Laubrausch der Reben 28::

Laurus 131.

Lawinensturz 632 .

Leben, Breite des 5.

lebensbäume, chinesische 139 .

- japanische 139 .

Leguminosen, Boden 2:32.

Leguminosensamen,Lichtlinien 420.

-- Hartschaligkeit 420 .

Lchmboden 188.

- Erweichen 190.

- Zergehen 190.

Lein, Gelbsucht (le jaun') 283.

- Liöte des (le rouge) 283.

Lenticellen, liartoffel 369.

Lepidium sativum 71 .

leptosphaeria, Halmknicken 541.

- herpotrichoides 134.

Lejtothyrium pomi 169.

Leuchtgas 736 .

Leuconostoc Lagerheimii 845 .

Libertella faginea 557 .

Libonia florilında, Blattfall 353 .

Lichenismus 7.

Liclitmangel 649 .

- Eiweifzersetzung bei 664 .

- Krankheitsdisposition 6fil.

- Säuregehalt bei $66: 3$.

- Zuckerstaung 66:3.

Lichtüberschuß 666.

- Gelblaubigkeit 666.

- Roträrbung 668 .

- Schattenbilder 668 .

Ligustrum 103.

Liliaceen, mangelhafte Blütenbildung 417.

Lingua 50.

Littles Soluble Phenyle 750 .

Lohkrankheit, Apfel 210.

- liirsche 210.

Lokalerkrankungen der Pflanzen 6 .

Loranthus 50.

- senegalensis 701.

Iopas 39.

lösung von liohlehydraten 782 .

Loupe 853.

Loxas 39.

Luftfeuchtigkeit 72.120 .422$. $4 \div 5$.

Luft, trockene 408.

Luftverdünnung, EinfluB 314.

Lupelbildung des Hopfeus :34:.

Lutidin 459 .

Lychnis diurna 145.

- vespertina 145 .

Lyciun barbarum 147.
Leiclıte Böden 145.

Leistenzellen 329. 
Lycogala 50.

Lycopus europaeus, Anpassung $32 \%$.

Lysol 750.

Lythrum $32: 3$.

Mafutakrankheit des Sorghum 414.

Magnesiamangel :305.

Magnesiaüberschu13 399.

IIagnesimmverbindungen $: 361$.

Magnolia hypoleuca 157.

Maiblumen, Versagen 89.;.

Mais, Boden 232.

Nal della gonmua 702 .

Mal nero 219. 703.

Ialope, Stengelschwielen 443.

Malus sinensis, Maserbildung 380.

Maminia fimbriata iss.

Mannatluti 705.

Nareimme del fïco 70:?

Markasit 250.

Narkflecke, lirost 611 .

Markstrahl, Zerrung i7o.

Markstrahlwucherungen : $:-0$.

Jlarkwiederbolungen 611 .

Iarktpflanzen 1835.

Maser, Cydonia vulgaris :8.5.

- Malus sinensis 380 .

- schwarzed ohannisheere 3-2.

Maserige Uberwallıngsränder 849.

Maseriges IIolz \& \&!?.

Nlastkulturen 1:39.

Naulbeerbaum, krankheit (ist.

Iaximum os

Meerrettich, hernfaule - 110, - i:

- Schwarzringigkeit 710 .

Neeresspiegel, Fithebung üher 69.

Mehl, Backfahigkeit :321.

Mehligwerden der Frichte 16i:

Nlel aëris $41: 2$.

Melligo +12

Membranlockerung d.l.rost .79.

Mercurialis annua 14:

Mergeln 194. 2:38.

- Schorfkrankheit lee :30.

Mr tamorphose, vorschreitende 372.

Micrococcus dendroportus 84.$)$.

Nilchglanz der Blitter ati).

- Kalkmangel $2 s t$.

Milchreife 29.5 .

Nilchsäure 751.

Mimosa pudica, Trockenstarre 281 .

Mimulus Tilingii 73 .

Minismus 298.

Nißbildungen 3 .

Nißerfolge bei Tropenkulturen 81.

Mobilisierung der Reservestoffe 104 .
Mombacher Aprikosenkrankheit $47 x$.

Mlondringe, Frost 1511 .

Monilia cinerea 700 .

- fructigena ion.

Monstra i.t.

Moorborlen, Baliterientlora

- liesandung sis.

- ('hlorkialinm 2is.

- Düngung 2.57. 2...

- Entwäsirime 257.

- Cirundwasser lis. kinltur 25.5. empfindlichkeit 2:2.

Moosige Wiesen 361.

Morphasthesie 13\%.

Mosaikkrankleit, (ontagium visum thuidum $6 \times 1$.

- l'rüldisposition tiø1. Tabak 2:00, 6ī1.

- virus list

Mucor 50. 7 .

- alhus 50 .

- racemoshs !).

- spinosir 96. tolonifer 9. 9ז. 29:3

Mycoplasma 31.61 .

Nyeorhizat 7 .

Mermecolia echinata f:i.

Nirtus $1: 31$.

Nabthostlurse 6:27.

Nilchteile de's Simthodems 1 th.

Nadelholzer, Blitzwunden t>?. - Frostwumben try.

- ciptiddurre toti.

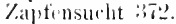

Nahrboden, Pallasit 14.

Nahrstothe, Komzentrationserhöhung der : (iti).

- Yerhalten der 27t.

Verhalten zim limilengerüst 264.

Nahrstotlinangel 174. 27.; : $20 \%$

Nahrstoffriberschuls :11!

Nisse :319.

- stagnieremdr 197.

Nagewumden $7 \% 2$

Nihrungenangerl, Verdunstung 318.

Nanisums 139

Narrenliopt bei llopfen :34?.

Nitbitule 19

Nasse, kalte Witterung 1-.

Natrondampfe $7: 35$.

Neleel 45:

- Baumwolle 4is.

- Schutzwirkung $\$ 10$.

Necrosis 53.

Nectria ditissima 4\%, 1:35. 5-7 590.

Neigung der Bodenoberfliche s.3.

Sekrobiose 697.

Neptun 750.
Nickel- und kobalthaltige $\mathrm{Ab}$ wisser 7 ti.

Nicotin 4.)!!.

Nibularia in.

Nitragin 270.

Notreatio 1ti.i.

- der lifumenzwioledn tifis Howe lit.

der Kartoftioln line.

des (1) otes lai:i.

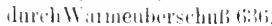
(i.).'.

Nectomeness os:

utilie ill.

Dhertachensehere dere linbert :iitio.

()hat, frosthates ficul Mehligwerden lii.,

- Notroife des 16:?.

- rostige schale l6?.

- relbstoterilitat 291.

()bstsorten fir trockene Bölen $17: 3$.

Msthitume, Istwurzelkmos :3!1.

- Numelveredlumer sion.

Collema :3itis.

Thologrische Vartetaten 70.

()lballm, filmmonose 704.

Mdimupe, linflub 717.

()hener lirehs $5 x-2$

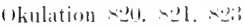

1)phiobulus 1:34.

- Maholinicken ill.

(1)timum is.

(j)mentia, horkancht 4:3

bangen, bir-batk :?

orebileen, leckigwerden der '2 4 is.'.

Glasigwerden 6.17.

- Lauberde 26:?.

()ganismon, kontwielinnesmechanik 6,3 .

hulturzwedk 2.

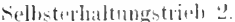
sellost\%wekt?

Hobus velums 72.

1)iterele 214

(1)totein 19.2. 211.

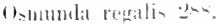

Oxalis fremata $10 \%$.

(1)

- Viuben e.s:?

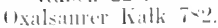

1) xyphintusature in:?.

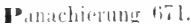

Fanalume :30:

l'andanus javanicus, fiellsprenkelung 4:3t.

l'angene 22 .

lapaver someniferum, I'istillodice 372.

P'arasitare lirankheiten 10. 
Parasiten, absolute 11

- takultative 11.

- Nährboden 14. oliligate 12.

- schwäche 11.

- Wachstumsenergic 12. Wund- 11.

Parasitismus \&.

Parenchymatosis 1 . :38.

Parenchymholz durch Frost li1t.

l'arenchymholznester 610 .

Parthenogenesis 177. 342 .

Pathogenie 4.

Pathographie 3.

Peach-Rosette 691.

Peach rot 7.54 .

Peach Yellow 691.

Pektine 16.5.

Pektinkrankheit (maladie pectique der Reben) 284.

Pektinvergärer 271.

Pelargonium 144.

- zonale, Intumescen 435.

Pelzen 8:2\%.

l'enicillium 10. 327. $75 \%$.

- glaucum 9. 204. 451.

Pennisetum spicatum, Boden 23.3.

Periodizität, korrigierende 35.

Perlzellen 4.

Peronospora Viciae 445.

Petalodie :372.

Peziza 49.

- Willkommii s 0 .

Pfirsichknospen, Abwerfen 6it?.

Pfirsich, Peach Yellow 6!)1.

l'flanzen, Allgemeinerkrankung 6. Aufreiben der :i21.

Beharrungsvermögen der:3i. Beziehung zur Ungebung 6 . etiolierte 423 .

- Geschichte der 37. Gewohnheit der :36.

- Konstitutionskrankheit 6 .

-- Kulturstanil 52.

Lokalerkrankung 6.

- Schutzvorrichtungen 15.

- Siechtum 5.

- Starre 5.

- Statistik derKrankheiten 6io.

- Widerstandsf ahigkeit 14 .

- Winterruhe der 122.

l'flanzen, zu flaches $10: \%$.

- zu tiefes 95. 10\%.

Pflanzenhygiene $6 \checkmark$.

l'tlanzenschutz 56.

l'flaumen, fuchsige $16 ;$.

- tür trockene, leichte Böden 17.

l'flügen, Bodengare 273.

Pfropfen 828.

l'froptsymbionten 877 .

l'halaenopsis anabilis, Fleckigwerden 262 .
Phaseolus 27. 12:;

Phenol 459.

Phillyrea 474.

Philodendron, Ifroptiversuche (i2).

Phleum pratense 12:3.

Phoma s. $26^{\circ}$.

- Betae 223.

Phosphorsäure, Ilangel300.312.

- Überschuß 405.

Phragmidium 56.

Phyllachora pomigena 169 .

Phyllerium 178.

Phyllocactus, liorksucht 428.

Phyllodie 34\%.

Phyllomorphie $: 042$.

Phyllosticta $26 \%$.

Phyllosticta sycophila 704

l'hysiologische Trocknis 24ti. 740.

Phytopathologie :

I'hytophthora 5y.

- infestans $1 \diamond$.

Phytophthorafiule der Kakaofrichte 461.

Phytoptus 144 .

licea 103.

- excelsa, fasciatio :332.

Picolin 459.

Pilobolus 51.

Pilosis $17 \%$.

l'imelea 1:32.

Pillosol 751.

Pinus $10: 3$.

- Nanismus 141.

- montana 248. 474.

- silvestris 91. 105.

- - f. turfosa 250 .

Piricularia Oryzae 315.

Pirus communis $2 \times 0$.

Pissodes Herciniae 711 i.

- scabricollis 716 .

P'isum 7.

- sativum 105.

Pistillodie 372.

- Papaver somniferum 37:.

Plantago alpina $\$ 1$.

- maritima 81.

Plasma, embryonales 28.

Plasmodiophora Brassicae :36t.

Plasmopara viticola $2 \times 0$.

P'lastidentheorje 59.

Plastidulen 2r.

l'lectridien, l'elitinvergärer 272.

Pleophyllie :366.

l'leospora gummipara 701 .

Poa alpina 73.

Pockenlirankheit d. Tabaks 68:?.

Podocarpus, Nanismus 141.

Podosphaera leucotricha $6: 36$. Polycladie 144.

Polygonum amphilium 175.

- viviparum 73.

Polyporus sulfureus 266 .

Polysarchia 50 .

Pomeranzen, Gummiflub 701.
Pomologischer Zaubering 779.

l'rädlisposition 22. 48 ; s. I)isposition.

-- abnorme 23.

- Frllichkeit der 28.

- durch Lichtmangel 661 .

- Mosaikkrankheit 681 .

- notmale 23 .

für Raucherkrankung $71 \%$, hei Rüben 223. 225.

Prateolus 50 .

Prolepsis, Kartofteln 162.

Proliferatio 373.

Prophylaxis 4.

Protandrie 29:3.

Prothallien, ameristisch $28 \mathrm{r}$.

l'rotogynie 293.

Proventivknospen 775 .

Prunulus 50.

Prunus 105.

- avium (Verfäbung) 280.

- Cerasus (Verfärbung) 280.

- domestica (Verfärbung) 2\$0.

- Nanismus 141.

- Palus, líropfmaser 385.

- persica (Verfärbung) 280 .

Pseudomonas campestris 2:3.

- vascularum 690 .

P'seudopeziza tracheïphila $2 x: ?$.

Psychroklinie 547.

Puccinia 50. 134.

- dispersa 1:6.

- glumarum 126 .

- graminis 61. 126.

Pultenaea 132.

PyramilenpappeIn, Absterlen 5.57.

Pyridin 459.

Pyrus Cydonia 48.

I'ythium de Baryanum 22:3.

- an \%uckerrohr 228.

Qualitait des Samens 109.

Tuaternaria Persoonii 557.

(juellung der Saat 104.

(Q) uellsäure 241.

()uellsatzsäure 241 .

Quercus pedunculata 77.95.

(?uitten, Senkervermehrung \&06.

Radiumstrahlen, Hemmung 667.

Raps, Hagel 466.

Rasen, Ausbrennen 185. 285.

Raseneisenstein 245 .

Rasennarbe, Einflub 276.

liassen, biologische 12. 126.

Ratten, Rieselfelder 364 .

liauber 331.

liäude der Rüben :967.

Rauch 46. 459 .

- Bestandteile 730 .

- Bodenvergiftung 715 .

- chemischeBeschaffenheit 731.

Raucherkrankung, Prädisposition 715 . 
liancherzeugung, IIüttenwerke Ringelkrankhrit ıler liotbuche 730.

liauchgase 711.874 .

Rauchkommissionen, statliche $7: 36$.

lauchschäden, akute, chronische 714 .

- unsichtbare 714 .

- Kalkdïngung 716.

Rauhe Furche 236. 510.

Rauhreif 6:3:3.

lieben, Gabelwuchs 345. Krautern :346.

- Laubrausch 28:3.

- Pektinkrankheit 2st.

- Rindenwarzen s71.

- lingeln 354. 875 . rote Brenner $2 \times 3$.

- rieng 283 .

Reduktase 670 .

lieeren der Trauben $7 \pi$

liegen 460 .

Regeneration 871 .

Reif 634 .

Reife, späte, des Cirtruiles :i6.5.

Reifever"zögerung, Stickstoffüberschul' 394 .

Reinigen der Biume 295 .

lieis, Brusone-Krankheit :31;.

Reproduktion, Schwächung 144 .

lieseda odorata 12:).

Reservestoffe, Mobilisierung 104.

Resinose 70.5.

- akute, chronische 709.

Retinospora pricoilles $\times 17$.

Rhabarber, Uberdiungung 392 .

Rhabditis 4 .).

lihamnus 10:\%.

- Frangula 9:3.

- pumila 73 .

Rhizobium Beijeninckii 270.

- leguminosarum

- radicicola 270 .

Rhodanammonium 7.59.

libes 103 .

- aureum, Wassersucht 335.

Ricinus 9๖. 2:30.

- communis 12:;.

liieselfelder 364.

- liochsalzgehalt 711 .

- lirähen, Ratten :36it.

-- Virschlickung:366.

Rigolen 235.

Rinde, Alowurf 2.)9. 3\%.

- Sonnenbrand 644 .

liindenknollen 851 .

Rindenmulm 25:).

Rindenpropfen $8: 21$.

Rindensehorf :37:2.

Rindensprünge : $: 2$

Rindenwarzen 871 .

Ringelkrankheit d. Irazinthen 326. 453. 219.

Ringeln 777. ㄱ.

- der livben :ist

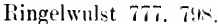

Ringschäle, Frost 612 .

Robinia 152.

- P'send-Acacia 105.

Roesleria lıypogaea $70:$.

liohbumus 146.190 .242 .271

lioncet $x+1$.

Röntgenstralılen, Ilemmung dureh 6 i67.

lioratio 40 .

lios mellis 412 .

liosa chinensis, (irünblütigkeit 342.

Rosa 105.

- gallica 10:?

liosenkönigin :?::3

liosenkrelss 5y!.

liosenstämme, (hangrivieren 4:34.

liosettentriebe 144.

liostige richale, Ohst 169 .

liostringe durch frost 52.2.

liostzeichmungen $4: 32$.

liote des Cietreiles .

- des Hoptens 2-2.

- (le rouge) des l,ein 243.

liothuche, lingelkranklueit 2-19.

- schwarzer Brand 5.5.

Rote Bremer der lieluen 203.

Rote Lohe des llopfens 2ac.

lioter Farlostoll 124.

- - l. Lichtuberschuli 6ris.

Rotfiule 612.

Rotholy $\therefore 0$.

liotz. Andropogon nutans 690 .

linbigo 4:3. 46. :0.

litiben, Baliteriorhiza 244.

- Bodenbearbeitum 2:7.

- Buckelschorf :367.

- Chilisalpeterdüngung 224.

- lrost 530 .

- Giirtelschorf :3is.

- Obertlachenschort :367.

- Oxalsäure 2:2:?.

- I'rudimposition 2.2:3. 20:.

- Rimle :367.

- Samenbeize :2.)

- Sichorflirankheiten $\$ 367$.

- schwarze Beine, Zwirn 2.2l.

- Tiet'schort 367 .

- üherdüngte :3ั9.

- unreife 390.

- Weibblattrigkeit si:;.

- Wurzelkropt stil.

Rückschreitencle Metamor phose :340.

Rinellia, Intumescenz 44x.

Rumex acctosella 145.

- - lialkmangel 23:

liup 7.29.

- Zusammensetzung 7:30.
Sact. Aufziehen durch Frost i.i.i.

- Ausbrimen 1<.5.

Anssinern 201.

- Bedeckime 107.

- mechanische bejuandlume 104.

- (juellung 101.

- Selbsterhitsung 6.I!)

- tiete ladere 1111.

- iblerjabriges lionen loi.

- versplitete. -20il).

salatgut, Finquellan $1: 1$

- Kamdieren - t.). - überdingertes :

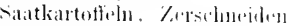
ils.

ratticte $10 x$.

- Sellistregulierum 111.

Salzeit, Verschiohmes tiai,

Saccharogenesis diabetica... .

saceharomyces !).

- Ludwigii s45.

sabelwuchs 47.3.

Situren im Botun 241.

silure, Wurzeln for).

siunegehalt lee lichtmangel $66: 3$.

Simrerucligang. Stickstoffuluerschub :3!:?.

Salix arenaria 147.

- cinerea !).

- herbacea $>1$.

- reticulata sl.

- serpyllitolia $7:$.

valpeteriüngung $19 \%$

salpetersillue 723 .

Salvini.l natans 7 .

Salzsaure 71 .

Sambucus 10:3.

Samen, Alter lori.

- Bedeckinng 10\%.

- in Fis I!9.

- Erweckung lori.

- IIartschaligkeit 11:?.

- kandierte :2-

- kimment in lincht :i2l. livimliratt 12:?. ?ualitat 10!1

- scliwaclibiche syos.

- Vorpuellin lus. 295.

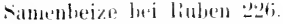

samenloriels dureh sommen bramel tif:i.

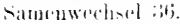

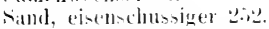

— in Gartnerei 206. Elerthingunes :35.5.

camblboden, duswarchen 116 . betaumngfihigkeit 146 . prostgefahr 147

- Nachteile der boden 11 .

sapokarlol 7.51 .

Saproplutiomus $\because$

rattolscliaten s..l. 
Satureja hortensis 71 .

canerstoff' 106.

Sanerstoftmangel :312.

Sanerstoffstarye $: 12$.

Canerstoffübersehmb 315.

sammlinien dureh salzsainre 717.

Saxifraga cernua 73 .

schälliche Gase und Flüssigkeiten 711 .

schälen d. Bodens 18:3.

- durch Wild 771.

sichälwunde 787. 820 .

Sehattenanlagen f. IIopfen 24:3.

Schattenbäume, Kaffeckulturen 653.

sichattenhilder bei Liehtïlıer sehub 668.

sicheideschlamm 415.

- Herz-und Troekenfäule 194.

sehizomyeetes 5,9 .

sichlamm 191. 195.

Sichleimflub der liame st4.

Schleimkork 279.

Sehmanchfener als Frostsehutzmittel 625 .

Sehneelrueh 631.

rehneedecke 73,622 .

sehneedruck 631 .

schorf krankheiten $\$ 367$. Nergeln : $: 70$.

Schornstein, Auswurtstofte 729 .

sichobriuben durel Frost 515 .

Sehröpfwunde 7 it6.

Sichrumpf krankheit des Maulbcerbanmes 684 . Tee 686.

Sehüttekrankheiten 349.

schutzvorriehtungen der l'flanze 15.

sichutzwald 147.

Schwächliche Samen 295.

Schwächeparasiten 11.

schwanztiule der Rüben 691.

Seliwarze Johannisheeren, Maserliblung 380 .

Schwarzer Rost des Kaffees $2: 31$.

Schwarze 'Trockenfäule, liartotfel 391 .

Schwarzwerden der Getreide. körner 69.

sichwefelcaleium $7: 3$.

schwefeleisen 192. 250.

Sehwefelkies 250.

schwefelkohlenstoff $26 \%$.

Schwefelmetalle, Bodenvergiftung 250 ).

schwofelmangel 312.

schwefelnatrimm $7: 33$.

Schwefelsiure, freic 250.871

- als puellungsmittel 121 .

Sichwefelsaures Ammoniak 7.59.

sichwefelwasserstofi 198. 7\%:, $7: 34$.

Shothe Sanre 711. S74.
'Schwerer Boden, Nachteile 233.' Spiralismus 335.

Sciadopytis, Nanismus 141.

relerotinia Lilsertiana 25.

Scoroglia 50.

secca molla 202.

Sedum aere 72 .

- allum 72.

- hexangulare 72.

Seeklima 128.

Seewasser, Überschwemmung durch 191 .

Sellosterhaltungstrieb des (1)ganismus '2.

Sellostzwerk des Organismus 2.

rellerie, Ibrdüngung :39:.

Seng der Reben 2×:3.

Senkervermehrung bei guitten 806.

Senkung des Grundwasserspiegels $10 \% 148$.

sepedoniun clirysosjermm 204 .

Serch, Andropogon 68ti.

serúhrankheit $\$ 2$.

- des Zuckerrohres $6 \times 6$.

Serumtherapie 20.

Senehen, Topographie 20.

Sexualorgane, Kryptogamen $28 \%$.

Shikuyohyo 694 .

Siechtım der Pflanze 5.

Silpha atrata 364 .

Sippen, klimatische $1: 31$.

Sodastaub $7: 35$.

Solidago Virga aurea šl.

Sommerlurand des Hopfens $2 \times 2$.

Sommerlaubtall 347 . 411. 657 .

sommerreif 634 .

Sommertrockenheit 500 .

Sonnenbrand, an Blüten und Blättern 64:.

- Clivia nobilis 629.

- Knospenbeschädigung $6+1$.

- Rindenbeschädigung 644 .

- Samenliruch 643.

- Risse 64t.

Sorghum, Boden 2:32.

- Mafuta-Krankheit 414.

späte Saat, Parasiten 200.

spritfrost 134. 432.

Spaltpfropfen 8:1. 82\%.

Spaltwunden 820 .

spammungsifferenzen flurch Frost 513 .

sperielle Erkrankungen Tr.

sphacelus 606;.

Sphaerocarpus 50.

Sphagnum 186. 250. 257.

Splagnmmtorf, Gätnerei 261.

sphakelismos :89.

- piloeaea pomi 166.

Spinacia oleracea 14:.

Spiraea $10: 3$.

- Krelss 596.

Spiralilrehnng der stamme $\times 07$. spitzenbrand 55:?.

spitzendiure $29 !$ \%

sporodesmium 704.

sprossung der Früchte $37 \%$.

spüljauche 366 .

citarliebäume $4 \times 3$.

Stärkebildung 299.

Stallmist, triseher 269.

staminodie 342 .

Stangenrot bei Hopfen 2s:3.

Starre der Pflanze 5.

Statistik der Pflanzenkranklreiten $6 r$.

sitatoeyten 848 .

sitauchlinge 174 .

Stecklinge, von verschiedenen Organen 814.

- neue Varietäten durch 817.

Steine $2: 37$.

Steinigwerden der Birnen 169.

Stelzenkiefer 92.

Stelzenwuehs 89 .

Stereum hirsutum 611.

Sterigmatocystis nigra 300 .

Sticktoffhunger 270 .

- Gellosueht durch 310 .

Stiekstoff kalk 761 .

Stickstoffmangel $2 \times 7$. :300.

Stickstoffsammlung, Bodenbakterien 269.

Stickstoffsäure 723 .

Stickstoffüberschuß $365,3 \times 7$. 394.

- Säurerückgang 39:3.

- Zierpflanzen 99:3.

Stillım 51.

Stippflecke, Äpfel 166.

- Kartoffeln 397.

Stoekausschlag :376. 377. 774.

ctraßendämme, Asphaltieren 103.

straßenpflanzungen 151 .

Sitratifizieren 105. 157.

streptothrix-Arte'n, Humusvergärer 272.

Streublitze 486.

- anf Felilern und Wiesen 49.i.

- Weinstock 49:3.

Strenentnahme 146 .

stremutzung, übermäbige $1 \%$.

Stremrechen I\$9.

Strueuschieht 242.

Strolndüngnng 269 .

Strohwüchsigkeit des Gietreides 365 .

Strophomanie 835.

siuillus 50 .

sulfarin :37.

Superphosphat 759 .

symbiose, antagonistische 7 .

- mutualistische 7 .

Symphoria 103.

rymptomatik:?. 


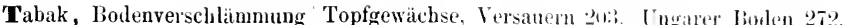
193.

- Bosuch 1779.

- Brindle 679 .

- Bunt 679.

- Calico 679.

- Chlorose 679 .

- Fäule 679 .

- Frenching disease 67\%.

- Kali 40.).

- Kopf bunt 230.

- La Mosaique 679.

- Mal de Mosaico 679.

- Mal della bolla 679.

- Mauche 679.

- Mongrel lisease 679.

- Mosaikbetegsege 679.

- Mosaikkrankheit 230. 6i-

- Nielle 679.

- Peh-sen 679.

Pockenkrankheit $68: 3$.

- P'oetih 679.

- Rost 679.

- Rouille blanche ti79.

- I berwachsen 230. ungünstiger Boden 2:30.

- weißer Rost 65:3.

Tagetes 144 .

Tamarix gallica 474.

Taphrina 143. 178.

Taro, Boden 2:3:3.

Taubildung 130.

Taubblütigkeit 289

Taxus baccata 254 .

Tecoma radicans, tasciatio $3: 44$.

Tee, Schrumpfkrankheit tivti.

- ungünstiger Boden 231.

Teeranstrich 746 .

Teerdämpte 725 .

Teernebel $7: 9$.

Temperaturscliwankungen 8 . 505 .

Teratologie 3.

Terpentindimpfe $7 t<$.

T'etranychus telarius 412 .

Therapie 4.

- innere 20.

Thielaviopsis etbaceticus $6 \times 7$.

Thiophen 459 .

Thuja 141.

- obtusa, Zwergwuchs $13:$.

- occidentalis 103 .

- orientalis 10:3.

- plicata 10:3.

- Warreana 10:3.

Thujopsis 141 .

Tiefpflügen 2:35.

T'iefschorf der Kartofteln $4: 30$.

- der Rüben 367.

Tilia 93.

- parvifolia 61:3.

Tipula suspecta 611 .

Tomate, Iagel 466 .

Tonböden, Aufreißen 1rs.

Topfgewächse, Gelrauch 208.
Topographie der reurlen 24 . Ungunstige Bodenleschatlen-

Torferde 184.

Torfstren 26.5 .

Torula monilioides 4 .

Tradescantia 2.

- virginiea 312 .

Trametes P'ini 61?.

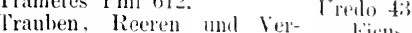
rieben 7 :

duch l rengung is Citilauo $16 \%$

Trammatischer lieiz 8 is

Treiblanbfall :34. 412.

Trichia 50.

Triebe, Abstocken der 1::2.

Trifolimm pratense $10 \%$.

Triticum 1.23.

Trockenfïnle der Rüben $4 \mathrm{I} 4$.

'Trockinheit 129.

- Gelbsucht dureh :311.

- Kirsehe 281.

- physiologische 204ti. 740.

anille, Proptorsuche

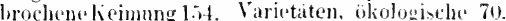

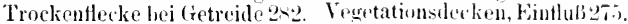

Trockenrisse 56,8 .

Trockenstarre, Nimosa pulina Veltheimia glatuca, Vertrocknen 281 .

Trockene Luft lis.

Trockene Witterming 19.

Tropenklima, fiemise 6:-.i.

Tropenkulturen I IIiBerfolge $\times 1$.

- ungünstiger boden 2.27.

Tuber 4!t.

Tubercularia 51.

Tulipa $10 \tau$.

Tulpen, Vmfallen 6ts.

Turgenia latifolia 71 .

Turgor, Blattfall :351.

Tuv 750 .

Tylenchus devastatrix is.

- hyacinthi $32 \times$.

- sacchari 158.

Überdiungung, Feldgewälise 392.

Gemiise :392.

- Kartofleln :390.

- Rhabarber 392.

liublen : $; 29$.

silatgut

Sand 395 .

- Sellerie :39:.

Tlierflutungen 195.

I'bersprossung 373 .

I berwallung von Wunden iz:. 775.

I berwallungsrander, maserige $8+4$.

Tlex europaeus $14 i$.

I $\operatorname{lm}$ in 242 .

I'lmus, limelenaburf 259.

Unfruchtbarkeit $28 y$. Erblichkeit 291. der Hluten 297.

Verbinderung 3030 : s. fisctiatio. lei File :

Jrost 5.

Picea excelsa : :3:;.

Verbrennen der Blatter 6:3.

- nasser Boden 19\%.

Verdoplelung :37t.

Verdumstung hei Nabrungsmangel $31 \mathrm{x}$.

Vereellung - l:!

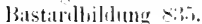

liutluls :31.

Wein $\$ 34$.

Wunden $\quad 0$.

Vereillungsunterlage, Vergithen $2 \times 4$.

Verfirloung von Geholyen 20.6.

Vergiftung durch killimanut :301.

Vereillen durch frowt sis.

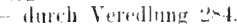

Vergrunumg :34.

Verbatarung $17 \%$.

Verloben aler Wurzeln bis.

Verhumern der Bluten s:97.

Virkrmatme des liodens 1:3:.

Verlambuner :36.

Vermicularial it.

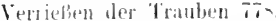

Vursagen der Mathlmenes sis.

Versindung toy.

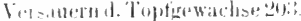

Vif-cheinen,Hul-enfruchtelis. lintreicle lis.

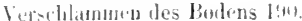

Verspatete raiat 200.

Verspillern 649 .
Vershlickung, Rifeselfedder 3tif: 
Versumptung 195.

- Frostemptindlichkeit durch 196.

- Wurzelfiule durch 196.

Verticillium ruberrimum 204. - Sacchari 228.

Vertorfung des Düngers 271.

Vertrocknen der Bliiten 296. - Veltheimia glauca 297.

- des Laubes 284.

Verwachsung, natüliche

Verwesung 195. 205.

Verwundung, Intumescenz d. 441.

Verzwergung aus Wassermangel 142.

Viburnum Opulus 103.

Vicia Faba 77. 98.

Yiola arvensis 71 .

- cucullata 72.

- tricolor 73.

Virescentia 342.

Virulenztheorie 10.

Virus 678 ; s. Enzyme.

- Mosaikkrankheit 681.

Yitis vinifera, Verfärbung 280 .

Viviparität 378.

Volutella 51.

Vorbeugungsverfalıren 4. 20.

Vorfrucht 275.

Vorquellen der Samen 295.

Vorschreitende Netamorphose 372.

Vulkane 742.

Wärmemangel 497.

Wärmeüberschuß 634, s. Sonnenlirand.

Entlaubung 640 .

- Notreife 636.

Wald, Einfluß des 132. 18T.

Waldbäume, Astwurzelkrebs 591.

- Freistellung 328.

Waldstreu 186. 270.

Walzen 183.

Warmhauspflanzen, 276.

Wasser, Frostschutzmittel $6 \% 3$. - stagnierendes 198.

Wasserkalk 399.

Wasserloden 331 .

Wassermangel 275 .

- im Boden 181.

- Gipfeldürre 189.

- Produktionsänderung 277.

- Verzwergung aus 142.

Wasserreiser 331. 473.

Wassersucht 335 .

- Beerenobst 335.

- Ribes aureum 3:35.

- bei Kernobst 338.

- bei Reben 871.

Wasserüberschuf 319 .

Wechsler, Reben 346.
Weinbeeren, Frostgeschmack 517.

- Hagelgeschmack 469.

- kernlose 355.

Weinblüten, Abröhren :iis

- Durchfallen 354.

Weinessig gegen Gummiflub 701.

Weinstock, Cblorose 402.

- Gelbsucht 402.

- Gelivüre 494.

- Grind 594. 598.

- Icterus 310. 402.

- Intumescenz 438.

- Kalküberschuß 402.

- Kírebs 594. 598.

- Kiupferung 440.

- Streublitze 493.

- Veredlung 834.

Weißblätterigkeit 308 .

- der Rüben 879.

Weißer Rost, Taloak 683.

Welken 276. gewächsen 365.

- dureb Frost 547.

- durch Gießen $20 \%$.

Welkkrankheit der Baumwolle 229.

Widerstandsfähigkeit der Pflanzen 14.

Wiesen, Ammonsalze 363.

- Aufeggen 2:37.

- Geilstellen 364.

- Kaliüberschiß 405.

- moosige 364 . Streublitze 495.

- Veränderungen der 362 .

Wiesenmoor, Gärtnerei 260.

Wildschaden 771 .

Wilt disease 299.

Wimmeriges Holz 849.

Wind 19. 462. 470. Blattbeschädigung 476 .

- als Frostschutzmittel 625.

- scherende Wirkung 472.

Windbruch 470. 471.

Windschutz 134.

Windwurf 470.

Winteräpfel, Aut bewahren 3:5.3.

Winterfeuchtigkeit 189.

Wintergewitter 486.

Winterreif 634.

IV interrube der Pflanzen 12:.

Wintersaaten, Aufeggen 2:

Wintersomenbrand 644 .

Witterung, kalte, nasse 18.

- trockine 19.

Wollstreifen, Apfelkernhaus 324.

Wunden des Achsenorganes 762.

- durch Hagel 467 .

- durch Harznutzung 770.

- durch Inschriften 771 .
Wunden durch Veredlung s20.

- I'berwallung 77:. $77 \%$.

Wundgummi 840 .

Wundholz 762. 782 .

Wundkernbolz 842.

Wundparasiten 11.

Wundreiz 861. 875. 876 .

Wundrinde 782.

Wundschutz 840 .

IVundwall 826.

Wurzel. Anpassung 7..

- Ausscheidungen 136. 148. 270.

- Auswïchse 191.

- Brand, Rïhen 221. Brut 861.

- Erfrieren 561.

- Fäıle, Kaffee 2:31. des Zuckerrohres 22૪. Fäulnis 196.

- Gewächse, Welken der Blätter 365 .

- Knöllchen 8.

- - durch Versumpfung 196.

- Liropf der Rüben 861.

- Krïmmungeu 135.

- Säure, 402.

- Stecklinge 818. 876.

- Veredlung 830.

- - bei Obstbäumen 831.

- Verholzen der 179.

- Verletzungen 845.

- - Förderung der Blütenentwicklung 877.

$\mathbf{X}$ anthium 175.

Xanthoria parietina 330.

Yamswurzel, Boden 2:3:3.

Zapfensucht der Nadelhölzer 372.

Zellgänge, Frost 611 .

Zeolithe 265.

Zerklüftung d. Polyporus sulfureus 566.

Zierpflanzen, Stickstoffïberschuf 393 .

Zimmerkulturen 419.

Zimmerpflanzen, Blattfall :352.

Zink 732.

Zinkblende $74:$.

Zinkoxyd 743.

Zinksalze 743 .

Zinksulfathaltige Abwässer 713.

Zinnia 144.

Zopftrocknis 89.

Zuchtauslese 661 .

Zuckerrobr, Blattfleckenkiankheit 229. 
Zuckerrohr, Coppsche Krank- Zuckerrüben, Ilerz-n. Trocken- \%weige, Irehen so.;. heit des 690 .

- Dongkellanziekte 22x.

- Kalkmangel 304 .

- Krankheiten 22১.

- P'ulverkrankheit $6 \$ 9$.

- liotz 6₫9.

- Seréhkrankheit $6 \times 6$.

- ungünstiger Bollen 2.29.

- Wurzelfiule $22 s$.

\%uckerrülıen, bakteriöse (ium- \%weighranda. Walthimmenn. mosis 691 . fiule 414.

- Schwanzfiule 691.

- Wurzelliamil 2:1.

Zugholz 5.).

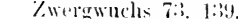

Zwangsdrehung liti. :-is. \% Wieselbrind side.

\%weigablisse 3.;.

Zweigalsprunge :

\%wigstecklinge 811.

\%weirspitzen. Abfrieren 5i?.

\%weigsterhen durch Frost liz.

\%erenterlage los.

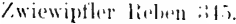

\%wiewuchs $15: 3$

\%weige, Biegen sou.

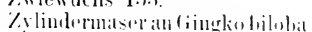
:Biti.

\section{B⿺辶⿻日禸

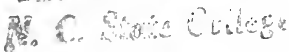






